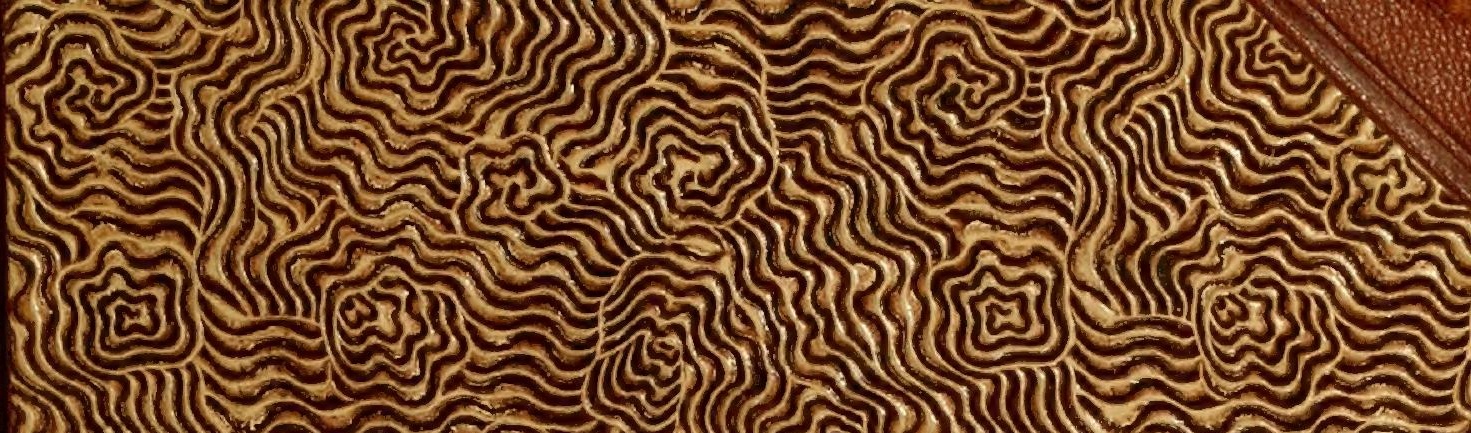

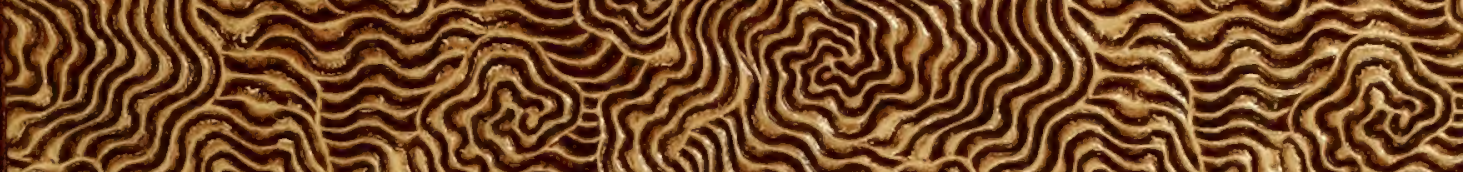

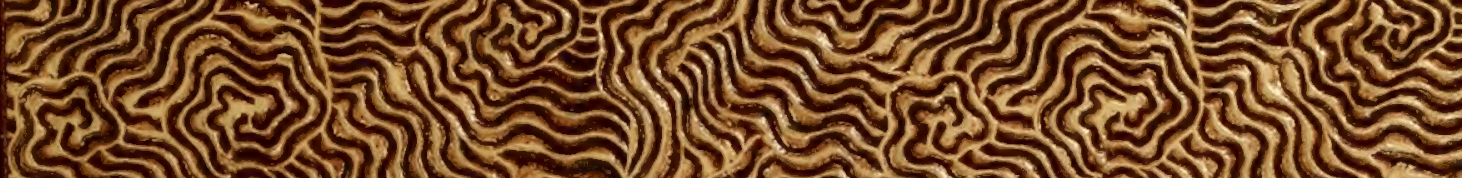

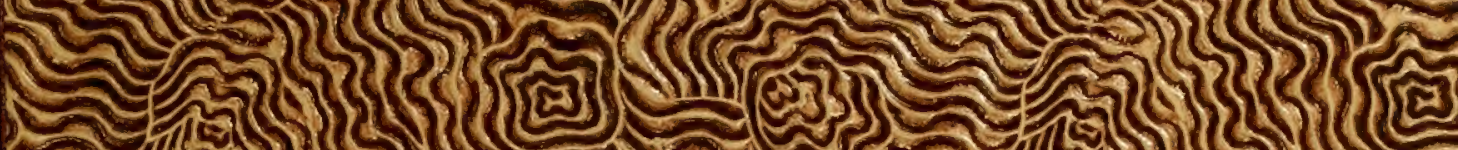

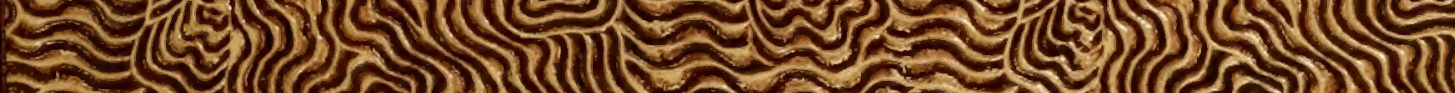

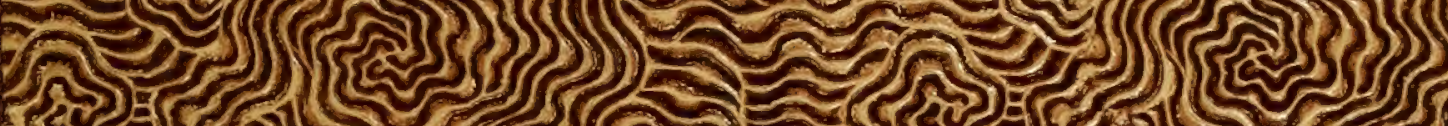
s.

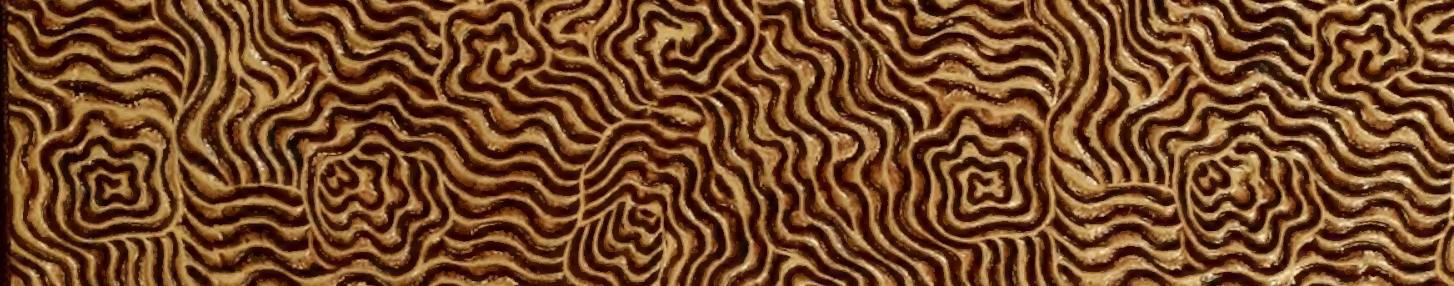

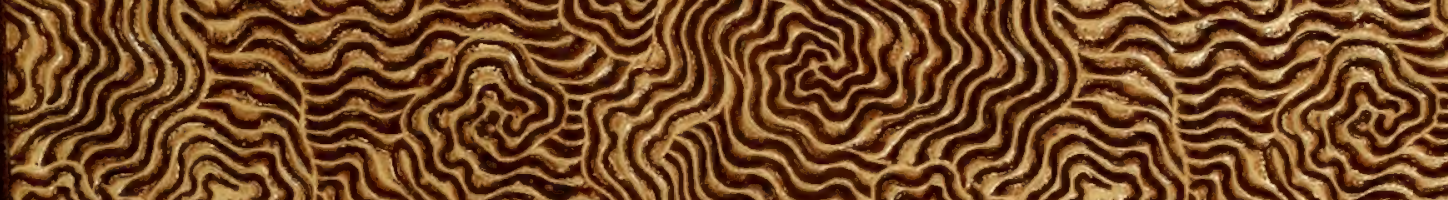

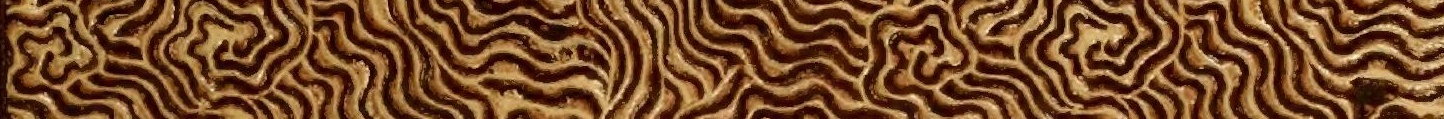

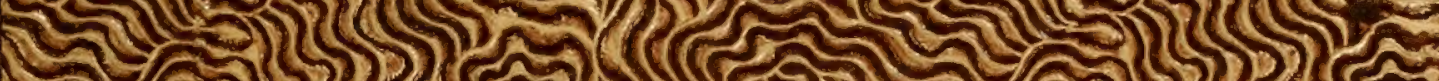

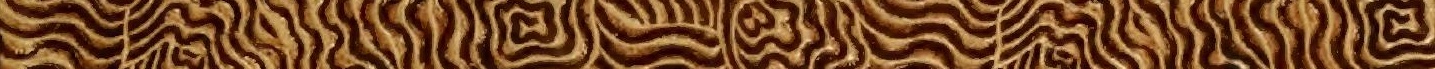

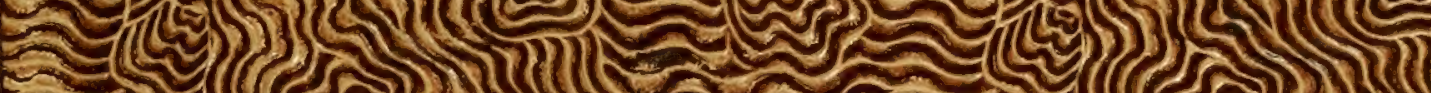

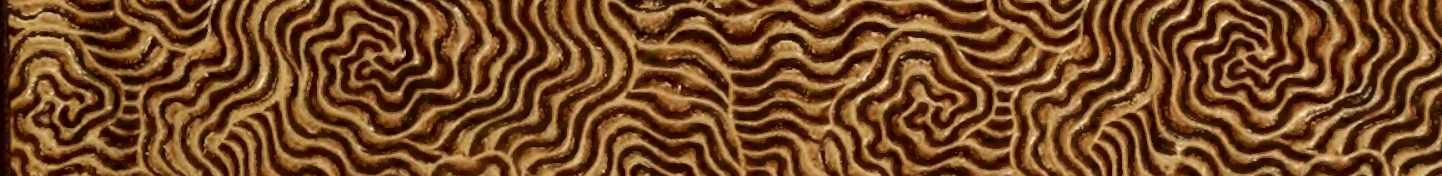

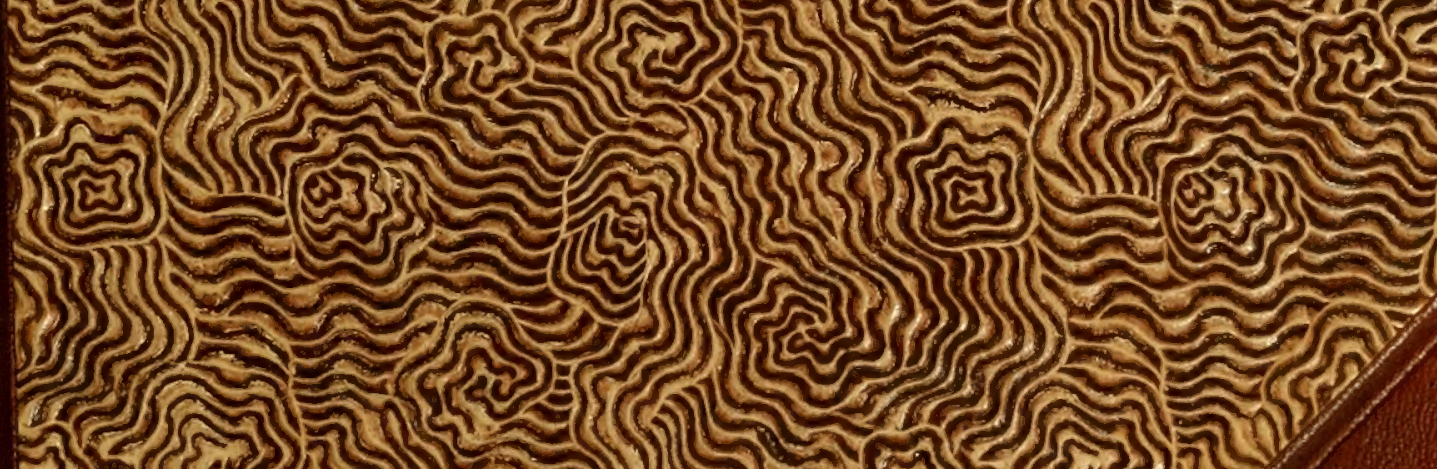




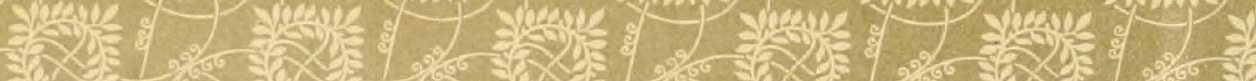

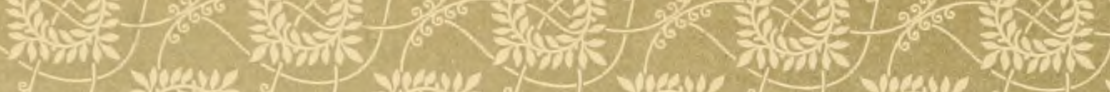

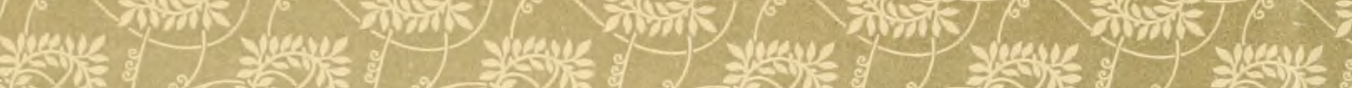

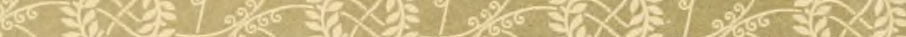

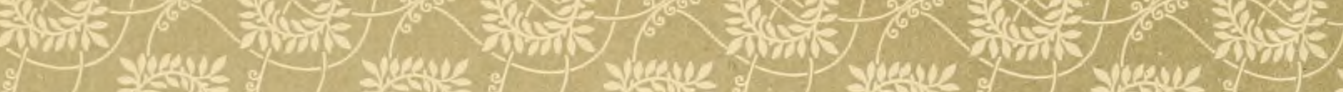

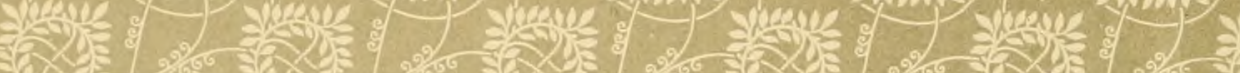

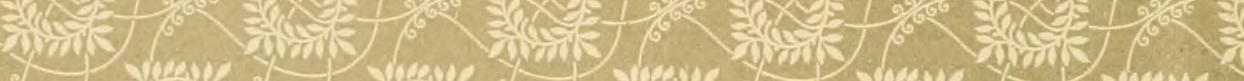

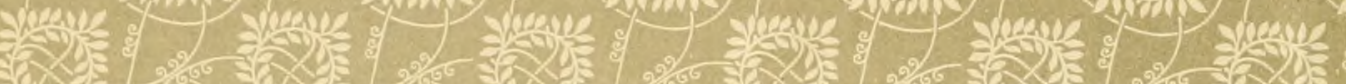

arrit)

equivel/

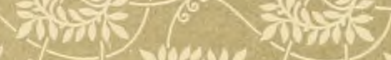

estorid 3 .

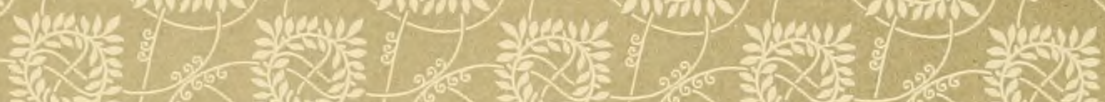

Waye of
ही $(20)$
elc 201
ही?

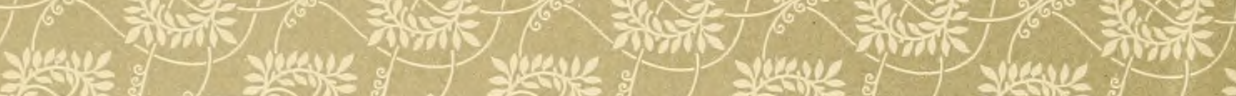

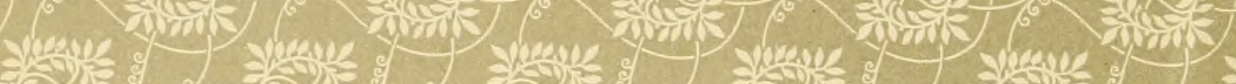

and
and
sen

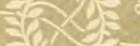

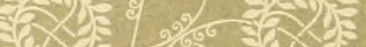

esivis)

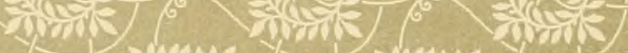

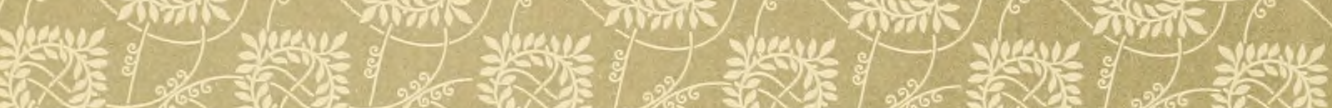

ed

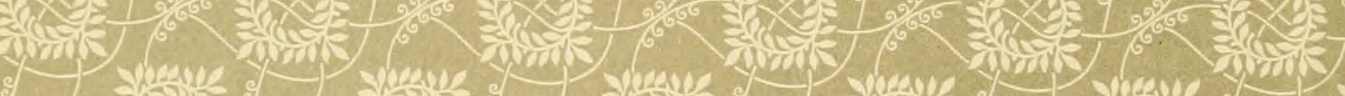

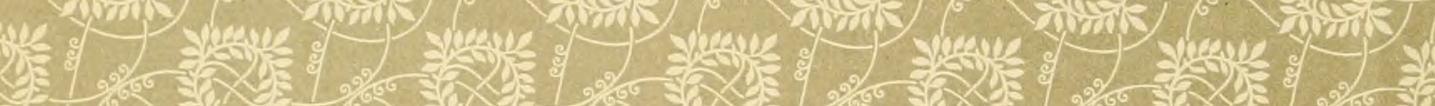

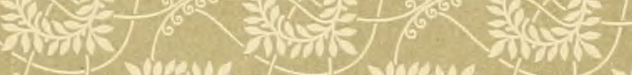

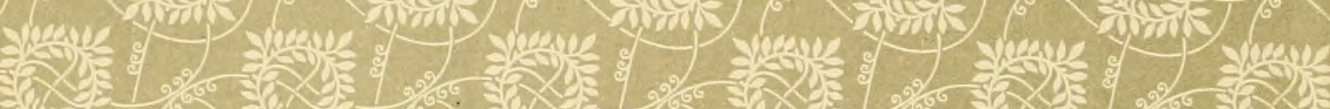

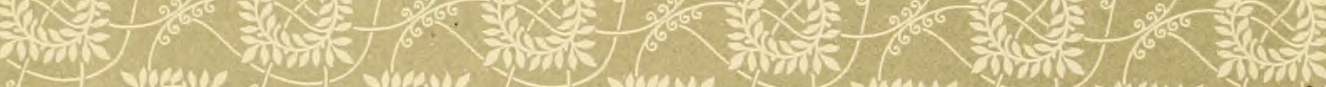

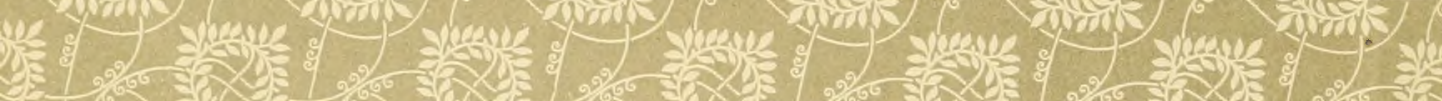
है

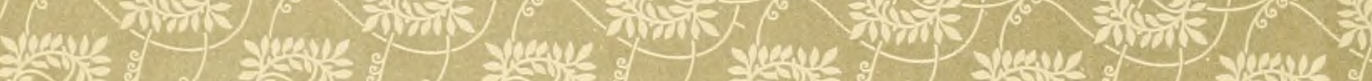

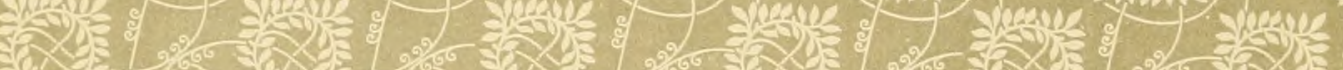

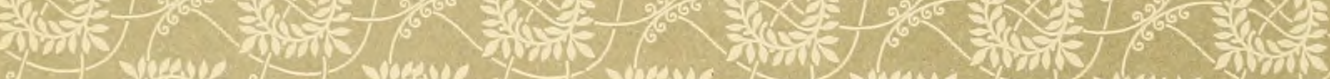
a

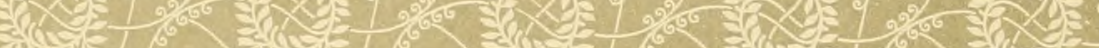

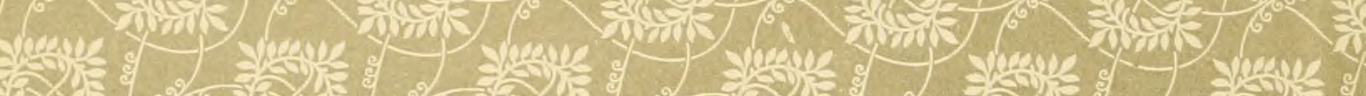

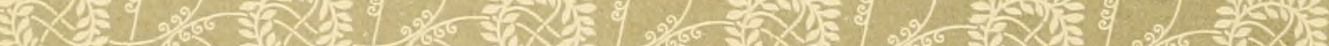

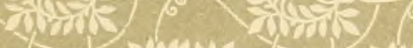

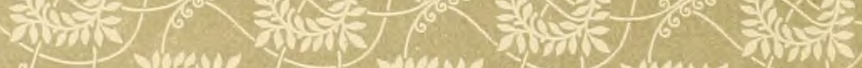

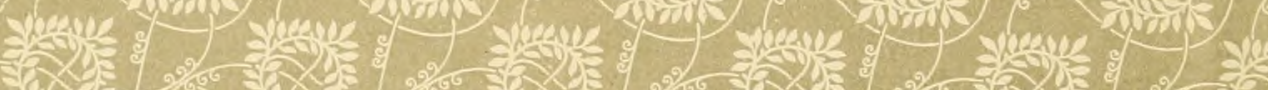

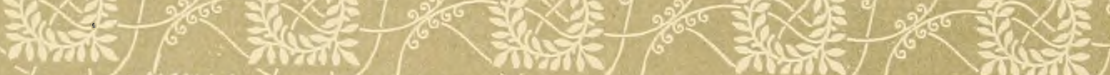

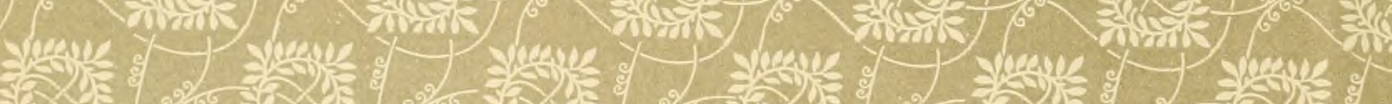

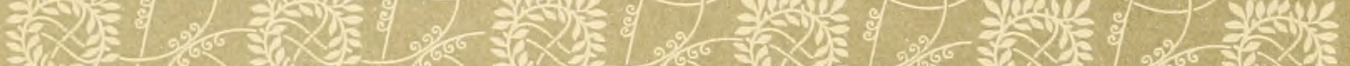

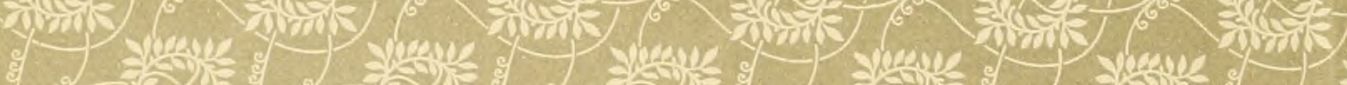

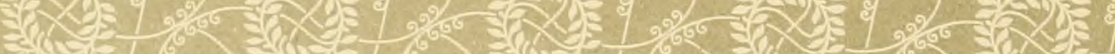

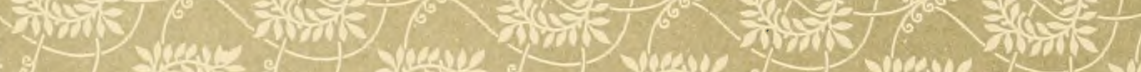

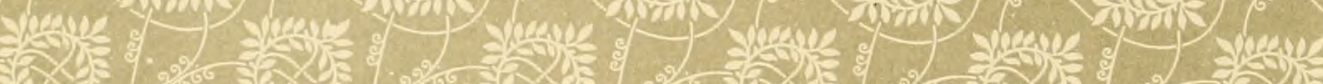

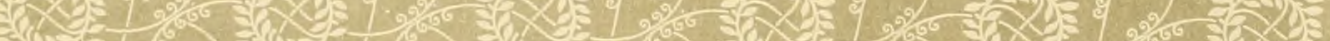





\section{Deutichlands}

\section{2ümphibien unt septilien.}

\section{Eine Bejchreibung und Schilderung}

fämmtliđḩer

in Dentichland und den angrenzenden Bebieten vorfommenden surche und Kriechthiere.

Don

Brutto Diutigen.

Mit den Zbbilonngen jämmtliher 2lrten anf 12 farbendruffafeln, ausgeführt nadi Zquarelfen von Chr. Dotteler, fowie mit 4 z Cextbildern.

2Tagdebura.

Ereuţ'fdqe Derlagsbuḑhandung. 1897. 


\section{Dorwort.}

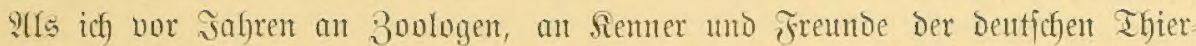
melt und insbejondere Der in unjerem $\mathfrak{B}$ aterlande und Den angrenzenden mitteleuropäifichen (Sebieten Yebenden 2 mphibien und Reptifien einen Fragebogen ausjandte mit Der Bitte,

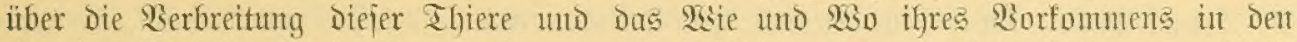
einzelnen Strichen fowie itber beachtenswerthe Erfichemungen aus ifrem Reben mir gütigit

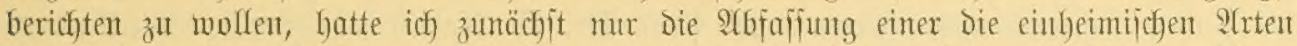

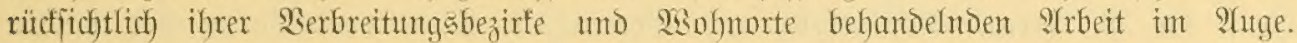
Inteffen find mir nidgt mut Damals jogleich), fonden auch fpäter fortgejebt von vielen Seiten aufßer midftigen zoogeographifichen Potizen zalf(reiche und fobone Mittheilungen ïber Rebensmeije uno fortpflanzung jener Gejchöpfe, ïber ifre $23 e j e n$ und Gebafren in Freien uno int Räfig zugegangen, welche Die vont nit jeit mehreren Sabrzehnten Durdf Beobactutung freilebender uno in Bimmer gehaltener $2(m p h i b i e n$ und Fieptilien, durch

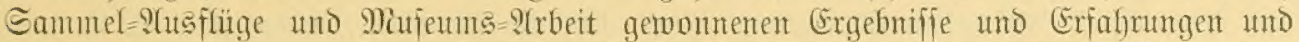
Die in Der Riteratur vorftegenden authentifdhen Surzeichnutgen aufs Sillfonmemite ergänzter.

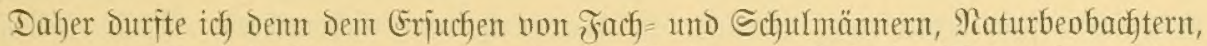
Sanmlern und Terrarienbejizern: Das mir zur Berfügung itebende Miaterial zu einer umfajienden Mionographie der Deutichen \&urche und Rrtechthiere auszugeitalten und in ifyr ein Bifl von bem Sein und פserden Diejer Bürger Der vaterländijchen Fluren zu entrollen, gern nadhfomment.

3u bent Befufe murden vorerit Die Sronungen, Familien und Battungen im SIllgemeinen betrachtet und Die 3üge, weldhe Den zu ifnnen gehörigen Spejies eigen fino, 3u einem (Banzen bereinigt. Sobann murbe bon jeber ?frt, nachoem einfeitend ifhre hervoritechenditen Mierfmale furz herausgehoben, ein umfaffendes (Sharafterbifo gezenchnet,

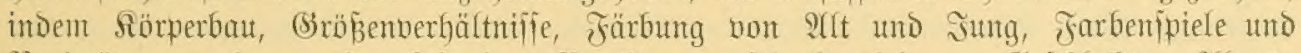
Barietäten - Denen eine bejondere Beadhtung gefdhenft wiro -, Beichlechter, S(lters=

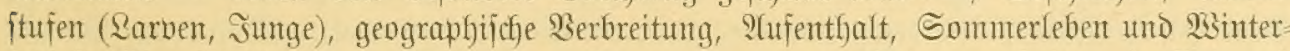
ichlaf, Eigenichaften und Fäbigfeiten, Bemegungen uno Stimme, Beit uno Drt uno

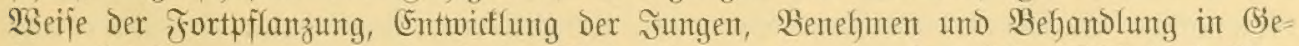

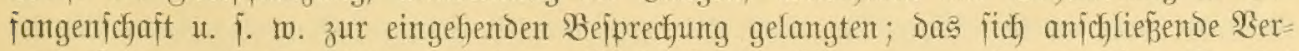

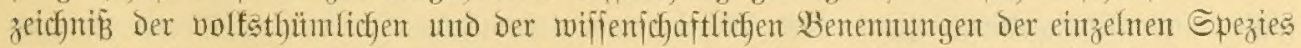

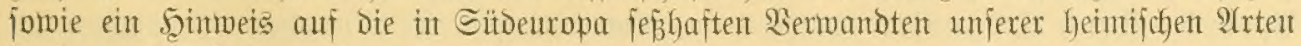
Durfte twohl gleidjermeije nidft fehlen.

Betreu aber Dem Reitgedanfen, mit Dem geplanten Werfe einen Beitrag zur vater-

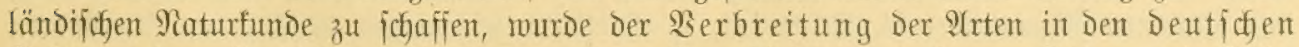
(Bebieten, Der allmählichen Slusbreitung Der allem Sfnichein nach von SitDen uno Sind= weiten her bei uns eingewanderten Spezies (26ürfel= mo Hestulap=Natter, Biper, 
Smarago und Mauer-(Sidechje, Seburtshelferfröte, Reijtemtolch) eine gand bejondere 9ufmerfianfeit gentiomet uno Deshalb Der biejen \$Buft behandelnde Theil jeweils zu

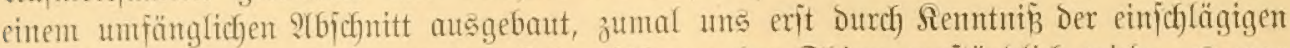
2)erbältniffe jo manches aus Der Sebensfithrumg Der Ihiere veritämblidg wiro; es war

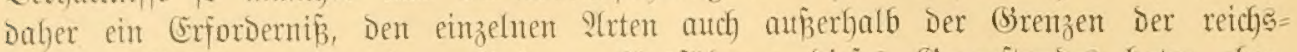
Deutichen (Bebiete nad)zugehen. Uno zur Alsfithrung diejes (Siegenitandes boten eben,

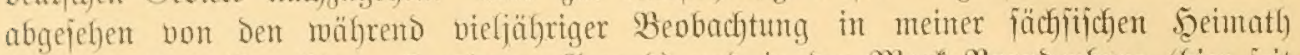
(3idjopanthal, Erzgebirge, Dresbenter (Segend) und in Der Marf Branbenburg (hier jeit

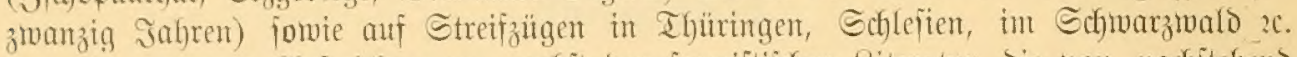
gentadfen eigenen ?(ufzetdyungen, nebit Der faunififichen Siteratur bie von nadjiteheno genanten Fachmännern mir freundichit eingefdicten angaben bie nothwendigen (Srund: lagen uno Bautofie.

So beridfteten uber die Frovinzen Dit= und Weitpreufien die Serren Dr. 5ू. Dewib

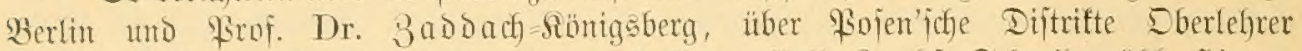

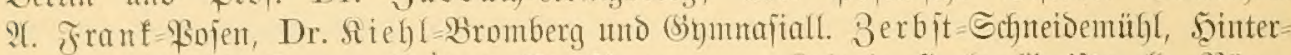

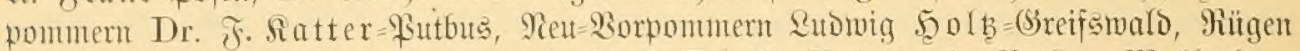
die beiben lebterwälnnten Serren und Frof. Dr. D. Keinlarot-Berfin, Miectenburg

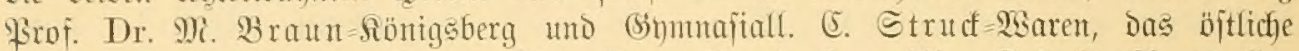

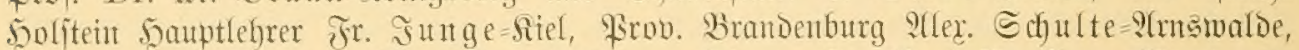
Sebrer Sange=Doerberg, Frof. Dr. B. Altum =5erswalde, Brof. Dr. E. v. Martens= Berlin, Brof. Dr. C. Miuller= Sharlottenburg, Dir. Frof. Dr. D. Reinfardt=Berliu,

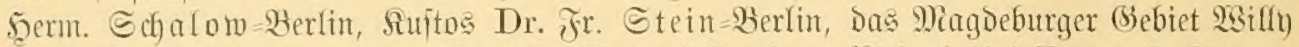

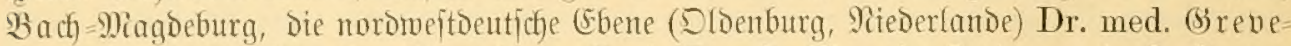

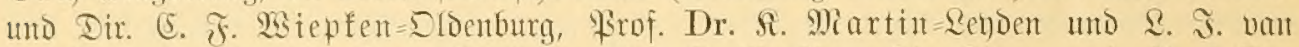
Der Been=Utrecht, Die Brow. Weftalen Dr. S. 23. Stuguftin= Sünen uno Wrof. Dr.

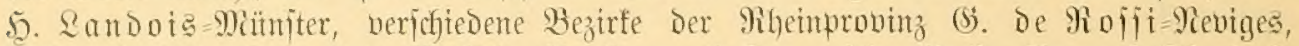

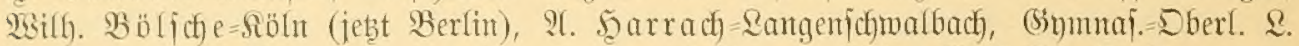

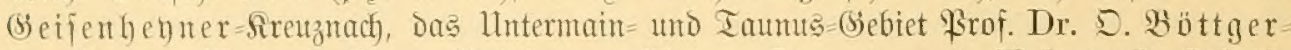

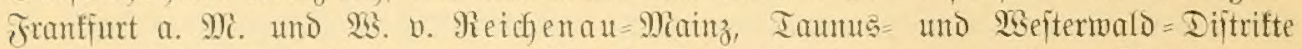
(Taffau, Dberbeflen) Zandesgeologe Dr. (5. Rody=2stesbaben und 23. v. Reichenau,

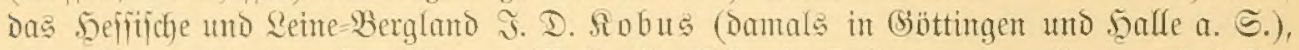

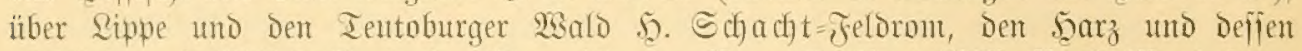

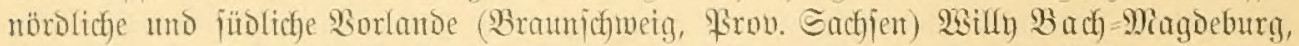

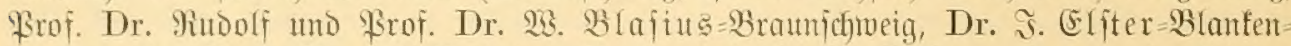
burg a. 5., Brof. Dr. 2t. Rebring=Berlin uno S. D. Robus, Den nordweitlichen Ihuringer Wald Seminarl. (5. Scheller=(sijenach, Theile des Boigtlandes Frof. Dr.

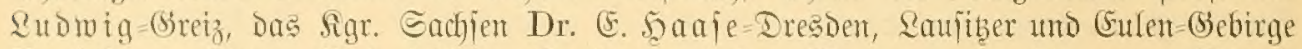

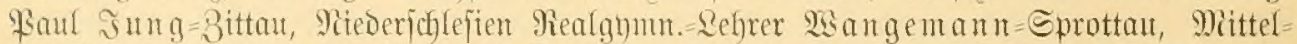
und Sberjolefien (Riejengebirge zc) Prof. Dr. (5. Bo rn=Breslau, Brof. Dr. Mi. Braun, (5)mnafiall. (5. Merfel=Breslau, Prof. Dr. (5. Mäller, fonjervator F. Tiemann= Breslau, vom oberen Main Dr. med. Blumm und S. Sippel=Banberg, vom Mittel= main und Ribüngebirge Frof. Dr. Mi. Braun, Slpothefer F. Reller Dermbach und

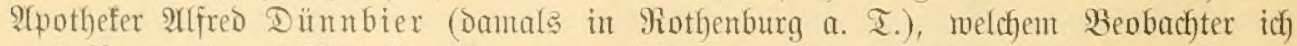
auch Tactiveife aus Mittelfranfen und Der Sberpfalz verdante, über Die Erlanger (SegenD

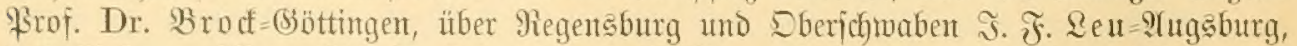
Das Sinbauer Aflpengebiet $\mathcal{A}$. Dietrich, i. 3. Frem. Sientenant in Sinbau, Dberbatern 5. Sippel uno 23. v. Reidjenau, Wünttemberg Frof. (5. v. Martens, die :ab umb

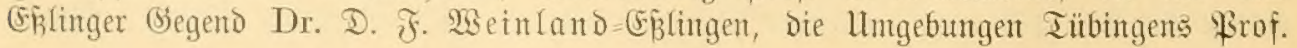




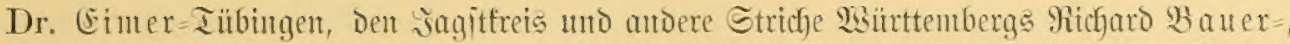

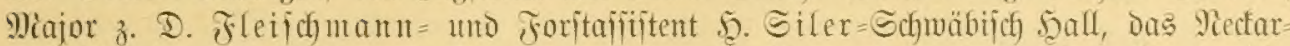

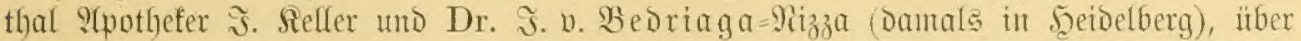

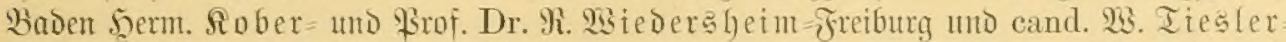

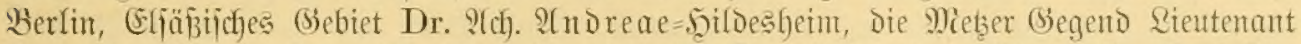

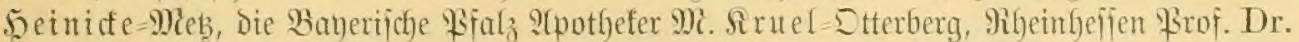

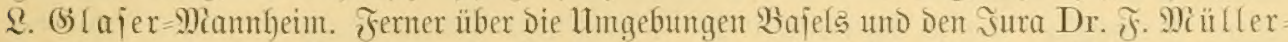

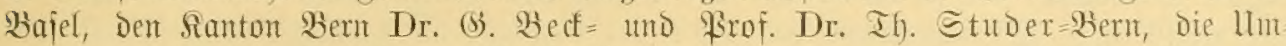
gebung Des Benfer See Sehrer Mi. Soffmann=(Senf, Den mittleren Theil des Schweizer 5odplateait 5. Fifcher= Sigmart in Bofingen, Das Tiroler Sllpentant 5. Schalow,

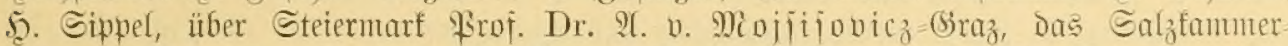

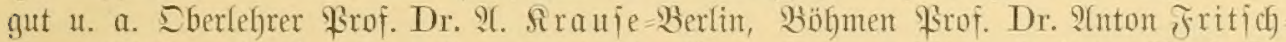

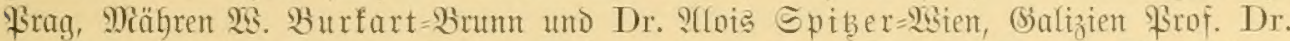
M. Nowicfi Sirafau, bie rujitichen Ditjeeprovinzen Frof. Dr. Mi. Braun=Rönigsberg;

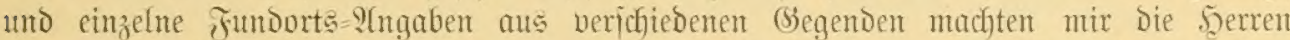

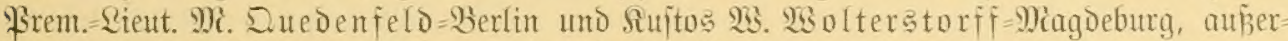
Dem iiber Die Mändhenter Begento Die Borftandichaft Des Bereins "sfis" in Mïndhen.

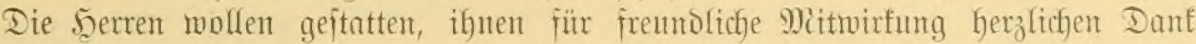
zu jagen. Esberio ift es mir angenefume Hiflidgt, Der Direftion und Den Sultoden Der Boologijugen Ganmulung Des Rönigl. Mujeum für Naturfunde zu Berlin, Serren (Seb). Math Frof. Dr. R. Miobius, Wrof. Dr. (5. v. Martens, B. Matichie, Dr. (3).

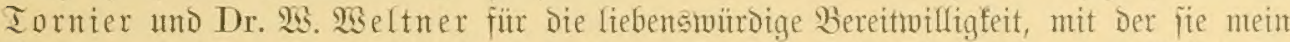

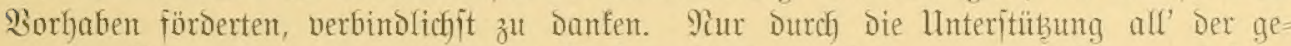

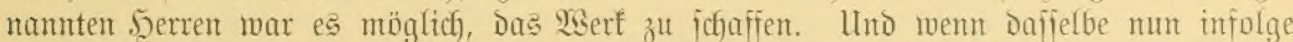

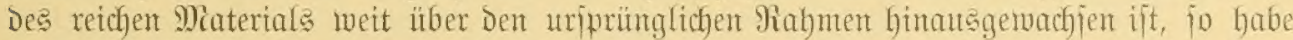

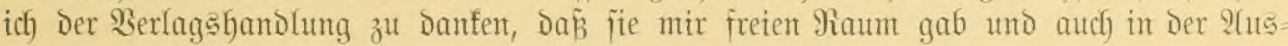
itattung fein Dyjer jichente.

Die 12 Farbentafeln jollen Dem Budh aber nidft als bloker Sannucf Dienter; igre eigentliche Beitimumang berubt vielmehr Darauf, alle Deutichen Smphibien uno Pieptilien in naturwabrer Darjtellung z̆ vergegemwärtigen uno fomit Das (Sejd)riebene

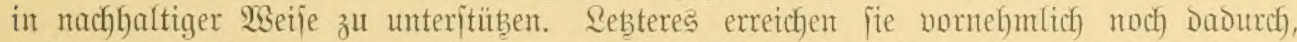

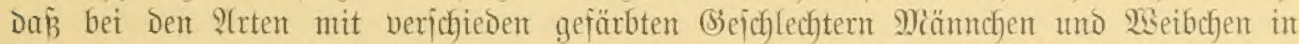
ifren abweichenden Farbenfleidern, von einigen Spezies auch Spielarten, junge Ihiere und Larven veranichaulicht twerden. Sämmtliche 2(bbiloungen find von Shr. Botteler in Etuttgart nadf lebenden Ifieren gezeichnet uno in Farben autsgejührt. Diejelben fanden unter Itnderen bei dem befannten Thierntaler (5). Miẗbel joldten beifall, daj er

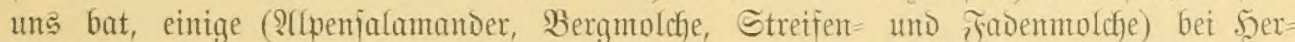
itellung Der von ihm für bie neue ?Guflage von Brefm's "Thierleben" anzufertigenden

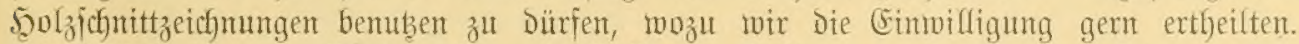
Die Stbbildongen in Tert merden gleidffalle zut Erläuterung Des lebteren beitragen.

Das Berzeichní́s Der Qiteratur folgt meiterhin. Bei Citaten im Text genitgte

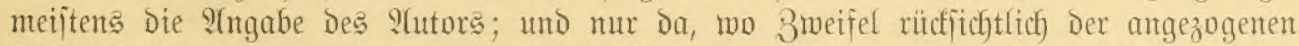

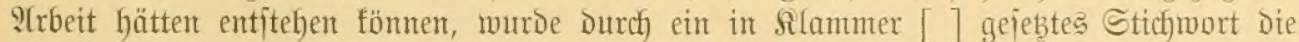

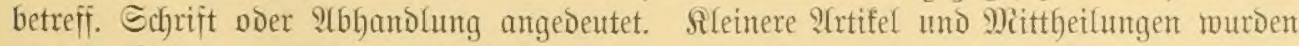
mur im Text genannt.

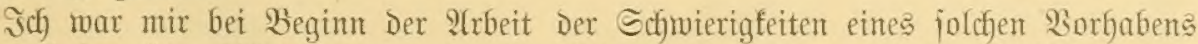
reaft wohl bemuft. Aflein ich trat im Şinblicf auf bie mir gemordene Mithilfe getroit

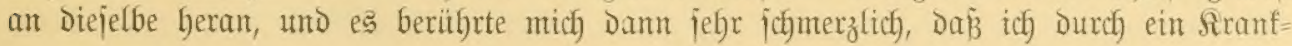


jein und andere Semmnifie wiederbolt an Der Beendigung Des Wserfes gehindert wurde. $23 e n n$ es num abgeichlofien vorliegt, jo bitte ich alfe \&ejer, es wohlwolfento aufaunehmen als einen Beitrag zur Deutichen Naturfunde, der nicht eine einfache, trodfene Belebrungs =

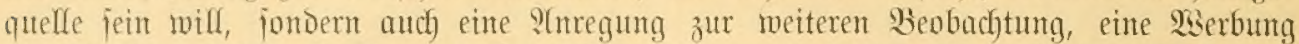

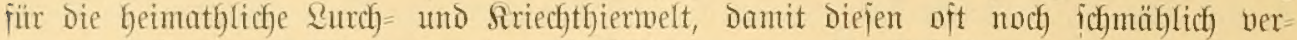
famenten uno - abgejeben bon Den (Biftichlangen - obne Urjache verachteten mo ge=

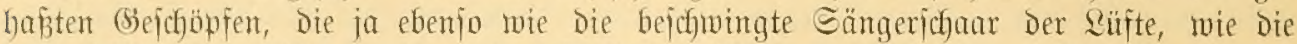

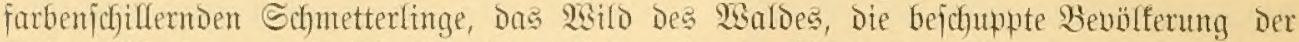

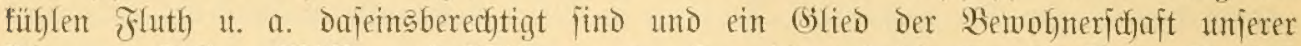

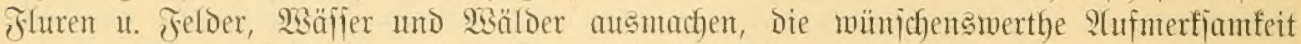
und beachtung zu Theil merbe! Rur wer ein Thter fennt, lernt es audf idfäben und ich it been.

Berlin=Egarlottenburg, im Sonumer 1896.

Brum Dürignen. 


\section{Inhalt.}

23ormort

Jubaltsperseiduriß . . . . . . . . . . . . . . . . . . VII

(Etite Rlafie.

\section{stricd)thicte, Reptilia.}

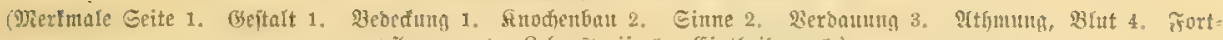
pî̃lanjurtg 4. Qebenstweije 5. (Eintheiluttg 5.)

I. E to un $\mathrm{g}$ : Edjilofruten, Chelonia

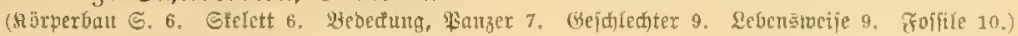

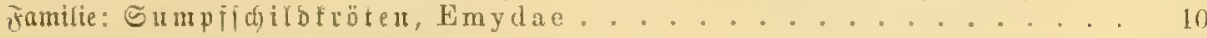

Gattung: Eumpfidjilbfröte, Emys . . . . . . . . . . . . . . . . . . 11

Wt: Surop. Eumpijd)iloti., E. europaea . . . . . . . . . . . . . . 12

Eübeuropäijde Gdjilbfröten . . . . . . . . . . . . . . . 37

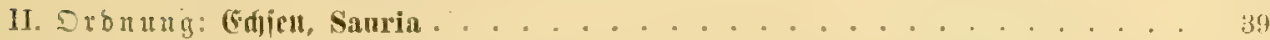

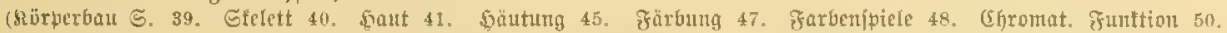

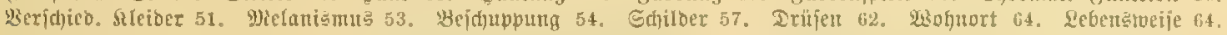
Siorweltiche 66. (5intheilung 67. Tabelie 68.)

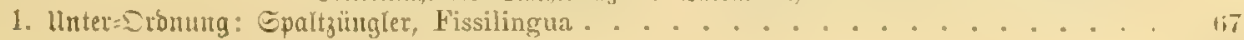

1. Fantlie: (Ed) te (Eibed) fen, Lacertidae............... tis

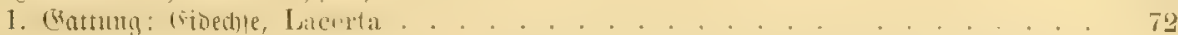

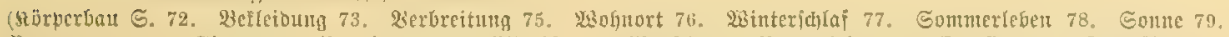

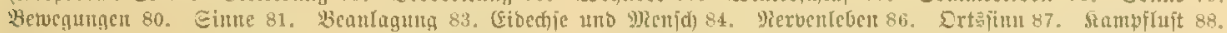

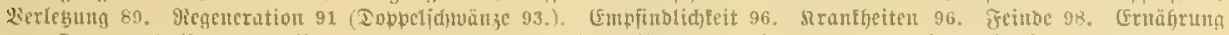

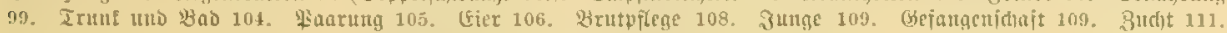
इurdininterung 112. Yianten 112. Tahelle 113.)

1. 2rt: Gmatago=(Eibechje, Lac, viridis

2. .tt: Baut =(Gibedje, Lac. agilis . . . . . . . . . . . . . . . . . . 145

3. 21rt: Liald (Gibchje, Lac. rivipara. . . . . . . . . . . . . . . . . . . 167

4. 2rt: Minuel=(Gioed)je, Lac. muralis . . . . . . . . . . . . . . . . . . . 188

2. Inter=Eronung: Nurzgüngler, Brevilingua... . . . . . . . . . . . . . . . . . 16

2. Franilie: 16 üblfd leiden, Scincoidae . . . . . . . . . . . . 21t

2. Gattung: Edhlangentdyleidbe, Anguis . . . . . . . . . . . . . . . 17

5. Yrt: Wlinojdjleidje, Ang. fragilis . . . . . . . . . . . . . . . . 218

Glibeuropäifdje (cdjen . . . . . . . . . . . . . . . . . $2: 34$

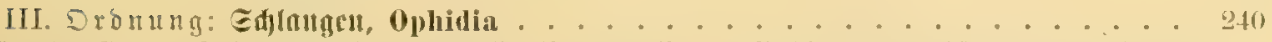

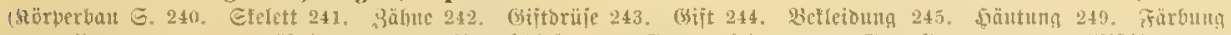

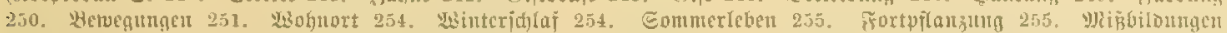

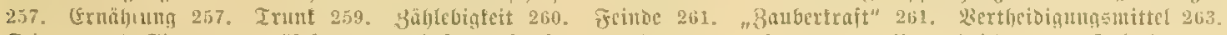

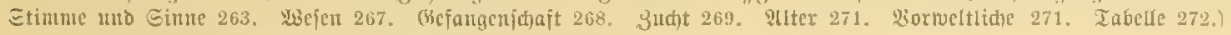

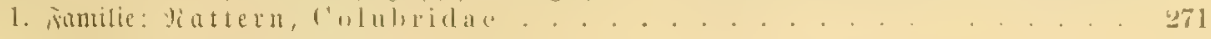

1. (Gattung: Waffentatter, Tropidonotus . . . . . . . . . . . . . . 274

1. 2tt: Mingelnatter, Trop. natrix . . . . . . . . . . . . . . . . . . 274

2. 2rt: 2iärelnatter, Trop. tessellatus . . . . . . . . . . . . . . . . . 295

2. Gattung: Lonbnatter, Coluber . . . . . . . . . . . . . . . . . . . 308

3. Irt: Col Aesculapii . . . . . . . . . . . . . . . . . . . . . 308

3. Battung: Glattuatter, Coronella. . . . . . . . . . . . . . . . . . . . . . 321

4. Utt: SLlatte Tiatter, Cor. austriaca. . . . . . . . . . . . . . . . . . . . 321

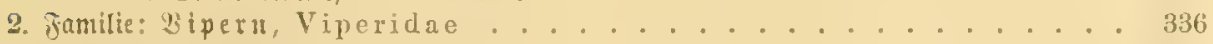

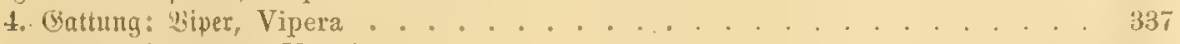

5. 2tr: Jieugotter, Vip. berus . . . . . . . . . . . . . . . . . . 337

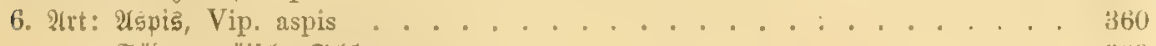

Cübeuropäił̆ Sd)langen . . . . . . . . . . . . . . . . . 369 


\section{Sutde, Amphibia.}

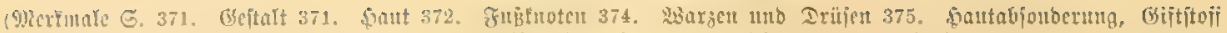

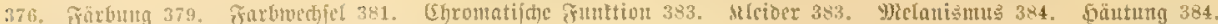

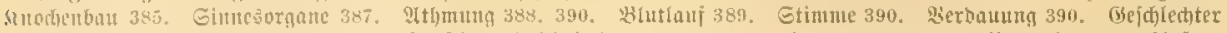

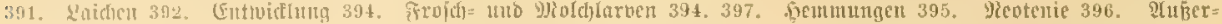

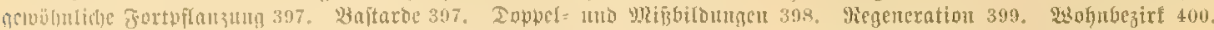

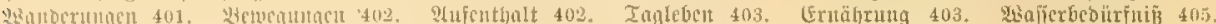

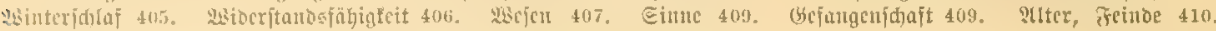
Brantbeiten 411 . Tivifite 412.)

\section{Dronug: Frvidjlude, Aunra}

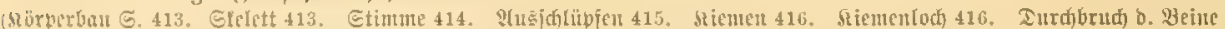

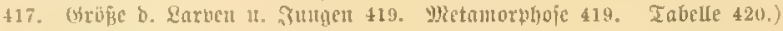

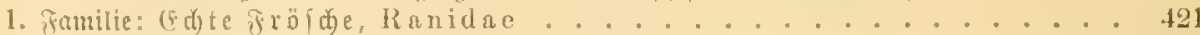

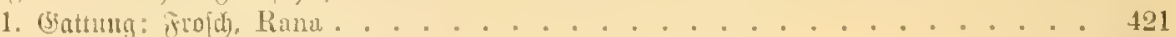

a. Grïne sisalieriöfdje, Ranae virides ............... 422

1. Srt: פSofjerfrojd, Rana esculenta . . . . . . . . . . . 422

b. Lìraune Ranofröjde, Ranae fuscae . . . . . . . . . . . . 437

2. Irt: Grastroja), Rana muta ............... 437

3. Mtt: Moorfrojh, hana arvalis .............. 448

4. Yrt: Epriugirof(f), Rana agilis .............. 459

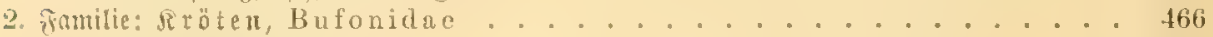

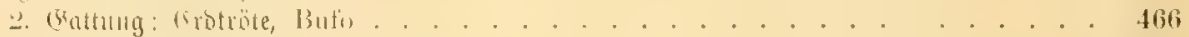

5. Mrt: (5route fröte, B. vulgaris . . . . . . . . . . . 467

6. Irt: Grime Rröte, B. viridis .............. 481

7. Irt: Mrenatröte, B, calamita ................ 494

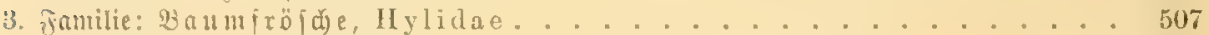

3. Gattung: \&aubirold, Hyla .............. 507

8. Ift: (Europ. Saubrold), H. arborea ............. 507

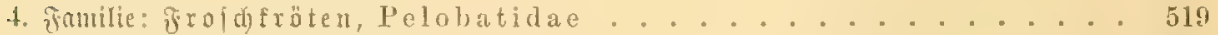

4. Gintung: Eand Llute, Pelobates ............... 519

9. Yrt: Minoblaudhatröte, l'el. fuscus . . . . . . . . . . . 519

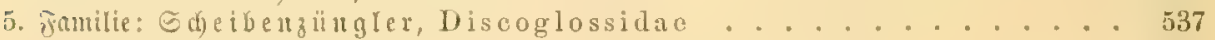

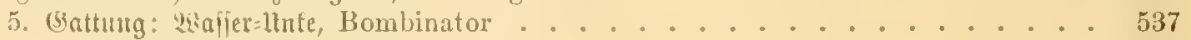

10. Itt: Gelbbanctige llute, B. pachypus .............. 543

11. Itt: Rothbautdige lnte, B. bombinus (igneus) .......... 543

6. Gattung: Jebler, Alytos . . . . . . . . . . . . 558

12. 2rt: (Geburtahelietföte, Al. obstetricans ........... 558

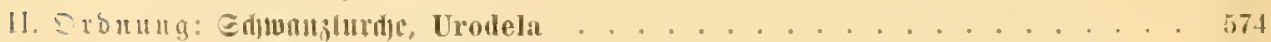

Tamilie: Ealamander, salamandridac........... 575

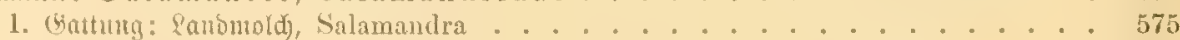

1. Yrt: Ferterfalamanber, S’al maculosa ............ 576

2. Wtrt: Itpenjalamander, Sal. atra ............. 594

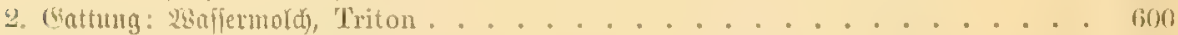

(9)

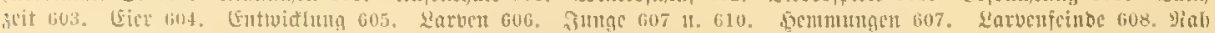

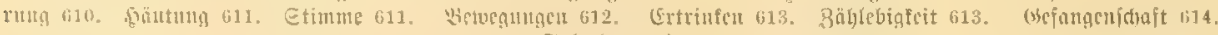
Inticlie 616.)

3. Irt: Manm=9Rold), 'Tr. cristatus

4. Irt: Lergmoldy, I'r. alpestris .............. 624

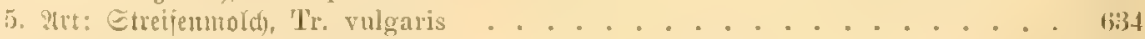

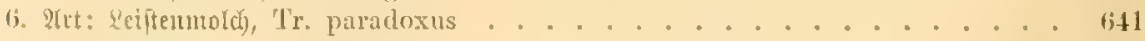

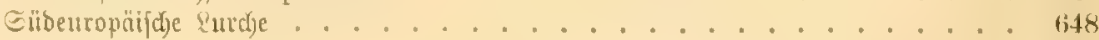

3njäke . . . . . . . . . . . . . . . . . . . . . . . . . . . . .

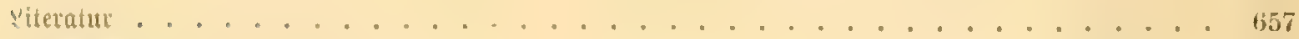

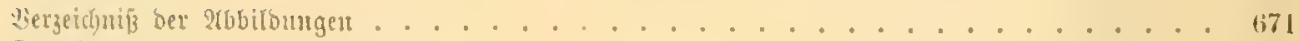

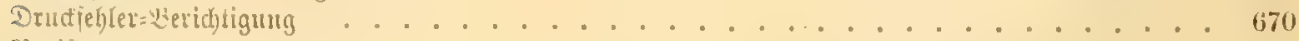

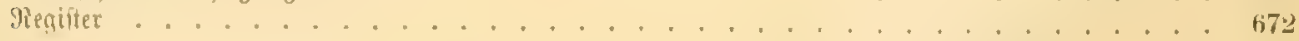




\section{Erite Lilafie. \\ Dientilien oder Siriedifliere. Reptilia.}

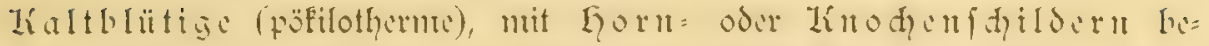

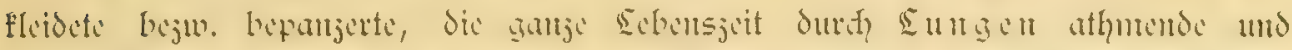

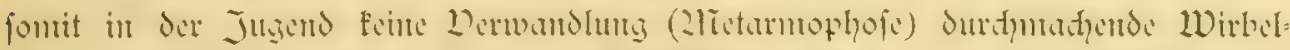

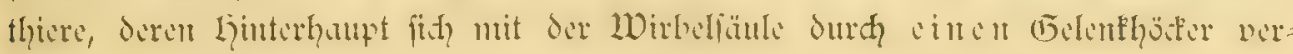
bitrdet.

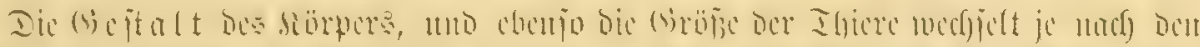

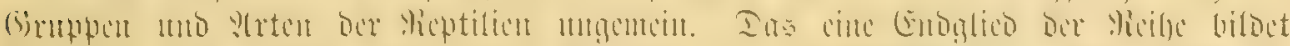

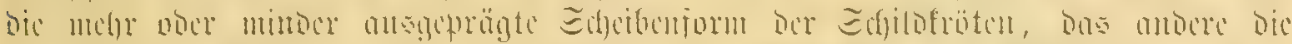

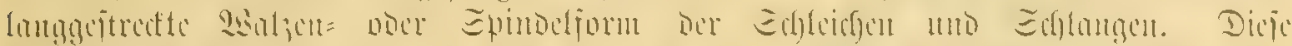

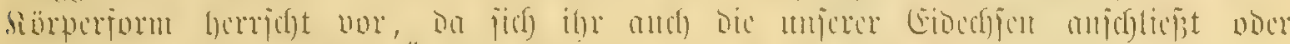

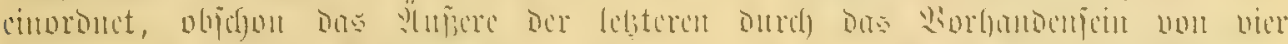

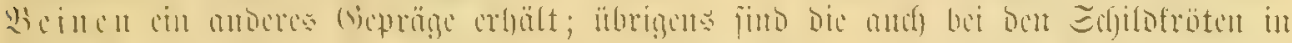

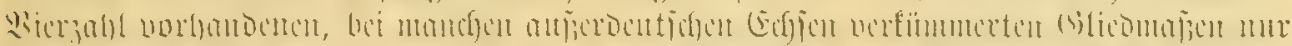

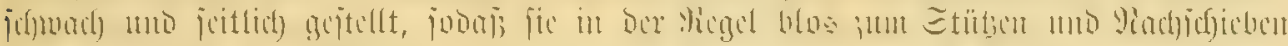

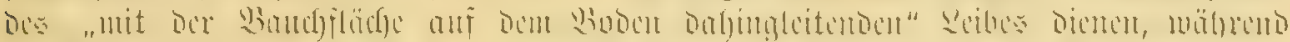

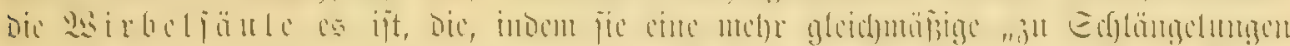

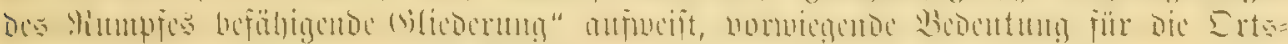

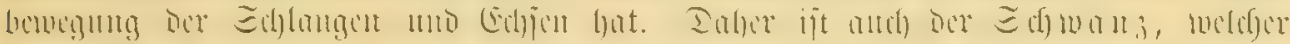

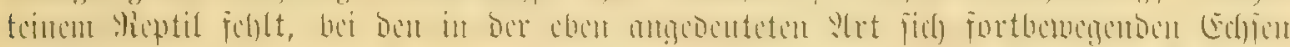

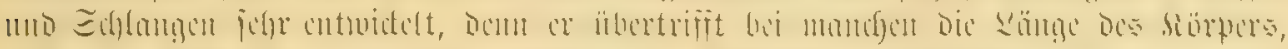

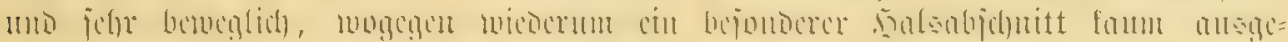

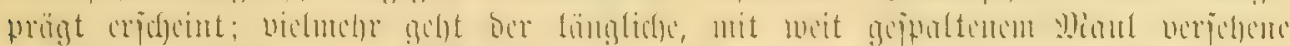

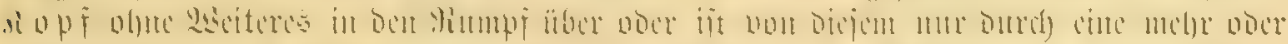

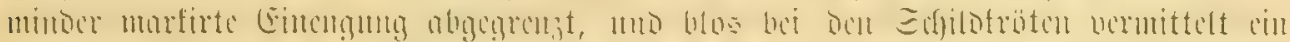

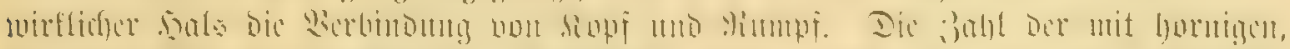

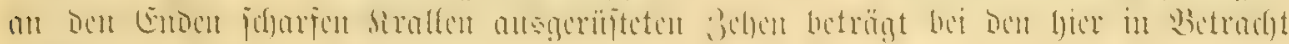
fommenden ?rten fïnf vocr vier.

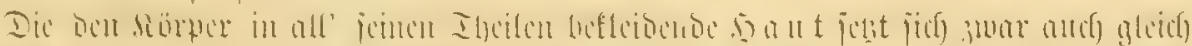

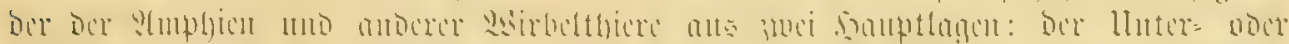

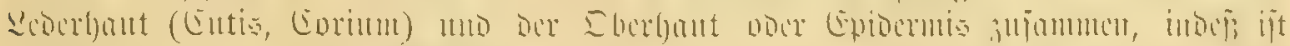

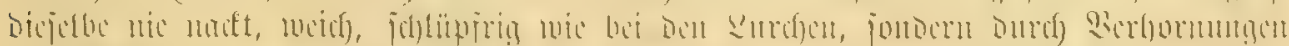

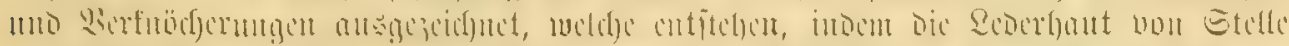

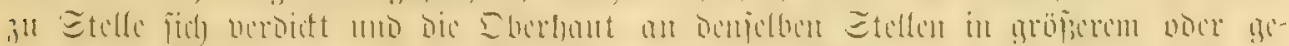

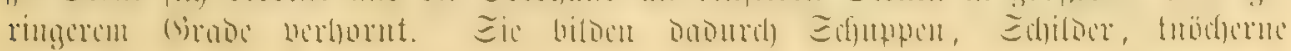




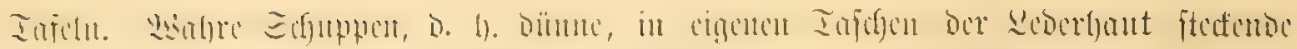

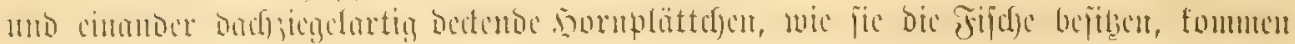

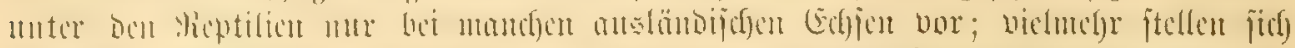

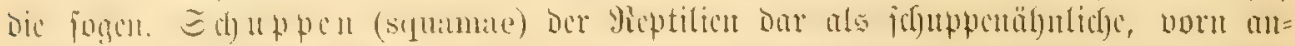

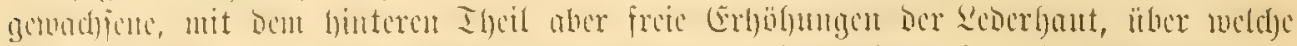

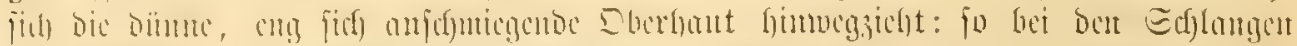
mib (B)

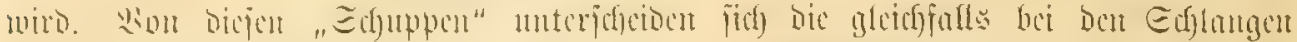

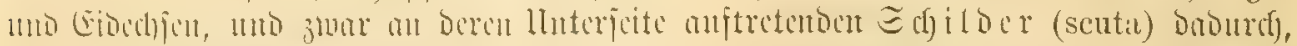

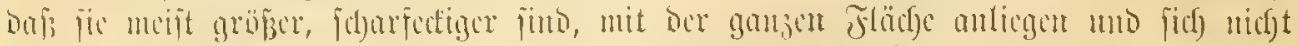

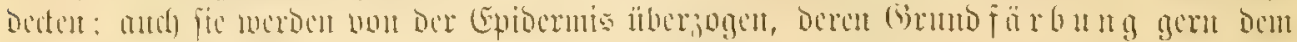

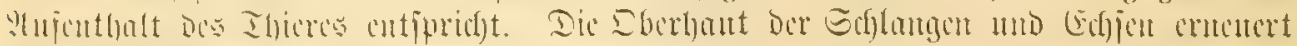

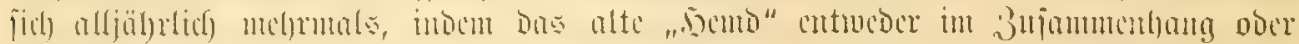

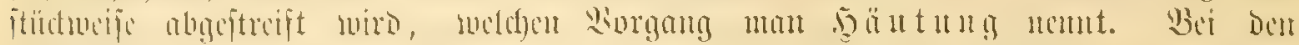

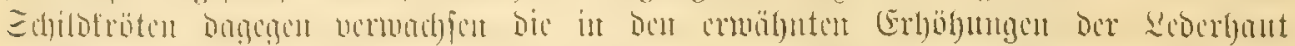

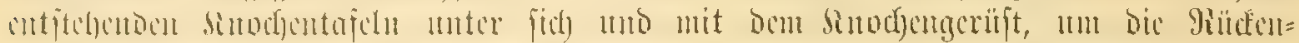

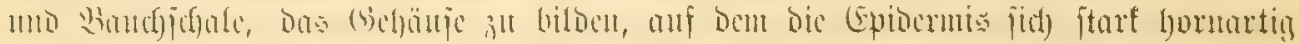

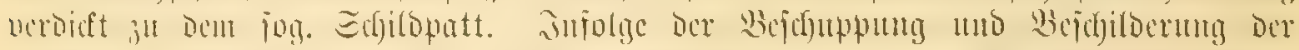

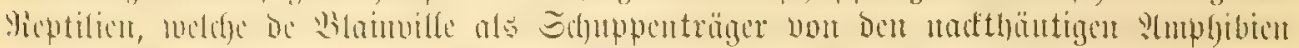

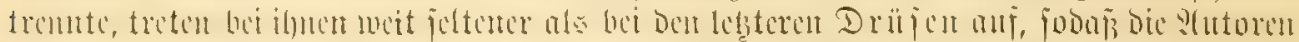

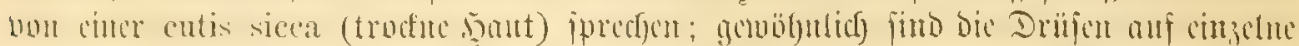

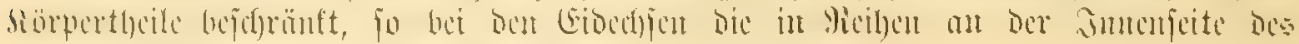

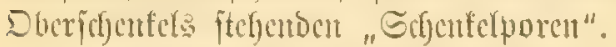

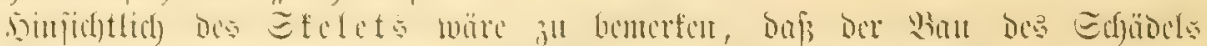

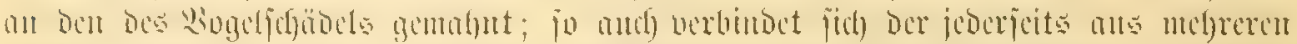

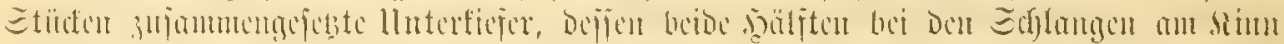

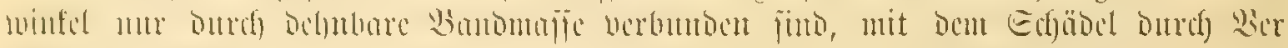

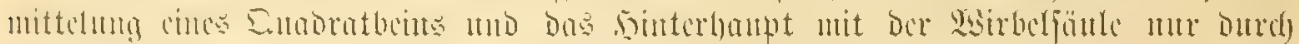

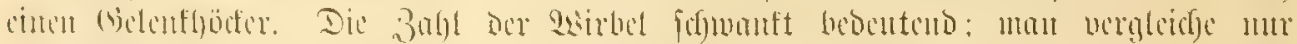
Din fur,

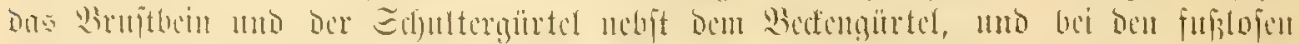

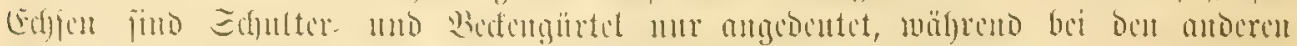

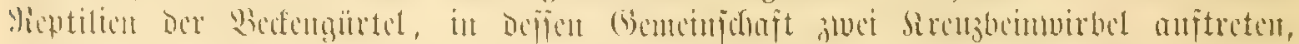

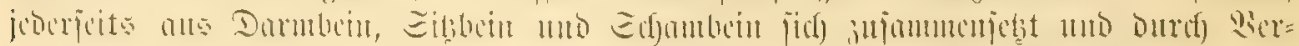

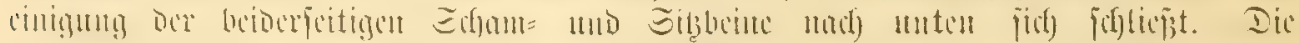

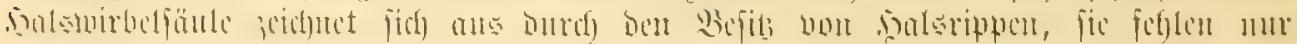

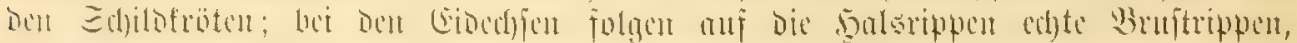

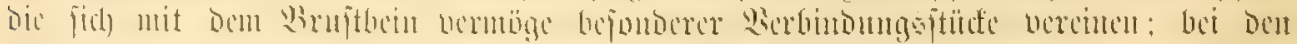

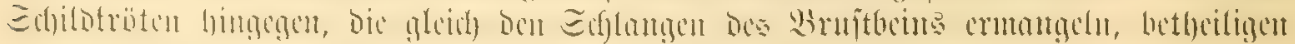

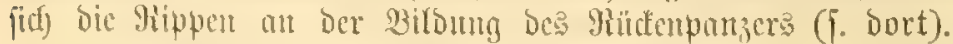

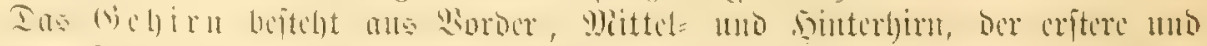

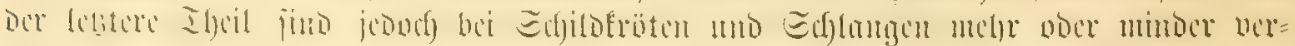

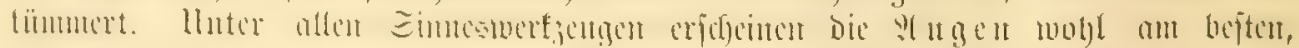

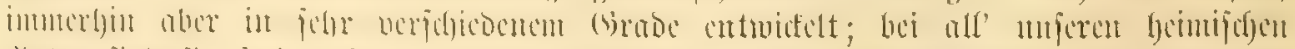

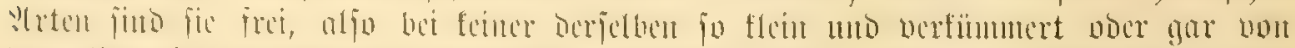

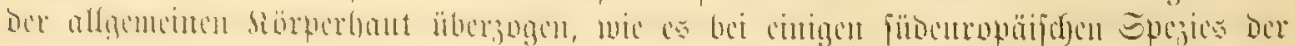

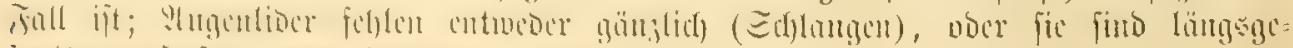

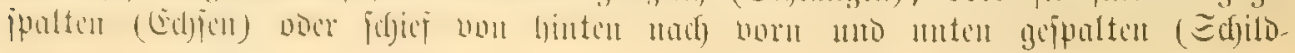




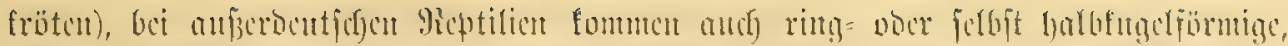

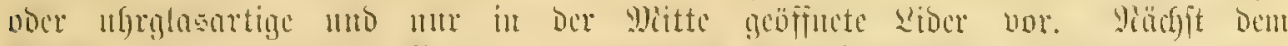

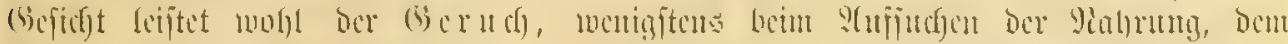

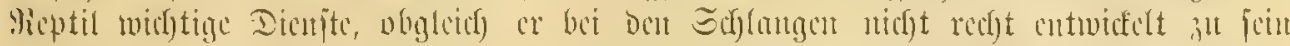

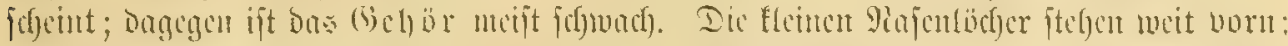

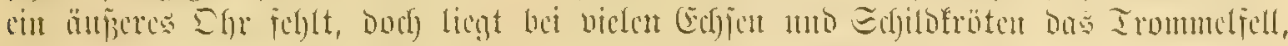

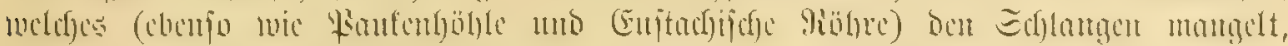

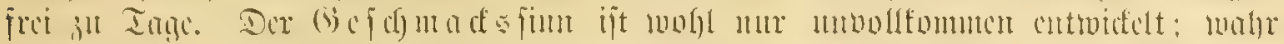

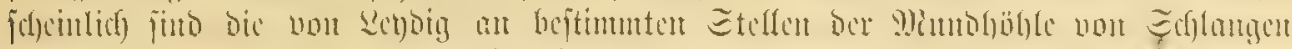

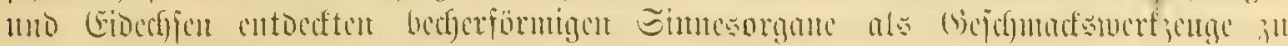
betracften, wäfreno bic $3 u$ ge zutm I a ften bicnt.

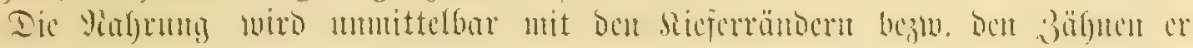

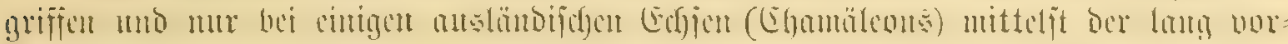

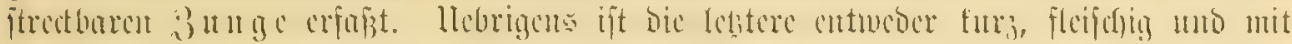

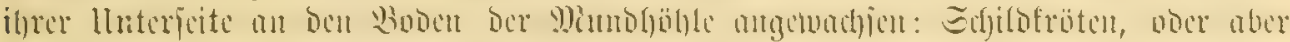

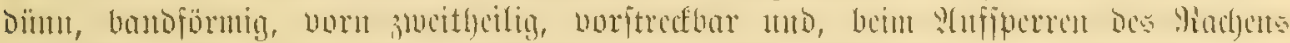

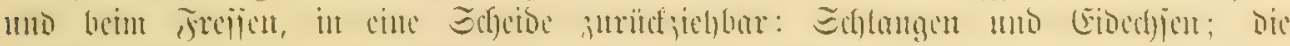

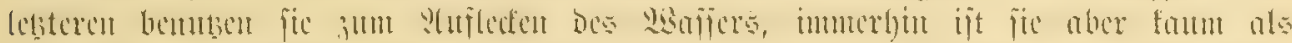

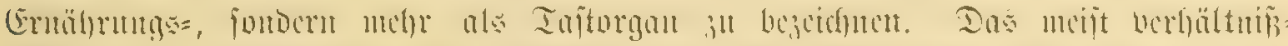

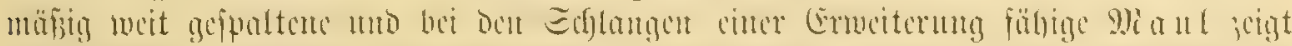

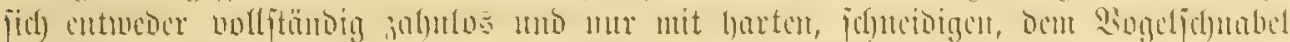

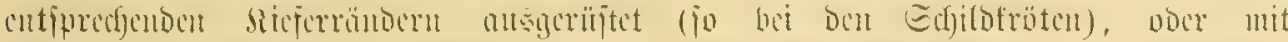

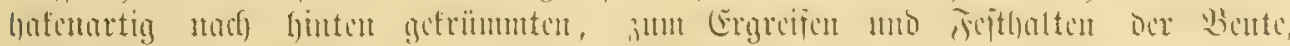

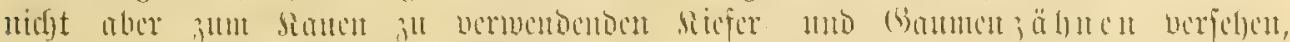

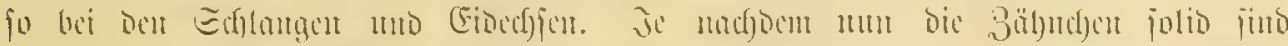

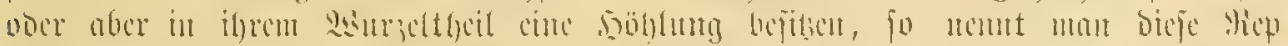

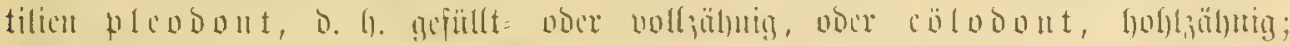

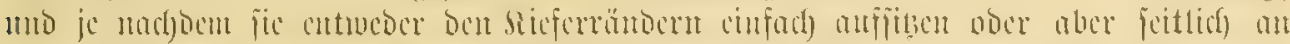

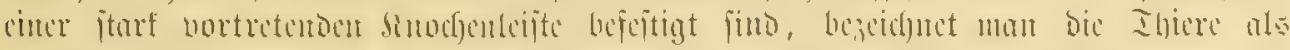

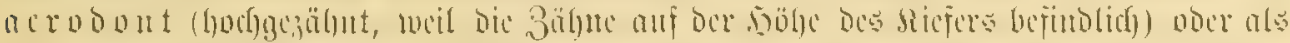

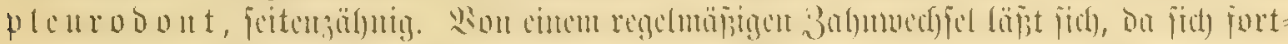

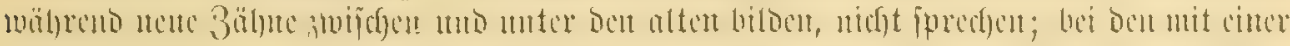

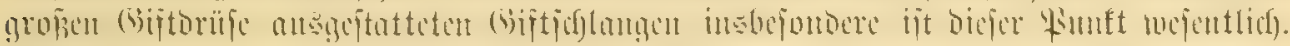

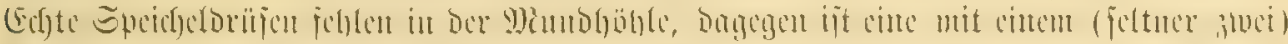

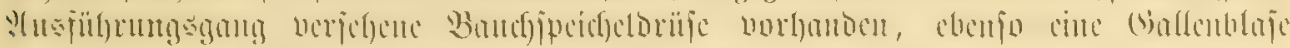

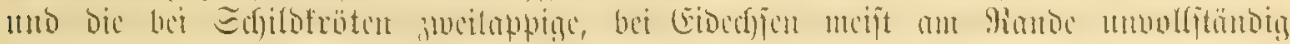

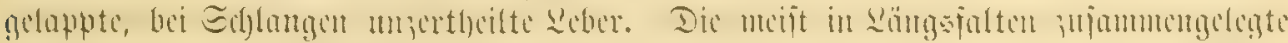

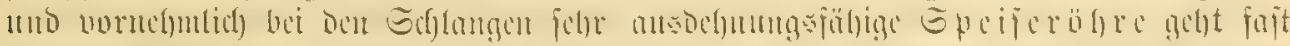

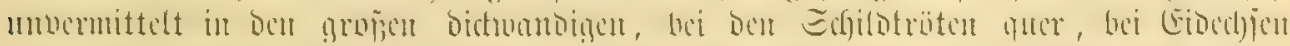

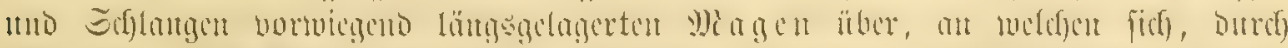

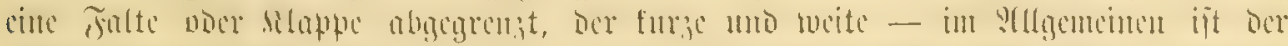

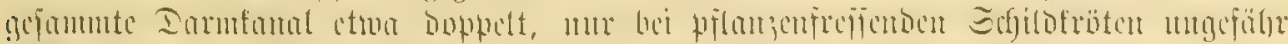

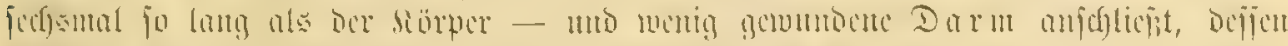

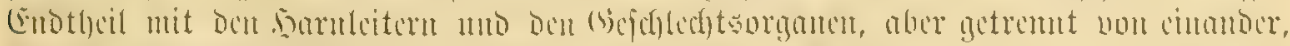

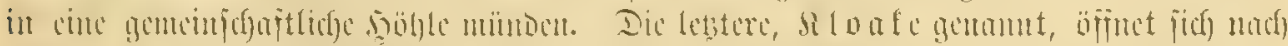

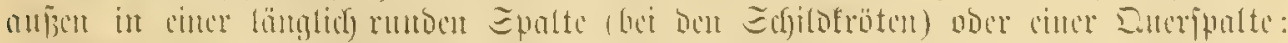

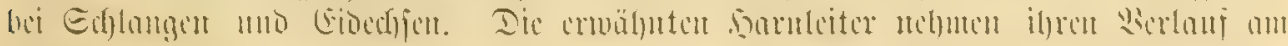

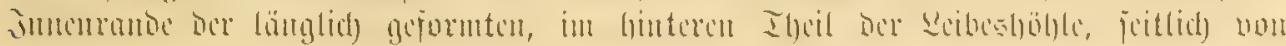




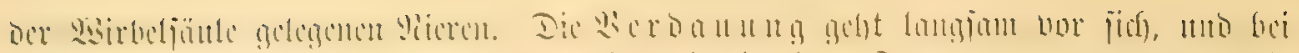

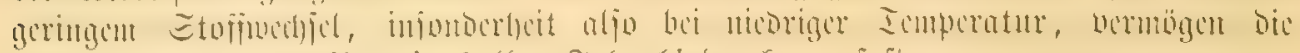

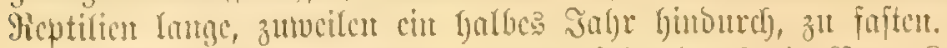

Utthmung. 난?

Zortpflanzung.

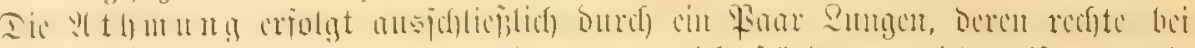

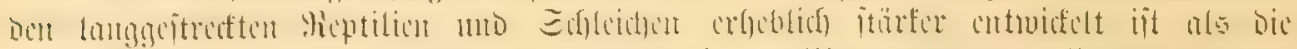

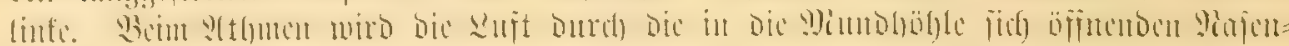

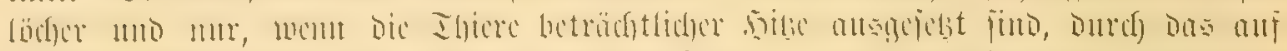

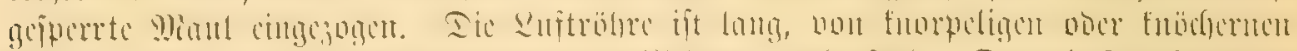

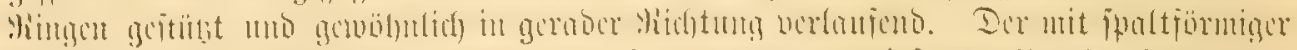

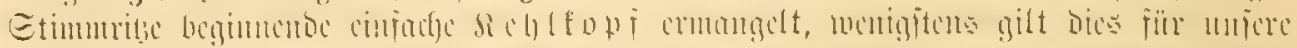

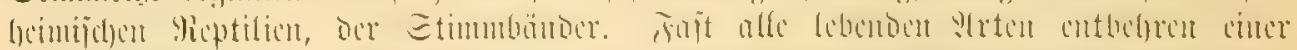

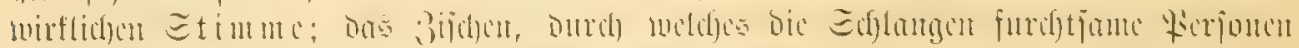

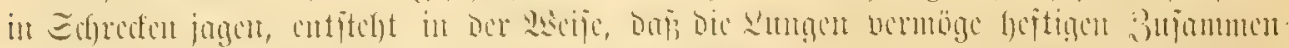

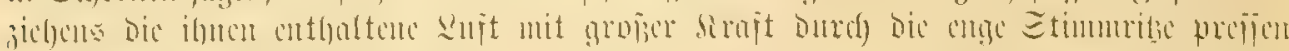

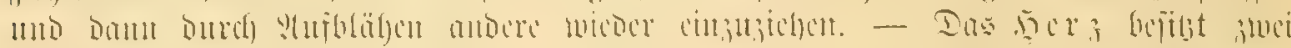

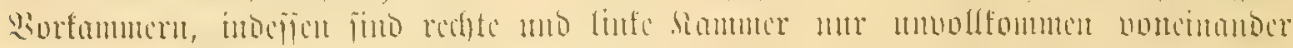

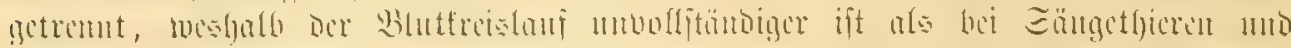

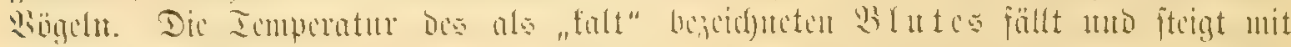

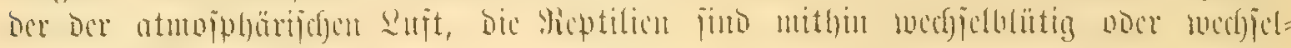
tuarm (pöfilotbermit).

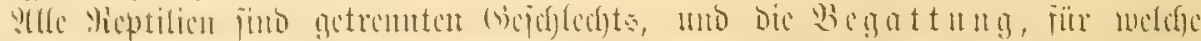

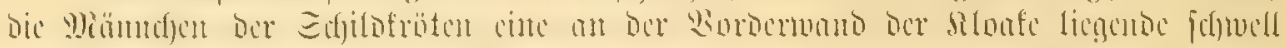

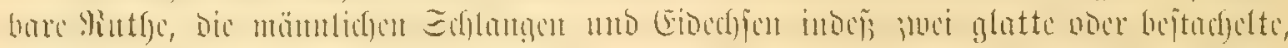

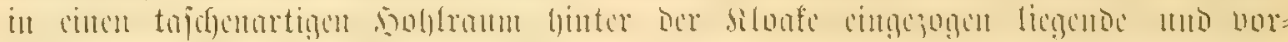

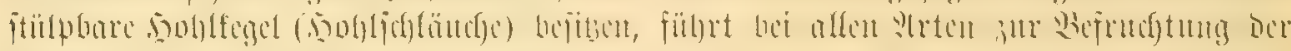

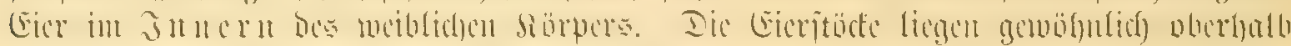

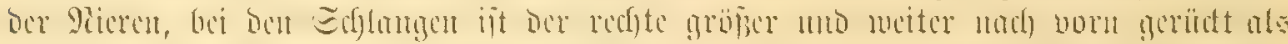

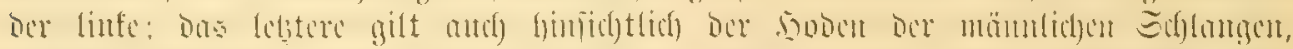

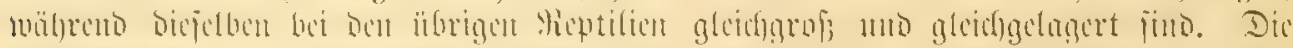

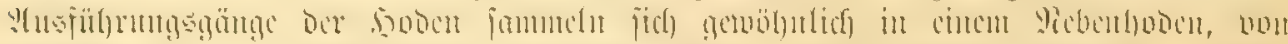

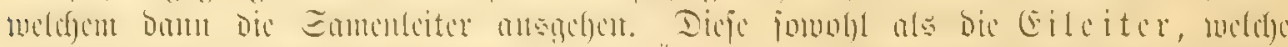

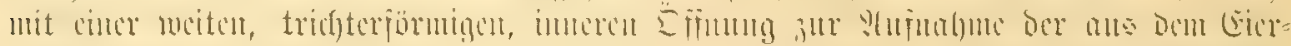

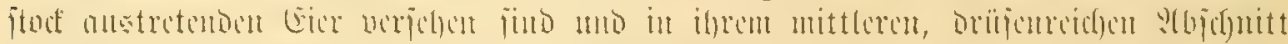

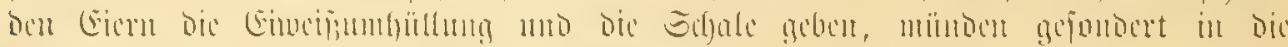

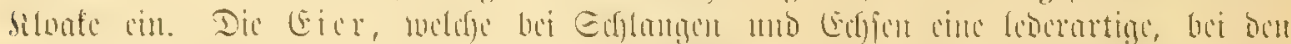

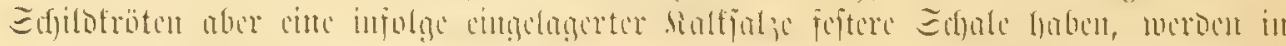

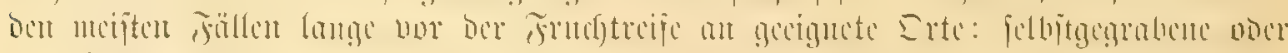

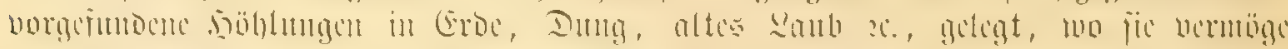

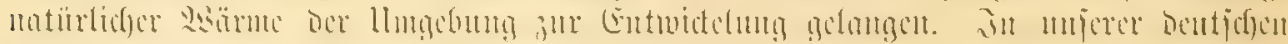

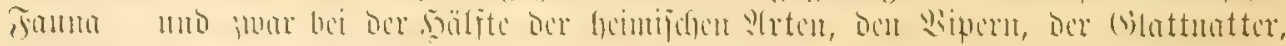

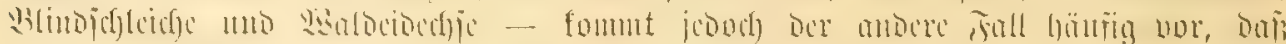
mämlech bos

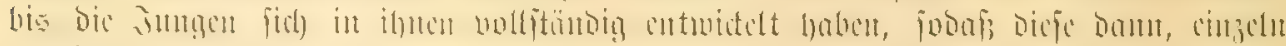

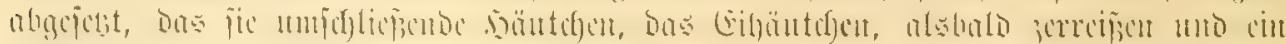

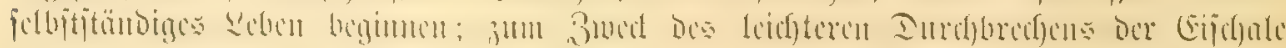

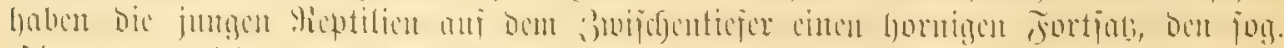
(E)

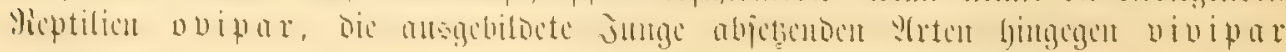




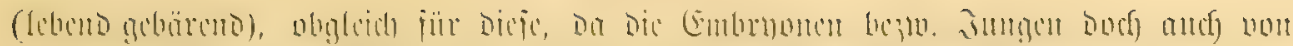

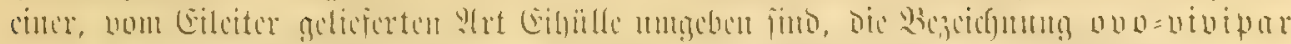

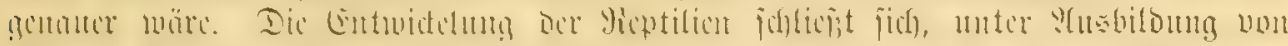

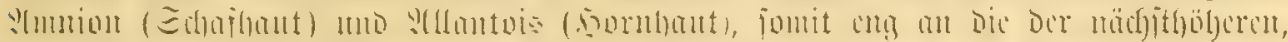

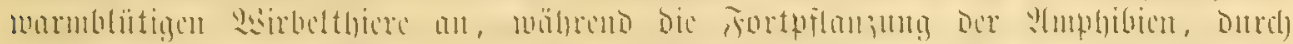

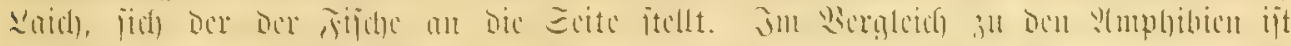

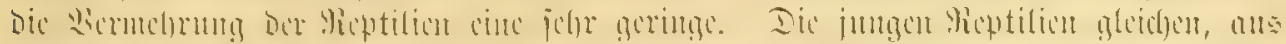

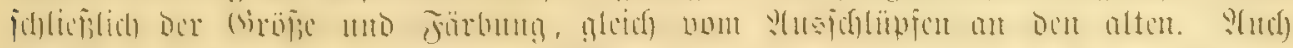

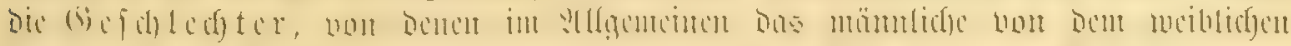

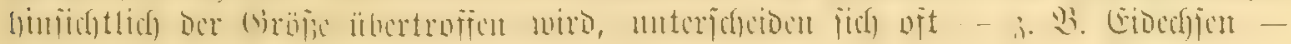
betreffe Der färbung mub Bcidfumu.

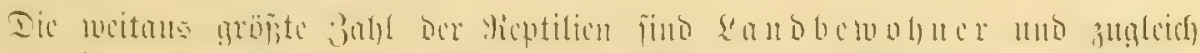

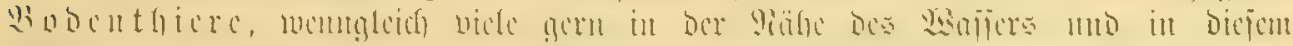

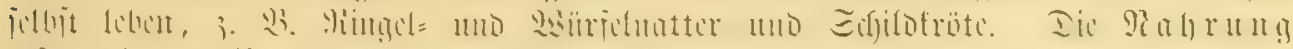

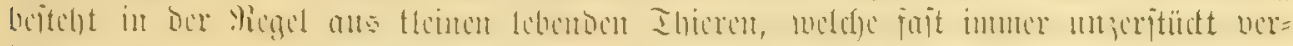

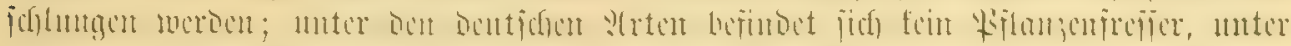

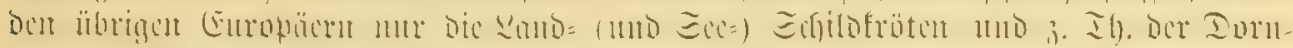

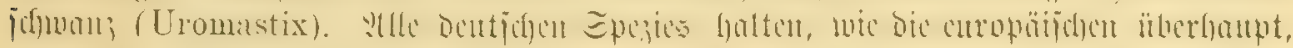

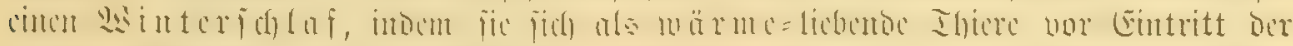

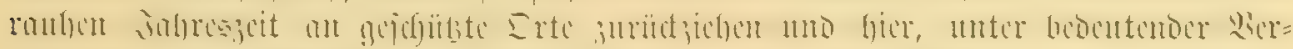

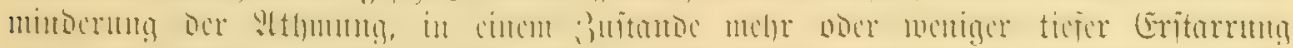

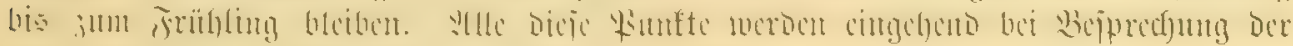

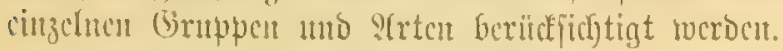

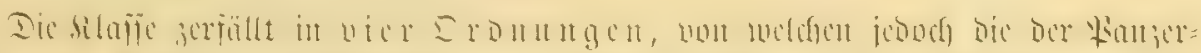

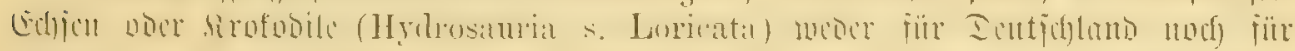

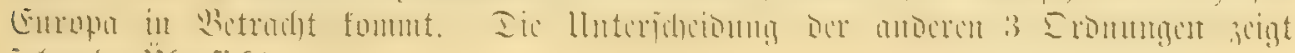
jolgenbe llberificht:

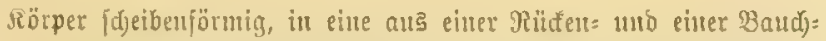

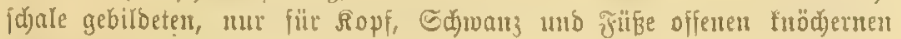

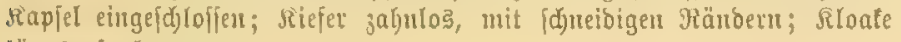
läıgร̈gefpalteı

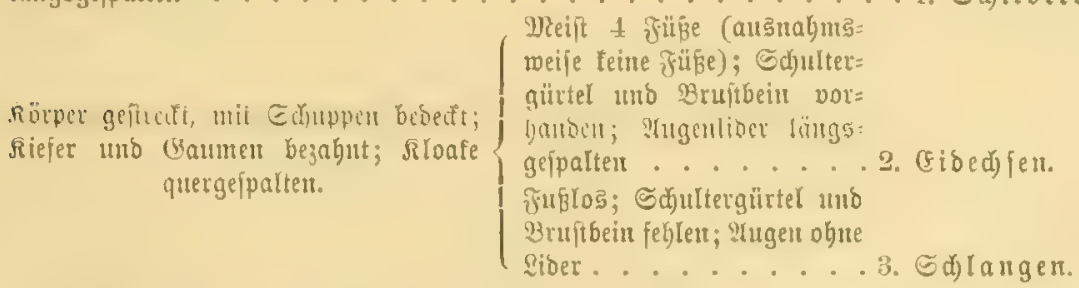

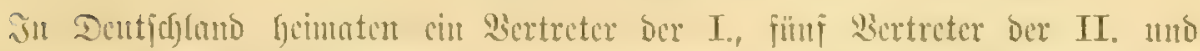
Fots

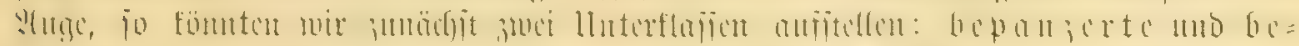

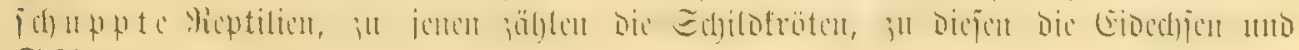
Edjlangeu. 


\section{I. (1)romunta.}

\section{Sidjilokröten. Chelonia.}

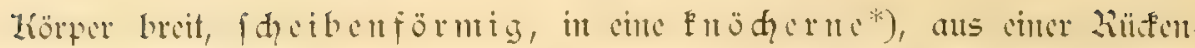

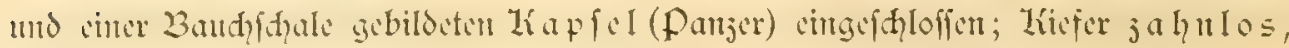

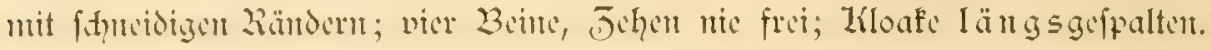

Rörperbas.

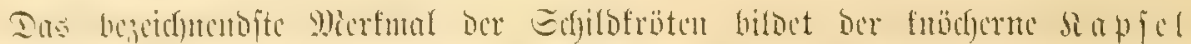

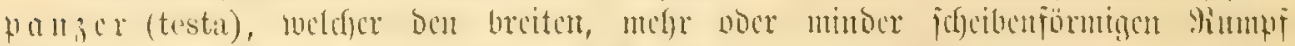

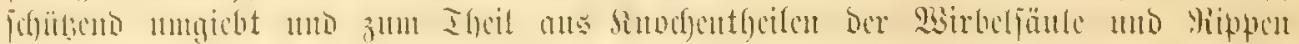

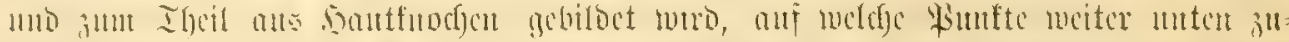

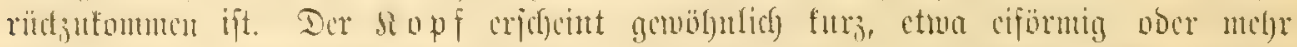

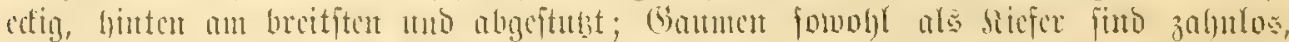

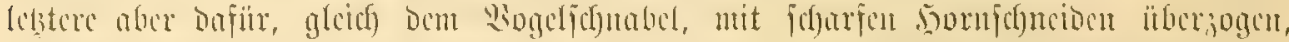

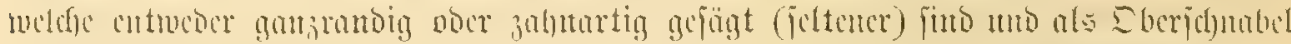

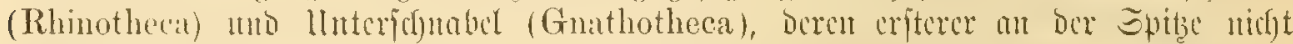

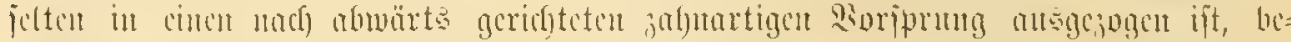

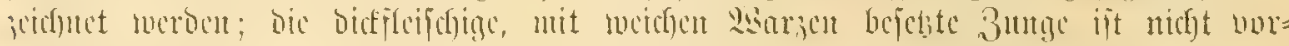

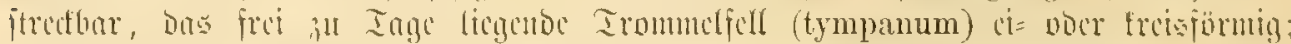

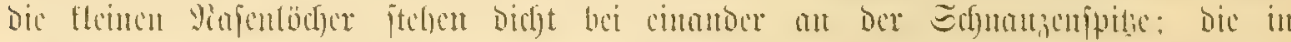

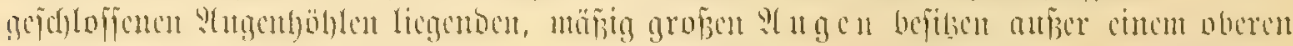

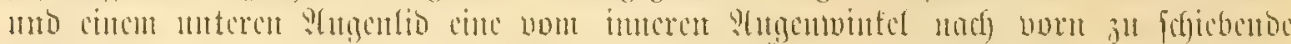
Yiidhant

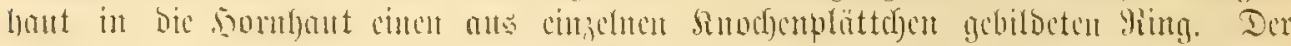

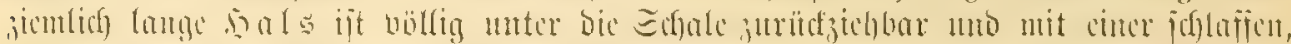

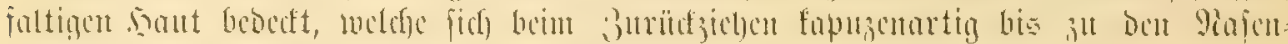

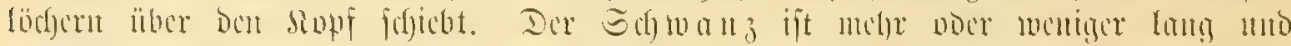

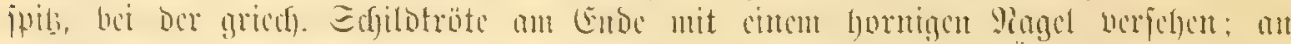

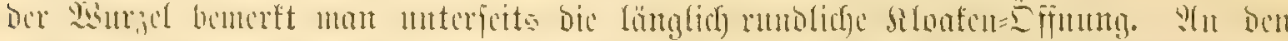

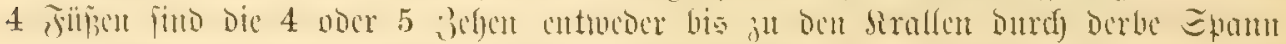

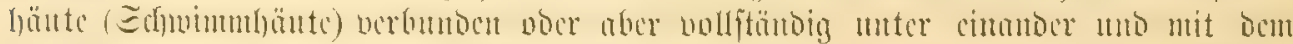

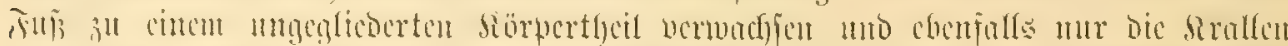

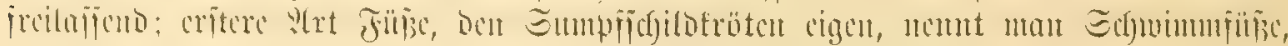

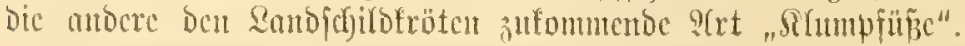

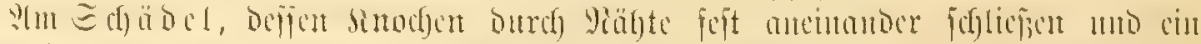

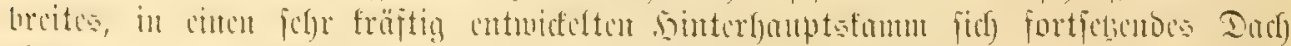

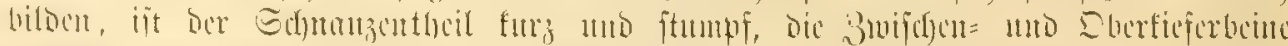

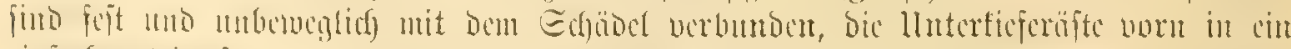

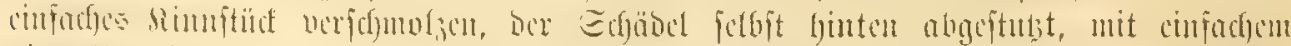

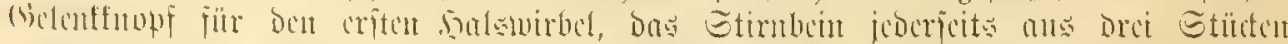

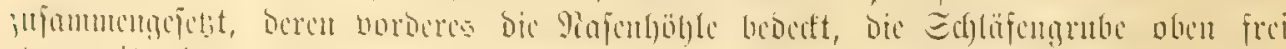

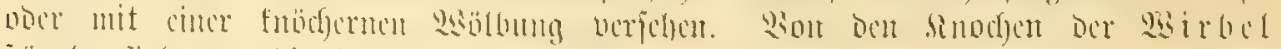

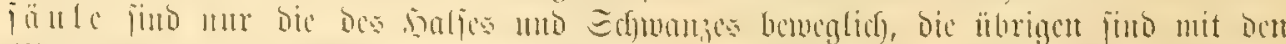

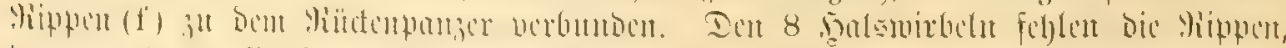

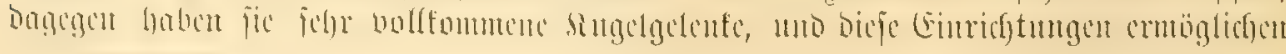

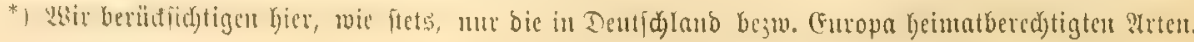




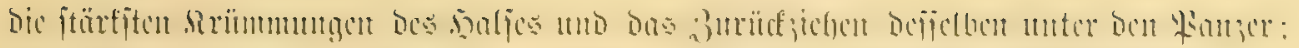

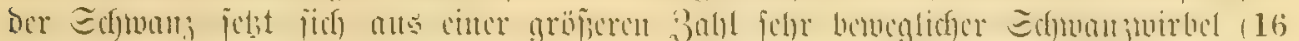

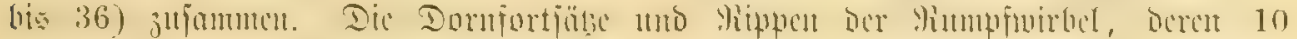

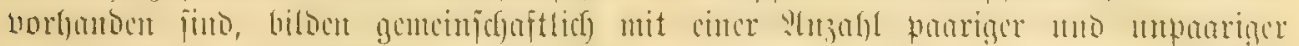

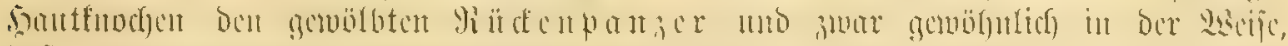

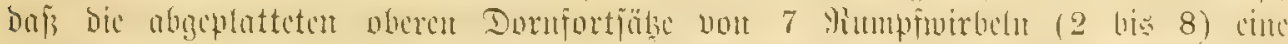

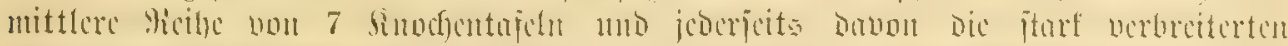

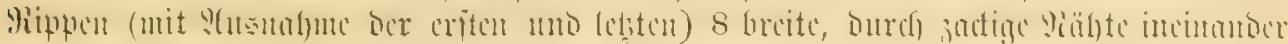

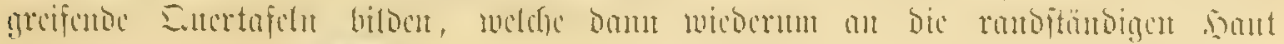

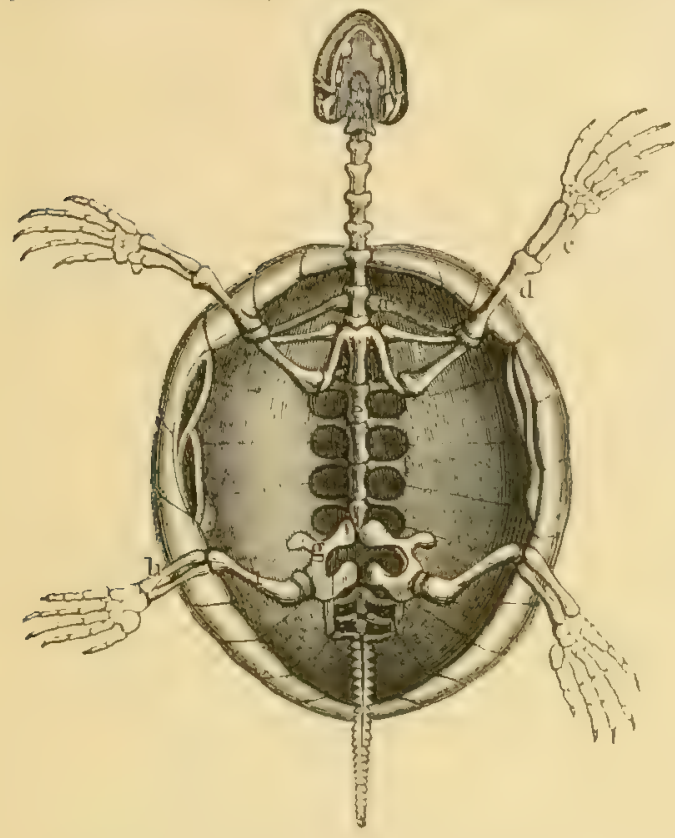

Fig. 1. Rnod)engerült einer Gujilbftöte.

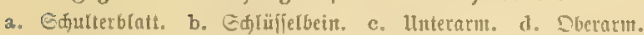

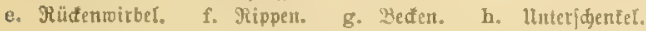
i. Dberidjentet. fuodjen ftojen; bicje imnige Sermadjfung

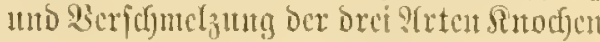

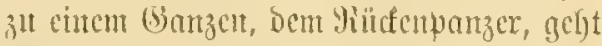
aber sur allmäblich vor ficf, wovout ntun (id) Durd Ilnterjudyutg junger Gdyillo fröten liberzergen farm. Der fladic

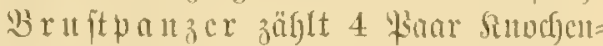
platten, juijhen Deren vurberes PBan

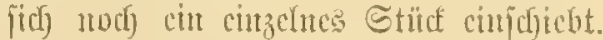
Dic cigenartige Bangerbilom berwirt Ituu abor, bajp fidf ber Echultergärtel mit ber zugeljörigen Deustulatur nidjet auber แี Dert Siruttuften aulegen

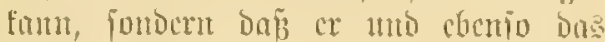
Beden innerlyalb ber Jimmfgöble fteden uno bic betreffendon Minsfeln fidy an biv Snucuficite Der bezüglidjen Sirtodjen ljeften. Der Sdyultergürtel befteft ats bem, cincu aufferigenden ftabïrmigen Sinochen bilbentom Sifulterblatt, Defien oberes Ende fich Dem Duerfortiats bes vorberiten Wrutrtwirbcle anfitgt, aute bem Sdjlitifel= und Den Gabelbcin. Buci breite, plattc 2birbel feben Den Siruztheil, Drei furze

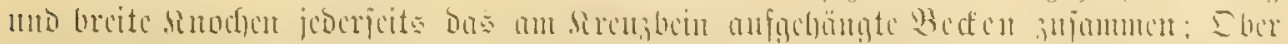

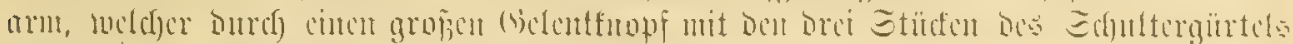

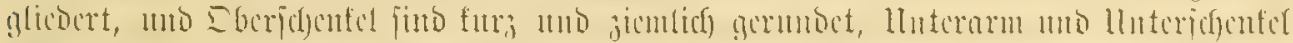

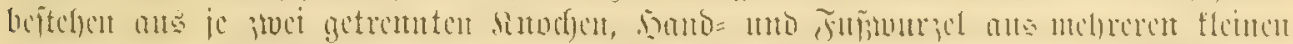

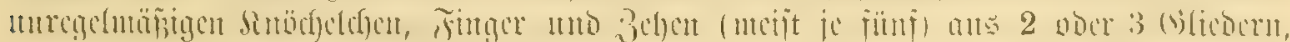

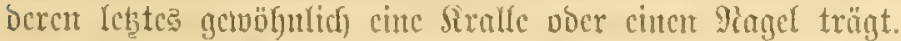

Dic ben hu

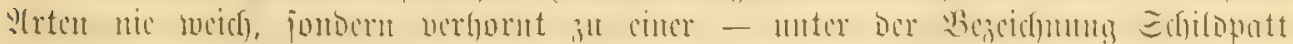

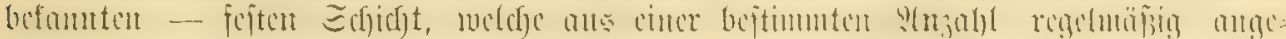

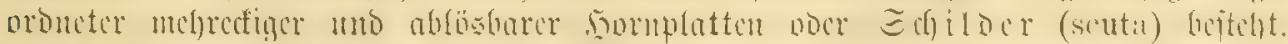

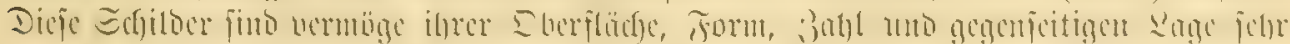

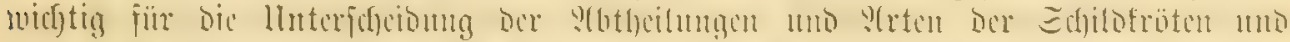

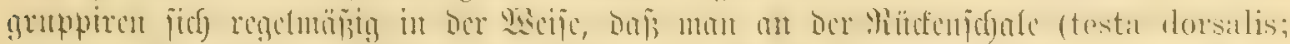

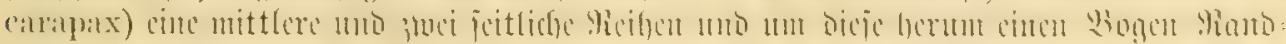

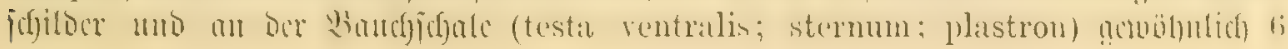




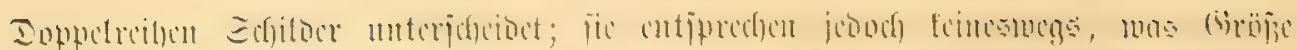

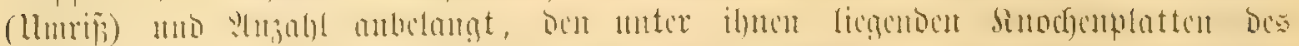

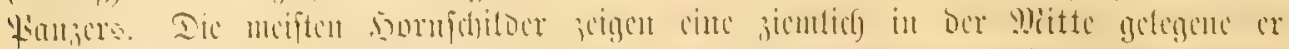

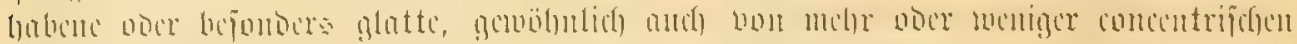

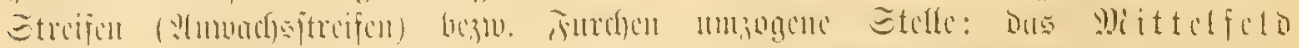

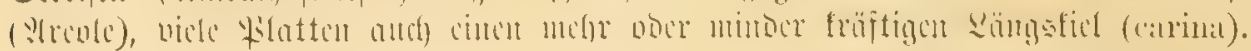

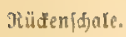

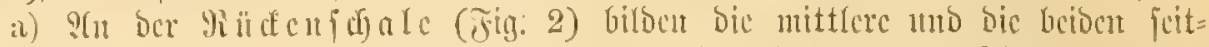

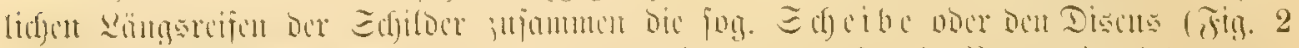

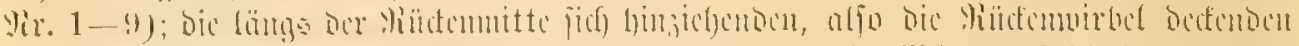

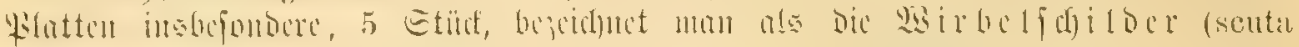

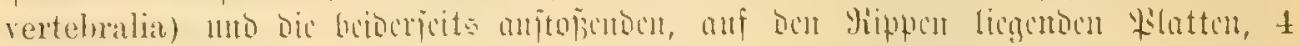

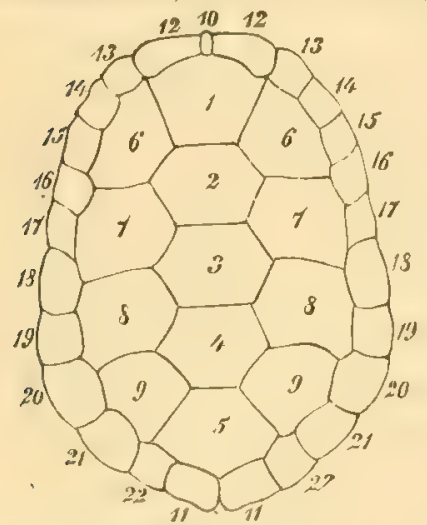

jig. 2. Miüdentidjale ber entrop. Simpfidjildröte.

$1-5$ witibet: 6-9 Mippenjaildet, 10 Yiaden

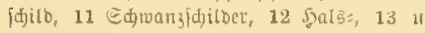

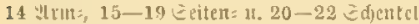
Manbjoilber.

femoraliat: Yir. $20-22$, 140 gegeno licgendon 5 tiann lateralia; 9 ir. 15-19).

Boutdjidjate.

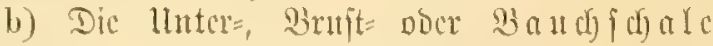
(Fig. 3) beitelyt aus Jucriger Blatten als bic

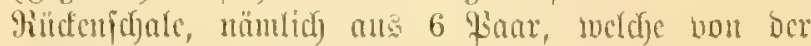
Jitte bor Echale ans nady vorn unt finten an

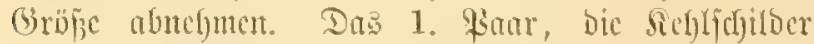
(scuta gularia), Dect dic Sichlgegend; Daß 2. Sianr, bie 9(rmicfilder (se. brachialia), bic Plrune; bas 3. Winar, bic Brutitjullocr (sc. pectoralia), bic Brruft; Das 4. Banar, bic Bandffidjilocr (sc. abdominalia), Dou Ecib, bant folgen bic Grfentel= (sc. femoralia)

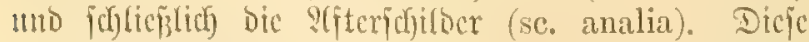

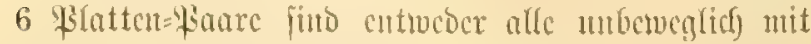
cutantor verbundert; voce fic frilocu, zll je orci

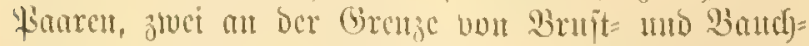
fdjilbern betweglich ancinantor geiügte Duteritücfe,

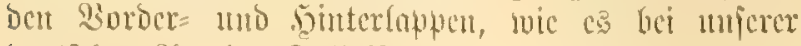
Dentjofen ?trt Der Jull ift.

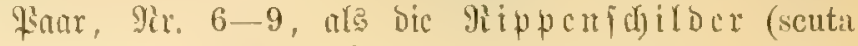
costalia). Dic Miarginal= oder Minudplatten (sc. alia) betocu bic altipere begrenzlng Der Mitctenjefr.

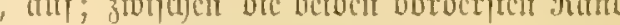

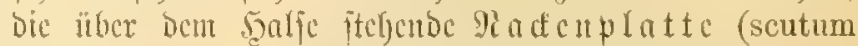
nuchale, Sir. 10), uto zwijcyen bas finterite fian norf

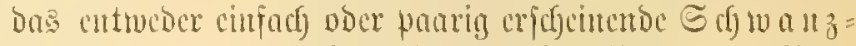
f ch illd (sc. supracaudale; 92r. 11) cit. 3on ben 11 \&aar Gi a m

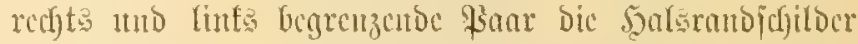
(scuta margino-collaria; Mir. 12), bic folgendon juci, ilber

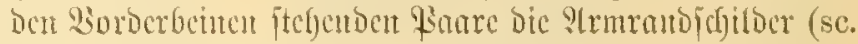
margino-brachialia; Jir. 13 und 14), bie it ber Sdjenfel=

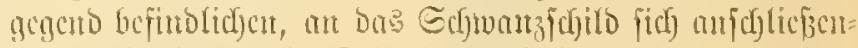

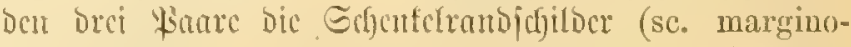

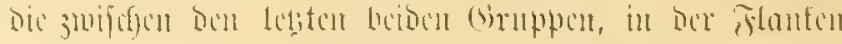

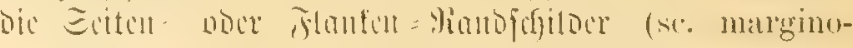

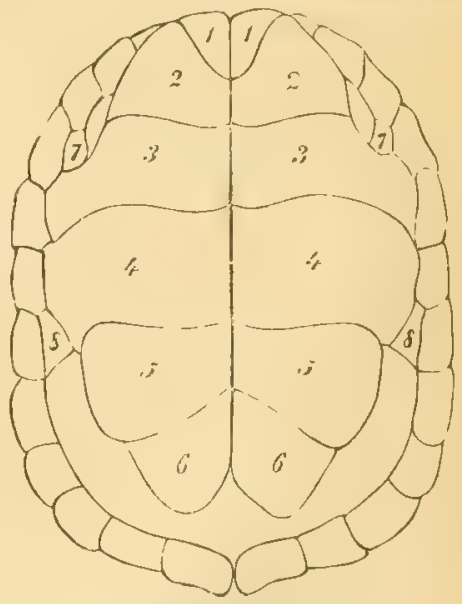

jig. 3. Bandidjale ber faspifdjen Sumpfidjild fröte.

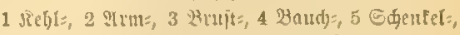
6 stitet=, 7 gtajet=, 8 setijtenjailder. 


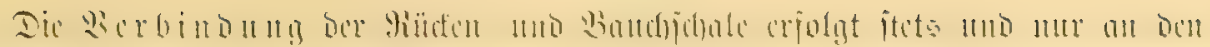

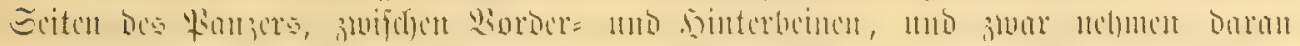

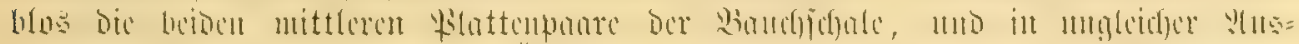

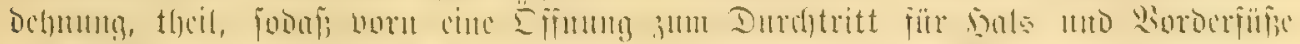

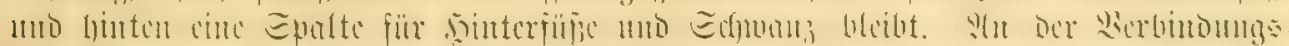

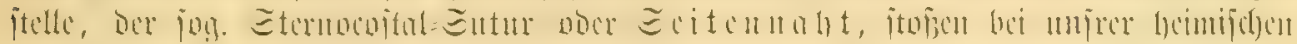

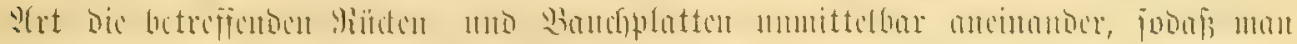

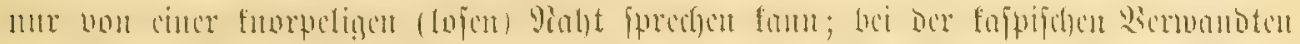

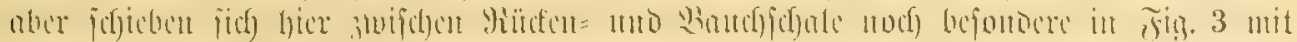

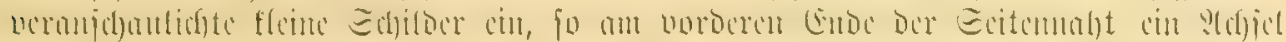

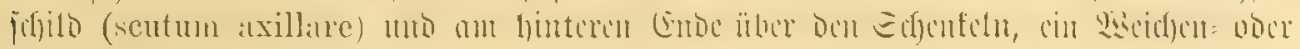
Eciftenfifilo (sc. inguinale).

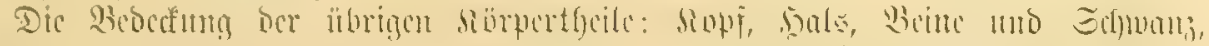

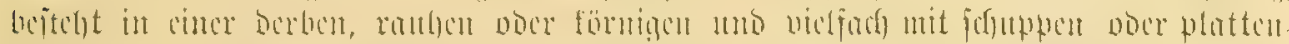

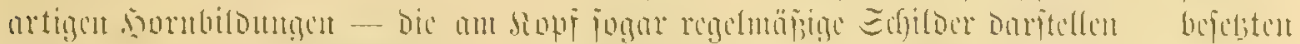

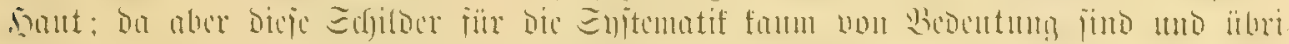

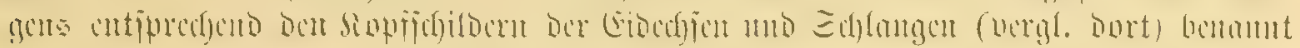

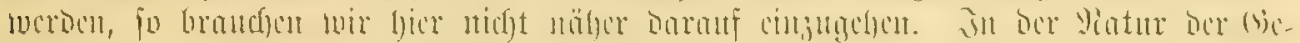

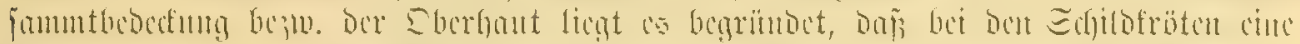

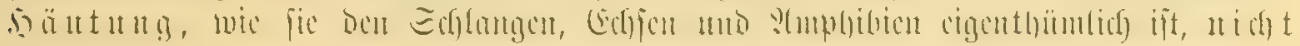
itattfiubet.

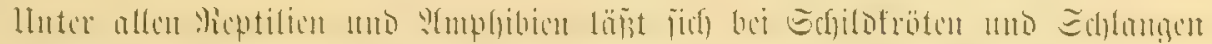

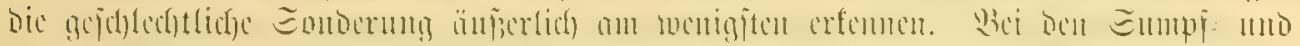

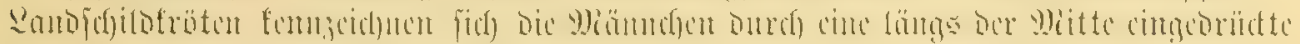

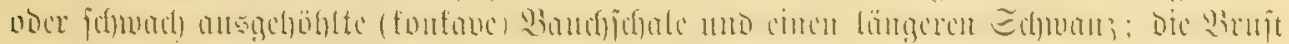

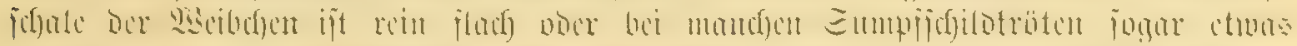

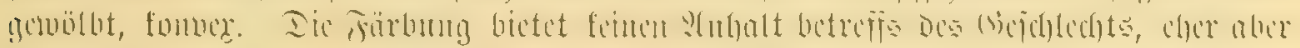
bejuiglidy des ?llters.

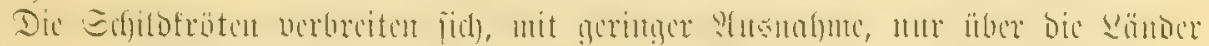

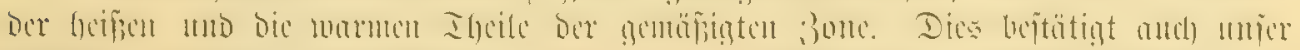

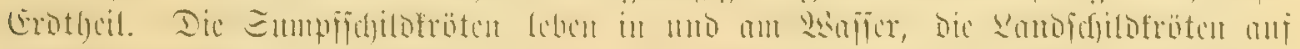

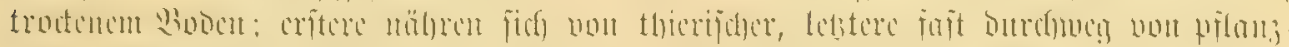

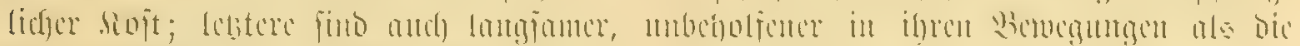

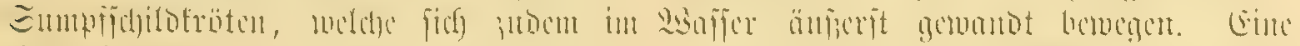

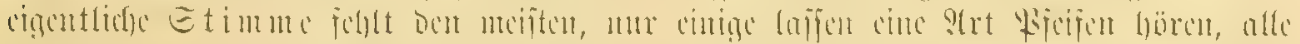

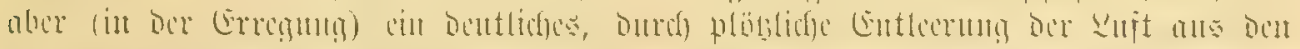

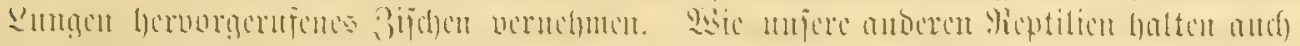

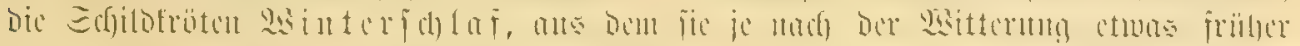

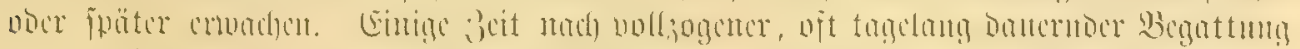

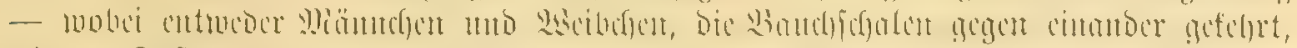

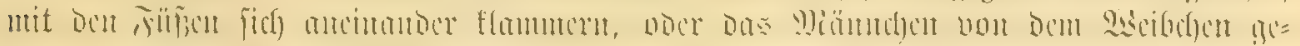

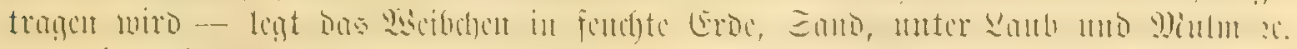

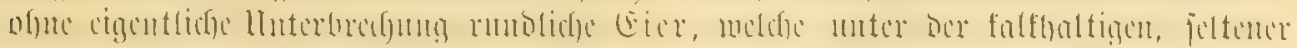

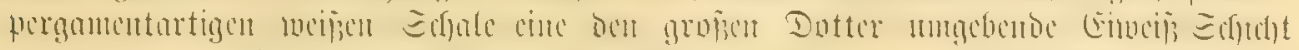

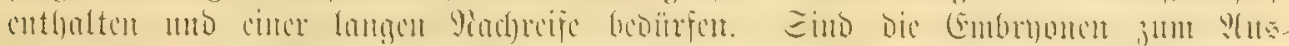

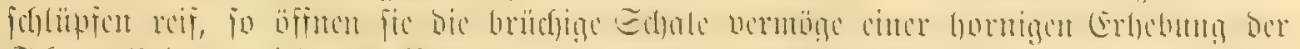

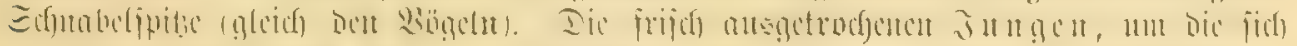

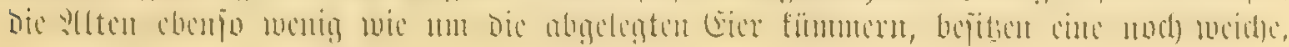




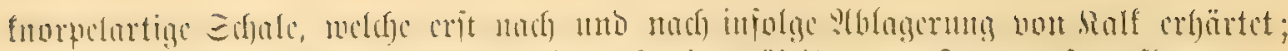

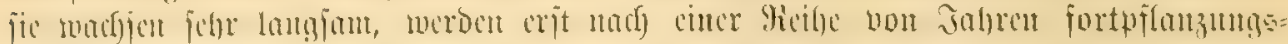

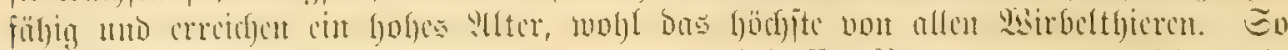

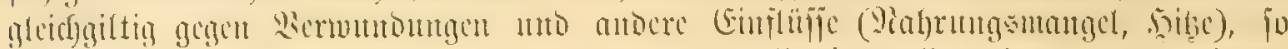

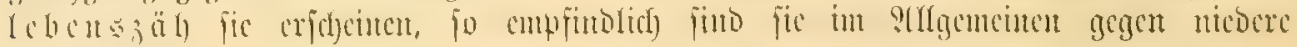
Imperatur.

ঔorifite.

T)

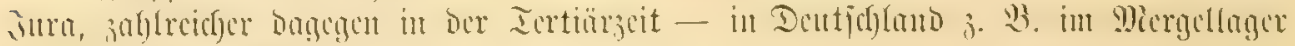
bei Deningent a. 9if). (Dberifjwaben) - anf.

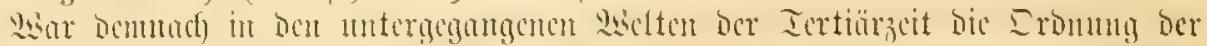

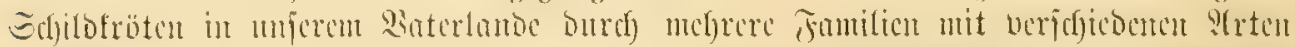

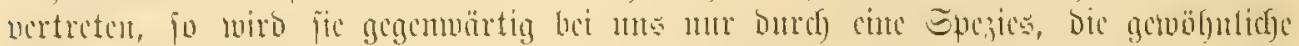

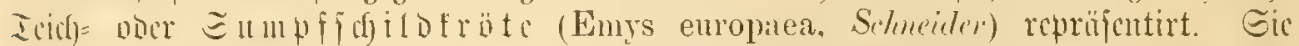

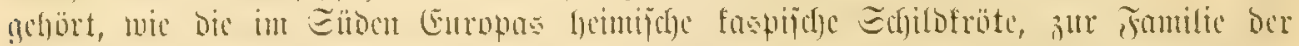

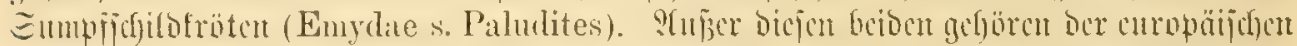

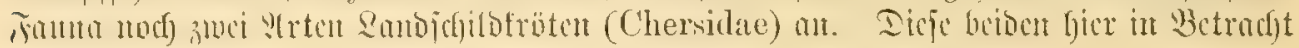

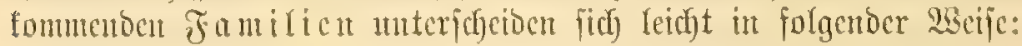

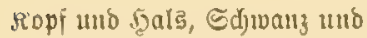

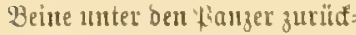
jieljbar; Trommelfell (tym: panum) ftets fidytbar;

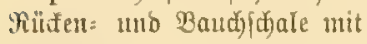
Sormplatten; Disłus (ber Rüutenfdale) mit 13 Wlatten; Borberfitipe mit 5, Yintere mit \pm 3ethen.

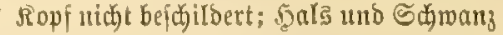

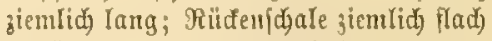

gemölbt, mit ber Brmftidale mandjual

beroglich verbunben, $\mathfrak{A}$ reolen bei alten

Shieren unbeutlid; Fübe mit beutlid)

unterjdjiebentr, berneglidjen, burd)

Schmimmbäute verbunbenen Behen;

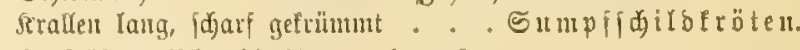

R̂op bis zrmifden bie atugen mit grosen

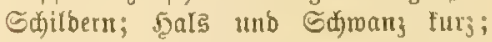

Milifenidjate hod) gevoölbt, le hr hart,

mit ber Bruftidale ftets unberweglid)

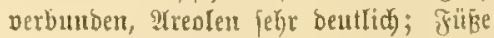

plump, ungegliebert, Bebett nid)t unter=

id)ciobar, nur bie ftarfen, ziemlid geraben

R̂tallen frei

gaudiditofröten.

\section{fimilic: Sumpridilofrötcu, Emyalae s. Paludites.}

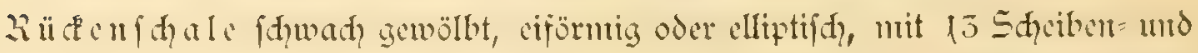

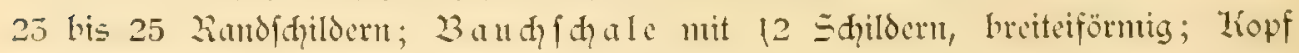

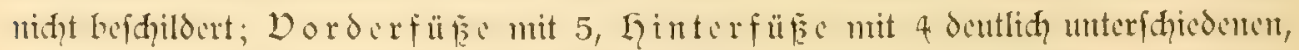

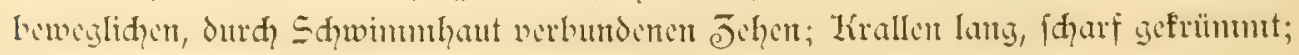
Sohlengänger.

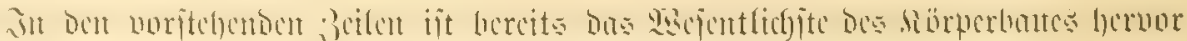

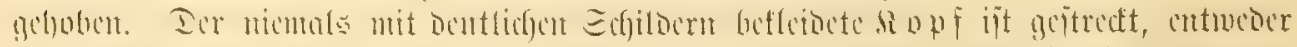

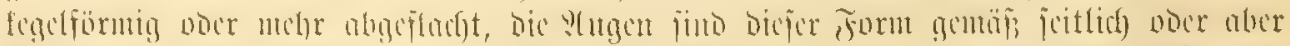

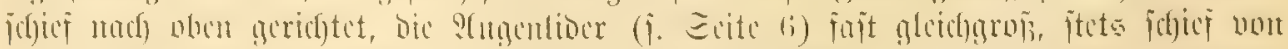

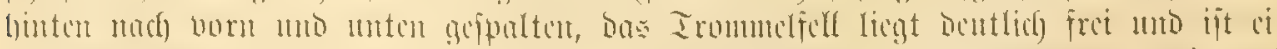

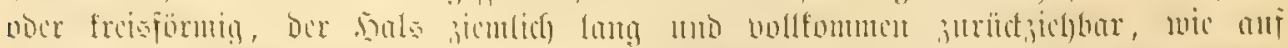

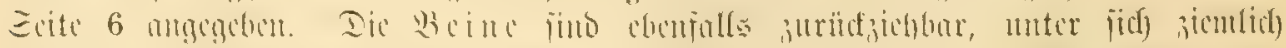

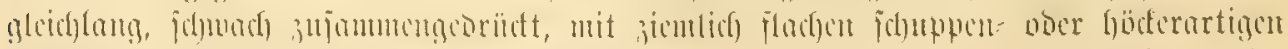

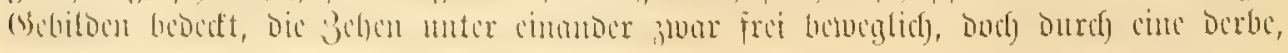




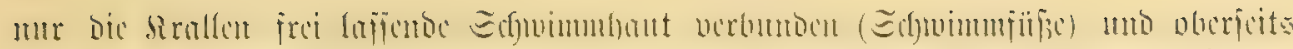

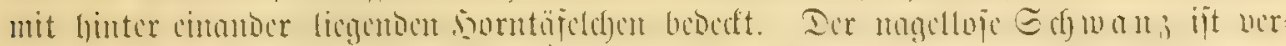

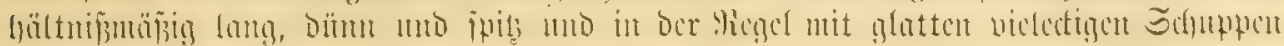
tïfeldyen beffecioct.

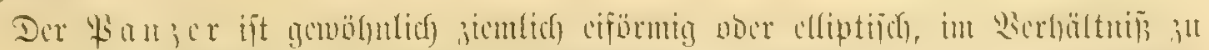

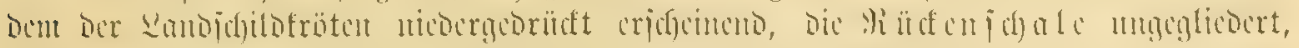

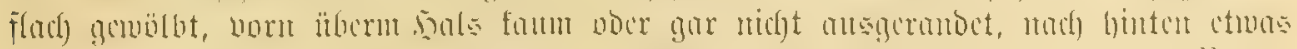

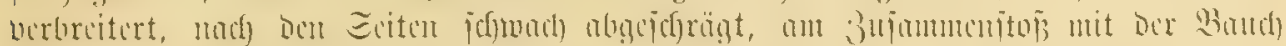

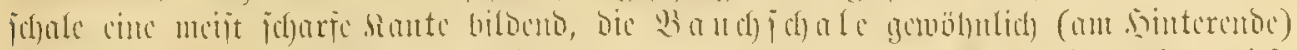

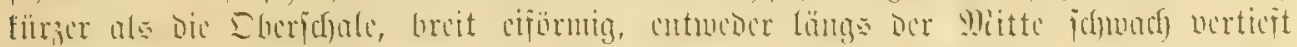

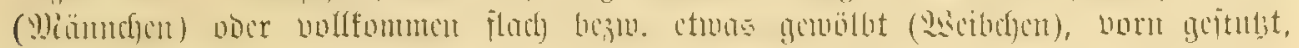

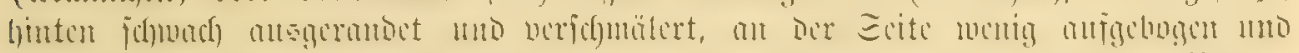

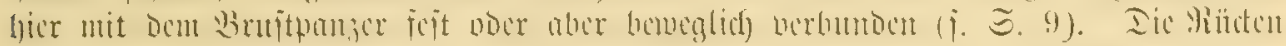

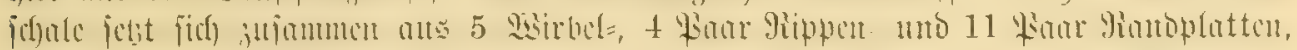

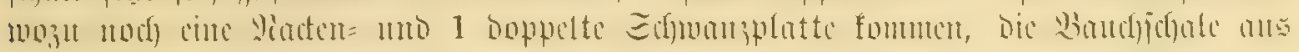

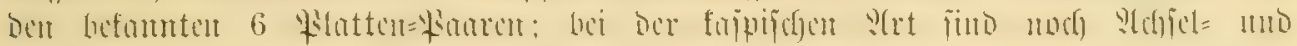

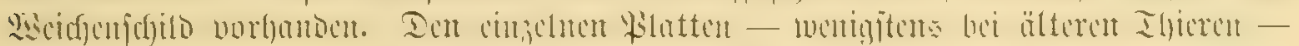

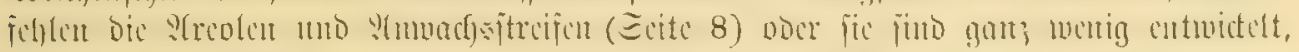

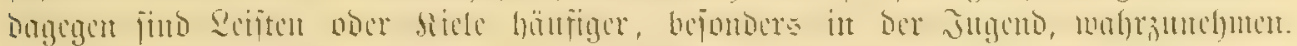

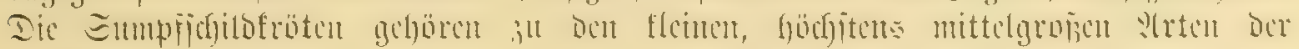
Droutung.

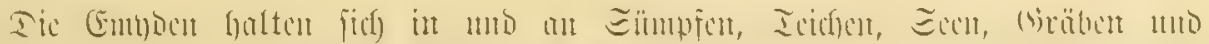

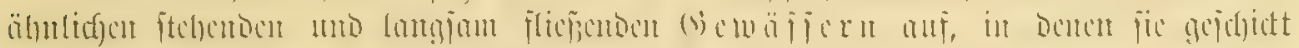

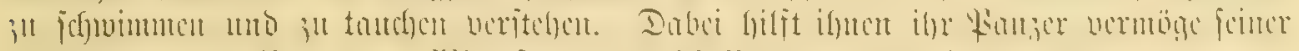

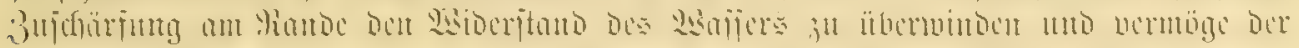

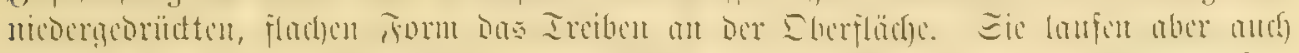

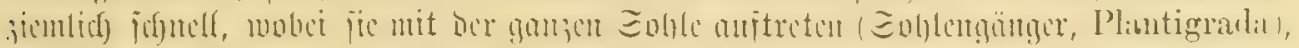

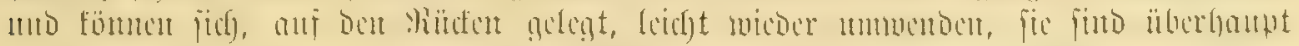

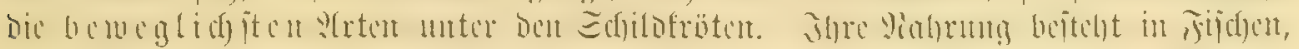

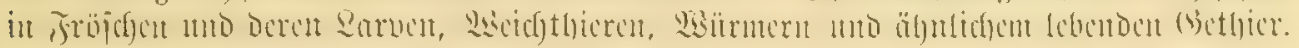
Regen twie alfe Edjilbfröten berbjdjalige Eicr.

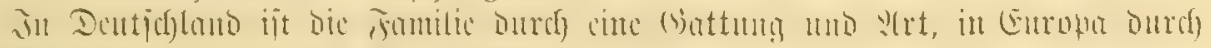

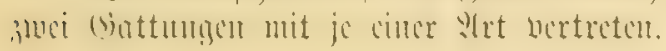

\section{(5attung: Gumpifidilofröte. Emys, Merrem.}

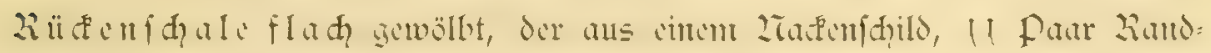

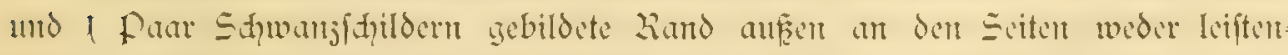

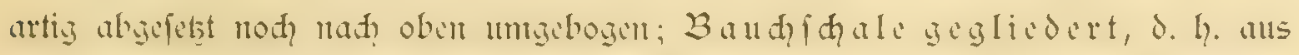

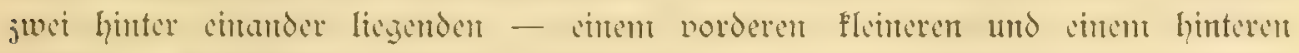

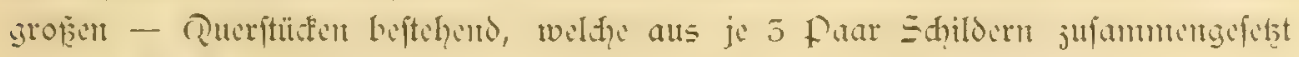

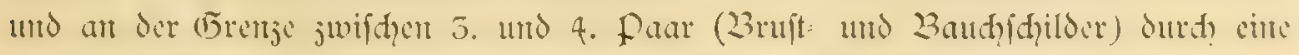

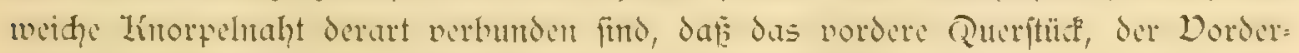

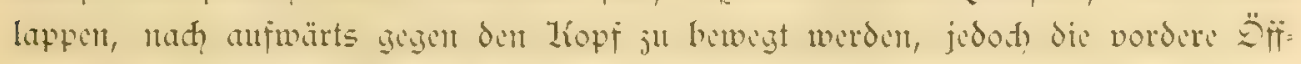

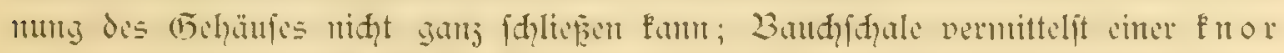

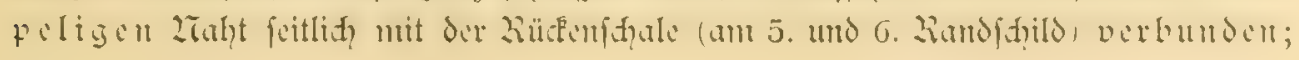


2 dyfl und Weidyentatten fehlen*); Gals mo Beine oberpets mit

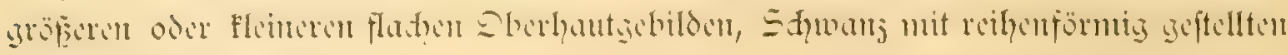
Sdildden befect.

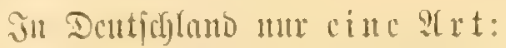

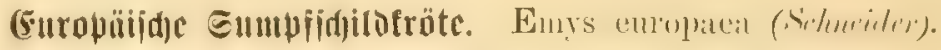
:lbbitbung: jajet VI yir. 1.

Urtfentreid)er.

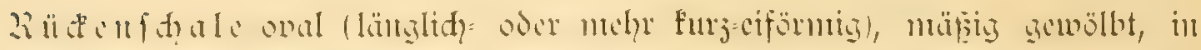

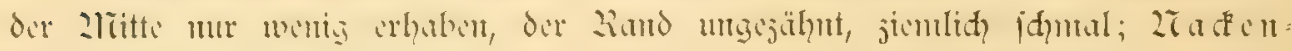

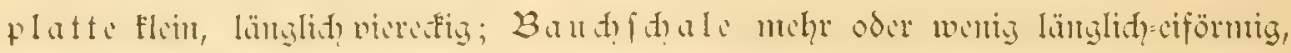

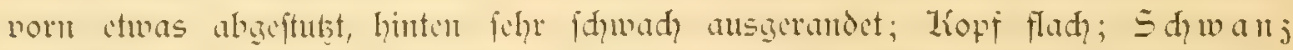

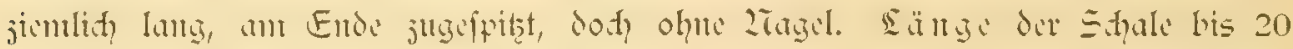

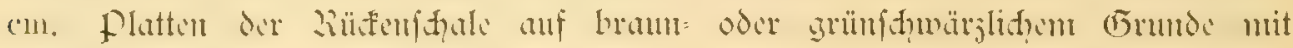

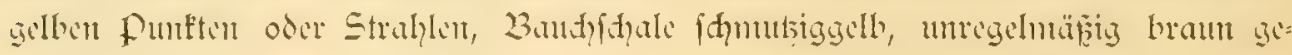
jeiḑutet.

Uröke.

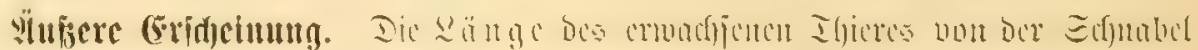

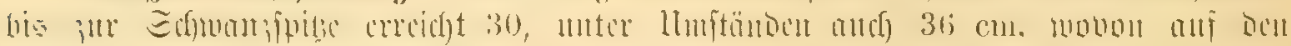

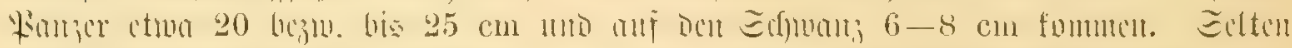

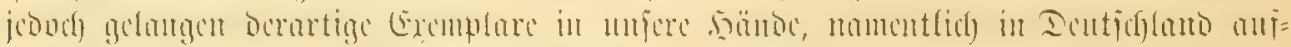

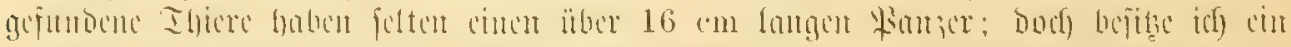

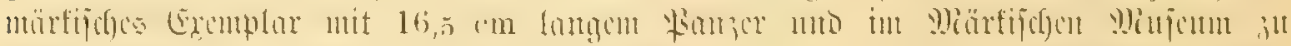

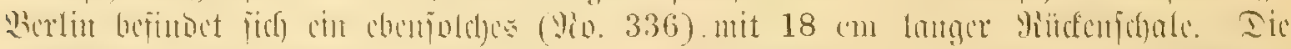

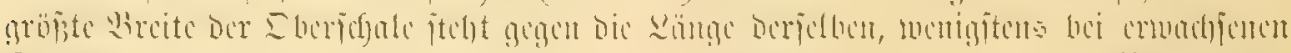

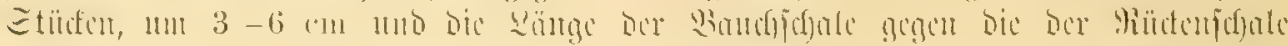

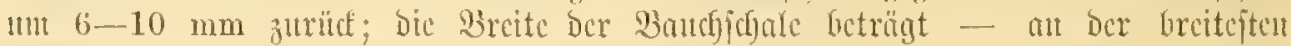

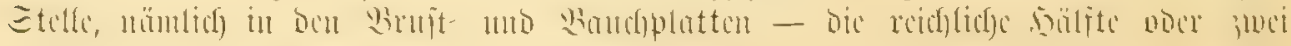

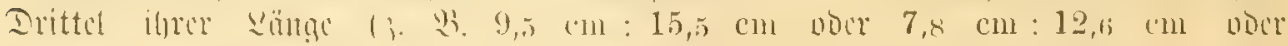

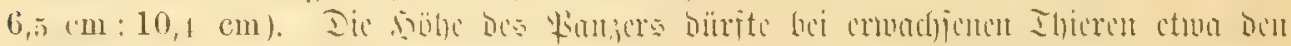

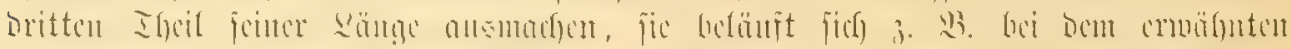

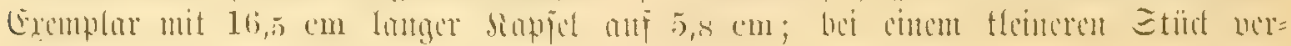

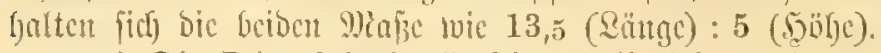

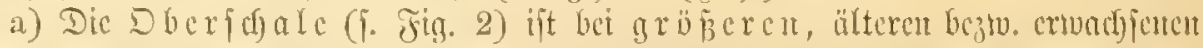

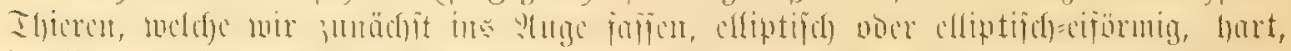

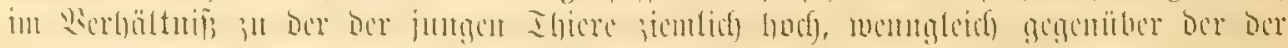

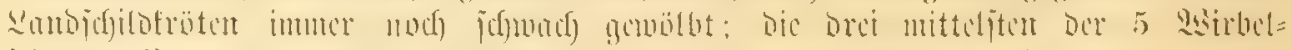

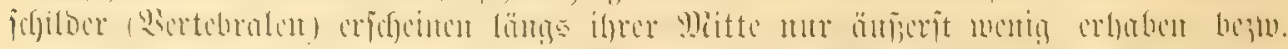

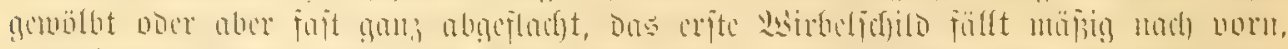

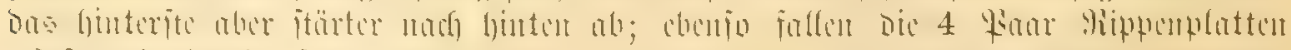

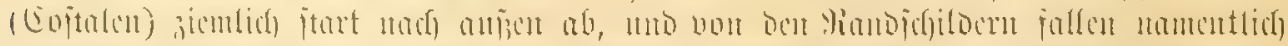

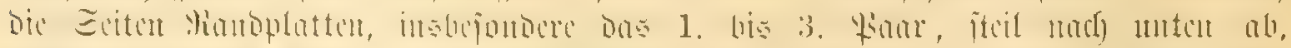

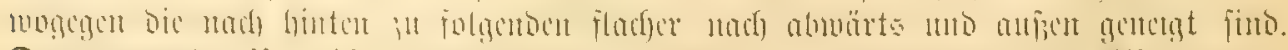

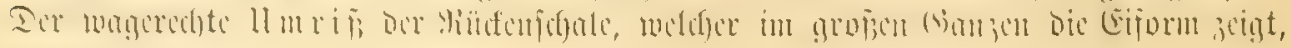

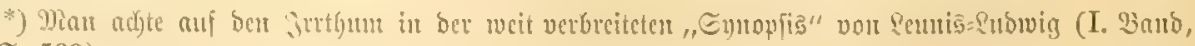




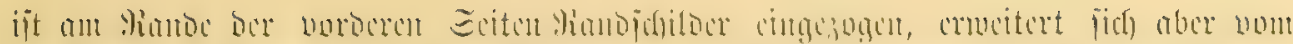

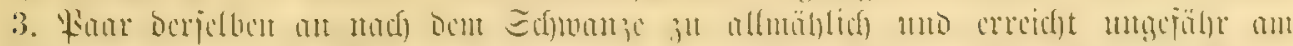

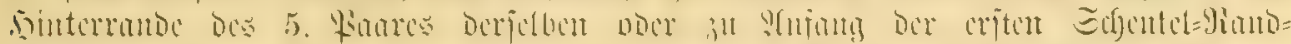

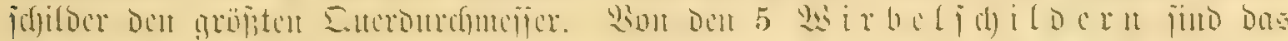

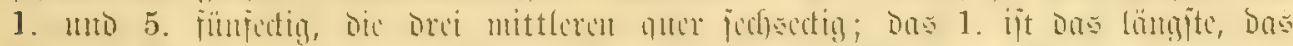

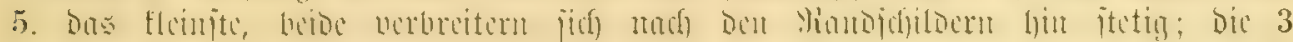

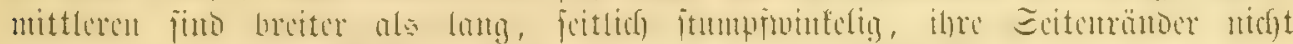

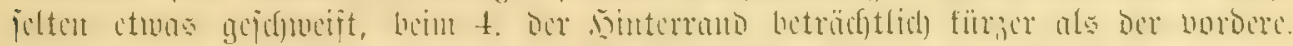

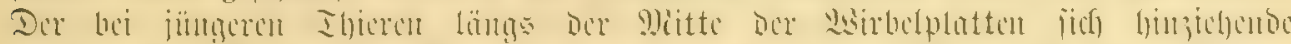

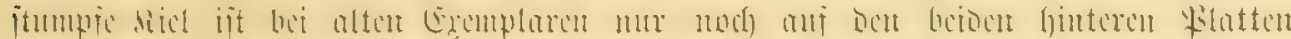

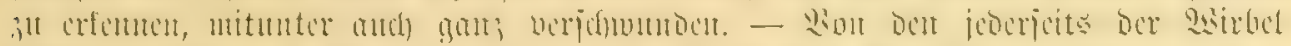

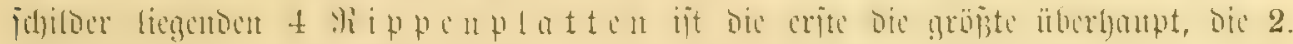

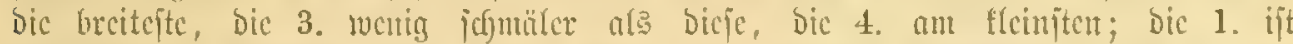

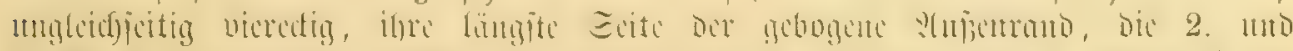

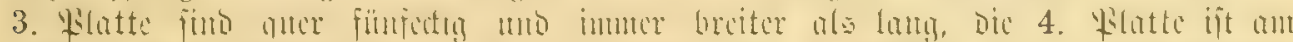

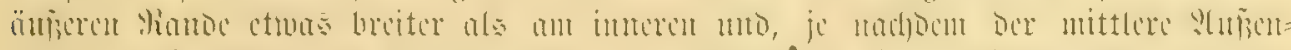

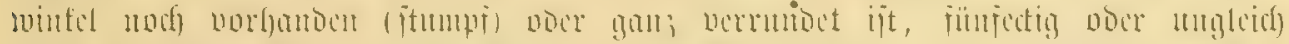

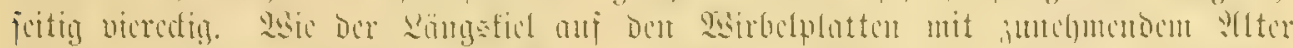

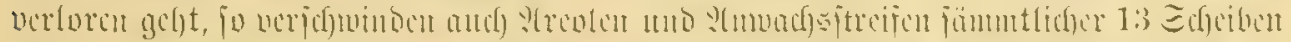

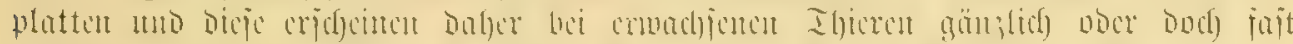

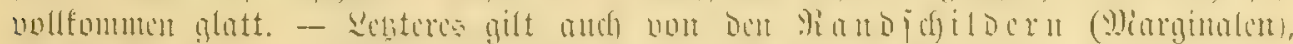

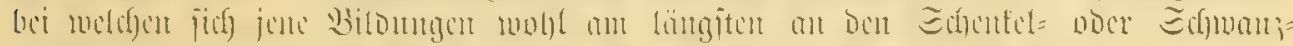

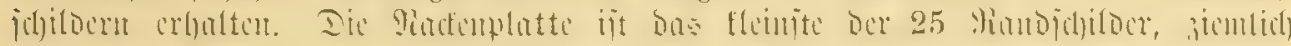

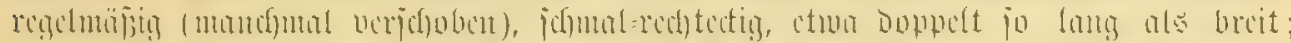

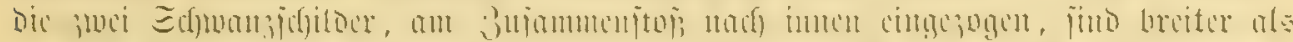

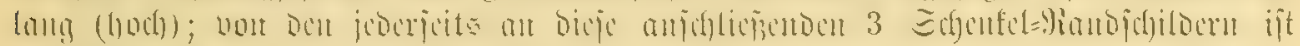

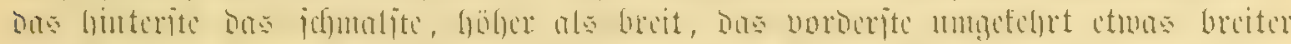

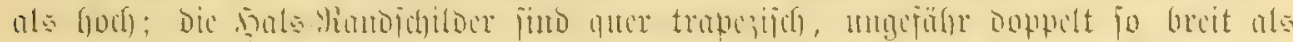

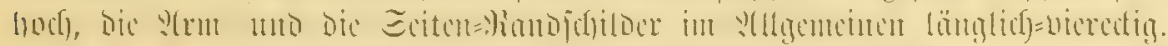

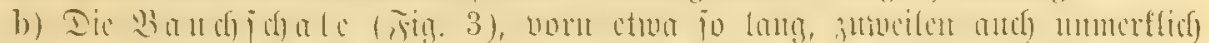

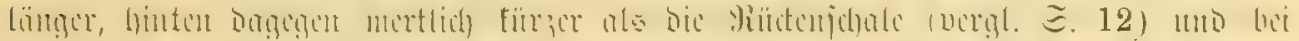

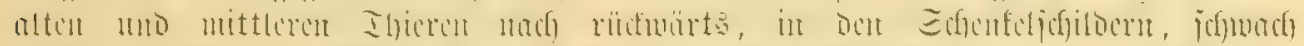

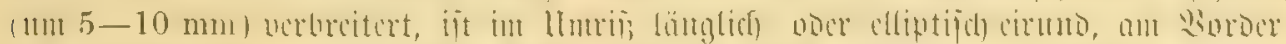

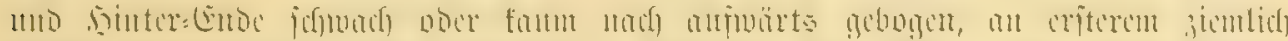

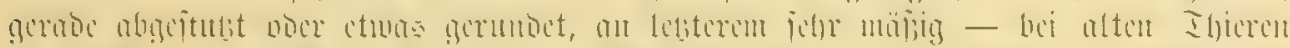

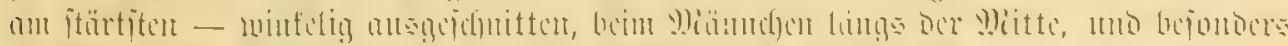

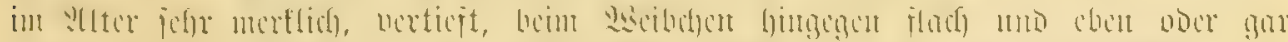

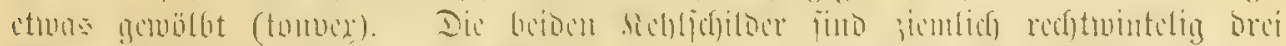

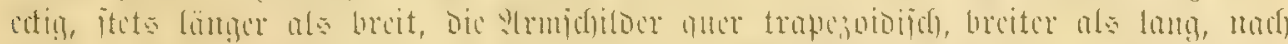

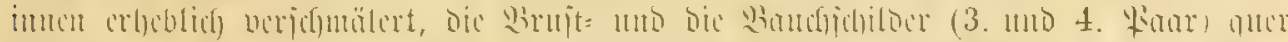

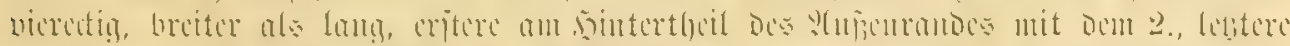

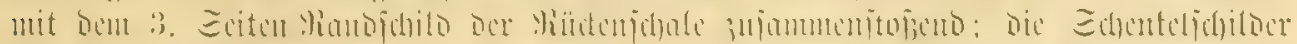

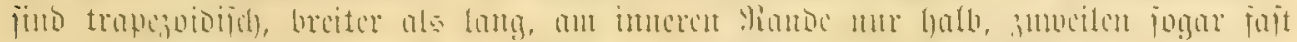

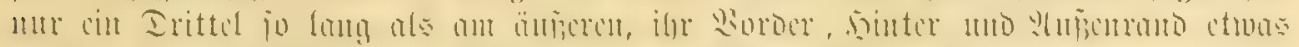

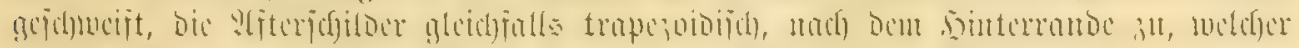

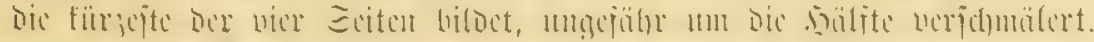

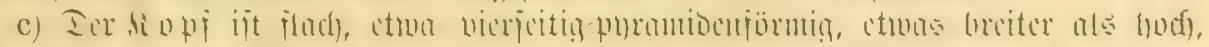

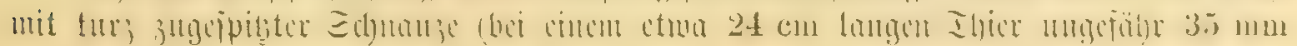




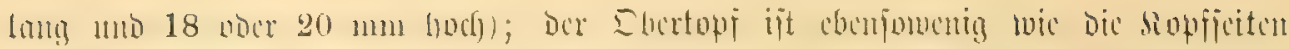

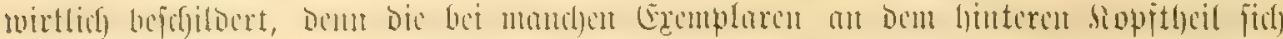

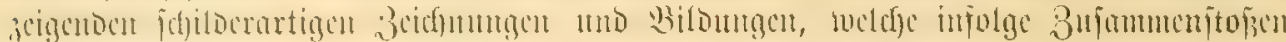

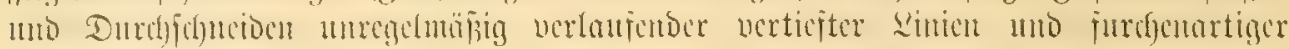

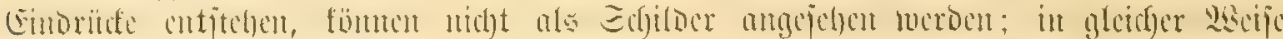

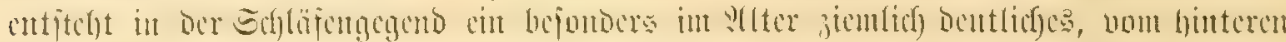

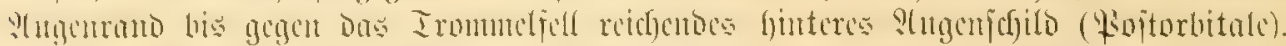

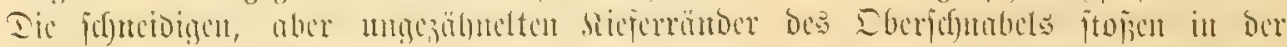

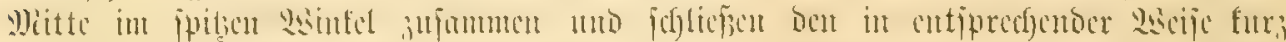

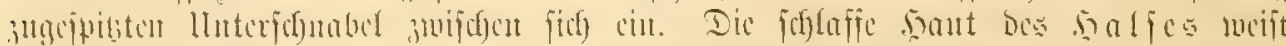

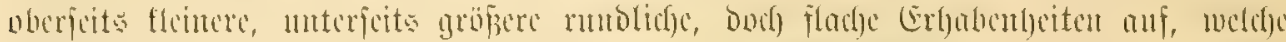

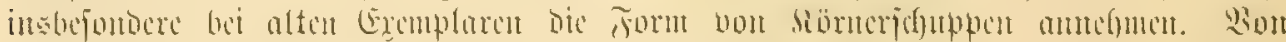

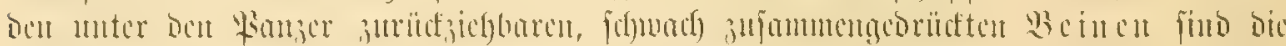

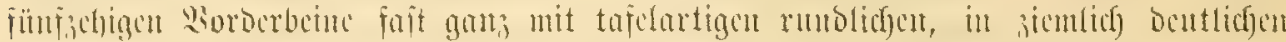

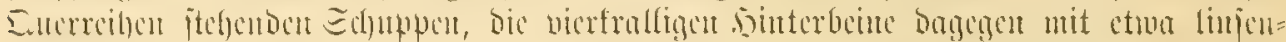

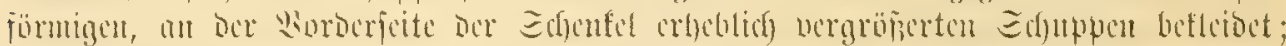

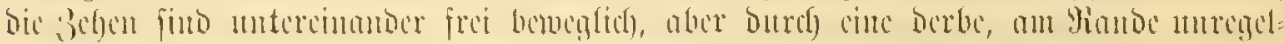

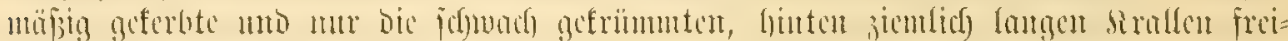

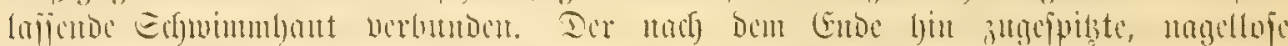

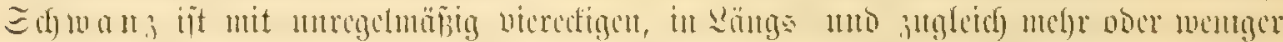

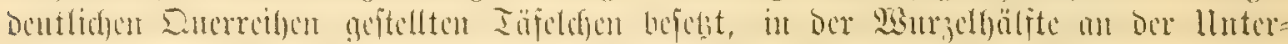

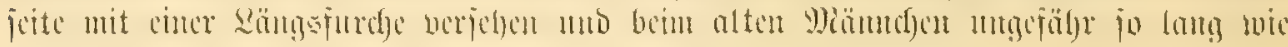

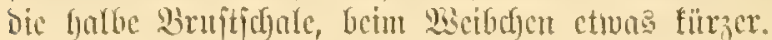

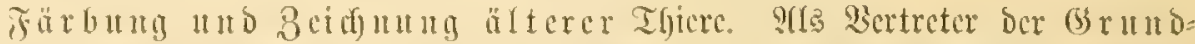

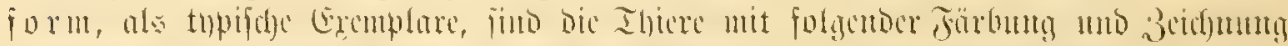

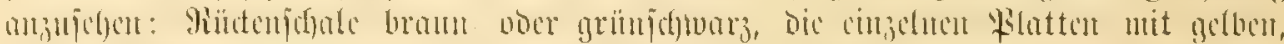

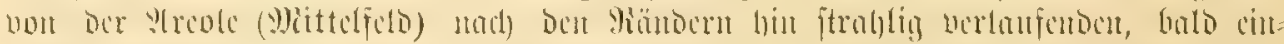

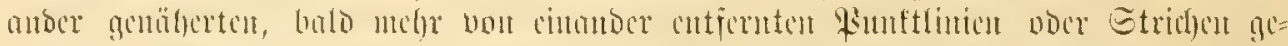

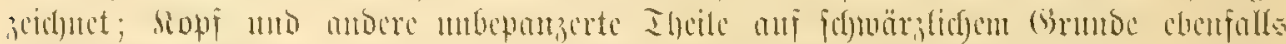

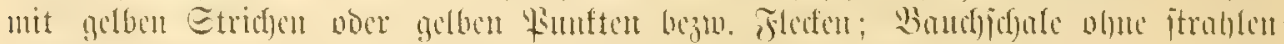

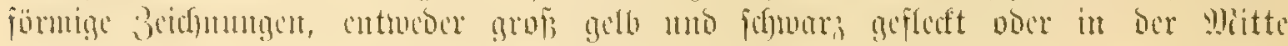

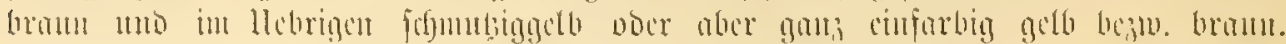
St ugenteru (Jris) gelb mit fdywarzen Duerffed.

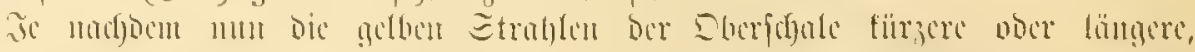

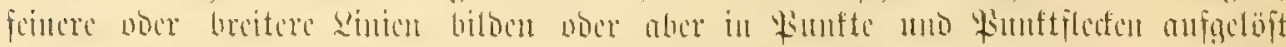

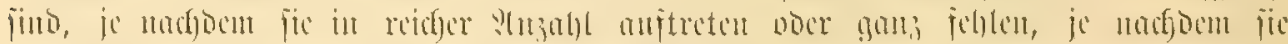

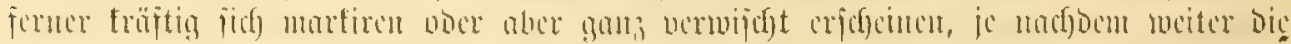

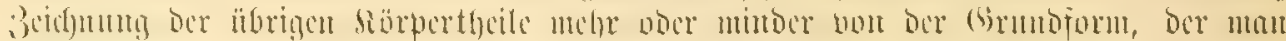

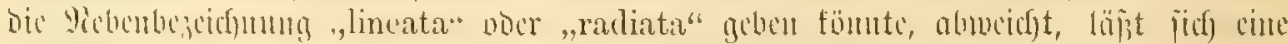

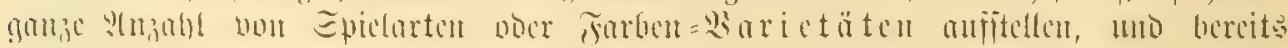

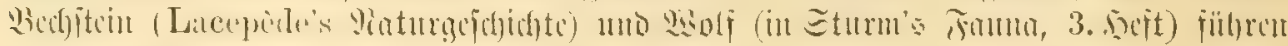

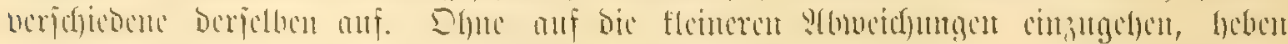
twir unt bic weichtigften herwor.

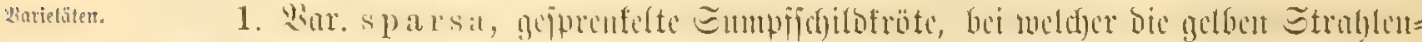

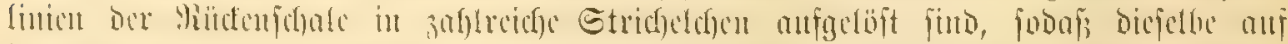

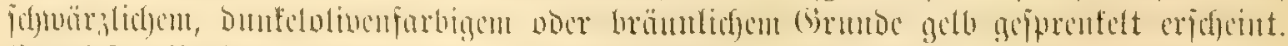

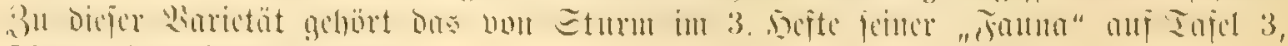
Fig. c, Dargeftellte Ercmplar. 


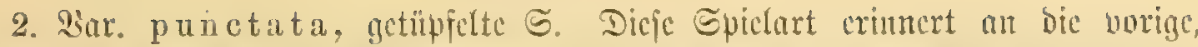

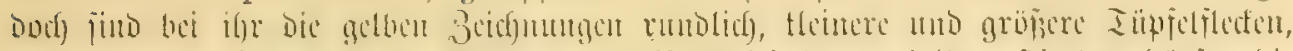

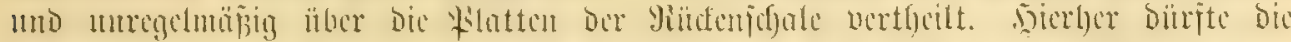

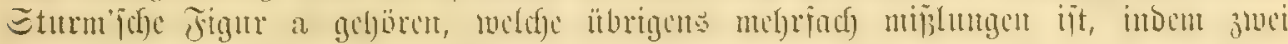

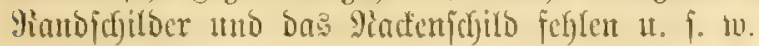

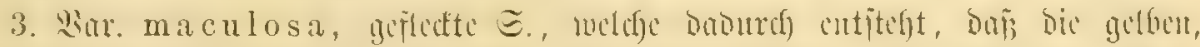

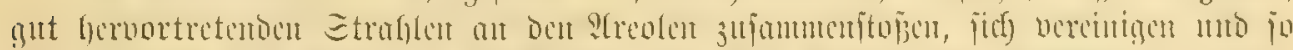

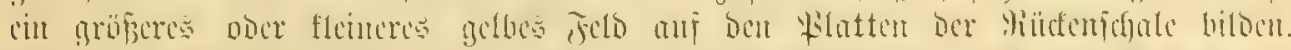

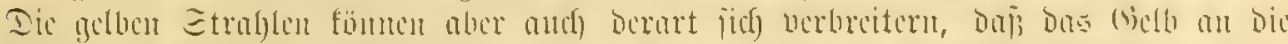

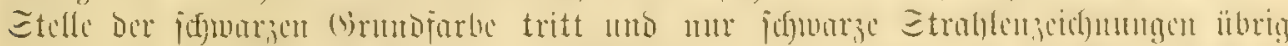

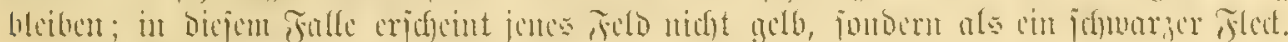

4. Sar. concolor, cinfarbige S. Gie bilbet Den Gegenjaly zut Sar. 3, Denu

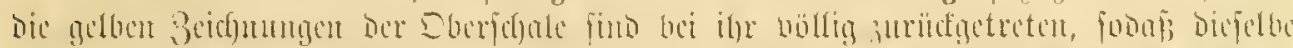

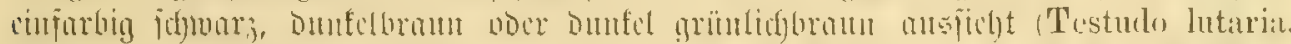

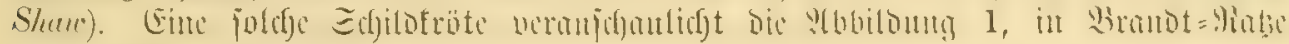
burg's "ग̉esicint. 3uologic".

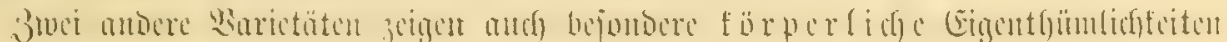

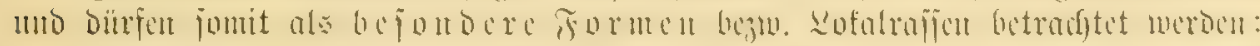

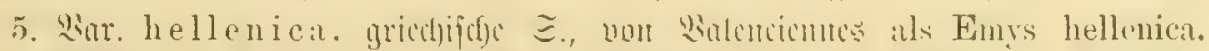

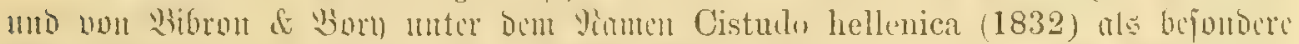

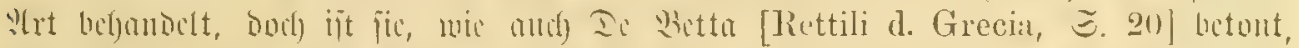

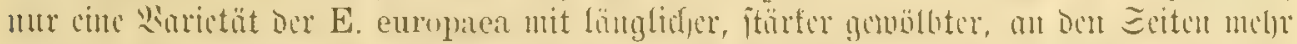

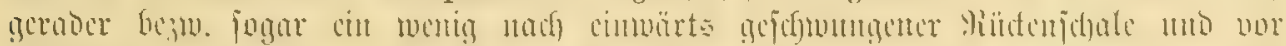

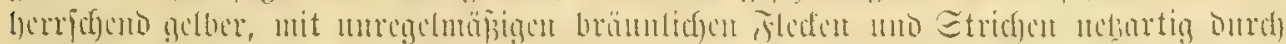

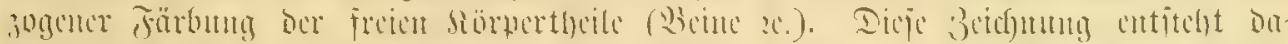

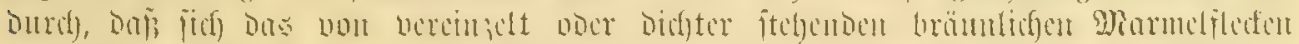

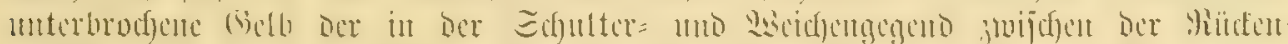

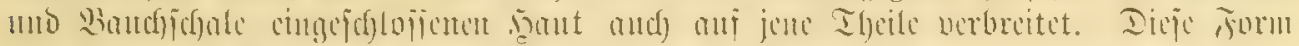

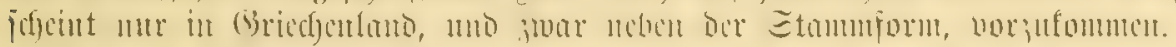

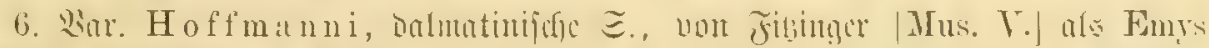

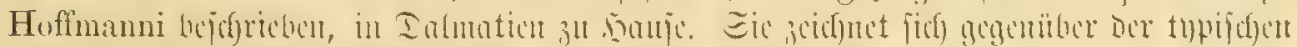

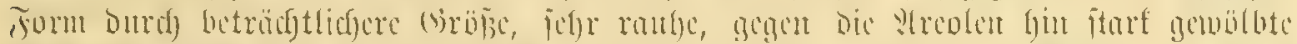

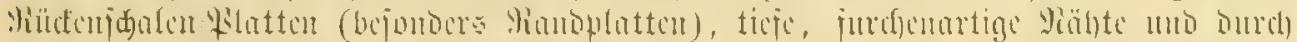
im glön,

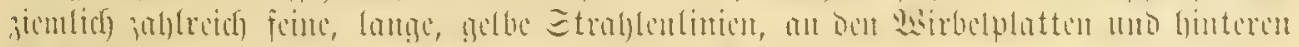

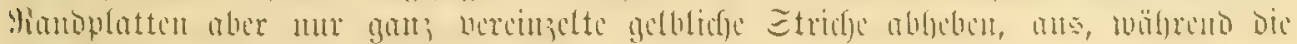
Baudjidjale glatt mo cinfarbig gelblidj ijt.

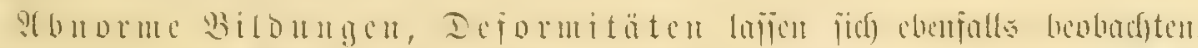

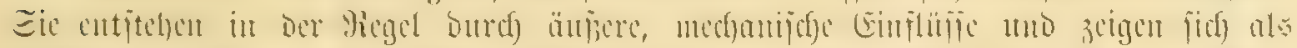

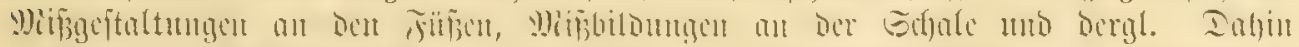

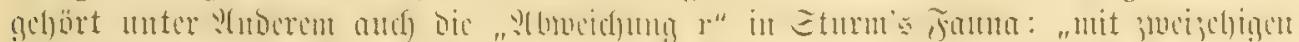

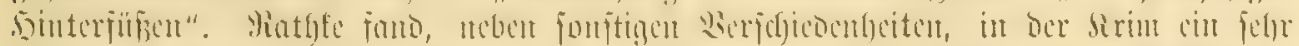

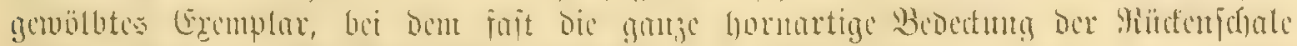

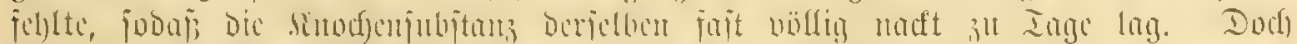

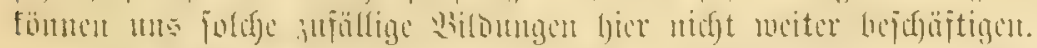

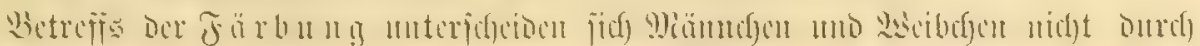

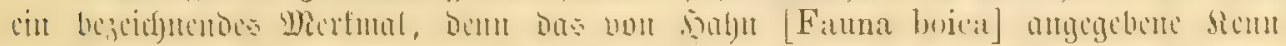




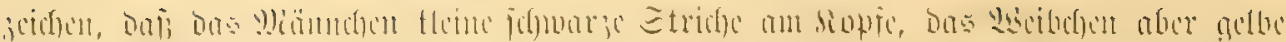

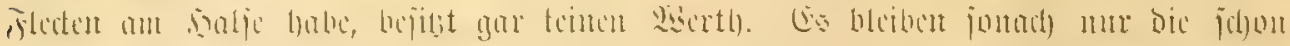

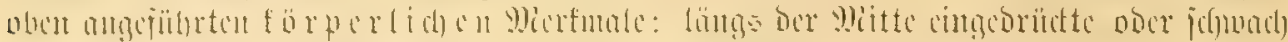

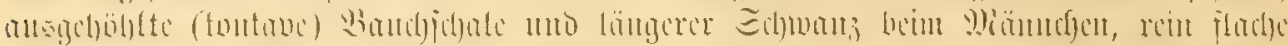

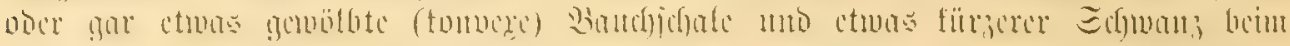

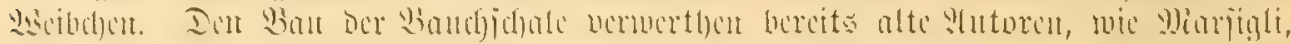

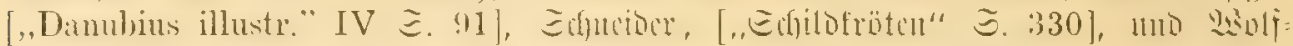

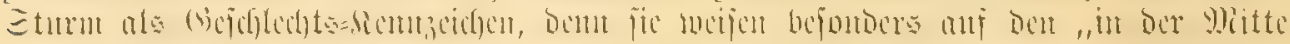

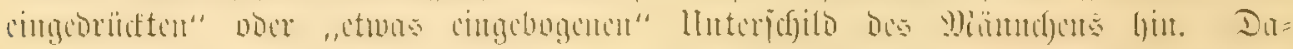

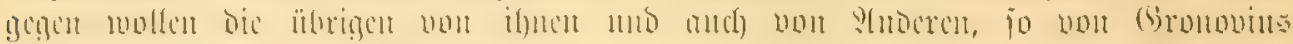

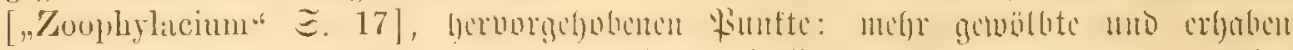

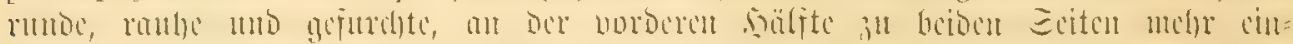

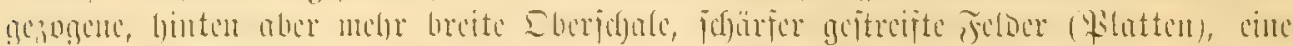

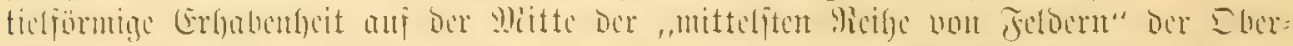

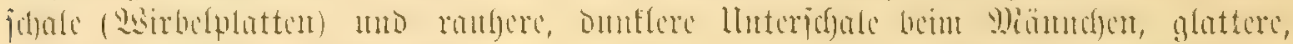

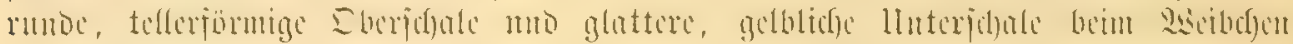
- uicht zutrefferto eridjeinen.

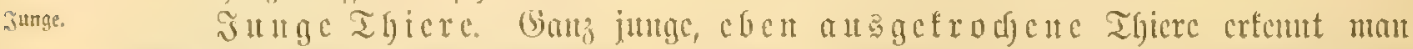

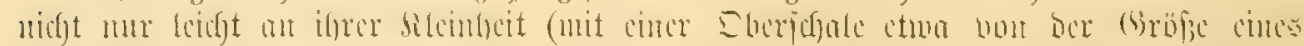

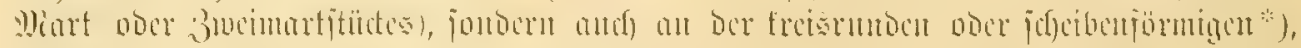

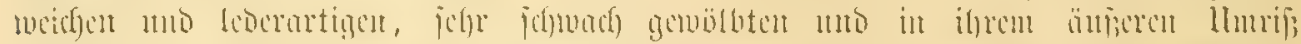

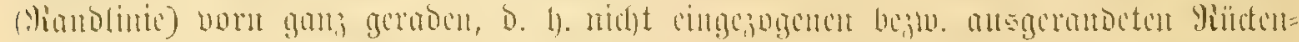

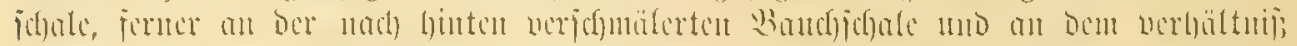

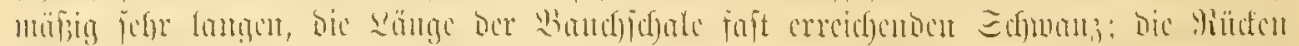

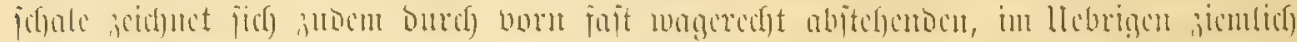

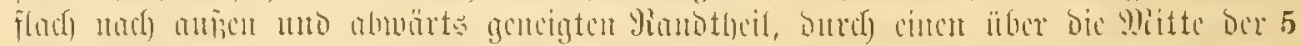

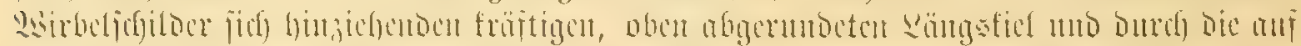

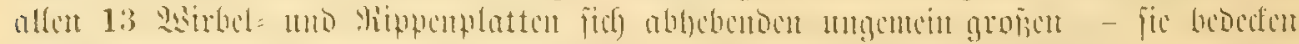

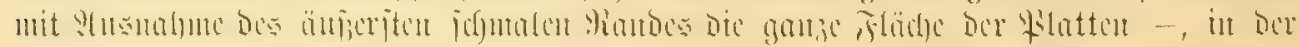

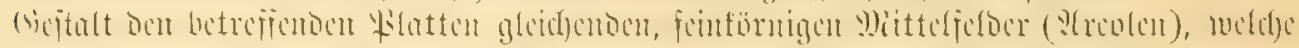

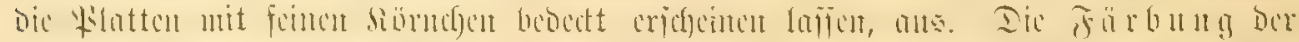

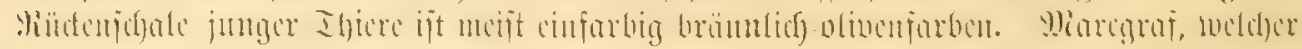

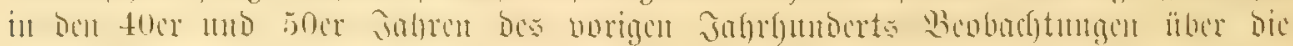

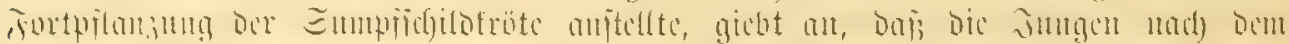

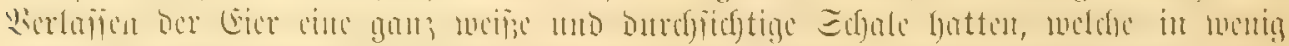

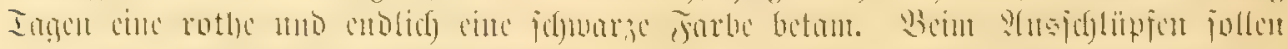

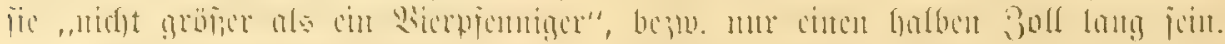

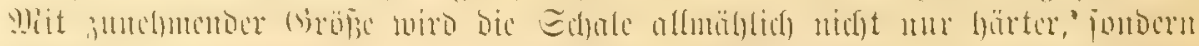

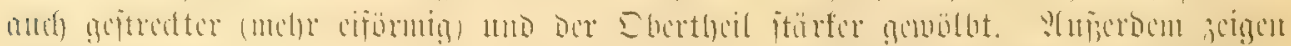

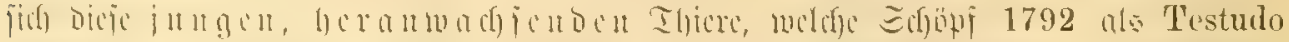

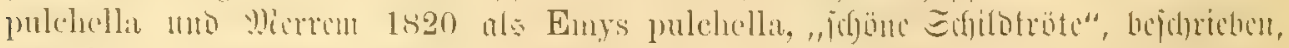

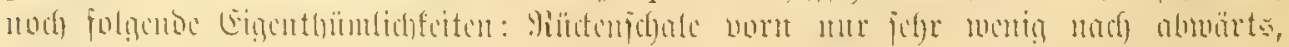

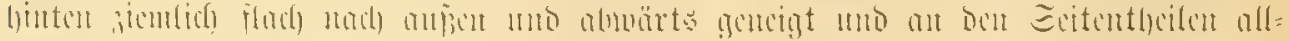

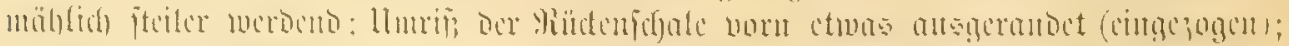

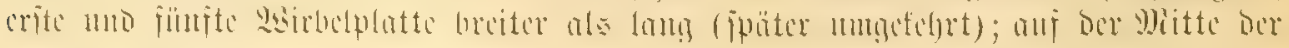

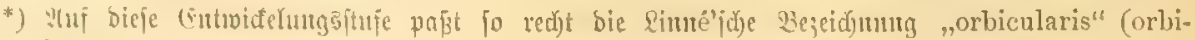
culus $=$ Edyeibdjen . 


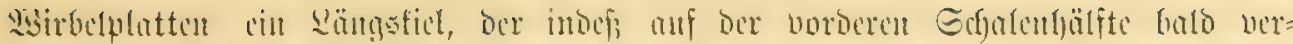

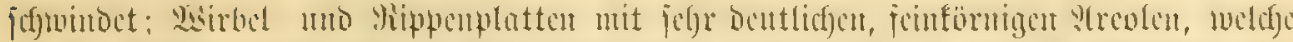

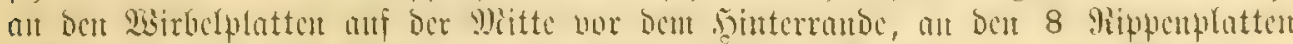

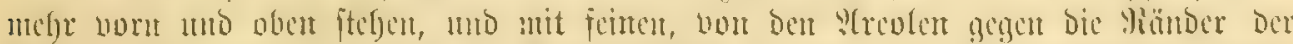

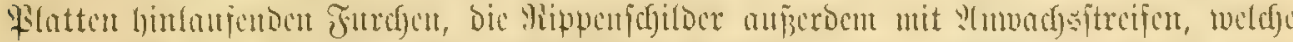

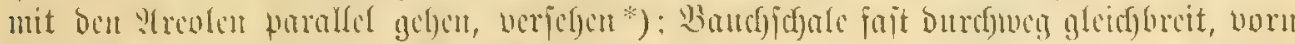

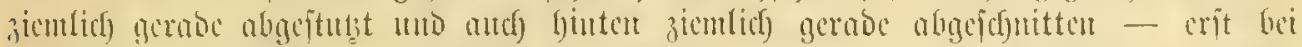

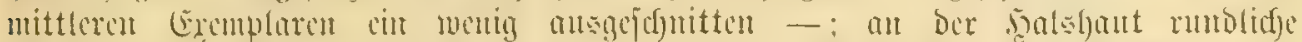

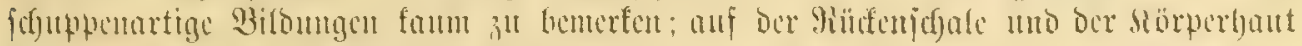

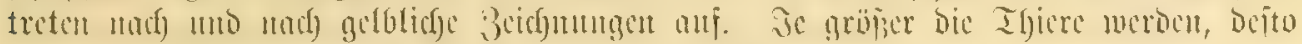
attagcprägter zcigent fie bic Mierfmale alter Stücfe.

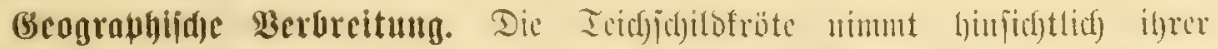

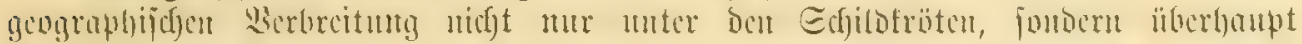

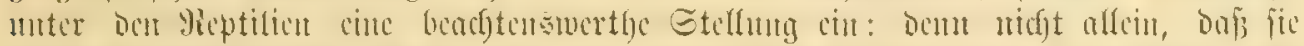

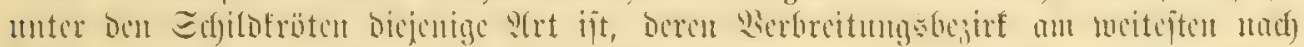

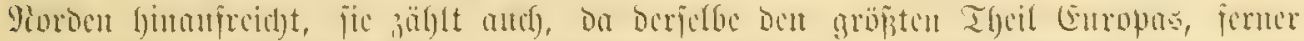

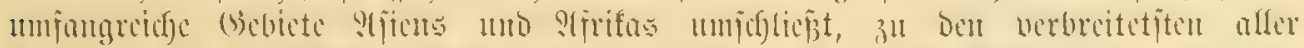

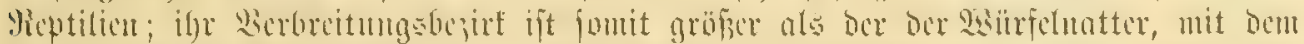

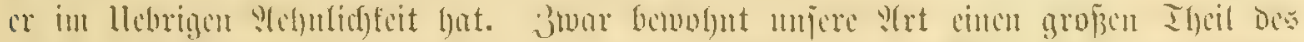

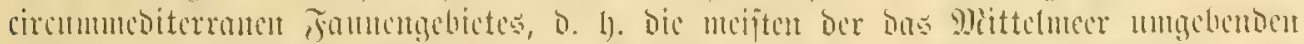

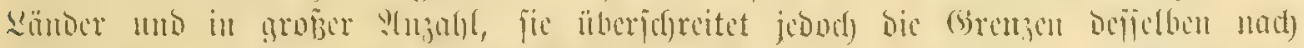

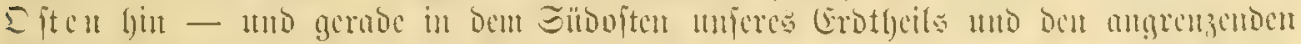

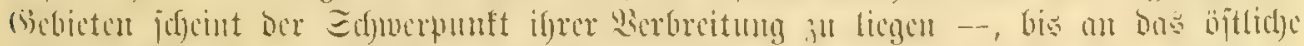

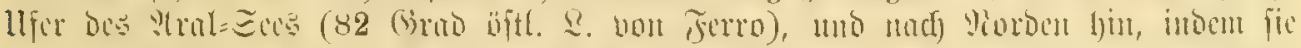

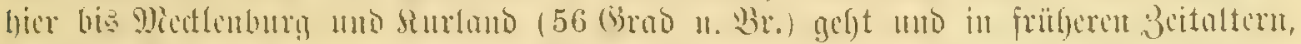

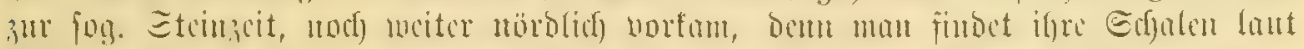

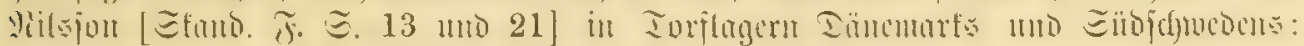
fübliches uno jüböftlidjes Sdjonten, Ditgotlano 2 .

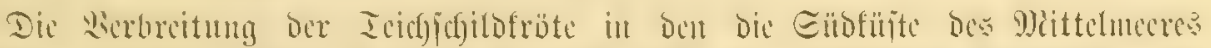

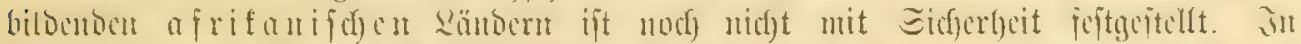

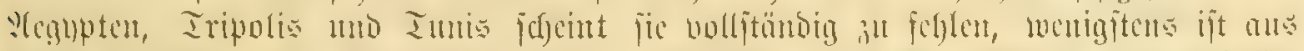

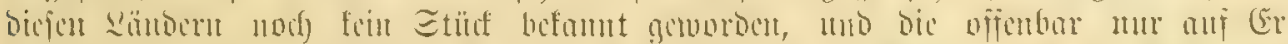

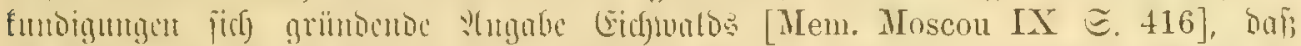

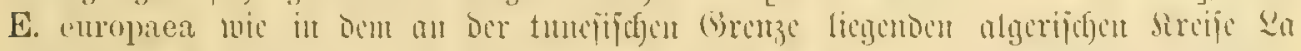

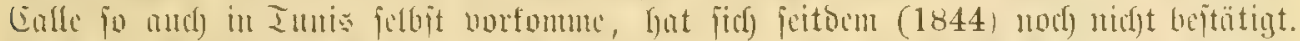

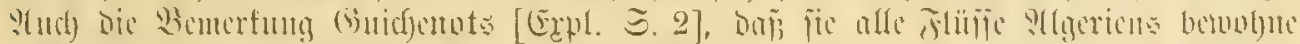

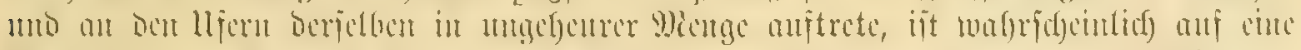

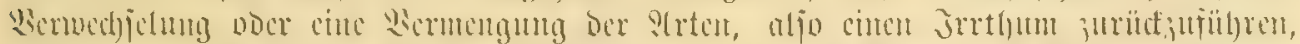

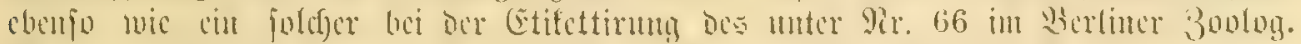

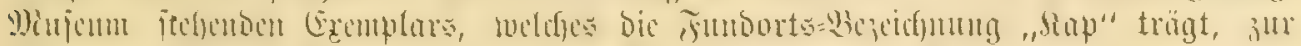

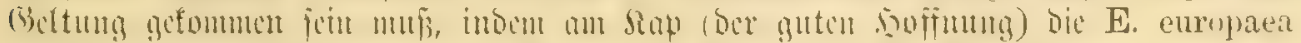

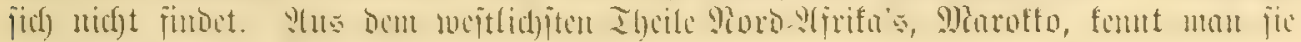
glcirlfoule atodi) midjt.

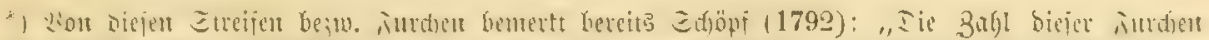

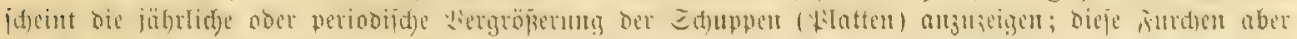

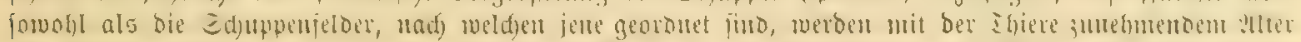

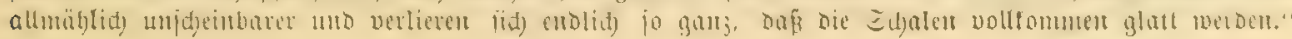


"illelmet Yänber.

แltpen:Gebict.

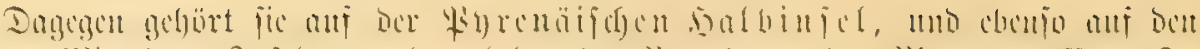

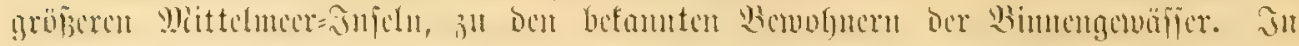

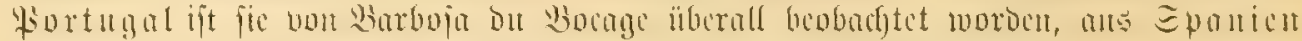

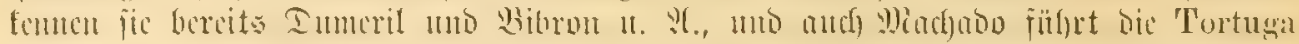

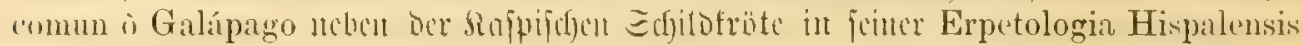

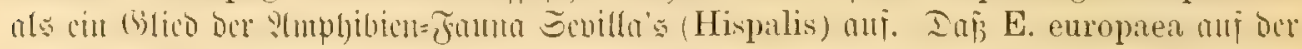

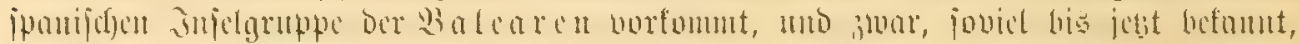

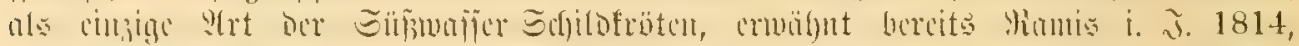

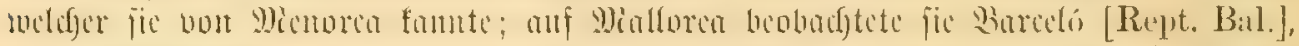

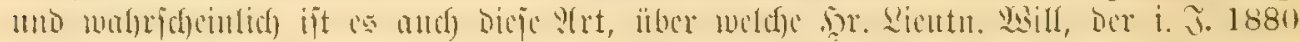

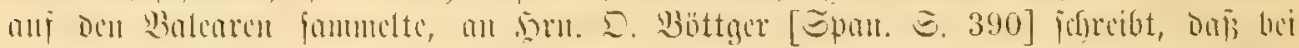

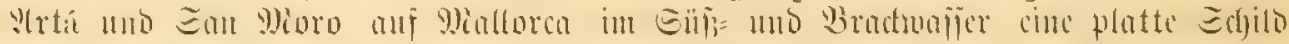

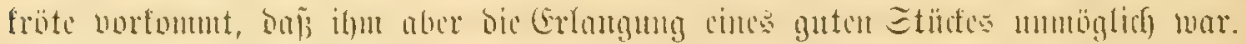

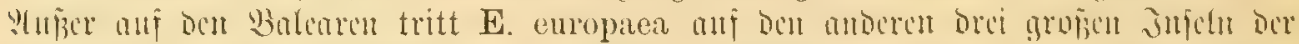

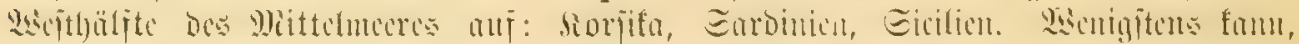

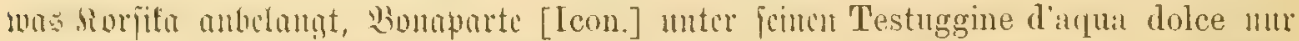

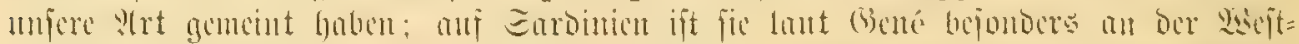

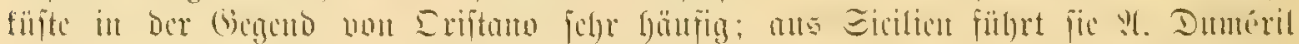

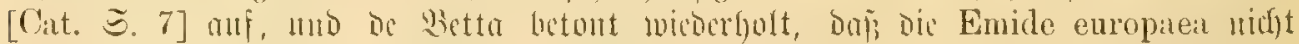

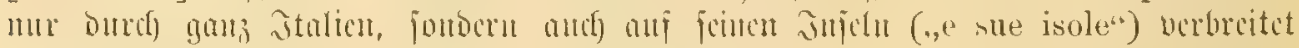

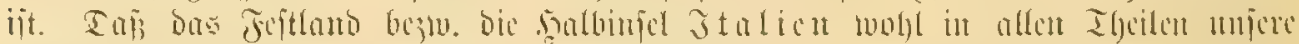

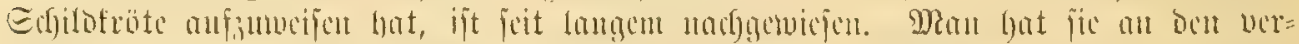

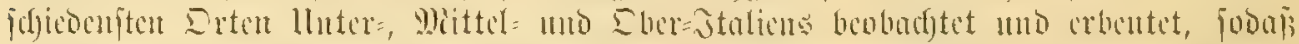

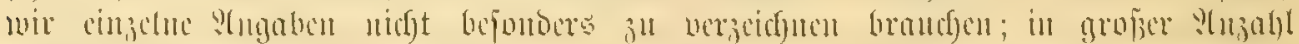

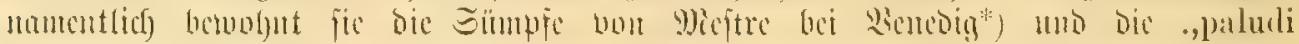
euganee del Padorano".

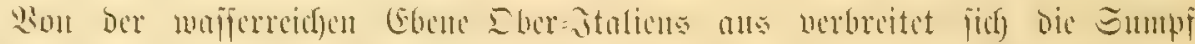

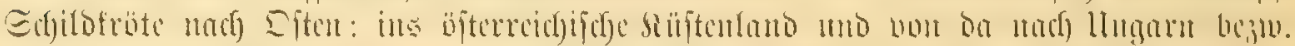

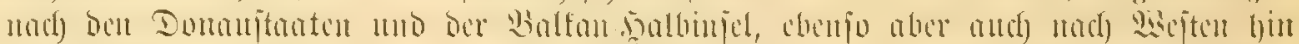

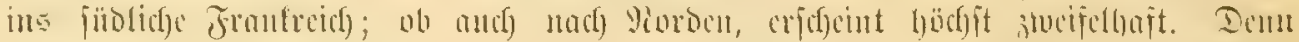

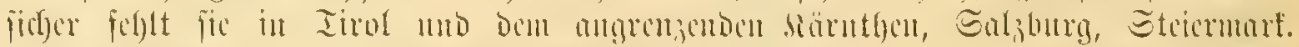

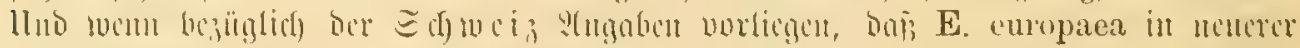

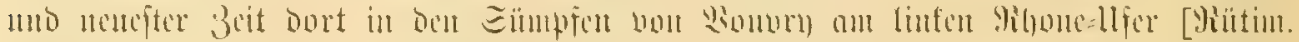

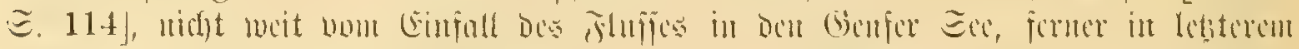

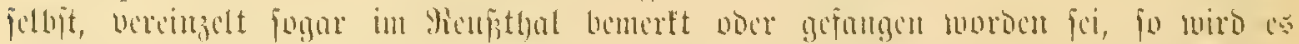

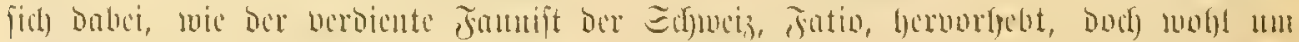

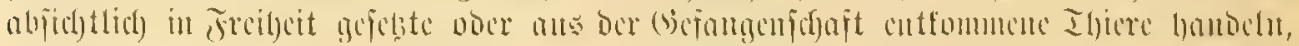

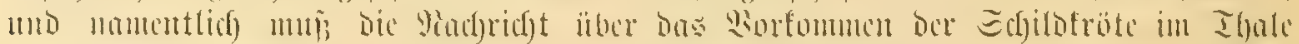

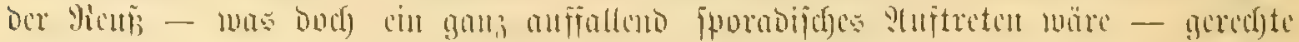

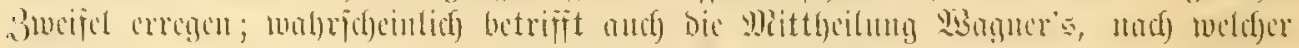

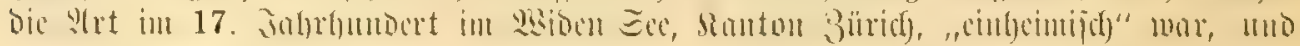

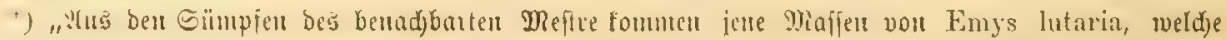

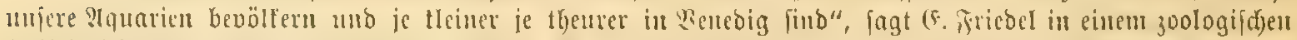

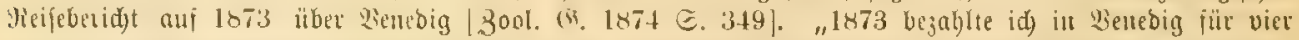

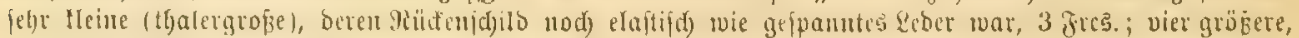

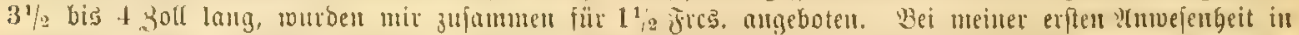

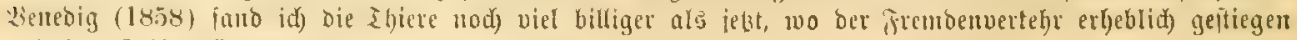
uno ber Sdailbfrötertyanbel von ber Stiefelpusern monopolifirt iff." 


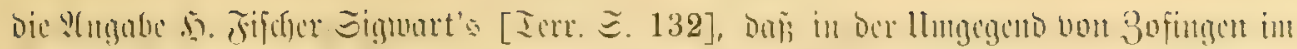

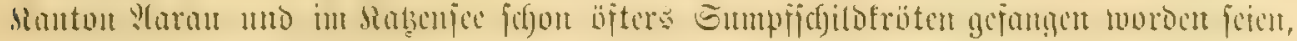

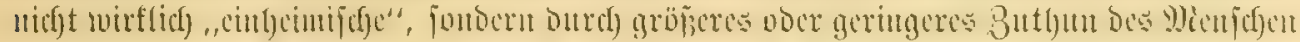

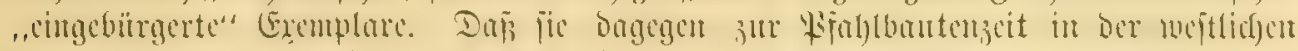

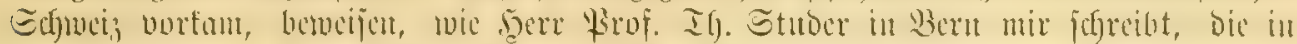

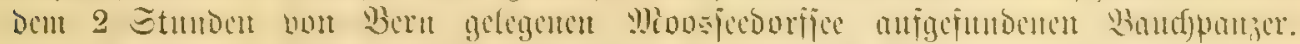

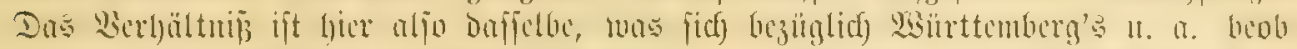

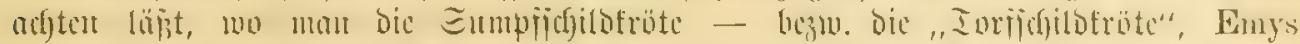

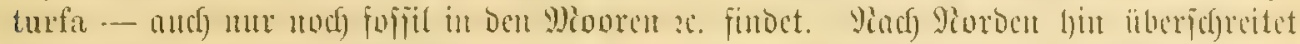

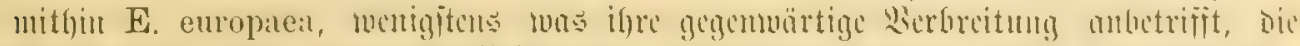

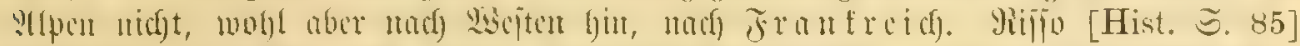

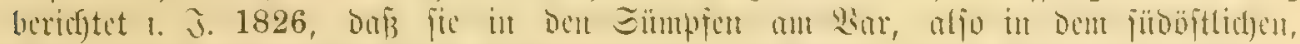

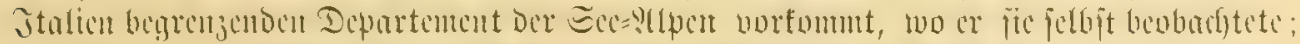

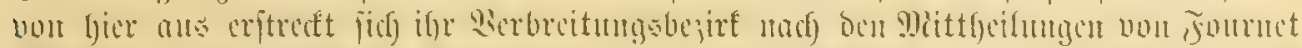

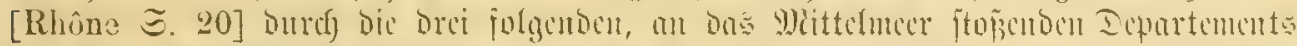

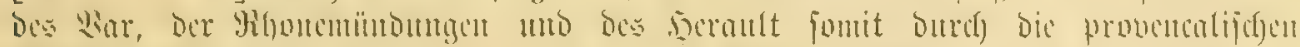

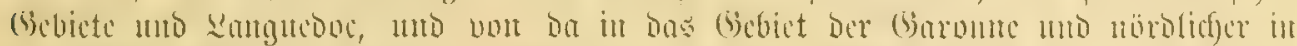

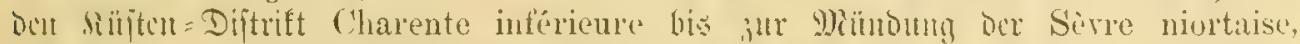

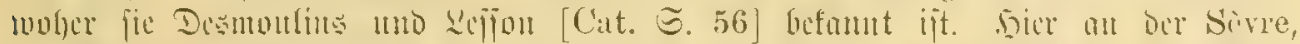

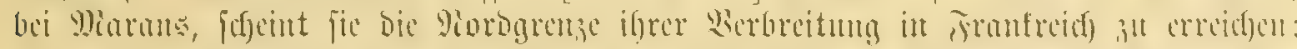

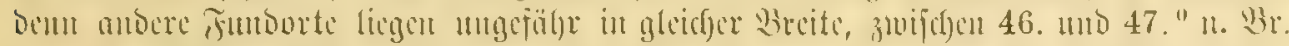

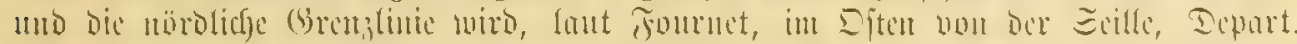

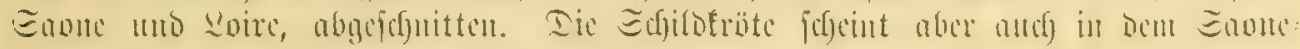

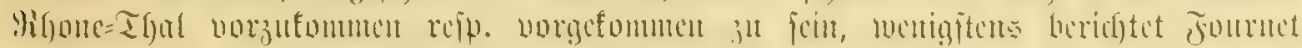

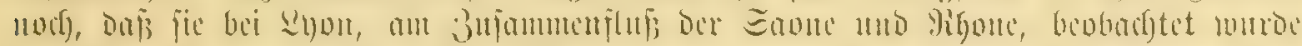

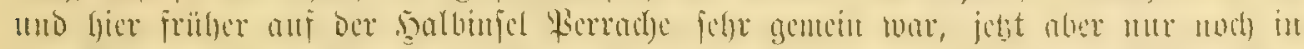

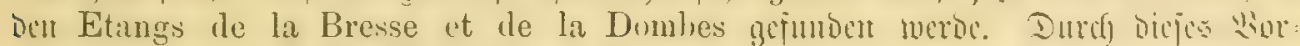

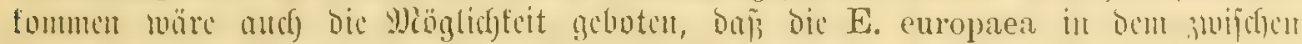

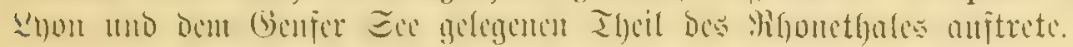

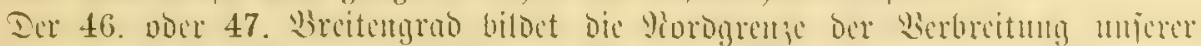

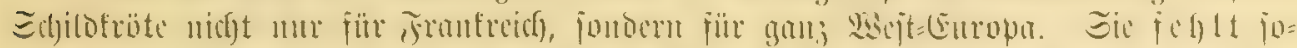

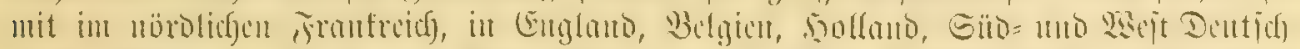

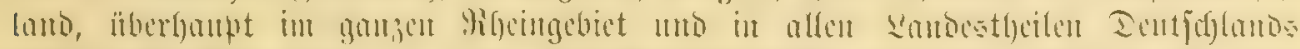

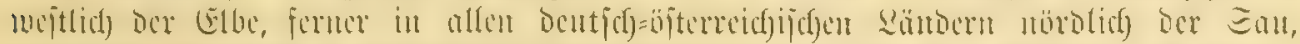

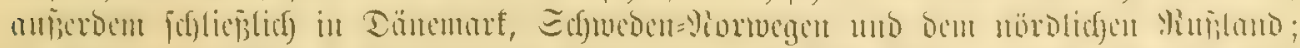

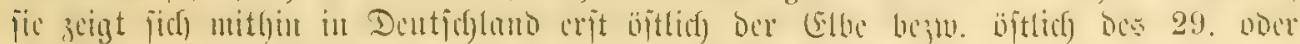

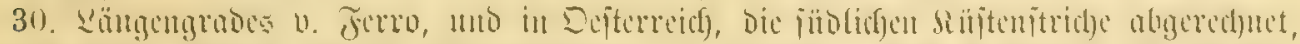

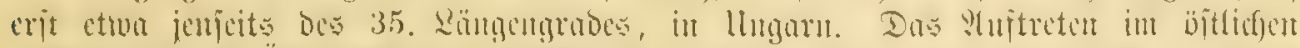

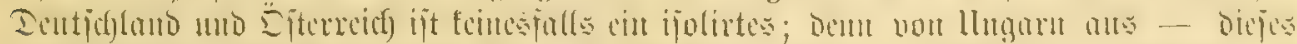

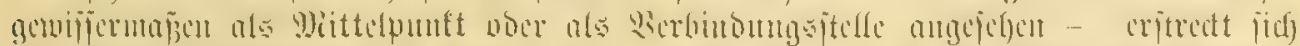

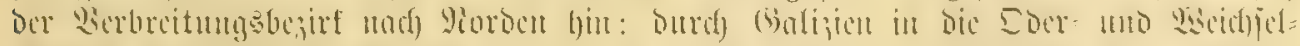

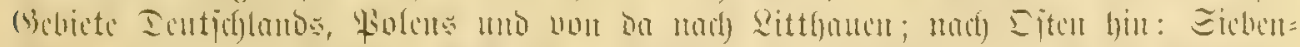

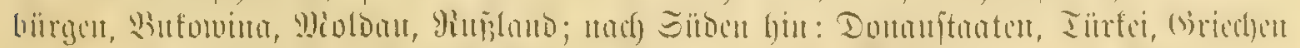

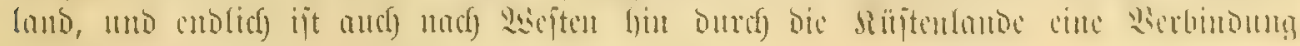
mit Dem jofilofrötentercfen Doer= Stalicu hergeftellt.

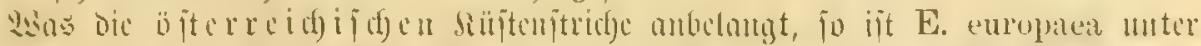

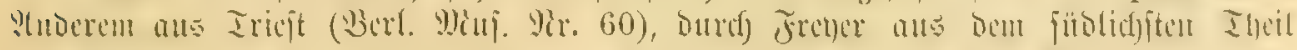

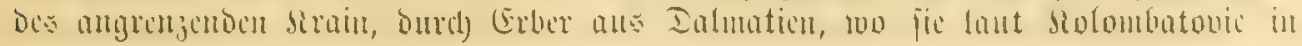




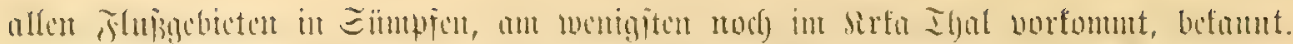

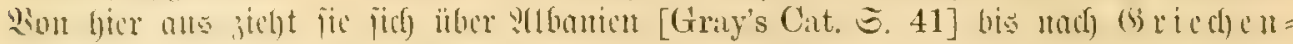

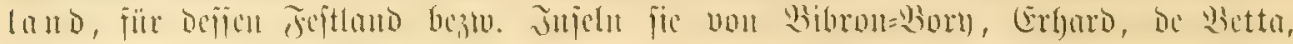

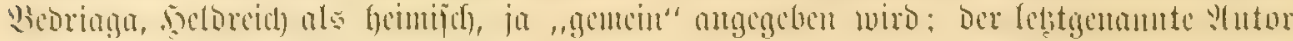

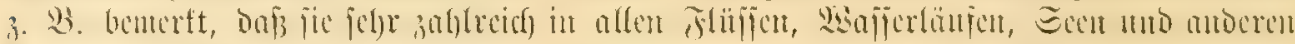

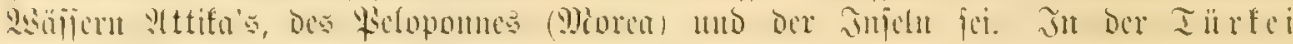

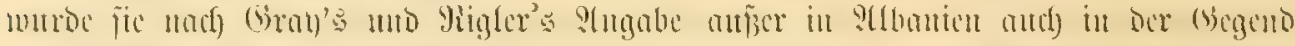

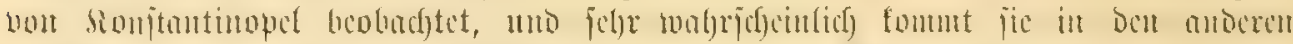

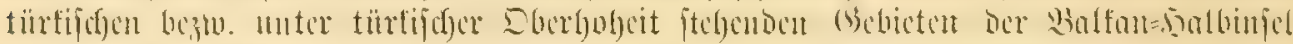

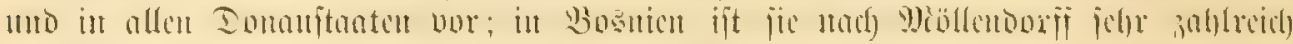

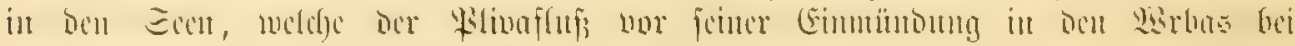

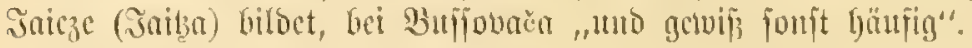

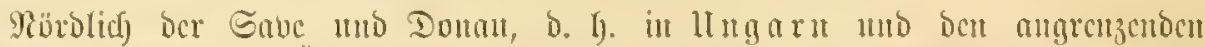

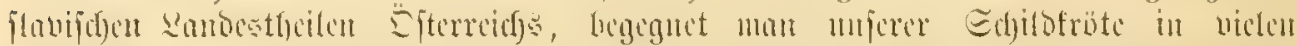

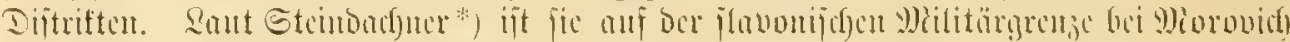

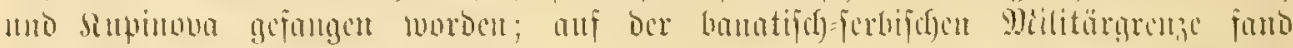

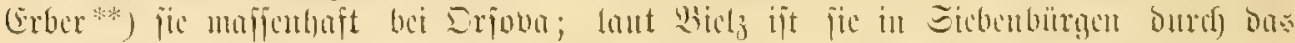

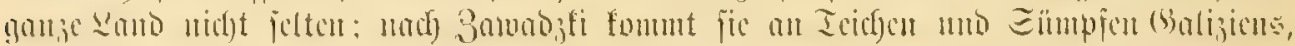

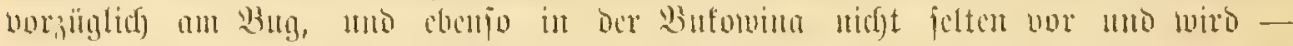

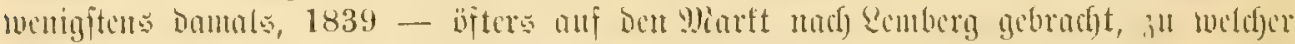

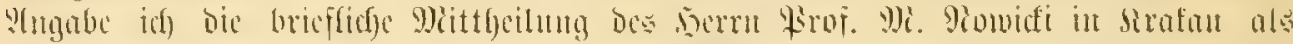

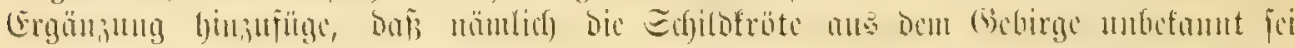

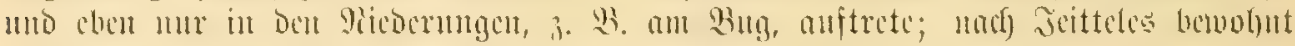

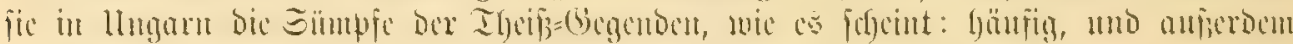

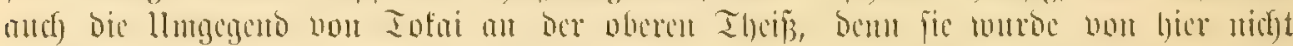

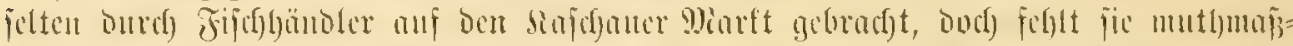

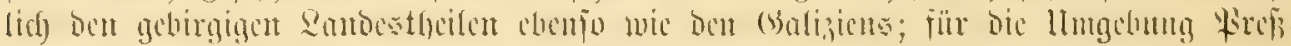

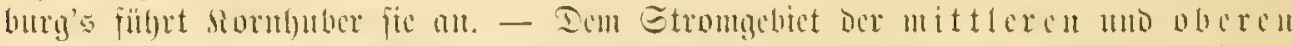

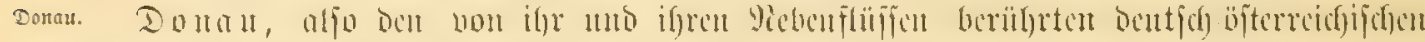

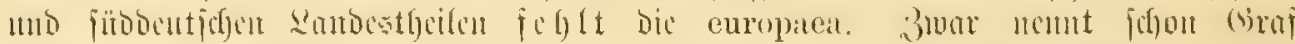

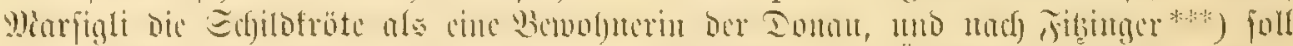

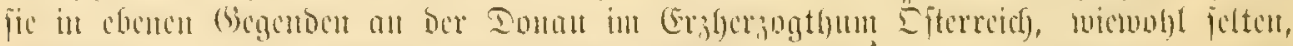

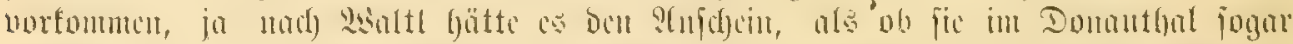

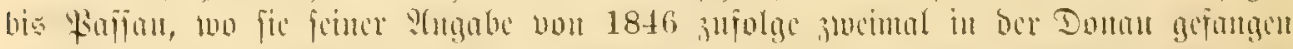

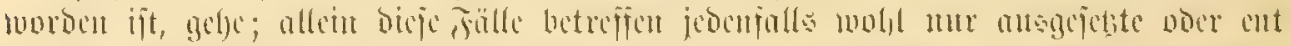

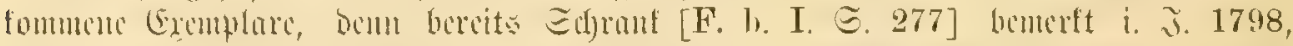

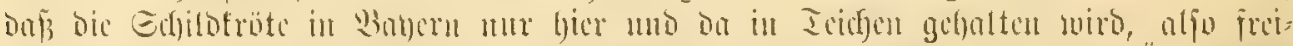

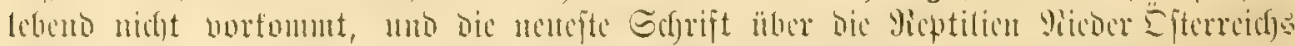

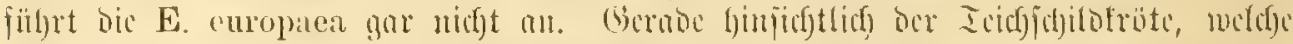

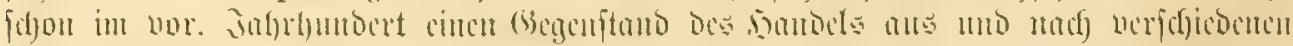

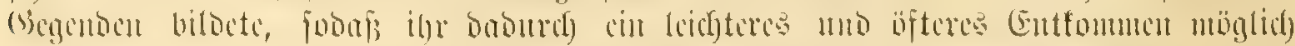

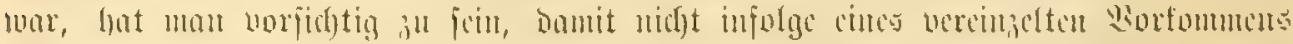

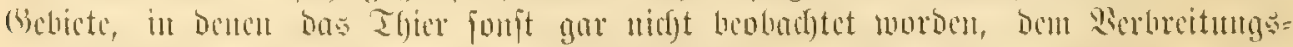

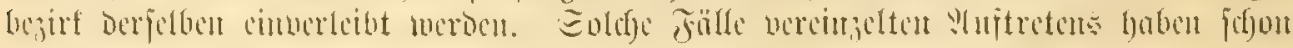




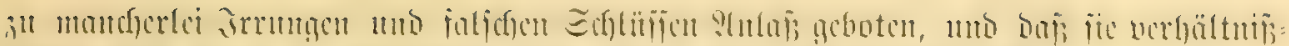

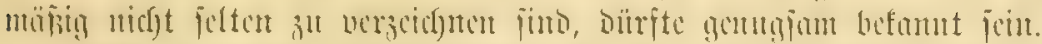

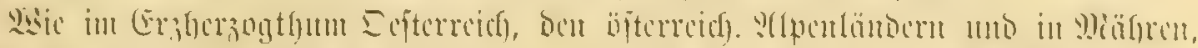

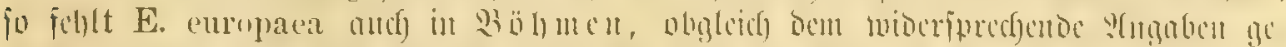

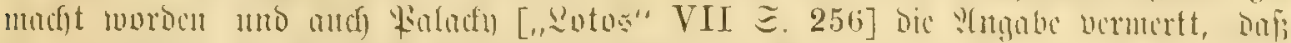

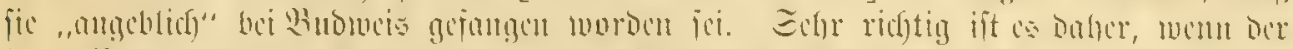
lelite Bearbiter Dex

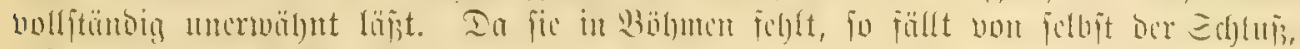

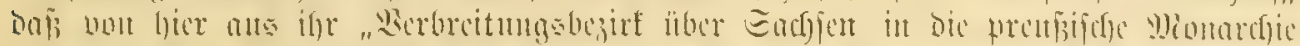

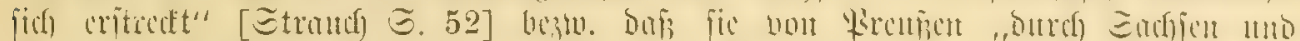

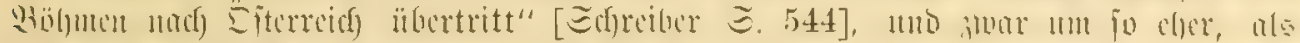

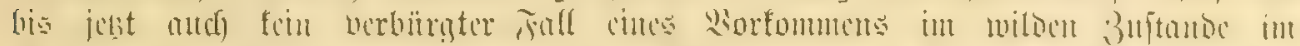

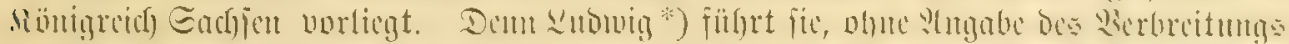

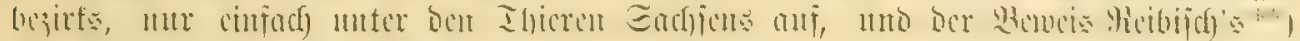

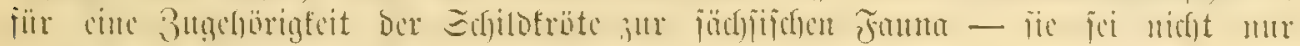

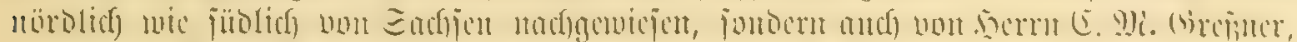

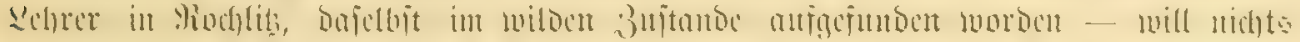

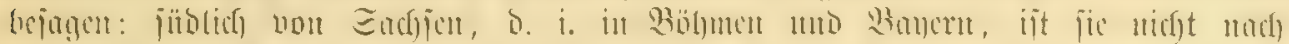

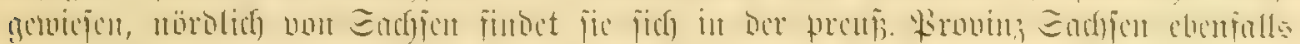

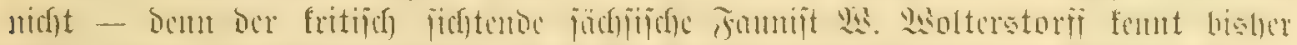

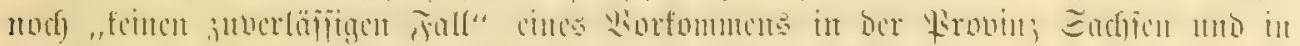

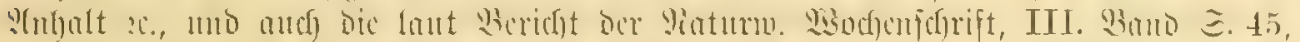

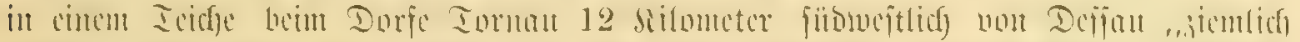

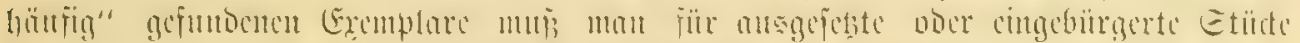

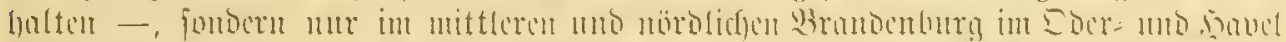

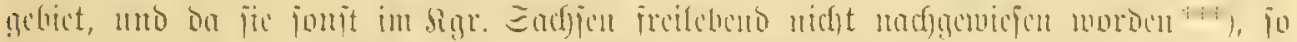

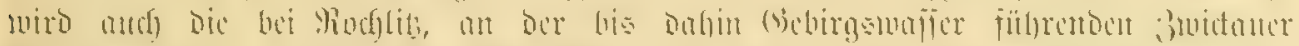

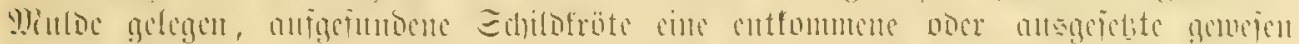

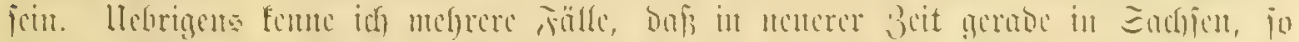

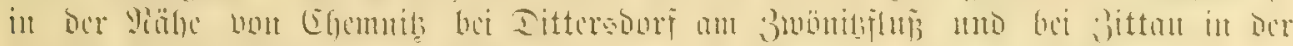

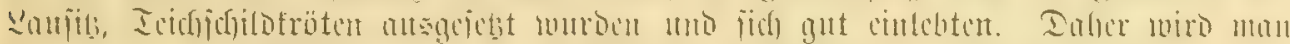

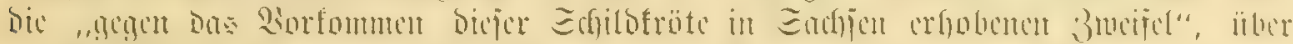

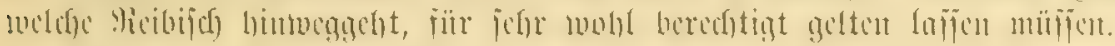

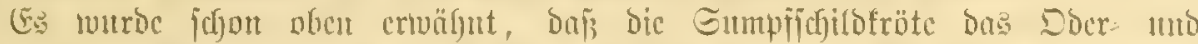

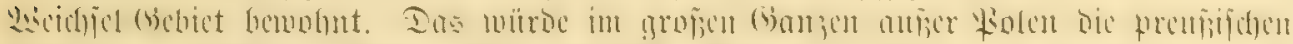

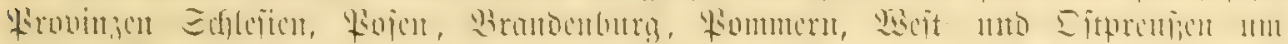

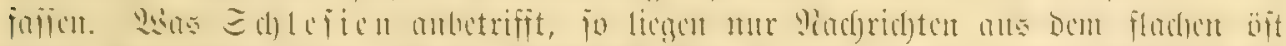

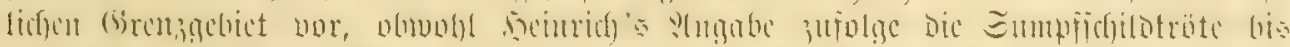

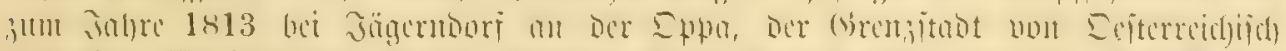

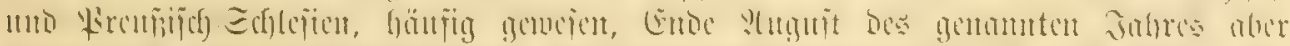

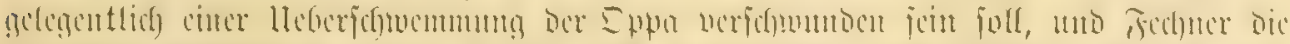

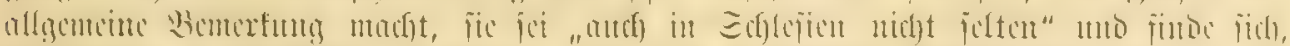

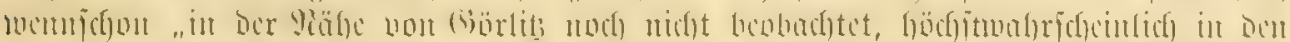

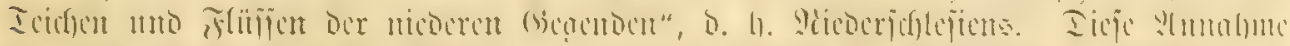

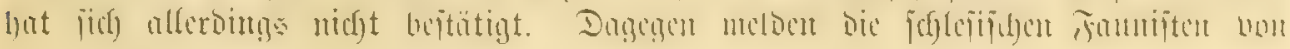

*) Initia Faunae Saxonicae p. 12. - ***) Siis, Dreşben 1866, S. 114. - ***) In ber Spejial=

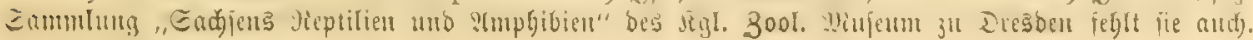




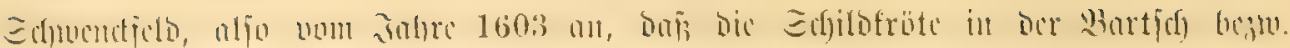

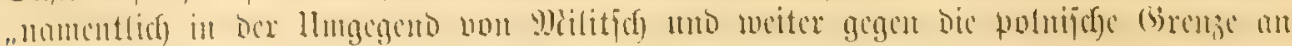

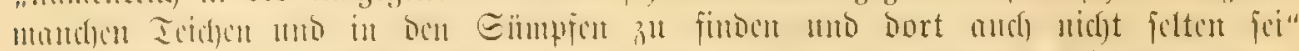

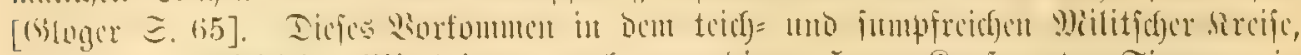

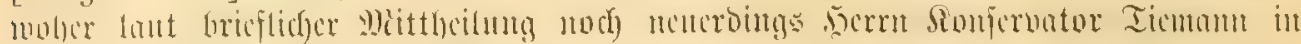

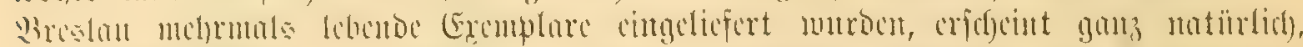

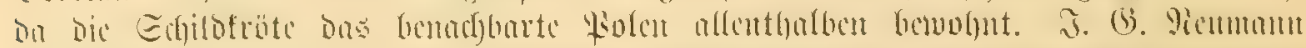

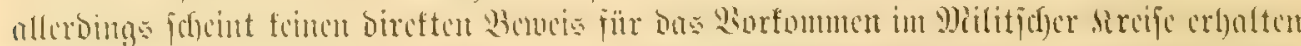

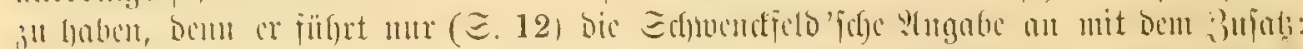

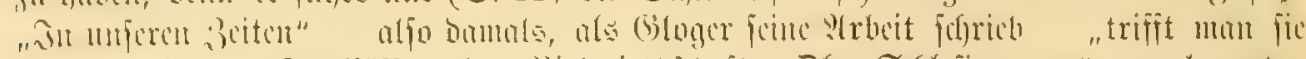

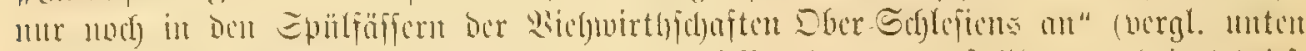

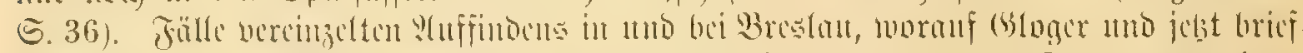

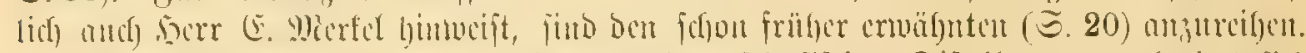

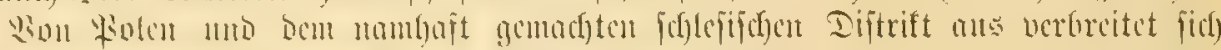

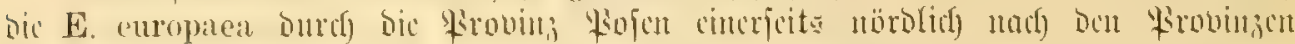

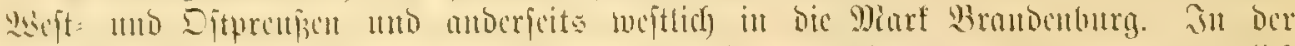

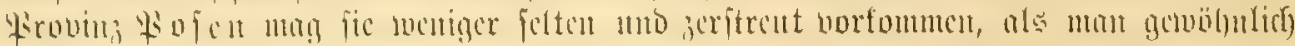

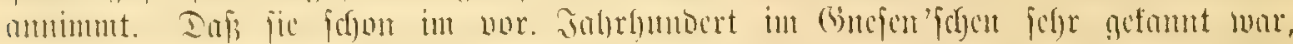

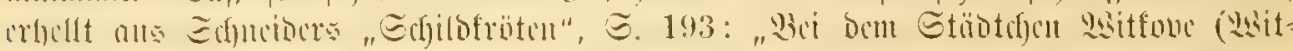

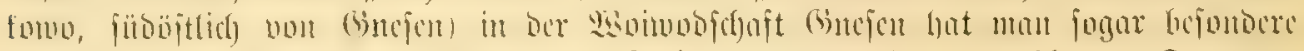

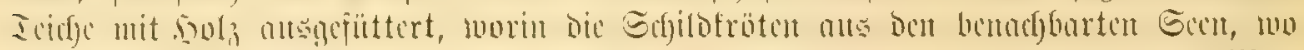

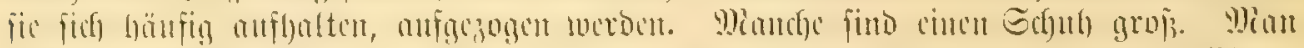

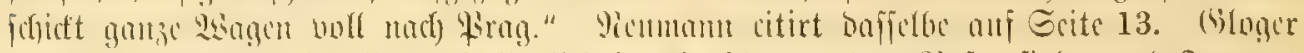

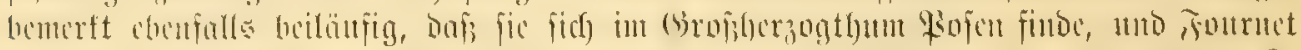

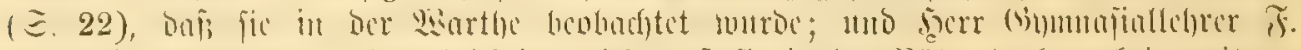

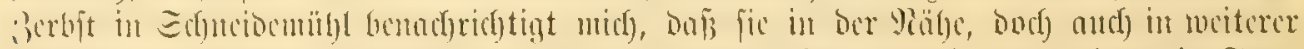

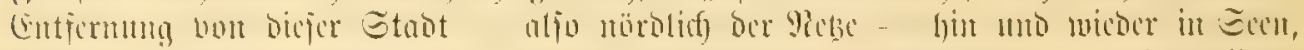

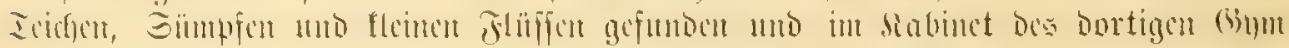

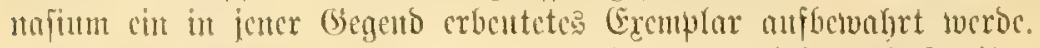

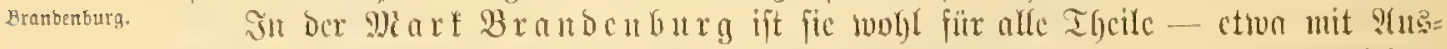

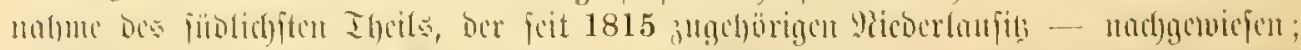

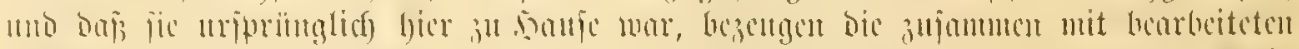

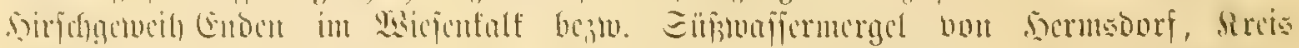

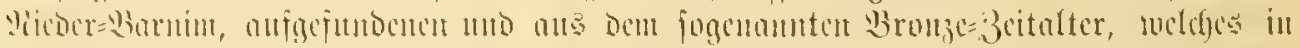

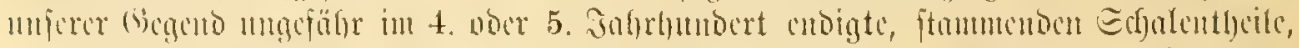

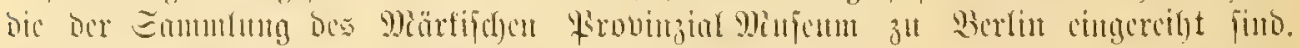

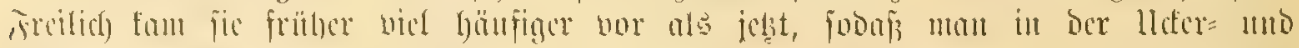

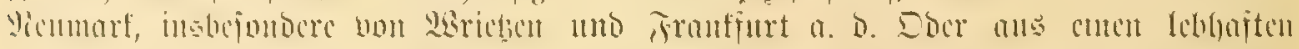

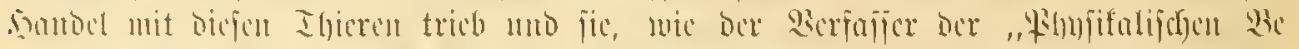

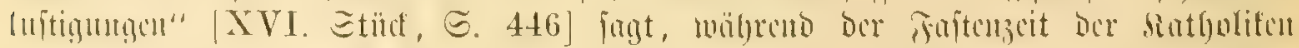

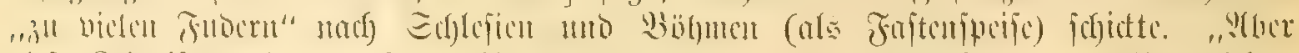

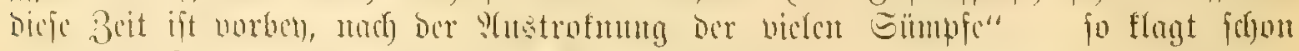

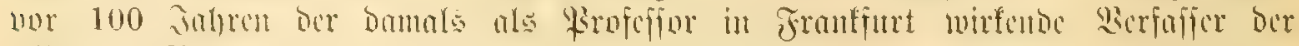

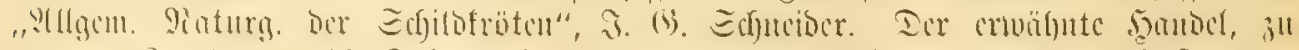

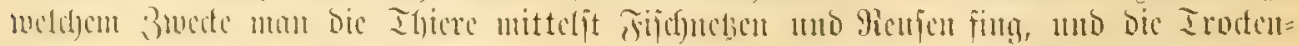

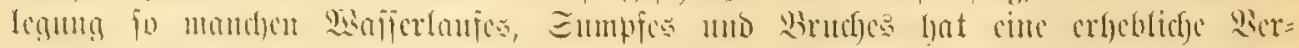

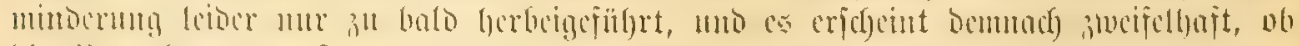

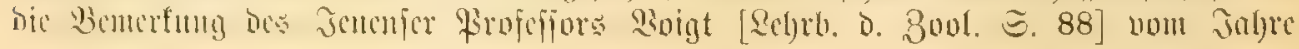




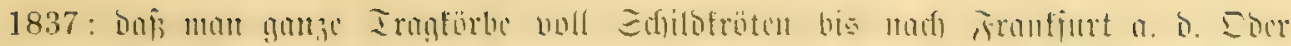

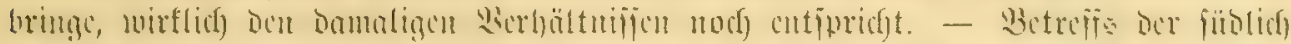

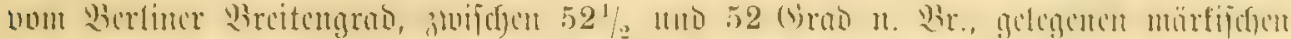

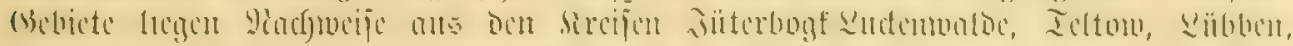

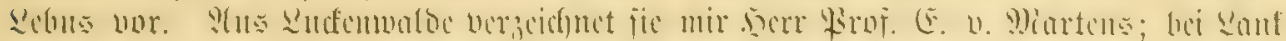

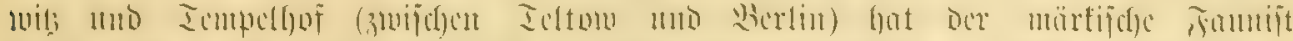

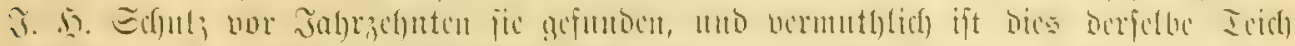

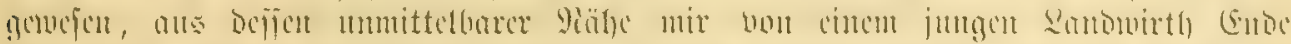

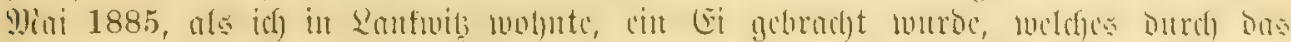

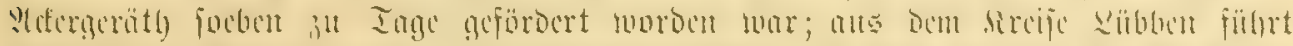

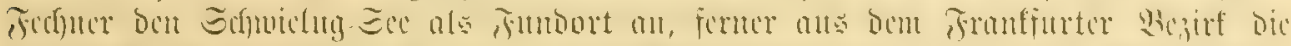

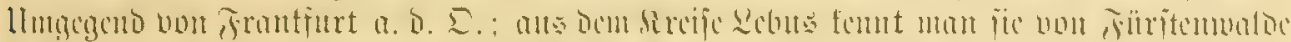

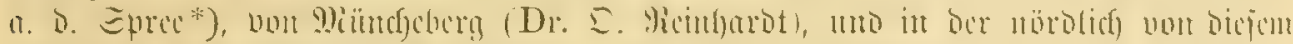

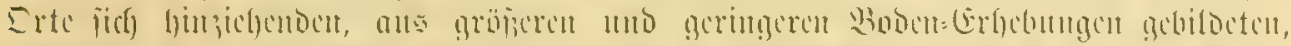

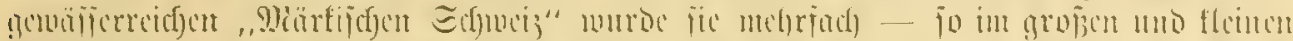

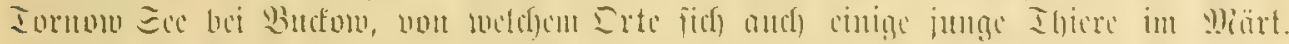
Whajem ;

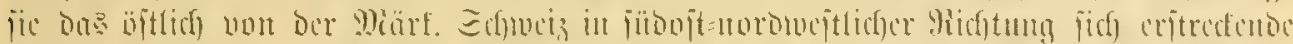

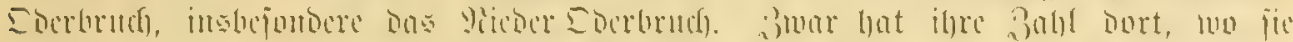

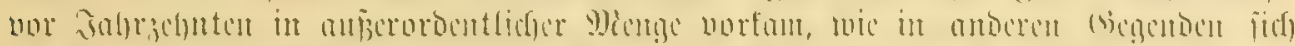

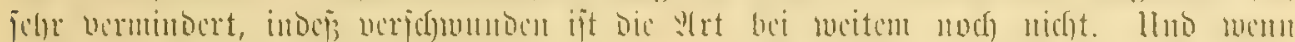

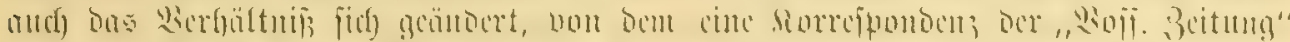

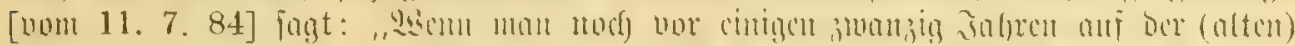

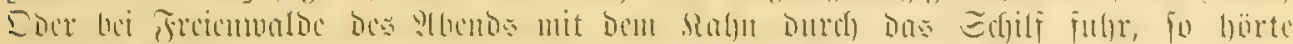

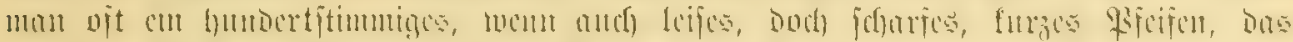

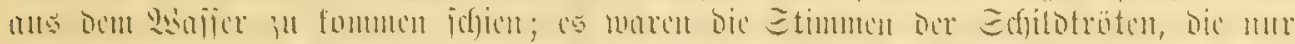

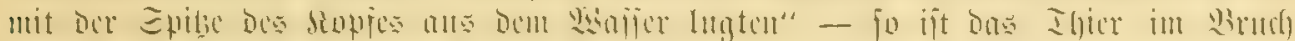

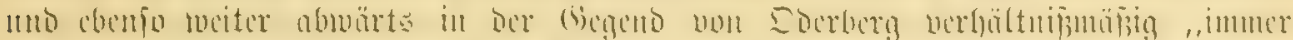

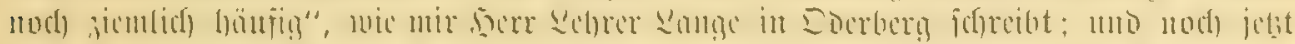

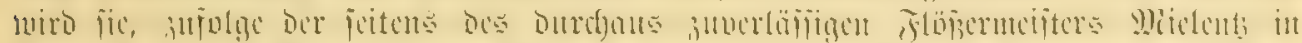

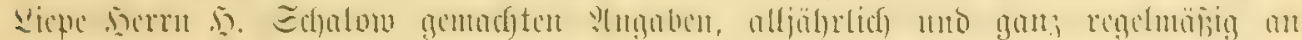

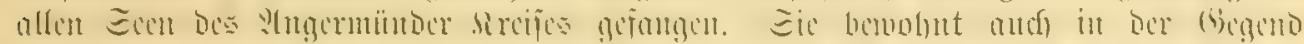

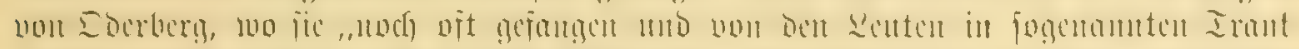

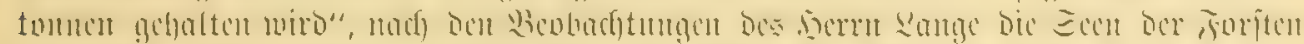

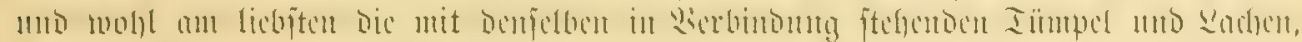

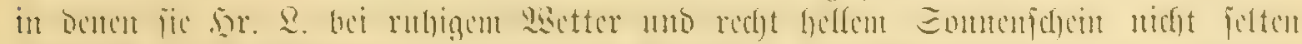

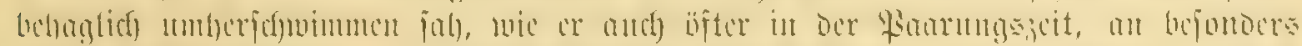

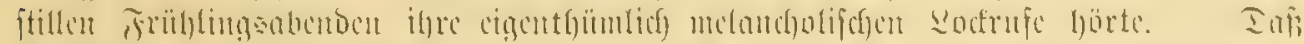

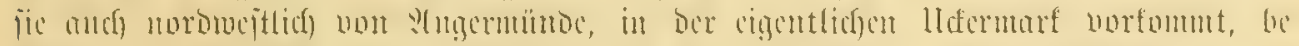

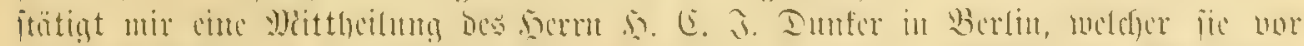

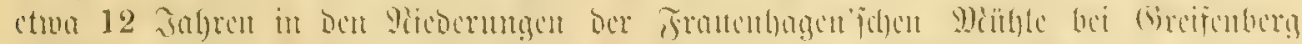

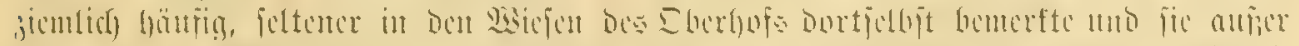

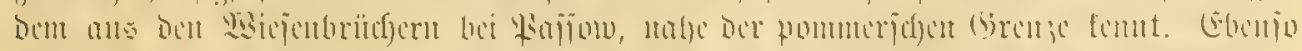

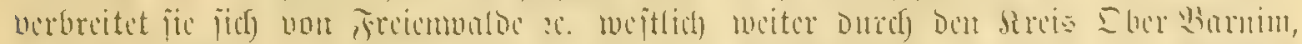

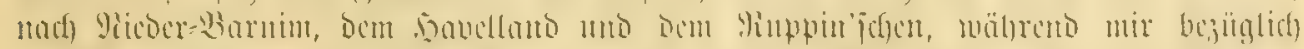

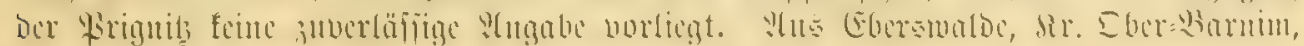




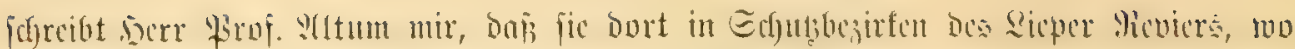

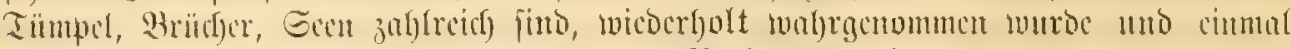

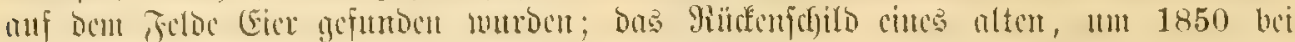

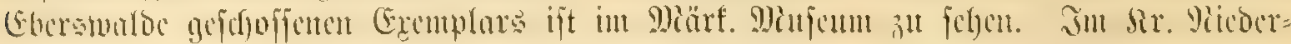
BHarnim findet fic fid) in Sicpntie:

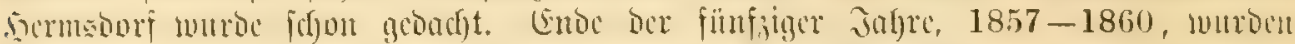

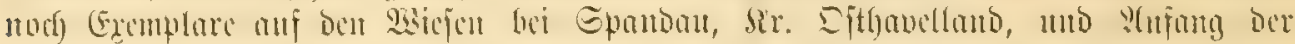

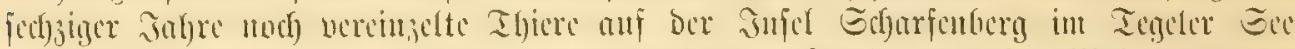

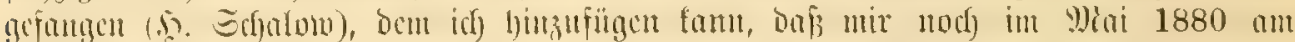

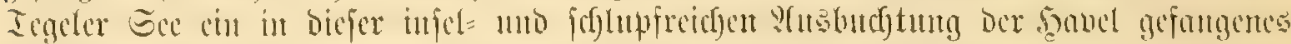

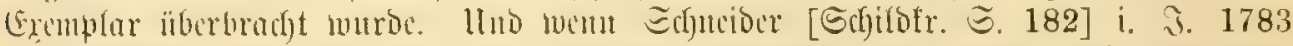

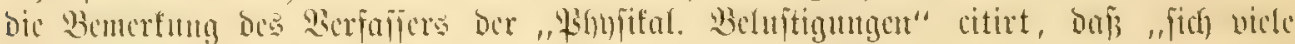

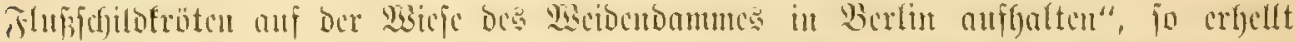

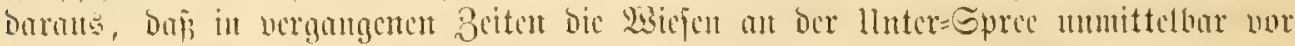

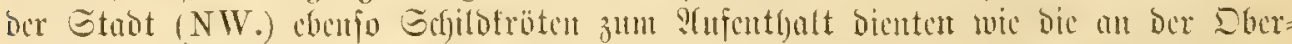

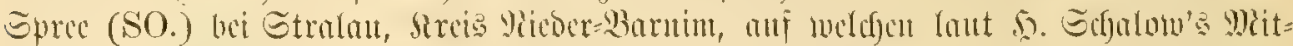

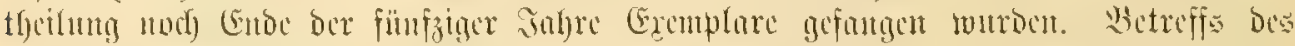

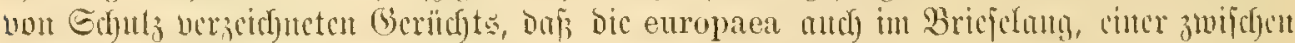

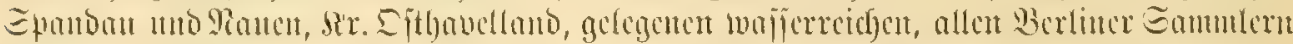

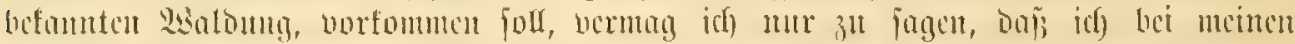

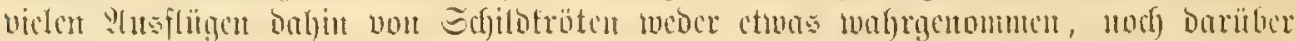

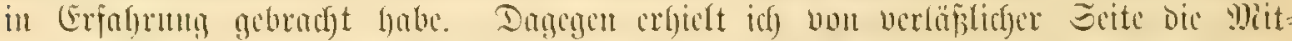

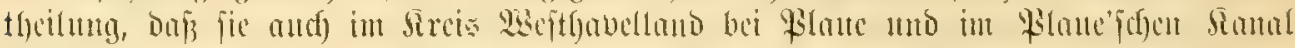

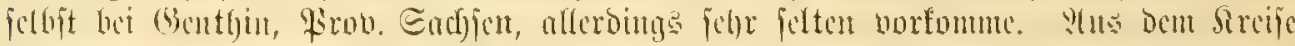

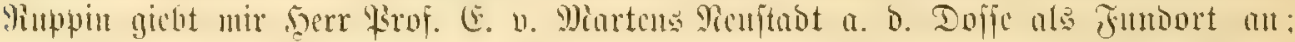

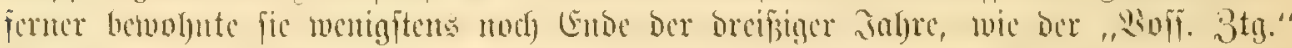

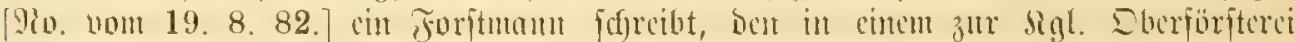

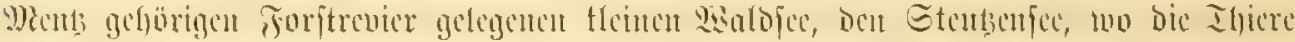

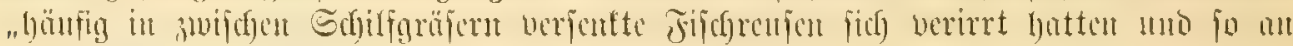
Dos Iagęlicht gefobert whtrocn".

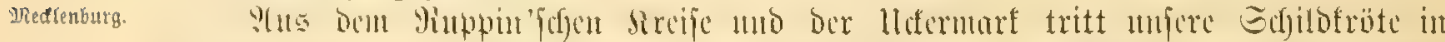

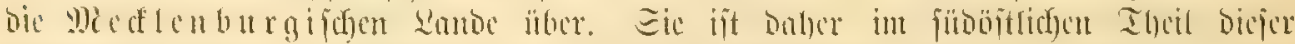

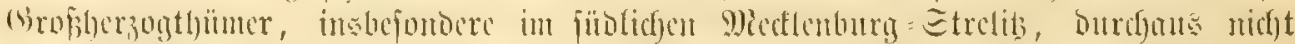

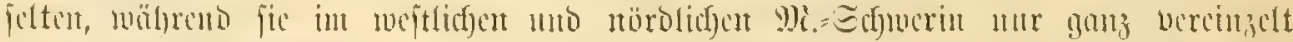

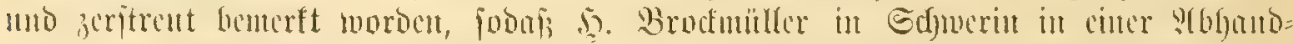

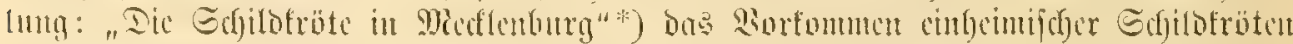

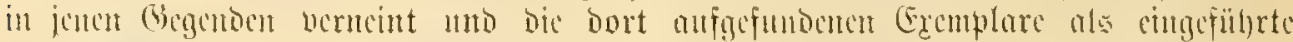

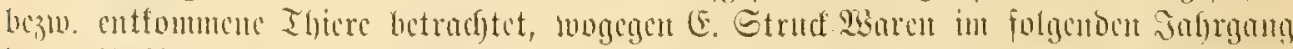

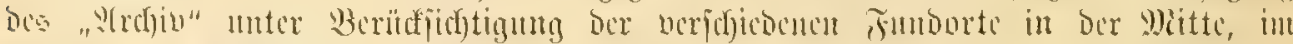

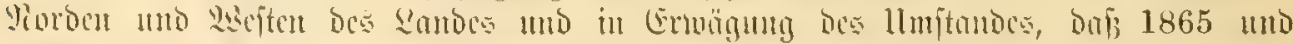

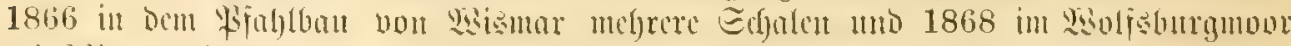
be

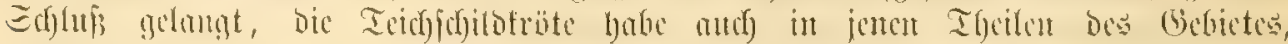

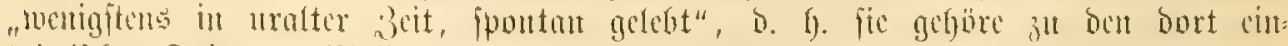

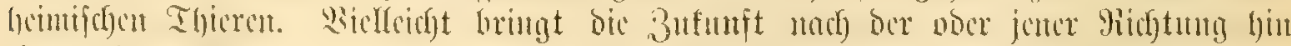

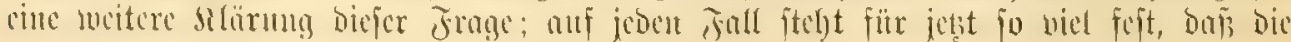

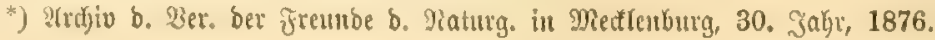




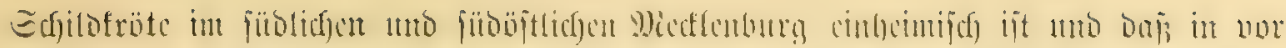

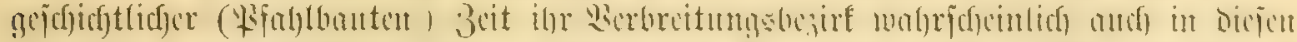

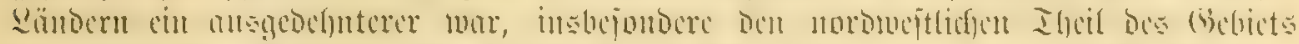

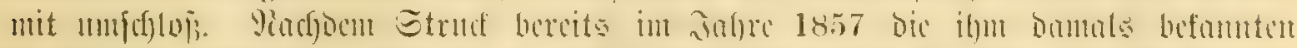

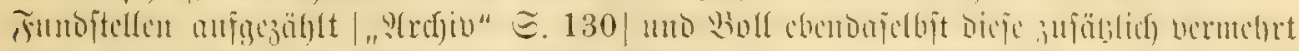

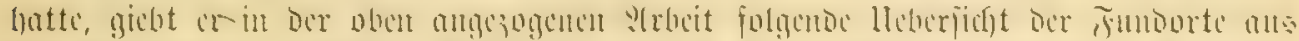

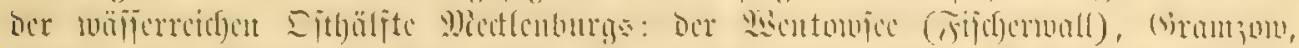

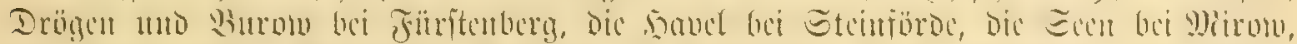

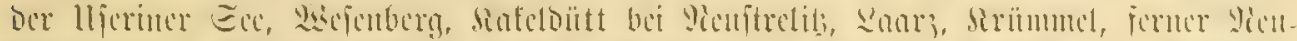

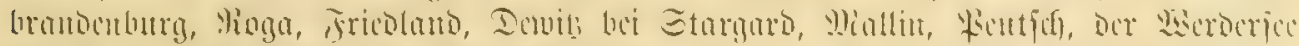

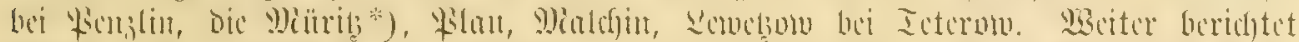

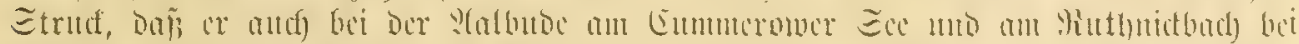

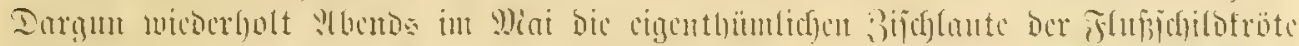

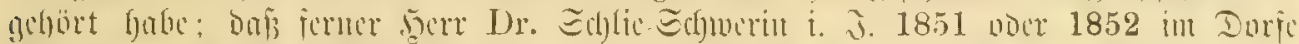

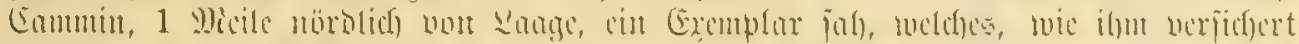

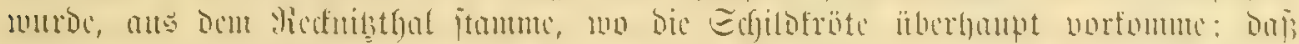

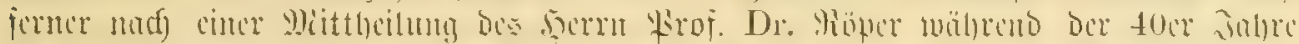

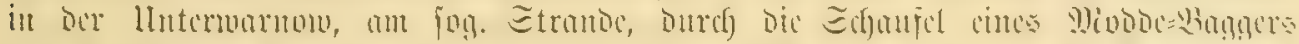

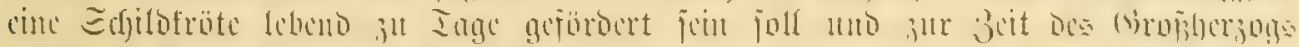

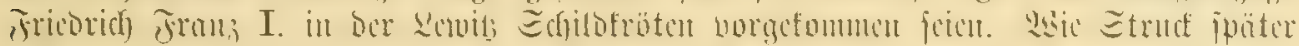

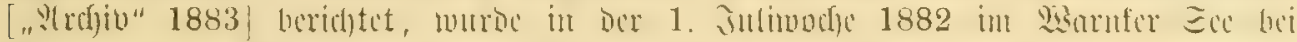

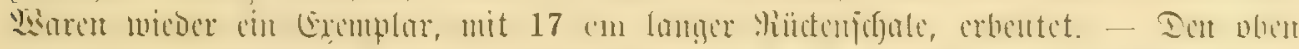

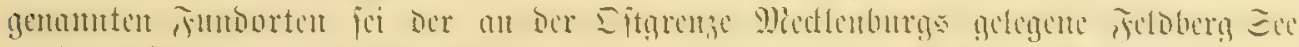

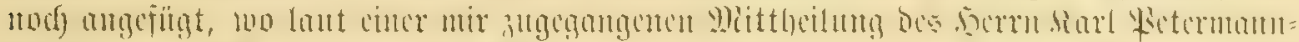

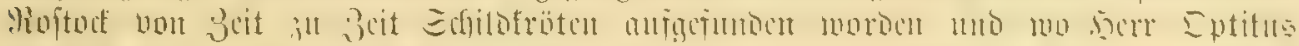

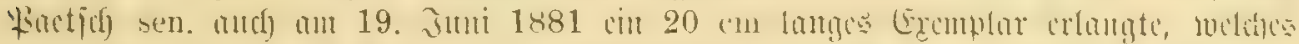

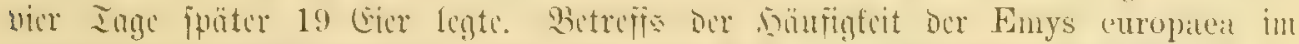

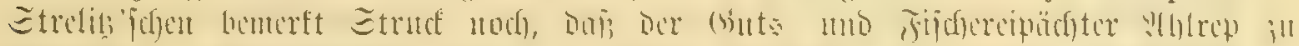

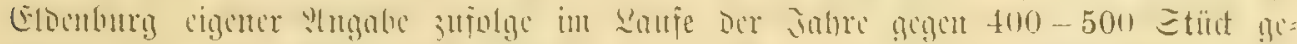

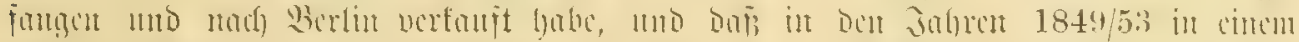

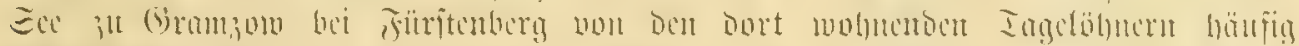

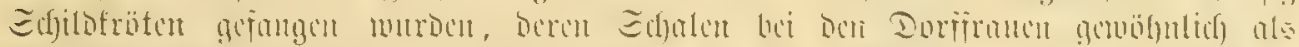

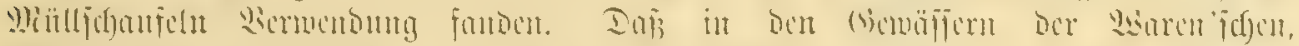

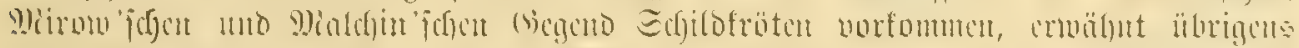

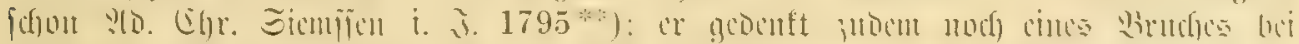

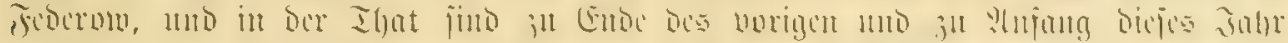

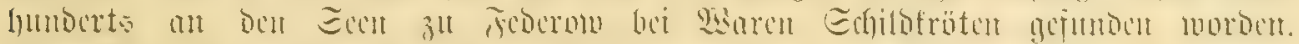

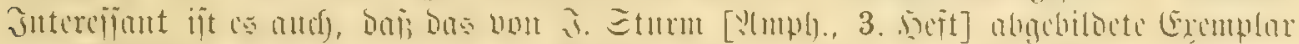

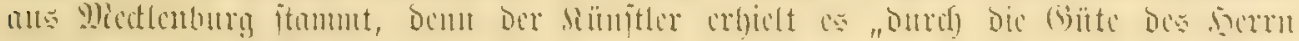

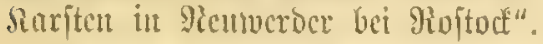

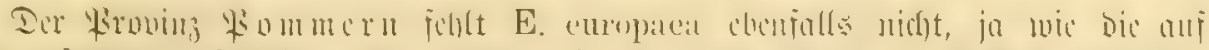

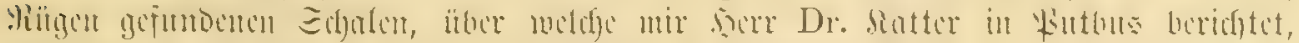

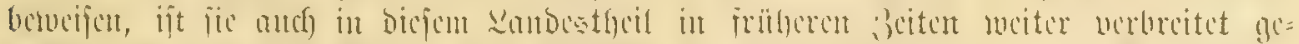

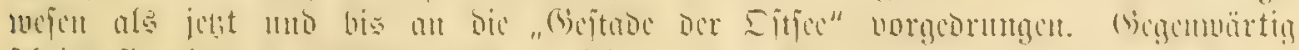

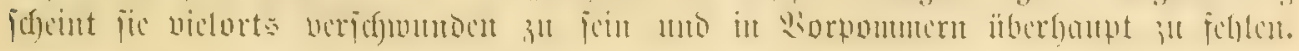

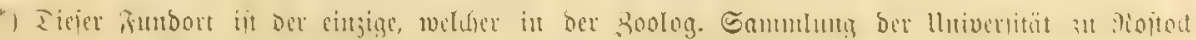

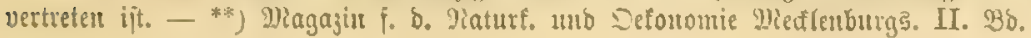




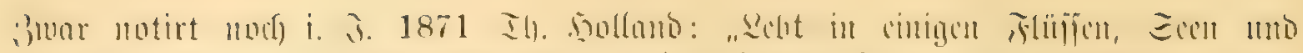
Eimpfen

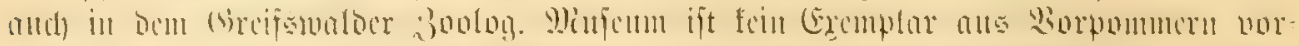

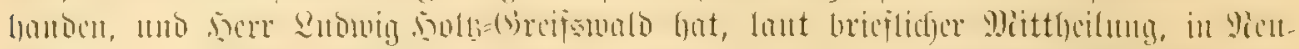

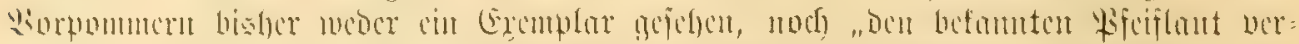

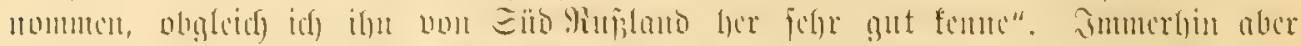
man jic ficl) in manden (4)

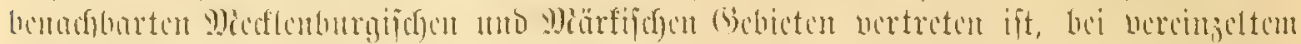

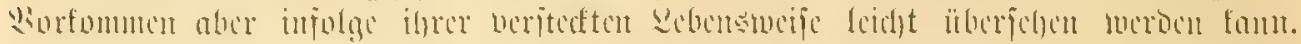

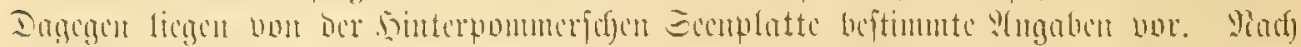

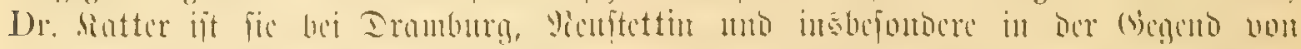

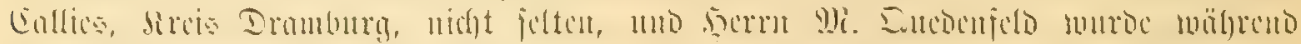

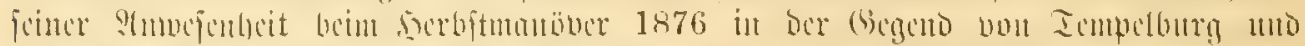

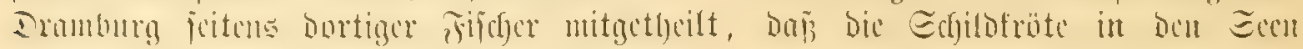
Dojelojt ficten mo cingclu vorfomme.

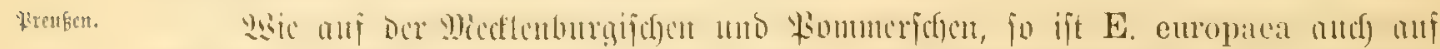

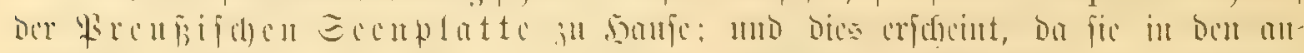

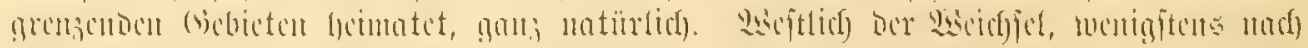

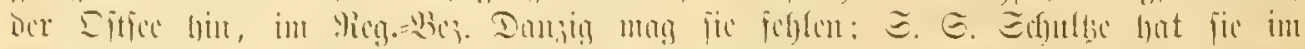

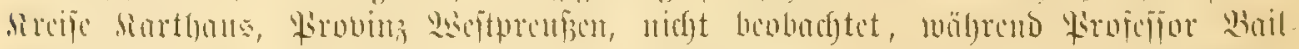

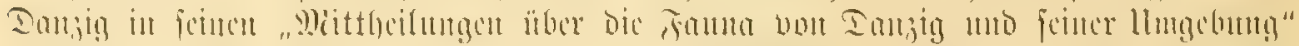

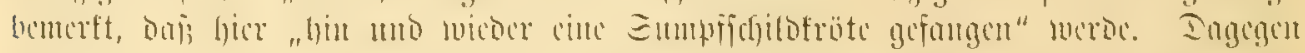

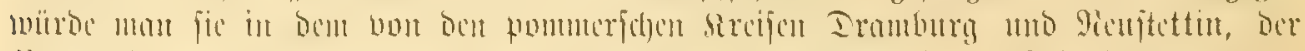

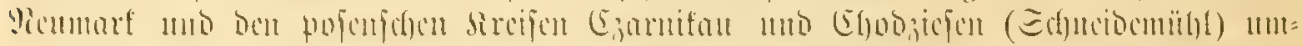

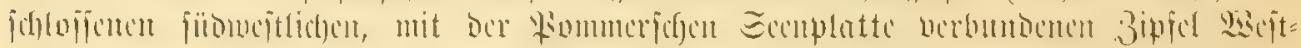

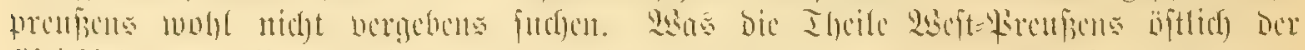

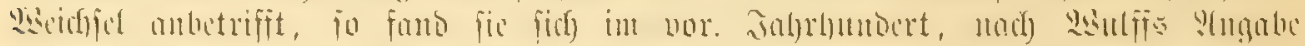

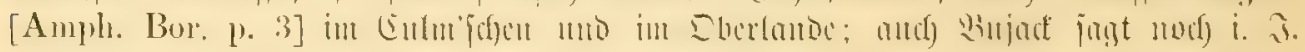

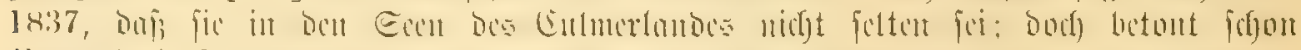

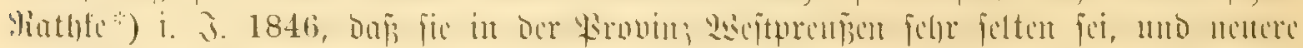

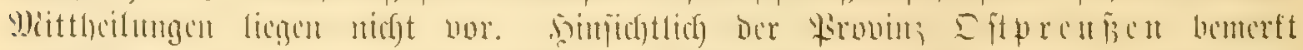

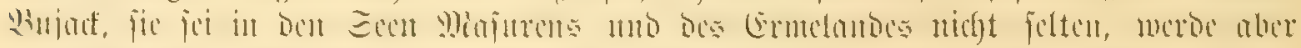

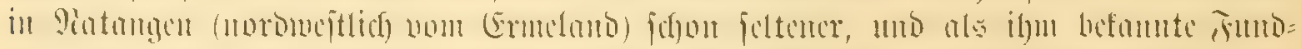

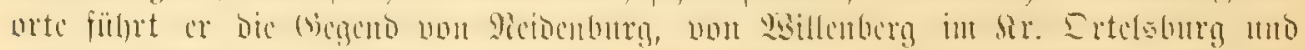

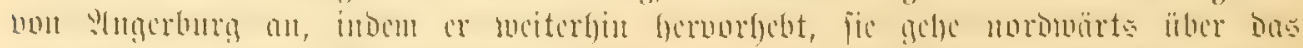

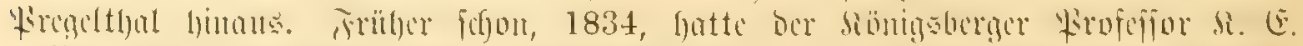

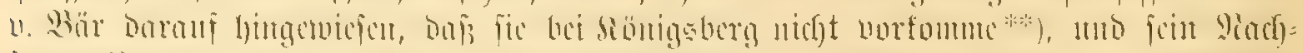

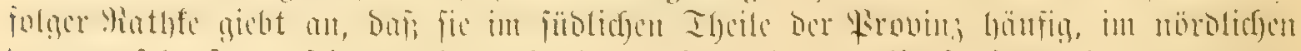

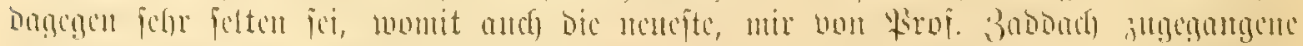

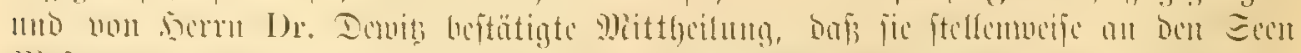

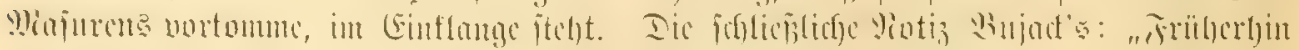

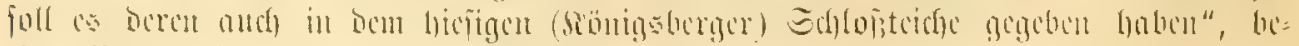
jicht ficf wobl uแt atf gefoge Exemplare.

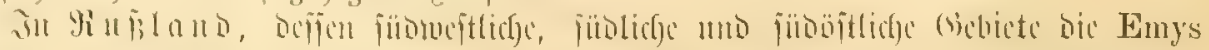

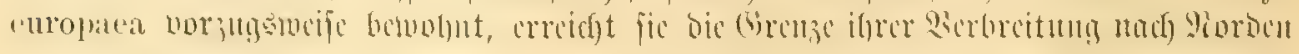

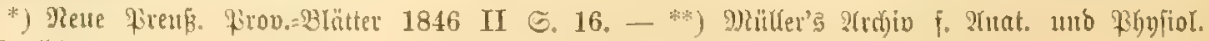




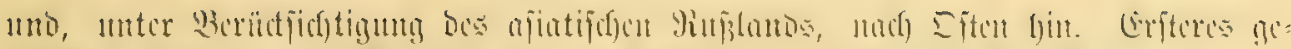

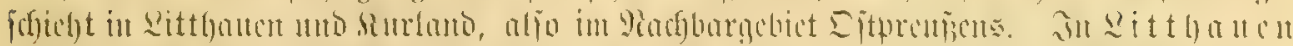

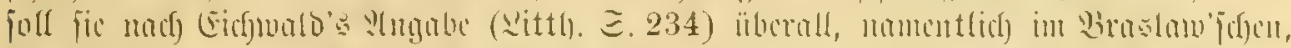

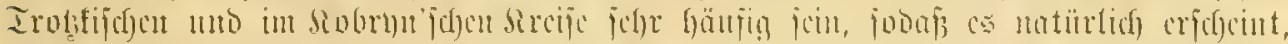

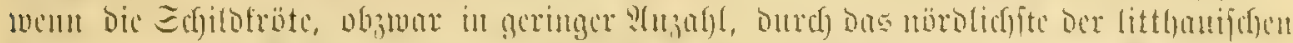

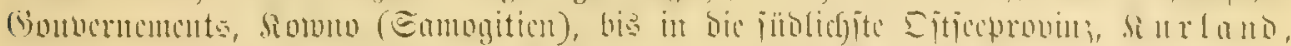

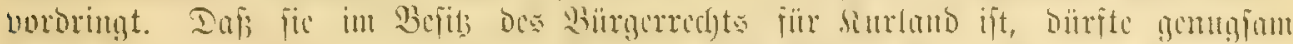

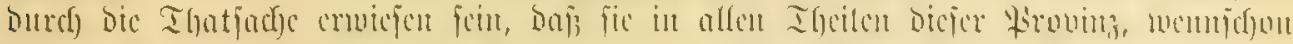

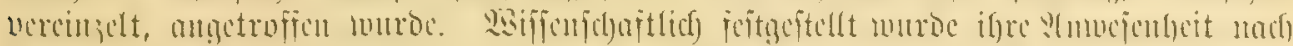

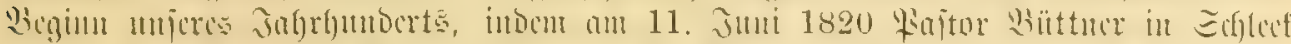

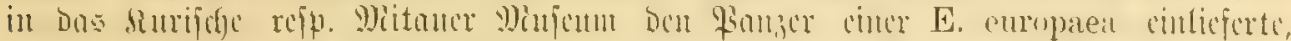

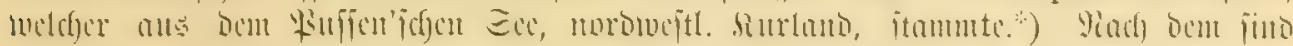

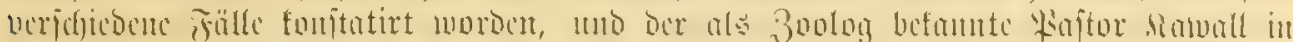

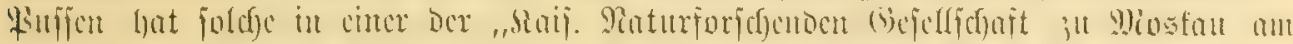

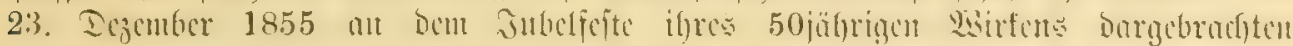

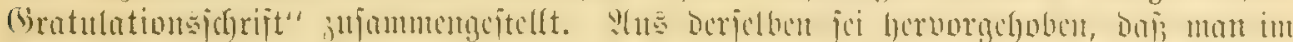

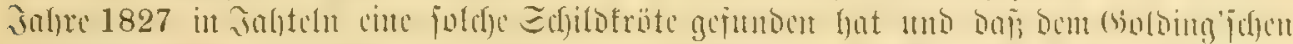

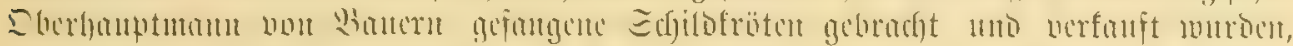

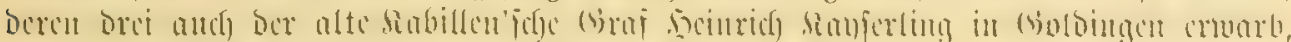

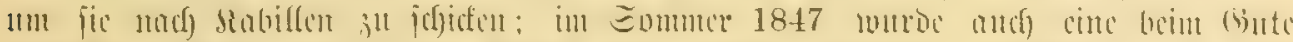

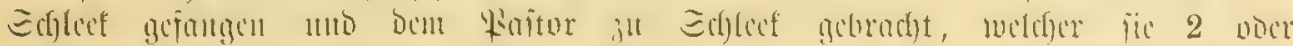

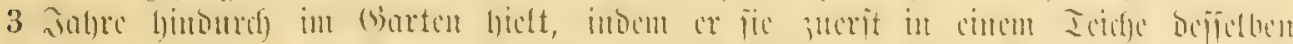

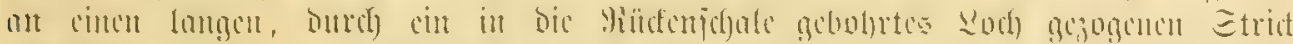

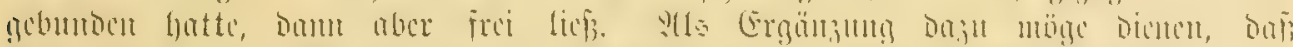

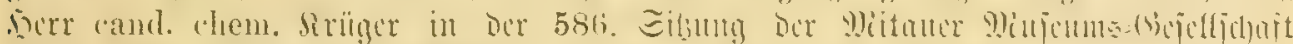

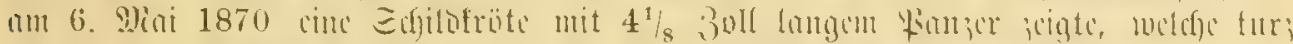

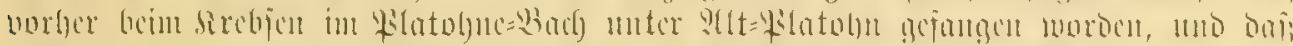

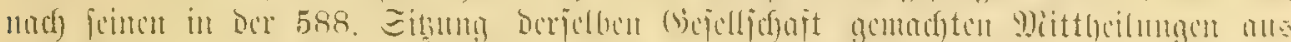

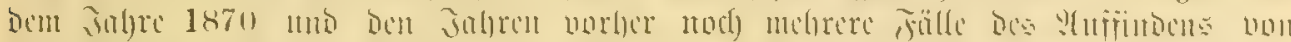

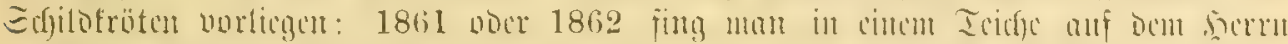

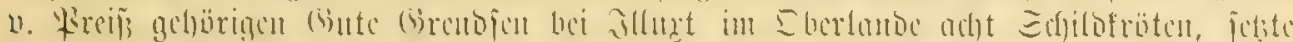

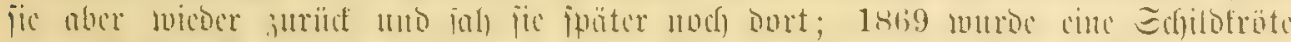

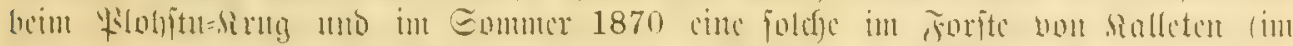

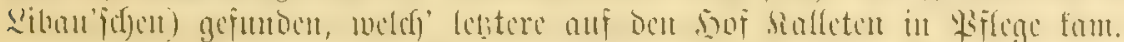

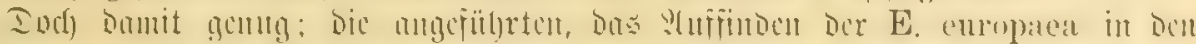

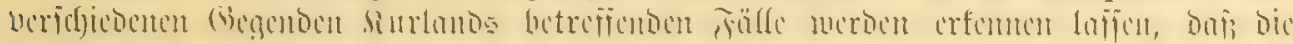

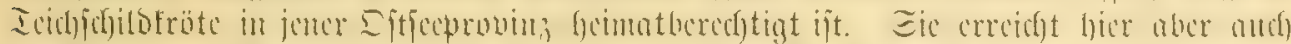

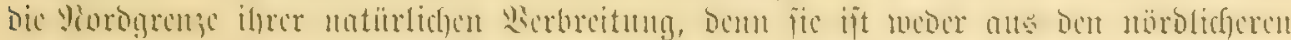

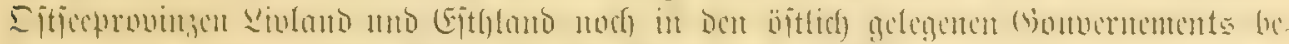

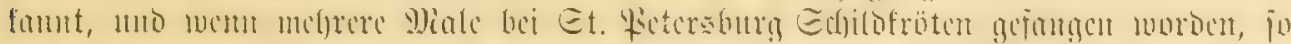

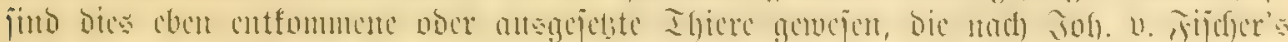

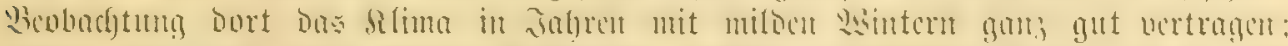

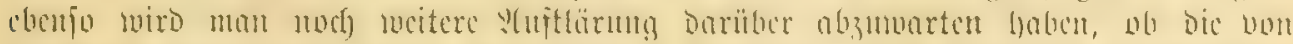

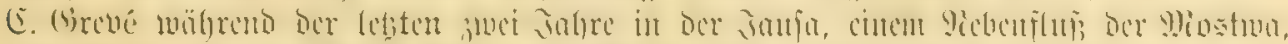

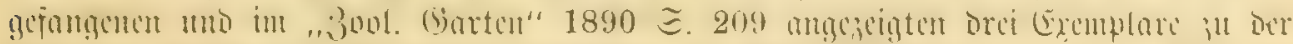

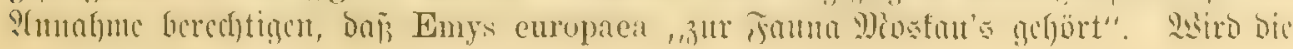

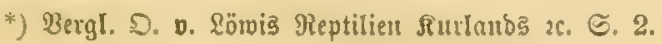




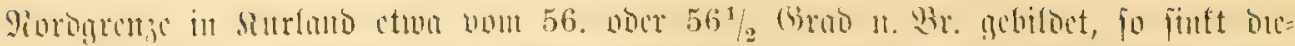

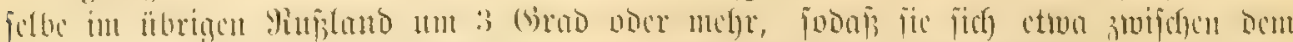

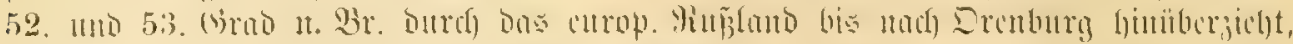

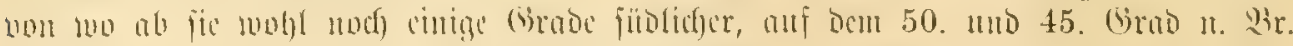

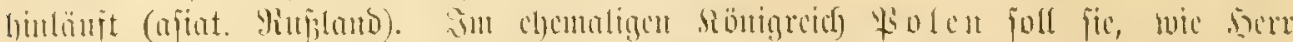

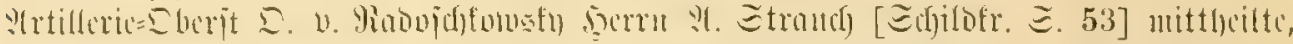

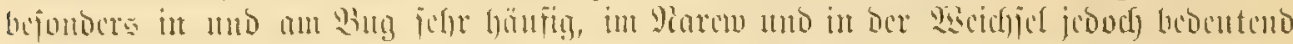

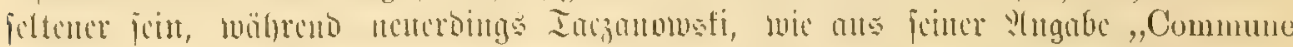

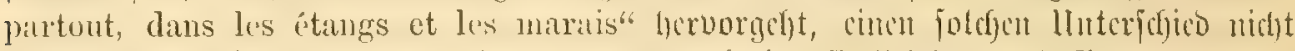

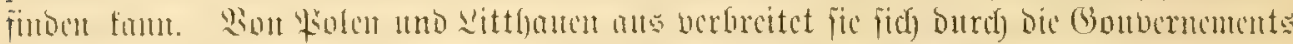

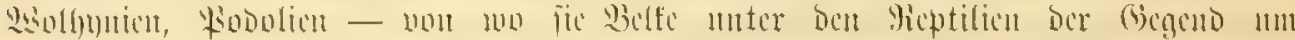

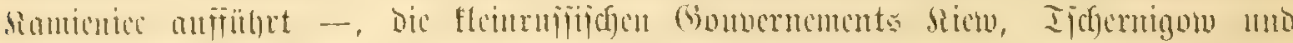

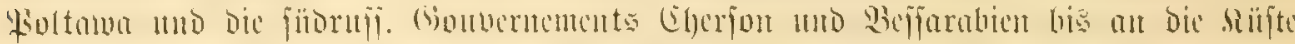

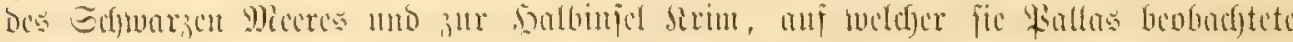

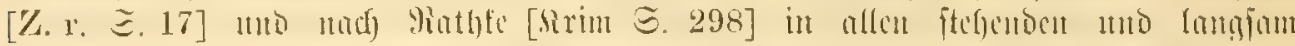

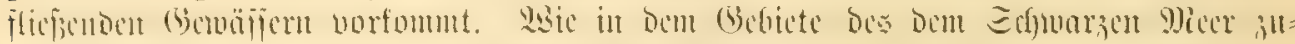

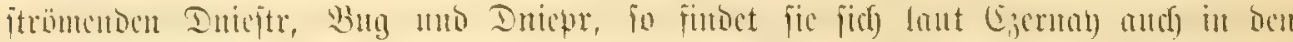

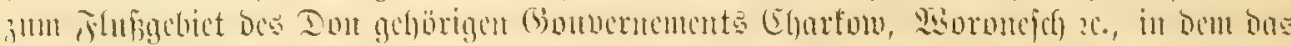

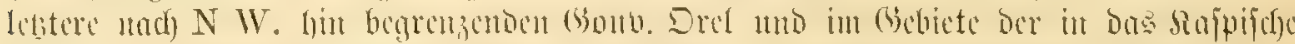

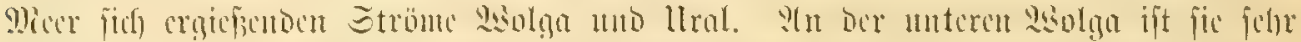

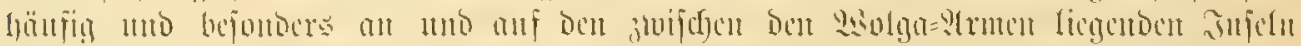

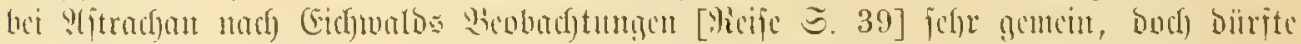

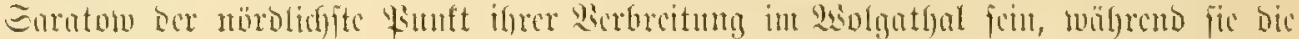

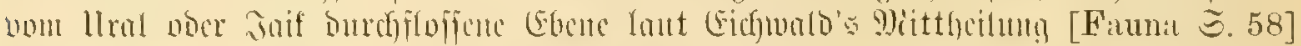

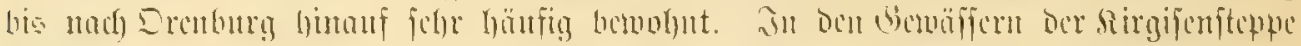

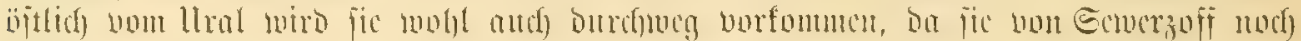

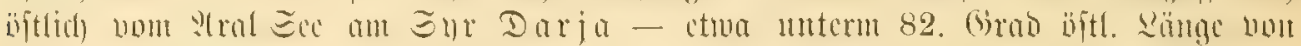

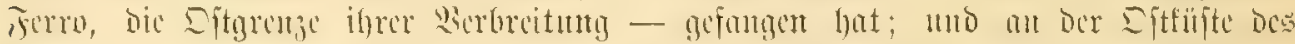

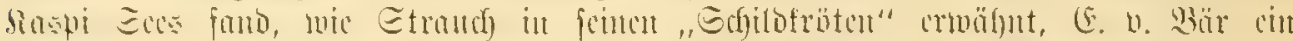

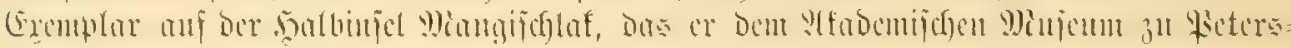

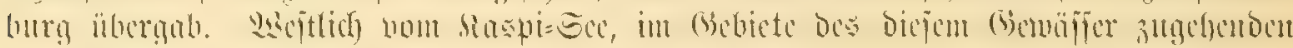

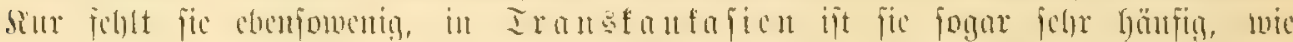

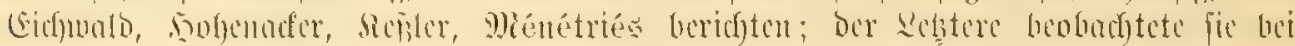

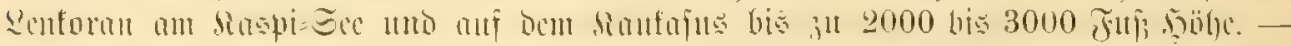

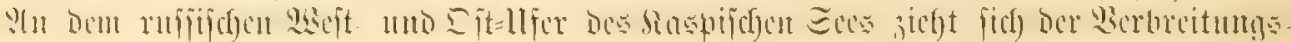

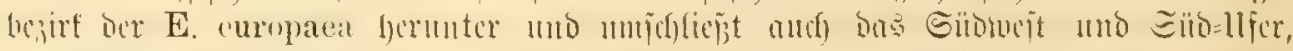

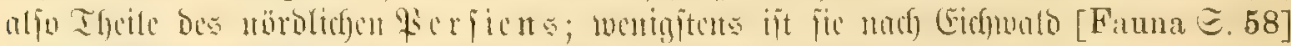

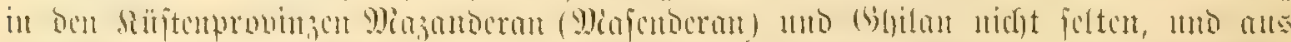

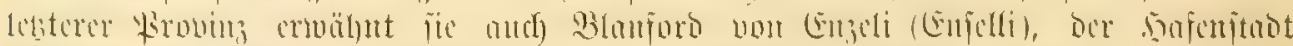

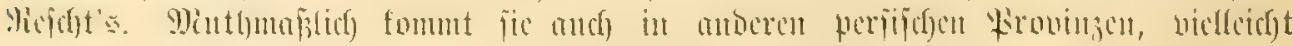

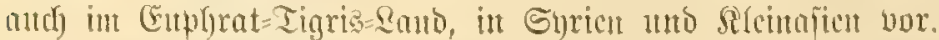

23 arciturns

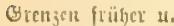
Icst.

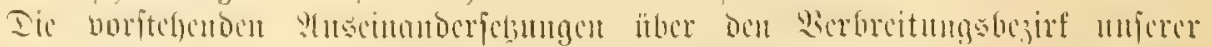

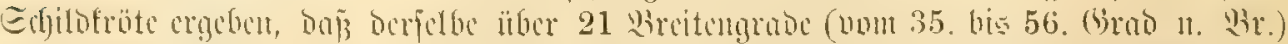

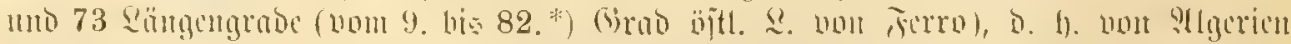

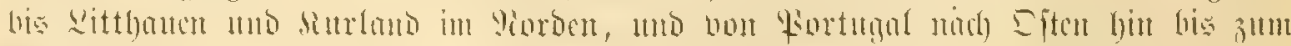

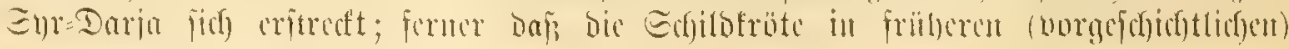




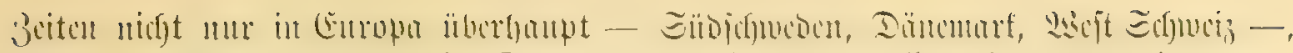

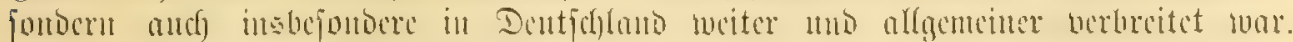

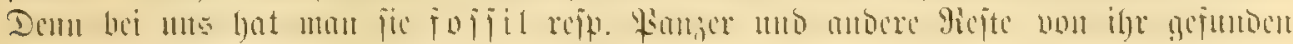

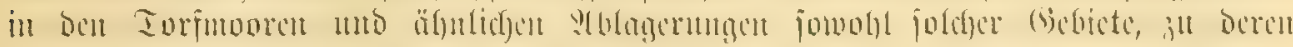

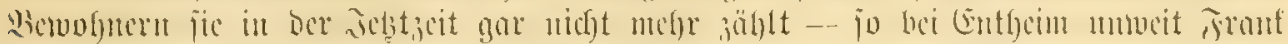

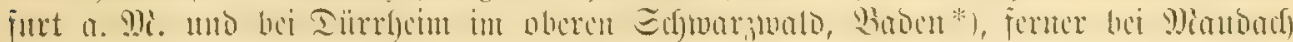

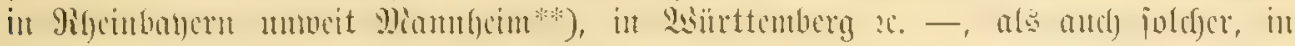

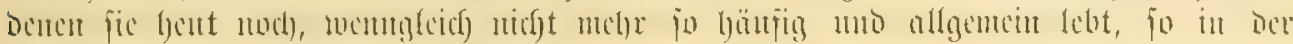

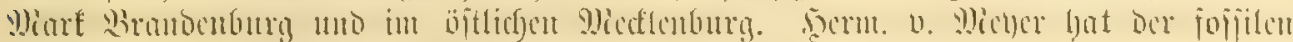
Torfichildofröte bic Bezcidjunty Emys turfa beigelegt.

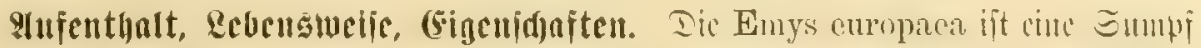

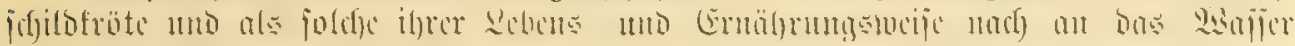

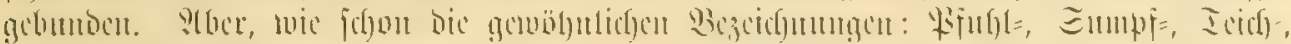

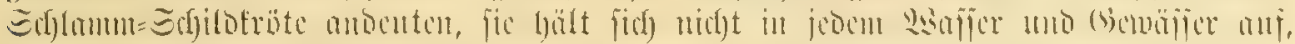

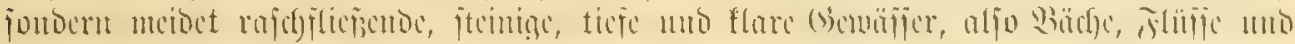

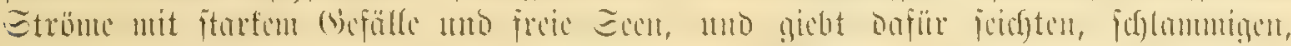

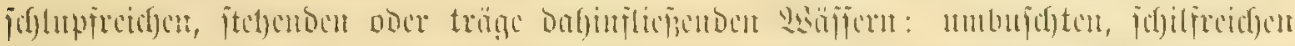

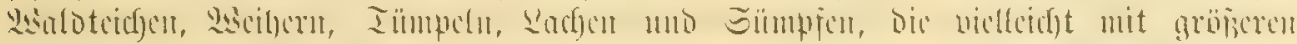

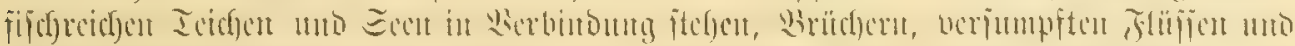

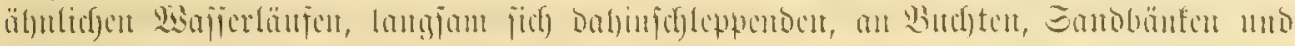

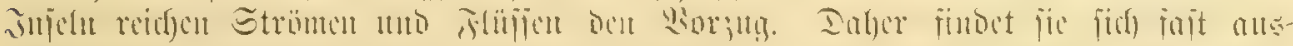

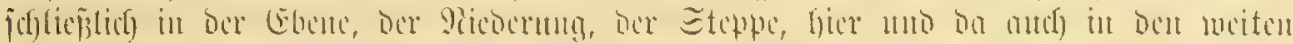

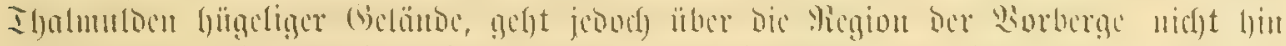

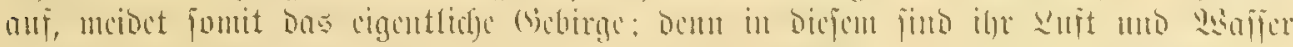

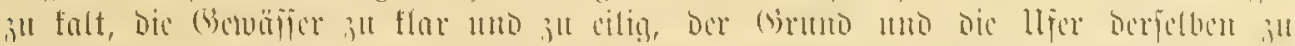

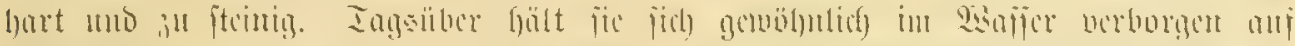

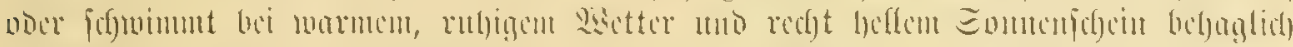

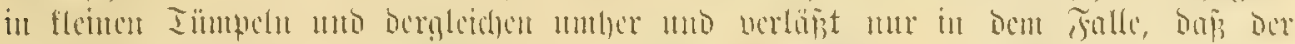

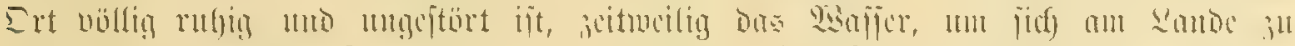

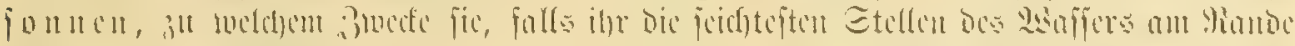

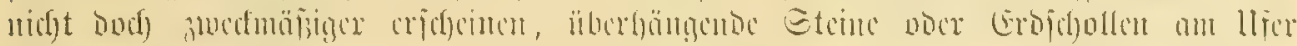

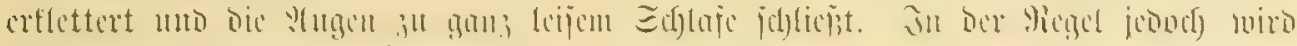

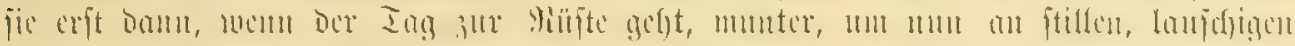

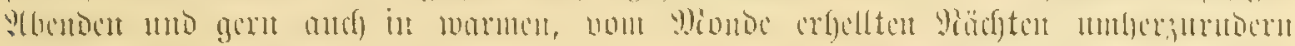

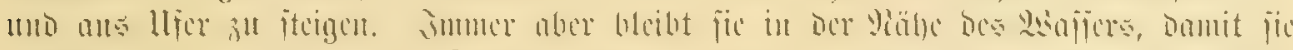

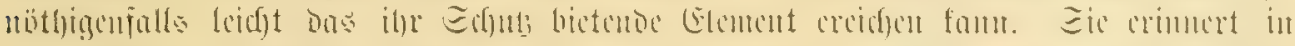

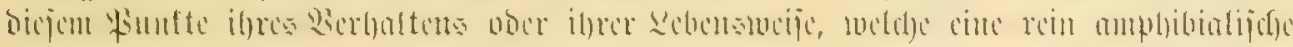

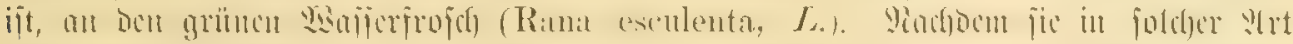

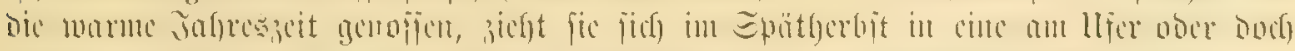

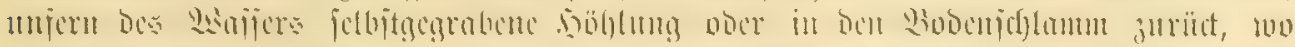

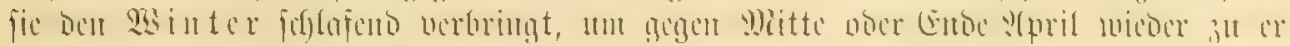
machen mo ifje Sommerlcben anf

(E)

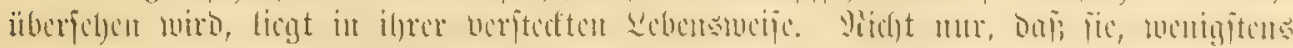

Weritedte Rebents meile.

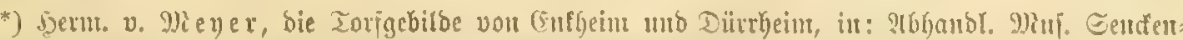

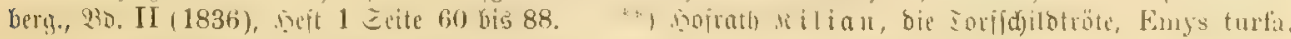
in: 10. Jahreaberidgt bes Jiaubeimer Werein jü Tiaturtbe. (auj 1843), 5. 29. 


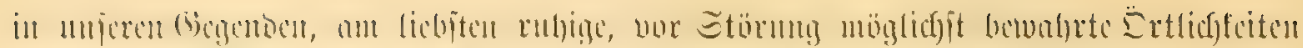

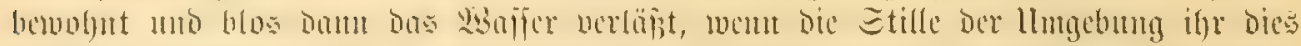

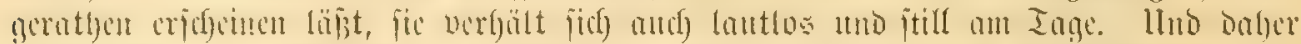

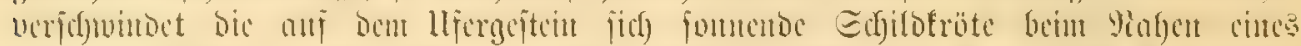

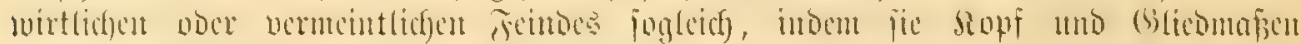

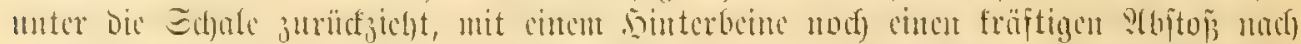

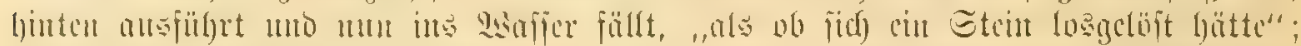

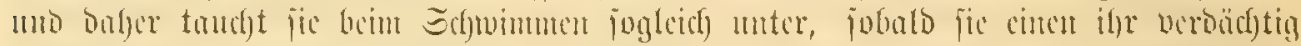

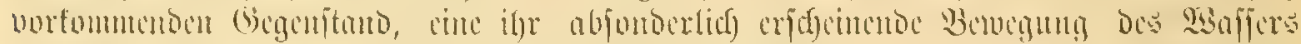

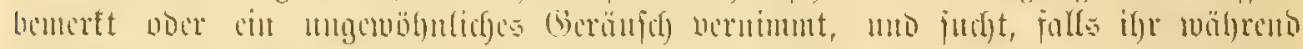

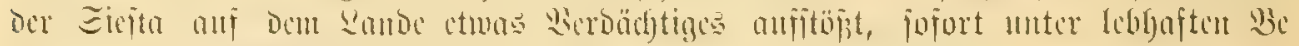

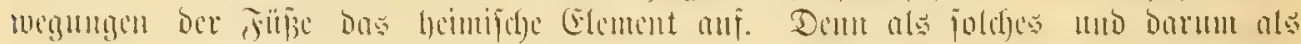

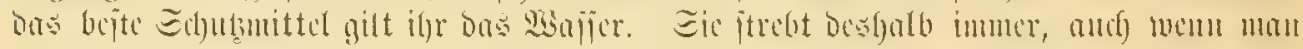

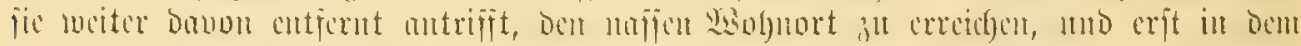

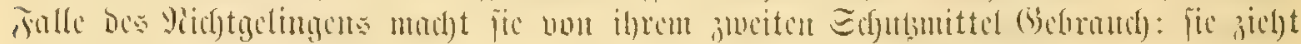

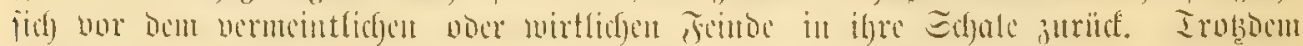

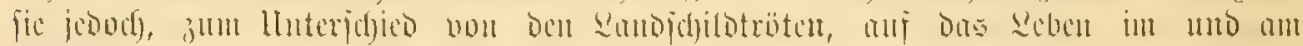

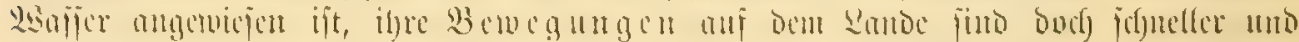

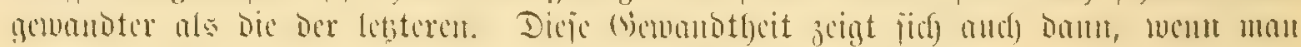

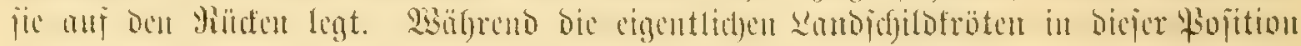

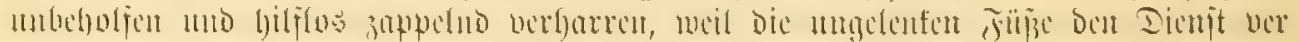

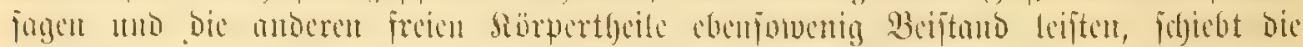

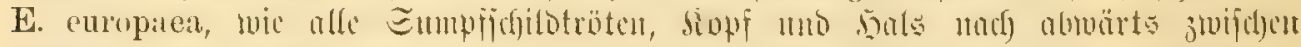

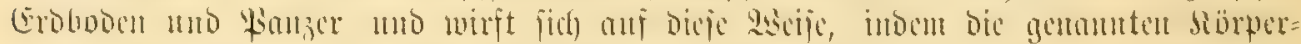

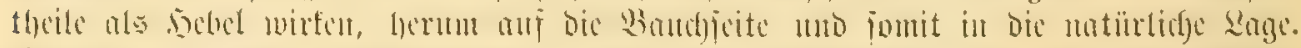

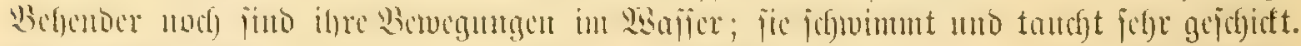

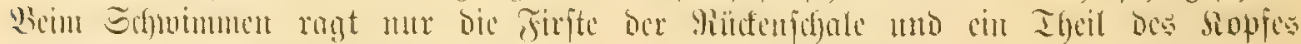

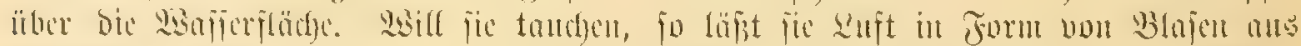

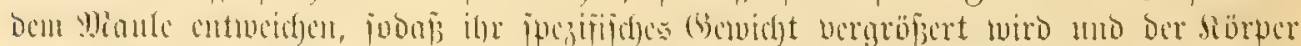

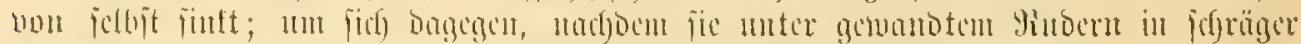

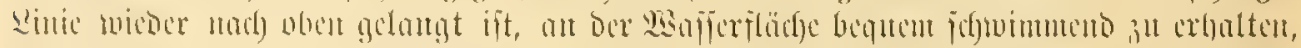

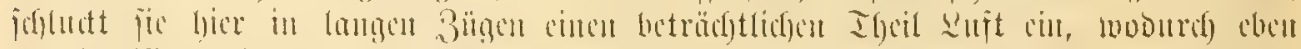

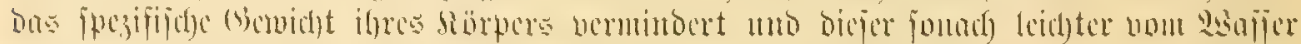

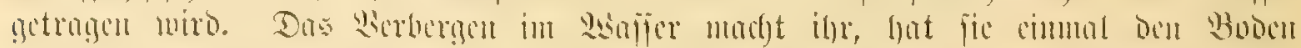

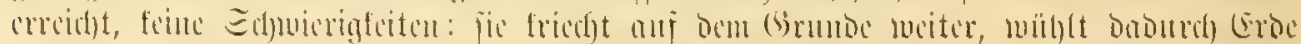

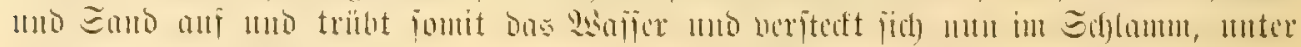

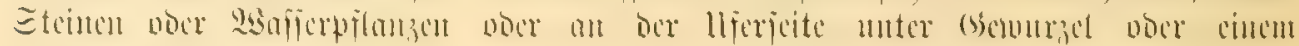
äfulidfen Esflupt.

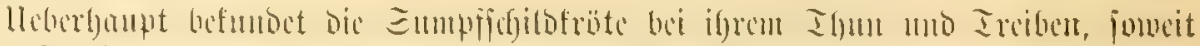

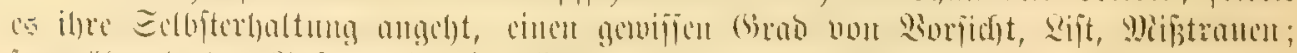

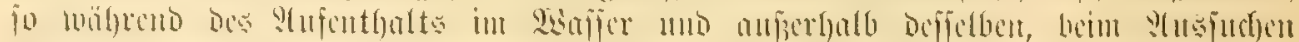

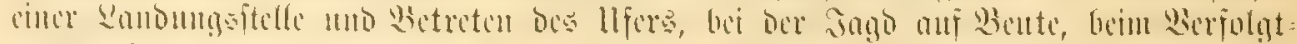

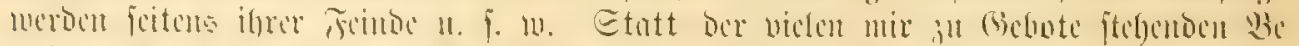

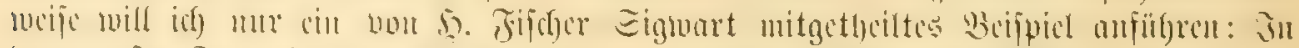

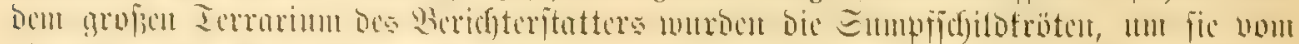

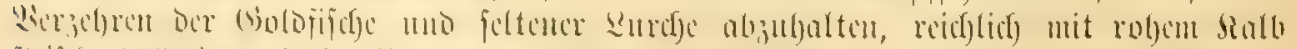

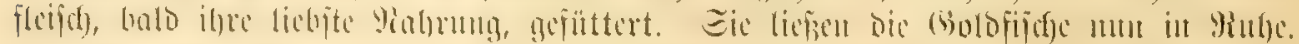

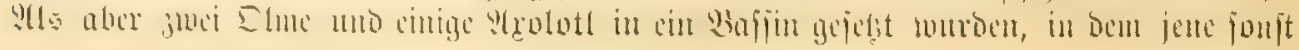




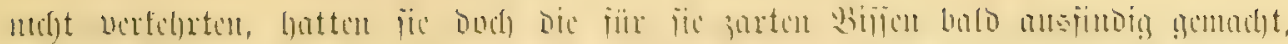

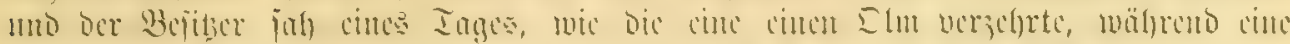

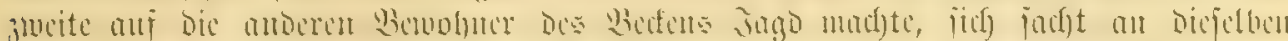

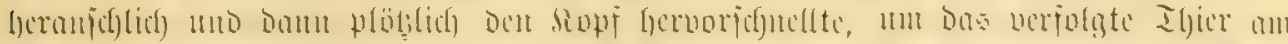

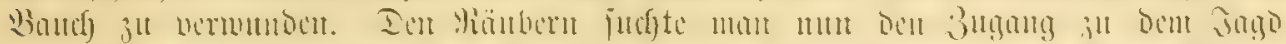

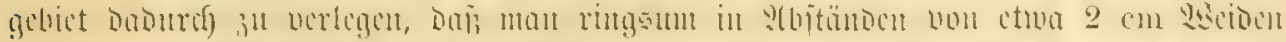

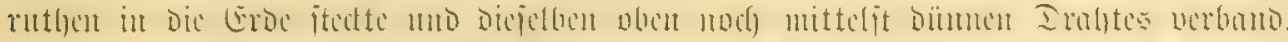

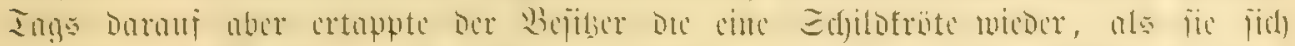
;)

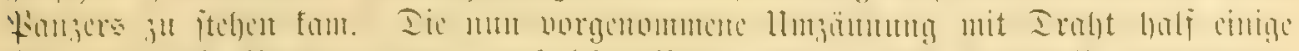

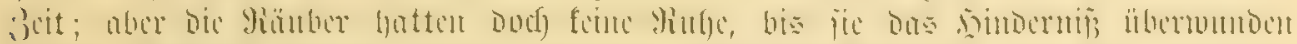

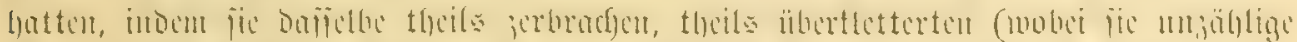

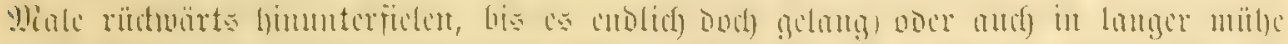

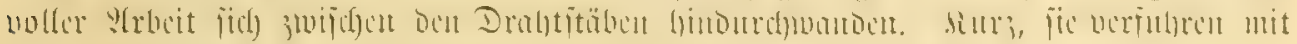

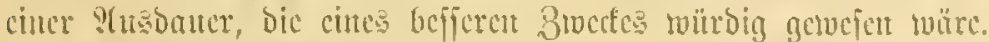

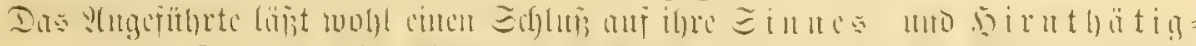

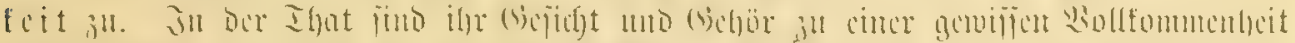

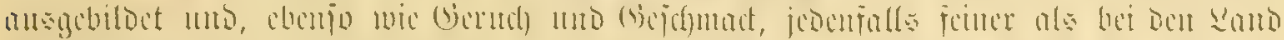

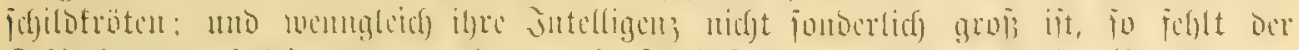

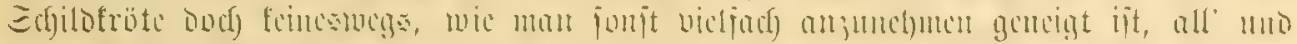
jobs

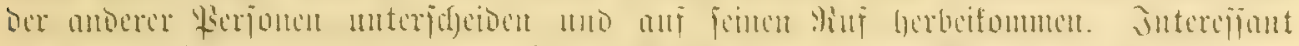

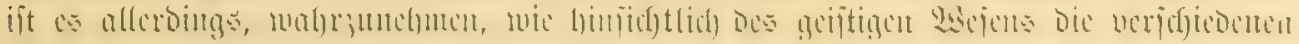

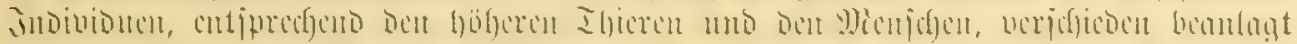

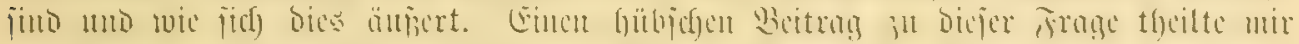

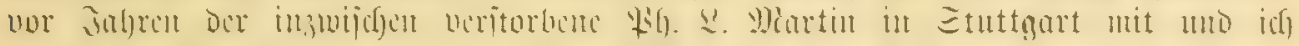

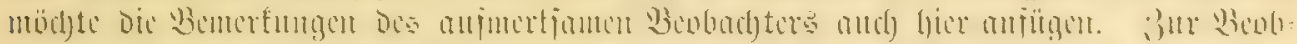

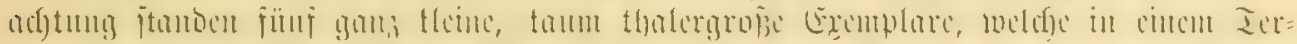

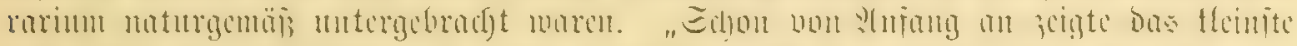

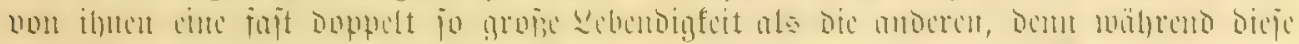

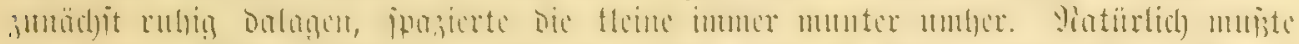

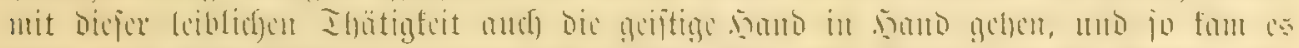

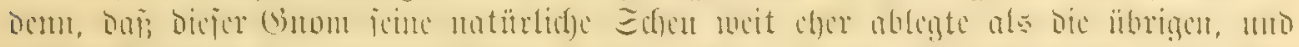

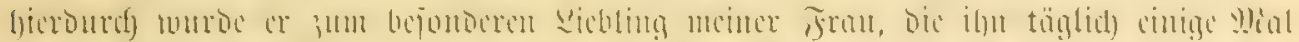

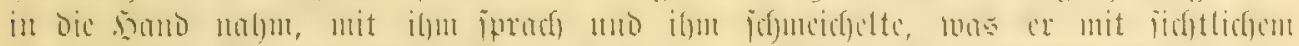

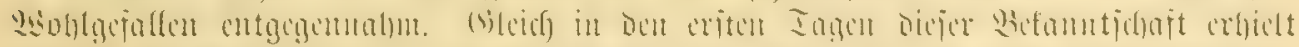

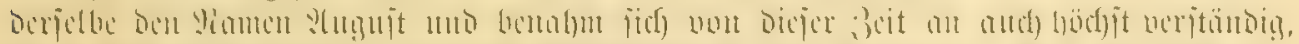

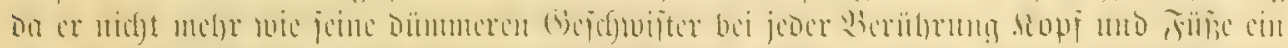

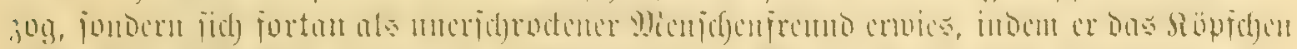

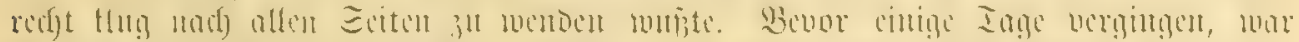

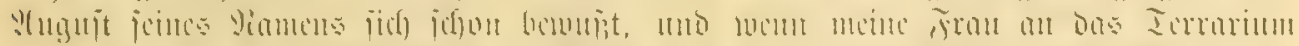

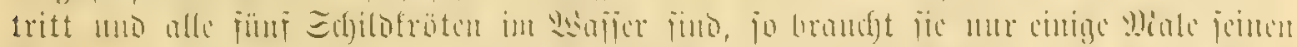

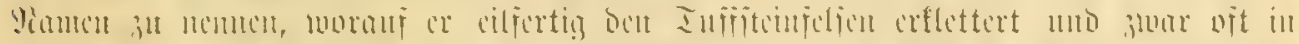

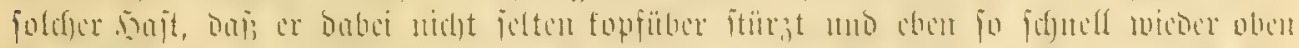

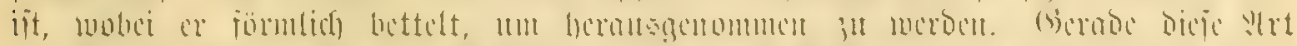

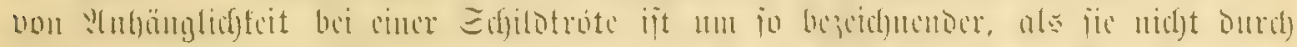

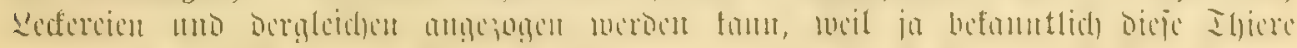

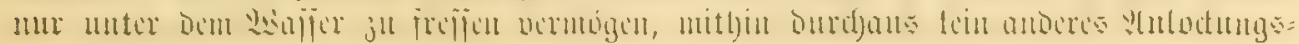




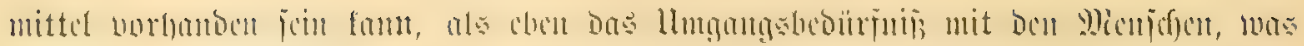

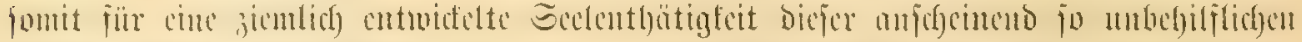

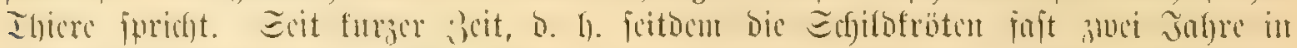

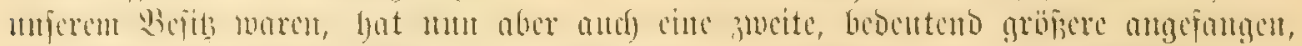

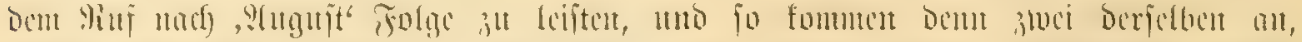

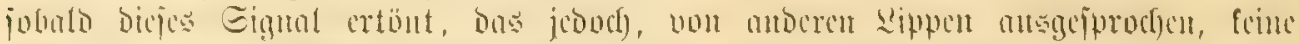

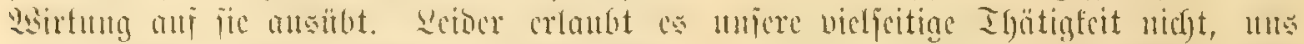

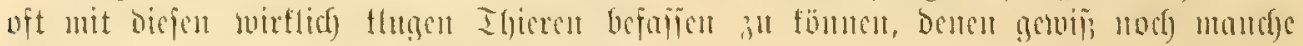

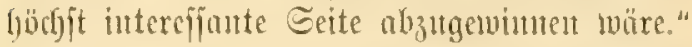

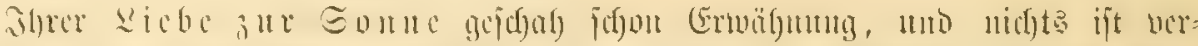

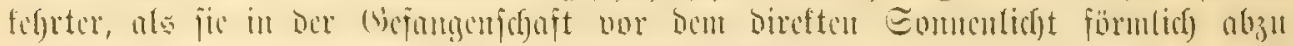

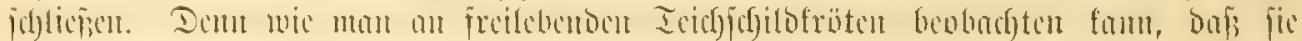

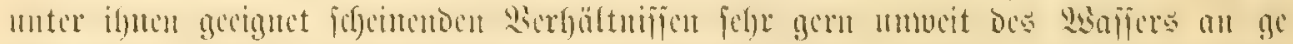

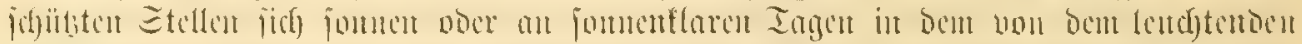

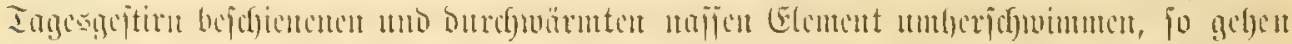

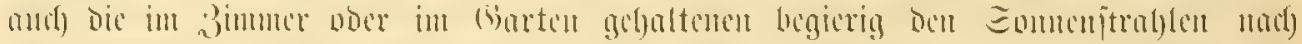

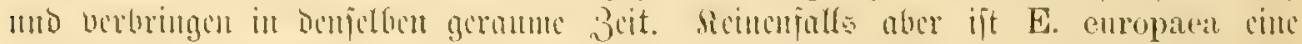

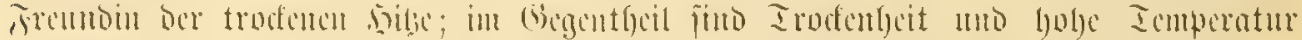

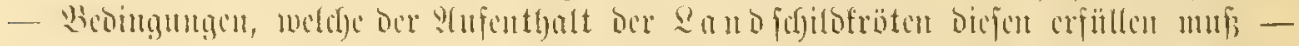

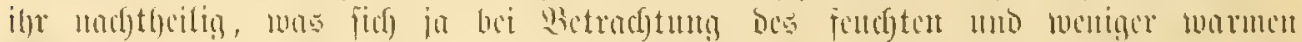

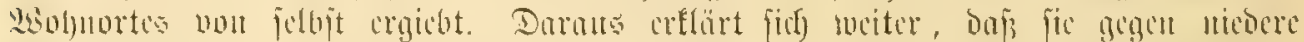

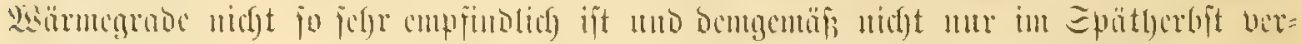

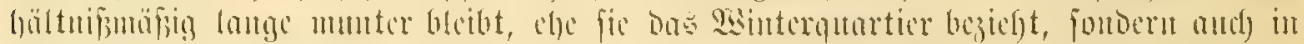

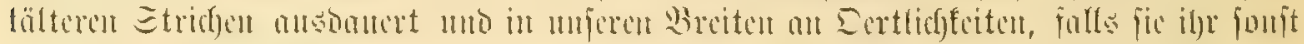

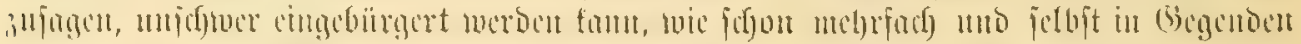

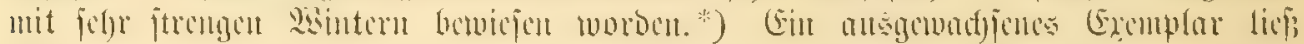

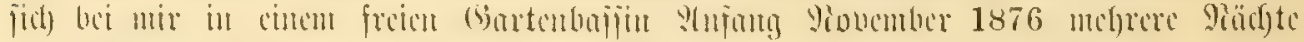

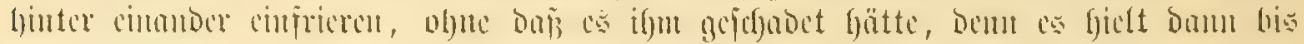

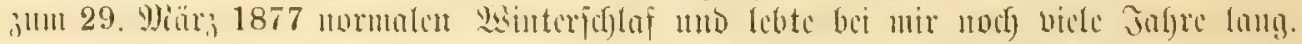

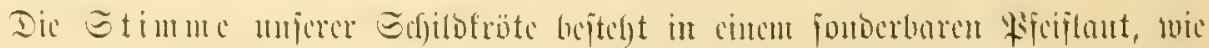

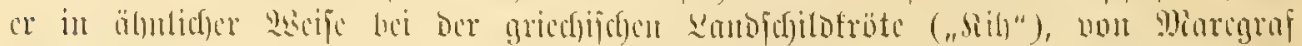

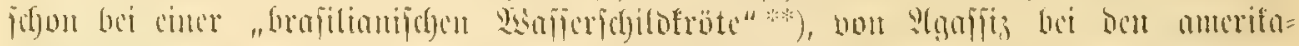

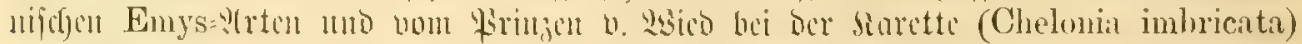

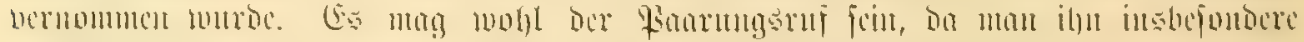

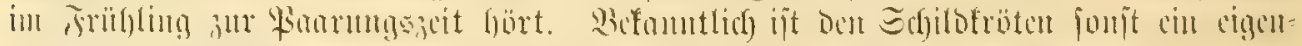

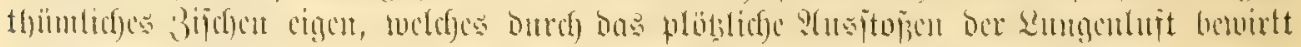

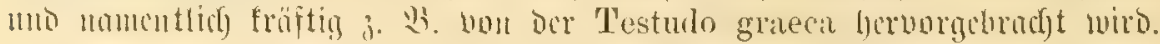

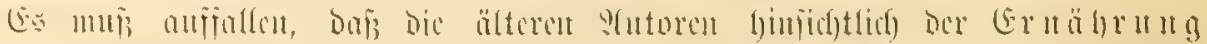

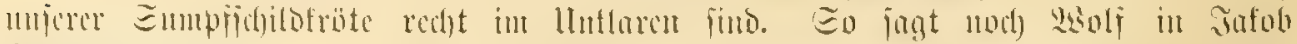

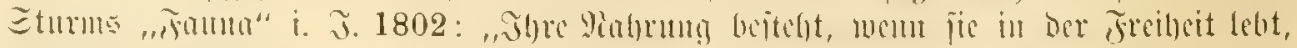

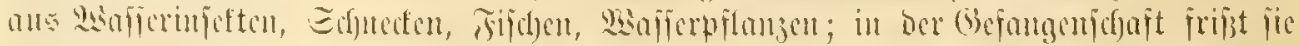

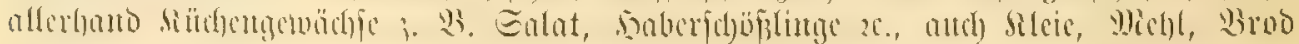

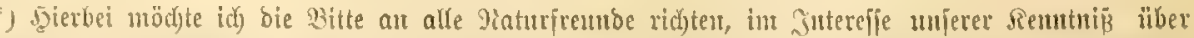

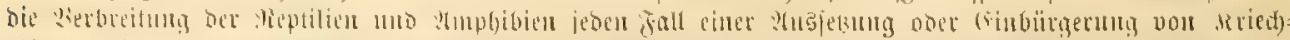

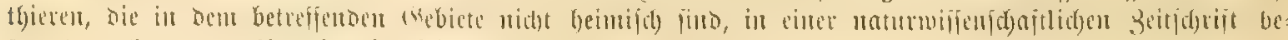
famt madjen zu wotlen, bantit midjt juttjümer entifteken.

**) Edyueiber, Edjildotröter ఠ. 175. 


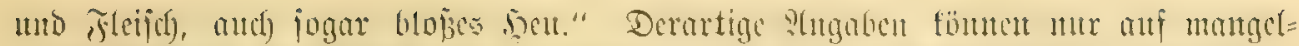

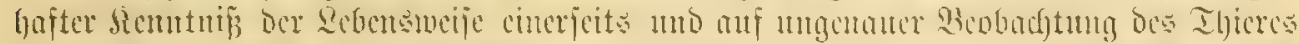

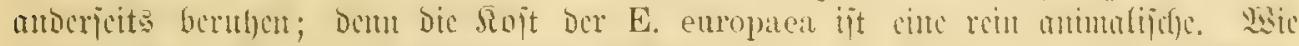

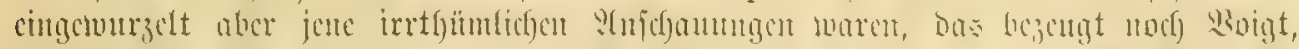

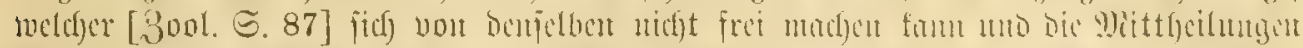

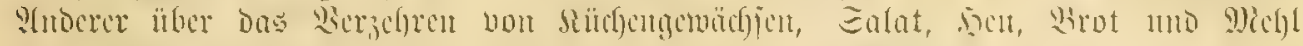

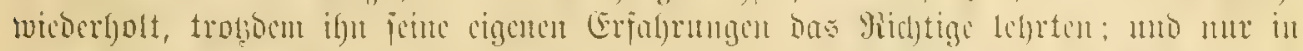

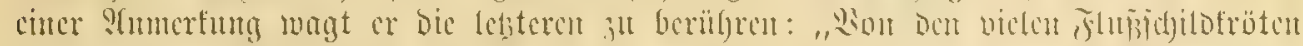

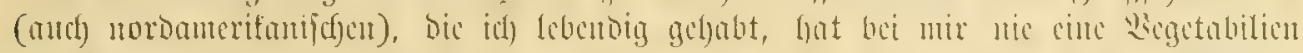

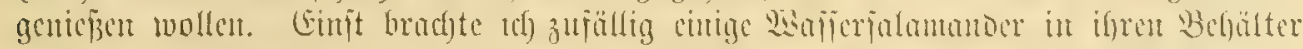

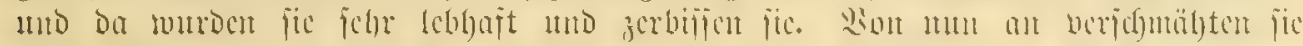

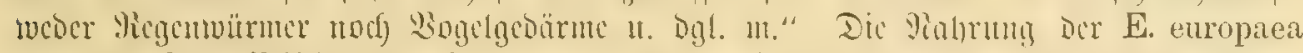

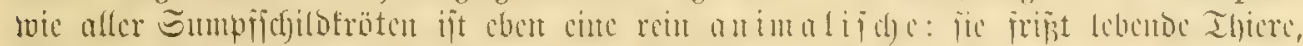

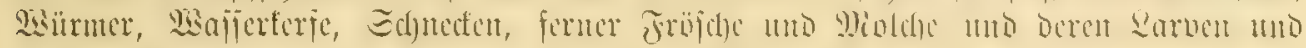

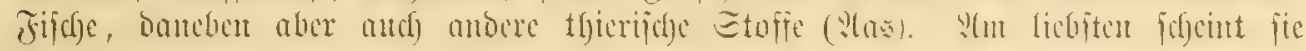
Jifiche zu frefifert.

Dies bemerfte bereits ber alte Miaregraj, weldfer weiter bubachtete, Daj bie

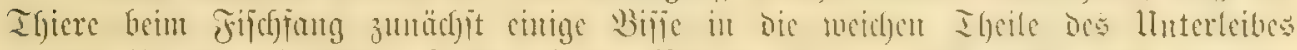

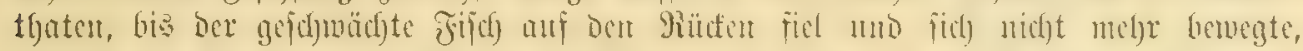

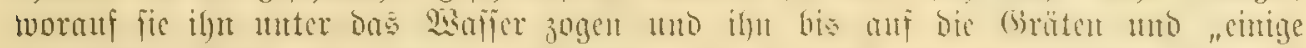

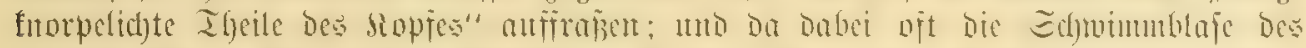

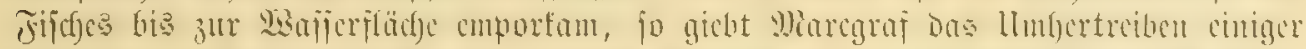

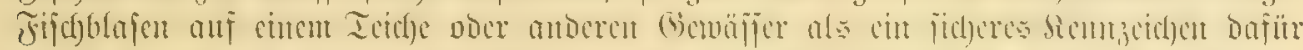

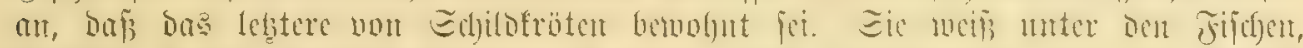

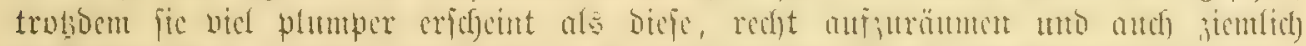

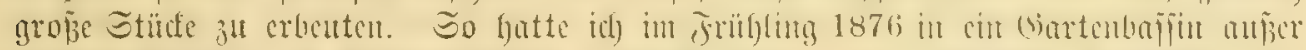

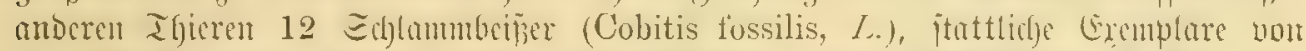

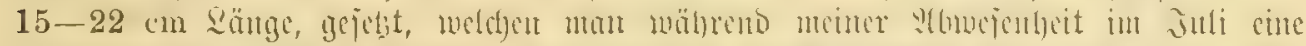

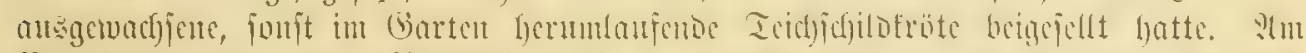

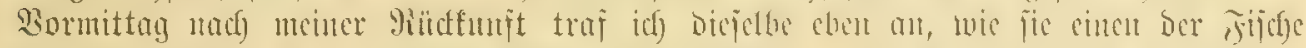

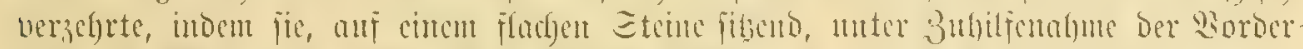

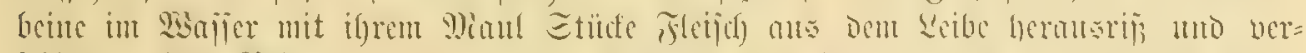

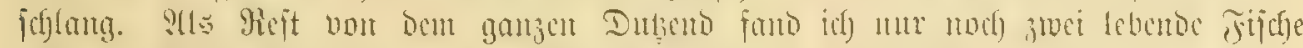

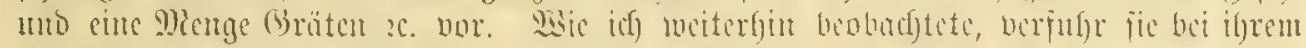

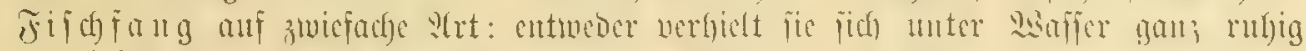

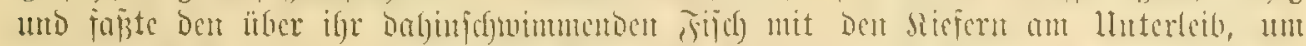

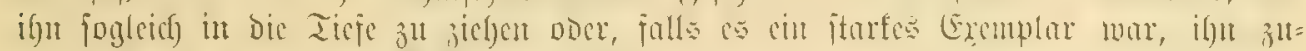

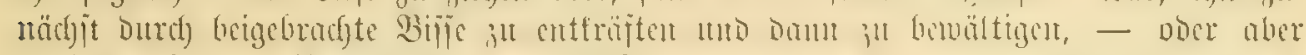

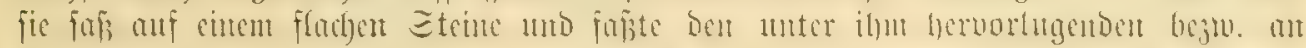

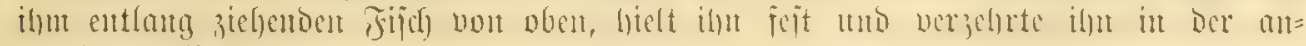
gegebenten $23 s e i f e$.

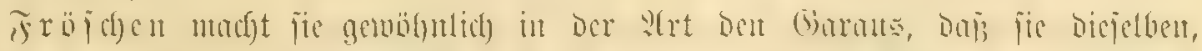
Kaub.

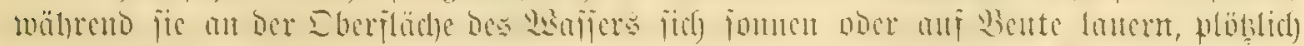

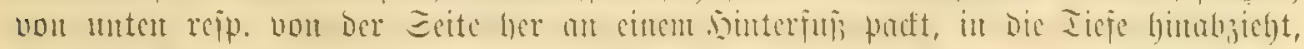

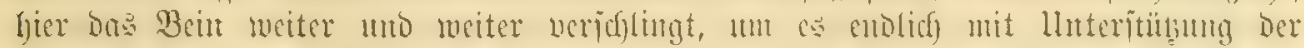

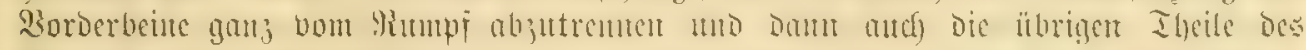

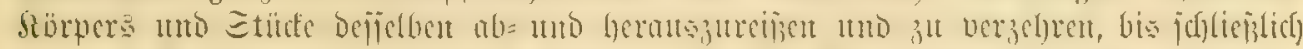

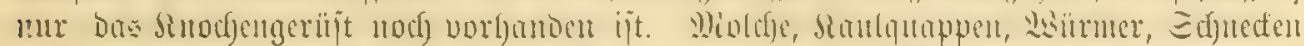




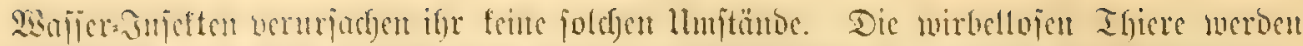

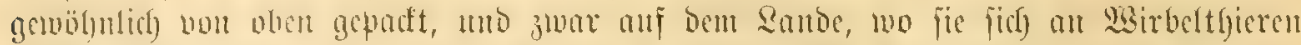

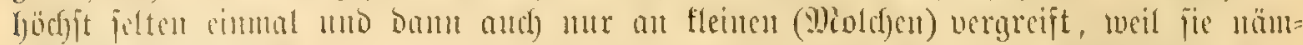

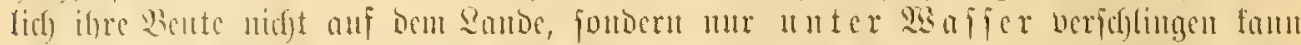

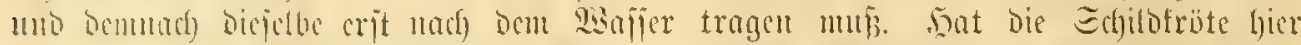

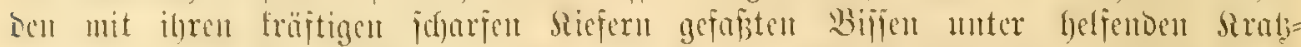

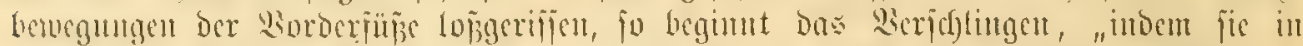

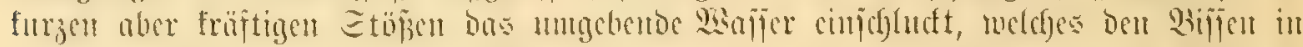

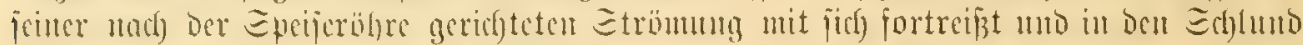

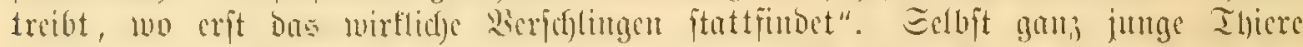

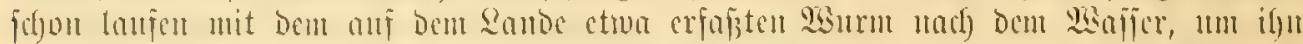

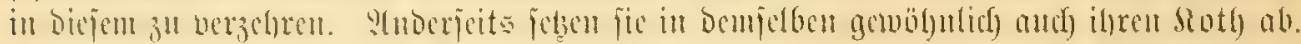

Madreife bet Eier.

Giertegen.

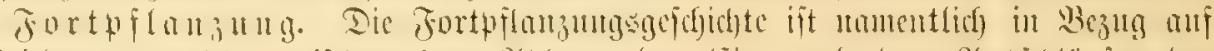

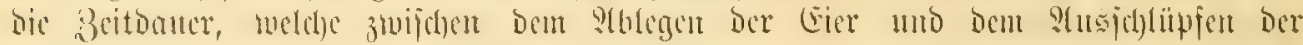

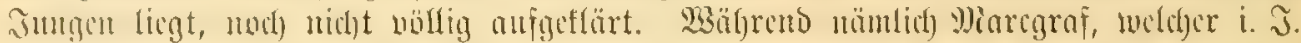

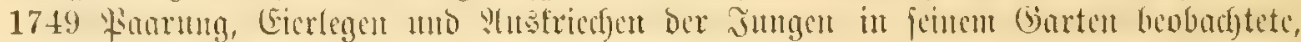

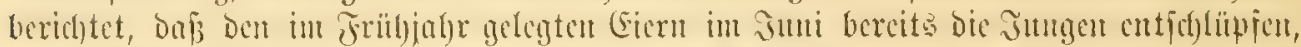

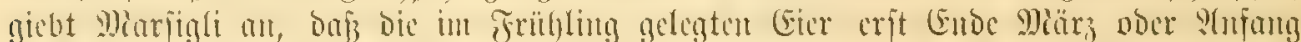

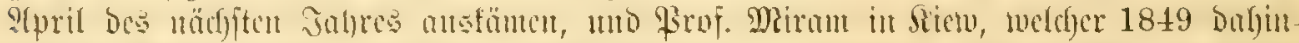

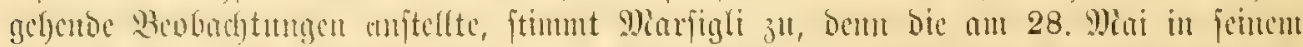

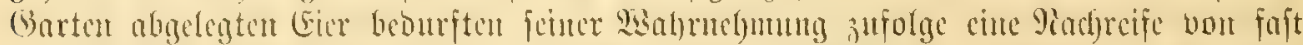

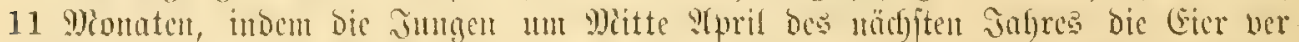

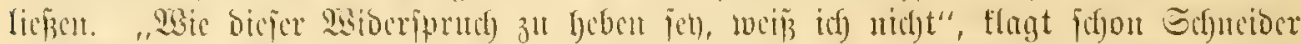

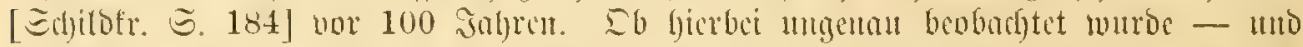

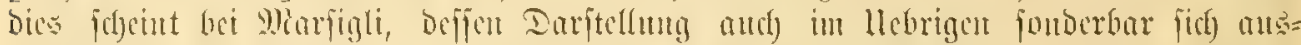

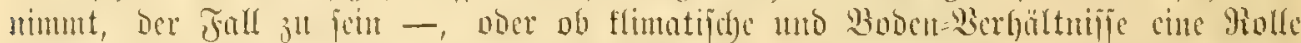

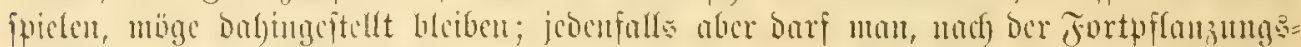

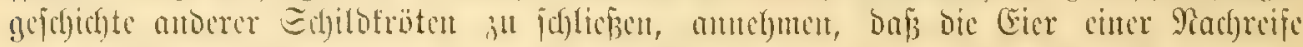

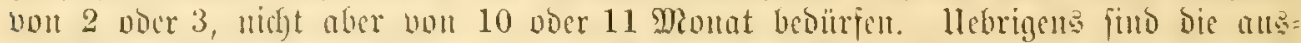

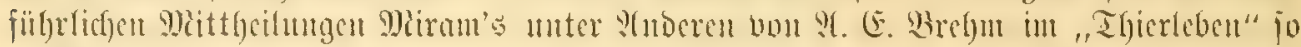

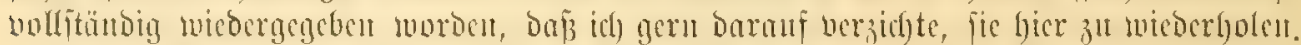

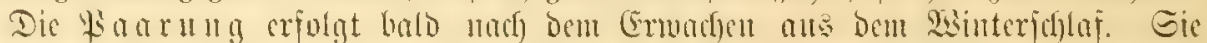

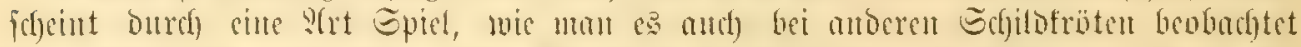

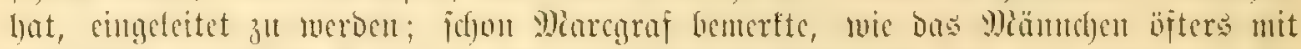

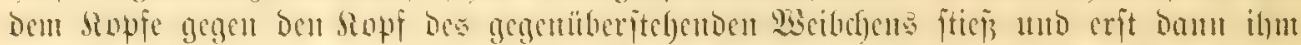

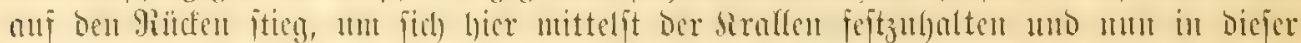

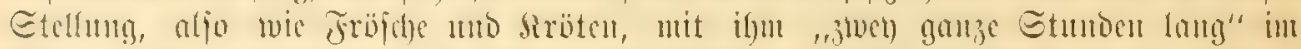

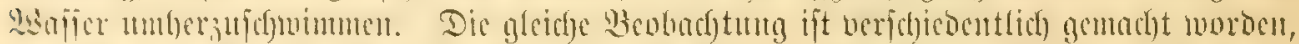

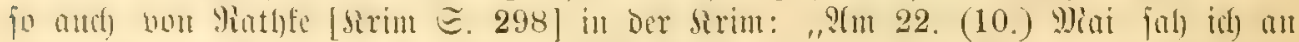

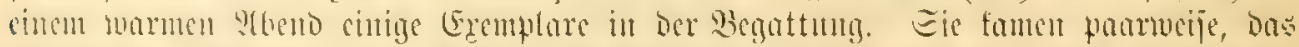

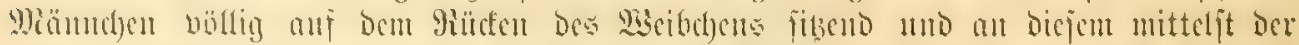

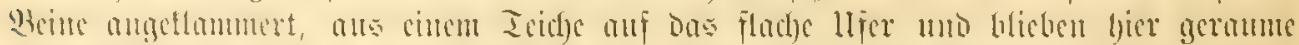

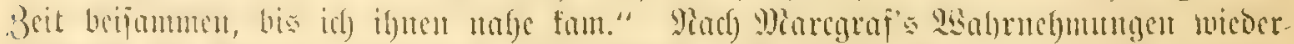

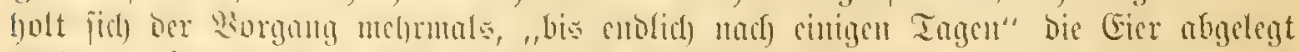

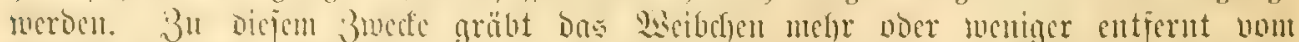

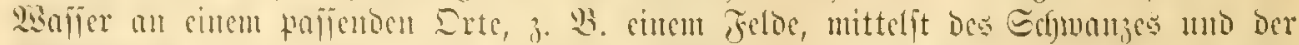

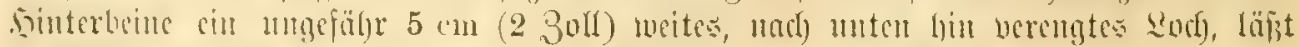

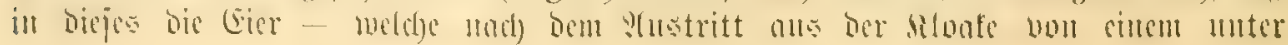




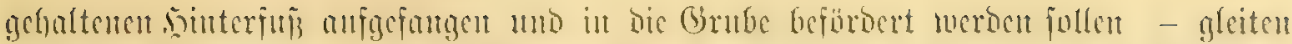

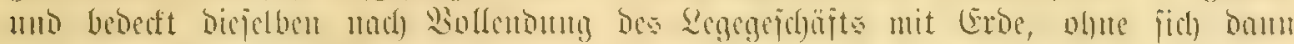

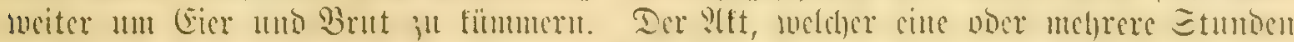

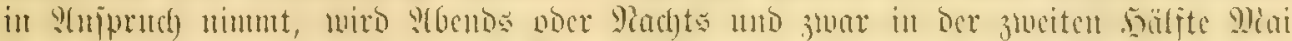

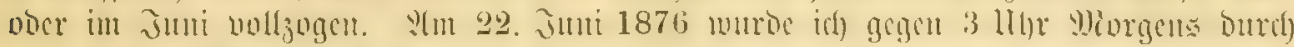

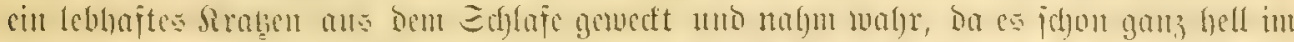

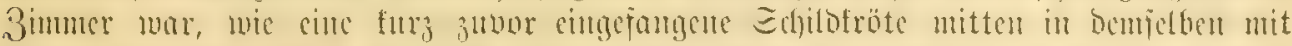

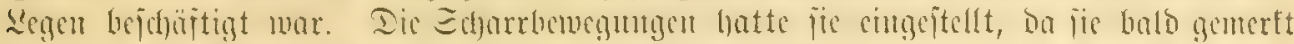

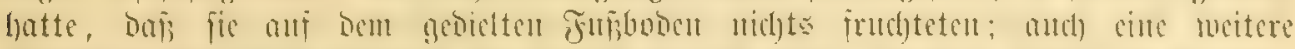

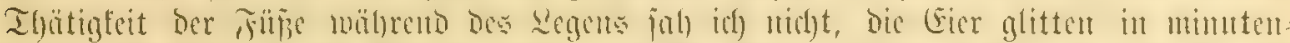

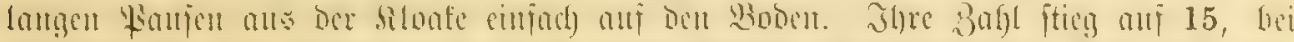

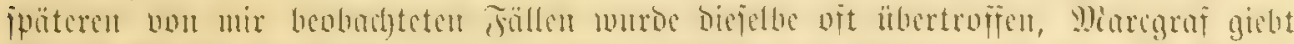

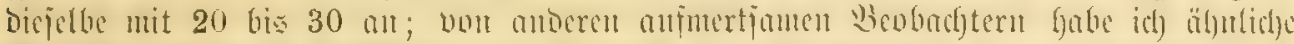

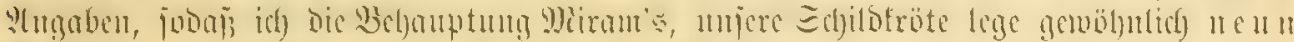
Eier - nur einmal will ex elf haben legen jeben -, nicht verftegen fantu. Sie

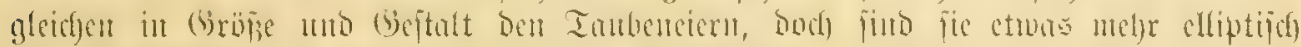

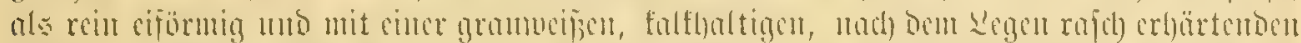

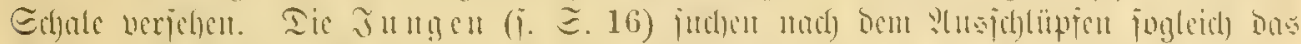

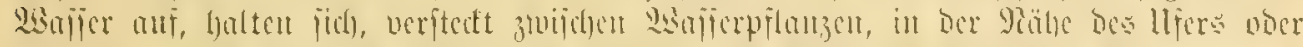

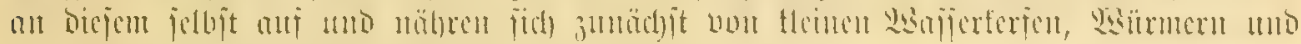

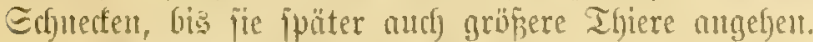

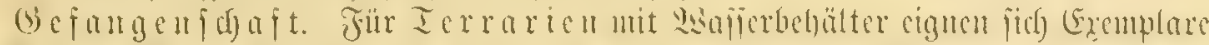
Bejangenjgaft.

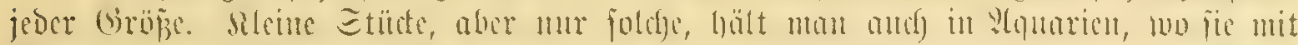

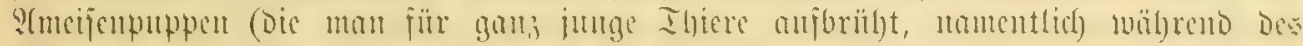

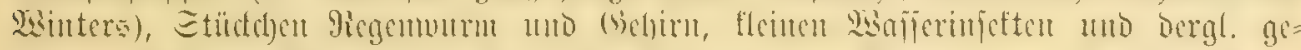

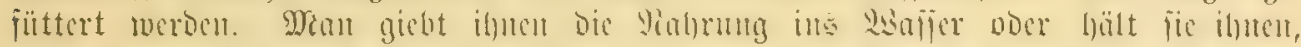

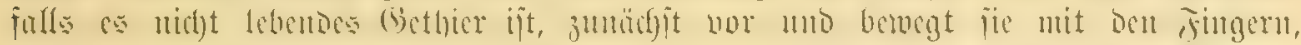

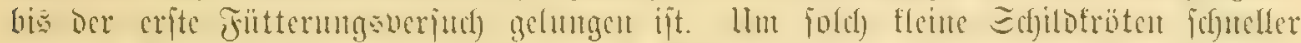

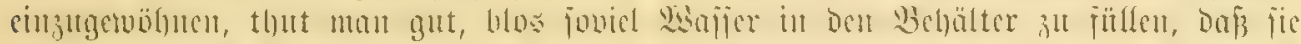

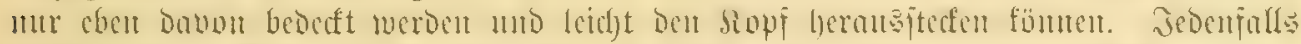

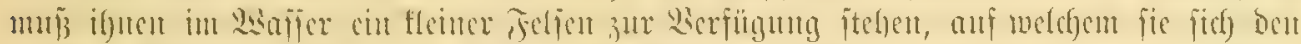

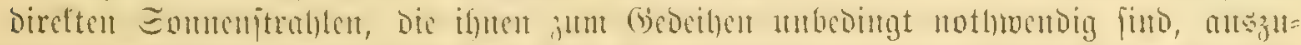

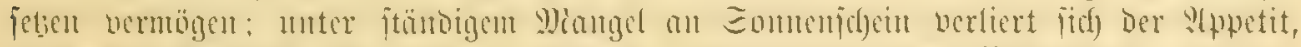

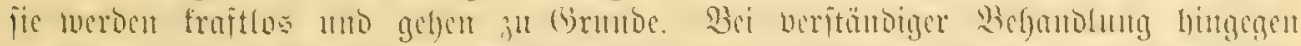

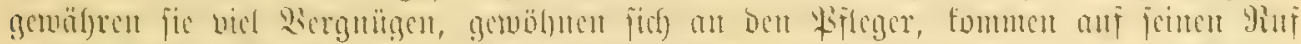

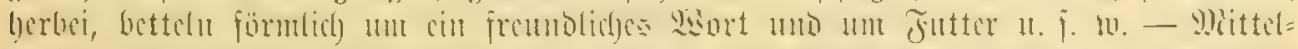

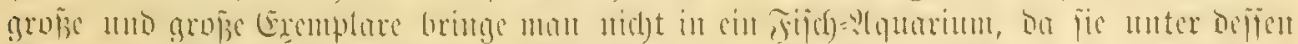

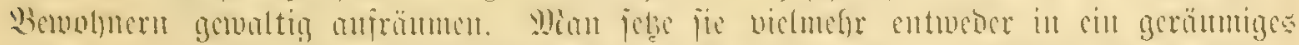

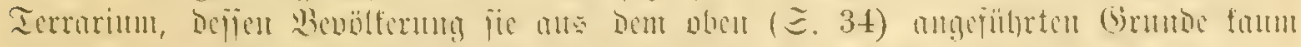

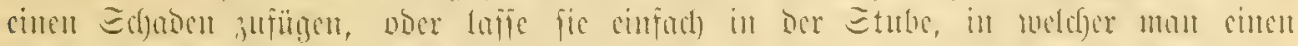

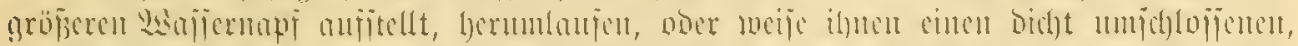

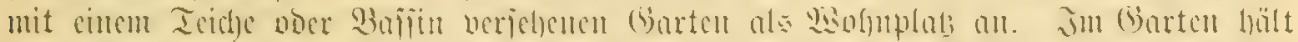

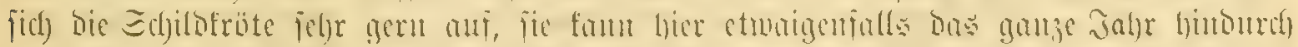

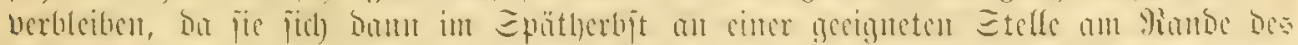

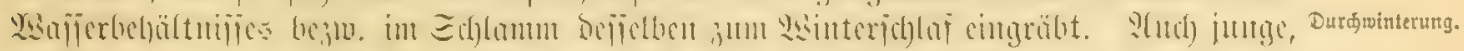

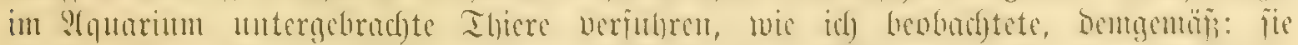

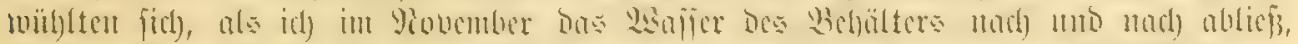
in ben (B) 


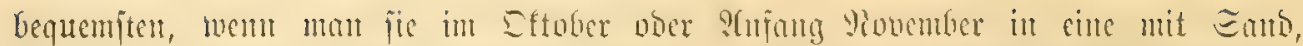

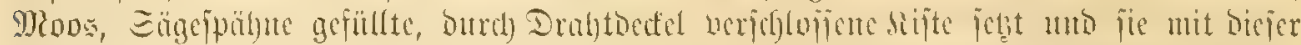

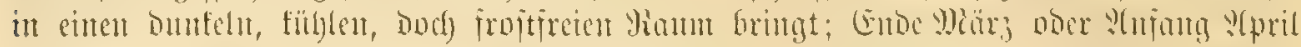

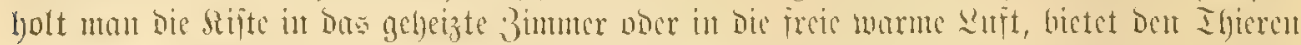

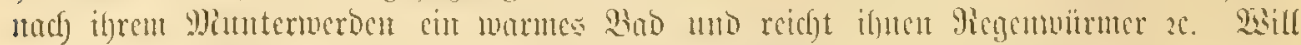

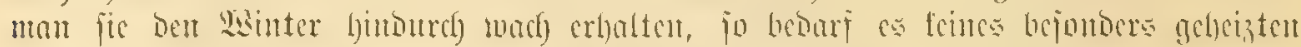

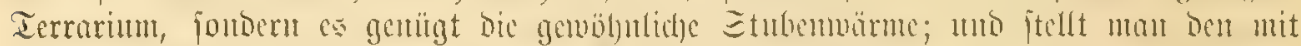

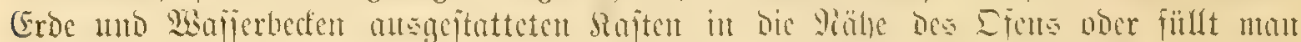

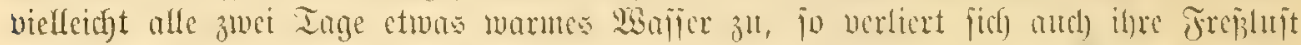

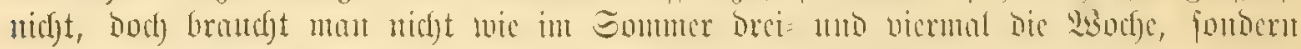

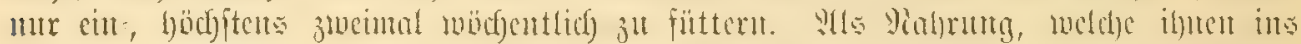

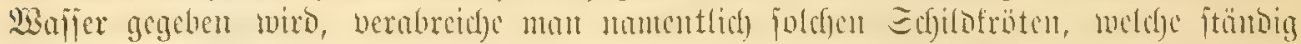

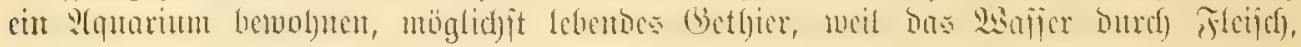

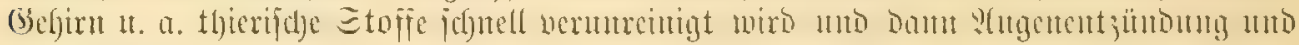

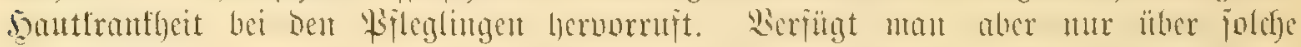

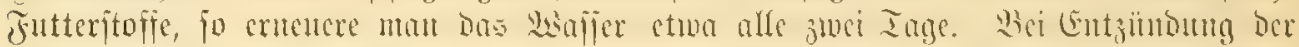

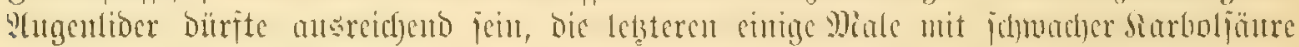

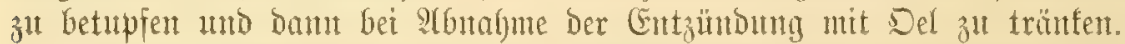

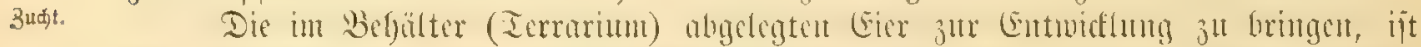

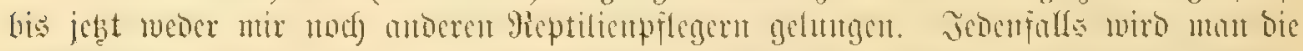

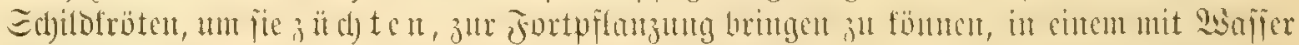

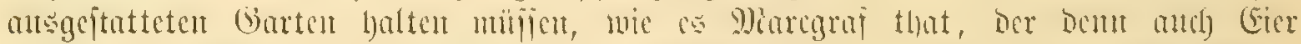

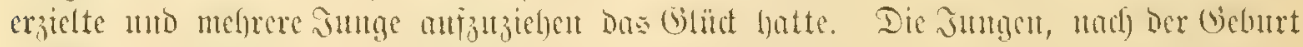

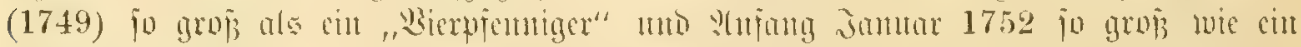

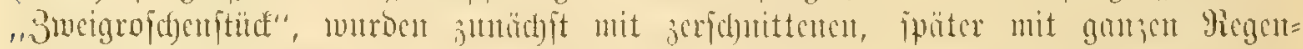

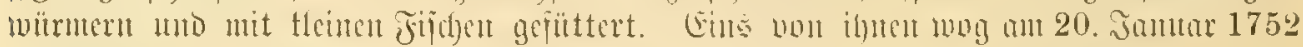

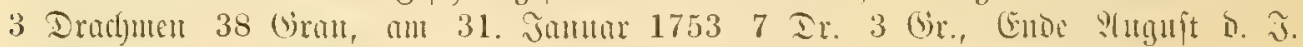

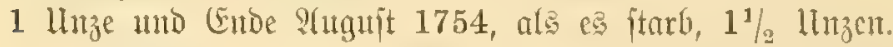

Antauf. 2orurtheir.

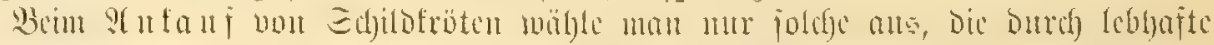

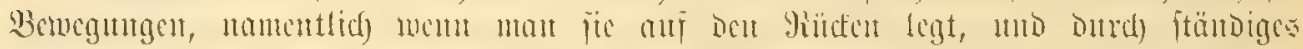

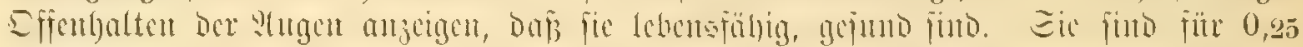

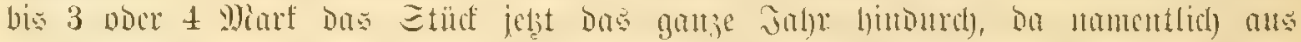

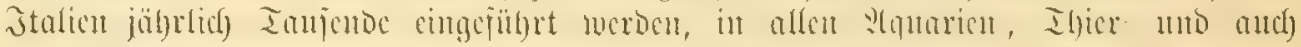

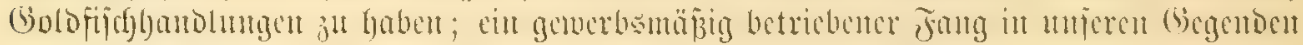

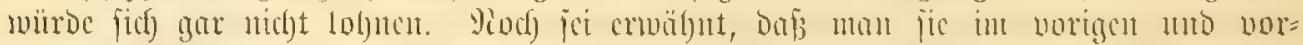

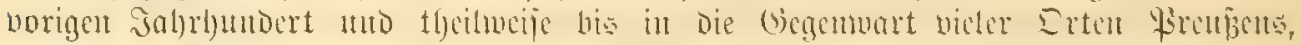

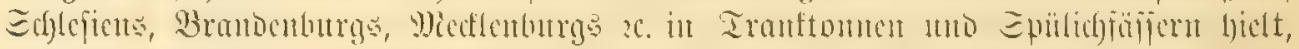

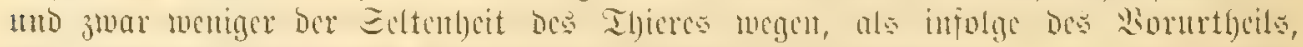

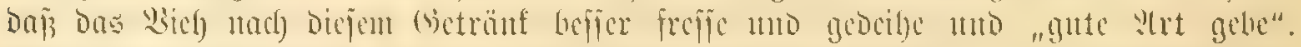

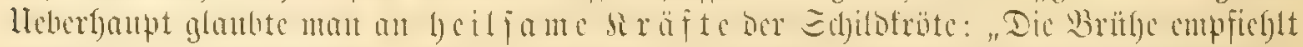

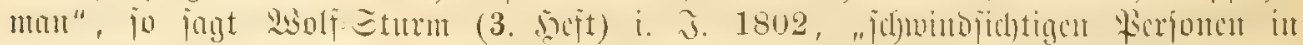

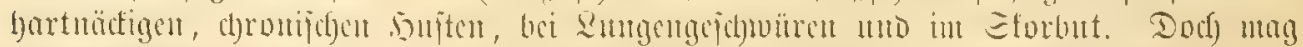

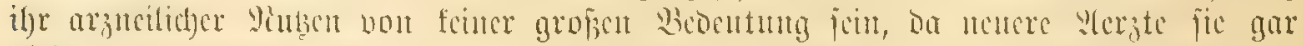

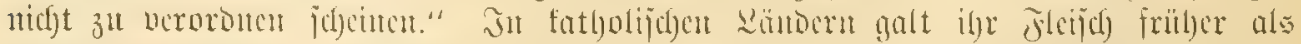

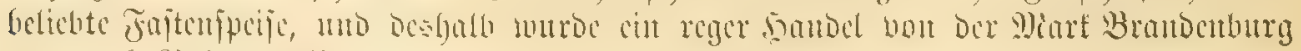
aţ nad) Bölymen, Babern, Defterrcicf Getrichen.

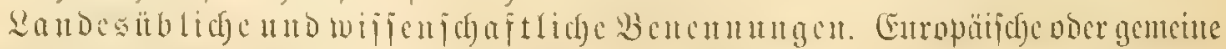

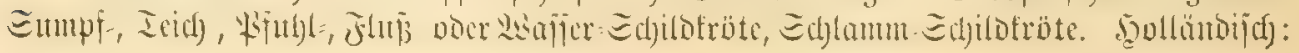


Schildpadde: E(f)modifd): Kärskrildpadda; Eutglif(f): Europenn Pond-Tortoise (Turtle); Fran;ijitid): Cistude europienne, Tortue hourheuse; Italienif(f): Testuggine palustre, Tartaruga; Eparifil): Tortuga comun o Galápago; Mufiticf): Tscherepacha; Loluiid): Worlozolw: L'ettij(l): Brumu-rupuzis; Elanijd): Skornjalea blatarica.

Testudo Luturia. Grsue, 1617 (Plinius, Mrarigli). - T. orbicularis, Limne 1758. - T. europea, Schneider 1783. - T. meleagris, Shaw 1789 [natur. miscell. IV, 323]. - T. flava, Daudin 1803. - Emys lutaria, Merrem 1820. - Emys europaea, Wuter 1830. - Cistudo europalea, Gruy 1831 [Swn. rept.]. - Terrapene ("urnpzea, Bill [Znol. Journ. II, 209]. - Clemmys lutaria, Fitzinuer 1853 [Menag. p. 661]. - Cistudo lutaria, Strunch 1862. - Eofale Formen: Cistudo hellenica, Bilr. Bory 1832 = Eny's hellenica, Tultur. 1832. Emys Hoffmanni, Fitzinq. Mus. Vindol. - Das junţe Ihier: Testudo pulchella, Schüpif 1792 ; Emys pulchella, Merrem 1820.

\section{Südeuropäifđ̨e Sđịildéröten.}

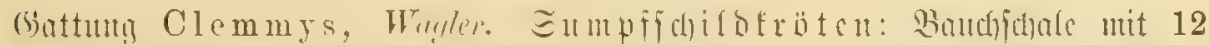

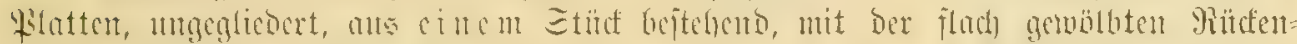

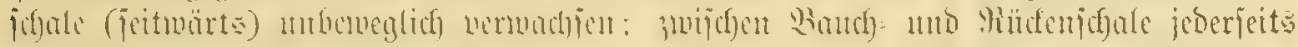

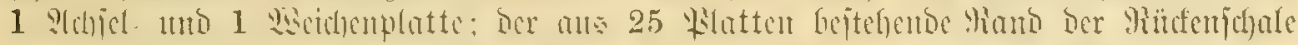

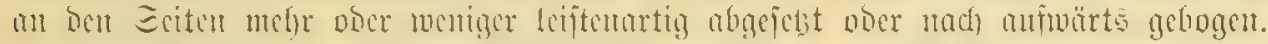

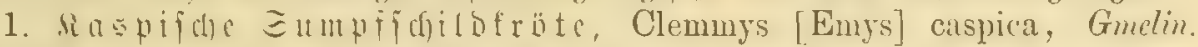

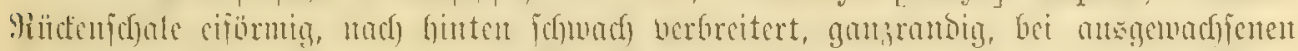

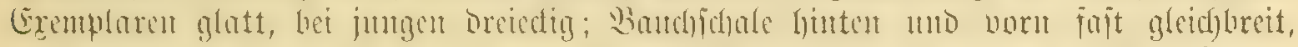

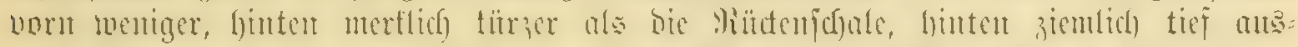

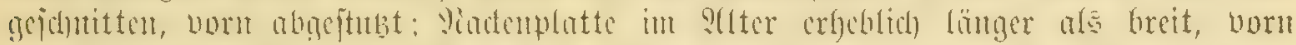

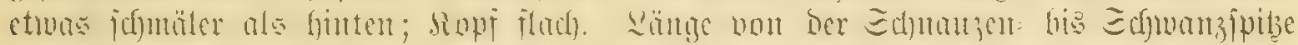

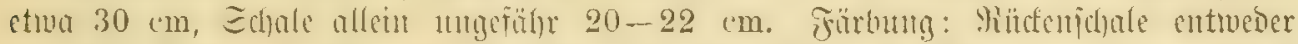

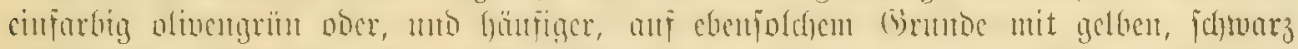

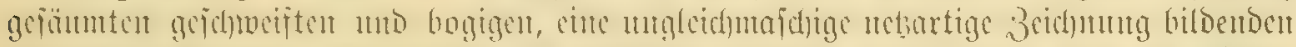

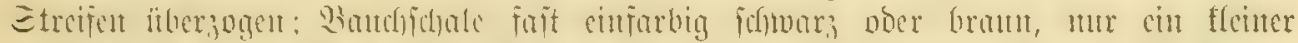

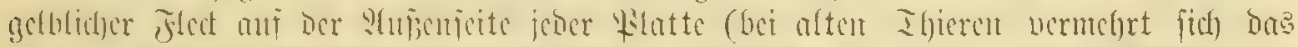

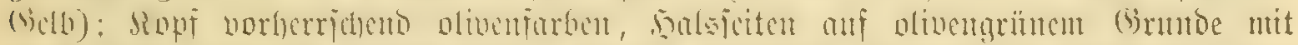

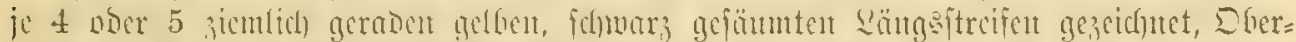

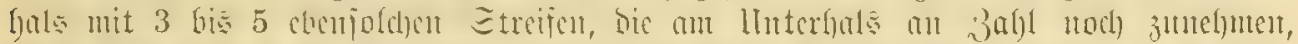

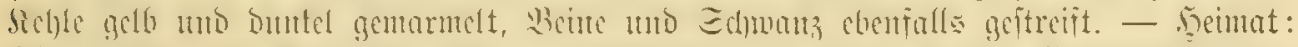

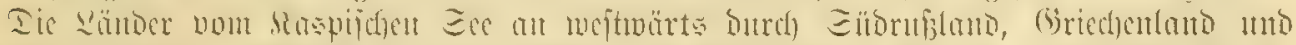

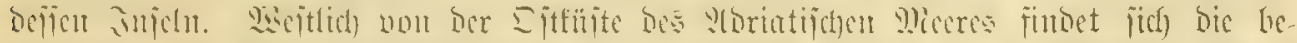

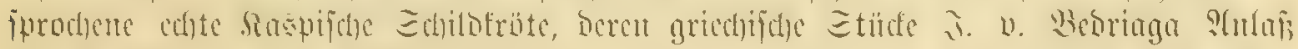

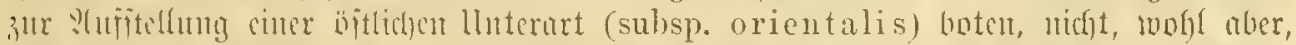

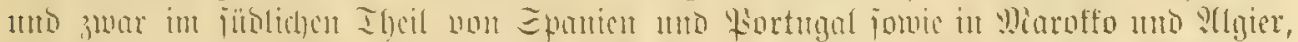

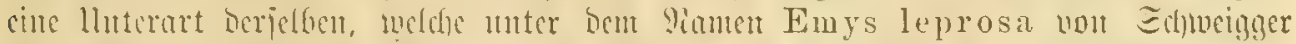

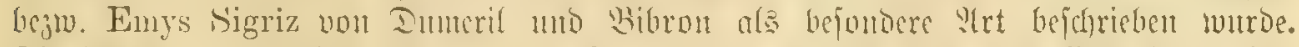

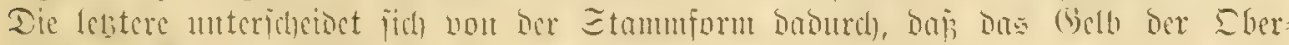

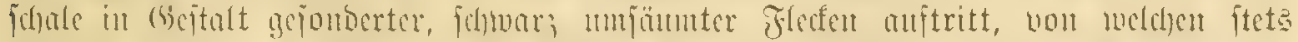

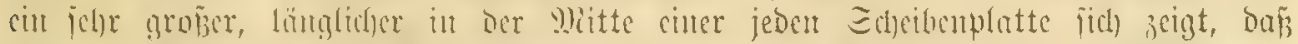

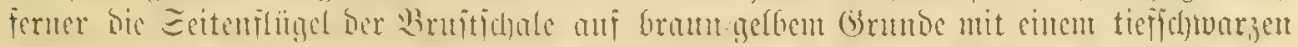

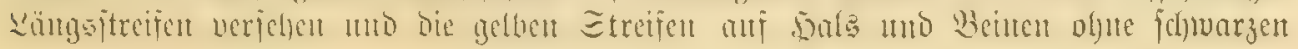




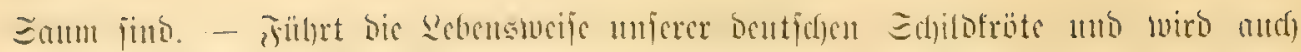
in Der Gefungenichaft bementipredyend berpifegt.

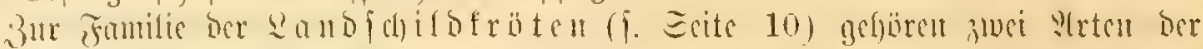

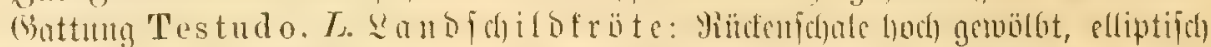

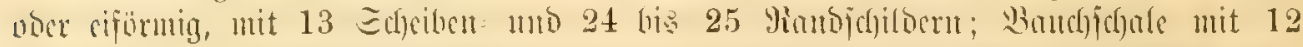

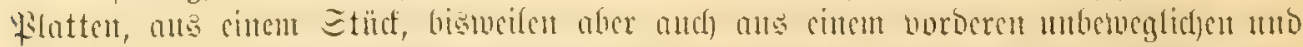

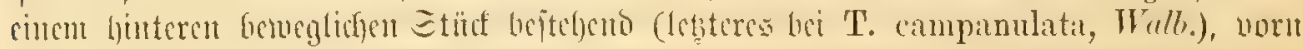

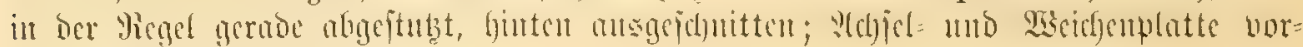
foutoen; Sopf bejojilbert.

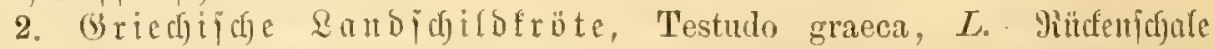

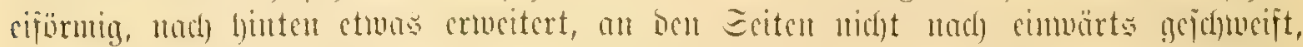

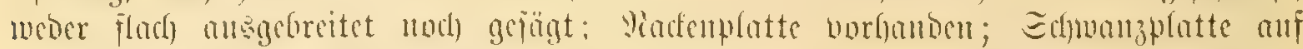

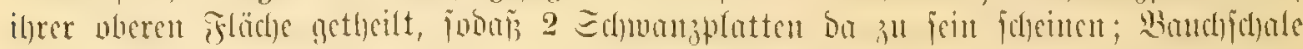

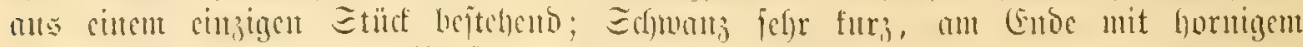

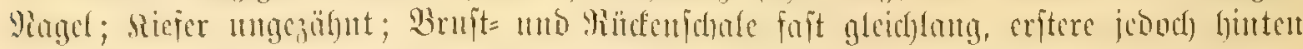

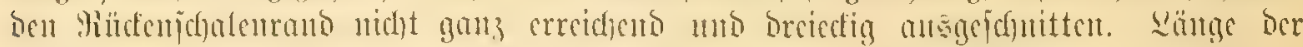

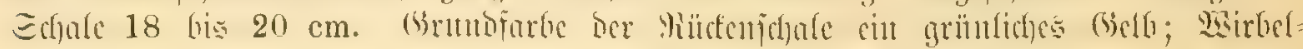

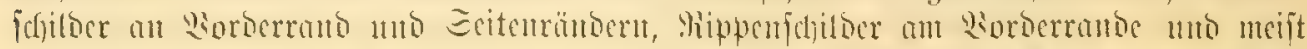

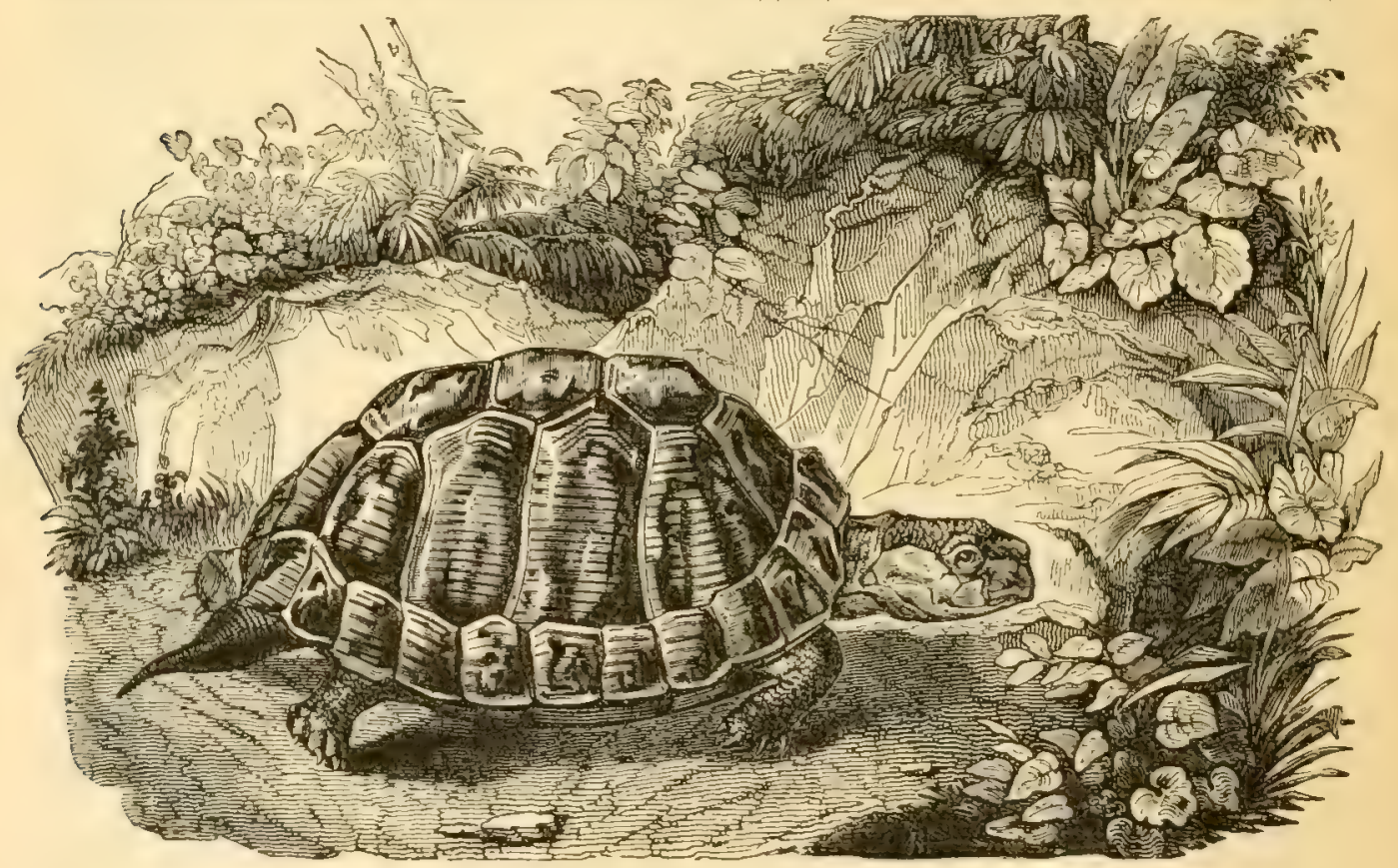

ijig. 4. Griedijdje Cdjitstiöte.

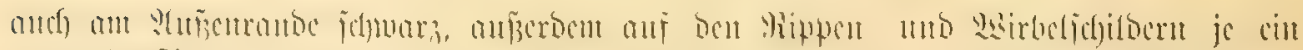

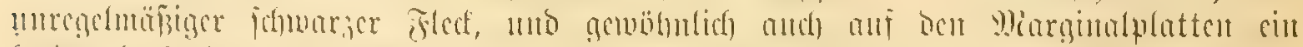

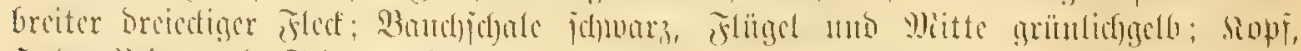

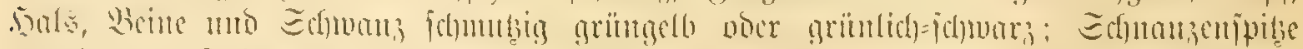

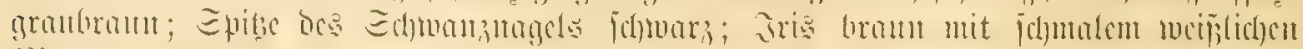

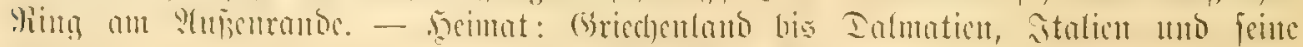

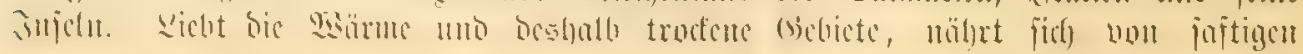




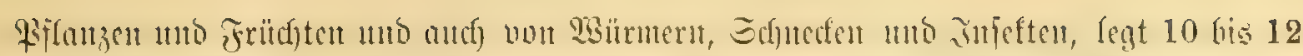

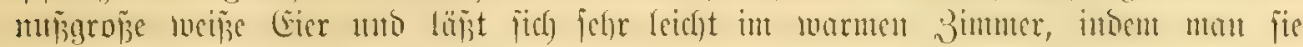
frei herumfaufen läpst, erfaltert.

3. Breitrandige Randidilbfröte, Testudo campanulata, Walbaum

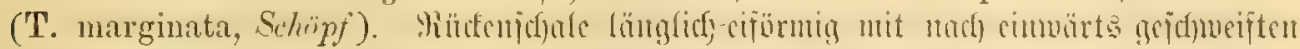

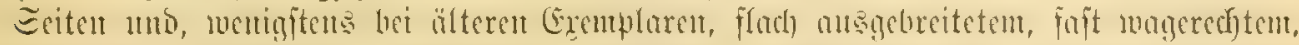

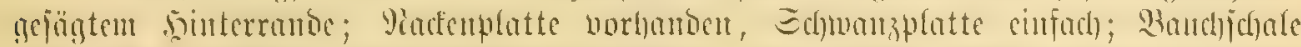

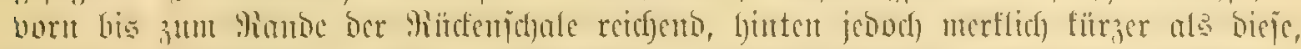

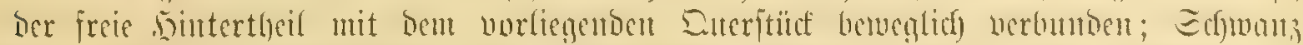

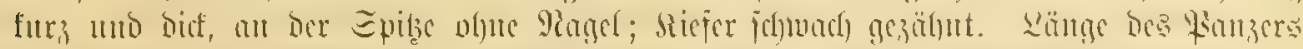

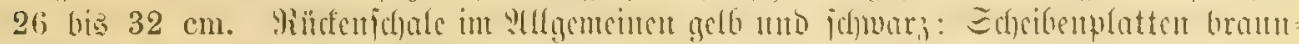

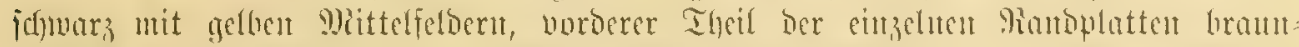

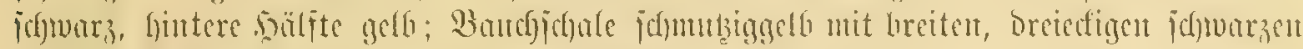

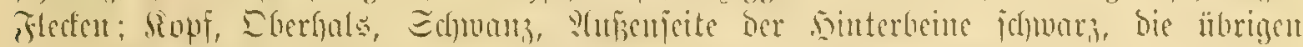

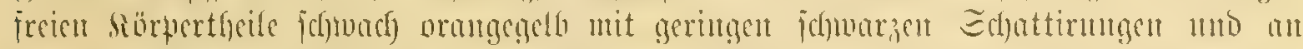

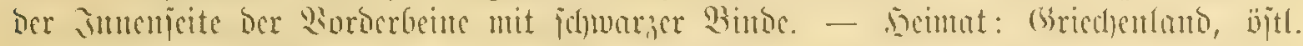

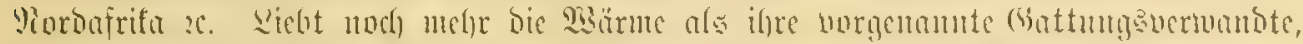

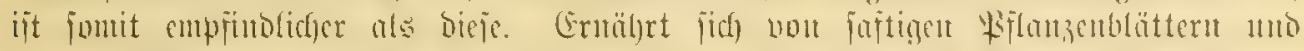

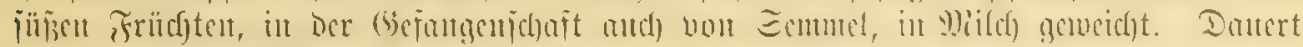

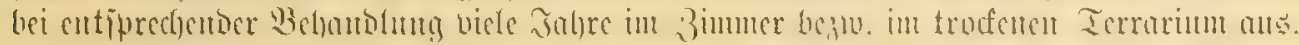

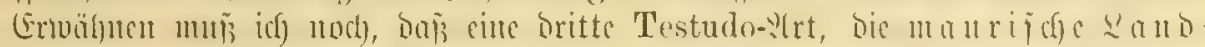

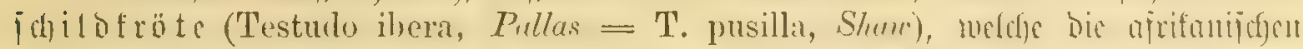

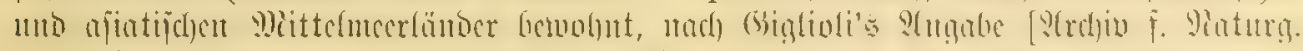

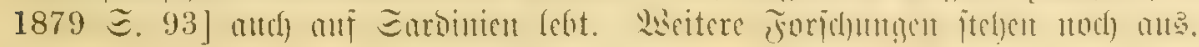

\section{II. (1)ronung.}

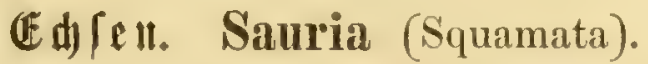

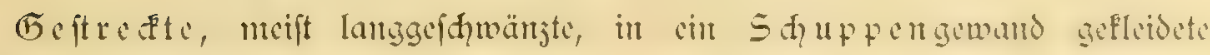

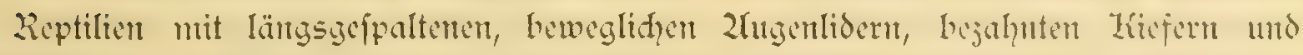

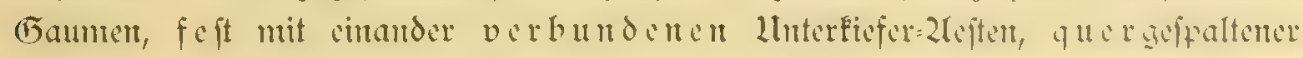
Zlloake und in Ser kigel mit Edqultergürtel und Bruftein und vier moht ans:

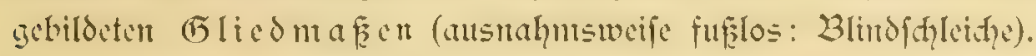

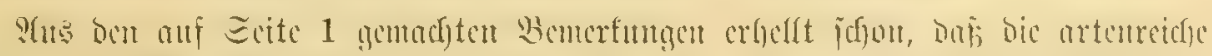

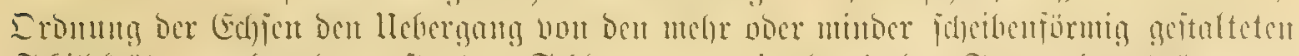

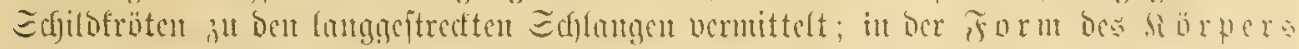

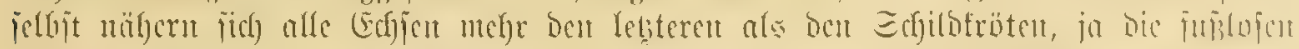

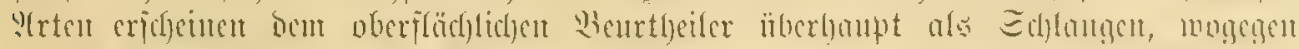

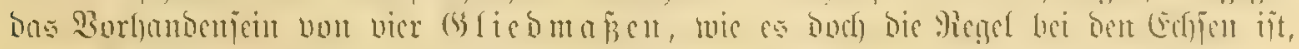

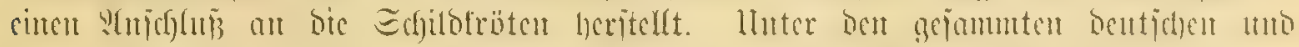

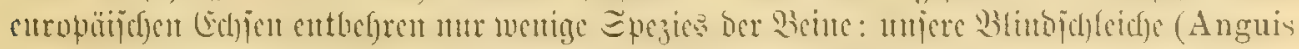

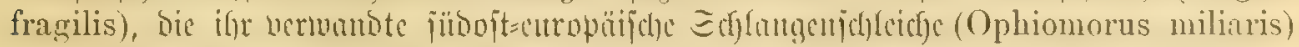

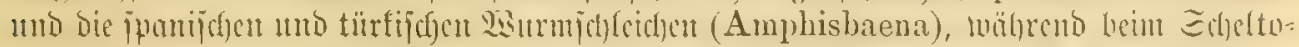

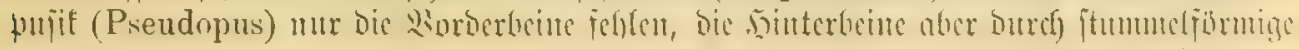

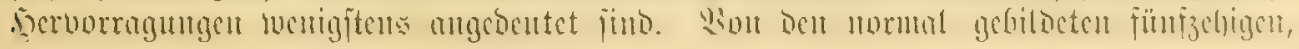




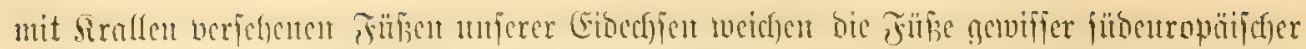

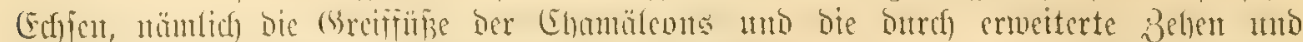

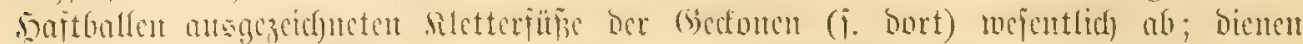

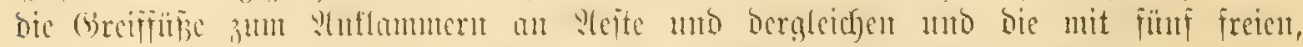

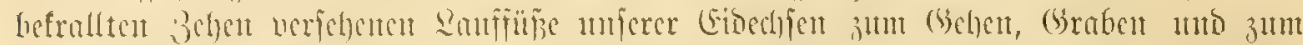

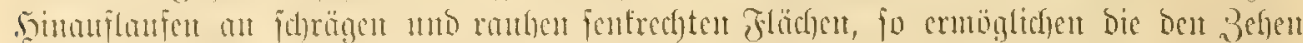

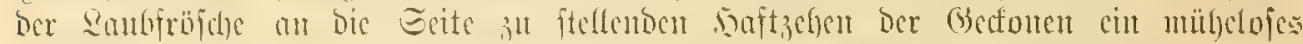

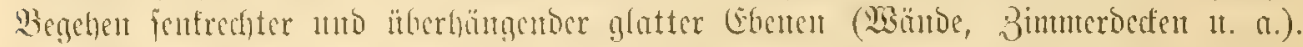

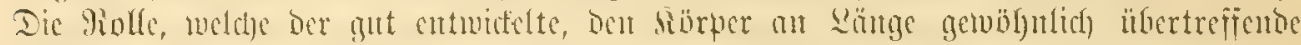

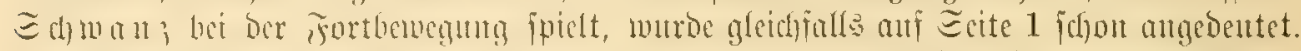

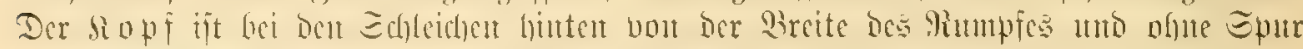

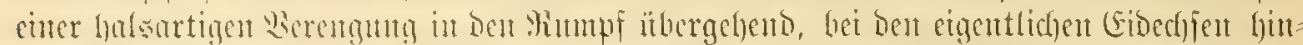

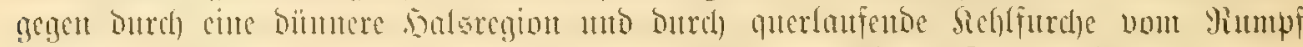

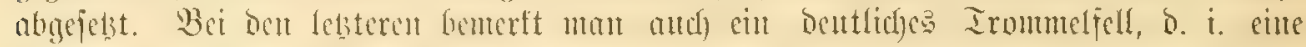

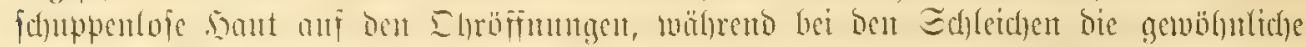

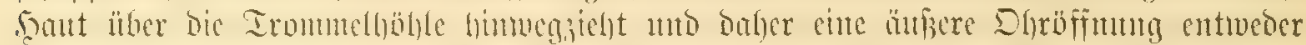

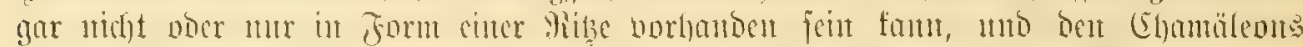

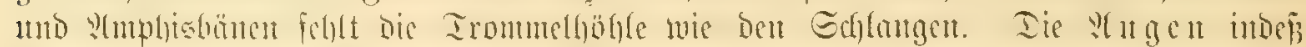

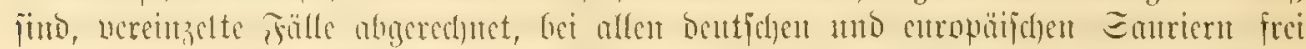

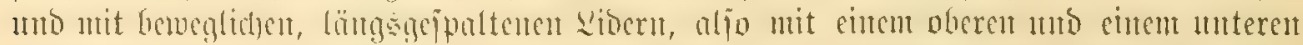

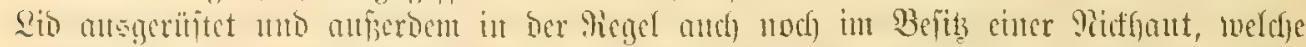

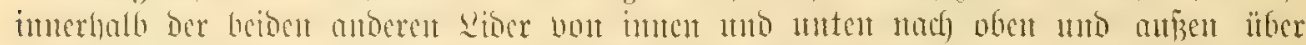

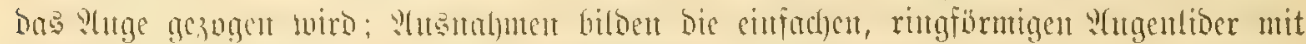

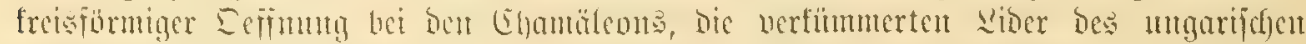

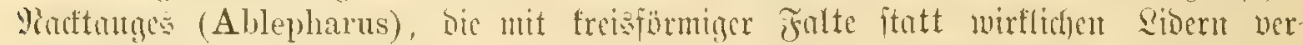

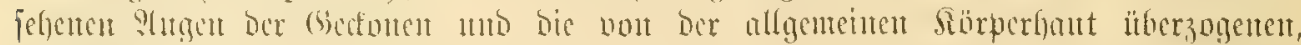

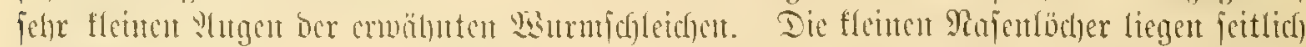

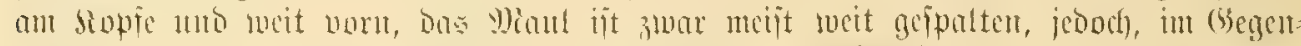

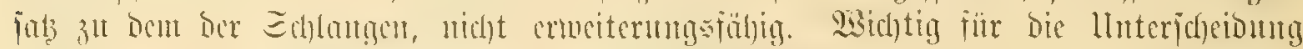

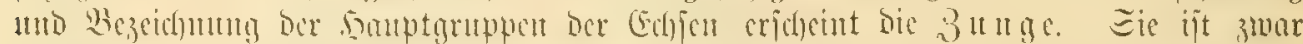

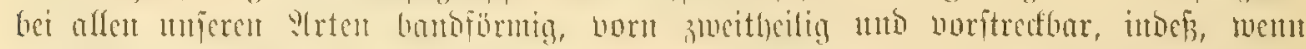

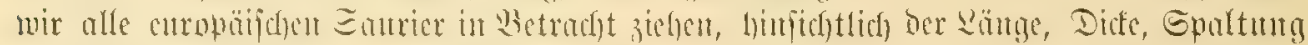

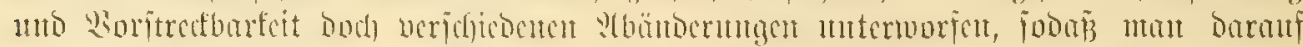

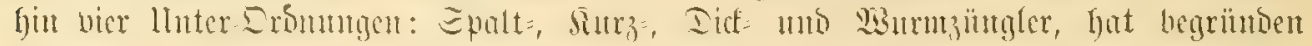

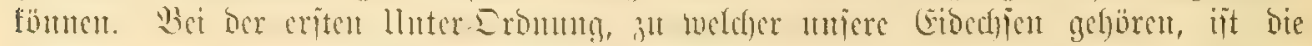

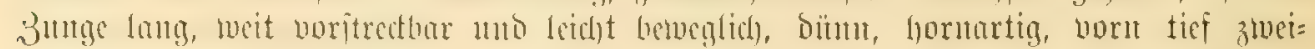

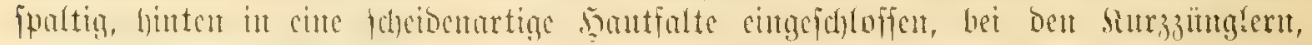

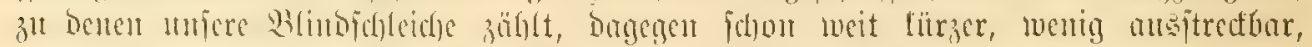

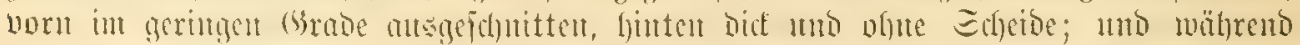

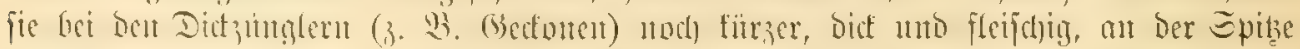

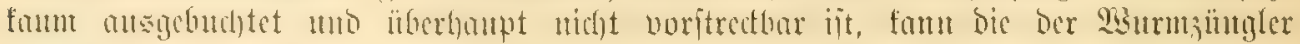

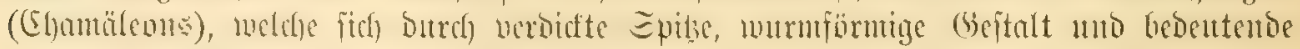

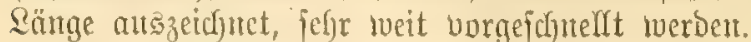

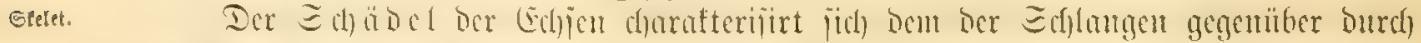

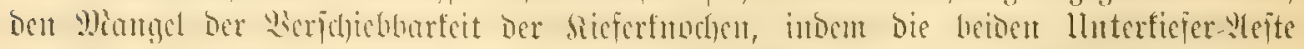

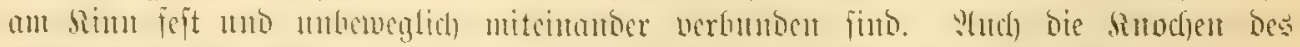

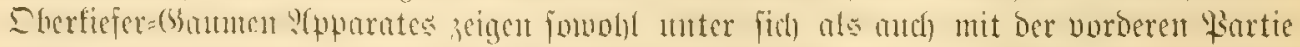

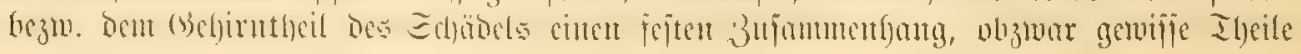




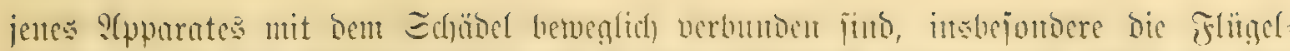

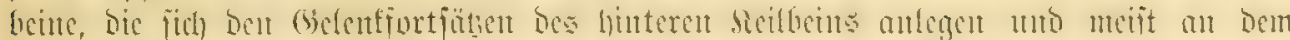

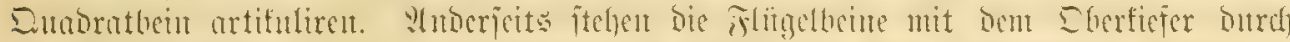

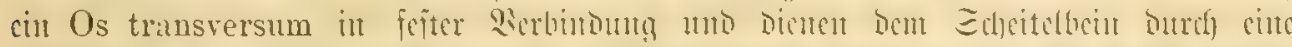

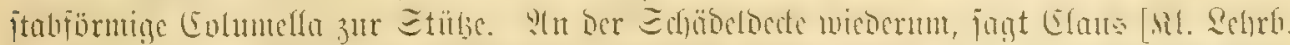

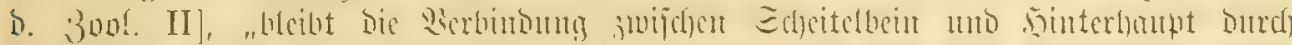

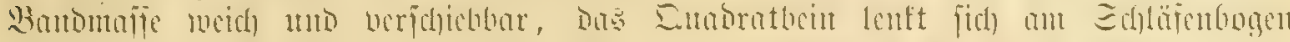

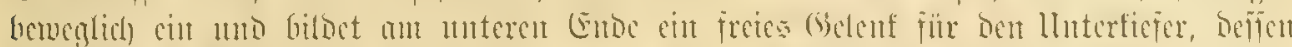

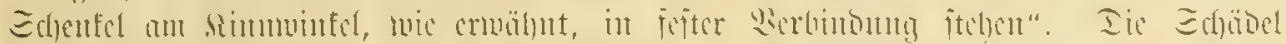

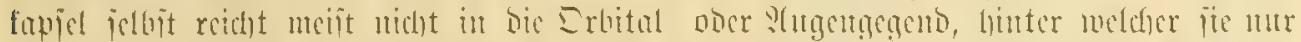

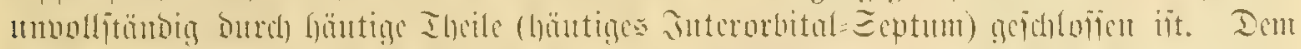

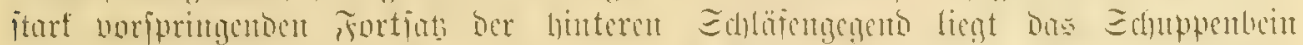

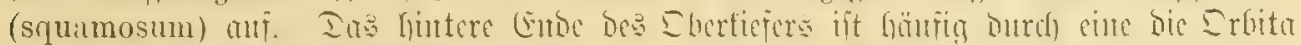

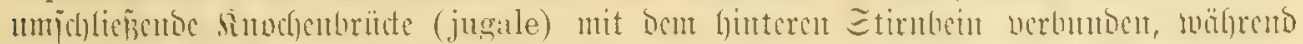

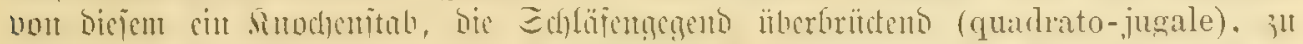

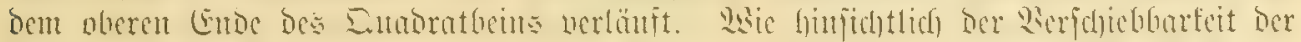

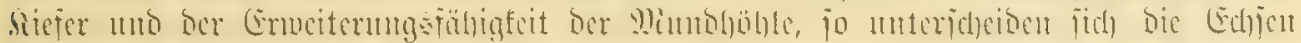

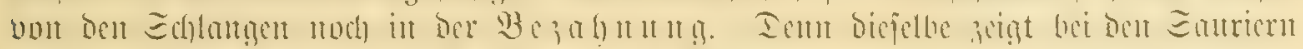

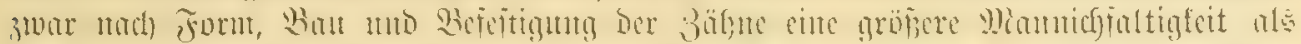

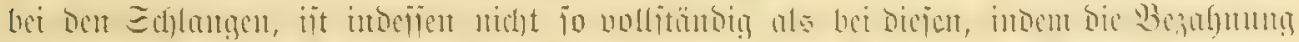

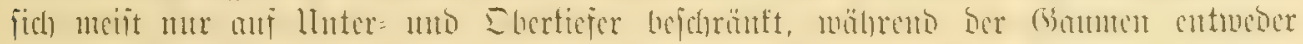

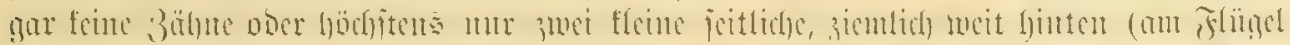

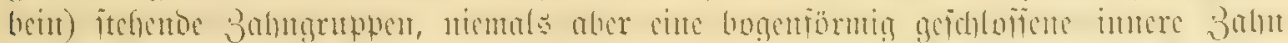

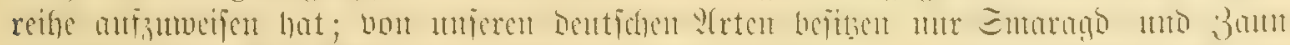

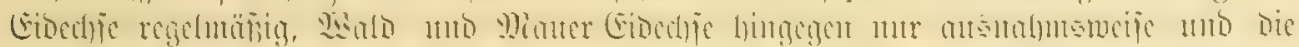

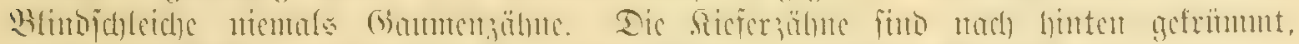

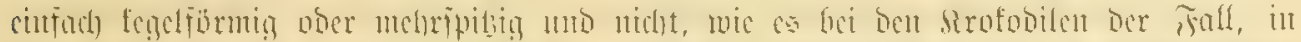

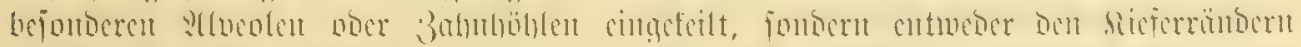

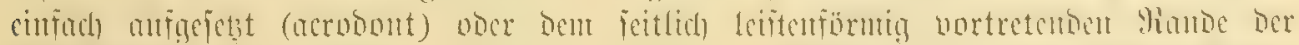

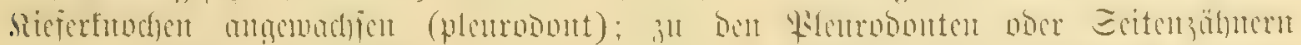

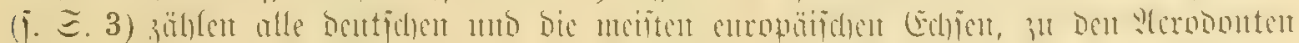

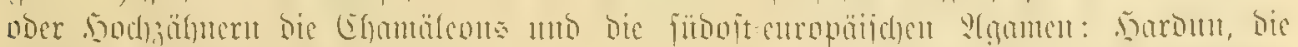

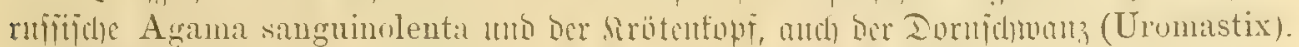

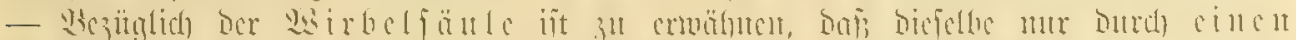

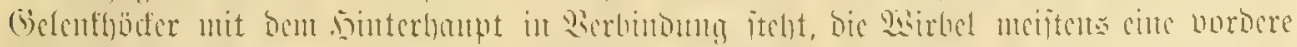

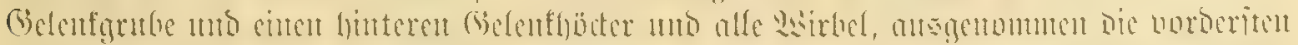

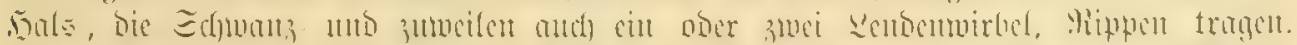

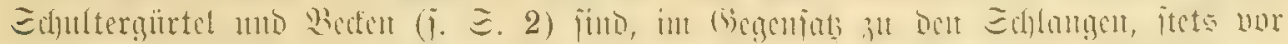

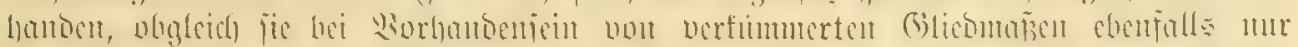

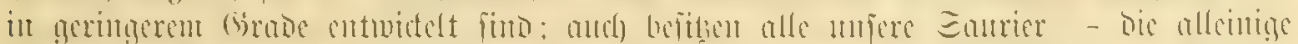

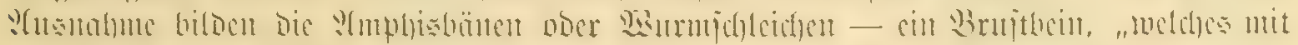

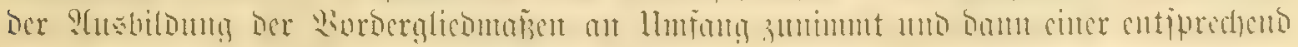

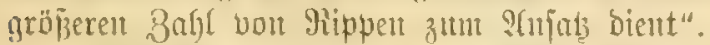

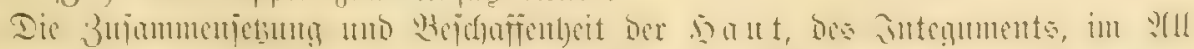

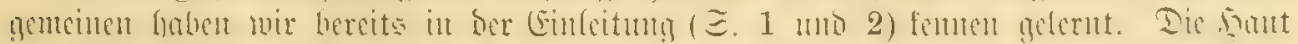

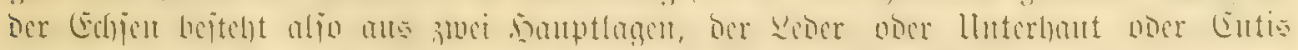

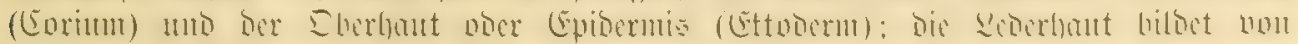

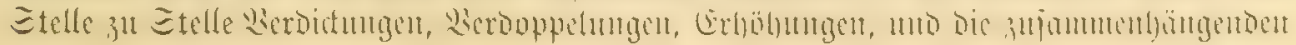




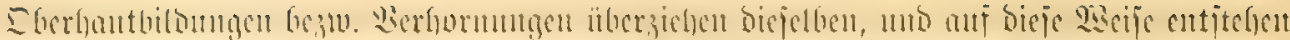

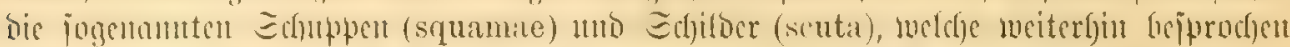

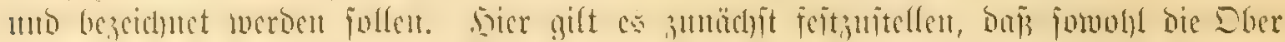

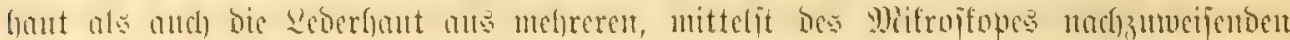

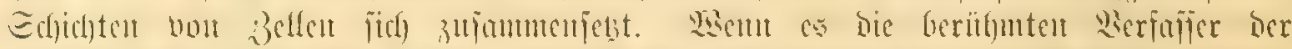

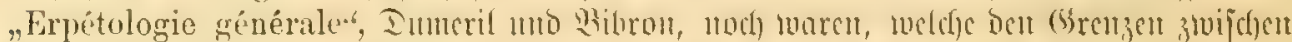

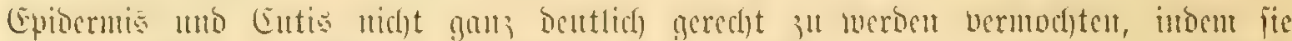

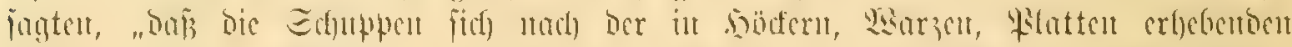

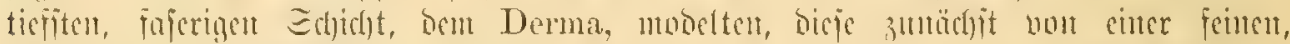

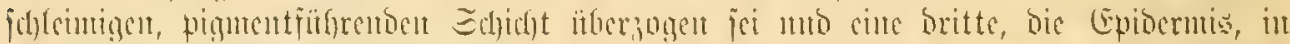

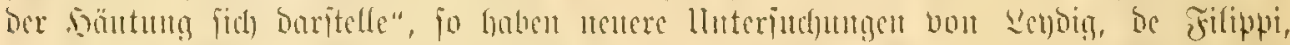

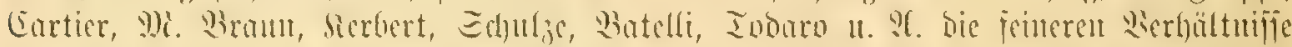

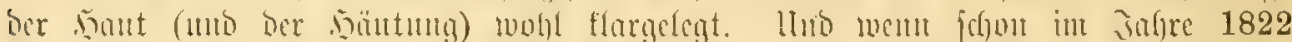

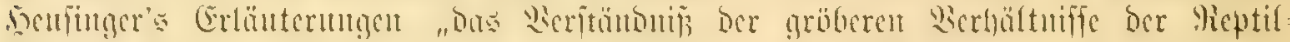

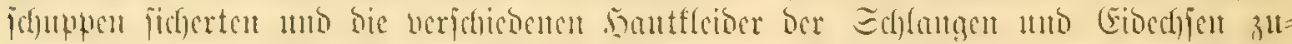

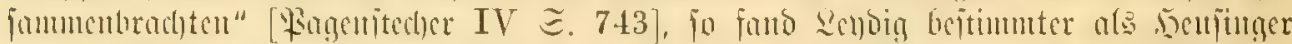

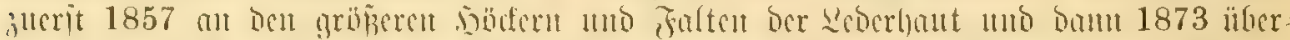

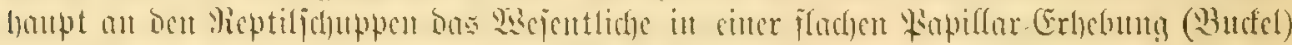

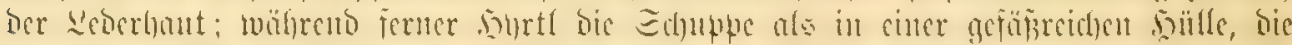

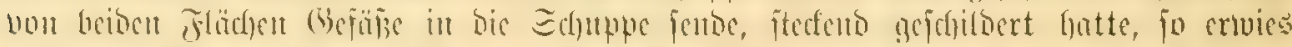

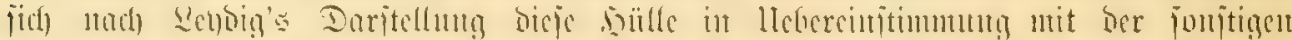

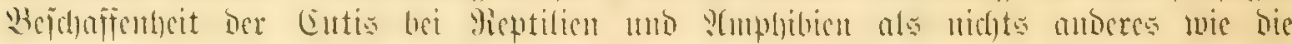

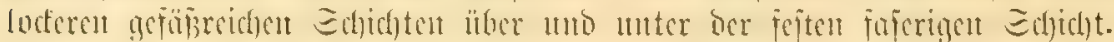

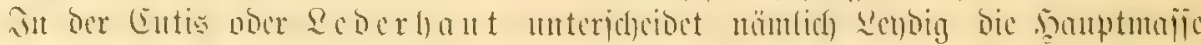

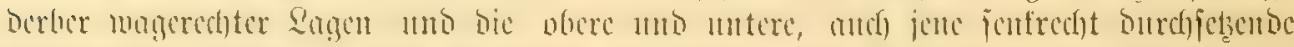

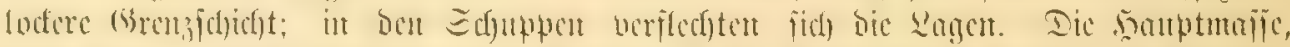

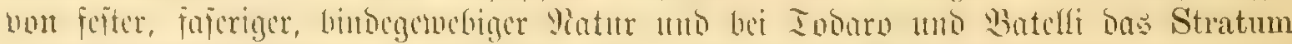

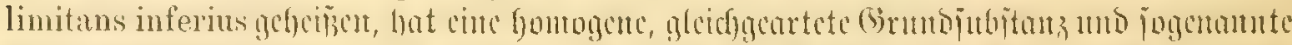

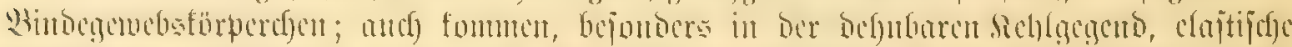

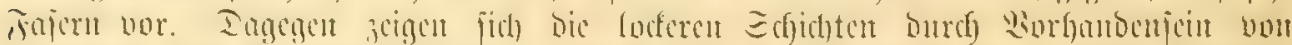

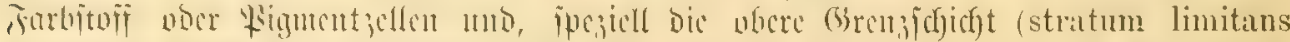

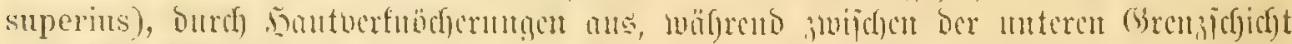

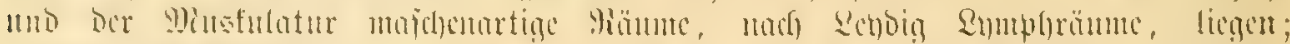

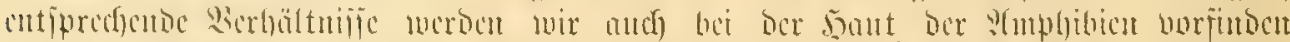

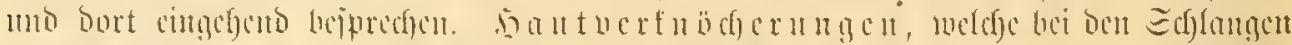

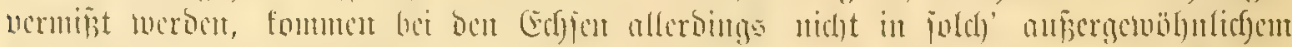

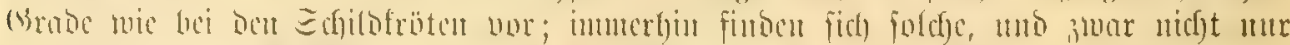

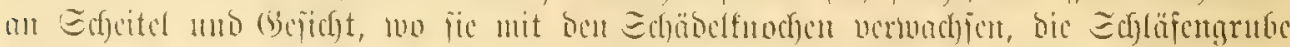

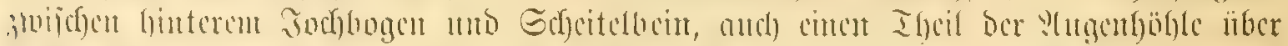

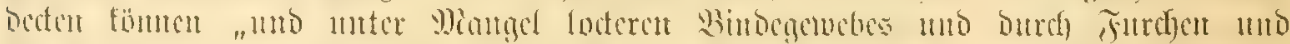

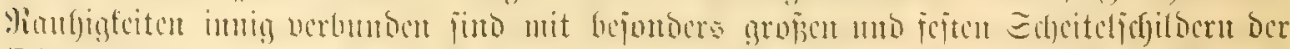

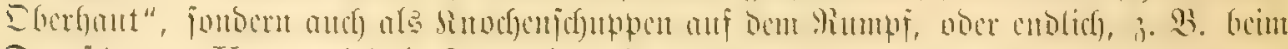

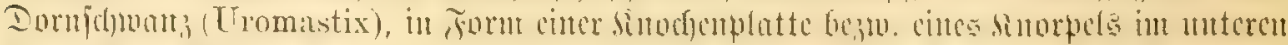

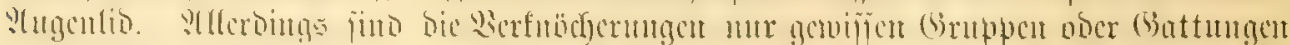

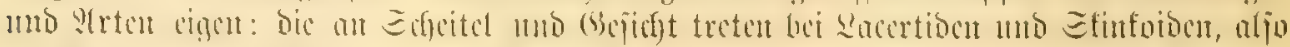

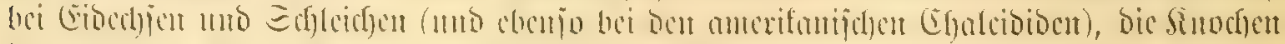

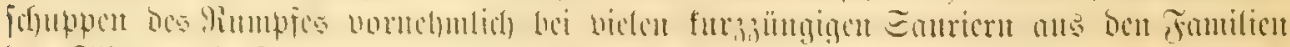

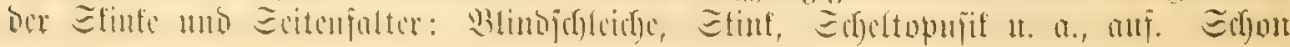




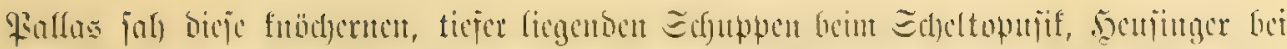

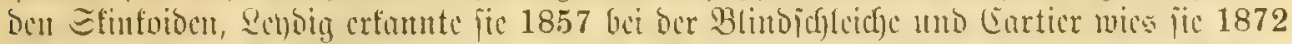

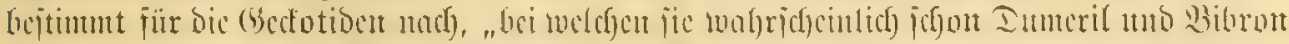

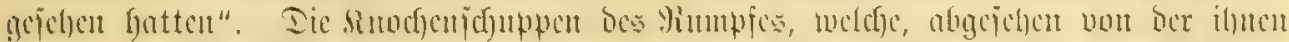

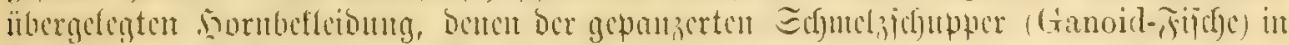

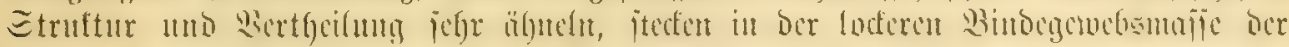

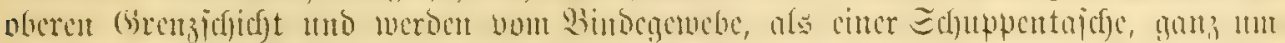

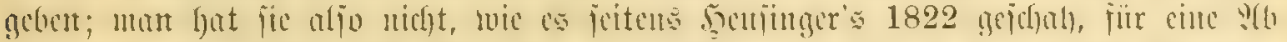

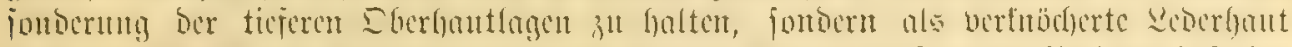

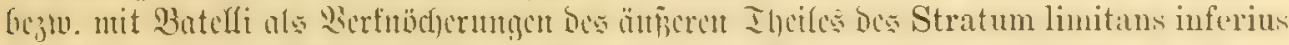

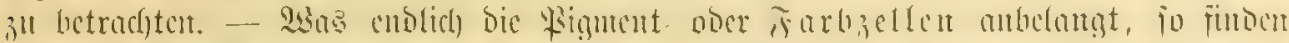

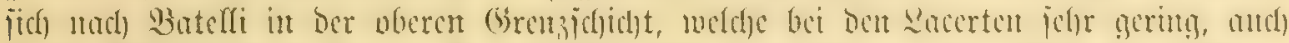

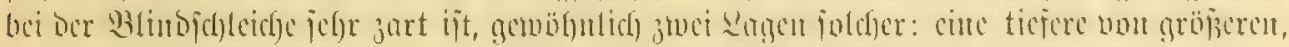

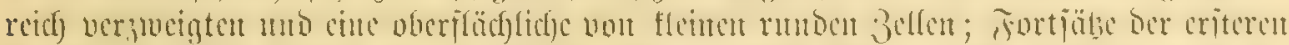

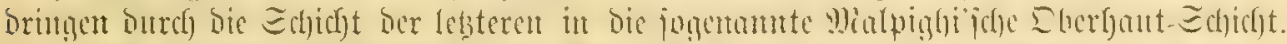

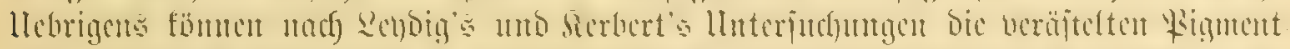

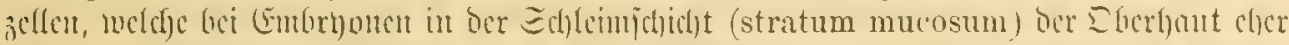

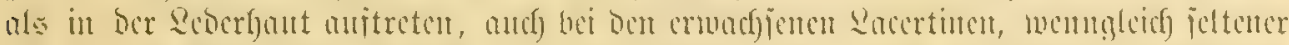

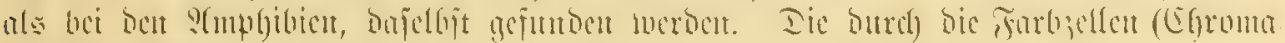

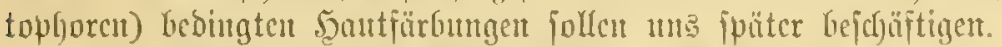

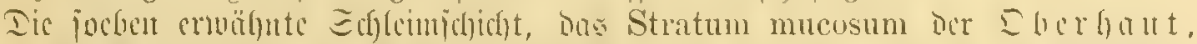

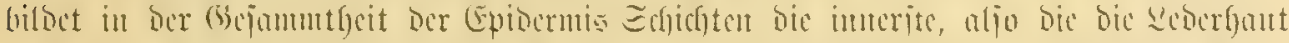

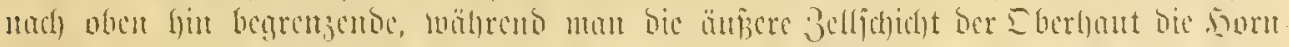

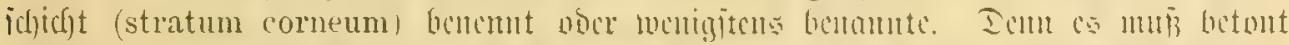

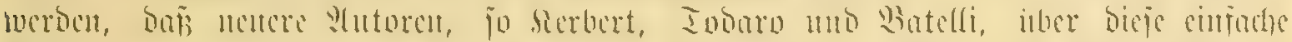

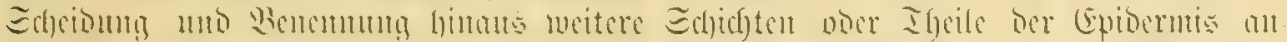

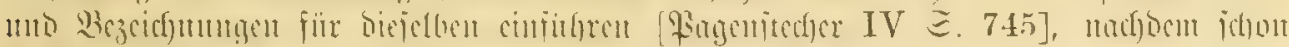

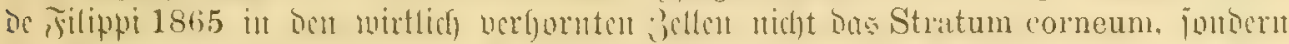

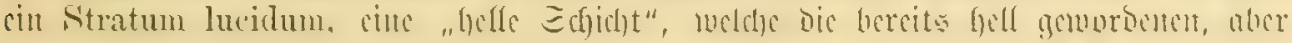

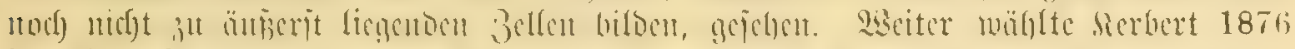

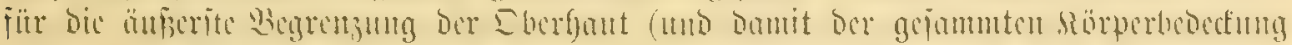

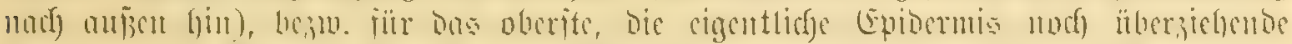

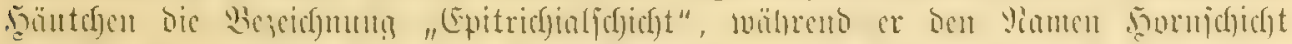

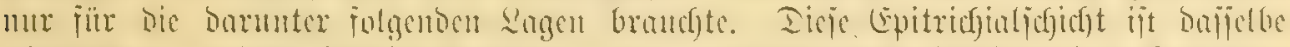

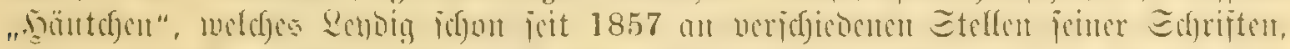

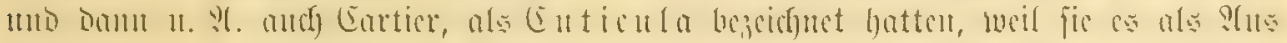

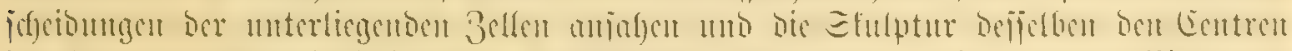

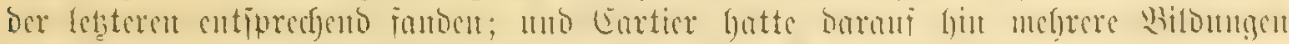

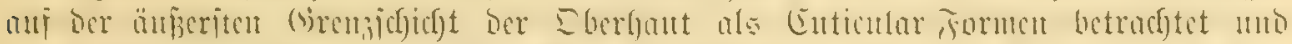

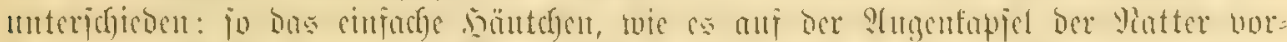

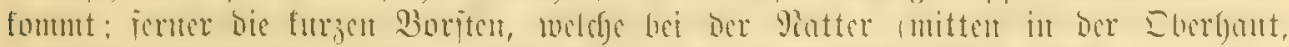

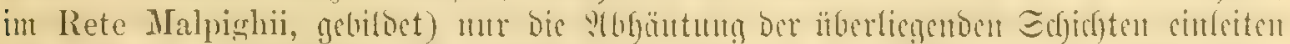

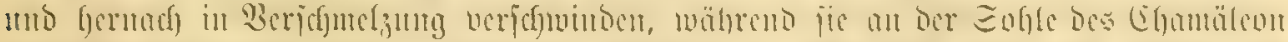

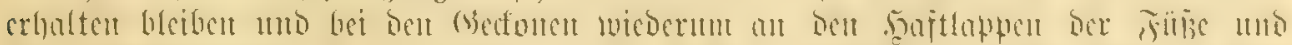

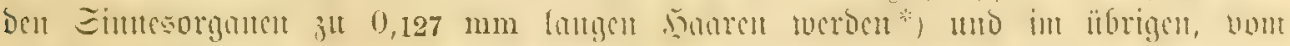

*) 21. Braun jantb ganı gleid) wie (Eartier bei Phyllodactylus (3Lattinger) fo bei Anolis bie

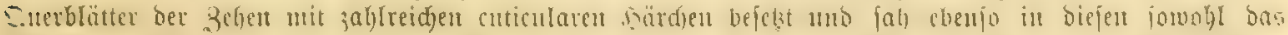

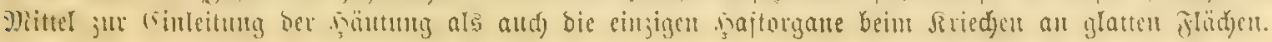




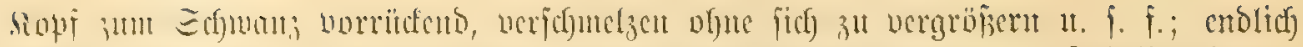

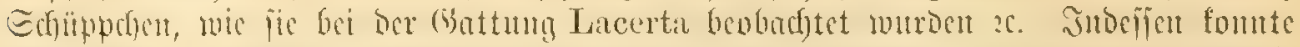

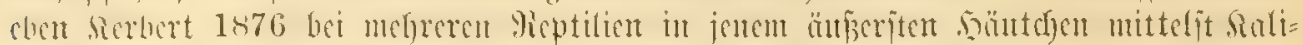

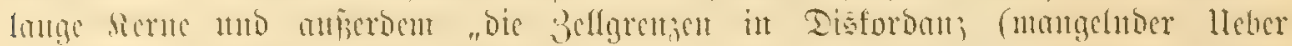

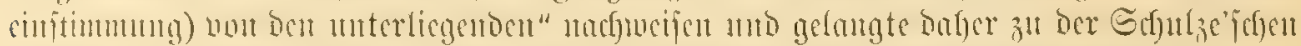

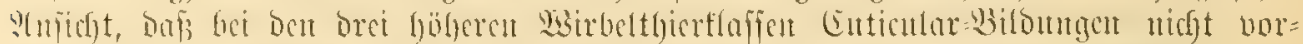

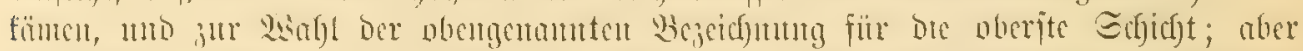

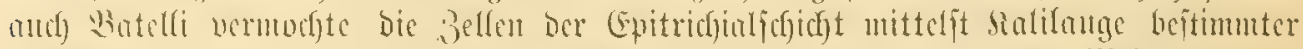

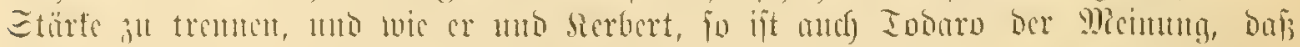

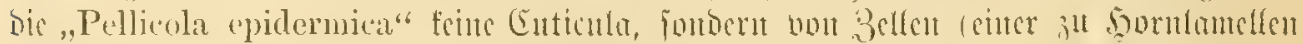

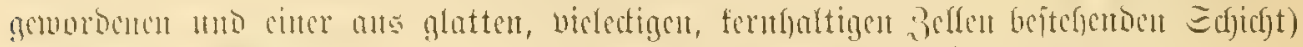

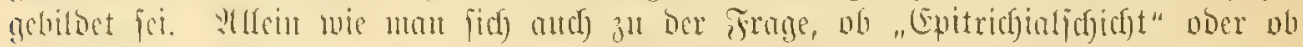

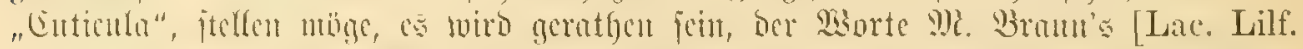

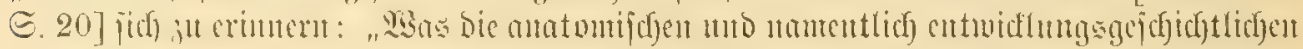

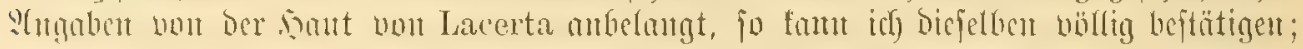

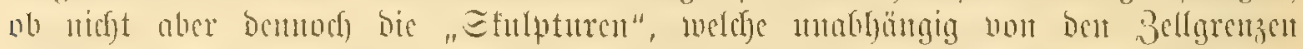

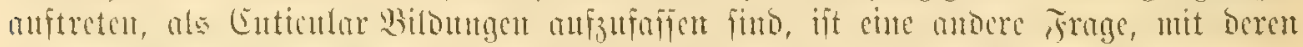

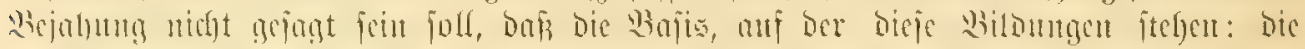

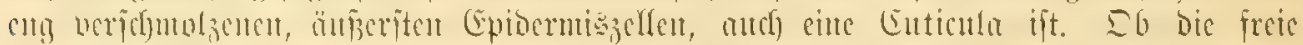

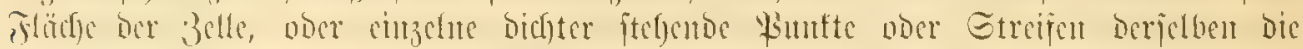

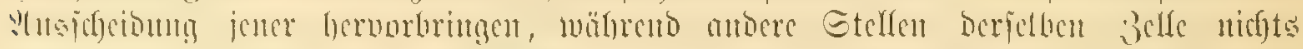

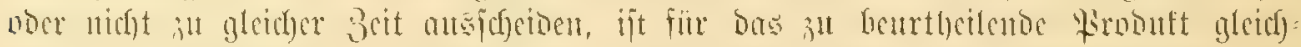

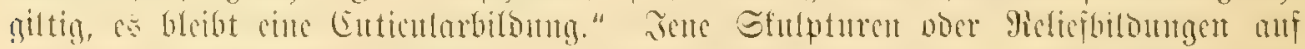

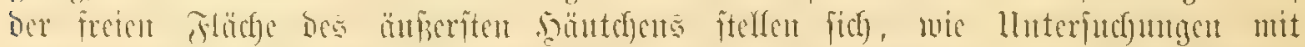

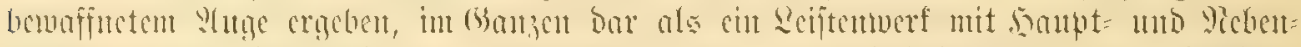

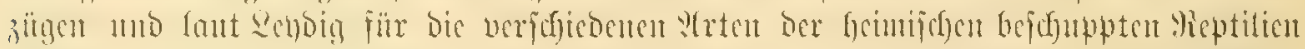

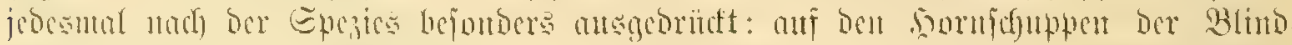

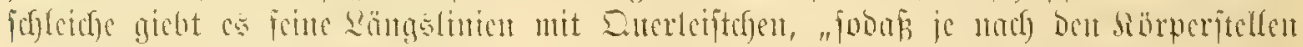

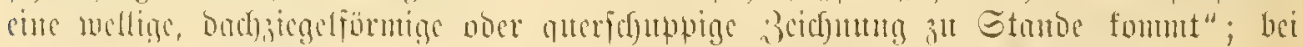

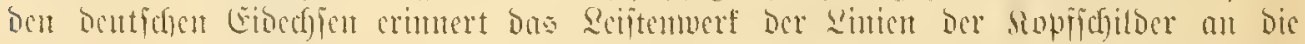

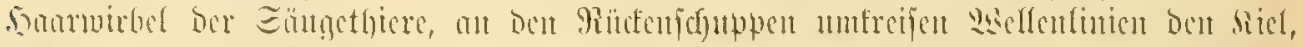

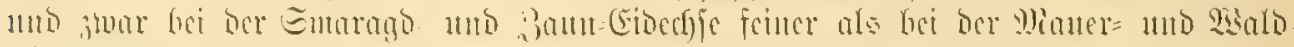

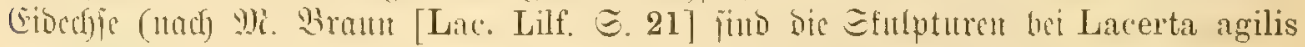

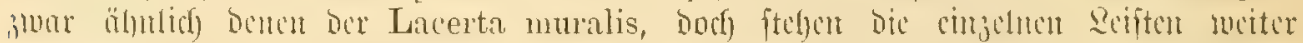

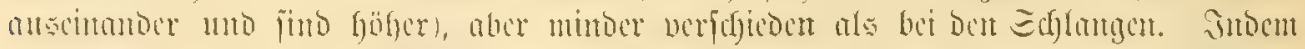

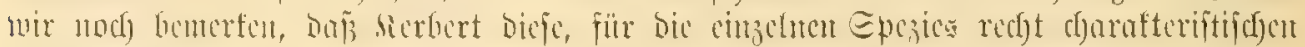

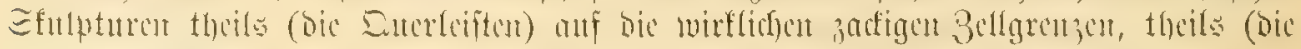

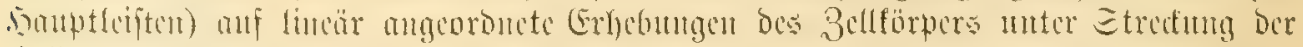

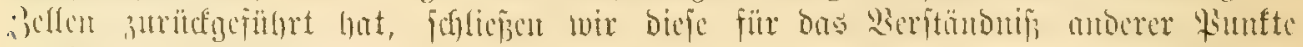

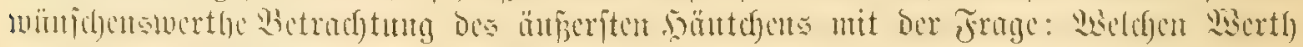

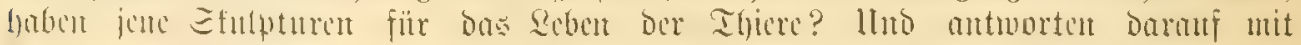

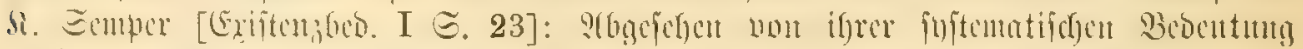

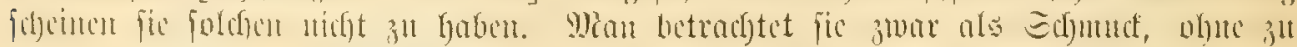

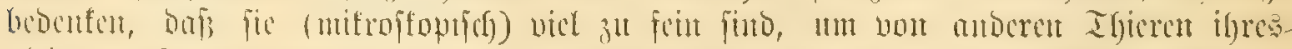

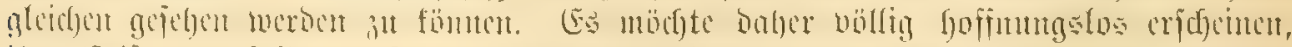

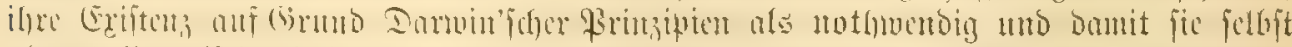

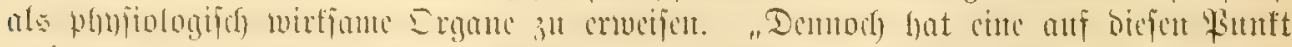

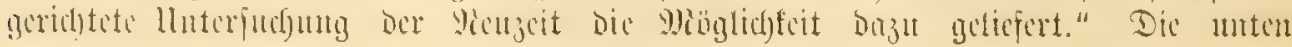




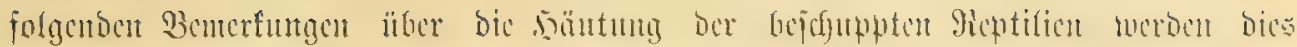

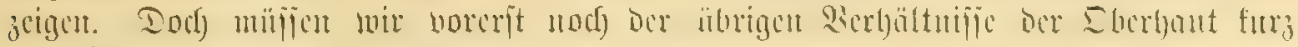
gedenfeut.

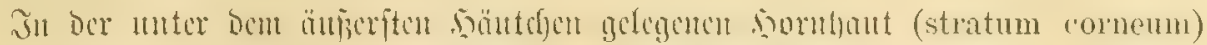

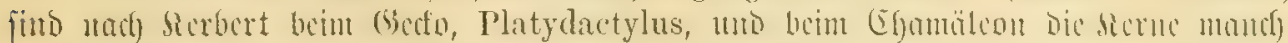

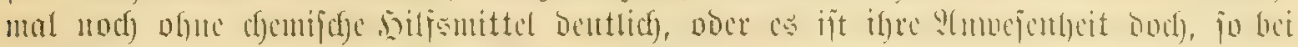

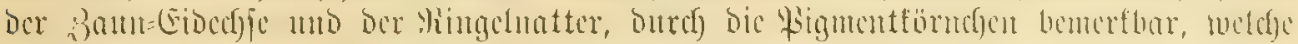

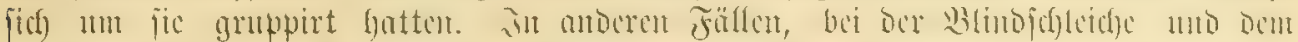

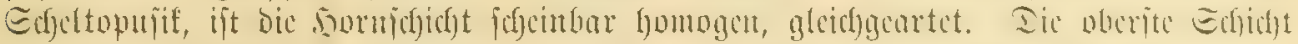

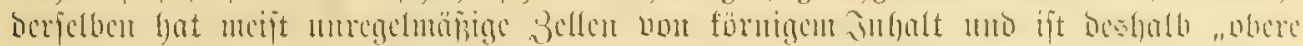

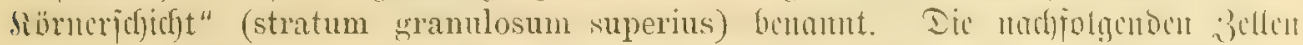

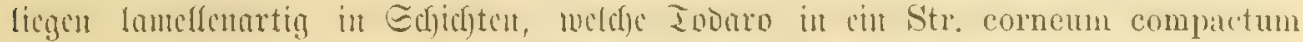

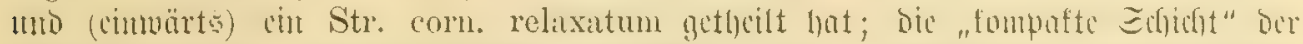

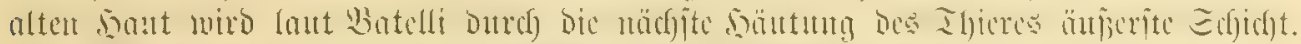

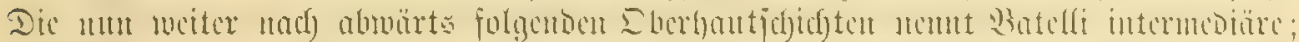

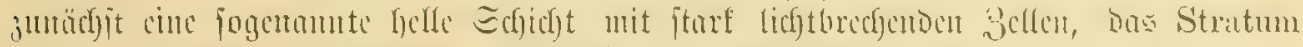

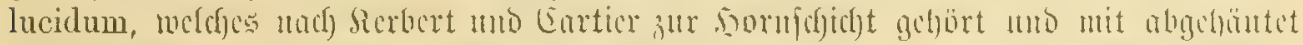

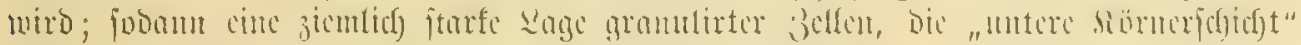

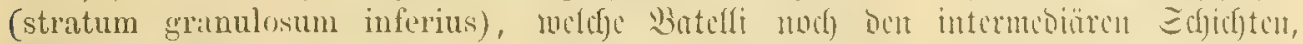

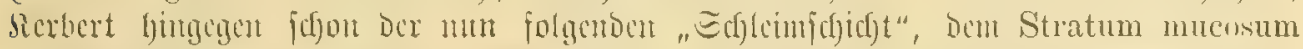

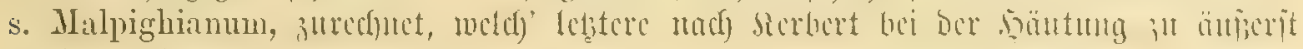
31t liegert fonment.

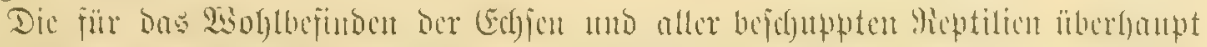

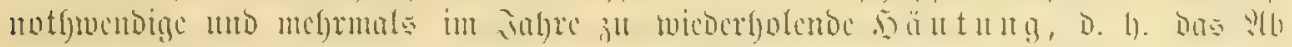

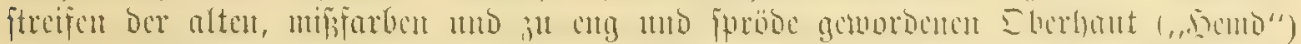

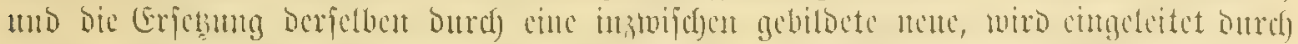

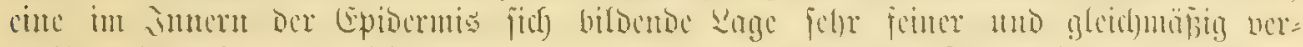

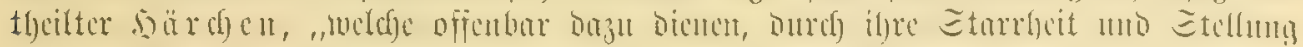

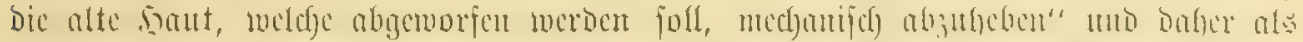

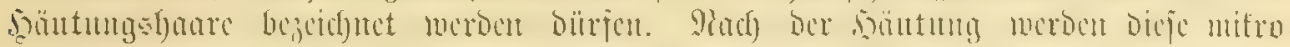

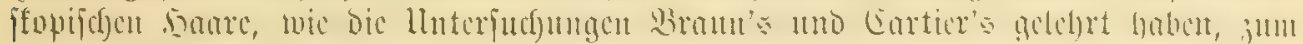

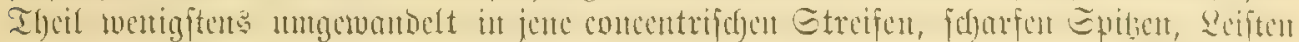

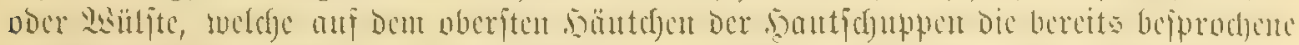

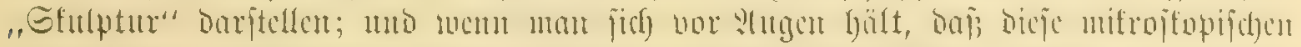

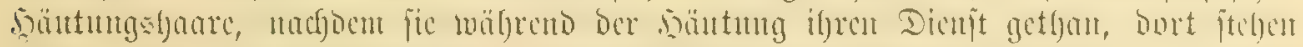

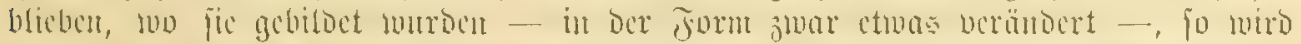

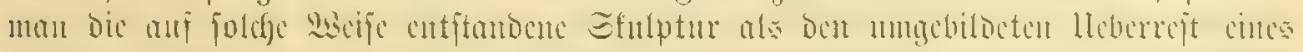

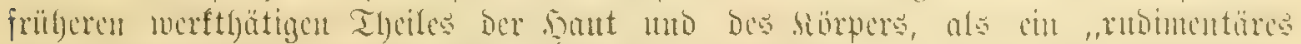

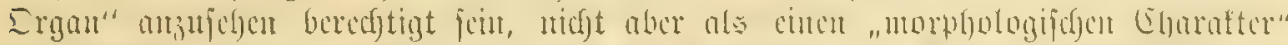

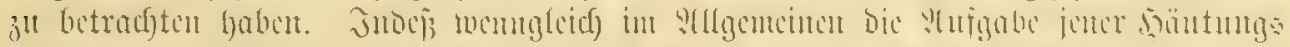

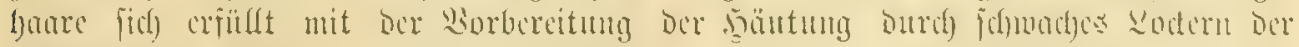

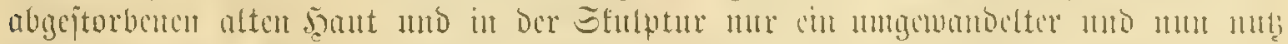

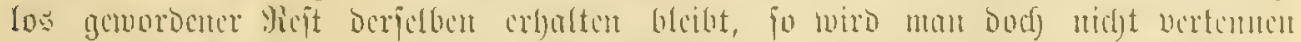

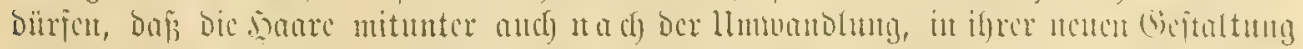

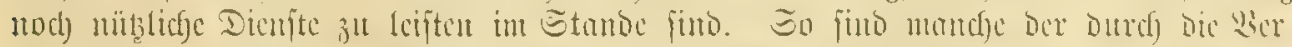

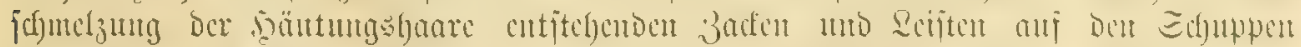

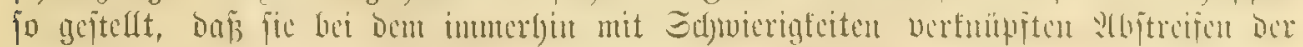

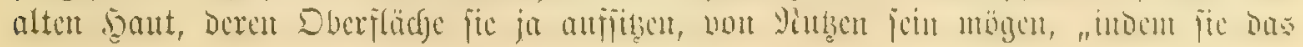




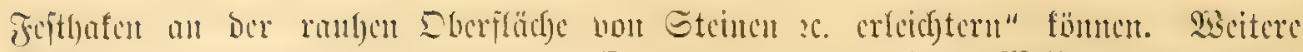

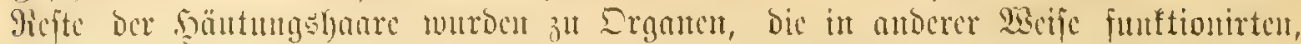

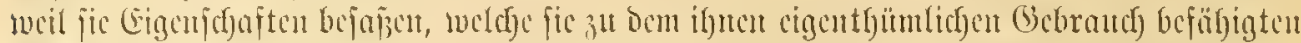

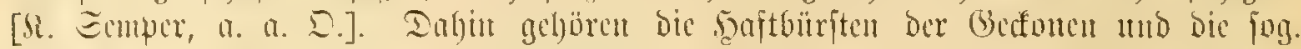

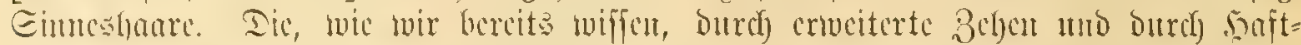

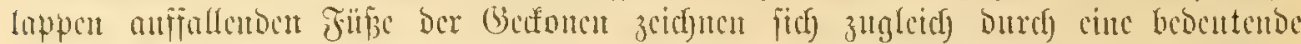

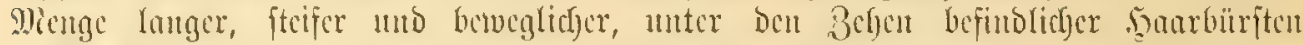

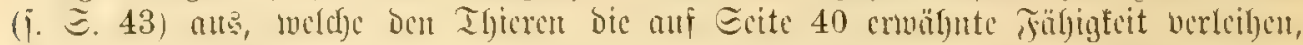

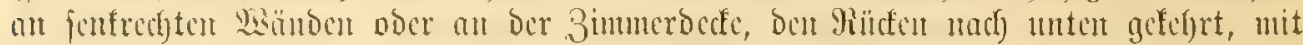

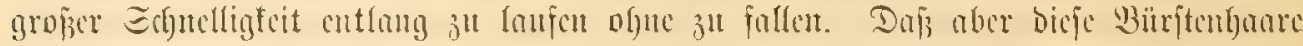

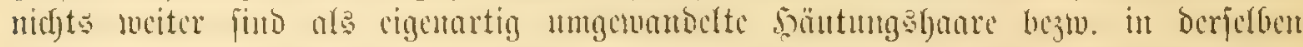

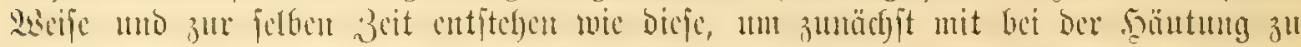

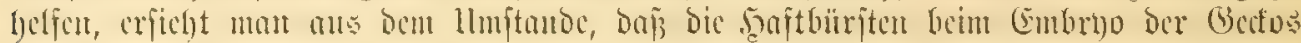

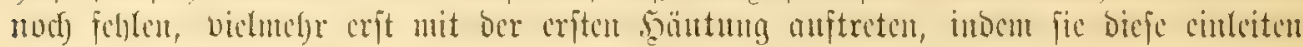

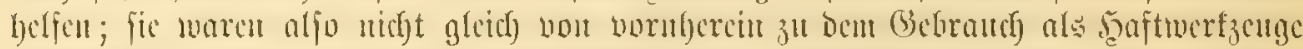
beftumnt, jonbern erlangten bicje Fülfigfeit arft, nachbom fie vorljer cinem anberen

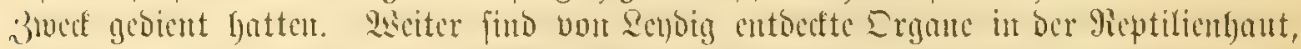

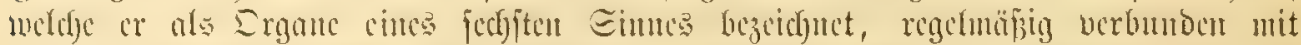

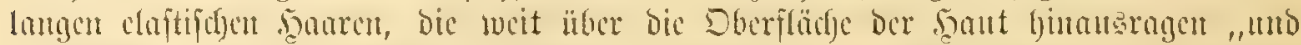

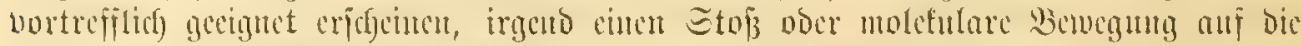

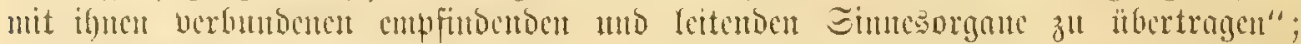

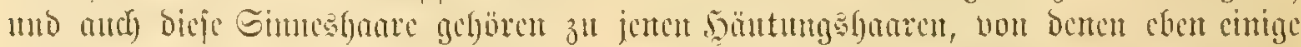

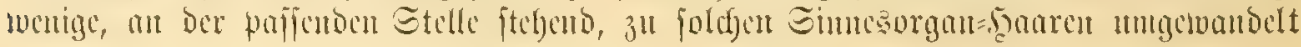
mutrden.

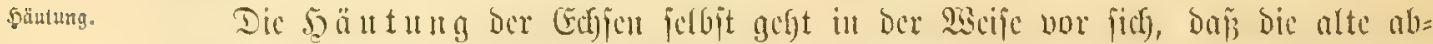

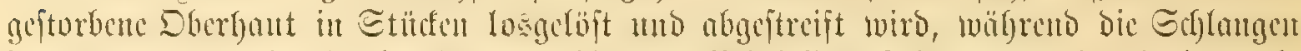

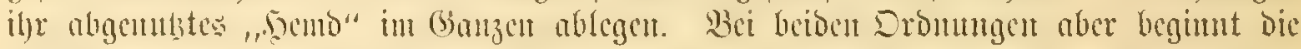

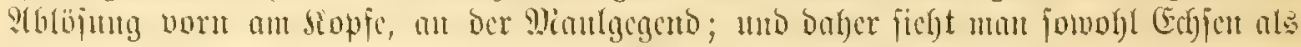

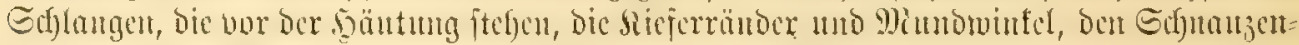

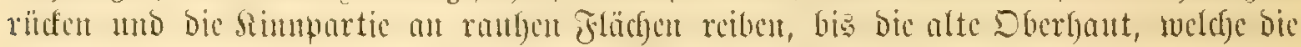

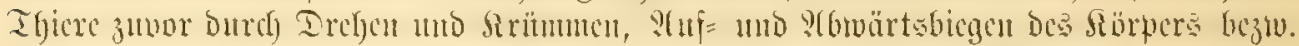

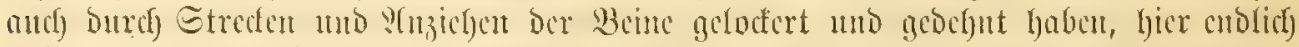
reifist tmo mu bos ?

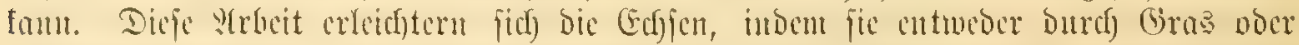

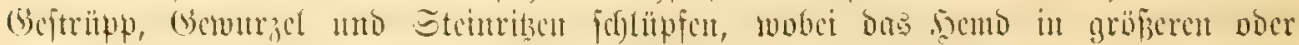

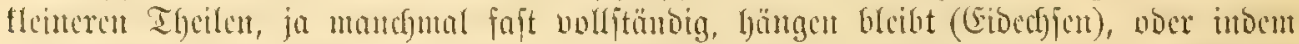

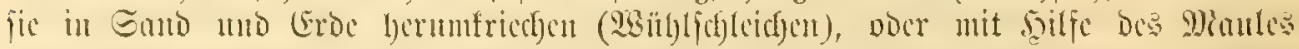

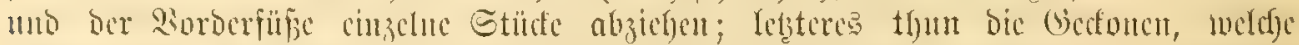

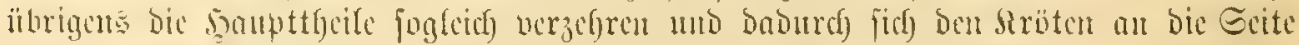

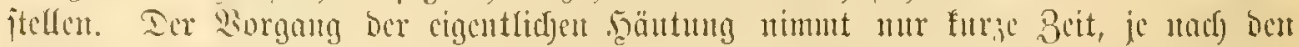

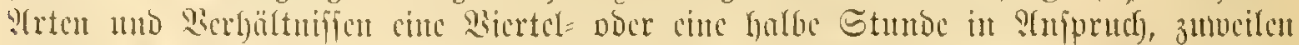

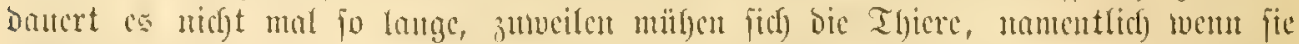

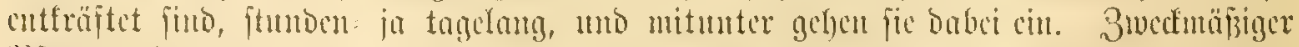

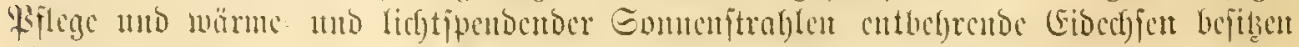

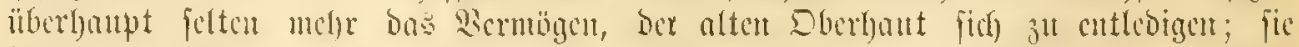

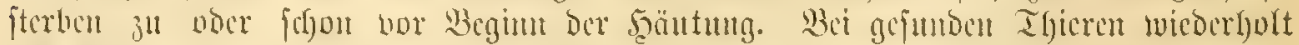

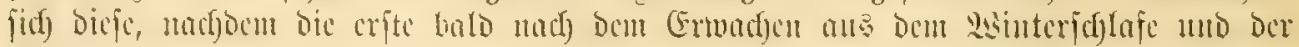

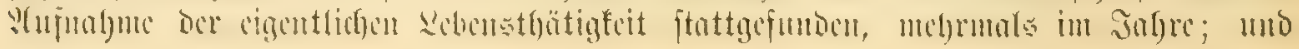




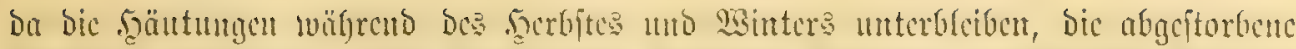

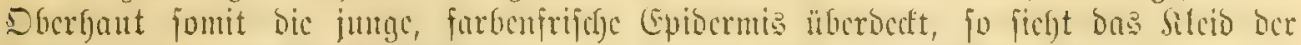

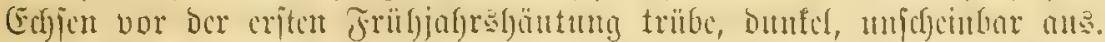

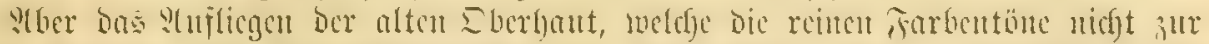

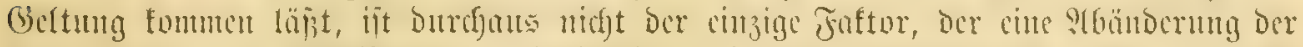

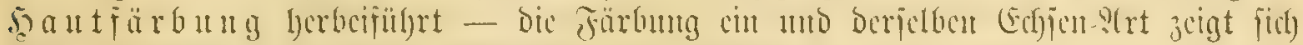

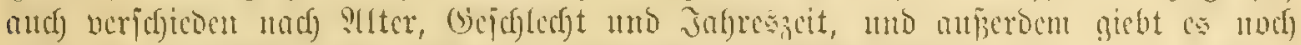

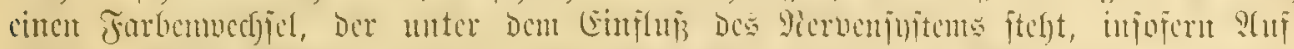

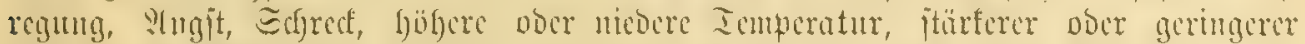

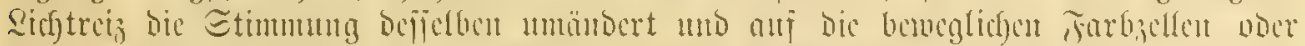

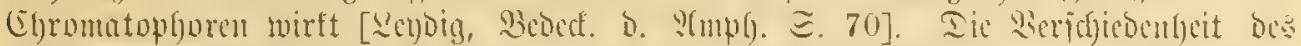

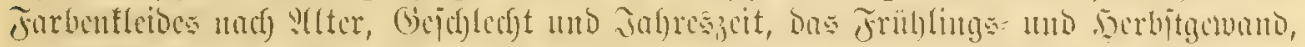

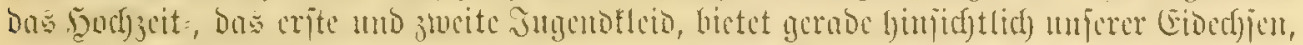

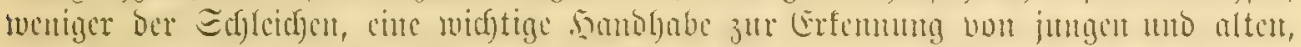

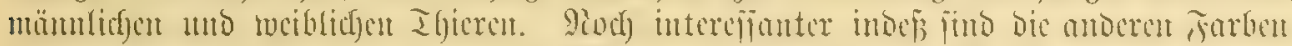

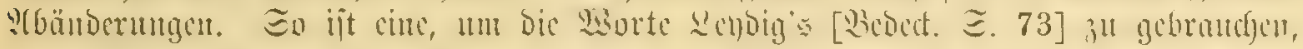

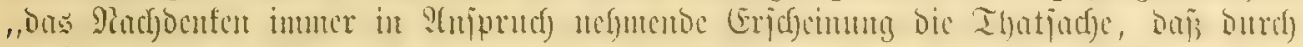

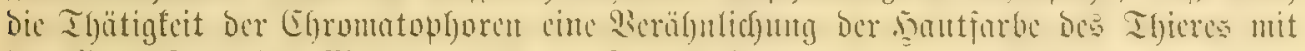

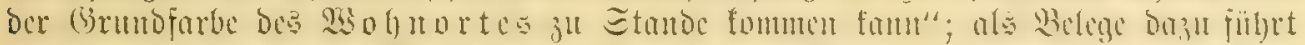

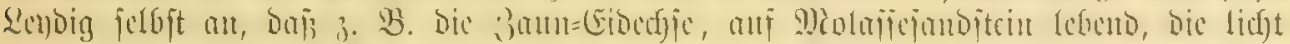

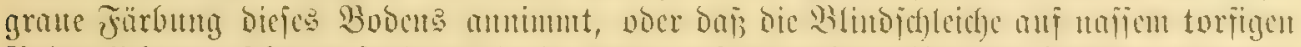

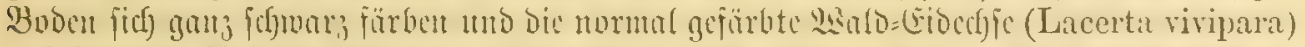

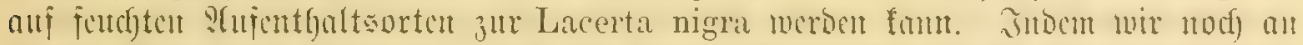

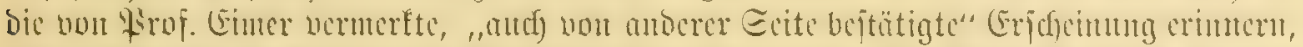

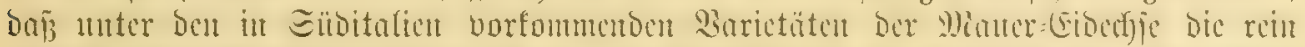

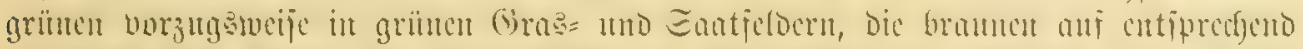

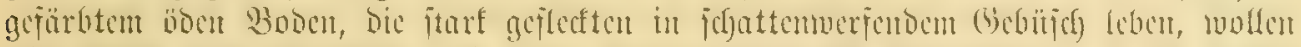

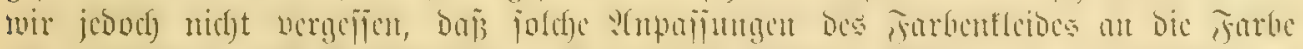

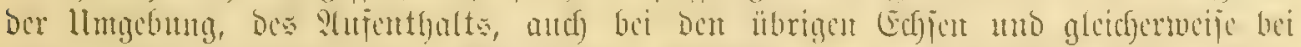

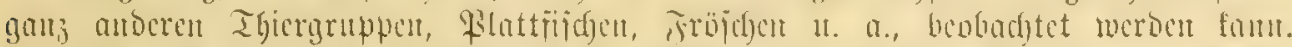

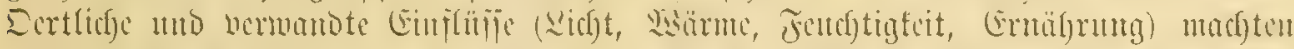

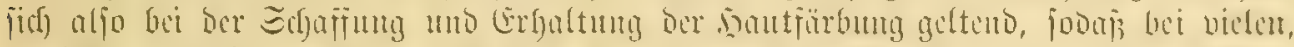

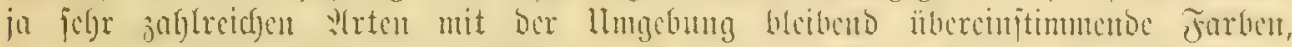

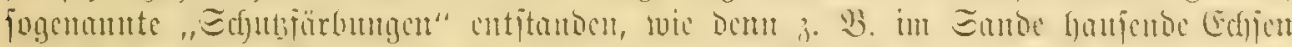

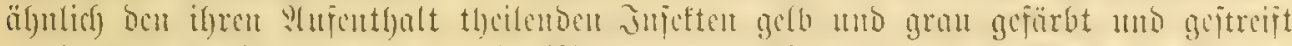

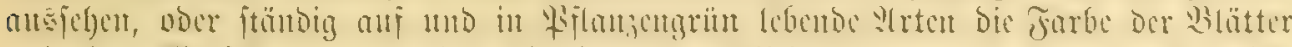

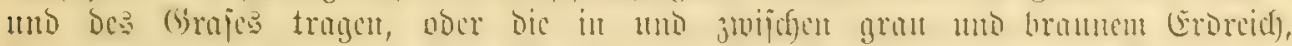

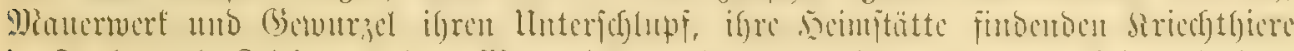

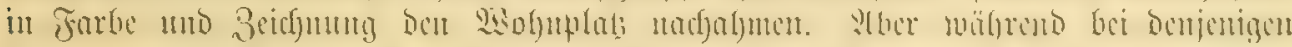

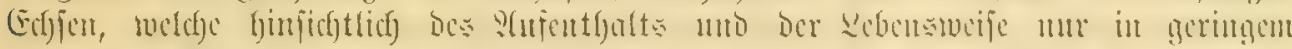

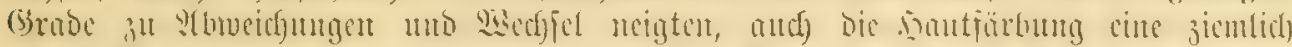

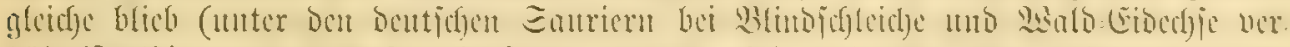

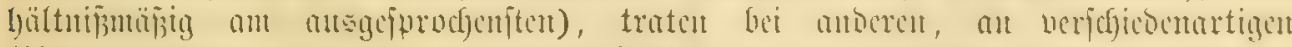

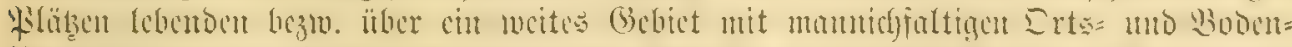

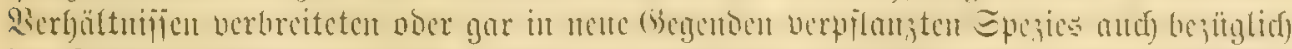

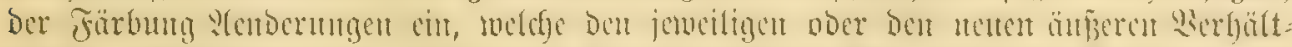

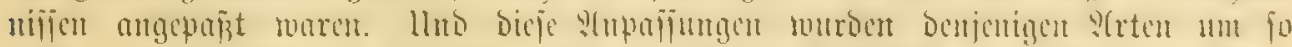

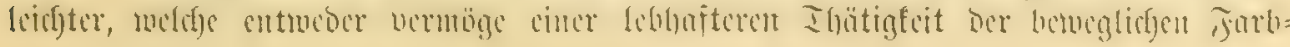




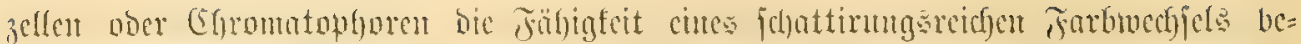

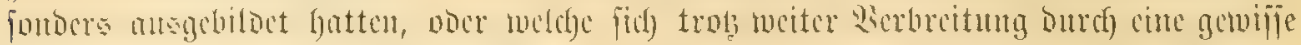

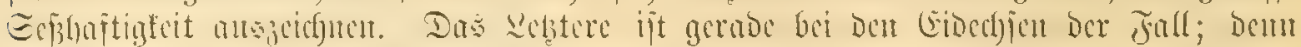

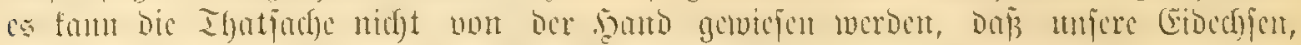

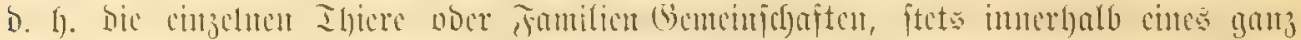

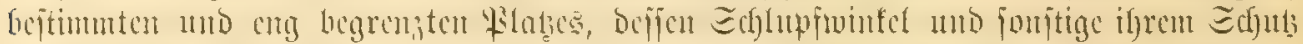

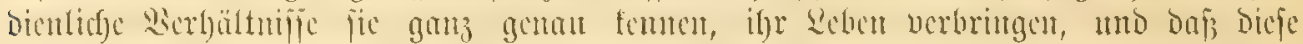

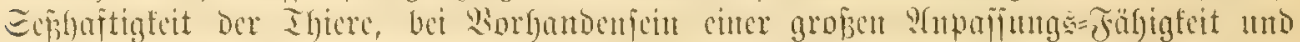

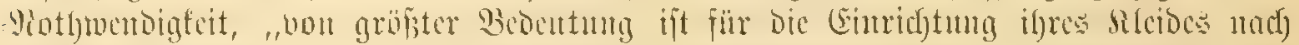

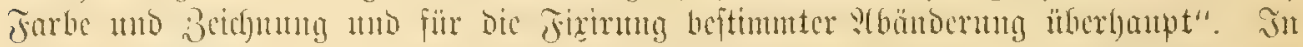

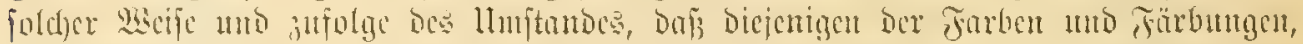

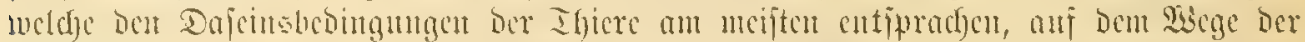

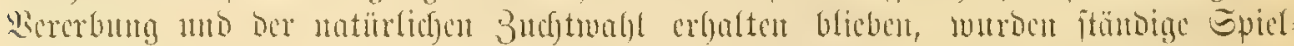

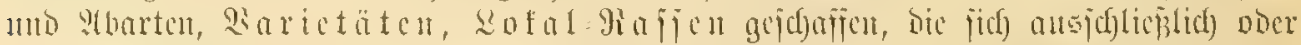

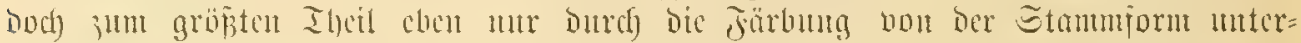

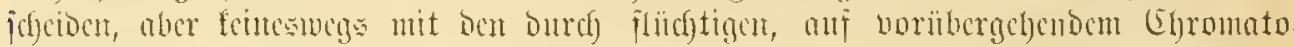

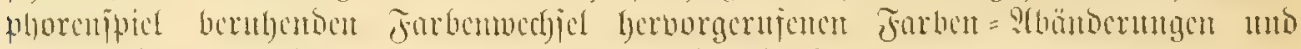
Farbenfielen verglidjen uno gleidgeitellt werben bürfent.

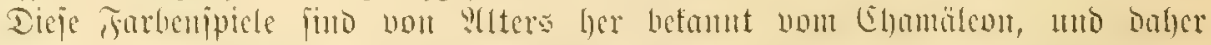

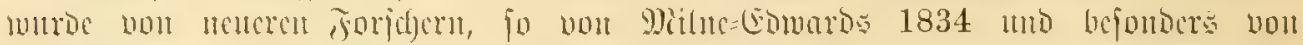

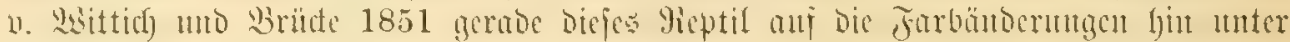

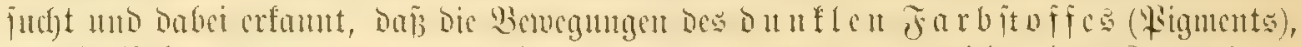

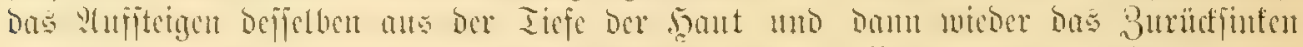

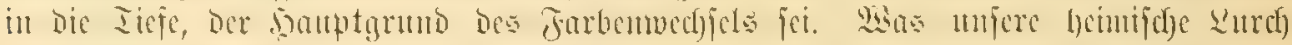

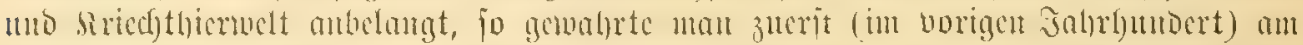

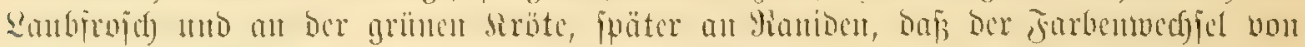

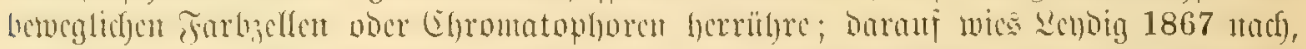

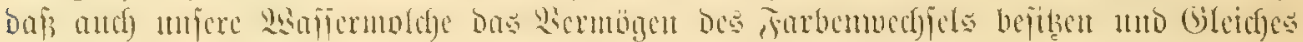

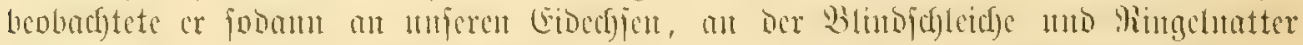

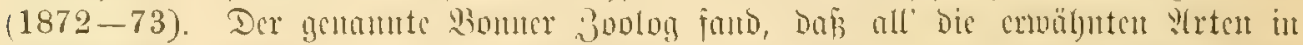

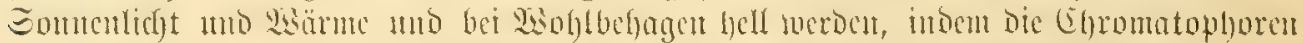

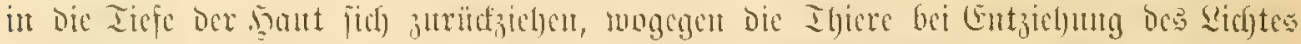

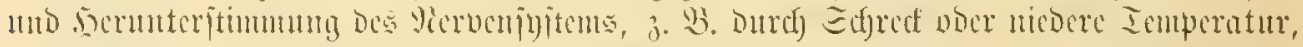

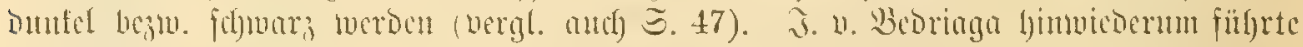

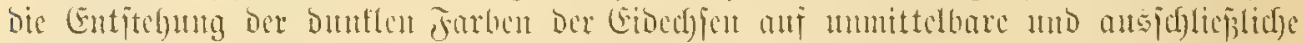

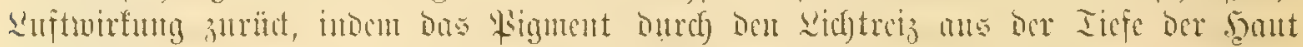

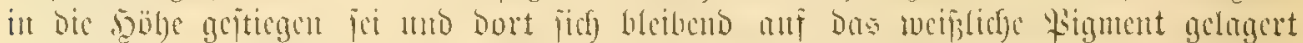

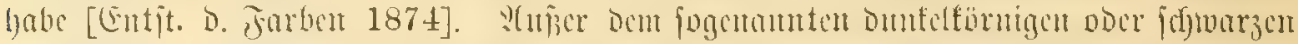

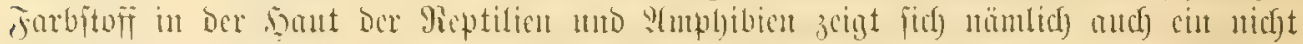

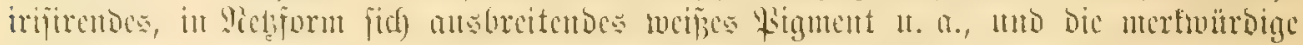

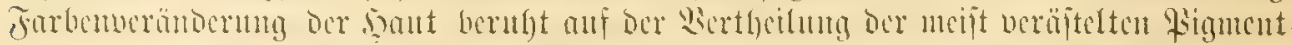

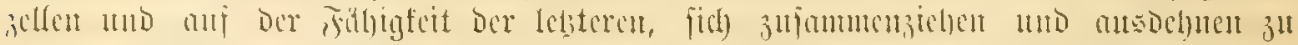

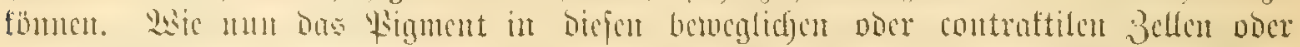

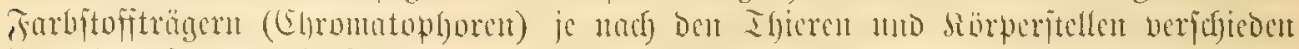

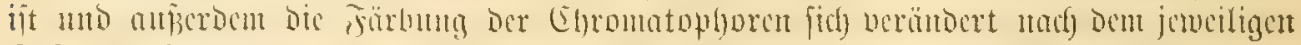

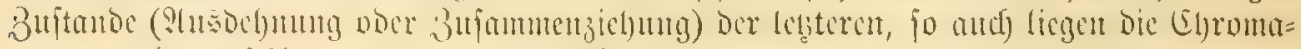

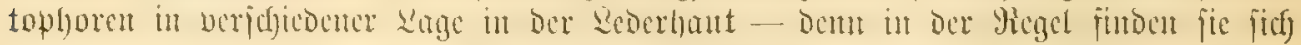

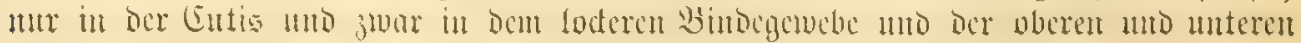




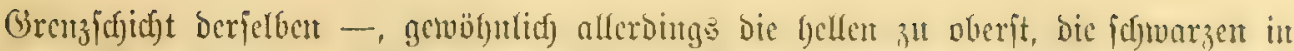

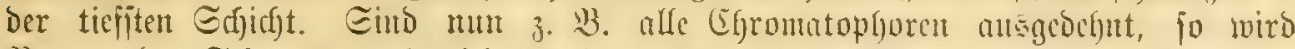

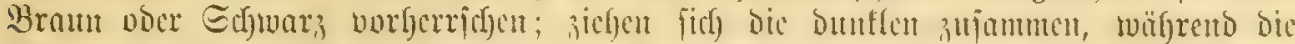
lellen ausgedebut bleiben, fo wirb bie Farbe ber letiteren iur beltung fonmen;

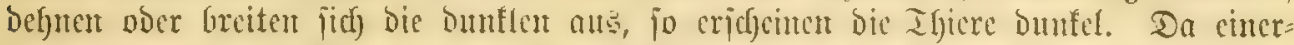
jeits bicje "aftiven Bewegutgen" Der Farbzelfen bezw. ifre Contraftionsizutünde und

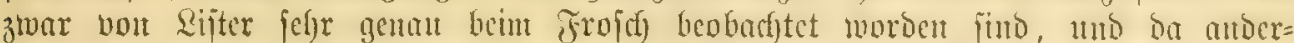

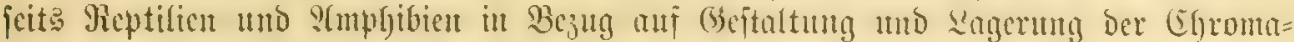

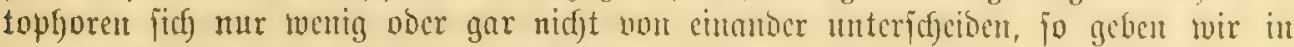

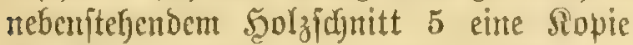
Der Sifter'fdjen Beidyuntugen, indem wir gleidjzeitig idjon lier auf das bei Be= fprecfutug ber S(mpfibien nod) zu (er= toähnende Gimbeijen. - Went vir aljo wilfen, Daßs bie Farbitoffe theile in ber unteriten Scjidjt ber Dberhaut, theils uno vornefmelich in ber Rederhant abgelagert fino und Die beräjtelten Farbzellen auf

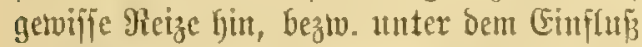
bes 9iervenityiteme fid) zujammenzichen und ausbreiten, überfaupt ijre Bcitalt uno Lage ändern tönten uno baburd) einen Farbentwectfjel bebingen, jo vermögen vir nidft mit Bejtimmthcit autangeben, wa as beut cigentficf fid) betuege, to a sem die treibento Sraft bei ben Bewegumgen ber Farbzellent jei, b. G. uns ijt bie Eigenjchajt, auj tweldjer

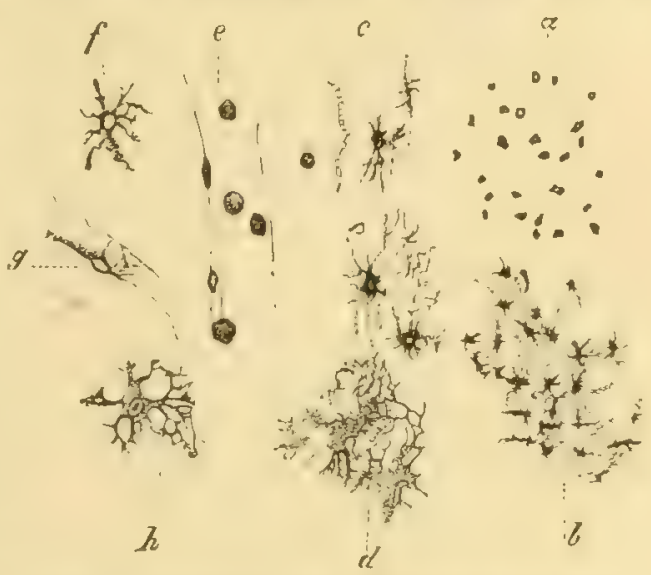

Jig. 5. Farbjellen ober (5hromatophoren ber :(mphibiengaut (joid)), nad) Rijter.

2. unb e in gan; atiantmengejog. Zujanbe (e an cintem sadur: gejäb liezeno), b uno c balb ausgefretete, f $\mathrm{g}$ h ausgebtcitete. a gans auggebreitete.

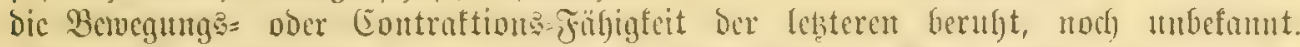

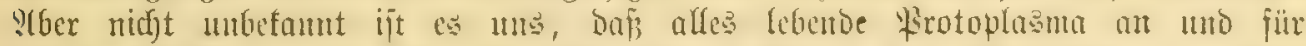

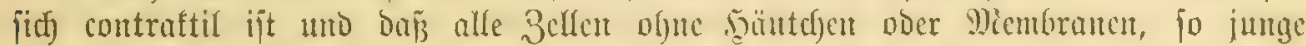

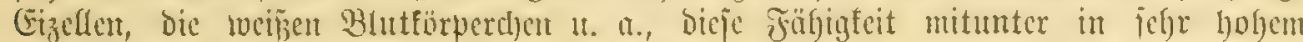

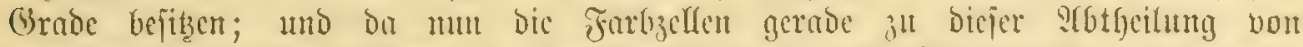

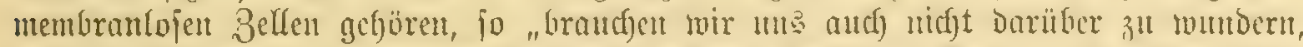

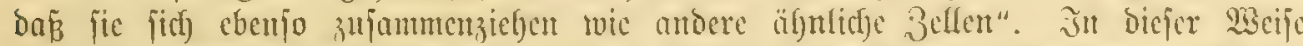

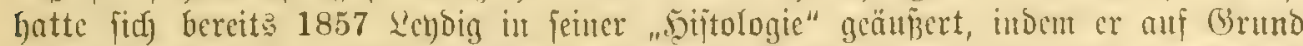

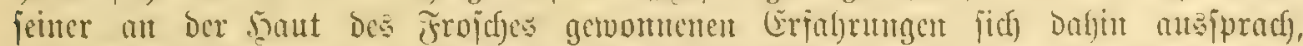

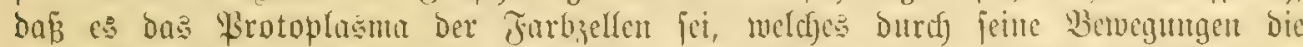
Formveründerungen ber Egromatopfyoren bervormfe; แnd mälgreno (5. Th. won

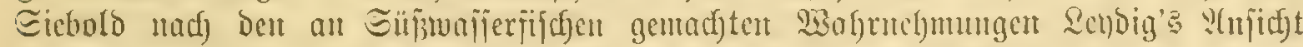

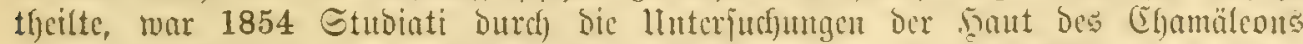

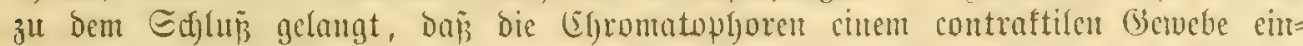

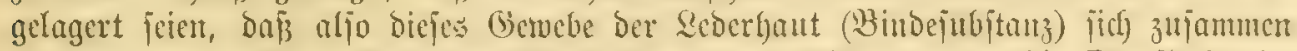
ziefe und auf foldje ?(rt Den Juthalt Der Farbejücfdjen gegen bie Eberfläd)e ber

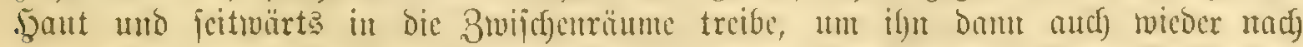

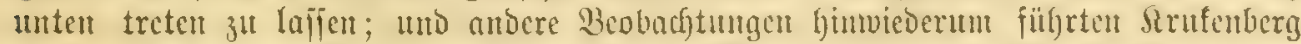

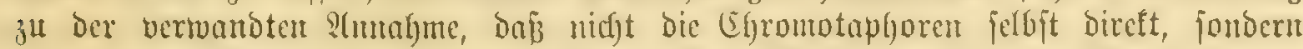

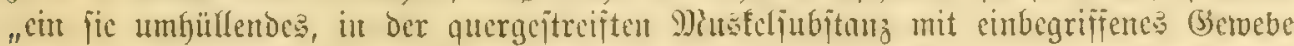

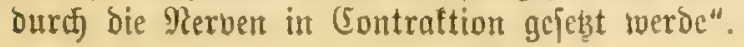




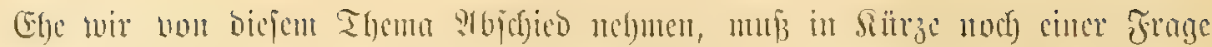

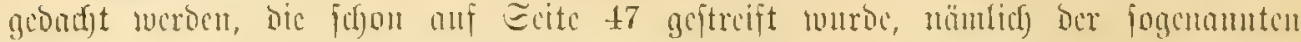

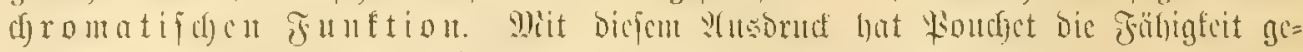

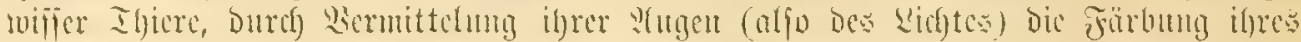

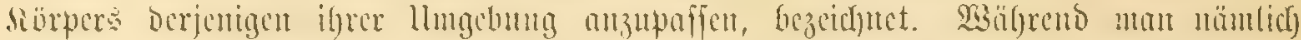

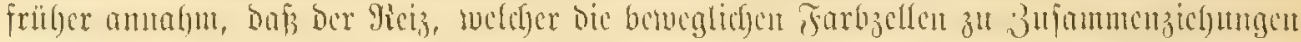

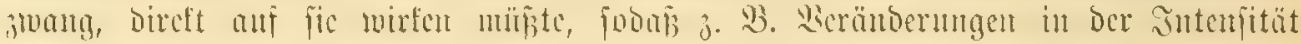

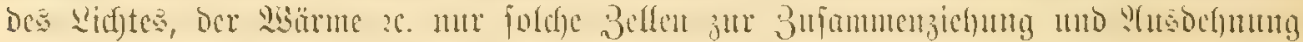

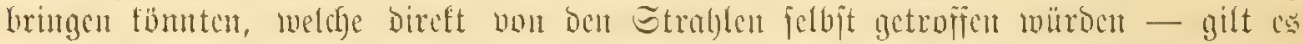

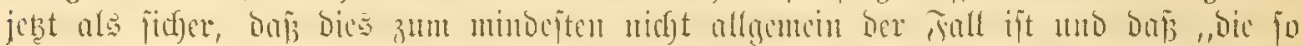

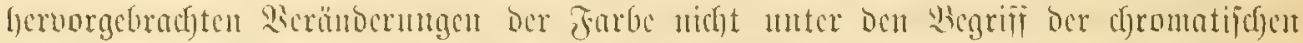

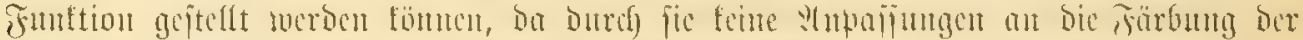

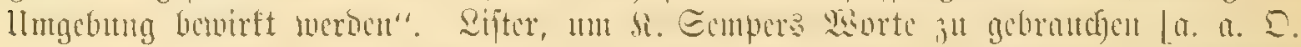

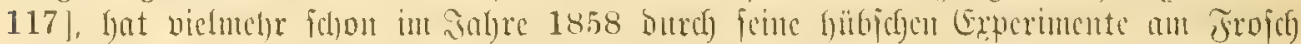

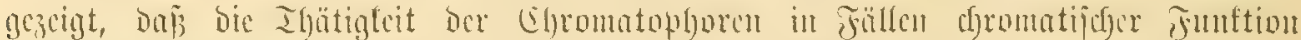

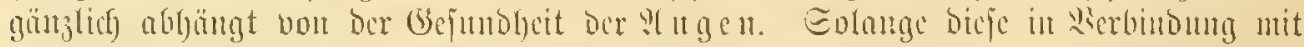

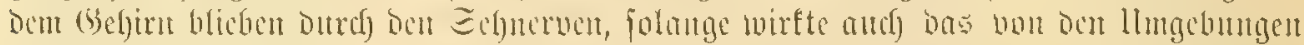

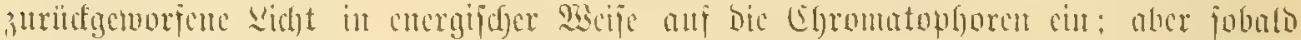

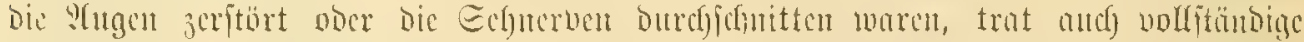

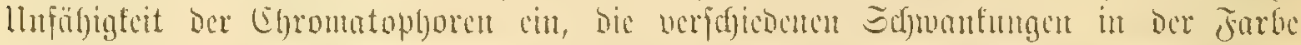

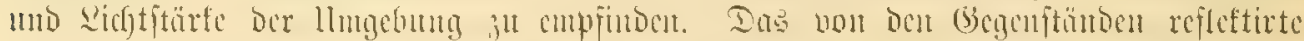
Licht fom alfo mur Durd)

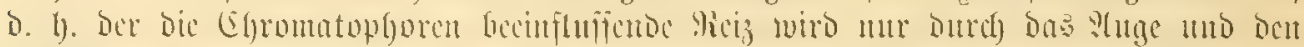

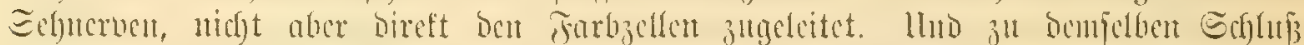

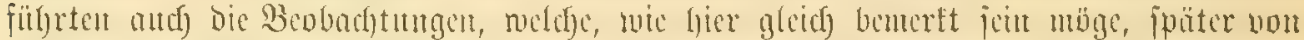

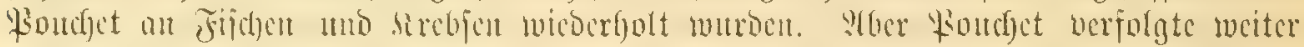
bie Frage, ,anf neldem fejomberen

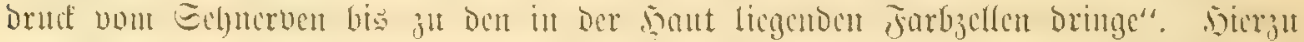

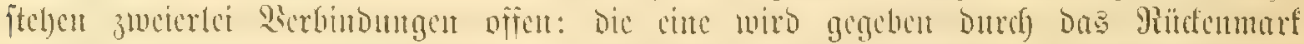

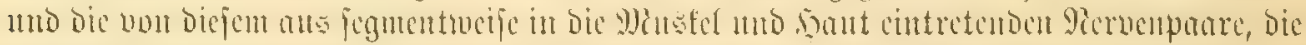

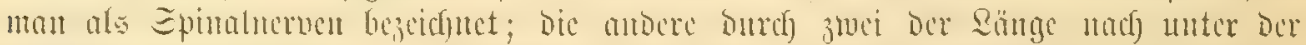

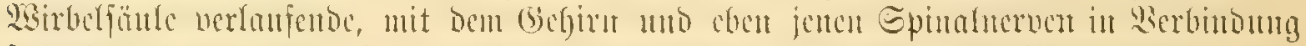

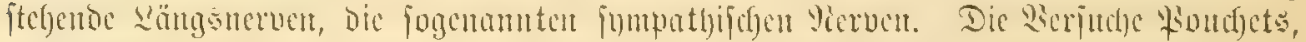

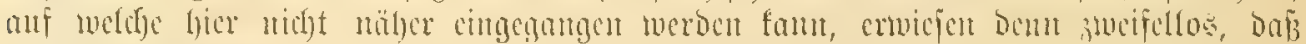

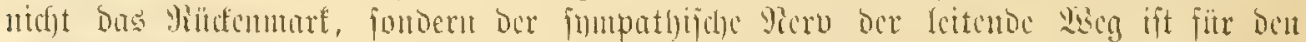

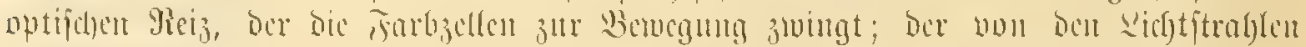

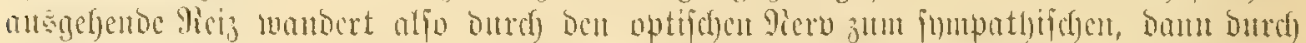

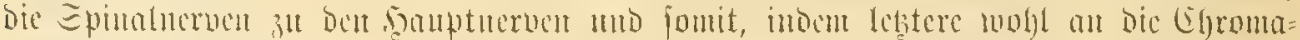

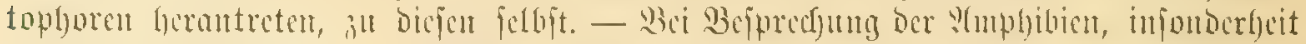

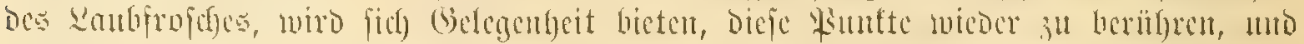

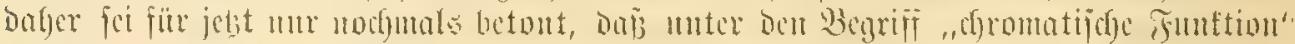

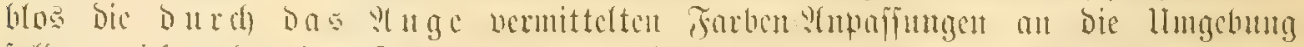

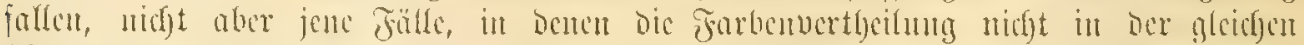

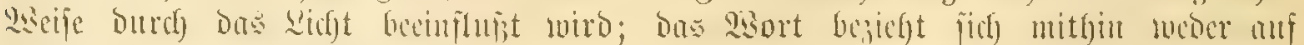

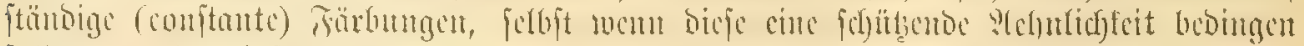

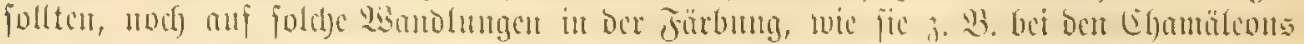

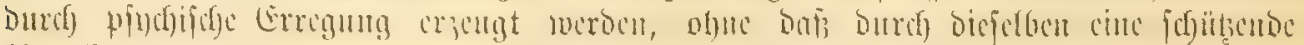
2(elulichteit bervorgerufen mütroc. 


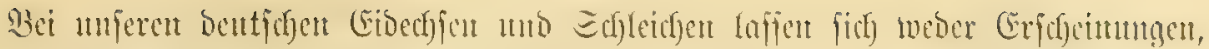

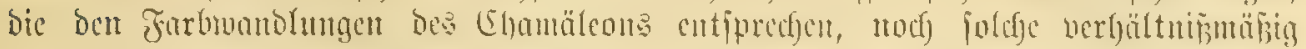

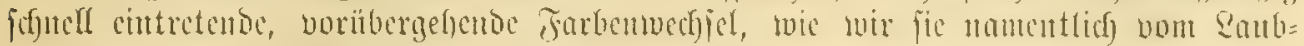

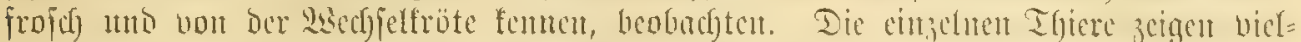

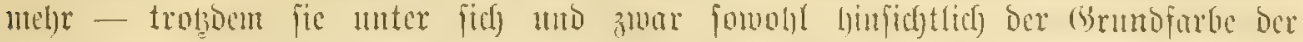

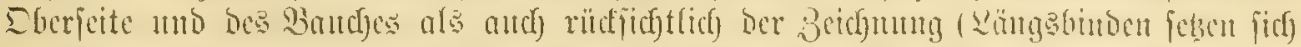

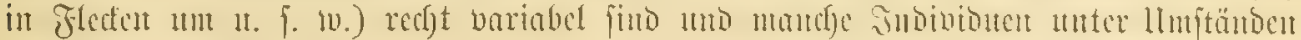

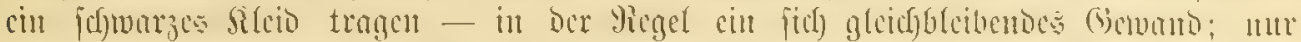

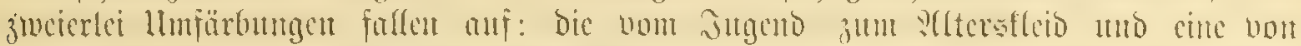

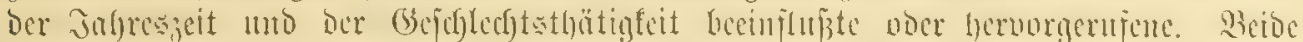

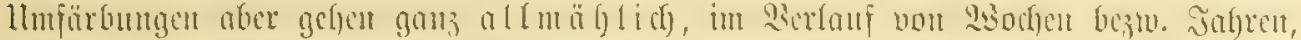
nor firf) und betreffen wor

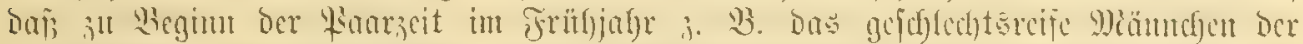

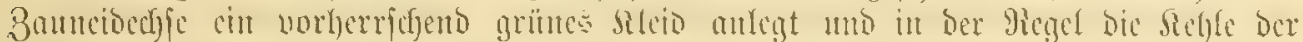

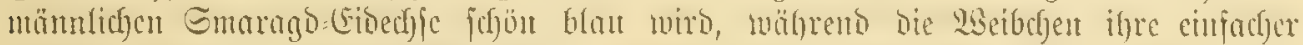

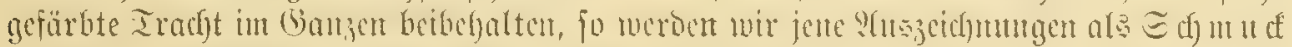

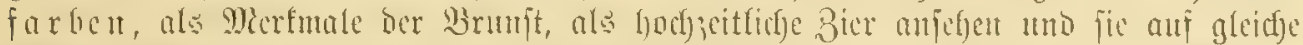

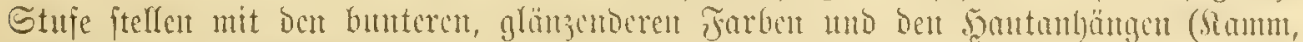

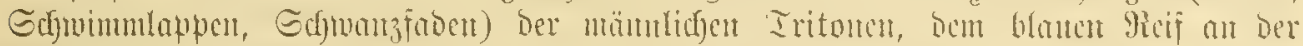

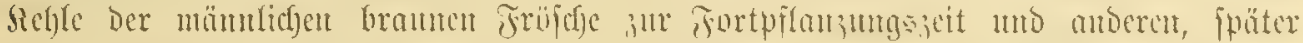

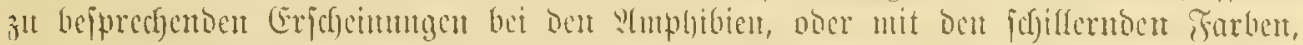

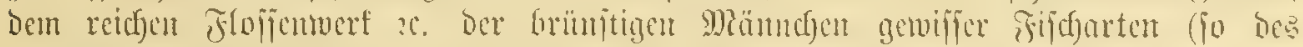

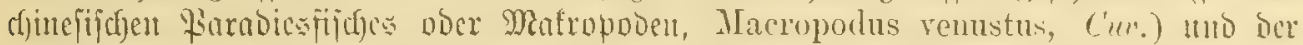

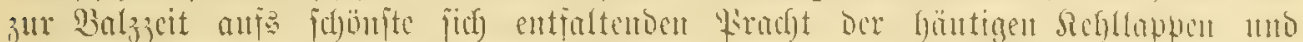

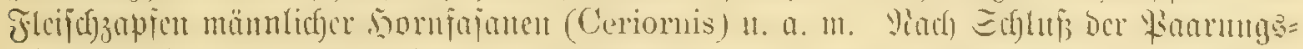

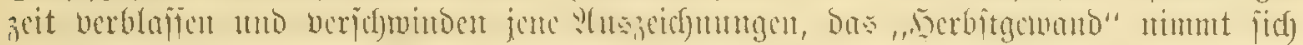

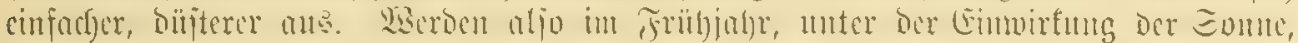

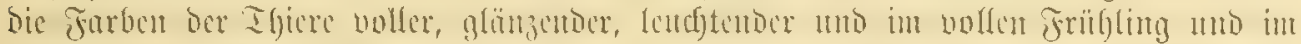

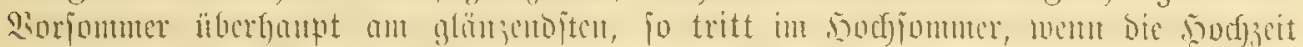

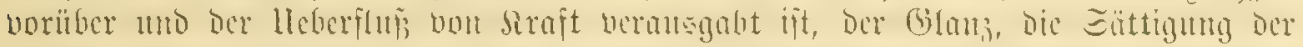

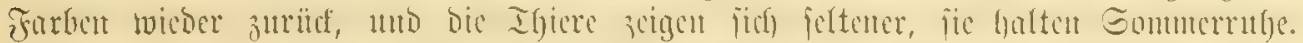

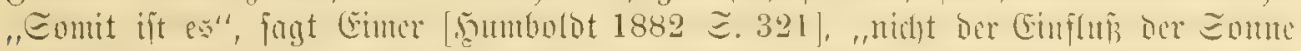

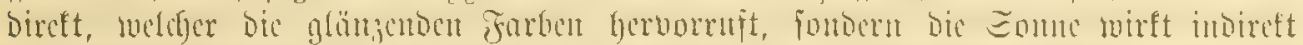

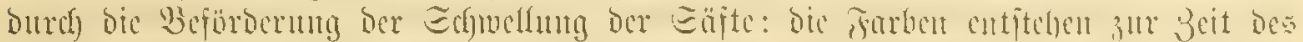

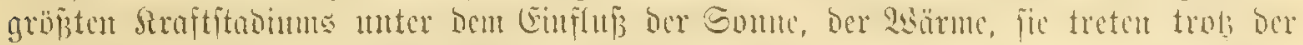

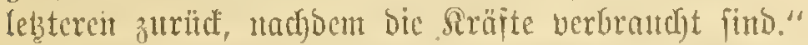

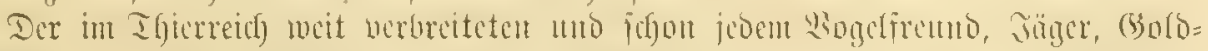

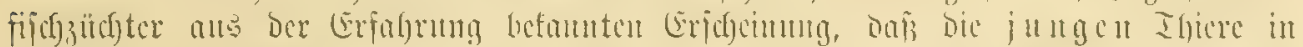

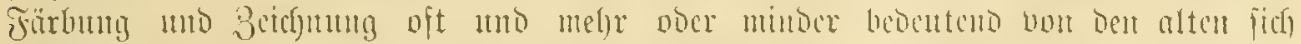

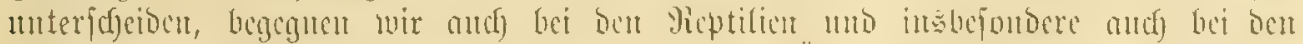

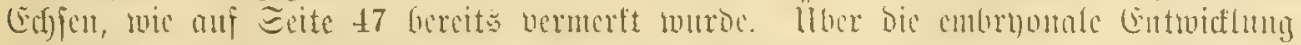

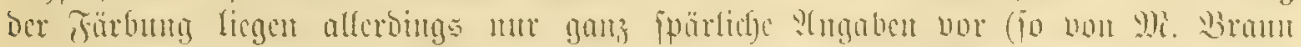

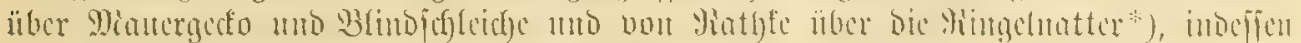

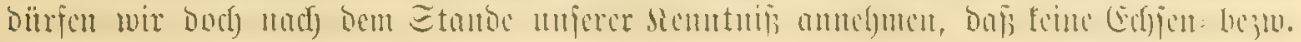

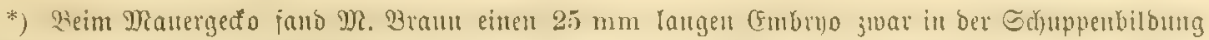

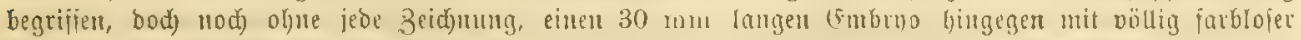

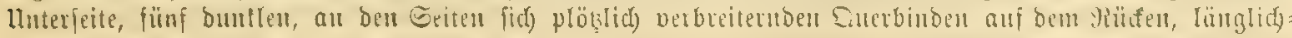

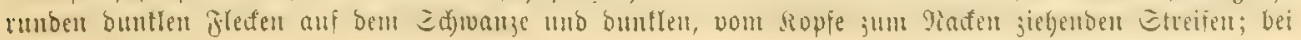




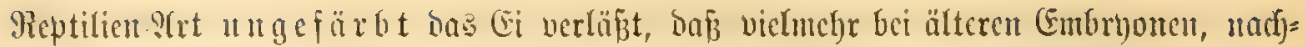

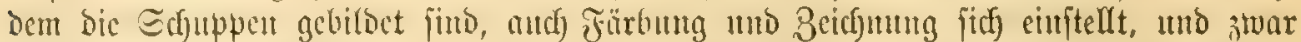
tritt, wic folyon Mi. Bran in feincr "Lacerta Lilfordi" forvorbcbt, bie Förbung

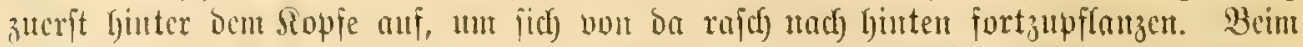

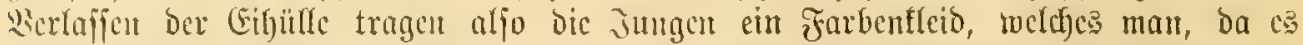

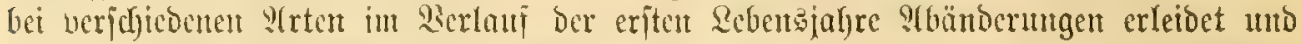

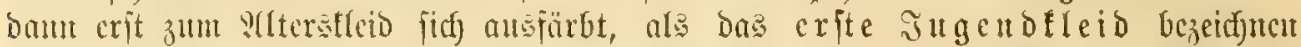

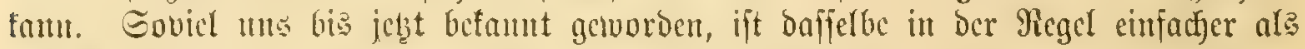

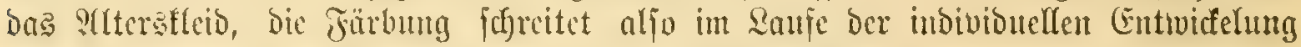

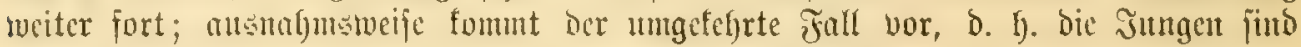

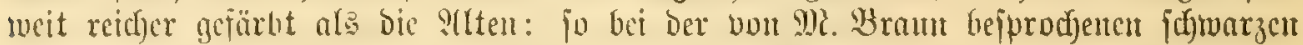

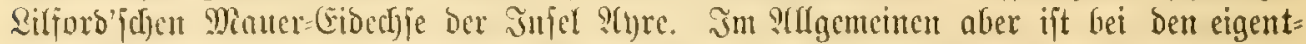

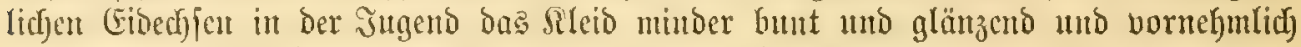
bie Grumbfarbe bifiterer, Dunfler als im Iflter; idf Grautche in biejer Beziefutg mur an bie unjdycinbar gelb= ober grautraumen Jutngen ber Smaragos, an bic gleidförmig

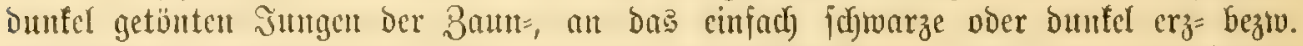

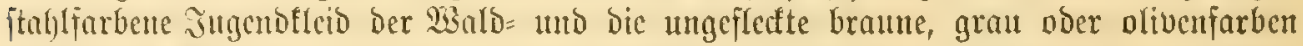

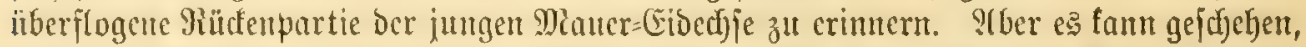

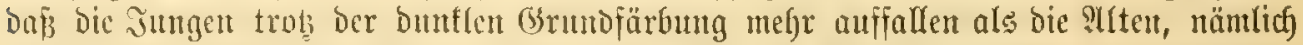

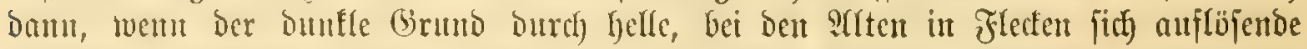
Etreifu unterbrudfen wird. Dics tritt bei jübeuropäifden Racertiben hervor, am

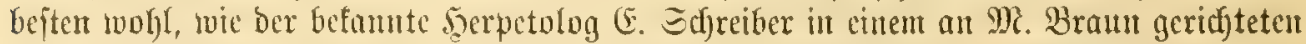
"tut you biejen in jeincr "Lacerta Lilfordi" verüffentlidgten Brieje vermertt, bei Dem fparifdyen Stadyelfinger (Acanthodactylus vulgaris, $D$. B.) und ber fübruffifid)en Buffehaje (Eremias velox, Pall.), indem hier die tieffanmetjdywarze, bon brei biz

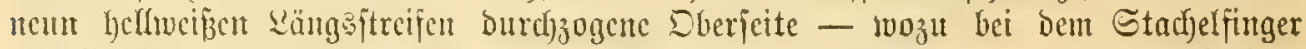

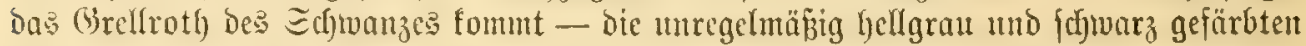

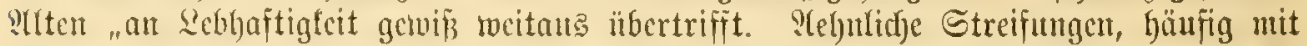

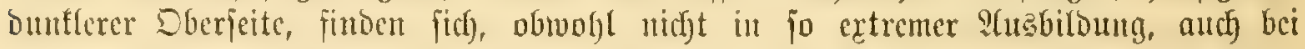
Ophiops, Acanthodactylus Savignyi, Psammodromus, Lacerta taurica und felbjt bei L. muralis, obwohjl namentlid) bei Der lebteren itrt oft utr auf bie Rörperjeiten

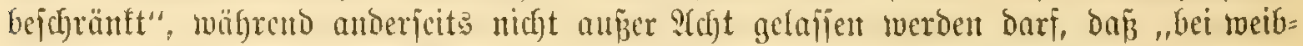

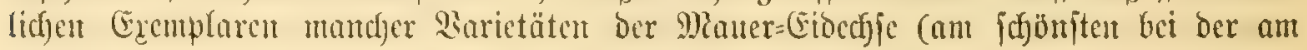
Siarit vorfommendent campestris) Dicje Streifon in vollfommencr Edjürje Das ganze

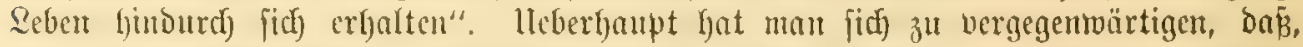

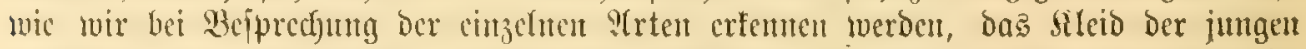

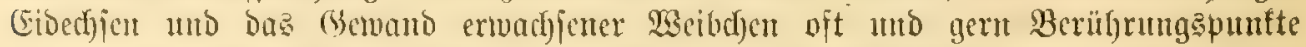
zcigen, cute (Erid)einung, weld)e uns z.

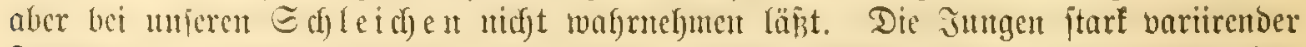
Formen, bei Denen bic sllten jefre lebgafte Farben befiben, Gaben (entfpredjend ben

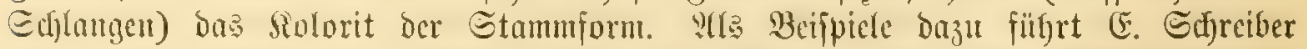

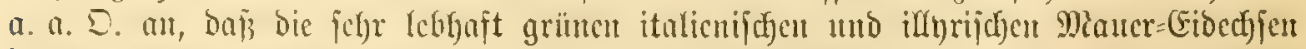

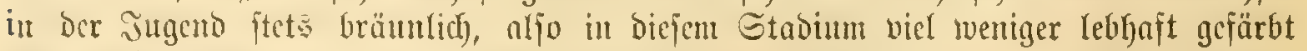
finto; unt baffelbe gilt von ber Smarago (Eibechfe. Endich müge mant nidgt vergeffen,

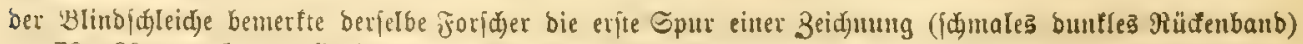
an 70-80 mm langen (Embryonen. Bei einer Reige Embryouen ber Zaun=(Sibedfle, beren (Entridelung

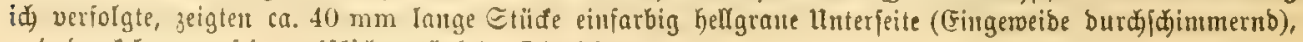
unb bumfelgraue, fein reiklid getüpfeIte Dberfeite. 


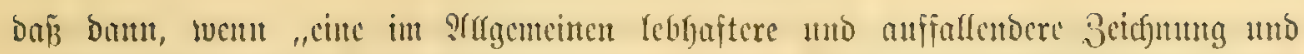

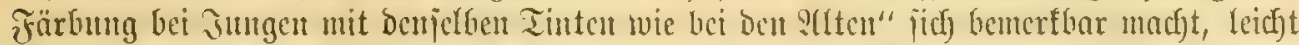
cinc Täujdung unterloufentan, indom bie erfterc bei Den Jungen un infolge Didjter=

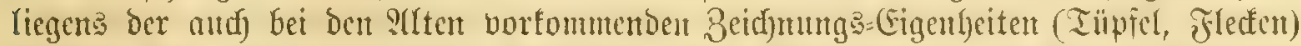

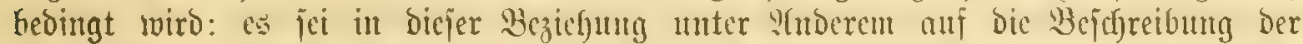

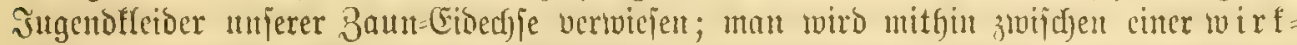

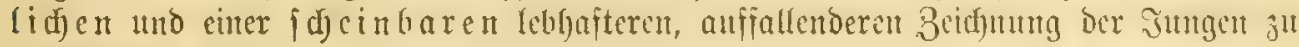
unterjajeiden baben.

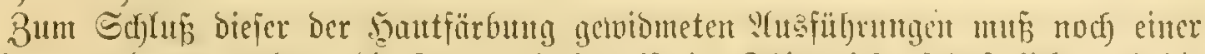

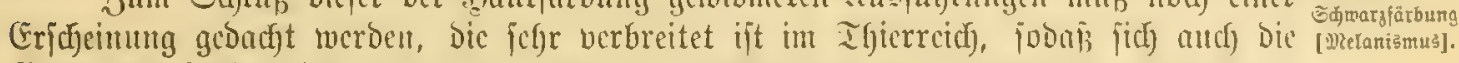

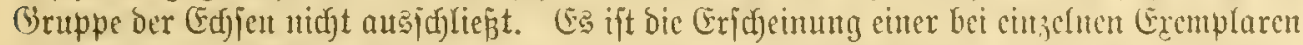

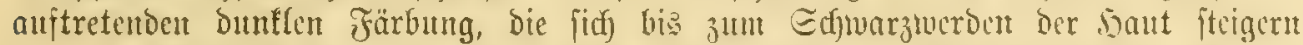

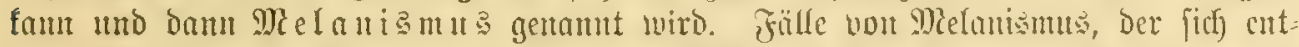
tocber auf bie ganze Rörperbant ober mur auf Particu berfelben erftrect (totaler und

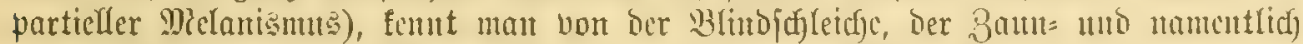

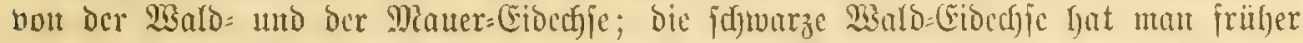

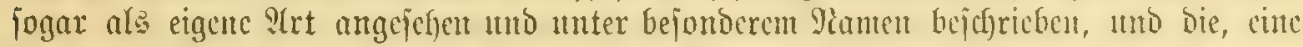

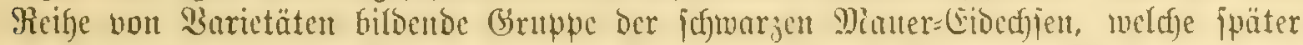

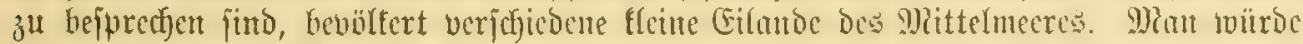
fefyl gehen, twollte man Den Melanismus ooer dic Melanoje, wie Di. Braut Dent auf

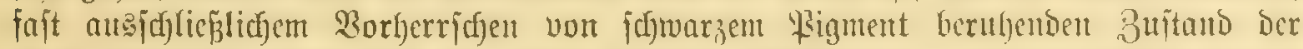

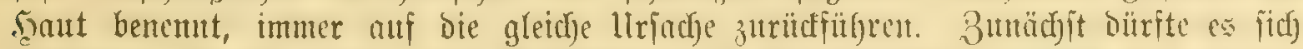

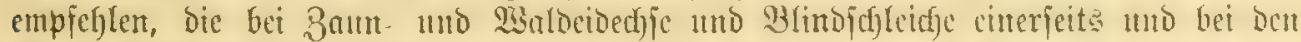

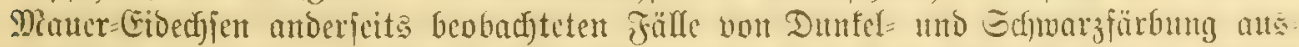

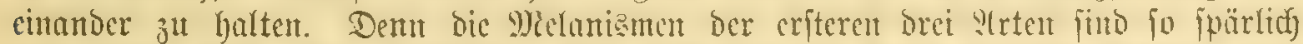

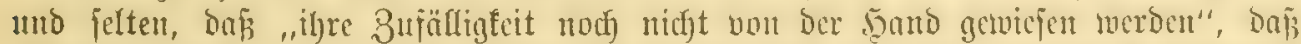
alfo bei Lacerta vivipara, Anguis fragilis mo Lacerta agilis ein zufälliger Diclanismus

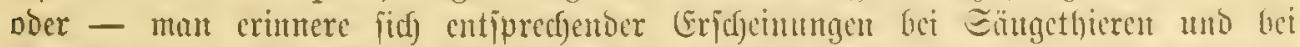

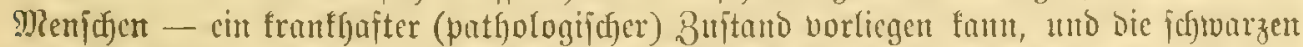

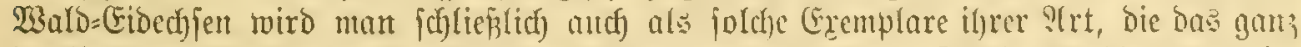

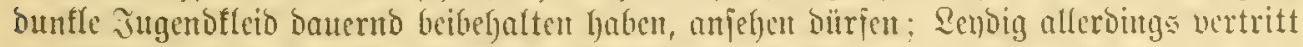

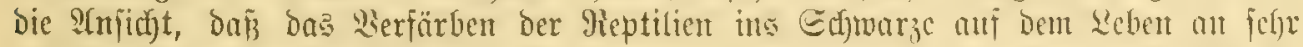
feudften Srten beruft, mo feme Erjafrung - Derzufolge or Dret jufuarie Stüde ber

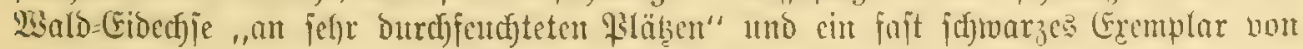
Anguis fragilis anf felt fendfem, torfigem Boben fand Itto Lacerta agilis beim

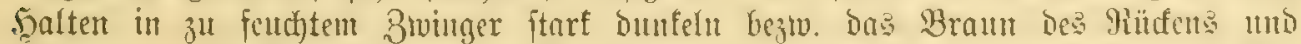

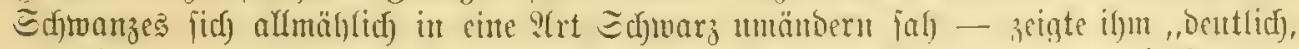

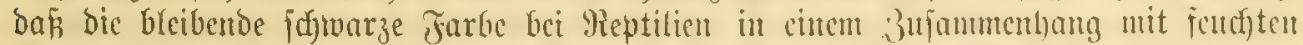

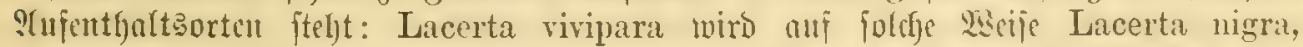

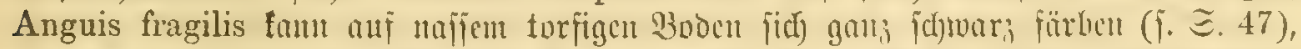

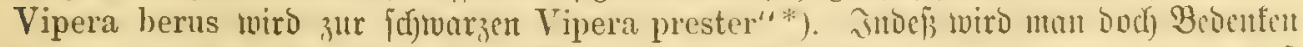

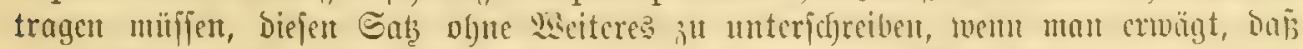

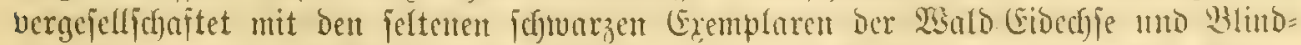

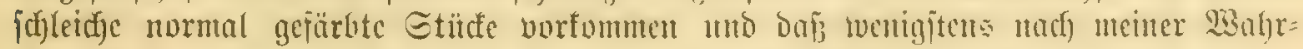

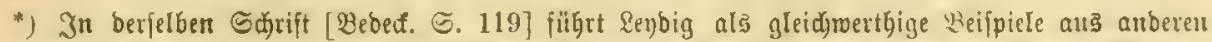

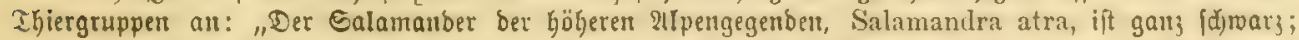

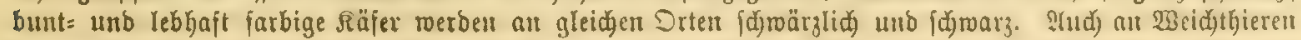

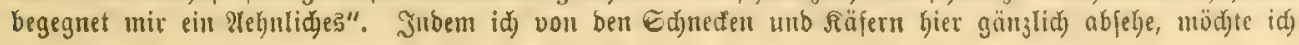




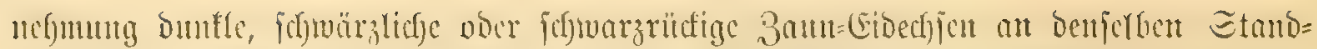
orten anzutreffen fino we bic Etammform. Das Mioment ber Bufälligfeit fom alfo,

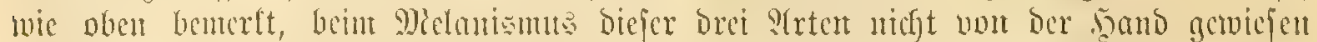

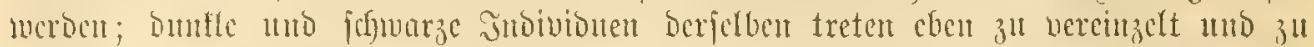

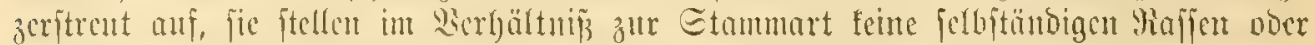

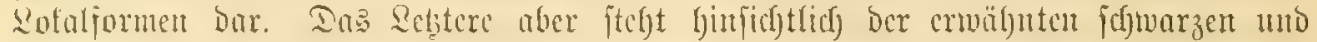

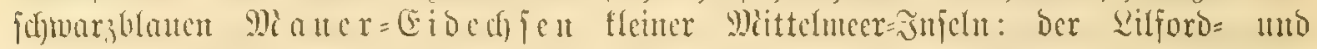

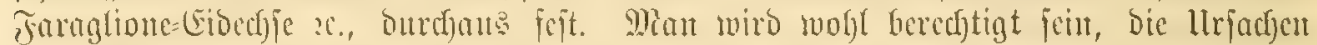

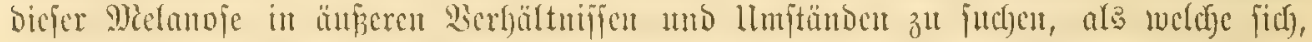

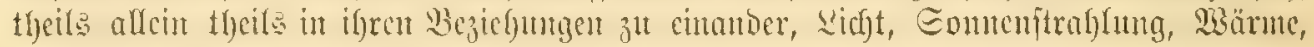

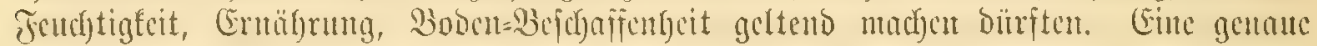

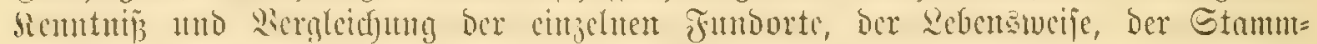

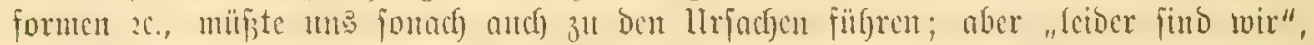

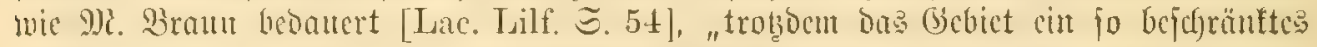

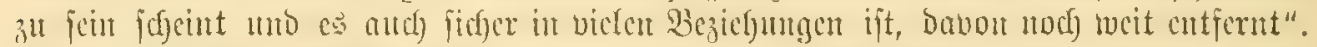

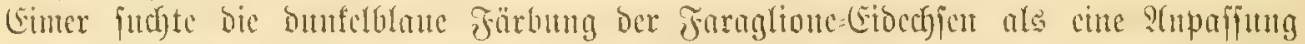

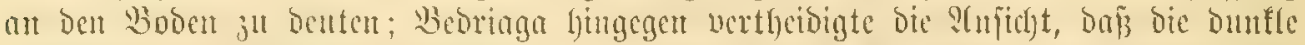

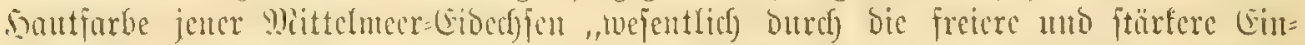

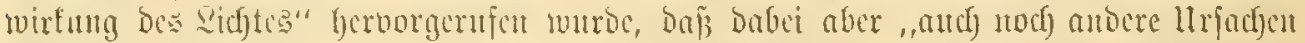

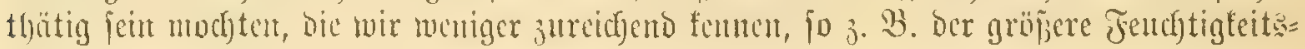
gehalt Der Sec=?tmojphäre".

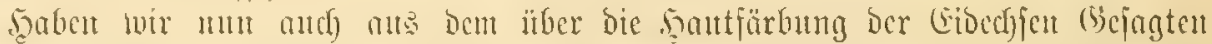

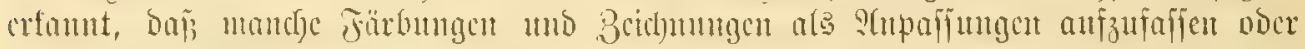

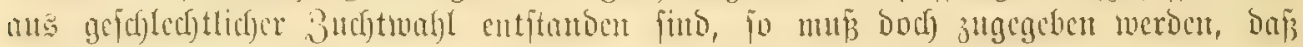

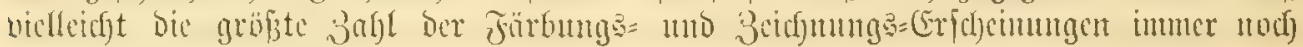
Der eigentlicfout Erflärung horet.

Satilber unt Gduppen [3ergleid)].

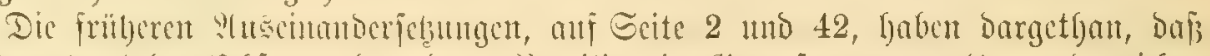

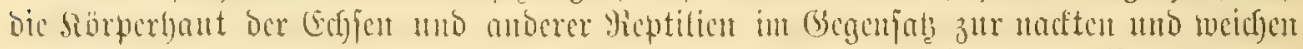

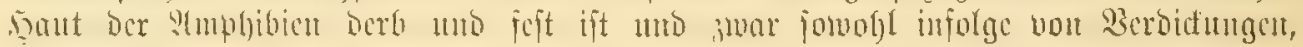

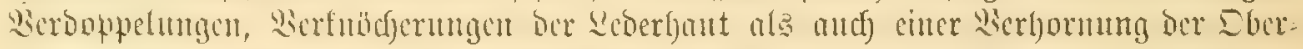

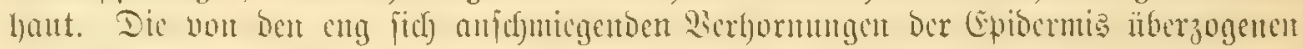

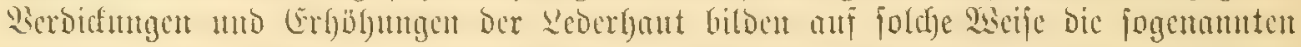

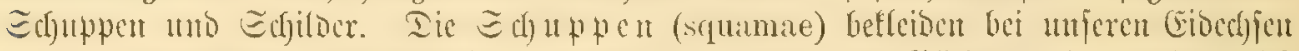

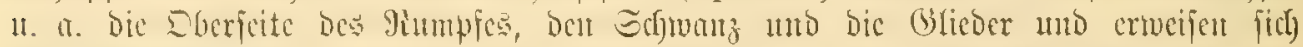

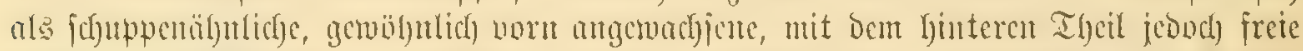

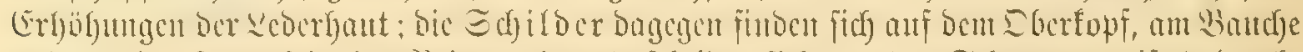

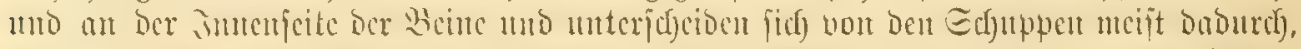

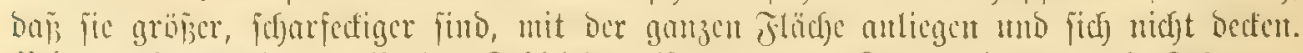

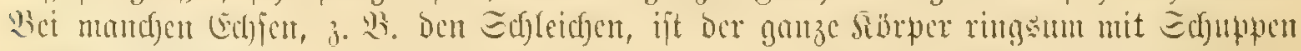

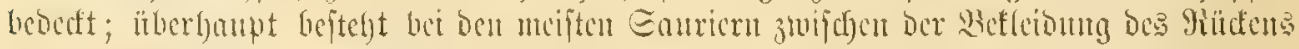

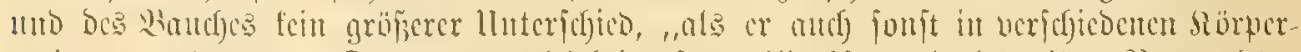

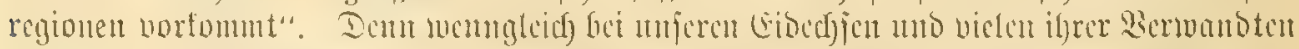

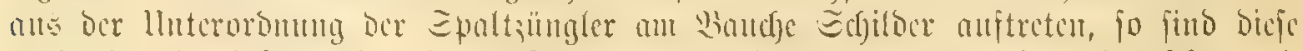

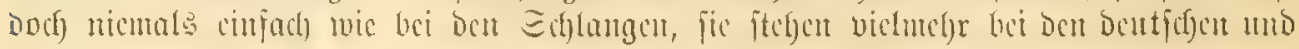

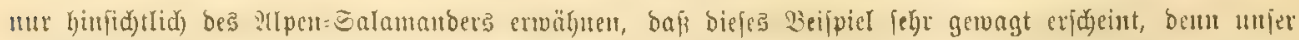

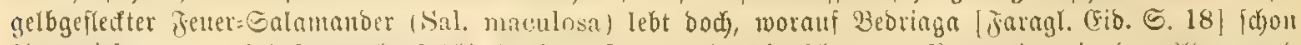

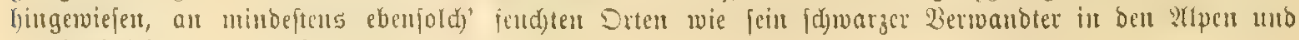
bat bow frime teudyteno gelben flecten beibegalten. 


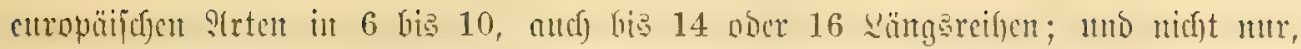

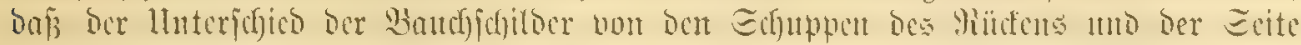

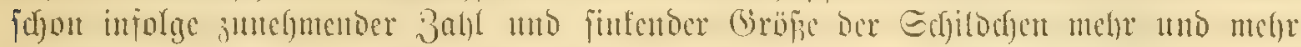

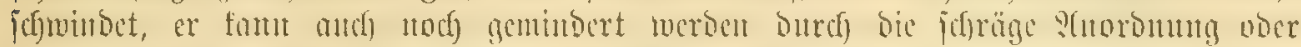

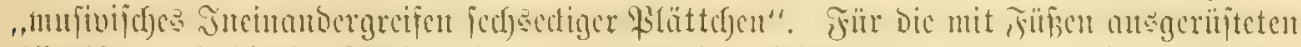

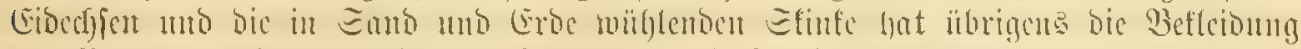

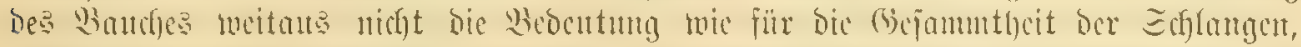

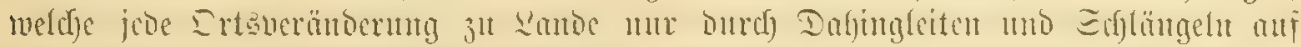

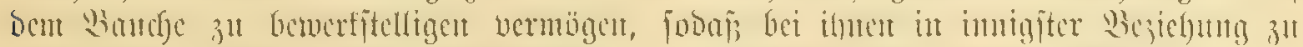

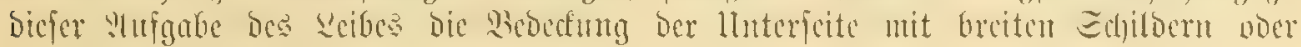
Ducrichienen ftcht.

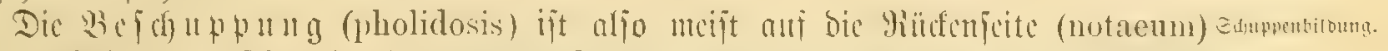

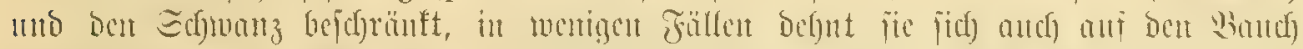

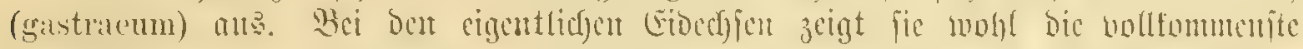

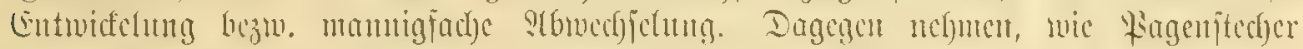

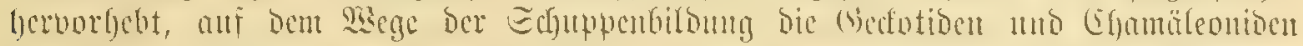

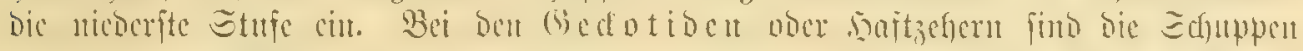

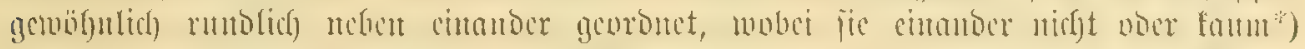

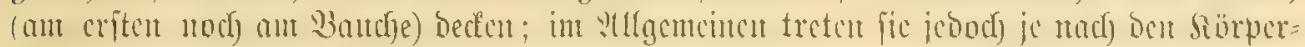

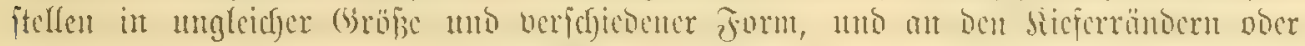

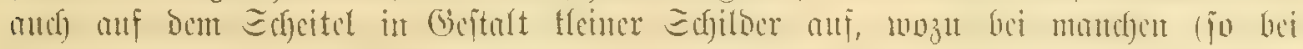

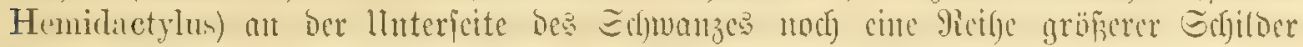

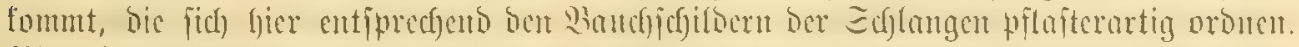

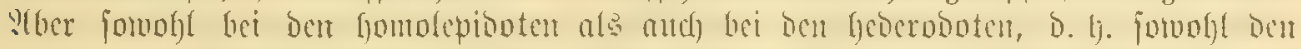

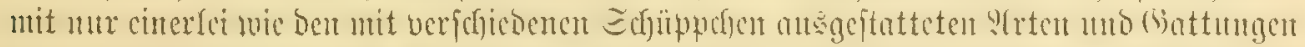

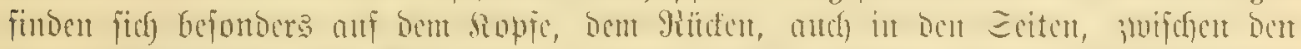

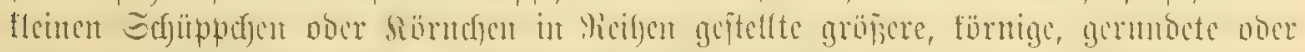

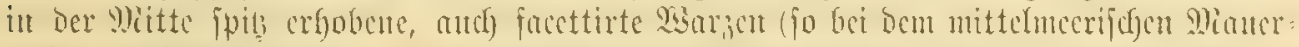

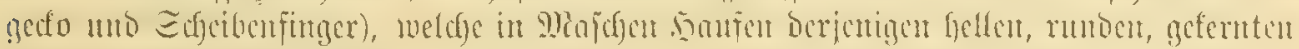

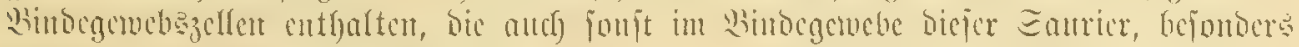

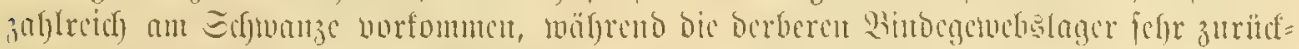

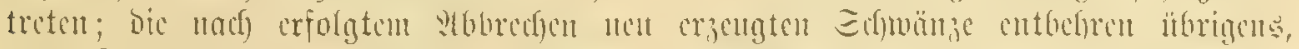

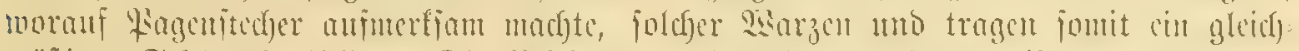

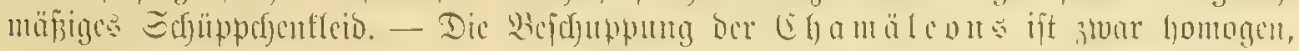

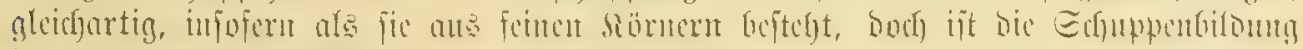

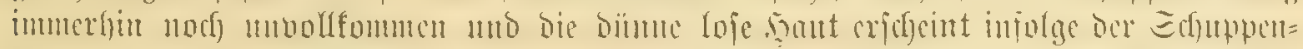

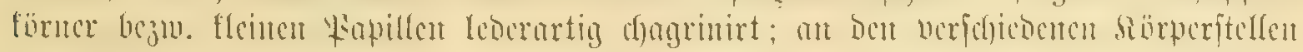

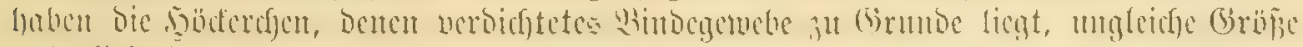

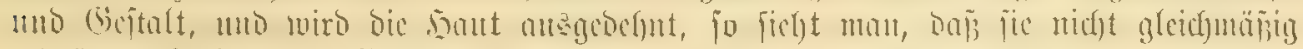

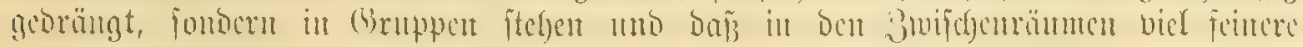

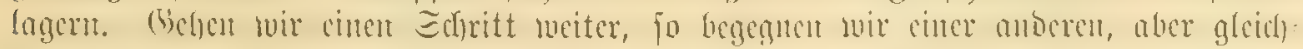

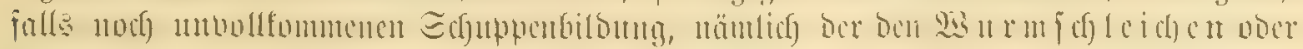
lingel=(E)

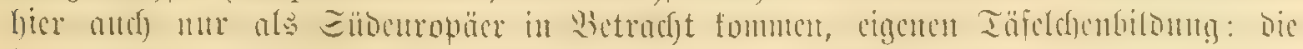

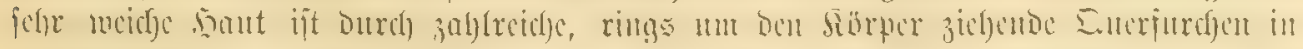

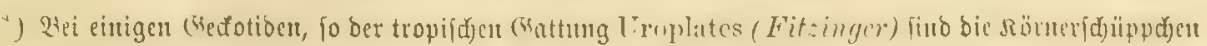

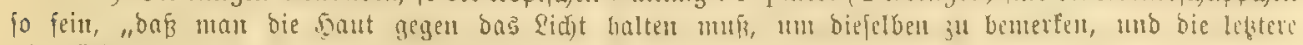
oberfläd)lid glatt erfdyeint roie bei Tritonen" [Ragenit. IV, 771]. 


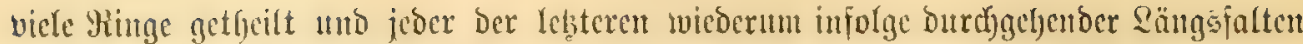

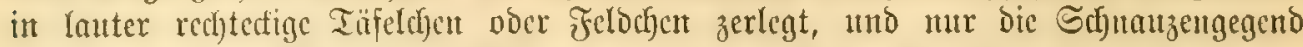

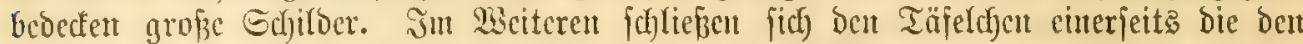

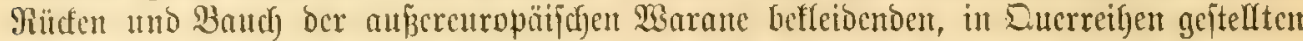
utro mojaifurtig in cinamber greifenton Flättchen= ober Tafeljchuppen (squamae tessellatae), ferner bie fich nidgt becfenden Siörnerjchuppen (squ. granulosae) ober swarzigen

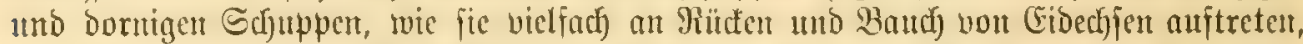

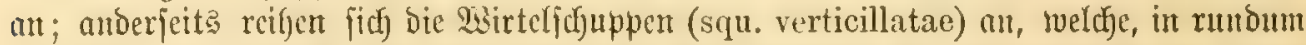
Ianfenden, au Den Rumpfieiten Dutrif einte fleimfduppige Falte unterbrocfenen Duer= gïrteln georonct, am ausgeprägteften bei ben Seitenfaltlern voer Zonuridae (z. : Echeltopufit) uno cinigen werwanoten angereuropäifdent Familien (Eljalciocn, Egamä= fauren) gefutocu werben. B̧ci anberent Edffen treten bicje ut. त. Ecfuppenformen

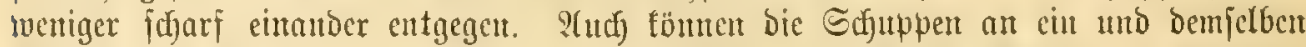
Sörper, swie fdjon oben angeoentet, ic nady Piidfen tho Saudf, Jiumpf und Sdjwanz

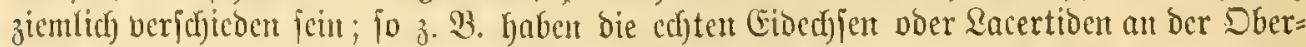

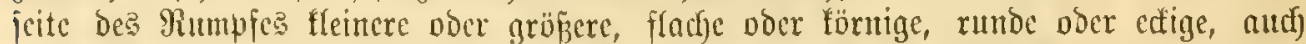

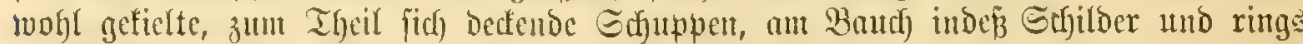

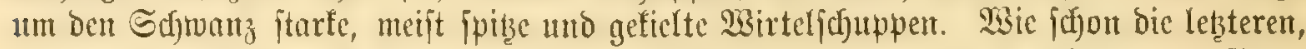
bejonders am Edjmanze bornig voritchend, nidjt jelten eimander zul überragen pflegen

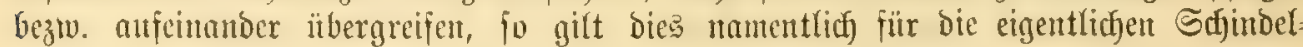

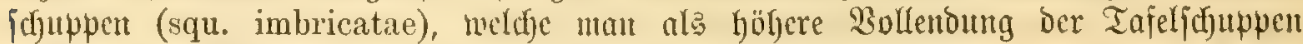

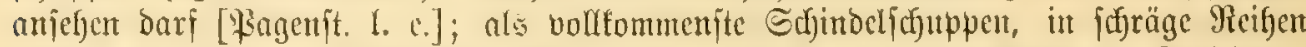

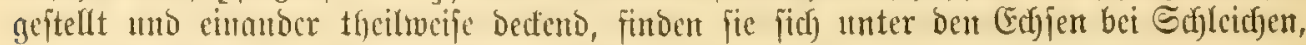
ferner an giüdent fildocuropäijd)er Eidedjent=(Battungen: Tropidosaura, Notopholis und Psammodromus, utto aužerdem an Der Bïftenpartie ber meiften Saflangen.

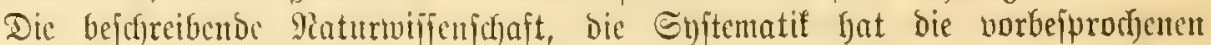

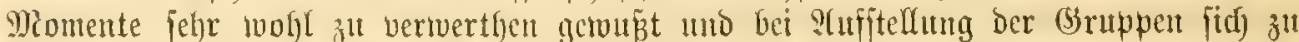

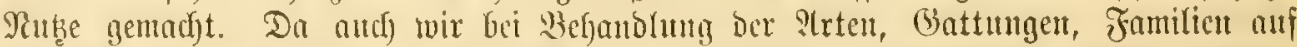

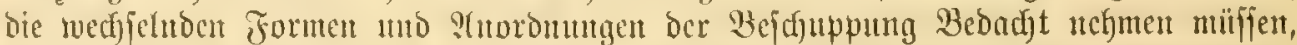

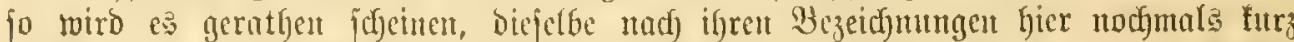

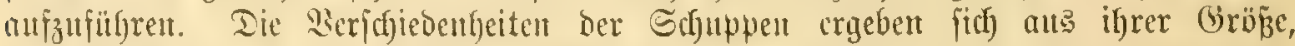

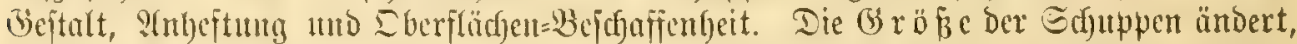

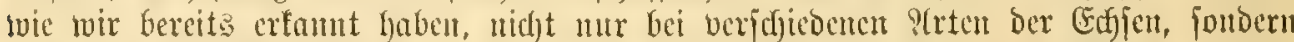

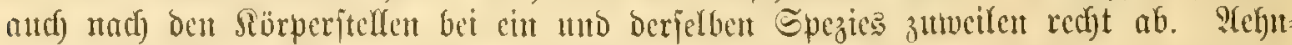
lidfes trifift Ginjicftfidy Der Diffe ober Derbfeit ber Sifuppen zu, ja beides geft getwiffer

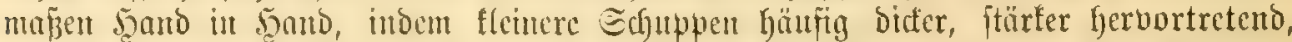

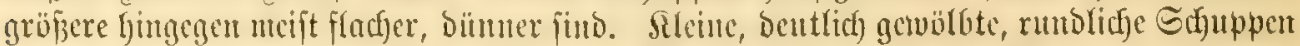

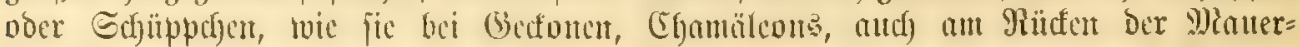

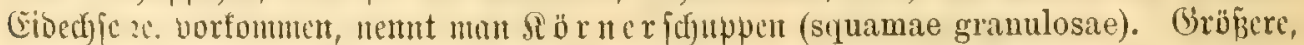

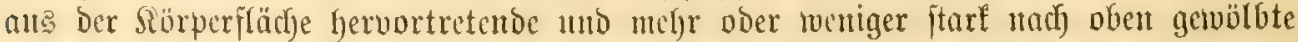

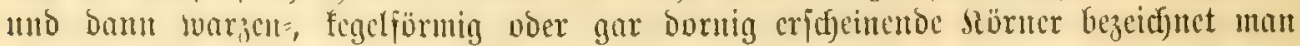

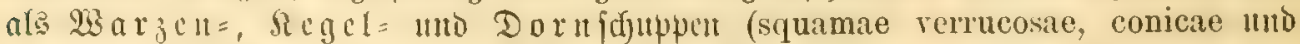

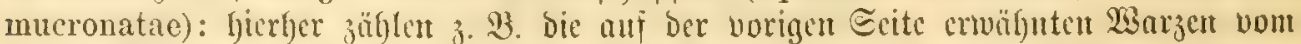

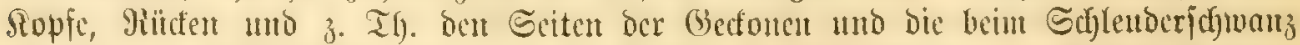

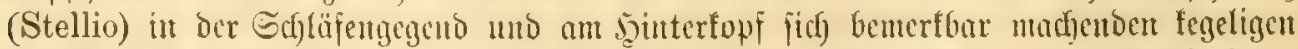

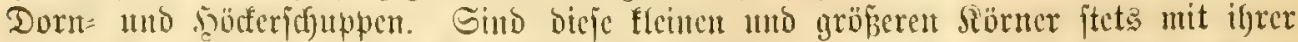
ganzen lhuterfeite anf ber Dberfläcje ber bant angetoadjen, fo fommt bies bet

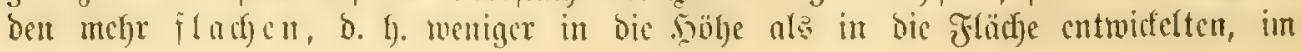




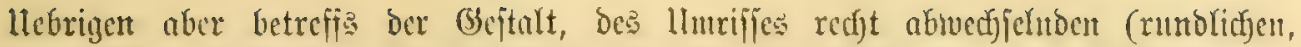
rhombijafu, fedfactigen, it bie Ränge vocr aber in bic Breite gezogenen) Schupwen mur Daun und wann vor, z. $\mathfrak{B}$. an ben Rumpficiten Der Emarago=Eidecfjic; bielmed)r

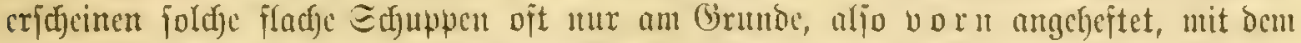

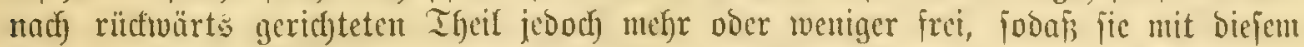
hinteren Enoc anf bie hier anjtojenten Echuppen ïbergreifen uto benfelbent bad)ziegelig Doer jdjutbelartig anfliegen; Irüger Derartiger Dadjziegel= oder $\Xi$ d) in bel fduppen

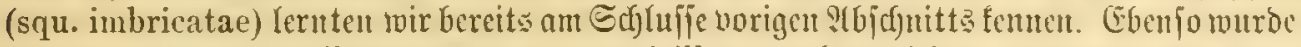

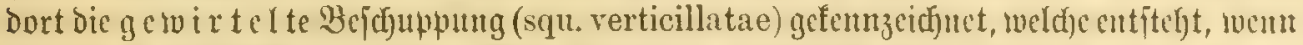

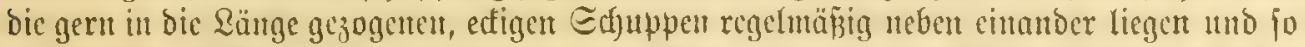

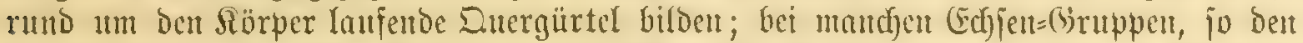
Ecitenfaltlern, umzichen bicje Eutergärtel Mumpi uno Edjwanj, fei anderen tuto zafl=

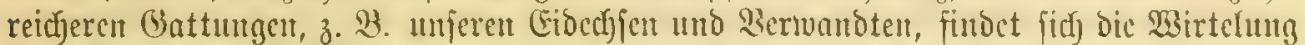

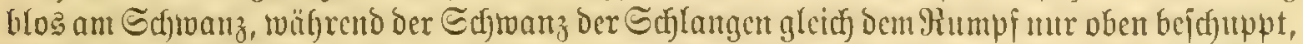

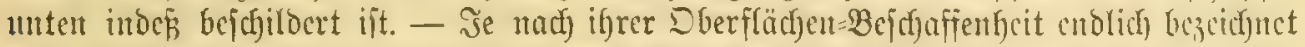
man bic Edjuppen als glatt (squ. laeves) oder aber als gefielt (squ. carinatae). Der

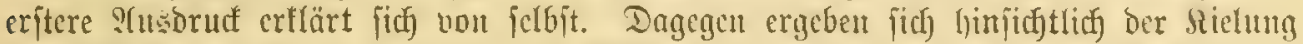

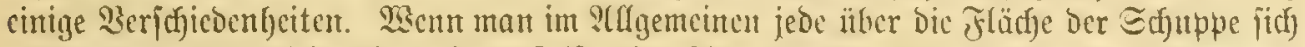
crhebende uno auf biejer Ginlaufende Qeifte ober Qinie als Siel betrachten barf, jo fant bodf)

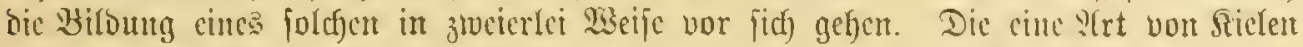

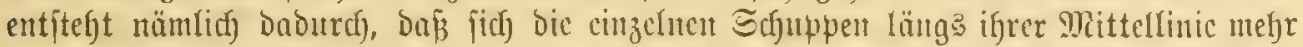

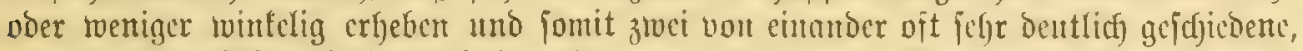

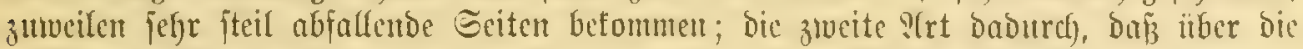

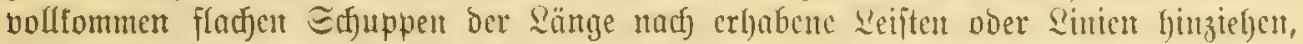
bie bon ben lebeteren bald in größzerem, bald in geringerem Grabe abgehoben erjacincu.

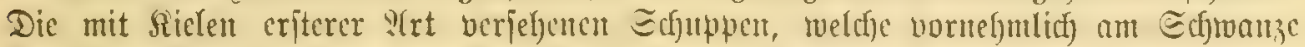

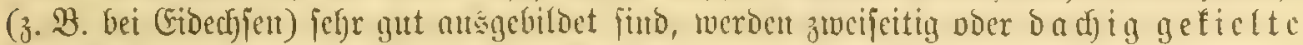

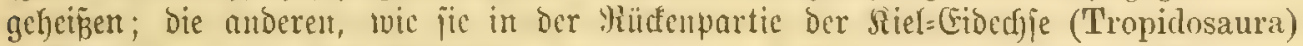
vorfommen, neunt Egió Edfrciber aufliegend gefielte. Sin beiocn Fällen fino

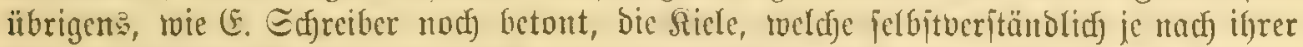

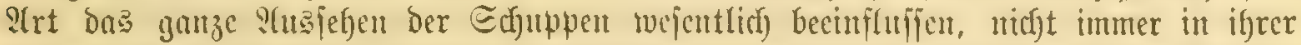
ganjen Sünge gleidjhod), namentlid) eridjeincu jie nad) finten zu oft mefre ober weniger

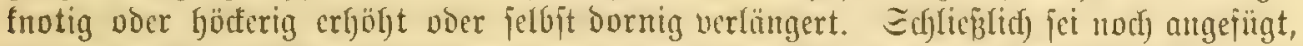

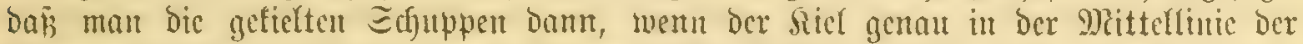

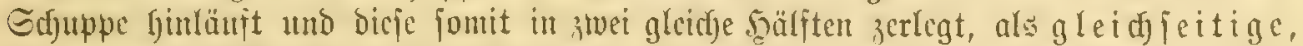

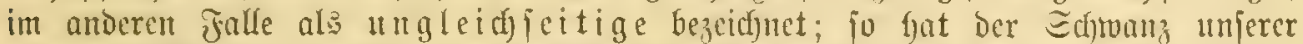

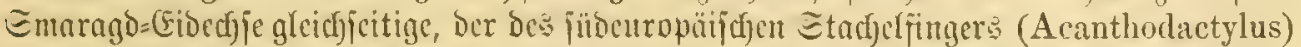

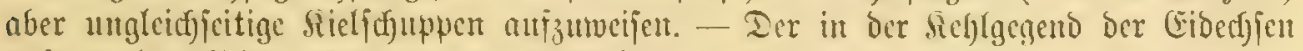
muftretenden fleinen G(huppen werben wir weiterfin nod) geòenfen.

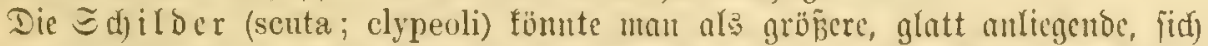

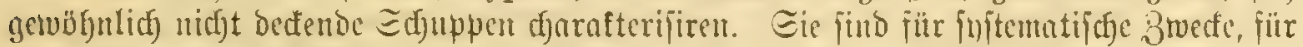

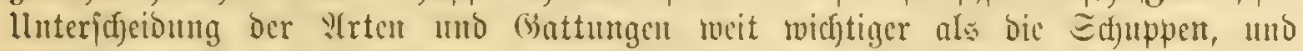

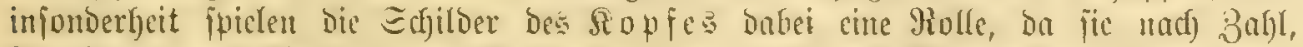

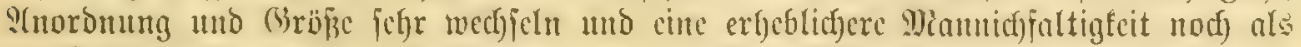

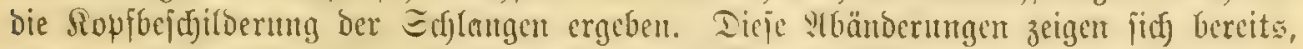

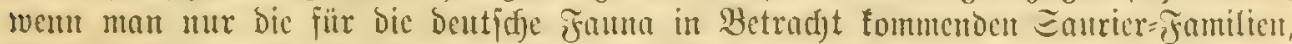

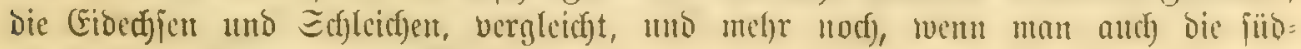
curopäifđ)en Bruppen berĭdfidjtigt. 


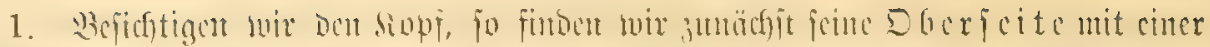

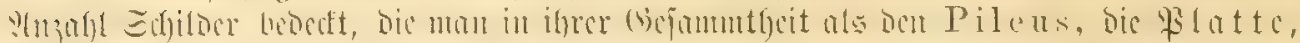
(w)

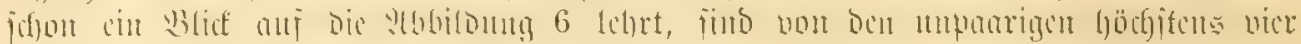
(a bis d), bie fid) lünģ Der 9littcllintic Des Dber= fopfes oroncat, worfanden; dic Bafl ocr parrigen jdyanft mefre. Das vorberite ber unpaareu, a,

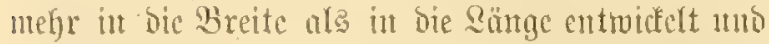

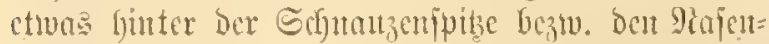

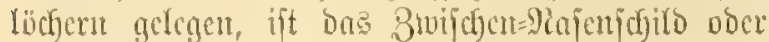
Jitternajal= Sdjild (scutum internasale); als zlucitce

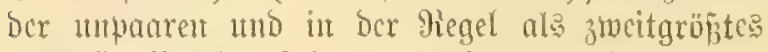
aller Siopfichilder folgt nady lyuten zu bas Stirn= fditlo b (sc. frontale), ant beldyes jidi mittel= ober

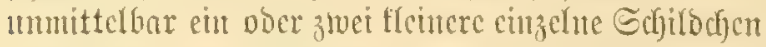

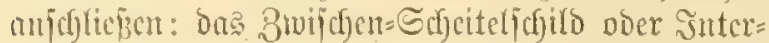
parictalfaldo c (sc. interparietale) แno зu fiutcrft bas binterfaupt= obcr Decipitalichild d (sc. occipi-

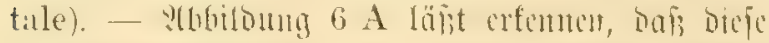
mupanrigen Edjilder nidyt immer bireft cimanber fich anfïgen, tur begentgeil werocu fic bei vielen yrten umb (3)

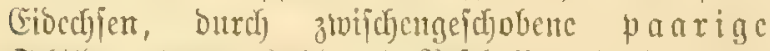
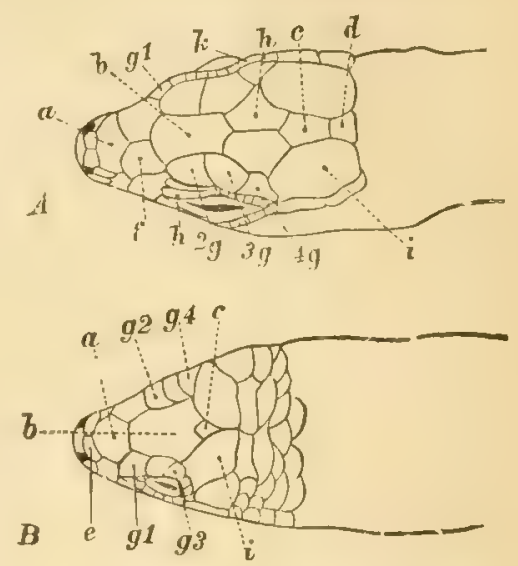

Jig. 6. Okerfetie des Sioples (A Sma=

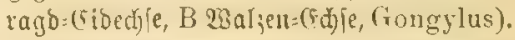

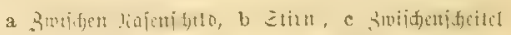

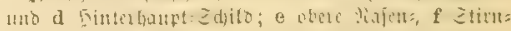

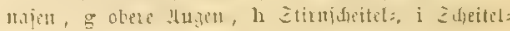

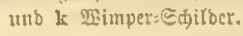

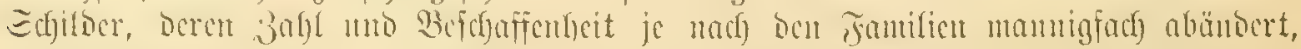

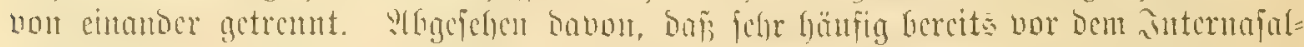

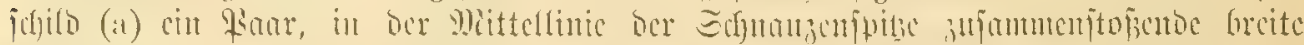

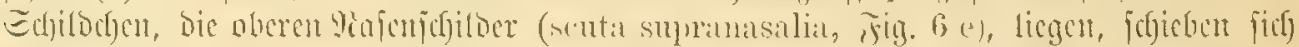

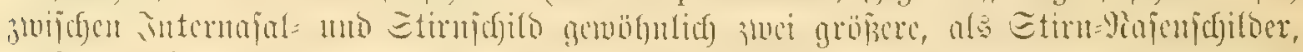

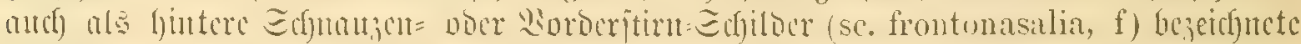

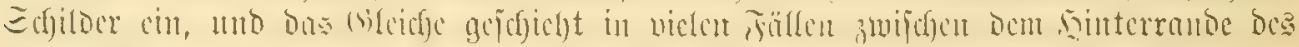

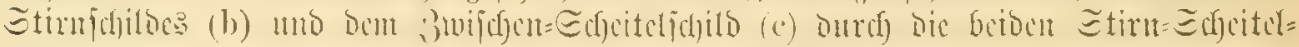

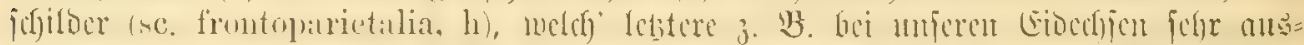

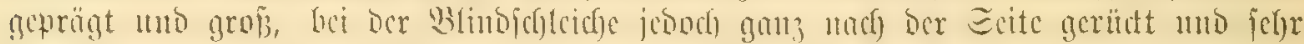

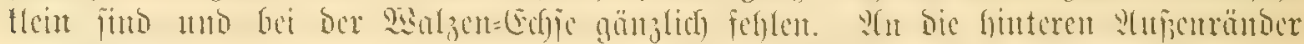

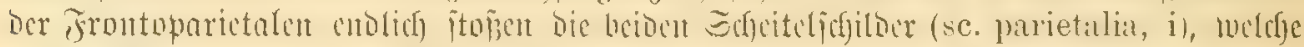

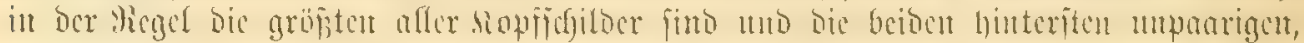

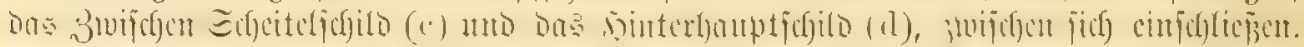

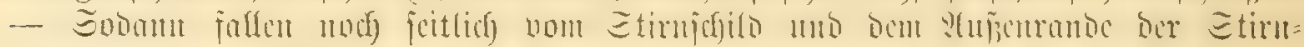

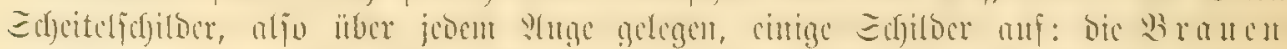

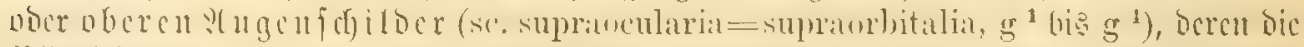

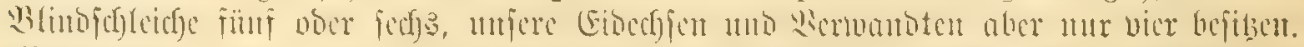

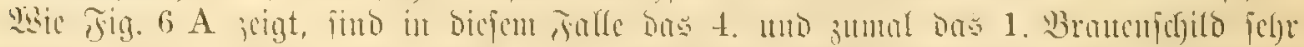

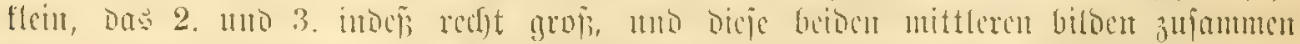

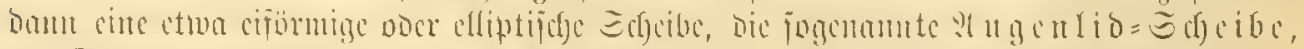

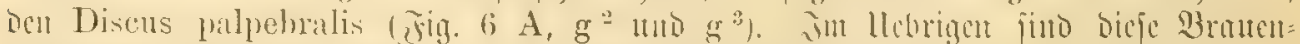

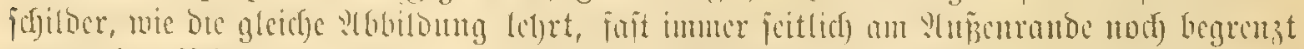

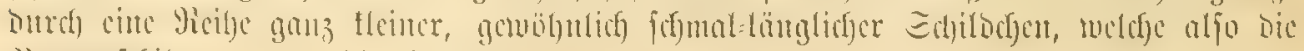

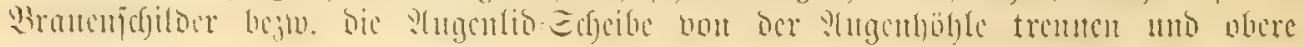




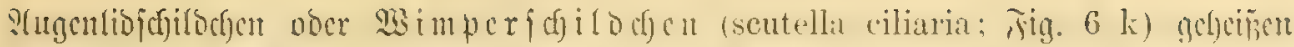

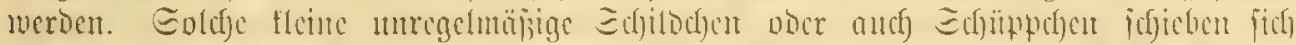

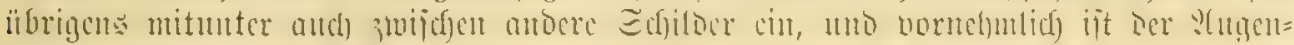

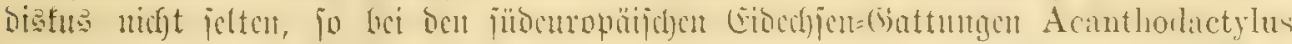

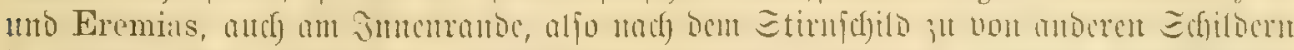

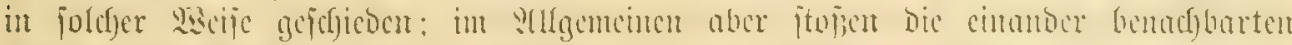

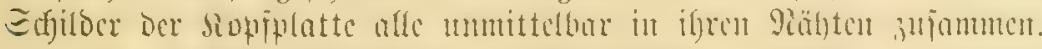

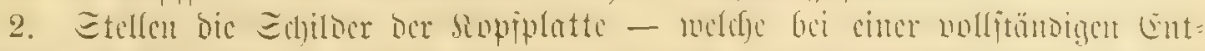

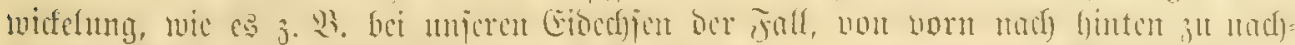

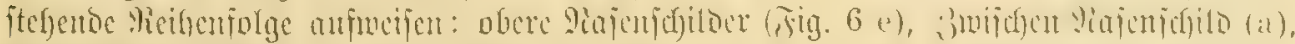

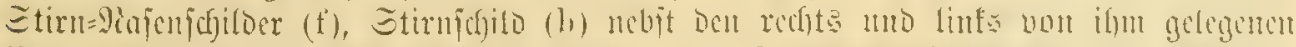

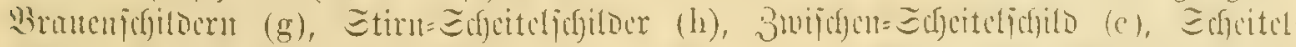

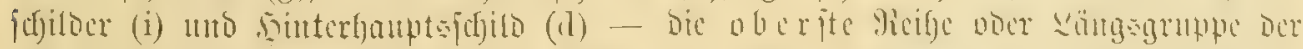

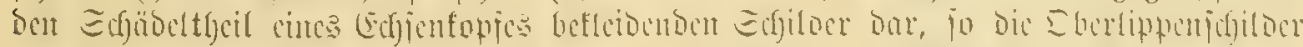

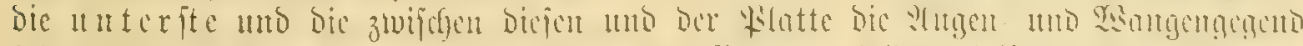

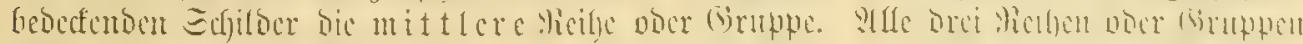

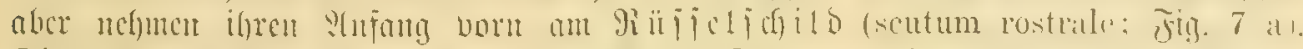

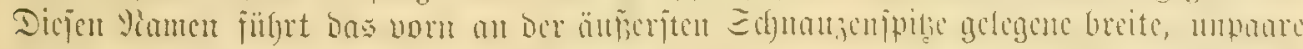

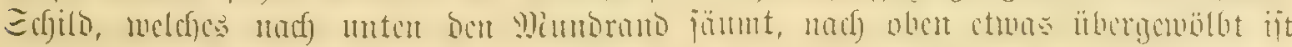

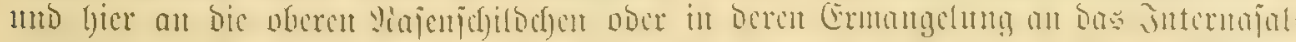

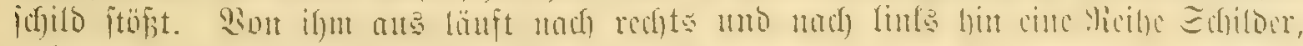

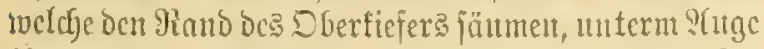

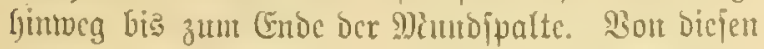
oberlippenjolitocen (scuta supralabialia;

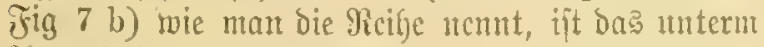

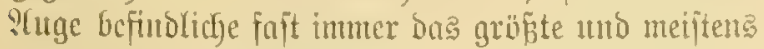
nach obcr fin etwas verbreitert; Die fyuter ifnn liegen=

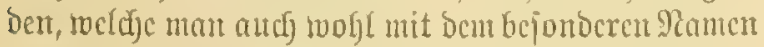
supralabialia posteriora (Gintere Dbcrlippcujpfilloer) bejcicfnet, während man bic żtwifdyent ifju und Dem Binffelfchildo gelegenten bie supralabialia anteriora

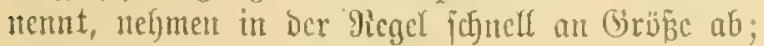
bci unjeren edjten Eibedjjen zăfyen wir an jeber Siopficite 7 oder 8 , bei ber Blinbidjleicle etwa 10 Dberlippenidjilder. - Brijdjen ben Yeßeteren unten und Der Siopiplatte oben ziegt fich aljo ant jeder Siopfieite nod) cine Qängareife verichicben geitalteter

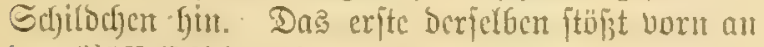

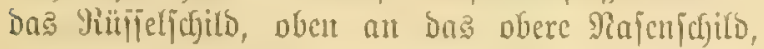
unten an Das 1. Dberlippenfojilo und füfyrt Dent

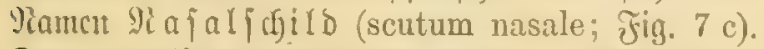

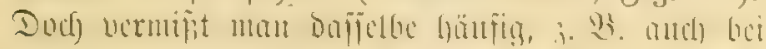

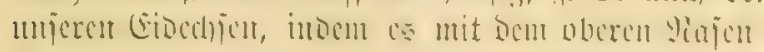

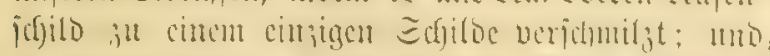
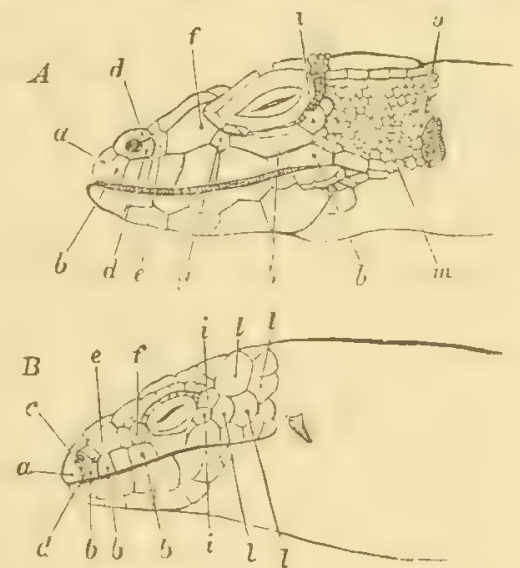

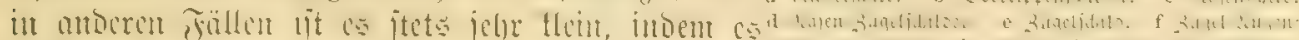

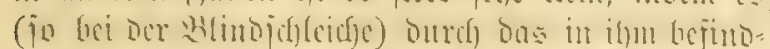

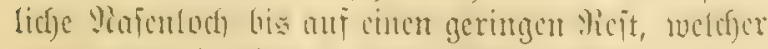

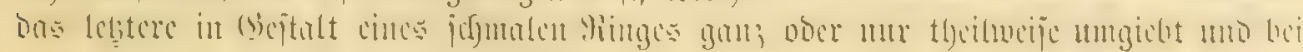




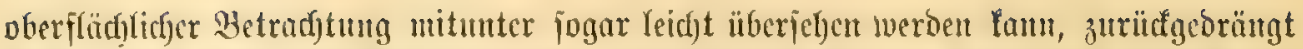

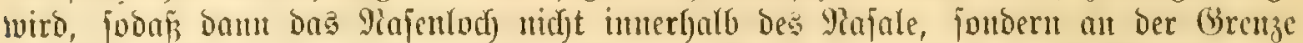

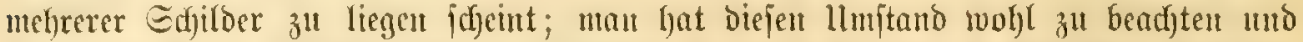

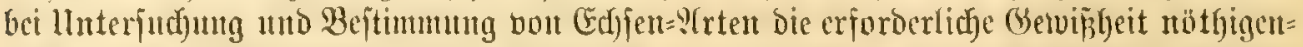

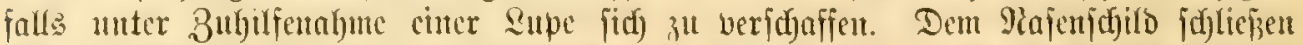

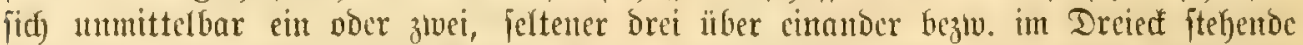

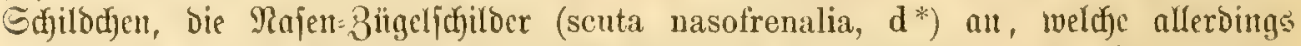

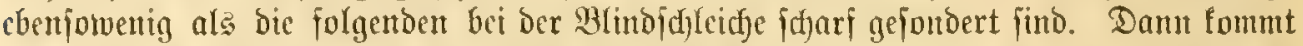
cin größeres Edfild e, Das eigentlidje Bügelfdjild (sc. frenale) mb hinter biejcm eit

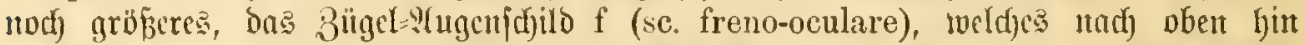
gern fich verbrcitert unto mit ber hinteren Ede bis gegen bic \$(ugengähle reicht. Direft

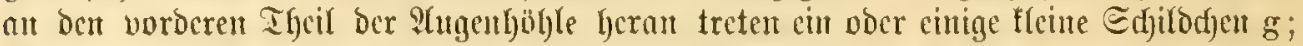

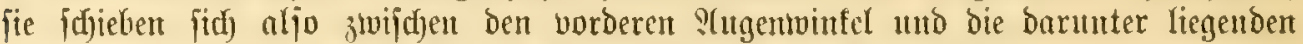

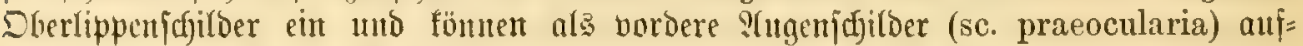

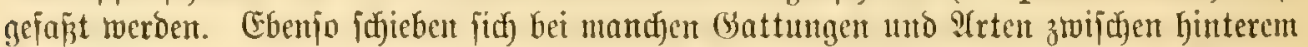

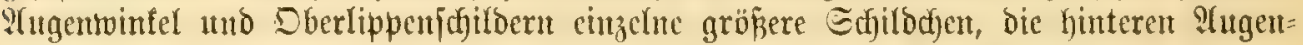

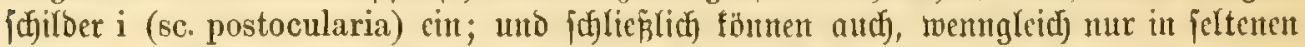

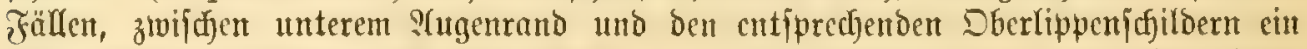

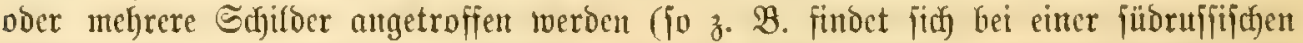

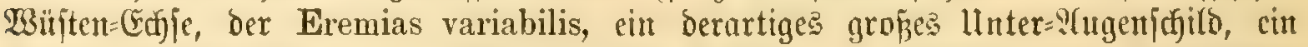
scutum suboculare, A h). Weit fäufiger bagegen, ja meiftens ift bie Q(ugenfjb̈le an ifrem unteren Yande gejäunt mit ciner Reife flciner, fofuppenartiger Sefildocfen,

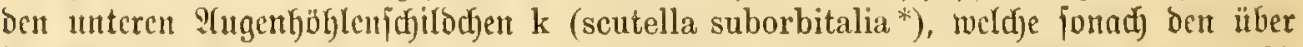
Der Stugentyähle hinzieljenben uno bercits erwäfynten, fowie auf ben ?tbbildoungen $6(\mathrm{k})$

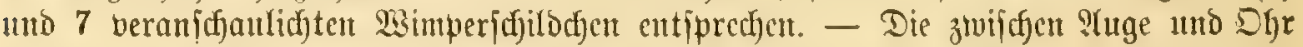

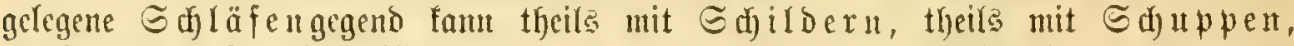

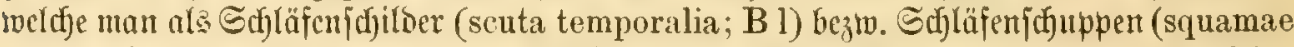
temporales; A uno $\mathrm{C} \mathrm{m}$ ) bezcidjnet, beffcidet jein ; Sdjildor bejibeu unter umferen deutidjen

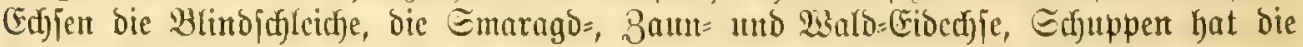

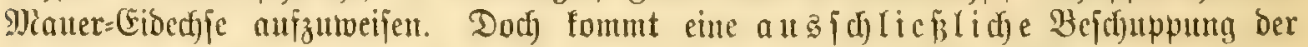

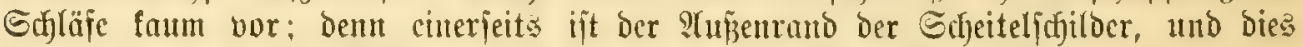

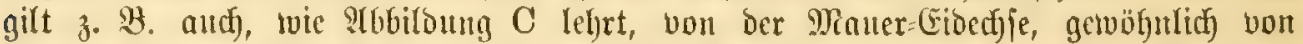

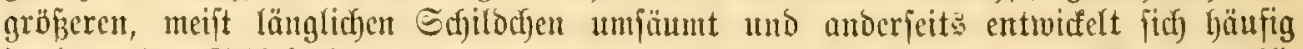

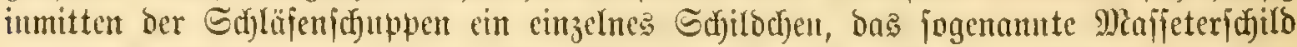
(scutum massetericum; C n); und endficf bemerlt man noch am Dherrande ber Dhr-

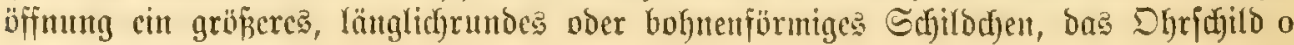
(sc. tympanale).

Unterfiefer: unt seblbetleibung.

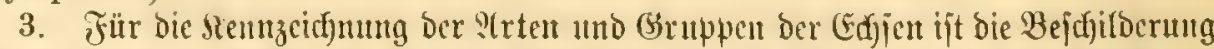

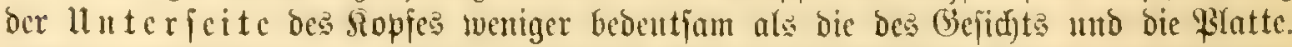

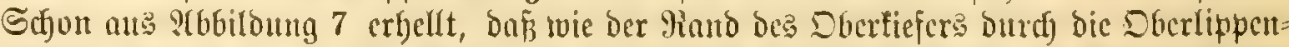

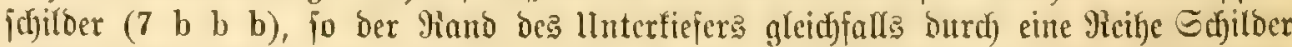

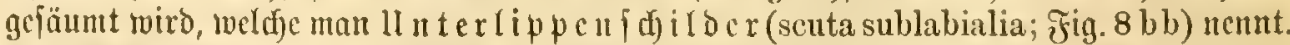

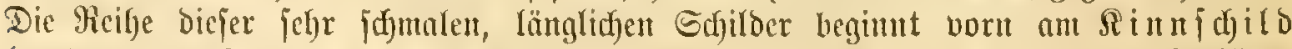

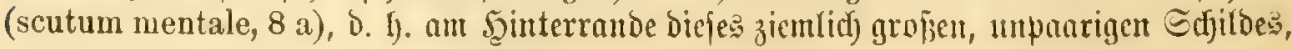

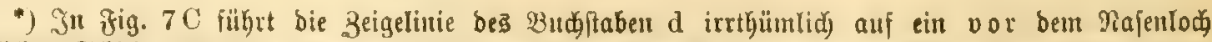

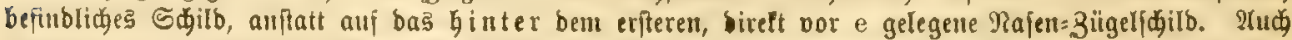
แน

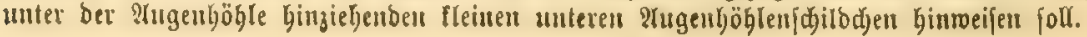




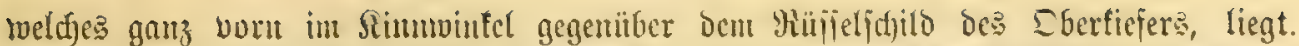

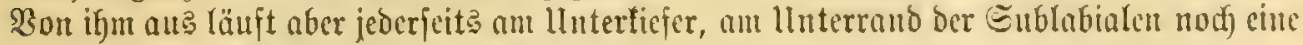

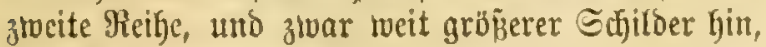
bie Rinnen= ober Untertieferidirber (sc. submaxillaria; $8 \mathrm{c} \mathrm{c}$ ); bie vorberiten ats den beiben

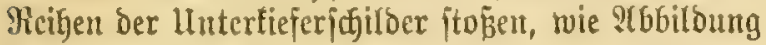

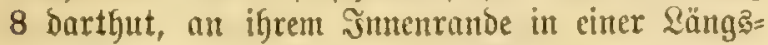
rinne zujammen. Son Dem $B u n f t c a b$, wo bie bei= Den Reifen auseinander tweicfen, nacif linten zu be= Decft fich bie IIntericite des Ropfes fait immer mit

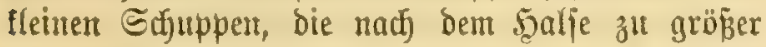
twerden und am Ende des lesteren bei Den ¿acertiben cine Duerreife getwöhnlidf nod gröp̈erer Edfuppen, daz 5 a

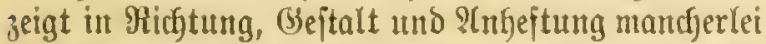

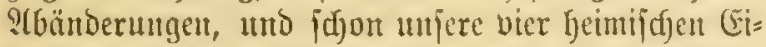
bedjien tweichen barin unter einander ab. Jn ber Megel befteft ca aus $\Xi$ djuppen, bie mur am (Brunde ange= heitet jind, mit ifrent fintercn freien Theile jedod)
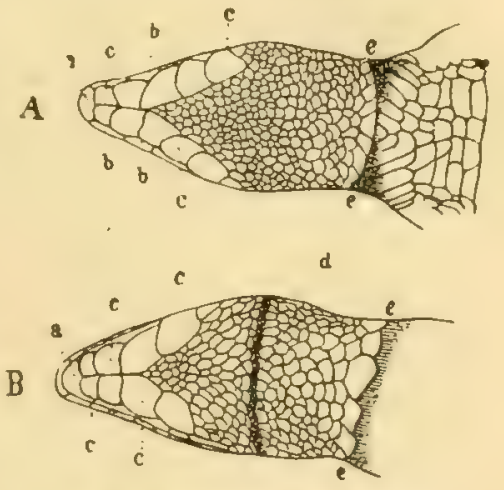

Jig. 8. Ilnterjeite bes Ropies

(A Mauter=, B Smaragb=(Fibedjie).

2 simfifilb, b unterlippenjibiber, c Interliefet fđilber, d Rehlfurdie, e-e Salsband (bei A ganz. ranbig u. (đ)raad bogig, bei B gezäbnt unb gerabe).

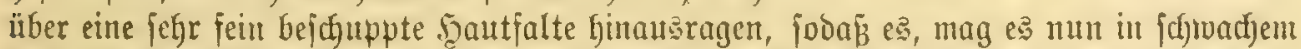
Bogen (96bitd. 8 A) oder in gernocr Richtung (B) ïber bas Jinterende bes Unter

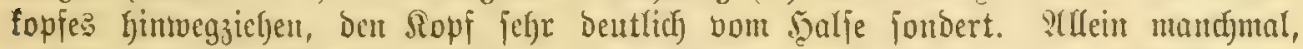

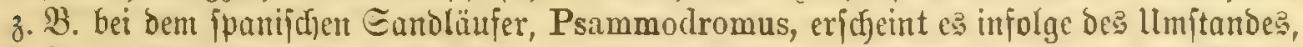
Dá̉ bic Schuppen ganz fejt anliegen und nod) Dazu von ben ifnen folgenden Bruit=

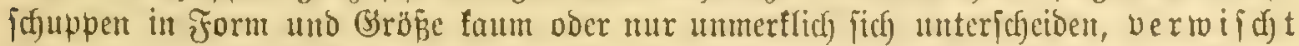

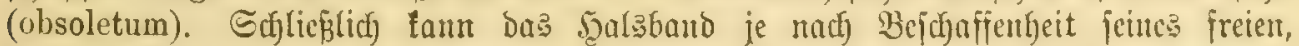
Ginteren Ranbes entweder ganzrandig (integrum) ober nber gcferbt (crenulatum), gezähnt doer gejägt (serrulatum) jein; ganzrandig nemt mant ङchuppen finten gerabe abgejtubit find und hier jomit cinc fajt ununterbrodjene Sinic bilbent, wie es bei ber Mauer=(Eibedje (8 A) Der Fall ijt, wäfrend ein geferbte

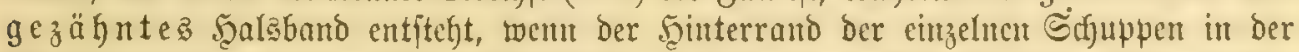

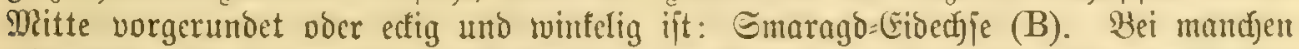
(Fibedjen twird bie getwöhnlidje Bejüuppung Der Reglgegend (gularia) nod) unterbrodjen Durd) cine etrua über bie Slitte beffelben laufende, mit febr feinen Edjuppen befleiocte

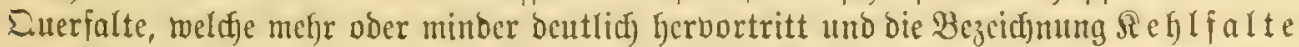
ober Sieflfurd)c (plica v. sulcus gularis; Fig. 8 B d) füfrt. llno cine jogenannte

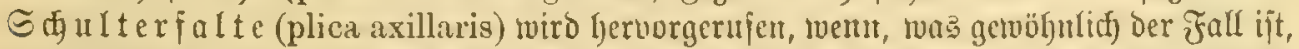

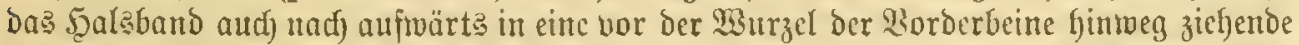

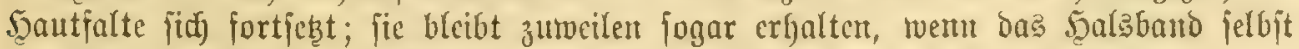

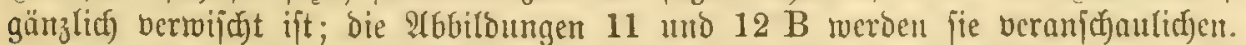

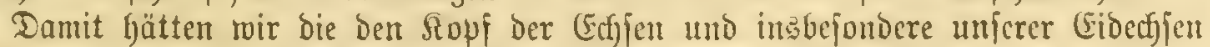
in all' jeinent 'iartien bebedtenden Ecfjilder unto Edjildden bejprodjen, und fomen

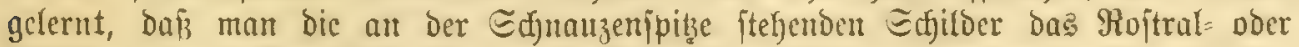

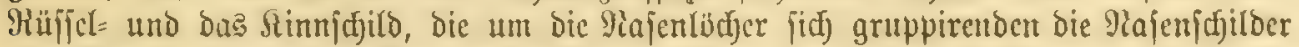
Dder Nasalia, bic auf ber fiopfplatte (Pileus) fid) mabreitenden bie Etirn= un Edfeitel fajilder oder Frontalia uno Parietalia (Verticalia) und beren binterites ba: fointer-

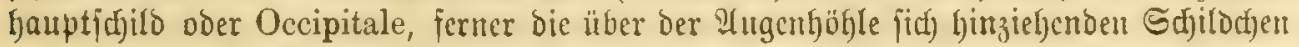

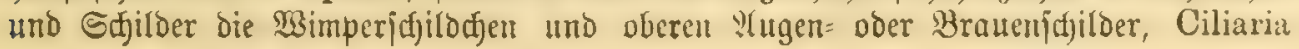




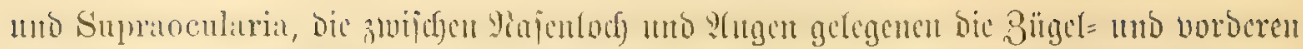

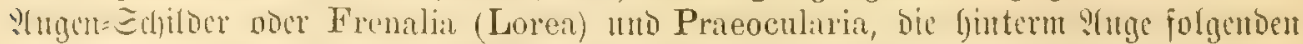

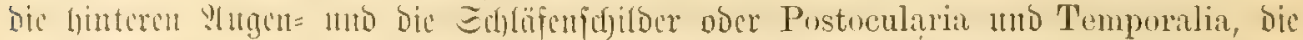

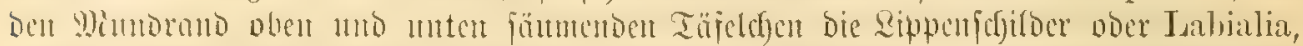

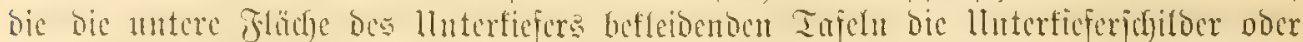

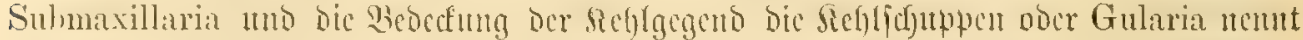

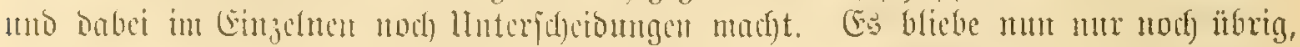

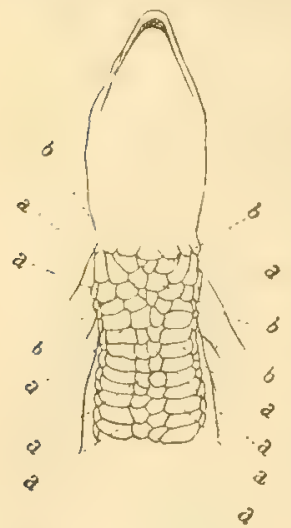

Tig. 9. Baudjidjitber: Peifen (a) und Brult? fdjilber $=$ Dreiect $(b)$ ber

Simatago=(Gibedye.

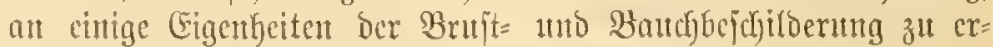

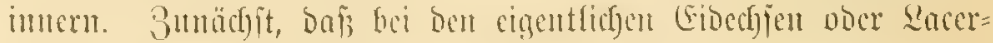

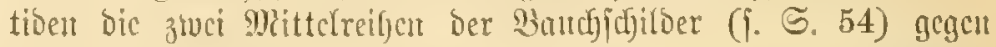

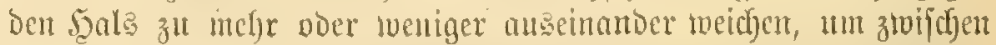

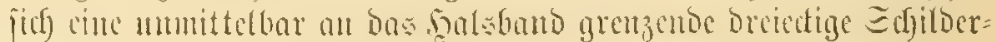
gruppe, Das auf ?6biloung 9 vergegentwärtigte "Bruft= Dreied",

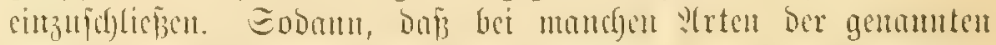

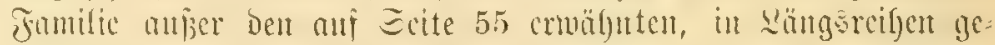

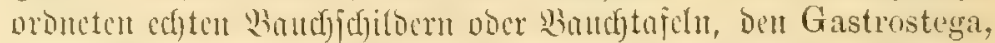

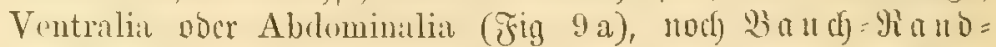

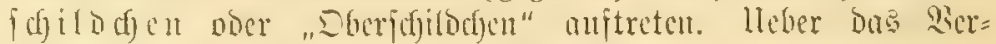

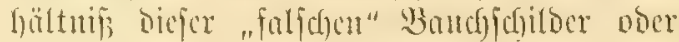
Pseudo-Gastrostega, weldje an jeder Flanfe an Der Grenze wou Rüfenidjupen mo

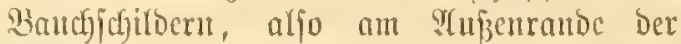
criten und - rebten Bautjichilder = Räugsreibe

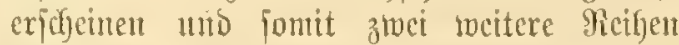

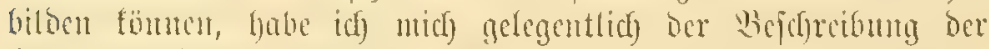

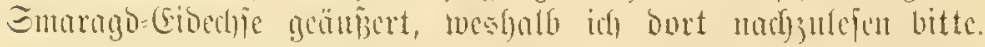

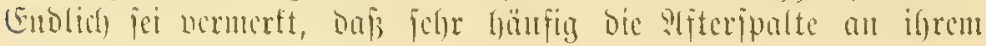

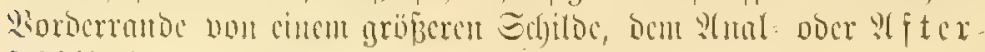
fdill (scutum anale; Fig. 10 sc. a.), begrenzt ijt.

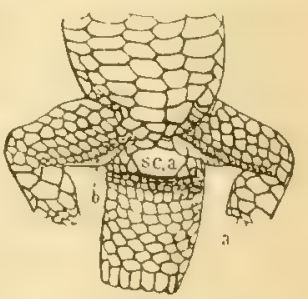

fig. 10. Mifterpartie ber 3aun=(5ibed) 9 .

a Suentaufente stoutenfunte, sc. a Mfterfidito ober seutum anale, b cdjentelporensieige.

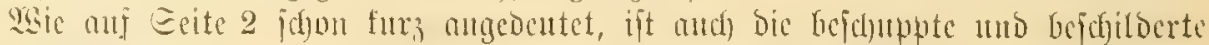

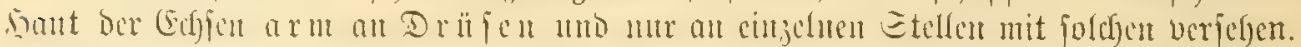

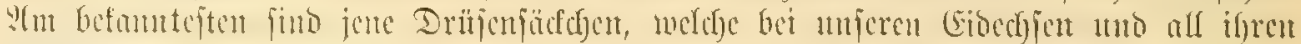

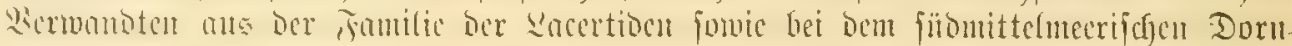

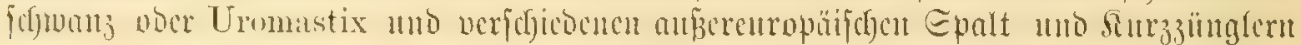

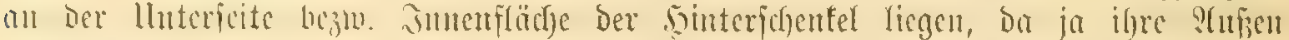

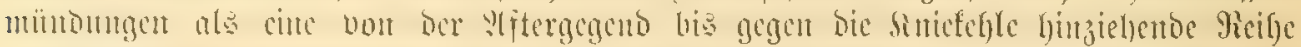

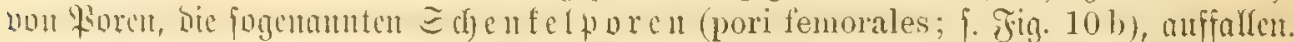

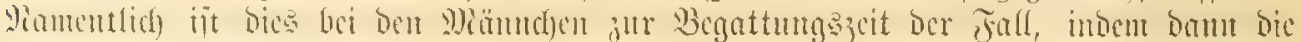

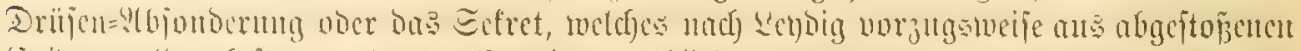

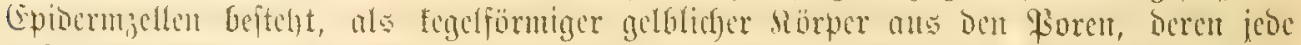

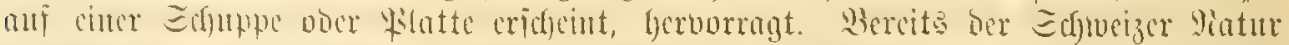
forjer Dr. Etth in Bern, ber ?tutur bes Triton "lohatus" (- vulgaris), hemerft

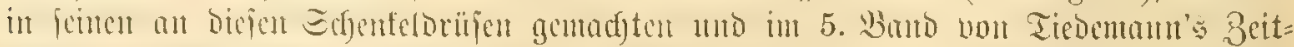

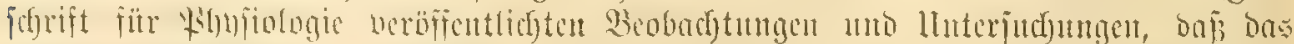

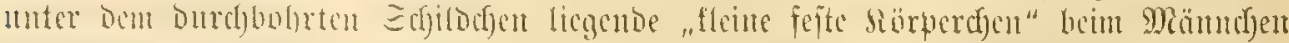

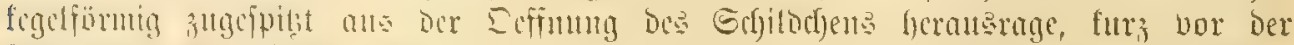

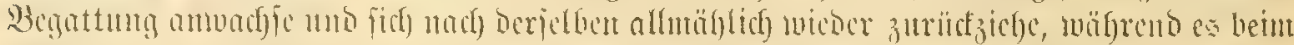

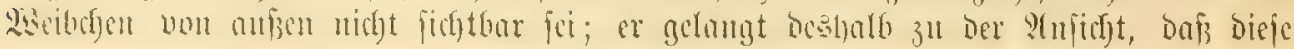




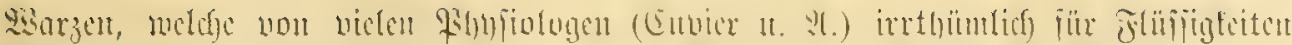

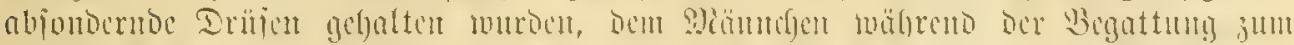

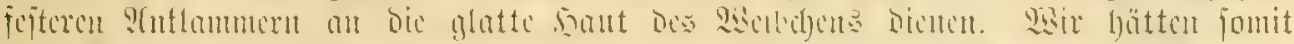

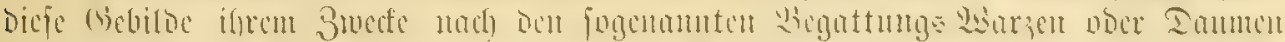

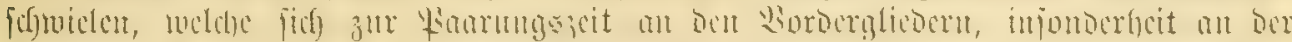

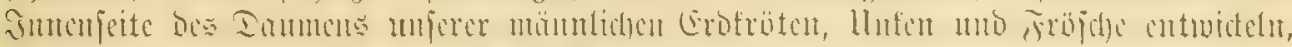

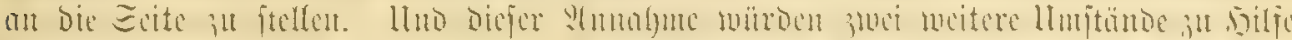

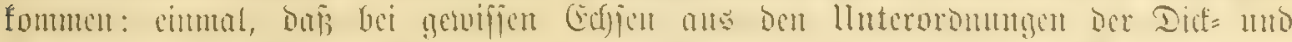

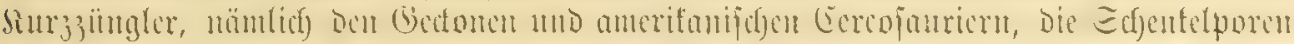

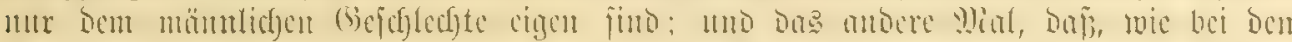

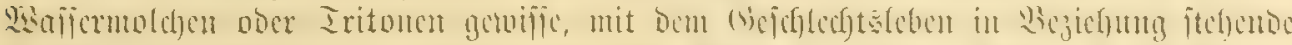

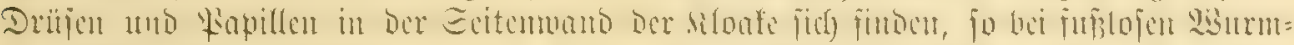

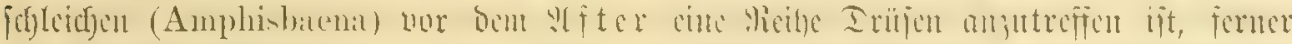

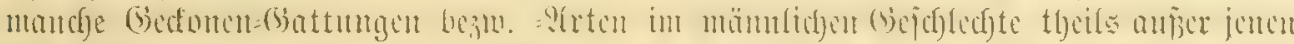

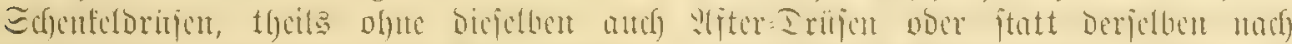

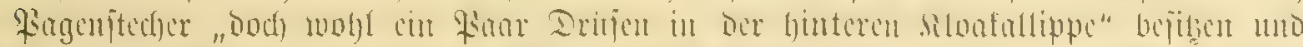

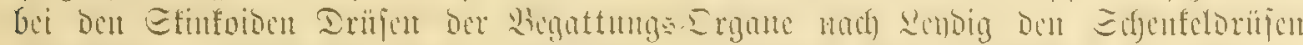

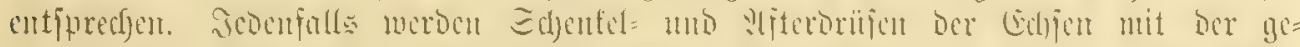

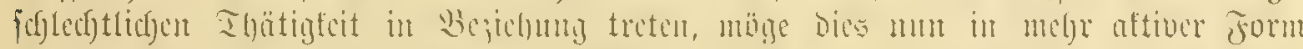

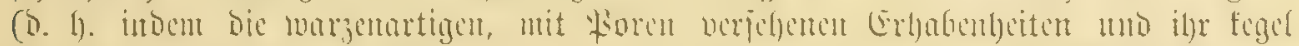

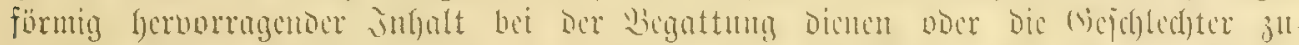

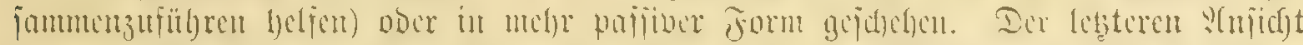

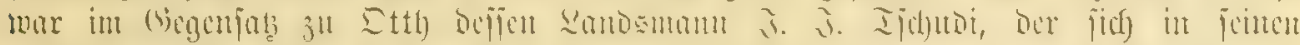

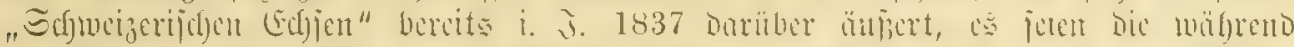

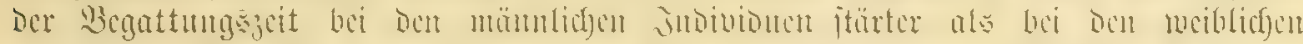

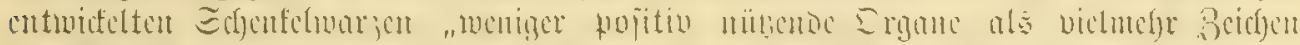

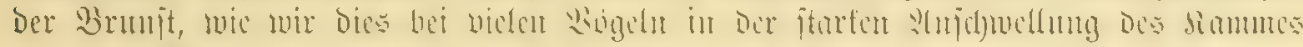

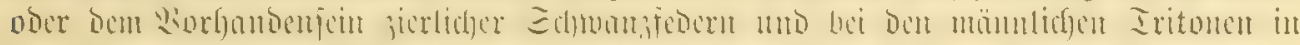
Der Gegenmart Des 9iüdentfammes loüfrend bicjer Beit finden".

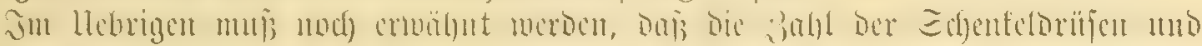

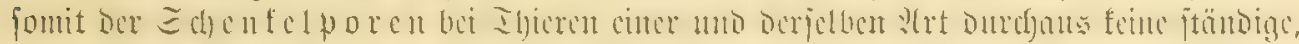

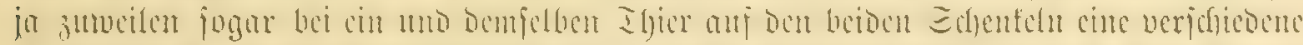

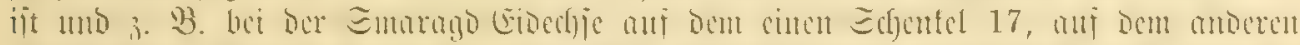

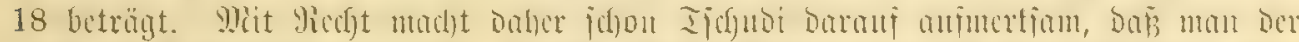

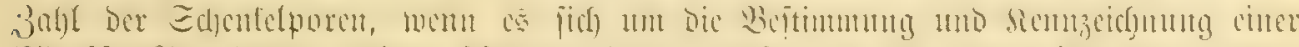

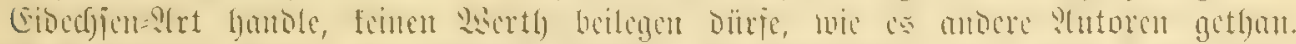

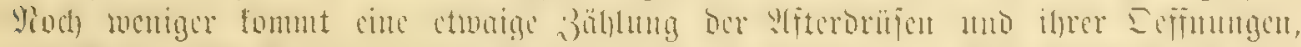

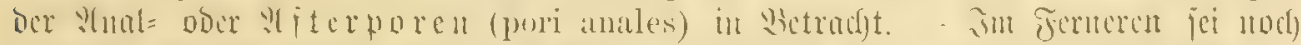

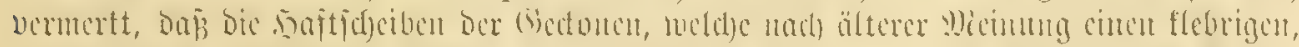

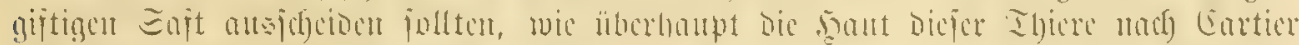

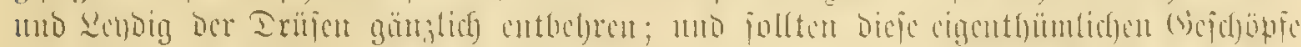

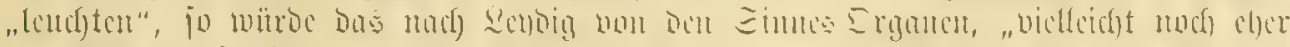

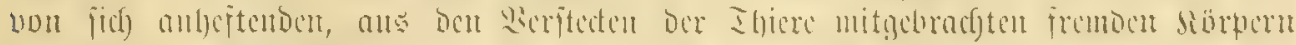

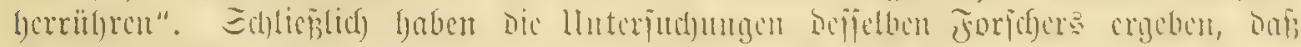

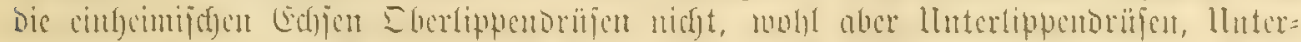

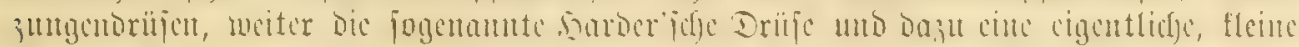

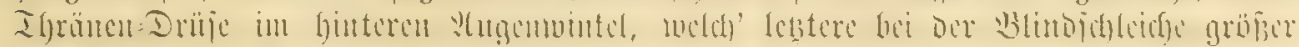
ale bei ber Eibedje ijt, bejitzen. 


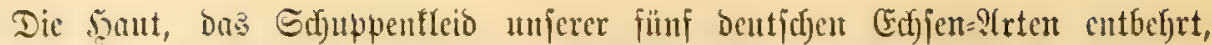
twent wir vou ben frifdjercu Jarben bes jodjzeitgewandes abjehen, jeber bejonderen

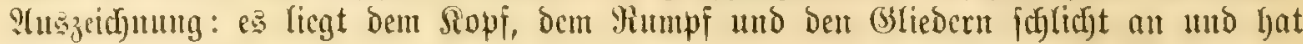
feinc häutigen, als Bicr anzjelyende ober zur llnteritübung der Bemegungen

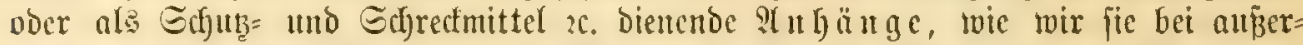

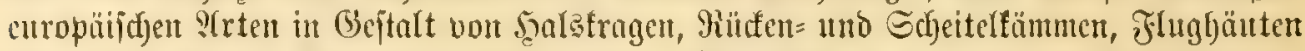
oder Fallichirmen, Edjwanzuerbrciterungen, Sieblfäden u. a. vorfinden, aufzuweijen. Dagegen treten un' cinige Forment derjelben, wemuleid) nicht in joldjer ?(usbefmung

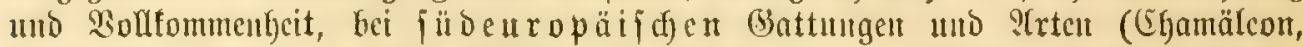
Srötenlopf, 9game, Saroun, Plattfinger) bercits cntgegen; cbenfo gefören hicrher bie

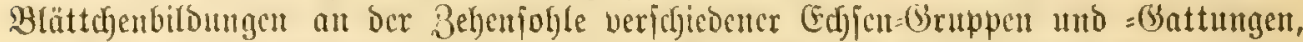

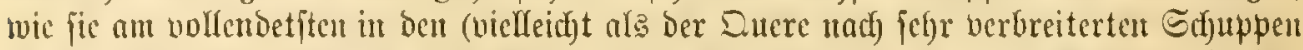

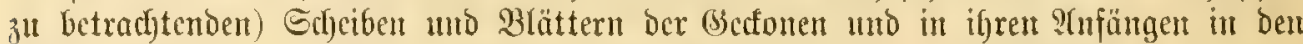

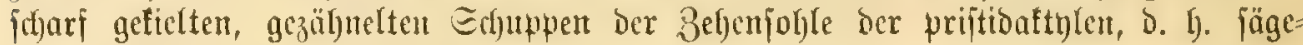
fingerigen Eidedhen exjobeinen.

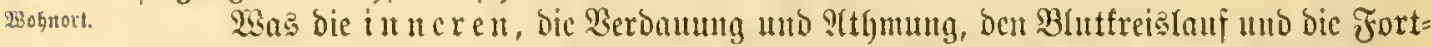
pflanzung bewerfitelfigenoen Rörpertbcile anbetrifft, fo wolle mau bas auf ben eriten Eeiten Des Budjes (Scjagte beadjten. Ilut ba anderjeits ju einer Edfilderung der

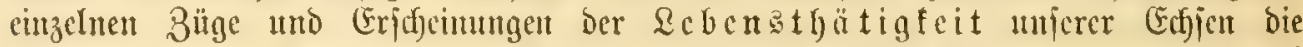
Bejorcibung ber Gattungen uno Sirten uns füfren wiro, fo bürfen twir uns fier auf

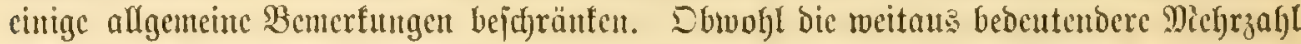

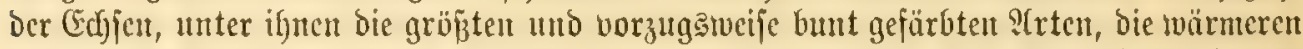

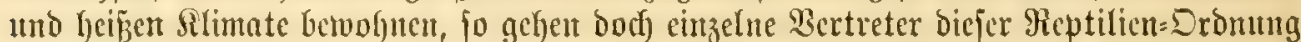

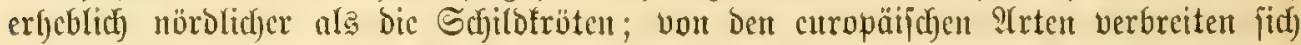

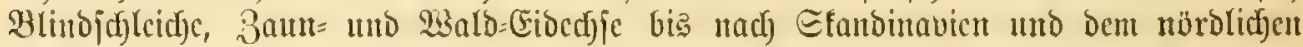

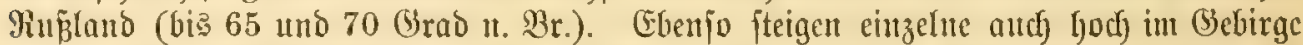

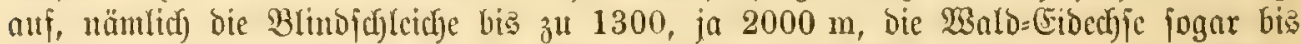
$3000 \mathrm{~m}$ ̈̈berm Mieerespipiegel. Die meijten aber lieben offenc, trodene, foumige Gebiete, mögen bicjelben aud) wajjerarm fein: Der Thau bcjriebigt nöthigenfallz igr Bebürfní̈ nad) Waffer. Daber giebt cs wenigiten: unter bon Europäern feine cigentlicjen Wafier =

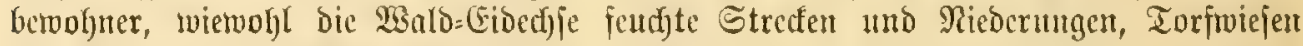

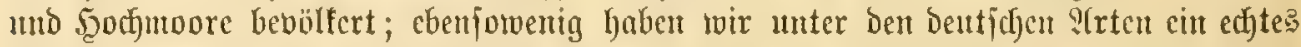

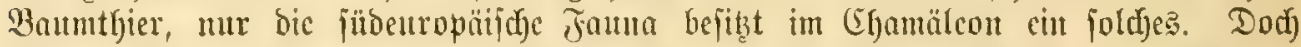
flettern bie meipten ganz gut un aucly gern, mandje in Sträudgern แno auf Bäumen,

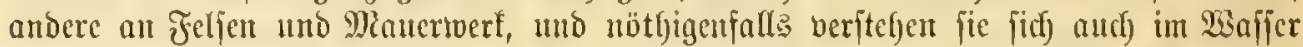

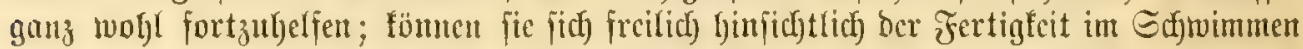

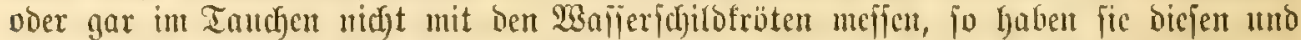

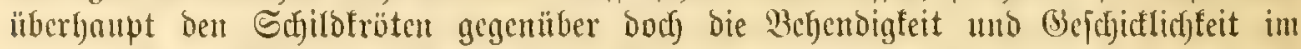

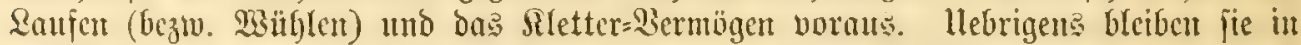
ber Yegel bem gewählten Etandort, ber ifnen fo vertrante Edjlupfwintel bietet und oft audf betreffe ber Färbung mit ibnen barmonirt, in :Huänglidfteit jtetig zugethan.

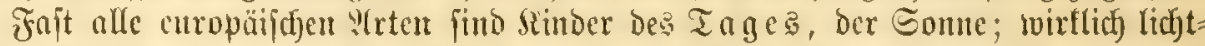

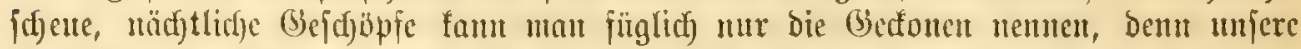

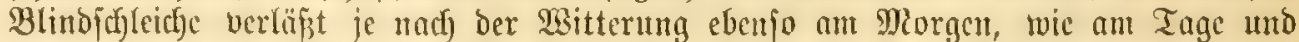

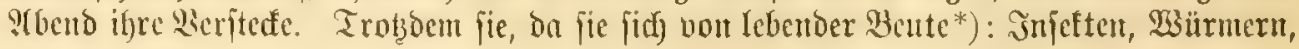

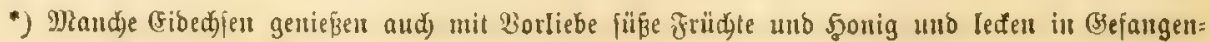

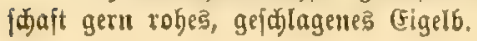




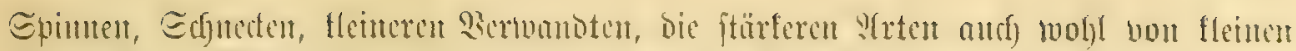

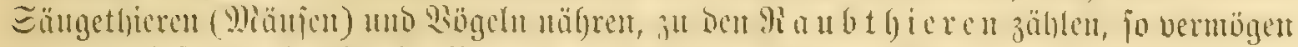

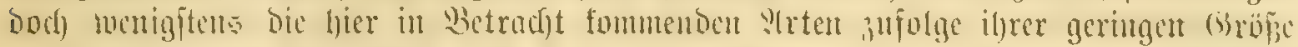

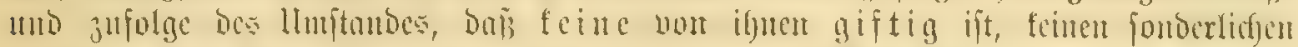

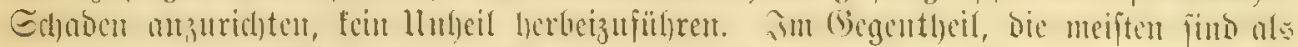

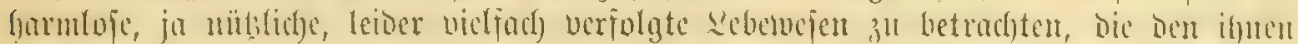

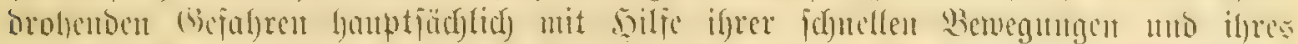

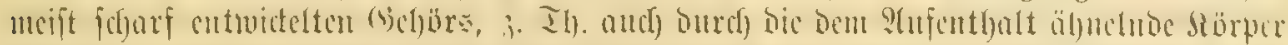

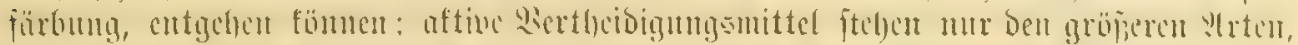

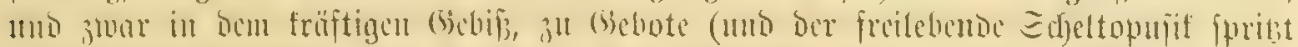

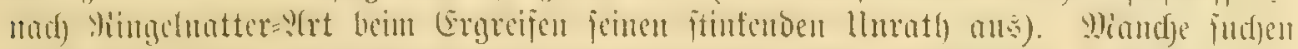

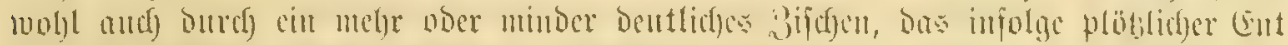

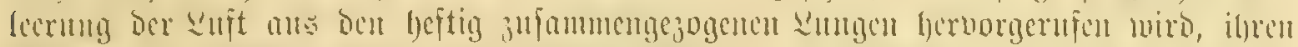

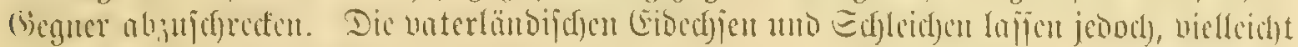

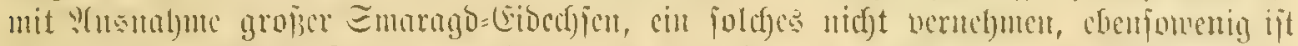

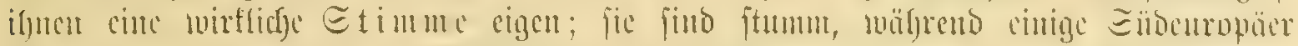

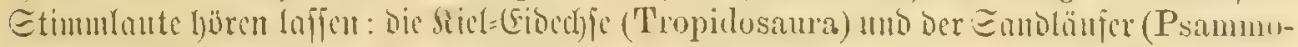

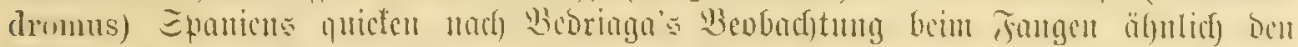

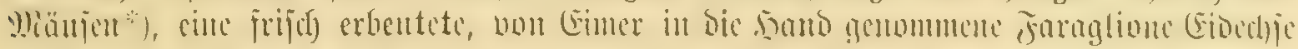

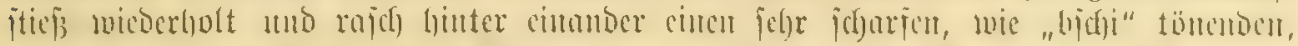

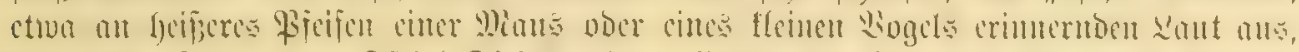

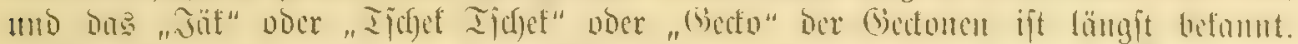

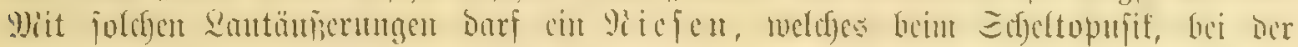

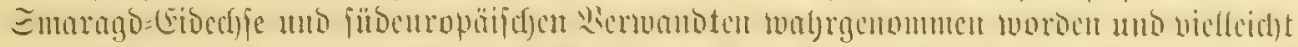

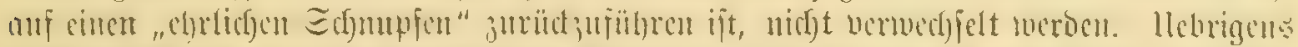

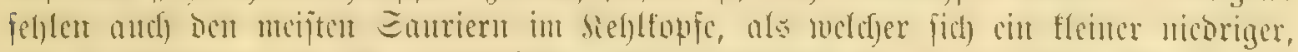

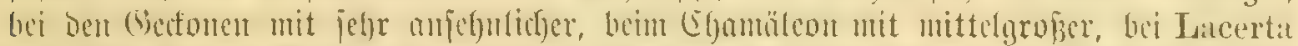

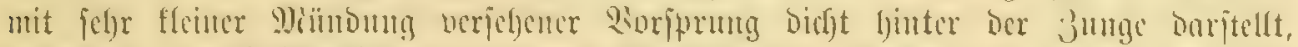

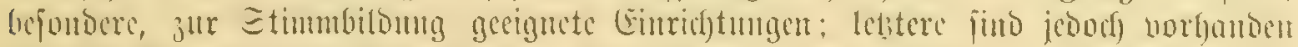

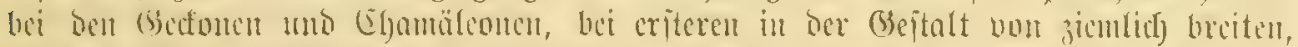

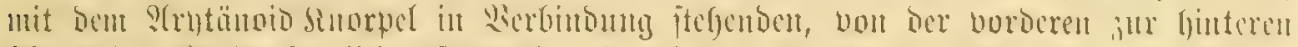

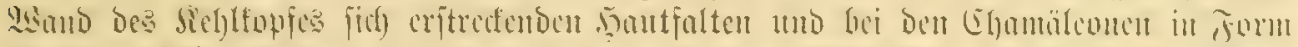

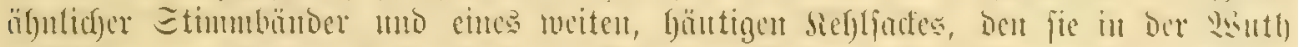

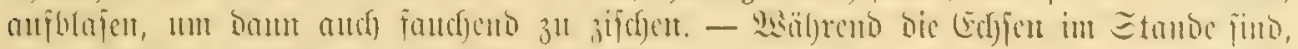

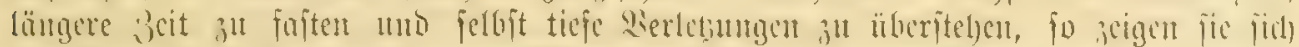

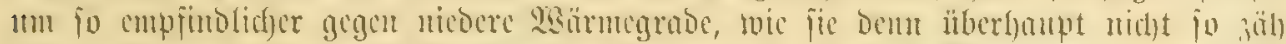

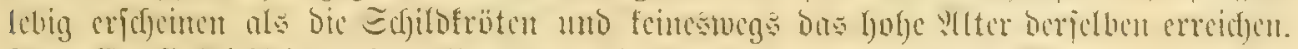

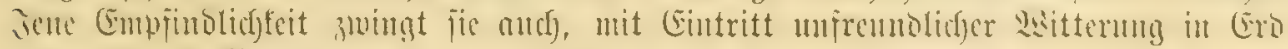

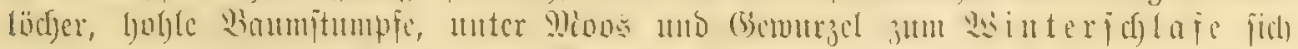

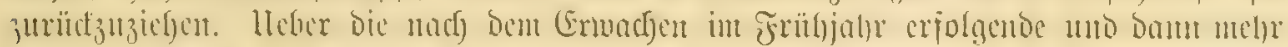

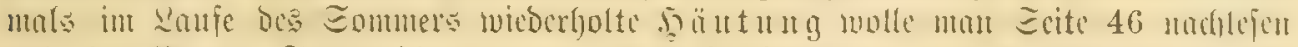

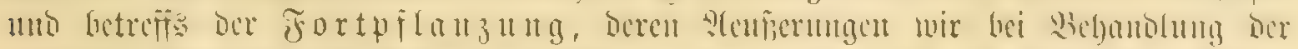

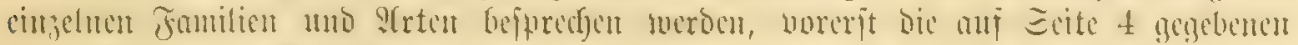
Bemerfungen beriocticftigen.

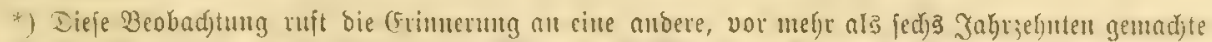

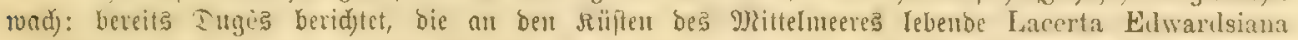
(= Psammolromus hispanicus) gebe unter lluftünden einen sant von fid), bet an oas sinarten oiner Birpex ber Bod̆täfer genualue. 


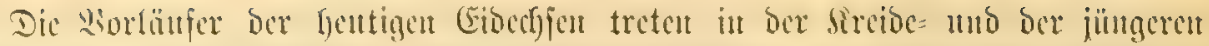

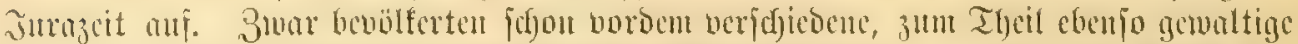

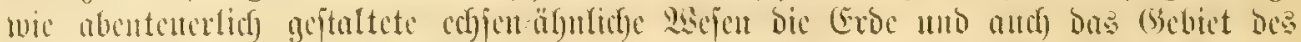

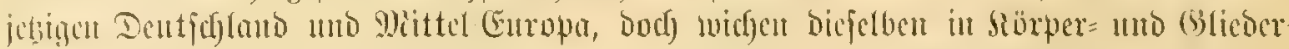

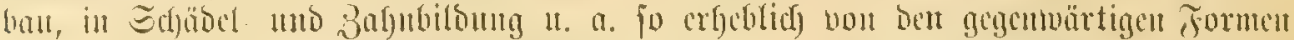

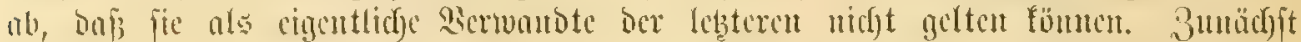

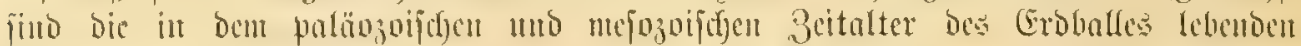

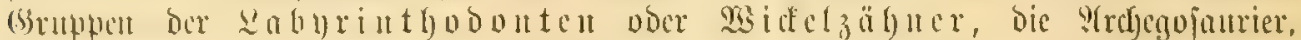

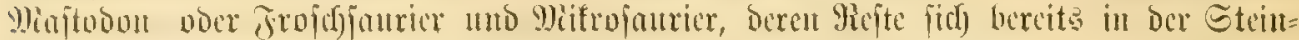

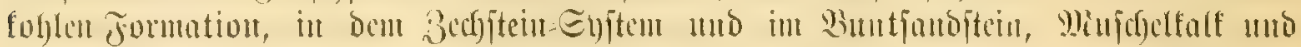

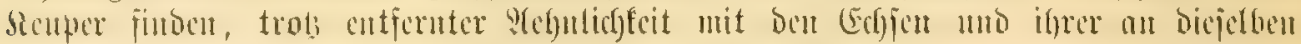

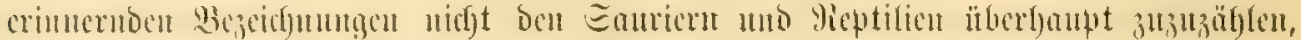

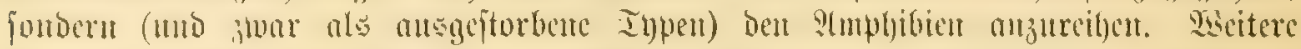

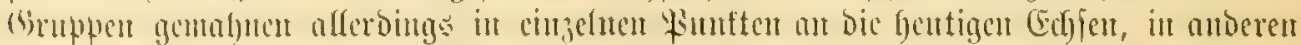

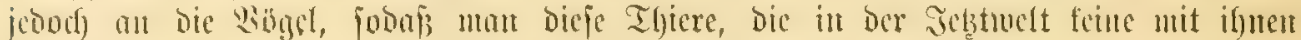

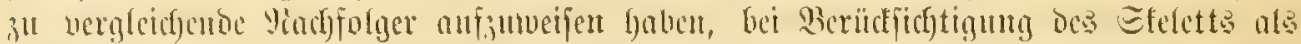

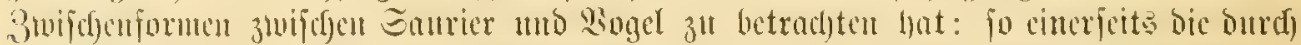

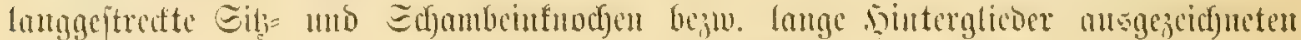

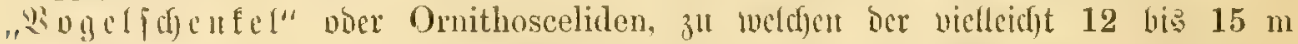

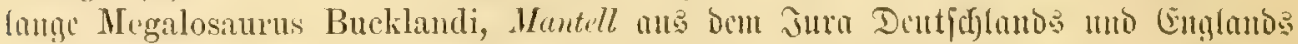

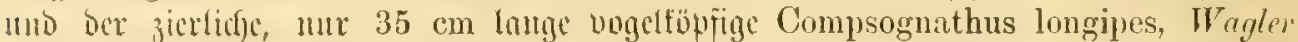

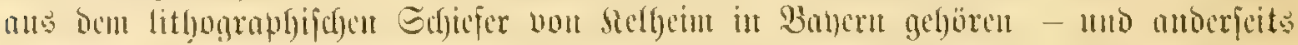

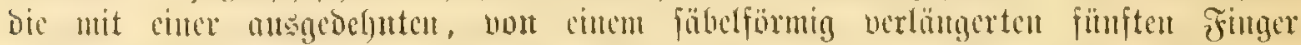

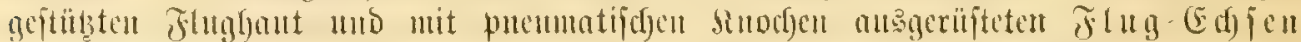

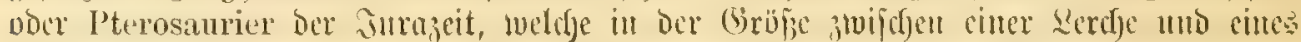

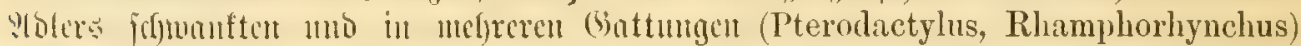

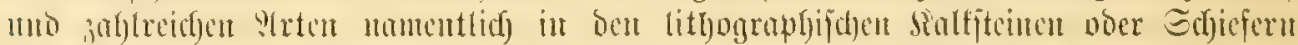

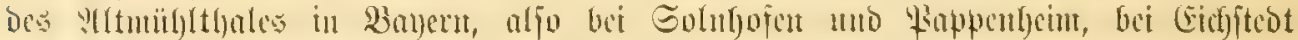

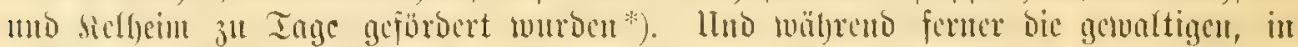

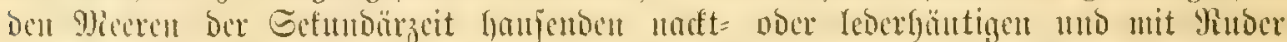

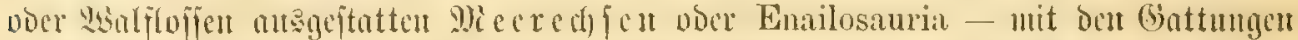

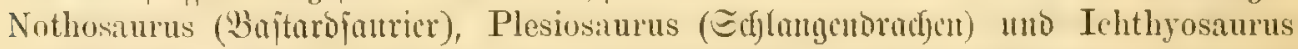

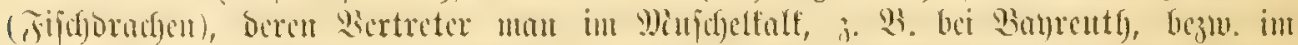

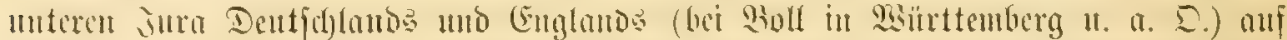

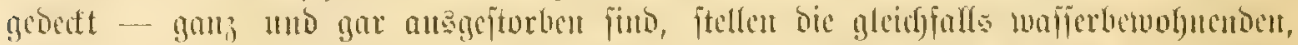

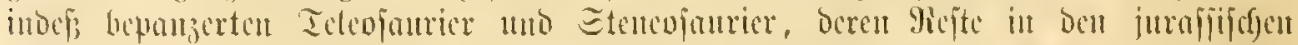

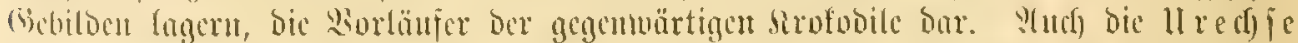

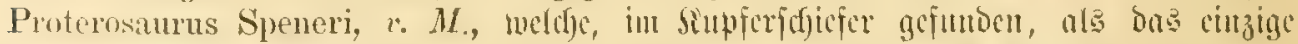
ben fulto;

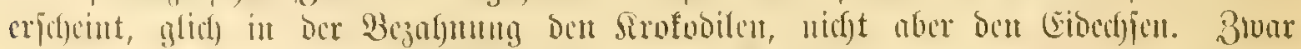

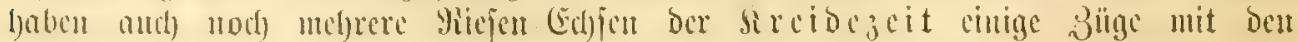

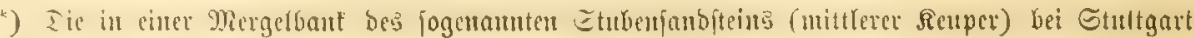

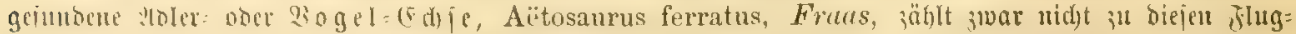

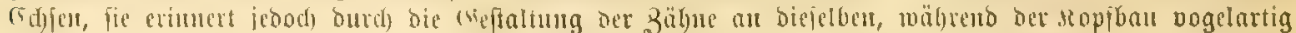

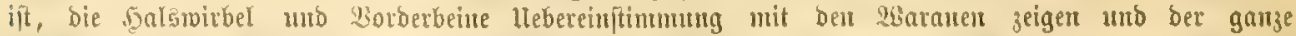

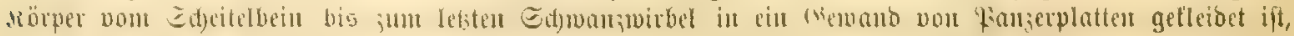

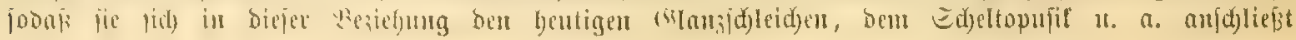
(vergl. 5. 43). 


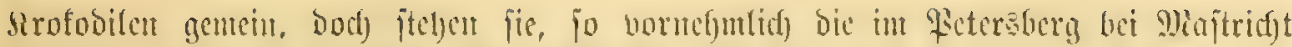

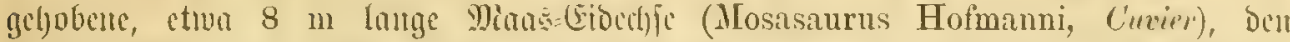

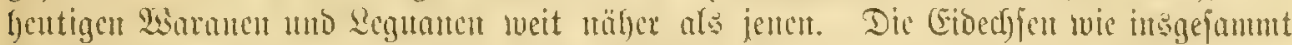

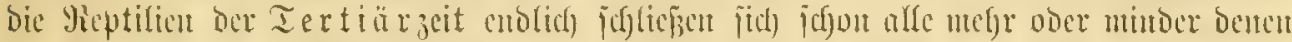

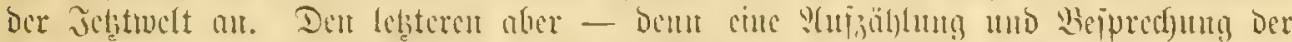

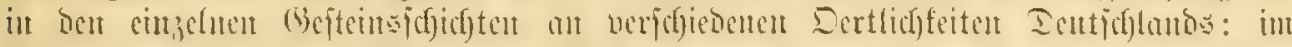

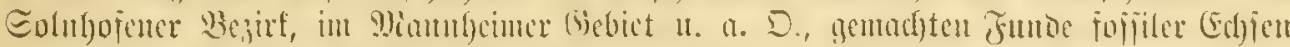

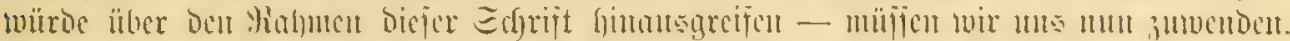

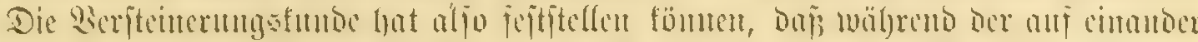

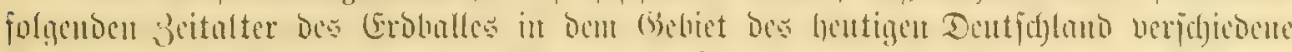

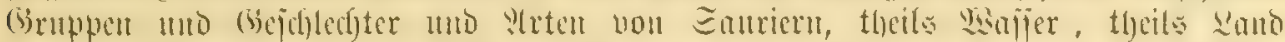

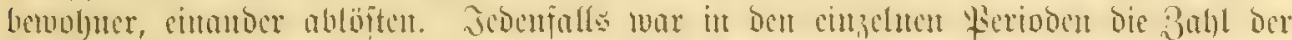

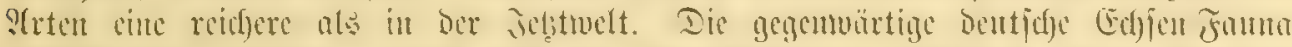

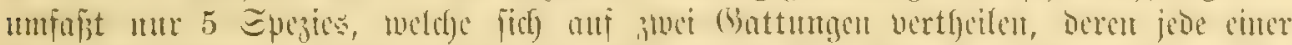

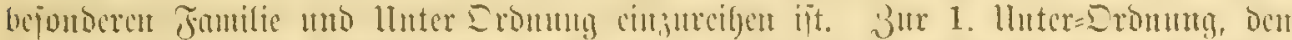

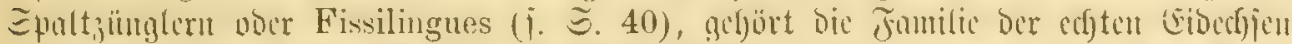

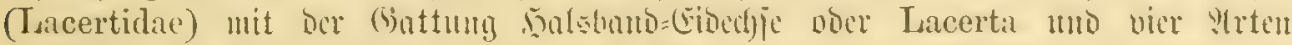

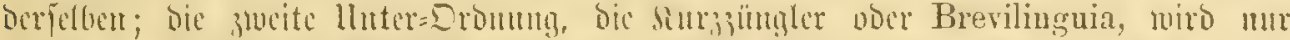

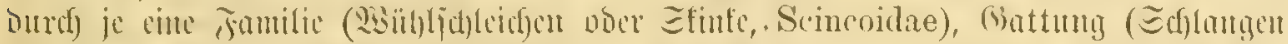

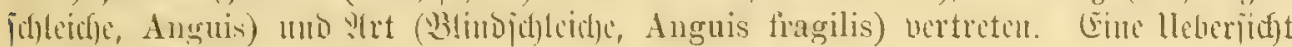
bietet nebenitefento Inbelle*).

\section{Lluter = (1) romung: \\ Spaltzïngler. Fissilinguia (S'chistoglossi).}

Das mefentlite 2rierpmal der Ltnter:Drdmung liegt in ber Junge (ङ. 40).

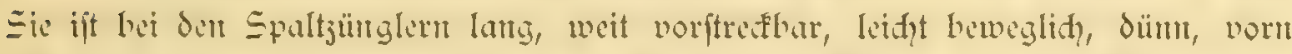

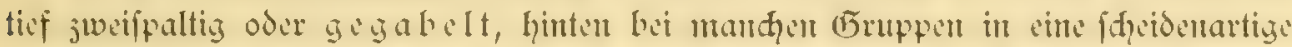
Limatfalte cingef

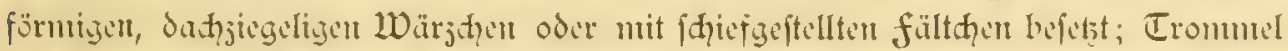

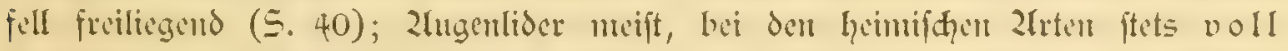

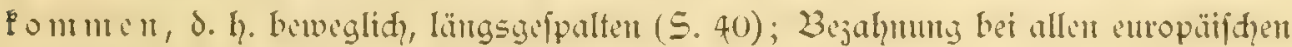
Urten pleurodout $(5.41)$; vier gut ausgebildete Beine.

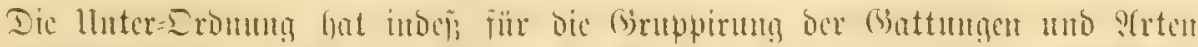

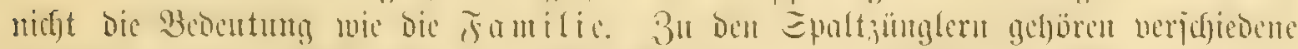

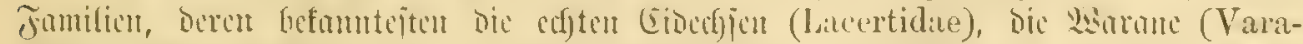

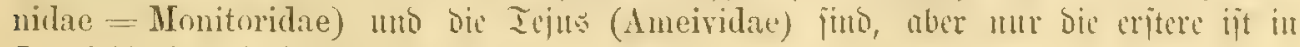
Deutficlano und Guropa vertreter.

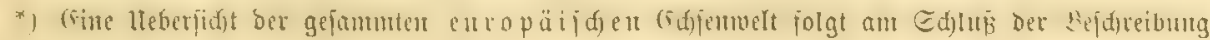
unjeret jüแ beutiden 9trett. 
3unge Inug, weit voritreftor unto leid)t beneglid, büm, vorn tiej zoeijpaltig (gabelig); Eromutelfll frei; slugeuliber meift volltomnen; 4 finke:

1. Luter $=5$. D 4 ut $\mathrm{g}$, Epaftzůngler, Fissilinguia.

3utuge fur's, wenig vorifred bar, Ginten bitt und obue Gdjeibe, vorm verbünt uno roenig ausgefdutrten; Trommel= fell oft unter ber jout verforger; ?tugeuliber meift por:

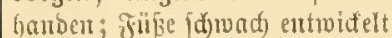
ober ganz feglent:

2. $11 .=0$. , sursunugler, Brerilinguia. Reble jefre ojt mit einem aus grözeren Sduppen gebilbeten

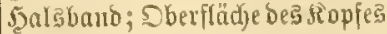
mit größeren Cdjilberu reget=

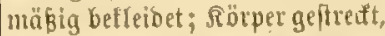
walig, oberjeits bejouppt, aber obute diuodjenplattent itt ber

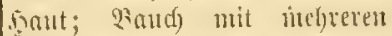
xängstriben suerdaltom; ber ïbrige Börper, bitum nats= lanicut, rmoun mirtelig be: idjuppt; (SIteomásen gut ent= widelt, 5 zegig, ans ber lluter= ieite bes Oberidjentels mit einer Poremreige:

1. $\pi$ a m, (Ed)te (Etoedien, I Lacertidae. ふ઼opi vom 5yals abgeiest, Ed)wans lang, neift linger als

Jinterbanptidirlo vorbanben, aljo au Der Sopfoberflädje auper utefrexen parigen 4 แแะ parige Sditber; Trtgentistus Göd)ftens an अañentande nit fleinen tömerartigen Gduppen gejäแแก im (3anzen 4 Brauenjiditoer; unteres Ingenlio viel gröker als bas obere; nalstanto jebr ansge=

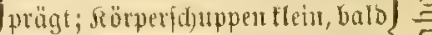
töutig, balo mefyr ober ventiger $1-1$ frads, weser amiliegento getielt und beutida gefdumbelt; SFaud idjilber grofi, quer ermeitert, bie Der 2 mittTeren \&üngşreifest meift fleiser als bie ber jifbriger; Unterjeite ber Behen mit glatten Sduppen, Bebemränber nidbt ge= 3älinelt:

1. (3attug, gatsbano= (EiDedife, Lacerta.

Ropi hiuten ohnte (Einfdunturng in ben walgigen Rumpf über:= gehento, oberjeits mit gropen, flad)en Edjilbern betteibet; $5 a l 5=$ band fehlt; Rörper 1 mo Gdymans ober" 1 uto unterfeits mit gleid)= artigen, gropen, glatten, feitant liegenbent, polltonment gejuju= betten, mebre breit als laugen, lan Sinterranto bogigen Sd)te = peu beocdt, mit Sinod)enplatten (Ralttafehi) in ber 5aut: Edjwalt; felter ütber fiörper: räuge; Bstiebmaisen bei ber lyei= mijd)en Gatung jehtend:

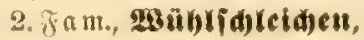
Scincoidae.
Sïrper walgig geftredt mo ohne äubere OSliebningen, baker

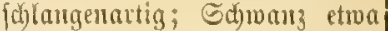
vou Rörperlärge, cylindrif (d); Sinterbautptjabilo vortantoen; Stirmidjild u. 3wifden=Sdjeiteljdjilb länger als breit; Majen= (odj in Ser Mitte bes Majen= idjilbes: Shröfmung in ber

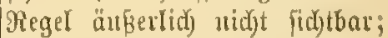
läugsjpaltigen, beiduppten visen; Éfuppen glatt uno gläแ⿰纟勺⿺

2. (5attung, Ed)tangens

Ed)(eid)e, Anguis. Thgen tleur, nit beutlidjer,

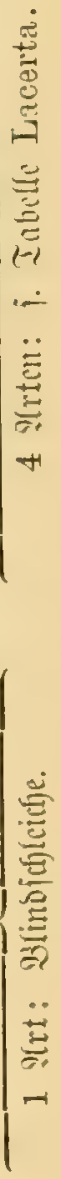




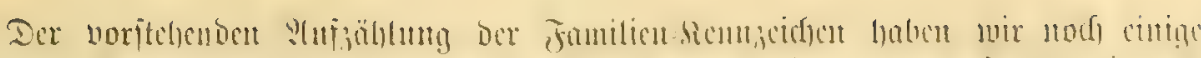

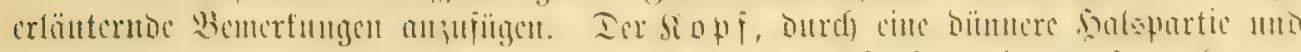

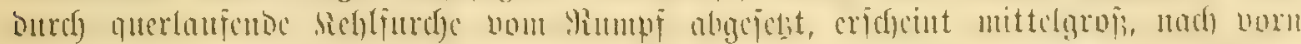

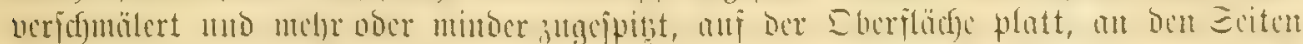

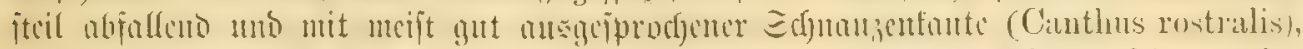

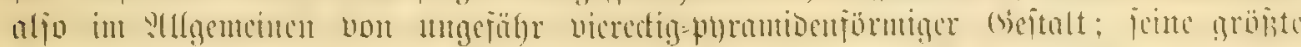

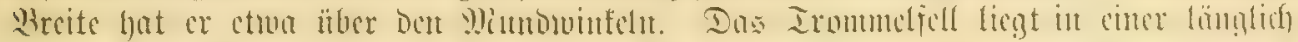

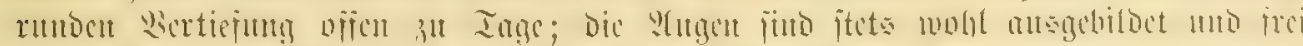

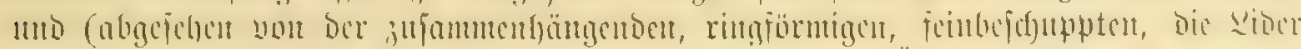

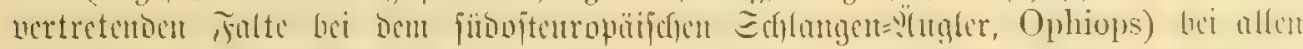

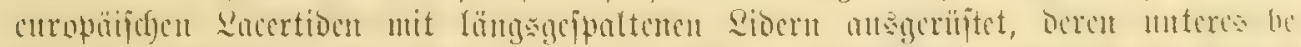

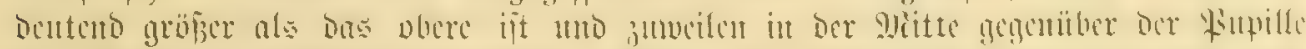

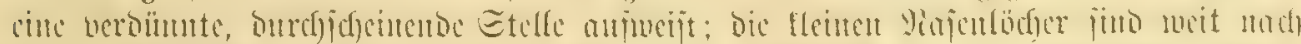

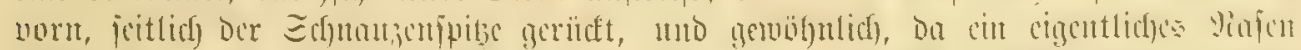

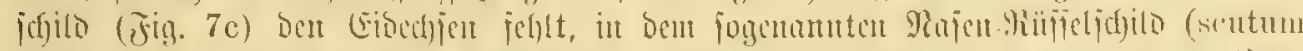

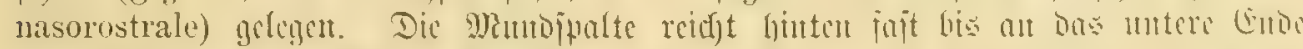

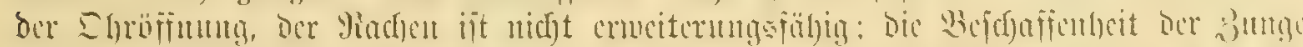

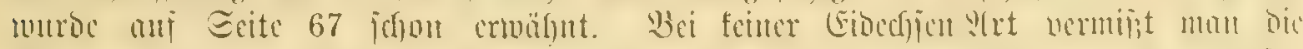

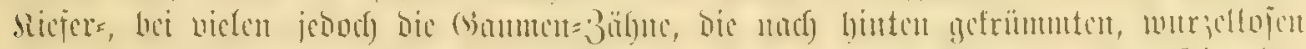

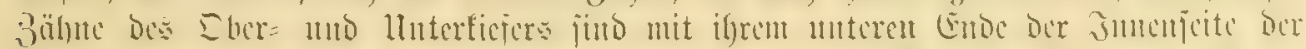

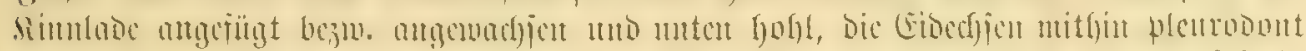

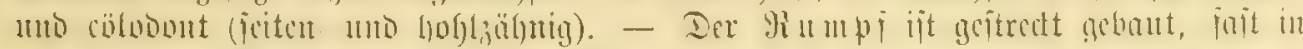

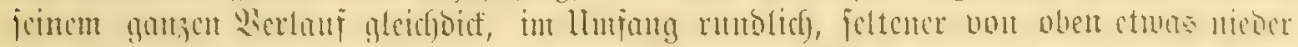

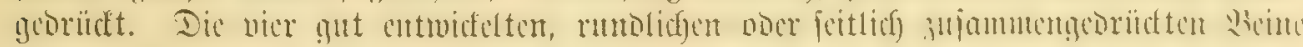

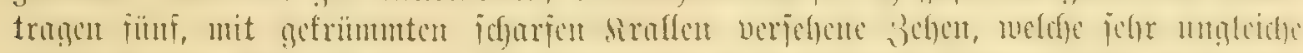

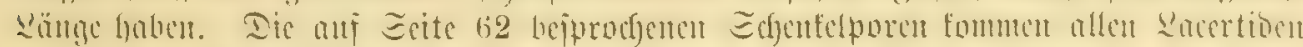

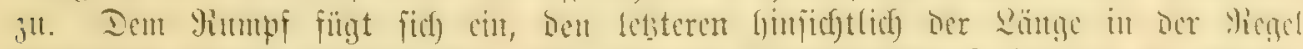

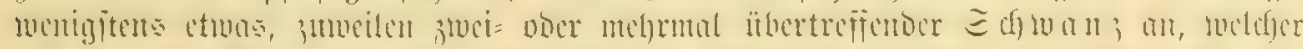

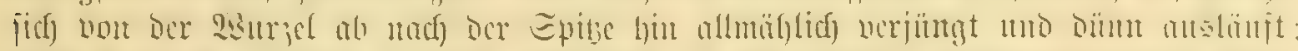

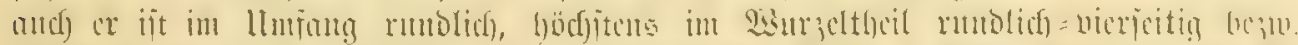

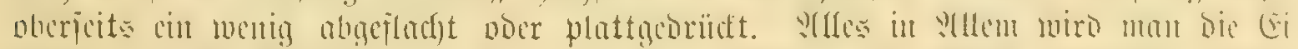

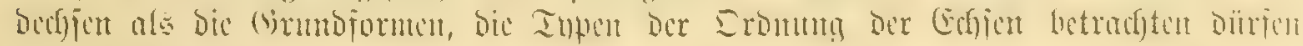
atio mïijen.

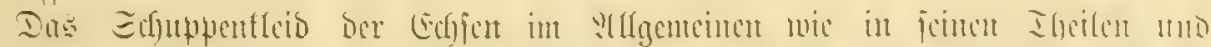

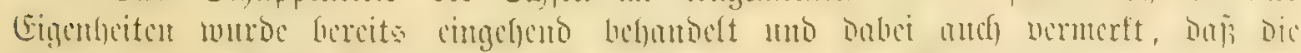

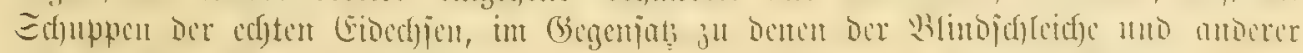

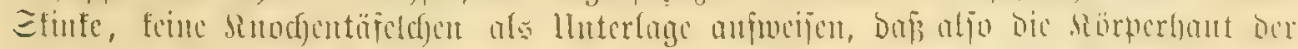

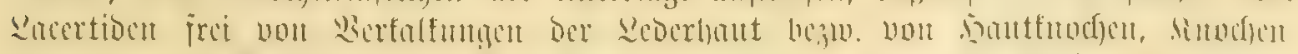

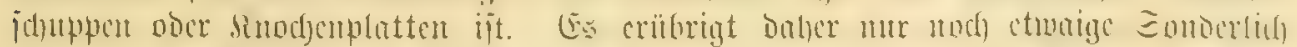

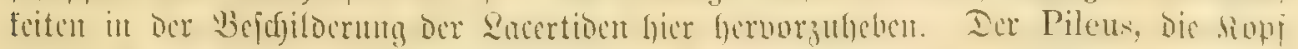

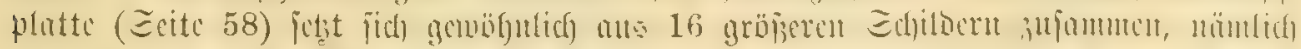

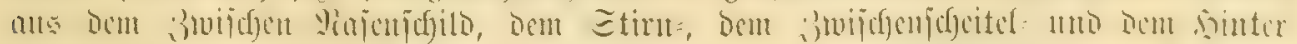

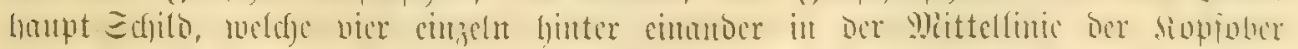

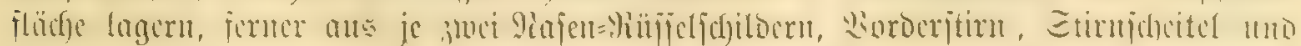

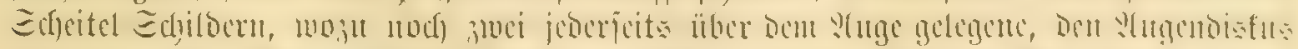

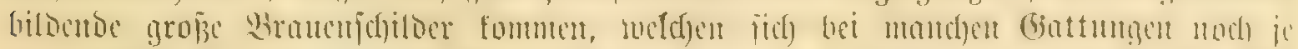

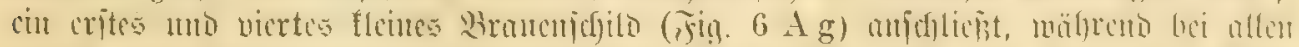

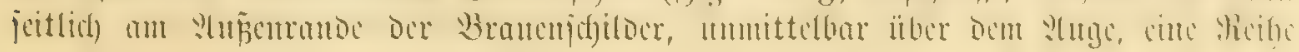




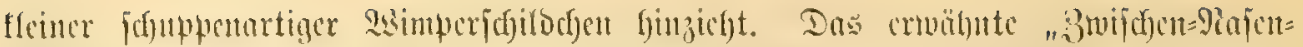

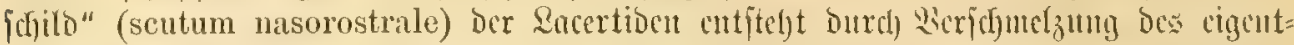

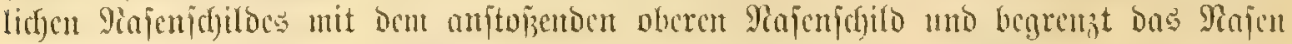

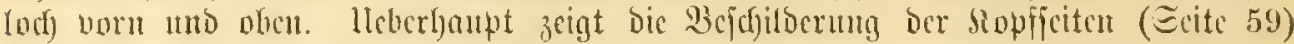

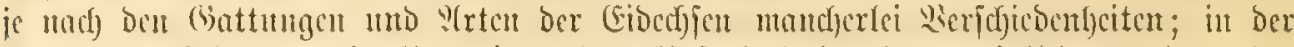

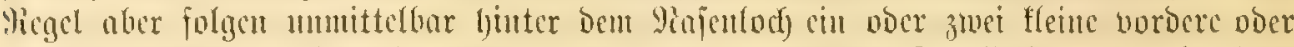

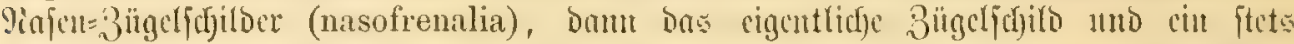

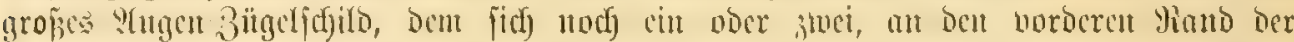

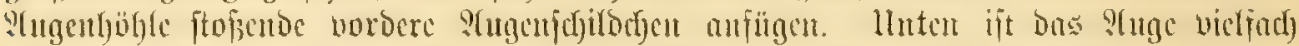

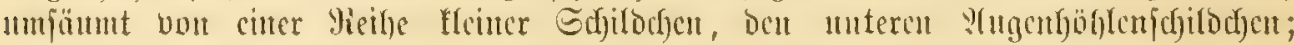

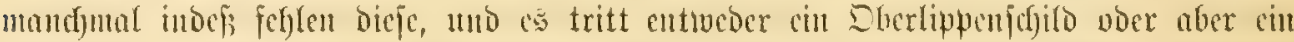

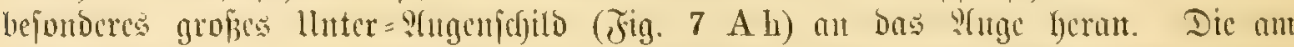

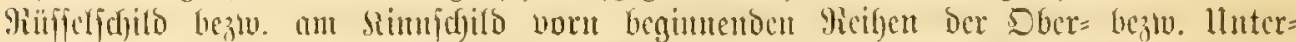

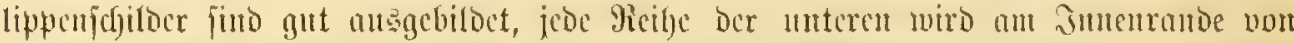

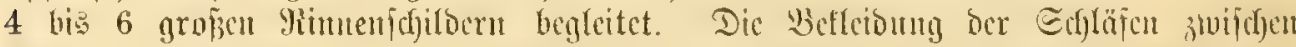

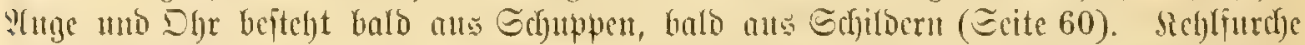

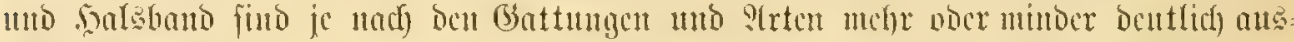

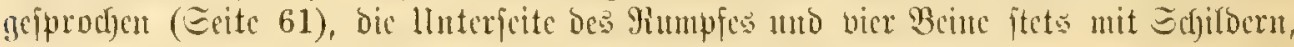

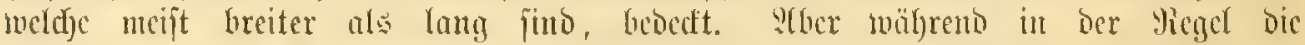

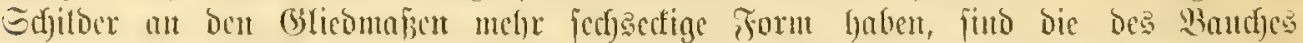

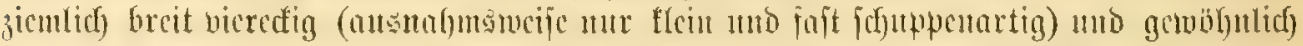

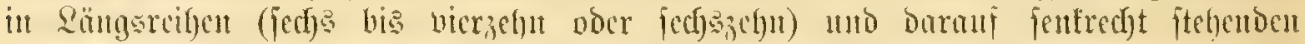

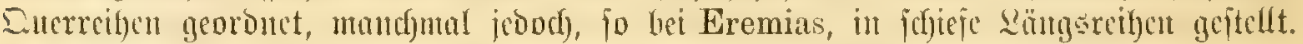

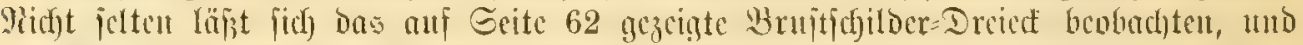

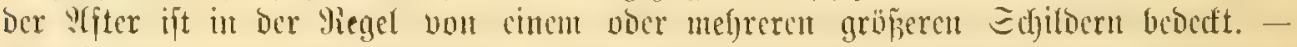
Dic Ed)

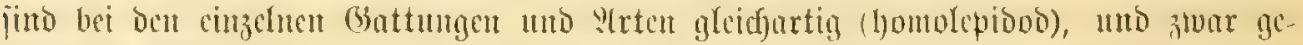

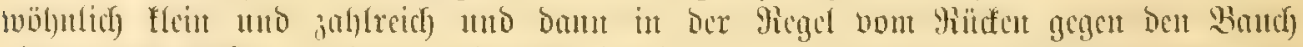

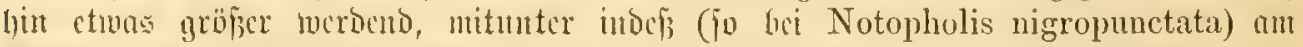

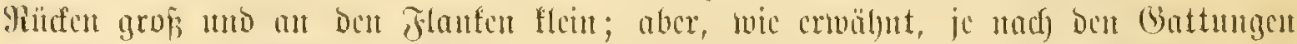

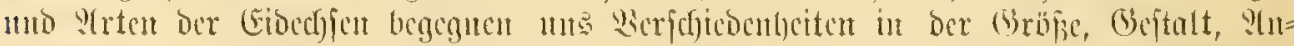

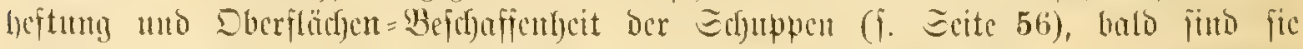

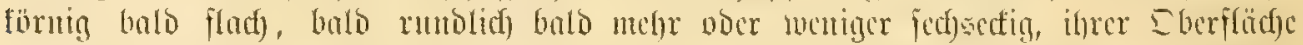

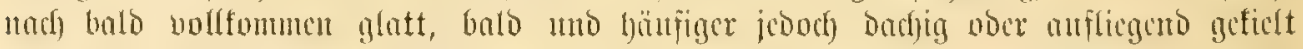

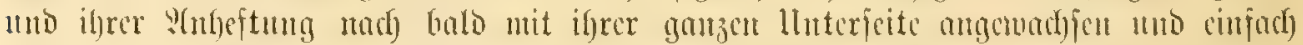

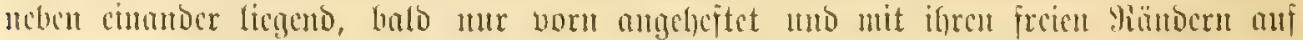

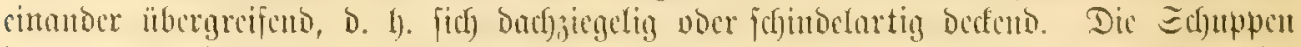
Der unteren 3ehenflädye funo bei cinigen Gattunțen: Lacerta, Notopholis, Tropido-

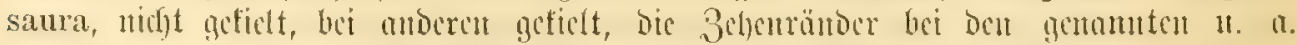

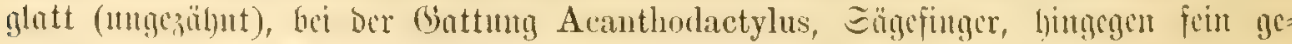

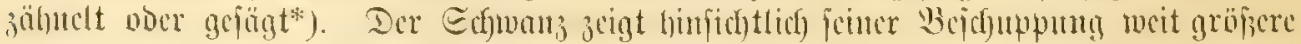

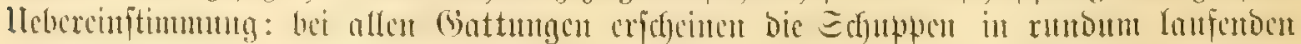

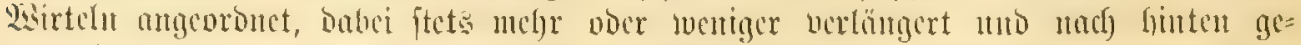

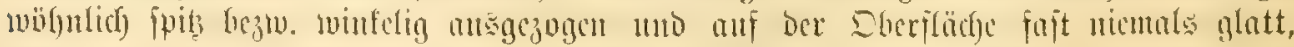

*) Dic pranjöpifden Serpetologen Dumeril-Bibron jdieben anf biefes Merfmal hin bie familie ber

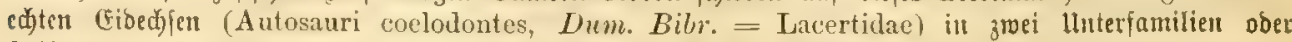
Tribus: Die Leiodactyles un bie Pristidactyles, b. h. Die (Eibedifen mit glat ten unb bie mit getielten bezw. gefäg ten Fingern unb Behert. 


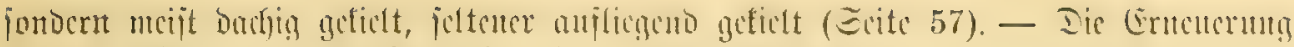

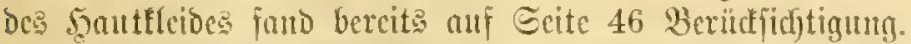

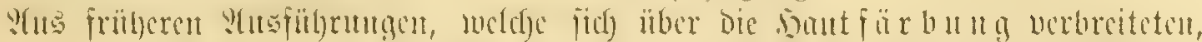

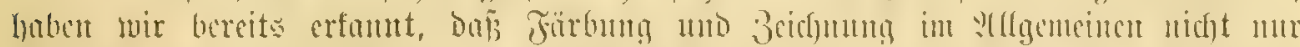

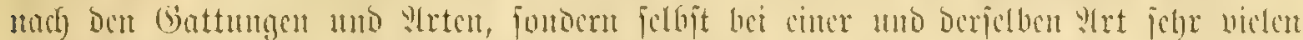

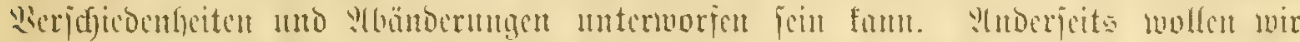

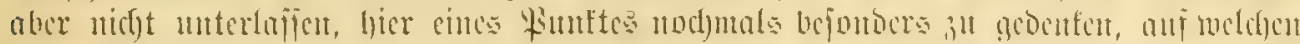

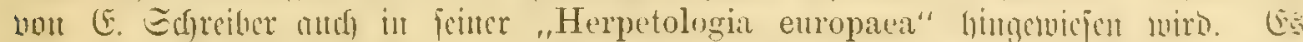

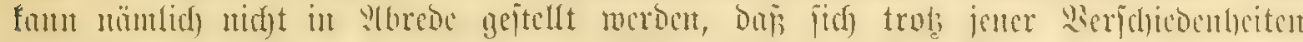

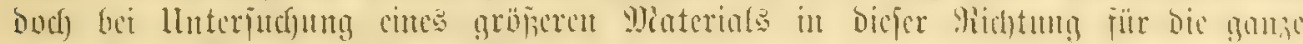

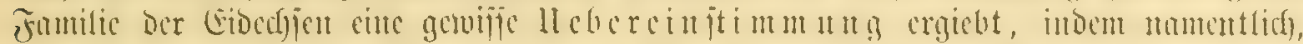

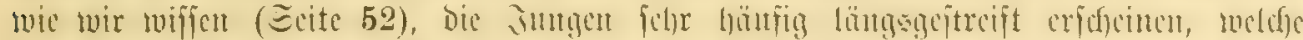

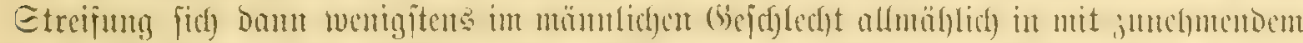

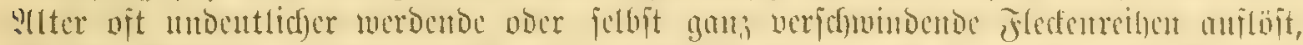

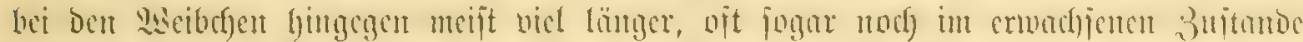

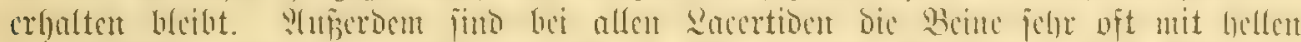

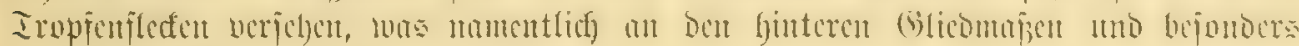
in ber Jugend fajt immer ber Fall iit.

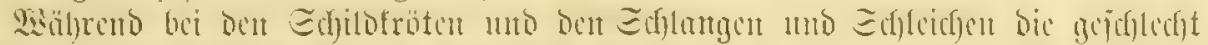

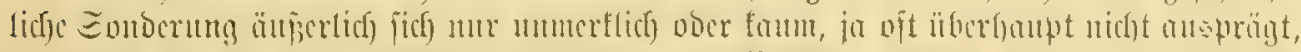

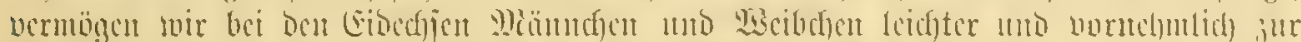

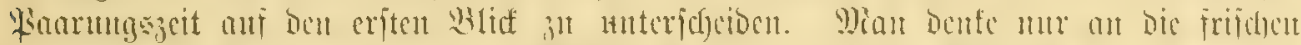

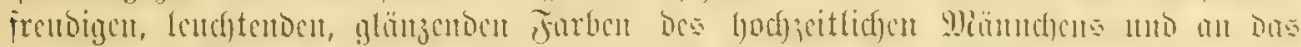

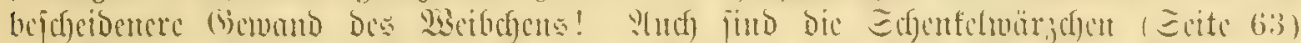

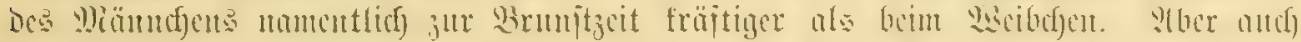

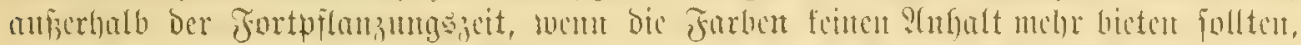

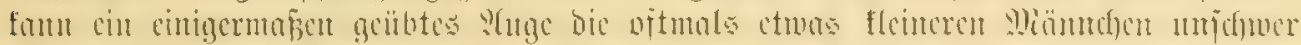

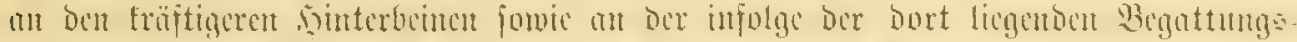

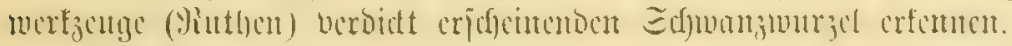

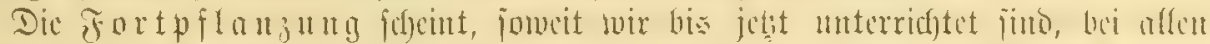

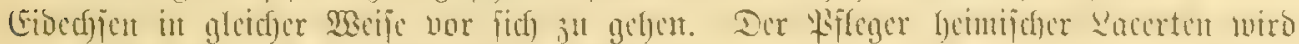

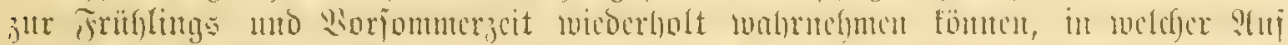

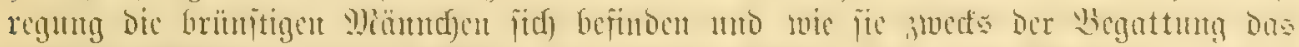

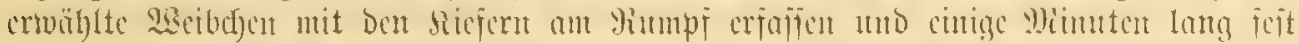

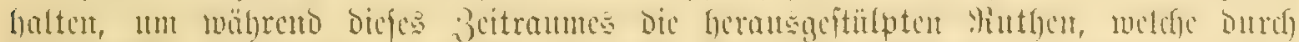

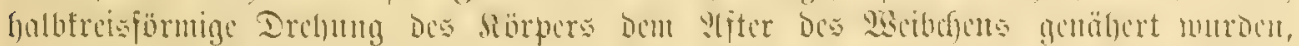

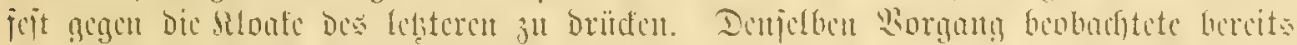

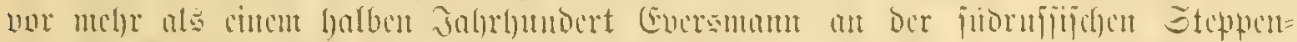

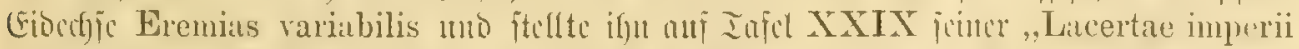

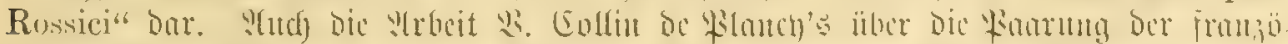
jiiffen Effjon (Lacerta ocellata, viridis, agilis, muralis, vivipara, Anguis fragili, Seps chalcites), tucldec 1877 in "Bulletin de la soc. zool. de France”, 2. vol.,

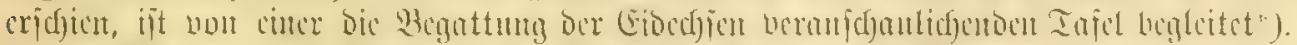
Einige

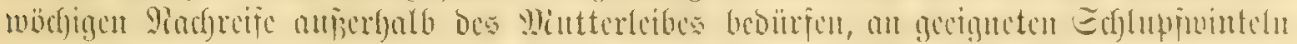

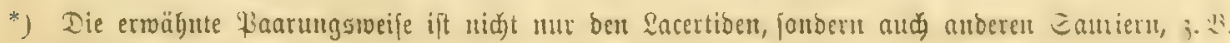

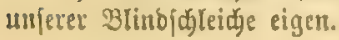




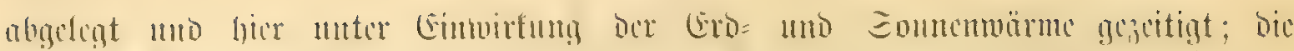

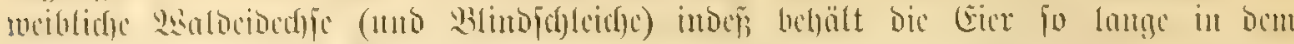

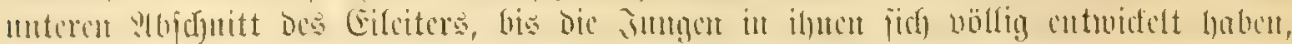

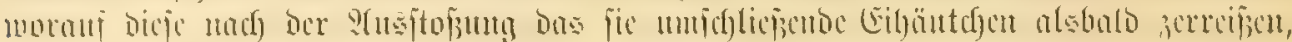
ım ify cigentlidjes Frcileben zu beginnen (Ecite 4).

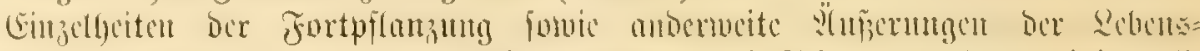

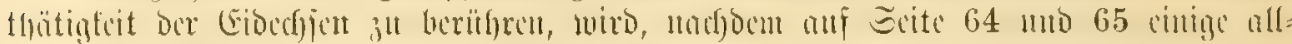

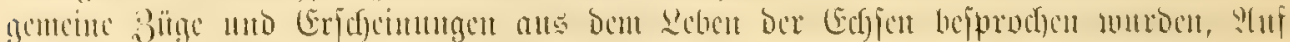

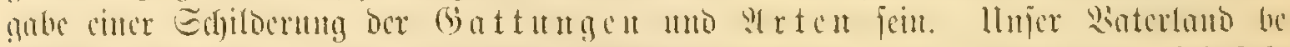

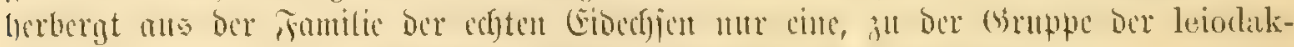

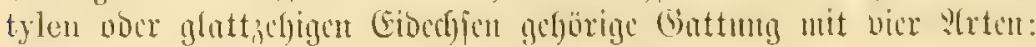

\section{Gattung: Giocdjic. Lacerta, $L$.}

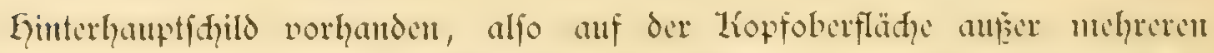
faurigen vier unparige Edfilder; por mo hinter bem 2lugendisfus nod jo

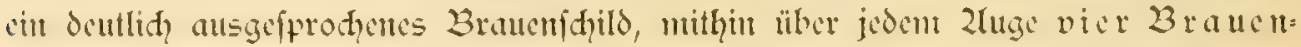

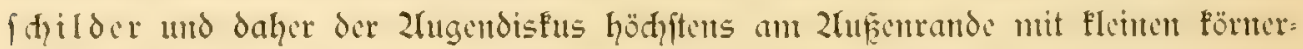

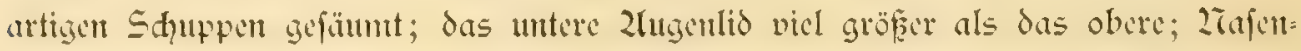

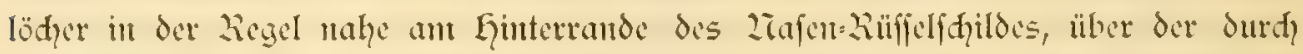

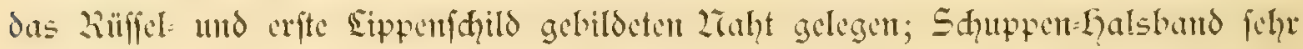

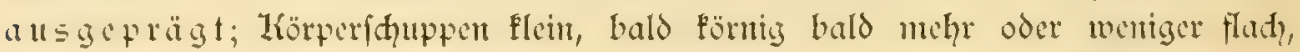

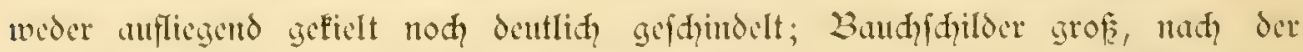

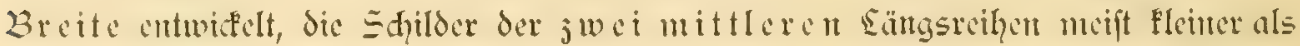

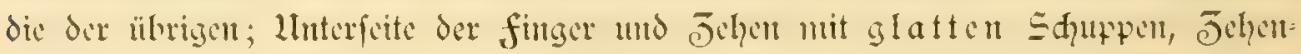
$\mathfrak{r}$ ändcr niḑt gejäbnelt.

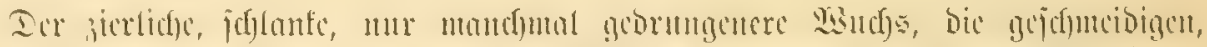

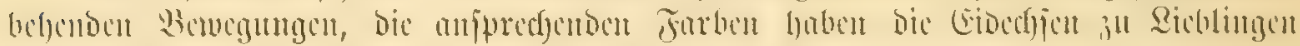

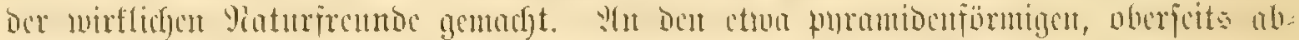

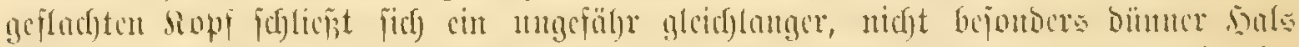

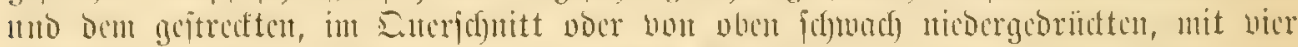

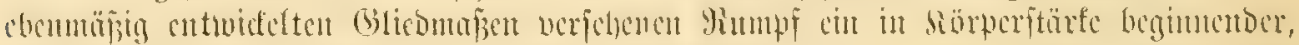

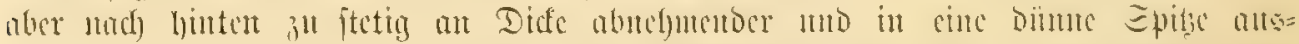

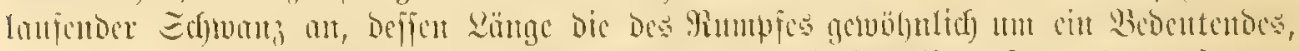

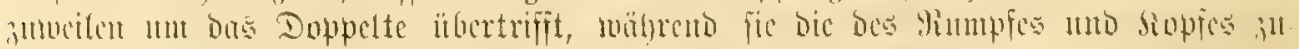

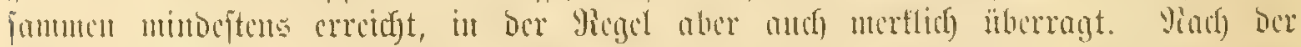

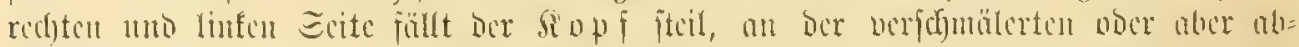

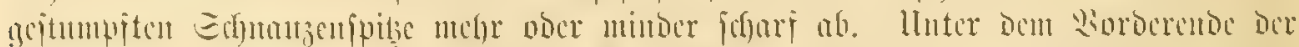

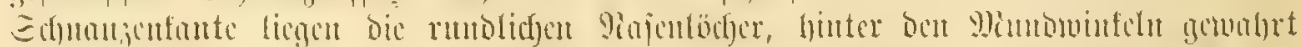

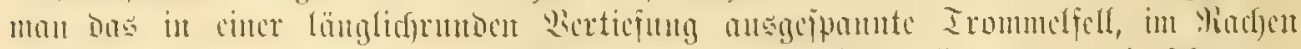

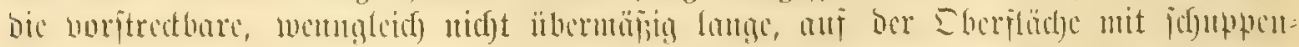

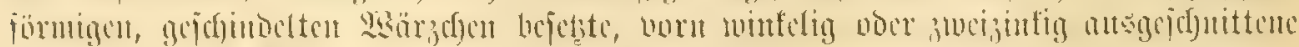

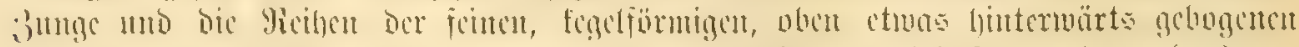

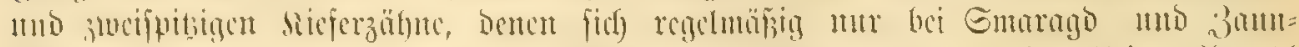

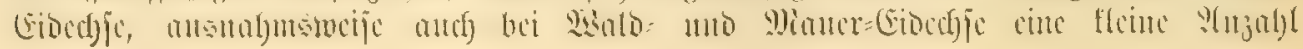




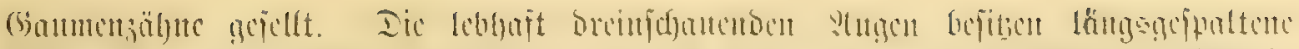

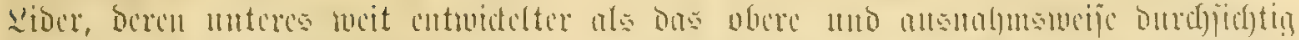

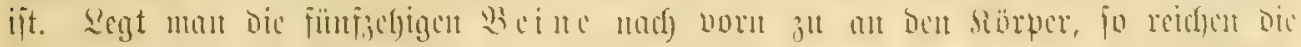

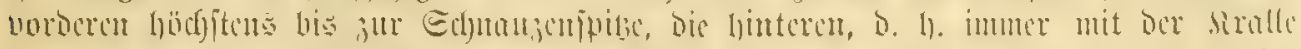

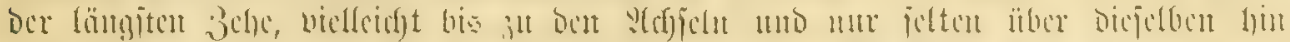

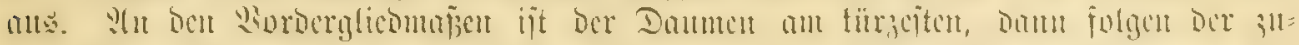

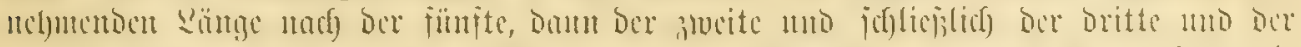

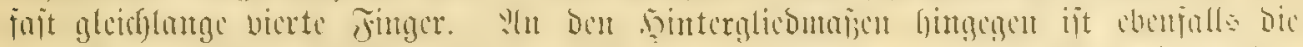

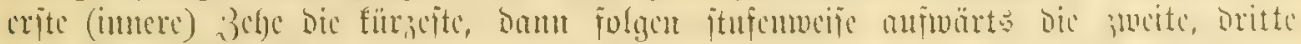

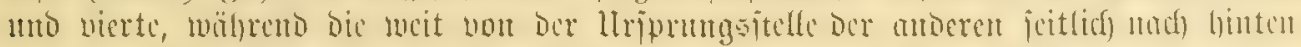

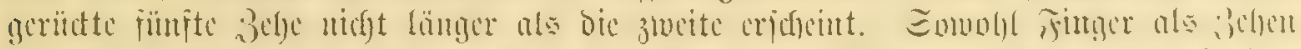

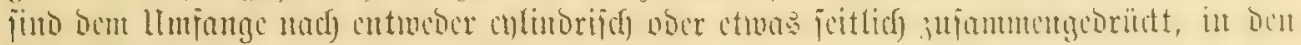

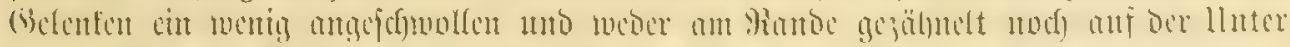

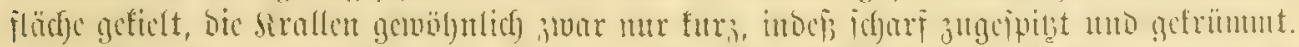

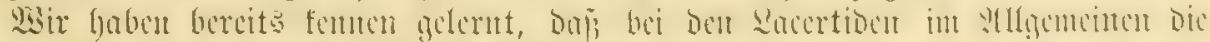

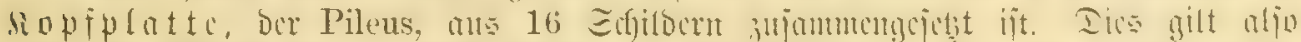

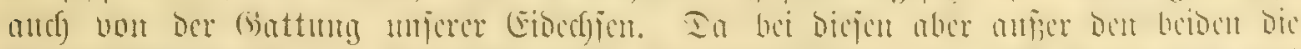

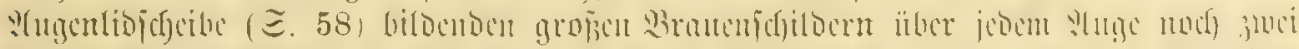

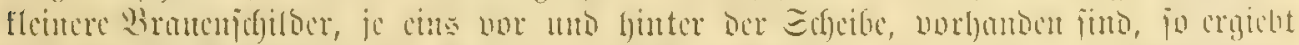

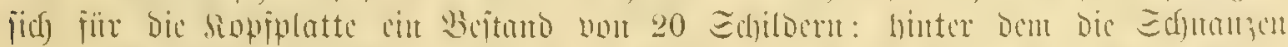

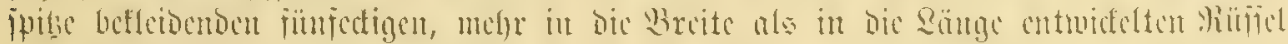

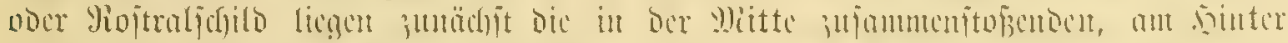

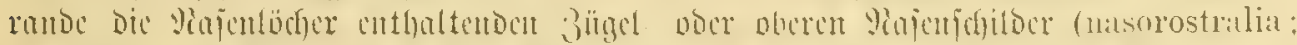

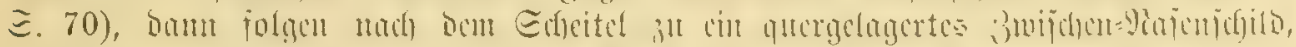

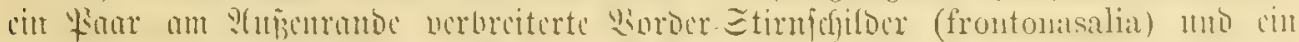

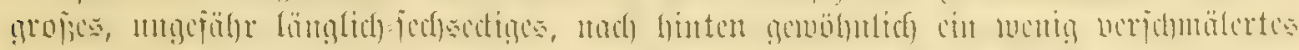

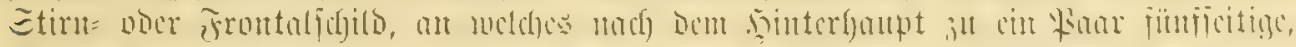

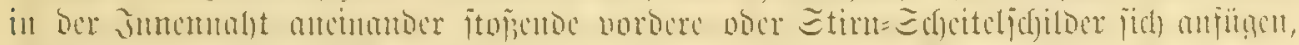

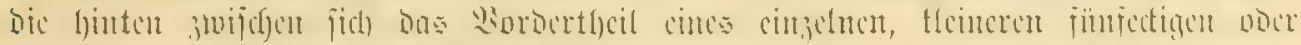

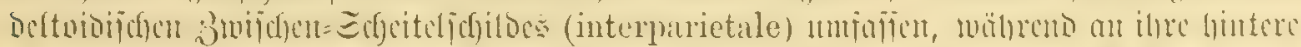

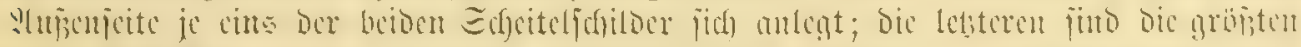

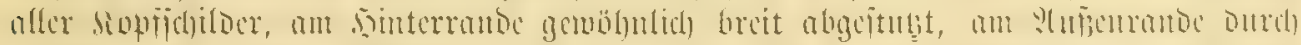

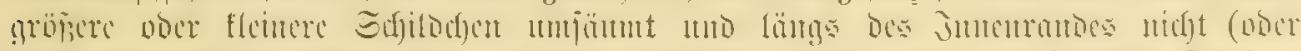

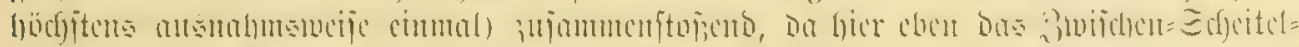

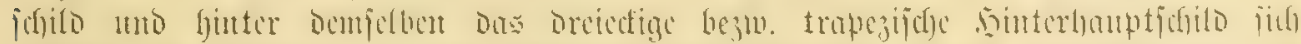

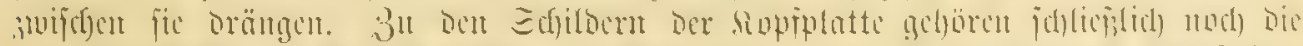

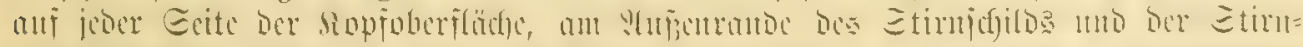

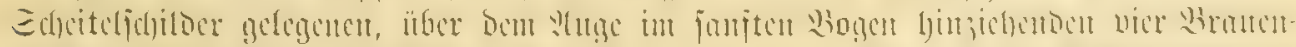

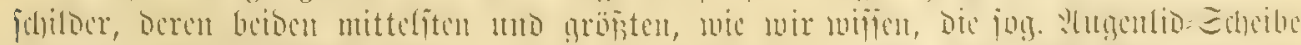

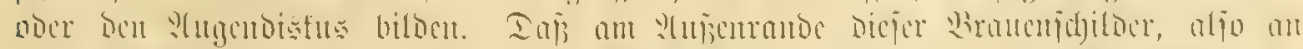

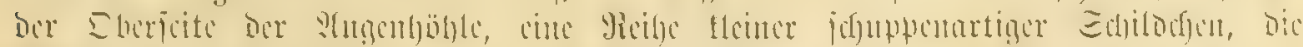

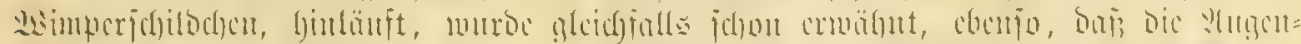

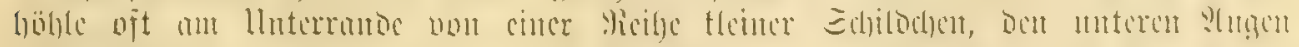

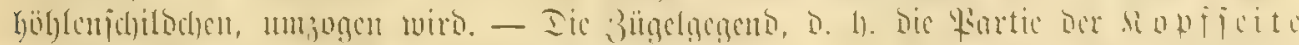

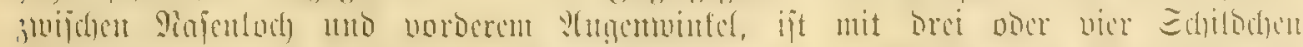

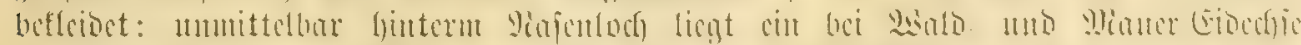

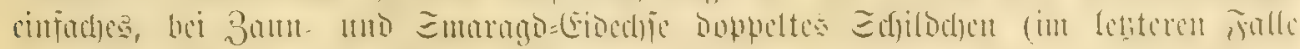

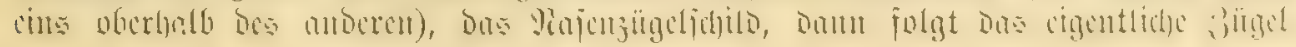




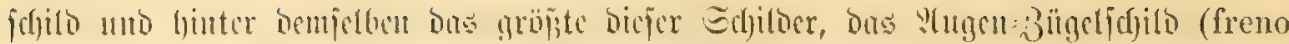

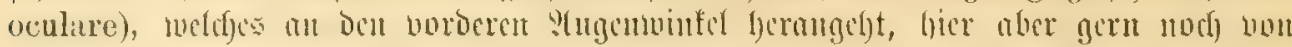

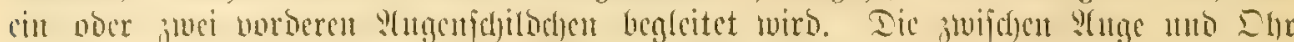

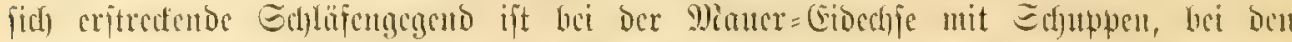

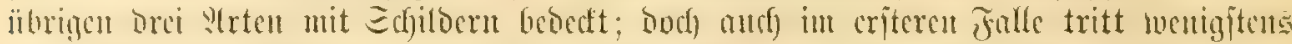

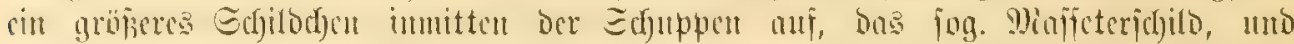

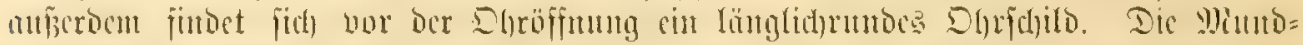

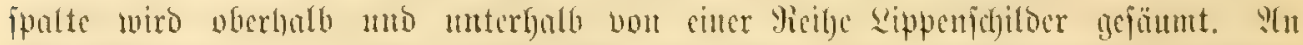

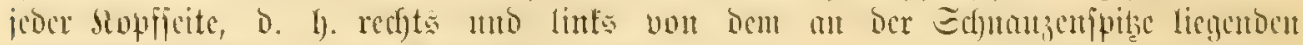

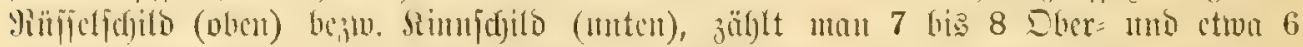

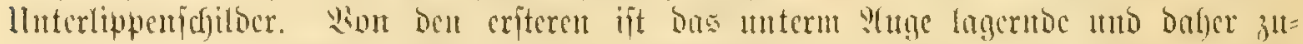

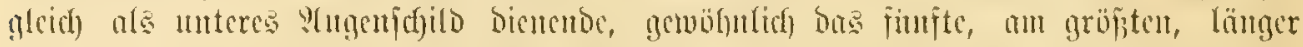

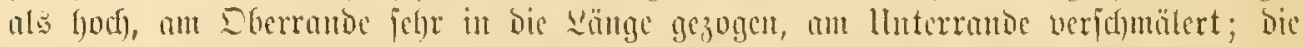

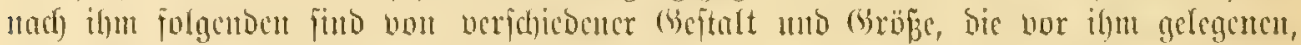

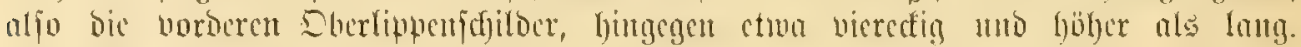

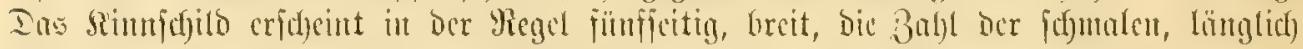

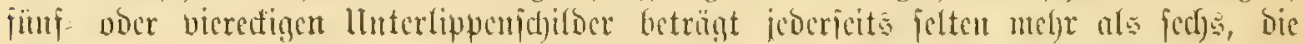

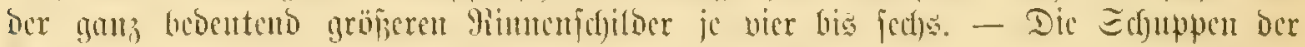

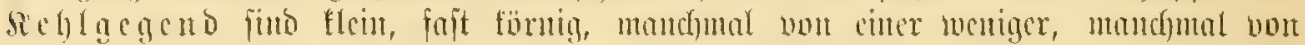

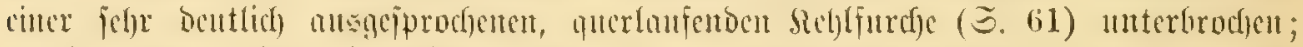

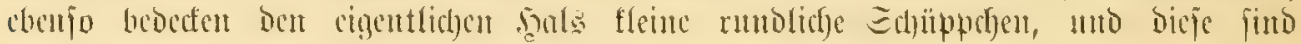

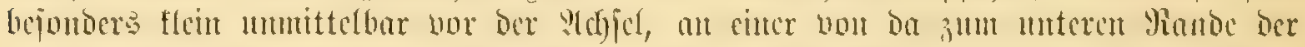

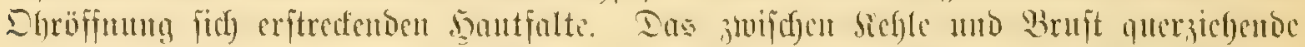

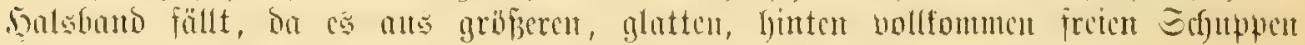

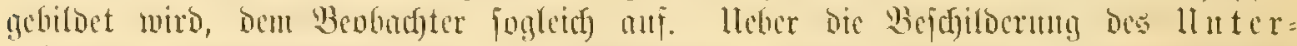

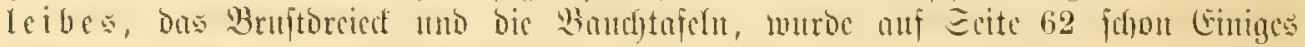

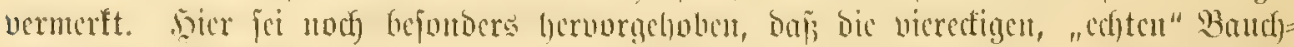

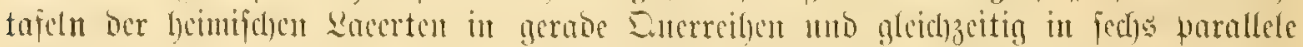

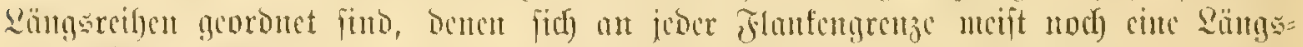

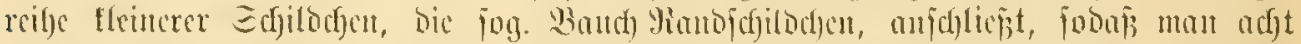

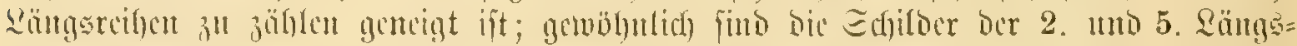

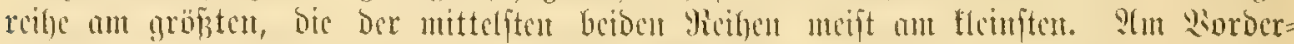

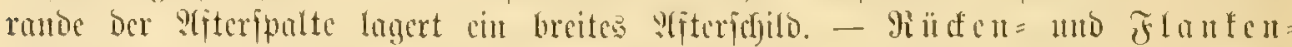

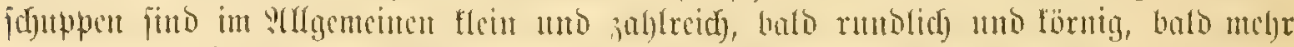

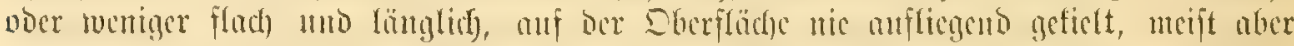

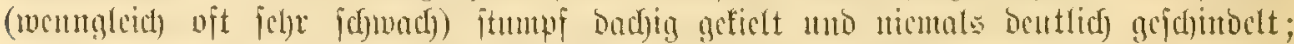

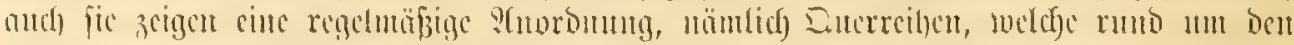

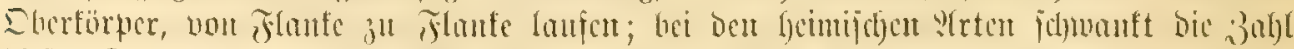

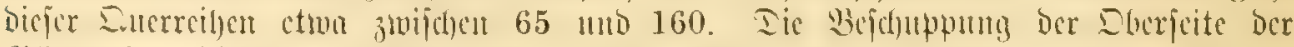

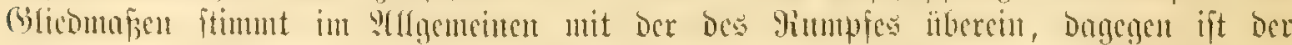

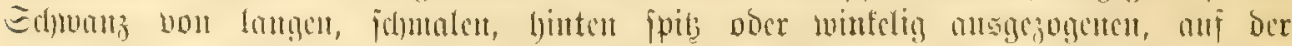

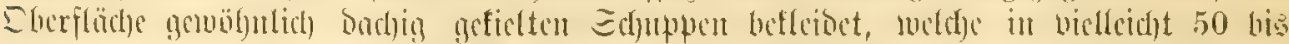

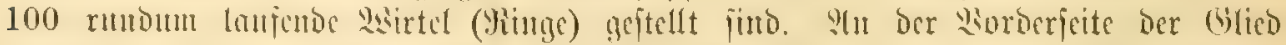

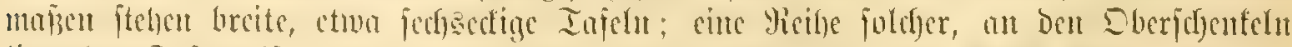

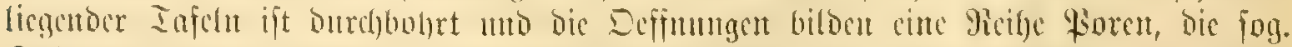

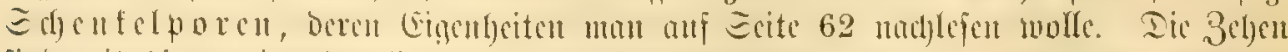

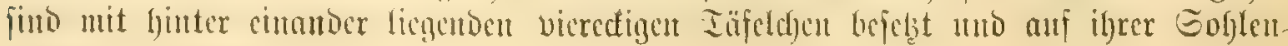
flitdje ftets glutt. 


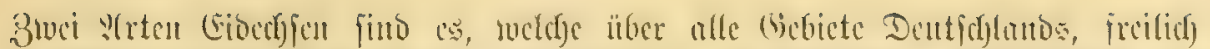

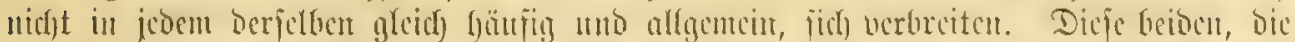

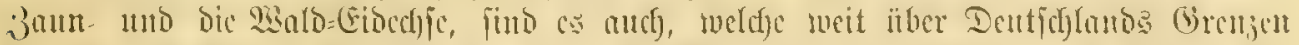

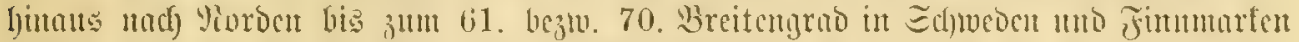

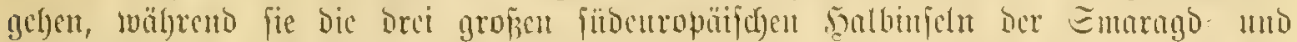

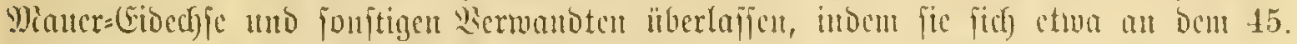

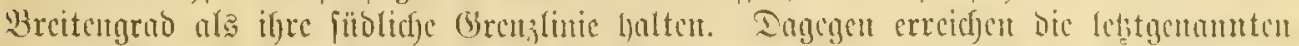

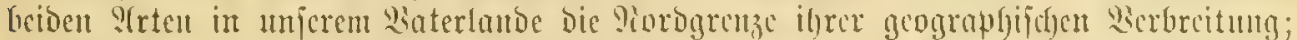

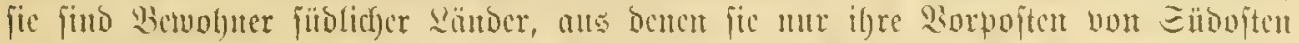

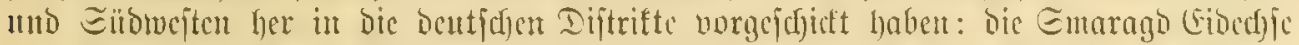

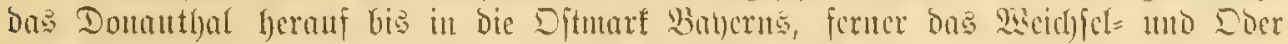

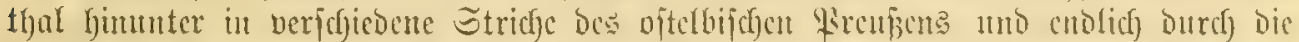

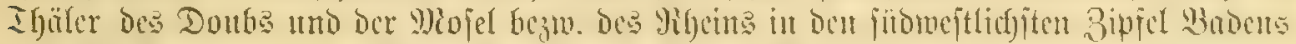

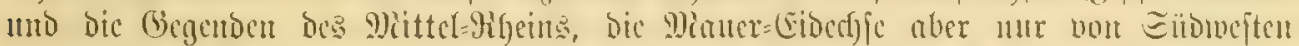

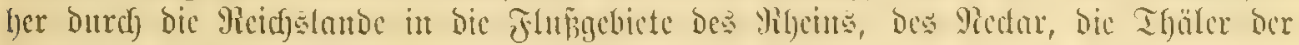

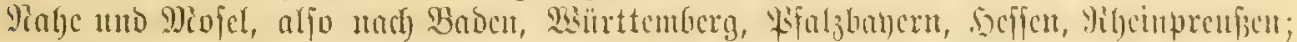

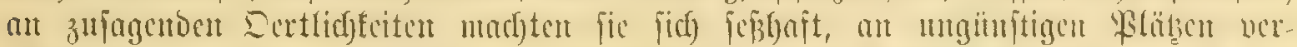

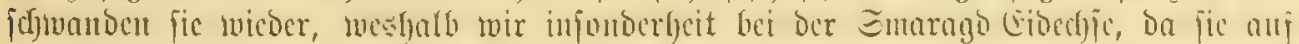

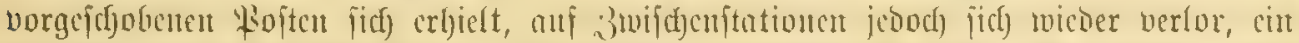

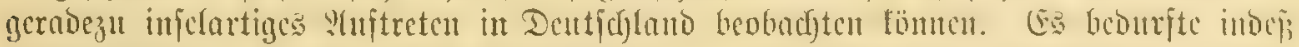

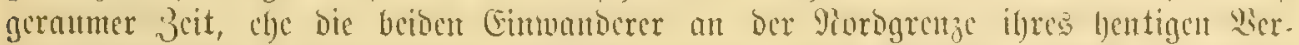

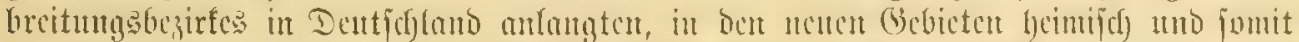

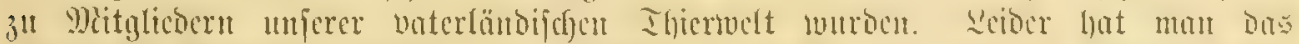

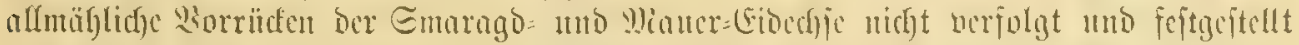

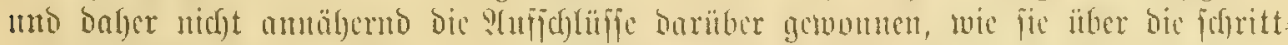

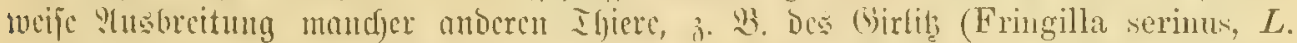

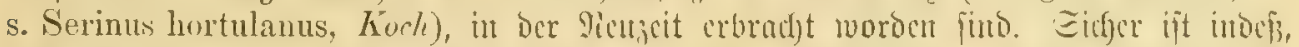

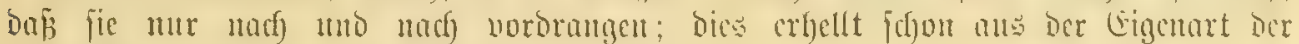
Eiocchjen, bie svir meiterfint bejprecten werden.

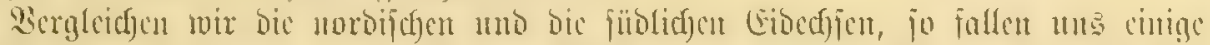

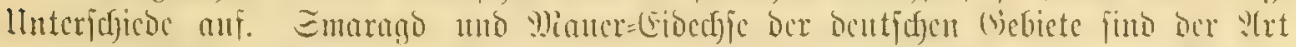

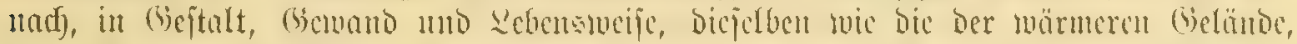

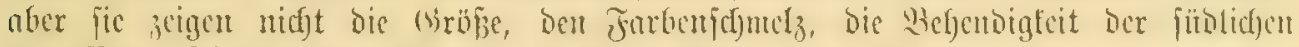

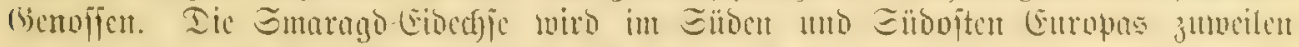

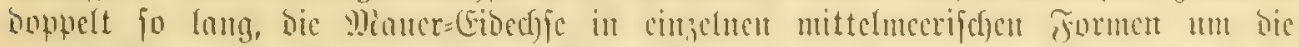

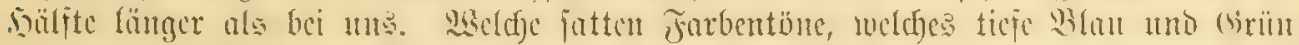

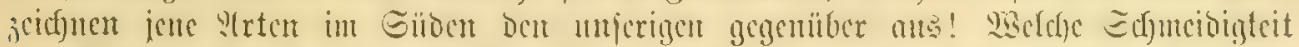

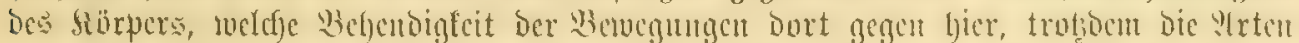

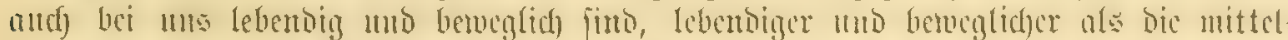

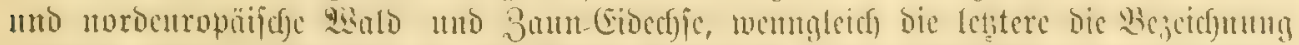

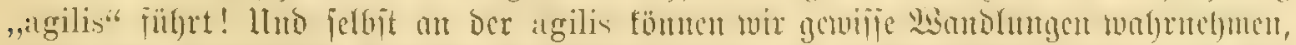

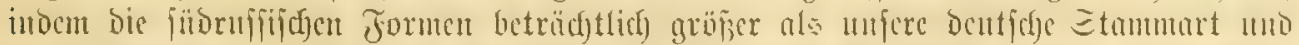

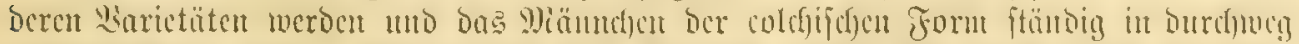

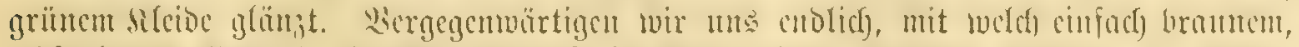

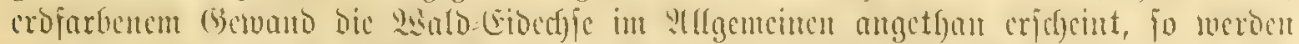

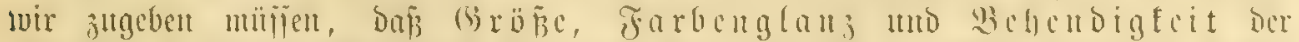

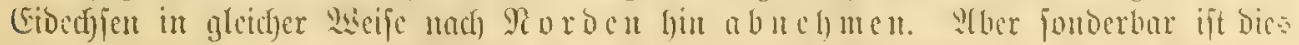

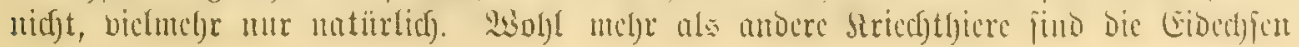




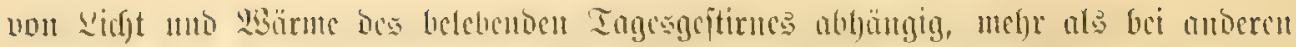

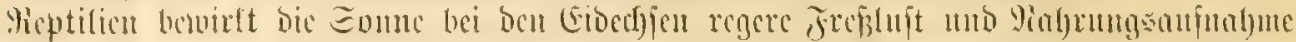

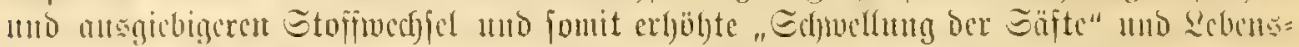

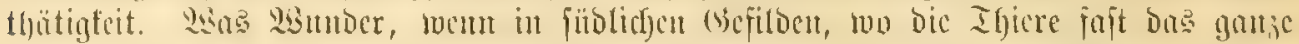

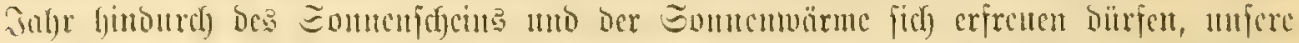

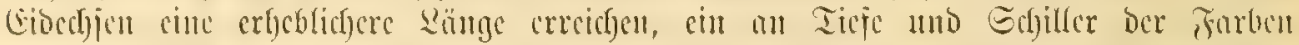

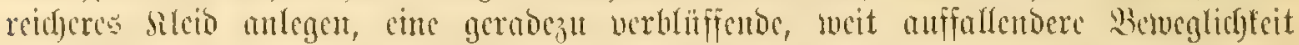

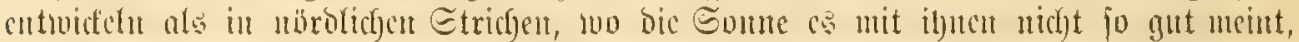

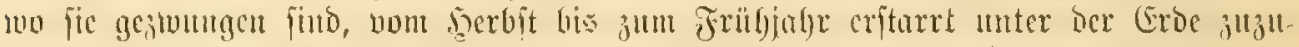

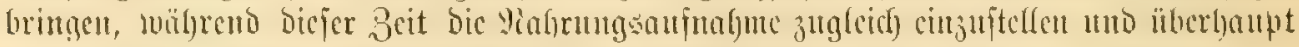
bic Ihätigfcit ibrer Rcbensorgane an bas bentbar geringite Maanj ju verringern?

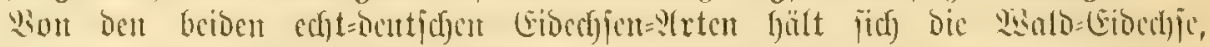

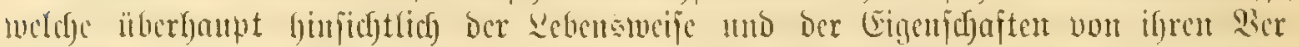

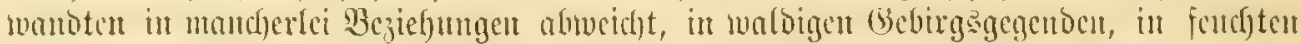

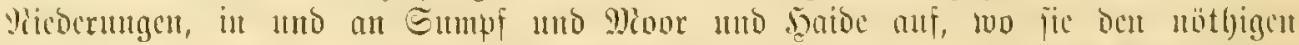

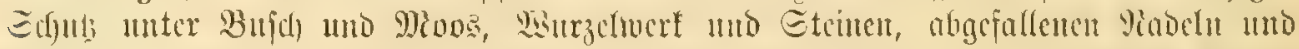

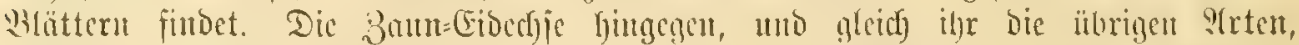

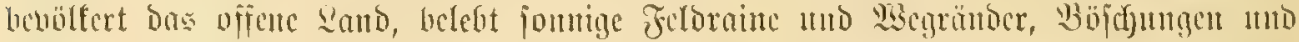

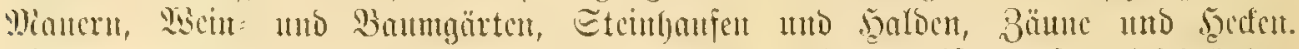

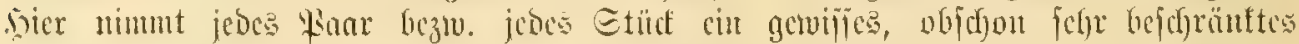

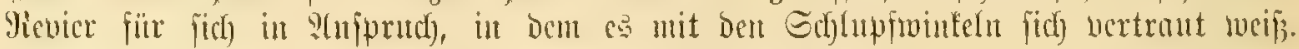

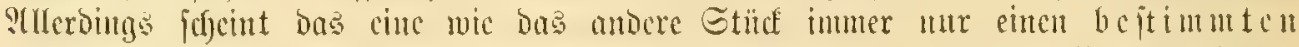

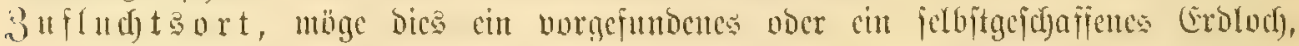

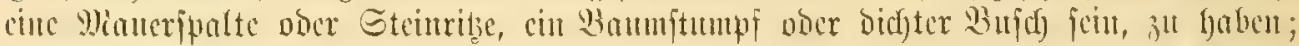

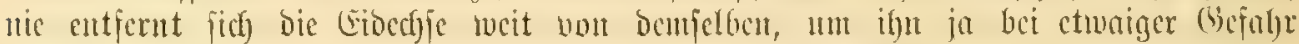

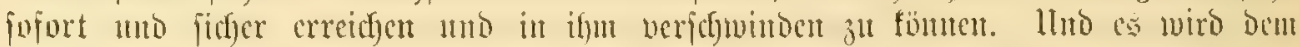

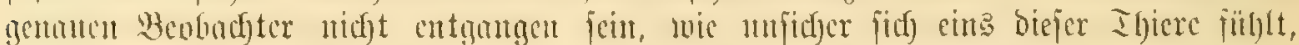

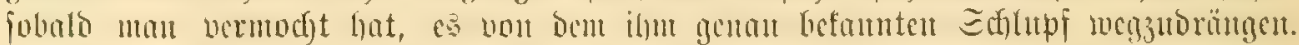

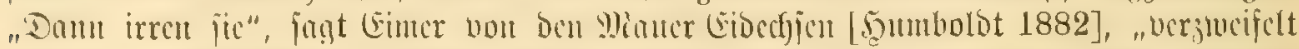

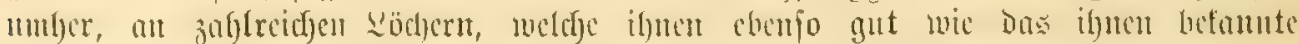

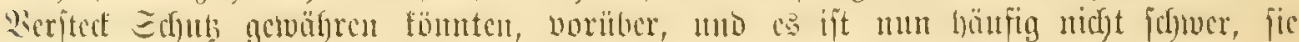

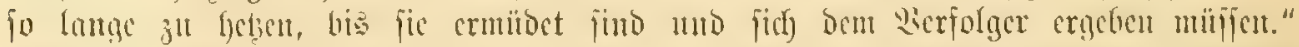

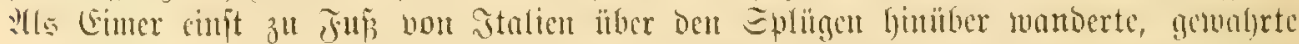

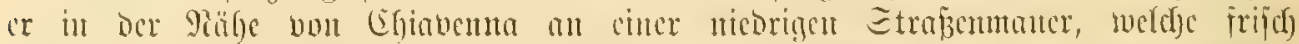

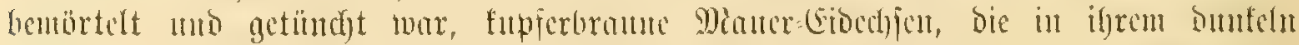

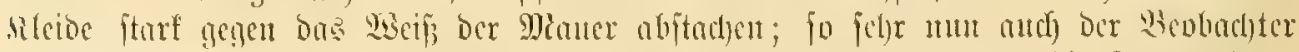

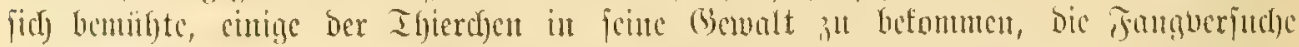

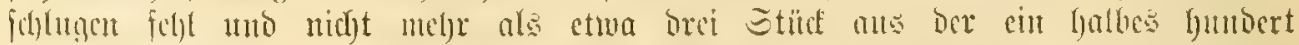

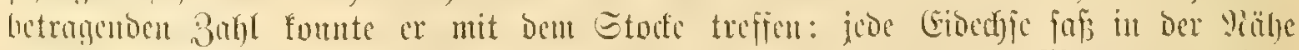

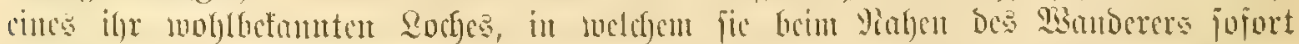

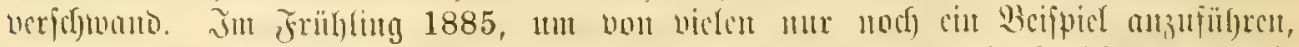

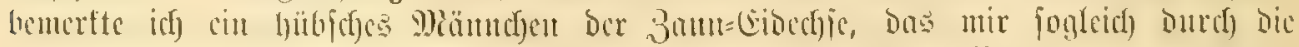

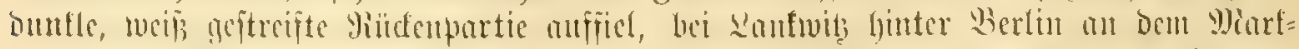

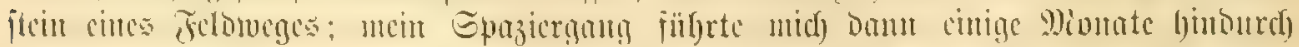
melyemals tïglich bort bubed

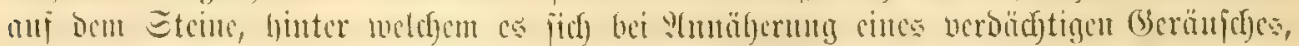

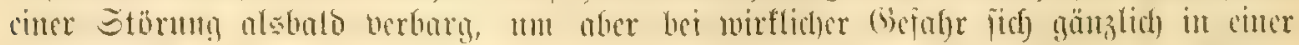

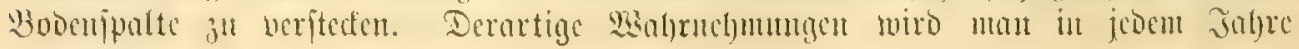




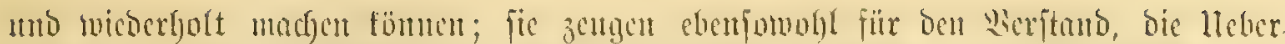

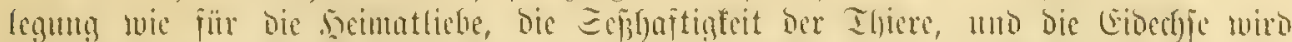

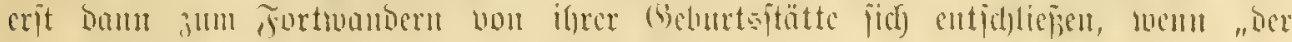
Zilab itberfilllt ift" oder ftändig ladifitellung oroht.

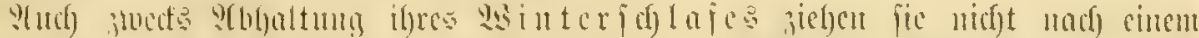

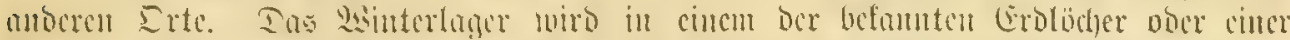

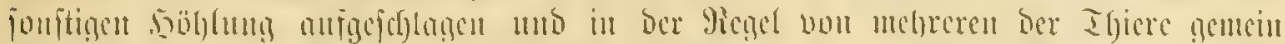

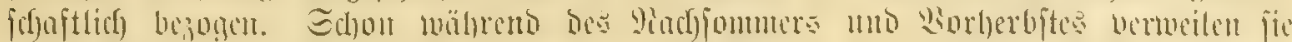

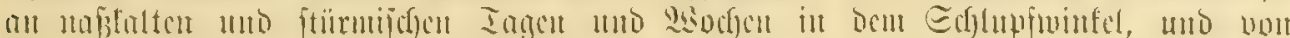

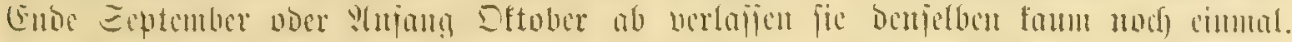

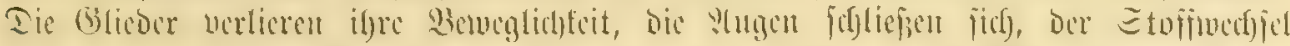

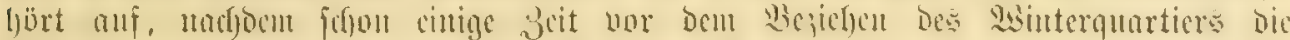

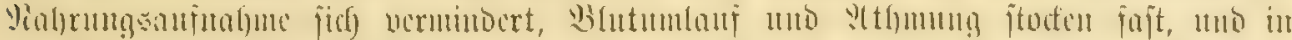

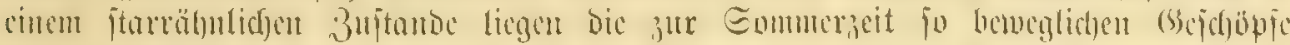

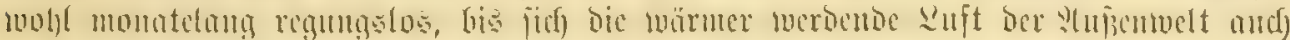

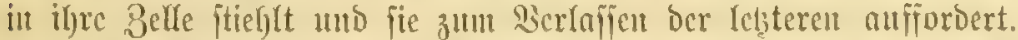

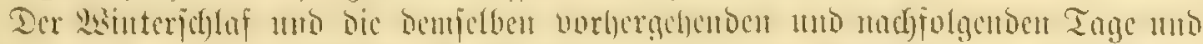

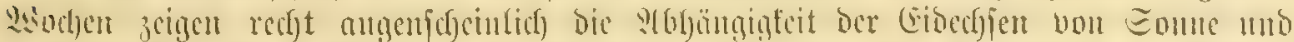

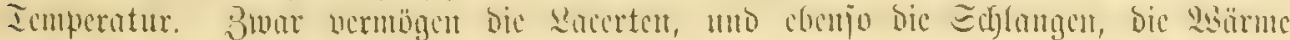

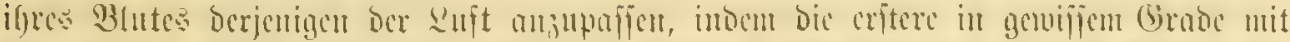

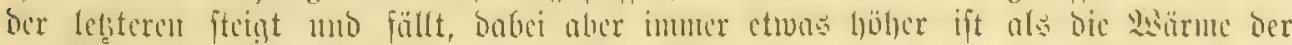

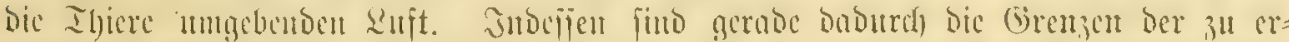

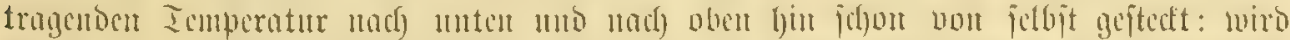

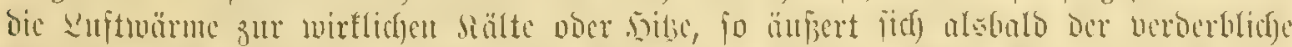

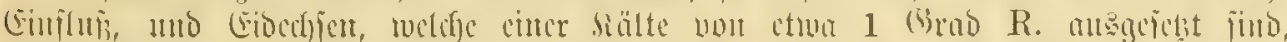

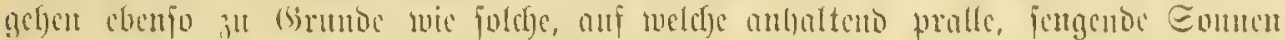

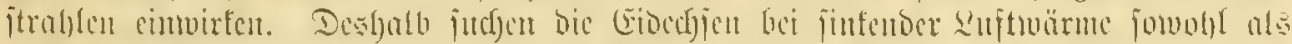

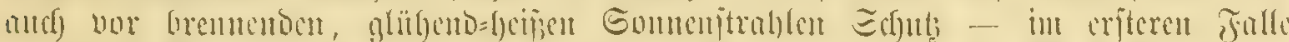

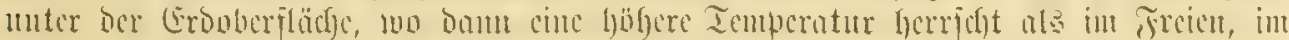

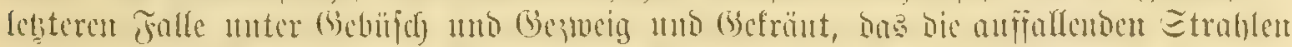

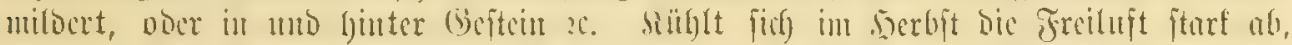

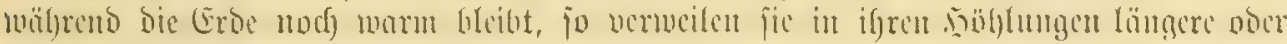

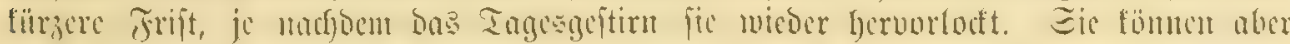

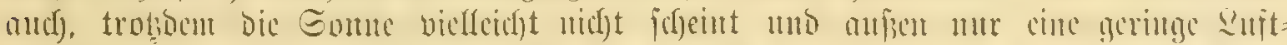

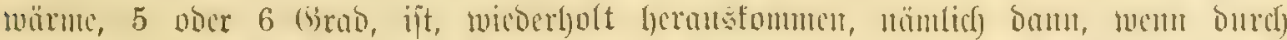

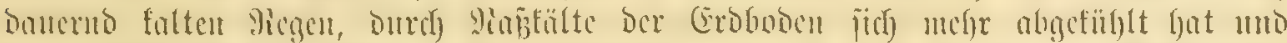

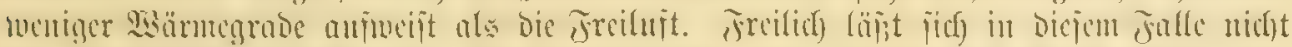

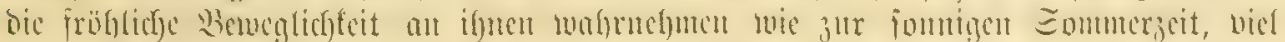

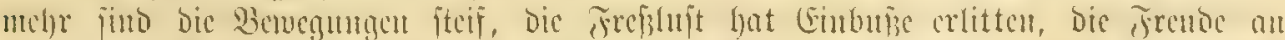

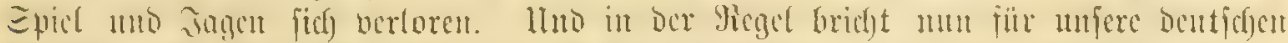

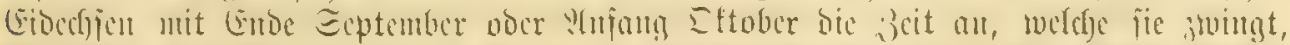

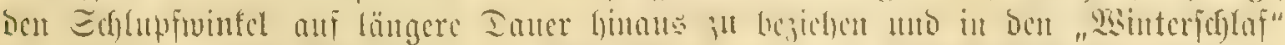

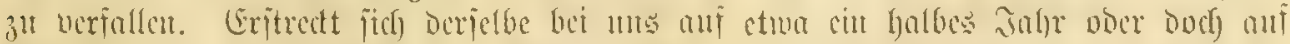

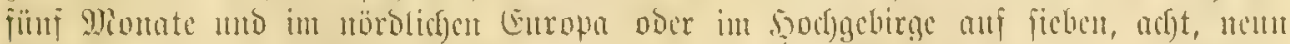

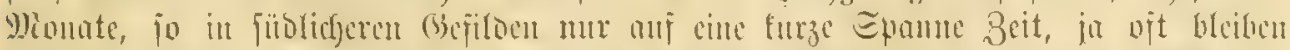

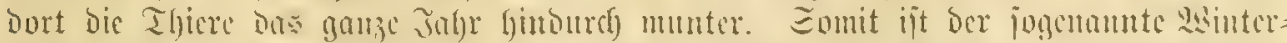

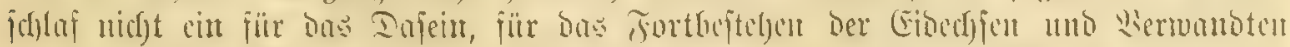

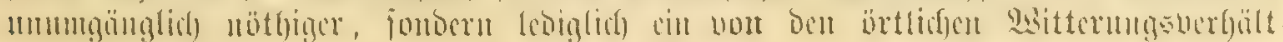




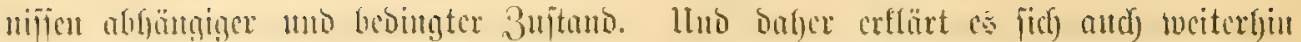

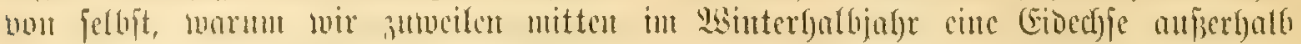

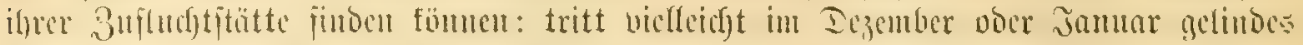

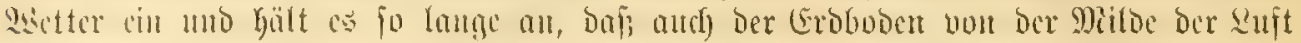

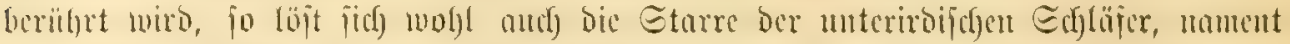

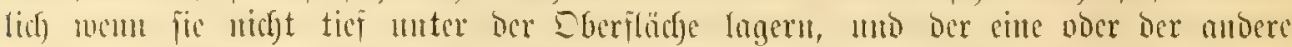

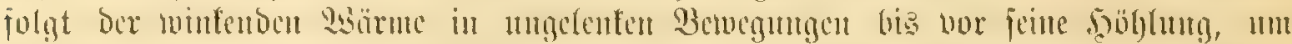

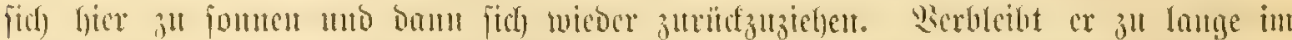

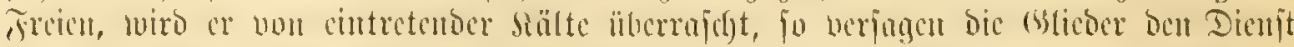

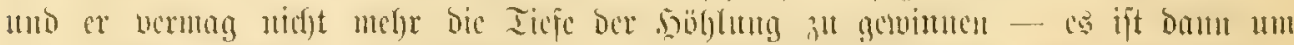

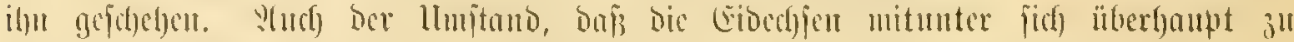

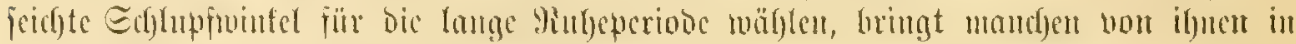
ftrengen 2 sintern ben Too.

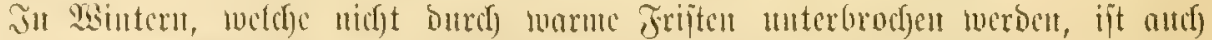

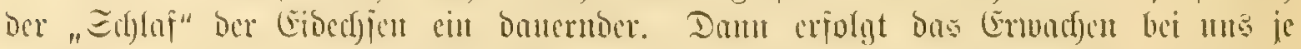

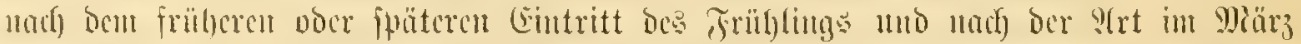

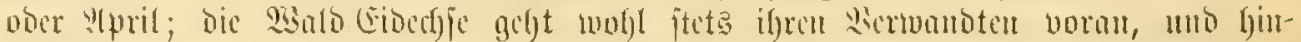

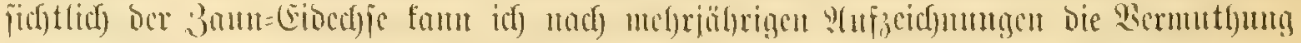

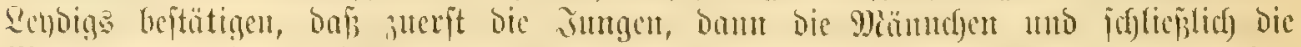

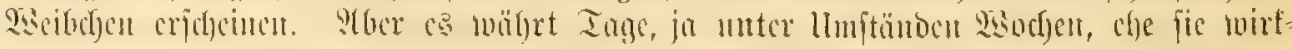

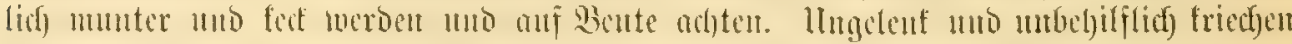

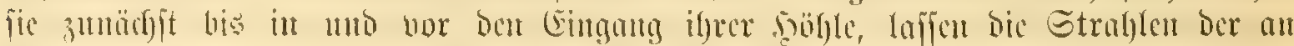

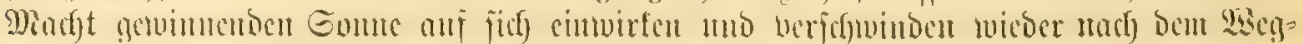

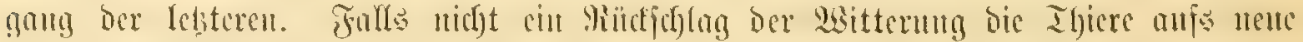

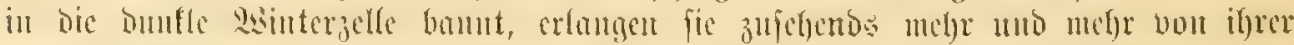

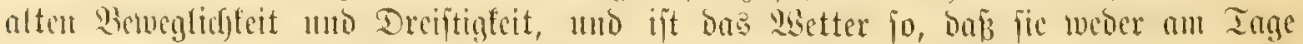

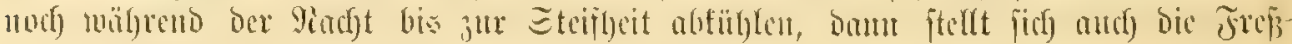

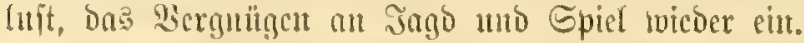

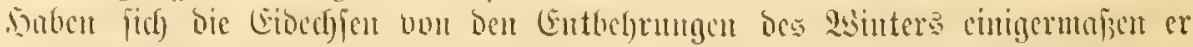

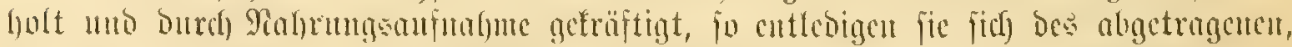

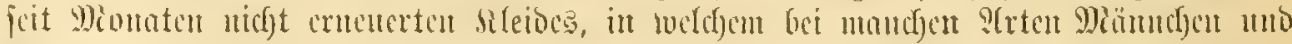

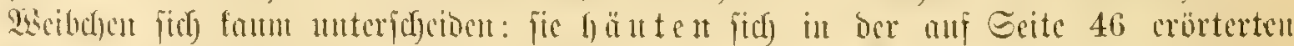

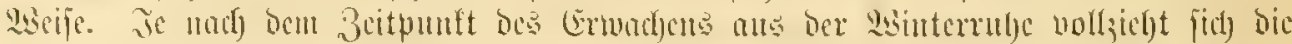

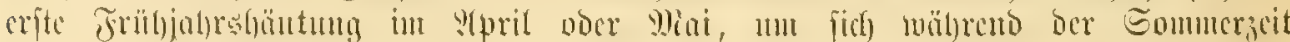

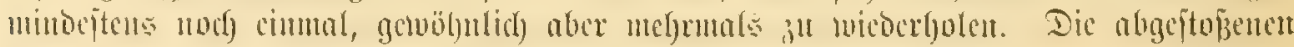

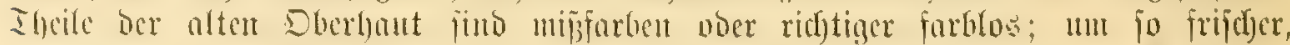

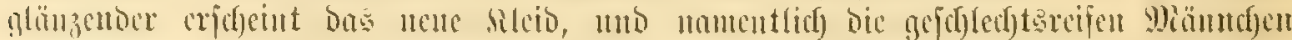

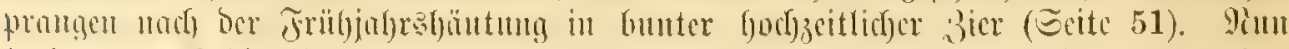

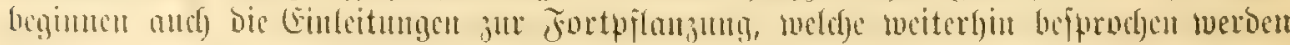

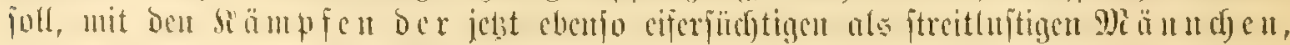

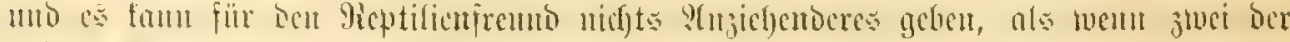

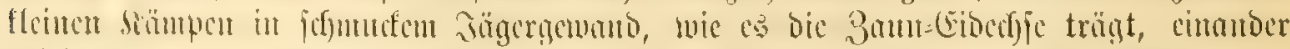

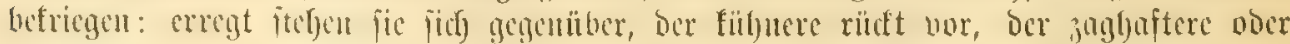

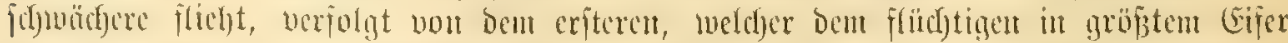

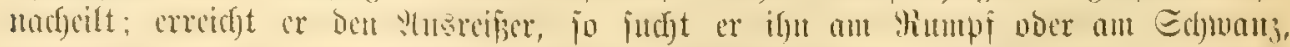

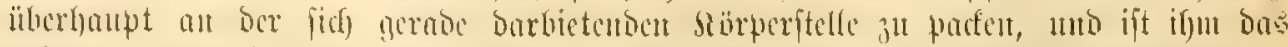

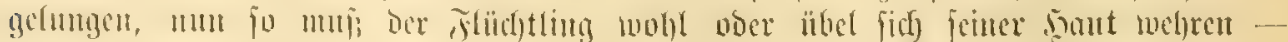

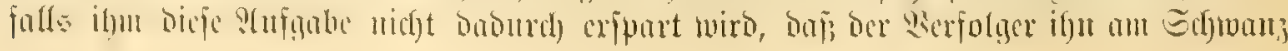




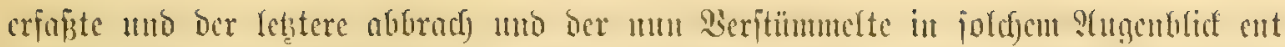

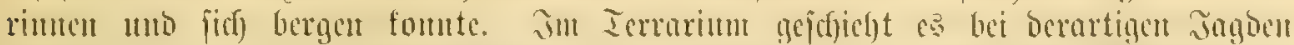
3)

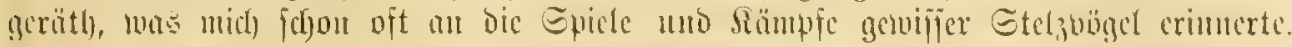

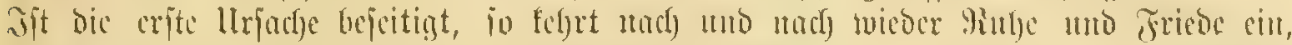

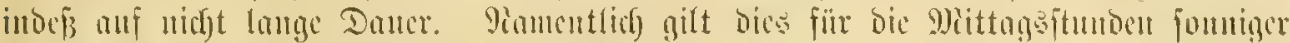

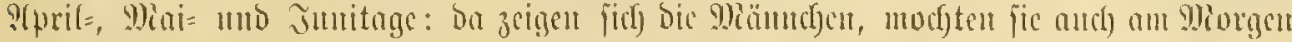

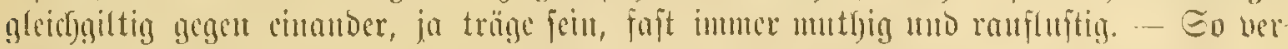
geben Fribling und

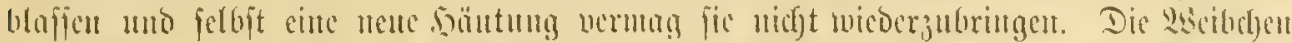

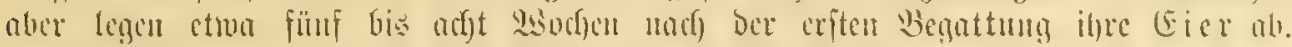

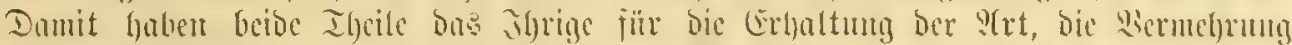

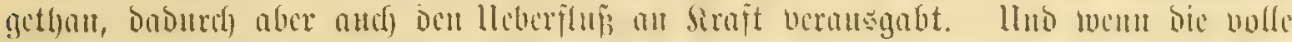

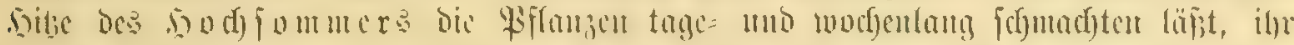

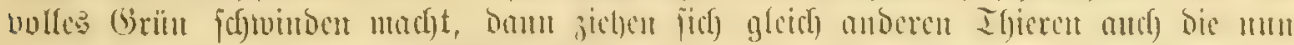

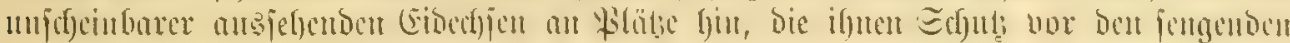

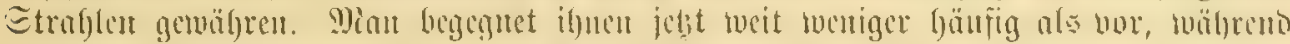

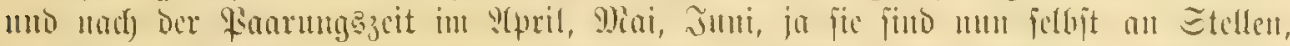

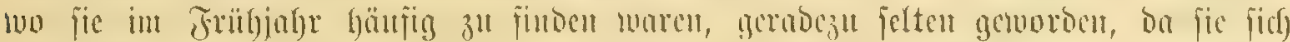

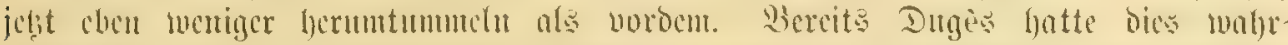

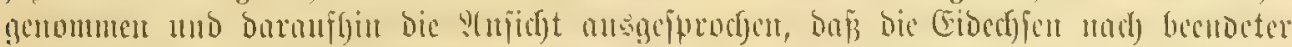

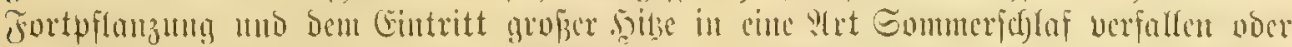

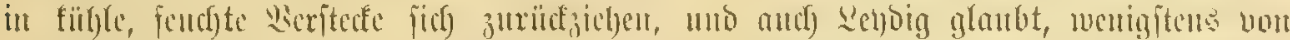

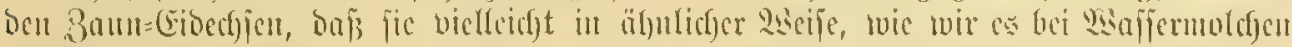

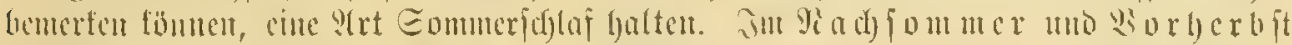

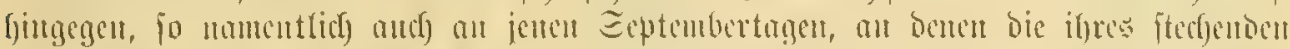

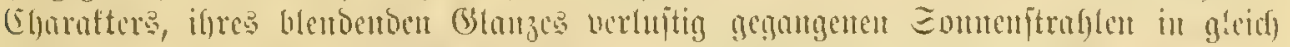

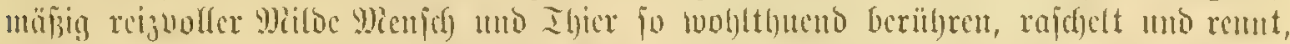

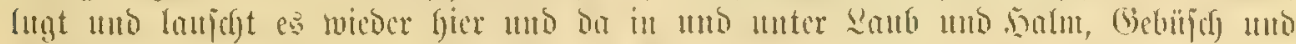

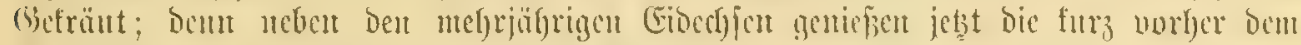

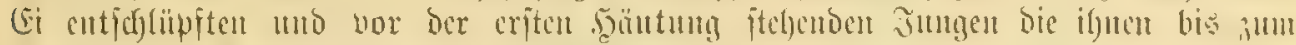

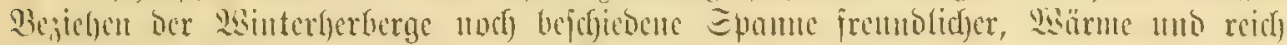

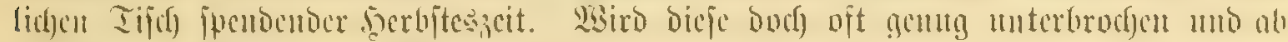

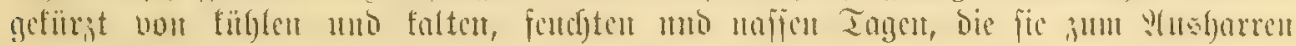
iı Dumflem, weunjodjon tvärmerem Serfted zwingen!

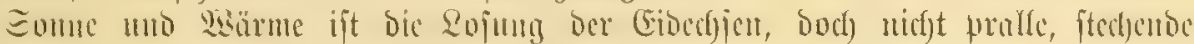

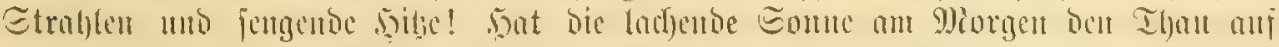

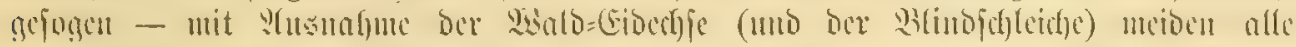

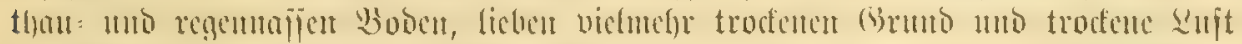

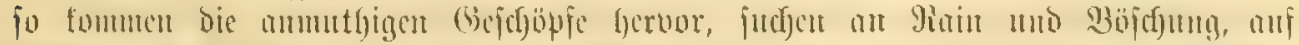

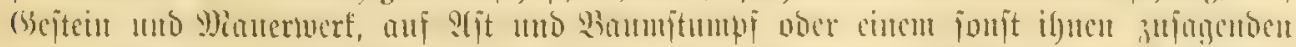

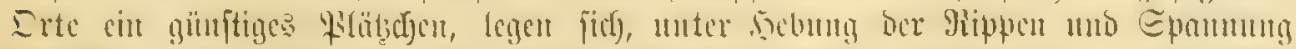

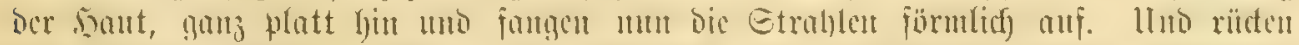

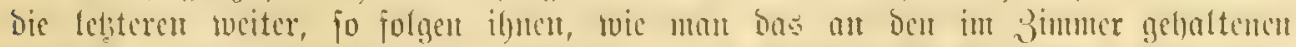

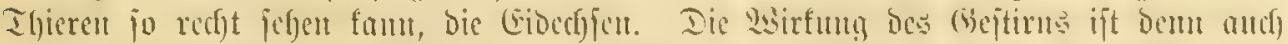

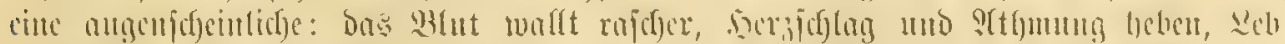

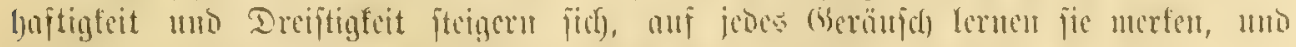

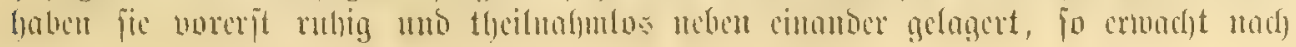




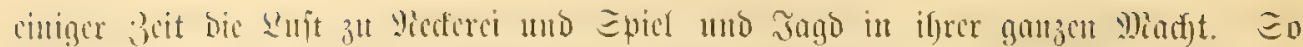

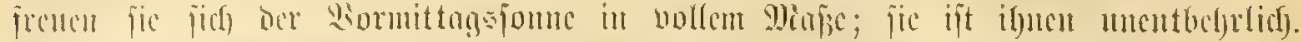

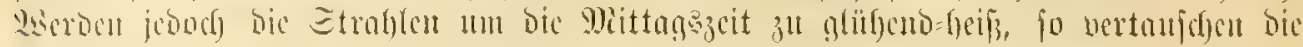

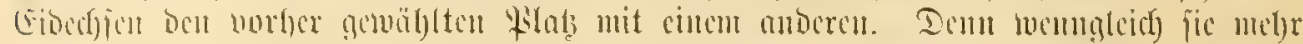

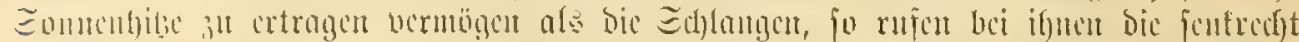

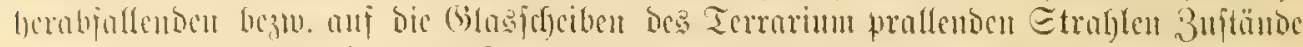

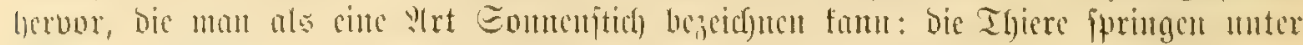

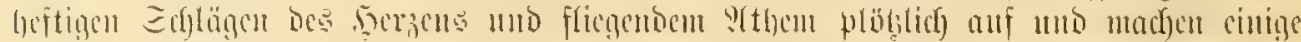

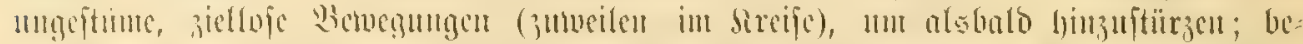

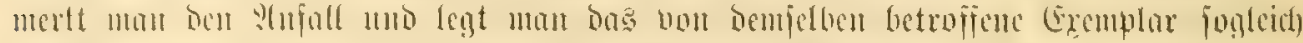

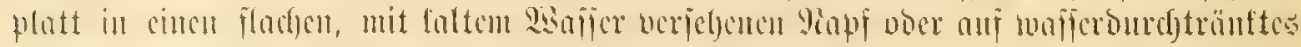

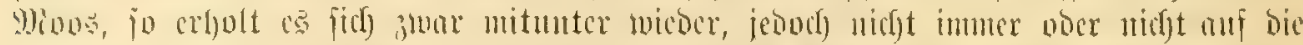

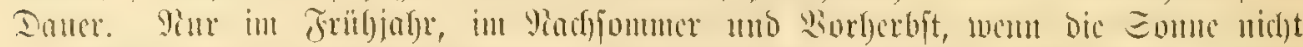

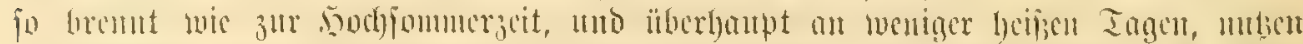

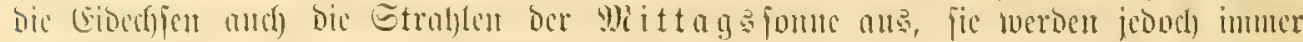

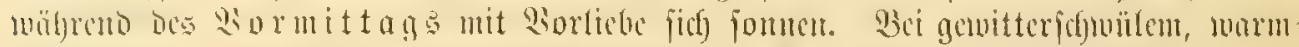

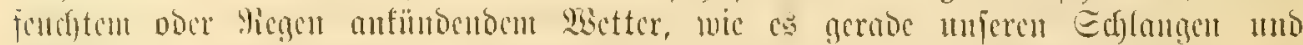

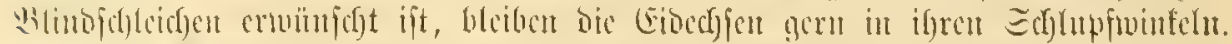

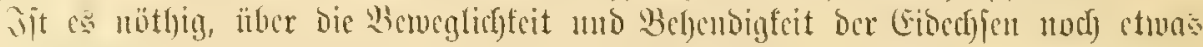

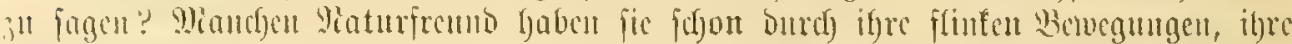

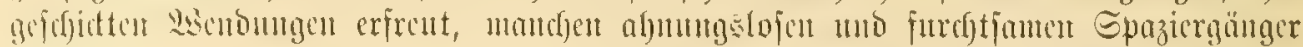

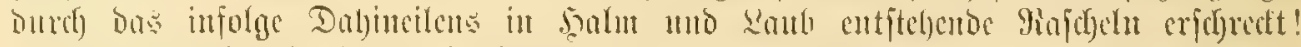

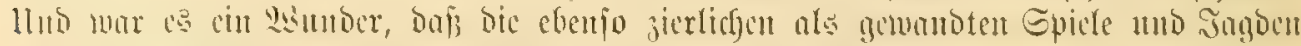

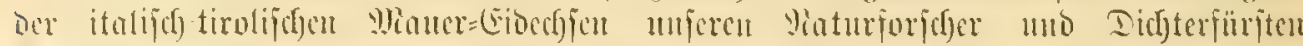

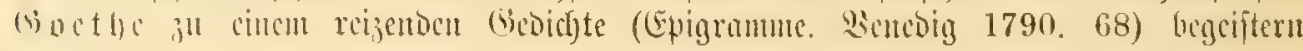
founten?

\footnotetext{
„2ängft fidon bätt' id end) gern von jenen Thierdyen geipprodjen,

Die fo zierlid utb fduell jahren babiu unb baher.

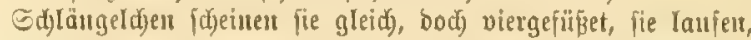

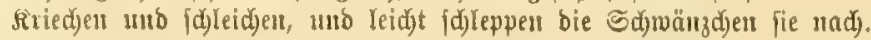

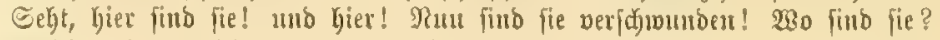

Weldje Mitze, weld) Sraut nahu bie (Entfieghenden auf?

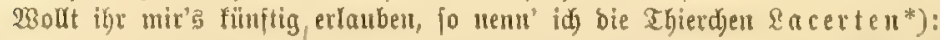

Dent id braudje fie nod) oft als gefälliges Bilb."
}

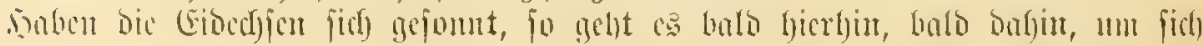

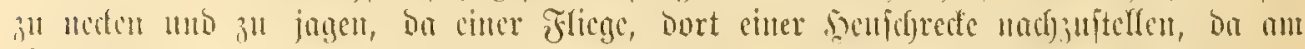

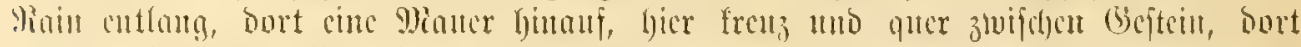

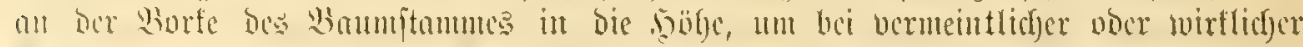

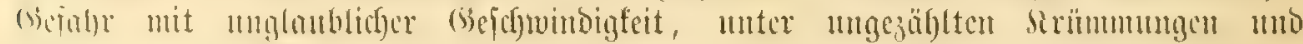

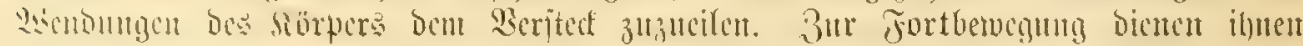

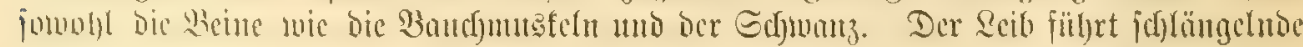

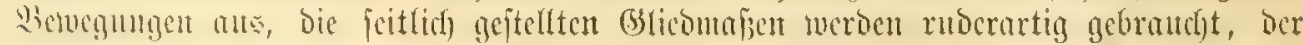

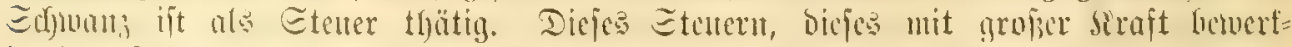

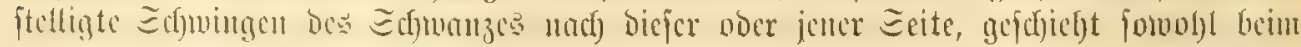

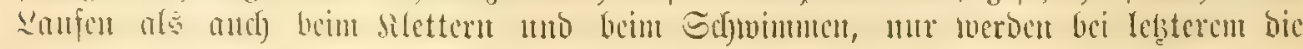

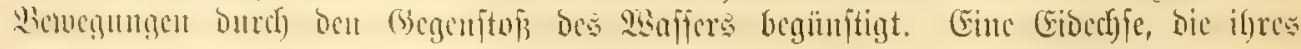

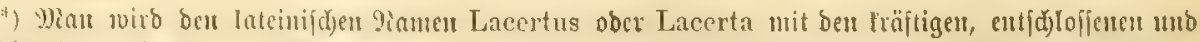

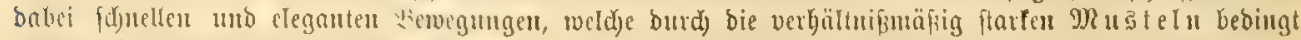

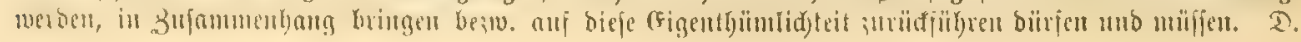




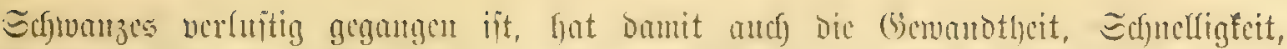

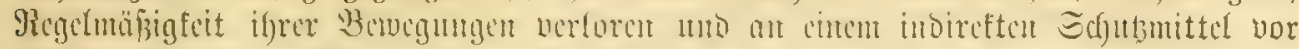

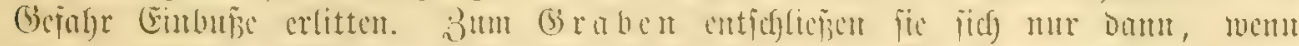

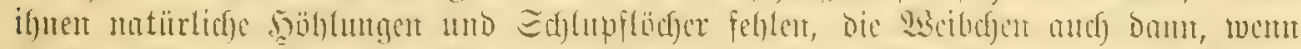

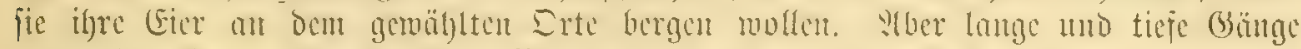

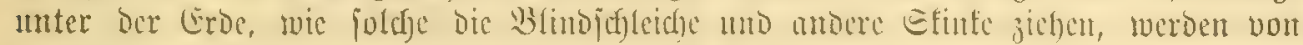
ifnen nie getwitg)(t.

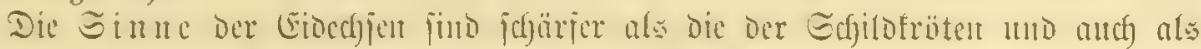

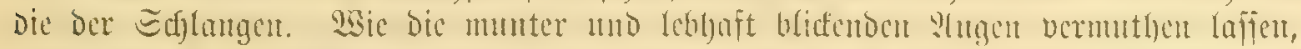

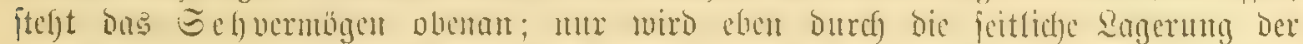

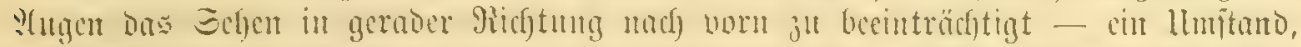

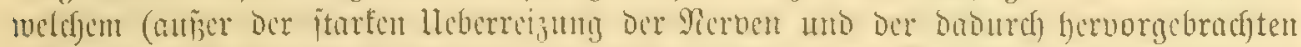

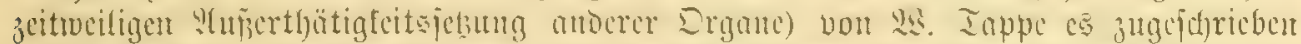

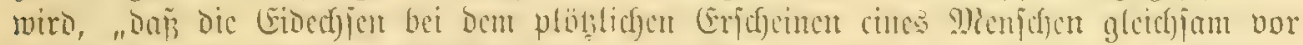

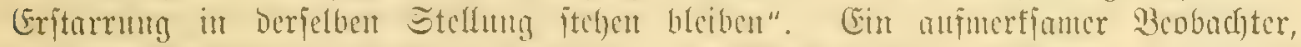

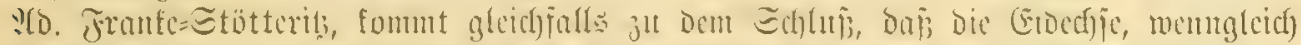

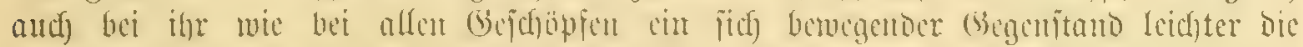

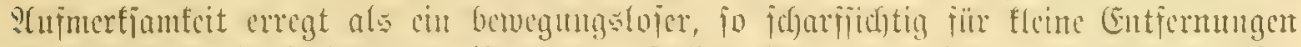

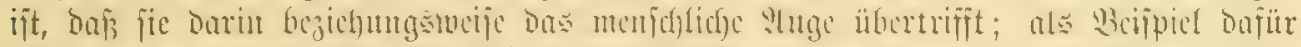

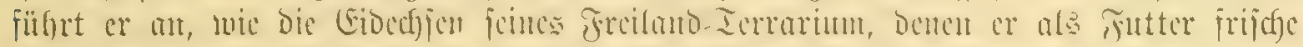

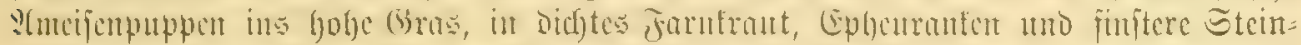

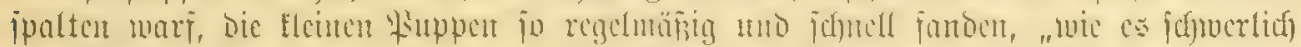

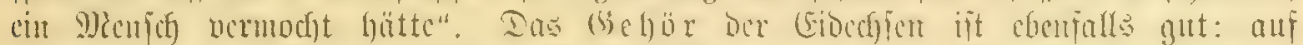

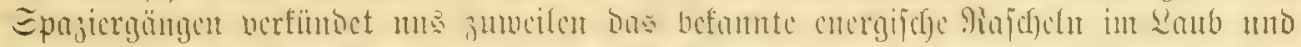

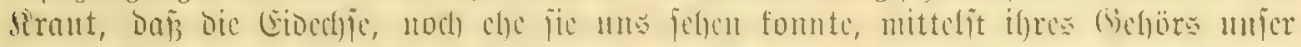

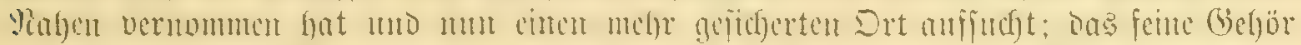

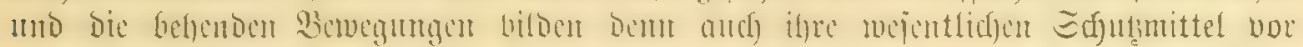

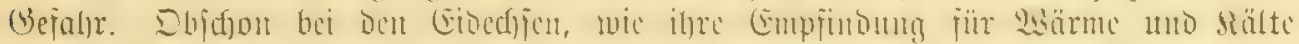

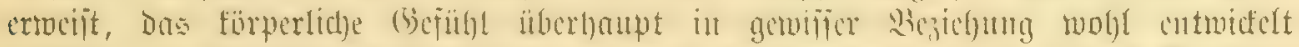

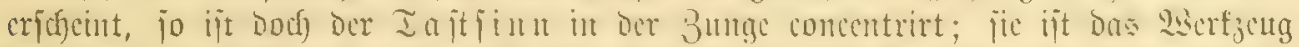

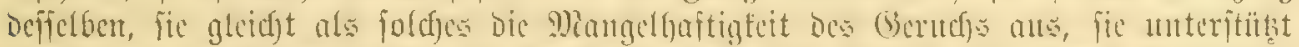

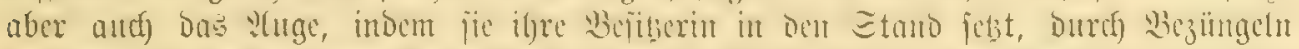

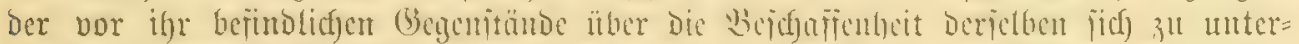

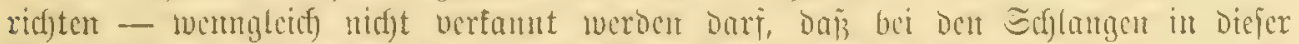

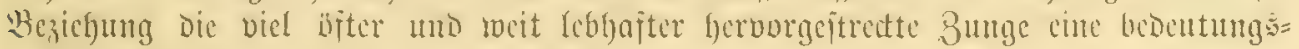
pollere Rolle fpiclt als bei ben Eidechjer.

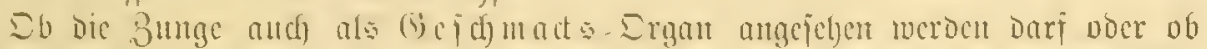

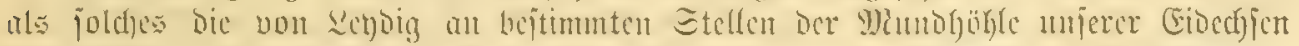

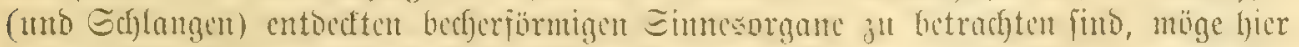

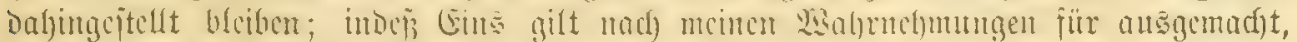

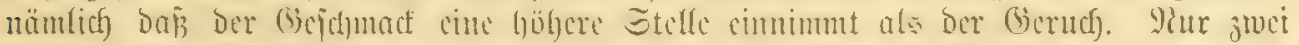

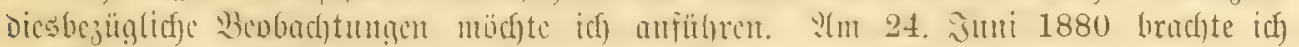

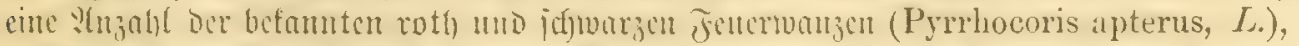

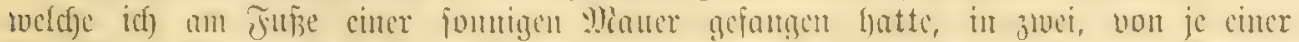

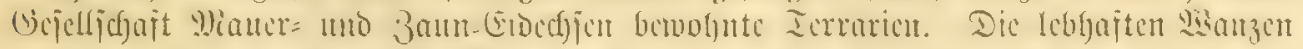

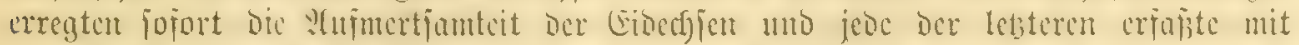

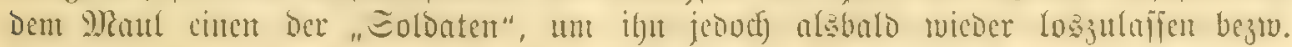

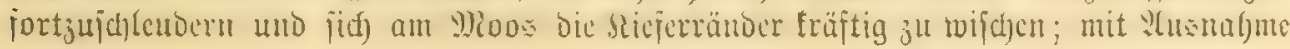


eimer cimjigut

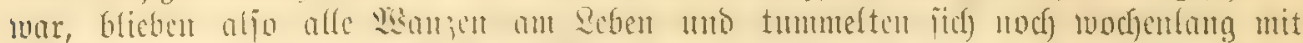

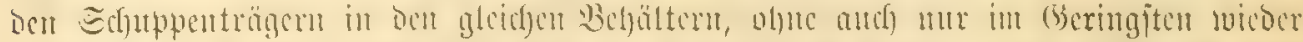

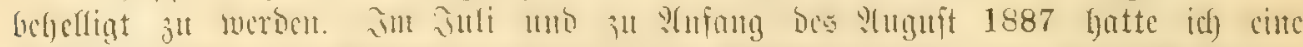

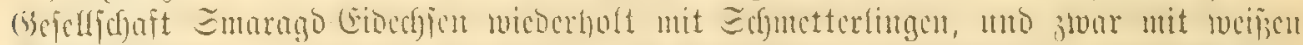

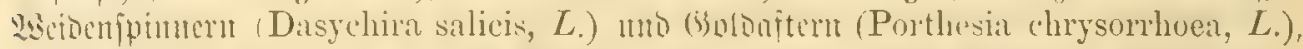

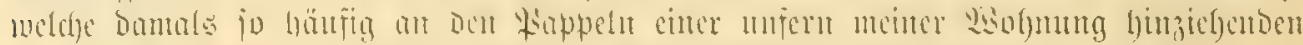

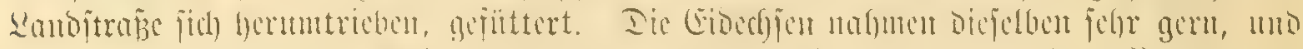

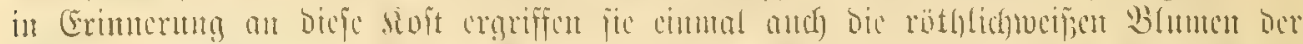

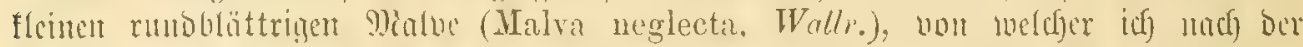

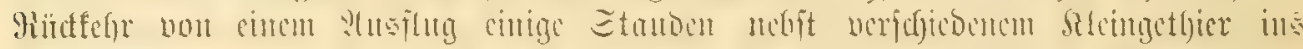

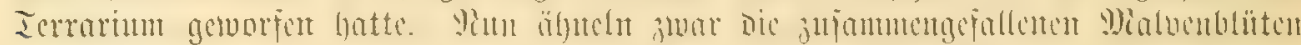

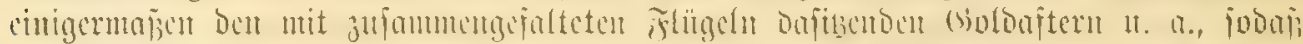

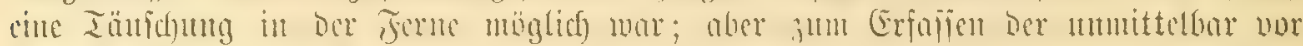

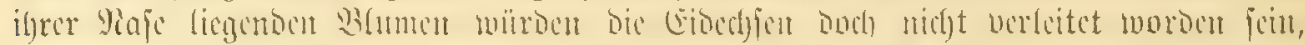

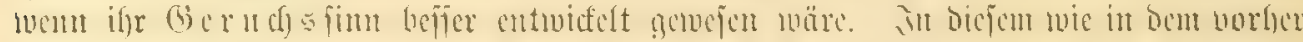

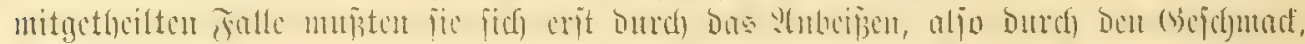

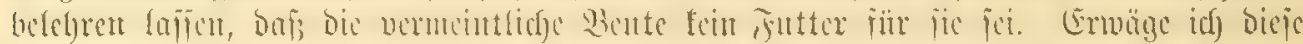

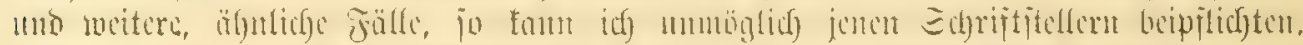

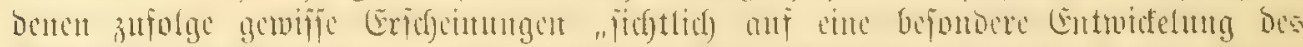

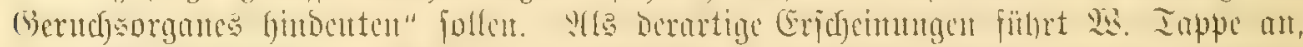

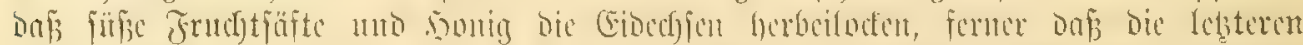

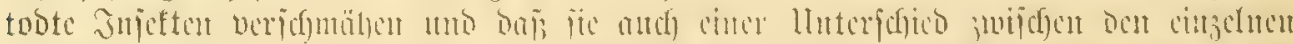

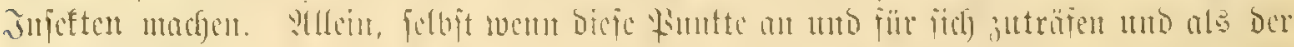

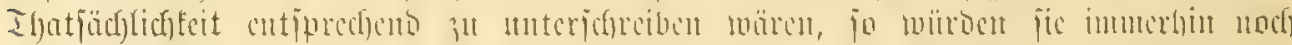

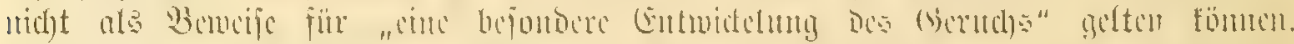

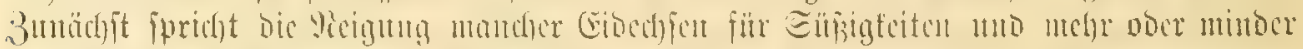

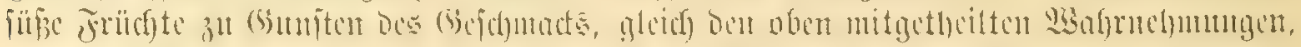

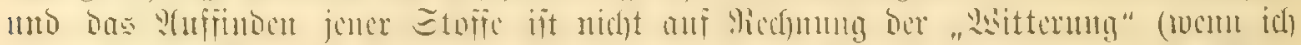

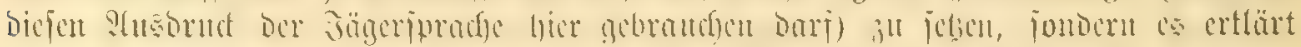

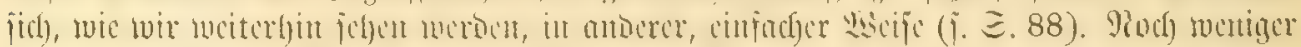

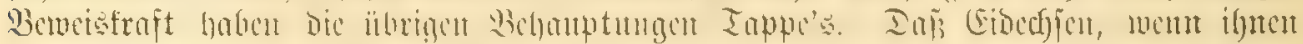

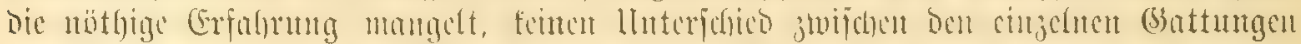

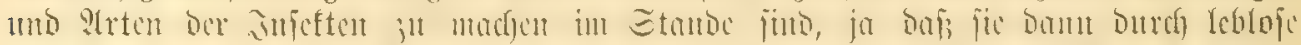

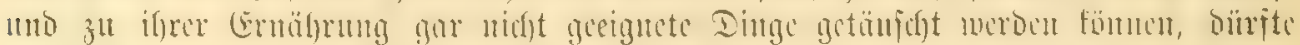

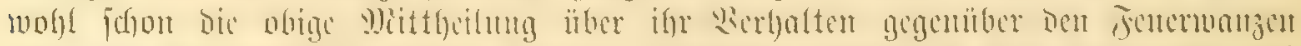

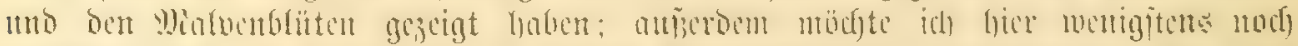

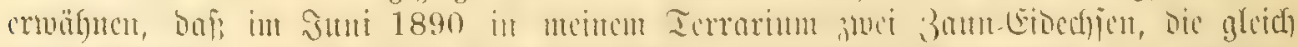

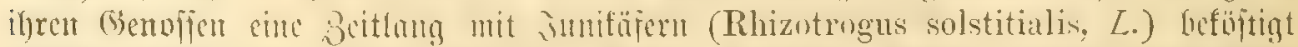

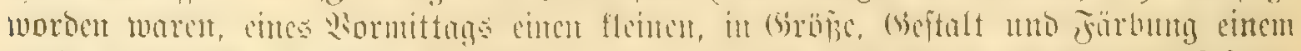

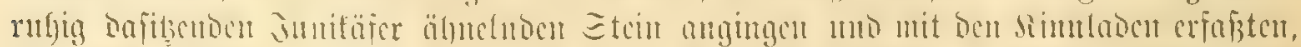

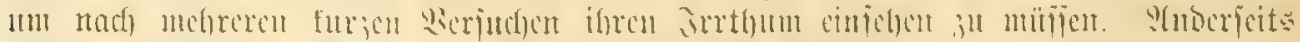

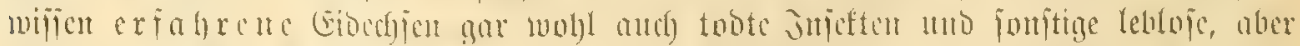

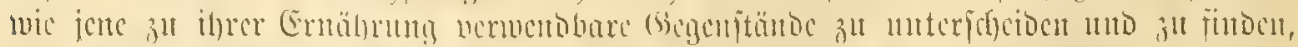

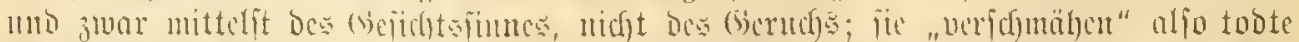

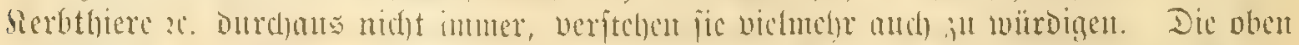

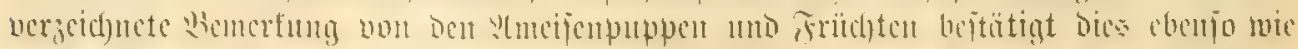

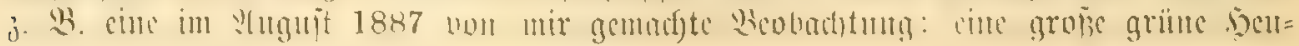




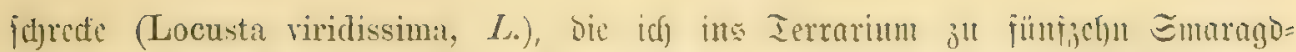

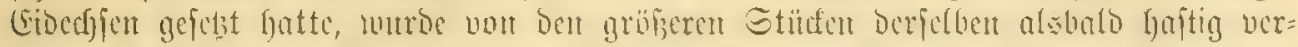

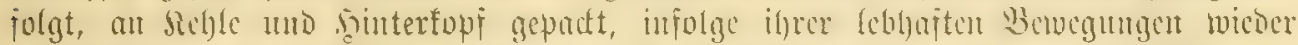

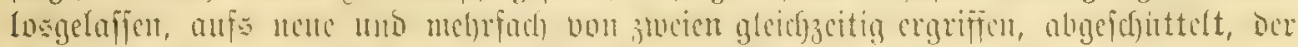

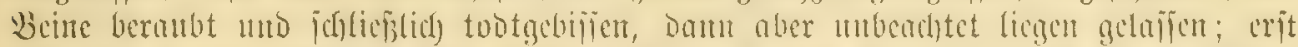

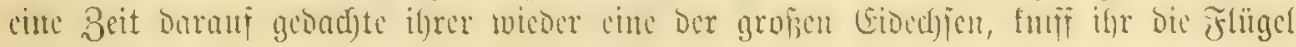
ato unt verzefrete fie.

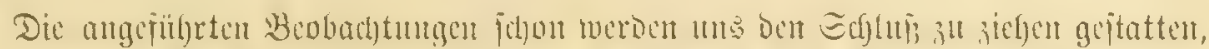

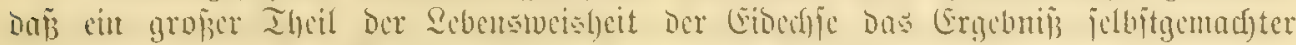

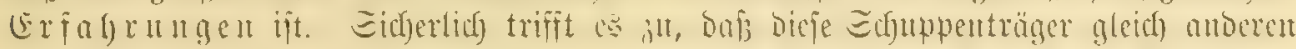

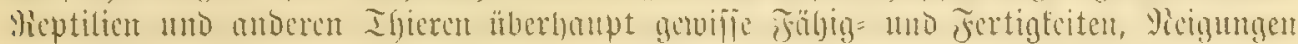

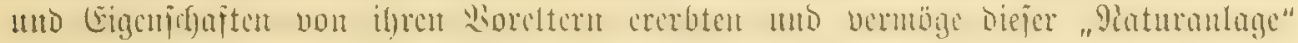

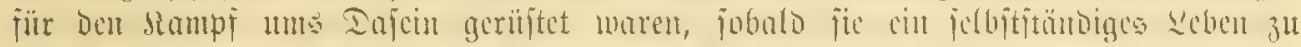

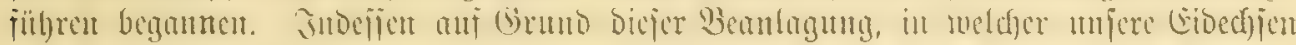

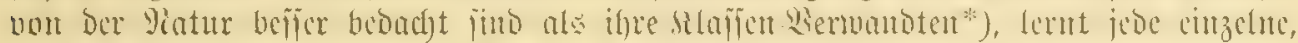

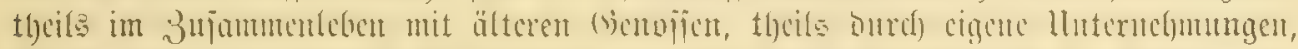

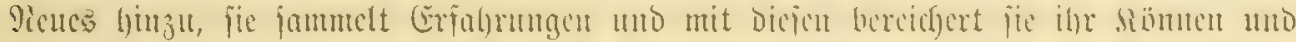

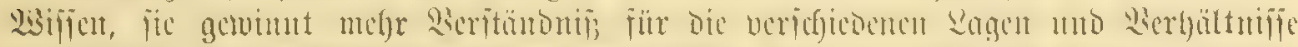

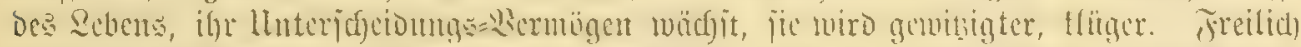

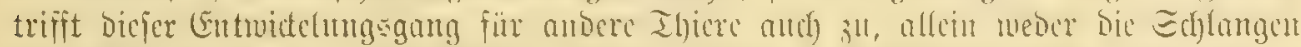

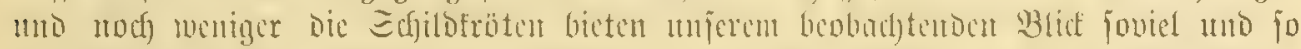

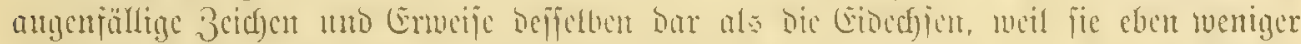

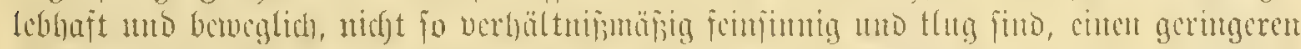

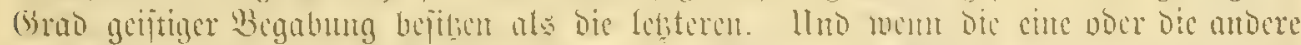

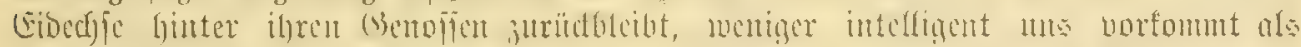

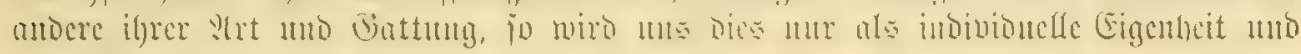
folgeridjtig erid)einert.

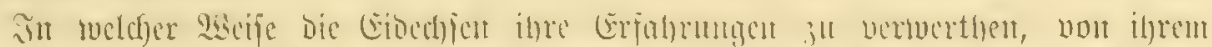

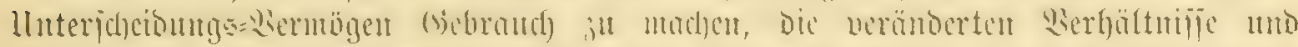

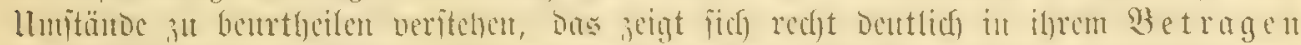

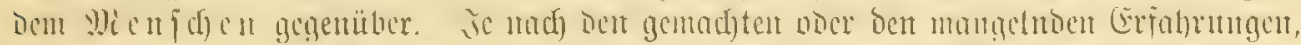

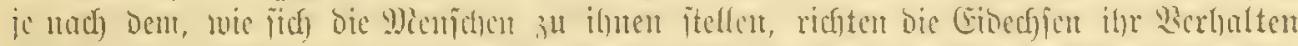

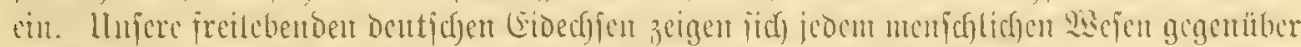

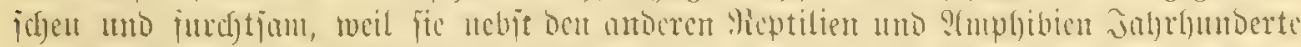

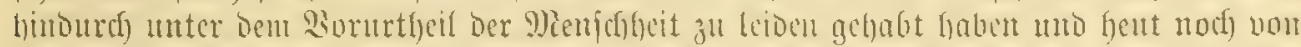

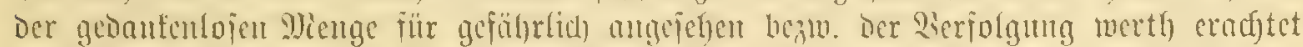

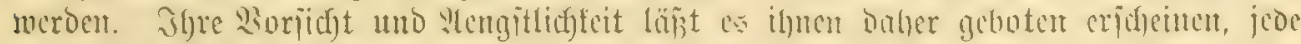

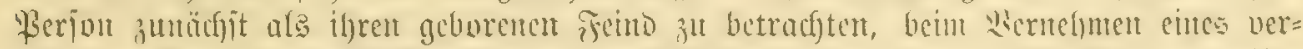

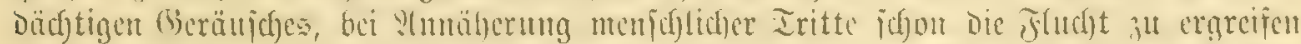

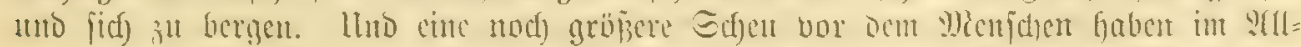

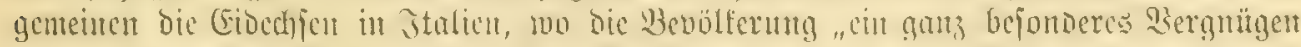

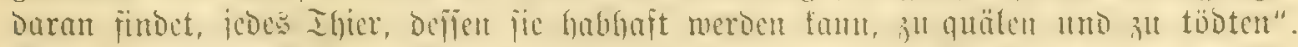

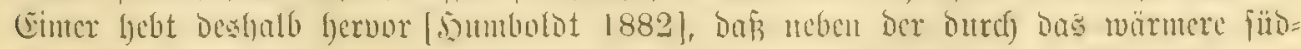

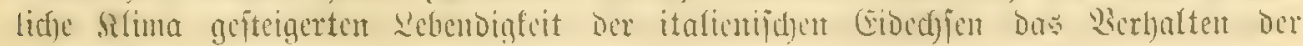

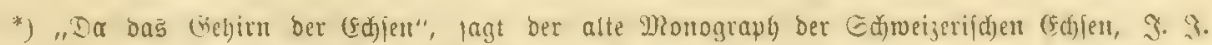

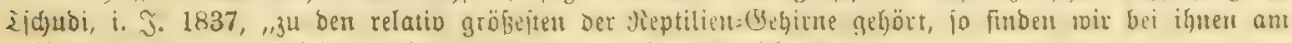
meiften Intelligenz, bie bebeutenbfte Denffraft unter ben Meptilien." 


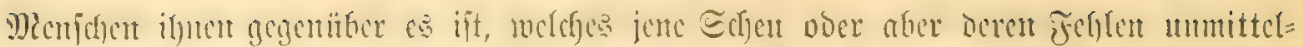

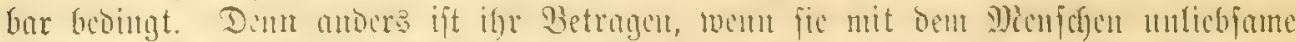

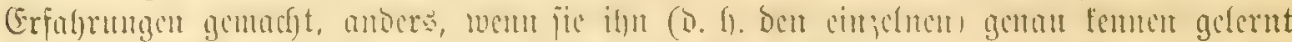

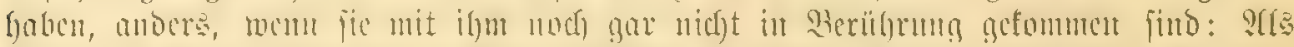

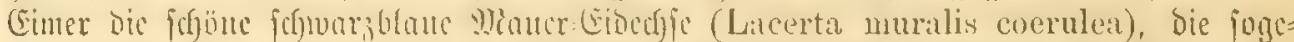

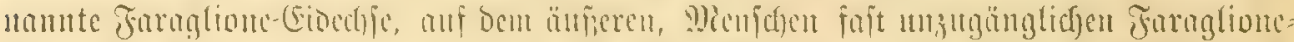

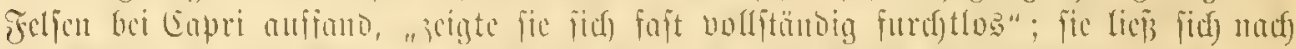

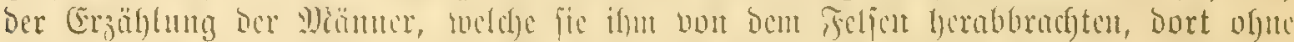

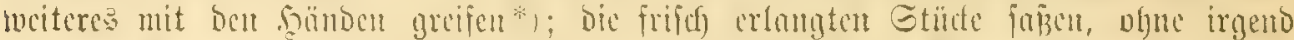

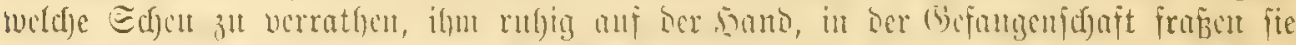

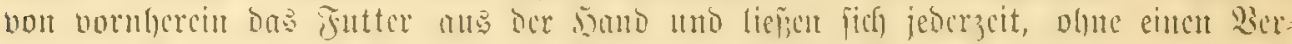

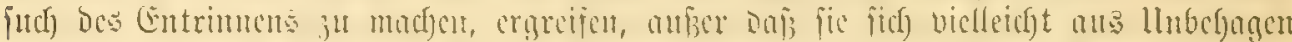

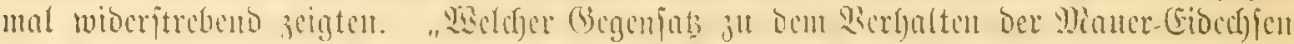

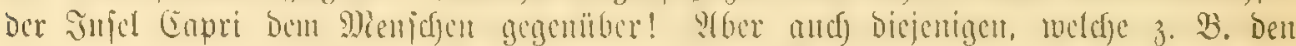

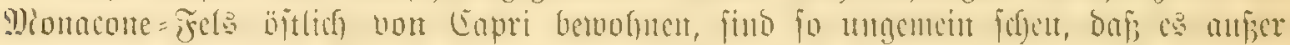

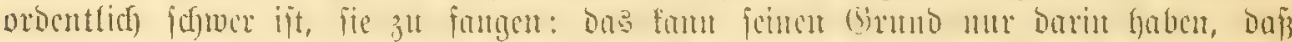

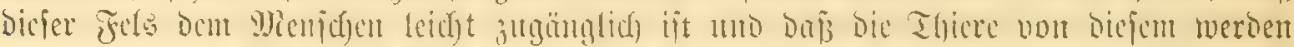

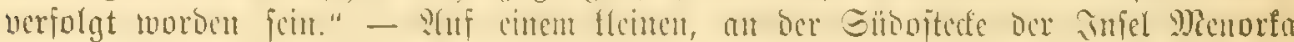

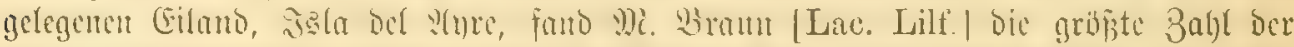

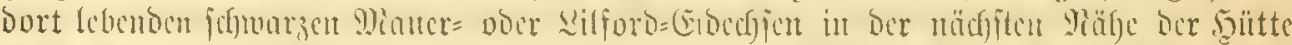

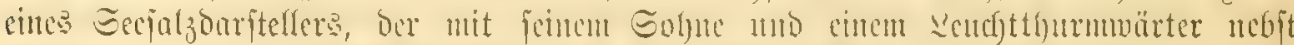

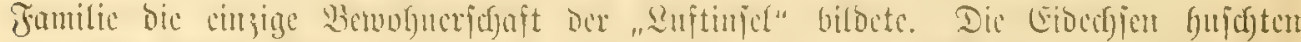

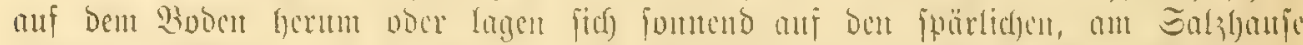

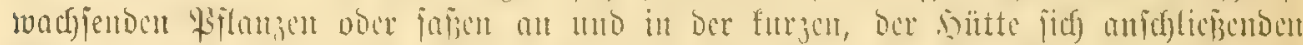

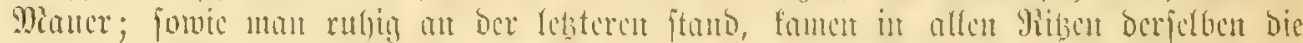

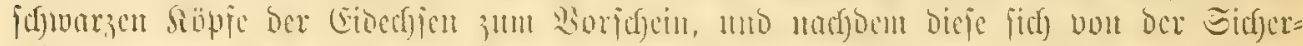

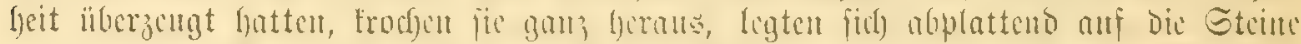

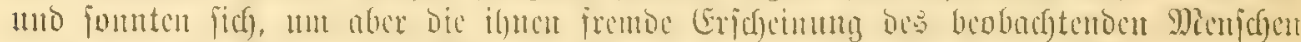

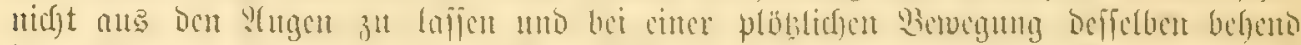

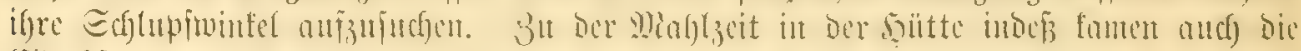

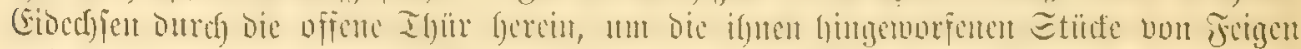

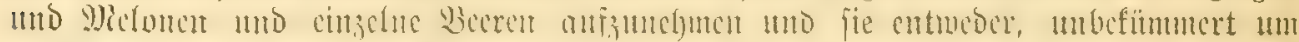

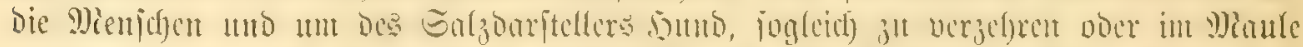

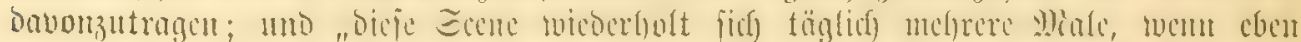

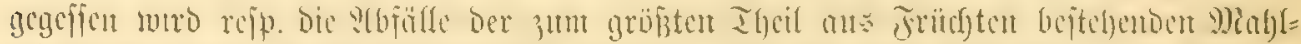

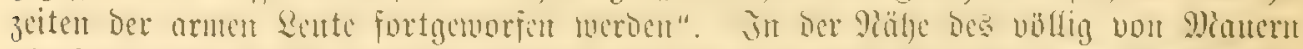

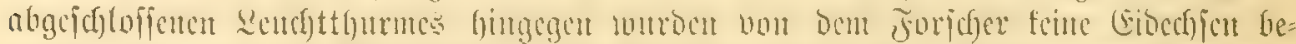

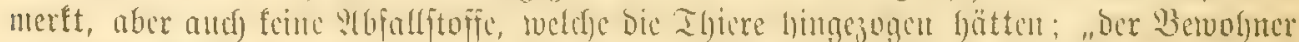

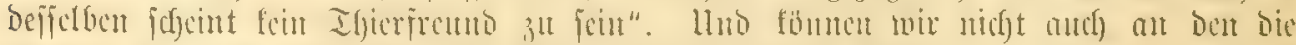

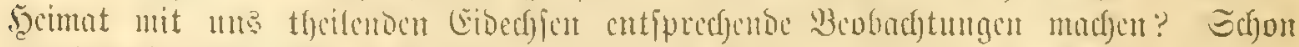

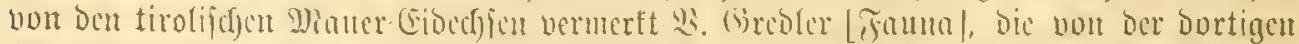

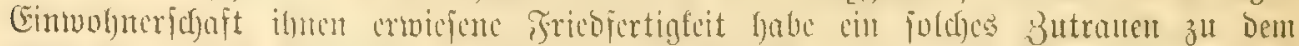

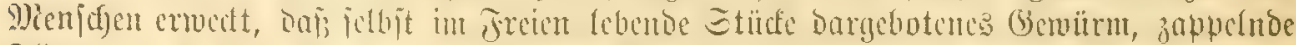

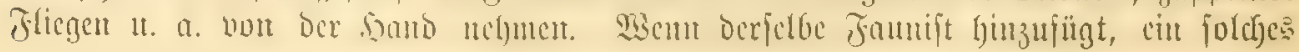

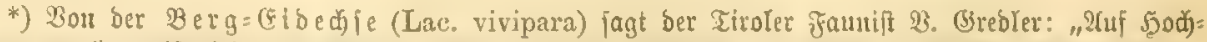

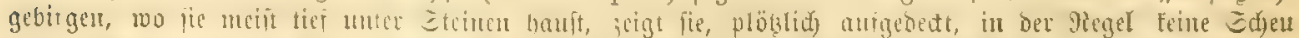

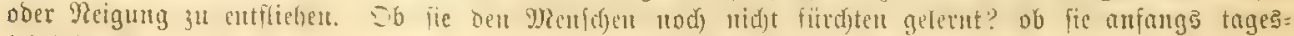

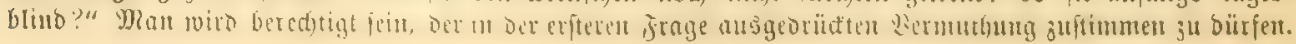




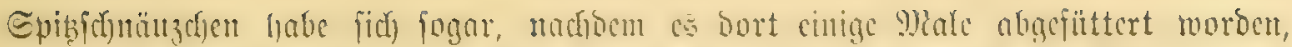

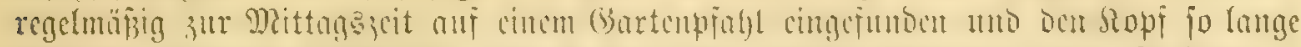

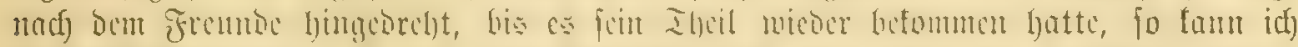

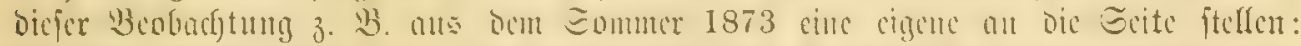

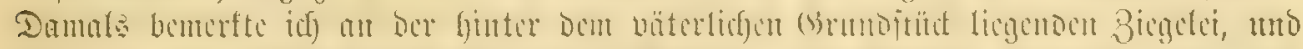

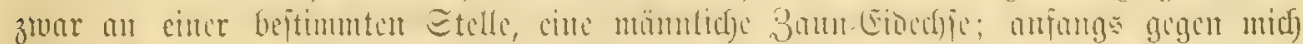

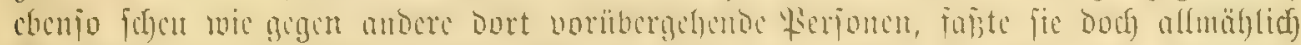

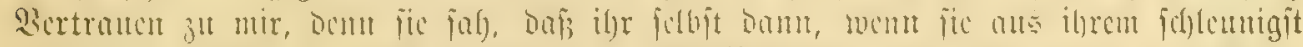

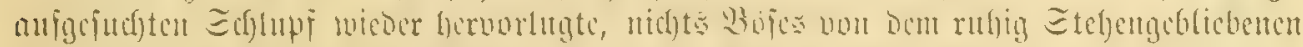

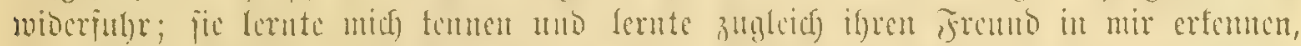

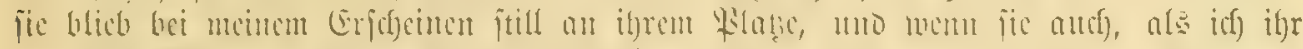

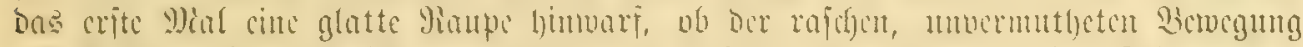

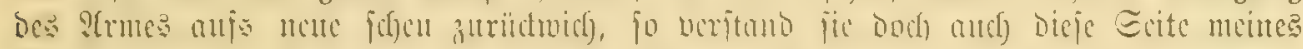

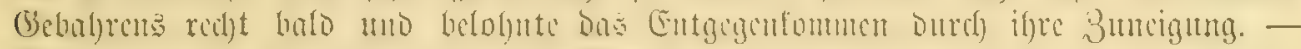

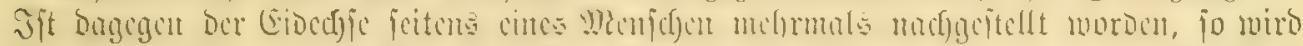

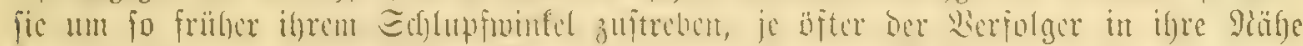

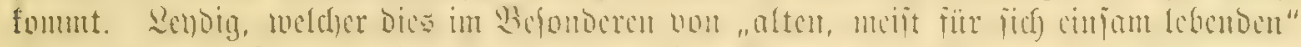

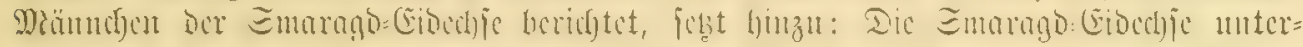

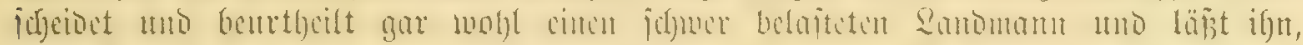

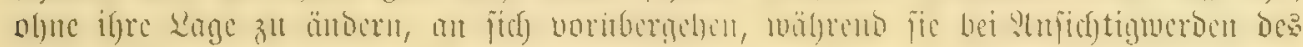

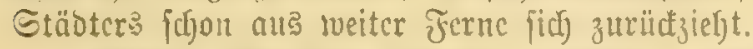

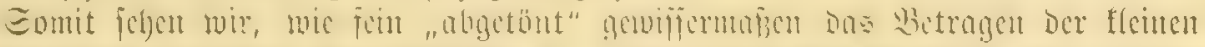

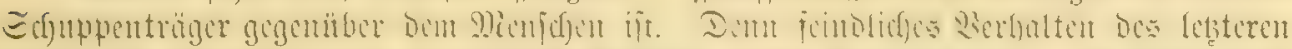

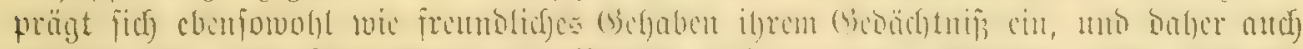

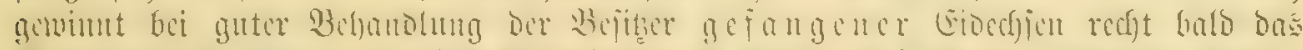

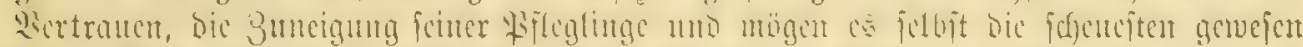

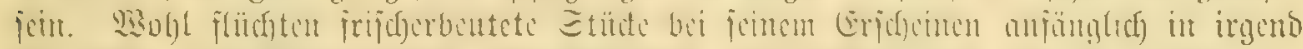

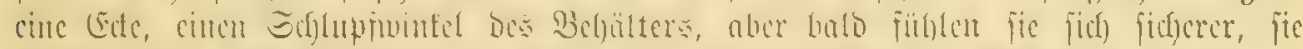

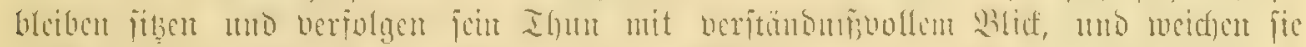

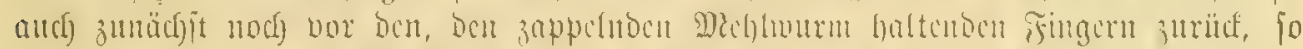

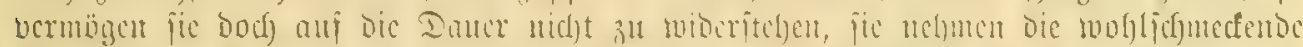

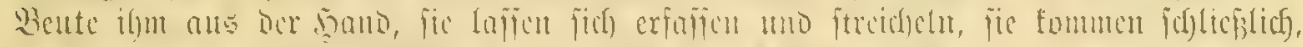

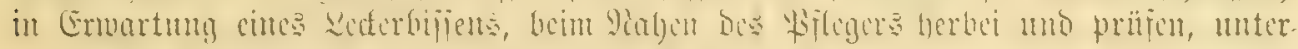

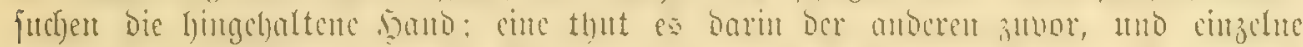

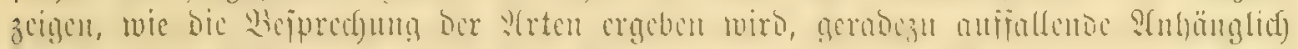

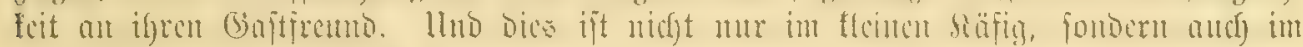
Jreiland= Terrarium ber Fall.

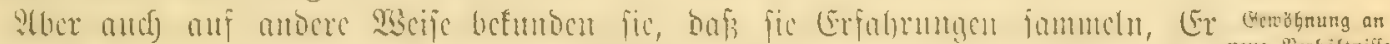

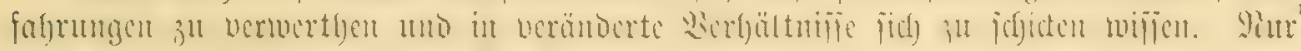

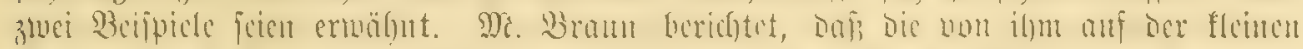

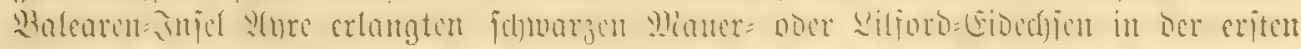

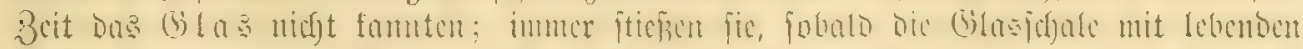

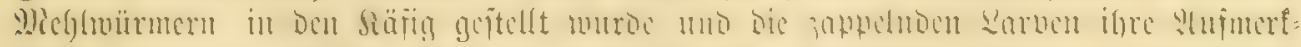

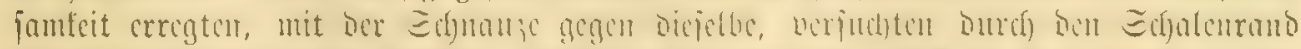

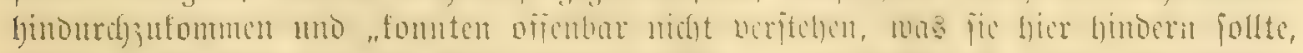

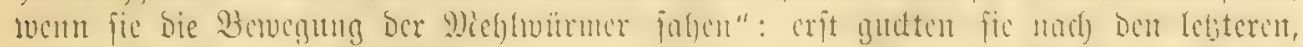

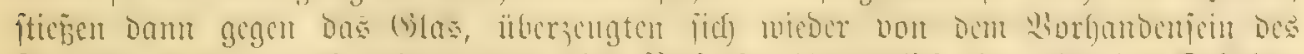

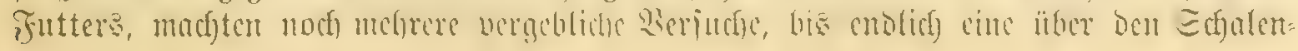


rano frod) uno baburd) ben autocren bou

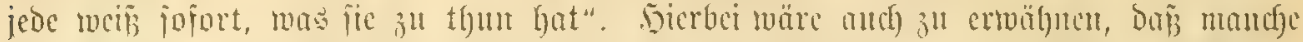

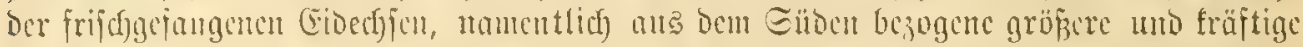

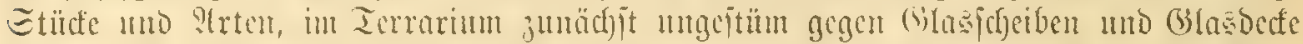

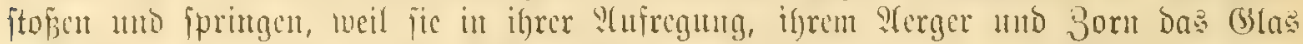

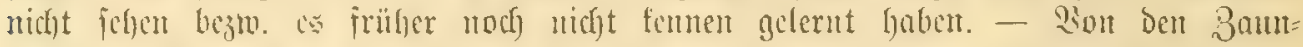

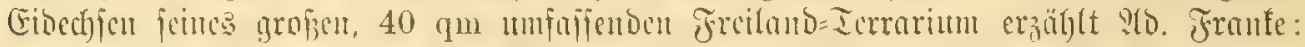

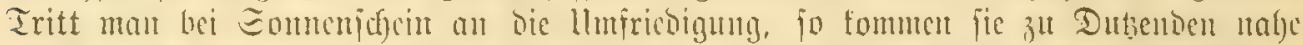

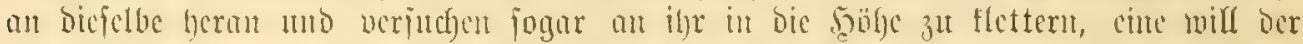

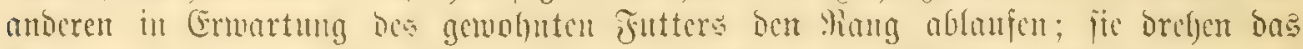

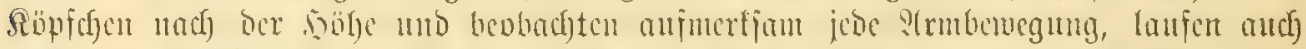

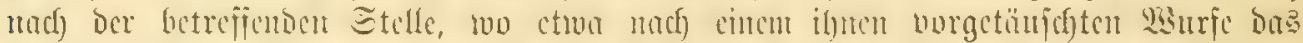

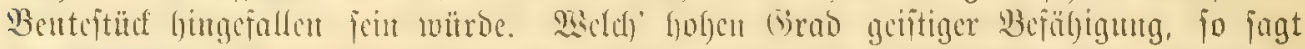

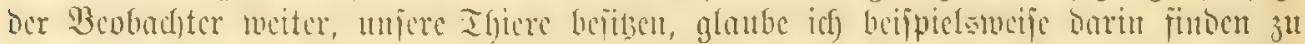

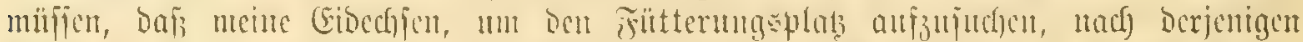

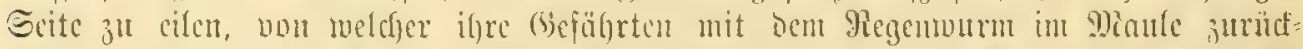

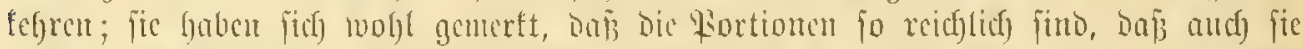

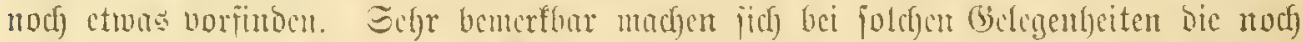

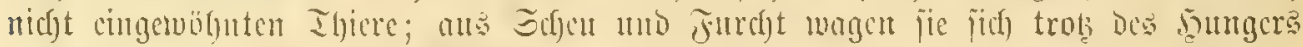

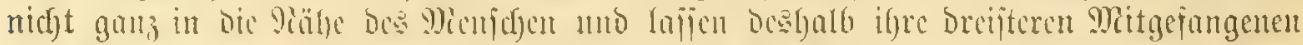

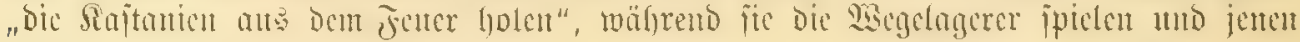
bie Beute abjagcut.

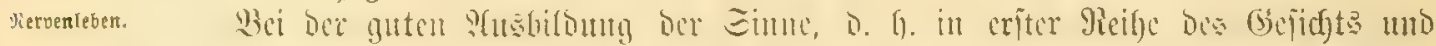

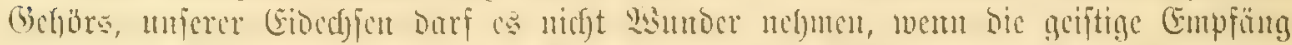

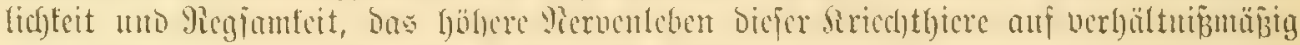

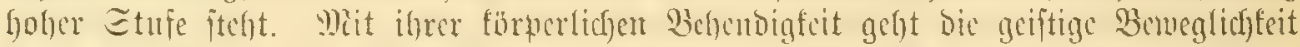

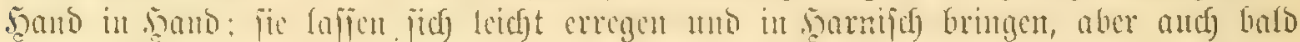

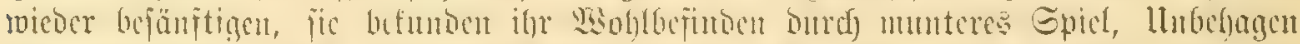

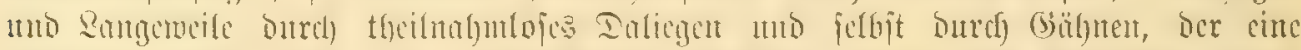

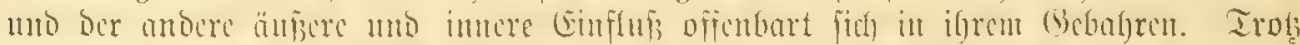

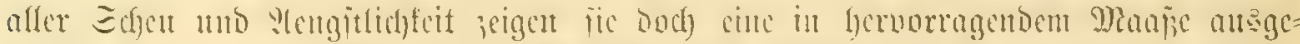

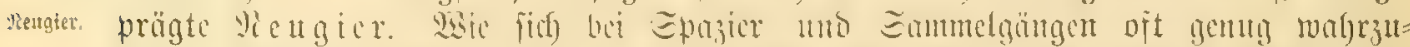

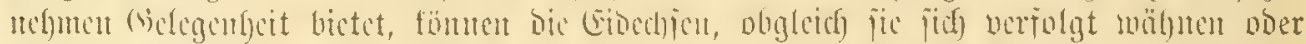

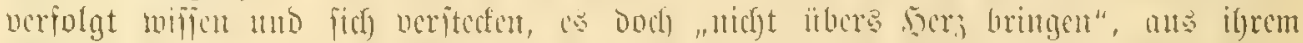

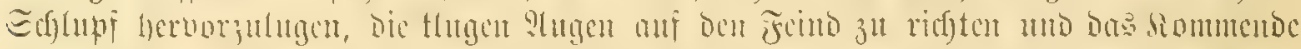

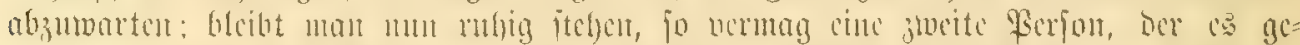

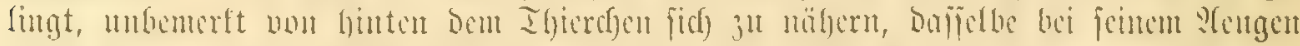

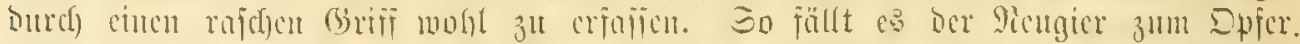

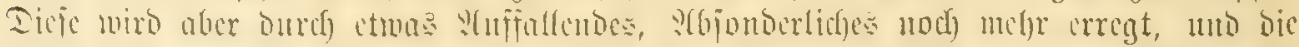

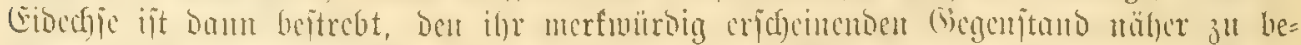

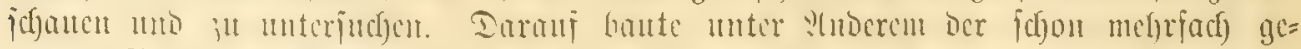

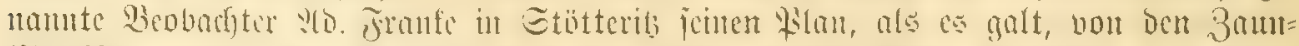

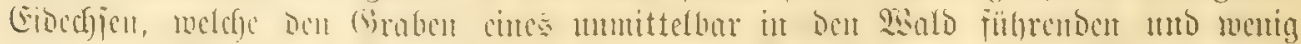

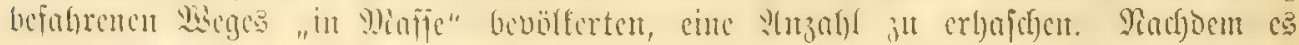

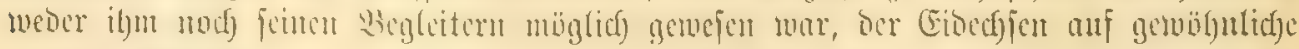

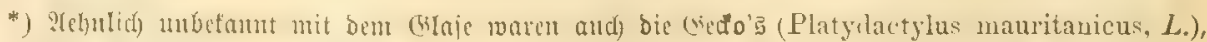

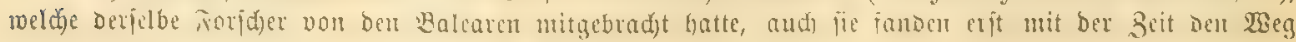

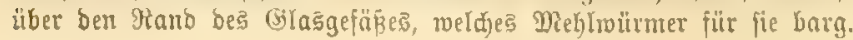




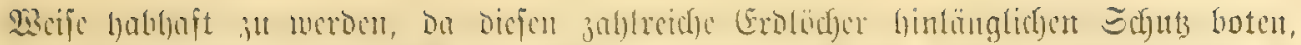

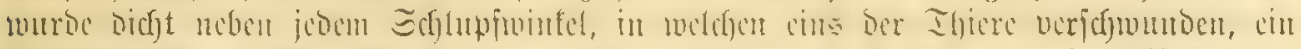

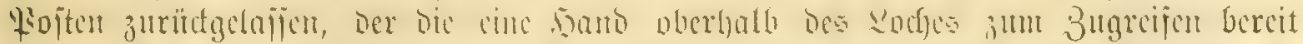

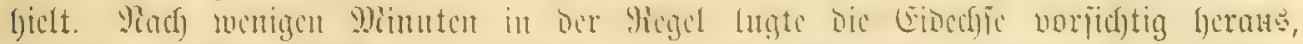

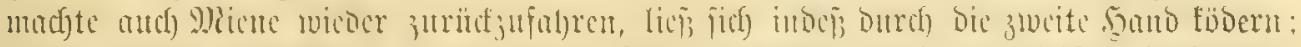

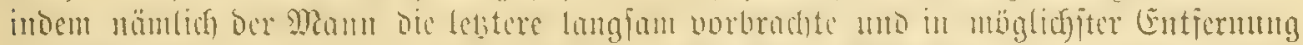

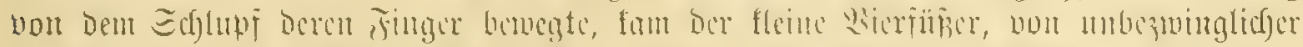

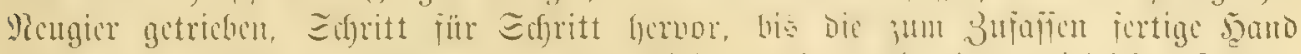

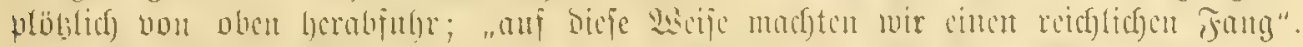

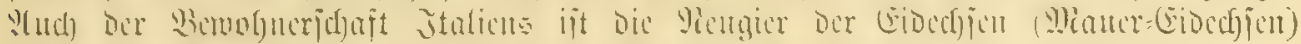

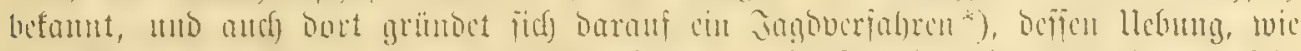

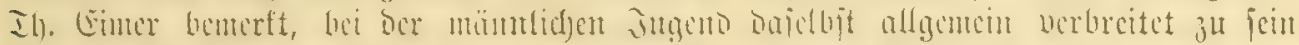

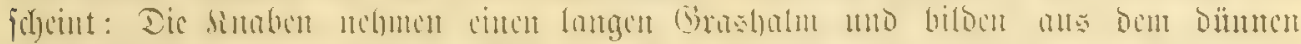

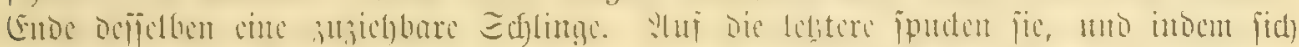

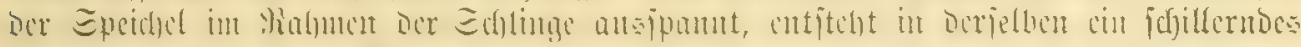

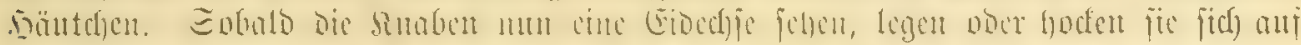

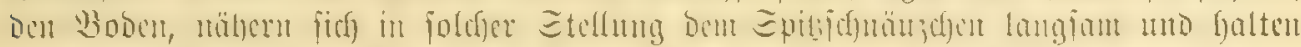

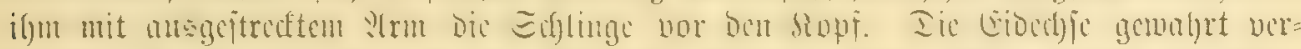

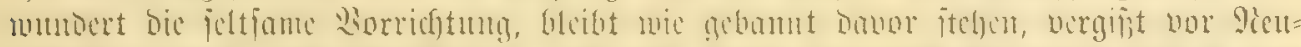

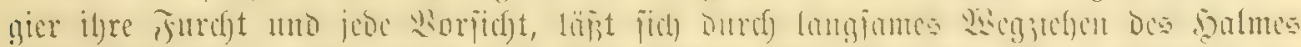

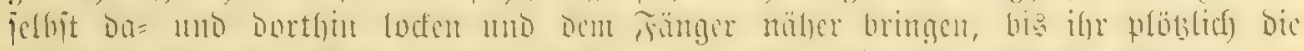

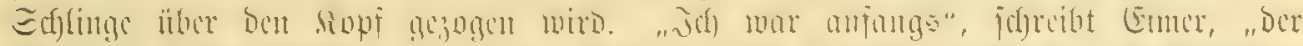

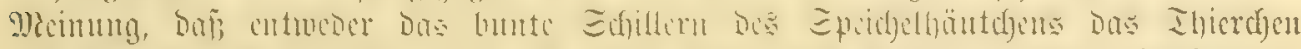

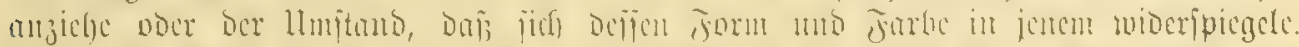

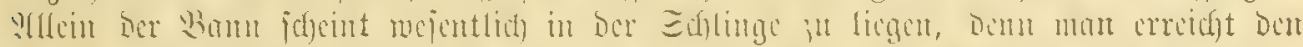

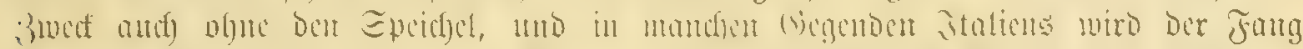

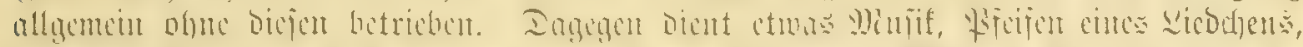

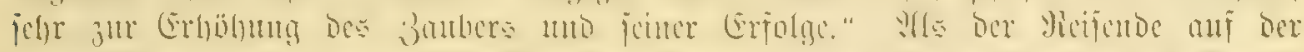

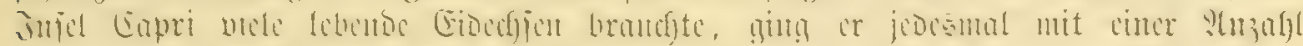

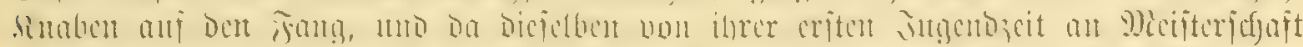

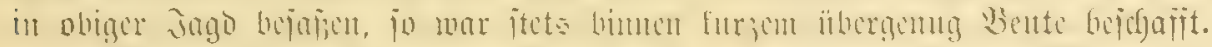

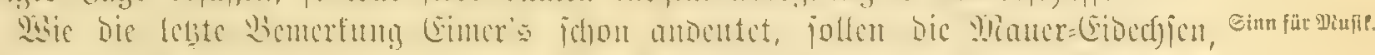

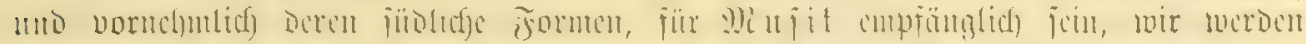

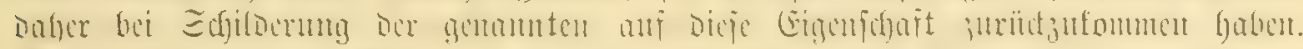

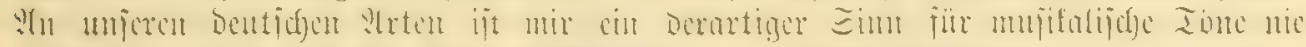

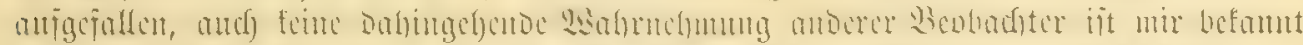

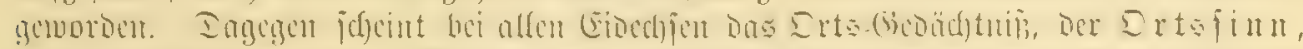

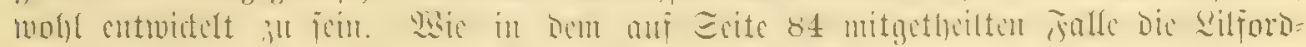

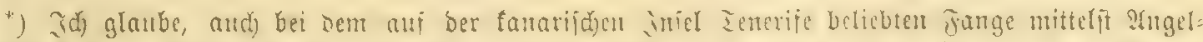

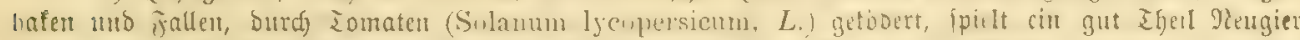

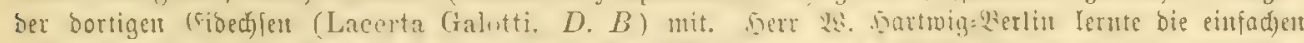

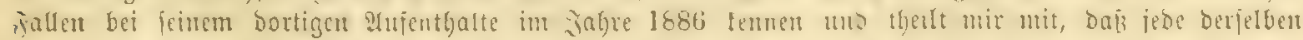
au

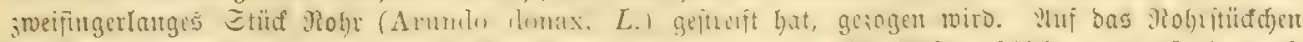

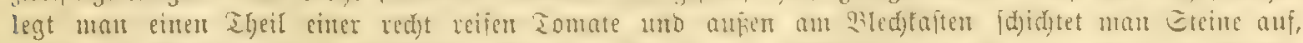

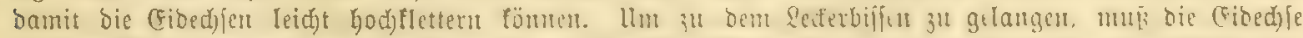

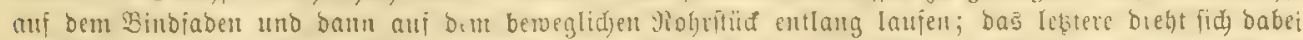

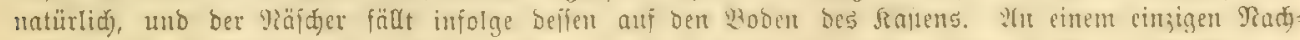

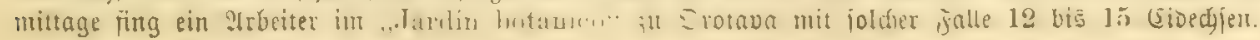




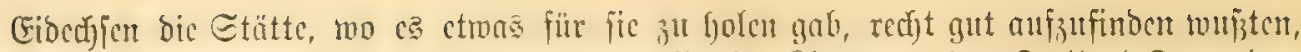
fo merfen anch anbere Eidedjjen, mïgen fie im Bimmer= ober Freiland: Ierrarium

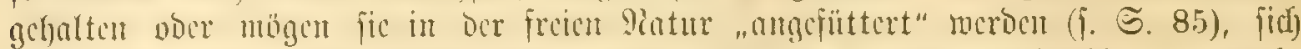

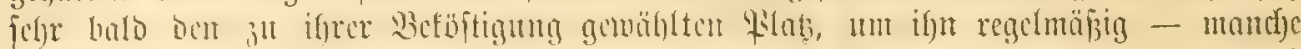

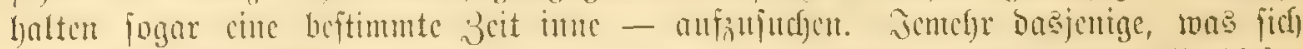
ihnen an cincm Siunte bictet, Secteres für fite ijt, Dejto gentuer frägen fie biejon

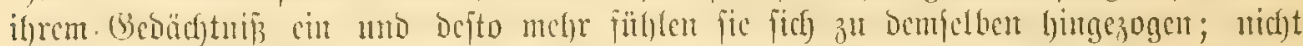

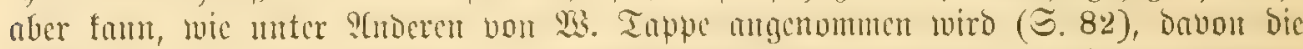

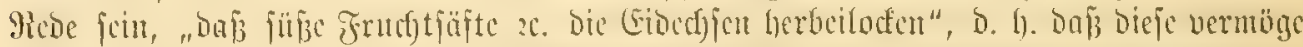

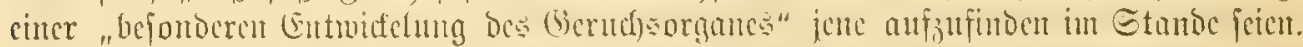

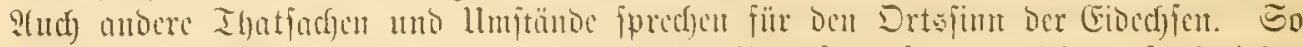

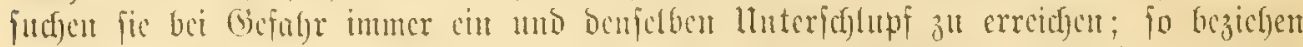

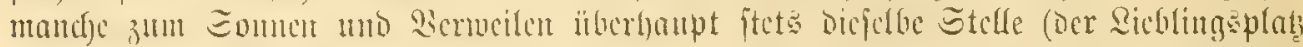
ciner meiner

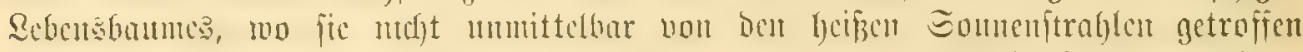

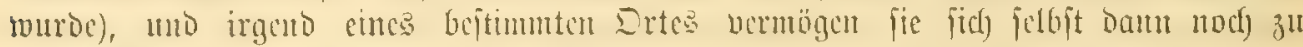

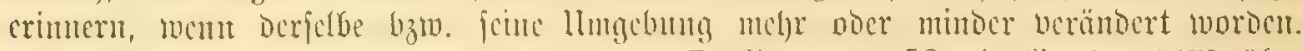

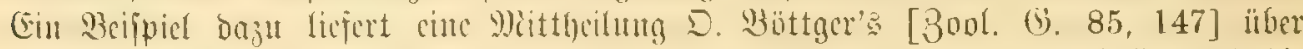

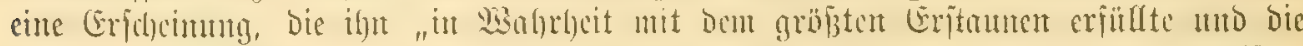

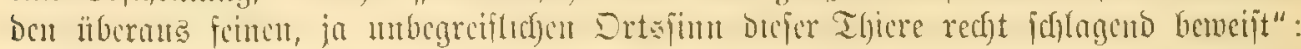
Eine bom Beridsterjtatter im Ierrarium gehalteme Emarago=(Eibechje lyatte bort am

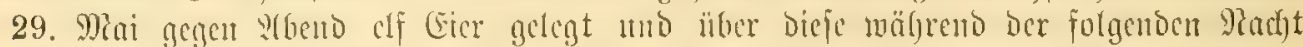

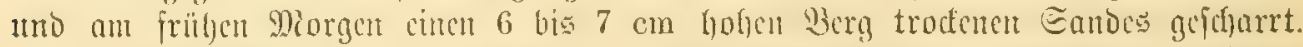

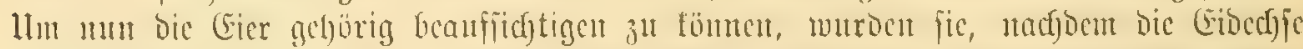

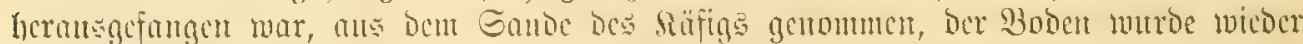

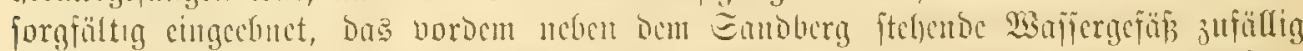

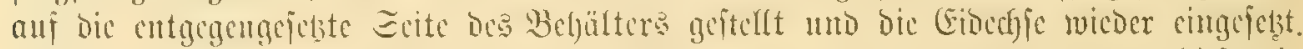

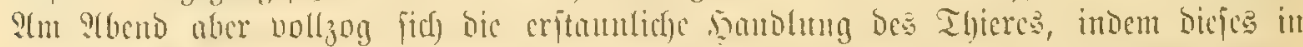

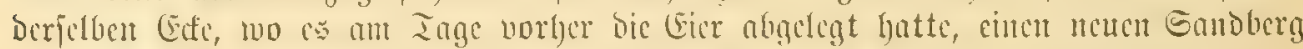

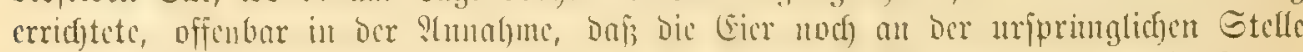

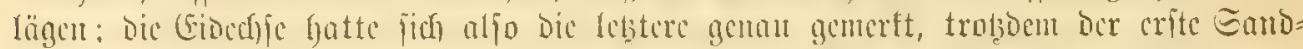

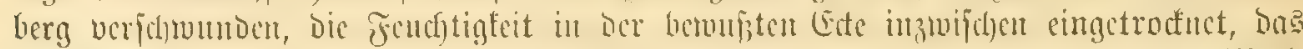

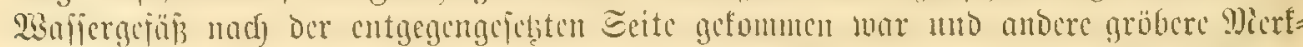

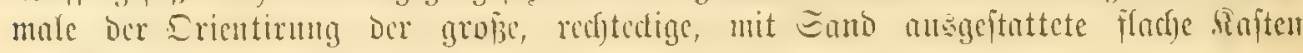
äberbnupt nidyt mclyr bot.

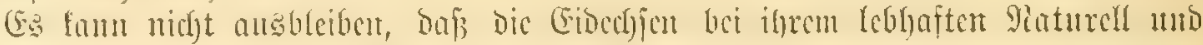

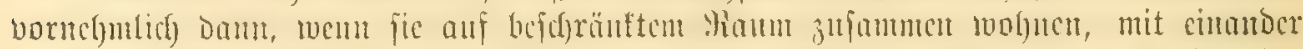

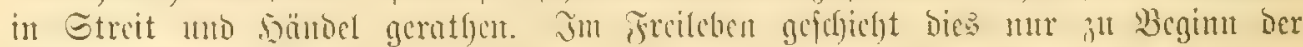

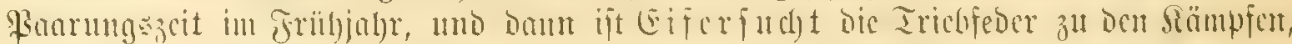

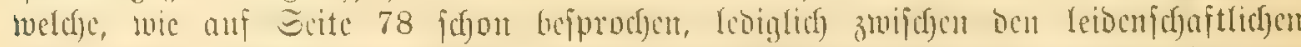

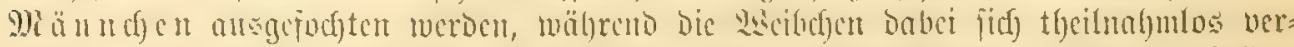

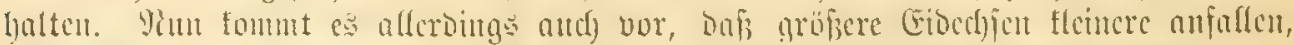

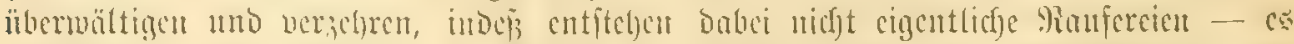

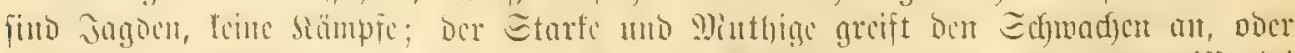

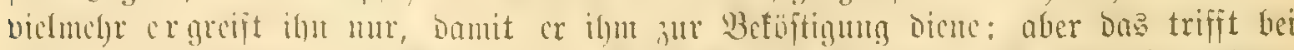

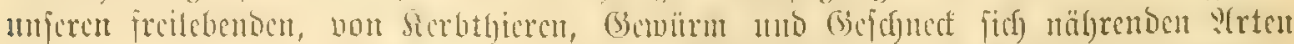

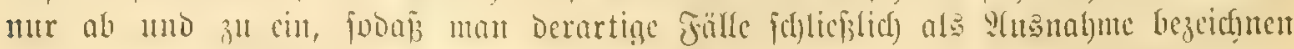

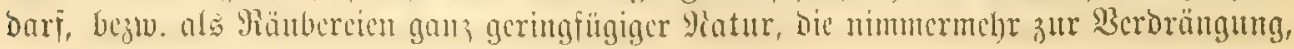




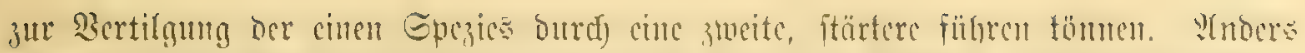

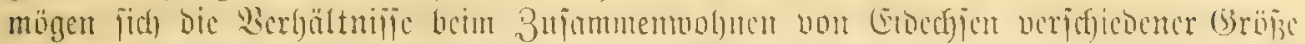

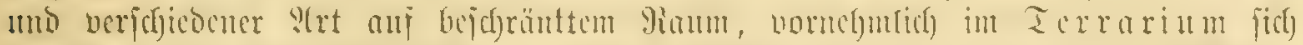

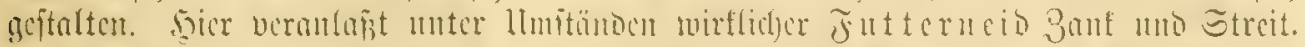

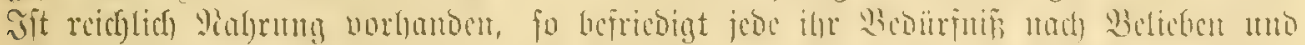

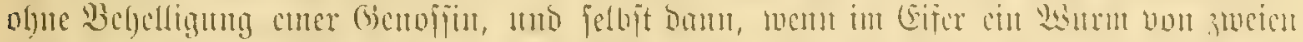

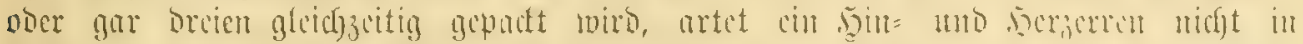

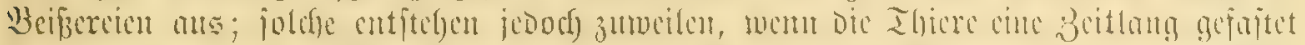

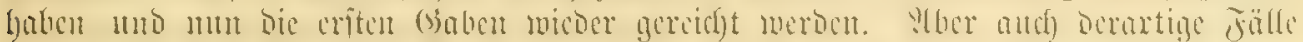

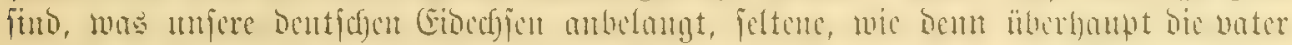

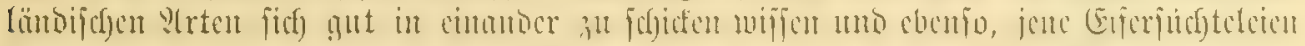

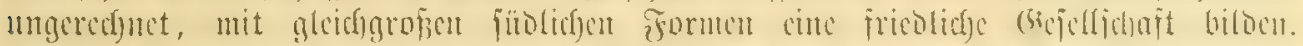

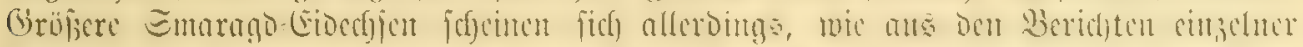

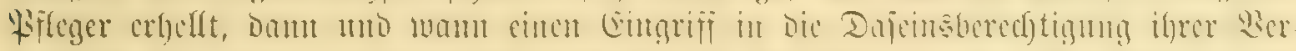

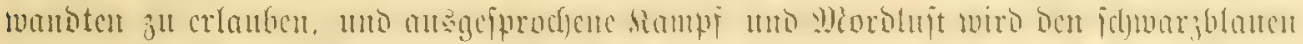

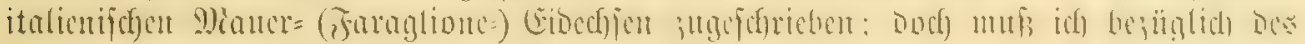

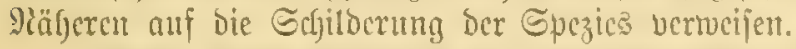

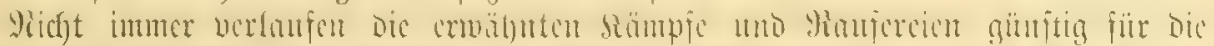

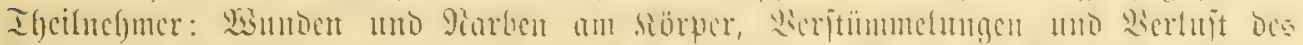

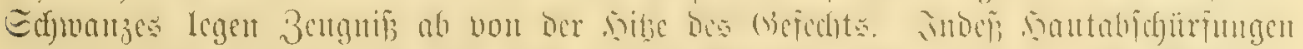

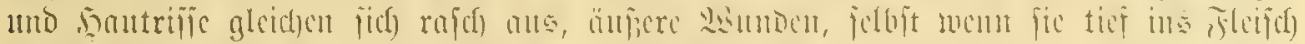

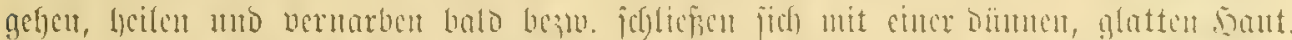

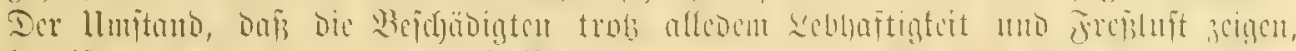

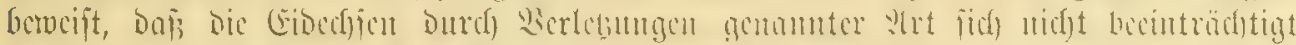

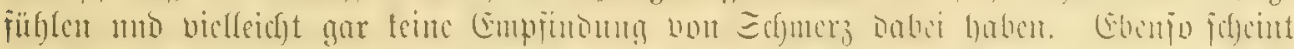

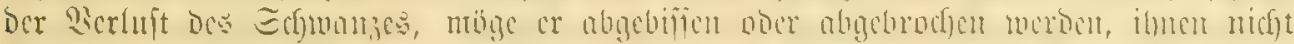

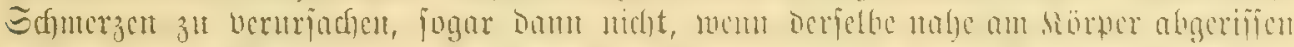

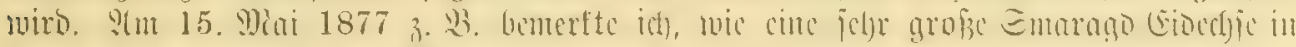

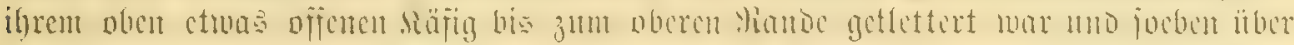

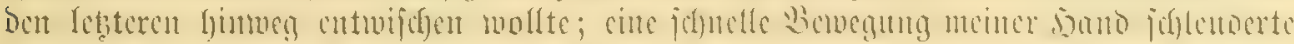

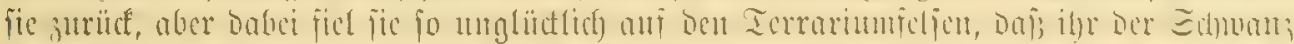

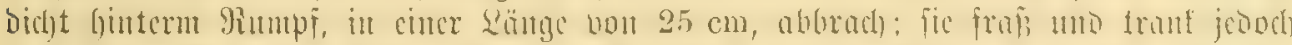

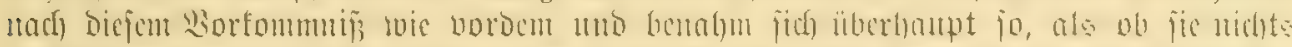

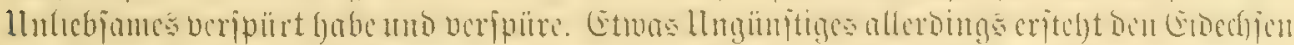

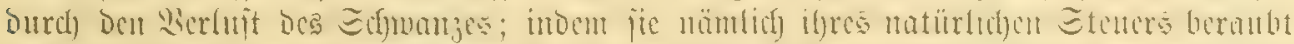

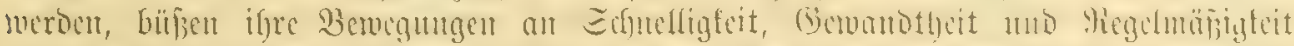

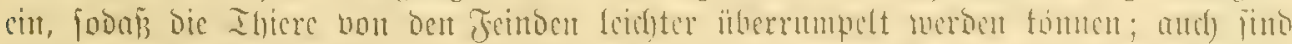

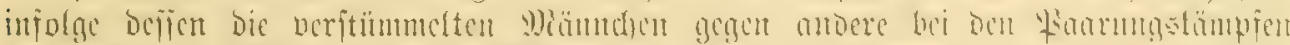

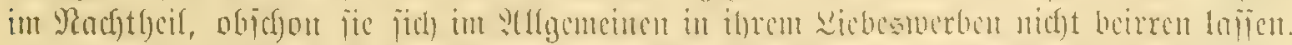

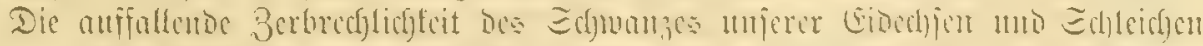

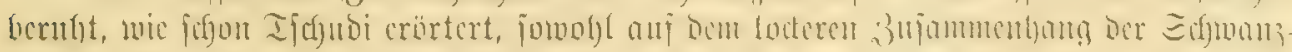

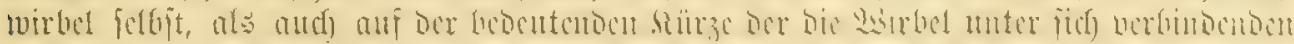

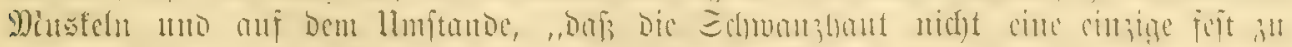

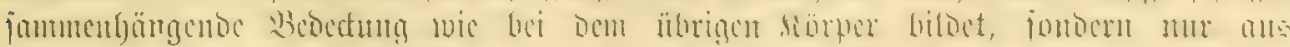

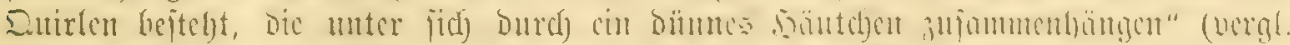

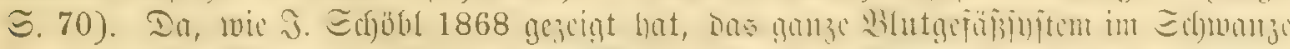

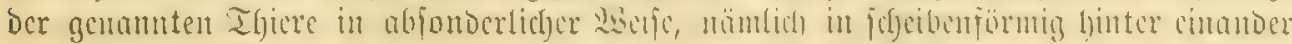

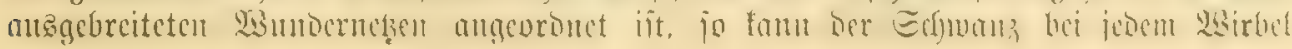




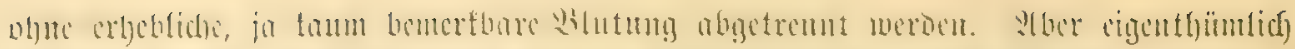

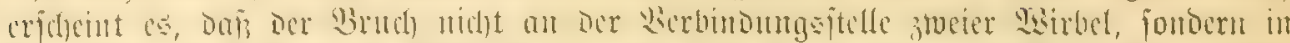

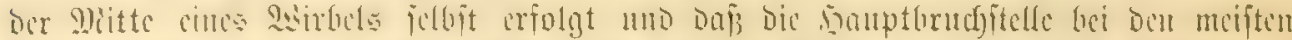

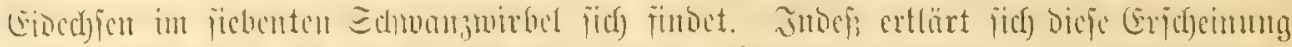

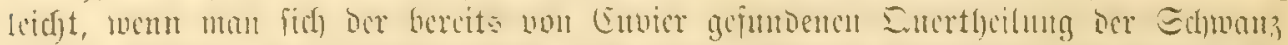

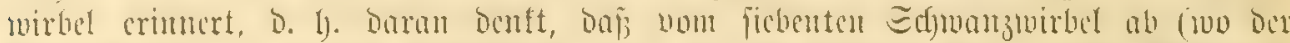

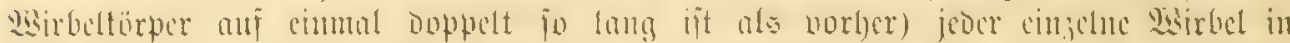

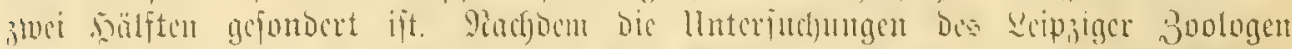

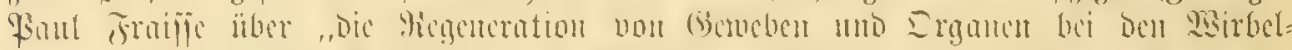

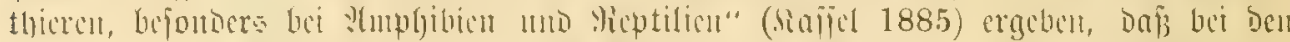

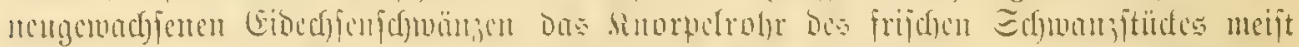

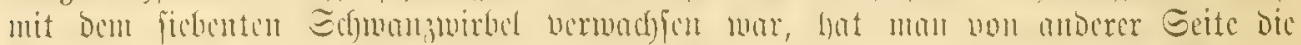

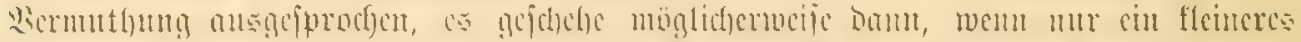

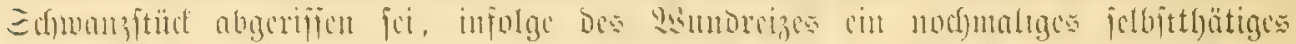

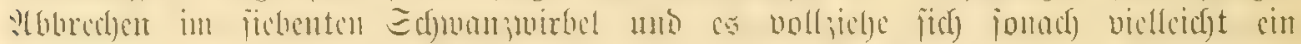

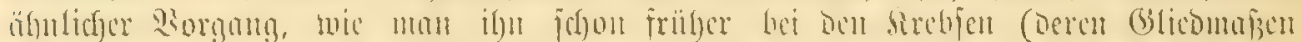

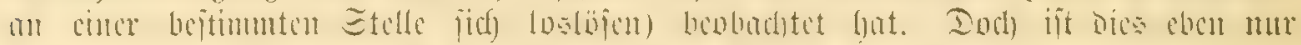

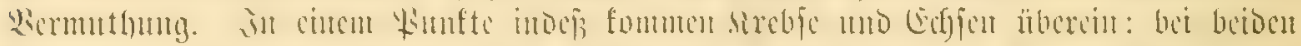

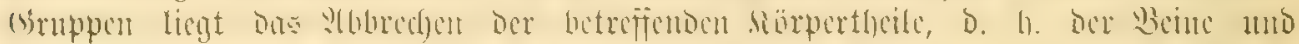

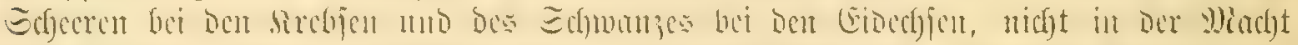

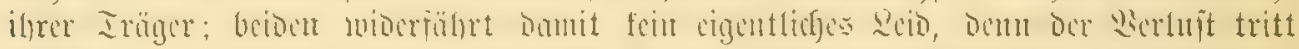

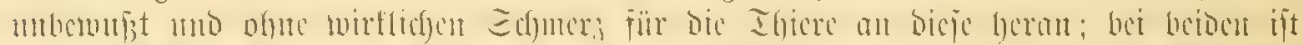

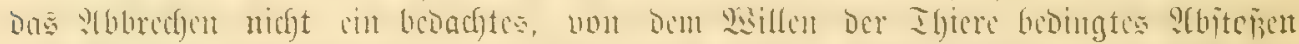

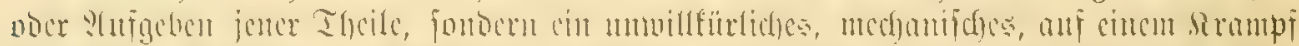

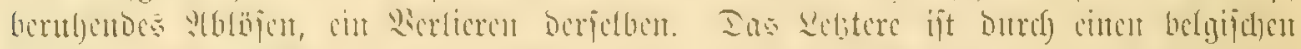

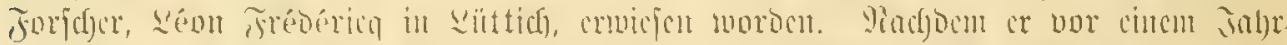

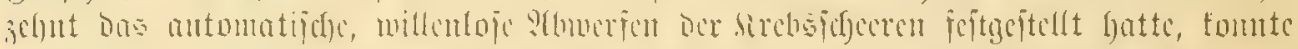

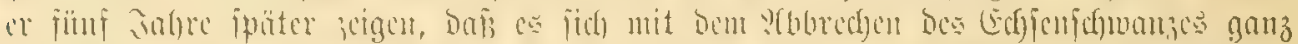

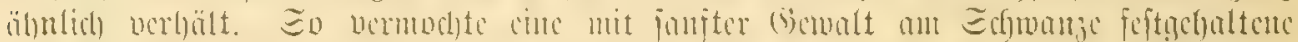

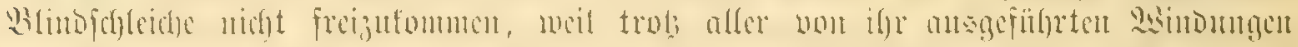

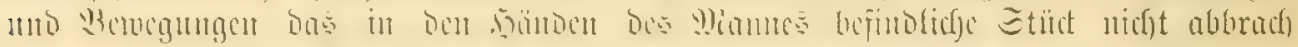

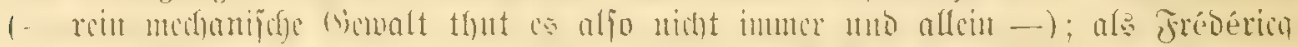

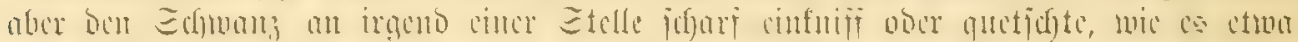

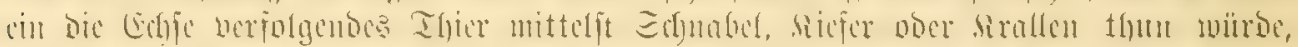

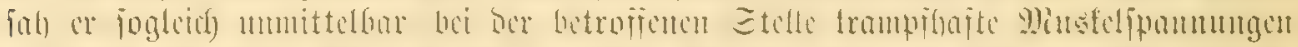

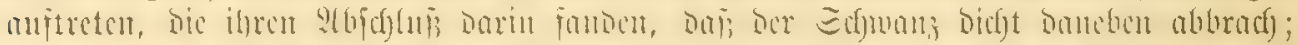

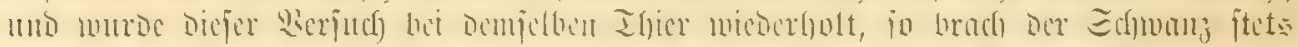

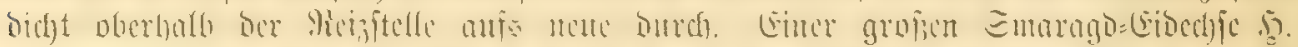

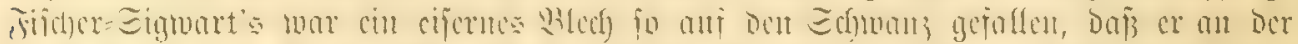

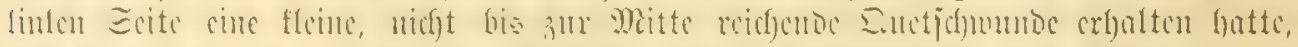

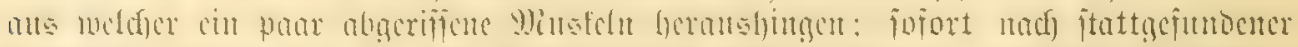

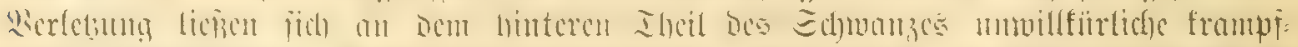

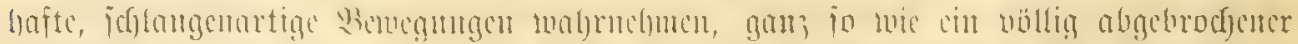

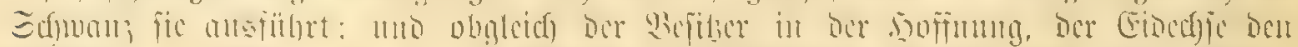

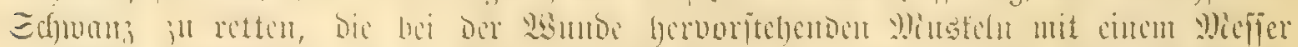

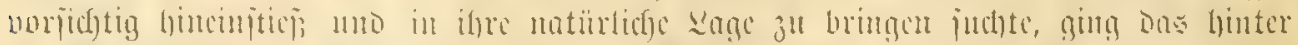

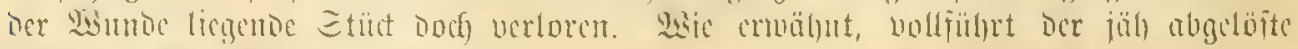

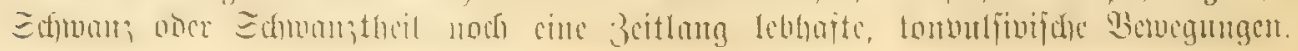




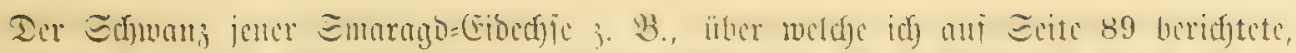

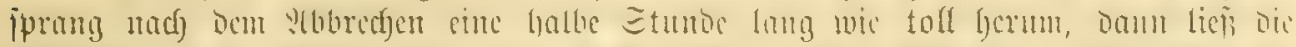

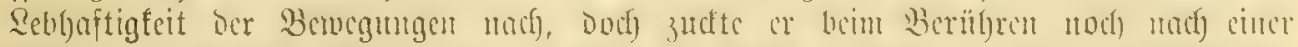

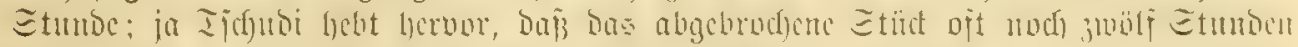

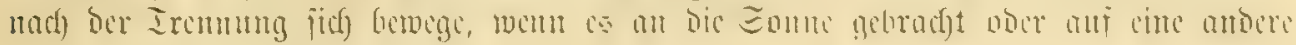
WScije "feitig afficirt" merbe.

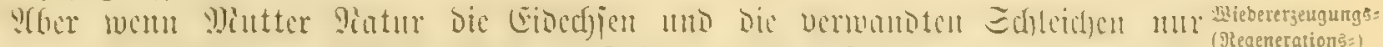

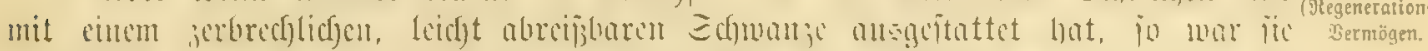

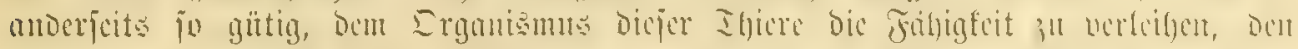

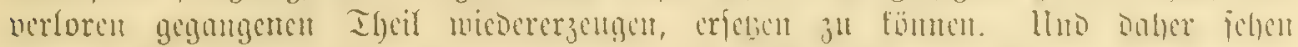

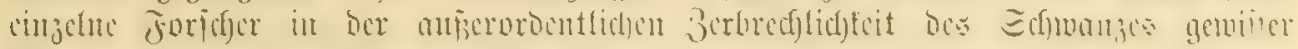

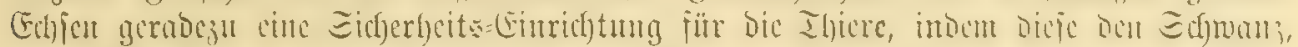

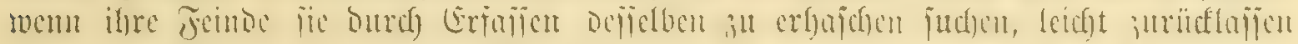

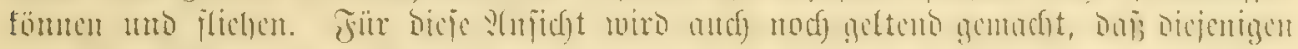

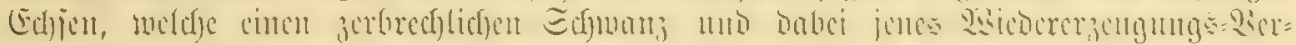

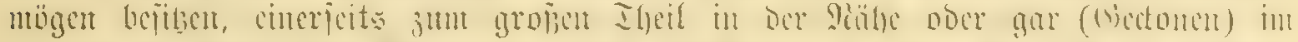

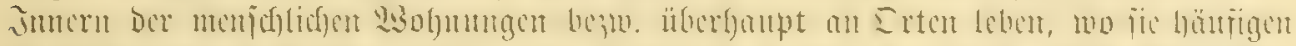

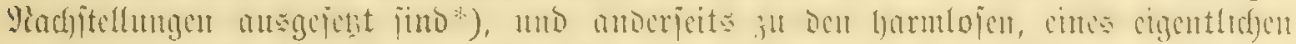

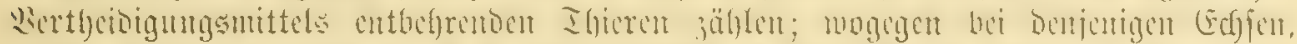

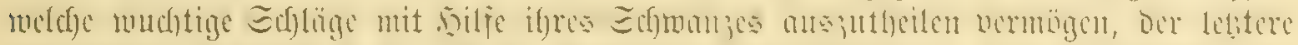

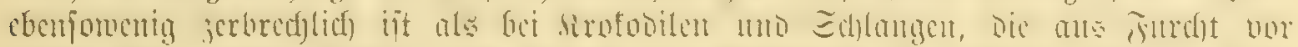

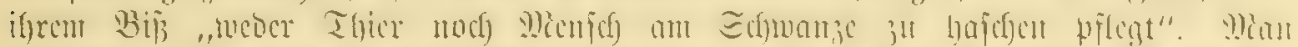

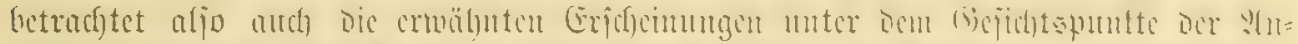

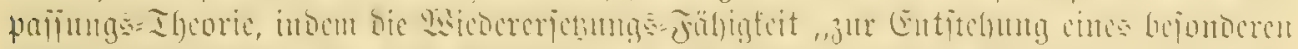

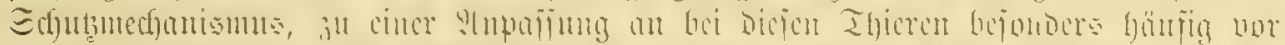

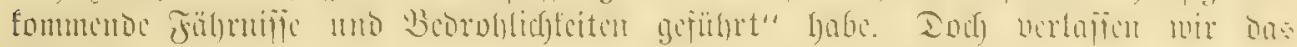
(Sicbict ber Theorien umb Ivenden tvir uns Den cinfachen Thatfachen 3u!

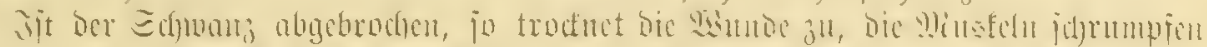

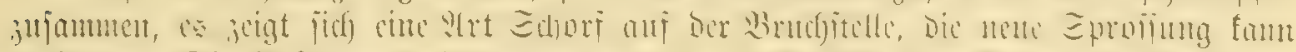

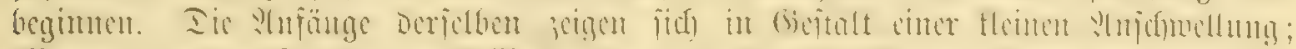
(Womet, welder Epallan;

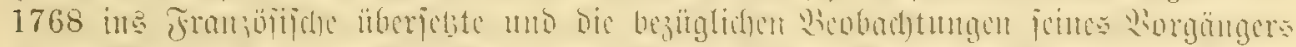

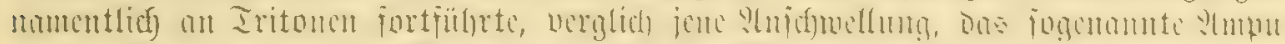
tations

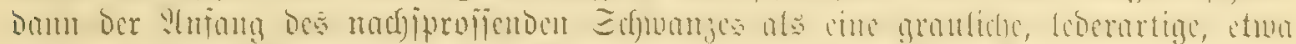

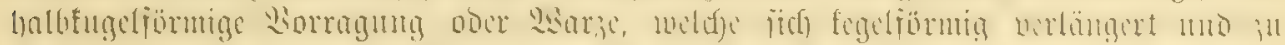

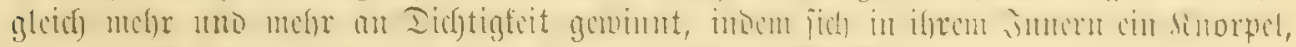

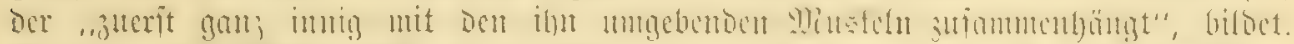

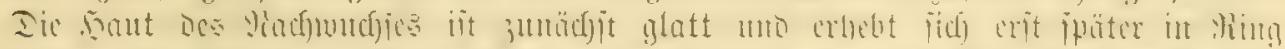

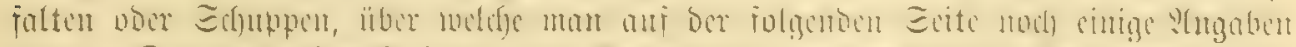

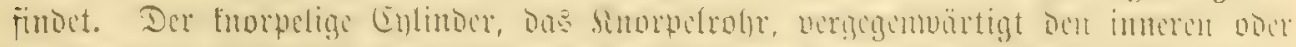

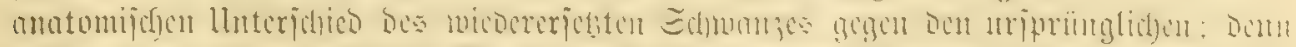

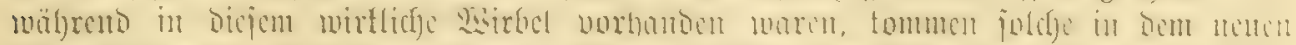

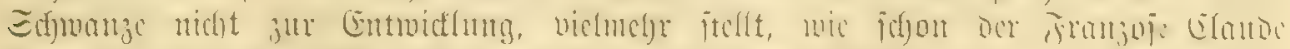

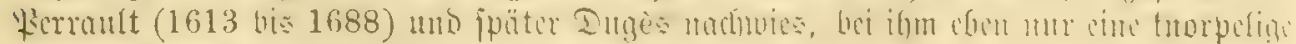

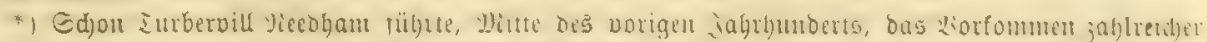

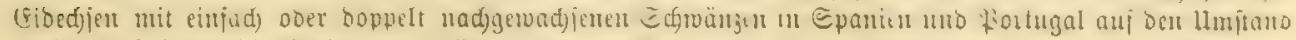

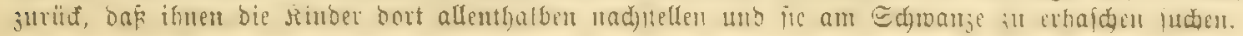




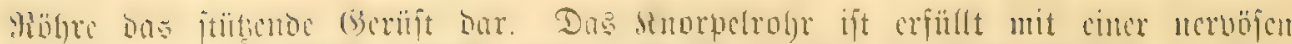

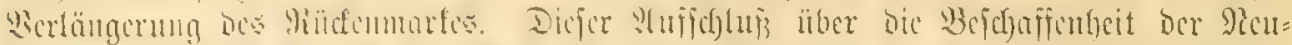

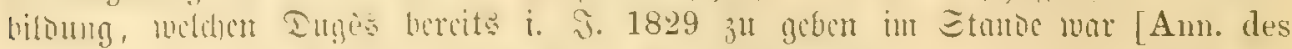

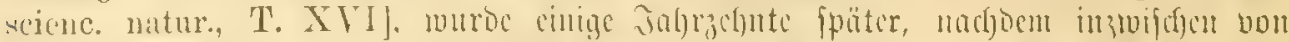

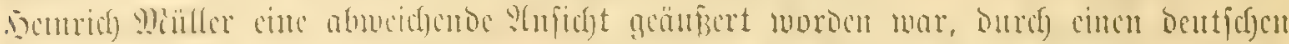

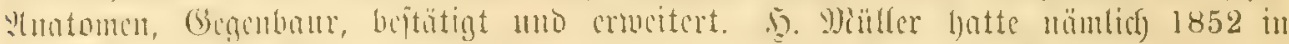
ben Wïr;

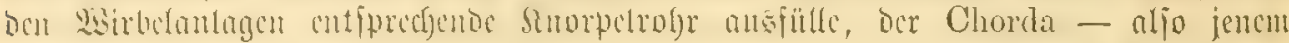

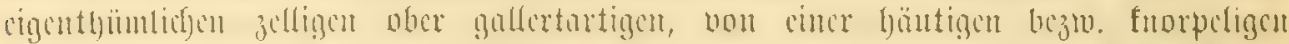

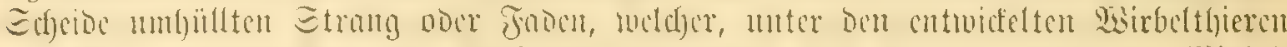

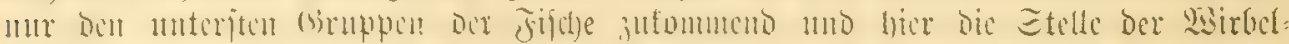

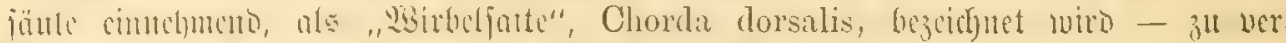

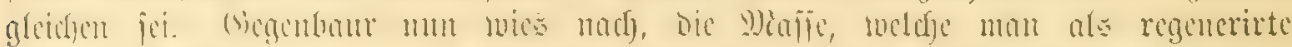

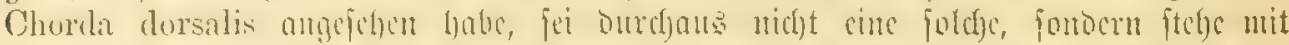

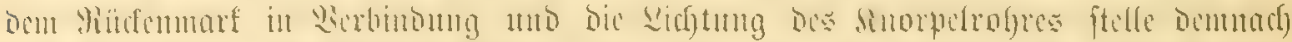

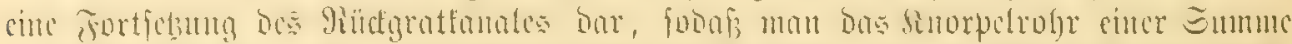

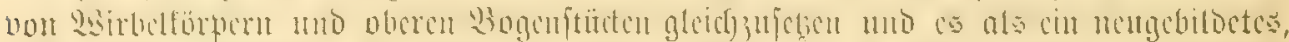

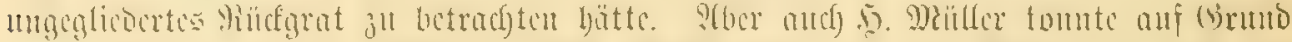

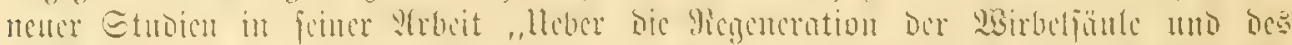

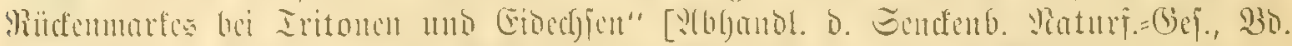

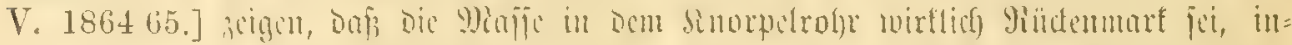

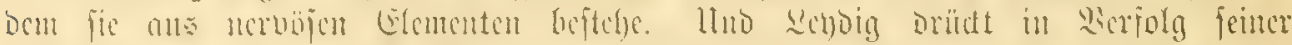

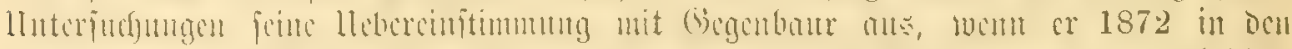

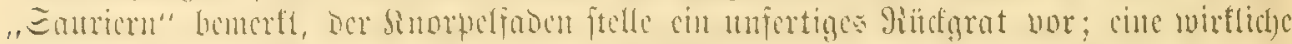

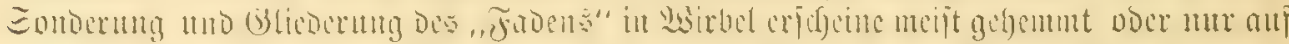

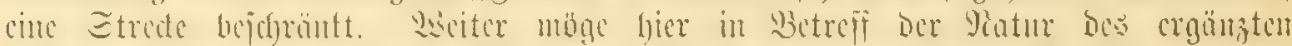

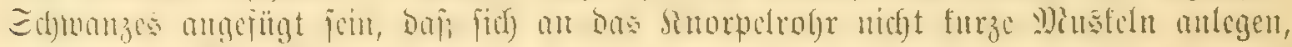

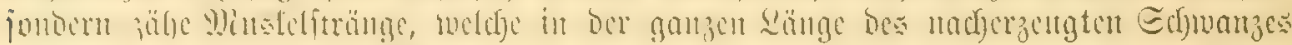

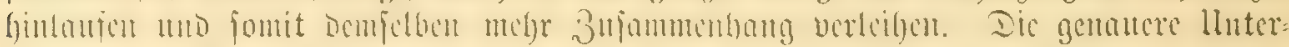

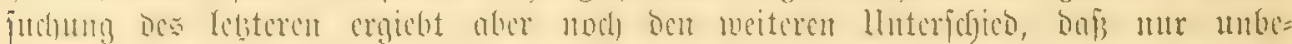

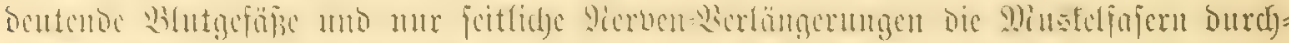

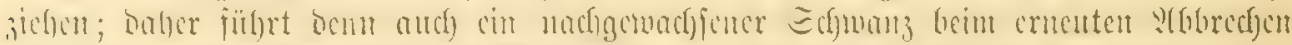

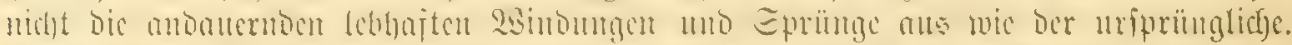

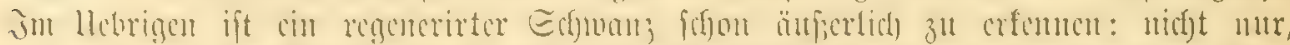

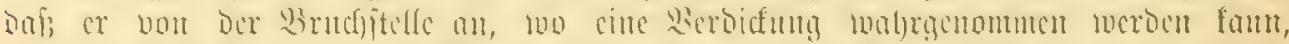

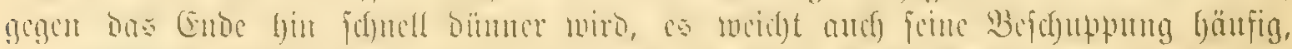

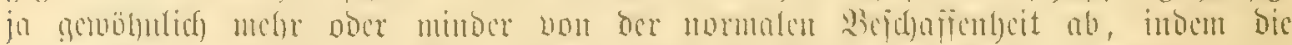

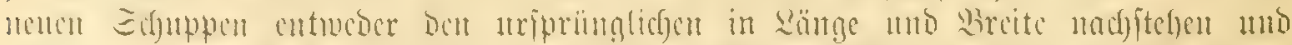

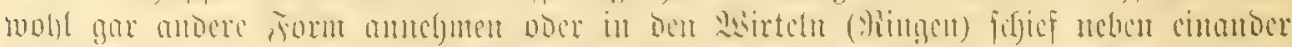

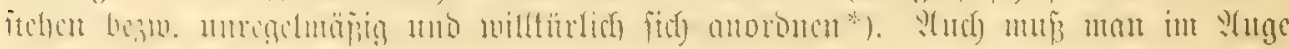

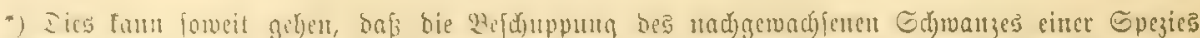

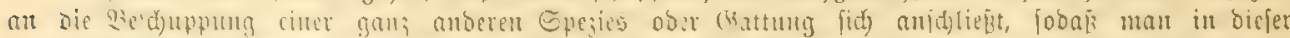

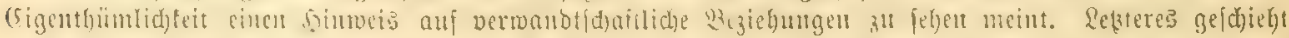

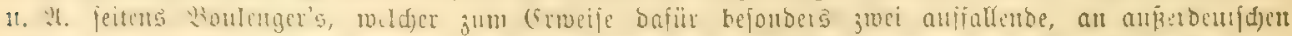

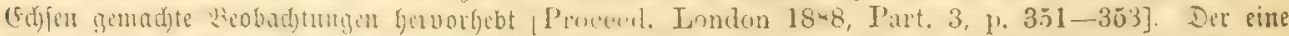

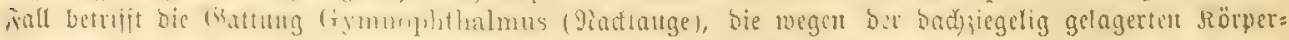

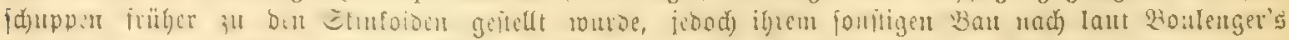

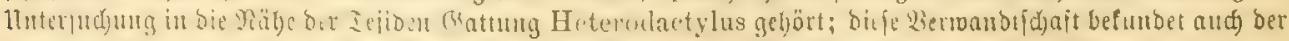

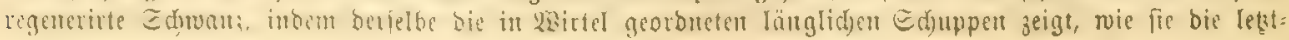




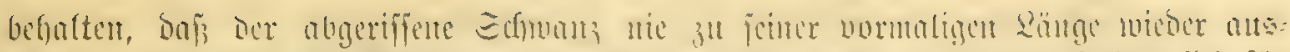

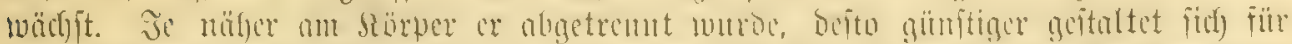

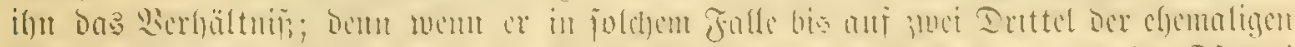

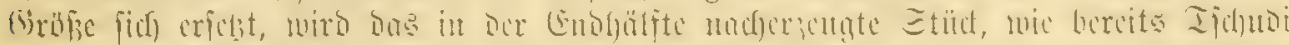

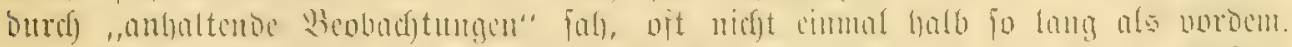

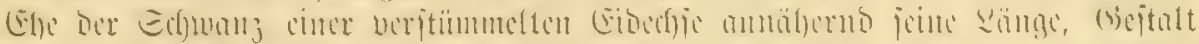

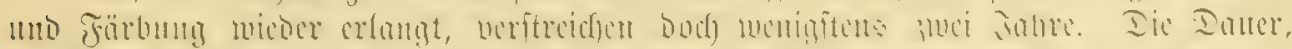

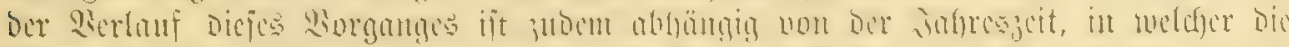

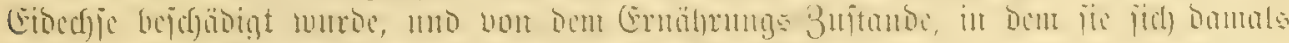

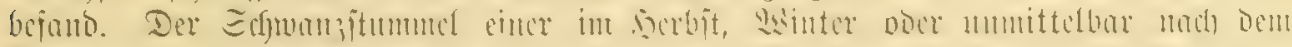

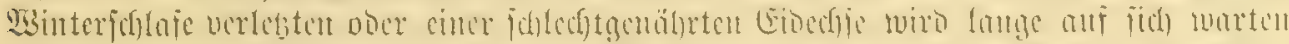

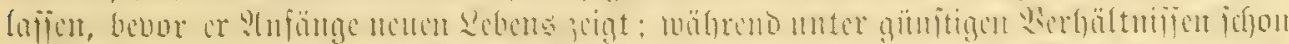

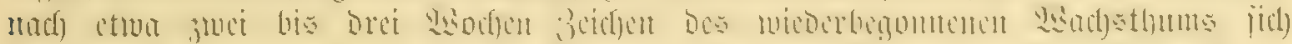

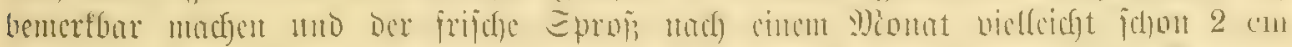

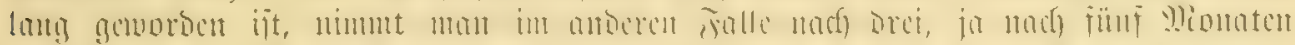

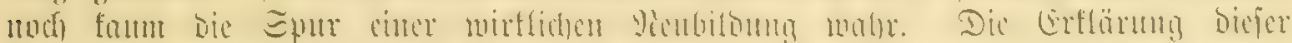

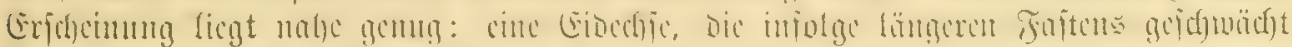

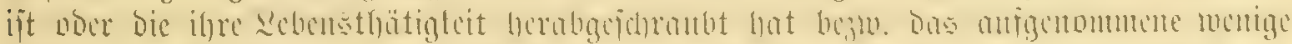

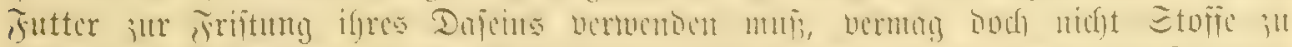

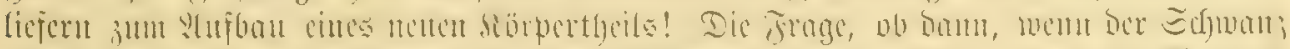
g) ö

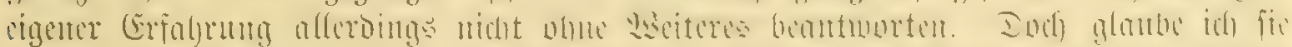

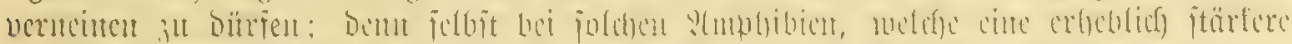

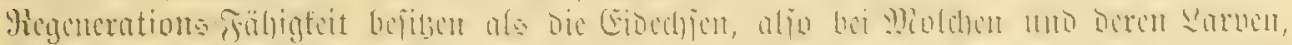

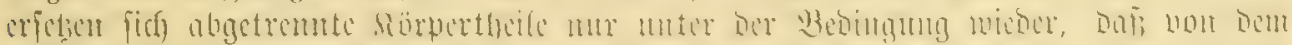

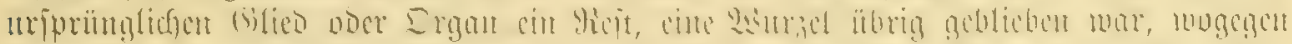

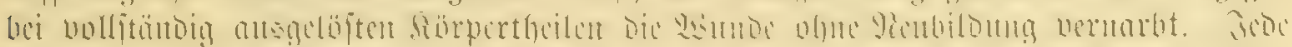

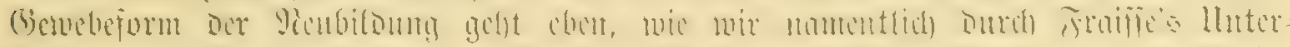

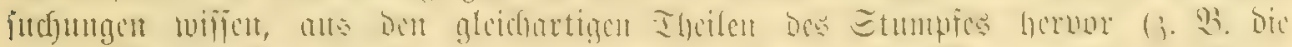

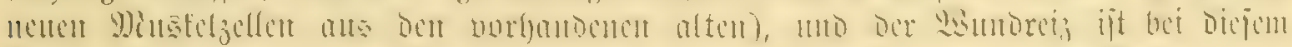

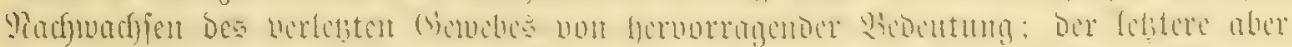

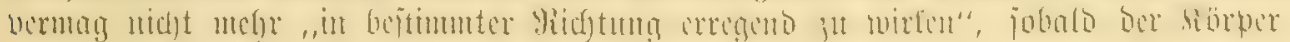
theil bout Giruno aus bejeitigt twurbe, und ber Erjats unterbleibt bafjer.

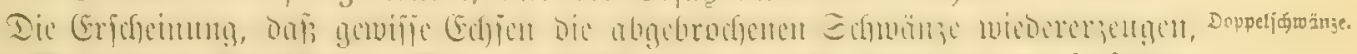

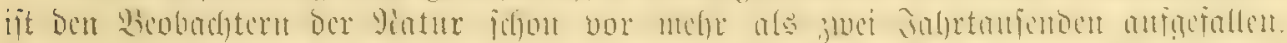

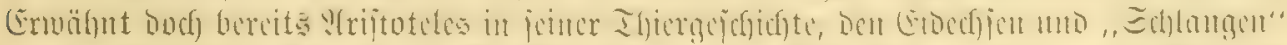

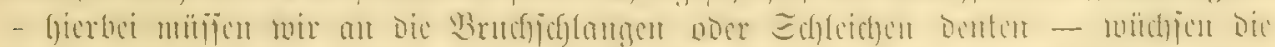

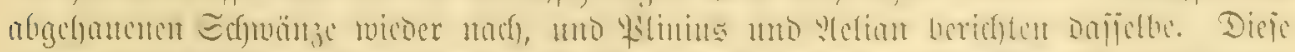

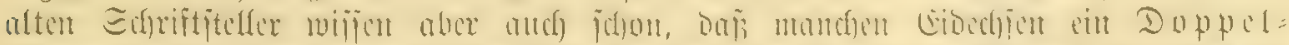

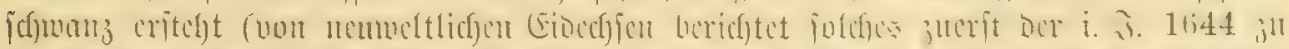

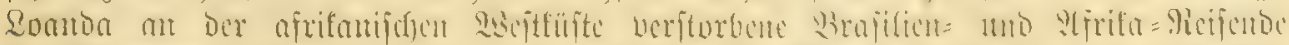

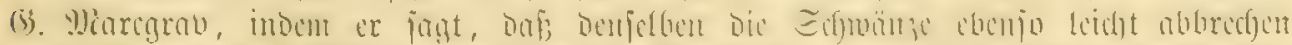

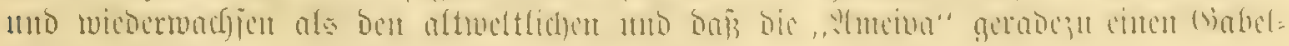

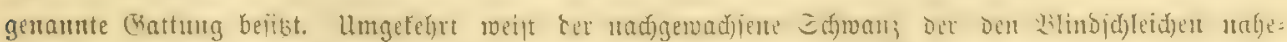

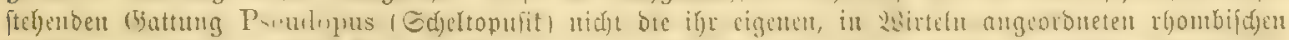

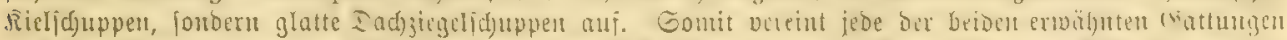

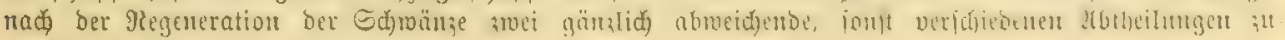
fommenbe formen ber Beiduppung. 


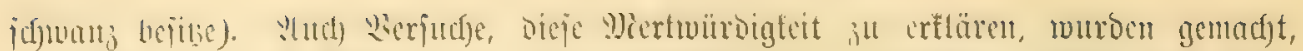

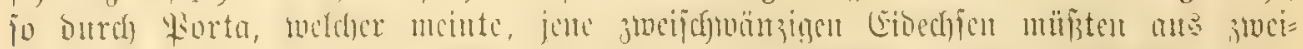

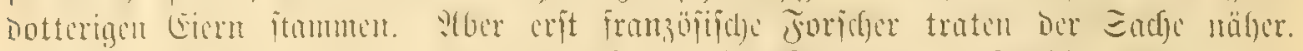

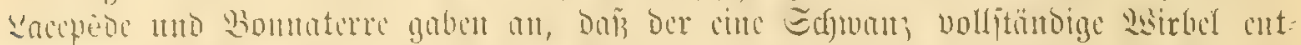

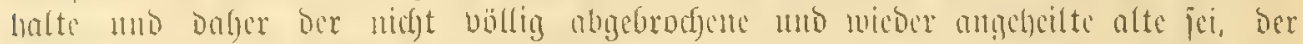

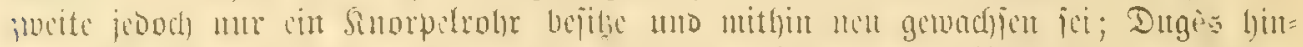

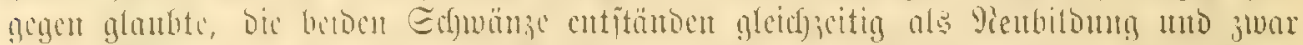

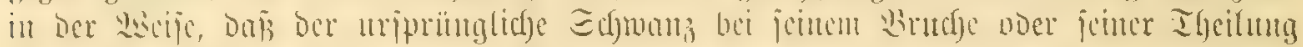

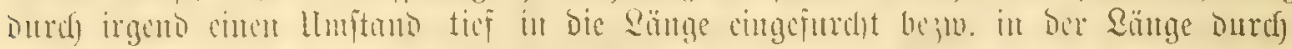

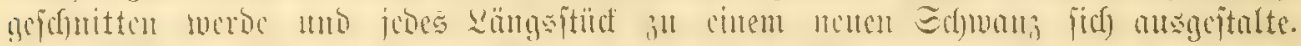

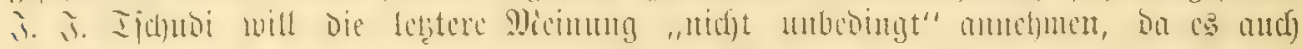

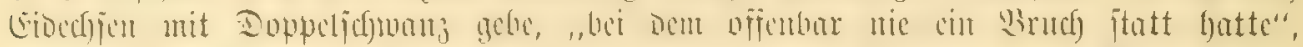

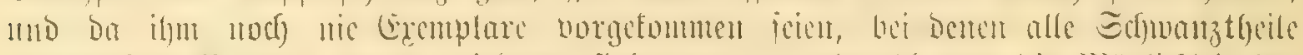

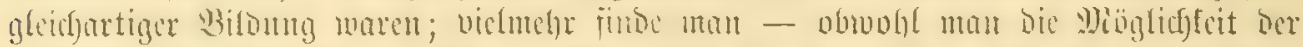

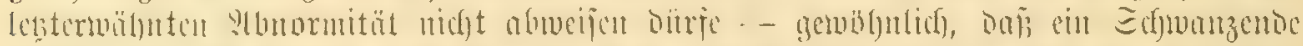

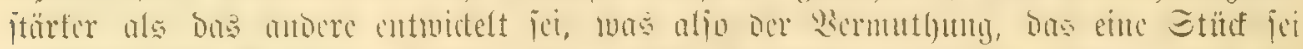

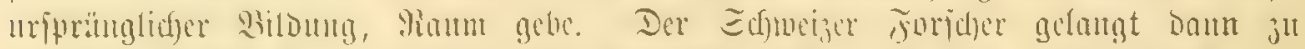

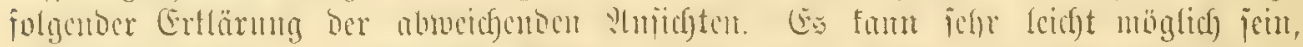

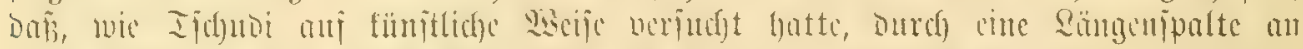

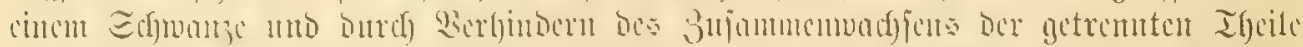

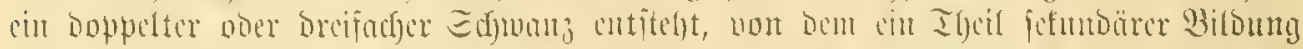

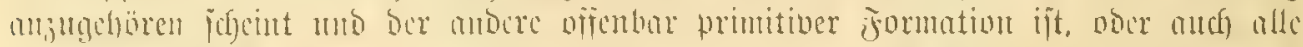

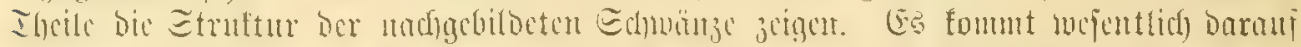

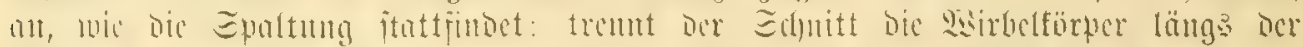

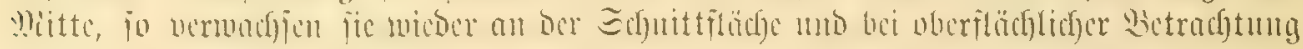

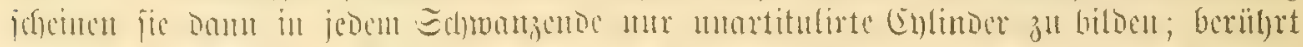

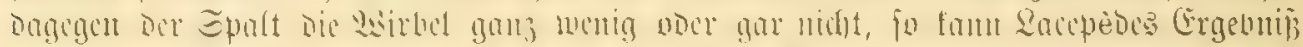

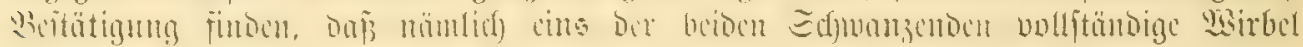

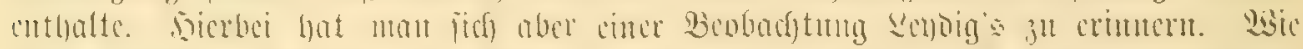

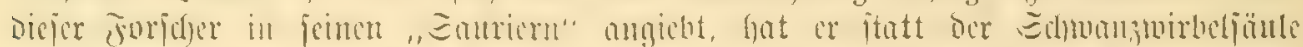

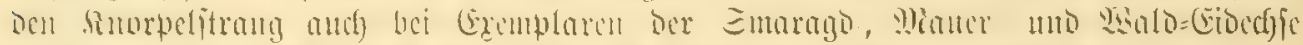

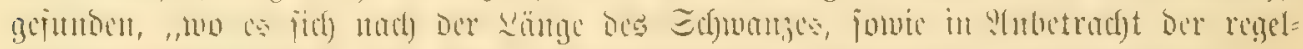

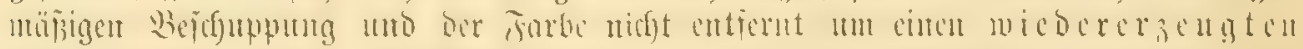

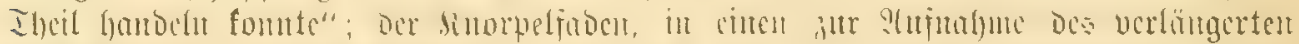

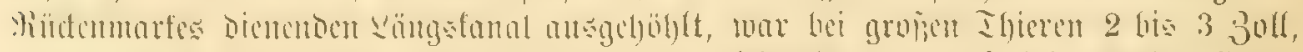

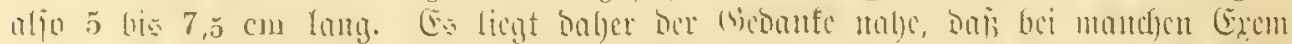

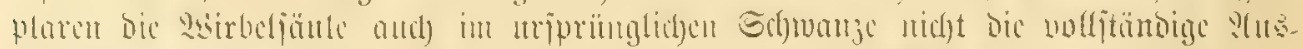

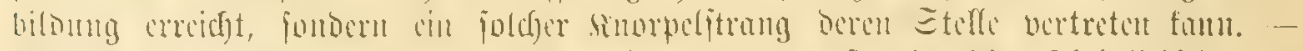

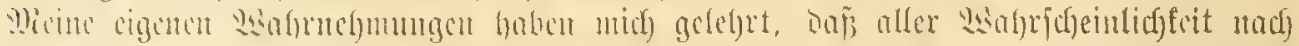

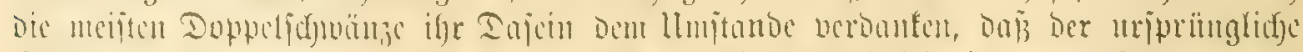

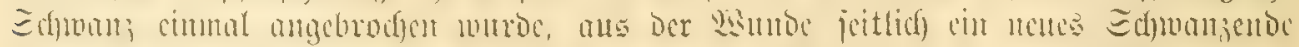

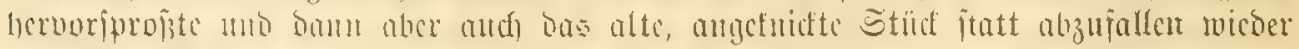

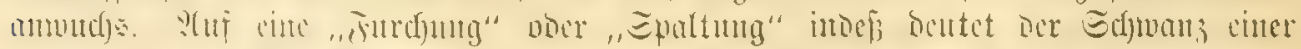

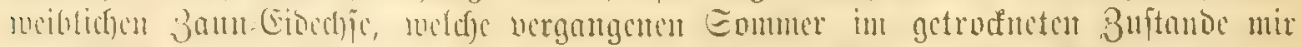

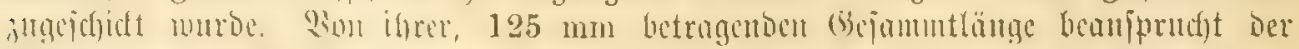

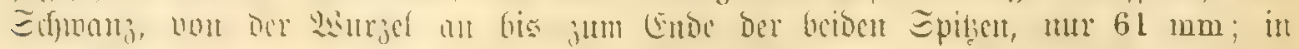

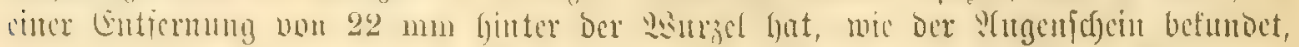

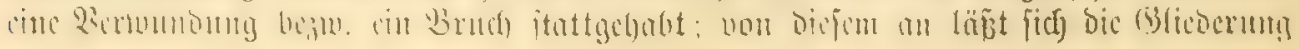




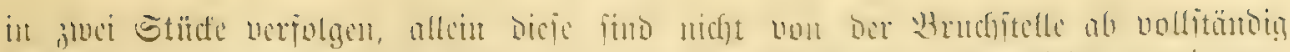

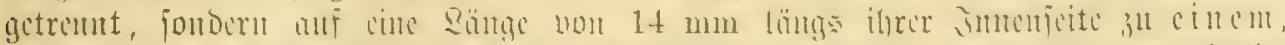

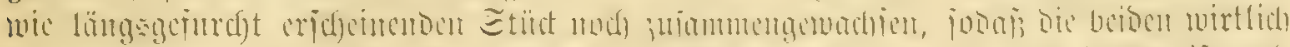

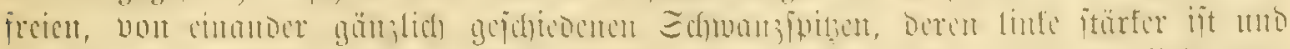

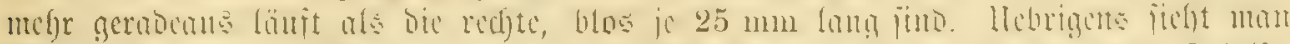

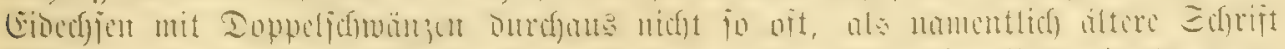

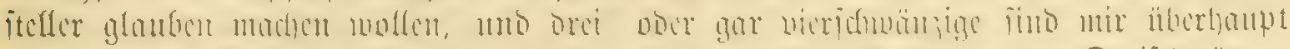

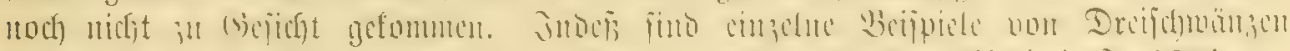

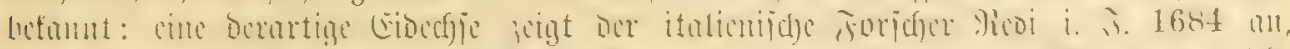

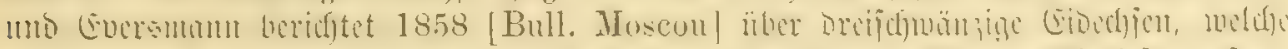

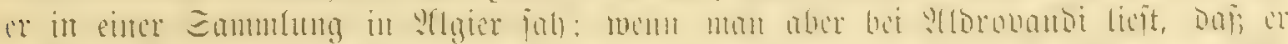

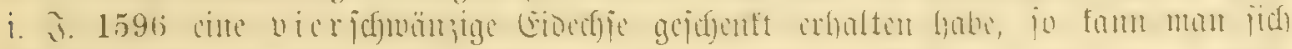

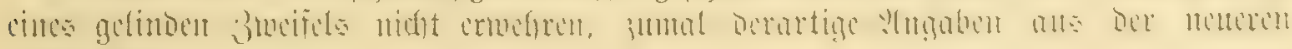
Beit feglet.*)

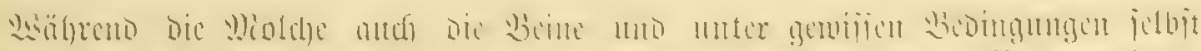
liadjuadifer ber seine:

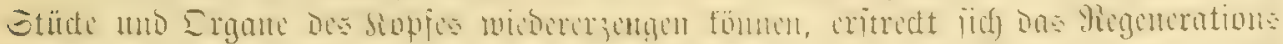

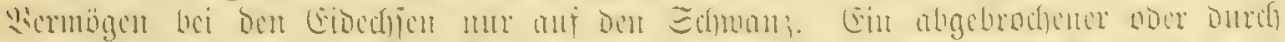

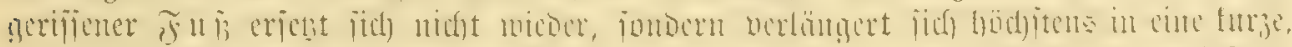

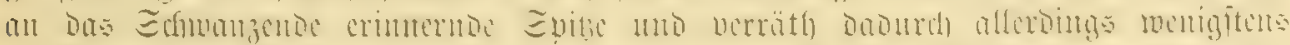

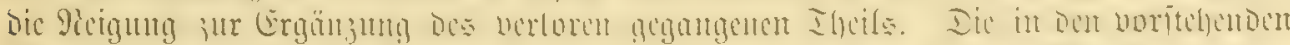

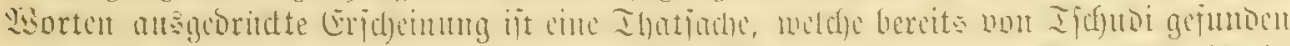

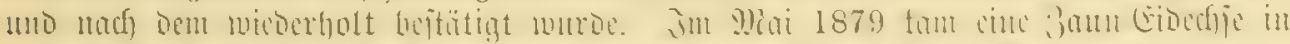

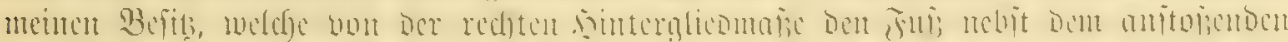

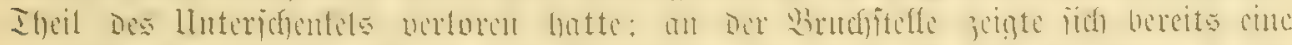

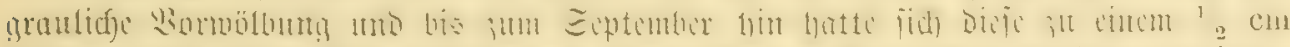

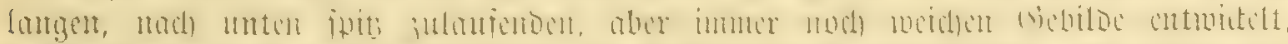

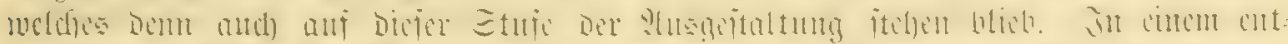

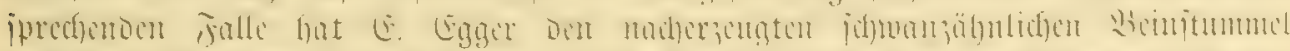

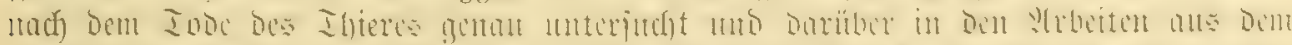

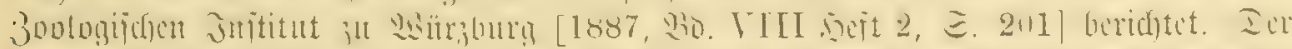

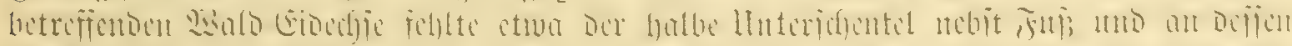

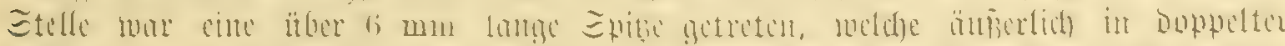

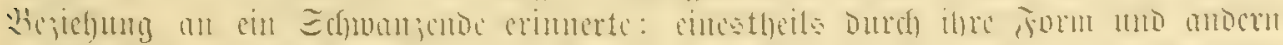

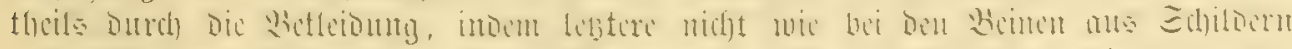

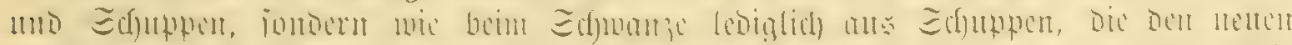

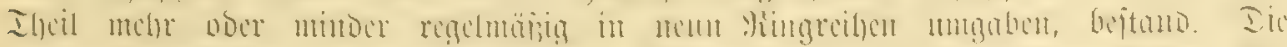

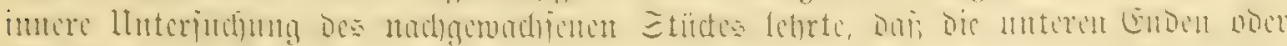

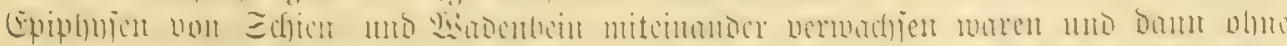

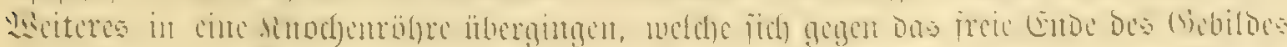

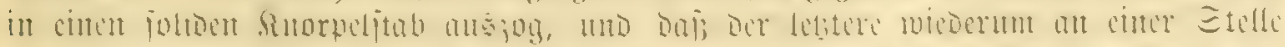

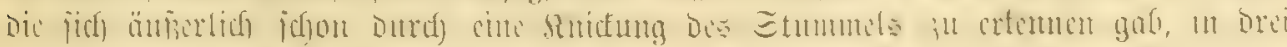

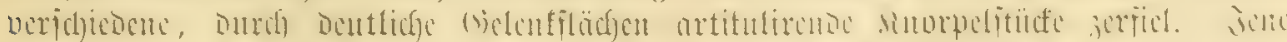

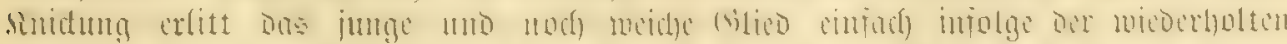

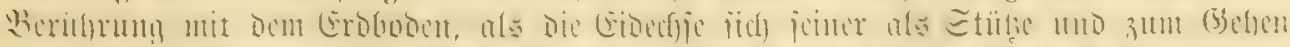

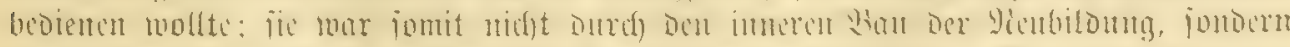

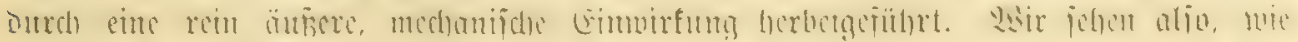

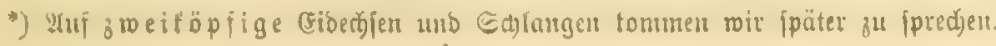




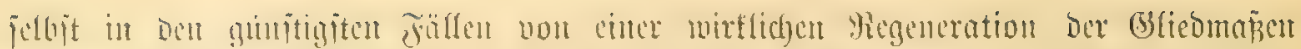

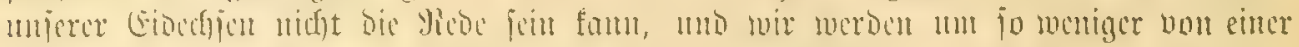

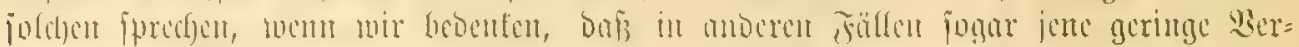

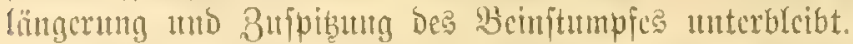

(5mpinblidjecit (Yifte).

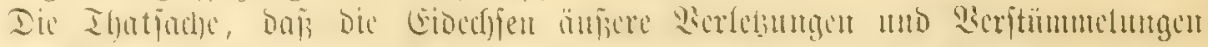

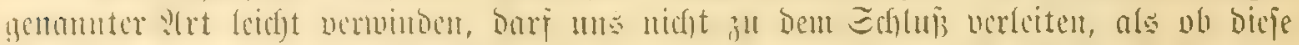

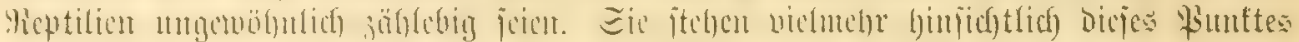

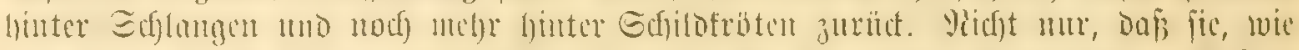

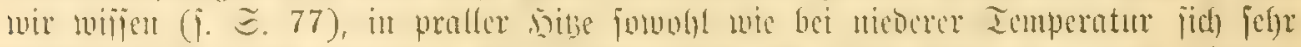

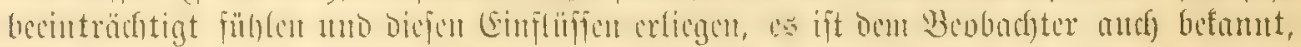

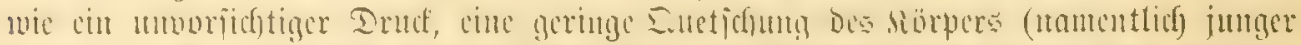

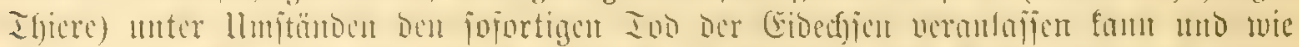

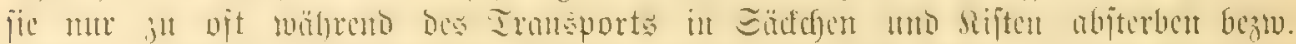

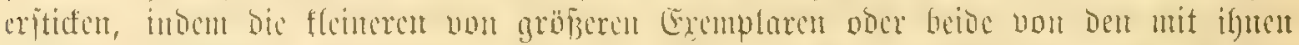

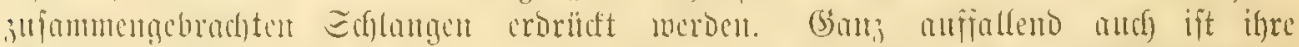

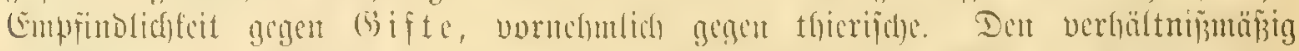

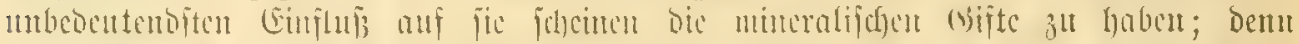

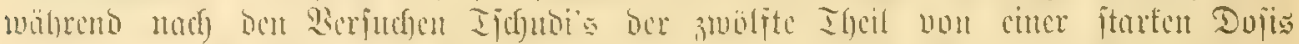

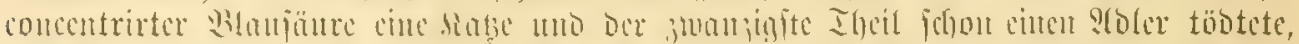

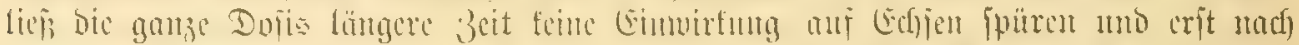

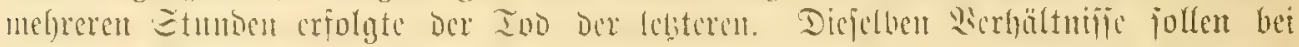

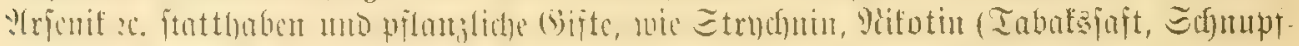

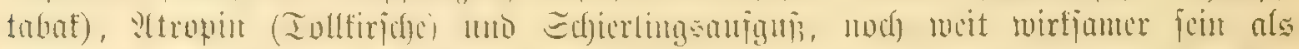

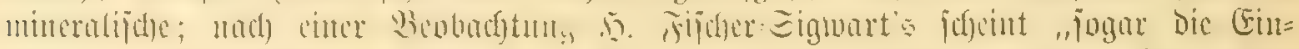

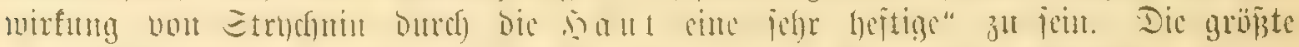

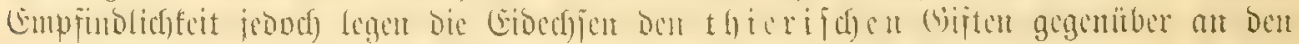

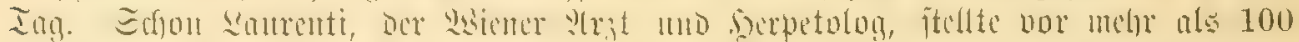

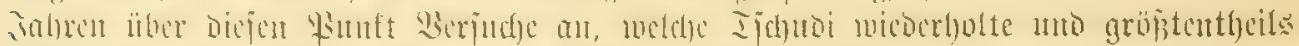

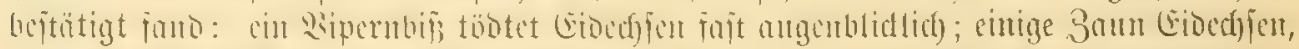

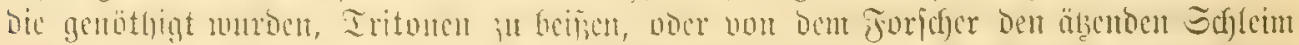

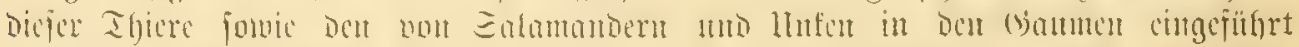

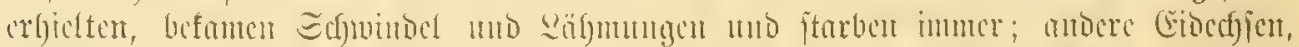

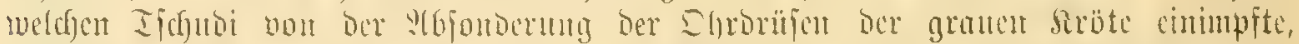

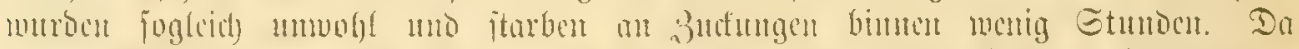

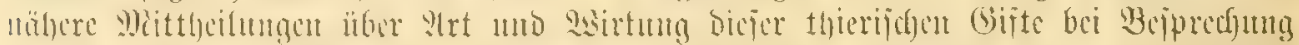

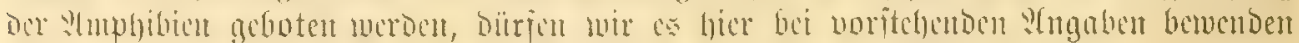

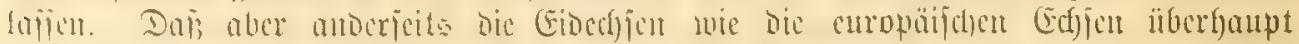

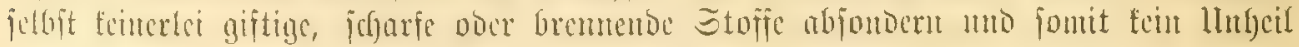
auzurichten nermögen, fam nicht oft genug betont werben.

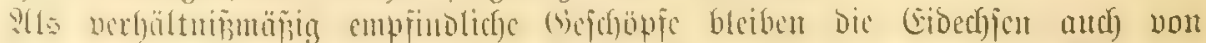

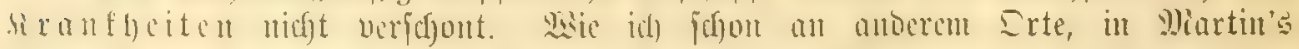

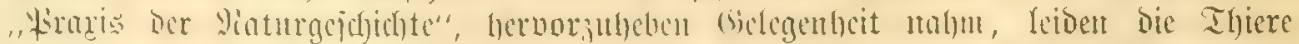

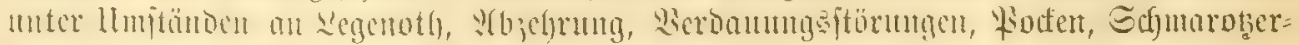

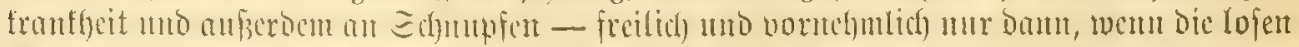

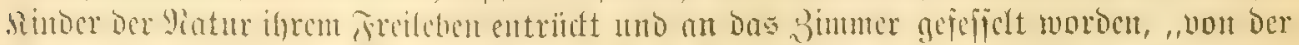

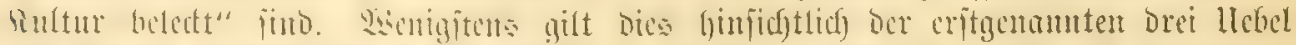

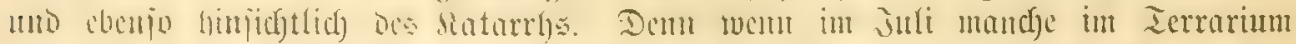

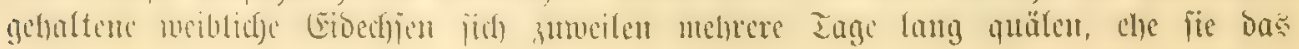


legereife (Ei herausbringen, unto wemt bies ifnen mitunter überbaupt nidjt gelingt, jo liegt bem llebclitunde cine Edfwädje ber Ifiere zแt Girmbe, weldje in ber Regel als

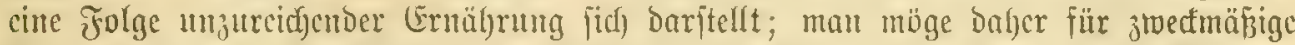

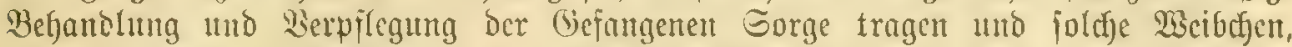

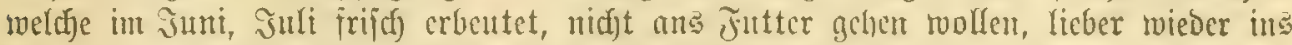

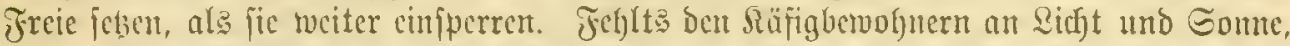

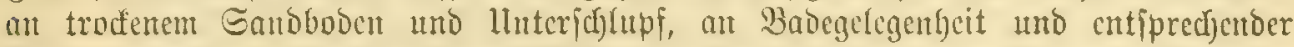

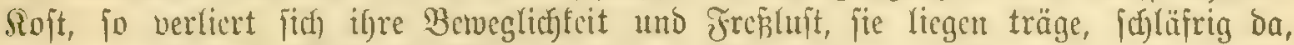

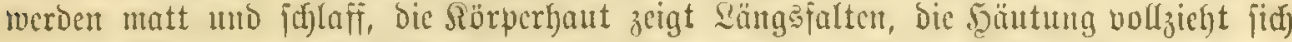

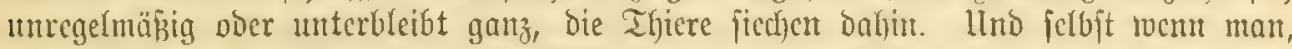
um biejelben noch ju retten, Den Befö̈lter an cinten bellen, fonnigen Ert bringen wollte, man wiurbe, jubald jiff) bic veroächtigen Falten cimmal gebiloct haben, ben

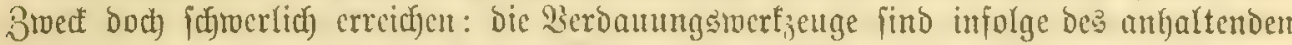

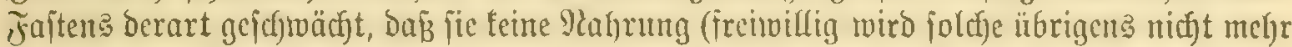
anfgenonmen) mehr zu verbauen im Stande jind - bie Eidectfen fterben an $\mathfrak{a} b=$ zebrung uno Entträftung. Rad) Bebriaga's (Erfafyrung fumt fid) aber auth bas

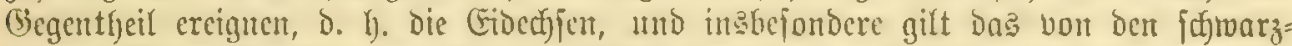
blauen Miauer=(Fibedj]en ber Faraglioniblöde, verzel)ren rafdh hinter einander unmäfig

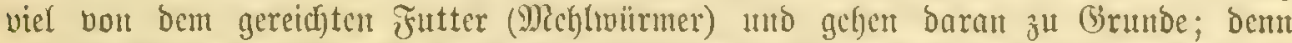

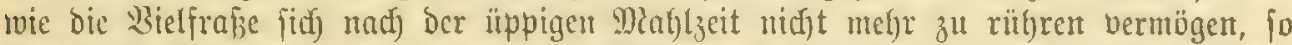

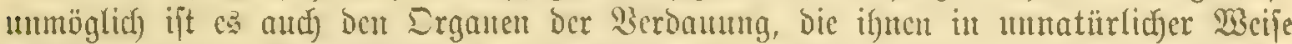

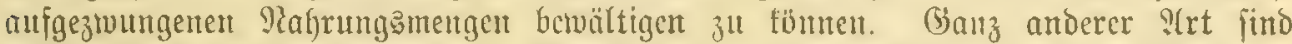

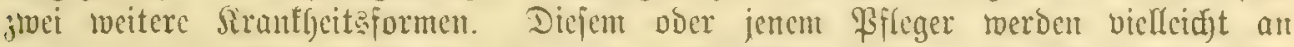

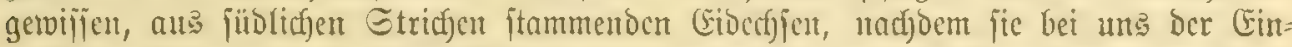

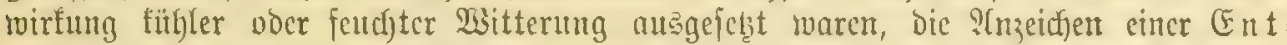

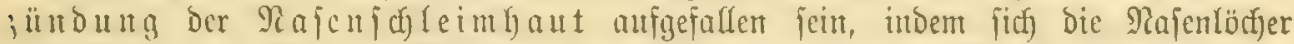

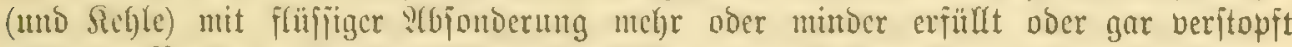

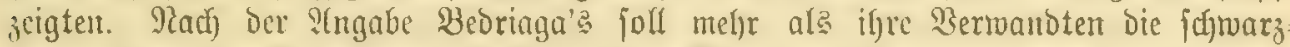

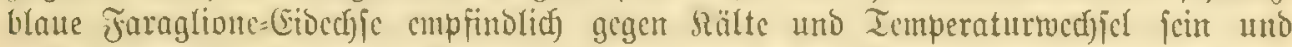

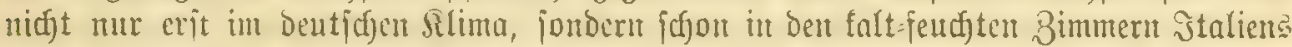

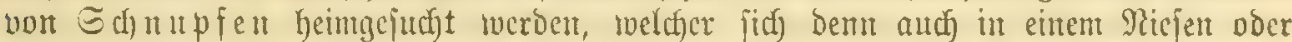

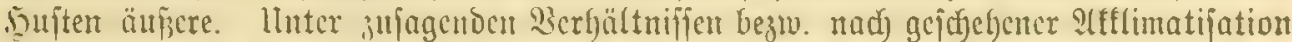

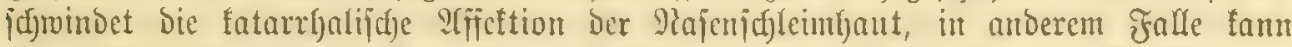

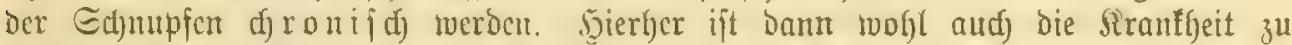

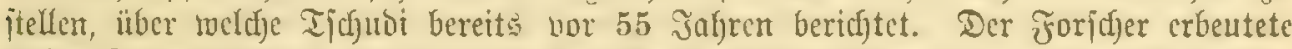

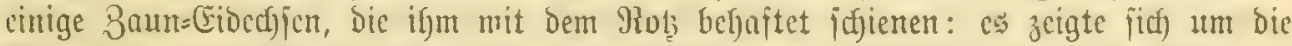

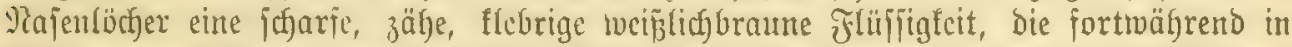

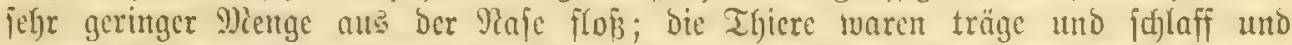

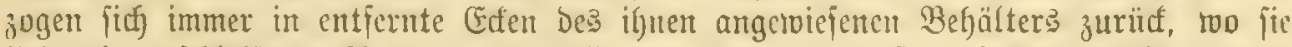

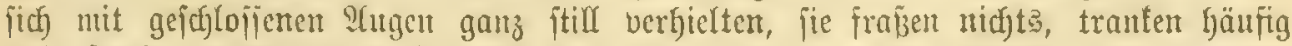

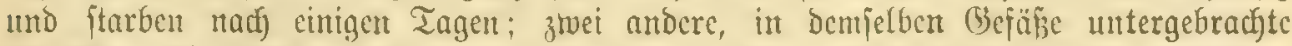
Cidecffen, Dic früfer ganz munter warcu, svurben offenbar bon ben Ginzugcjesten Sranten angeitedt, Denn fie gingen in turzer Beit am gleidjen Hebel ein; bie von Dem Seiden befallenen, namentlid) aber bie bemjelben crlegenen Stüde verbreitcten

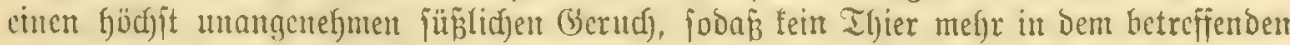

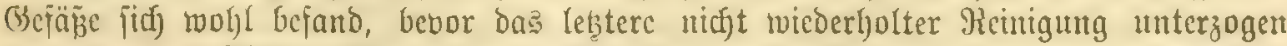
lworbent loar. Tldjudi fdjeint in ber Bejdjaffentyeit bes Slufentyaltes jencr gejammelten

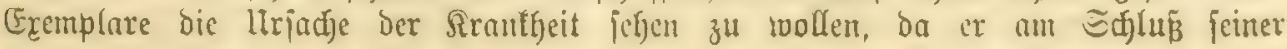




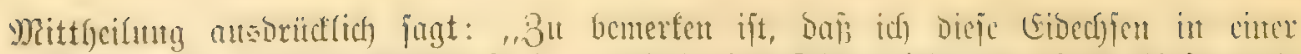

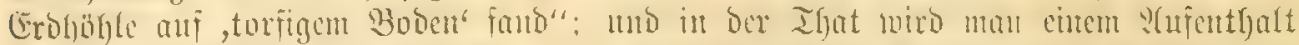

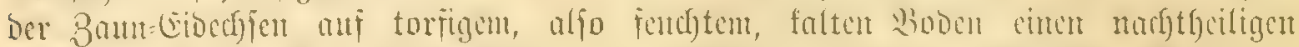

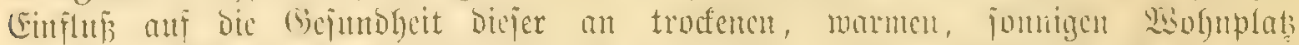

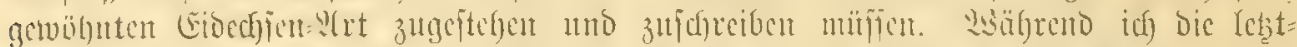

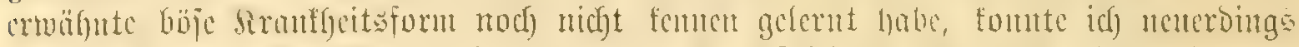

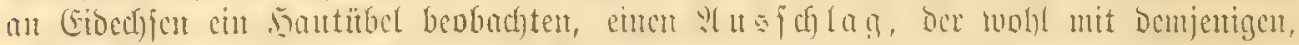

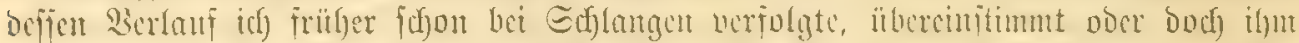

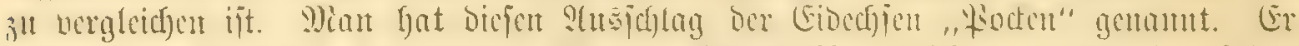

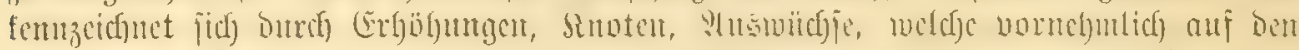

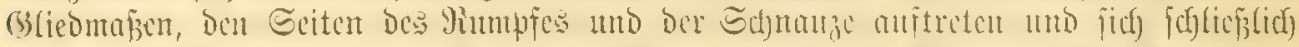

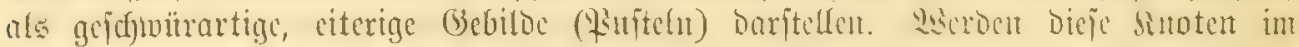

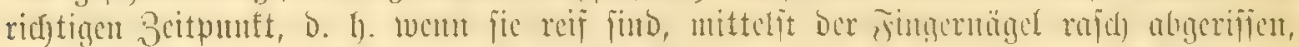

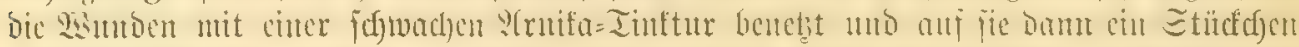

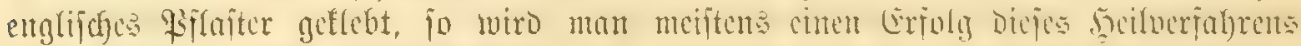

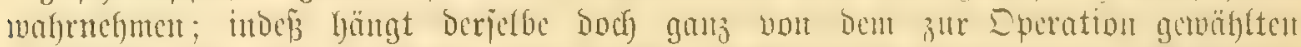

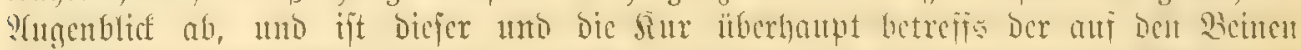

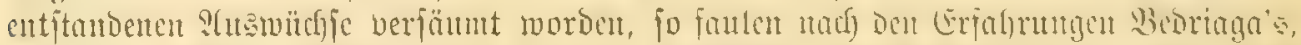

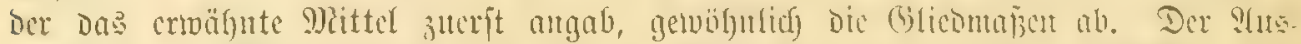

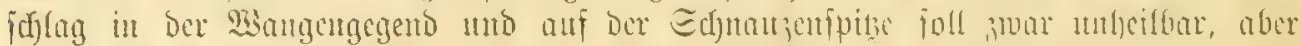

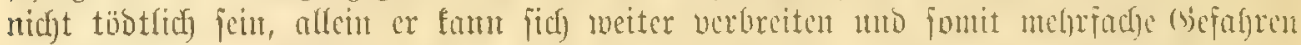

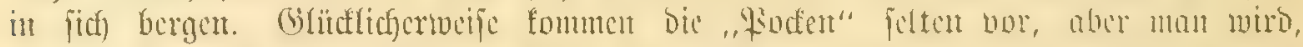

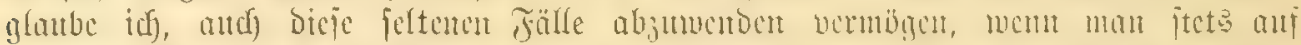

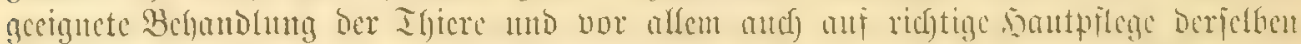

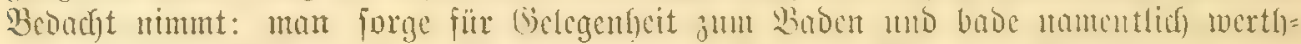

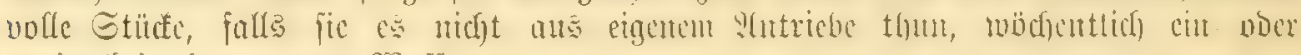
J̧tucimal in lautwarmem $13 a f f e r$.

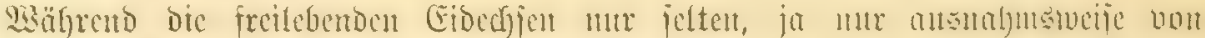

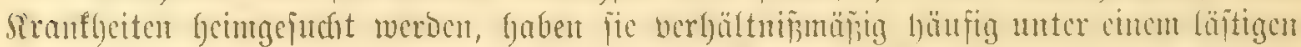

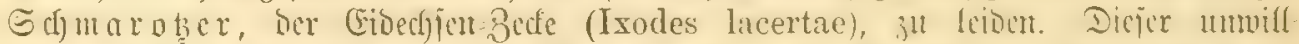

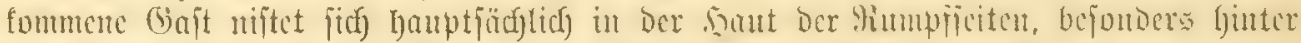

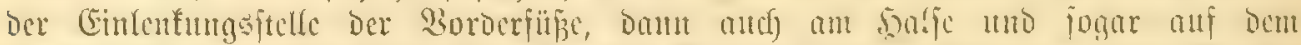

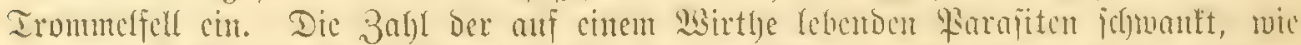

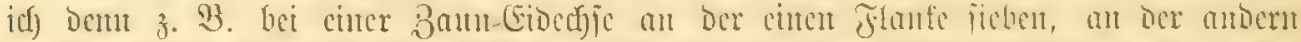

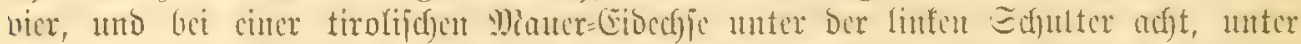

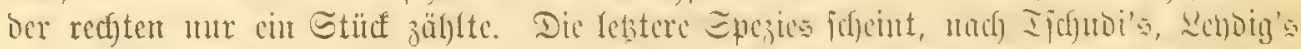

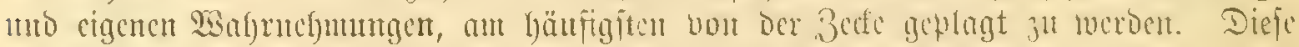

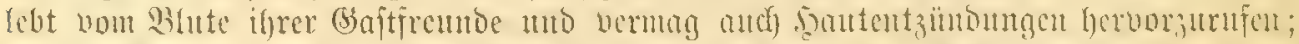

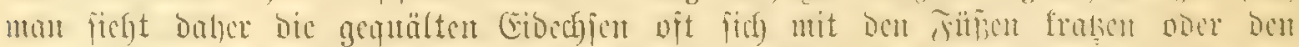

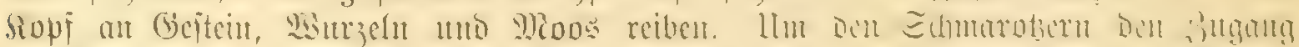

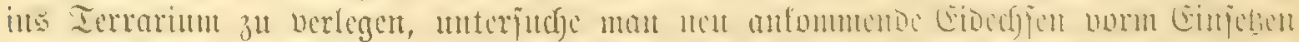

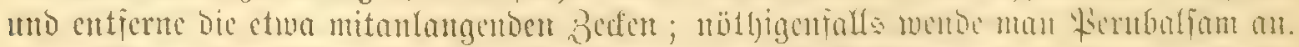

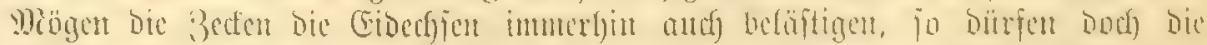

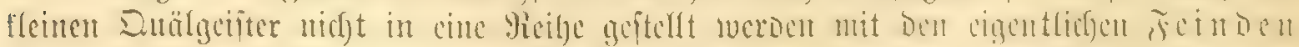

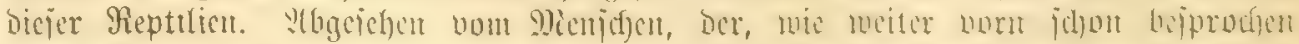

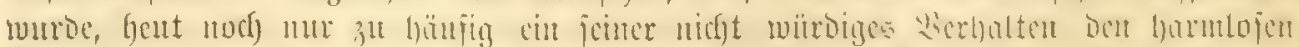

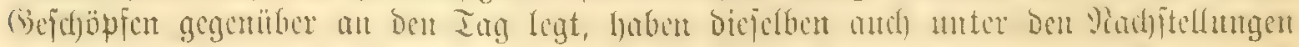

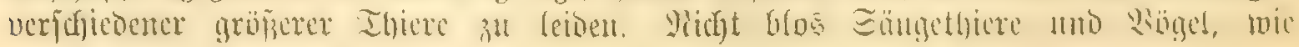




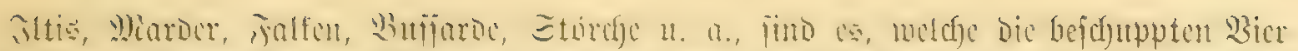

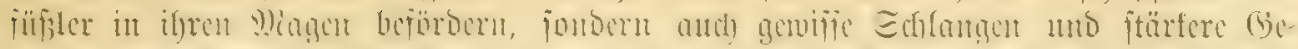

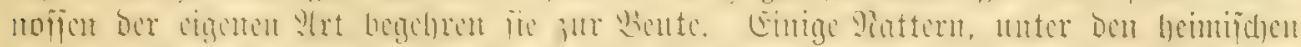

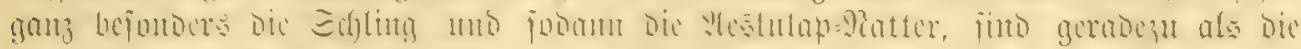

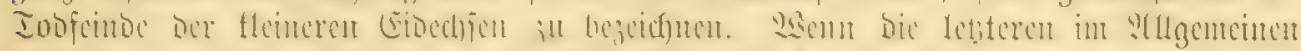

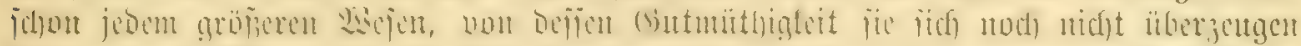

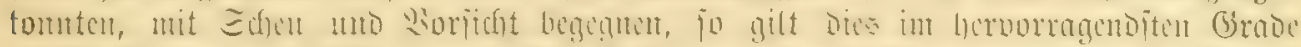

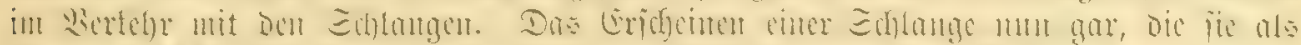

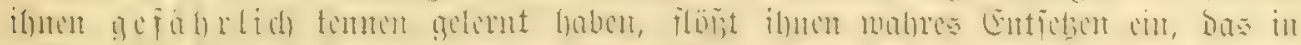

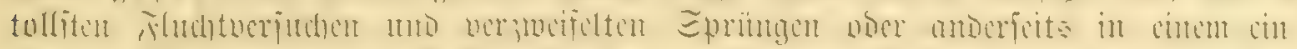

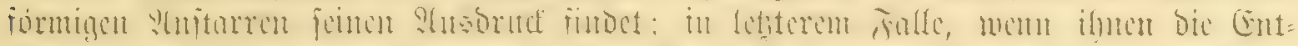

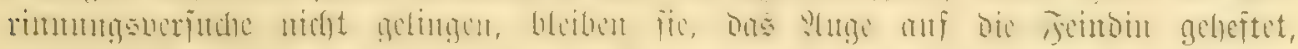

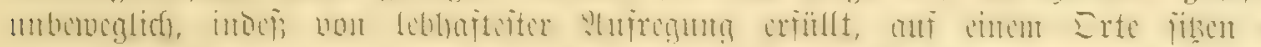

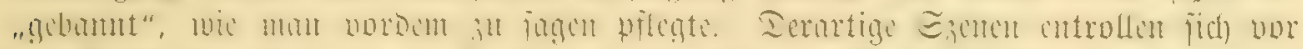

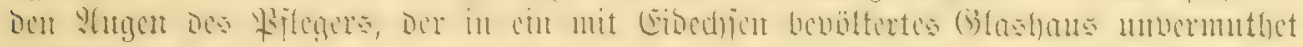

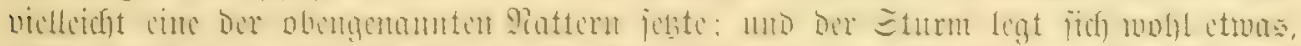

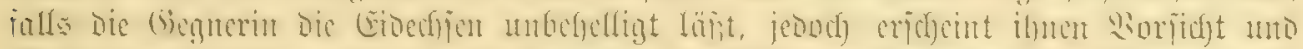

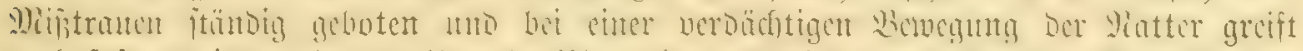

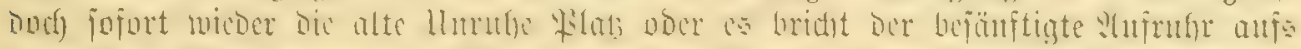

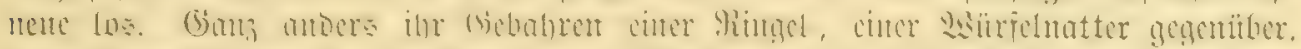

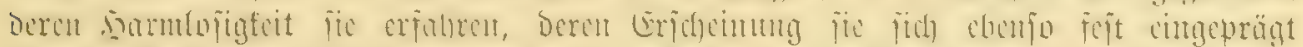

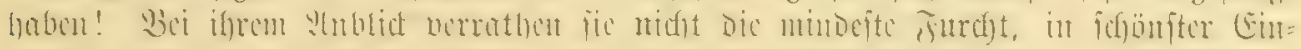

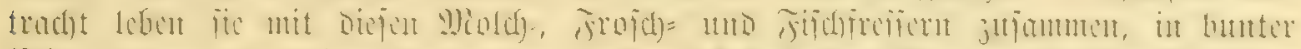

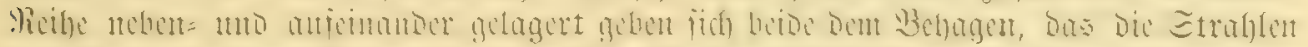

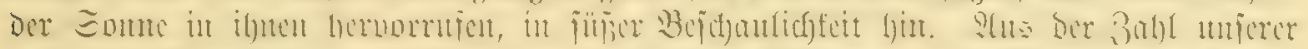

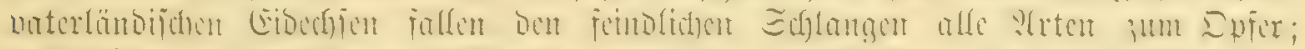

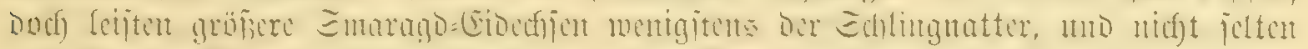

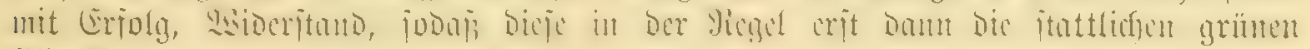
(Fidedjen angegt, nadjoen bie Heinen Gentijen berzelgrt find.

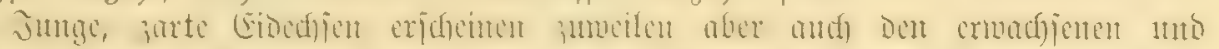

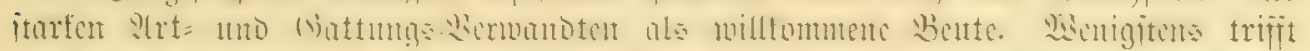

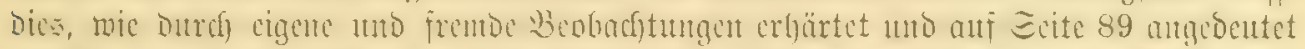

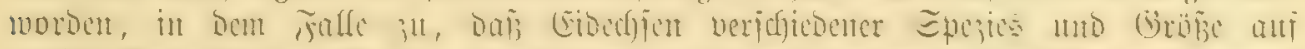

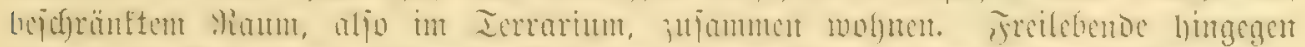

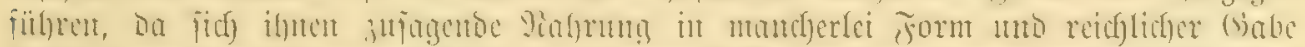

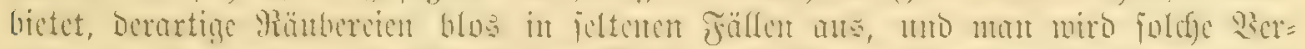

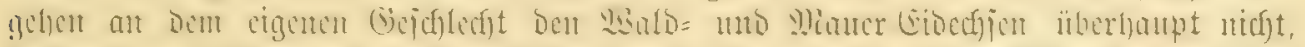

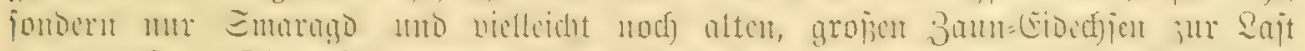

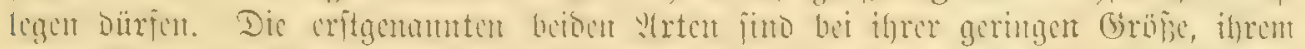

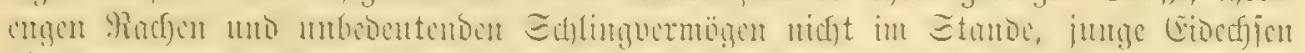

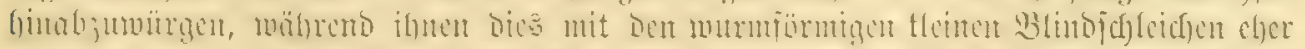

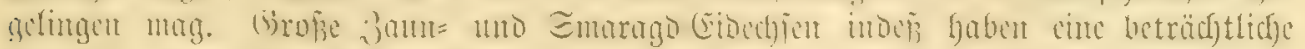

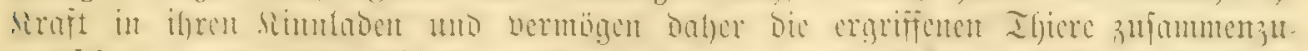

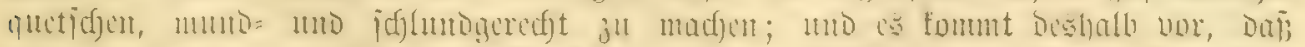

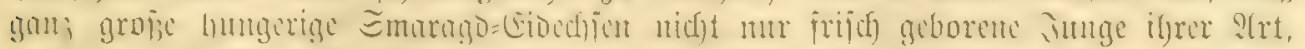

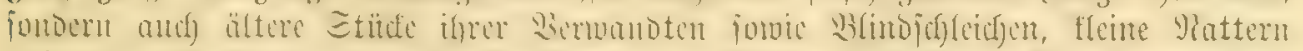

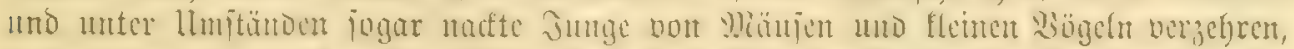

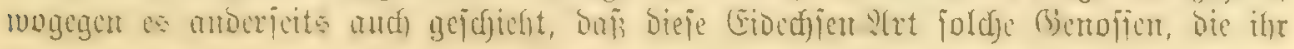




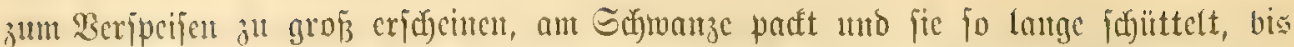

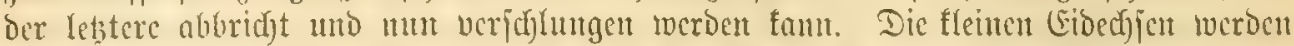

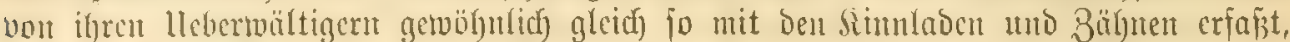

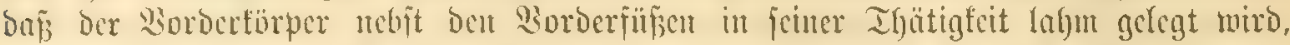

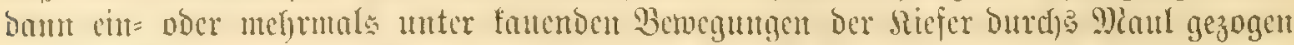

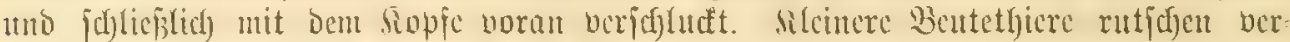

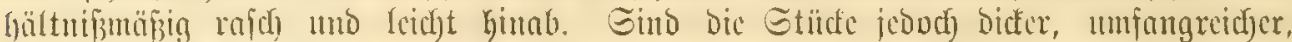

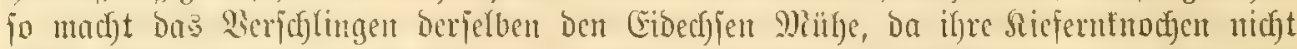

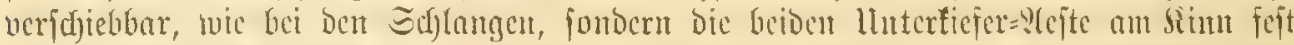

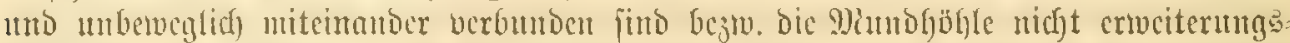

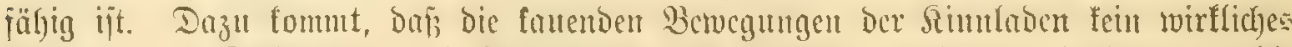

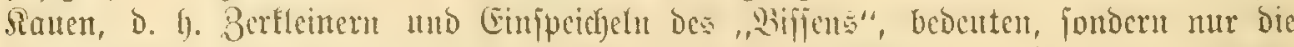

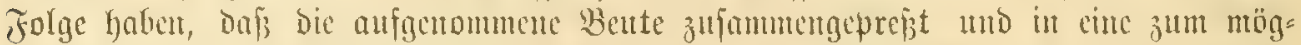

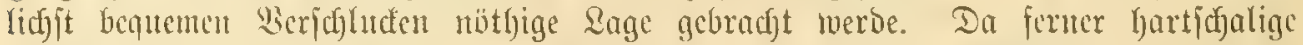
Dinge Dem Drud Der Silefern uno Büfne cinen merficheren $23 i$ iberitano Ieiften als meidhbüntige, fo erflärt es fich wicocrum von felbit, wem bic Eibedfen weidjerent

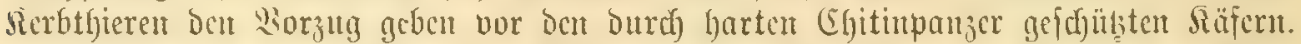

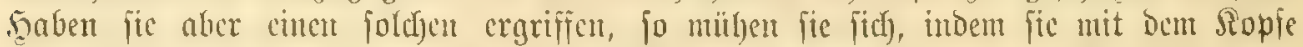

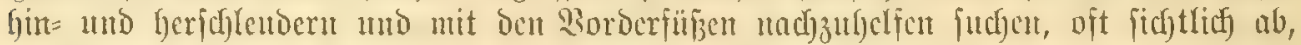

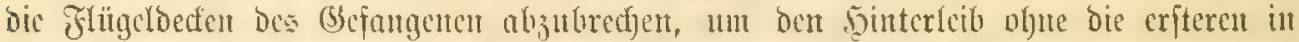

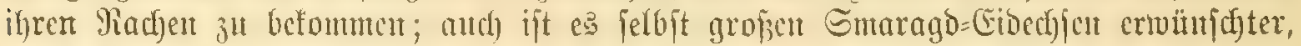

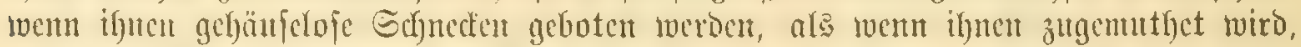

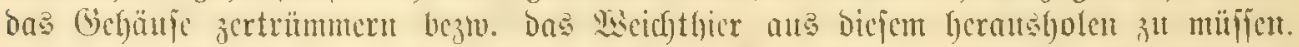

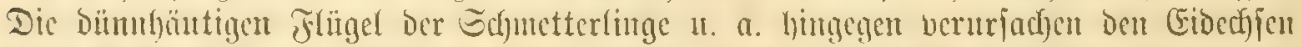

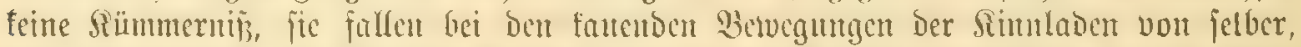

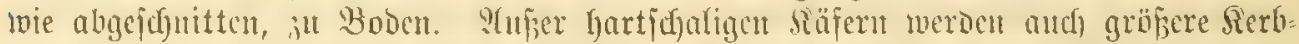

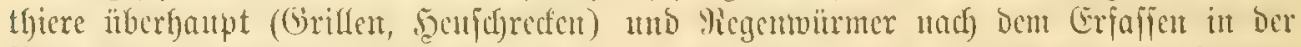

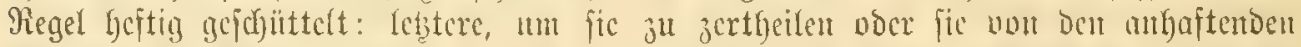

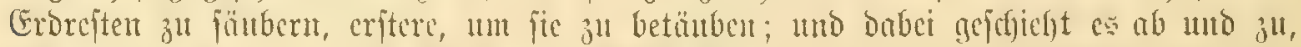

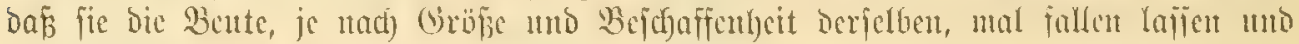
fie betrachten, un fie bann von neuent zut padtent.

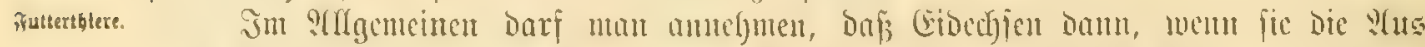

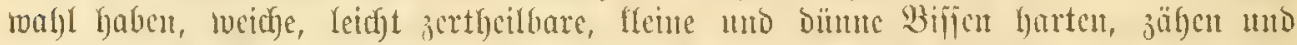
umfangreidjen Ethiden vor

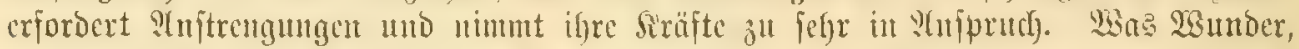

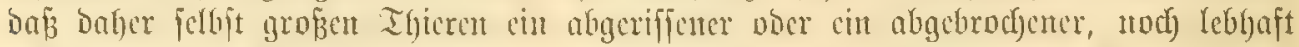

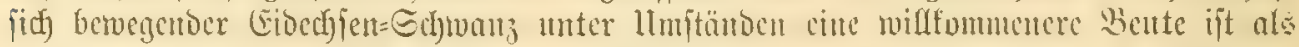

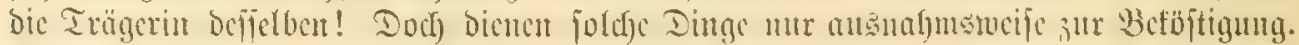

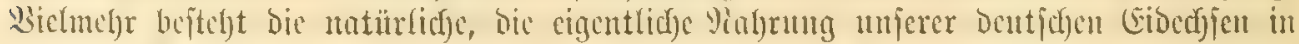

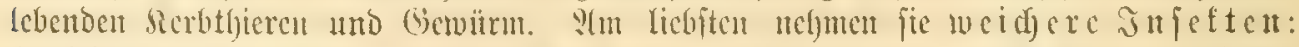

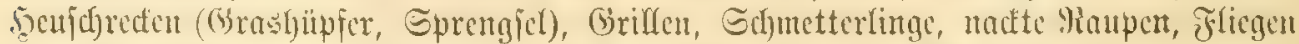

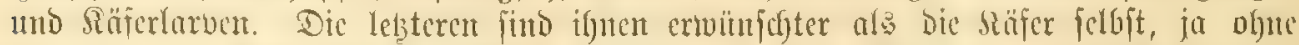

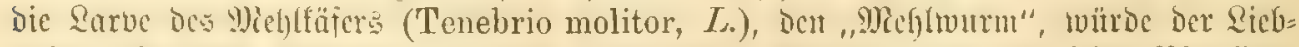

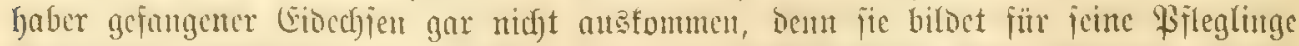

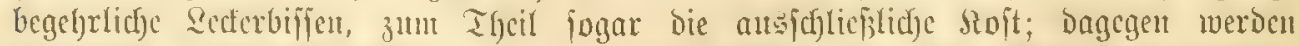

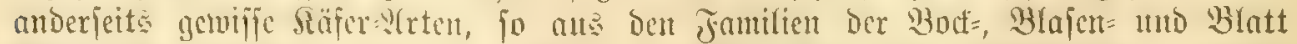

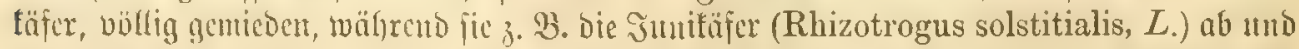
3u ganz gern nchmen. Die ohen aufgeführten Injeten theilen mit Den Eidedjen Dem 


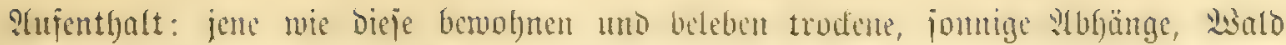

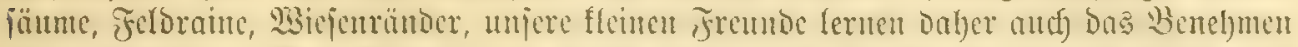

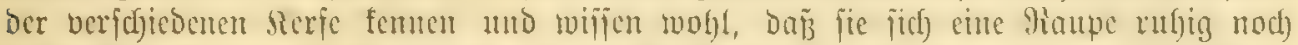

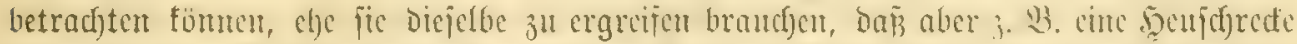

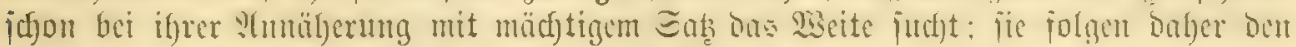
Bemegungen eines gemächlich Dafinfriedfenden uno =laufenocn Ibieres, cincr Raupe, Sarve, Spinne, cmes sismes oder ßäfers, gern eine Beitlang mit ben aufmerfiam

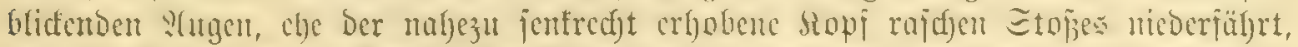

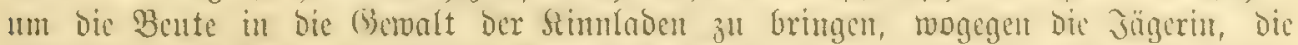

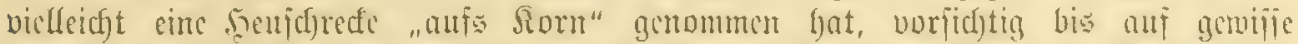

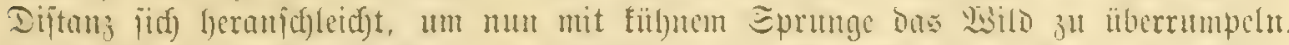

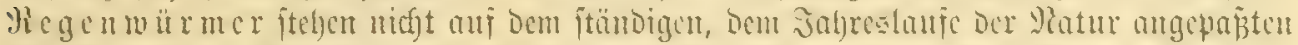

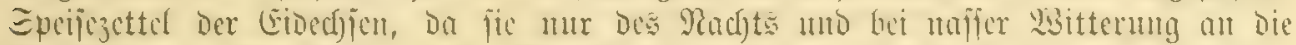

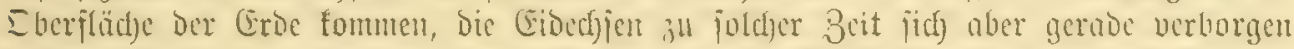

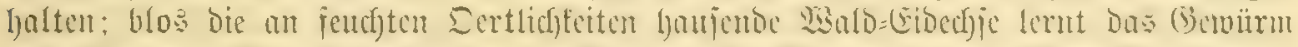

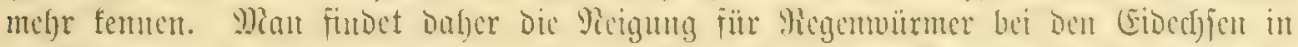

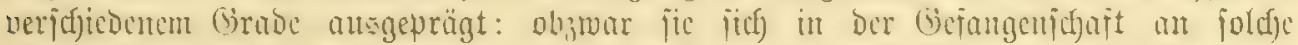

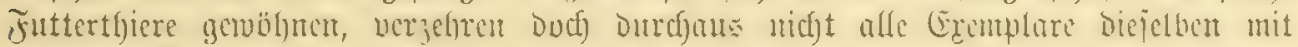

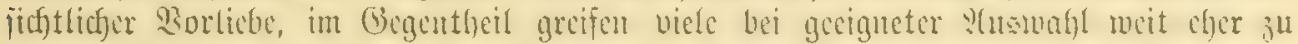

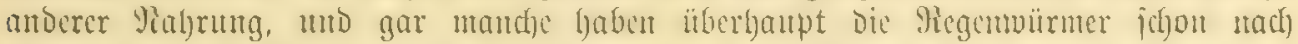

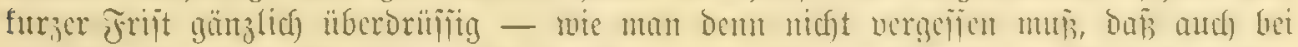

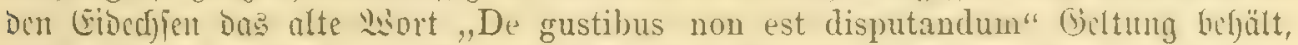

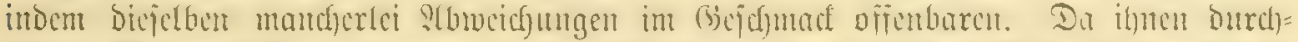

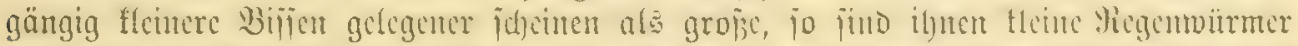

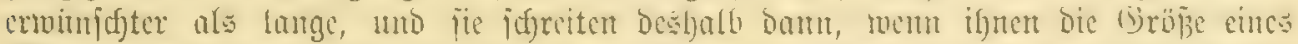

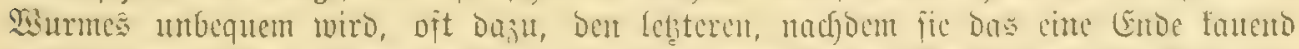

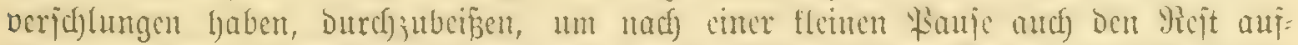

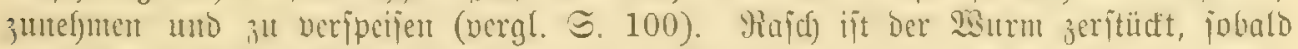

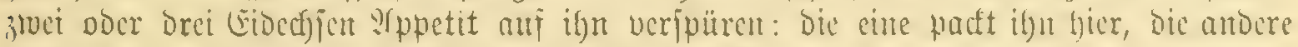

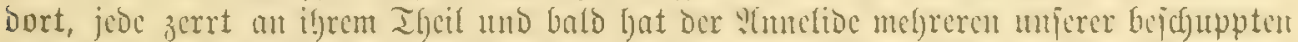

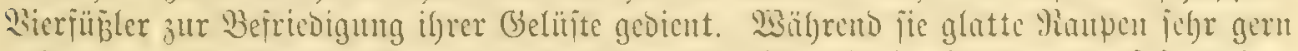

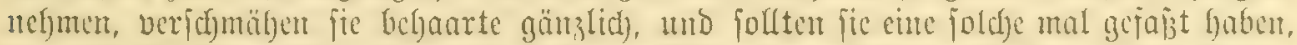

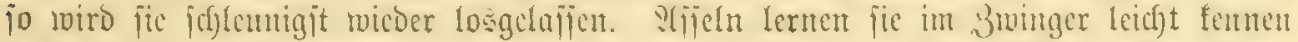

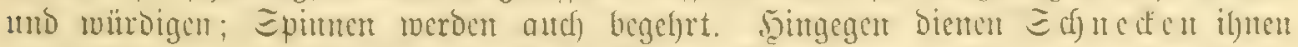

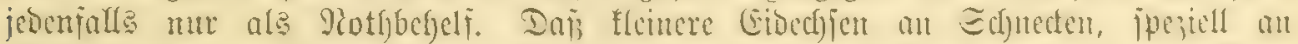

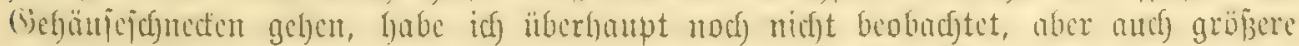

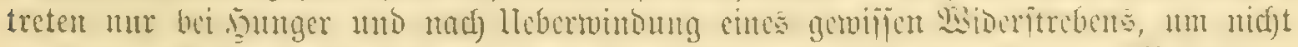

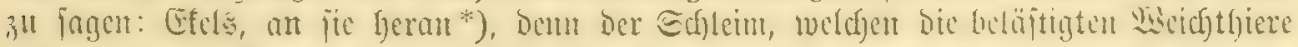

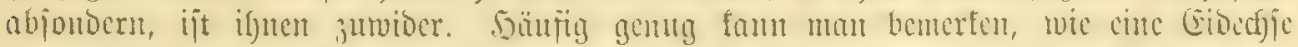

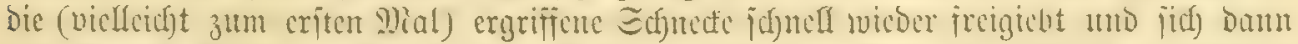

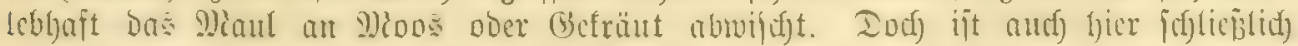

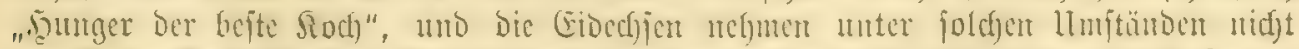
mur fleine Padfjuneden (Limaciden), jondern mad)en jich aud) Daran, Durd) Serren

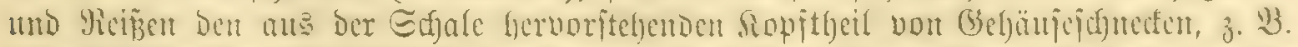
Edjnirfelidjnefen (Helicidae), abzutrenten, um ifn zu verjebrun. Da mu ber im

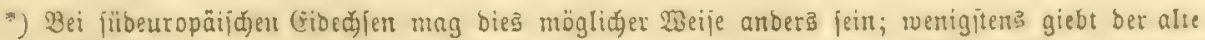

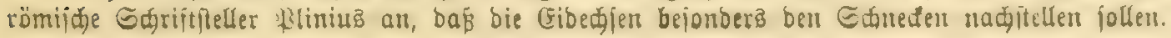




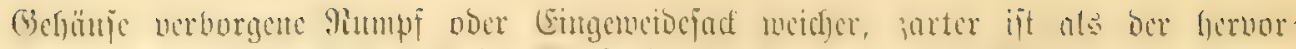

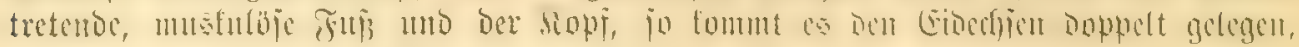
went baق (Schäujc zertrümmert tourbe.

2trbere \&utter

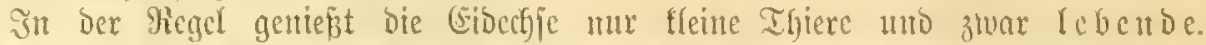
itoffe.

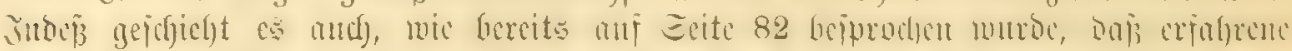

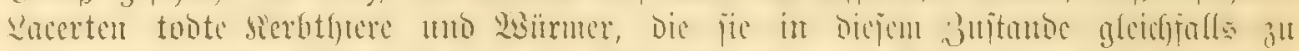

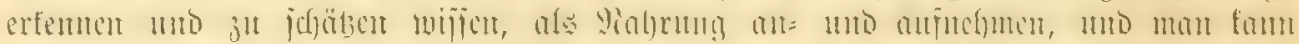

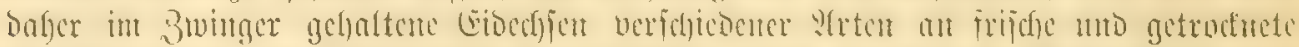

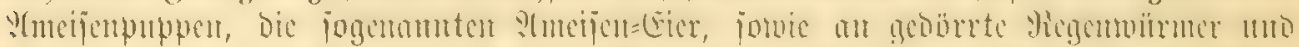

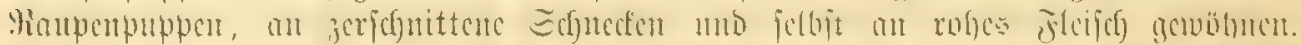

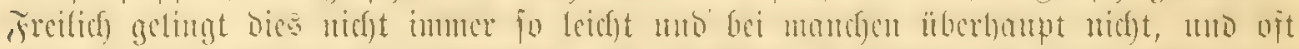

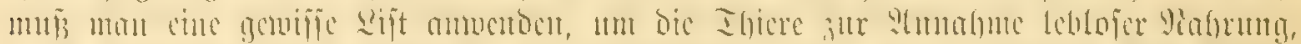

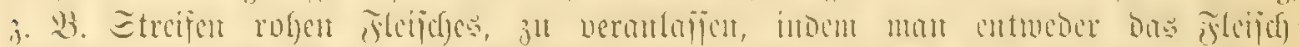

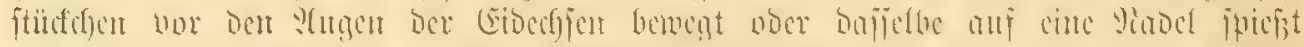

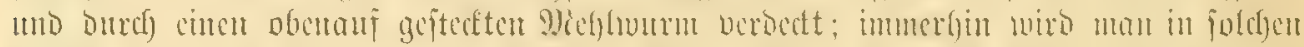

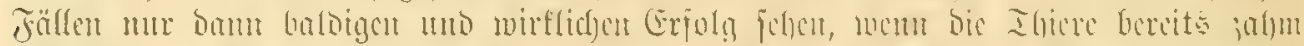

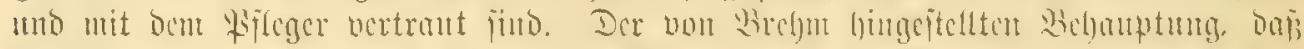

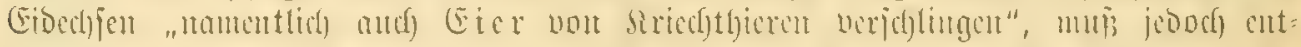

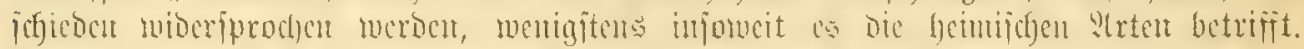

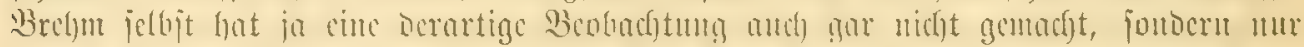

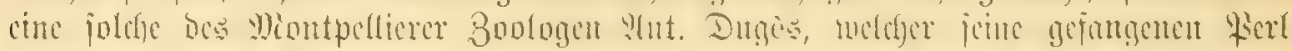

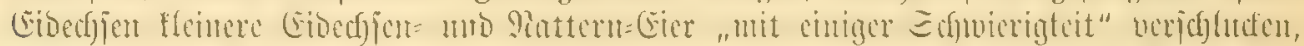

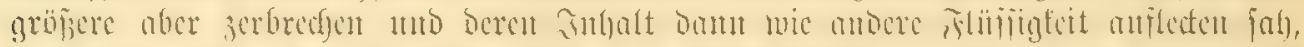

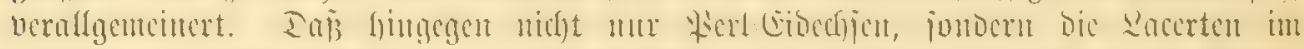

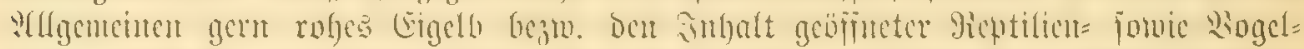

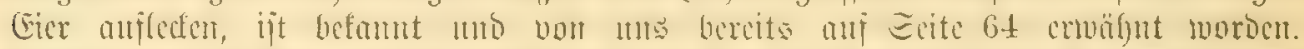

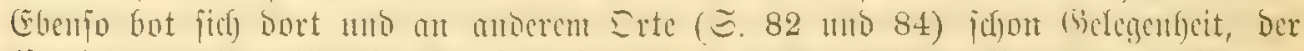

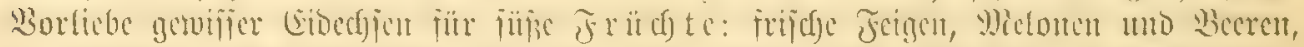

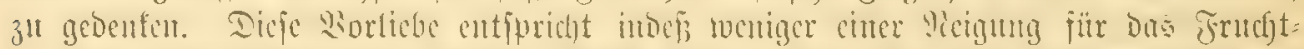

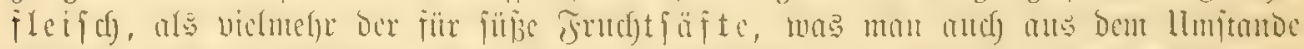

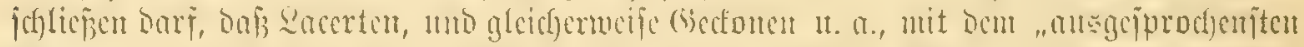

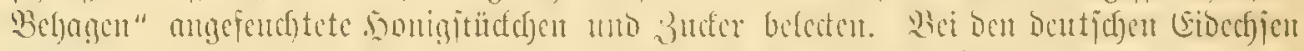

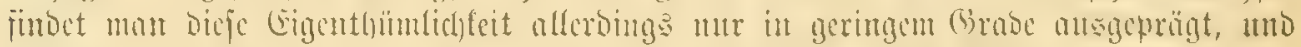

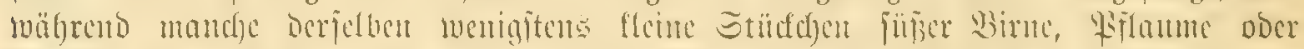

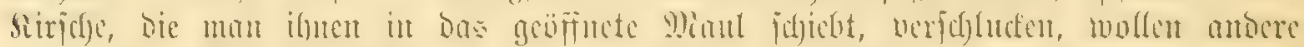

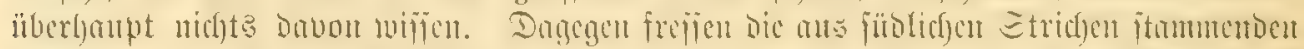

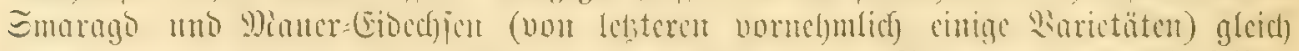

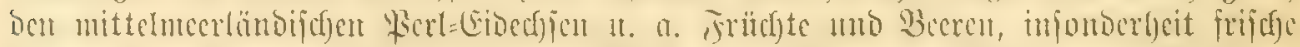

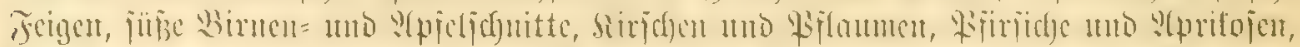

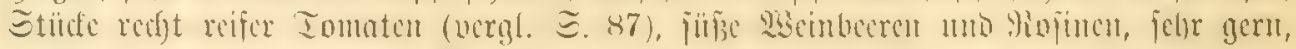

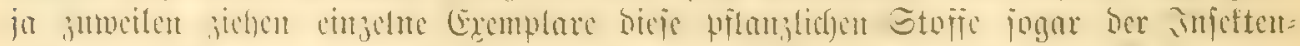

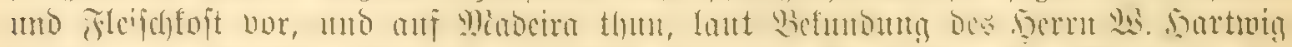

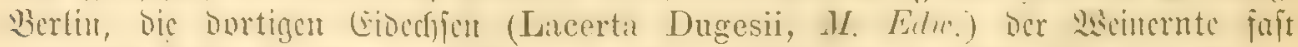

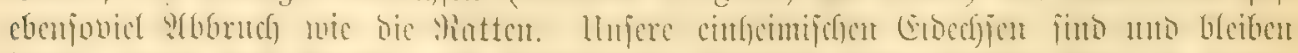

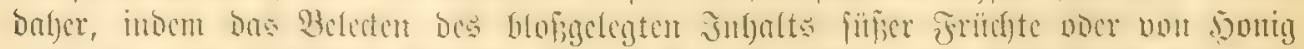

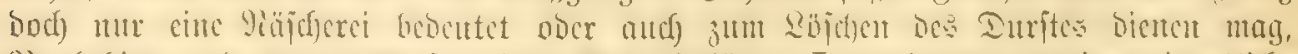

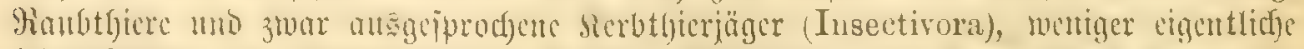

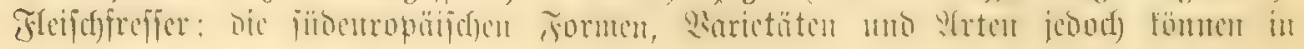




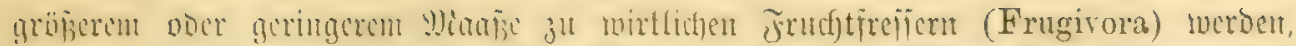

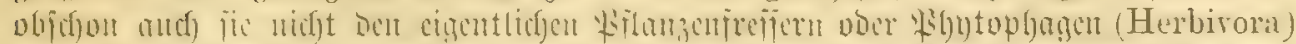

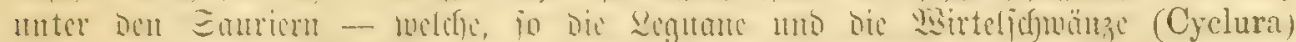

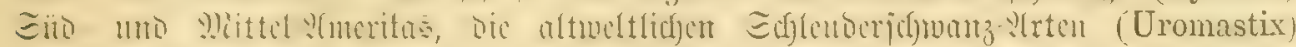

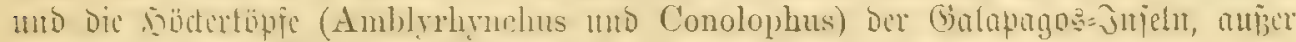

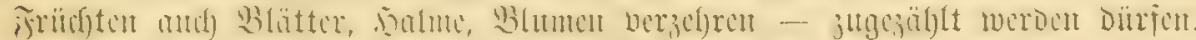

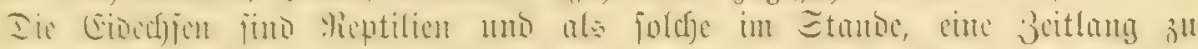

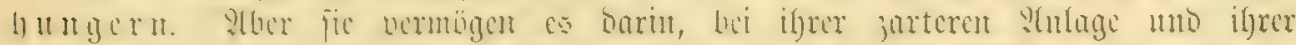

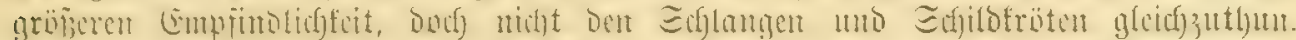

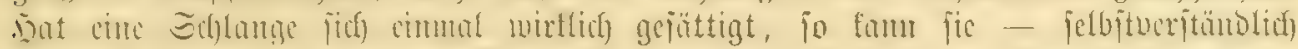

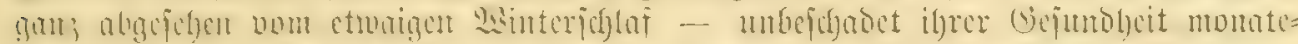

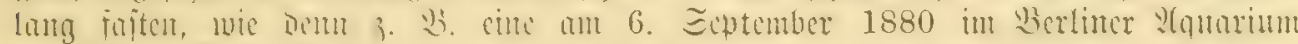

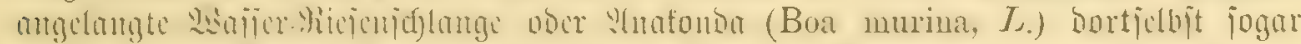

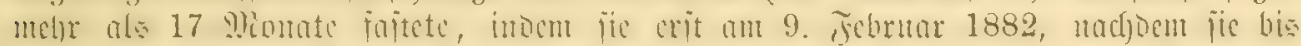

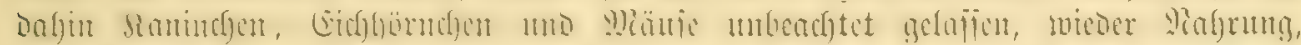

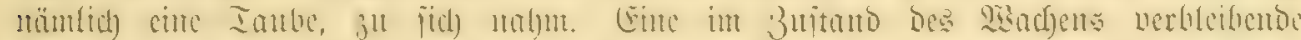

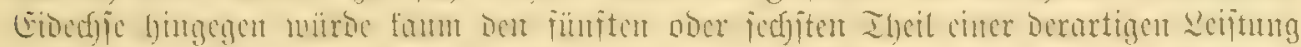

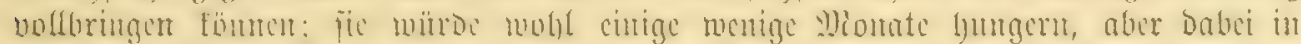

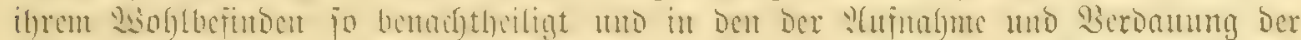

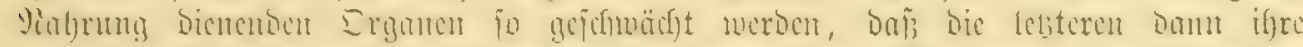

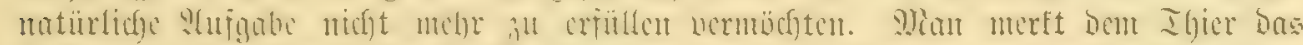

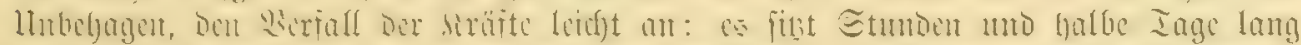

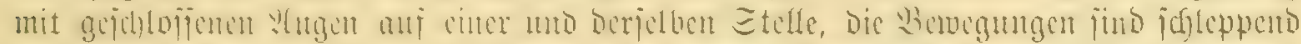

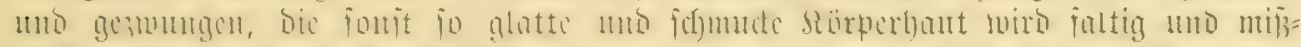

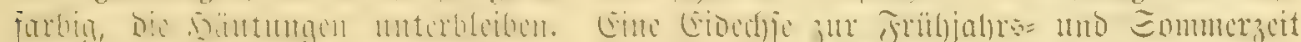

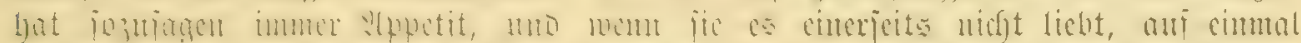

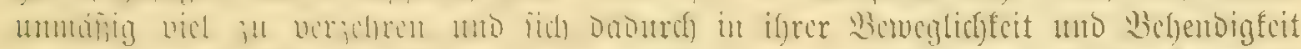

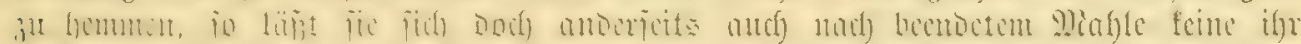

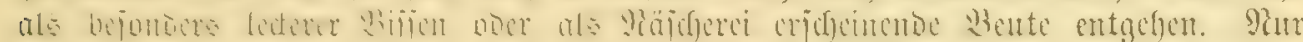

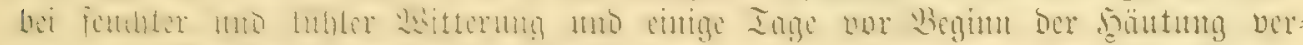

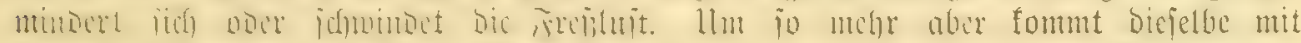

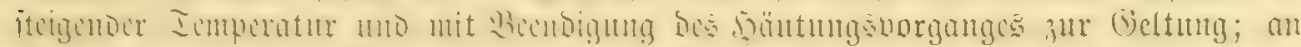

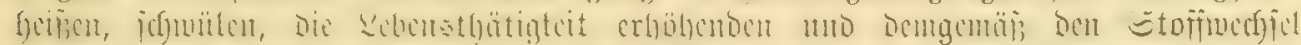

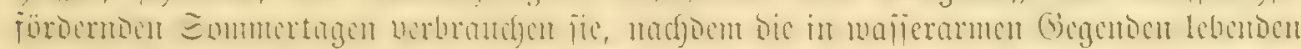

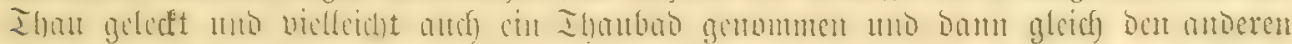

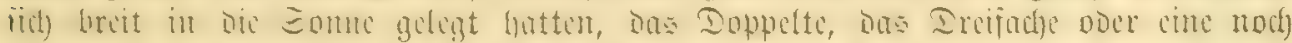

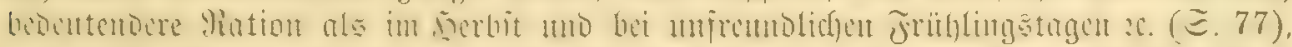

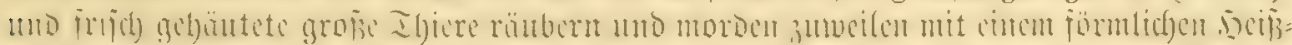

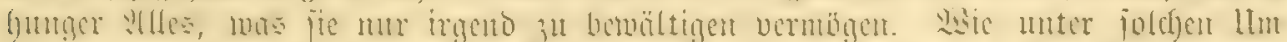

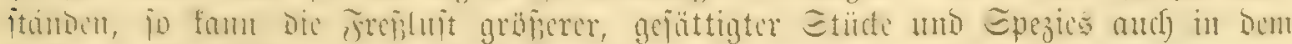

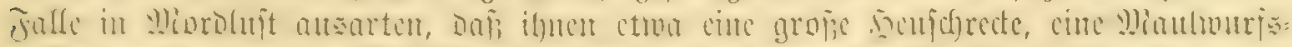

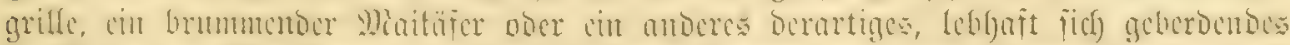

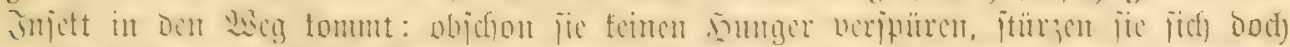

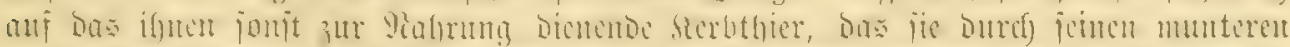

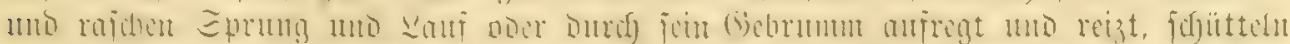

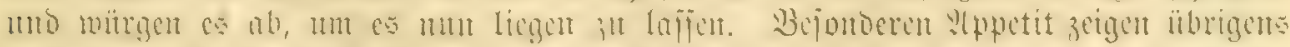

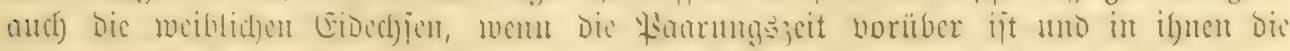

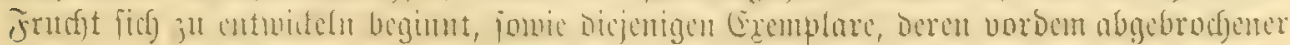




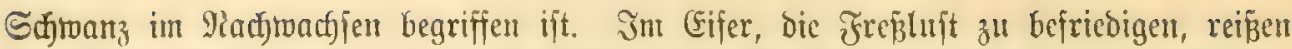
fie fidh auth twohl gegenfeitig bic Bente aub Den Sicfern ober ce zerren melgretc gleidzzeitig an einem fetten Biffen. Sobald berjelbe in Den Miagen beförocrt tworden,

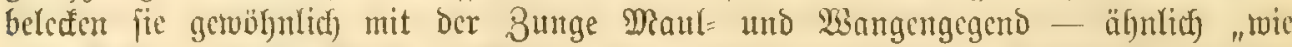

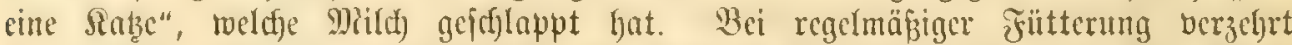

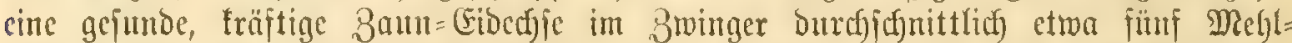

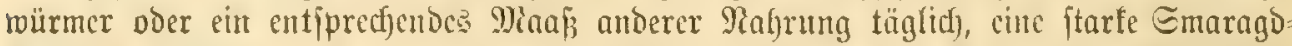

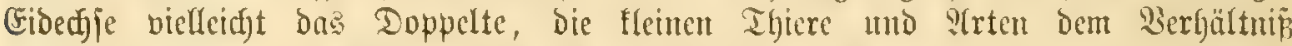
gemäв weniger. Im Jreien aber, bei ungehinderter Bewegung uno baher regerer Freçluit, wirb eine (Eidechje noch mehr Serbtgiere, Larven mo Giswürm vertilgen

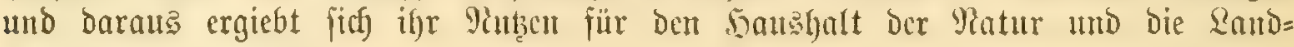
mirtbjichaft imsbejondere.

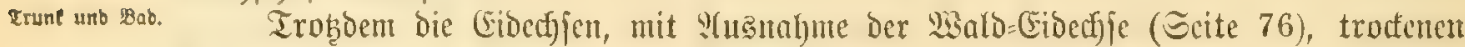
Boden uno trodene Ruft lieben uno thau= uno regemaffen Gruno meibat, fo fönten

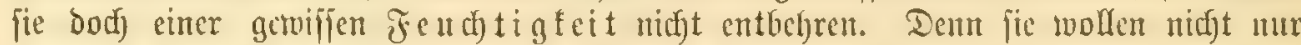
trinfen, fondern aud baben. In ber Freifeit furfen fie bafyer zu Dem cinen bie

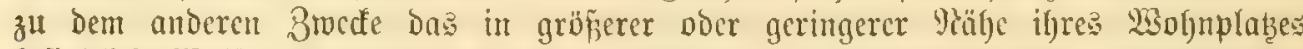

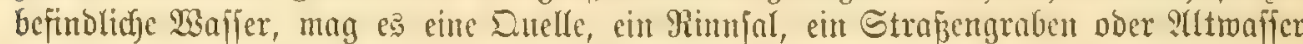

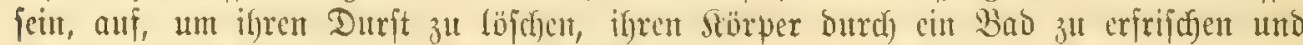

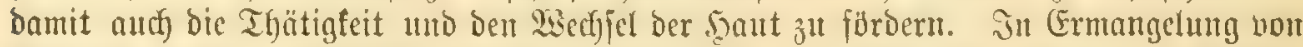

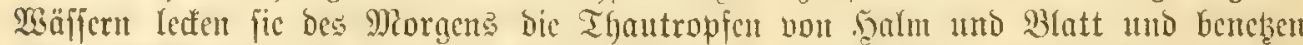

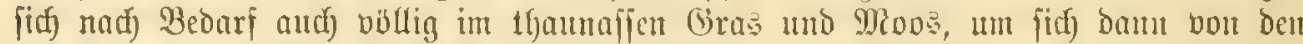
Strablen ber häber fteigenden Eomte trodnen und erwärmen ju lajpen. Qfber im

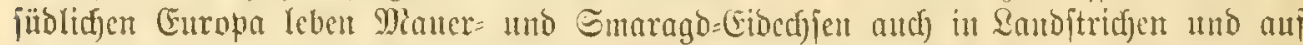

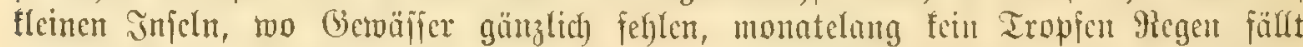

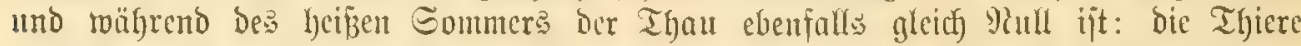

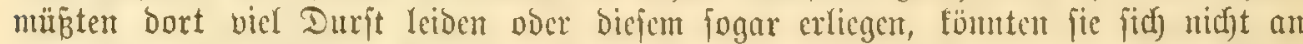

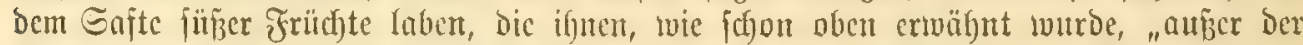

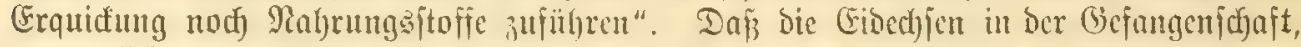
namentlid) vor unb ummittel(bor nad) ber bäutung, gleidjerweife badon soic in ber Freifeit, ja mitunter biertel= uno halbe Stunoen lang ganj ober theilweife im Laffer

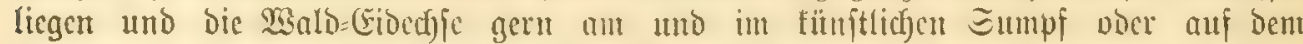

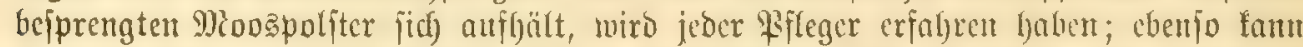
er beobadten, wie bie Thicre bie an Gila

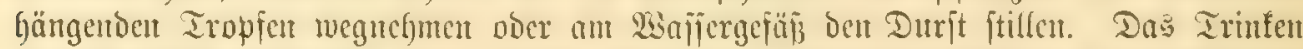

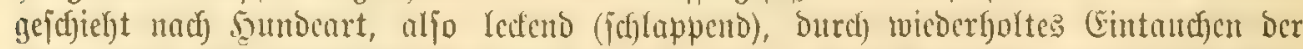

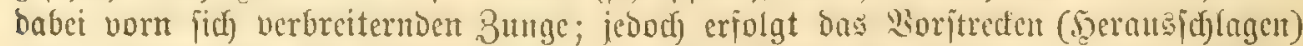
und Burïdziefen der letzteren nidjt fo fontig als bei ben seutoen, fondern langlam

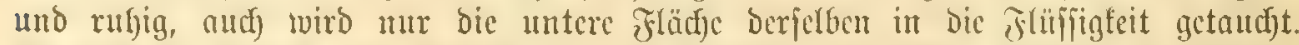

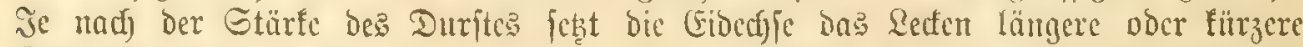
3eit fort: cine ber mir an 3. Stuguft 1880 zugcjanoten fpanifonen Smarago=Eidechjen

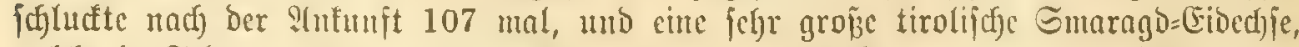

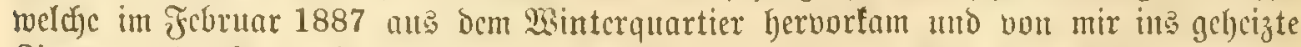

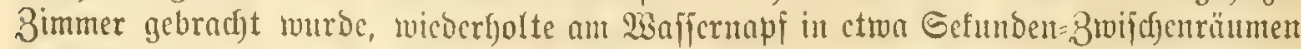
bas Eintautfen und 3urïtzichen ber 3unge $219 \mathrm{mal}$ - was mir idjicr unglaublicf) erjefeinen sürroc, bätte Der Wiorgang fid nidjt bor meinen eigenen Blicten abgejpielt.

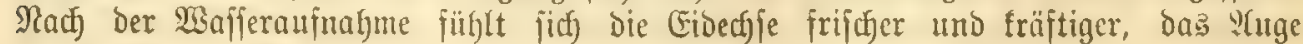
belebt fid, Der Sïrper wiro iffmetoiger, bie Sant glatter und ftraffer. 


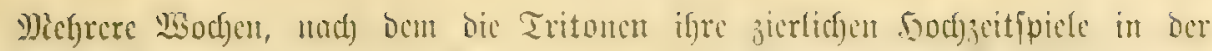

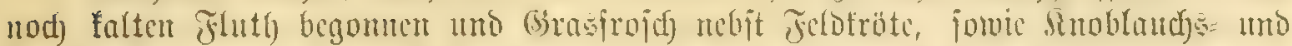

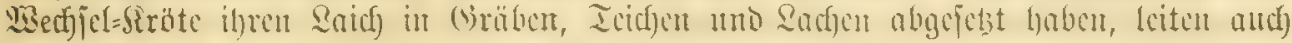

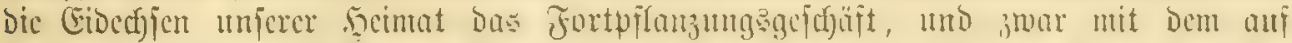

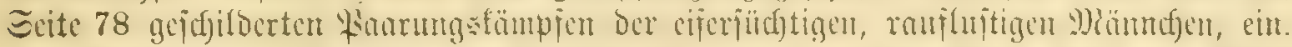

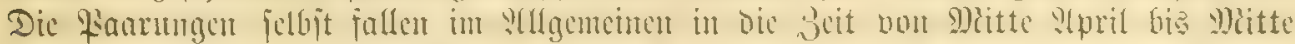

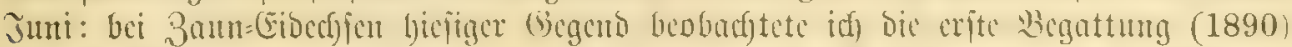

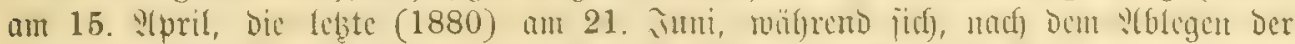

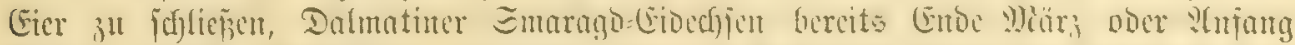

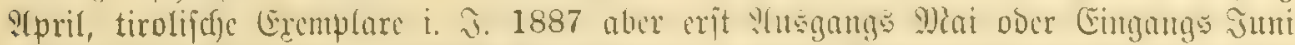

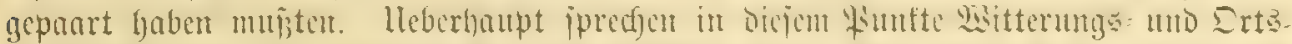
vergältuifie fehr mit, and bie

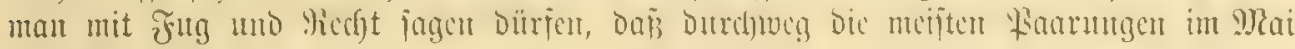
vollzogen twerden.

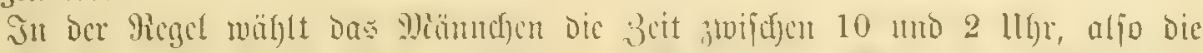

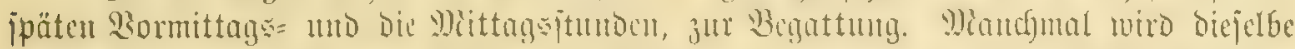

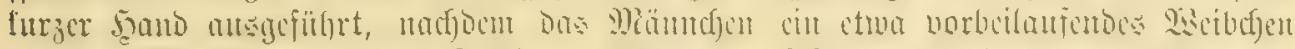

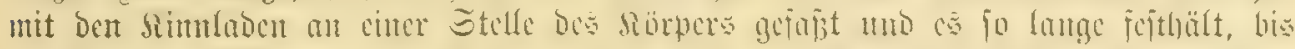

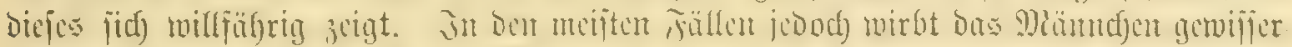

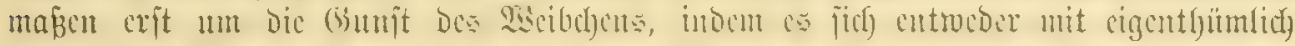

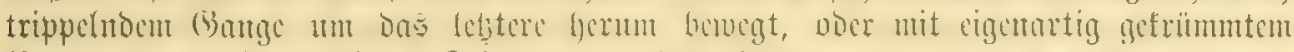

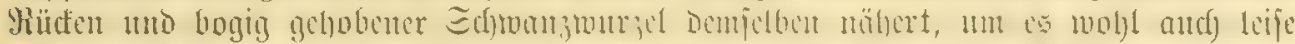

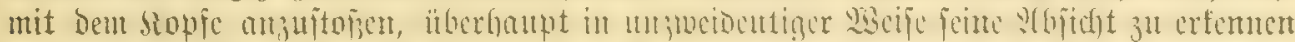

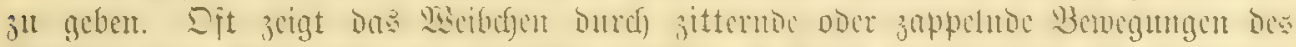

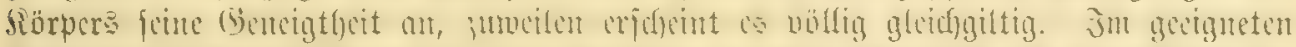

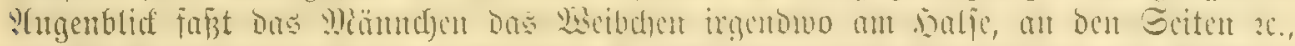

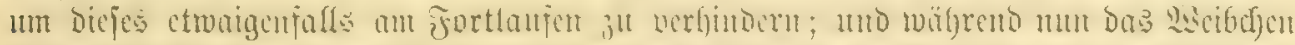

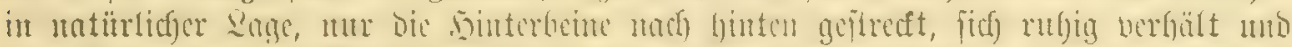

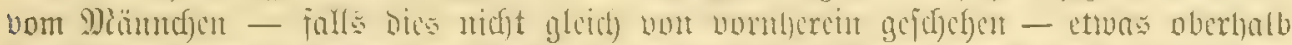

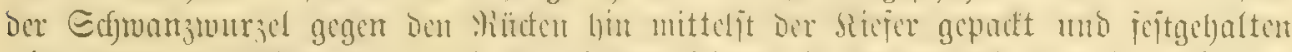

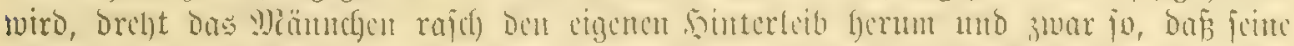

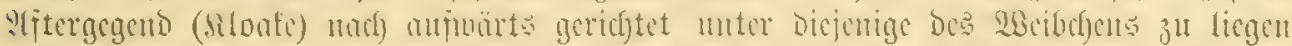

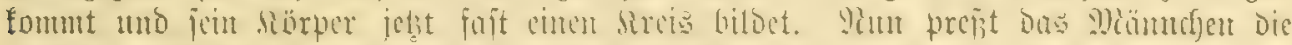

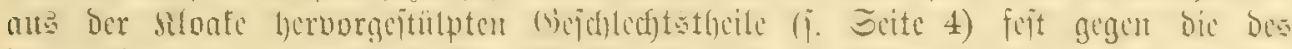

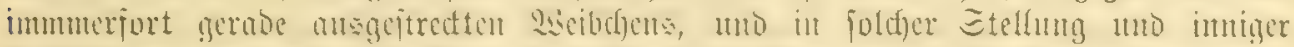

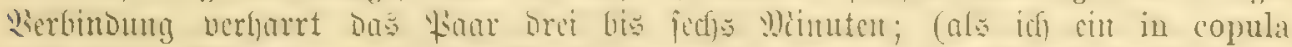

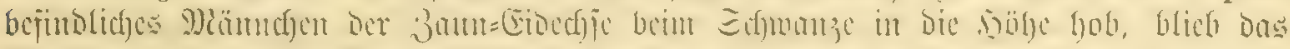

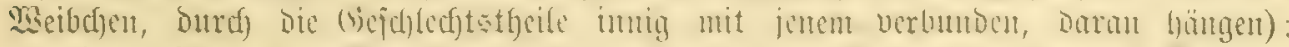

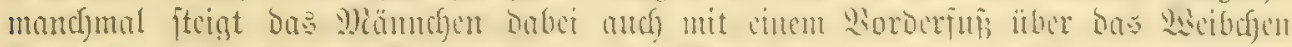

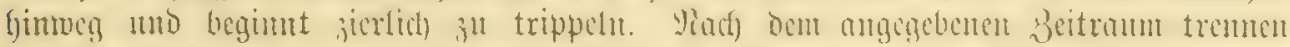

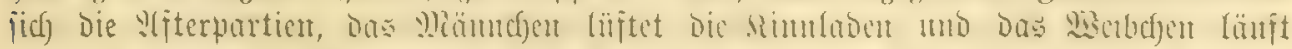

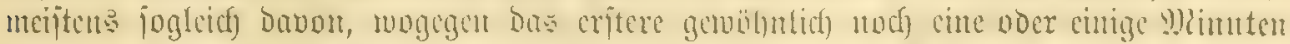

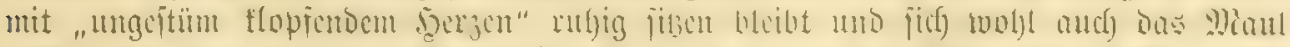

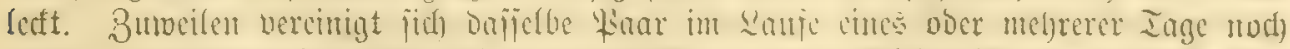

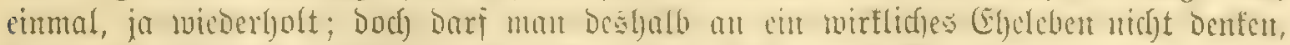

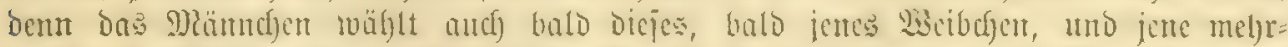

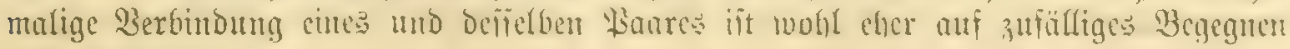
jurüdzufüfren. 


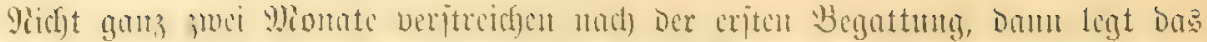

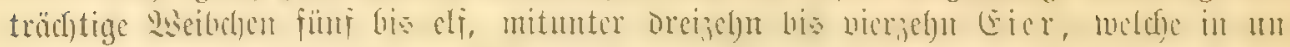

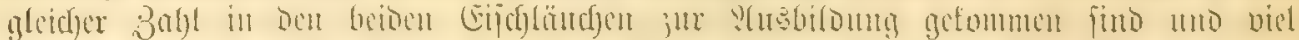

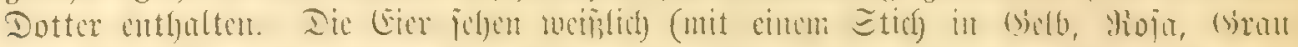

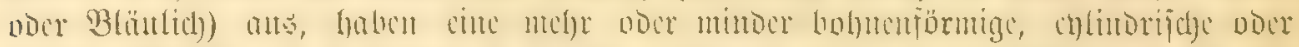

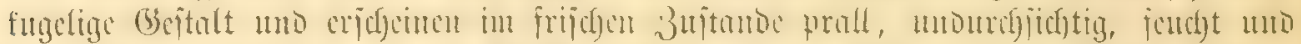

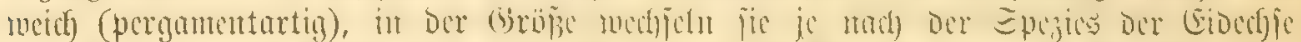

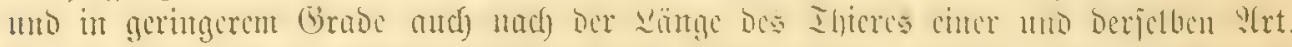

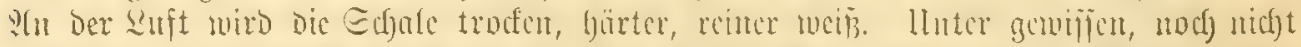

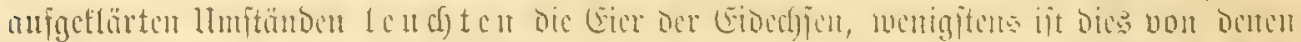

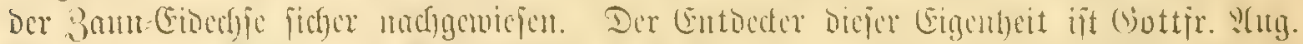

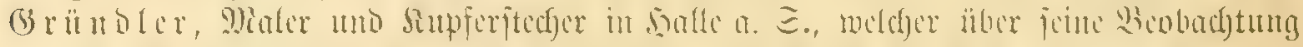

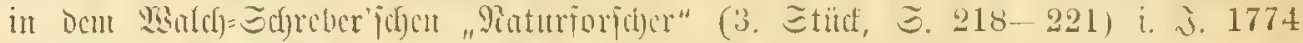

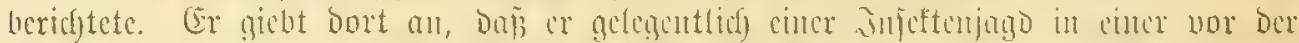

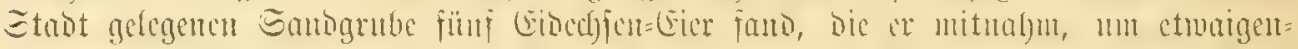

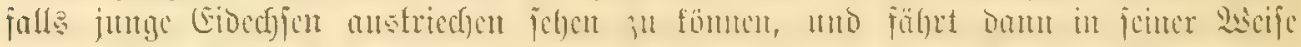
fort: "2)

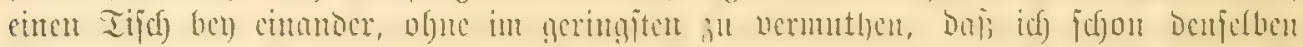

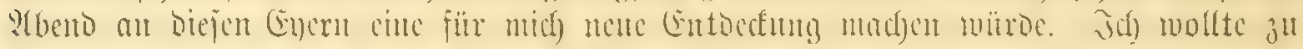

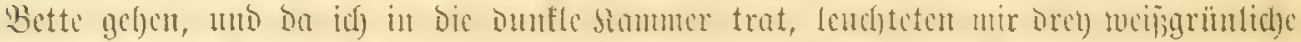

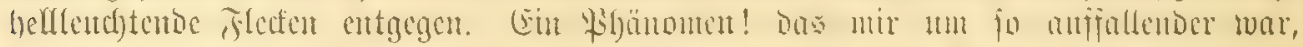

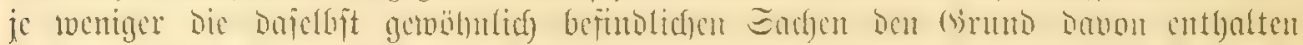

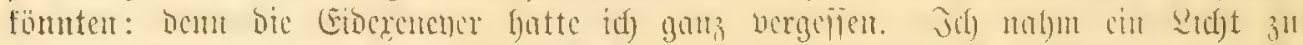

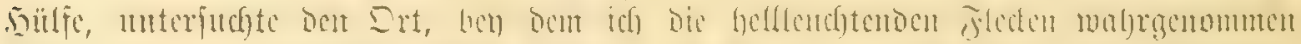

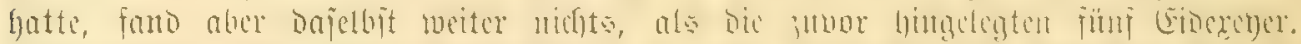

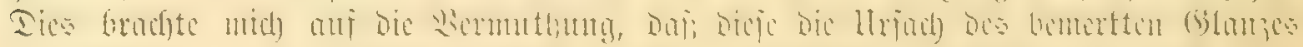

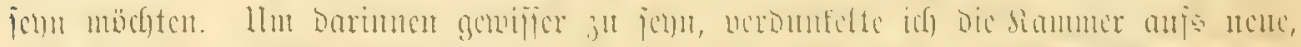

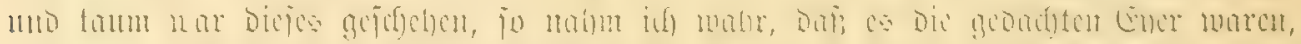

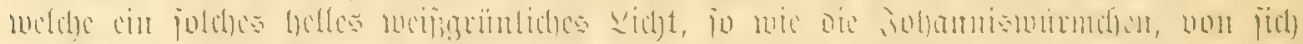

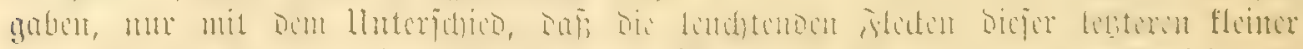

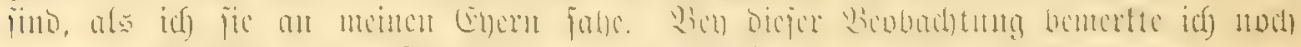

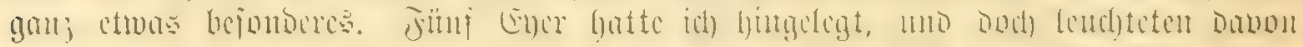

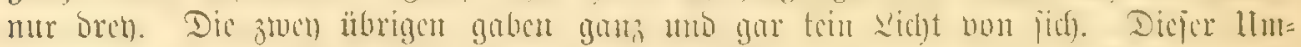

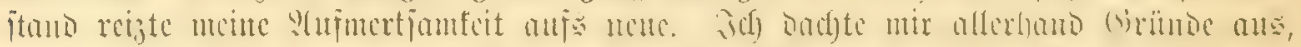

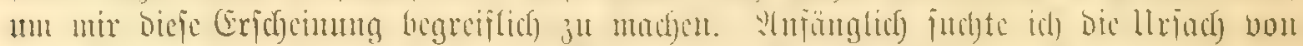

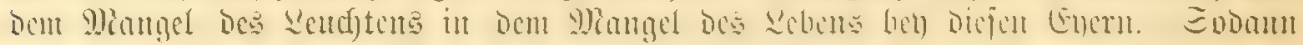

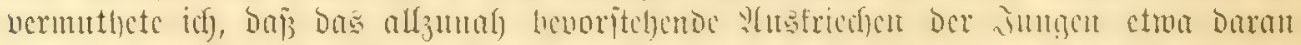

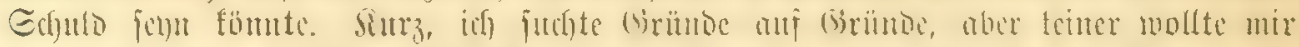

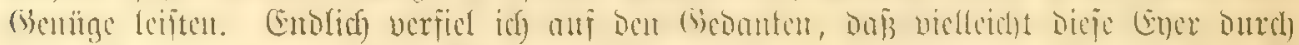

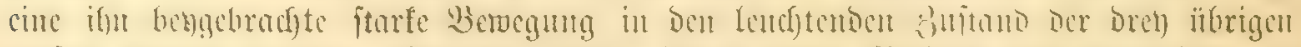

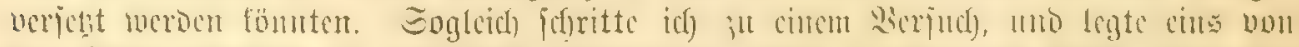

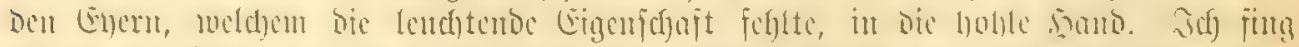

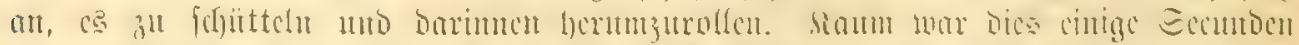

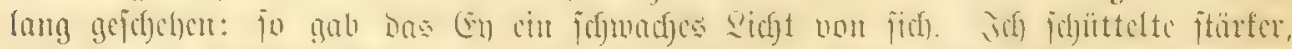

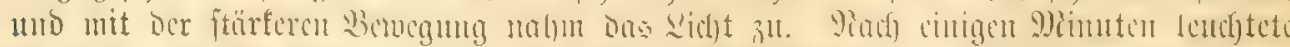

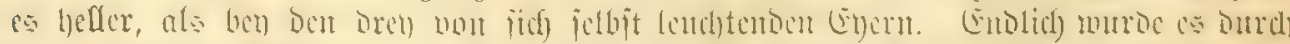

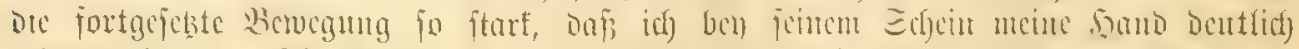

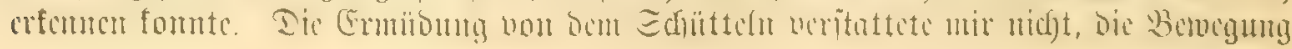




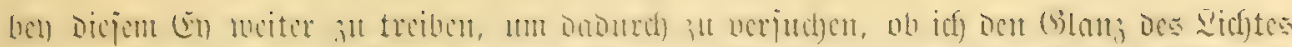

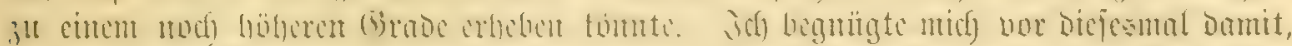

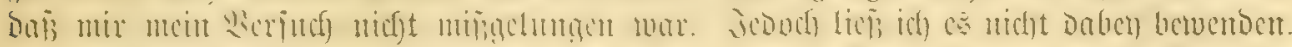

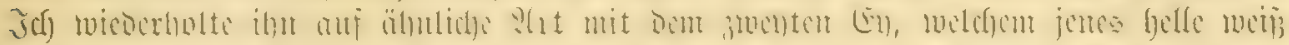

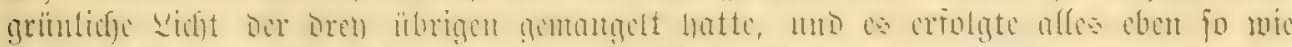

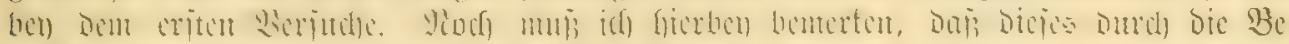

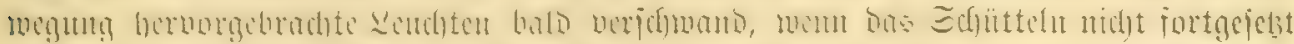

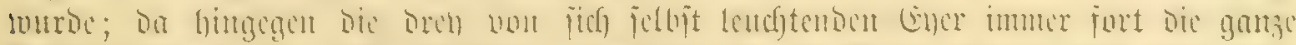

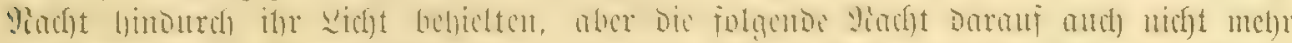

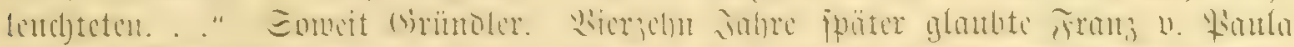

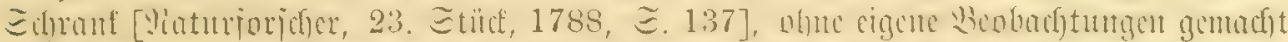

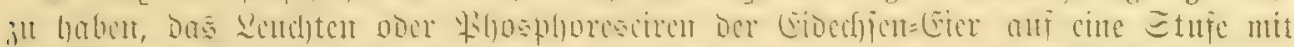

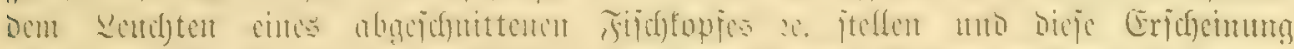

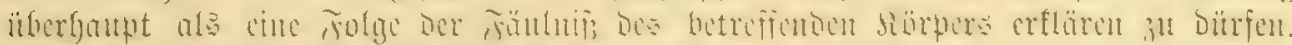

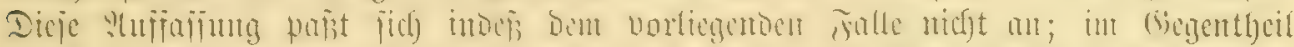

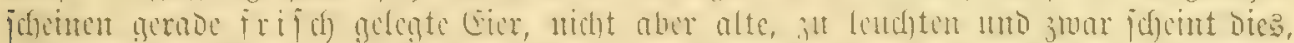

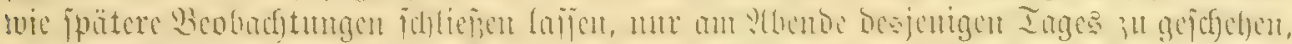

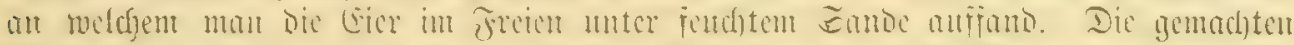

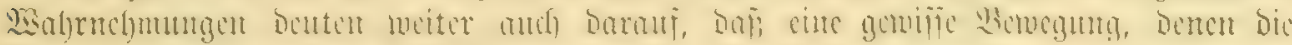

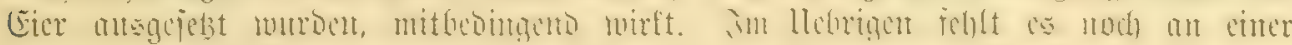
auBreidjenden Erflärung jener (Erjofinung.*)

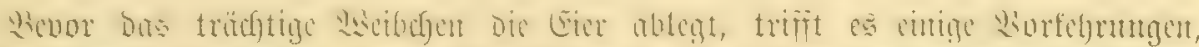

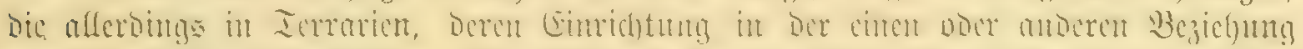

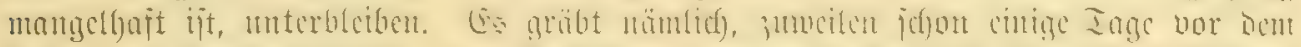

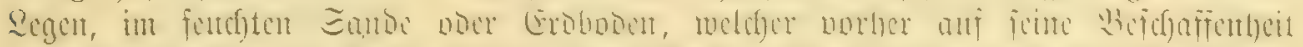

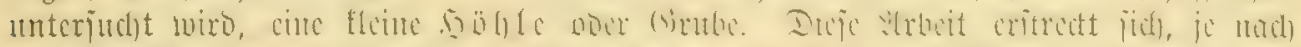

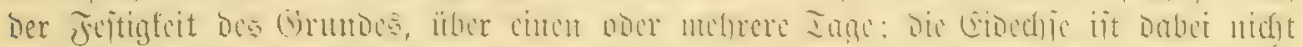

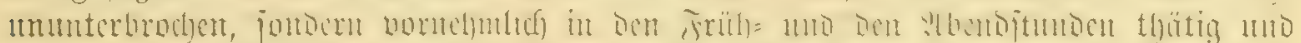

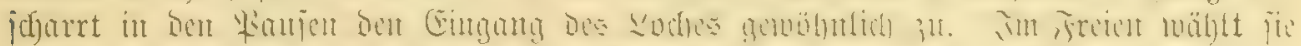

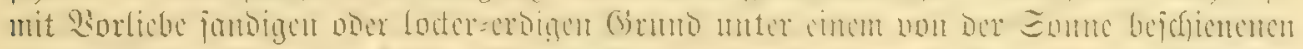

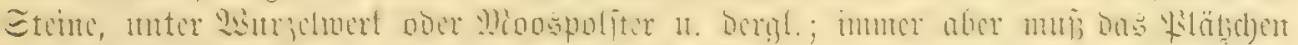

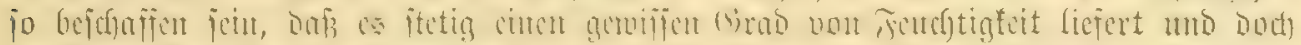

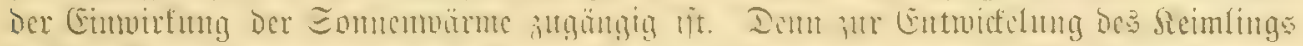

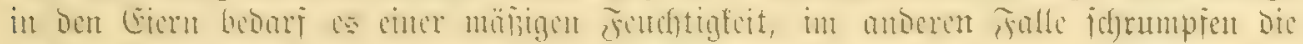

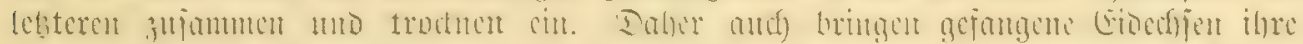

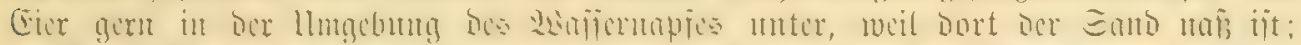

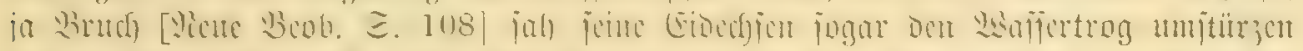

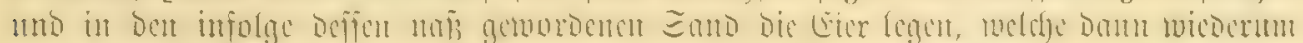

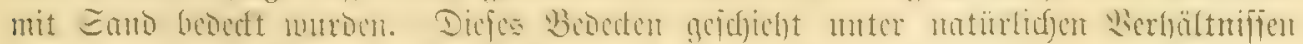

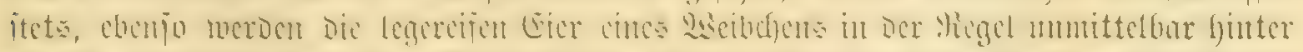

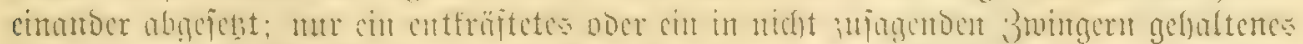

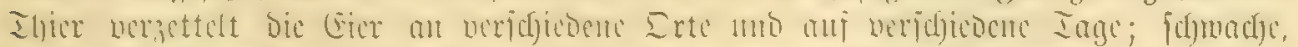

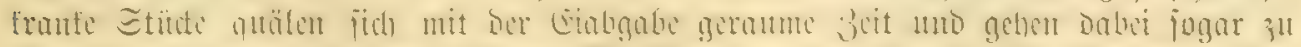

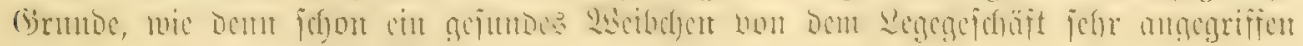

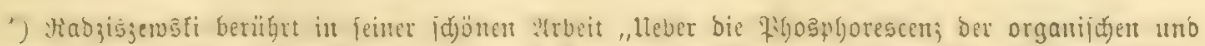

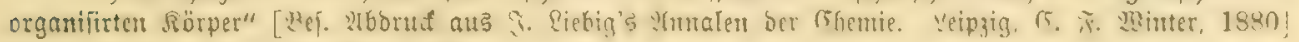
bos Reuditen ber (sibedien=(Eier nid̆t. 


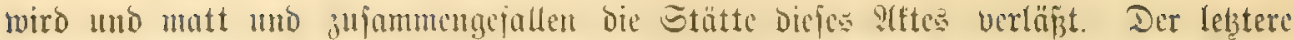

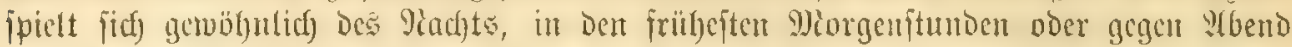

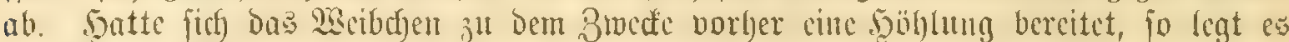
in biefer felbit foviel Eicr ab, als ocr Raum es geitattet; wirb Derjelbe ju beengt, jo frict)t cs, roic 910. Jranfe in femem jreiland- Ierrarium beobodytete, nad) ocm

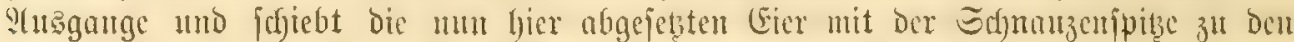
ïbrigen in bic Grube, แm bas Ganje Dam mit Dem nusgefforrten Bodengruno 孔นz山סetert.

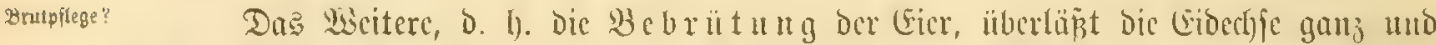

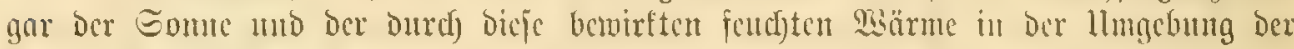

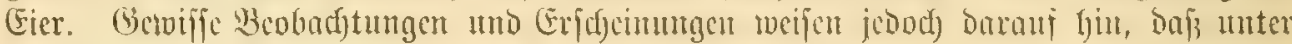

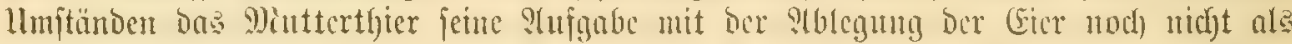

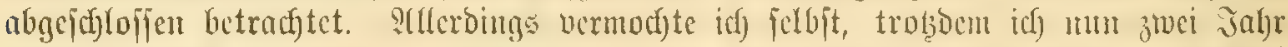

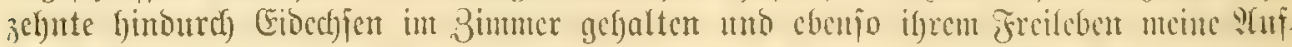

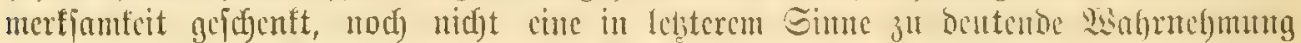

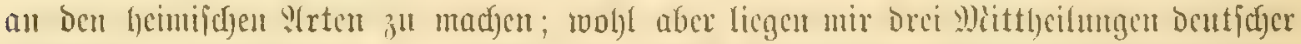

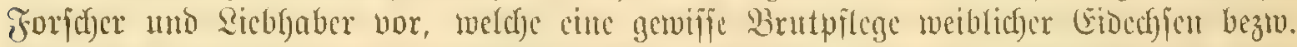
eine gewiffe Sorge un Dic abgelegten Eier befmben. in allen brei Fïllen bandelt

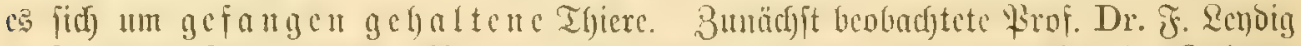

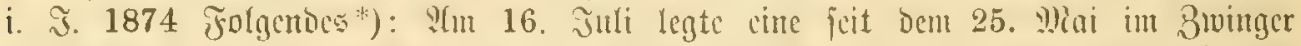
gefjaltene 3 a แ

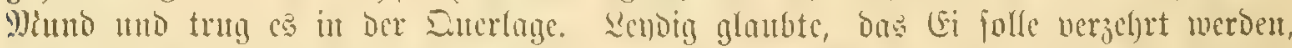

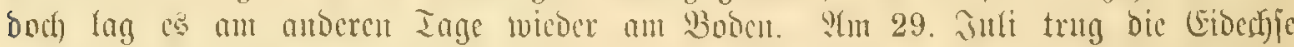

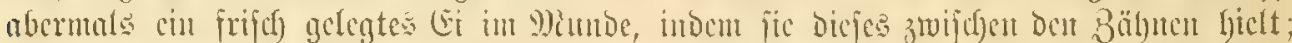

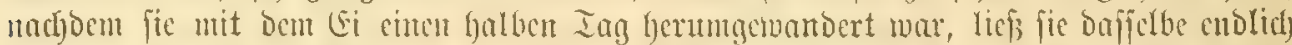

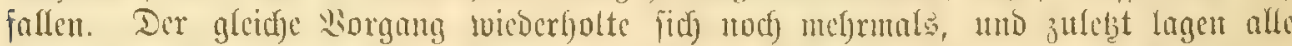

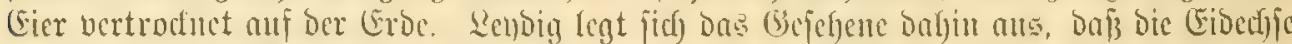

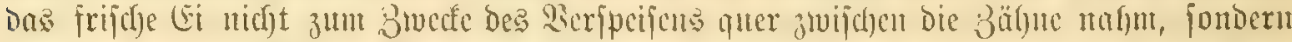

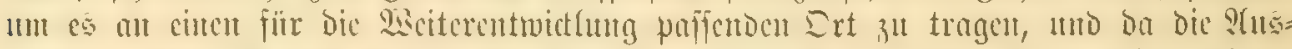

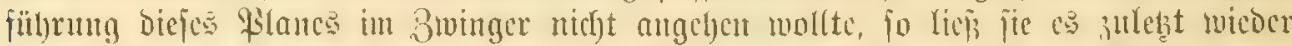

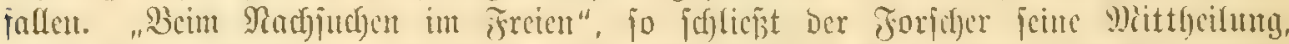

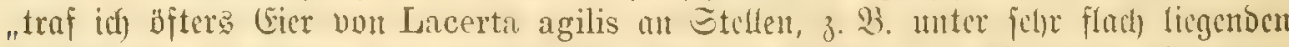

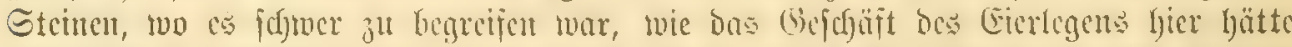

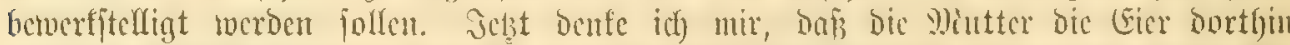

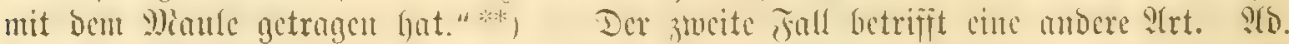

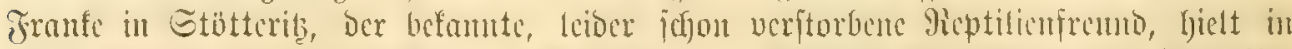

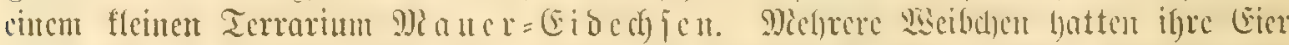

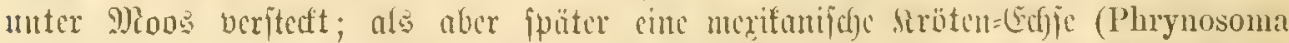

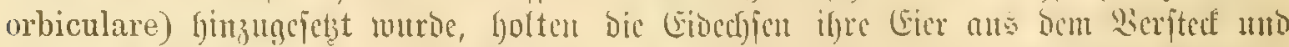

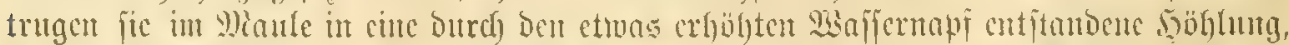

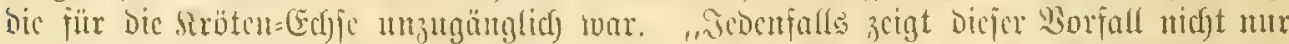

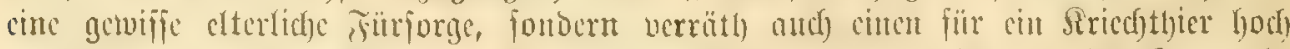

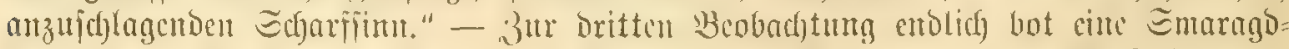

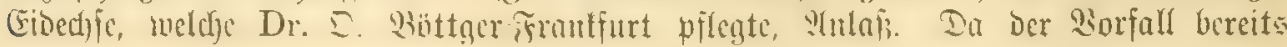

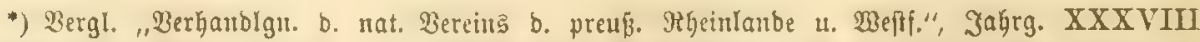

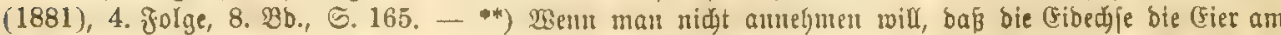

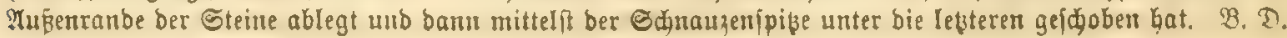




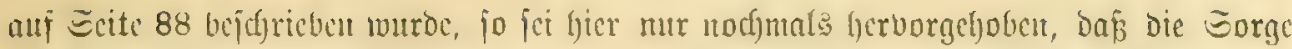

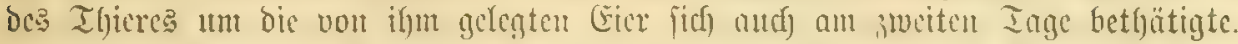

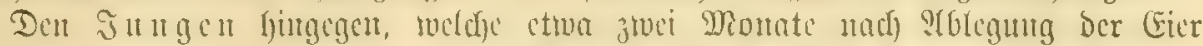

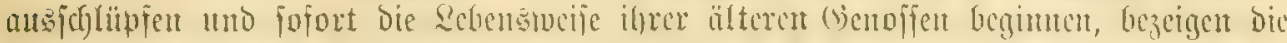

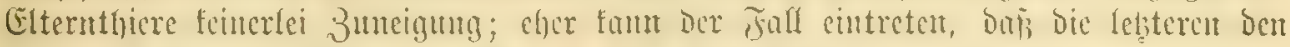

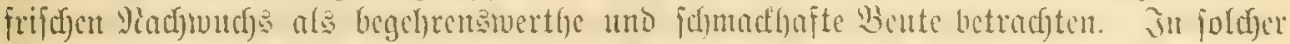

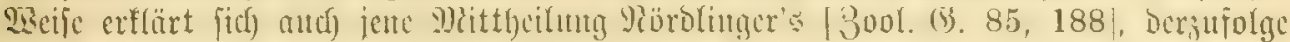
ber Welstere in feiner Jutgento Den Minule ciner jocben Duref) cinen Schlag getöbteten

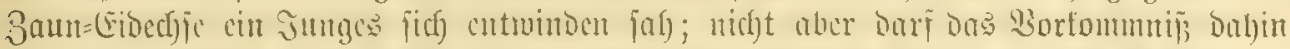

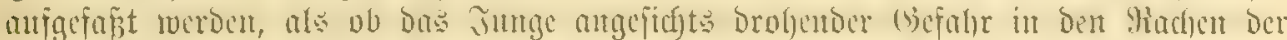

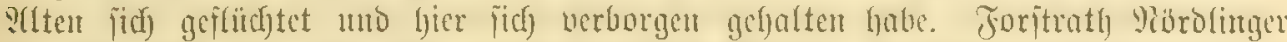

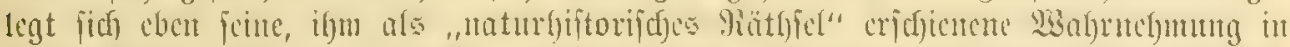

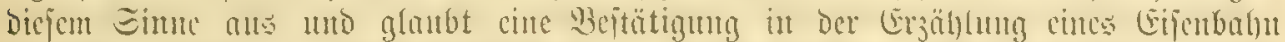

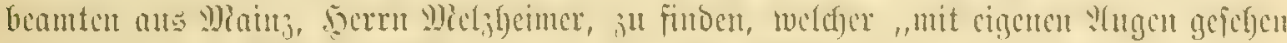

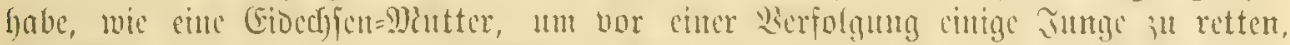

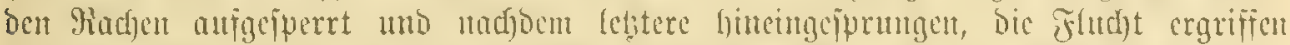

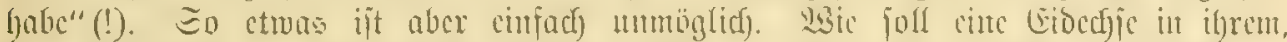

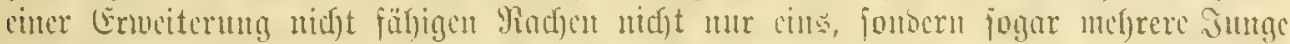

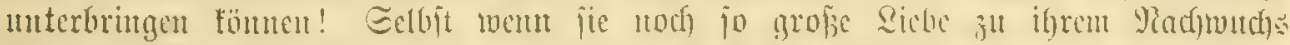

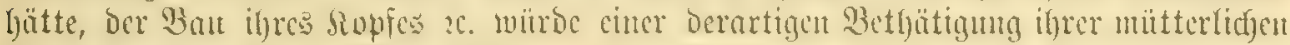

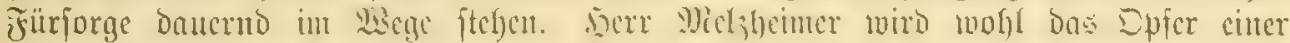

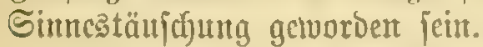

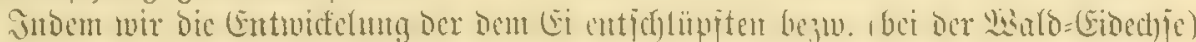

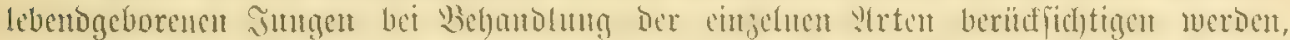

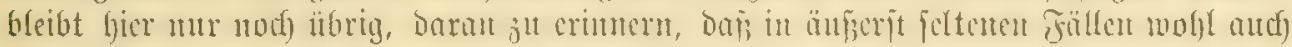

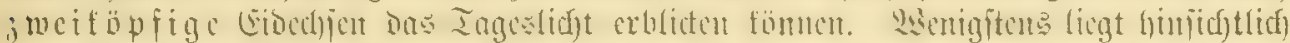

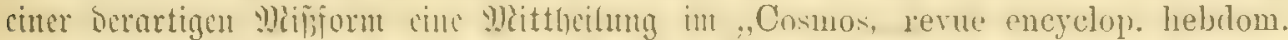

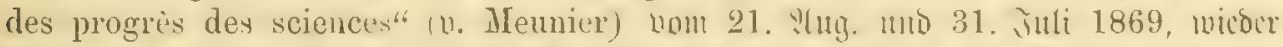

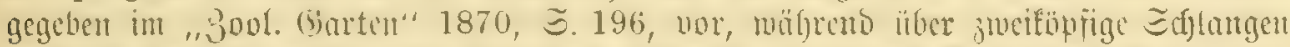

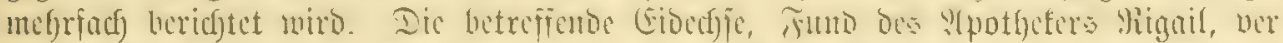

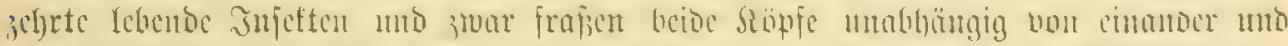

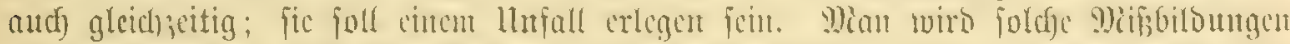

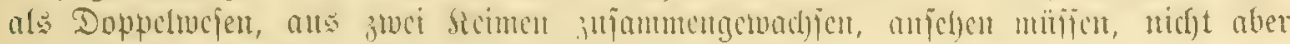
als theiltweis gedoppelte Eimzelwejen betraditen Dïrfen.

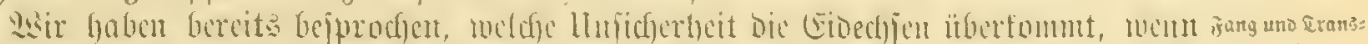

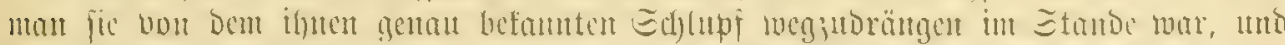

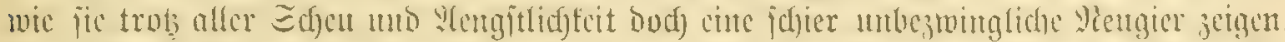

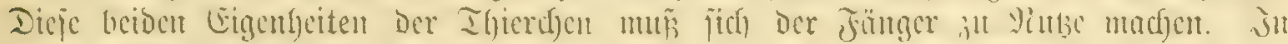

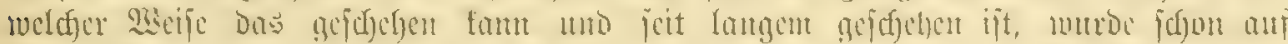

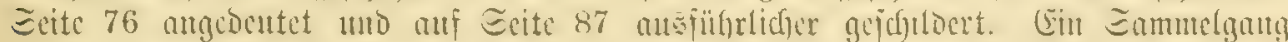

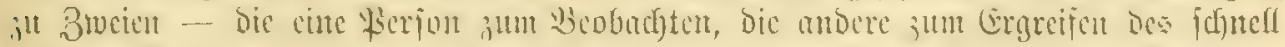

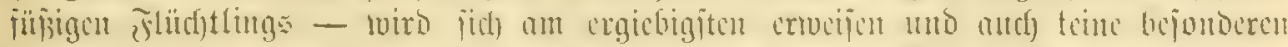

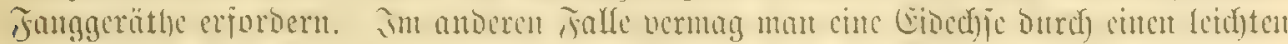

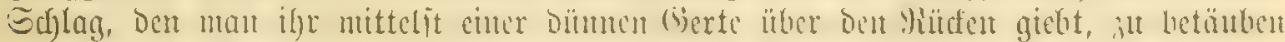

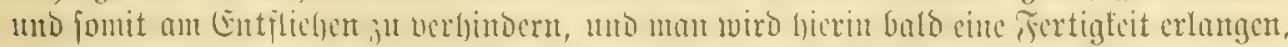

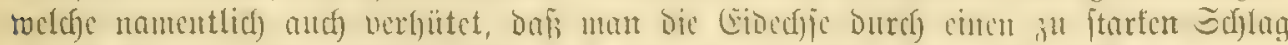

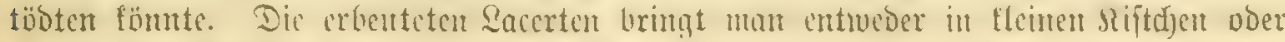

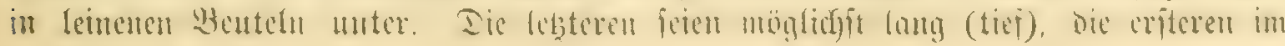




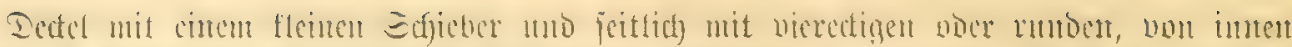

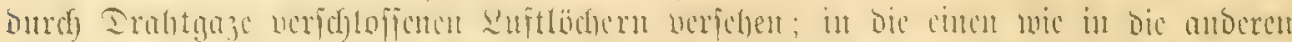

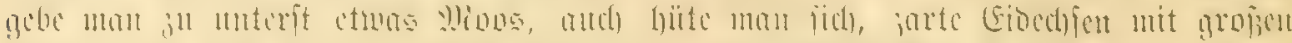

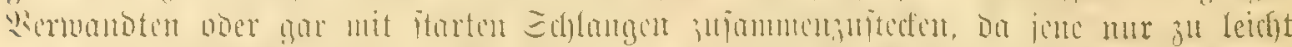

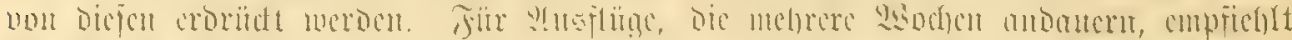

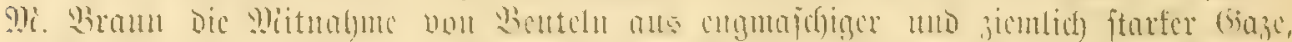

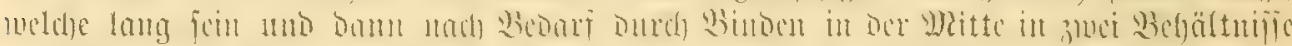

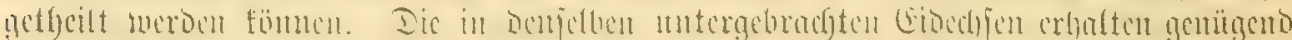

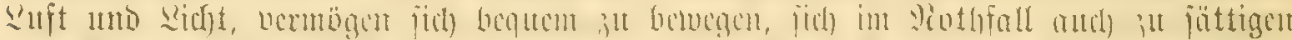

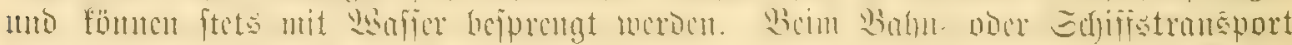

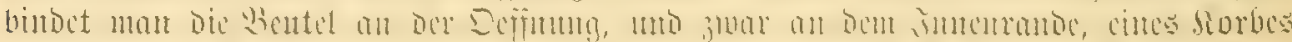

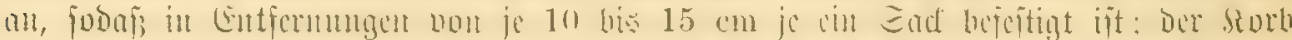

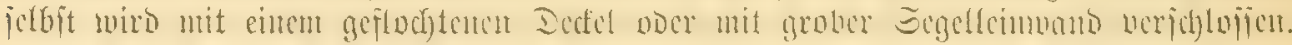

Eidedjen in 3 immmer.

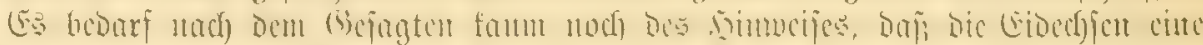

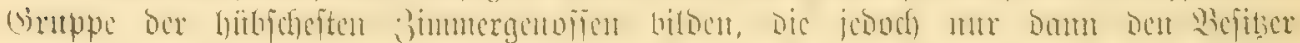

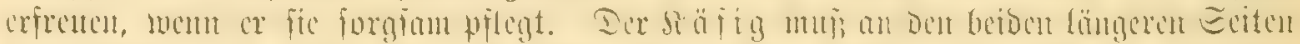

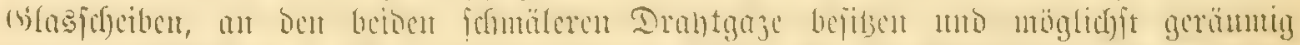

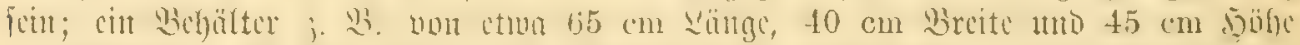

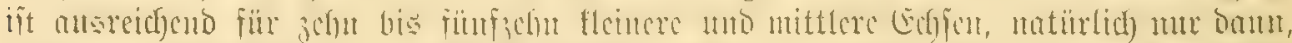

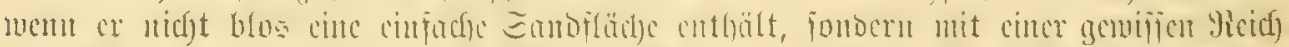

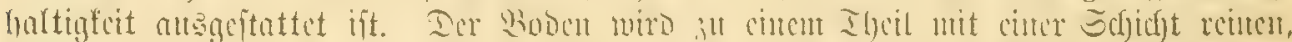

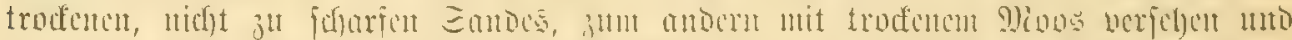

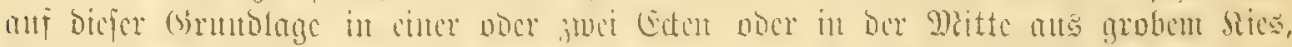

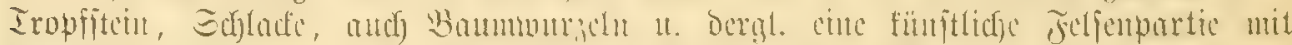

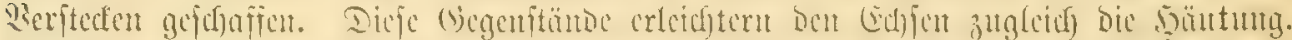

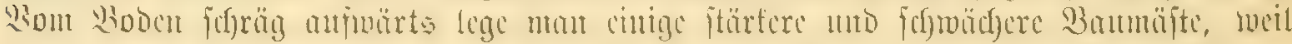

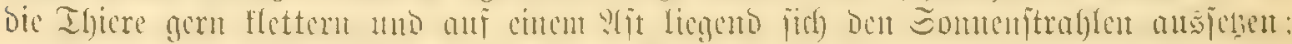

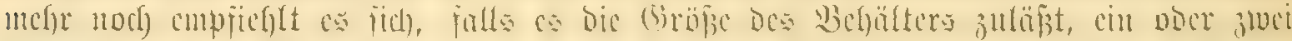

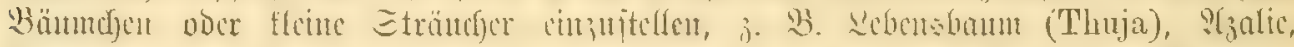

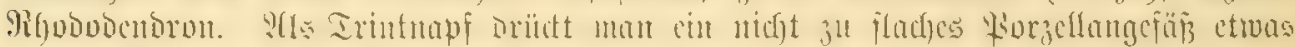

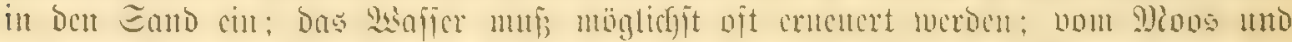

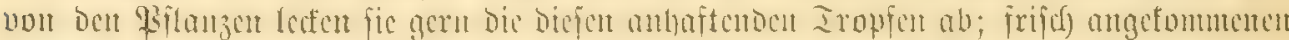

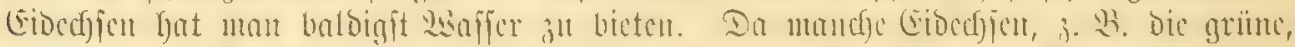

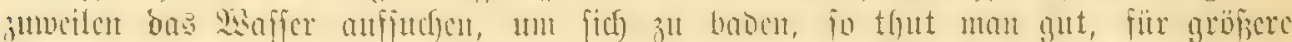
Ermplare cinen acrämmigen

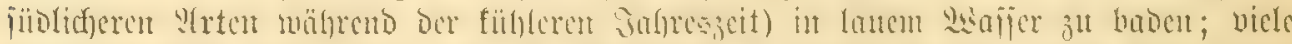

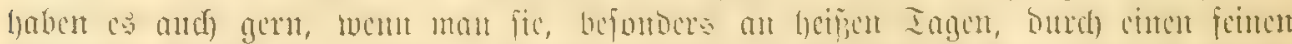

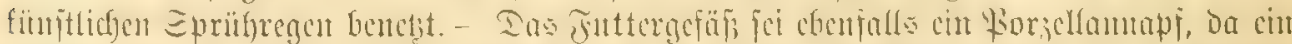

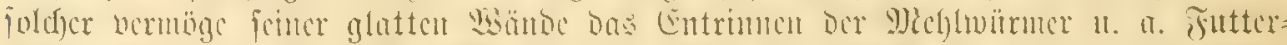

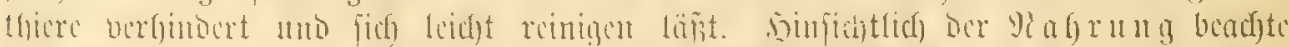

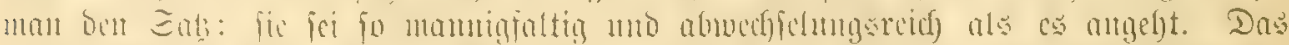

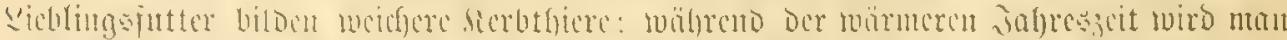

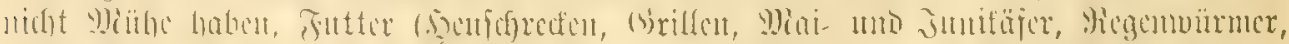

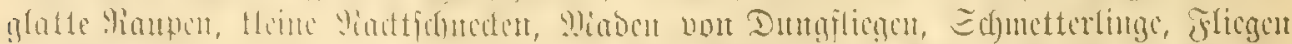

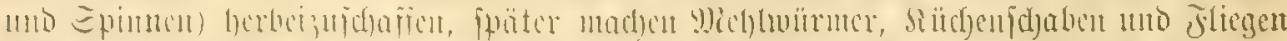

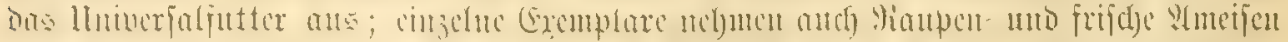

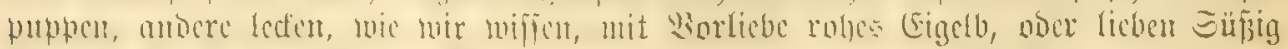

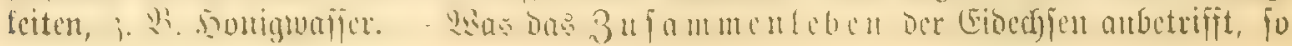




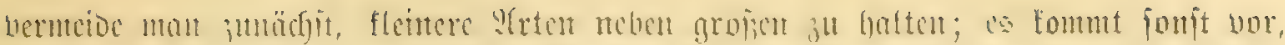

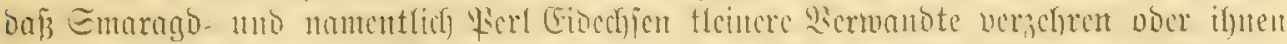

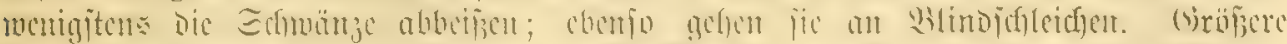

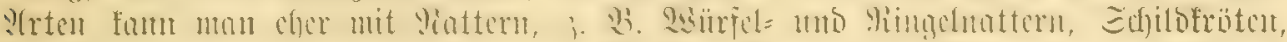

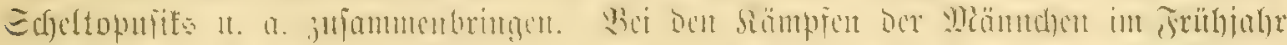

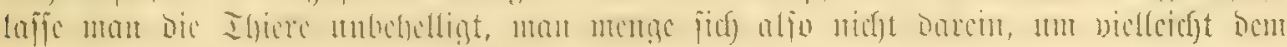

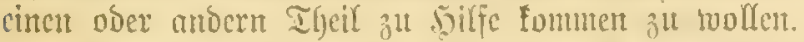

Sut Forthifan;

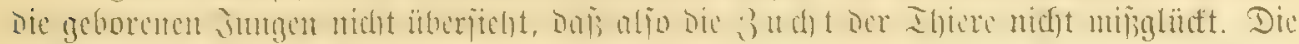

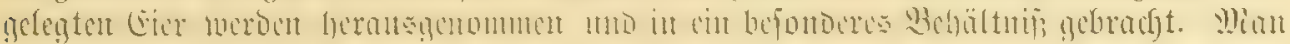

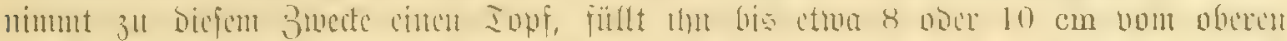

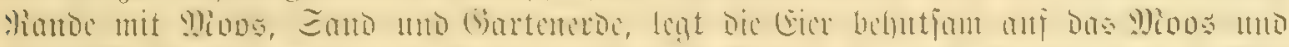

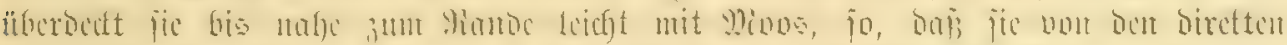

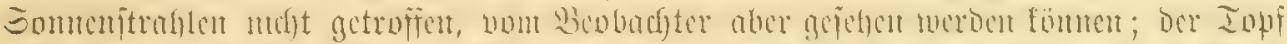

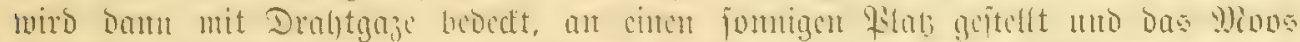

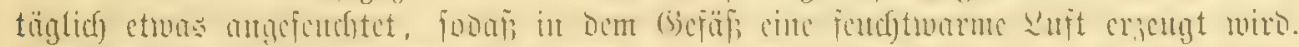

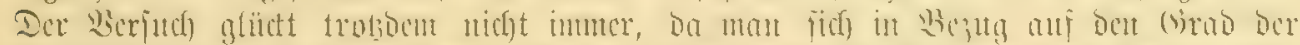

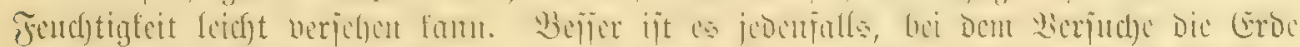

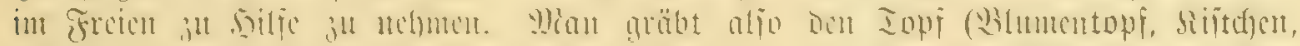

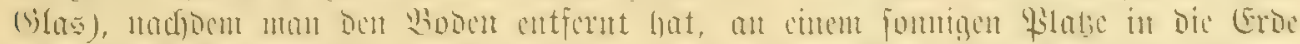

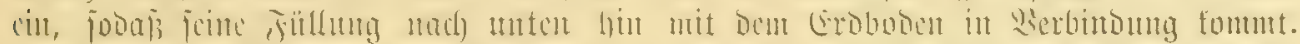
In (b)

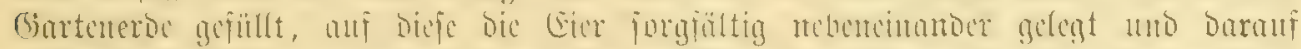

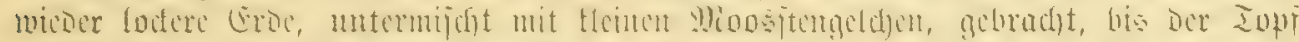

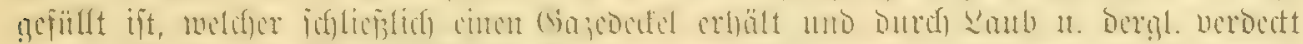

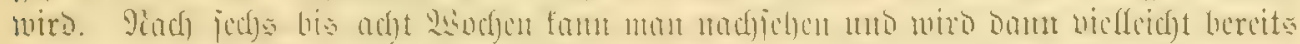

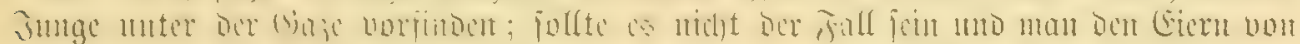

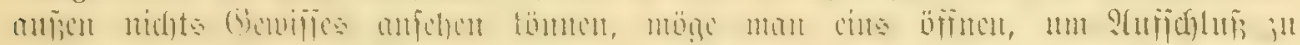

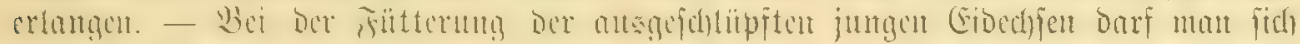

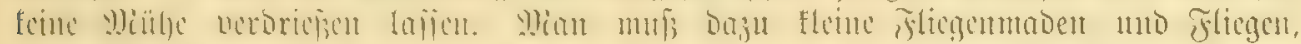

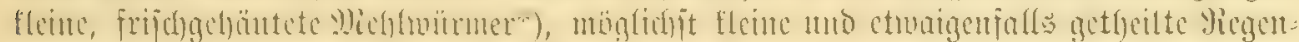

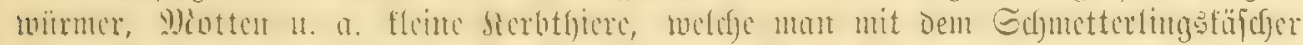

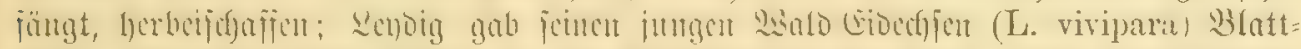

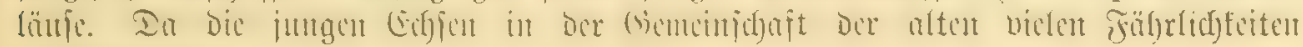

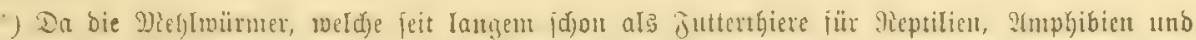

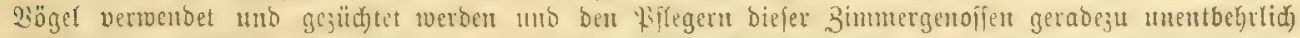

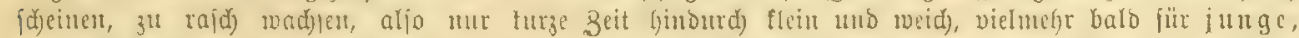

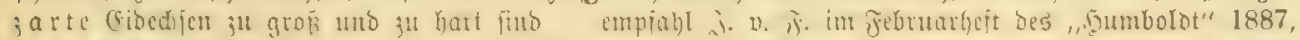

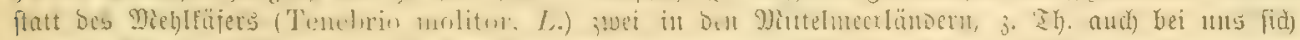

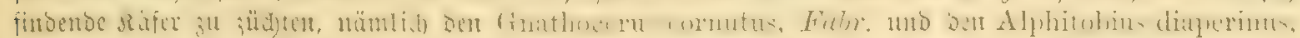

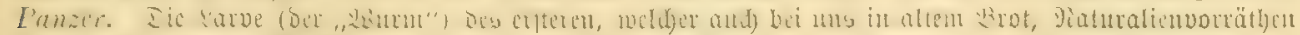

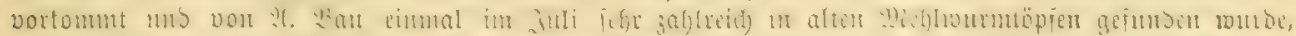

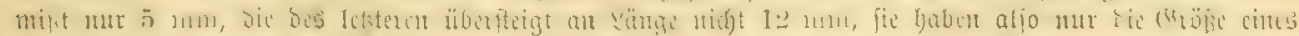

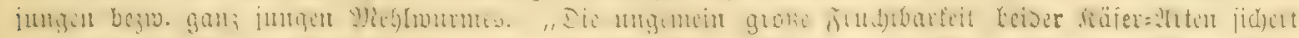

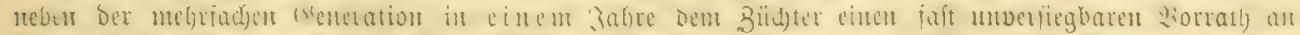

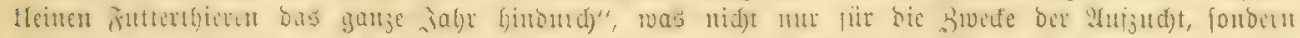

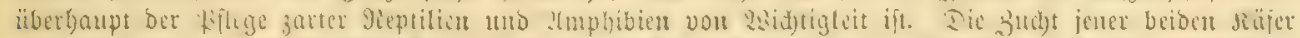

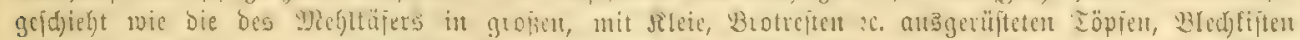

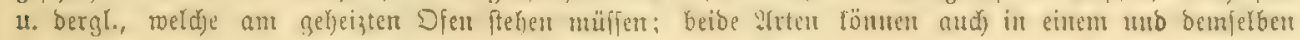
Begälter untergebradt zuerben. 
ausgejebt finto, bringt man ite licber it ein gerämmigu fijd)glas oder ein fleines

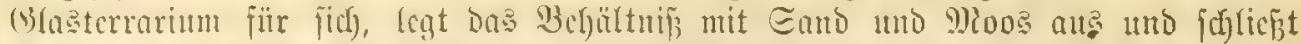

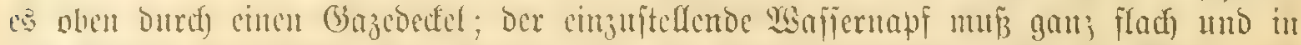

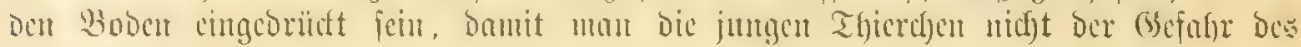

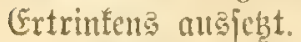

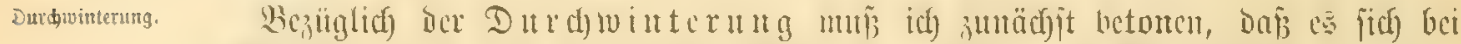

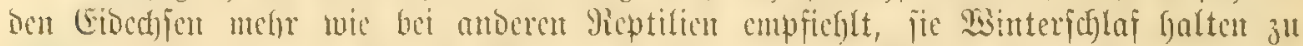

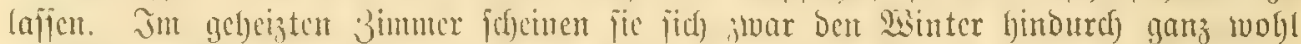

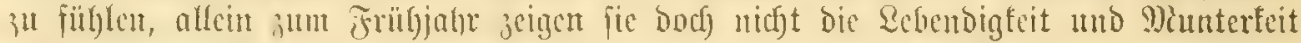

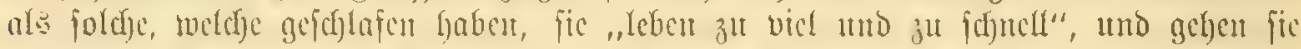

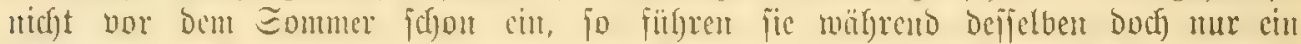

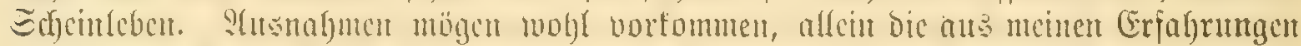
refultirende sicgel ift bie chen angegebene. Dan bringt bie Thicre aljo jum joerbit,

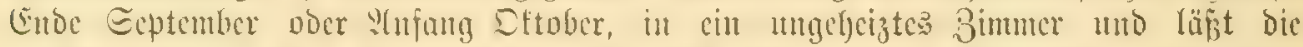

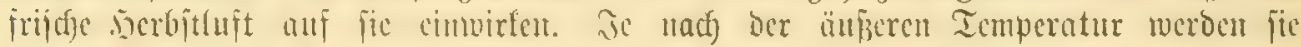

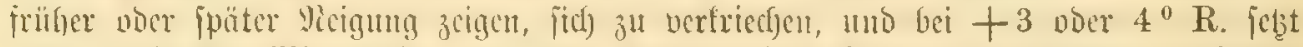

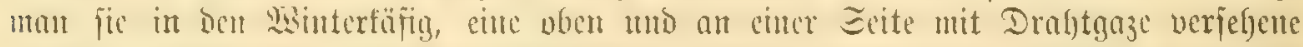

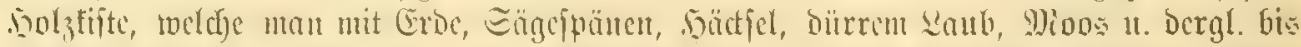
zicmlicf obenfiu gefüllt hat. Der Siajten blcibt an curm rubigen Drte im Bumer

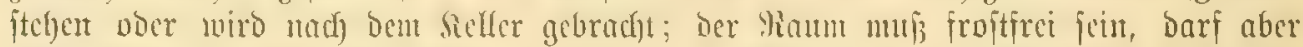

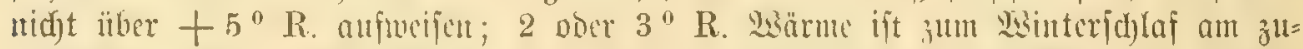

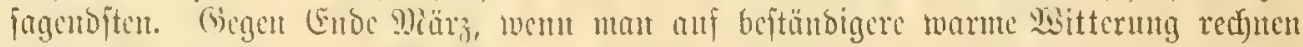

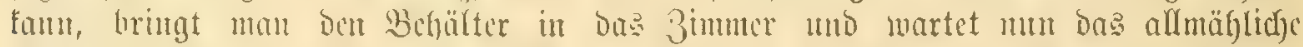

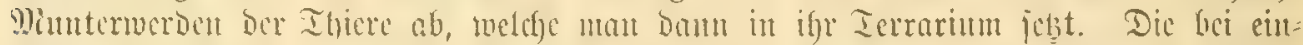

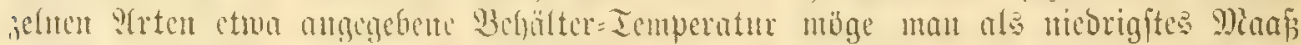

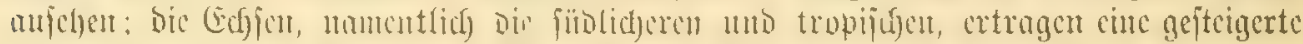

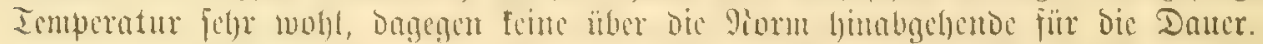

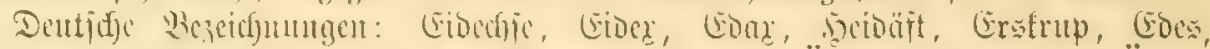

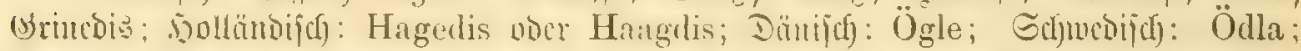
Ëglifd): Lizard; Fran,: Lézard; ital.: Lacerta, Lucerta; છpan.: Lagartija;

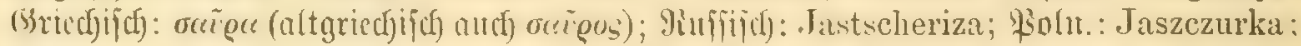

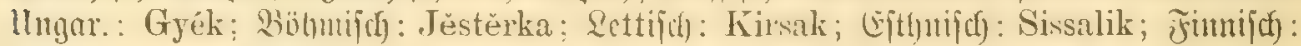

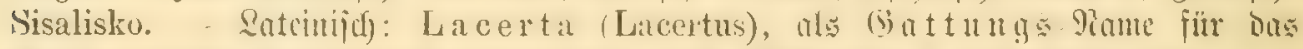
(Sents Cibedjic won Liแ ué anyenommen 1758 [Syst. nat. I pag. 200, 105].

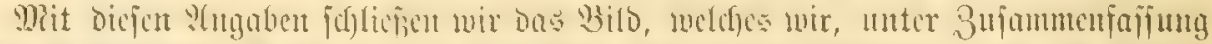

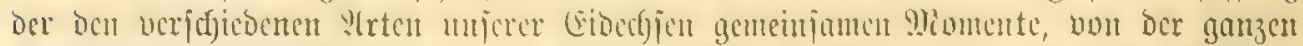

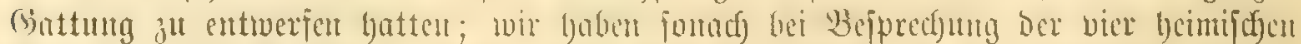

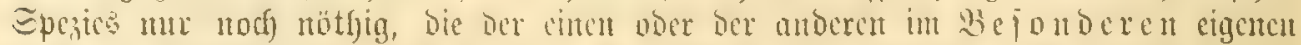

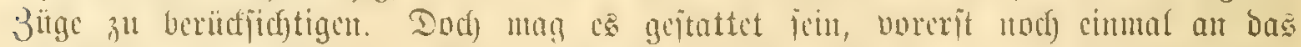

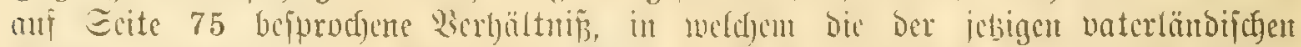

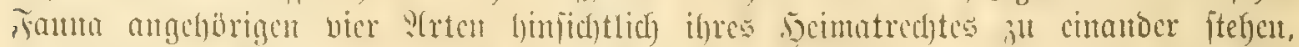

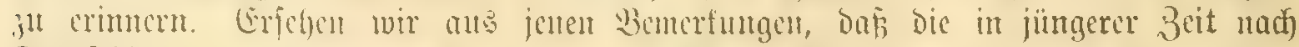

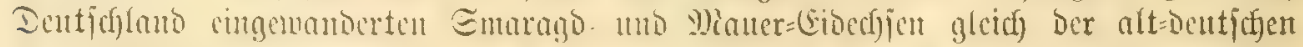

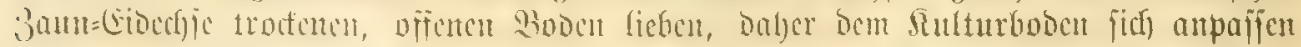

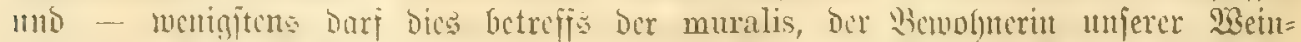
gelände mo beren llmugbung, gelten - ihm ittoaigufalls jogar folgen, fo weidjt

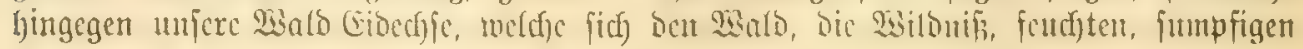

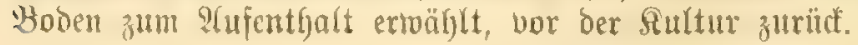




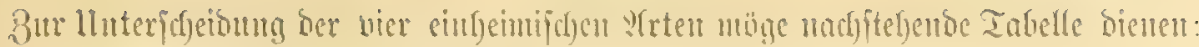

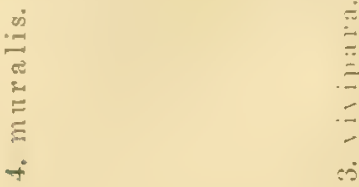

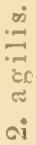

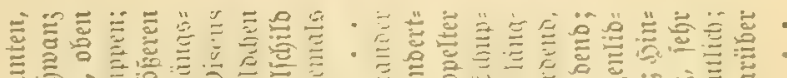
00

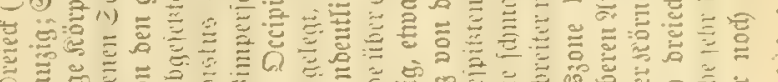

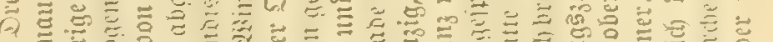

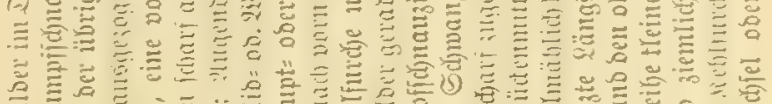

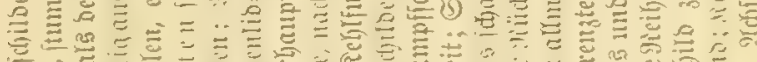

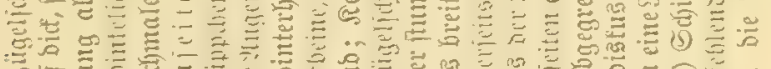

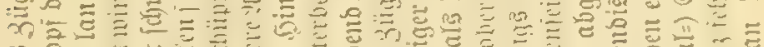

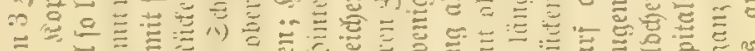

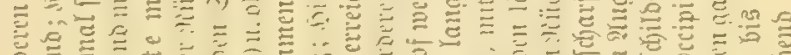

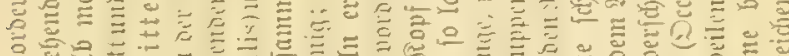

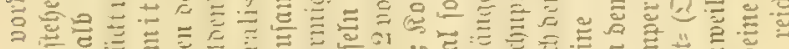

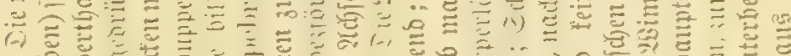

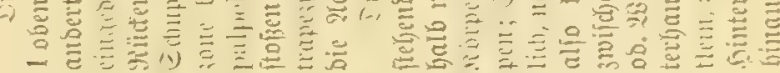

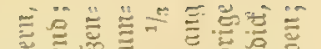

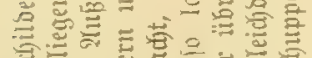

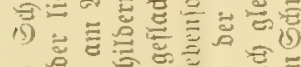

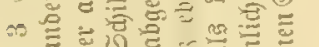
为送

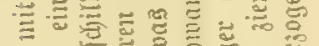

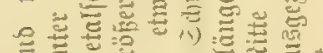

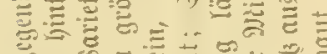

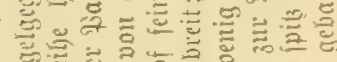
绨范 2

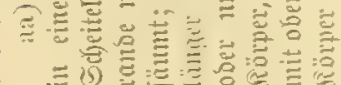

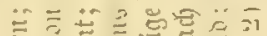

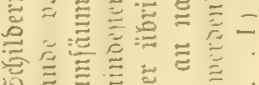

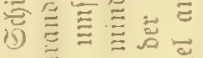

+

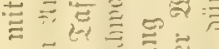

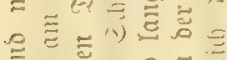

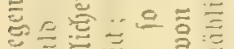

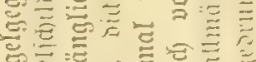

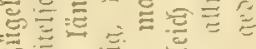
粞 ลิ)

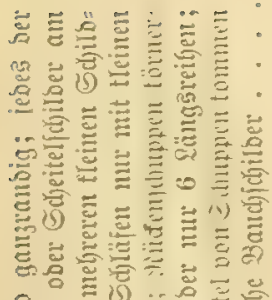

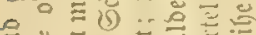

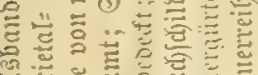

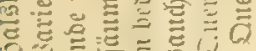

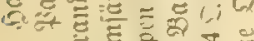
क

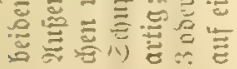

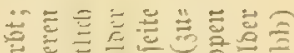

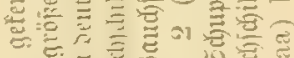

$\overrightarrow{\mathrm{a}}=\mathrm{E}$

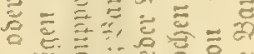

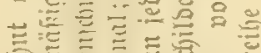

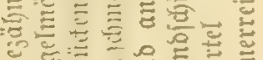

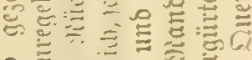

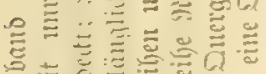

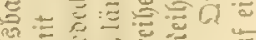

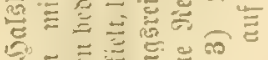

ऽ

ล 


\section{9.rt: Smaragd-Eidechfe. Lacerta viridis (Laur.). 2tbbildung: Tafel X Mr. 2, 3, 4.}

Kopi stwa anderthalb mal fo lang als brit mo wang bretter als hot,

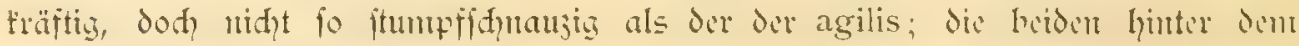

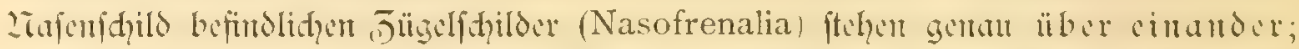

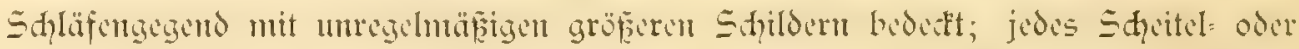

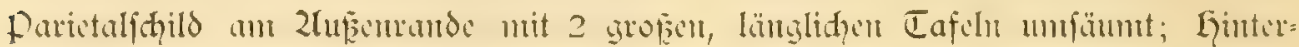

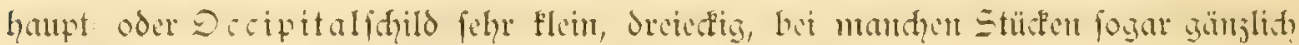

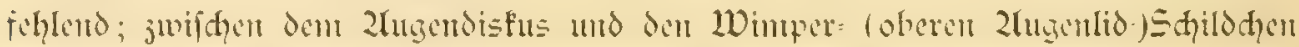

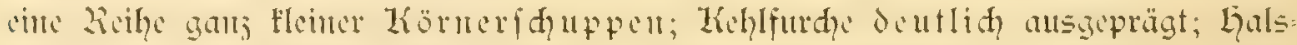

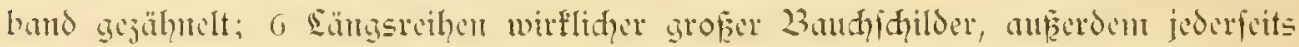

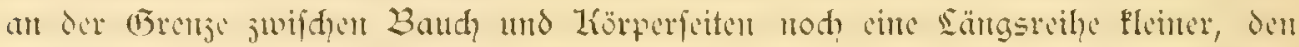

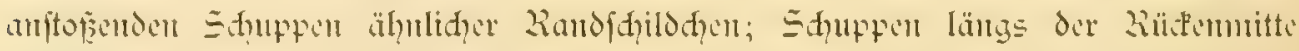

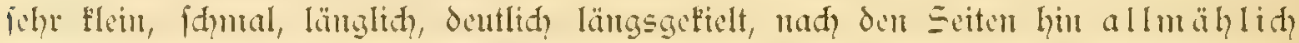

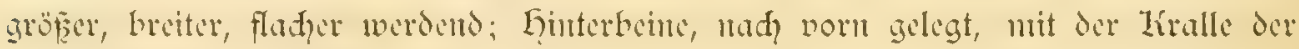

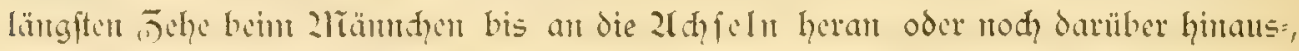

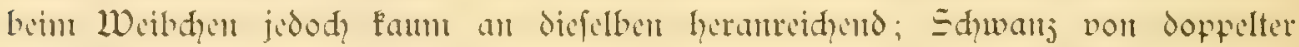

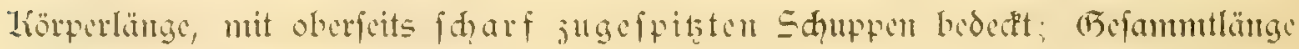
$50-50 \mathrm{cin}$, feltenter $60-66 \mathrm{~cm}$.

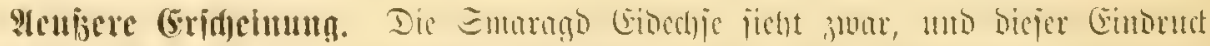

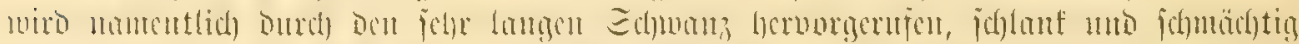

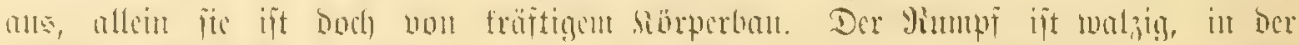

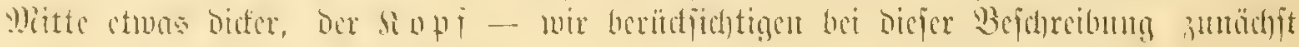

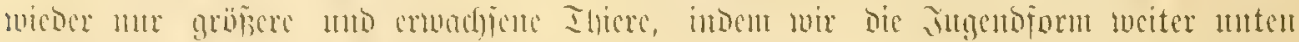

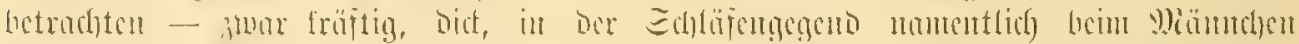

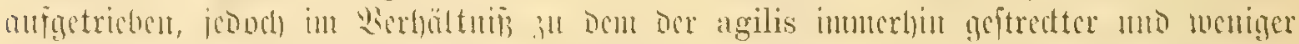

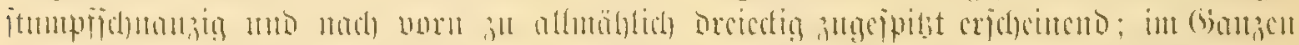

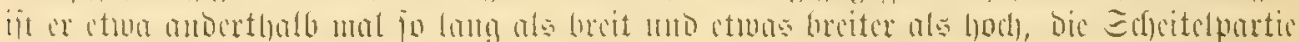

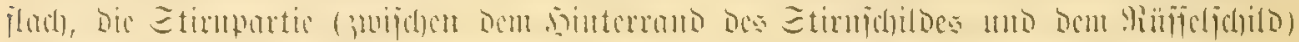

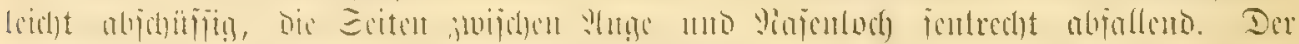

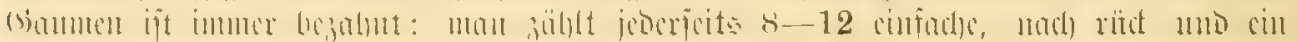

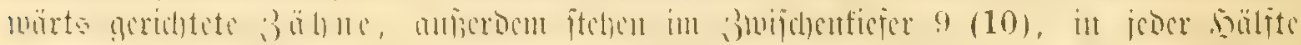

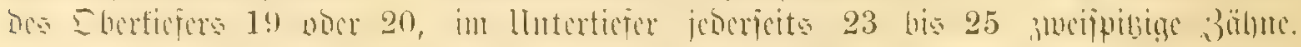

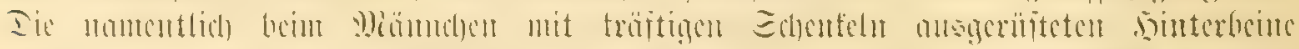

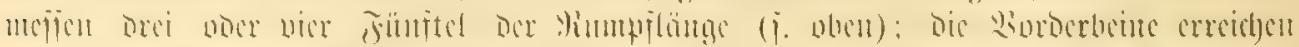

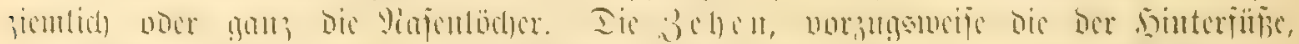

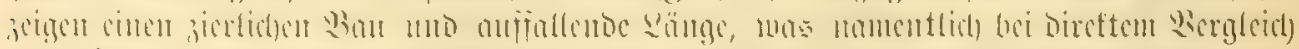

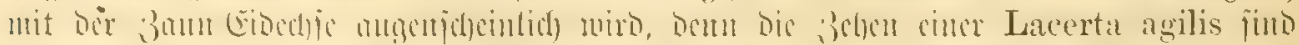

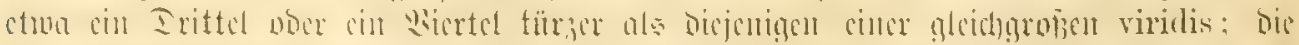

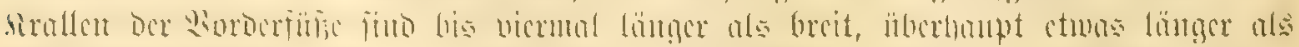

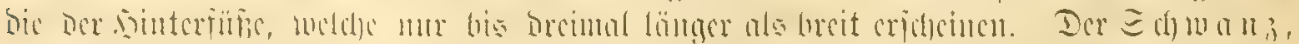

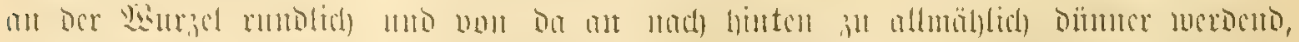

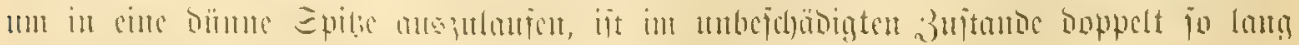

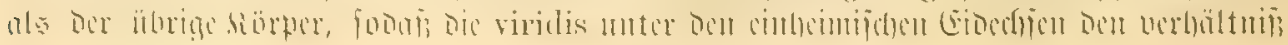




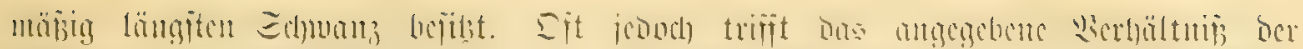

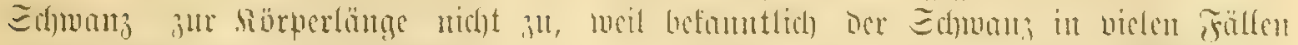

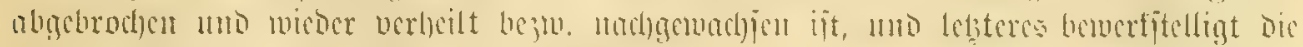

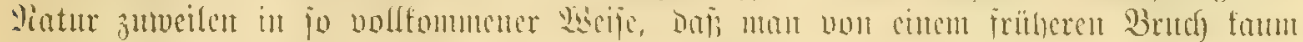

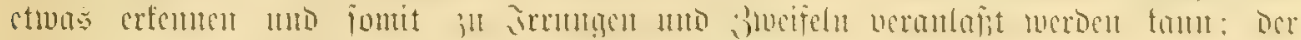

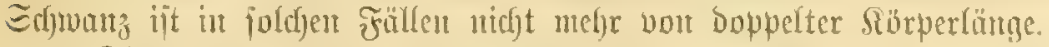

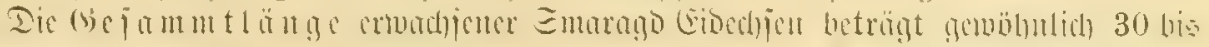

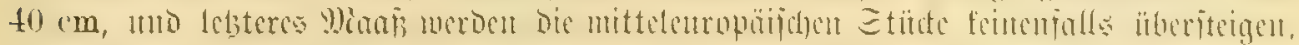

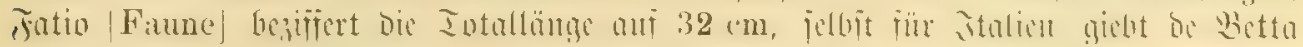

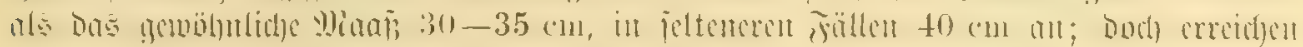

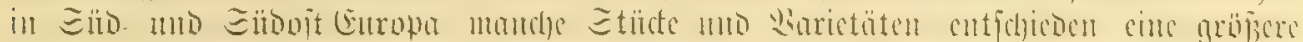

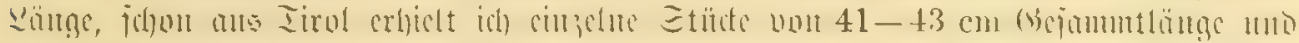

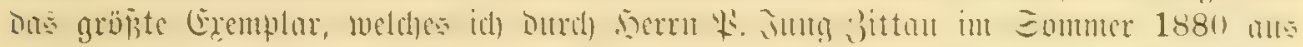

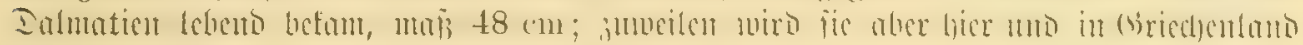

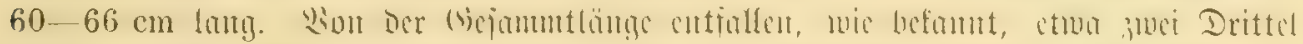

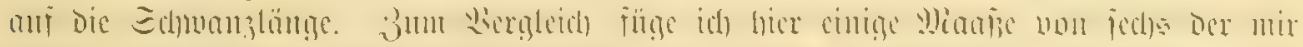

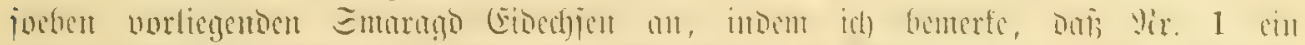

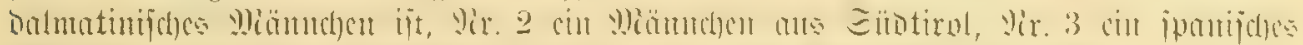

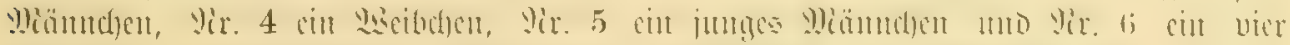

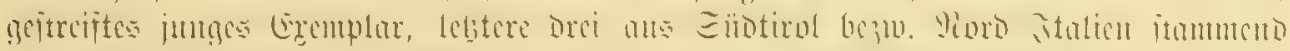

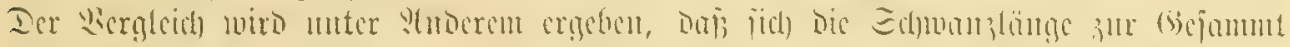

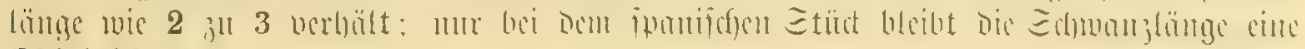
sîlemigfeit zuriät.

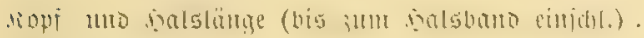
Sopilänge allein *)

humpilänge*).

Ed)mantjlănge.

(ije a unt İ̈nge.

\begin{tabular}{|c|c|c|c|c|c|}
\hline$\Re$ R: 1 & $\mathfrak{R i}_{1}, 2$ & $9 i x .3$ & gir: 4 & शir. 5 & 3 \\
\hline min & ImIII & $1 \mathrm{~mm}$ & $\mathrm{inm}$ & $\mathrm{mm}$ & $\mathrm{mm}$ \\
\hline 46 & 37 & 34 & שs & 28 & 21 \\
\hline 34 & 26 & 22 & 19 & 19 & 15 \\
\hline 94 & 77 & 77 & 64 & 57 & 43 \\
\hline 259 & 240 & 181 & 186 & 191 & 140 \\
\hline 402 & 354 & 292 & 278 & 276 & 204 \\
\hline 17,5 & 16 & 12 & 11,6 & 11 & \\
\hline 22 & 17 & 15 & 11 & 11 & \\
\hline 15 & 11 & 11 & 8 & 8 & \\
\hline
\end{tabular}

rivopte sopjoreite

Wireitt der Ropiplatte (Pileus)

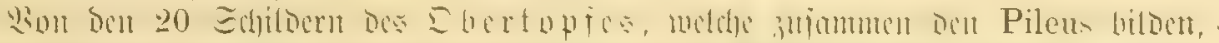

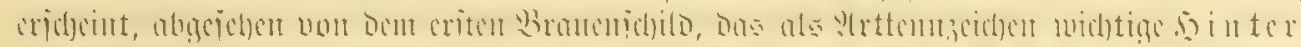

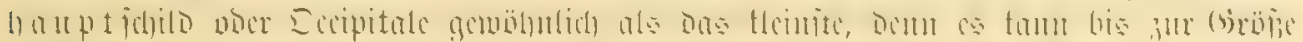

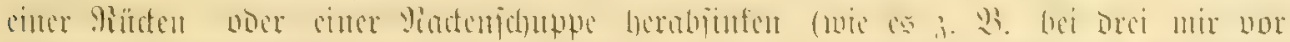

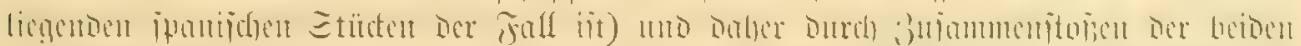

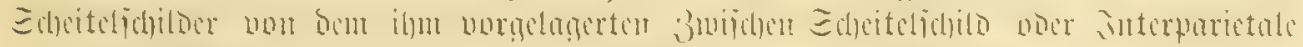

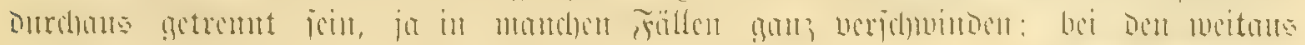
meciten ber vou mir Darauffit angejeffenen Exemplare war

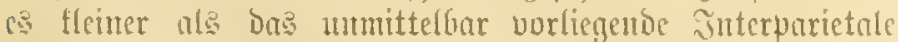

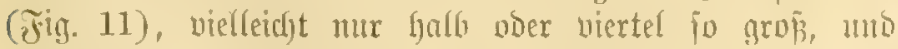
Stitcte, bei benent es ebenjo lang und ebempo breit voer gar noch etwos breiter ijt als Das letistgenmute Echilo, trifift man mur jelten, unter Den mittel= und enropäijchen Ifjicren

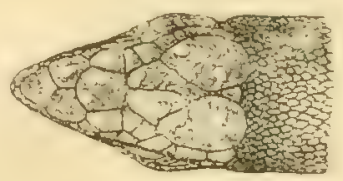

jig. 11. Ropiplatte.

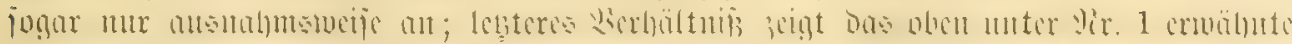

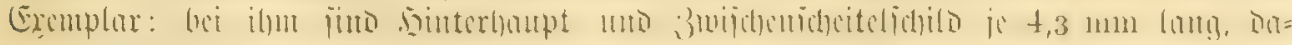

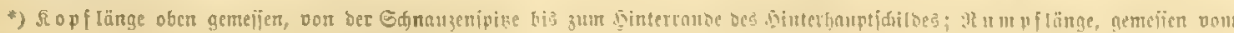
pinterranbe bes sealgbarbes bis zur theripalte. 
açeut bas criftere $1,5 \mathrm{~mm}$ lureiter $(3,8 \mathrm{~mm})$ ale bas leftere $(2,3 \mathrm{~mm})$. Ier (i)citalt

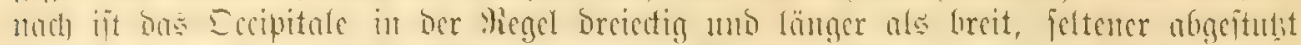

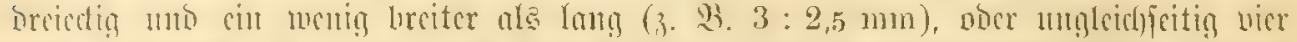

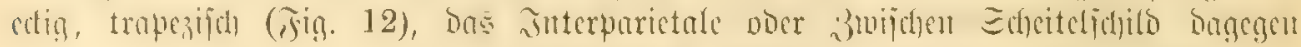

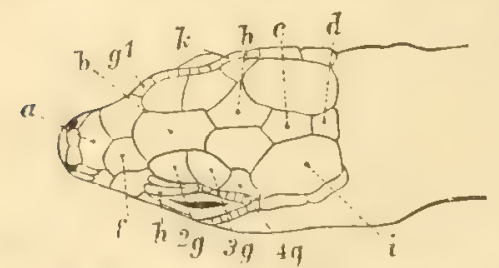

Fig. 12. Inpiplatte ber Gmarags:(Fibedje.

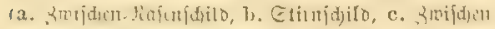

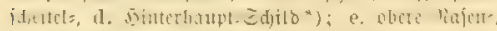

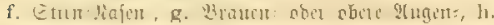

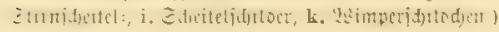
getoblynlidy fünfedig, geitredt, günten fodunal uno gerabe abgeitulst ober abgeruntet, mady born wer= breitert und mit ciner Epise ztvifdjen bie Etirn= Gdjeitelfdilder greifento. Bur Eeite Des Jnter= parietale und Des Decipitale liegen bie beiben größsten Dberfopfichilder, die Das Gtirnforild au Ränge twic an Sreite libertreffenden, vorn berfdumtälerten und

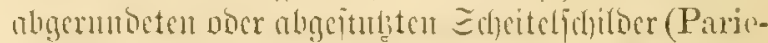

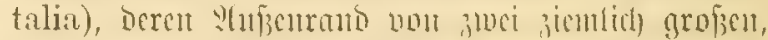

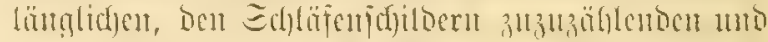
uvic bicje gelagertes Edjilderu umjiblofien mirs,

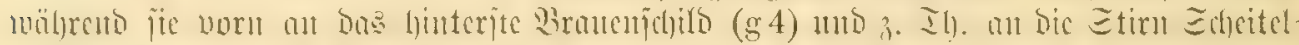

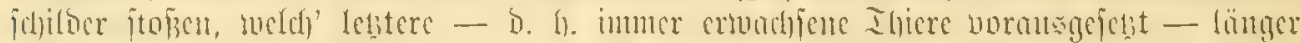

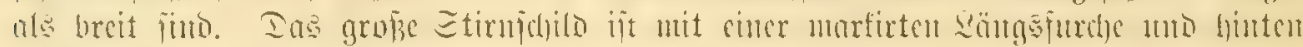

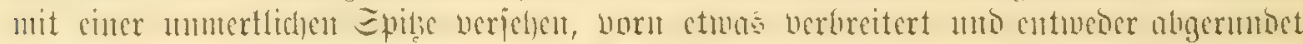

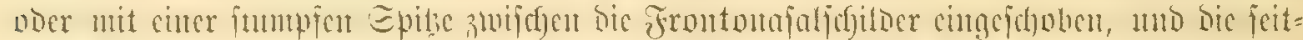

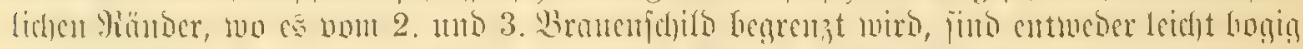

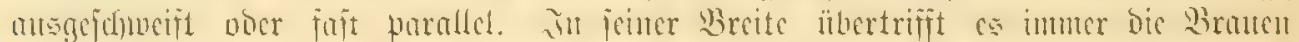

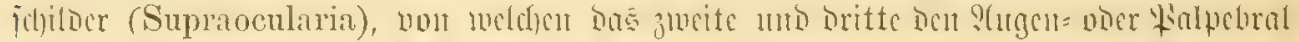

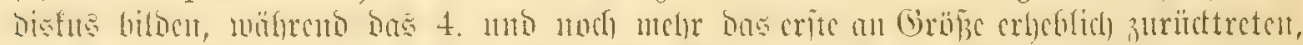

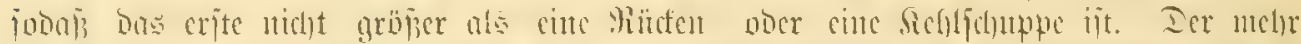

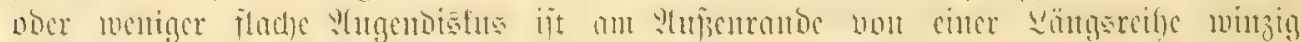

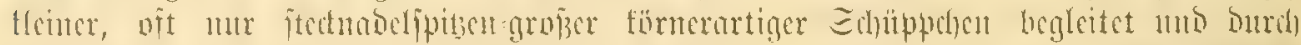

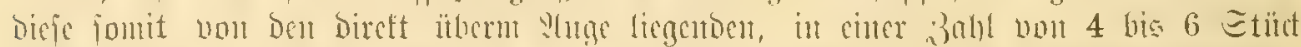

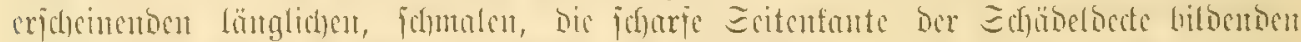

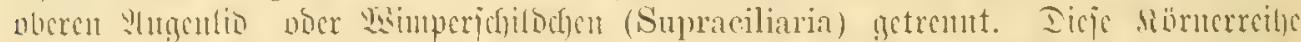

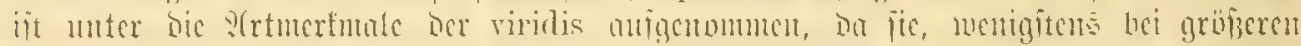

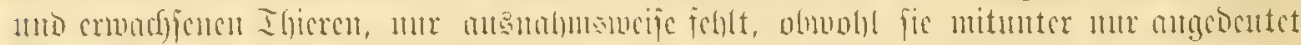

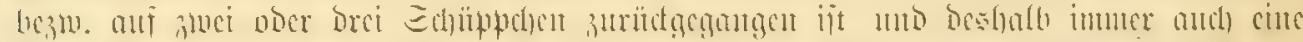

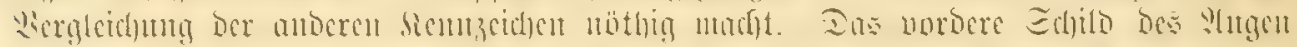

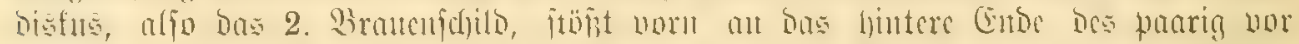

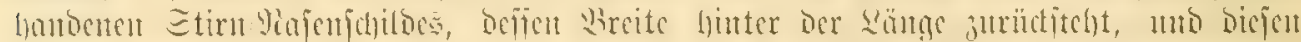

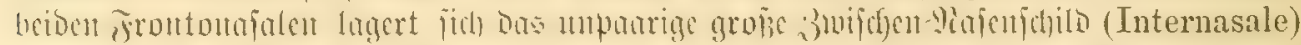

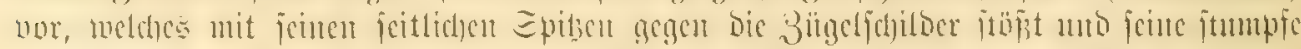

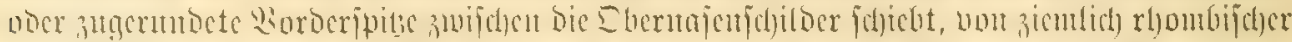

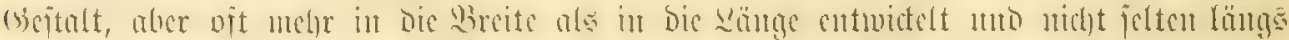

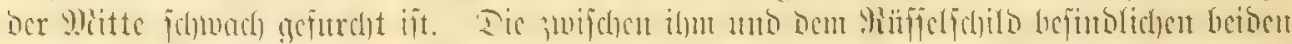

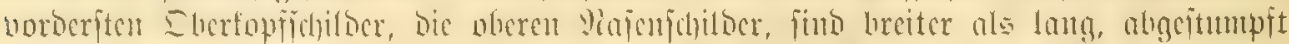

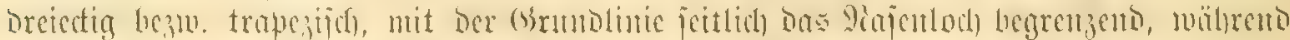

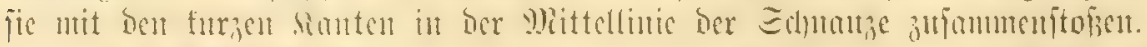

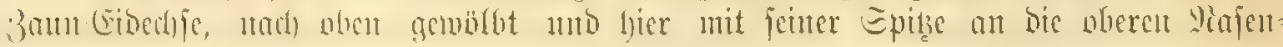




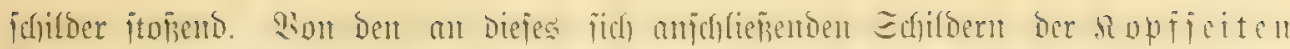

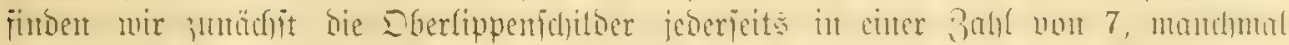

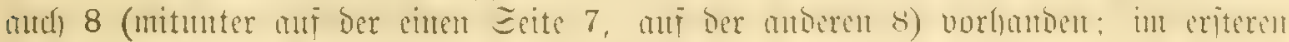

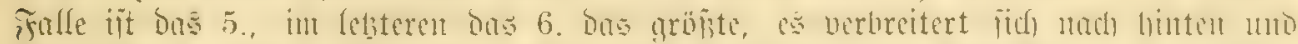

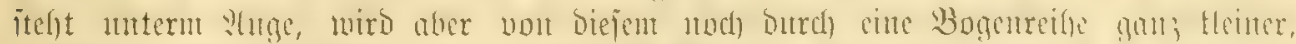

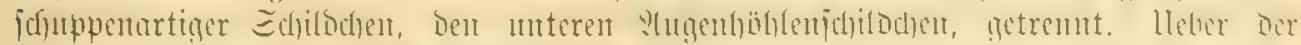

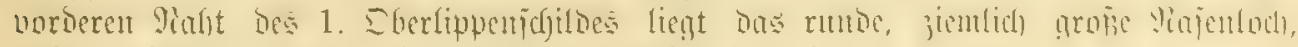
jueldjes hinten von zเvei fleinen, über einander itehenden Sdjildoden, Den গajent=Bügelfdjildern (Nasofrenalia), ım= geben wiro, Deren unteres Dem 1. Dberlippenjchild aufliegt, wälyrento Das etwa gleichgrop̉e obere an Das Jnternajale

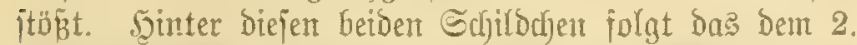

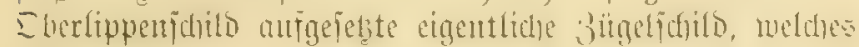
io hoch ijt als jente beiden zujammen and ungefäl)r boppelt fo breit wie ein einzelnes bon ifnen. Şinten wird es

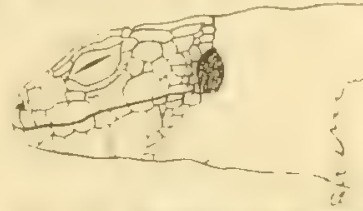

jig. 13. sopilette or Emarago. (Eibed fe

(a. Gdulterjafte.)

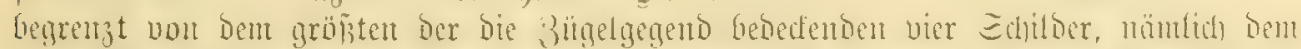

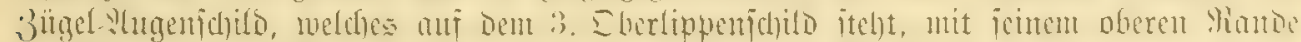

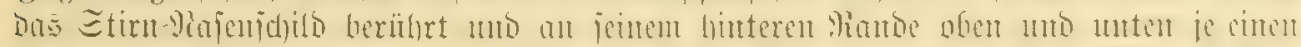

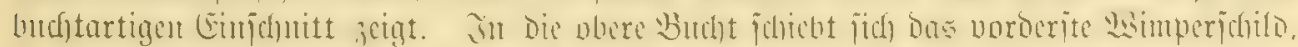

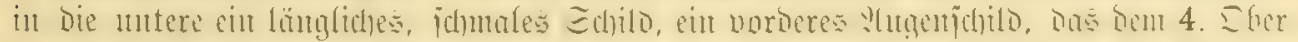

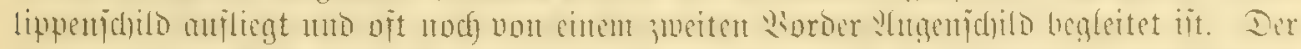

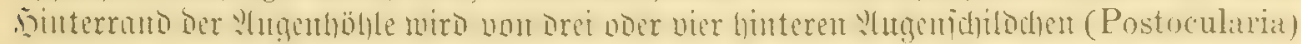

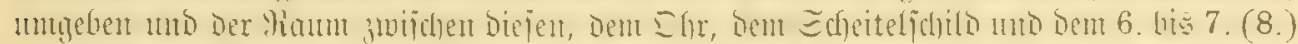

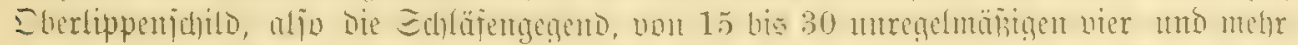

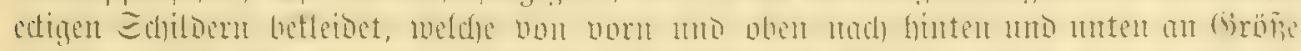

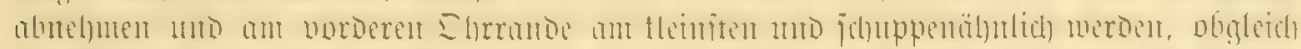

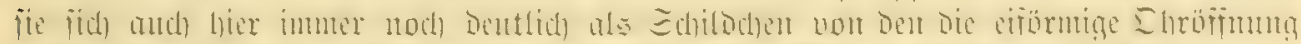

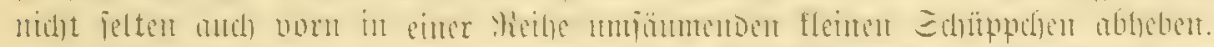

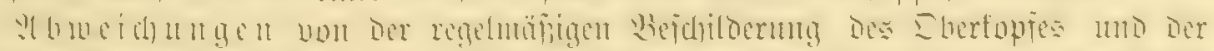

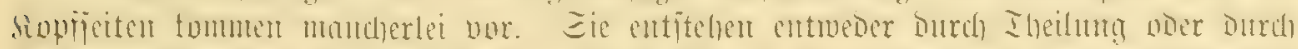

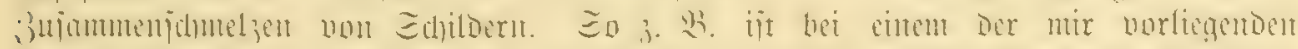

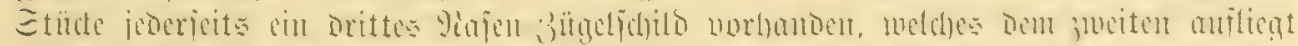

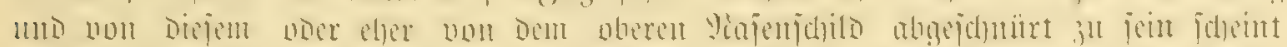

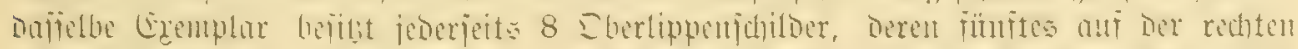

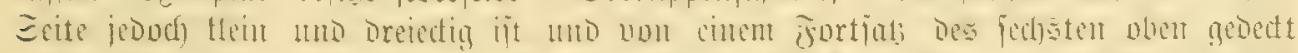

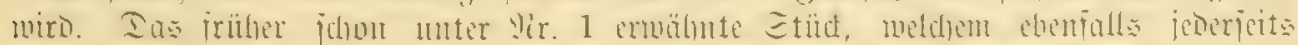

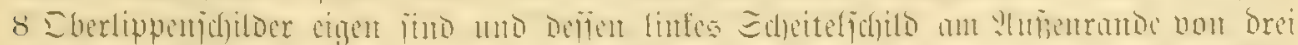

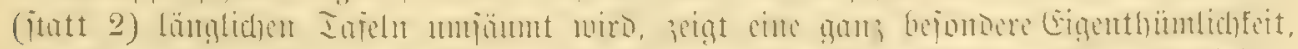

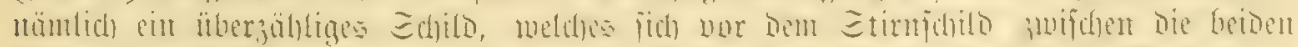

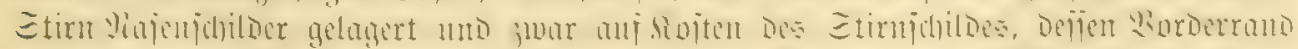

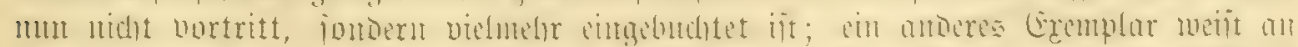

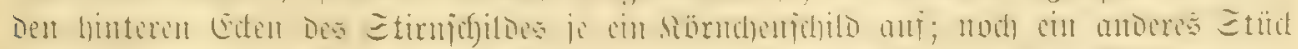

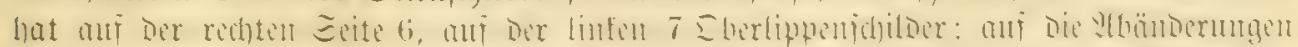

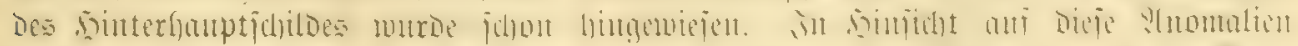

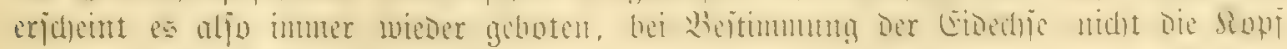
juilder allein zu kathe zu ziegen.

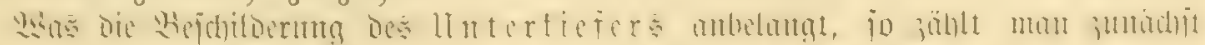

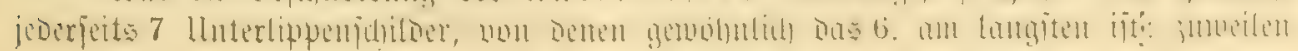

Homeichungen in ber ropi: bejhildeturts. Edilber. 


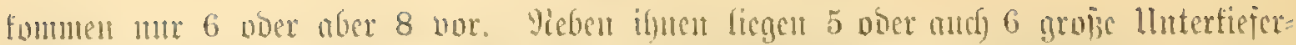

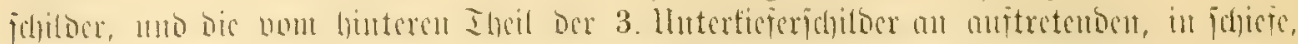

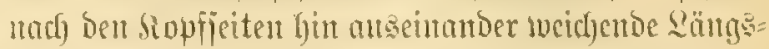
reifen geitcllten Siéglichuppen finb länglich), unbeutfich

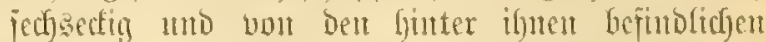

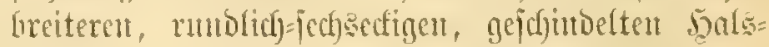

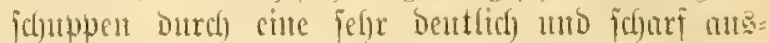
geprïgte, von fleimen Edjuppdjen begleitete Euer:

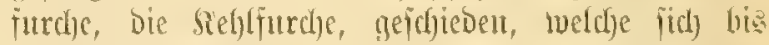
nad) Den Jintermute Der Dlgren finzielst. Das

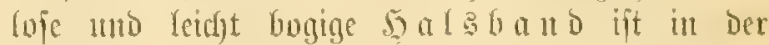
Hegel ats 9, jeltener ans 7 voer 11 แud mu

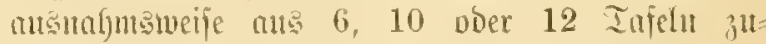
fammengejest, weldye von anken nad inten Dad)=

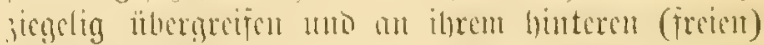

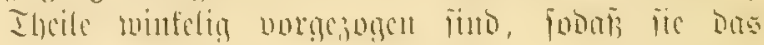

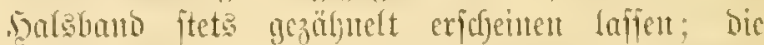
mittlers Injel ijt arijica als bic moeren und itcht gerabe. Da: pogenanute Brujt = Dreted umfajit 7

ijlg. 14. Unterleitc des Ropies (A MRauer:, B Sonarago = (Eibed) fe). a simmidito, b Ilnterippenidirber, c untettiefer:

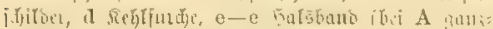

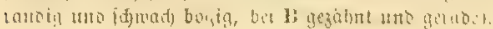

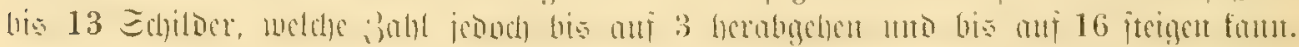

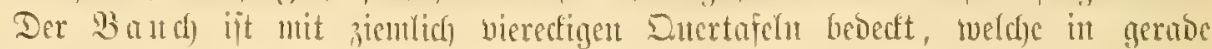

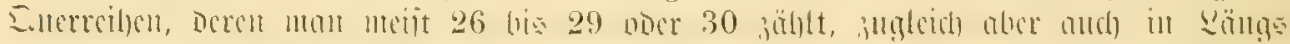

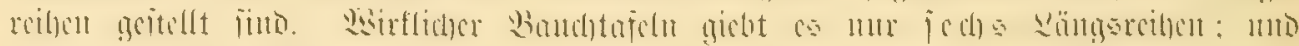

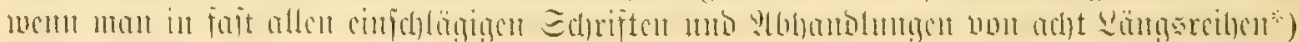

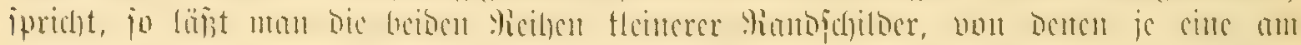

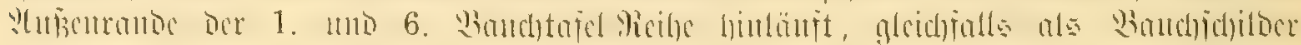

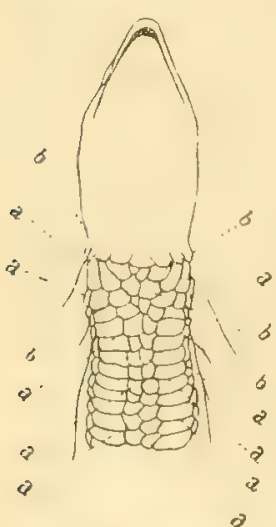

irig. 15. Waudjidilber: Teiben (a) unio brutit idj)ilder: $=$ Dreict $(1)$ bet Gmarago:(ribed)je.

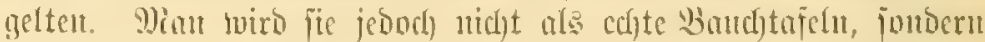
chen un als giondidjiber (Pseudo-Gastrostega) anfeben bitrfen,

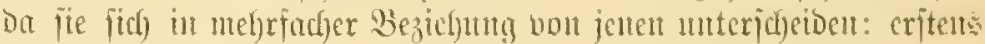

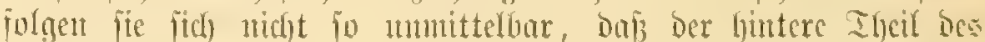
vorbergehenoen über ben Worberranto bes madyitehenden ariffe and

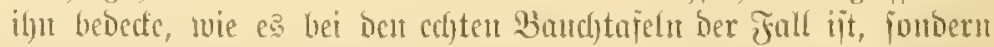

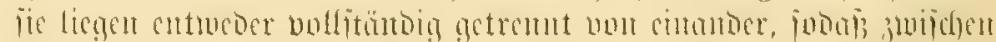
3wei benadjbarten cit ffeuter, vielleidjt gar sou cinter Edyuphe

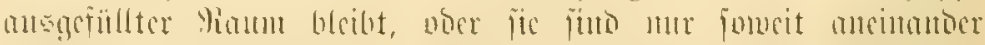

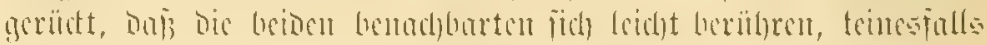
aber über chanber greifen ober fid gegenfeitig anfliegen; zweiten:

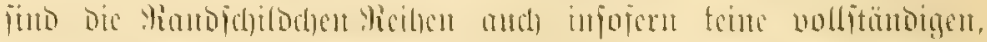

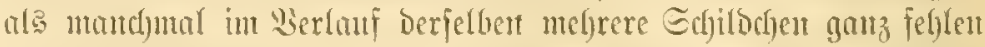

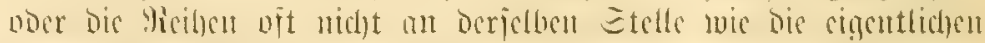

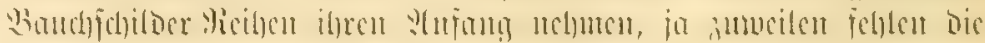

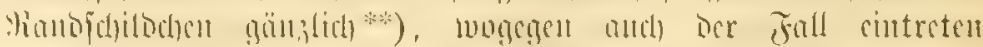

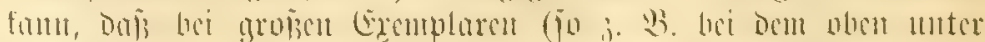

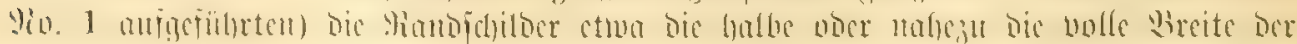

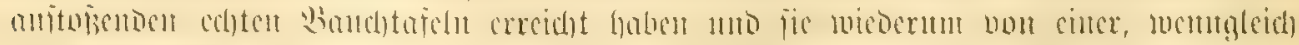

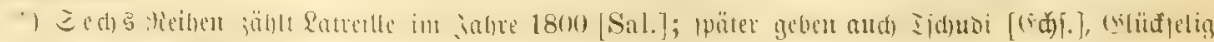

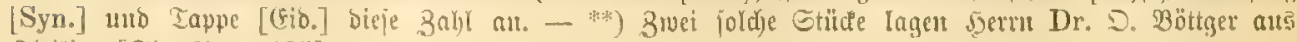
Sicilien [C̈ic. Yiept. 135] nor. 


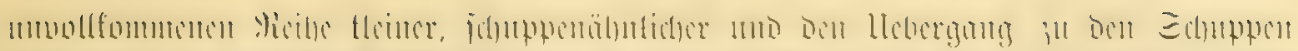

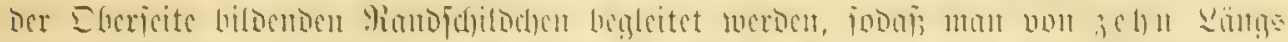

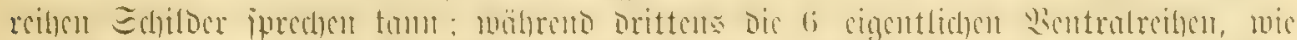

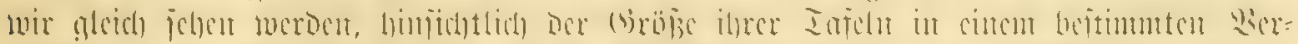

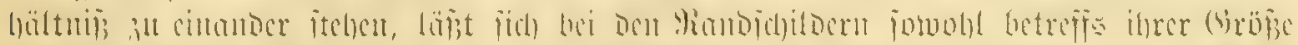

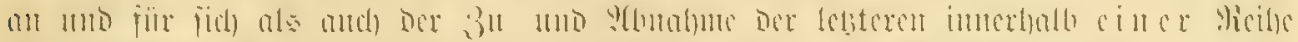

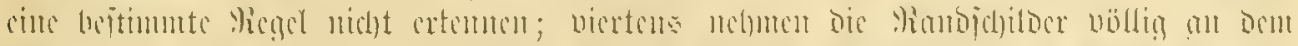

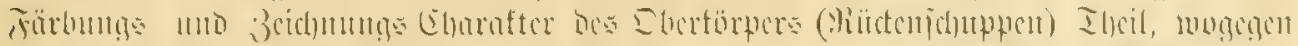

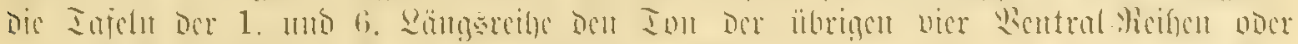

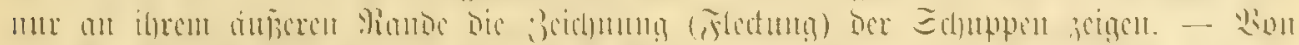

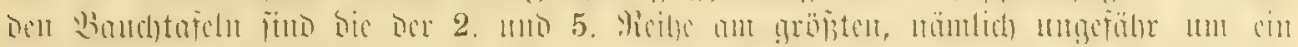

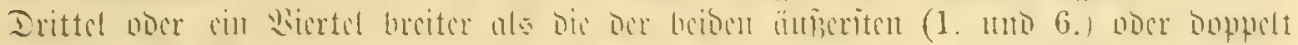

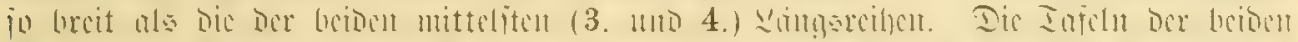

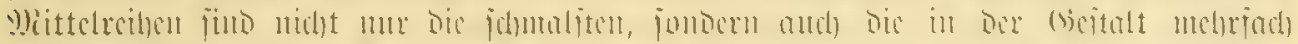

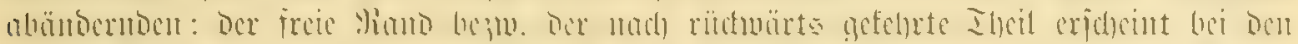

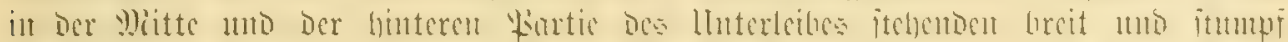

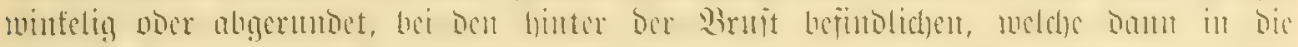

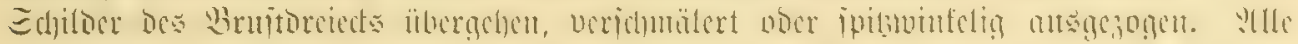

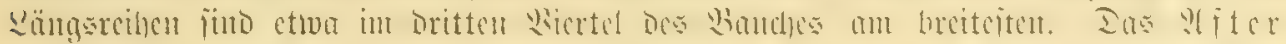

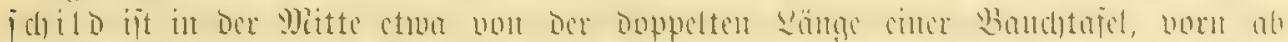

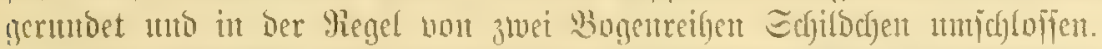

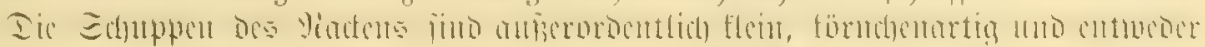

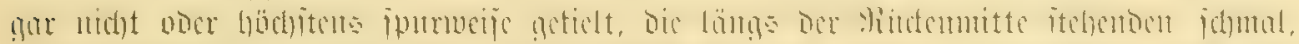

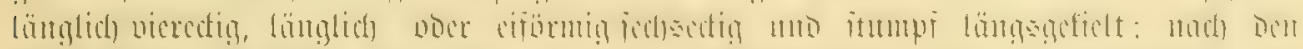

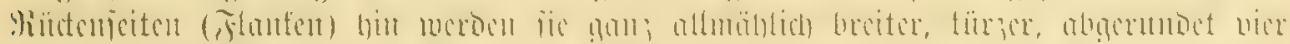

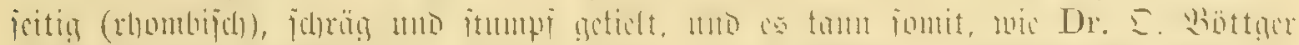

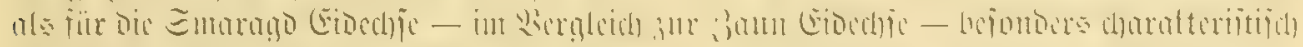

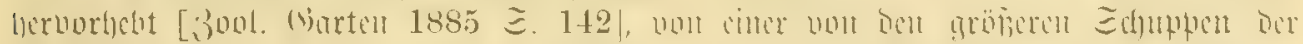

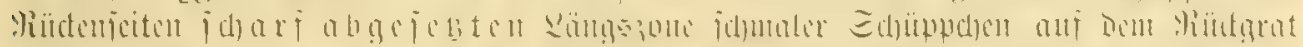

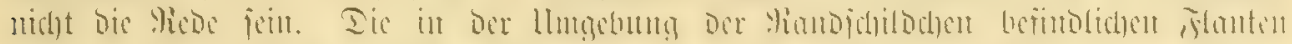

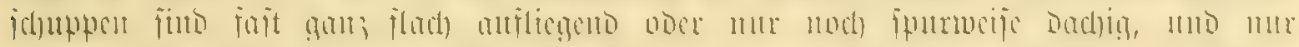

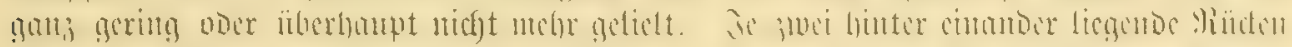

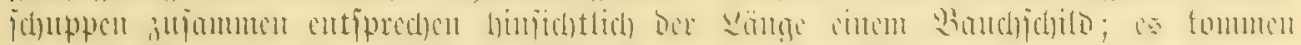

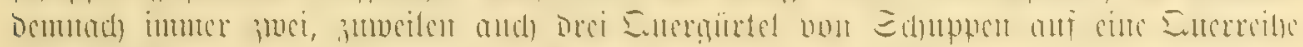

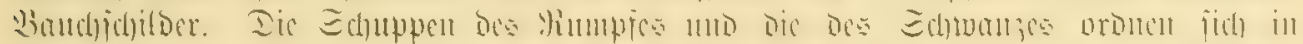

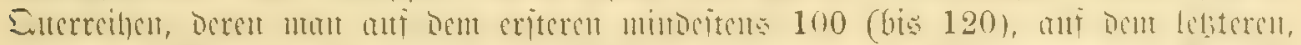

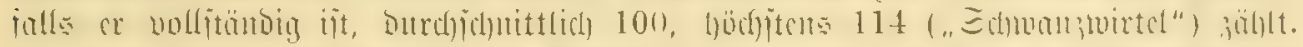

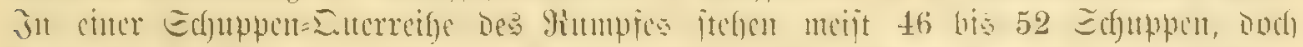

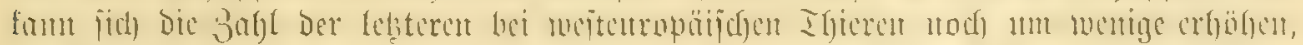

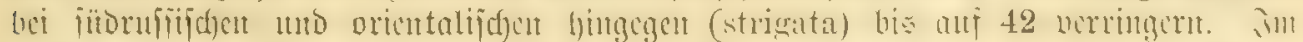

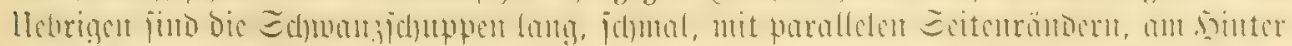

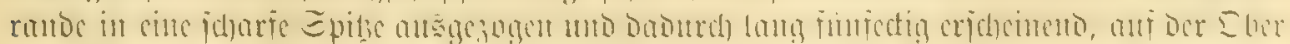

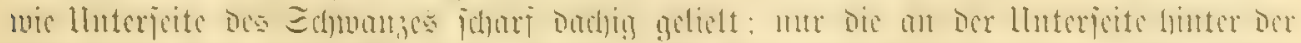

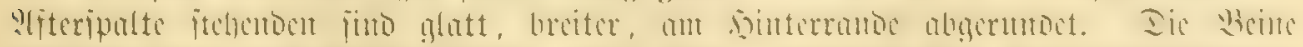

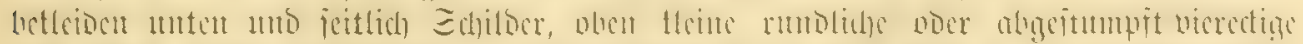

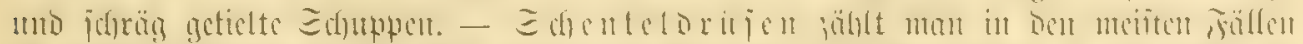

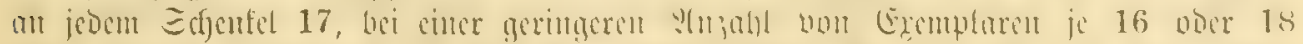

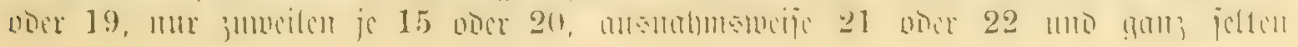




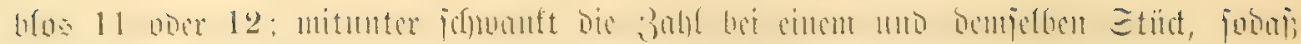
3. 23. anf Den einen Edjenfel 17, anf Dent anderen 18 ficl fintont.

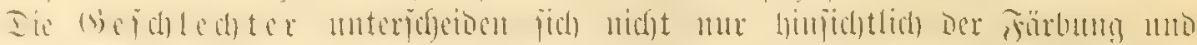

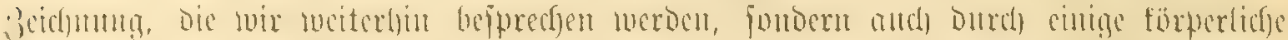

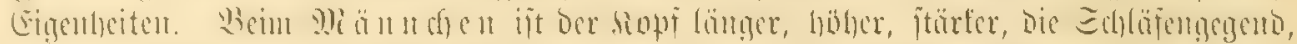

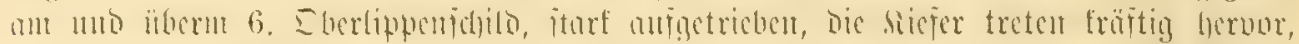
Die Eshmoni,

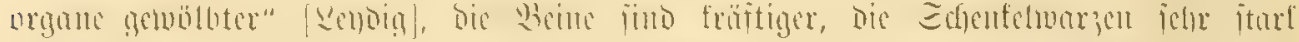

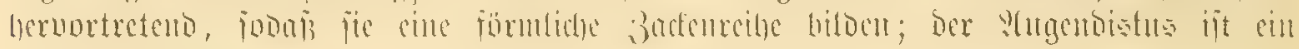
wocuig erfabent.

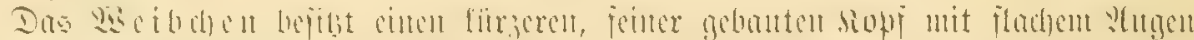

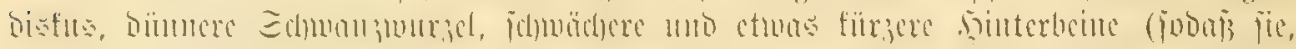

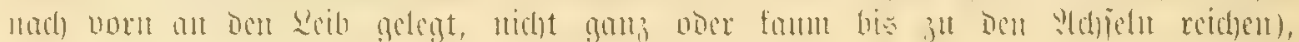
jdyuadie, wentig bemertbare Sdientelporen.

?(bugchen

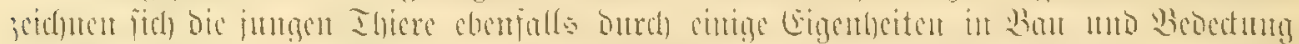

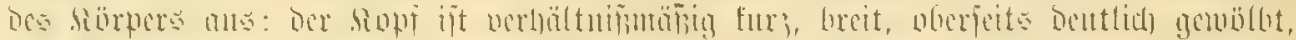

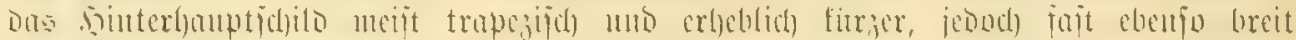

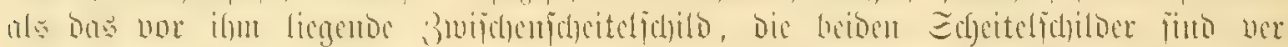

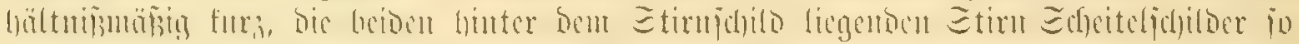

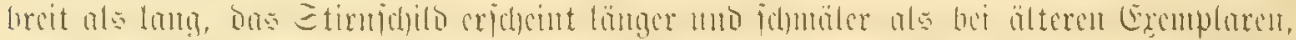

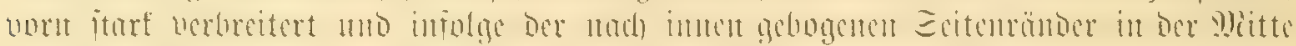

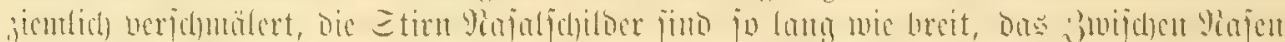

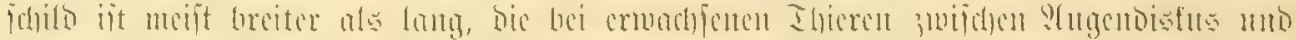

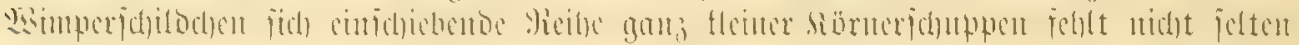
Dent Jutngent.

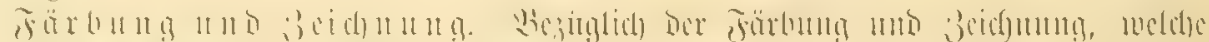

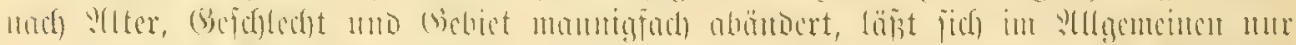

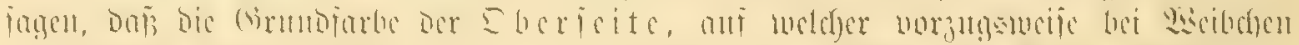

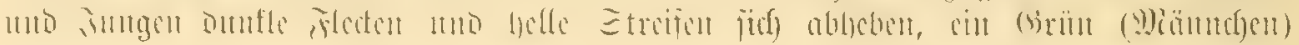

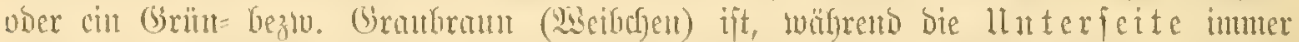

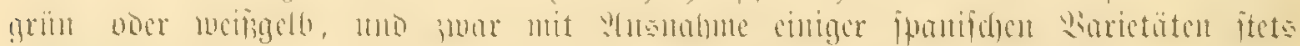

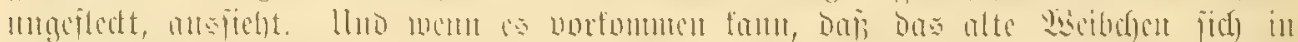

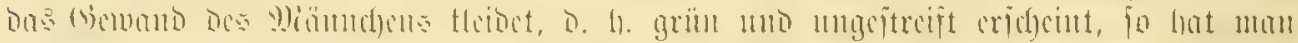

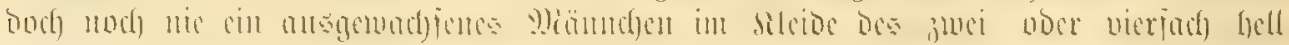

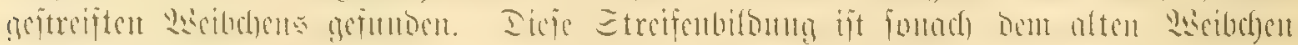

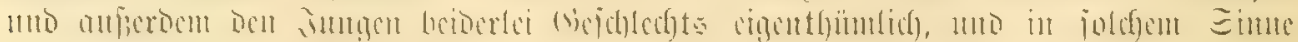

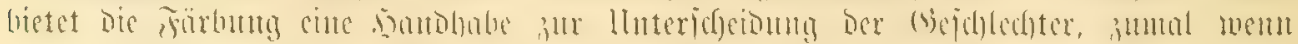

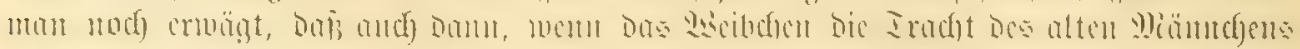

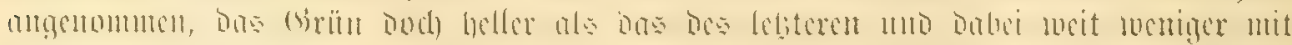

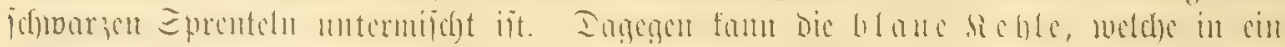

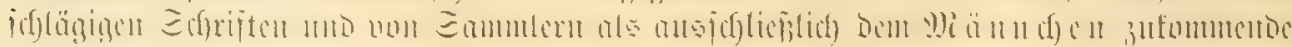

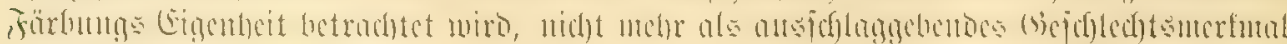

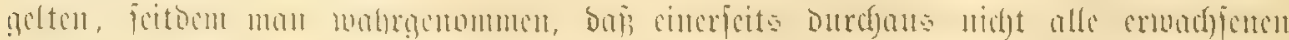

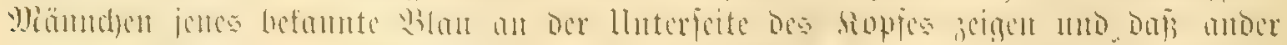

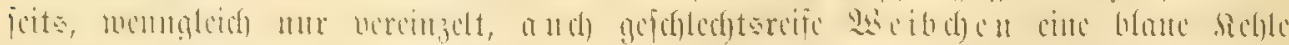

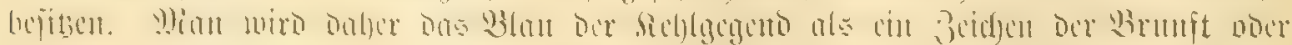

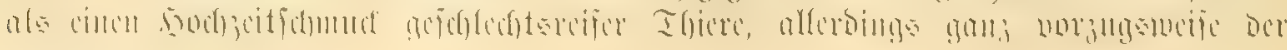




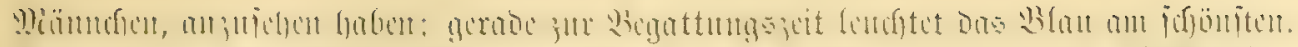

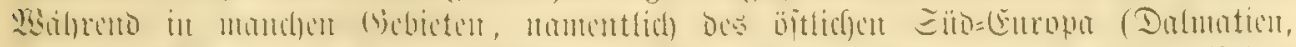

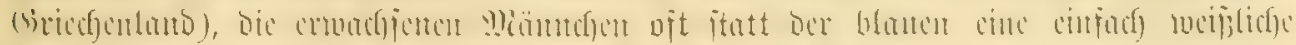

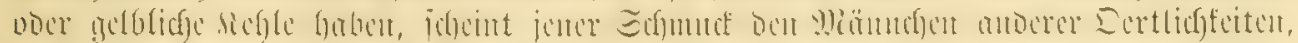

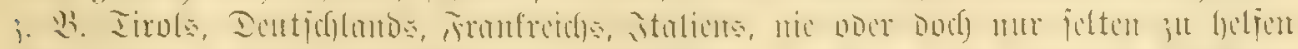

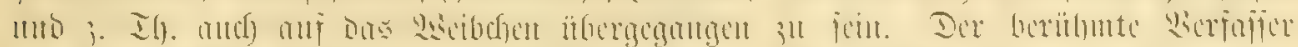

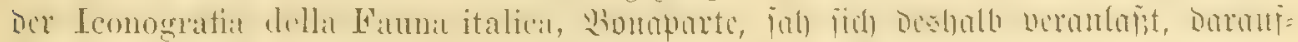

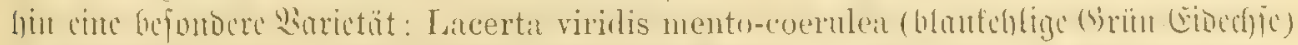

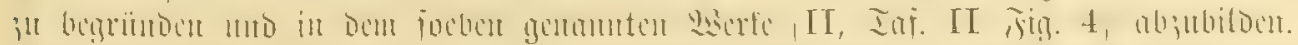

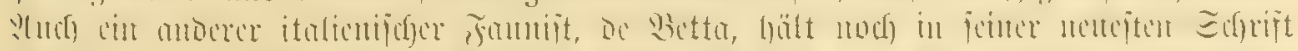

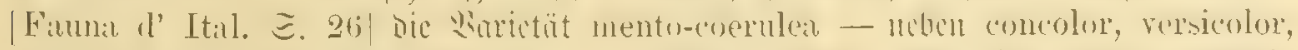

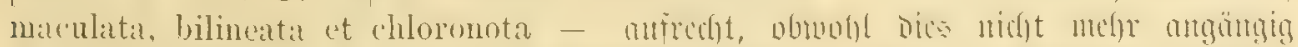

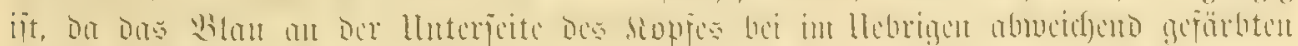
Ifieren, aljo bei mebrerm Spielarten, anjtritt.*) ธ. mpere Tajel $\mathbf{X}, 2$.

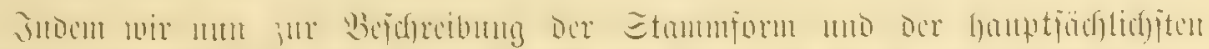

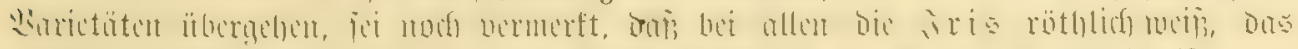

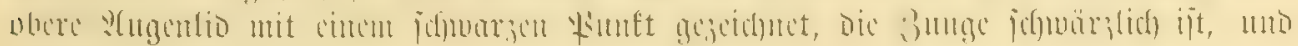
Dic Sirallert broun find.

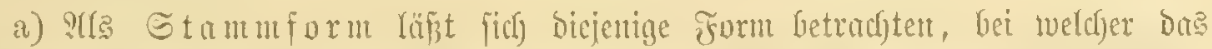

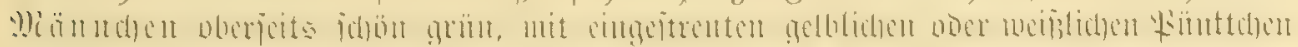

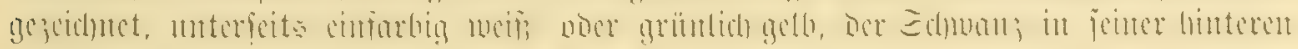
Sälite grau ober granbram iit.

Dą

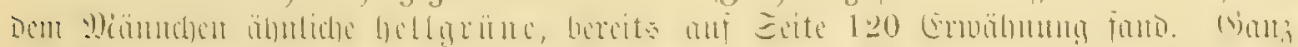

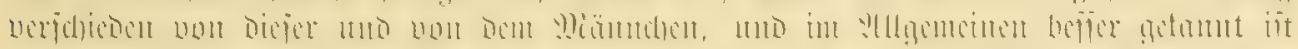

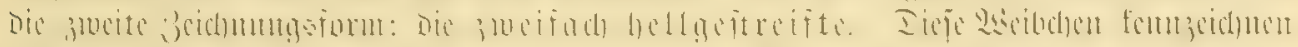

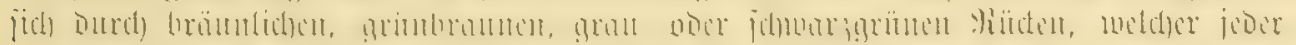

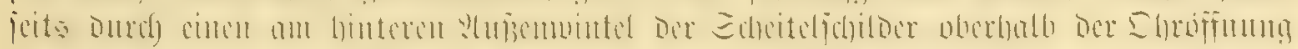

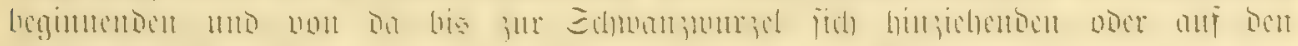

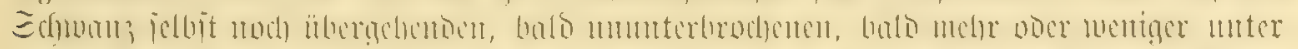

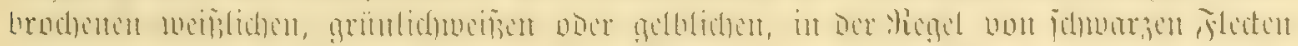

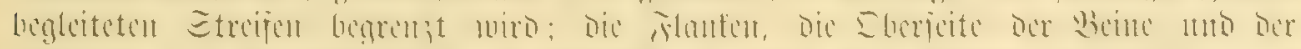

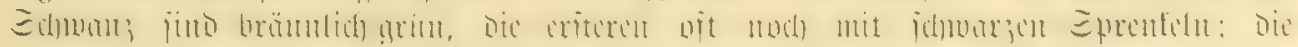

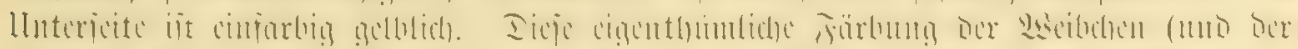

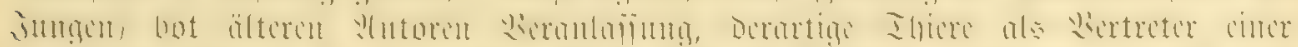

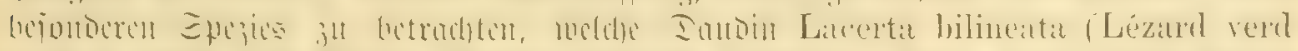

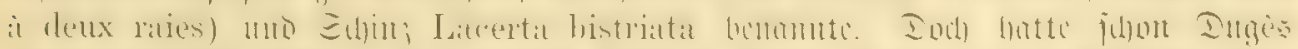

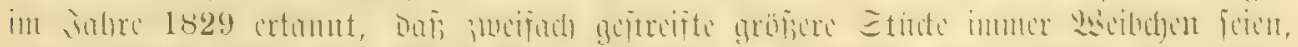

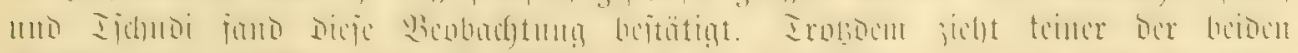

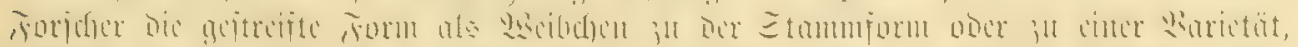

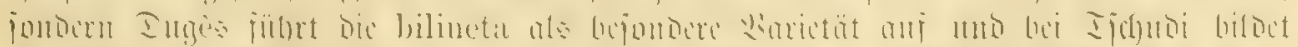

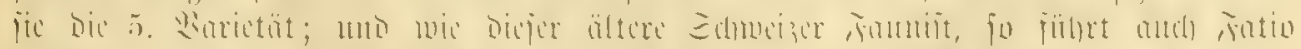

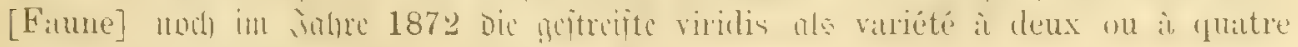
raies alt. Dafielbe thum be Betta u. :T.

*) Glïdielig hat Die branfeflige Grïnedje als Lacerta cyanolaema ober Podareis eyanolaema jogar зит Epezię erfjoben! 


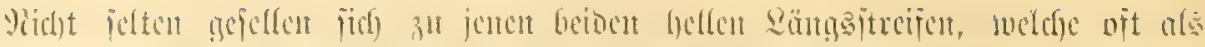

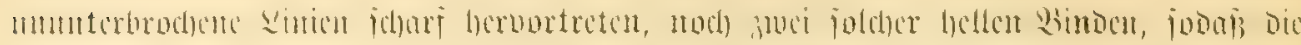

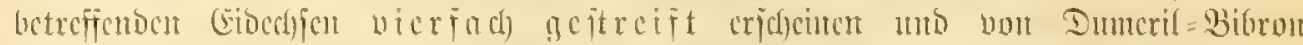

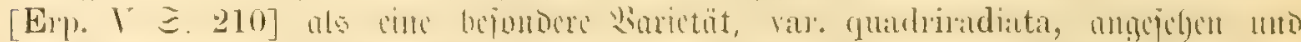

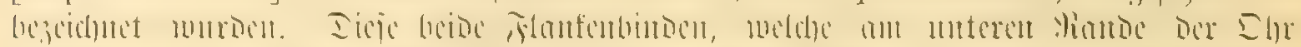

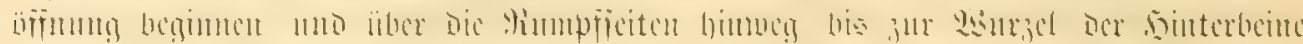

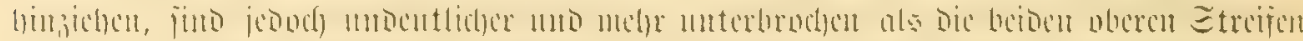

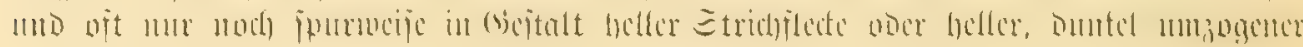

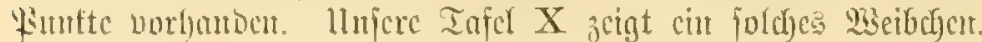

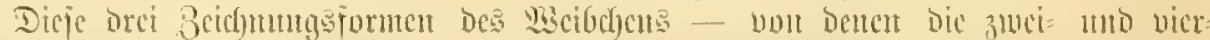

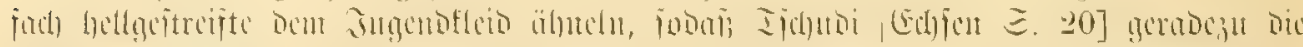

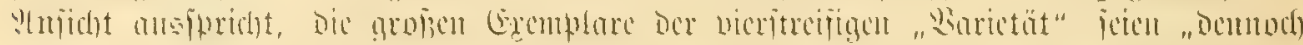

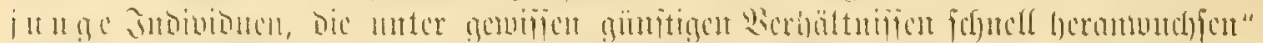
find än

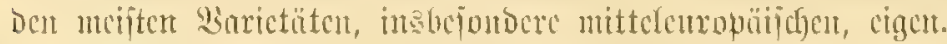

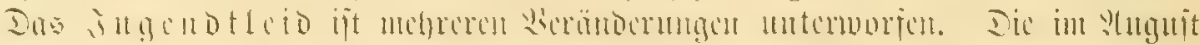

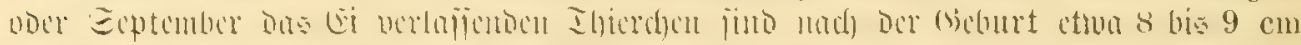

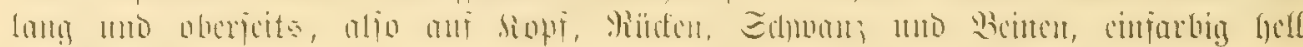

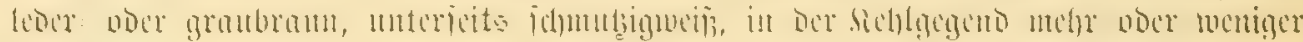
g)

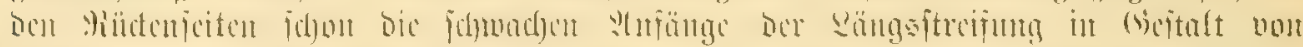

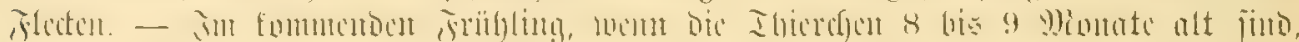

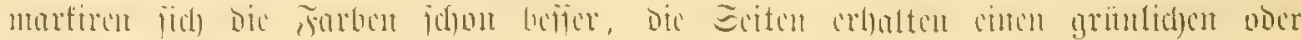

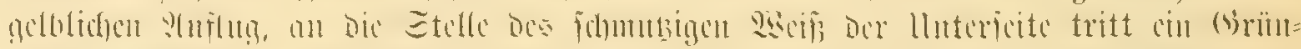

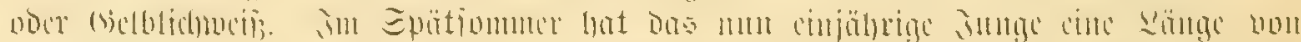

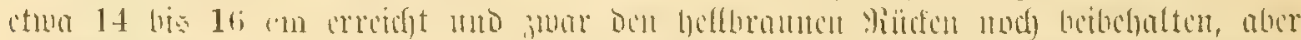

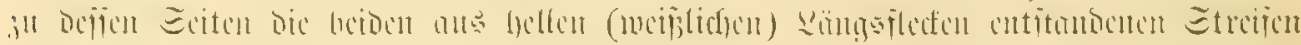

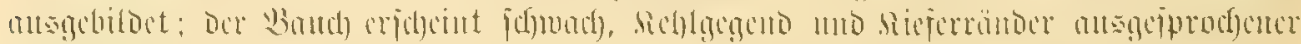

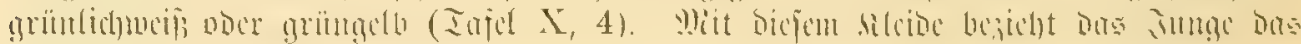
Minterquarticy.

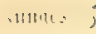

uni 9

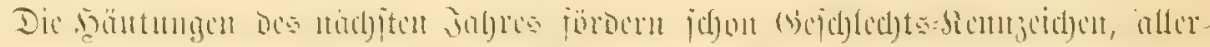

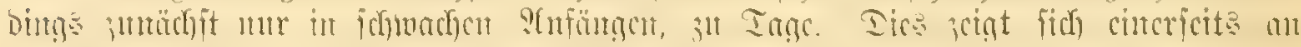

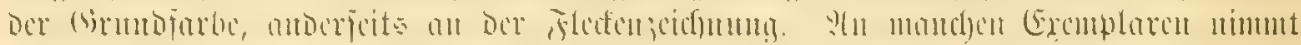

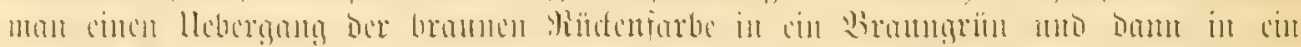

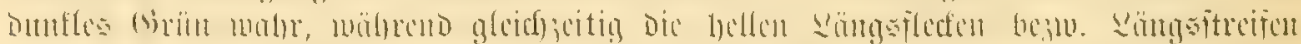

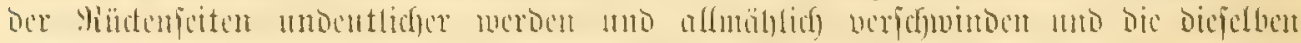

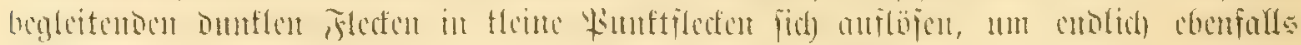

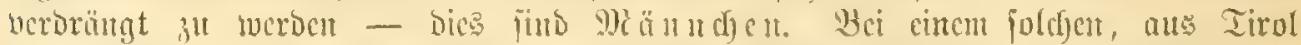

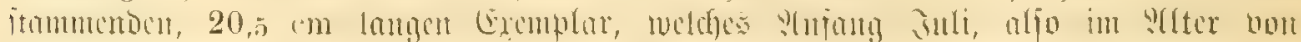

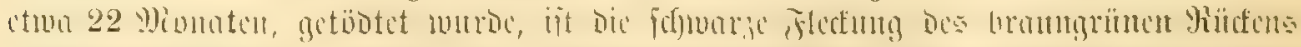

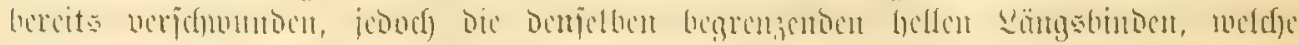

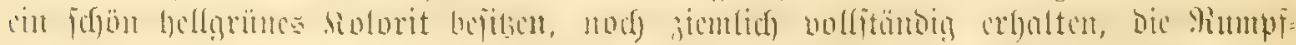

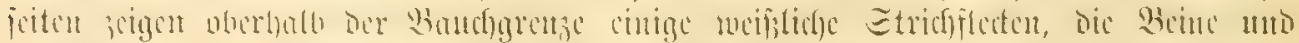

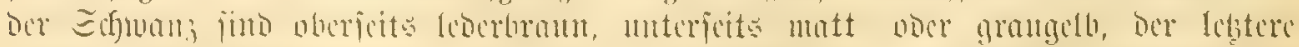

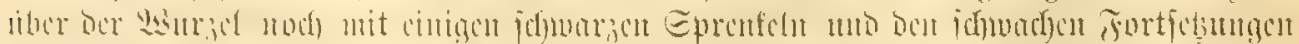

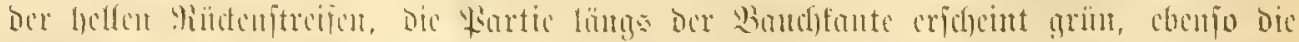

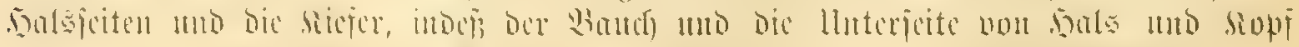

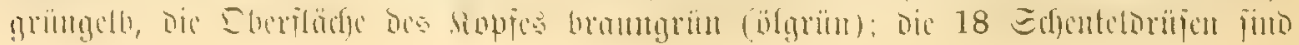




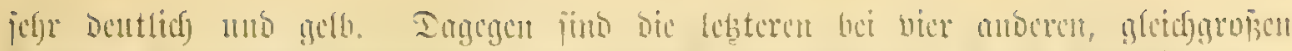

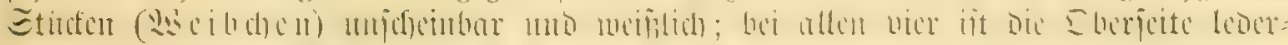

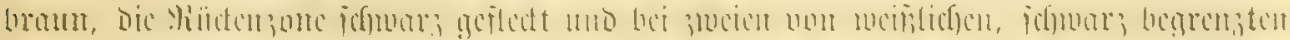

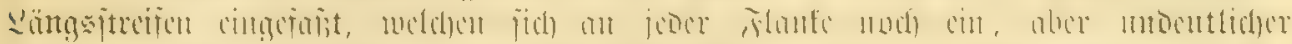

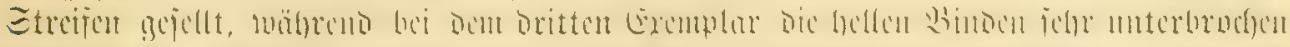

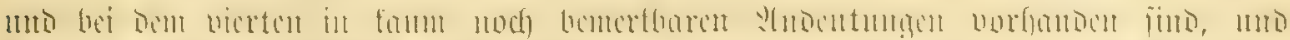

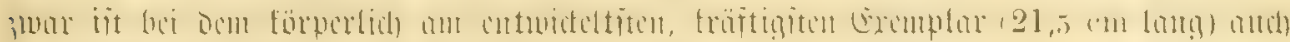

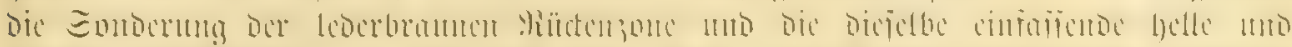

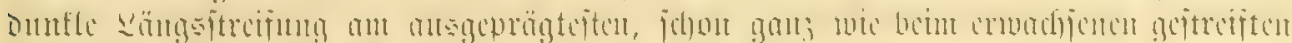

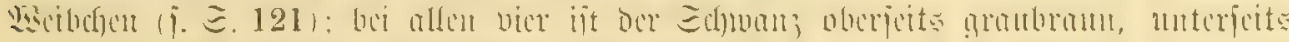

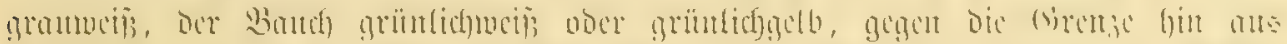

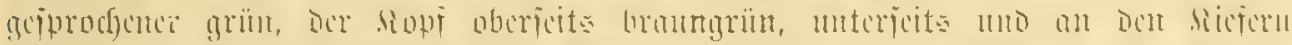

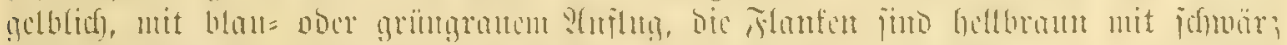

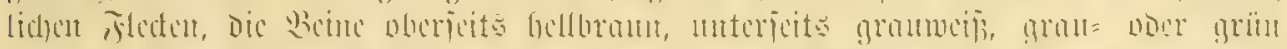

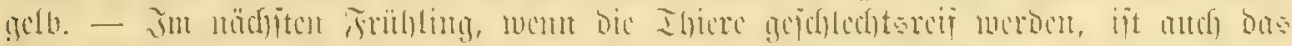

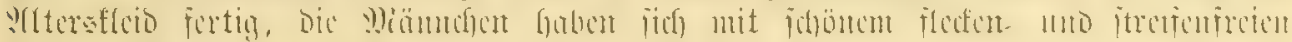

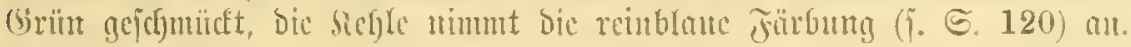

b) Barietätcu. 1. Bar. concolor (Dugis), cinfarbig grüme Emarags=

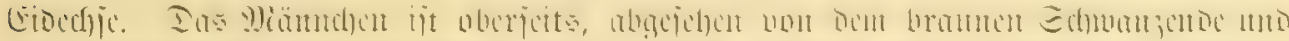

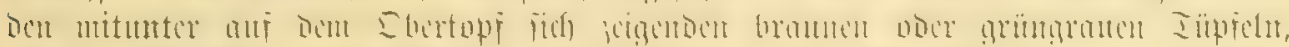

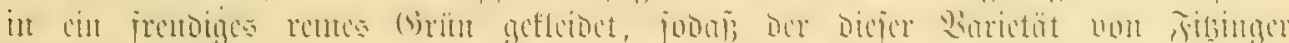

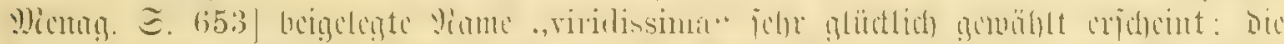

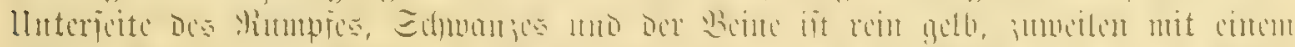

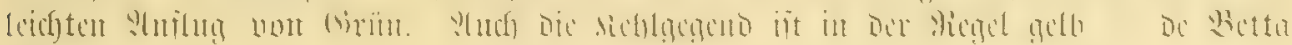

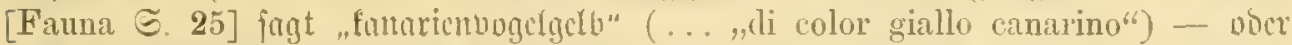

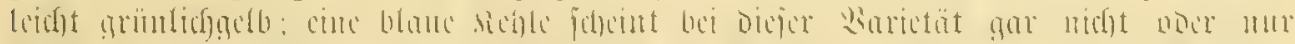

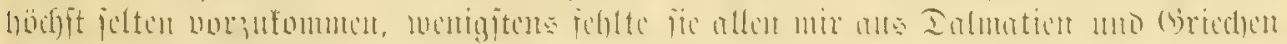

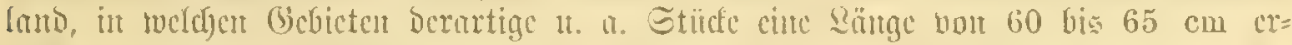

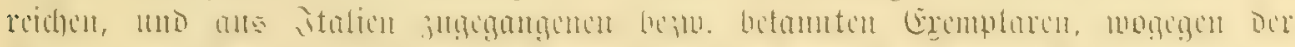

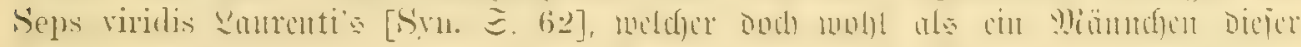

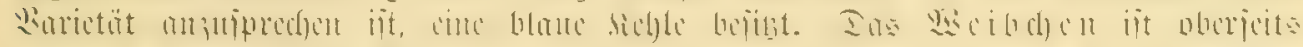

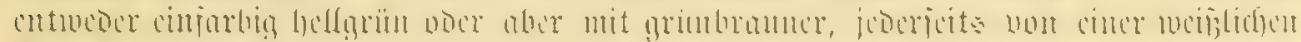

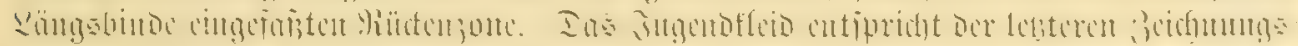

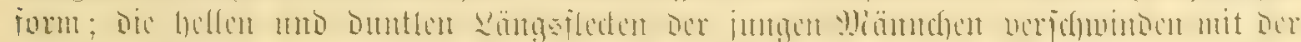

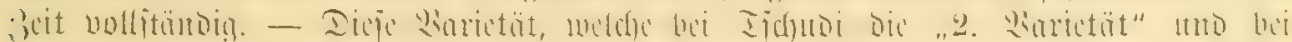

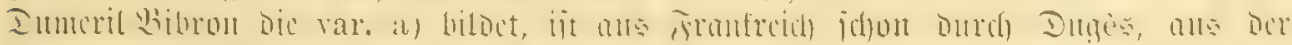

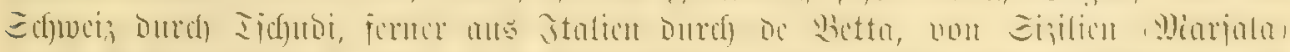

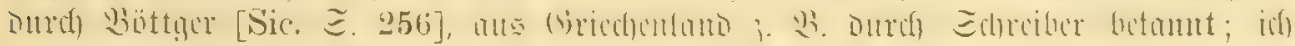

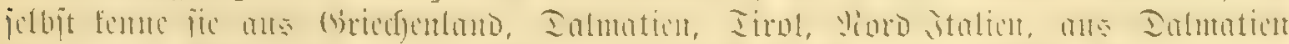

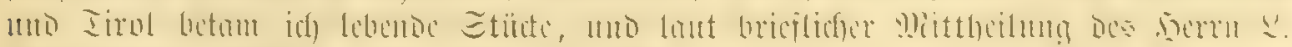

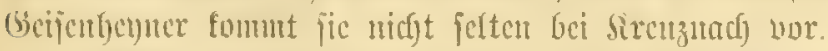

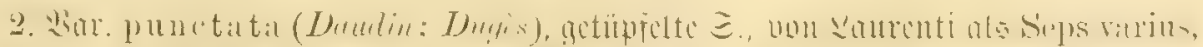

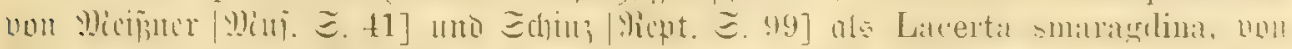

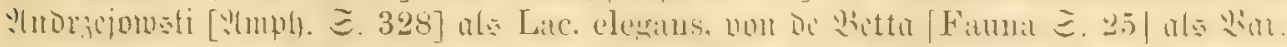

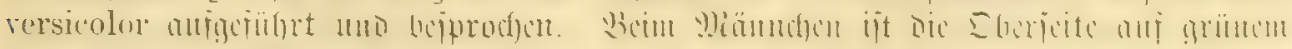

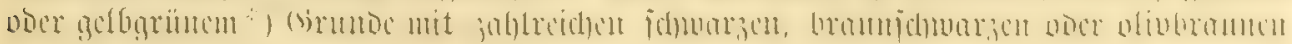

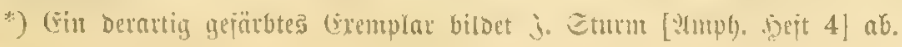




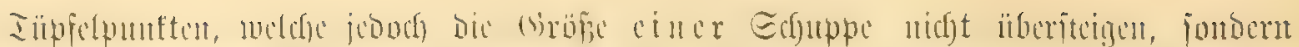

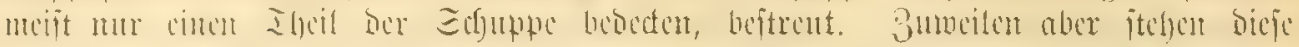

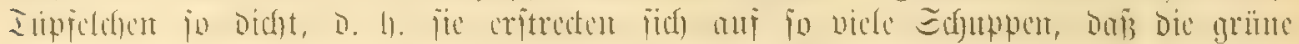

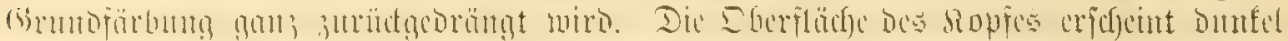

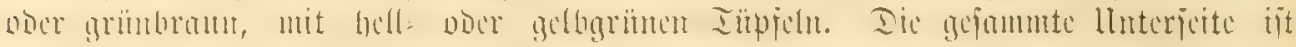

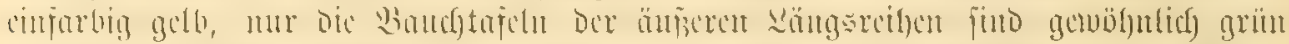

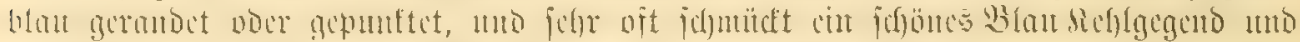

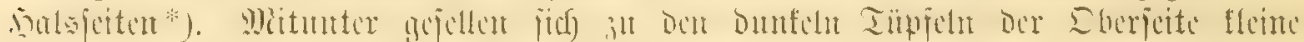

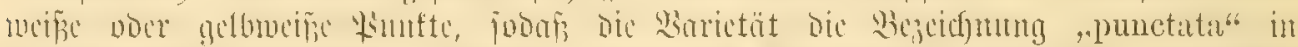

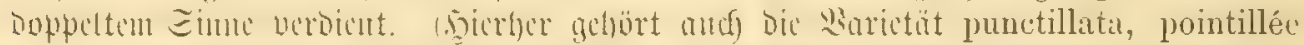

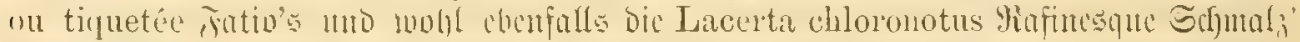

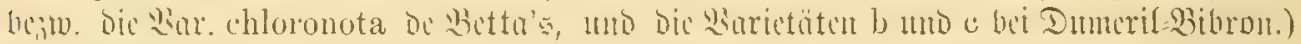

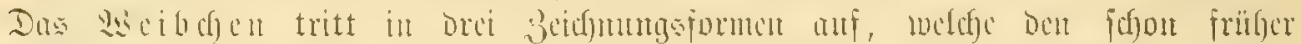

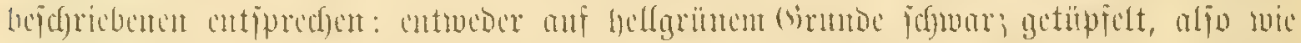

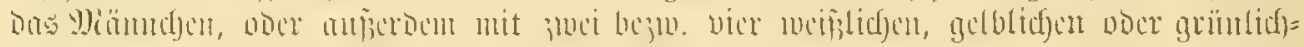

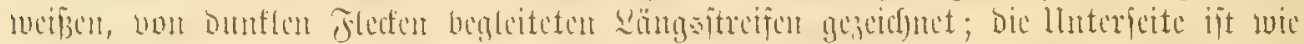

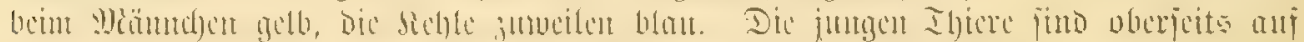

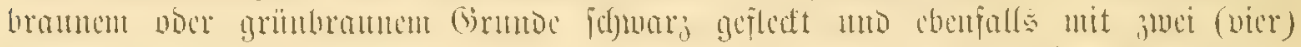

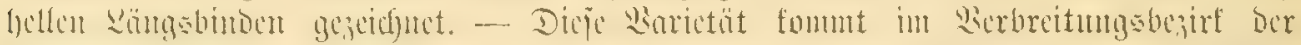

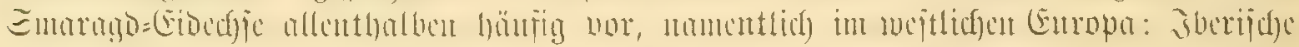

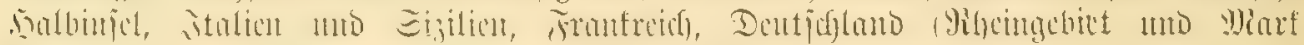

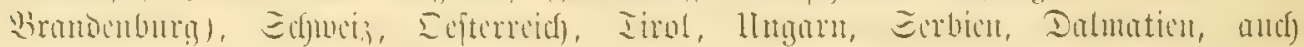

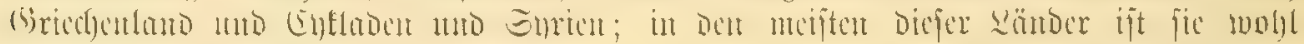
Dic bäutfigite aller Spielartent.

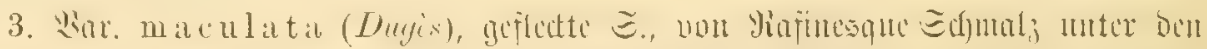

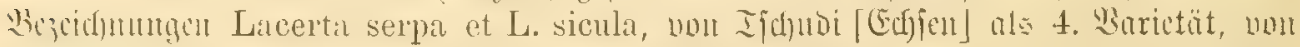

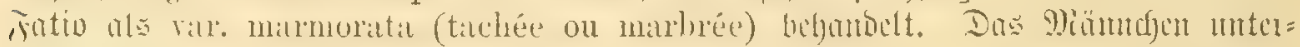

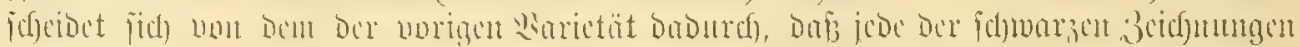

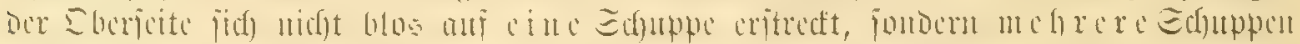

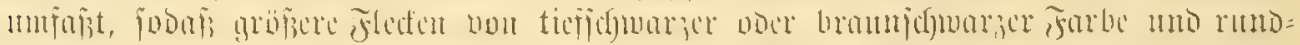

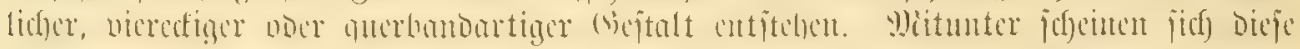

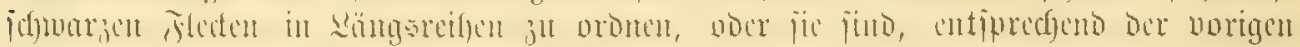

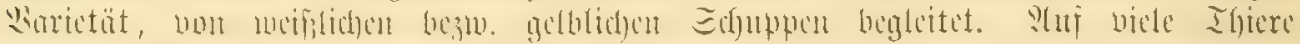

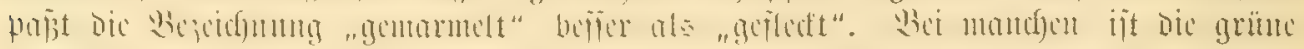

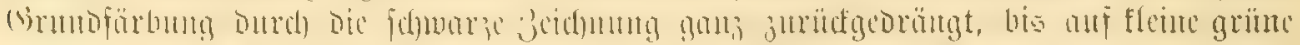

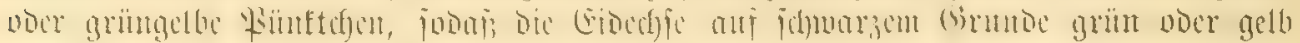

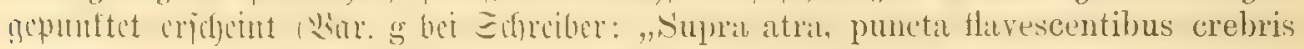

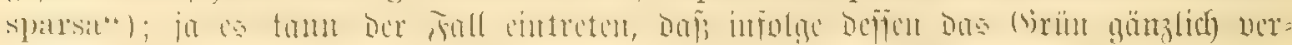

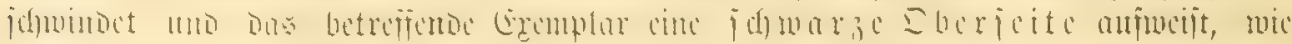
Dies Durd) cin non Gadfet [Act. Soc. Linn. de Bordeaux, t. VI, 1833, S. 168]

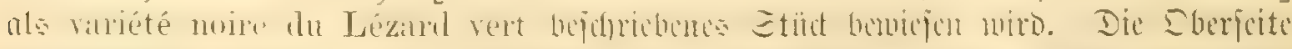

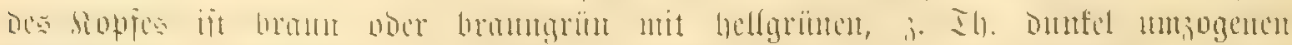

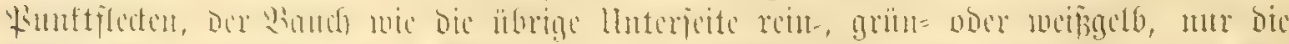

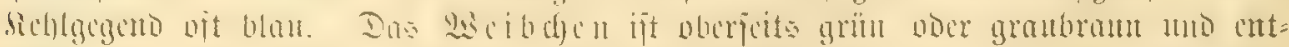

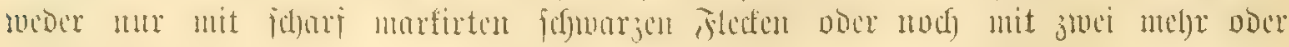

*) Das in Bontaparte"s Frune italica abgebildete (Extmplar ber, var, mento-cocrulea" ijt ein bran= fegliges Miämudyen ber getiipfelten Sarietät (punctata). 


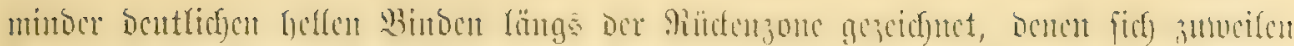

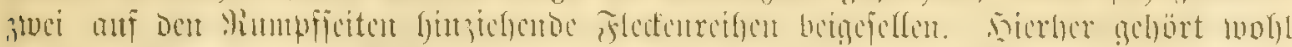

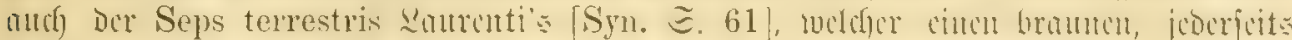

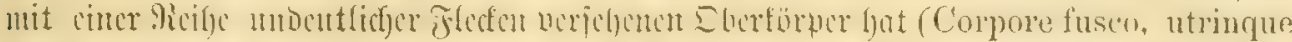

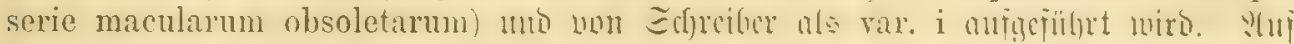

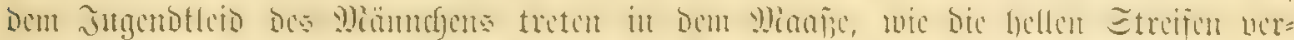

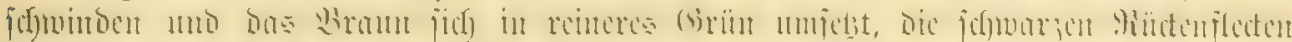

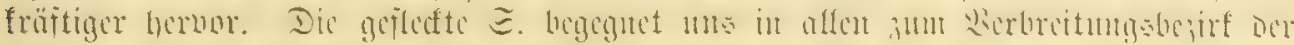

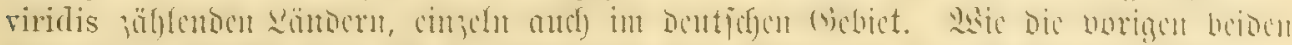

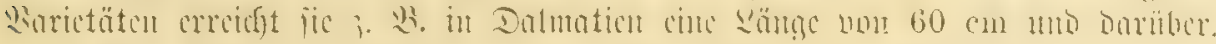

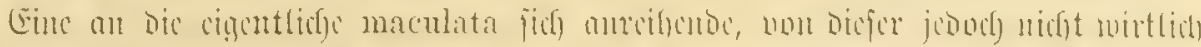

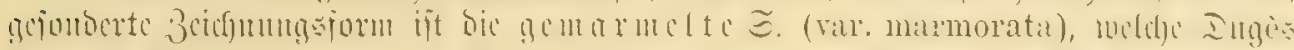

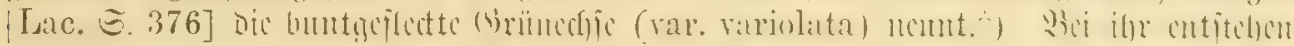

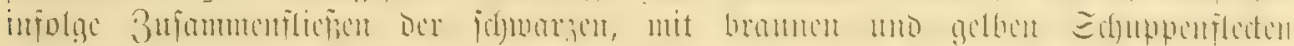

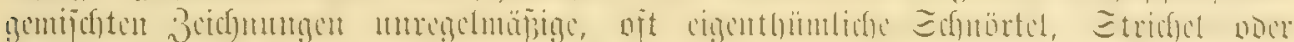

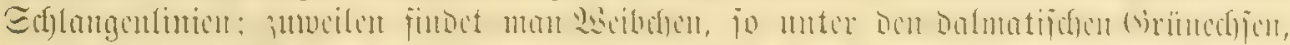

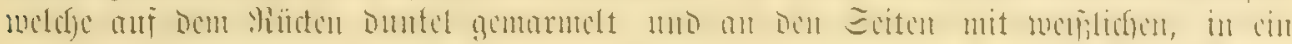

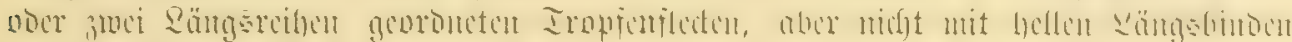

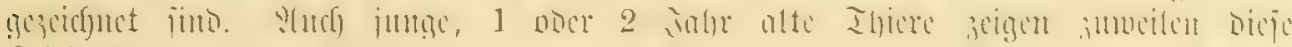
Bcidymutg.

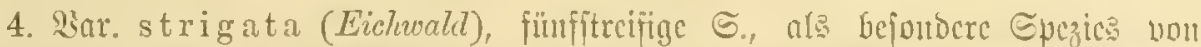

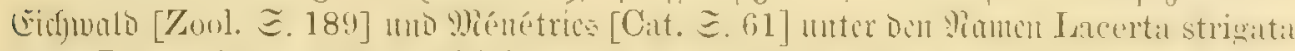

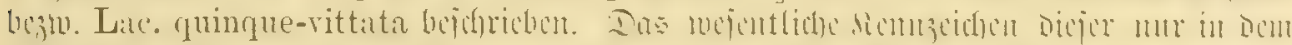

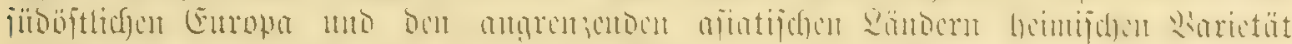

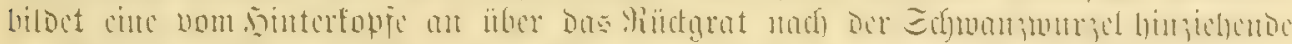

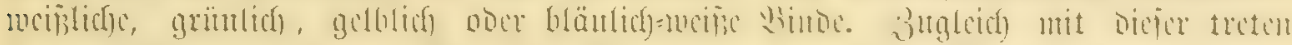

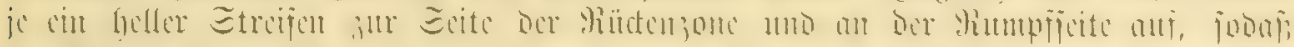

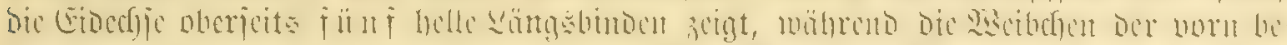

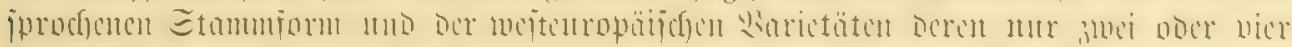

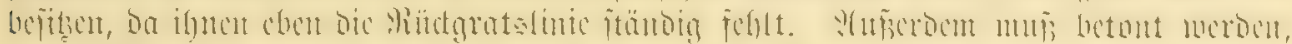

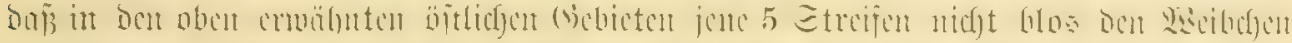

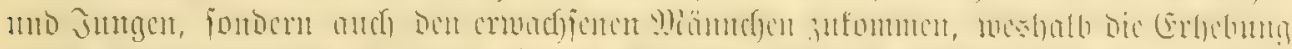

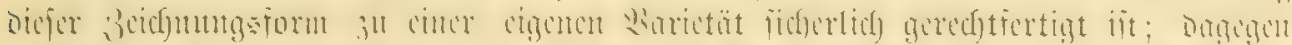

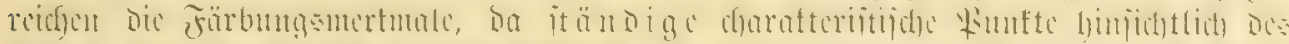

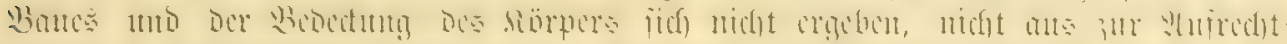

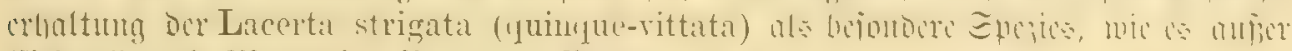

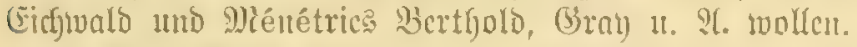

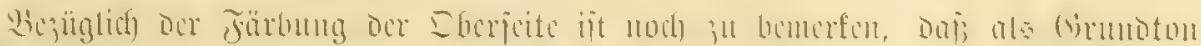

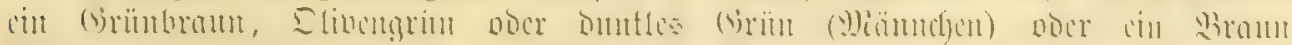

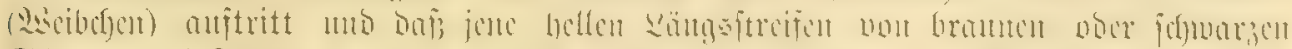

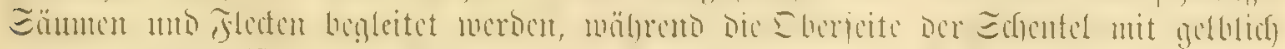

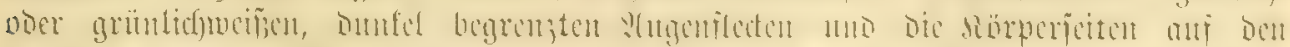

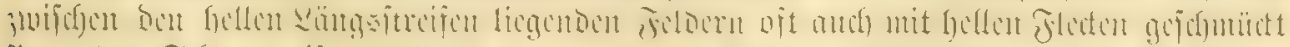

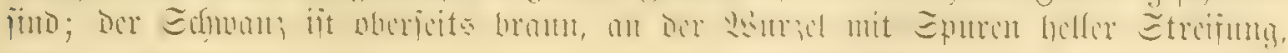

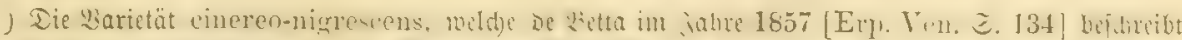

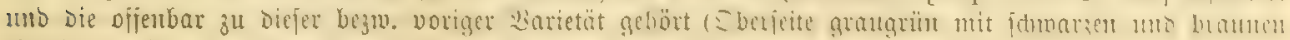

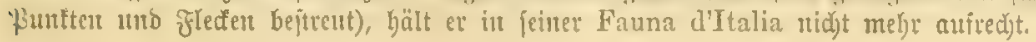




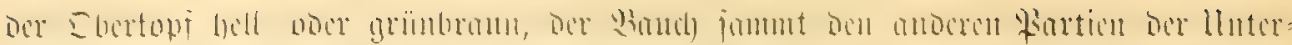

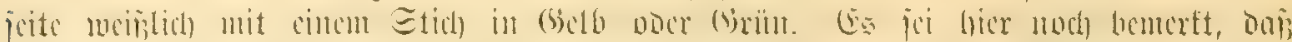

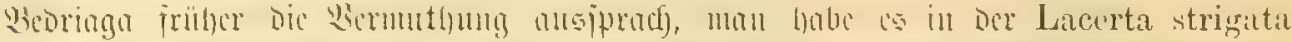

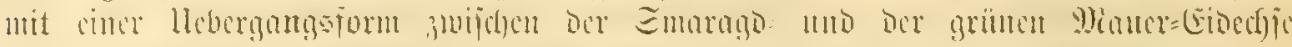

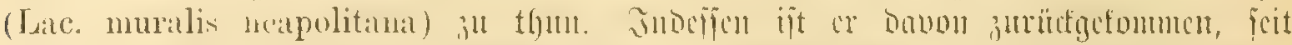

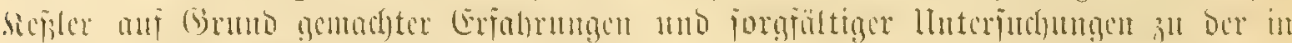

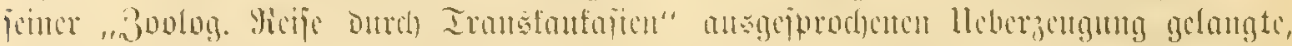

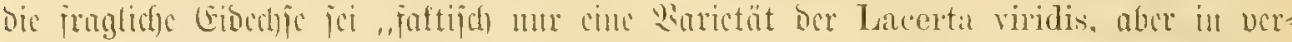

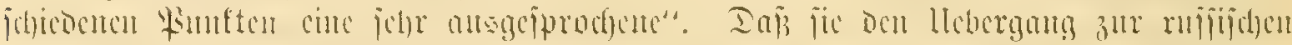

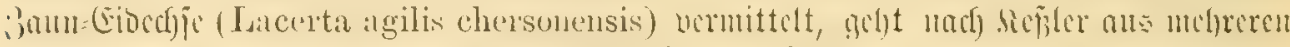

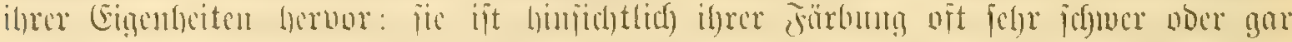

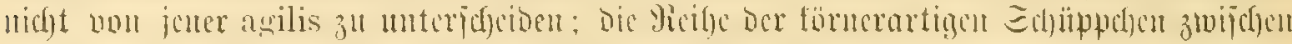

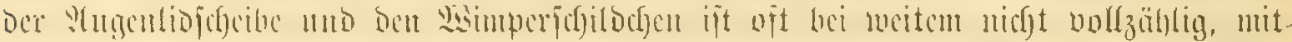

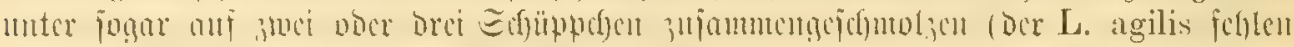

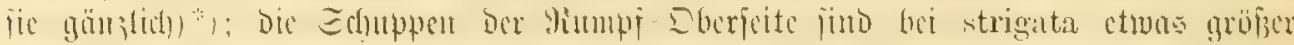

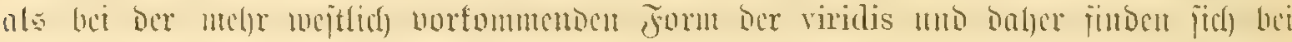

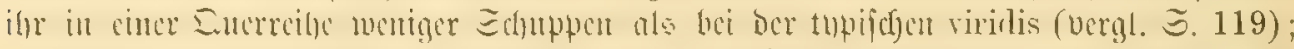

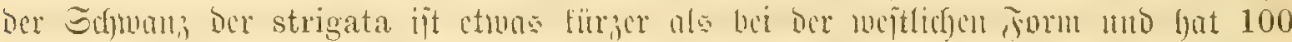

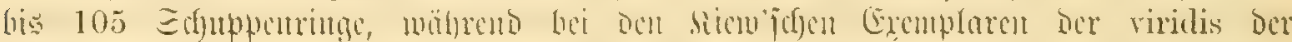

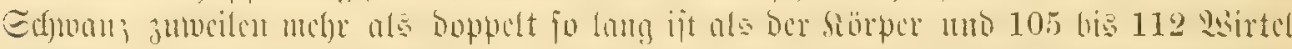

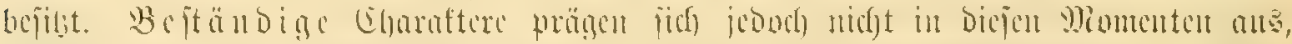

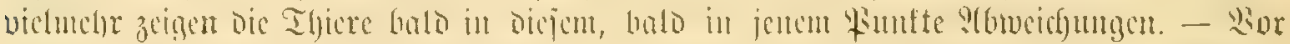

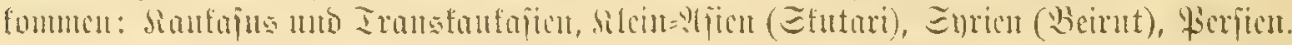

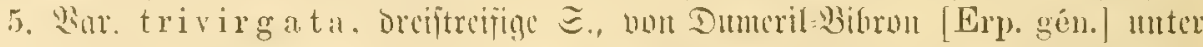

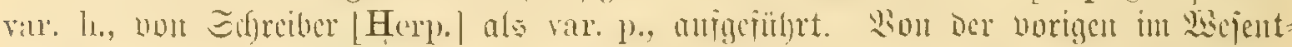

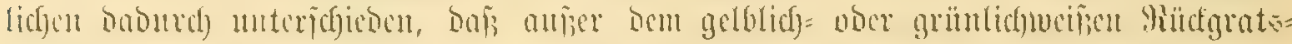

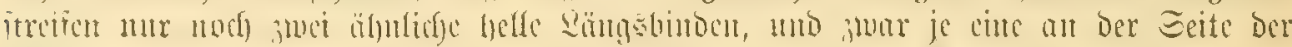

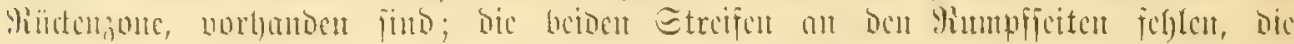

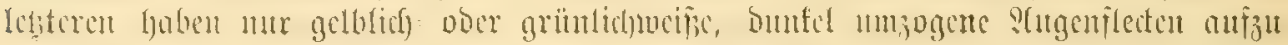

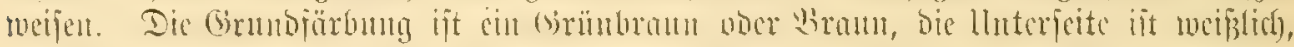

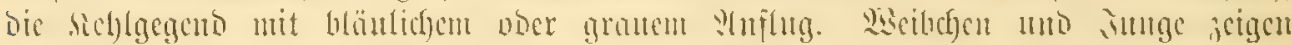

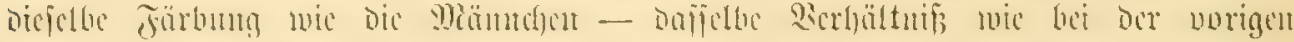

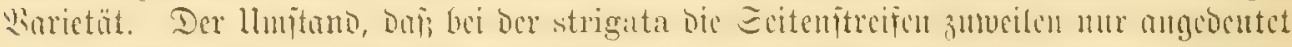

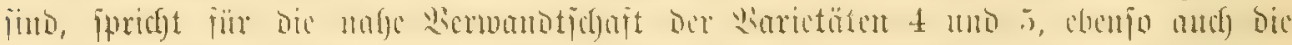

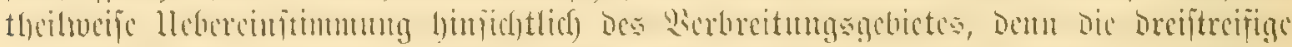

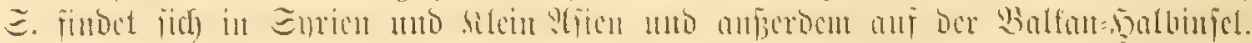

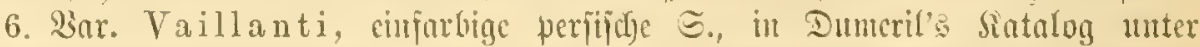

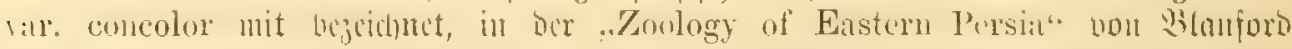

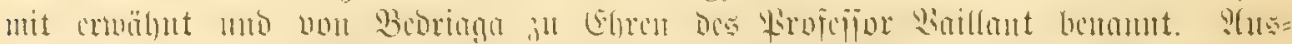

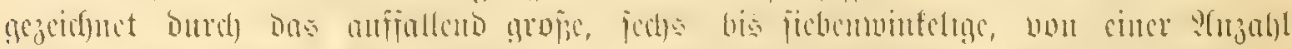

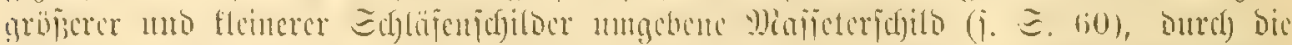

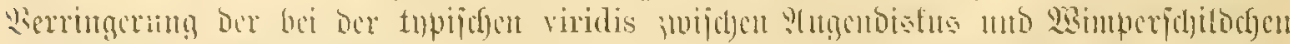

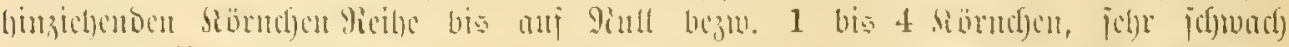

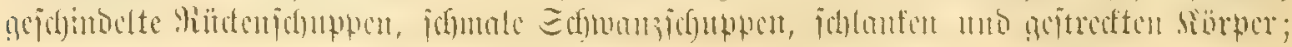

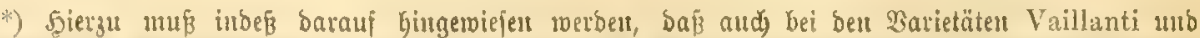

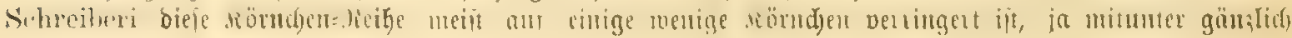
vermibist soits. 


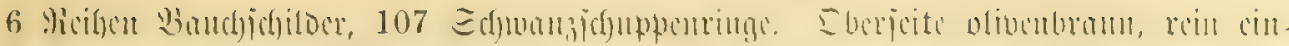

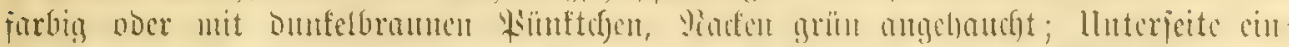

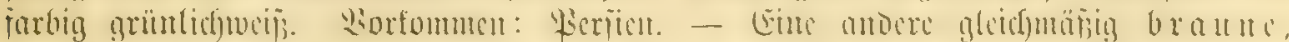

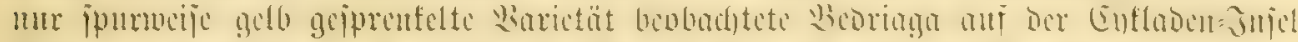

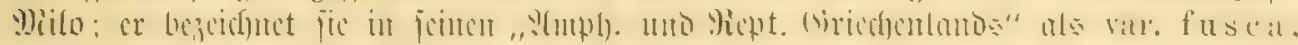

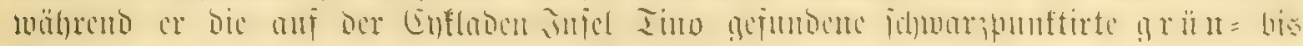
goldgclbe Epielart, , var. a uratabs nemut.

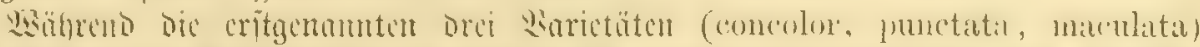

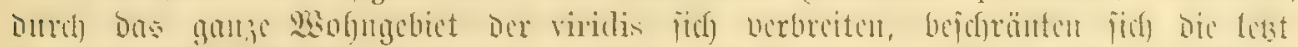

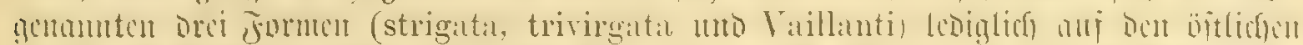

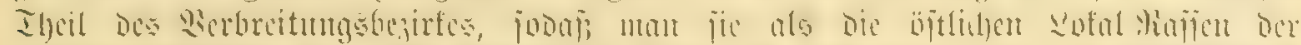

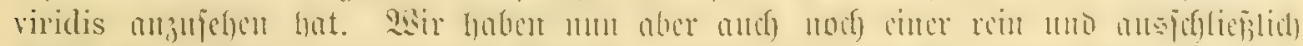

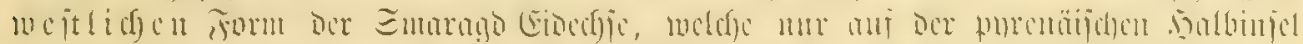

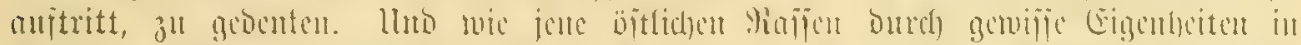

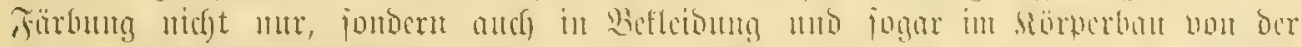

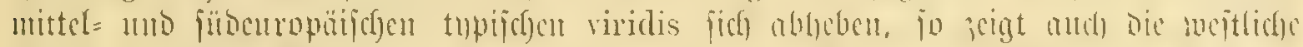

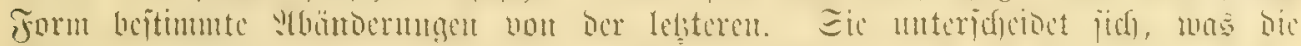

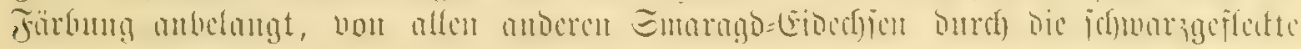
ober jdytwarzgctiupfelte lluterieite, jobâ; man fic als

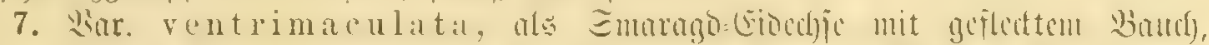

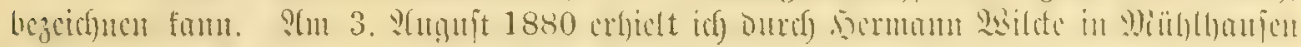

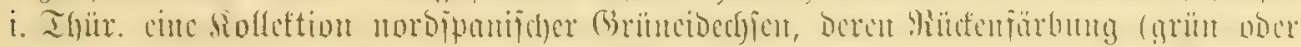

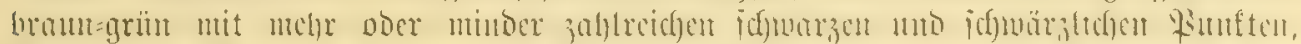

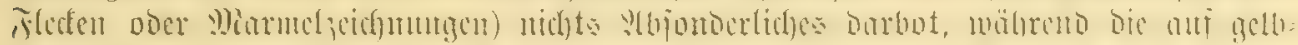

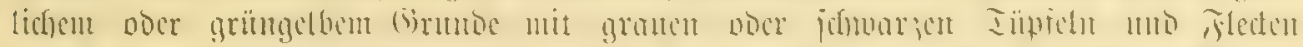

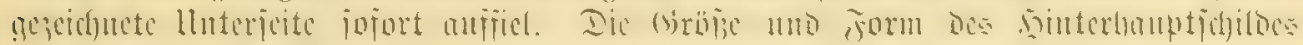

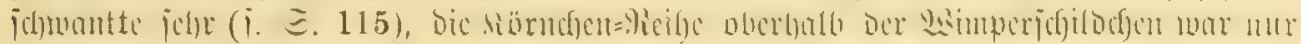

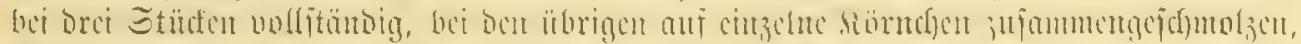

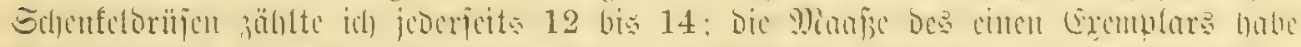

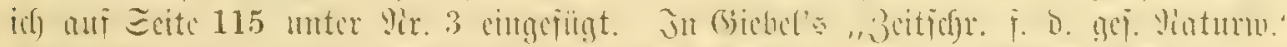

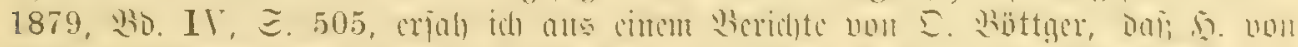

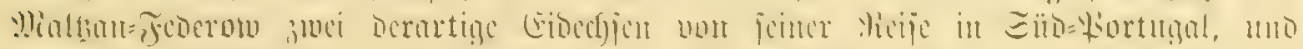

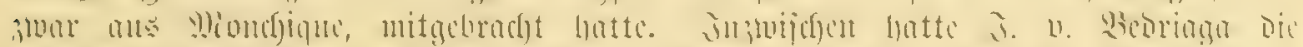

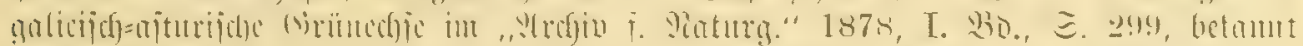

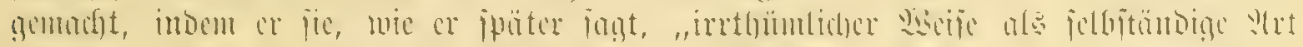

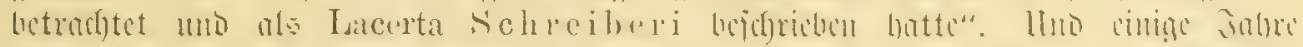

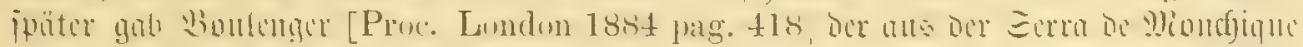

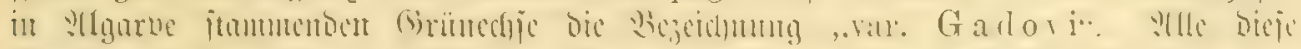

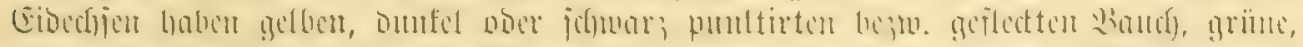

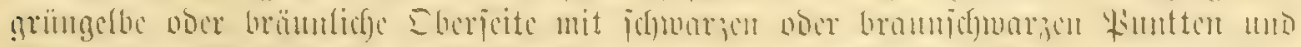
T)

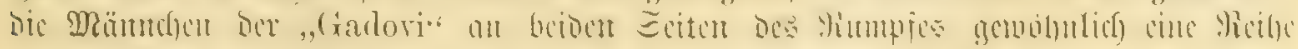

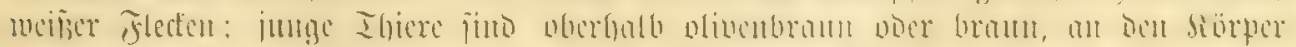

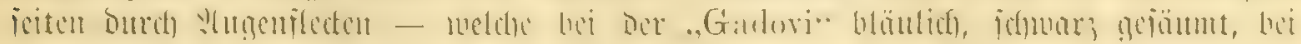

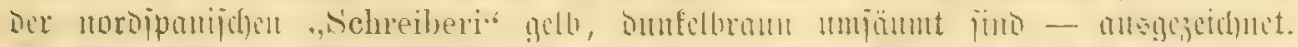

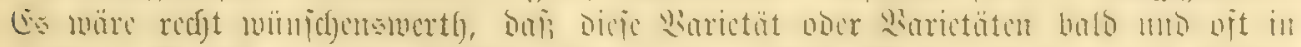

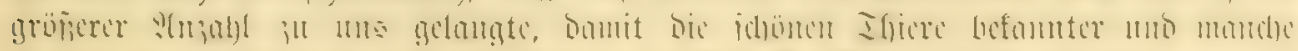

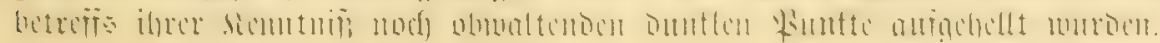




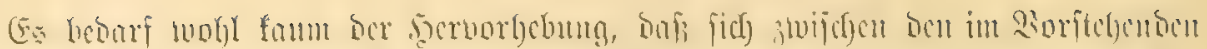

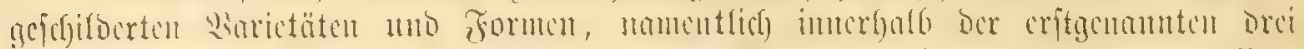

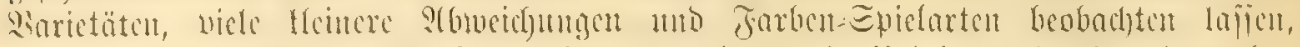

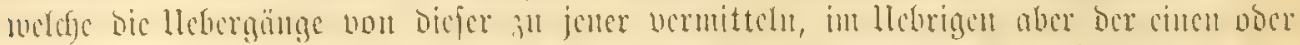

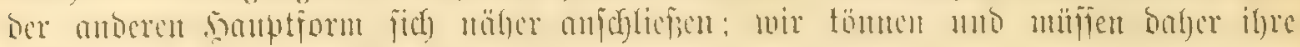
Bejureifung bier unterlaficu.

Beographlide Berbreitung. Dic cigentliche nemat ber Emarago=eribedjic

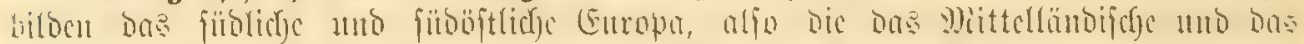

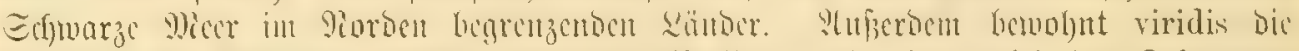

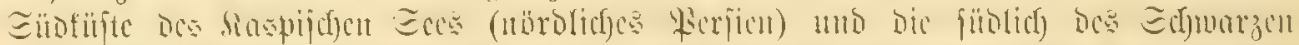

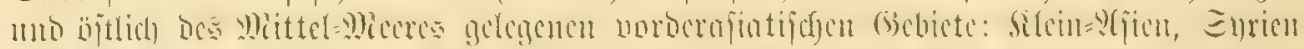

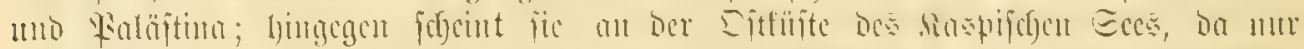

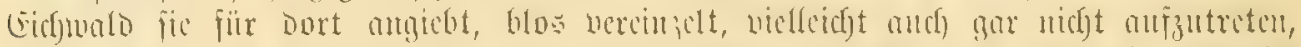

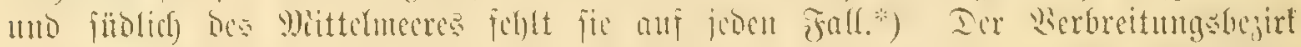

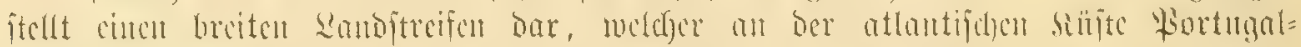

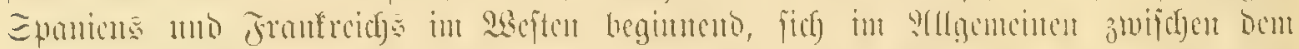

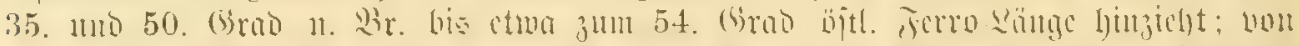

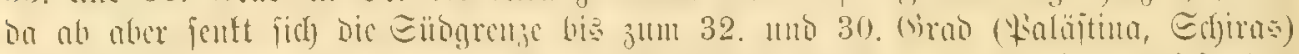

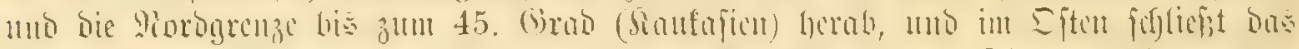

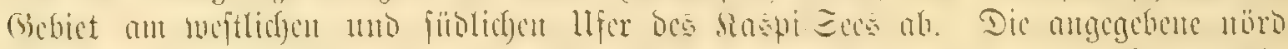

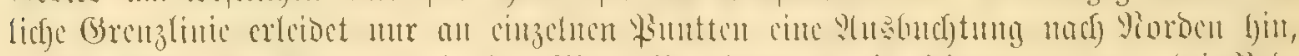

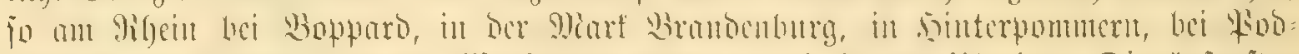

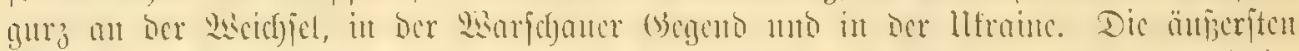

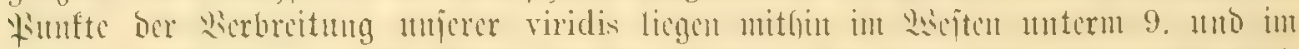

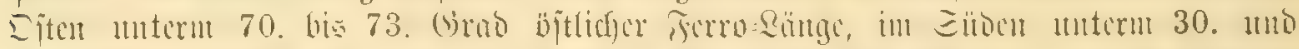

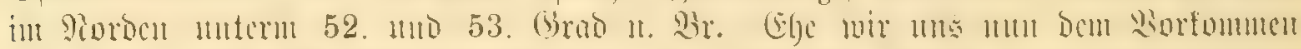

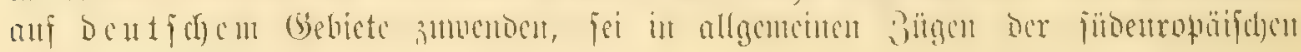
Sämocr gedact)t.

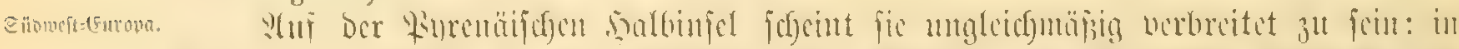

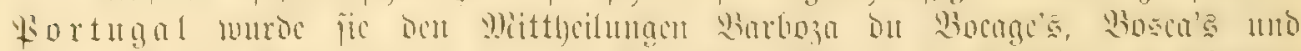

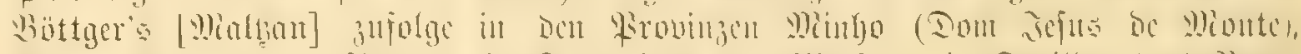

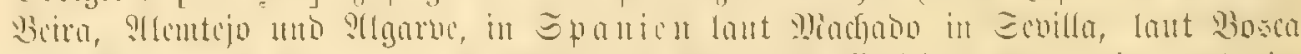

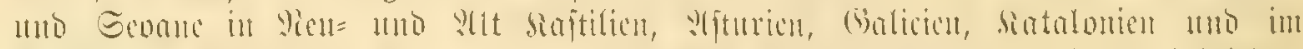

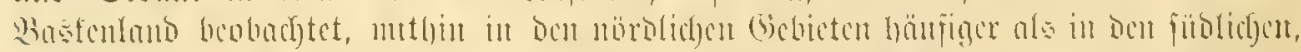

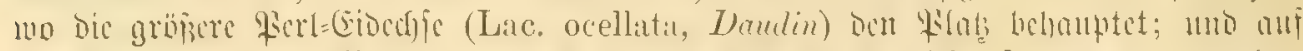

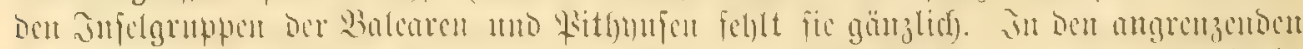

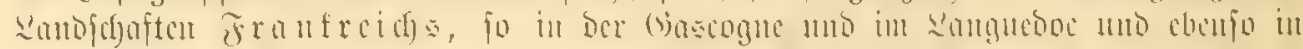

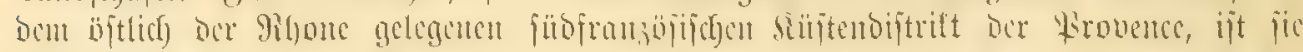

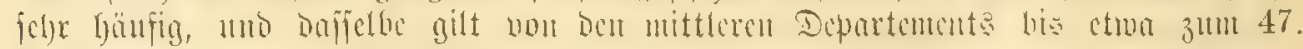

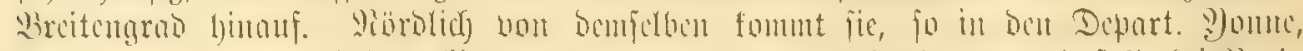

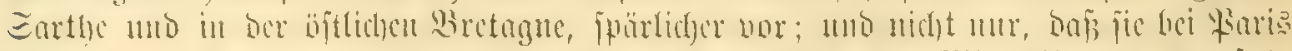

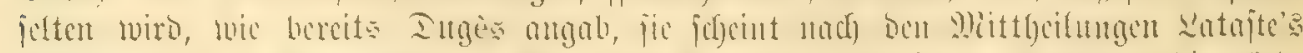

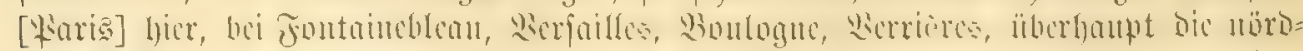

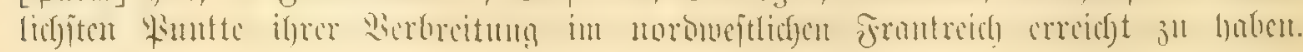

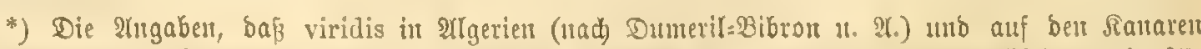

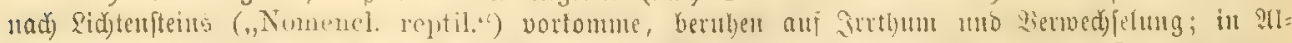

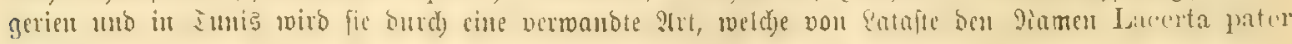
erbalteu bat, vertreter. 


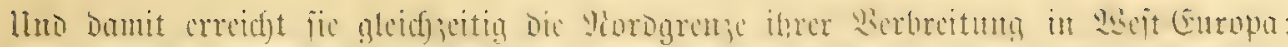

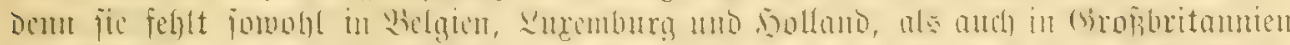

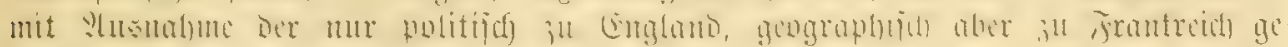

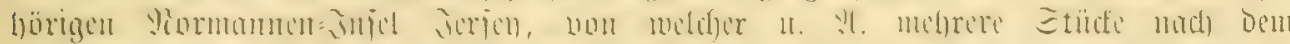

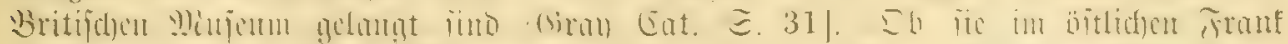

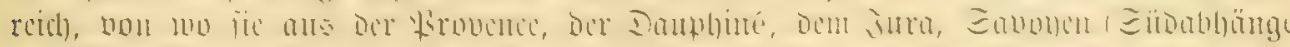

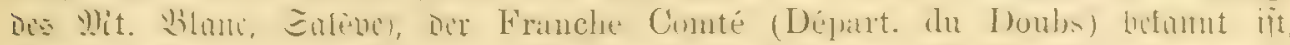

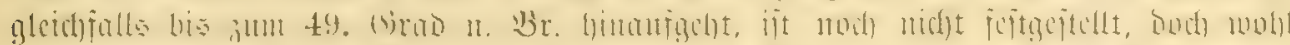

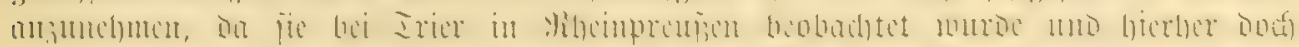

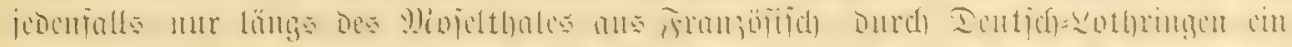

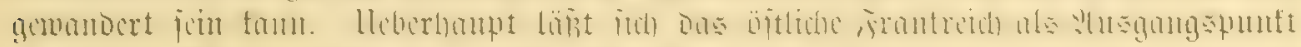

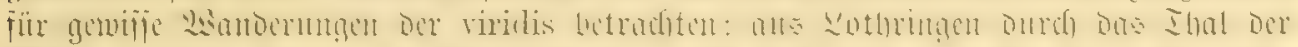

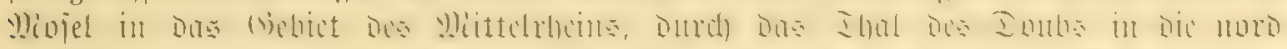

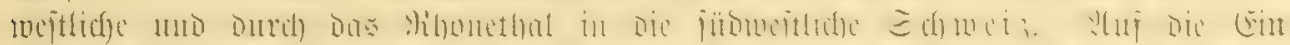

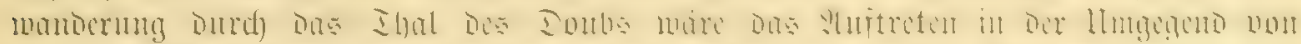

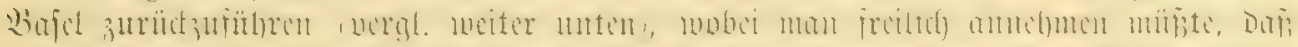

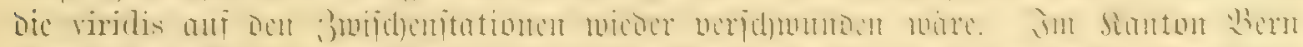

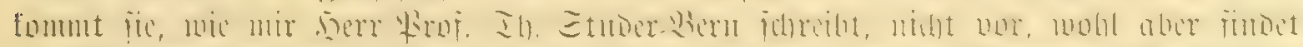

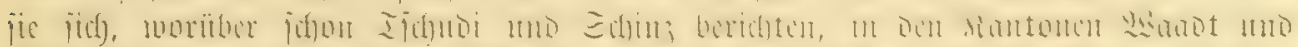

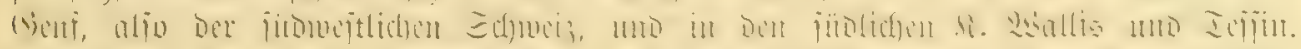

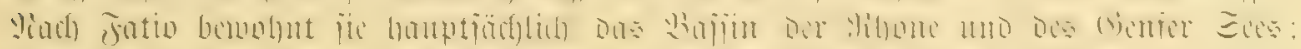

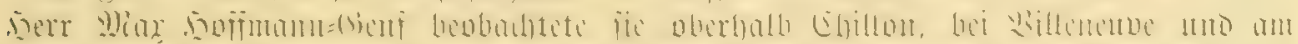

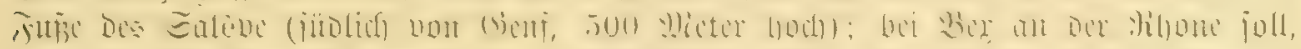

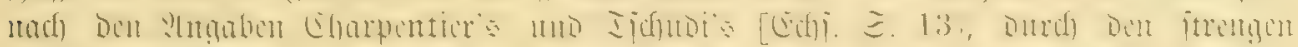

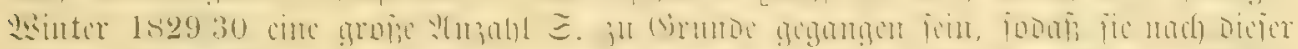

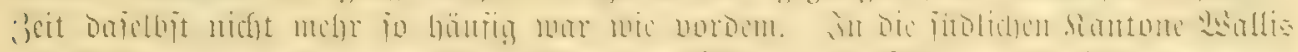

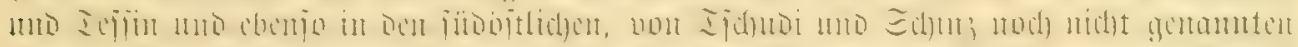

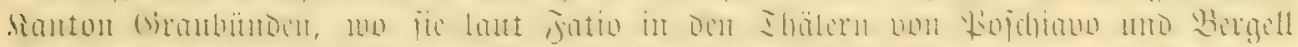

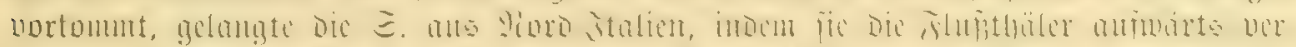

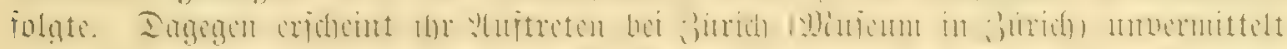

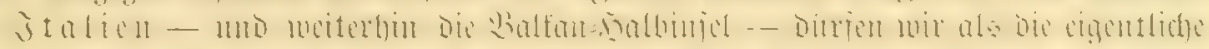

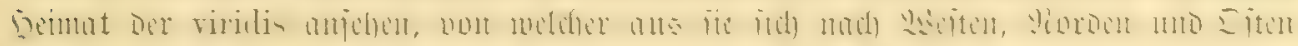

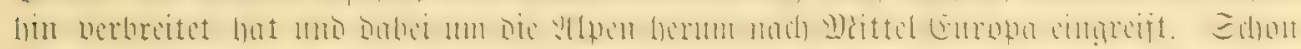

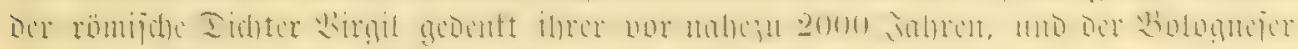

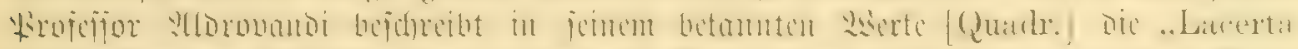

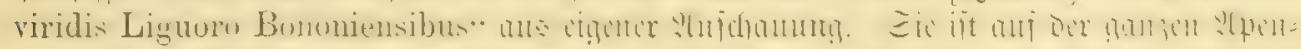

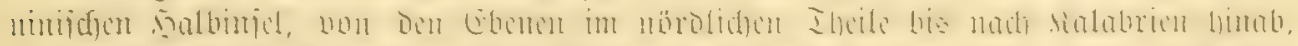

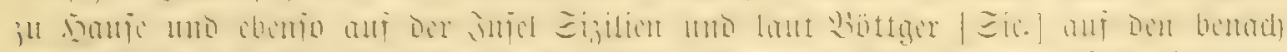

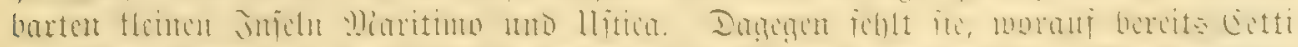

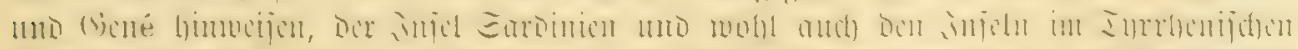

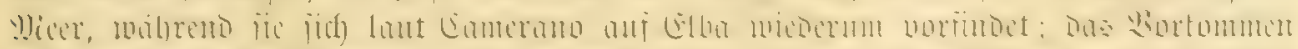

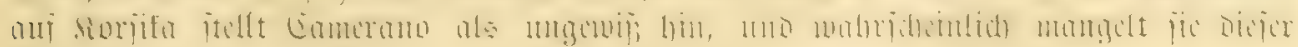

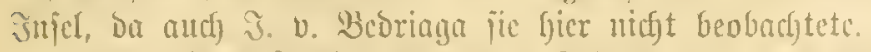

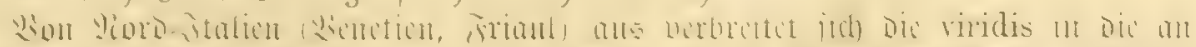

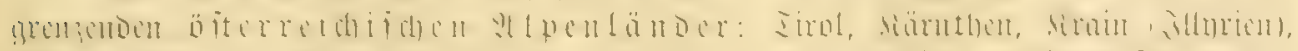

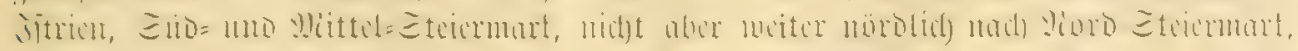

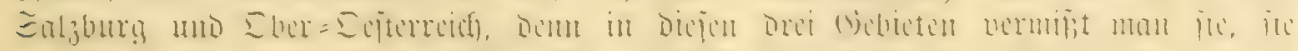

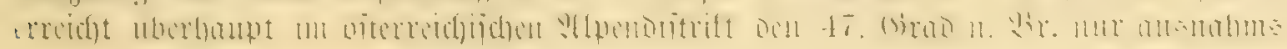




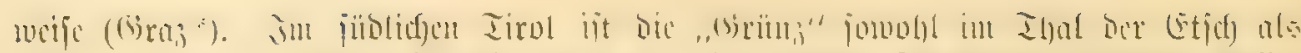

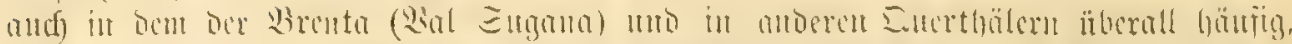

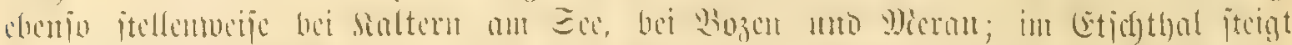

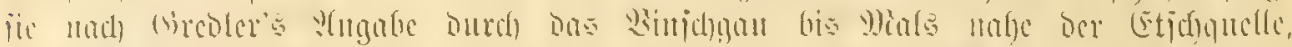
3300 Fuj

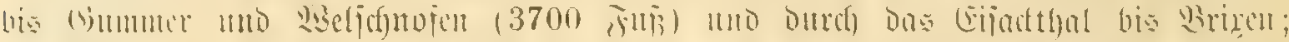

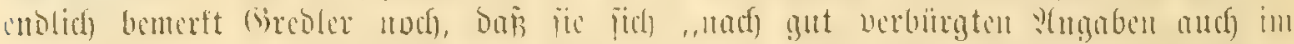

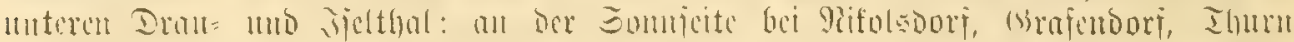

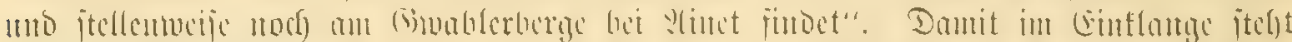

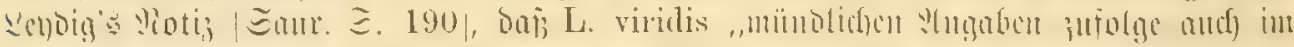

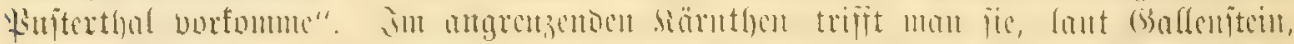

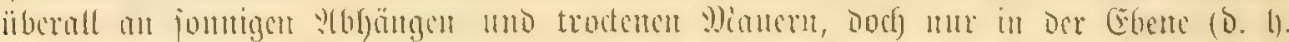

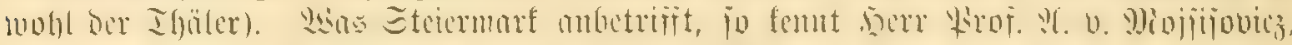

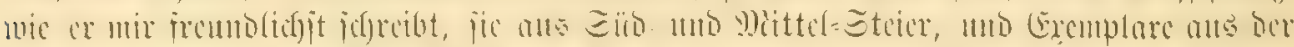

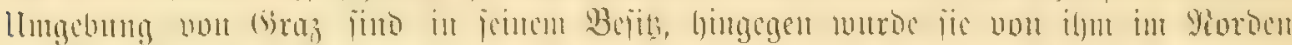

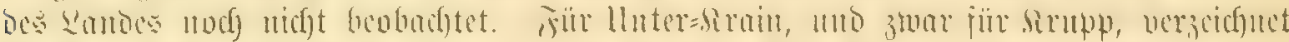

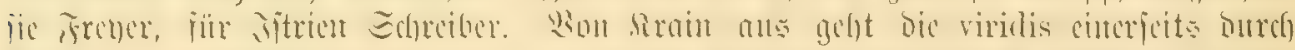

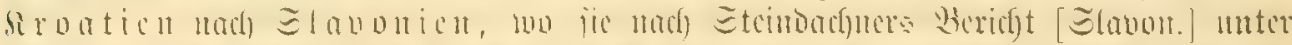

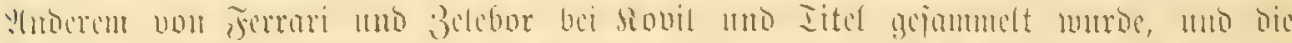

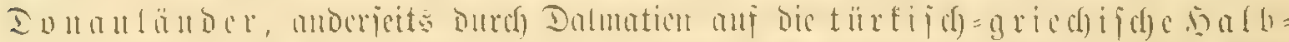

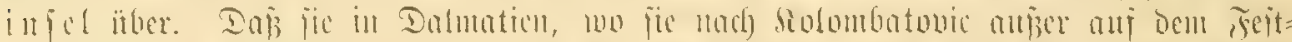

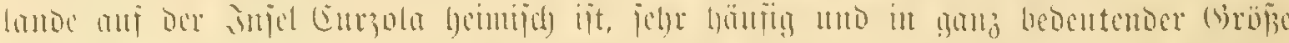

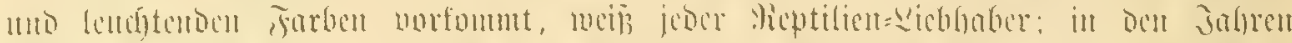

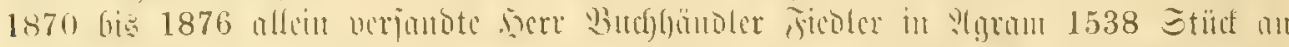

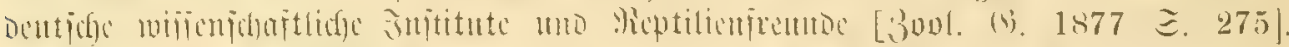
int

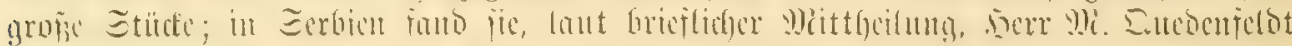

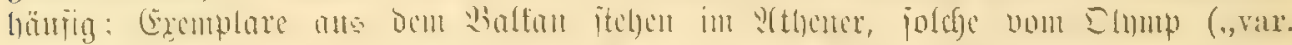

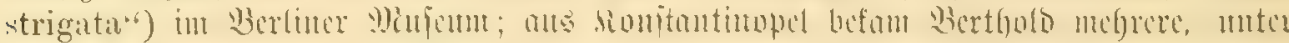

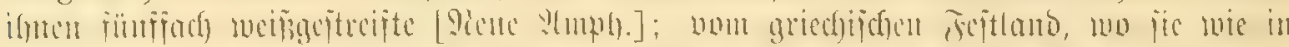

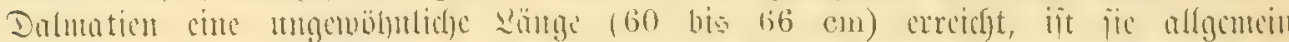

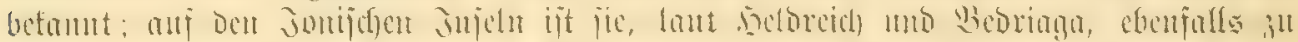

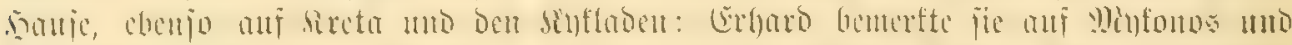

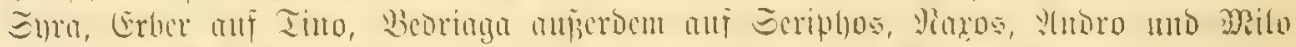

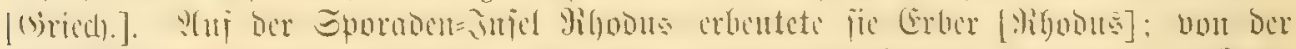

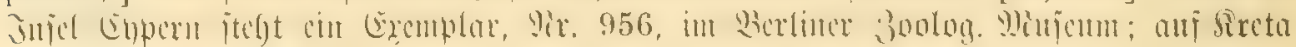
cutoclektc fie Raulin [Crète].

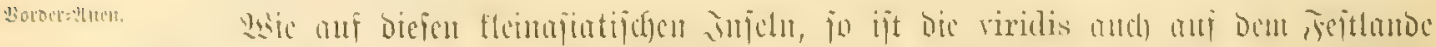

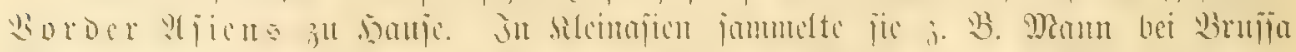

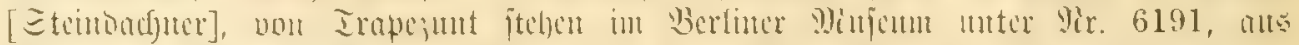

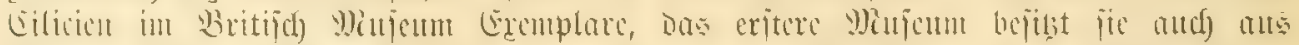

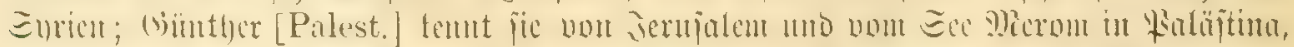

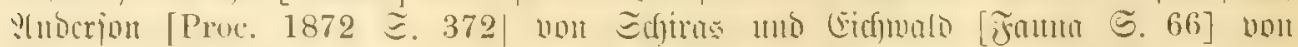

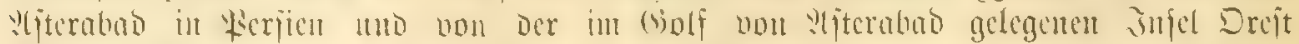

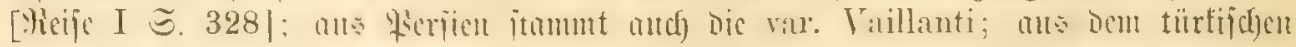

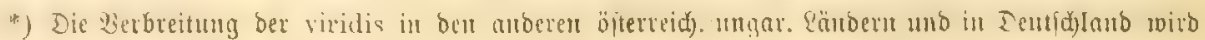

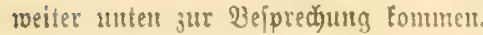




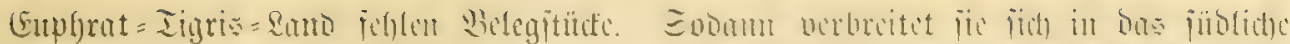

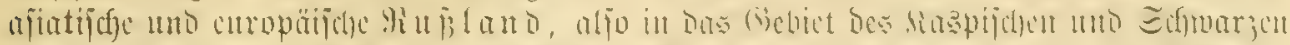

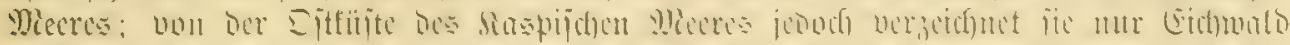

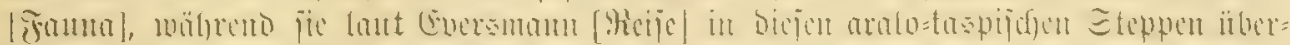

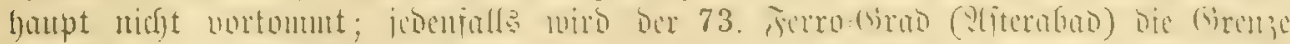

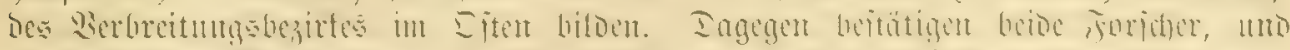

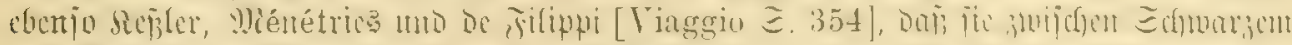

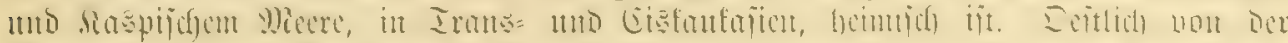

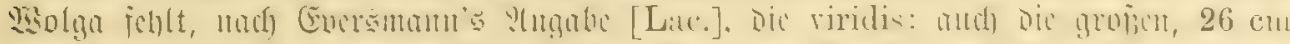

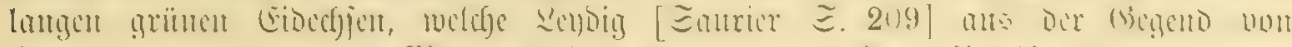

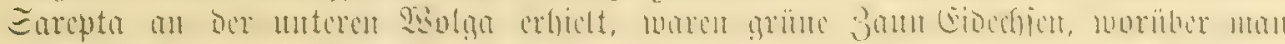

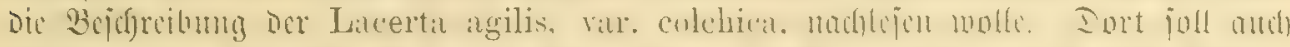

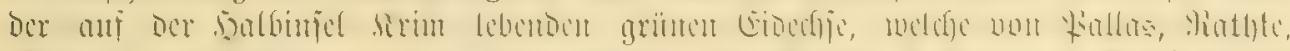

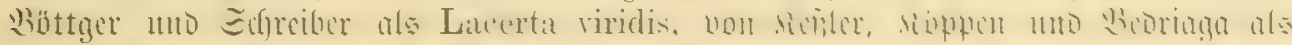

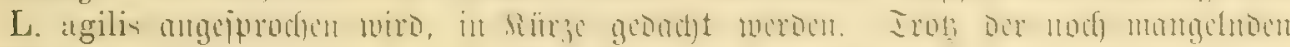

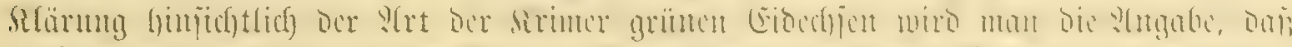

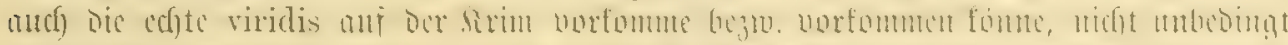

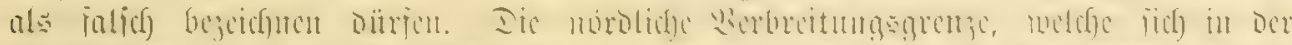

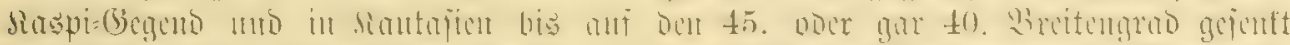

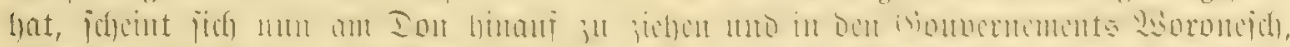

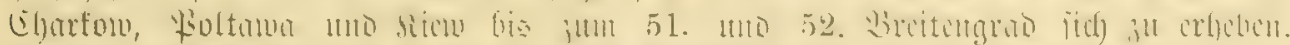

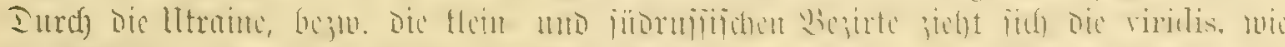

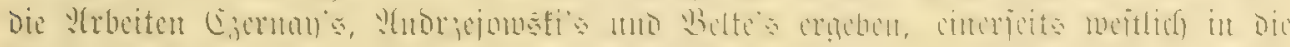

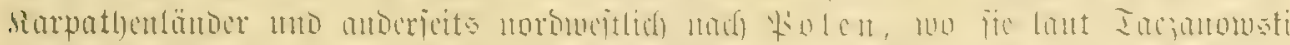

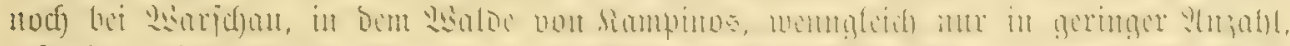

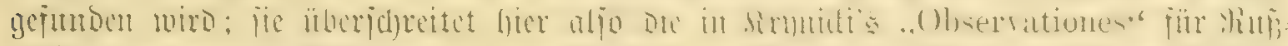

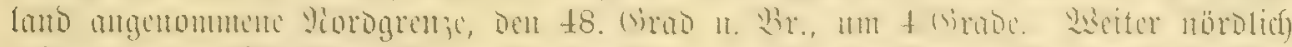

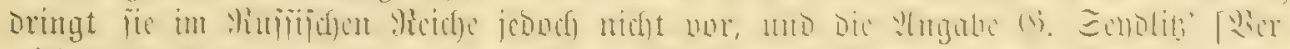

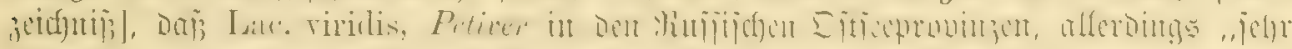

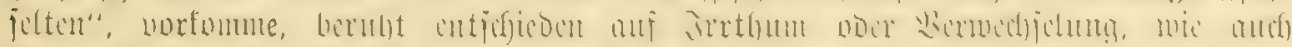

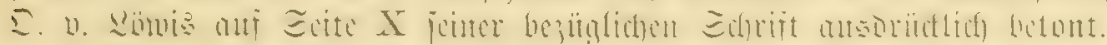

Dic juif(f)

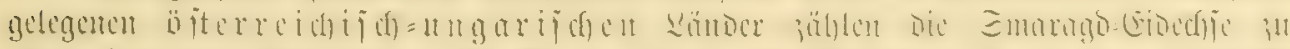

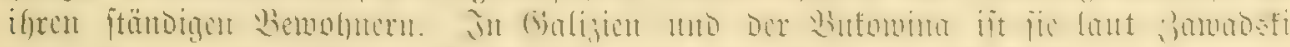

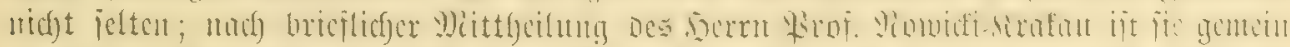

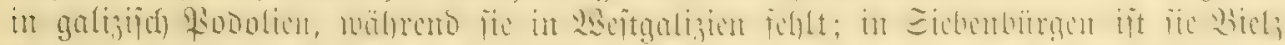

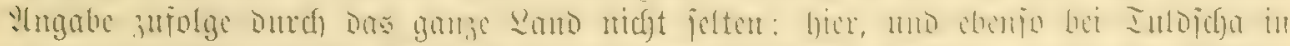

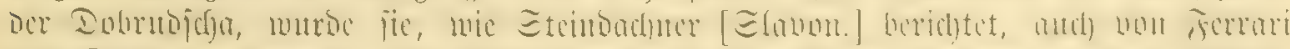

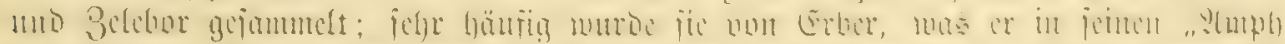

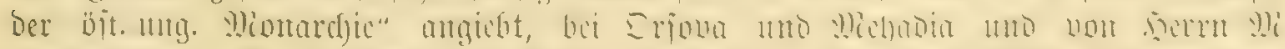

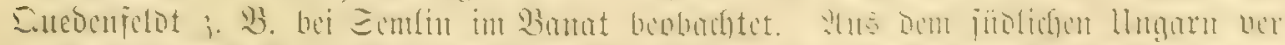

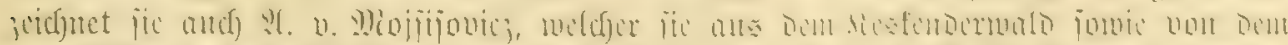

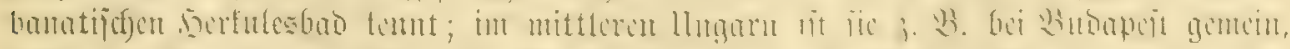

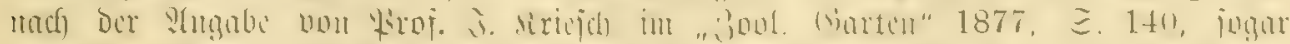

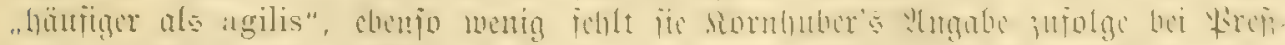

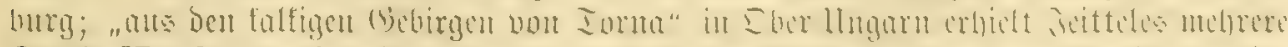

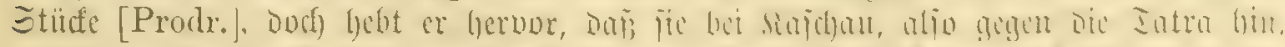

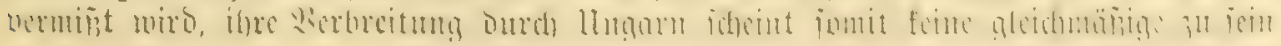




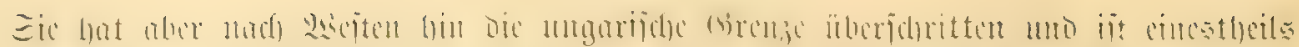

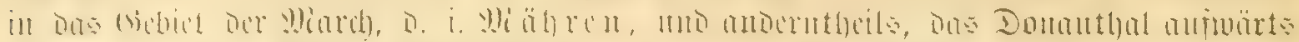

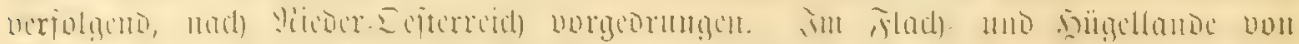

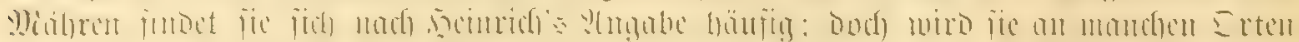

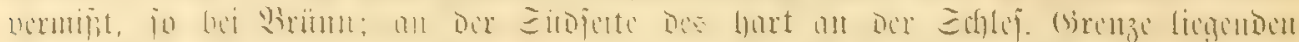

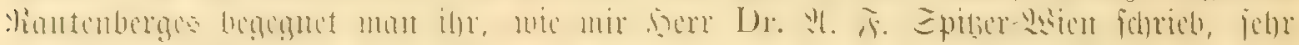

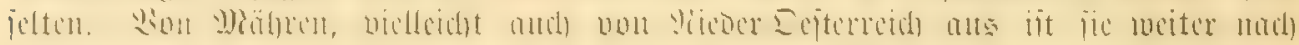

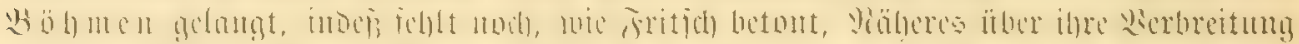

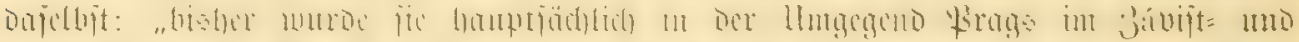

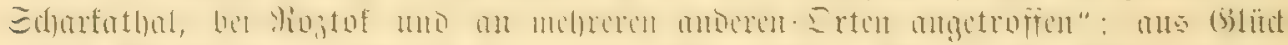

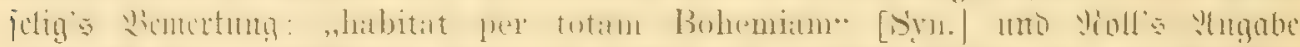
Lijool. (s). s1]: "in

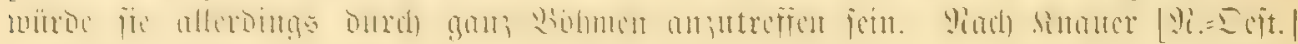

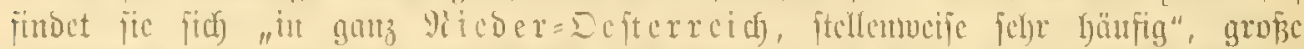

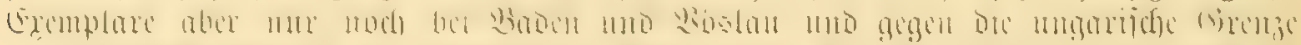

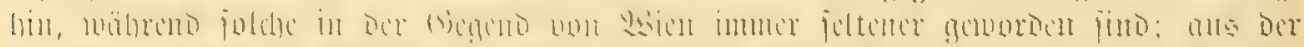

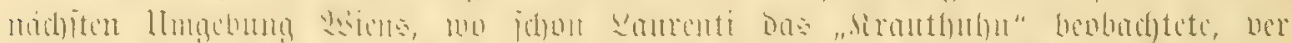

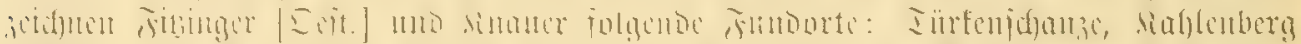

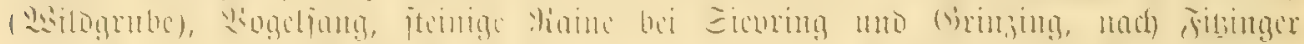

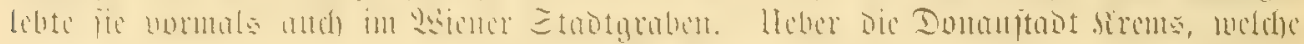

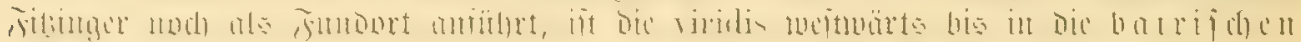

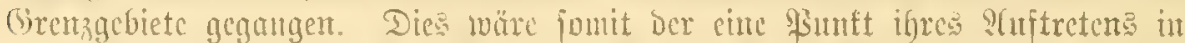

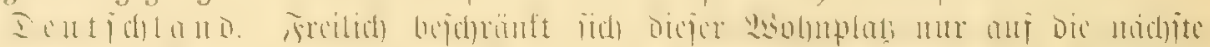

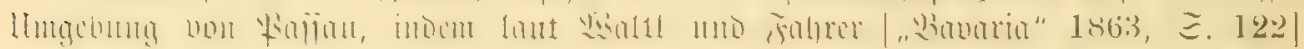

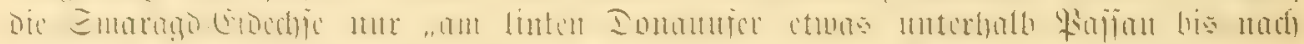

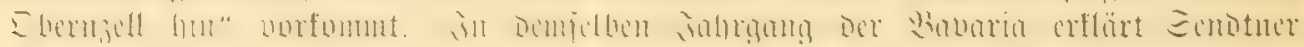

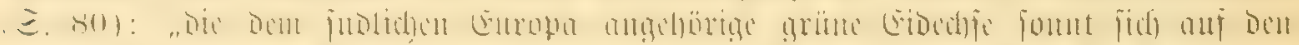

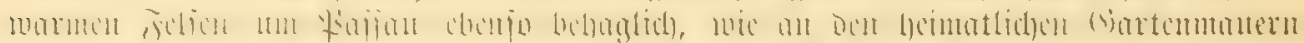

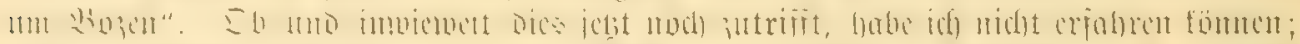

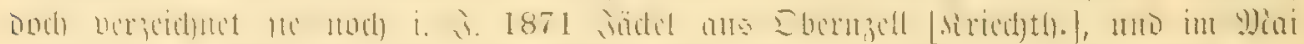

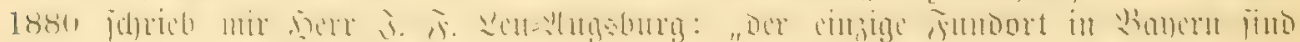

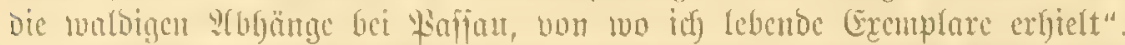

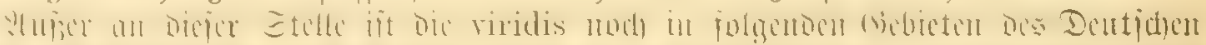

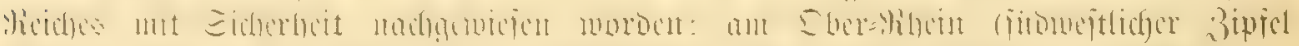

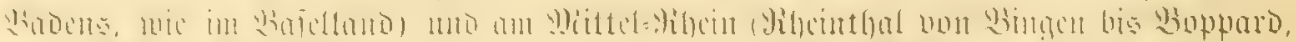

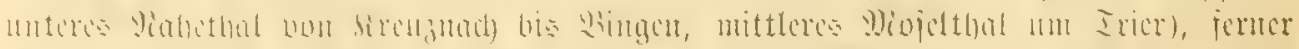

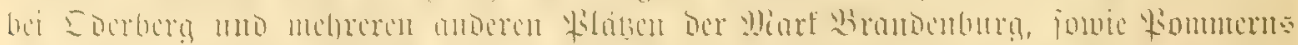

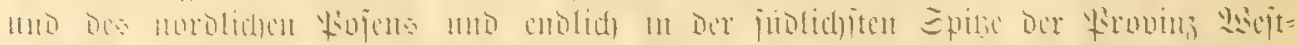

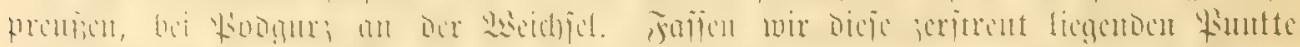

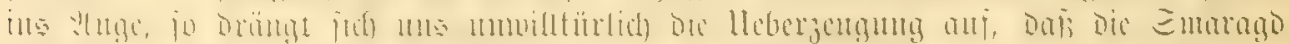

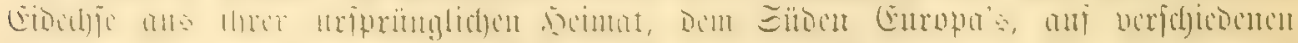

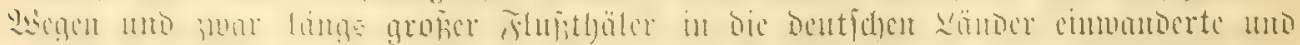

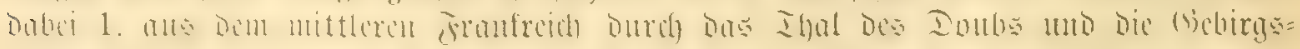

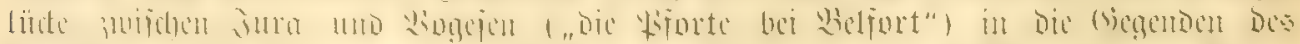

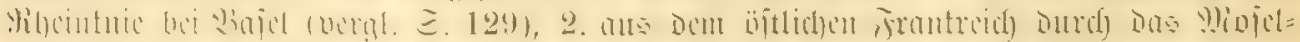

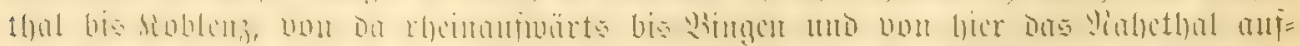

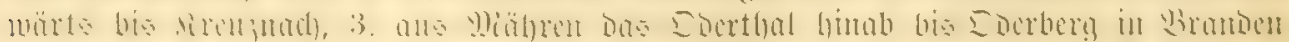

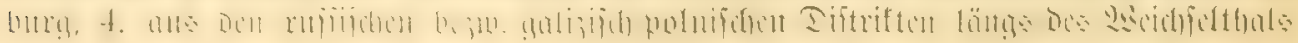




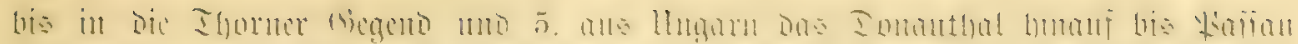

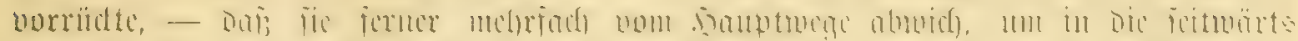

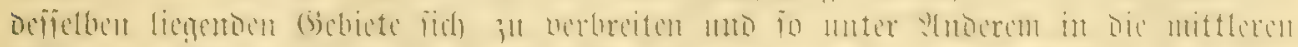

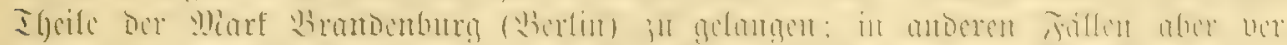

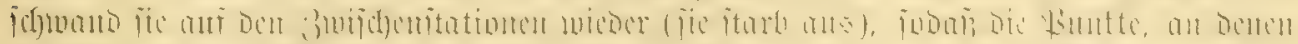

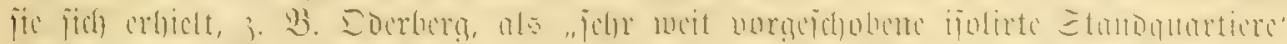

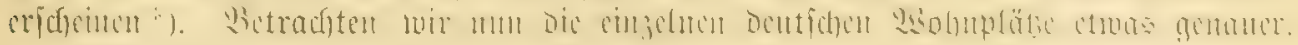

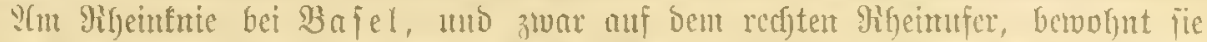

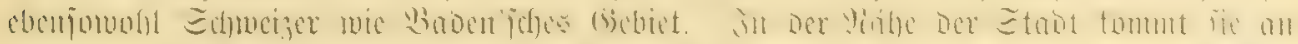

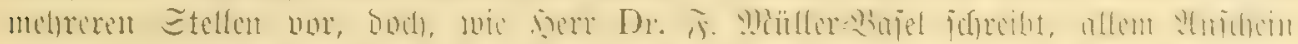

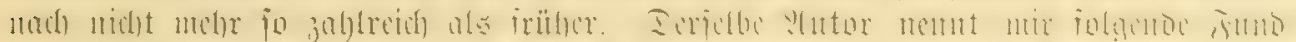

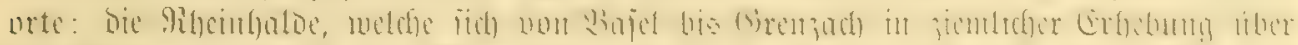

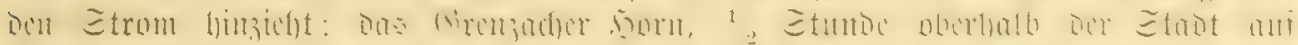

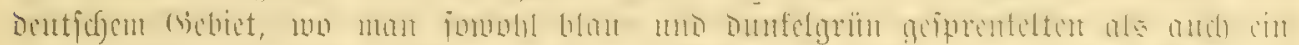

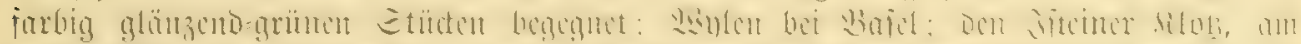

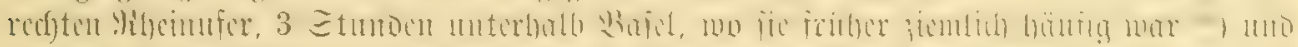

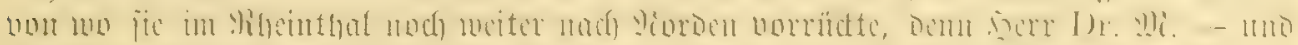

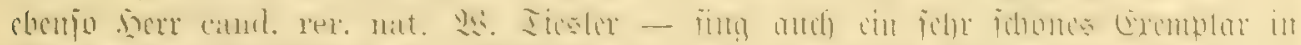

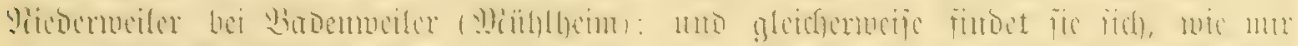
sere firot. 此.

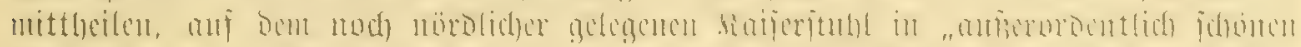

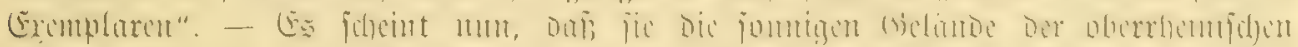

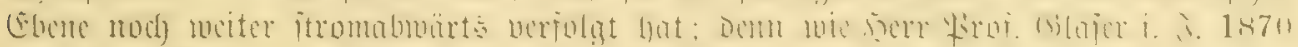

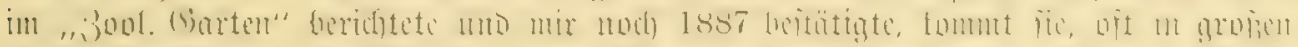

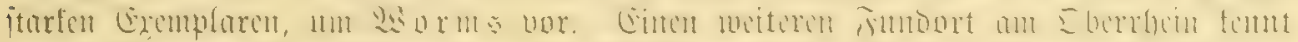

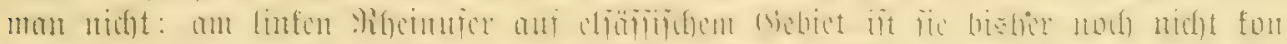

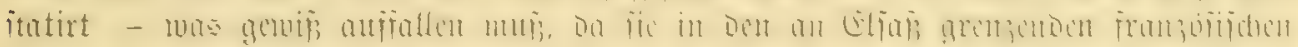

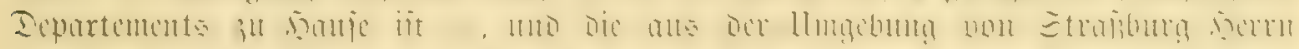

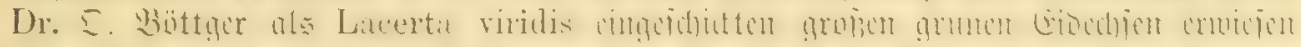

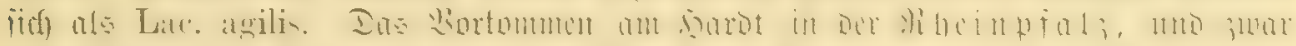

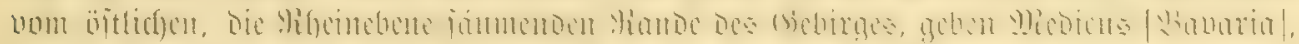

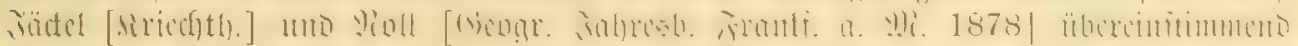

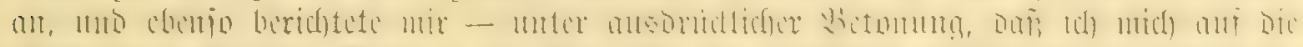

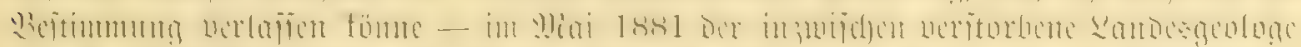

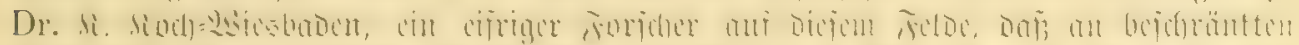

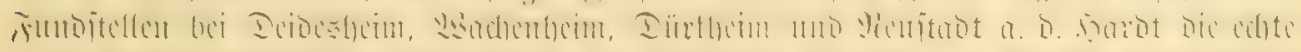

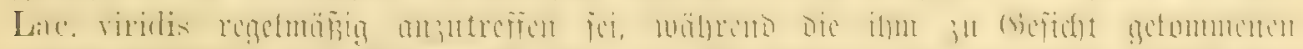

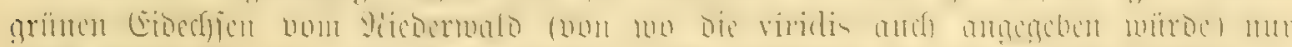

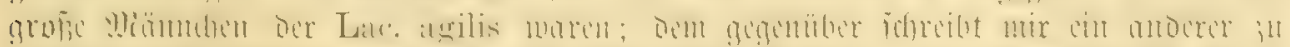

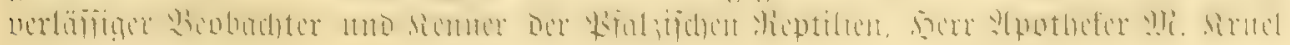

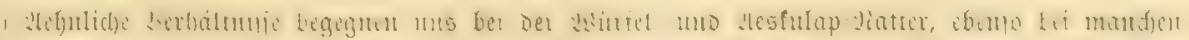

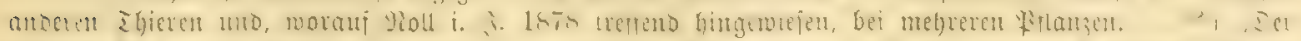

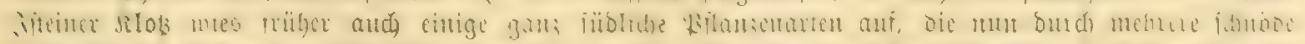

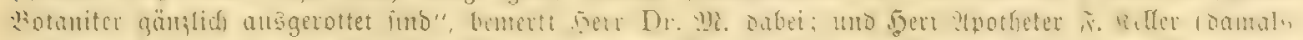

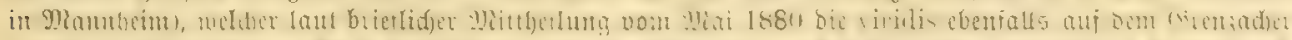

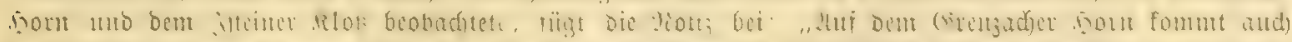

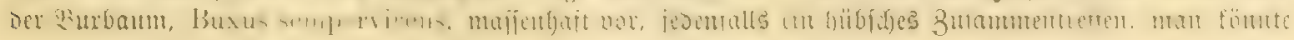

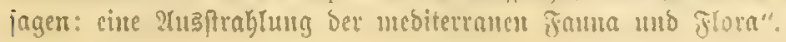




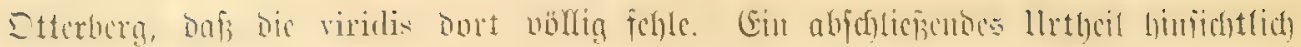

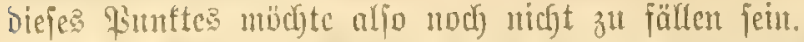

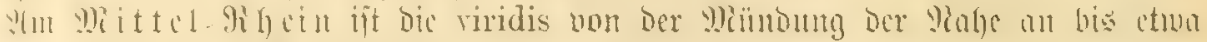

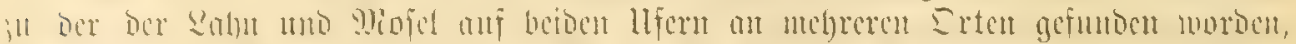

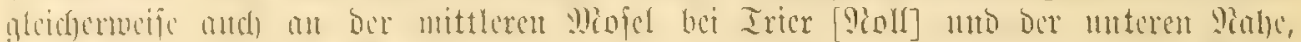

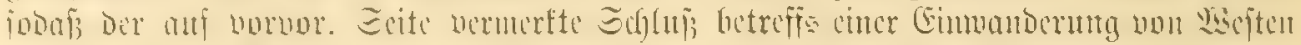

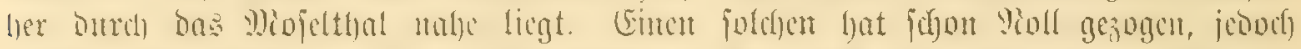

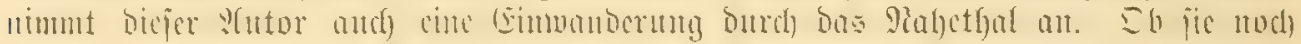

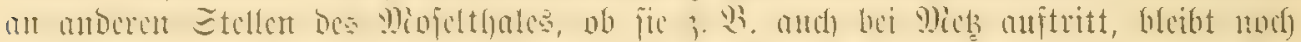

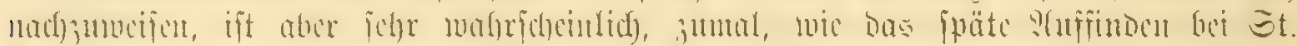

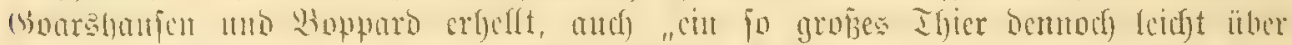

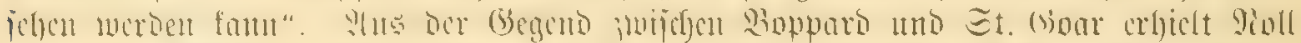

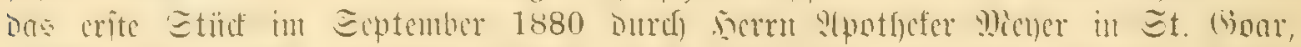

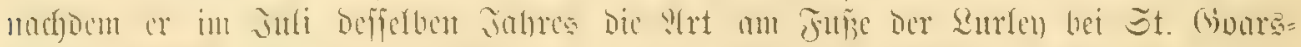

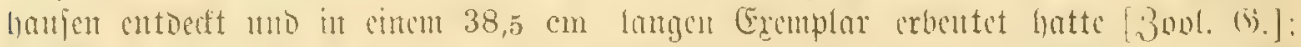

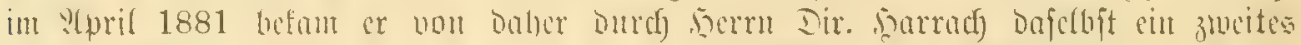

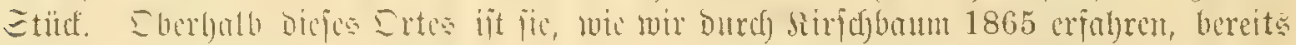

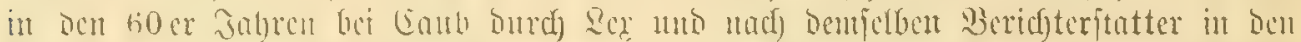

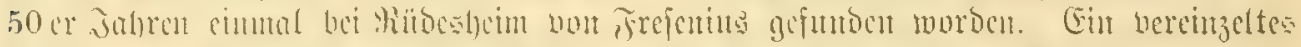

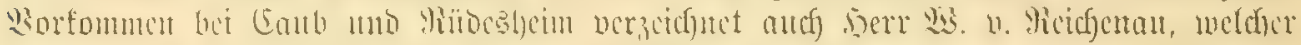

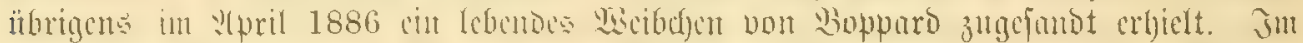

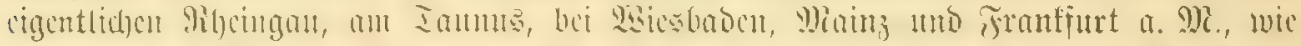

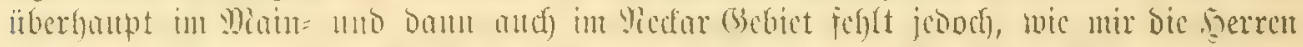

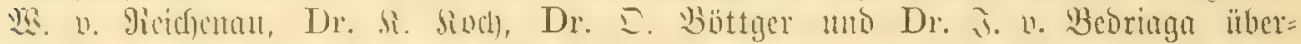

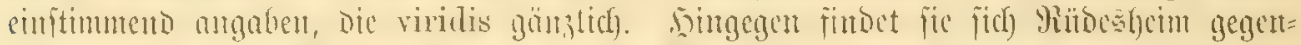

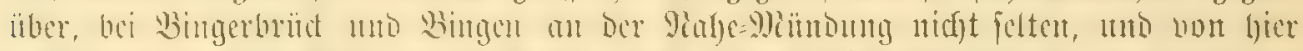

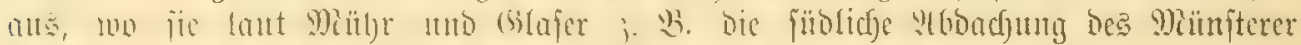

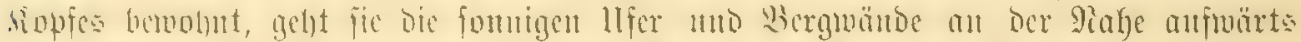

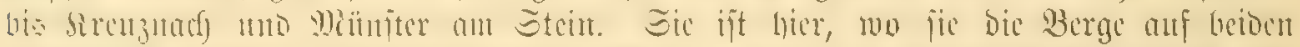

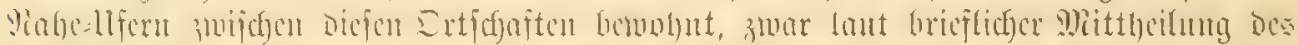

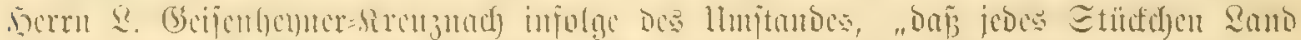

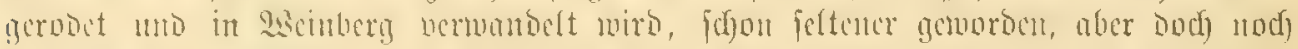

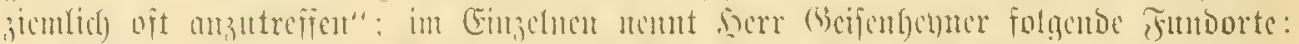

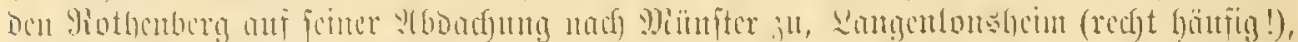

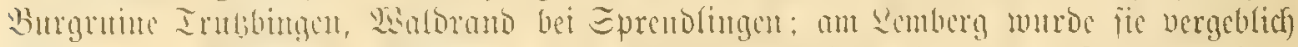

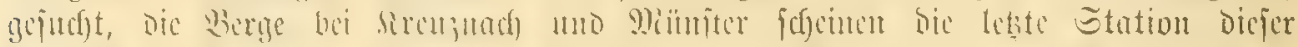

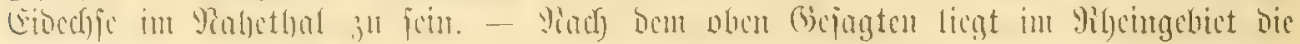

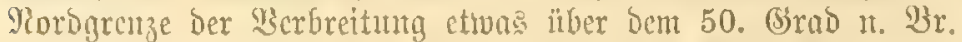

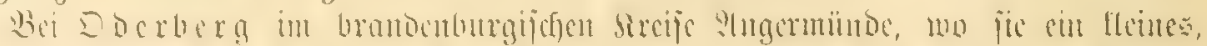

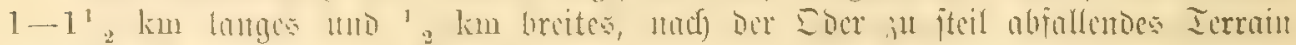

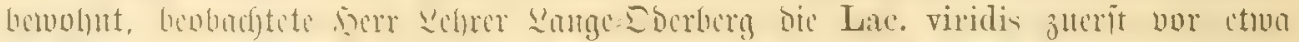

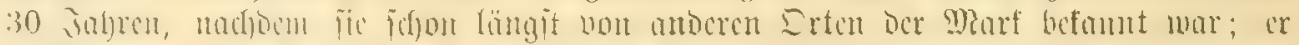
fïng bamals cin 22 ;)

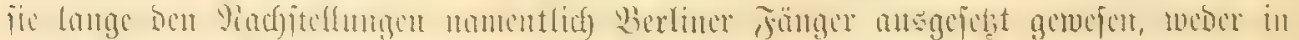

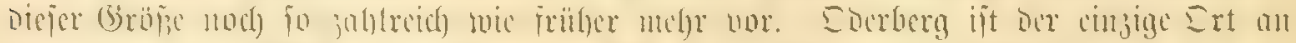

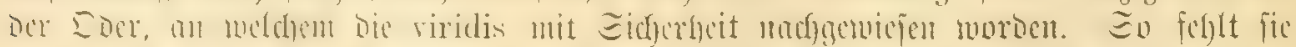

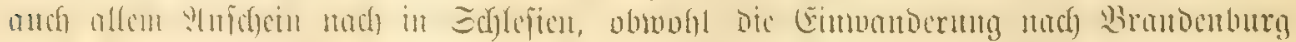

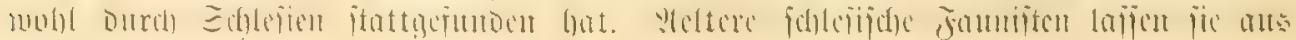




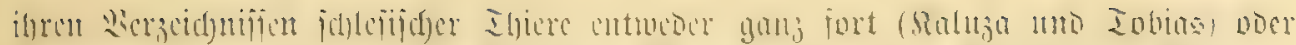

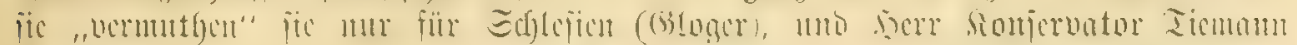

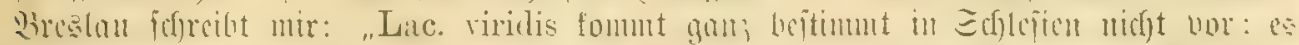

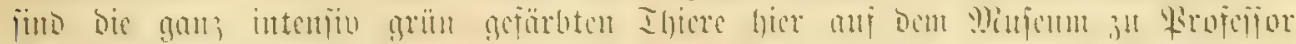

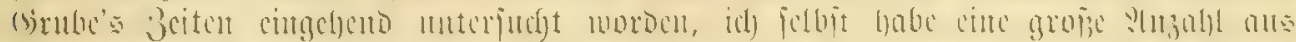

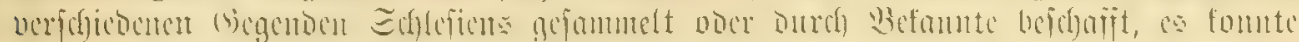

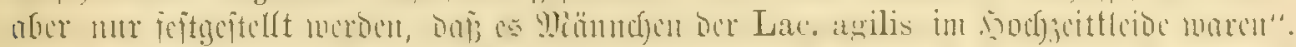

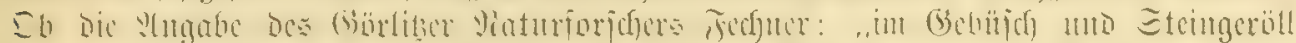

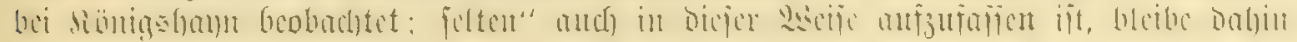

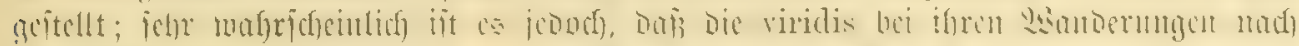

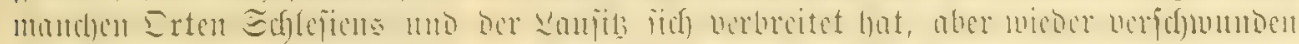

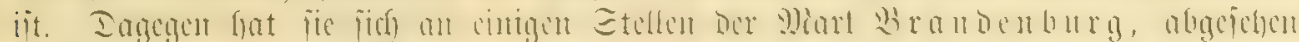

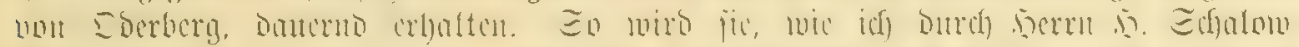

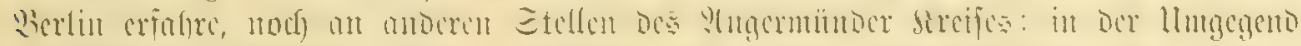

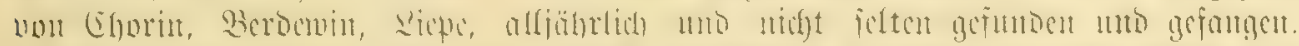

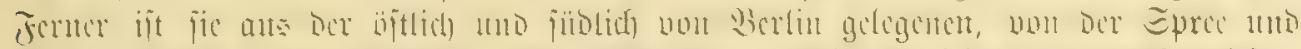

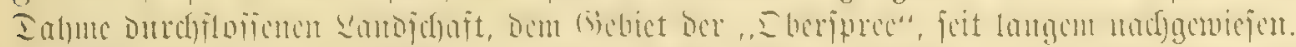

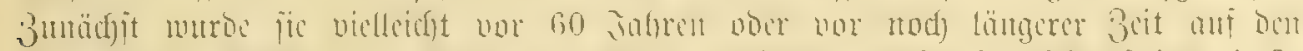

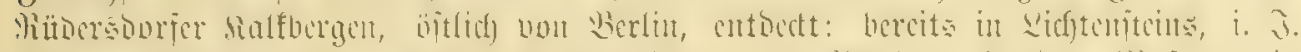

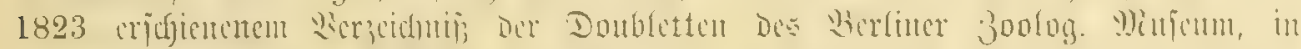

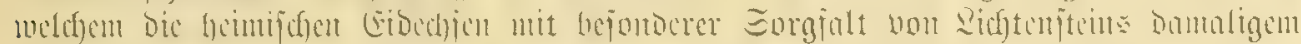

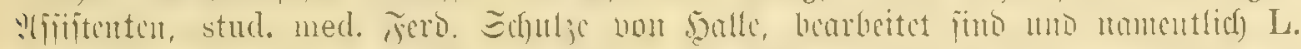

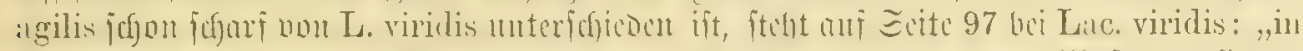

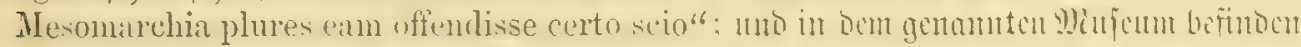

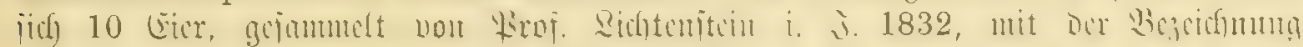

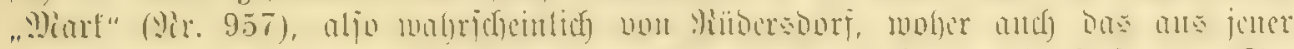

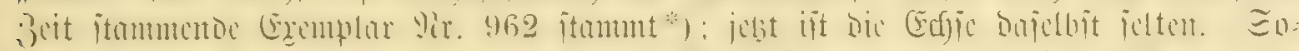

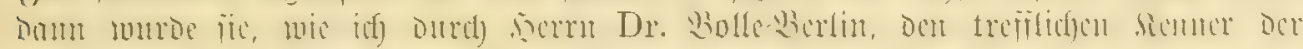

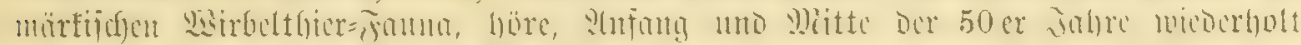

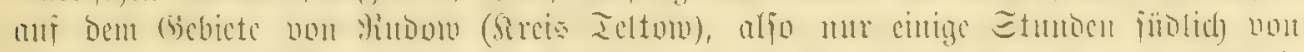

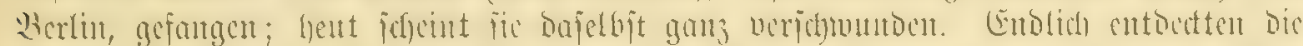

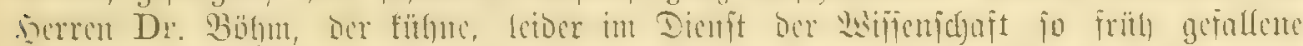

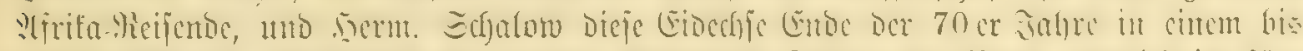

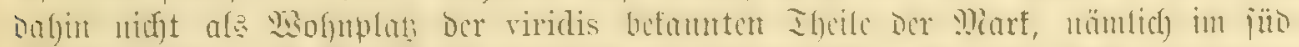

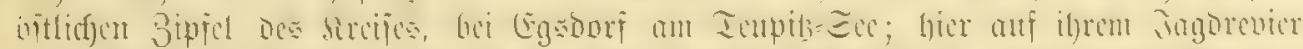

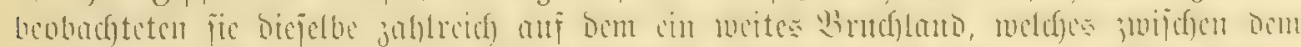

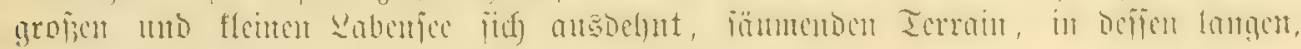
crgen Ersppalten bic Ificre jidy mit Borliebe aufbicltent.

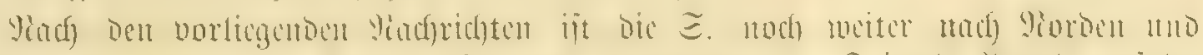

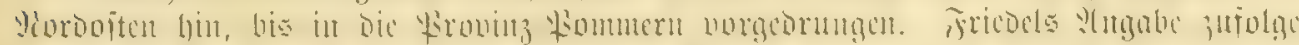

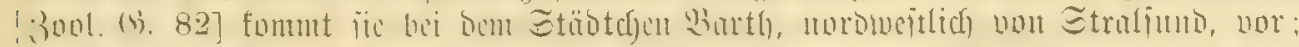

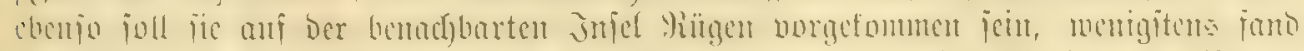

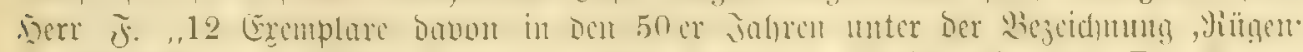

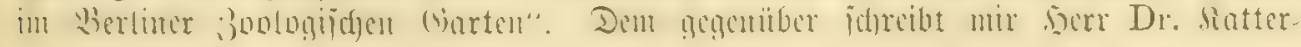

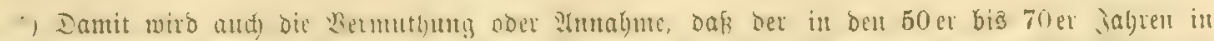

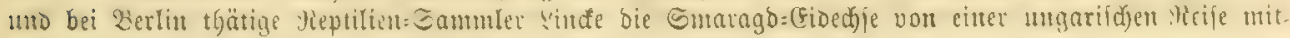

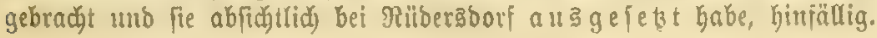




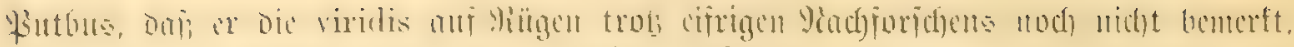
woht aber in hinterpommern bei Dramburg gefangen habe.

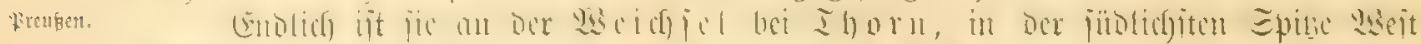

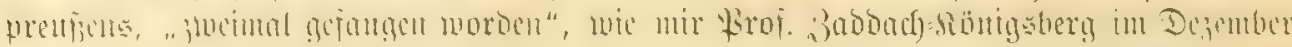
1880 mittheilte. Entoedt wurbe fic bort - und ebenjo bic Glattnatter - bei

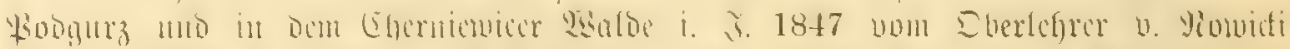

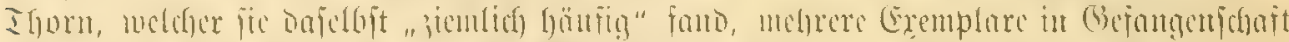

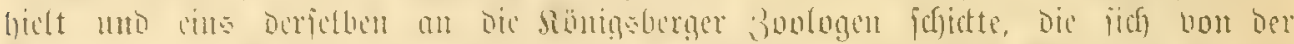

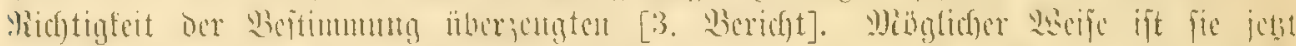

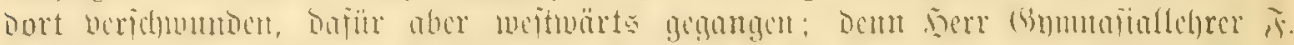

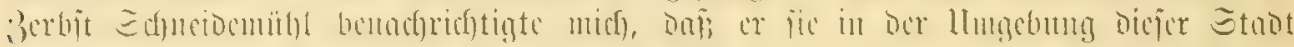

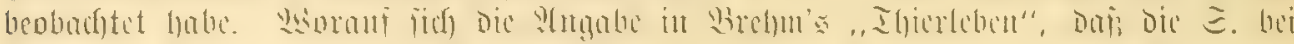

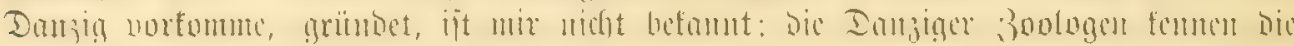
viridis ate Dortiger (Begend nicht.

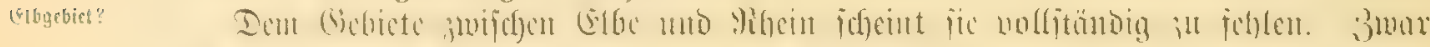

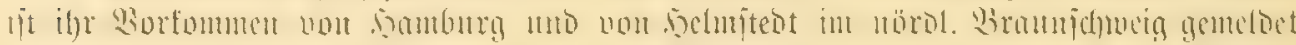

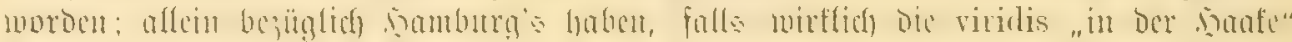

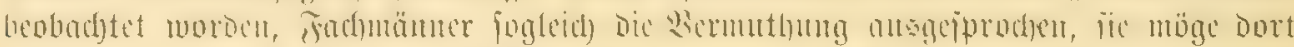

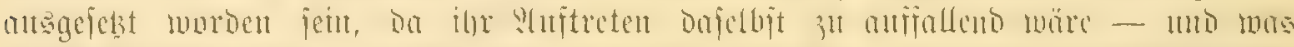

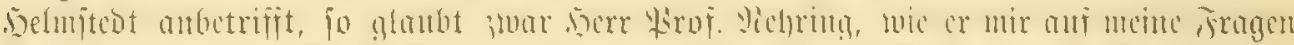

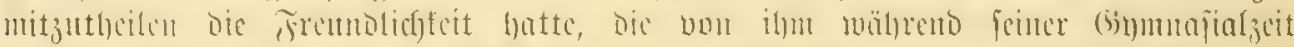

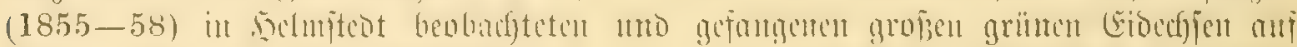

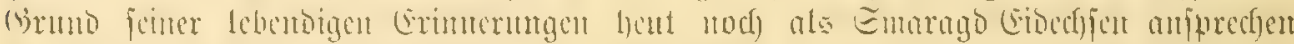

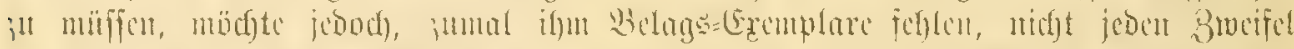

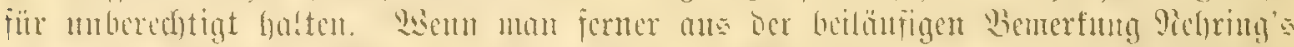

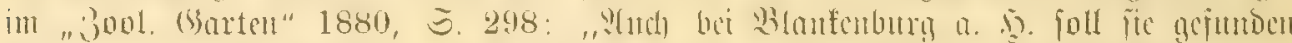

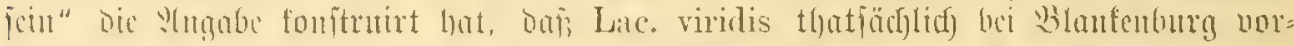

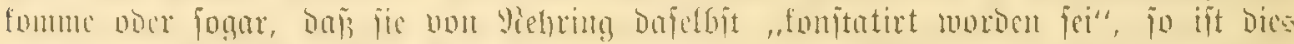

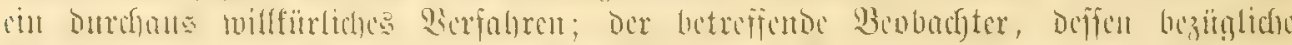

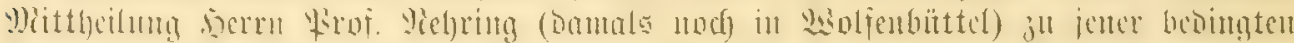

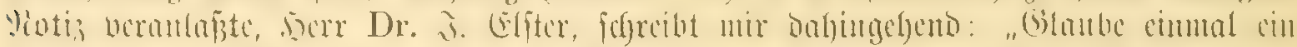

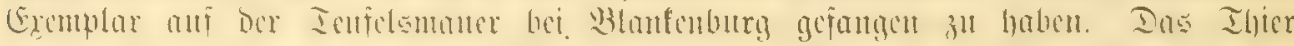

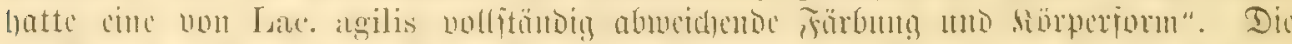

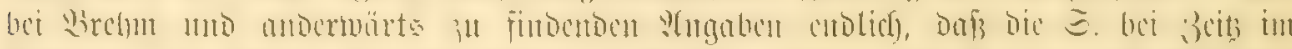

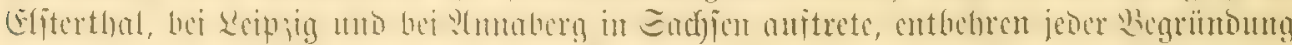

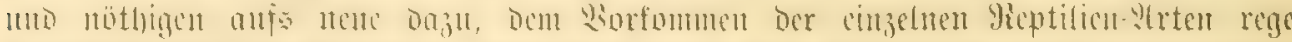

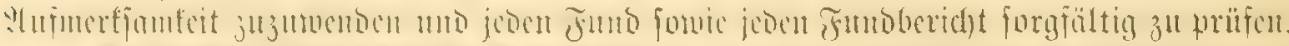

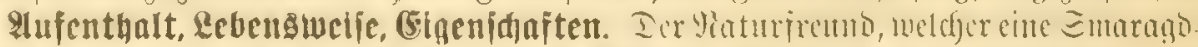

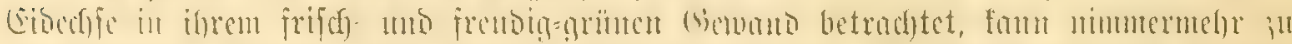

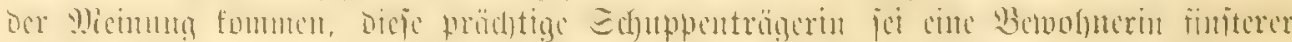

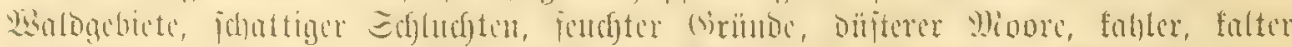

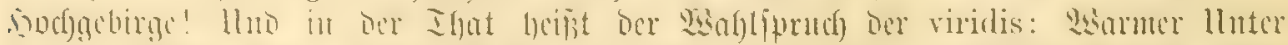

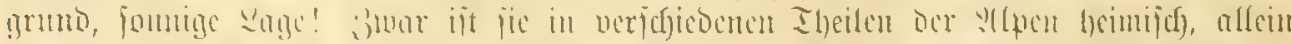

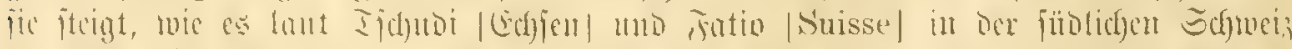

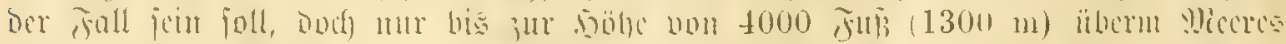

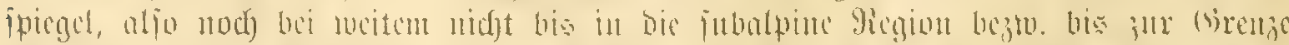

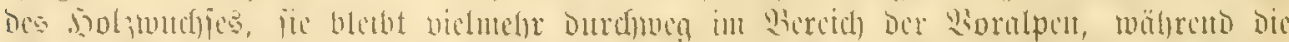

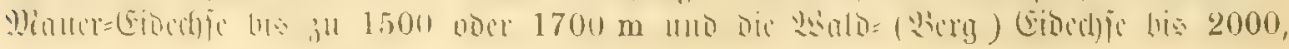




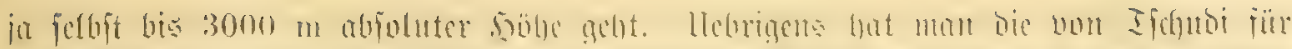

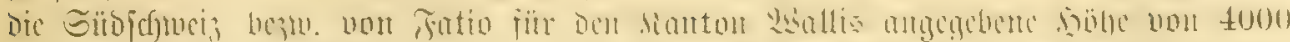

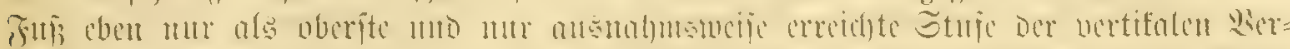

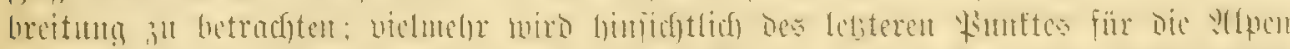

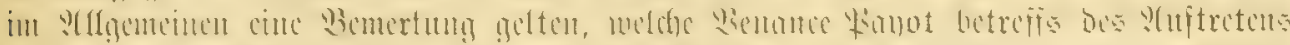

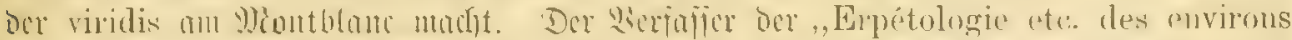

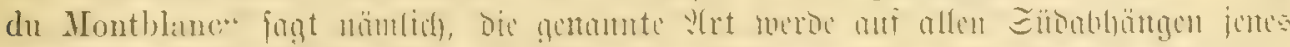

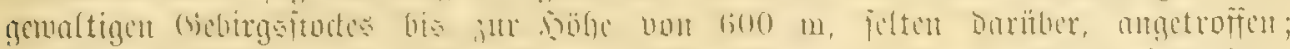

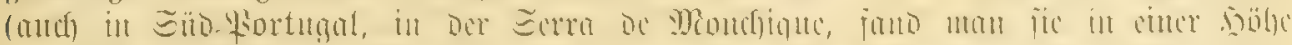

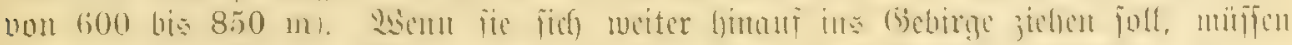

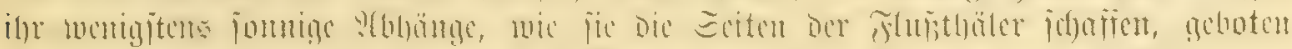

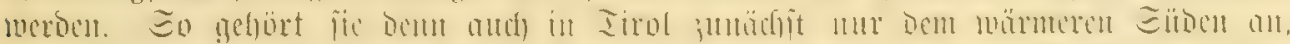

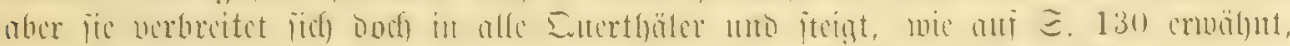

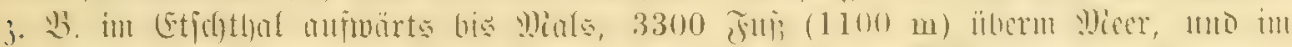

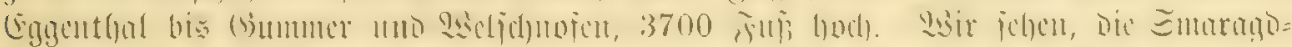

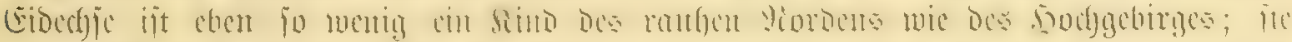

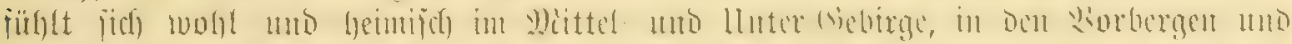

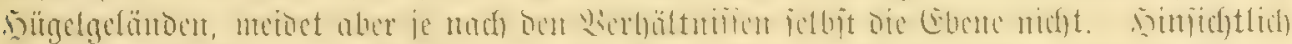

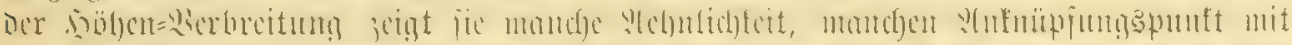

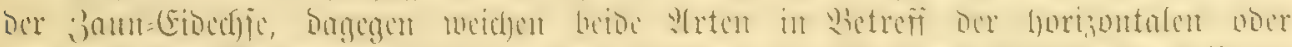
gographiod)

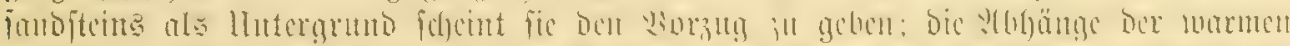

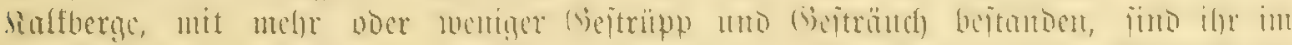

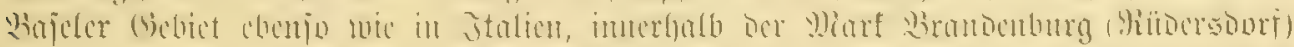

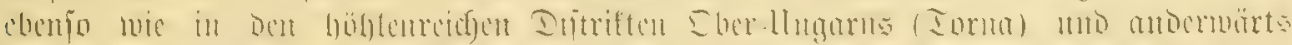

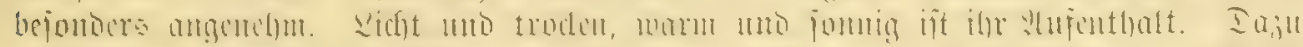

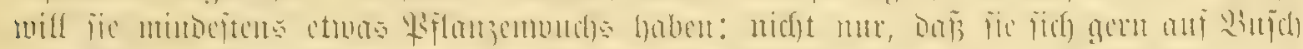

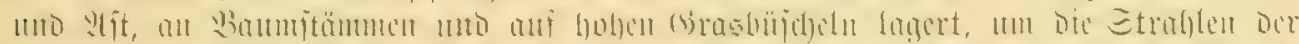

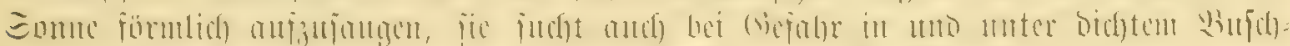

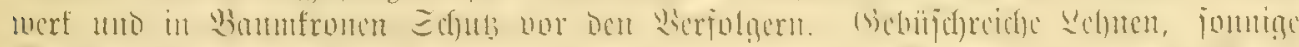

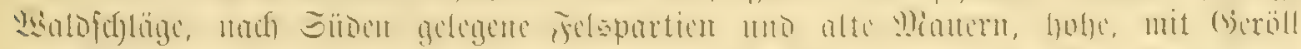

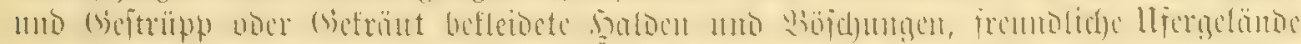

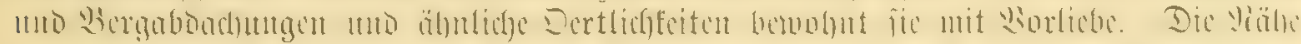

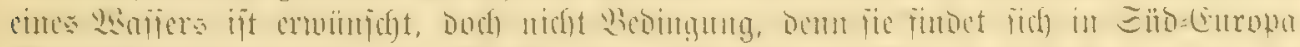

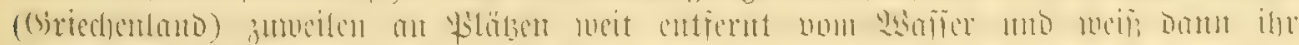

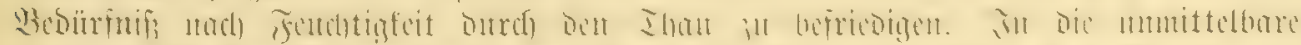

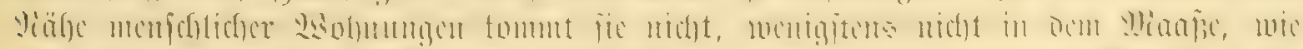

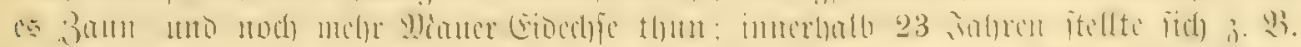

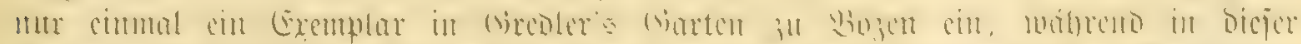

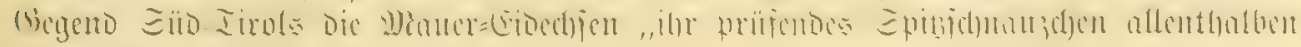
Dareinlubcu".

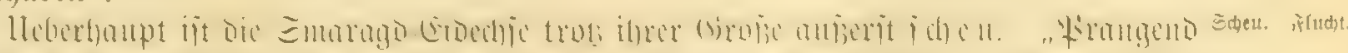

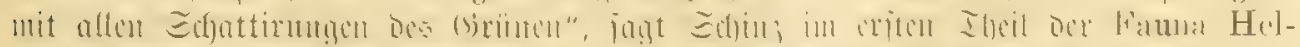

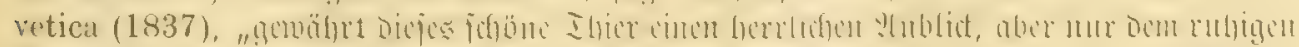

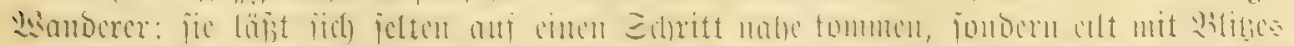

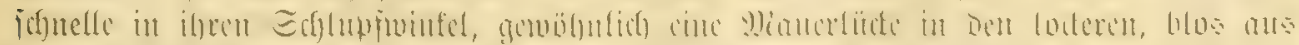

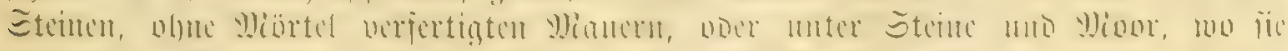

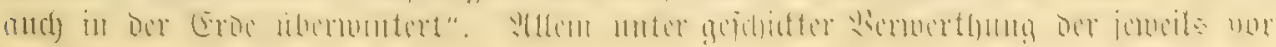




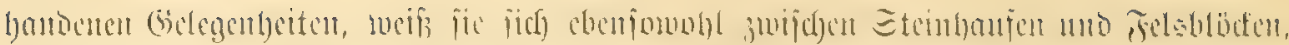

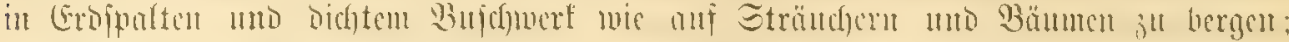

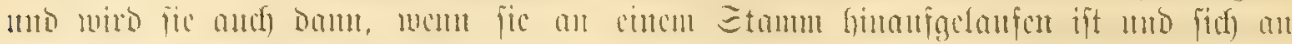

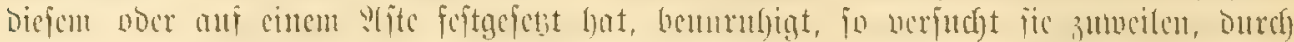

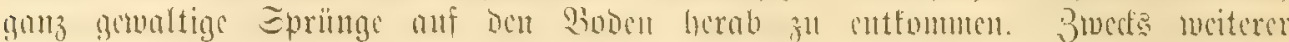

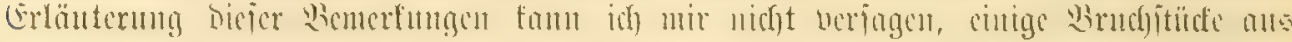

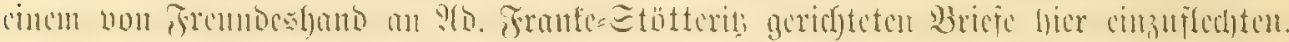

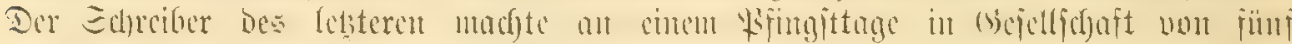

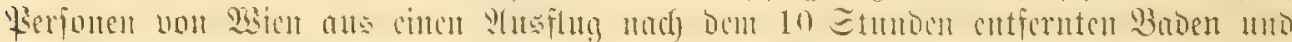

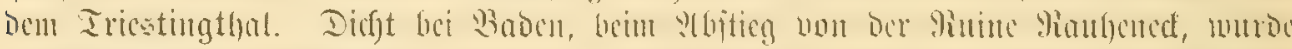

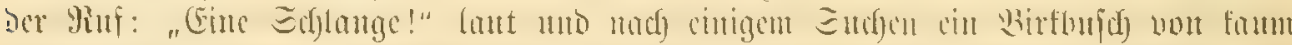

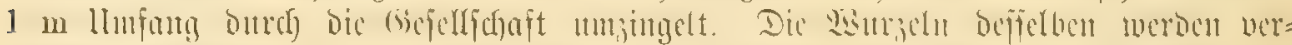

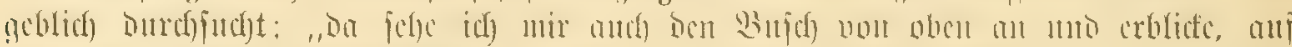

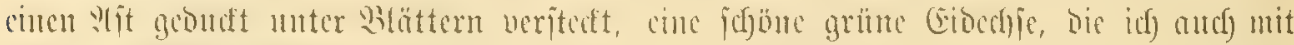

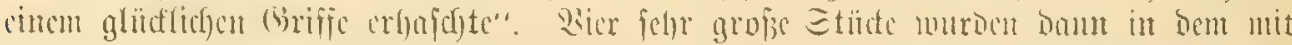

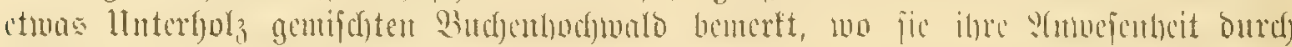

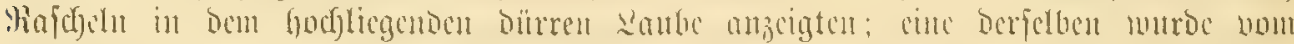

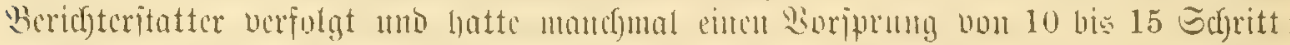

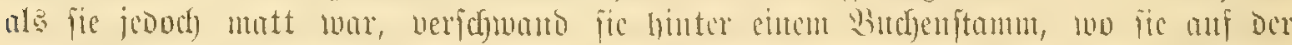

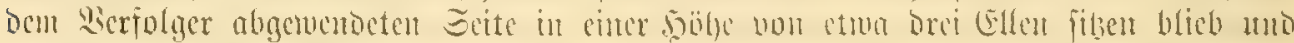

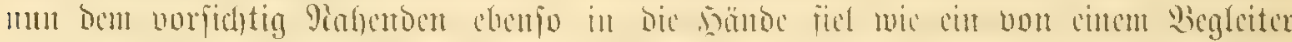

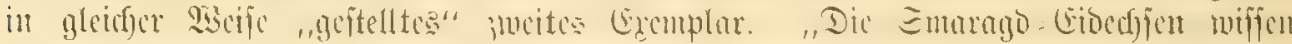

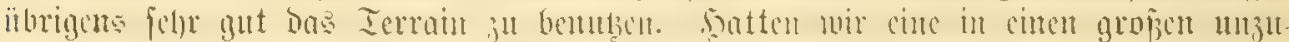

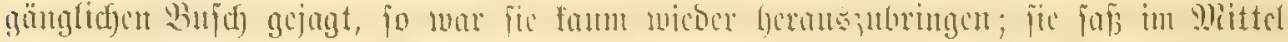

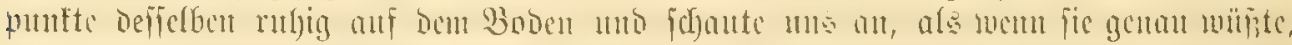

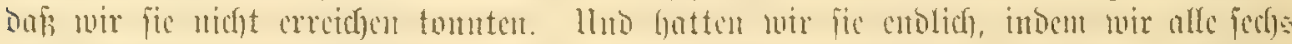

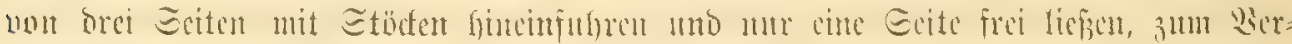

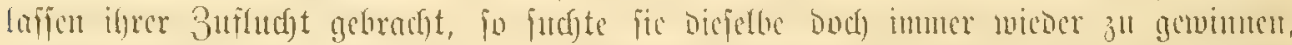

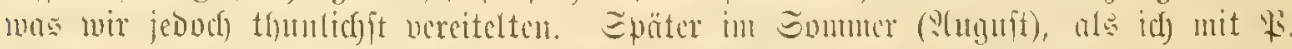

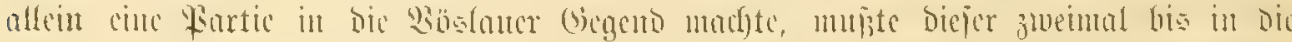

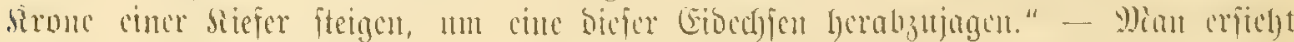

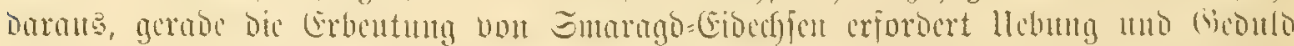

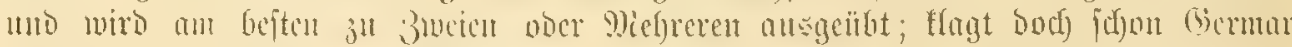

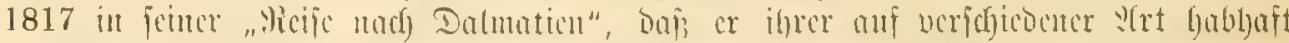

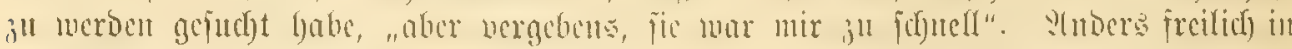

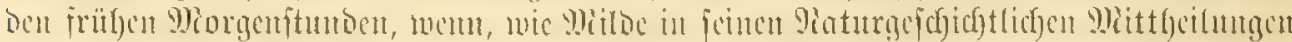

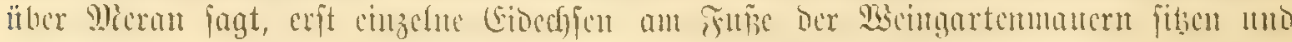

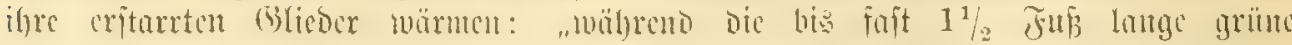

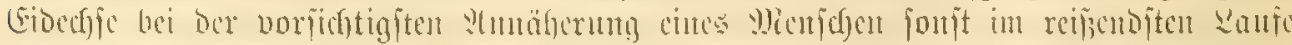

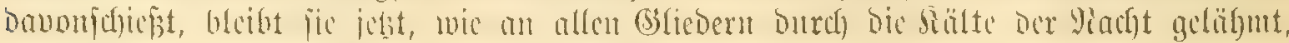

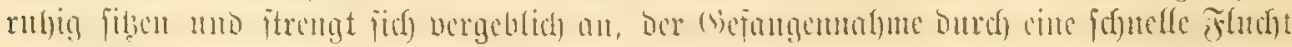

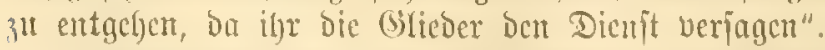

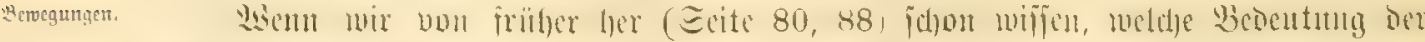

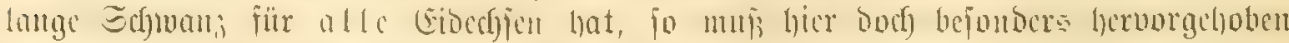

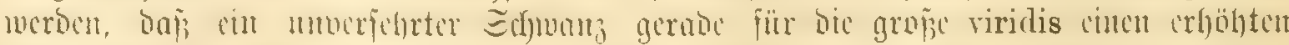

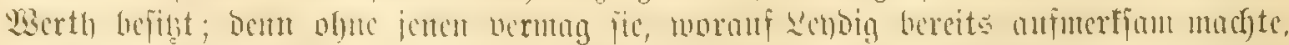

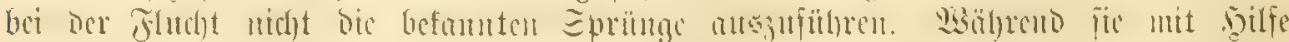

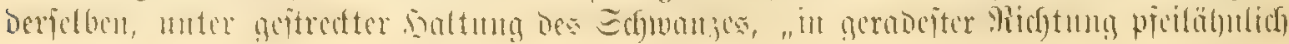




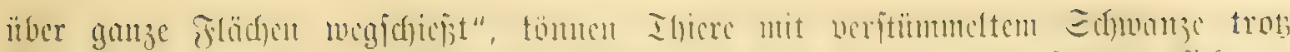

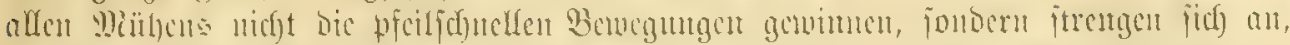

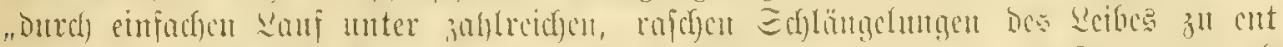

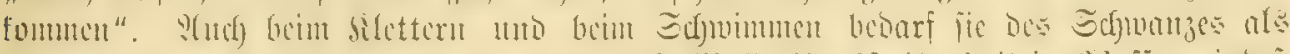

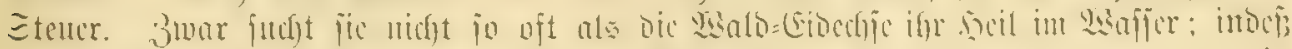

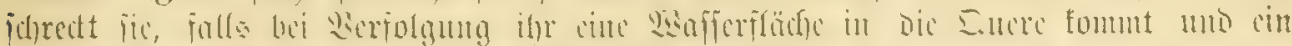

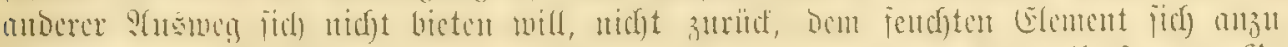

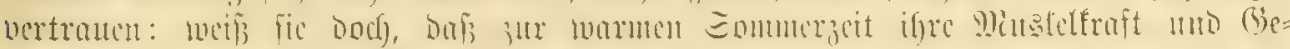

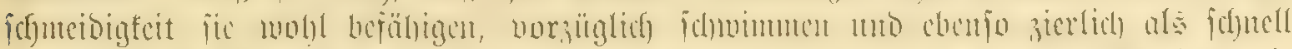

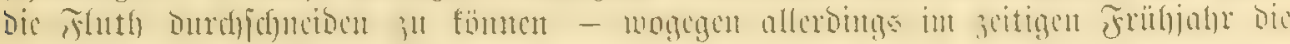

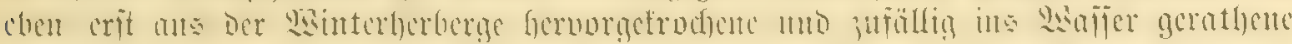

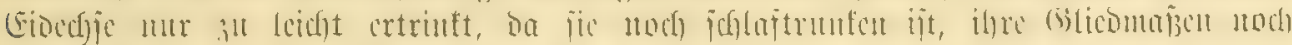

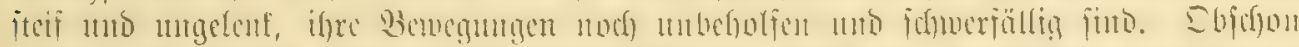

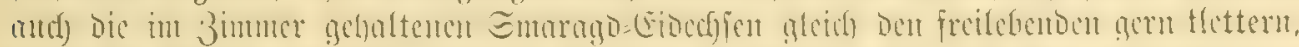

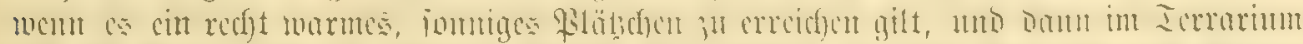

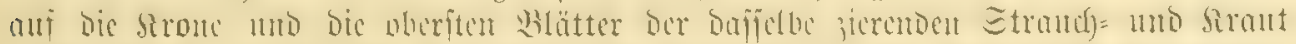

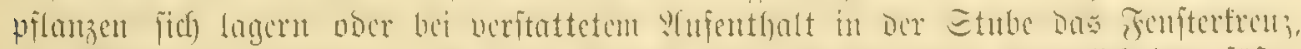

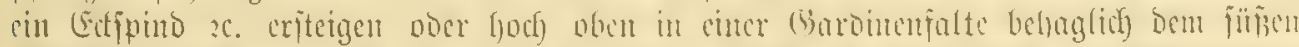

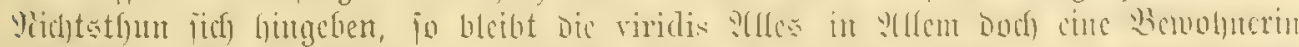

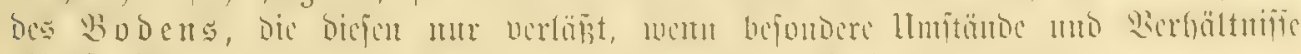

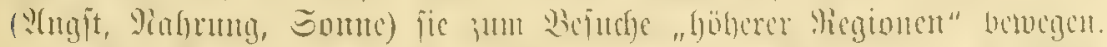

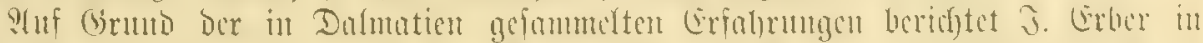

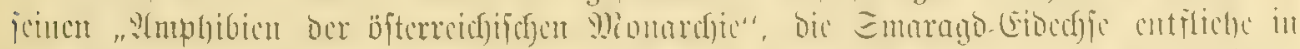

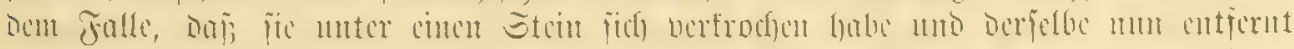

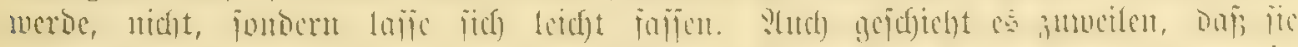

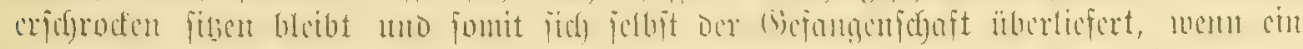

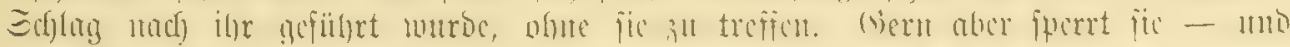

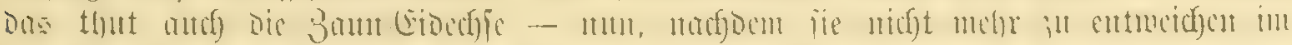

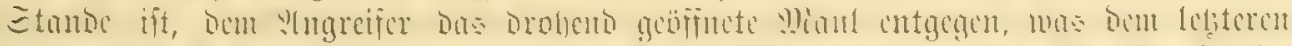

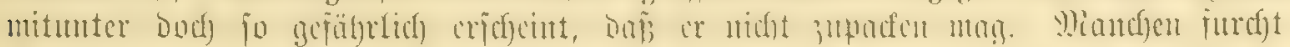

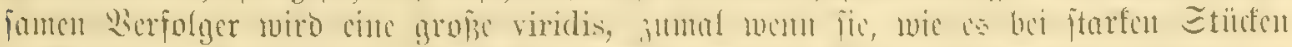

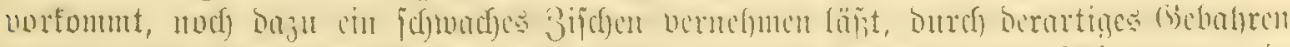

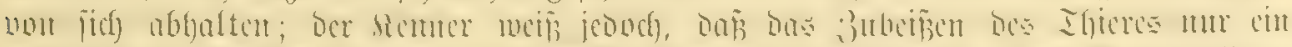

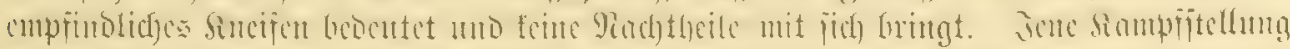

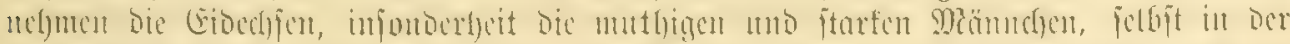

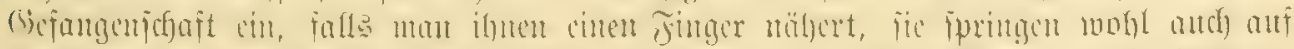

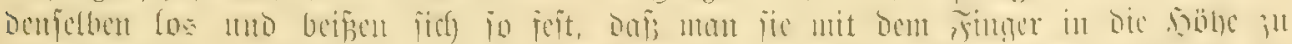

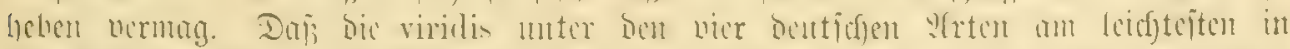

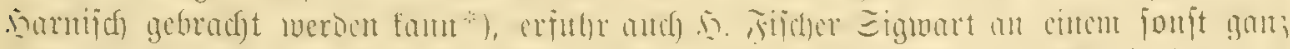

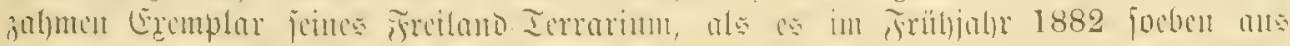

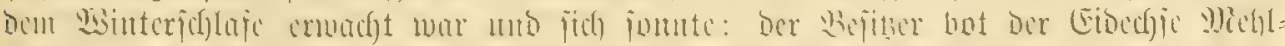

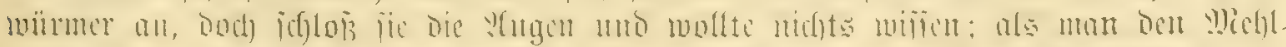

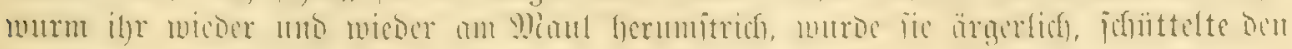

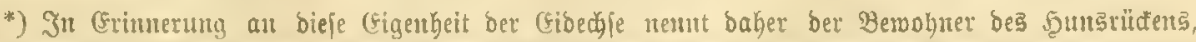

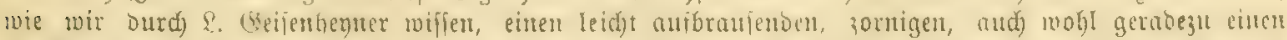

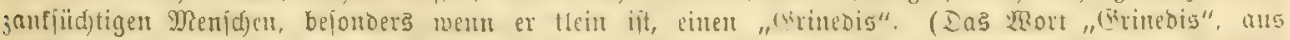

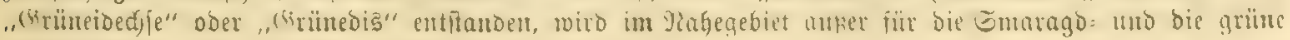

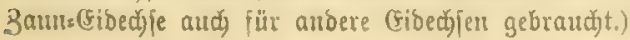




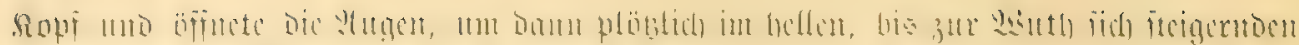
B.,

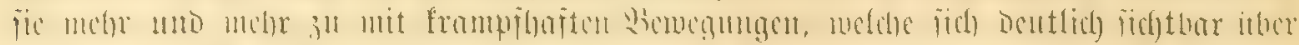

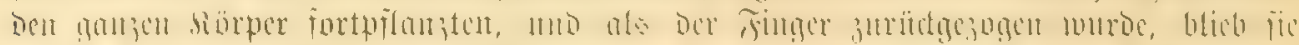

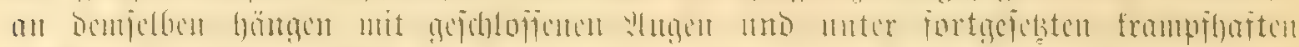

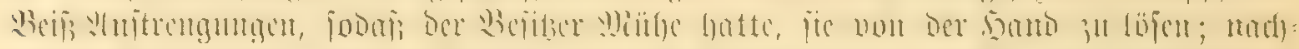

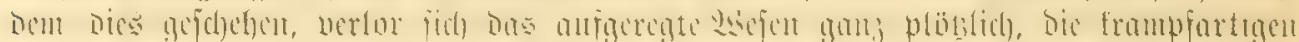

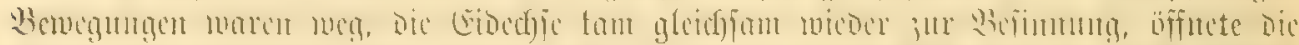

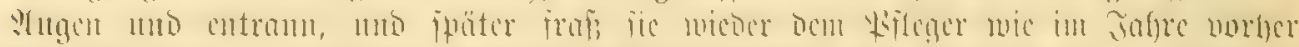

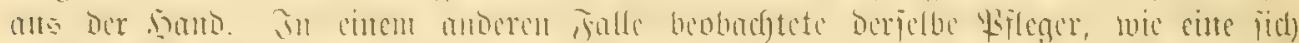

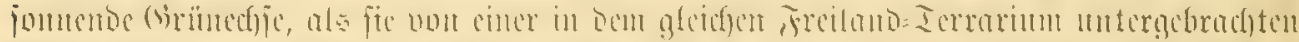

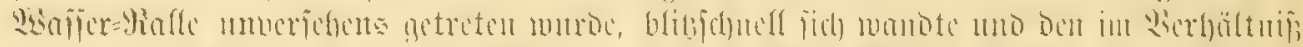

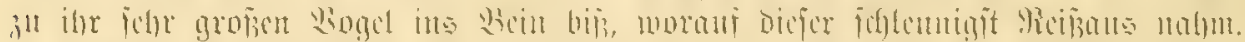

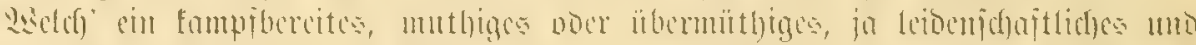

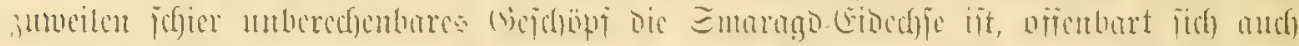

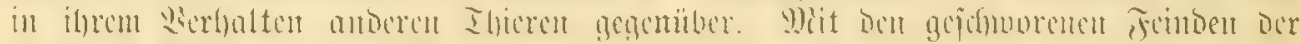

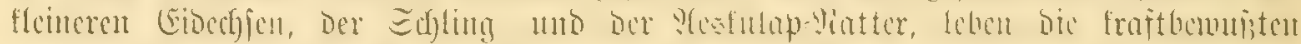

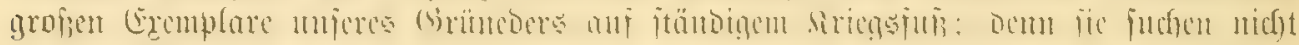

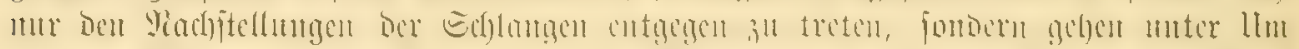

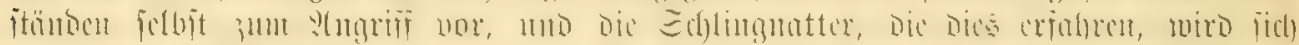

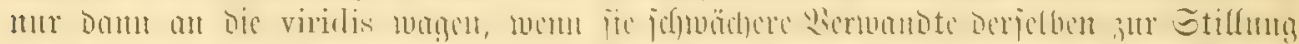

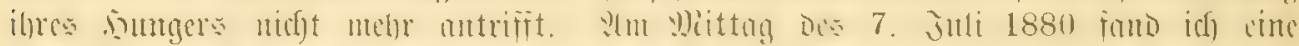

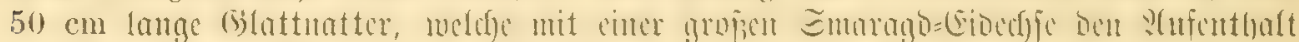

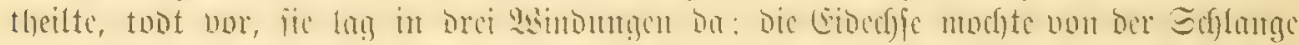

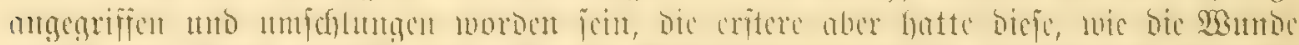

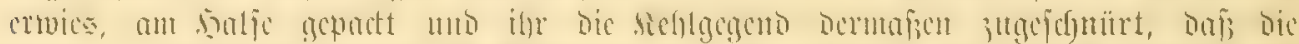

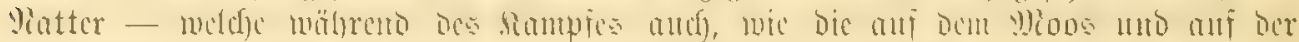

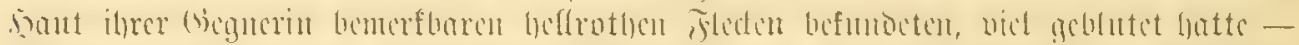

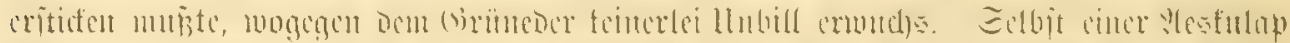

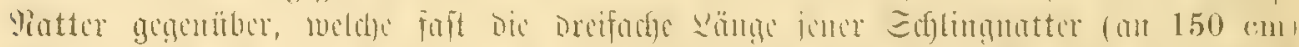

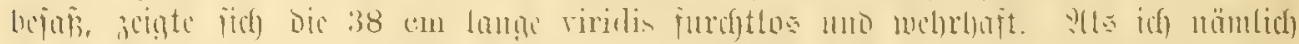

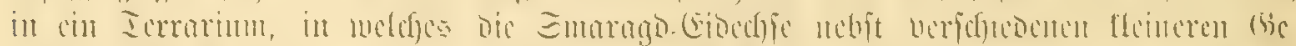

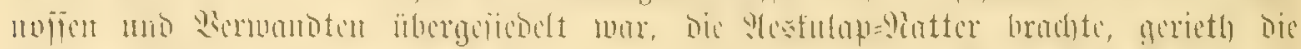

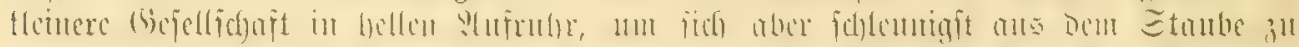

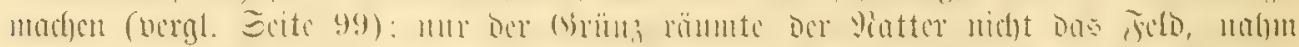

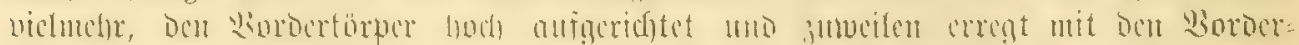

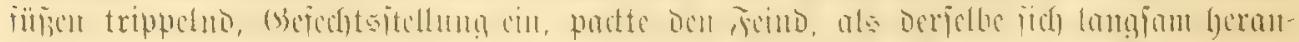

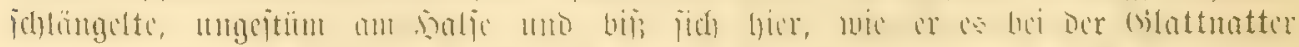

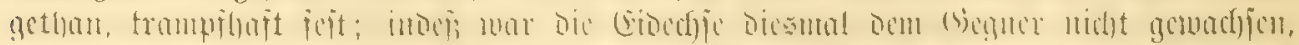

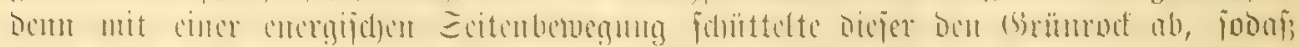
Deferer mu anch verbult bas

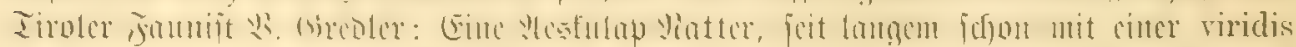

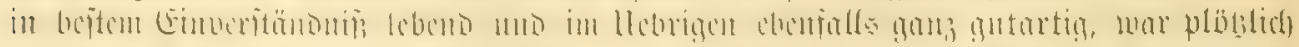

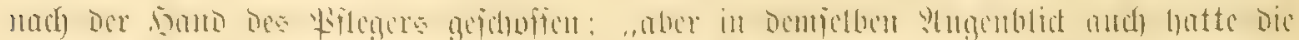

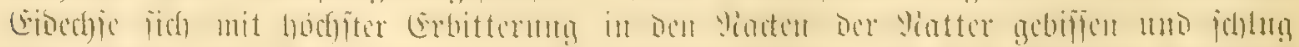

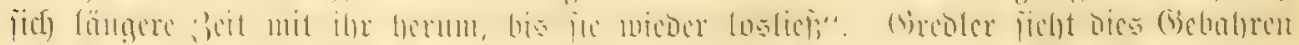

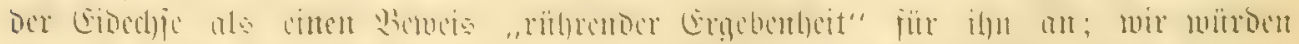

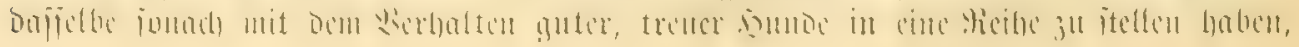




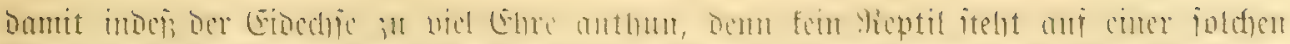

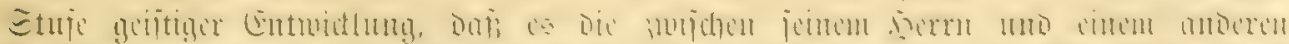

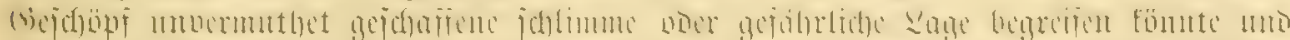

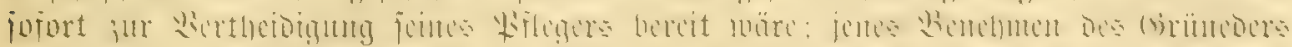

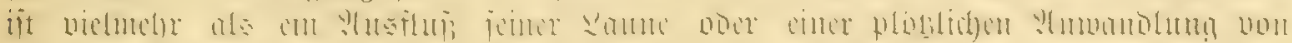

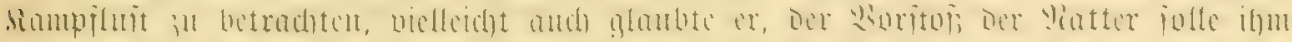
gelten. Ëmen

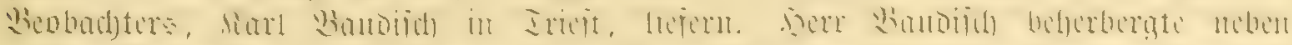

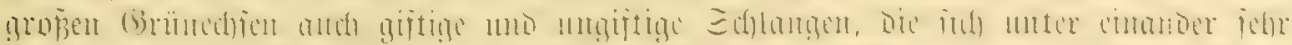

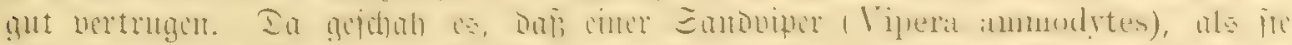

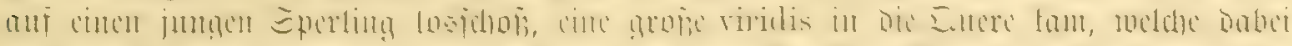

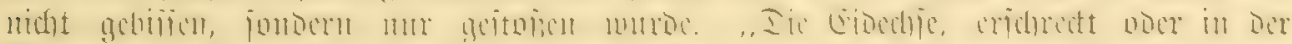

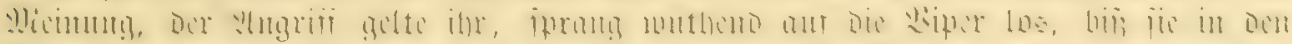

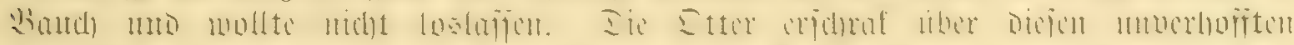

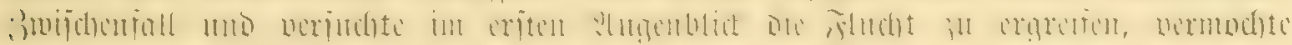

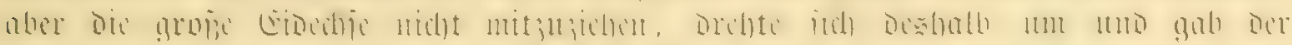

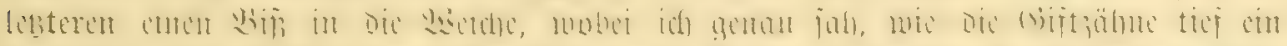

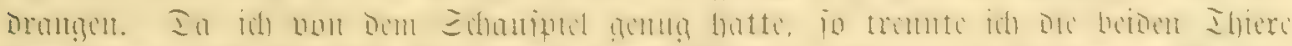

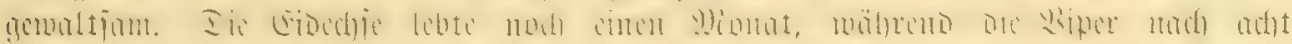

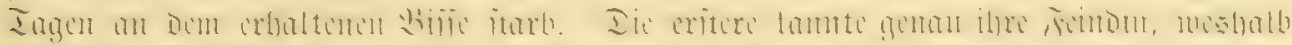

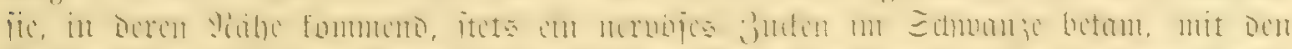

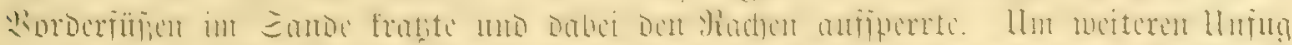

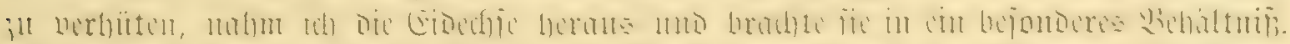

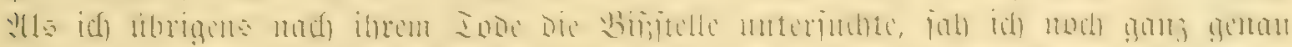

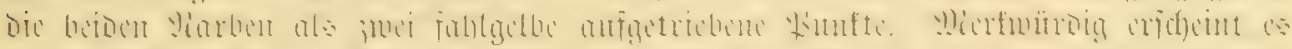

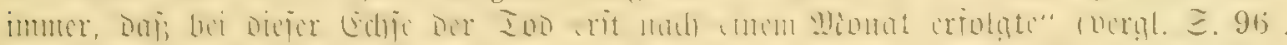

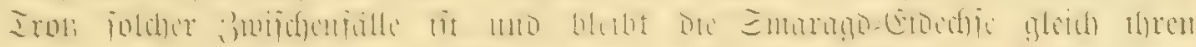

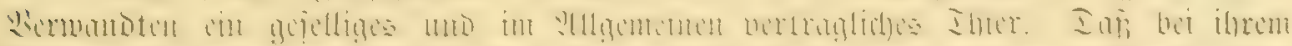

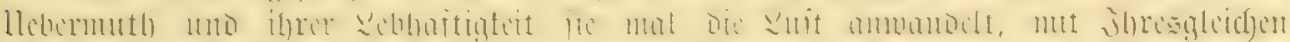

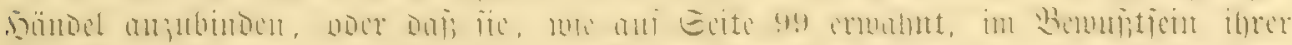

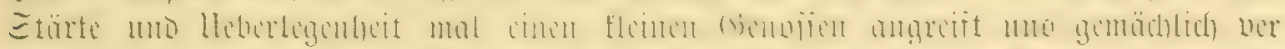

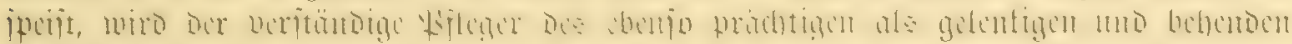

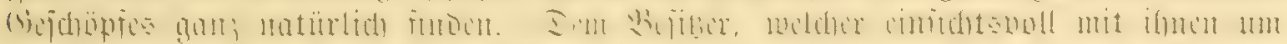

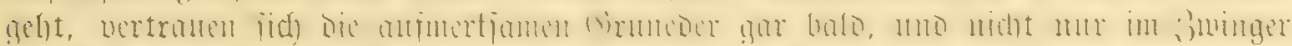

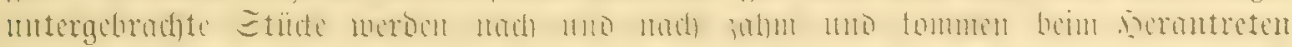

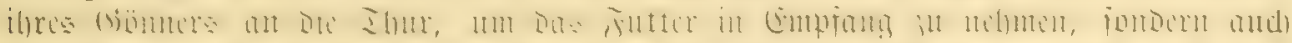

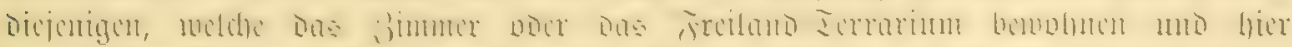

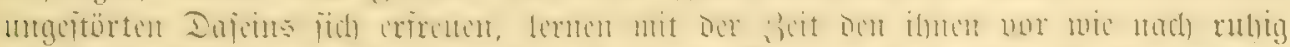

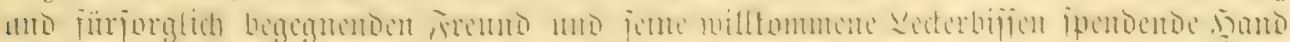

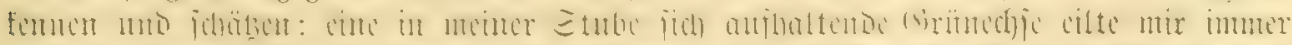

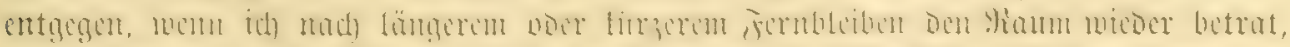

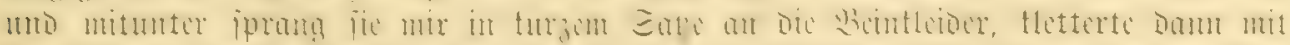

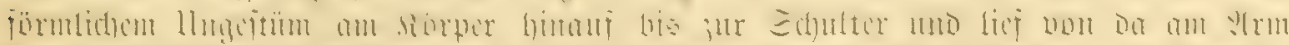

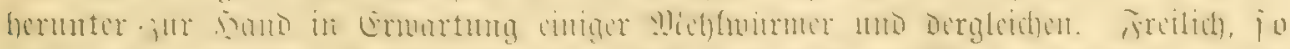

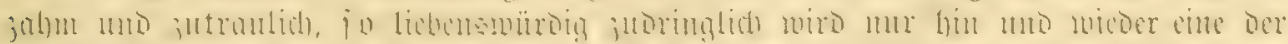

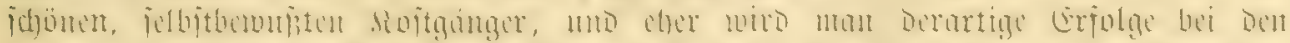

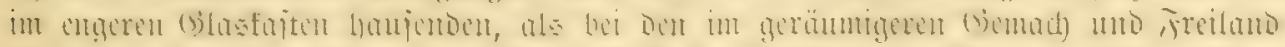

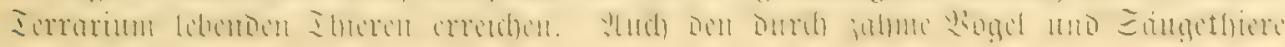




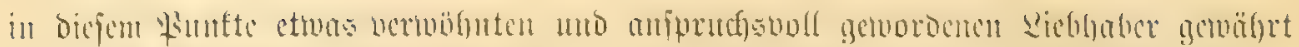
e grokes

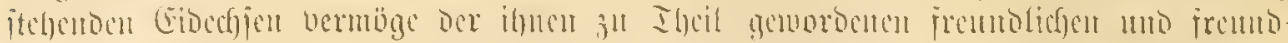

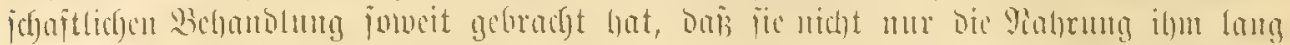

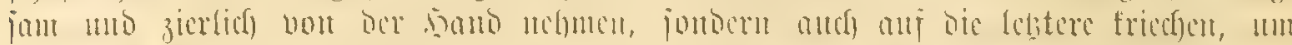

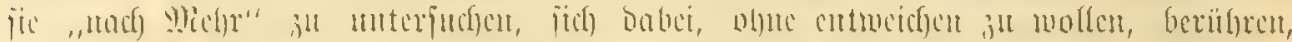

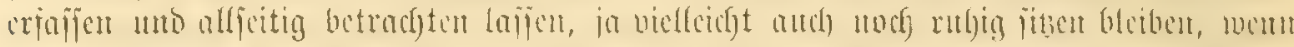

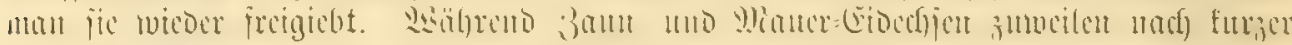
3eit Des (4)

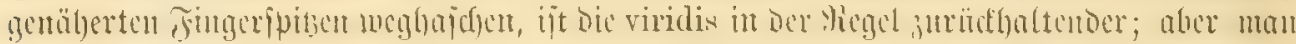

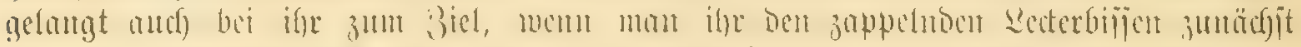

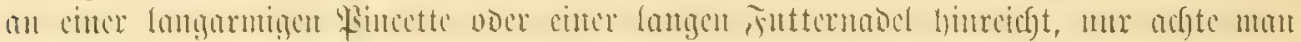

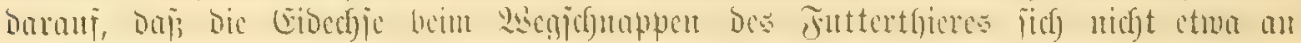

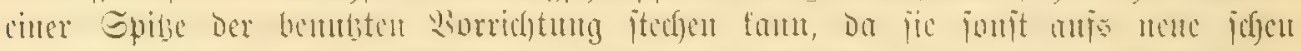

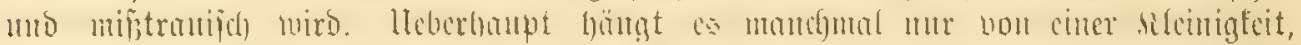

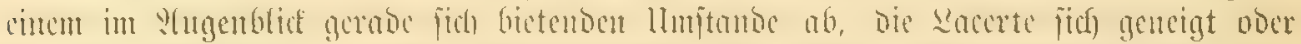

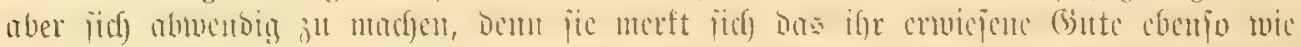

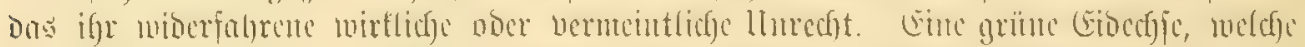

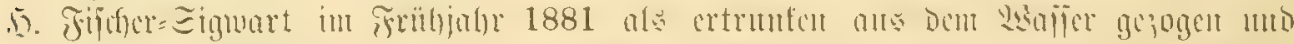

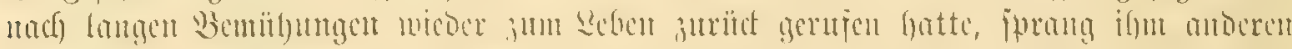

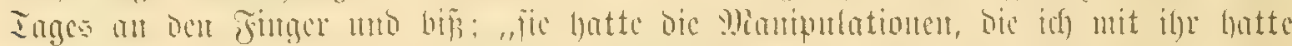

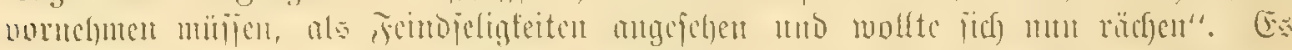

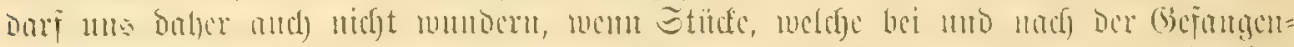

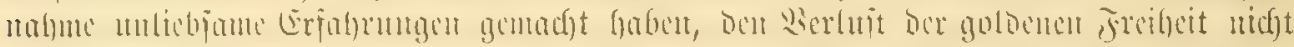

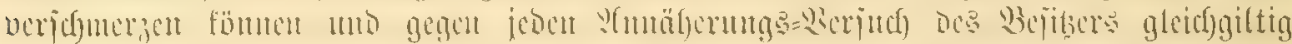

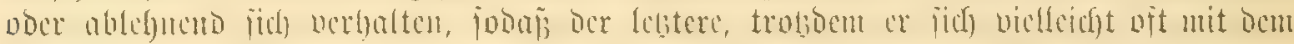

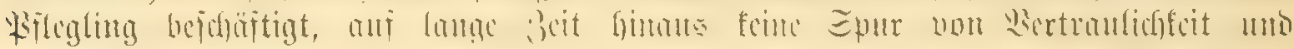
Balymbeit waljutimut.

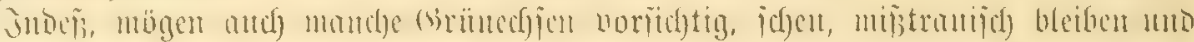

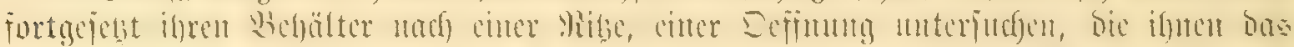

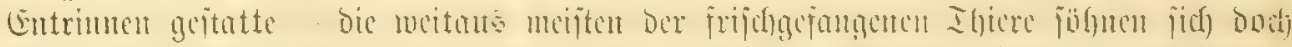

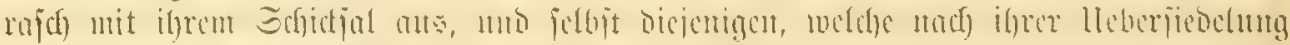

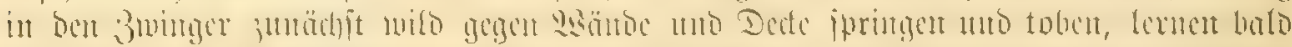

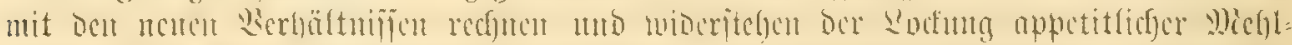

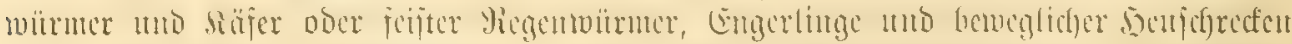

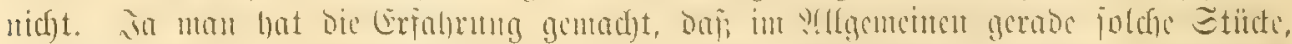

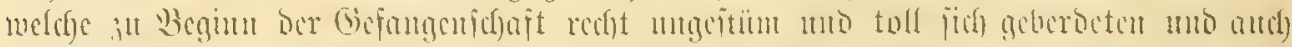

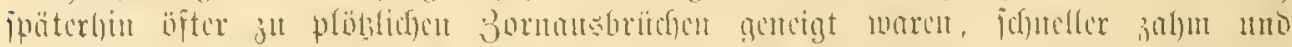

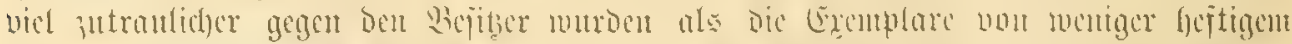

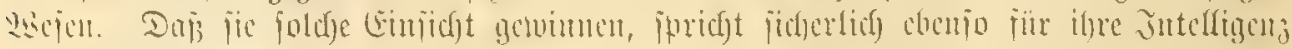

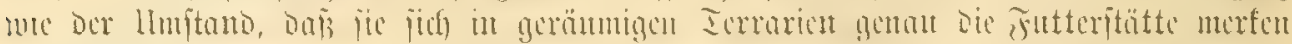

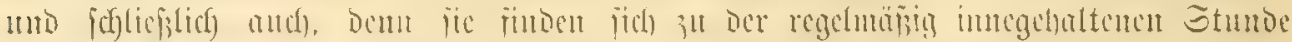

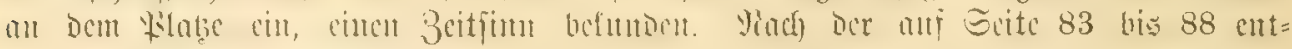

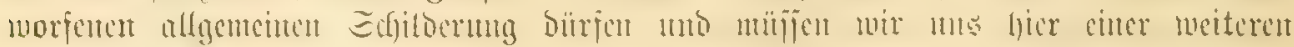
entgehonten Erröterung

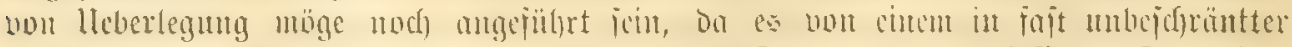

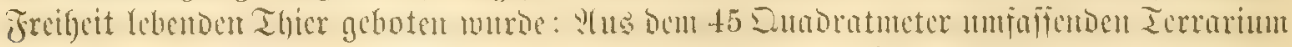

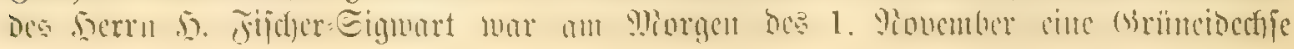




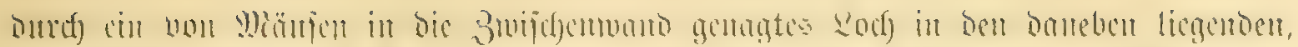

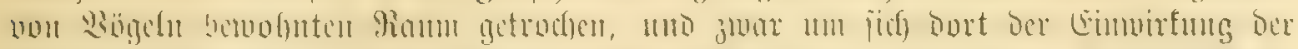

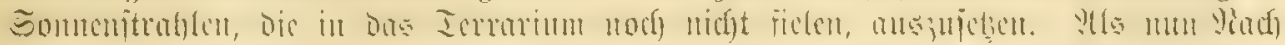

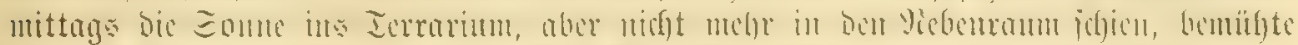

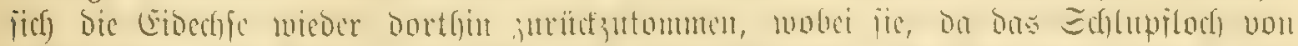
Dicjer Eeite ats iffuer ;

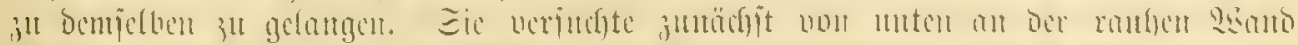

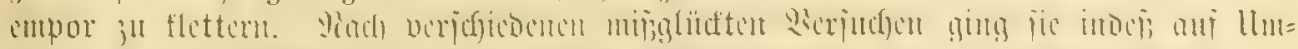

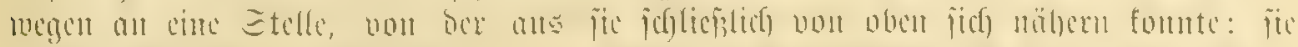

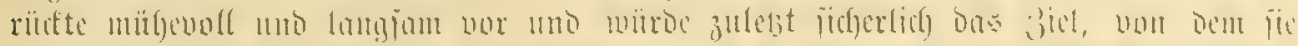

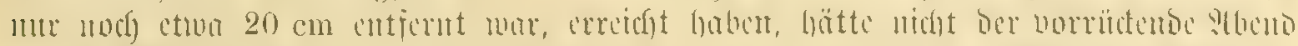

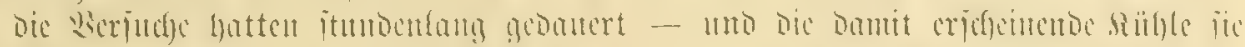

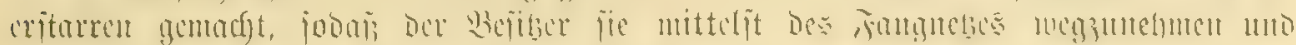

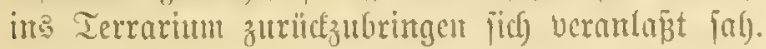

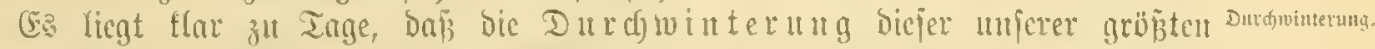

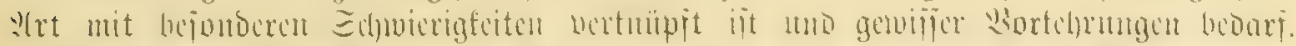

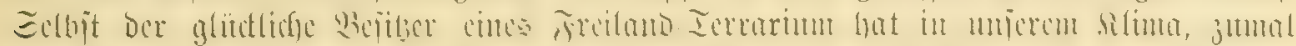

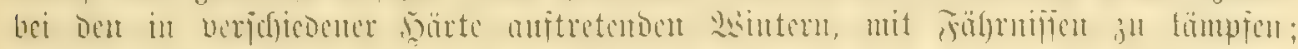

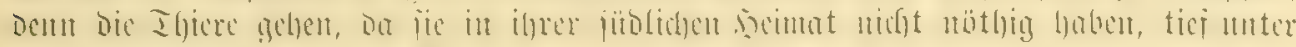

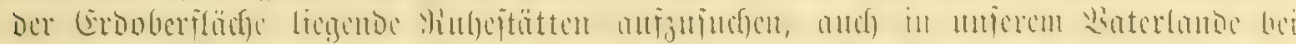

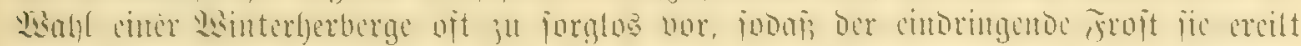

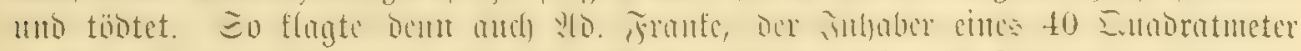

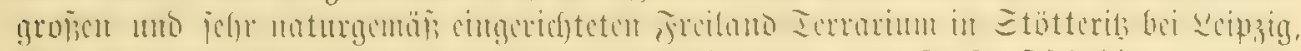

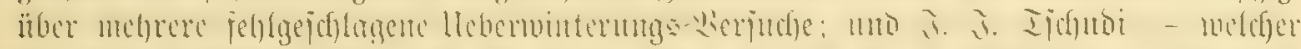

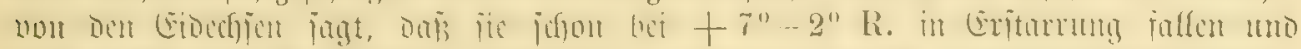

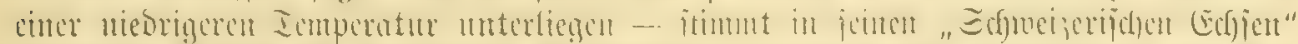

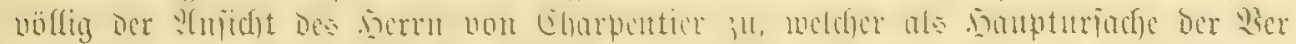

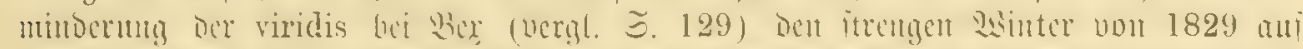

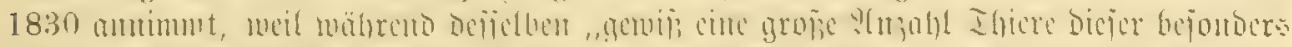

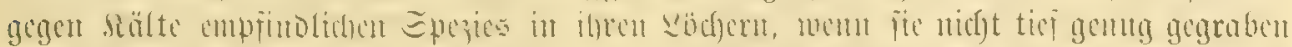

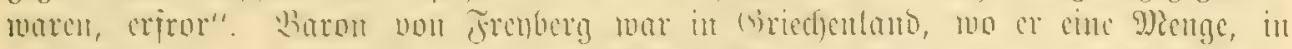

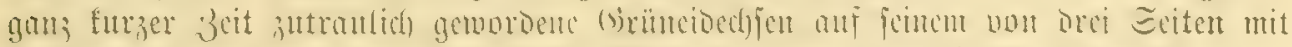

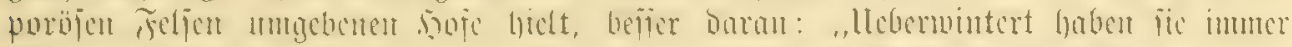

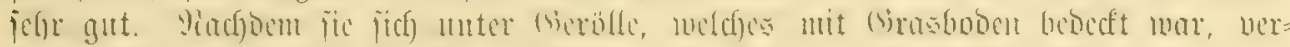

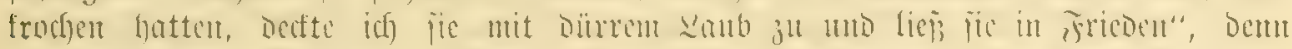

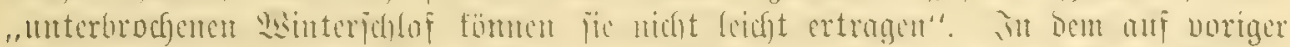

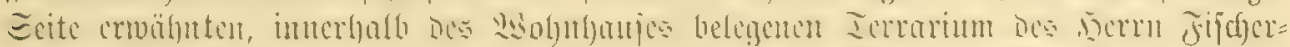

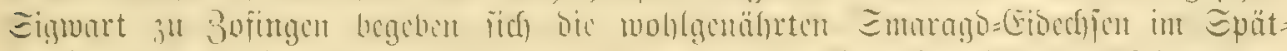

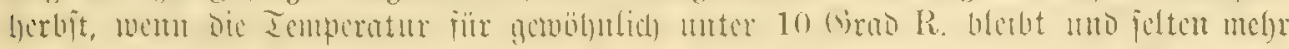

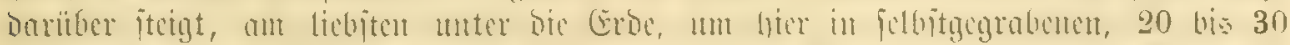

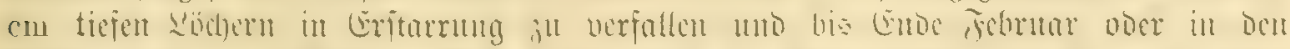

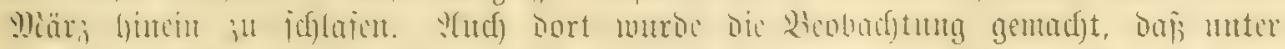

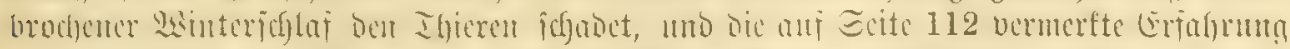

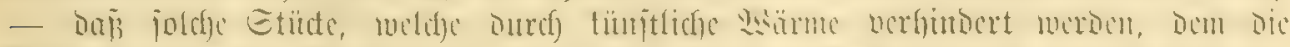

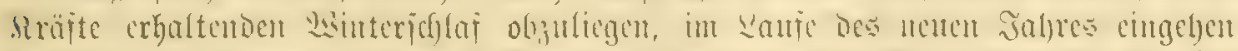

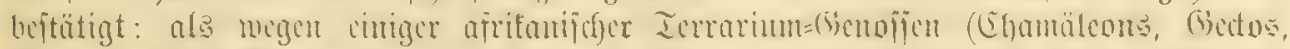

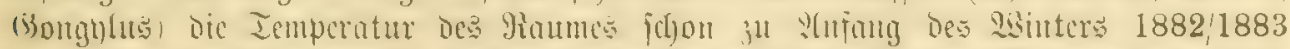

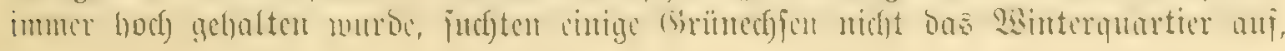




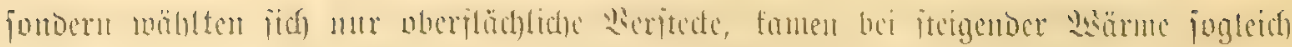

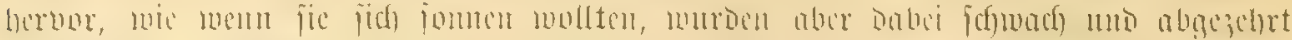

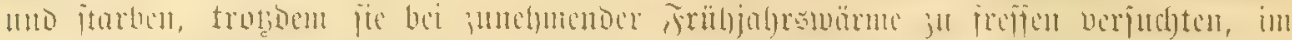

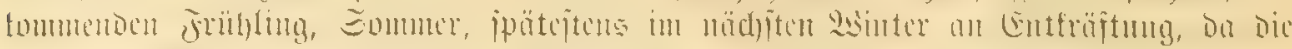

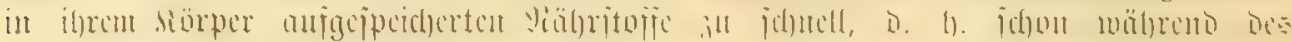

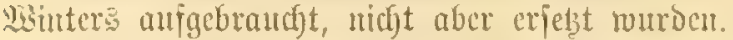

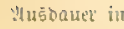
bejargenjitaft.

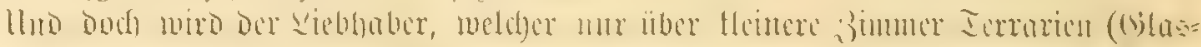

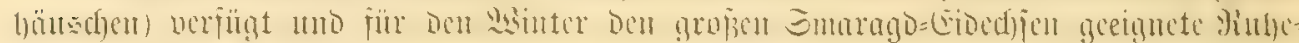

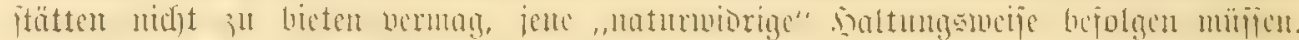

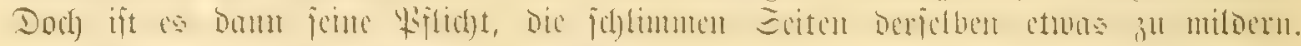

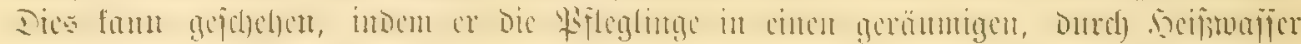

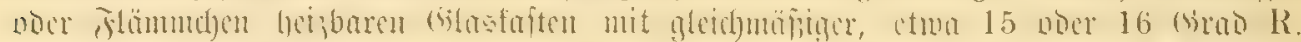

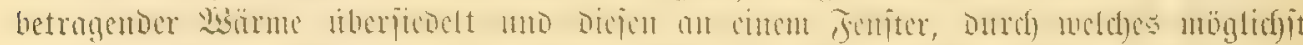

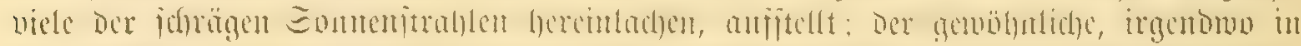

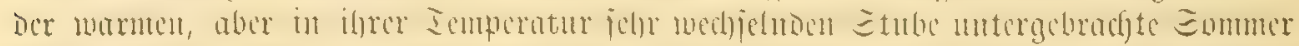

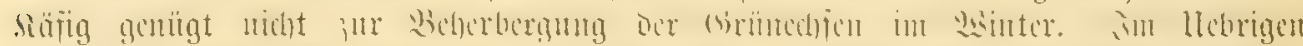

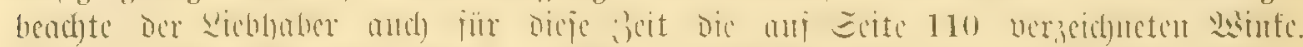

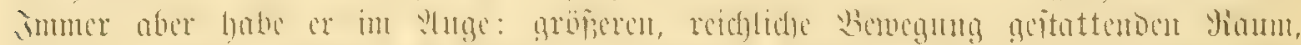

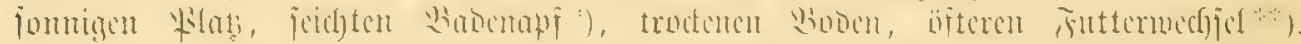

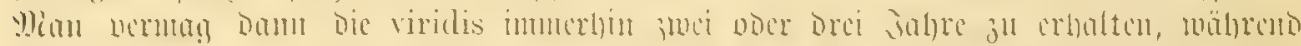

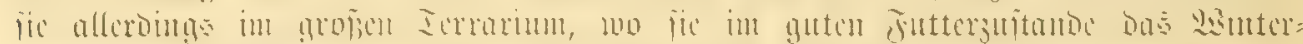

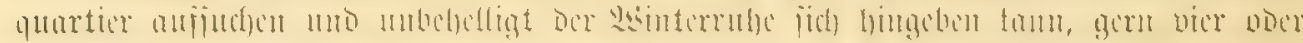

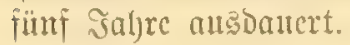

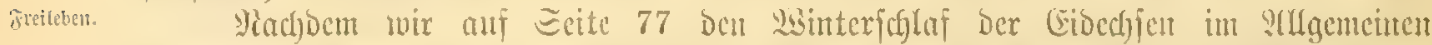

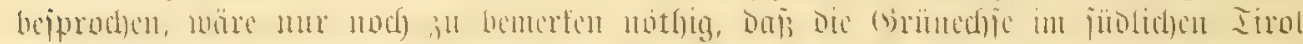

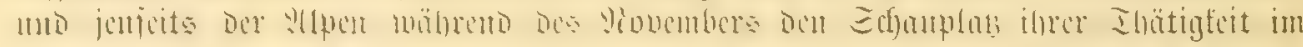

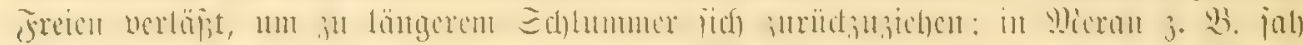

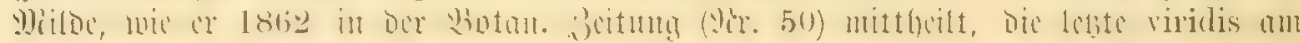

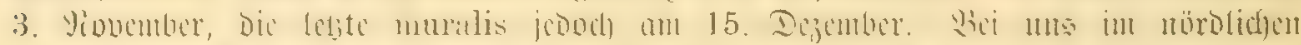

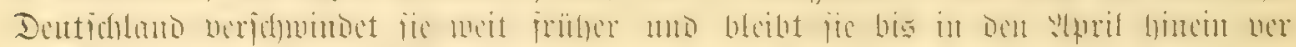

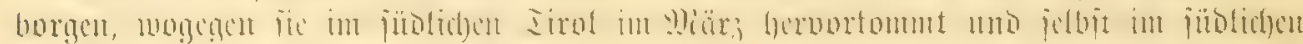

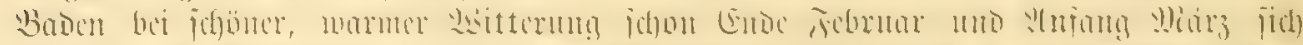

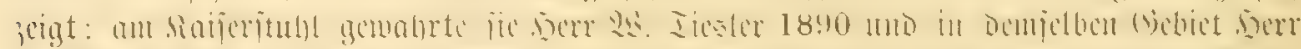

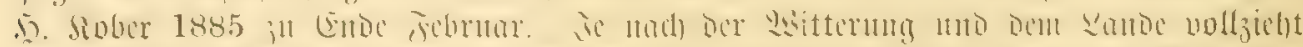

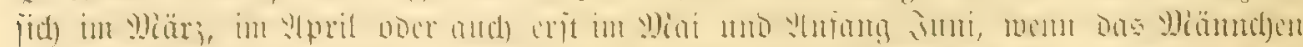

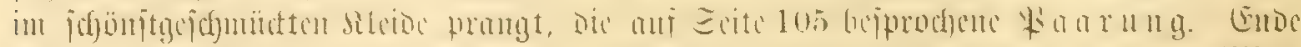

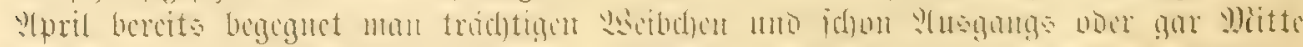

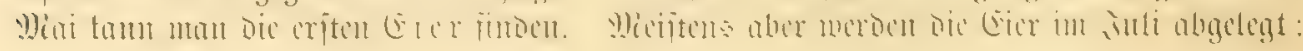

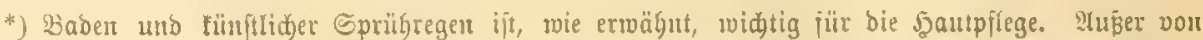
Der auf Eeire 98 genamten 3edfe Gat, wie wir von mehreren \&jlegern mitgetheilt wird, gerabe bie

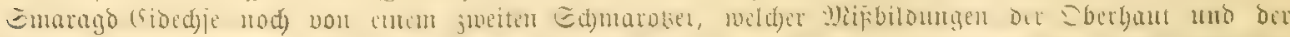

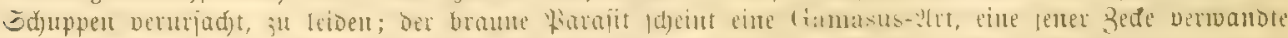

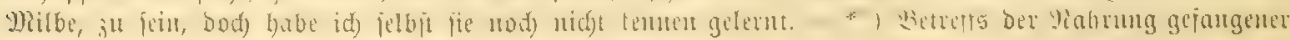

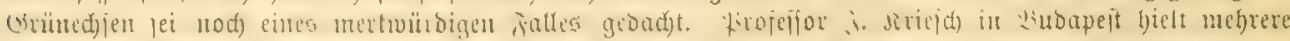

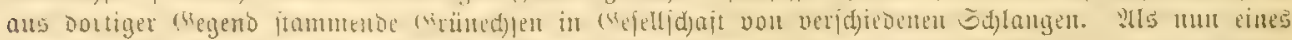

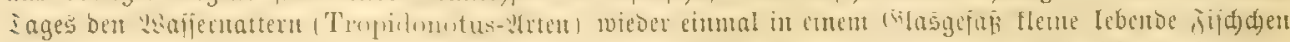
vorgejest rourbett, Golte fid, roie ber Bejiker im "Bool. Garten" 1877, E. 142, berichtet, einer der

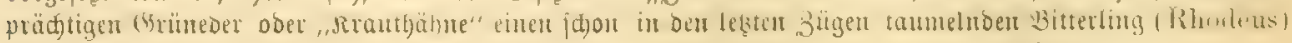

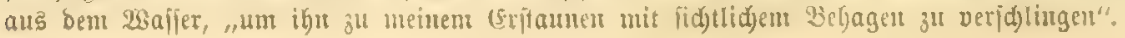




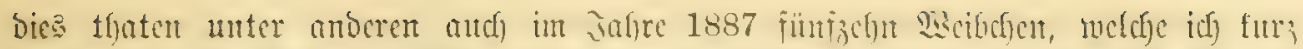

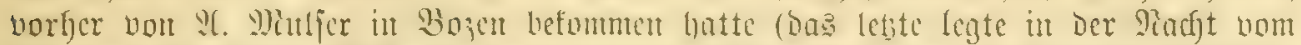

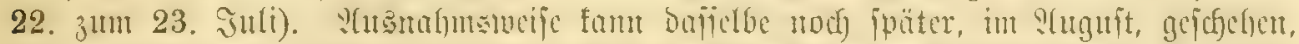

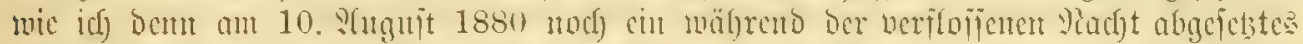

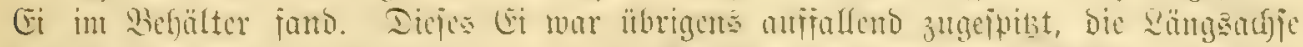

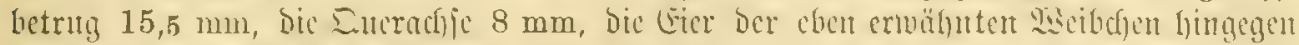

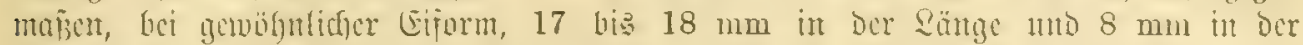

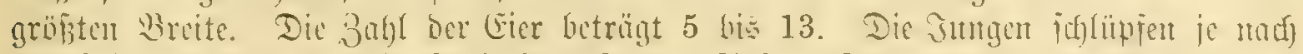

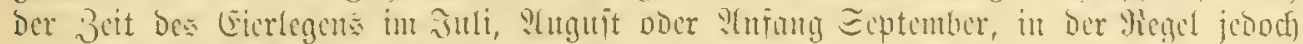

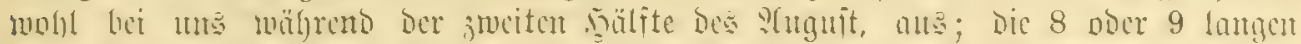

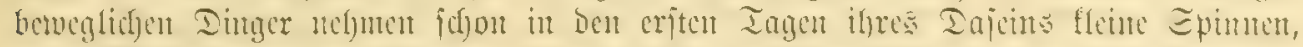

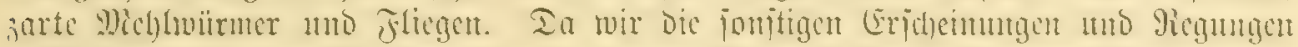

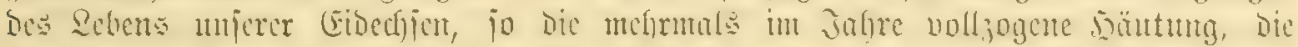

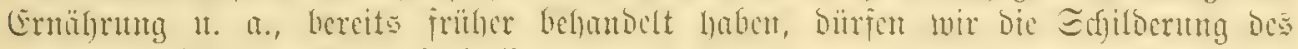

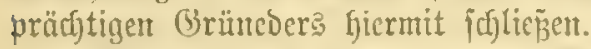

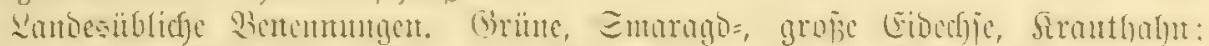

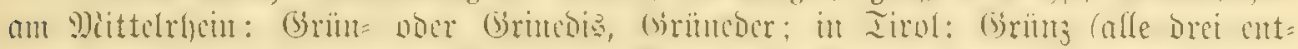

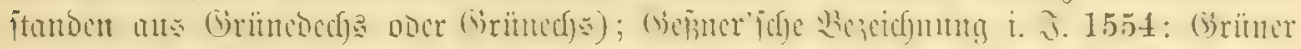

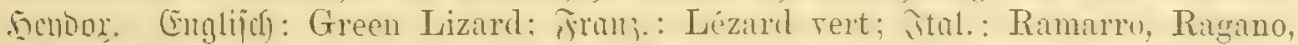

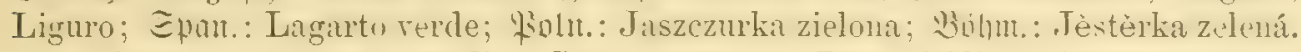

Lacerta major et viridis, Gesner 1554. - Lac. viridis, Aldrov. 1637. Seps riridis, S. varius et S. terrestris, Lmurenti 1768. - Lac. bilineata, Dumdin 1803. - Laic. chloronta, serpa et sicula, Rufin. 1810. - Lac. ririllis et tiliguerti,

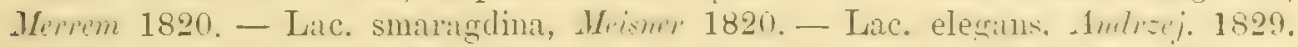
- Lac. strigata, Eichwald 1831. - Lac. quinquevittata, Ménétries 1832. -

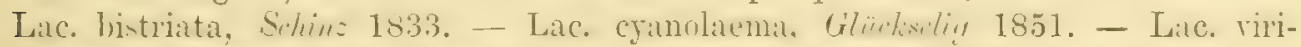
dissima, Fitsinger 18.55 [Menag.|. - Podareis cyanolatema, Gliekselig 1863.

\section{2. शtrt: Jaunt:Eidchlfe, Lacerta agilis, Wolj: Itbbildurg: Tajel XI gir. 1 bis 3.}

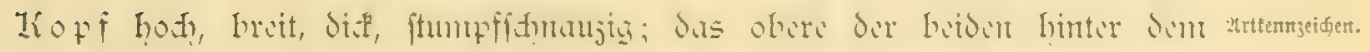

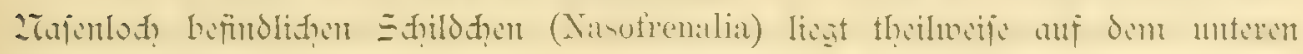

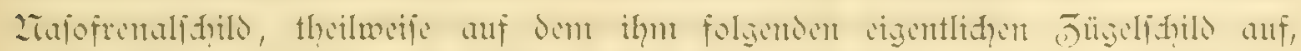

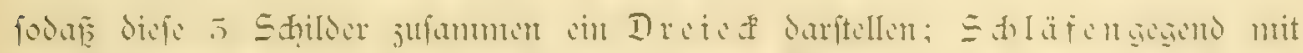

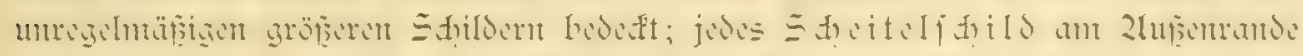

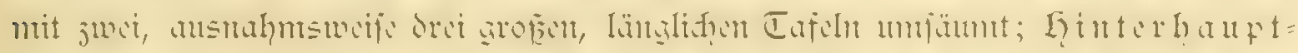

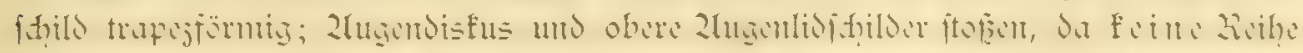

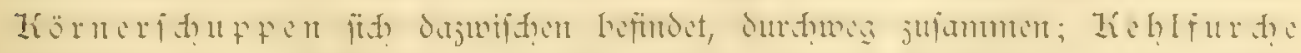

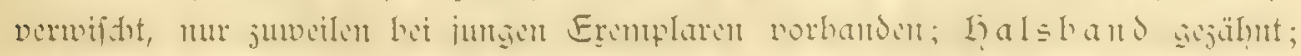

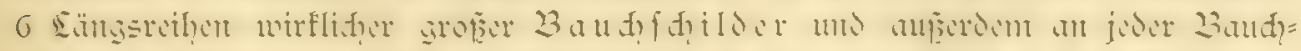
lite che Ëm

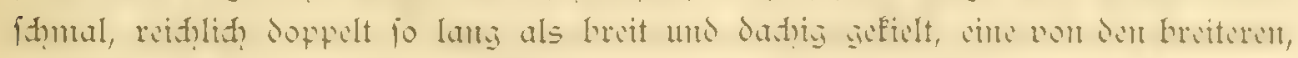

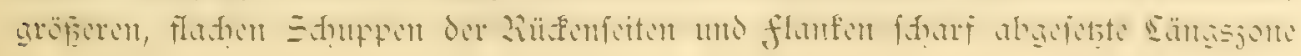




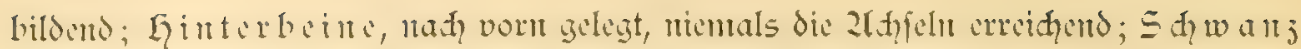

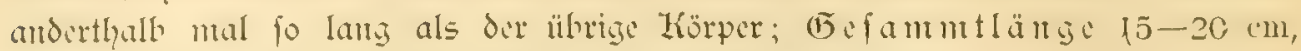
mir dic ofteuropäifber $\mathcal{D}$ arietäten bis 25 oder gar $27 \mathrm{~cm}$.

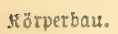

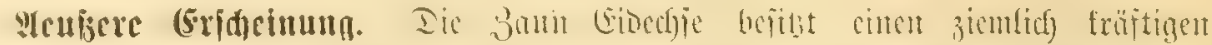

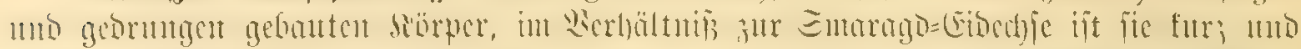

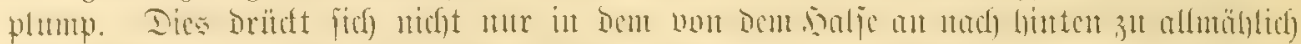

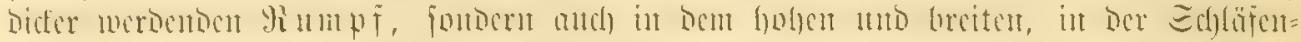

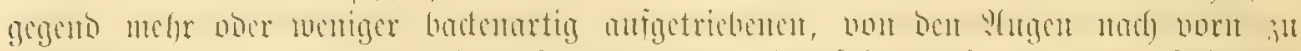

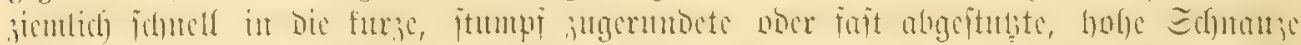

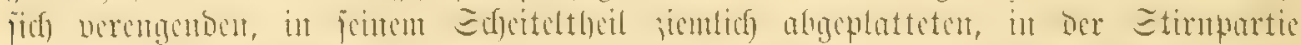

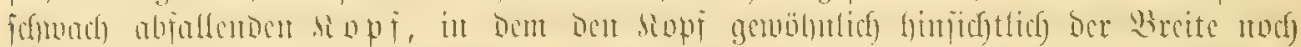

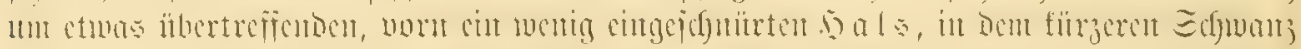

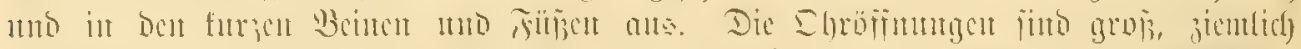

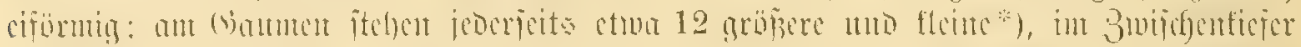

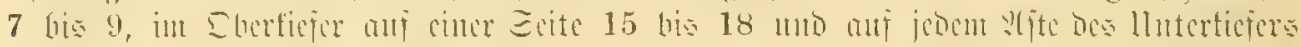

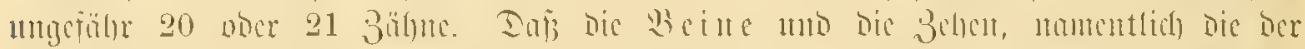

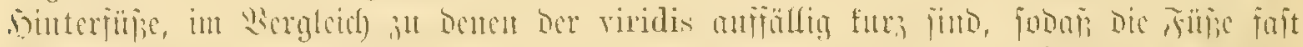

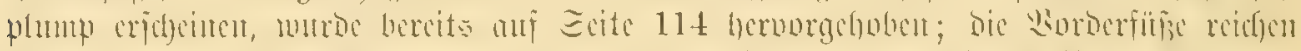

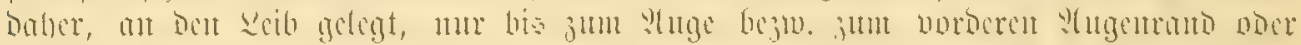

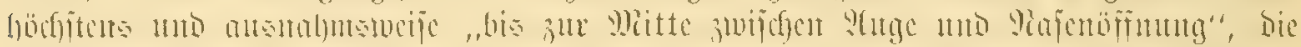

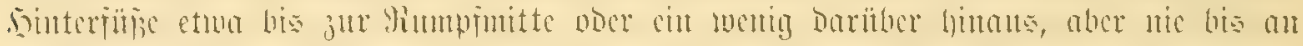

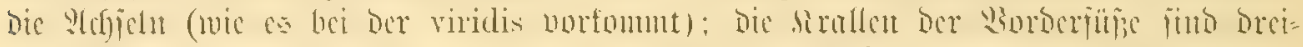

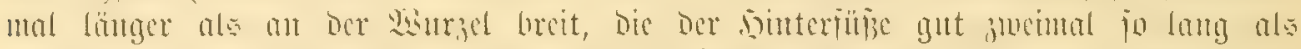

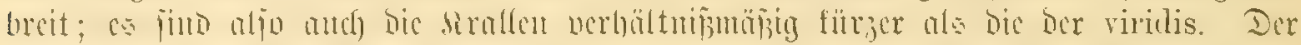

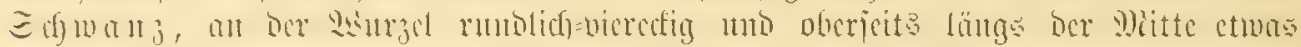

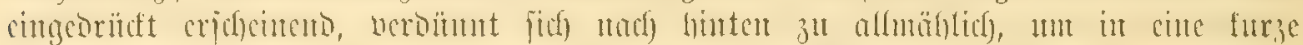

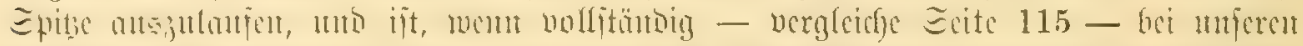

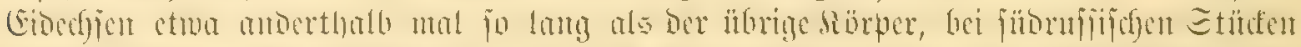

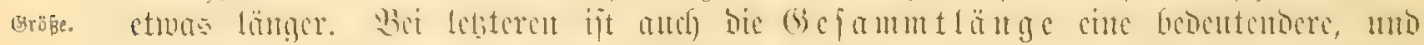

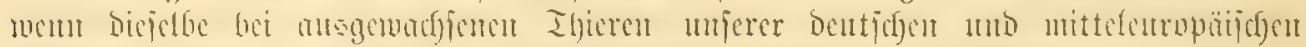

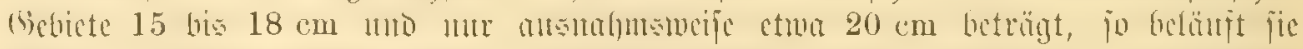

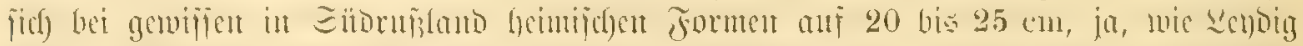

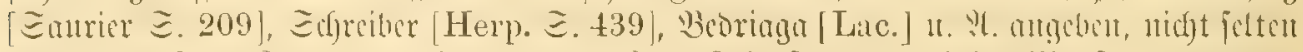

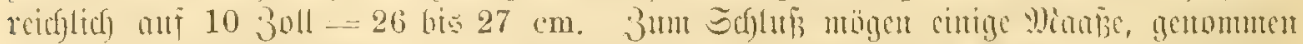

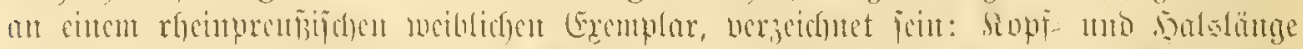

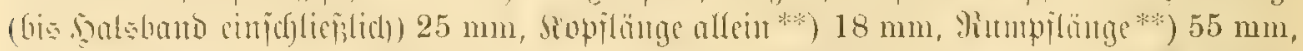

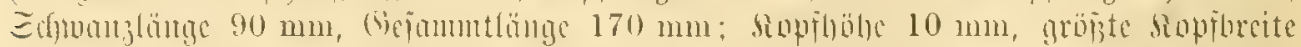

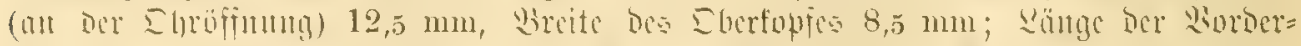

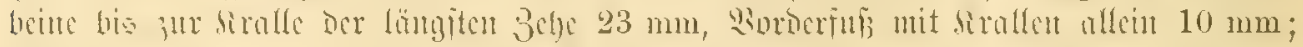

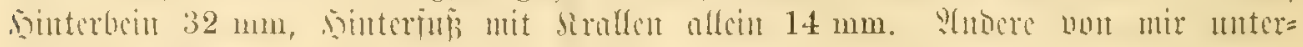

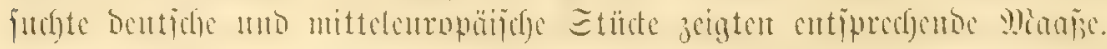

Drertopf: Sळhtlber.

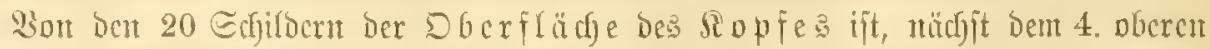

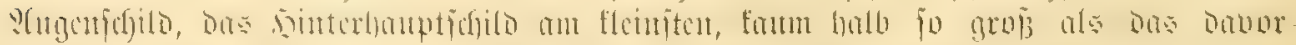

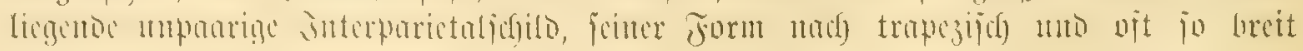
Seite 115.

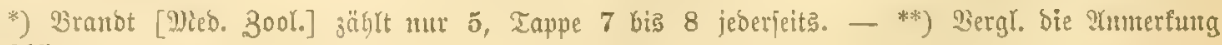




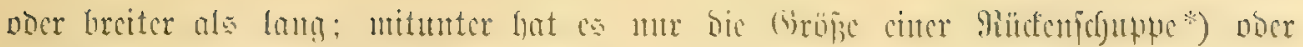

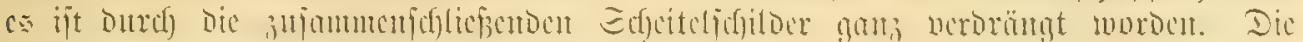

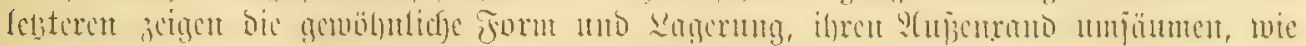

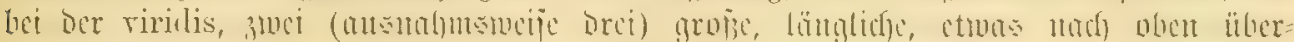

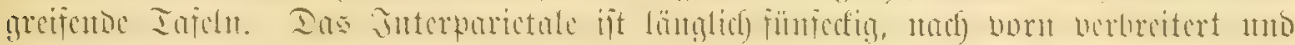
mit eitter ftumpien Spibe zroijhen Dent Sintertheil Der beiden

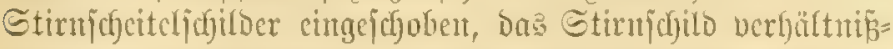

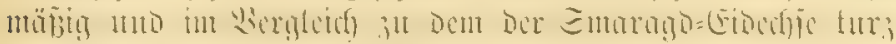
ıno breit, finten unmerffich berjomälert und mit einer gan furzen, mittleren Epise werjelyen, feitfich foljuach angigerandet แmb born Gogenförmig ober ftumpfrointelig zuijchent bie beiben vorbercn Stirnjchilder (Frontonasalia) vortretent, iveldy) letere mit ifrer filrzeften Siante, ber imteren, antunandor

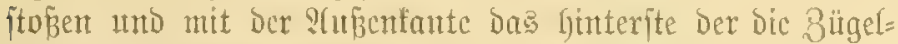

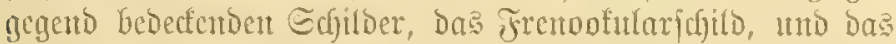

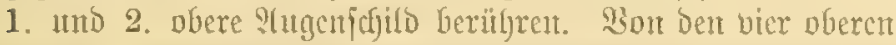

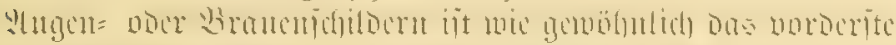

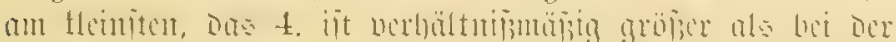

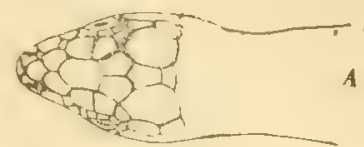

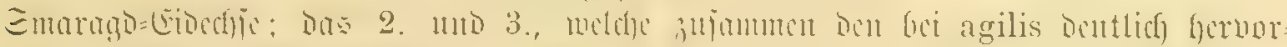

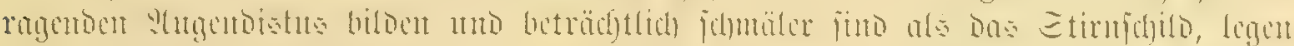

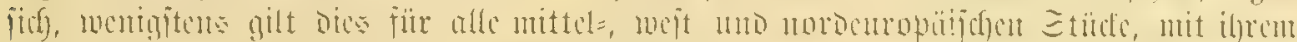

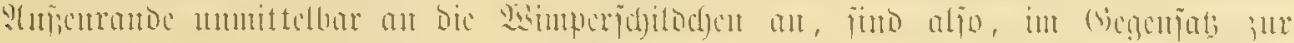

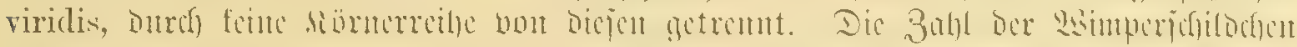

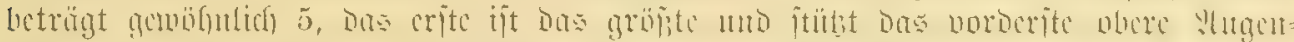

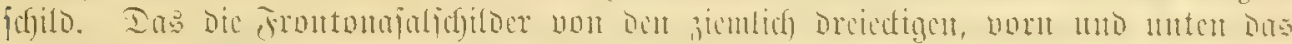

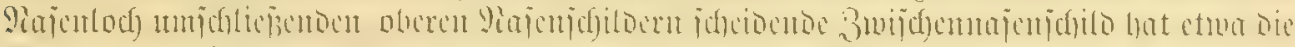

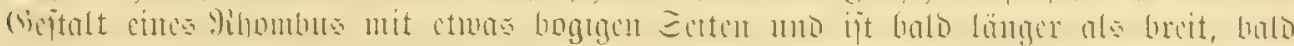

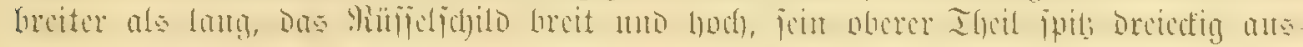

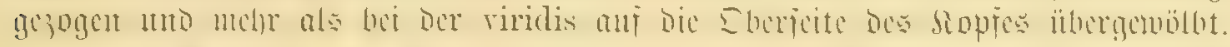

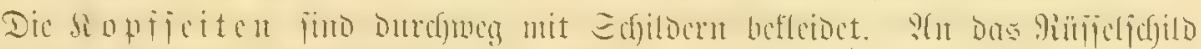

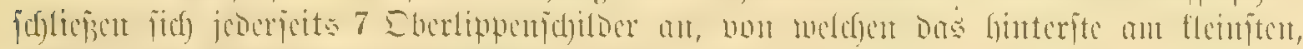

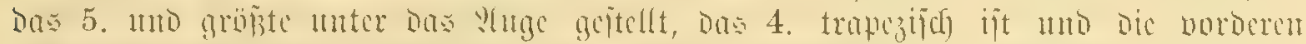

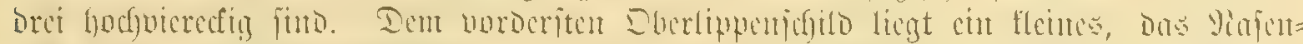

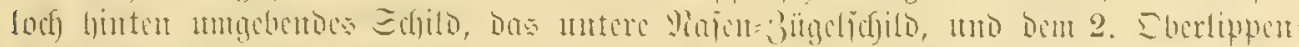

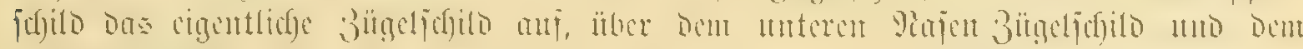

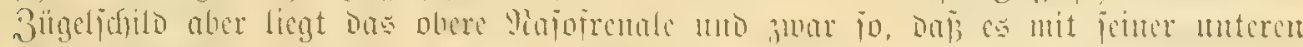

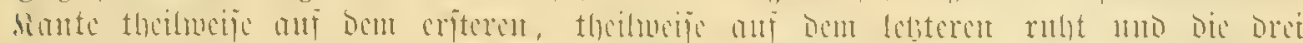

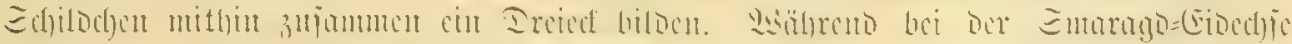

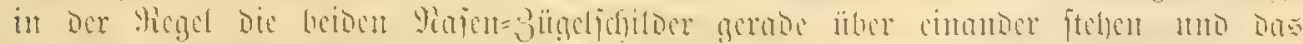

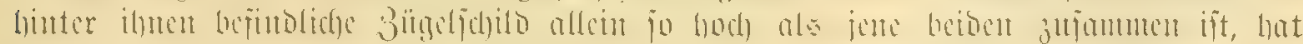

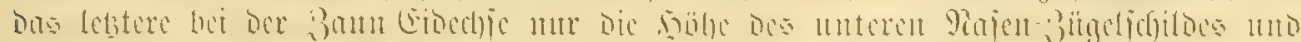

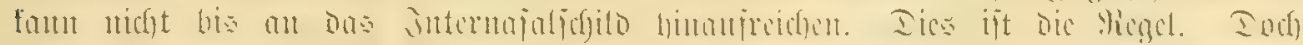

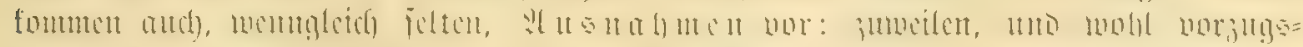

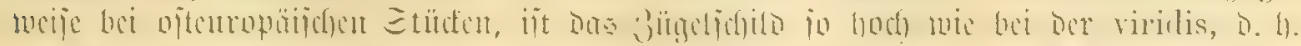

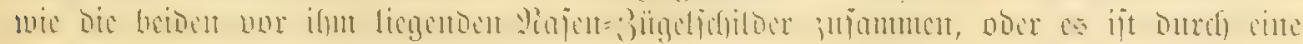

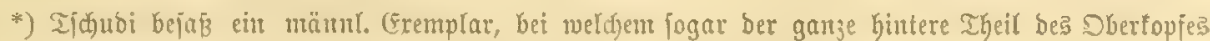

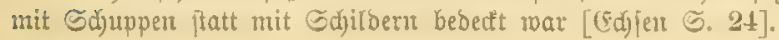




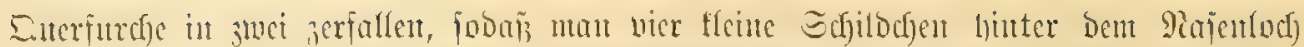

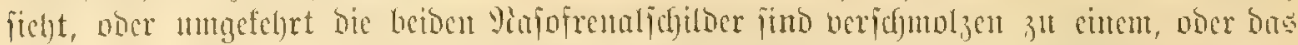

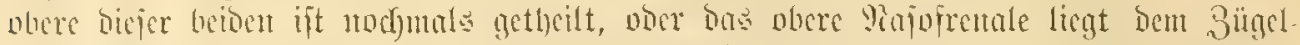

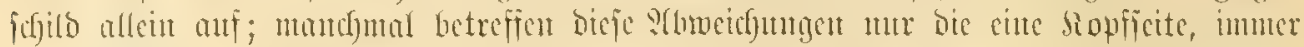

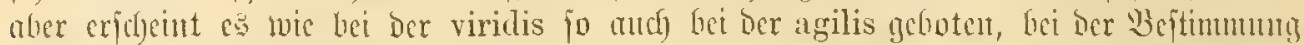

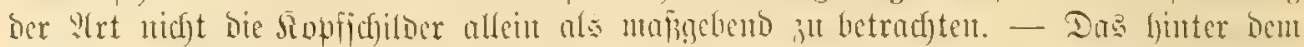

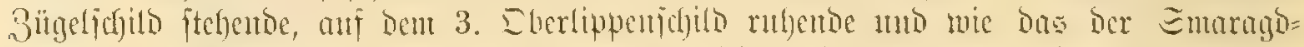

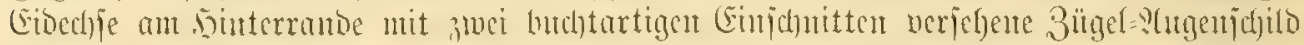

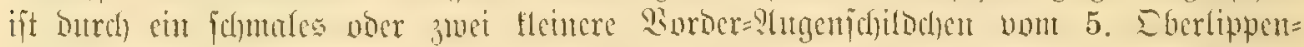

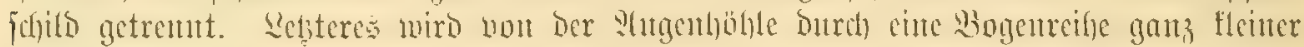

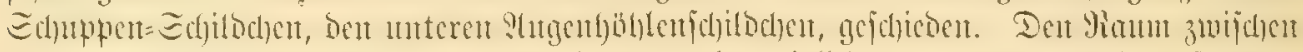

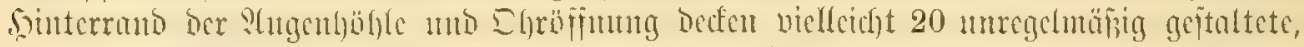

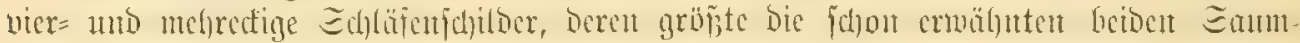

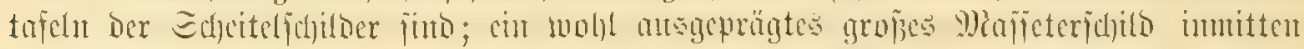

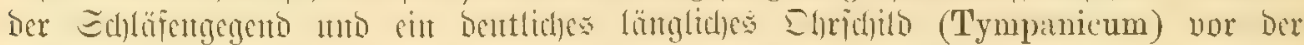

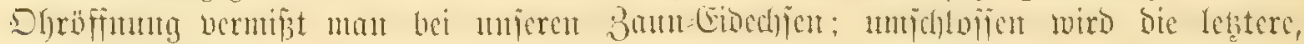

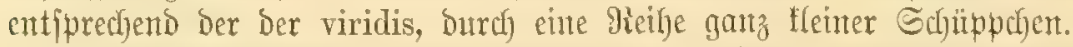

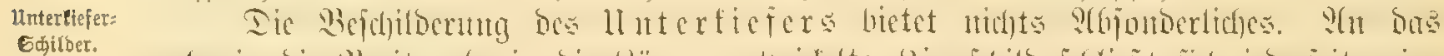

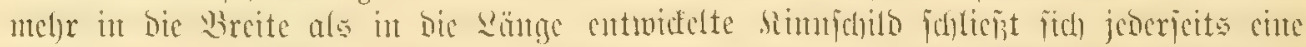

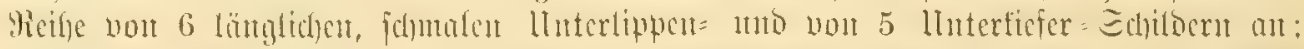

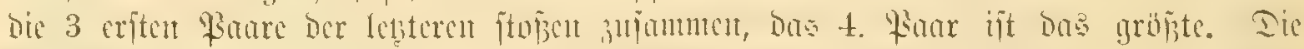

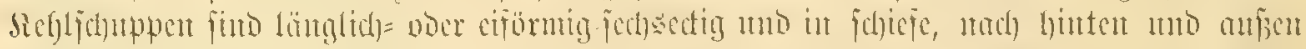

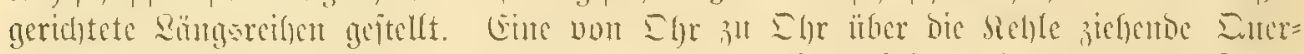

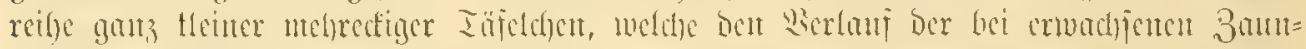

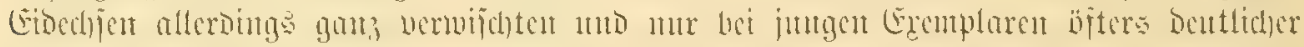

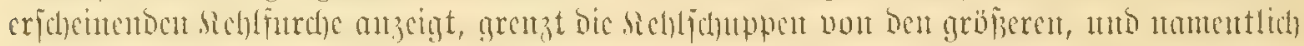

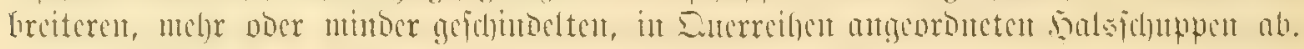

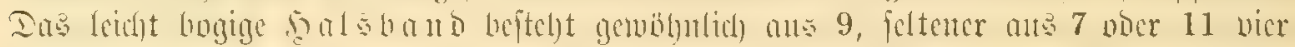

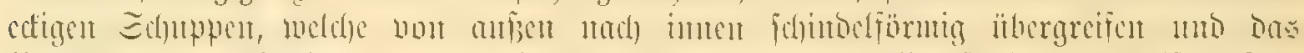

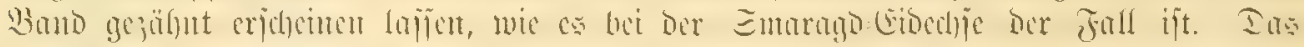

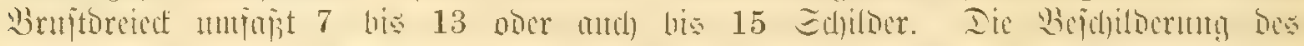

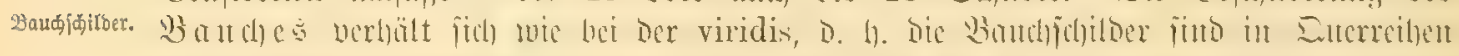

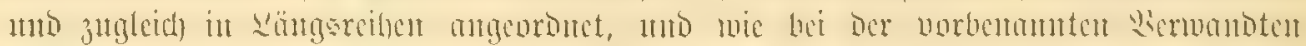

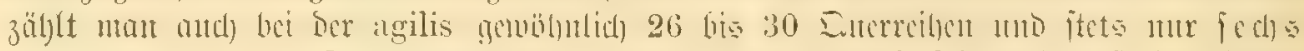

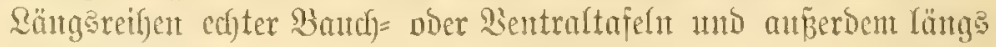

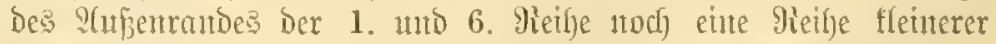

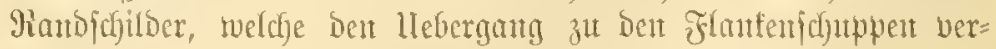
mittehr. Betreffs biejer Siandicfilloer gilt Das anf Eeite 118

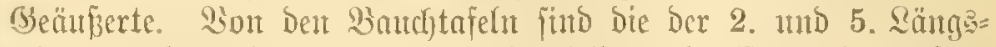
reige etwa boppelt fo Greit als bie ber beiben mittelitent unto untugefülyr

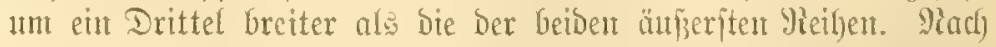

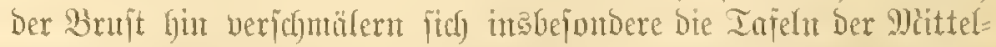

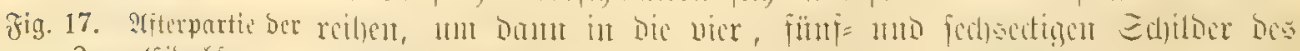
Bantu=(sibed)ie.

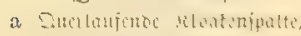
se. a. Ilitijuilo u: a soutum anale, b S̈dentelporensteige.

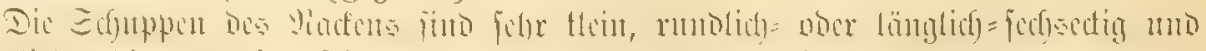

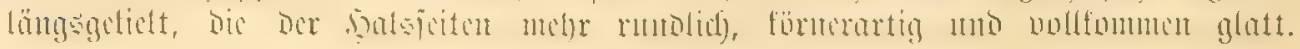




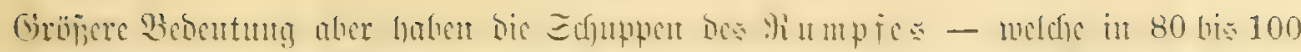

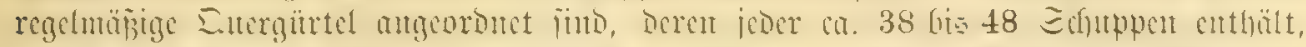

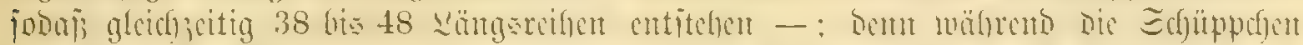

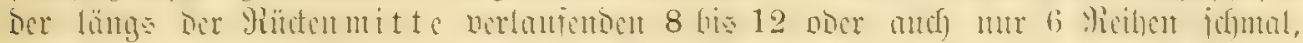

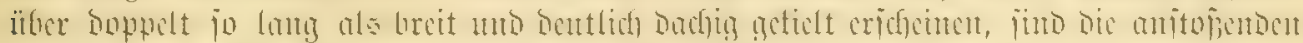

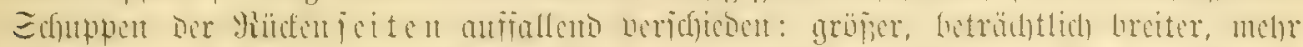

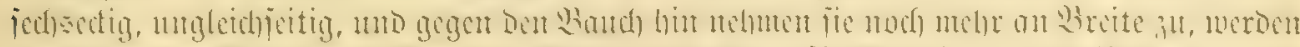

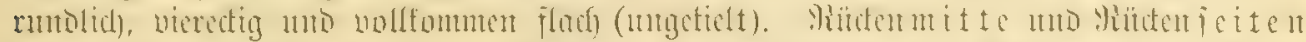

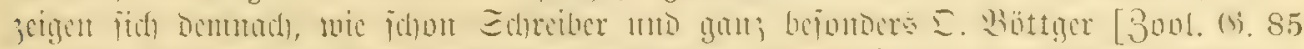

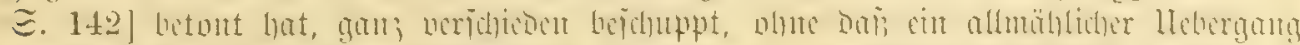

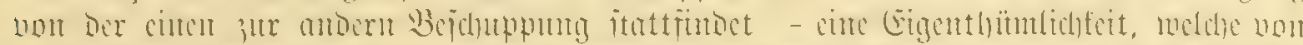

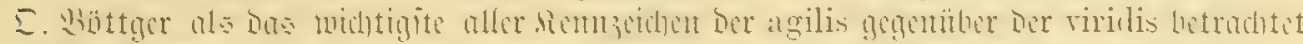

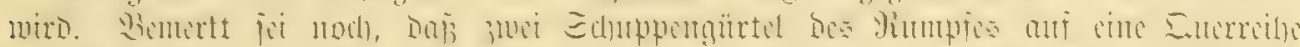

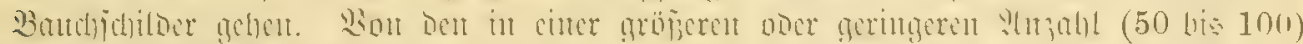

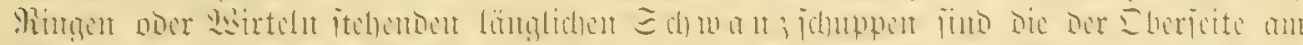

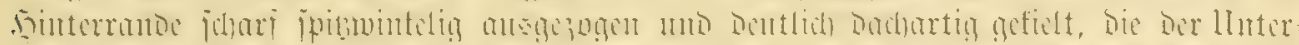

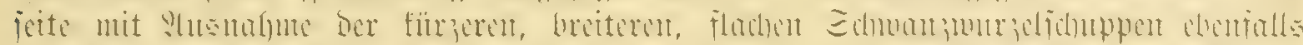

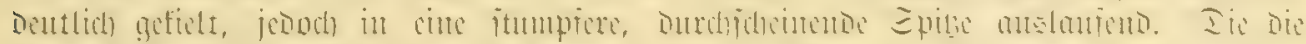

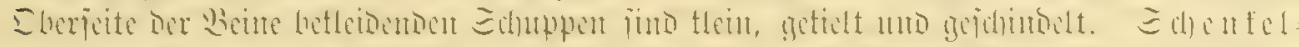

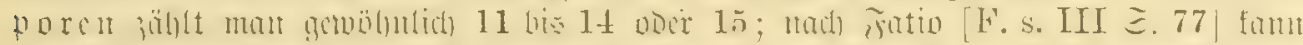

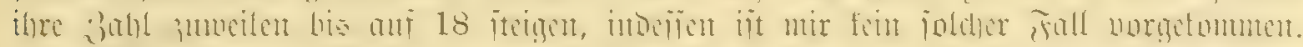

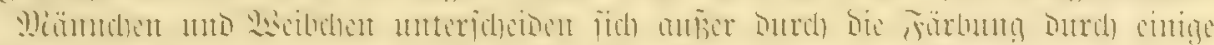

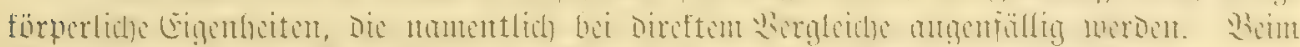

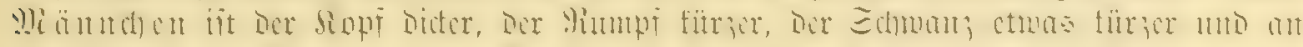

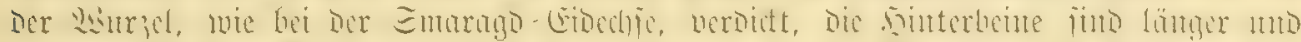

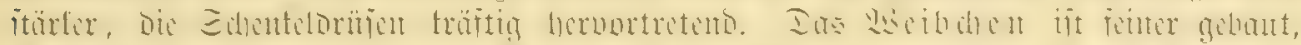

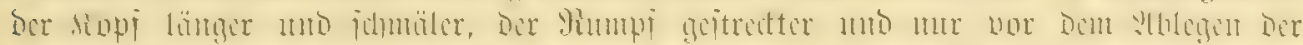

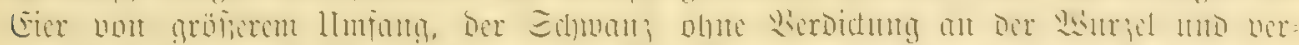

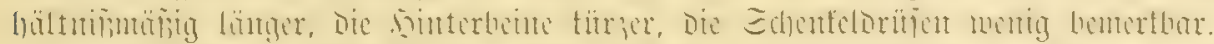

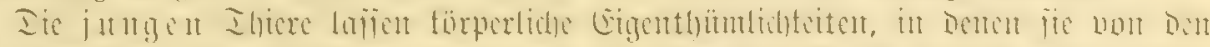

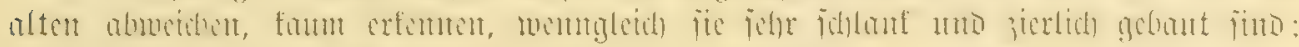

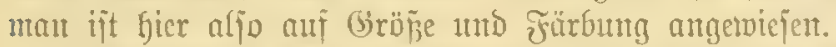

is a

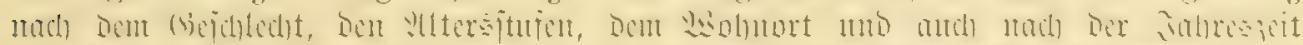

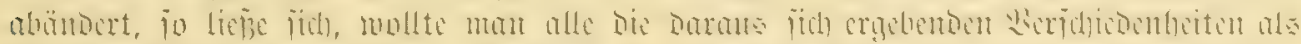

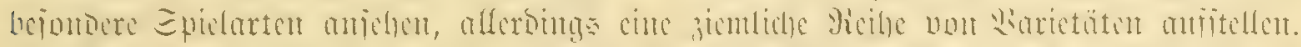

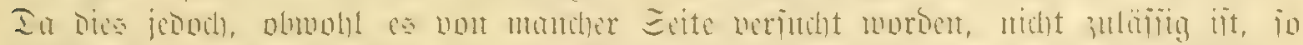

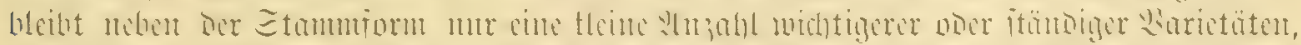

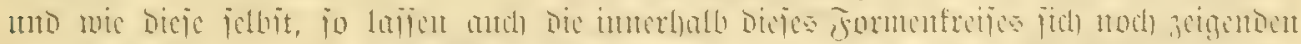

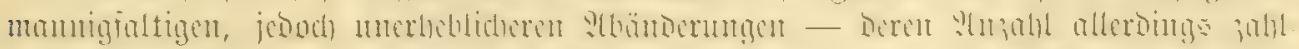

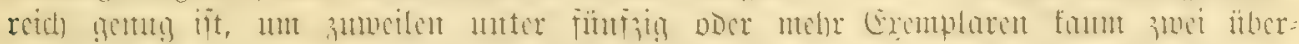

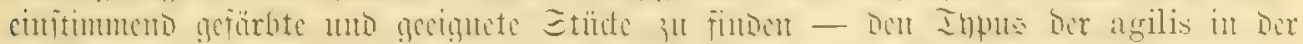

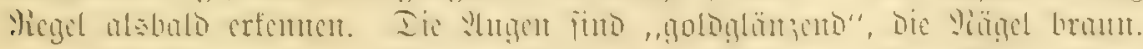

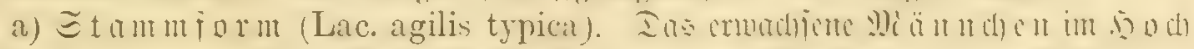

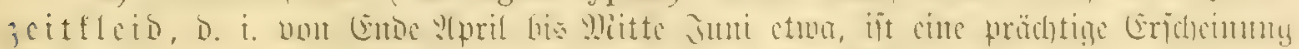

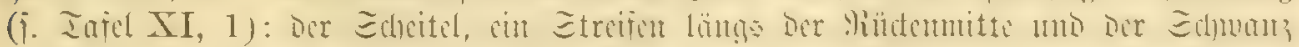

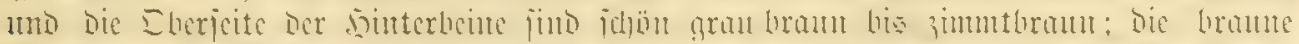

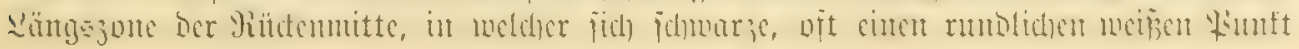




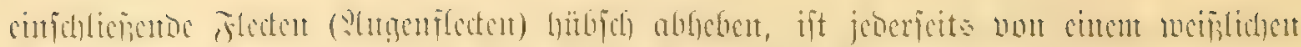

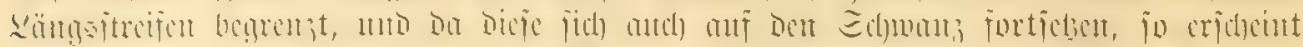

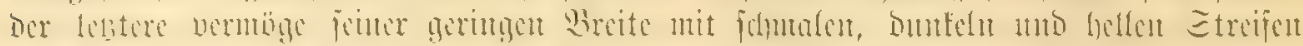

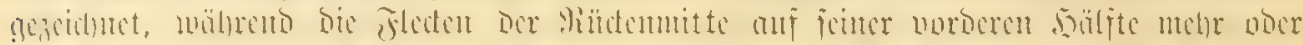

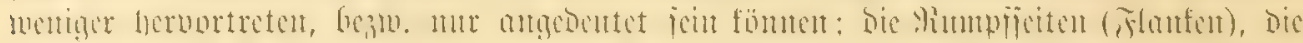

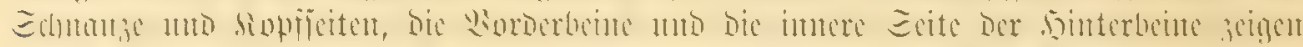

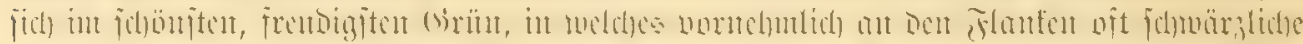

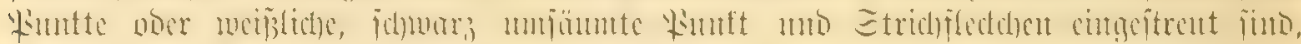

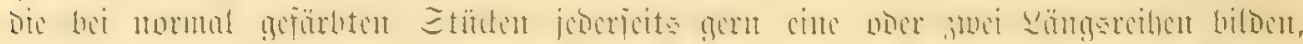

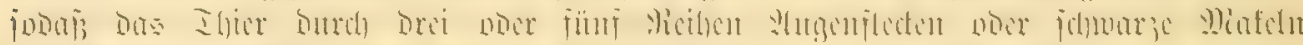

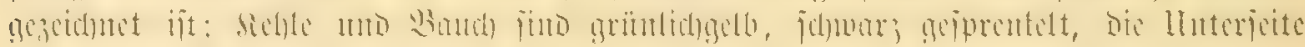

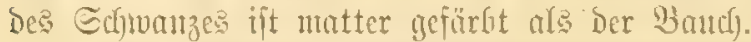

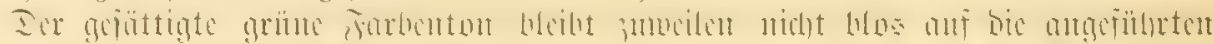

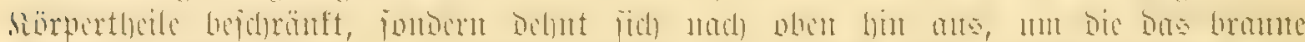

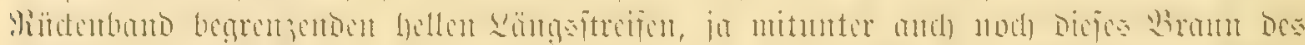

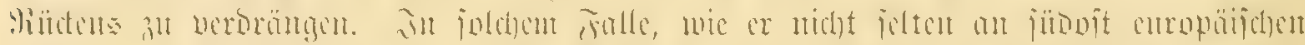

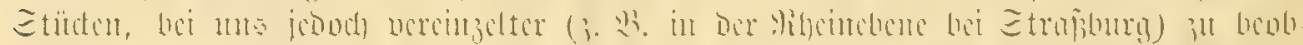

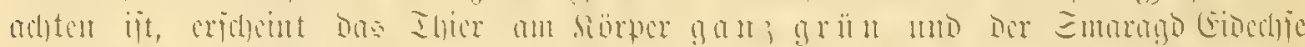

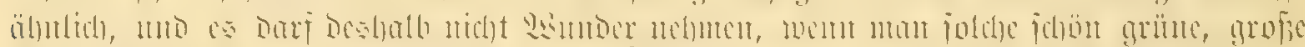

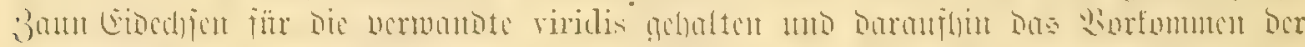

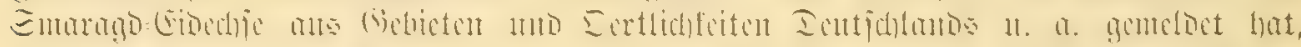

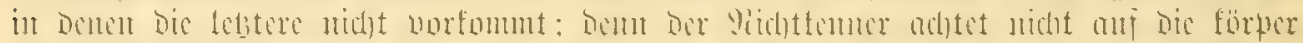

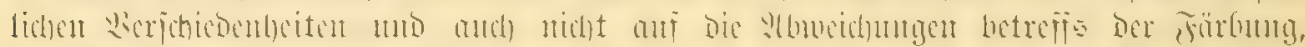

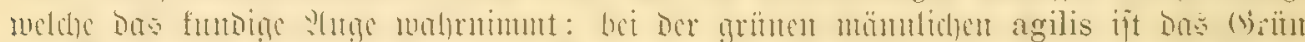

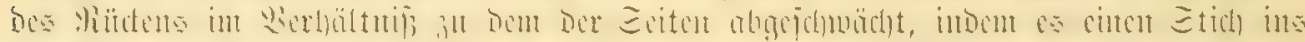

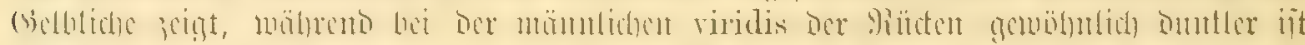

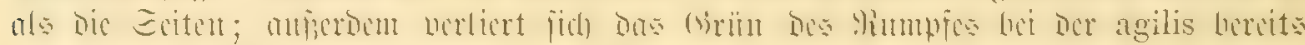

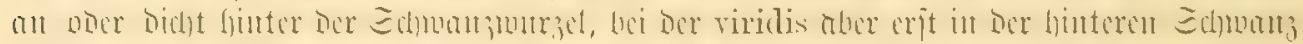

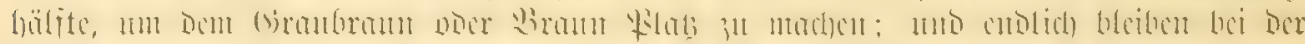

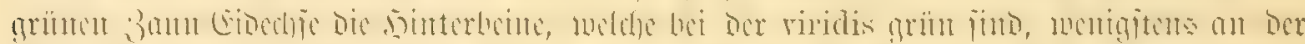

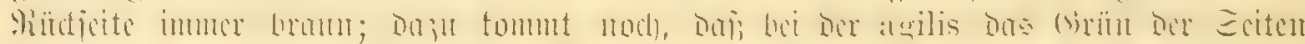

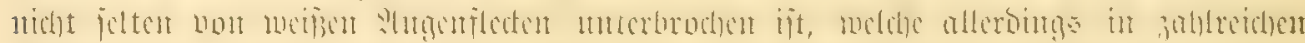

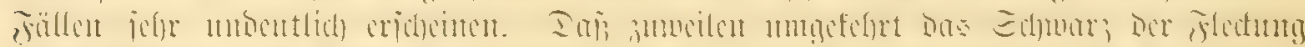

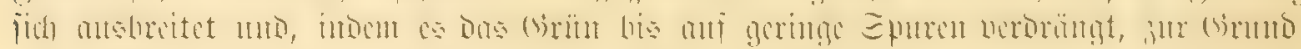
farbe wirb, fei hier mur beifältfig wermertt (vergl. Wartetät 3 ).

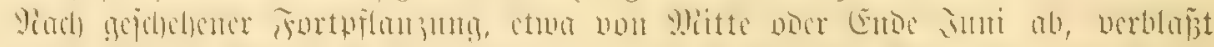

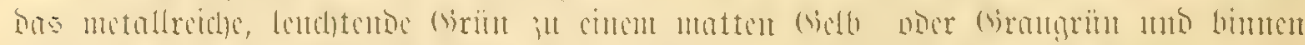

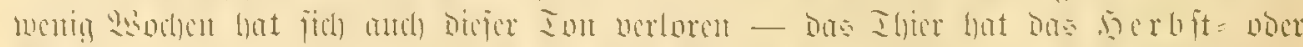

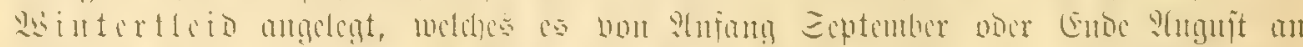

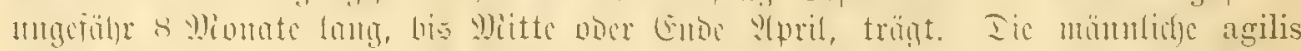

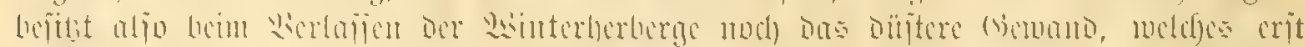

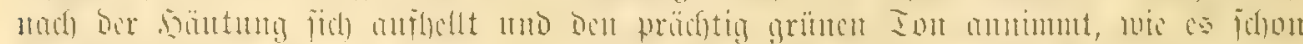

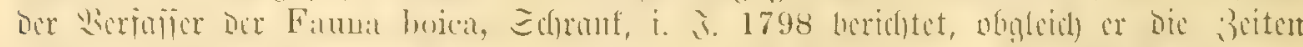

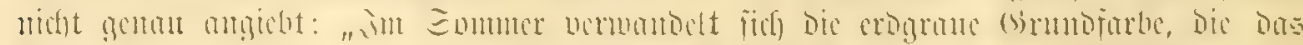

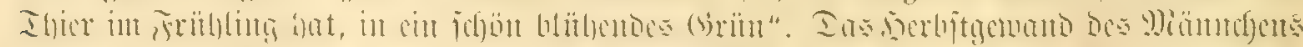

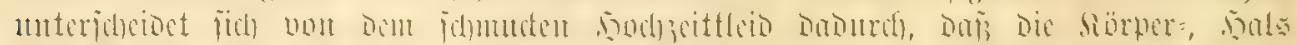

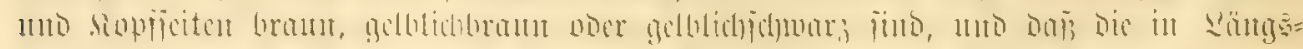

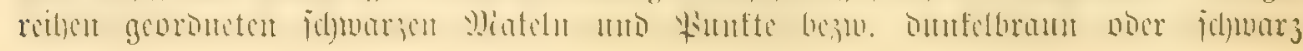




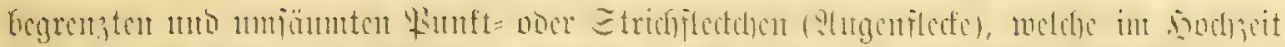

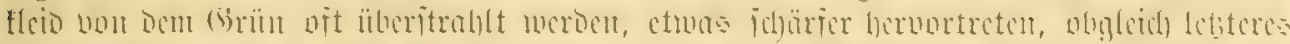

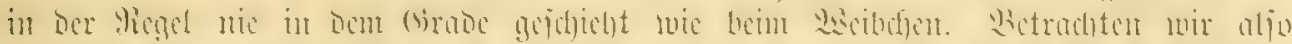

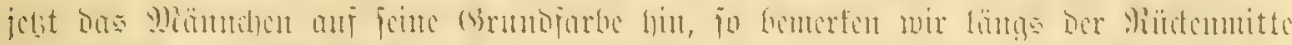

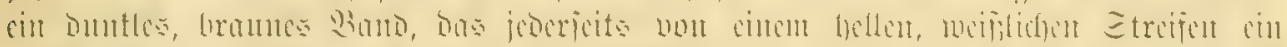

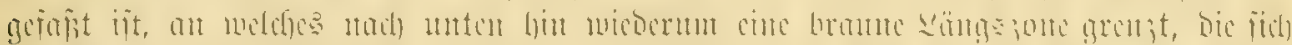

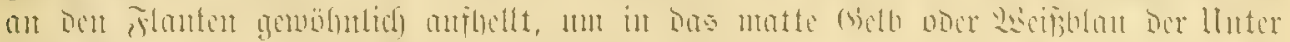

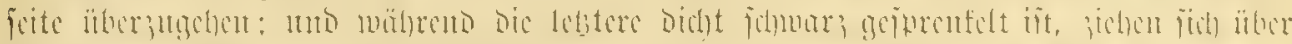

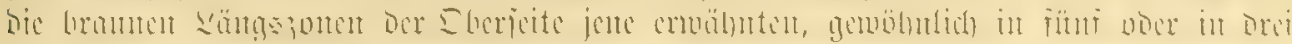
Micifyen geftellten flecter.

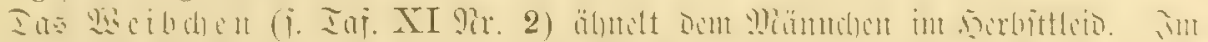

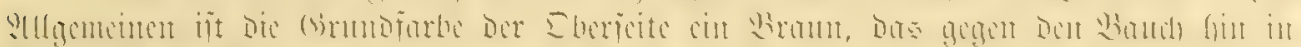

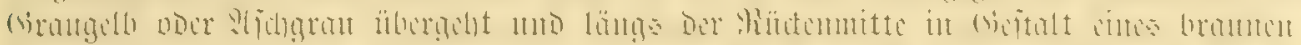

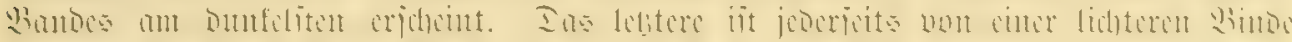

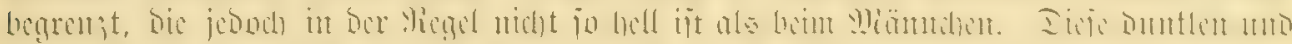

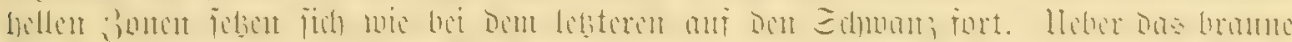

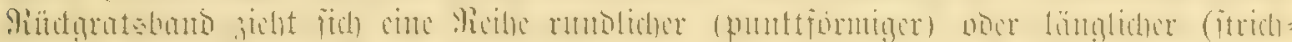

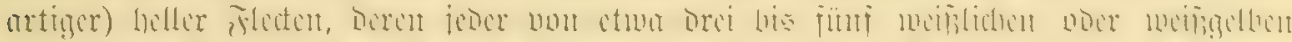

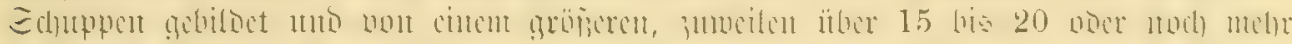

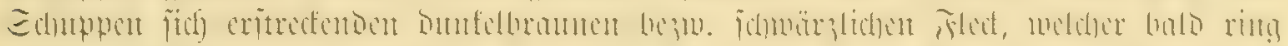

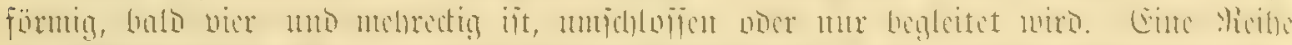

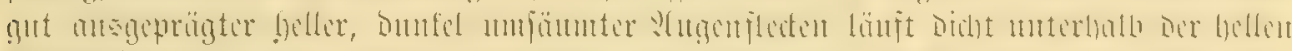

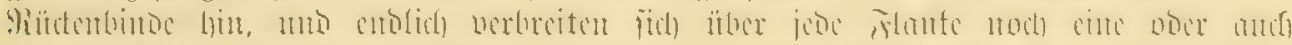

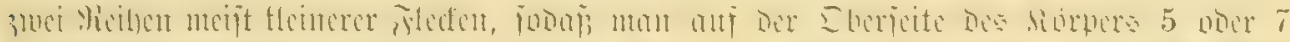

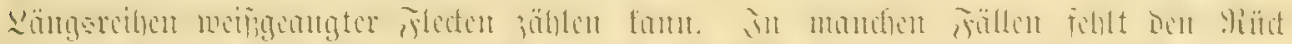

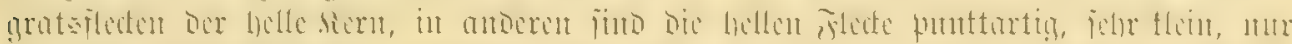

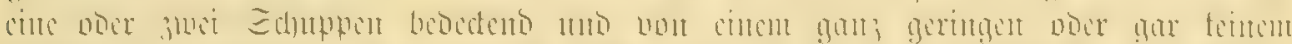

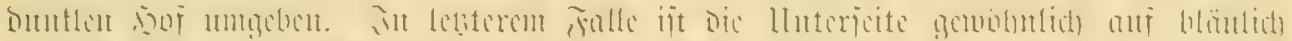

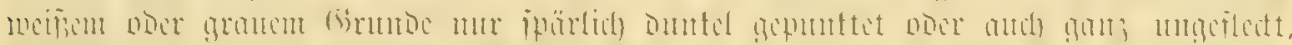

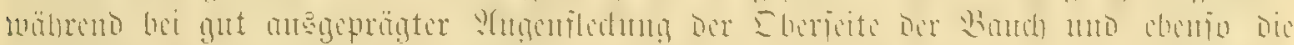

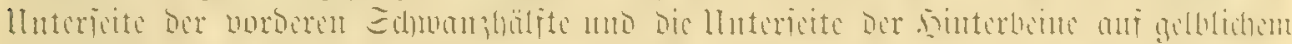

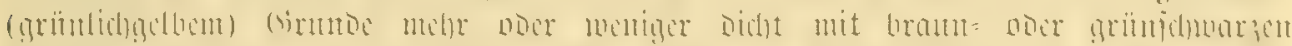

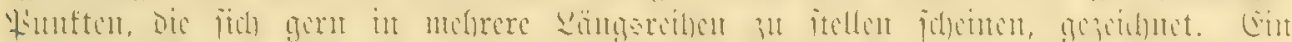

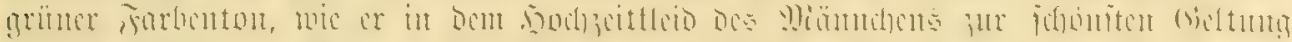

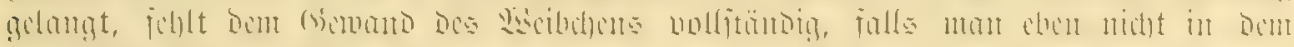

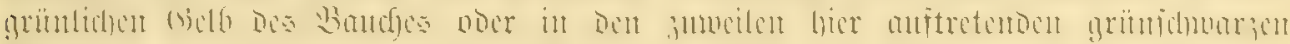

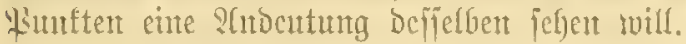

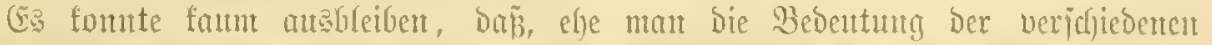

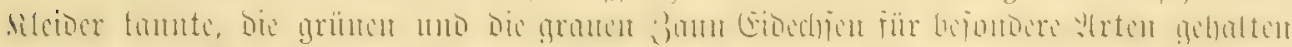

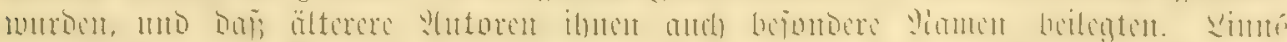

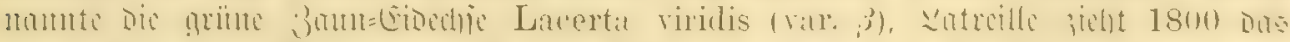

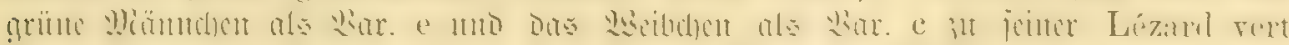

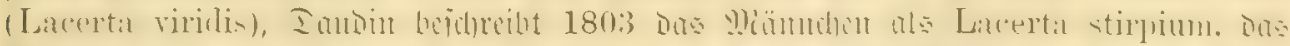

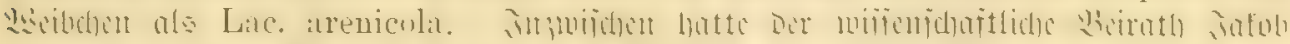

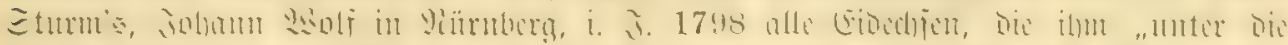

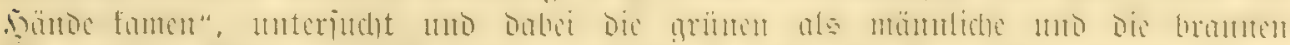

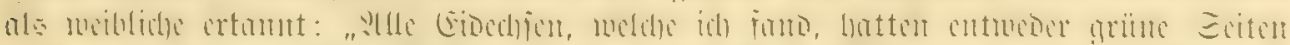

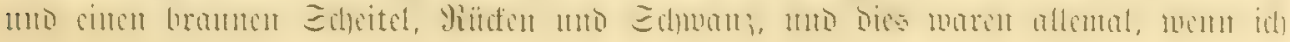




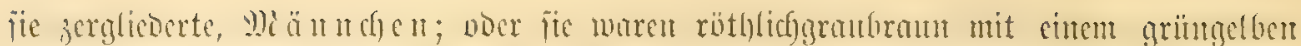

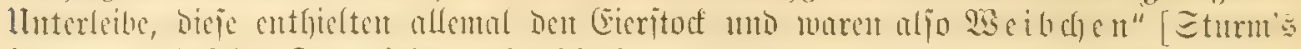

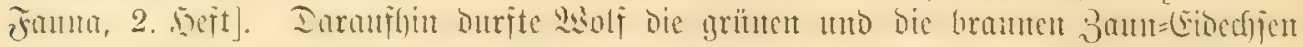

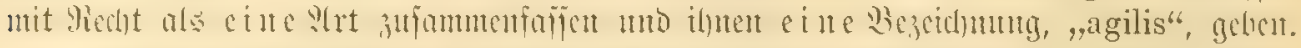

Erftes Jugertolteib.

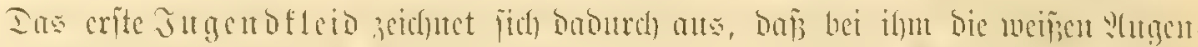

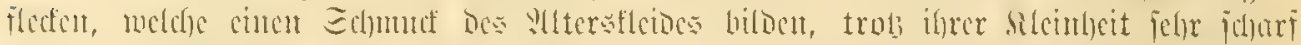

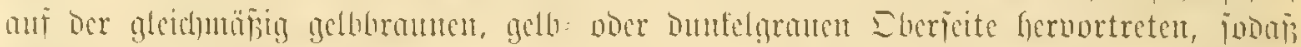

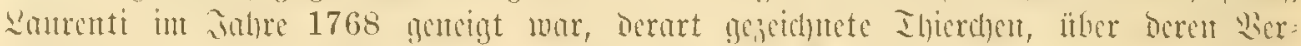

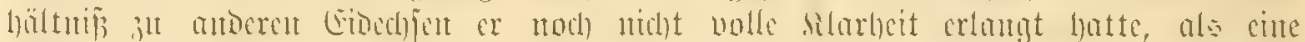

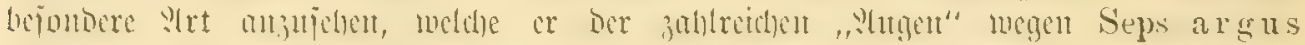

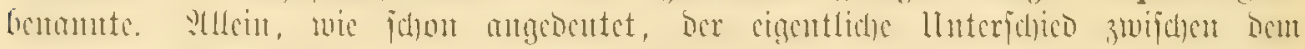

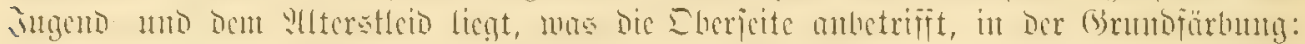

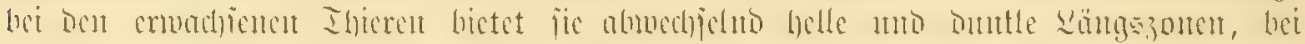

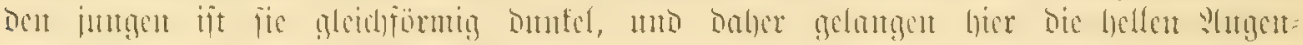

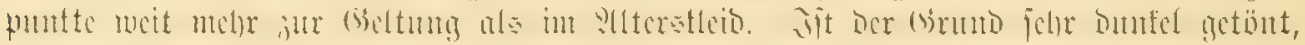

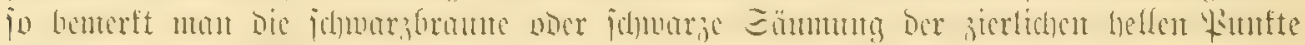

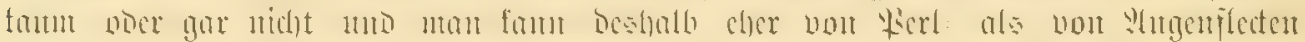

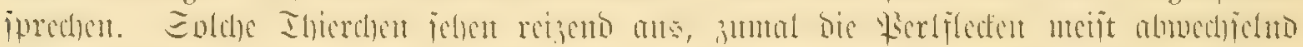

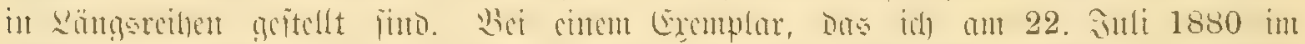

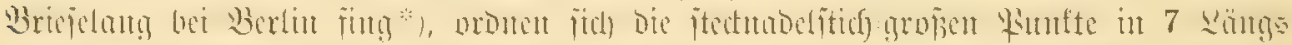

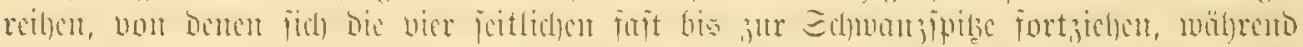

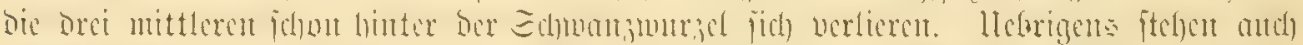

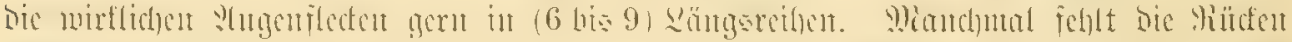

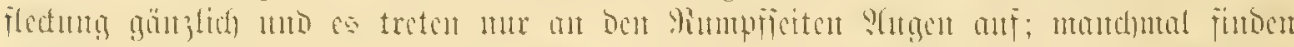

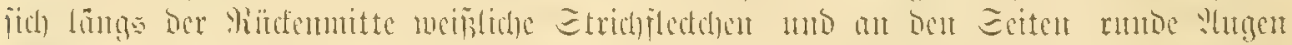

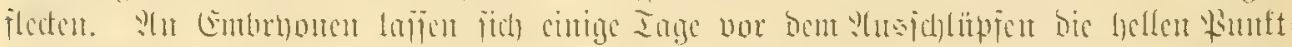

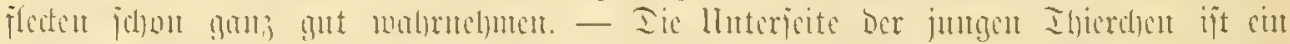

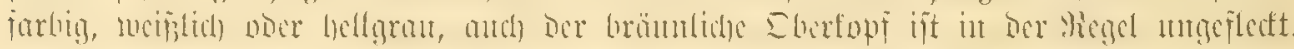

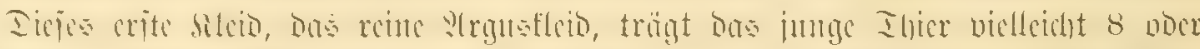

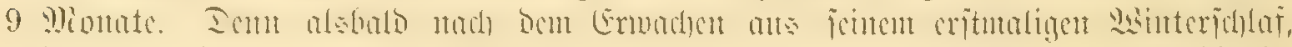

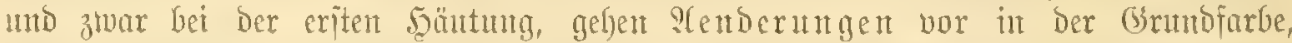

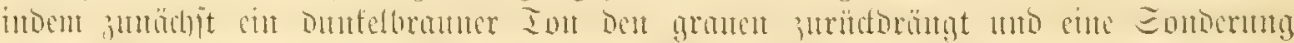

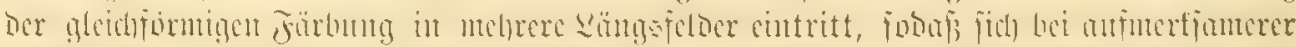

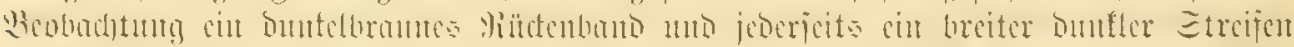

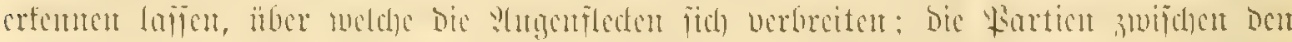

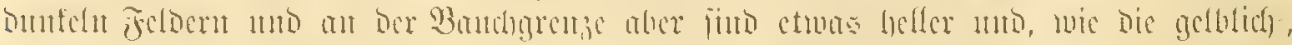

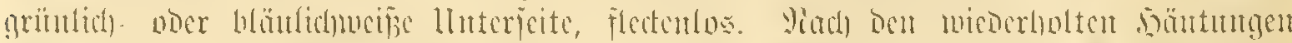

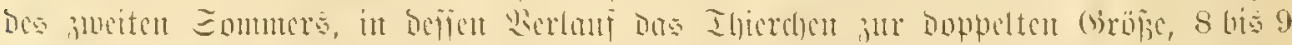

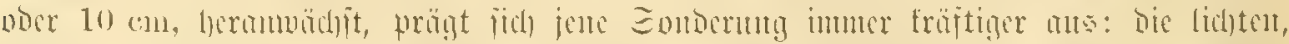

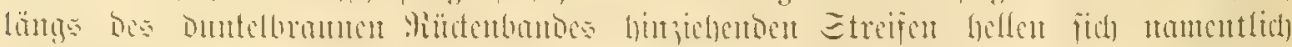

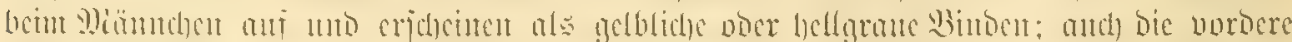

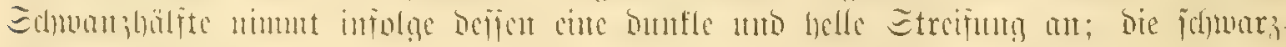

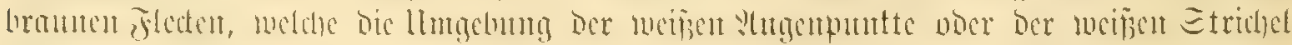

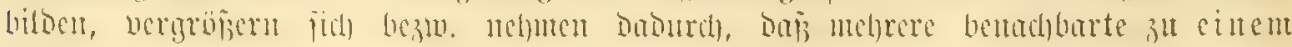

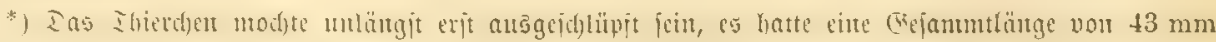

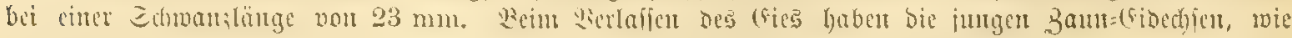
id) mic) soiedergolt ibberjührt Gabe, gemöhulidy eine (bejammtlänge von 42 bis $47 \mathrm{~mm}$. 


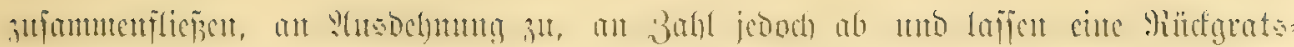

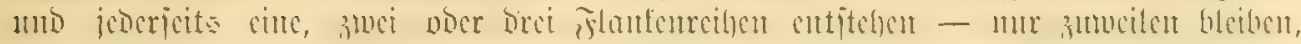

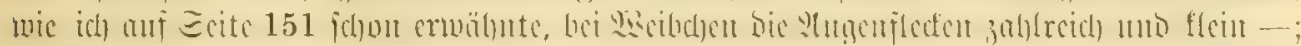

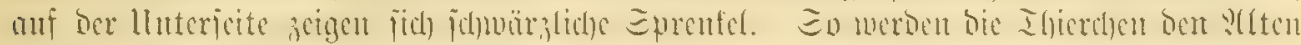

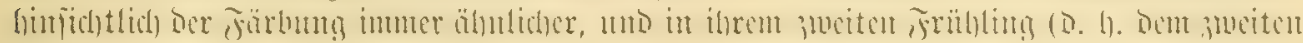

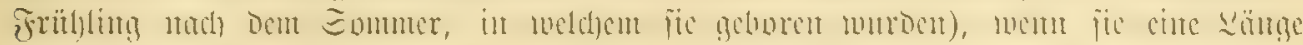

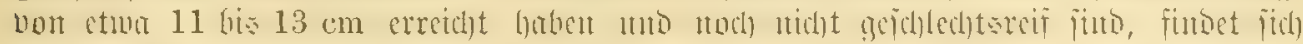

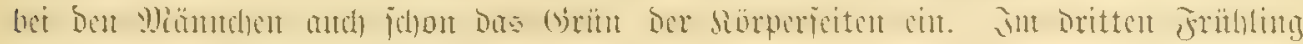

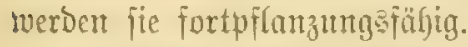

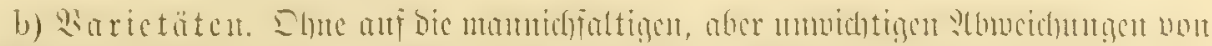

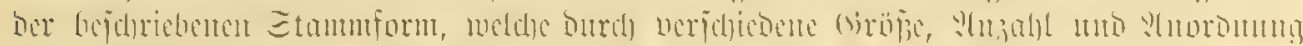

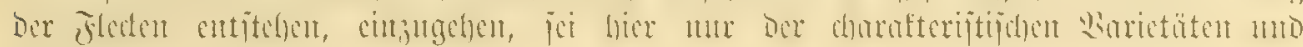
Formen gedadjt.

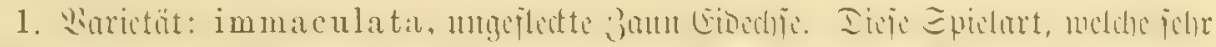

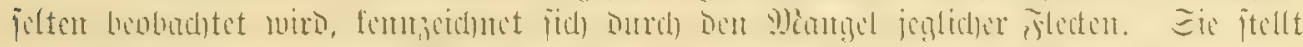

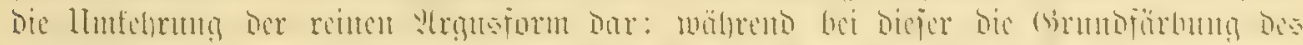

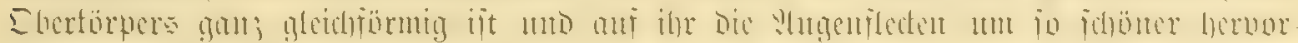

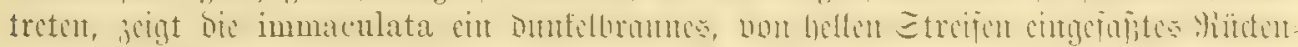
bano und bieberum Duntle Geitmfelder, indể teine Flecten.

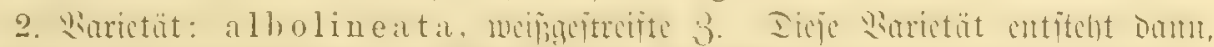

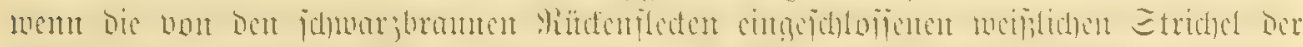

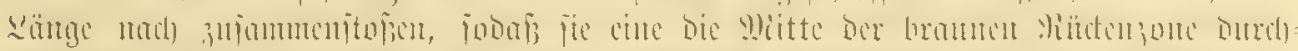

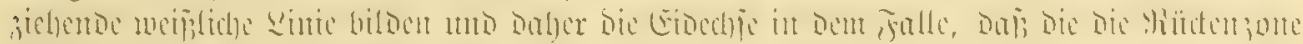

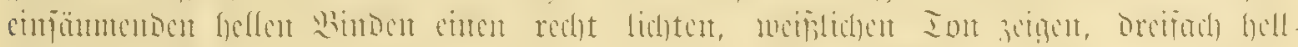

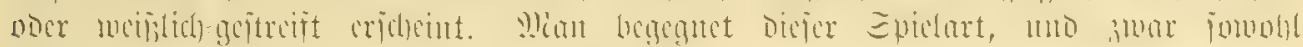

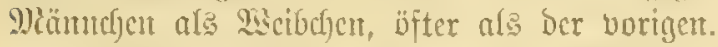

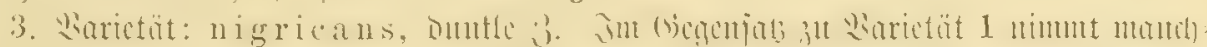

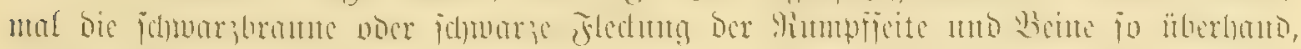

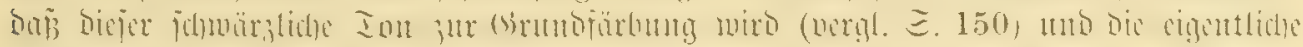

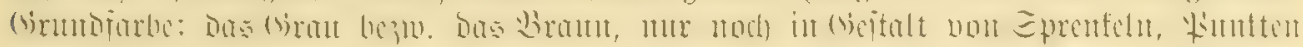

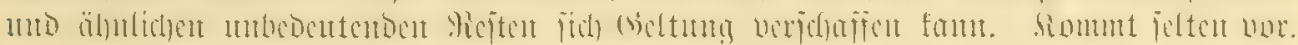

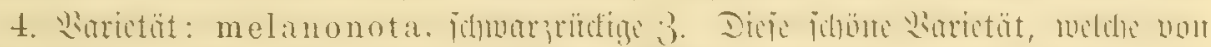

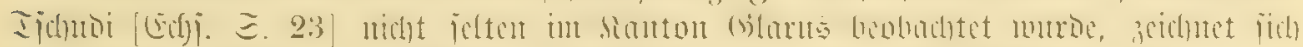

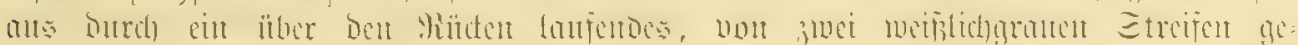

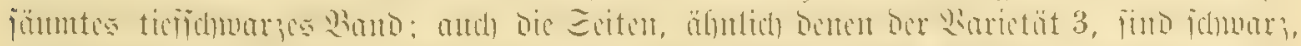

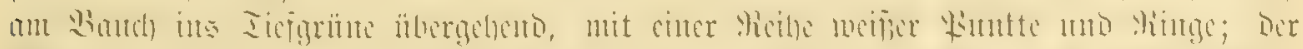

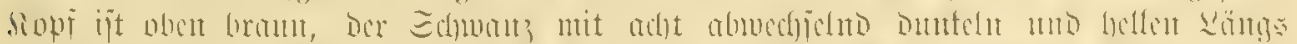

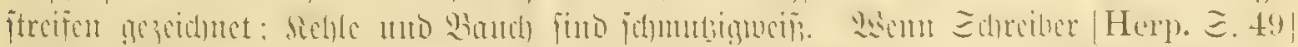

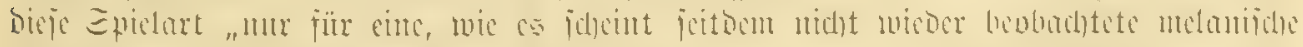

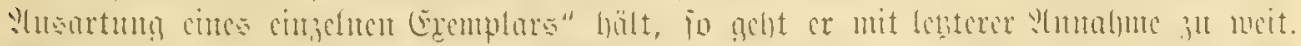

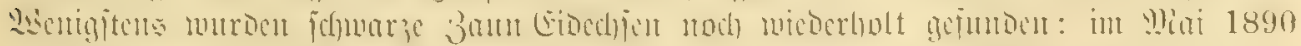

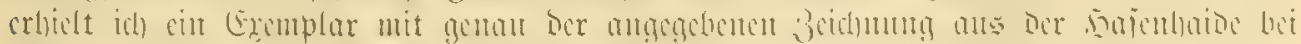

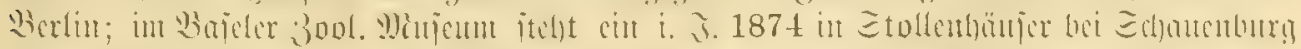

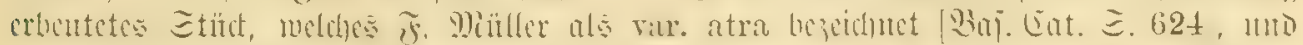

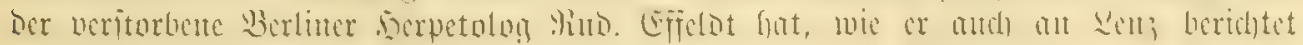

*) Die 2(ugen= ober Ctemflecte ermarbent biejer (Eibedje bie Bejeidjun ,stellatus", meldje Sodrant ifr beilegte. 


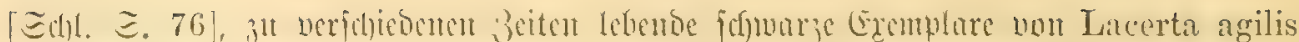
(uto ton Lac. vivipara) bejefjent.

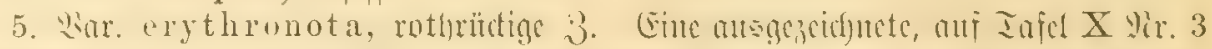

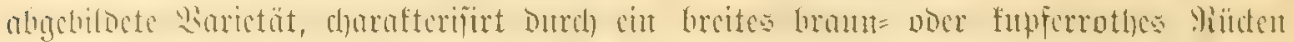

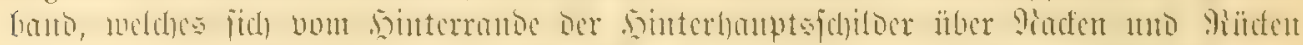

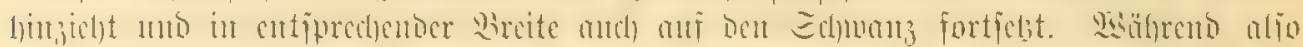

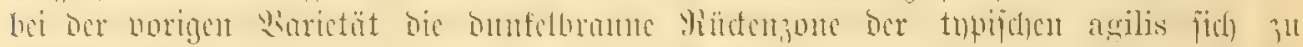

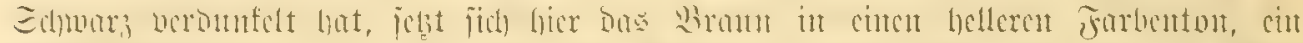

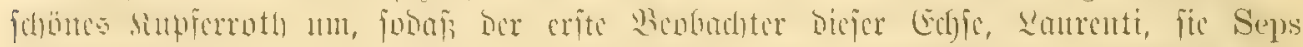

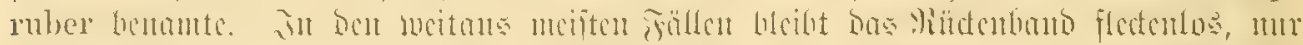

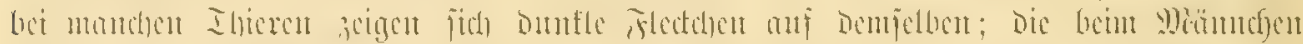

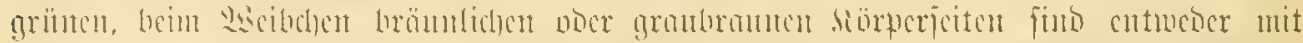

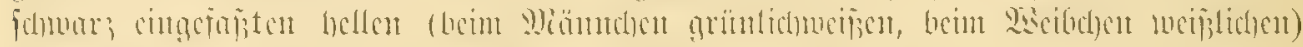

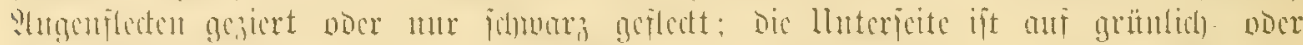

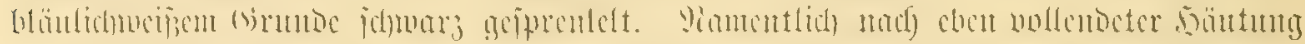

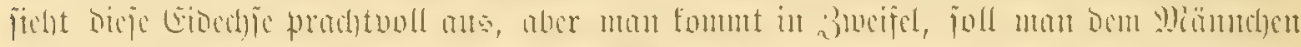

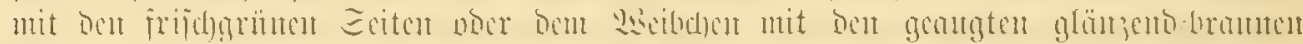

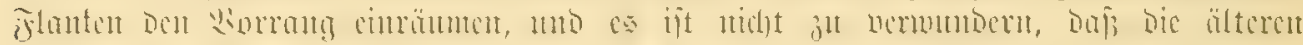

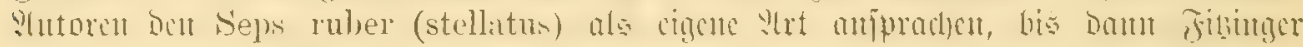

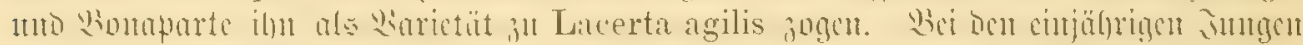

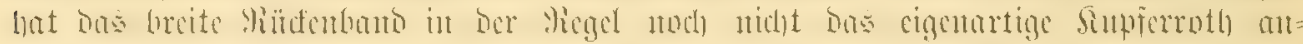

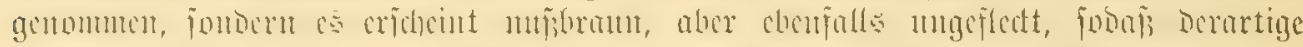

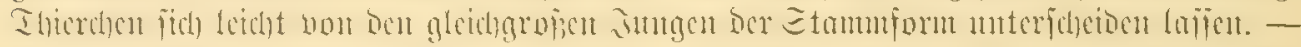

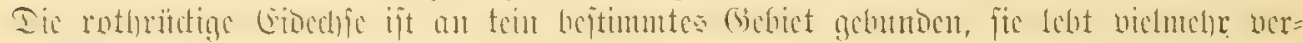

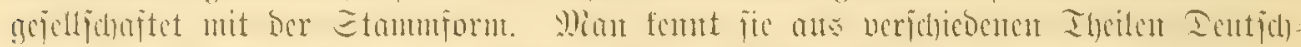

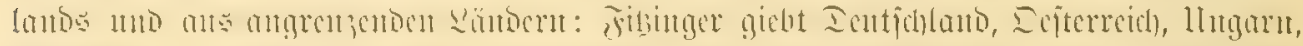

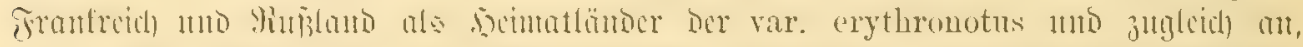

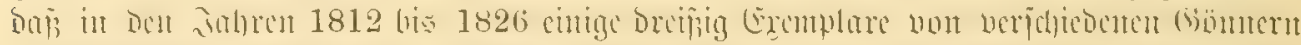

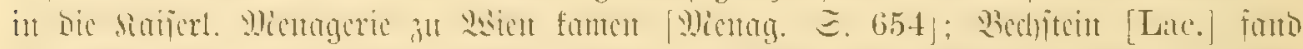

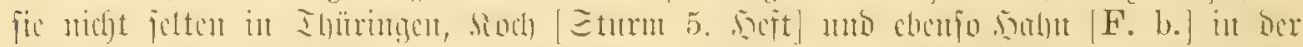

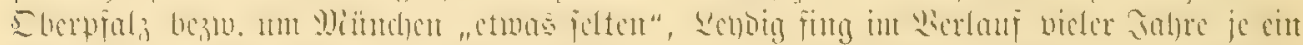

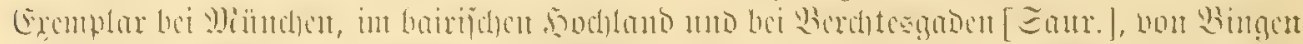

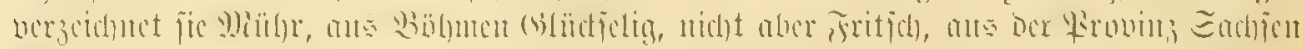

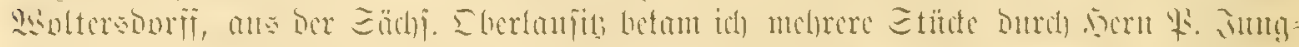

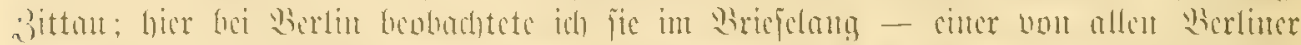

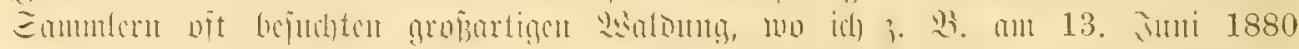

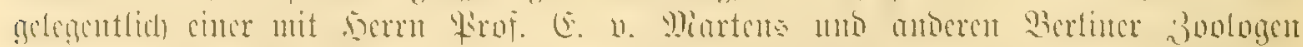

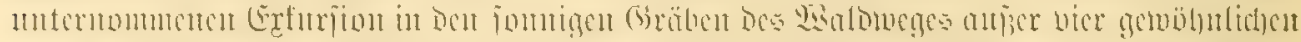

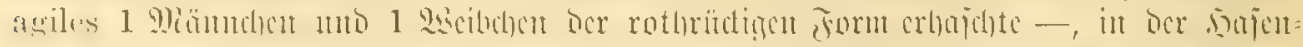

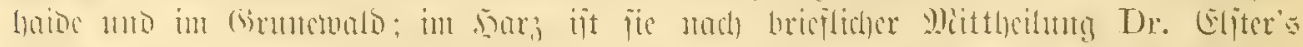

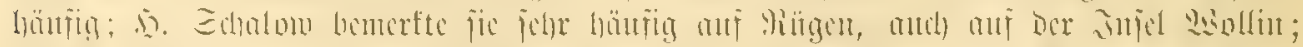

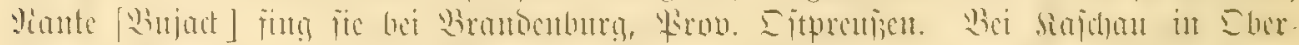

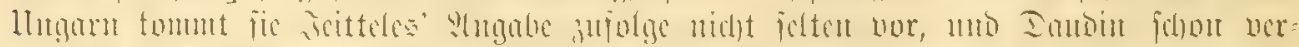

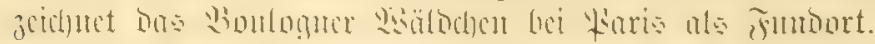

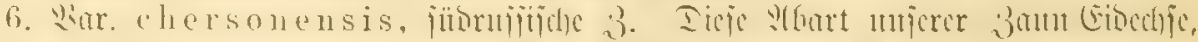

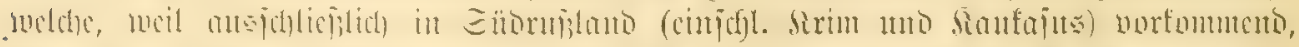

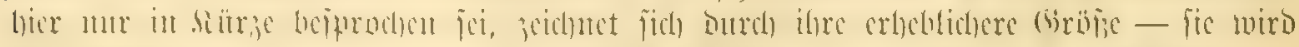

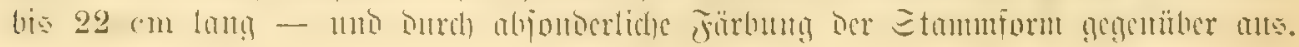




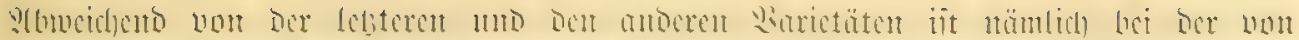

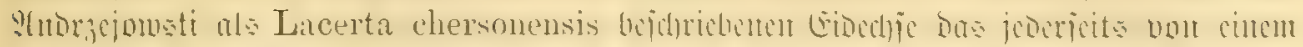

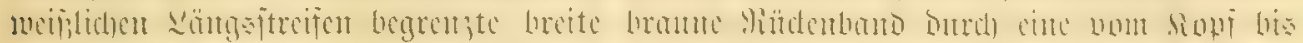

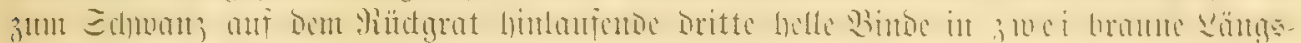

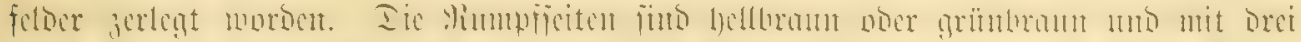

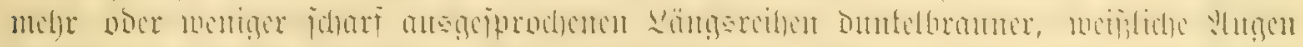

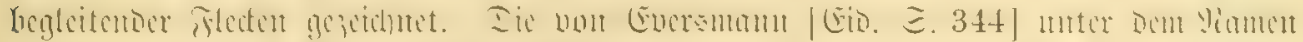

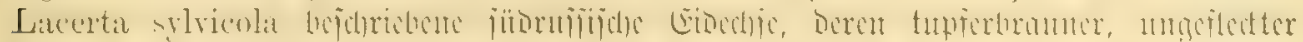

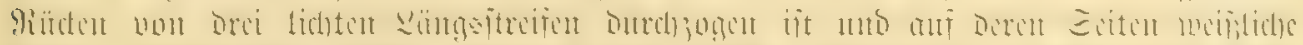

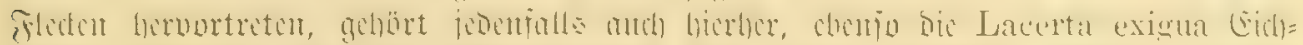

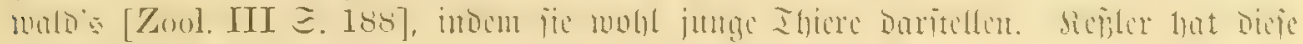
Qbart ala Lac. agilis var. orientalis bezcicfuet.

(E)

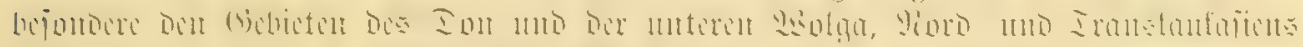

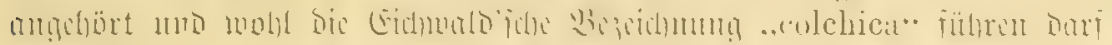

7. Diar. colchica, grime 3. D)an faum Diefe amberoroentficl groj̧e, cigen=

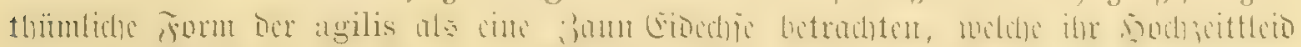

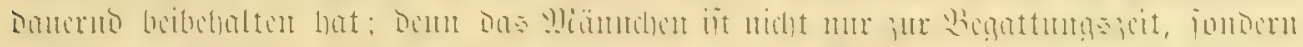

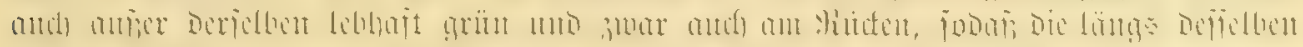

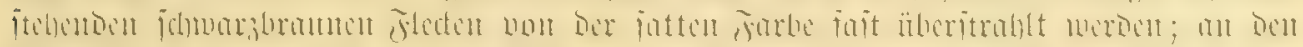

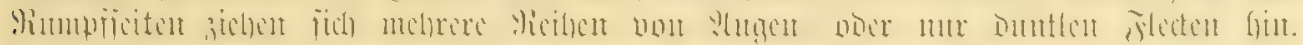

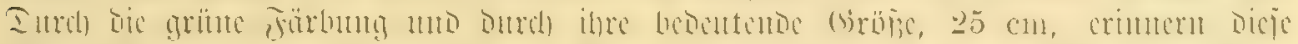

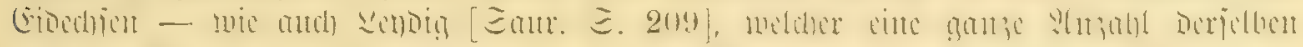

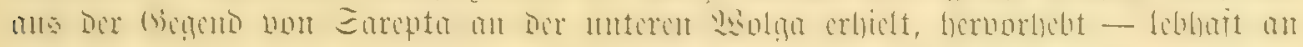

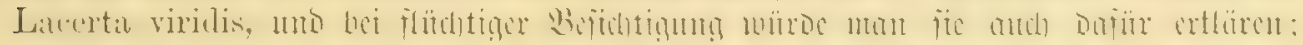

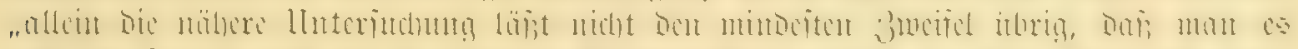

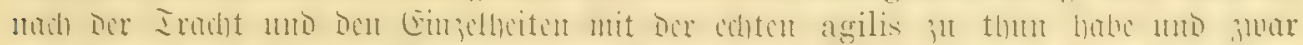

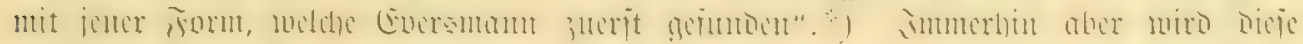

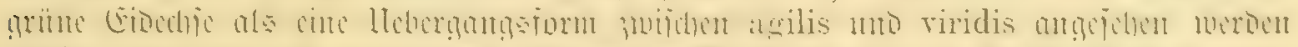

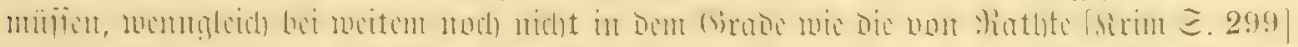

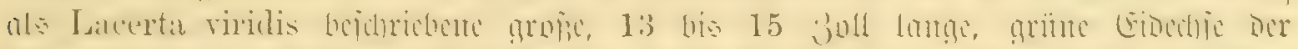

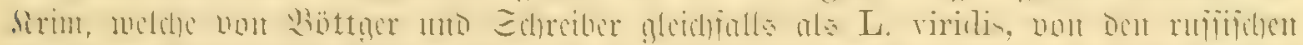

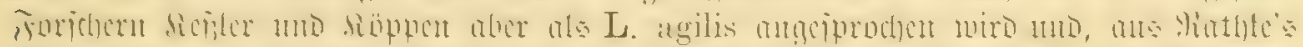

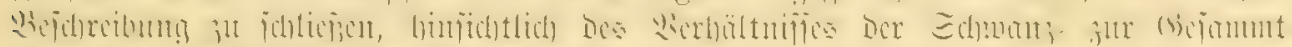

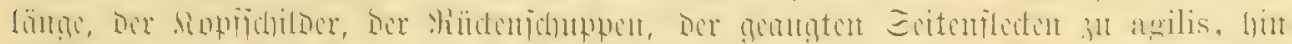

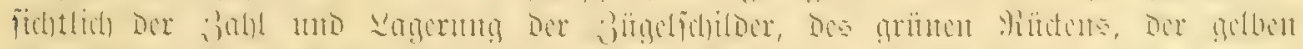

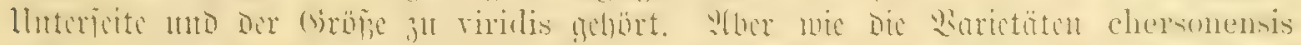

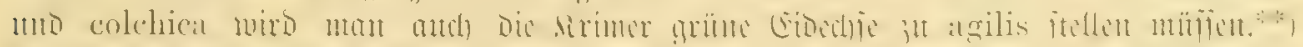

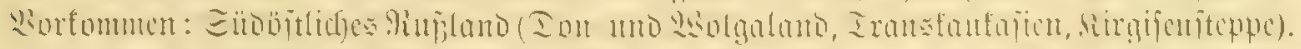

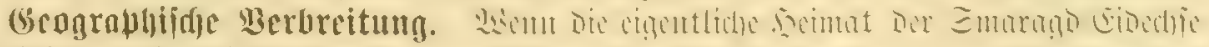

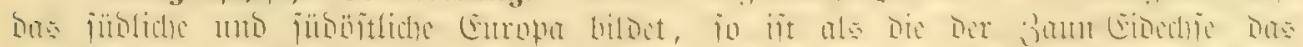

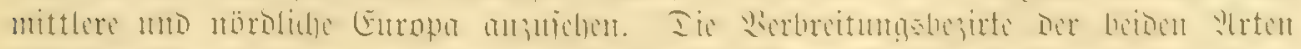

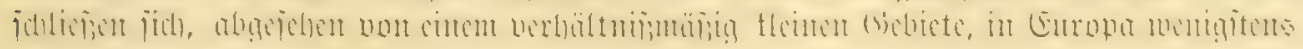

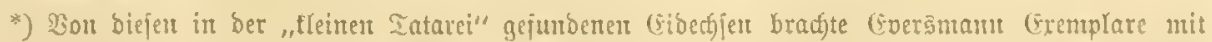

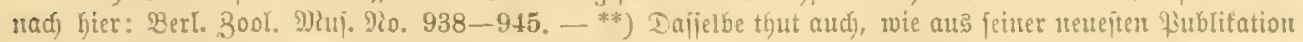

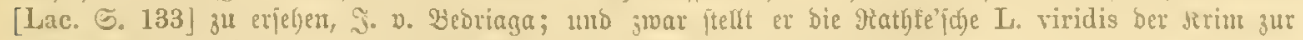

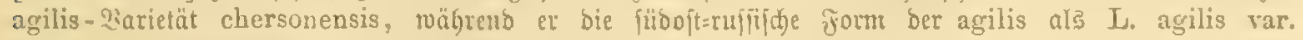
doniensis befanbelt. 


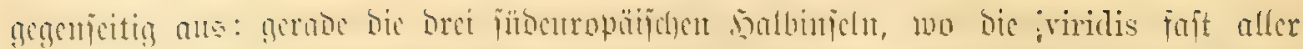

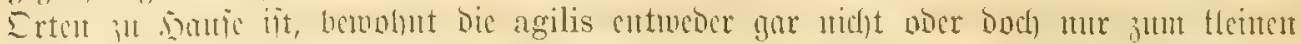

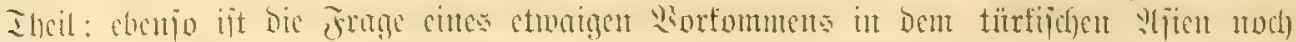

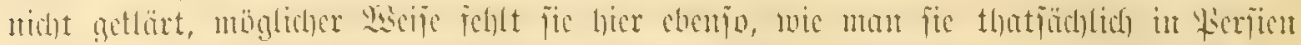

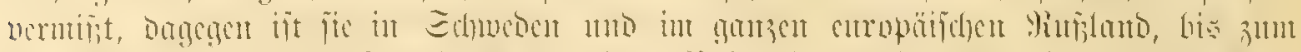

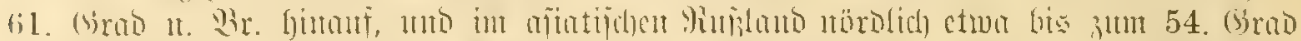

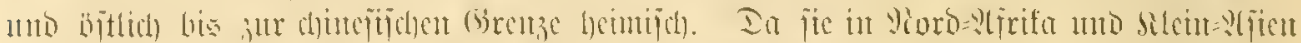

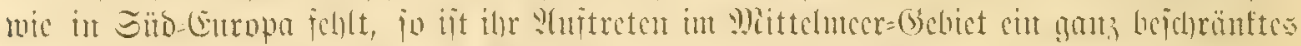

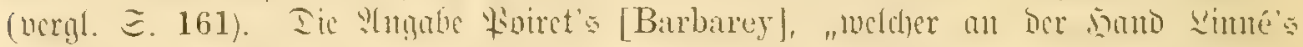

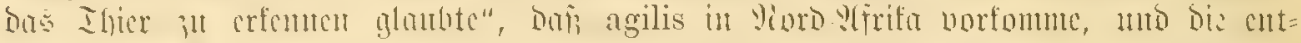

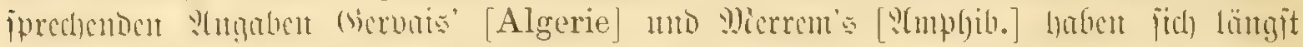

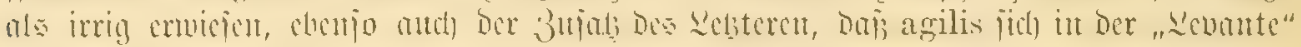

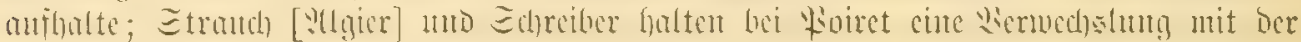
Rerleidedje für vorliegend.

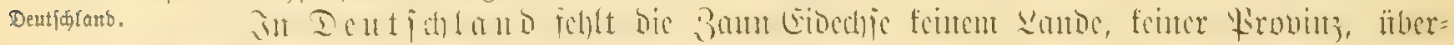

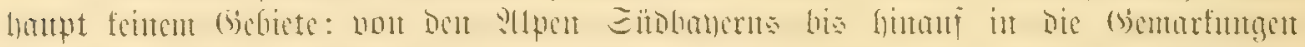

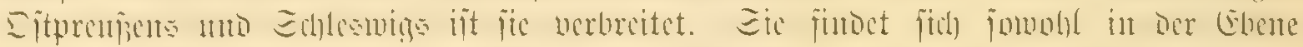

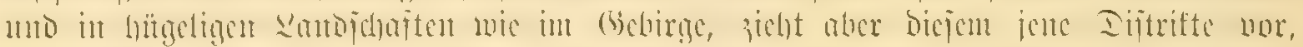

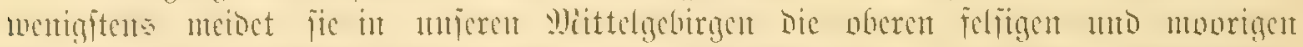

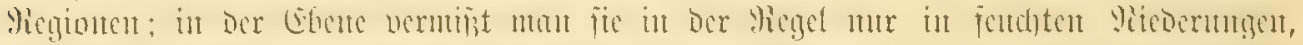

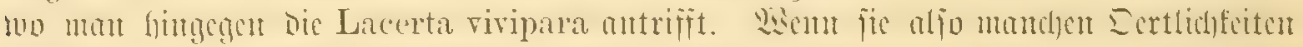

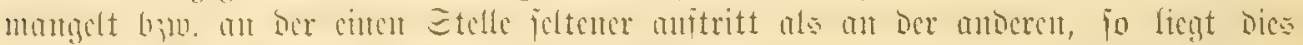

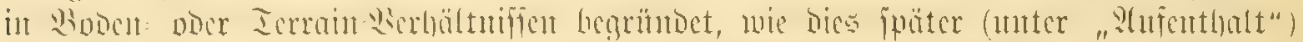

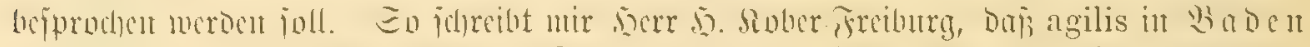

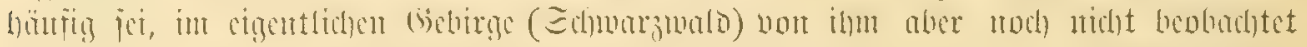

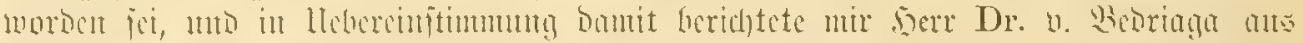

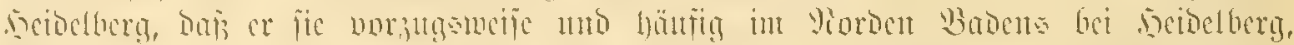

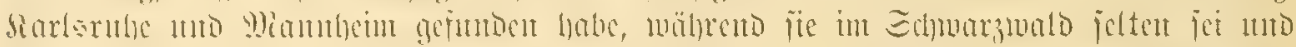

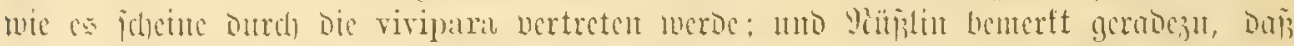

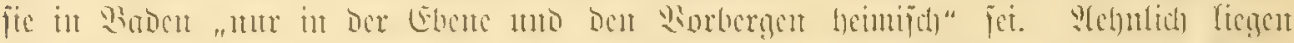

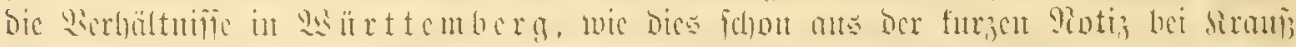

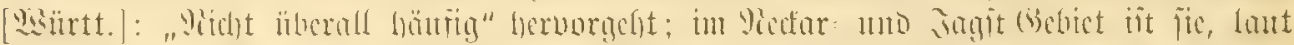

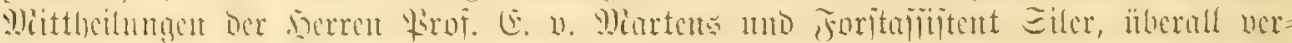

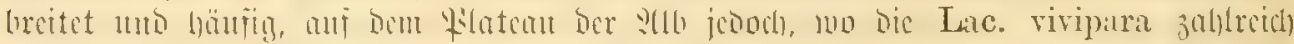

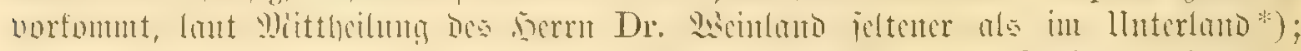

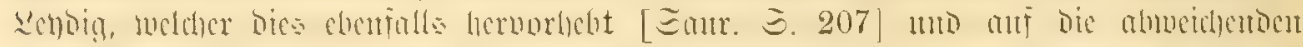

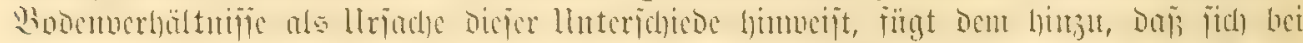

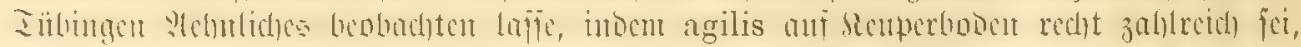

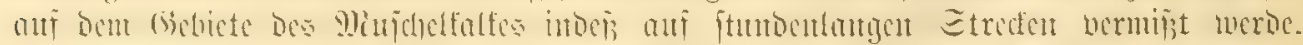

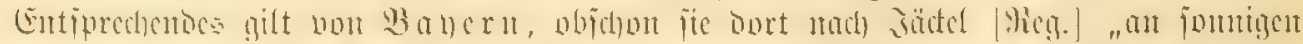

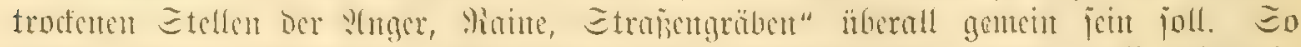

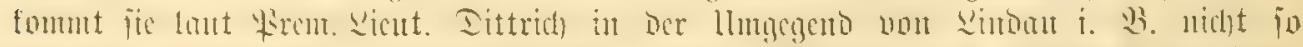

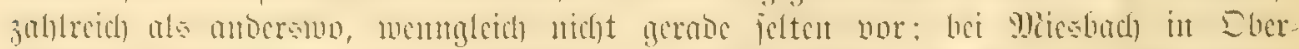

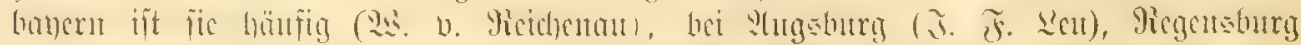

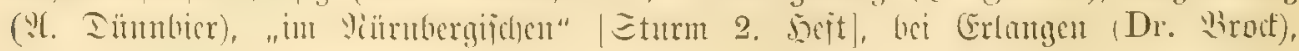

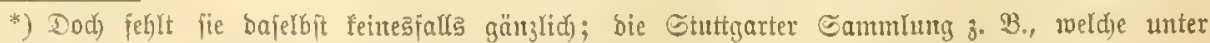

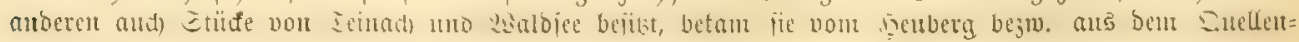
gebiet ber (Enad) (Oberamt Şailingen). 


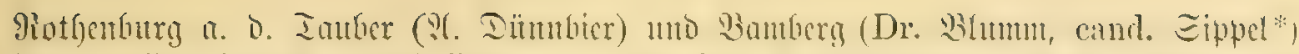

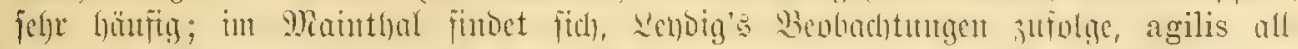

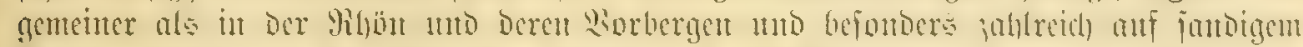

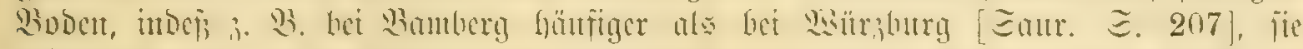

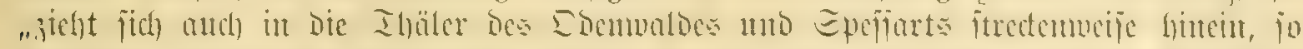

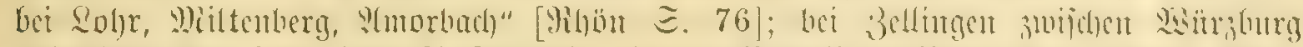

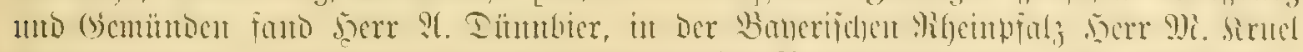

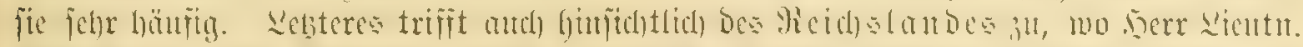

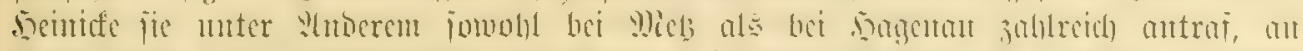

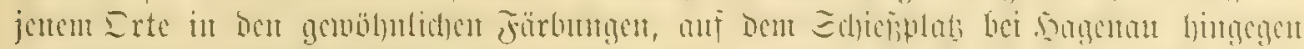

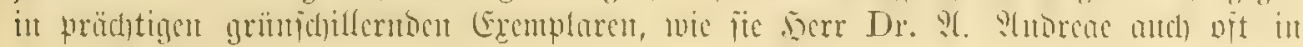
Der Mgeinebene bei Etrafburg beobadjtete.

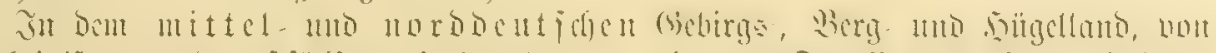

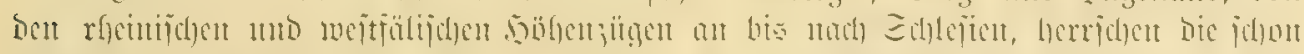

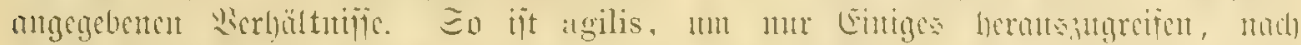

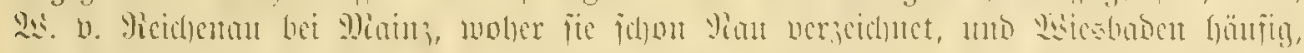

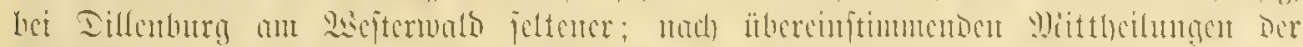

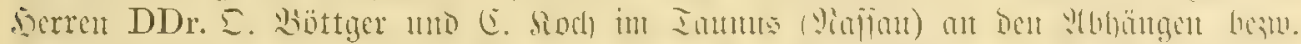

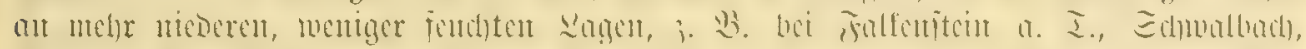

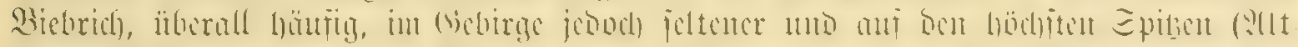

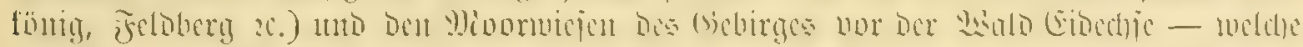

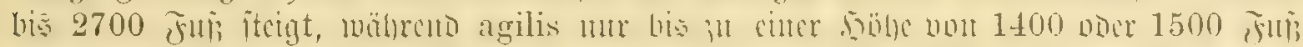

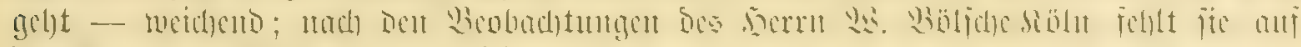

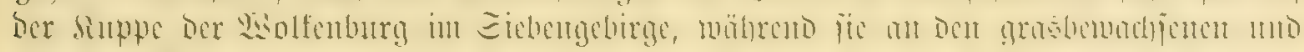

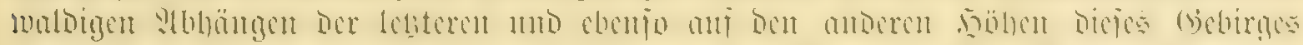

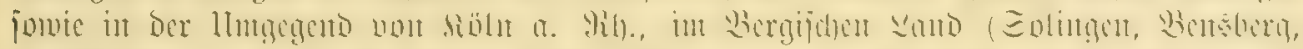

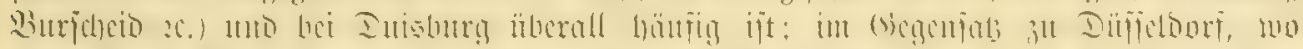

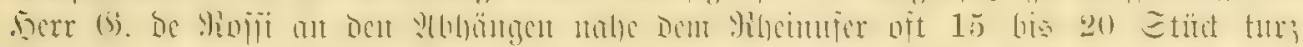

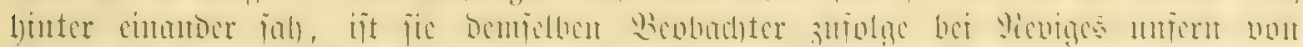

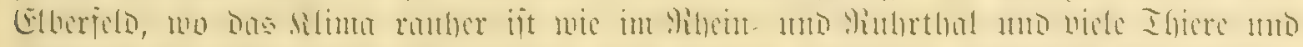

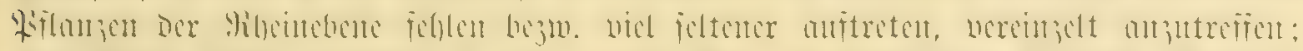

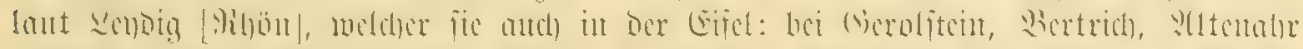

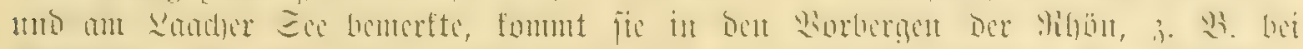

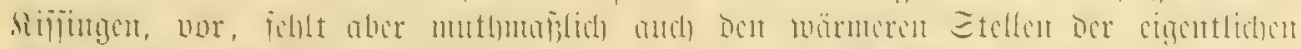

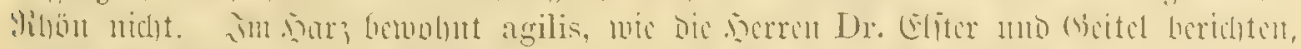

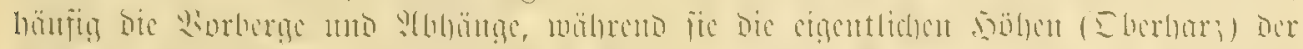

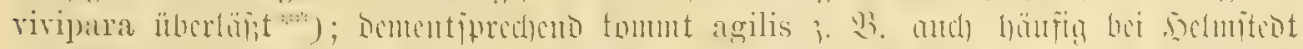

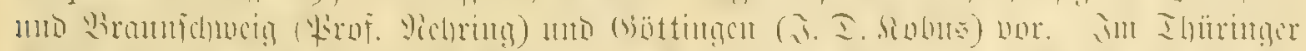

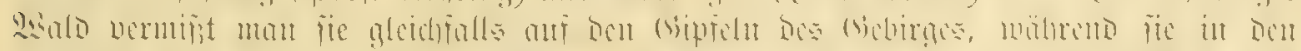

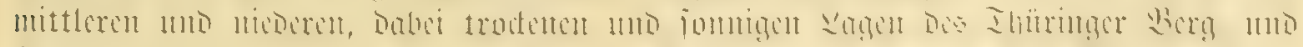

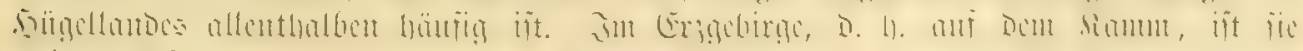

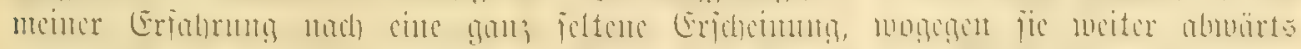

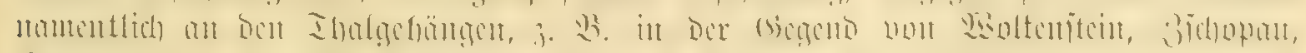

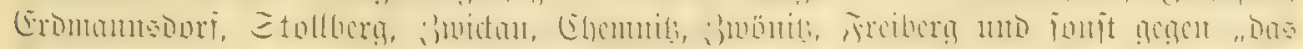

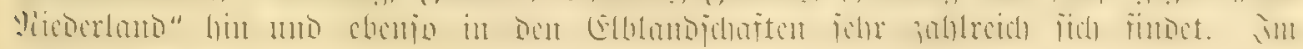

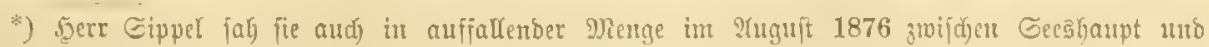

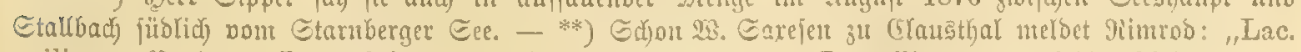

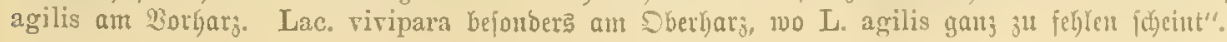




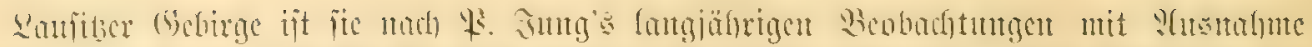

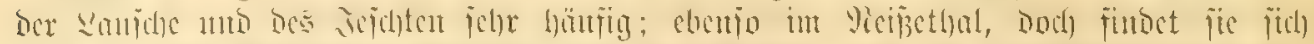

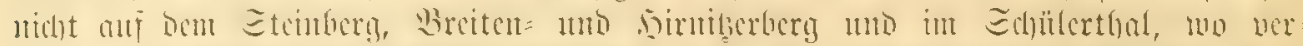

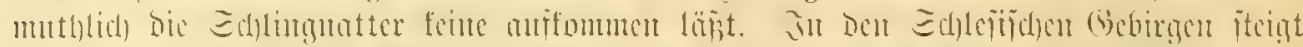

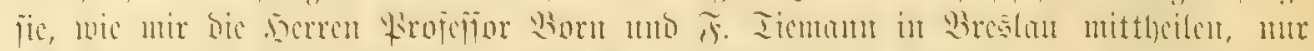

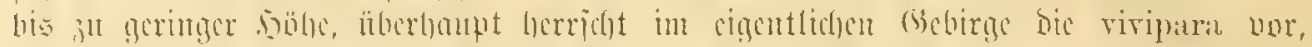

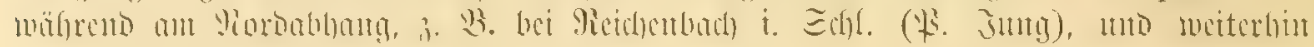
Durdy Edjefien unjere Sirt gemein ift.

Motbo. ช̆lad)tano.

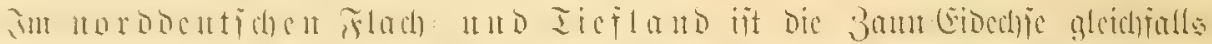

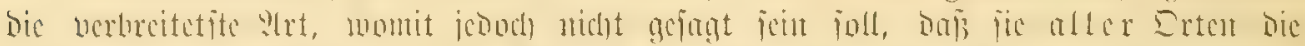

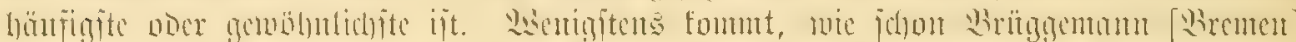

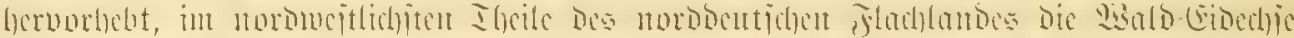

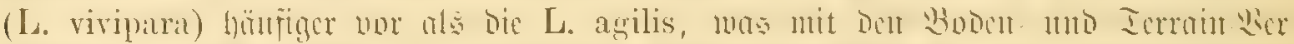

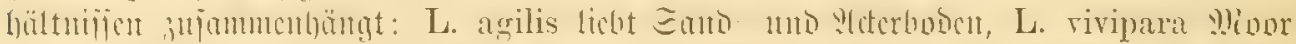

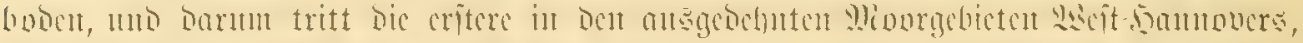

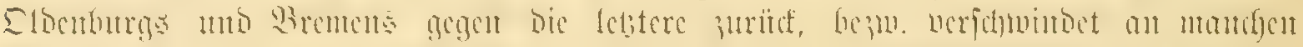

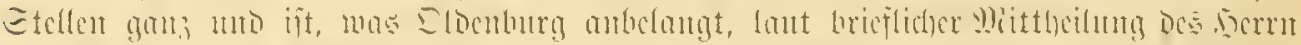

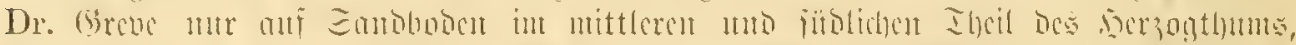

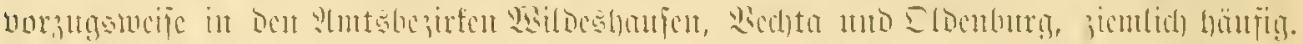

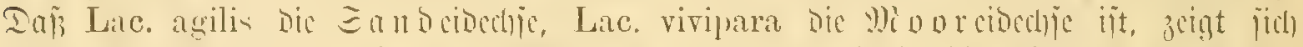

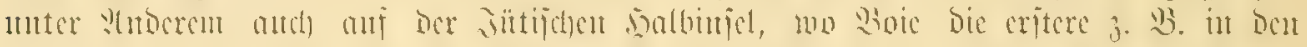

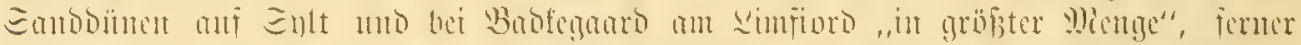

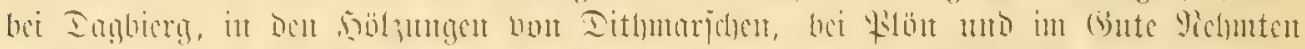

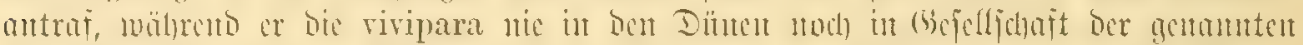

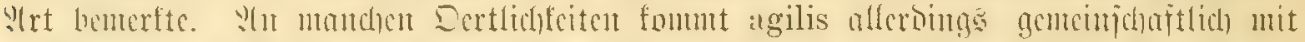

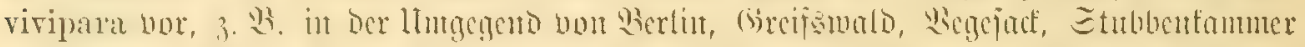

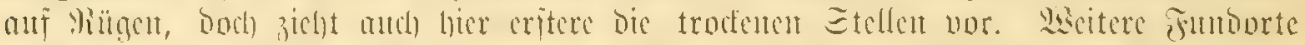

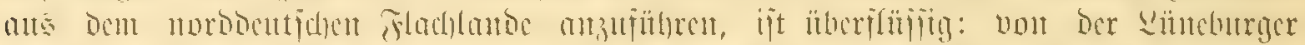

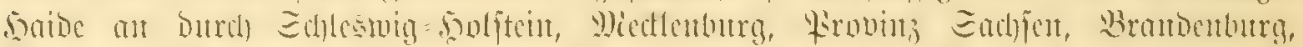

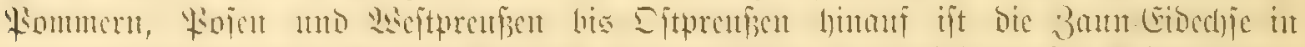

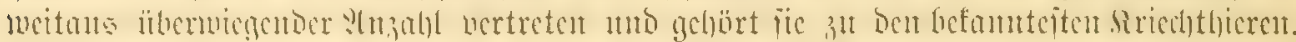

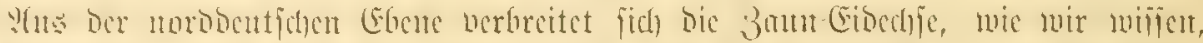

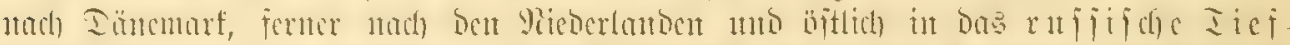

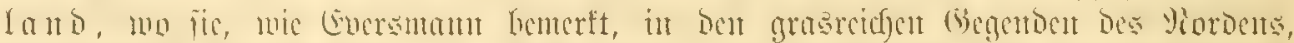

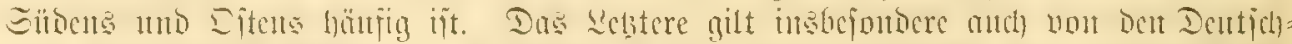

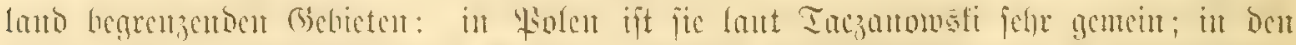

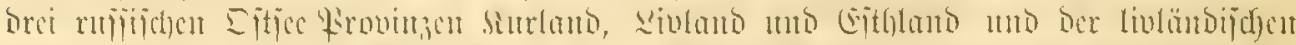

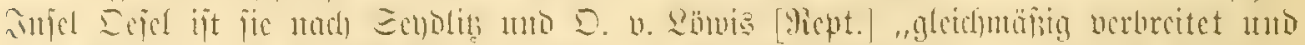

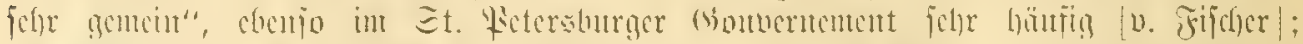

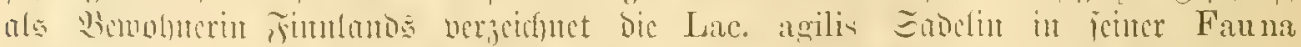

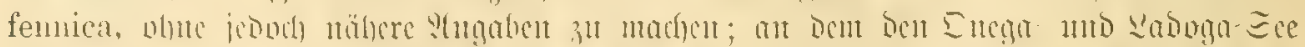

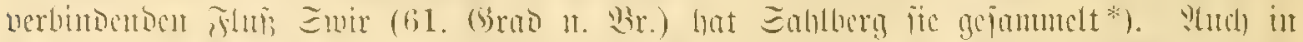

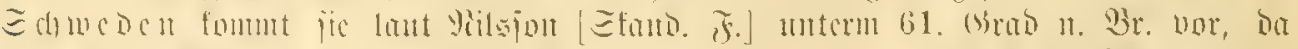

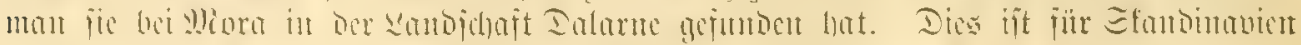

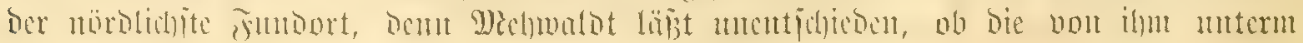

*) Sablberg: „Om Lacerta agilis (L., Nils.), och dess förekomst inom vårt fauna område in: Jreddelanden af societas pro fauna et flora fennica, Helsingfors 1876 ธ. $65-69$. 


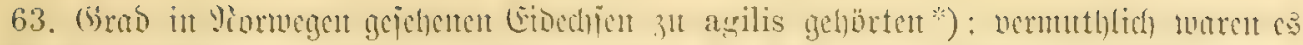

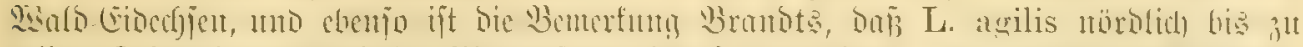

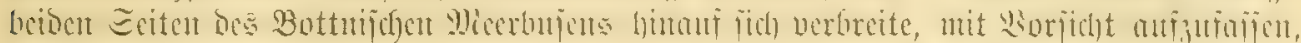

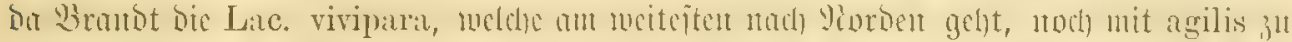

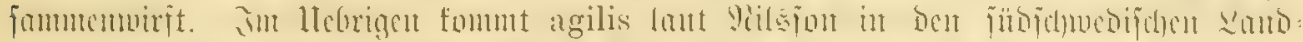

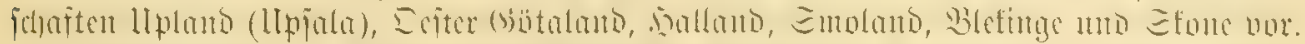

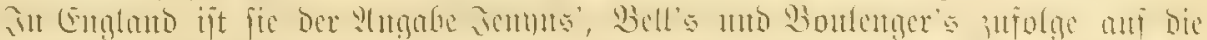

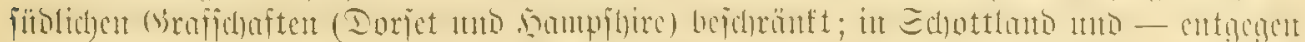

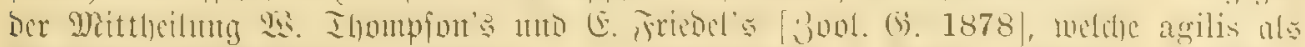

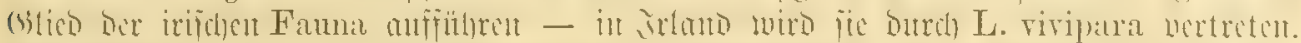

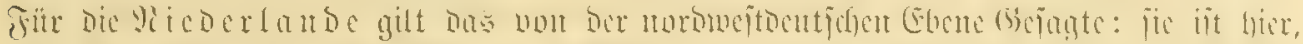

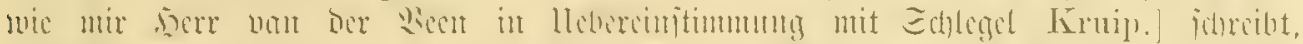

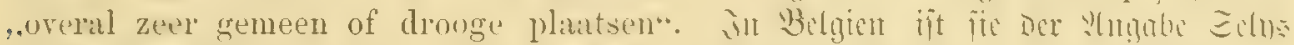

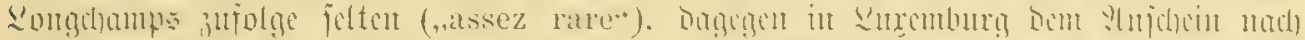

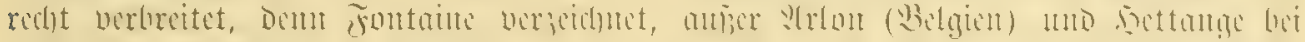

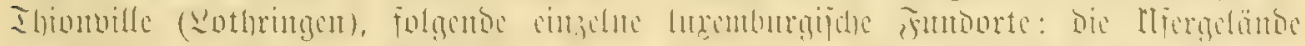

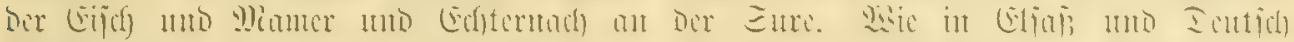

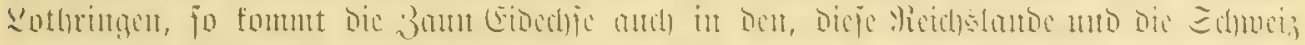

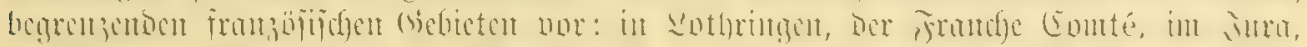

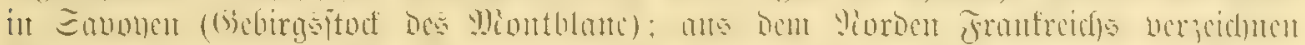

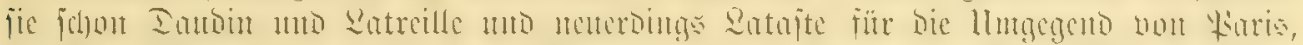

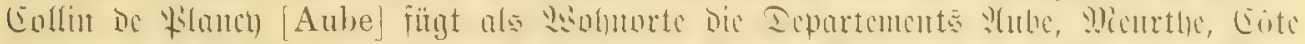

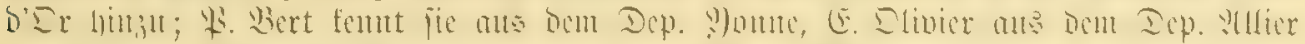

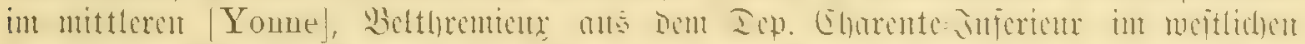

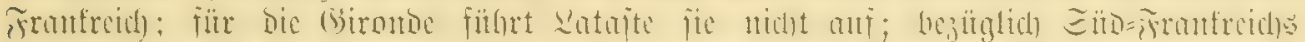

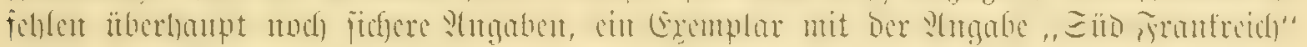

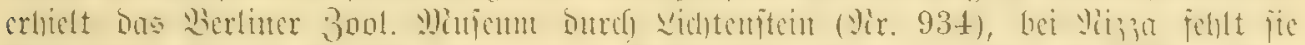

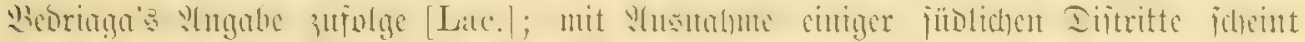

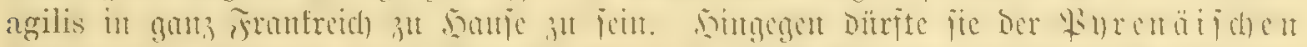

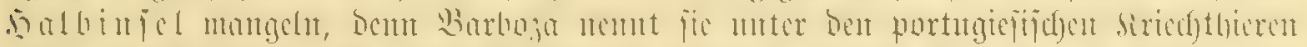

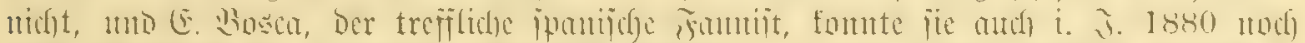

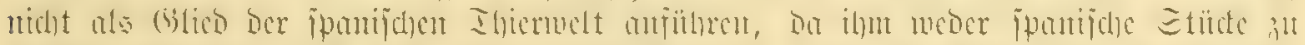

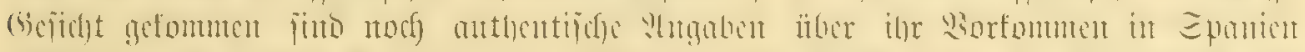

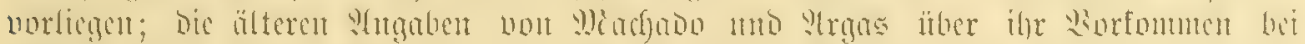

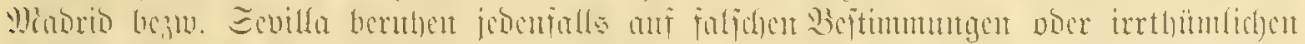

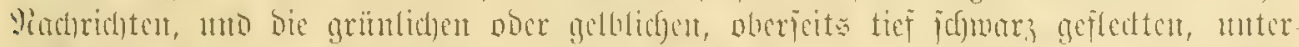

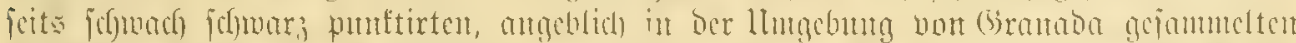

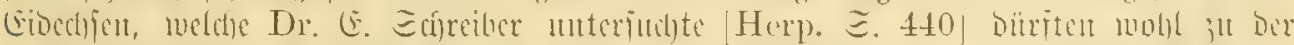

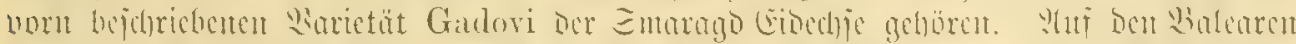

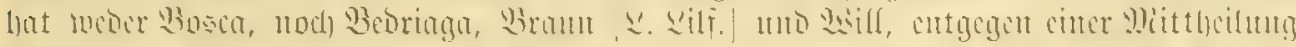

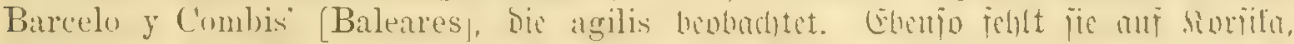

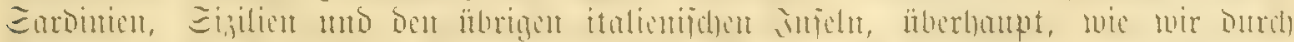

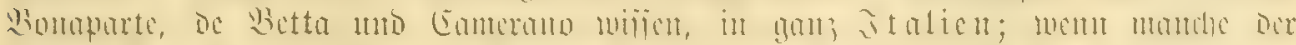

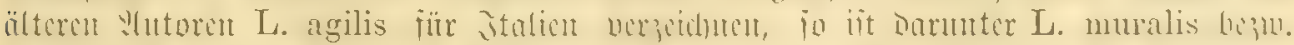

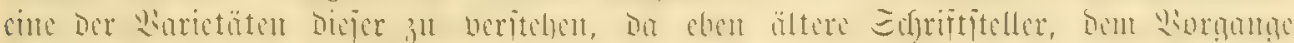

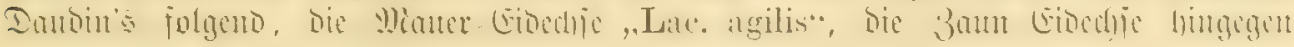

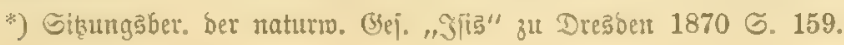




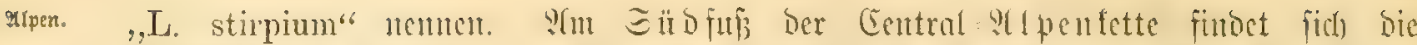

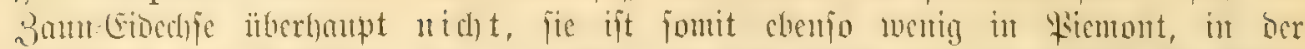

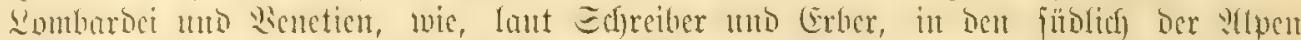

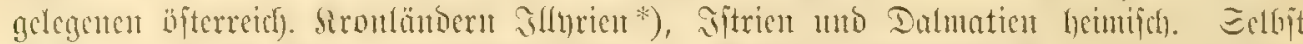

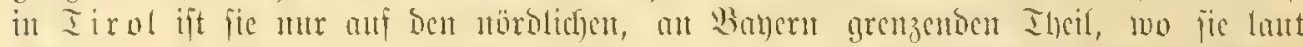

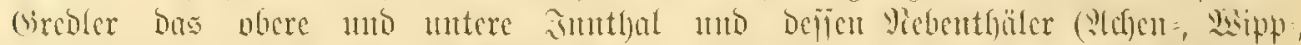

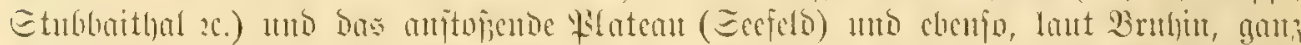

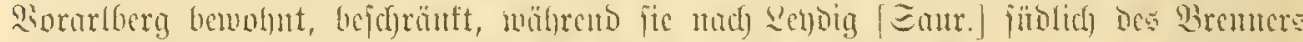
nicht metre angetroffen mird; Dex 47. (Grab u. Wr. mürbe hier alfo bie Elibgrenze

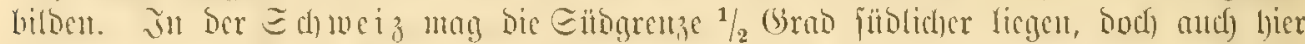

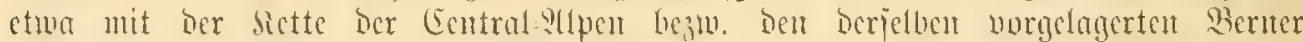

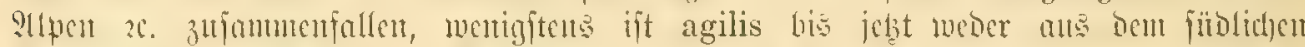

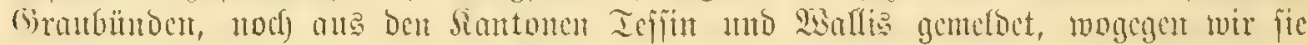

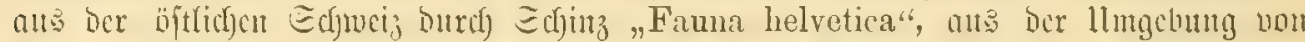

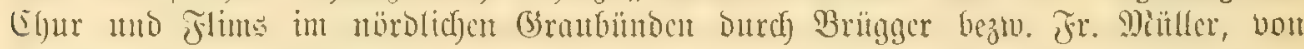

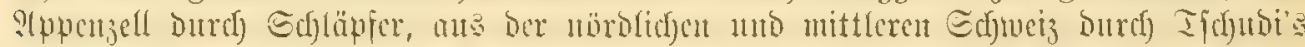

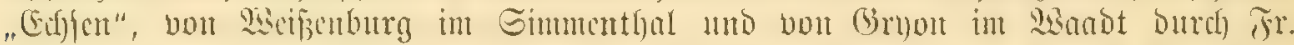

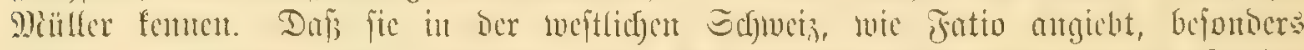

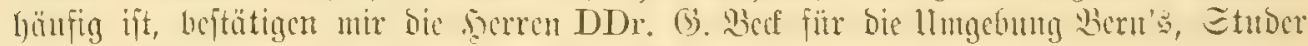
fït Den Santon Bern und Fr. Mëlller für Bafel.

Defterretd)= lingatn.

Hustants

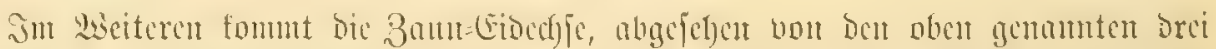

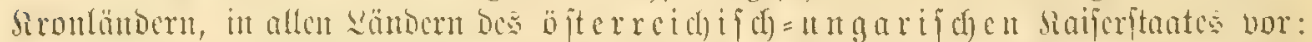

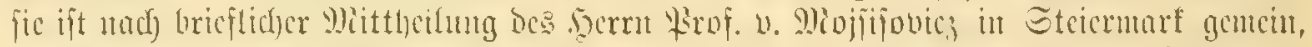

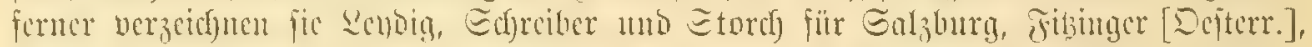

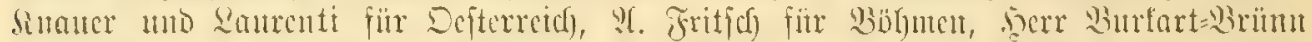

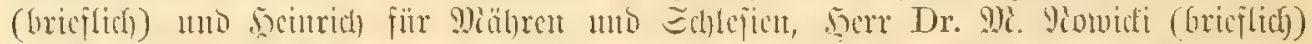

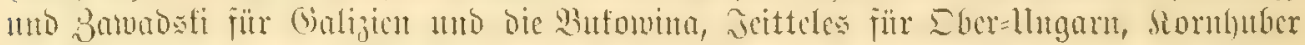

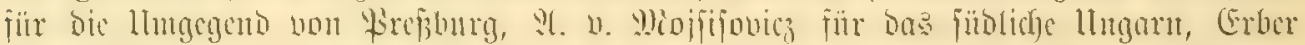

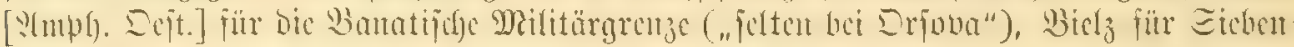

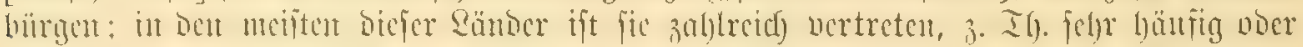

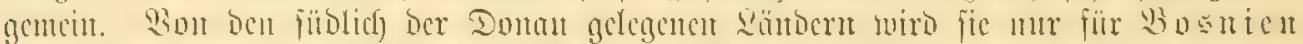

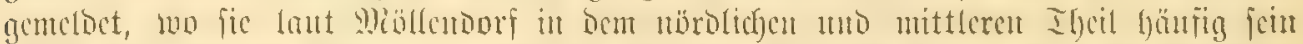

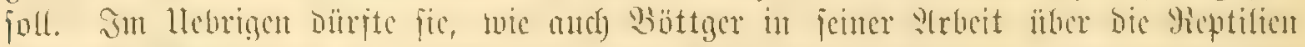

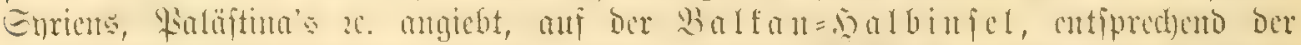

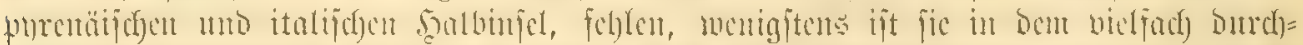

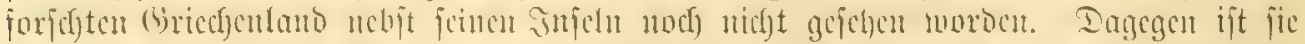

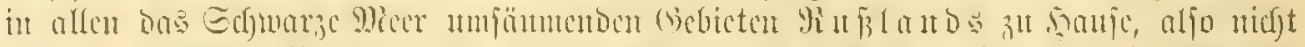

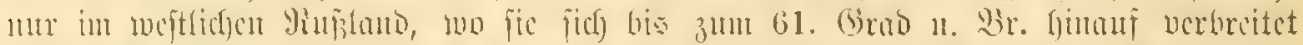

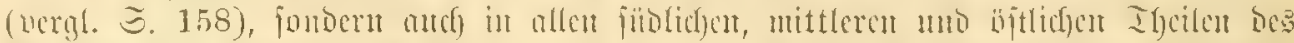

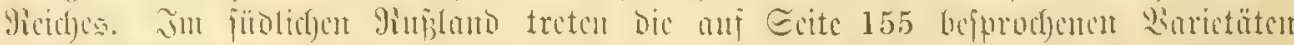

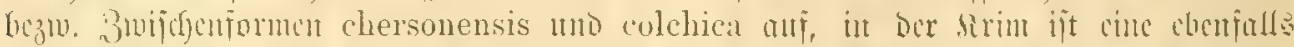

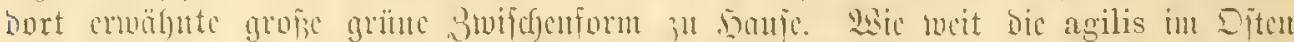

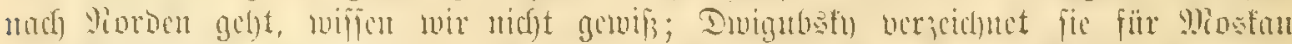

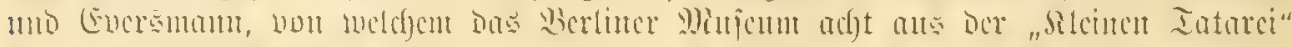

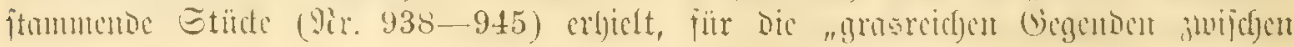

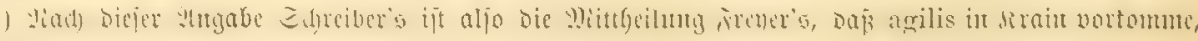
muridytig. 


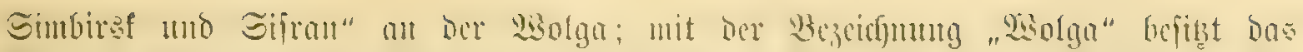

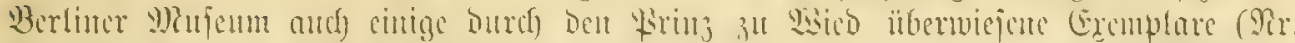

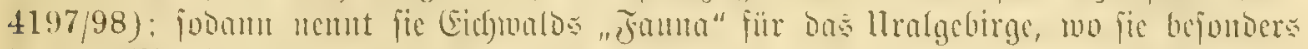

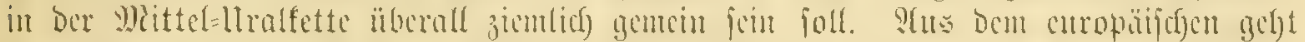

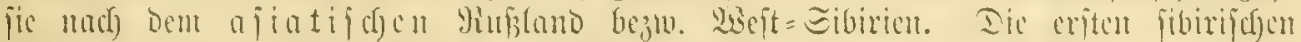

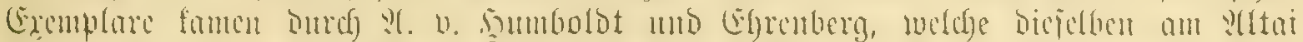

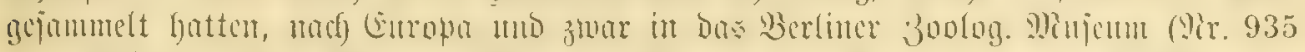

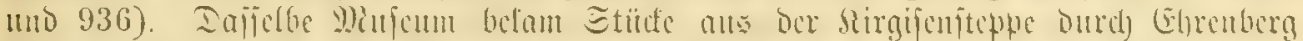

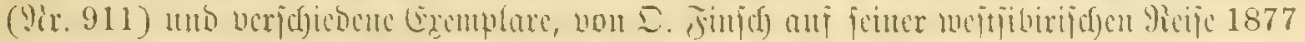

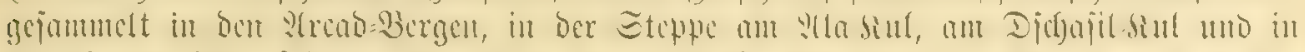

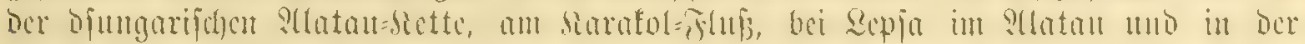

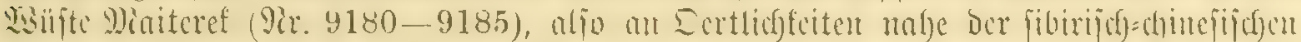

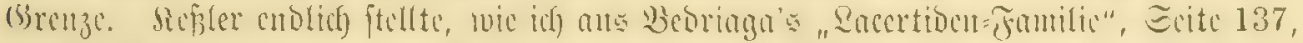

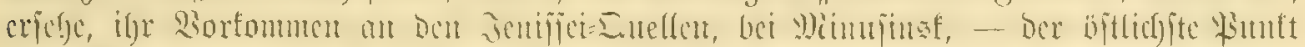

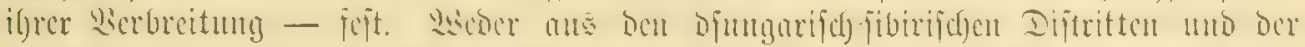

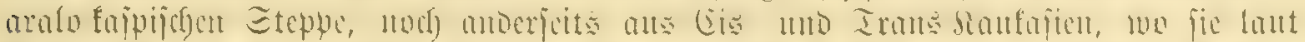

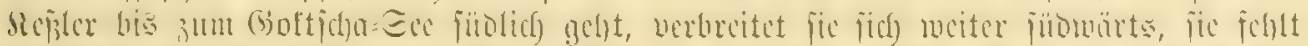

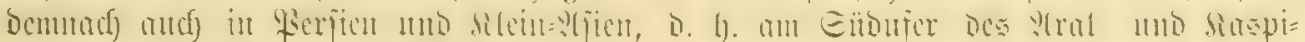
Sccs und Dcs Edfwarzen Mieerç*).

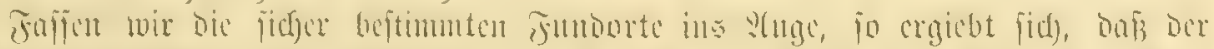

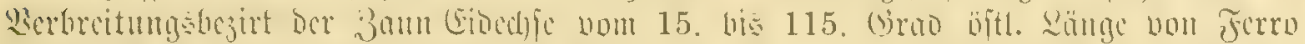

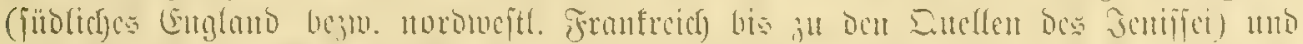

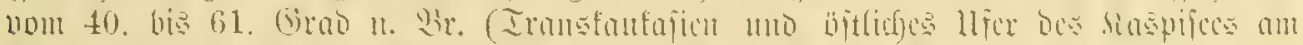

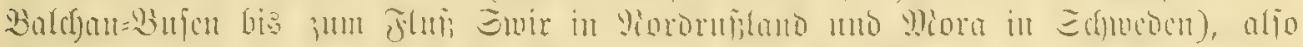

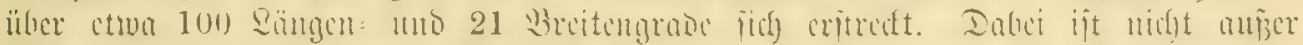

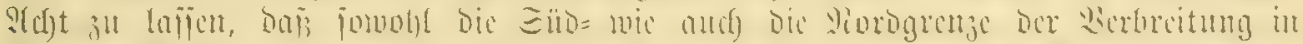

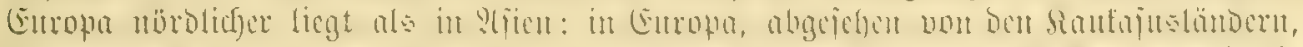

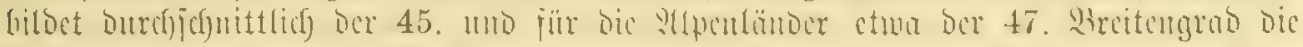

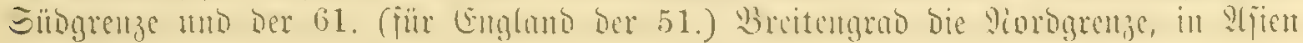

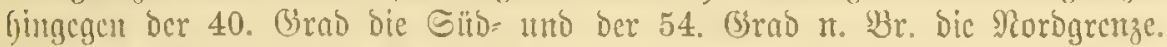

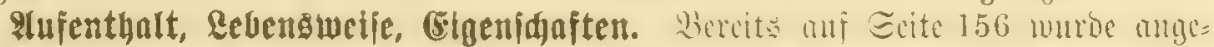

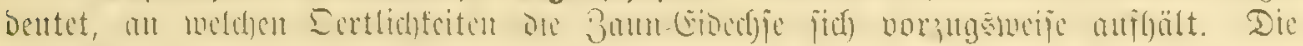

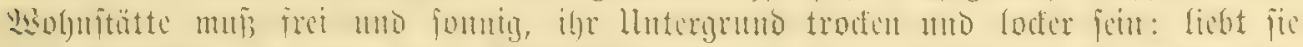

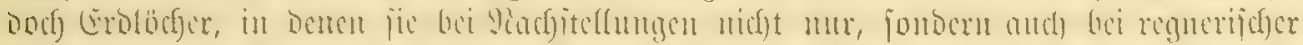

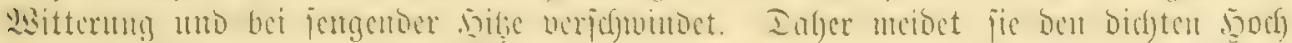

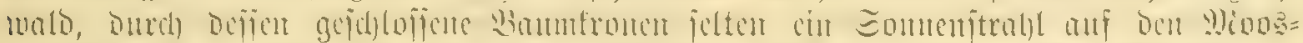

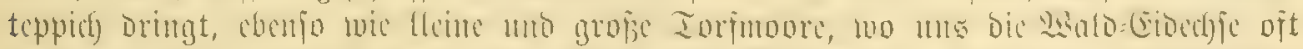

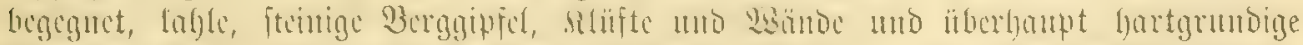

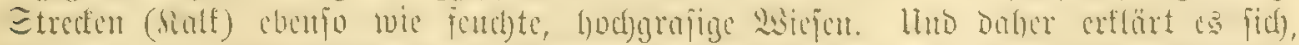

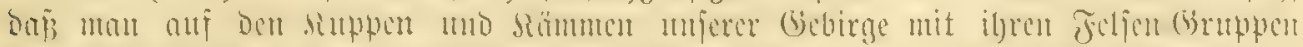

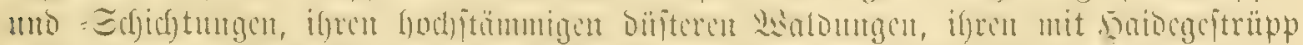

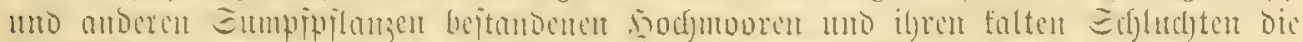

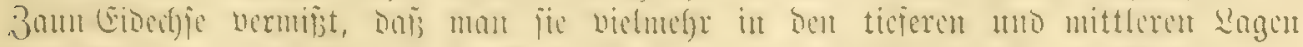

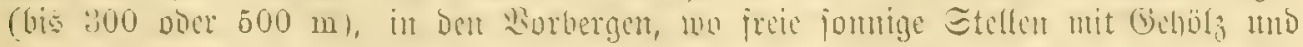

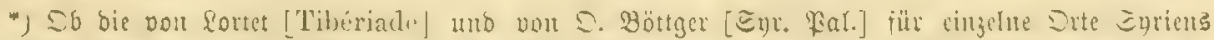

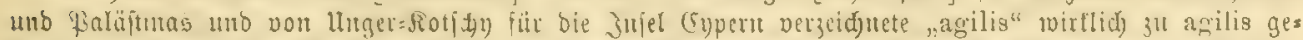

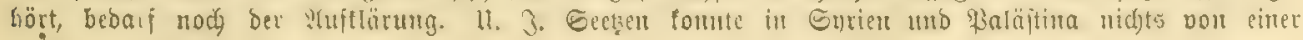
agilis entbefen. 


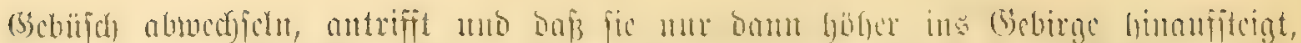

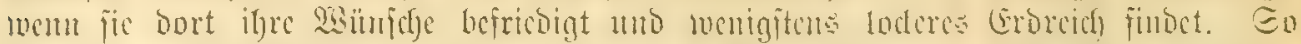

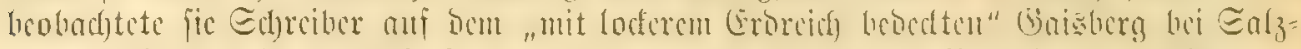

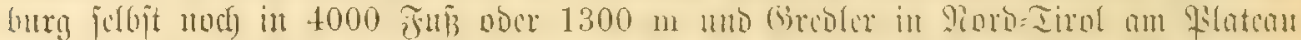

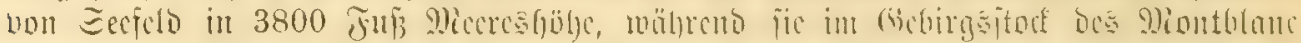

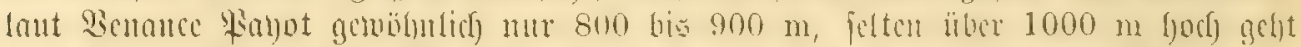

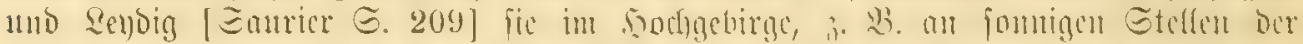

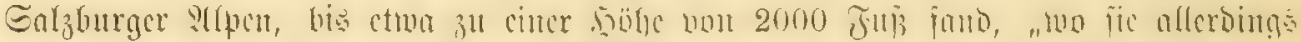

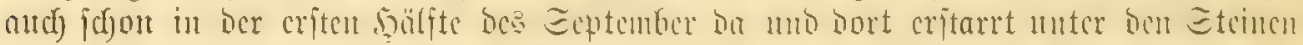

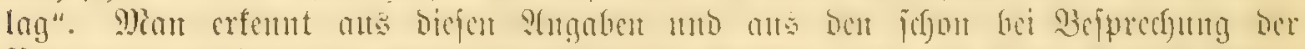

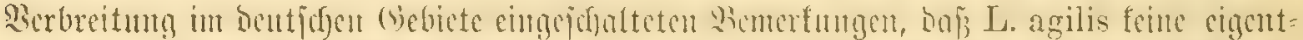

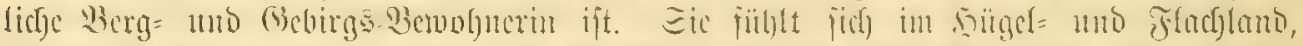

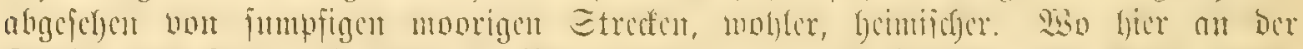

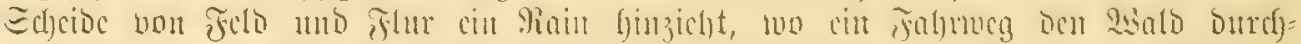

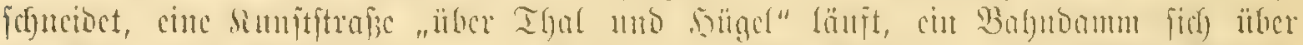

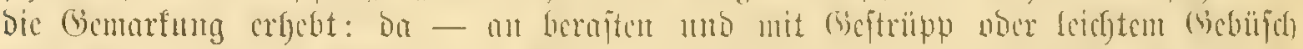

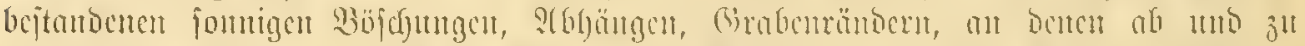

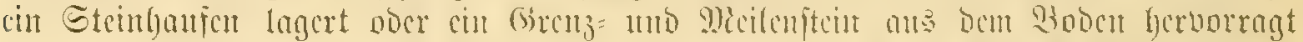

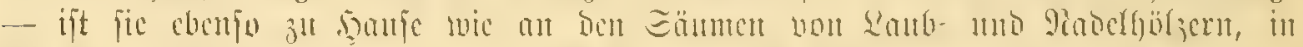

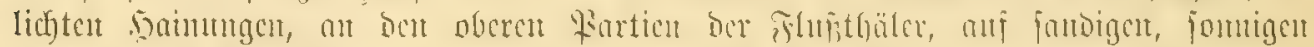

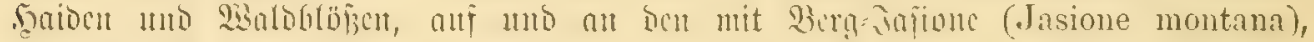

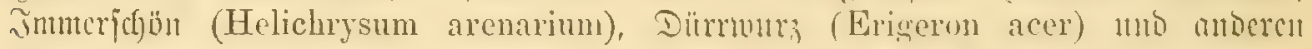

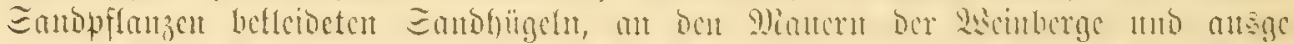

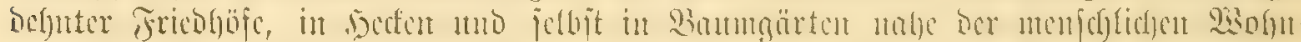

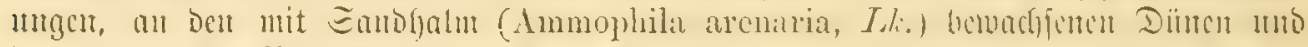

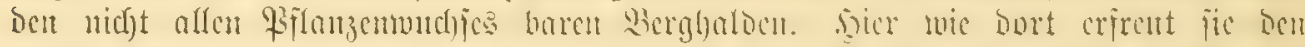

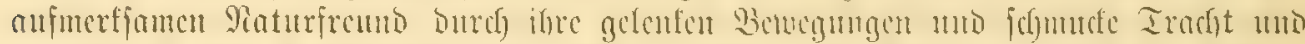

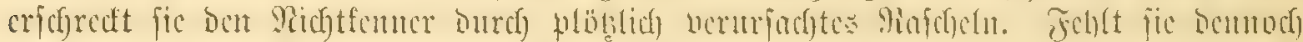

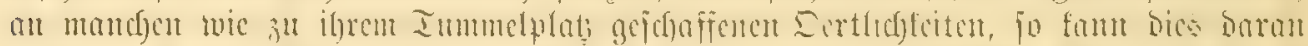

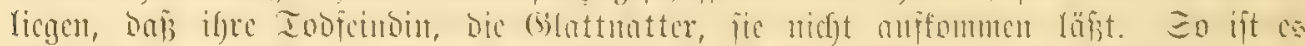
nad) 83 . Jung

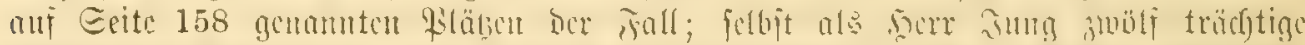

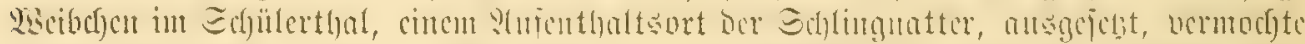

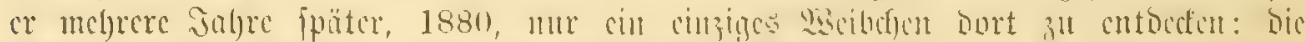

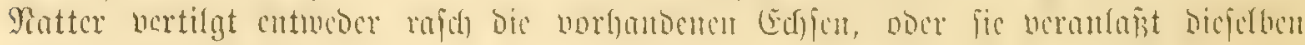
zum fortwanberu.

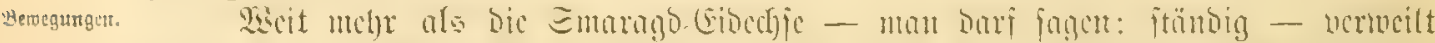

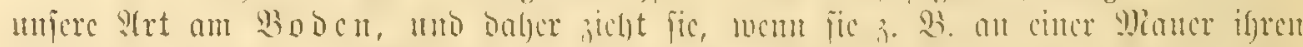

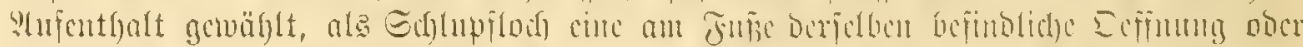

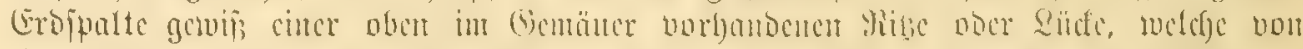

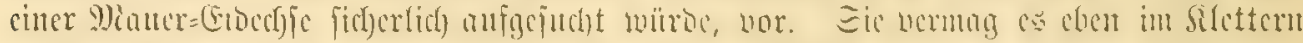

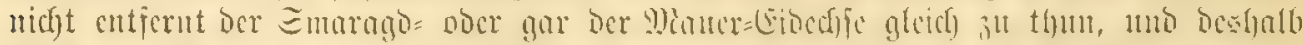

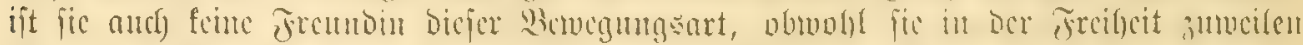

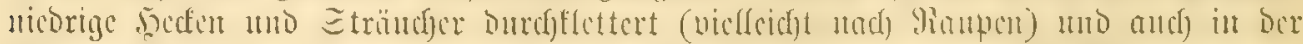

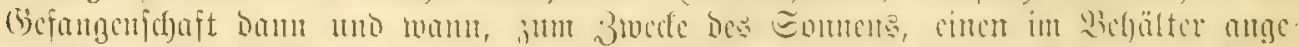

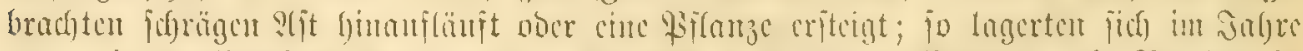

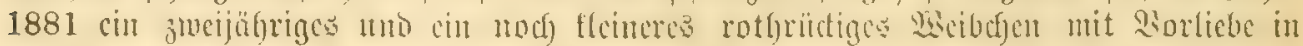

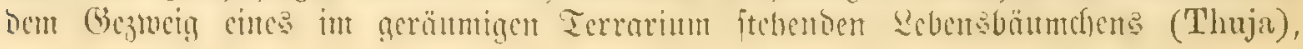




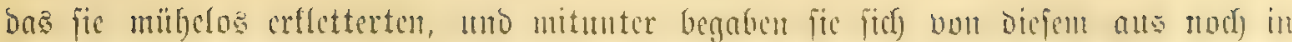

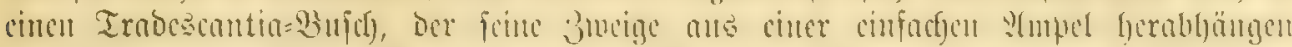

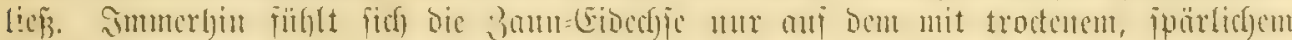

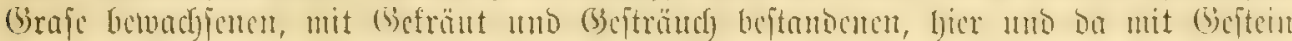

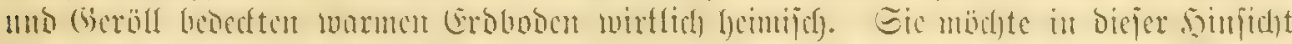

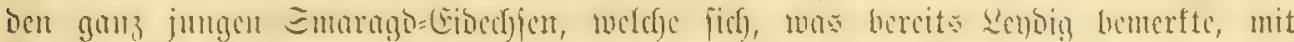

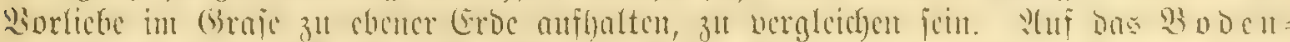

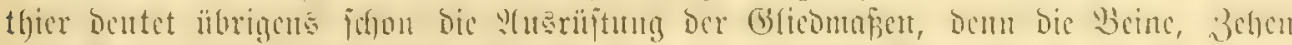

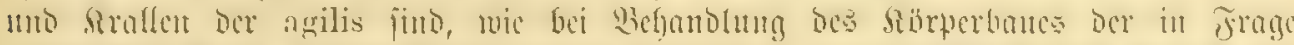

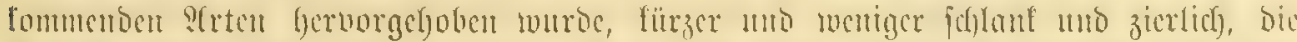

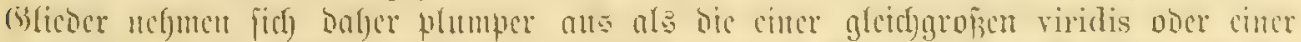

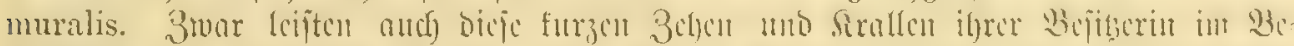

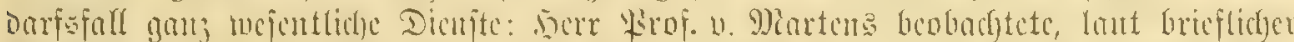

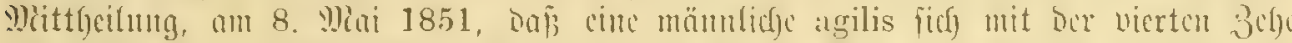

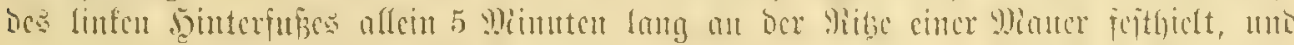

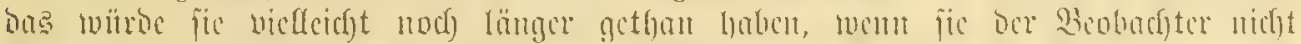

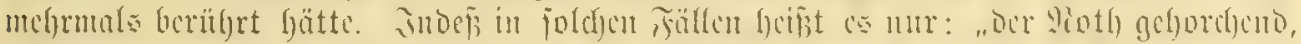

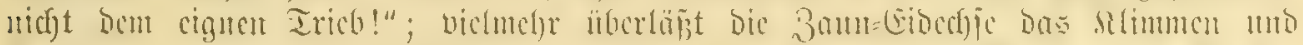

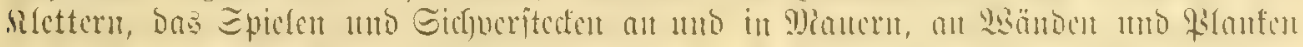

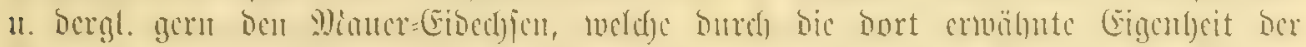

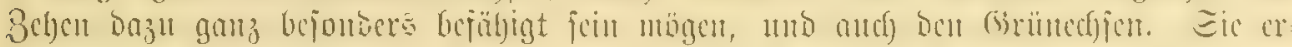

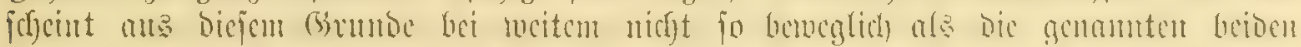

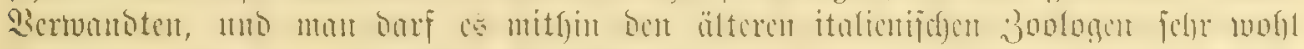

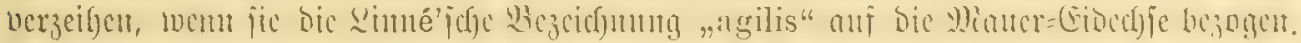

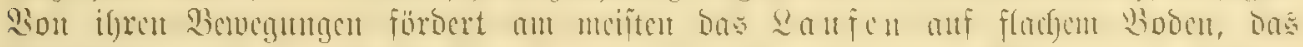

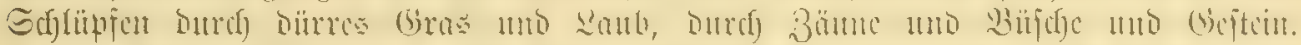

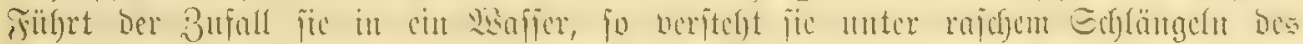

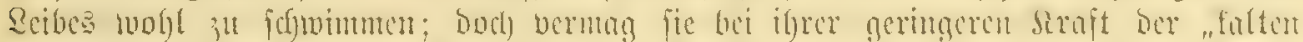

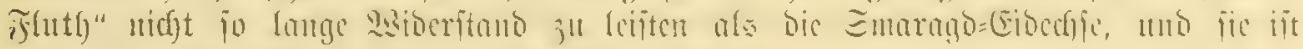
Daber bent Ertrinfen nodid cher ausgejebt ale bicje.

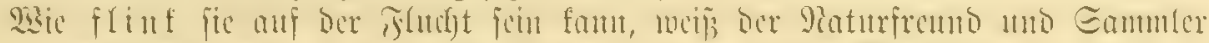

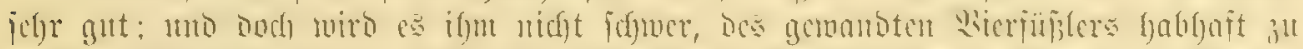

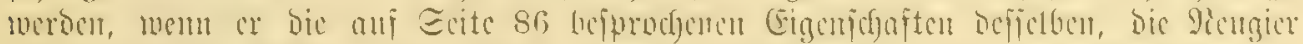

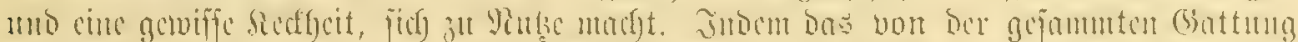

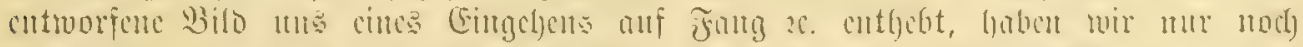

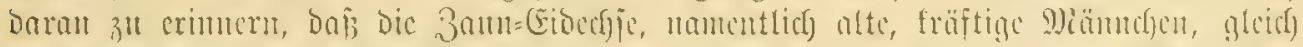

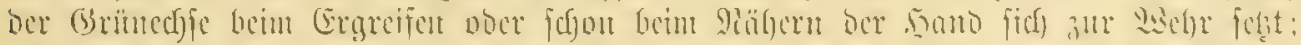

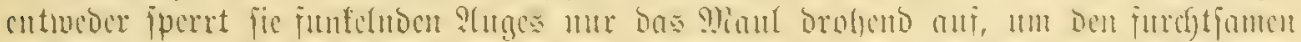

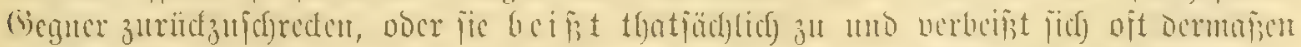

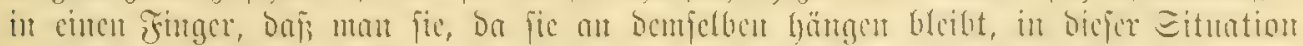

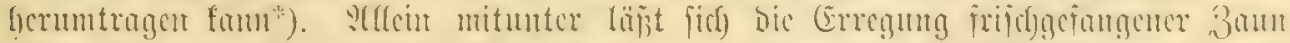

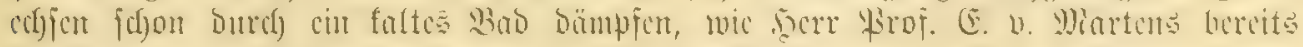

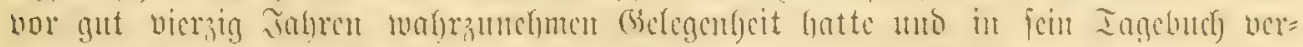

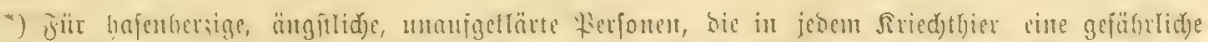

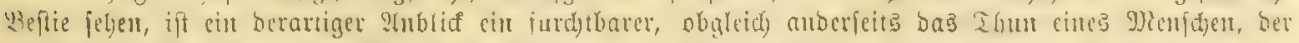

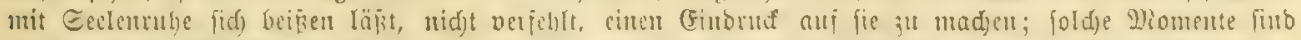

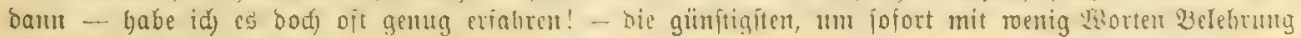
unb श口ifflärung su fdafien. 


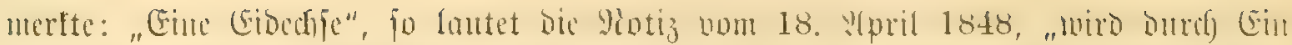

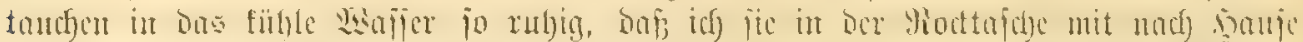

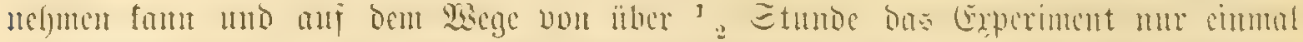

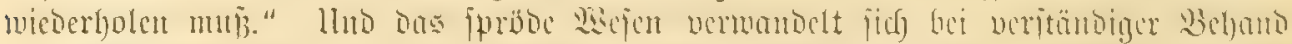

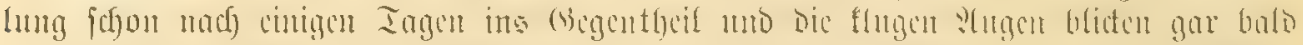

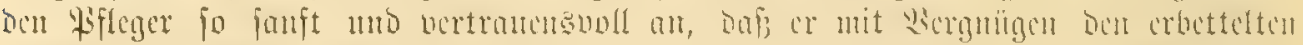

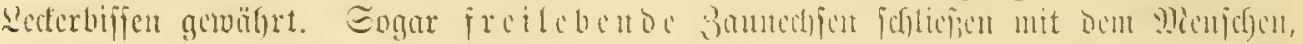

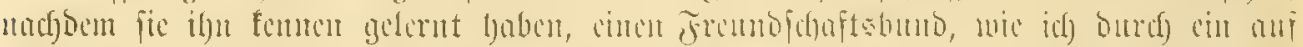

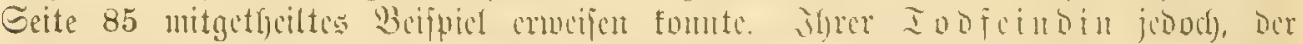

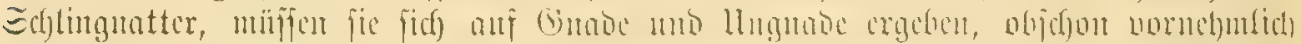

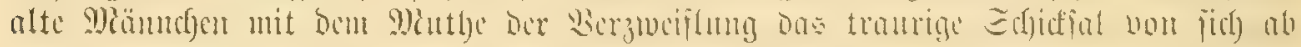

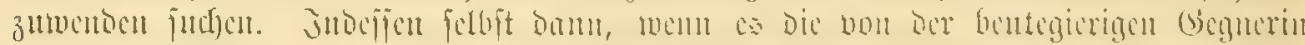

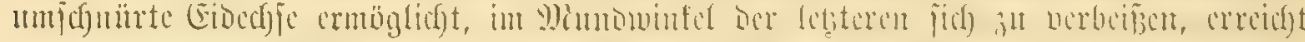

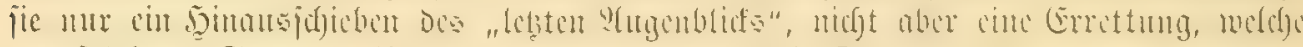

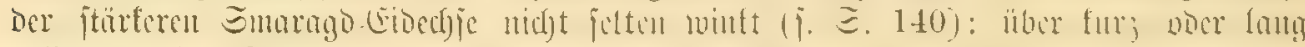

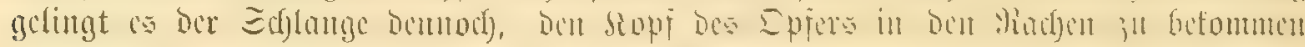

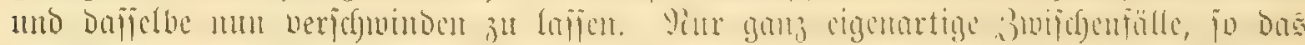

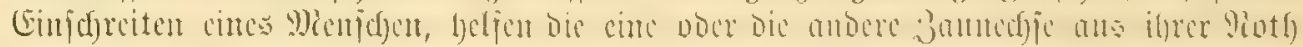

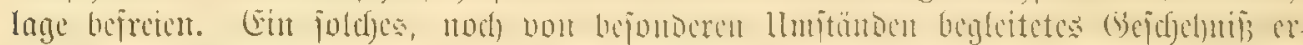

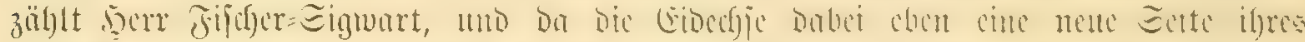

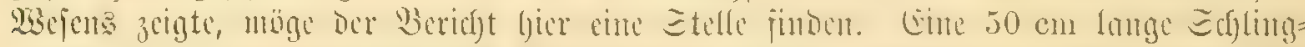

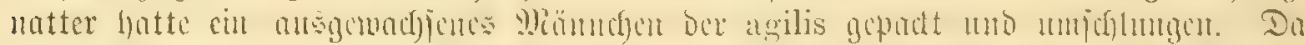

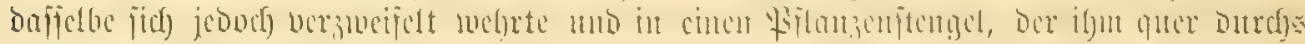

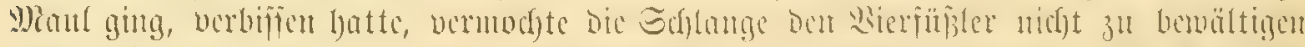

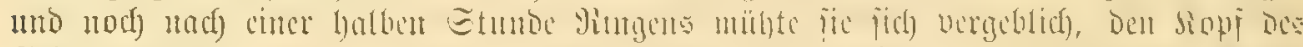

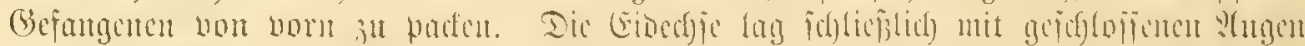

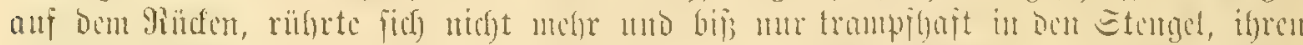

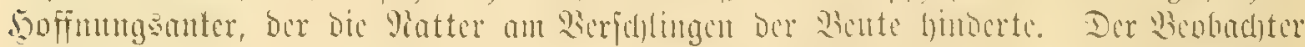

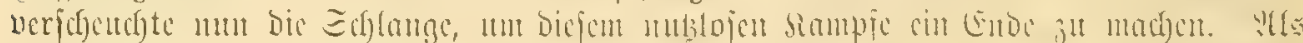

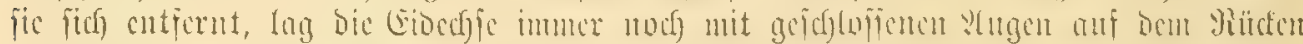

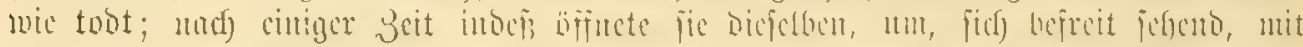

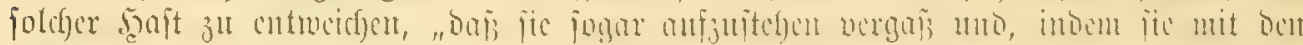

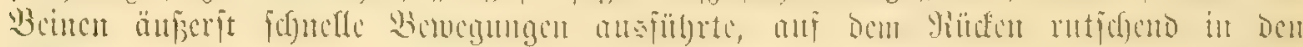

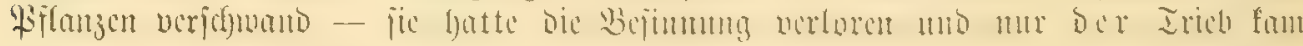
jebt iut ifr auf, fich möglichjt ichutell zu retten".

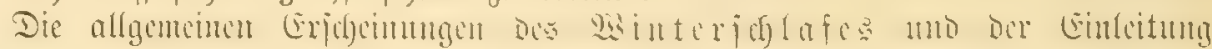

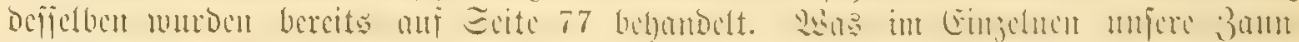

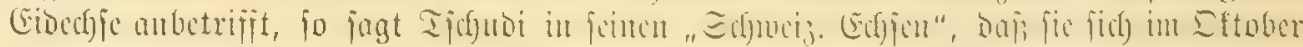

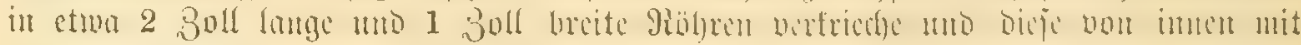

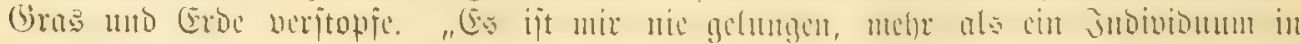

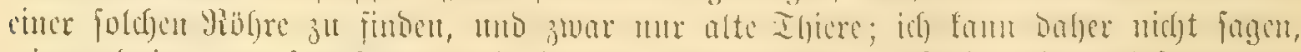

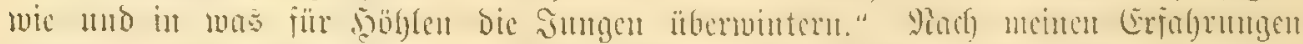

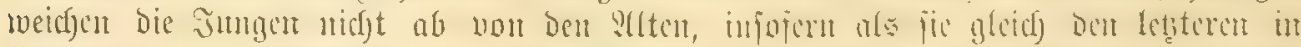

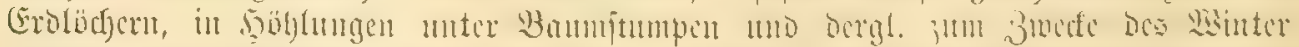

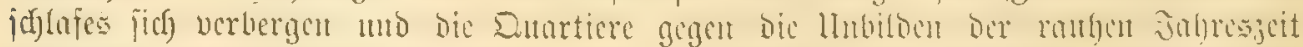

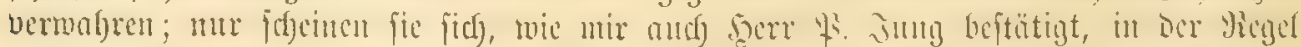

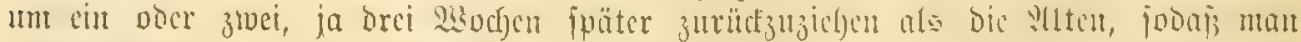

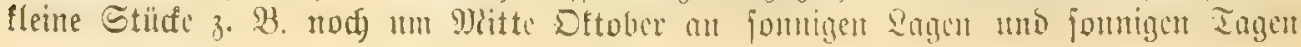




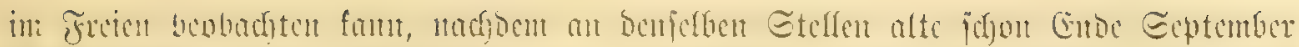

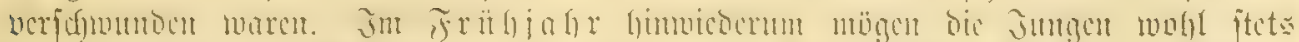

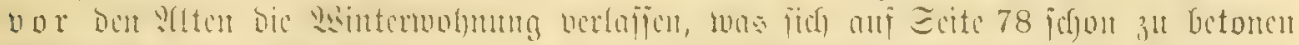

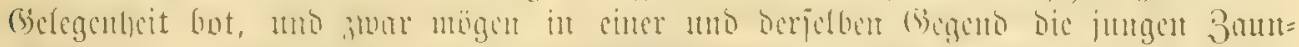

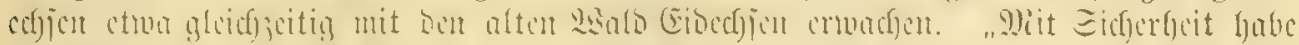

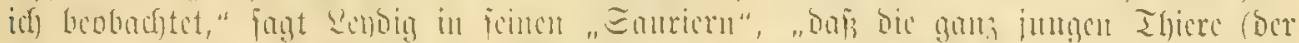

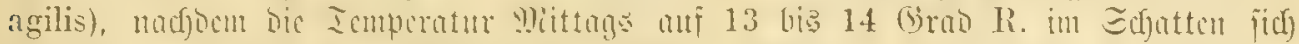

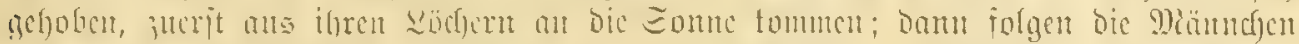

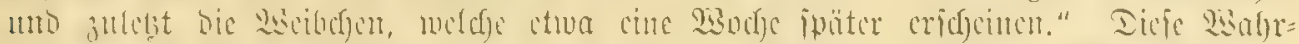

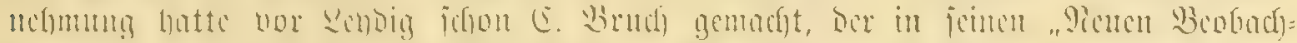

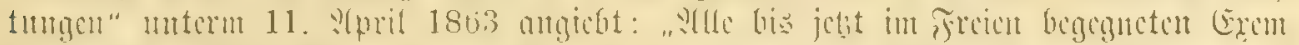

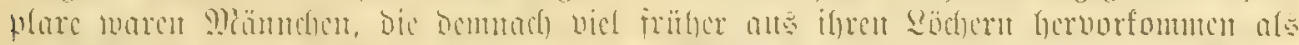

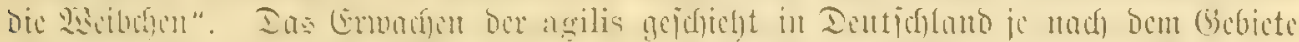

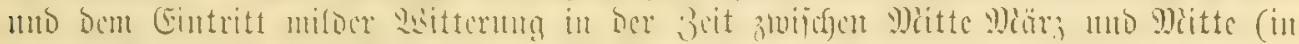

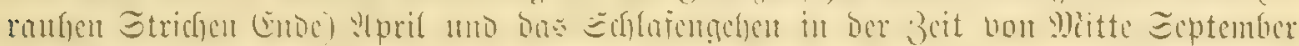

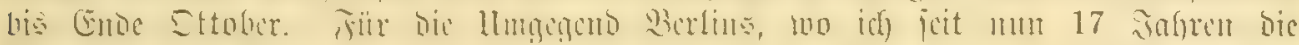

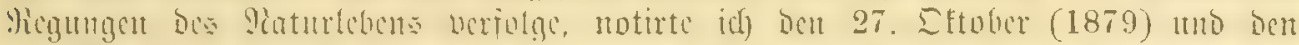

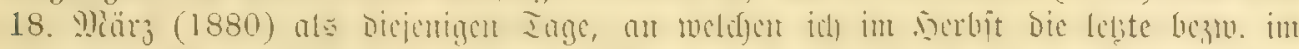

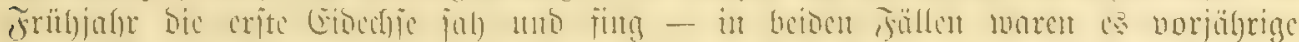

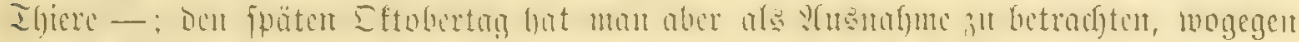

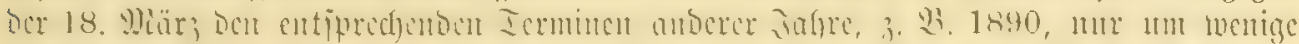

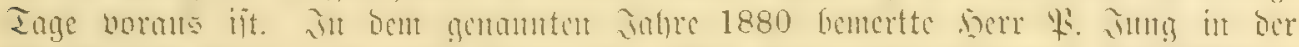

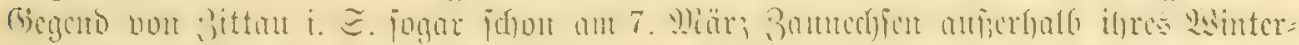

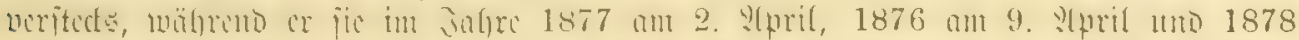

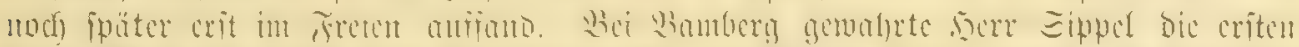

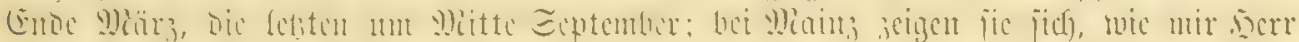

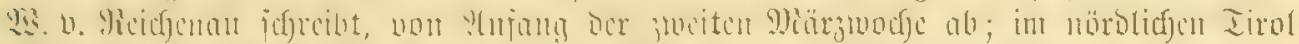

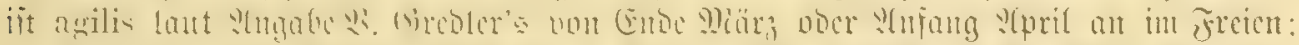

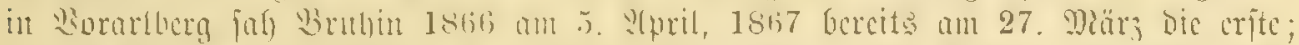

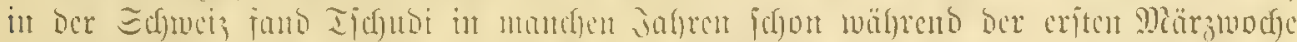

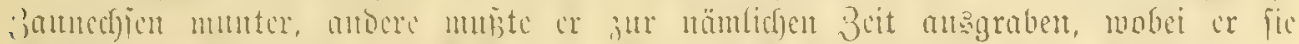

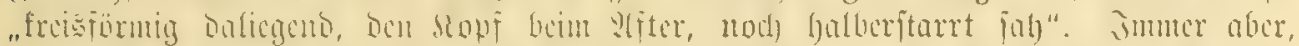

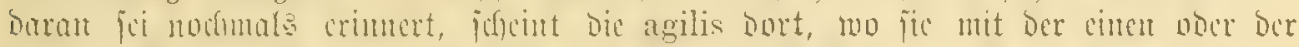

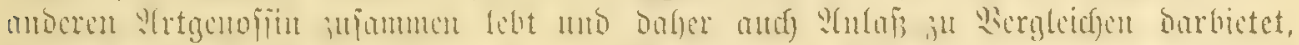

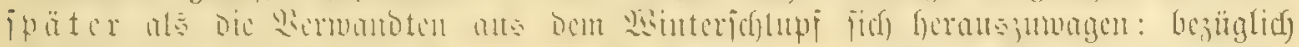

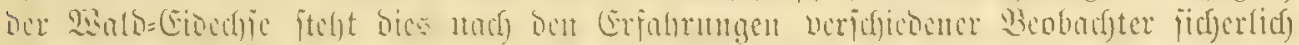

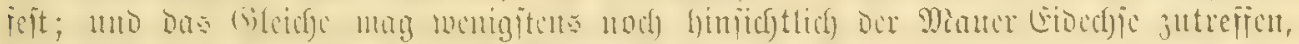

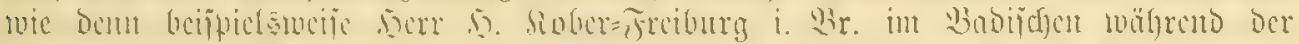

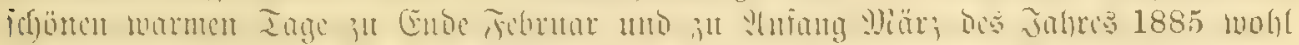

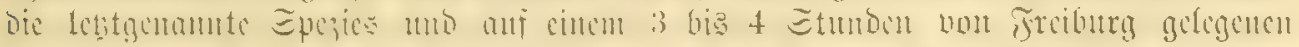

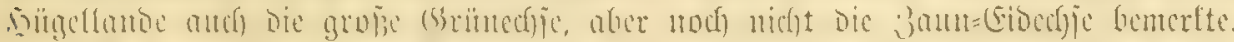

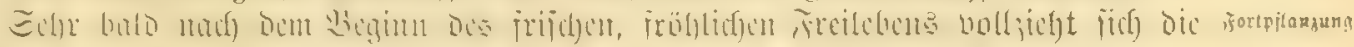

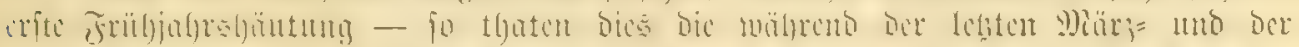

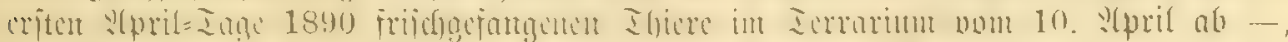

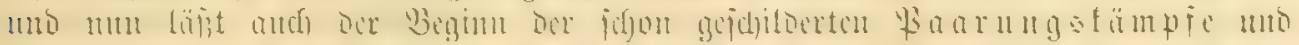

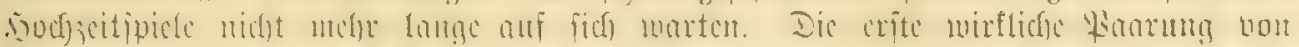

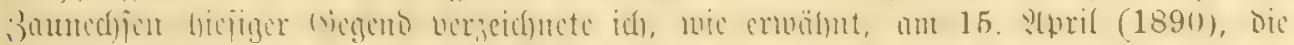

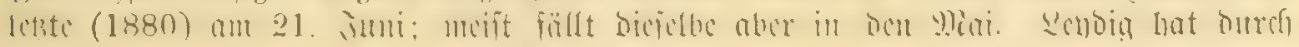




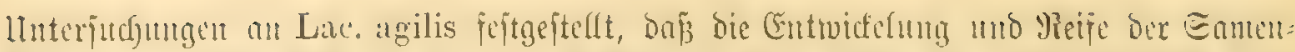

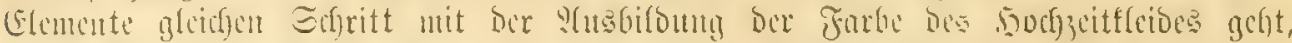

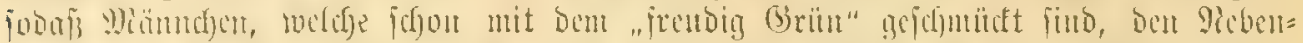

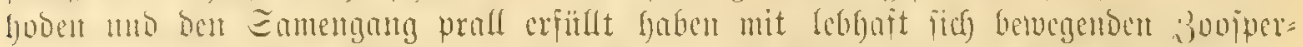

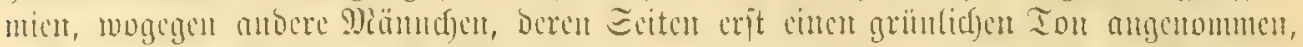

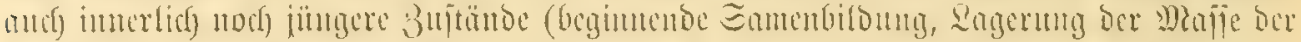

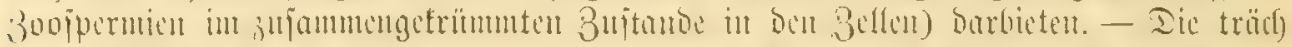
tigen

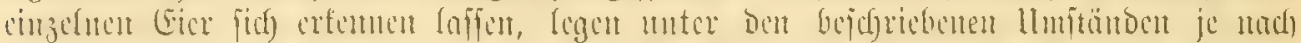

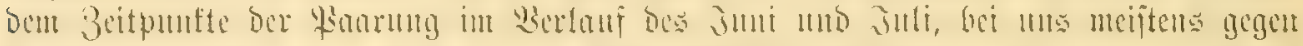

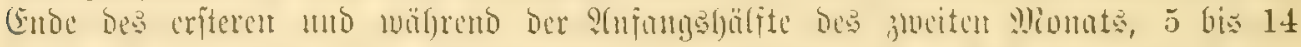

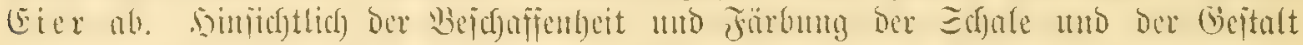

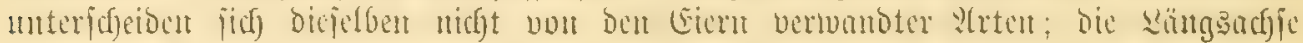

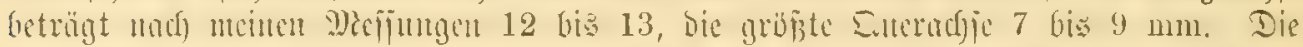

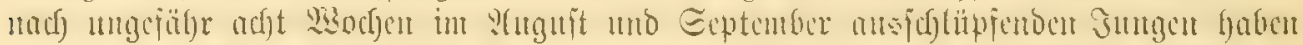

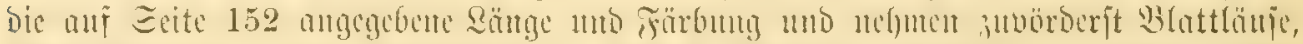

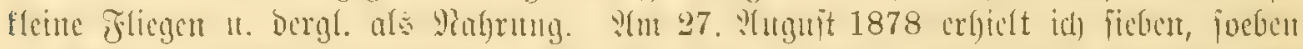

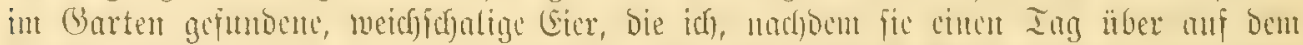

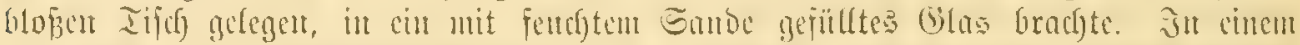

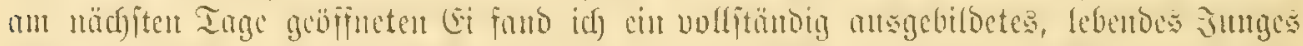

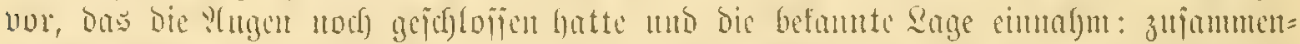

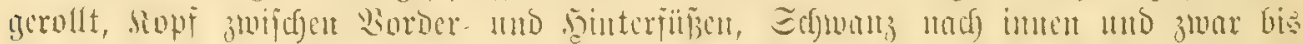

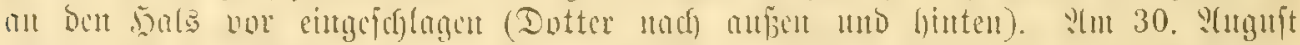

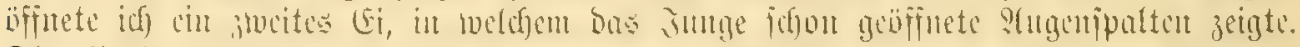

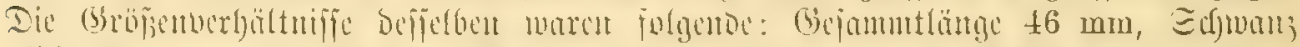

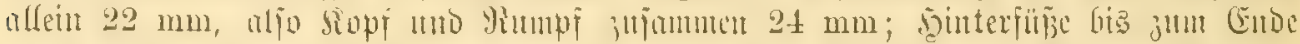

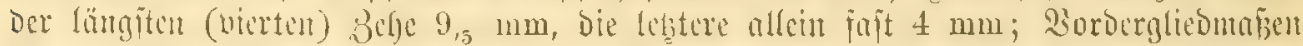

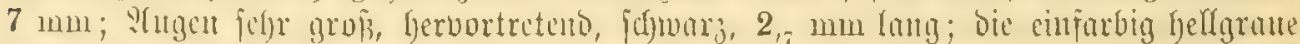

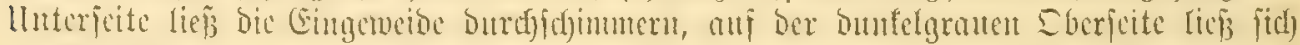

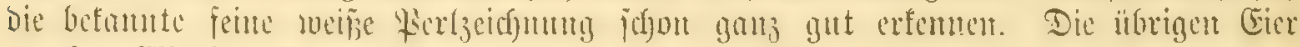

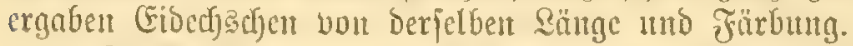

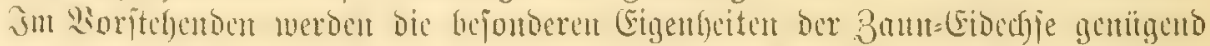

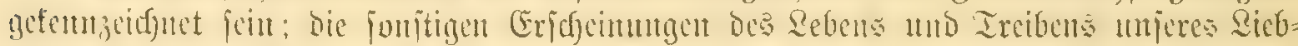

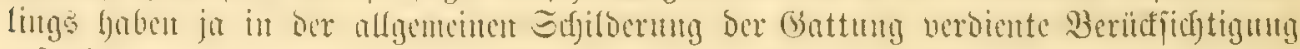
gefunden.

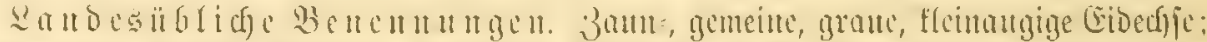

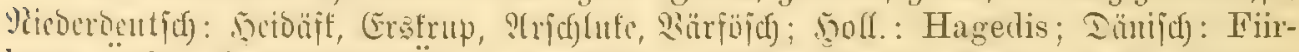
bene, Ögle: Erfowedifol: Ödla, Sandüdla, Fyrben, Fyrfot; Engl.: Samd Lizard: Tranj.: Lézard des Souches; Mindlonifor): Lougeard; Ital.: Lacerta dei ceppi;

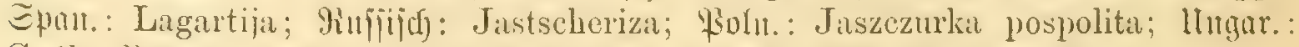

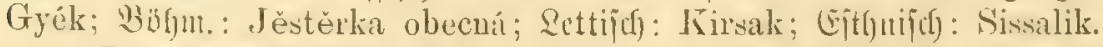

Lacertal communis, Gesner 1554. - Lacerta indigena viridis, Schu 1734. Lacertar agilis, Limmi 1766 [partim]. - Seps calerulescens, Lanrenti 1768. Lacerta agilis et Lacertus pardus, Razoumowsky 1789. - Lacerta agilis Wolff 1799. - Lacerta sepium, Griffith 1831. - Lacerta europaca, Pullas 1831 [partim]. - Lacerta stirpium, Bonaparte 1839. - - Eng Ma it ud c n: Lacertit viridis, Limu $17 \pm 6$ (var. (i) : Lacerta viridis var. c, Lutreille 1800; Lacerta stirpium, Daudin 1803. - Das ws cif cf c n: Lacerta viridis var. c, Latreille 1800; Lacerta 
arenicolat, Demelin 1803. - In Jüge: Sep; argus, Lementi 1768; Lacerta

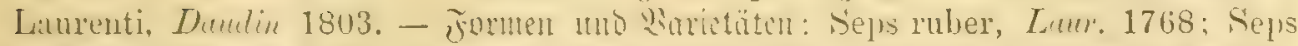
stellatus. Silerank 179s; Lacerta rubra, Mluhu 18:31; Lacerta agilis vill. ("rythronotus, Fit:imer 1826; Lacertal stellatit, filieliselin 1832. Lalcertat sericea, Glüclix. 1851. Lacertal chersoneusis, Awlrij. 1832. Lacentar sylvicola, Eversmemn 1834. Lacerta exigua et colchica, Eichwald 1842.

\section{3. $\mathfrak{L}$ rt: Wald=Eidedffe, Lacerta vivipara, Jaquin. 2bbildung: ₹ajel XII भir. 1 u. 2.}

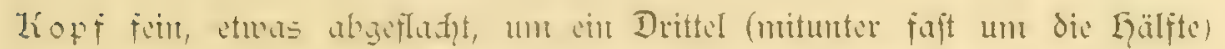

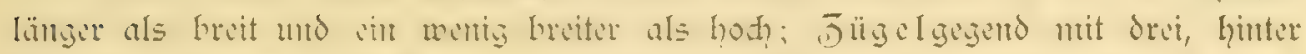

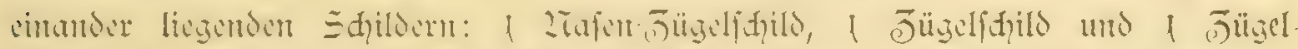

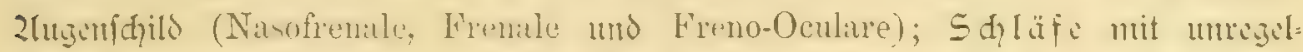

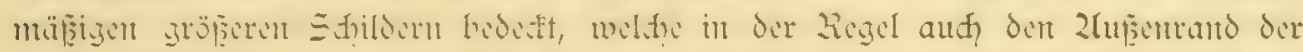

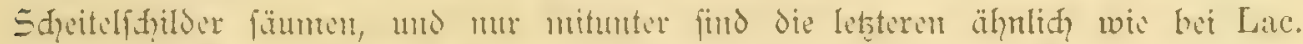

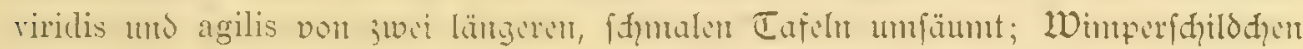

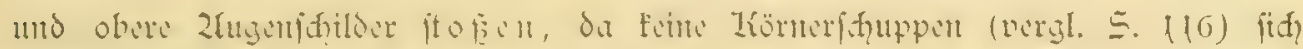

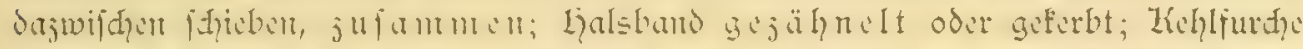

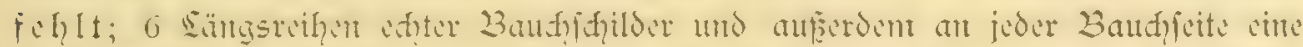

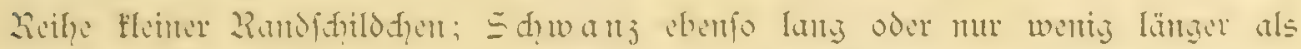

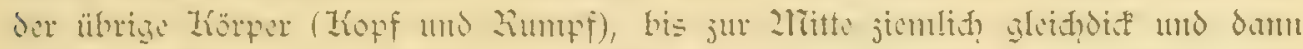

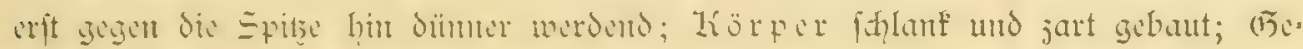
fantmtlänge 10,5 bis 15 oder $16 \mathrm{~cm}$.

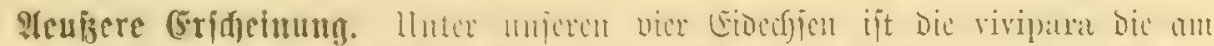

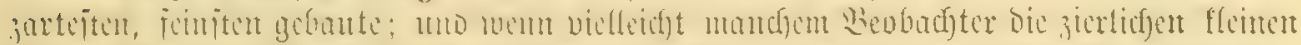

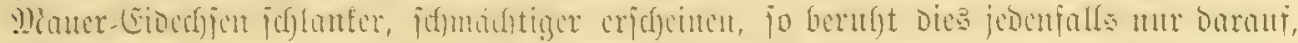

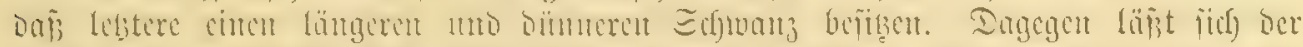

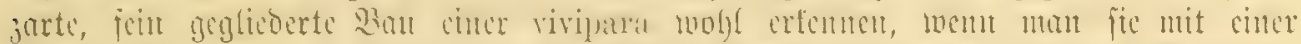

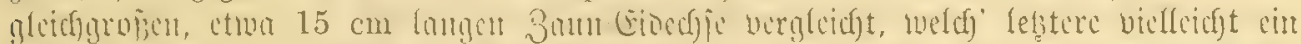

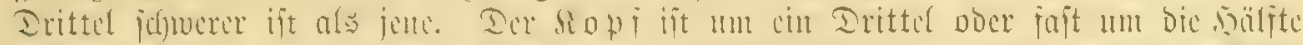

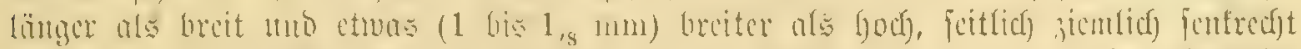

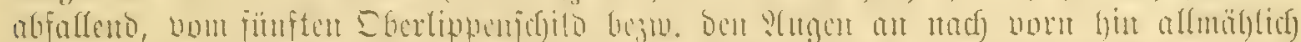

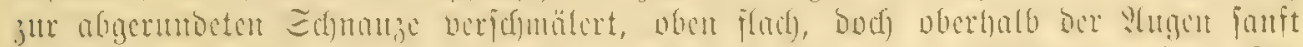

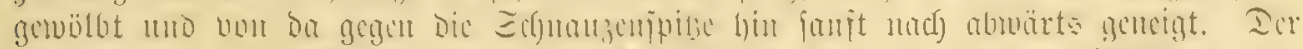

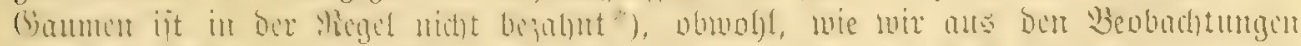
menge

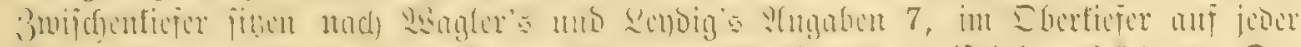

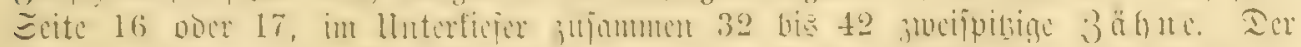

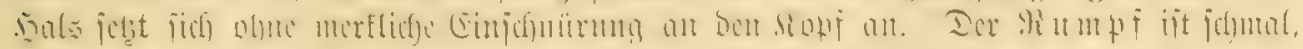

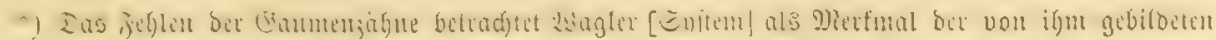

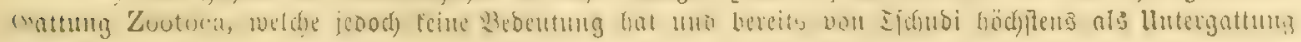
angefegen witb. 


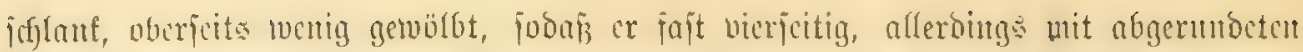

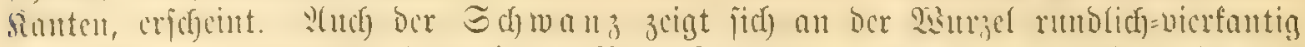

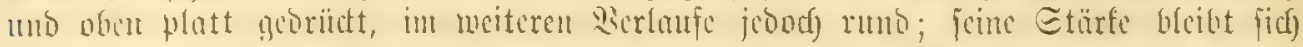

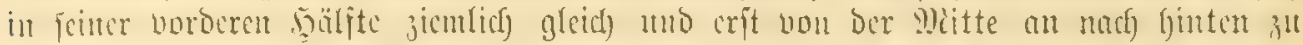

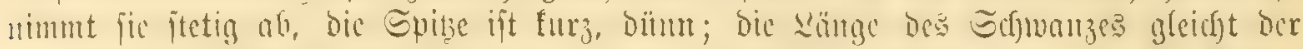

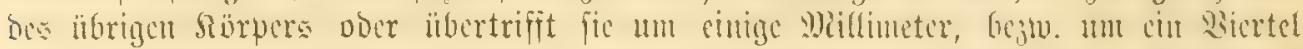

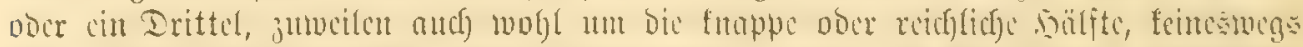

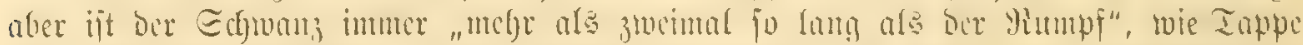

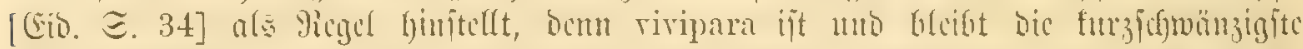

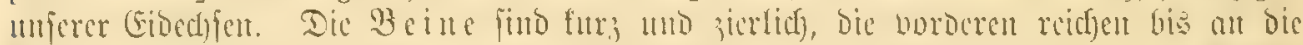

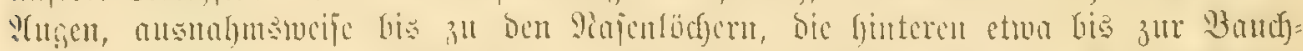

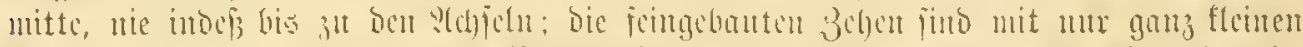

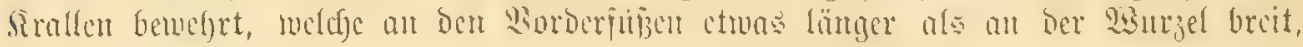
an ben Sinteriüizen fajt boppelt jo lang als breit erfichenen.

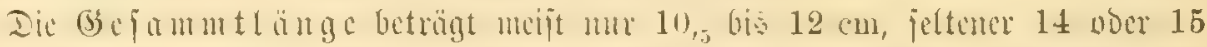

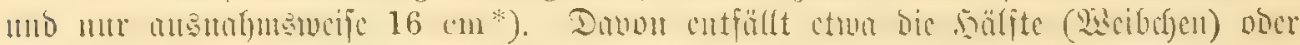

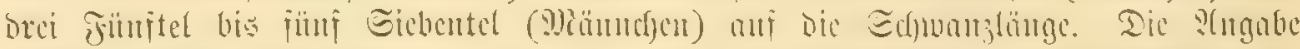

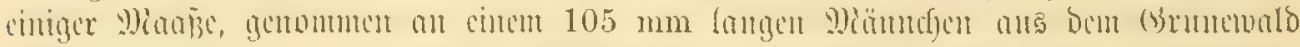

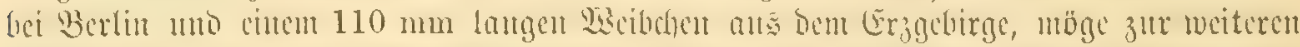

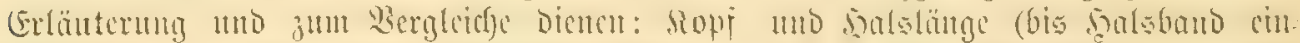

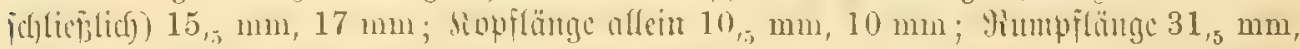

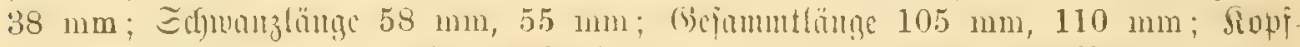

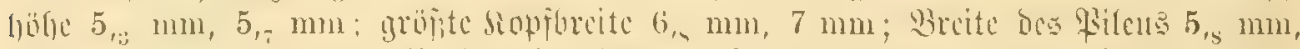

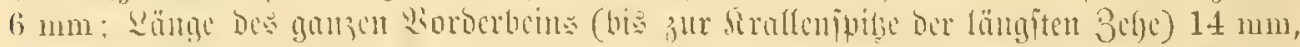

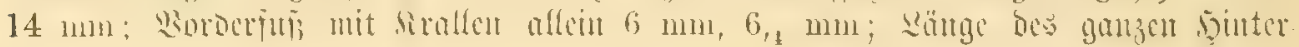
bein $20, \mathrm{~mm}, 21 \mathrm{~mm}$; 5intcruin mit Sirallen alleit $10 \mathrm{~mm}, 10_{15} \mathrm{~mm}$.

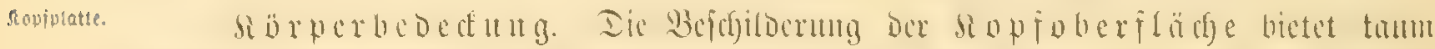

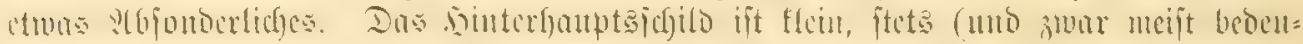
-... tend) flemer ale bas bavor liegende meift fünfectige, vorut

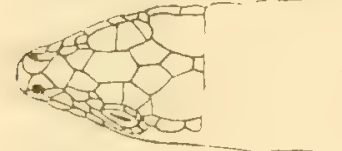

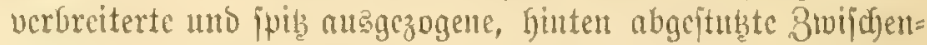

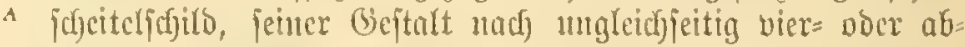

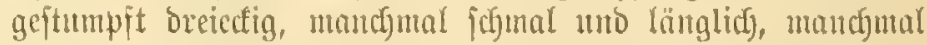
breiter. Dic Sdjeiteljujlocr jumb furz und breit und an ber

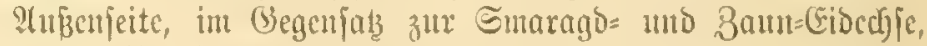

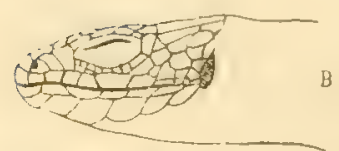

Fịn. 18. Sopf ber 28alb: (Gibed)ie.

A. Don obch, B. won ar Eure. in ber Plegel nicht Durd) größzere Tafelu umfäumt, fondern von gewb̈hnlidjen Sdyläfenfdjilodjen umgeten. Dic beiben Stinjicheitelfdjilder fün fünffeitig, mitunter ebenfo lang als Greit, bie Den ?(ugendistuts bildenden beiden mittleren Brauen=

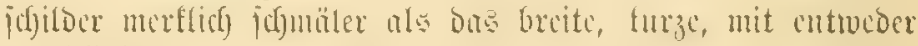
gerublinigen uno parallden ober mur feicht ansgelutchteton

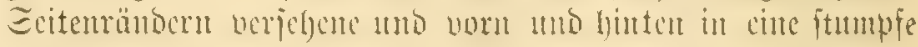

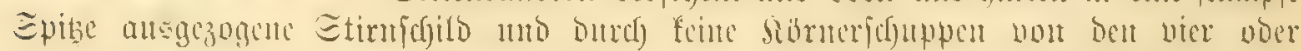

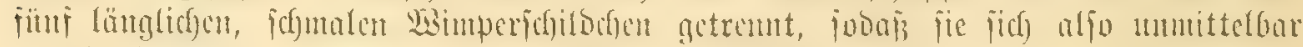

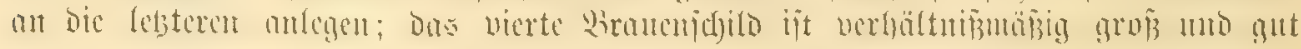

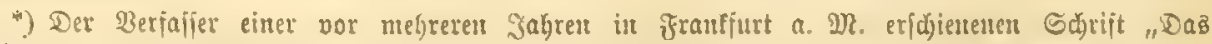

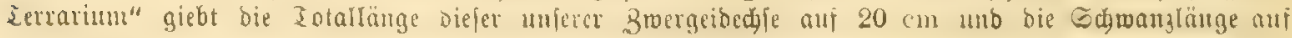
$11,2 \mathrm{~cm}$ aut 


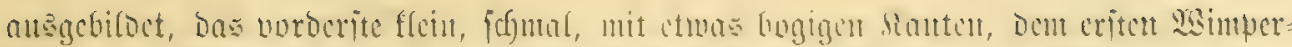

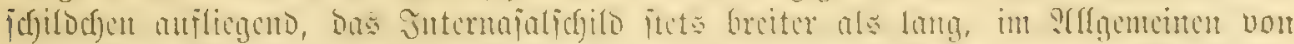

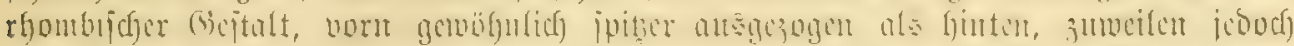

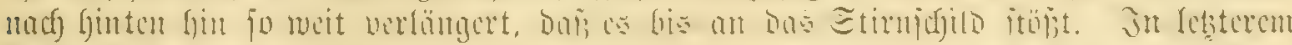

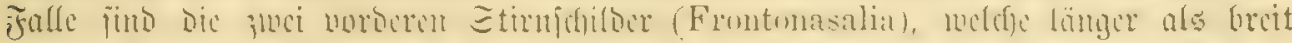

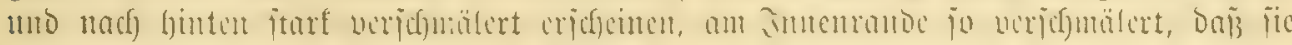

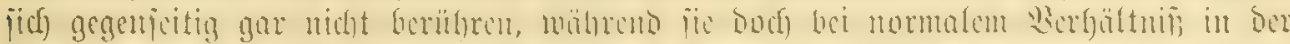

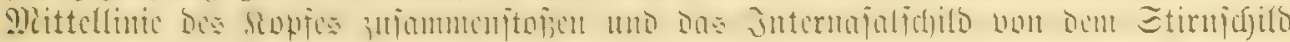

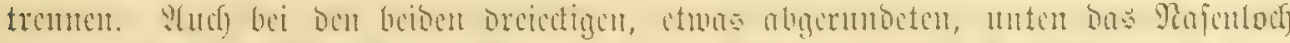

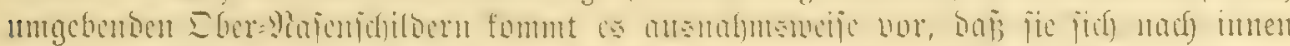

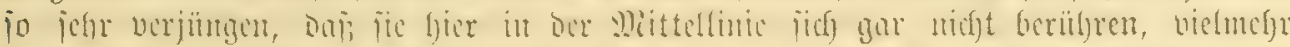

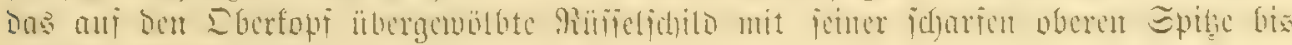
an bas Sinternajalicjillo rcicjt.

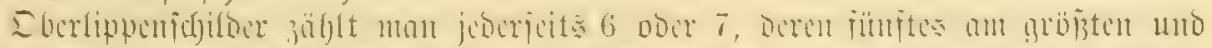

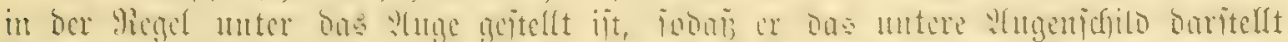

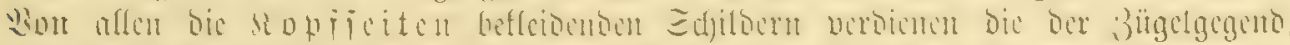

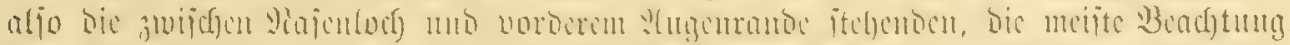

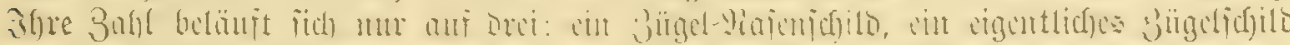

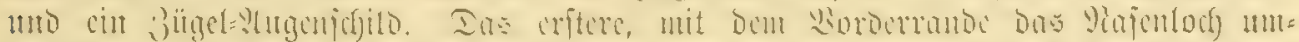

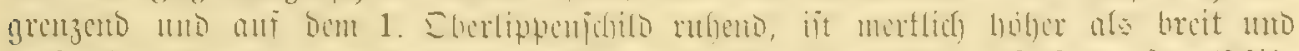

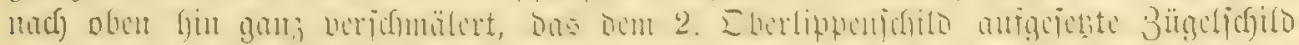

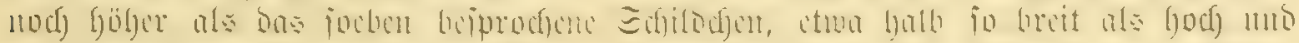

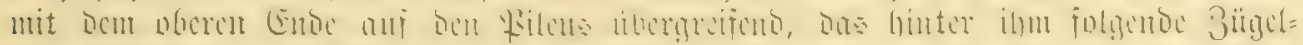

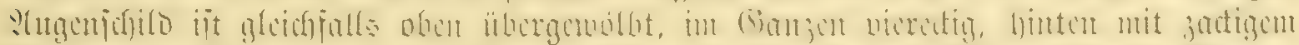

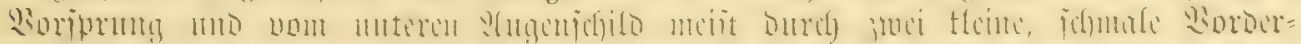

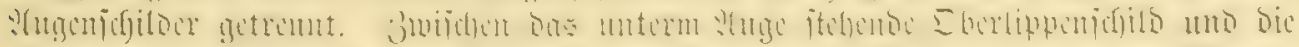

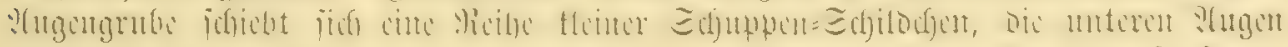

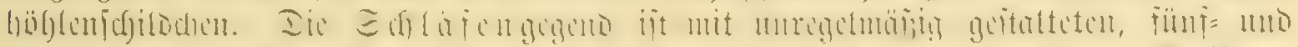

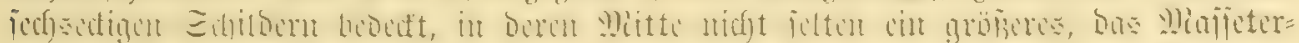

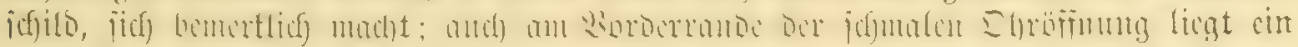

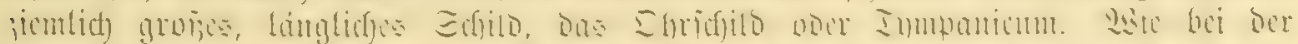

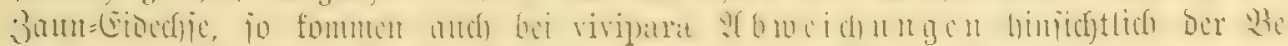

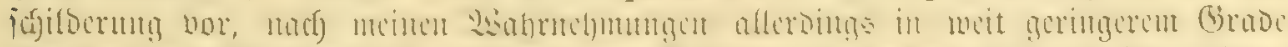

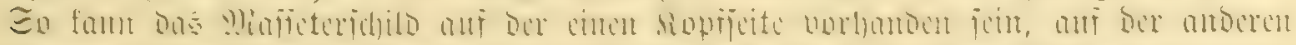

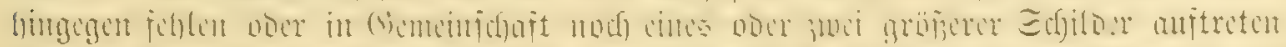

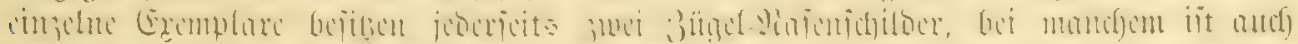

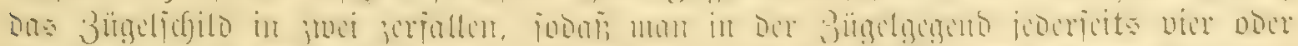

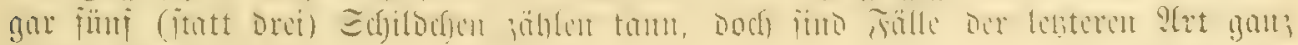

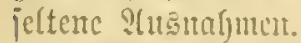

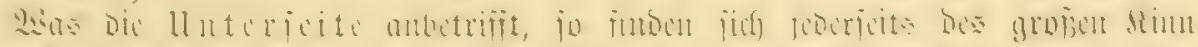

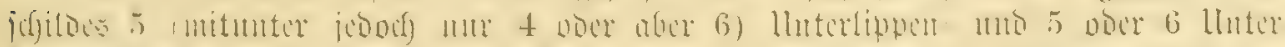

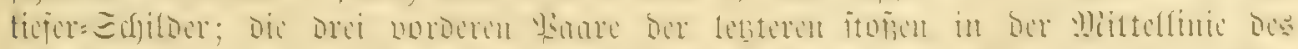

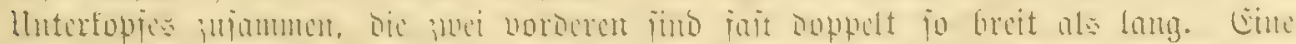

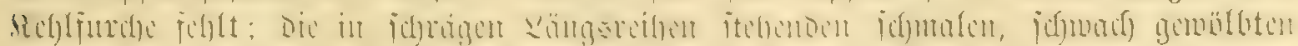

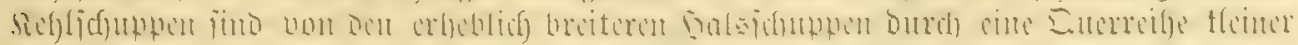

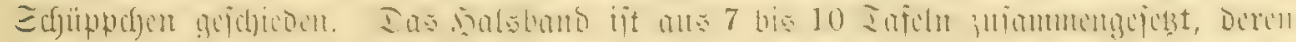

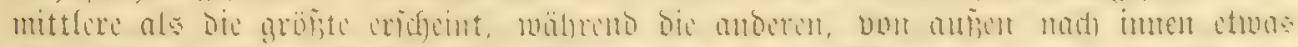

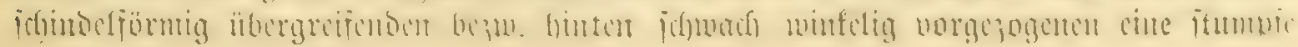




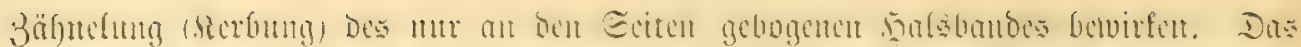

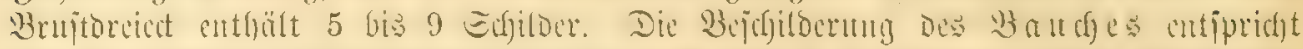

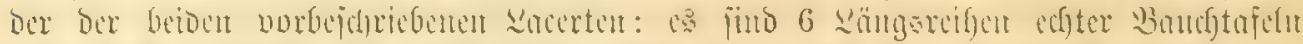

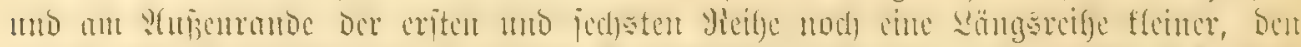

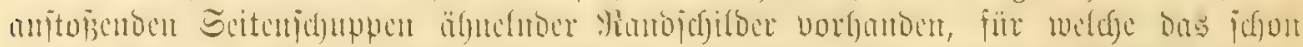

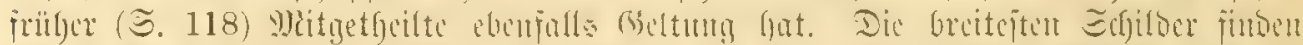

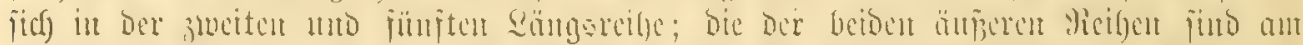

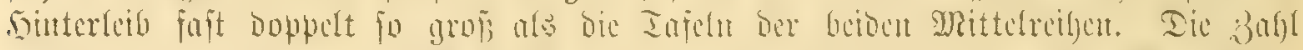

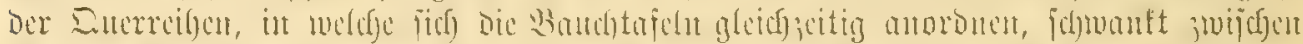

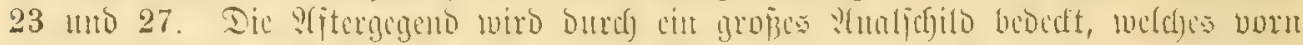

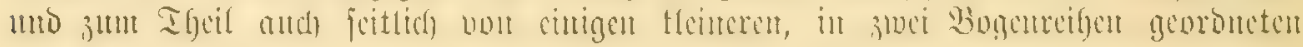
Tafelt umgebent ift, beren beibe mittleren ant gröjten fiub.

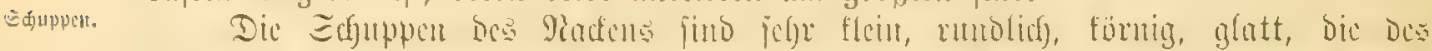

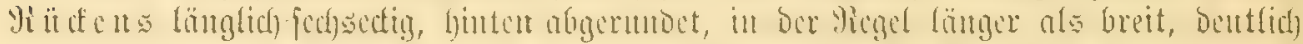

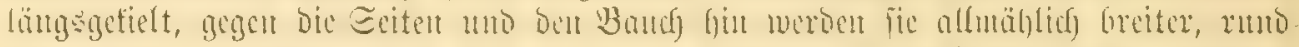

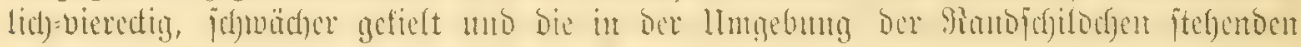

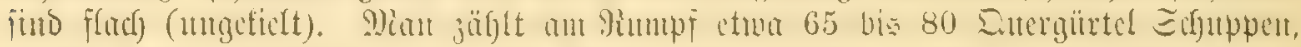

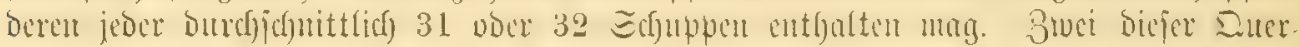

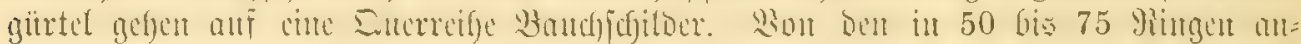

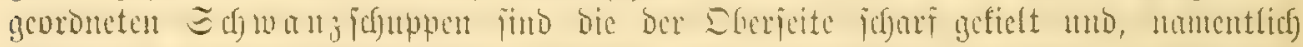

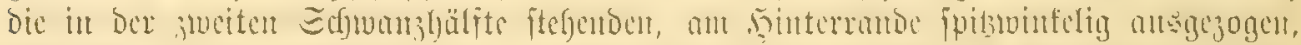

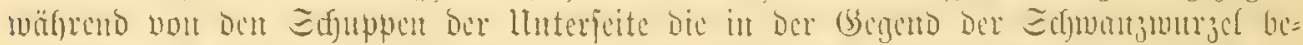

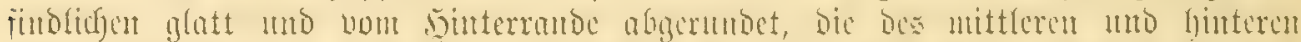

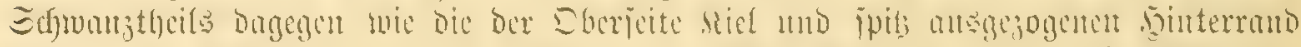

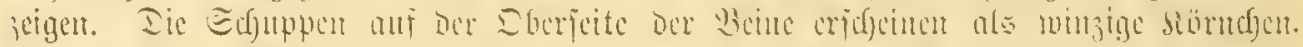

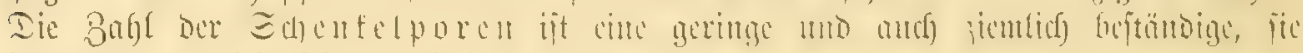
jofwantt nux (jederjeits) ztwijchen 9 utto 12.

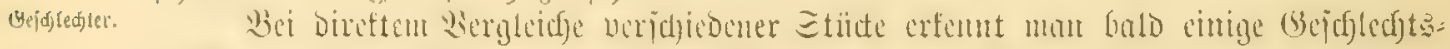

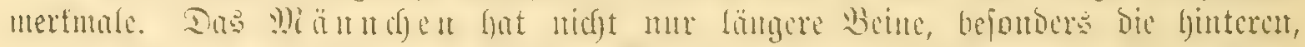

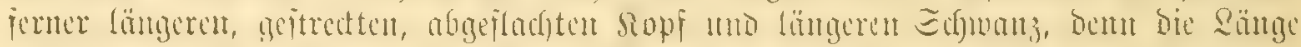

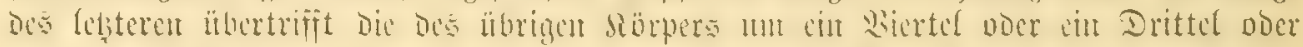

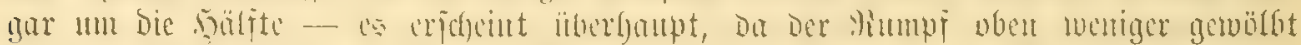

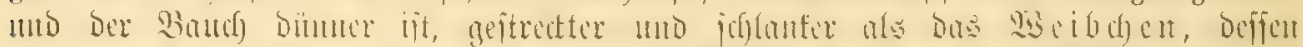

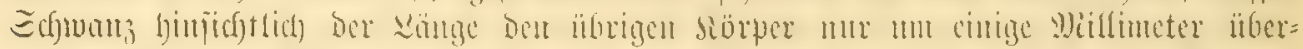

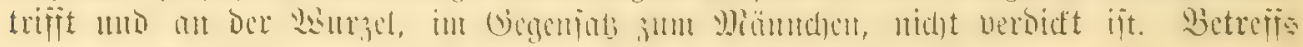

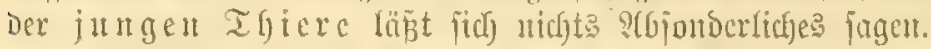

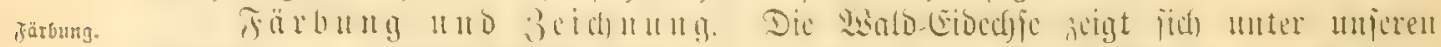

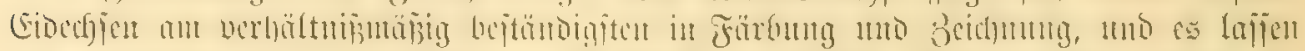

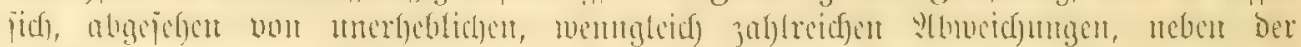

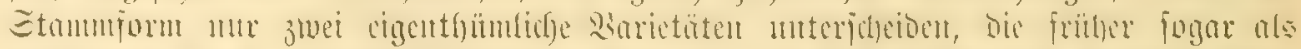

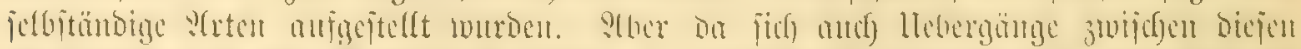

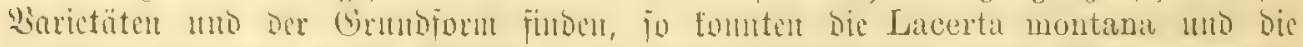

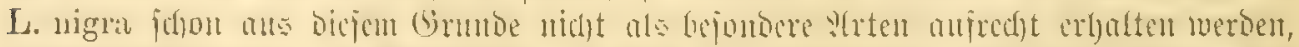

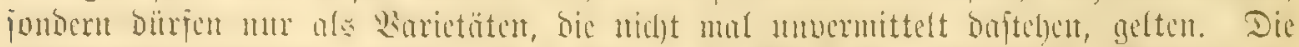

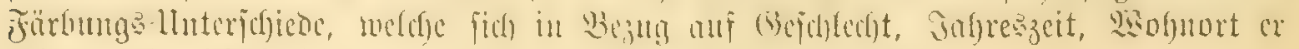
gebest, fino greichfalf mur gering, ja z. Th. Lam bemerfficf.

a) $\Xi$ tamm

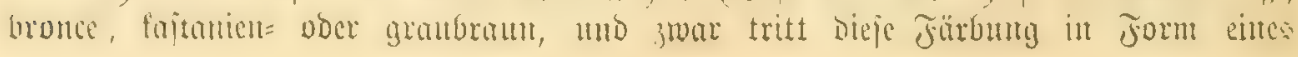




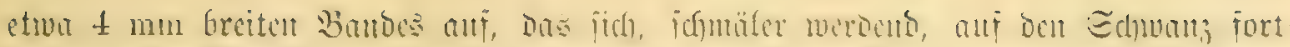

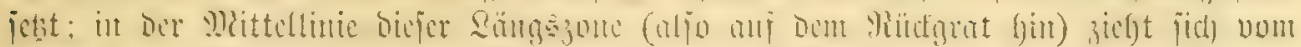

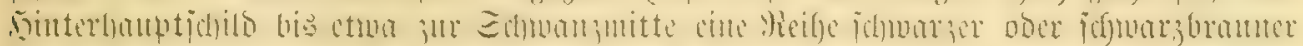

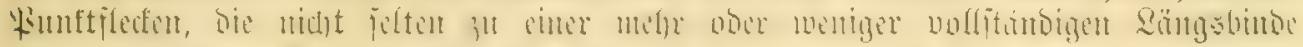

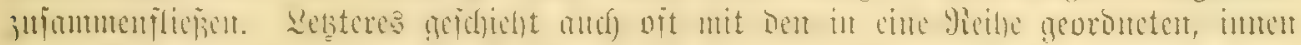

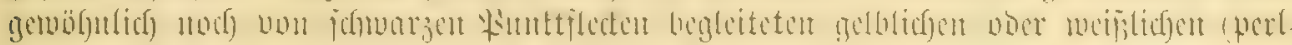

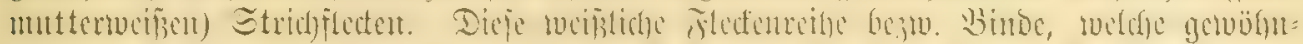

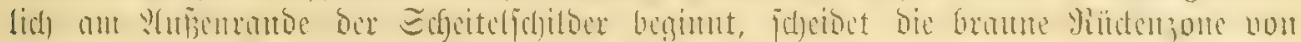

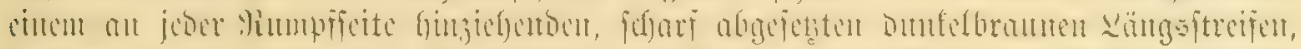

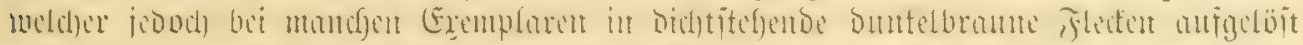

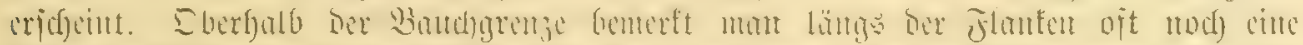

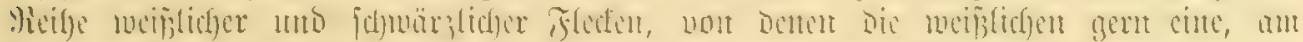

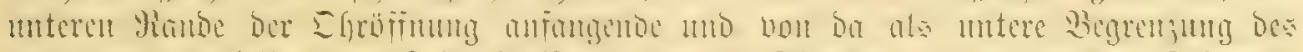

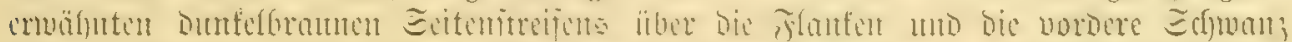

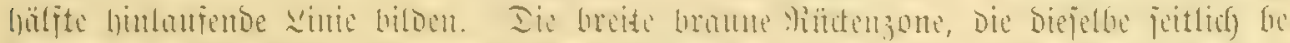

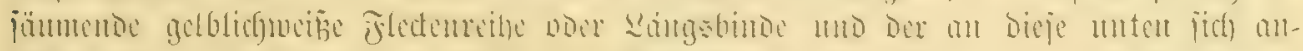

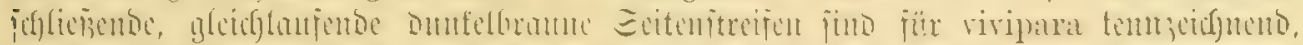

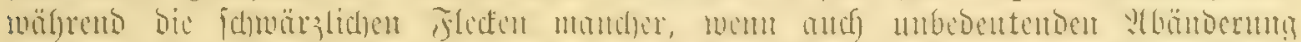

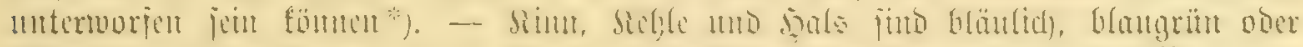

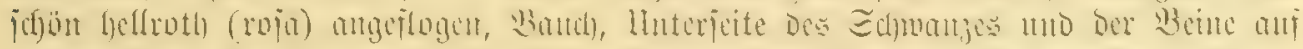

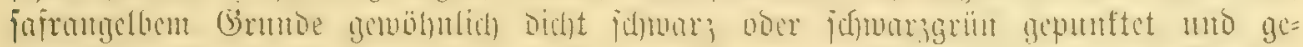

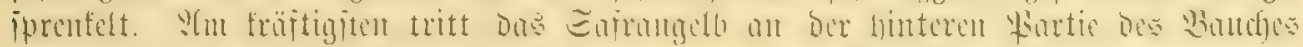

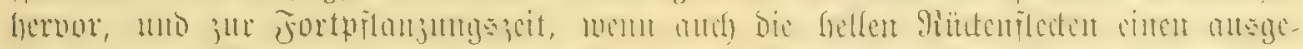

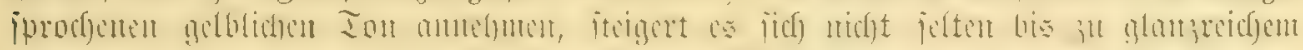

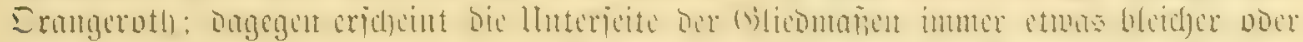

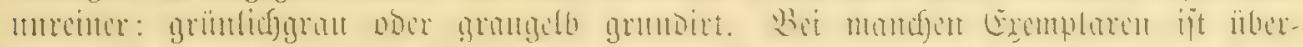

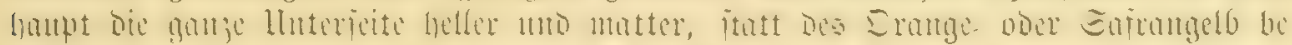

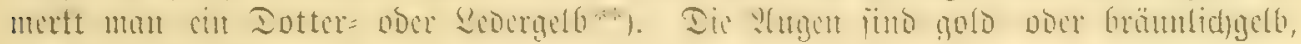
bie Sirulfent Grantu.

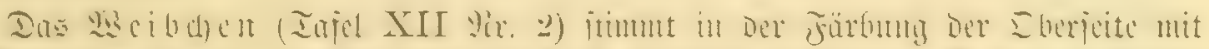

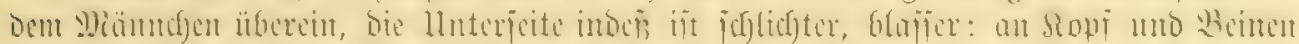

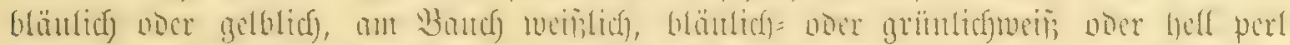

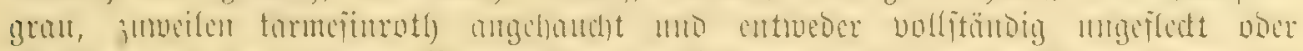

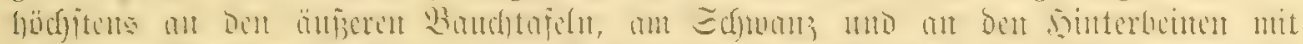

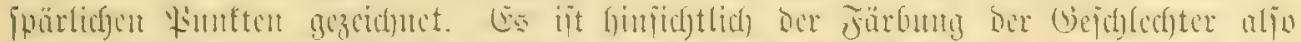

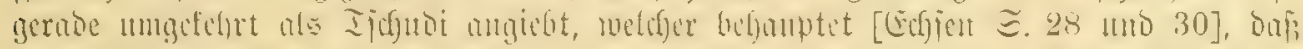

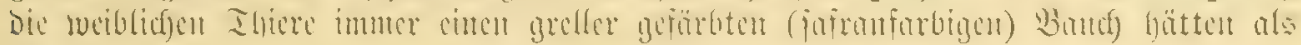
die männtiçcut.

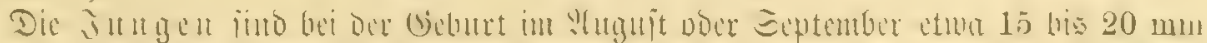

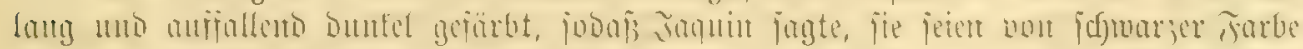

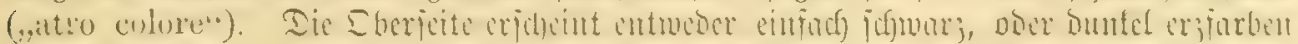

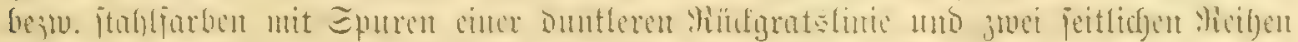

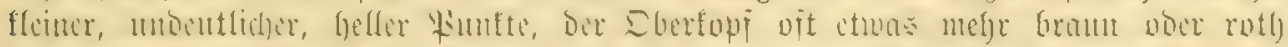

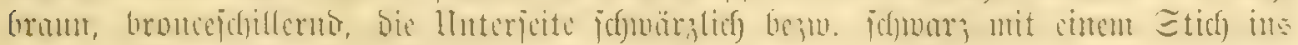

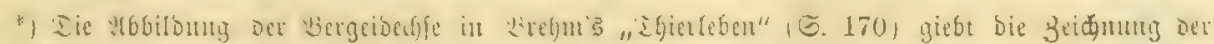

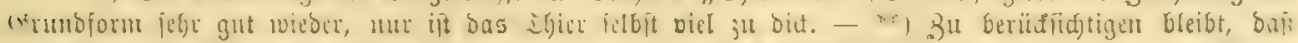

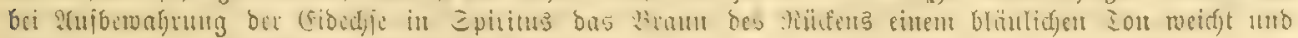
bas Drange bes 2audjes in Oraumeiß übergegt. 


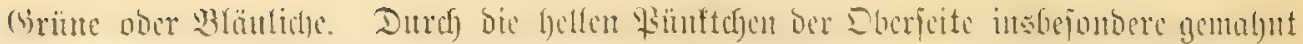

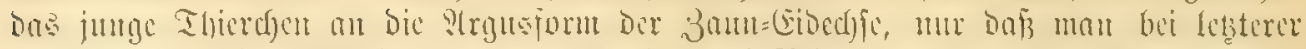

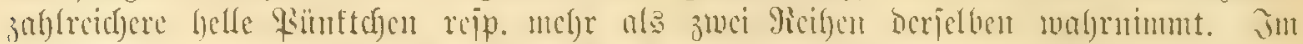

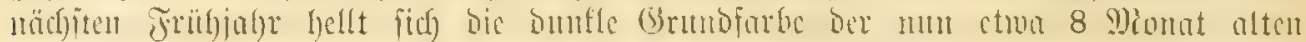

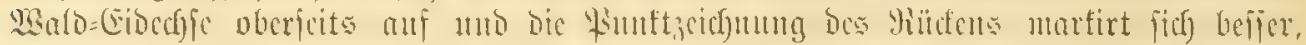

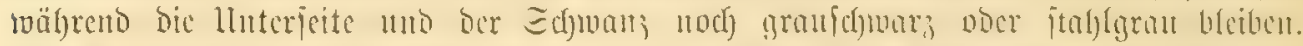

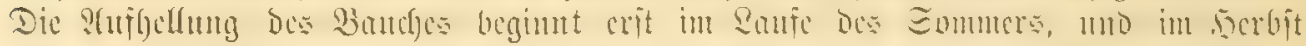

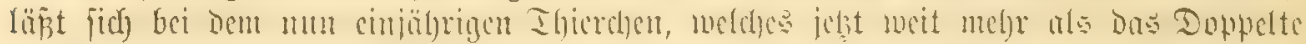

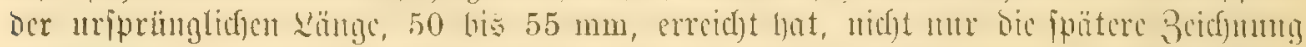

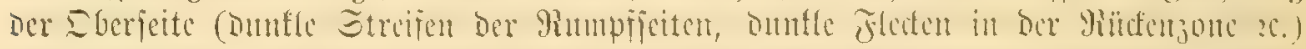

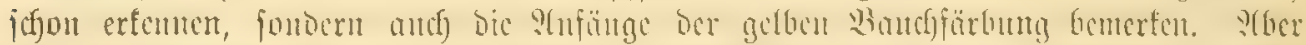

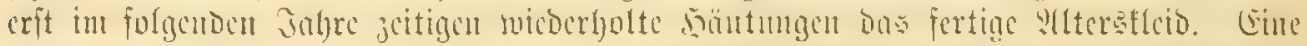

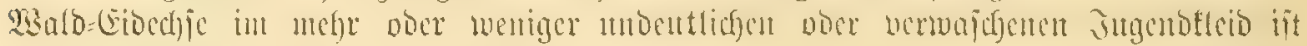
wohl die Sithl'jue Lacerta unicolor:

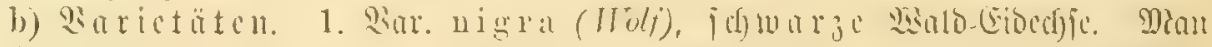

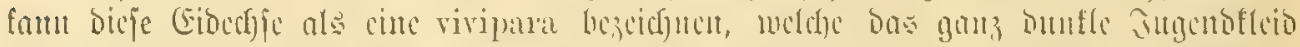

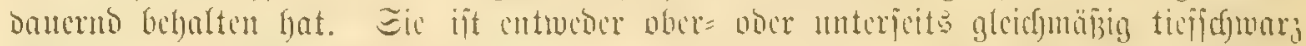

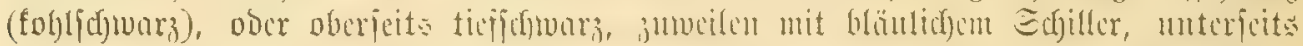

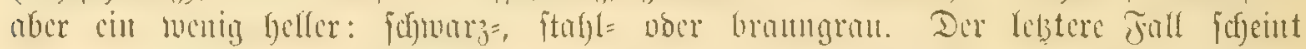

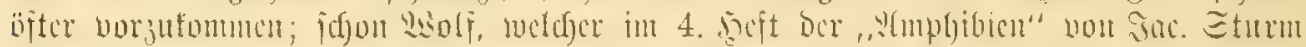

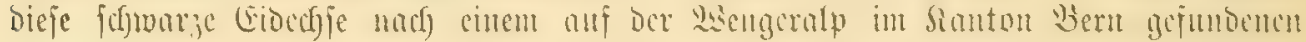

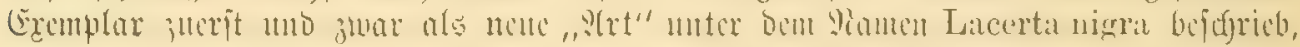

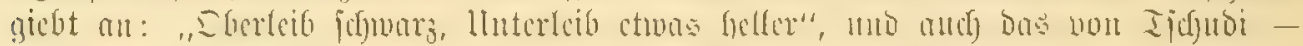

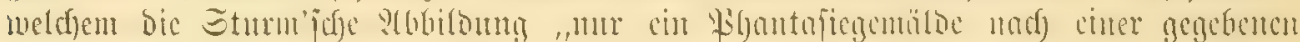

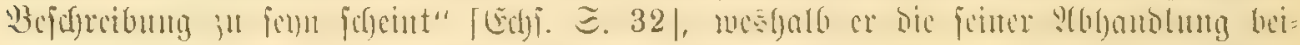

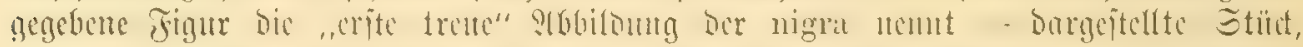

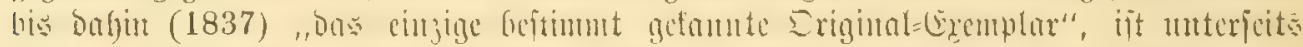

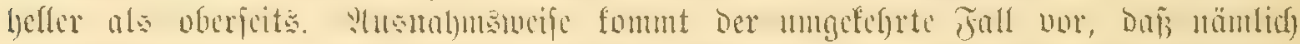

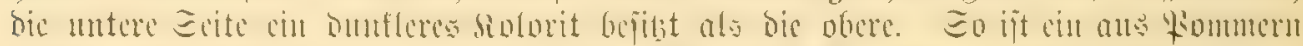

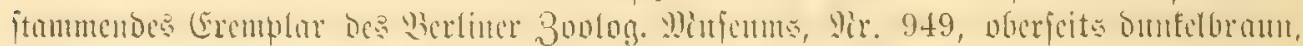

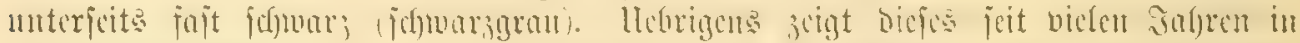

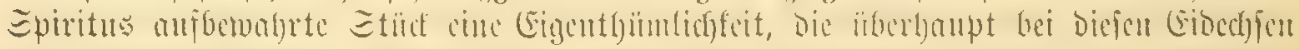

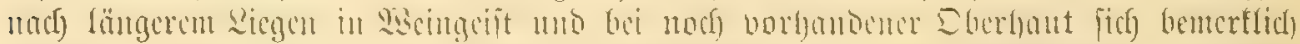

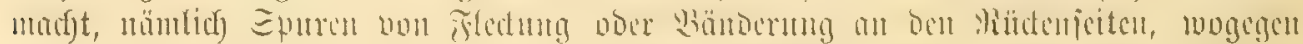

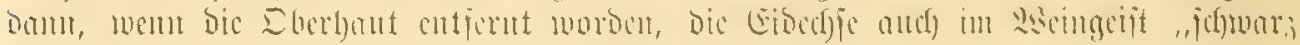

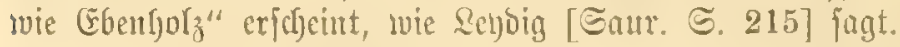

2. Bar. montana, Berg=Eibedfe, von Mifan in Eturn's "20mpfibien",

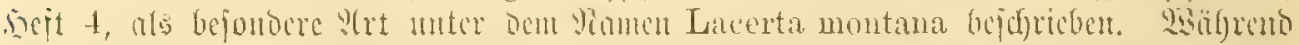

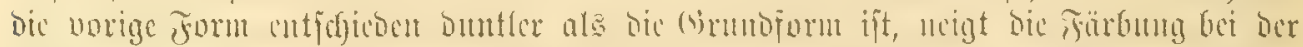

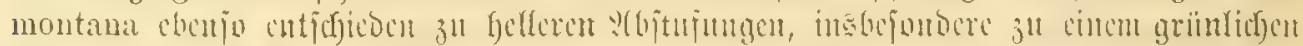

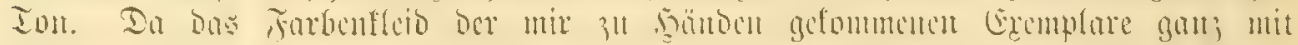

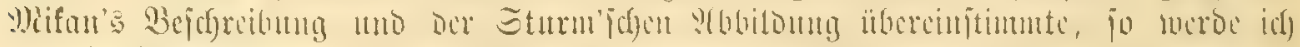

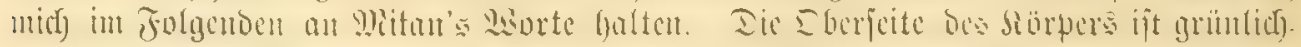

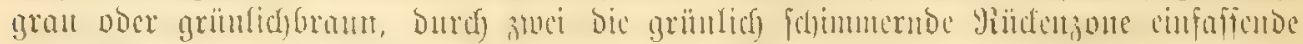

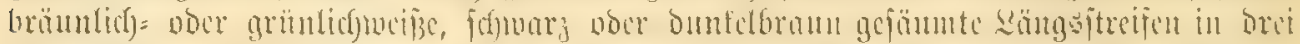

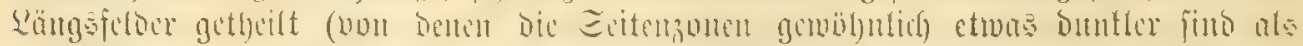

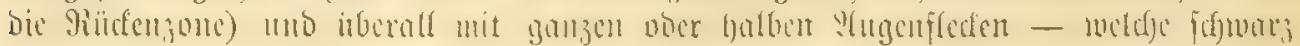

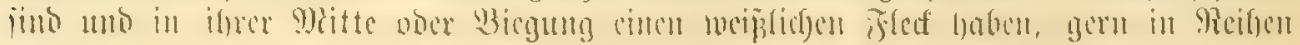




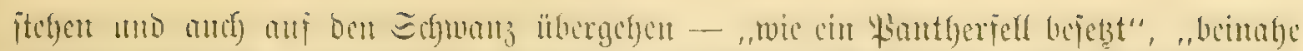

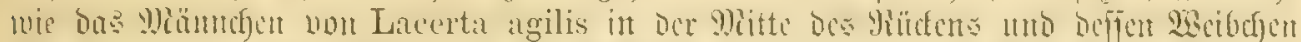

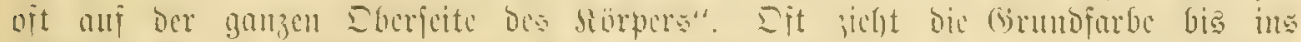

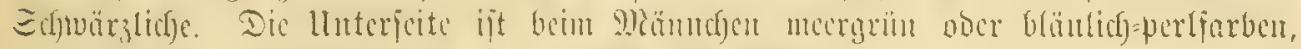

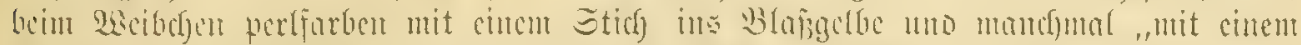

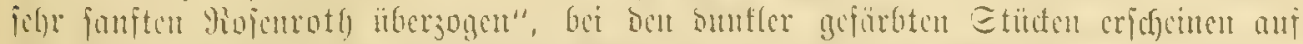

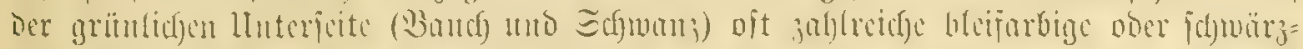

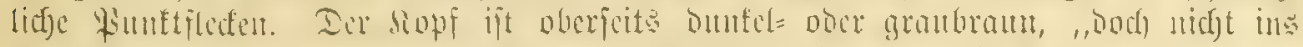

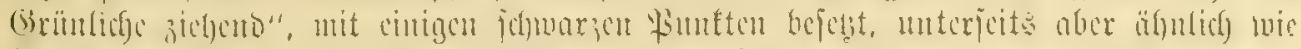

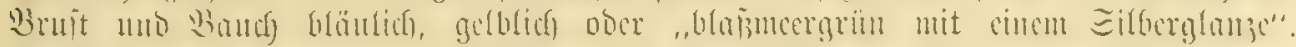

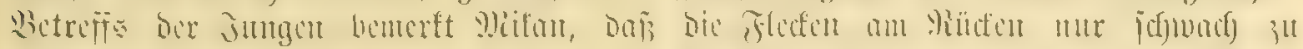

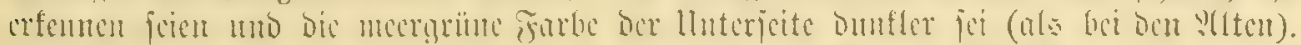

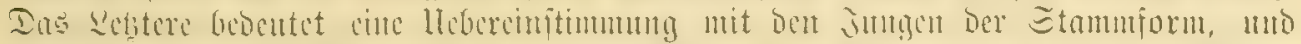

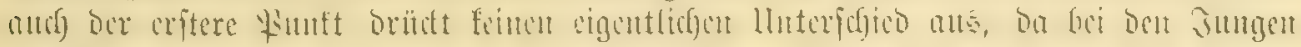

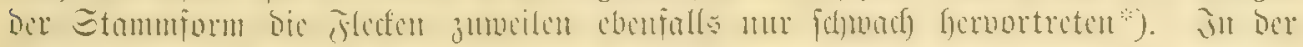

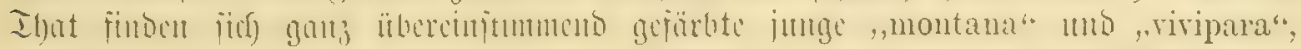

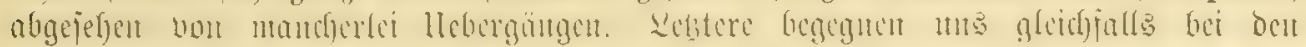

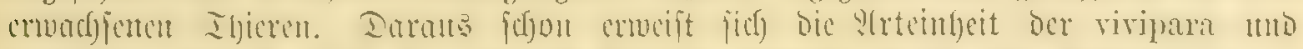

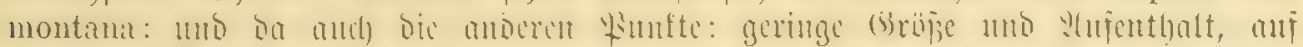

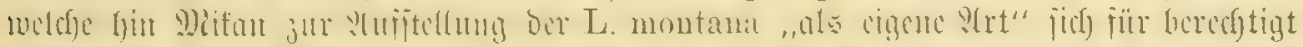

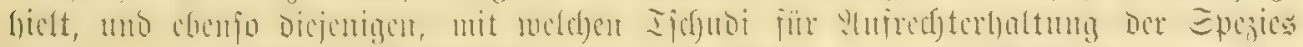

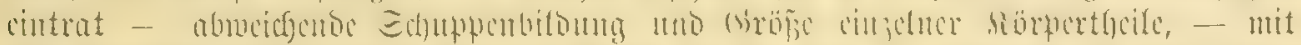

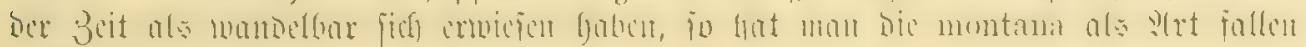
lafien miiffat.

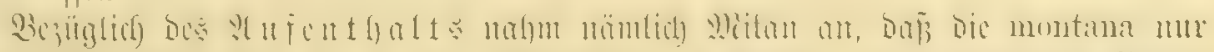

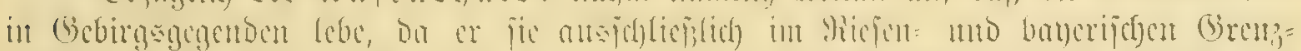

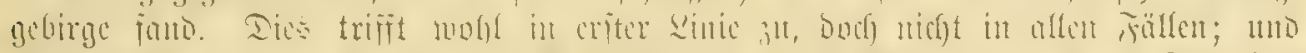

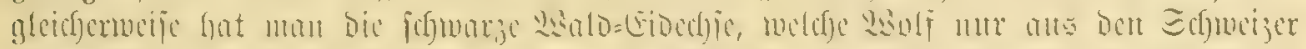

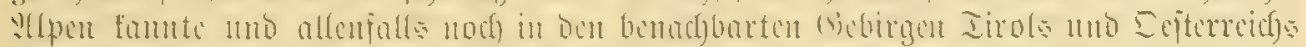

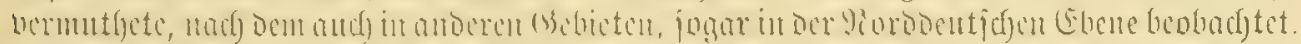

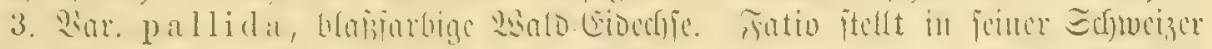

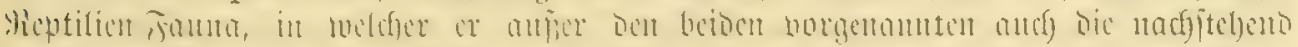

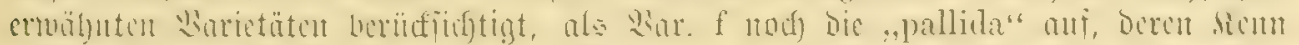

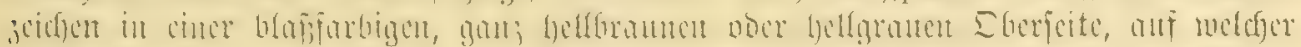

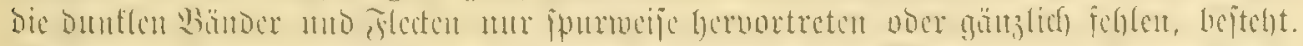

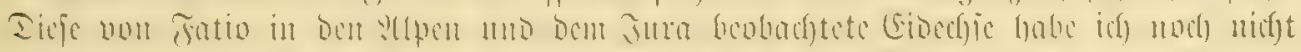

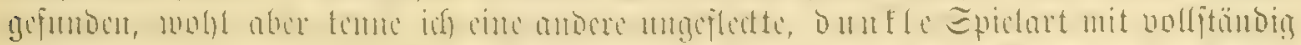

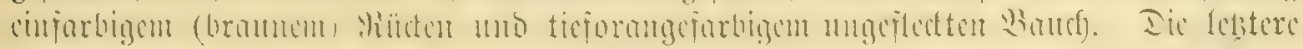

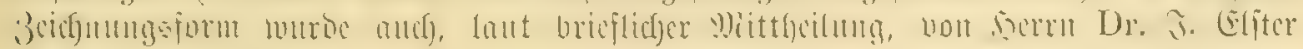
iun searz bcobadtet.

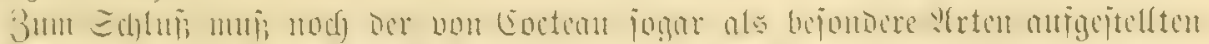

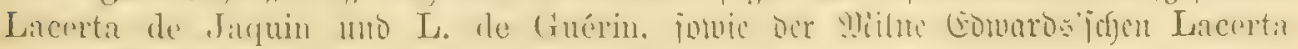

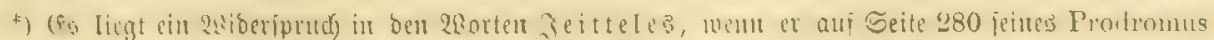

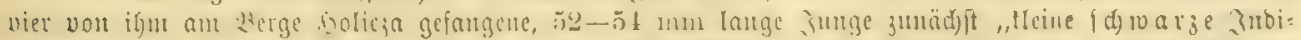

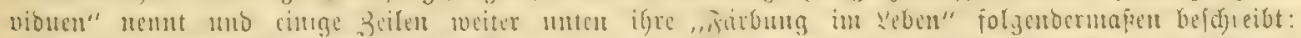

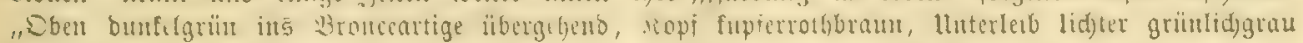

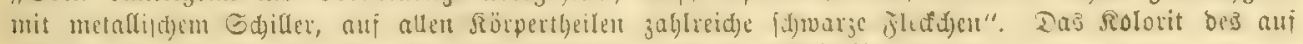
Tafel 4, Fig. 4, bargeptelten (Exemplars bect fic mit biejer Beldideibung. 


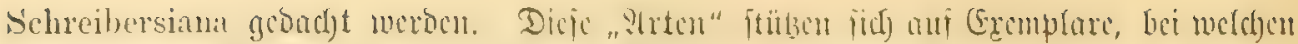

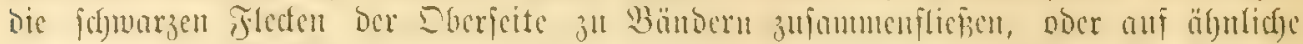

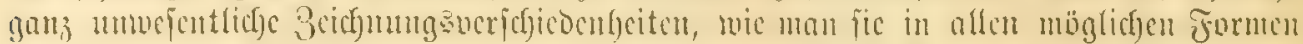

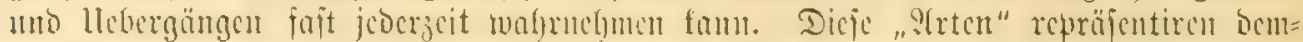

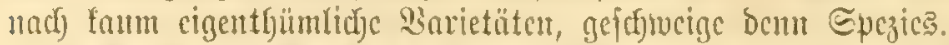

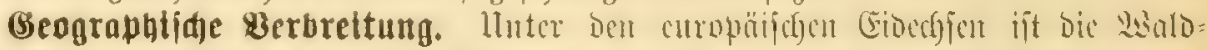

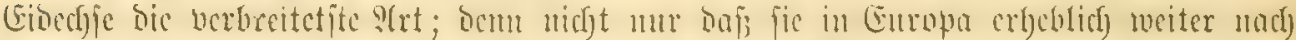

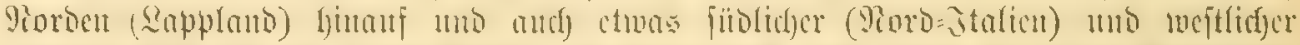

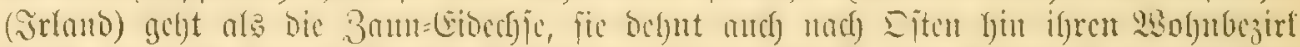

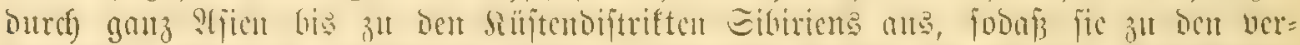

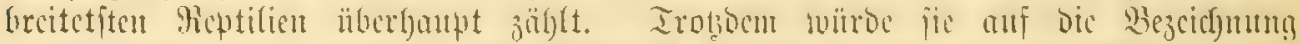

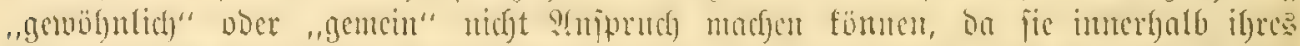

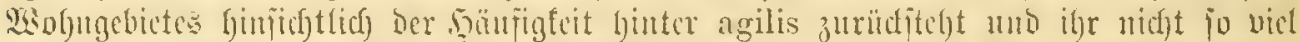

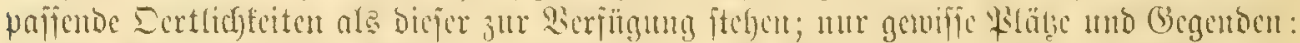

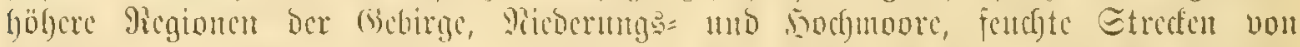

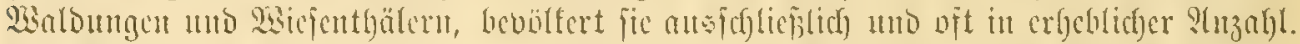

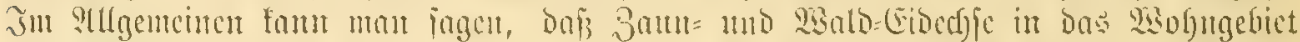
(iich theilen; unr an wenigen Erten fommen fic gemeinj(f)oftlidf vor. Das Päbere

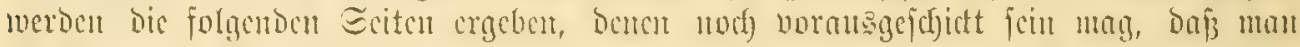

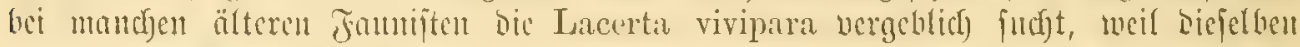

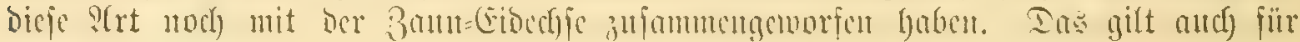
einige Begenocu

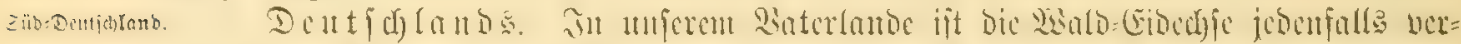

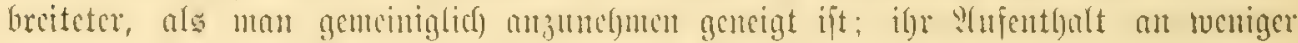

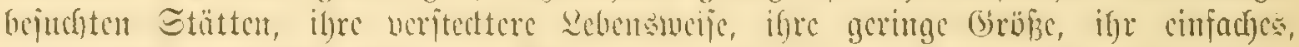

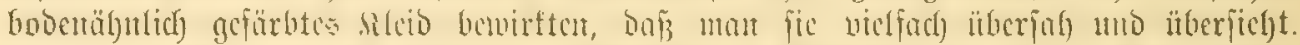

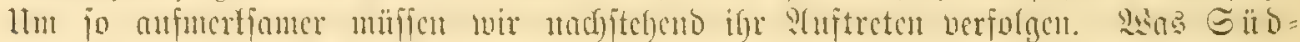

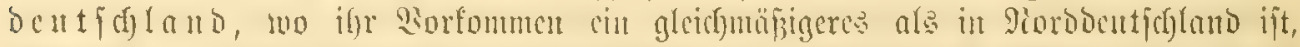

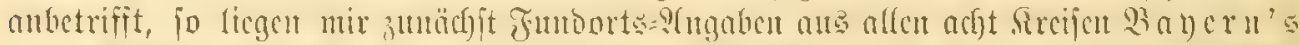

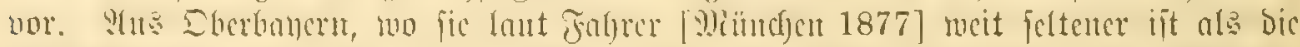

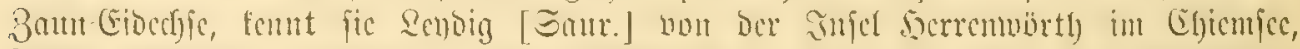

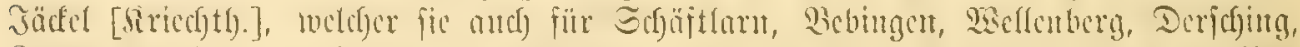

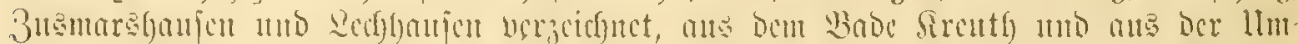

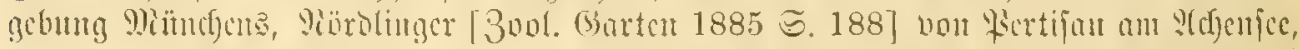

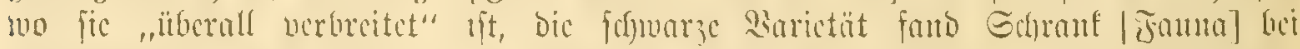

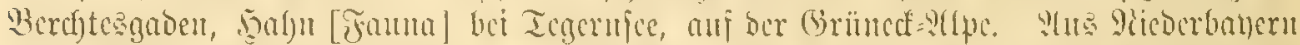

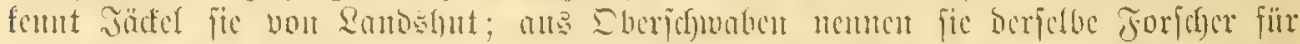

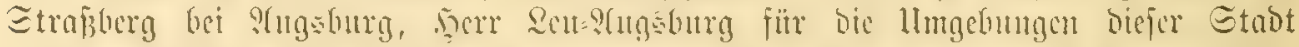

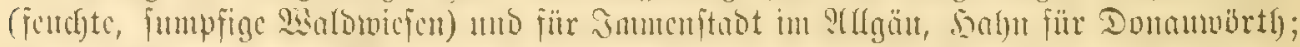

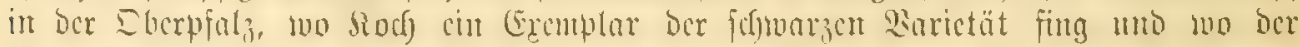

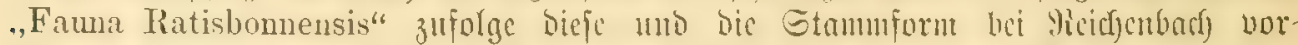

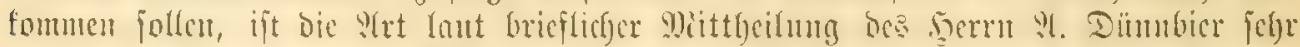

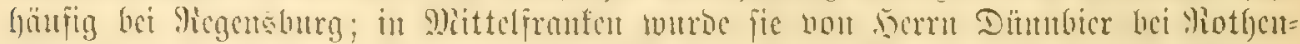

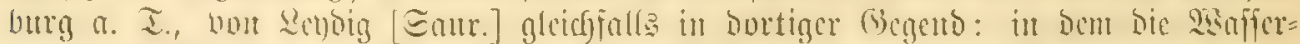

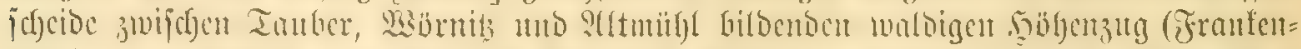

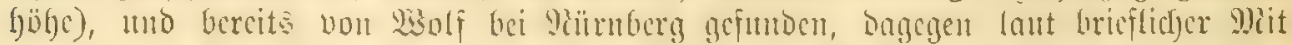

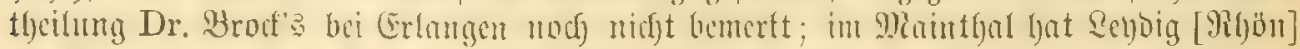

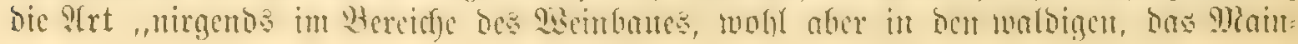




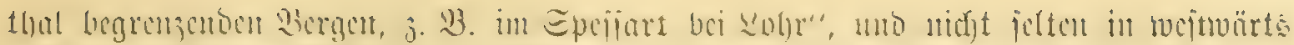

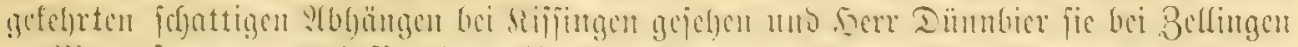

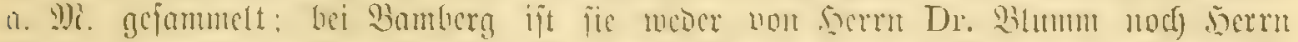

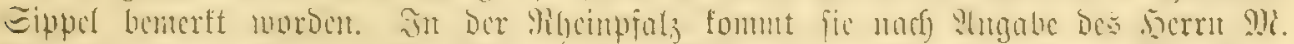

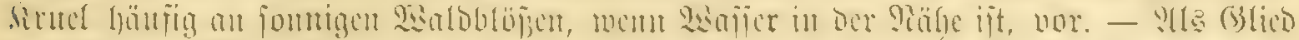

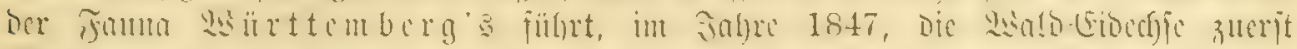

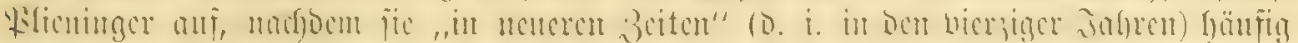

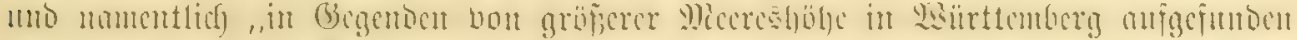

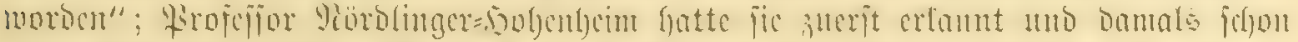

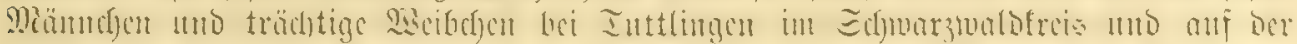

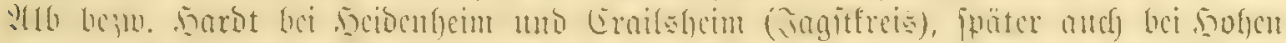

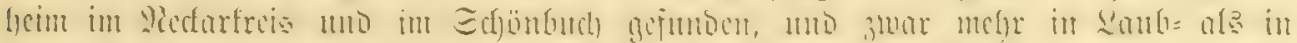

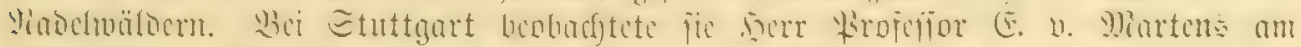

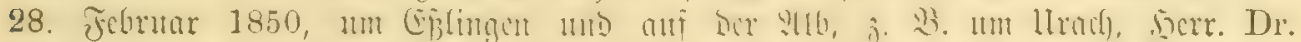

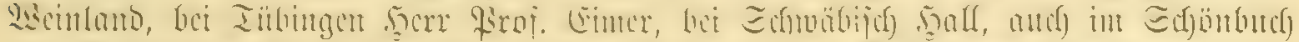

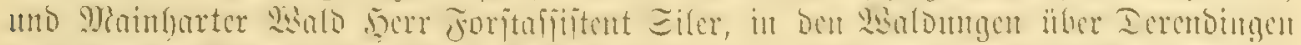

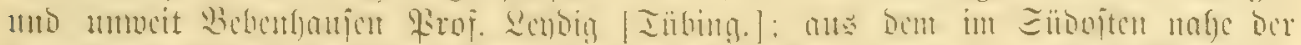

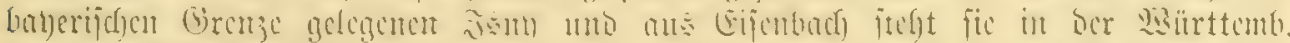

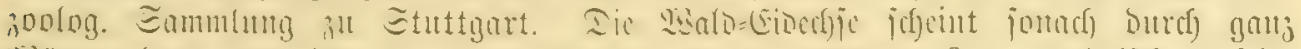

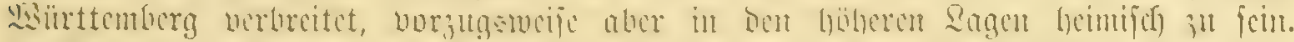

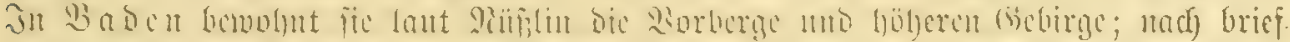

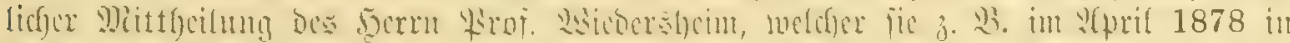

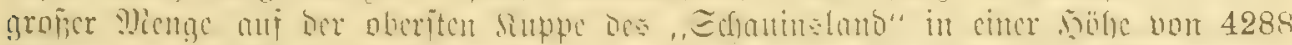

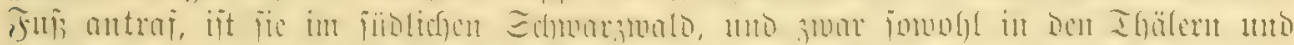

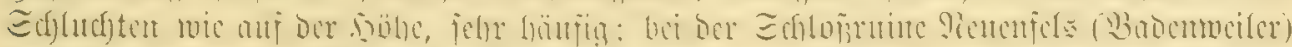

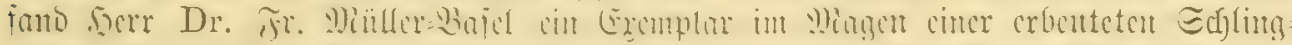

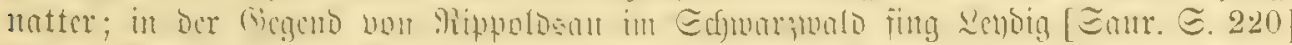

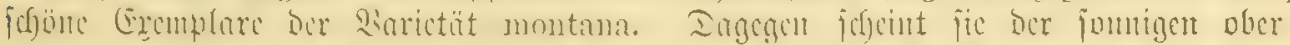

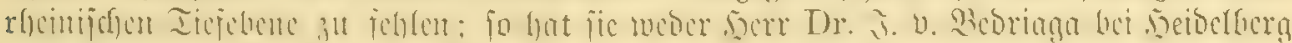

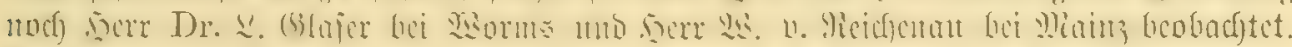

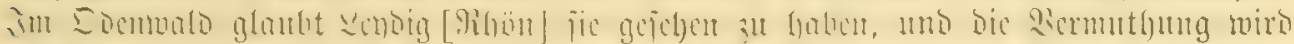

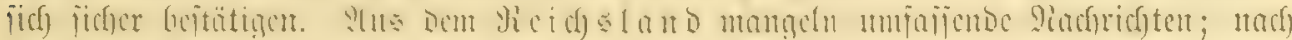

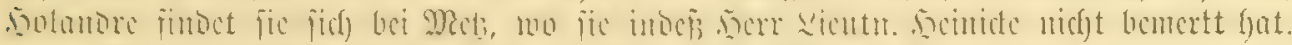

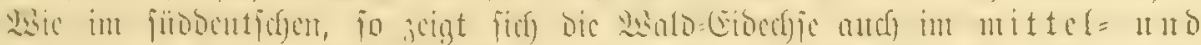

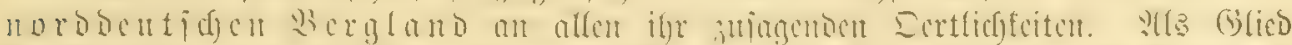

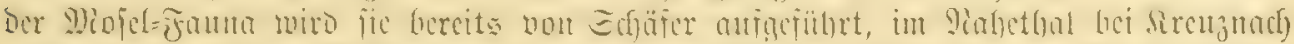

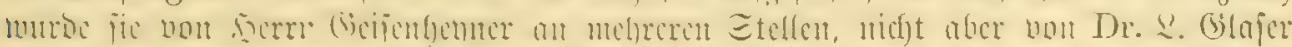

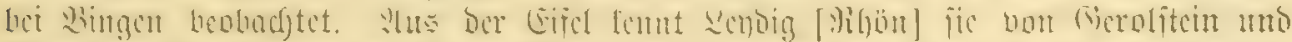

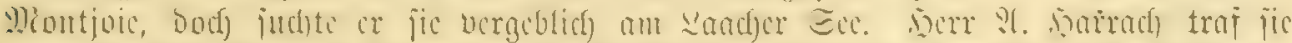

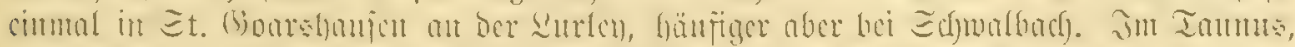

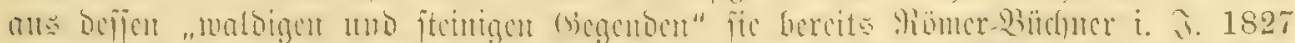

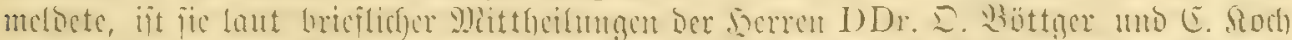

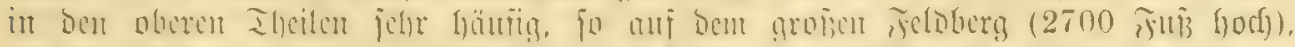

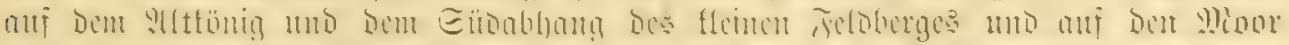

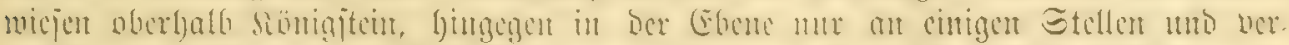

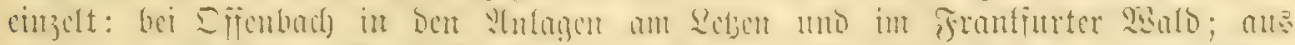

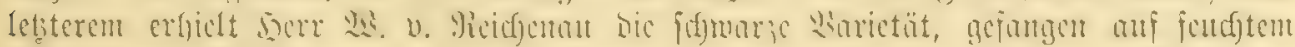

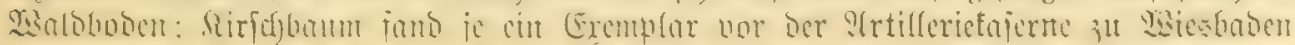




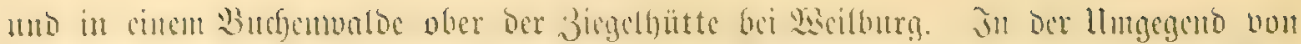

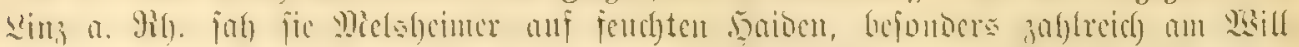

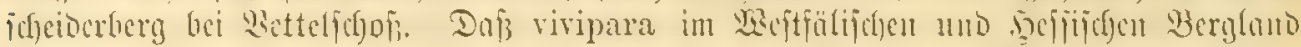

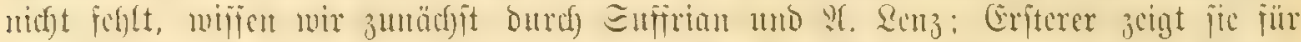

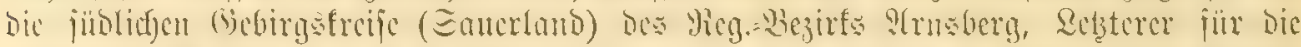

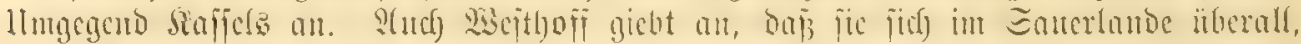

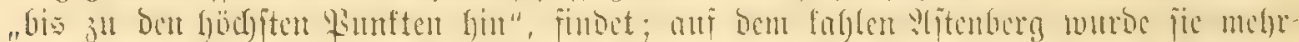

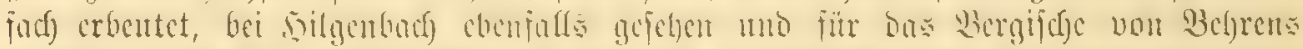

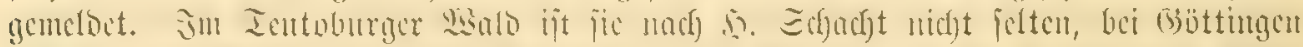

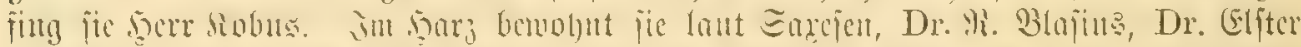

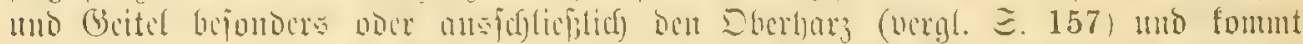

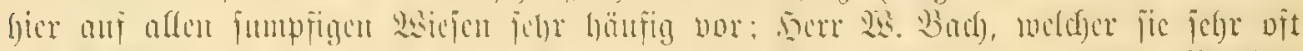
bu (b)

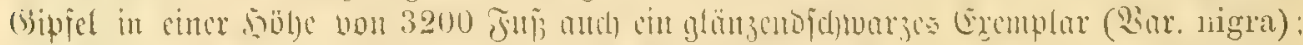

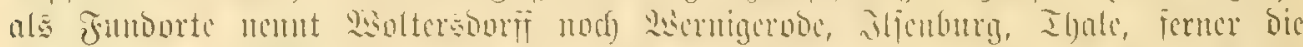

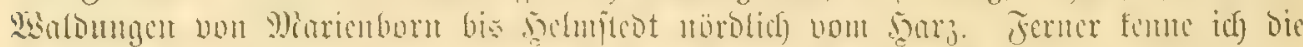

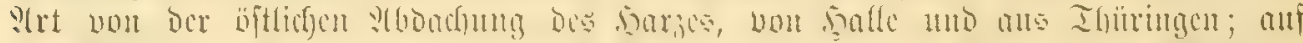

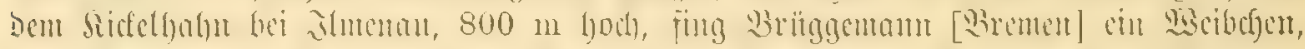

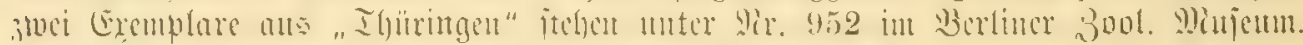

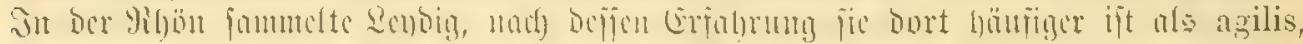

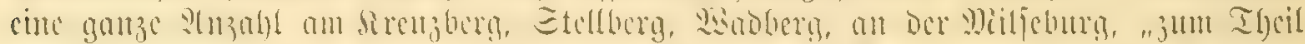

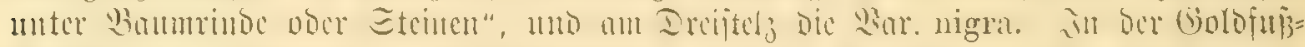

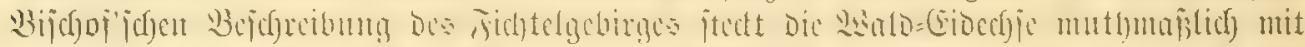

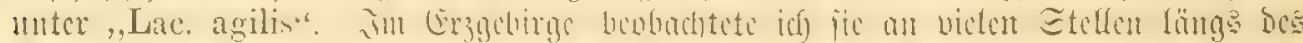

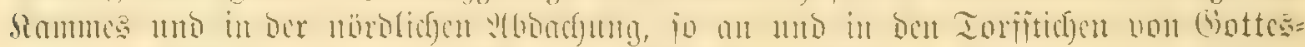

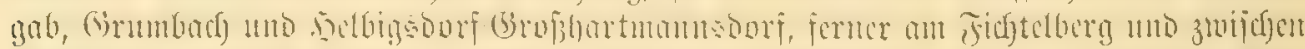

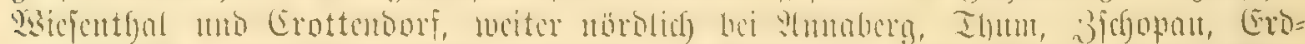

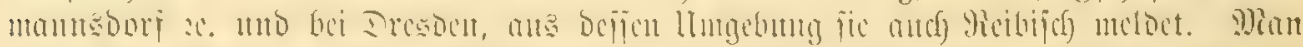

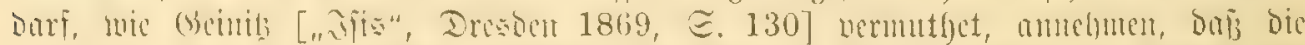

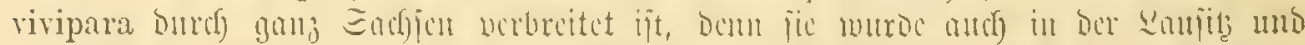

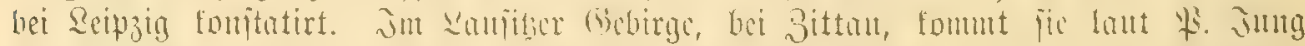

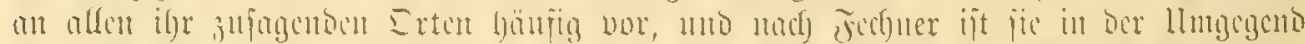

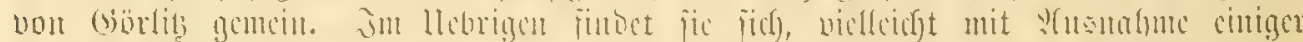

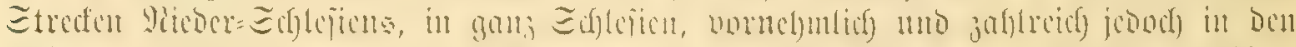

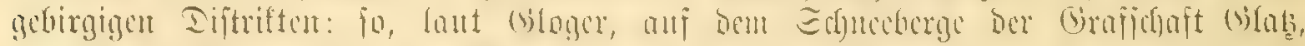

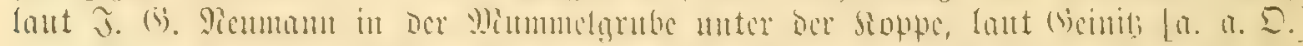

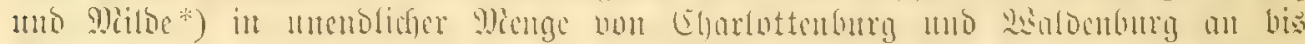

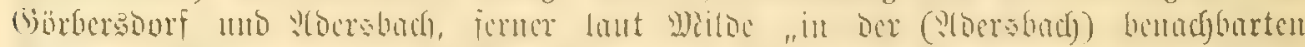

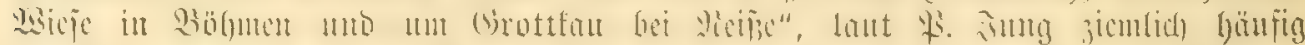

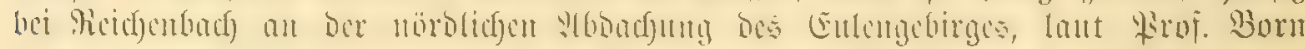

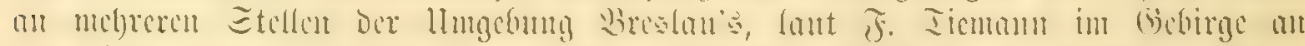

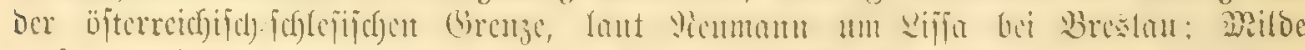

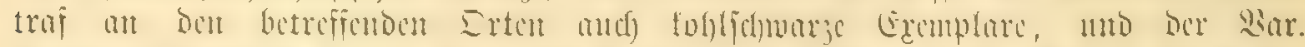

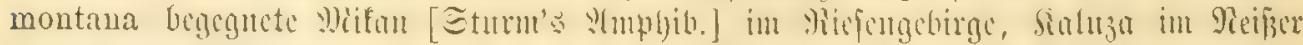

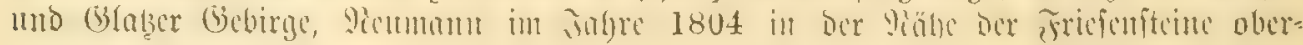
halb Sichmicoeberg.

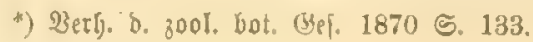




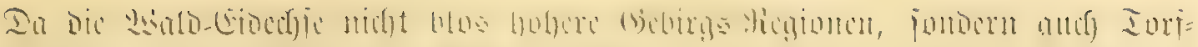

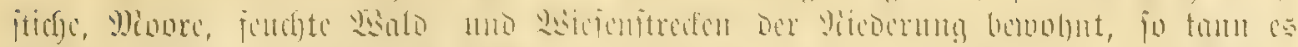

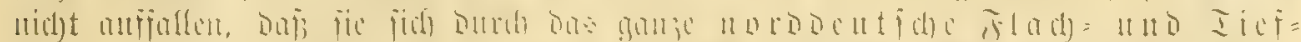

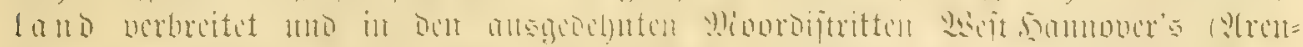

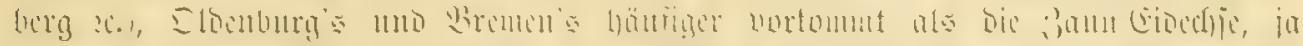

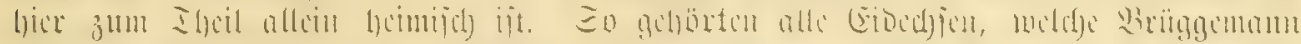

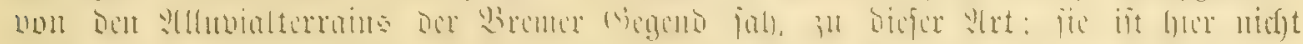

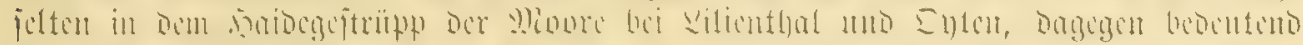

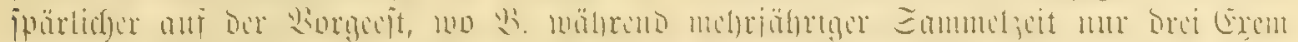

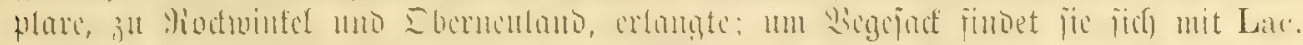

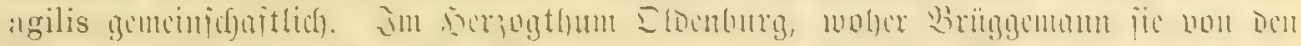

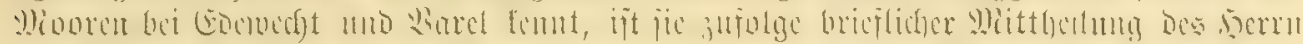

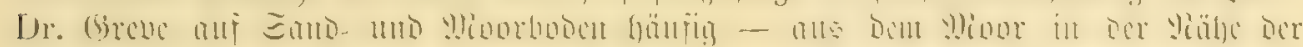

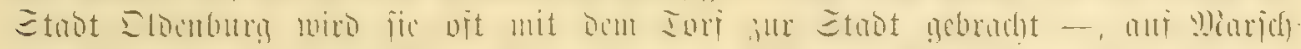

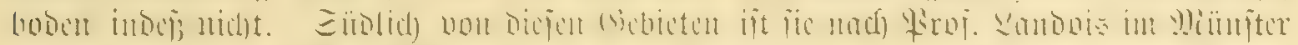

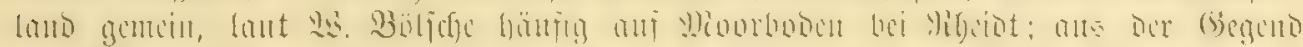

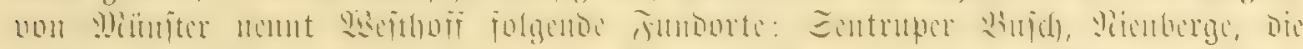

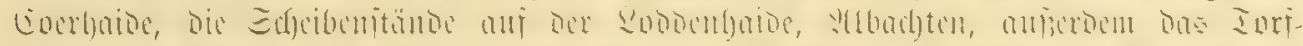
แtom vou

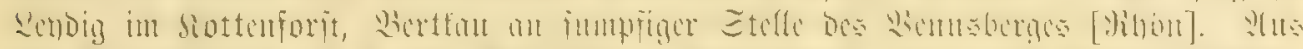

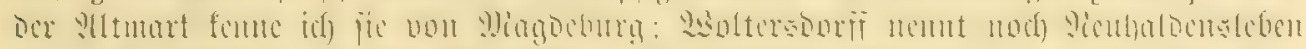

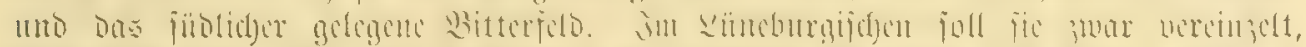

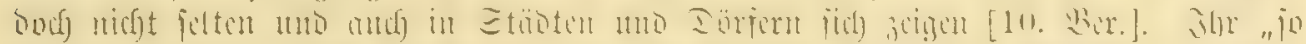

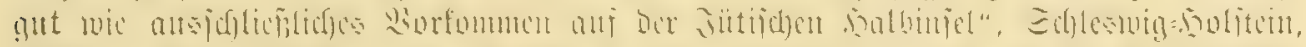

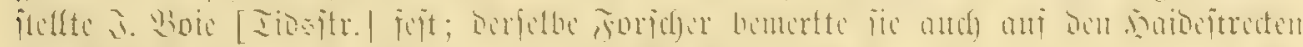

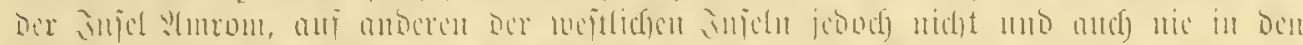

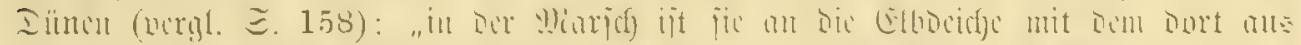

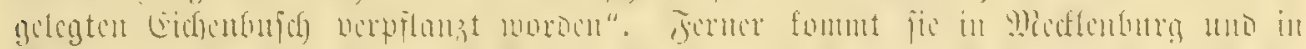

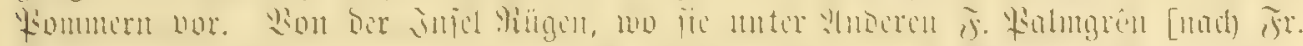

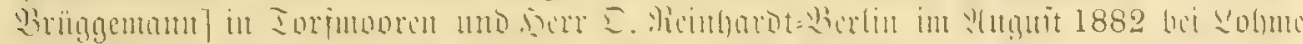

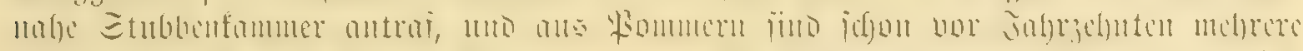

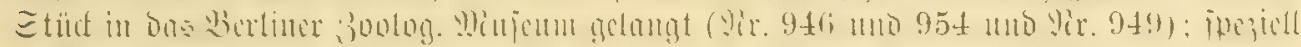

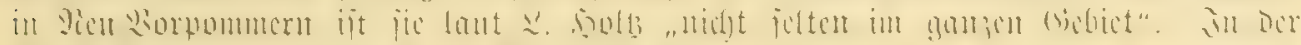

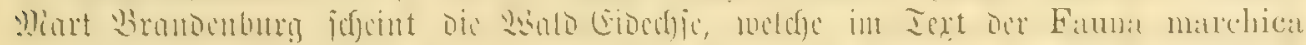

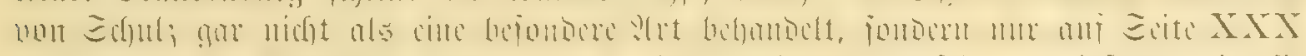

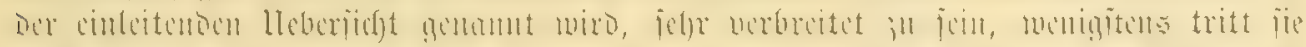

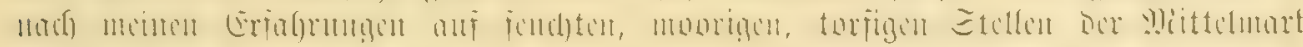

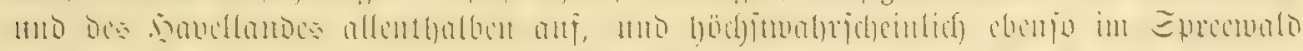

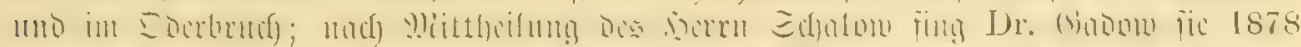

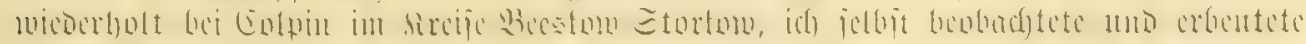

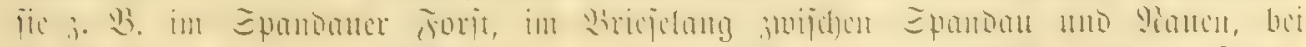

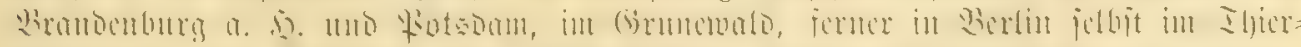

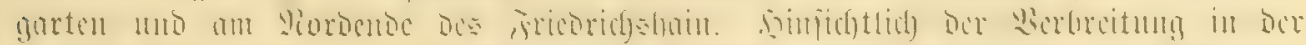

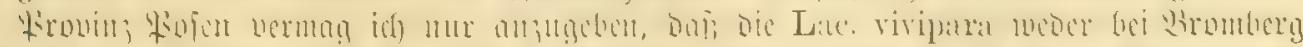

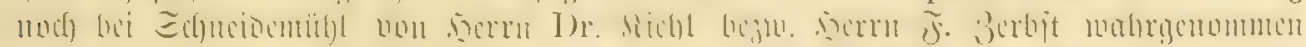

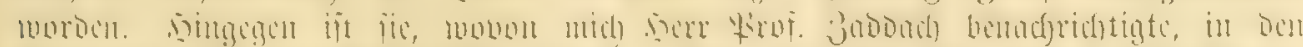

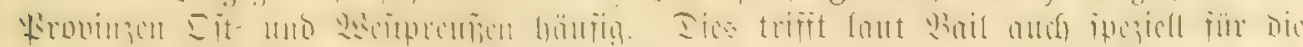

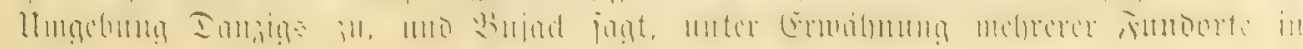




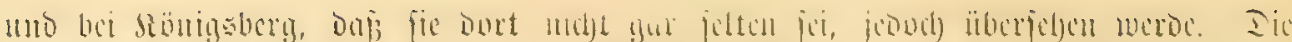

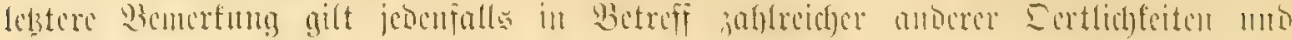
Gegendert.

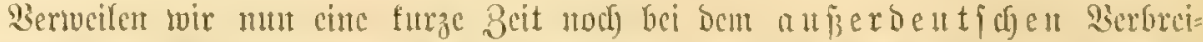

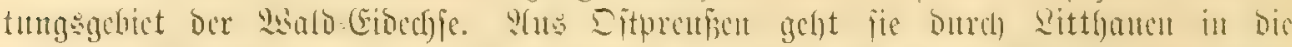

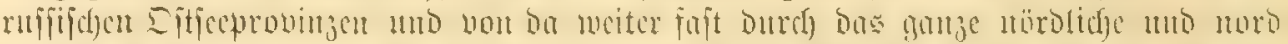

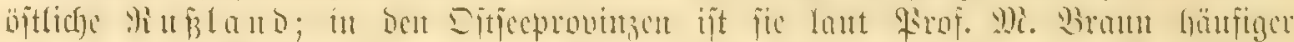

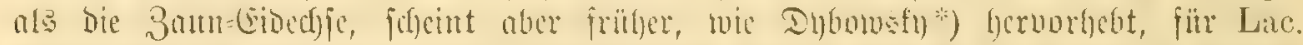

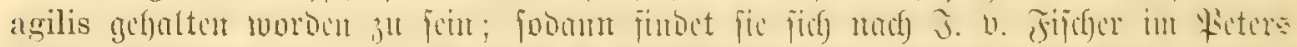

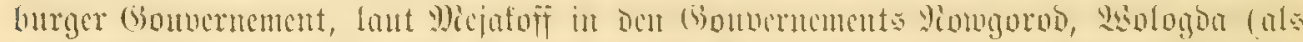

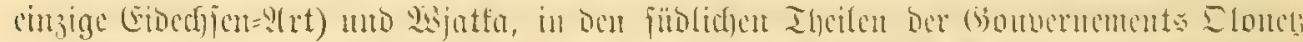

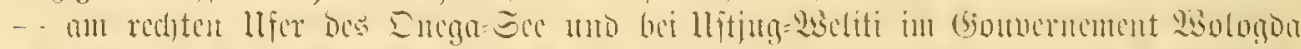

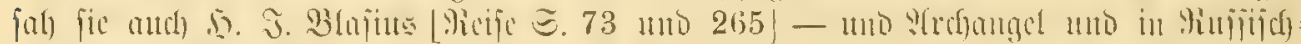

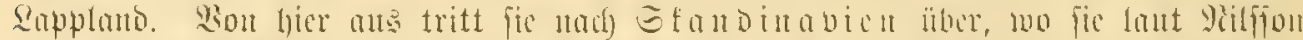

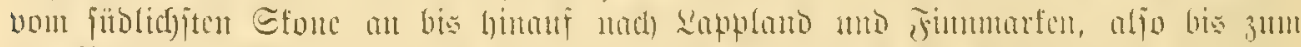

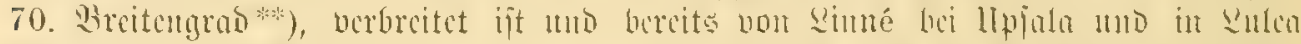

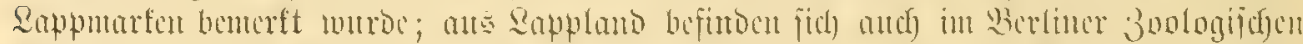

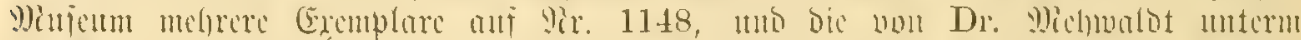

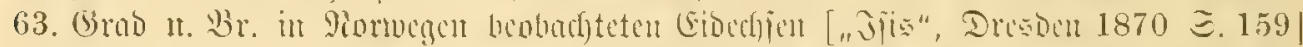

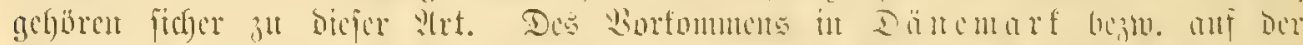

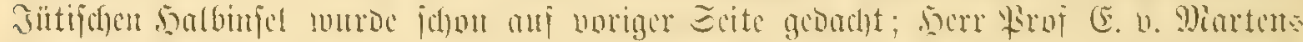

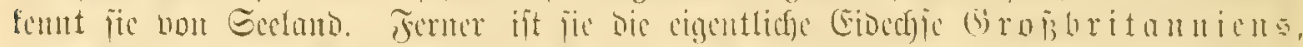

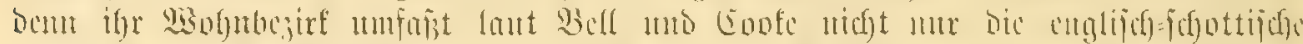

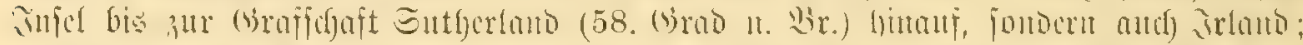

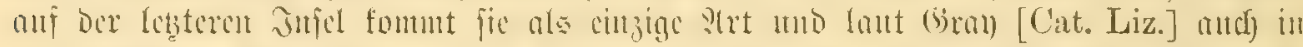

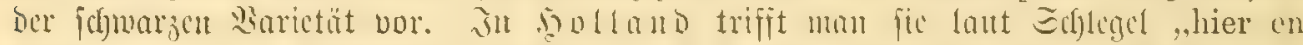

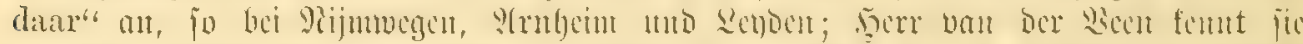

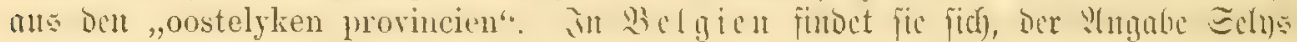

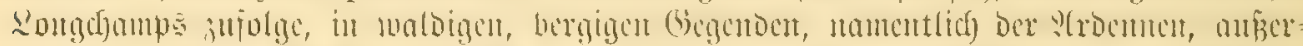

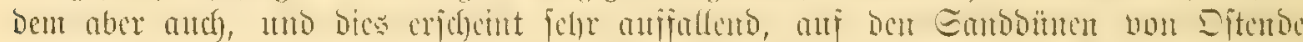

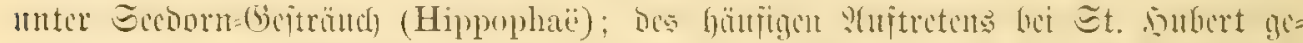

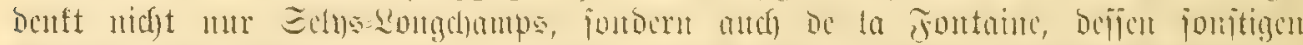

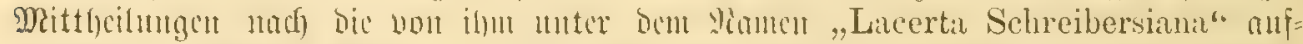

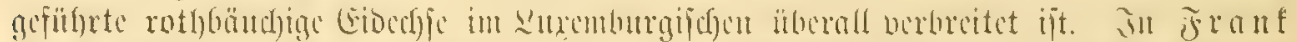

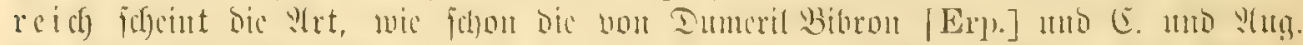

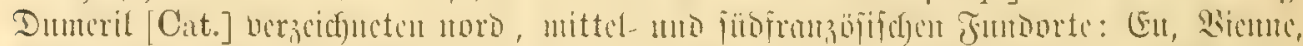

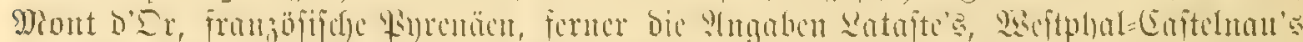

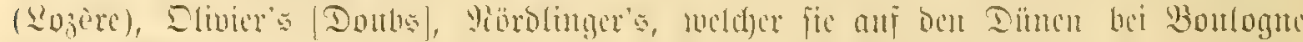

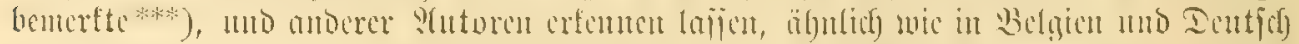

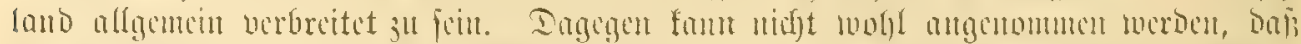

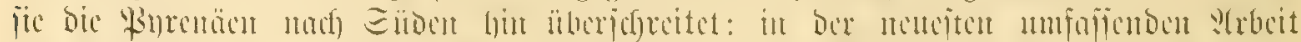

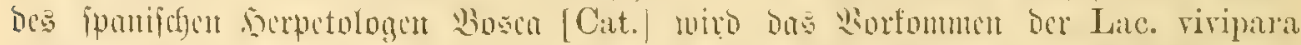

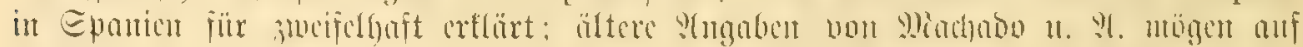
Berwedjeclung berufjen.

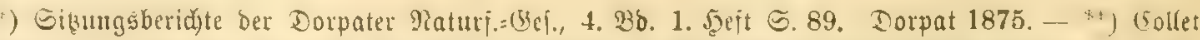

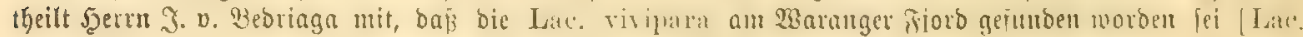

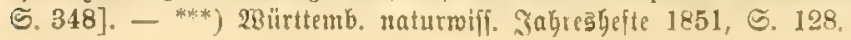




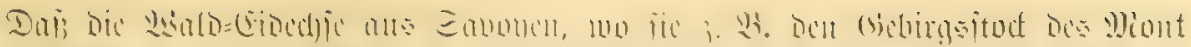

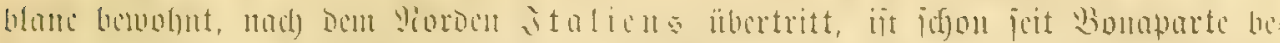

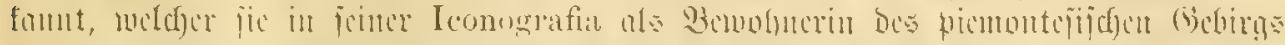

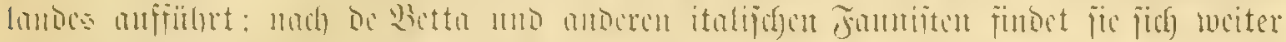

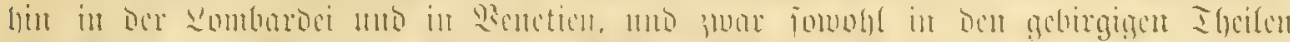

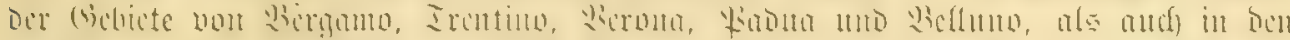

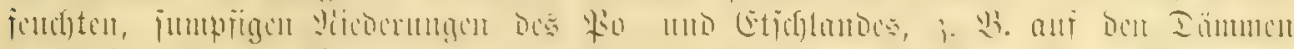

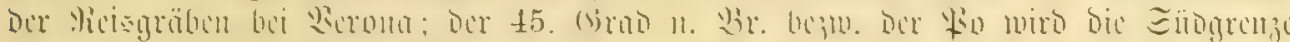

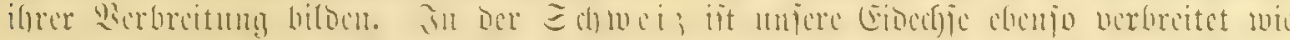

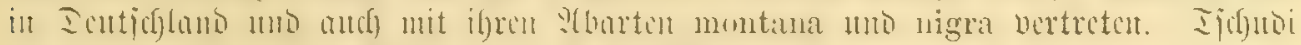

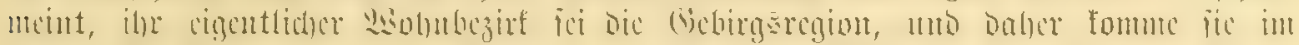

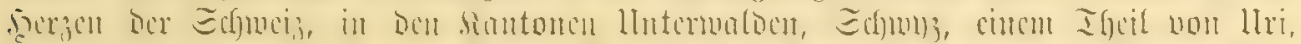

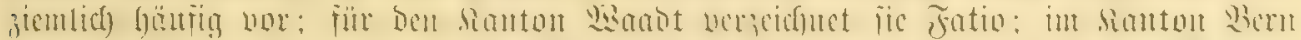

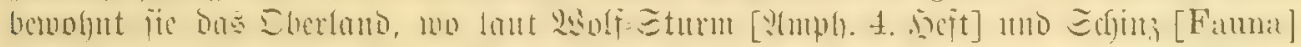

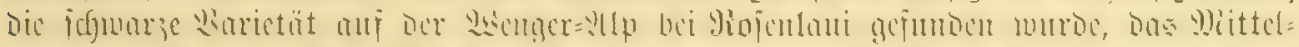

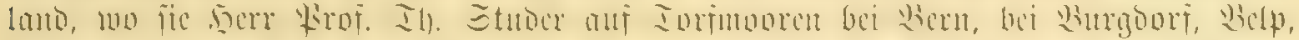

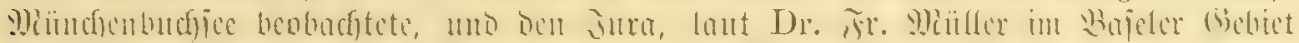

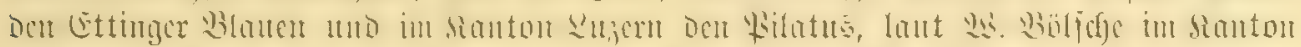

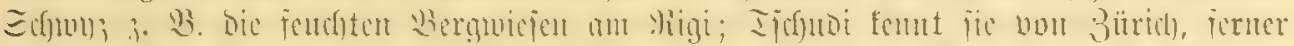

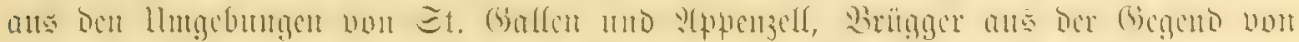

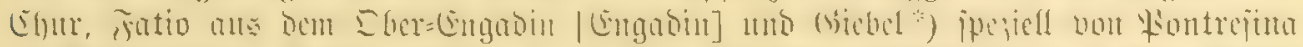

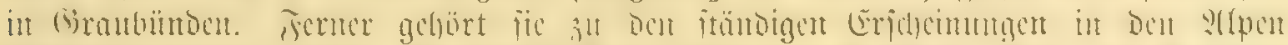

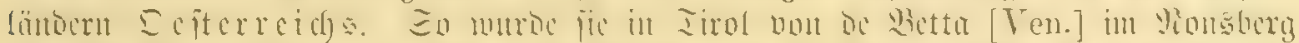

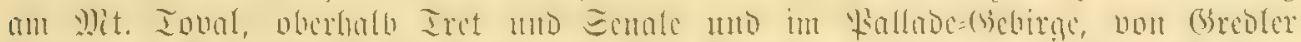

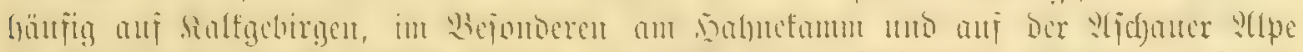

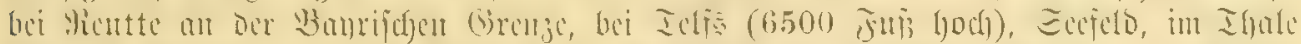

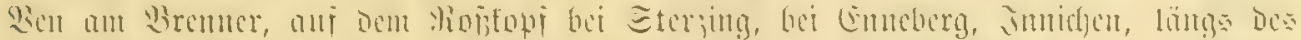

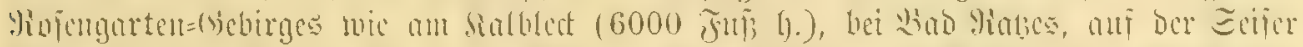

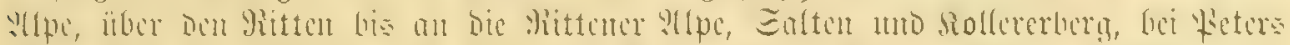
ber!y, äber ben Zabberg

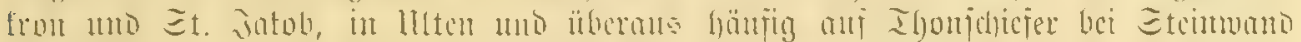

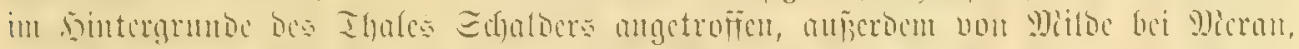

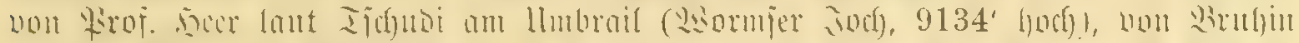
an on :Ifpen ocs

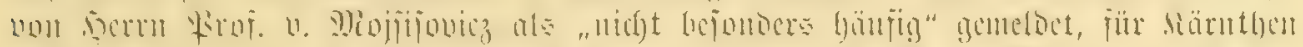

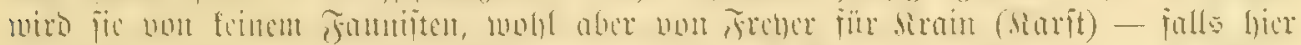

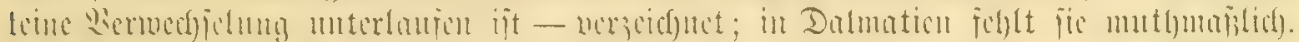

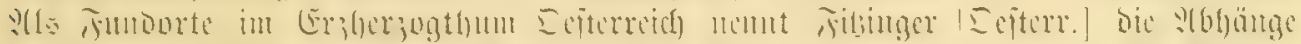

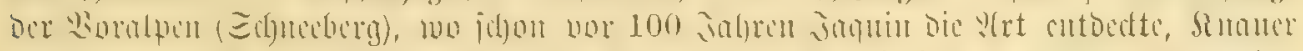

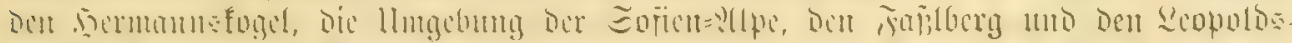

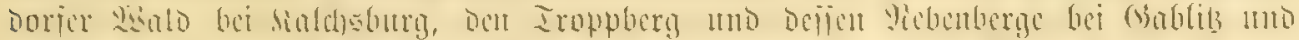
sen grojen simofoged be

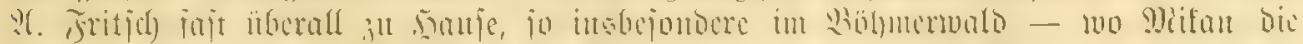

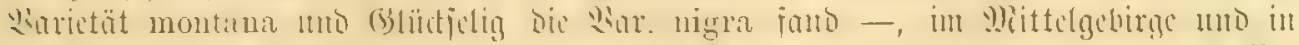

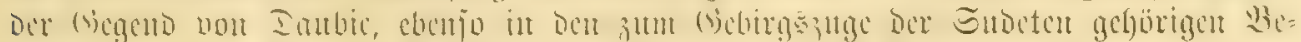

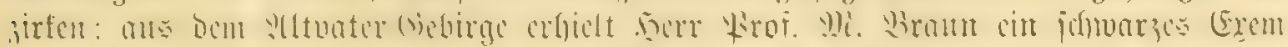




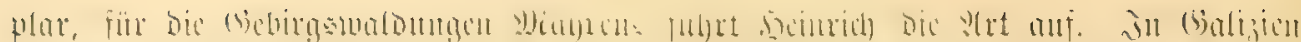

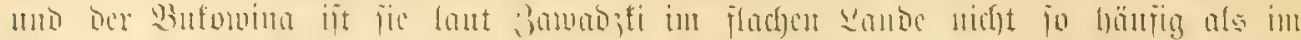

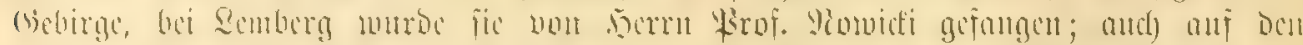

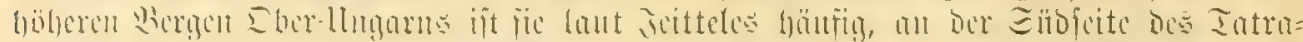

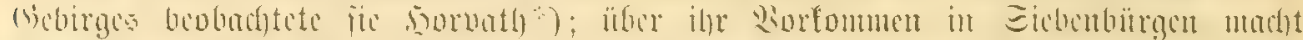

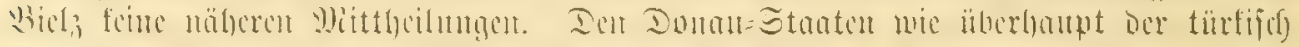

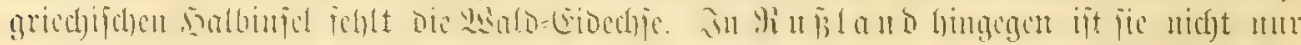

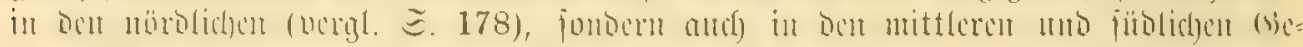

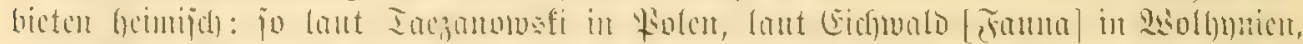

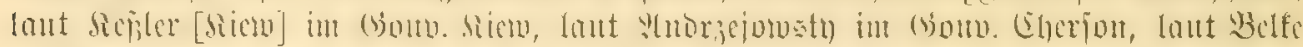

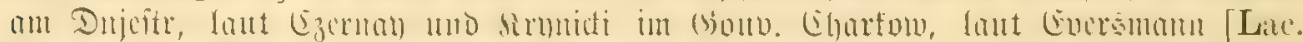

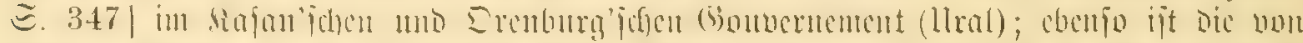

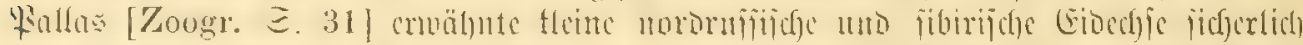

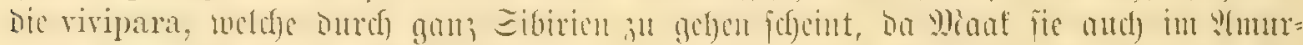

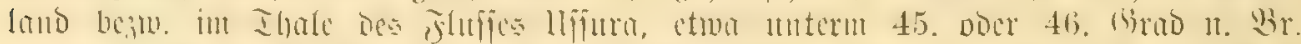

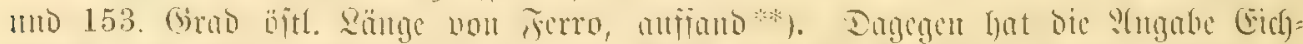

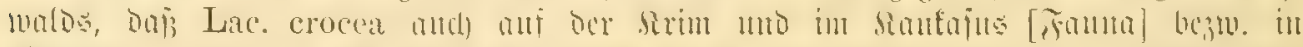

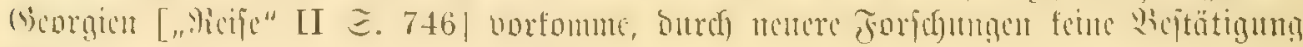
crialyren; jedenfalls bitritc fite ber firm fehlent.

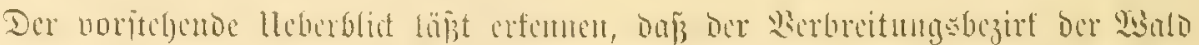

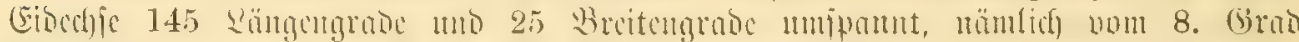

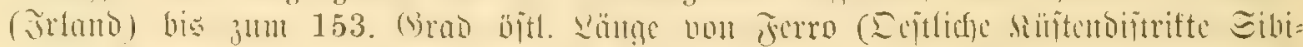

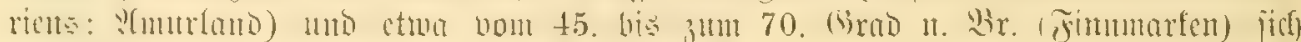

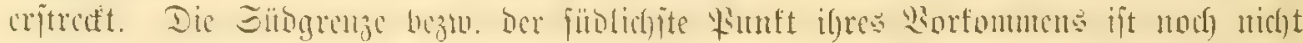

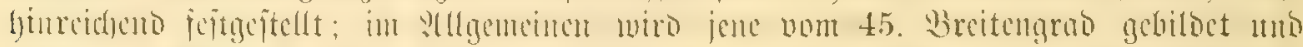

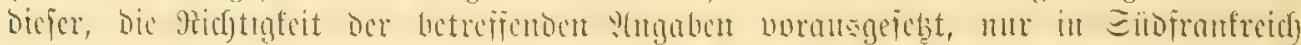

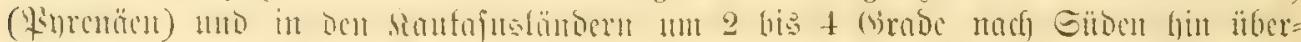

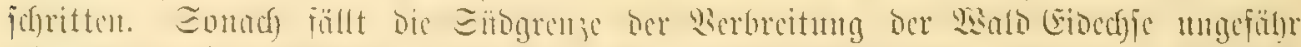
mit ber ber 3am (E)

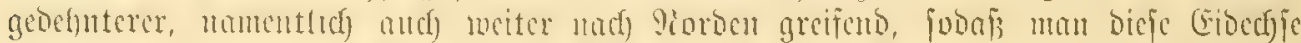
als "Dic nordifdye" bezcid)ncu fünnte.

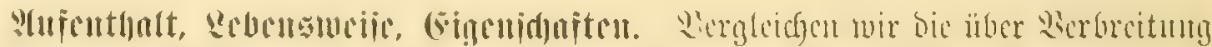

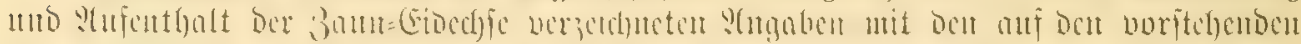

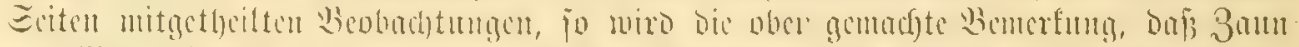

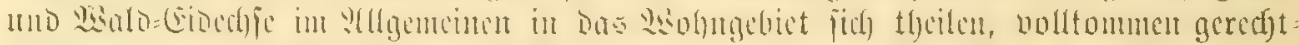

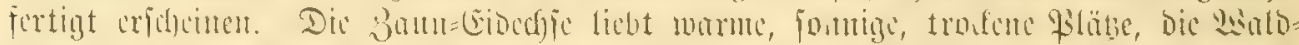

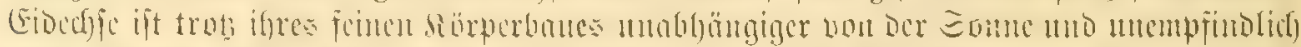

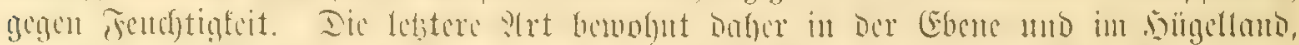

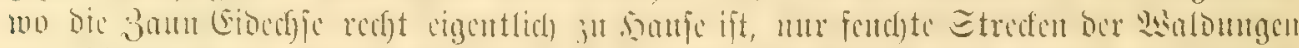

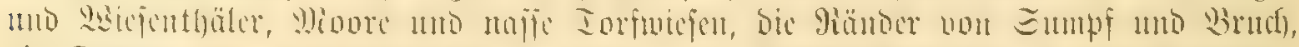

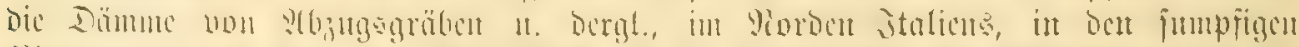

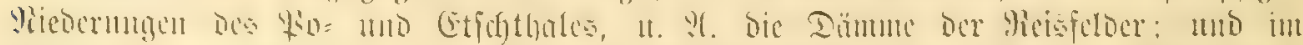

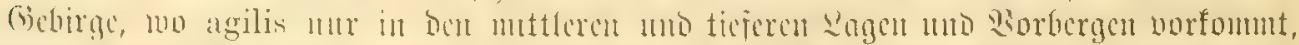

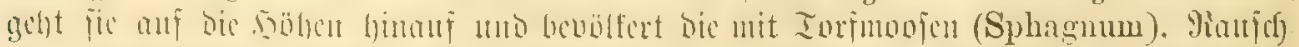

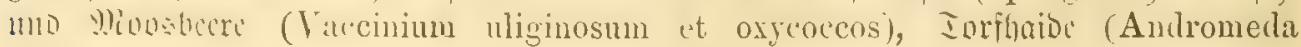

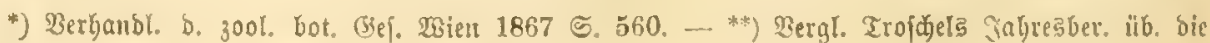

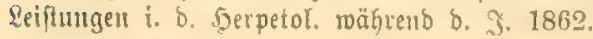




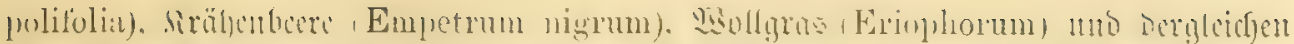

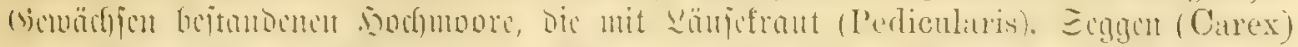

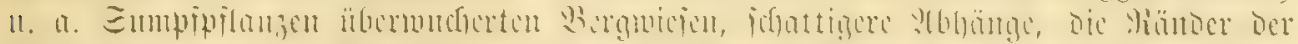

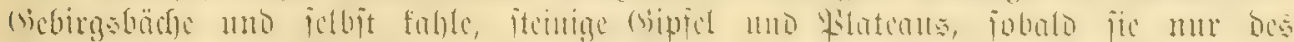

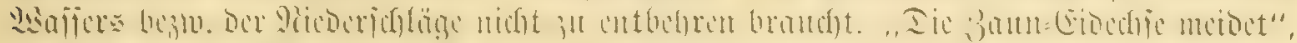

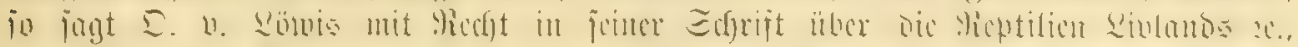

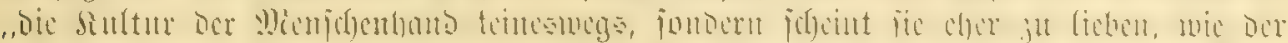

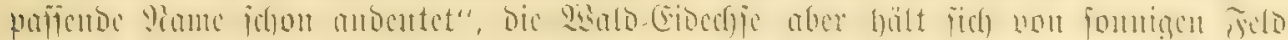

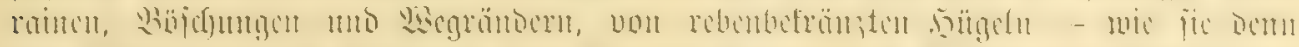

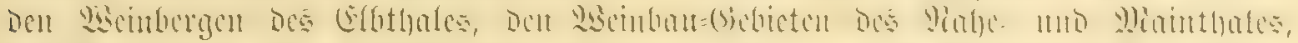

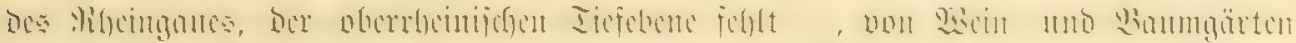

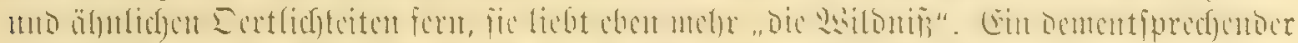

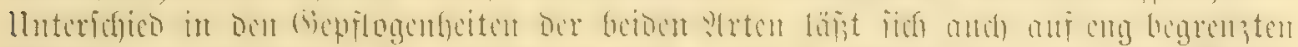

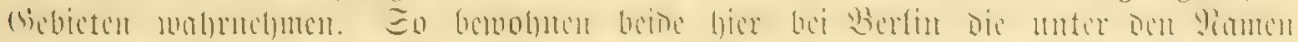

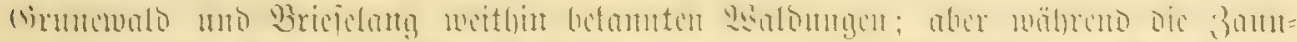

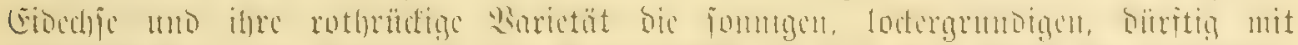

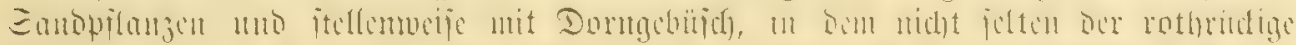

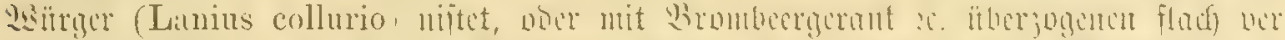

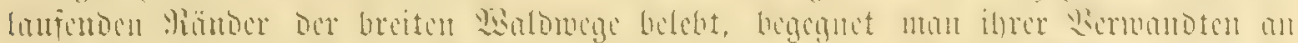

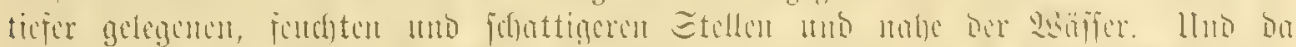

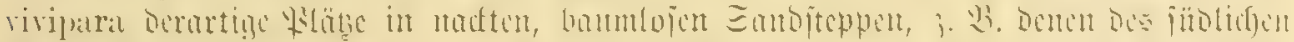

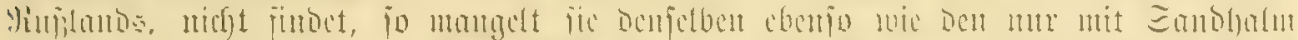

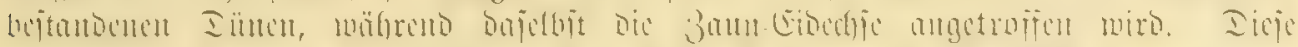

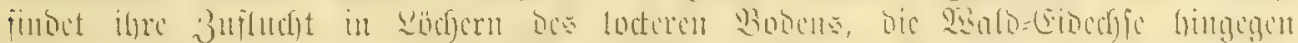

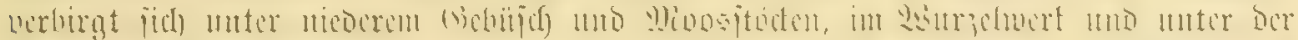

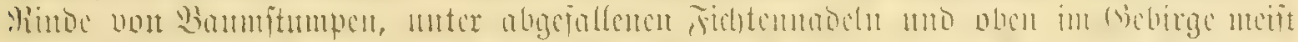

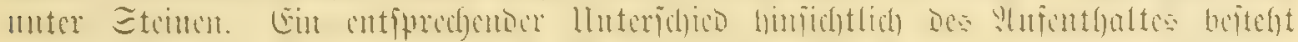

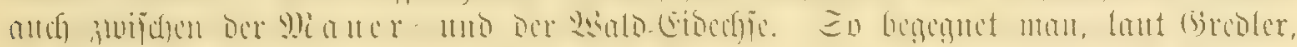

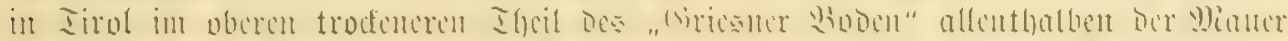

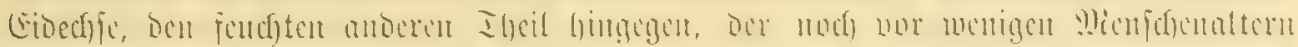

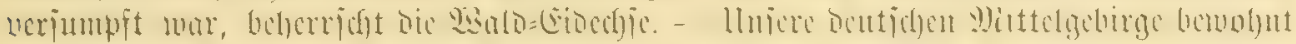

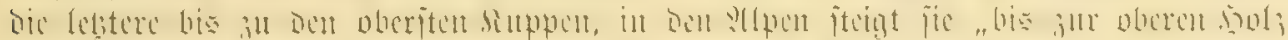

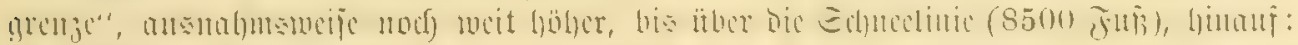

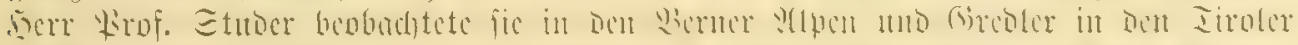

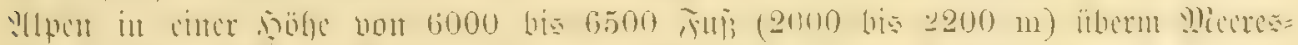

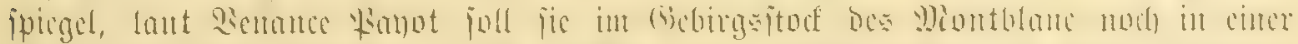

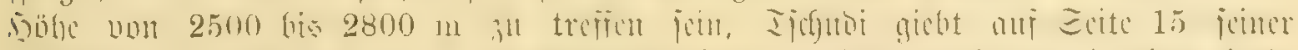

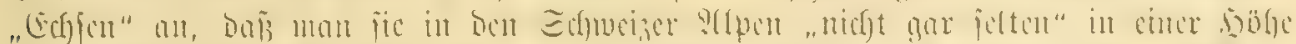

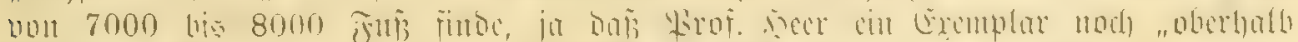

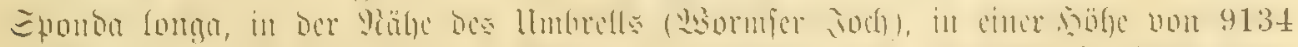

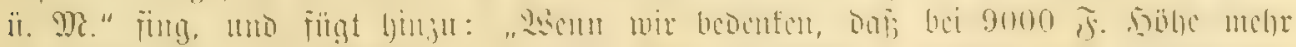

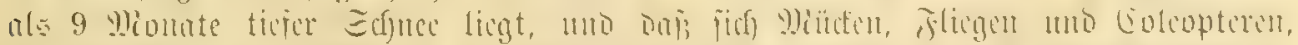

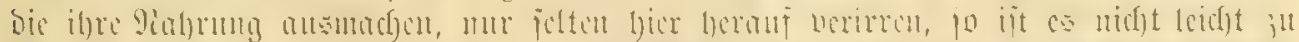

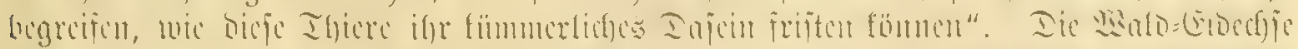

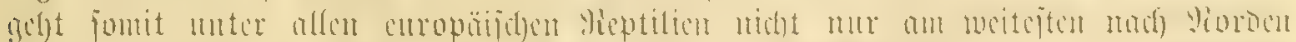

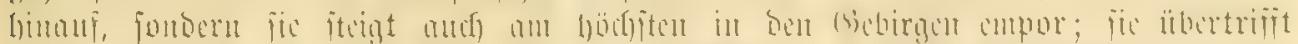

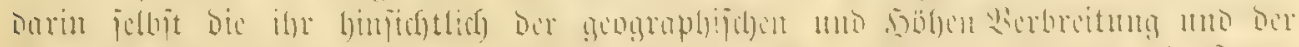

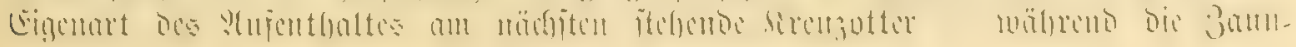




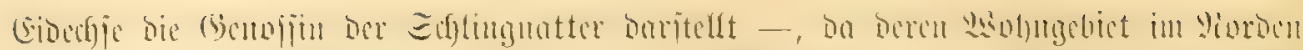

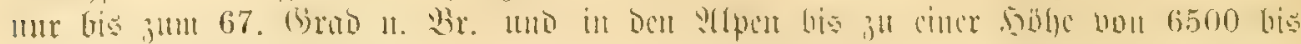

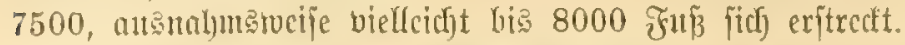

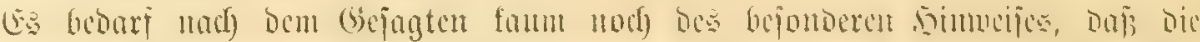

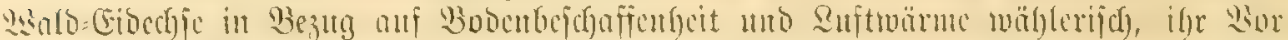

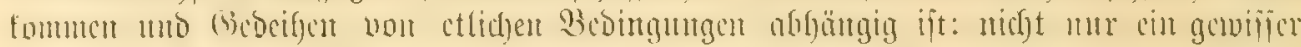

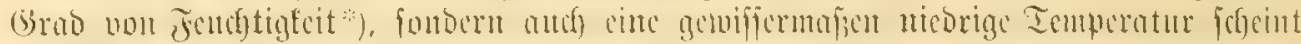

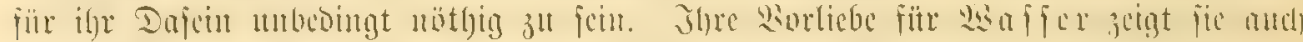

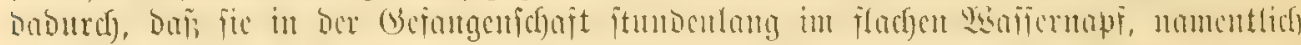

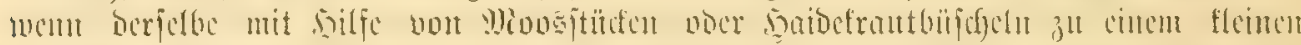

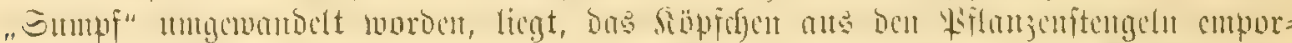

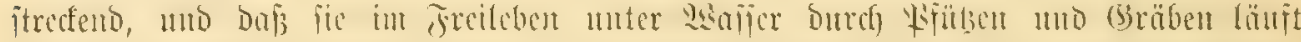

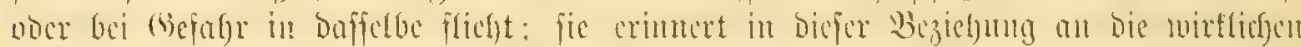

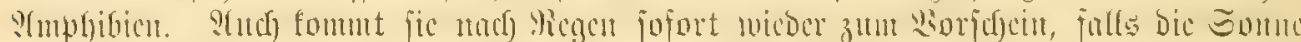

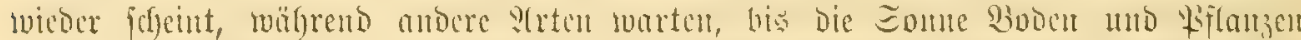

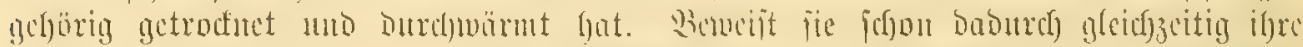

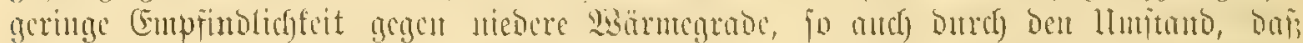

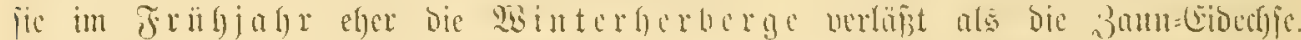

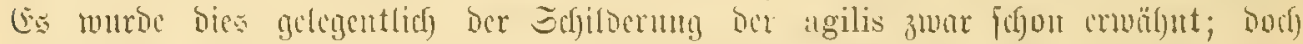

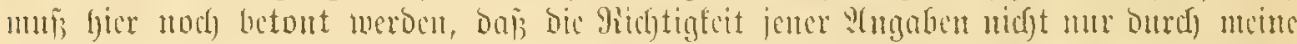

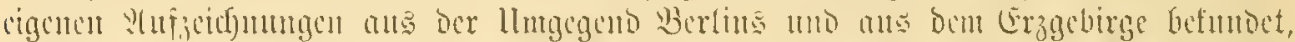

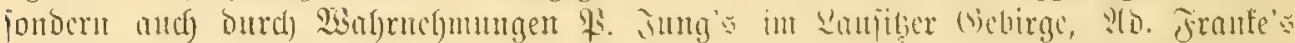

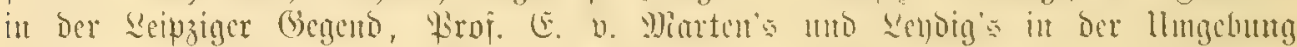

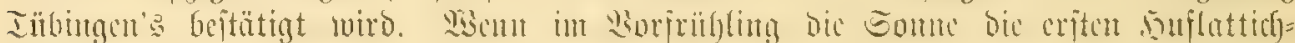

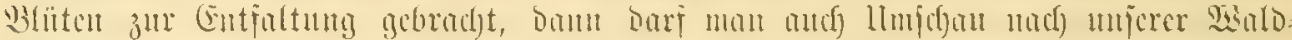

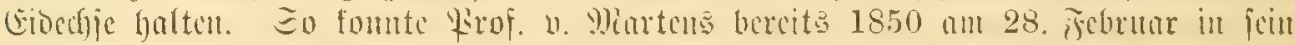

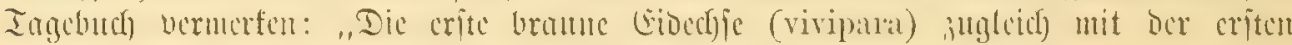

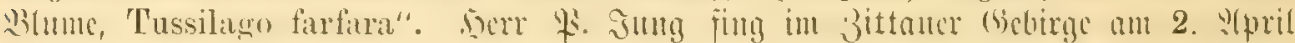

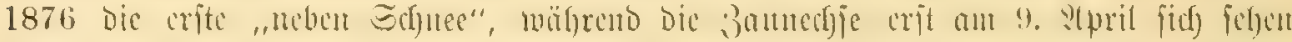

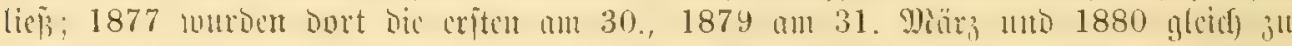

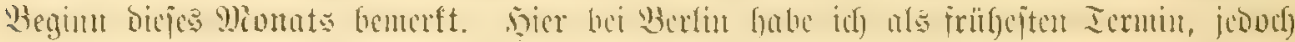

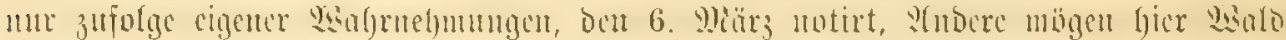

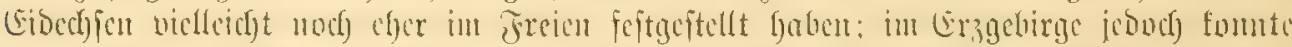

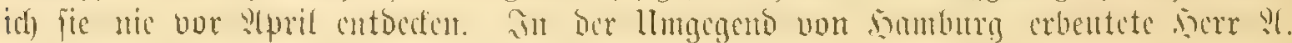
Sdjütb 1891 dic exfte, cu Männdyen, am 1. yiärz.

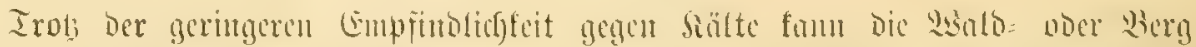

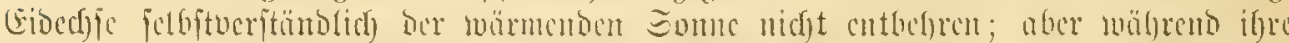

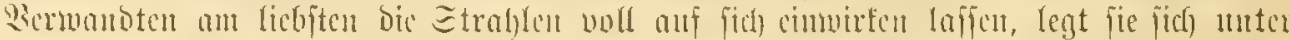

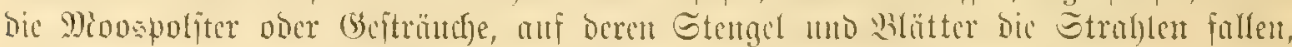

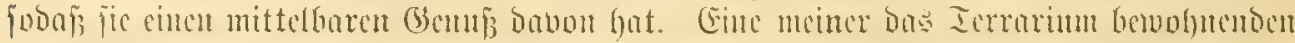

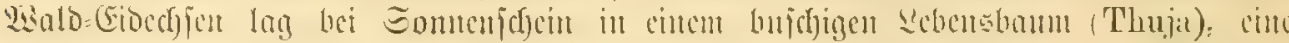

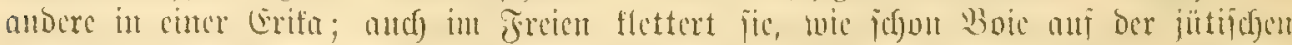

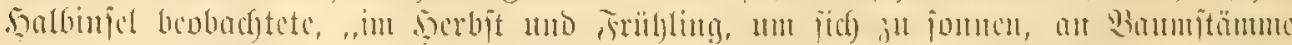

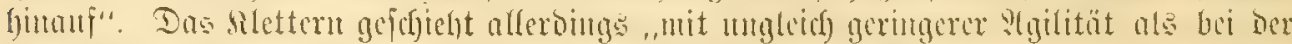

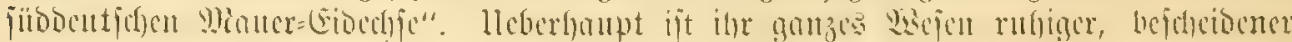

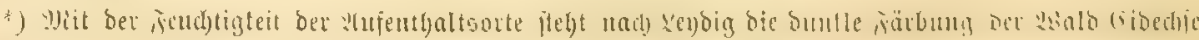

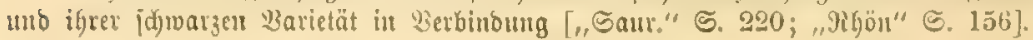




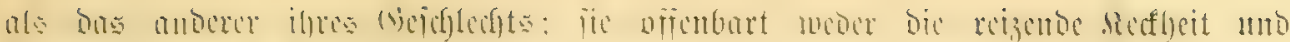

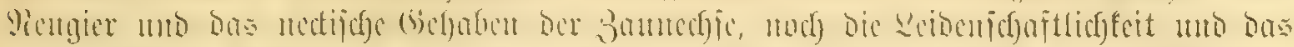

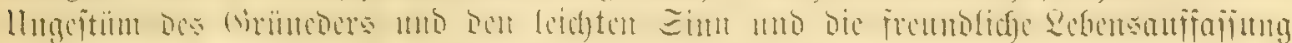

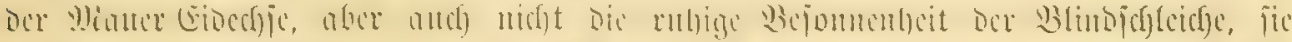

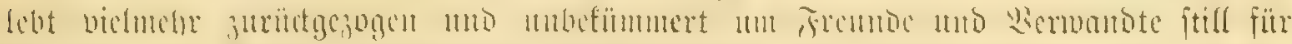

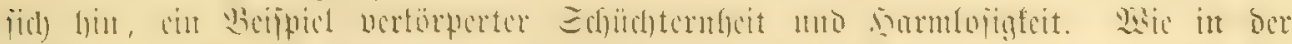

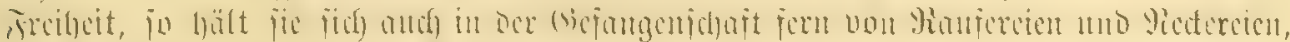

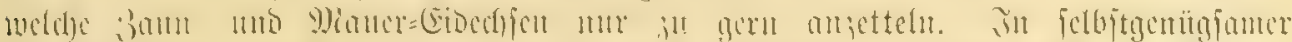

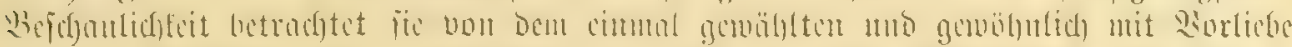

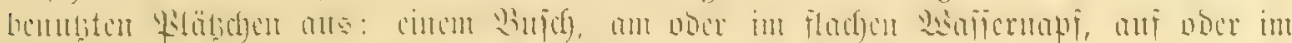

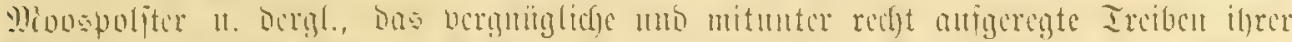

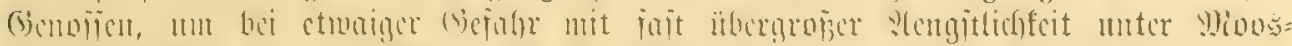

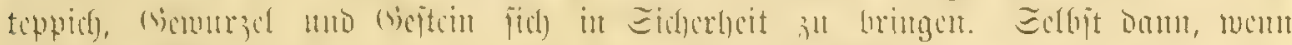

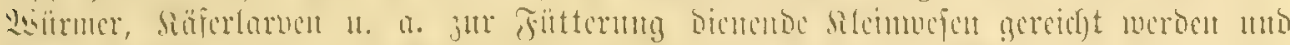

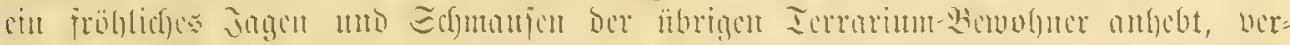

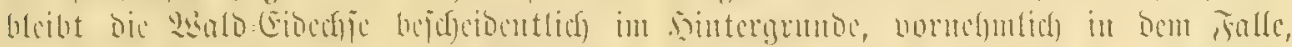

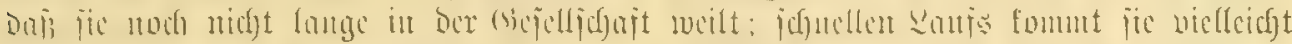

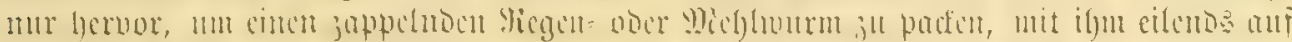

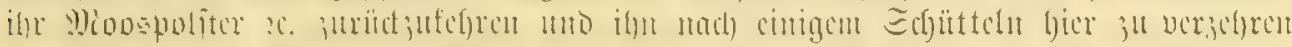

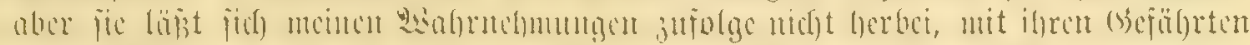

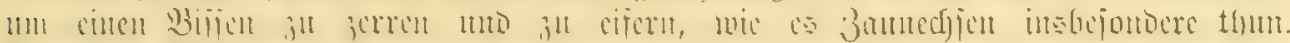

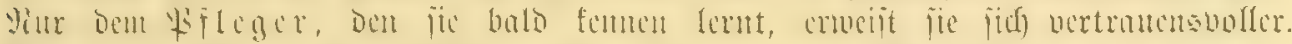

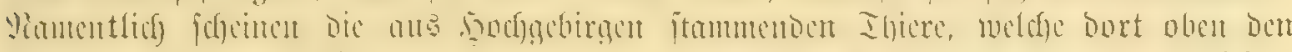

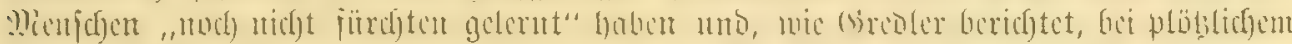

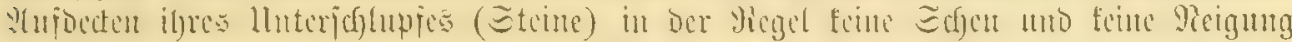

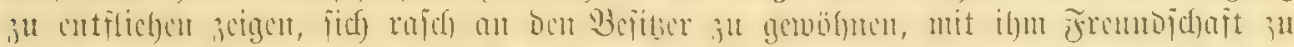

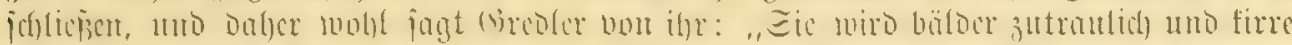

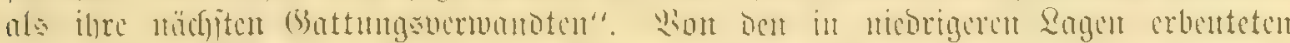

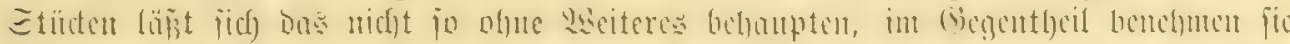

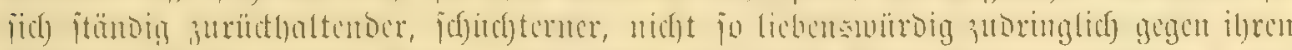

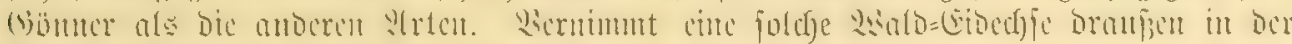

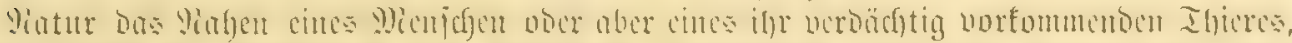

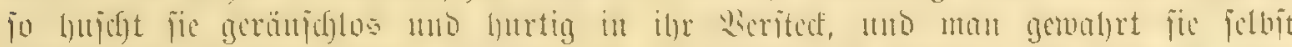

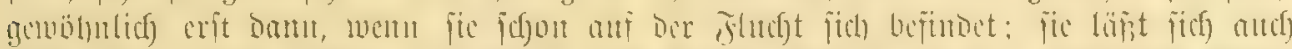

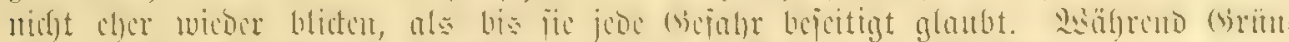

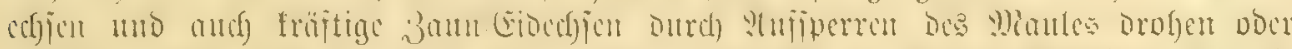

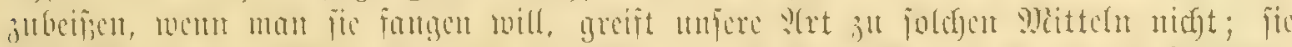

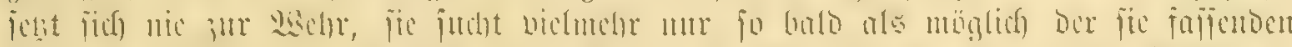

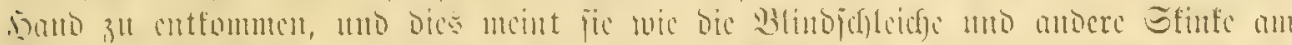

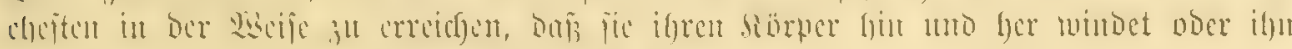

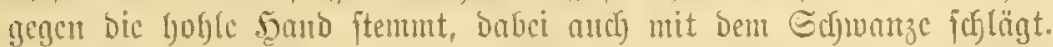

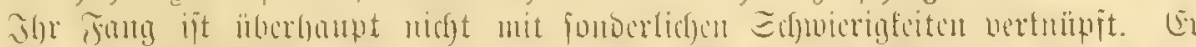

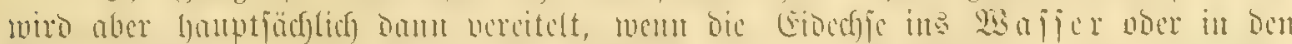

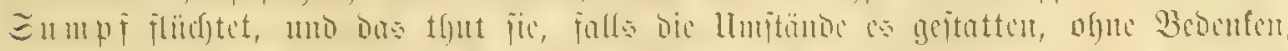

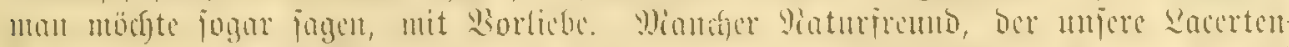

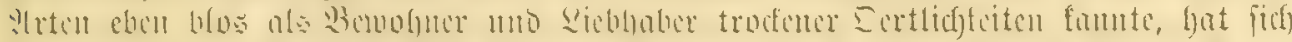
idfon

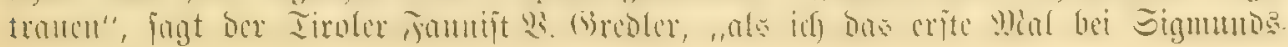




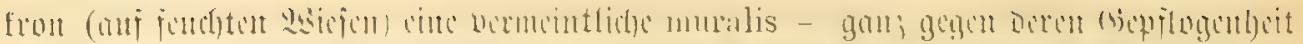

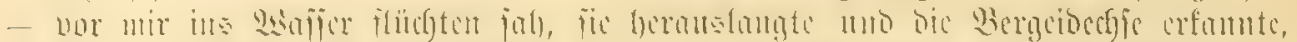

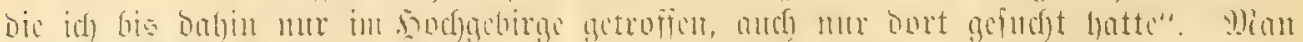

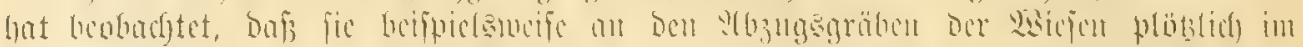

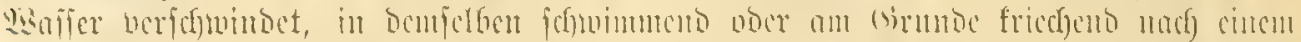

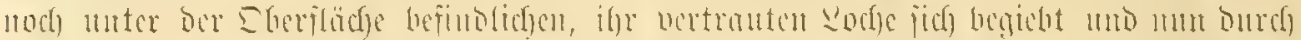

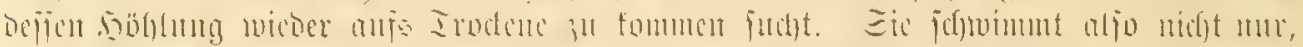

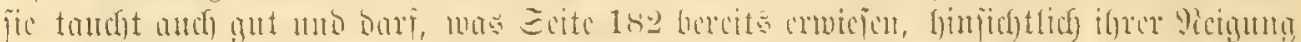

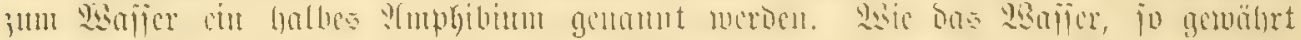

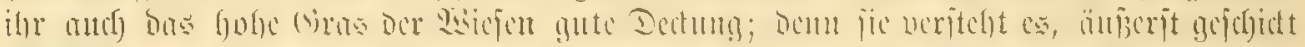

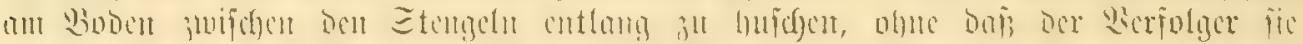

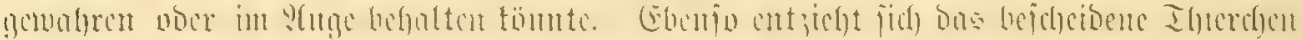

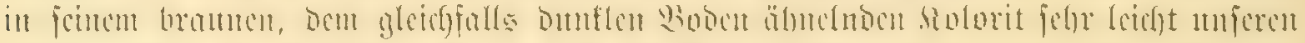

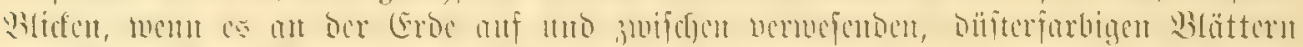

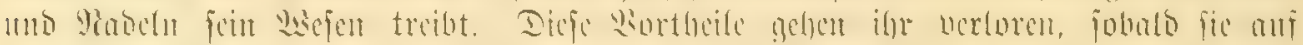

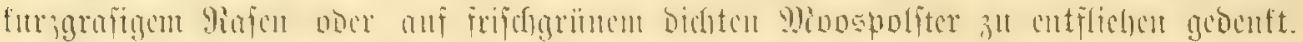

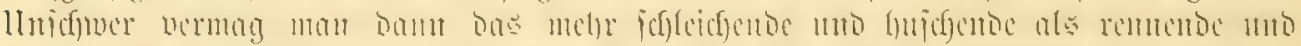

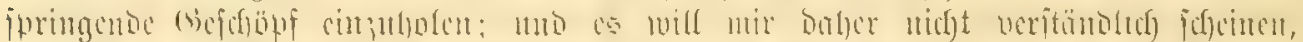

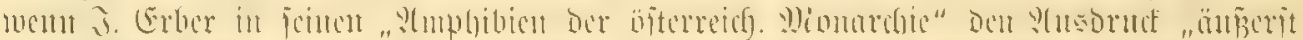

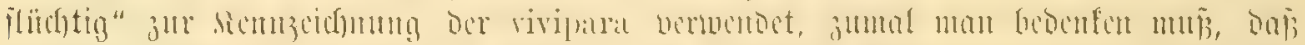

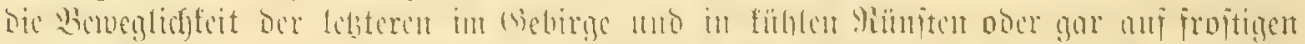

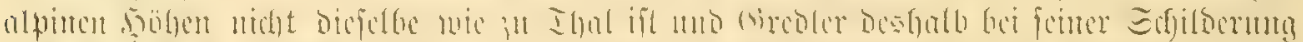

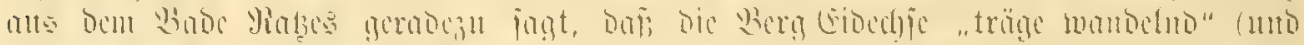

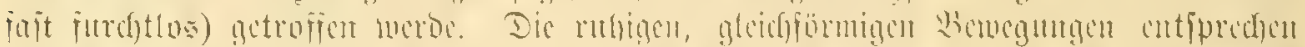

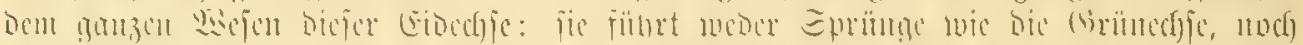

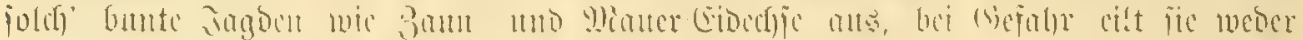

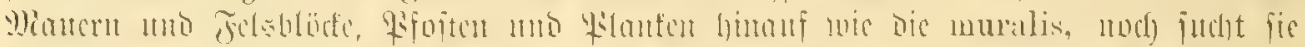

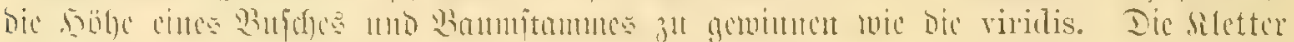

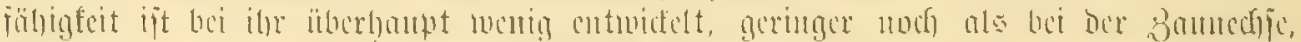

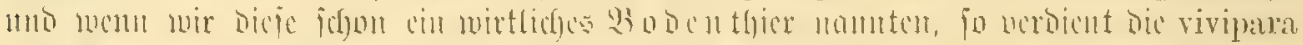

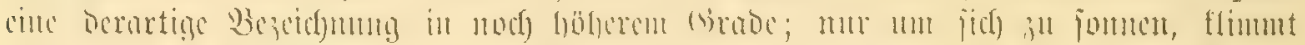

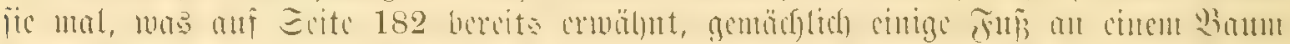

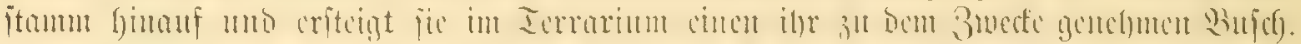

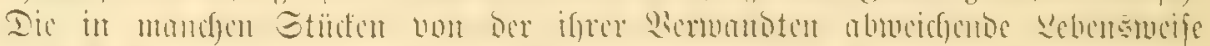

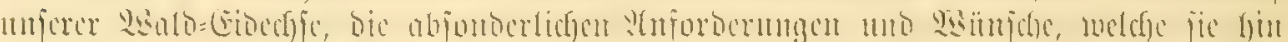

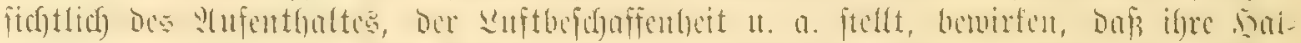

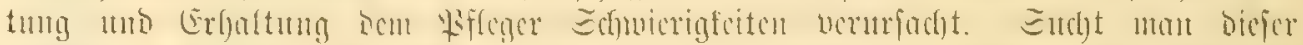

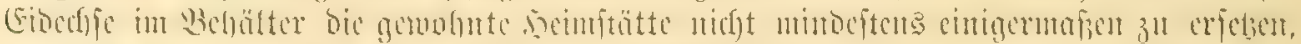

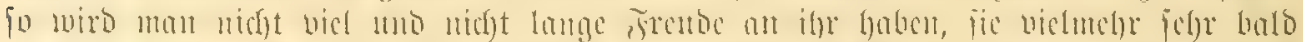

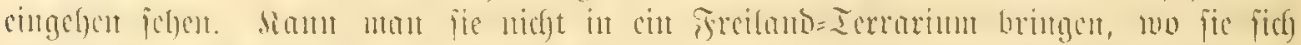

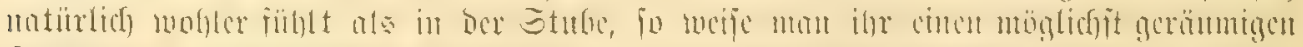

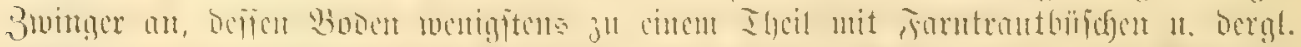

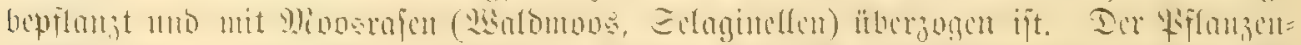

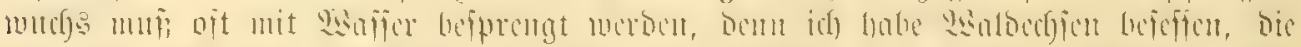

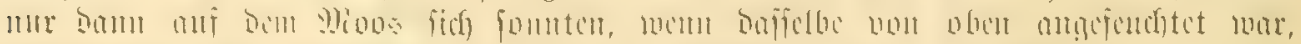

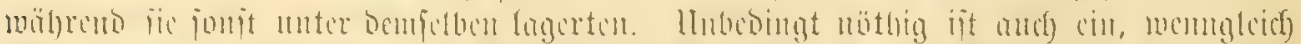

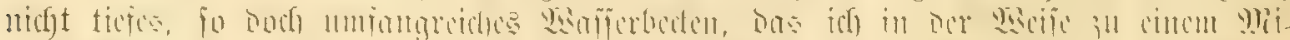

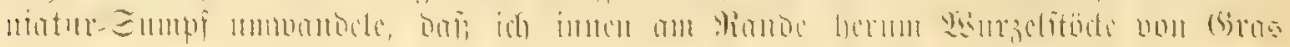




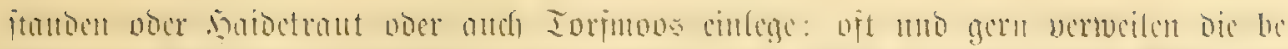

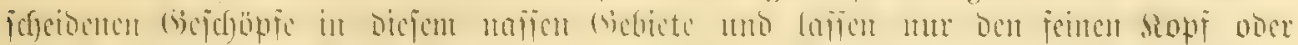

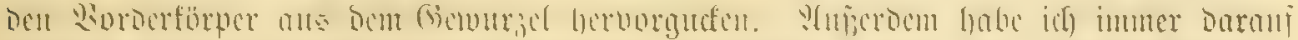

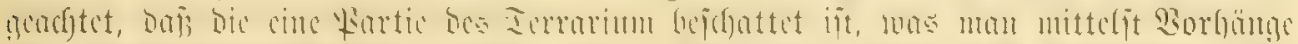

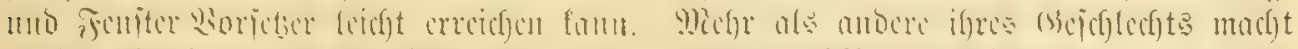

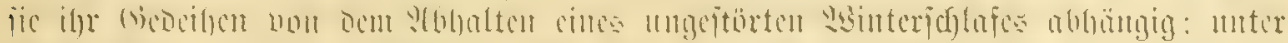

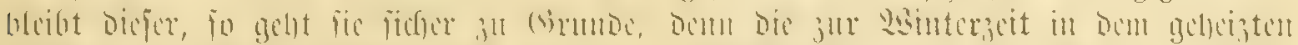

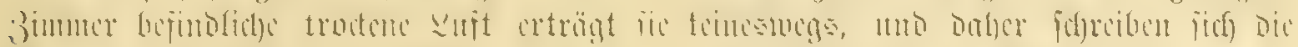

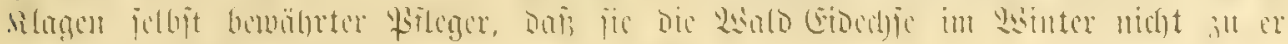
galten vermodfen.

(ำ

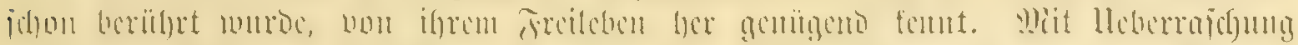

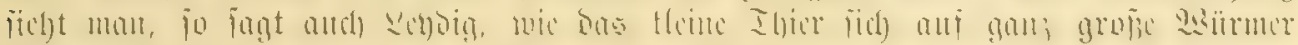

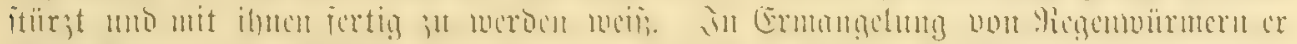

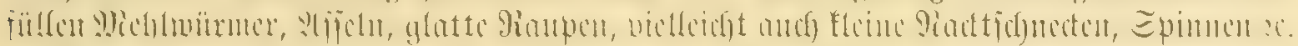

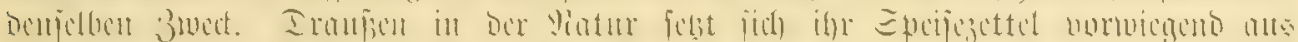

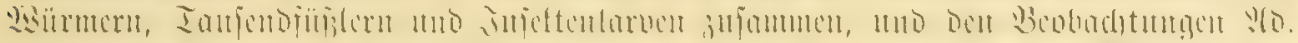

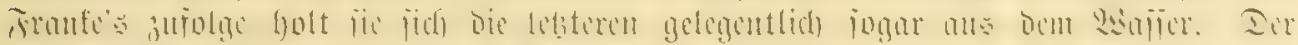

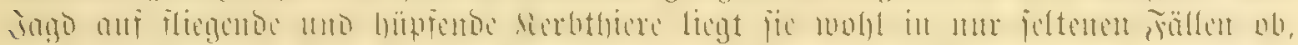

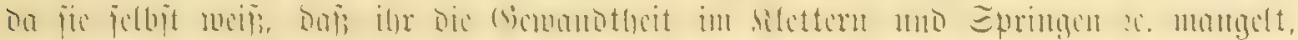

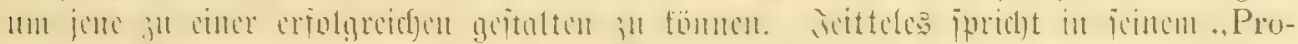

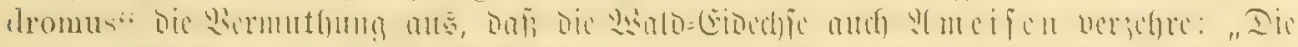

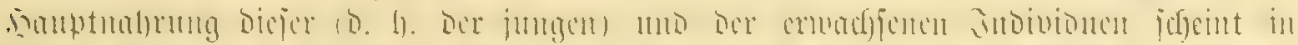

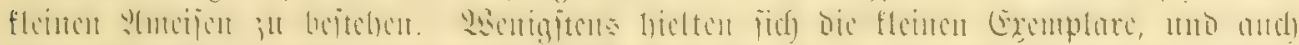

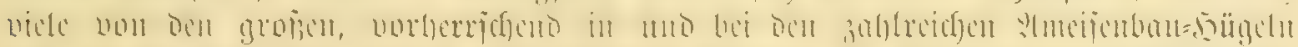

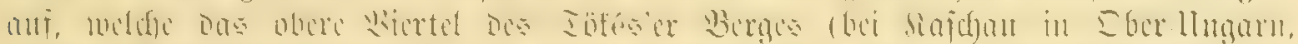

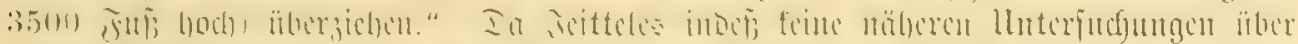

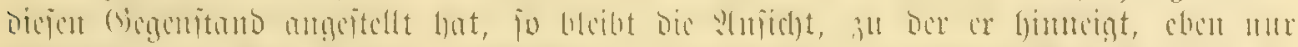

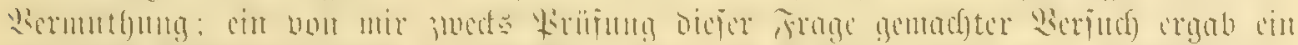

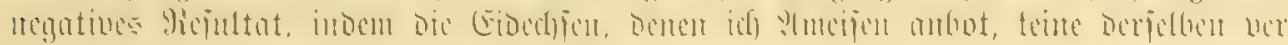
iclitent.

然as aber Dic

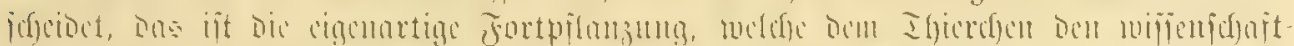

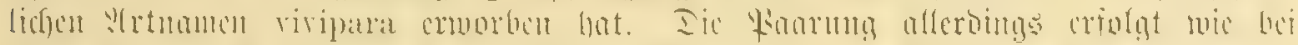

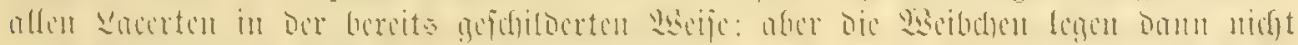

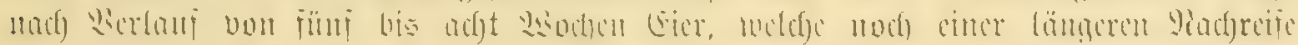

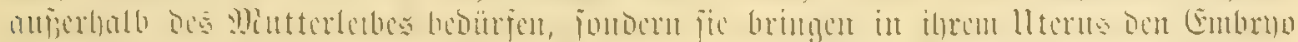

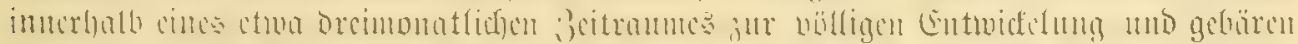

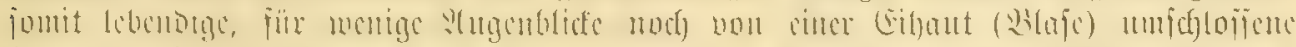

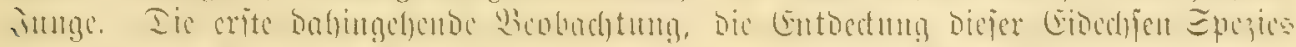

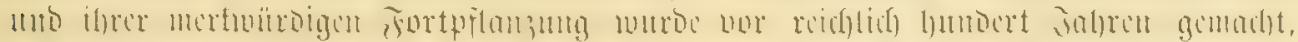

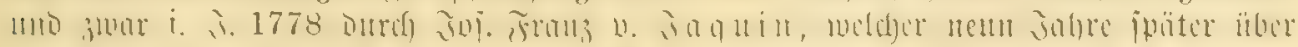

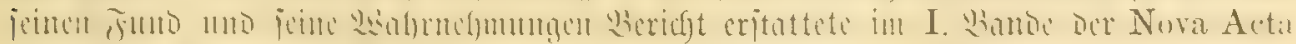

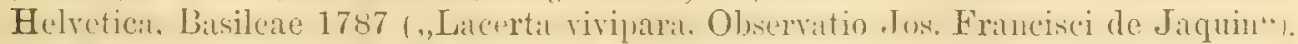

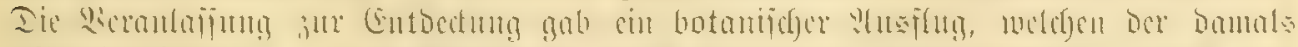

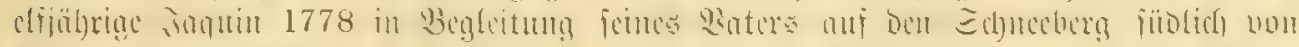

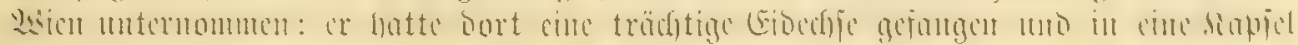

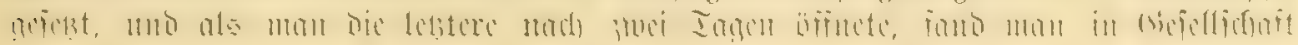




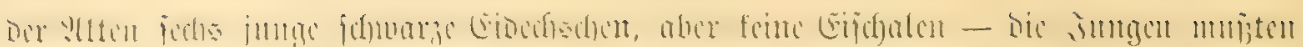

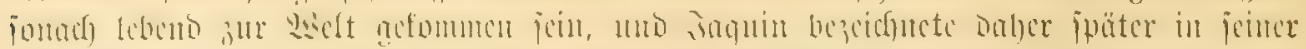

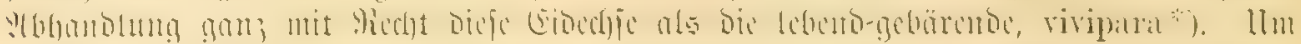

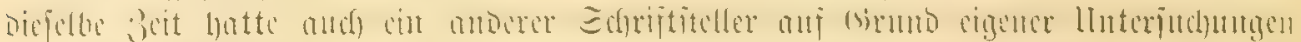

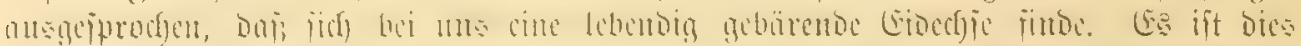

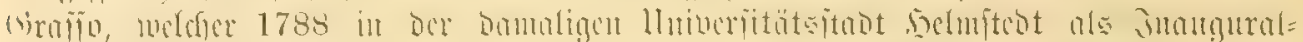

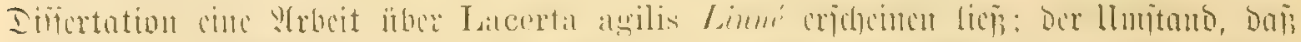

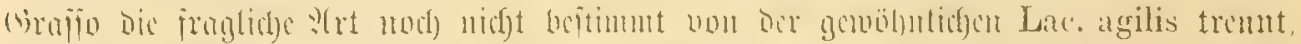

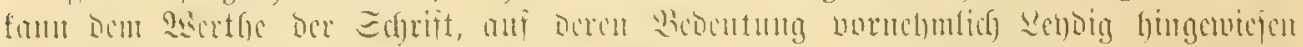

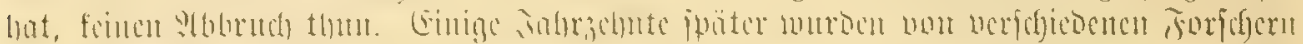

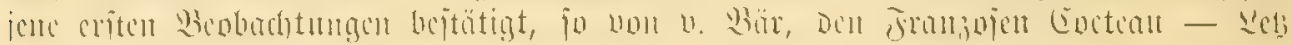
tcrer bcnannte bie Cibcdjic aber wieber bejonders: Lacerta de Jaquin und Lac.

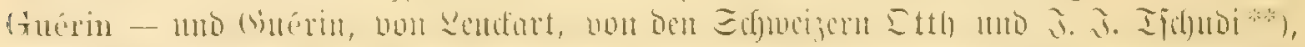

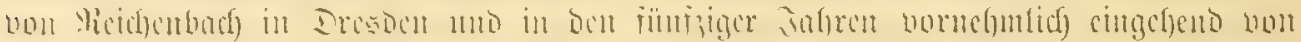

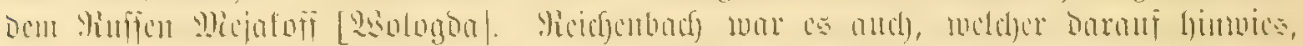

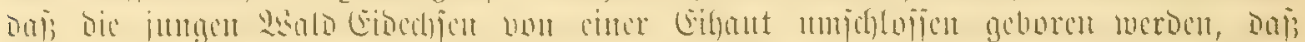

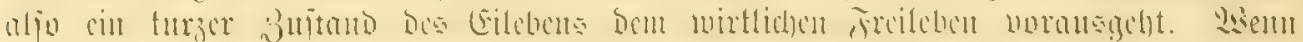

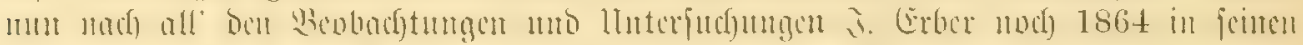

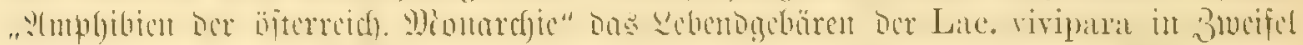

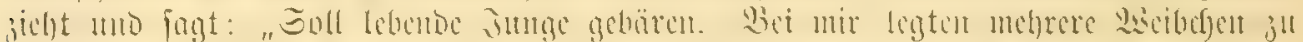

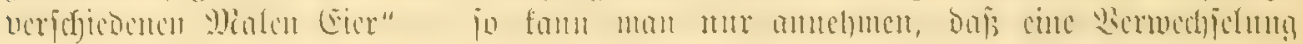

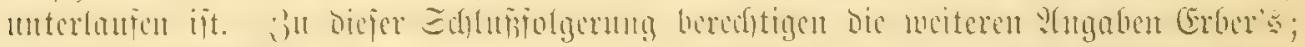

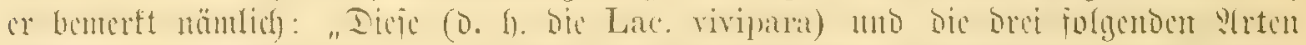

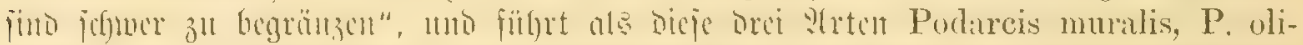

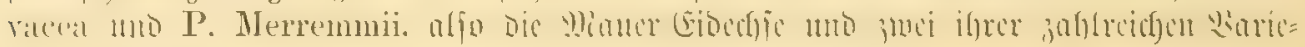
tïtelt auf! *****)

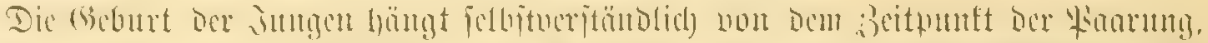

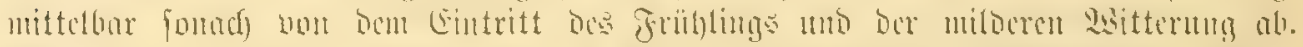

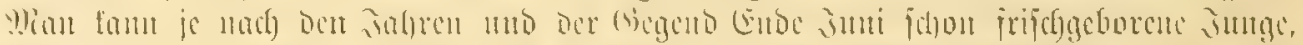

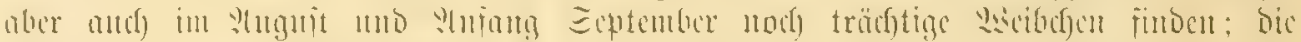

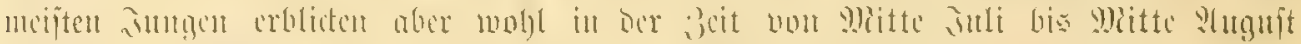

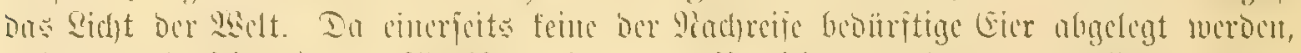

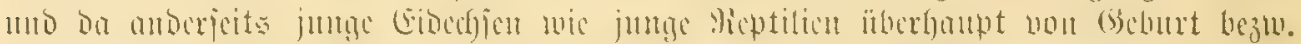

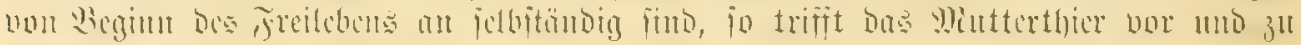
bem beregten seft feme

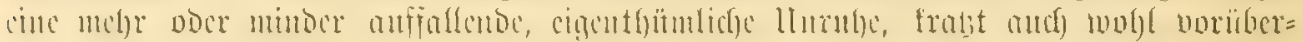

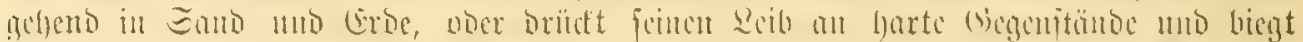

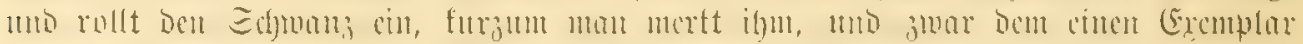

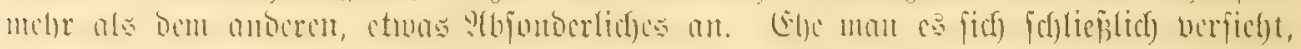

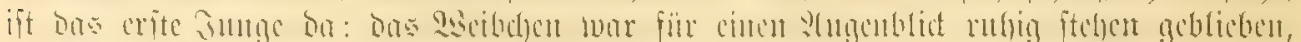

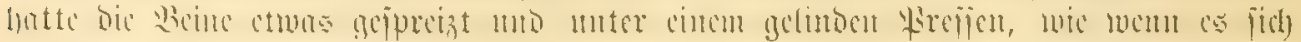

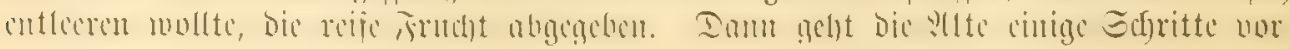

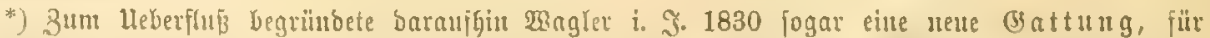

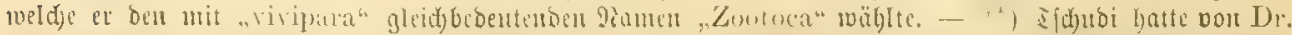

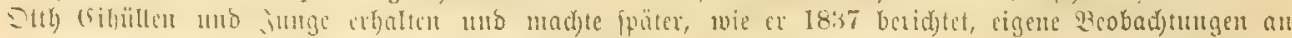

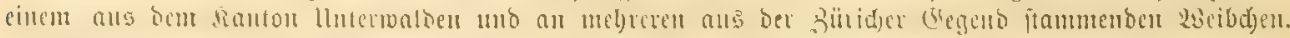

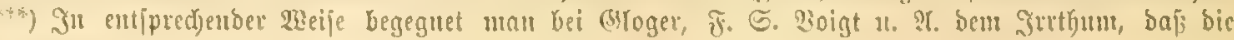

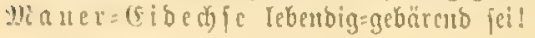




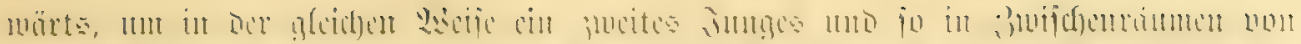

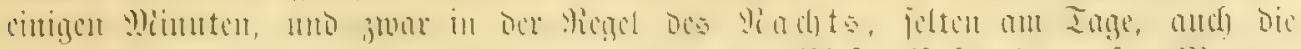

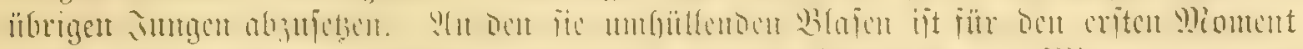

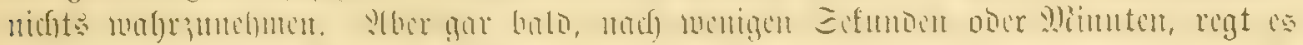

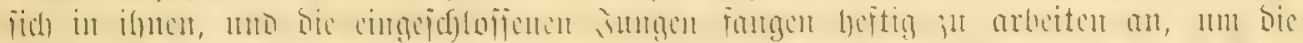

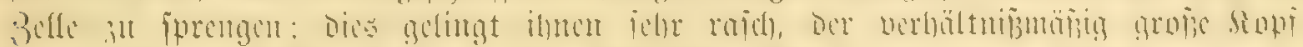

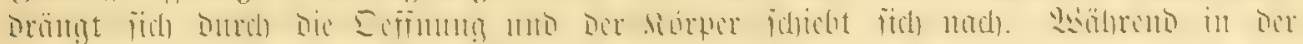

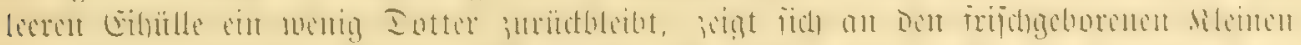

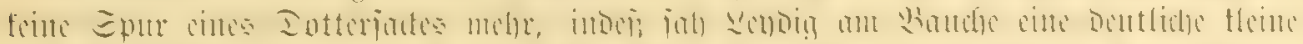

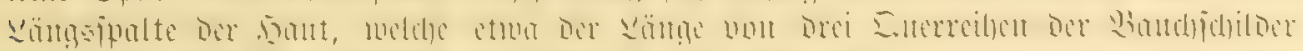

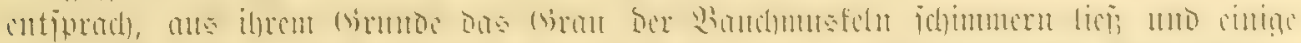

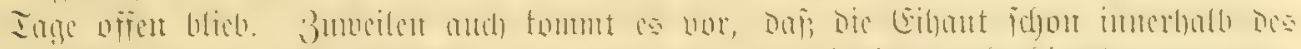

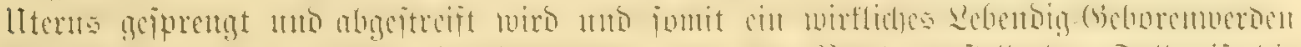

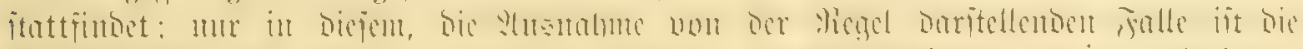

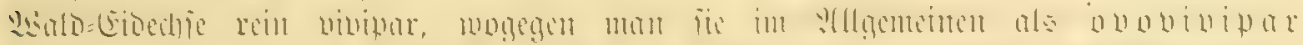

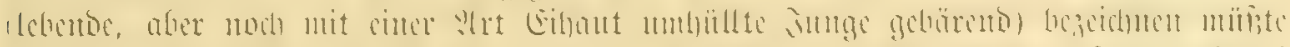

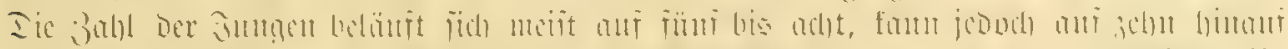

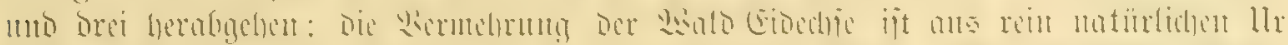

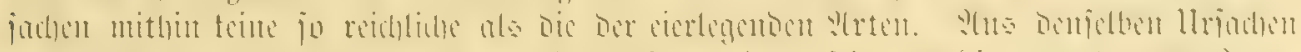

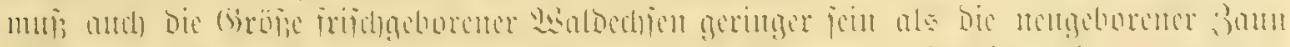

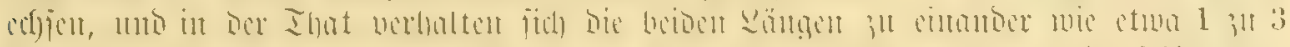

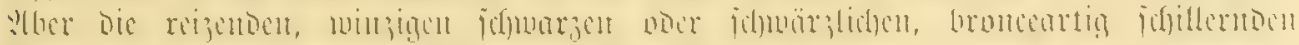

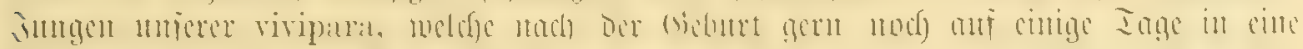

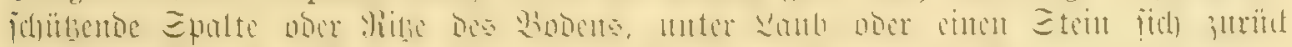

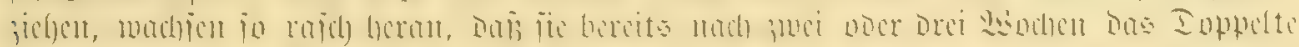

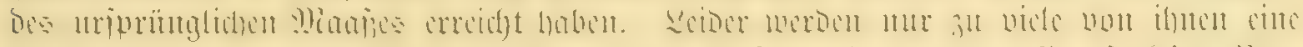
Bente alter :3am mo

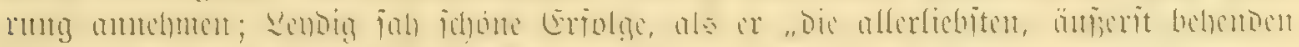

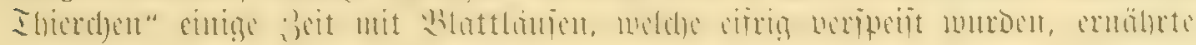

Sa

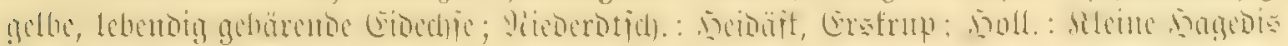

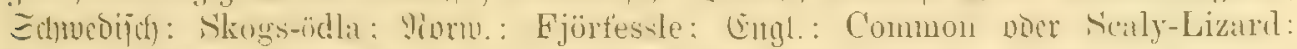

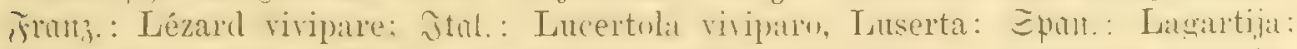

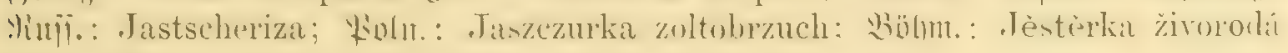
Zett.: Kirsak; (Ejtyuijd): Sissalik; Jimn.: Sisalisko.

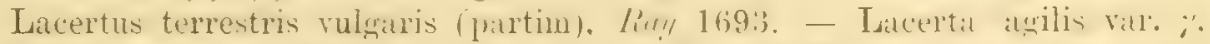

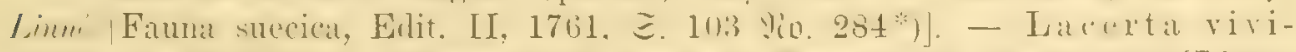

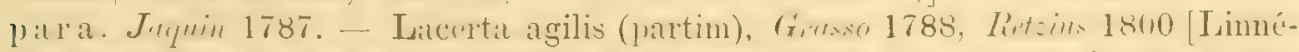

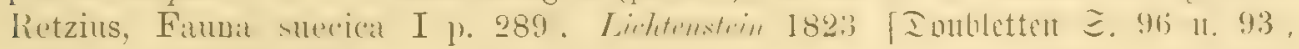
Brandt-Ratzeburg 1825. - Lacerta viridis var. g, Latreille 1800. - Lacerta nedura, Sheppard 1801. - Lacerta clocea, Wolf-Sturm 1805. - Lacerta pyrhogaster, Merrem 1820. - Lacerta Schreibersiana, Milne Edwards 1829. -

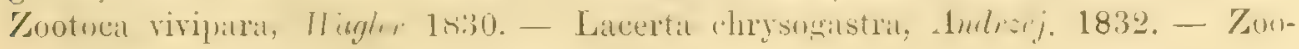

*) Mit ber turzen Diagnoje: "Lacertus dorso punctis albis, duplice serie" un bem 5imucis,

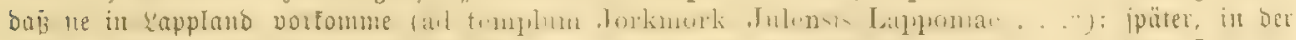

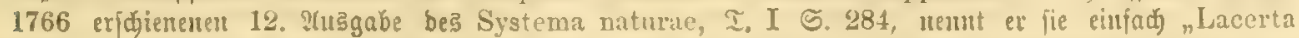

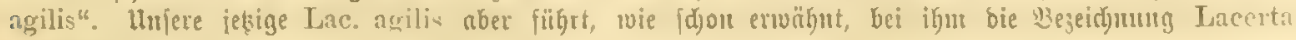
indi. 
toca crocea, TViegmann 1834. — Lacerta de Jaquin et Guérin, Cocteau 1835. Zootoca pyrrhogastra, Tschudi 1837. - Z. muralis, Grag 1838, - b̉ arietïtcu:

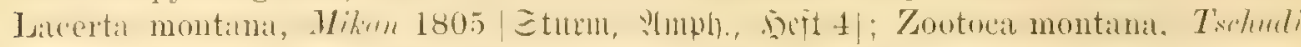

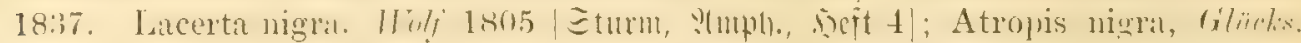
1851; Podarcis nigra, Prach 1861. - Laccrta micolor, Kuhl 1820.

\section{P(rt: 2lauer=(Eided)fi, Lacertit muralis (Taur:). Qtbbilbung: Tafel XI 9 ใr. 4 unb 5.}

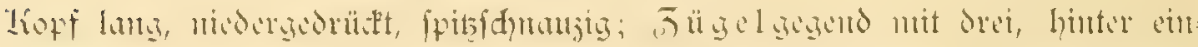

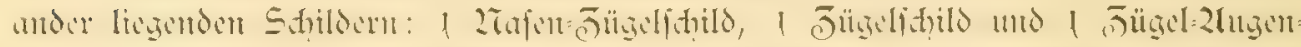

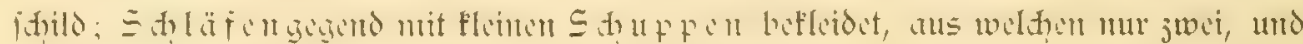

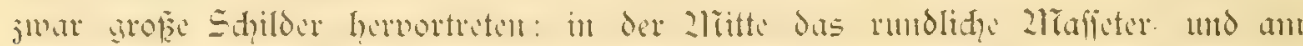

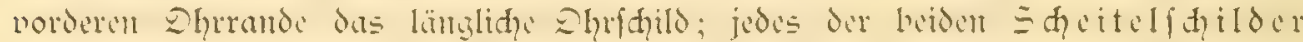

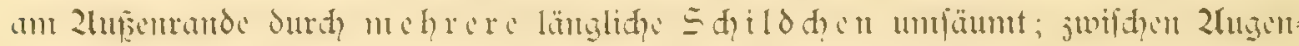

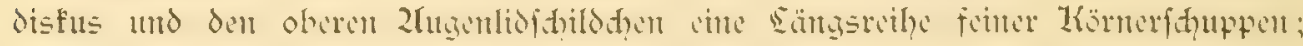

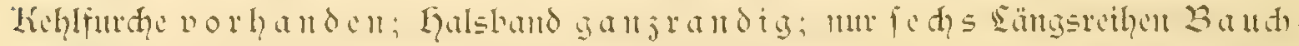

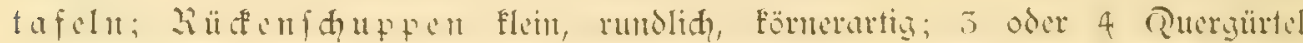

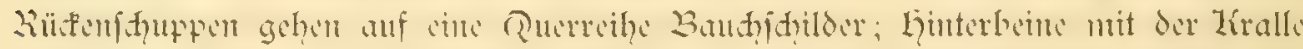

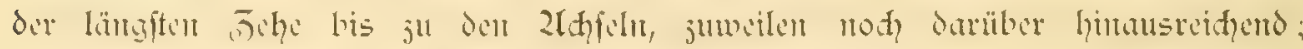

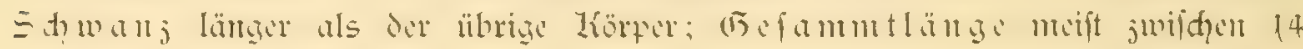
แnt $18 \mathrm{~cm}$ fínwantend.

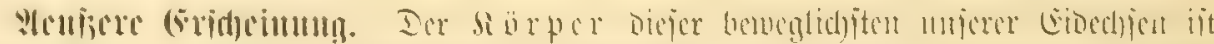

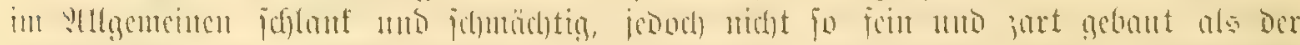

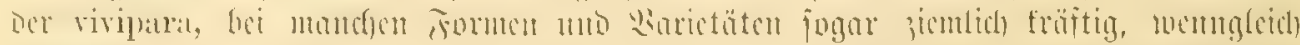

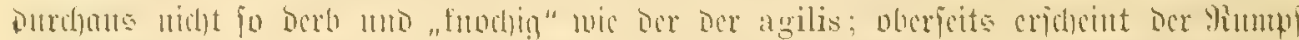

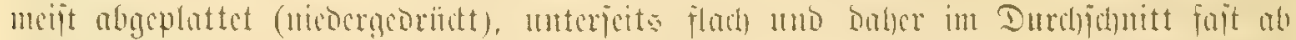

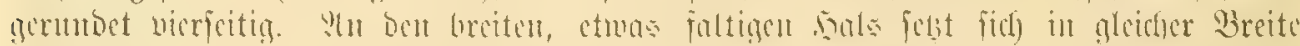

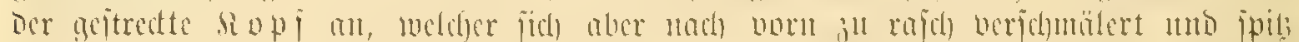

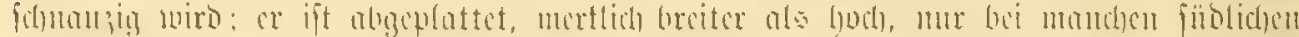

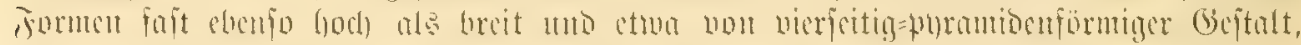

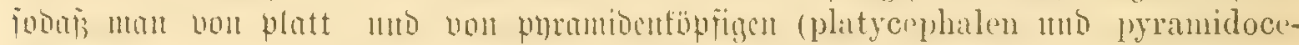

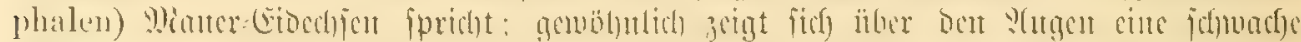

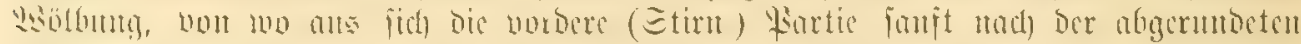

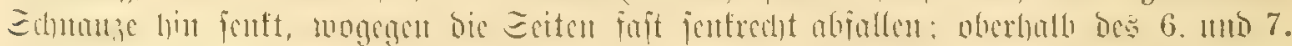

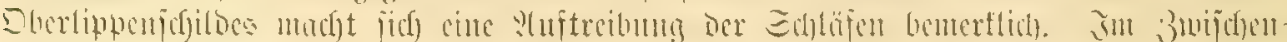

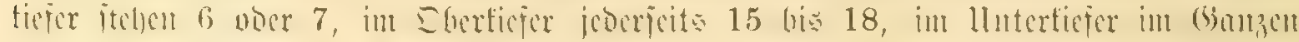

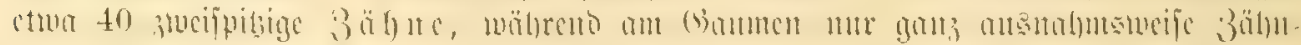

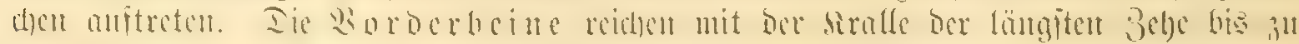

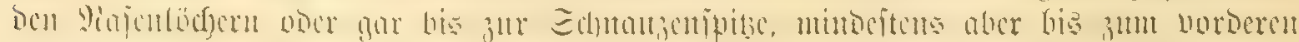

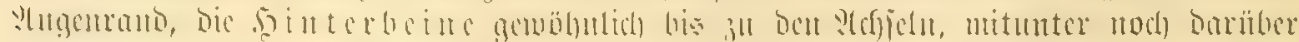

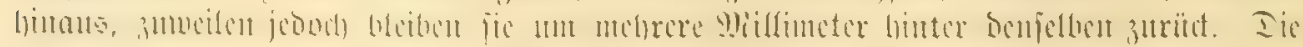

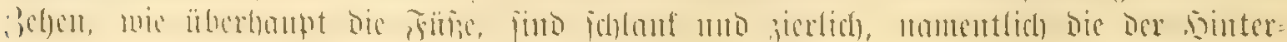

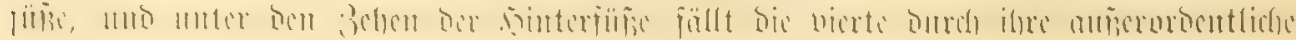




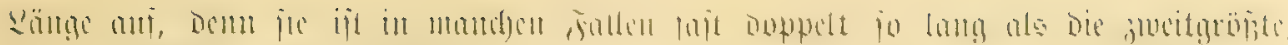

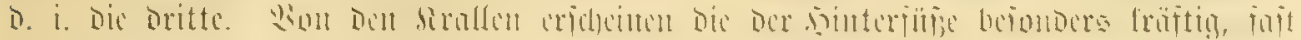

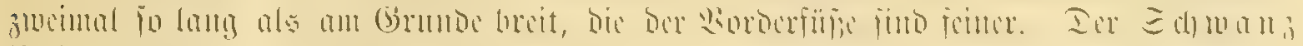

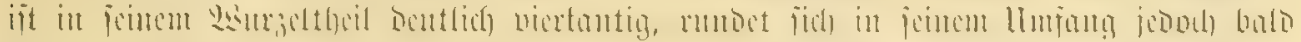

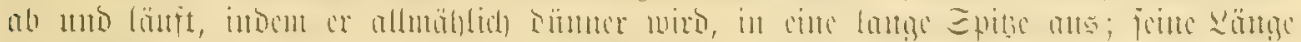

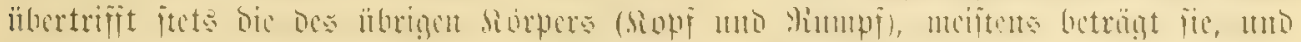

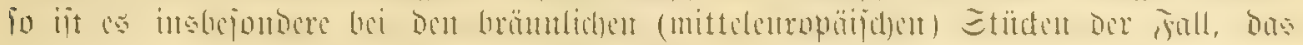

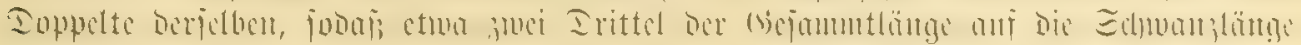

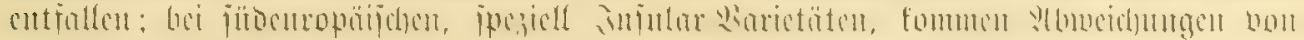
biejer Riegel vor.

Eit bo

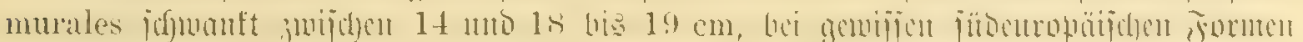

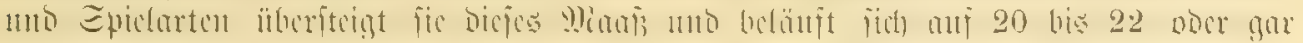

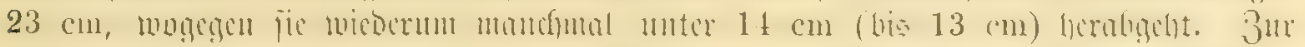

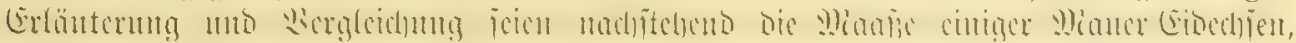

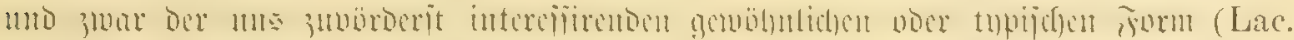

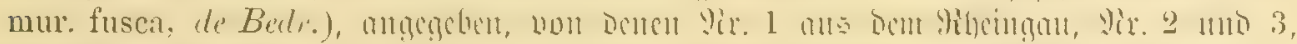

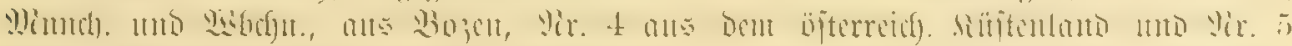

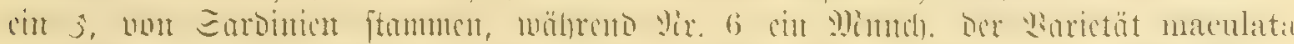

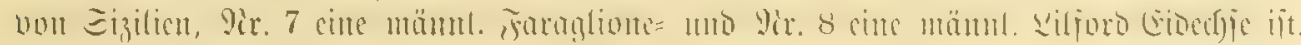

\begin{tabular}{|c|c|c|c|c|c|c|c|c|}
\hline & $1 \mathrm{r} .1$ & 2 & x. 3 & 92,4 & 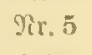 & & 7 & \\
\hline & 1311 & $\mathrm{~mm}$ & $m 11 m$ & $\mathrm{~mm}$ & $\mathrm{~m}$ & n & $\mathrm{mm}$ & $m m$ \\
\hline opf(äıเge**) & 14 & $13, ;$ & $12,$. & 15,5 & 15,5 & 19 & 20 & 8 \\
\hline 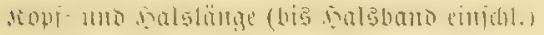 & $3(1)$ & $19, ;$ & 19 & 23 & 23 & -8 & 29 & 27, \\
\hline mpfläıge $\left.{ }^{*}\right) \ldots \ldots . . . .$. & 37 & 34,3 & 36 & $3 \varepsilon$ & $3 \varepsilon$ & 46 & 53 & $42, ;$ \\
\hline 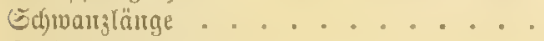 & 113 & 106 & 101 & 12 & 131 & 23 & 136 & 95 \\
\hline ejammtläuge. & 70 & 160 & 56 & 85 & 194 & 197 & 218 & 165 \\
\hline öhe .... & 6 & 6 & $\mathbf{5}_{5}$ & 7,3 & 8,5 & 9,5 & 10,2 & 0 \\
\hline te Topibreite & 8,3 & 8,8 & 7,5 & 10 & 9,5 & 11 & 12,4 & 2 \\
\hline e Der Ropibefdilberung & 6 , & 6 & I & 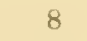 & 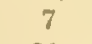 & 8 & 9,6 & 8 \\
\hline bes 23orberbens ${ }^{* *}$ J.. & 19 & 20 & 18 , & 21 & 21 & 7 & 26 & \\
\hline e beకె Borberfuges mit längiter 3ebe. & 8 & 8 & 0 & 9,5 & 9,5 & 3 & 12,5 & \\
\hline 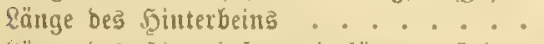 & 3 & 2 & 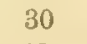 & & & 47 & $4=$ & \\
\hline änge bes Jinteriates mit längler $3 \mathrm{ebe}$ & 1 & 13 & 15 & 15 & 20 ; & 23, & 9.2 & \\
\hline
\end{tabular}

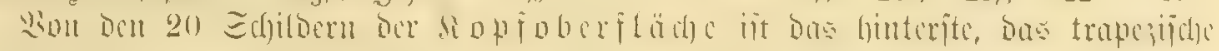

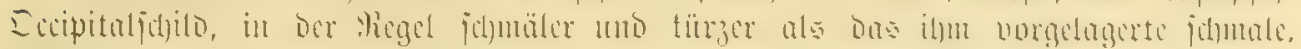

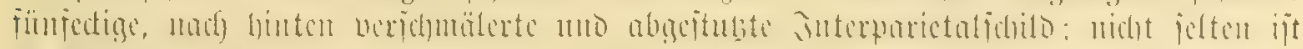

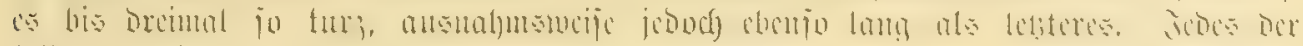
beiben grop̈en, an Sinterrande janft abgerumbeten

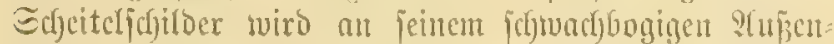

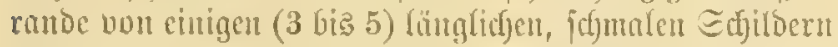

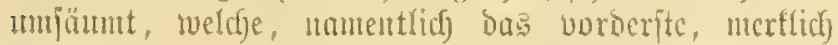
größjer find alg die Sofuppen ber Schläfe, jedoch utut immer gut entwidfelt, fundern zuveilen in cinc ?(uzafyl

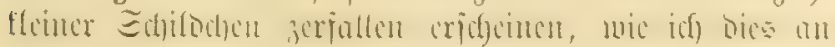
jïbtirolifben Gtirden toafrnafm. Die melyr in bic

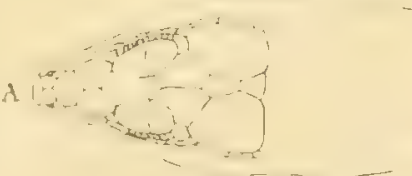

sig. 19. Nopiplatte ber Mante: (sibedjle.

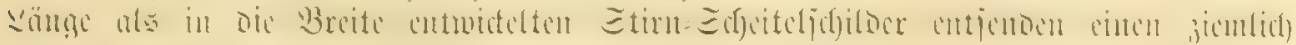

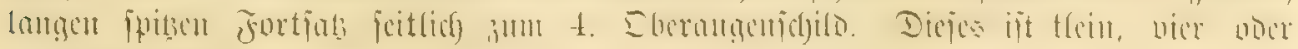

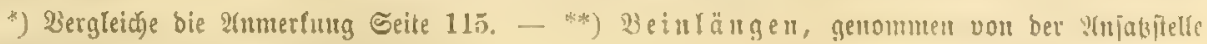
ลแแ Rumpi bis zur Rralle ber längiten Behe. 


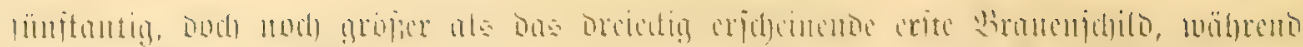

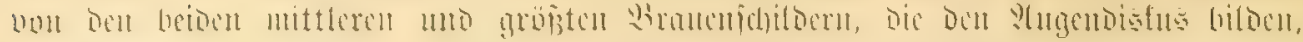

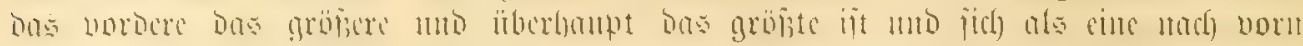

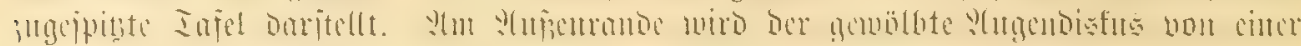

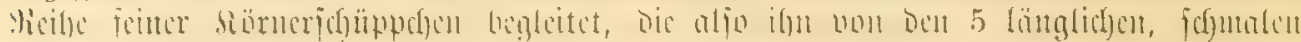

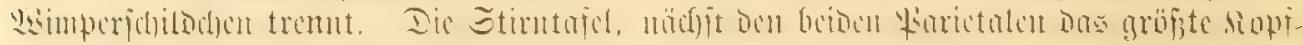

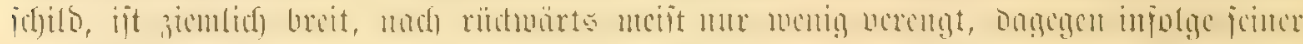

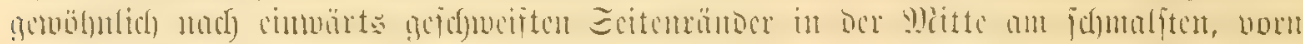

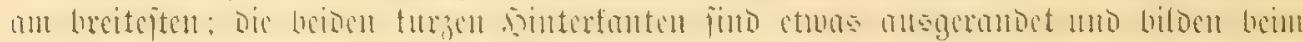

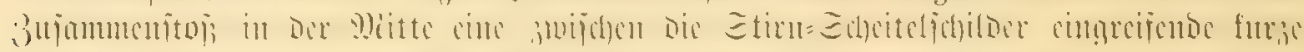

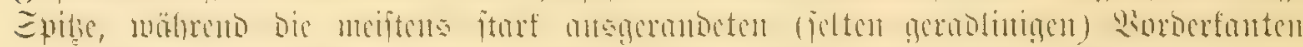

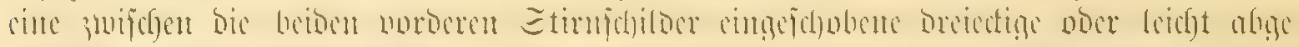

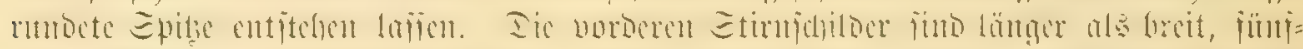

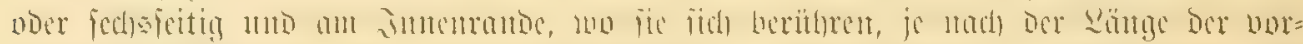

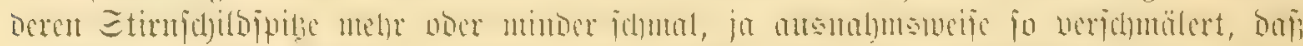

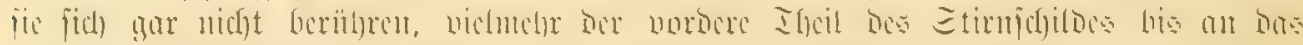

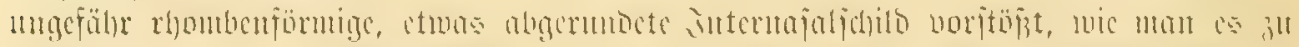

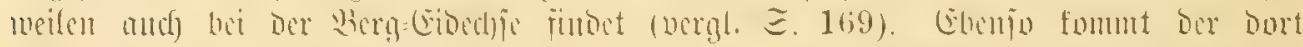

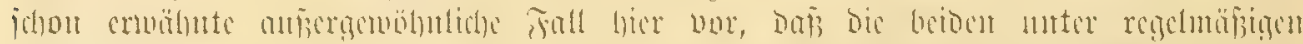

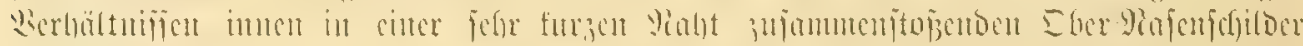

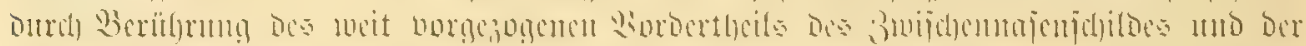

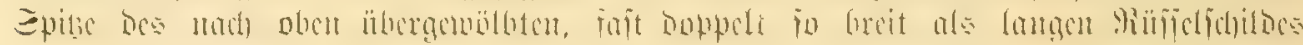
bou cinamber getrenut merden.

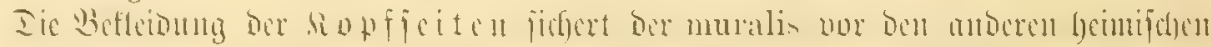

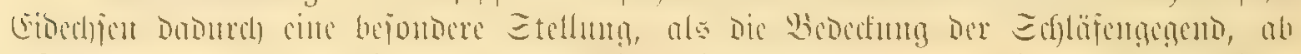

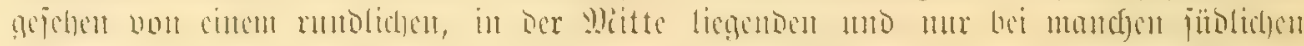

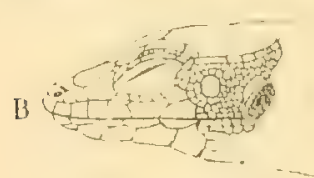

Tig. 20. Repijeite ber Mauer=(cibed)je. Formen feflenten 9)infeterichild uno einem an Dem Borocr= ranbe ber ovalen Dgriffintng Kefindicfent lünglichen, Gofuen= förmigen Dhrjofillo, lebiglich aus flement rutblichen, fajt förnes= urtigen Schuppent beiteht; ztwei pDer brei lieifent Der Yeţteren

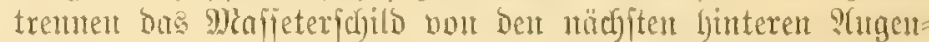
jdjildert. Bon Den 6 ooer 7 Dberlippenichildorn ift bas

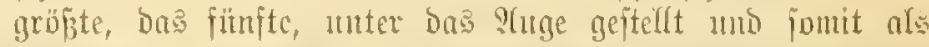

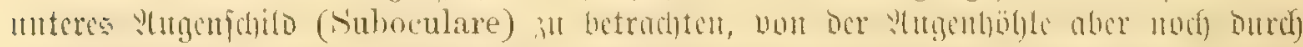

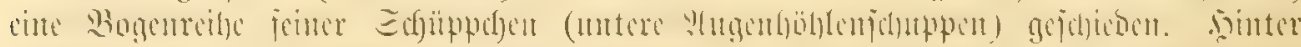

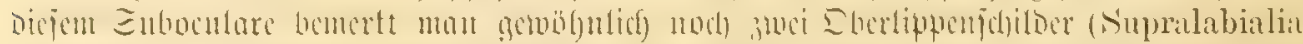

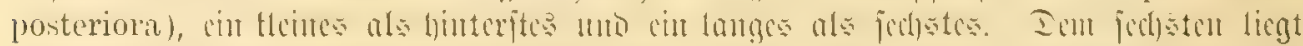

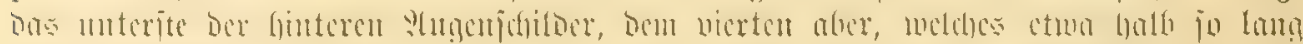

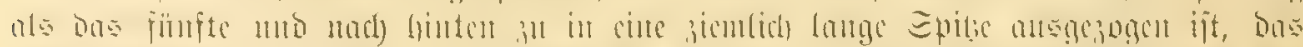

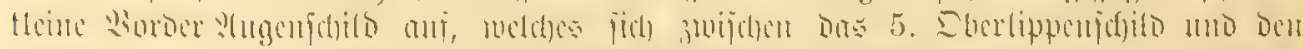

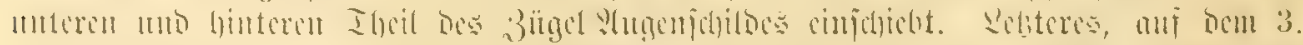

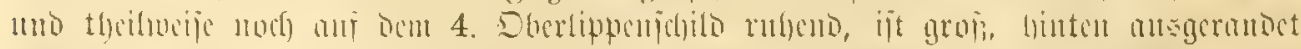

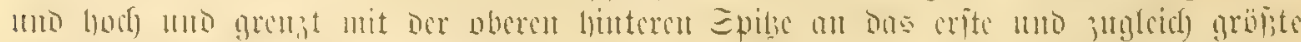

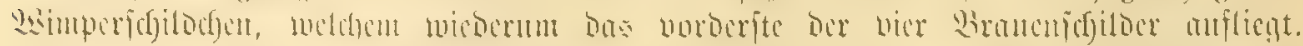

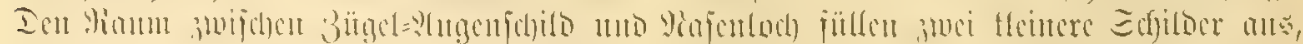

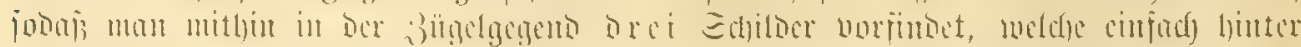

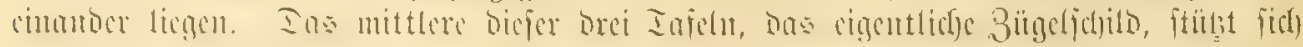

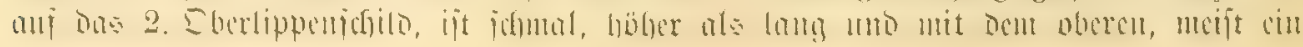




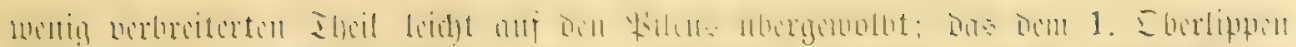

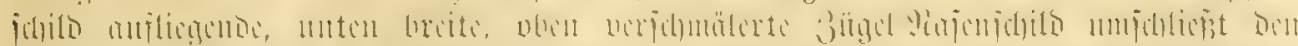

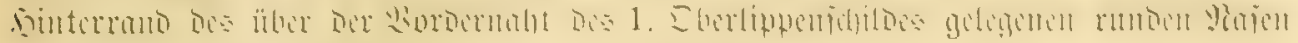

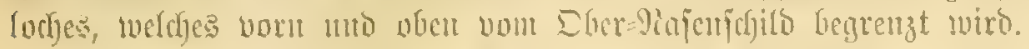

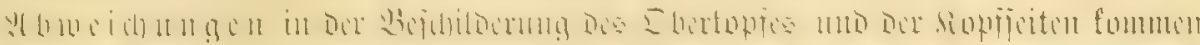

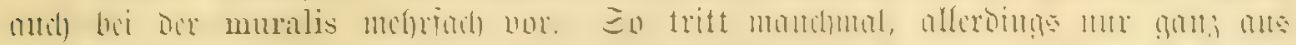

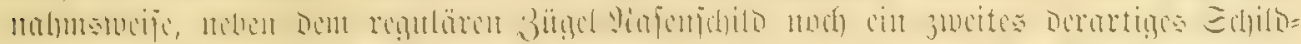

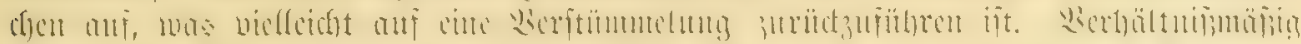

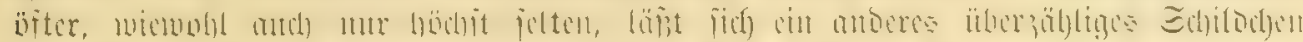

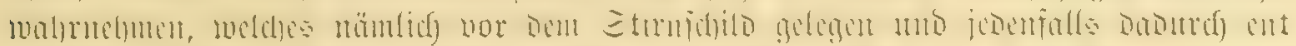

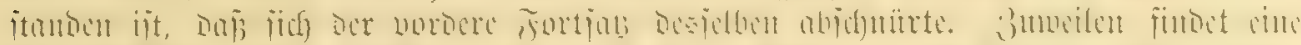

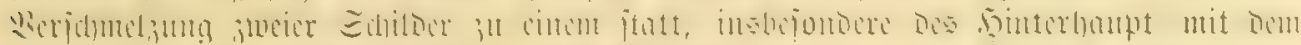

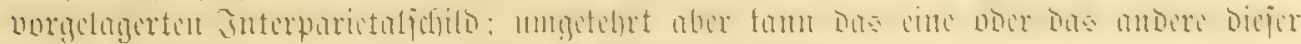

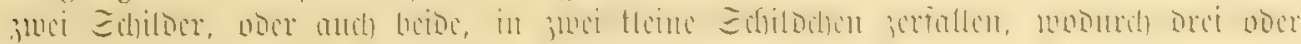
yar vier mittlere sinterfyaptydyilder entiteljen.

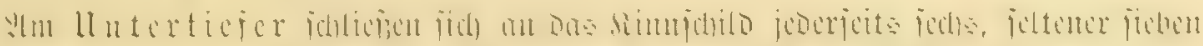

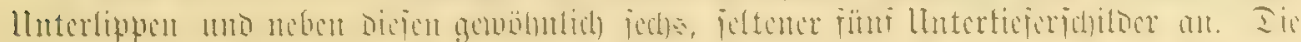

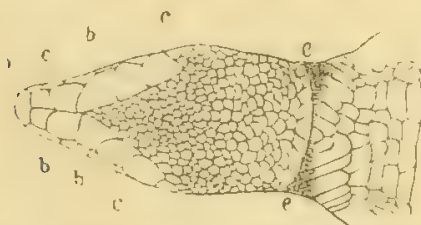

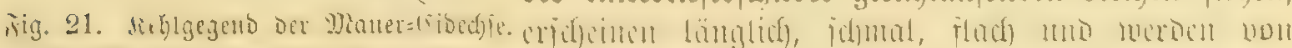

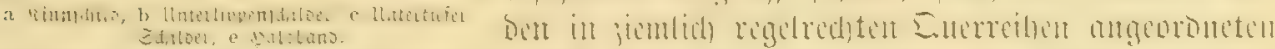

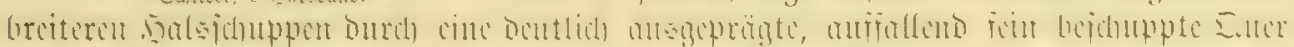

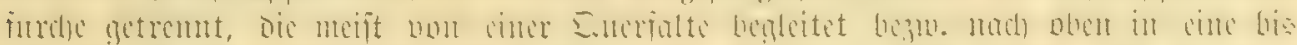

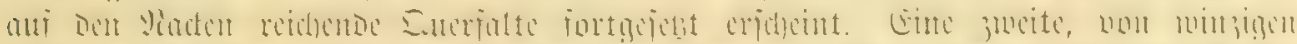

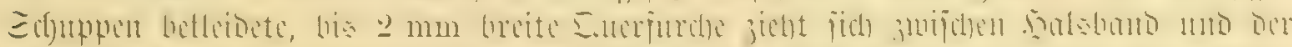

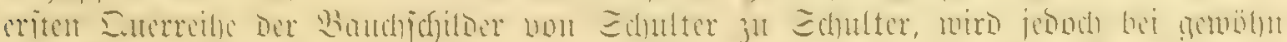

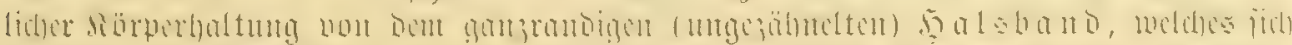

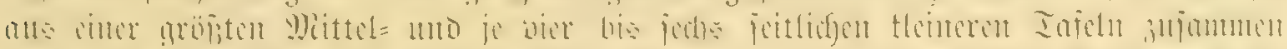

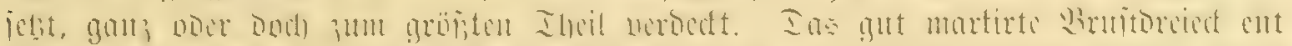

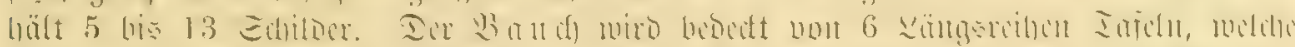

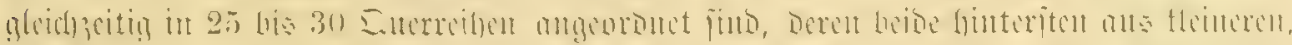

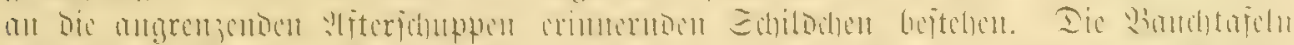

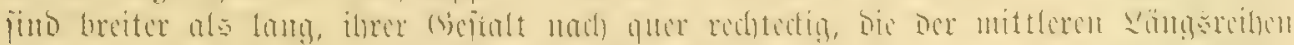

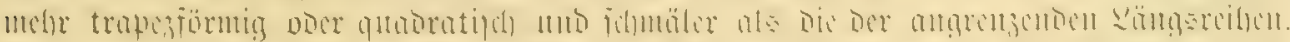

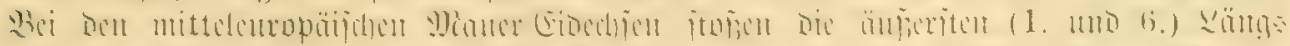

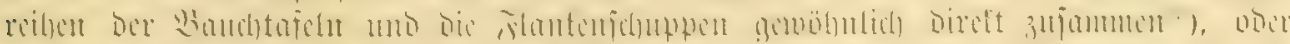

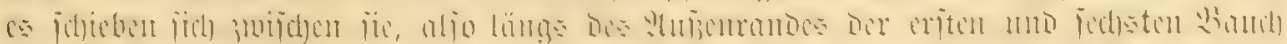

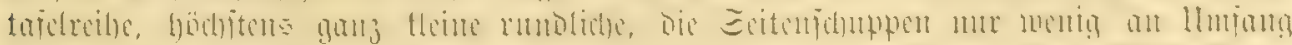

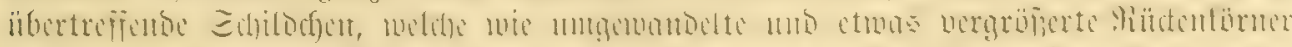

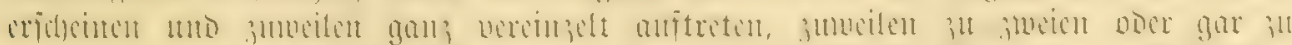

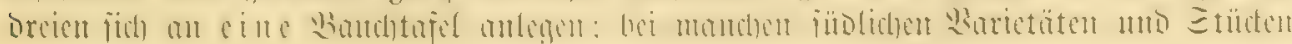

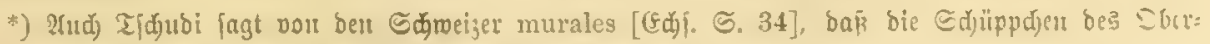

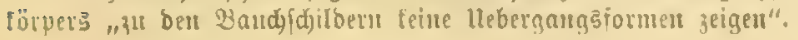




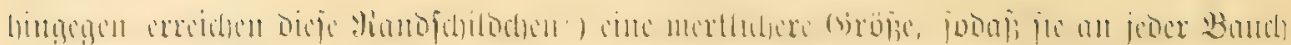

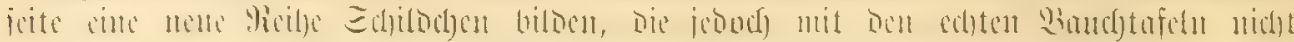

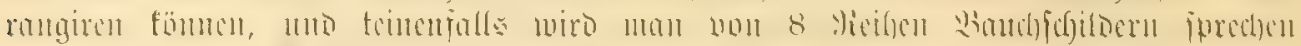

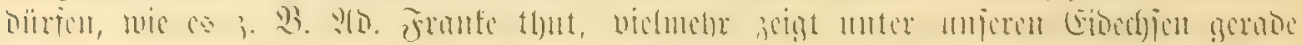

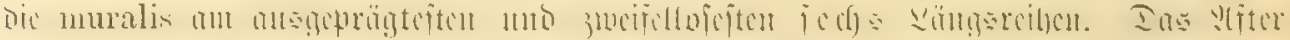

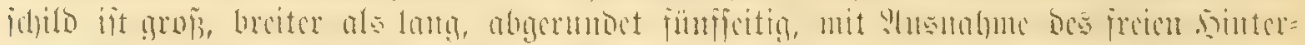

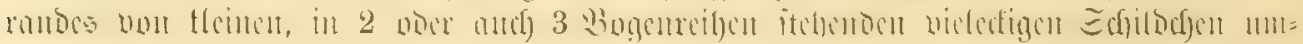
geben, Deren größjte numittelbar an 9(jterichillo liegen.

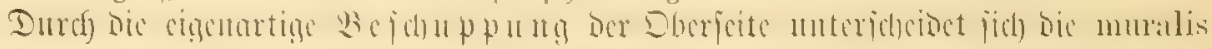

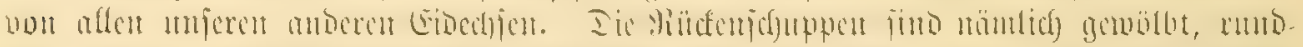

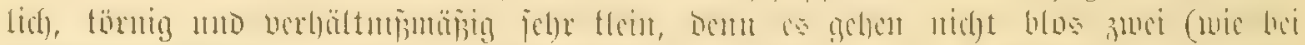

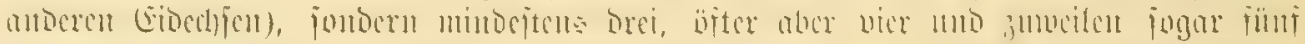

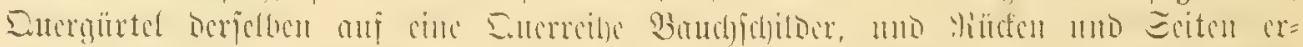

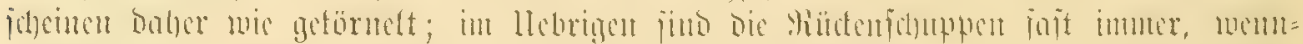

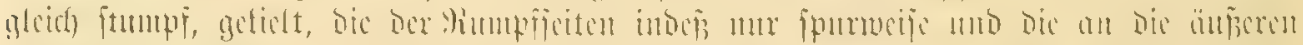

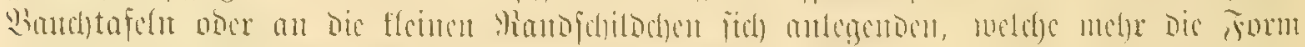

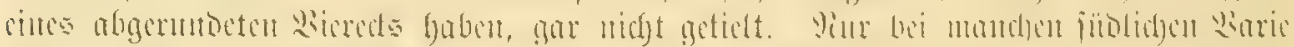

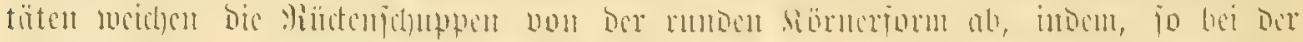

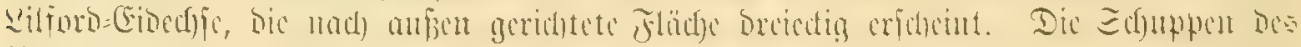

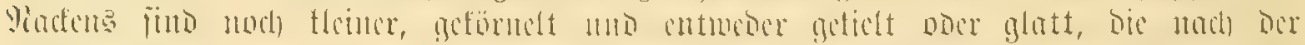

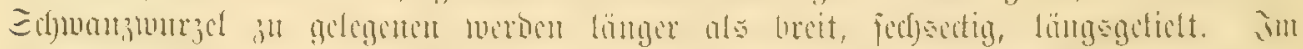

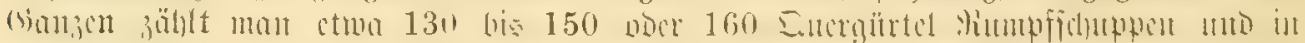

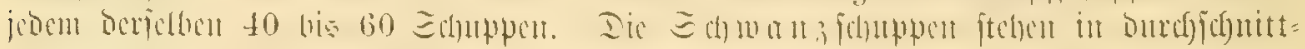

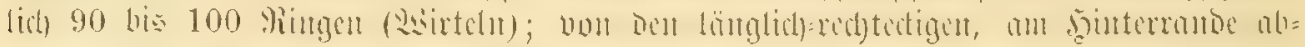

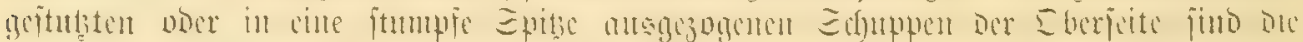

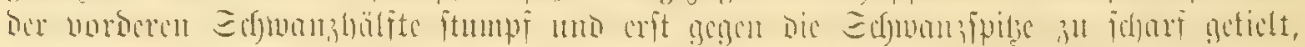

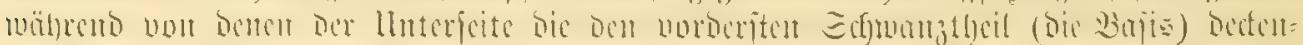

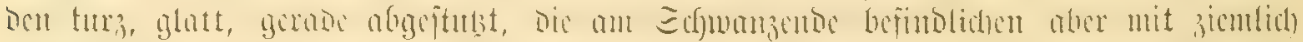

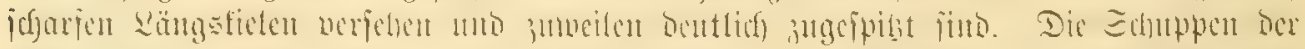

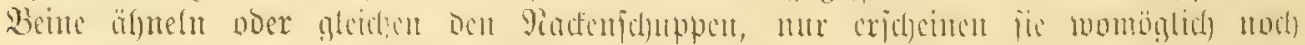

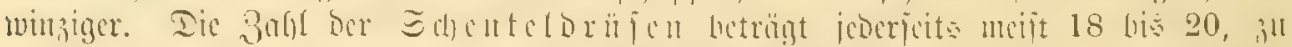

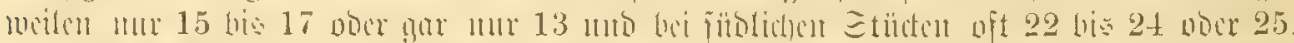

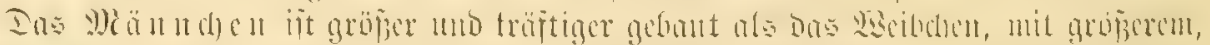

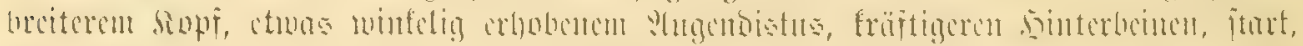

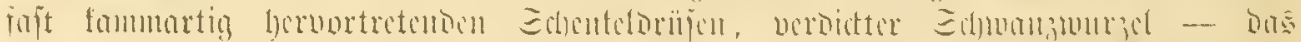
然 cibof)

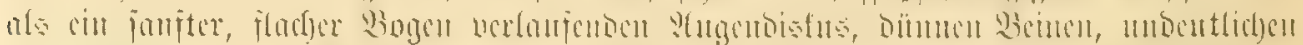

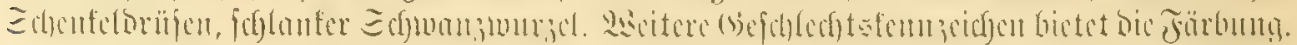

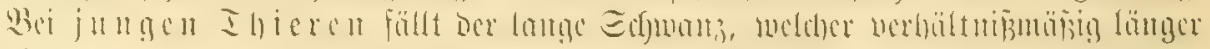

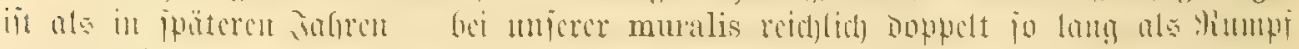

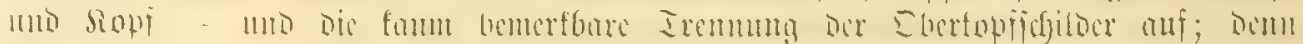

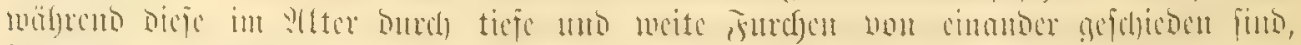

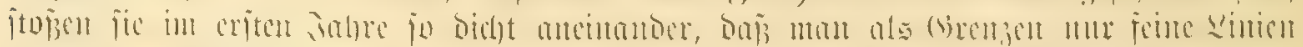

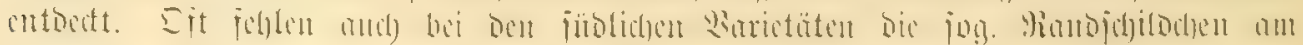

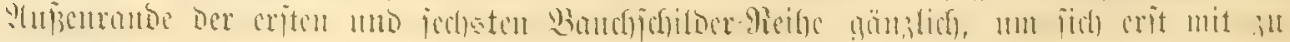

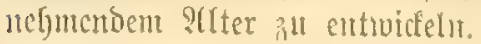

*) (Eimer bezeidunet fie [Lac. mur. coer. S. 13] als Oberidyirodyen. 


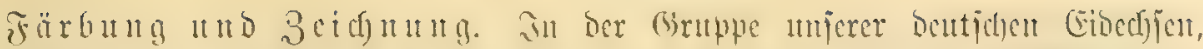

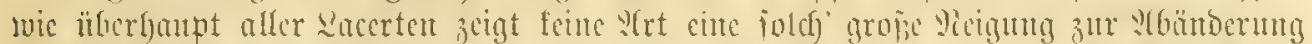

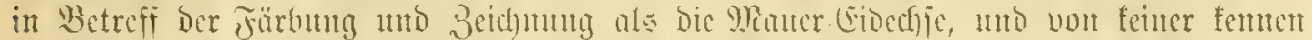

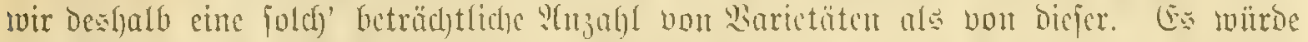

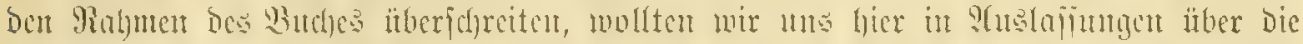

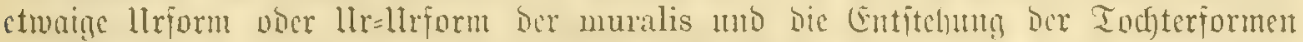

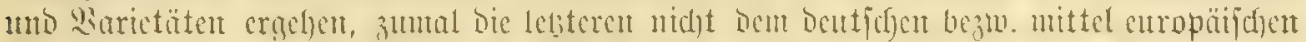

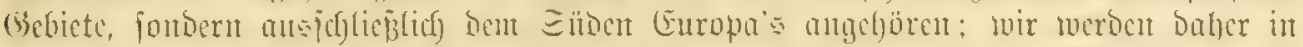

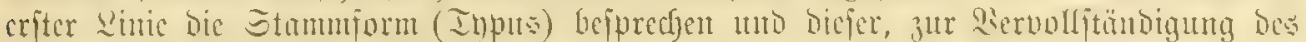

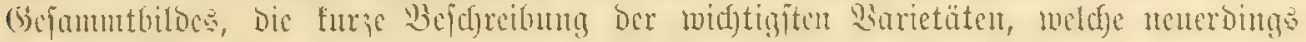

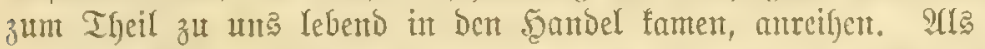

a) $こ t a n m f o r m$ (Lacerta muralis typica) betradsten wir bie Form, melde

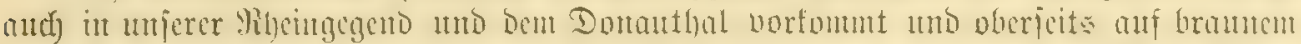

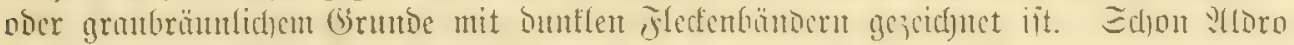

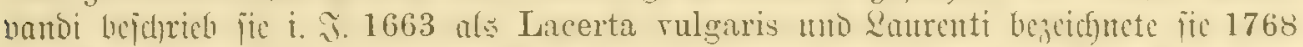

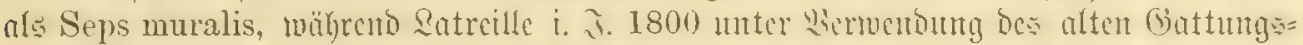

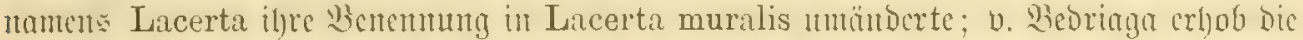

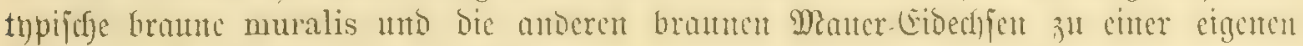
lluterart: zu Der Subjpezies fusca.

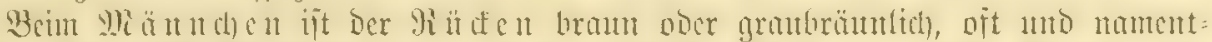

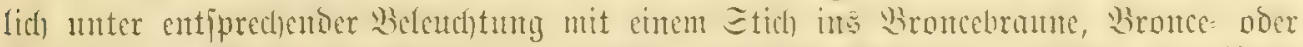

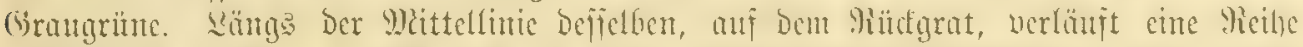

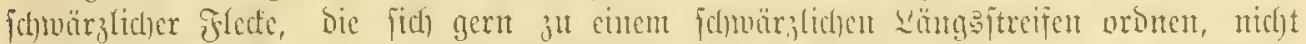

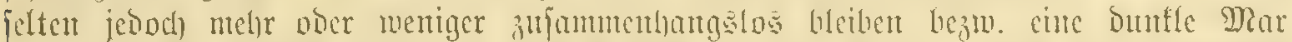

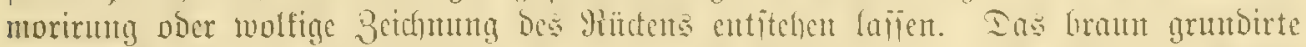

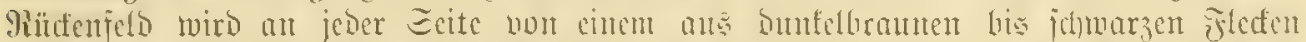

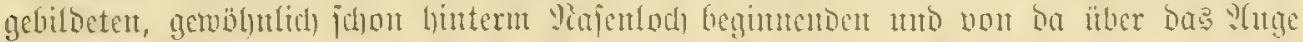

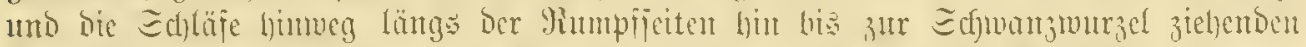

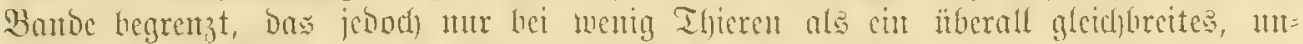

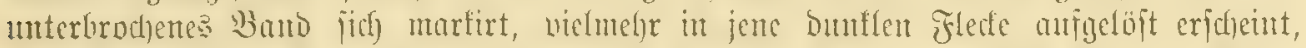

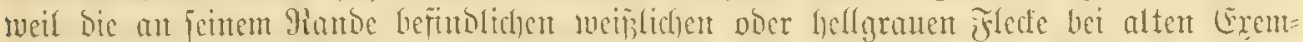
plaren in groberen, bei jüngeren in geringeren (Girude in Die Duntle binde eingreifen;

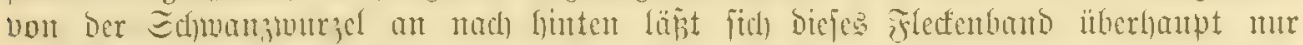

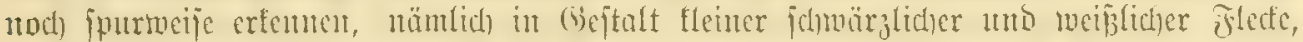

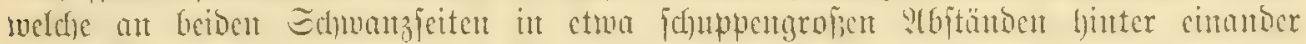

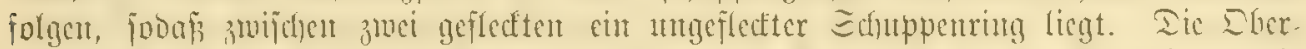

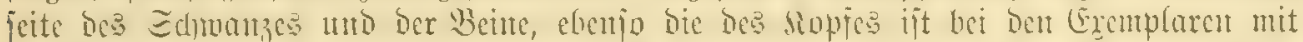

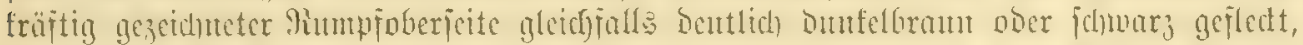

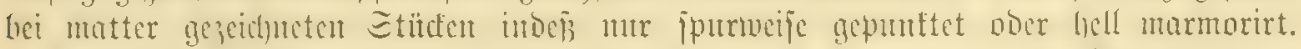

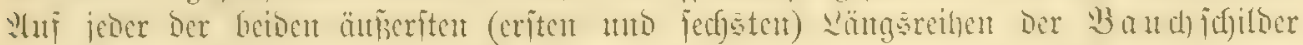

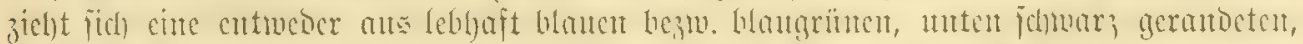

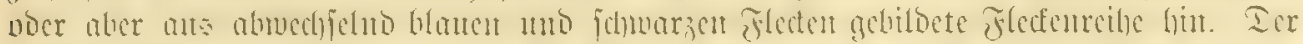

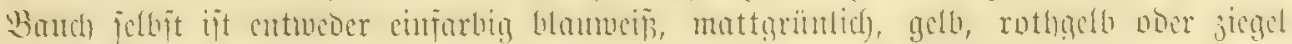

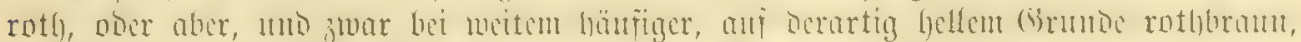
f(b)

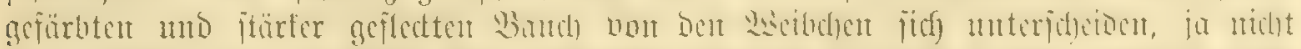

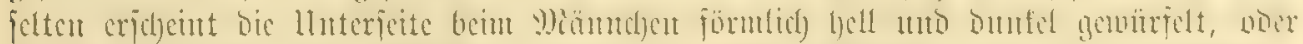

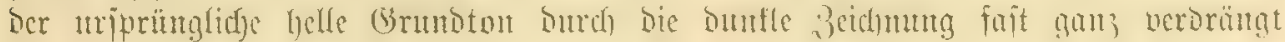


numentlich zur Frühjahrszeit, mentu juberbaupt die Farben voller, glanzreicher werben unb ber Shitclen cinent ampred)enden broncegrünen Echiller zeigt, nummt Der

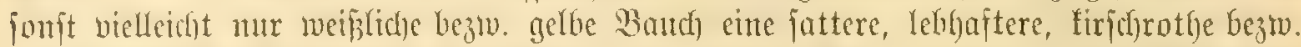

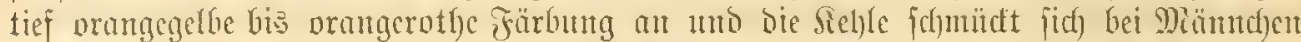

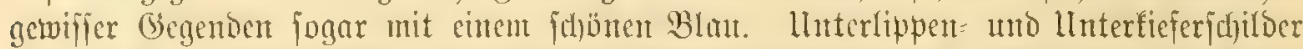

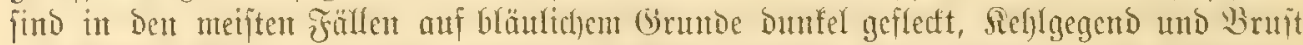
faft innter, felbft bei einfarbigen Baud), Dunfel getüpfelt und gemarmelt; bie lluterjeite

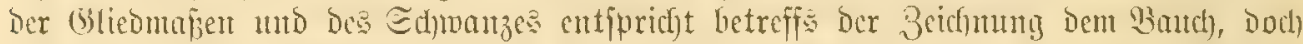

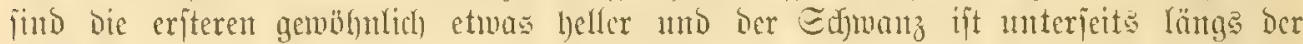
Mittellinie gelblid ober graurötblidg grundirt.

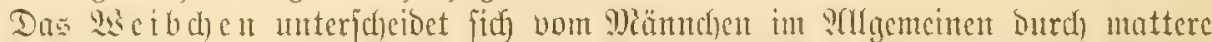

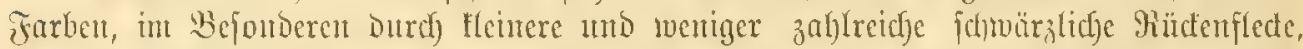
bie fidh aber chenfalls gern in cine Sängereibe oronen, ferner burcf fifürfer murfirtes,

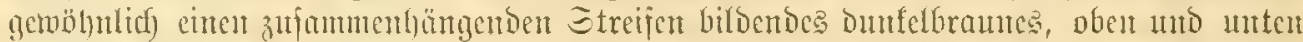

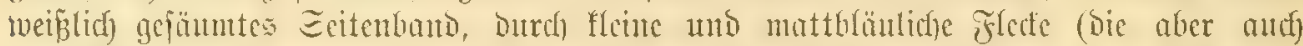

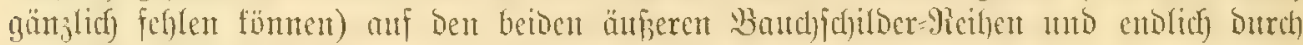
weiplid)e, allenfallo bleigran, bläulidh oocr bellgelb angeflogente cinfarbige, tur in ber

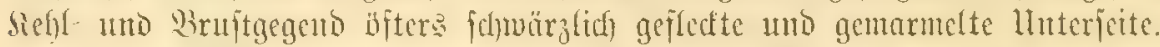

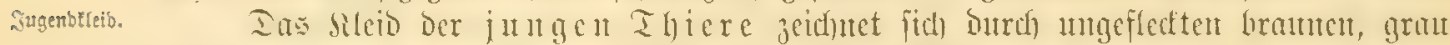
ober olivenfarben überflogenen inüfen uno gleidjoulls neift fledenlofe Elerjeite Des

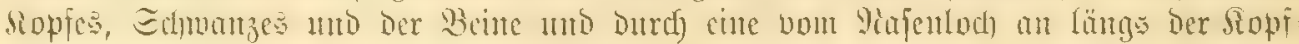

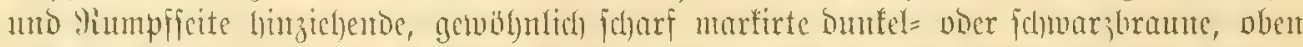

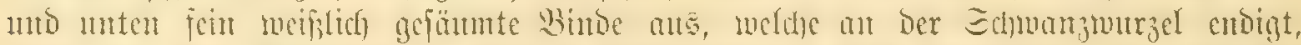

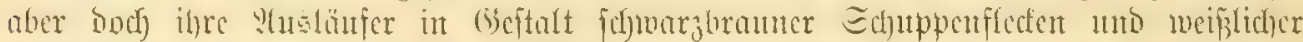

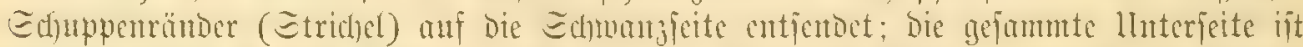

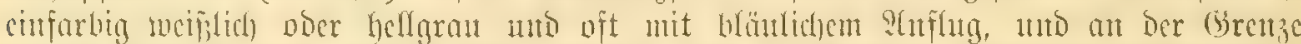

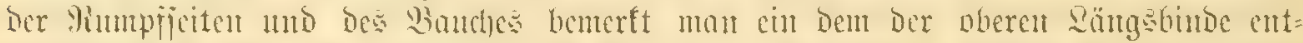

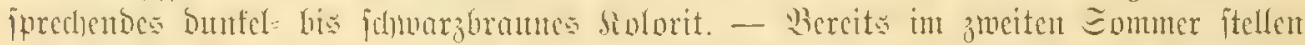

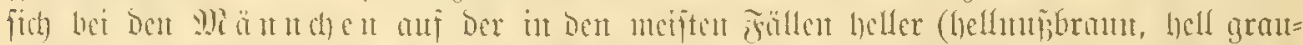

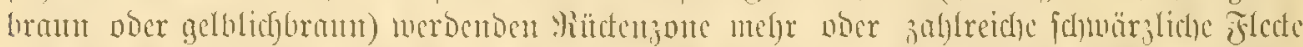

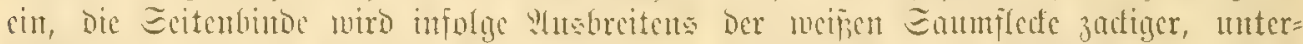

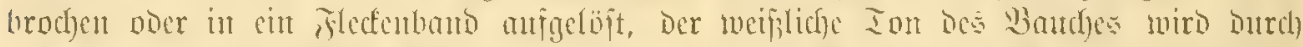

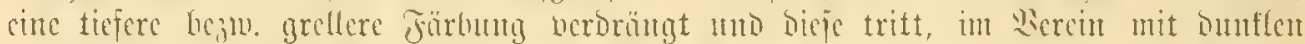

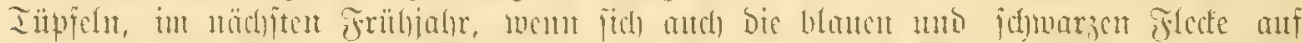

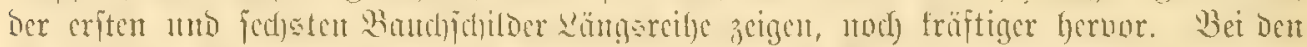
2e:

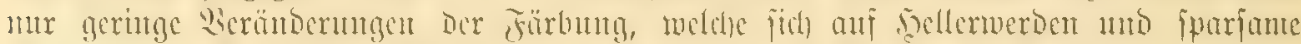

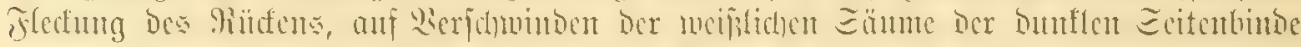

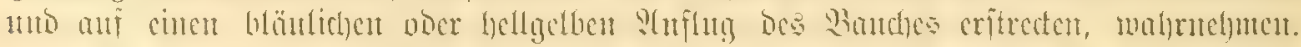

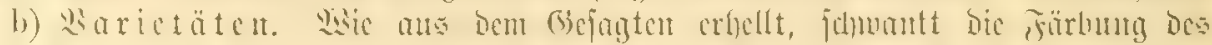

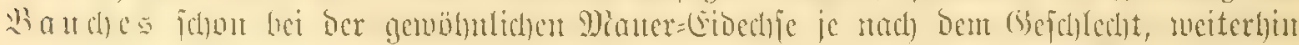

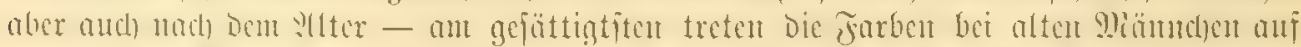

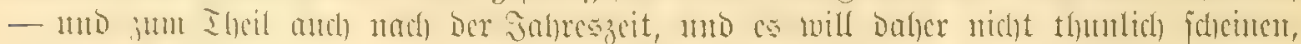

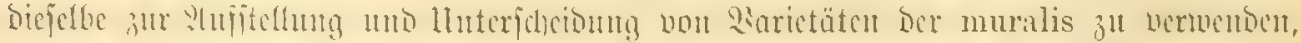

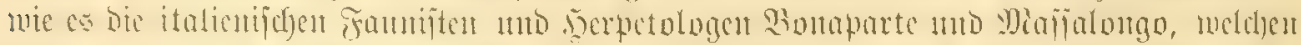

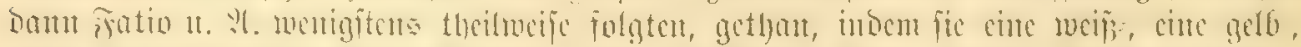

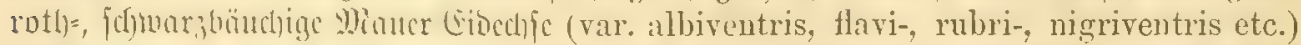

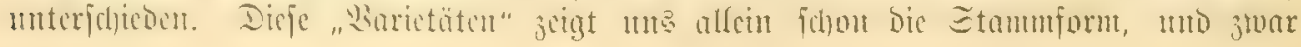




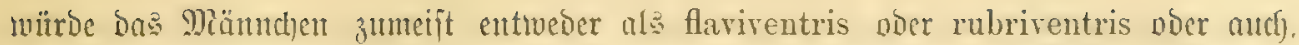

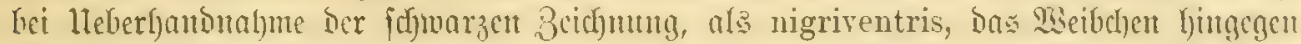

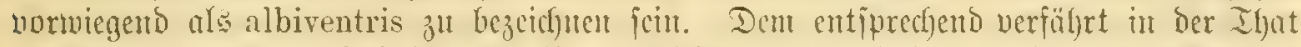
be Betta, wenn or auf Eeite 152 bis 154 feiner 1857 crjfficnentu Erpetologia delle

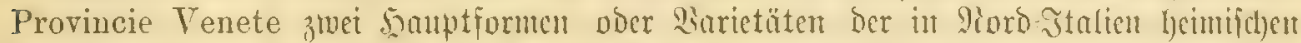
Podarcis muralis, nämlid) A. Die gewbifyuliche muralis (muralis auctorum) und B. Die var. campestris, anfitellt unb bei ber erfteren bic fünf llnter=2iarietüten nigriventris Bonap., albi-, rubri-, flaviventris und bie cupreiventris Massal. 1uterjofeibet. Int cince meneren, 1879 publicirten ?frbeit jedod), auf Eeite 14 bis 18 feiner ,Nuova serie di Note erpetologiche - "6, bringt berjelbe Forjofer alle ify befannten itnlifduen

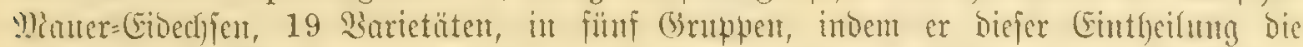

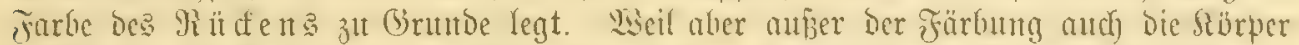

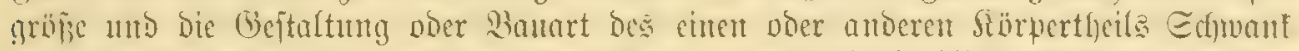

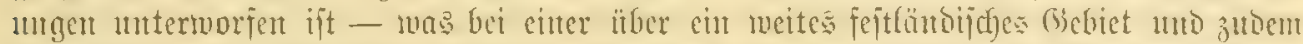

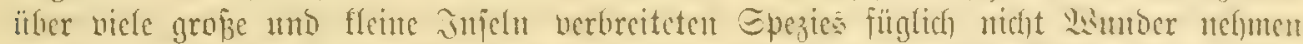

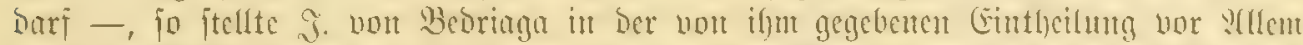

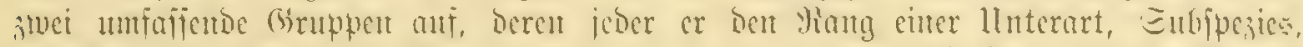

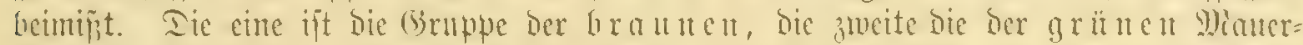
Eibedjen, Gejw. Die Eubipejies fusca uno neapolitana. Die wou ilum jur criteren

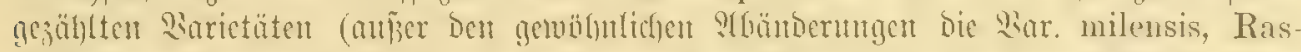
quineti, persica, saxicola, flaviundata, corsica, Erhardii, melisellensis) font;ciclynen

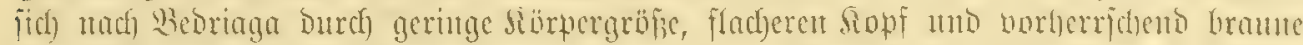

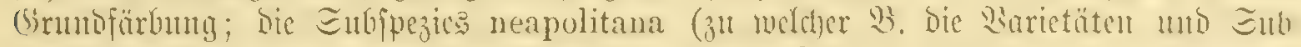
parictäten olifacea, campestris, albiventris, lineata, Cettii, sicula, reticulata, Isatastei,

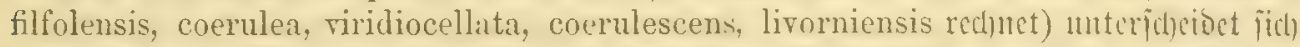

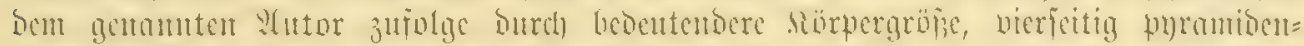

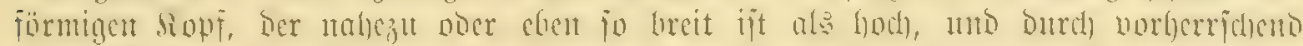

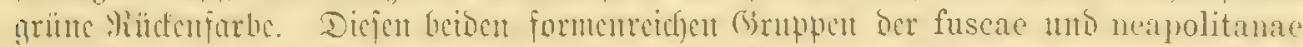

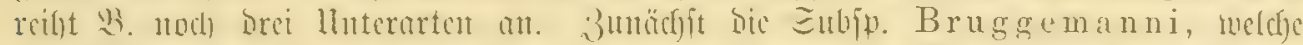

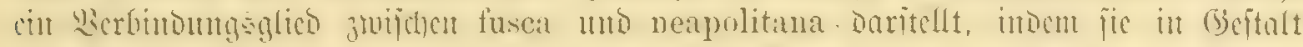

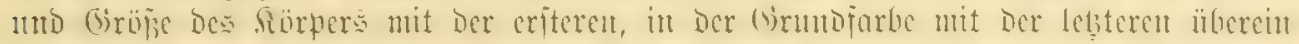

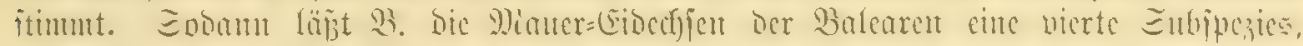

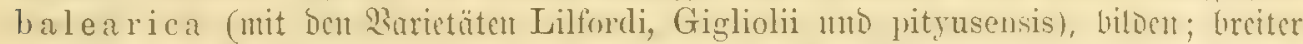

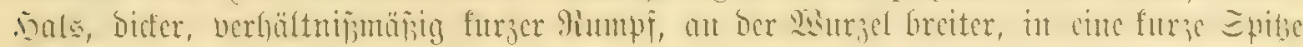

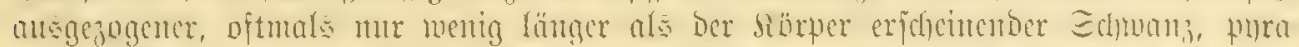

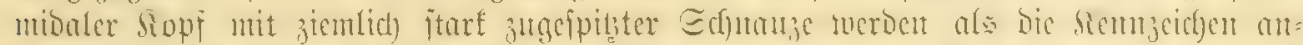

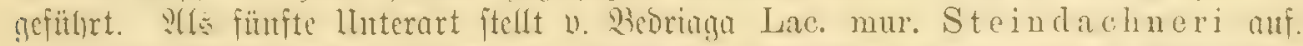

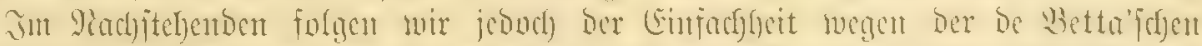

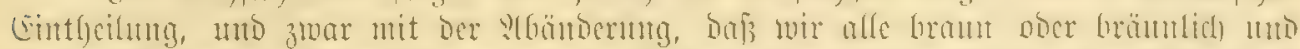

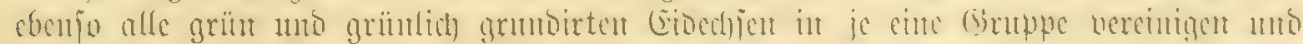

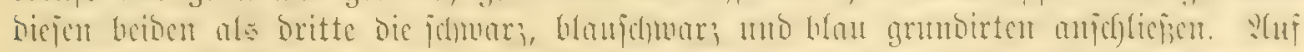

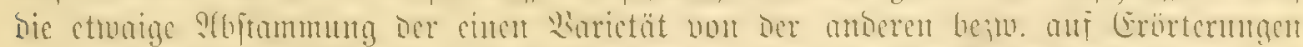

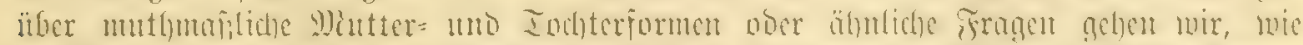

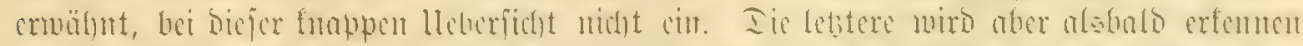

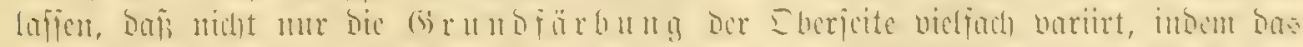

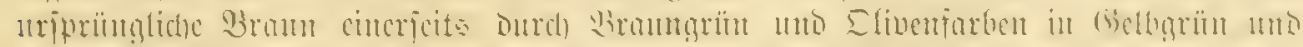

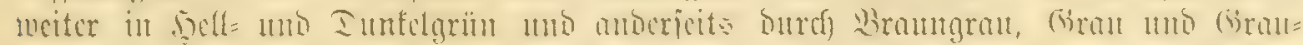

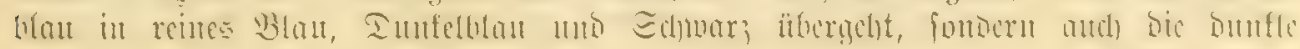




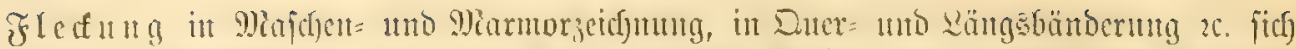

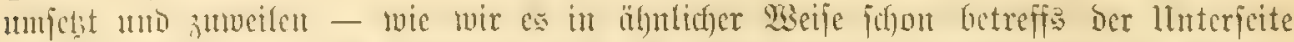

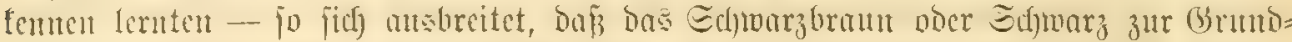

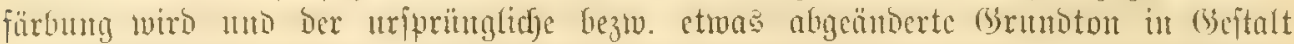

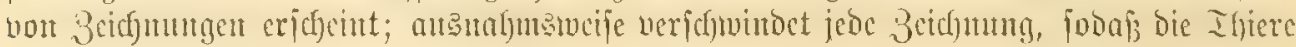
cinfarbig ausfelget.

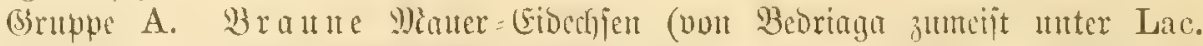

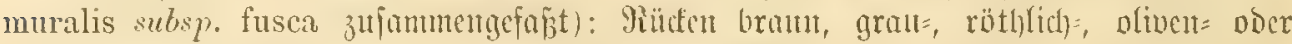

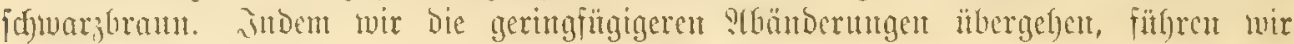
mur folgende Sarietäten auf.

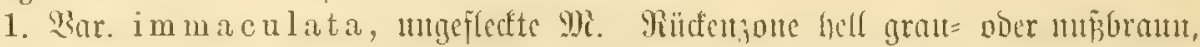

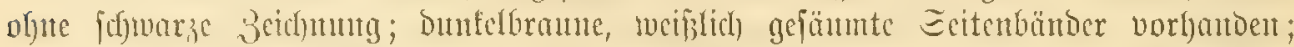

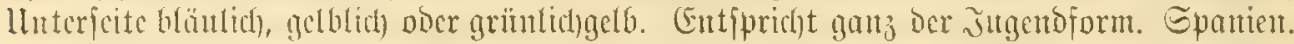

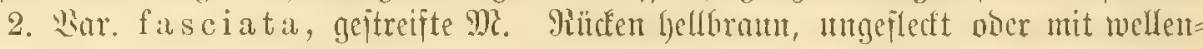

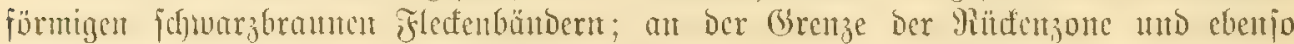

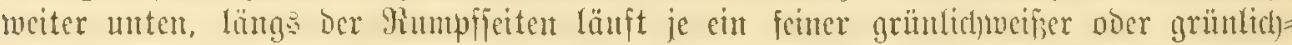

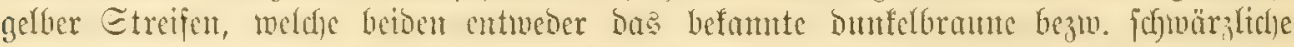

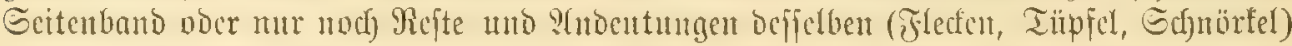

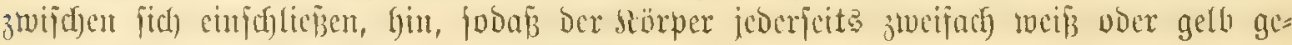
ftreift erjicheint. Berbrcitung: Süb=Europa.

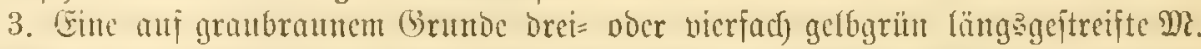

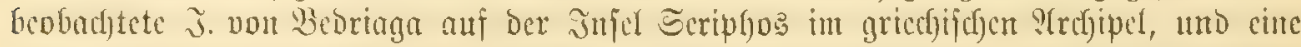

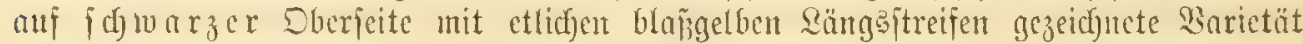

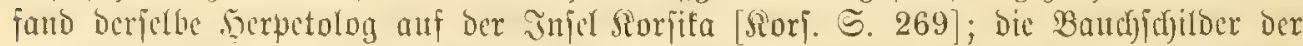

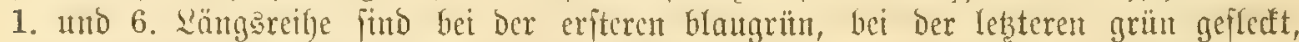

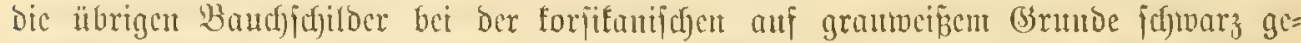

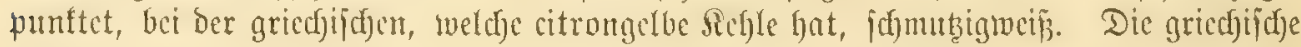
Barietät ift Erhardi, bie anberc corsica bentunt toorber.

4. Bar. milens is (de Bedriaga), getitpfilte Me. [Grtch. S. 98]. Rüctem uno

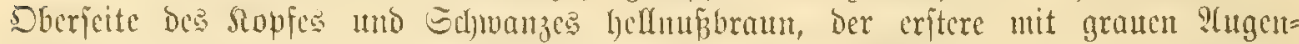

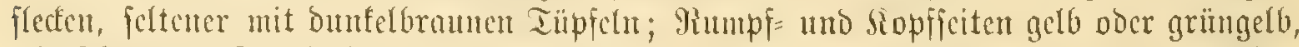

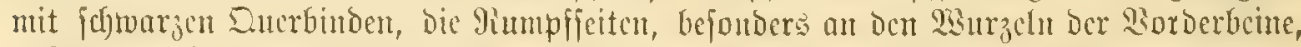

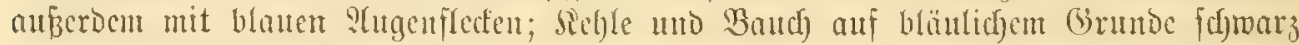

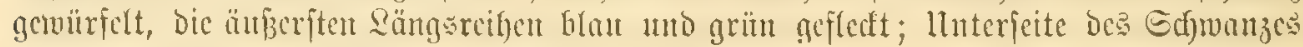
rötglich angeflogen. Funbort: (Enflabent= Sntfel Milo.

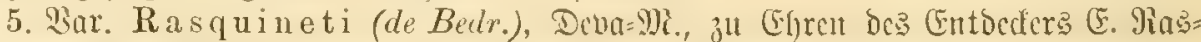

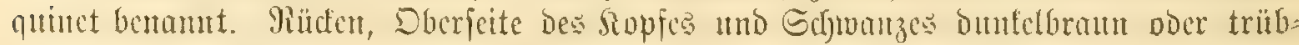

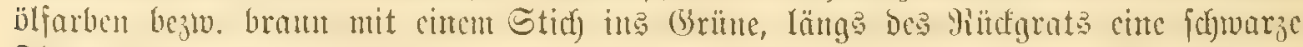

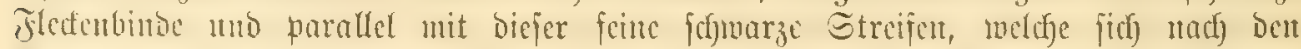

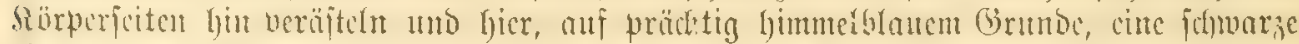

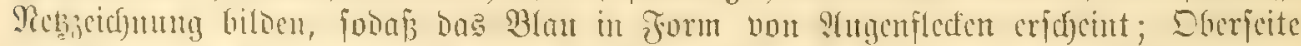

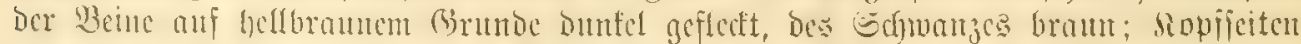

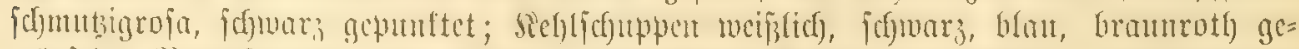

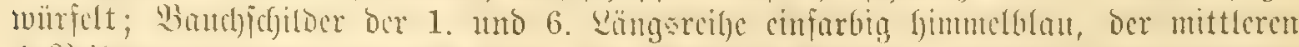

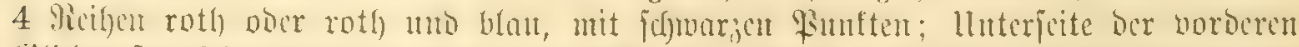

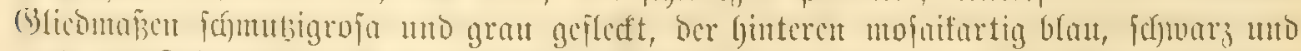

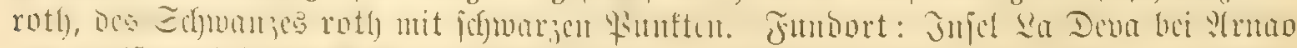

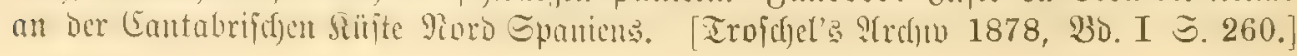




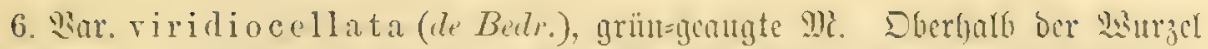

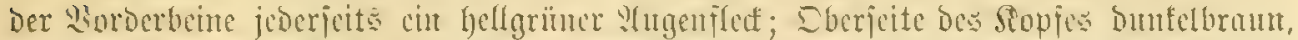

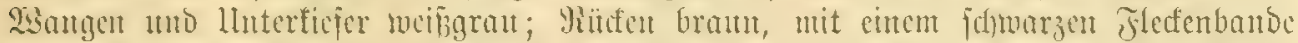

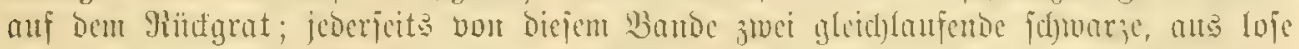

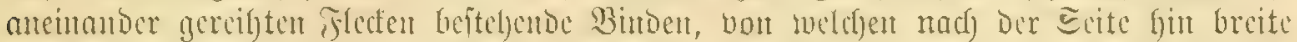

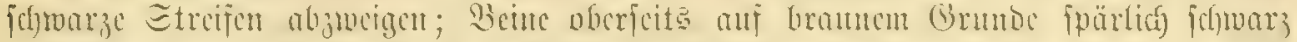

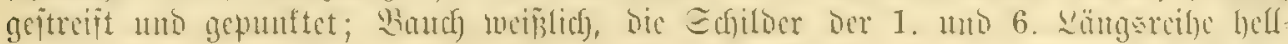

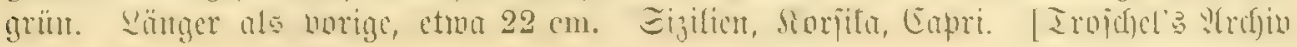
1877, 36. I ऽ. 115.]

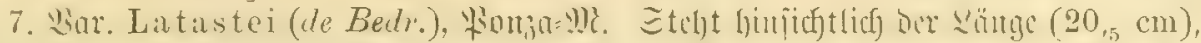

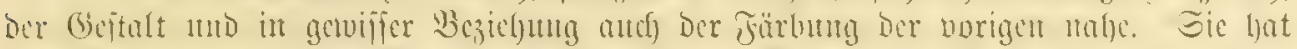

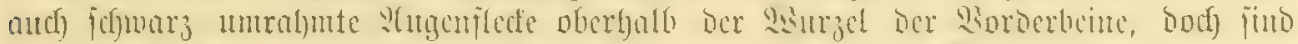

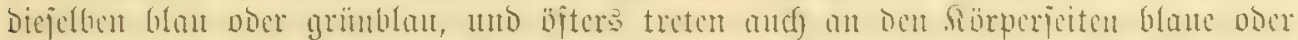

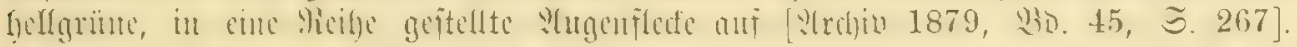

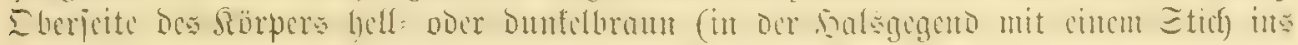

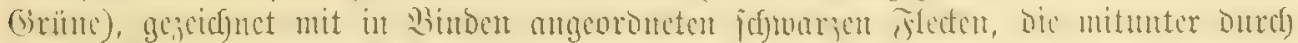

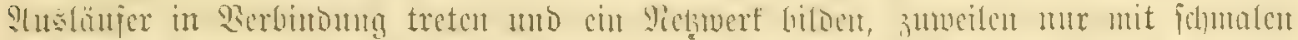

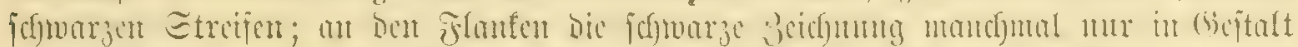

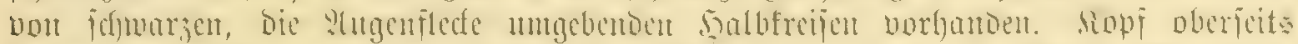

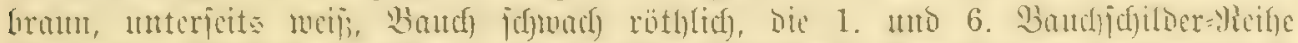

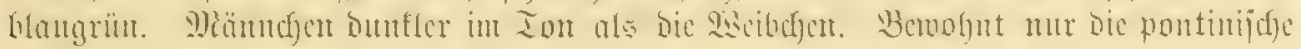

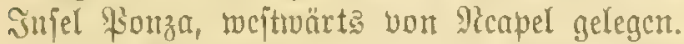

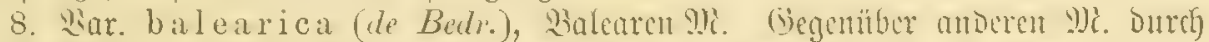

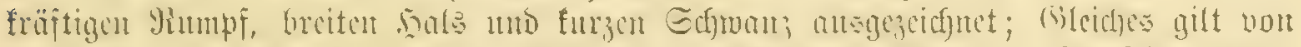

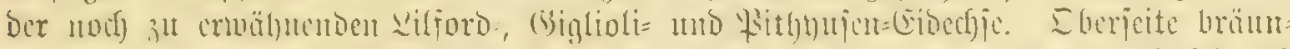

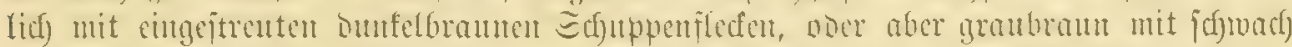

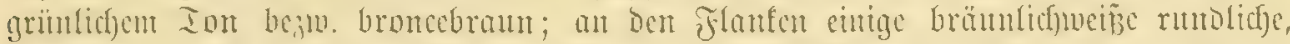

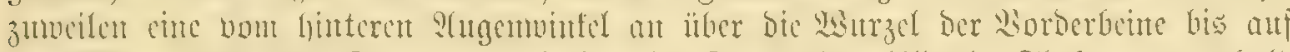

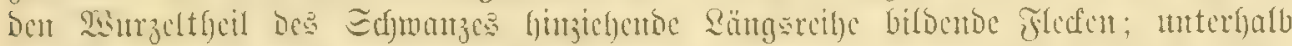

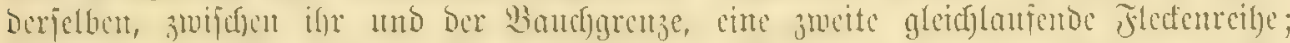

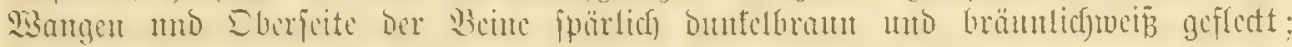

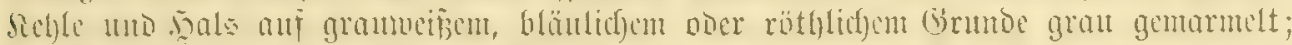

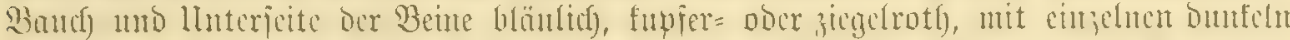

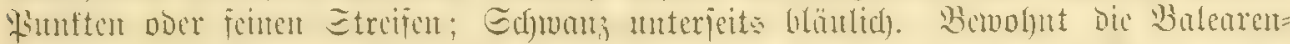

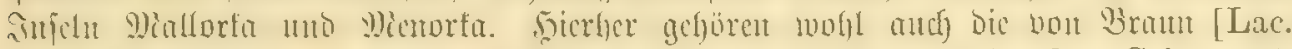

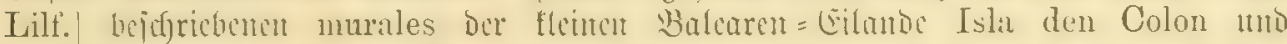
Isla del Rey.

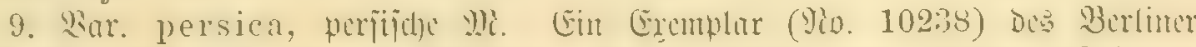

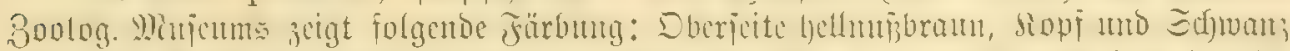

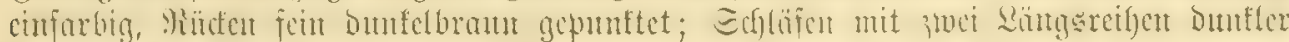

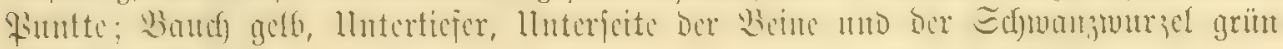
licfgelb. \$serficu.

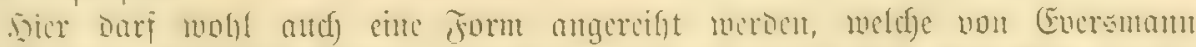

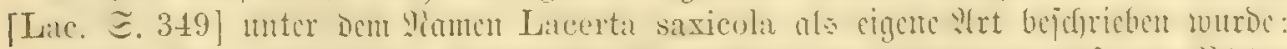

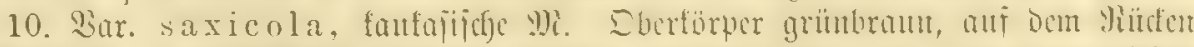

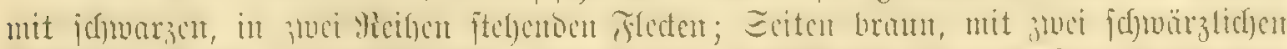

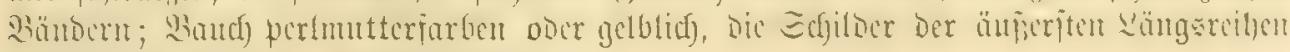
lyimuclblau gefledt. Saufajuslänoer. 
11. Enblidf jei bier nody ber Weoriagaffen Subpesies Steindachneri,

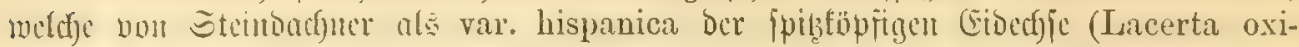

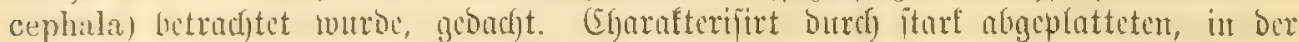

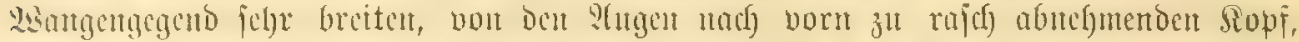

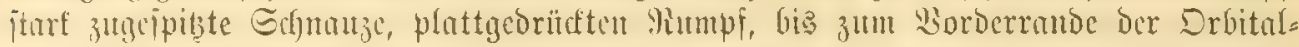

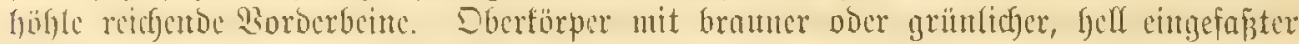

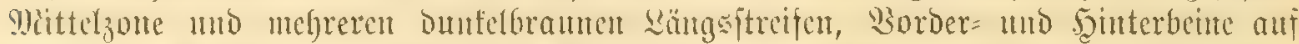

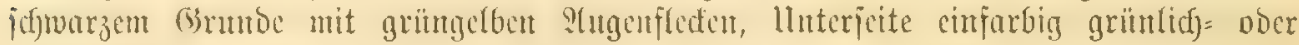

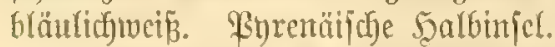

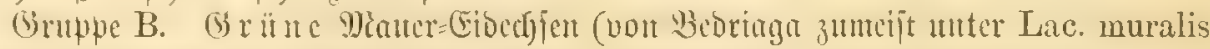

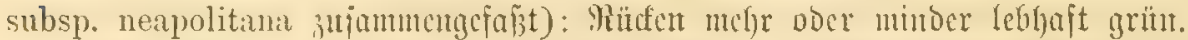

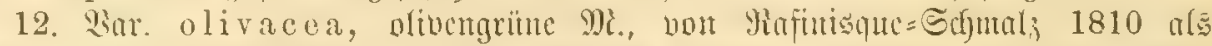
Lacerta olivacea befchrichen (Lac. mur. molesta, Eimer). Dberieite cinfurbiy oliven= noter grangrün, an Den Rumpficiten, anf Dem Ropf, Dem Sifwan; un Den Beintn mefr olivengrau, jimut= oder broncebrau; Sumpfieiten zumeilen mit brïunlichen

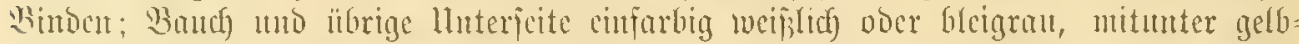

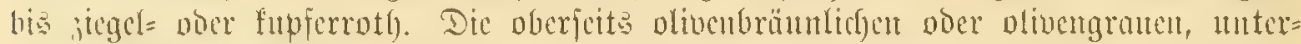

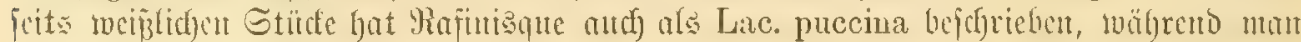
die unterfeits cinfarbig tupferfarbenen wohl unter Podarcis cupreiventris, Massal. 3ui fuchen hat. Dalmatien, Ştalien.

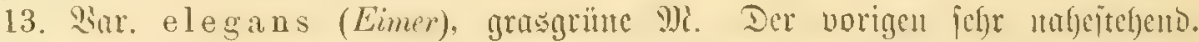

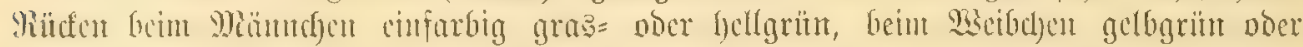

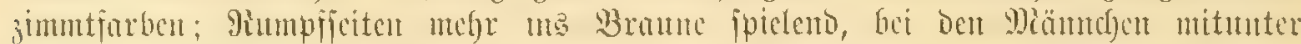

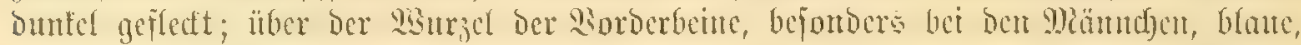

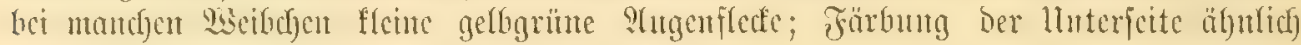
wie bet ber vorigen mefriady abändernd. Stalien.

14. War. campestris (de Betta [Ven. S. 152]), geitreifte Mc. Rüden

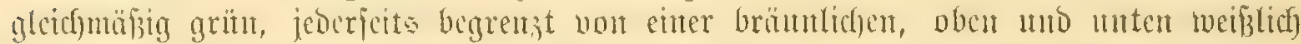

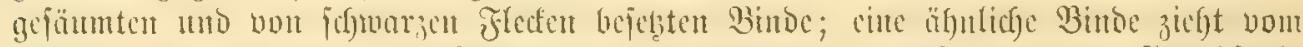

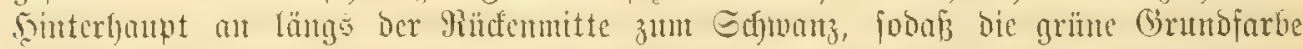
bes Rüuten zwifhen biefen orei bran und jefwarzen Streifen in Form zlveicr breiter

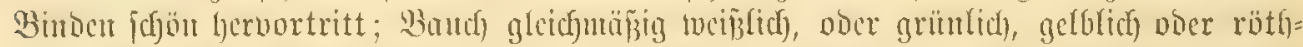
licf. Siit nach be Betta iscutifich mit Podarcis (Lacerta) tiliguerta, de Filippi, abcr

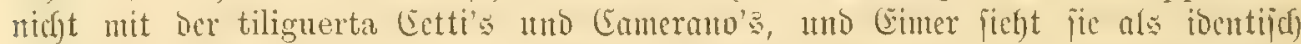
mit jeiner Lac. mur. striata ant, mä́freno Camcrano fic unter ben Rancu Lacerta

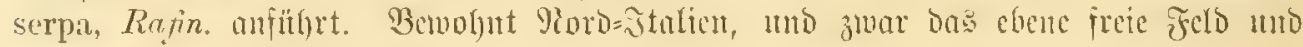
fandige llf́r, nicht an Fels und (Bemäuer.

15. Bar. albiventris, Bonop. = neapolitana albiventris, de Bedr.

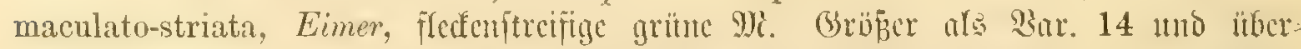

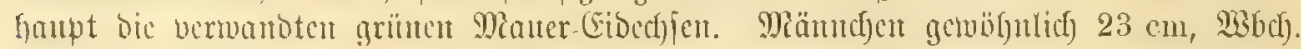

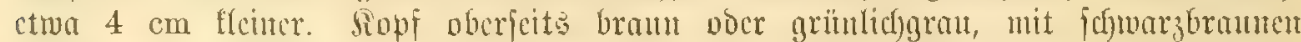

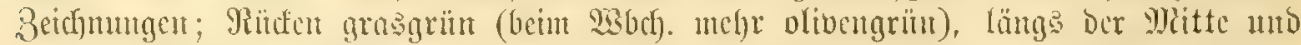

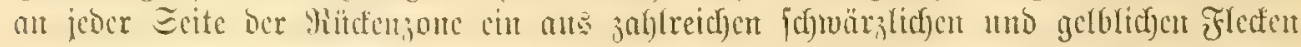
("molte macchie nerastre e giallistre") beftelender $\Xi t r e i f e n$, von benen ber mittlerc

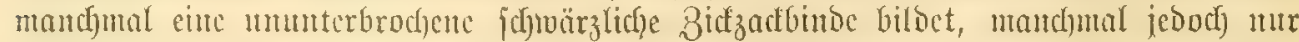

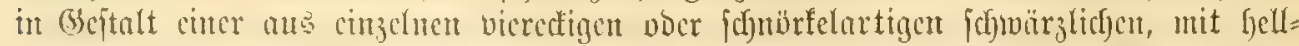

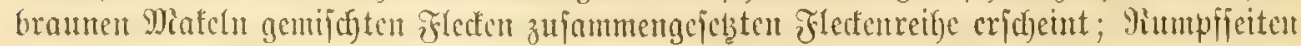

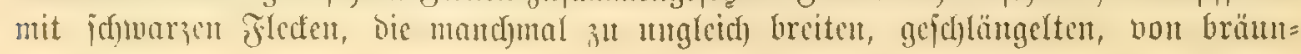




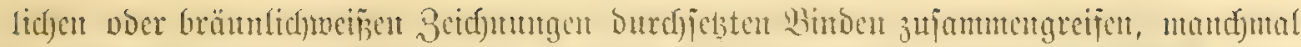

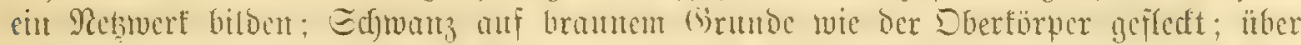

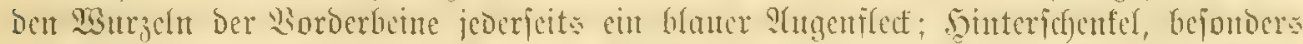

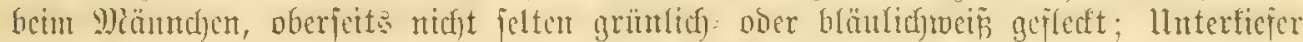

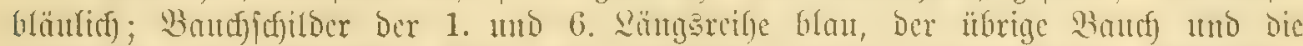

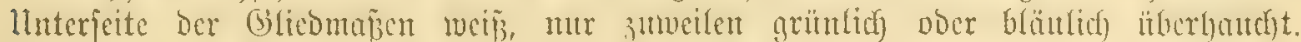
Mittel = mo Unter= Stalieu, Snicl Sapri, auch) Siziliert.

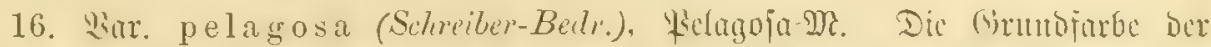

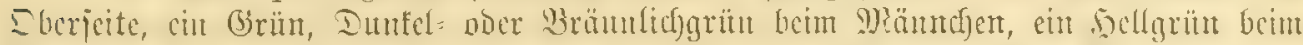

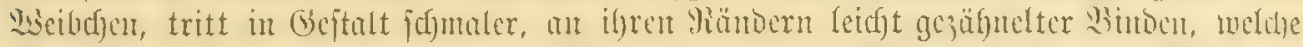

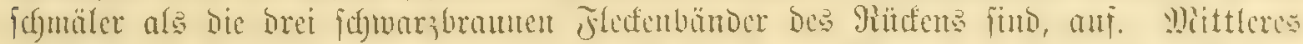

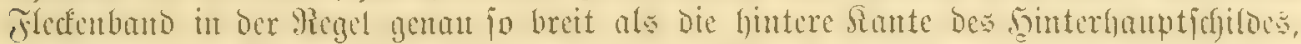

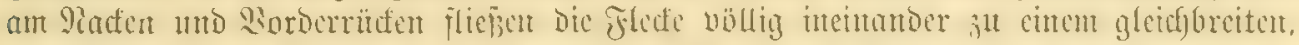

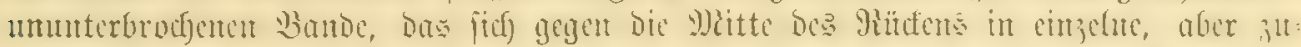

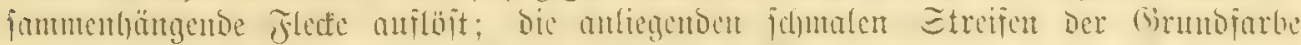
merben gegen bie Eamangum

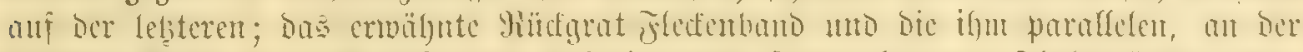

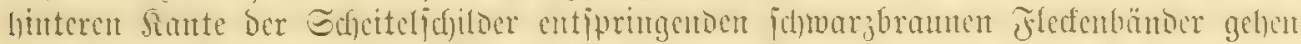

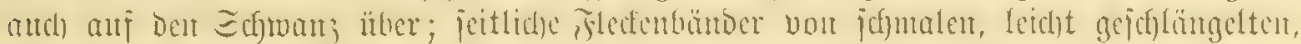

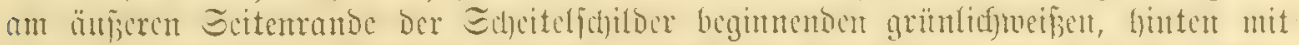

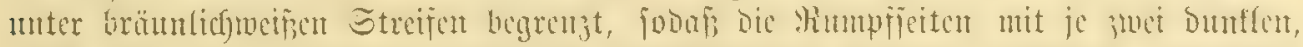

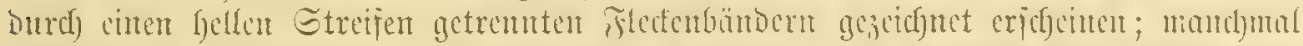

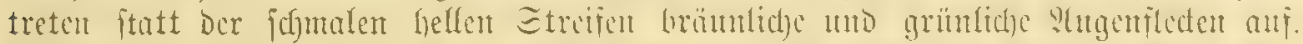

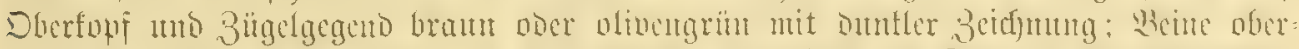

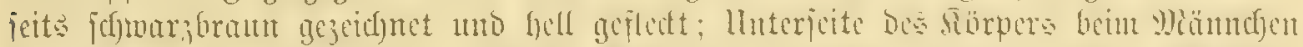

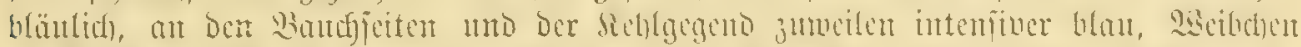

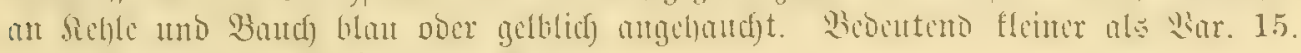
Sulel Pelagoia im :Loriatifdjen 9)ieer.

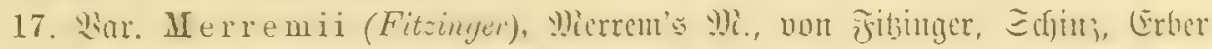

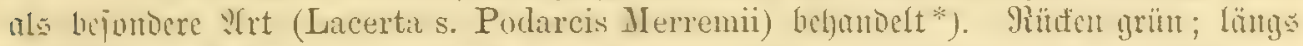

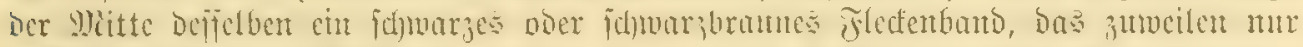

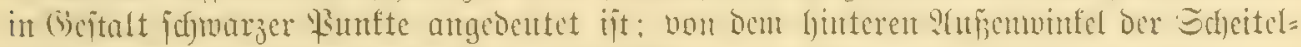

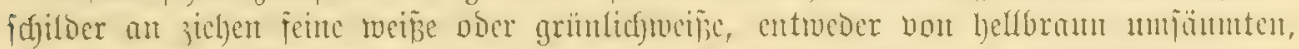

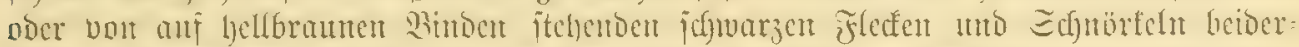

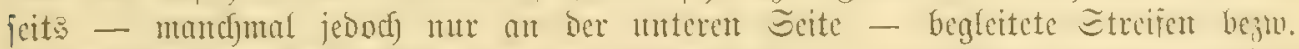

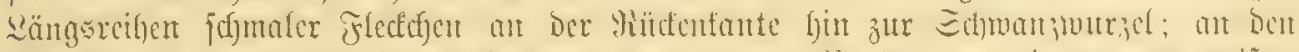

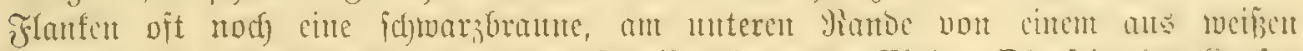

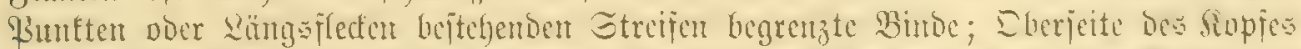

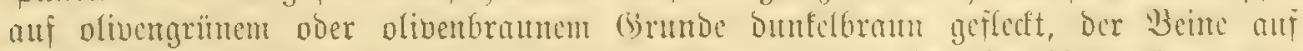

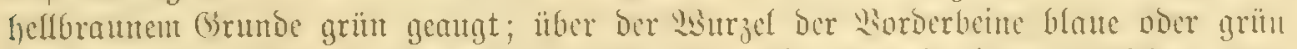

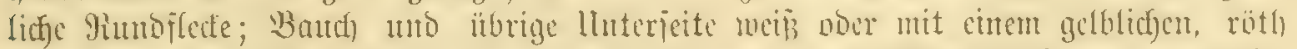

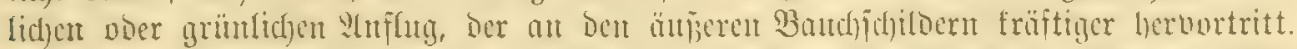

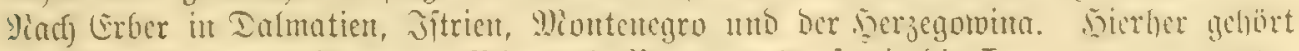
mol)l Die Podarcis olivaceus albiventris Bomparte 5 , joule dic Lac. mur. punctatostriata und punctato-fasciata Eimer's.

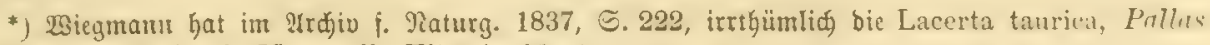
als ibentijळ mit Podarcis Merremii, Fitz. begeidnet. 


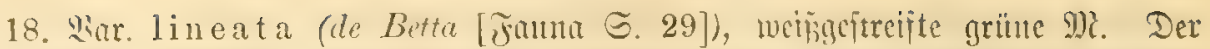

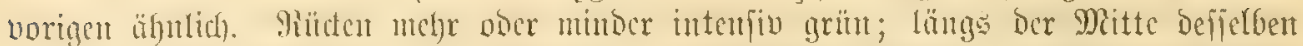

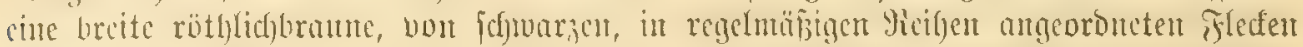

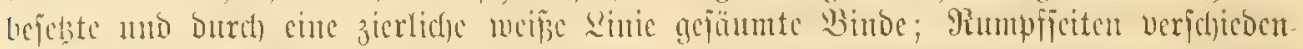

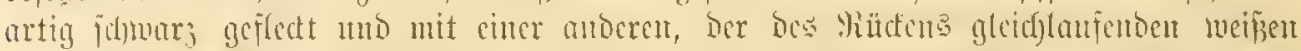

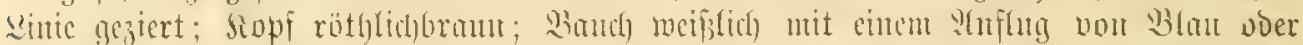

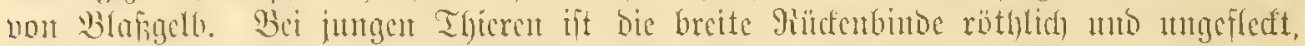

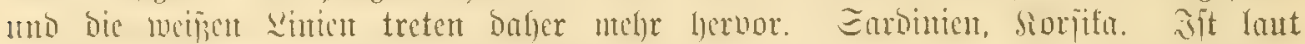
De Betta [Tiliguerta $\Xi .19]$ identijd) mit bor Lac. podarcis var. Genéi (5arr's uno

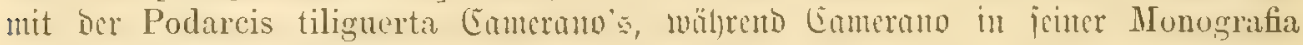

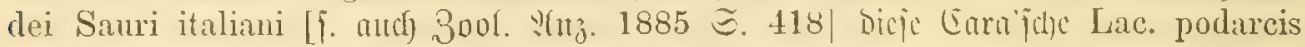

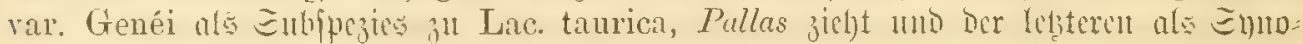
แ1) autd) ,Lac. tiliguerta 우, Gmelin" beifingt.

19. War. Cettii (Cara, de Betta), Tilignerta. Stücfen Des Meänthens Duntel=

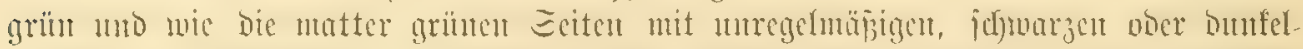

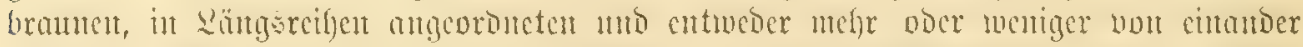

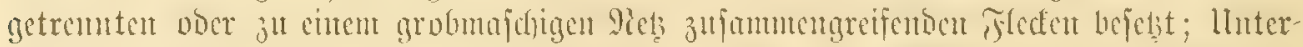

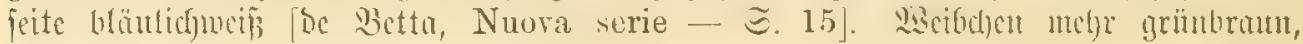
mit jobmarzen Fledtenbinbent. Sarbinien* ${ }^{*}$ ).

20. Rar. sicula (Bonap.), fizilijufe grïne Di. Bontaparte bildet auf Iajel II,

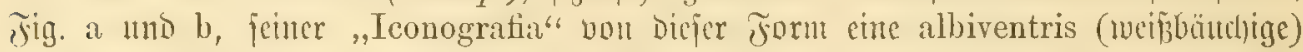
uto cinc rubriventris (rotbbäuclige Epiclart) afr. a) lluter-2iarictät sicula albi-

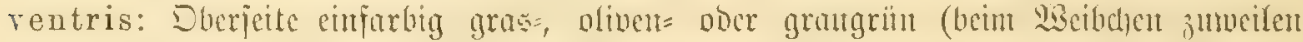

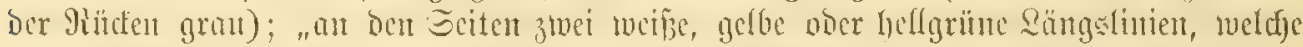

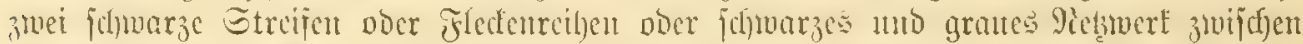

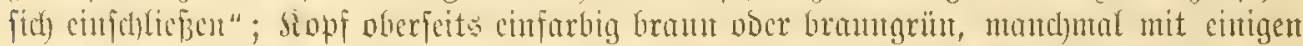

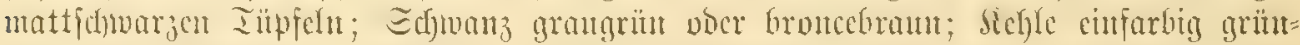

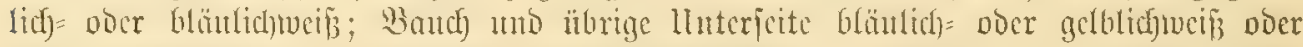

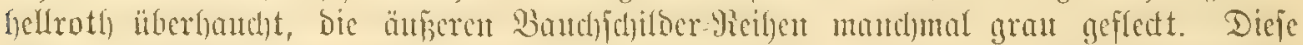

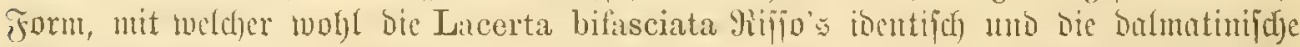

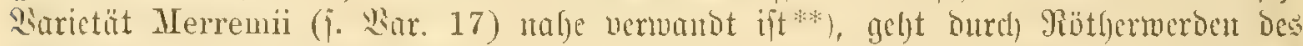

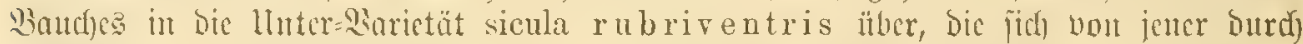

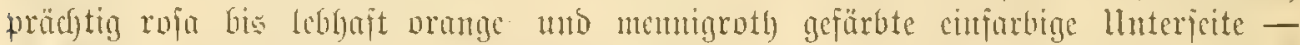

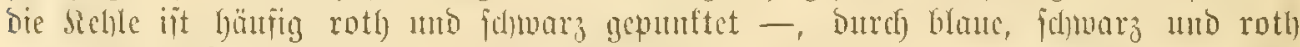

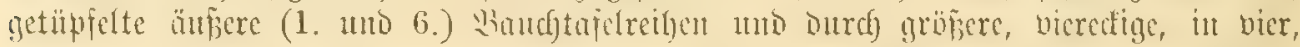

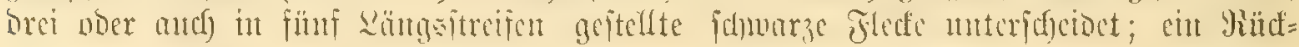

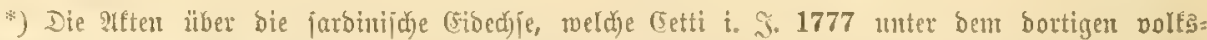
thïmlicten gianen "Caliscertula" ober "Tiliguerta" beidyrieb uno für eine bejonbere Atrt bielt, non

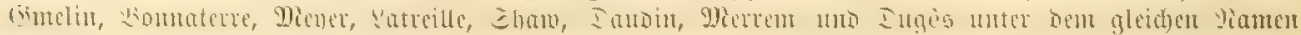

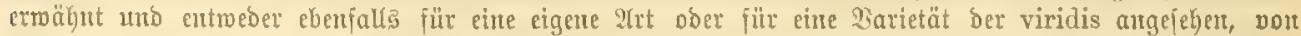
(j)ené aber als eine muralis erfannt murbe, finto nod) uidjt gejdylofien; be Betta erflärt 1878 in einer

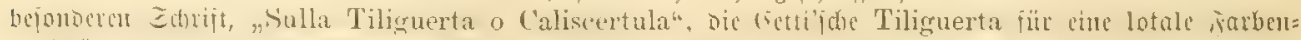

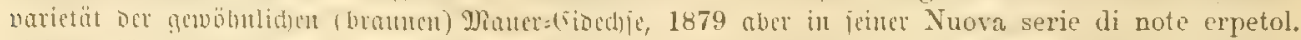

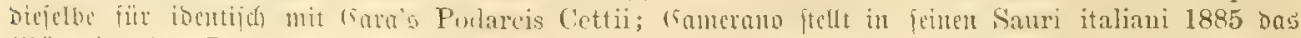

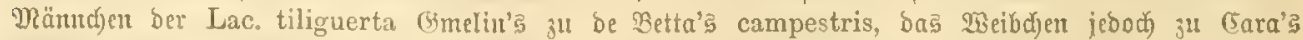

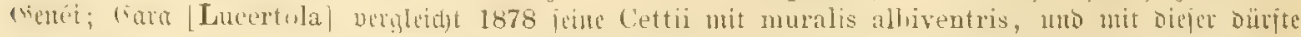

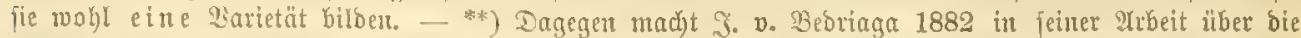

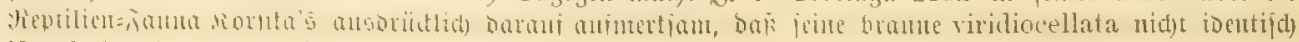
ift nit ber bonaparte'fiden uro be Besta'fden sicula albiventris. 


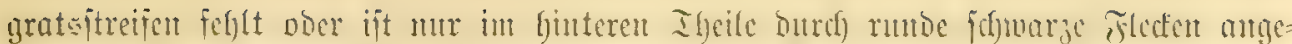
bentet. In feltenen Jällen ijt bie Sberfeite bes siörpers cenfarbig olibengrün and

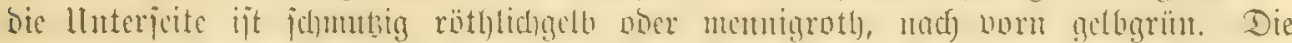

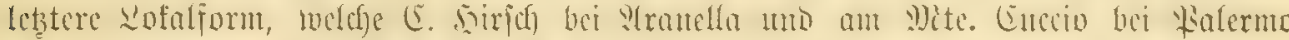

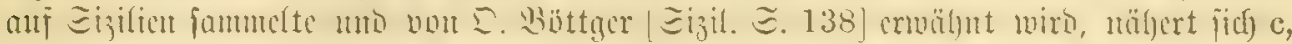

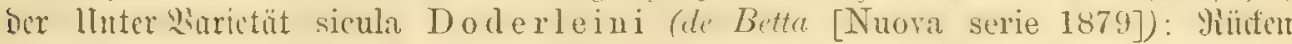

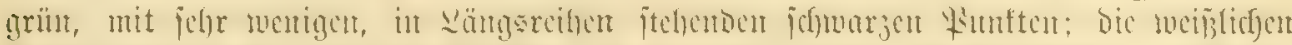

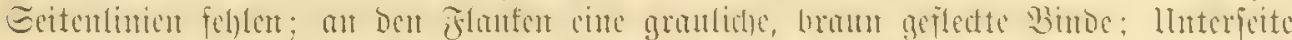

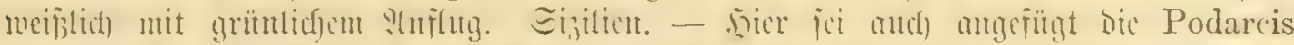

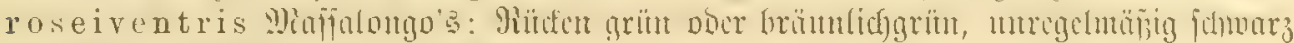
gcjprentelt; llnterjeite fleijchfarben.

21. Sar. livornensis (de Bedr. [atrcfiv f. Rat. 1879, I. Bூర. S. 279]),

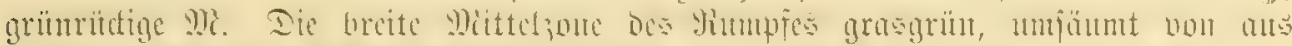

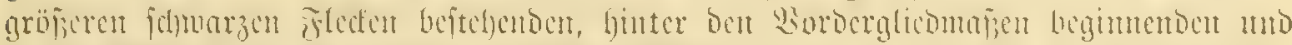

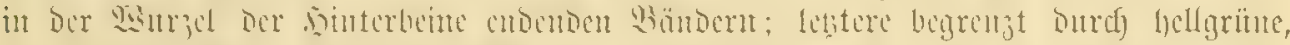

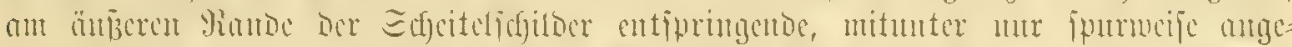

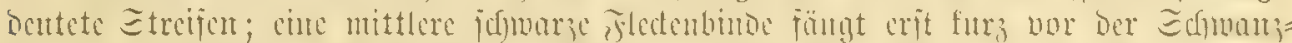

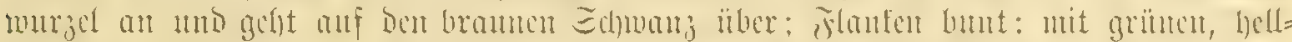

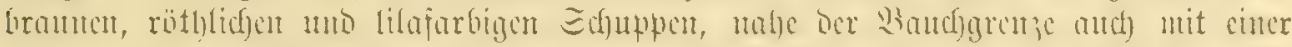

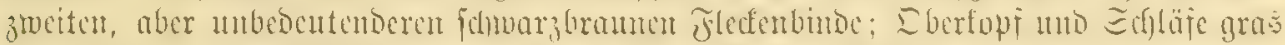

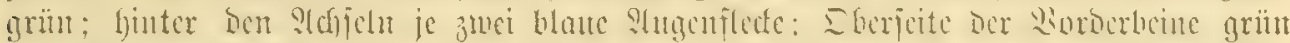

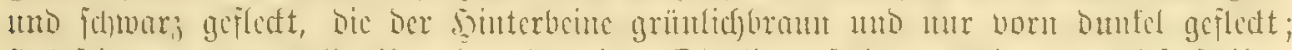

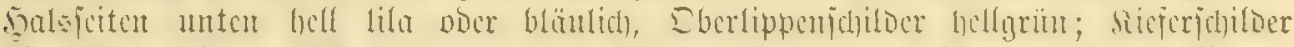

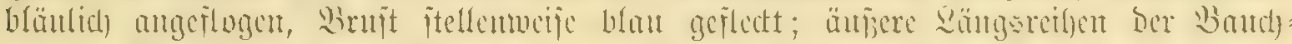

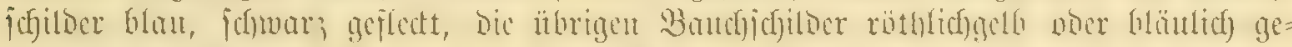

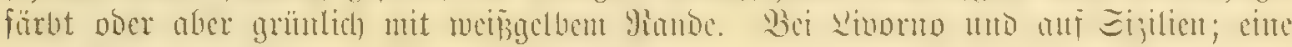
cd)te Felobewofnerin.

22. Wior. In a culata (Fitzinger, de Bette, Eimer) = var. reticulata, Schreiber

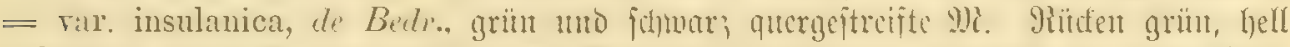

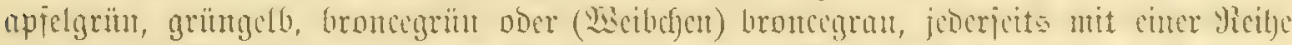

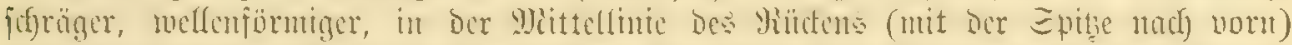

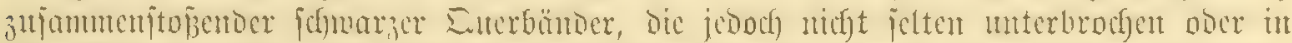

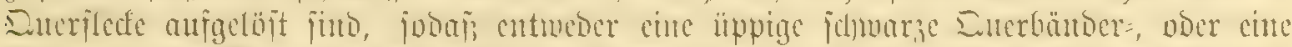

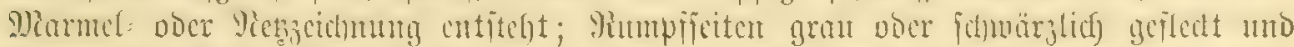

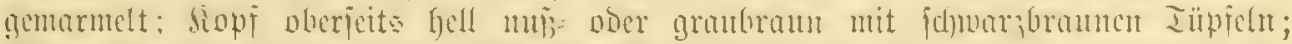

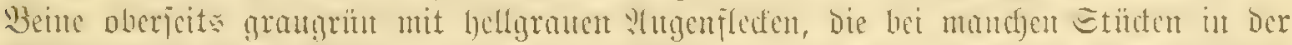

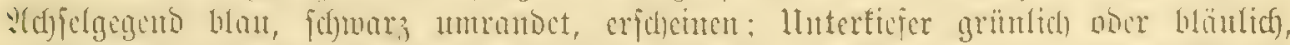

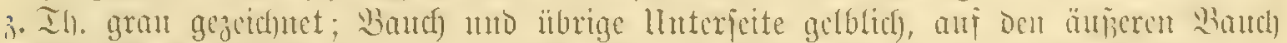

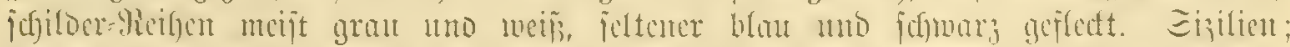

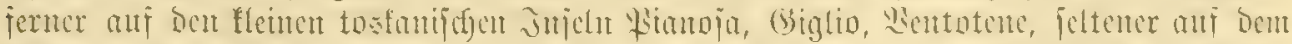

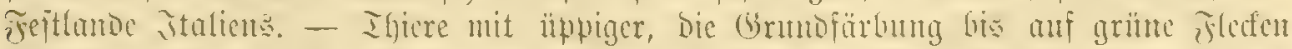

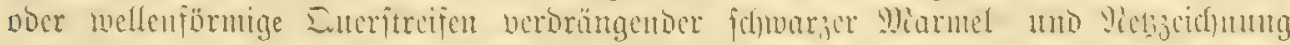
anf ber Ebericite uno meijer, jd)war, uno Duntelgran gemitrfelter llnterjate bilocn

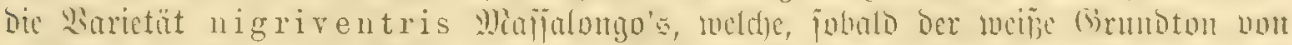

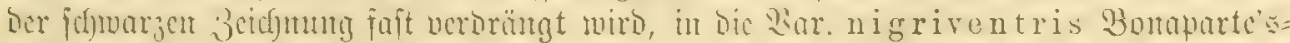

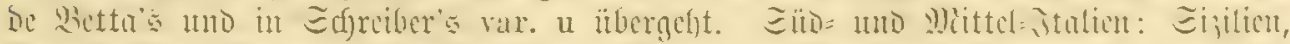

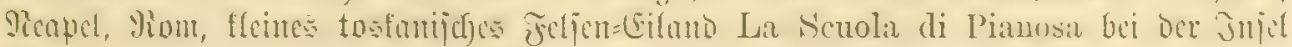
Bianoja. 


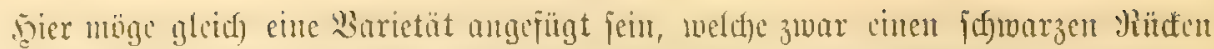

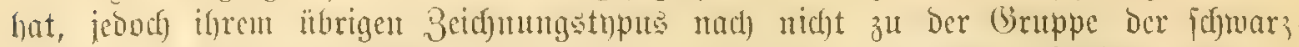

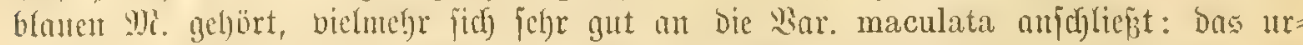

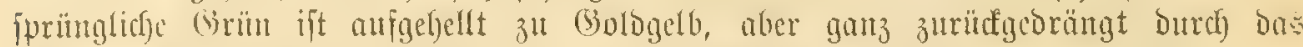

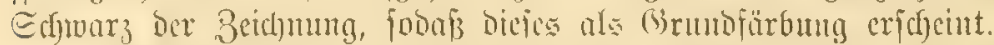

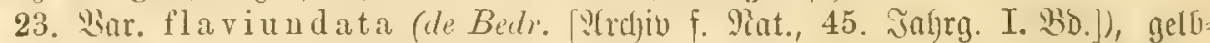

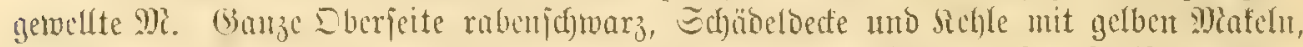

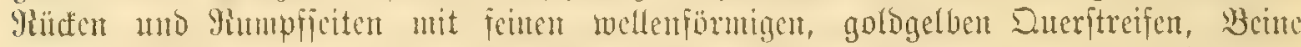

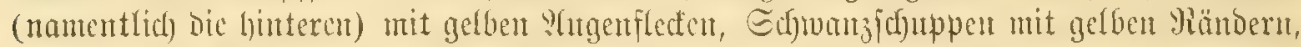

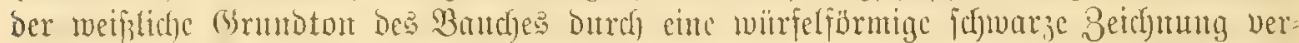

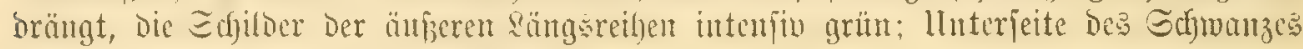
ftahlgrau mit gelbeu Flecten. Mont.

24. Whar. Brüggemanni (de Bedr. [*[robiv, 45. J., I. Wio.]). Dberjeits aui

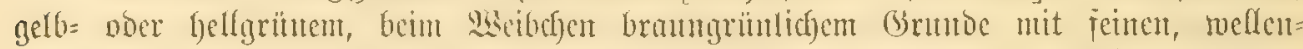
förmigen, an Den Shumpfieiten ein Debmert bilbenben fdywargen Enteritreifen; an ben

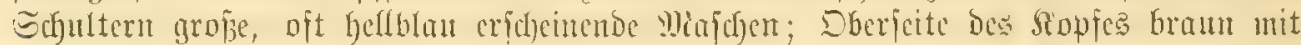

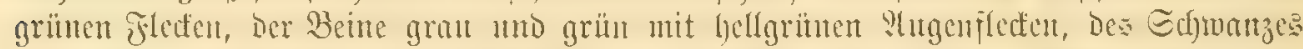

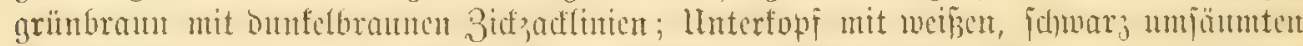

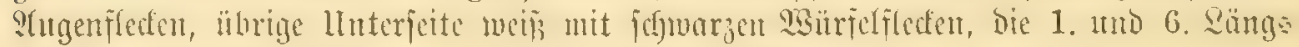

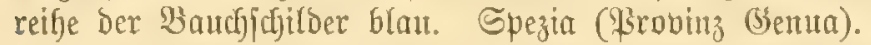

25. Sar. pity usens is (Bosca 1883), Witfnufat-2)i. Yitden ganj hellgrün

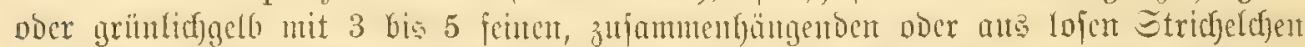

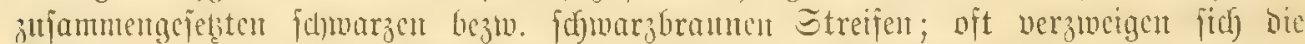

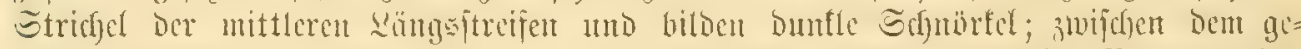

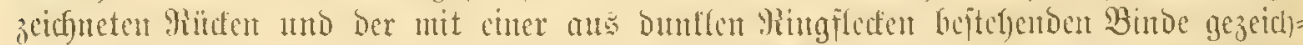

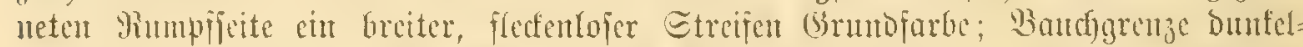

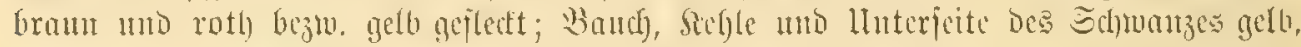

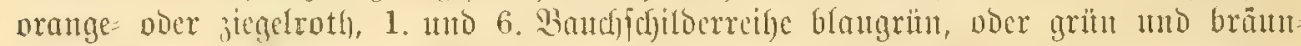

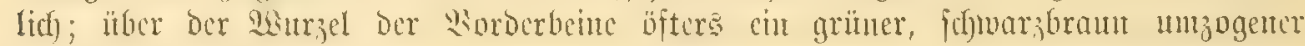
atugenffect. Bsitbuufent.

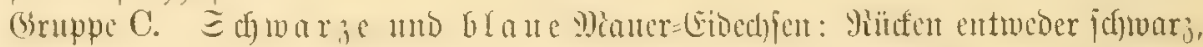

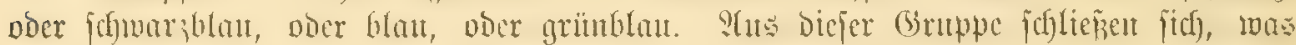
Den Sörperban anbetrift, bie Bartetüten Gigliolii uno Lilfordi an bie vorgenannte War. pityusensis eng an, mit ber fic an Der lluterart Der Walearen-9)aner-Cidochje zählen; fic feien Daher zuerit anfgefül)rt. Slls Etummform bor unter 9ir. 28 bis 33

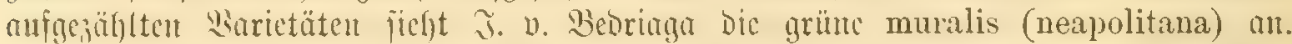

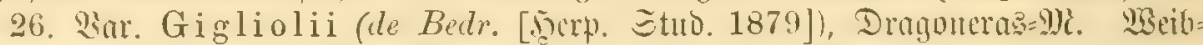

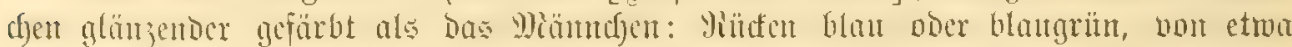

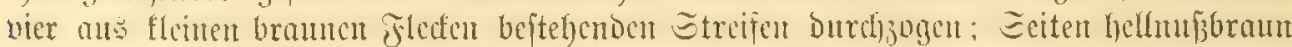

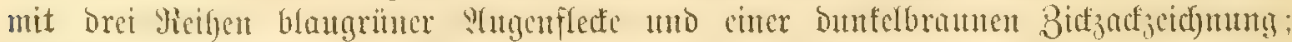

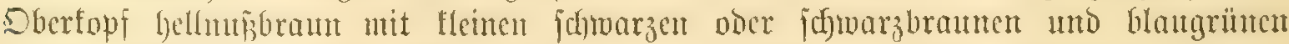

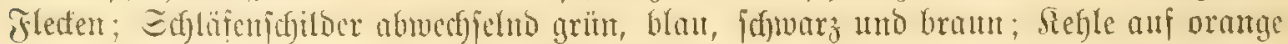

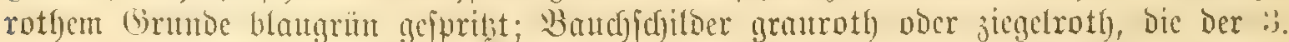
uno 4. Sängureige mit femen blanen Etreifen, bie Der 2. mo 5. Meifye mit blancu

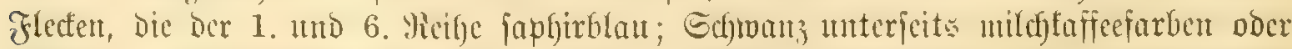
röthlicf, oberjeits blangriu bis faphirblan; Beine helfmubbram mit bunfelbraunen

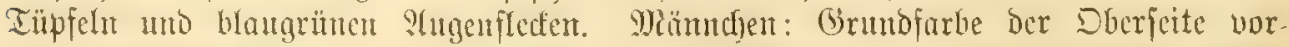

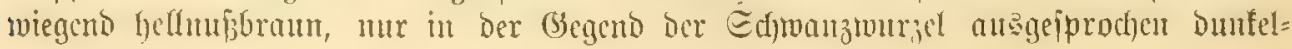




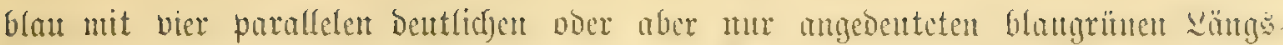

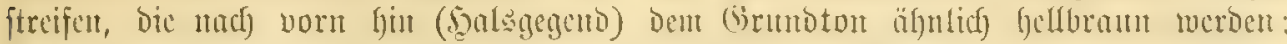
Siumpficiten uno Eberfeite Der Beine meijt cinfarbig belfumbrom, an ben erfteren

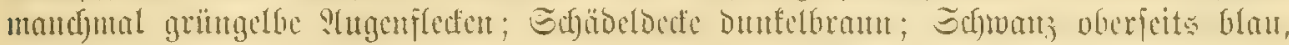

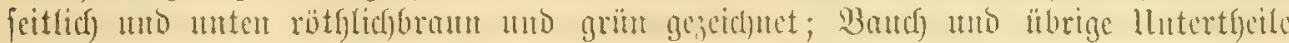

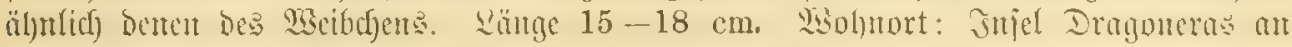
ber Weitliijte bon Miallorta.

27. War. Lilfordi, Zulforb (Ëbedjic, von Giunther i. 3. 1874 [Ann. and Magr. of nat. hist., Ser. IV, vol. XIV, $\Xi .158\rfloor$ al Zootoca Lilfurdi bejefricben

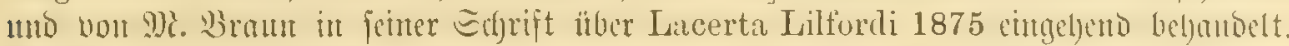

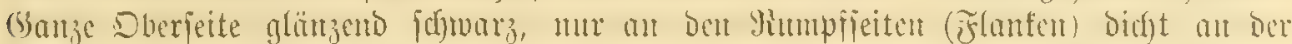

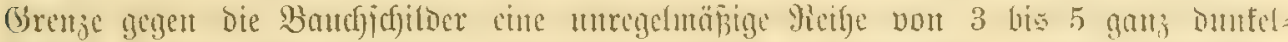

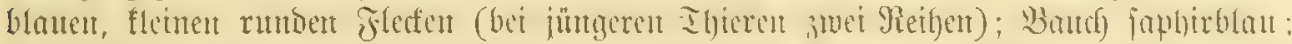

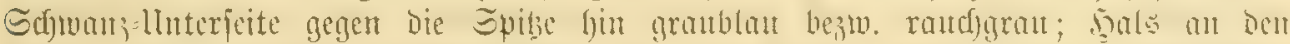

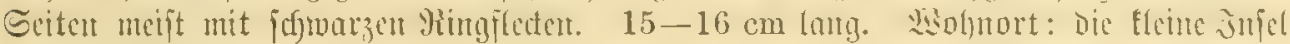
?(y)re fïböftlicf) von Mlenorfu.

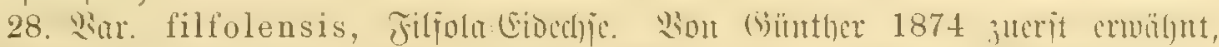

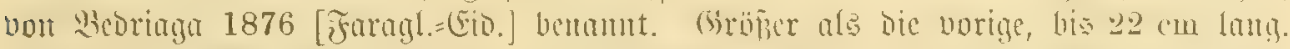

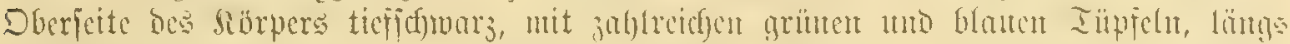

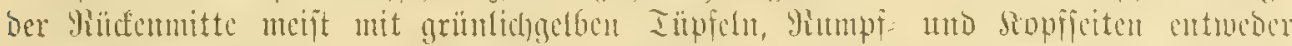

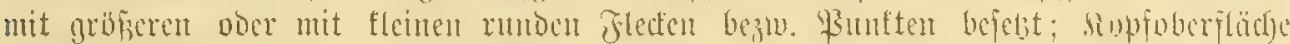

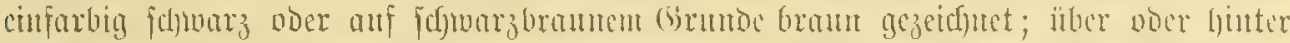

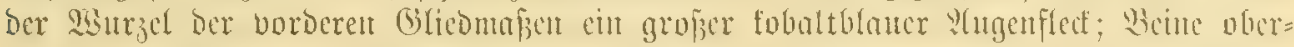

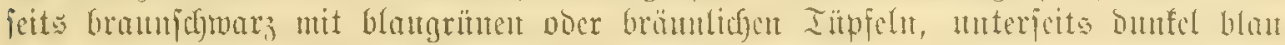

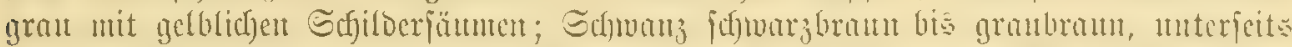

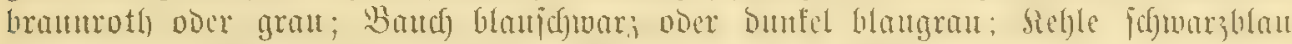

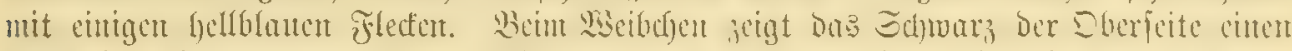

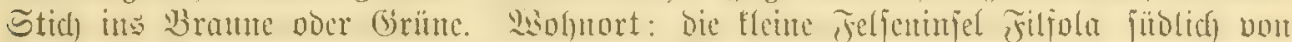

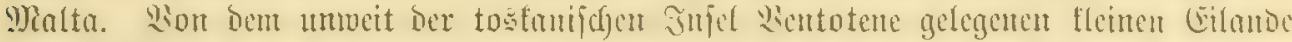

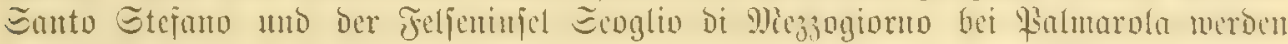

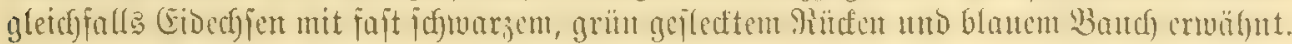

29. 2ur. coerulea, Eimer $1874=$ faraglionensis, de Bedr. 1876,

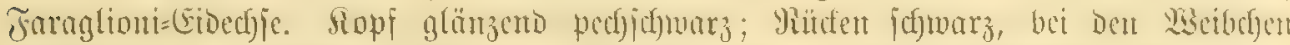

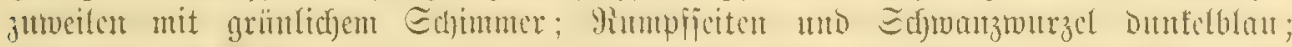

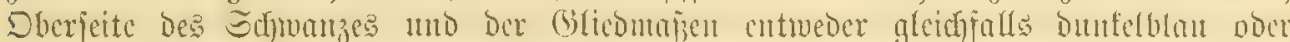

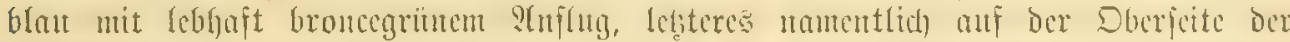

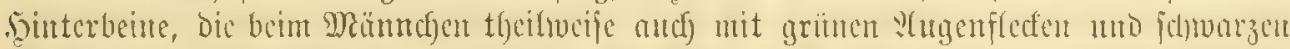

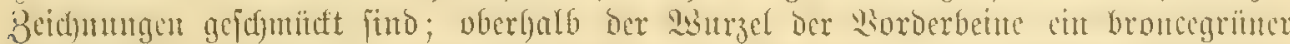

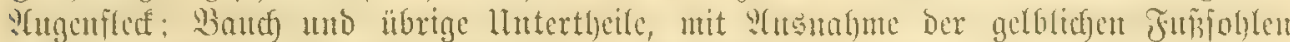

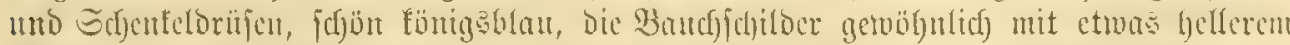

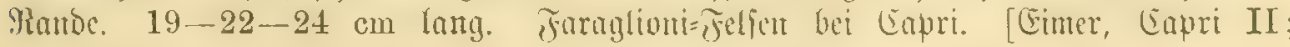

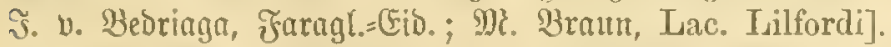

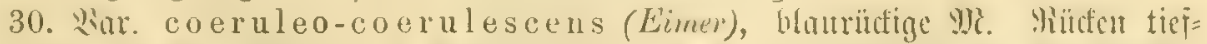

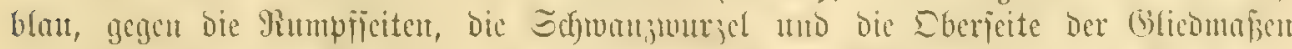

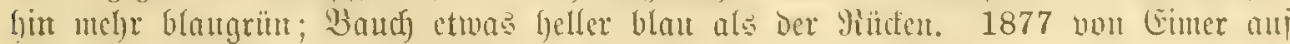
Dem mittleren Faraglione gefunben. [S(rch). f. Mat. 1881.]

31. War. coerulescens monaconensis (Eimer), Mionucont. Eidochjic.

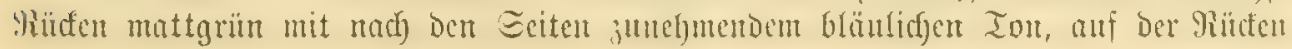




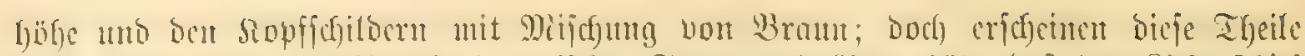

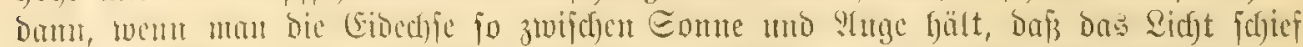

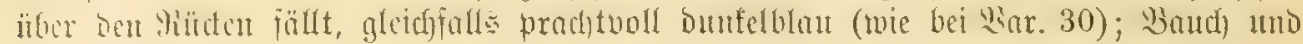
Selyle bläulidy. Mionacone Ffle öftlid) von Capri.

32. War. coerulescens gallens is (Eimer), (Balli-eiocdffe. Fürten grüu,

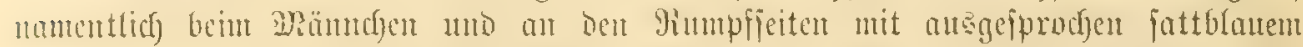

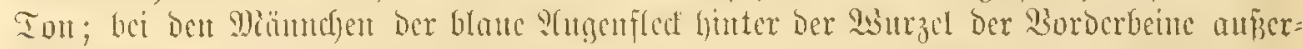

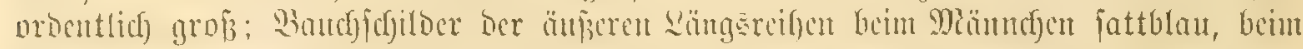

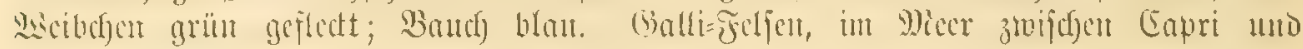
9lmalfi gelegest.

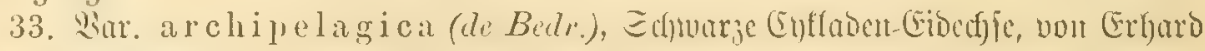

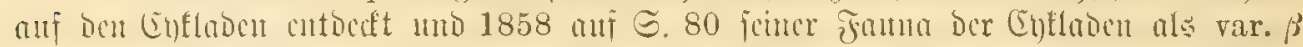

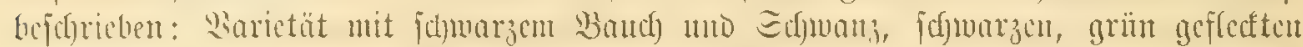

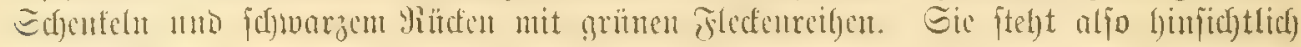
ber Färbung am nächiten Der Şar. filfolensis.*)

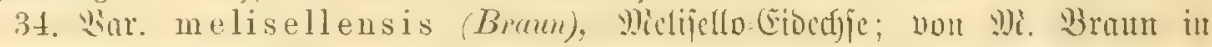

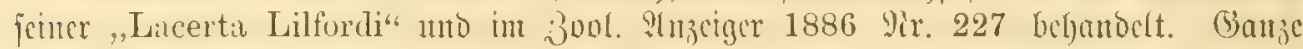

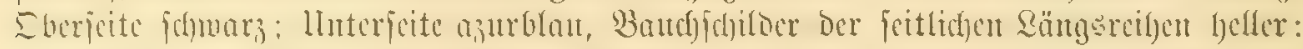

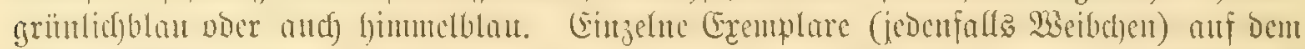

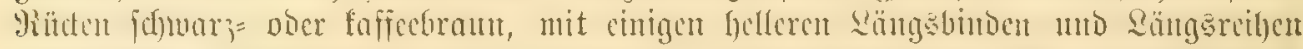

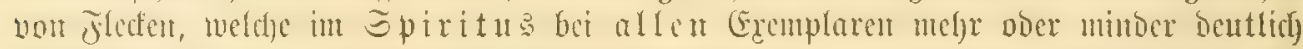

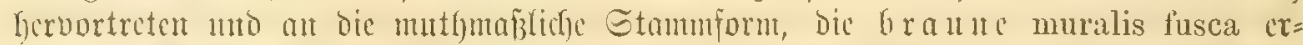

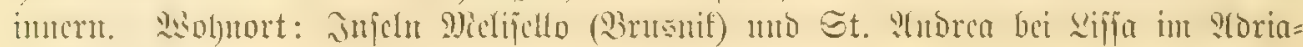
ifdent syeer.

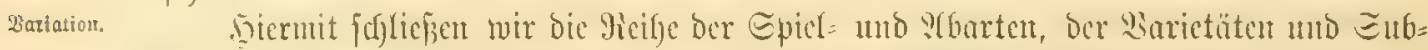

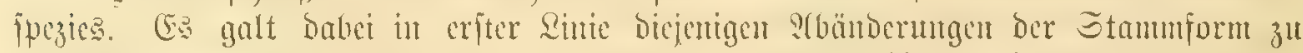

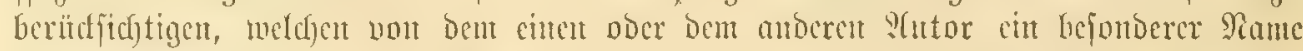

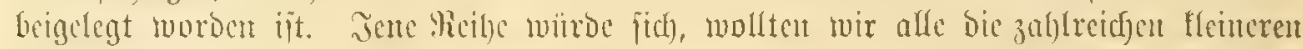

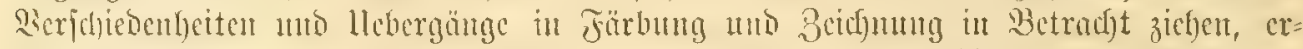

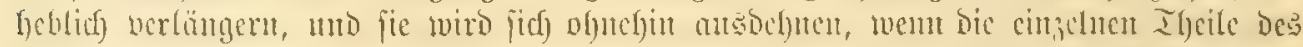

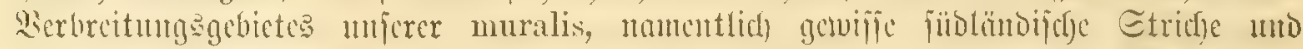

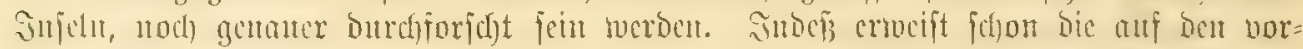

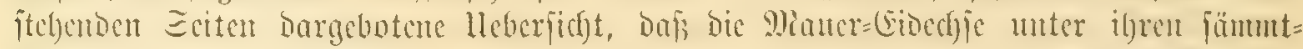

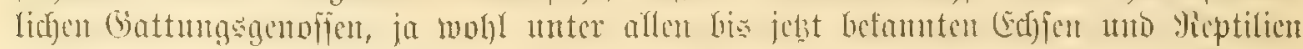

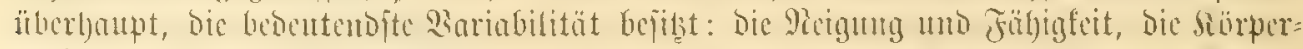

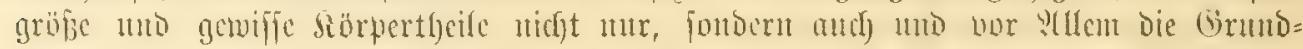

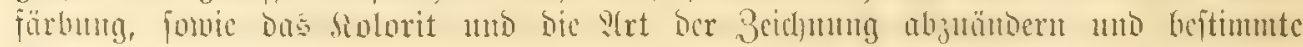

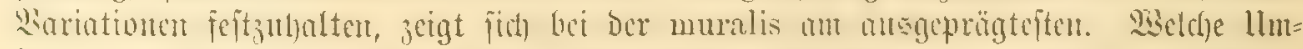

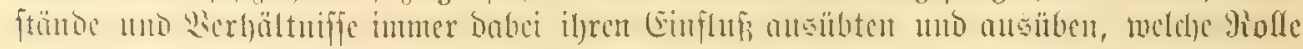

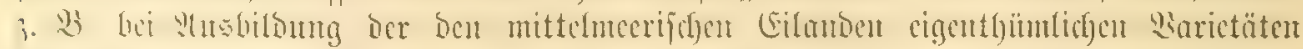

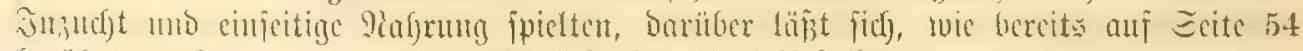

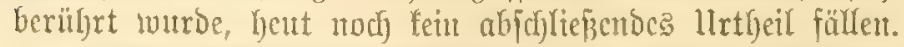

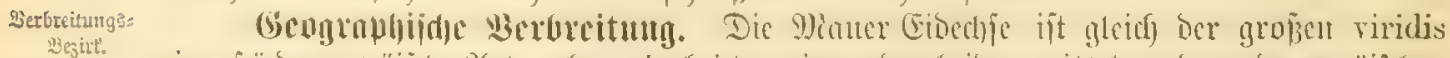

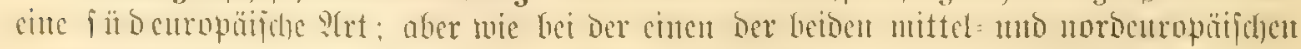

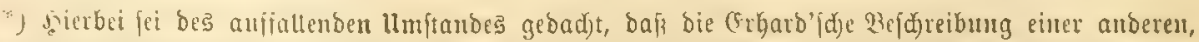

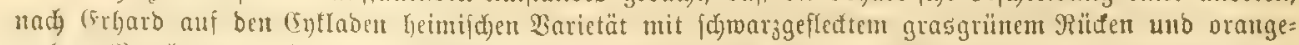

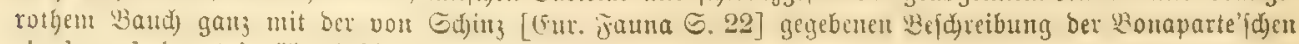
sicula rubriventris übereisptimmt (†. oben 5. 200). 


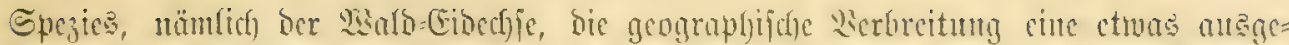

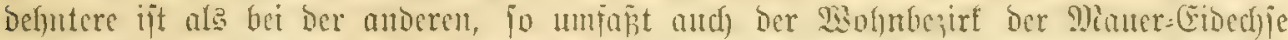

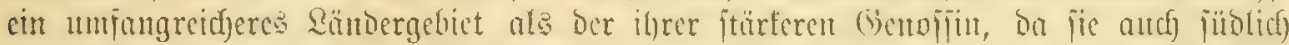

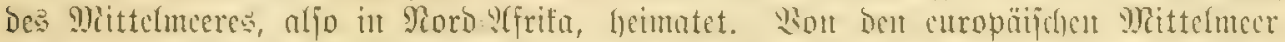
lünocen ans ift jie, wie bic viridis, weiter noromärts borgeobungen uno auj bicje

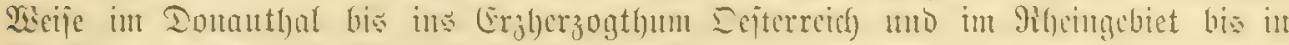

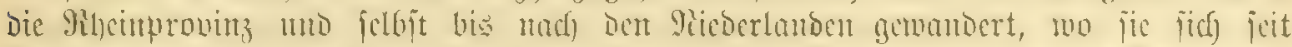

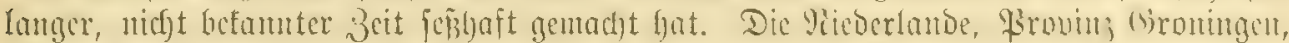

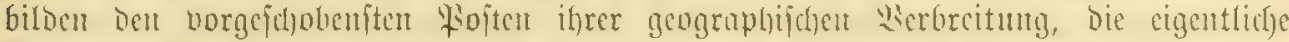

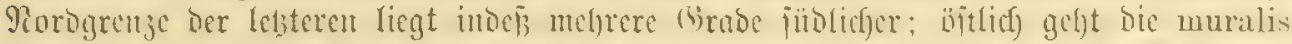

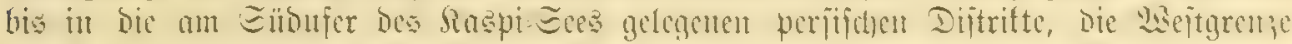

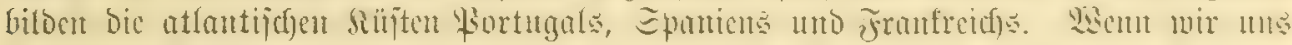
Der Geiben Souptgruppen der muralis, Der brauten und Der grïneu (Eubperies fuseat uno neapolitana), crimuern und bicje auf il)re geographifde

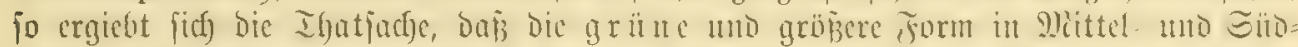

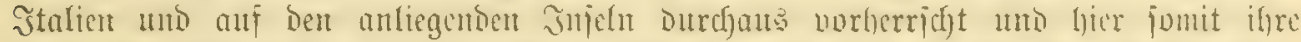

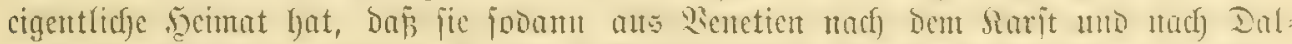
matien uno von fier aus nad) Der balfan-balfimiel uno nad) Sileinafien übertritt,

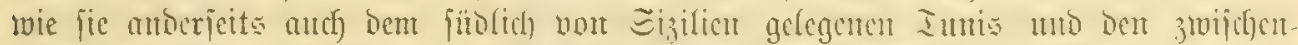

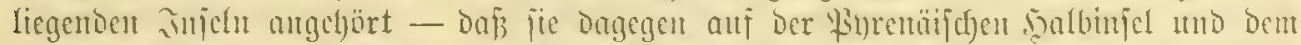

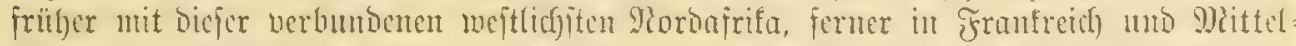
Enropa, wo überall bic braune muralis zu fintent ift, fehlt. Jun Jolgenden befan: Deln mir jedod) nicht Das Serbeitungagebiet Der einen ober Der andercm Birnppe im Einzefnen, jonbern Das Der muralis übcrbaupt.

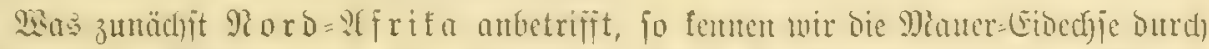

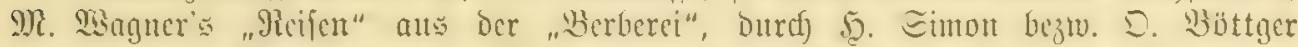

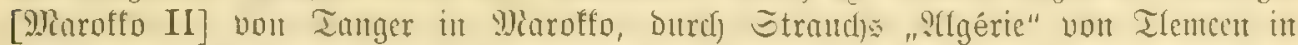

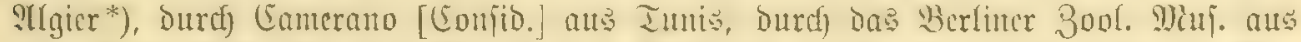

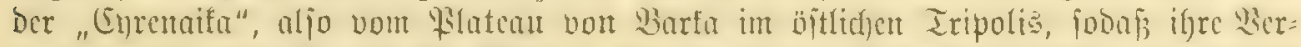

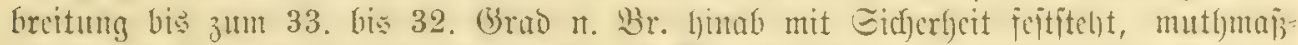

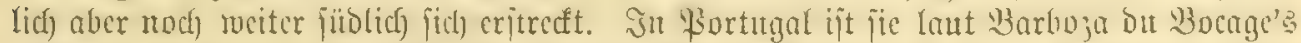

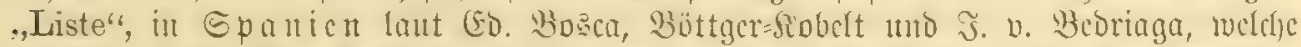

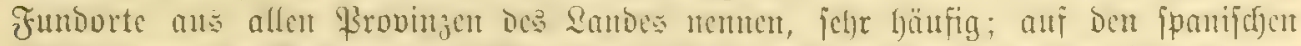

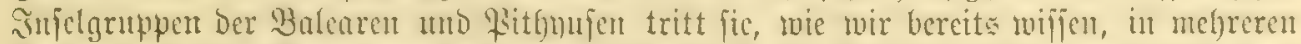

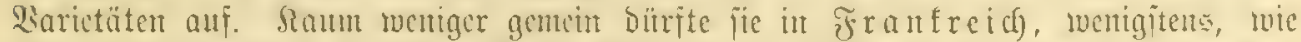

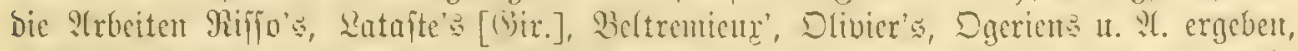
in Den jüblicfen und mittleren Theilen befielben, fein; Dodf fehlt jie audh Den ub̈ro=

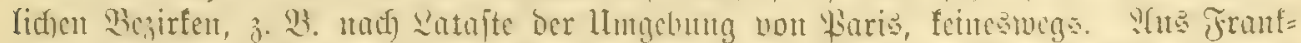

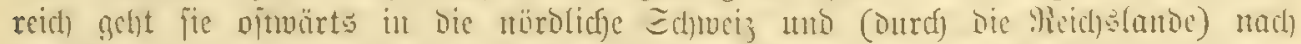

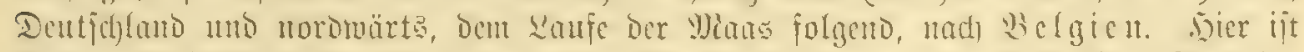

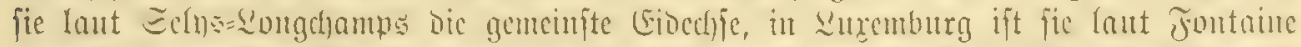

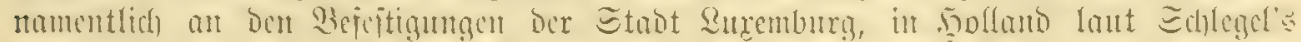
„Dieren ran Nederland" be "immegen

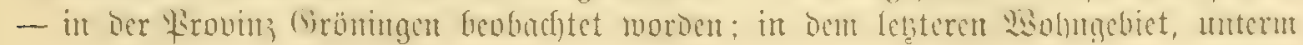

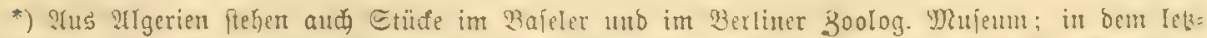

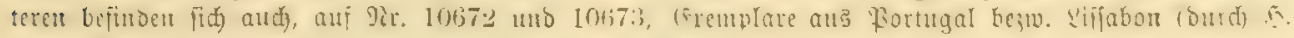

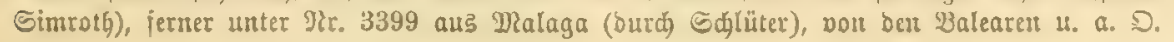




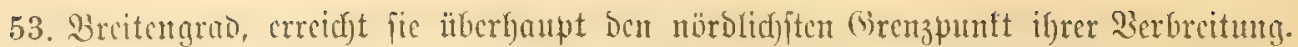
Denu in Englonio fommt jie, entgegen ber ângahe Mierrem's [Enftem S. 67], feinen= falle bor.

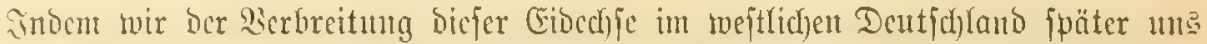

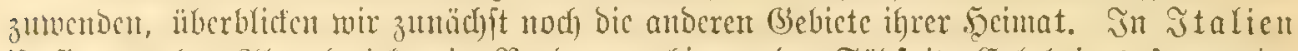

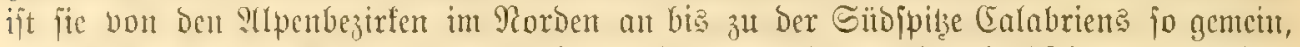

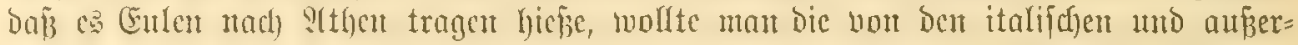

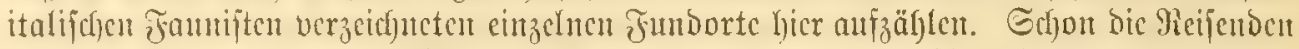

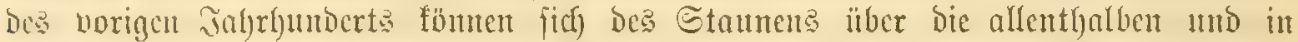

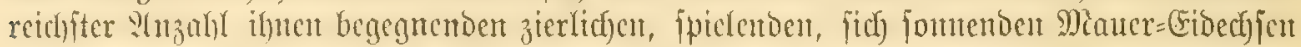

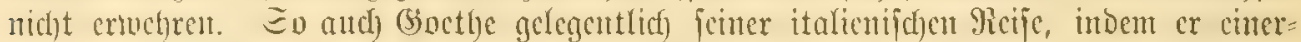
jeits unber bie Fahrt non Bozen nad) Irient (Eeptember 1786) folgende Beobachtungen

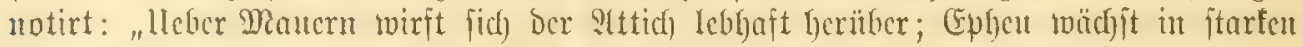
Etämmen bic Felfen hinnaf mo verbreitet fich weit iiber fie; bie Eibcchje fchlüpft

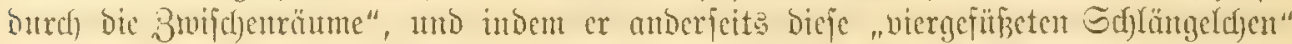

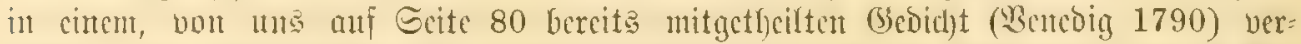

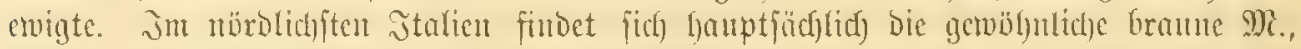

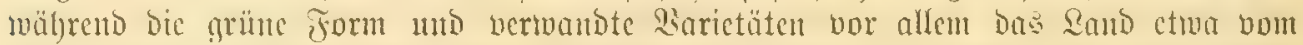
Wo an fiibmörts bewolnten; chenjo beviltert bie muralis in biejer obcr jener Form

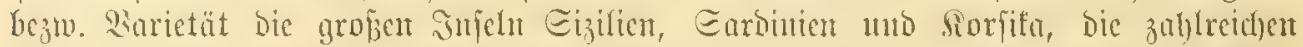

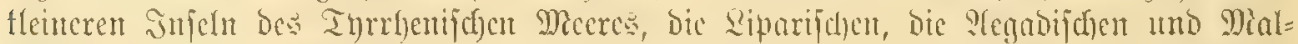

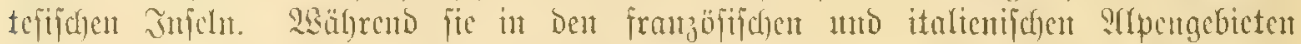

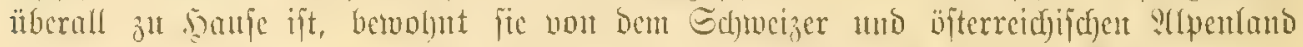
nur gemifife uno , whar bic jublichen Theile. 3mar fommt fic, mas bie $\Xi$ d) weiz an=

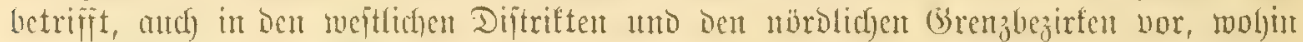
fie non wejten (Frantrcid) her cingemandert ift, allein im eigentliden Dodhgebirgs:

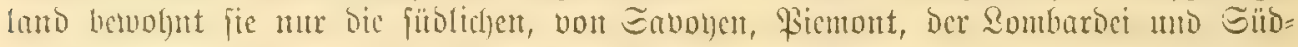

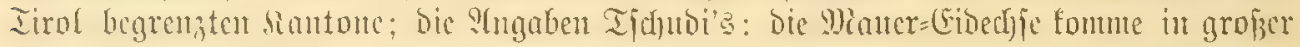

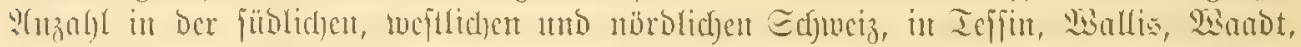

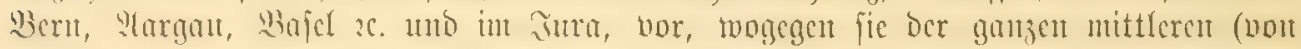

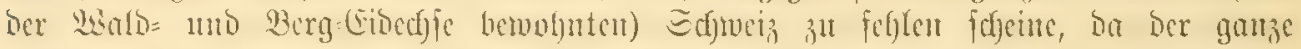

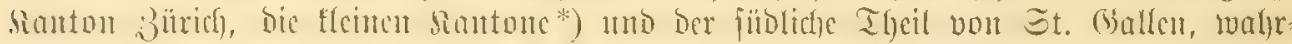

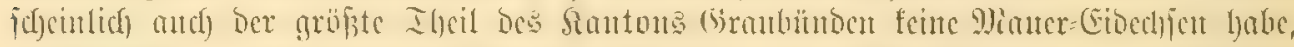

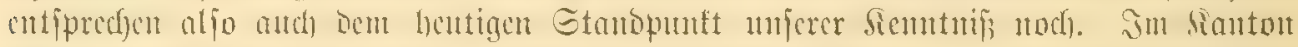

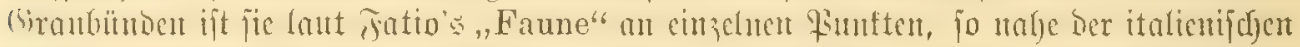

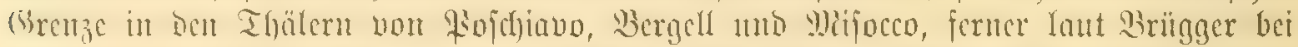

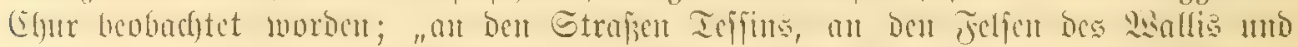

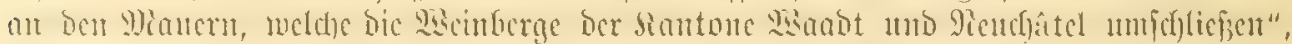

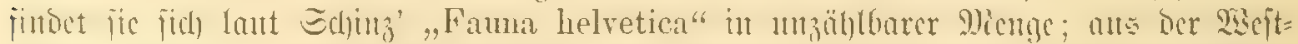

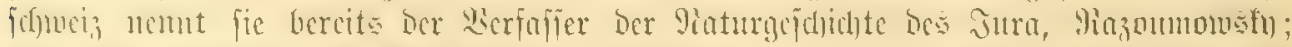

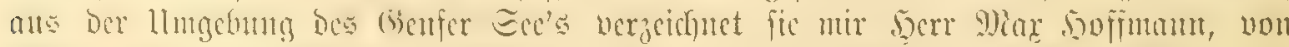

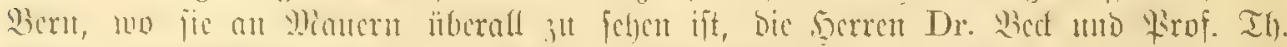

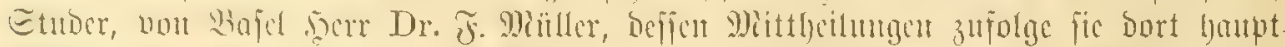

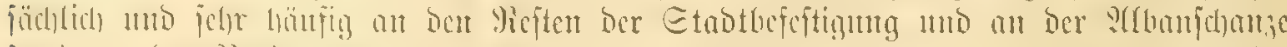

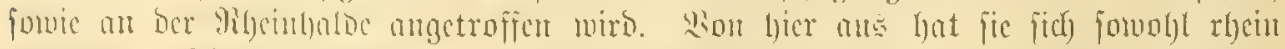

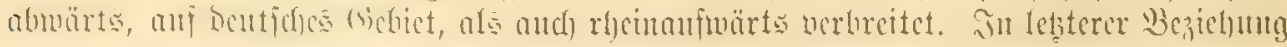




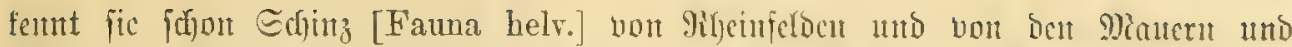

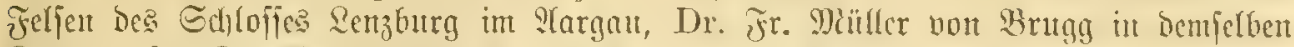
Santon; für St. Gallen wirb fic won Wirtulyin unt Fatio angezeigt.

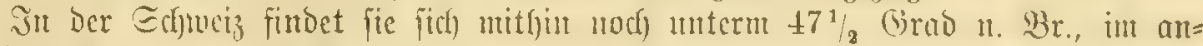

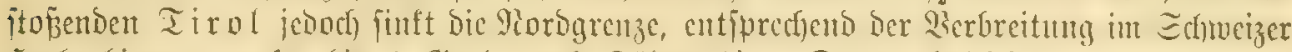

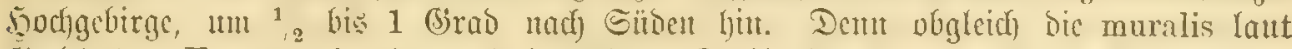

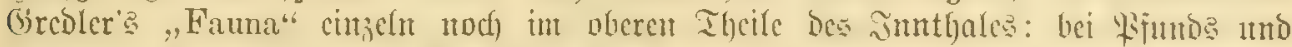

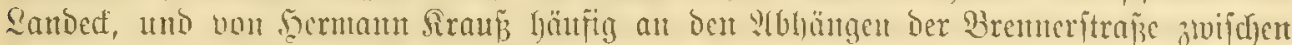

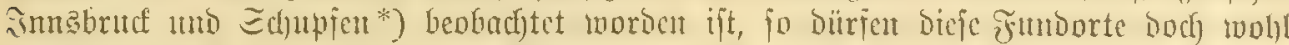

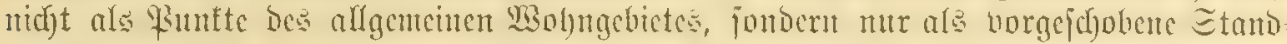

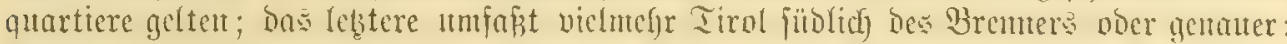

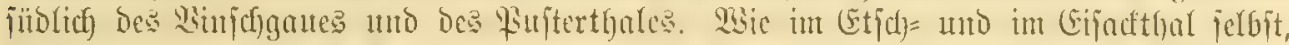

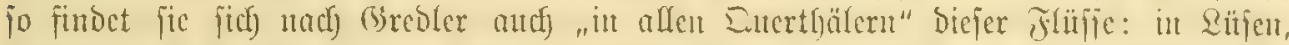

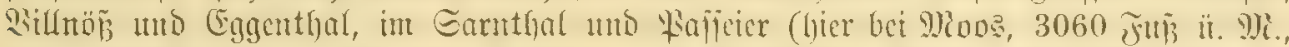

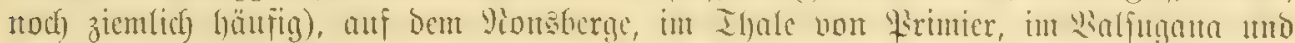

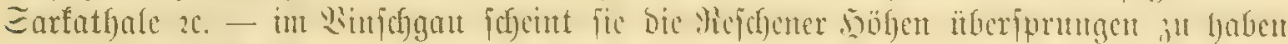

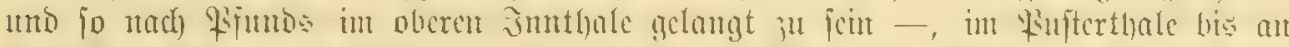

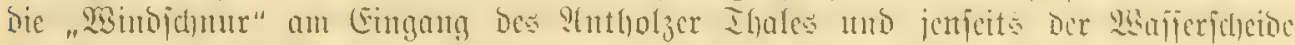

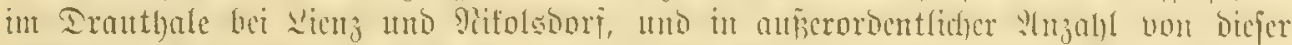

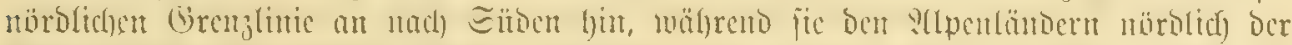

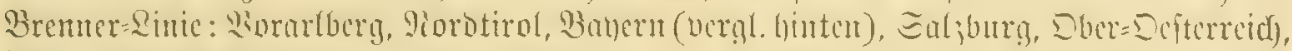

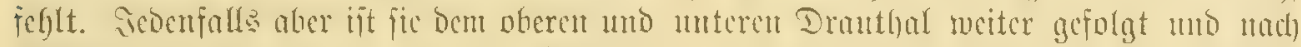

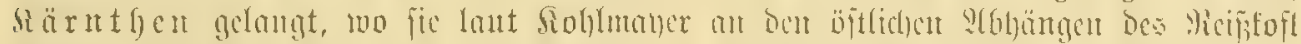

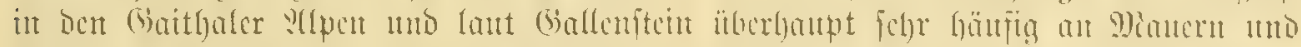

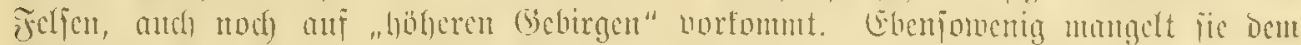

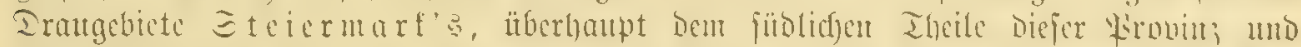

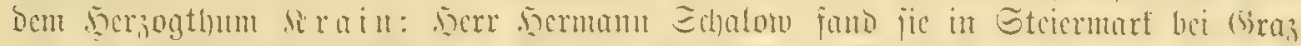

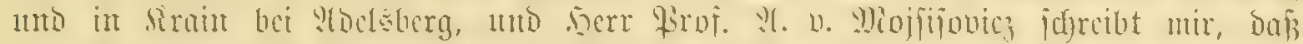

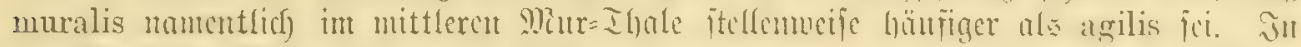

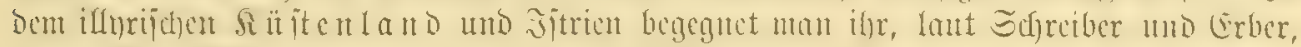

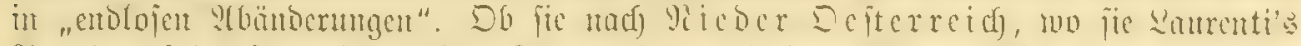

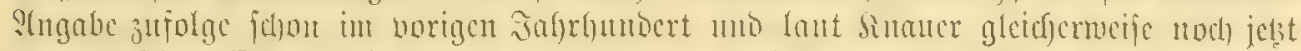

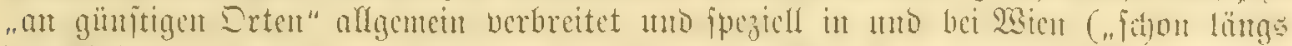

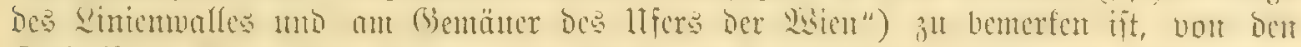

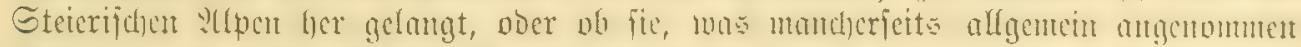

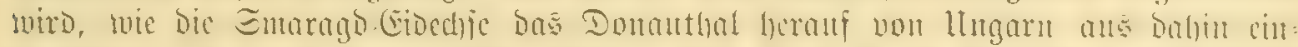

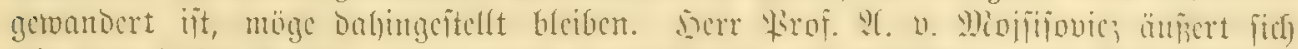

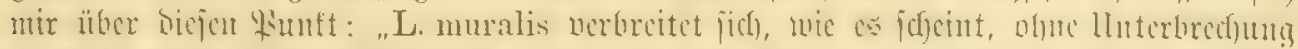

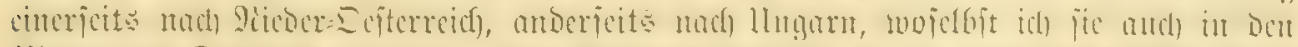

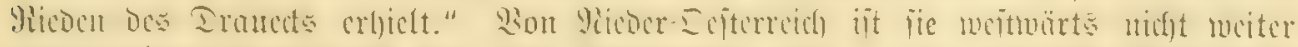

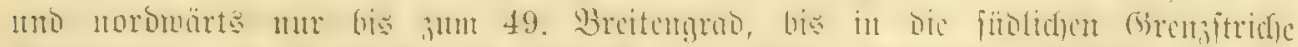

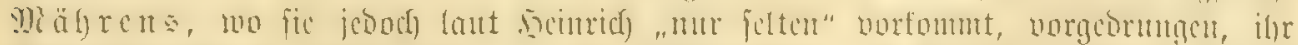

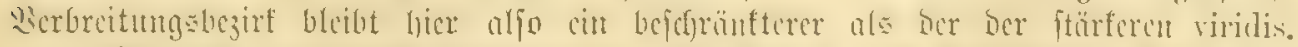

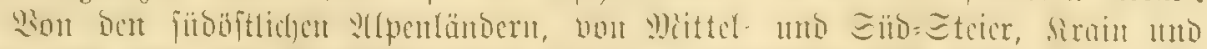

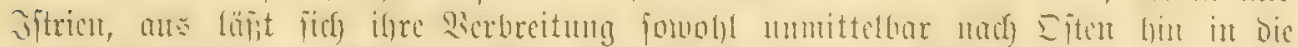

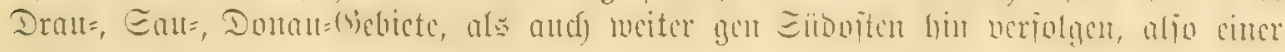




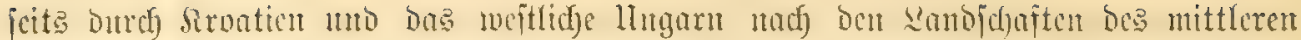

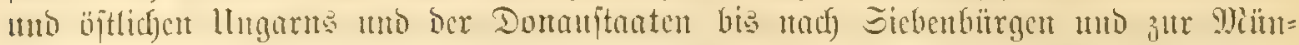

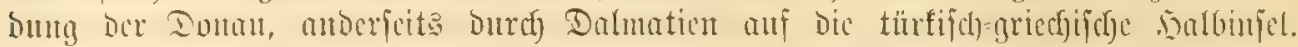

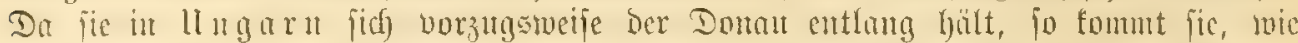

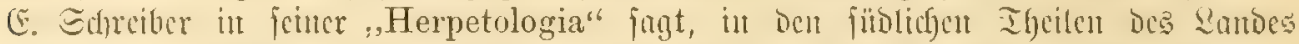

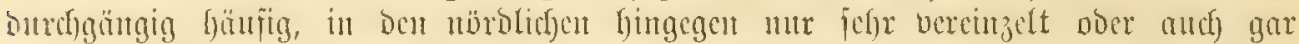
nicht wor. Eebteres miro beftütigt burch Ieitteles, ber wäl)eno jeites brcijährigen SInfenthaltes it Siafdhau mur, uno zwar in Sommer 1861, brei Etüdf erfielt, weldje

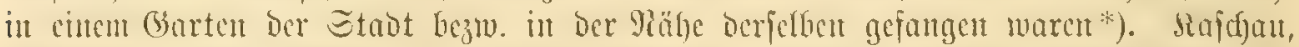

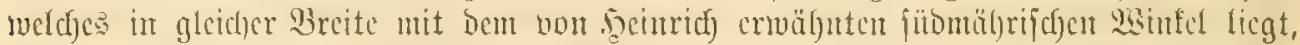

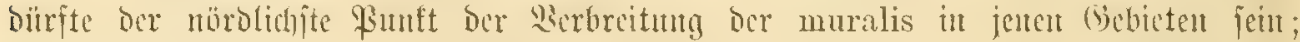

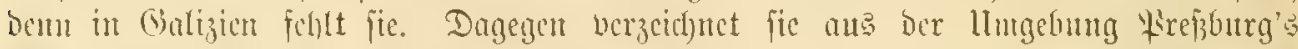

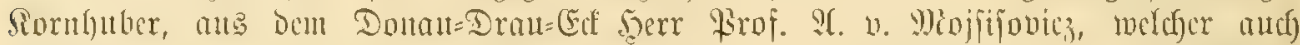

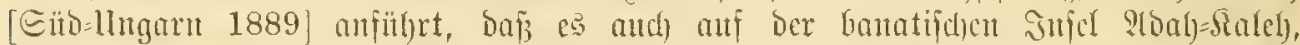

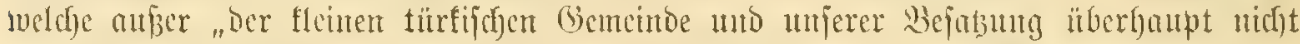

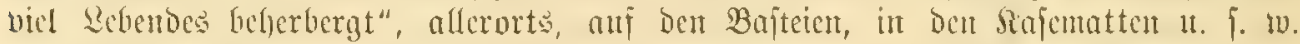

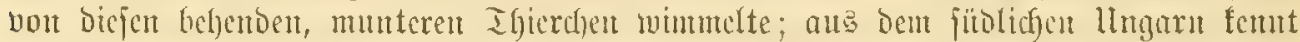

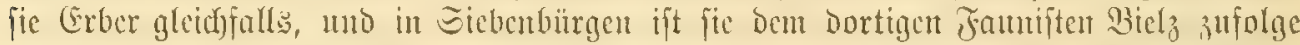

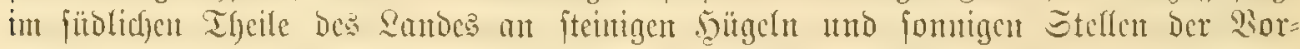

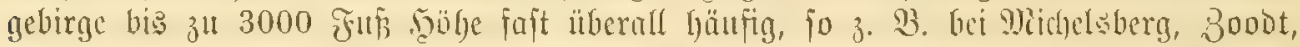

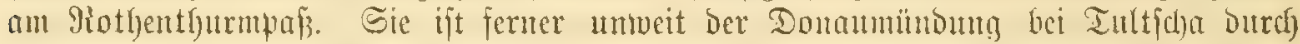

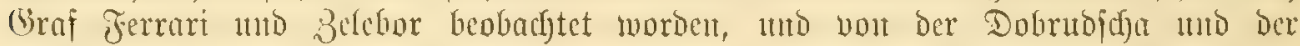

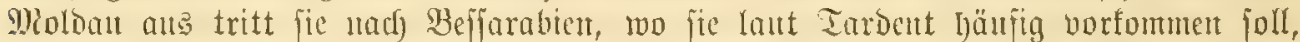

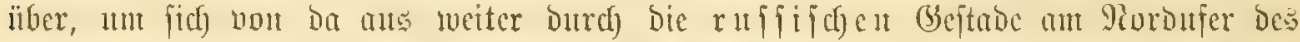

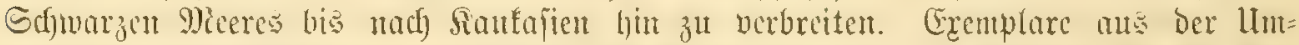

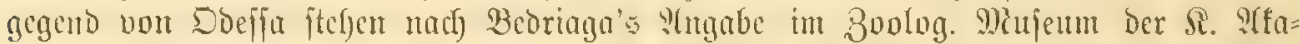

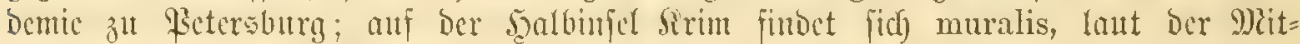

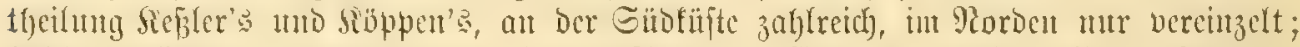

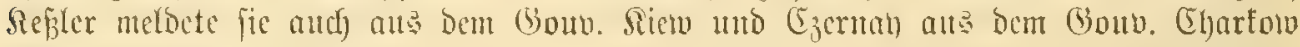

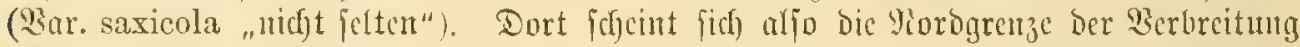

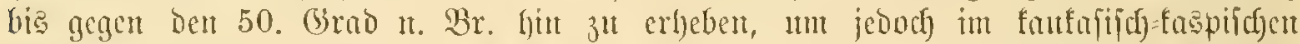

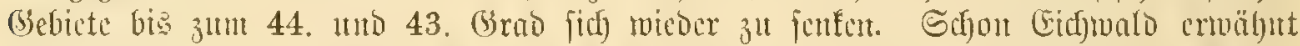

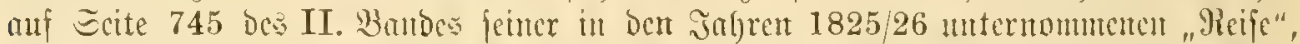

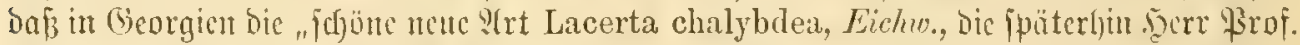
(Eversmann Lac. saxicola**) genaut hat", vortomme, mo jagt 1842 in feiner Fauna caspio-caucasica betreffo ifres walnngebietc: „Hab. in Caucaso, Iberia, ad Tiflisios urbem, Somchetia; etiam ad aquas carbonicas Kislawodskienses". Epejiclle Fumo=

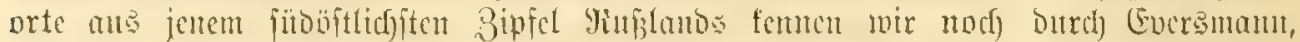

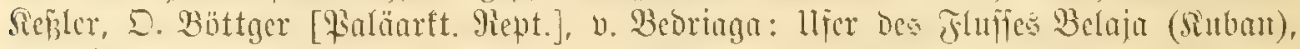

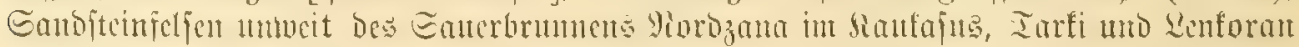

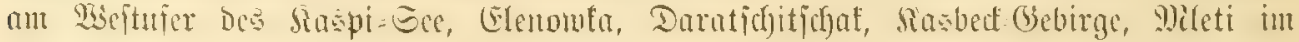

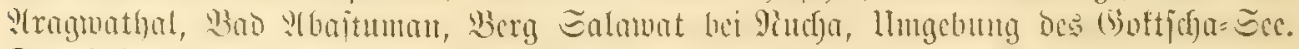

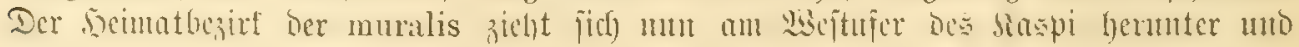

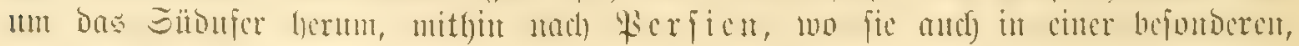

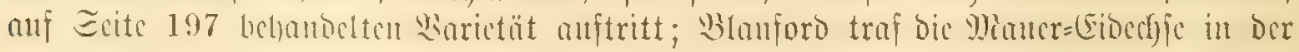

*) Gie maren 13,8 bis $15 \mathrm{~cm}$ lang uno gebörten, roie aus ber Befdreibung hervorgeht, zur ge=

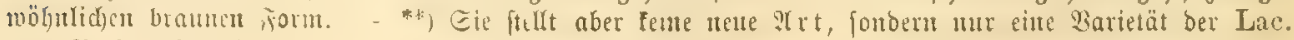
muralis dar (vergl. S. 197). 


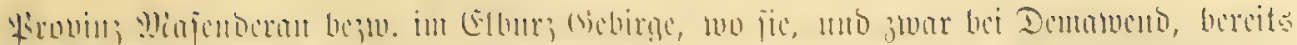

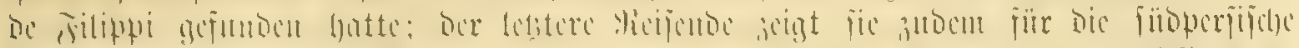

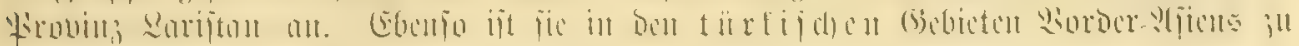

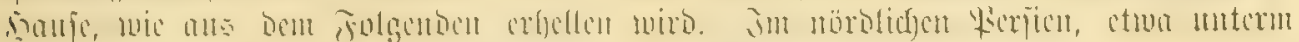

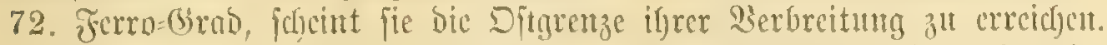

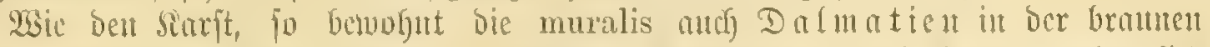

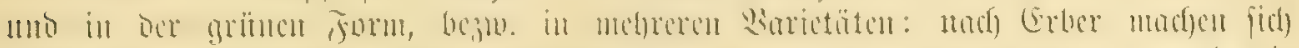

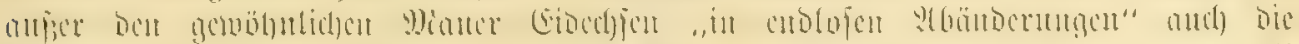

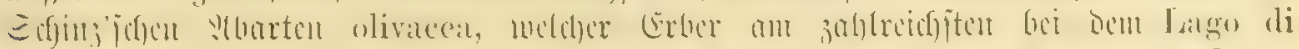

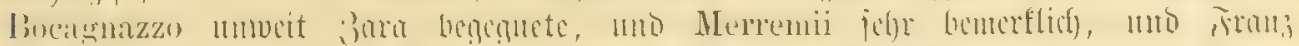

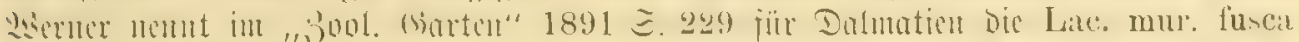

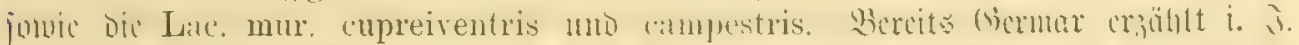

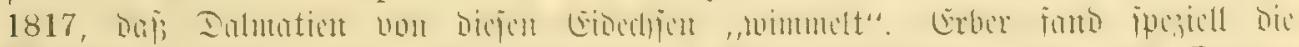

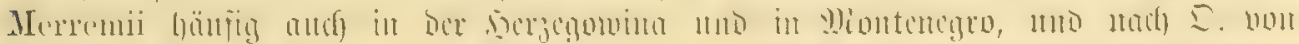

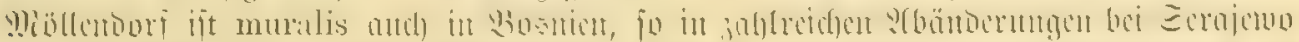

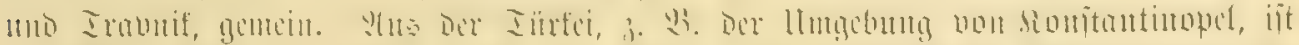

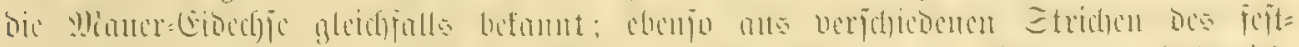

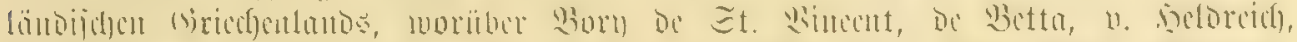

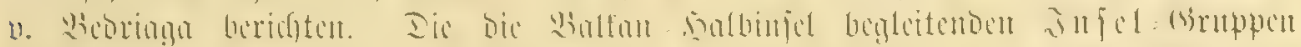

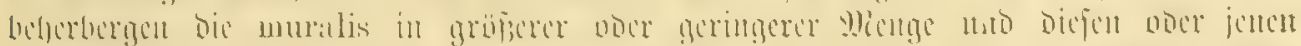

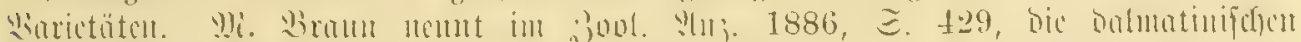

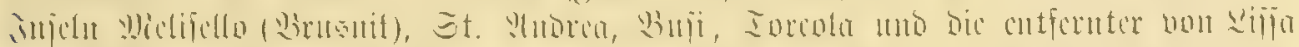

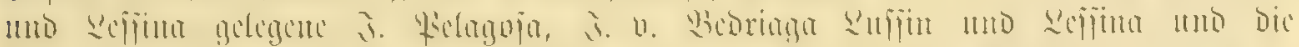

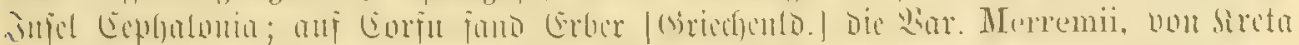

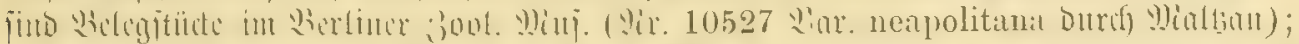

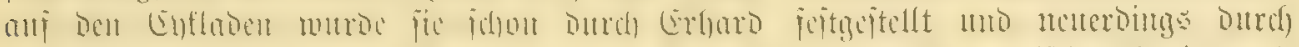

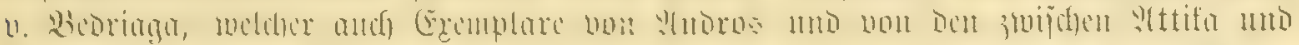

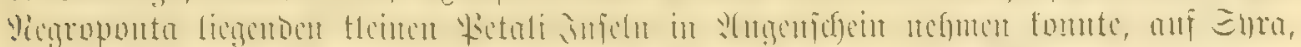

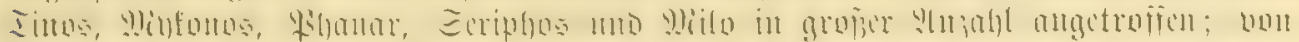
yih)

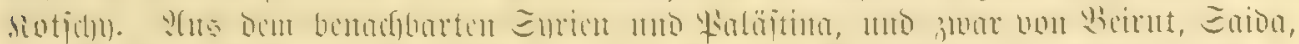

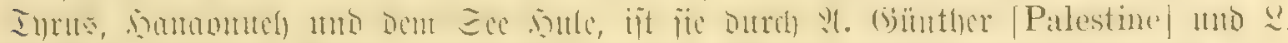

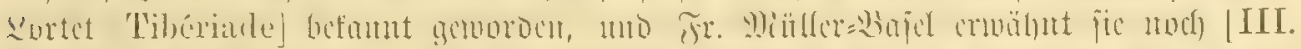

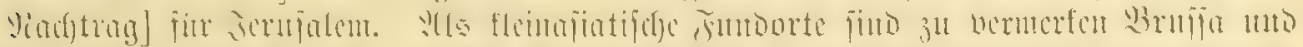

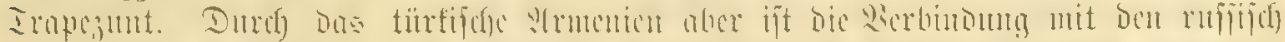

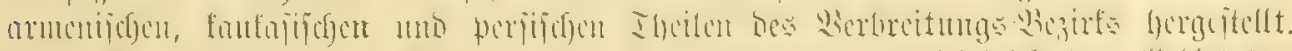

in I 2 at Deutjdjtan's.

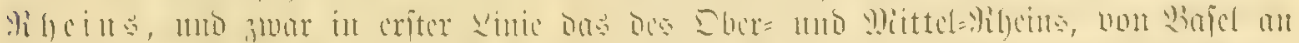

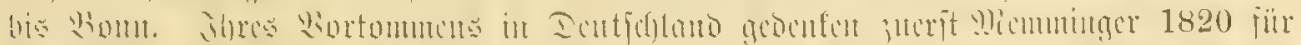

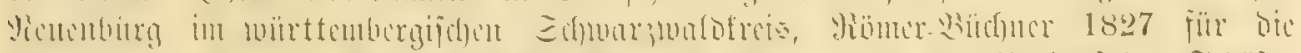

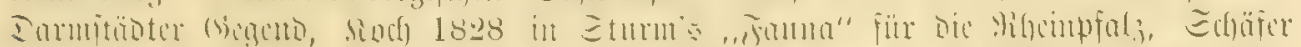

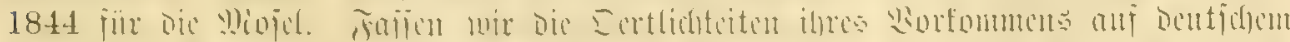

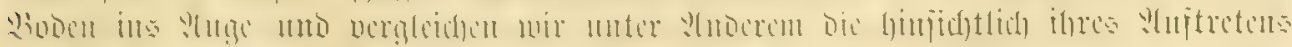

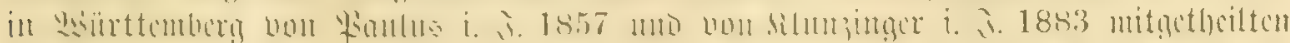

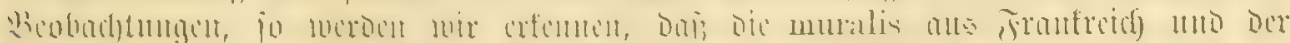

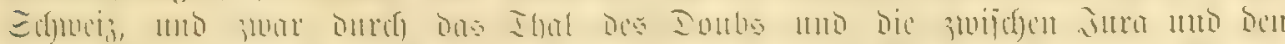

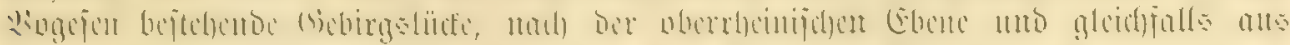

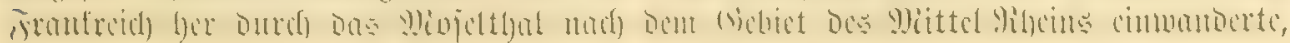




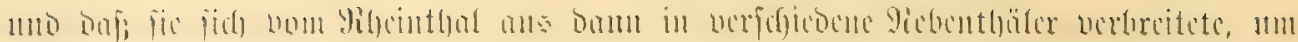

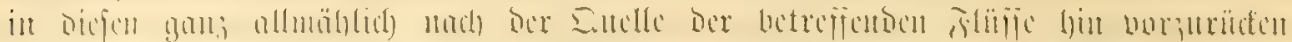

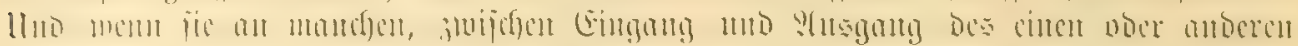

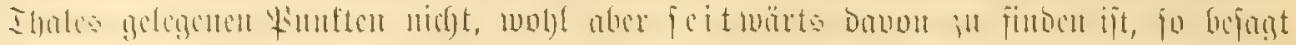

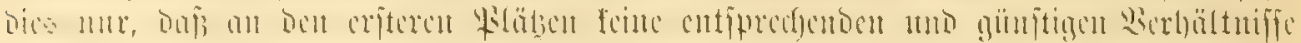

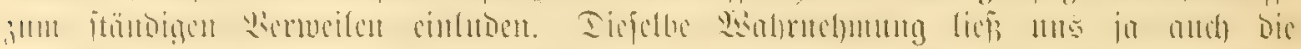
Emarapio (E)

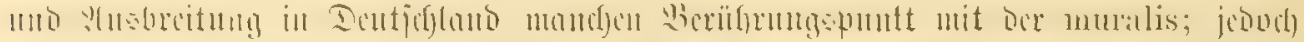

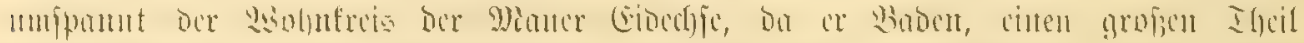

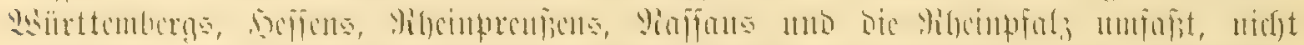

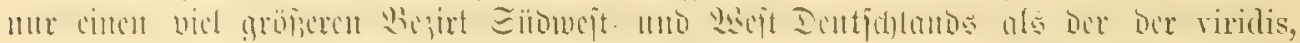

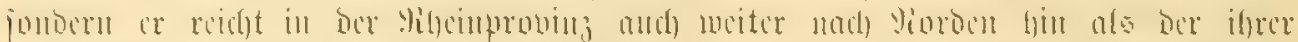

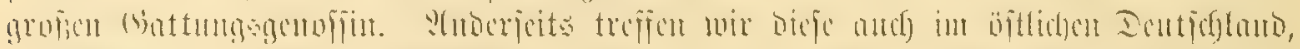

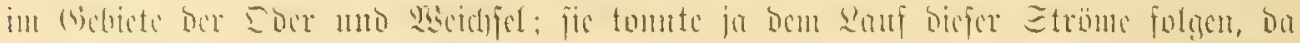

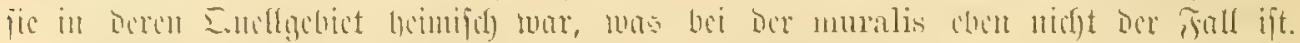

Meidjistanos. insoctr.

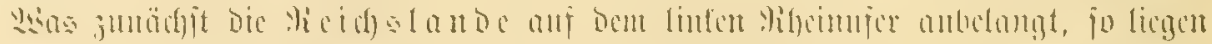

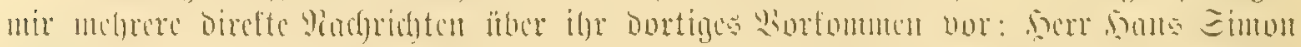

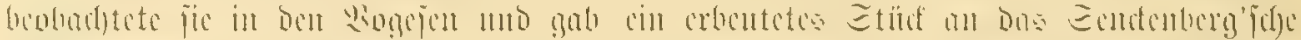

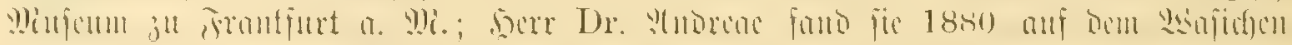

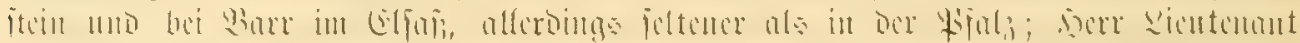

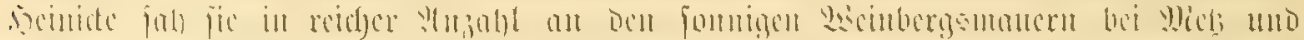

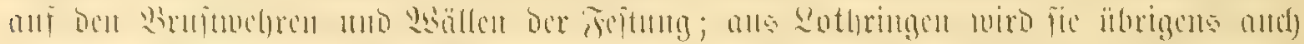

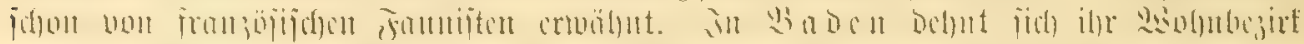

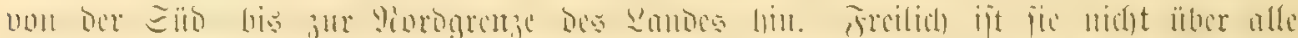

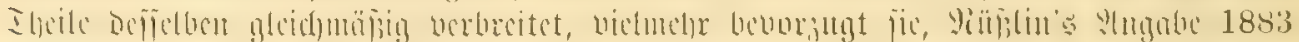

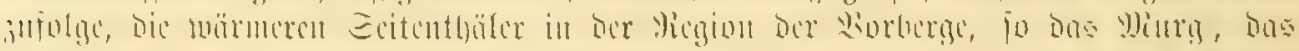

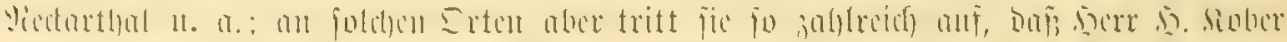

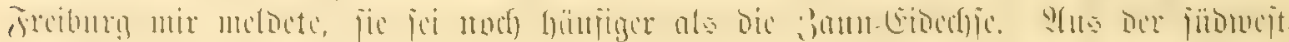

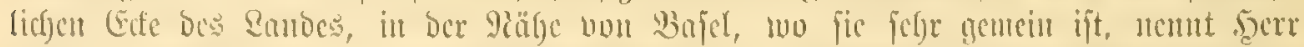

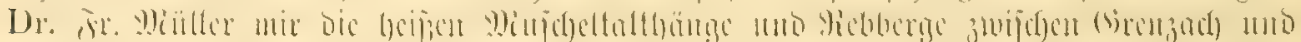

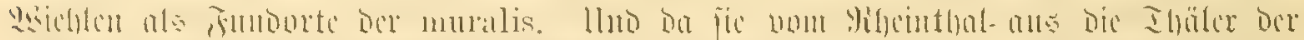

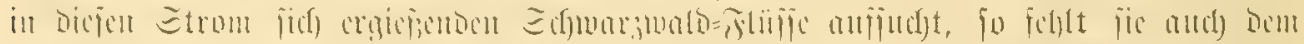

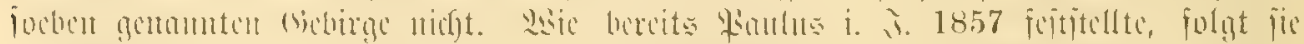
ber s.sutad)

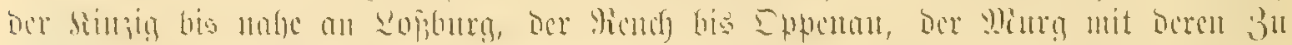

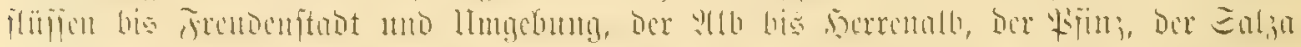

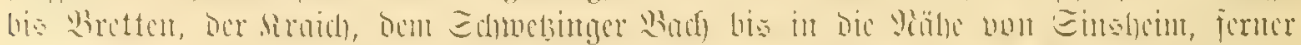

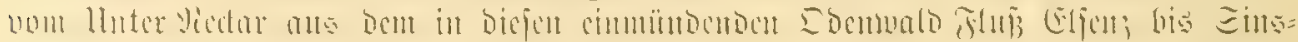

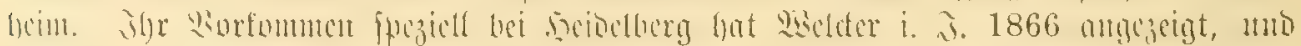

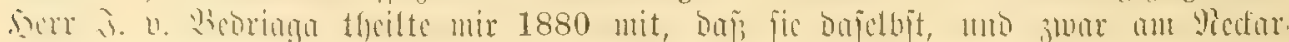

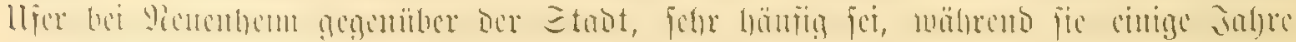
ipüter infolge bex lleberjulucmunugen bort redjt gelitten hat.

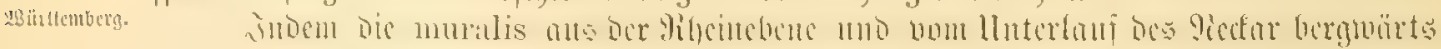

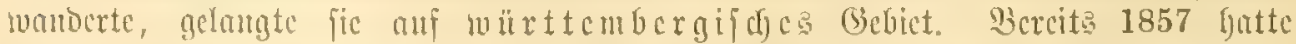

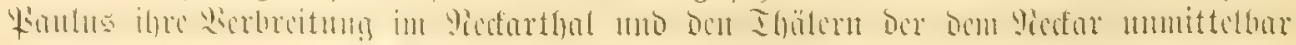

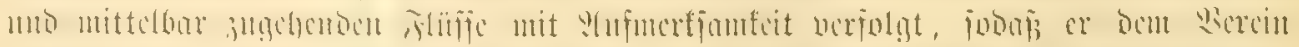

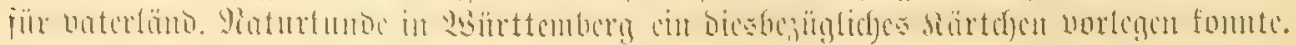

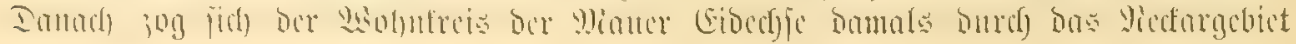




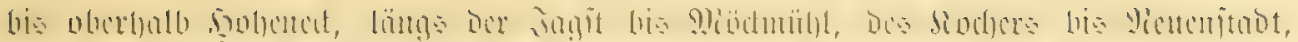

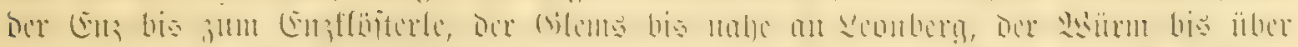

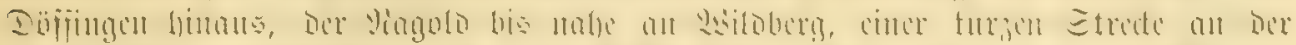
(E)

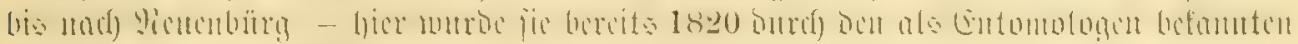

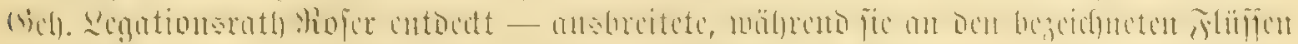

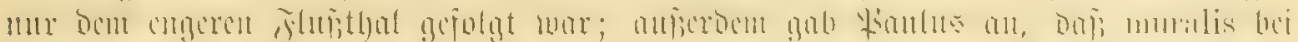

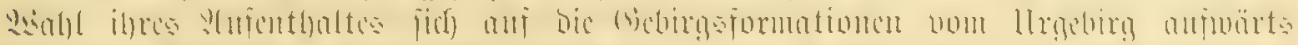

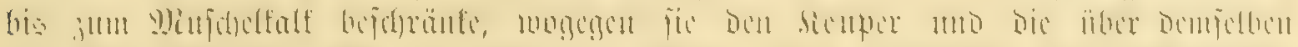

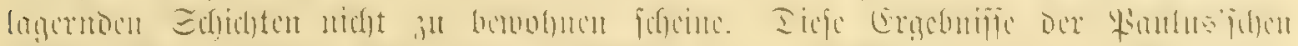
Yand)

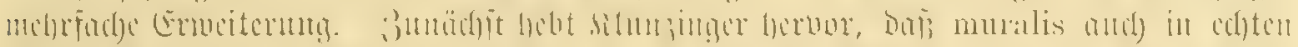

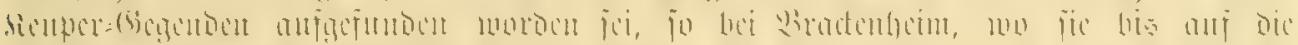

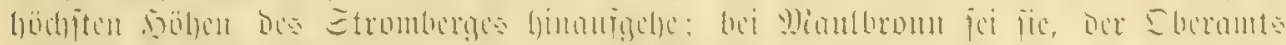

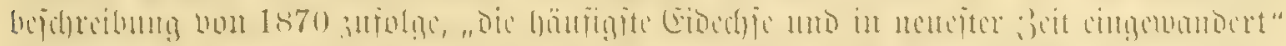

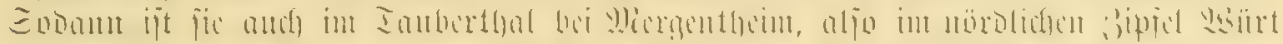

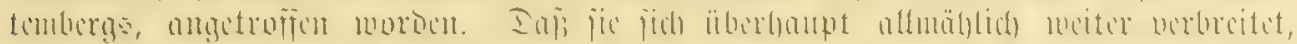

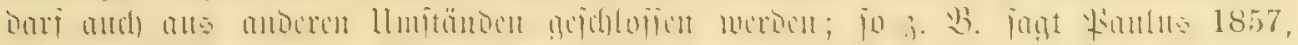

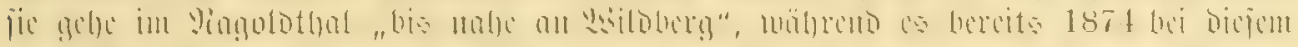

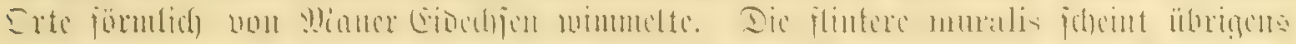

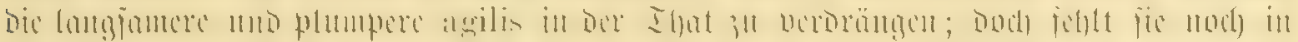

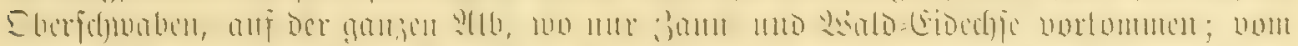

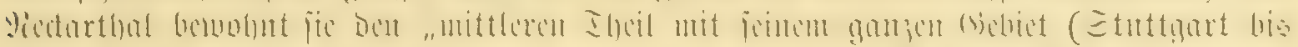

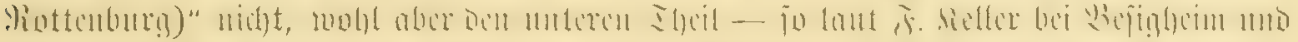

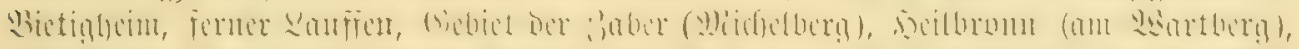

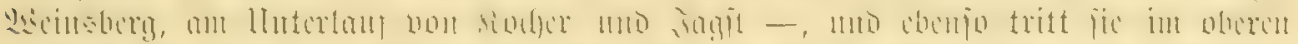

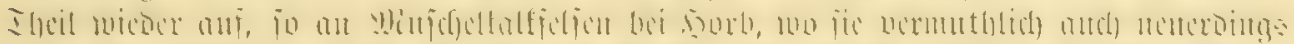

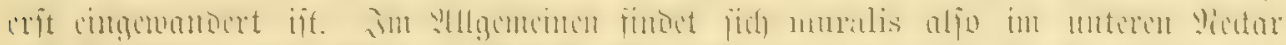

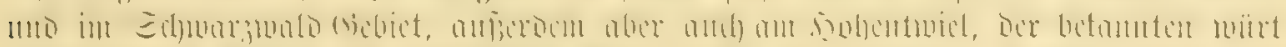

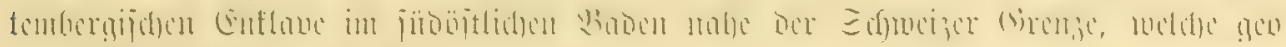

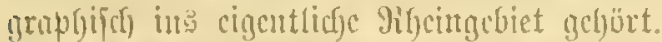

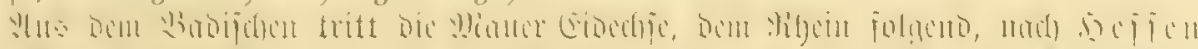
Mittelitycitt.

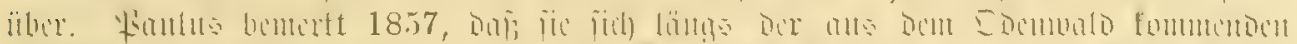

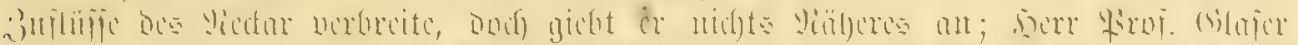

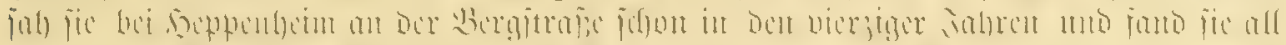

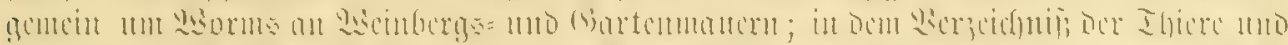

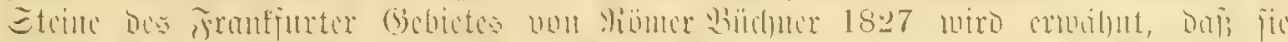

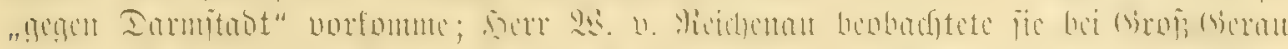

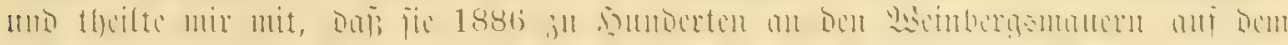

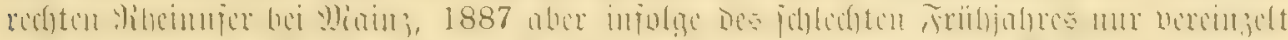

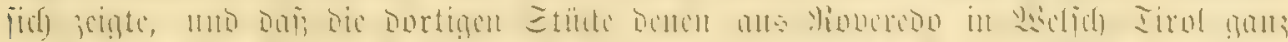

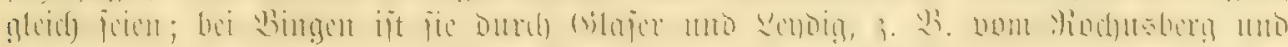

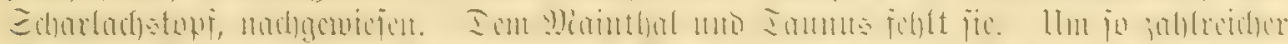

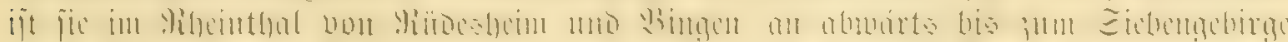

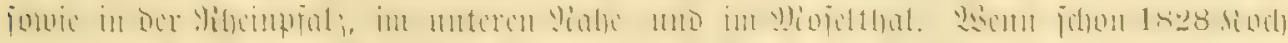

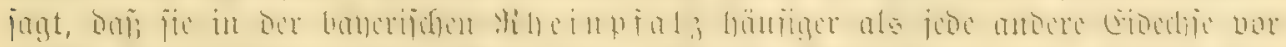

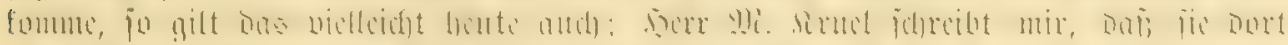

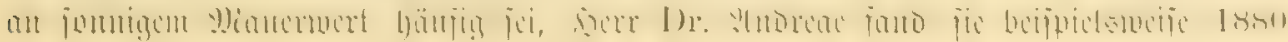




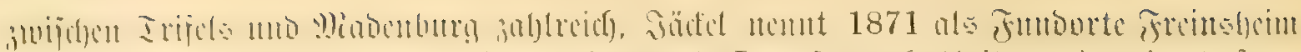

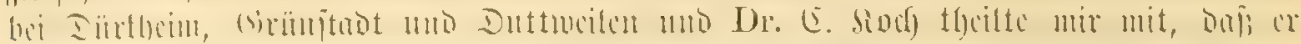

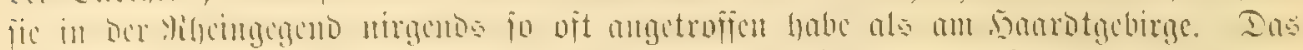

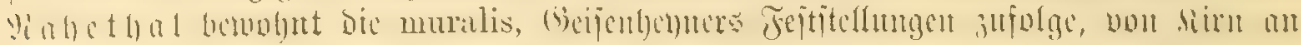

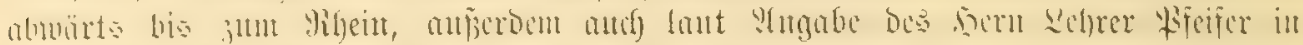
(4)

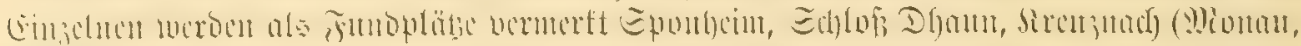

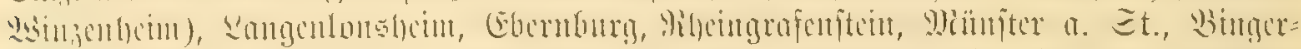

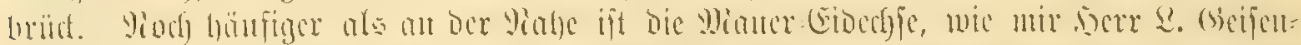

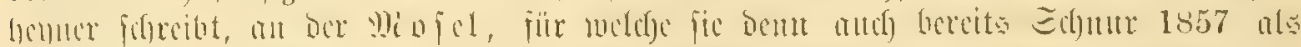

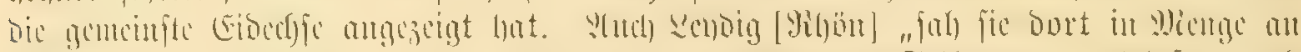

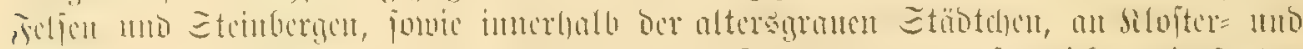

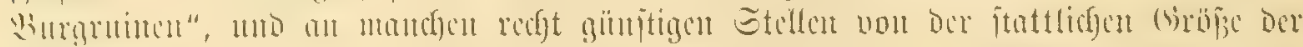

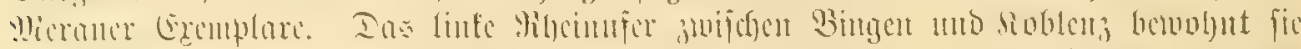

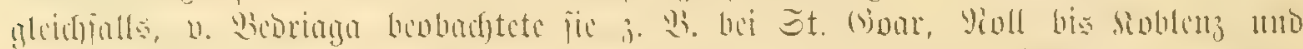

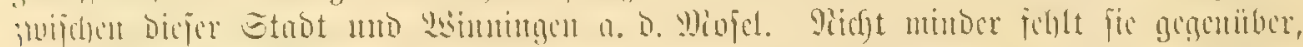

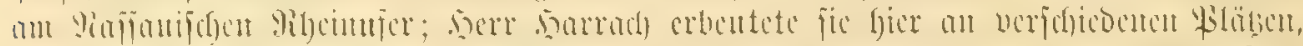

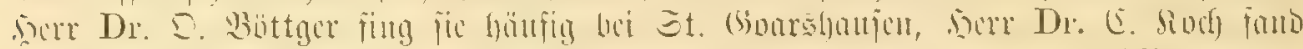

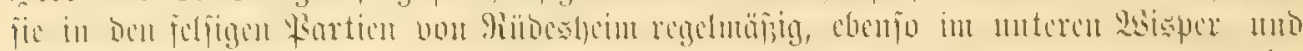

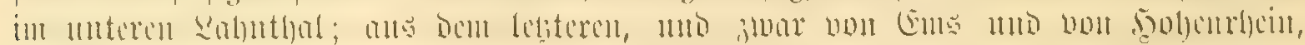

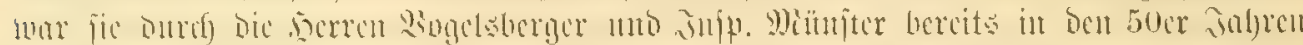

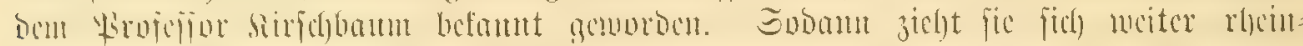

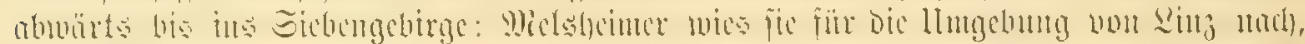

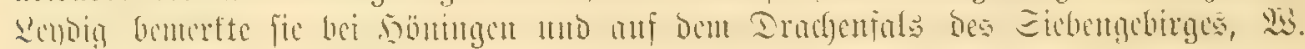
bölidje anf Der Moltenburg.

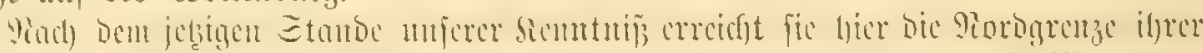

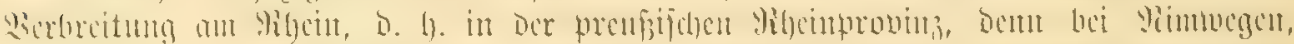

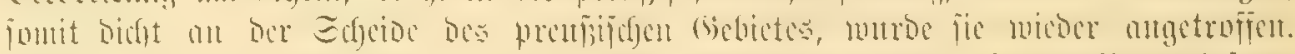

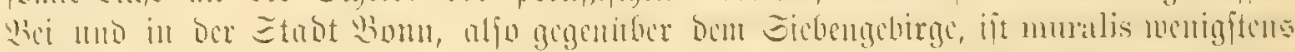

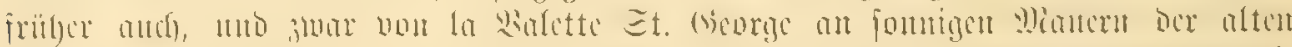

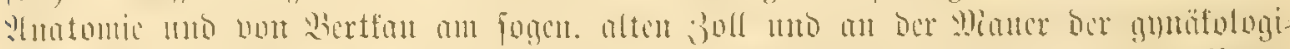

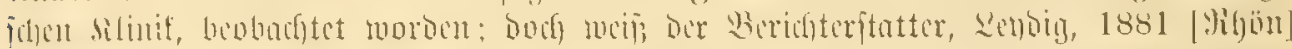

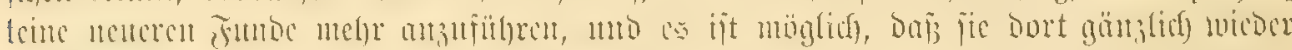

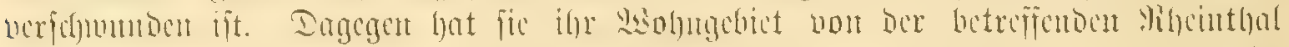

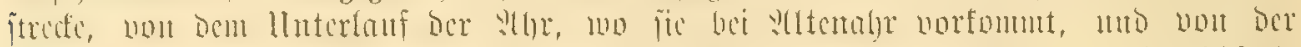

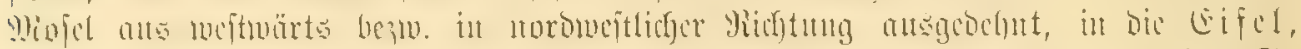

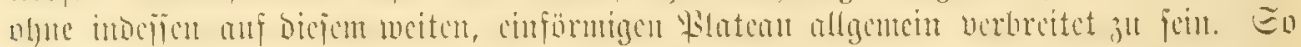

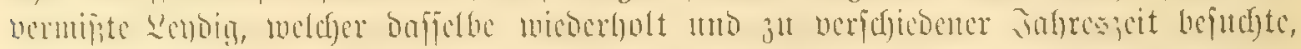

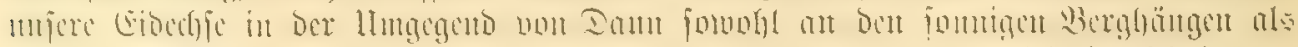

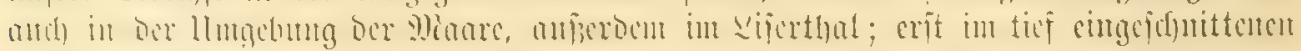

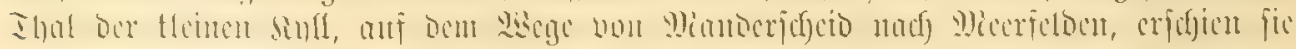
(an fom

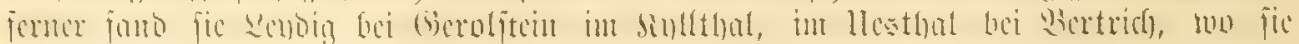

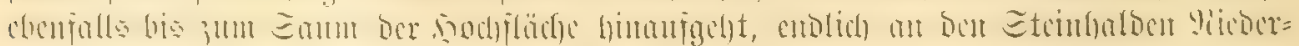

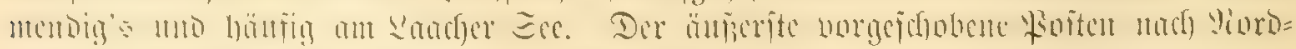

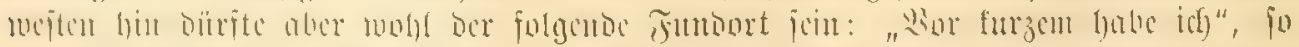

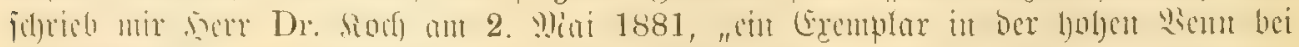

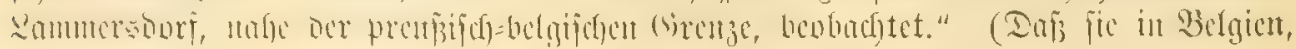




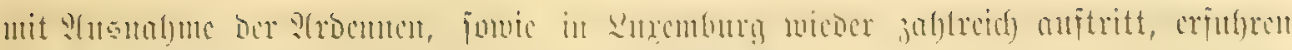

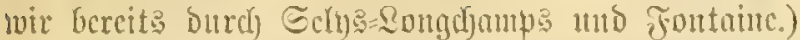

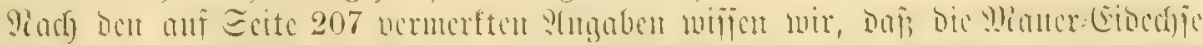

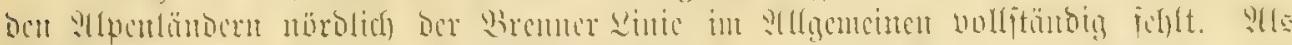

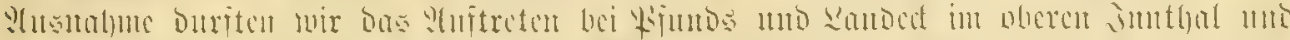

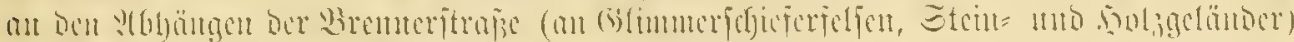

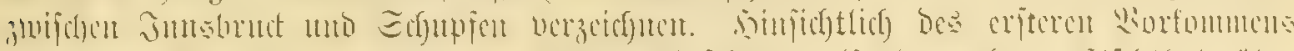

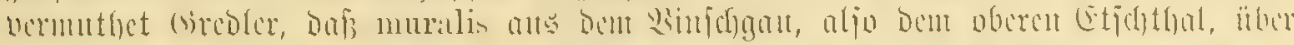

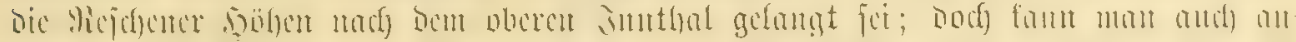

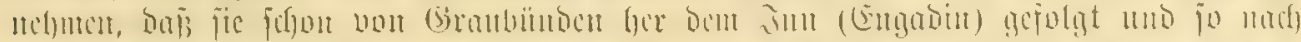

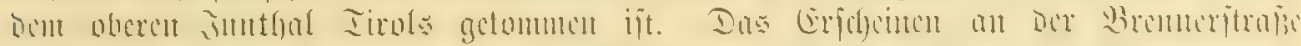

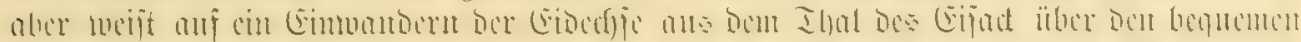

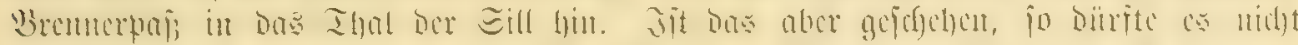

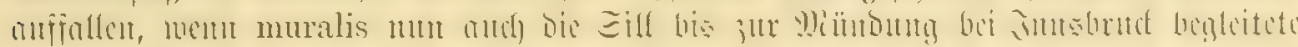

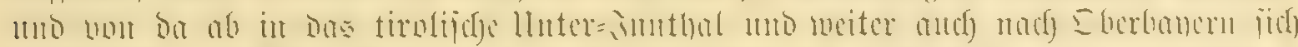

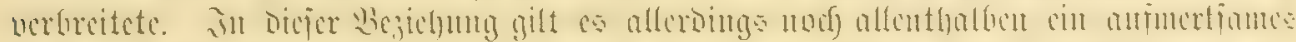

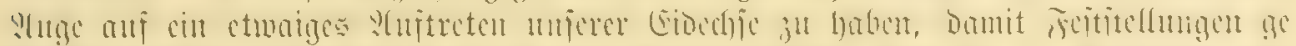

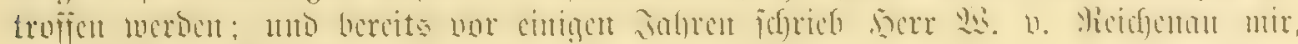

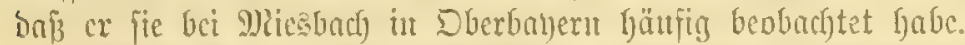

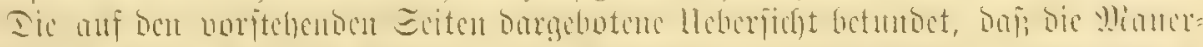

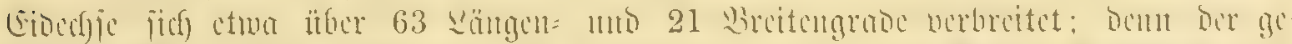

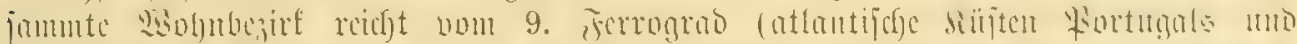

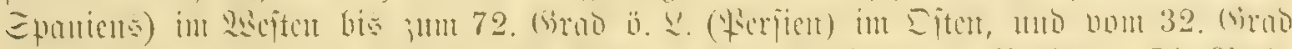

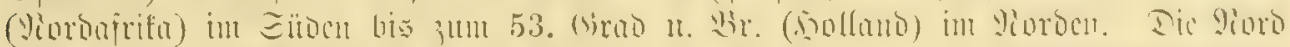

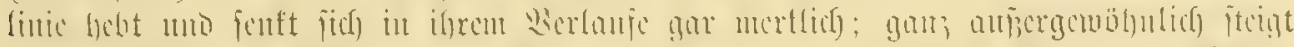

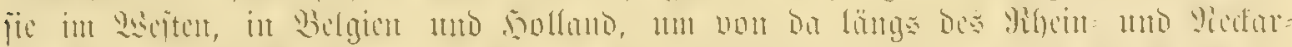

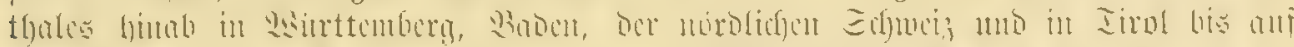

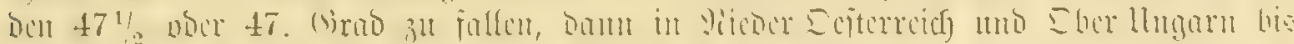

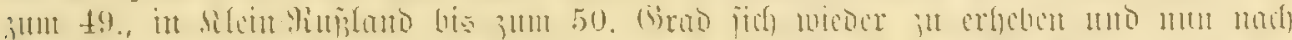

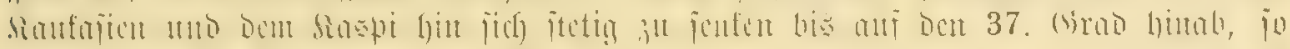

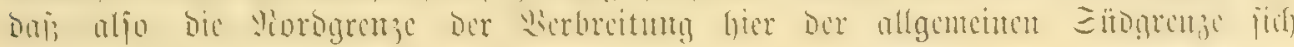
crbeblich mäbert.

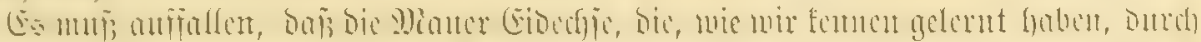

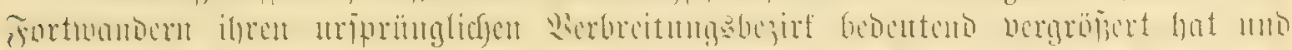

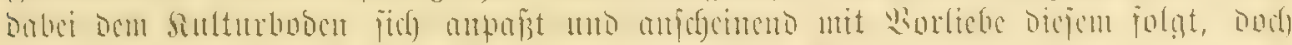

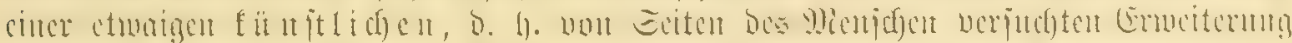

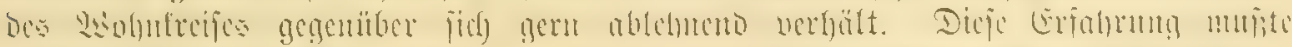
juntüf)

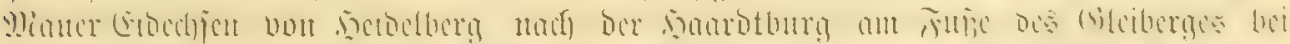

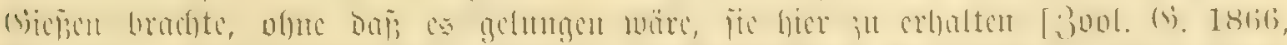
Е.210,.

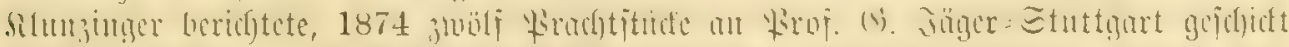

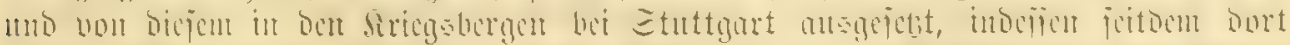

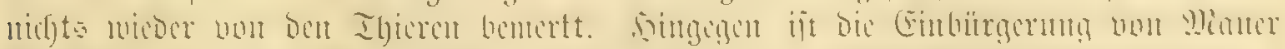

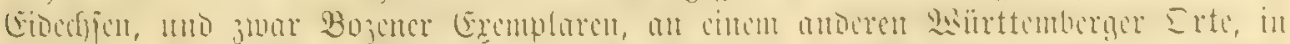

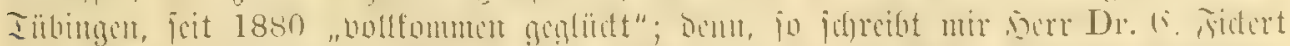

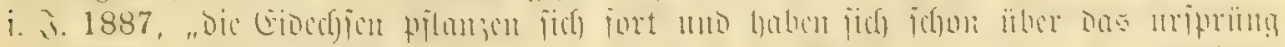

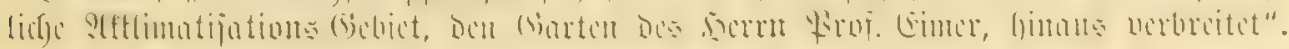




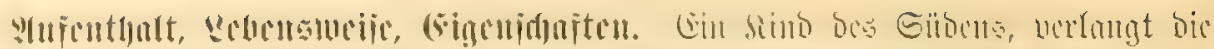

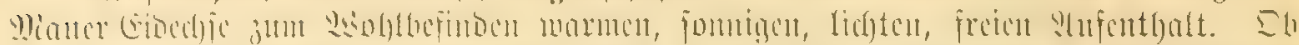

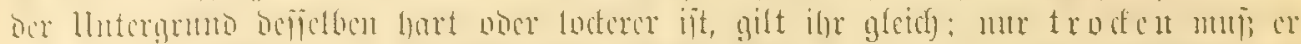

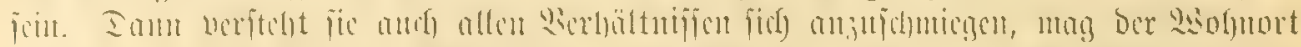

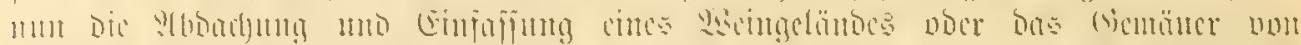

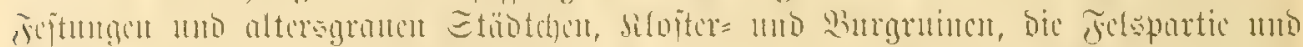

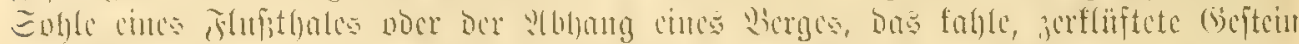

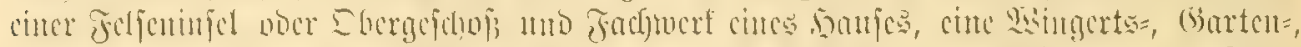

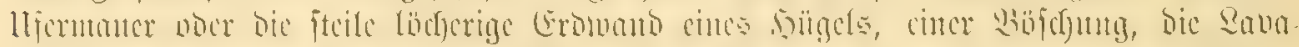

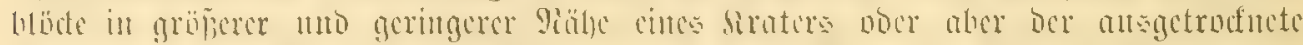

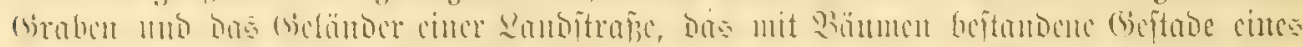

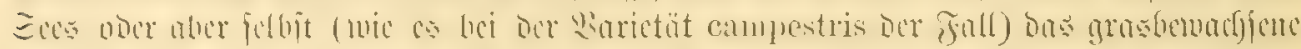

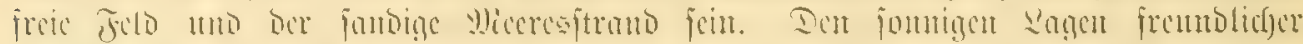

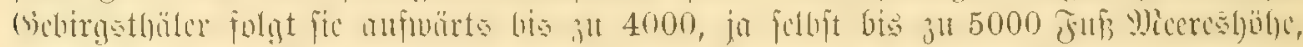

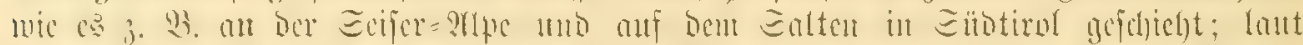

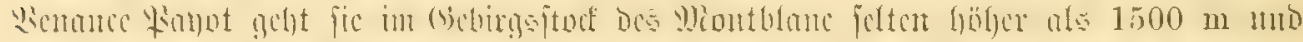

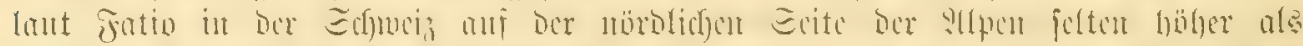

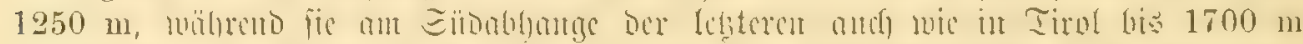

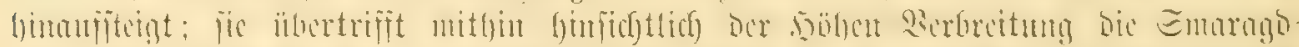

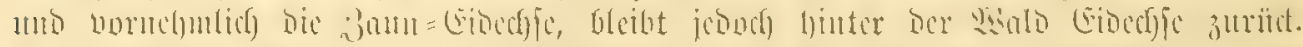

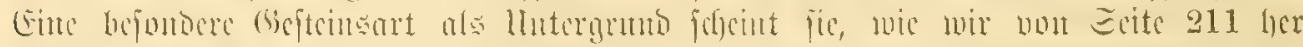

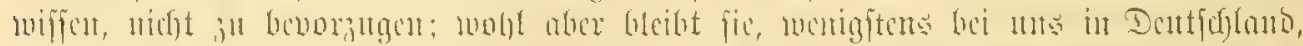

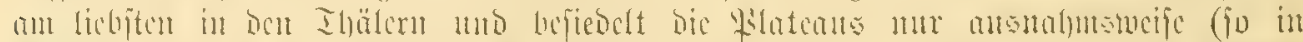

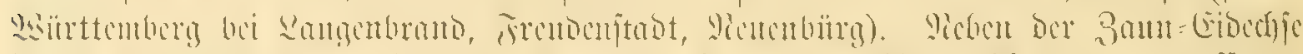

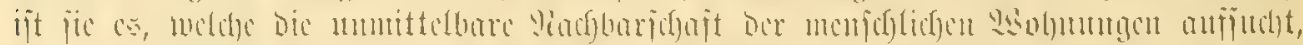

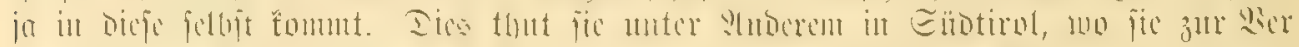

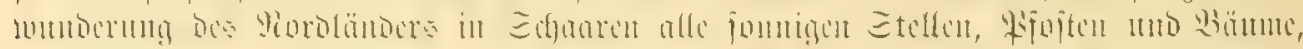

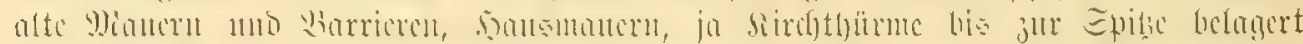

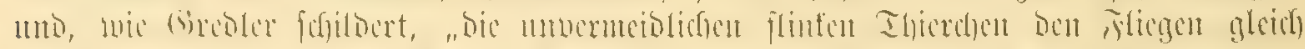

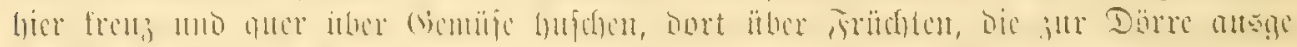

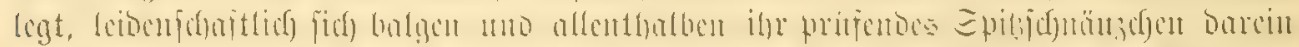

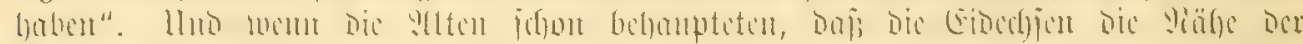

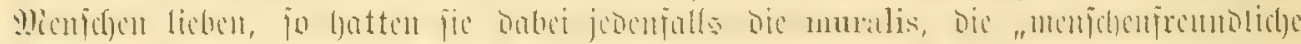

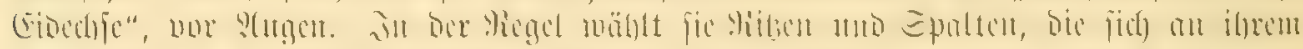

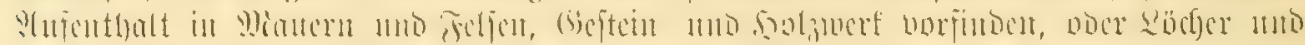

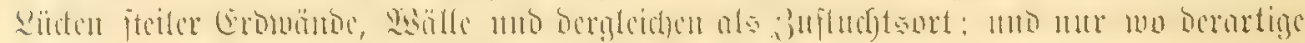

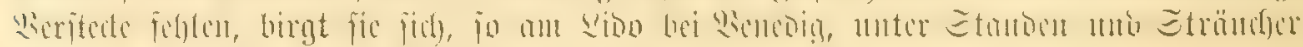

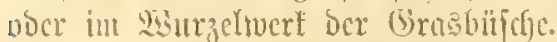

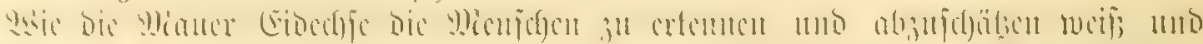

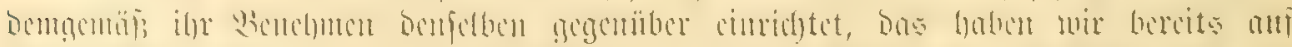

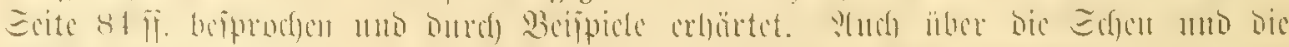

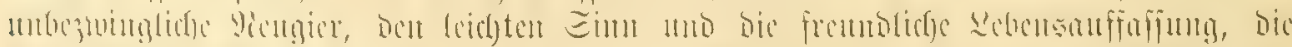

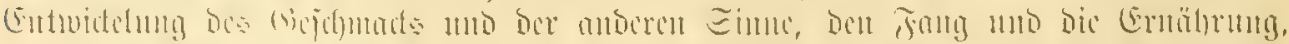

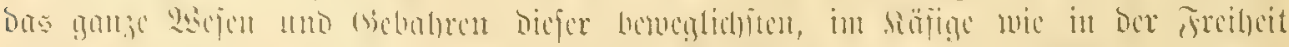

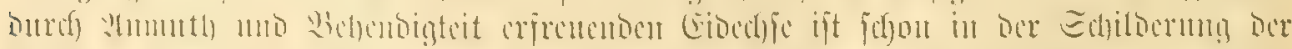

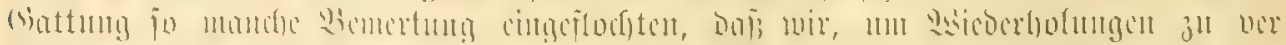

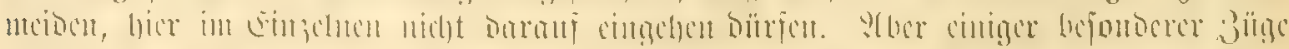

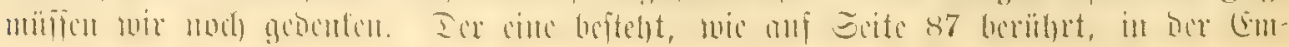




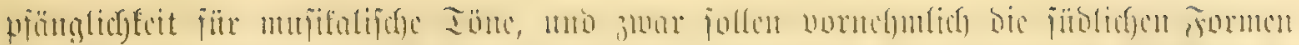

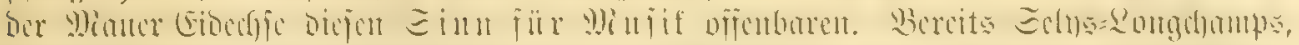

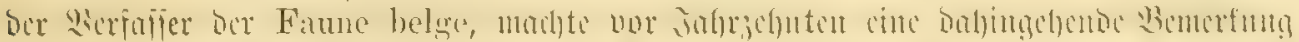

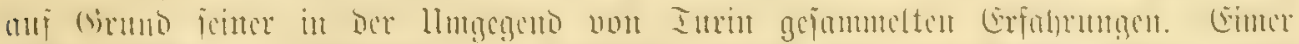

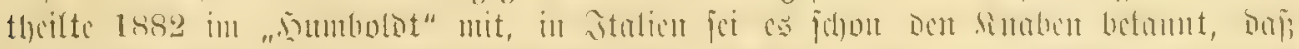

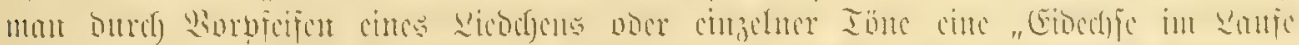

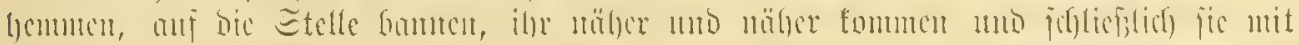

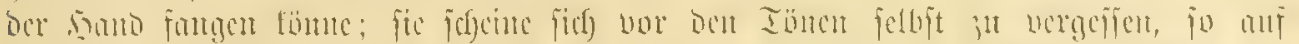

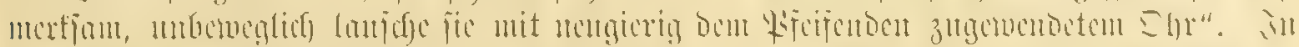

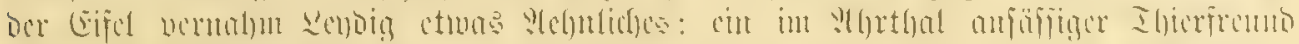

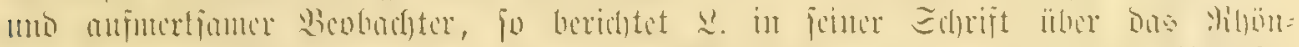

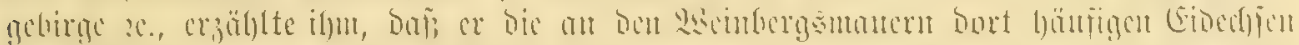

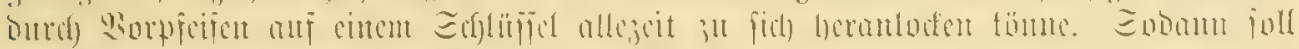

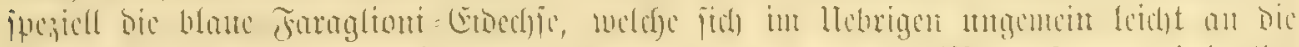

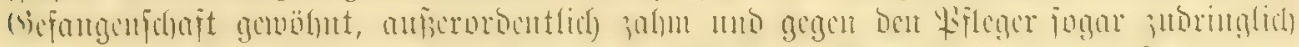

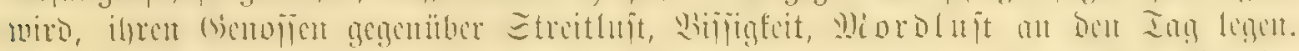

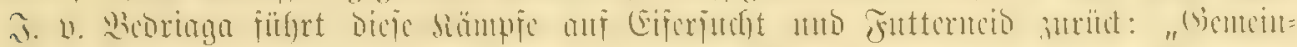

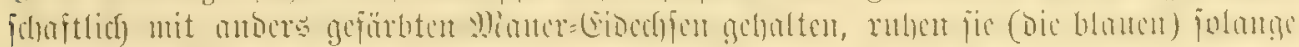

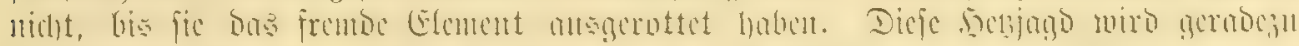

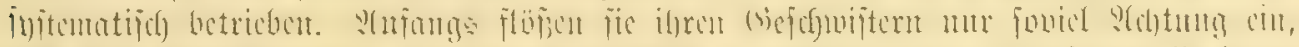

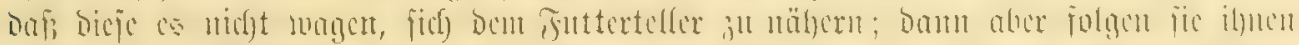

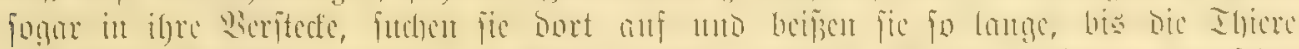

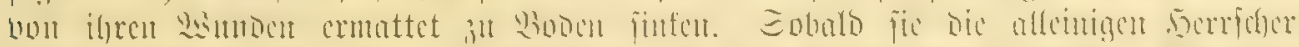

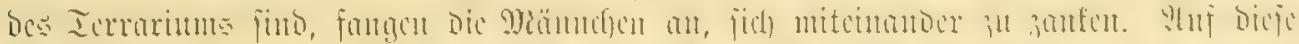

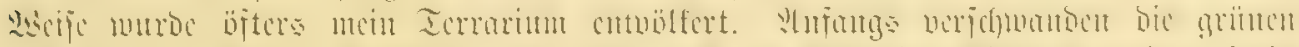

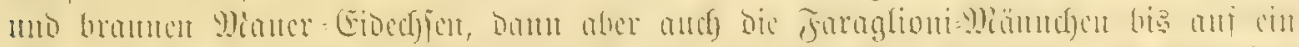

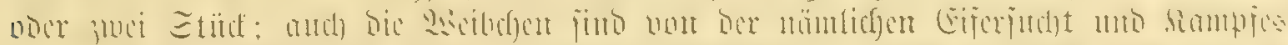

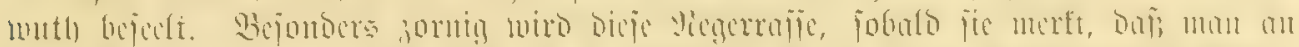

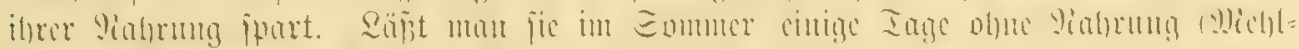

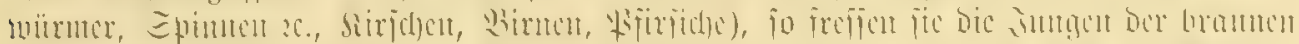

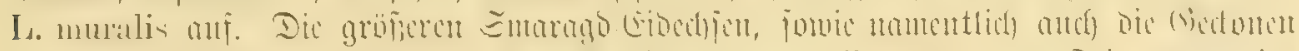

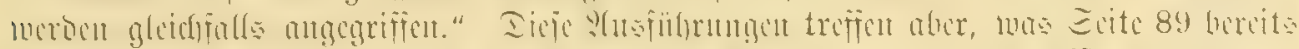

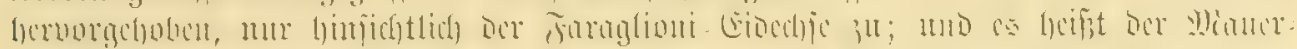

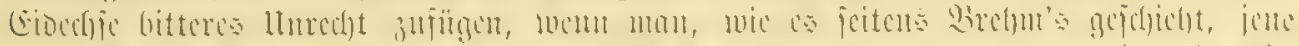

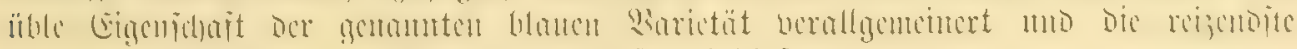
unferer Eibedfjen bic "zonffïdjtigfte and jtreitfujtigite" nennt.

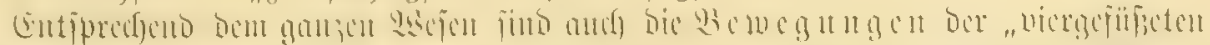

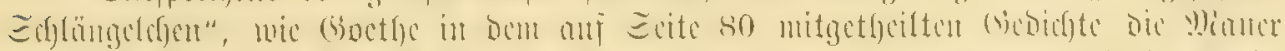

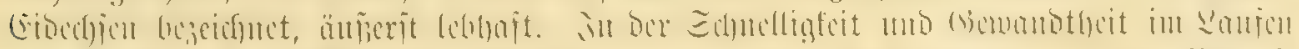

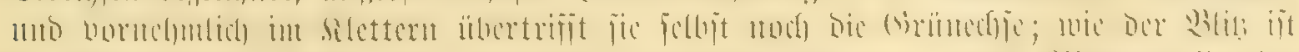

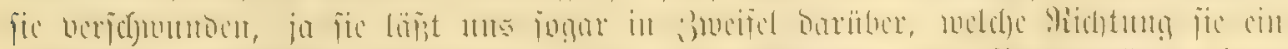

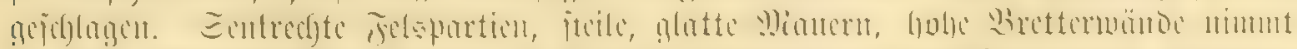

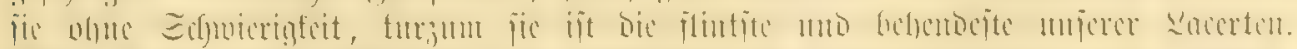

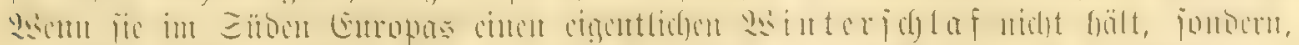

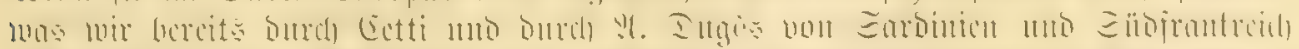

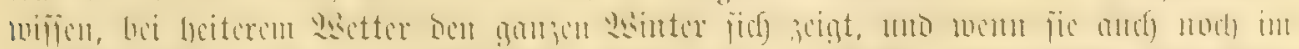

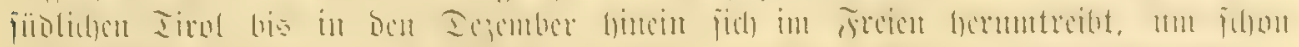

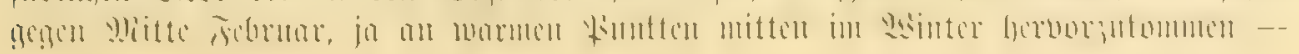




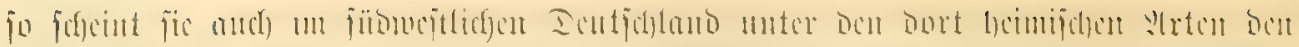

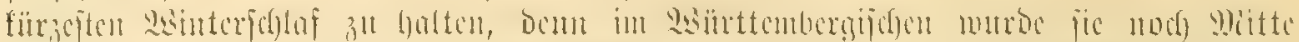

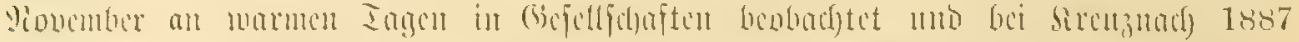

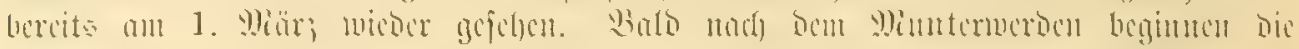

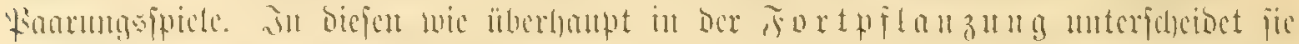

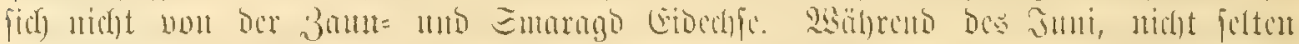

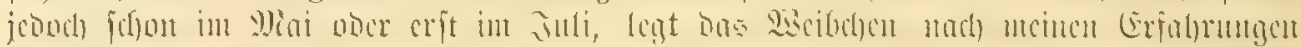

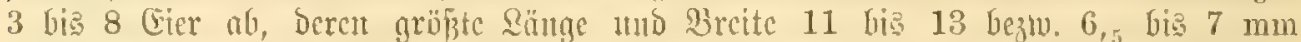

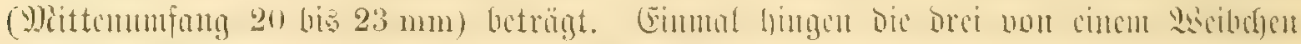

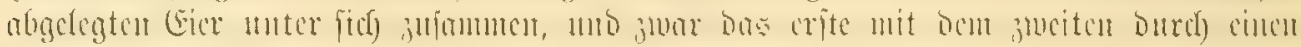

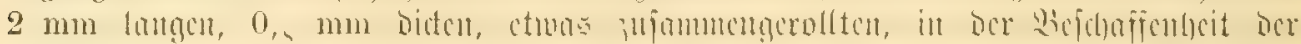

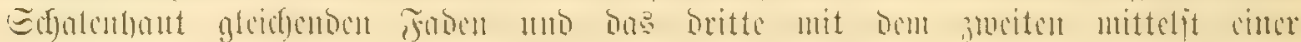
tlebrigent jant.

Miลnเที,

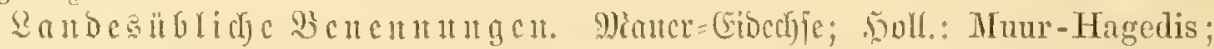
Engl.: Scaly Lizard; Franz.: Lézard des murailles (Lézard gris); Ital.: Luceltola, Lucertola delle muraglie, Caliscertula, 'Tiliguerta.

Lacerta vulgaris, Aldrov. 1663. - Seps muralis, Lourenti 1768. - Lac. caliscertula, Bomaterre 1789. - Ameiva tiliguerta, Meyer 1795. - Lacerta tiliguerta et argilis et murilis, Tutrill, 1802. Lac. Brognardii, Imentin 1803. - Lac. muralis, Merrem 1820. - Lac. agilis, Risso 1826. - Podarcis muralis, Wagler 1830. - Zootoca muralis, Gray 1838.

\section{Linter=(1)ronutg: \\ surzzingler. Brevilingua (Brachyglosii).}

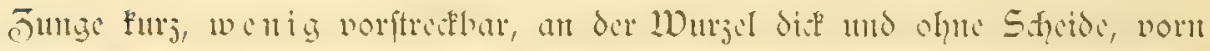

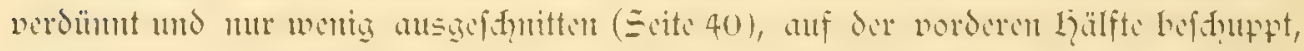

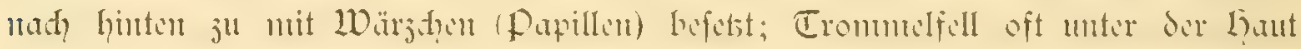

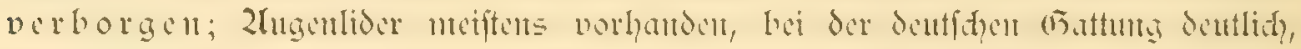

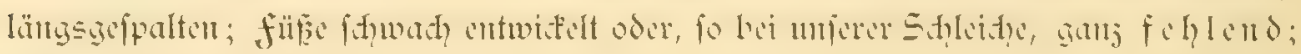
Bejabnuntg pleurodont $(5.41)$.

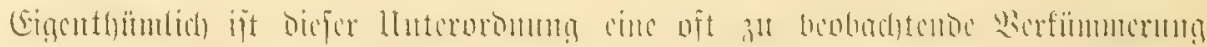

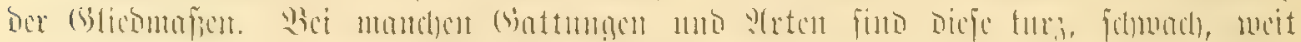

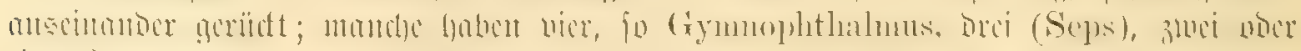

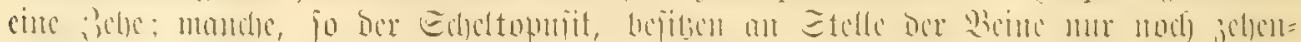

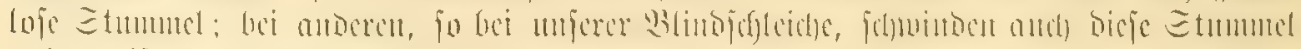

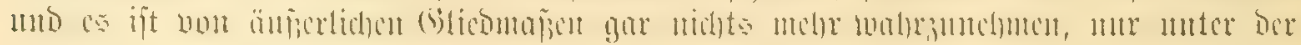
Şaut liçgen noch) Picfite.

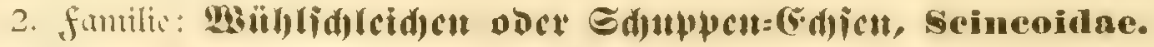

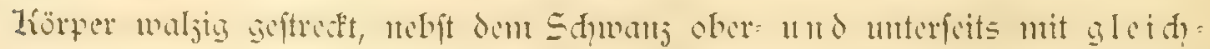

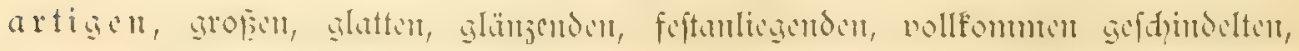

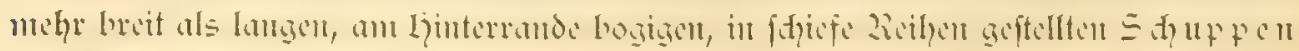




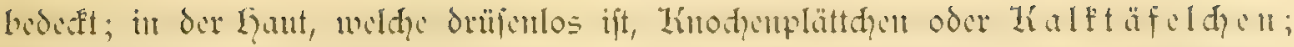

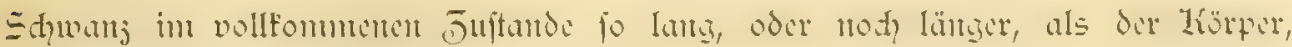

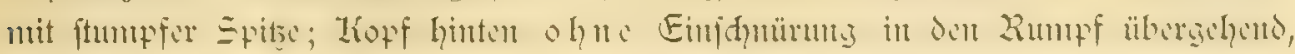

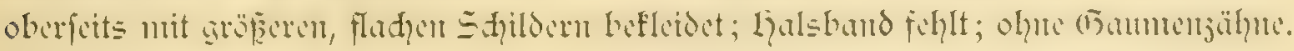

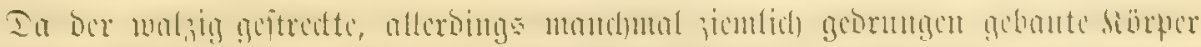

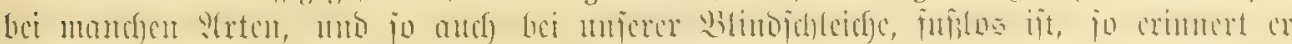

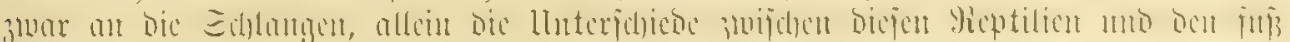

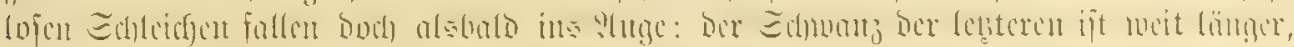

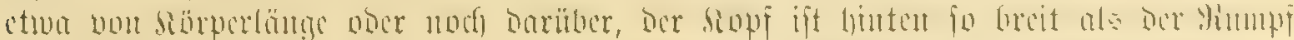

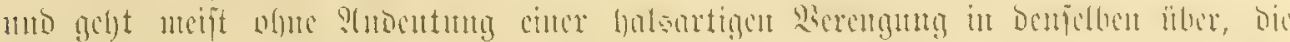

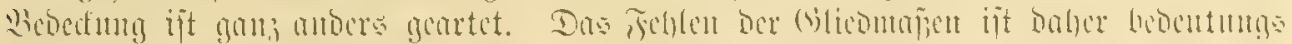

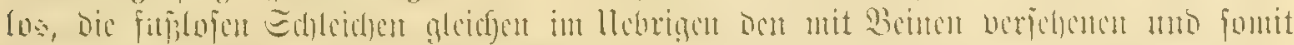

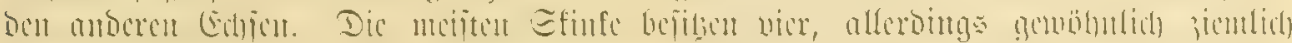

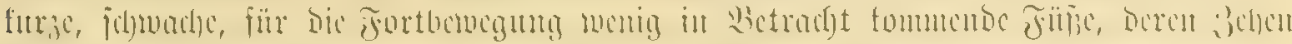

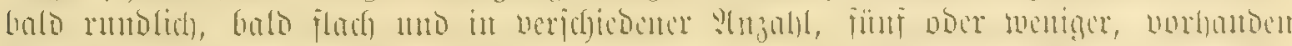

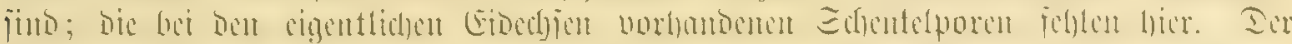

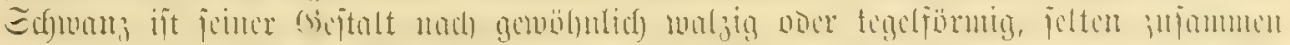

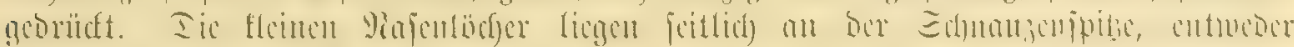

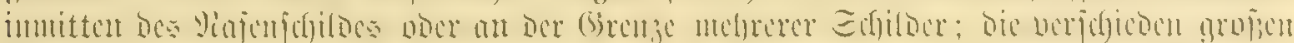

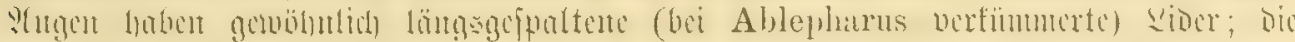

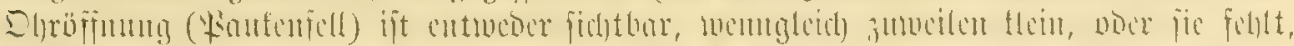

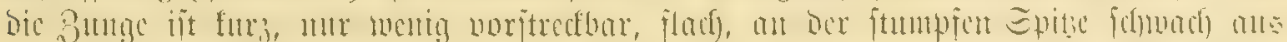

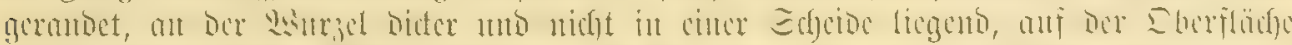

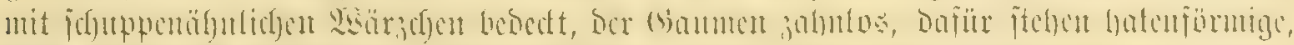

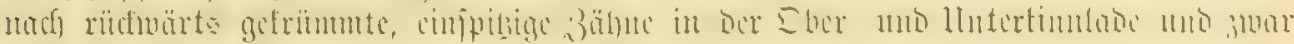
Dem imeren Ranoe Der 3afurinue angetwadjen (pleurodont).

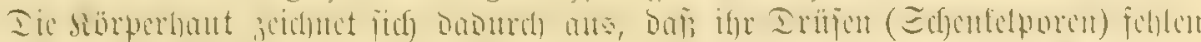

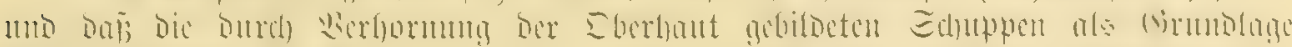

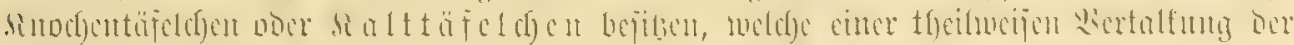

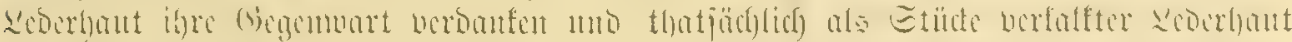

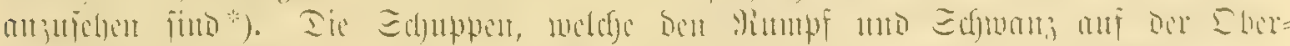

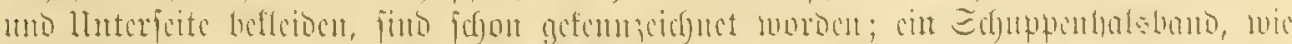

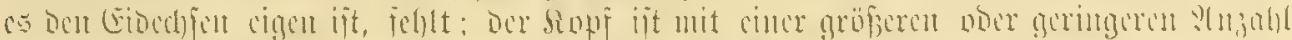

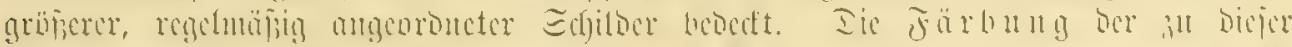

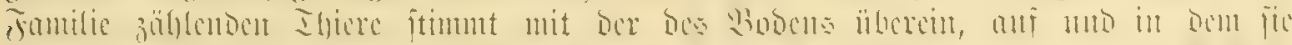

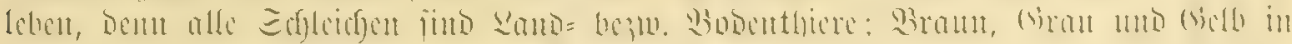

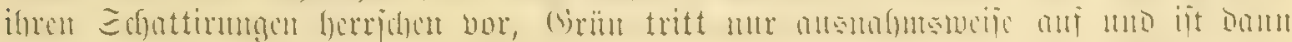

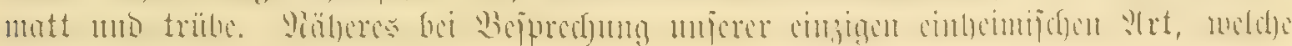
folgentor Gattung angegört.

\section{2. (Gattung: Edjlnumentuleid)c. Anguis, $L$.}

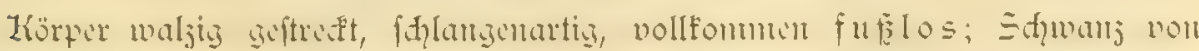

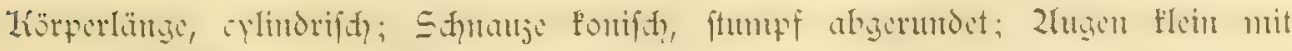

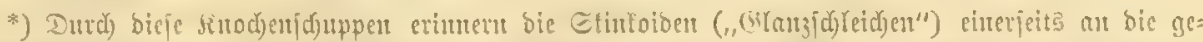

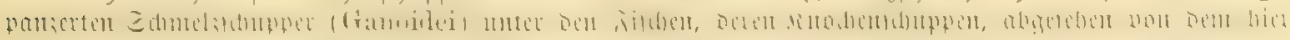

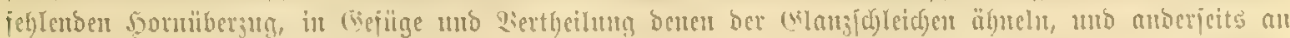

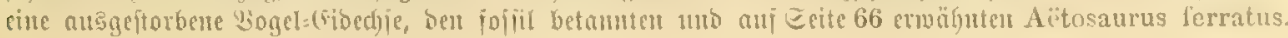




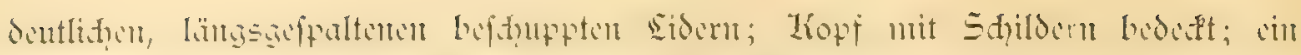

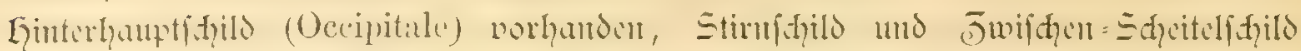

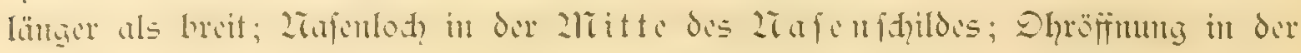

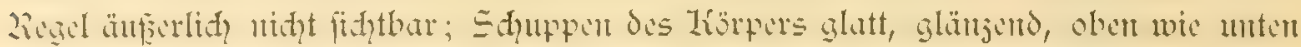

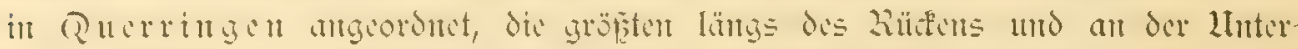

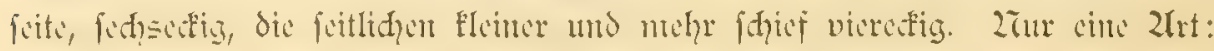

\section{Qrt: Blindiḑleidhe. Anguis fragilis, $L$.

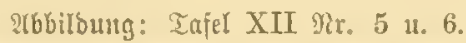

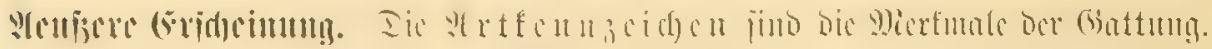

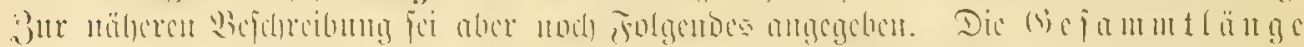

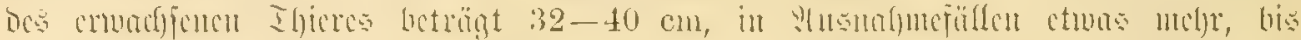

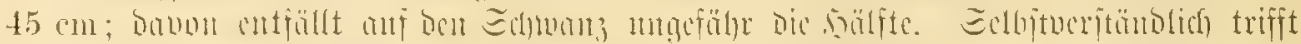

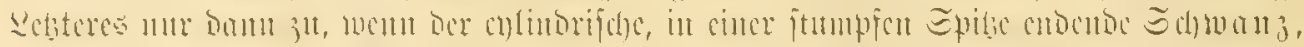

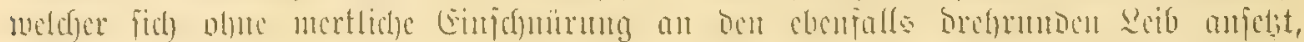

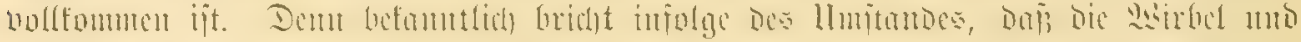

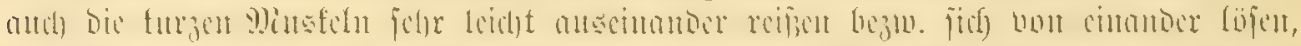

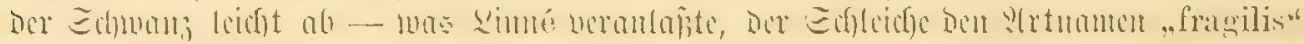

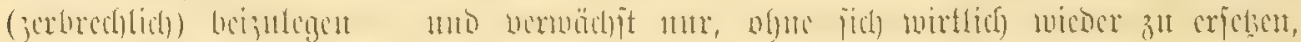

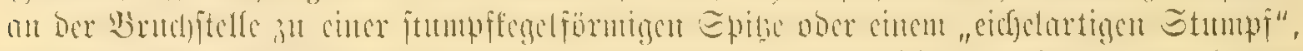

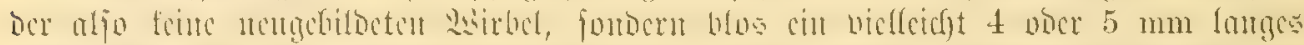

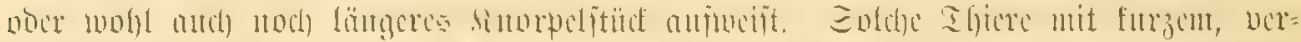

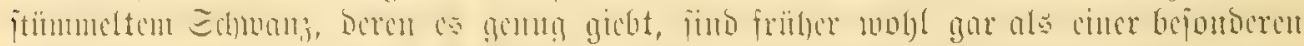

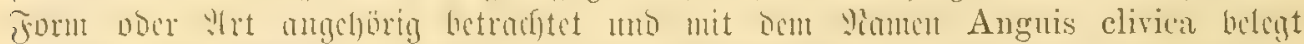

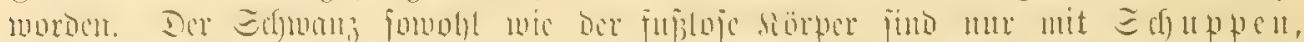

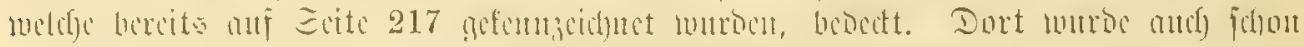

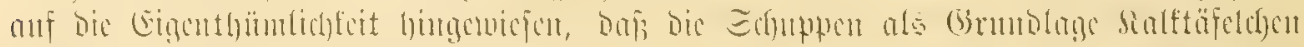

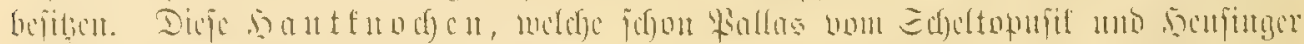

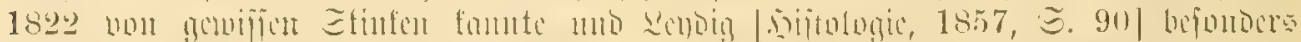

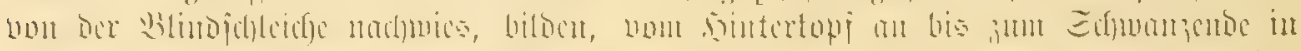

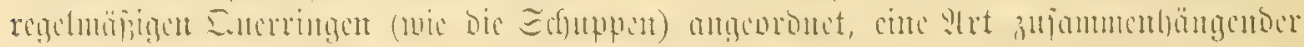

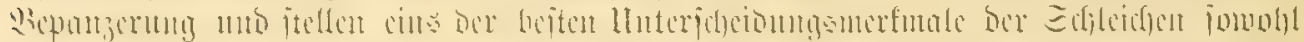

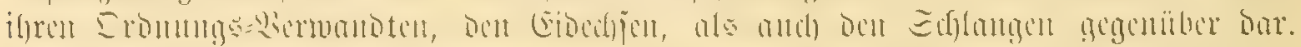

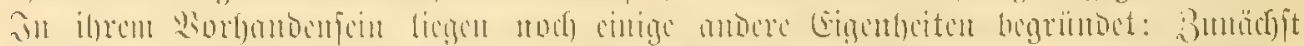

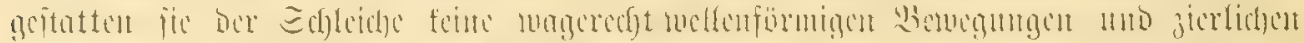

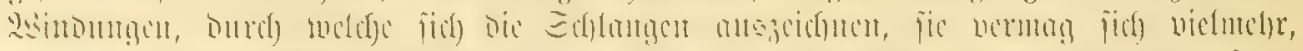

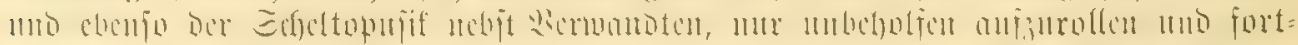

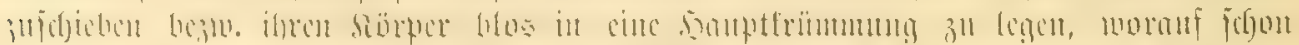
1832 dx

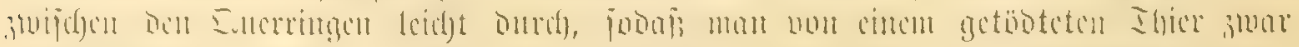

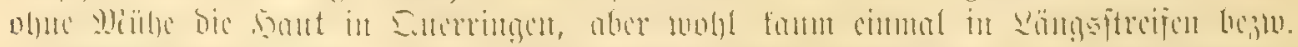

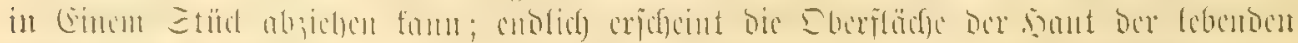

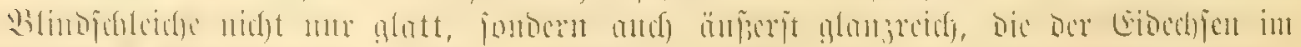

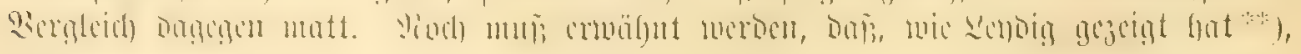

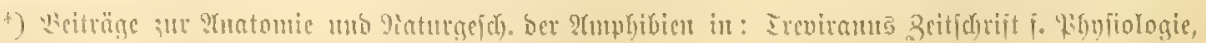

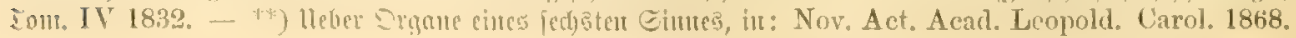




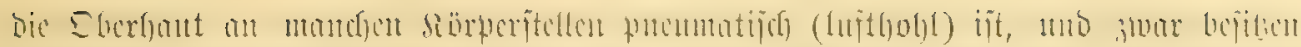

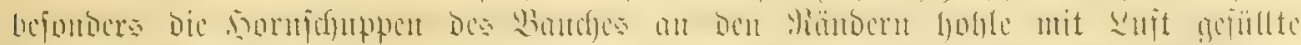

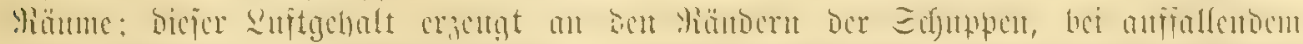

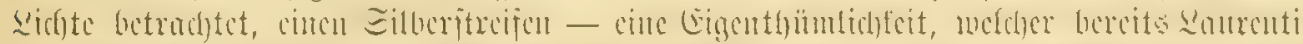

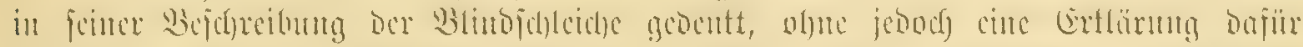

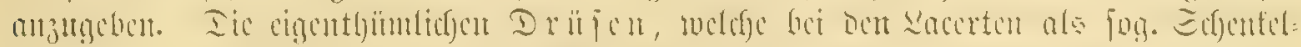

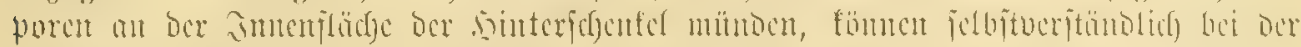

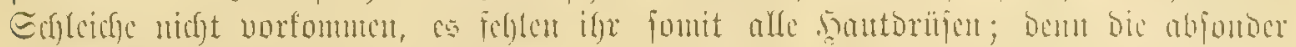

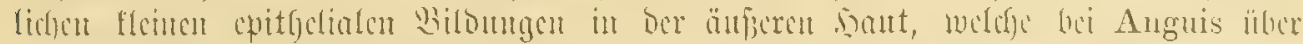

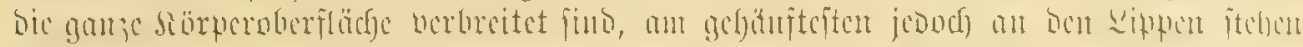

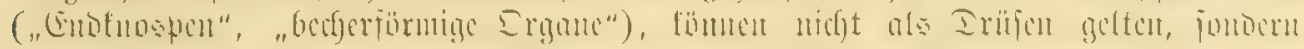

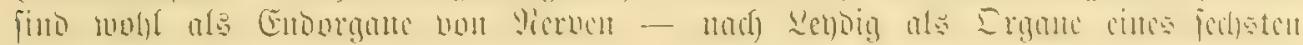
Simucs - anzujeljent.

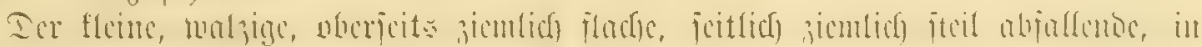

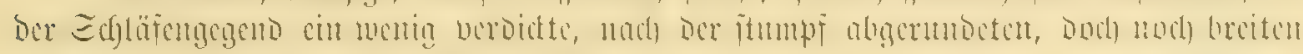

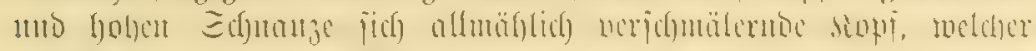

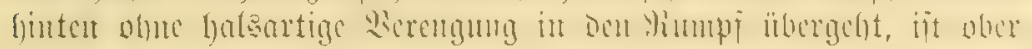
feits mit gröjzeren Edyilderu, in llebrigen mit Ecfupwen ober

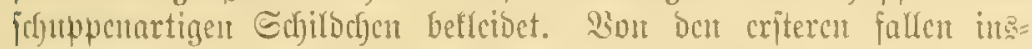

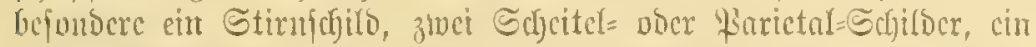

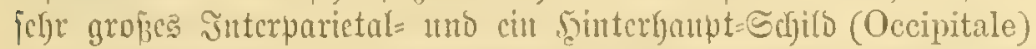

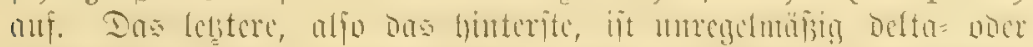

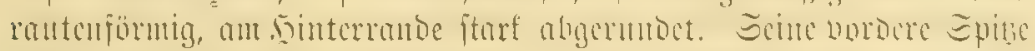

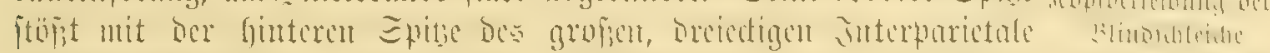

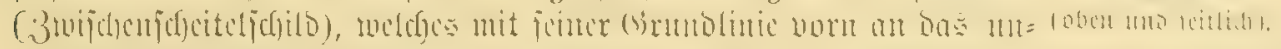

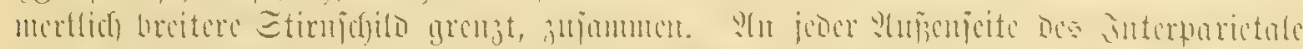

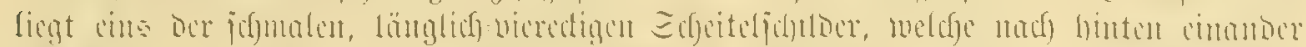

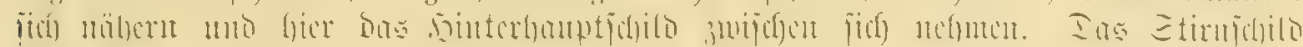

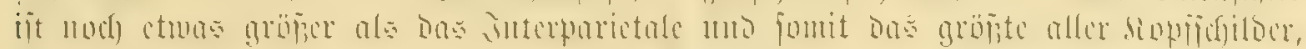

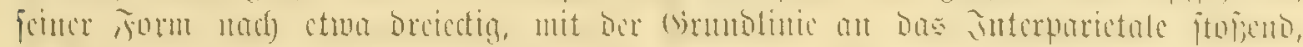

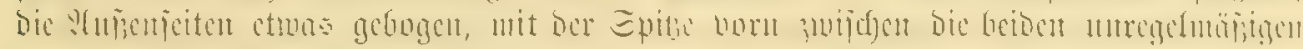

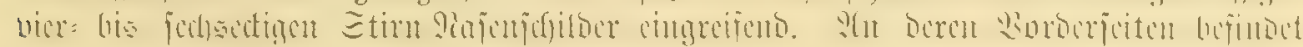

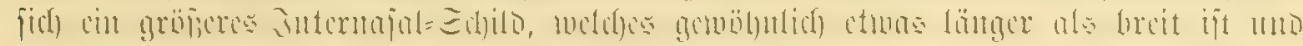

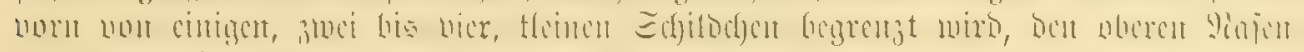

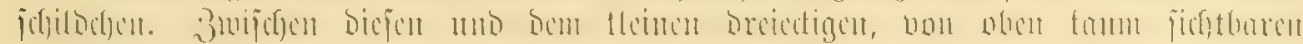

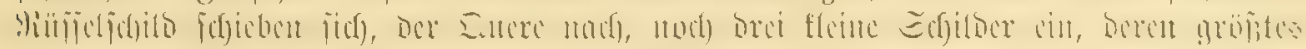

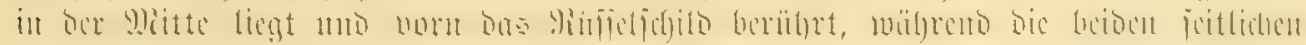

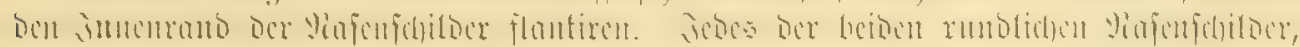

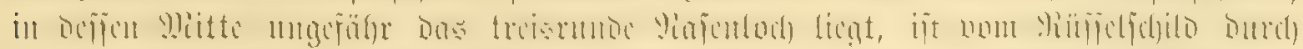

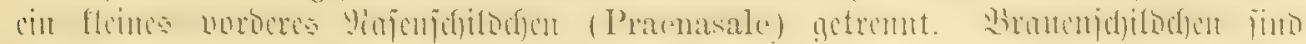

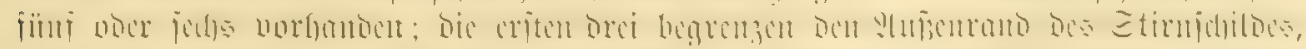

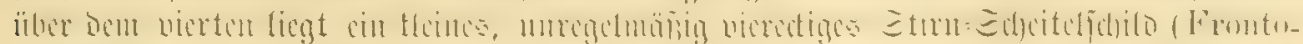

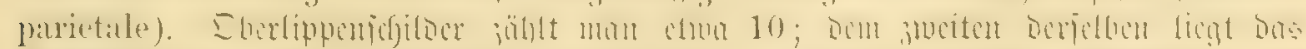

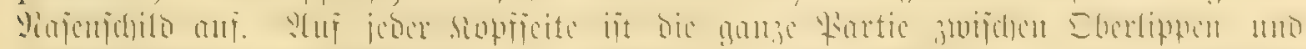

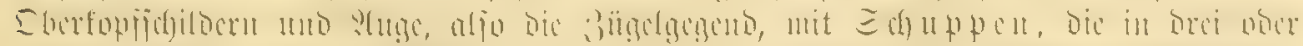

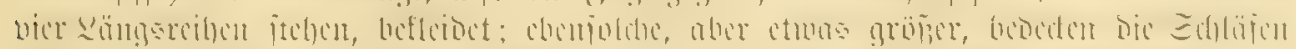

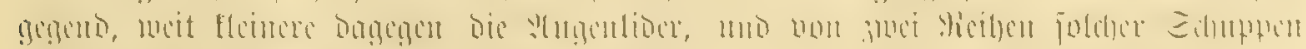

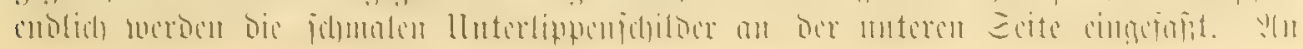




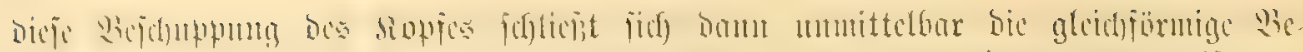

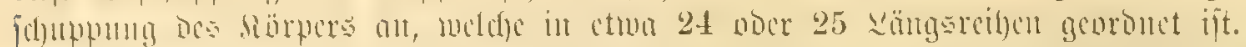

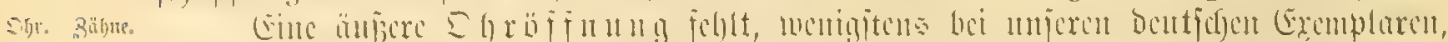

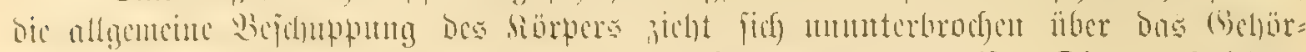

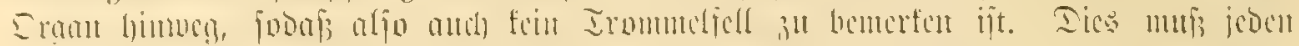

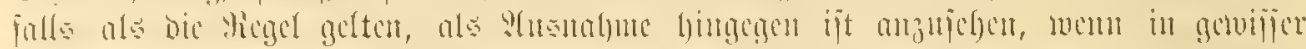

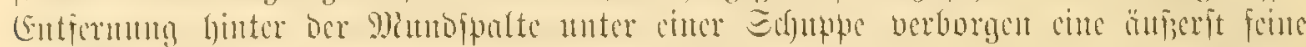

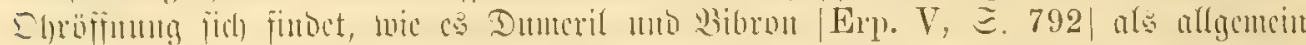

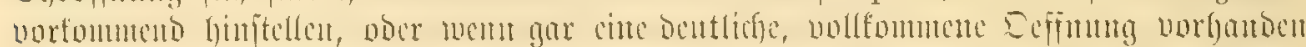

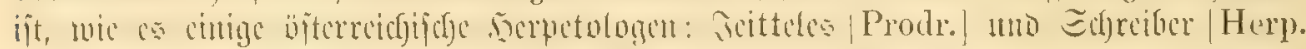
Е. 343 , wor,

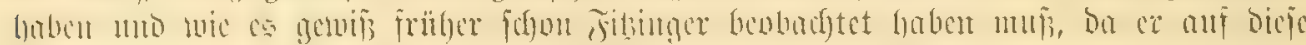

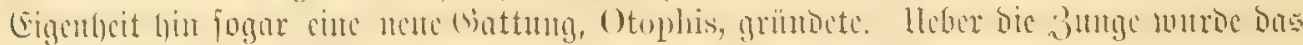

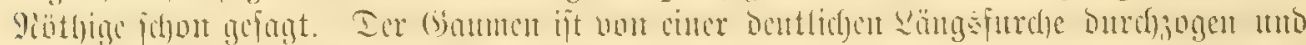

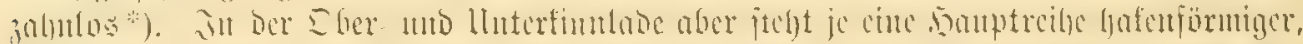

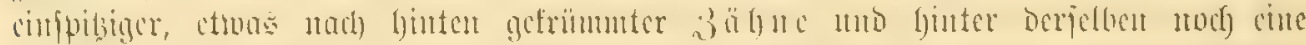

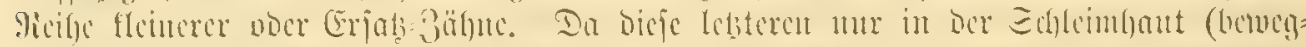

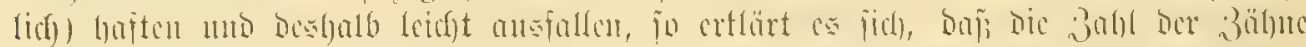

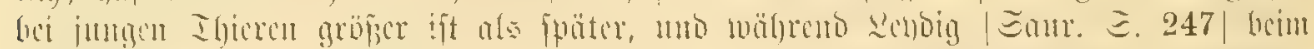

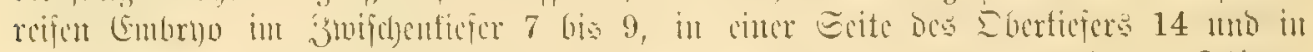

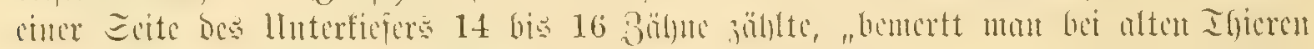

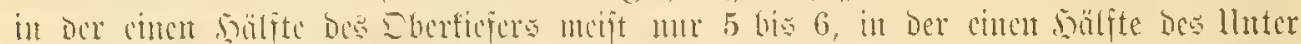

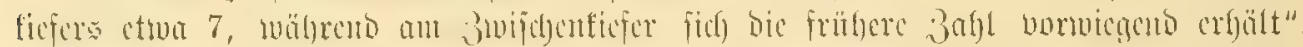
If(f)

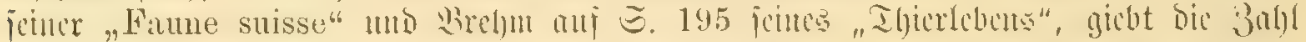

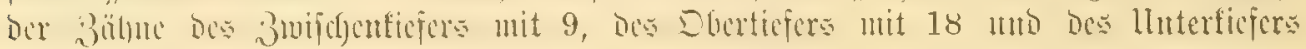
mit 28 mit.

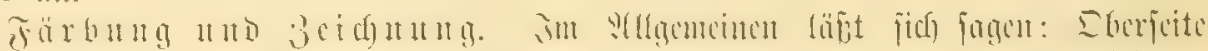

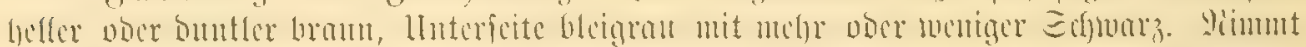

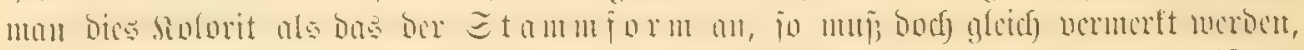

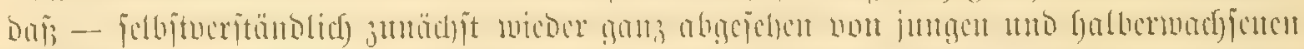

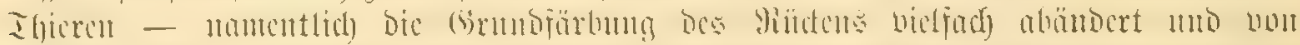

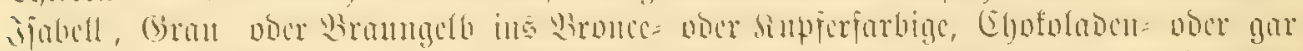

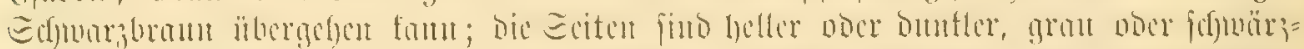

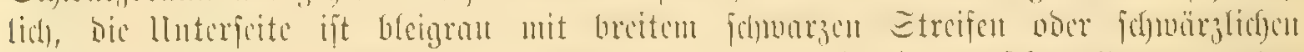

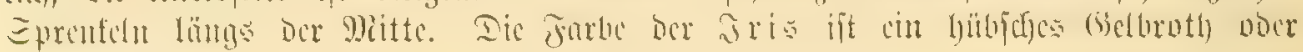
Wraturatr).

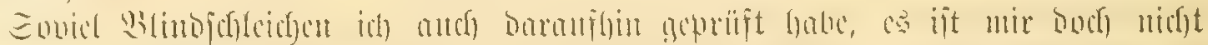

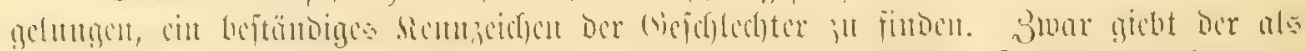

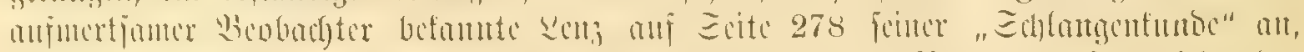

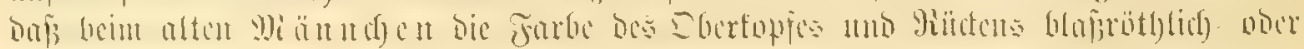

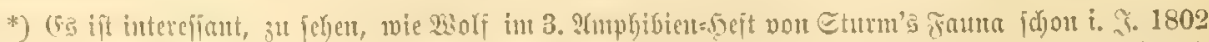

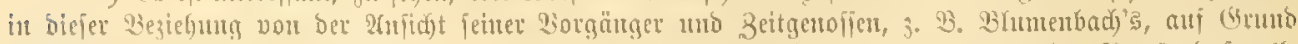

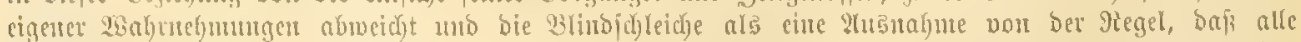

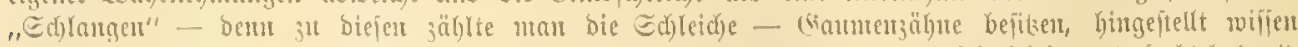

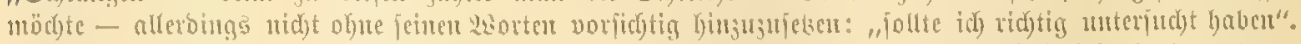

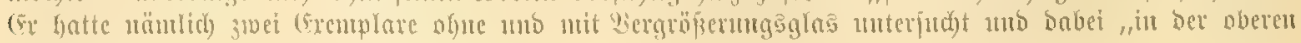

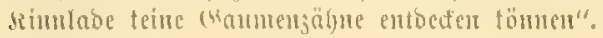




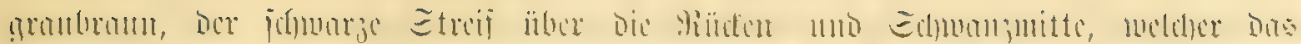

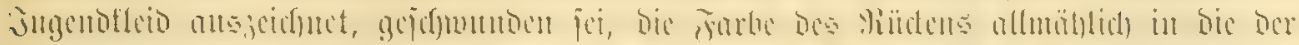

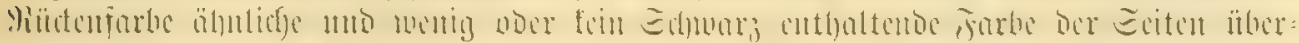

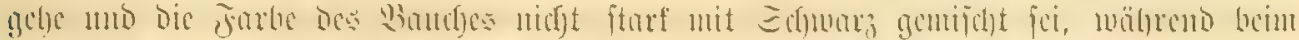

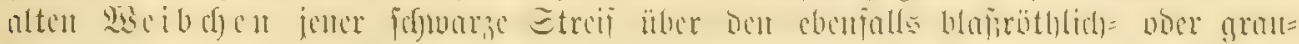

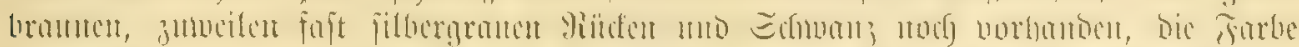

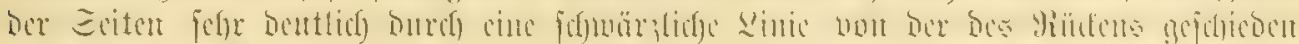

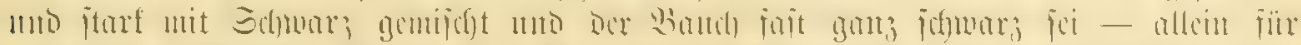

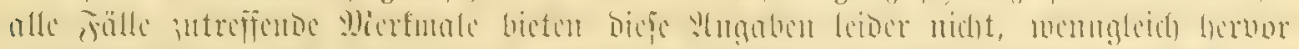

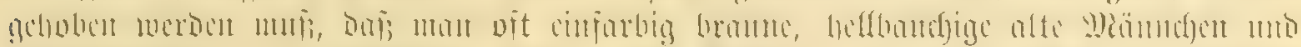

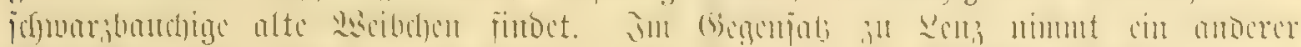

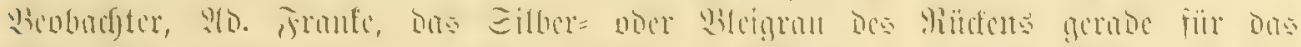

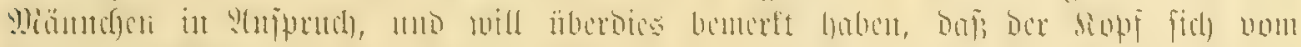

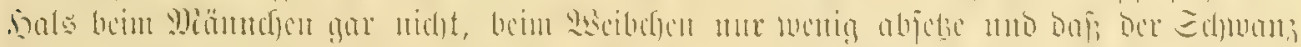

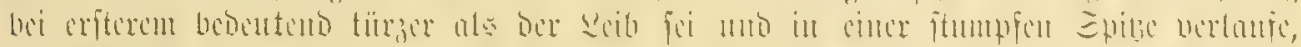

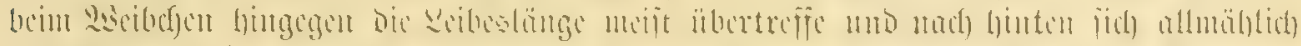

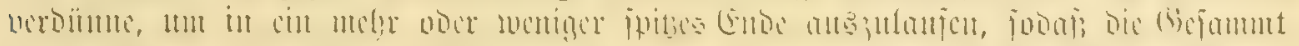

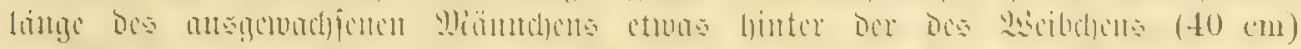

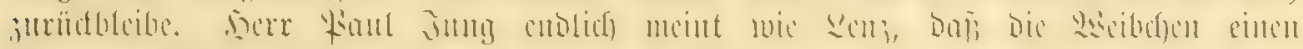

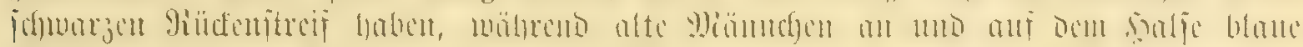

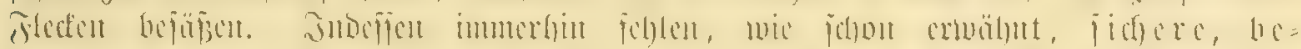
it

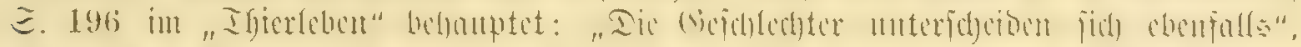

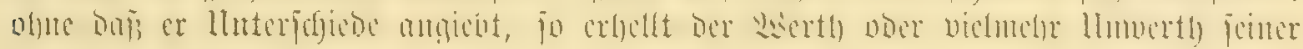
Diborte woul jelbit.

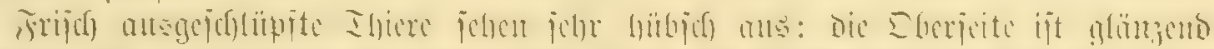

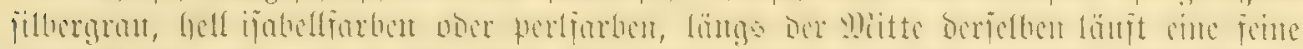

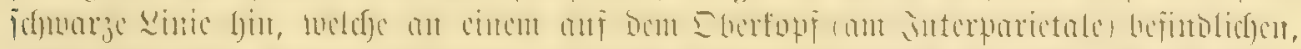

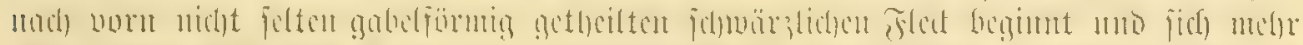

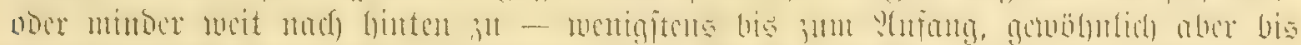

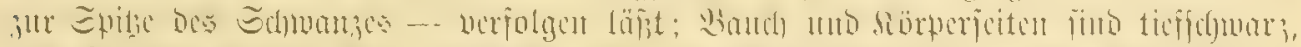

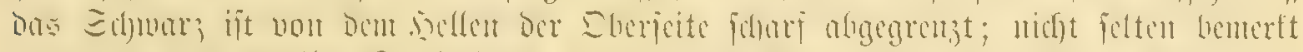

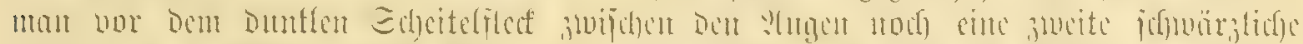

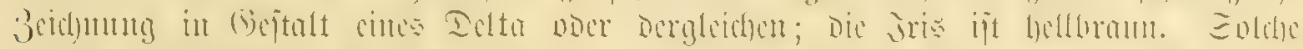

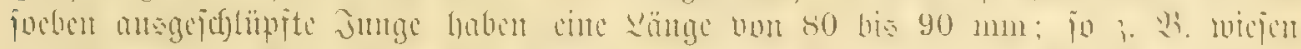

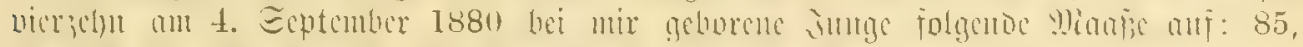
$87,84,85,89,81,819,92,86,85,91,82,84,89 \mathrm{~mm}$. (Dic critc Ełut cinter

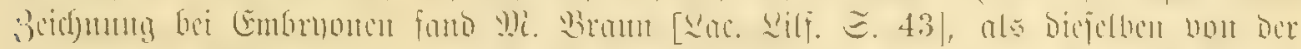

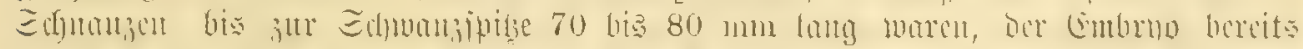

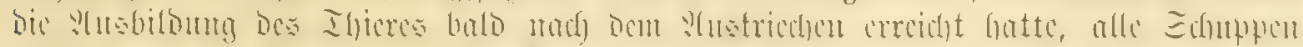

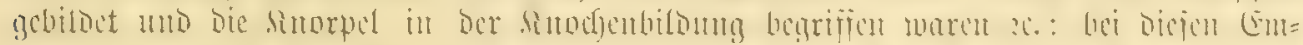

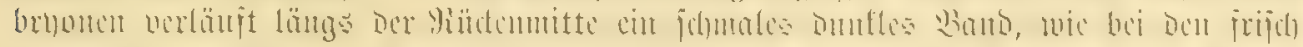

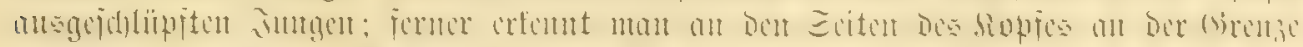

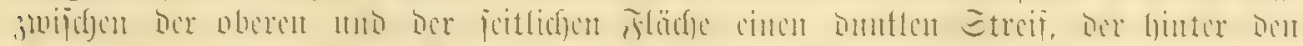

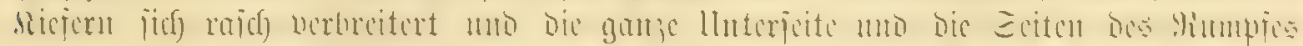

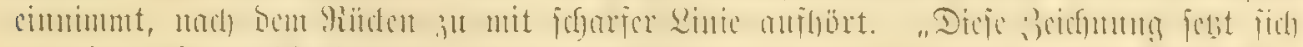

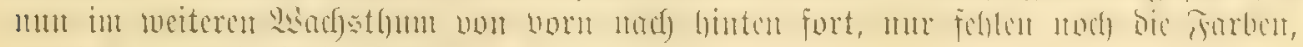

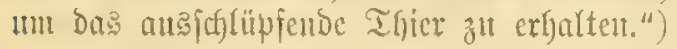




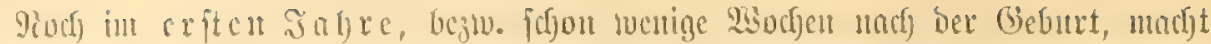

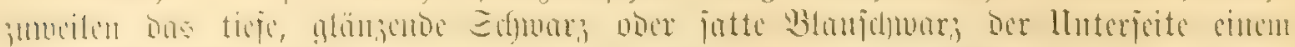

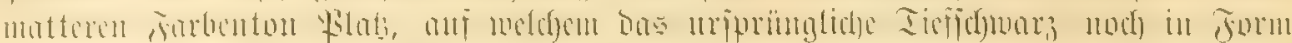

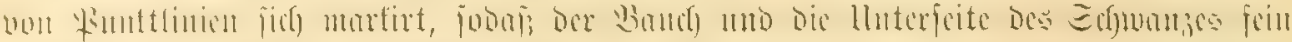

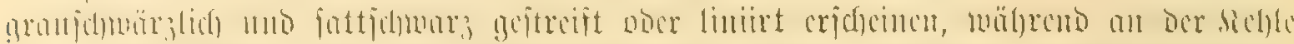

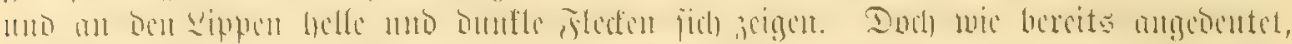

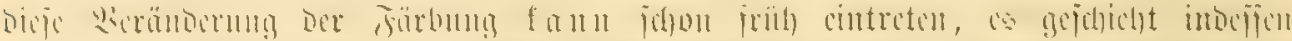

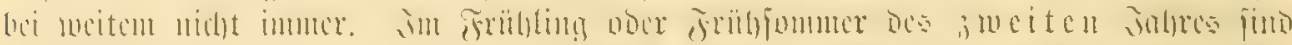

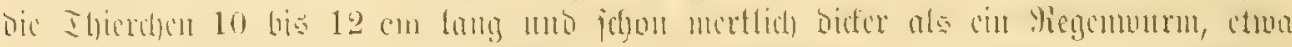

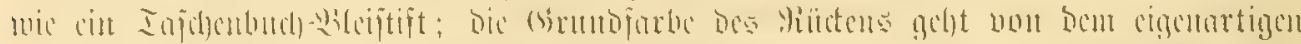

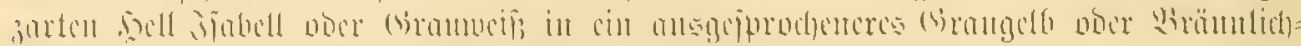

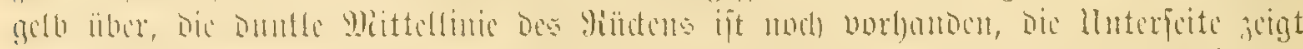

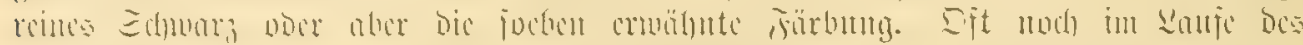

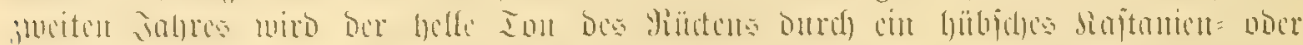

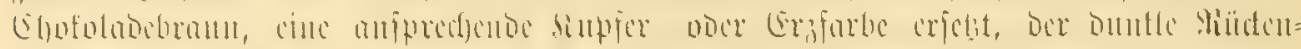

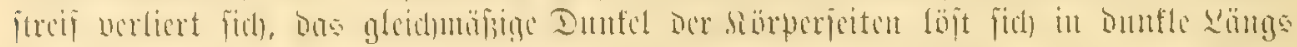

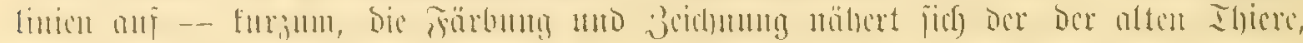
IIno Sarictüten entwidedn fid).

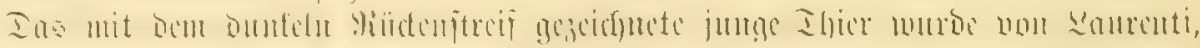

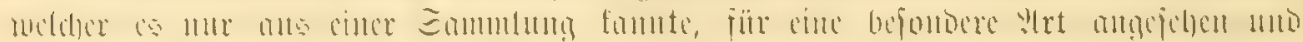

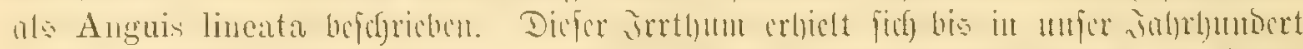

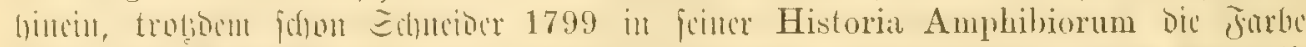
Der immene

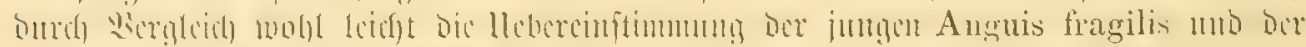

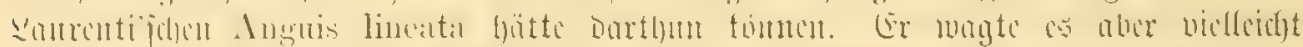

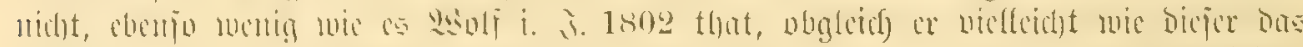

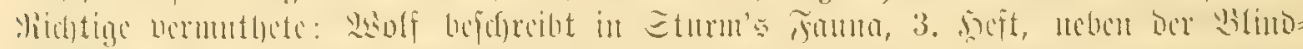

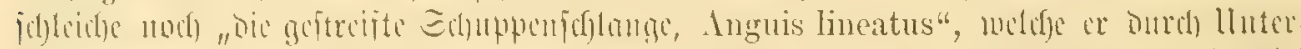

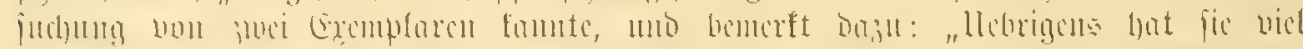

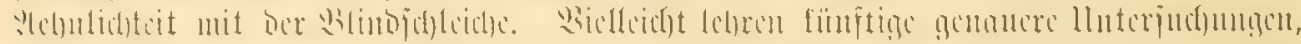

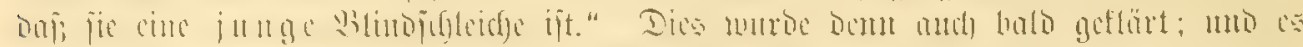

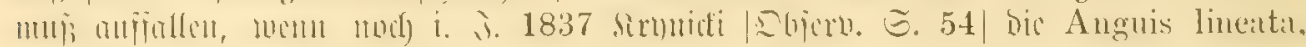

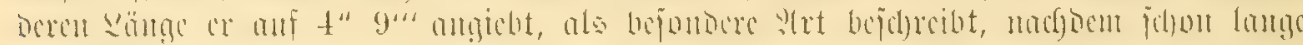

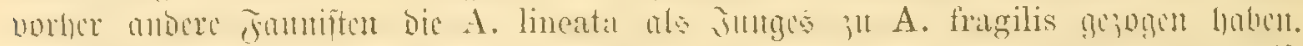

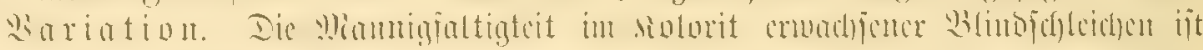

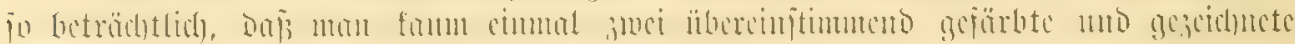

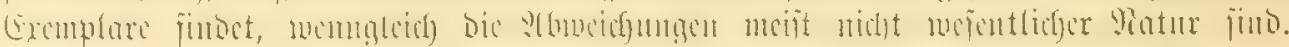

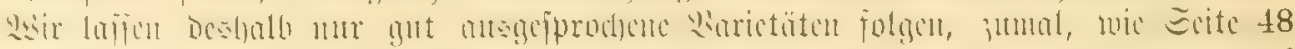

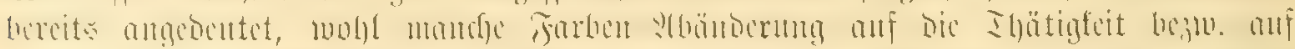

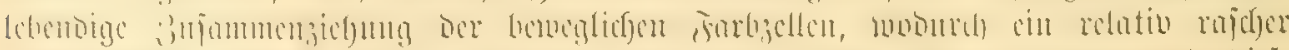

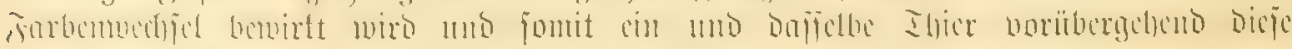

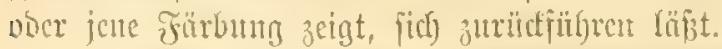

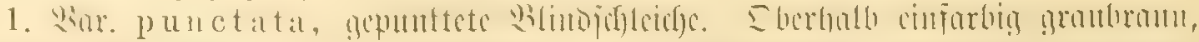

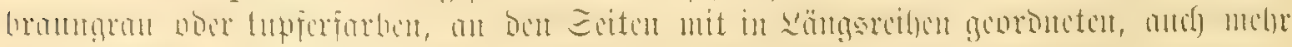

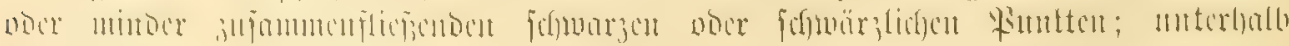

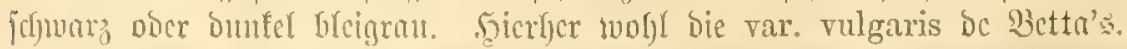

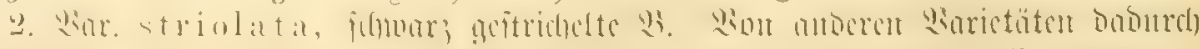

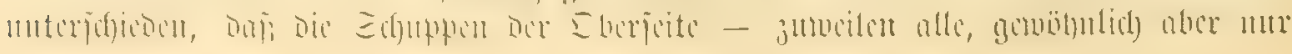




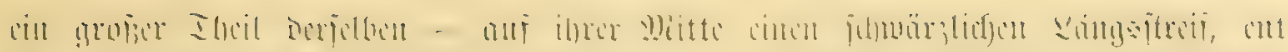

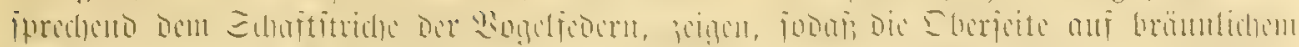

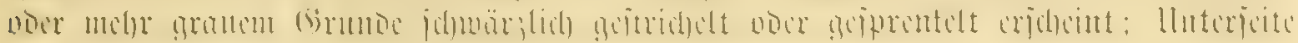
Dunfil. Eeltener als bic worige mo Liar. 6.

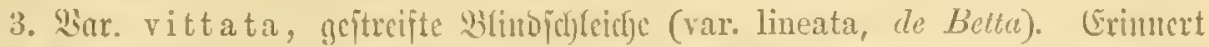

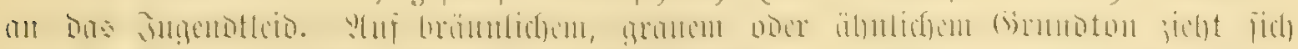

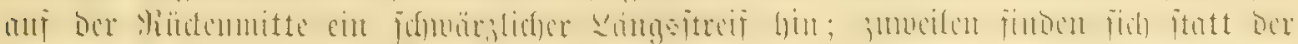

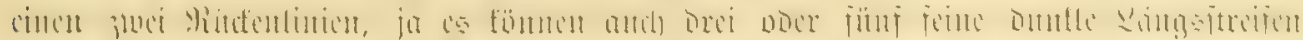

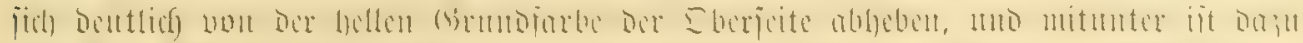

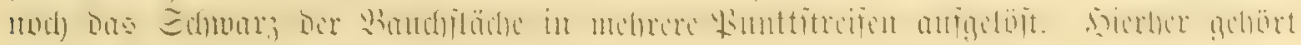

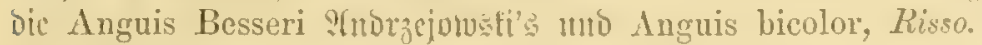

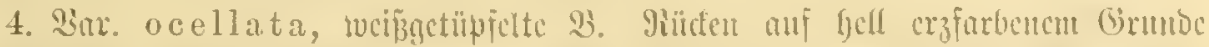

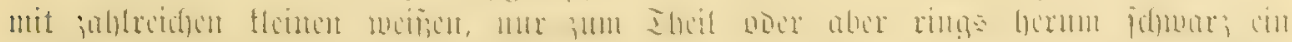

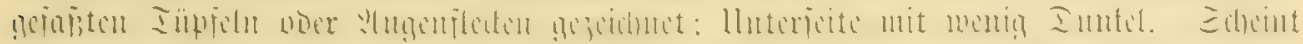

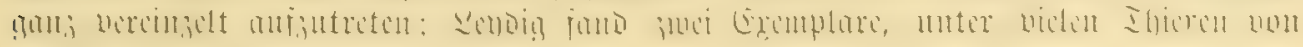

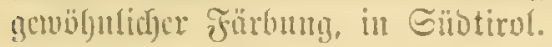

5. Bar. coeruleo-maculata, Jeitteles (1862)= cyaneo-punetata, Geisen-

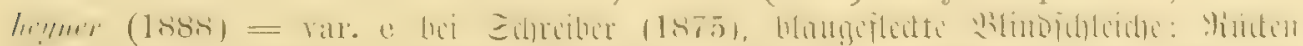

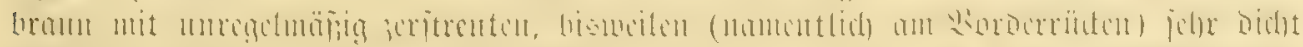
gritchton, ansmohns

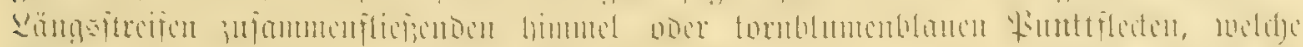

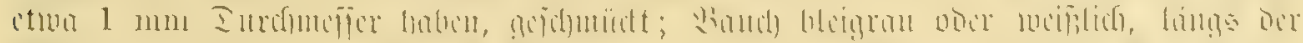

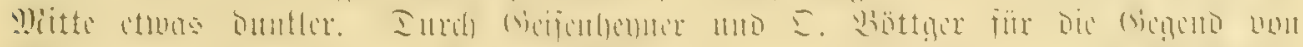

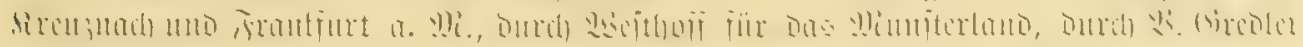

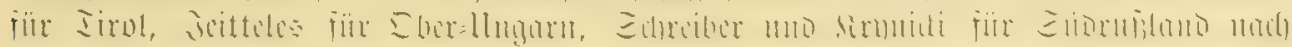
geviejert 2c.

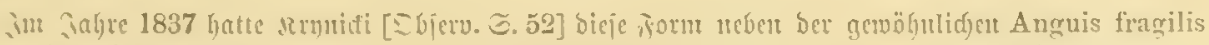

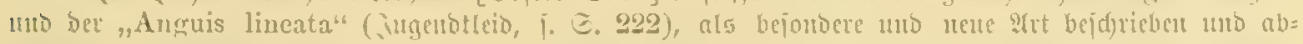

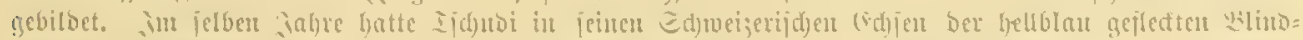

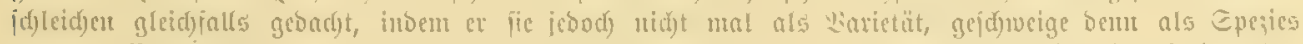

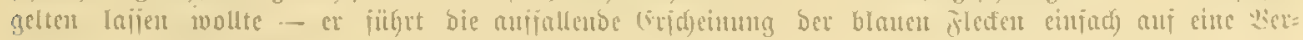

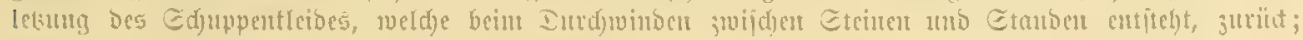

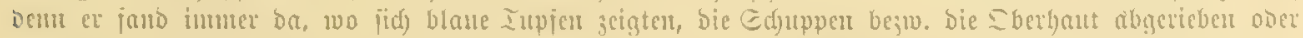

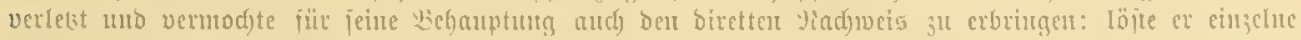

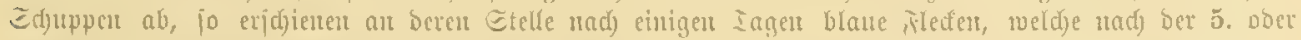

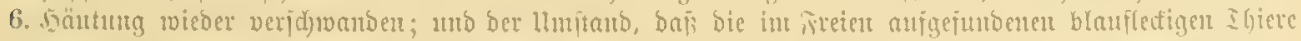

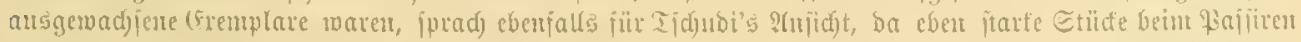

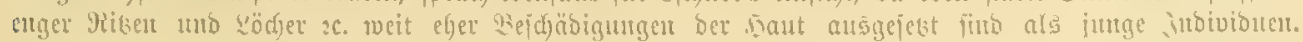

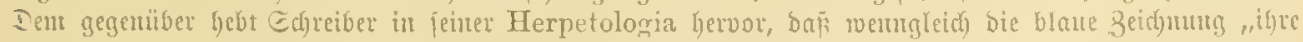

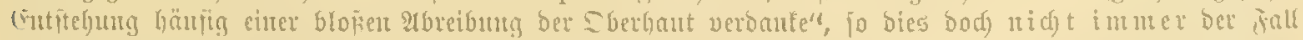

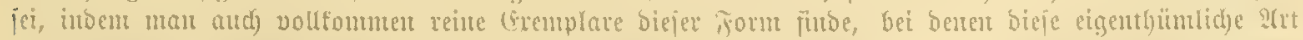

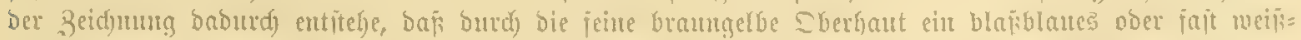

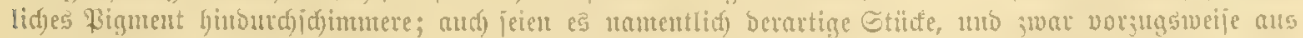

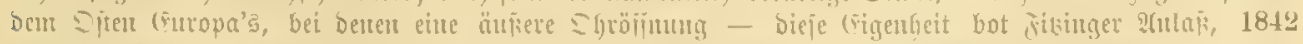

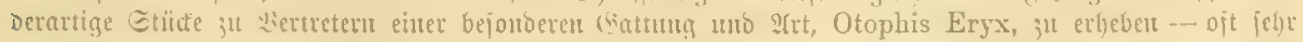

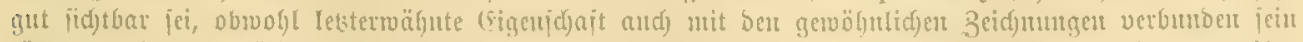

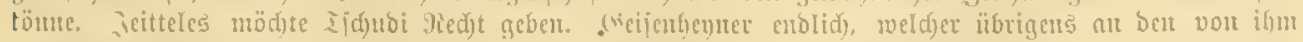

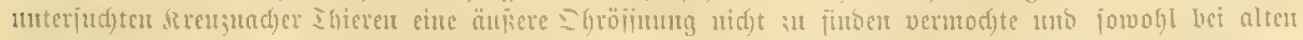

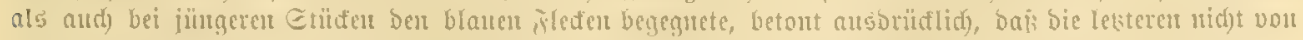

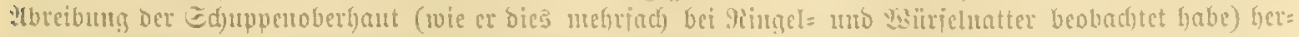

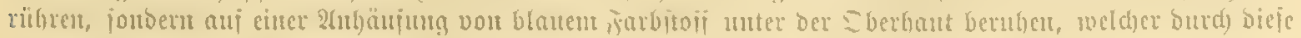

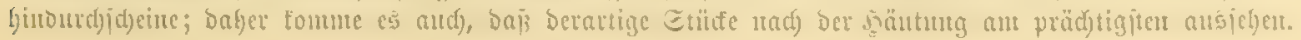


6. War. ventrimaculata, fledbaudjige 3. Sbericte grangelb, fupfer= ober

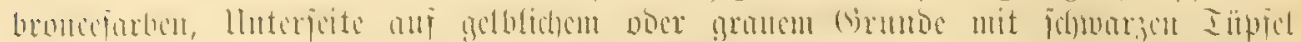

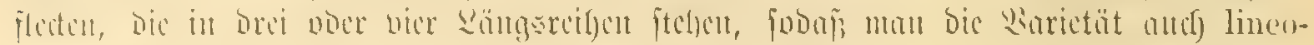
maculata bezcicynent fönutc. (Anguis cinerea, Risso.)

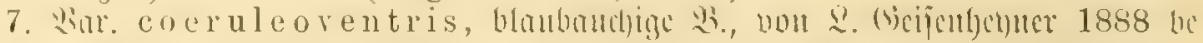

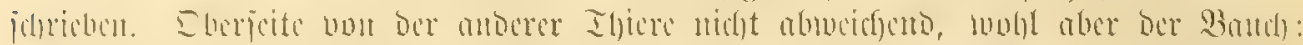

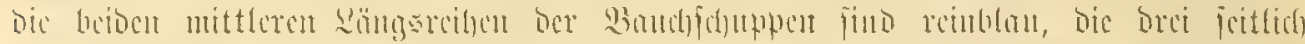

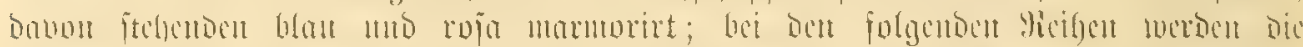

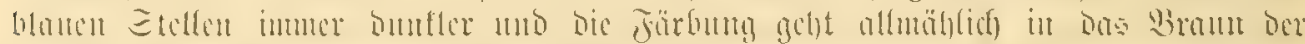
列anten

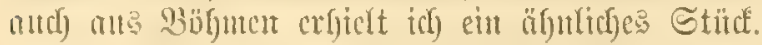

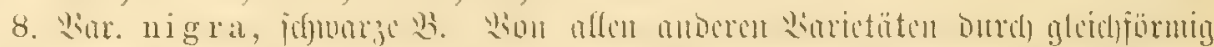

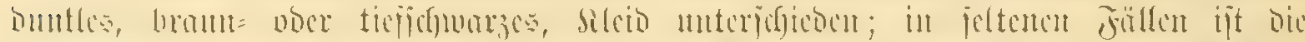

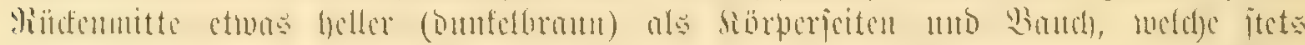

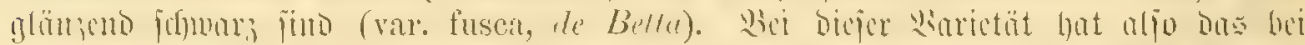

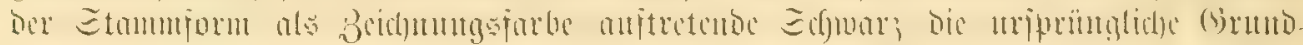

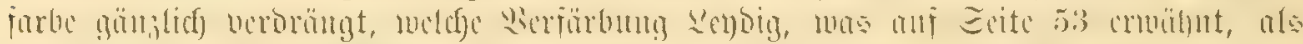

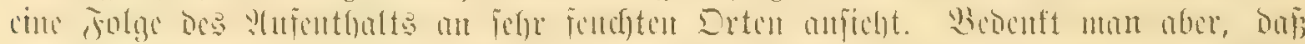

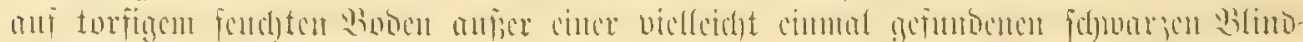

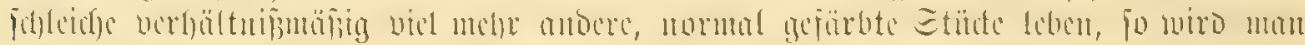

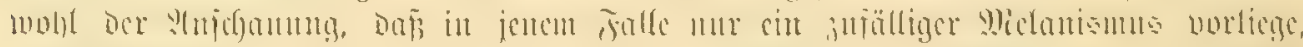

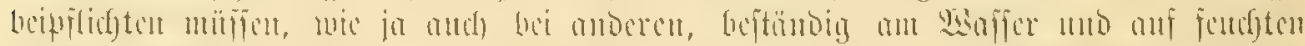

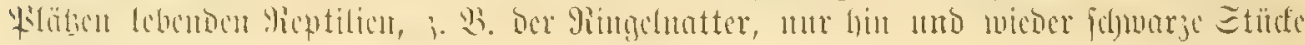
bevbadjtet werben.**)

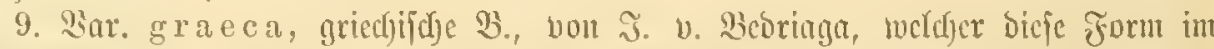

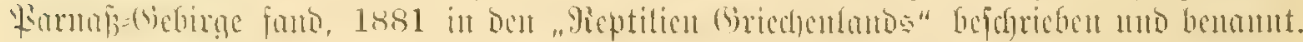

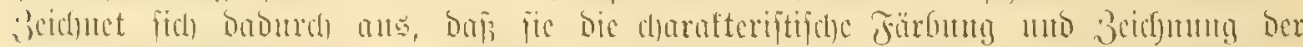

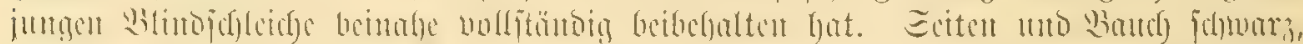

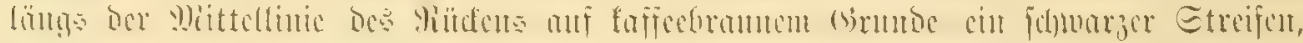

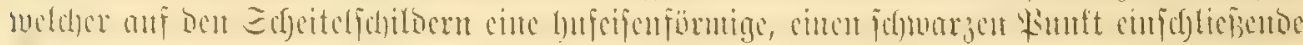

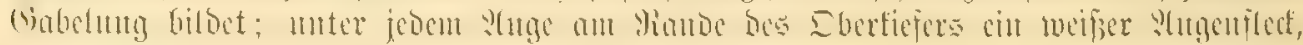
zuei joldye Fleden jeberfeits am llutertiefer.

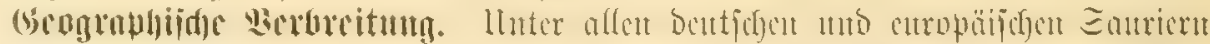

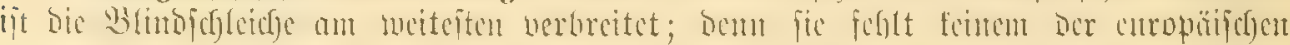

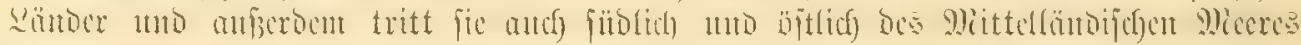

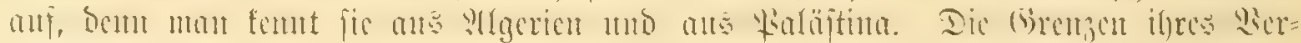

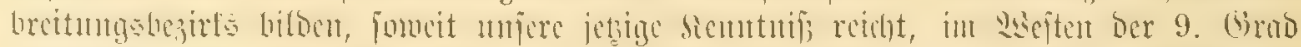

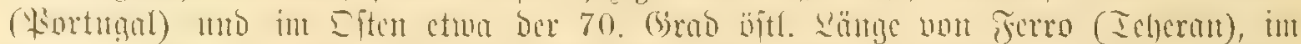

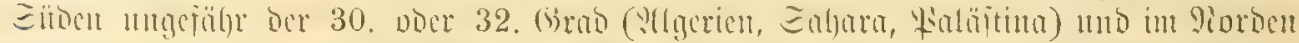

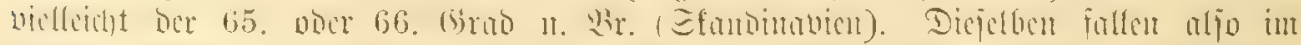

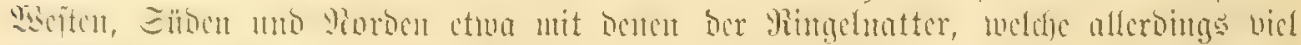

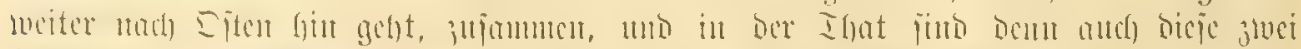

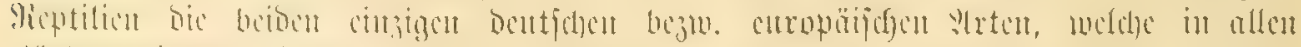

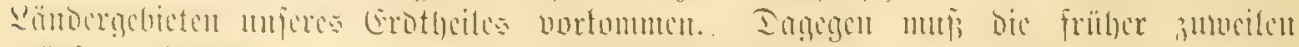

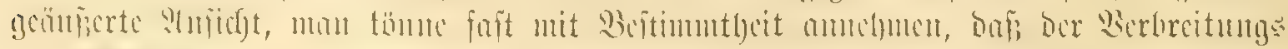

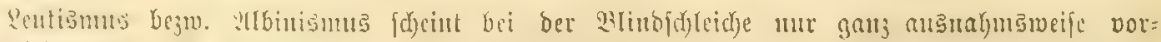

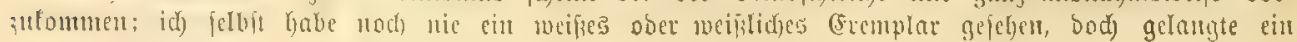

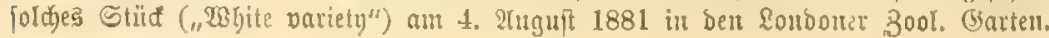




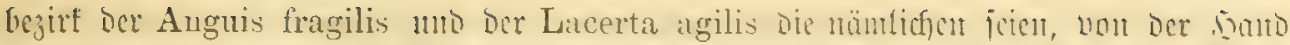

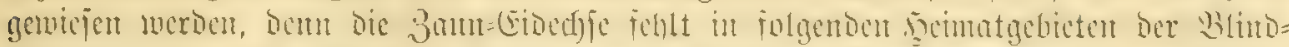

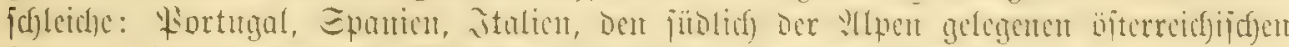

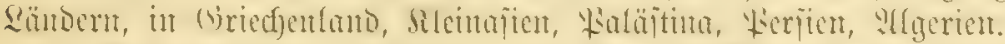

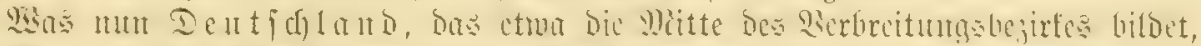

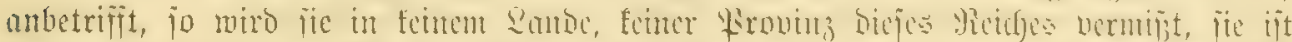

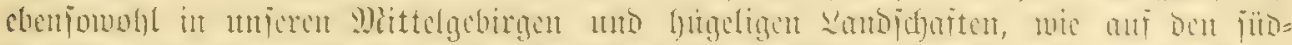

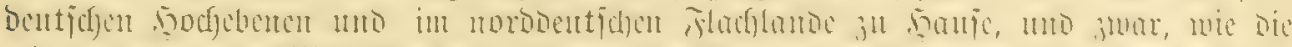

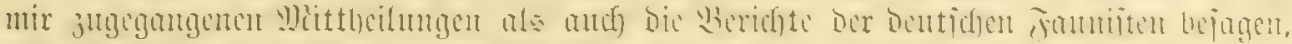

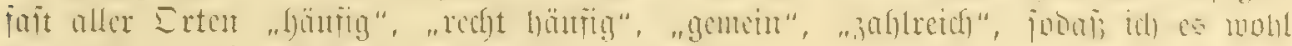
unterlajiet barf, all' dic Beobacfitcr zu nemen.

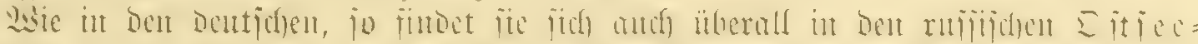

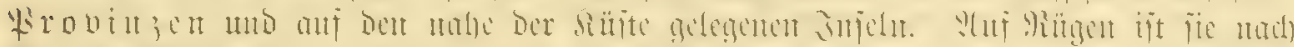

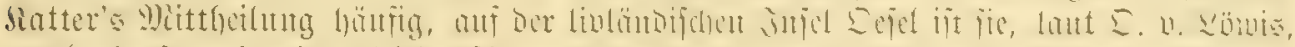

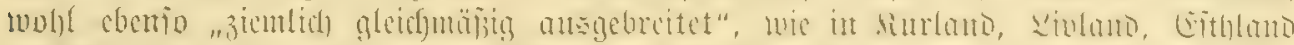

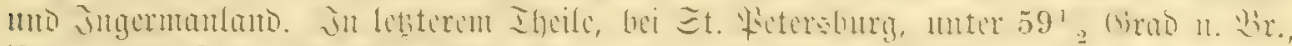

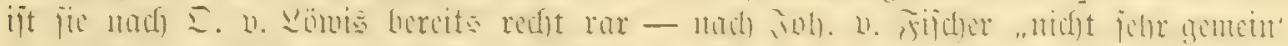

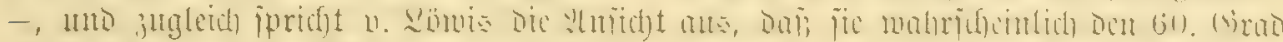

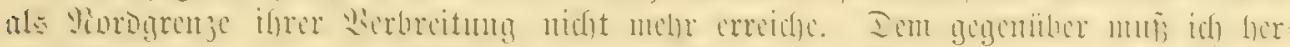

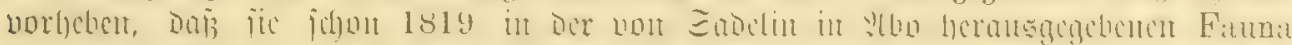

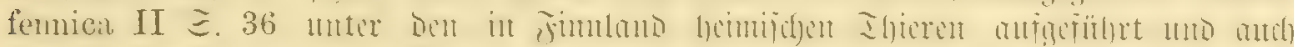

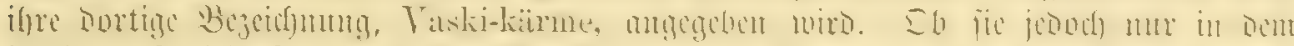

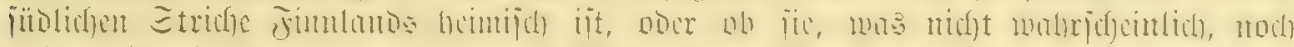

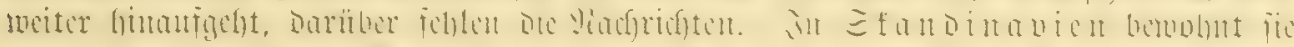

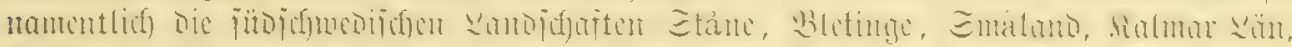

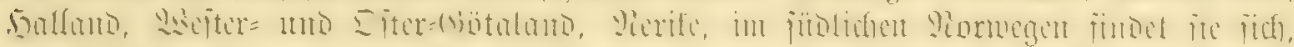

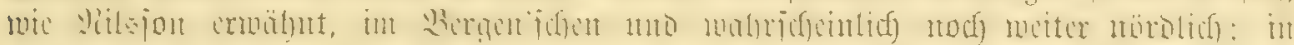

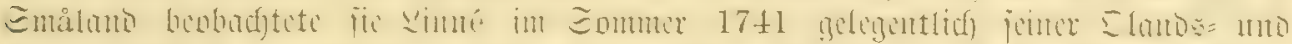

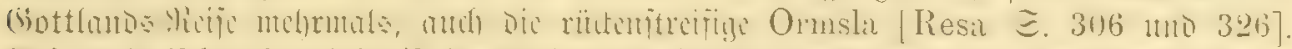

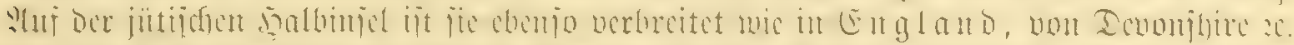

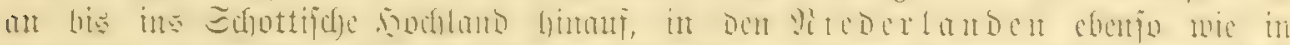

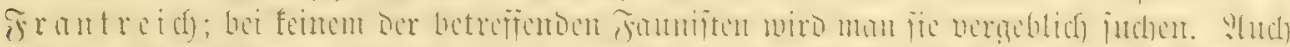

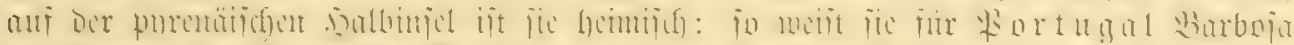

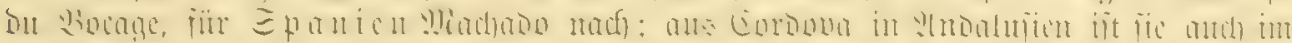

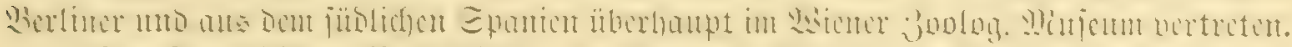

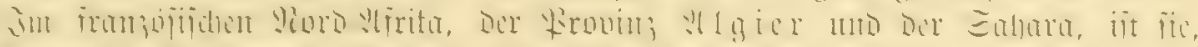

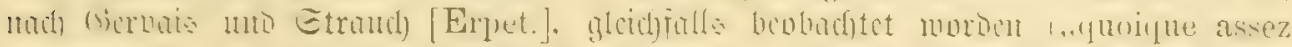

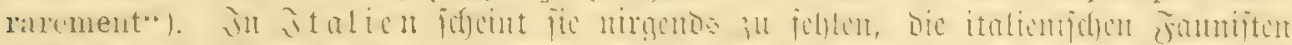

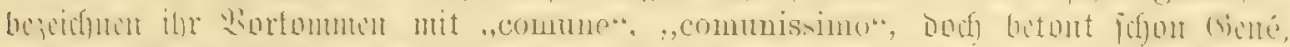

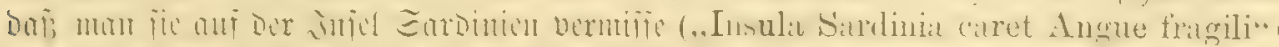

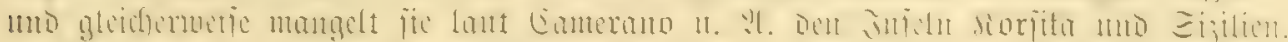

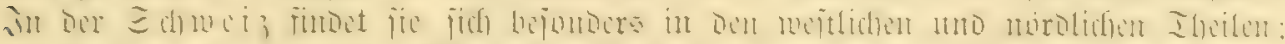

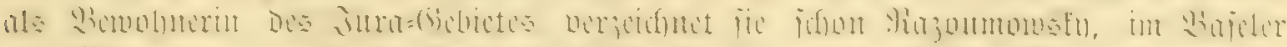

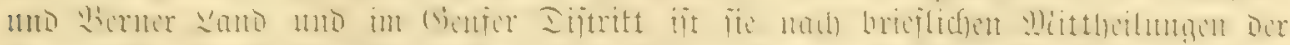

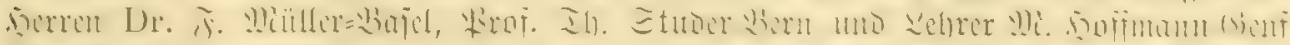

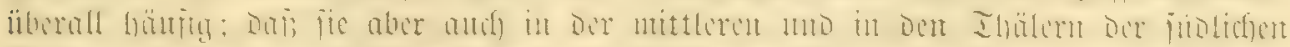

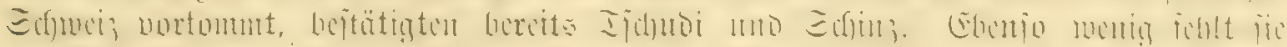

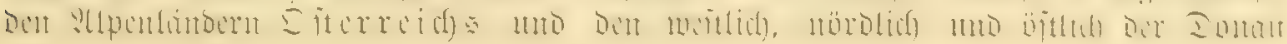




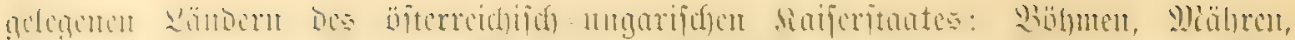

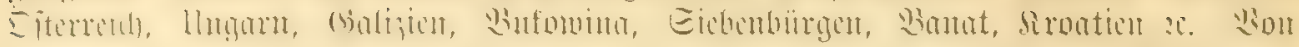

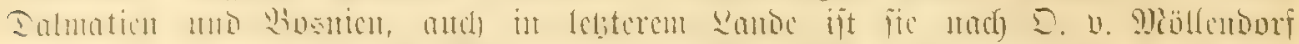

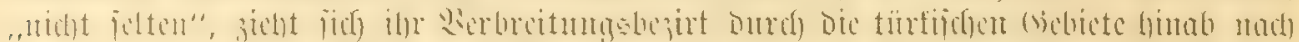

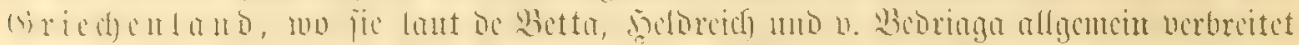

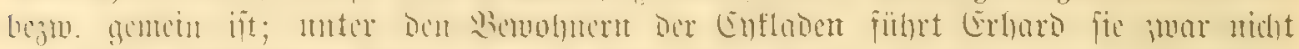

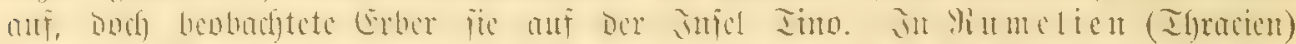

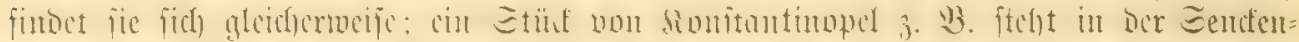

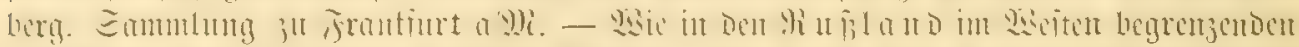

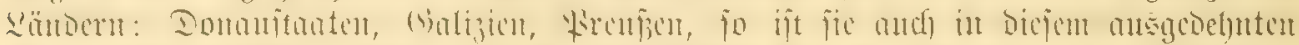

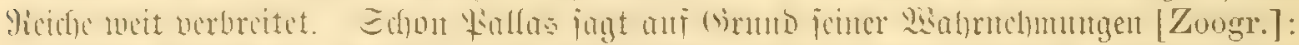
"In ommi Rossia tiln boreali, quam temporata, nee mon per Caucasm, in Georgiam

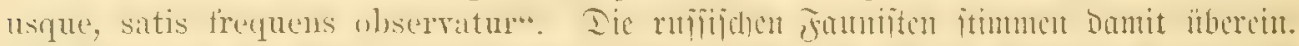

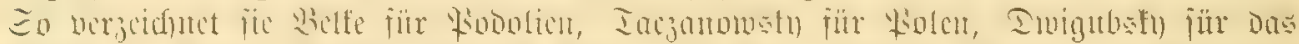

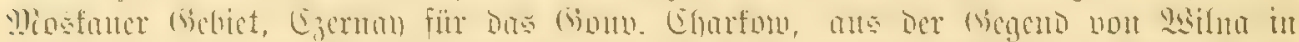

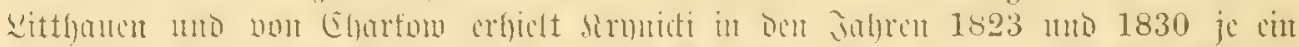

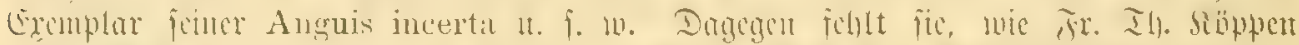

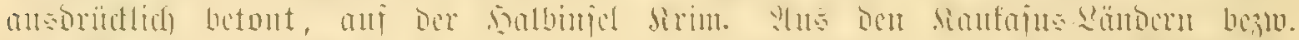

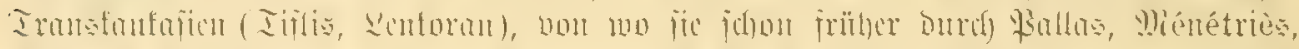

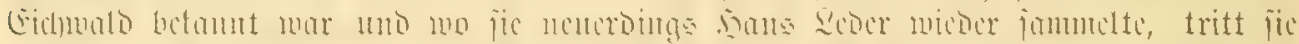

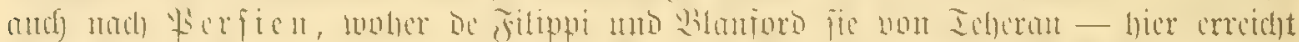

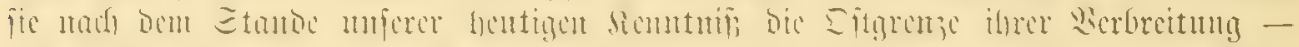

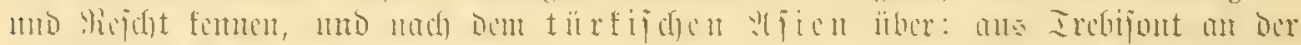

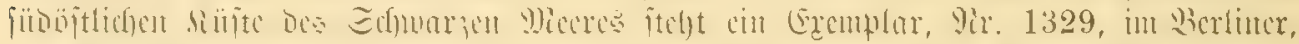

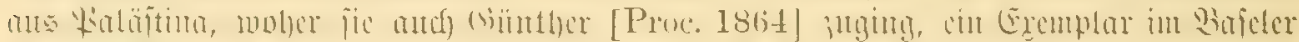

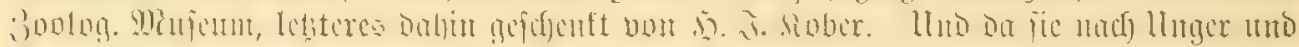

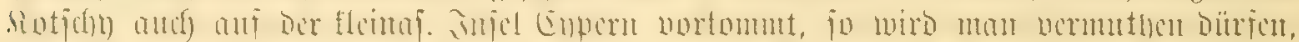

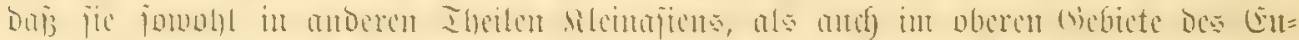

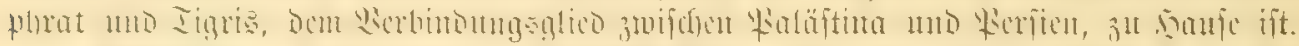

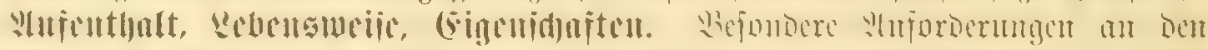

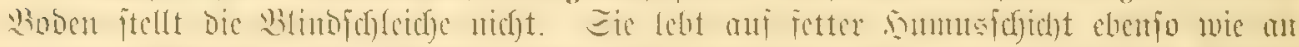

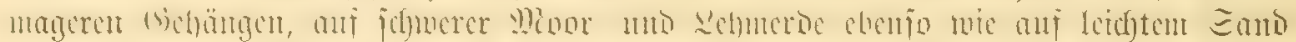

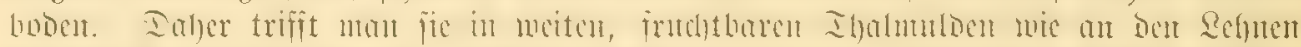

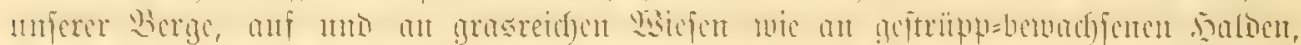

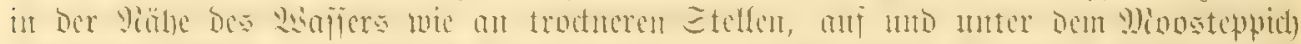

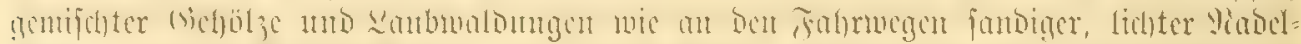

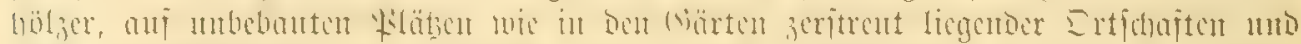

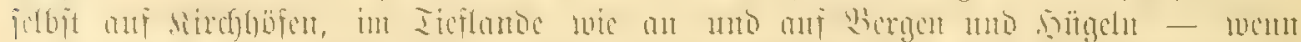

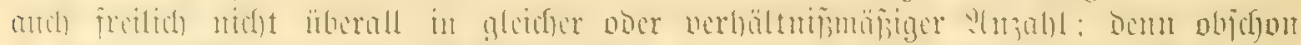

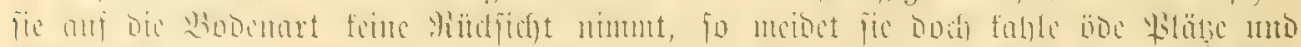

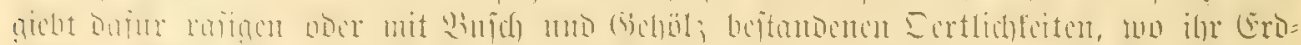

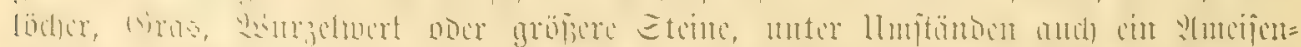

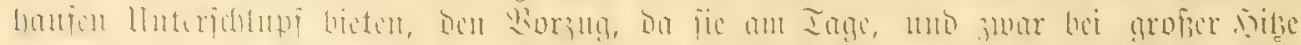

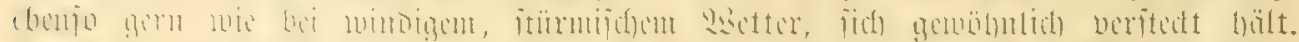

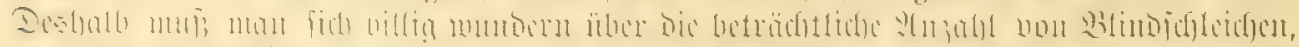

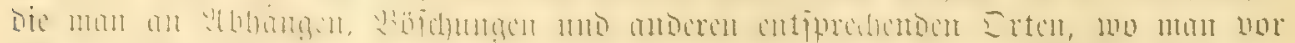

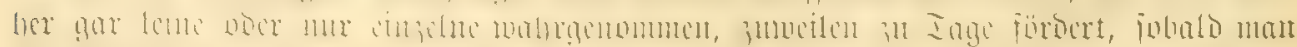

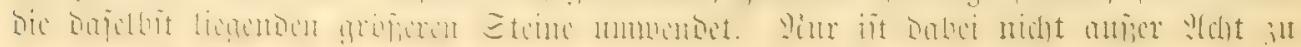




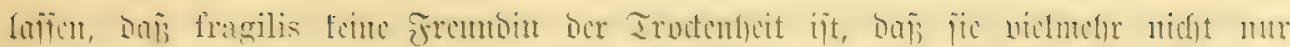

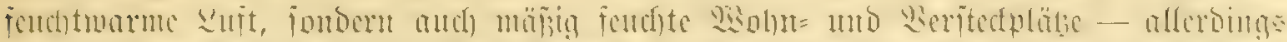

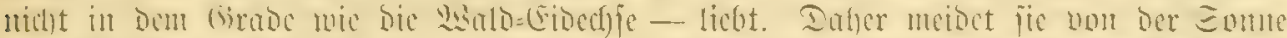

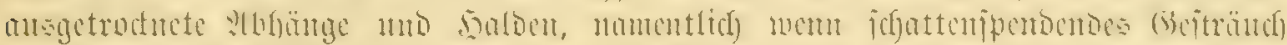

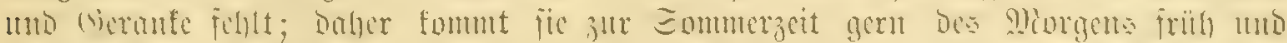

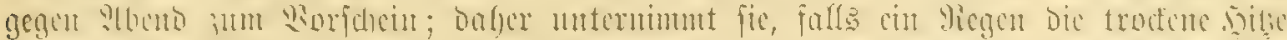

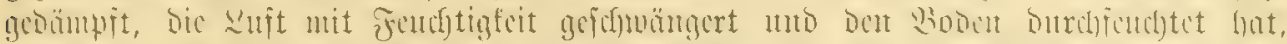

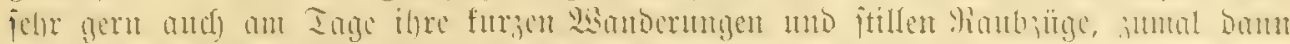

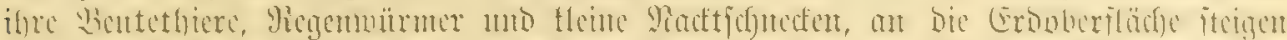

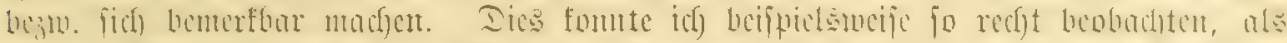

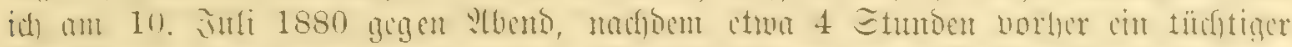

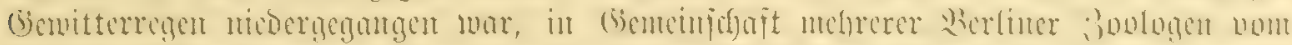

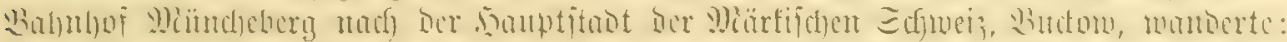

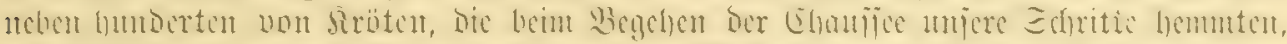

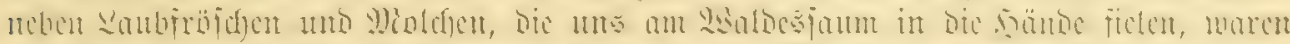

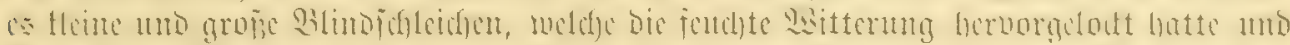

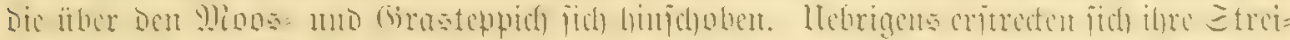

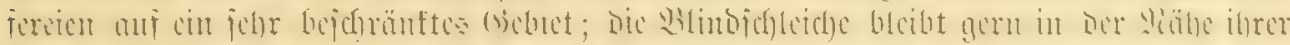

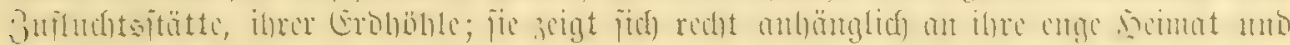

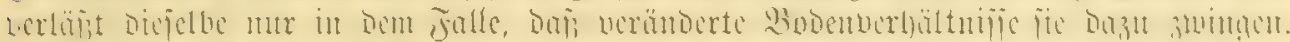

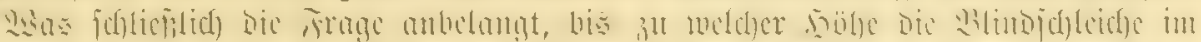

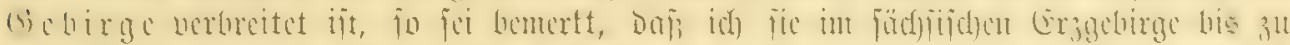

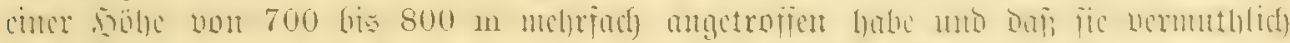

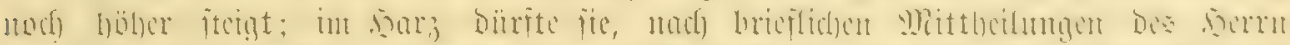
Dr. Ciliter

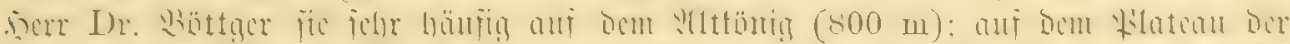

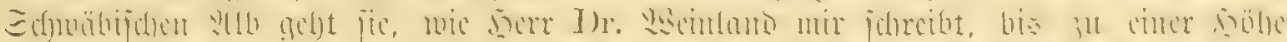

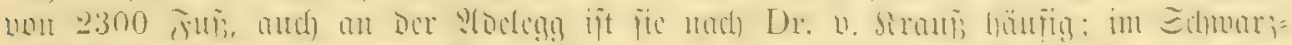

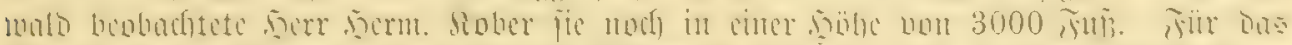

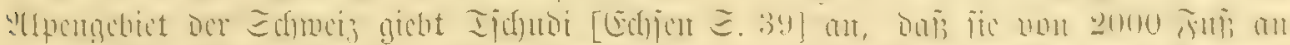

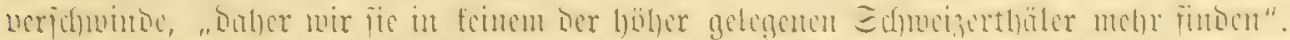

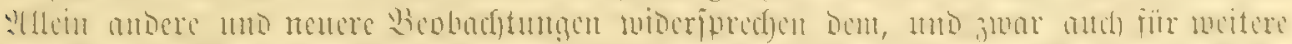

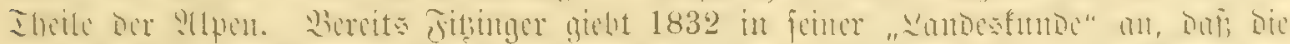

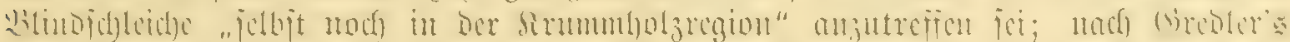

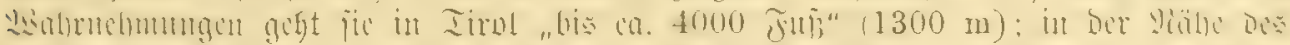

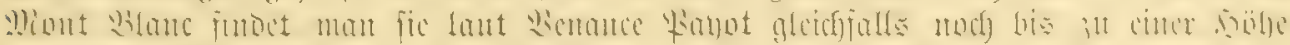

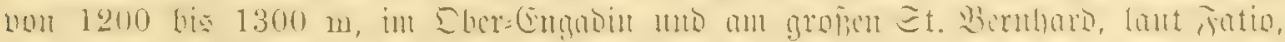

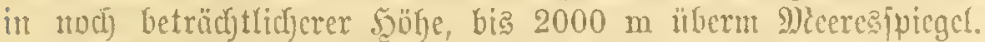

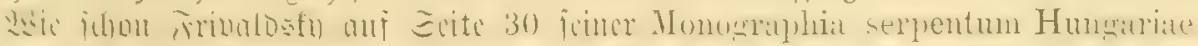

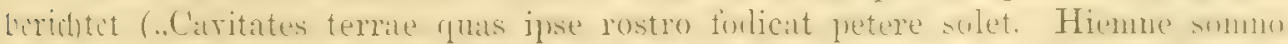

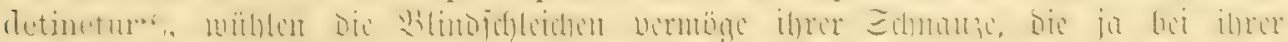

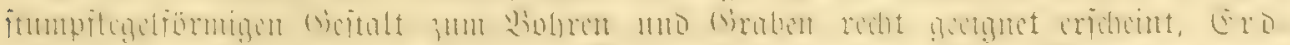

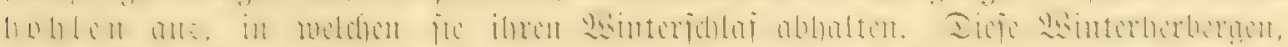

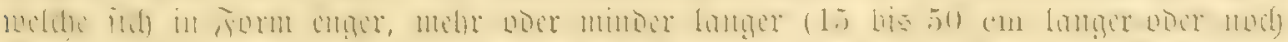

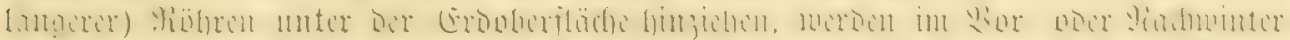

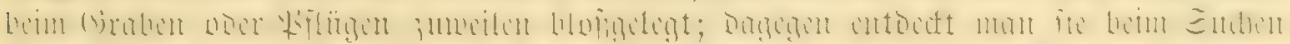

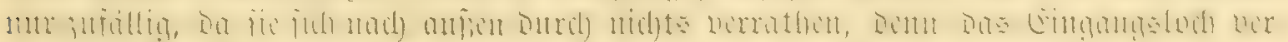

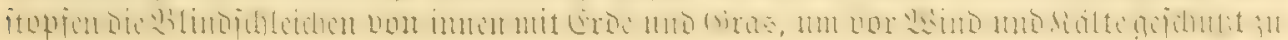




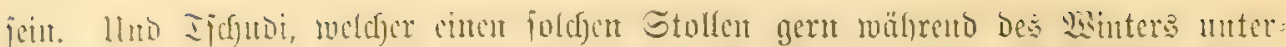

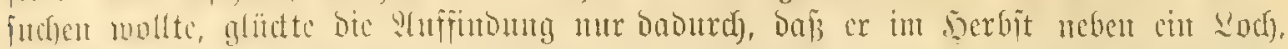

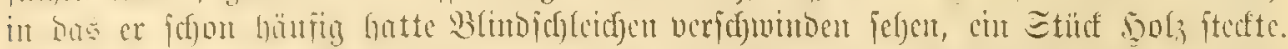

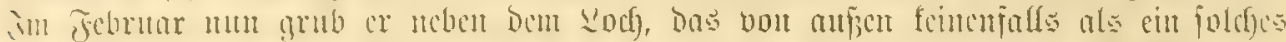

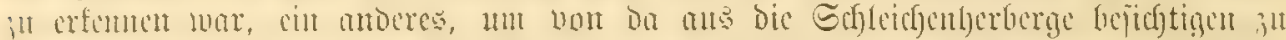

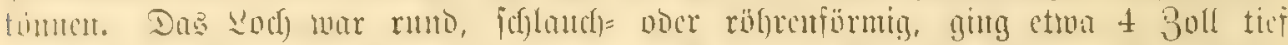

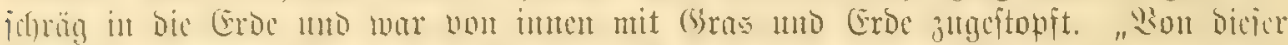

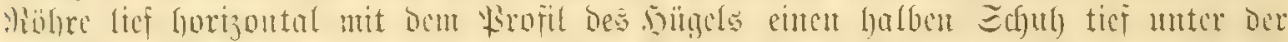

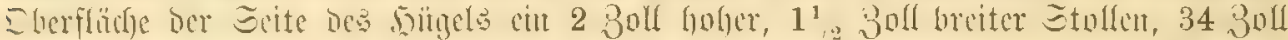

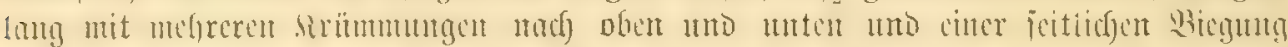

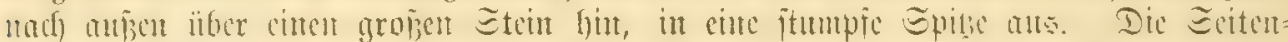

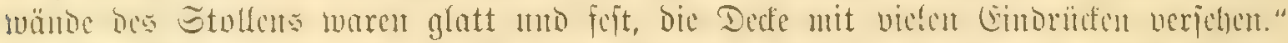

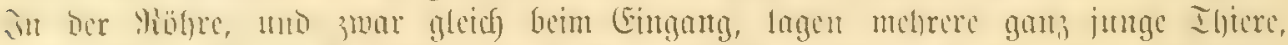

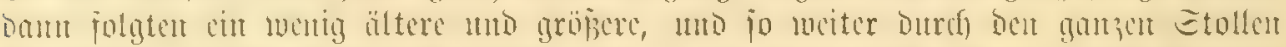

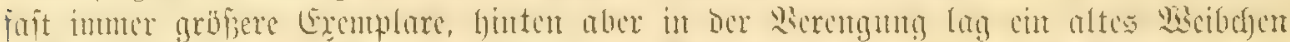

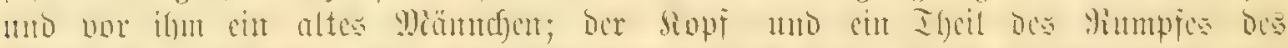

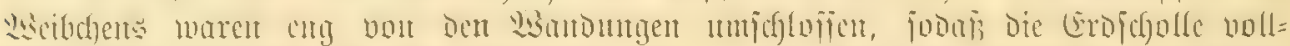

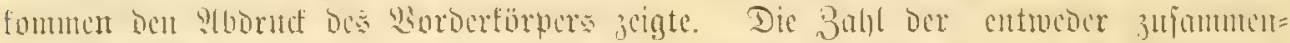

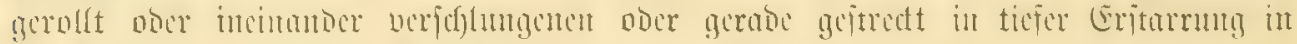

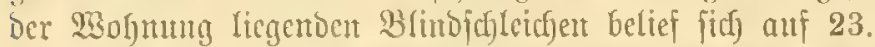

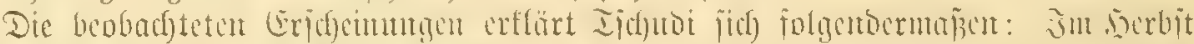

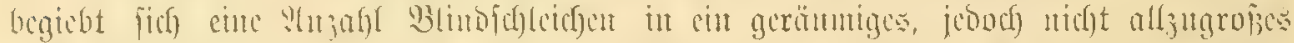

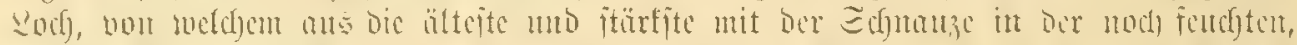

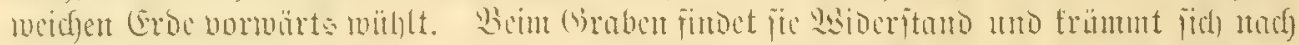

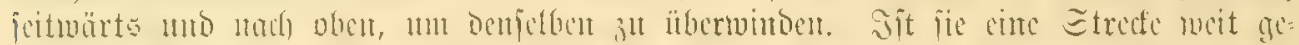

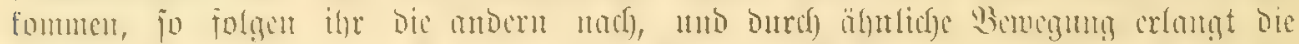

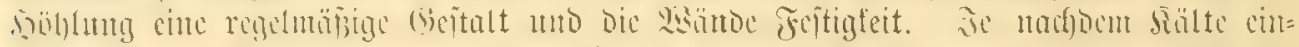

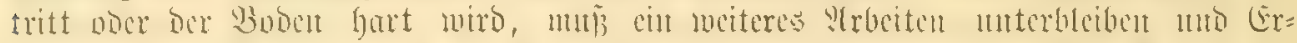

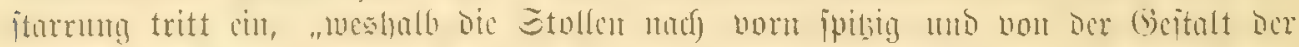

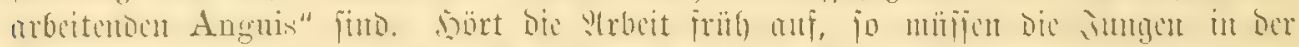

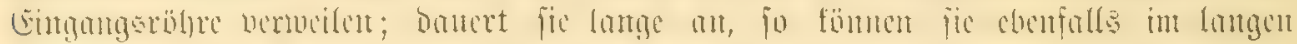

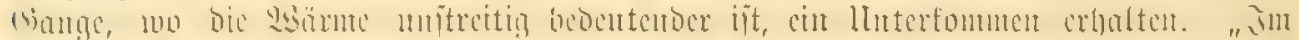

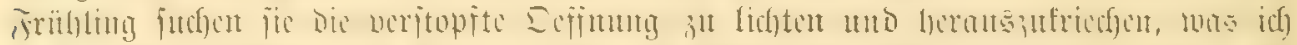

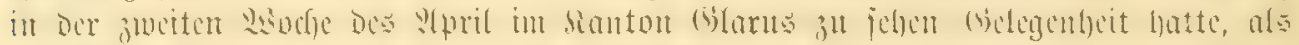

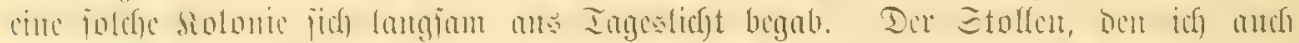

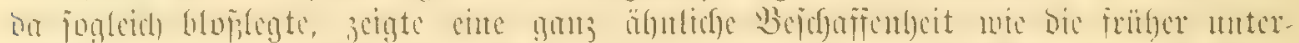

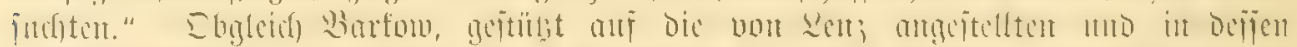

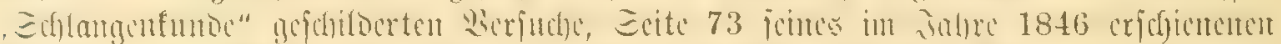

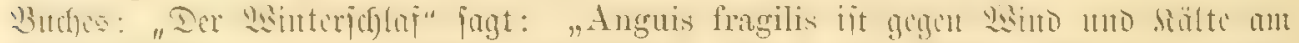

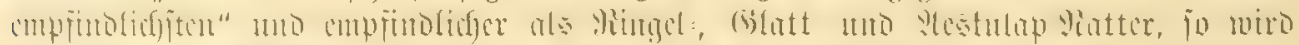

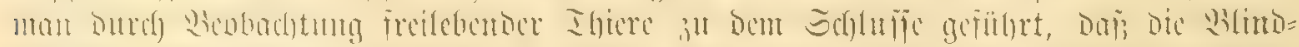

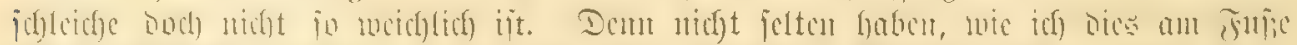

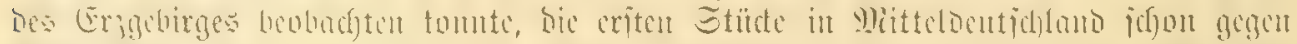

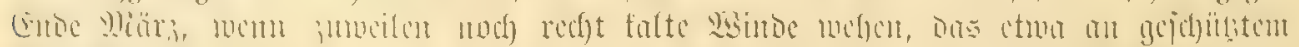

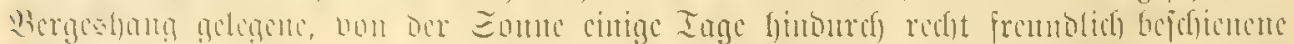

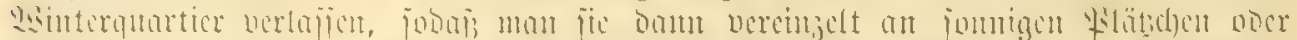

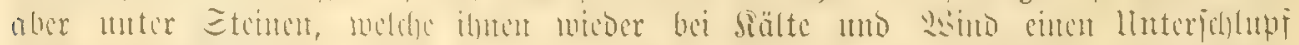

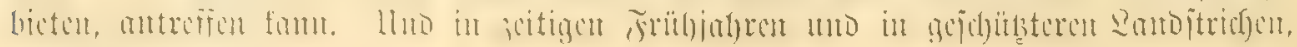




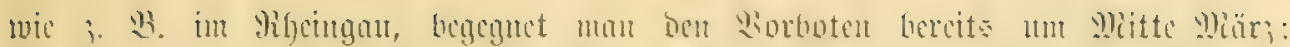

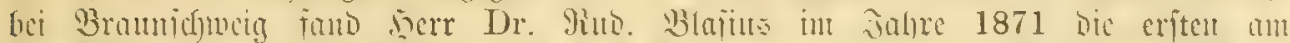

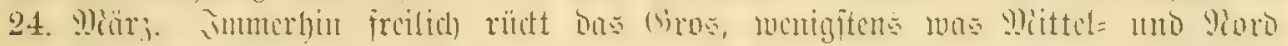

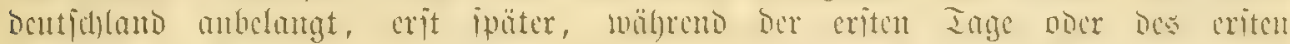

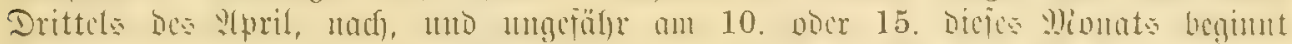

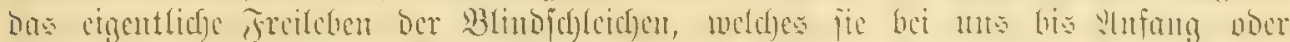

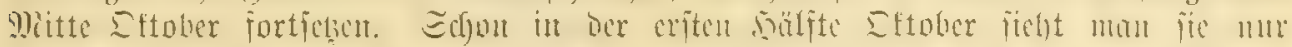

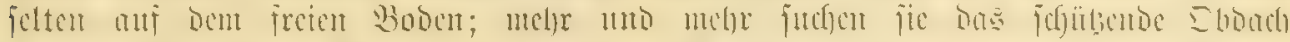

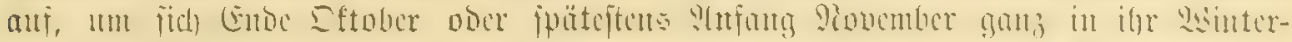
quartier zแrïdzนziçen.

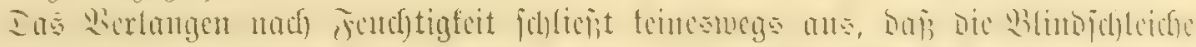

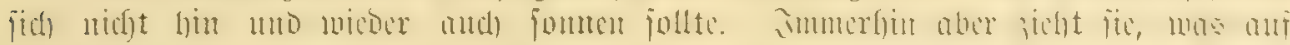

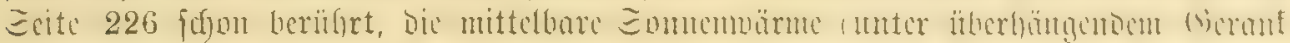

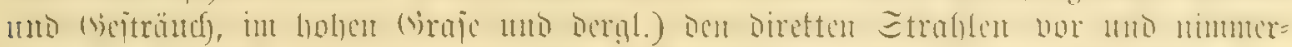

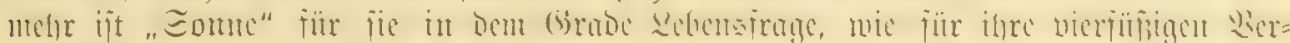

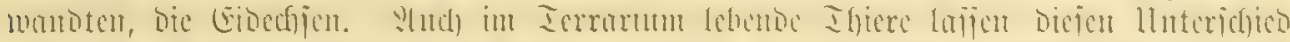

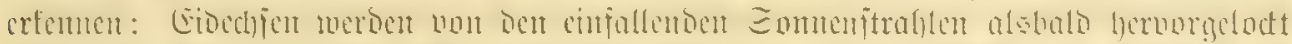

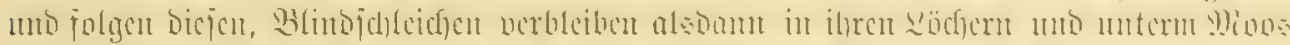

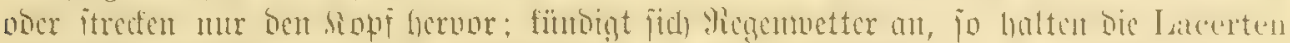

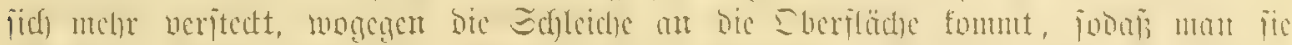

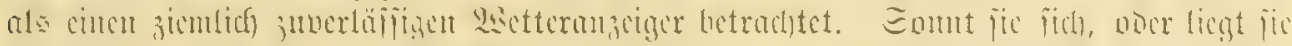

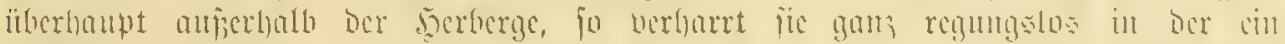

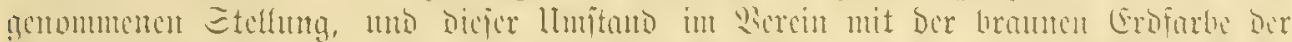

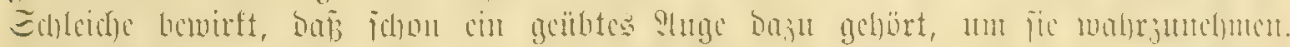

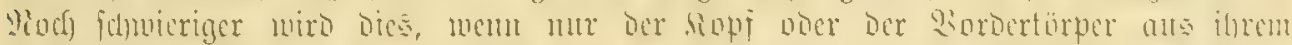

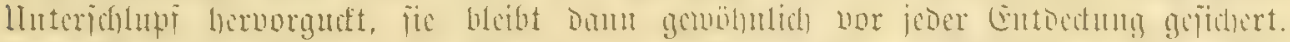

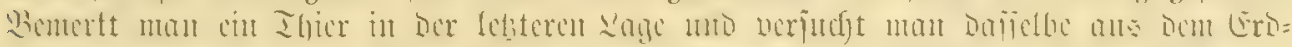

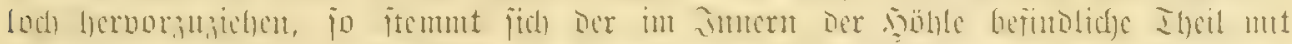

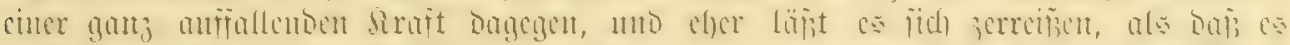

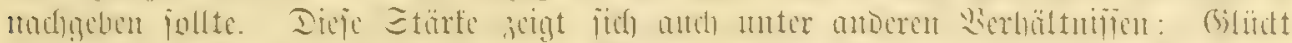

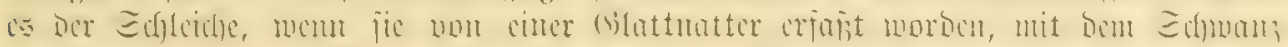

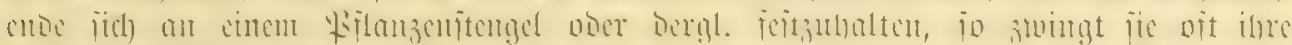

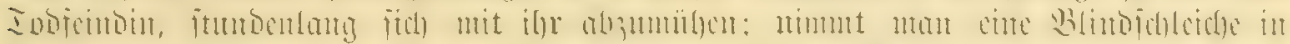

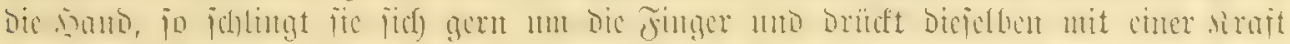

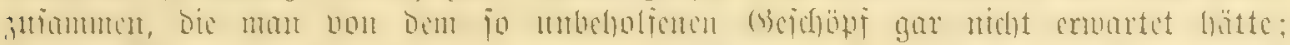

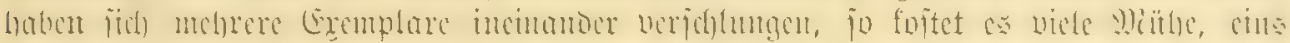

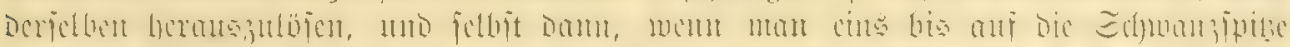

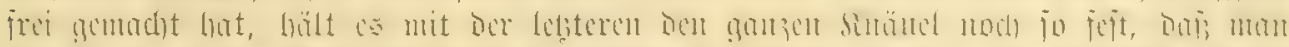

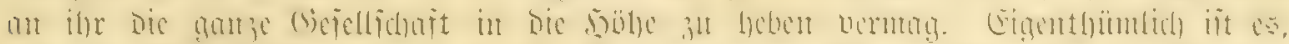

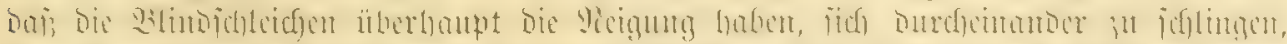

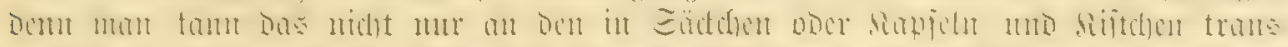

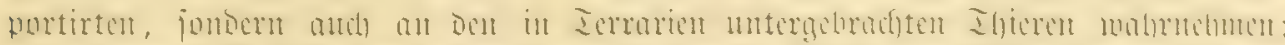

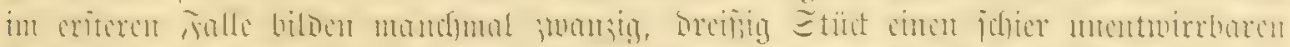

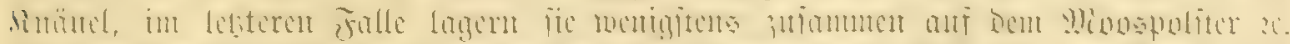

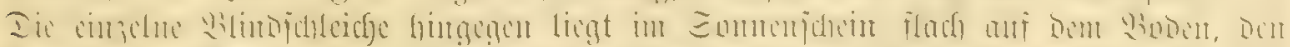

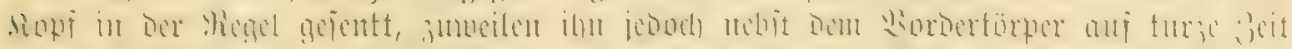

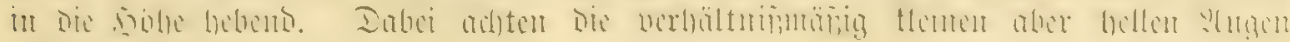
uobly auf bic limgebung. 


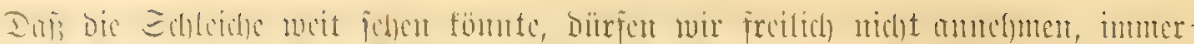

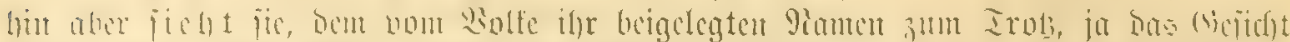

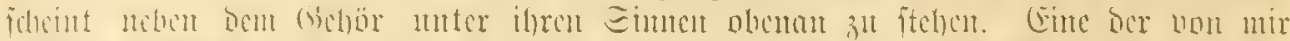

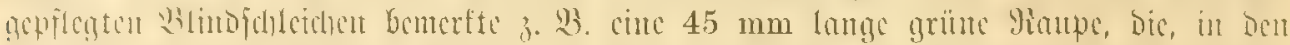

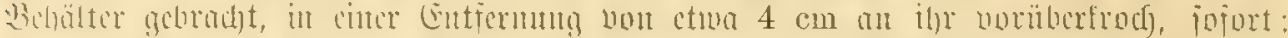

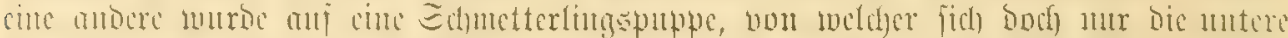

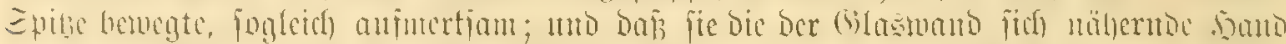

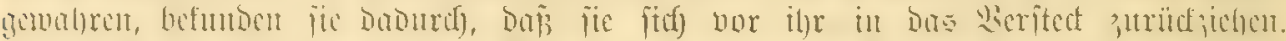

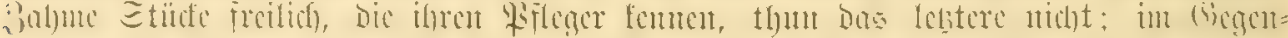

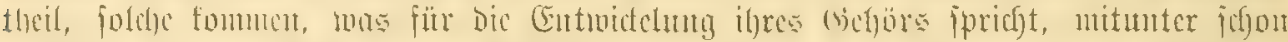

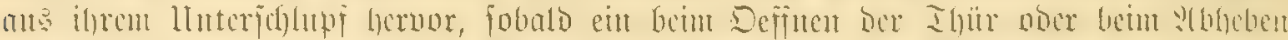

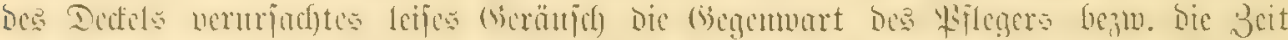

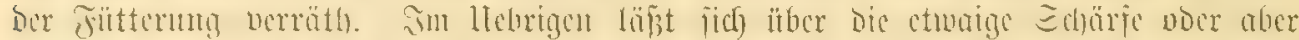

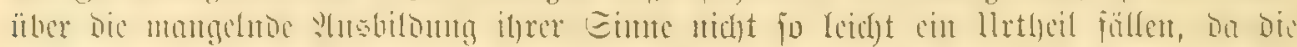

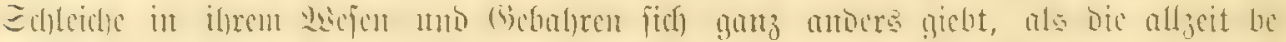

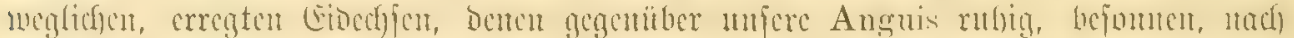

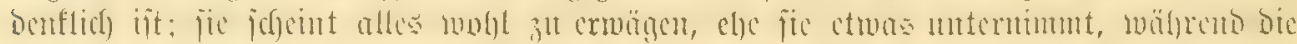

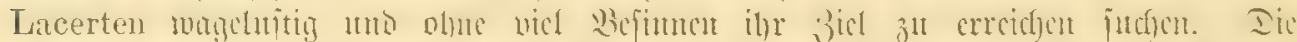

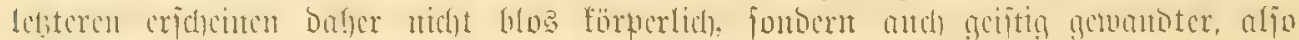

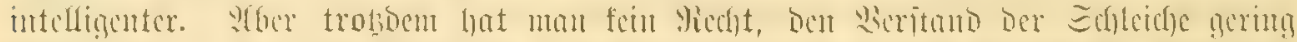

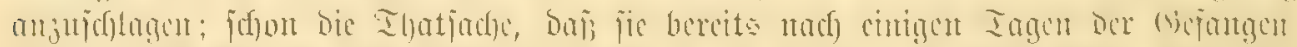

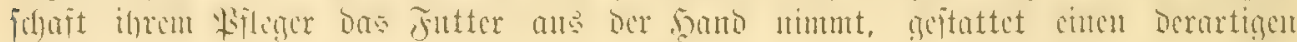
Entjucio nicljt.

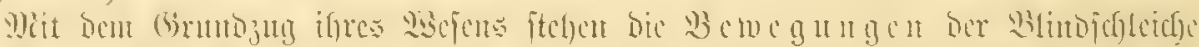

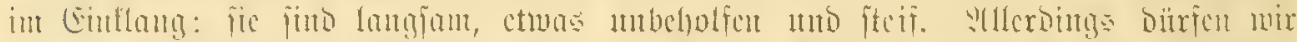

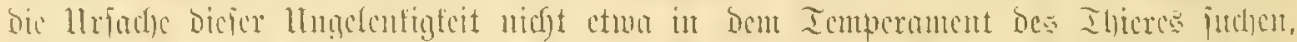

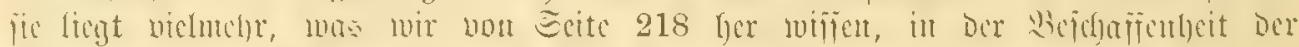

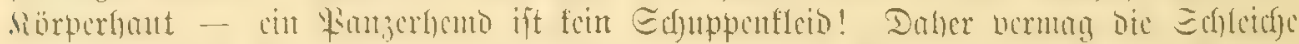

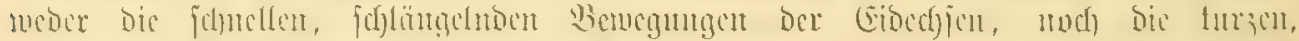

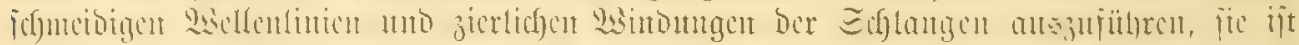

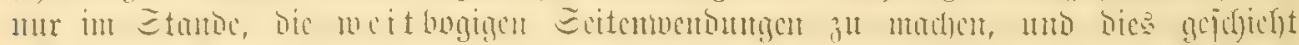

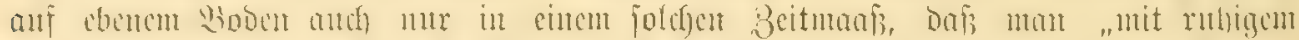

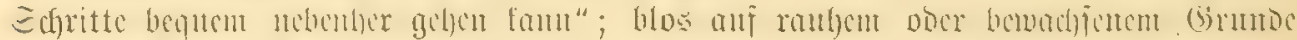

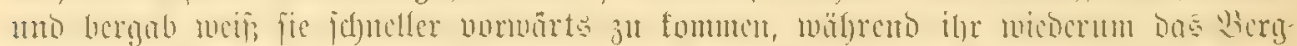

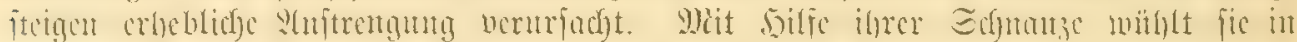

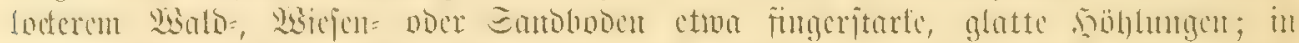

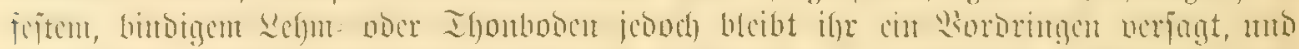

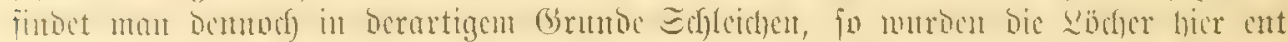

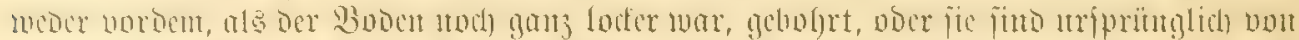

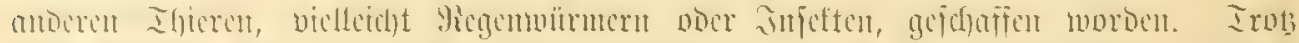

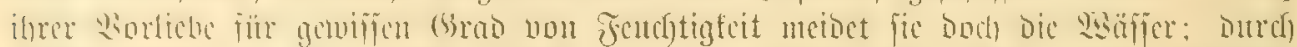

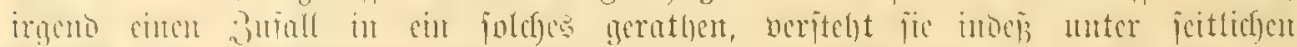

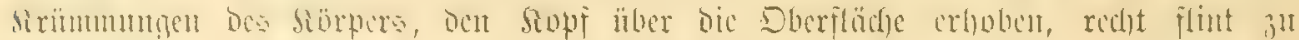

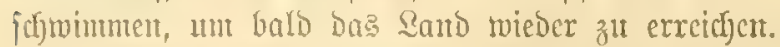

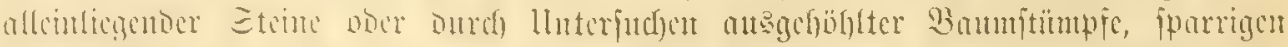

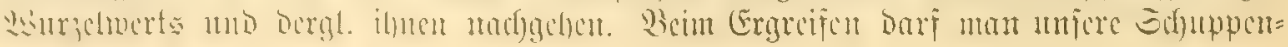




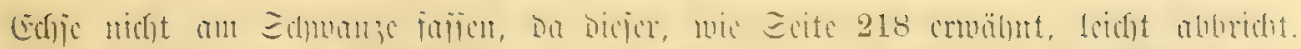

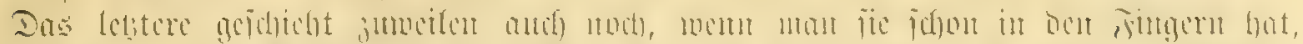

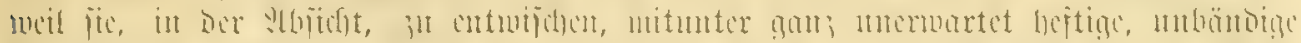

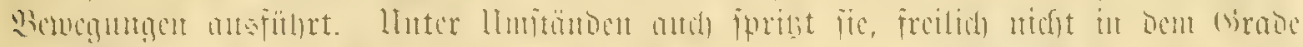

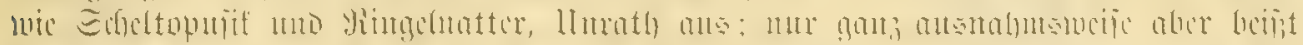

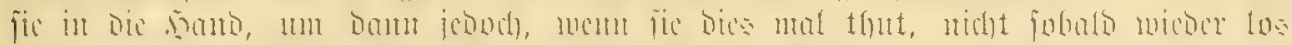

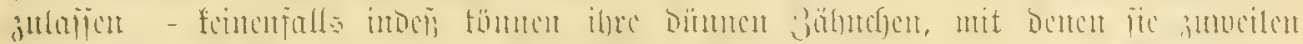

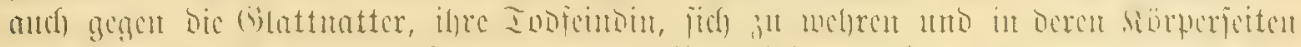

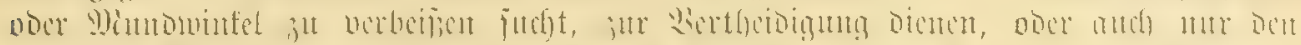

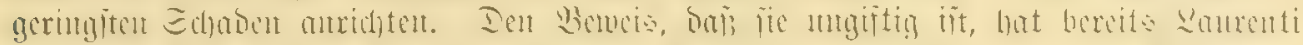

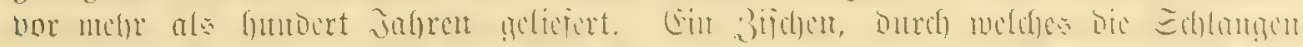

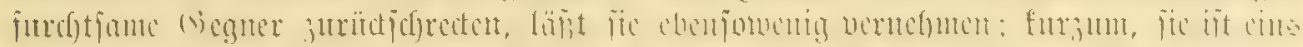

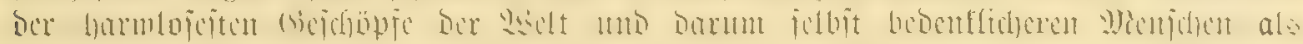

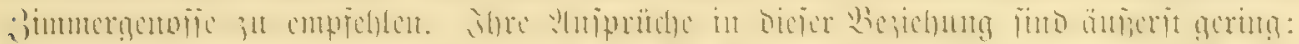

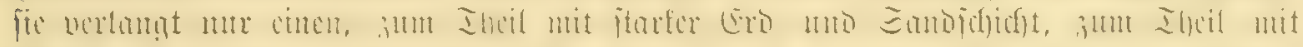

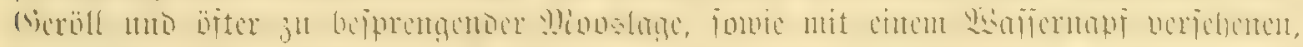

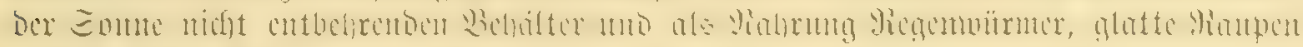

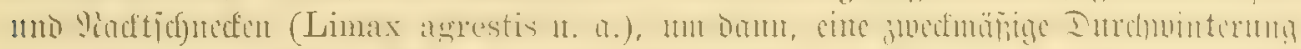

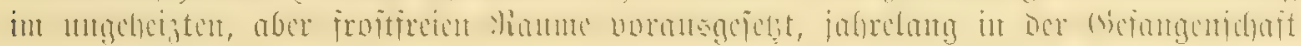

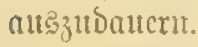

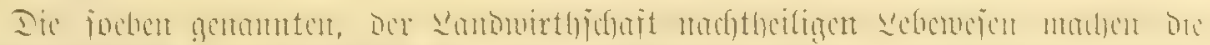

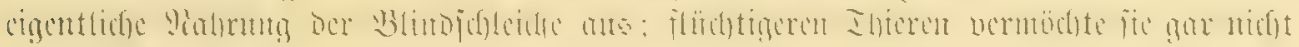
zul folgen. joat fie cinen 23 um oder Dergleicfen crblickt uno zur Batc crforen,

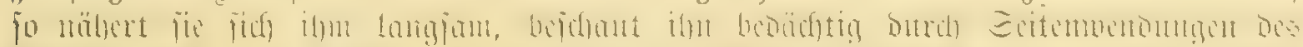

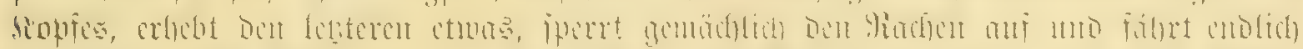

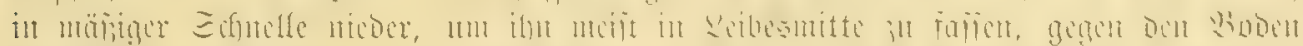

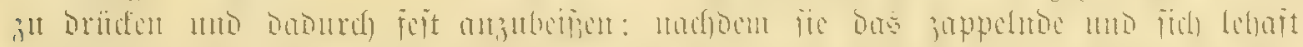

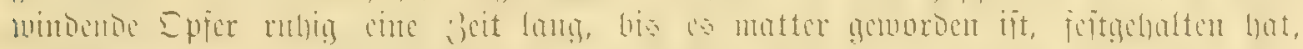

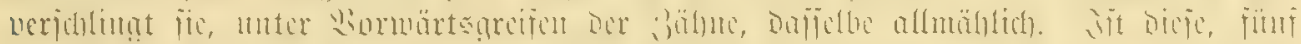

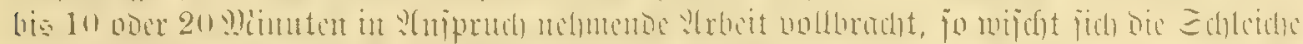

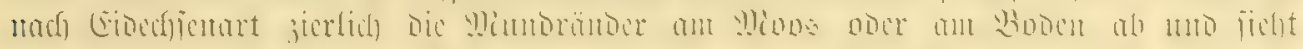

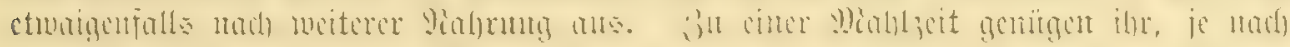

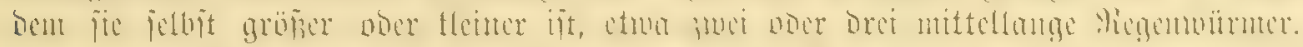

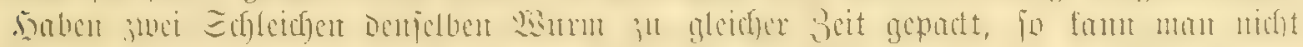

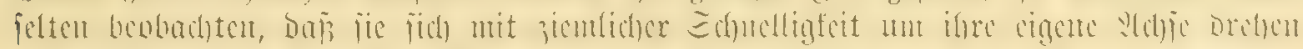

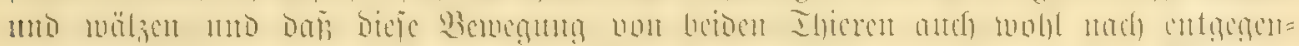

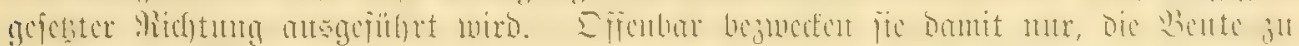

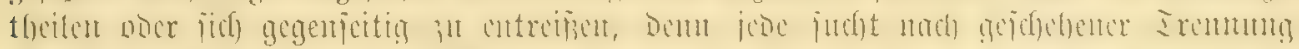

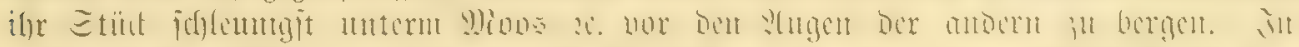

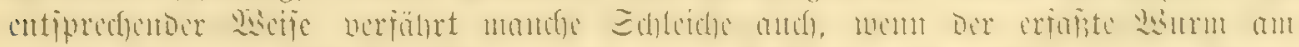

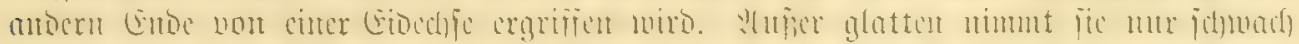

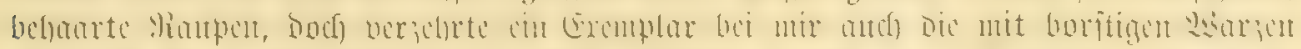

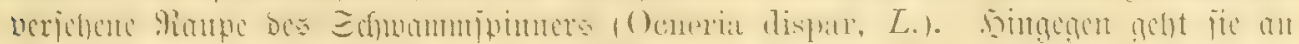

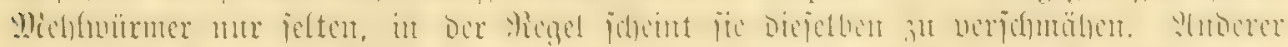

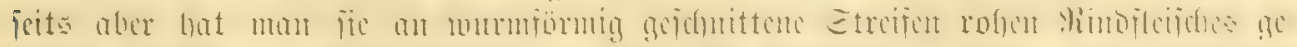

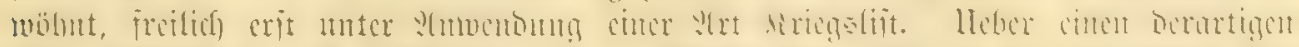

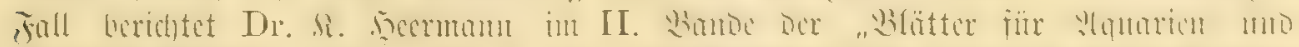

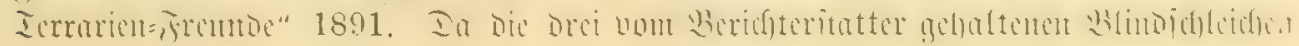




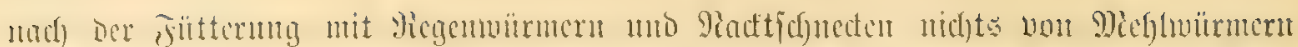

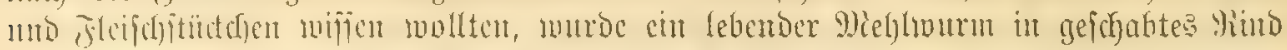

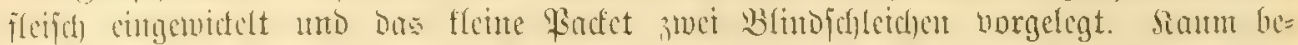

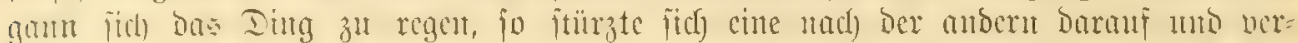

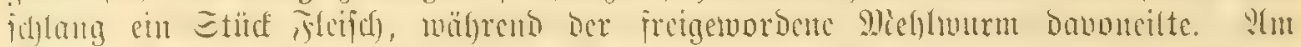

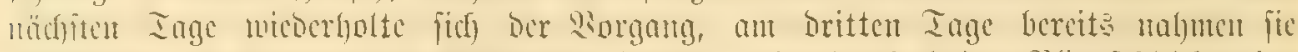

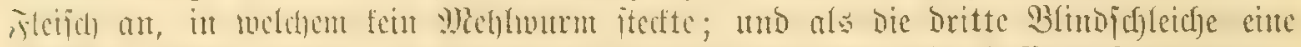

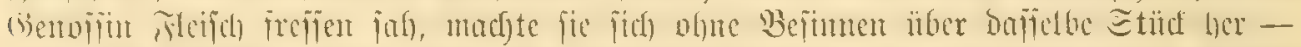

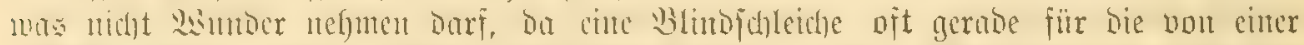

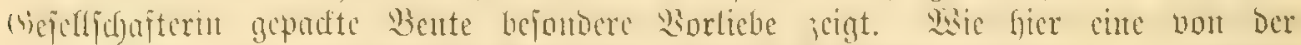

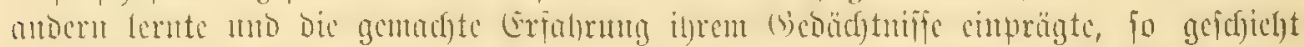

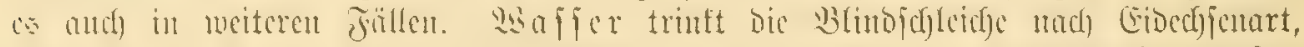

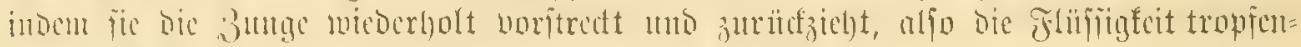
meije auflect.

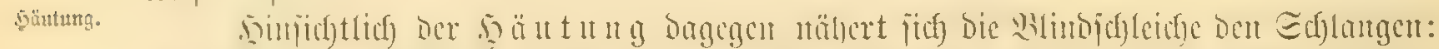

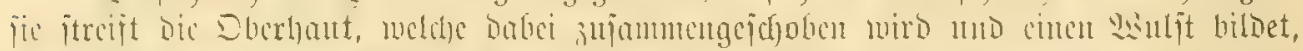

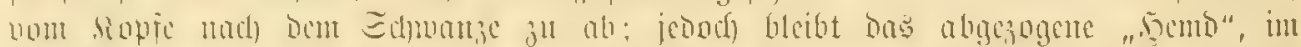

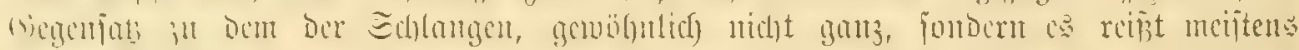

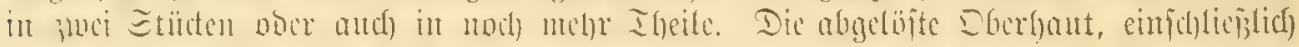

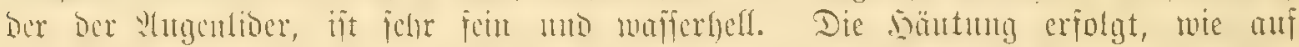

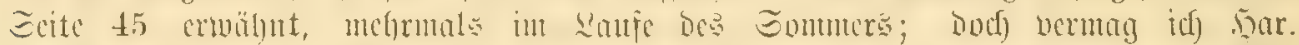

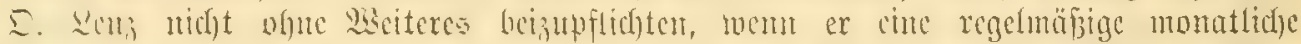

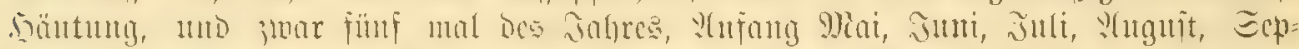

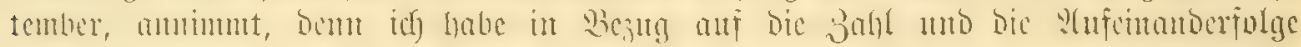

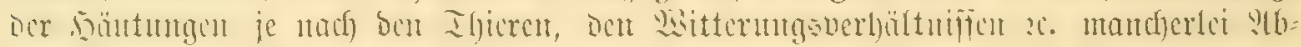
weidfungen ivaljrgenommen.

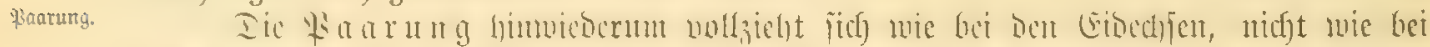

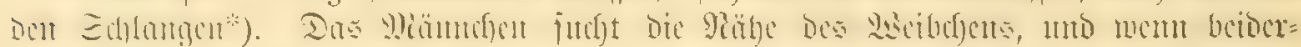

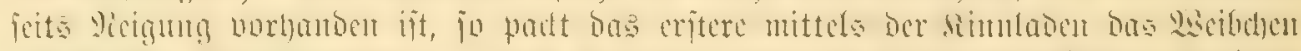

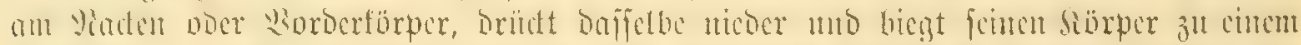

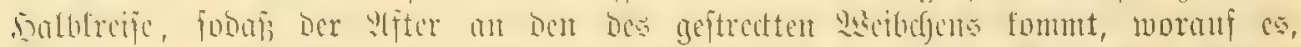

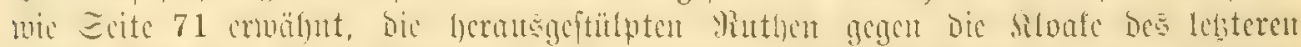

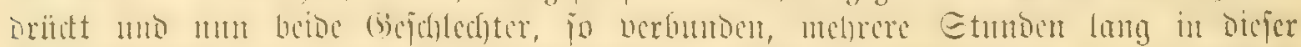

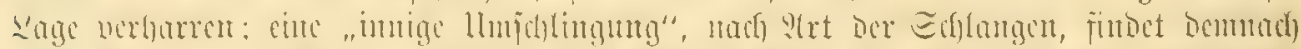

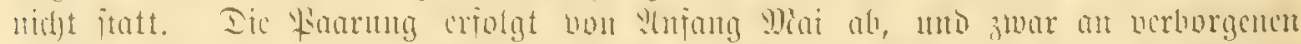

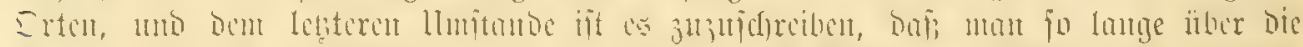

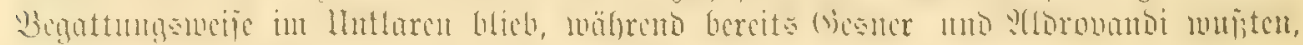

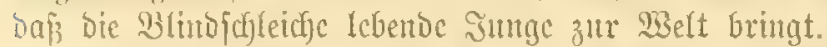

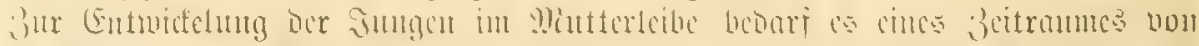

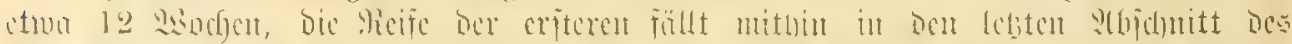

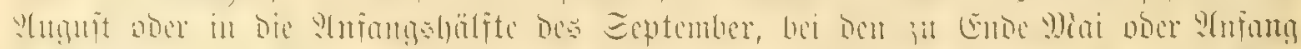

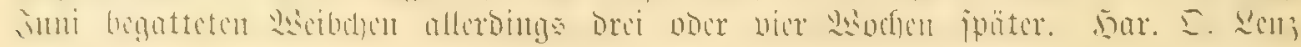

*) Das ift aber erit vor jwei Gabrzelynten ieftgeftellt; bie erite fidjere Beobadjtung barüber murbe

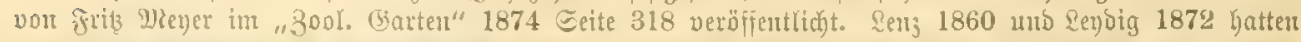

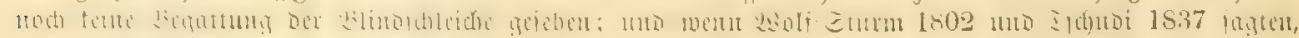

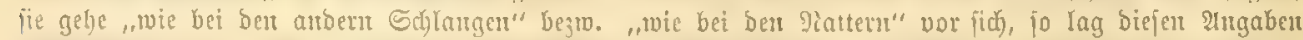

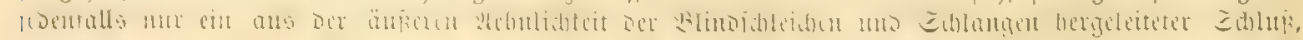
nidyt aber eine wirtliche 28 abrutebmung 310 (5imbe. 


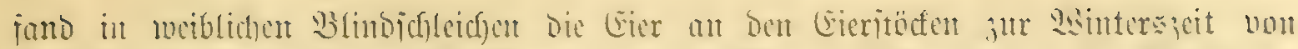

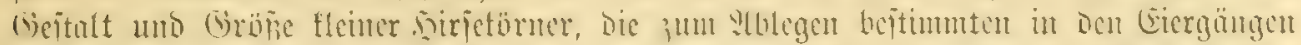

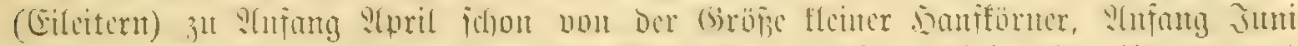

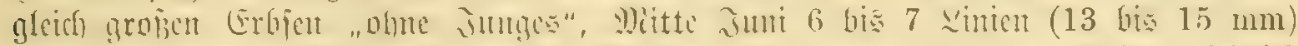

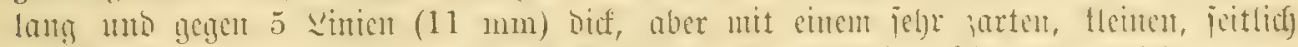

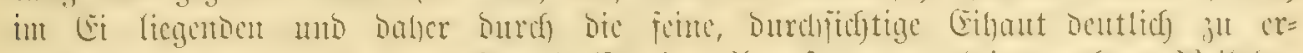

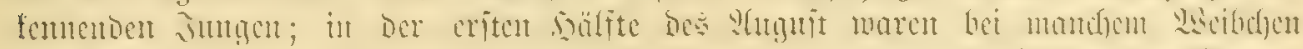

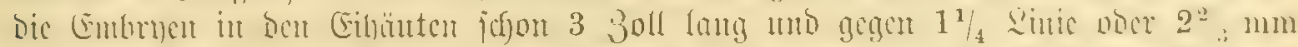

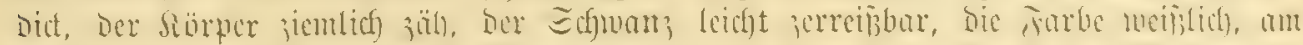

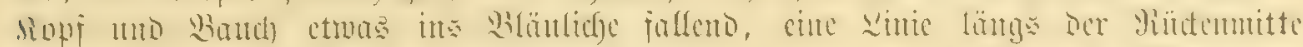

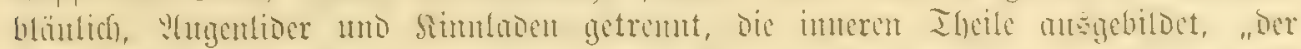

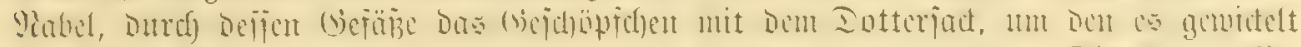

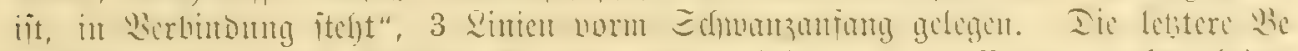

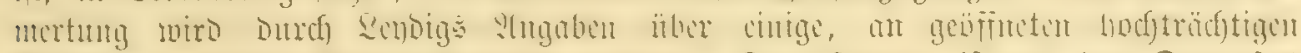

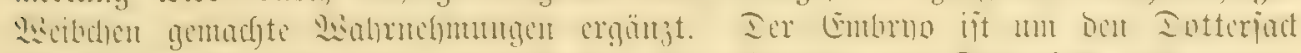

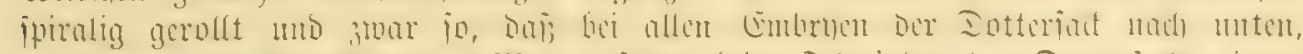

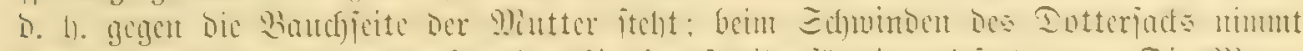

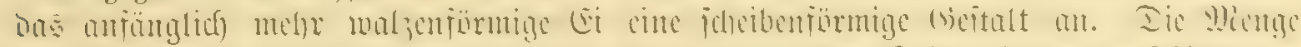

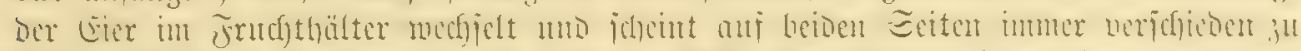

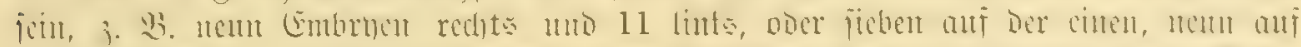

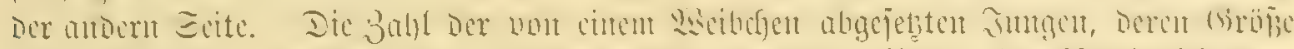

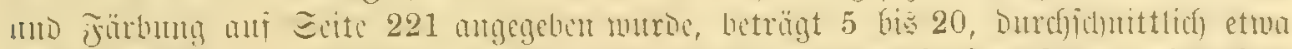

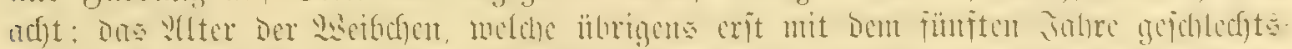

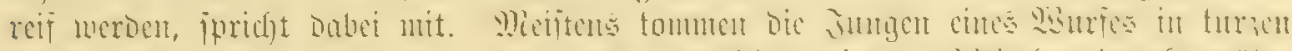

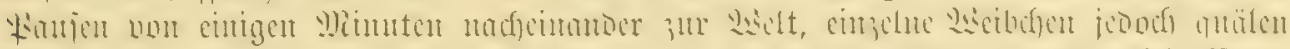

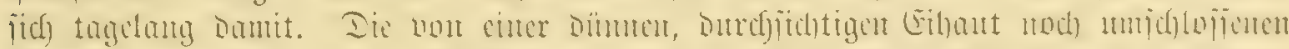

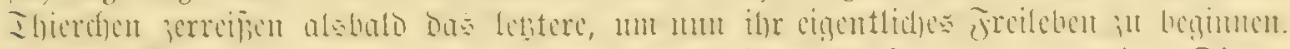

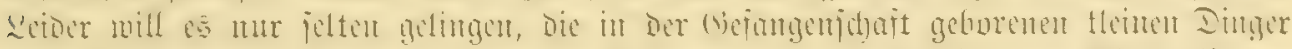

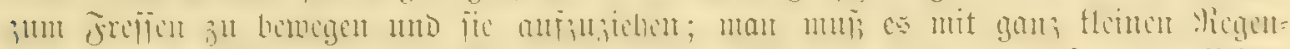

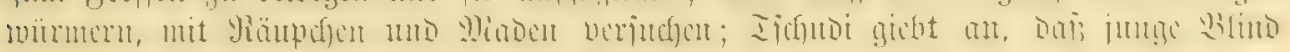

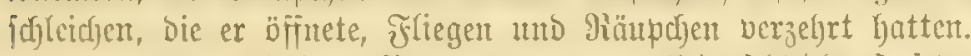

Za

Mantet.

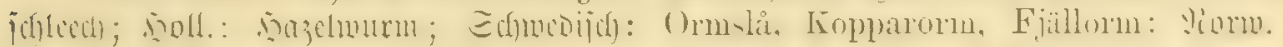
Blindonw. Kóbherslauge: Ëngl. : S'uwworm, Blindworm : Fran;.: Orvet f Invm, Anvan,

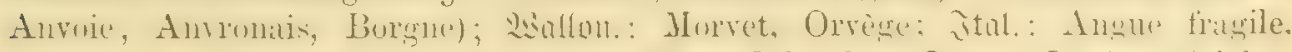

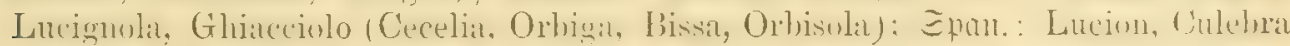

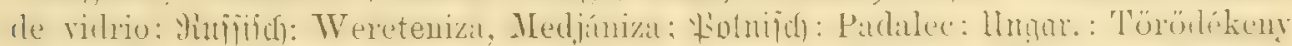

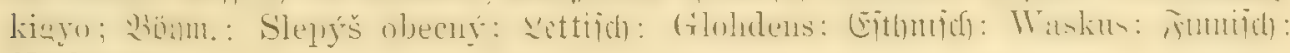
Vaskikärme.

Caecilia s. Typhlus graecis, Gesner 1621 [Serp. V, p. 36] - Caecilia vulgaris, Aldrov. 1640. - Caec. typhlus, Ray 1693. - Anguis fragilis et A. eryx, Linné 1758. - Anguis clivica et lineata, Laurenti 1768. - Erix cli-

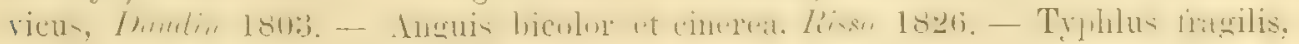

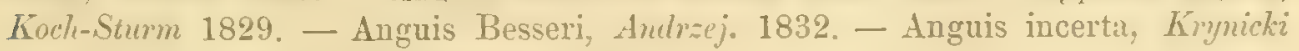
1837. - Otophis Eryx, Fitzinger 1428. 


\section{Südenropaifhe Edfen.}

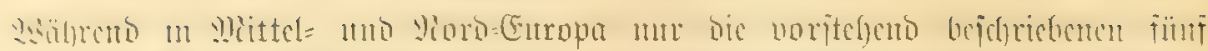

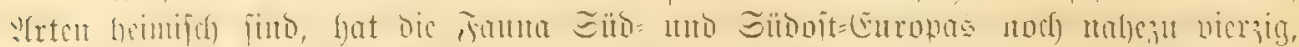

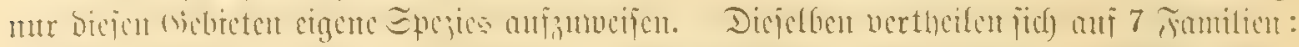

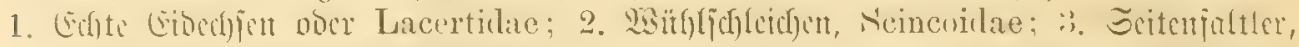

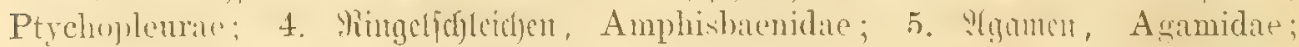
6. Saftzeher, Geckonidae; 7. Éamüleonæ, Chamaeleontidae.

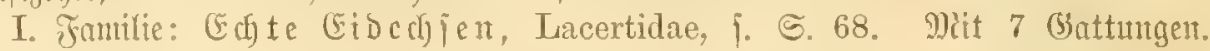
lleberitid:

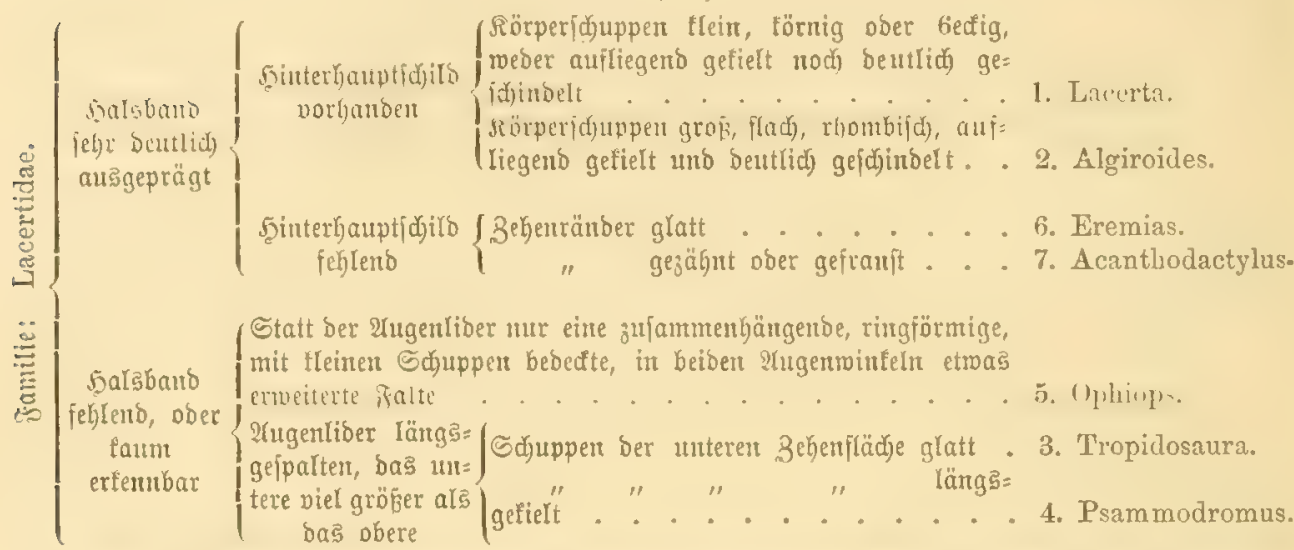

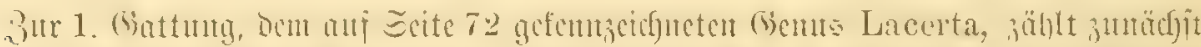

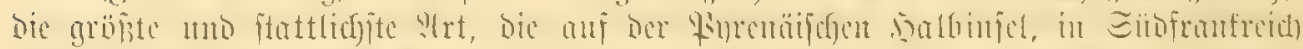

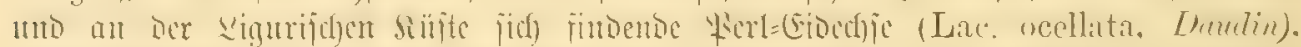

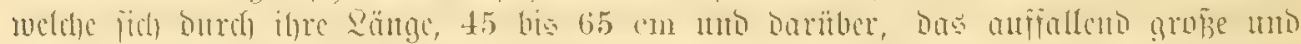

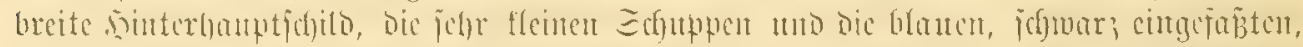

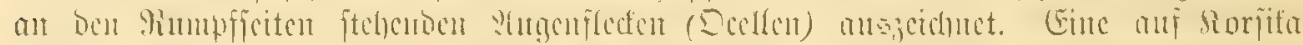

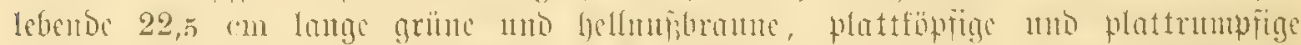

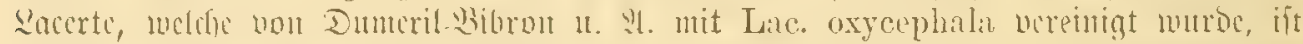

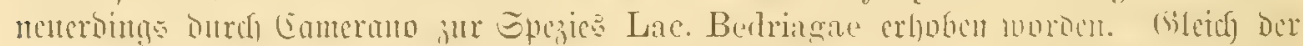

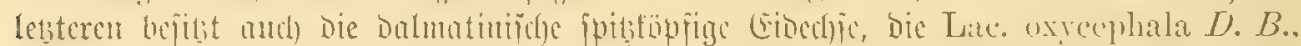

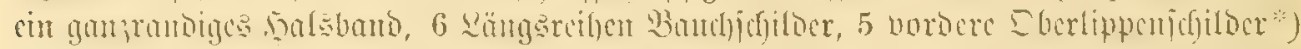

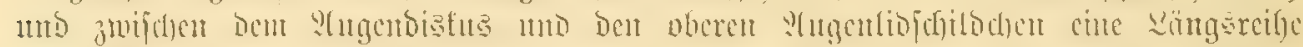

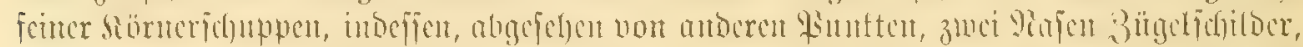

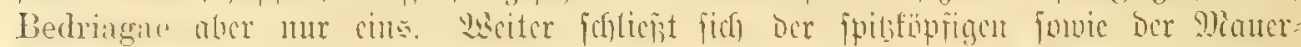

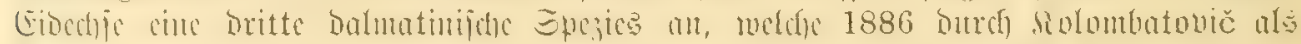

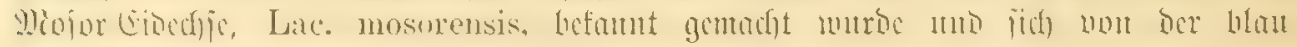

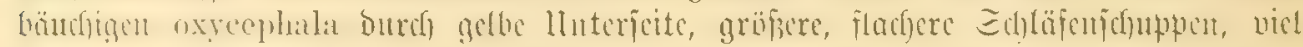

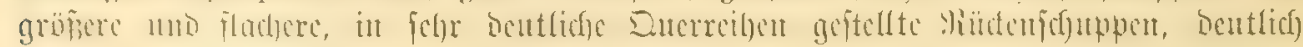

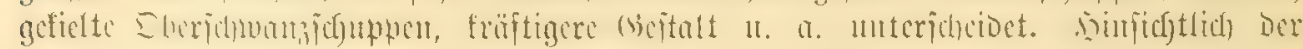

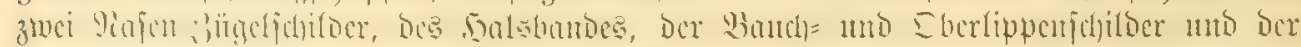

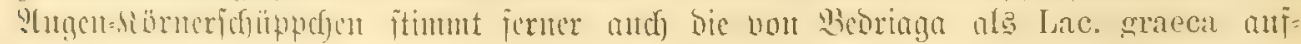

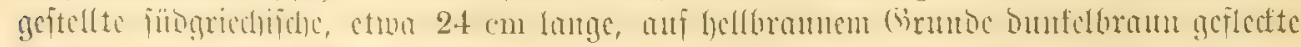

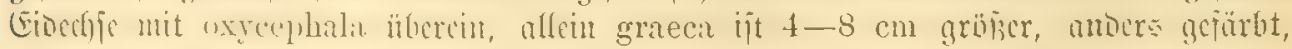




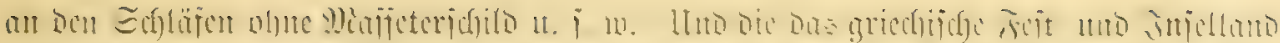

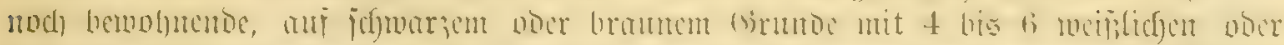

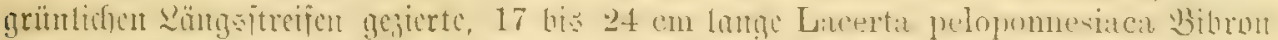

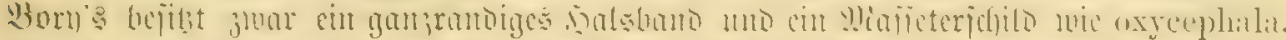

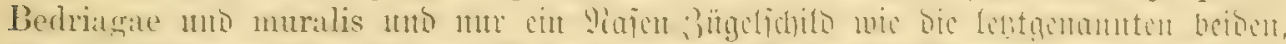

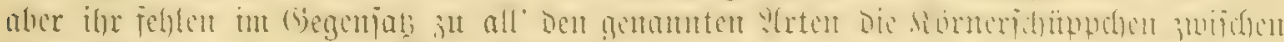

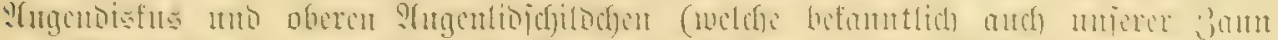

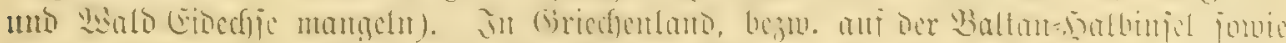

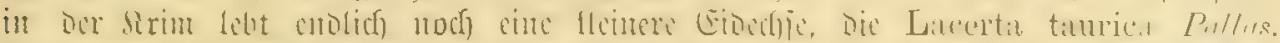

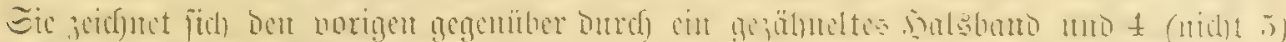

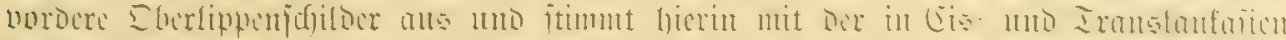

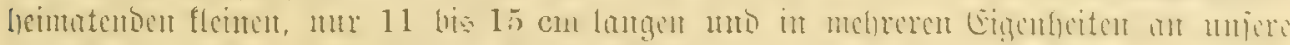

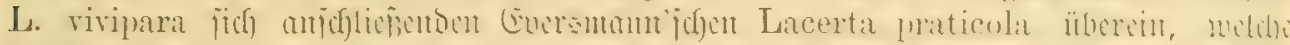

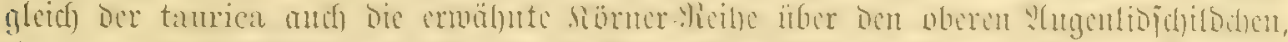

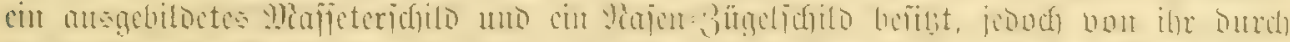

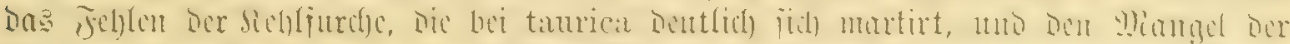

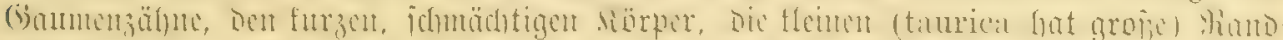

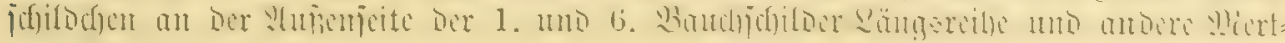
male fid unterforeibet.

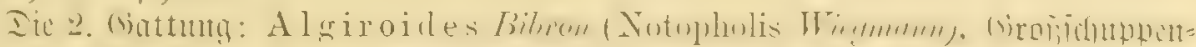

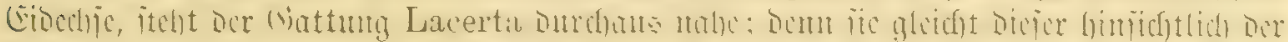

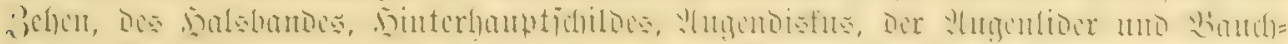

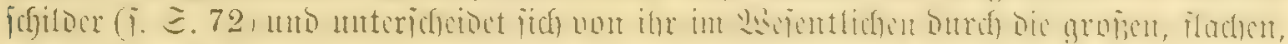

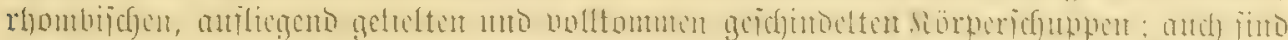

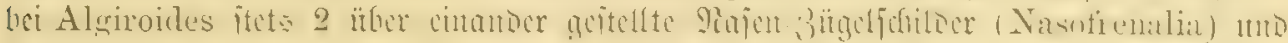

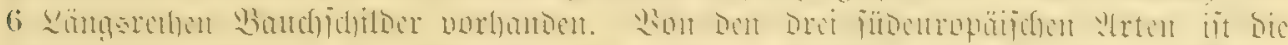

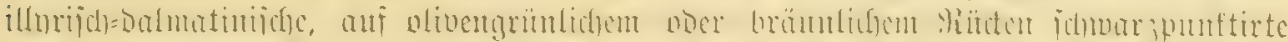

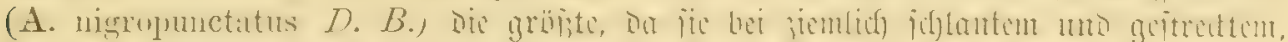

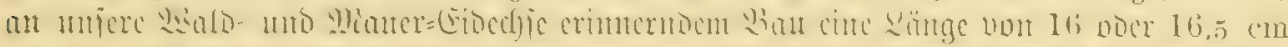

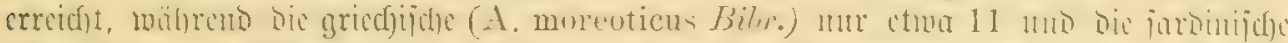

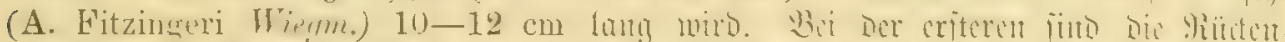

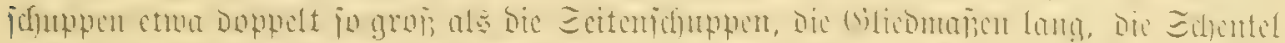

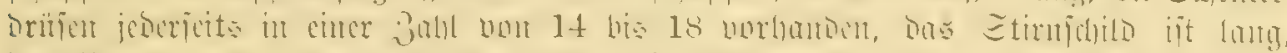

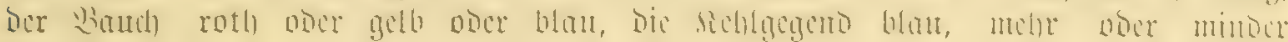
gefledt.

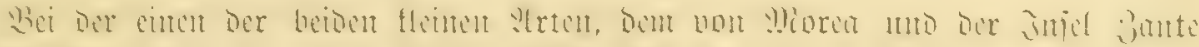

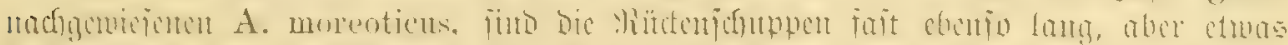

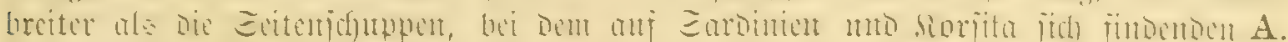

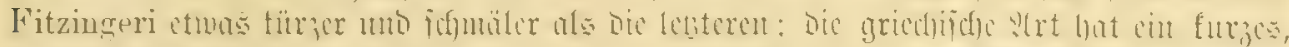

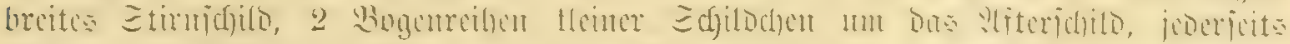

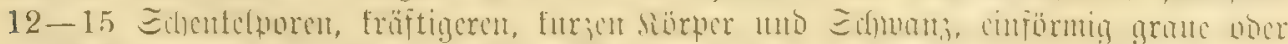

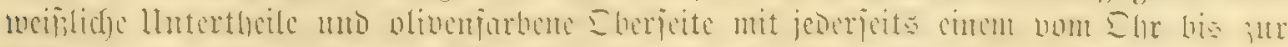

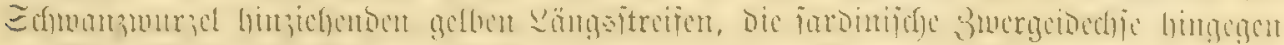

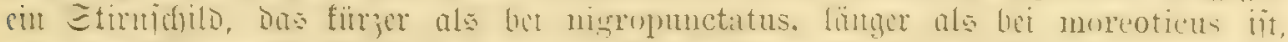

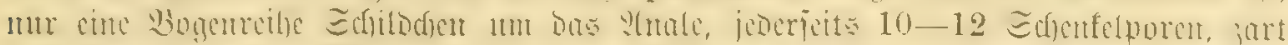

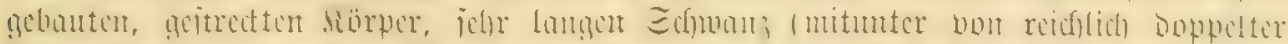

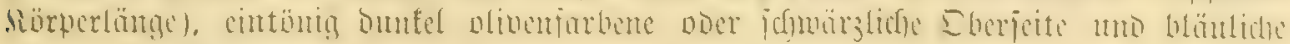
doce gelbe linterjeite. 
Iic 3. (Bottunty: Tropidosaura Fitzinger (Psammuros Wayle'), Dic Siel=

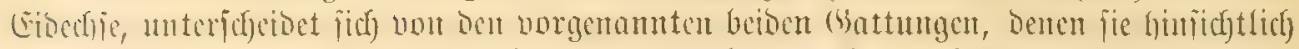

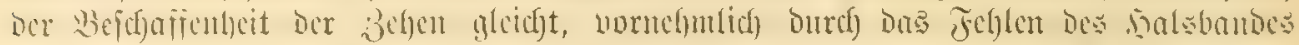

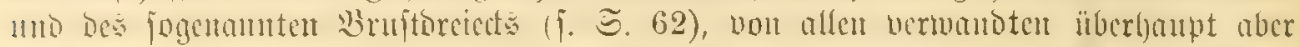

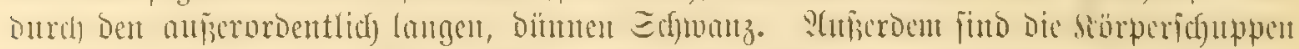

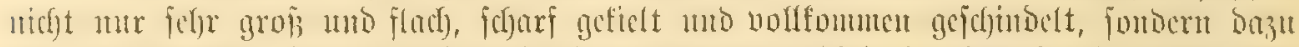
am ñuterranto infolge bes ftachelartig verlämgerten siels in cine jimlich longe und

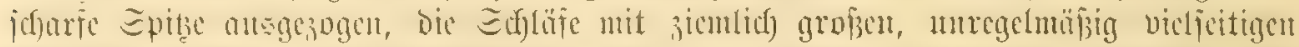

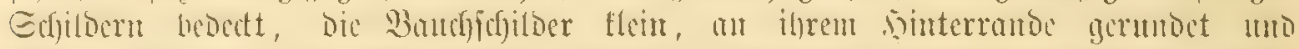

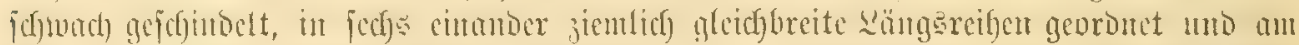

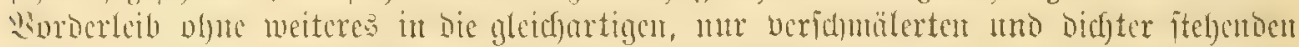

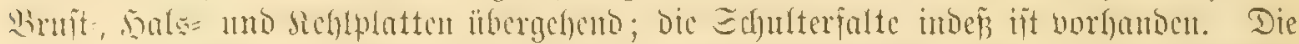

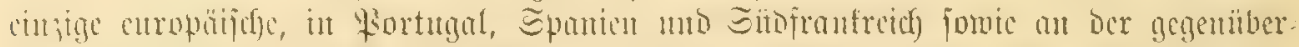

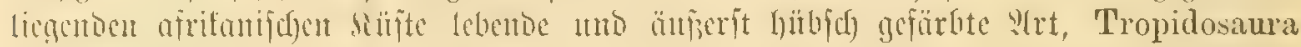

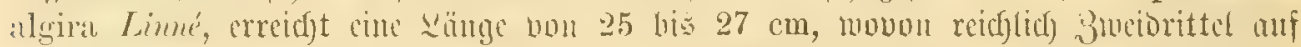

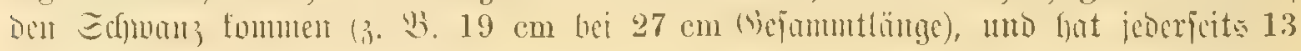
bi: 18 Sdienteliporct.

Dic 4. (sottung: Psammodromus Fits, Embläufor, gat jumar glcich bon

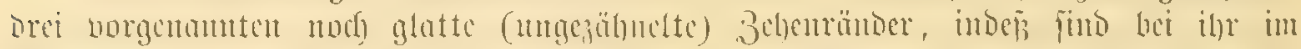

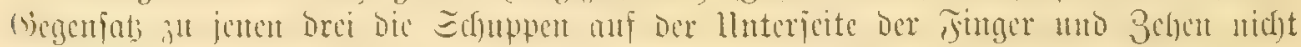

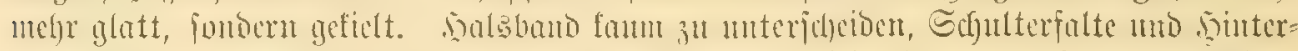

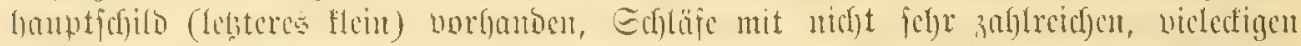

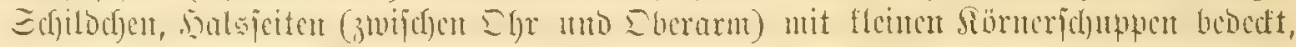

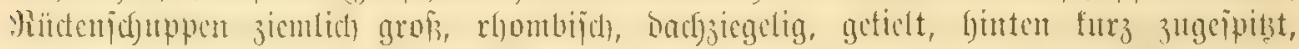

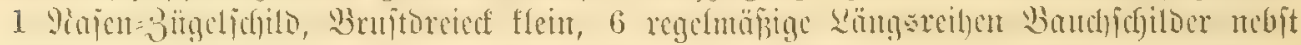

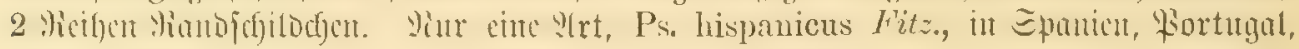
Sitbfranfretd), $10-13 \mathrm{~cm}$ lang, mit $9-15$ Sdjenfilporen.

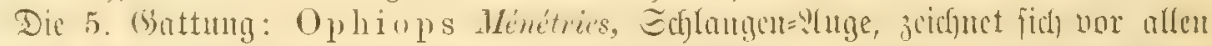

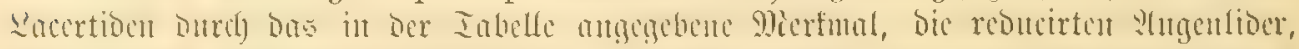

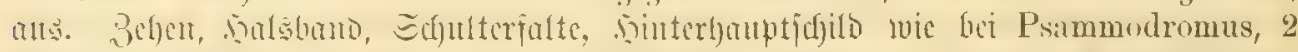

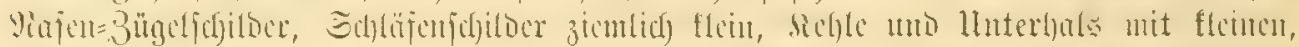

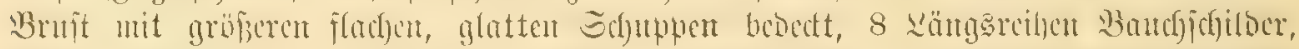

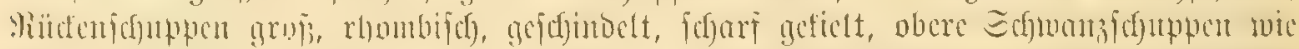

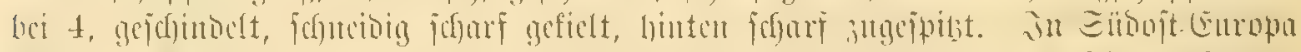

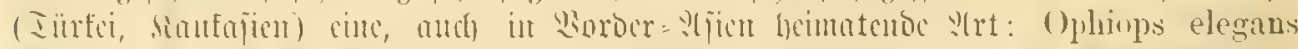

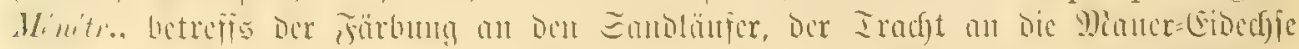

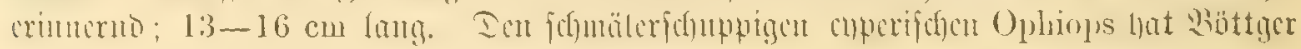
als 0 . Schlueteri aufgeitellt.

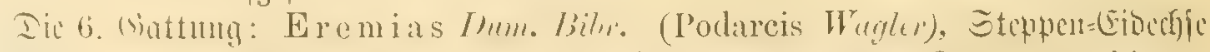

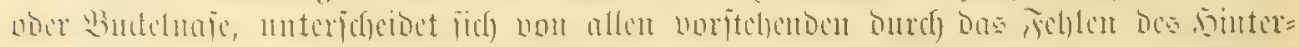

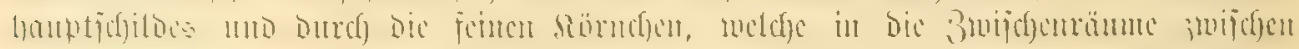

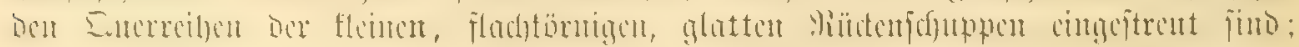

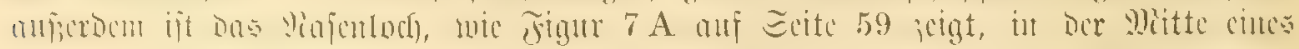

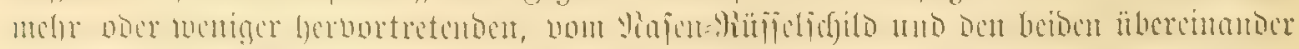

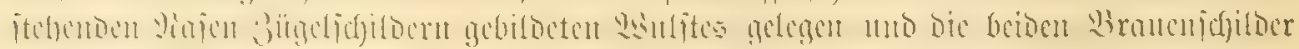

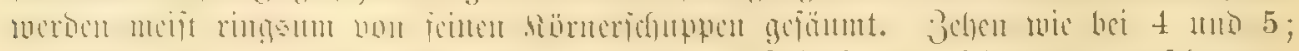

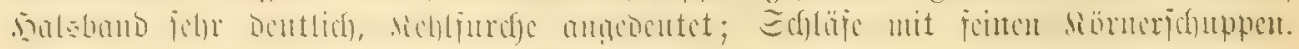

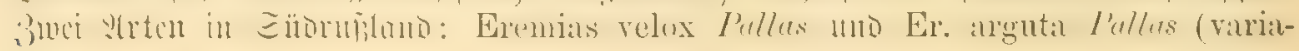




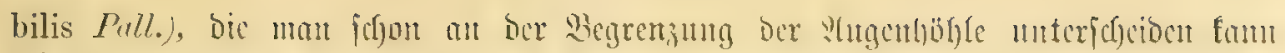

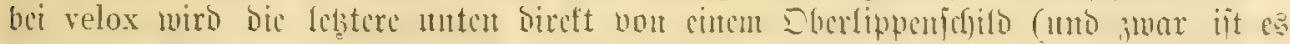

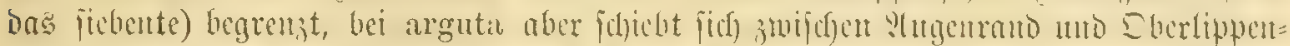

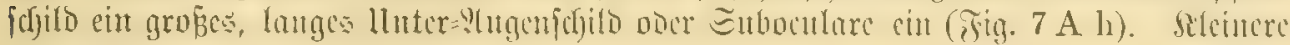
Eidectgien von etwa $16 \mathrm{~cm}$ \&änge.

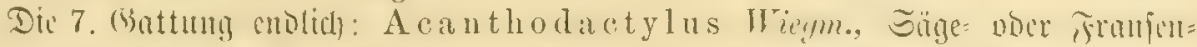

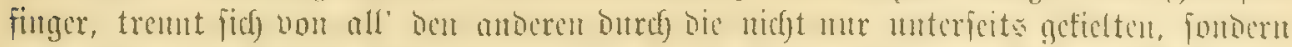

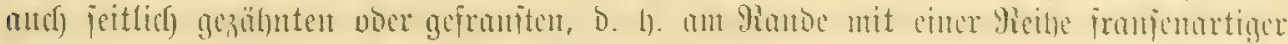

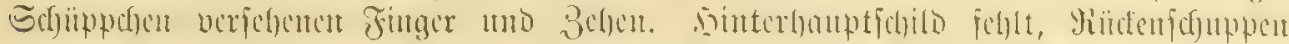

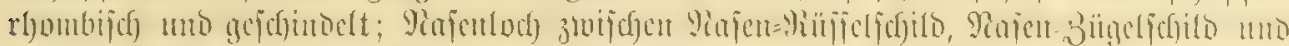

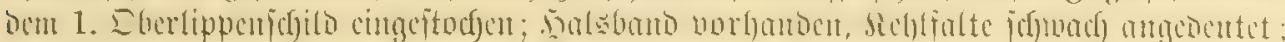

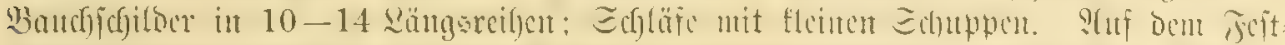

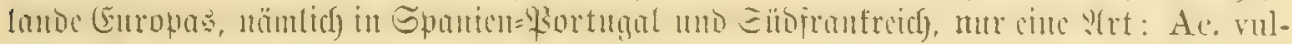

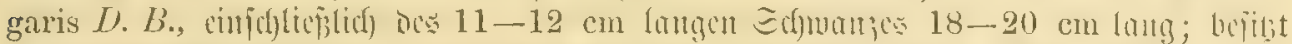

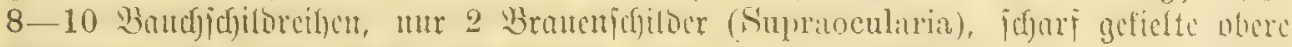

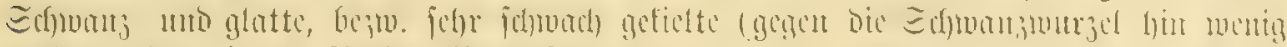

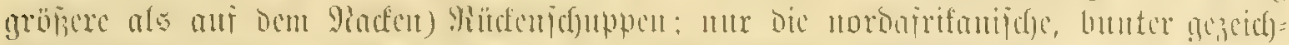

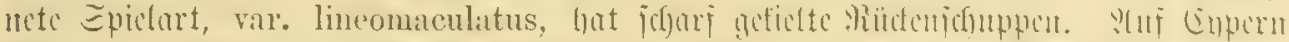

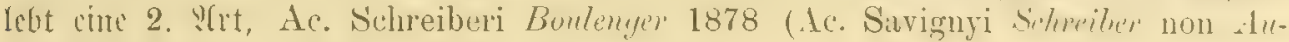
douin), etwa $17,5 \mathrm{~cm}$ lang, mit 4 Bratenjefifbern.

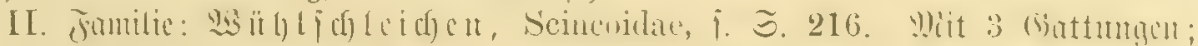
unfere bentiche Battung Anguis bat feinen weiteren Bertreter.

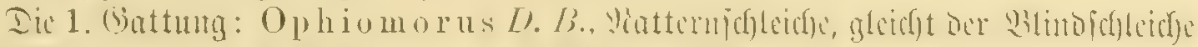

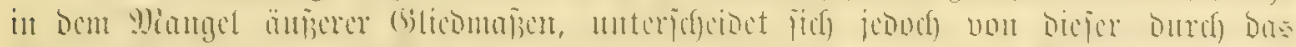

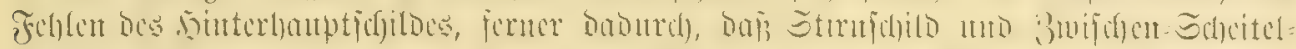

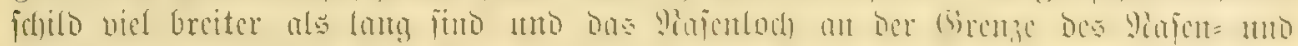

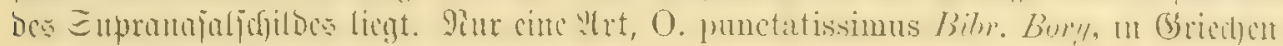
lano unto Siccinafien, ctrva $30 \mathrm{~cm}$ lantg.

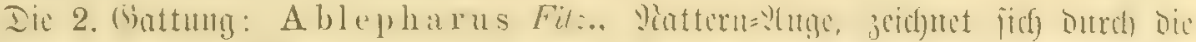

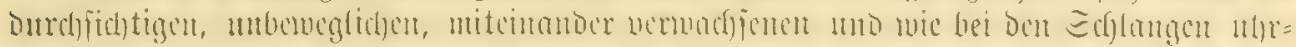

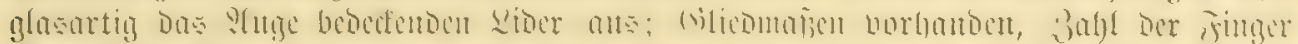

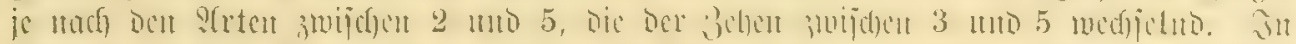

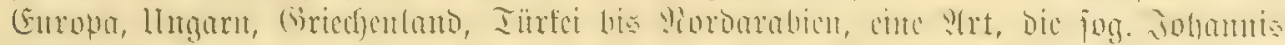

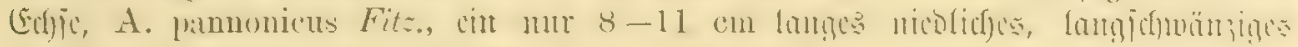

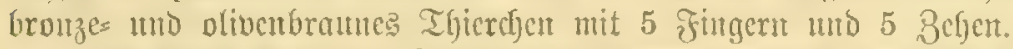

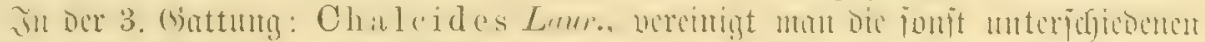

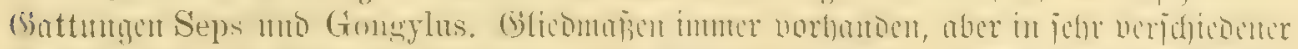

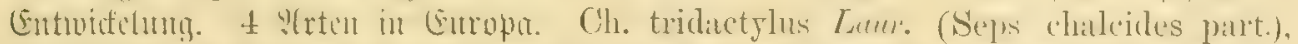

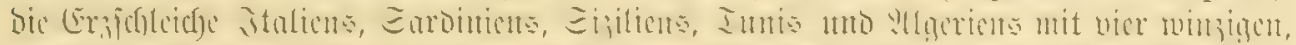

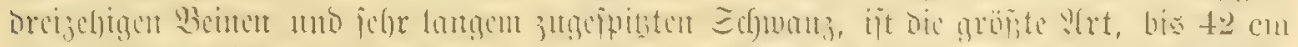

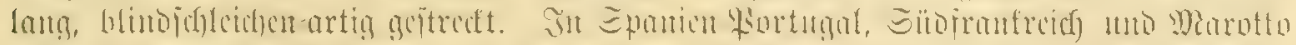

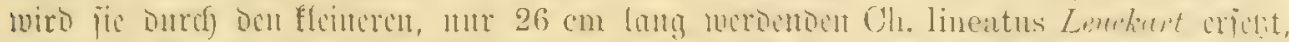

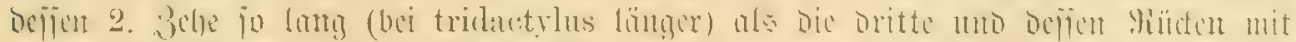

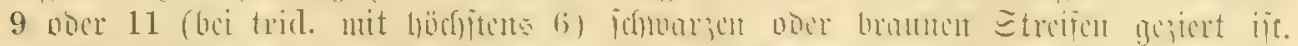

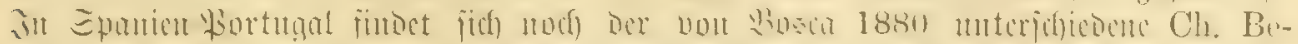

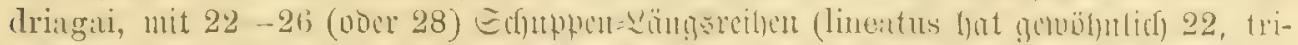

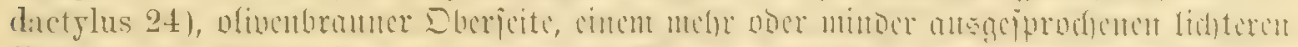

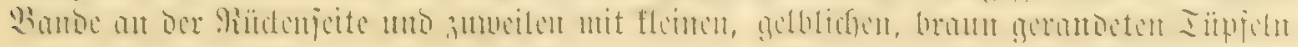




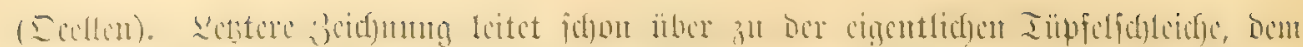

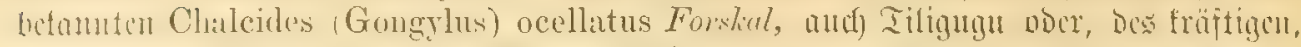

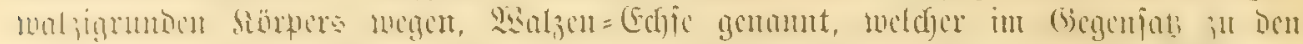

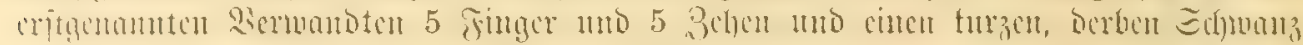

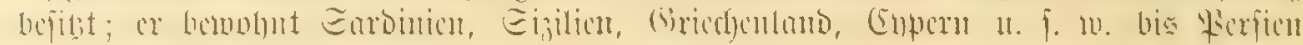
mo Somalilano.

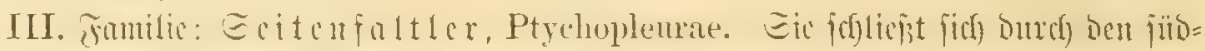

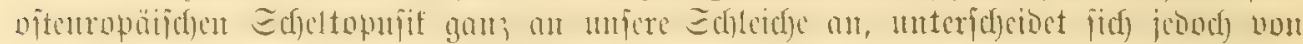

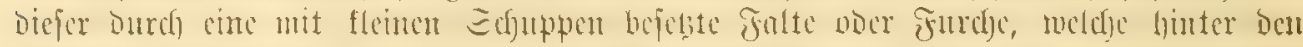

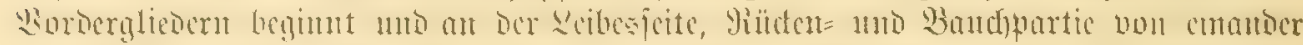

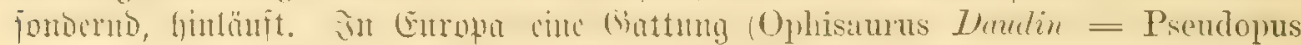

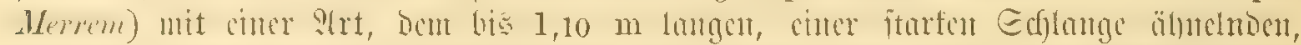

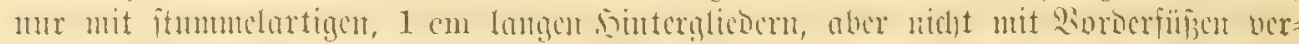

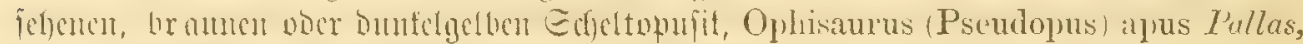

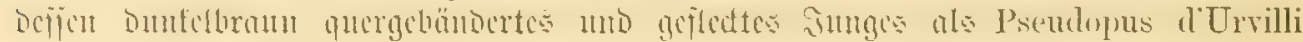
won Euvicr bejurieben tourbe.

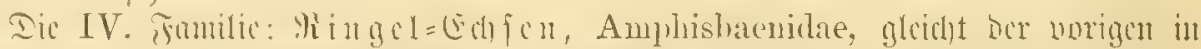

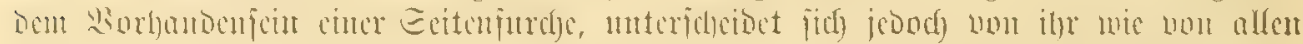

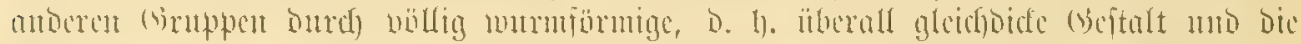

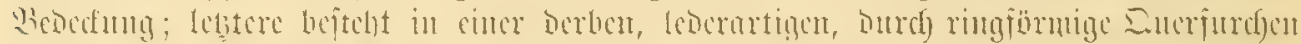

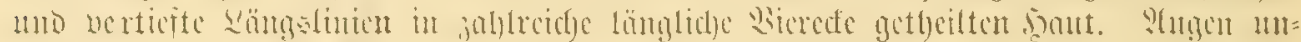

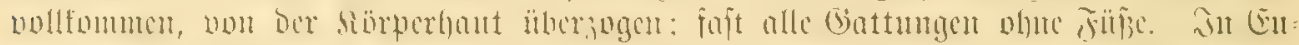

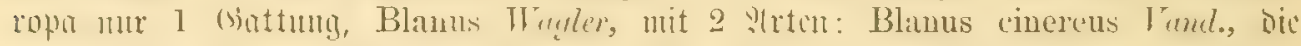

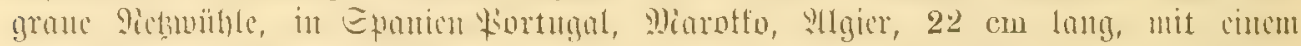

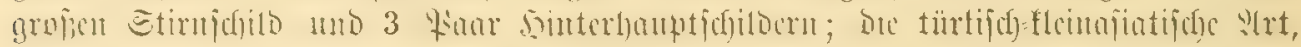

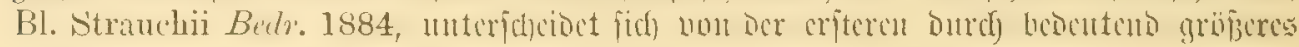

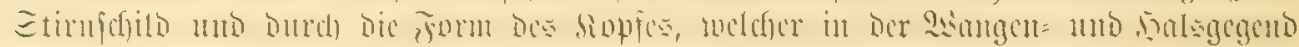
bicl breiter, in Der Sđjnatzengegend fdjmäler al: bei cin. ift.

V. Familic: :" g a

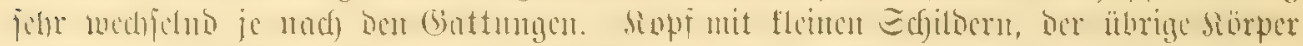

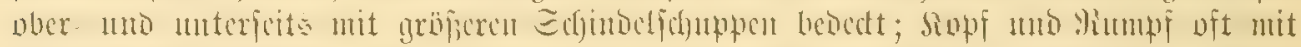

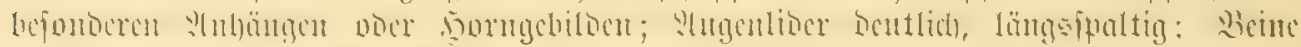

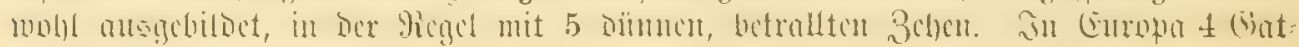

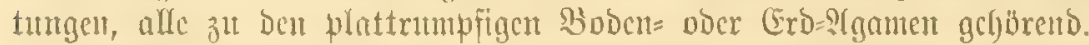

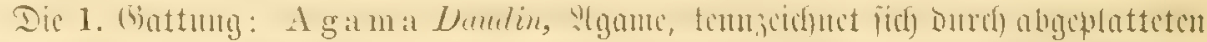

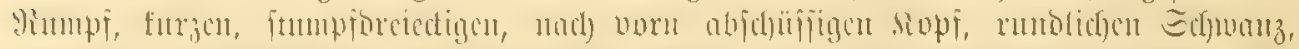

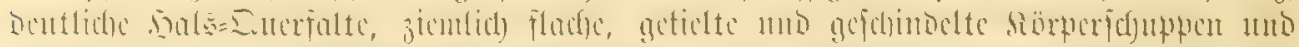

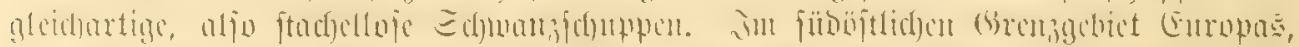

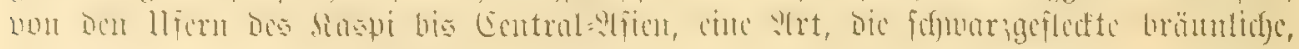
$32-40 \mathrm{~cm}$ lange A. sanguinolenta Pallas.

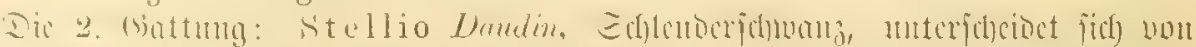

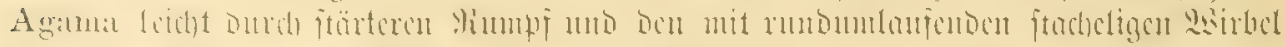

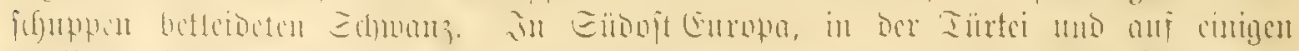

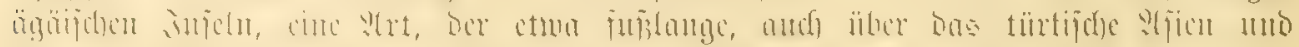

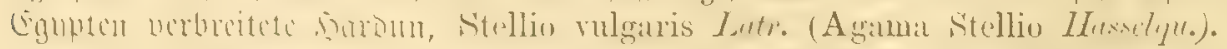

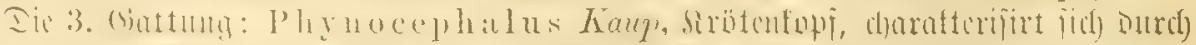

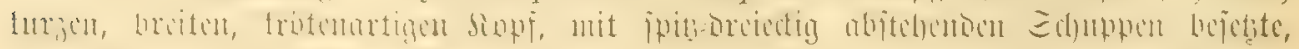

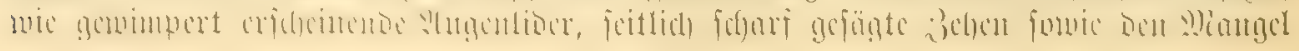




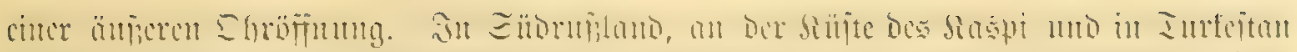

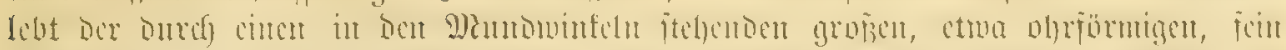

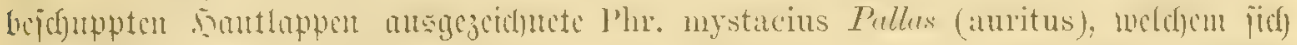

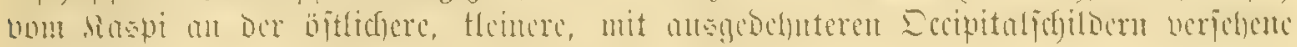
Phr. helioscopus Pall. uralensis Gmelin) autichlief̧t.

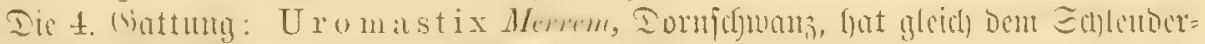

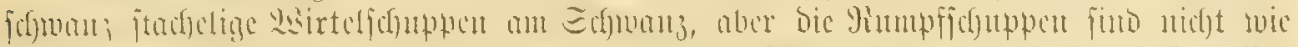

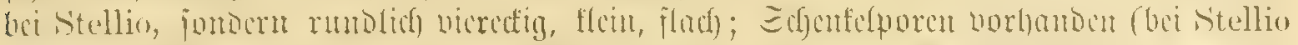

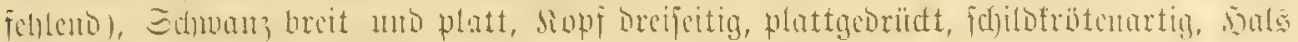

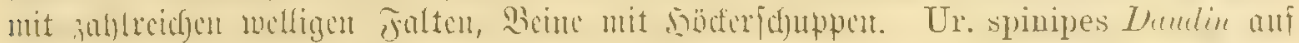
Sreta, in Egnpten und ?trabien.

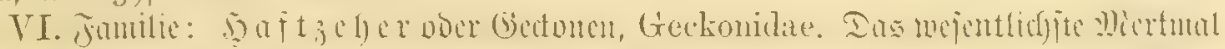

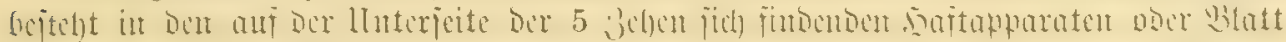

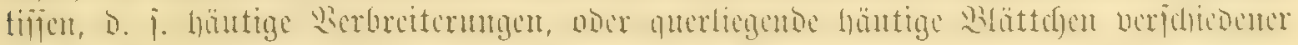

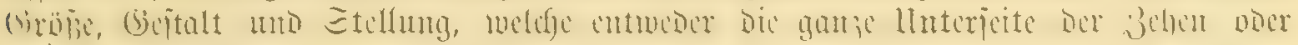

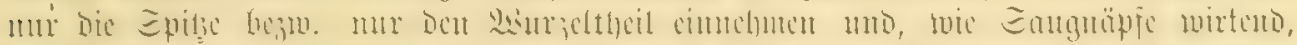

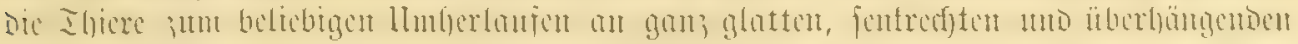

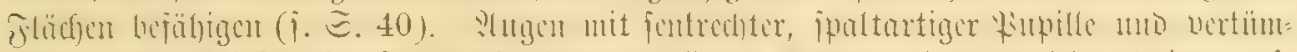

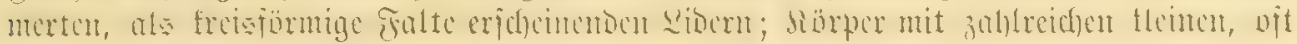

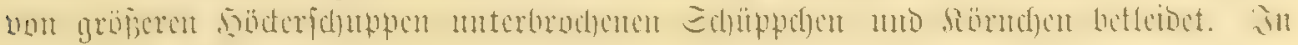
Europa 4 Battumgen.

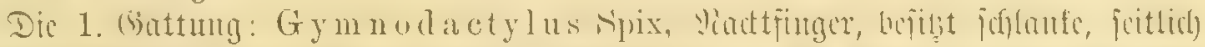

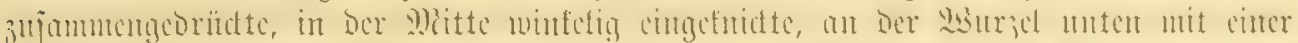

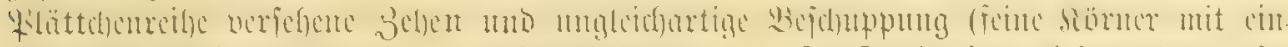

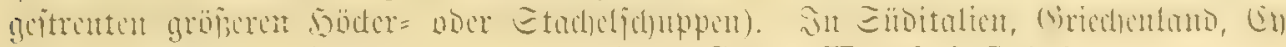
pern und weiter öjtlicf Der $8-10 \mathrm{~cm}$ Yange Gymn. Kotschyi Steind.

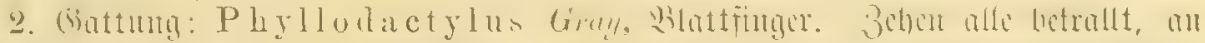

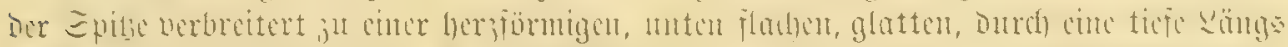

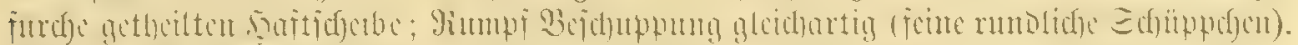

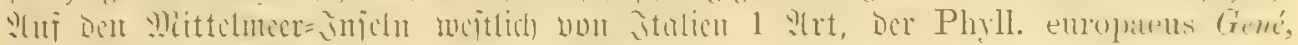
(Ph. Wagleri Fitz., Ph. Doriae Lataste), $7-8 \mathrm{~cm}$ lang.

3. Gattung: Hemidactylus Cuvier, Sctjeibenfinger. Bctyen mit cincr bie

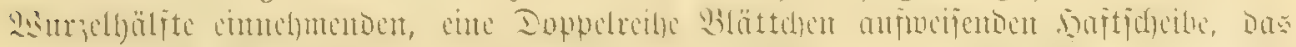

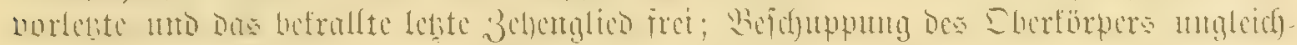

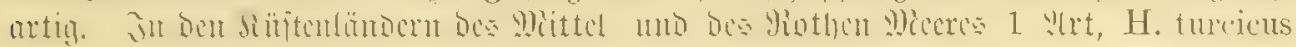
Linné (H. verruculatus Cuv.), $9-10 \mathrm{~cm}$ lang.

4. Giattung: Ta rentola Gray (Platydactylus Cuv. p.). Befjen mit einent,

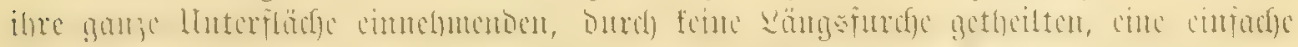

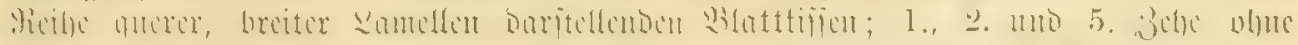

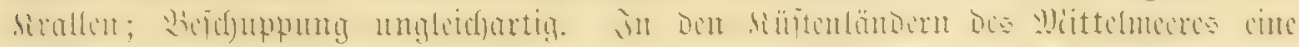

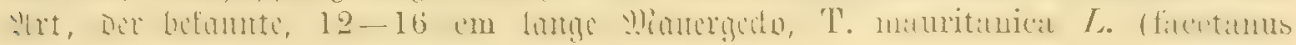
Aldror., muricatus Laur.).

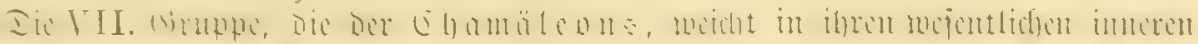

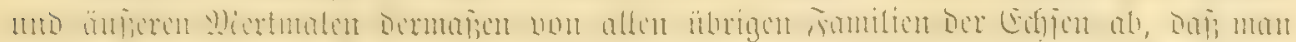

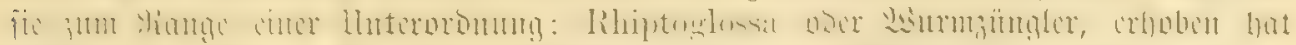

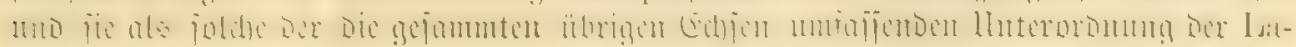

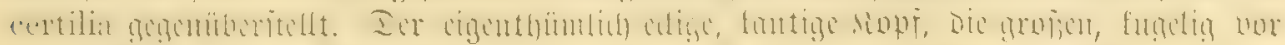

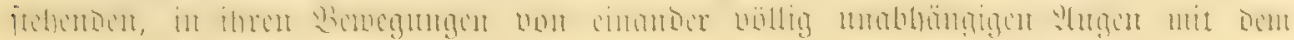




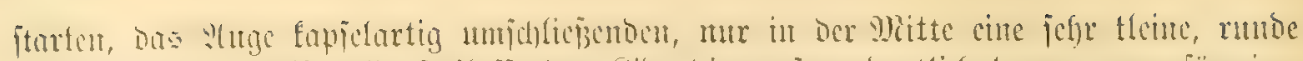

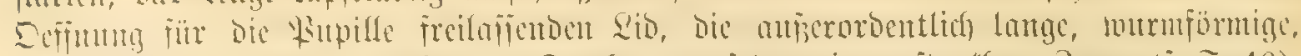

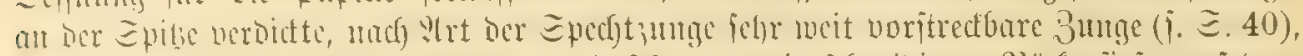

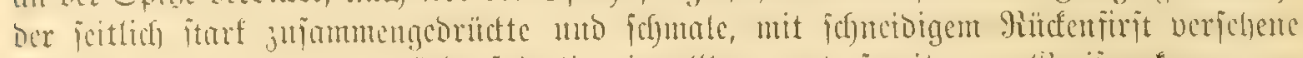

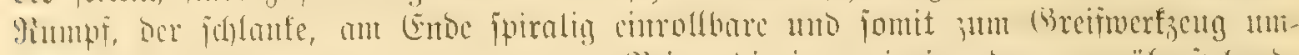

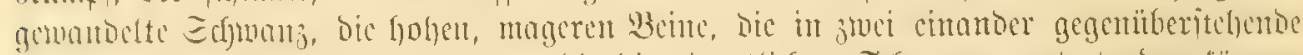

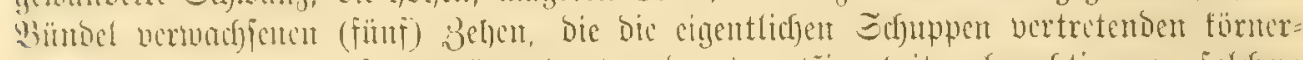

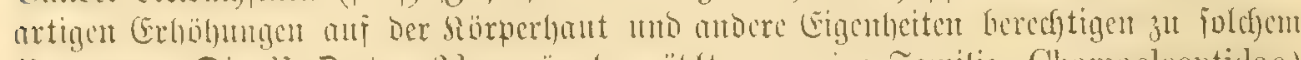

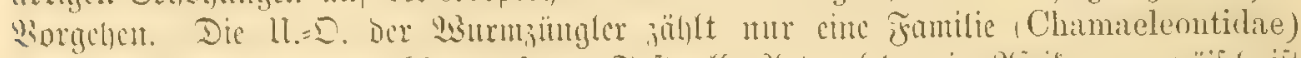

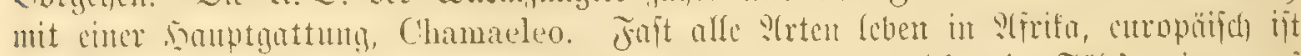

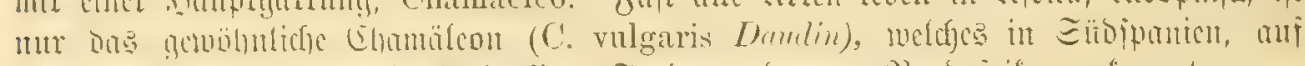

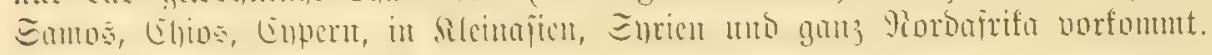

\section{III. (1)ronung. \\ Sd)lmager. Ophidia (serpentes).}

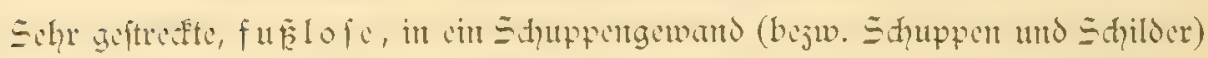

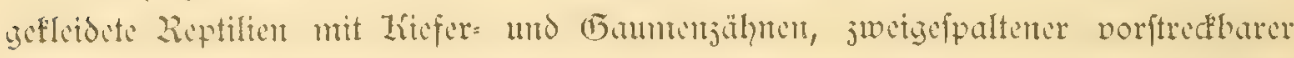

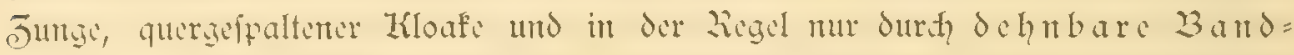

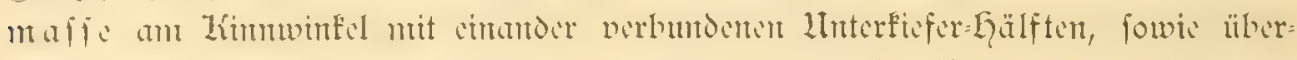

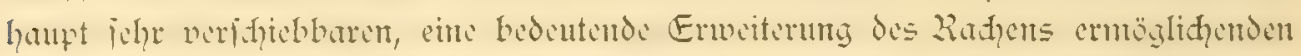

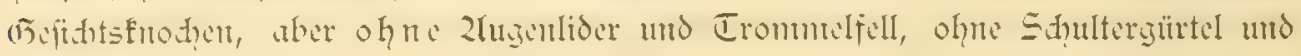
Bruitbein.

Sflangert uा⿰ ifibedjen.

Sörpcibuน.

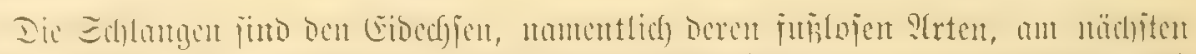

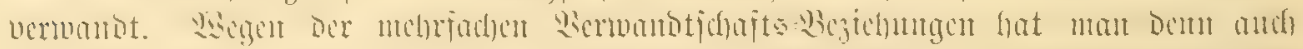

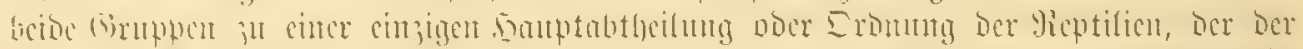

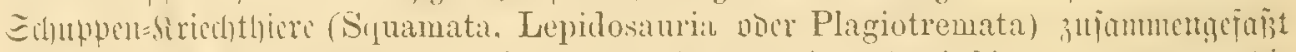

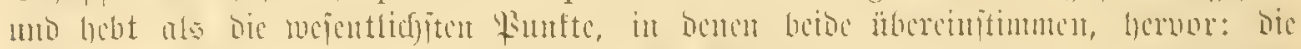

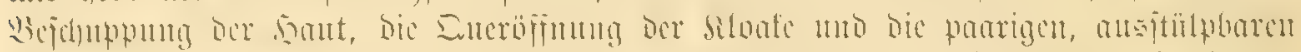

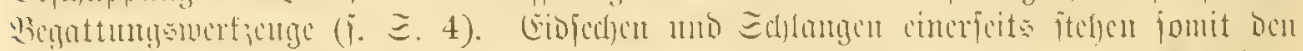

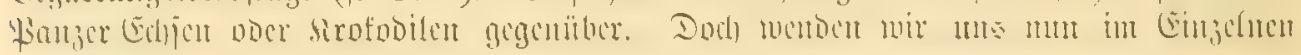
Dent Sclylangen zut.

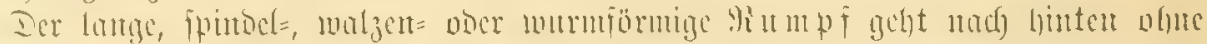

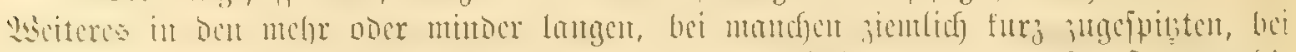

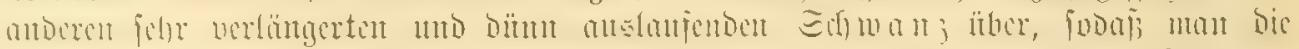

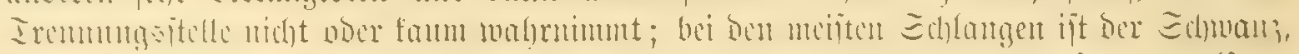

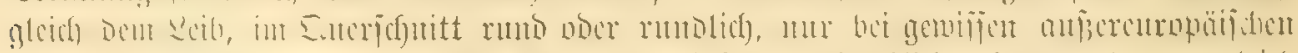

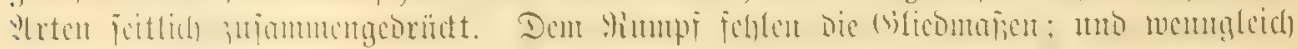

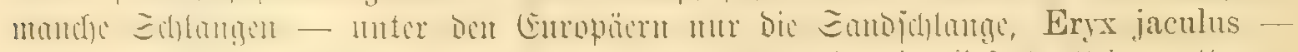

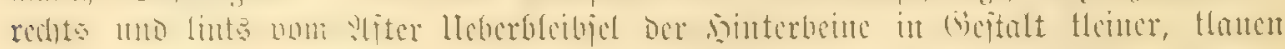

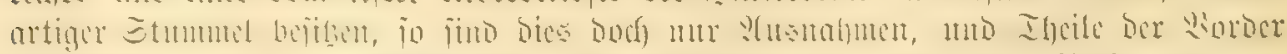

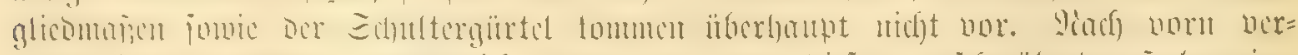

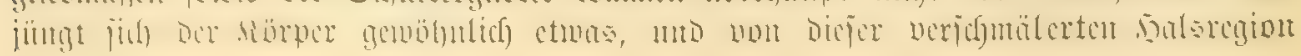




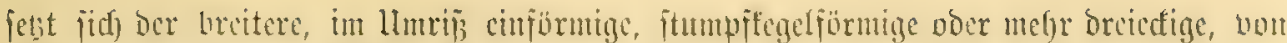

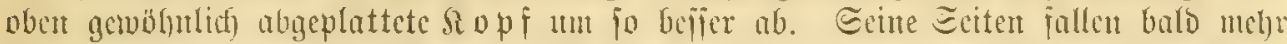

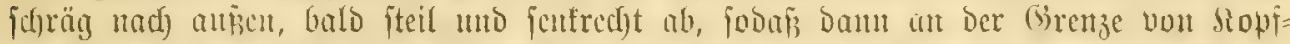

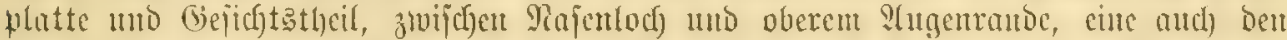

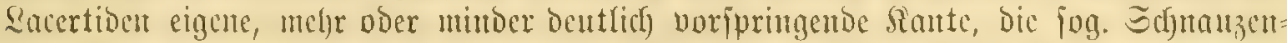

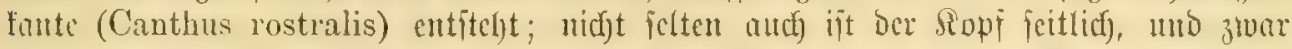

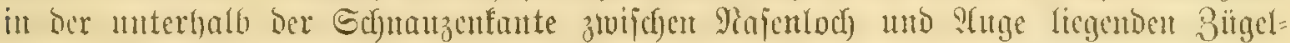
gegento (Regio frenalis), verticft, uno bie giftigen (Srutben= ober Sochottern vocr Cro-

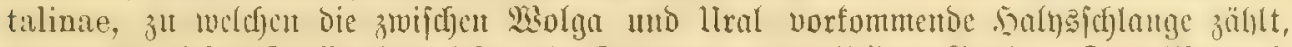
zeigen an biejer Etelle eine ticje, mit Edjupten ausgefleibete Girnbe. Das Mian ijt

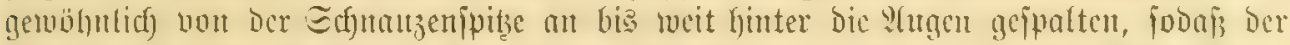

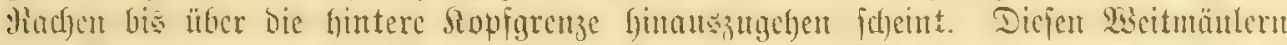

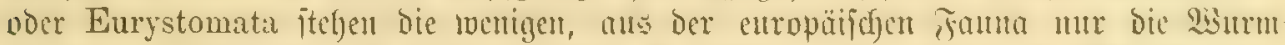
ifflongen (Thyphlops) in fidf begreifenocn Engmïufer (Angiostomata, Stenostomata)

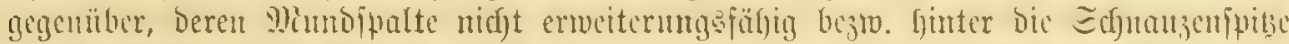

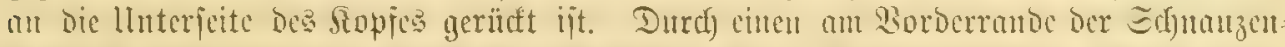

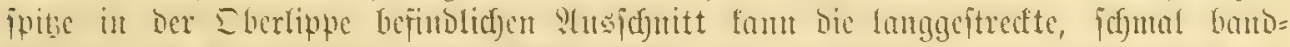

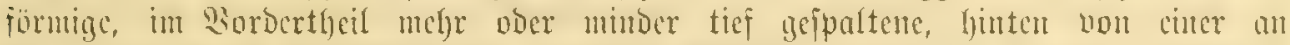

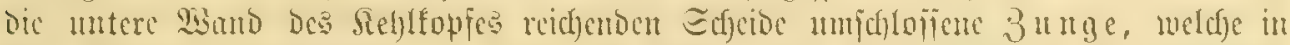

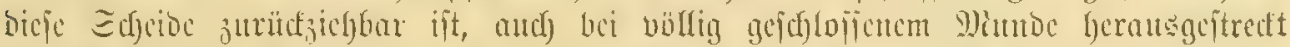

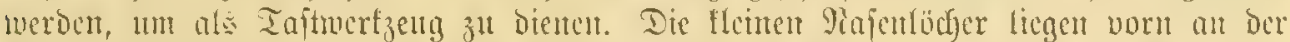

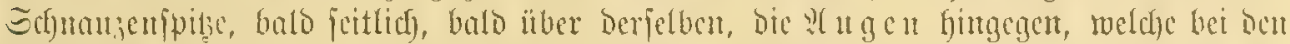

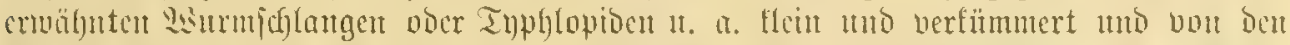

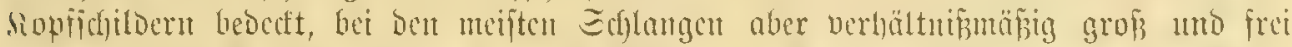

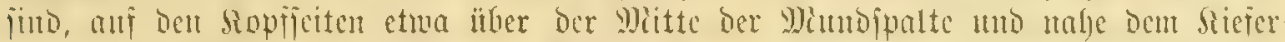

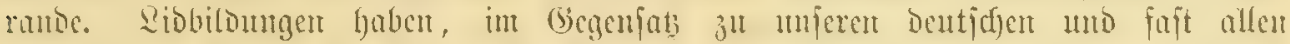

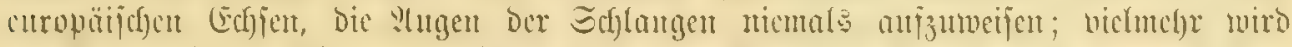

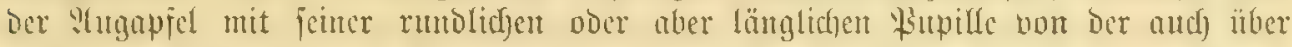

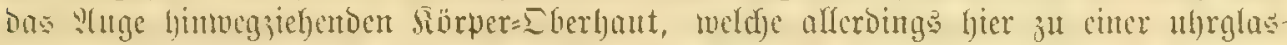

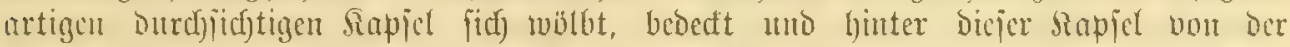

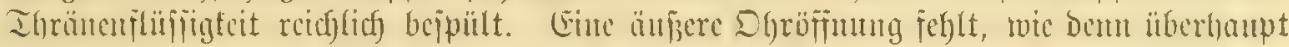

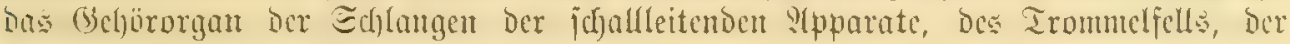

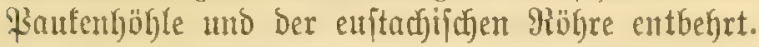

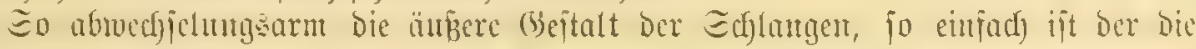
critere bebingendic Bau bes Sindefyengerifites, bas (veriple doir Etelet, wie cin Blitt anj ?t(b= bilountg 23 lef)rt. Dent, abgcichen won ben bei einigen Familien fitch nod) findenden titmumerlidjen Lleberreiten Des Bedfens IIIID Der Jeinterglico= maijou, icht iich do Stelct Der Scjlangent mur 3u[ammen aus bem Scjäbel mo ber \$yirbel=

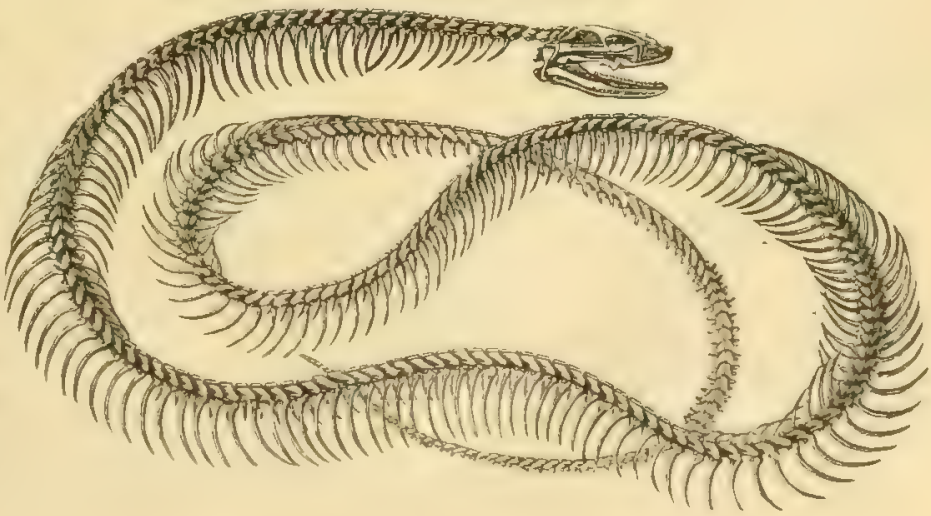

Fig. 23. Sfelet ber Saltange. 


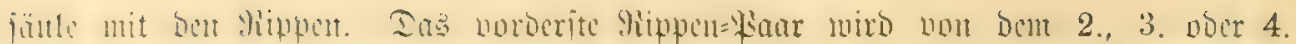

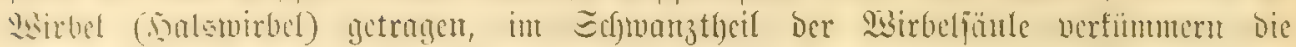

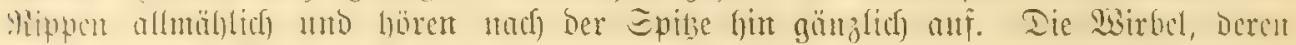

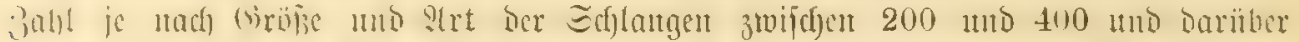

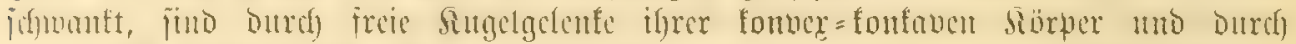

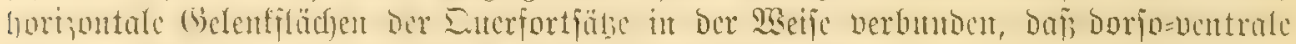

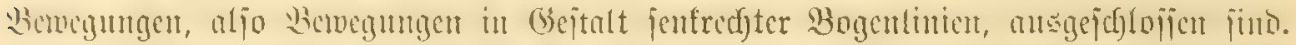

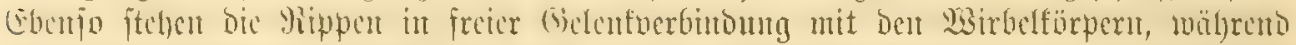

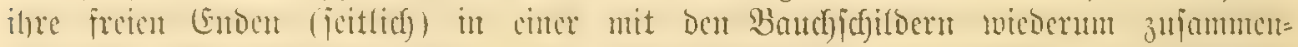

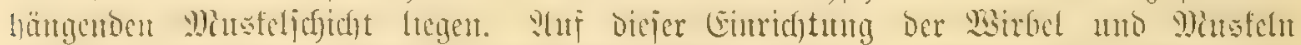

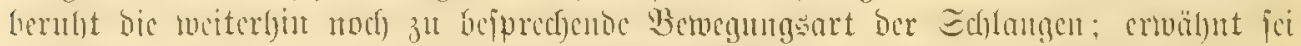

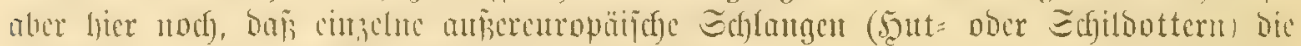

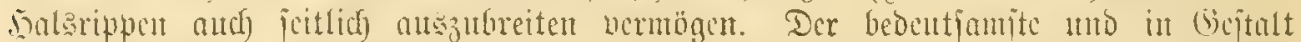

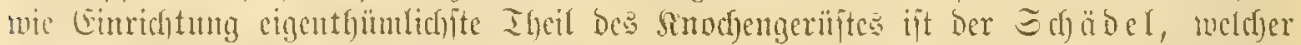

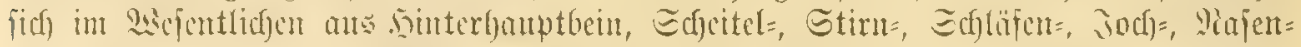

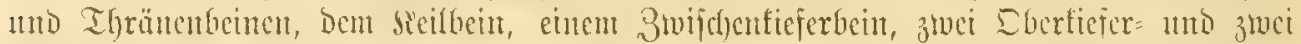

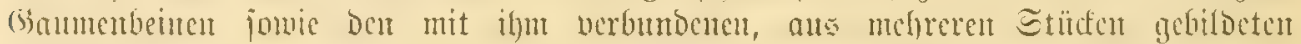
Ilnterfiferfnodien jufanmenjest. Eine llcberbrïdung Der Enjläfengegmo feblt. Die

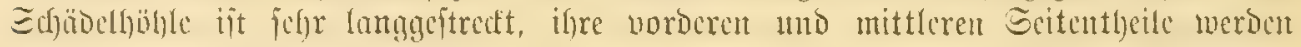

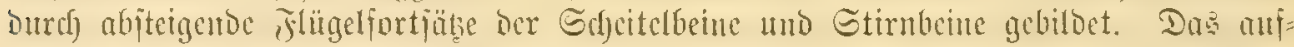
fallenofte und bejeidnendite Dierfmal bes Sdjäbels aber beruht, wie oben furg

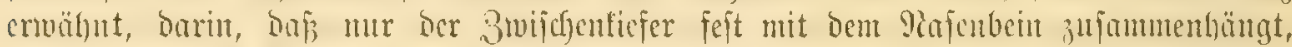

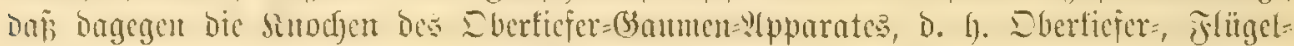

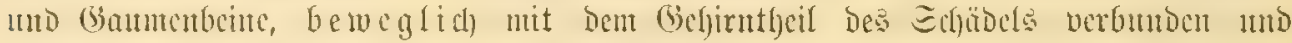

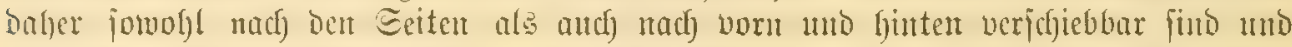

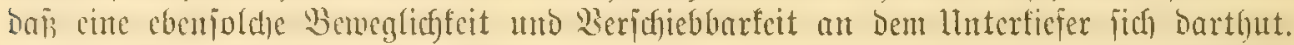

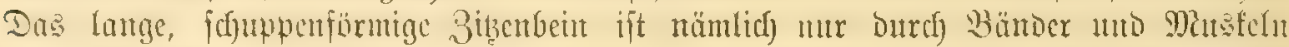
ant ninterbaupt angebejtet mo trägt an feinen Enbe bas gleichfolls lange, itub=

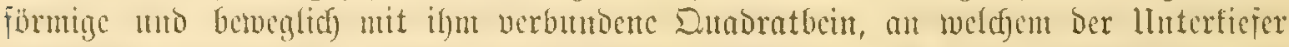

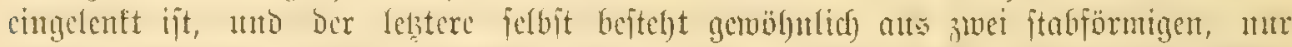
soenig gebogentr, völfig getrenuten, aljo vorn an Simminfd blos ourch loctere,

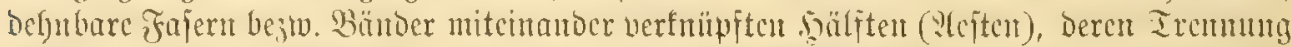

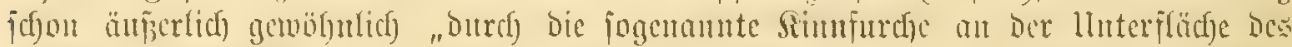

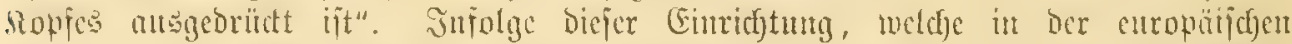

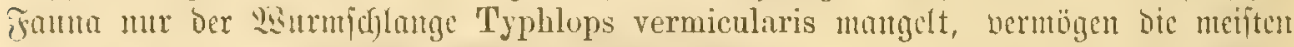

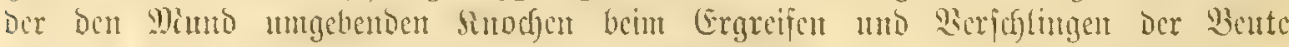

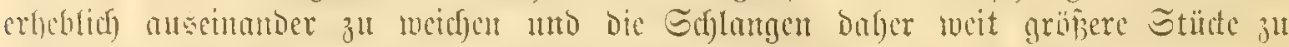

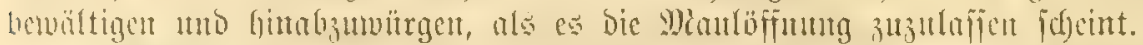

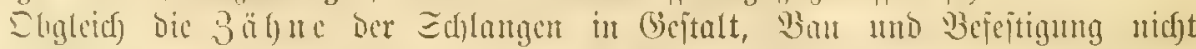

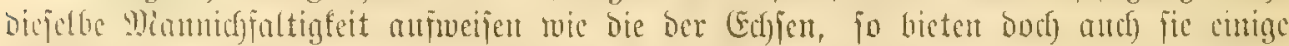

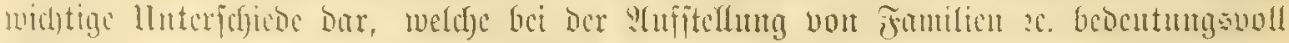

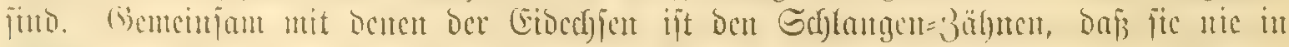

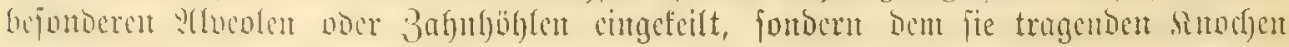

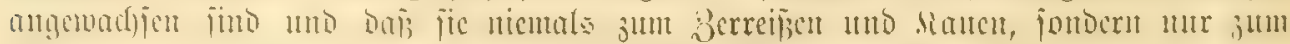

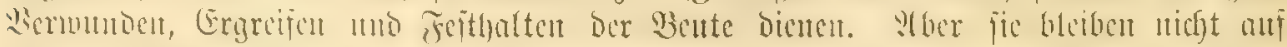

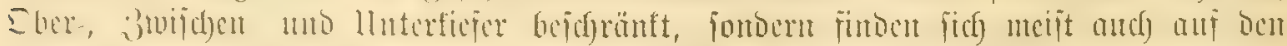

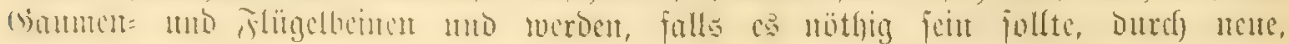

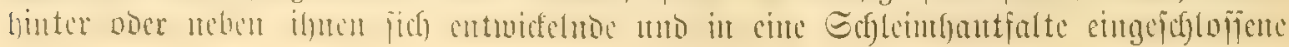




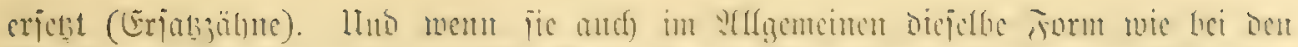

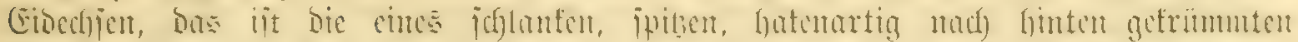

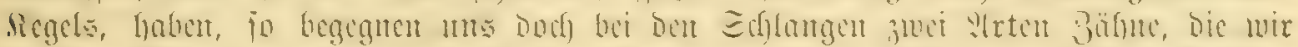

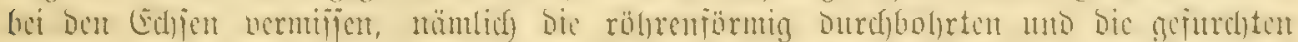

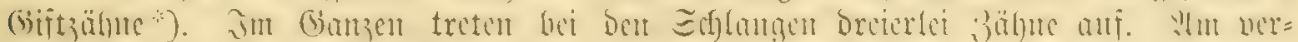

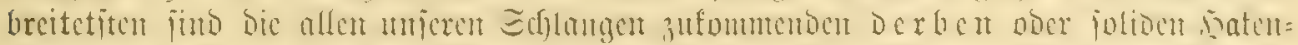

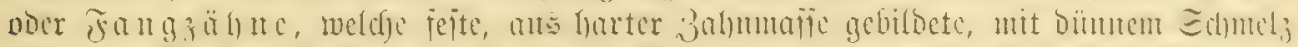

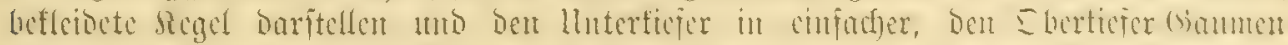

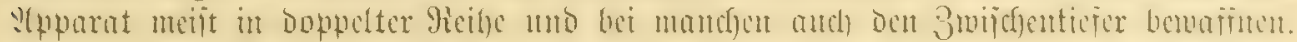

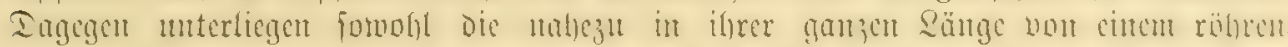

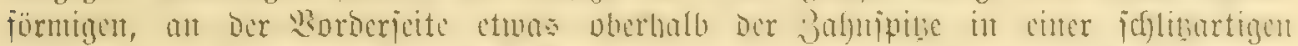

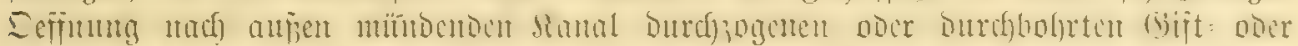

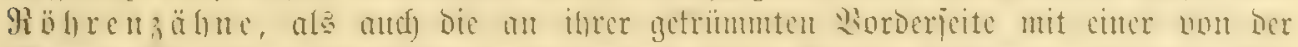

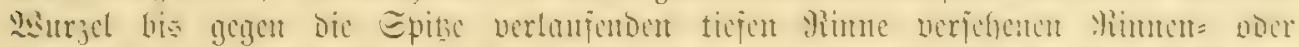

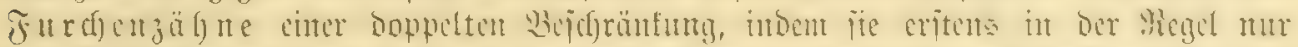

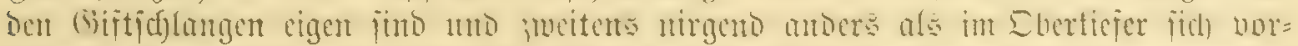

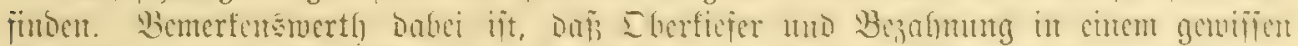

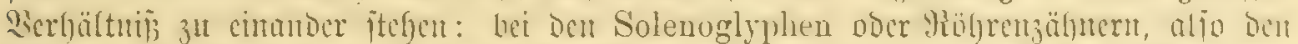

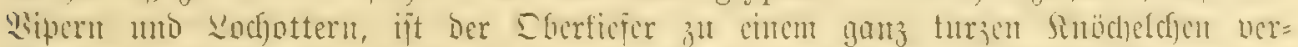

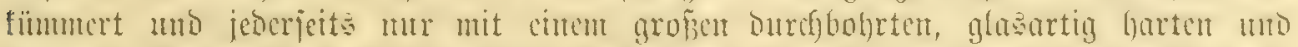

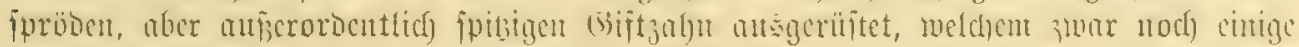

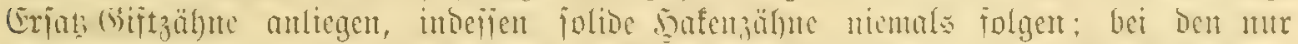

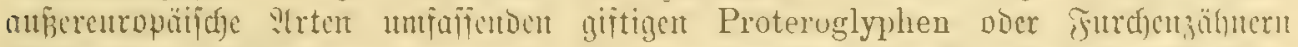
(Bijtuntern, Colubrina renenusa, mit Den Familien Der firuntotteru mo Eec=

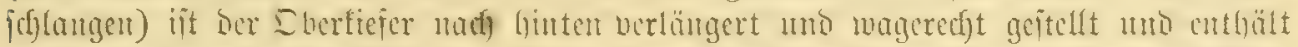

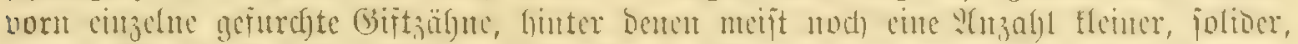

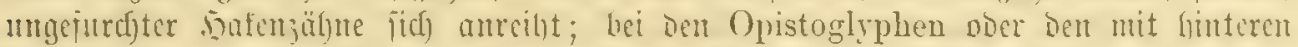

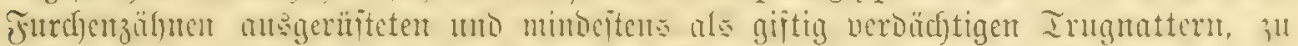

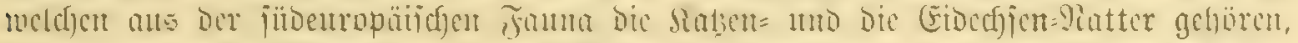

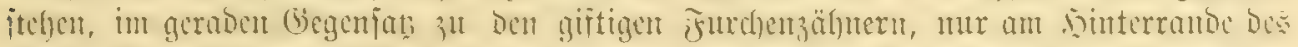

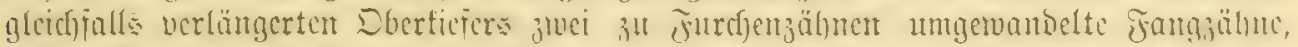

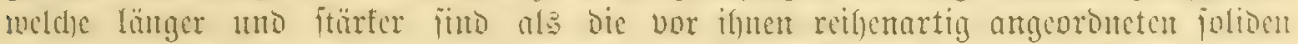

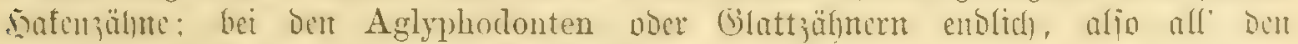

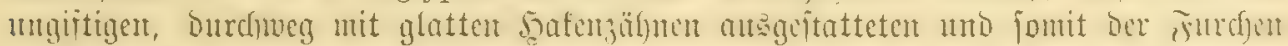

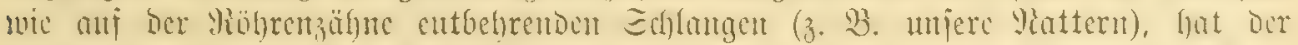

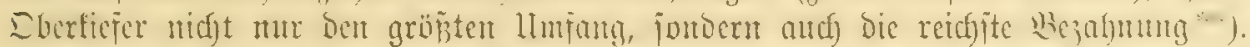

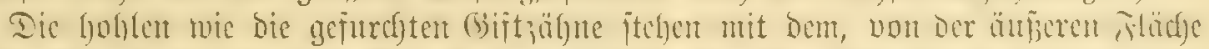

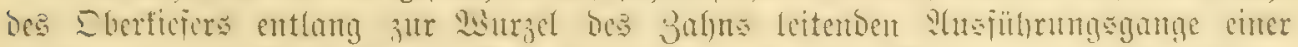

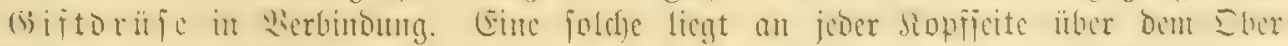

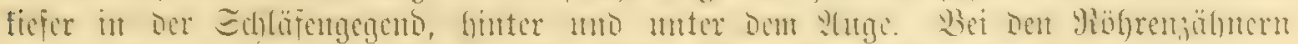

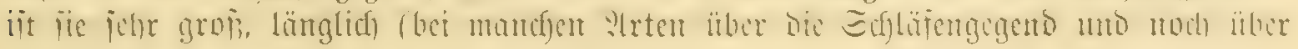

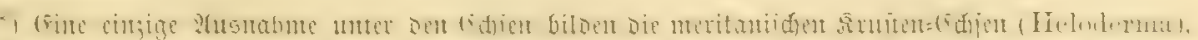

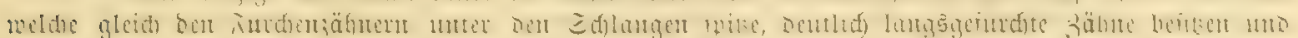

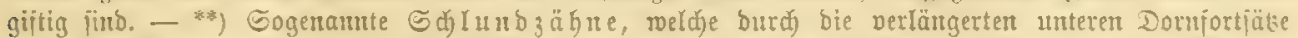

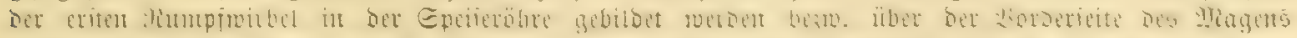

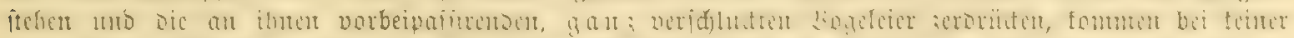

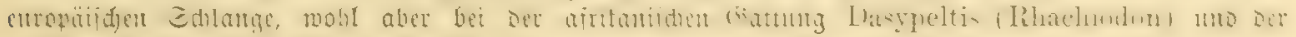
intoichen (stałtung Elachistodon vor. 


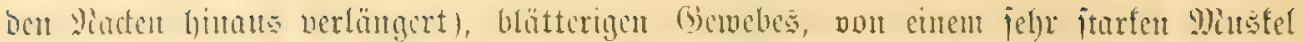

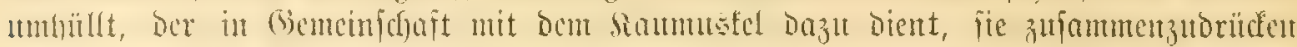

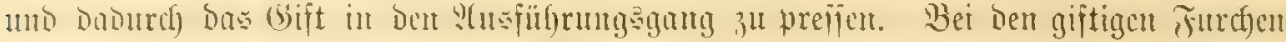

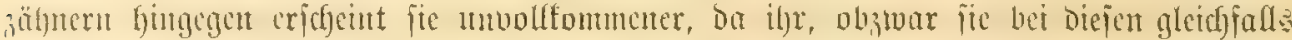

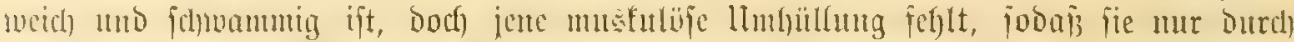

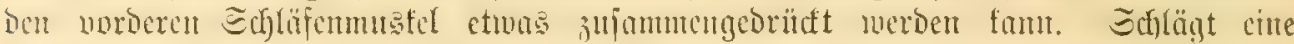

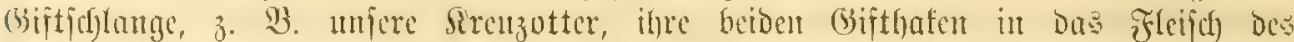

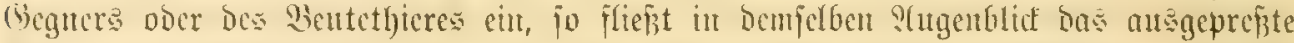

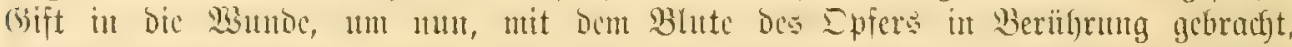

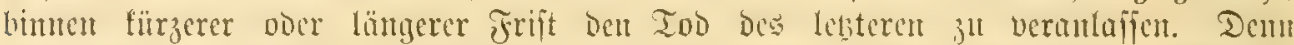

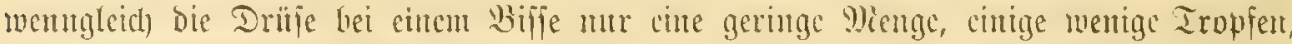

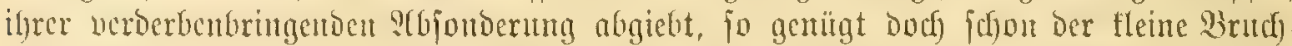

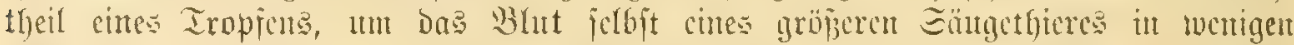
Dimuten zu ueründern, ju zericben. Freilich hängt bie mehr boer minder heftige und

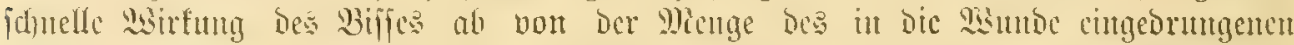

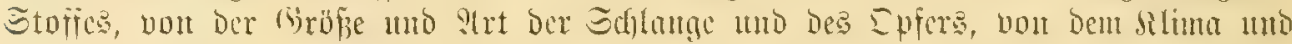

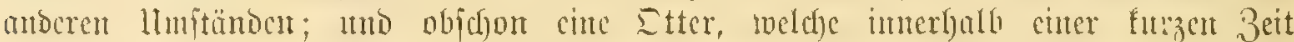

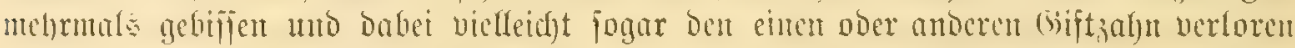

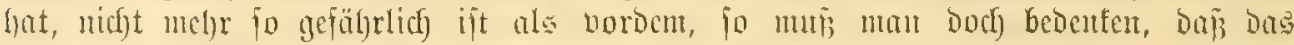

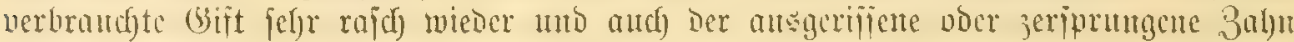

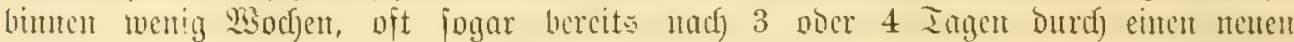
erictit Iwirb.

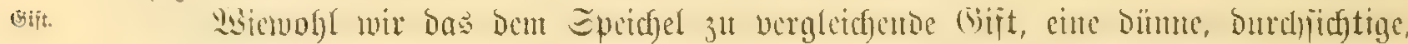

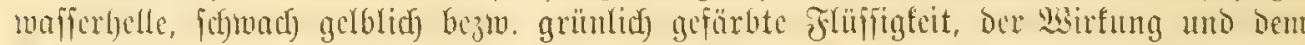

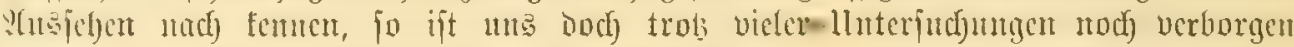

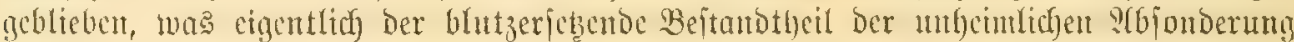

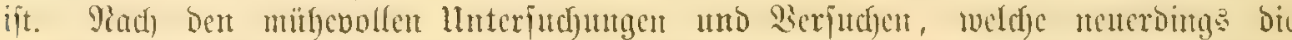

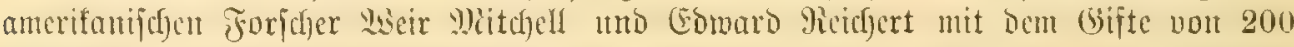

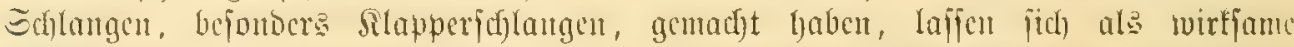

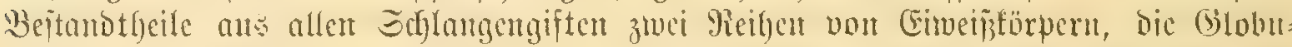

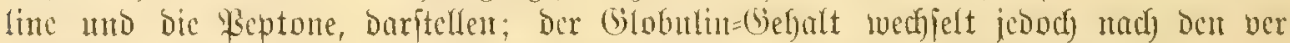

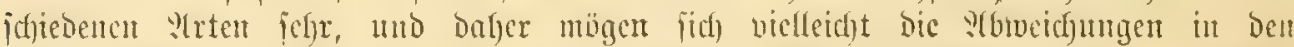

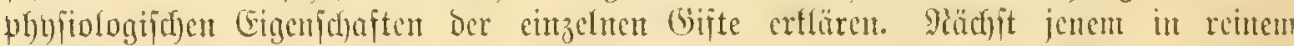

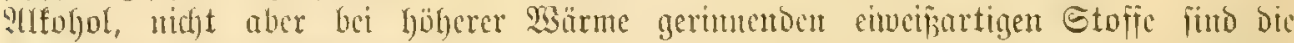

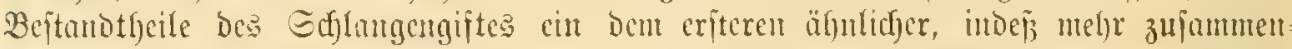

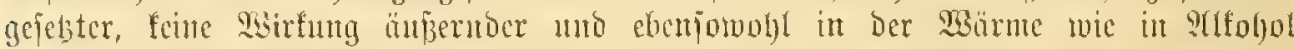

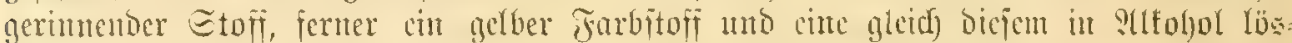

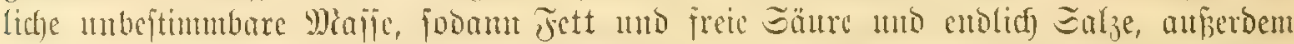

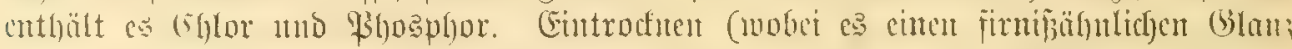

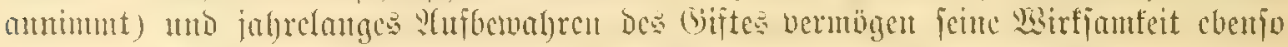

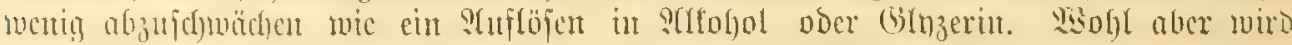

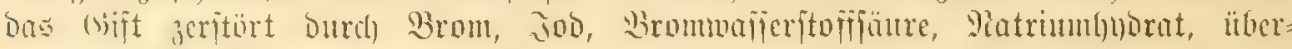

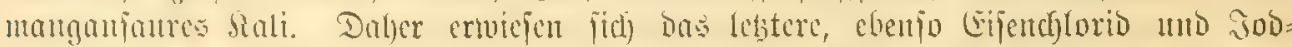

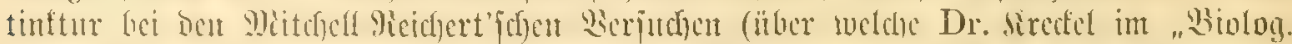

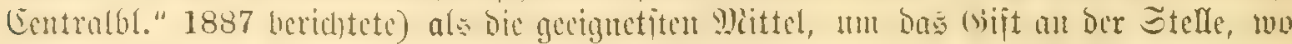

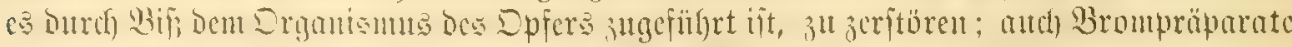

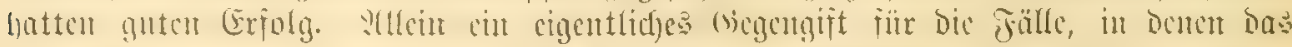

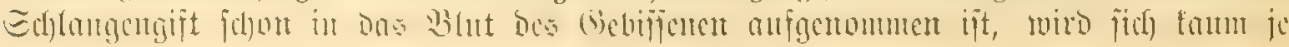




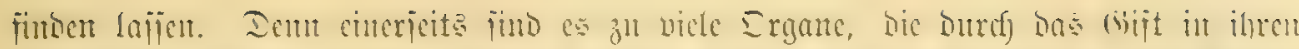

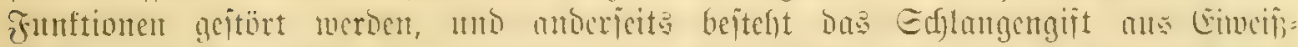

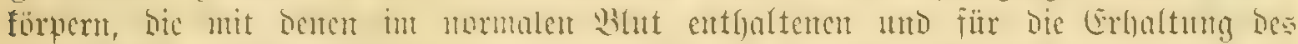

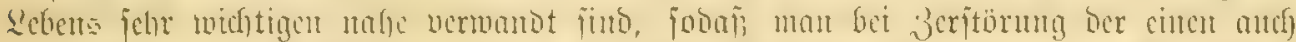

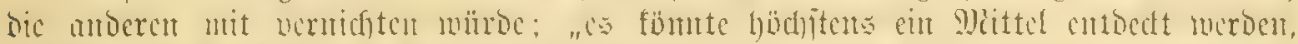

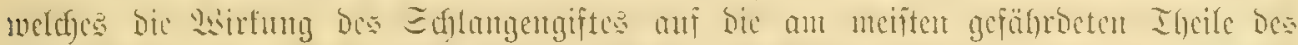

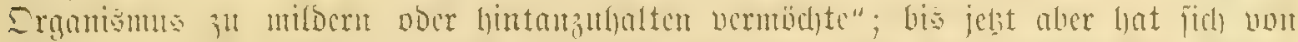

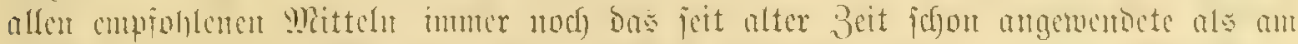

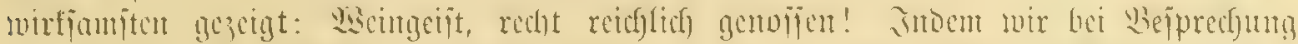

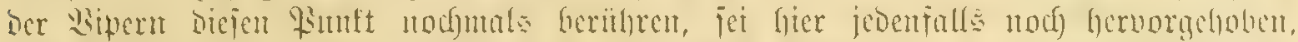

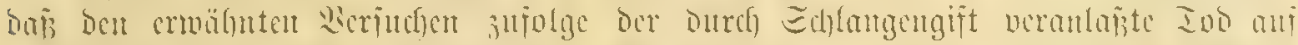

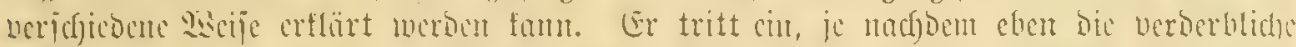

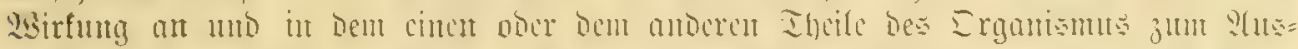

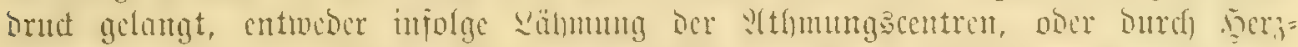

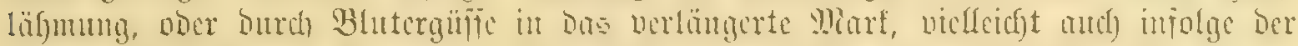

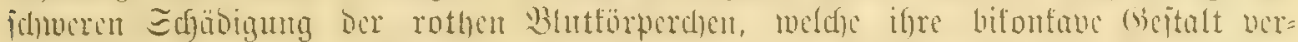

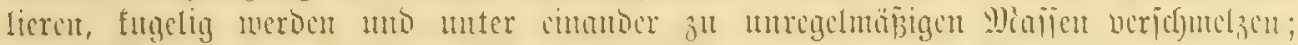

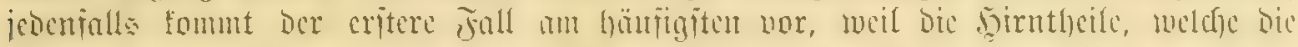

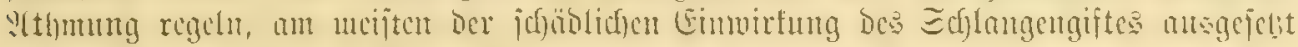

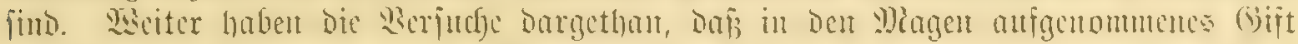

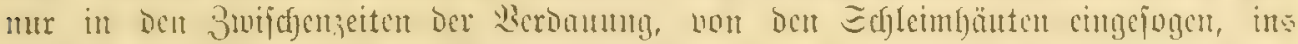

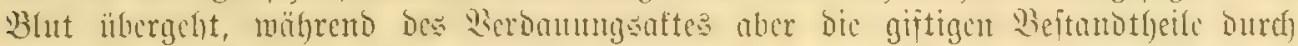

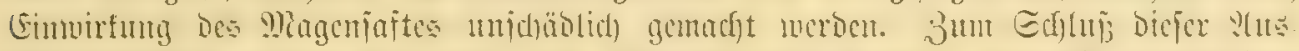

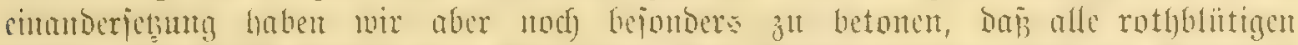

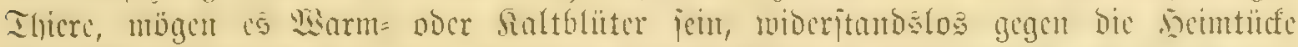

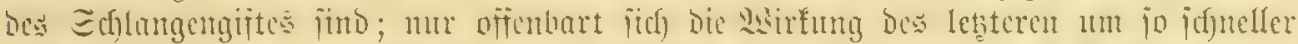

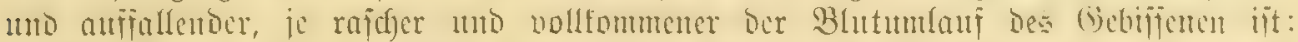

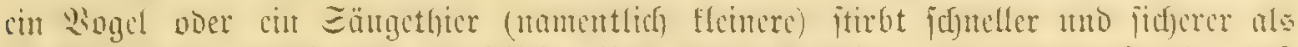

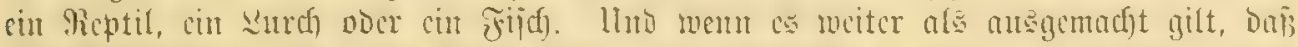

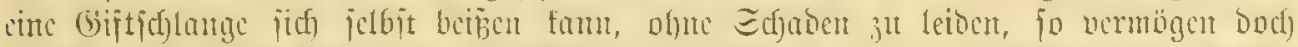

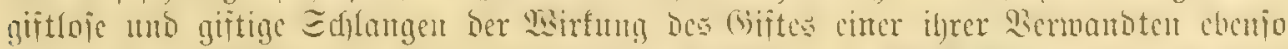

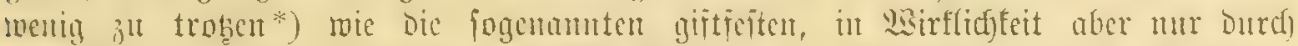

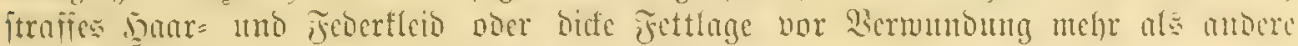

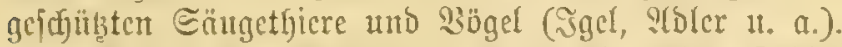

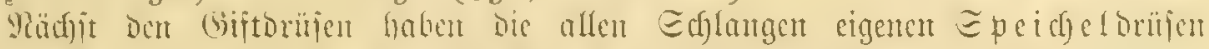

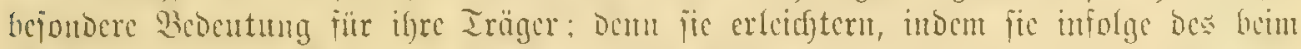

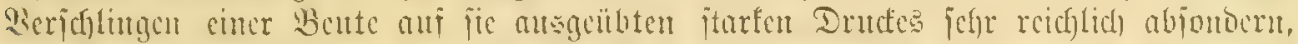

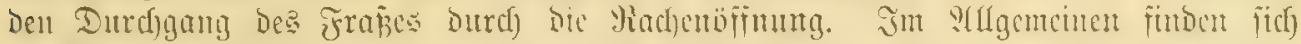

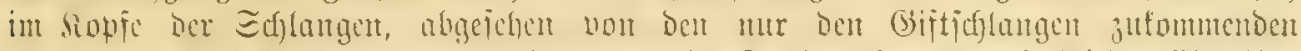

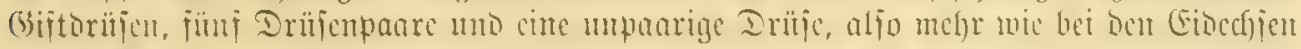

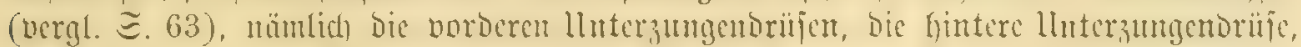

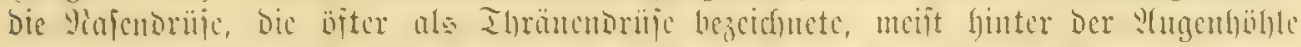

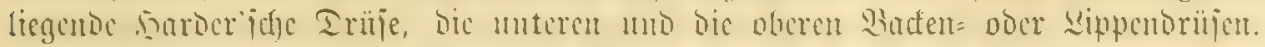

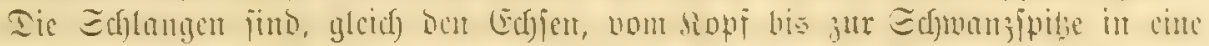

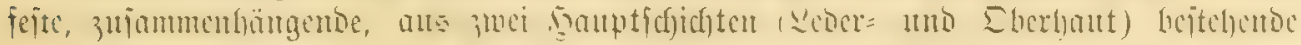

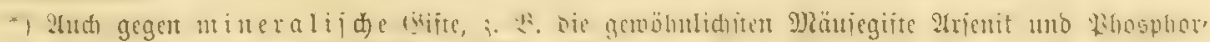

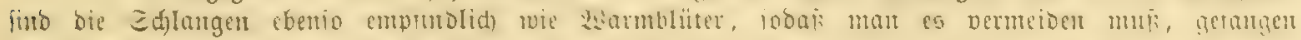

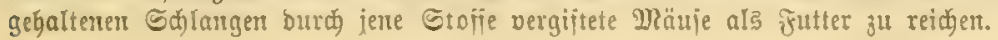




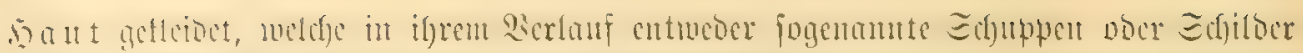

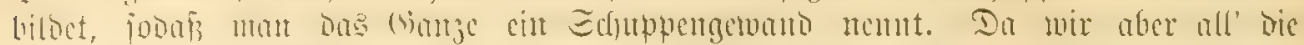

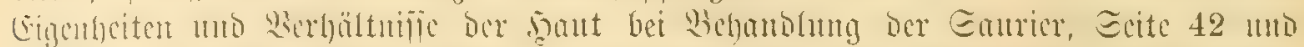

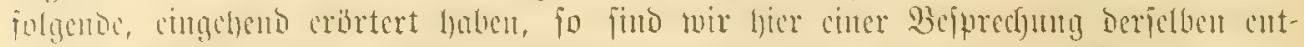

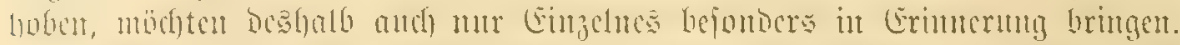

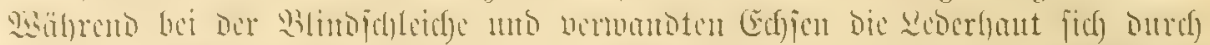

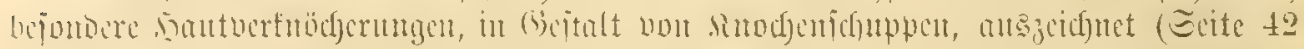

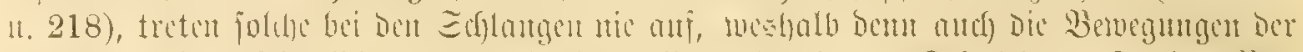

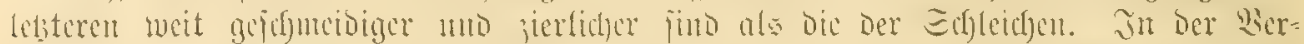

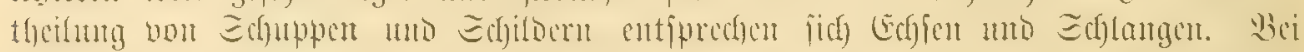

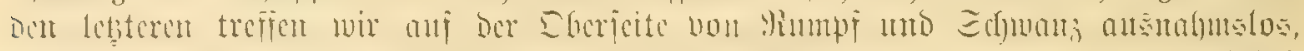

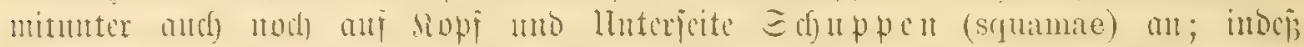

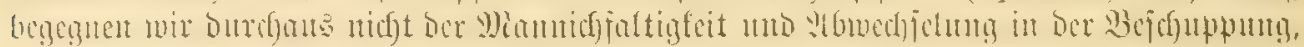

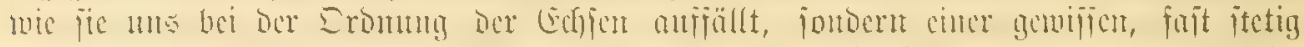

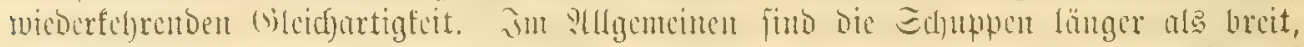

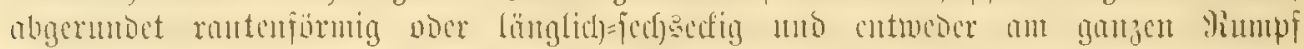

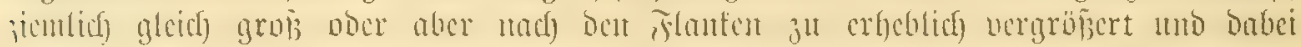

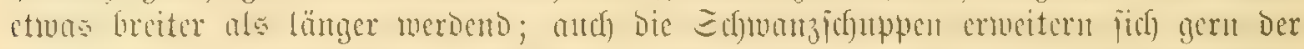

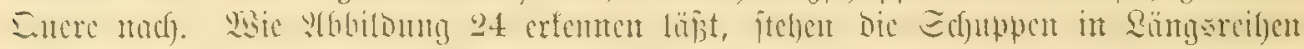

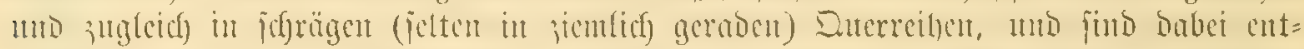

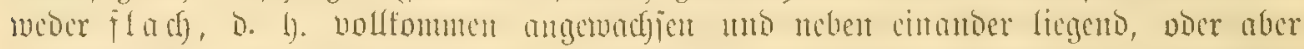

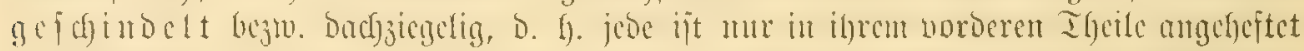

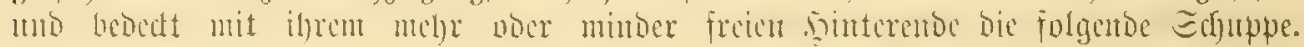
Die 及ahl ber Ränghreigen nimnt j̧war bei cint und

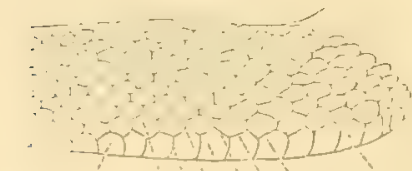

a.

$23,56 \mathrm{Cl}$

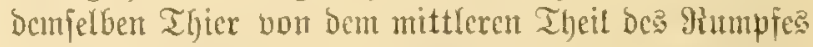
nud) Dem fopfe und Dem Schwautze zu allmählidf $a b$, jie bleibt jeonch an Den gleidjen fïrperftellen bei allen Ifieren einer uno Derjelben Sat ziemlich beftändig, fodaß fie als Mertmal bei llnterjcheioung ocr Spezies und Gattungen gut zu vermenden ijt. So 3. B.

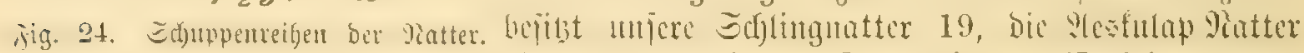
$1,2,3,4,5,6$ bie aufeimanber forgenber ljingegen 21 bis. 23 Ränģrecif)en. (Dabci hat man vängsteifjer, a a Baugitilber.

3̆ll beachten, Daf̧ bie Bäflung in mittlecen Theil be?

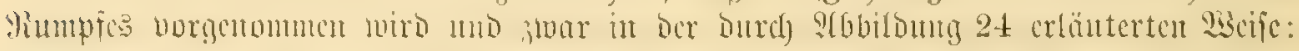

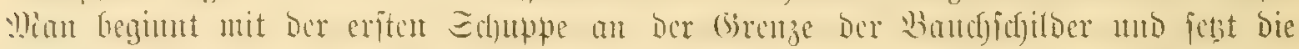

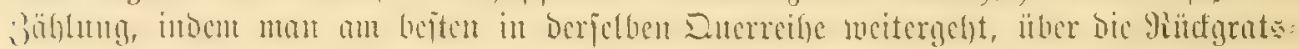

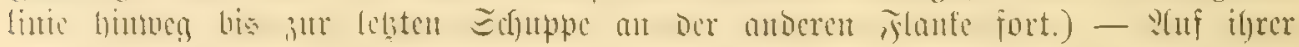

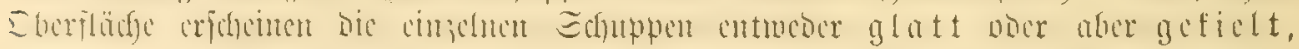

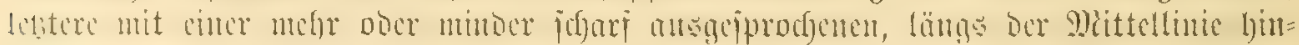

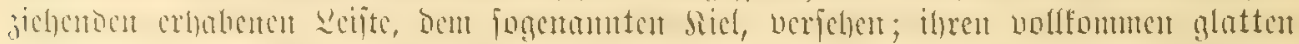

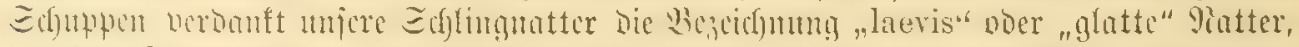

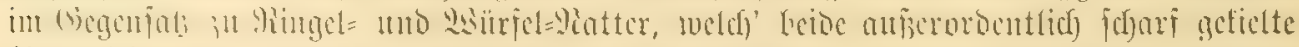

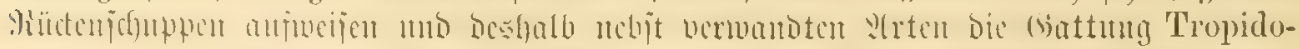

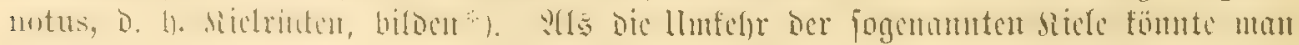

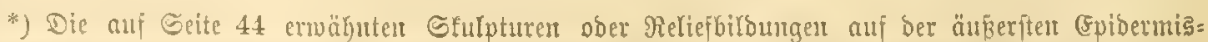

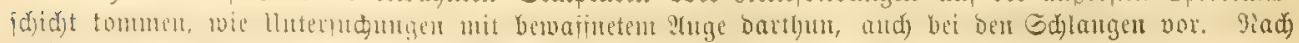

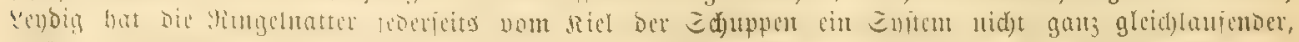

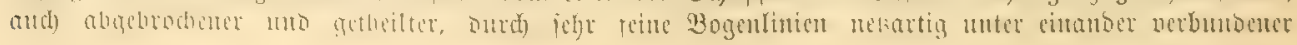




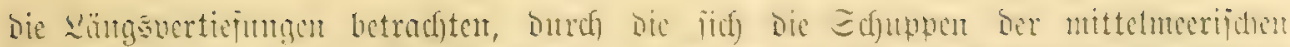

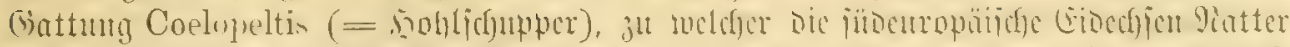

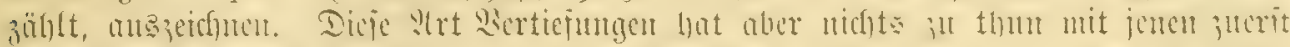

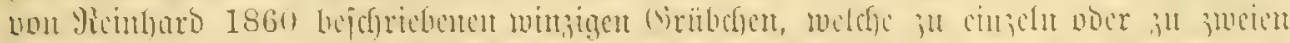

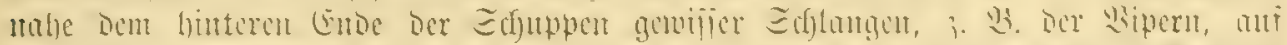

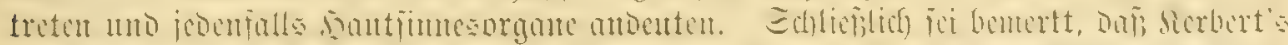

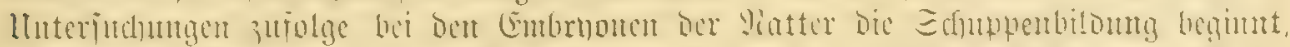

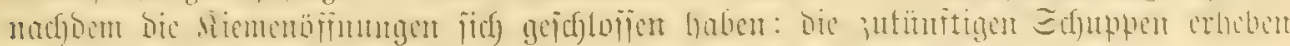

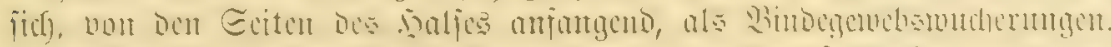

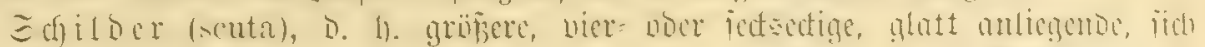
sopifidilber.

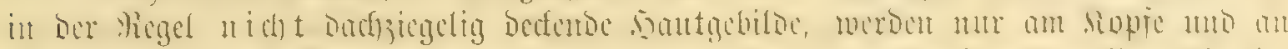

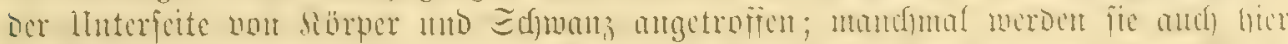

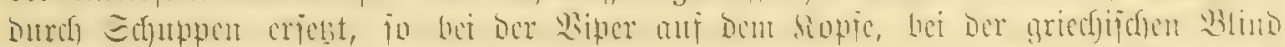

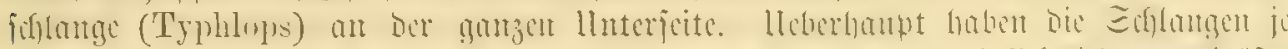

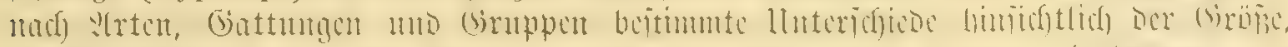

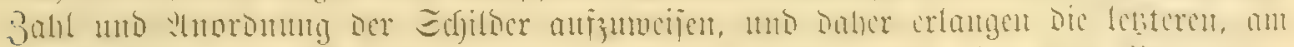

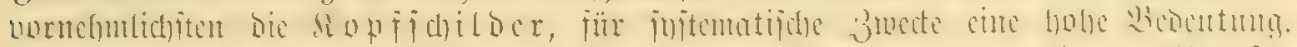

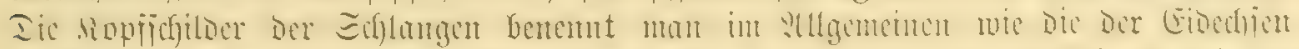

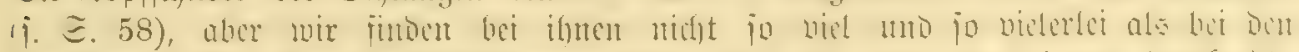

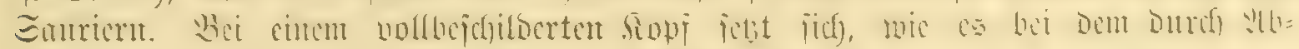
biloung 25 vergegentürtigten Sopf Der \&estulap= Jatter unb ifberbaupt bei Den meiften unjerer Deutjofyen und curopäififen Gdylangent ocr Fall ift, die Sopfplat $\mathrm{c}$ Doer Der Pileus aแ 9 Scfillocrt, nämlich vicr \$aaren umb einen unpaarigen, zufammen. Itnmittelbax äber Dem Die Sdyanzenipibe vorn bilbenden Rüfïl=, Sdynamen= oder Roftral= Edjilo (scutum rostrale) licgt bas critc

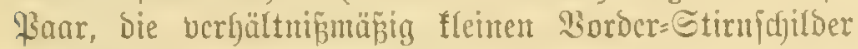
(praefrontalia; テig. $25 \mathrm{~d} d$ ), Dann folgen bie beiben cigentidyen ober liuteren Etirnjufloer (frontalia; 25 ce),

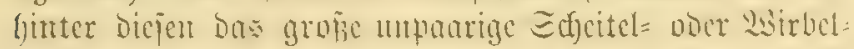

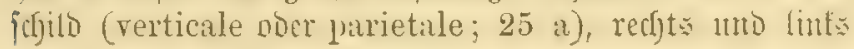
von ifm ic eit Brauct= ober Dberaugen=-Sdjils (supra-

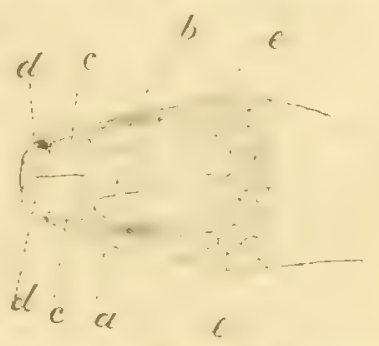

Fi.g. 25. Sopiplatte Der :Lestulap viattr.

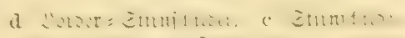

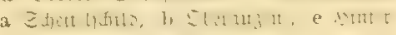
Gaupt= Gilber.

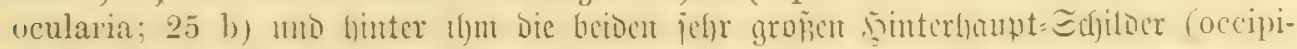

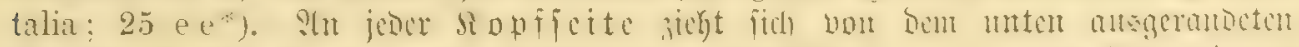

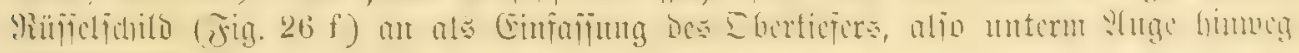

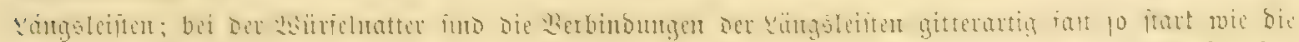

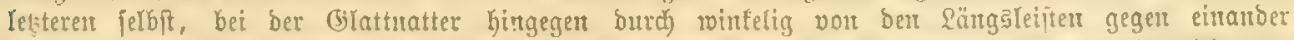

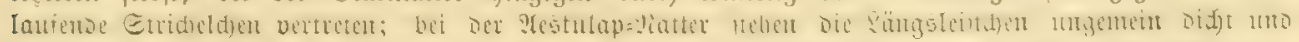

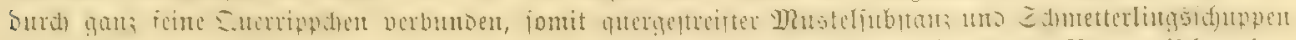

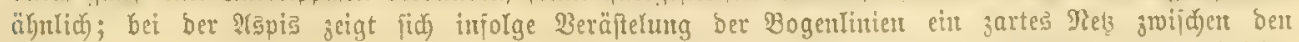

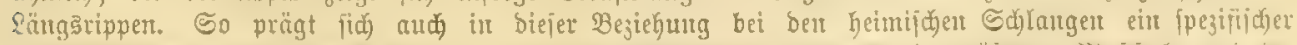

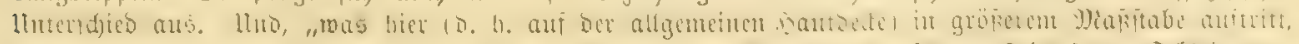

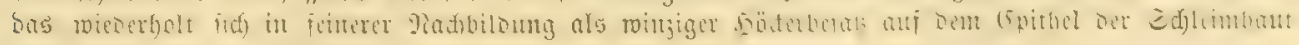
ber 3unge" [Regoig, Edylangen S. 44].

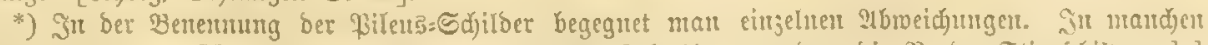
Cajriften, jo in ber Herpetologia europaea von (E. Ed)reiber, merben bie Borber=Etimidjiloer d d

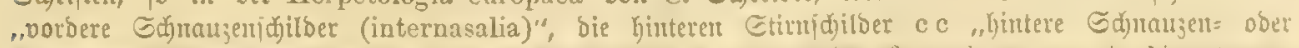

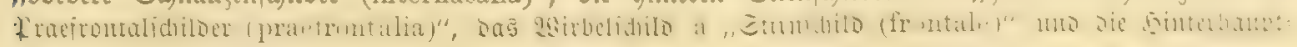
jojilber e e "Ed)eiteljoildoer (parietalia)" gentant. 


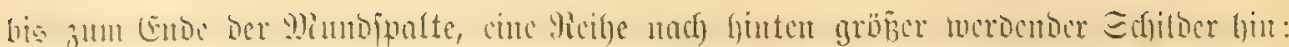

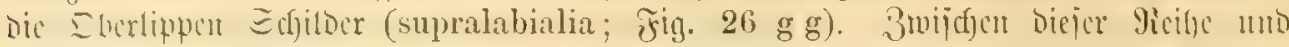

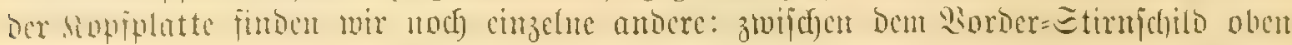
und Den eriten Dberlippenjdjildern unten bas bas Siajen=
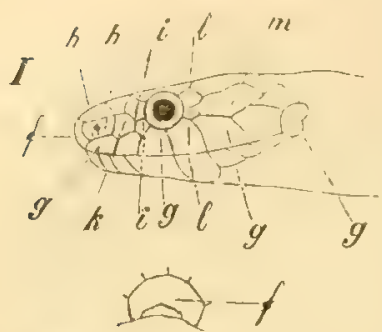

II.

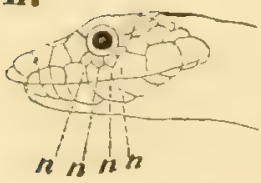

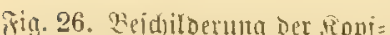
feite (I. Siper: II. Dupeijest= Yiatter).

f Muffel $=, \mathbf{h}$ linfen, $\mathrm{k}$ jügelftils, g Oket: lippen:, i volocts, 1 bintere 1 utb $\mathrm{n}$ untere

Trugenfdirber, m żläfenjdilber.

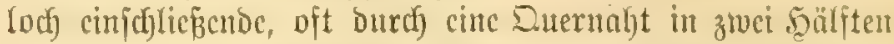

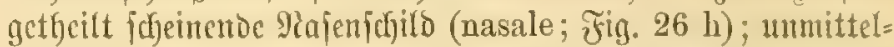

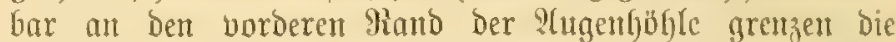
Borberaugen=Ed)ildoer (praeocularia; 26 i i), Derent $3 a b l$

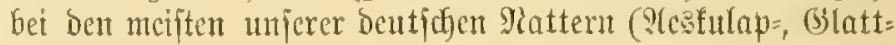
mo Ringelnatter) mur eine, bet ber 29 ïrichnatter zwei

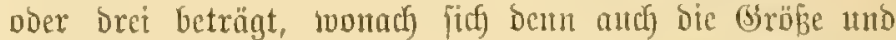

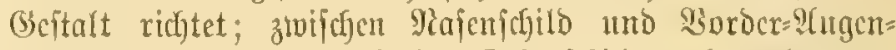
fofildoeru, alfo unterhalb ber Stimidfilder, bemerft man

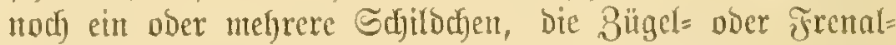
iffilder (frenalia, loria; $26 \mathrm{k}$ ), wägrend bic unmittelbare

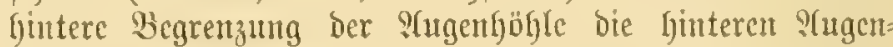
fufildocr (postocularia; 2611 ) billoen und biejen nadj) binten, Den ganzen Raum zwifden Seinterbauptidfildorn obent uno

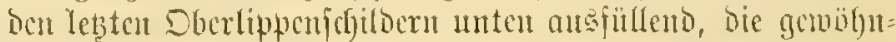
(ich) in mebreren Sicif)en über cinander ftel)enden Echläfenfajildoer (temporalia; $26 \mathrm{~m}$ ) folgen, wou weld)en ntun bie

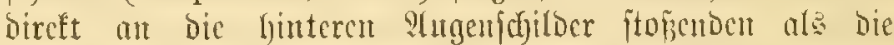

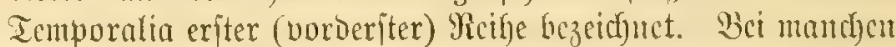

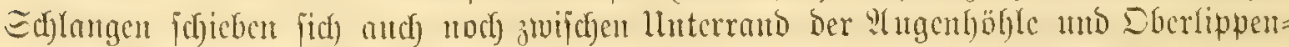

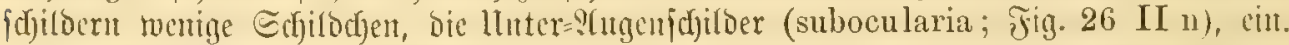
Die llnterfeite Des Sopfes Der Edjlungen bietet etmas (Eigentfümliches in ber

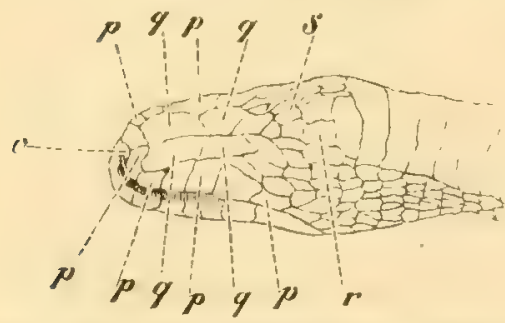

rig. 27. Ropf = Huterfeite ber 2restulap= Natter.

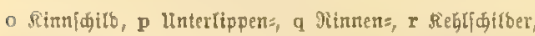

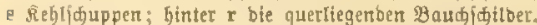

jogctanntent $\Omega$ in $n \mathfrak{f} u \mathfrak{r}$ c $c$ (sulcus gularis) Dar, weldje vorn an Dem unpaarigen Simnjdjild (mentale; Fig. 27 o) bogiunt, in bor \&ängs=

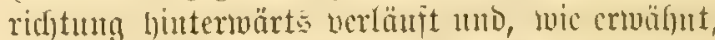
Dic völlige Trenmung der beiben llnterfiejer

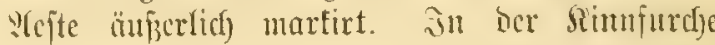
treffen fich zunädjit bais erite Faar ber lluterlippenjufilocr (sublabialia; 27 p) nto ljuter

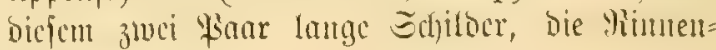
idjilber (inframaxillaria; 27

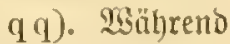

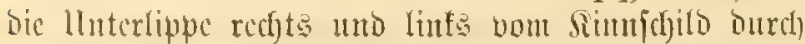
cinc gecife Unterlippenjachiloer gejüunt wiro, fofliç̄en

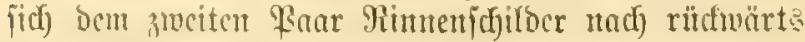

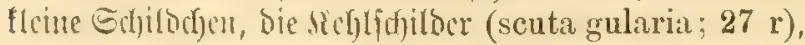
noer aber flewere (bicbilde, Siellifduppen (squamae gulares; $27 \mathrm{~s}$ ) an. Dann aber heginnt bie lange Geife ber grofsen, Greiten, querliegenden, fdjienen= ober

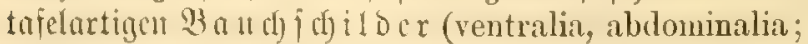
Fig. 28 a a), woldfo nidjt felten mit iffren jeitlichen

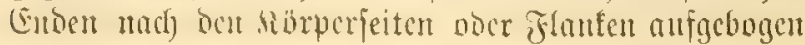

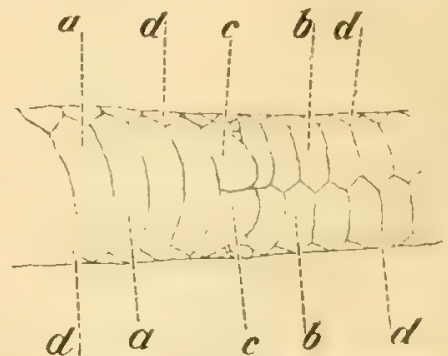

Fig. 28. Sheil ber Iluterfeite ber geib= grüntett Hatter.

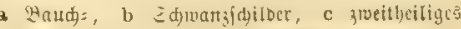

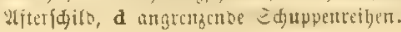




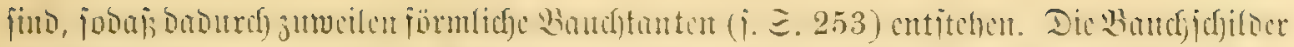

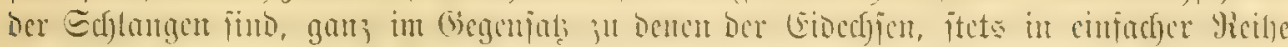

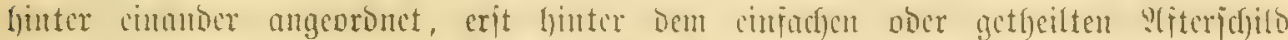

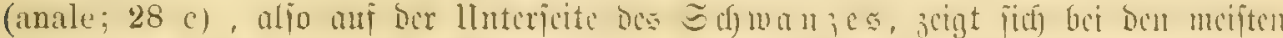

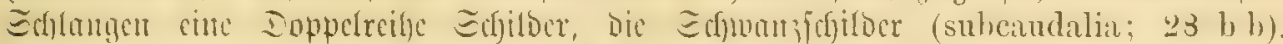

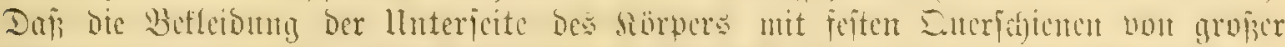

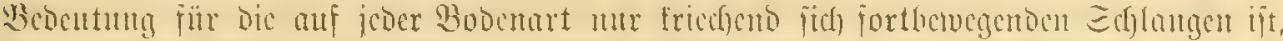

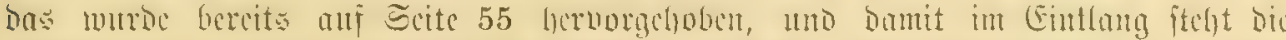

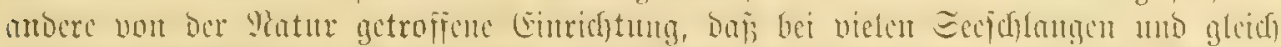

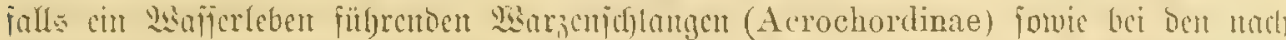

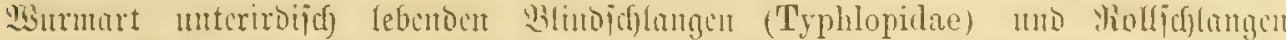

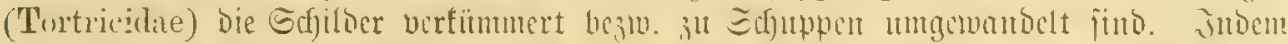

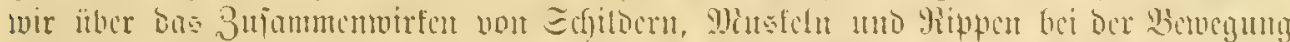

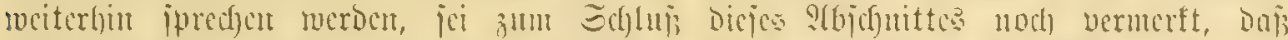

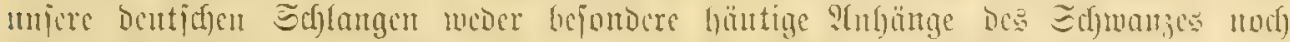

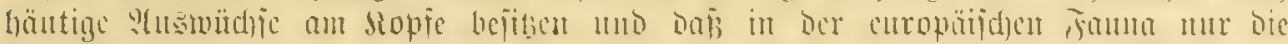

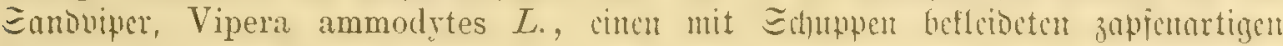
:Itrfat über ber Edynaze hat.

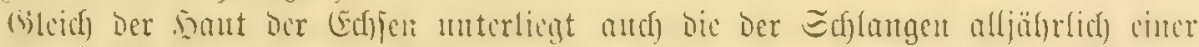

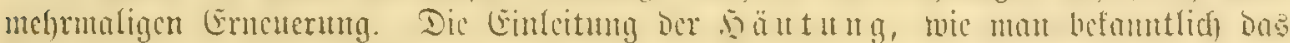

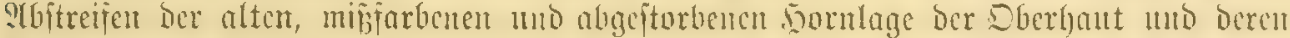

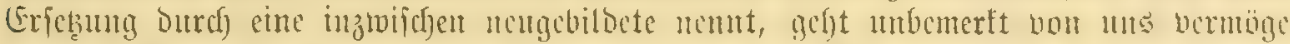

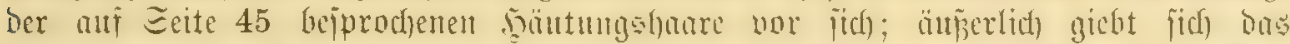

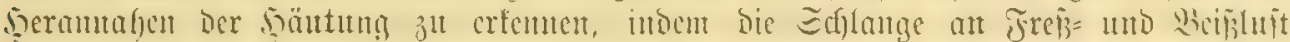

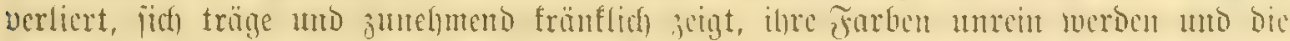

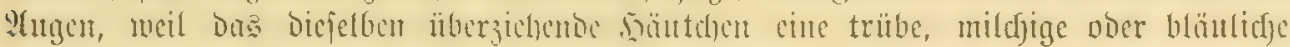

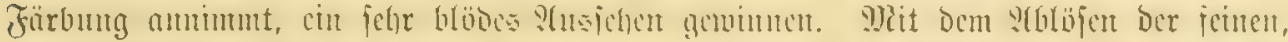

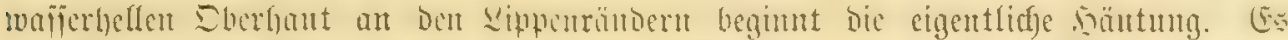

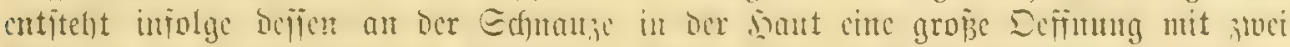

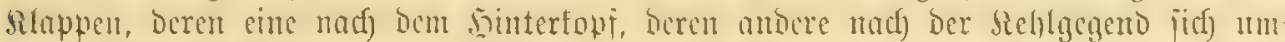

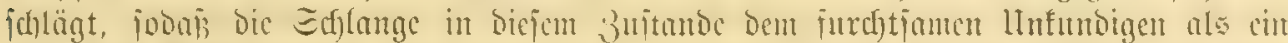

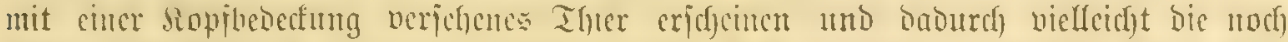

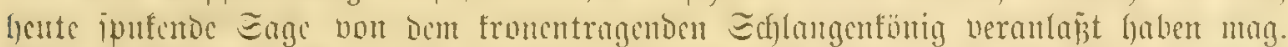

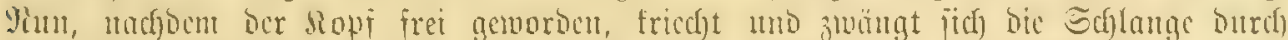

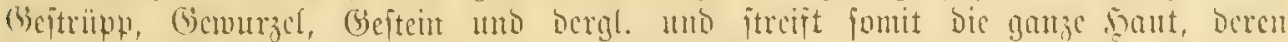

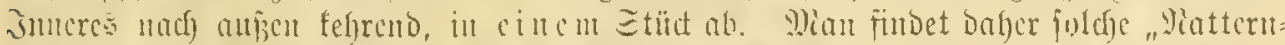

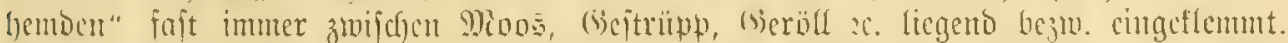

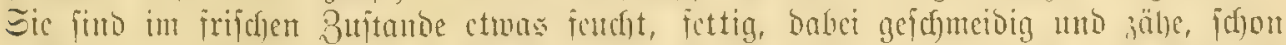

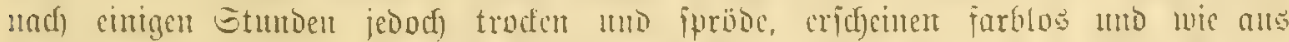

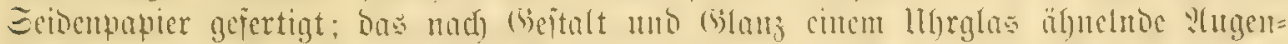

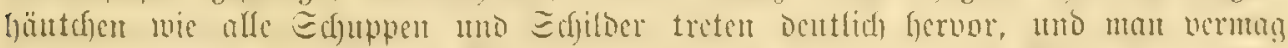

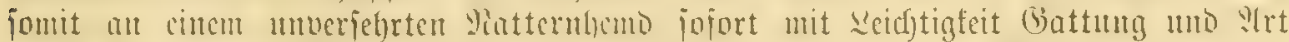

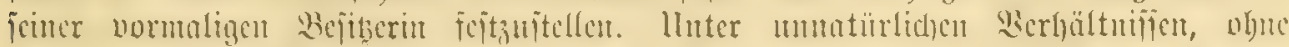

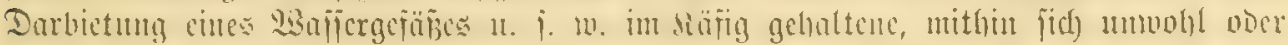

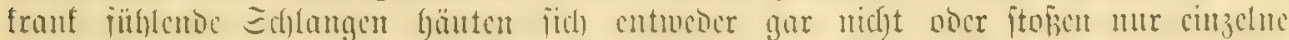

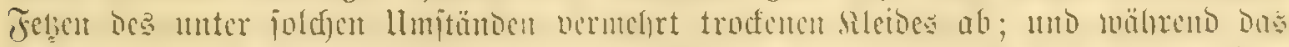

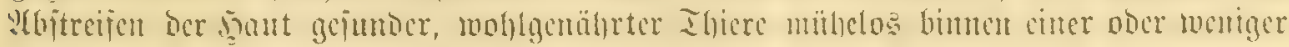

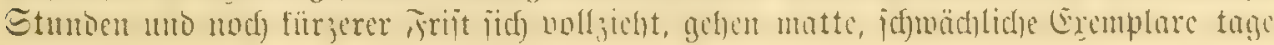




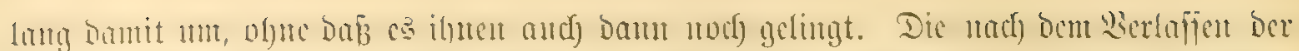

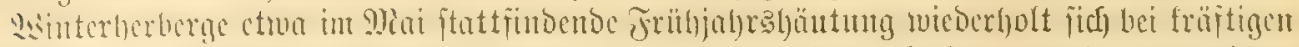

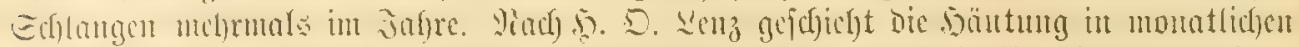

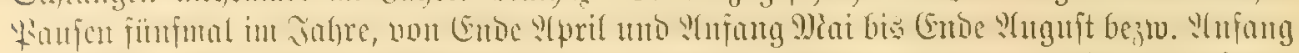

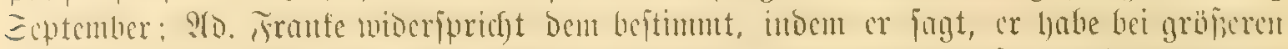

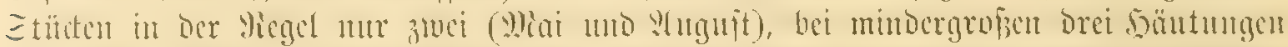

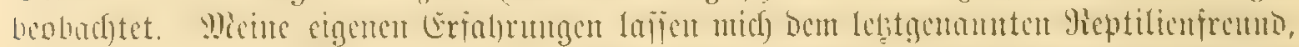

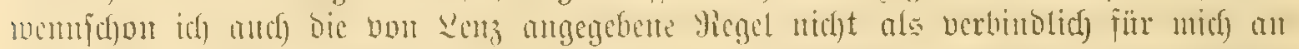

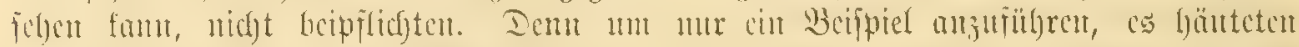

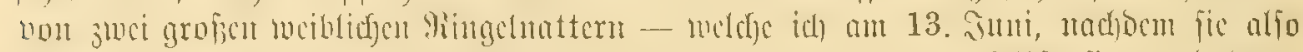

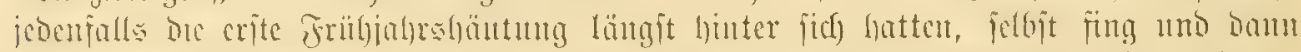
gum; gentu jubrumade -. Dic cinte am 27. Jmi, 23. Suguit, 22. Ecptenter umb 30.

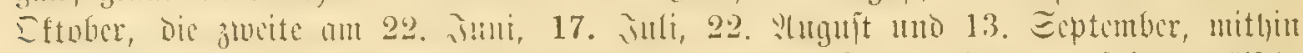

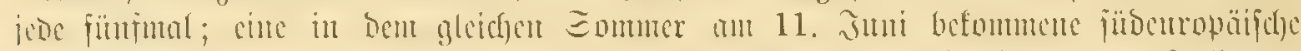

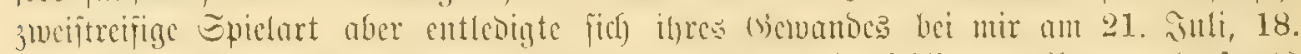

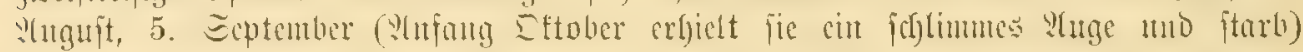

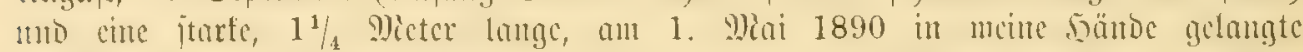

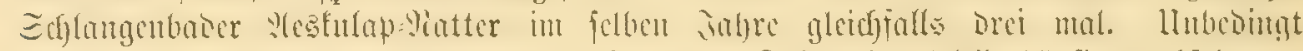

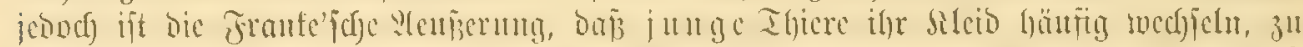

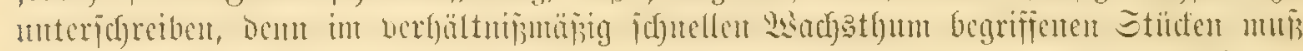

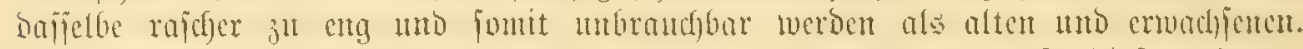

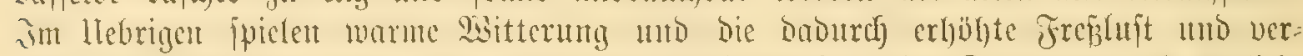

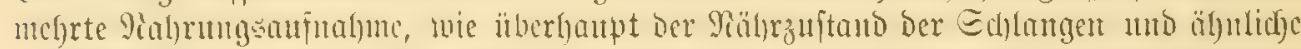

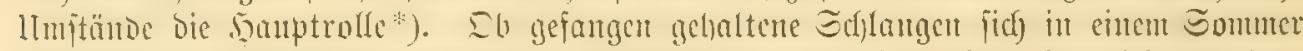

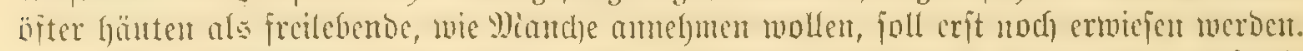

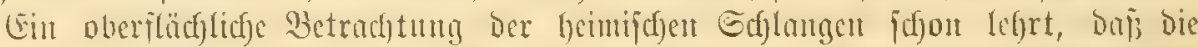

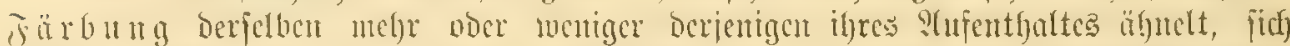

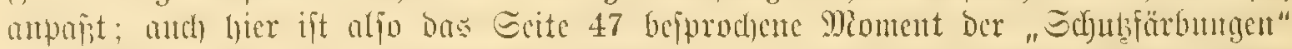

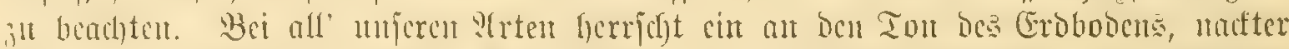

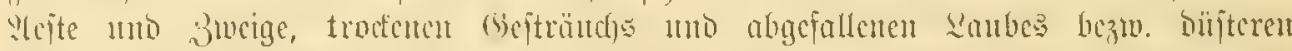

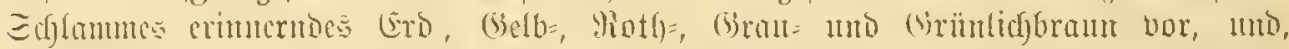

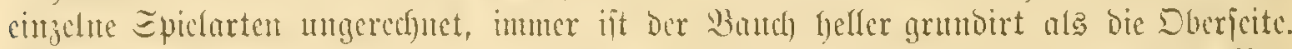

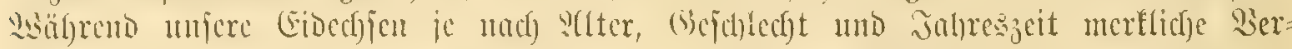

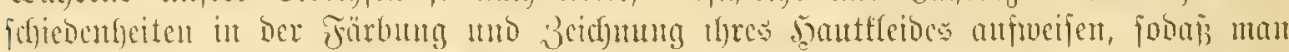

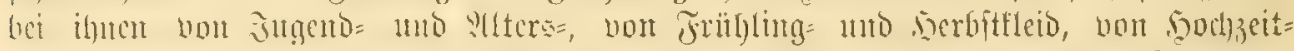

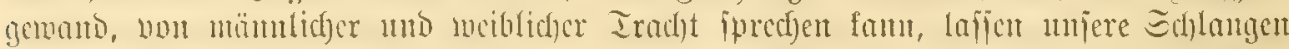

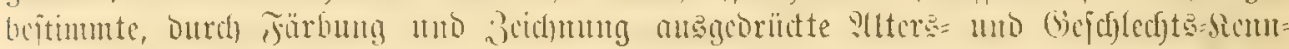

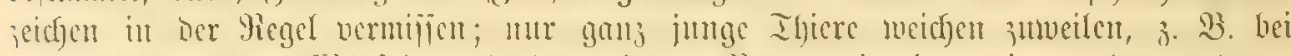

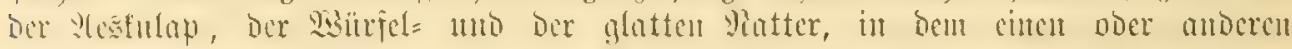

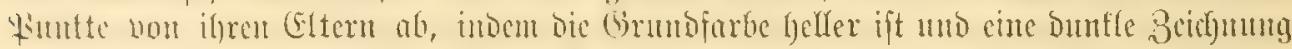

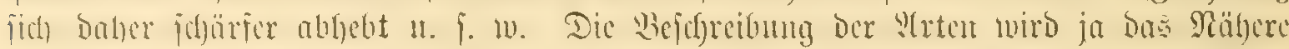

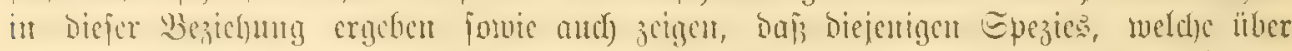

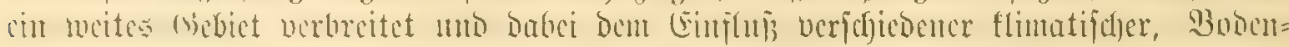

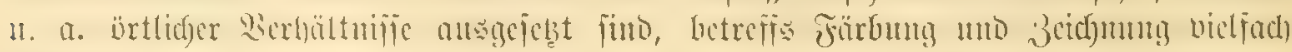

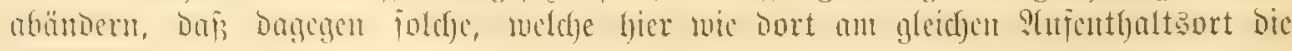

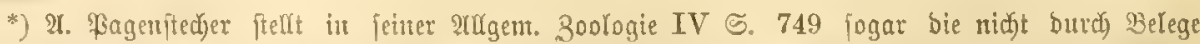

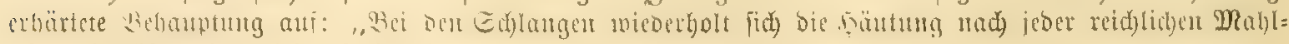
zeit, adjt= bis zehumal int Jahre"! 


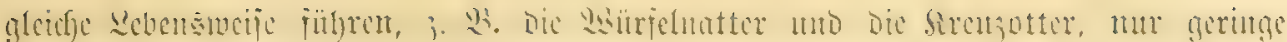

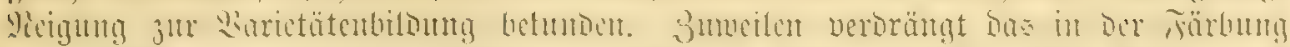

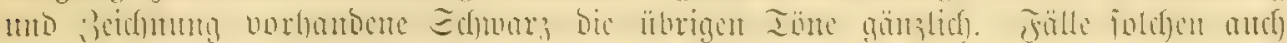

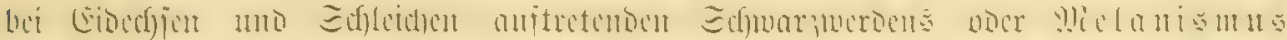

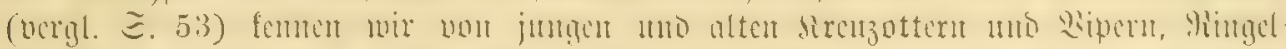

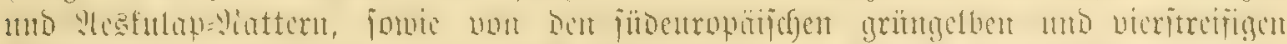

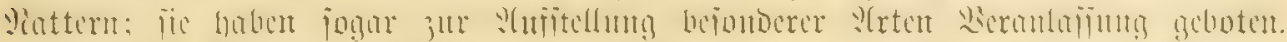

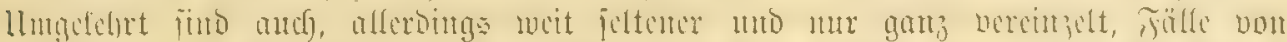

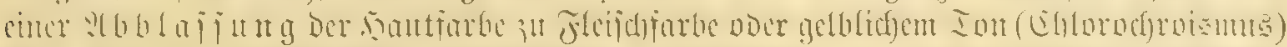

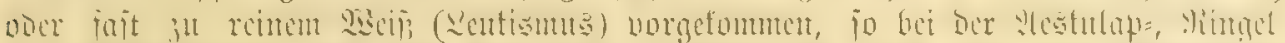

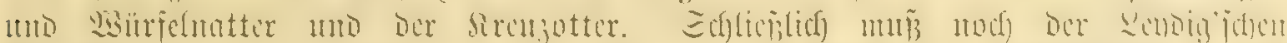

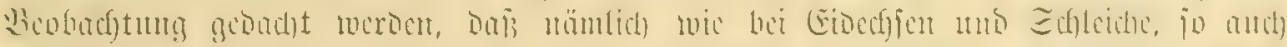

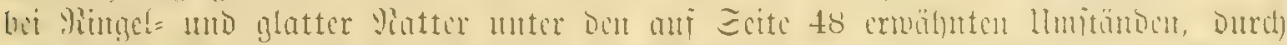

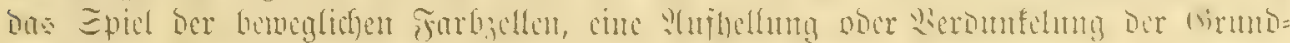
fürbung rerbeigefübrt toerocn fam.

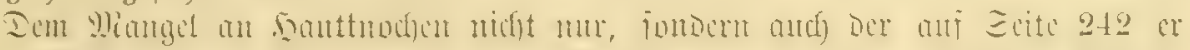

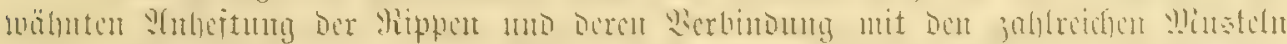

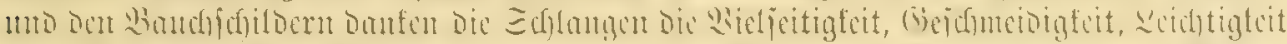

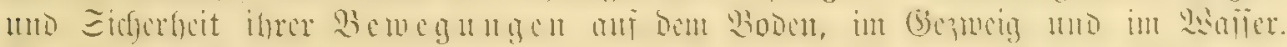

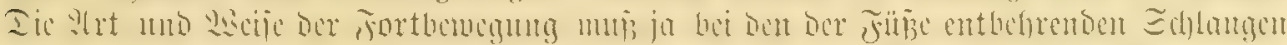

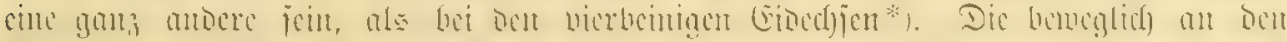

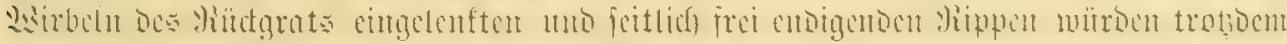

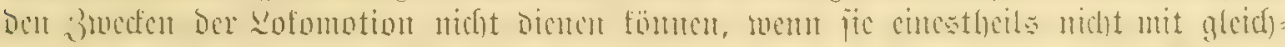

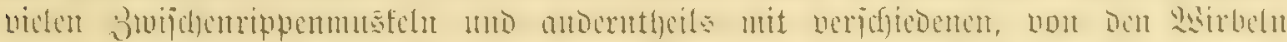

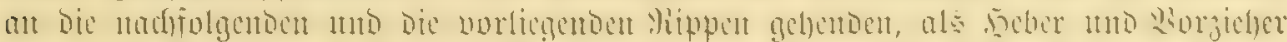

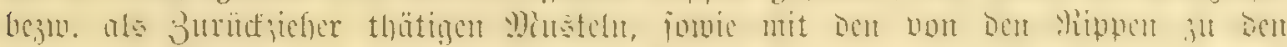

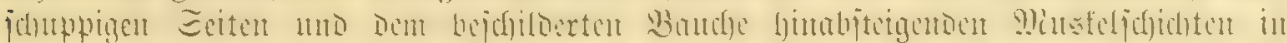

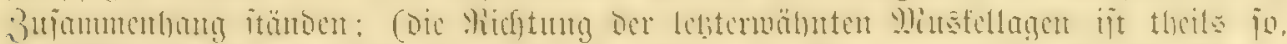

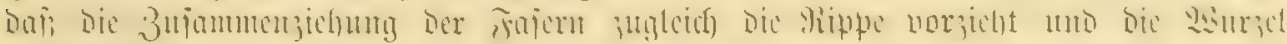

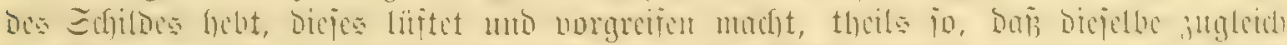

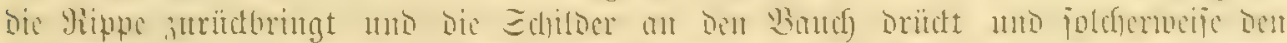

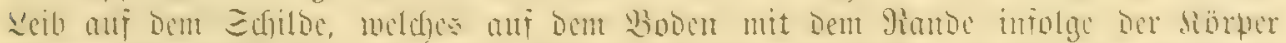

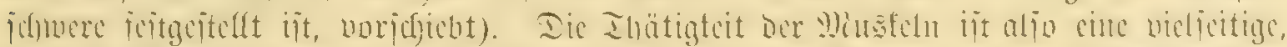

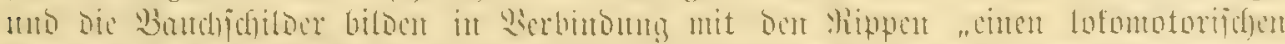

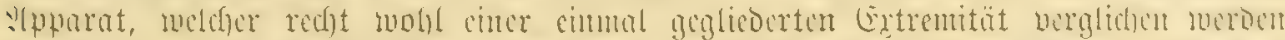

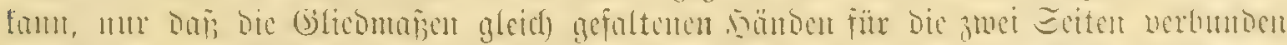

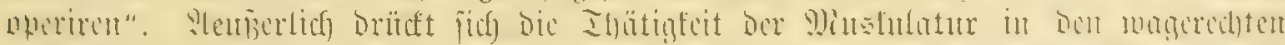
W.

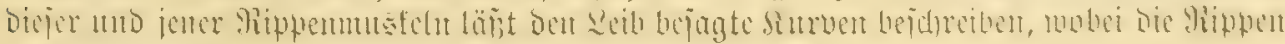

*) Cdjon an bem (Beräujd, weldjes bie einen ober bie anberen Ibiere bein Davoneilen im

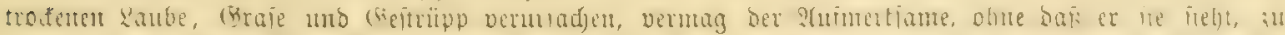

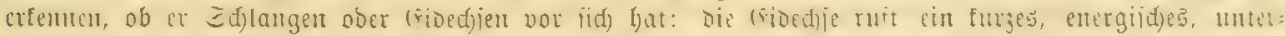
Brodjenes, bie Gdjlange ein ldleidjenbes, angaltenbes Majdjeln hetwor.

**) פRit ócjen Geitenbervegungen (mouvements de latéralité) ber wirbeljäule, melde ,jum

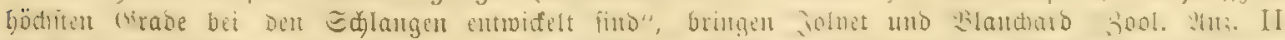

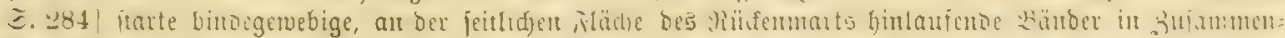

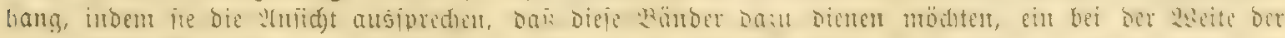

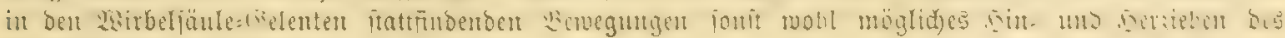
Mïcfemarfs zat vergütert. 


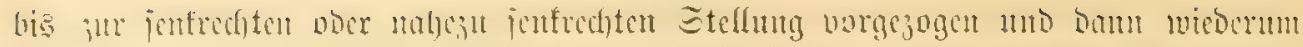

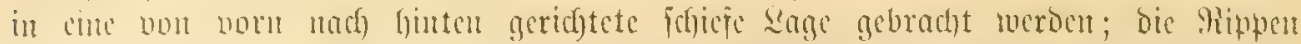

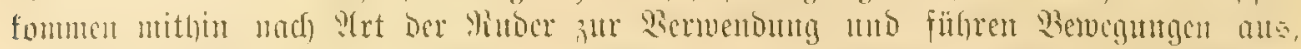

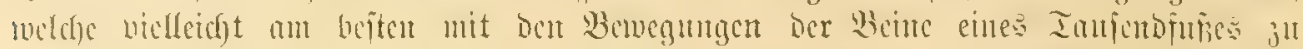

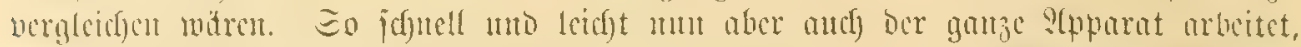

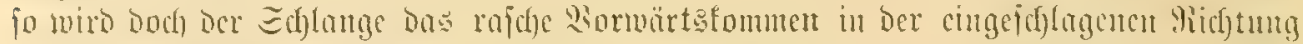

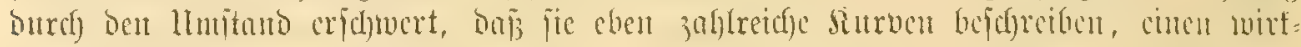

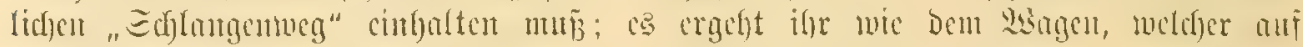

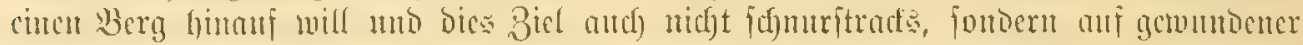

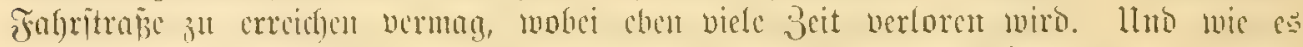

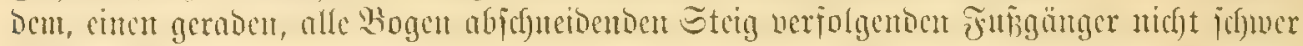

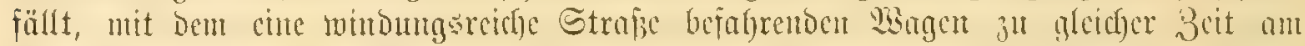

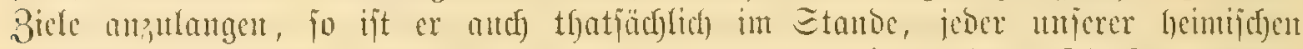

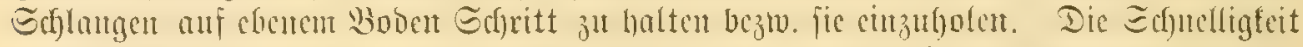

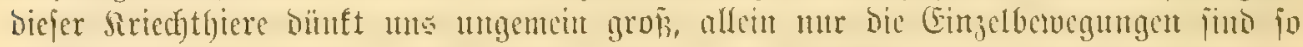

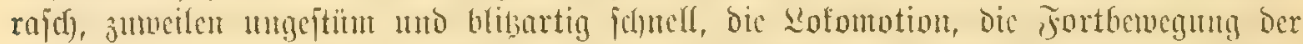

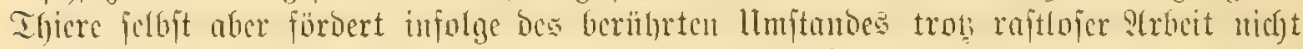

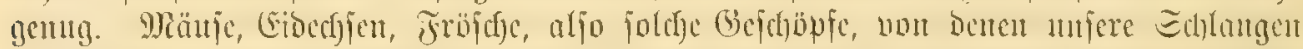

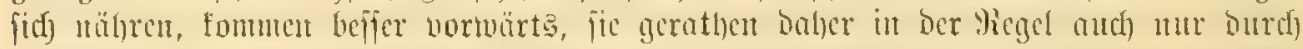

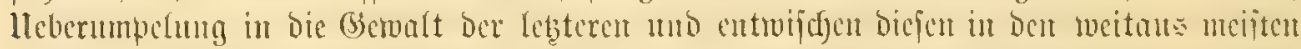

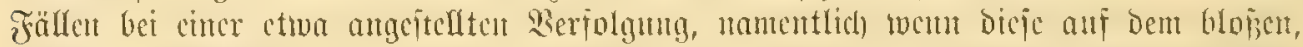

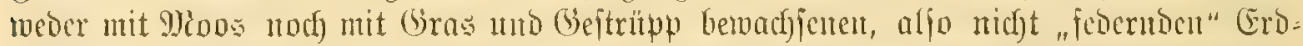

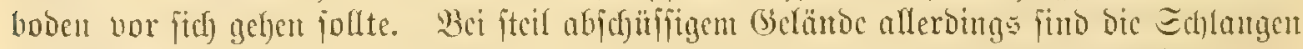

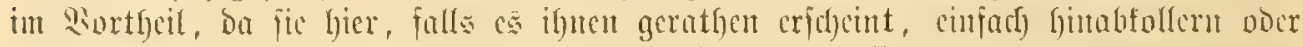

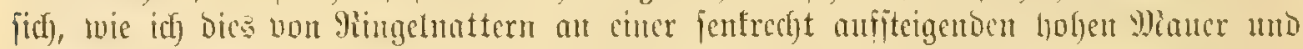

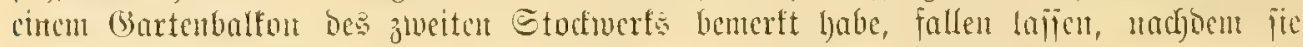

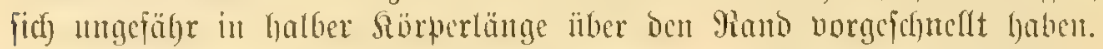

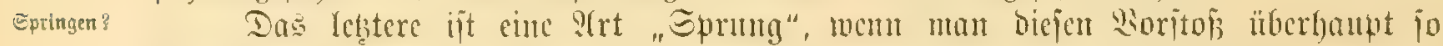

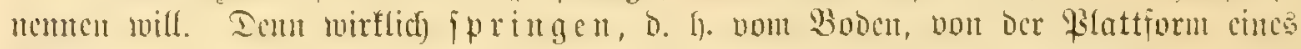

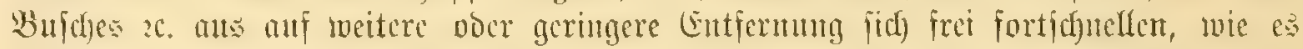

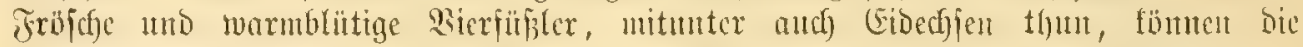

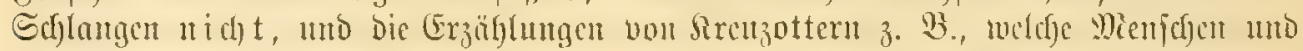

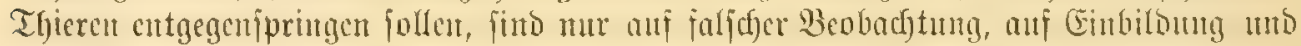

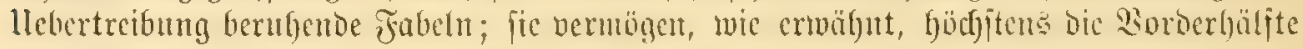
Des Sürpers vorzujhlenbern, nobei der nintertheil fejt gegen fine lluterlage gedrädt uniro. Eo unmiglich twie Das Epringen ift ifnen audf cin Erlgeben nom Boden, cin

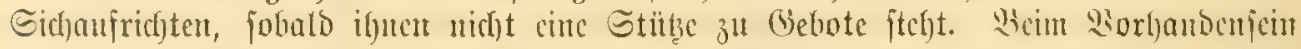

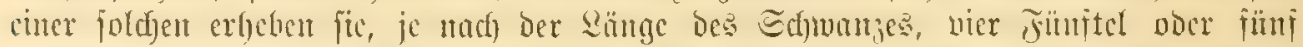
Ecd) nur ctua ben vierten Theil (bic Brillenjolangen freilid) cut Irittel) ibres Scibes

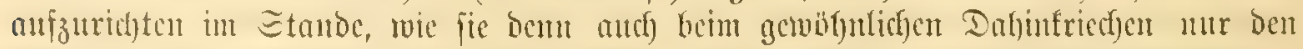
Siopf und Dic Salspartic frei itberm Boocu halten, uno in Dem falle, Daßj man fie

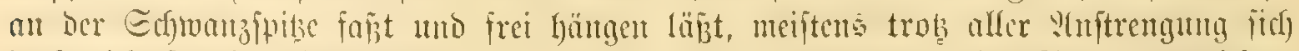

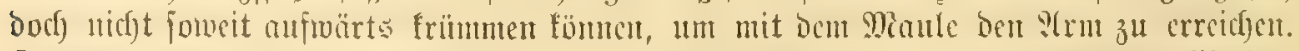

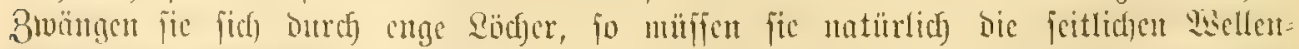

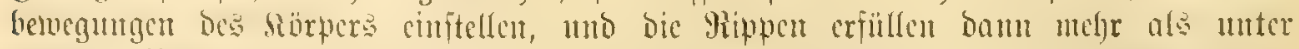

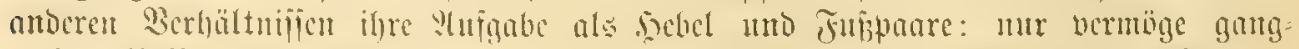

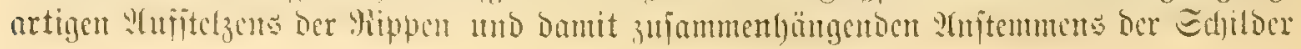




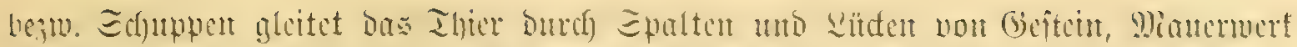

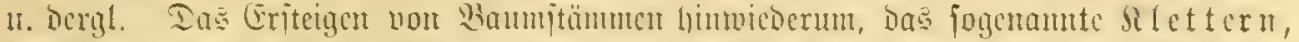

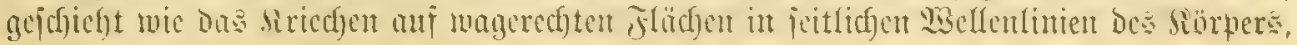

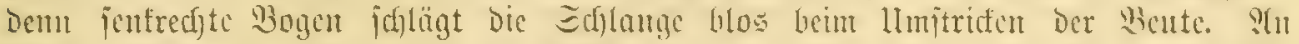

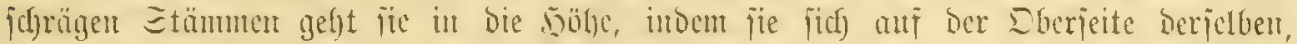

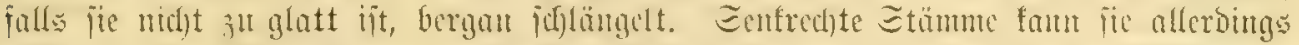

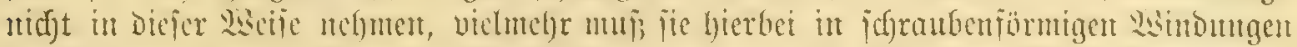

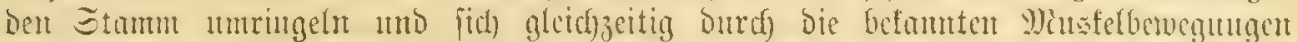

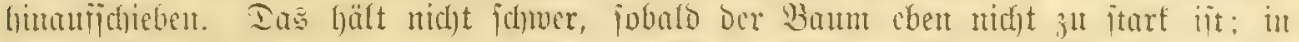

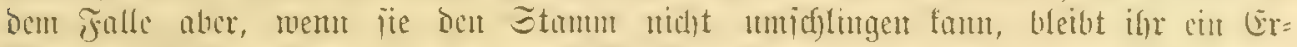

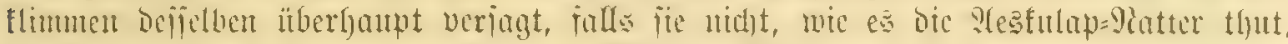

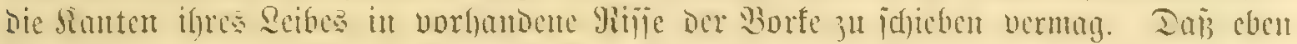

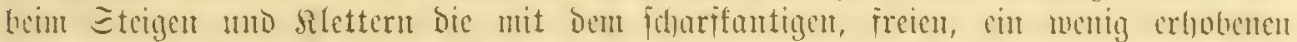

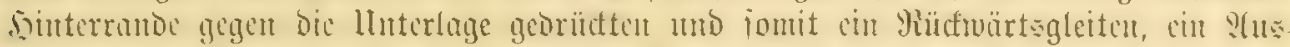

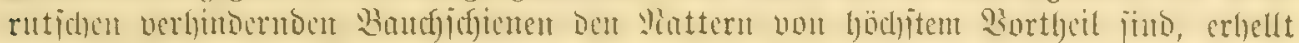

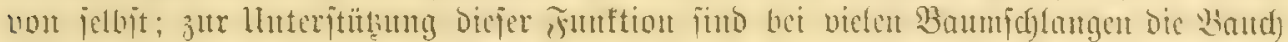

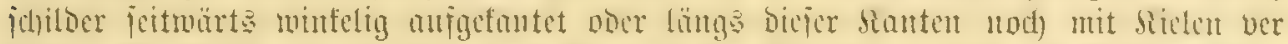

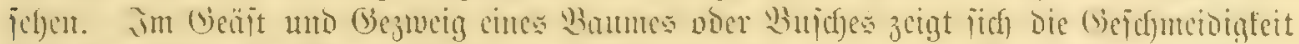

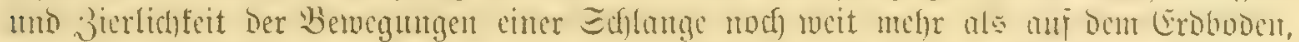

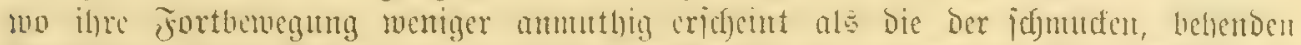

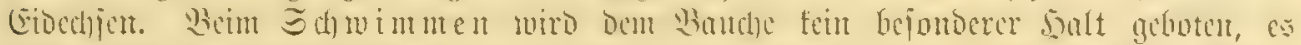

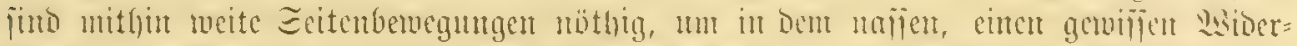

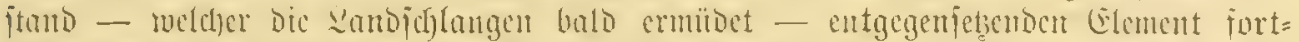

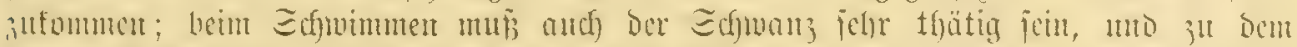

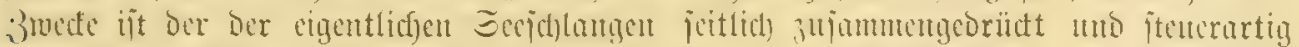

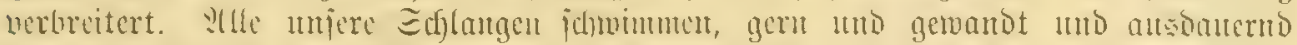

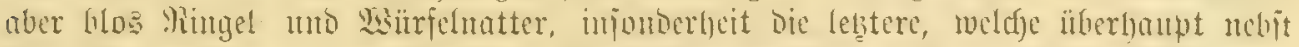

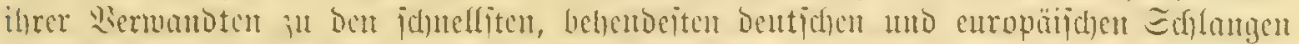

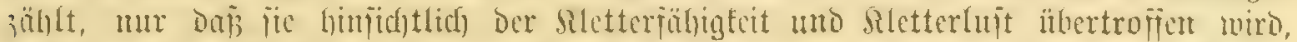

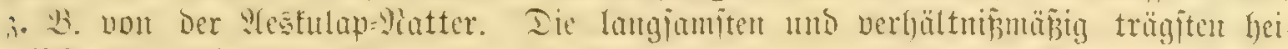

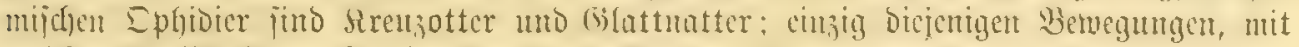

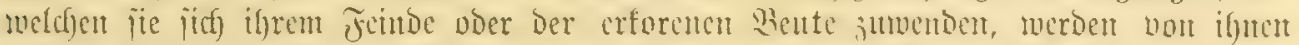

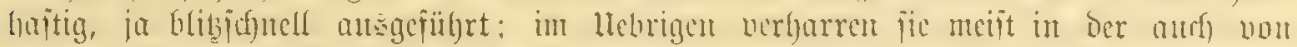

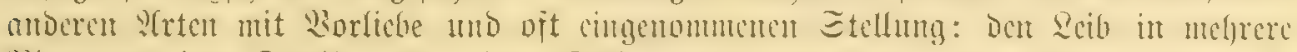

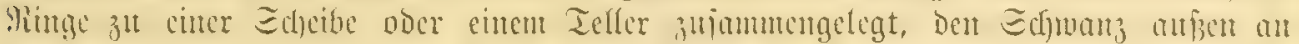

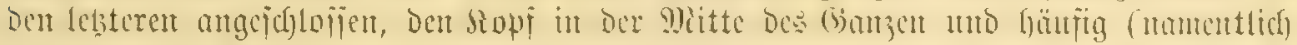

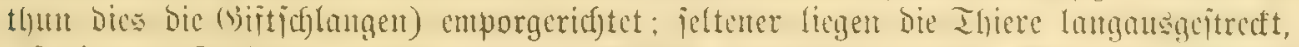

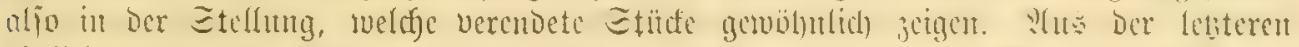

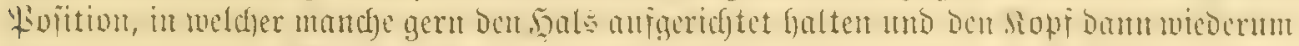

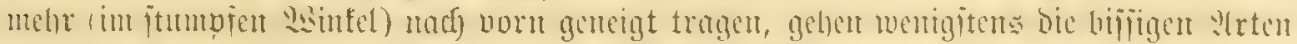

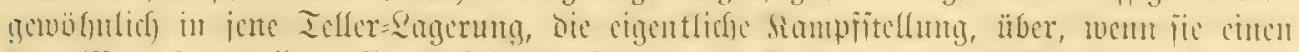

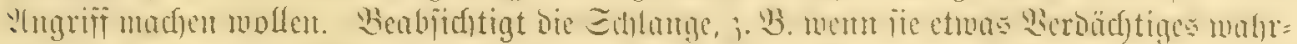

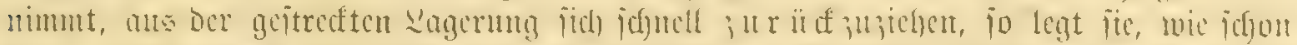

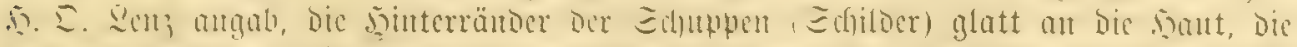

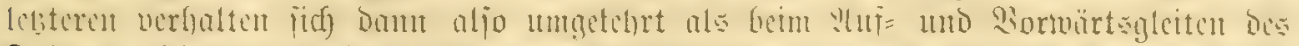

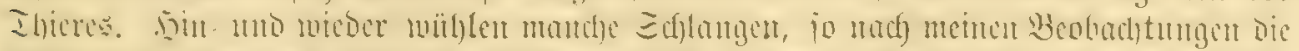

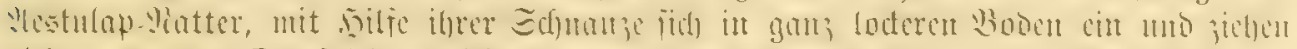

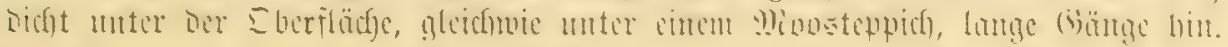


Wexbreitung. Wohnort.

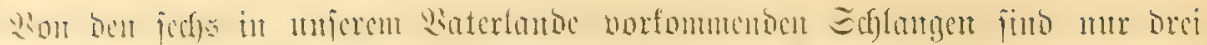

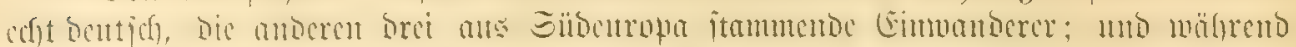

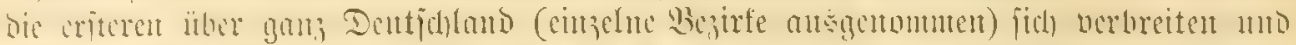

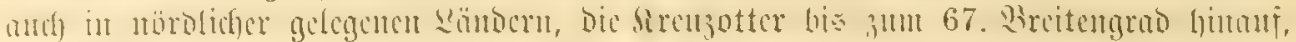

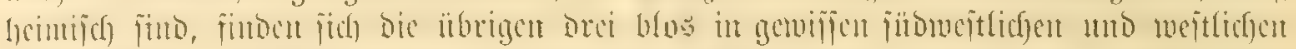

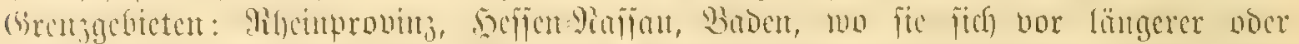

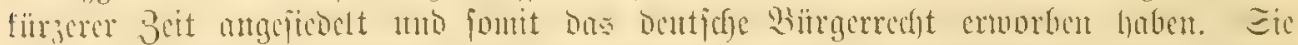

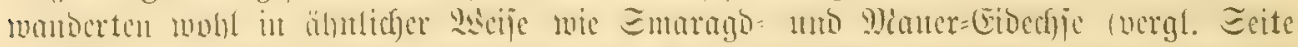

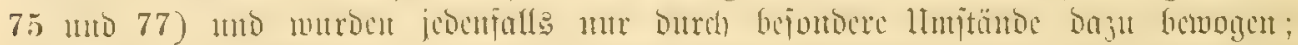

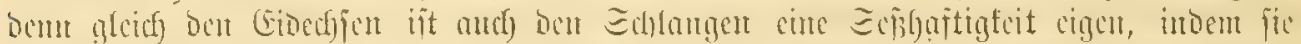

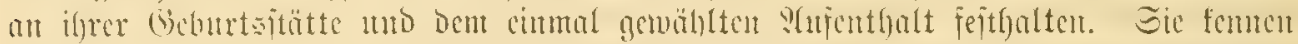

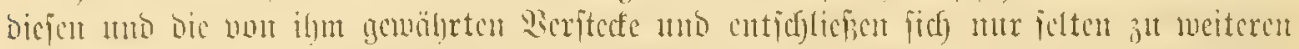

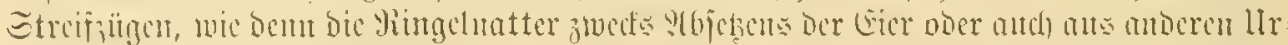

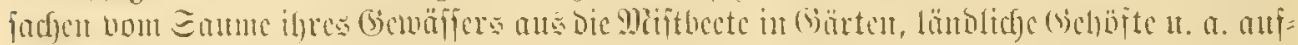

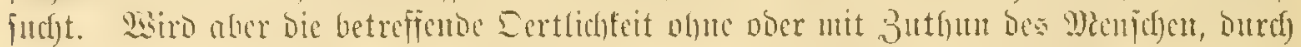

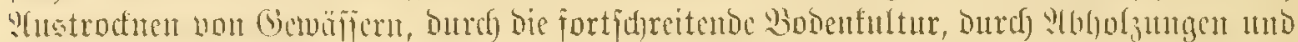

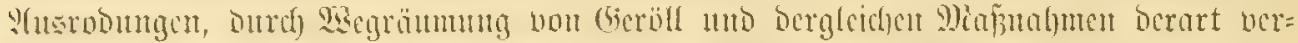

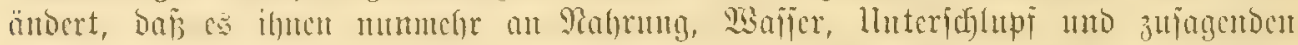

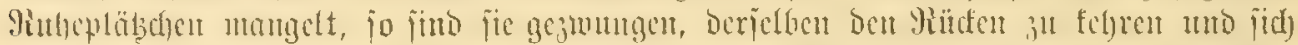

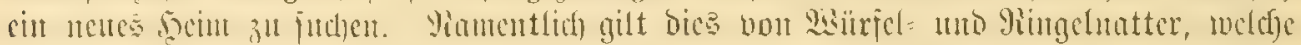

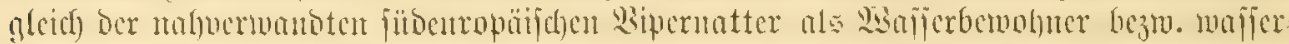

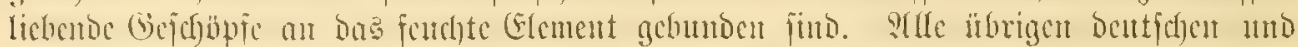

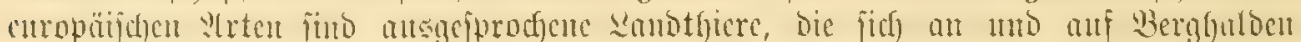

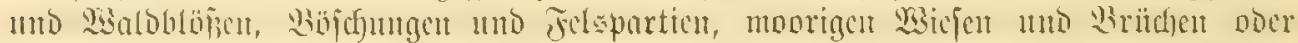

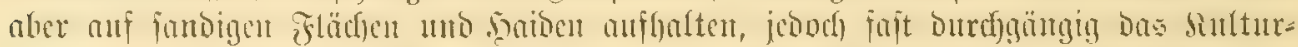

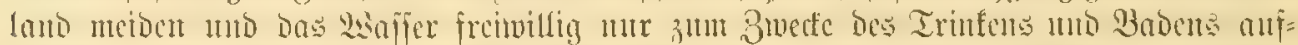

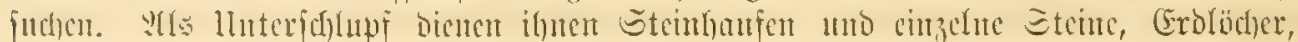

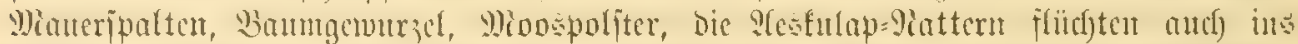

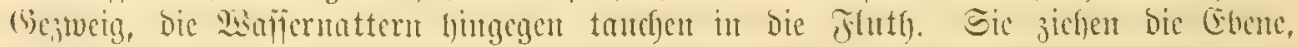

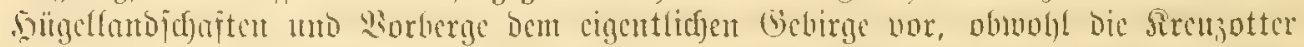

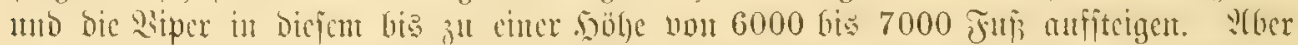

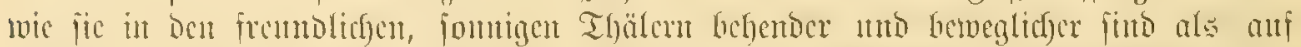

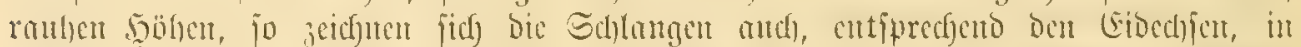

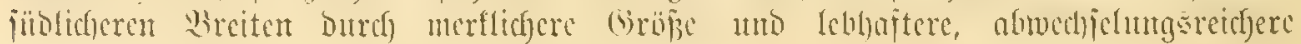
Färbung aนs.

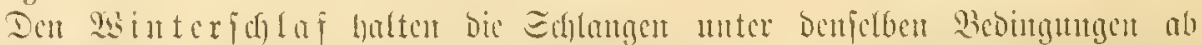

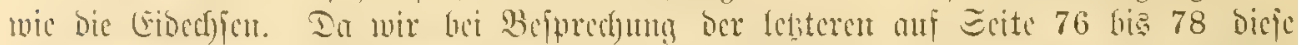

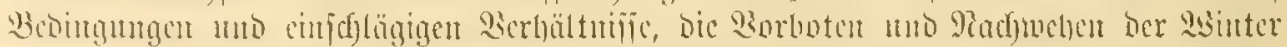

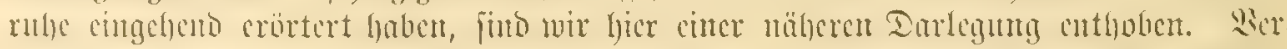

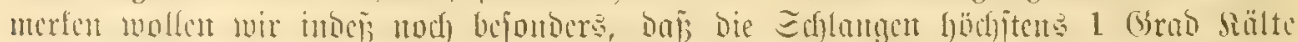

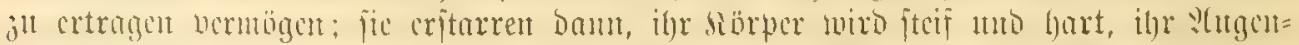

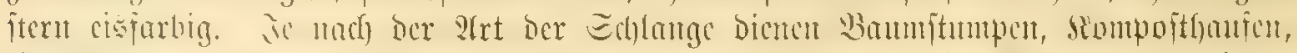

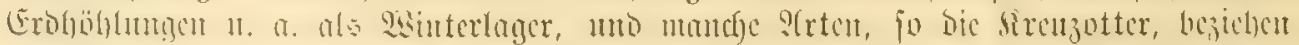

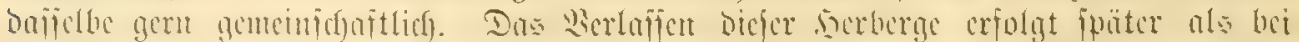

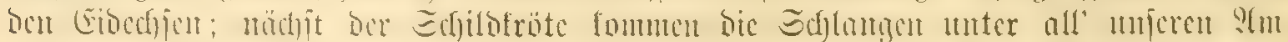

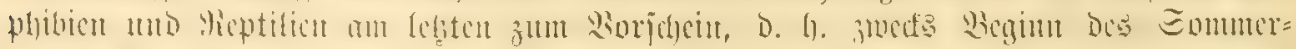

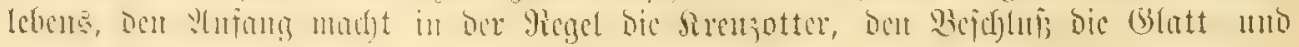
Die Pestutap:Siatter. 


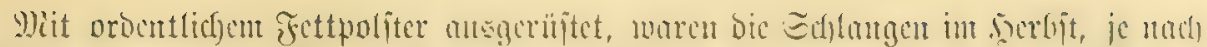

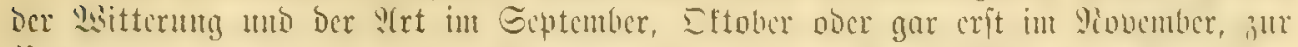

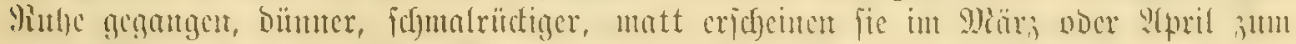

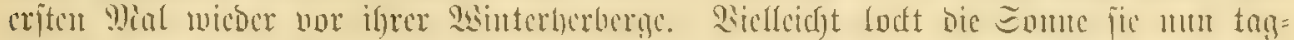

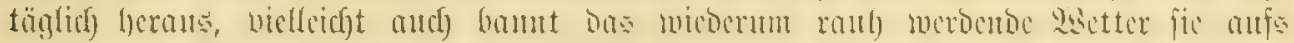

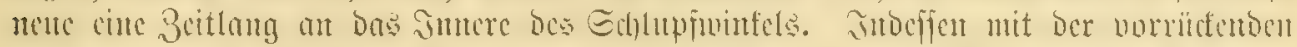

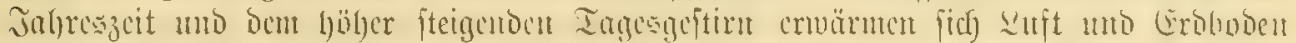

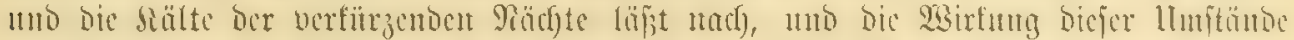

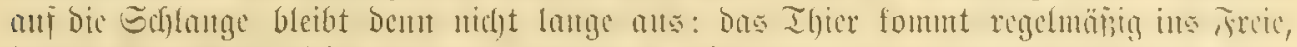

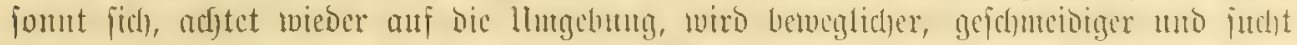

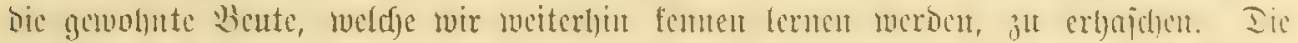

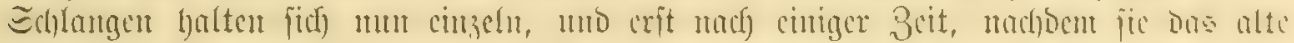

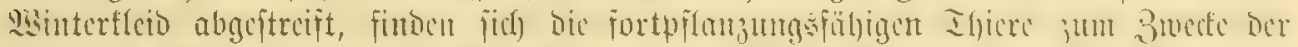

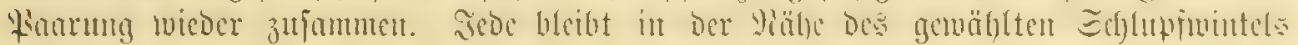

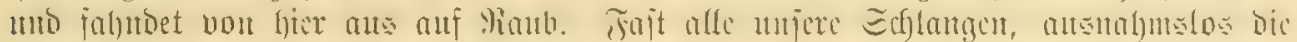

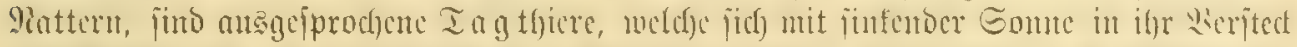

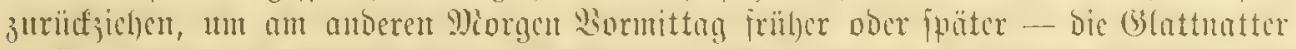

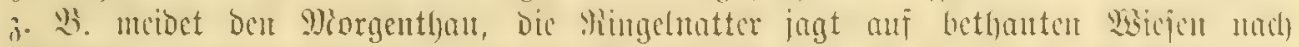

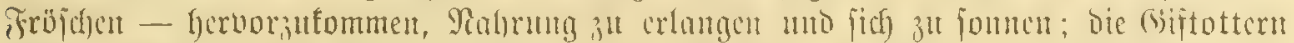

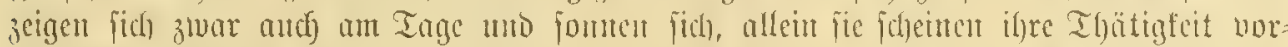

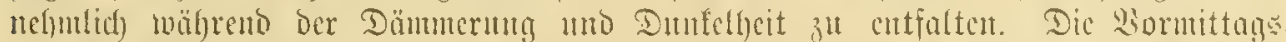

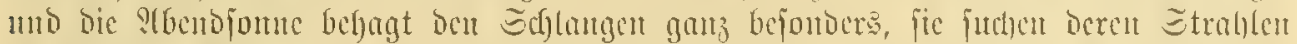

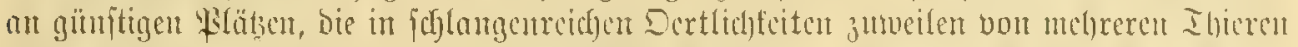

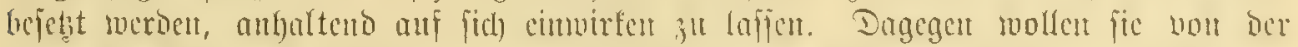

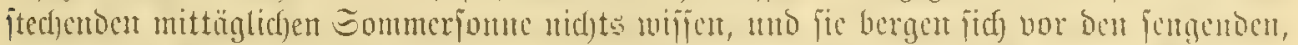

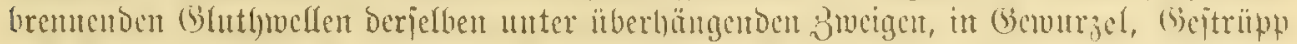

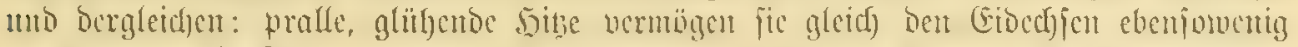

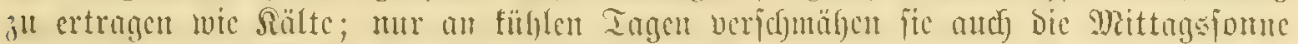

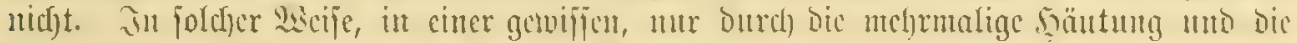

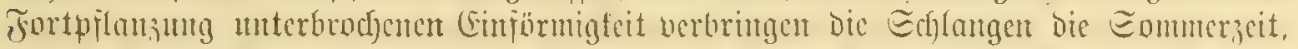

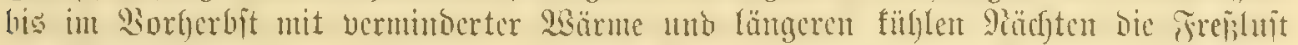

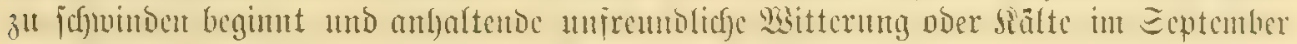
uno Dftober fie zum Quffuchen Des Winterlagers mafnt.

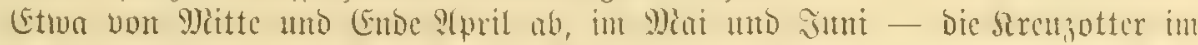

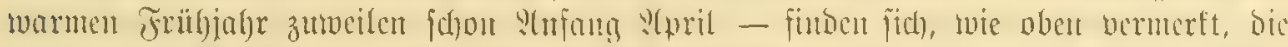

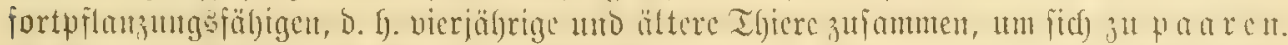

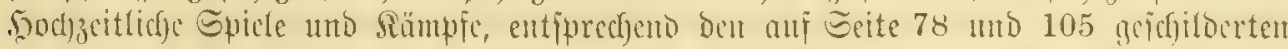

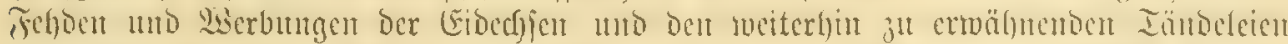

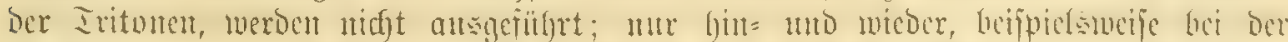

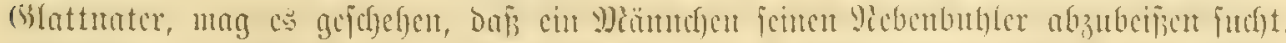

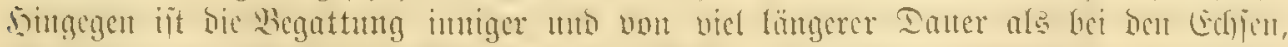

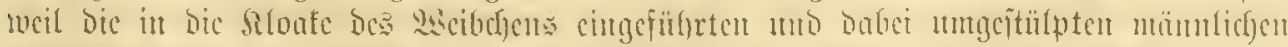

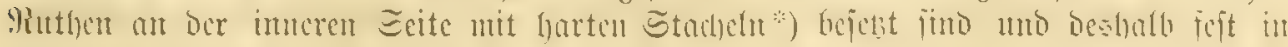

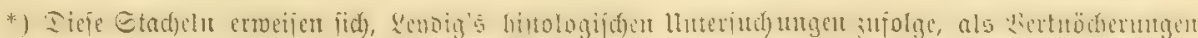

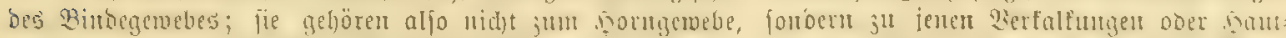

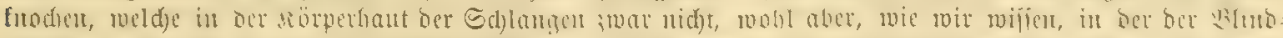

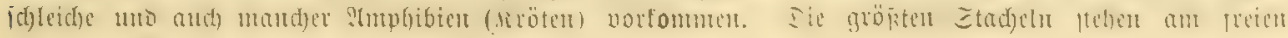
Gribe ber Mitthe. 


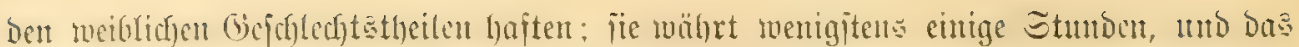
Fisar bleibt and beringht, mem es geptört mo belätigt wiro und ficf), um ju ent=

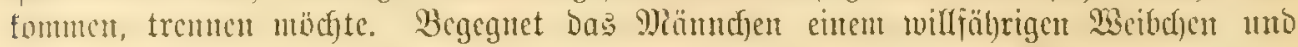

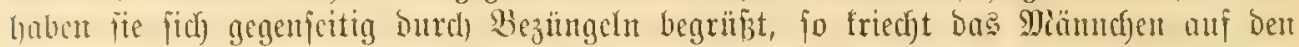

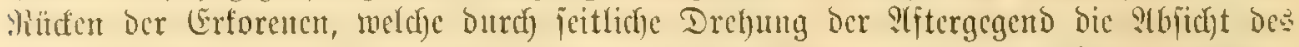

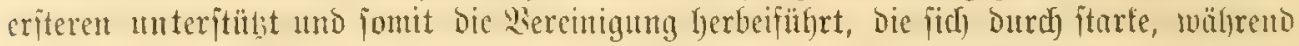
Der Sauer Derfelben ftünoig wicocrbolte 3uffungen uno Eajwanzbemegungen anzeigt.

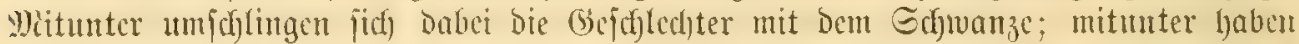

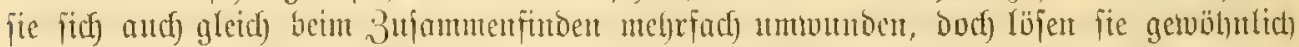

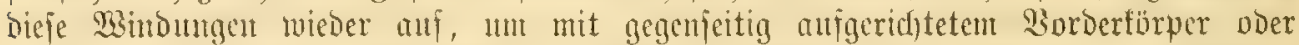

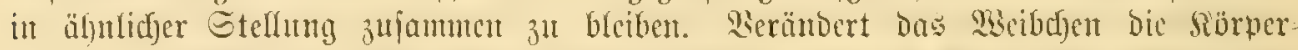

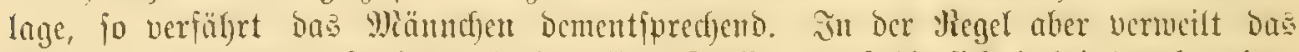

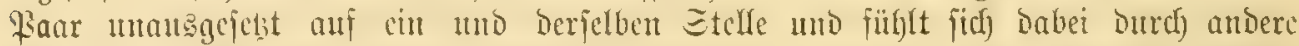

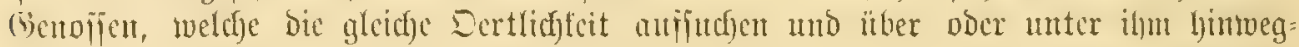

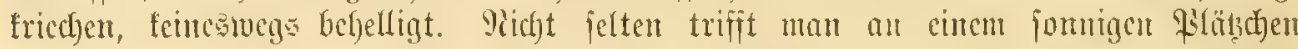

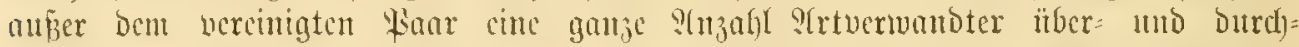
cunander verfnäult in cincm Ganfen beifanmen an, ba eben bie Edylangen gern

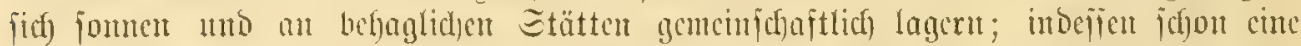

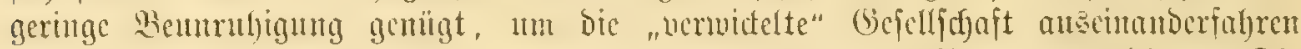

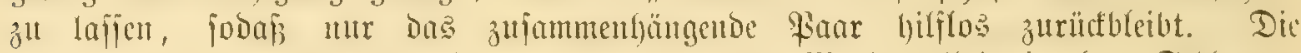

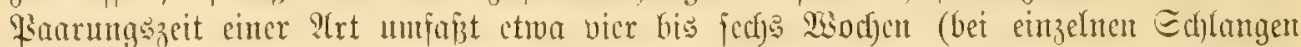

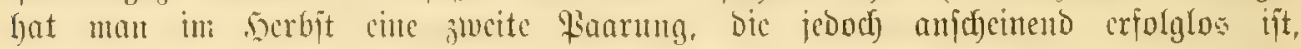

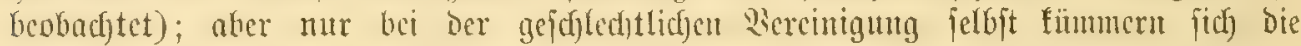

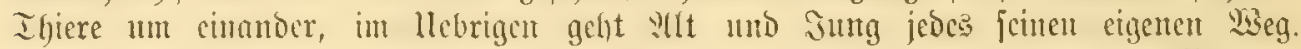

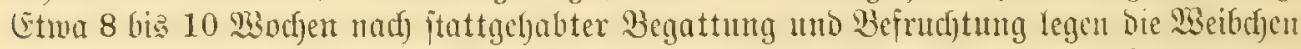

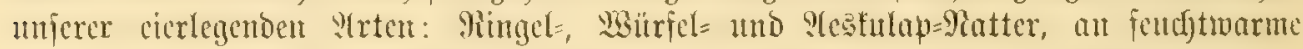
Drtc, unter Miops, Stciue, in Düngerhaujen, Miftbecte, Miuln, Eroböblungen z..

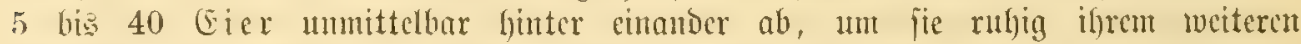

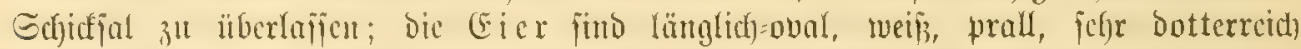

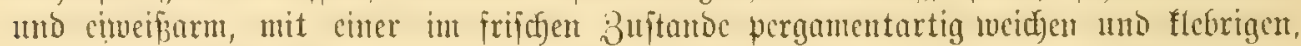

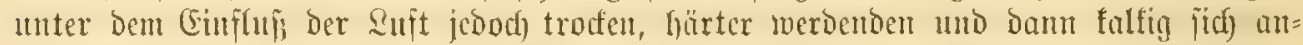

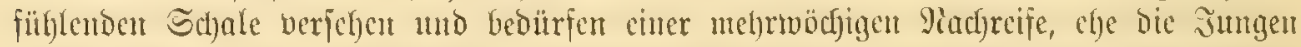

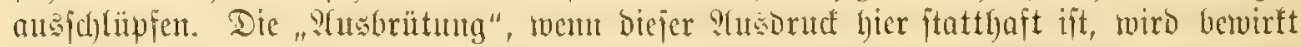
wermittelft der an Den Ragerpläben Dex Cier vorwaltenden feudften Wärme, aljo unter

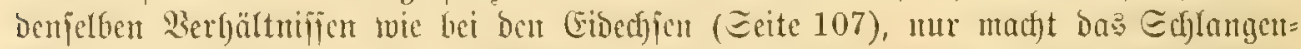

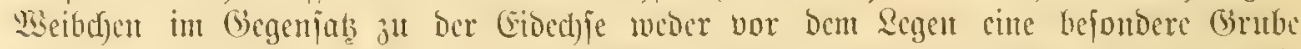

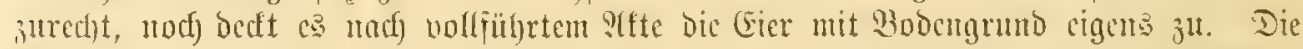

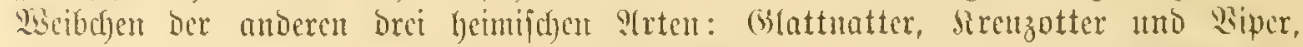

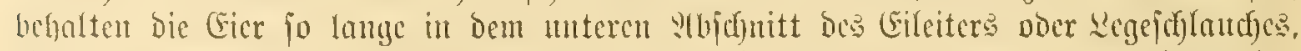

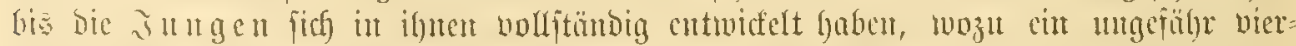

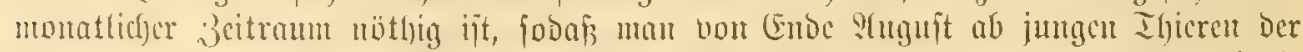

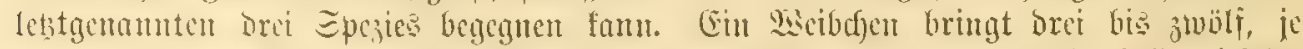

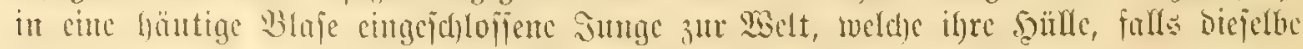

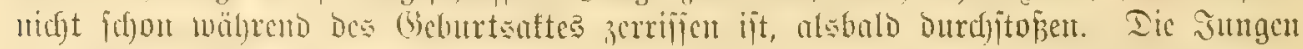

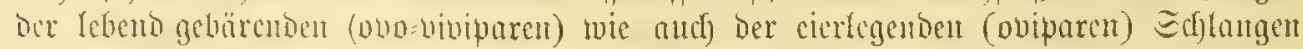

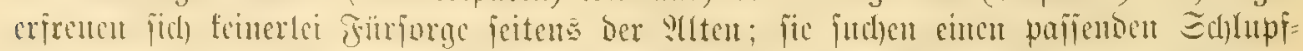

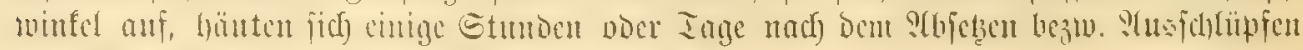

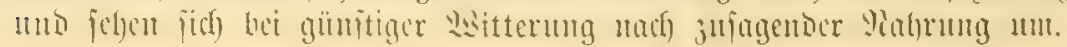




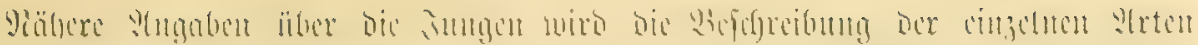
Wijuilbungen.

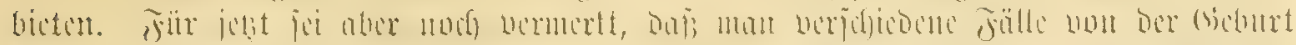

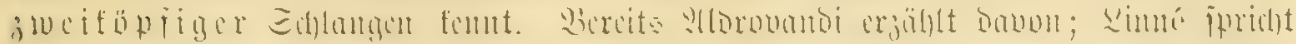

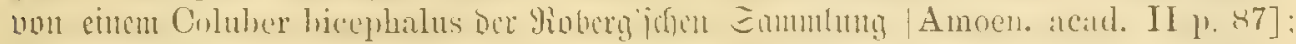

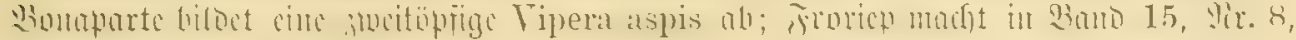

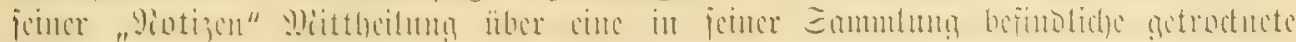

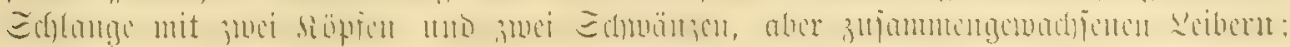

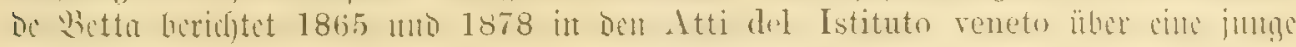

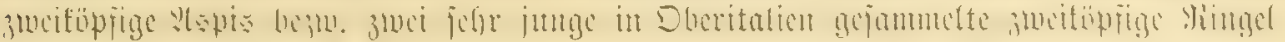

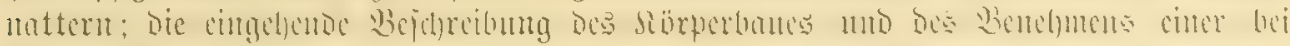

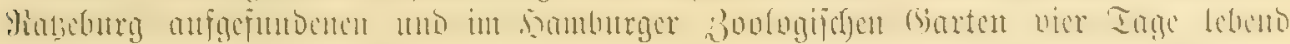

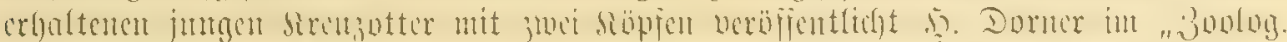

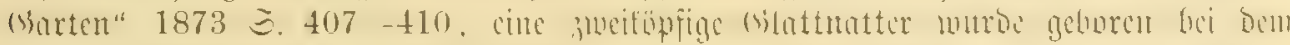

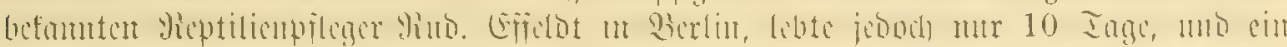

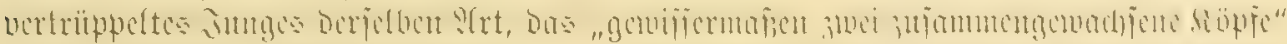

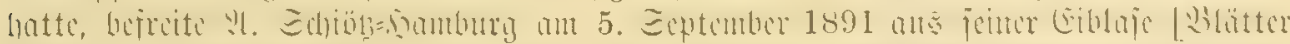

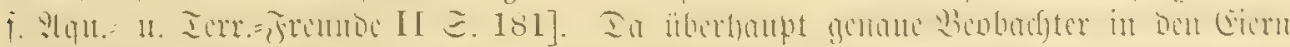

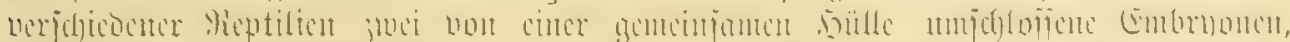

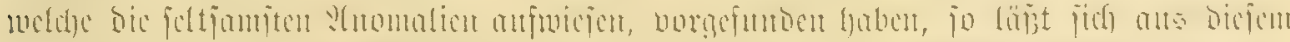

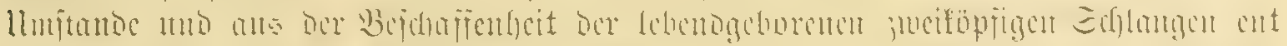

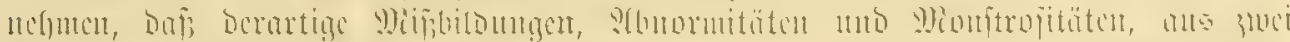

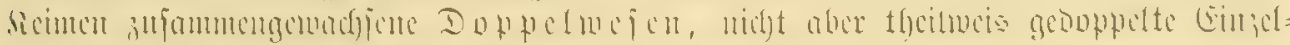
tocjent barjtellett.

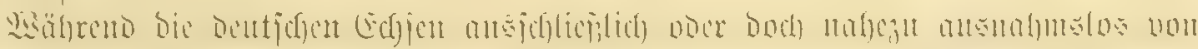

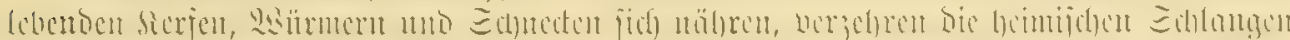

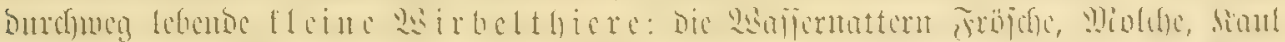

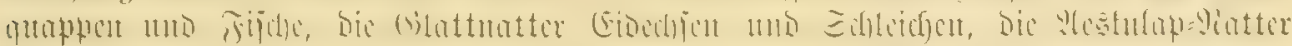

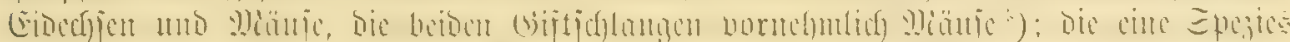
giebt dicjer, bic andere jener

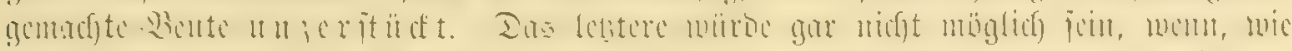

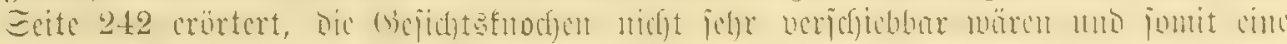

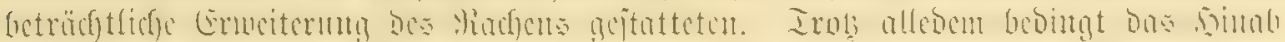

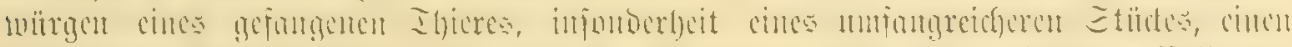

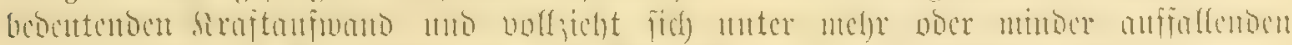

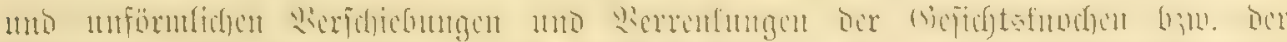

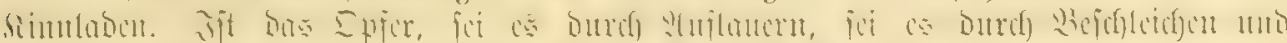

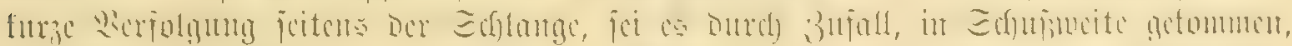

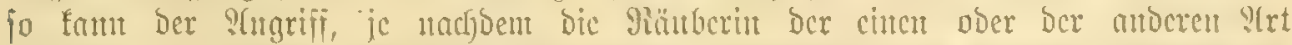

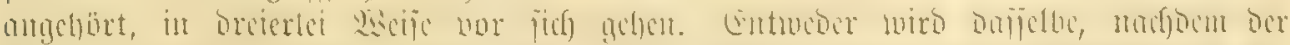

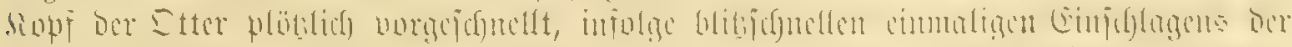

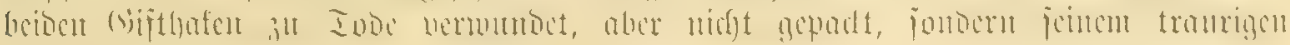

*) Die giagrung ber fübentopäifdent edjlanger ift in ber sauptfache biefelbe, jebact) ver=

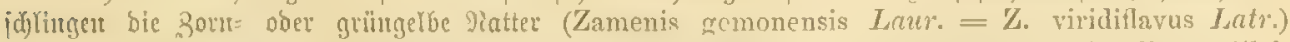

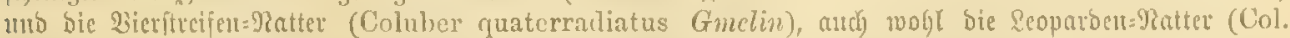

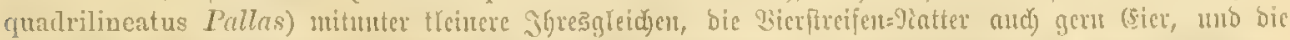

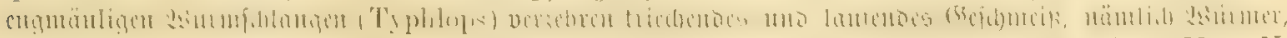

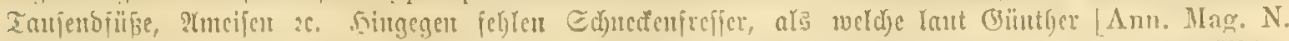

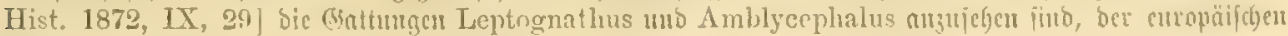
jัณนท gänเป็lity. 


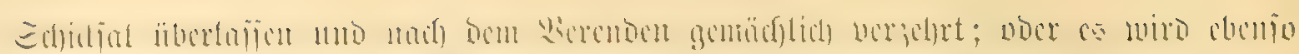

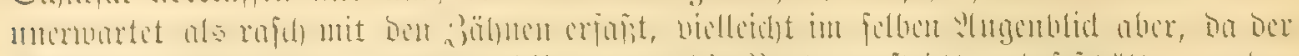

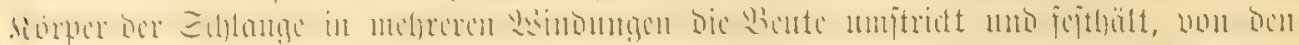

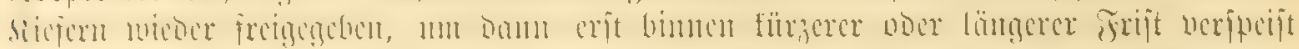

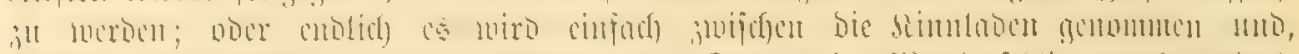

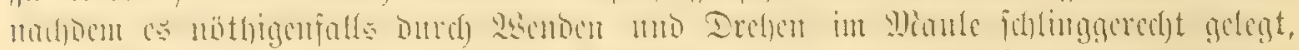

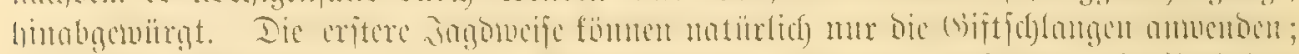
Das jucite

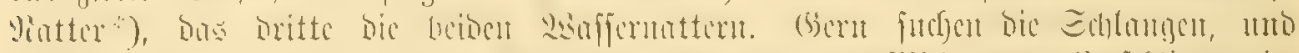

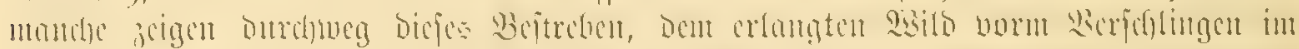

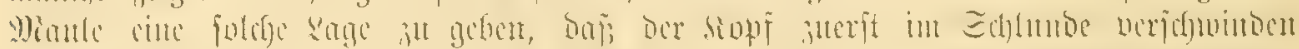

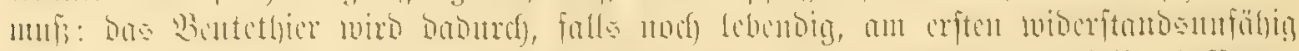

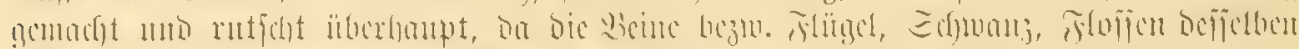

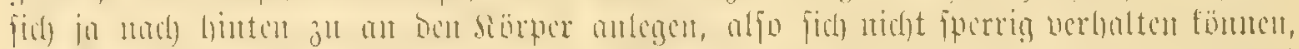

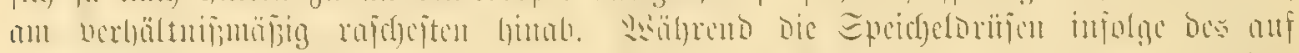

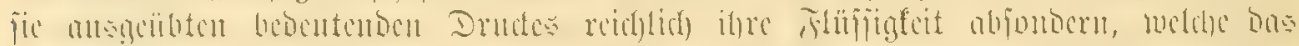

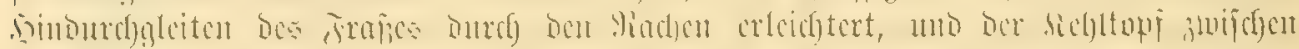

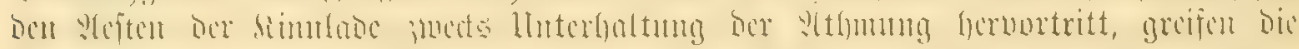

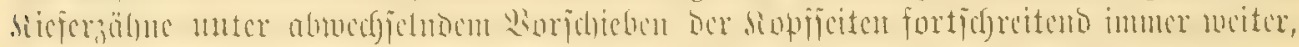

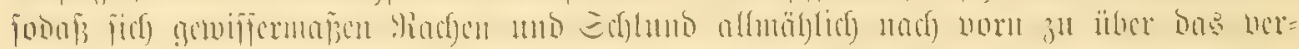

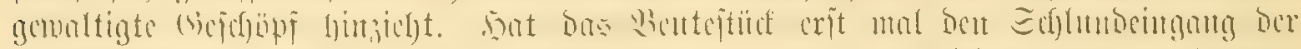

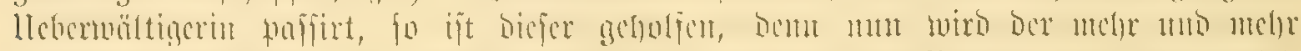

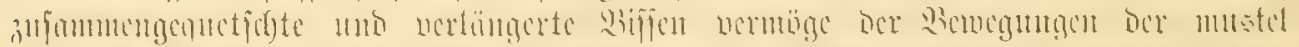

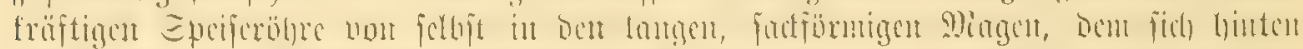

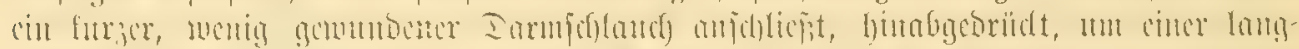

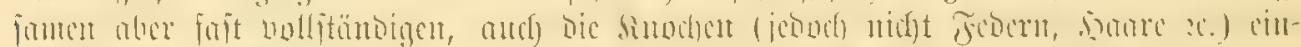

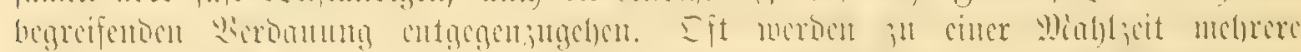

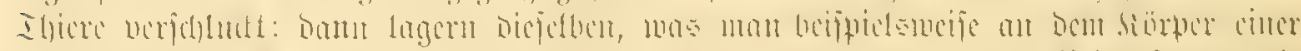

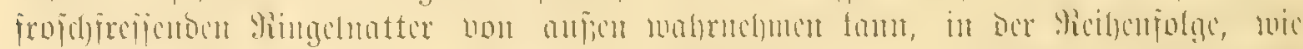

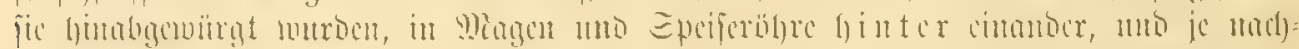

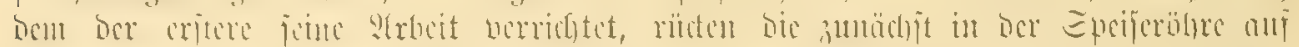

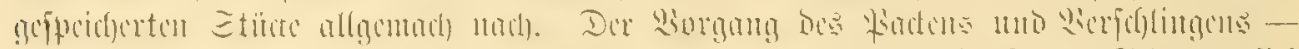

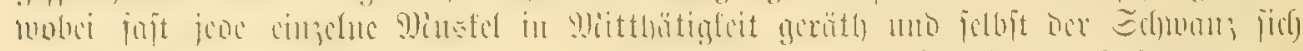

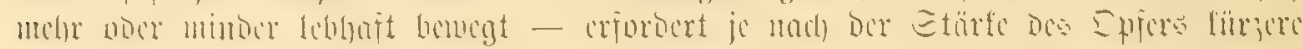

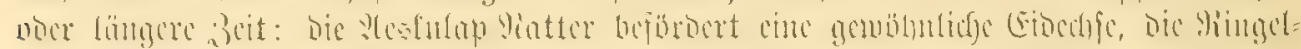

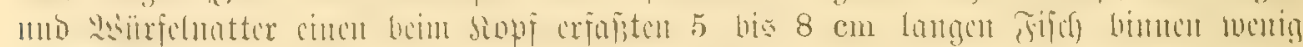

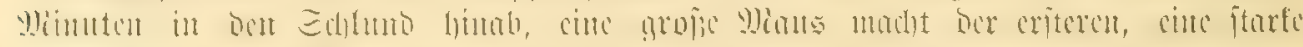

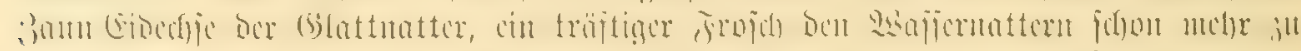

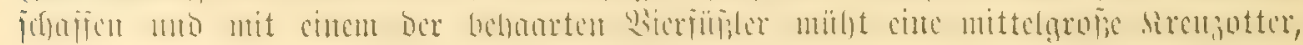

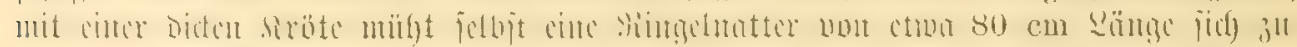

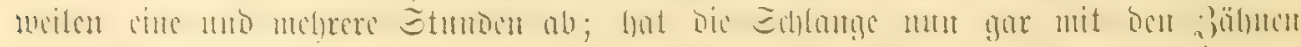

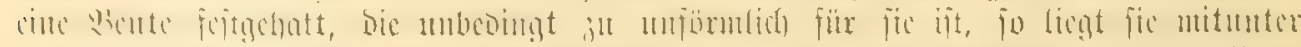

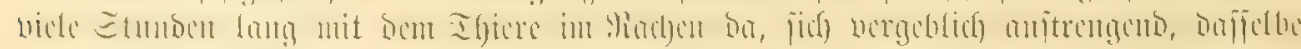

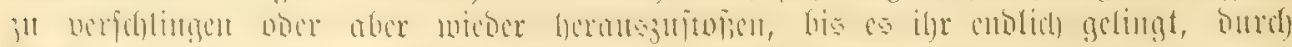

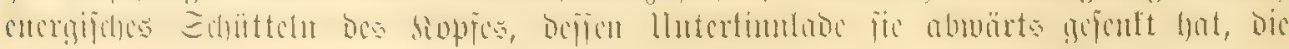

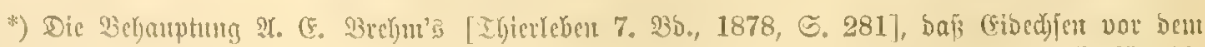

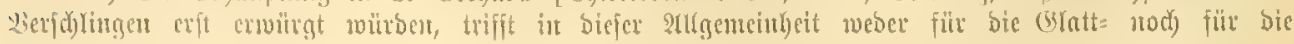

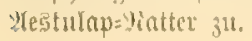




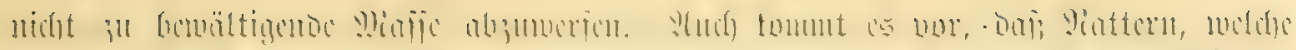

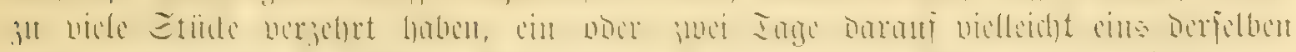

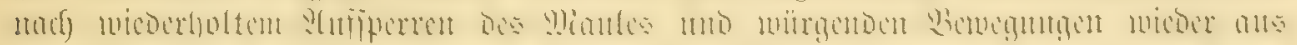

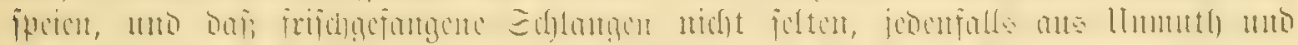

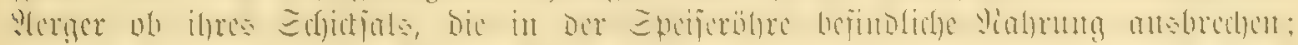

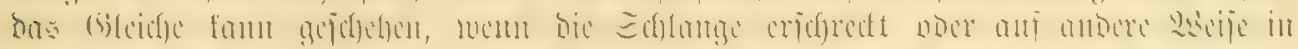

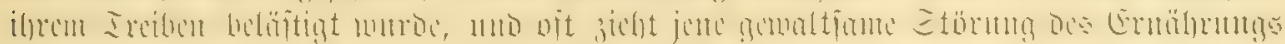

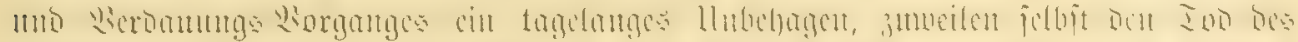

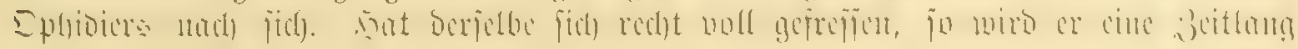
unbefuilficher und träger als foutit.

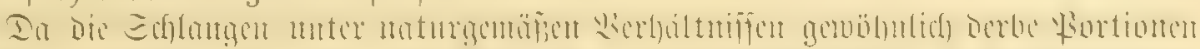

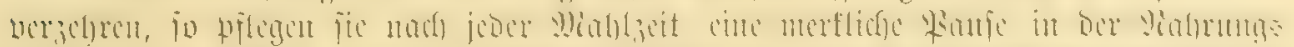

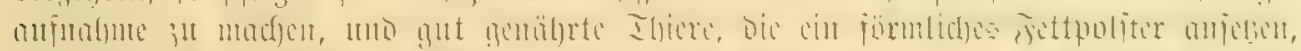

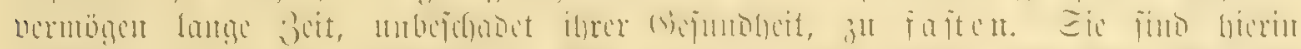

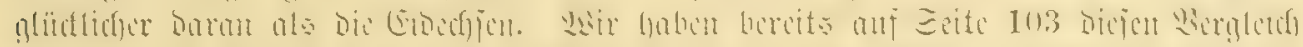

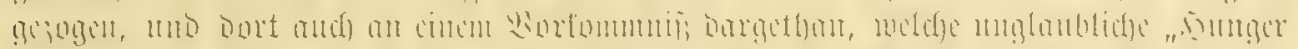

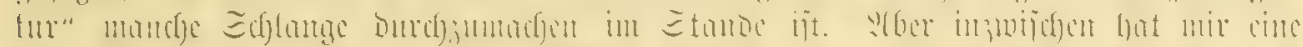

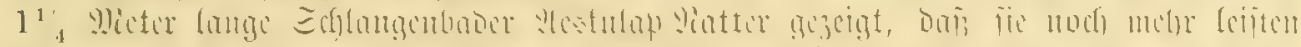

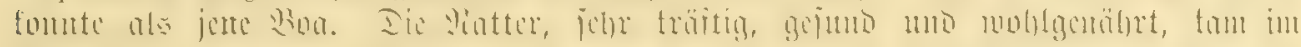

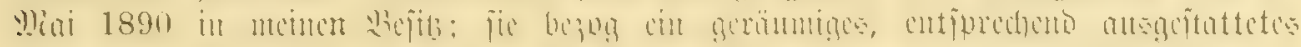

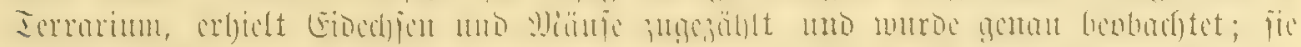

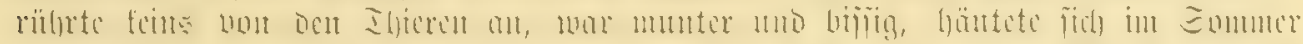

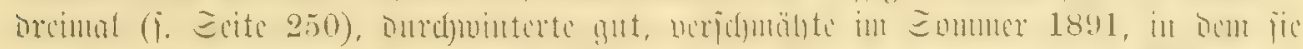

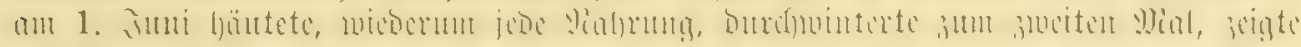

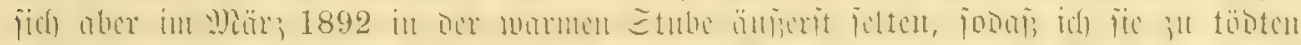

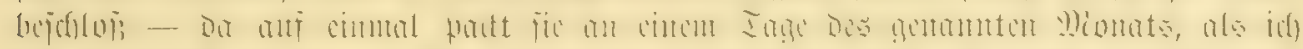

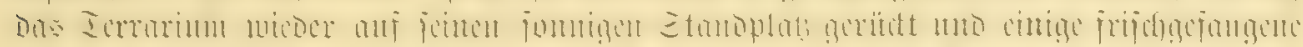

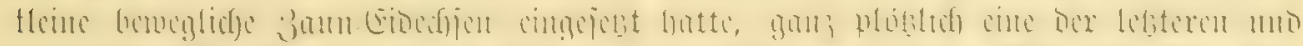

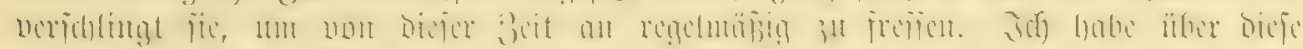

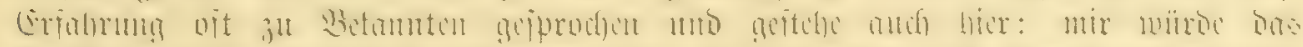

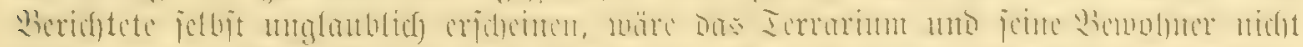

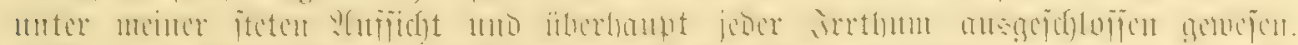

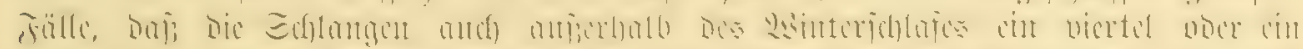

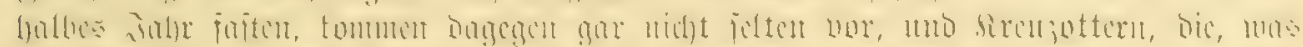

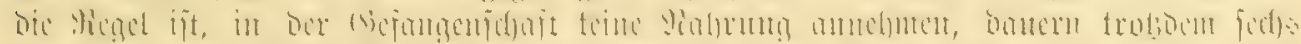

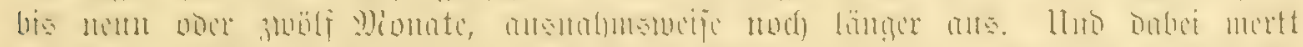

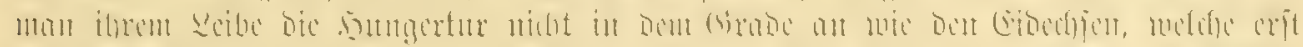

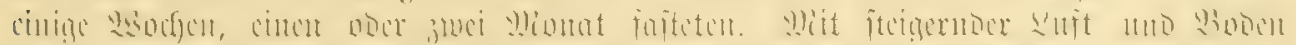

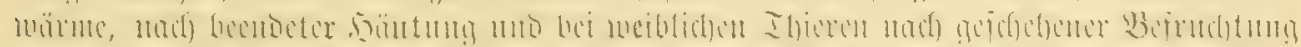

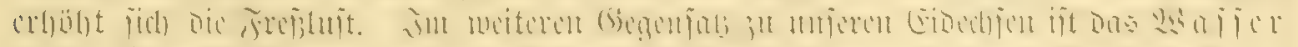

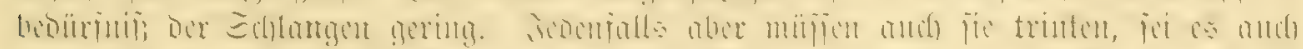

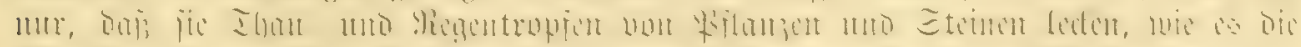

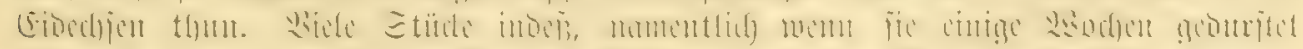

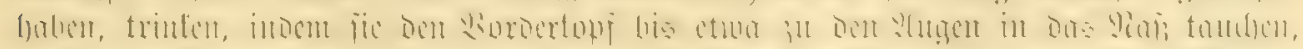

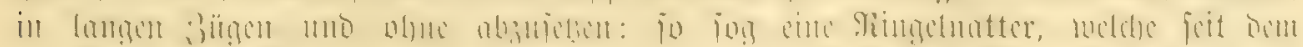

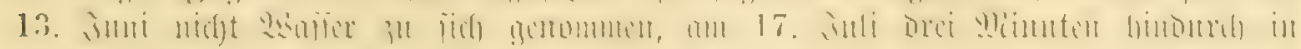

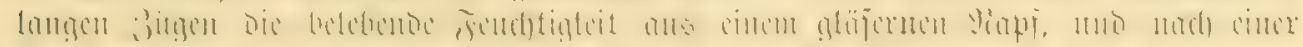

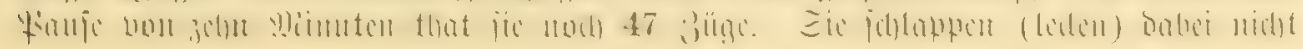




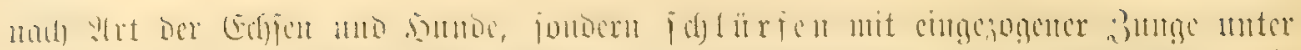

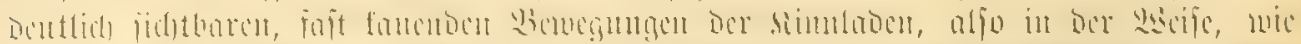

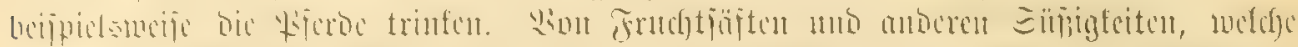

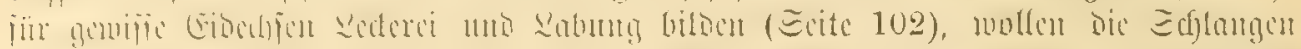

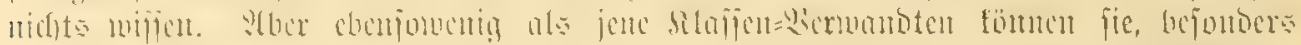

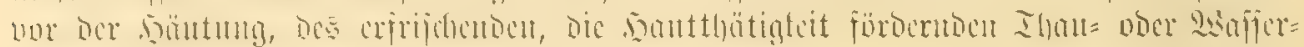
babes cutucl)rent.

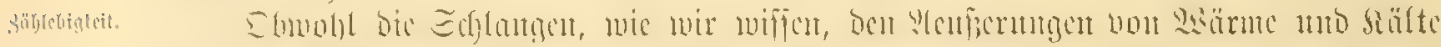

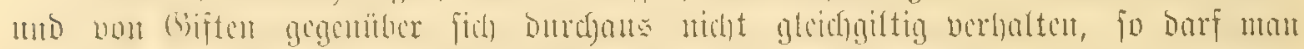

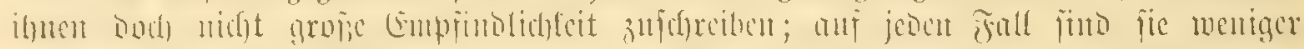

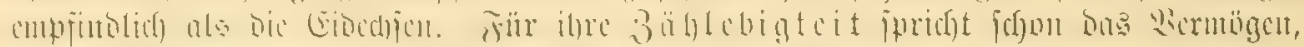

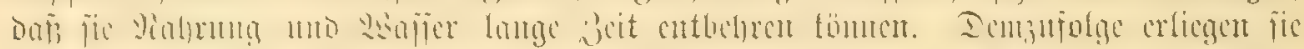

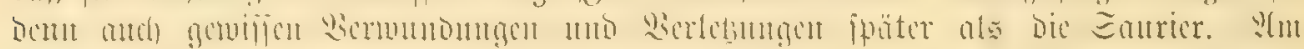

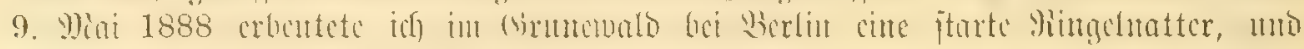

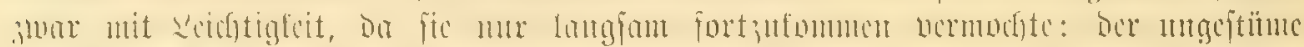

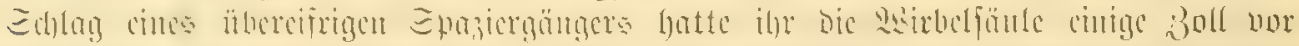

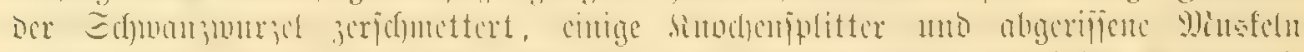

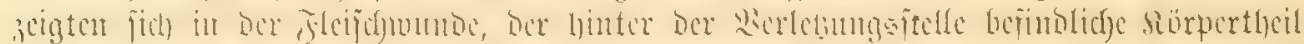

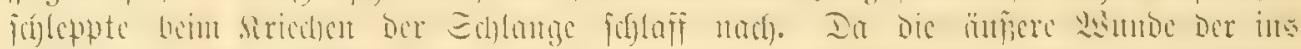

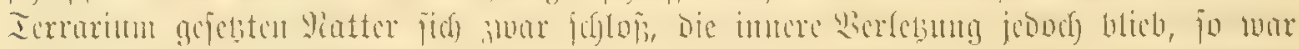

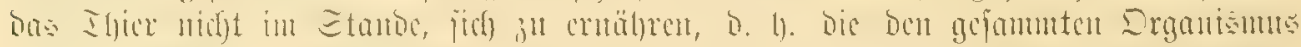

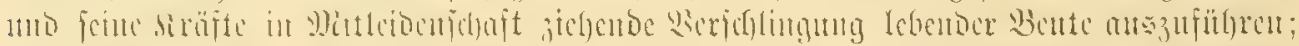

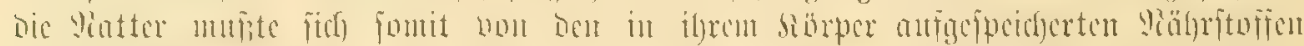

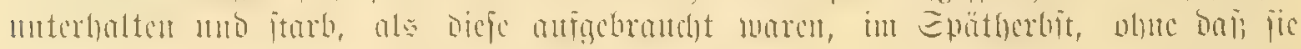

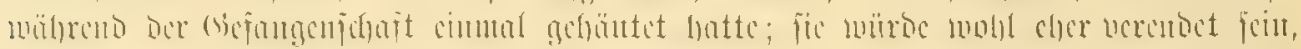

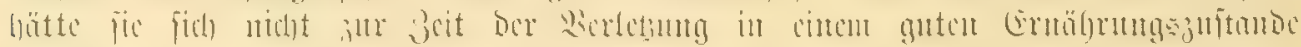

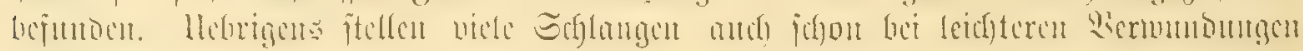

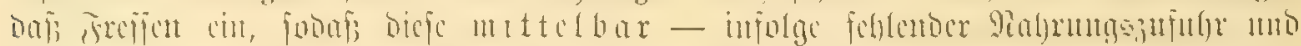

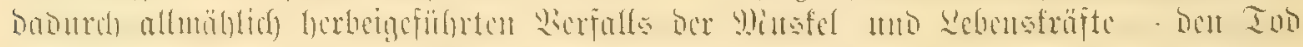

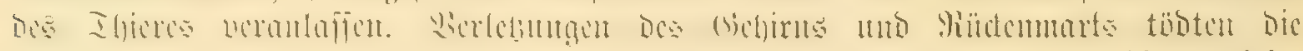

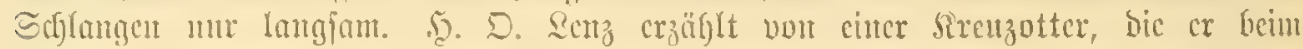

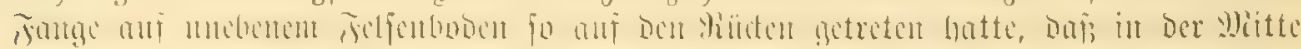

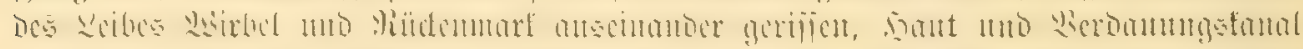

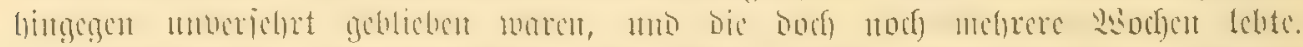

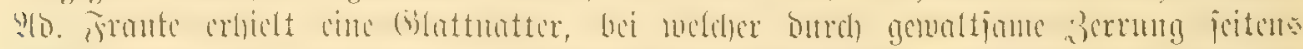

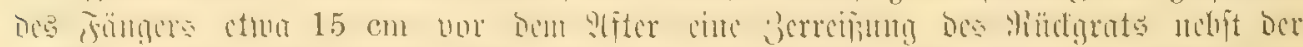

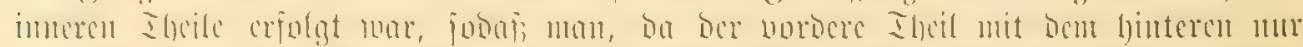

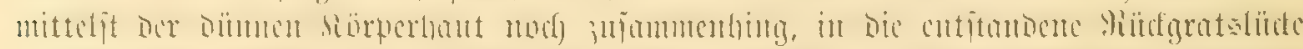

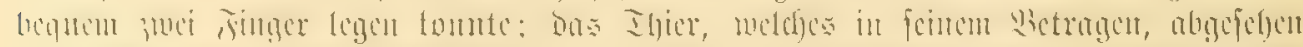

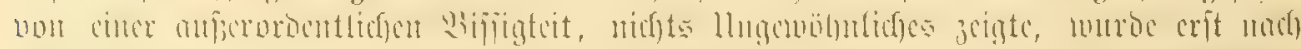

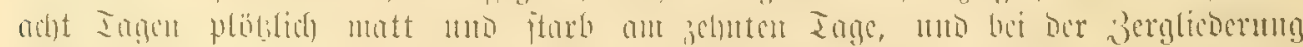

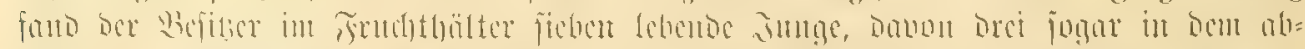

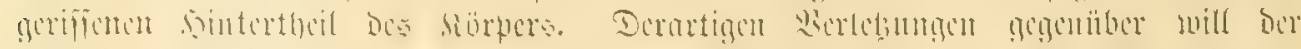

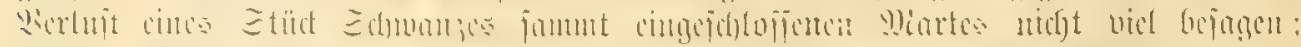

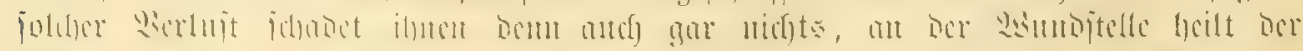

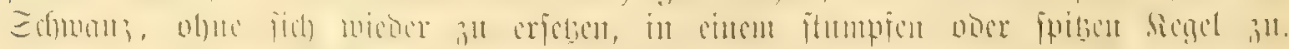

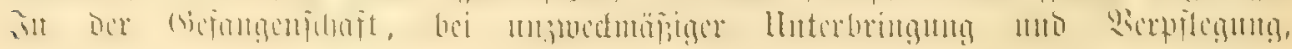

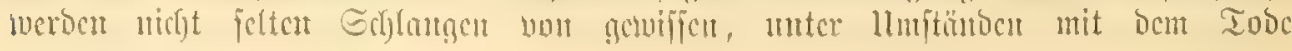




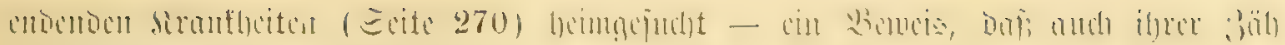
Icbigleit eine Girenge gejelst ijt.

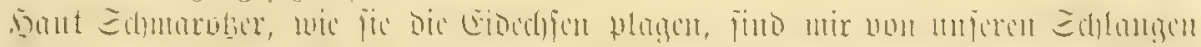

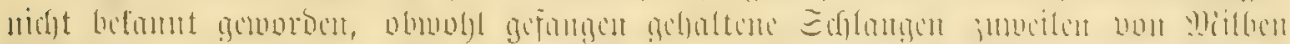

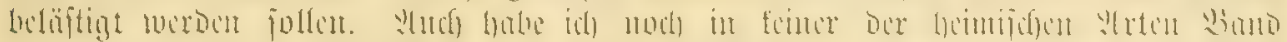

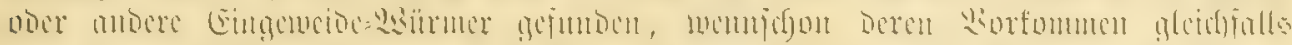

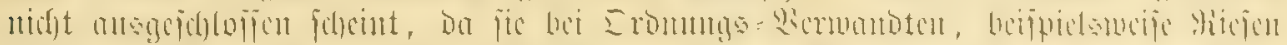

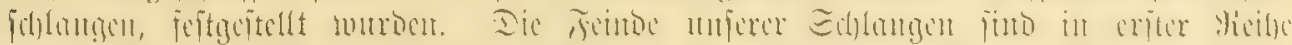

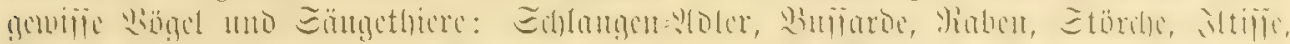

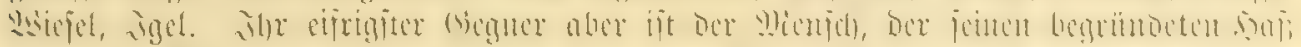

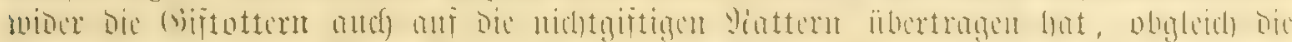

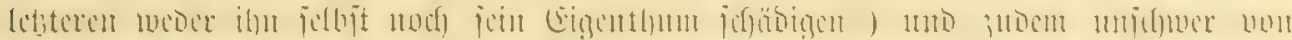

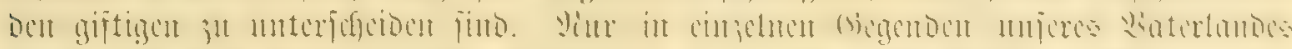

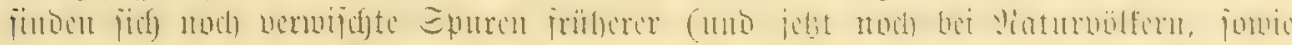

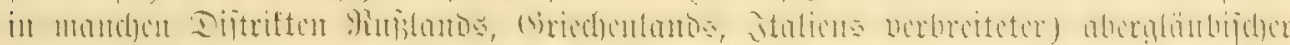

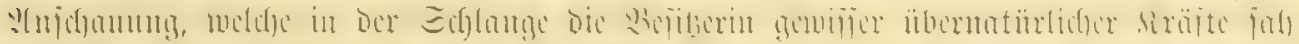

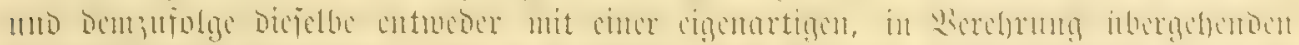

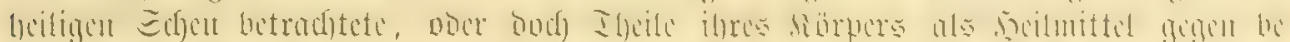

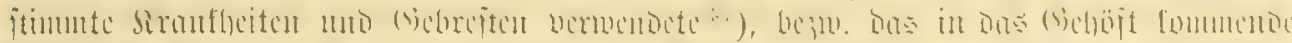

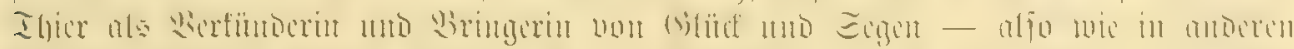

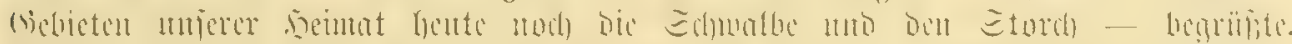

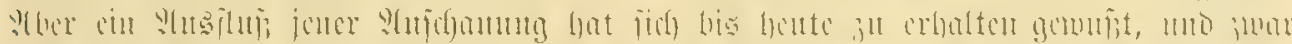

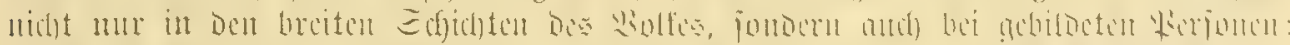

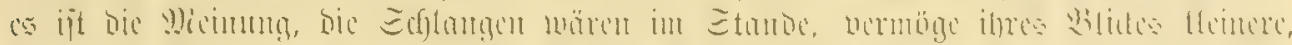

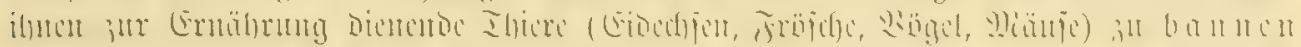

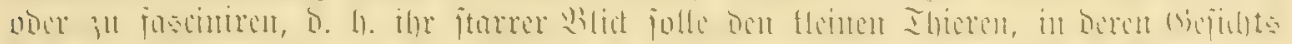

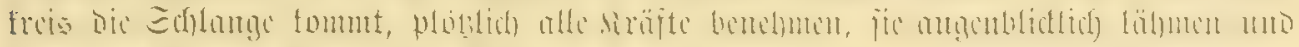

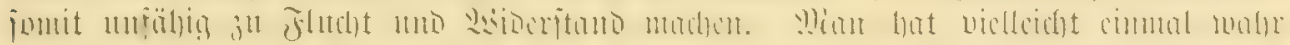

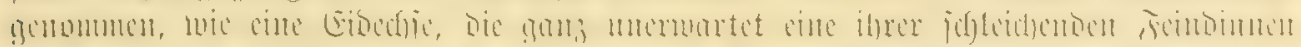

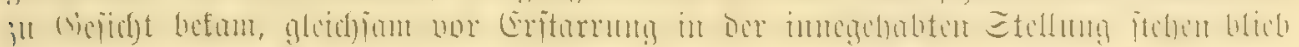

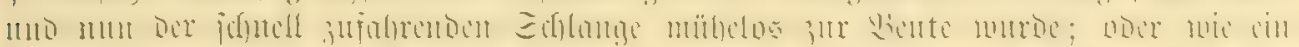

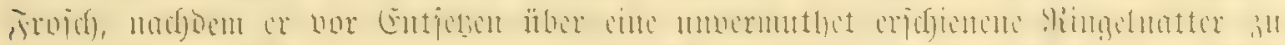

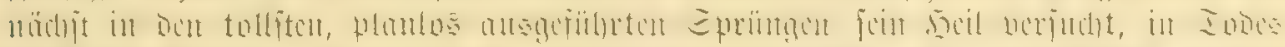

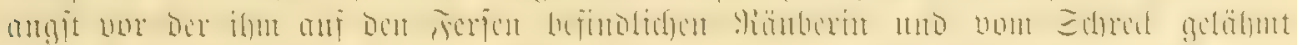

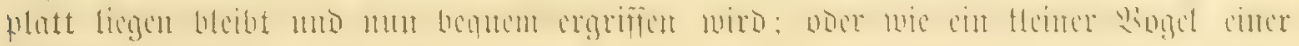

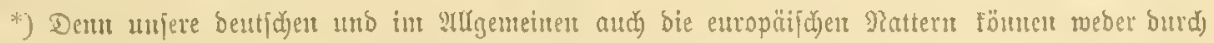

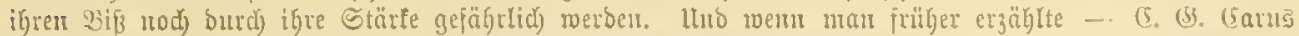

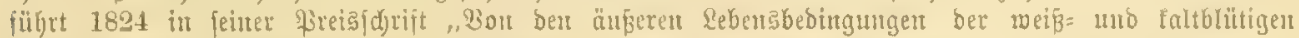

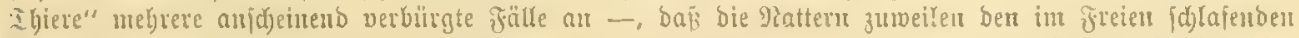

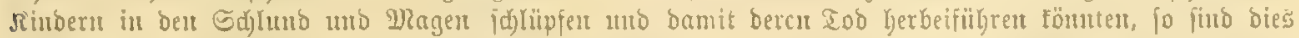

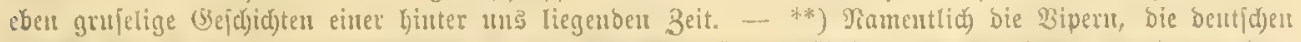

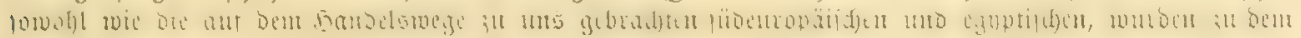

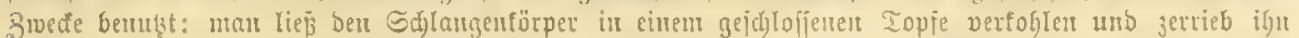

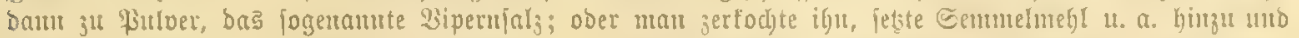

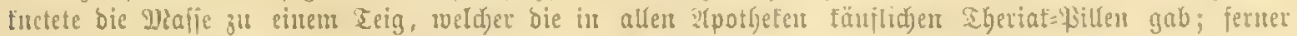

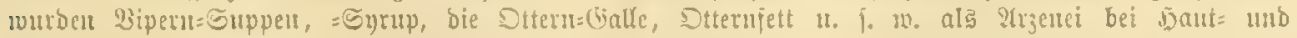

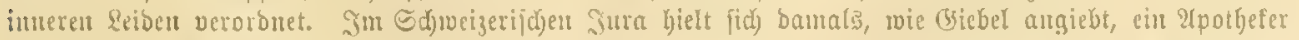

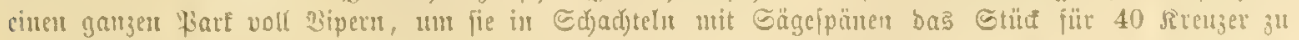

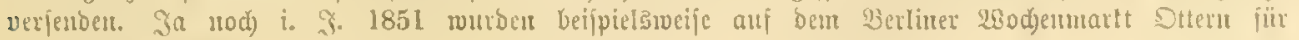
mebisuildie 3rede jeilgeboten. 


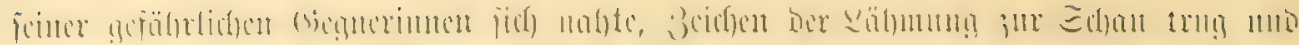

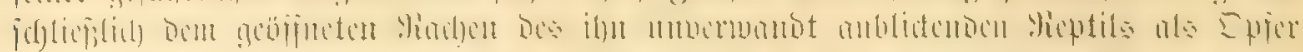

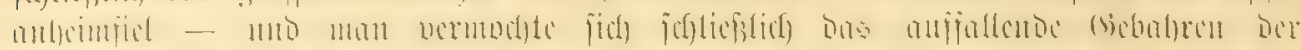

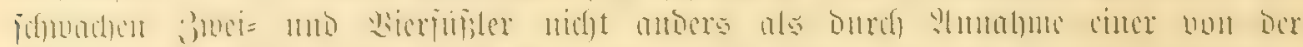

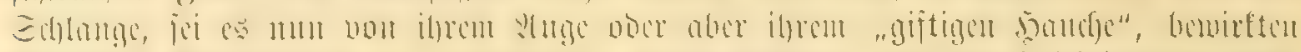

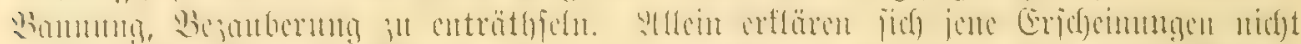

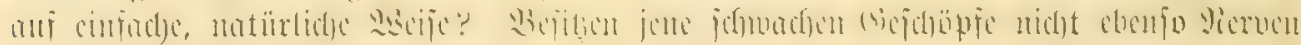

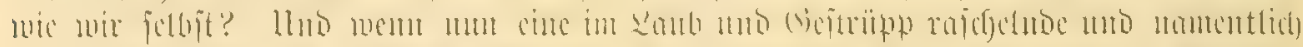

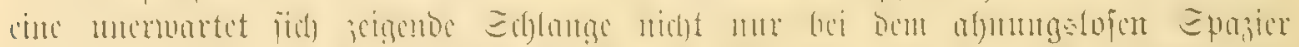

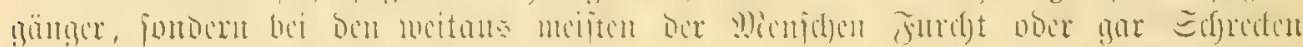

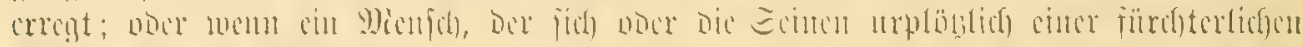

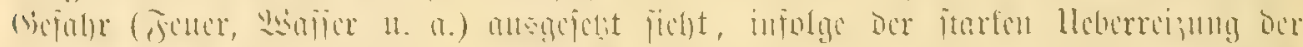

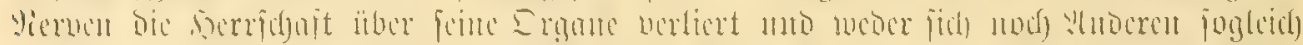

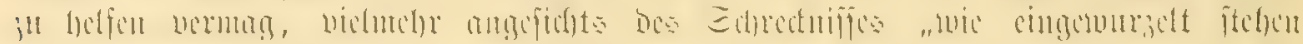

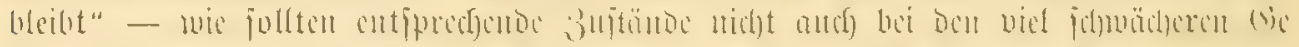

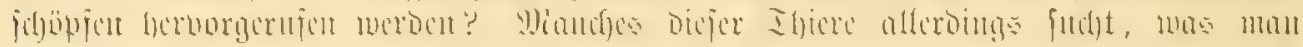

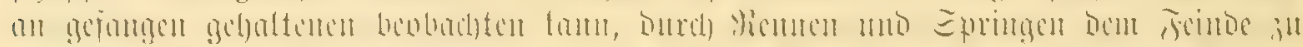

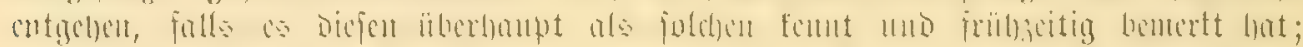

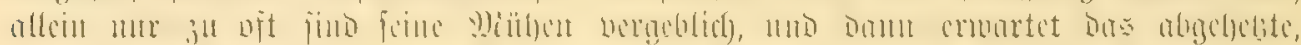

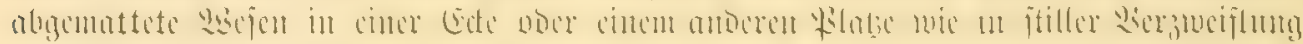

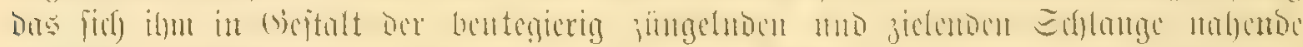

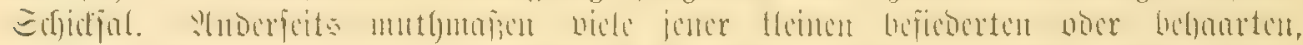

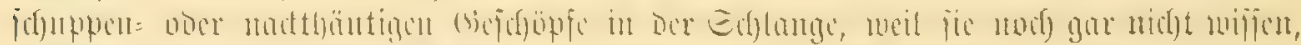

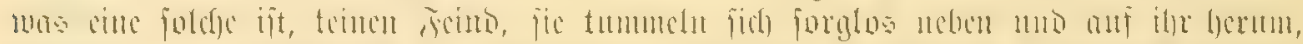

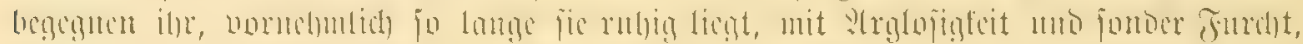

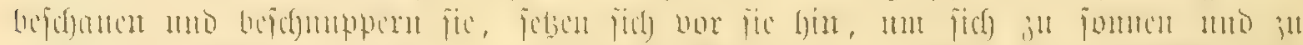

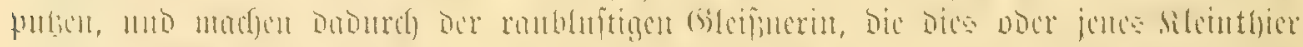

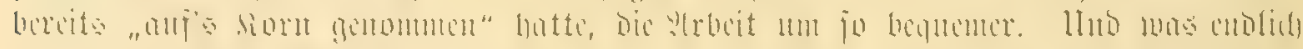

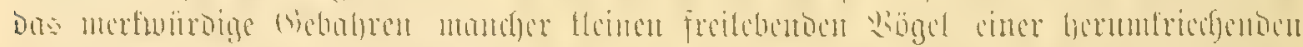

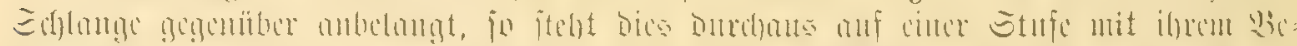

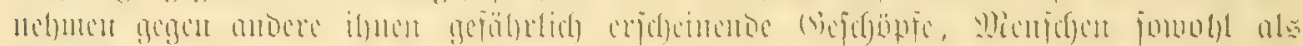

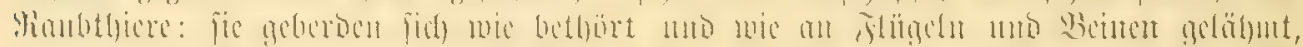

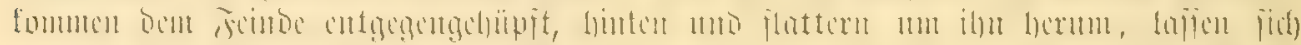

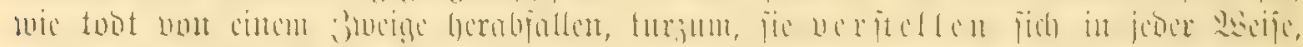

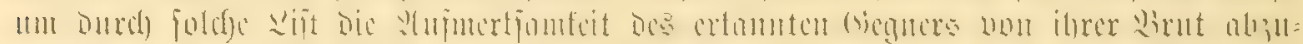

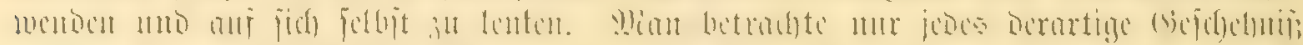

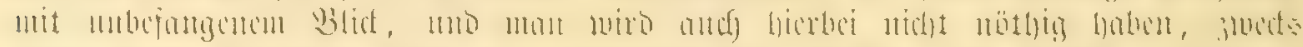

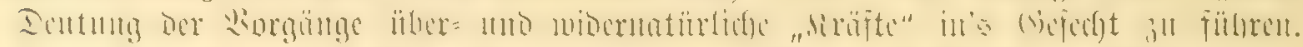

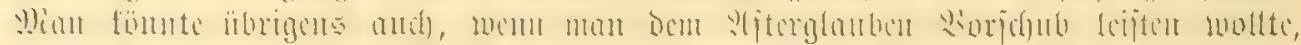

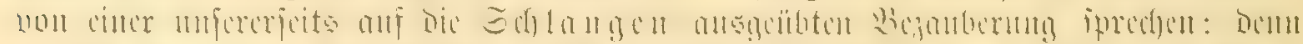

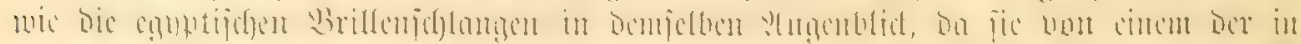

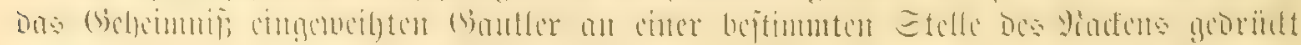

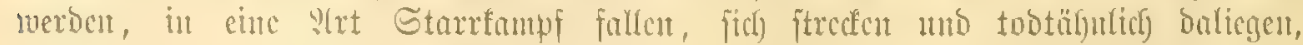

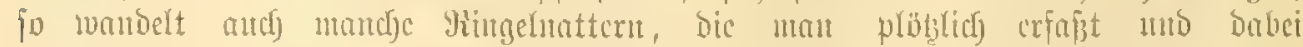

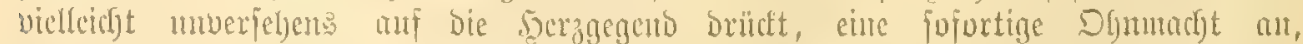

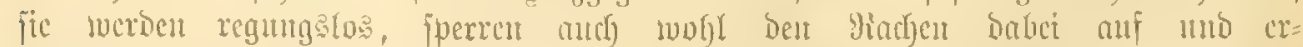

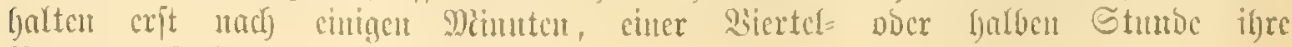
Bewegungeñulgigteit wicber. 


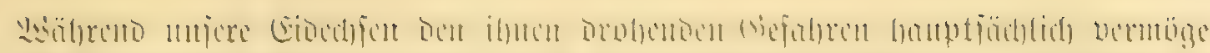

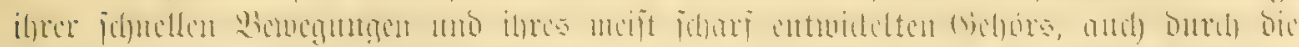

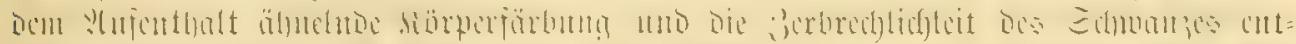

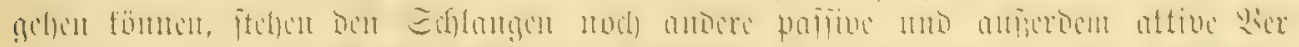

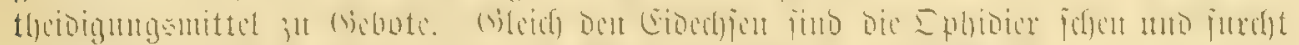

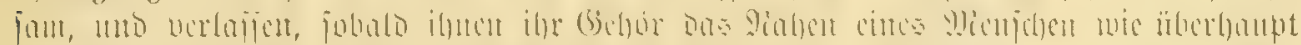

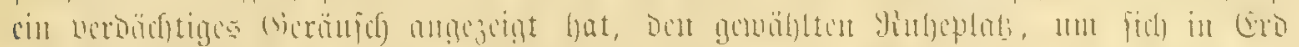

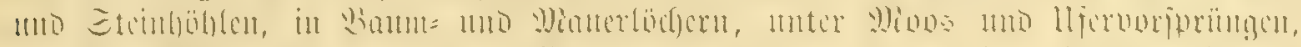
juifhen

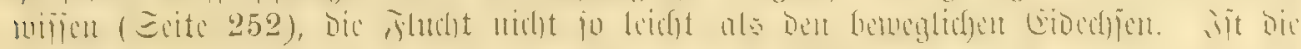

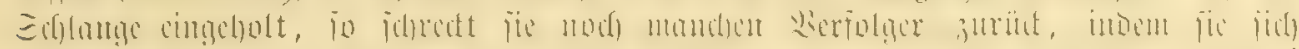

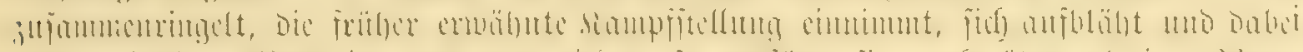

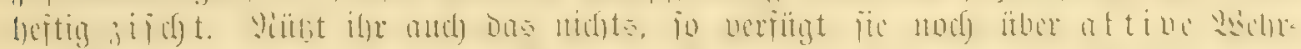

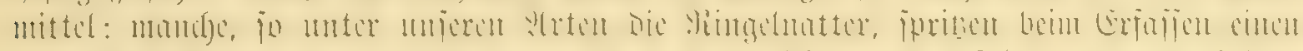
jer

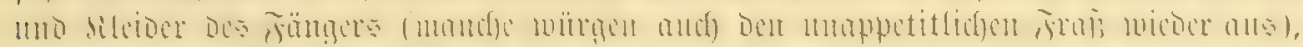

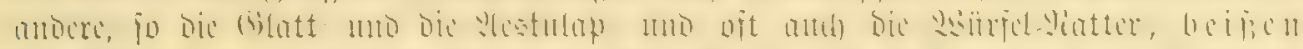

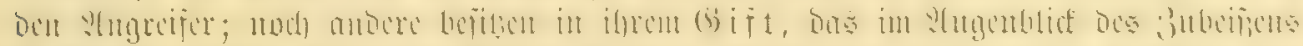

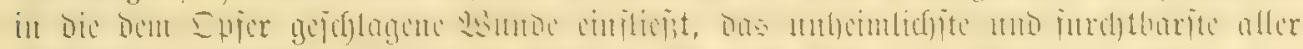

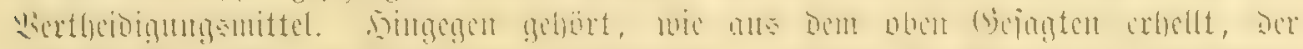

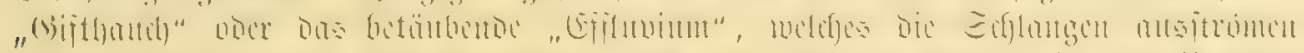

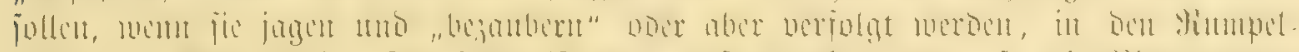

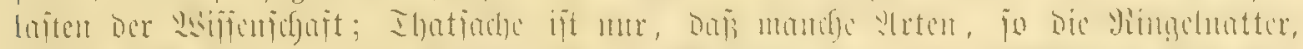

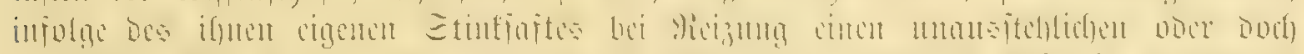

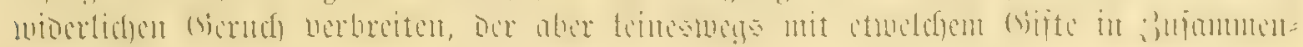

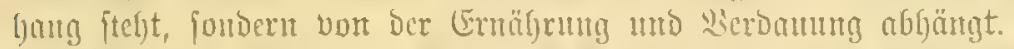

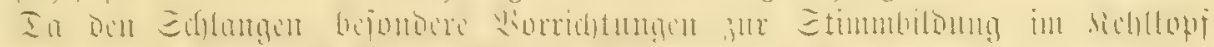

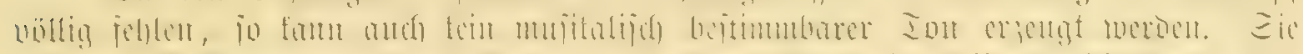

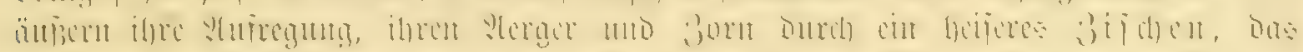

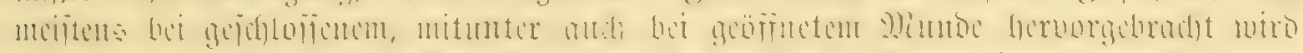

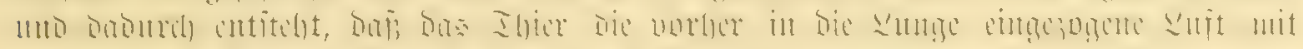

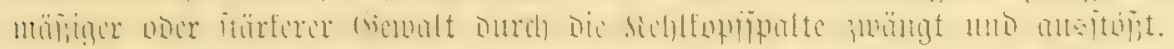

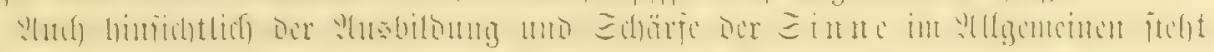

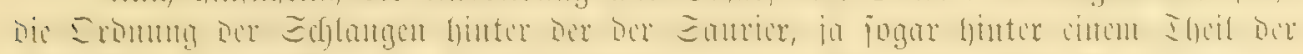

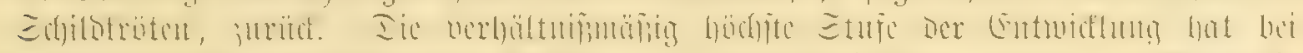

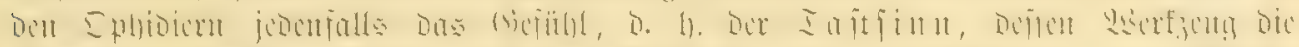

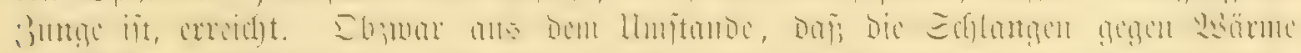

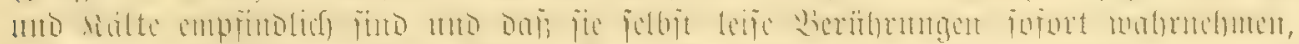

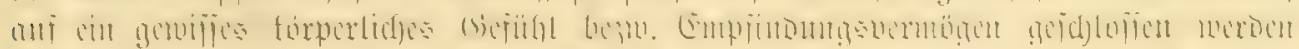

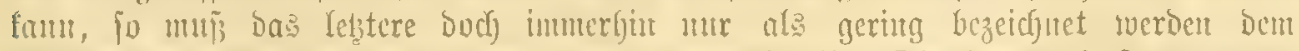

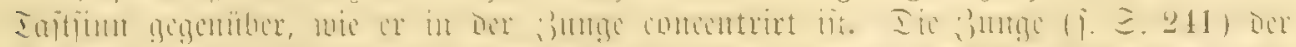

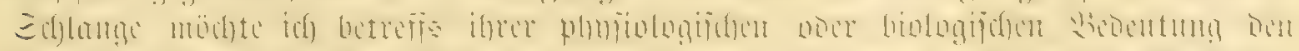

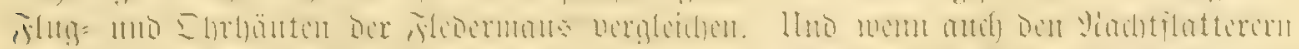

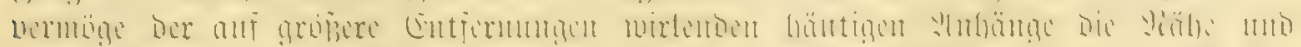

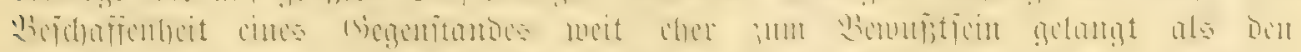

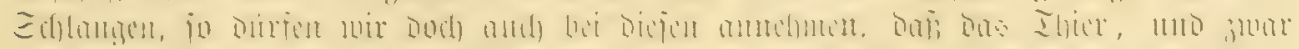

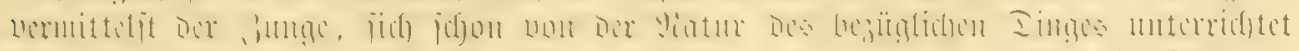

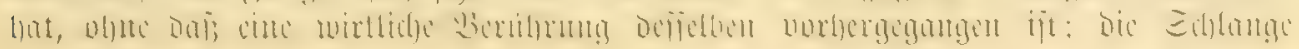




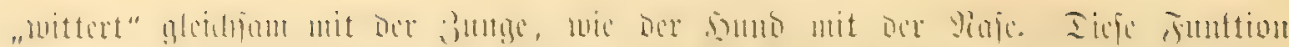

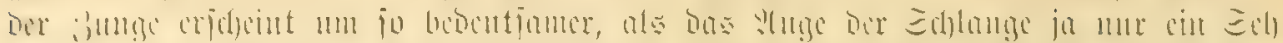

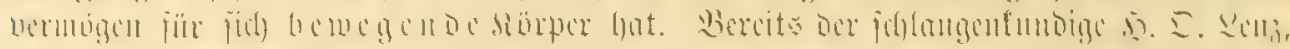

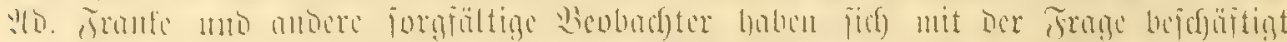

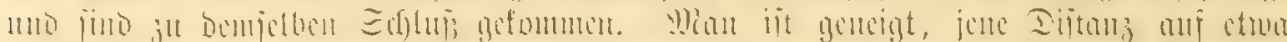

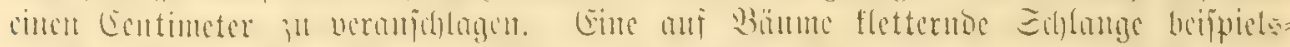

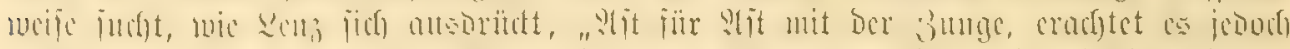

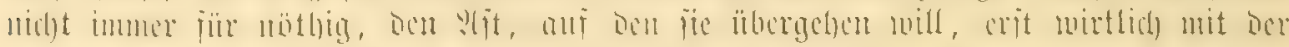

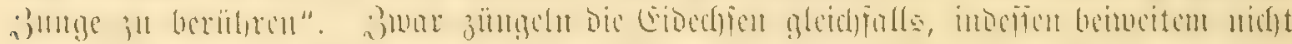

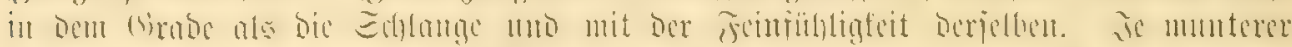

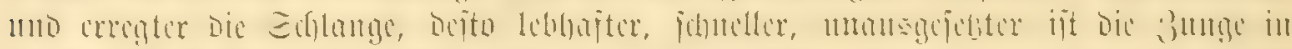

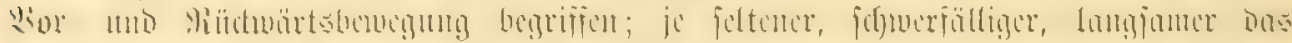
i)

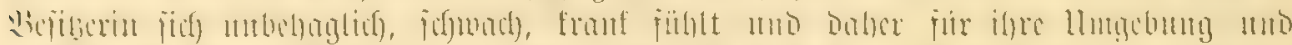

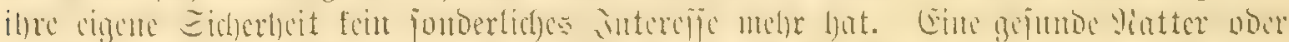

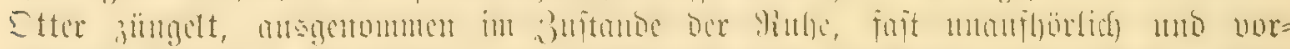

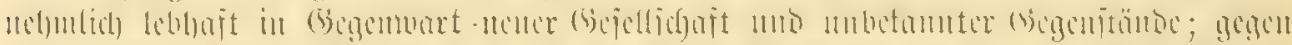

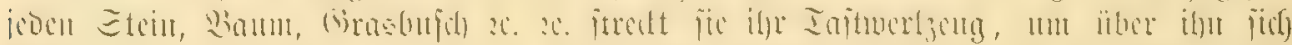

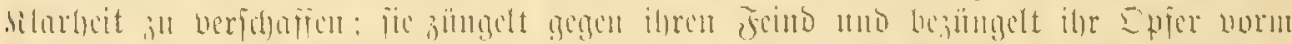

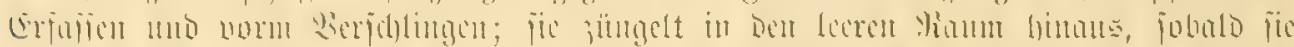

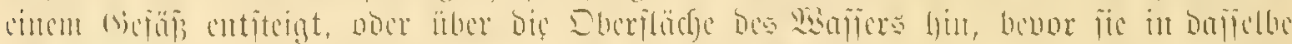

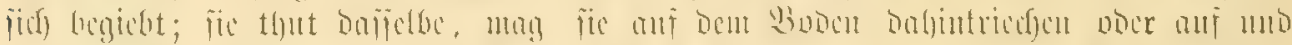

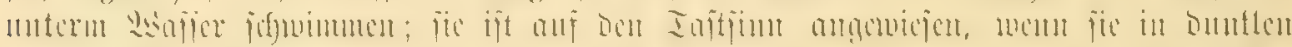

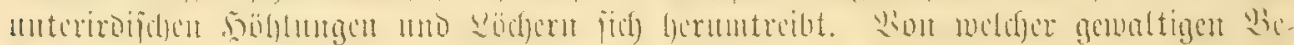

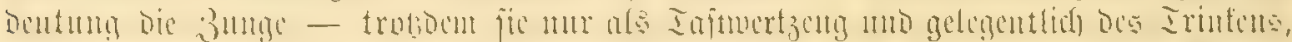

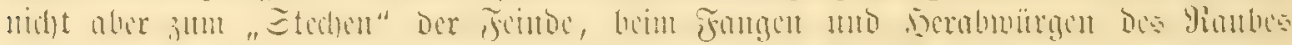

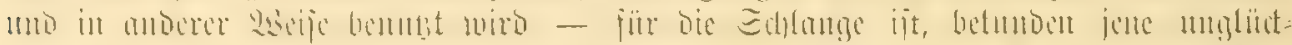

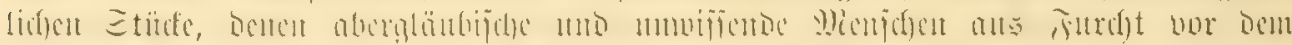

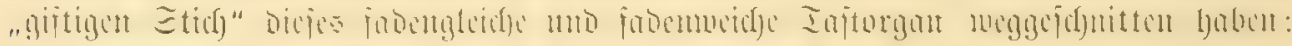

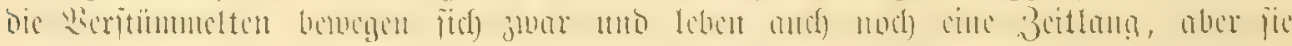

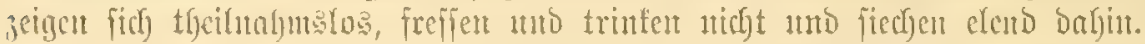

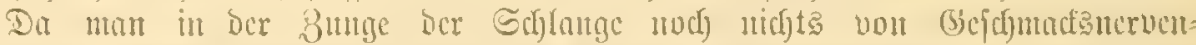

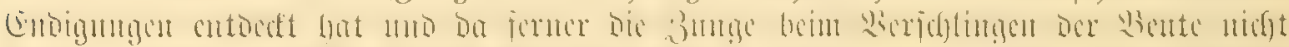

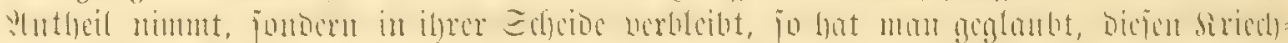
thicren Den (s)

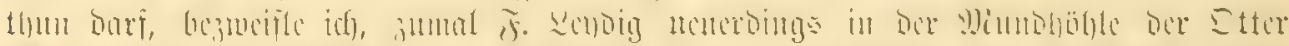

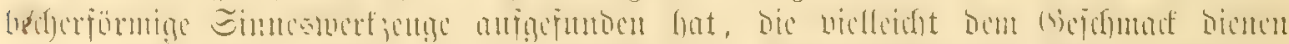

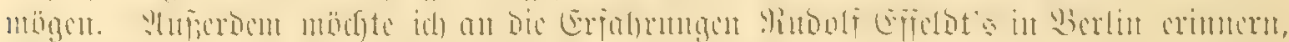

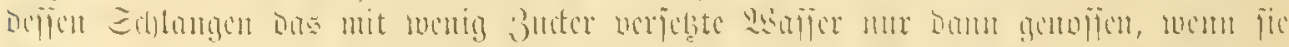

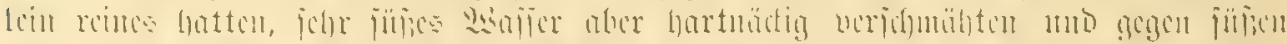

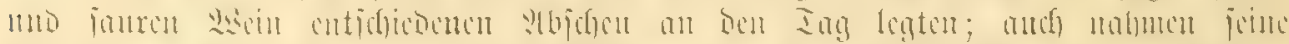

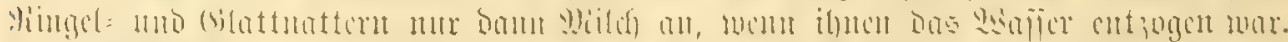

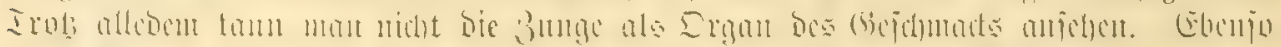

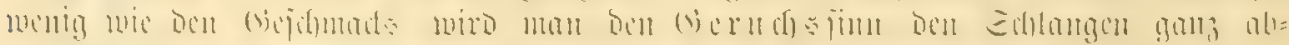

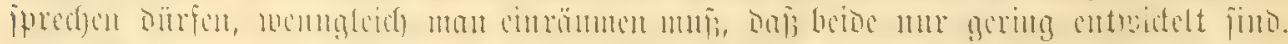

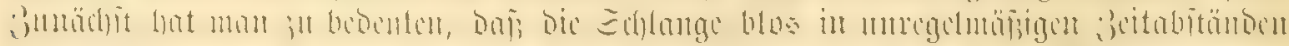

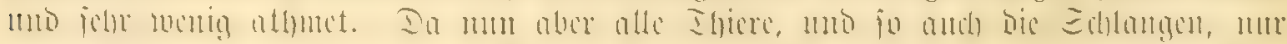

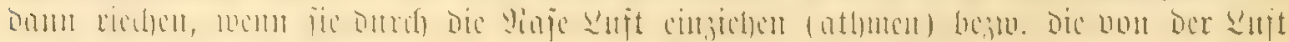




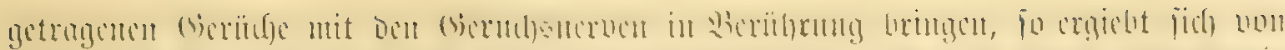

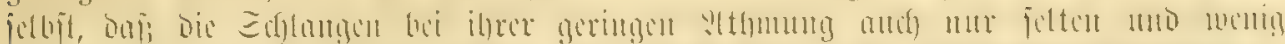

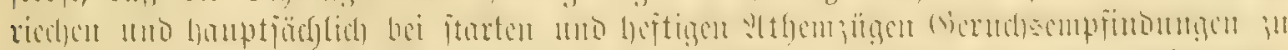

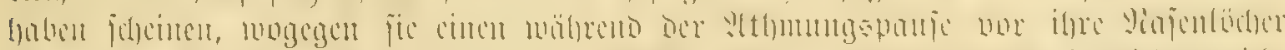

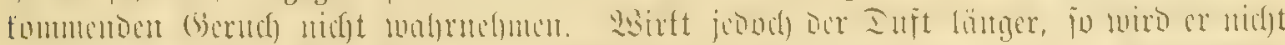

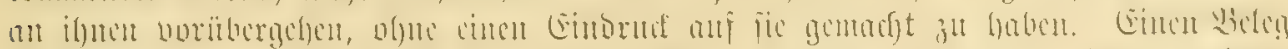

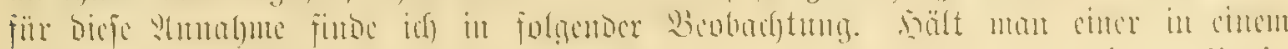

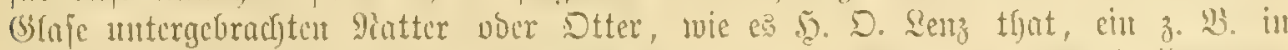

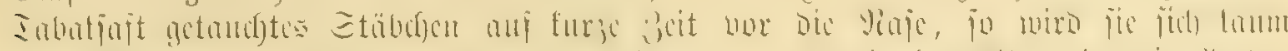

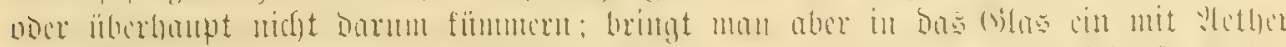

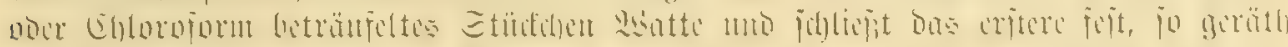

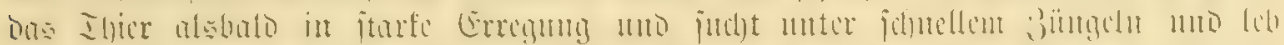

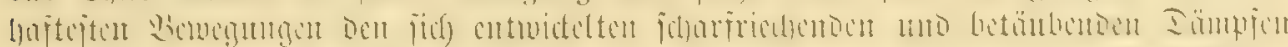

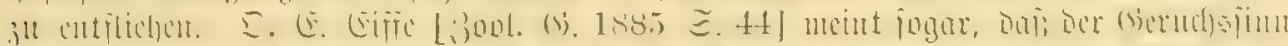

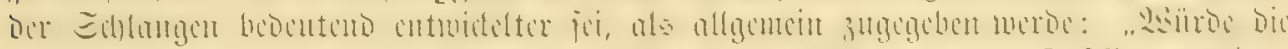

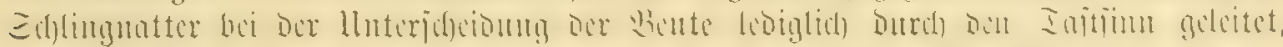

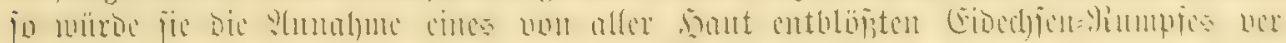

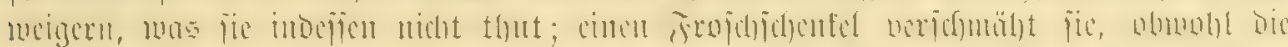

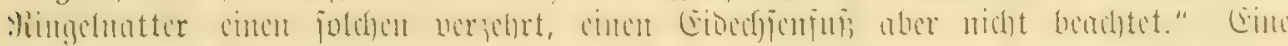

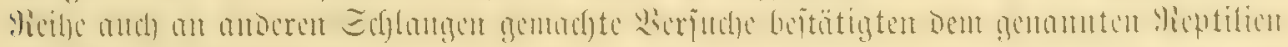
froutio jeine ?:njidyt.

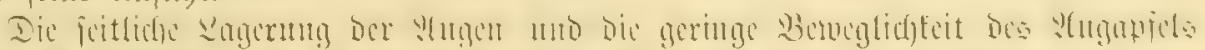

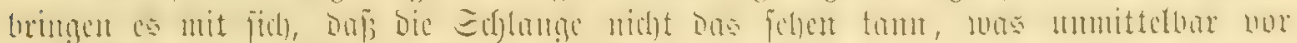

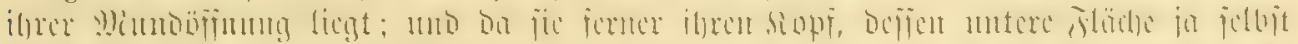

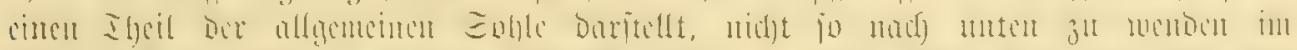

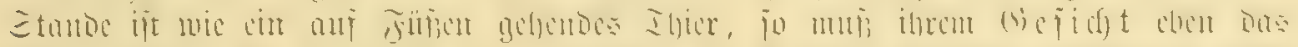

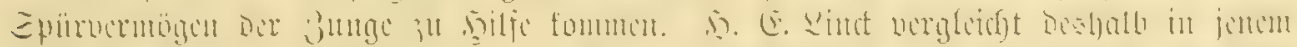

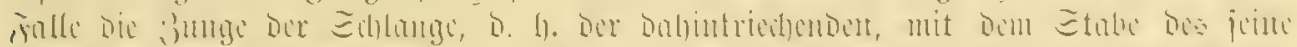

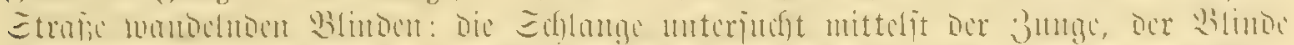

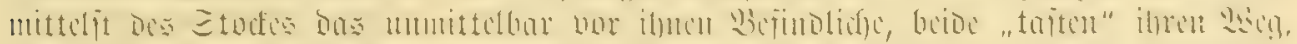

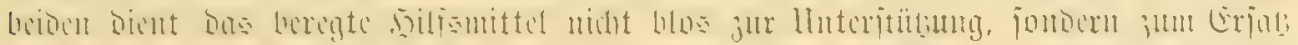

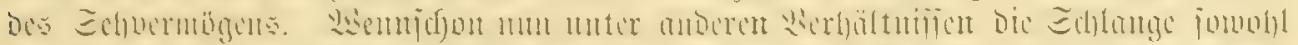

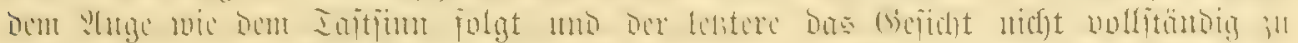

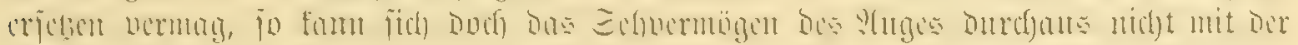

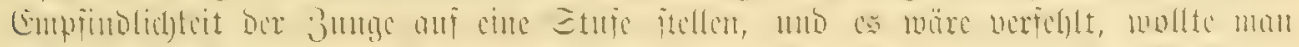

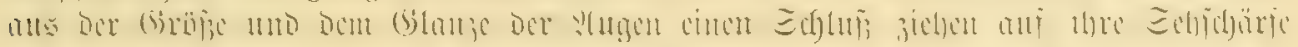

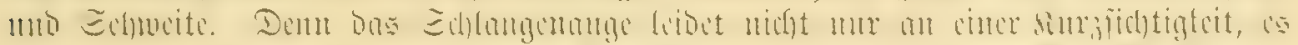

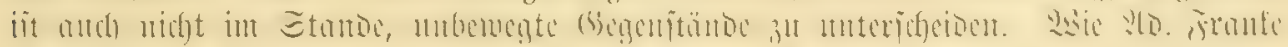

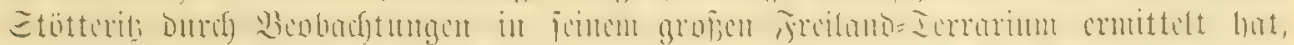

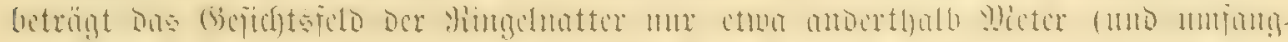

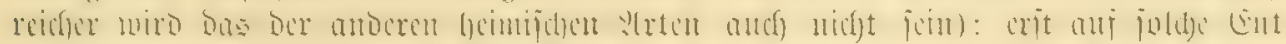

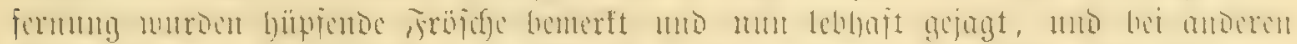

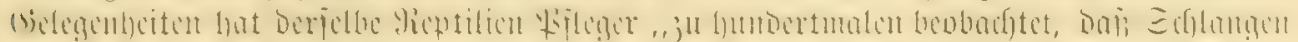

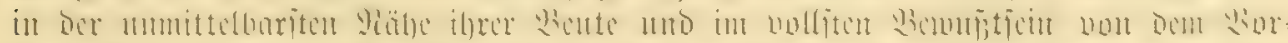

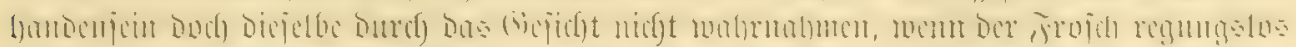

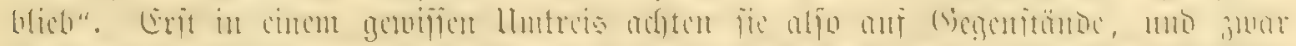

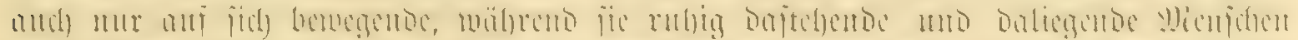

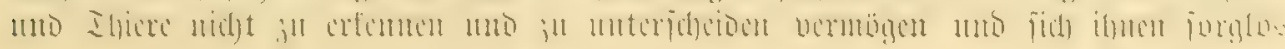




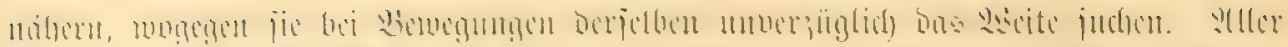

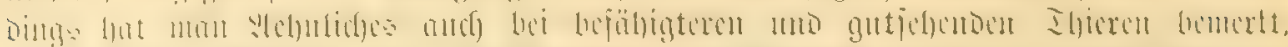

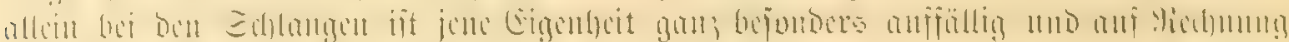

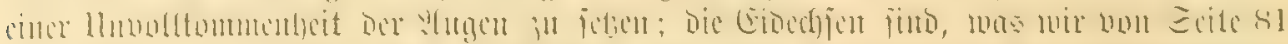

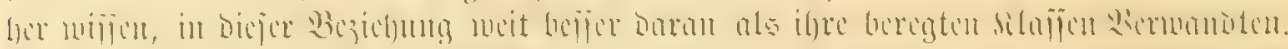

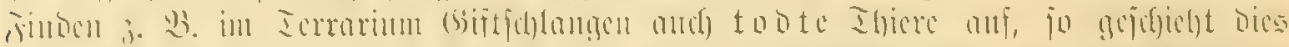

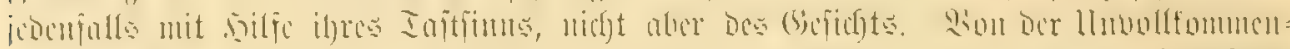

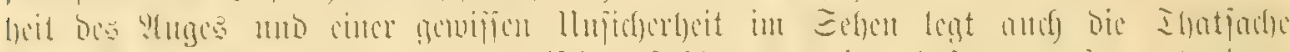
i)

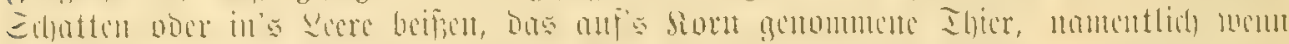

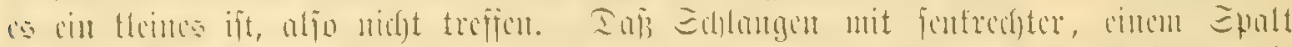

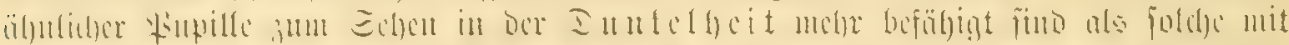

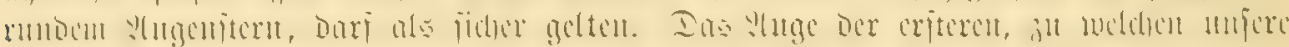

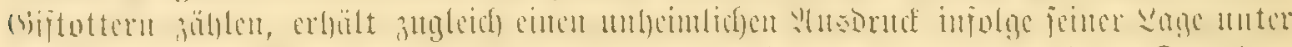

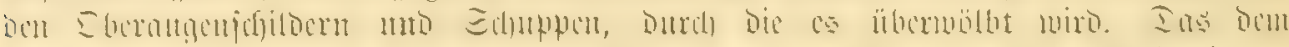

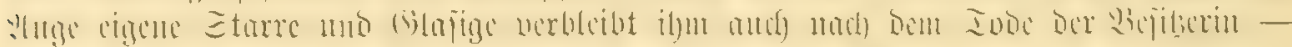

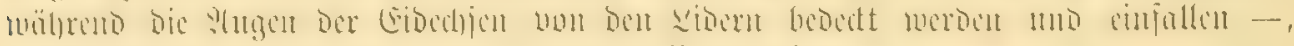

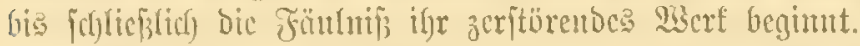

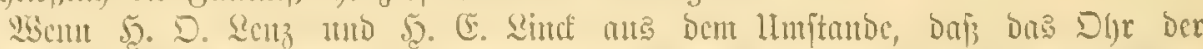
Edylamgen (†.

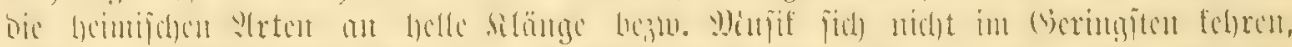

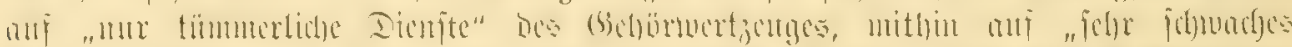

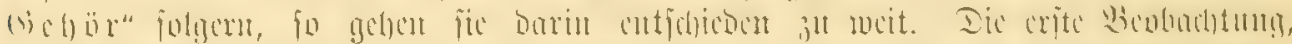

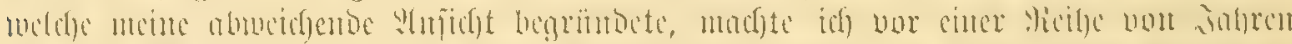

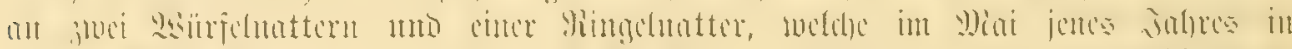

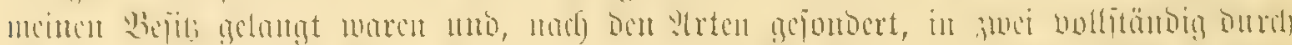

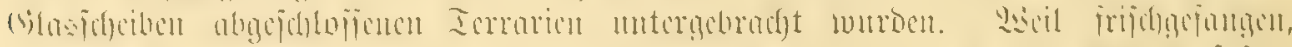

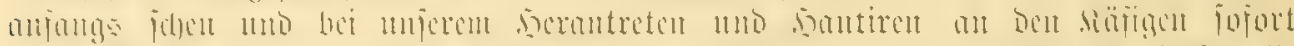

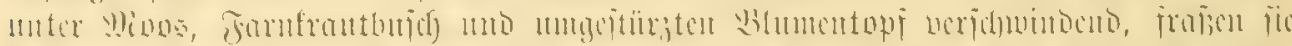

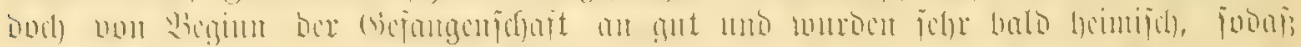
jit math

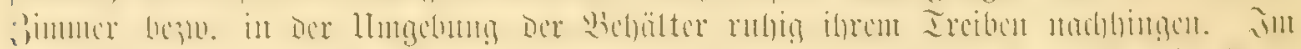

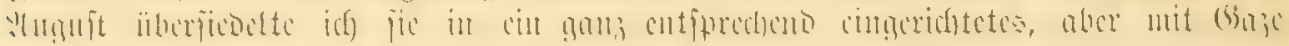

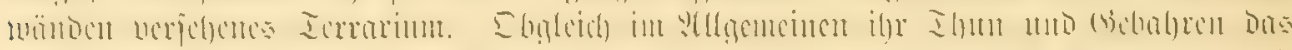

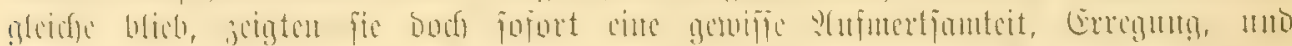

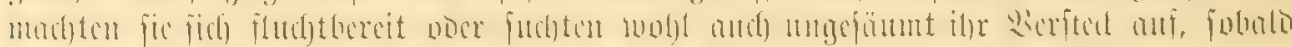

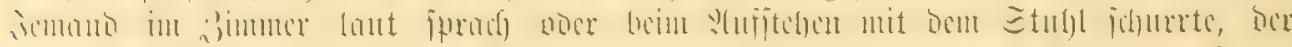

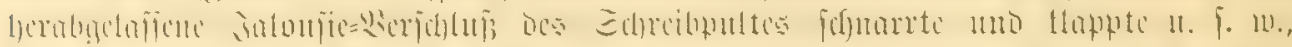

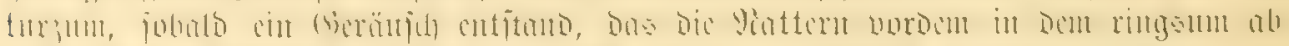

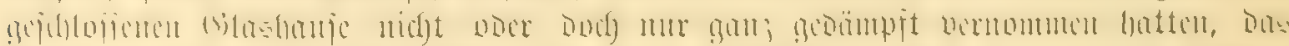

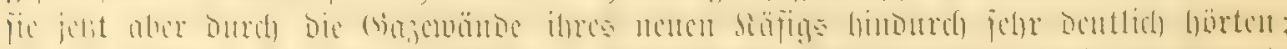

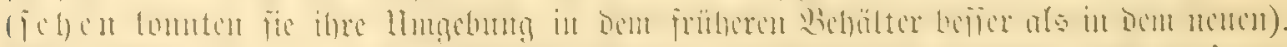

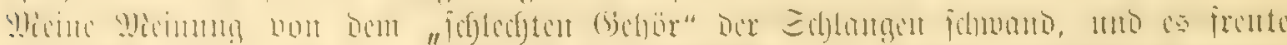

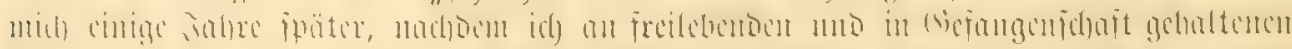

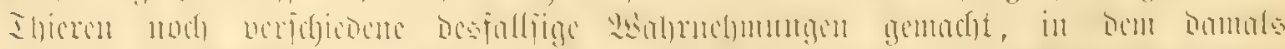

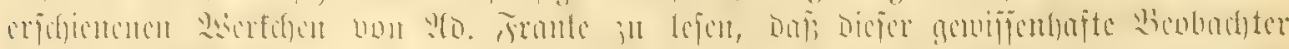

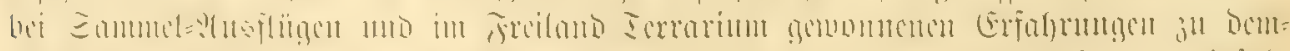

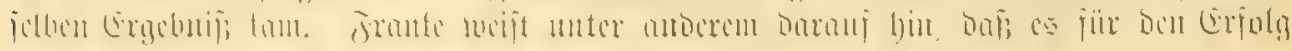




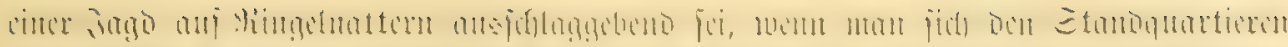

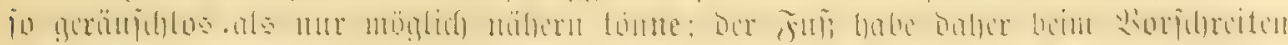

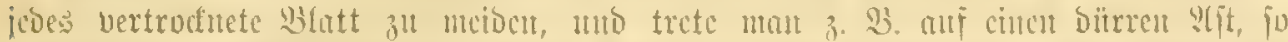

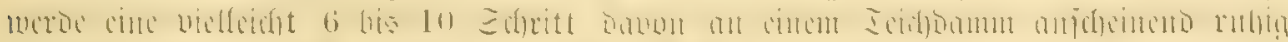

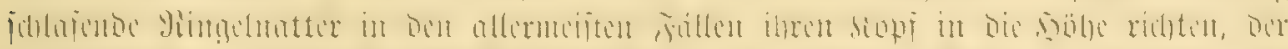

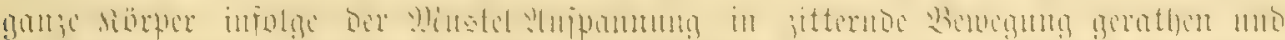

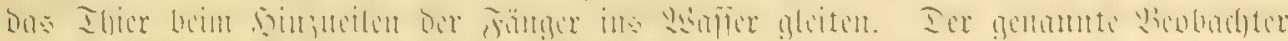

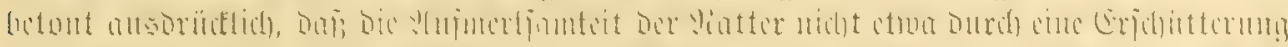
Des

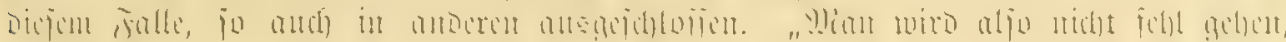

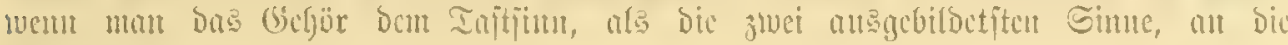
Ecite itcllt."

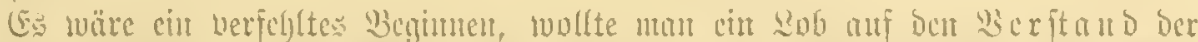

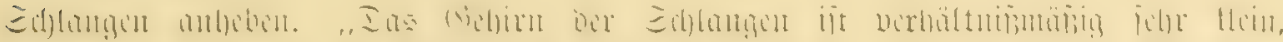

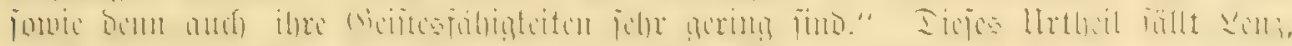

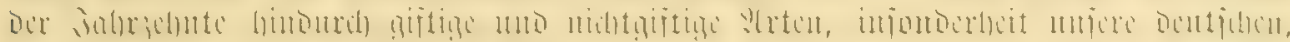
i)

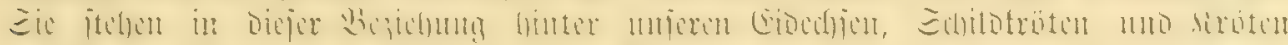

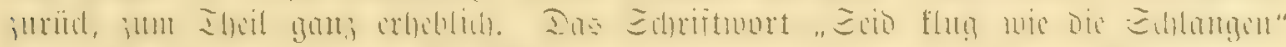

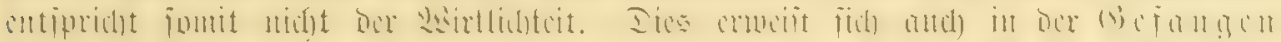

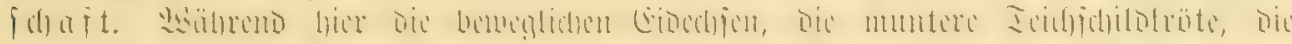

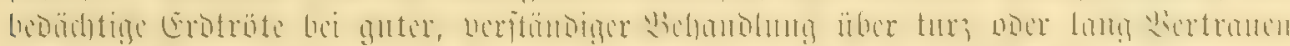

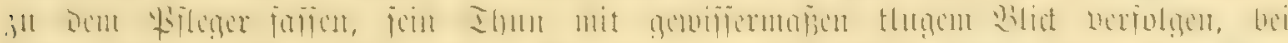

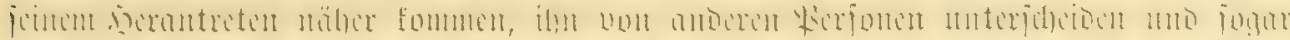

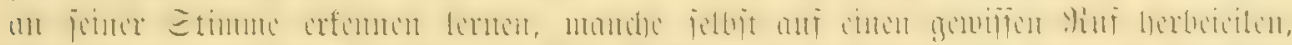

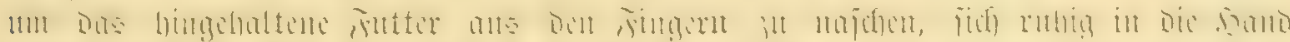

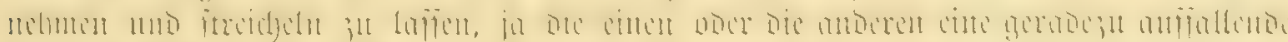

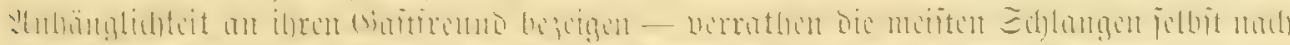

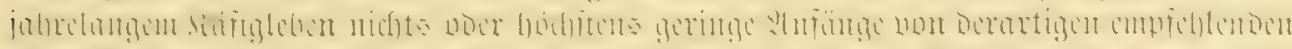

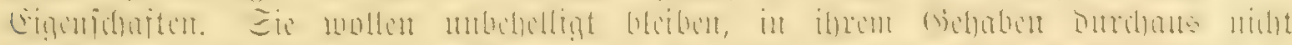

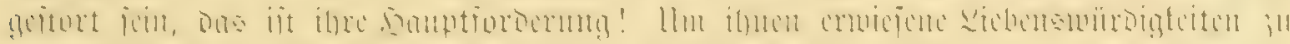

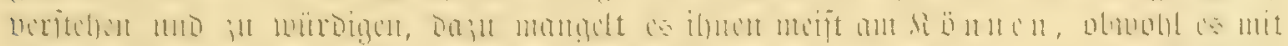

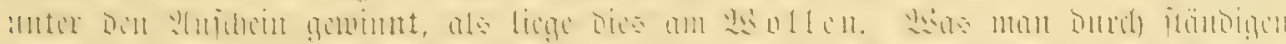

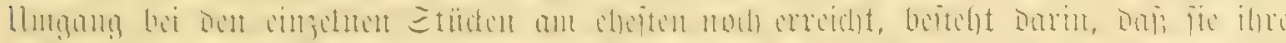

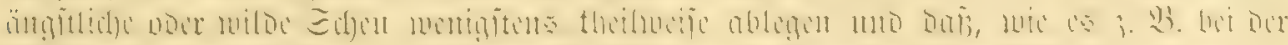

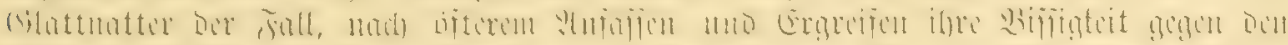

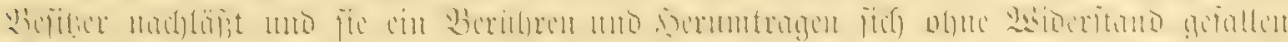

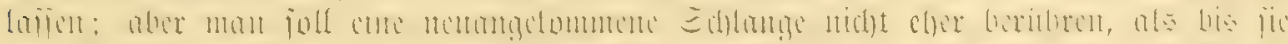

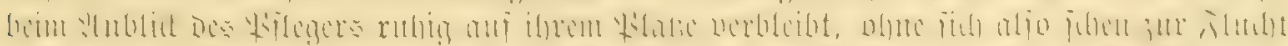

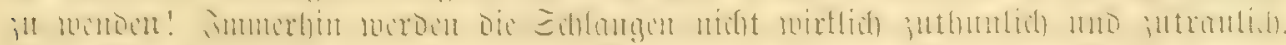

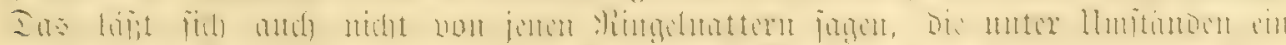

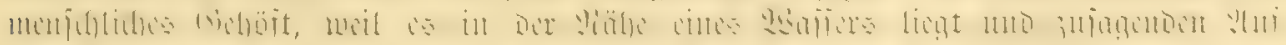

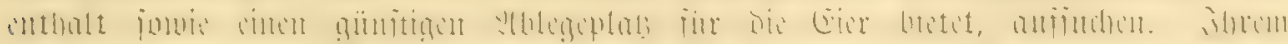

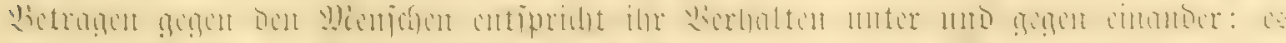

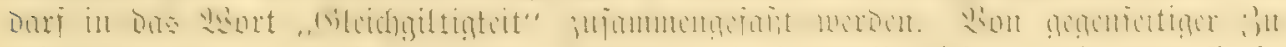

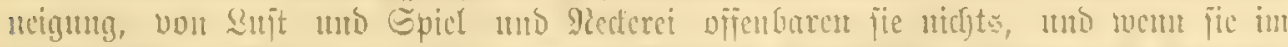

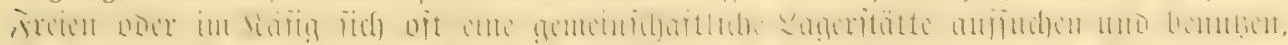

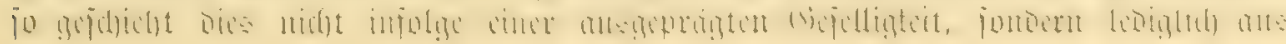




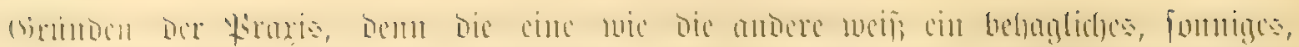

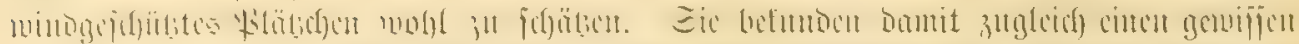

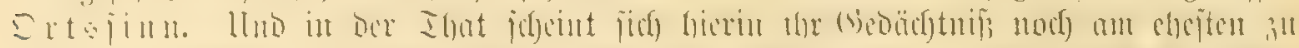

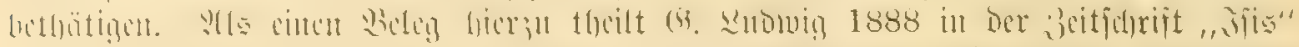

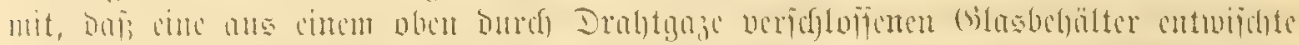

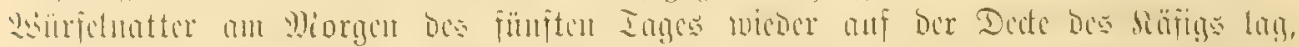

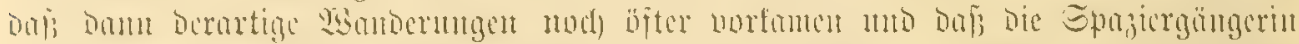

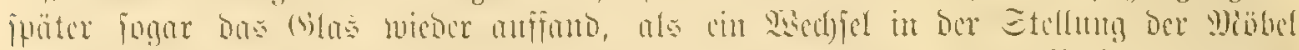

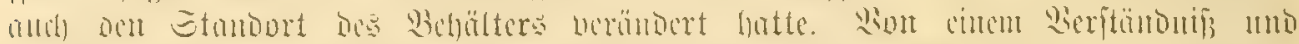

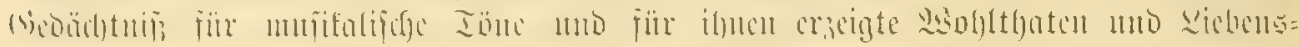

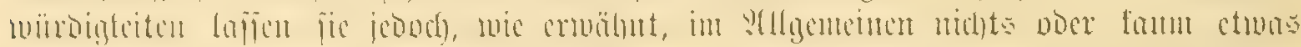

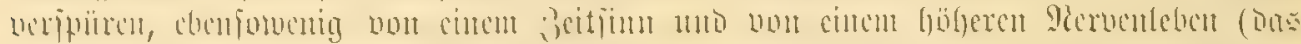

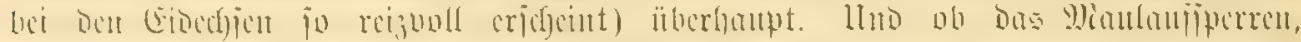

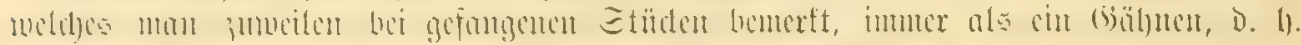

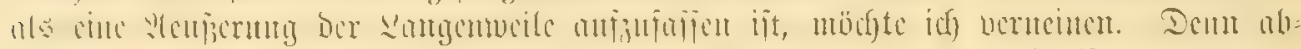

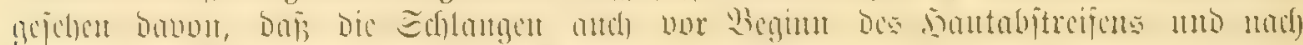

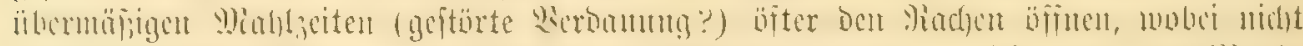

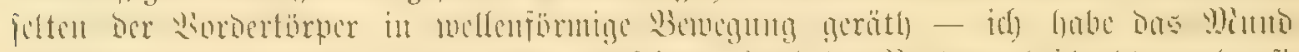

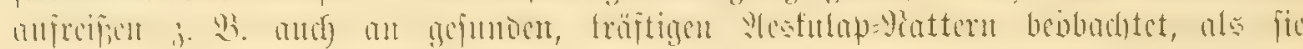

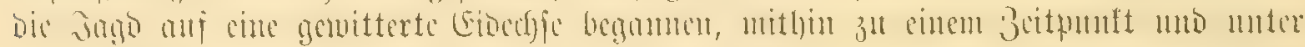

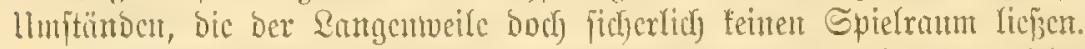

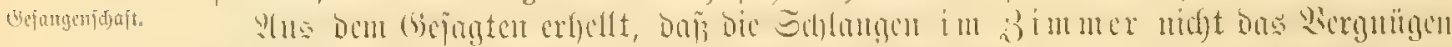

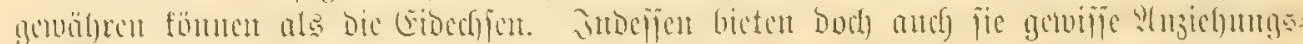

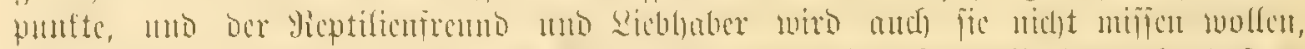

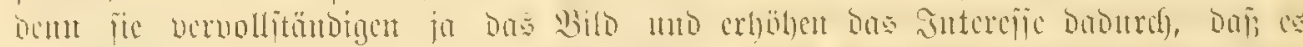

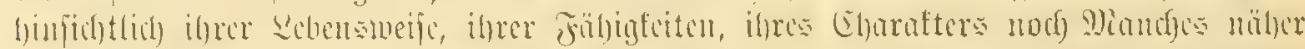

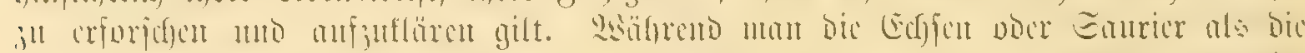

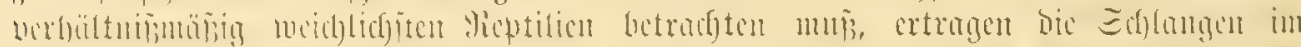

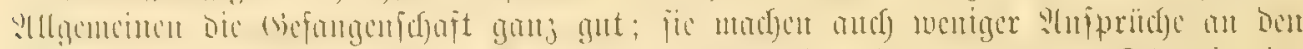

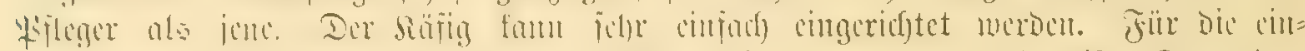
l)

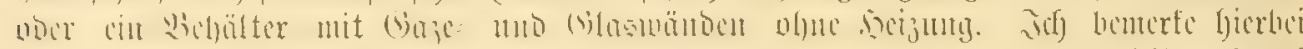

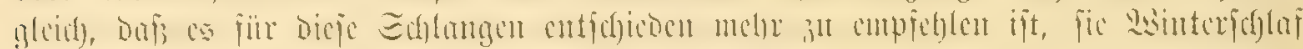

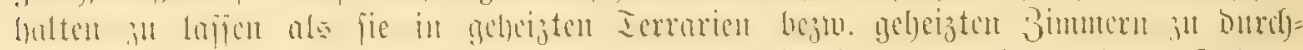

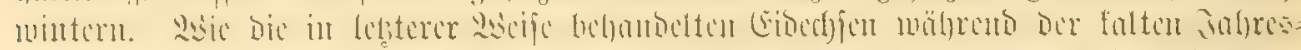

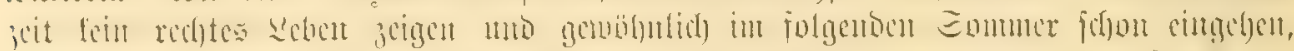

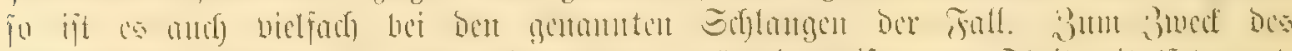

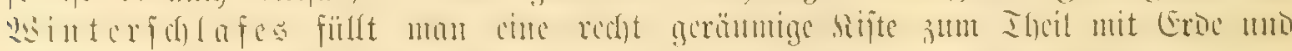

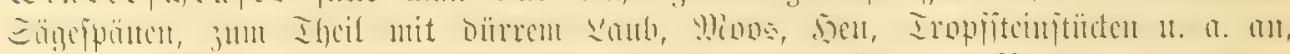

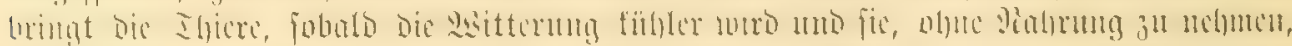

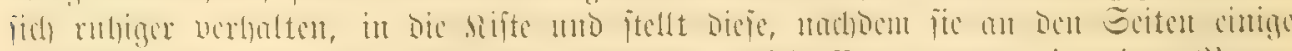

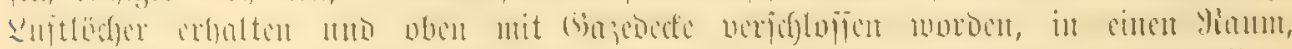

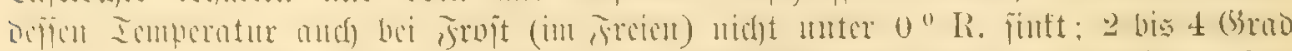

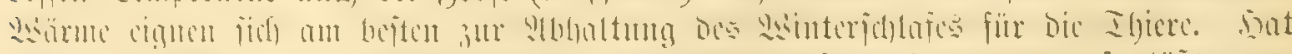

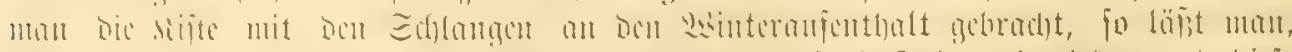

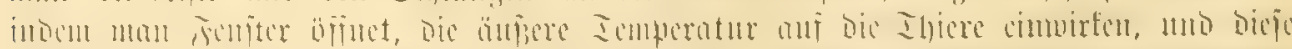

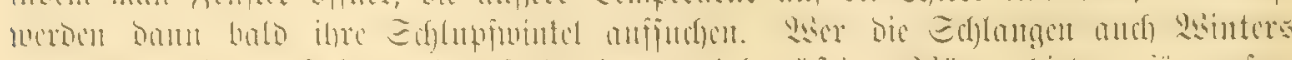

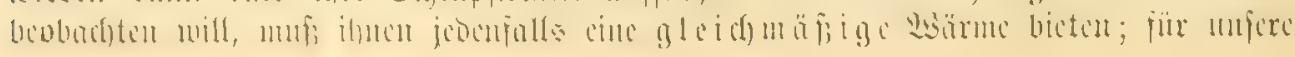




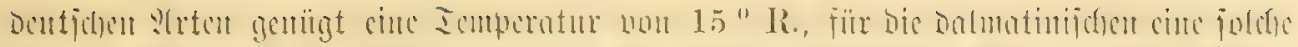

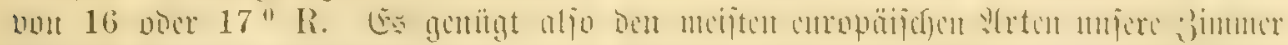

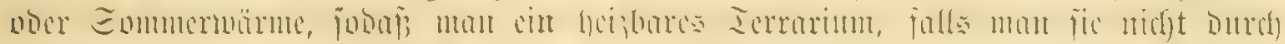

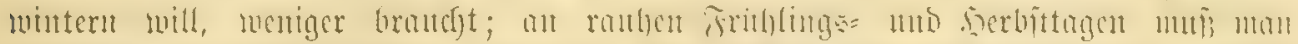

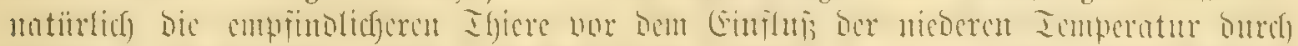

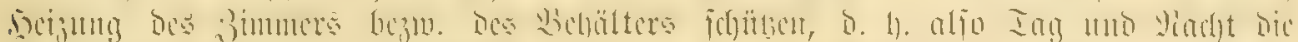

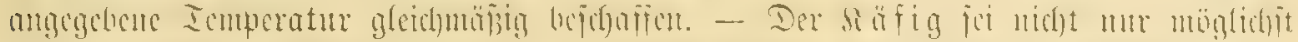

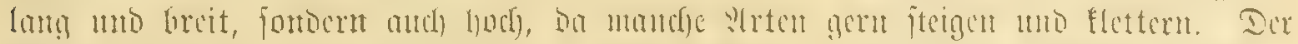

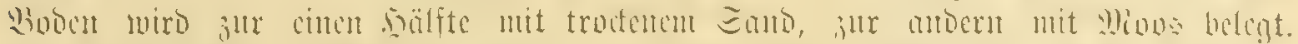

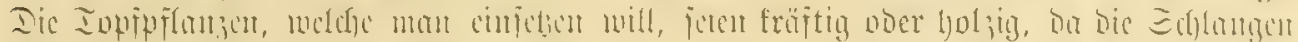

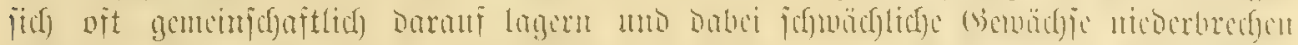

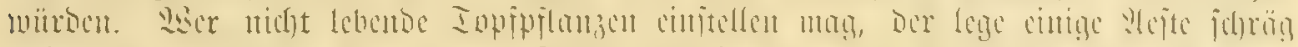

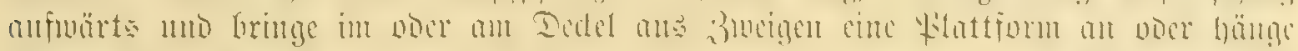

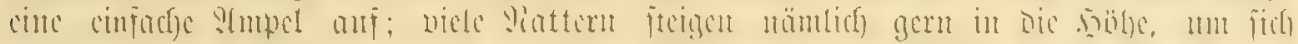

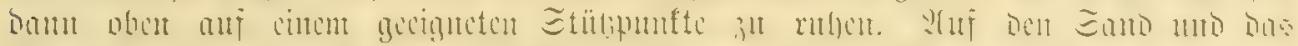

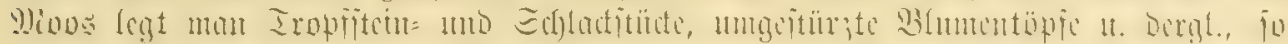

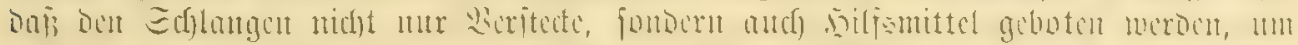

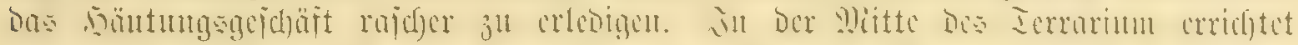
man nocf), falls ber than

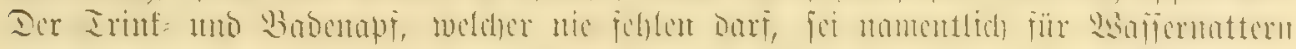

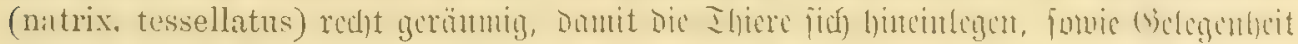

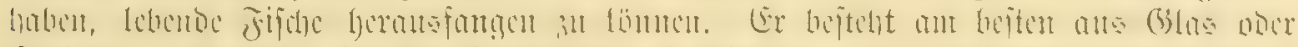

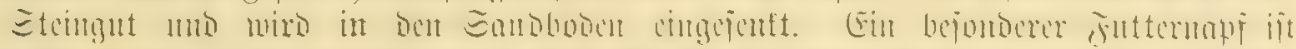

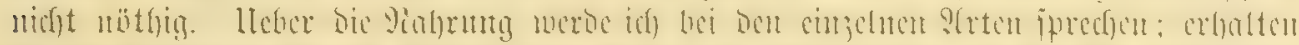

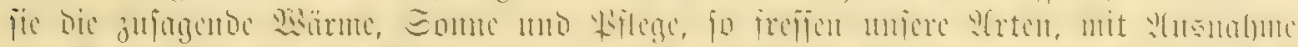

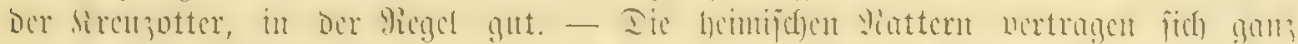

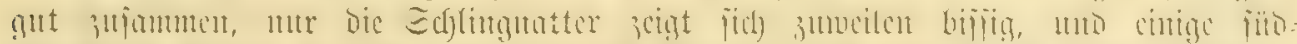

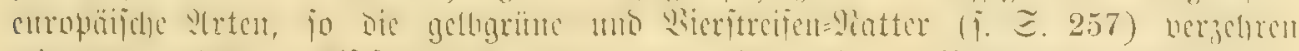

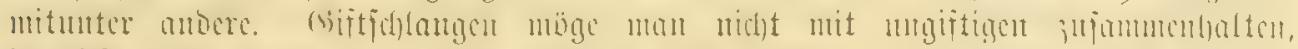

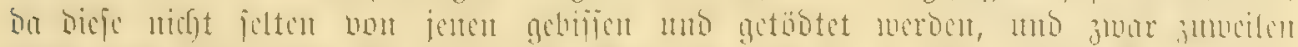

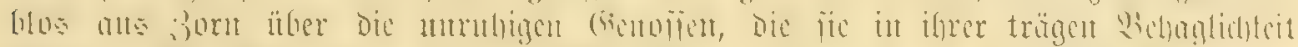

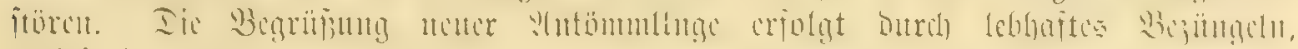

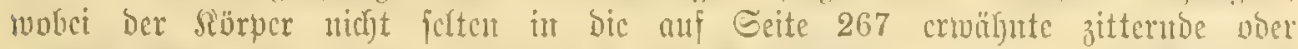

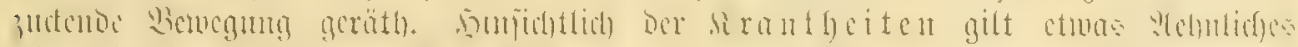

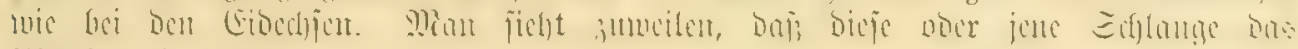

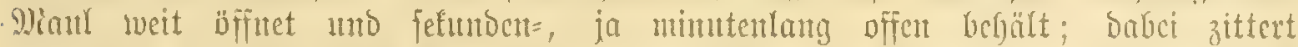

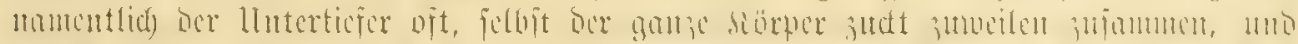

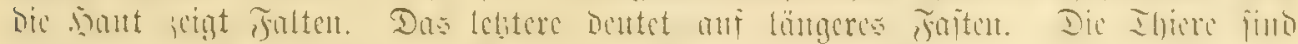

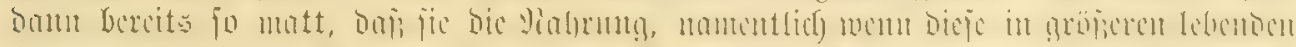

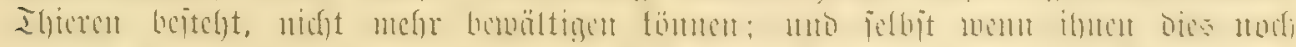

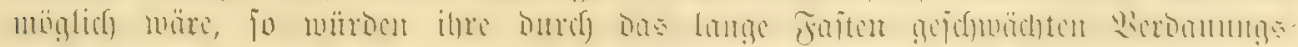

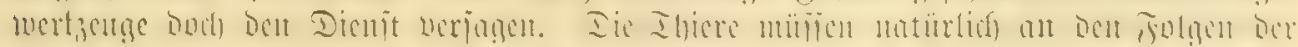

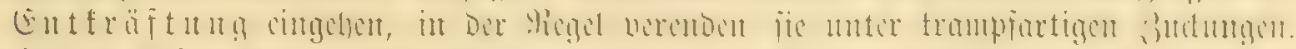

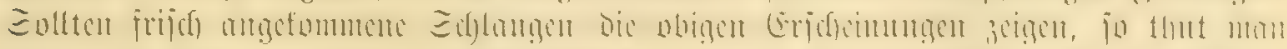

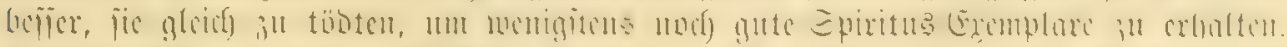

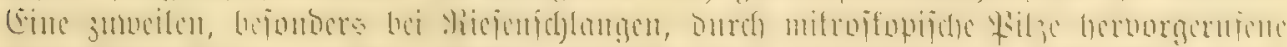

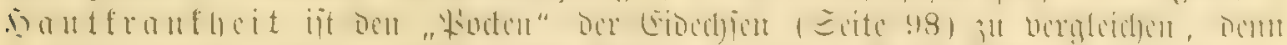

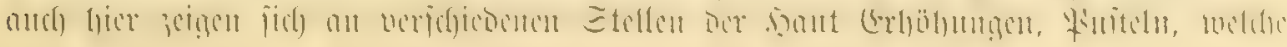




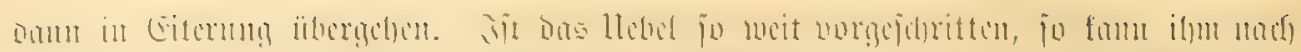

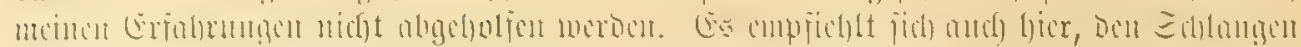

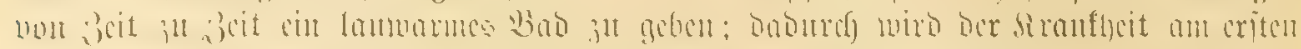

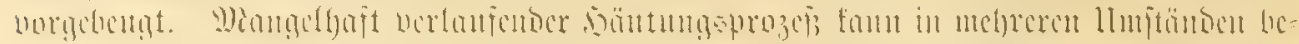

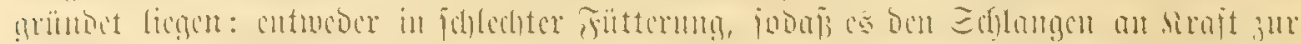

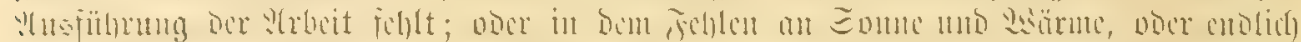

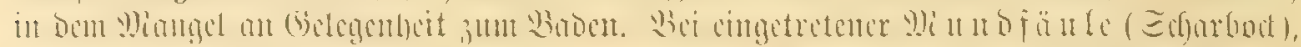

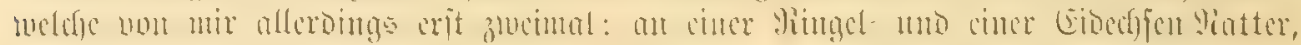

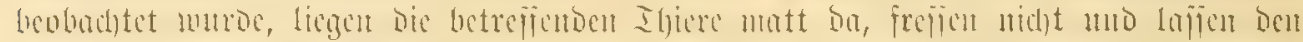

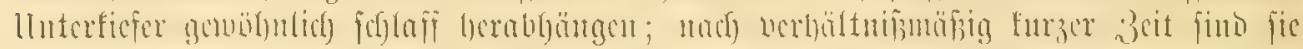

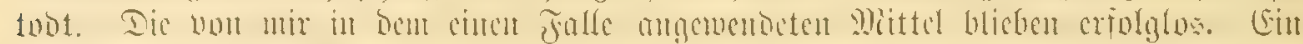

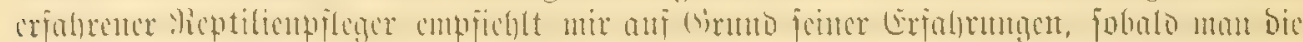

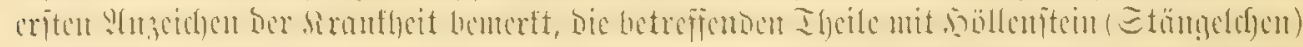

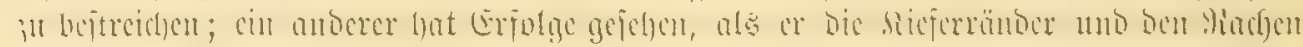

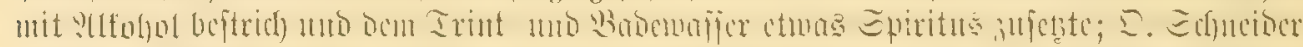

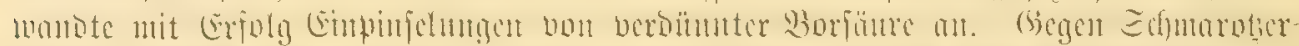

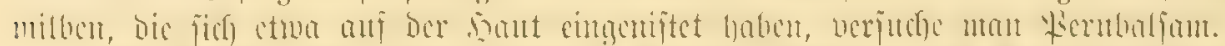

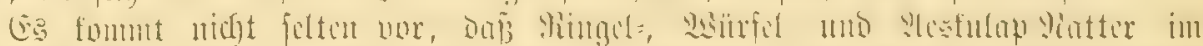

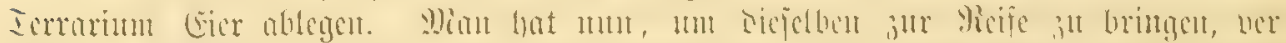

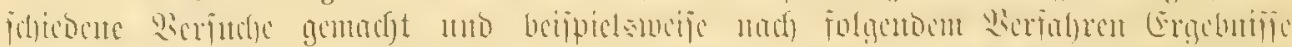

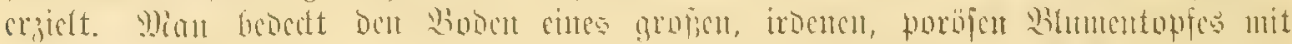

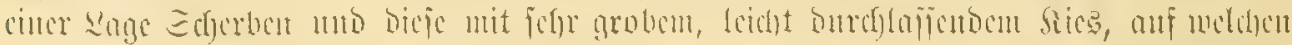

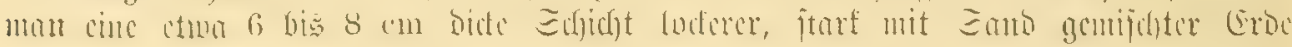

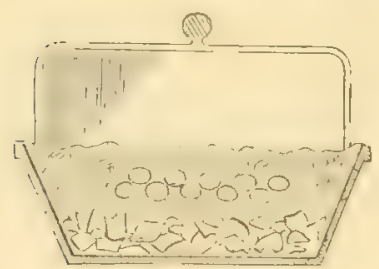

i) 29. 29. Enr(h)(b)titt cinco 3udututapfes.

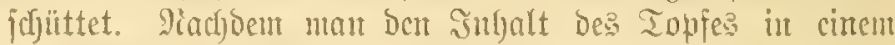

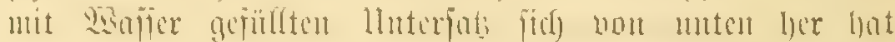

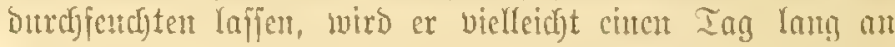
cincu jubattigen Drt geftellt, Dom bringt man anf bie $(5 \mathrm{rb}=$

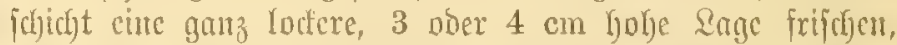

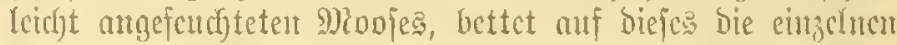

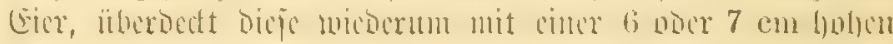

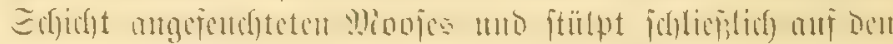

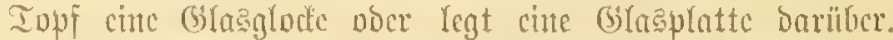

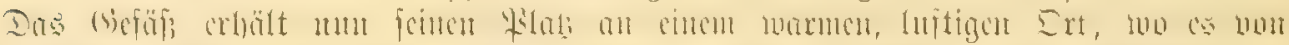

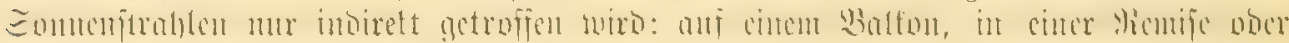

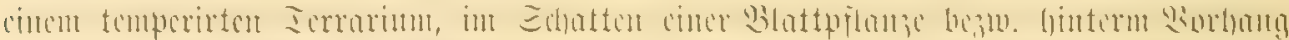

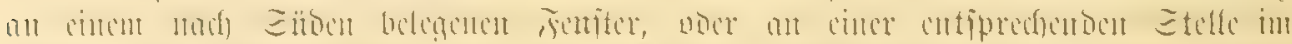

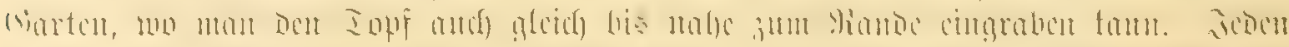

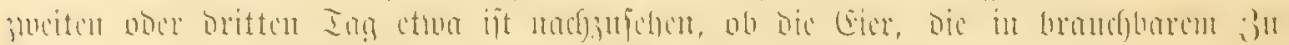

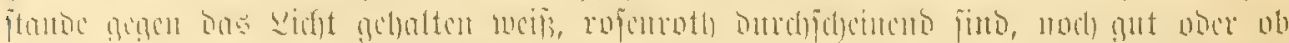

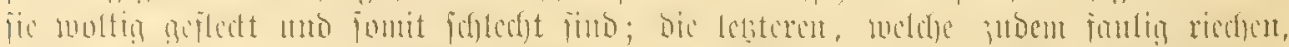

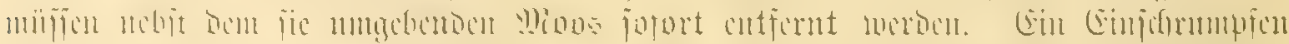

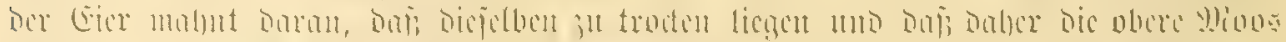

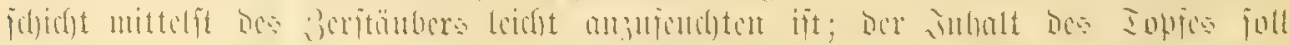

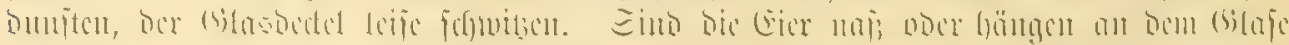

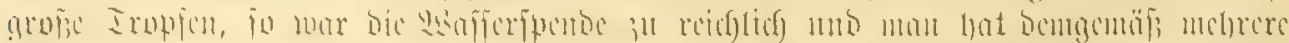

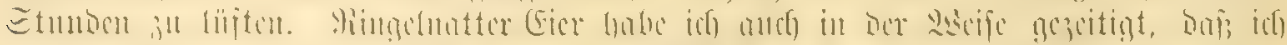

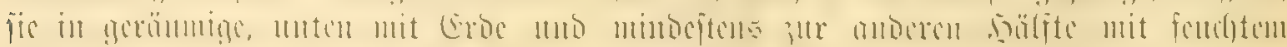

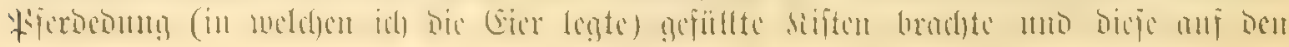




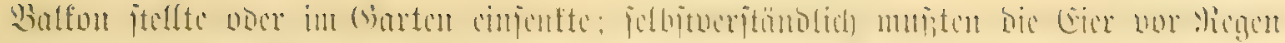

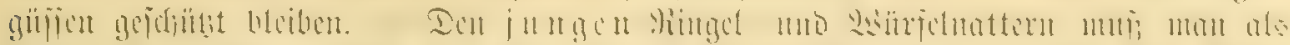

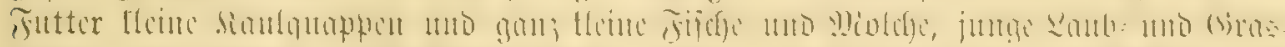

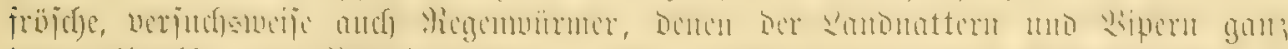

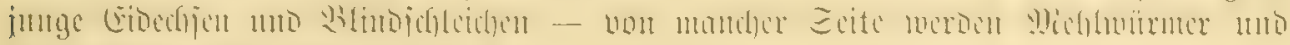
Sentidjectent cmpforjen - anbicter.

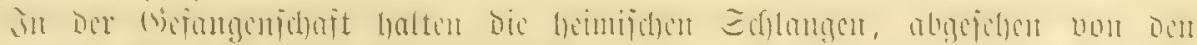

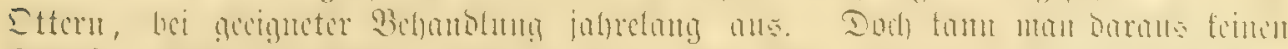

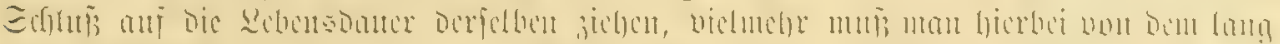

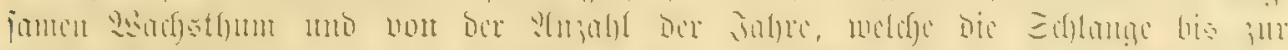

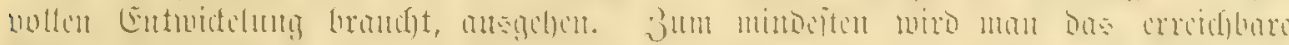

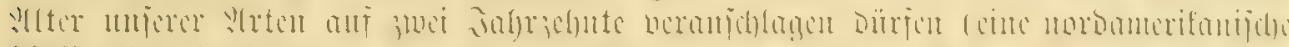

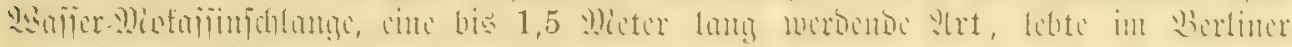
?(†utorium 22 รalgre).

Uluter ben (G)

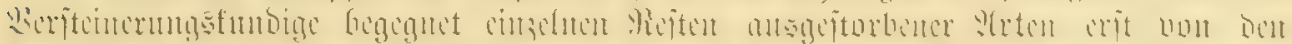

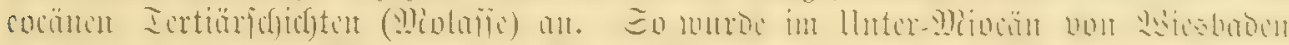

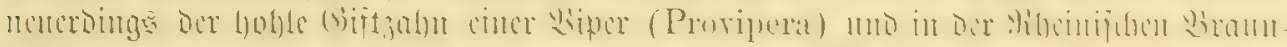

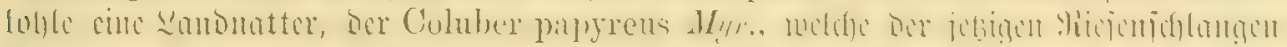

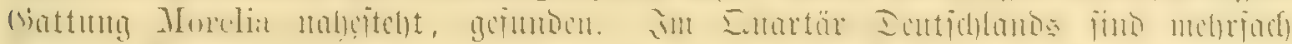

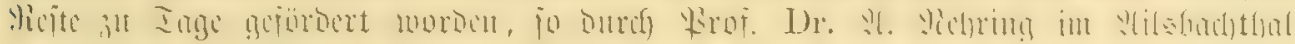

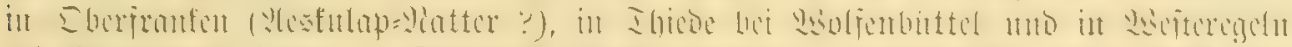

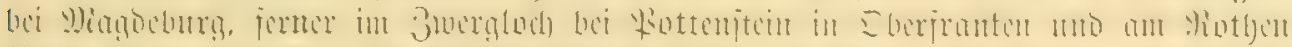

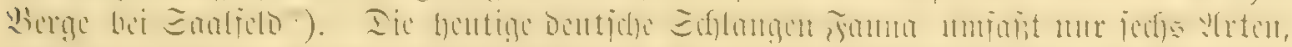

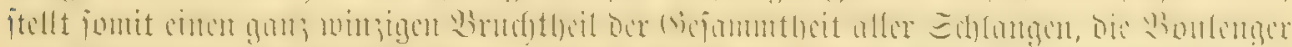

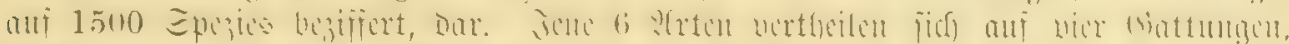

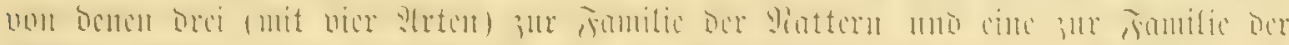

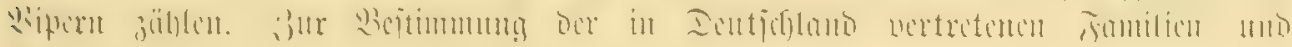

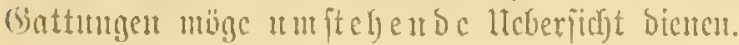

\section{1. famtic: Vattcru, Colnbridne.}

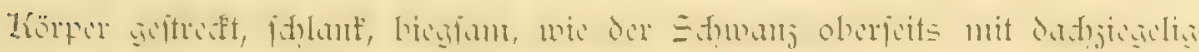

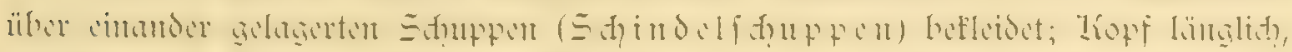

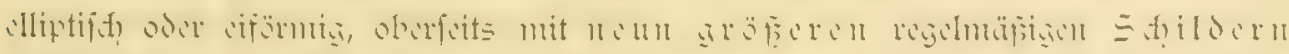

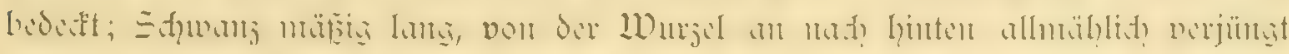

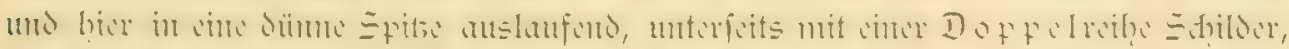

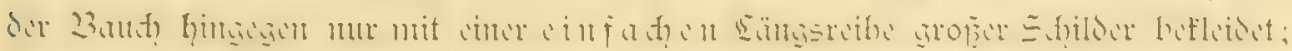

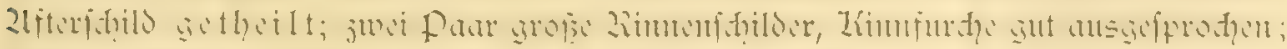

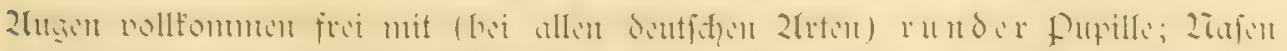

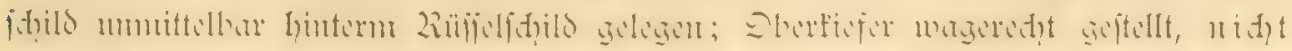
аи furje, unbueglithe, folibe fangzähnc.

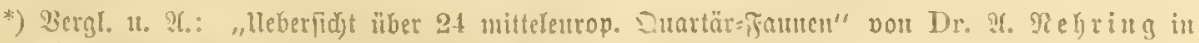
Der 3tidjr. o. Difidur. Beol. (3ep. 1880 5. 468 ff. 


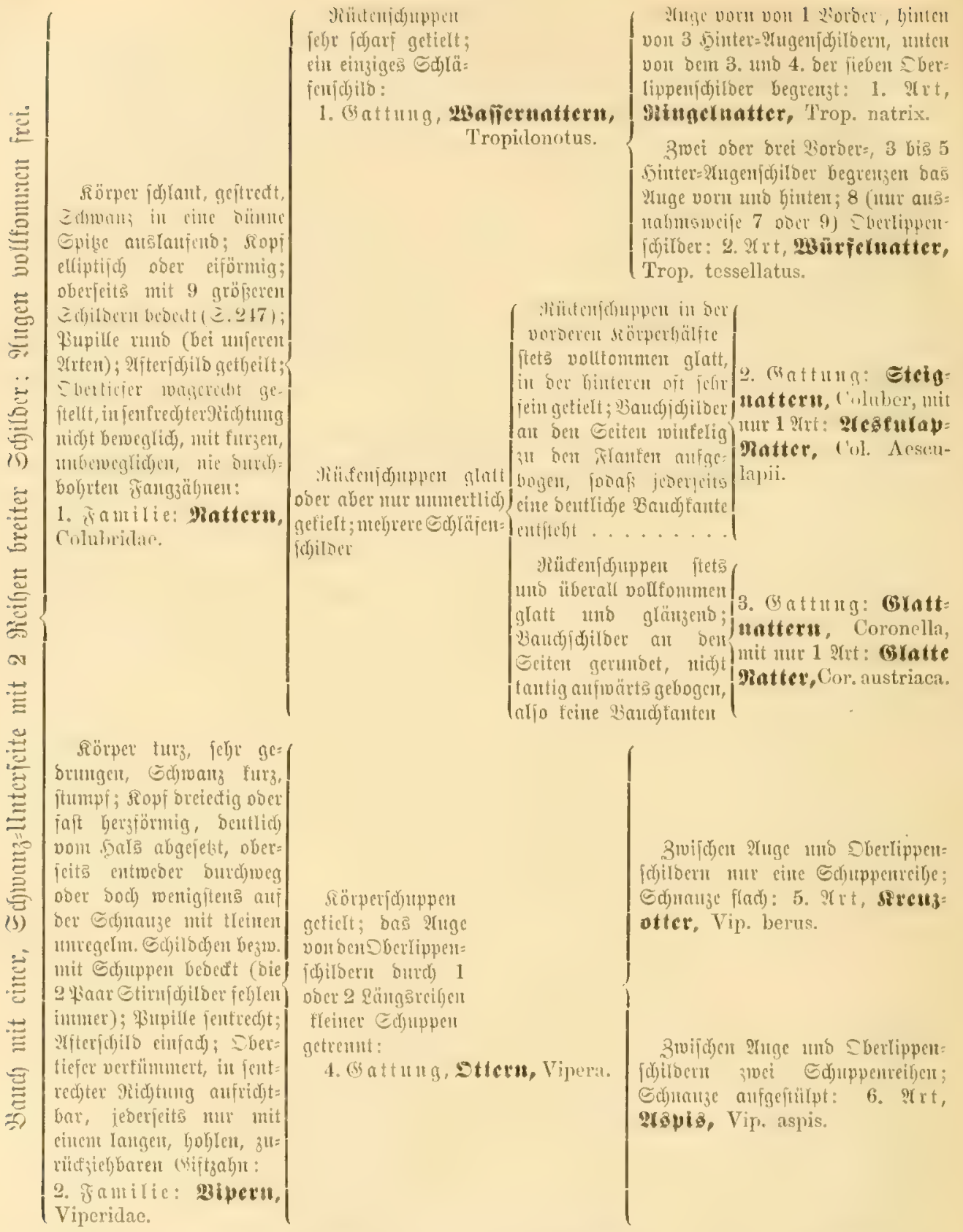

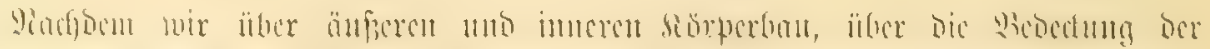

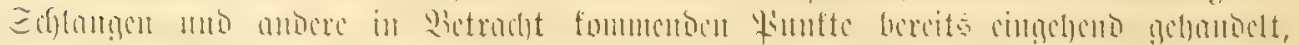

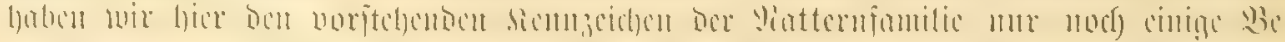

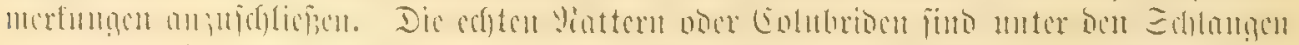

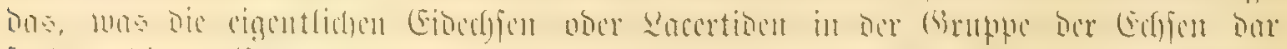

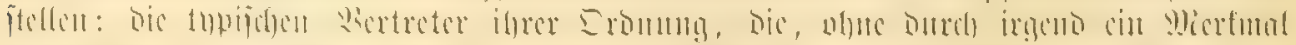

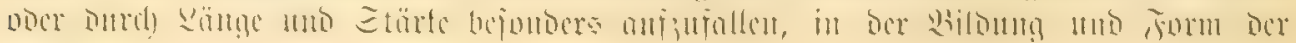




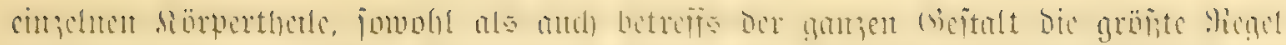

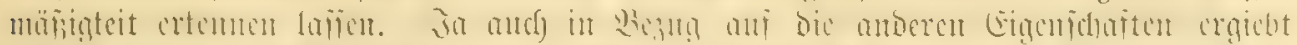

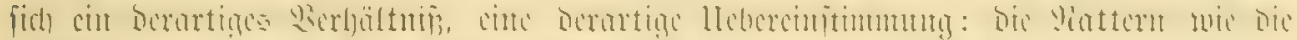

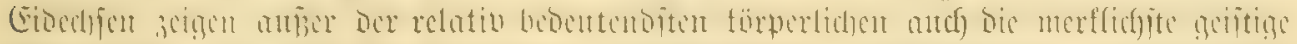

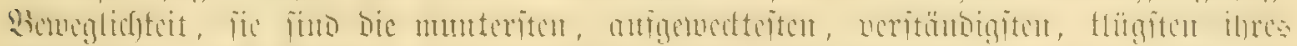

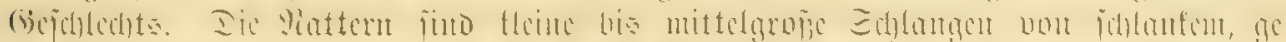

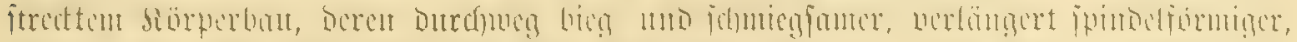

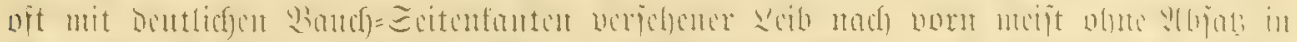

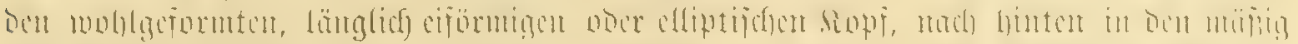

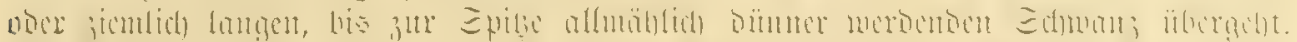

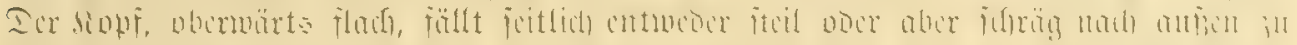

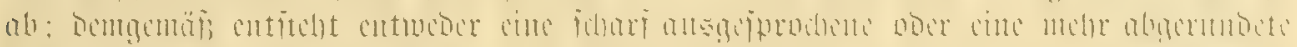

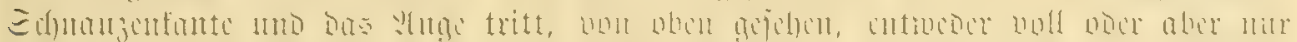

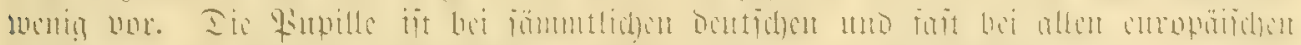

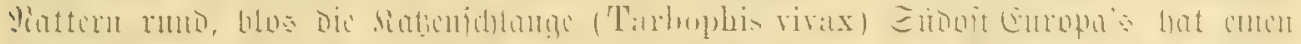

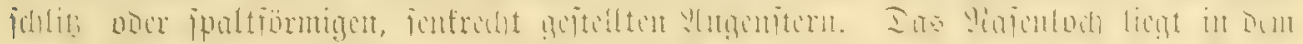

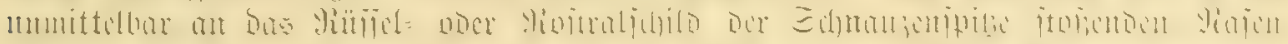

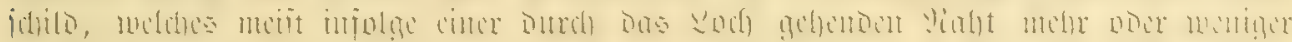

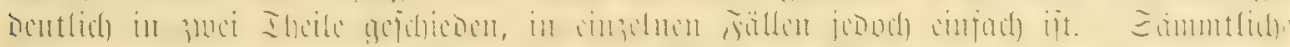

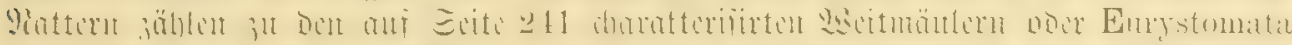

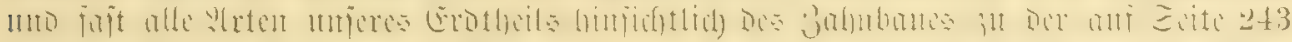

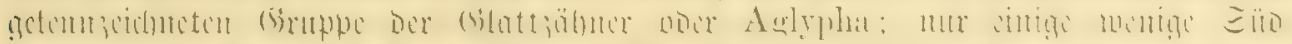

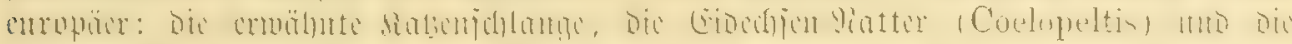

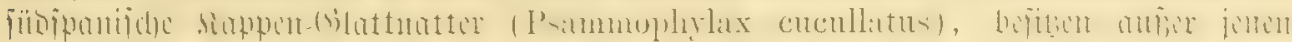

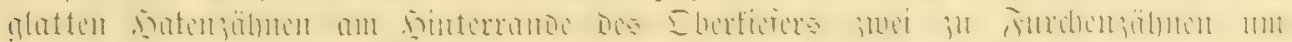

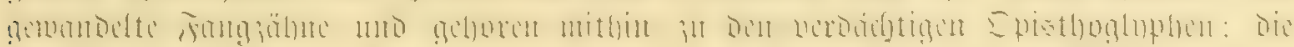

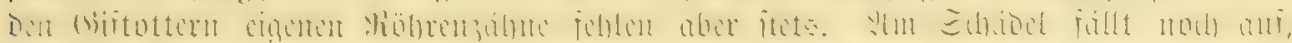

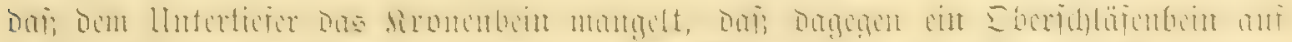

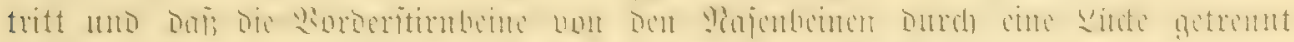

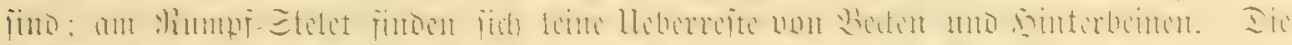
Huber

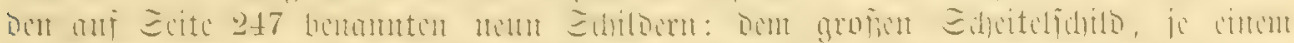

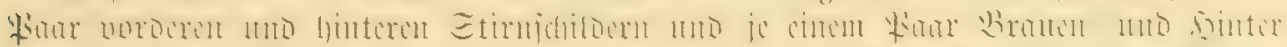

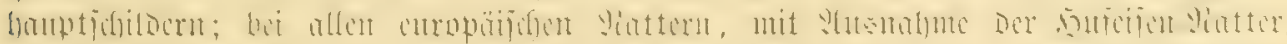

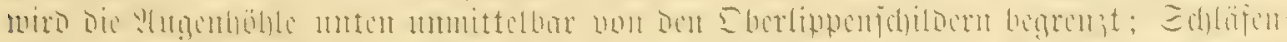

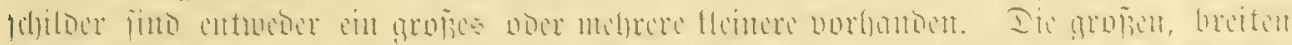

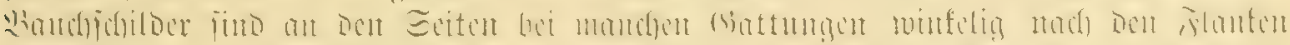

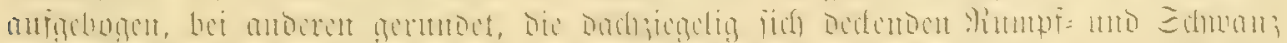

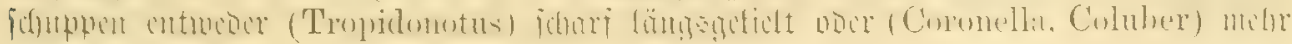
ober wentiger glatt.

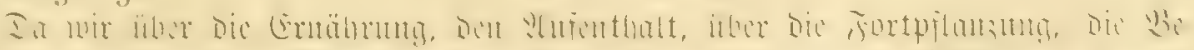

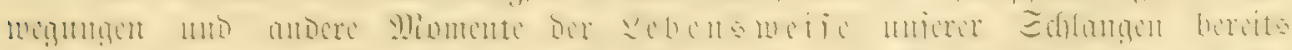

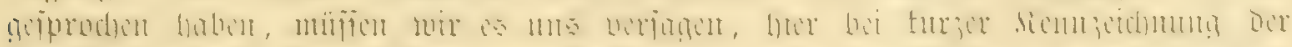

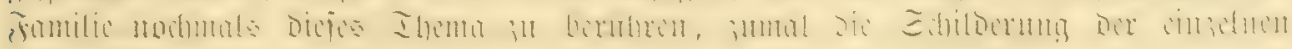
2(rten शäbcres crgeben miro. 


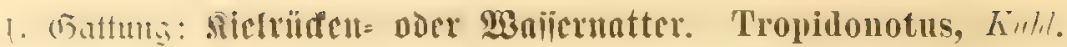

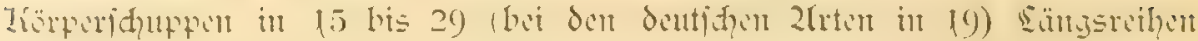
geftelit, dic des 2 ü dens namentlid mit fdarfem Eängsfel verfehen

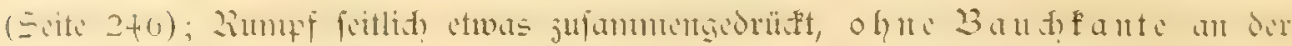

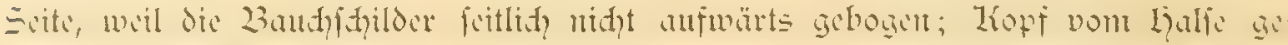

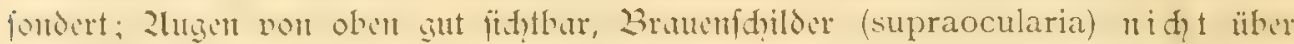

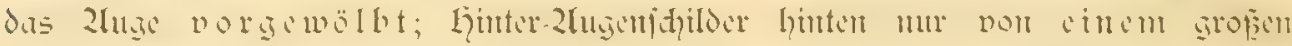

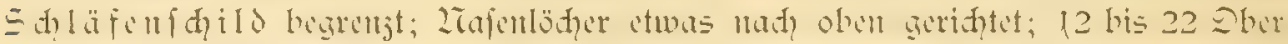

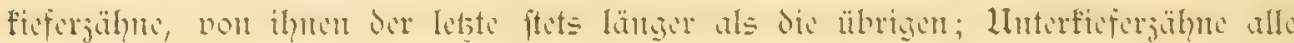
glcidigrof.

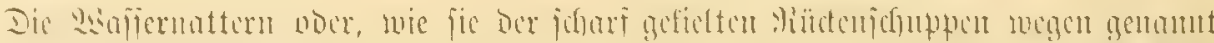

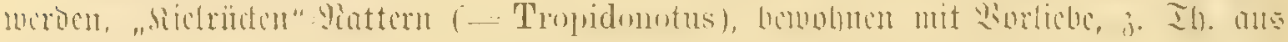

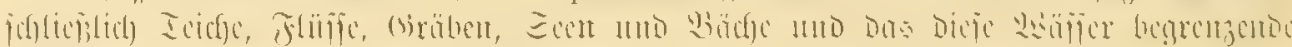

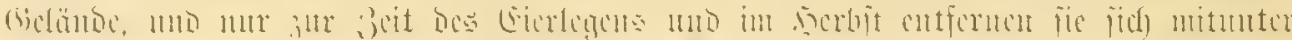

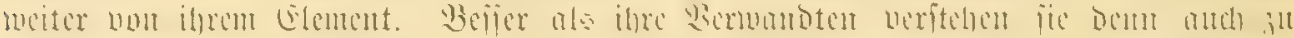

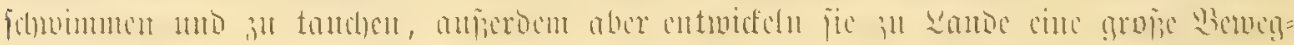

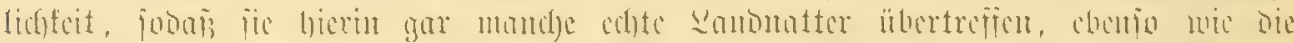

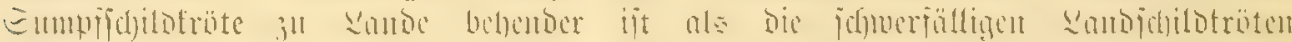

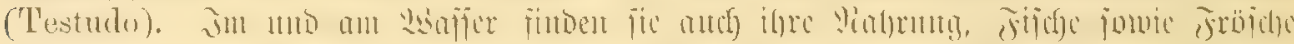

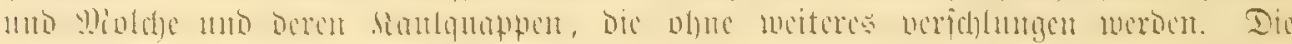

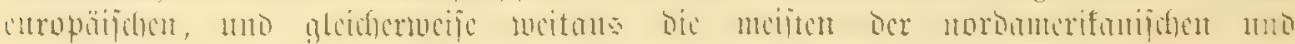

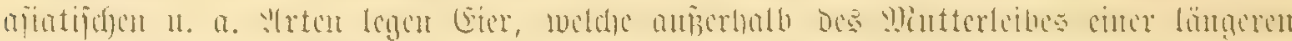

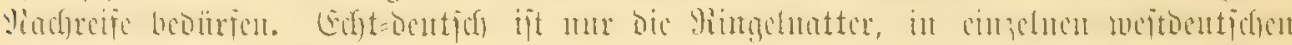

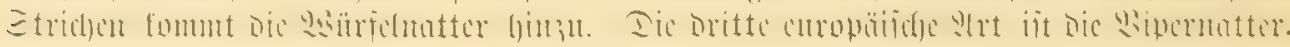

\section{9.rt: Ringelnatter. Tropidonotus natrix (L.).

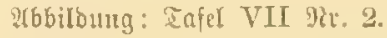

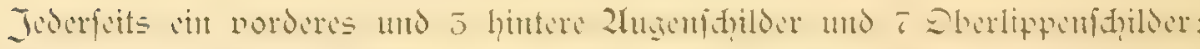

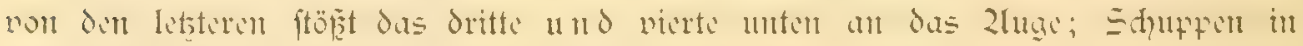
19 Sängsreihen; Bauḑidilder mindejtens 162.

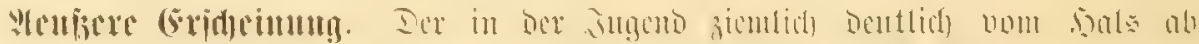

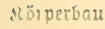
Gröbe.

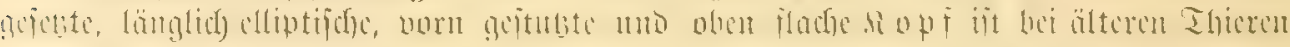

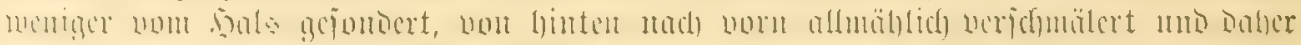

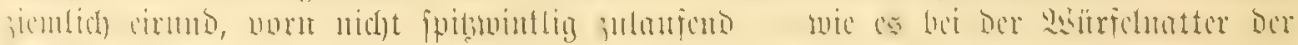

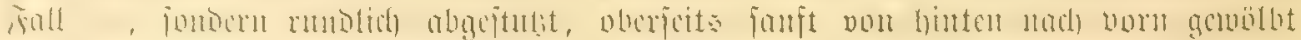

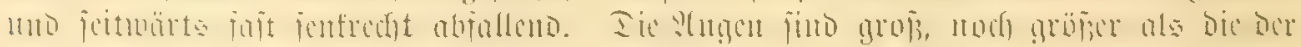

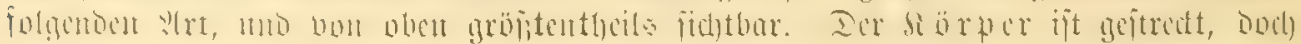

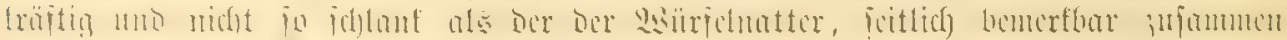

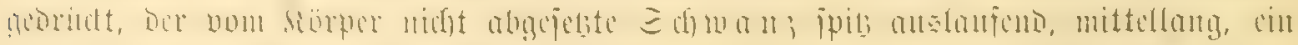

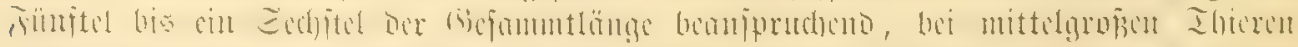

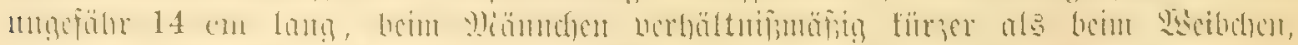
me Dem 


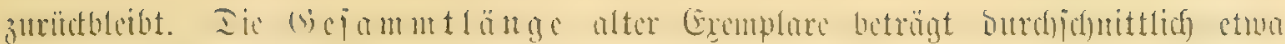

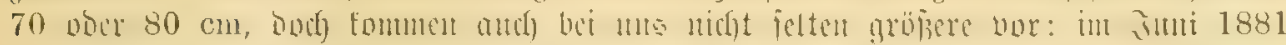

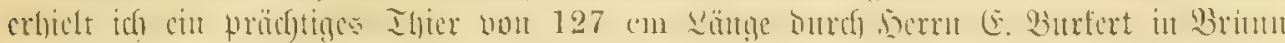

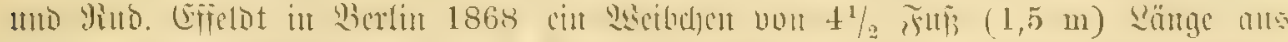

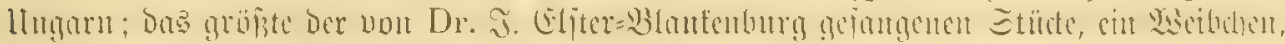

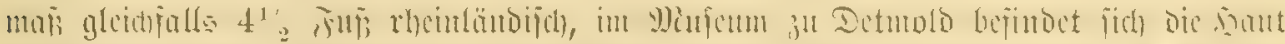

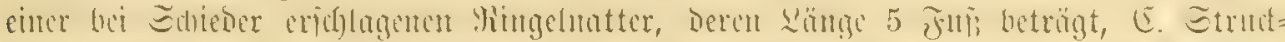

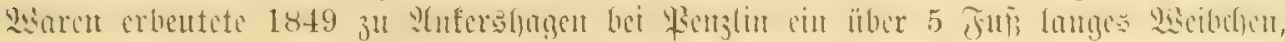

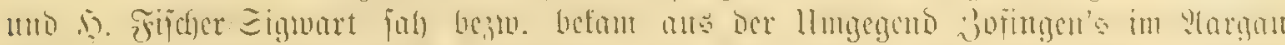

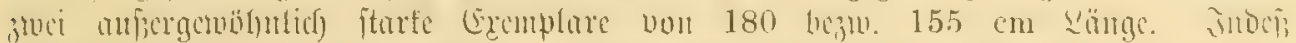

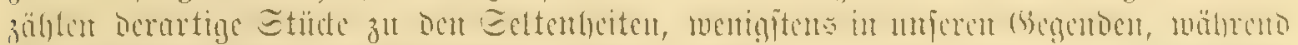

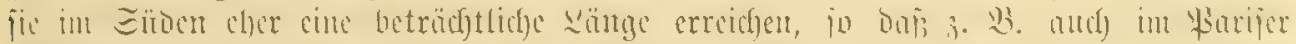

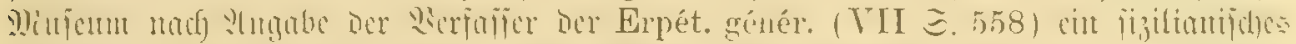

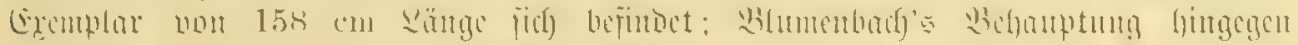

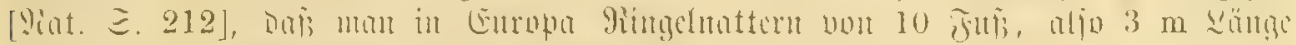

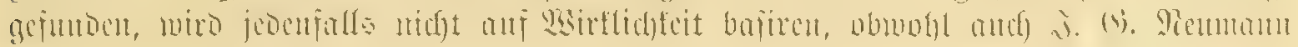
i. Э. 1831 berichtet: "In neteren Beiten fand man bergleidjen Dttern vou

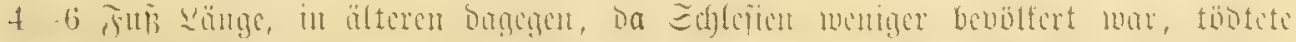

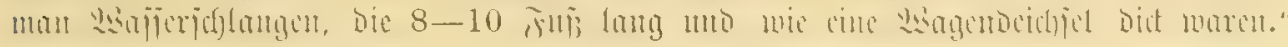

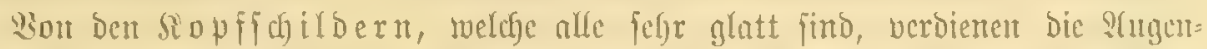

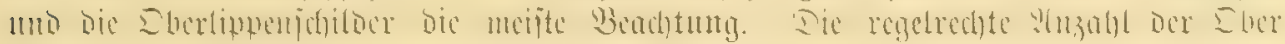

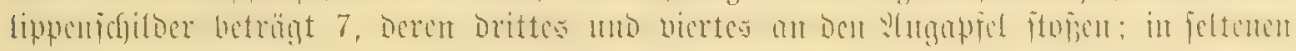

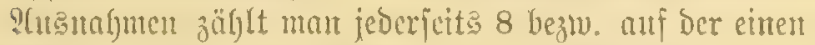
Seitc 7, auf ocr anderen 8 Supralabialen unto in nod) Felteren S(tignaf)men nur 6, non Denen bant nux Das britte an Daß 2 Luge grenst; eil Eremplar

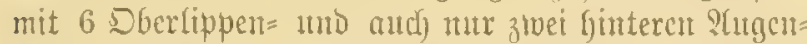
fcjilocrn anf Der linten Sette jtebt im Berner Majcun. Die Dreizahl Der Ginteren Stugentefitber fteigt auts

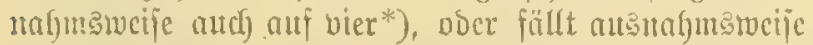
auf zwei und ztwar entweder betberjeits ober mur auf

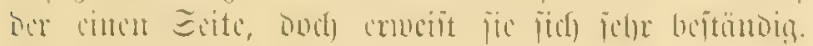

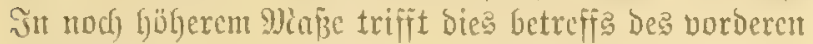

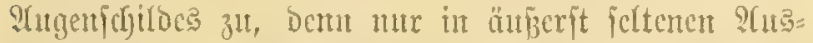

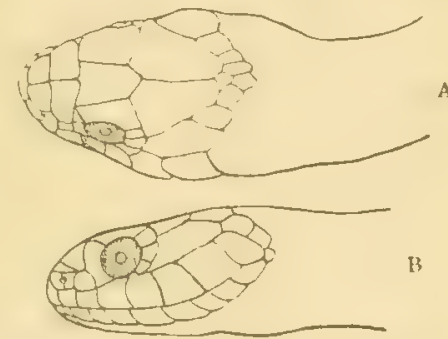

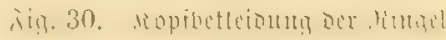
nattel:

A. Sopiplatte, 13. Siopfieite.

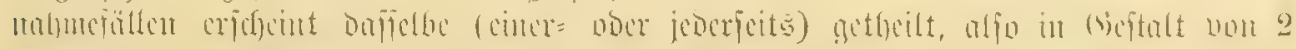

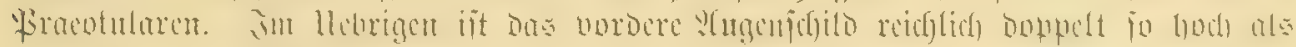

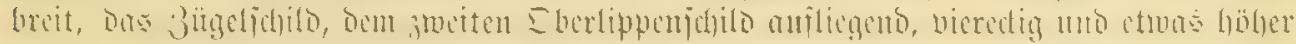

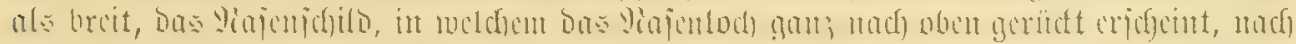

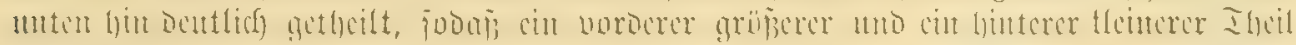

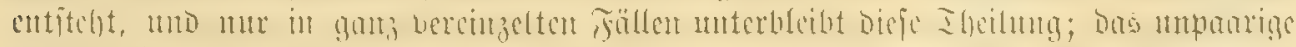

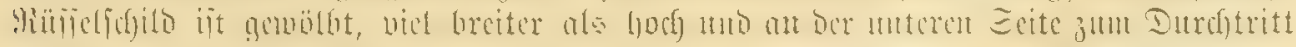

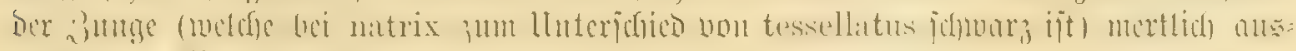

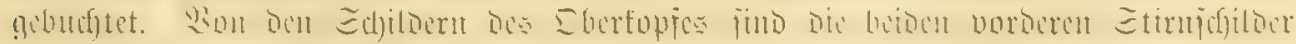

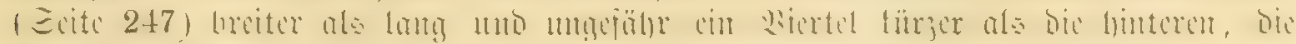

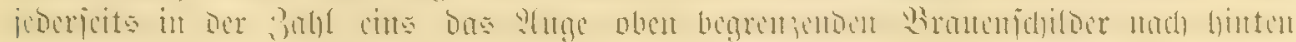

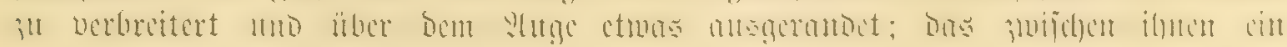

*) Dies gilt fpeziell fïr ben Trop. fallax fatio's. 


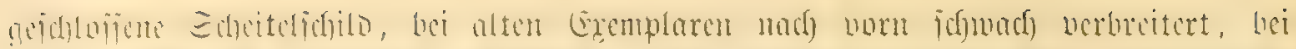

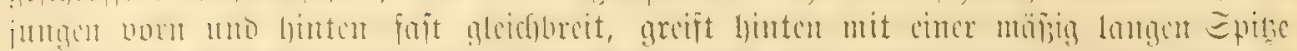

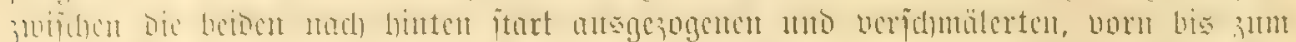

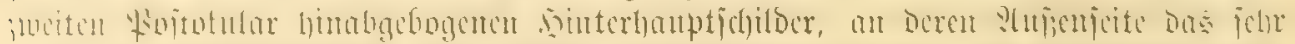

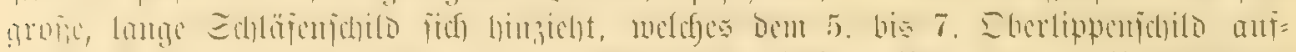

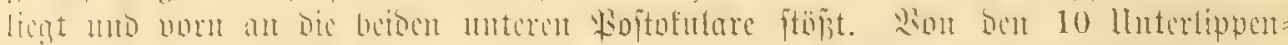

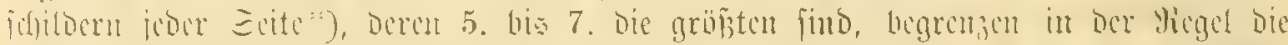

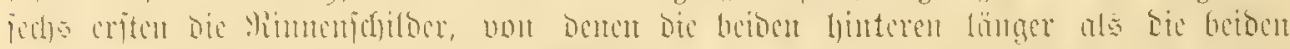

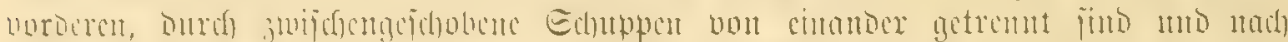

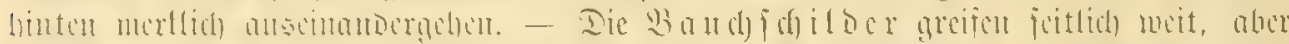

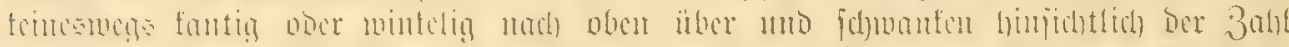

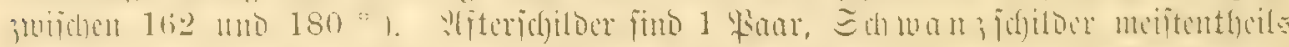

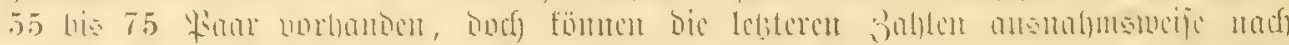

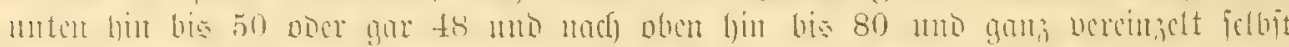

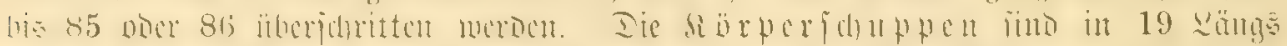

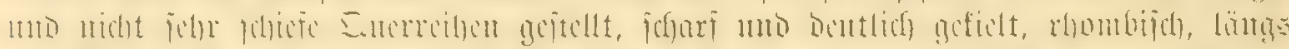

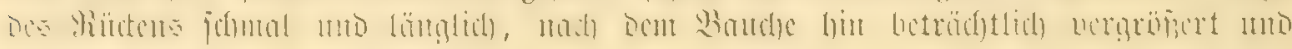
werrutubet.

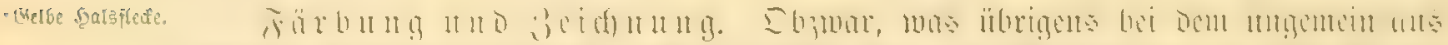

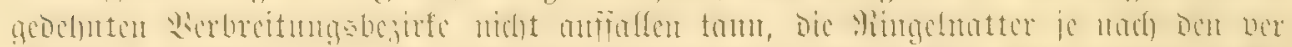

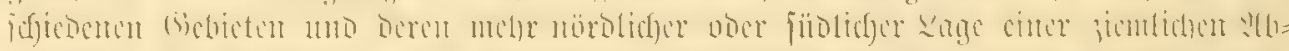

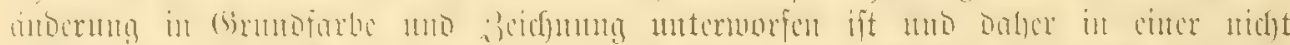

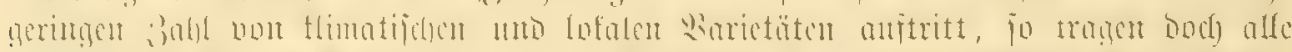

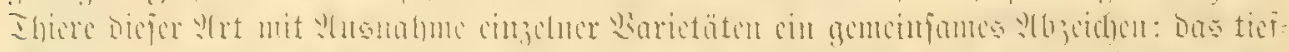

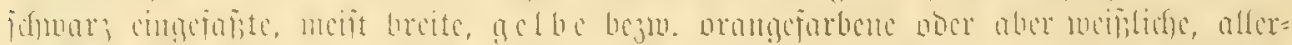

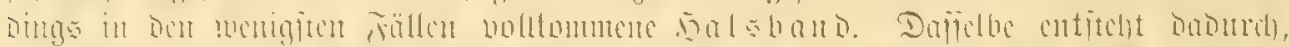

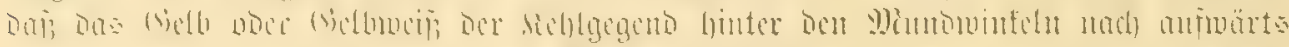

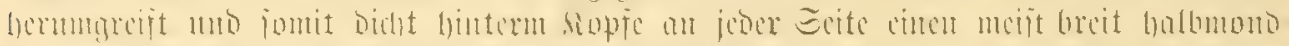

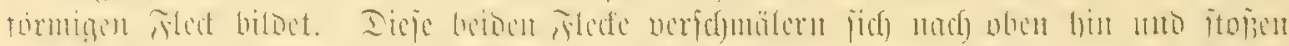

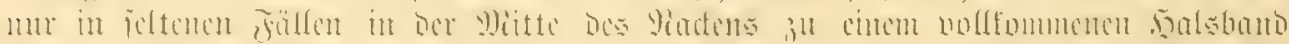

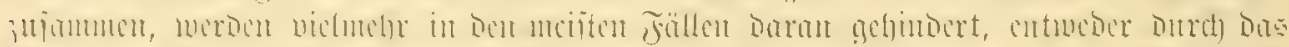

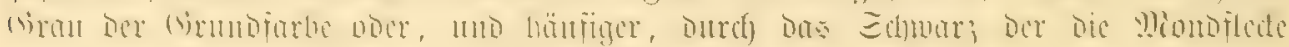

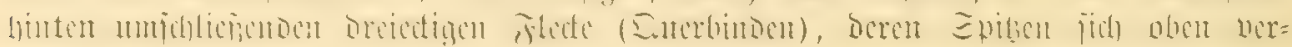

*) Cin mir joeben portiegenbes (Exemplar hat auf ber linfen Geite mu 9 Sublabialen. -

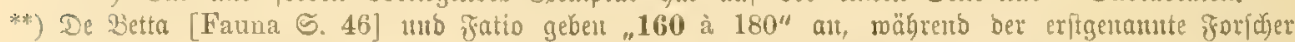
17 Sahte früher [Erp. S. 211] alङ niebrigfte 3ahl 162 anfübrt mo Sdjreiber [Hern. S. 241]

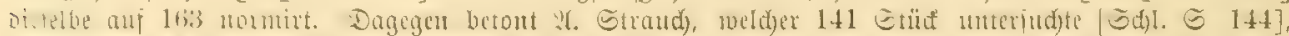

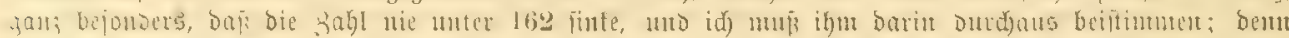
Die bei Sdjlegel [Ess., Bל. II S. 304] uto aud) bei Daubin [Rept., Th. VII S. 31] fid findentoe

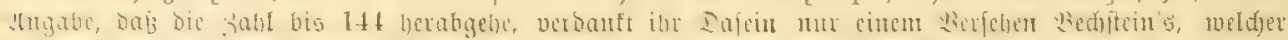

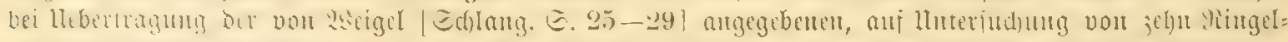

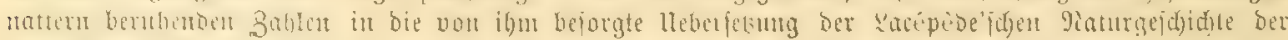

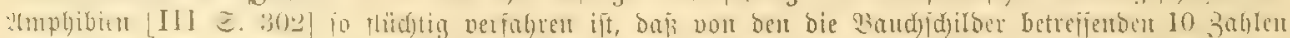

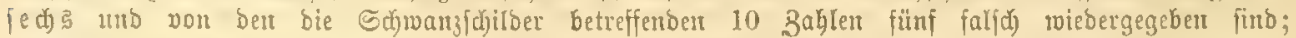

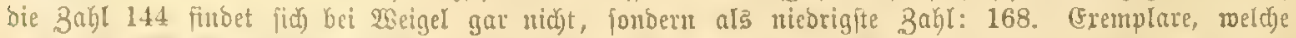

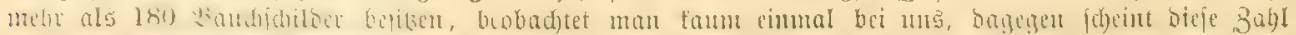

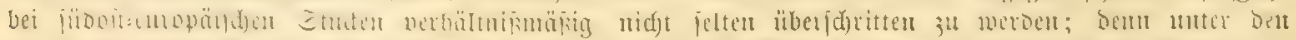

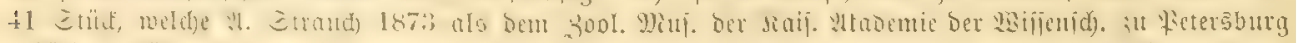

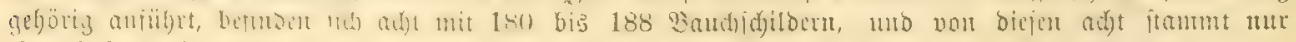

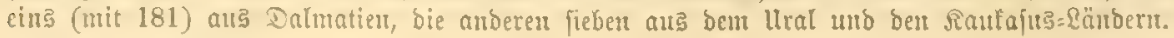




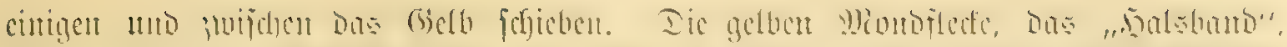

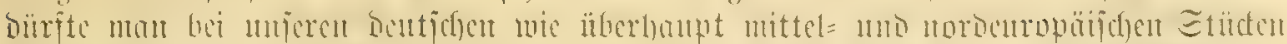

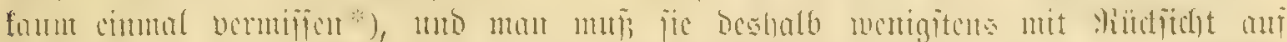

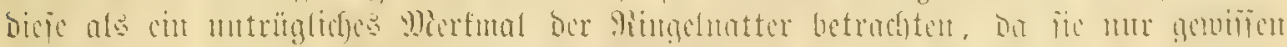

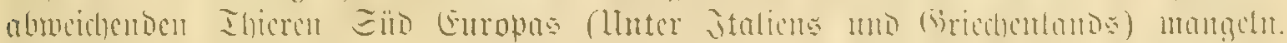

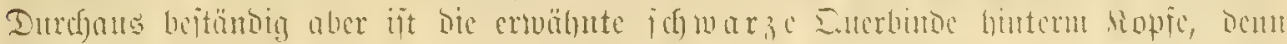

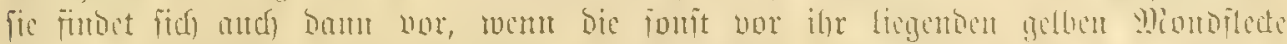

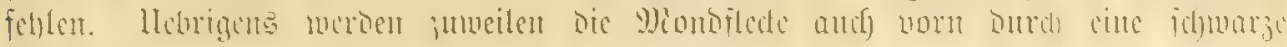
Dinto 1tutfäunt.

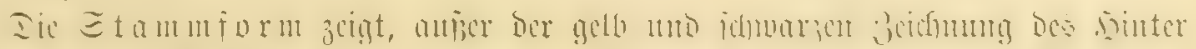

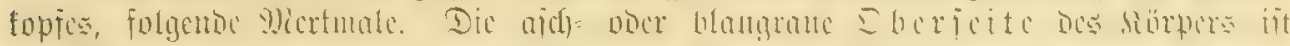

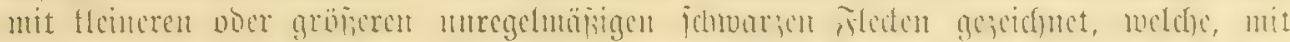

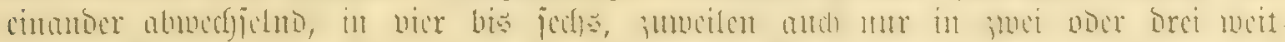

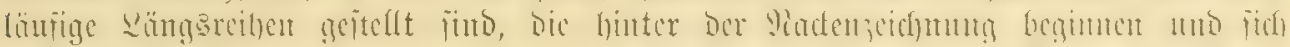

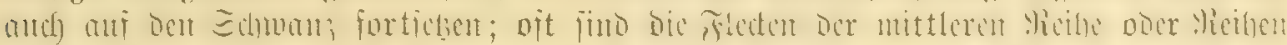

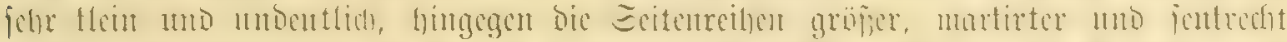

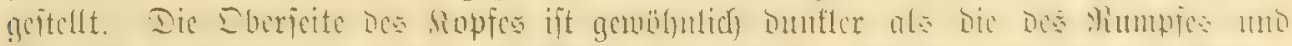

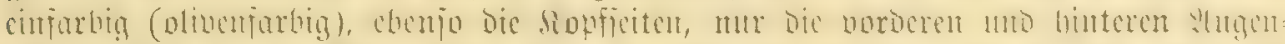

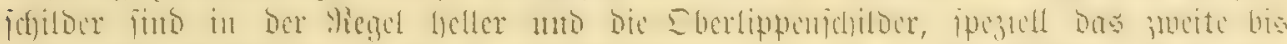

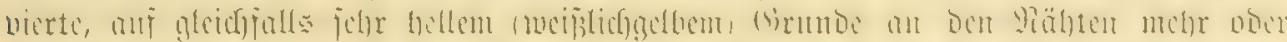

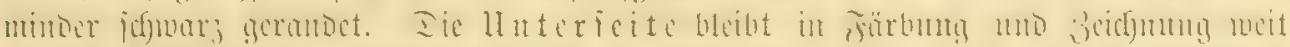

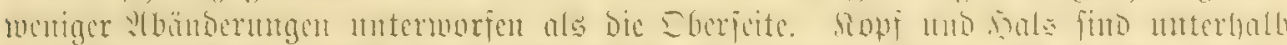

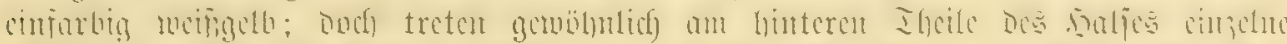

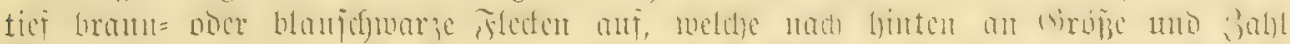

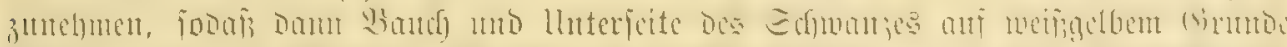

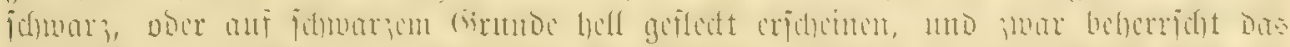

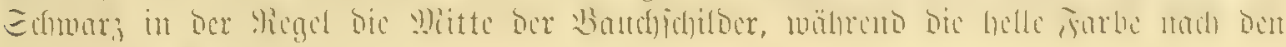
Eeiten zurïrfigcorängt twiro.

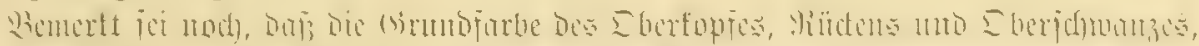

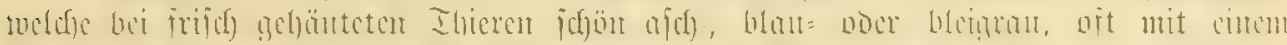

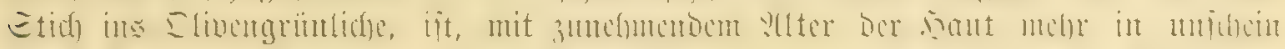

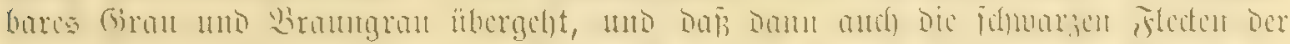

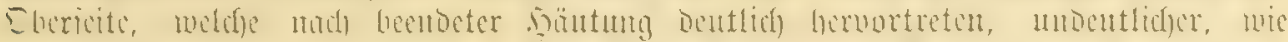

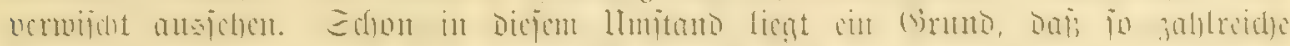

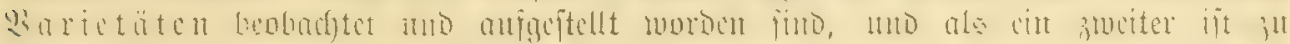

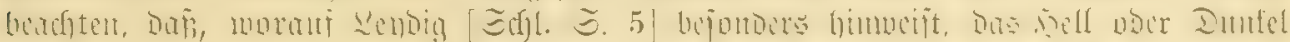

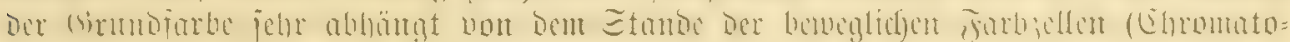

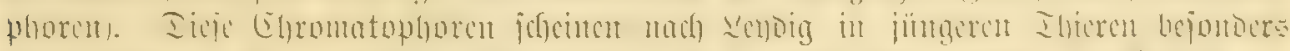

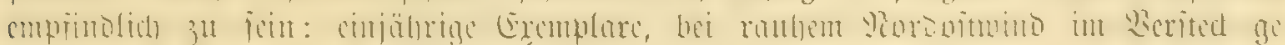

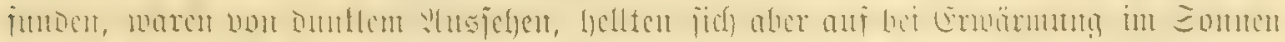

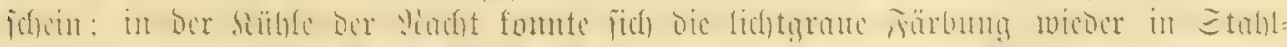

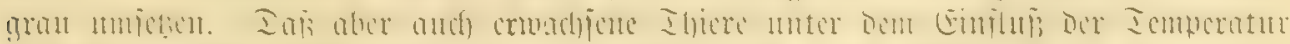

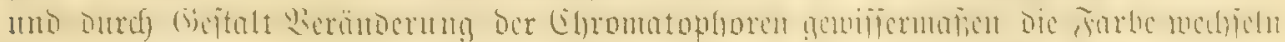

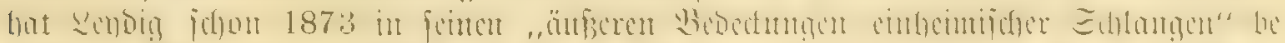

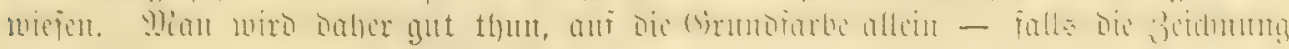

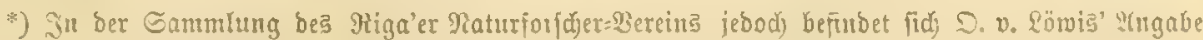

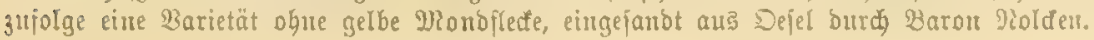




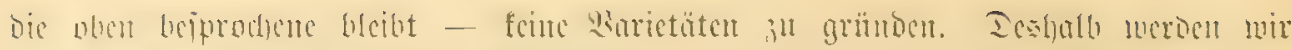

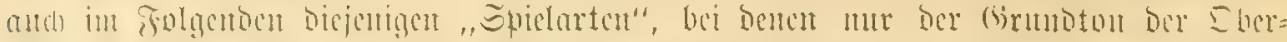

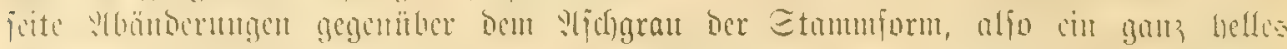

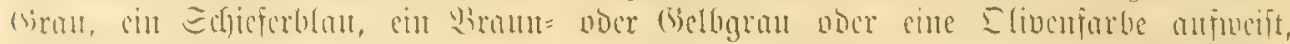

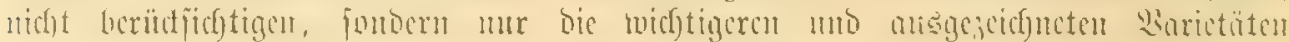
bervorlycbert.

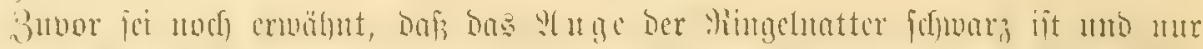

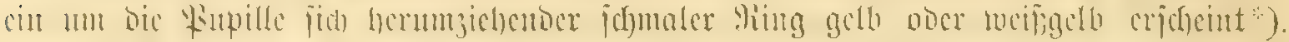

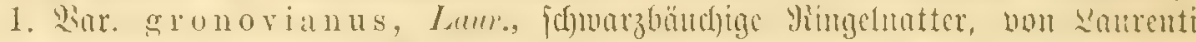

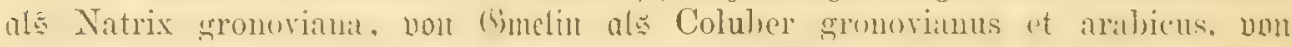

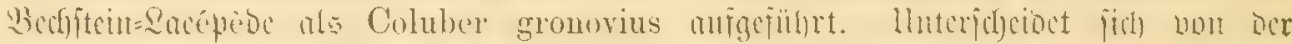

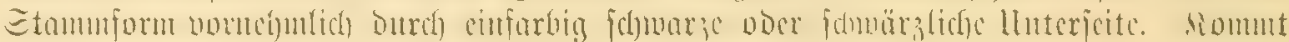
ntidyt jelten bor, namentlid) wenn bic Dberjeite cbenfalla Dunfel ift.

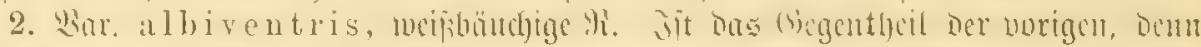

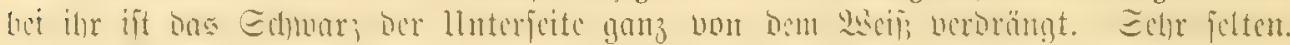

3. Sirr. concolor, einfarbige g. Bei ifr finto bic jdywarzen fflecten ber

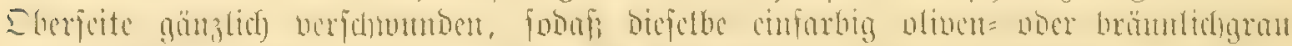

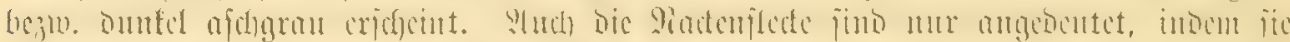

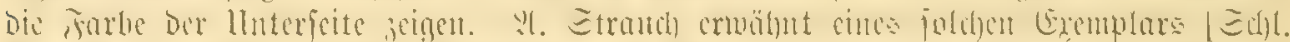

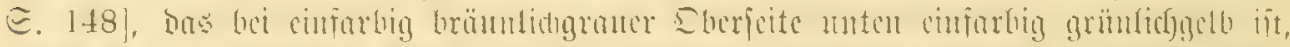

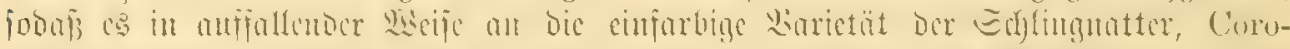

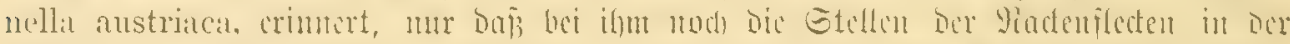

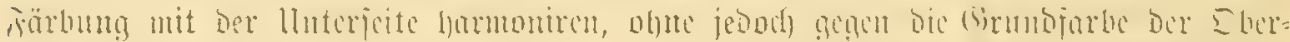

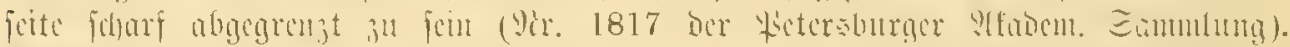

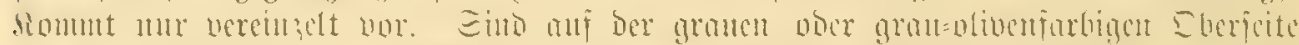

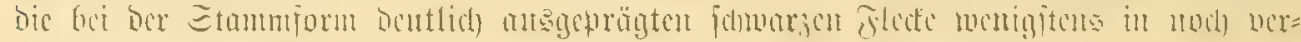

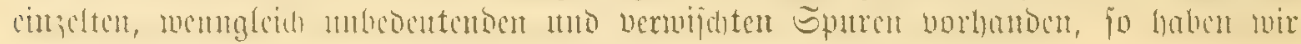
Die jogenante poutifdue Dararietät (Coluber ponticus Pallas) vor une.

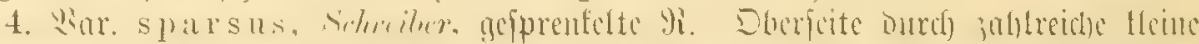

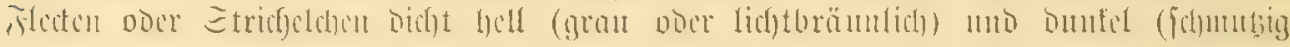

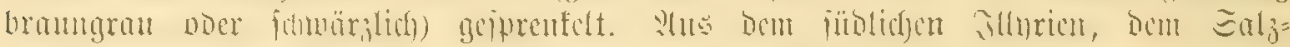

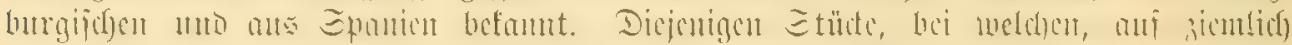

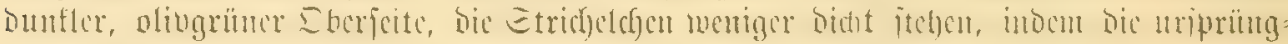

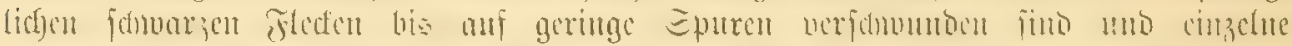

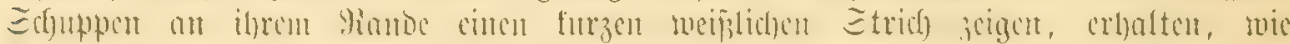

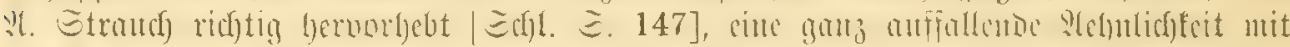

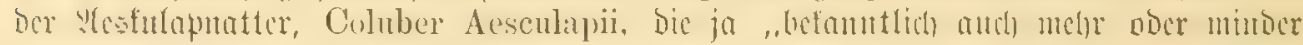

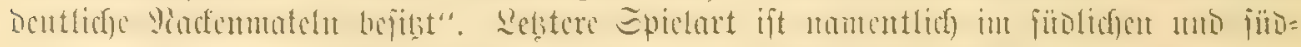

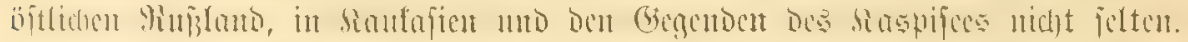

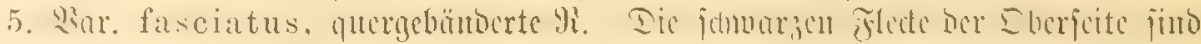

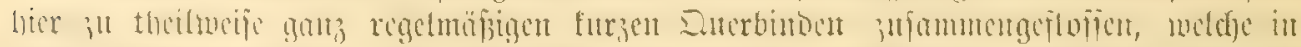

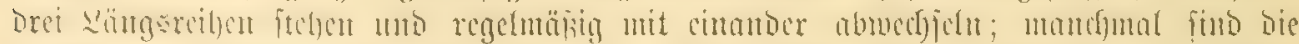

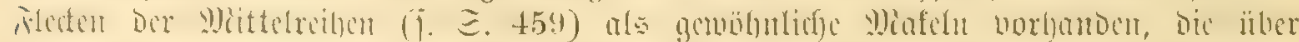

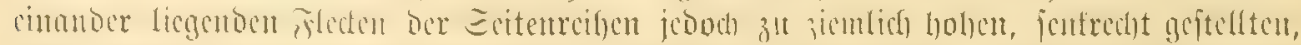

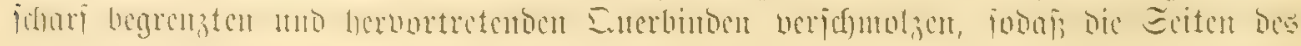

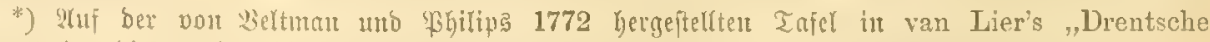

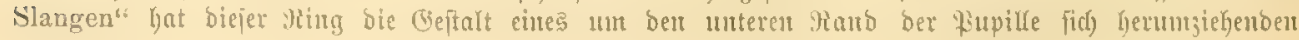
balbtreifes mo eine tothe fatbe erbalten. 


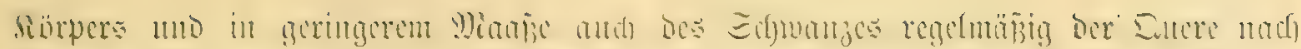

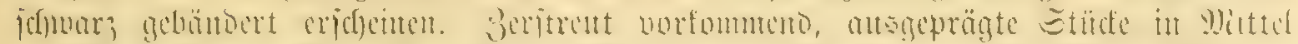

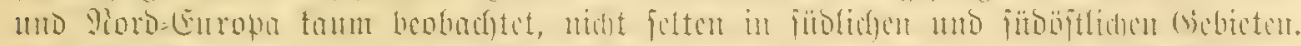

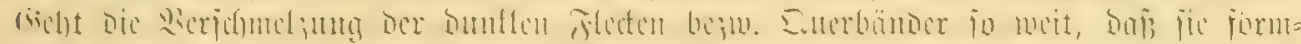

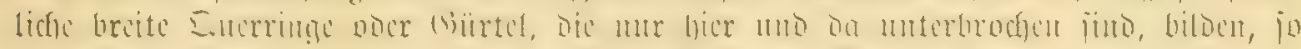

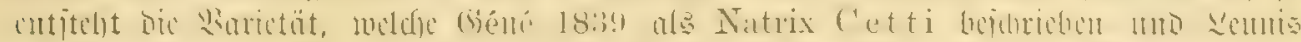

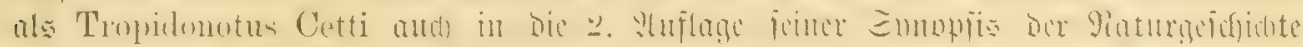

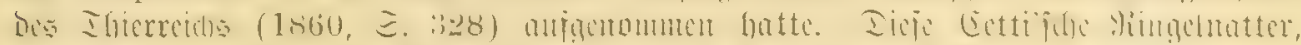

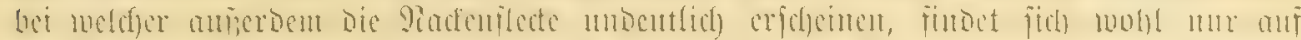

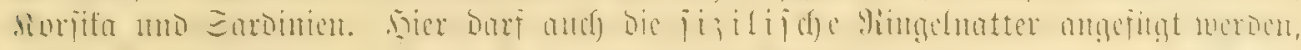

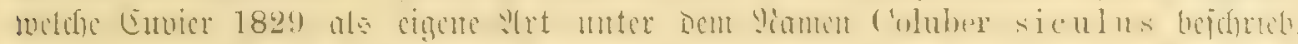

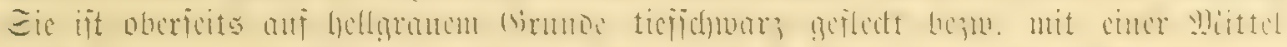

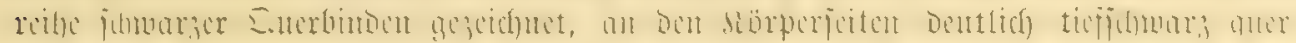

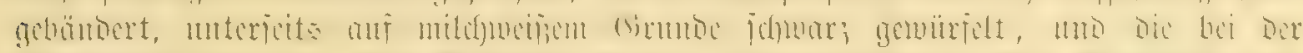

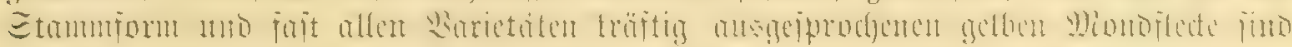

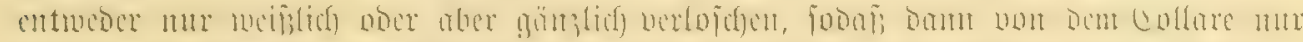

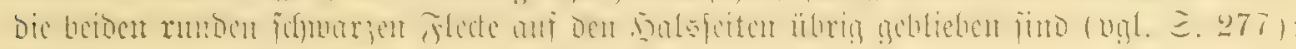
fie findet fich in Sizilien, linter=stalien, Grichentand.

6. Sar. persa, Pallas (= persicus Eichu.; dalmatinus Schinz; biliueatus

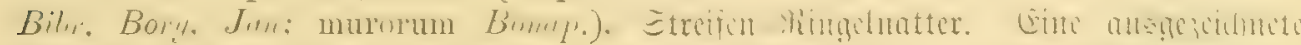

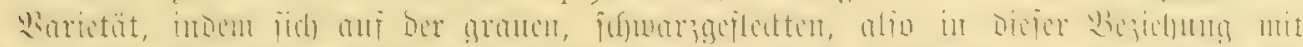

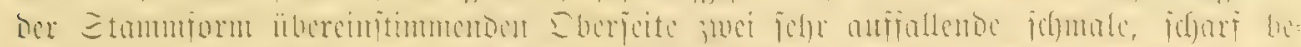

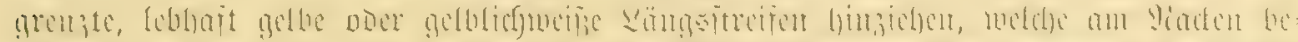

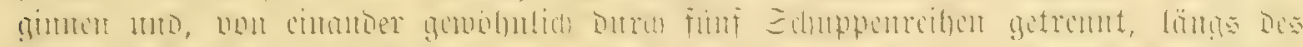

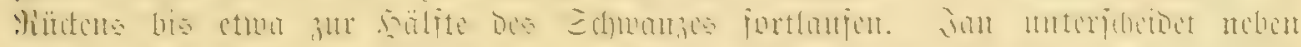

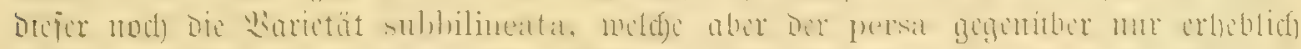

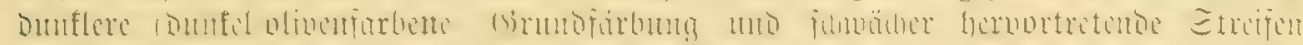

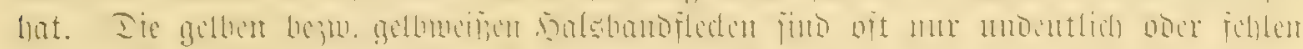

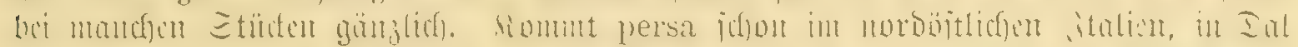

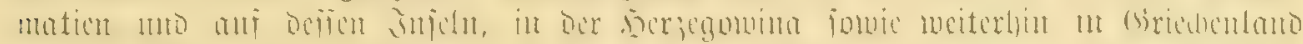

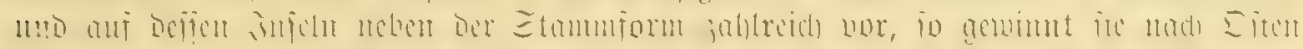

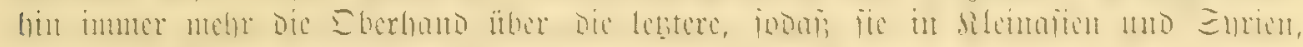

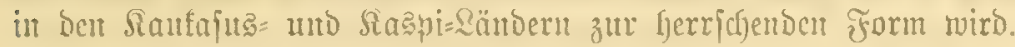

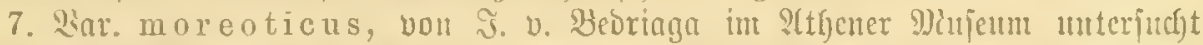

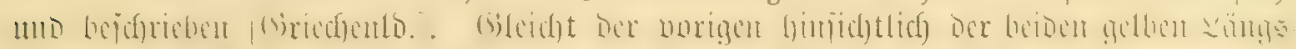

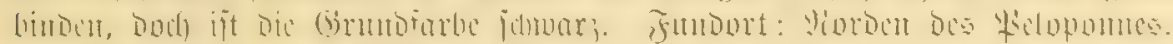

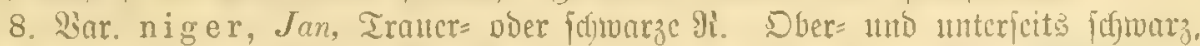

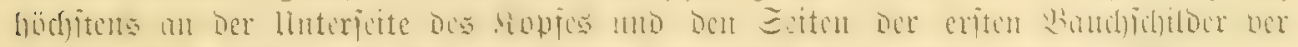

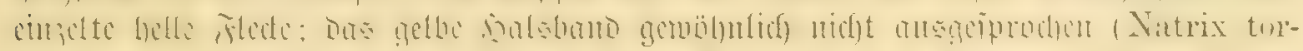

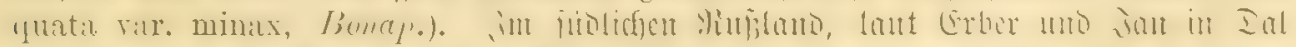

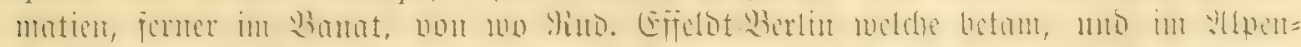

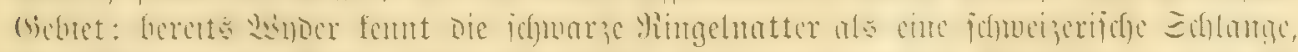

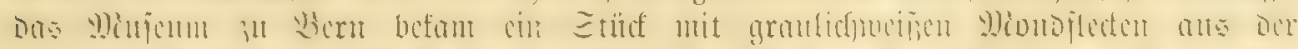

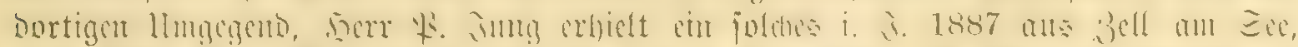

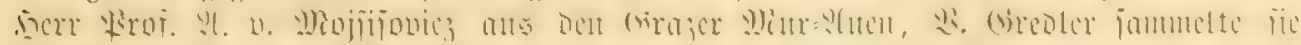

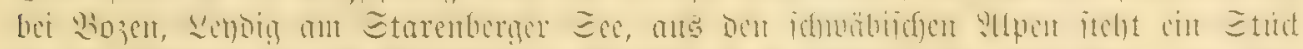

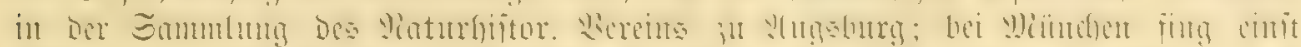

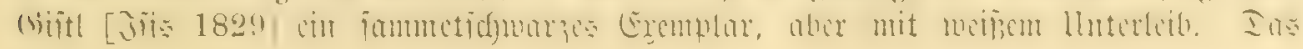




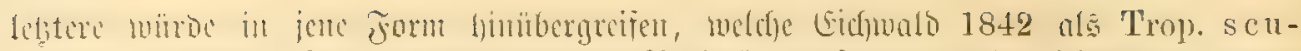

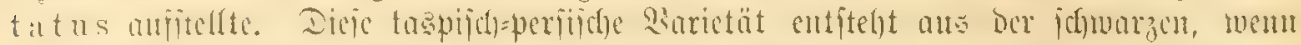

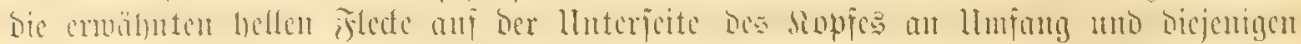
an Den

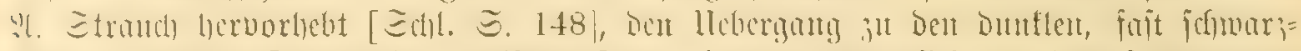

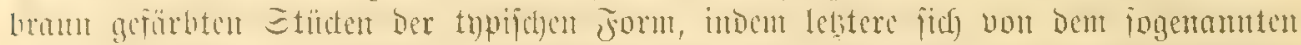

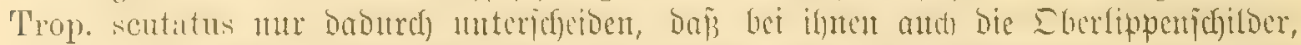

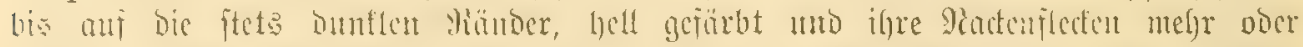

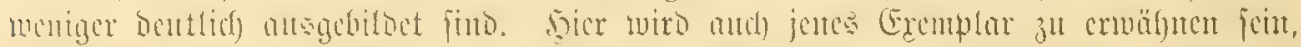

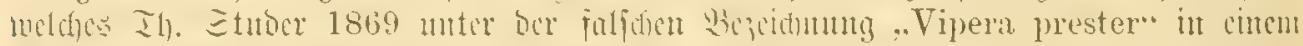

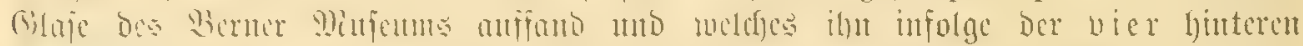

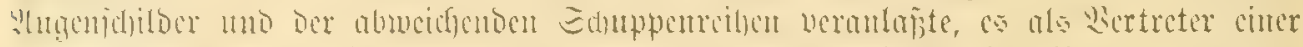

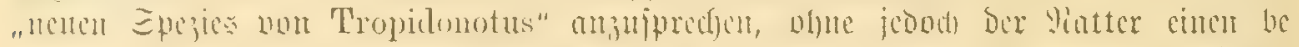

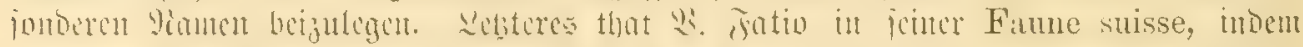

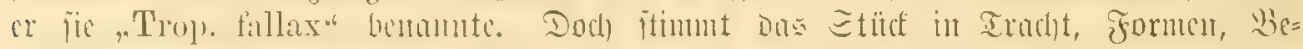

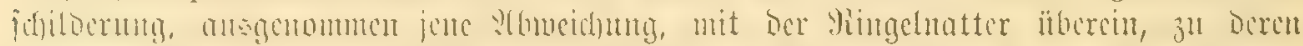

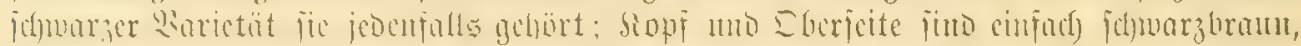

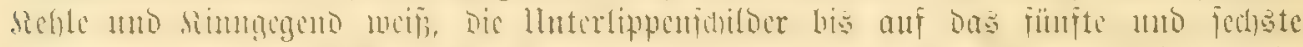

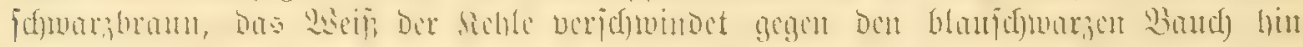

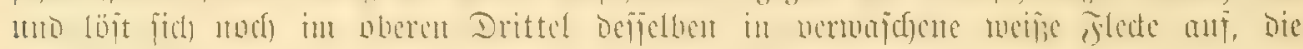

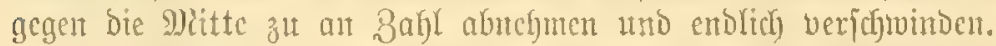

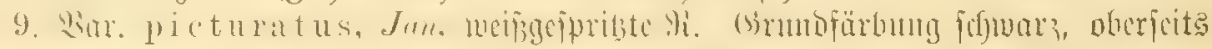

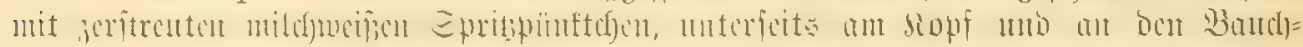

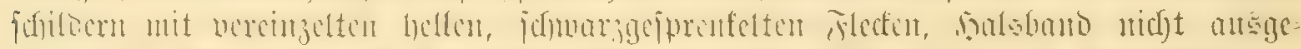

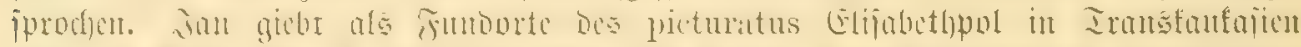

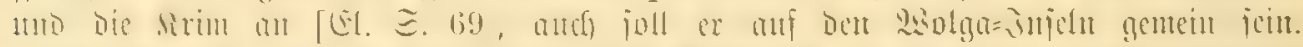

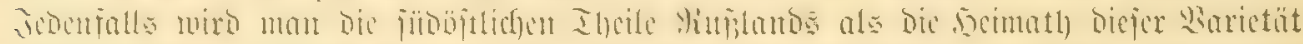

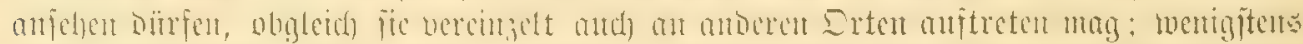

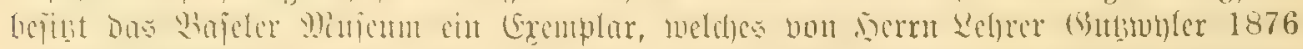

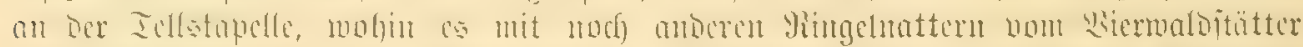

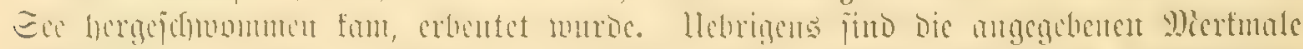
bicjor Q

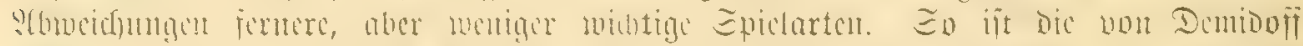

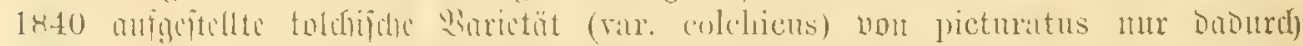

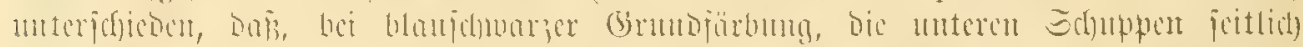

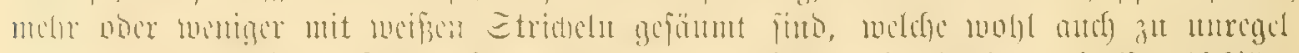

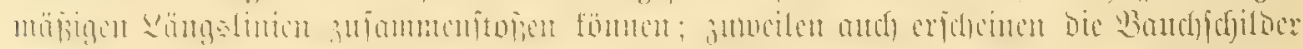

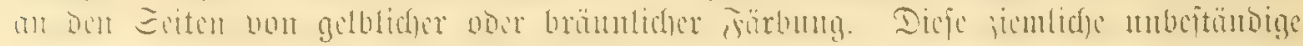

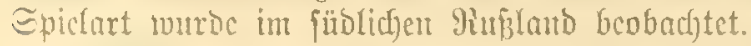

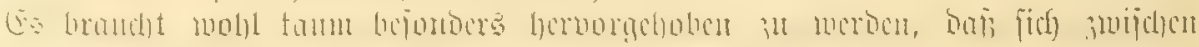

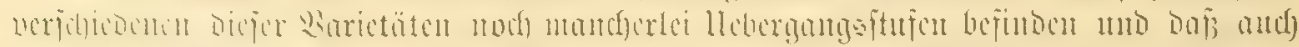

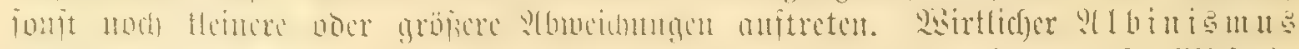

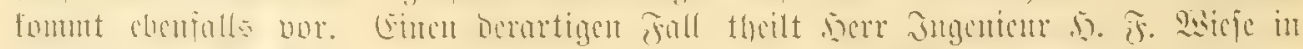

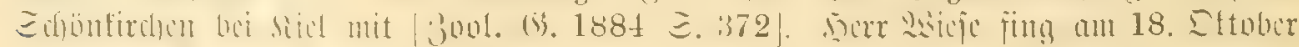

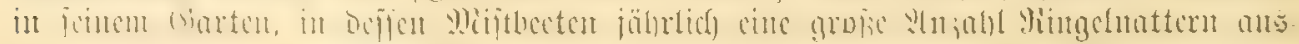

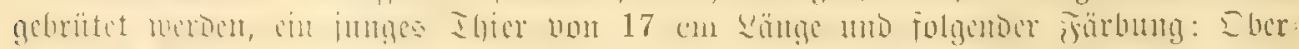

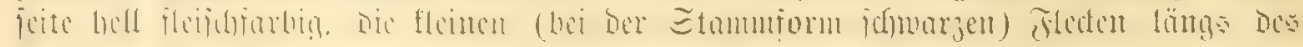

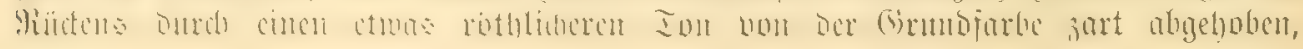




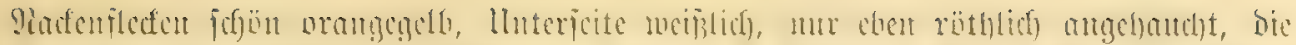

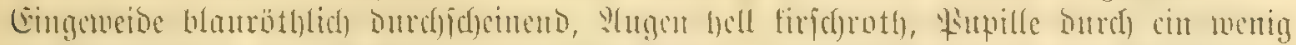

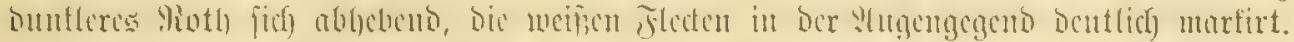

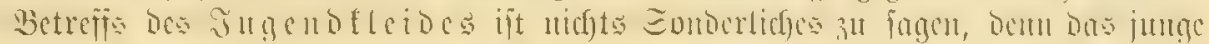

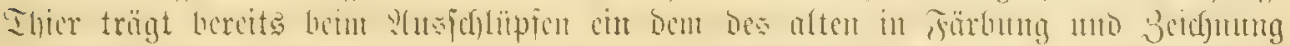

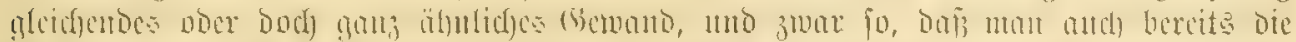

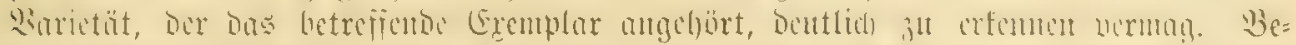

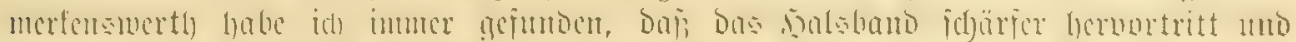

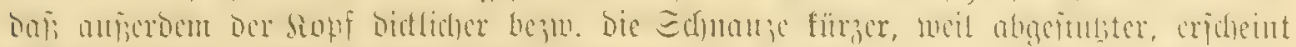

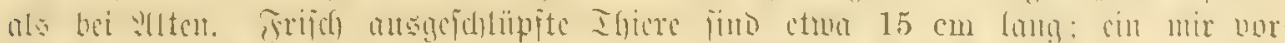

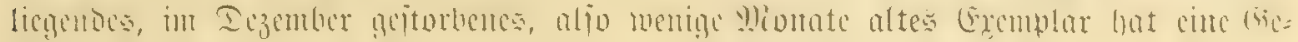
fanmtläntge wont $19 \mathrm{~cm}$, wovou $4 \mathrm{~cm}$ anf Delt Scljwantz fonmen.

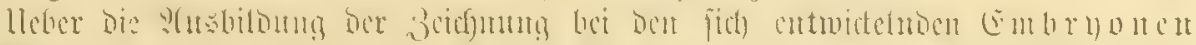

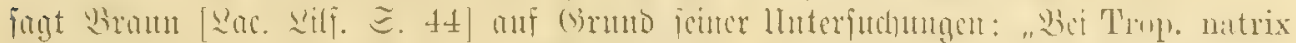

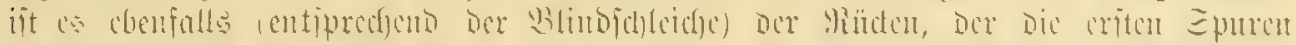

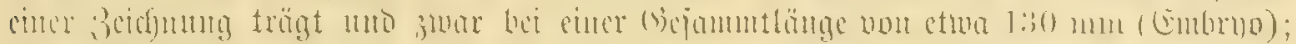

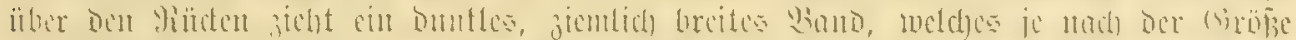

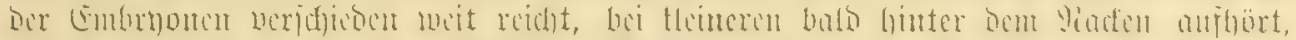

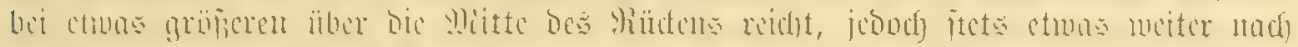

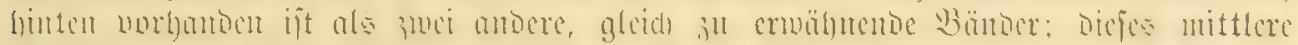

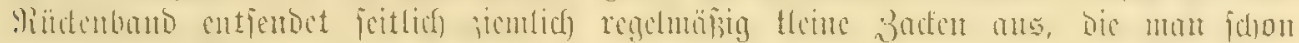

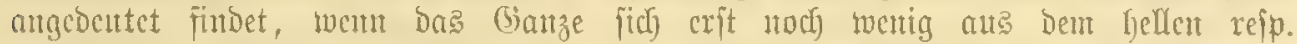

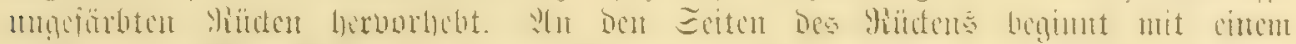

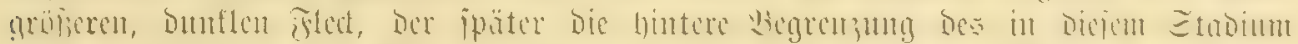

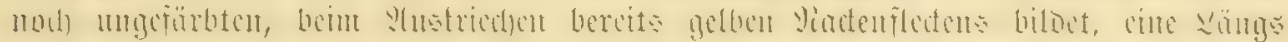

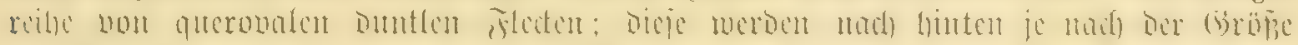

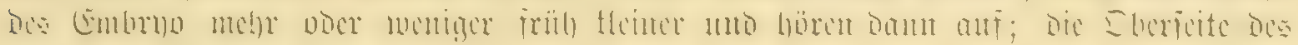
Siopies buntclt aud bereit?."

Bei älteren Sutoren, aber autd) noch in neucren Sdjriften, fo in ber zweitent (Wejd)ledtet.

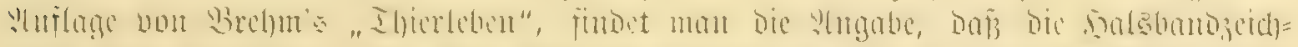

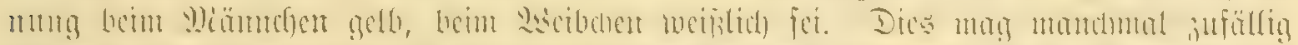

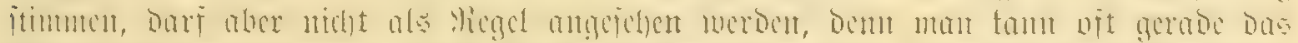

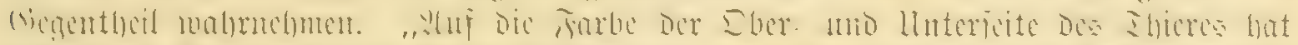

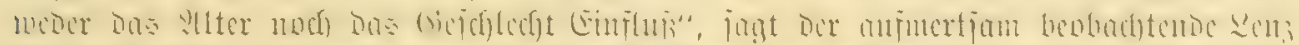

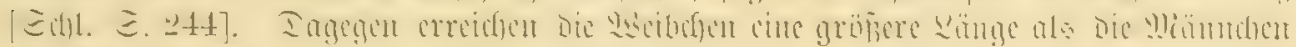

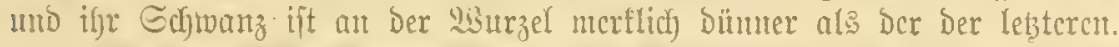

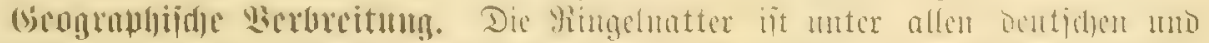

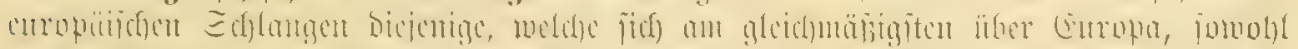

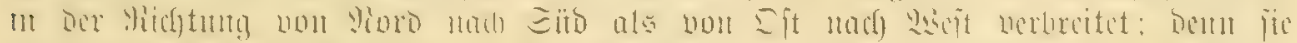

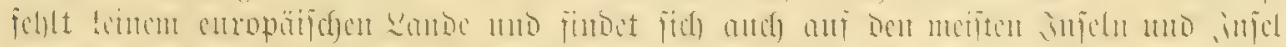

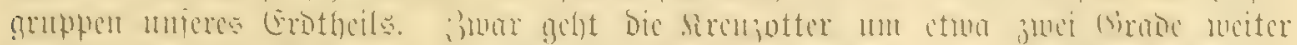

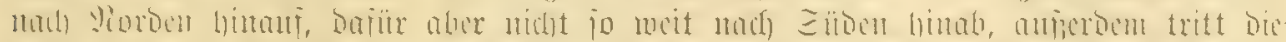

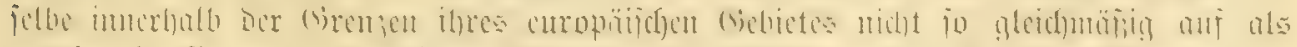

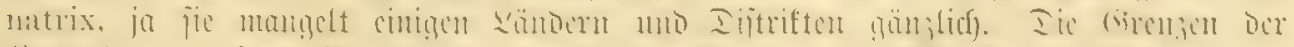

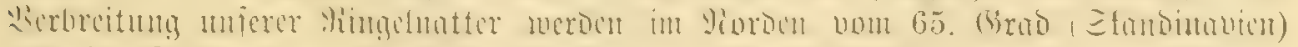

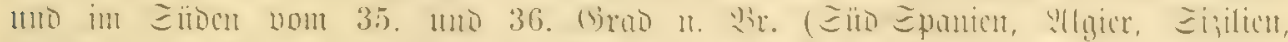

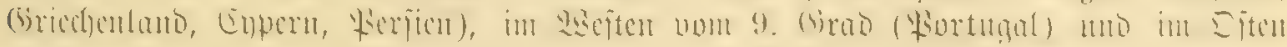
ctwa von 122. (Srad öftl. Ränge won Ferro (Baifal=Sce) gebilot. 


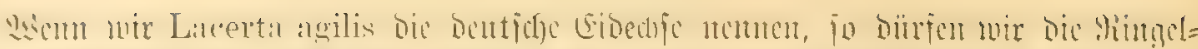

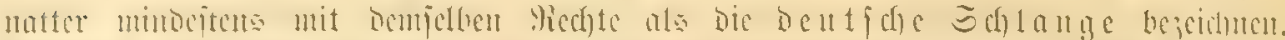

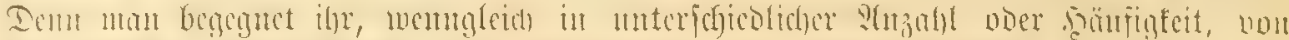

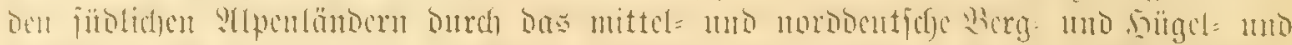

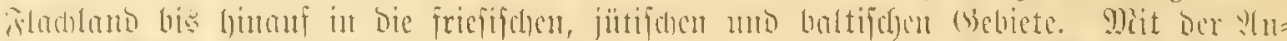

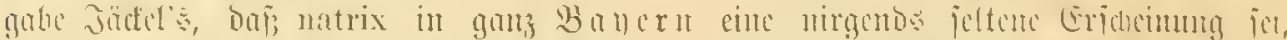

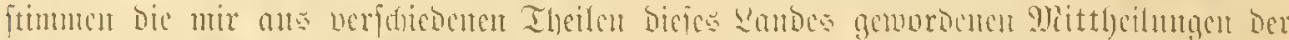

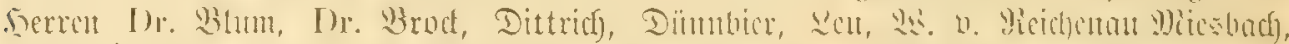

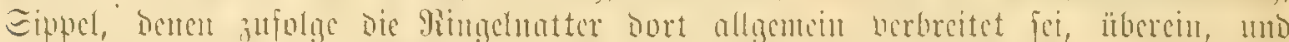

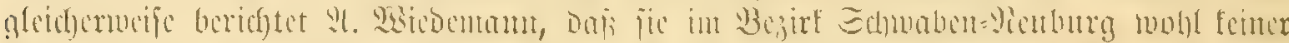

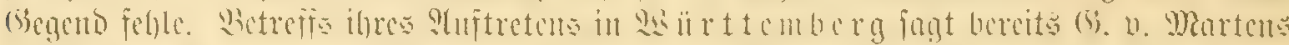

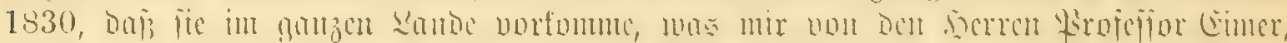

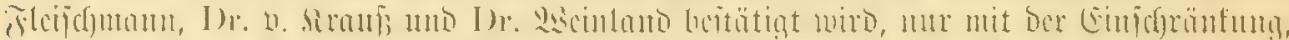

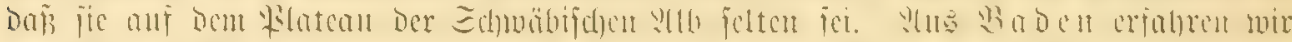

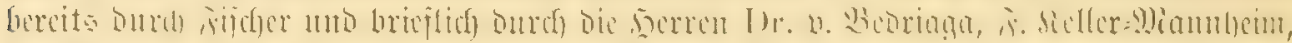

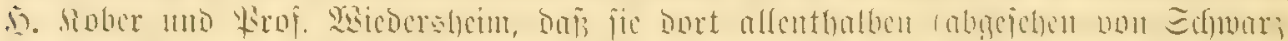

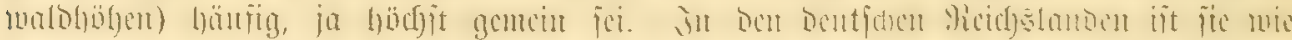

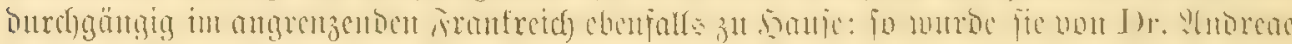

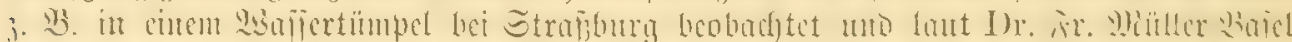

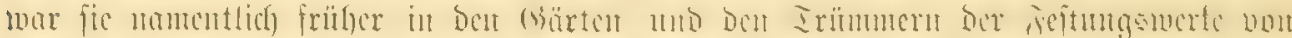

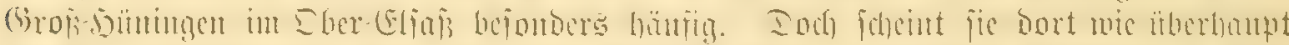

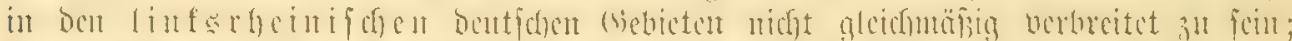

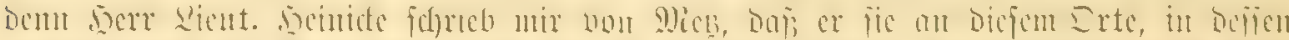

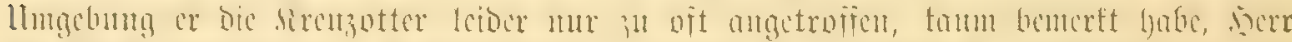

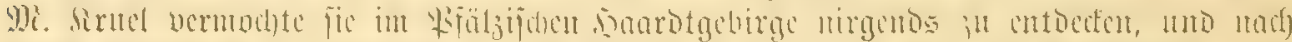

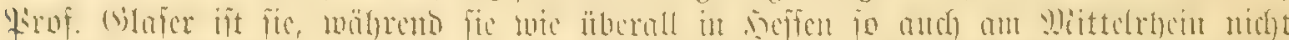

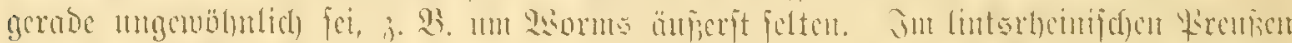

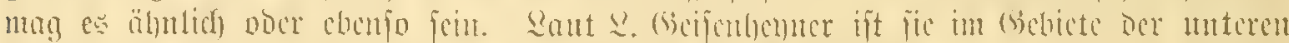

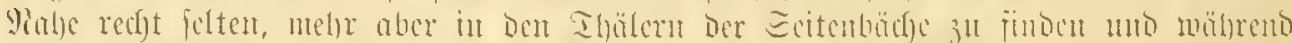

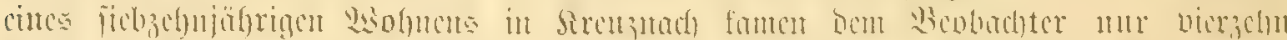

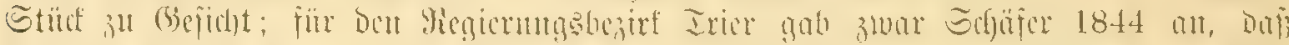

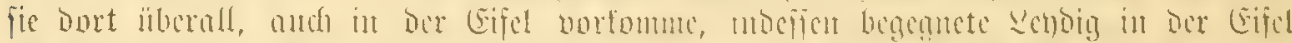

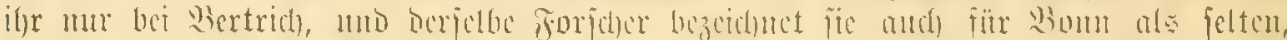

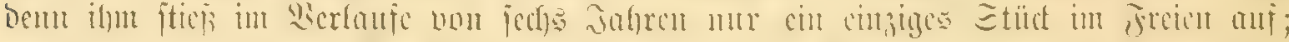

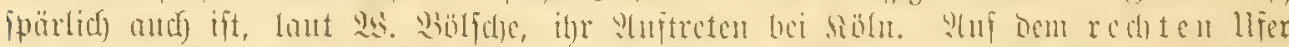

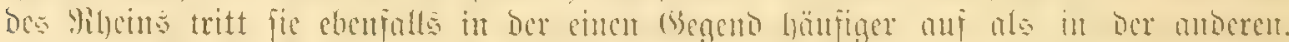

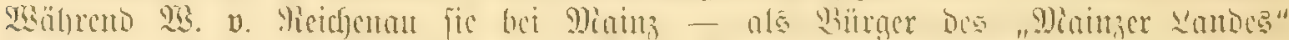

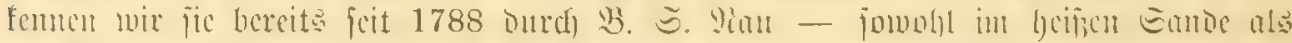

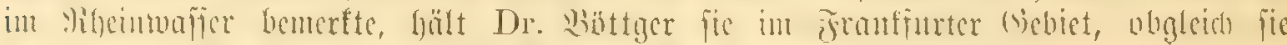

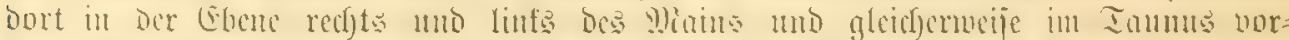

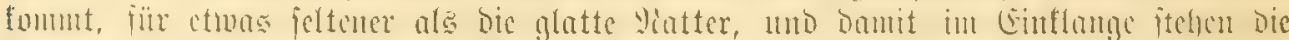

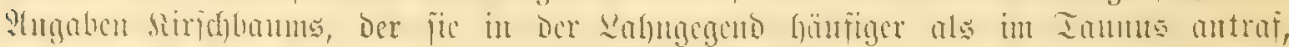

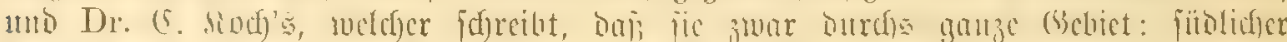

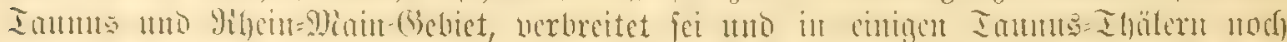

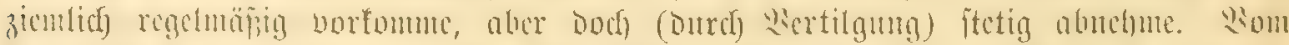

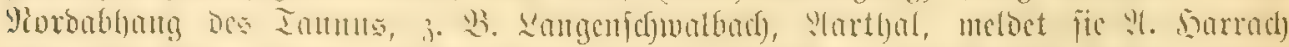

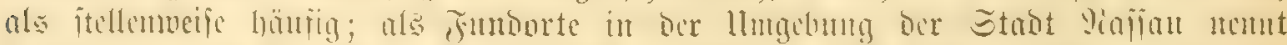

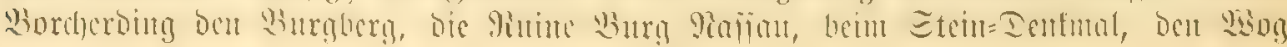




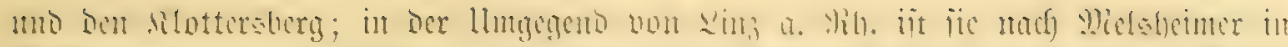

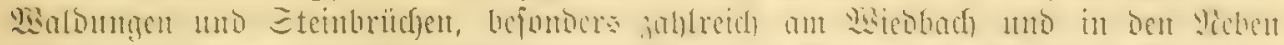

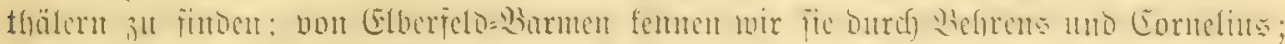

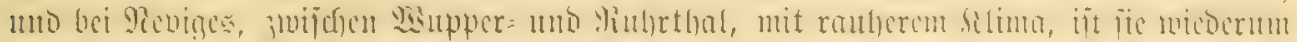

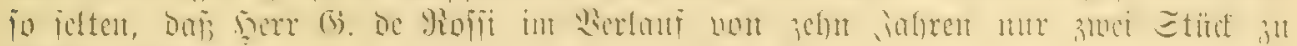
(beiticht befom.

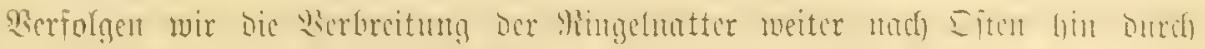

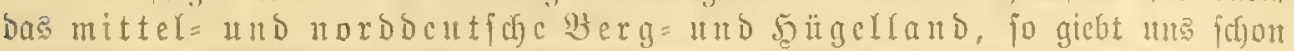

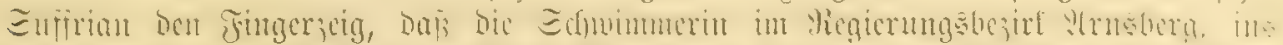

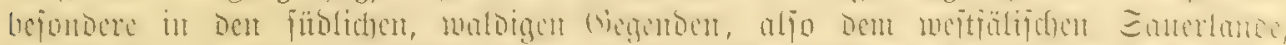

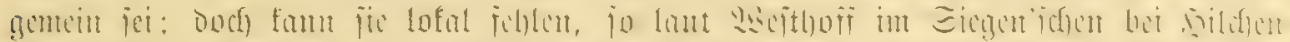

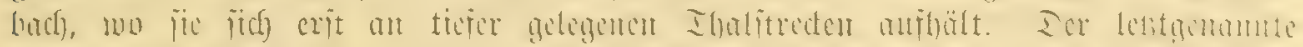

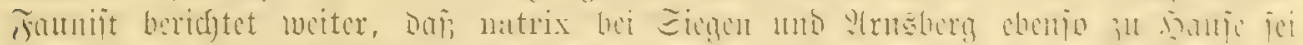

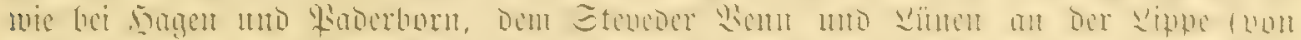

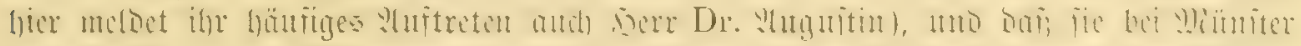

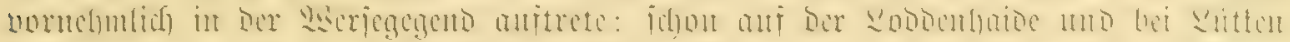

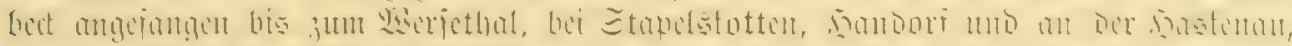

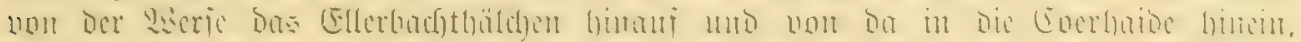

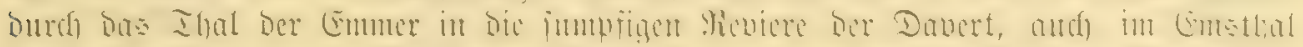

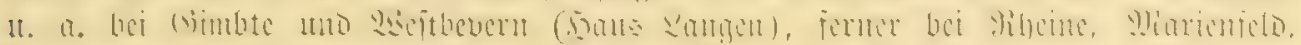

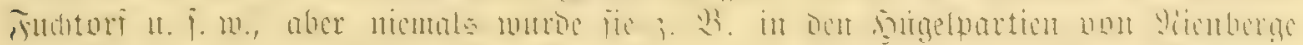

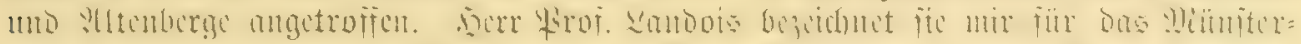

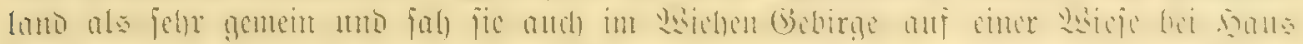

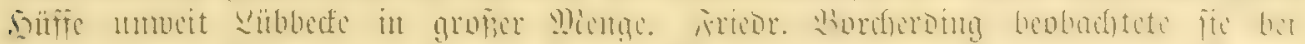

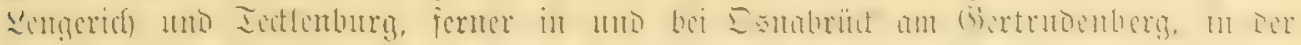

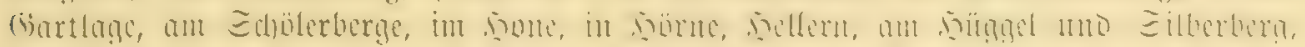

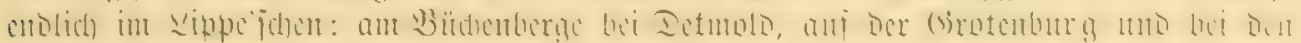

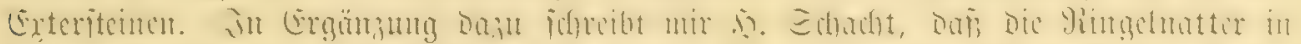

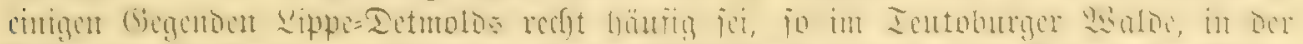

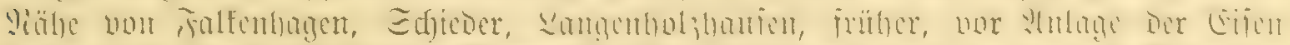

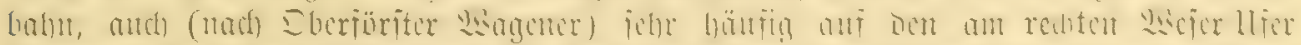
begence Burlejer soben, wo

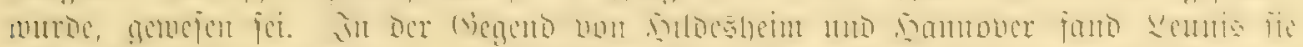

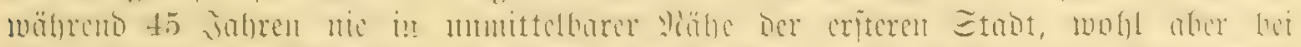

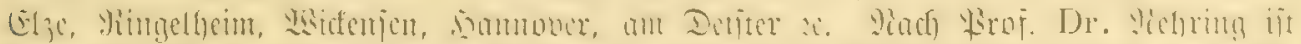

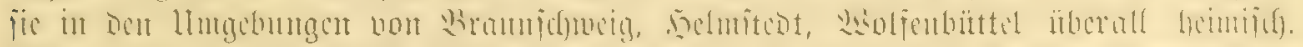

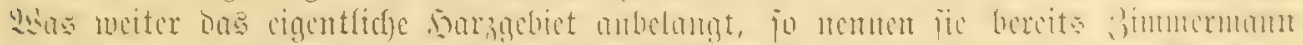

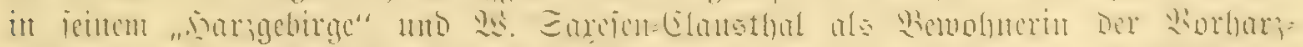

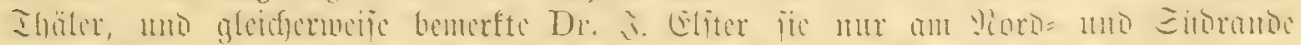

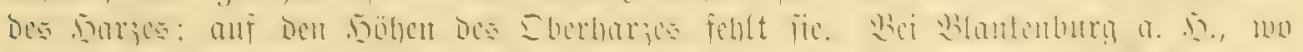

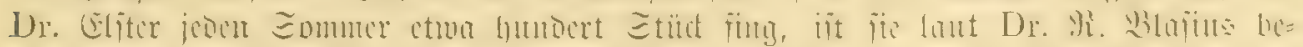

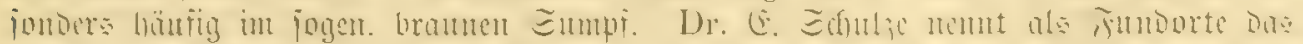

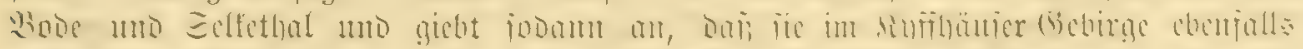

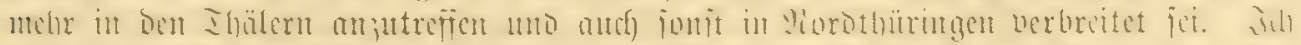

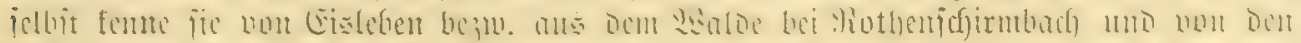

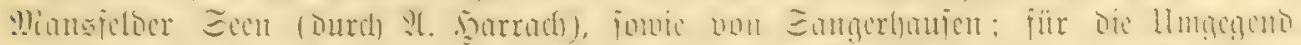

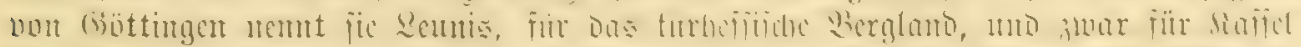

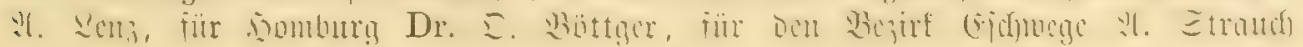




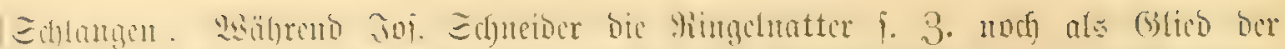

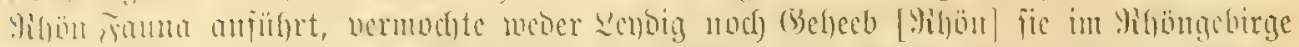

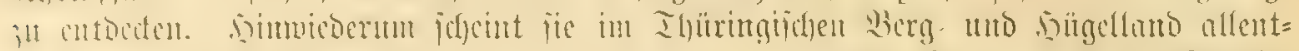

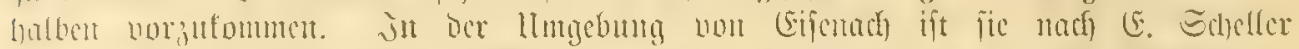

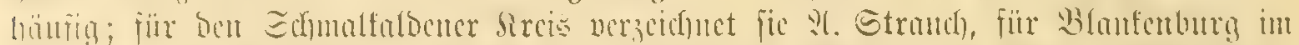

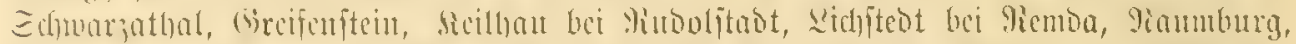

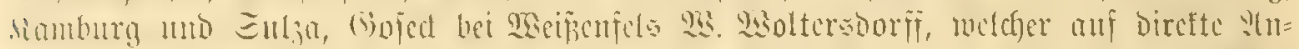

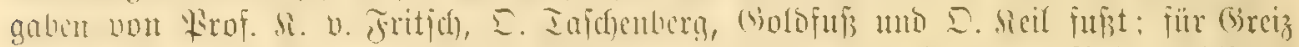

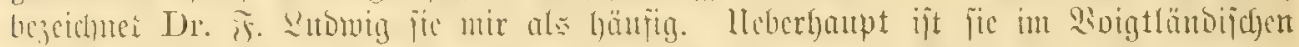

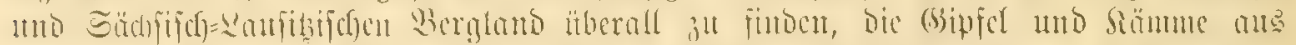

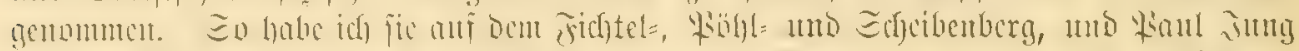

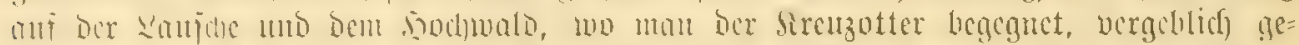

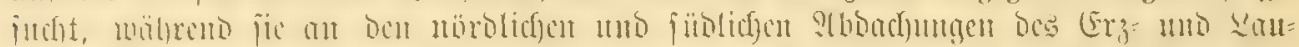

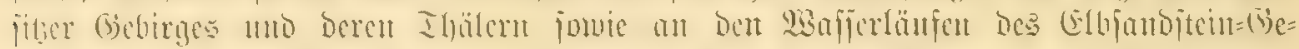

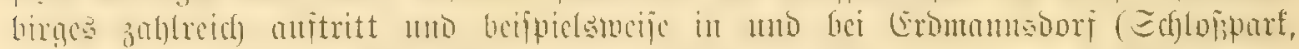

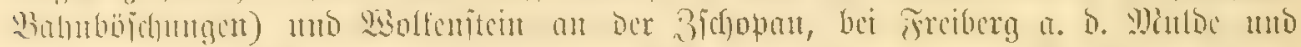

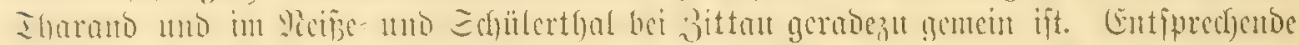

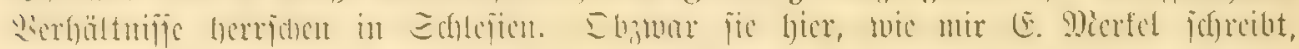

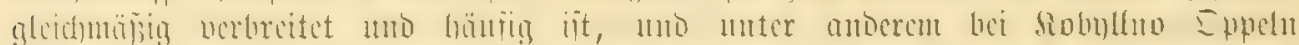

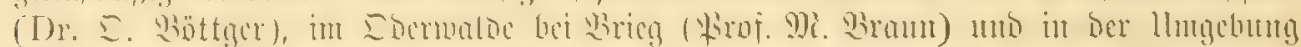

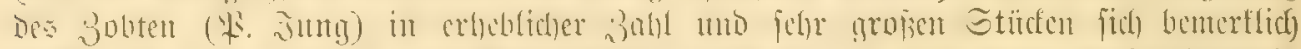

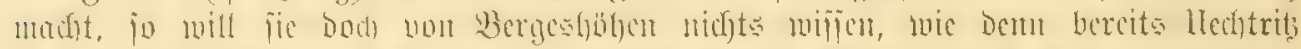

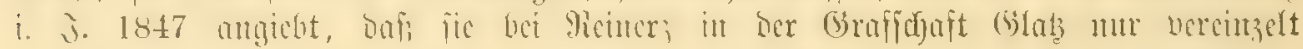
notfomme.

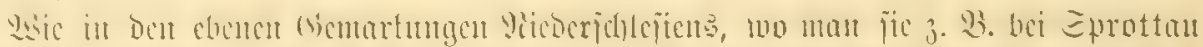

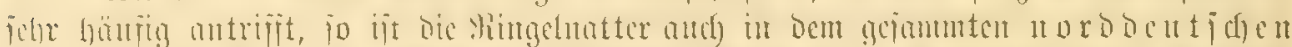

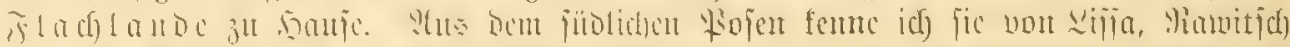

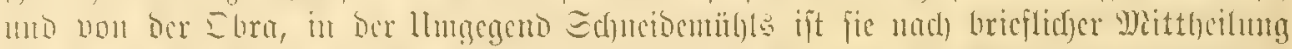

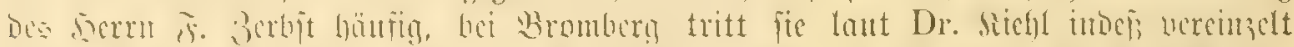

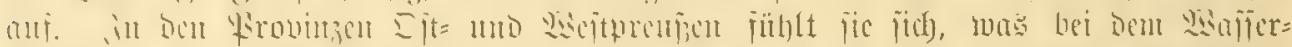

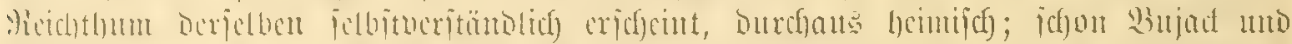

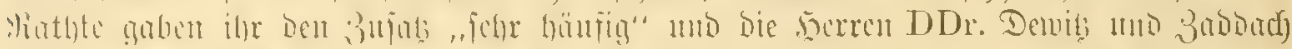

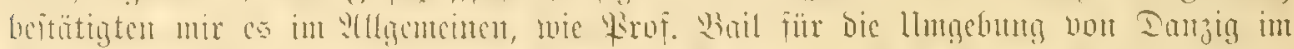

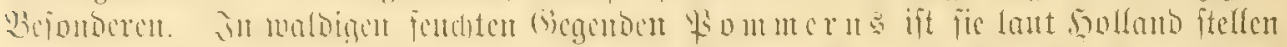

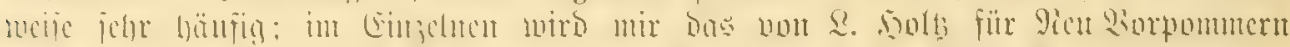

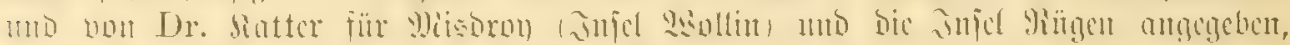

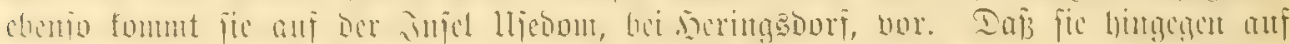

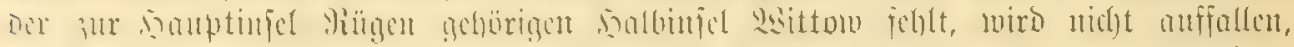

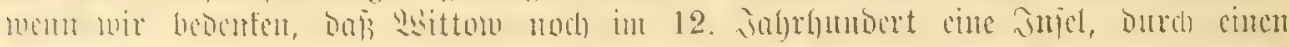

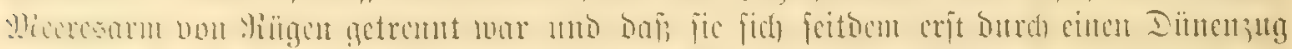

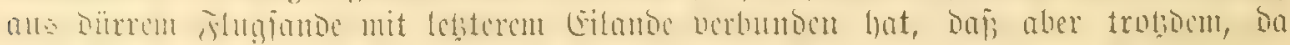

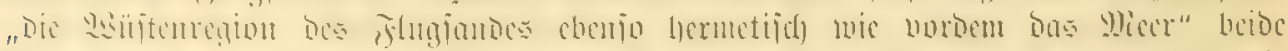

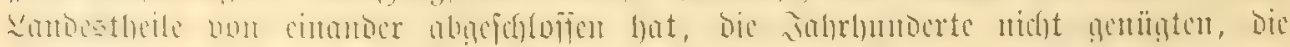

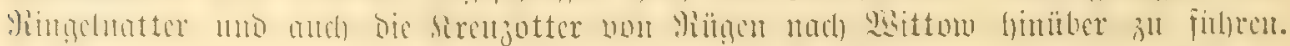

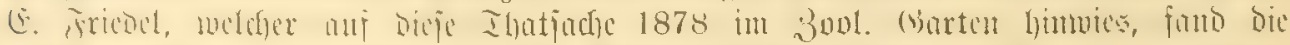

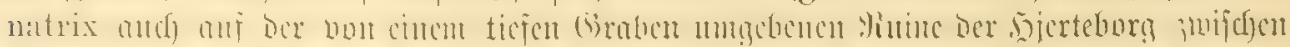

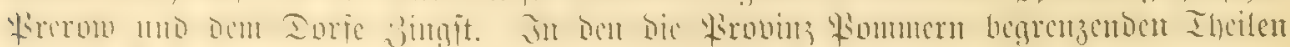

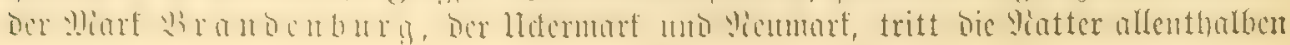




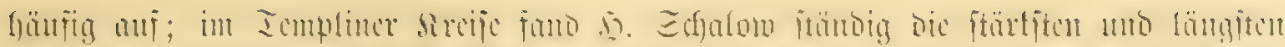

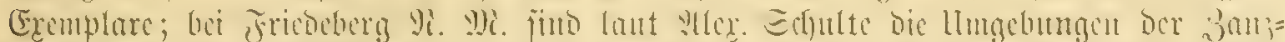

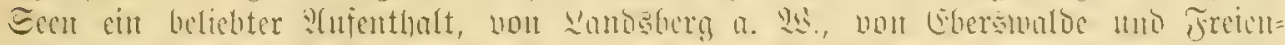

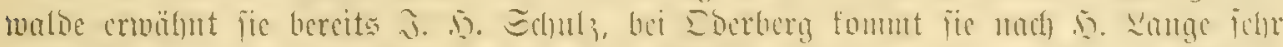

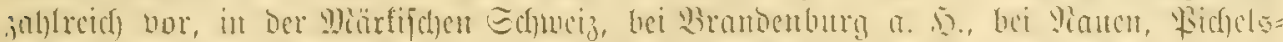

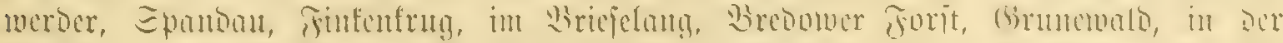

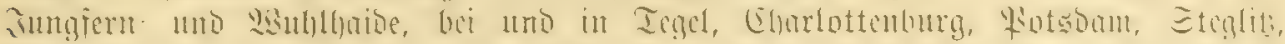

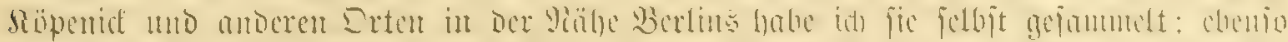

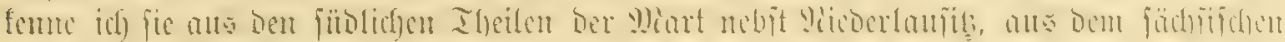

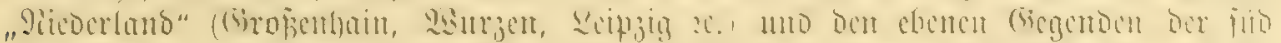

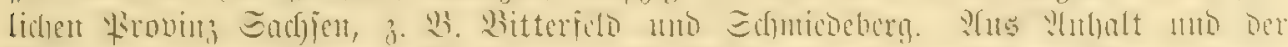

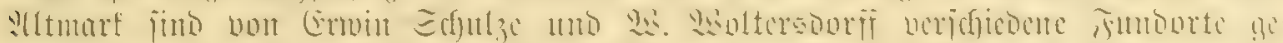

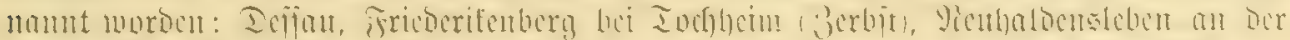

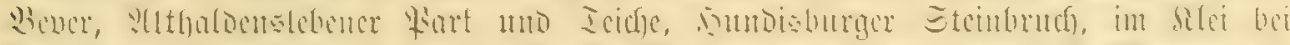

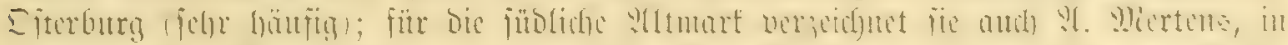

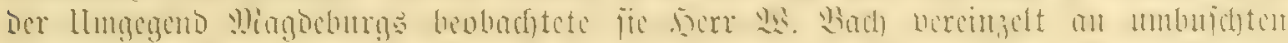

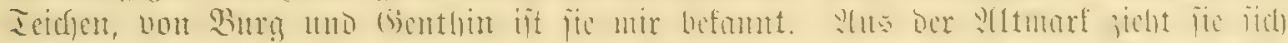

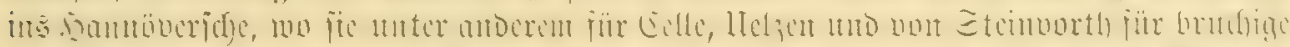

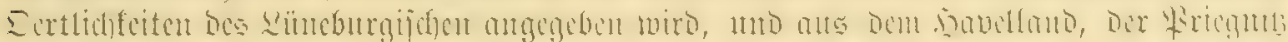

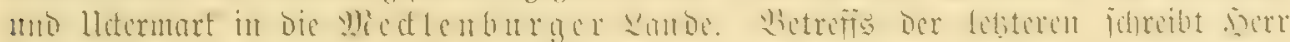

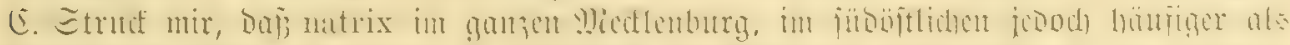

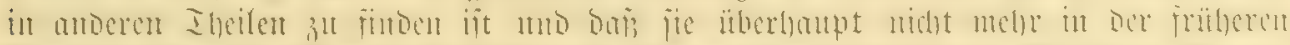

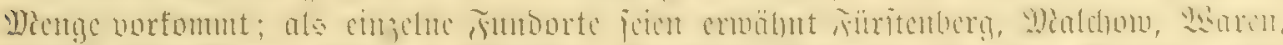

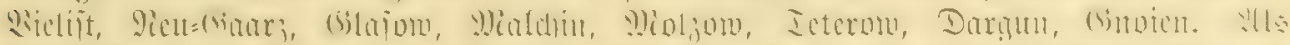

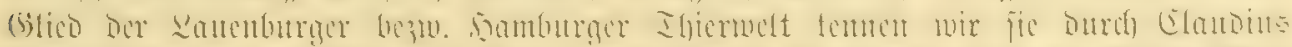

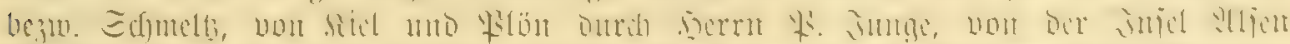

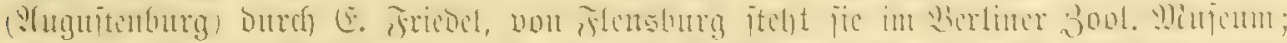

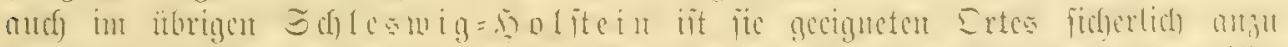

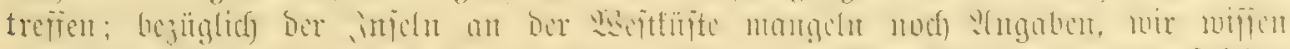

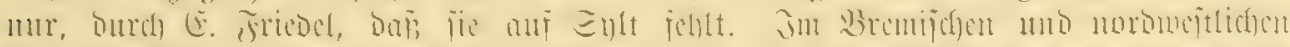

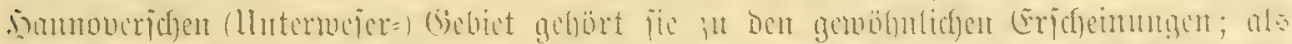

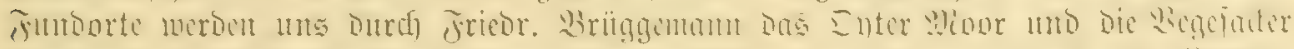

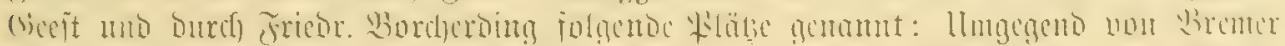

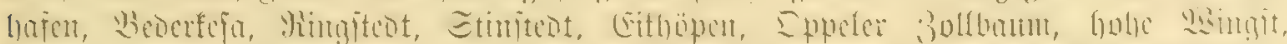

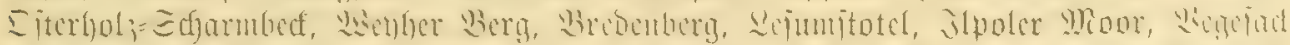

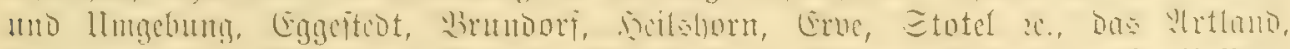

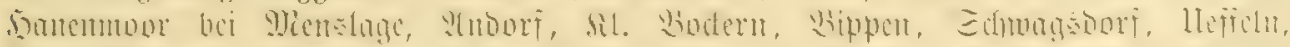

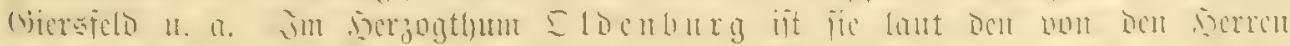

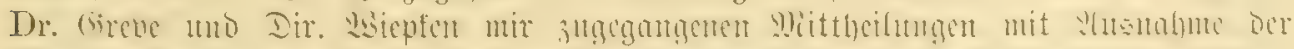

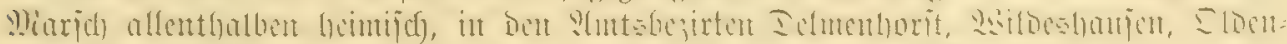

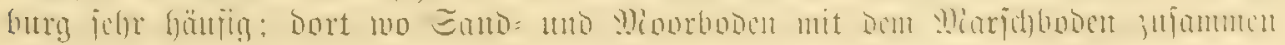
tritt, geht fic mitunter nod einc Streffe auj ben Iebteren ïber.

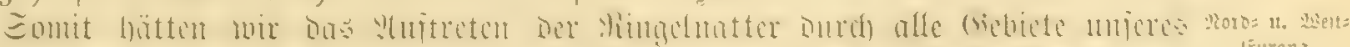

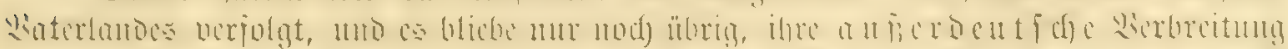

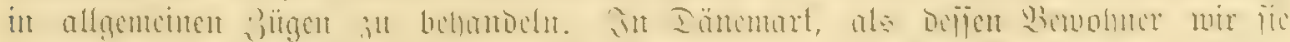

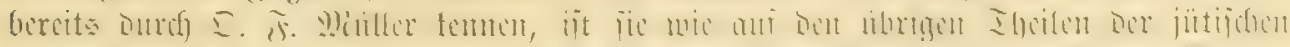

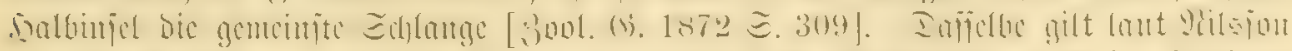

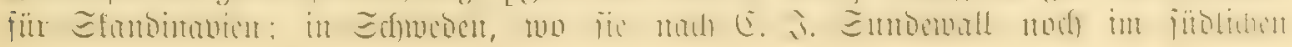




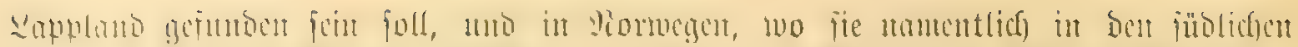

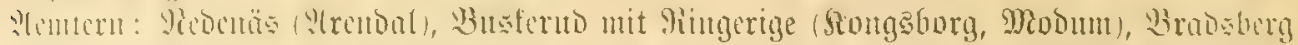

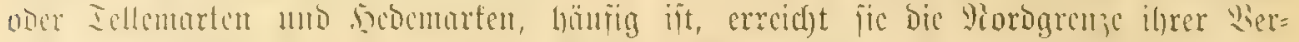

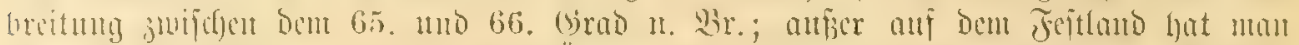

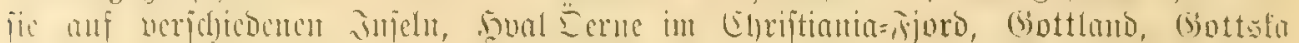

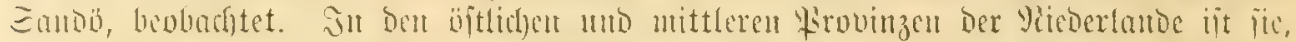

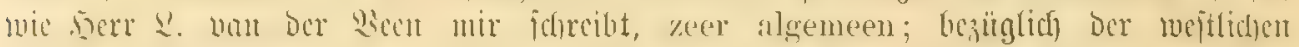

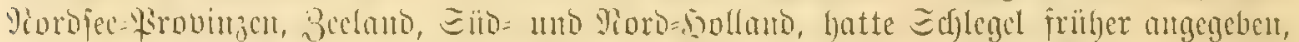

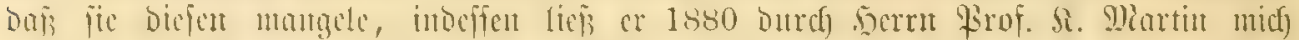

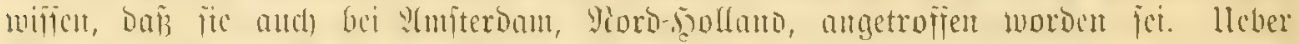

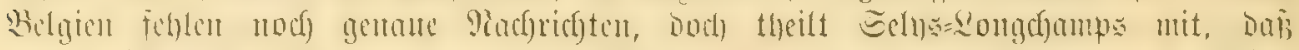

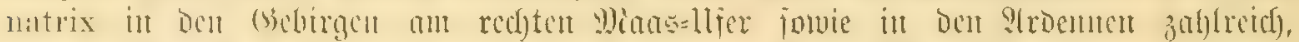

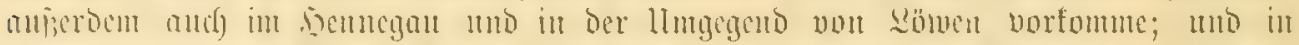

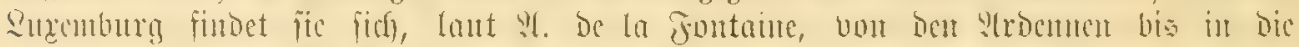

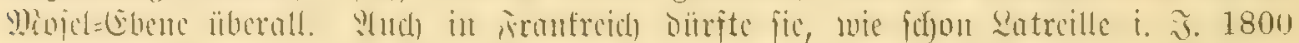

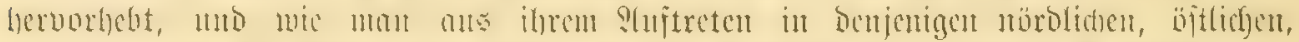

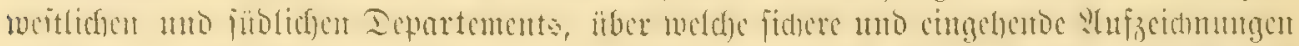

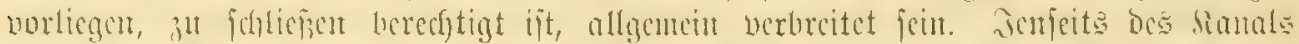

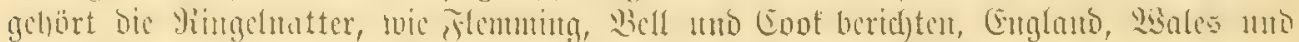

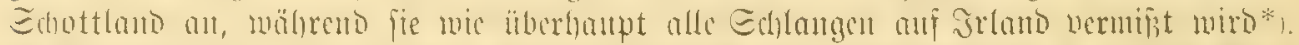

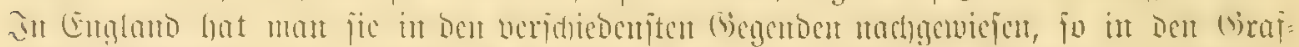

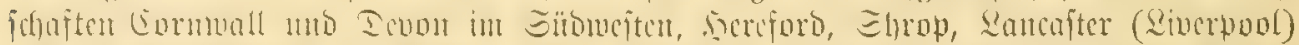

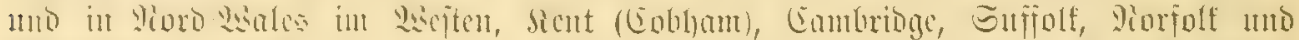

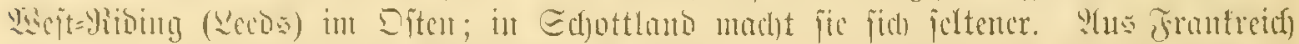

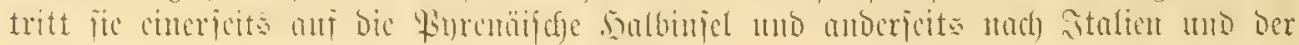
Sdjueiz ïber:

Ei⿱亠巾) 2 . Mittels (5uropa.

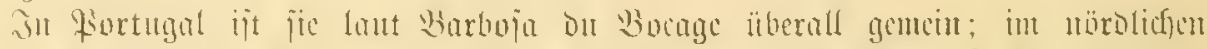

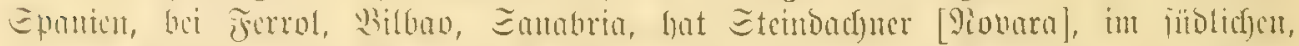

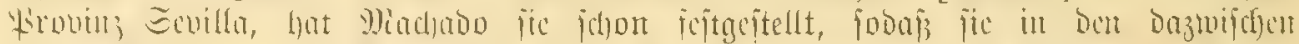

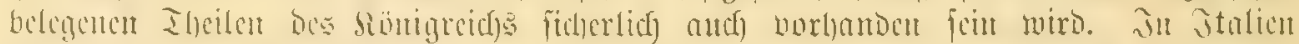

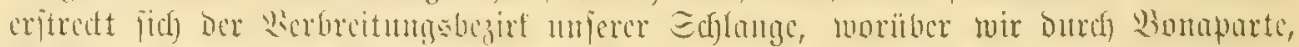

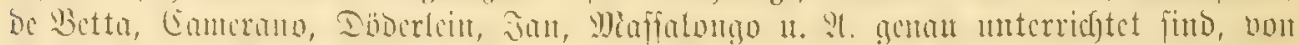

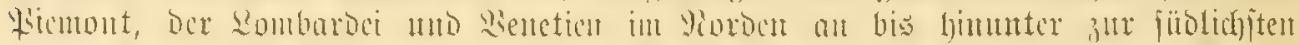

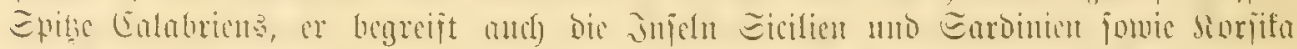

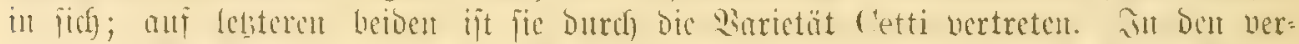

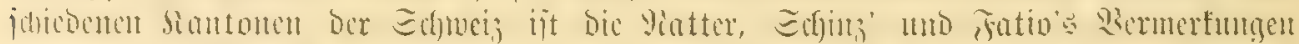

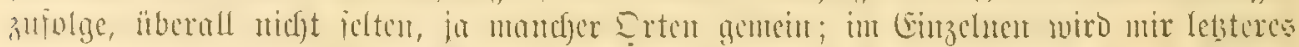

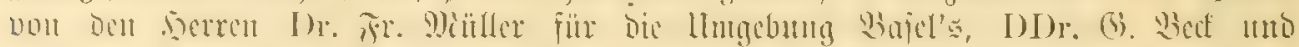

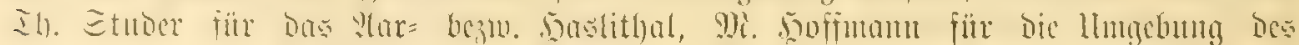

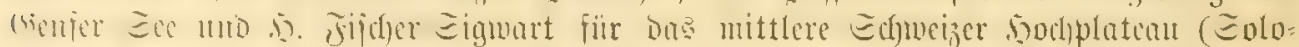

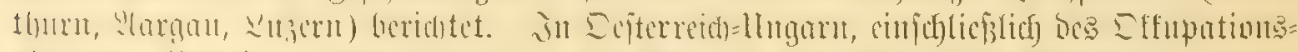

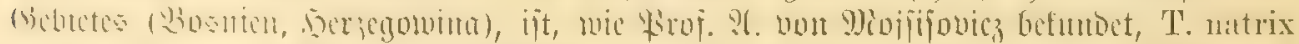

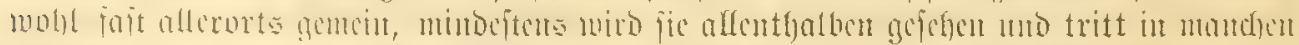

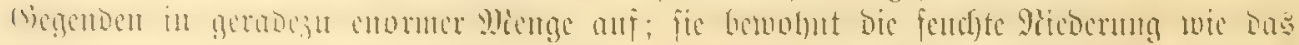

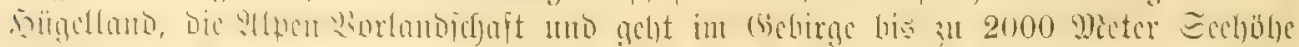

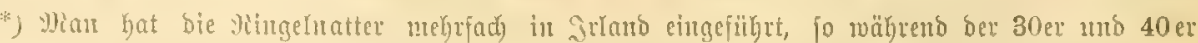

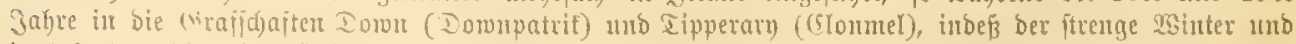

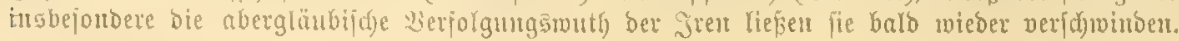




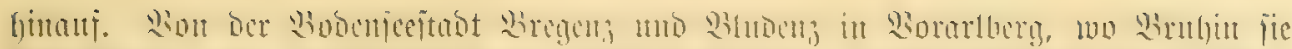

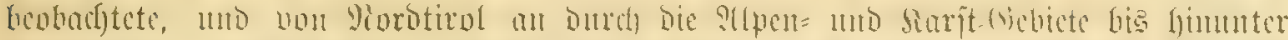

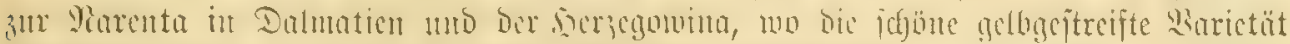

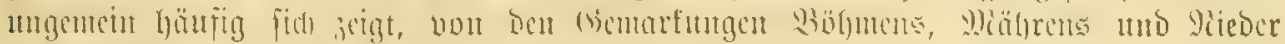

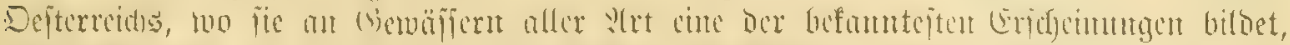

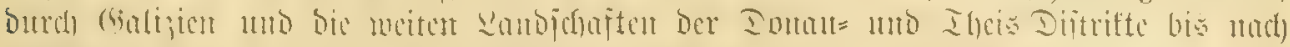

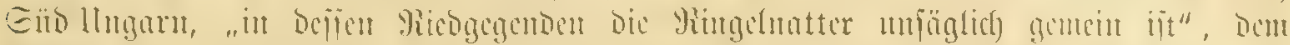

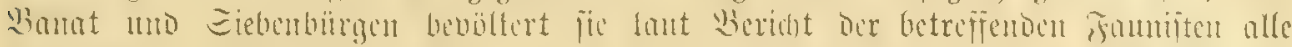

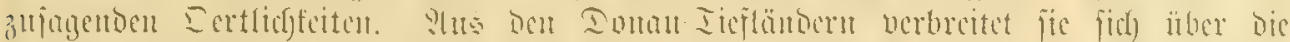

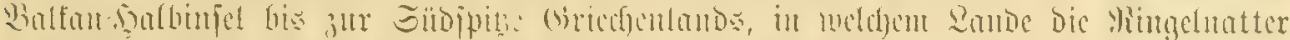

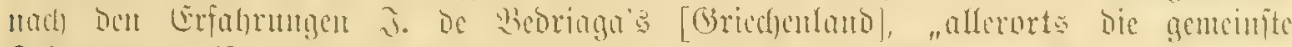

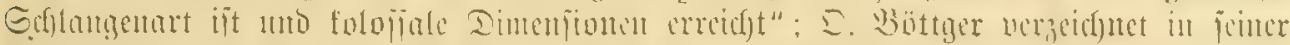

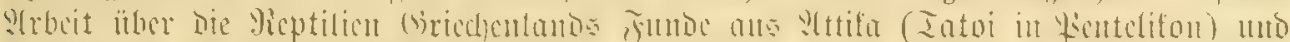

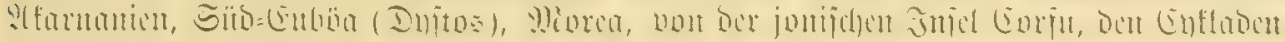

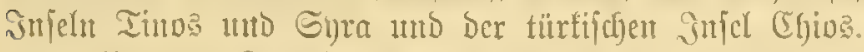

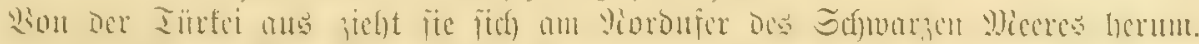

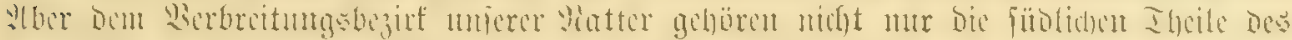

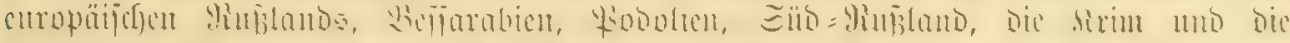

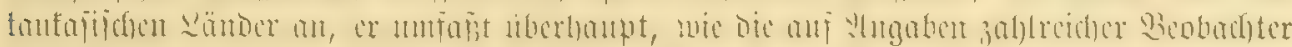

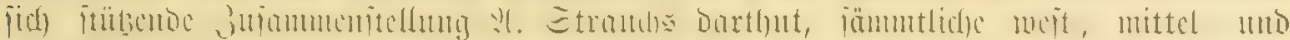

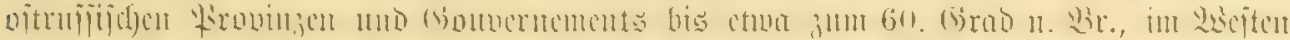

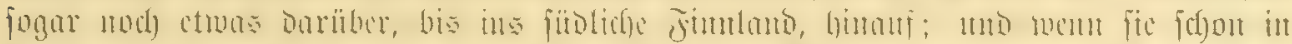

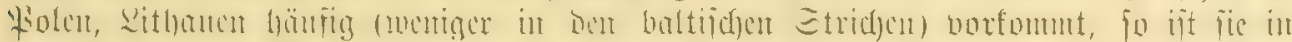

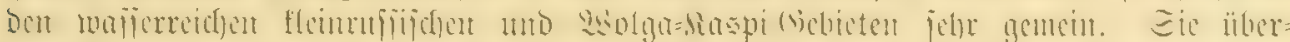

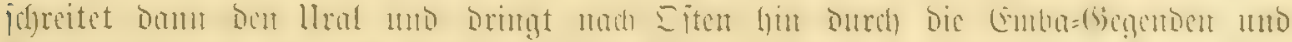

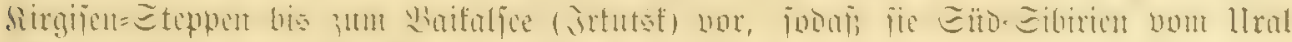

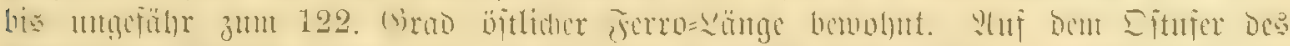

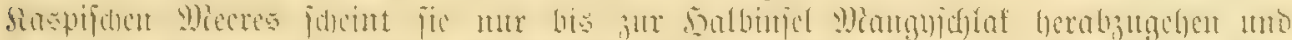

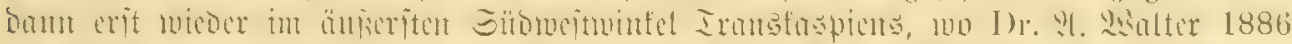

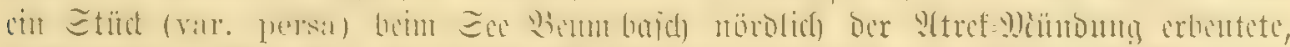

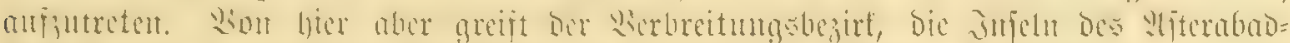

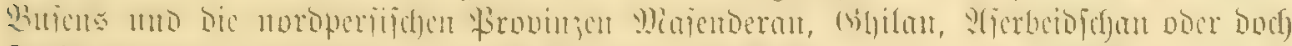

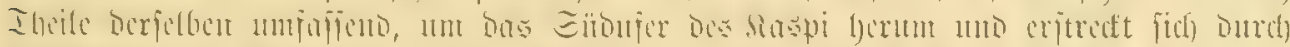

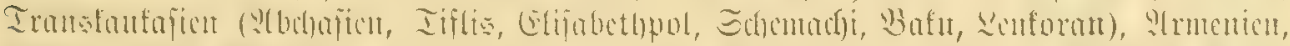

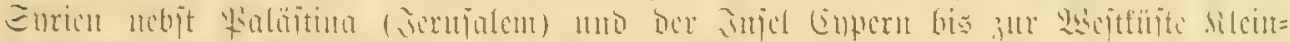

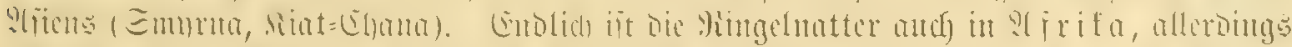

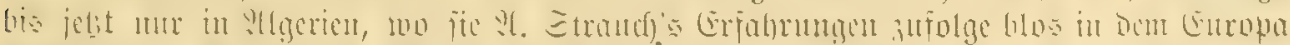

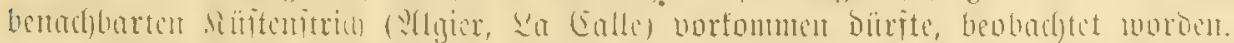

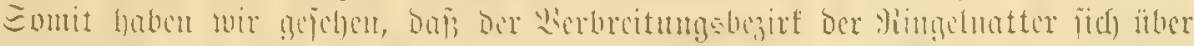

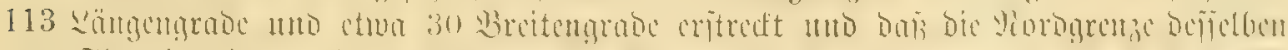

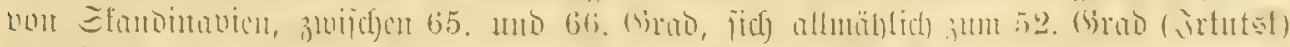

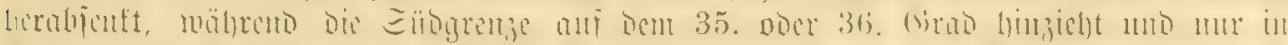

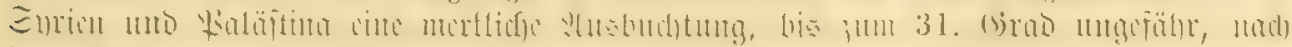

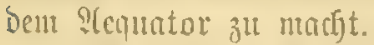

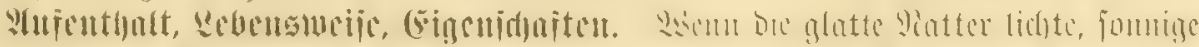

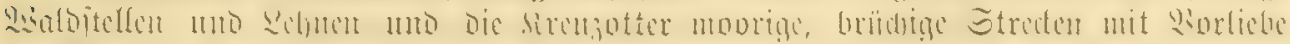

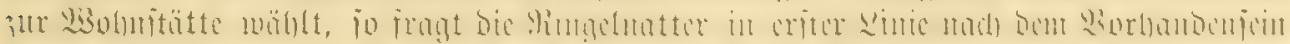

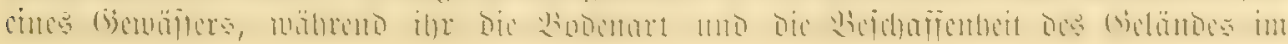




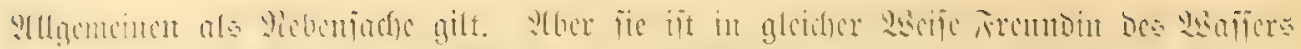

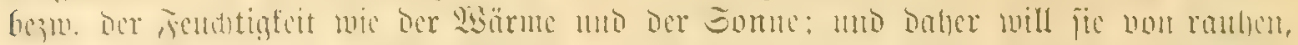

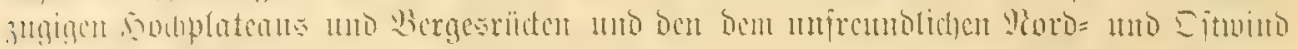

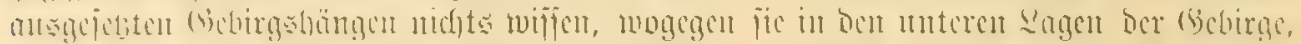

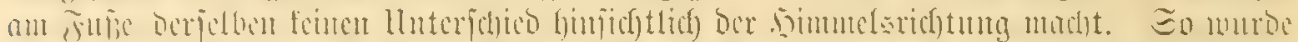

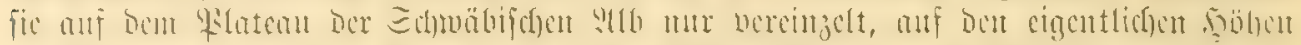

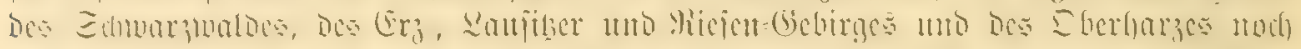

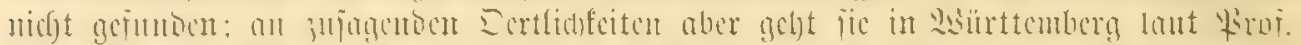

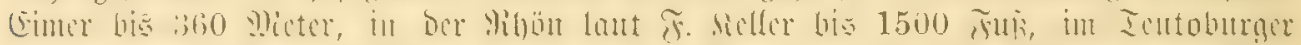

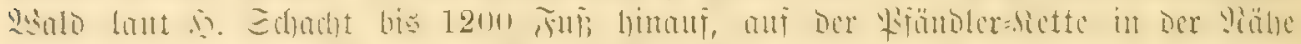

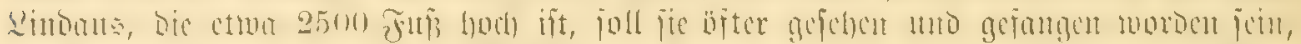

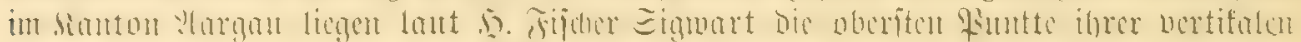

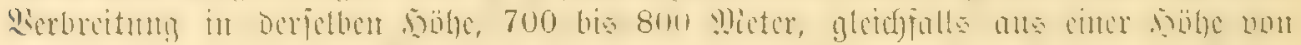

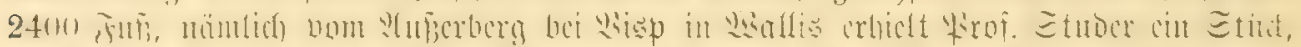

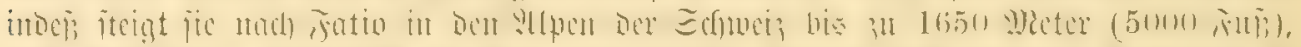

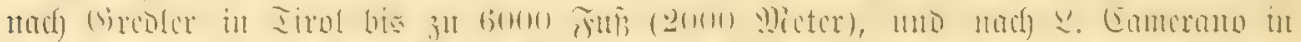

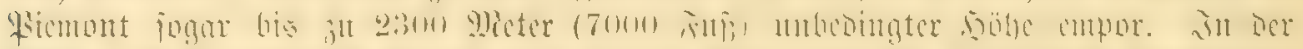

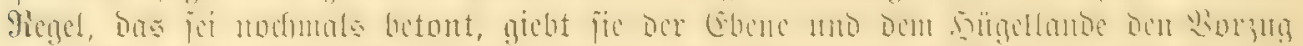

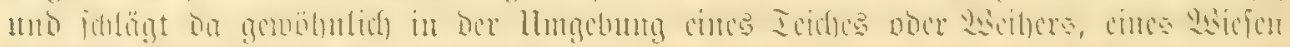

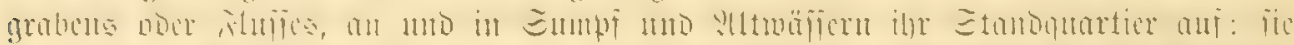

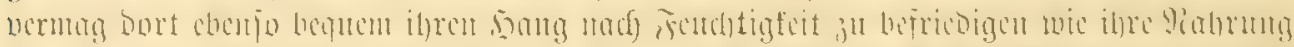

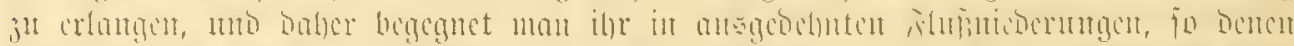

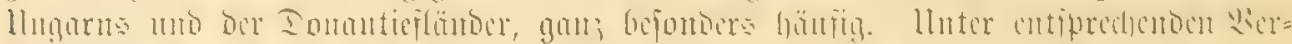

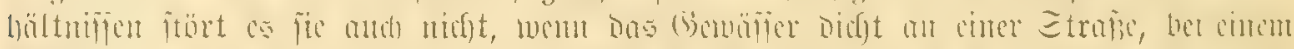

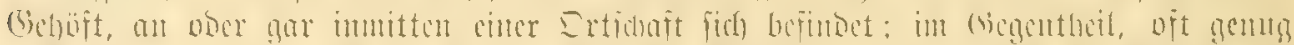

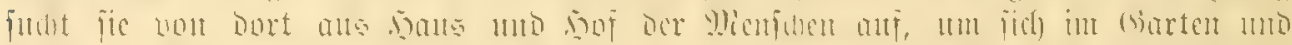

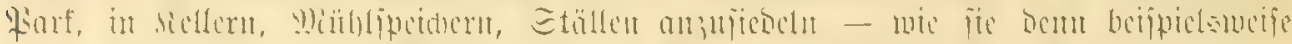

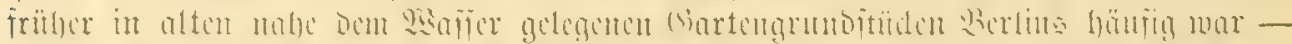

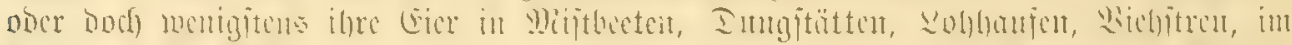

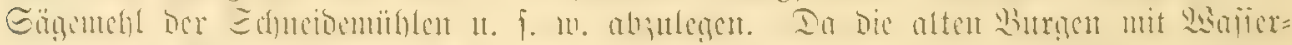

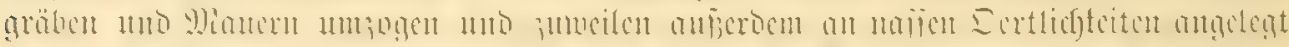

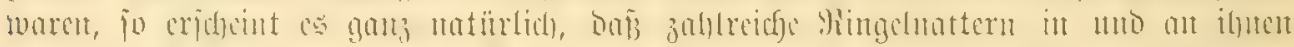

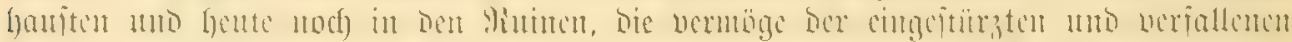

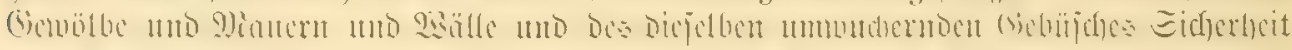

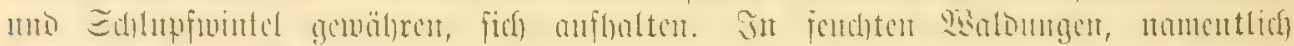

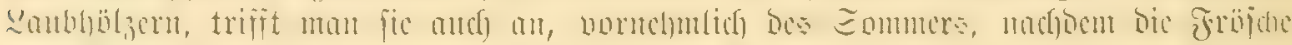

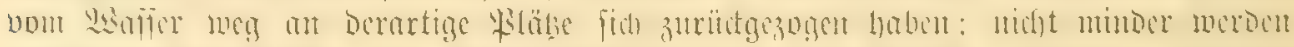

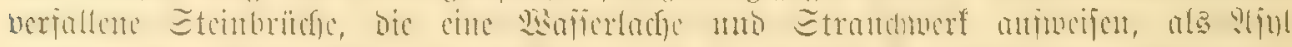

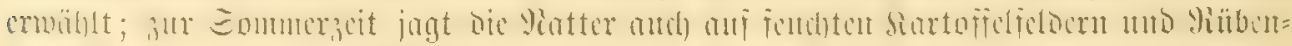

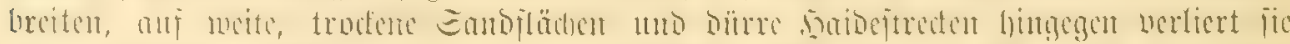

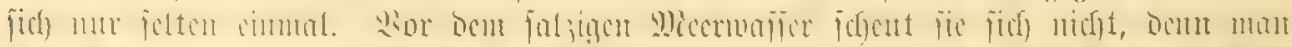

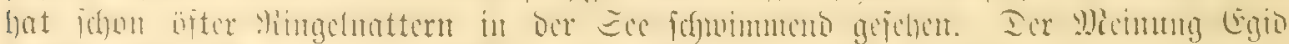

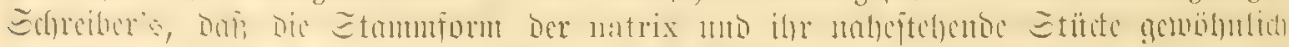

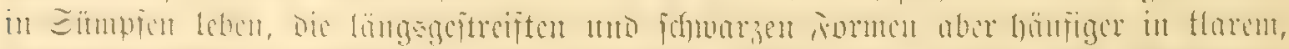

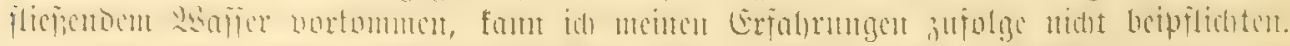

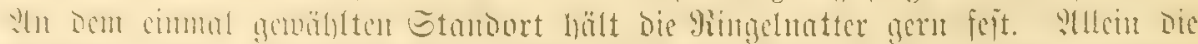

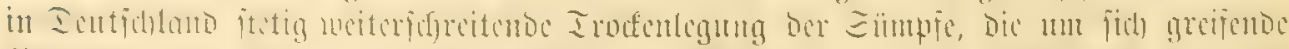

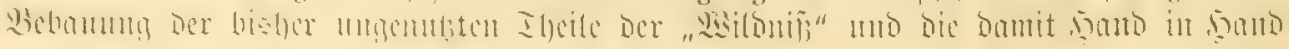




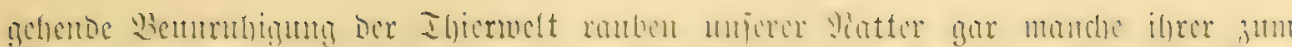

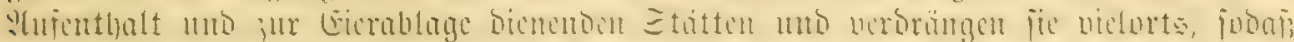

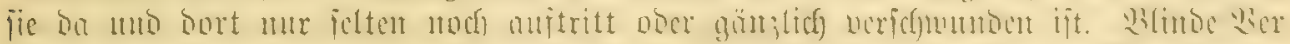

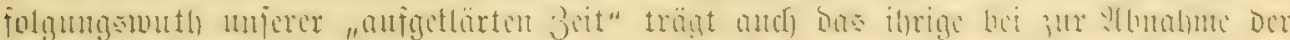

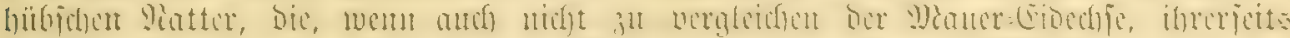

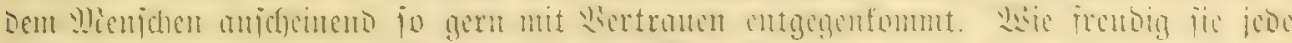

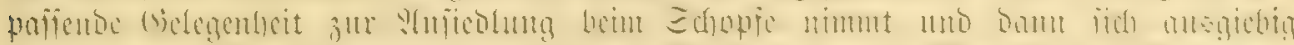

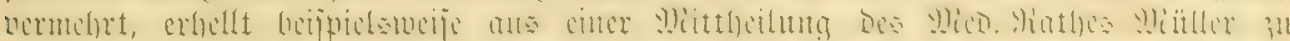

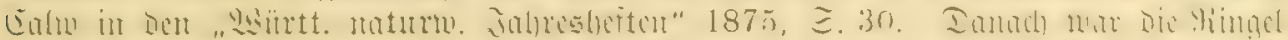

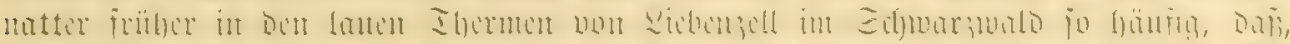

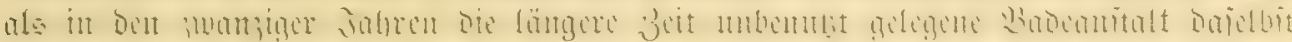

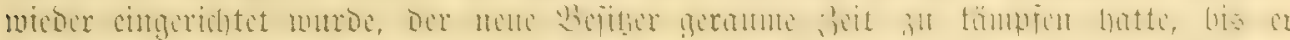

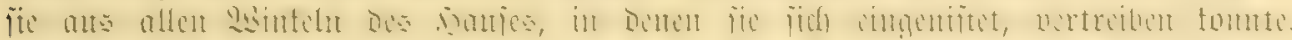

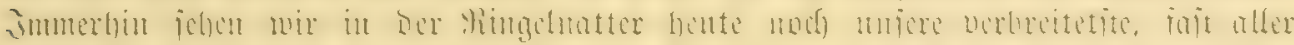

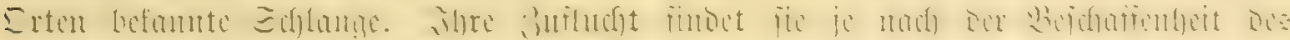

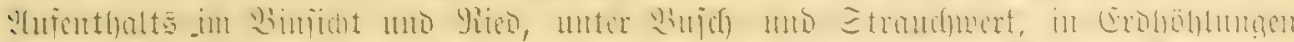

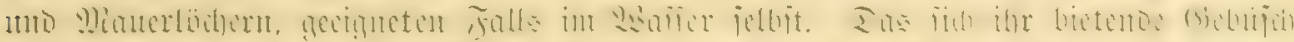

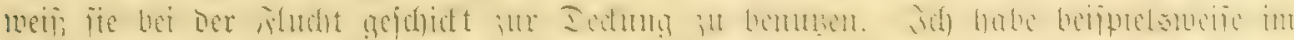

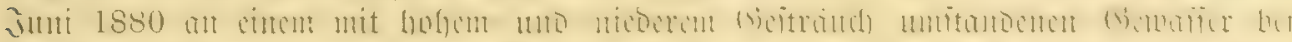

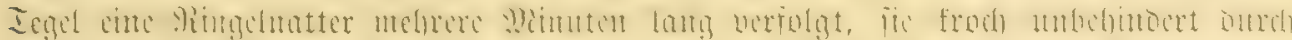

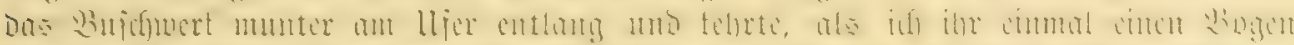

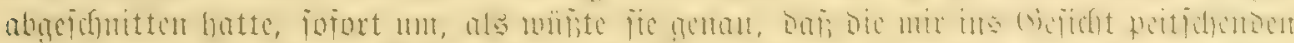

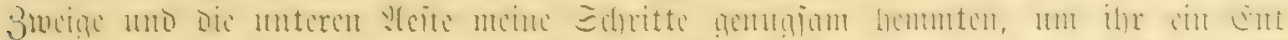

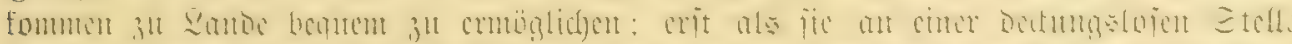

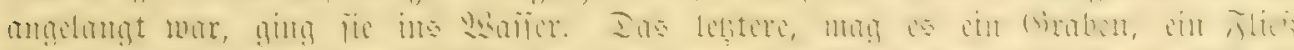

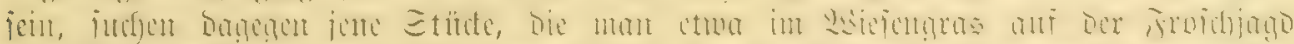

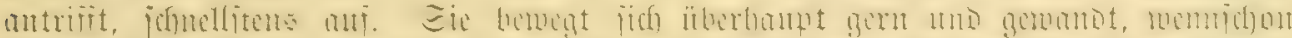

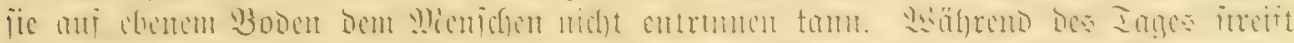

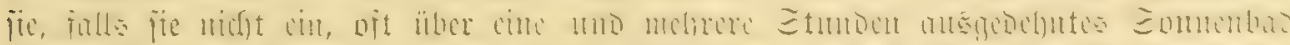

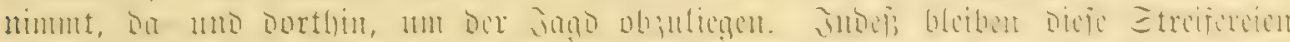
in chust (b)

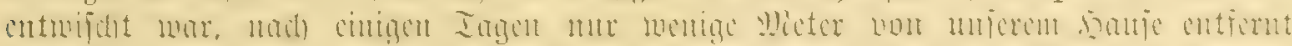

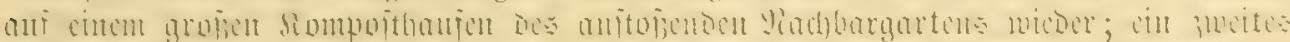

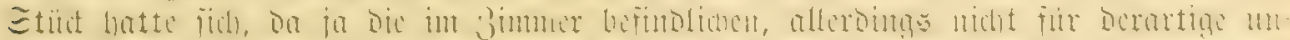

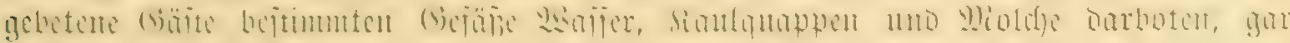

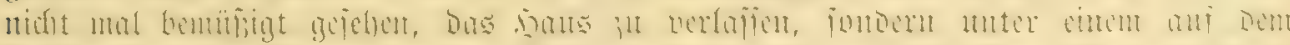

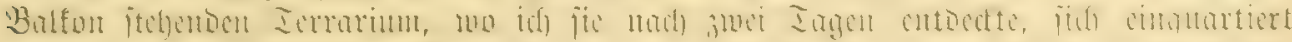

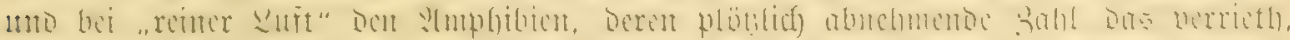

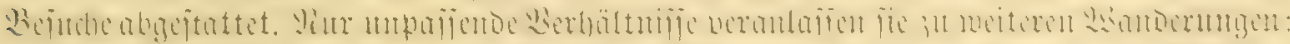

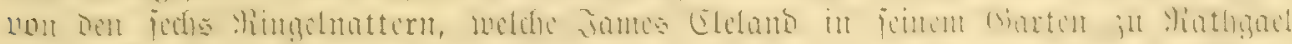

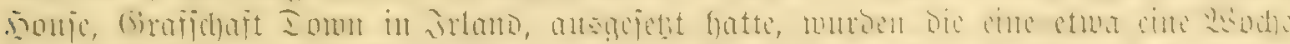

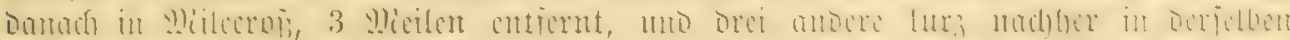

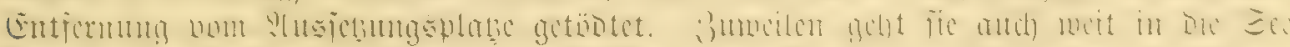

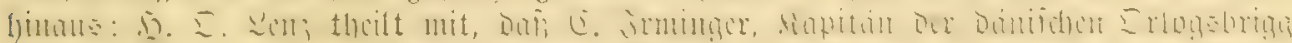

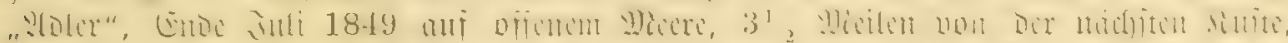

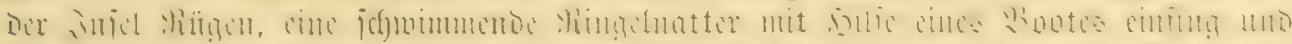

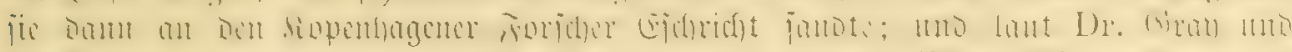

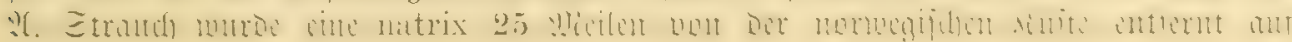




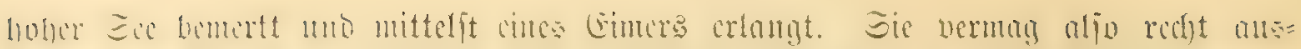

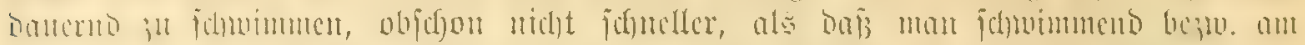

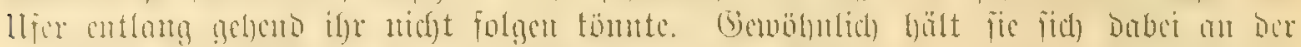

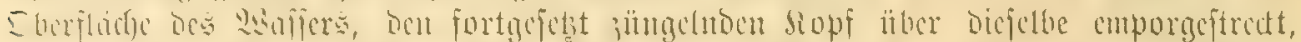

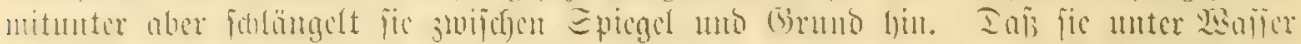

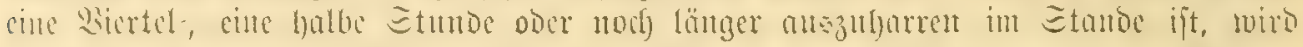

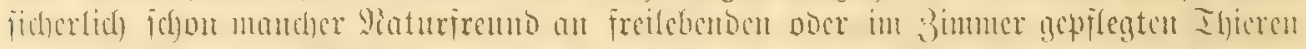

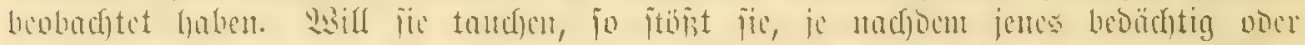

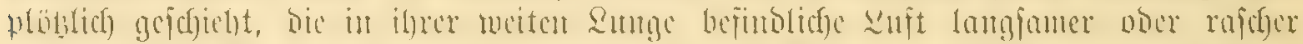

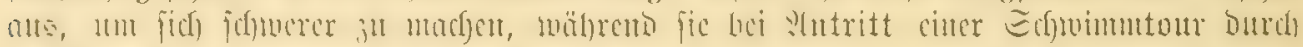

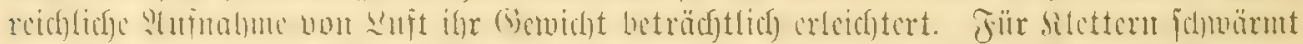

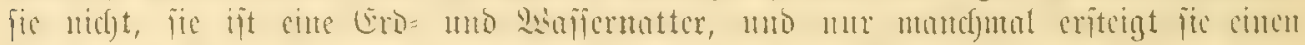

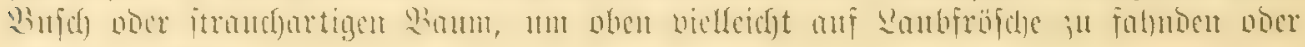
ficf) zu fonnert.

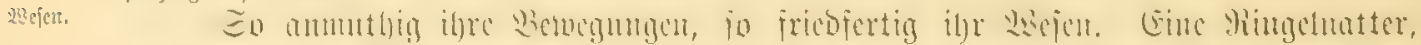

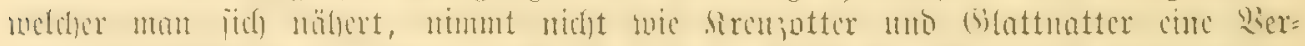

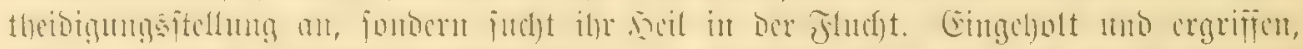

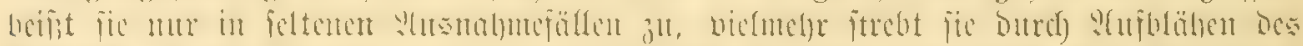

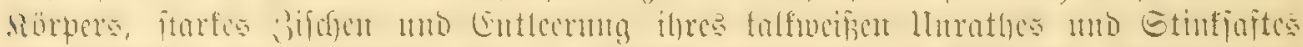

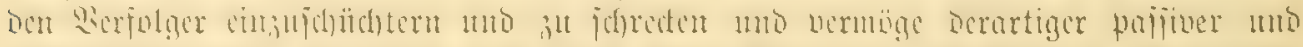

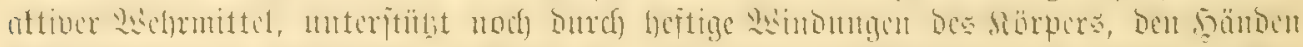

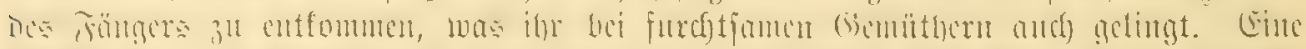

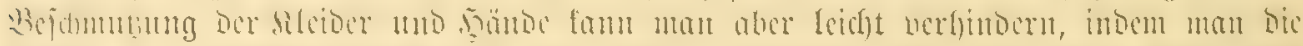

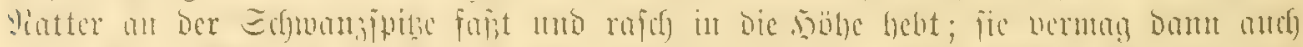

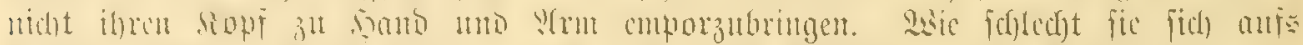

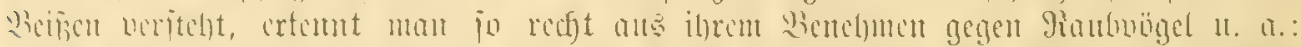

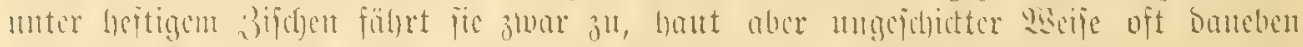

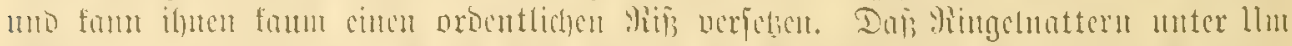

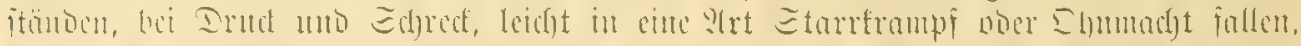

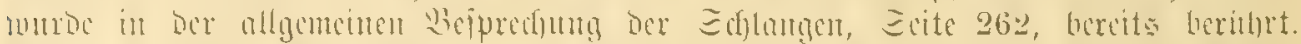

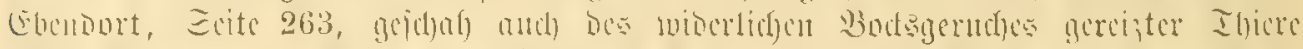

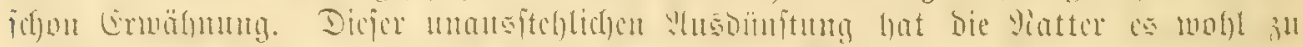

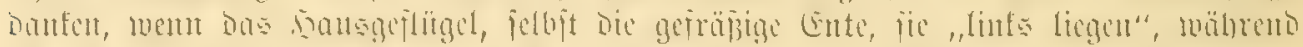

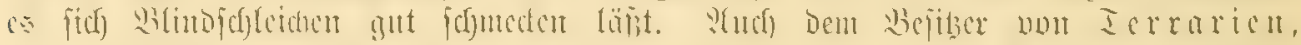

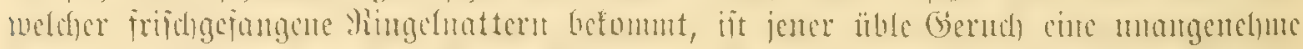

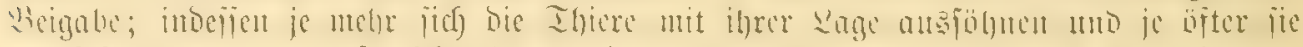

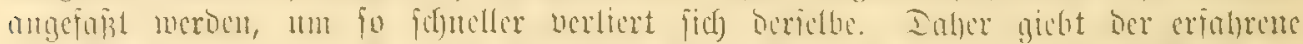

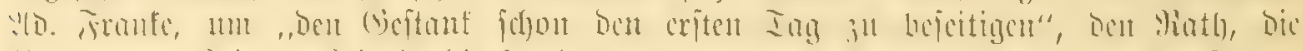

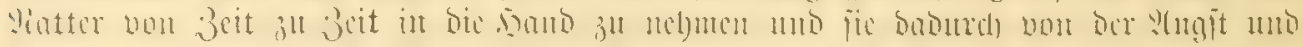

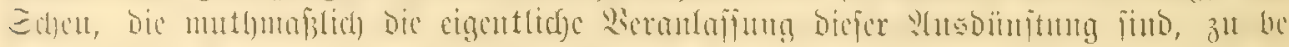

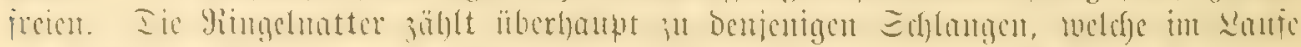

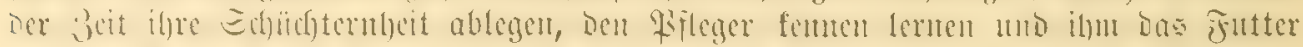

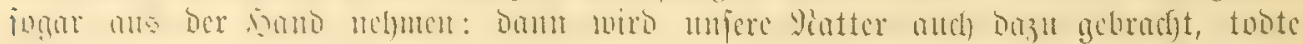

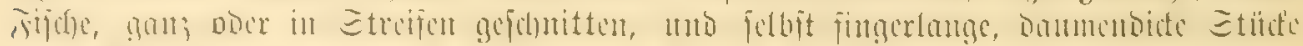

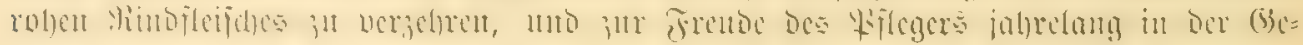
famgenichaft aubbaucru.

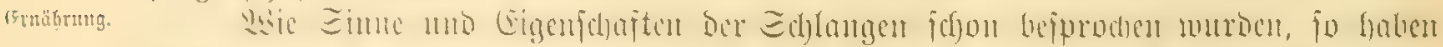

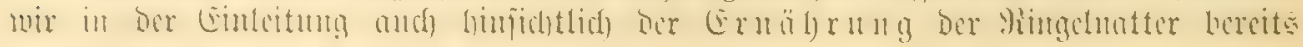




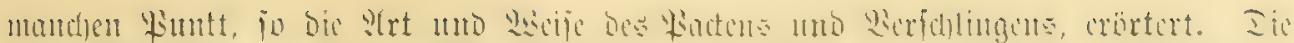

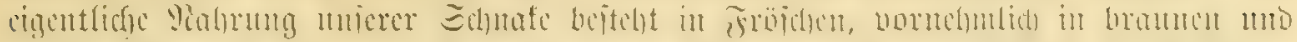

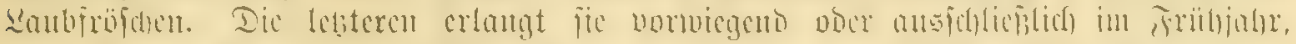

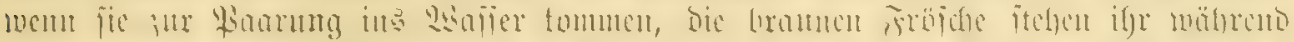

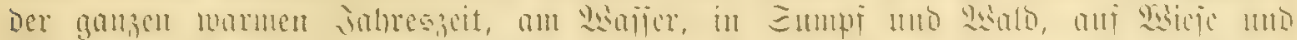

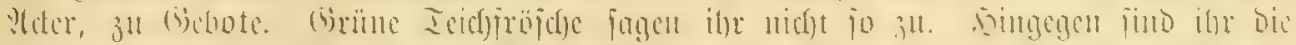

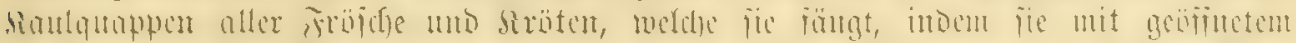

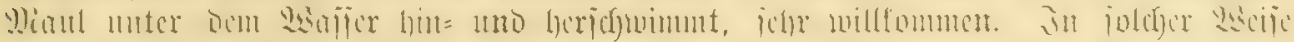

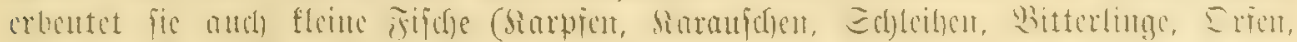

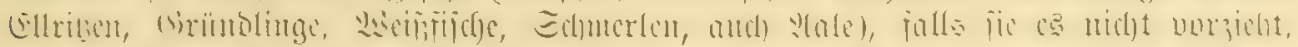
fidf

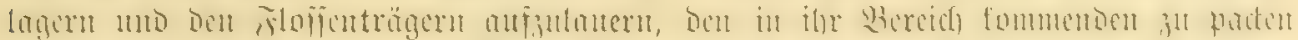

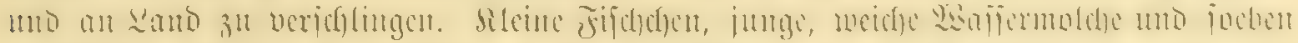

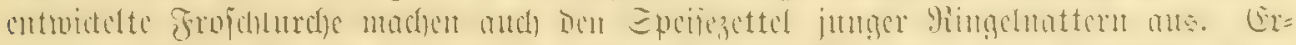

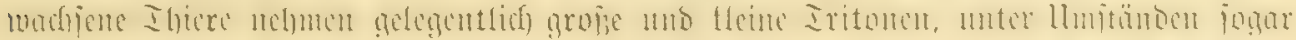

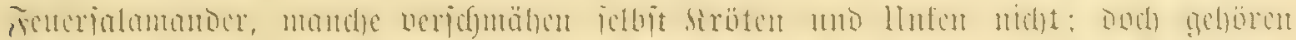

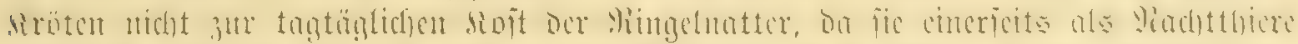

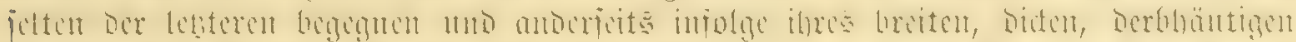
Sibuers bein

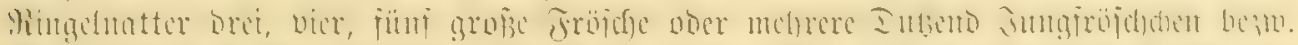

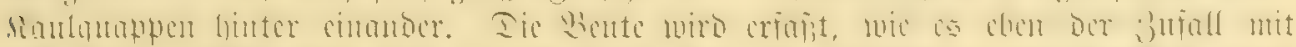

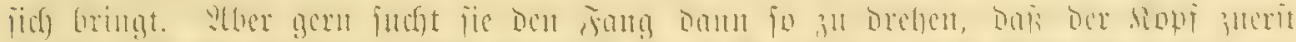

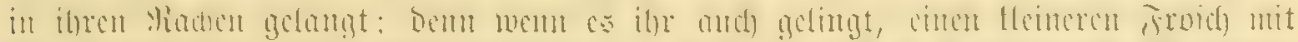

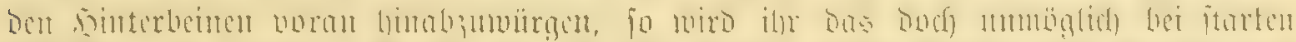

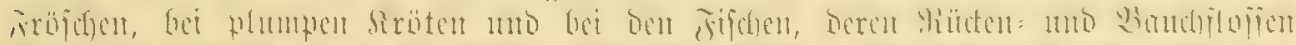

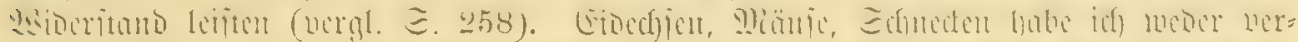

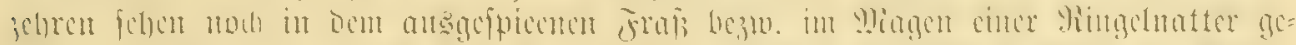

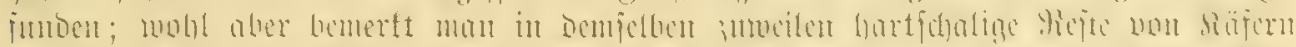

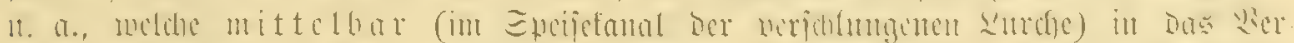

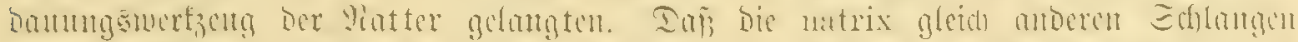

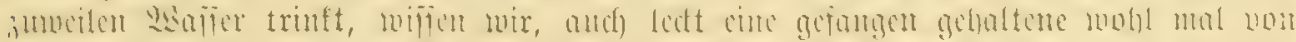

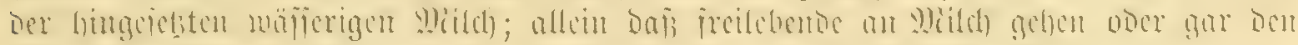

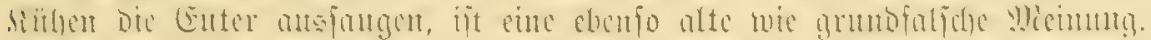

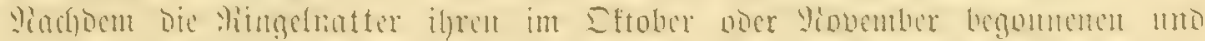

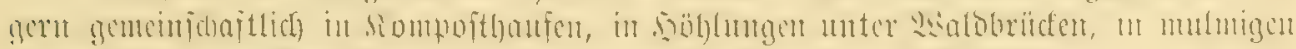

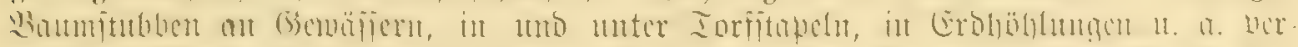

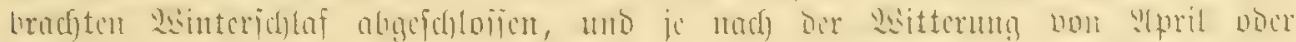

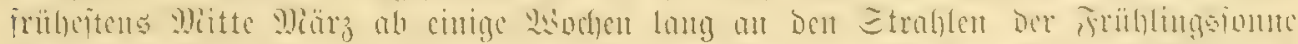

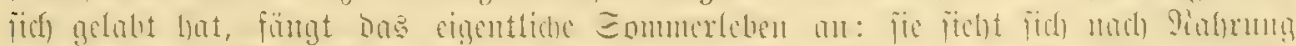

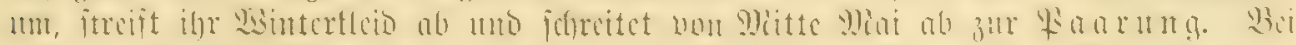

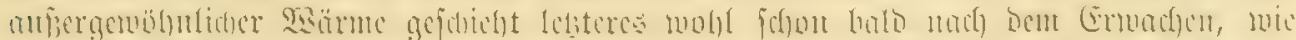

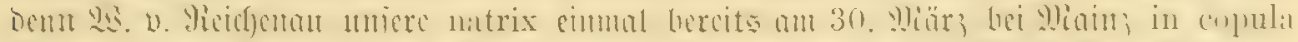

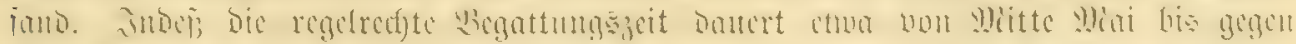

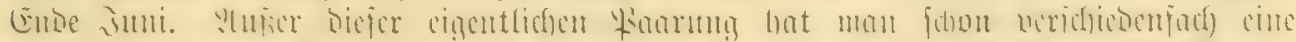

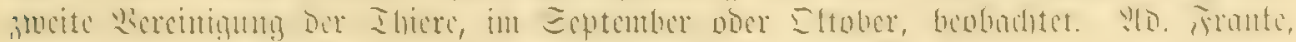

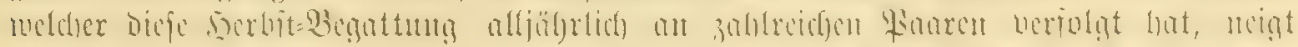
Det :

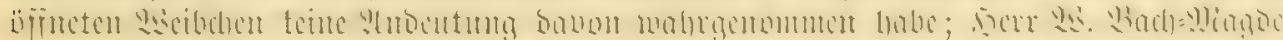




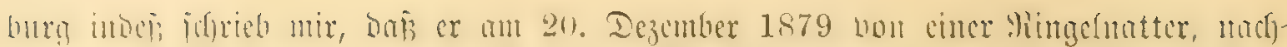

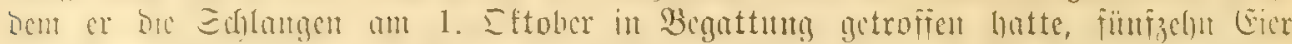

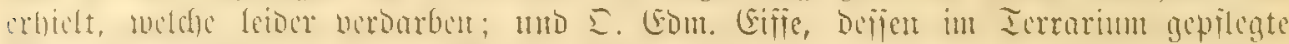

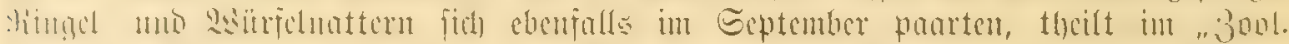

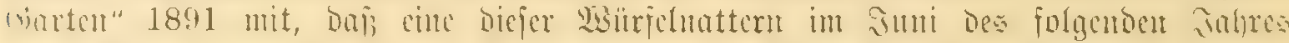

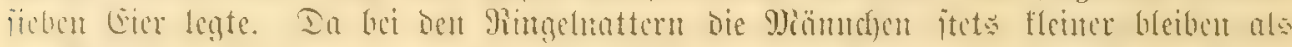

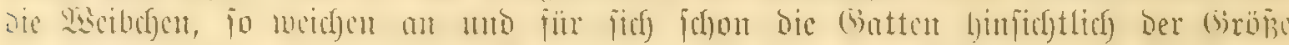

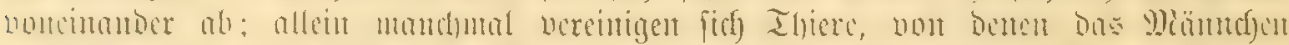

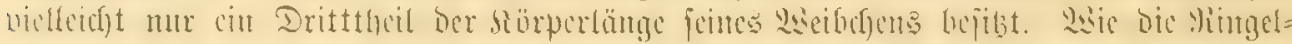

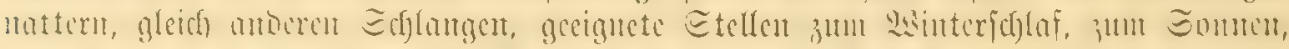

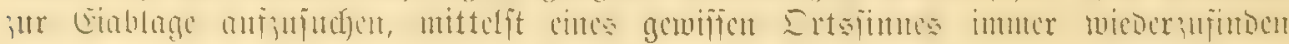

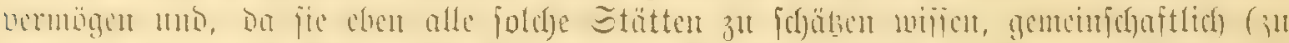

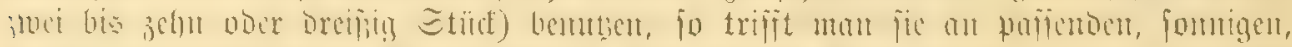

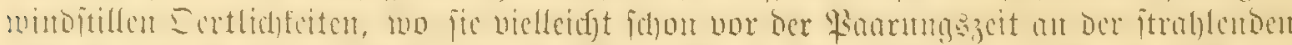

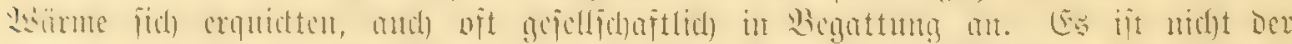

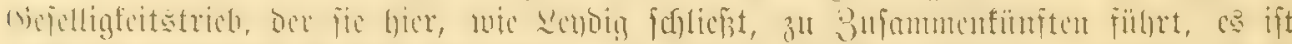

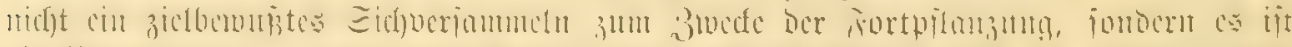

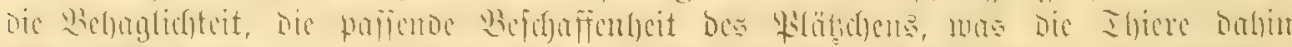

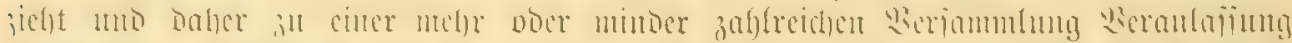

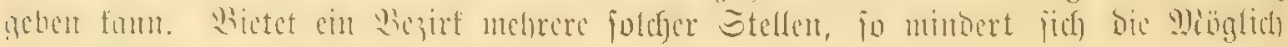
feit, größzeren Bejellfchaften zul begegnent.

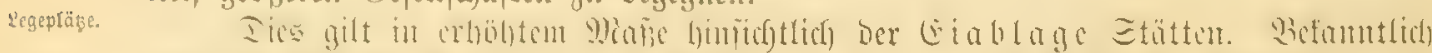

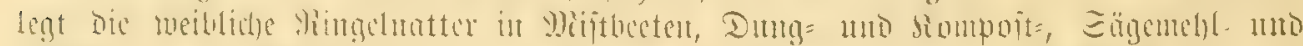

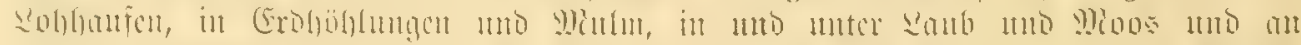

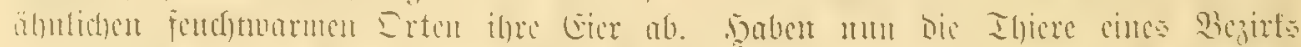

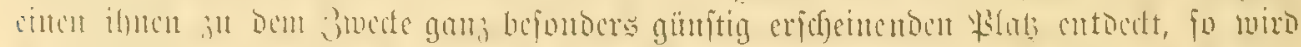

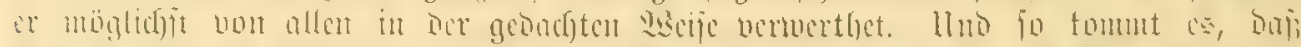

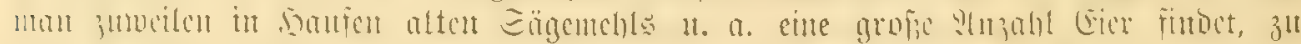

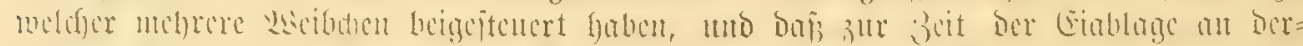

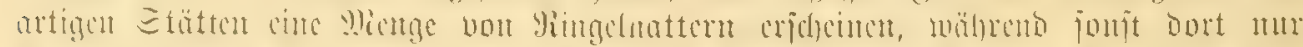

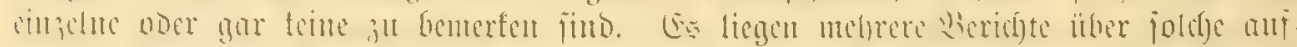

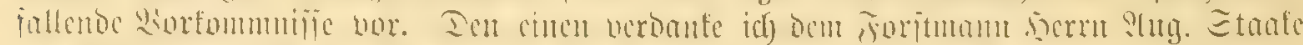

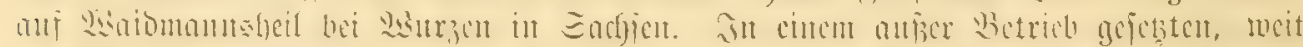

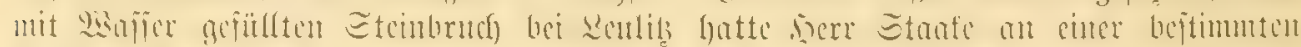

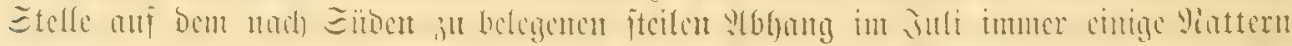

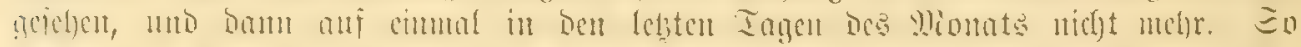

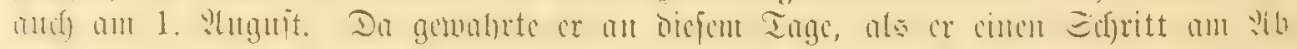

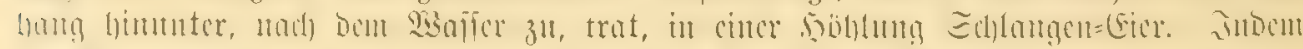

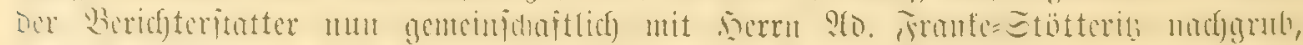

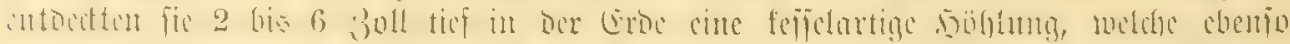

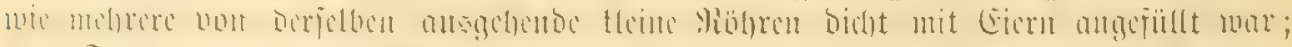

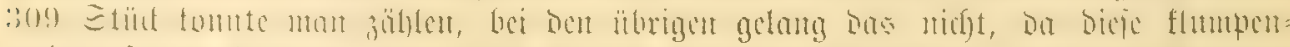

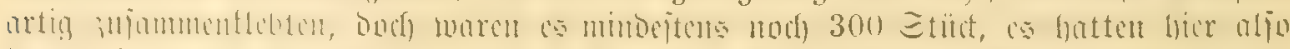

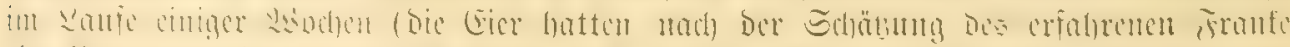

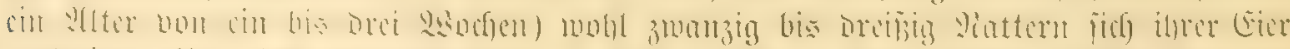

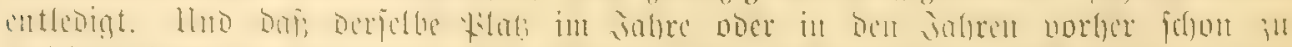

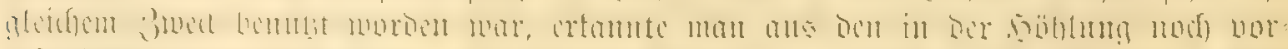

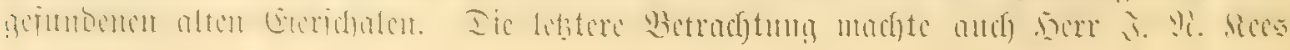




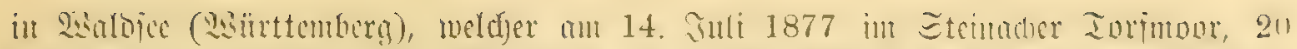

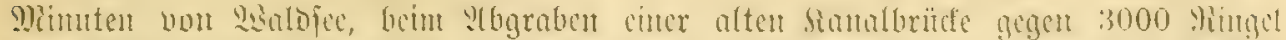

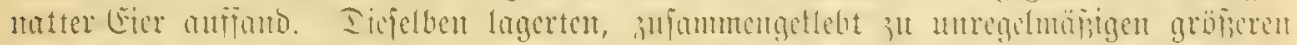

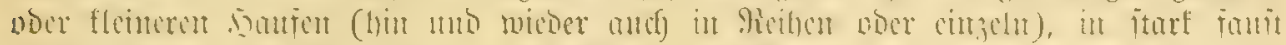

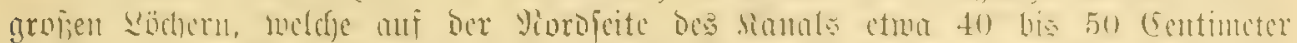

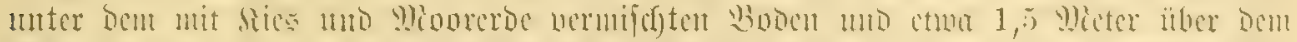

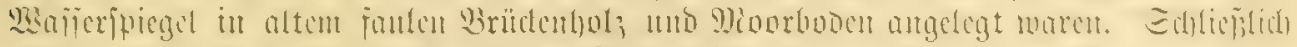

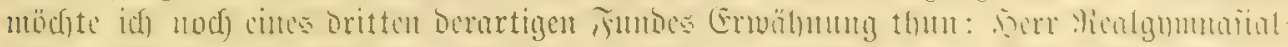

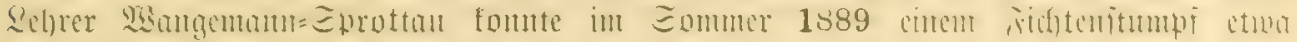
1500 9attern=Cicr, Drei Maffercimer voll, cntulymen.

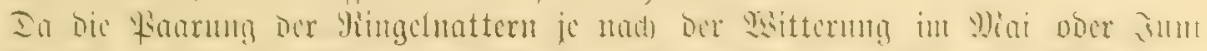

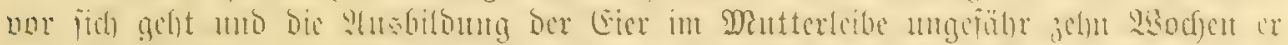

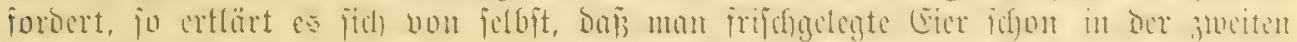

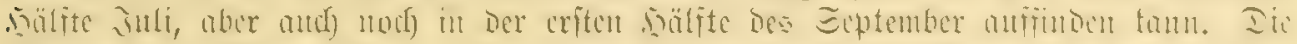

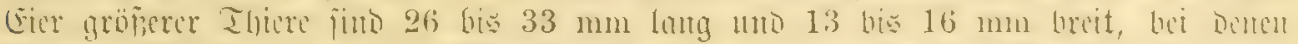

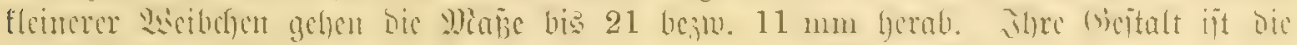

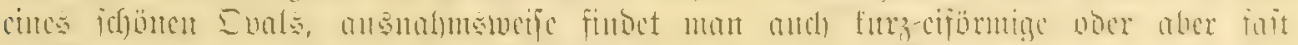

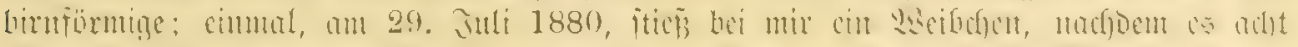

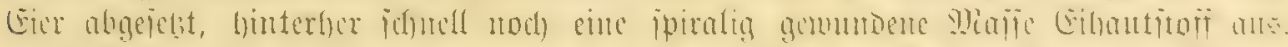

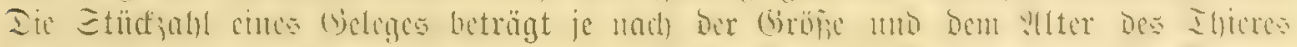

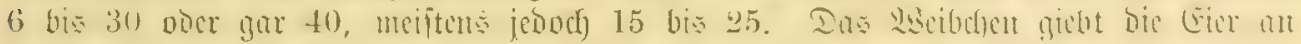

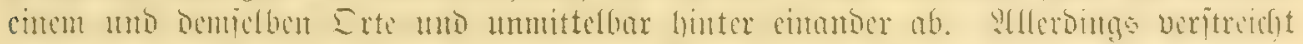

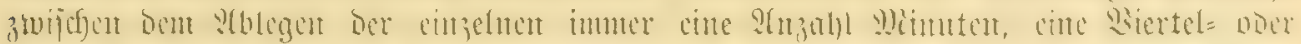

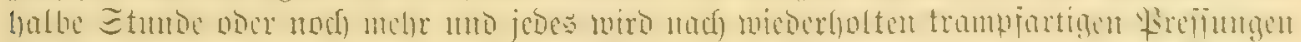

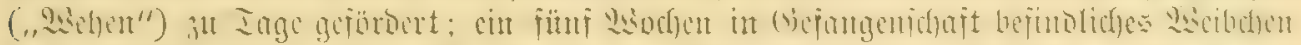

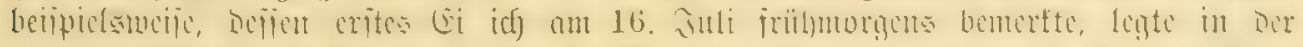

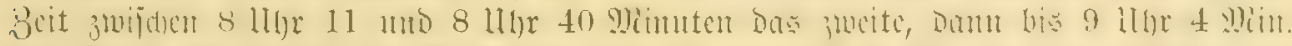

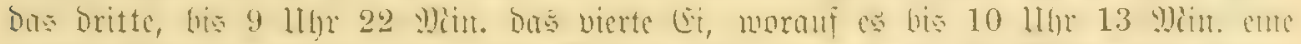

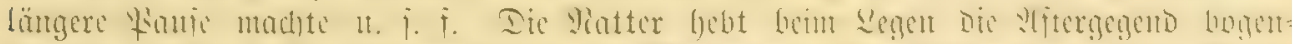

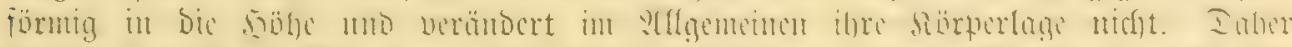

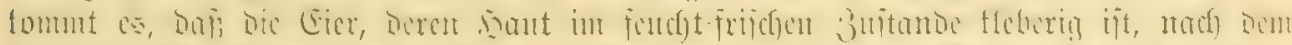

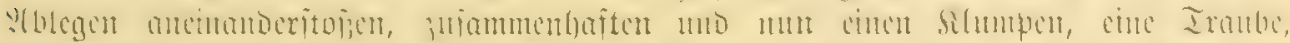

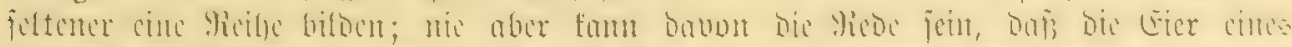

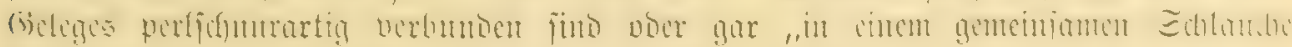

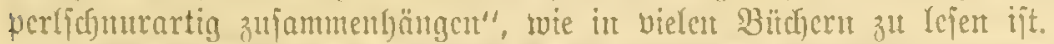

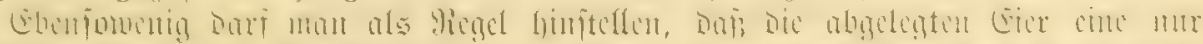

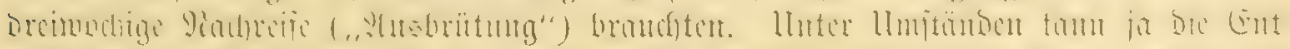

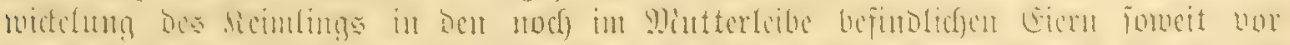

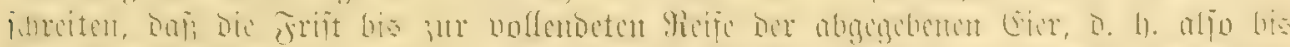

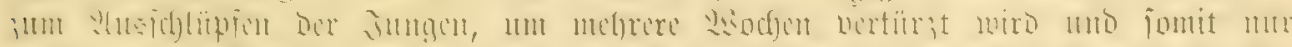

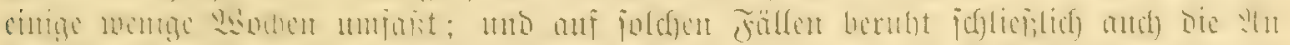

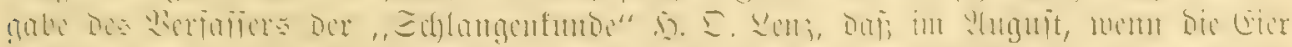

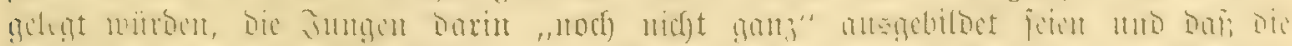

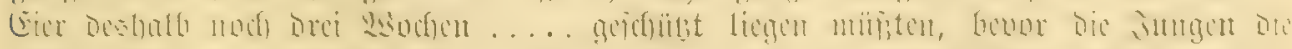

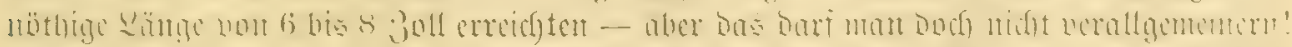

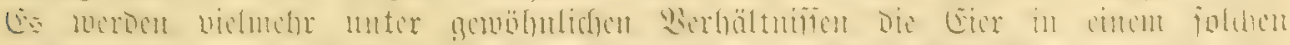

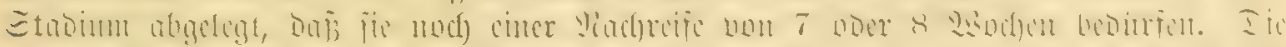

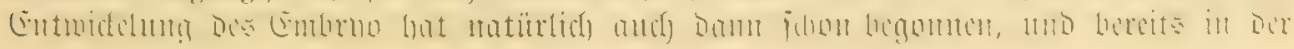




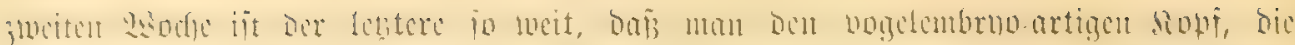

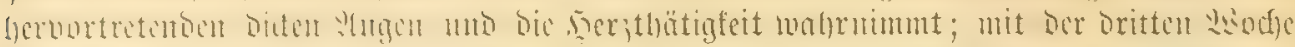

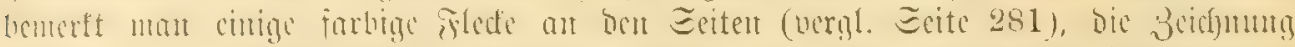

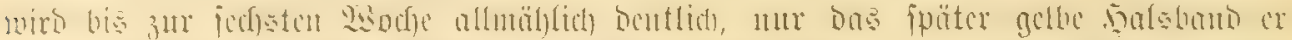
idsut noch meij: fichen

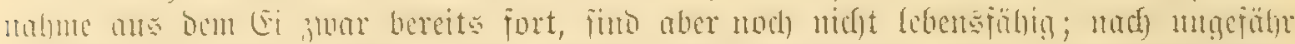

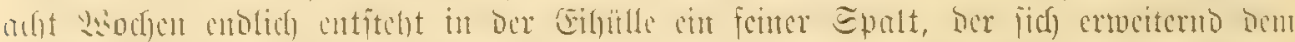

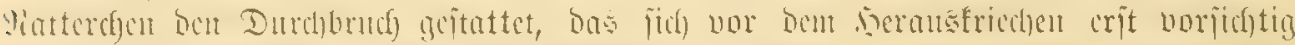

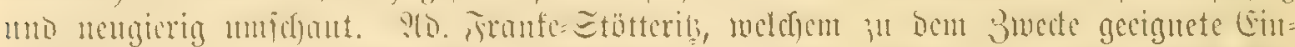

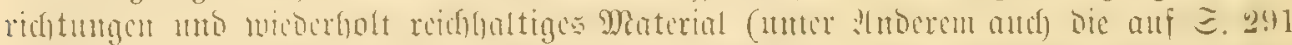

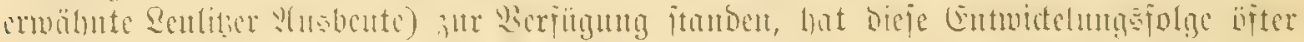

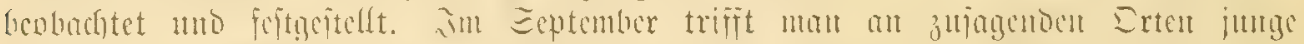

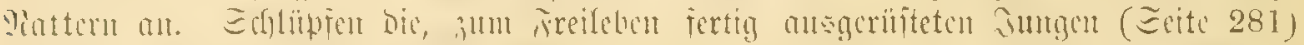

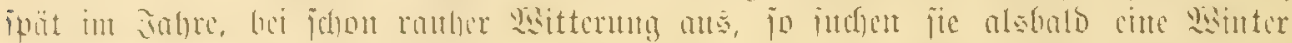

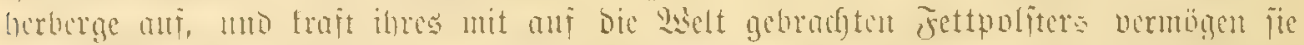

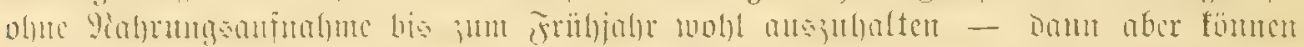

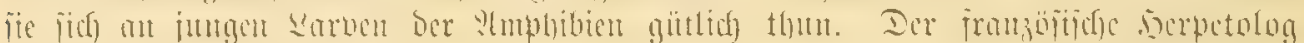
Entajt meint icsfult [Bull. Suc. zool. de France 1877 jag. 400], dic jungen

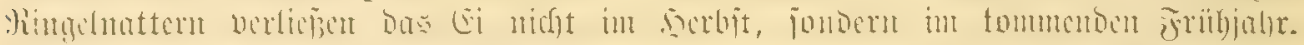

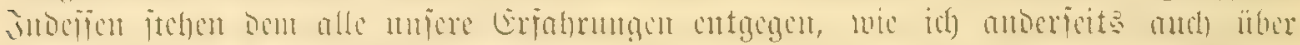

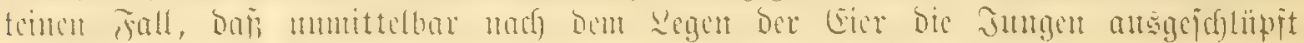

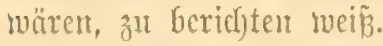

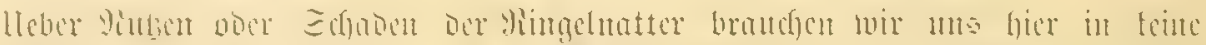

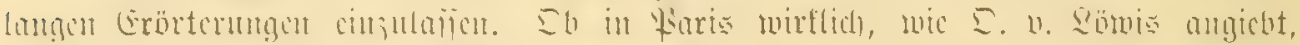

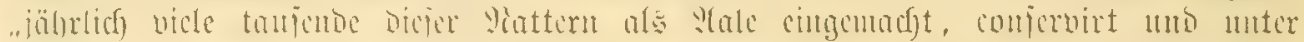

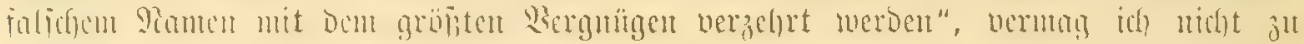

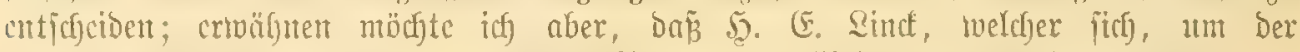

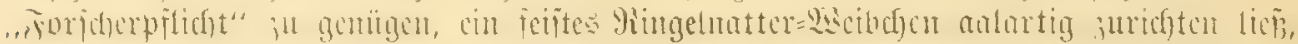

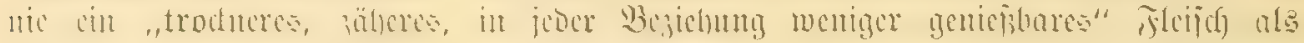

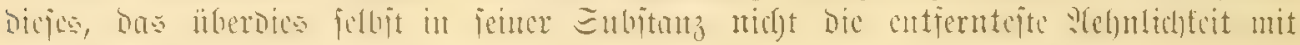
Fifobraten barbot, fentur lerute.

Zantes

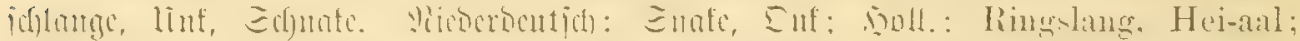

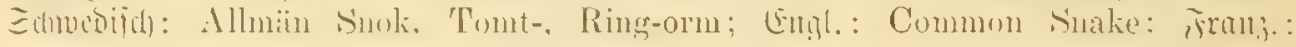
Couleurre à collier, serpent nageur, anguille de haies; $33_{a} l l o n .:$ Coulieuvre,

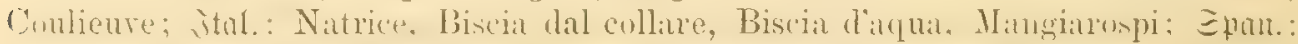

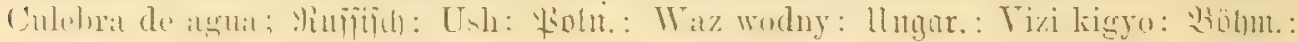
Užovka obecná.

Natrix torquata, Gesner 1621. - Natrix torquata et N. rubetaria, Aldrov. 1640. - Coluber natrix, Linné 1749 [Amoen. Acad. I]. - Natrix rulgaris et N. gronoviana, Laurenti 1768. - Coluber scutatus, Pallas 1771. - Col. helveticus, Bonnat. 1780. - Col. torquatus, Lacep. 1787; Risso 1826. - Col.

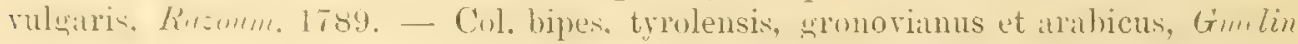
1790. - Col. bipectalis et gronovius, Bechst. 1802. - Col. scopolianus, Daudin 1803. - Natrix torquatus et $\mathrm{N}$. hybridus, Merven 1820. - Col. viperinus, Metaxa 1823. - Tropidonotus natrix, Boie 1826. - Trop. hybridus et 'T. Oppelii, Boie 1827. - Col. siculus, Cuvier 1829. - Col. ponticus, C. persa 
et C. minutus (juv.), Pallas 1831. - Trop. ater et T. persicus, Eichwall 1831. - Col. bilineatus, Bibron-Bory 1836. - Natrix Cetti, Géné 1839. - Trop. persa et T. scutatus, Eichw. 1842. - Trop. Cetti, Leunis 1860.

\section{9.rt: Würfelnatter. Tropidonotus tessellatus (Laner.).}

มbbildurg: zajel VII Эir. 1.

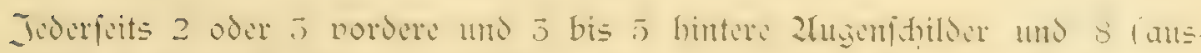

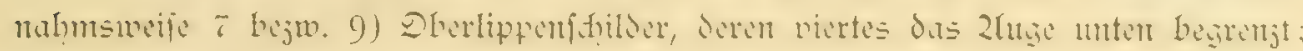
Shuppen in 19 sängsreihen; Kopf geftredt, länglid =oreiectig.

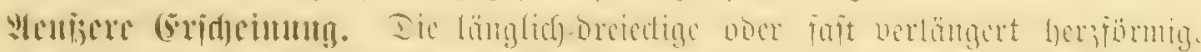

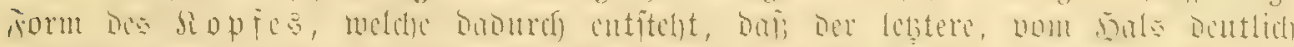

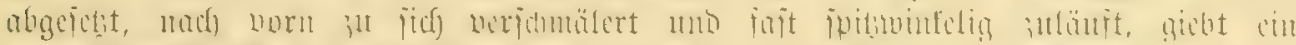

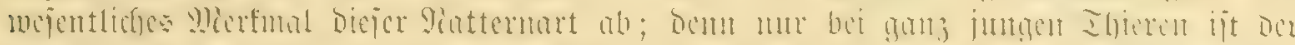

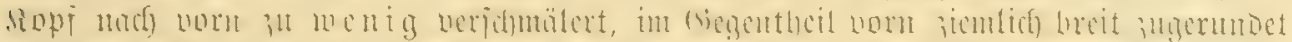

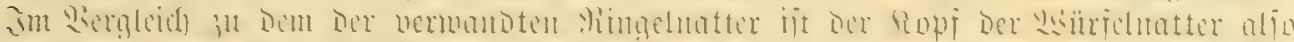

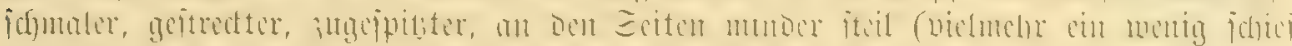

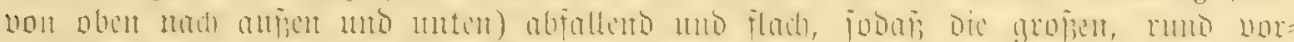

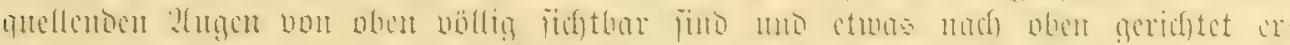

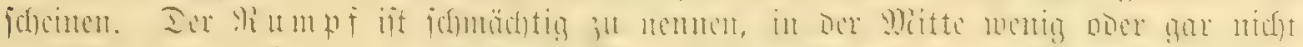

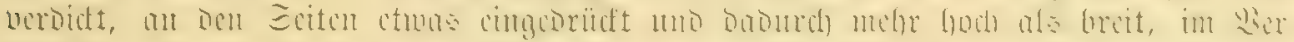

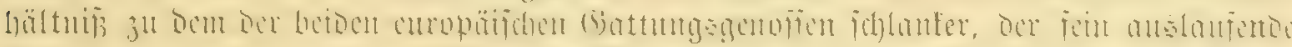
E (h)

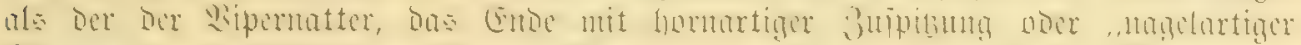

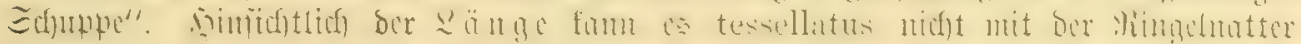

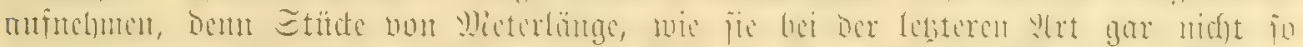

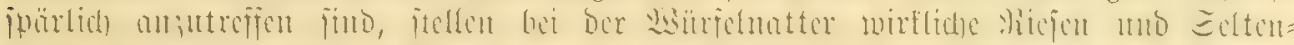

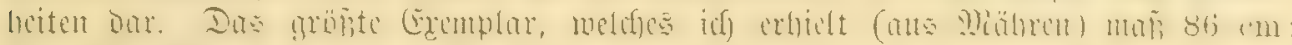

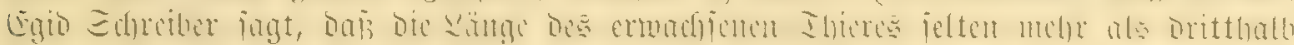

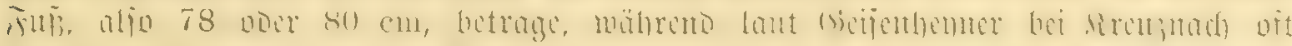

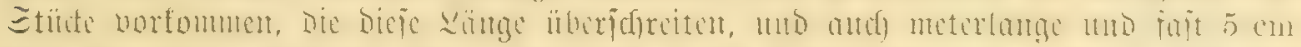

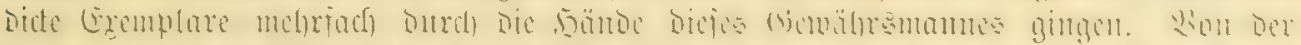

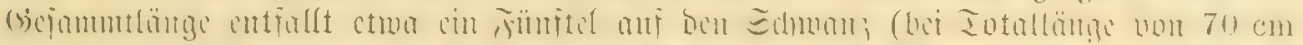

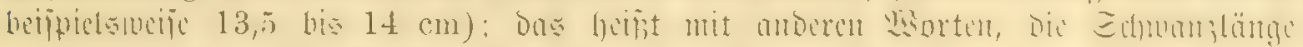
werfält fïc) zur ganzen (Sröfje wic 1 zı 5,2 bił 5,6 .

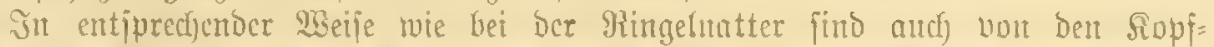

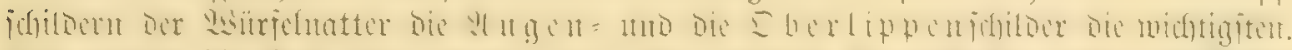

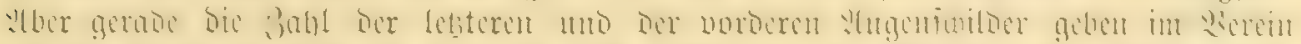

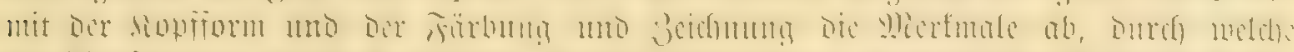

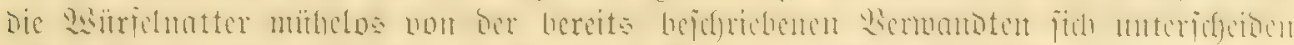

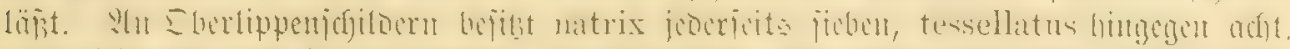

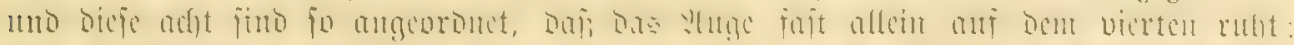

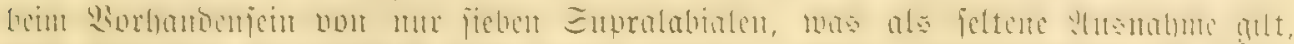

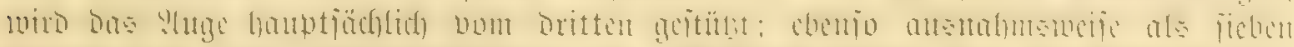

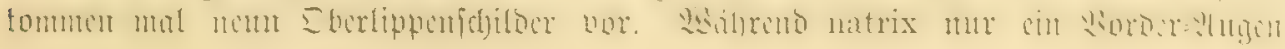




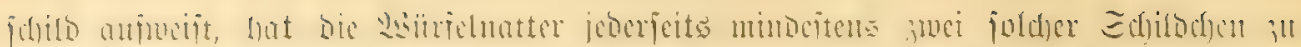

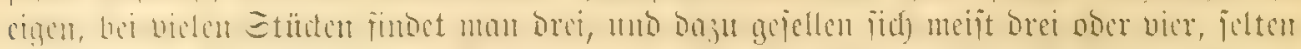

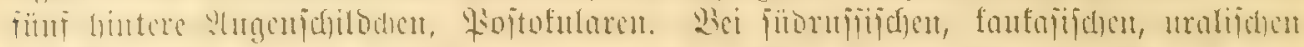

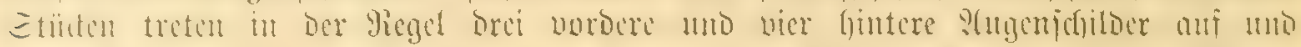

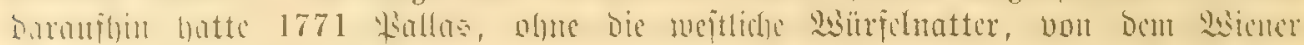

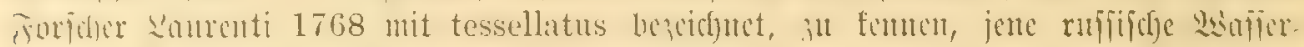

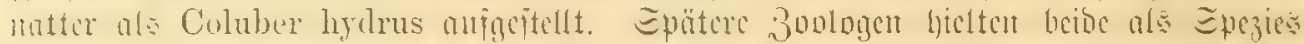

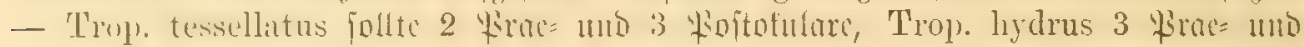

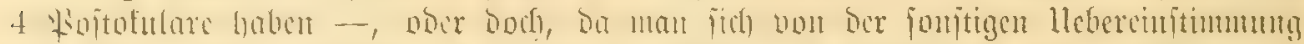

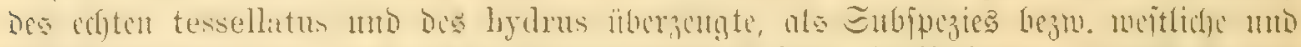

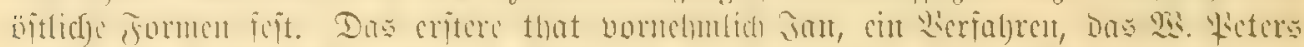

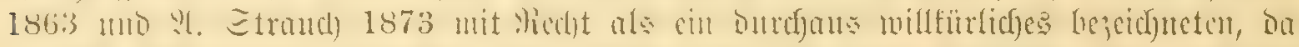

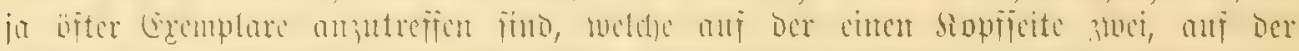

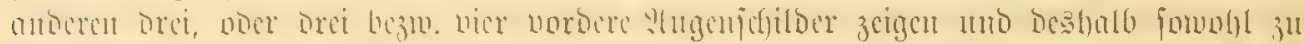

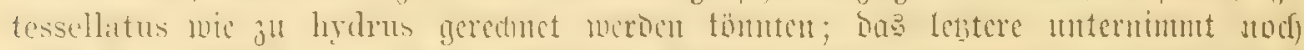

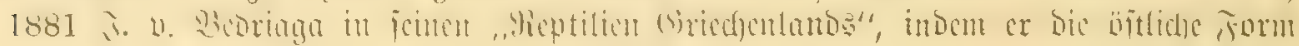
Dç tessellatus ala Subipcziç hydrus aufrecht exhält,

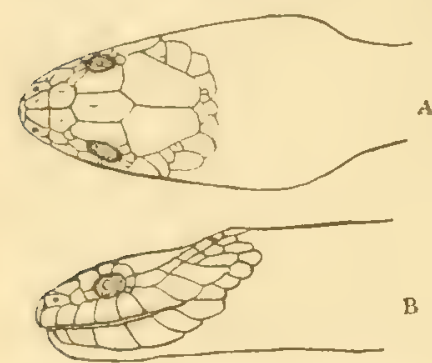

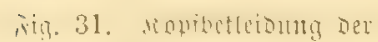
Iisiufeluteter.

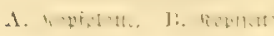
tvähreno or für bie sveitlidje Form mit geringerer Dfular= zahl jogar chten befonderen 9lamen: Subjp. ober Dar.

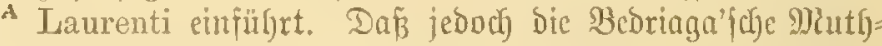
maj̄ıntg: "Die in Diten Europas cinfermijdje, meiftens mit ore Piracofularen berjefene 23ürfelnatter gabe cincn Gegrenzten Wohnbezinf und überichreite Denfelben nidft",

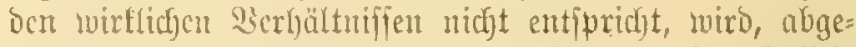

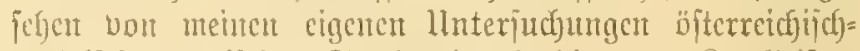

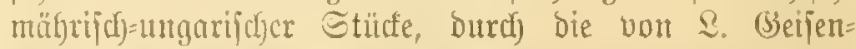

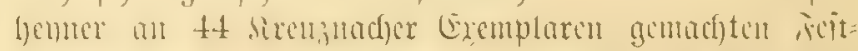
itellutgen vollan Dargethan. Eehs Diejer 44 Exemplare roiejen auf ber linten Ecite eine andore Befdjilderung

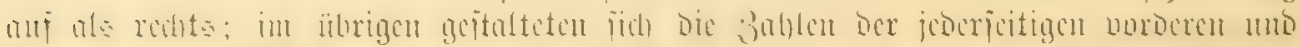

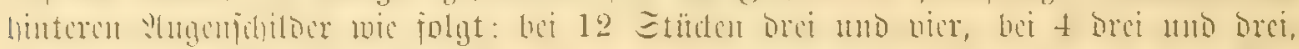

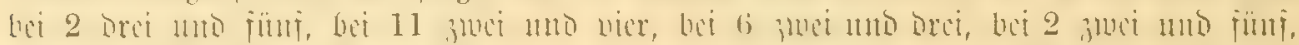

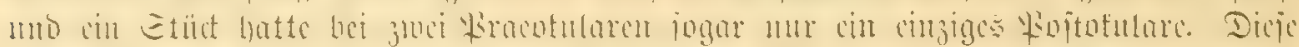

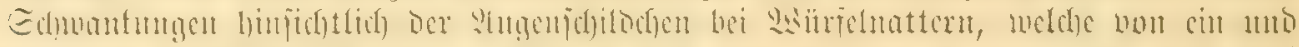

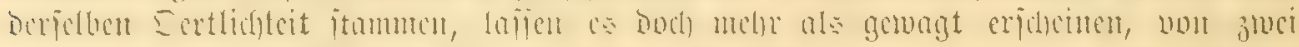

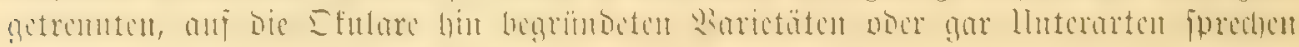
zll wollen!

:

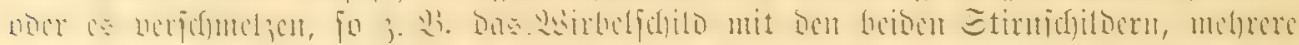

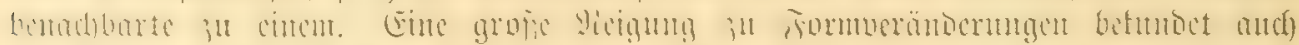

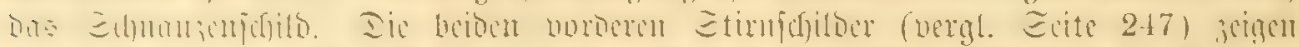

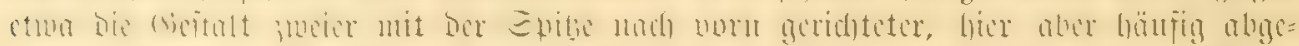

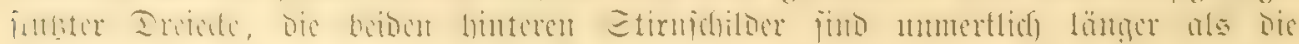

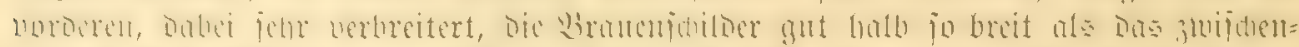

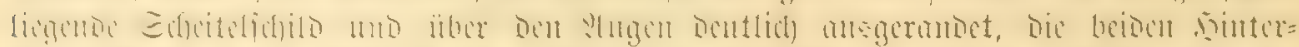

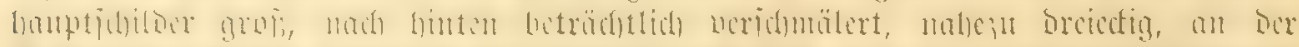

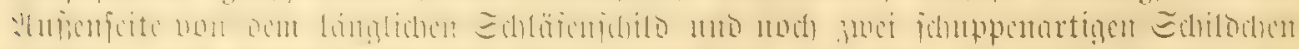

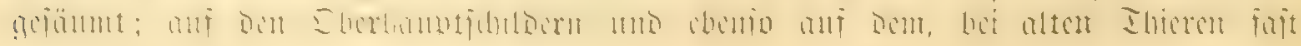




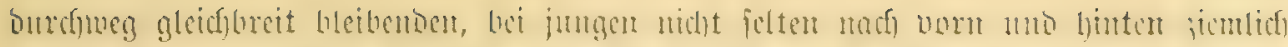

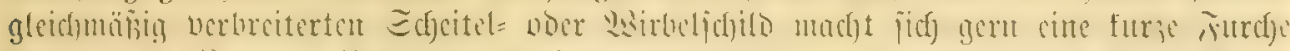

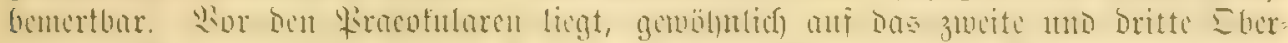

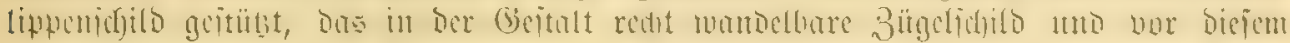

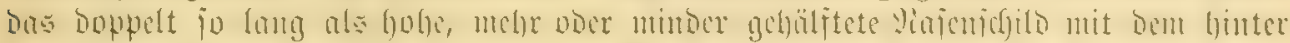

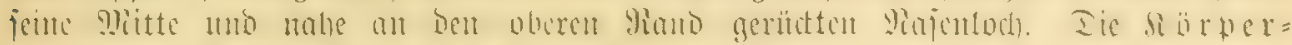

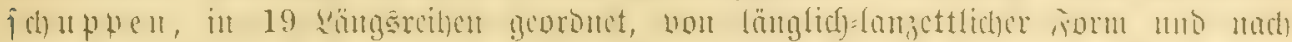

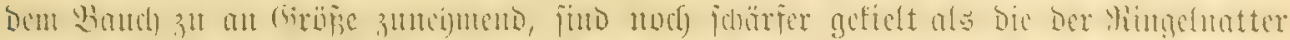

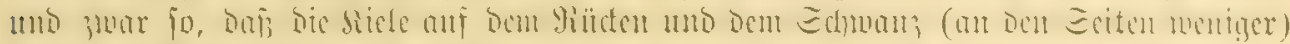

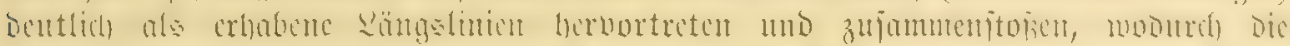

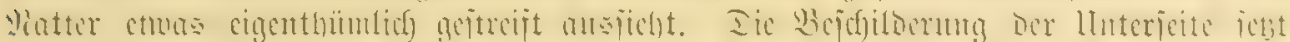

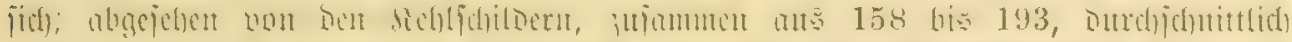

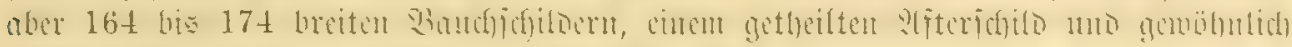
sinigen 60 (54 bie 76) Sufwanzidjilder=\$\$aren.

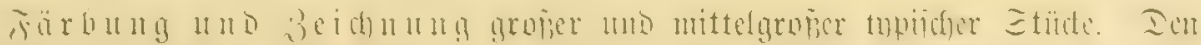

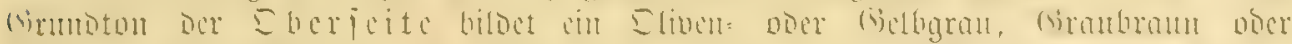

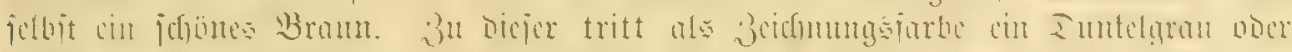

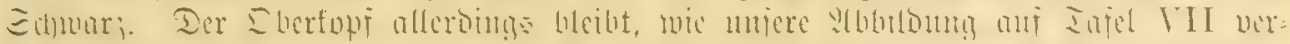

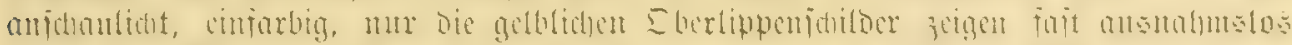

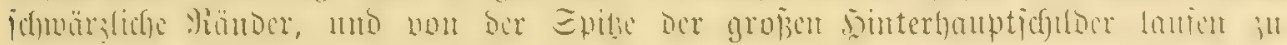

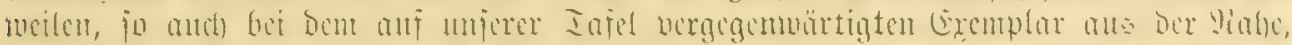

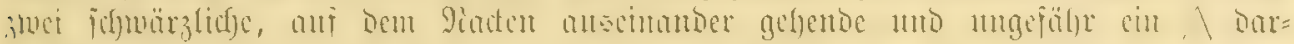

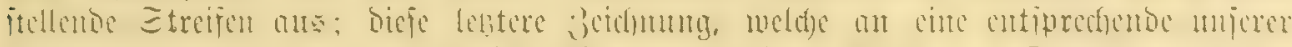

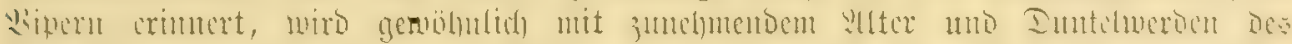

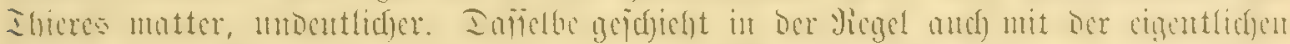

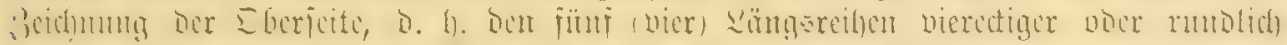

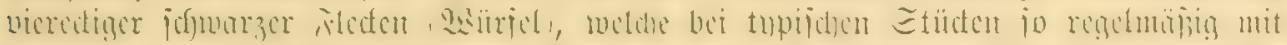

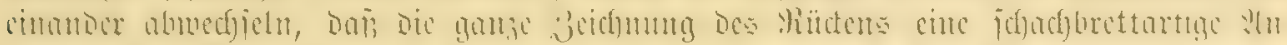

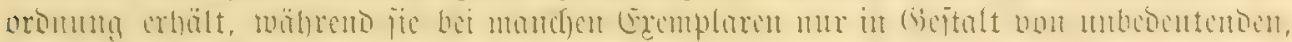

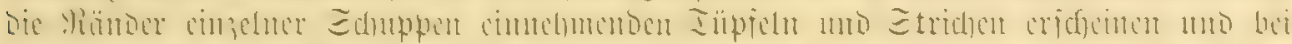

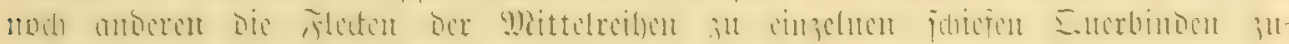
jammenT̄liç̄ent.

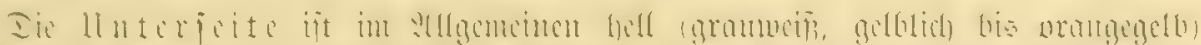
Interieite.

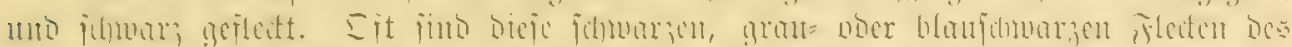

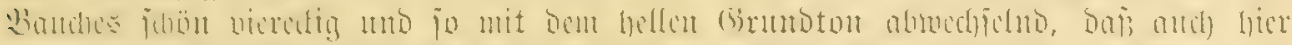

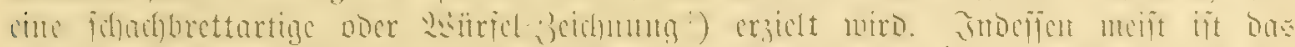

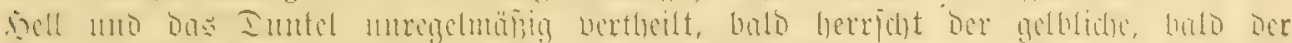

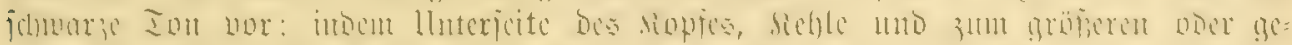

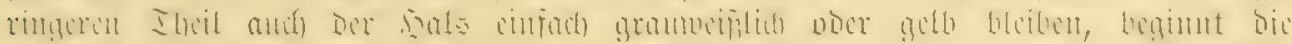

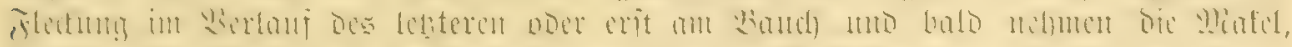

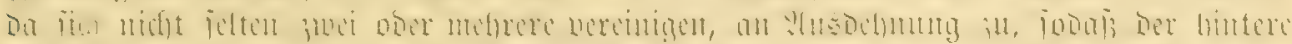

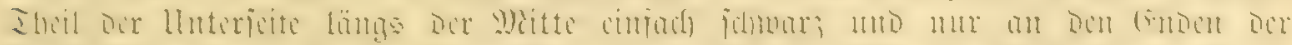

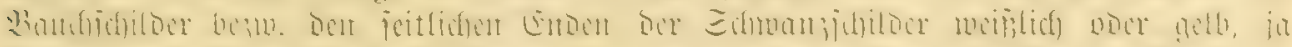

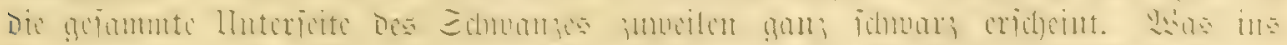

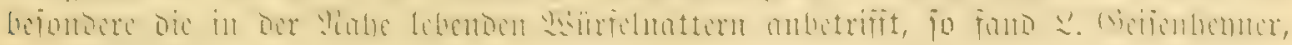




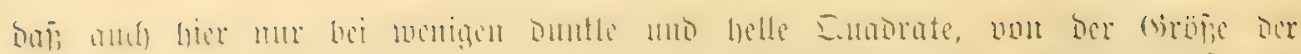

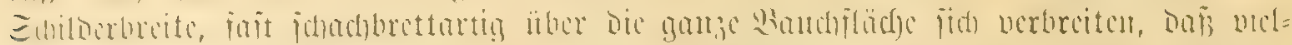

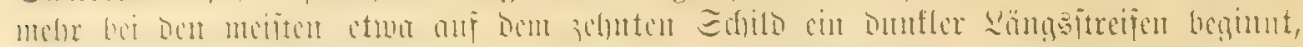

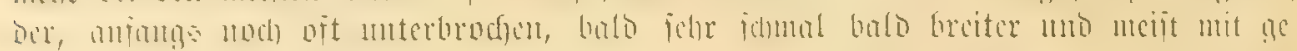

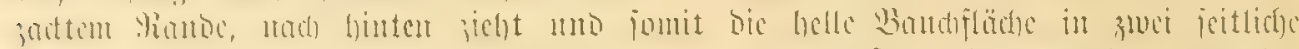

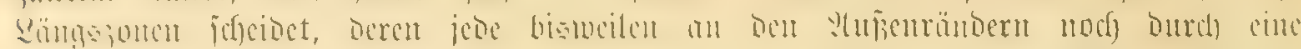

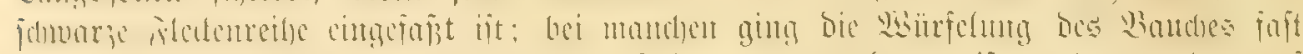

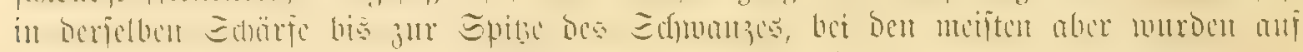

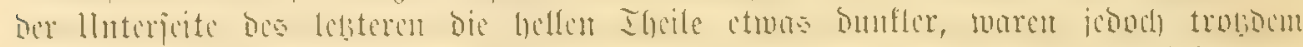

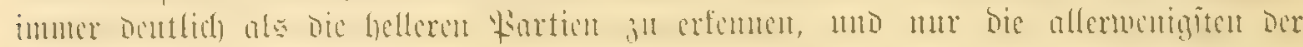

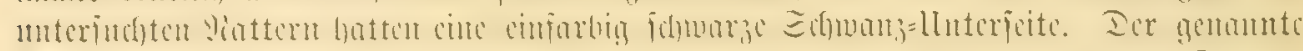

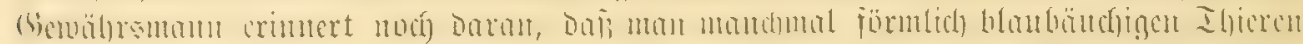

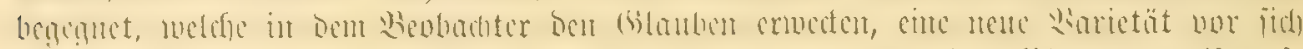

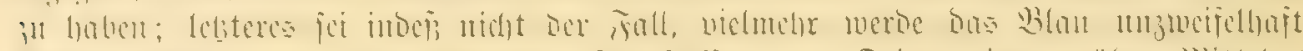

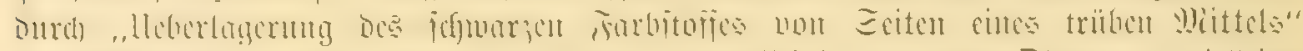

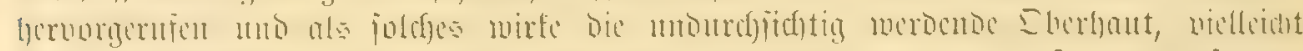

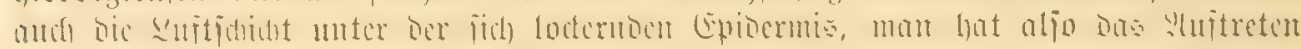

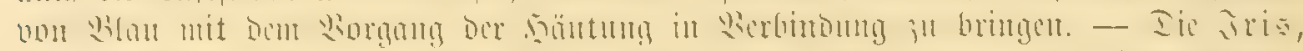

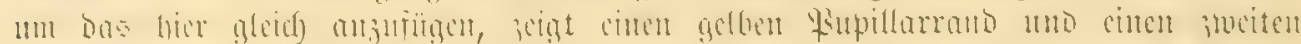

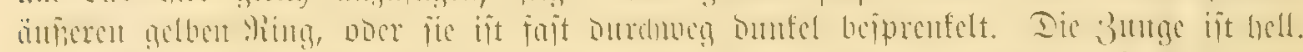

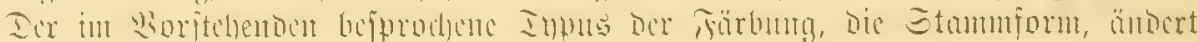

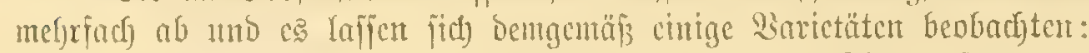

1. Bar. concolor, Jan, glcisfarbige 23 . Sie entitebt, entiprecheno ber

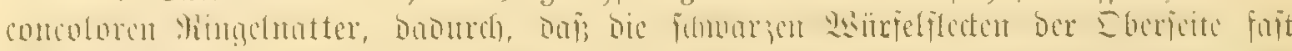

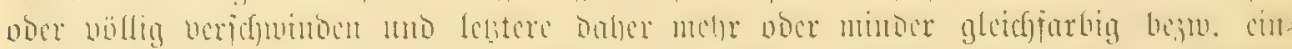

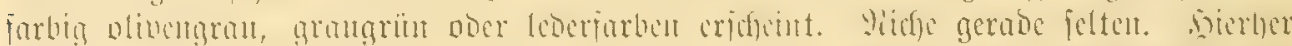

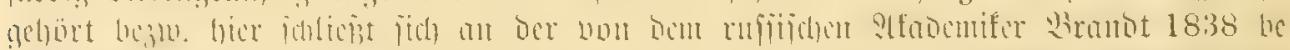

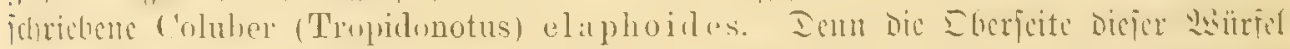

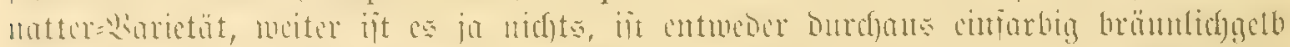

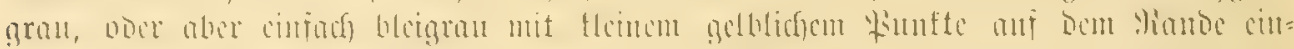

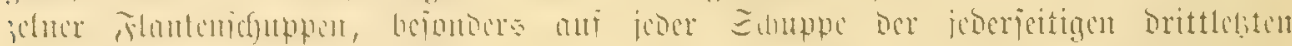

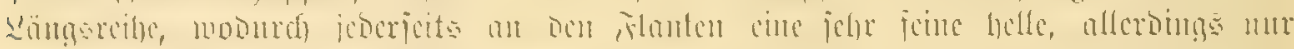

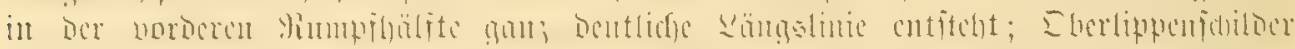

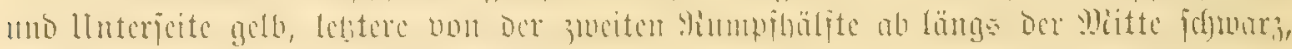
an Cofyuats Durdfineg fifwnarz.

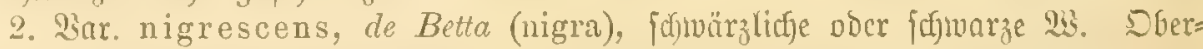

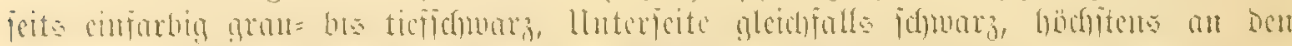

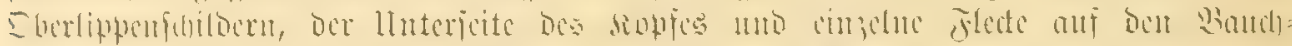

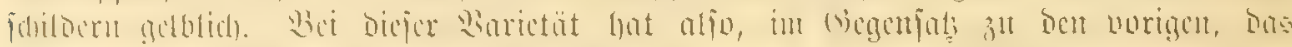

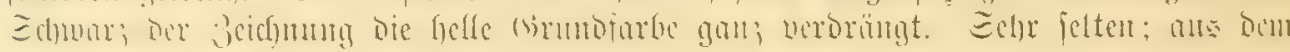

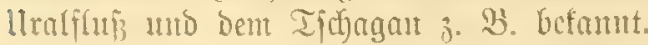

3. Bar. sparus, branngeprentelte 23 . Ilnterjeite wie bei bcr Stammiorm

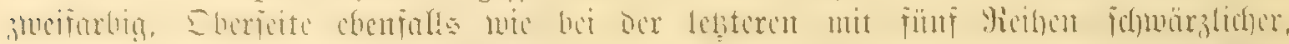

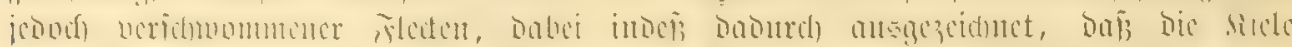

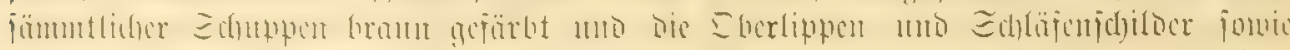

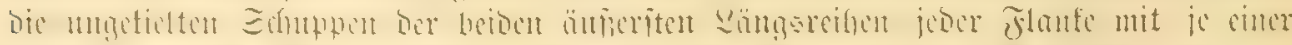

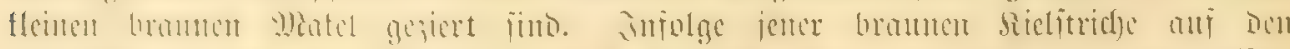

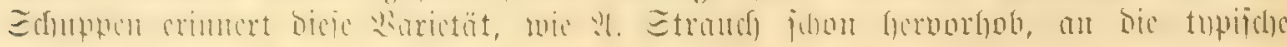




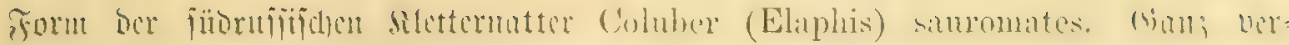
cinzelt vorfommeno (Ranfajus).

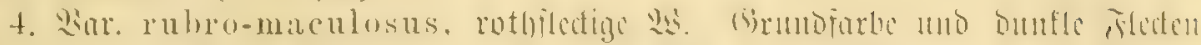

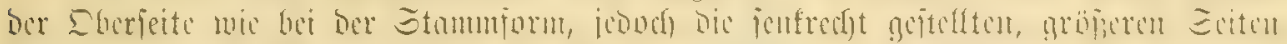

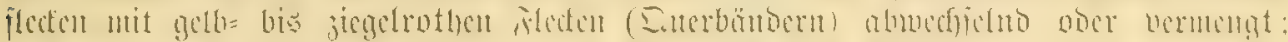

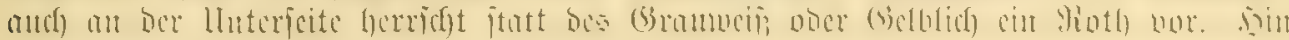

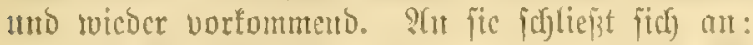

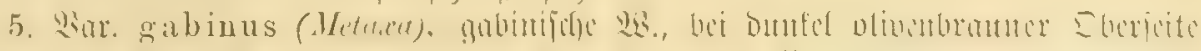

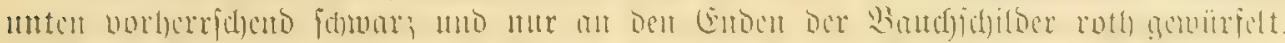

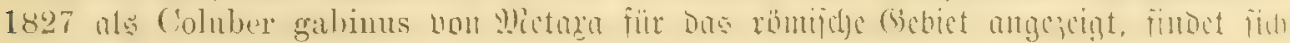
abcr aucj anderwärte.

6. Bar. flavescens, Werner, getblidic 23. Grumbfärbung ber Dbcrjettc ciu

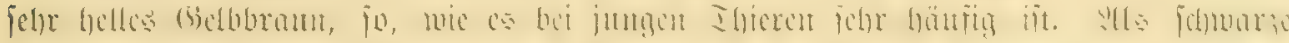

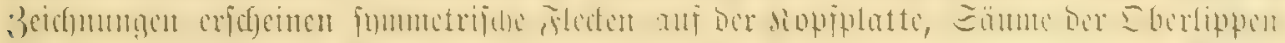

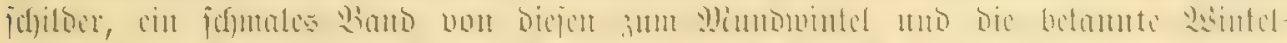

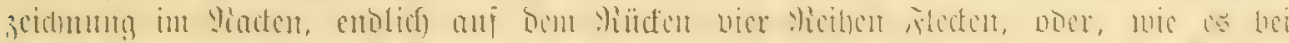

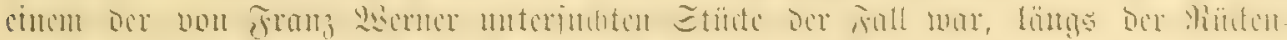

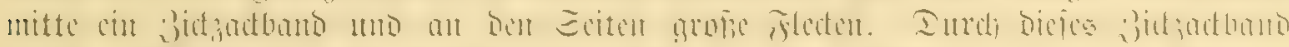

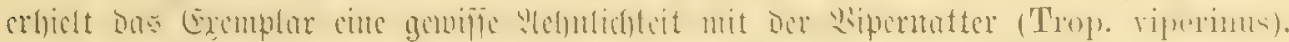

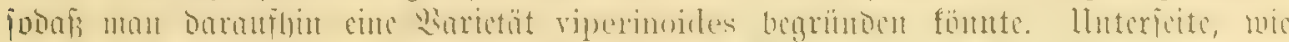

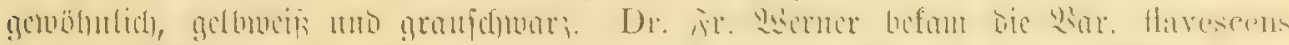

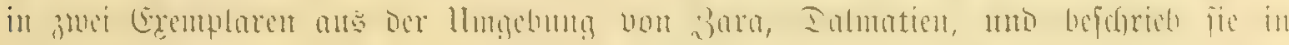
ben Berfond. Der 3ool.=bot. (Bef. W3ien 1891 ๔. 766.

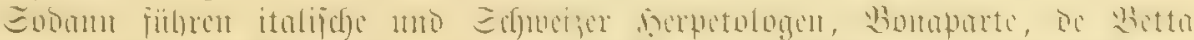

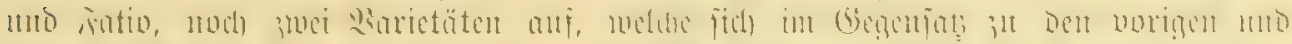

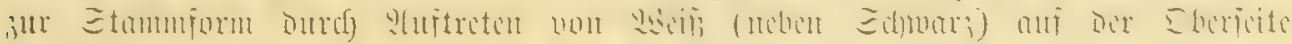

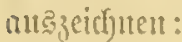

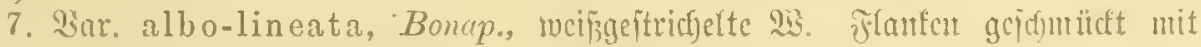

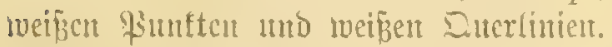

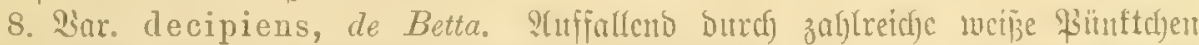

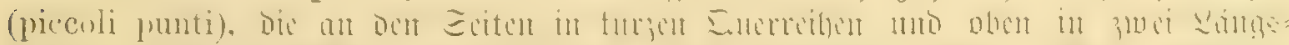

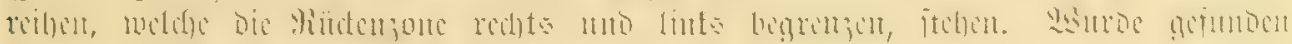
laut de Betta in Der Froviuz ßerona uno von Fatio in Santon Tefiut male bei sugumo.

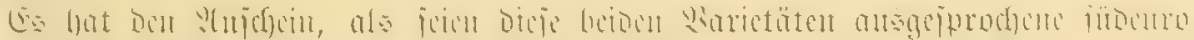

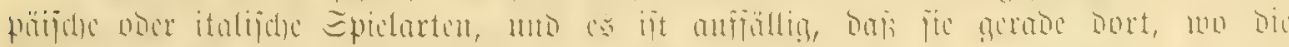

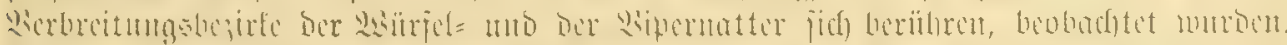

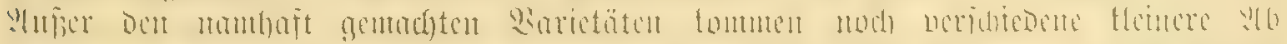

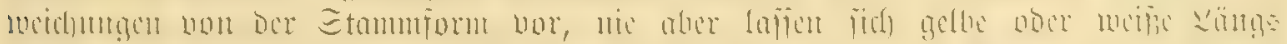

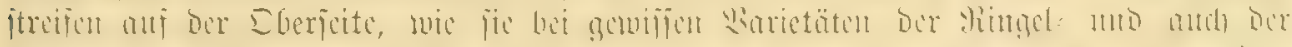

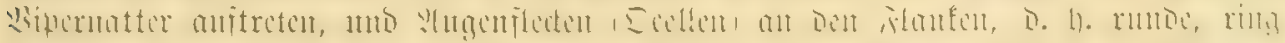

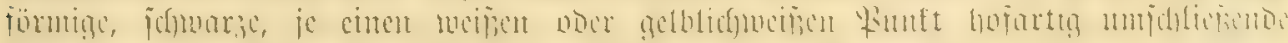

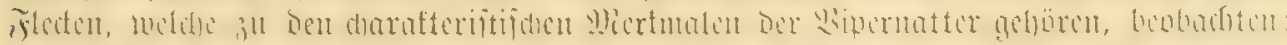

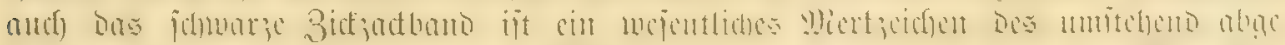

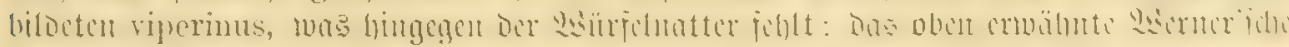

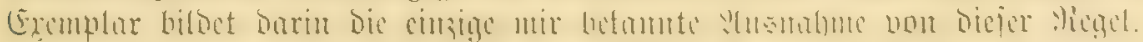

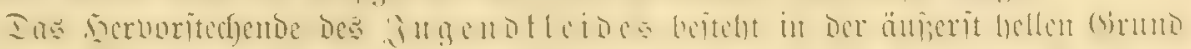

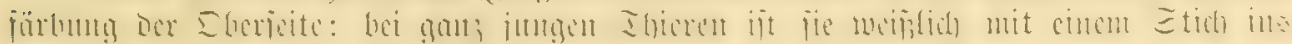




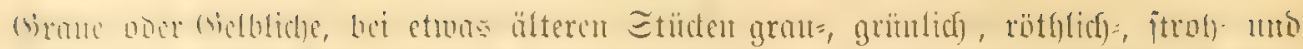

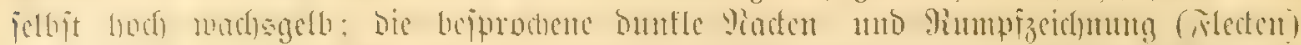

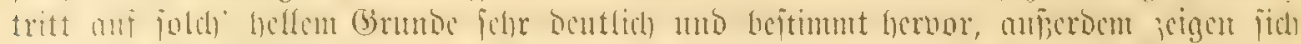

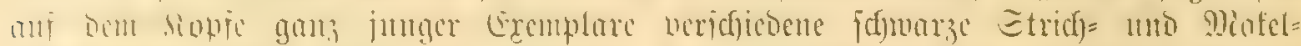

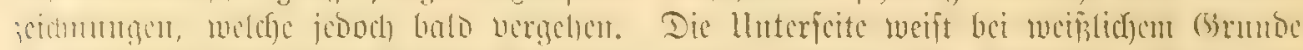

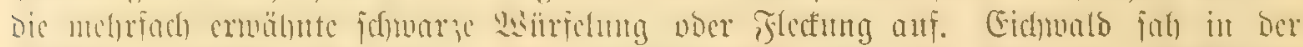

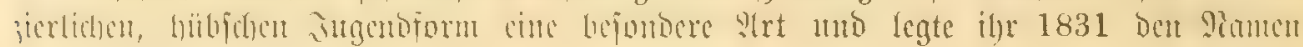
Iropidonotus gracilis bei.

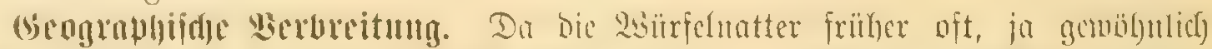

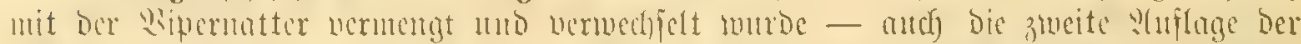

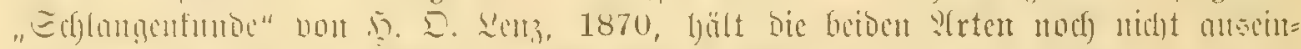

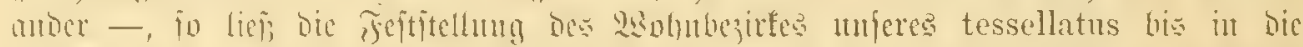

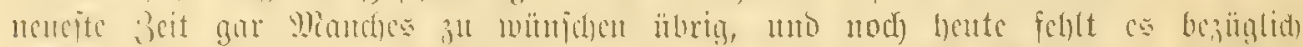

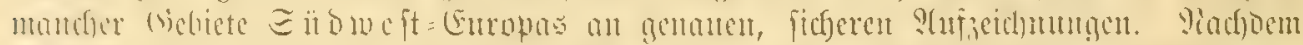

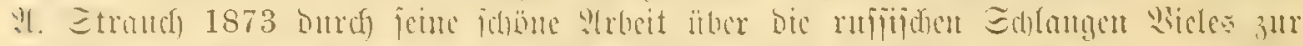

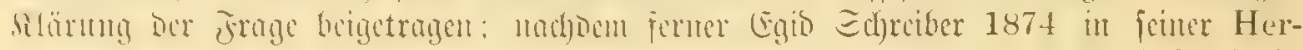

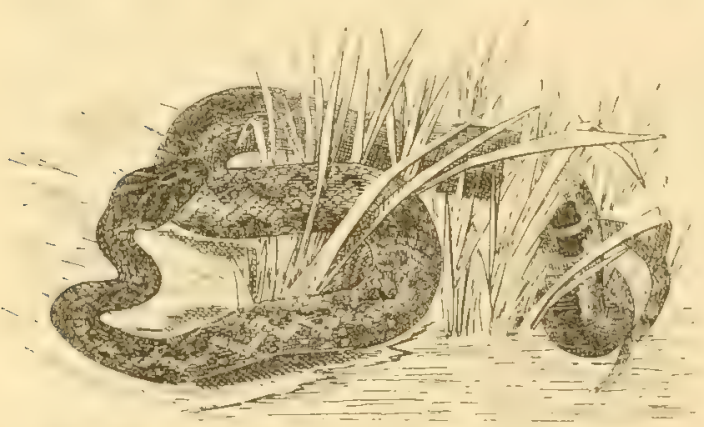

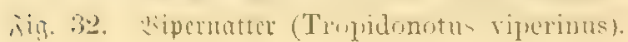
petologia crflärt hatte, DaßB Die in

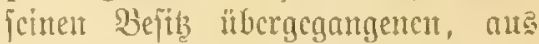
QInoaluften ftanmentoen, ,tessellatus" giojentyauces alle zt viperinus geGörten; nachbem tweiter ber betamite fangjährige Sammler unto tirctitige Sientuer der Sajlangen u. a. Micptilicu Mitoolf Gffeldot=Berfin im s(prilfeft Deß "3ovlog. Gartens" 1875 auf (B)rumo feiner eigencn Erfalbungen

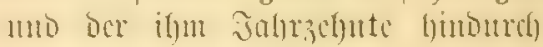
ingegangentent Eentumgen letender Mlattern mit Befinmtheit ausge=

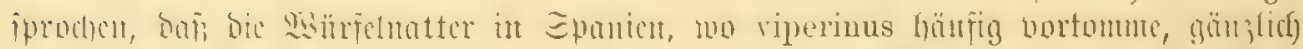

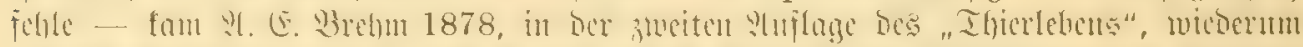

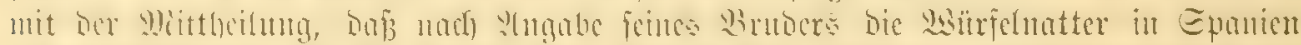

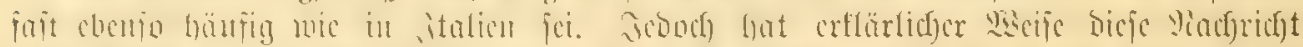

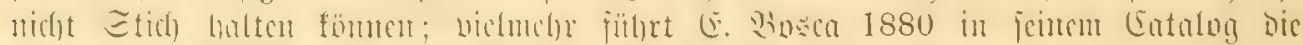

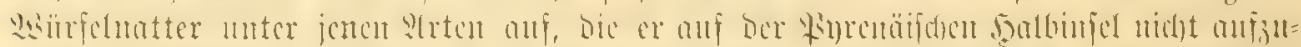

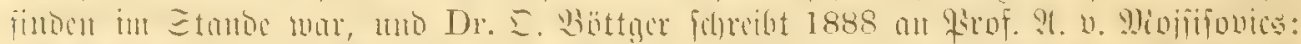

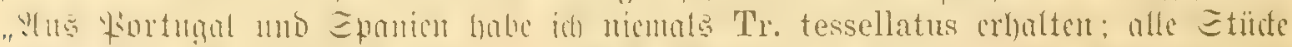

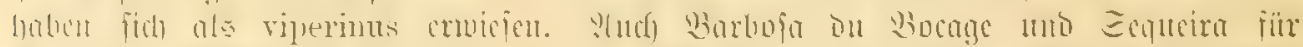

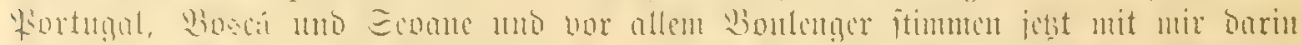

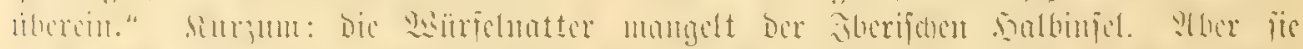

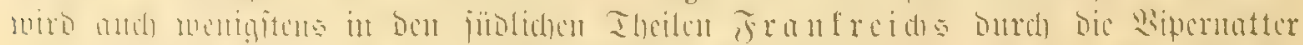

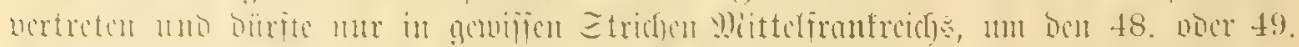

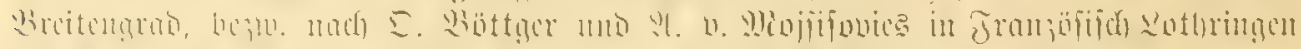

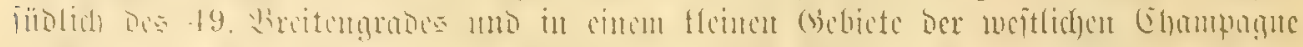

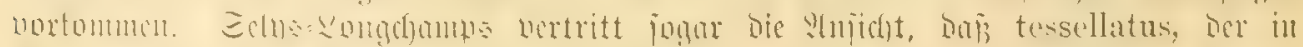

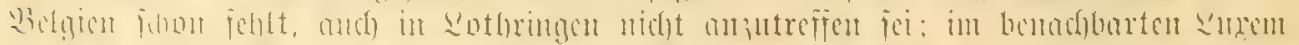

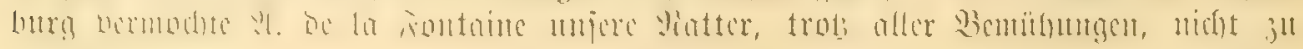
centoccten. 


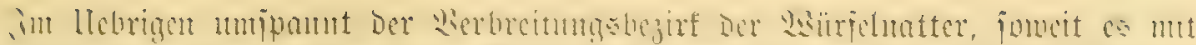

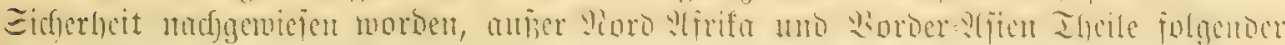

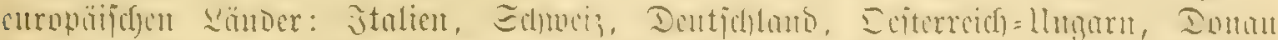

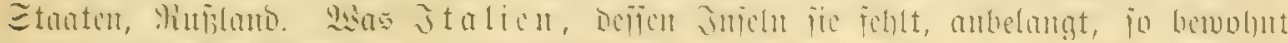

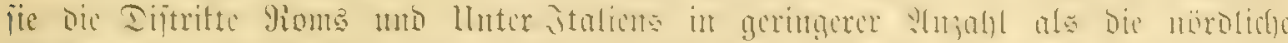

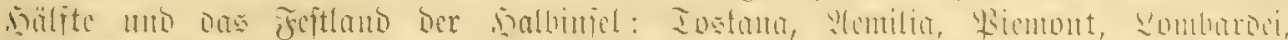

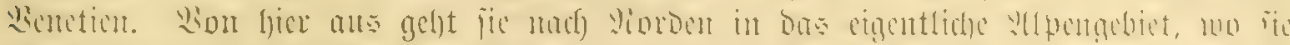

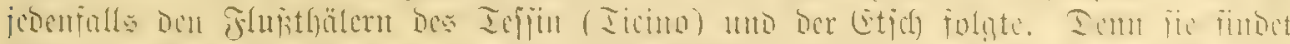

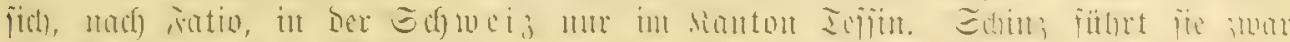

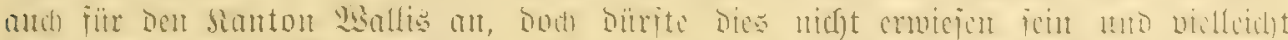

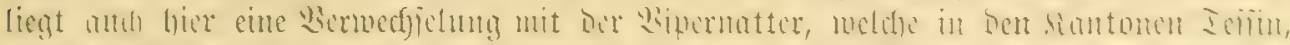

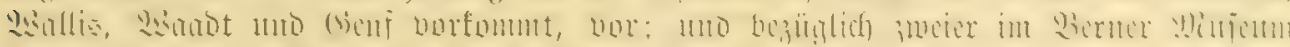

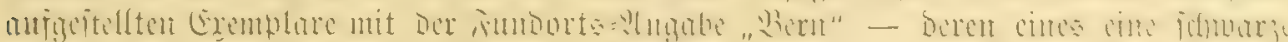

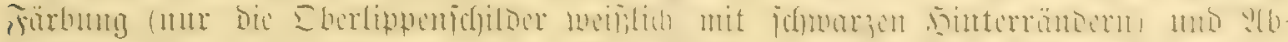

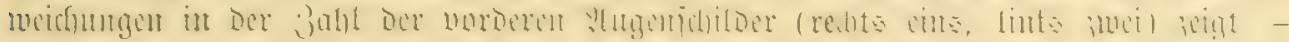

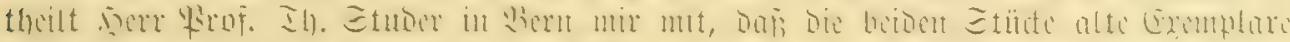

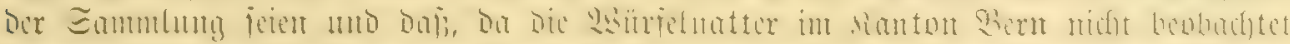

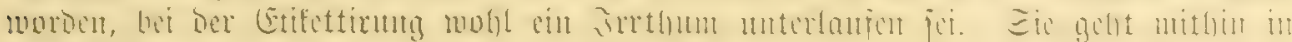

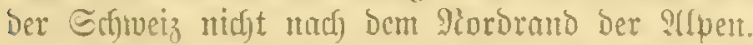

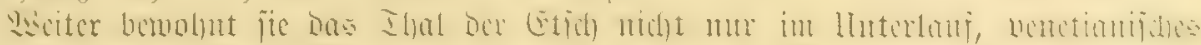

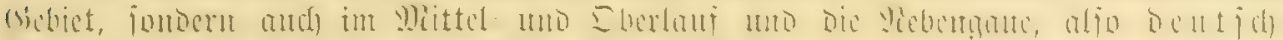

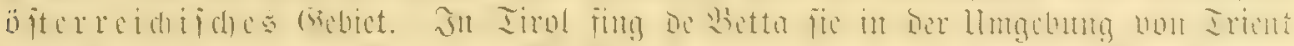

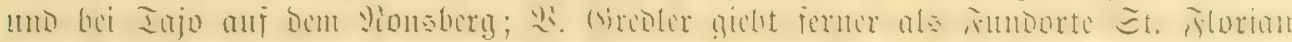

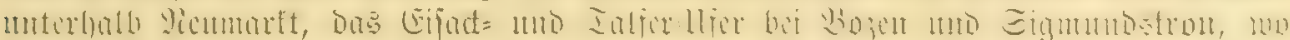

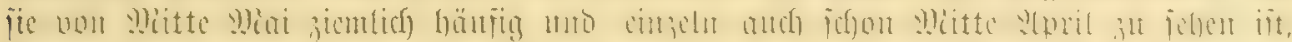

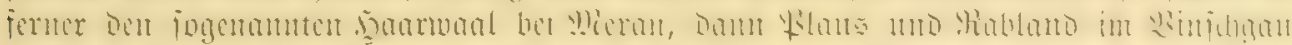

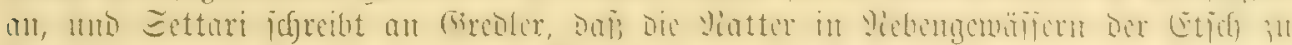

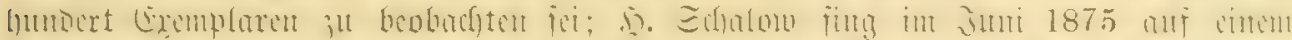

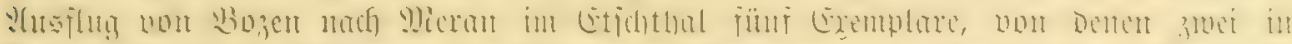

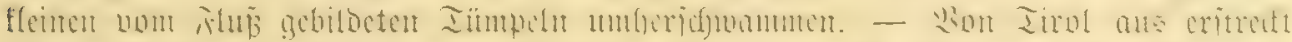

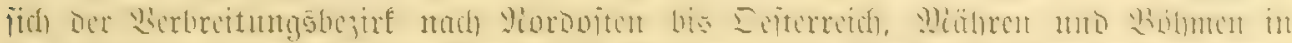

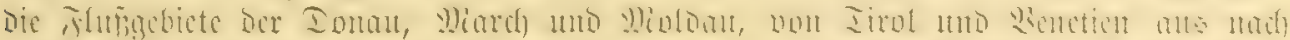

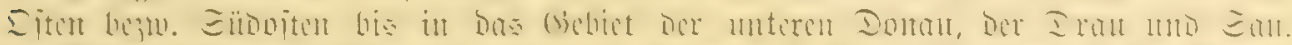

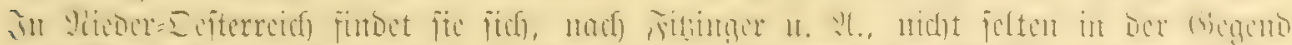
Lou

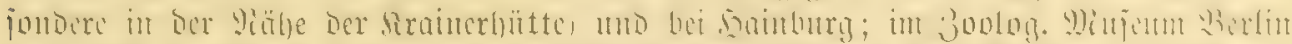

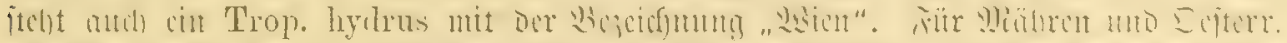

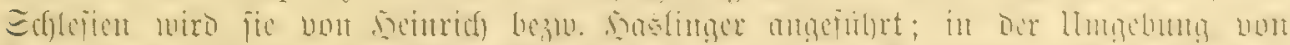

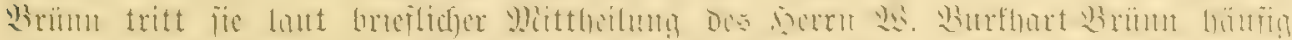

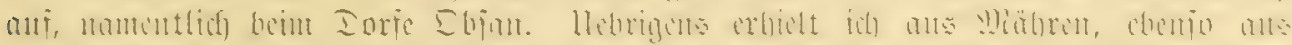

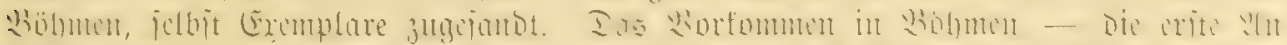

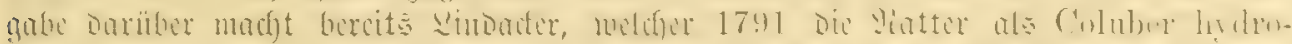

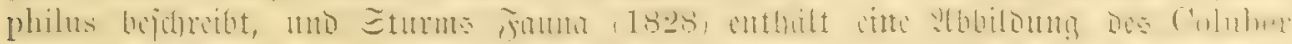

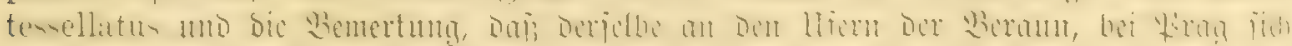

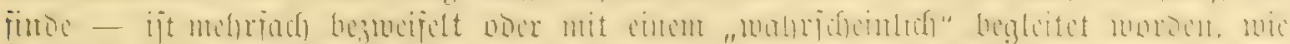

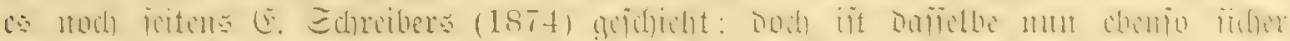

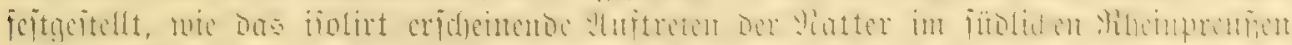

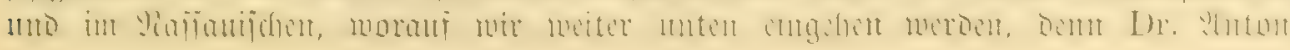




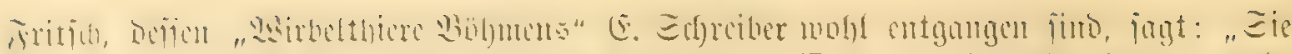

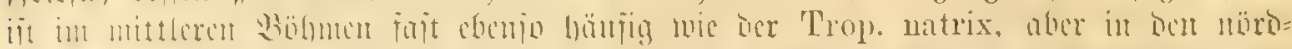

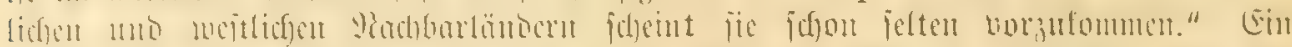

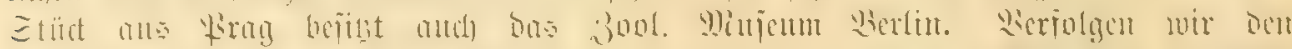

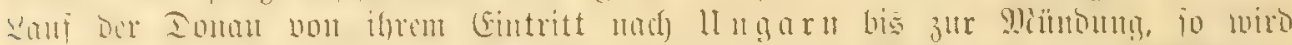

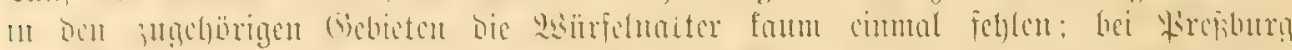

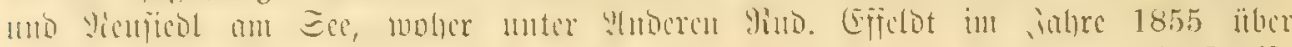

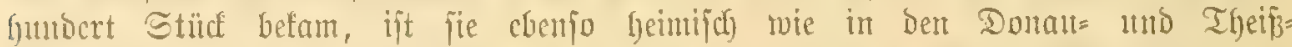

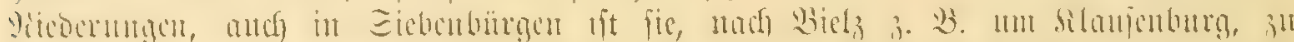

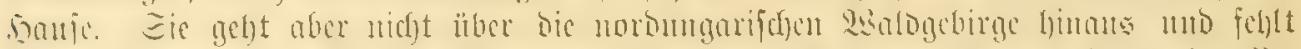

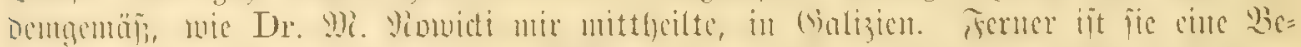

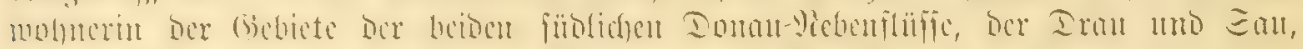

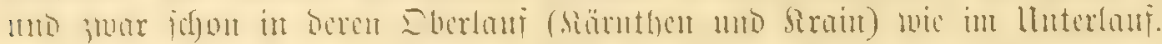

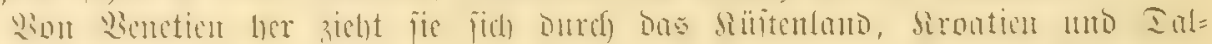
utatien, wo fie an zujagenden Exten oft in reidjer Suswabl anzutrefien ijt,

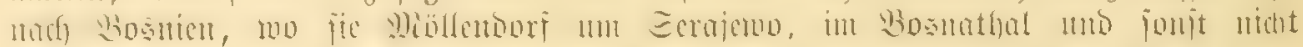

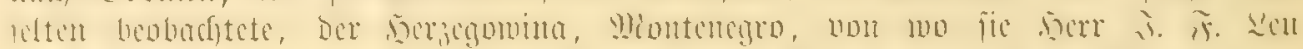

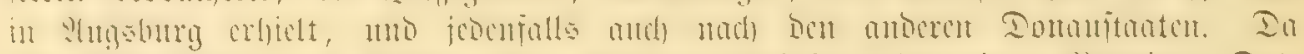

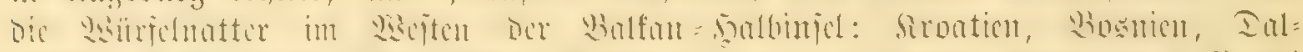

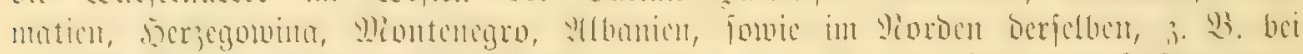

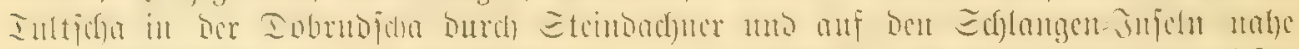

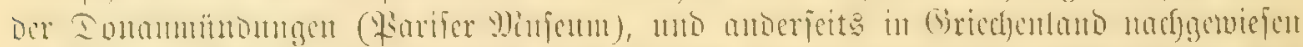

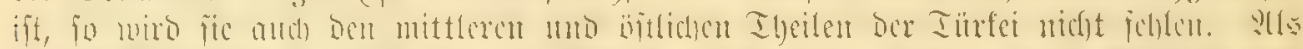

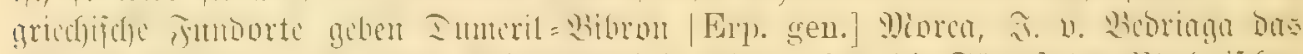

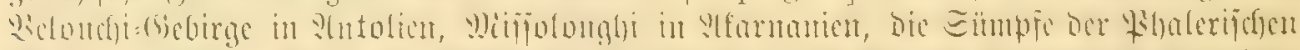

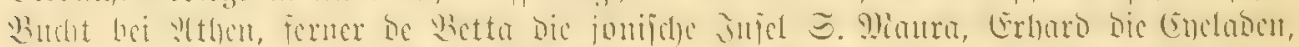

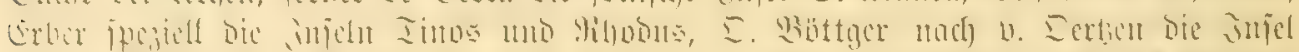

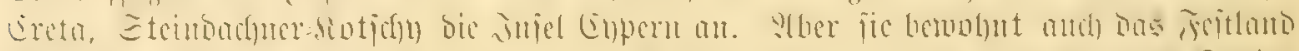

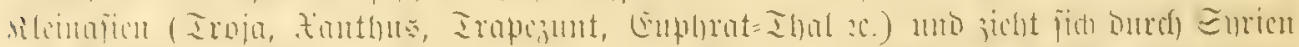

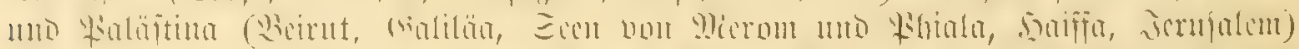

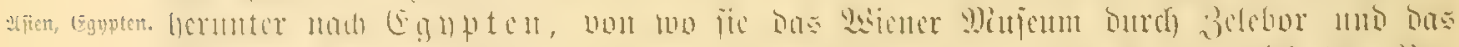

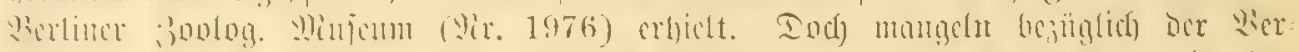

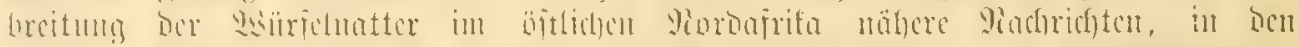

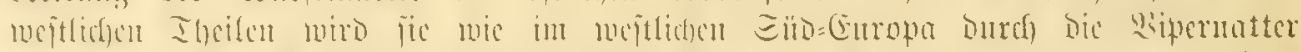

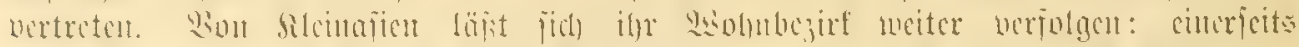

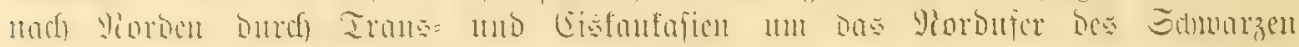

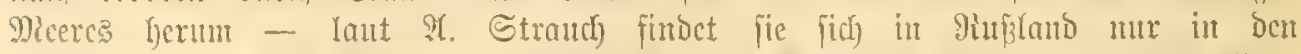

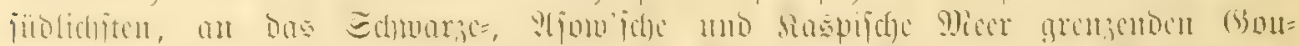

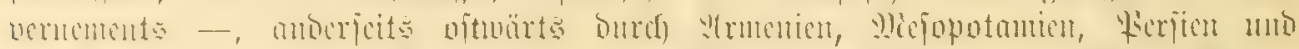

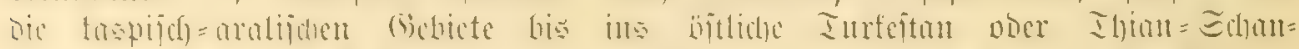

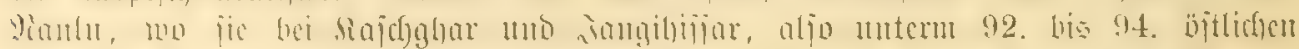

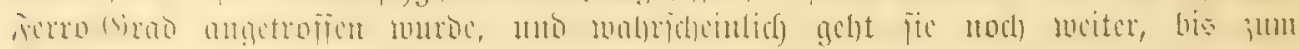

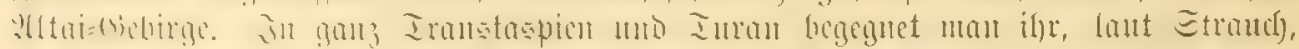

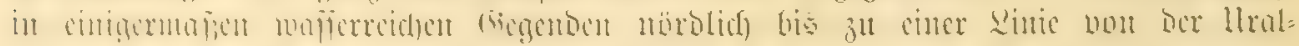

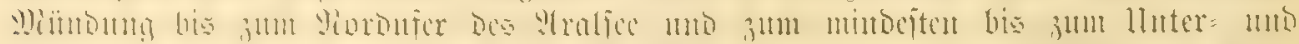

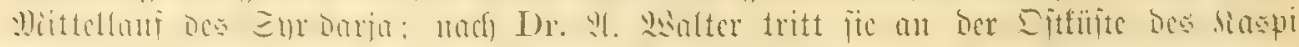

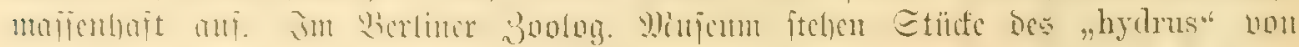

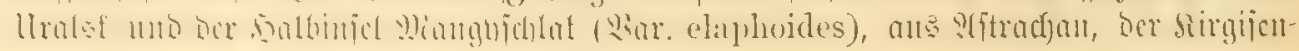




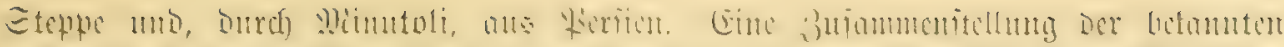

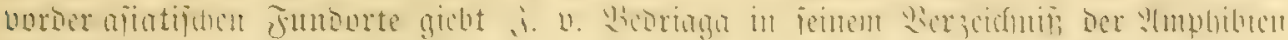
uto Pieptilien Borber=?lficut?.

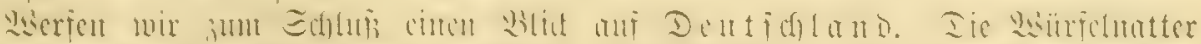
Deutidgtanto.

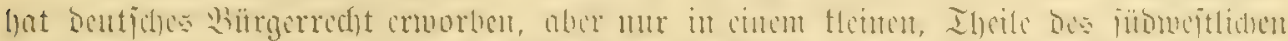

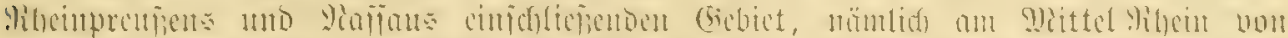

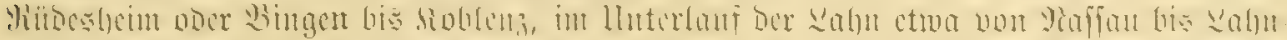

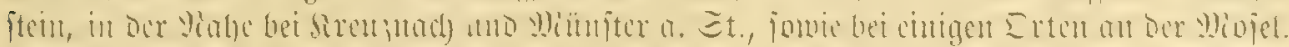

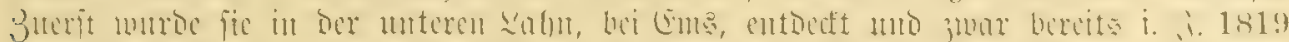

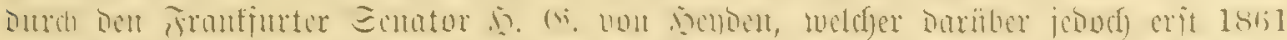

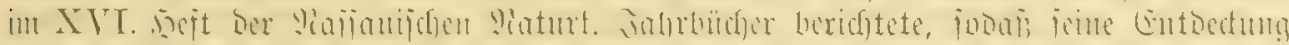

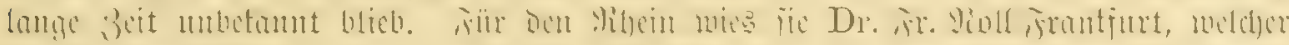

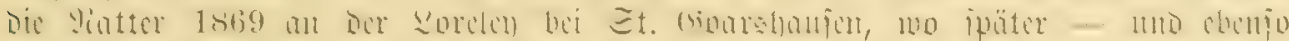

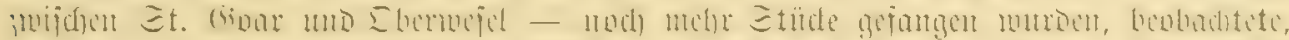

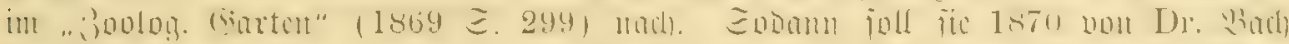

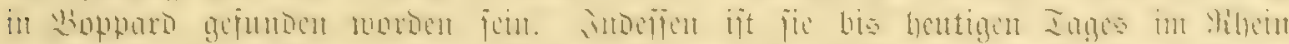

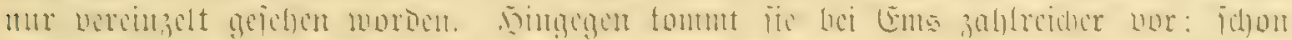

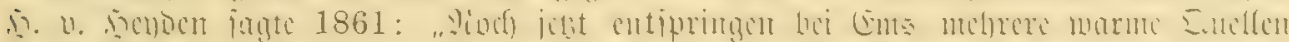

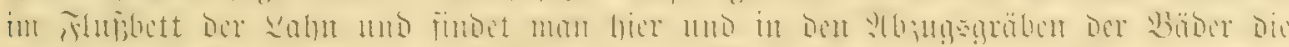

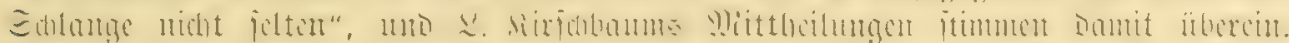

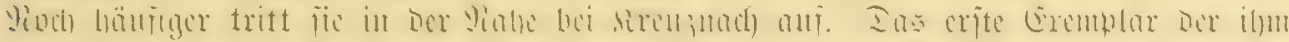

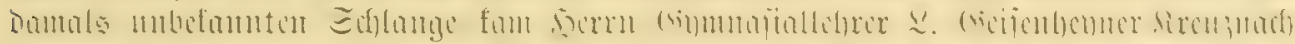

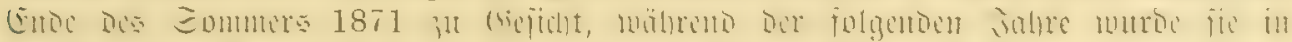
grengerex

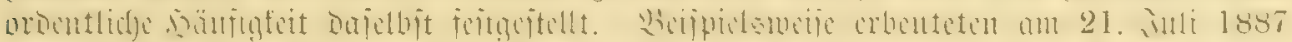

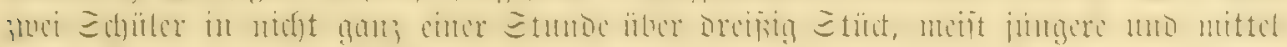

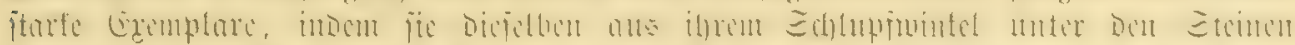

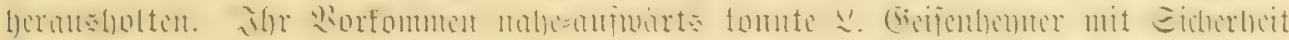

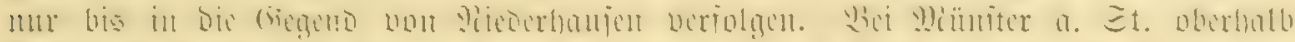

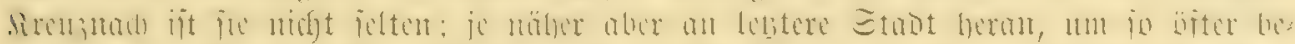

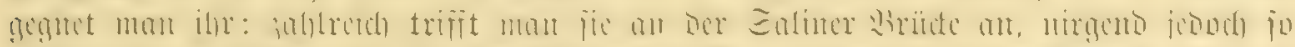

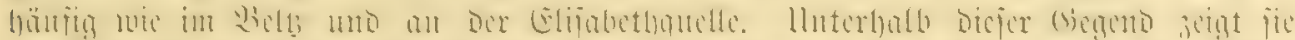

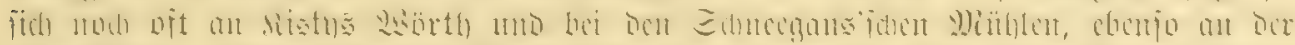

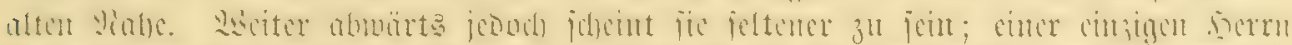
(B)

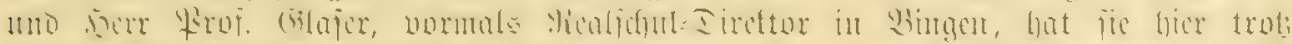

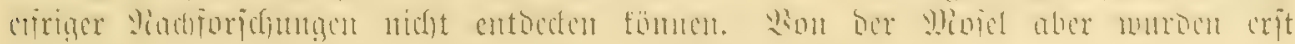
i. Э. 1888, Durdy Dr. Fr. Noll, ficherc Funde geneldet.

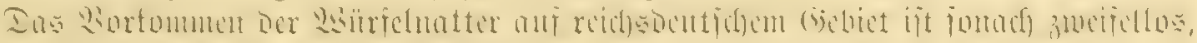

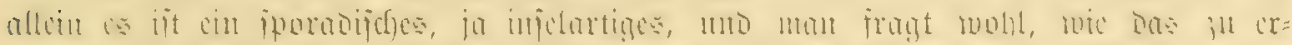

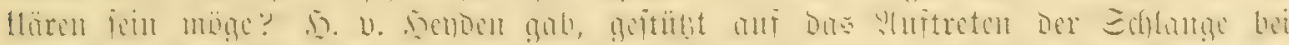

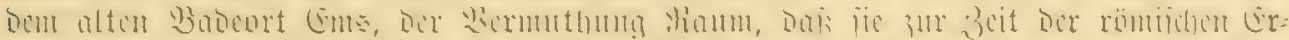
vbermes,

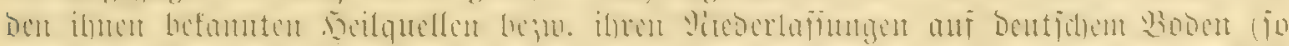

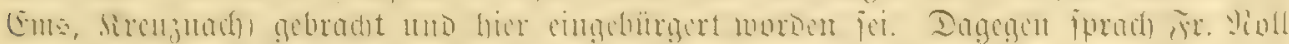
Dic

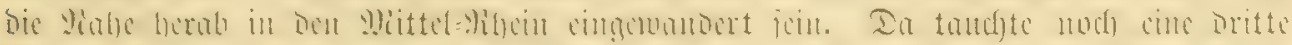

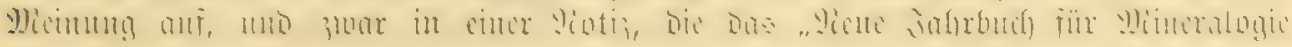




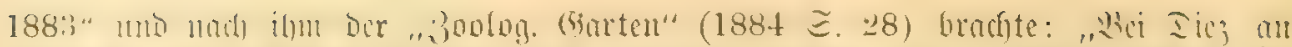

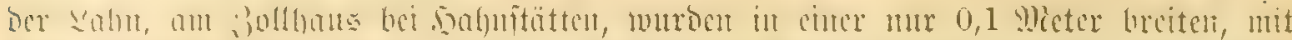

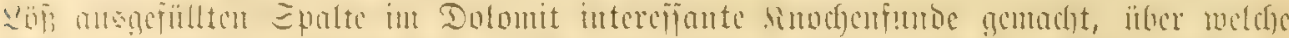

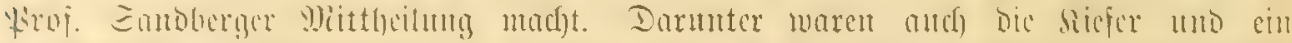

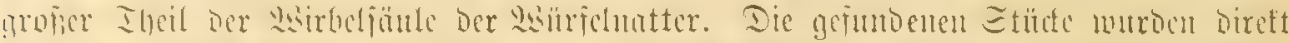

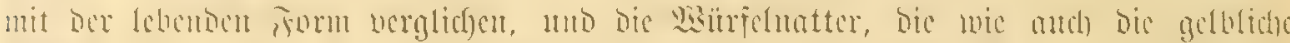

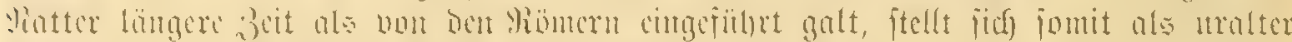

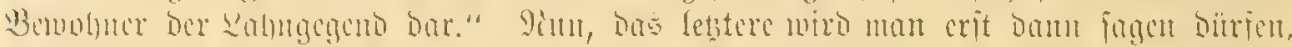

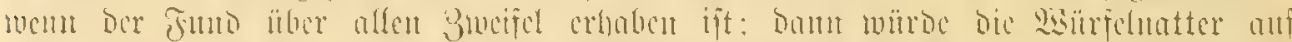

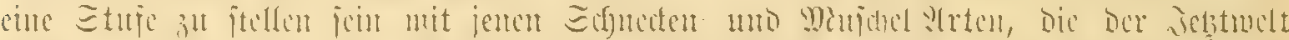

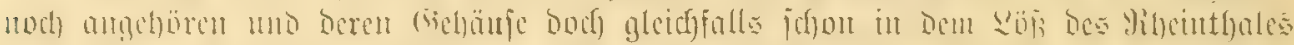

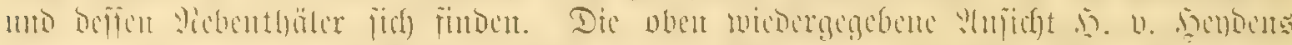

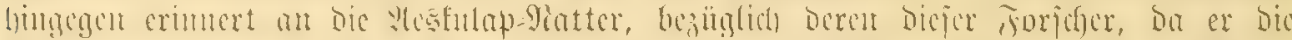

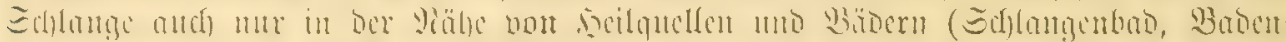

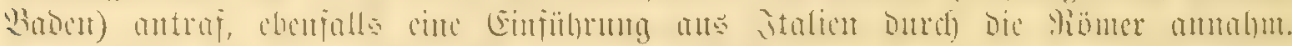

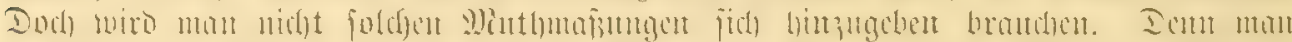

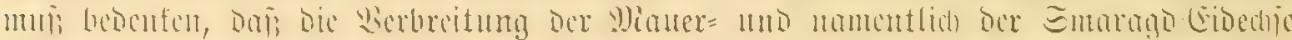

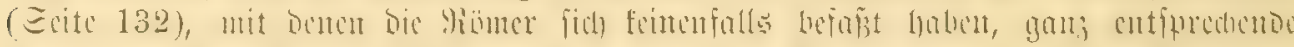

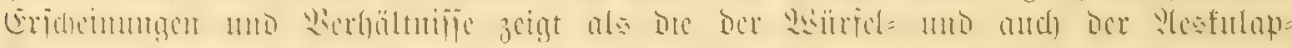

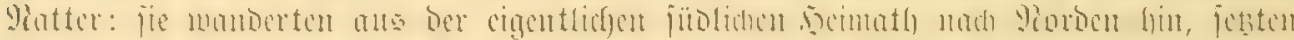

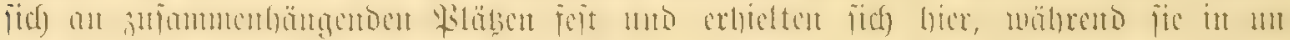

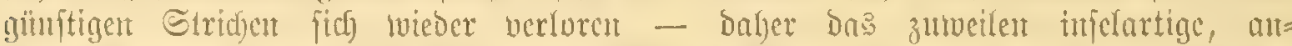

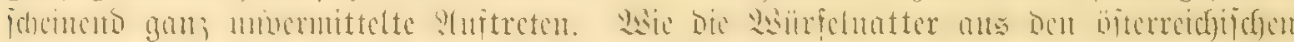

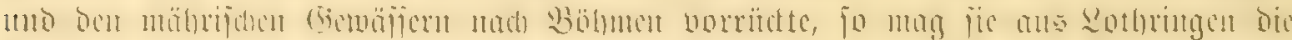

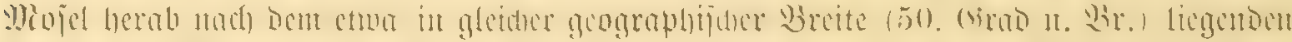

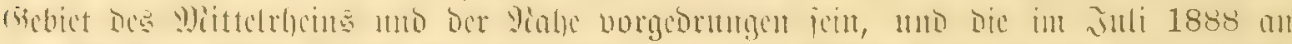

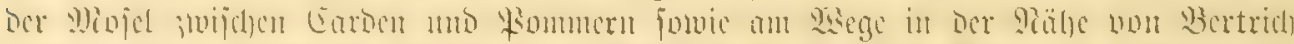

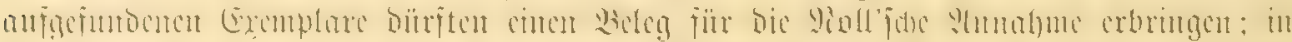

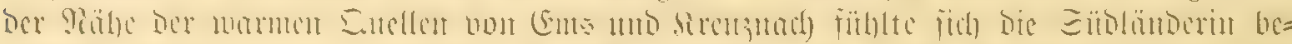

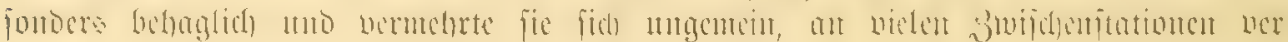

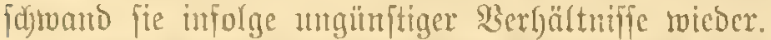

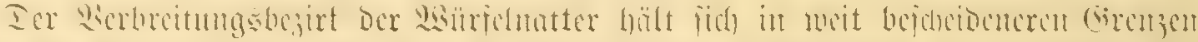

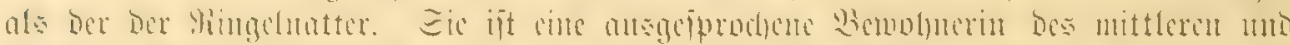

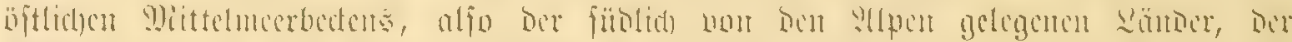
balfons)

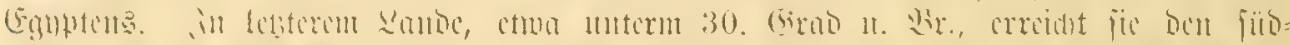

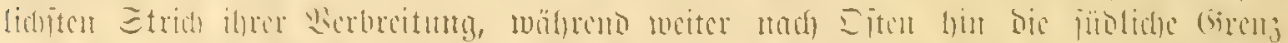

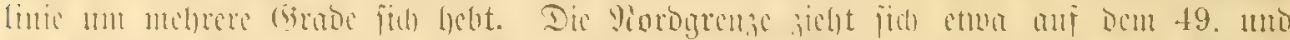

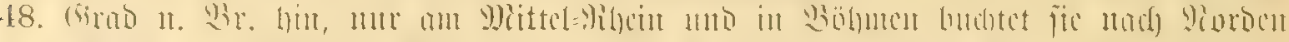

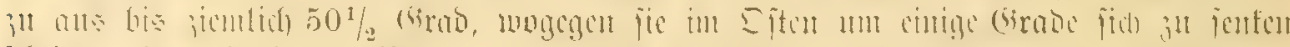

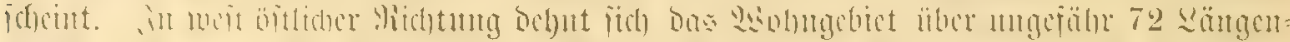

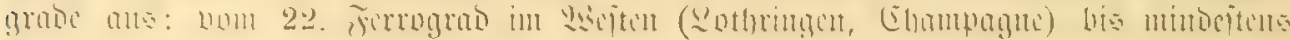
3um 94. Girad in Diten (Turfeftan).

ษแ⿰氵)

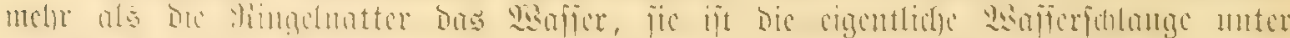

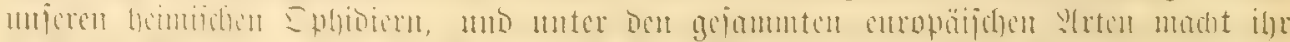

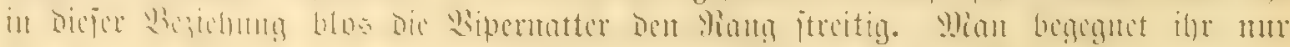

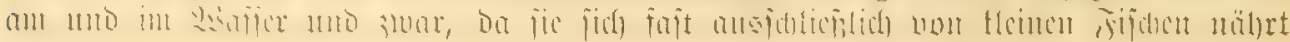




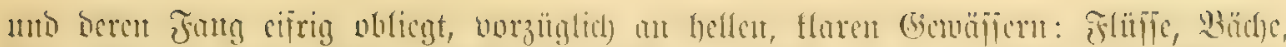

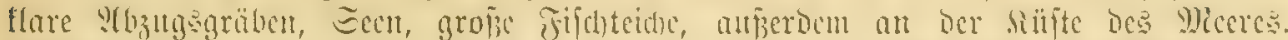

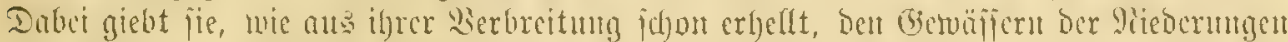

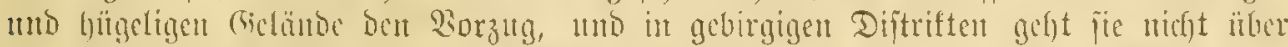

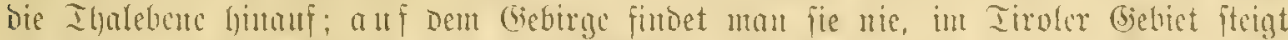

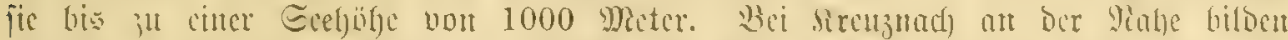

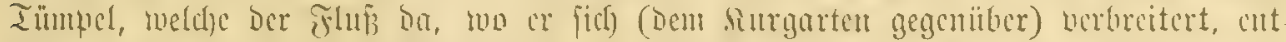

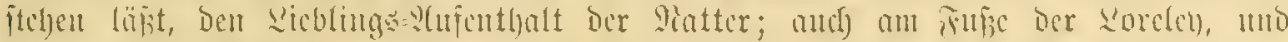

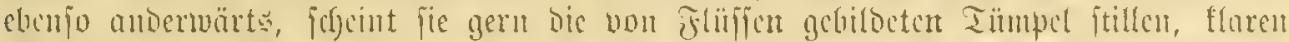

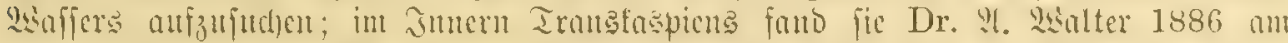

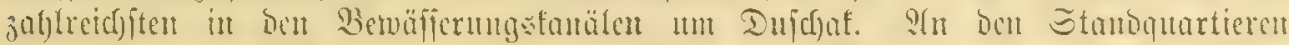

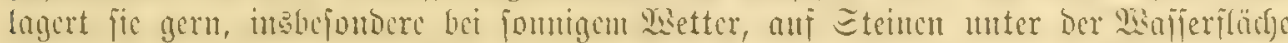

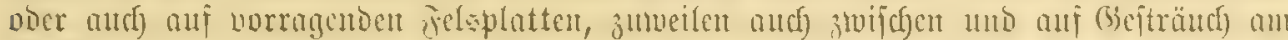

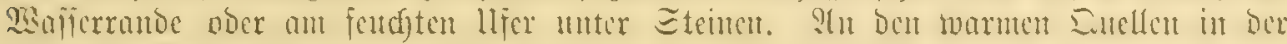

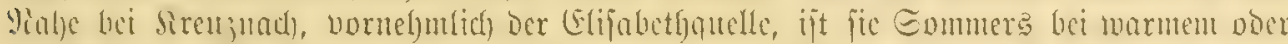

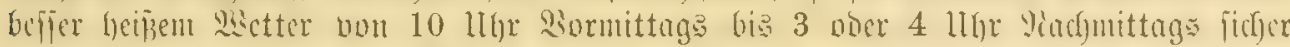

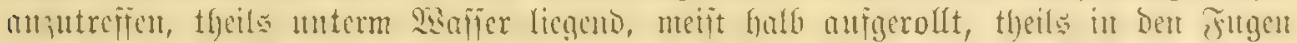
ber zur llferbefifigung aufenander gelegten Eteinc. ie nad ber switterung ver

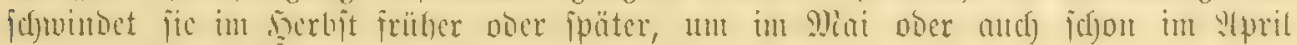

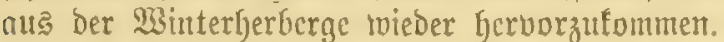

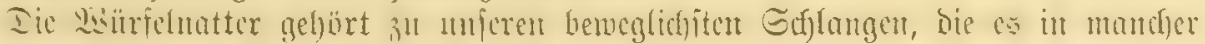

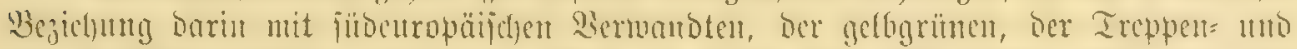

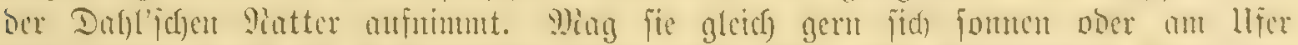

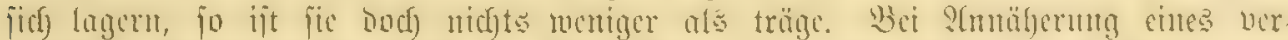

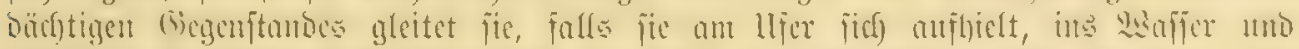

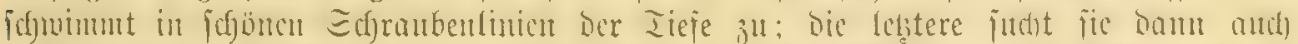

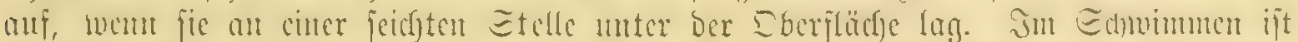

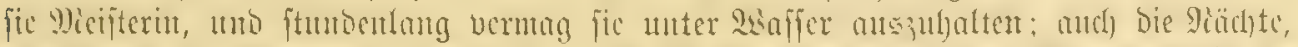

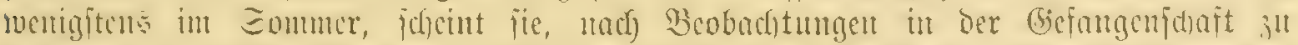

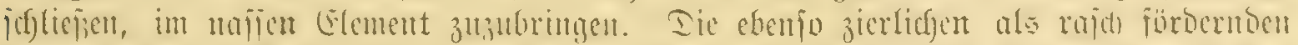

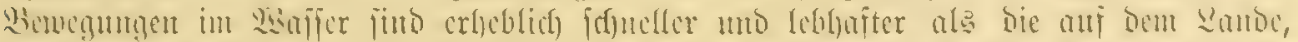

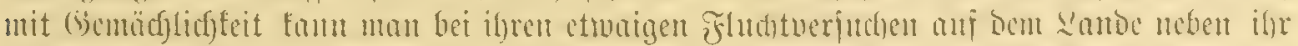

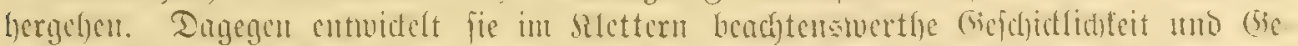

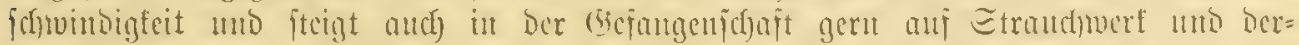

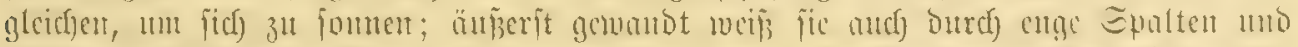

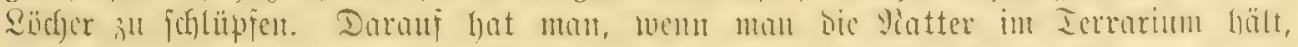

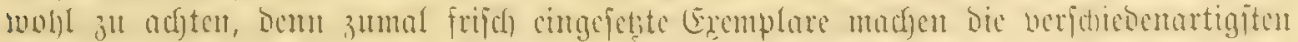

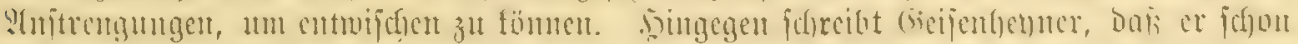

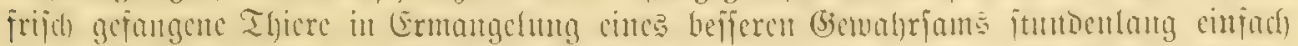

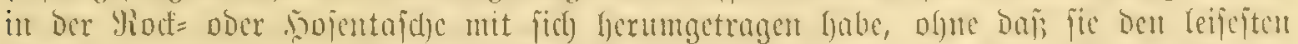

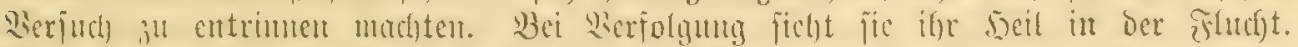

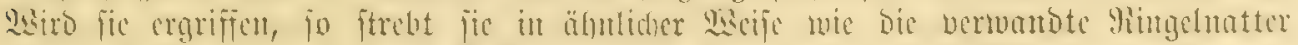

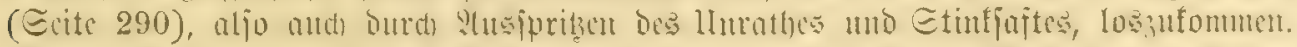

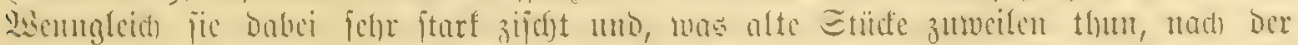

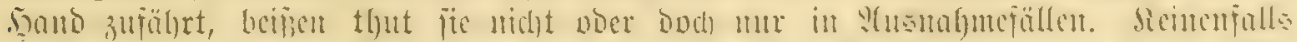

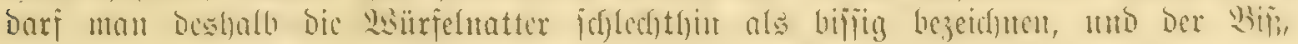

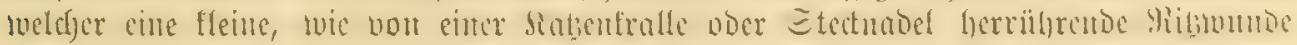

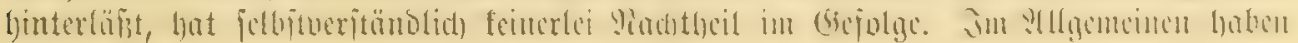




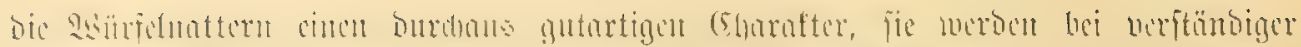

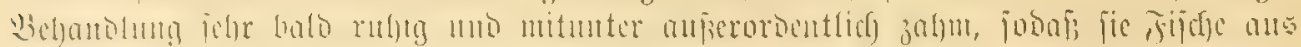
ber Jand Des Pfflegers nefmutr.

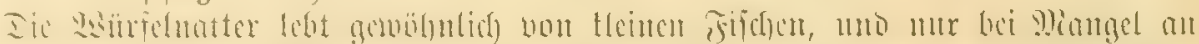

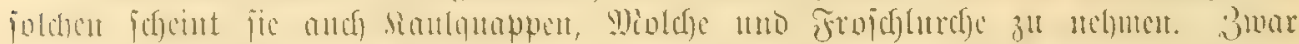

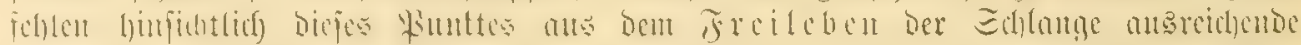

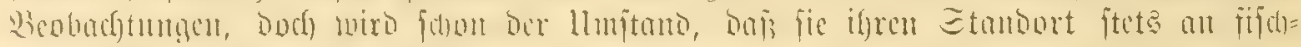

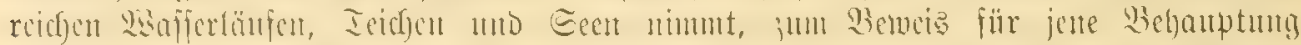

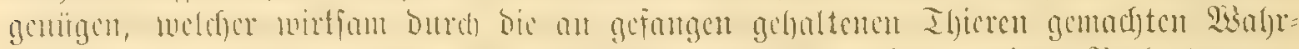

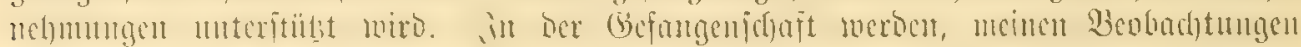

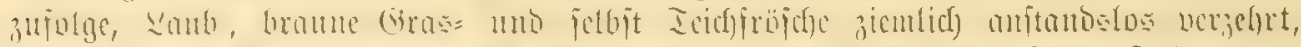

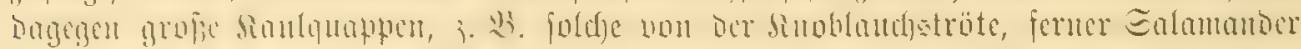

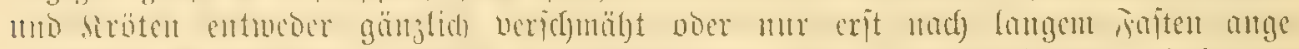

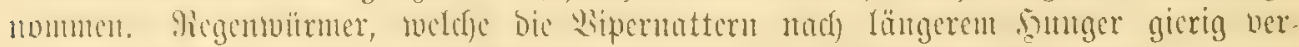

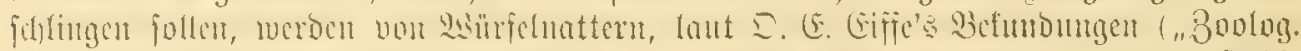

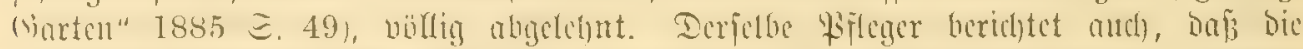

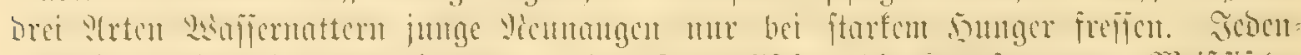

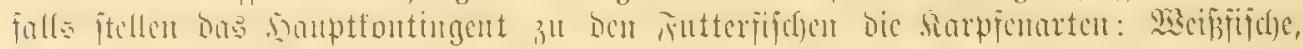

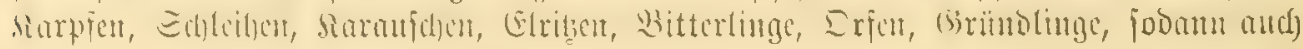
Échmerlcu, Sianlföpfe, jumge ?ale ut. a.

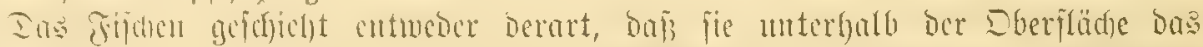

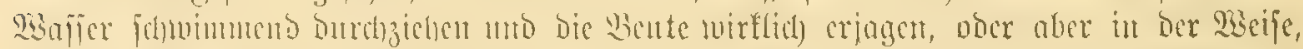

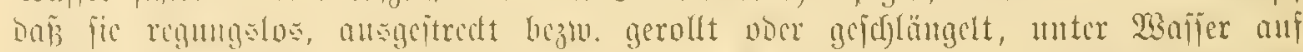

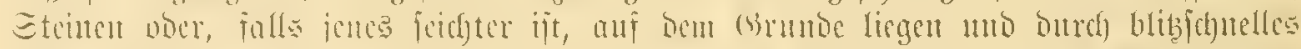

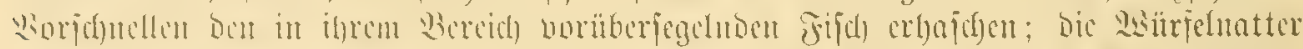

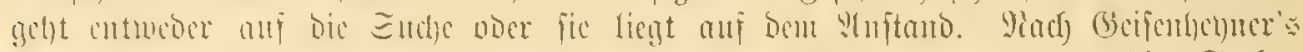

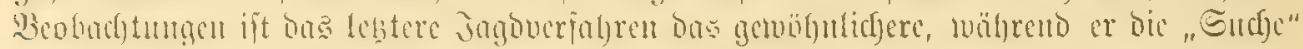

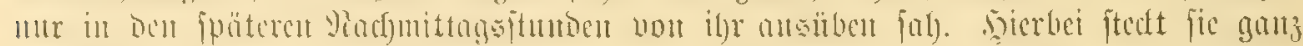

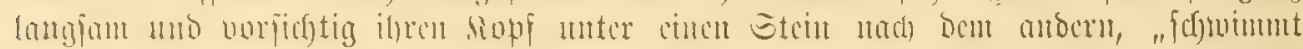

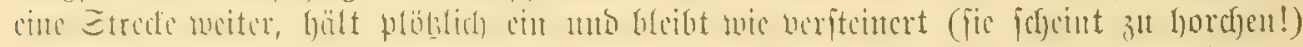

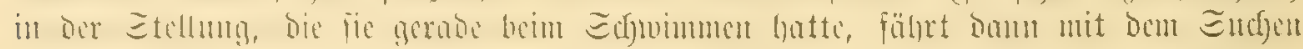

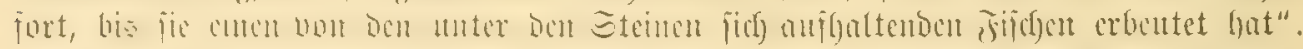

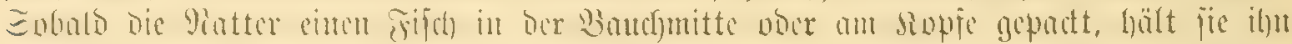

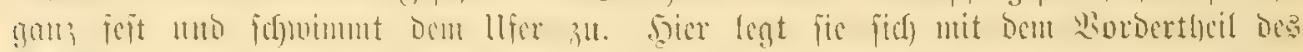

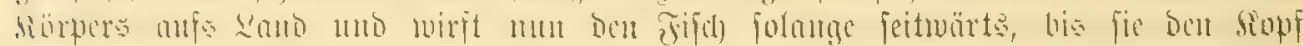

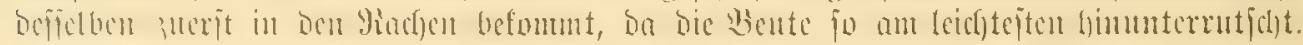

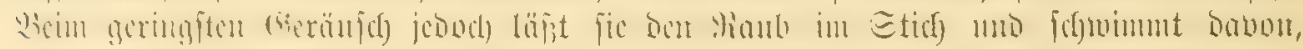

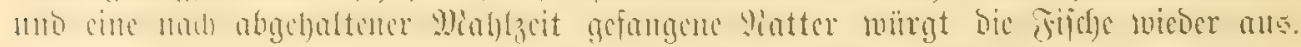

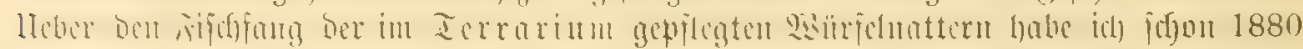

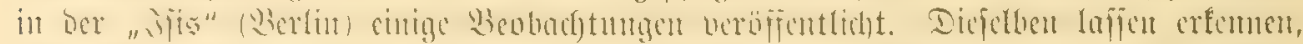

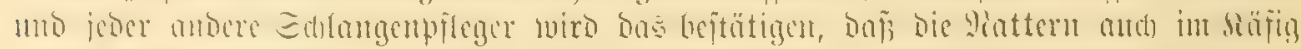

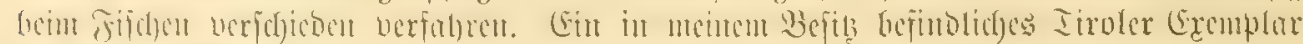

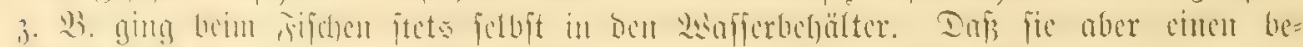

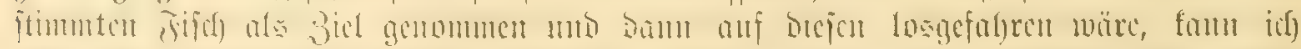

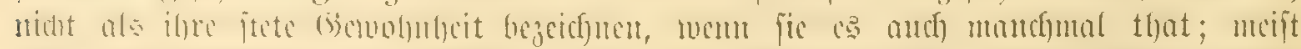

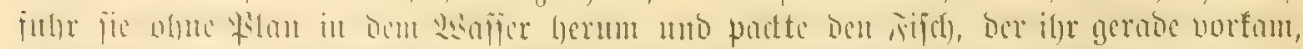

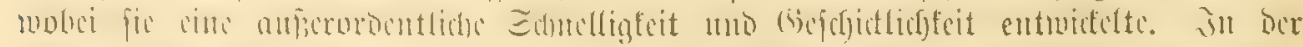

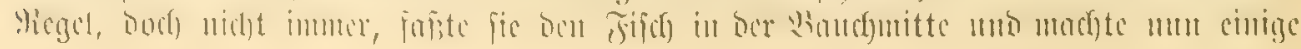




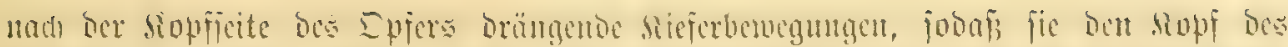

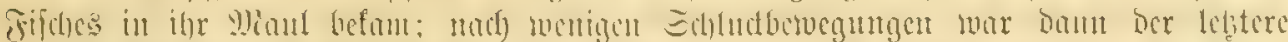

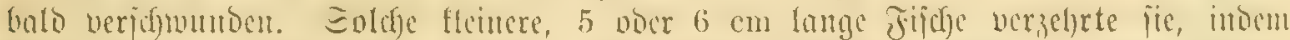

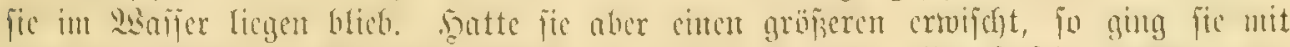

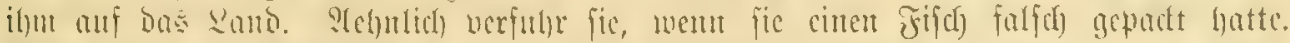

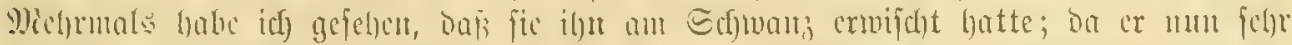

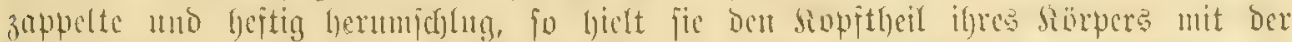

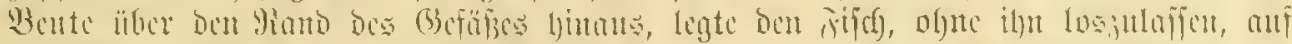

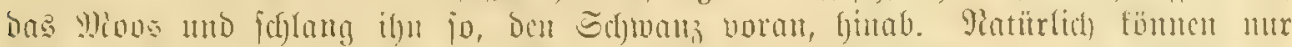

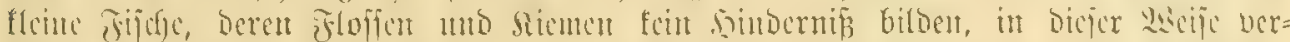

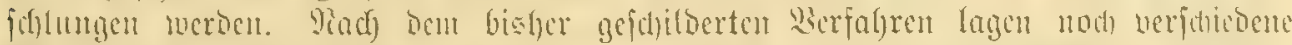

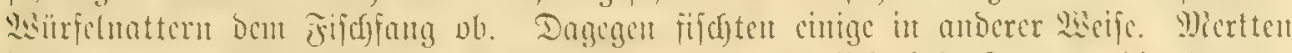

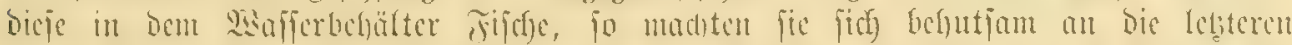

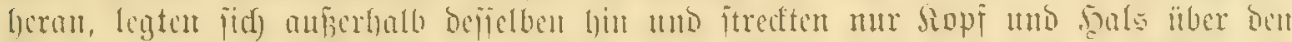

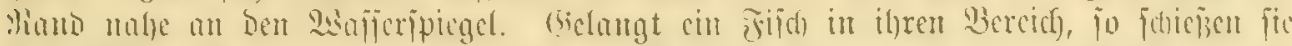

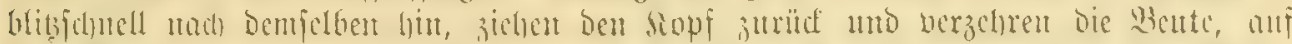

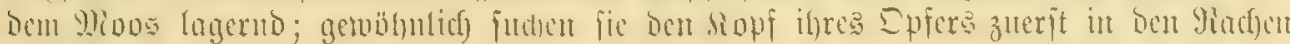

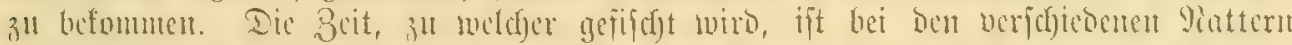

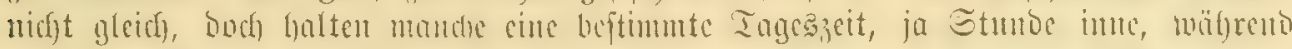

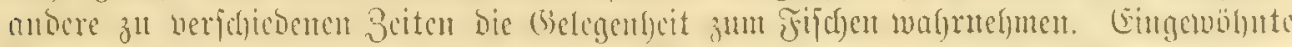

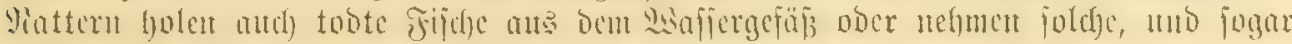

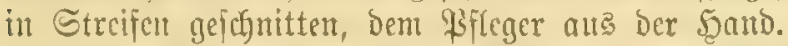

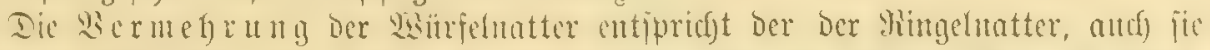

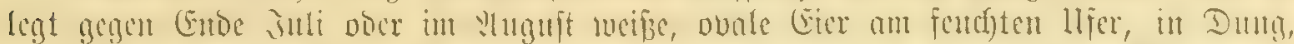

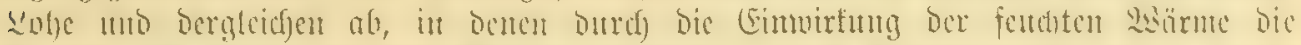

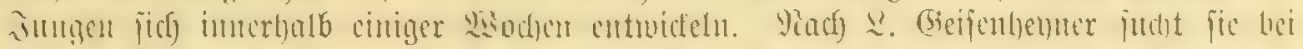

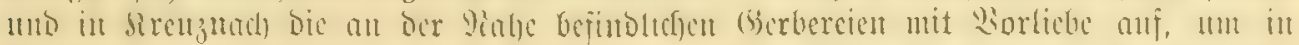

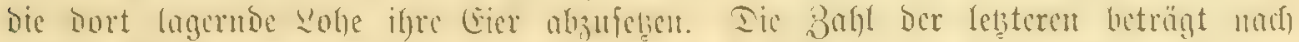

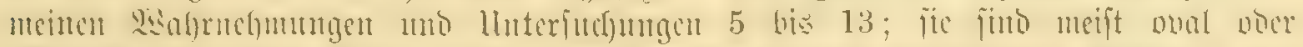

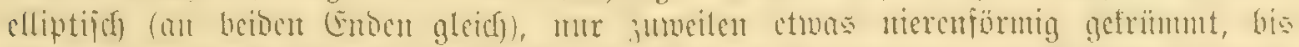

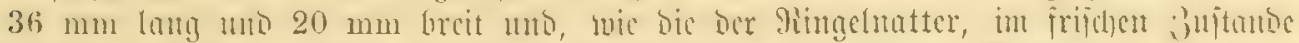

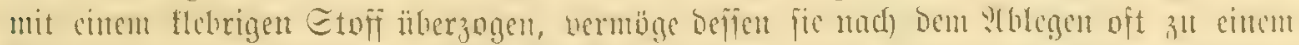

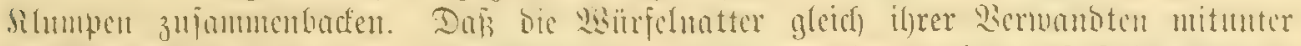

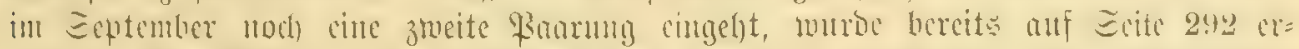

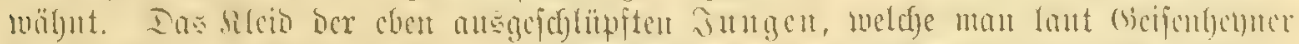

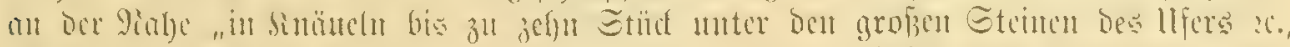

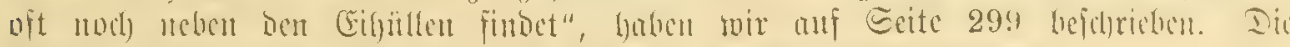

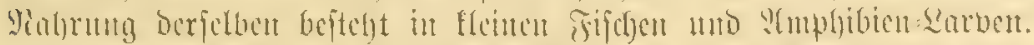

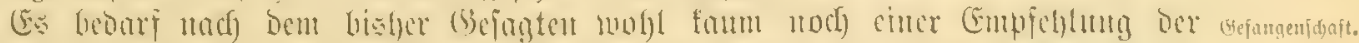

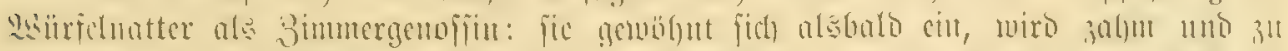

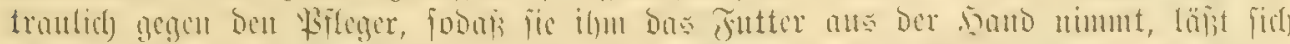

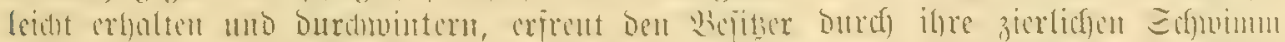

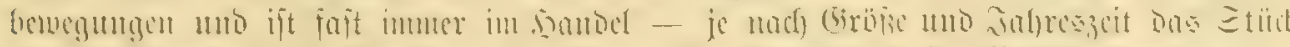

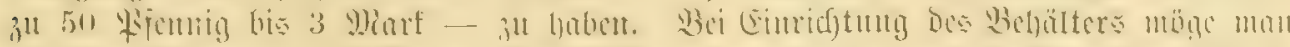

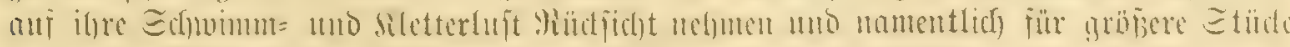

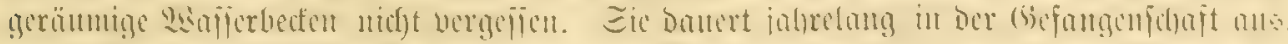

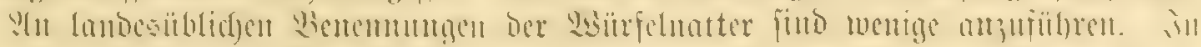

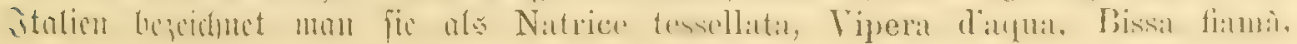




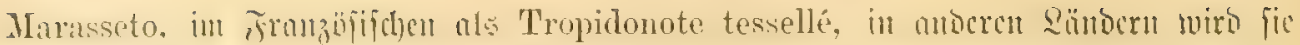
mit ber giutgchuatter zulfanmengeworfor.

Coronella tessellata, Laurenti 1768. - Coluber liydrus, Pallas 1771. Col. tessellatus, Bomet. 1789. - Col. hydrophilus, Limbeter 1791. - Natrix tessellatus et N. Hydrus, Herem 1820. - Col. gabinus, Metax" 1823. - Col. ripurinus, Bemlist. 1826. - Tropidonotus tessellatus, Wagler 1830. - Col. ponticus, l'ullas 1831. - Trop. hyydrus, T. Tantalus et T. gracilis (juv.). Eir.hwald 1831. - Col. hydrus, pontius et Col. griseus, Ducigubsky 1832. - Col. scuttatus (part.), hydrus et reticulatus, llinitriix 1832. - Natrix gabina et N. tessellata, Bonmurte 1832. - Trop. viperinus (partim), Schlegel 1837; Inum. Bitron 1854. - Col. (Trop.) elaphoides, Broult 1838. - Trop. scutatus var. elaphoides, Eichw. 1841.

\section{Gattung: Eanonatter. Coluber, $L$.}

Irörperfappen in 19 bis 27 Eängstihen geftellt, Glatt oder geficlt, mit End=

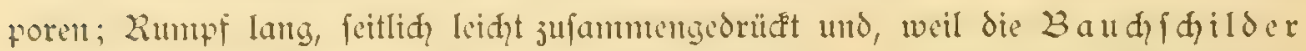
feitlid immer winfelig anfoarts gebogen, jederfeits cine mehr oder wentger

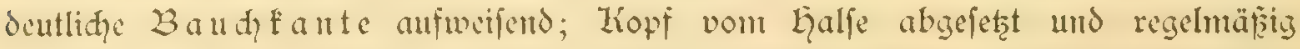
befdildert; 2husen mäpis grof mit runder Pupille; mihrere Sḑläfuldilder; 12 bis 22 gleiḑlange Dberfiefergähnte; Llnterfieferjähne gleidgftarł.

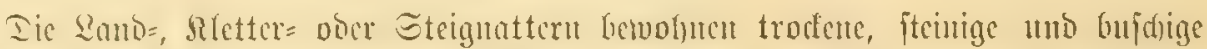

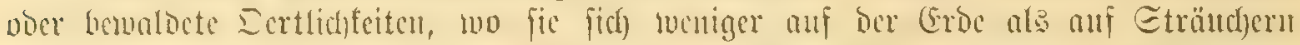

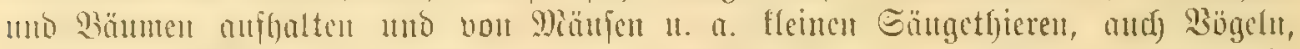

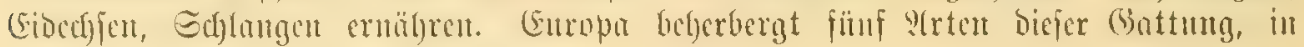
Deutfdyland tritt mur bie folgende auf.

\section{9ret: 2resfulap=2ratter. Coluber Aesculapii, Host. 2ubbitsung: Tajel VIII Tir. 1.}

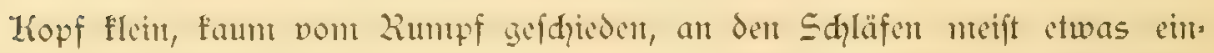

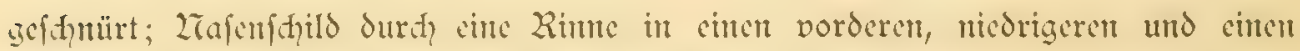
hintern, höharen Theil gefdieden; 1 Jilgelfhild, 1 vorderes und 2 hintere 2lugen=

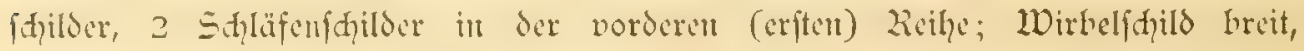
bifonders mah vorn hin; 8 Dberlippenfifilder, das 4. und 5. untern 2uge ftehend;

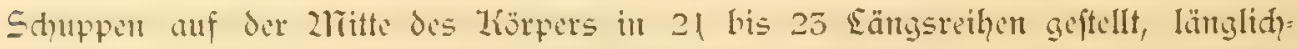

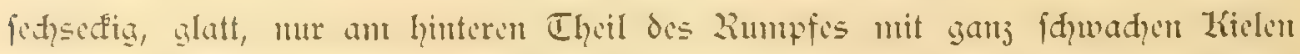

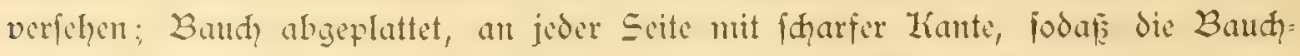
fdyilder an den flunten cinte deutlidge Lintelung nad oben jeigen; Sdywanj lang, fąlanf, unten chonfalls abgeplattet und dishalb faft dreicçis (im Pueridnitt).

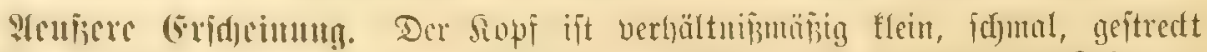

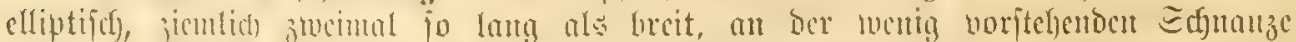

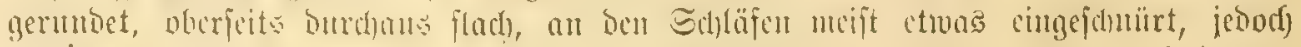

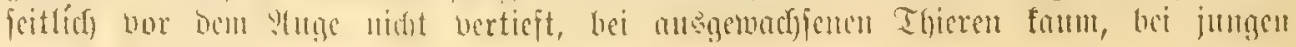




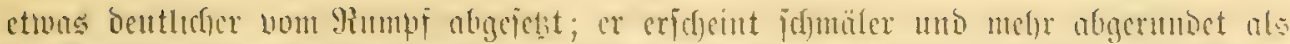

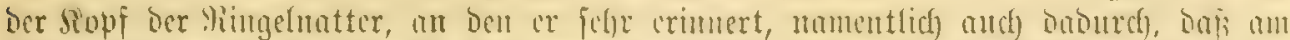

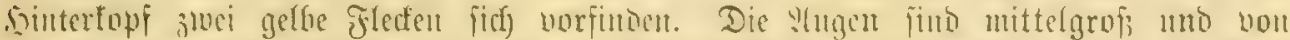

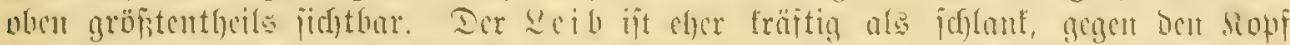

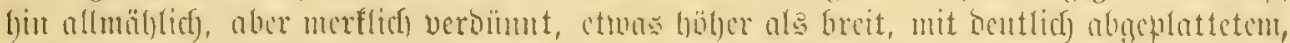

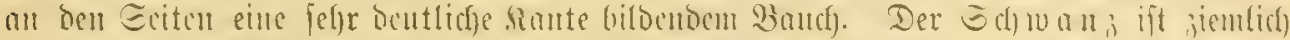

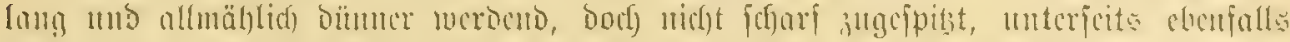

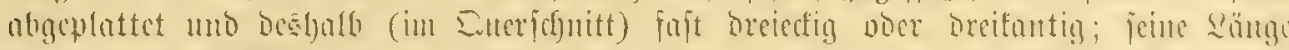

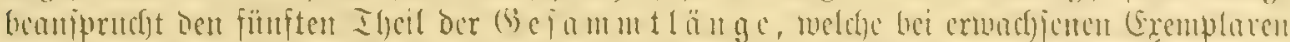

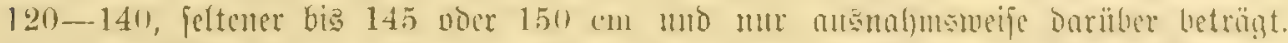
i) Diejen ?\$

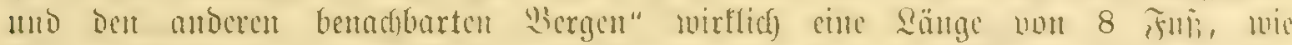

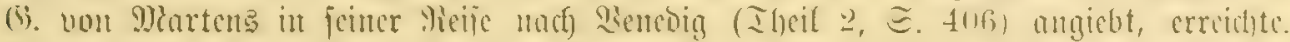
E. be Betta berscidnet in friner Erpetologia delle Provincie Venete. ¿. 2011,

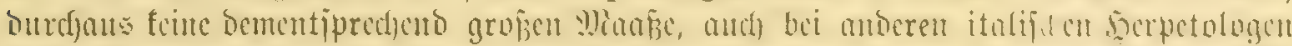

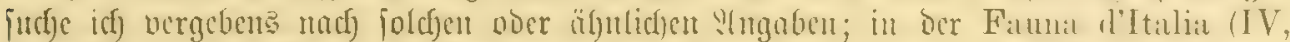

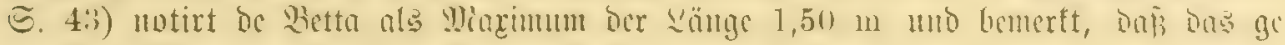
wölynlictie Miaẩ $1-1,20 \mathrm{~m}$ betrage.

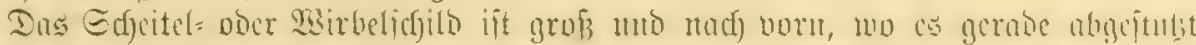

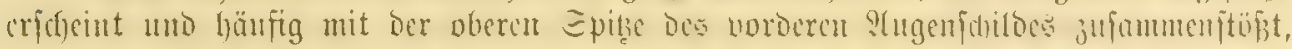

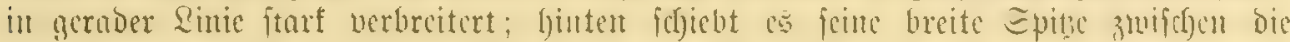
langen, nad) rüctwärte merffich verichmälerten, feitlich aber ein wenig auf bie finterent ?tugenfdjilber berabgebogenen Sinter=

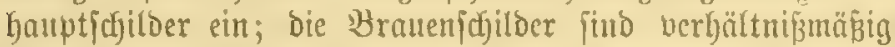

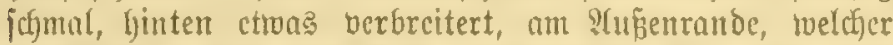

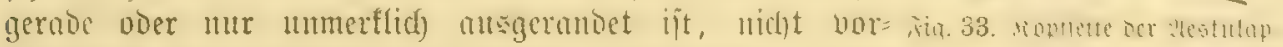
ipringent, bie borderent uno binteren Stirnjdjilder ctras

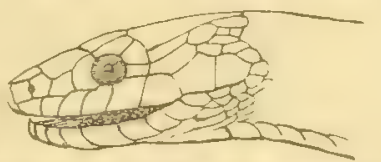

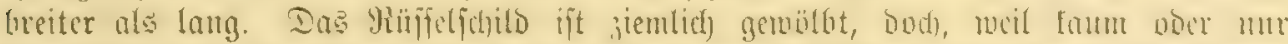

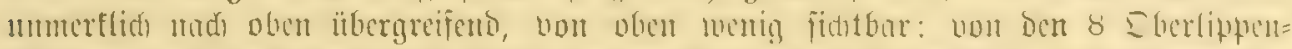

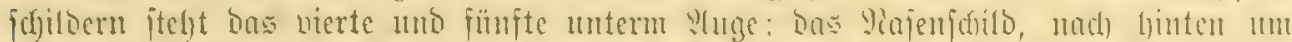

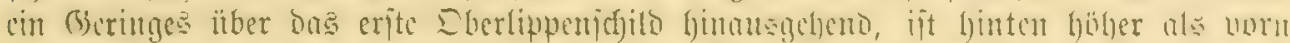

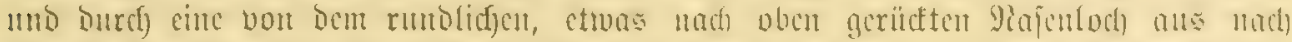

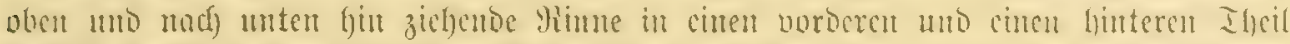

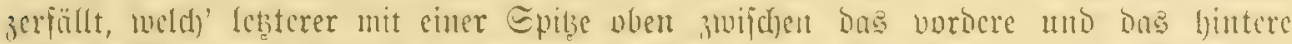

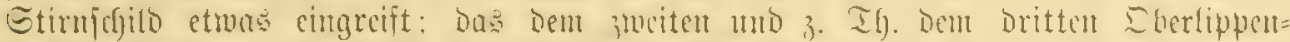

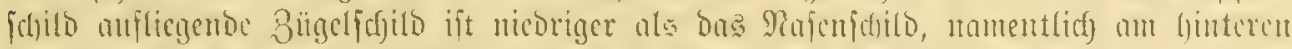

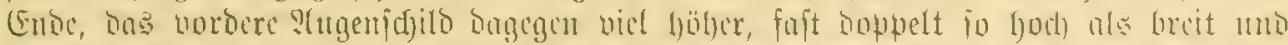

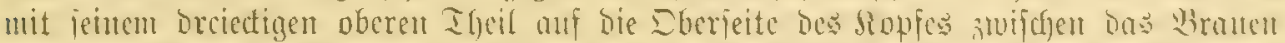

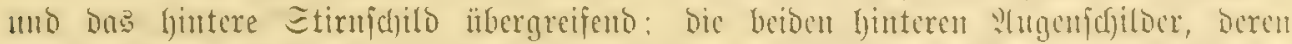

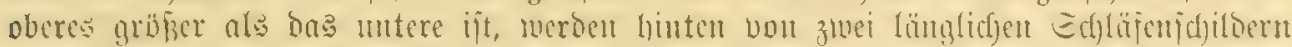

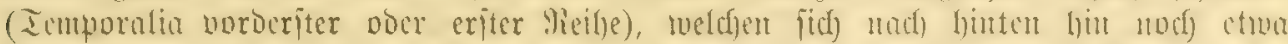

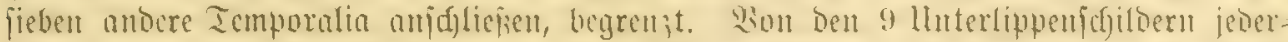

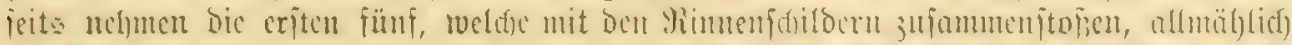

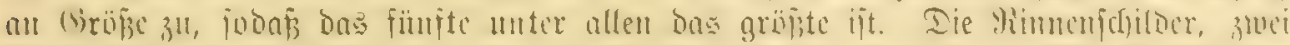

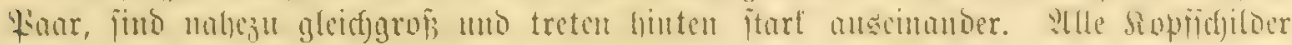
fino glatt.

*) Nlbbiloung ber ropiplatte ケ. ङ. 247. 


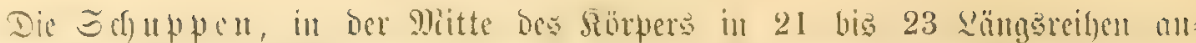

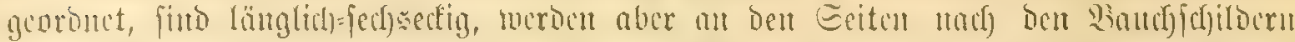

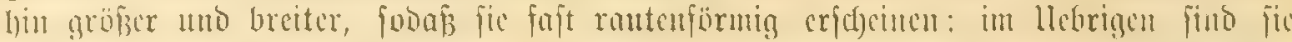

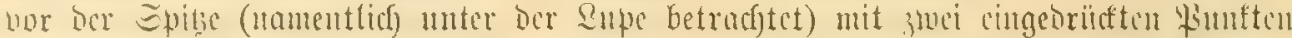

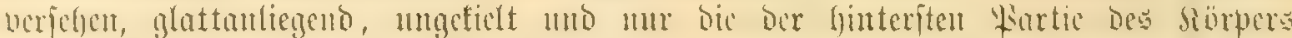

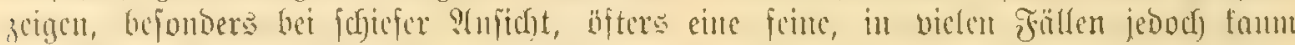
bemerfluare dielung. Dic

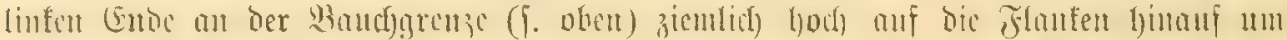

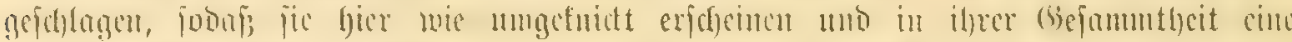

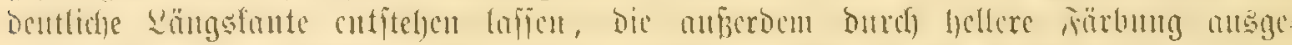

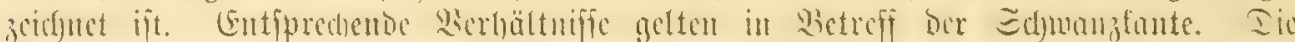

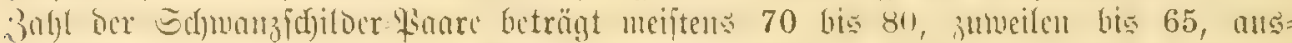

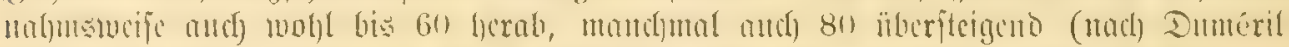

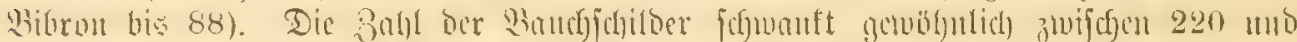

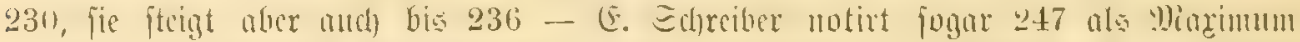

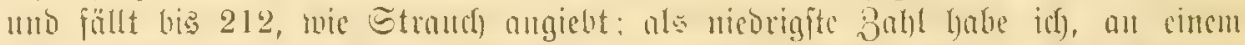

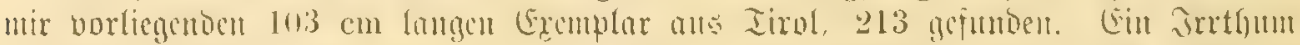

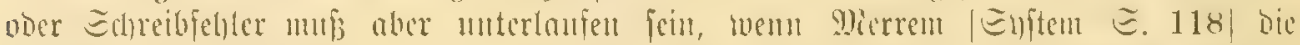

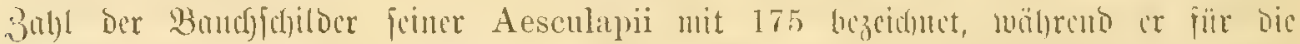

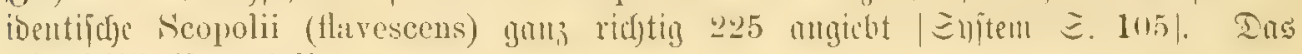
?(itcrictils ift getfocilt.

วิج̈chung.

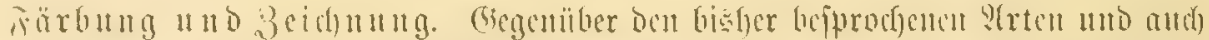

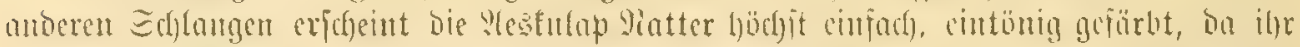

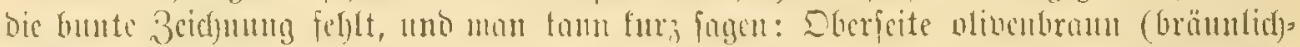

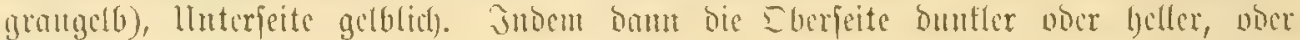

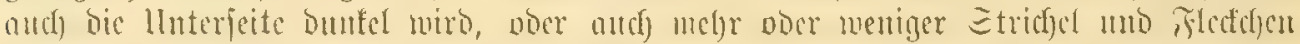

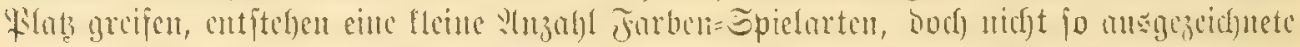

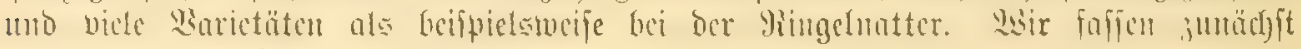
unicocr un alte Thiere

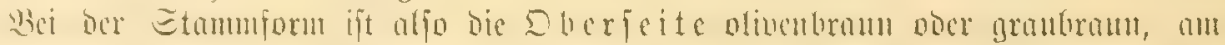

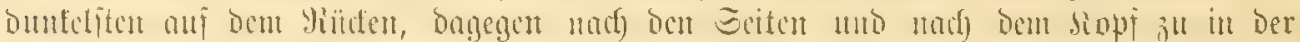

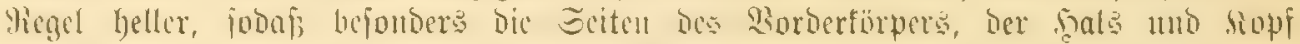

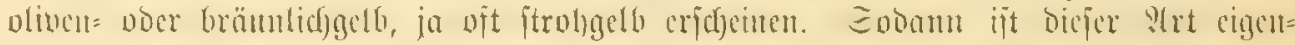

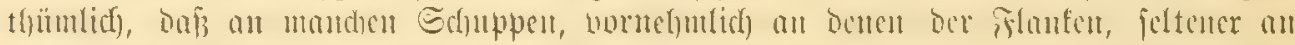

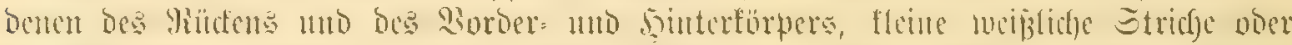

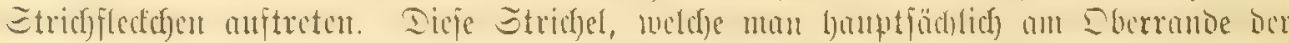

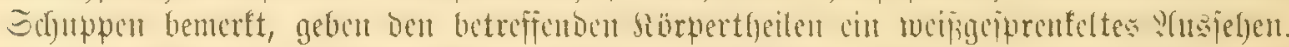

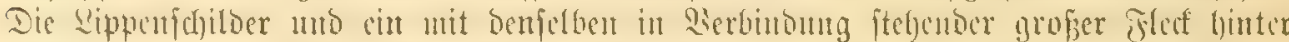

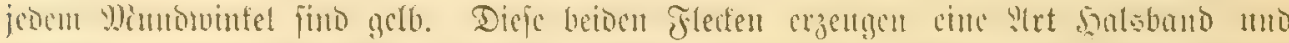

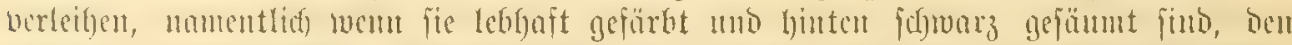

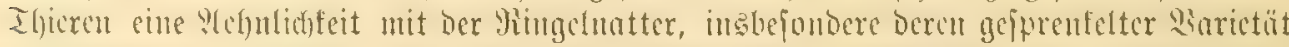

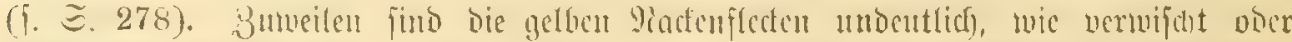

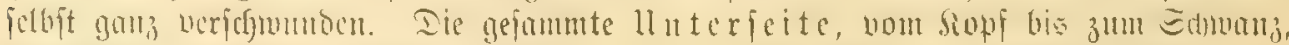

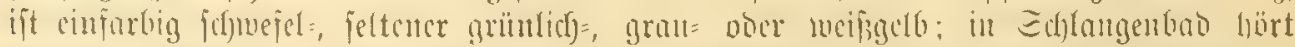

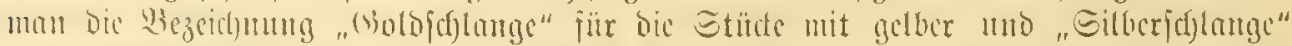

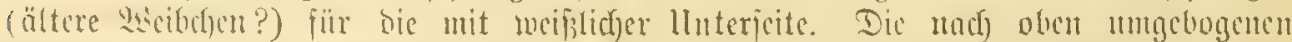

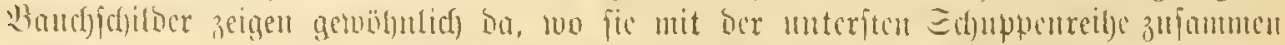

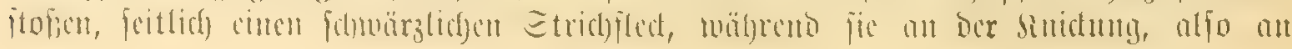




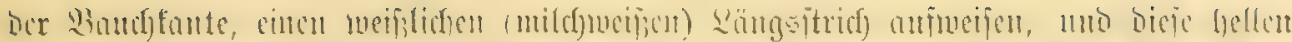

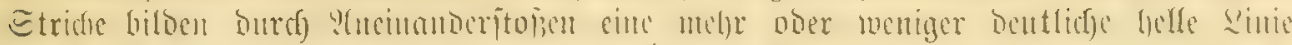

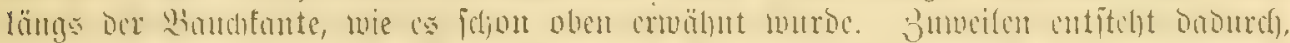

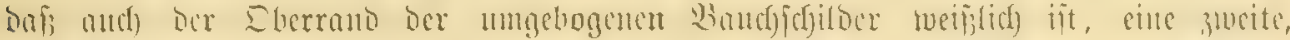

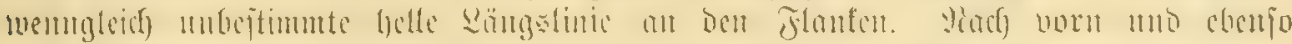

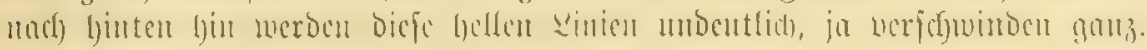

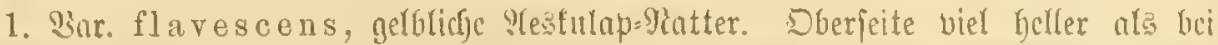

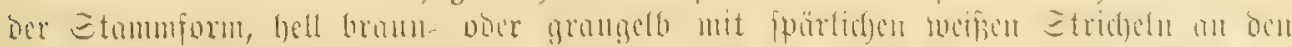

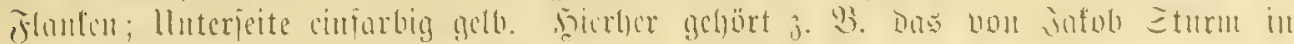
feimer Dentichen Fauna uncl) Soft Dargeitellte Eremplar a.

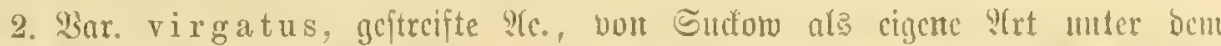

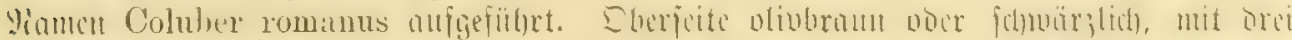

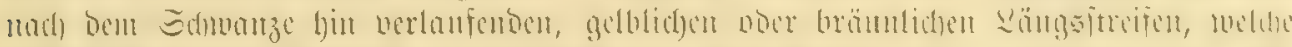

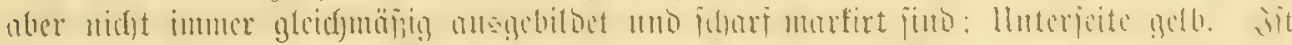

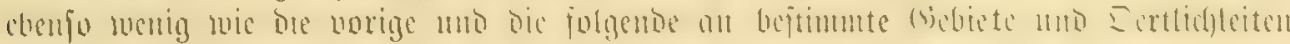
gefundent und fommt, nadj Groblir, 3. 23. nidjt felten bei Bozent wor.

3. 3ar. leprosus, graue 9fe, wou Sbedffein 1802 ate Coluber leprosus

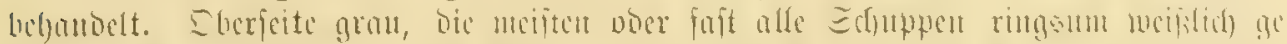

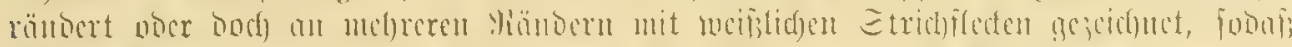

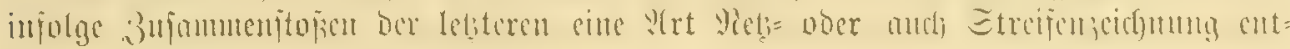
ftegt; lluterieite gelb ober weiplidy.

4. Snr. ventrimaculatus, flecteäudfige 9(e. Son Der Stammform vor=

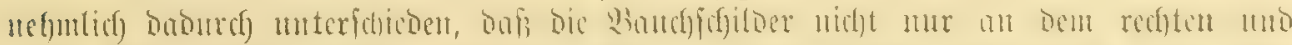

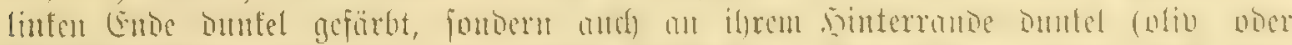

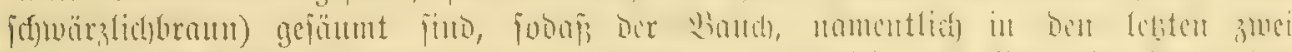

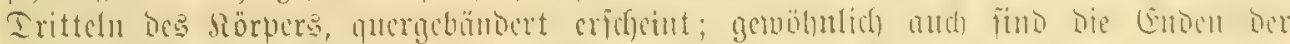

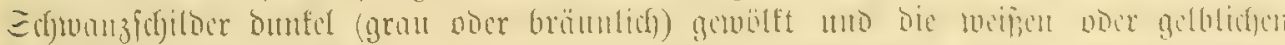

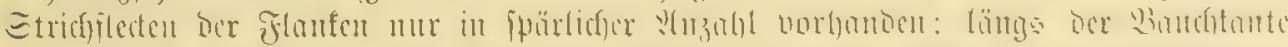

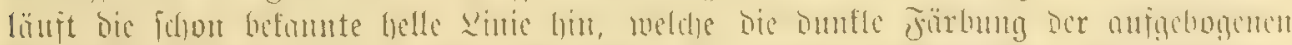

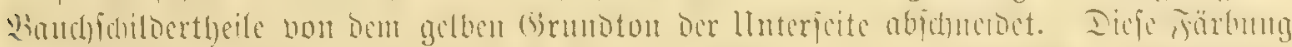

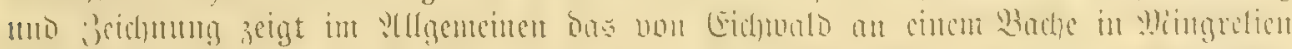

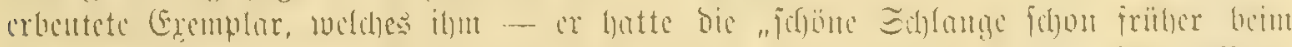

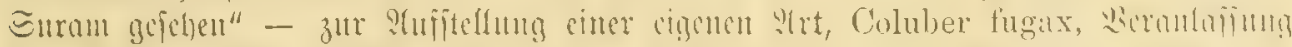

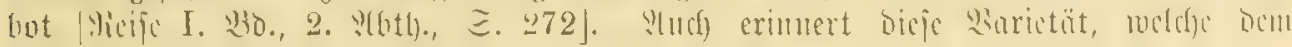

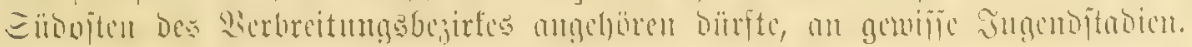

5. Bar. niger, Fitzinger [Mienag. S. 657], julwarze Ste. Entịteft, indem

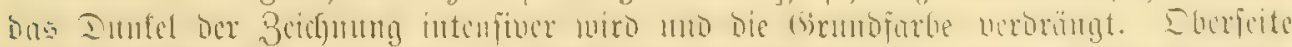

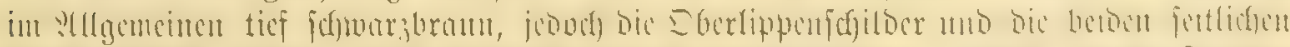

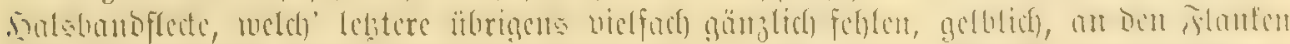

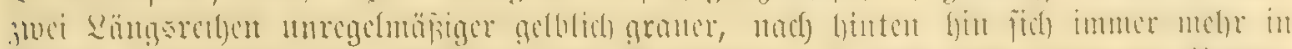

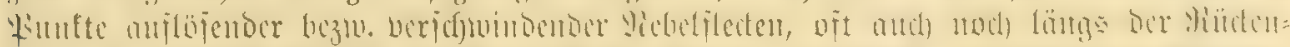

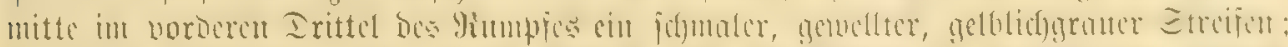

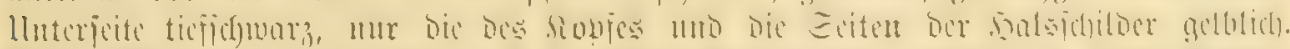

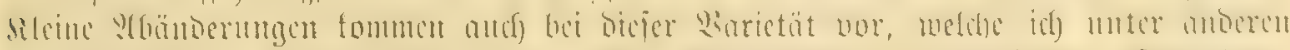

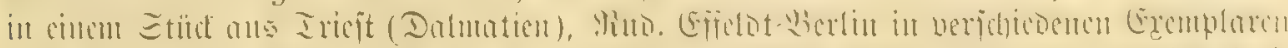

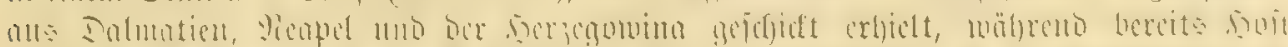

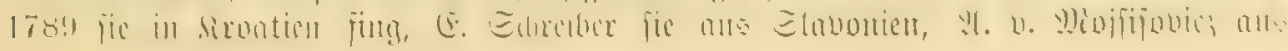




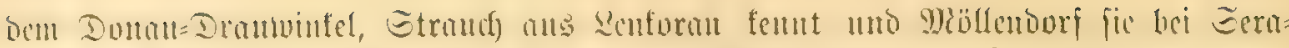

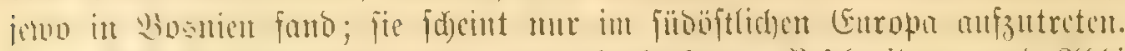

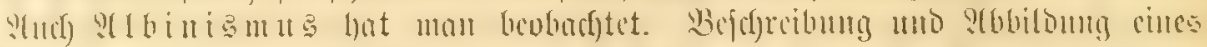

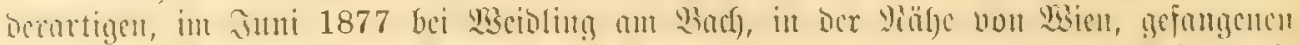

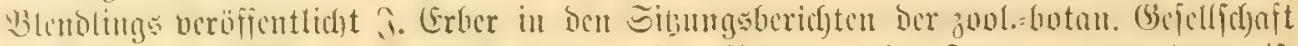

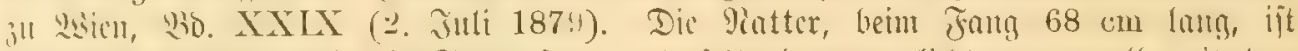

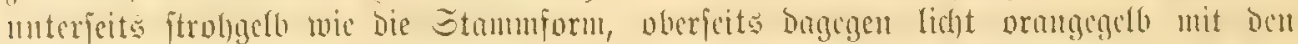

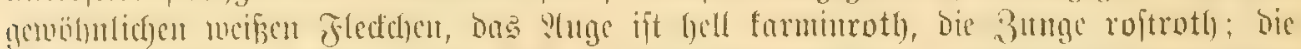

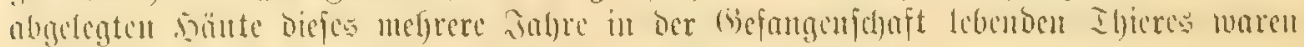
wecit feiter mo zarter als bie normal gefürbter Eremplare.

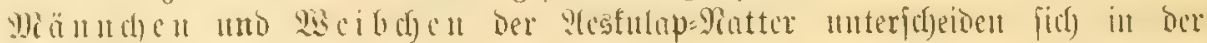
Färbung midjt.

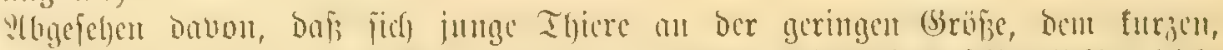

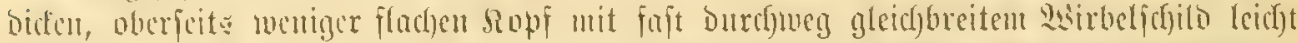

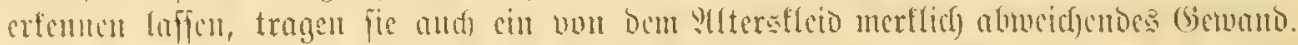

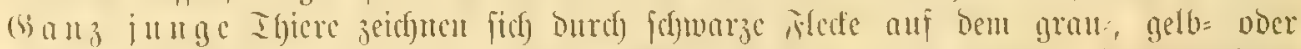

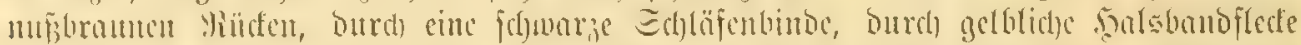

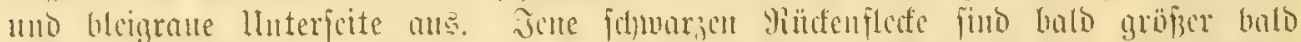

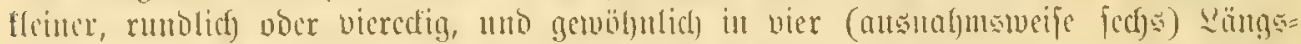

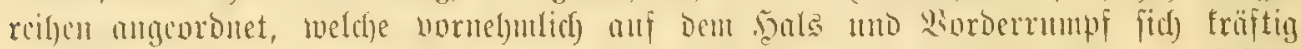

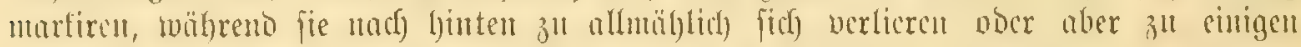

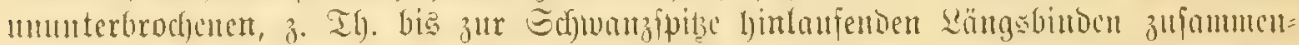
fliefien. Danden zeigt in Der Reget Der Yiütent getbliche noer weise Eprented, her=

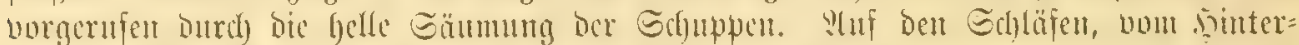

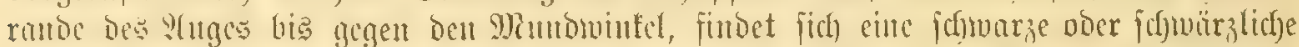

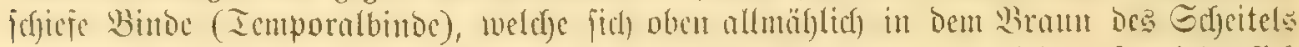

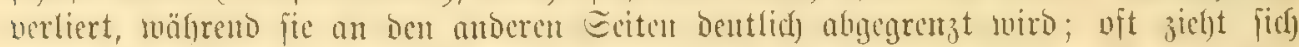

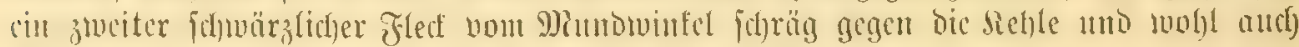

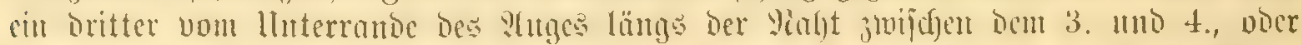

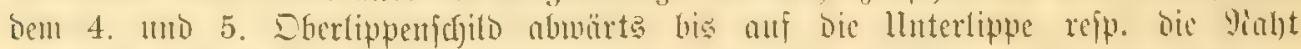

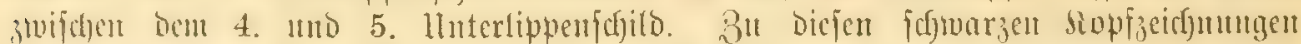

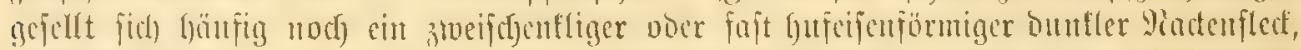

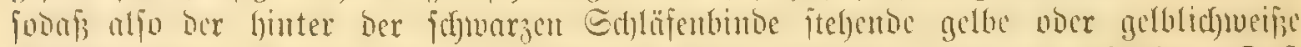

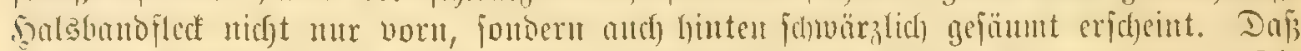
icrartige Ificre an bie Ringelnatter crimern, murbe hercits bervorgeboben. Die

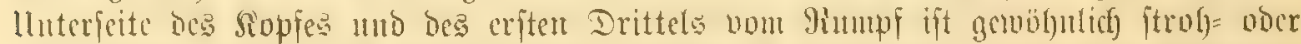
uräunlichgelb, allein nom smeiten Drittel ctwa an ift jie einfarbig grau boer bleifarben,

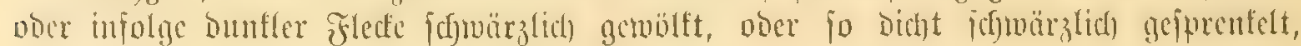

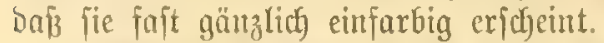

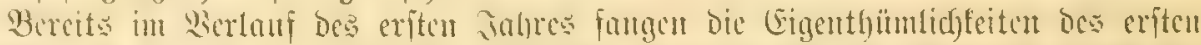

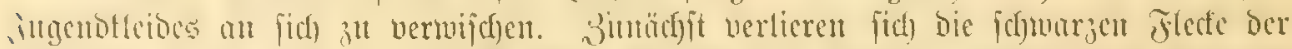

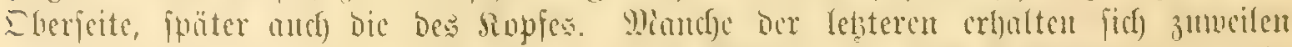

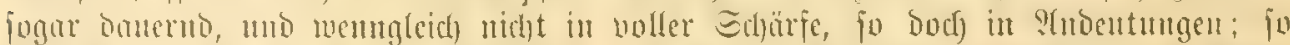

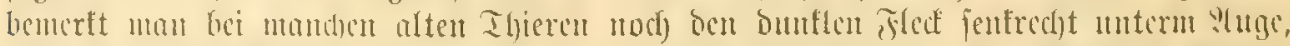

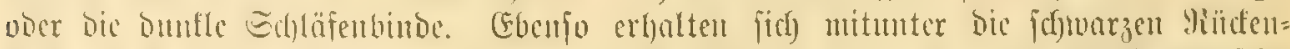

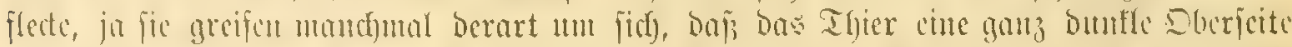

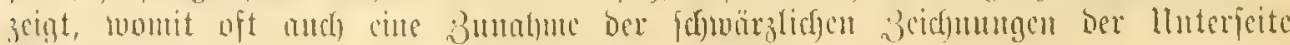
5̧and in sano geht uno baburd) bie Barictät niger cntiteht. 


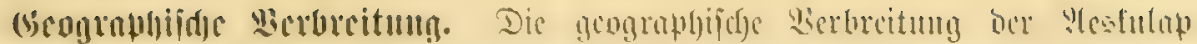

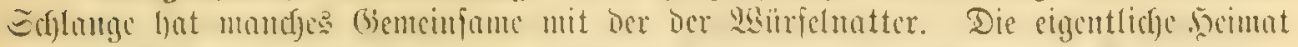

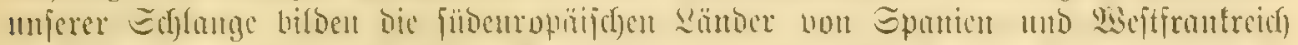

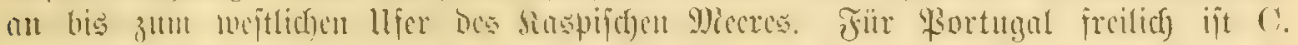

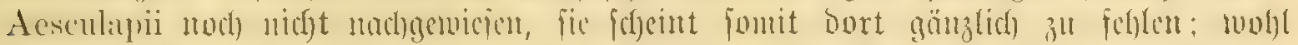

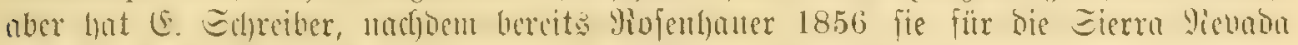

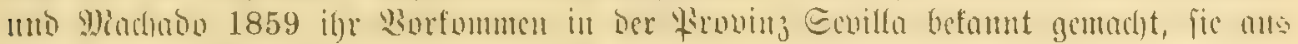

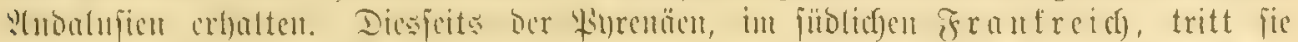

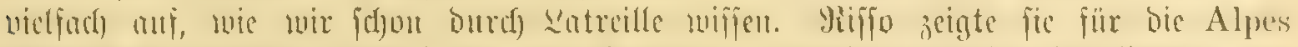

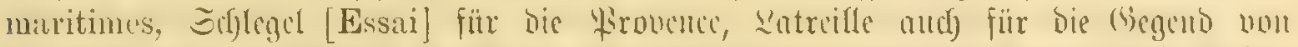

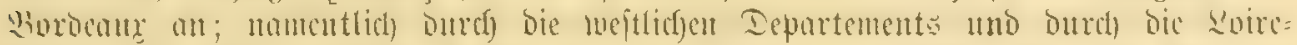
(iichicte (Loire inférieure, Maine et Loire, Vieme, Nière) zieht ficl) ocr virr

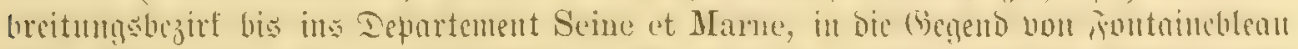

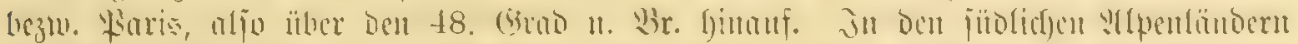

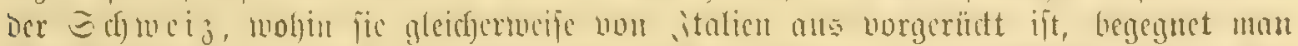

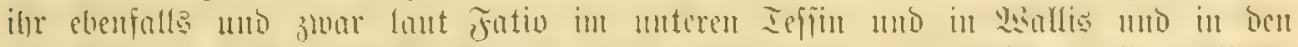
benadbarten Iforla bes

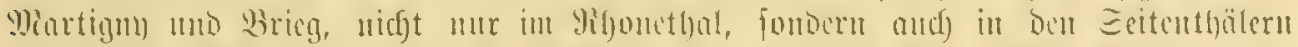

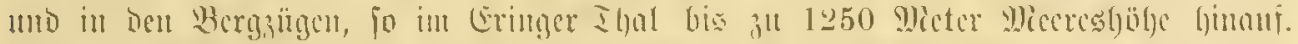

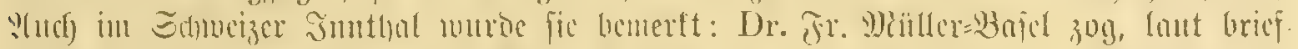

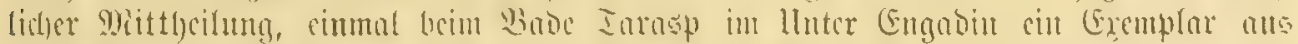

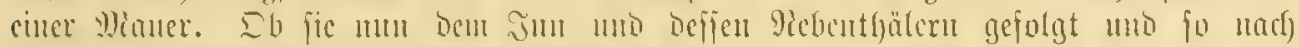

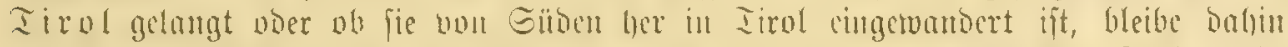

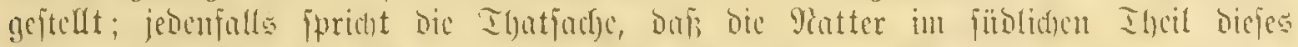

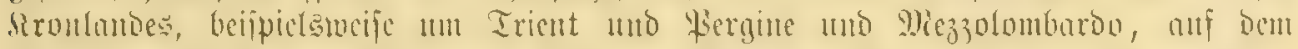

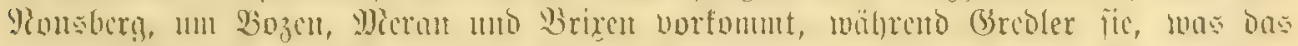

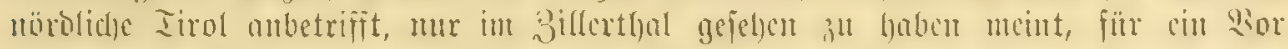

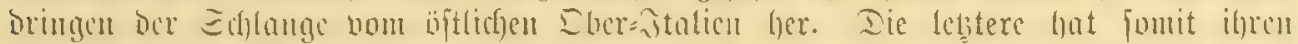

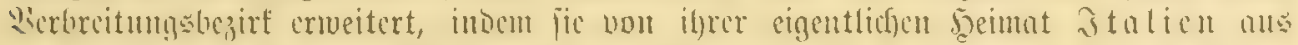

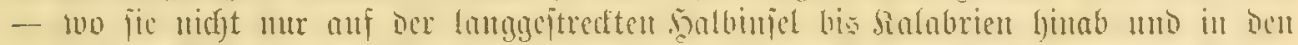

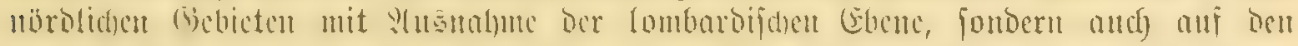

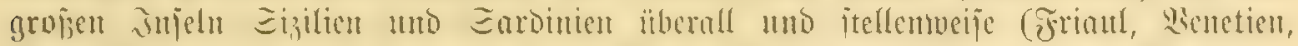

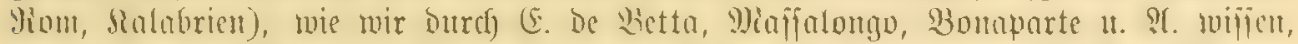

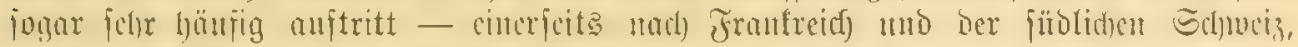

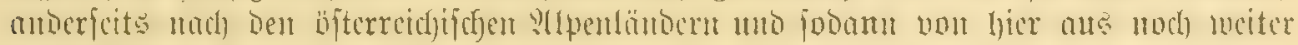
mad) Sioroen und Diten hiu borgeormugen ift, uno man viro nidft umbiu fünncu,

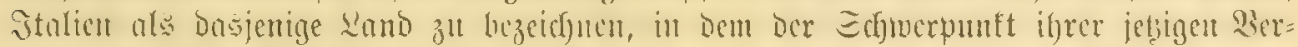

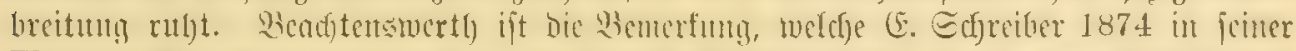

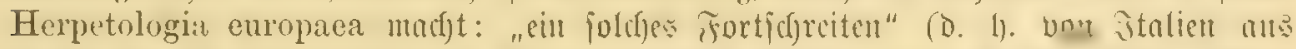

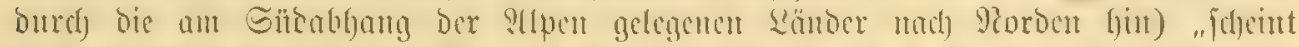

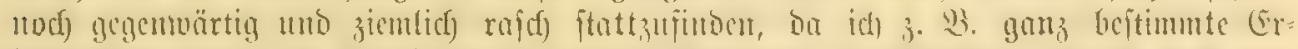

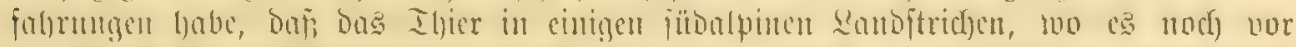

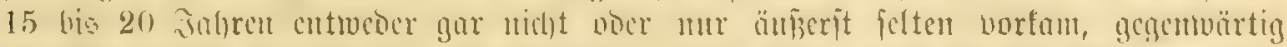

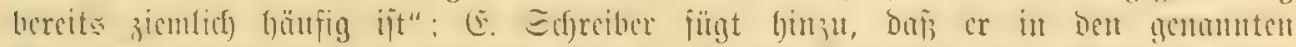

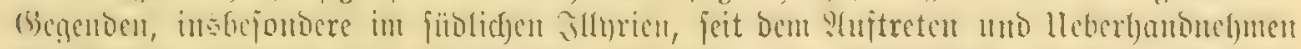

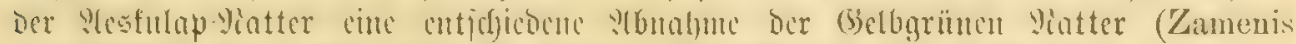

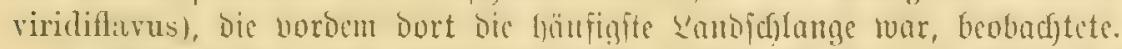

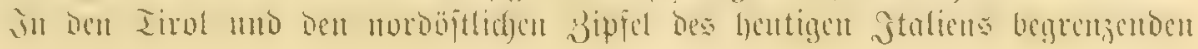




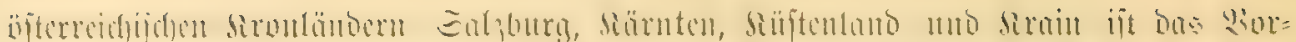

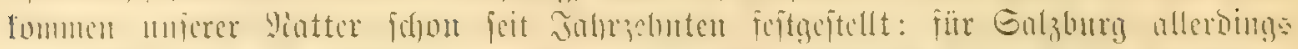

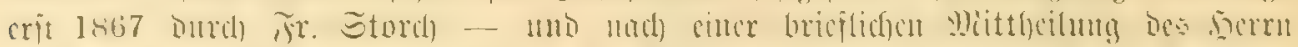

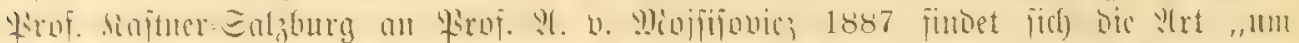

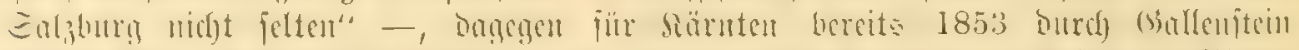

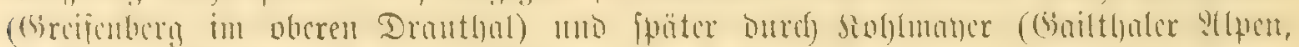

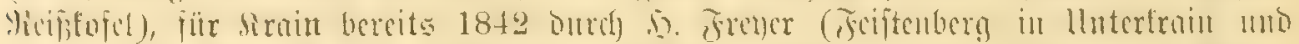

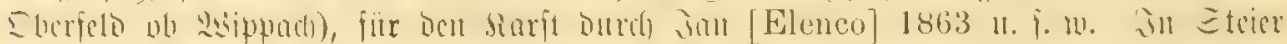

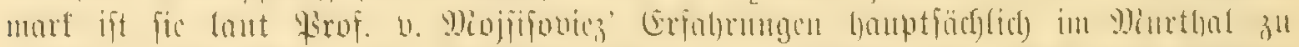

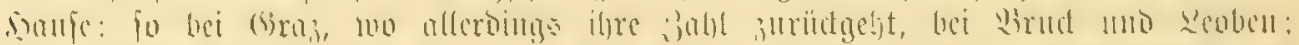

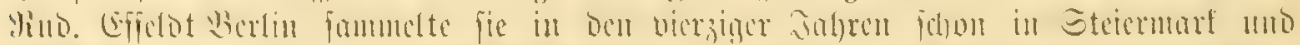

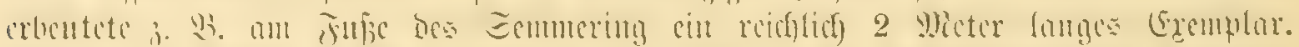

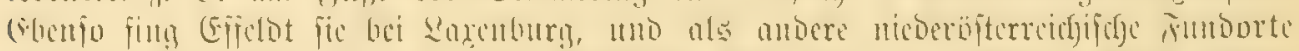

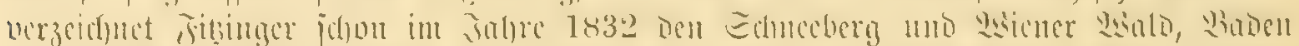

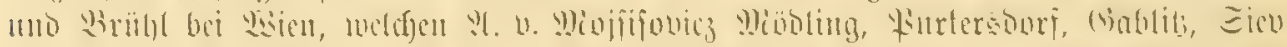

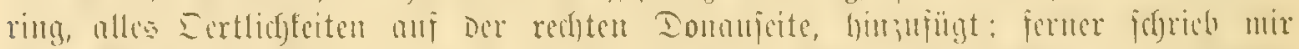

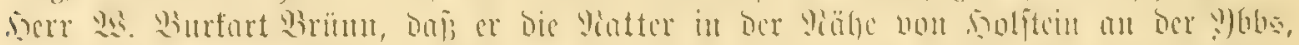

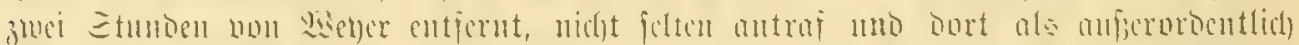

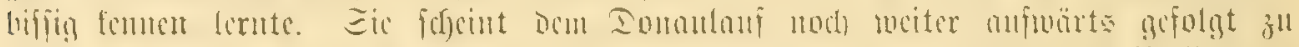

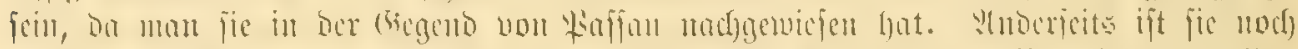

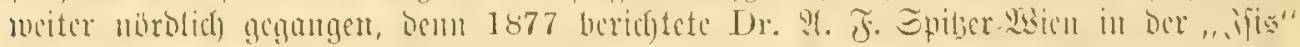

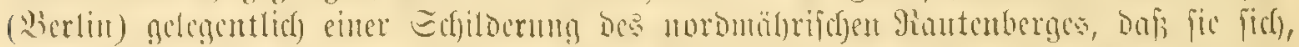

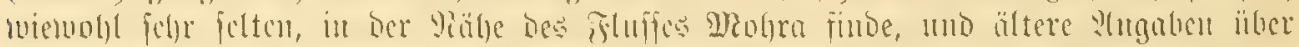

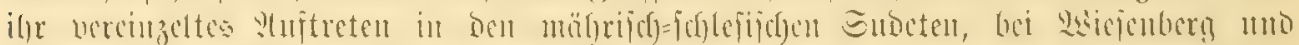

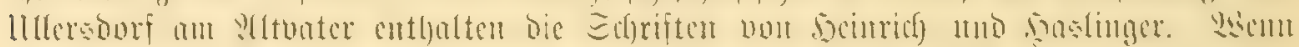

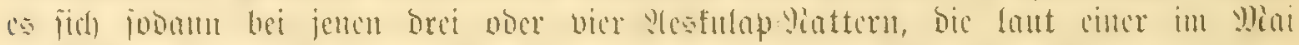

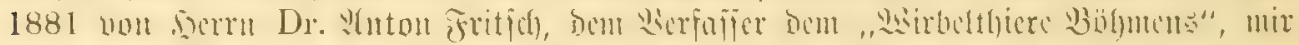

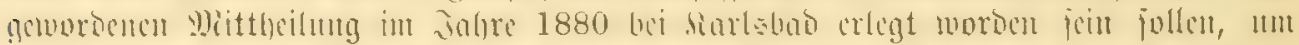

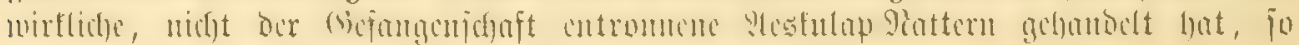

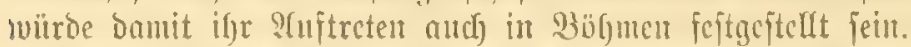

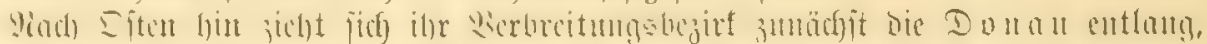

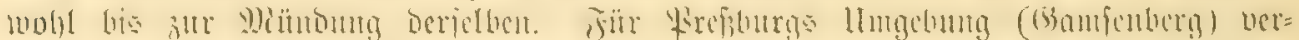

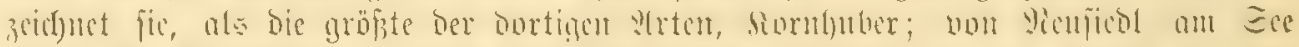

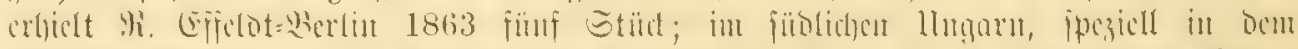

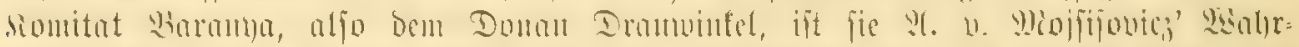

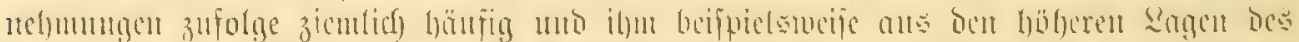

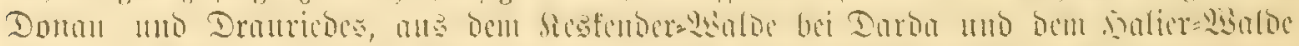

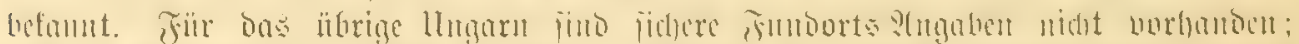

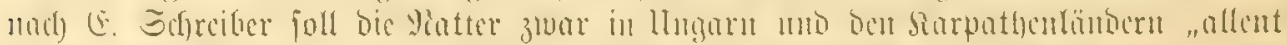

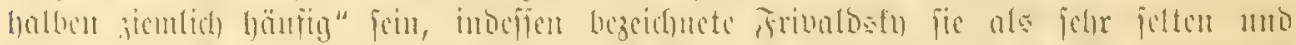

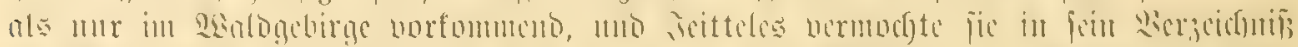

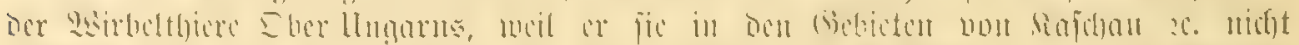

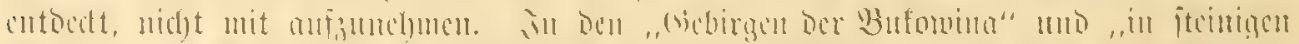

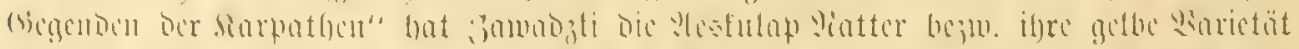

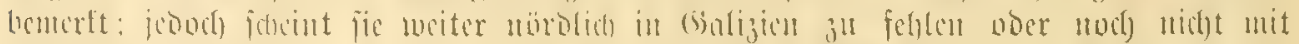

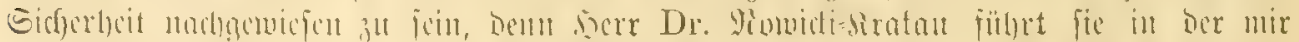

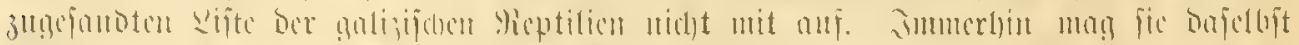

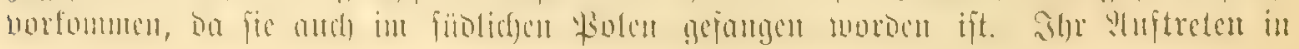




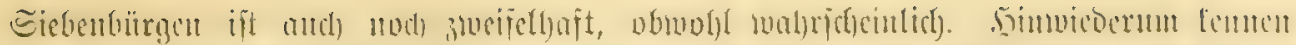

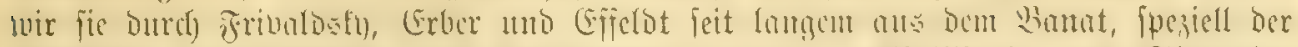

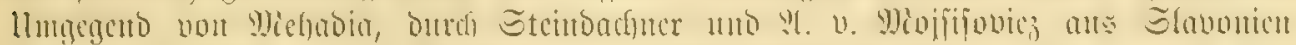

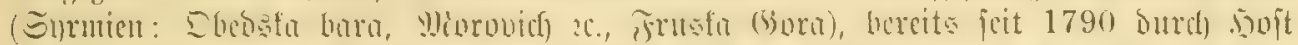

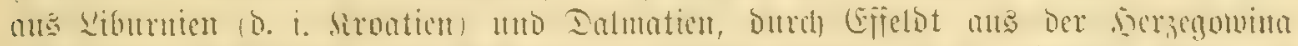

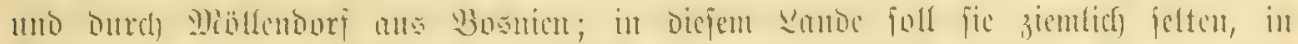

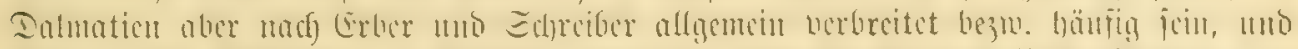

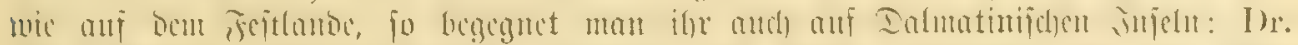

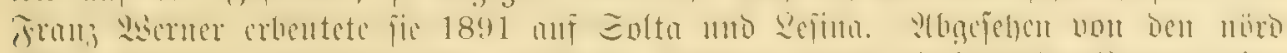

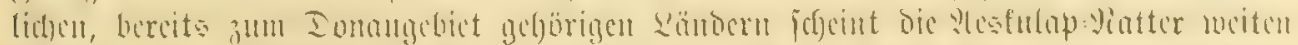

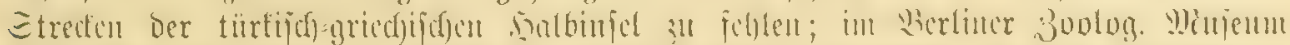

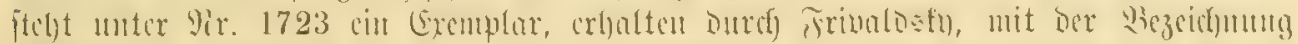

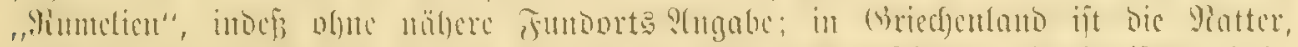

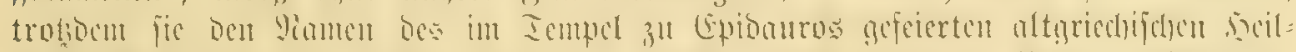

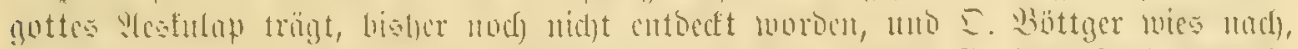

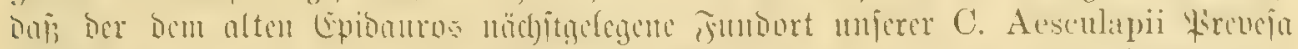

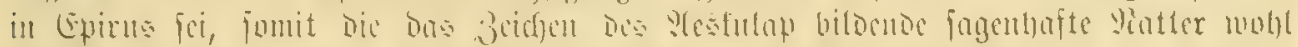

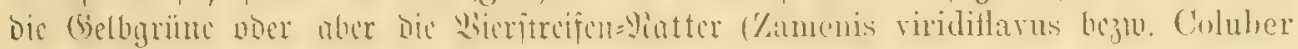
quaterradiatus) gewejeı jein müije.

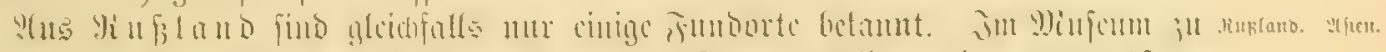

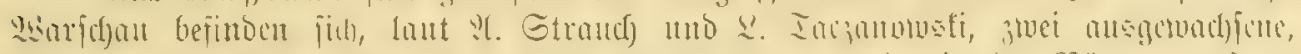

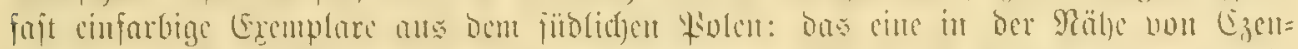

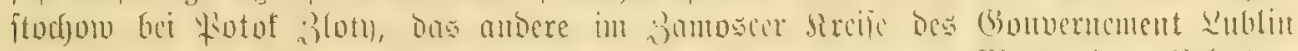

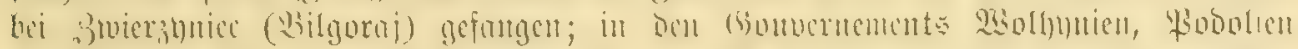

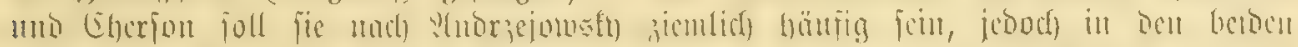

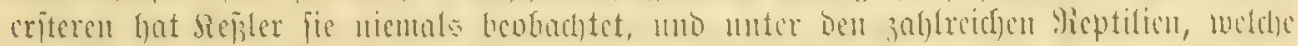

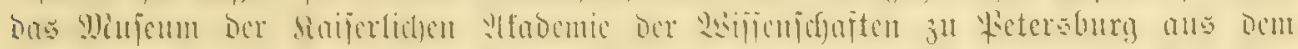

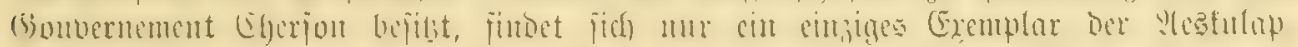

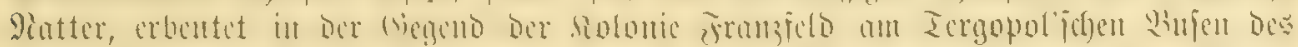

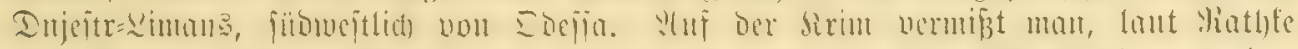

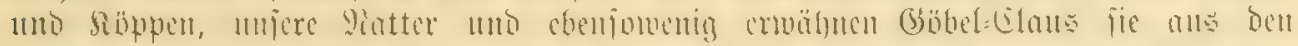

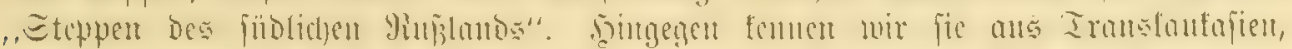

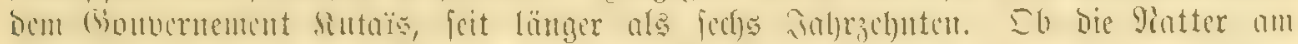

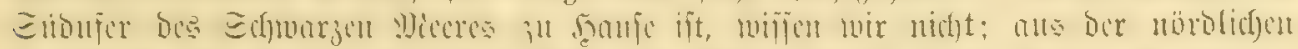

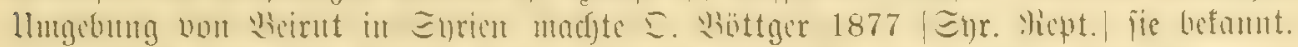

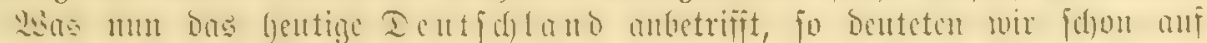

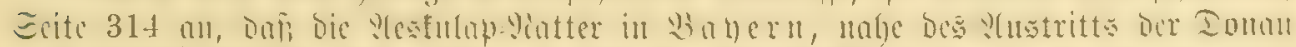

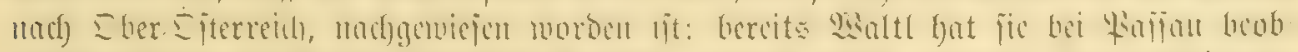

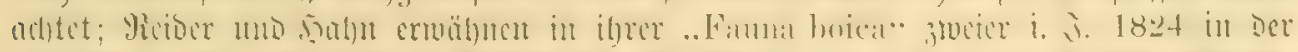

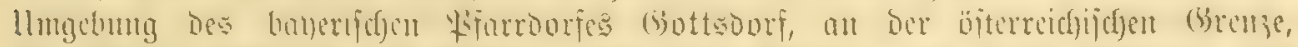

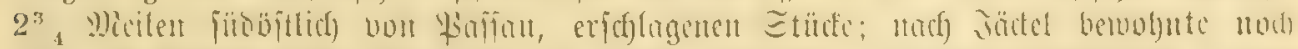

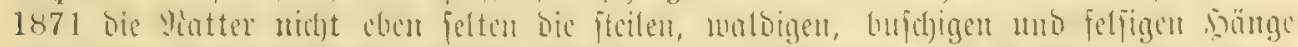

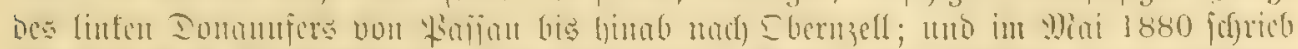

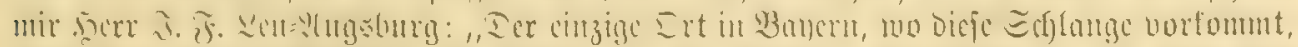

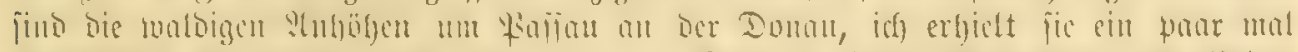

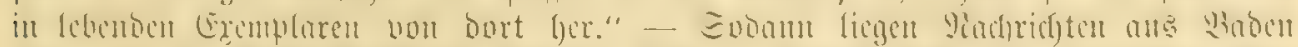

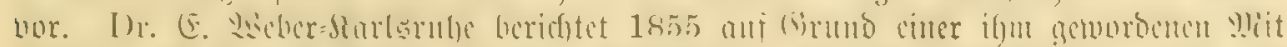

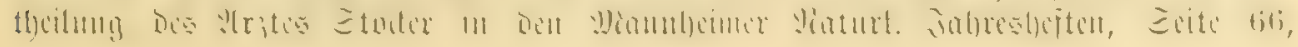




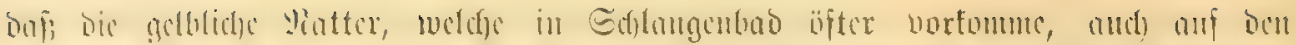

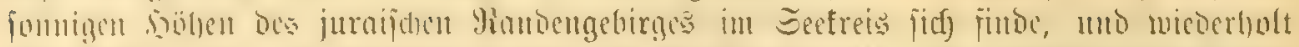

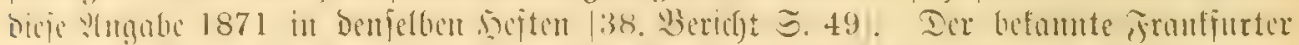

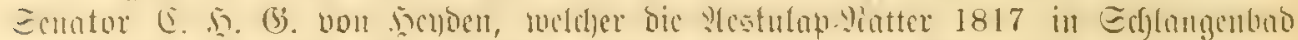

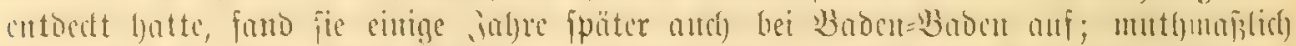

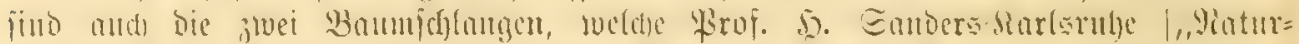

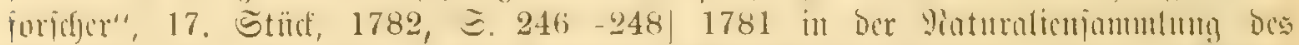

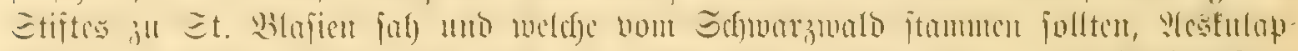

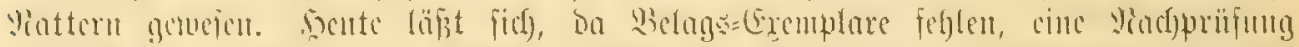

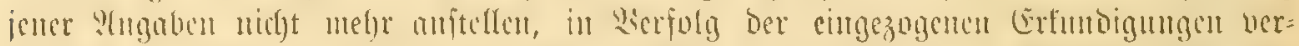

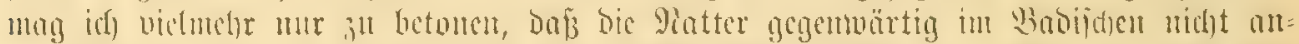

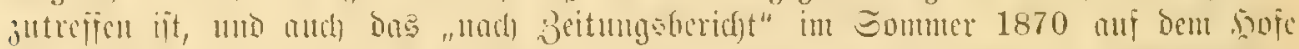

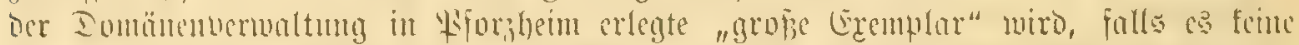

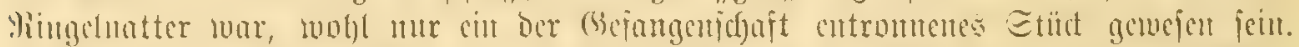

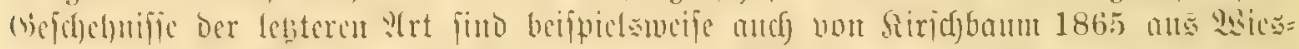

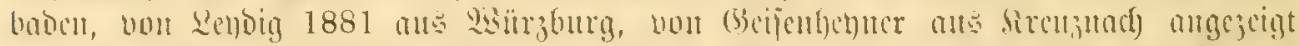

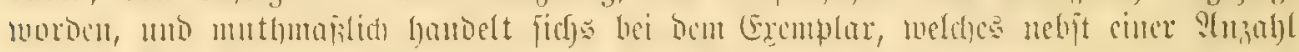

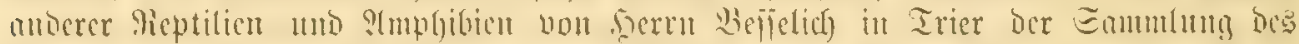

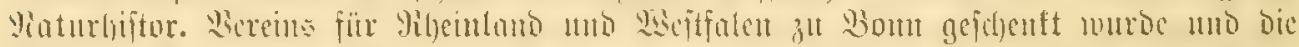

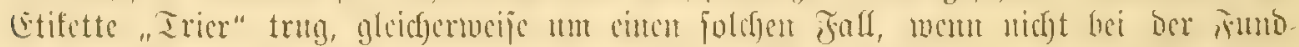

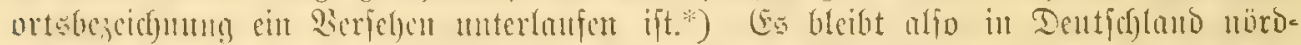

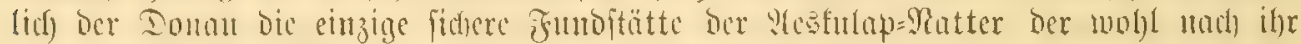

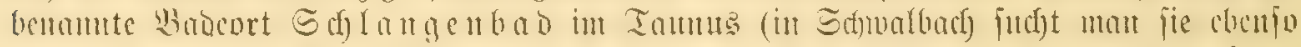

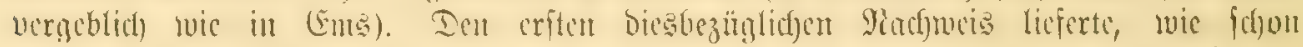

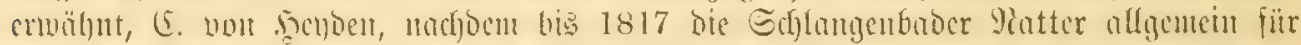

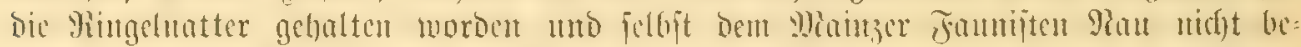

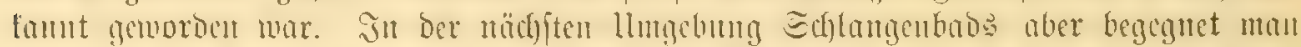

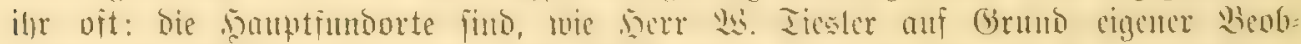

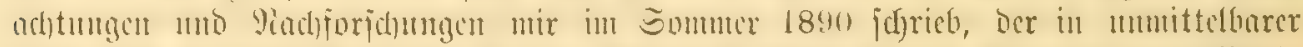

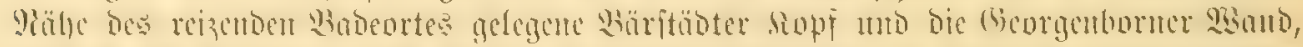

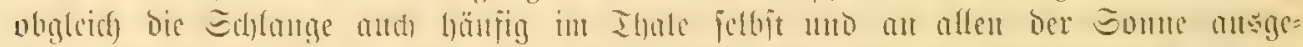

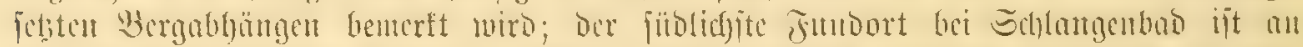

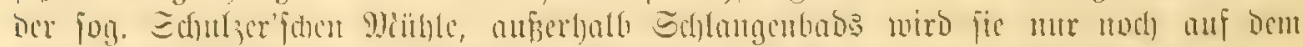

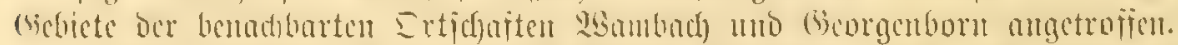

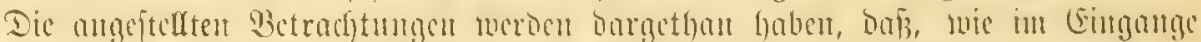

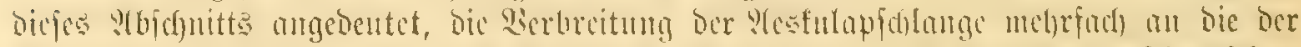

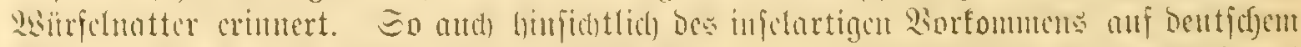

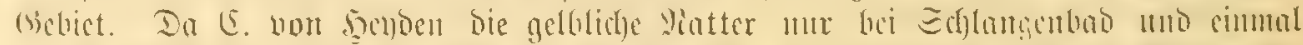

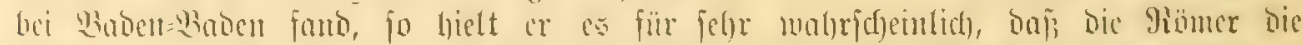

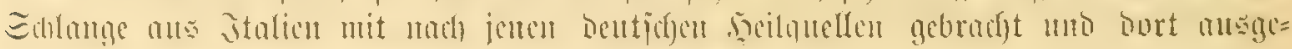

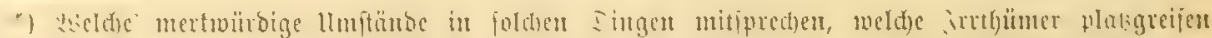

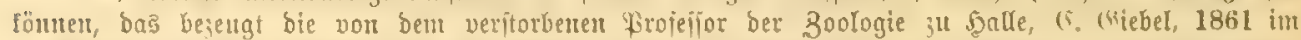

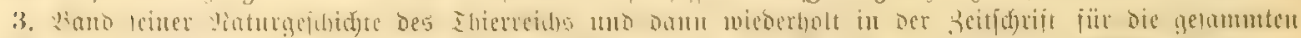

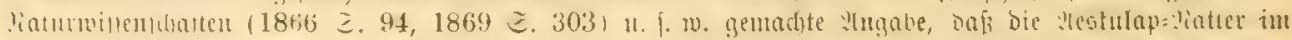

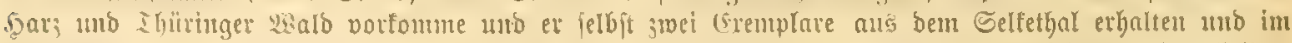

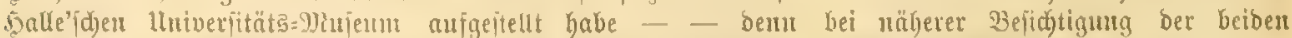

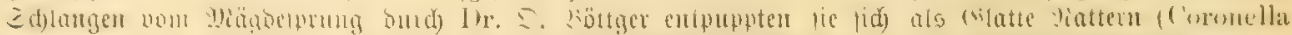

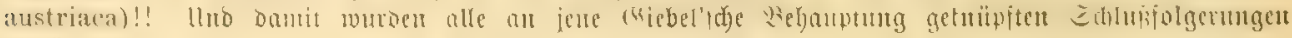
hiofällig. 


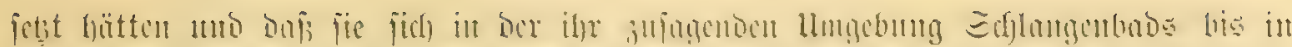

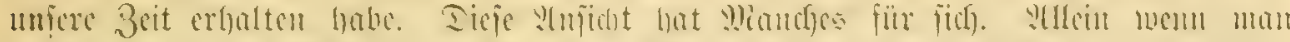

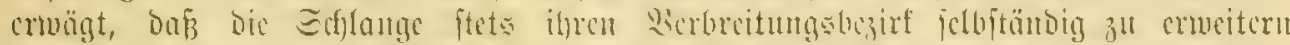

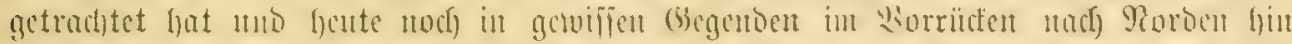

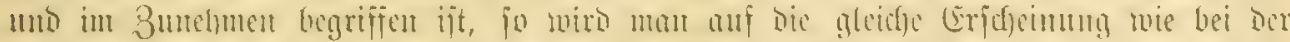

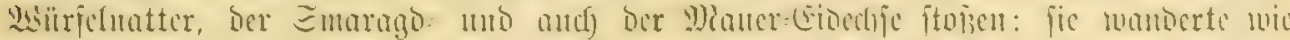

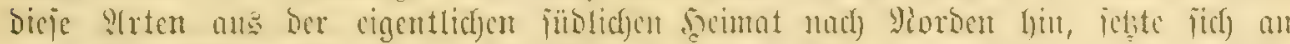

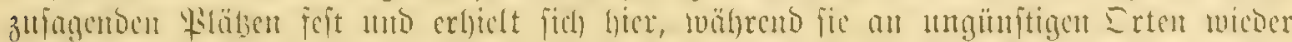

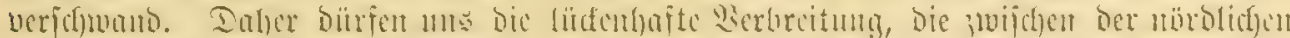

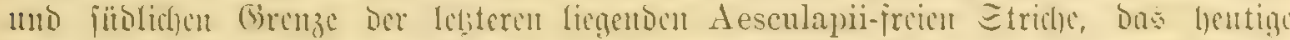

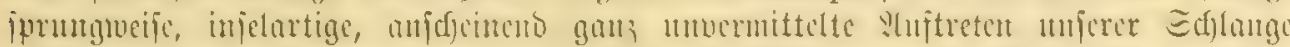

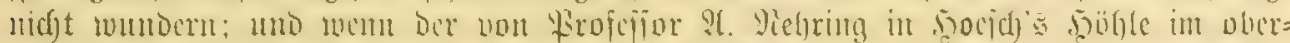

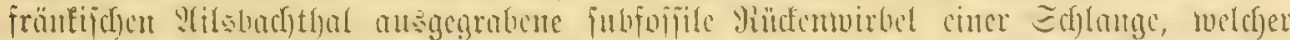

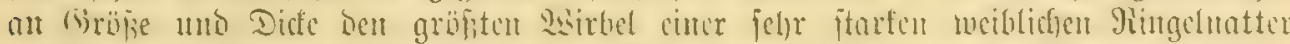

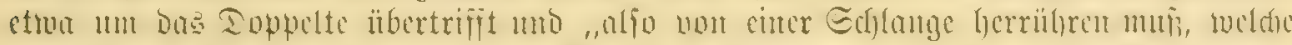

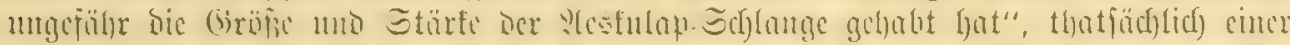

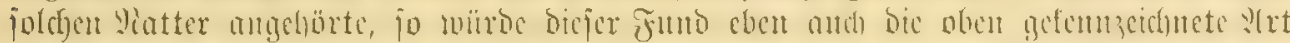

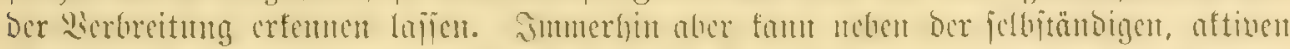

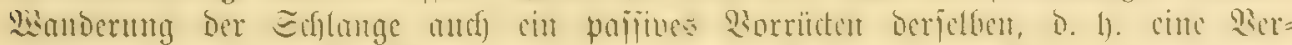

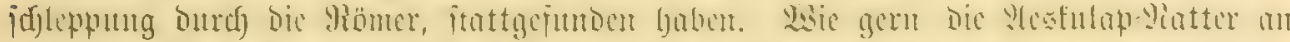

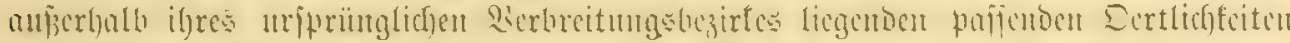

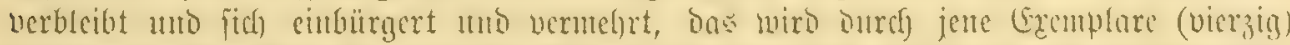

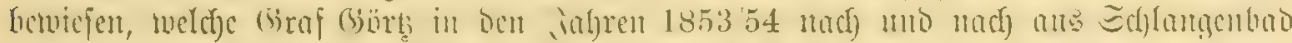

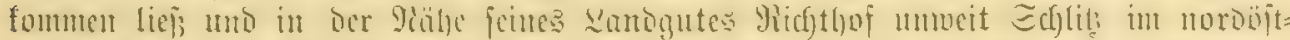

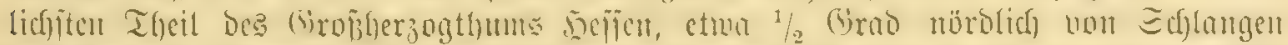

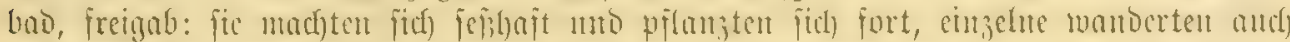

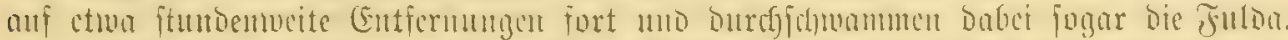

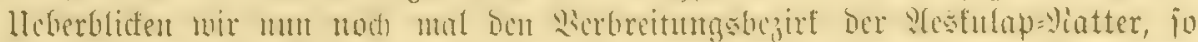

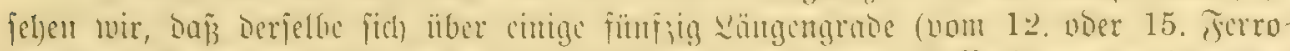
Werbreitung (Sterizert.

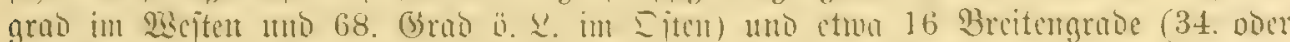

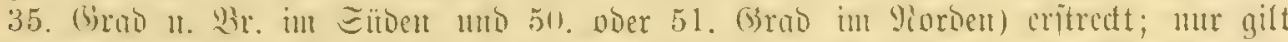

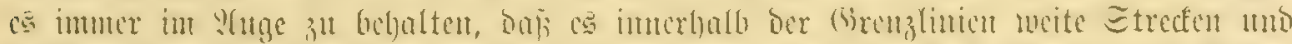

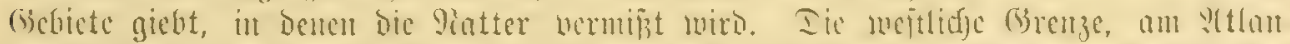

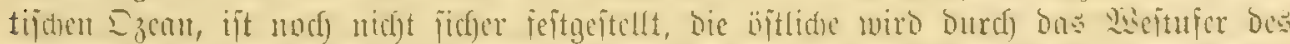

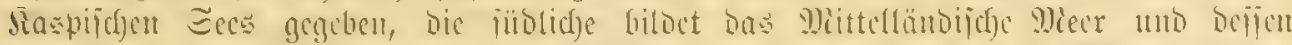

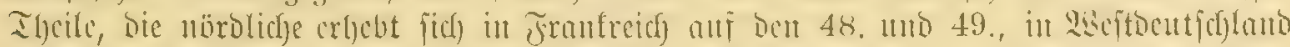

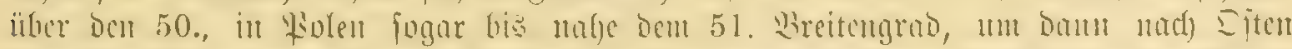

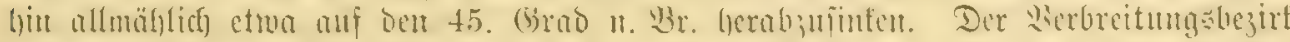

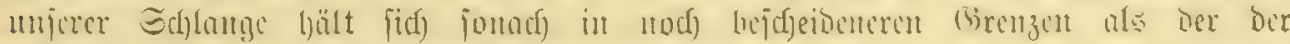
Wüurfehnatter.

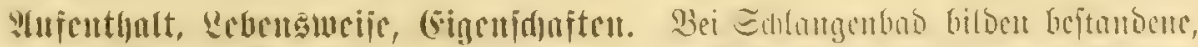

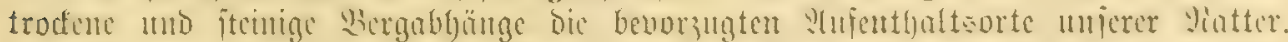

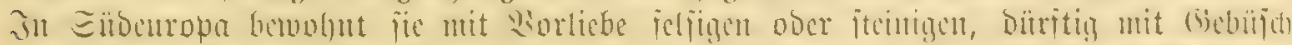

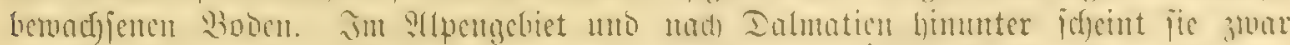

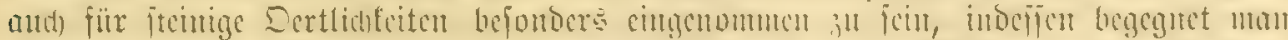

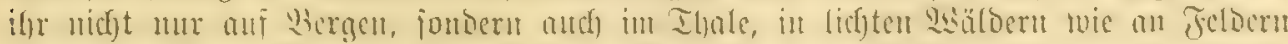

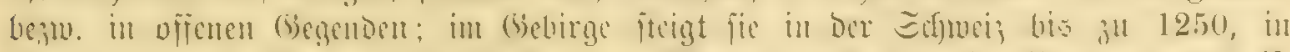

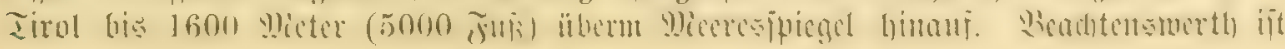




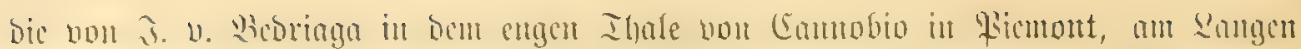

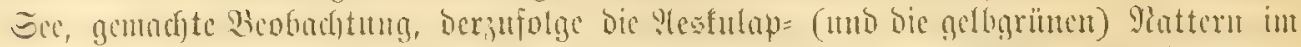

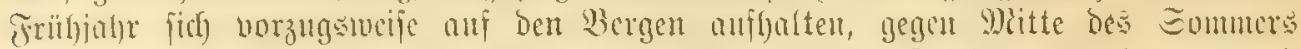

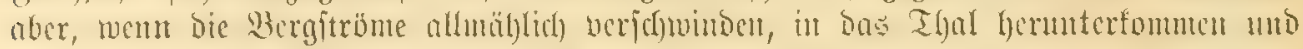

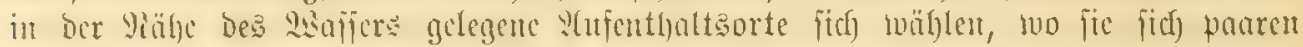

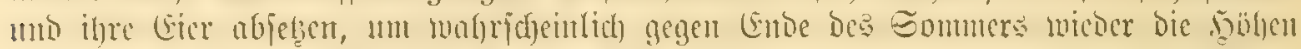

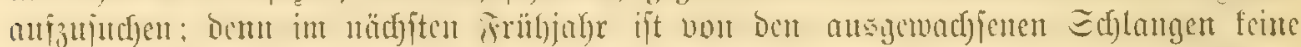
Epur mefse im Thale zu fehen, wobl aber zeigen jie fid bam, fobalo ber Edunce

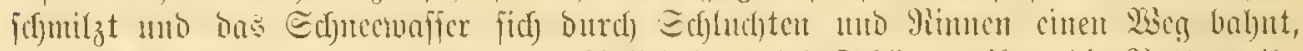

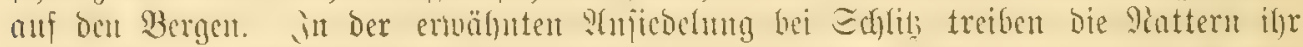

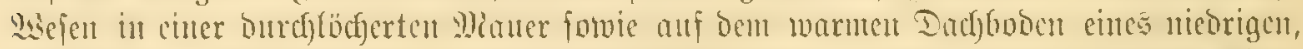

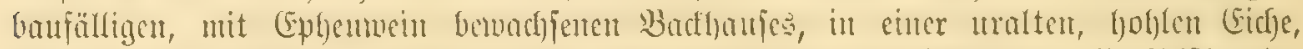

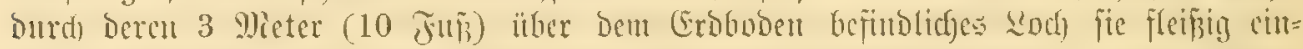

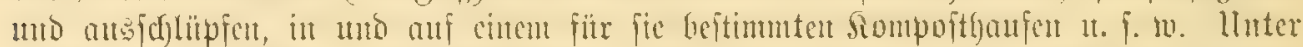

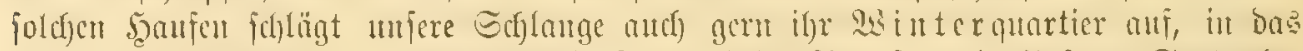

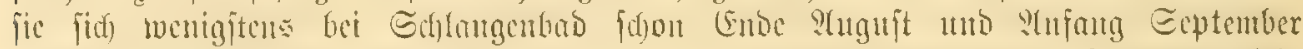

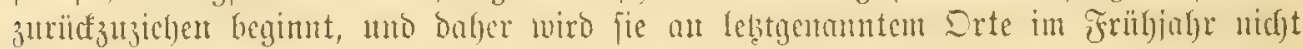
felten in Ställen aufgefundent.

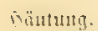

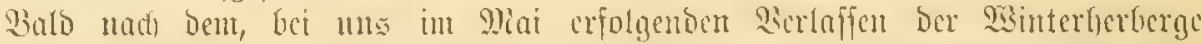

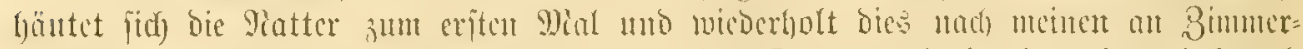

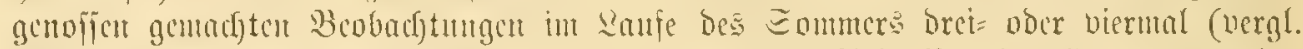

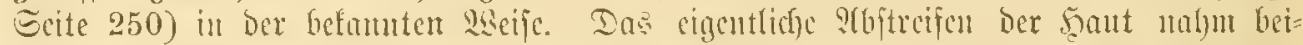

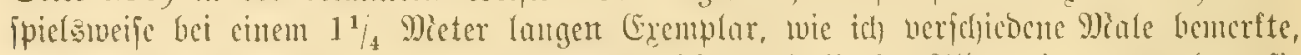

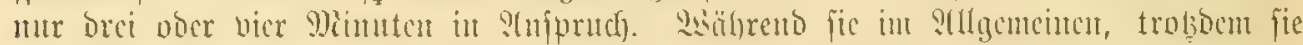

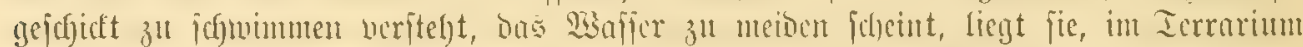

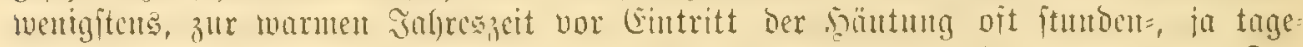

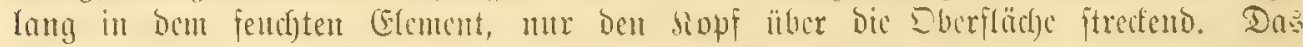

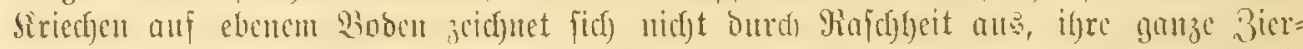

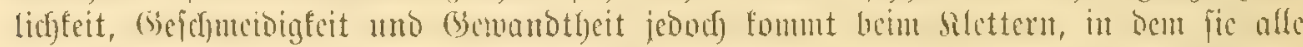

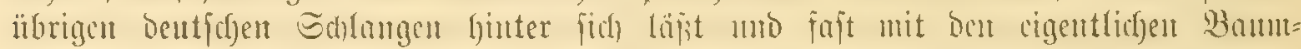

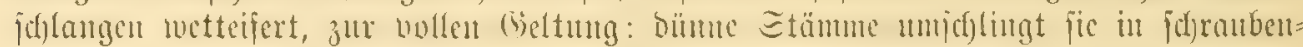

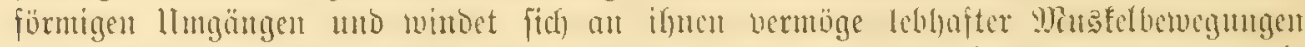

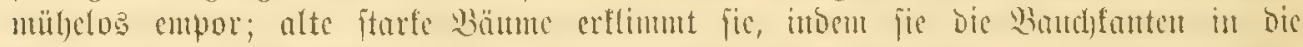

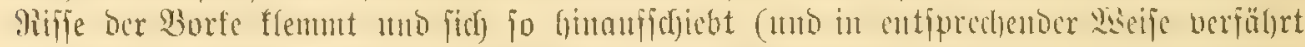

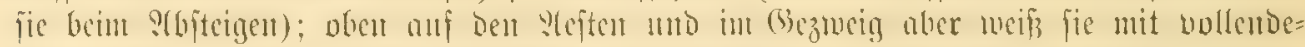

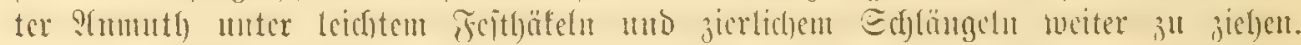

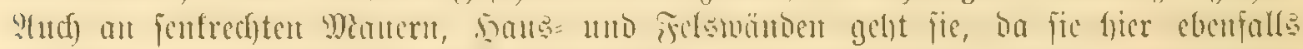

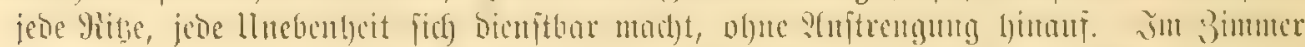

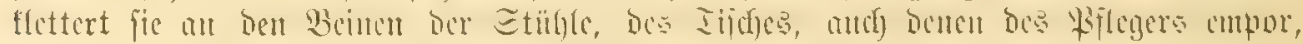

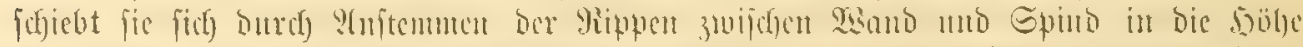

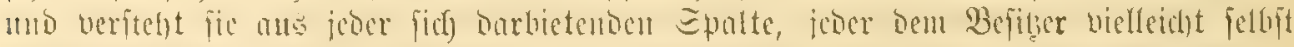

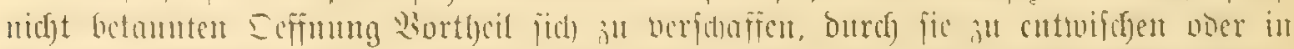

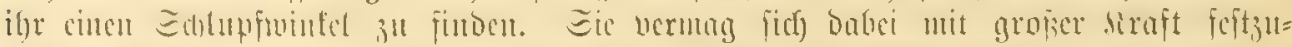

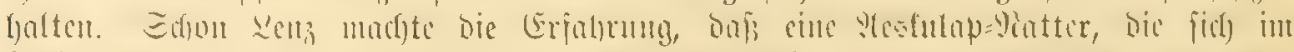
Freicu

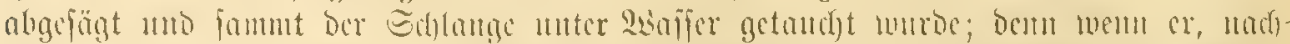

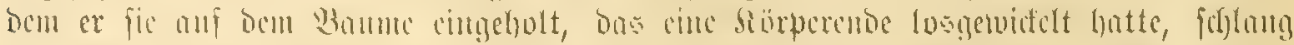

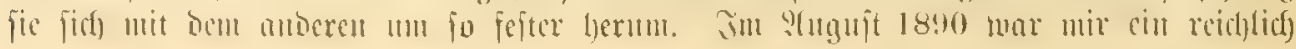




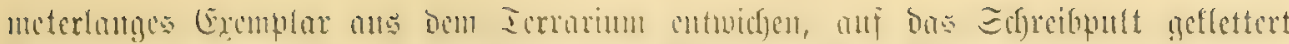

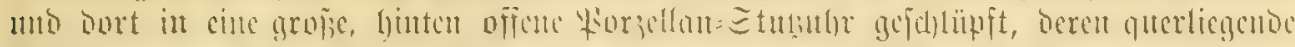

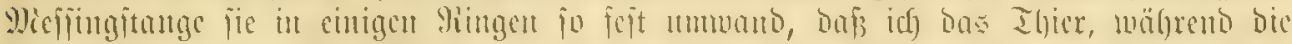

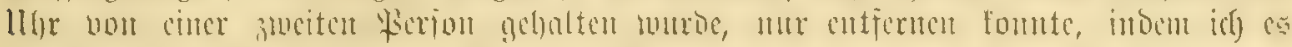

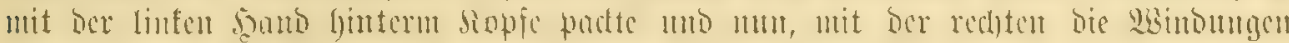
auffisfonto, cs zichento "Sdyritt por Sedjrtt" heratsbefüberte.

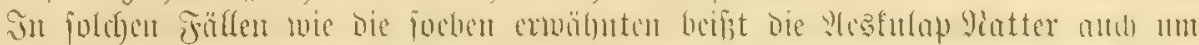

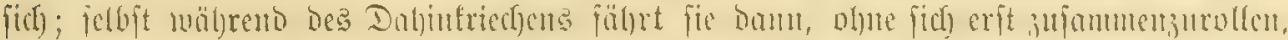

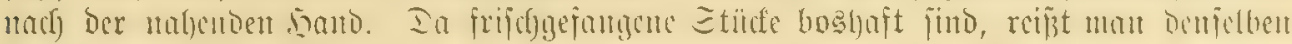

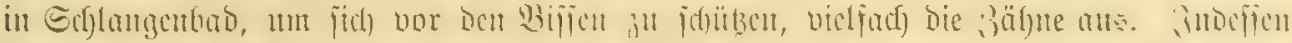

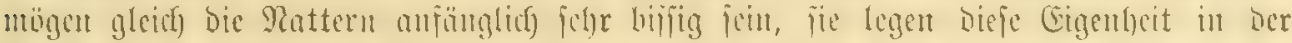

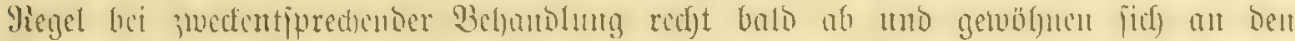

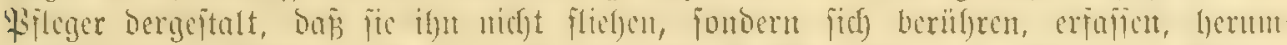

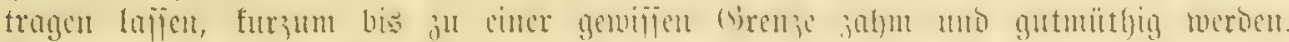

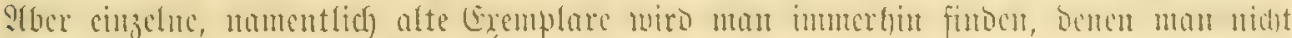

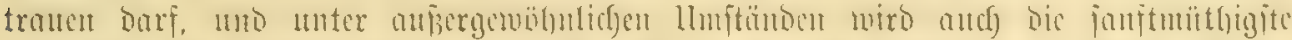

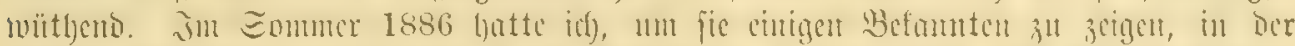

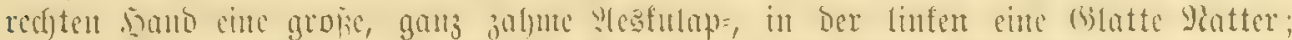

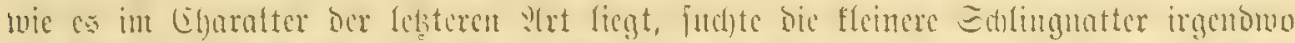

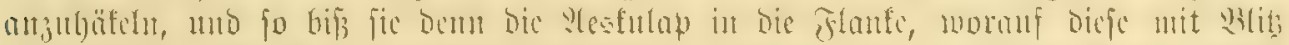

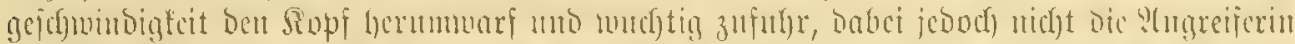

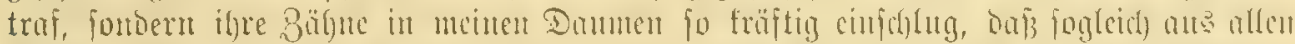
Etichan

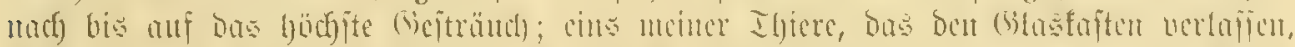

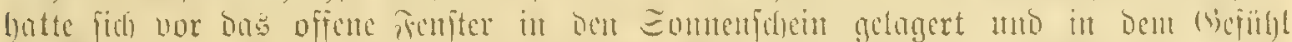

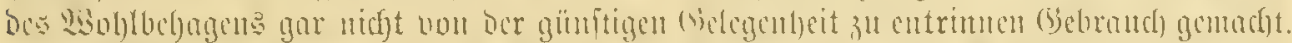

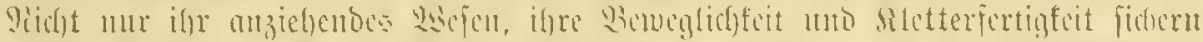

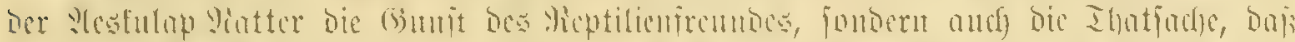

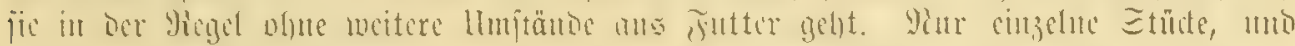

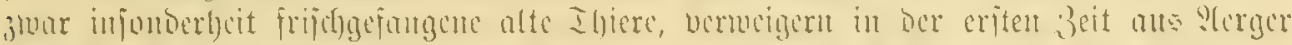

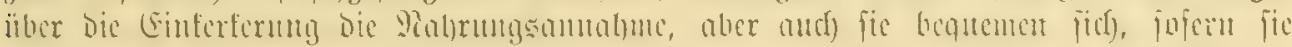

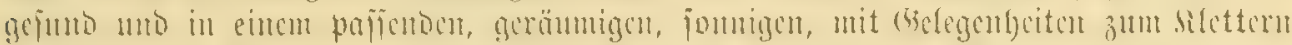

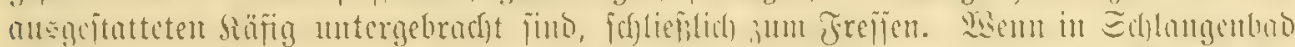

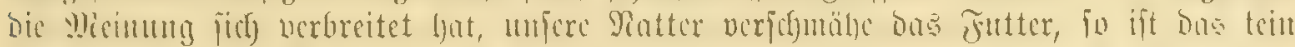

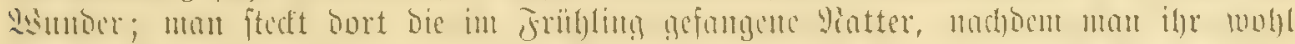

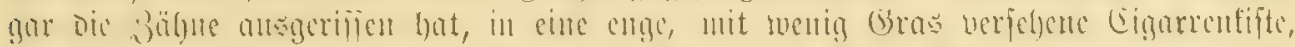

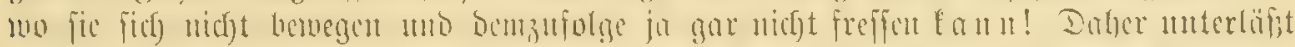

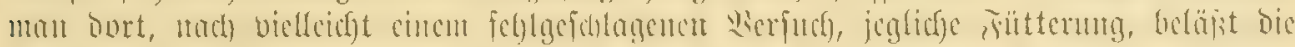

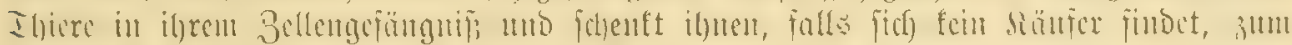

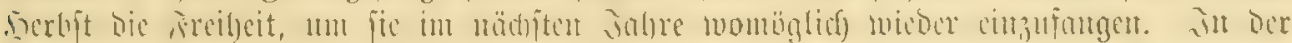

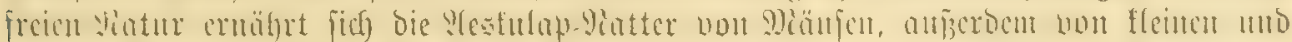

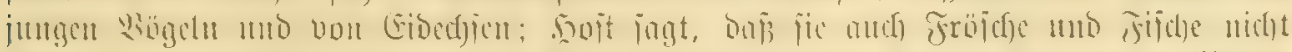

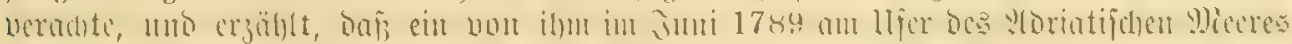

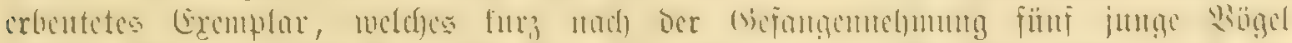

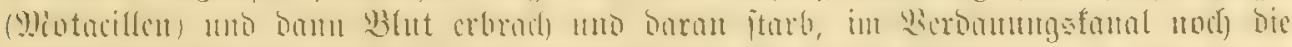

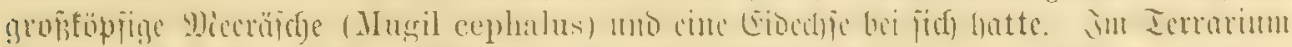

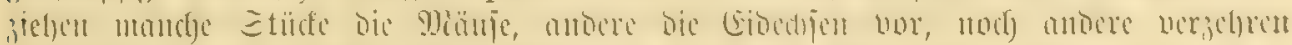

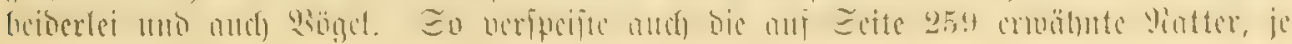




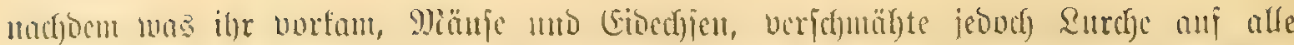

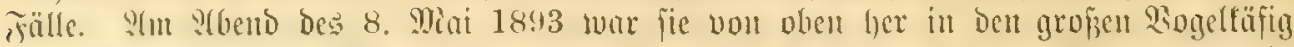

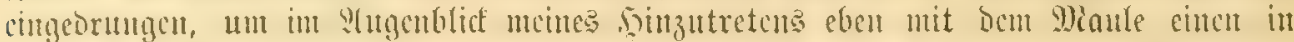
voller 5ont hin= uno herflutternoen $23 i c$ cupieper (Anthus pratensis) zu erfaffen uno

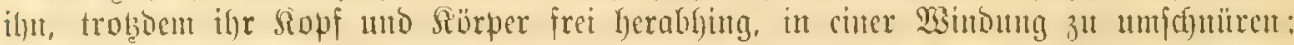

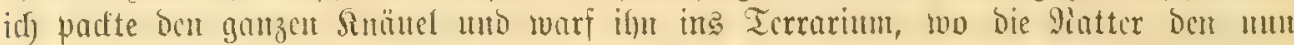

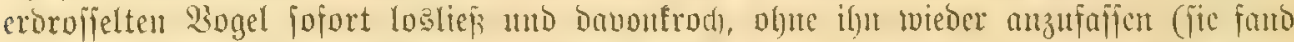

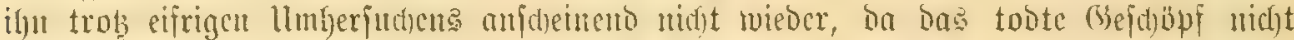

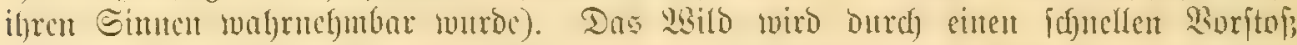

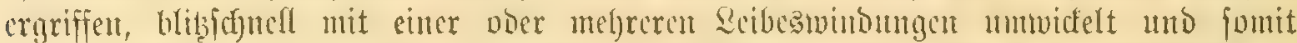

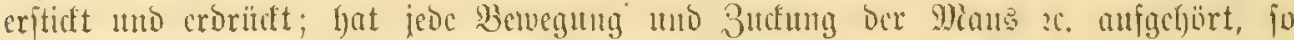

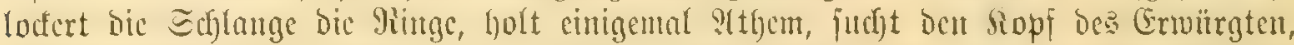

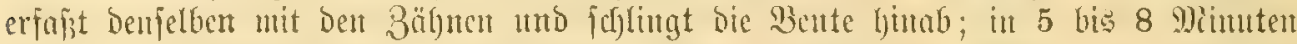

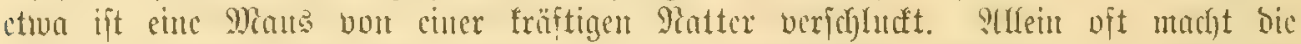

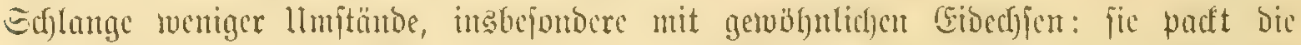

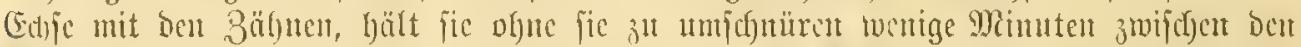

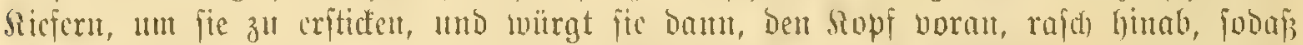

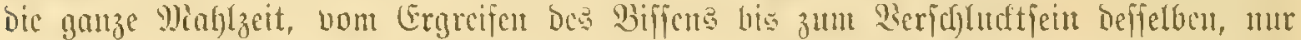

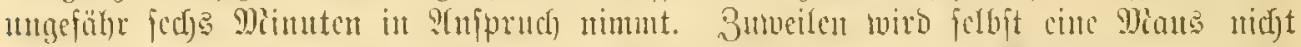

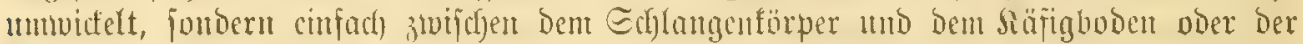

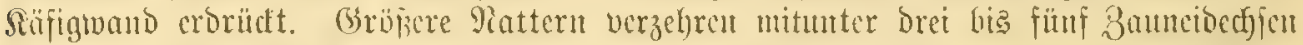

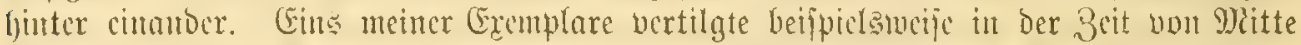

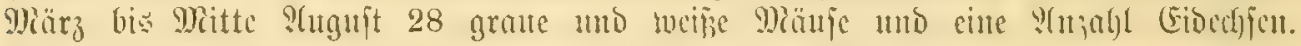

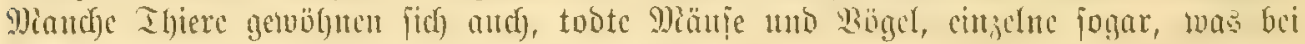

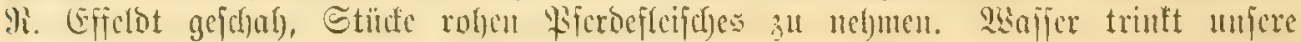

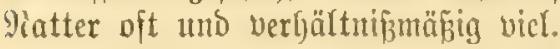

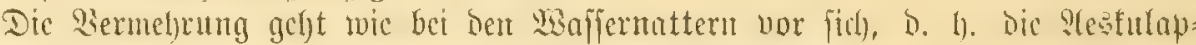

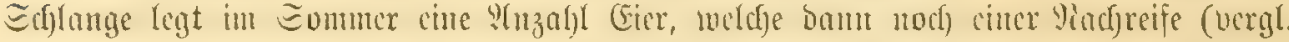
Eeite 256) beditrfen. (Eut (Gelege beftel)t nad) meinen Erfalgrumgen un aus fümf bis

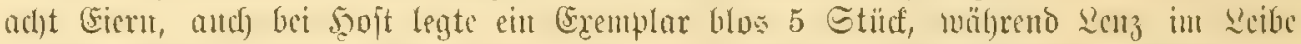

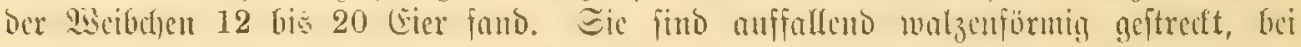

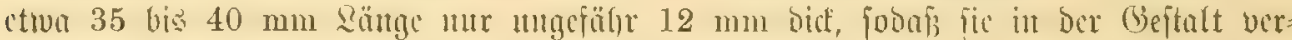

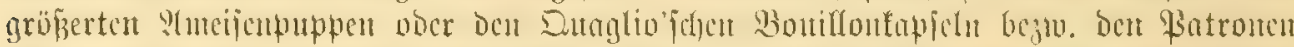

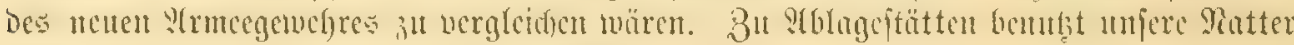
Rompoityaufen, Mlutm, ticfe Moosfdichiten u. a.

Int Italien mird bic Pestulap=Siatter Colubro saettone, Col. d'Esculapio docr Angio, in Frantrcicy Couleurre d'Esculape genannt.

Anguis Aesculapii, Aldrov. 1640. - Anguis Aesculapii Grecis, Ray 1713. - Coluber scut. abd. 225 et squam. caud. par. 78, Scopoli 1767. Natrix longissima, Lutrenti 1768. - Col. longissimus, Bumeterre 1789. - Coluber flavescens et Col. natrix var. $\beta$, Gmelin 1790. - Coluber A esculapii, Ilost 1790; Wolf-sturm 1799. - Col. asclepiadeus, Sellmanni et pannonicus, Lonndorf 1798. - Col. romanus, Suckow 1798. - Col. leprosus, Bechstein 1802. - Col. natrix var. a, Doudin 1803. - Col. (Natrix) Scopolii et Aesculapui, Merrem 1820. - Zamenis Aesculapii, Wayle 1830. Coluber fugax, Eichwald 1831.

Callopeltis flavescens, Bomurate 1839. - Elaphis Aesculapii, Mum. Bilmen 1854. - Elaphis flavescens, Iichtenstein 1856. 


\section{Gattun: Gilattnatter. Coronella, Laur.}

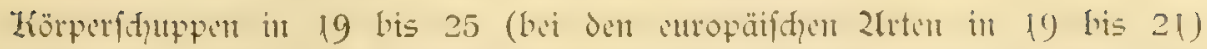

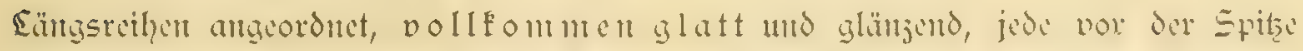

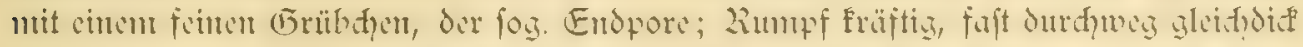

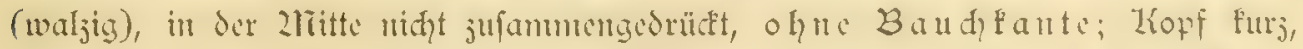

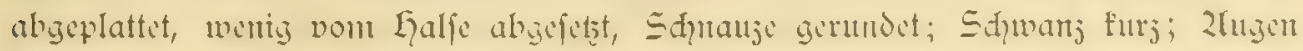

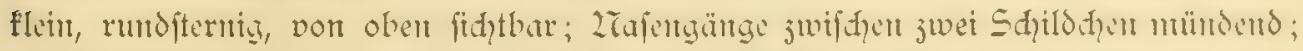

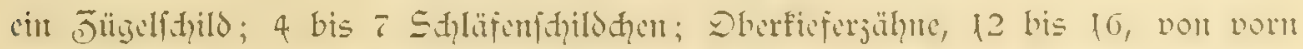

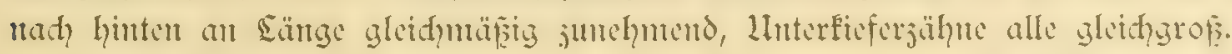

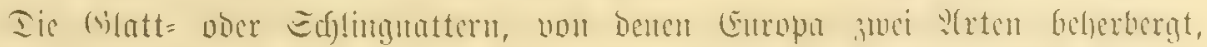

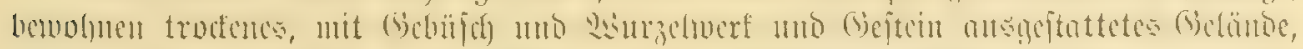

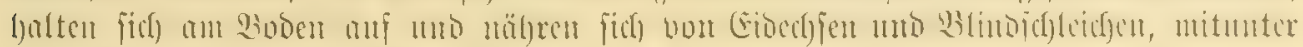
aud) von tlemen Sdjlangen.

\section{Sirt: Glatte 2ratter. Coronella austriaca, Lau?. MbGildurg: Tajer VIII 9ir. 2.}

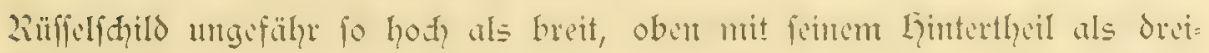

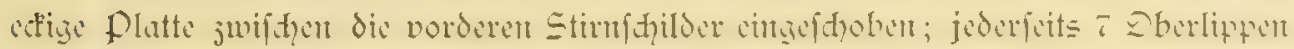

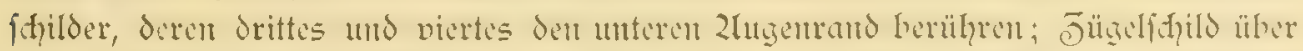

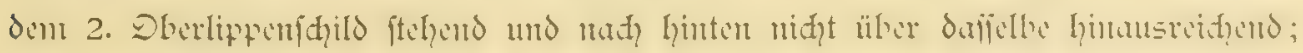

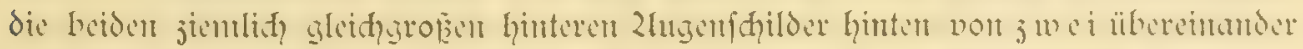

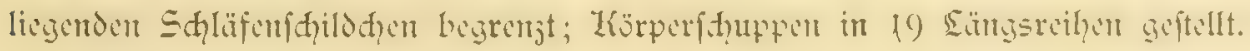

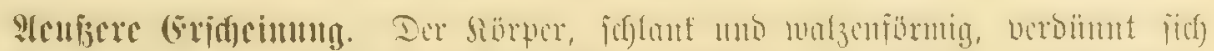

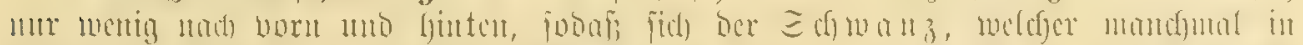

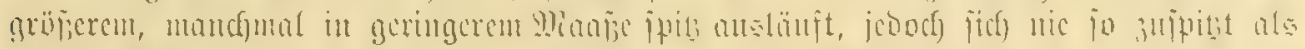

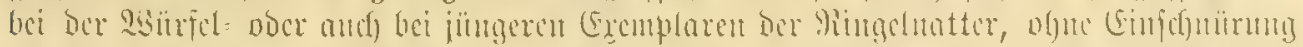

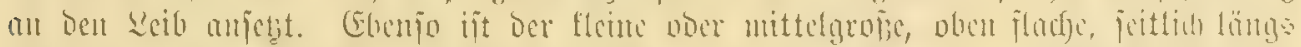

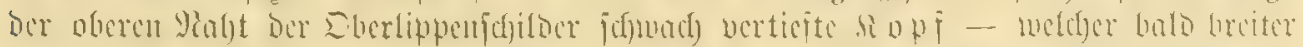

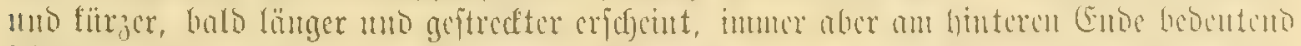

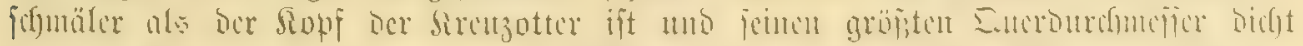

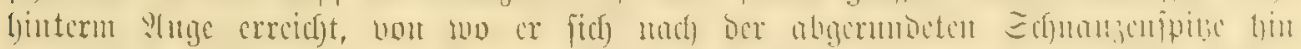

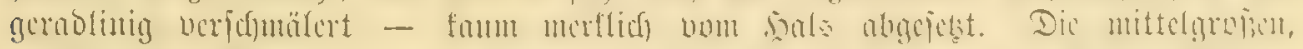

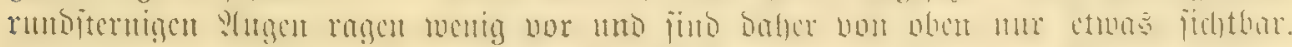

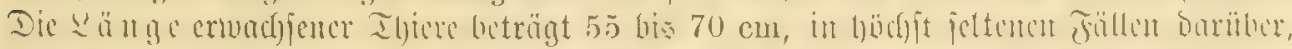

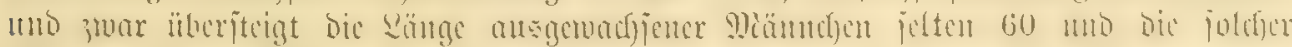

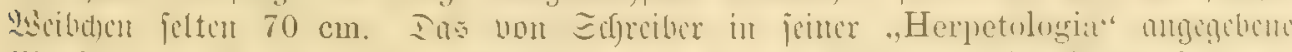

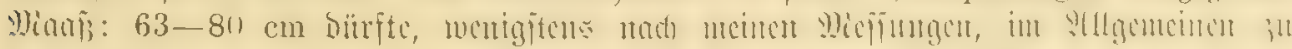

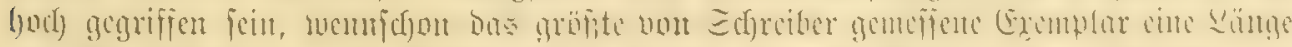

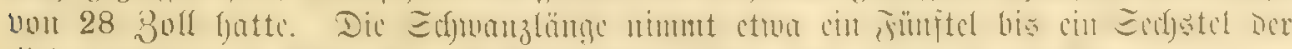

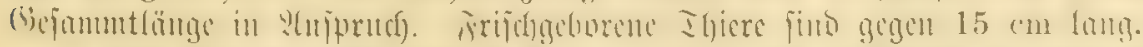

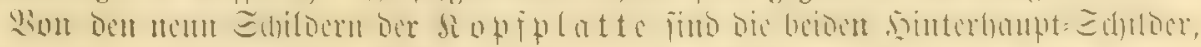

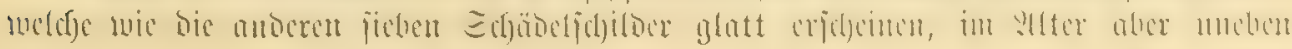




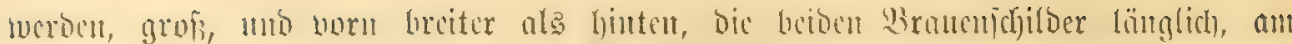

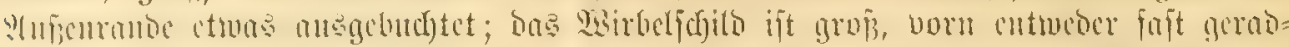

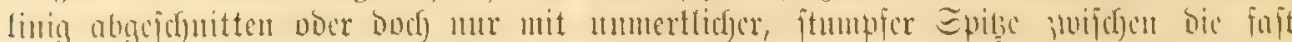

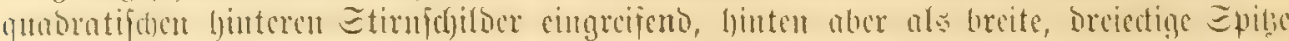

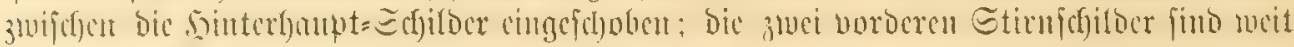

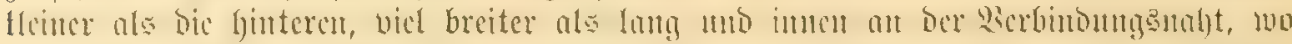

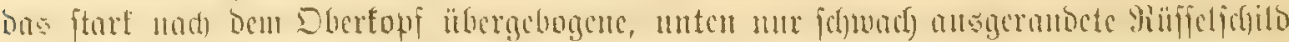

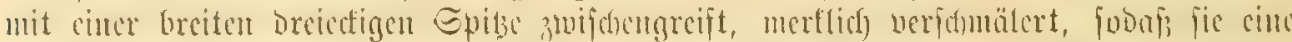

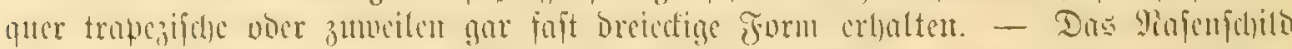

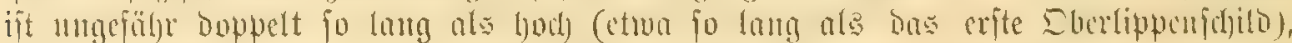

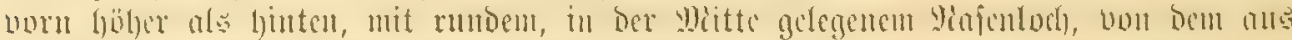

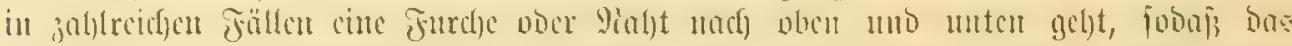

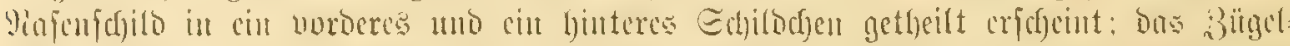

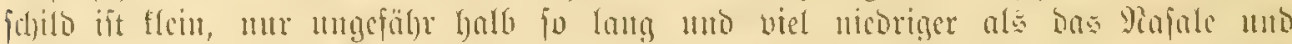

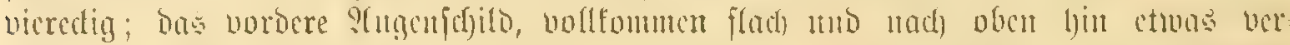

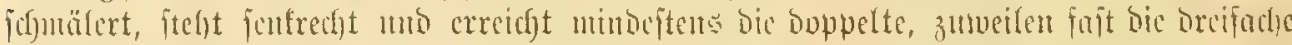

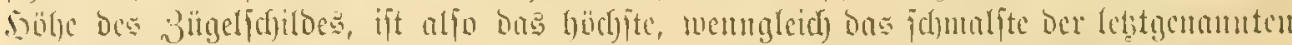

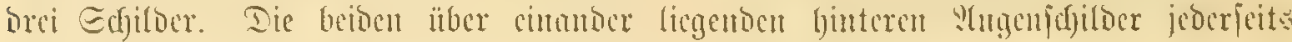

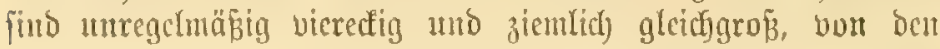
bciocu fie ginten begrenzenten uno cbenfalls über cinander liegenden Sd)läfenfdyildern jcoody ift das mntere mebr vocr swenigex ausgeprägt rautenförnig uno viel grüßper als bas vbere, weldjes langgeitredt, fdymal und mandfunal faft ftridf)=

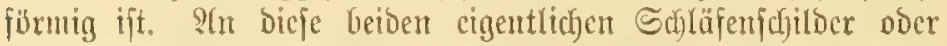

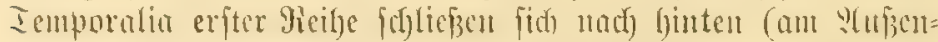

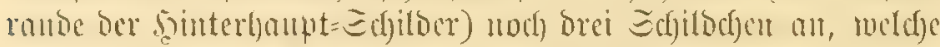
mot)l glcidfulfs als Edjläfenfdjilder bezcidnet werben, bod)

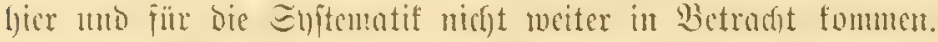

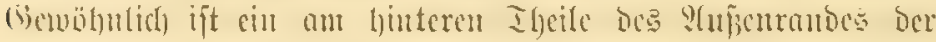

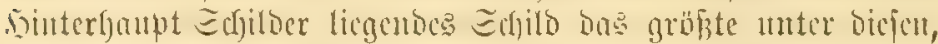

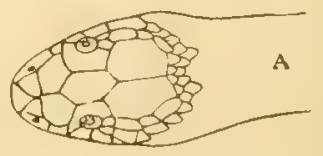

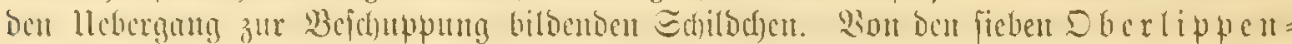

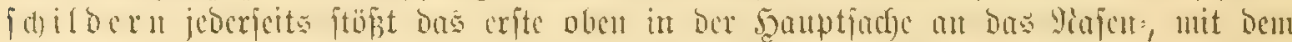

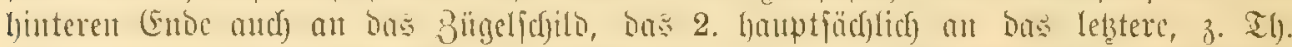

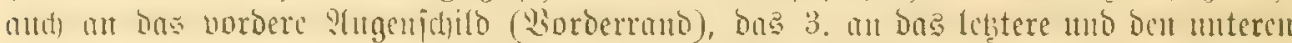

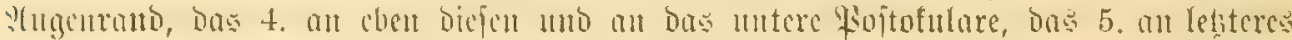

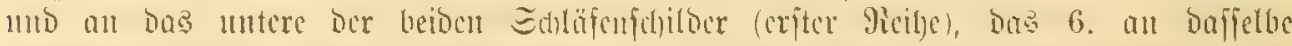

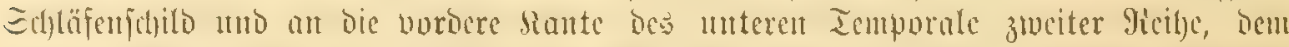

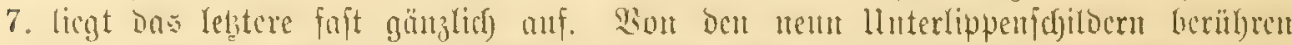

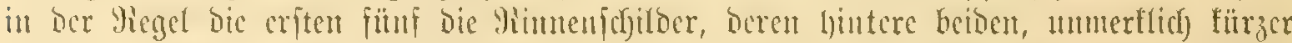

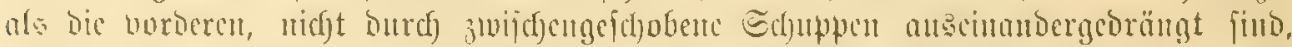

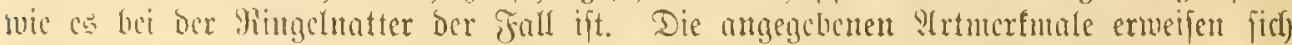

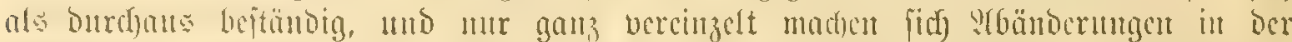

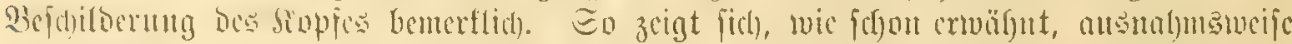

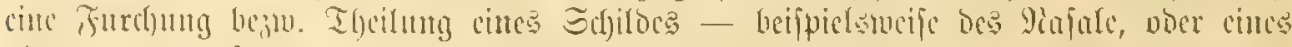

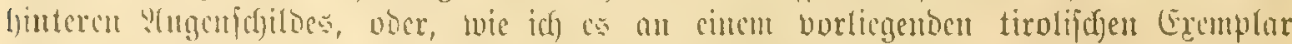

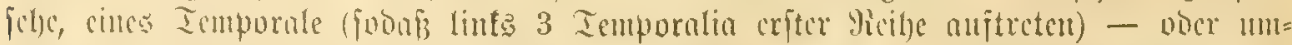

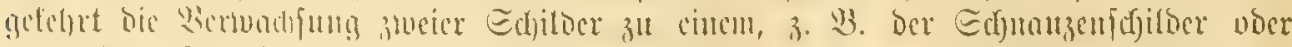

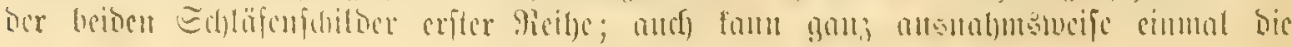




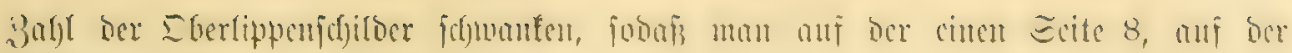
anderet 7 zălylt.

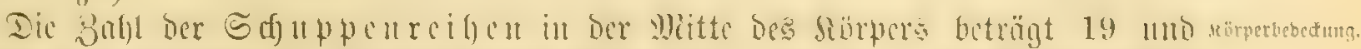

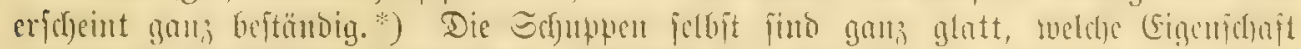

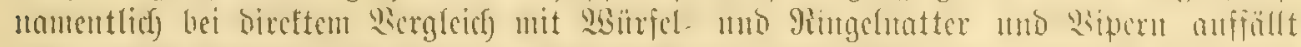

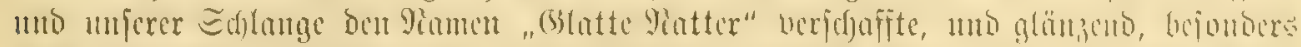

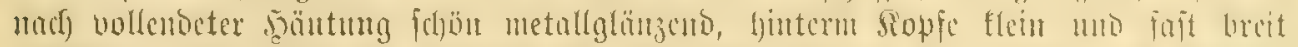

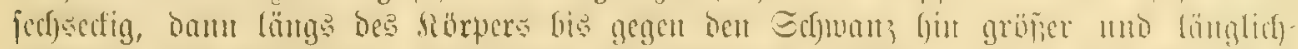

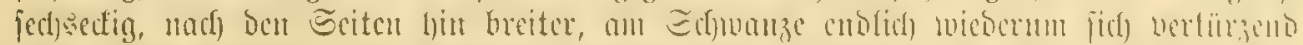

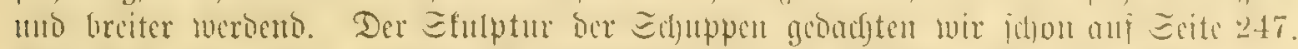

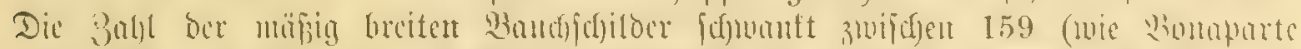

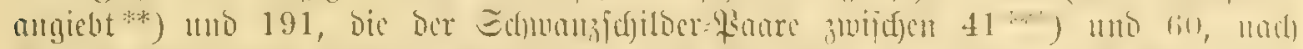

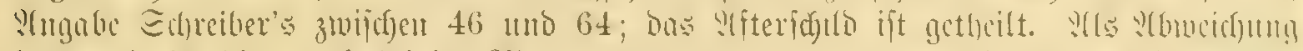

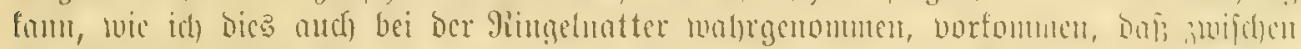

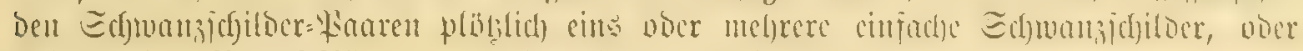

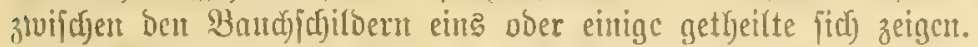

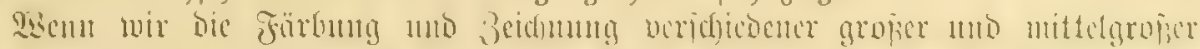

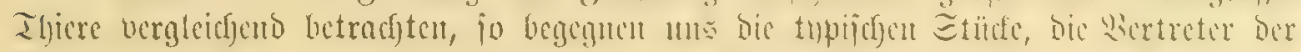

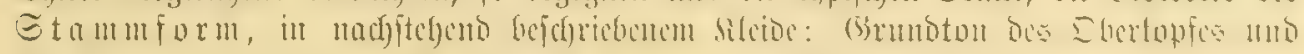

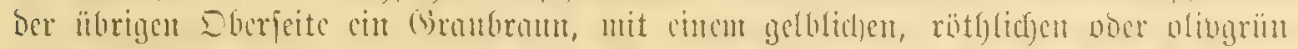

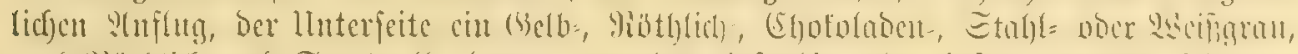

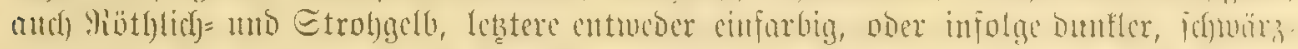

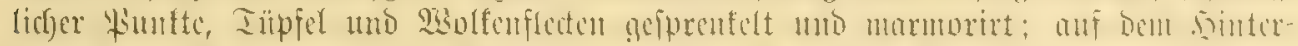

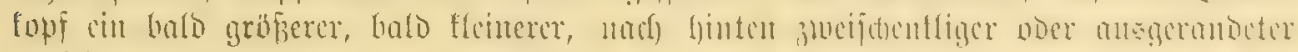

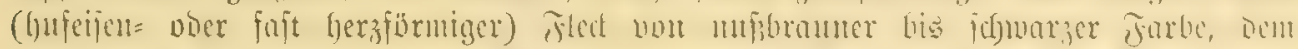

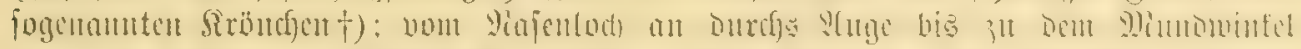

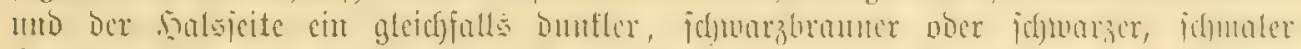

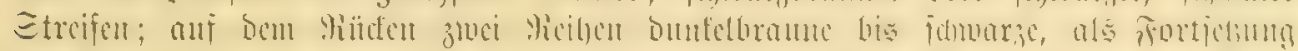

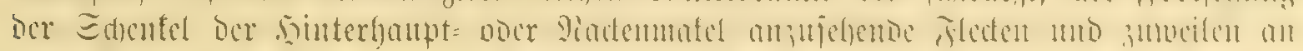

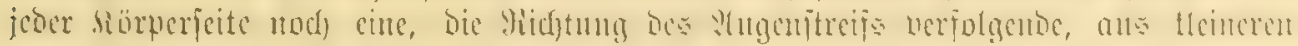
uno mocuttidyen Tüpfeln bejteljentoc Flectentrcige.

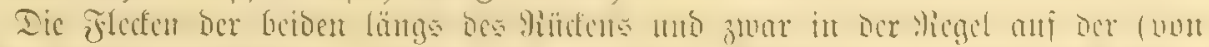

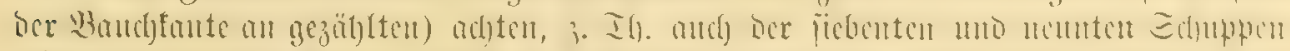

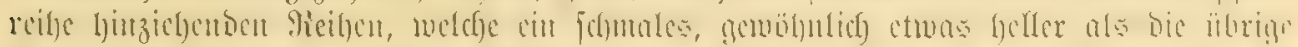

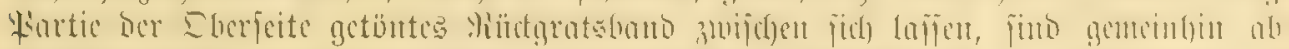

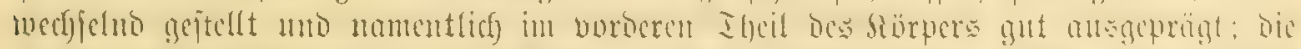

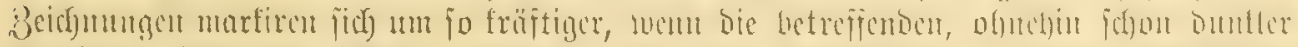

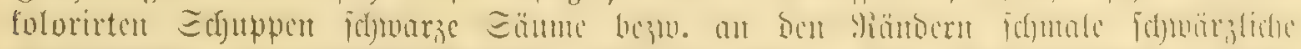

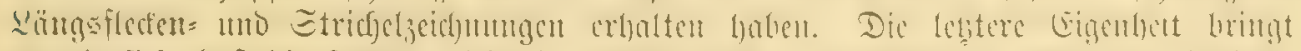

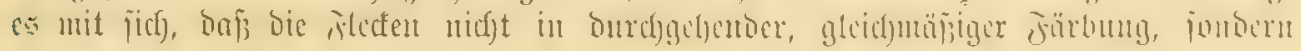

*) Tie von Gtrandy in feiner "Erpétologie de l'Algéri“, ธ. 54, gentadjte ștugabe, bap austriacn

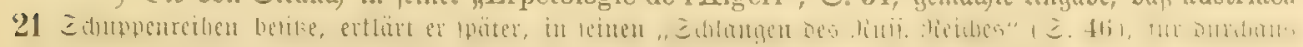

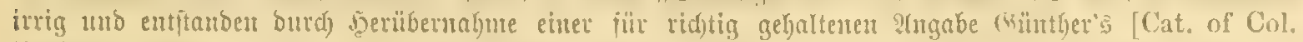

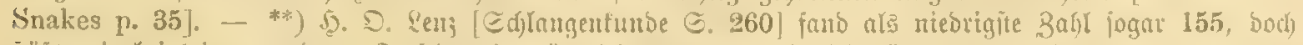

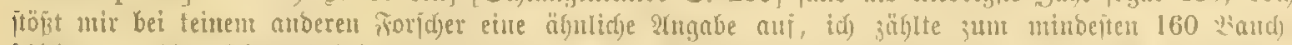

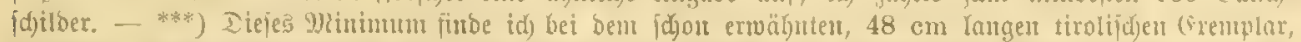

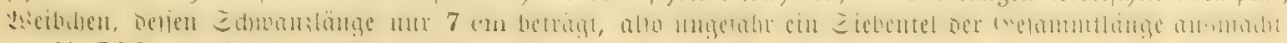

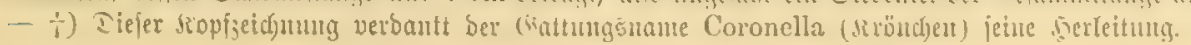




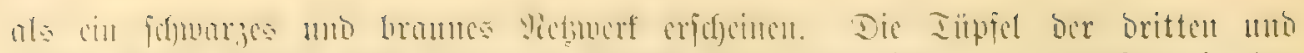

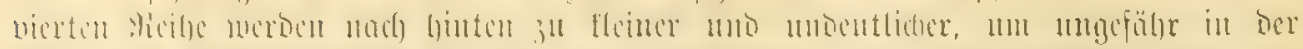

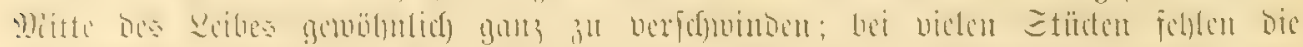

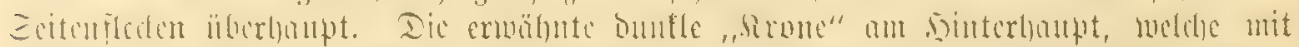

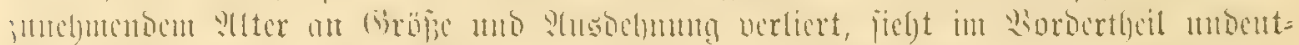

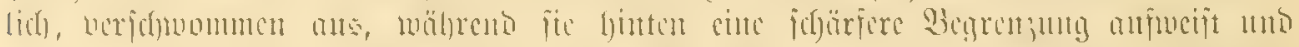

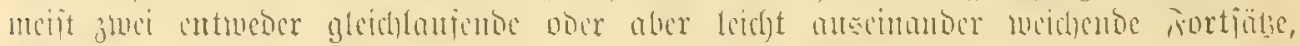

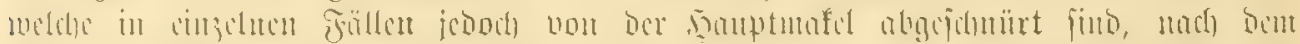

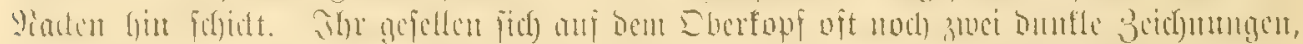

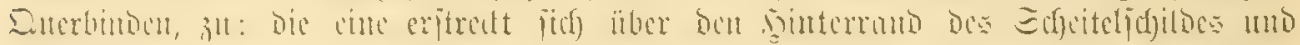

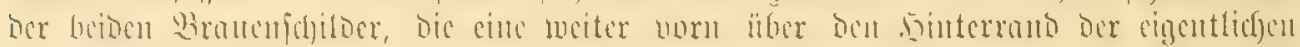

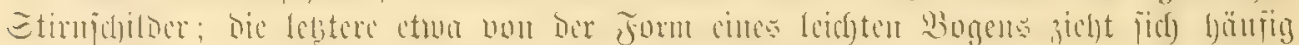

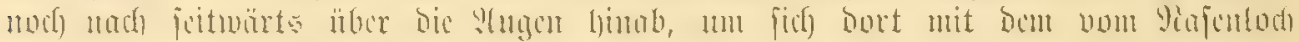

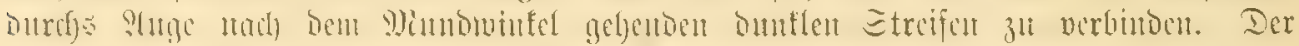

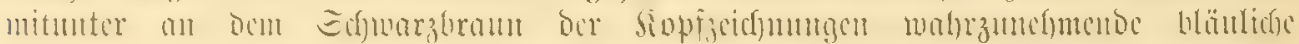

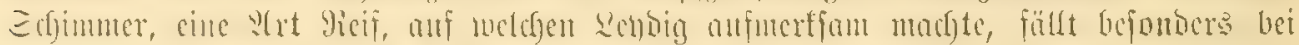

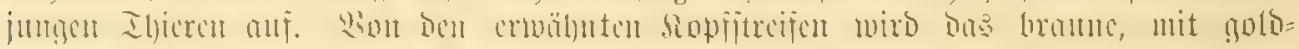
farbiger, iris ansugetattete

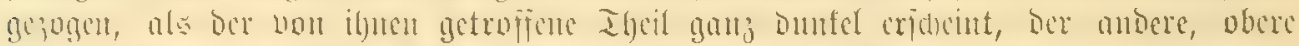

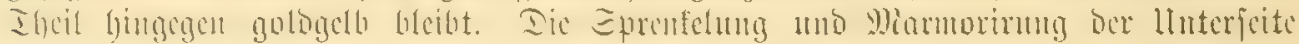

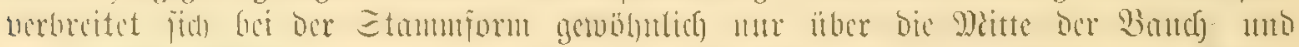

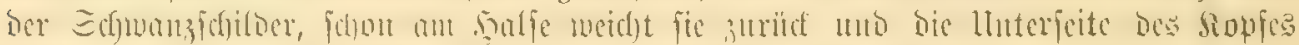

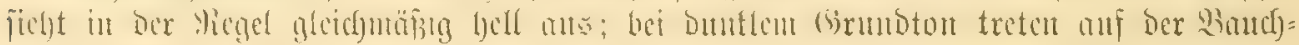
fläd)e zumeilen gelbe Sitpfel auf.

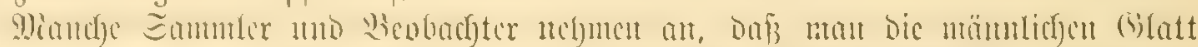

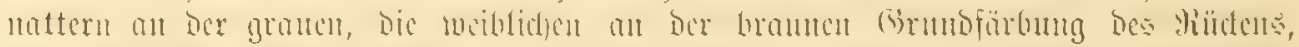

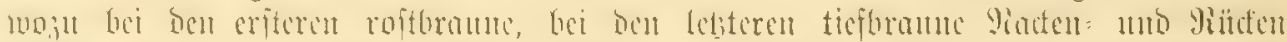

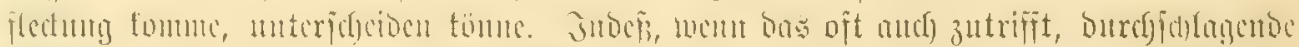

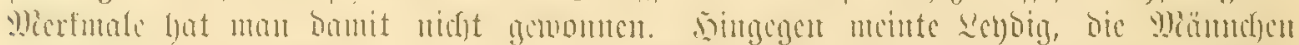

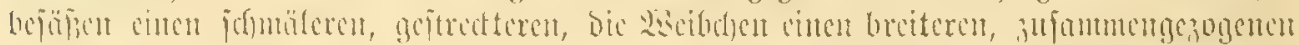
Siopf; Dod bedarf aud bicier Piuntt nod) weitcrer llnteriudyng.

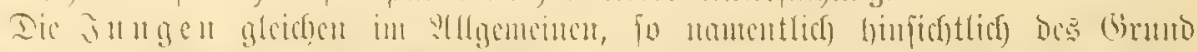

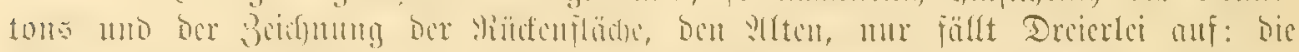

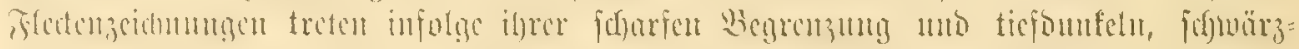

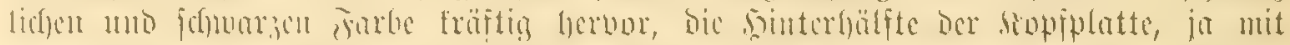

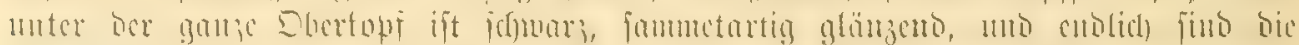

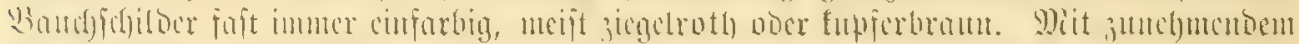

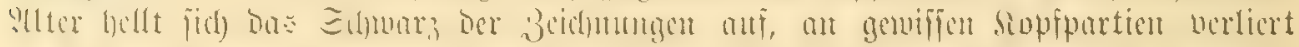

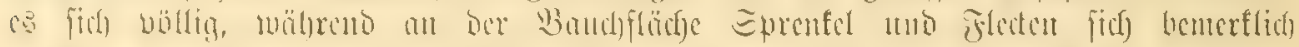

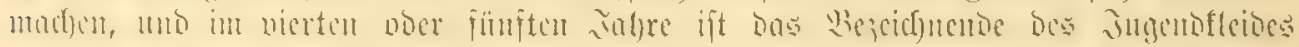
geidjumunent.

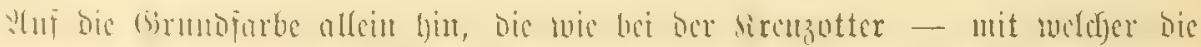

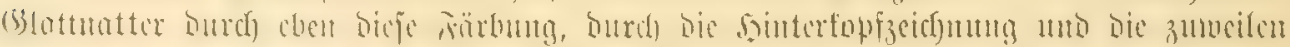

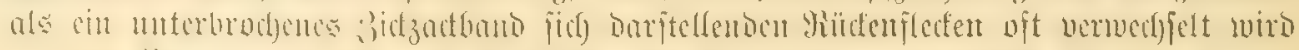
- wou

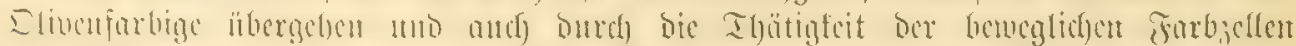

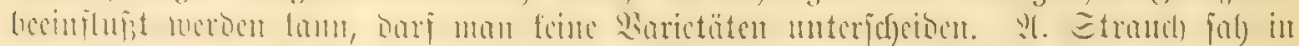

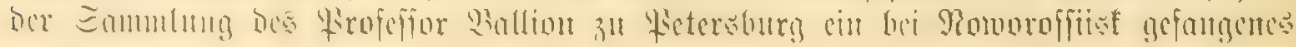




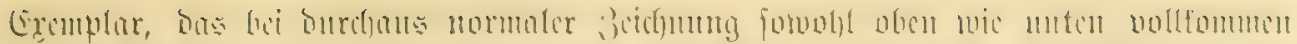

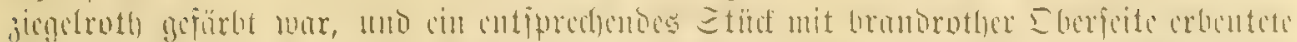

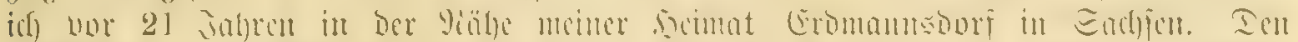

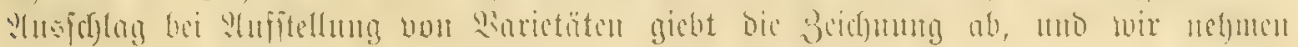
ocmznjolge mur cinige foldjer Spiclarten und Formen an.

1. Bar. fasciata, quergebänderte (GIattuatter. Unterichetbet fid) von ber

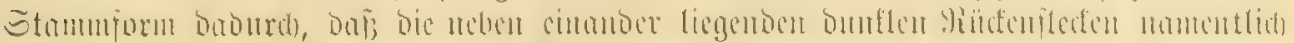

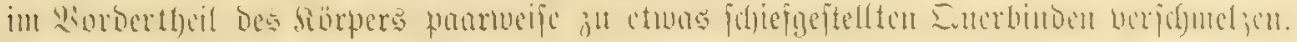
Siomut ljäufig vor.

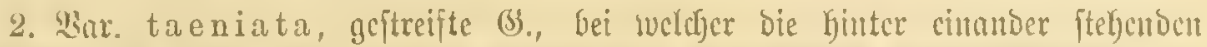

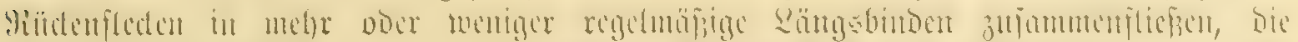

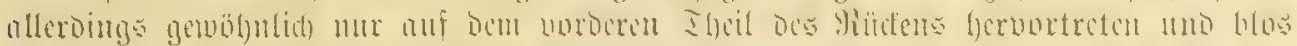

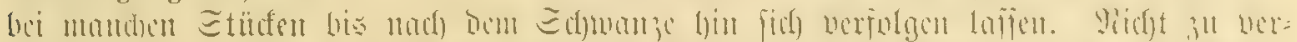

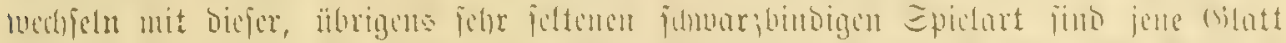

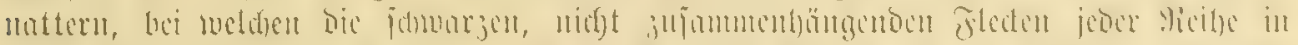

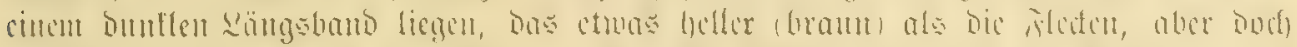

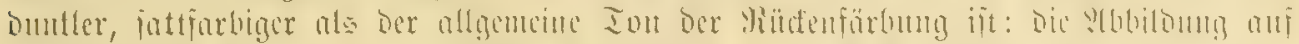

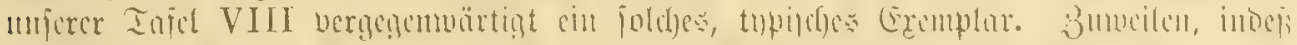

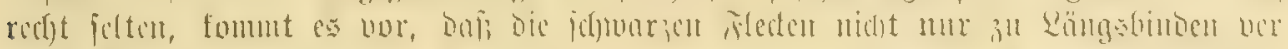

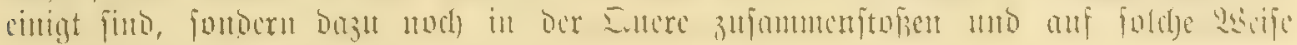
cinc ?rt Qeiterzeidnung herworrufen.

3. Bar. sparsa, gefprentelte (S\%. Doerfeitc nicfit mit Dumflen Fledtemeifen

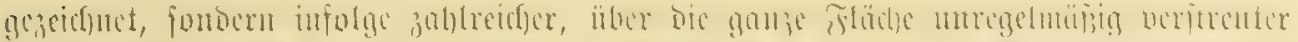

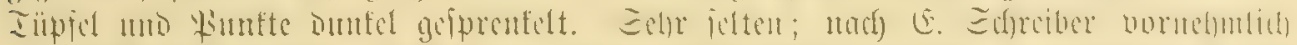

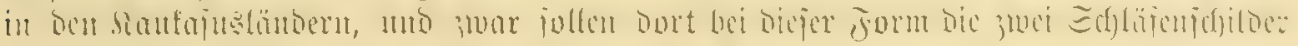
erfter gieifo gewobntidf zu einem cinzigen verfdymelzen.

4. Bar. immaculata, ungefledte 63. Sherjeitc broun oder braugrau, obuc

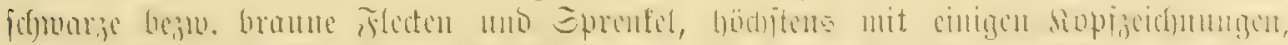

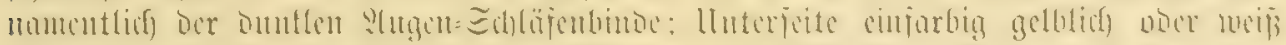

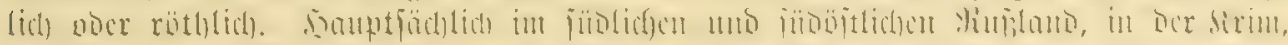

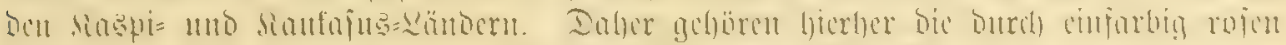

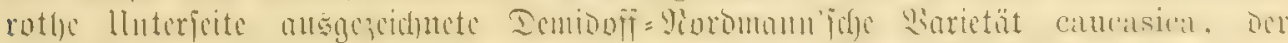

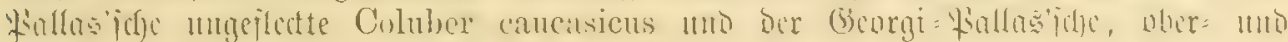
unterfeits gleidffarbig duttcl=fupferbrame Coluber cupreus.

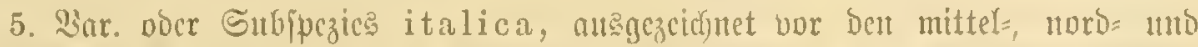

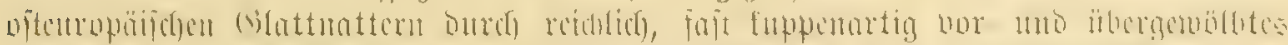

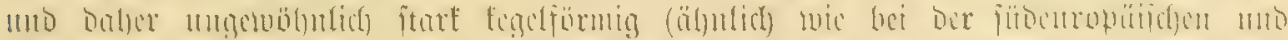

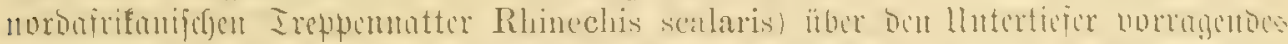

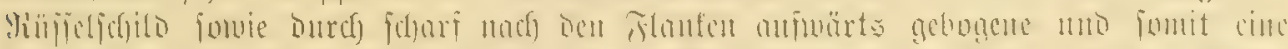

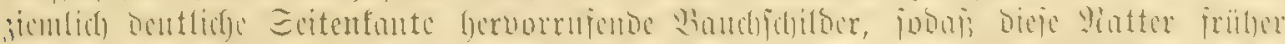

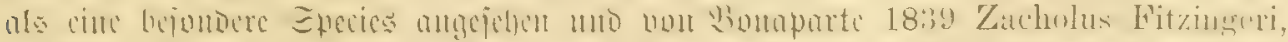

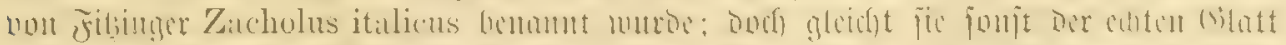

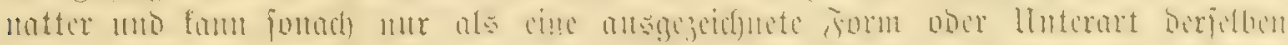

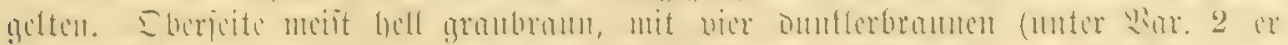

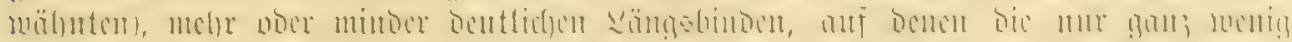

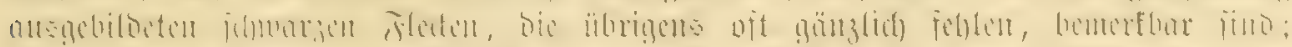

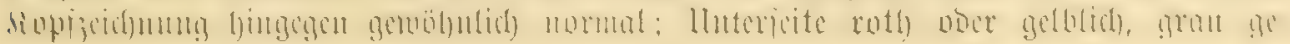




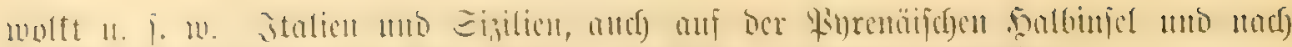

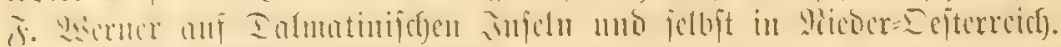

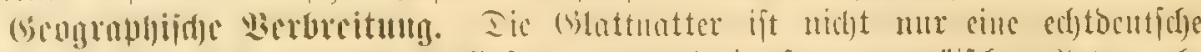

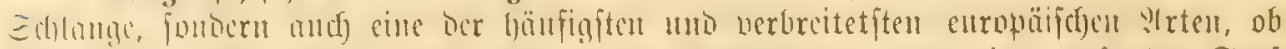

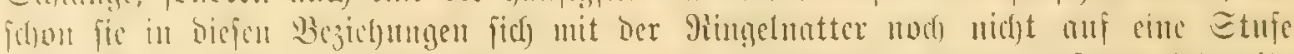

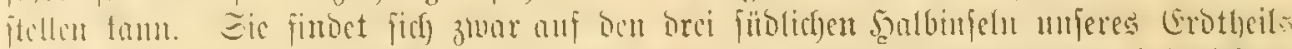

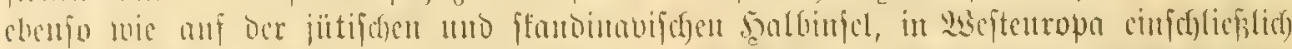

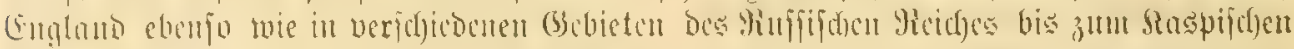

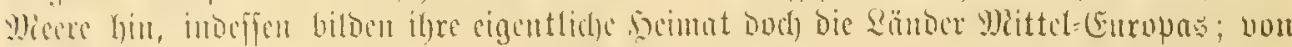

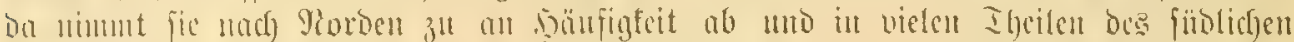

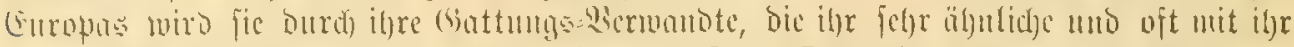

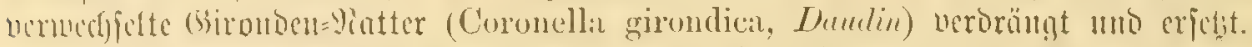

llujere mornchulidjite

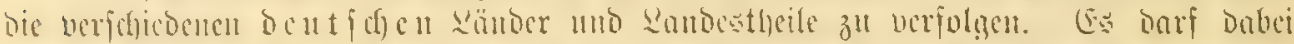

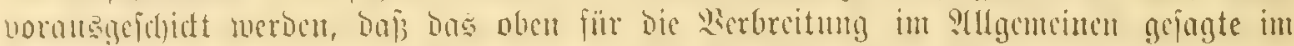

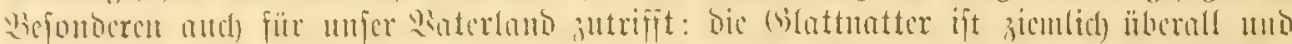

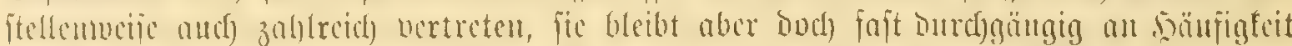

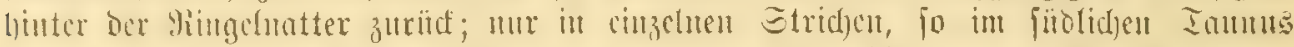

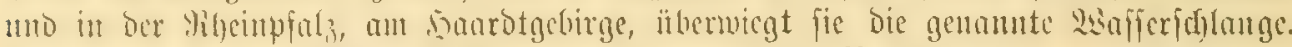

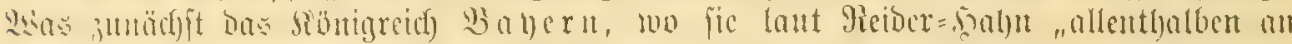

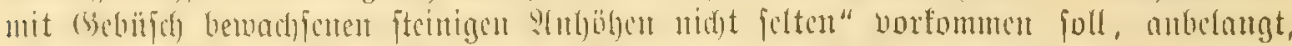

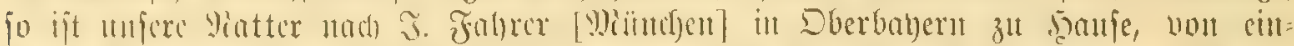

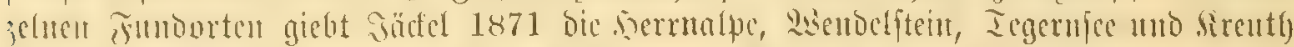

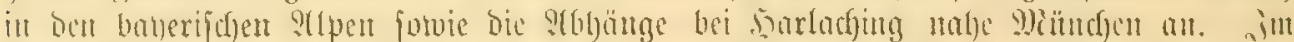

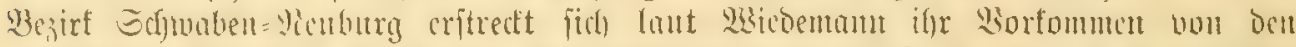

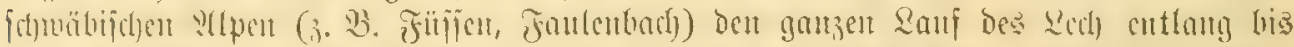

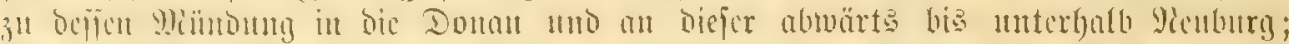

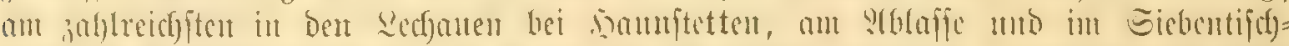

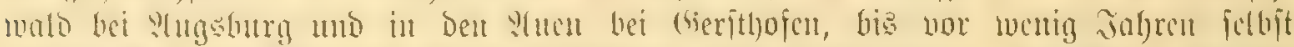

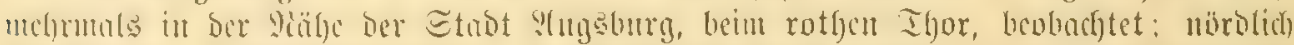

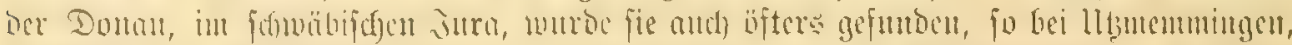

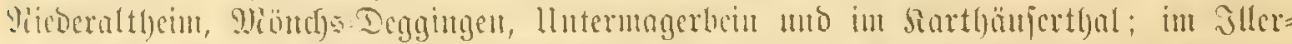

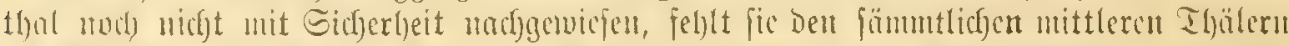

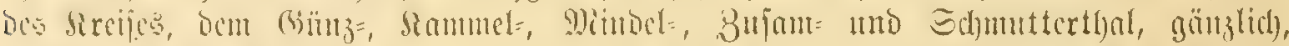

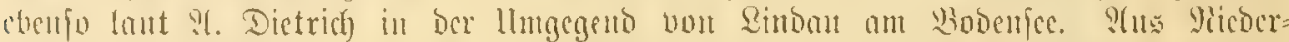

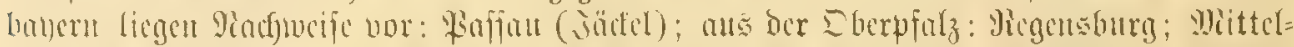

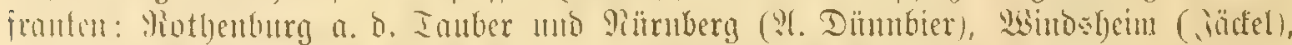

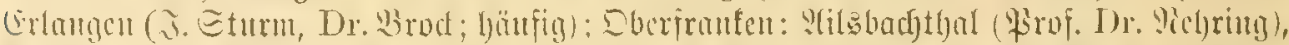

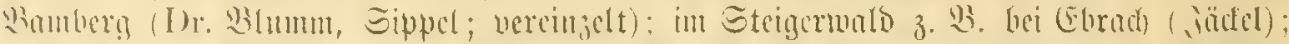

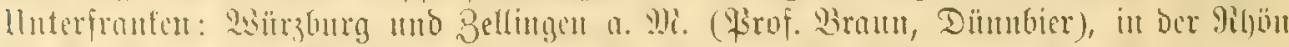

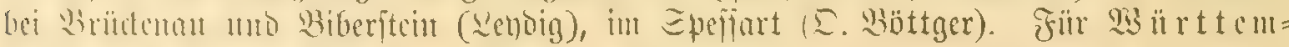
berg gicbt bercits 1830 (i). 13. Miartens folgento Funborte an: Etuttgart, Tübingen,

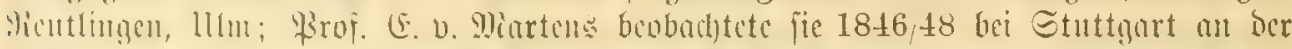

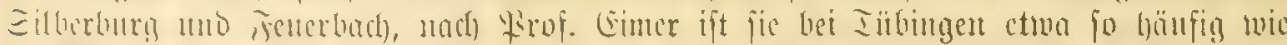

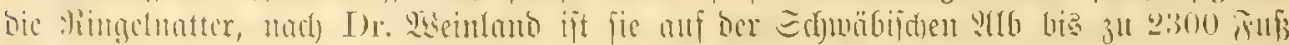

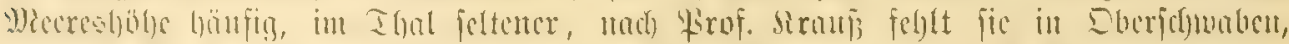

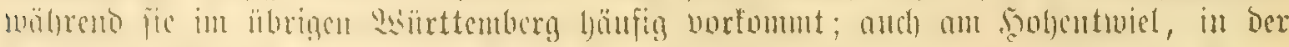

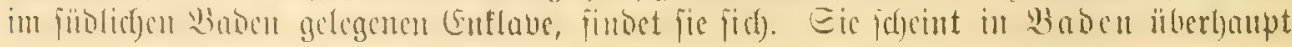




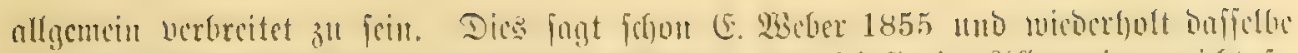

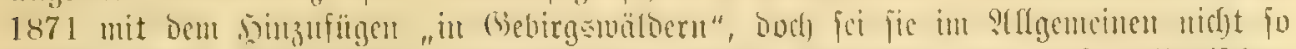

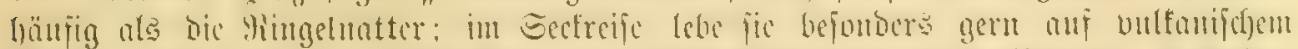

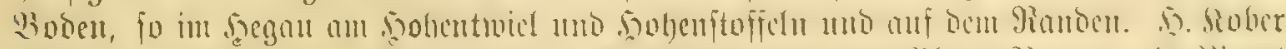

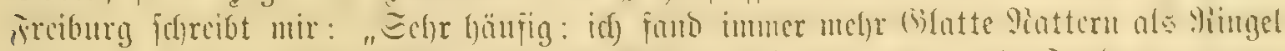

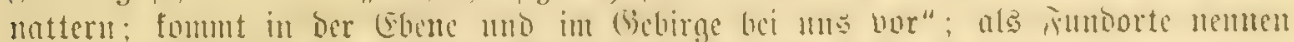

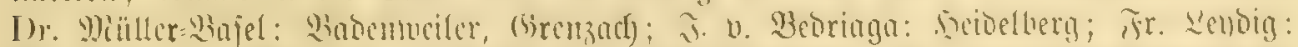

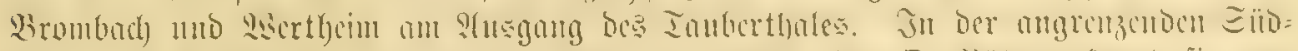

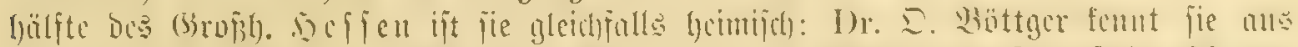

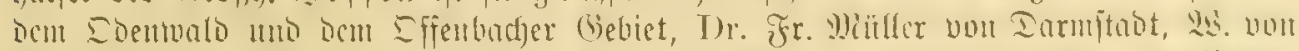

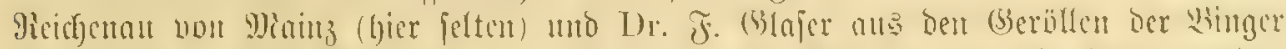

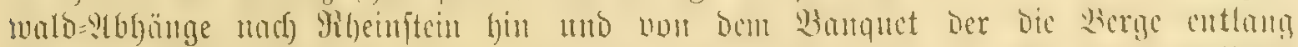

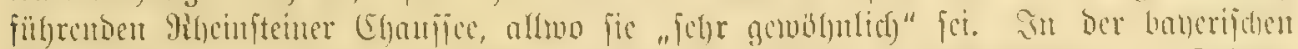

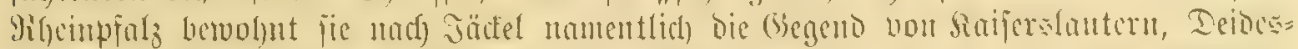

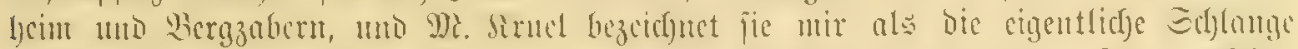

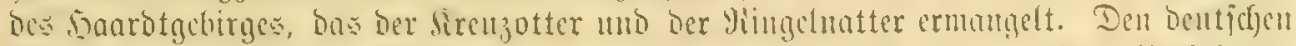

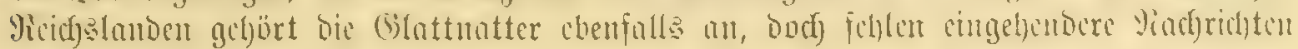
barïber.

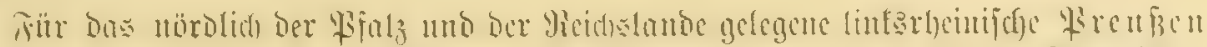

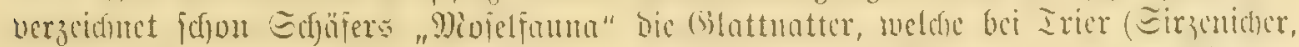

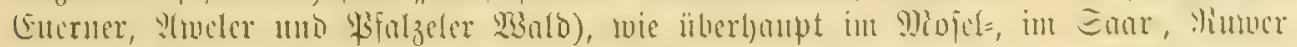

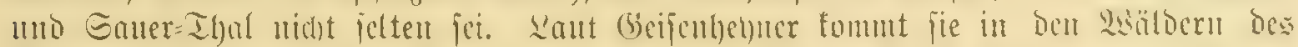

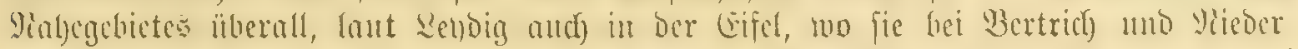

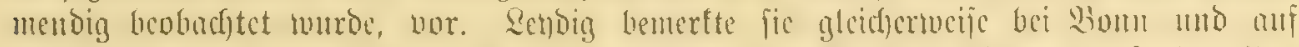

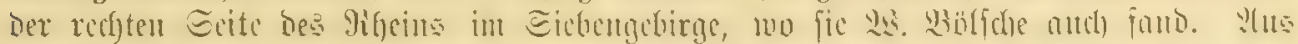

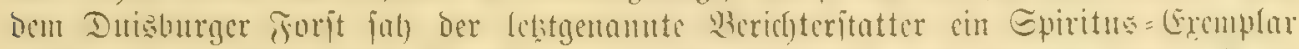

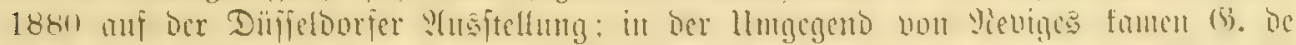

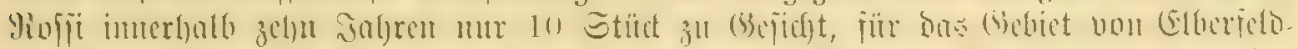

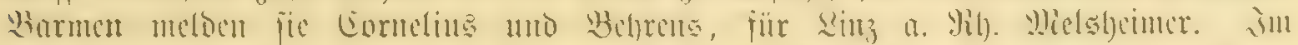

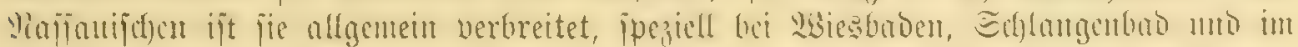

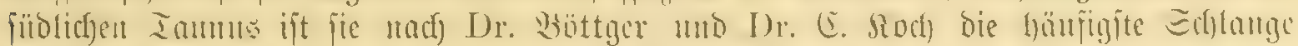

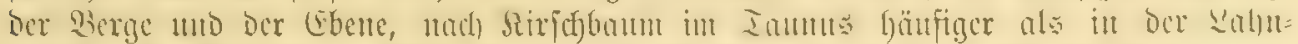

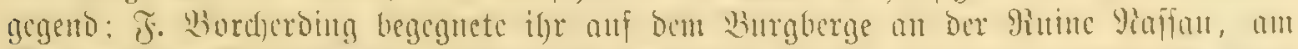

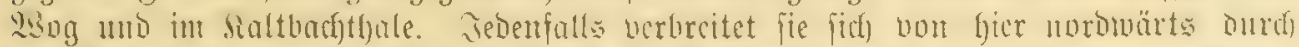

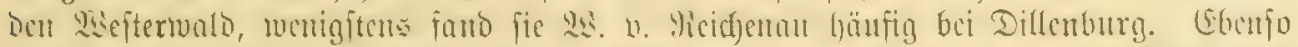

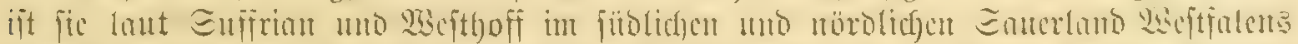

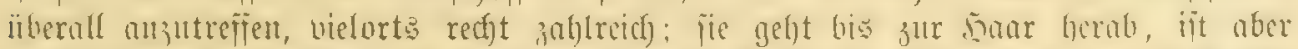

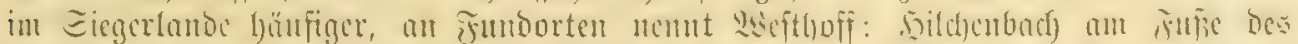

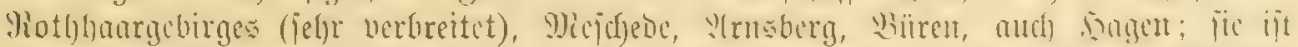

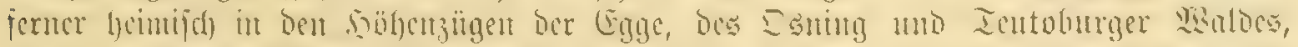

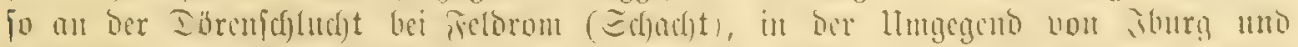

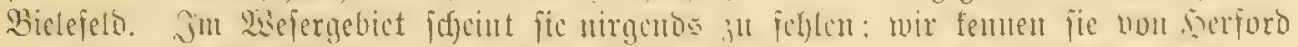

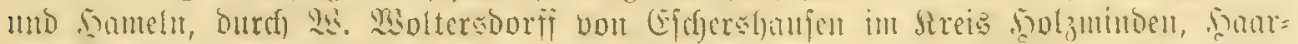

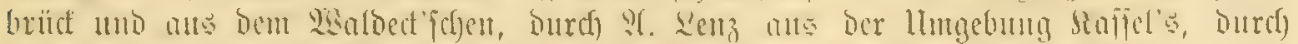

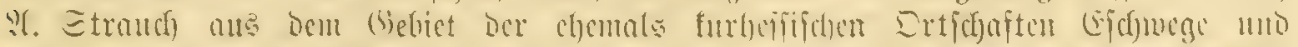

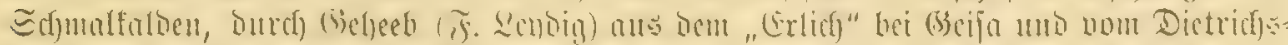

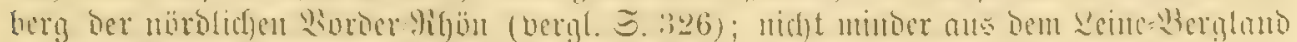

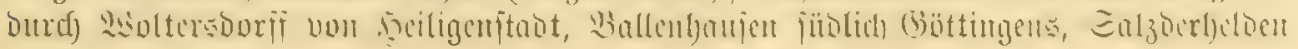




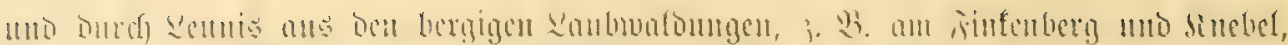

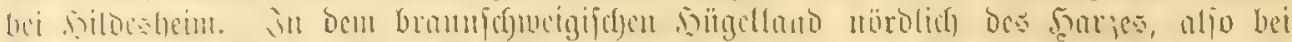

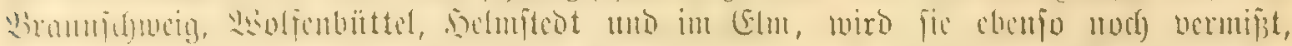

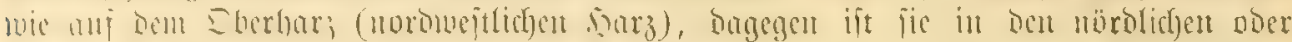

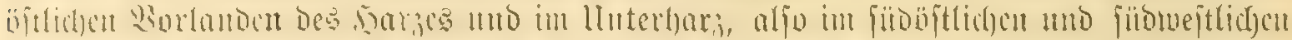

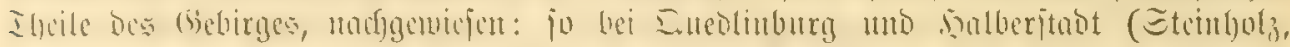

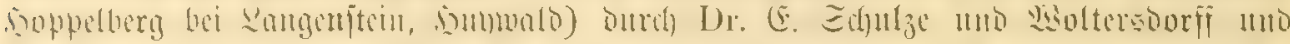

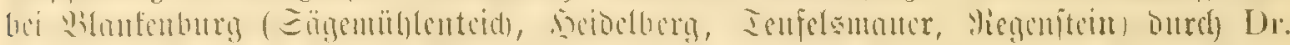

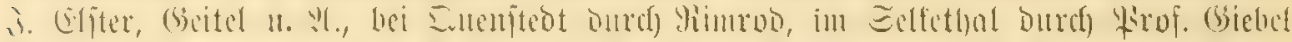

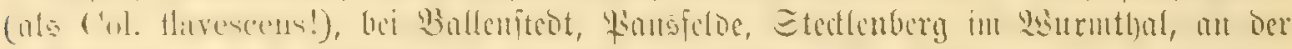

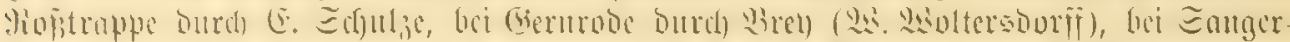

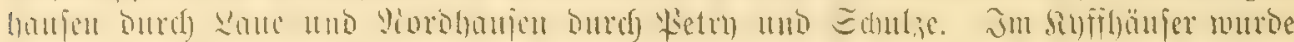

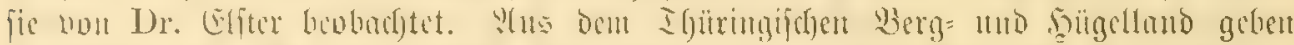

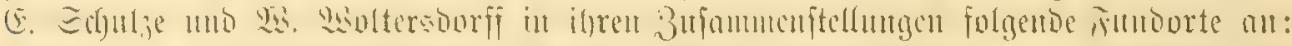

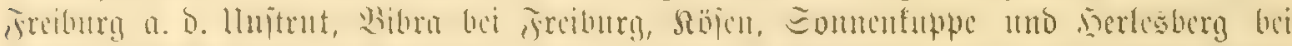

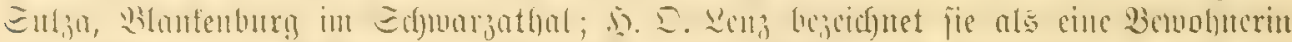

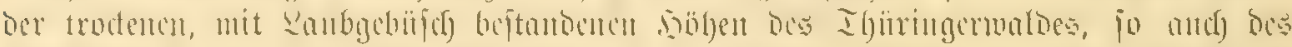

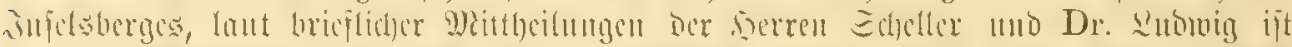

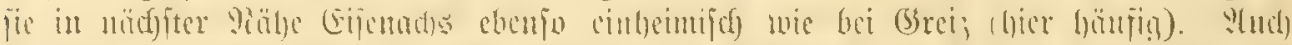

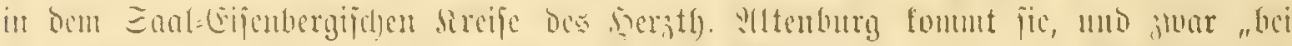

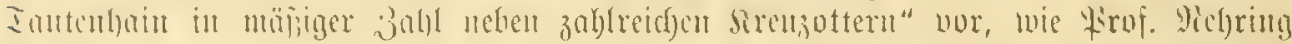

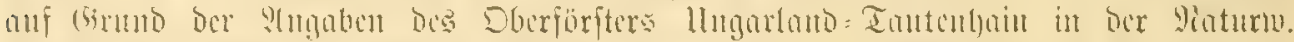

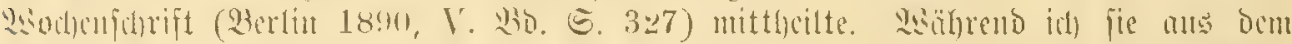

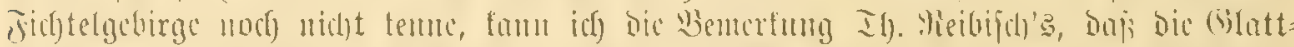

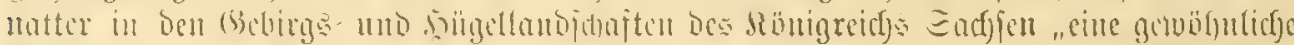

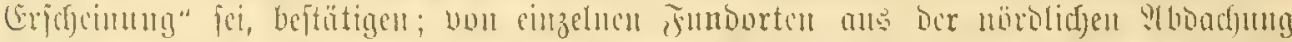

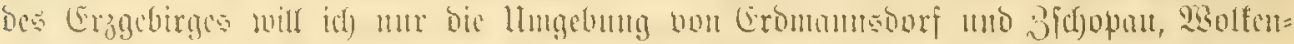

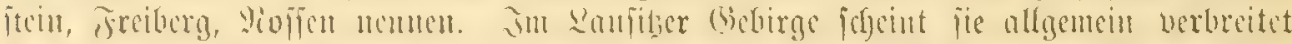

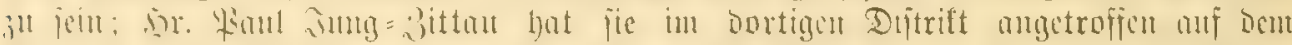

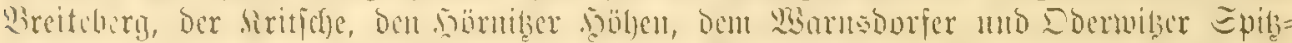

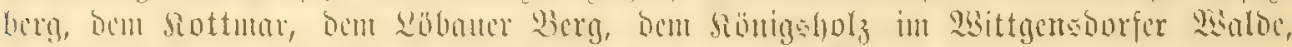

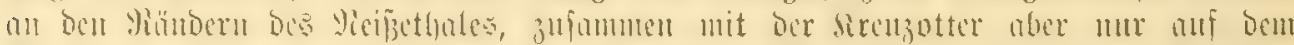

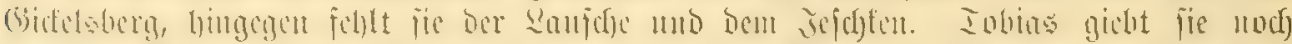

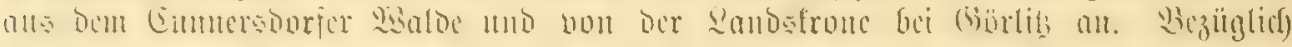

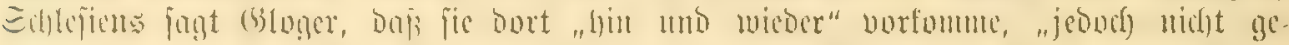

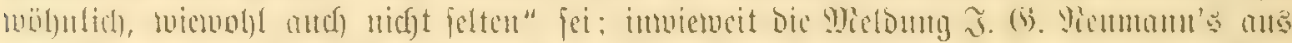

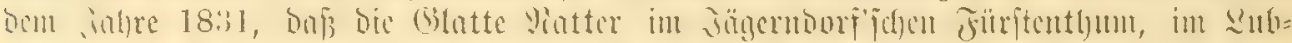

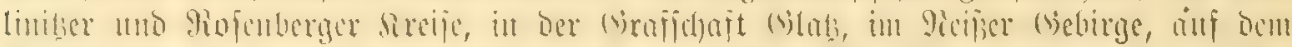

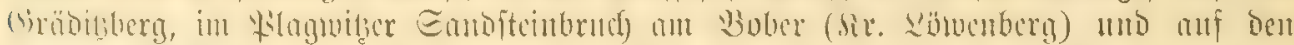

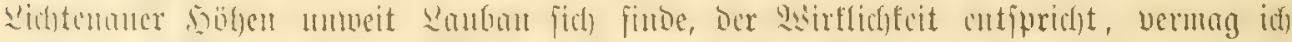

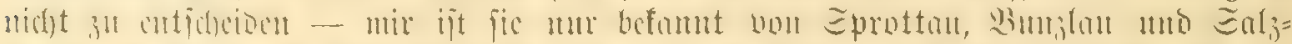

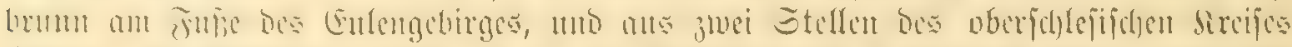

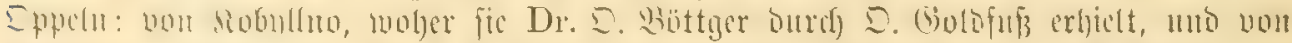

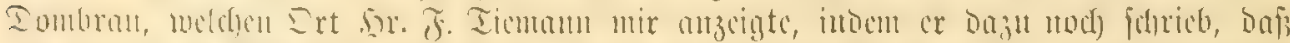

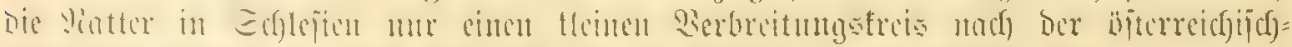

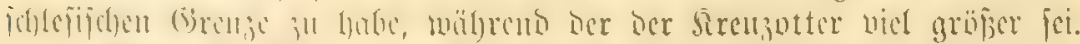

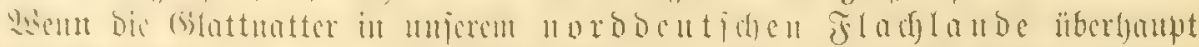

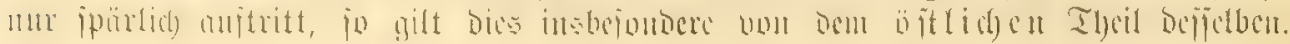




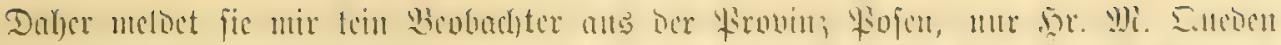

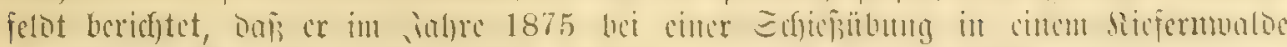

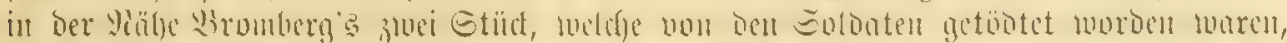

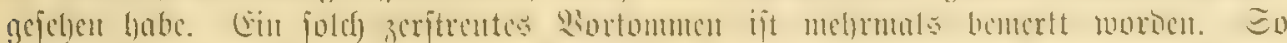

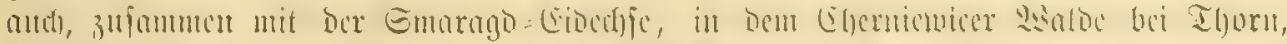

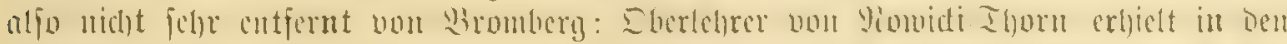

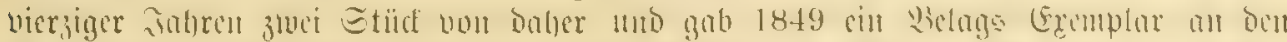

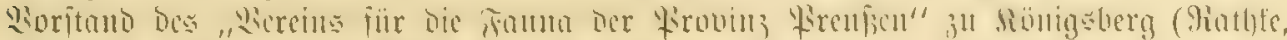

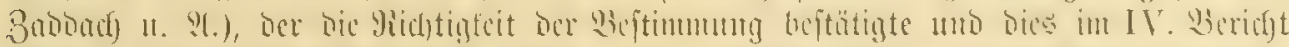

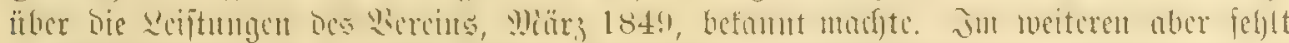

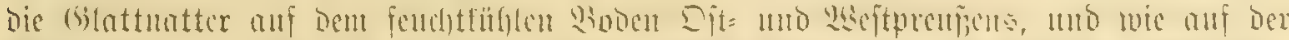

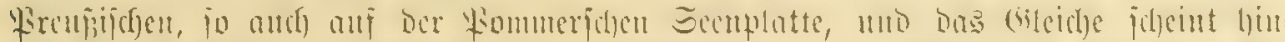

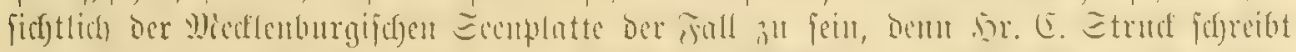

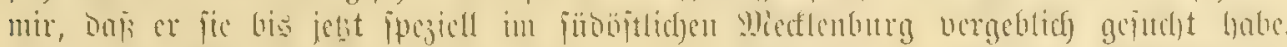

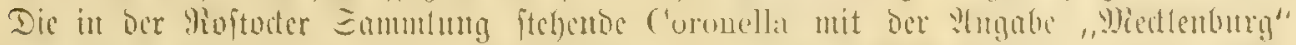

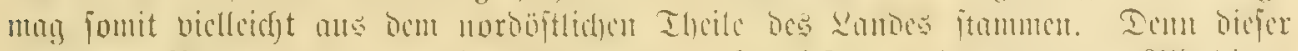

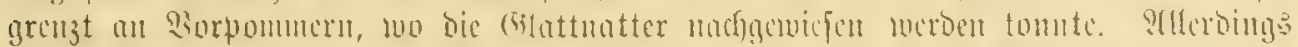

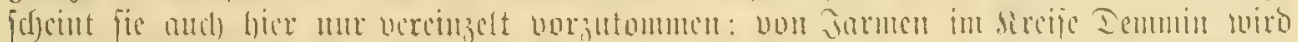

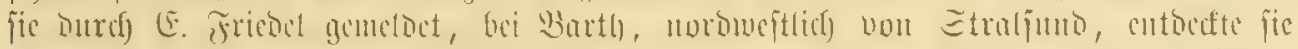

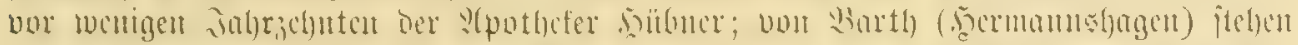

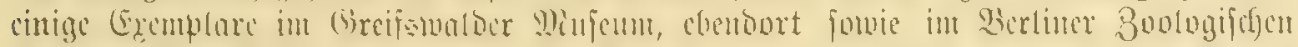

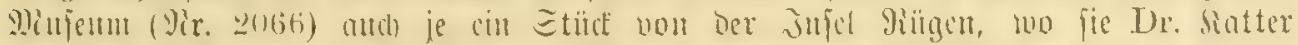

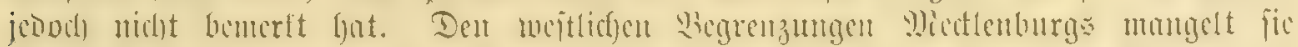

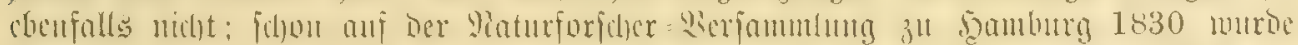

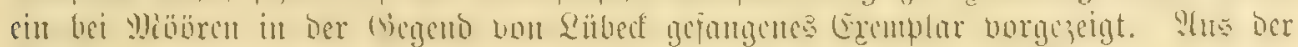

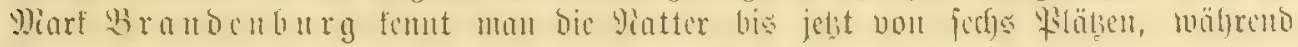

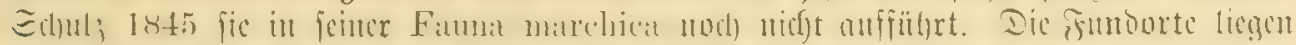

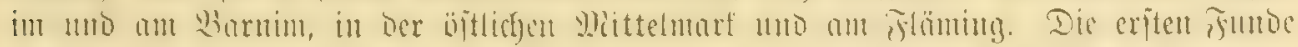

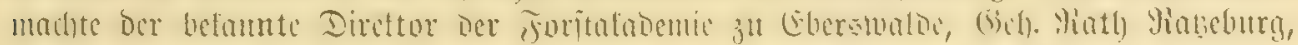

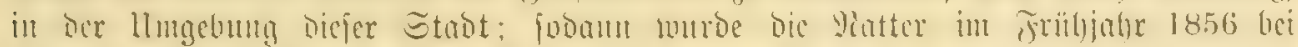

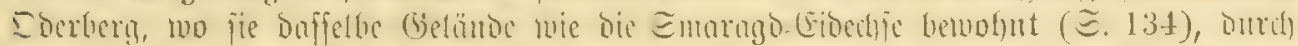

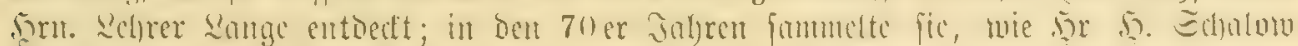

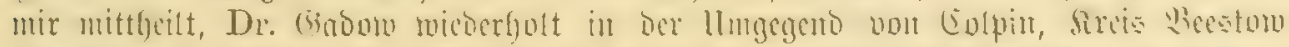

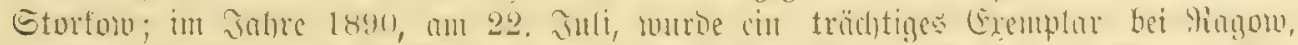

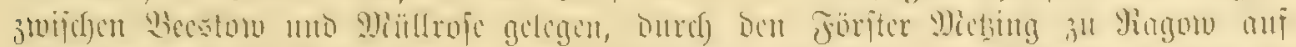

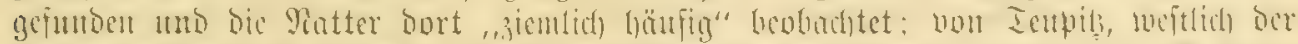

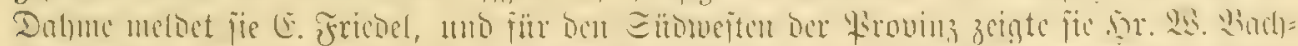

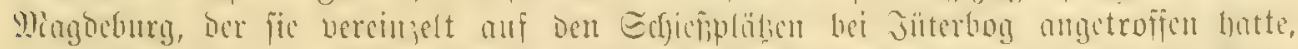

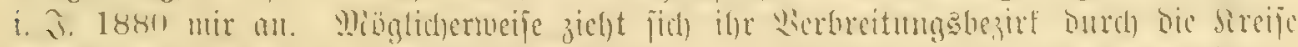

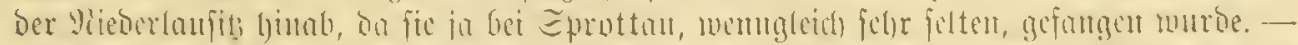

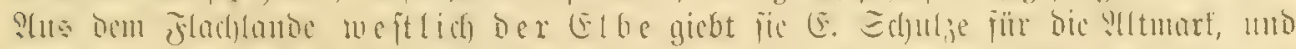

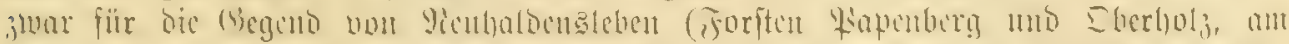

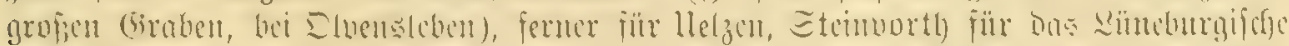

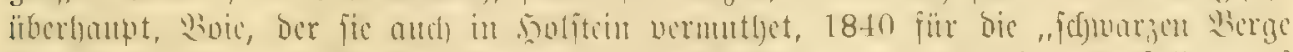
bet narburg" an. Jn ber llmgegend namburgs begegnet man ilur cbenfalls: aup

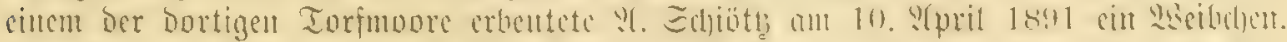

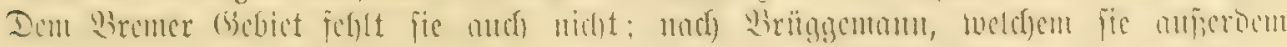

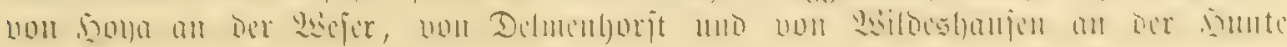




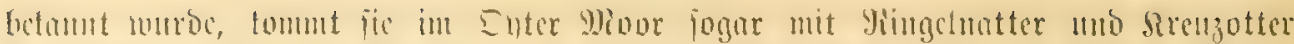
i)

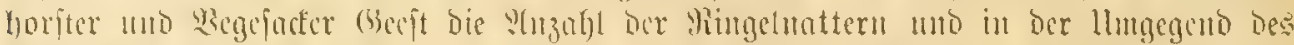

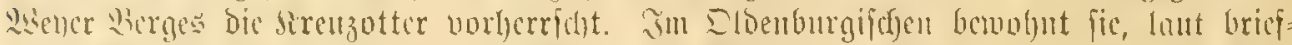

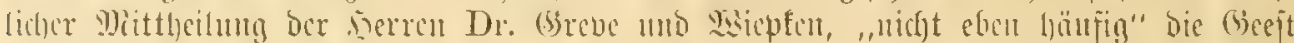

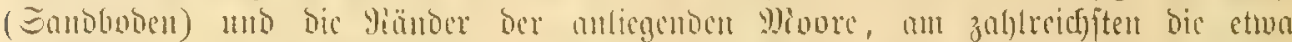

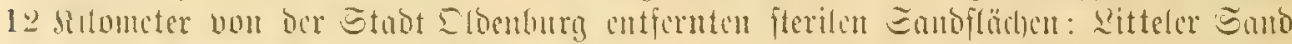

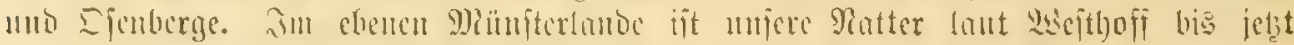

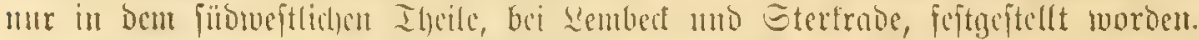

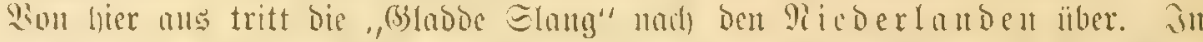

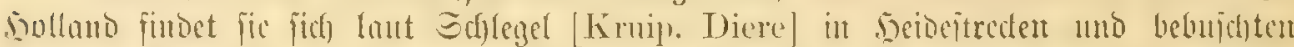

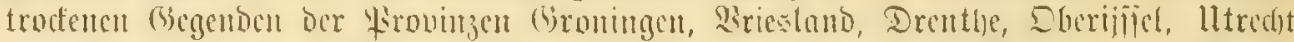

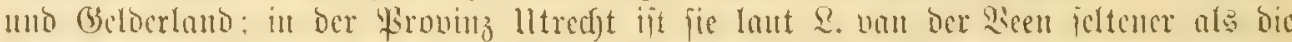

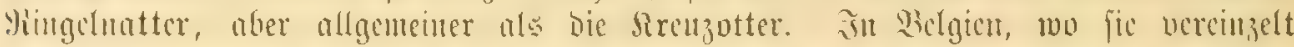

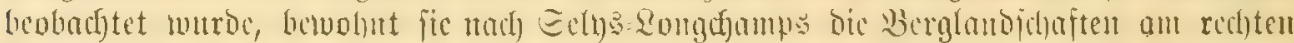

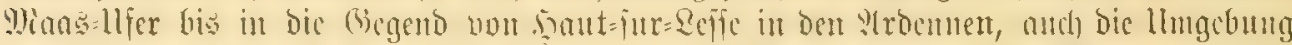

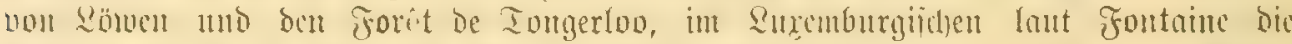

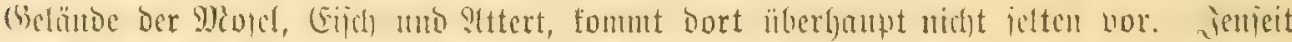

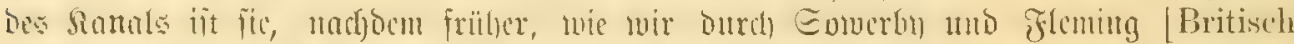

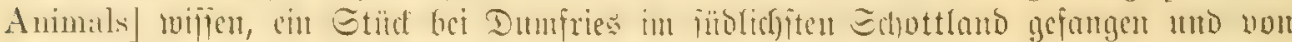

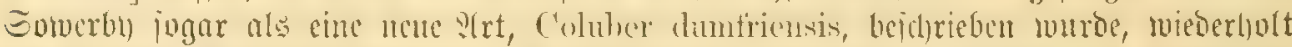

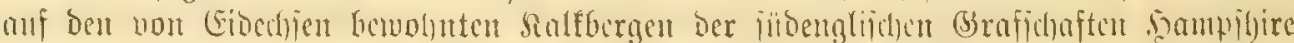

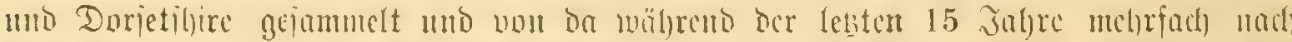

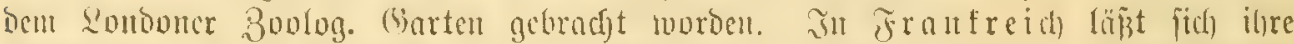

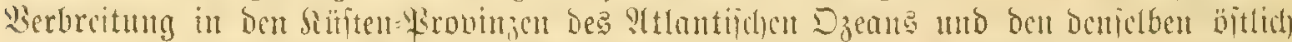

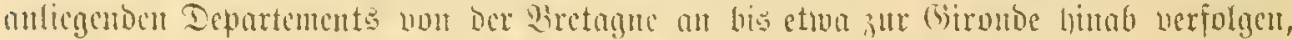

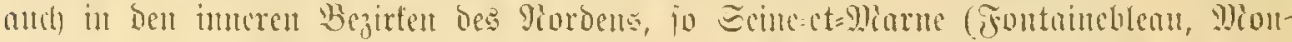

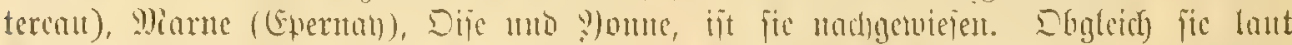

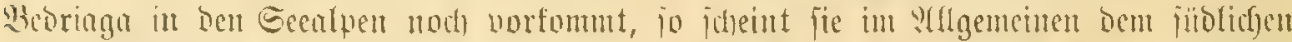

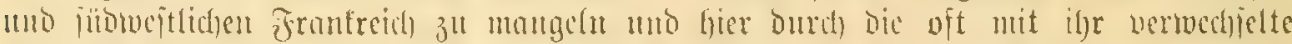

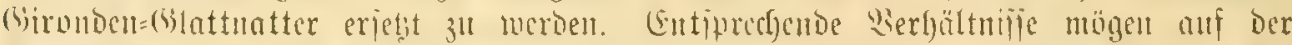

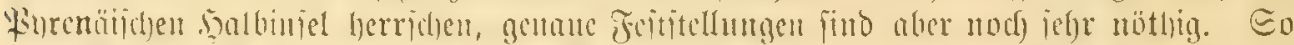

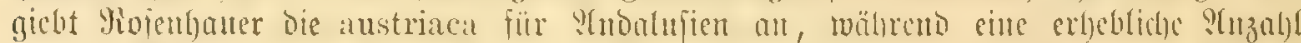

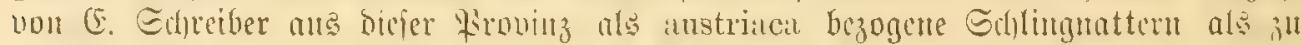

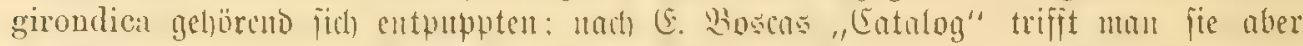

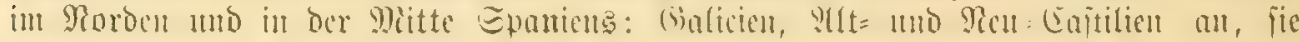

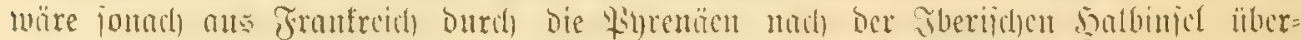

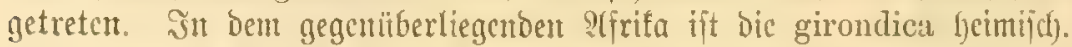

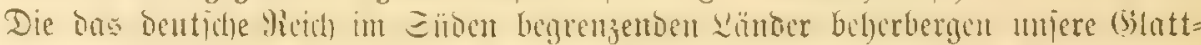

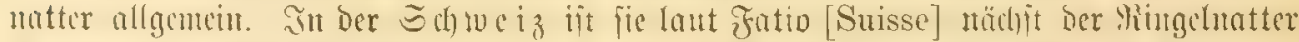

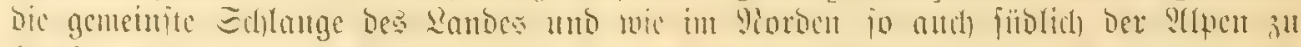

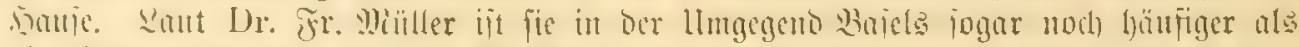

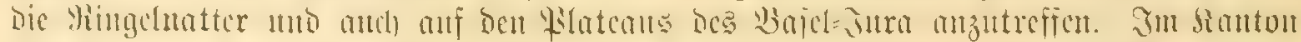

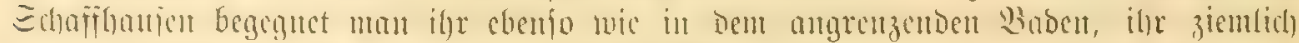

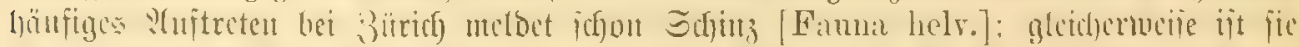

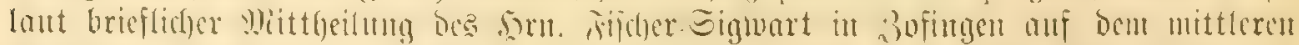

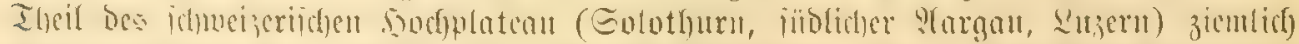

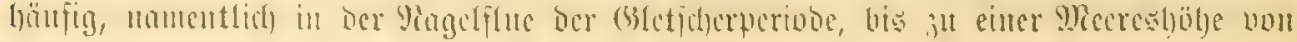




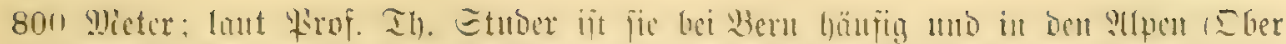

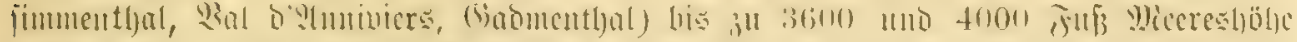

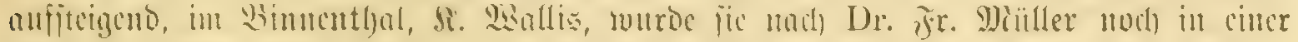

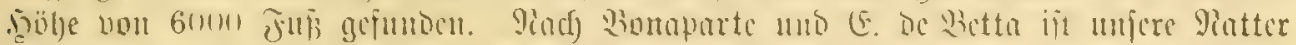

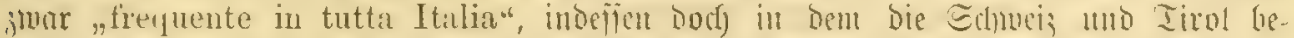

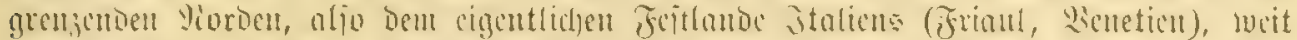

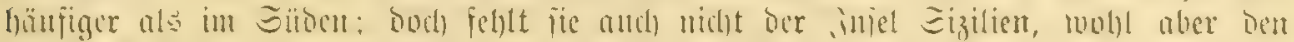

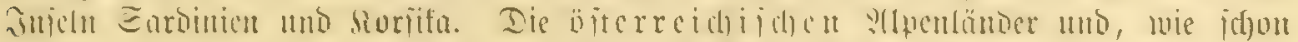

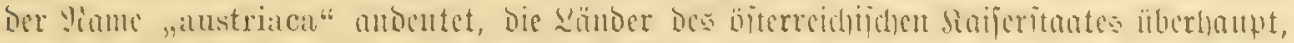

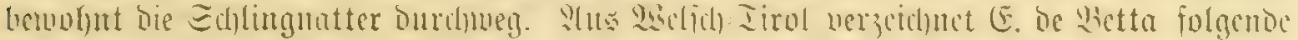

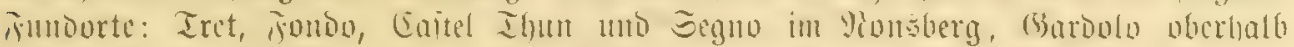

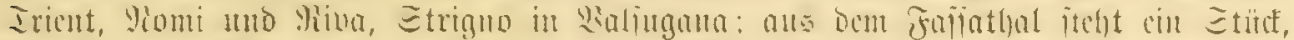

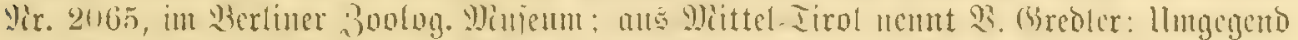

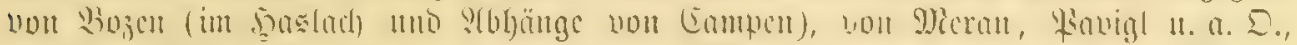

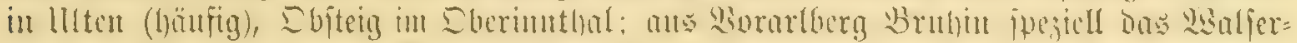

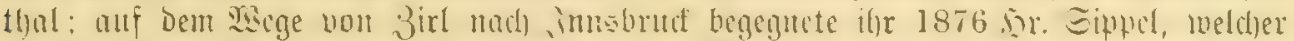

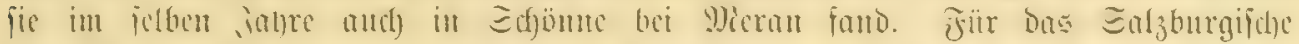

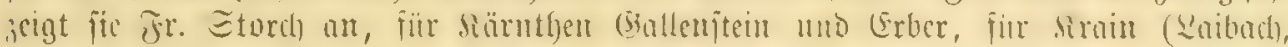

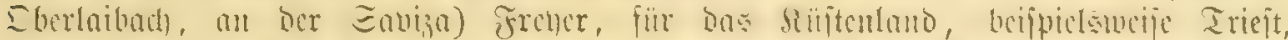

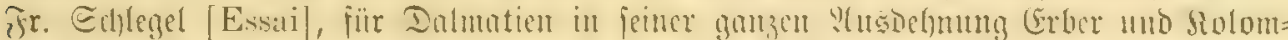

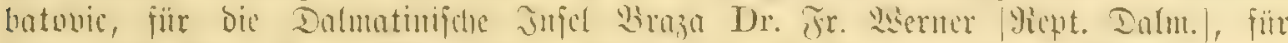

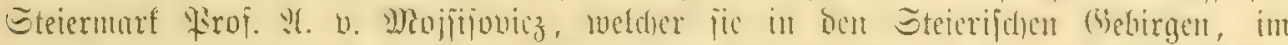

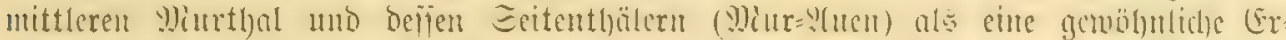

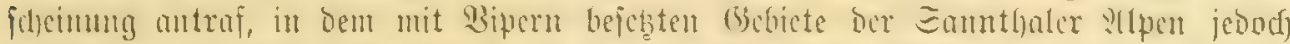

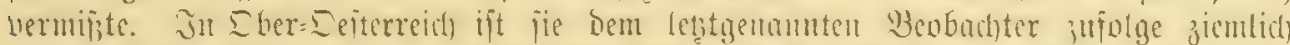

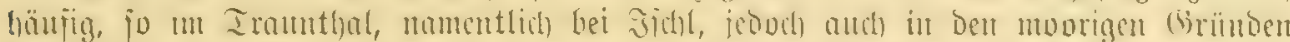

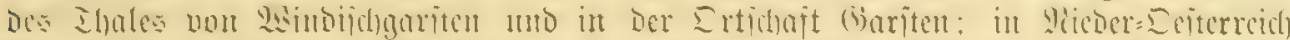

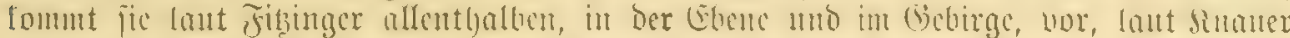

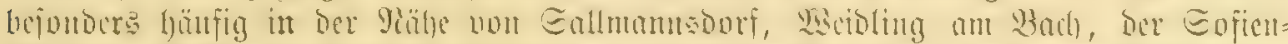

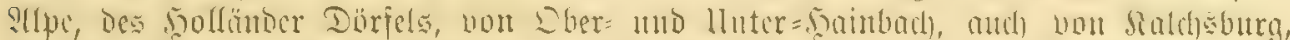

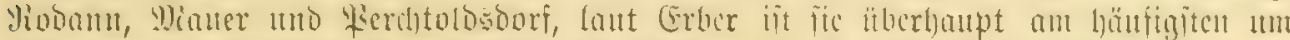

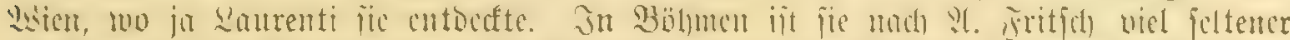

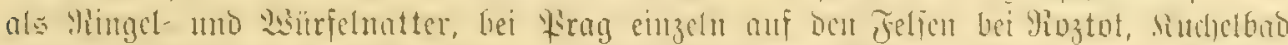

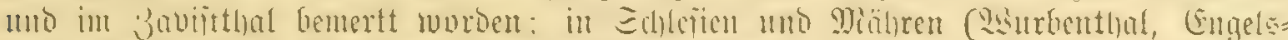

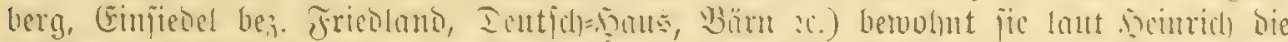

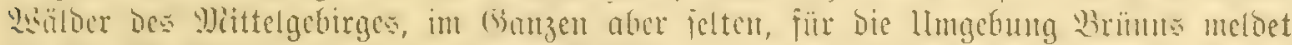

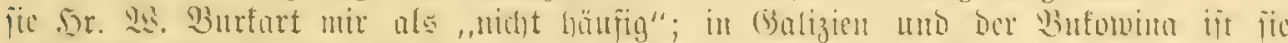

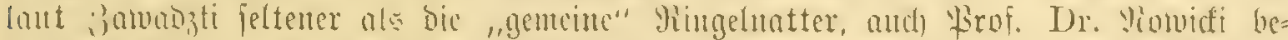

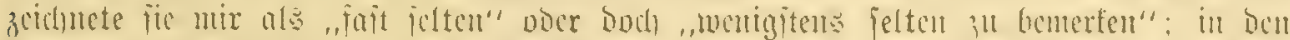

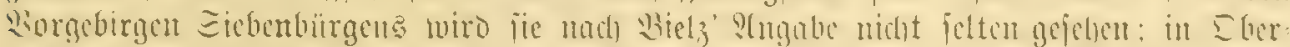

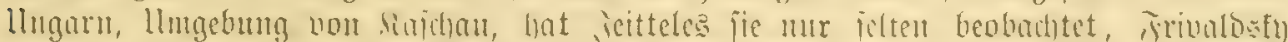

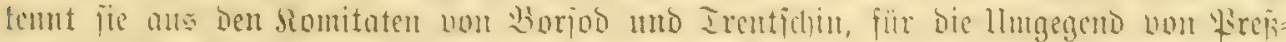

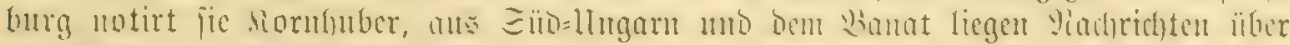

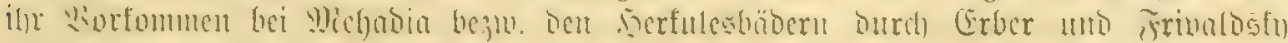

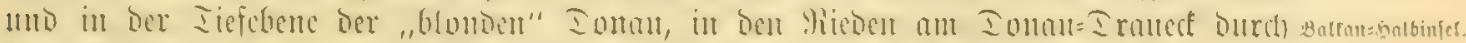

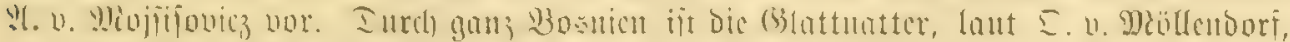

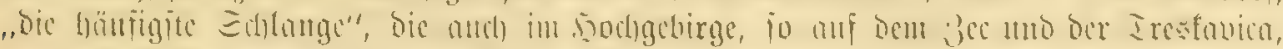

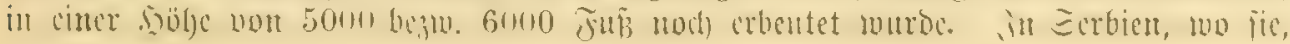




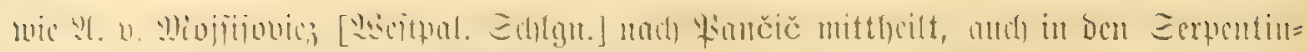

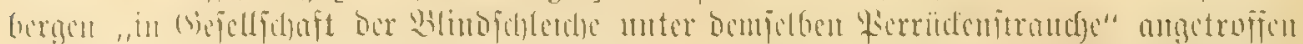

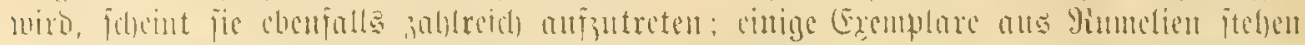

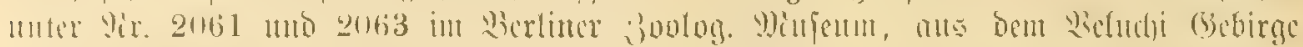

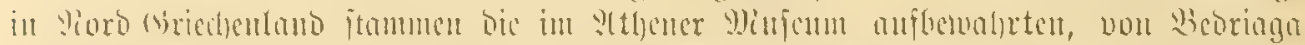

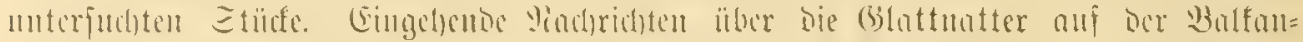

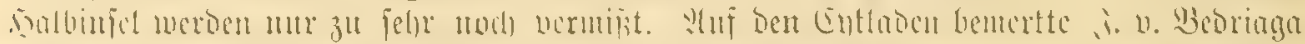

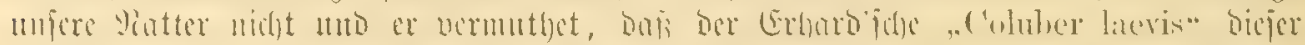

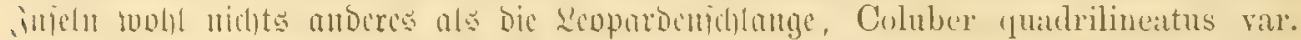
leopardinus, ït, uähreno (5. De betta in inn Rettili (irecia bieje nermeintliche laevis als cine girondica anjpricht.

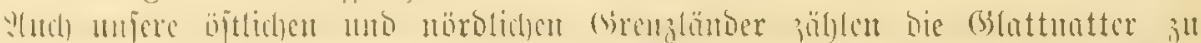

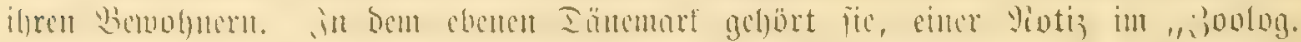

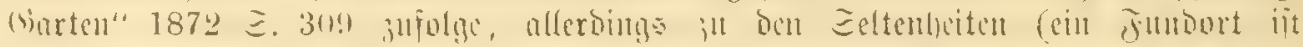

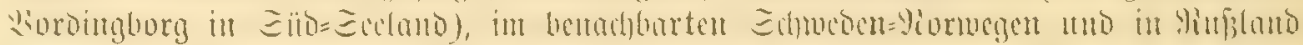

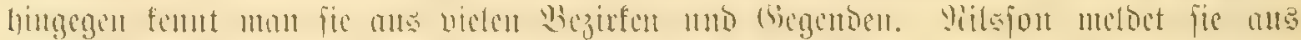

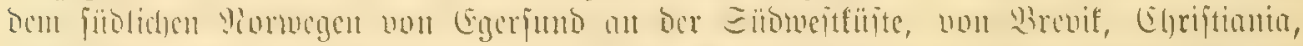

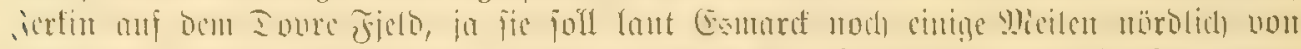

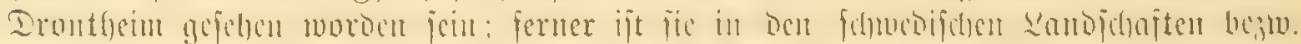

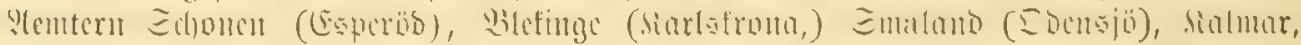

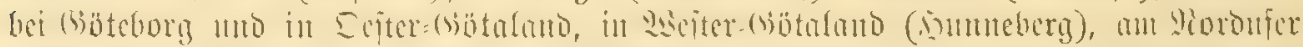

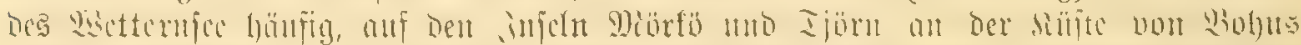

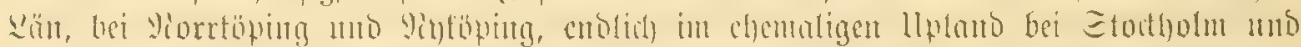

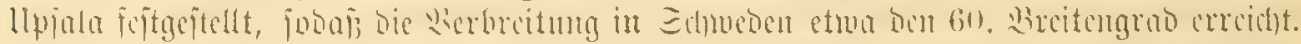

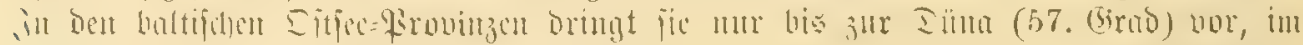

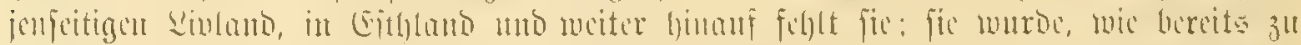

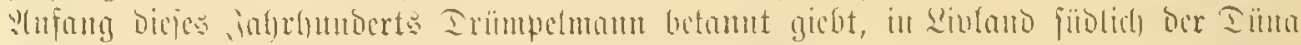

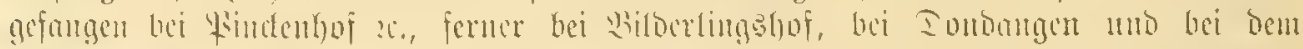

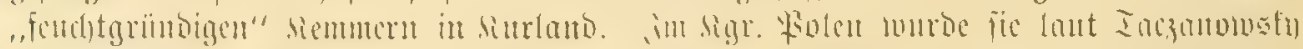

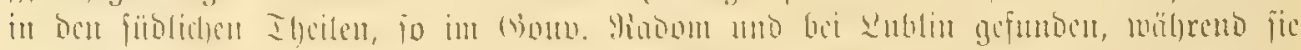

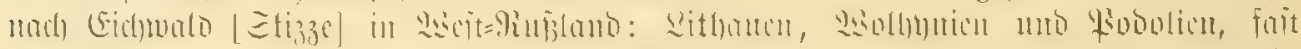

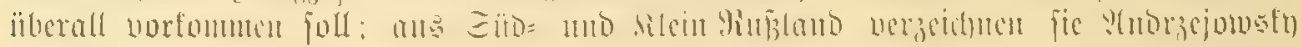

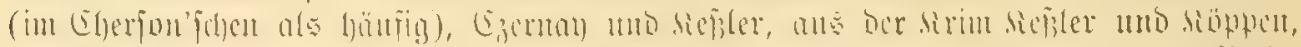

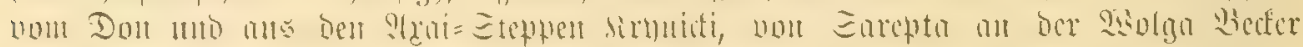

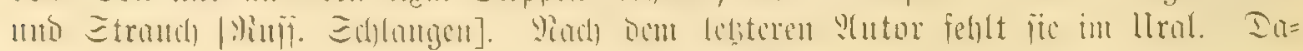

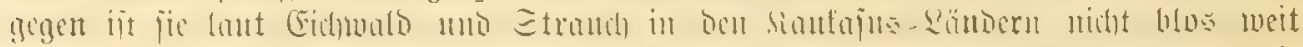

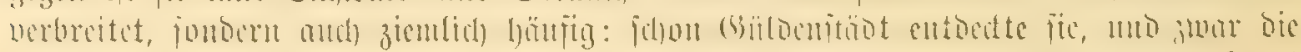

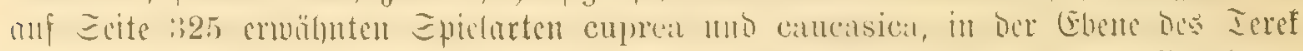

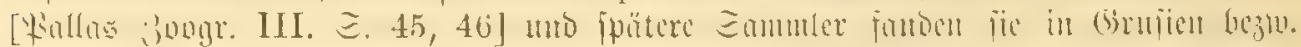

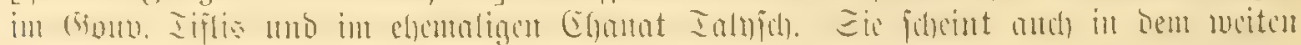

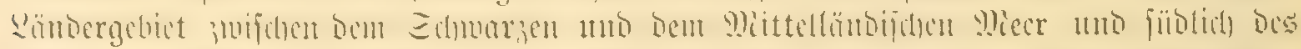

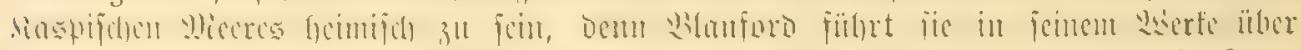

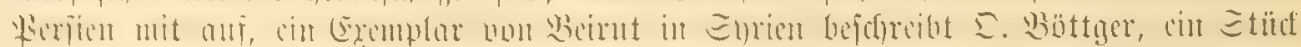

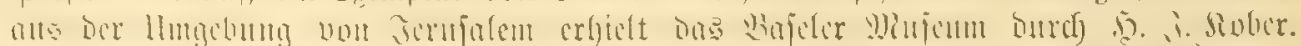

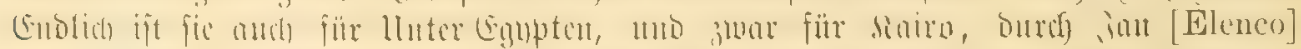

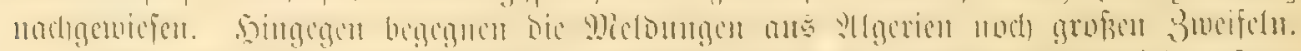

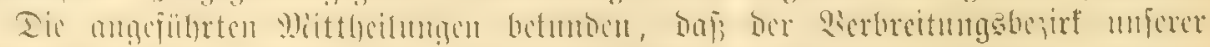




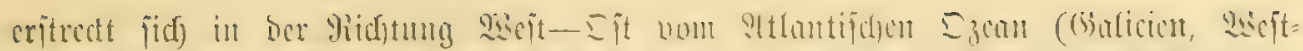

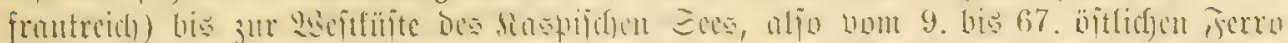

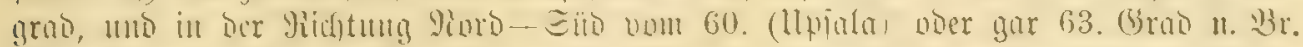

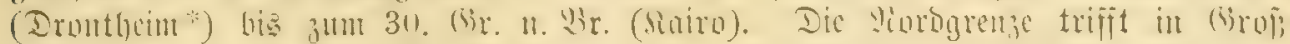

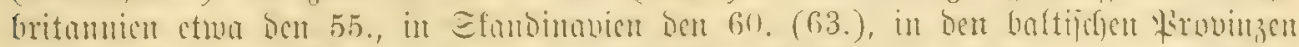

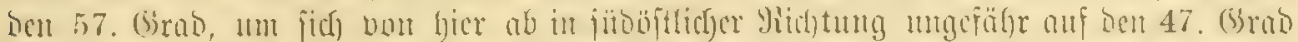

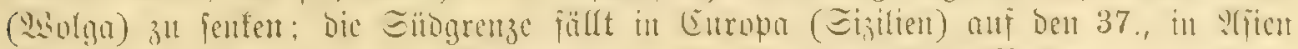

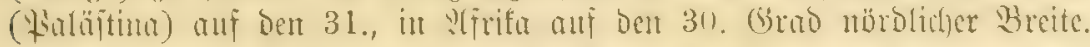

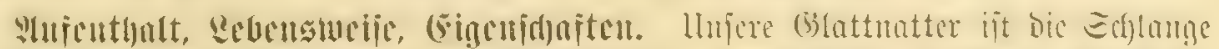
*turentgalt.

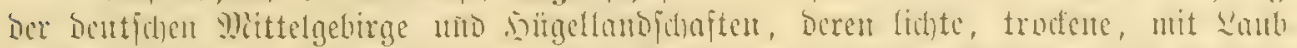

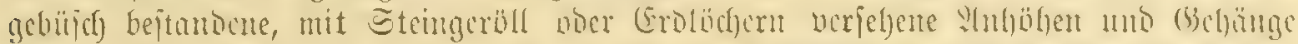

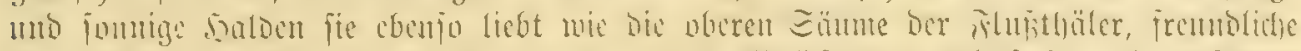

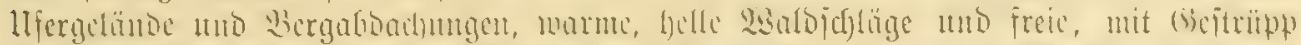

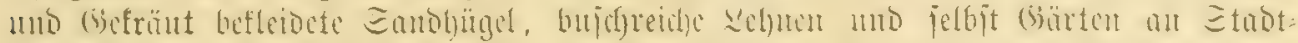

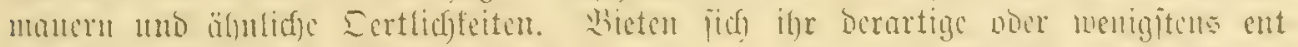

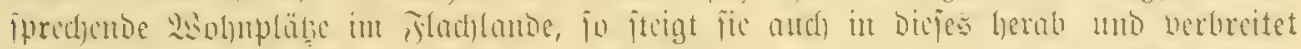

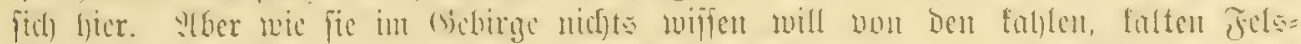

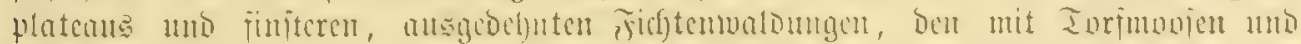

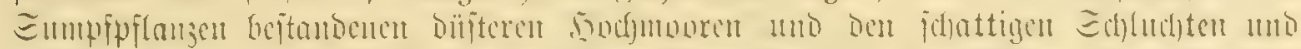

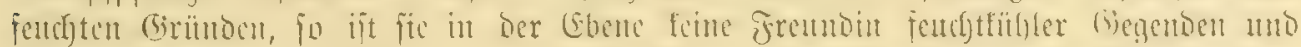

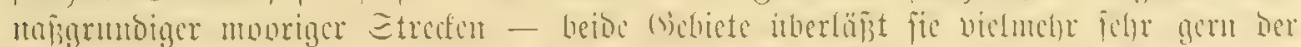

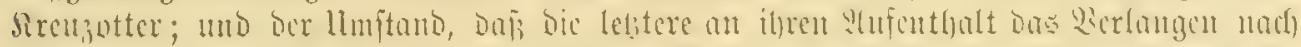

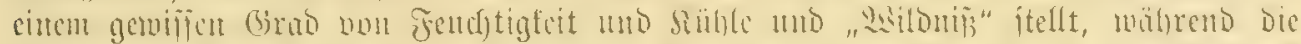

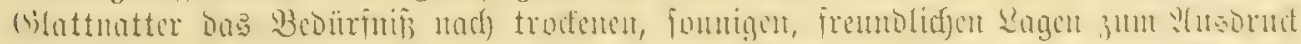

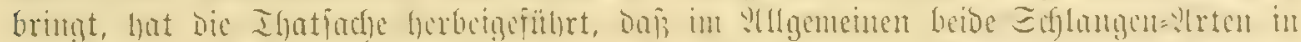

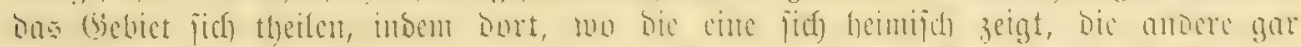

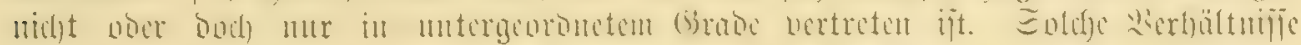

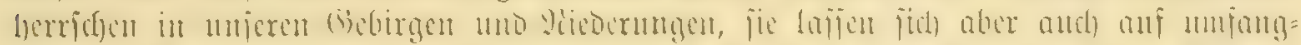

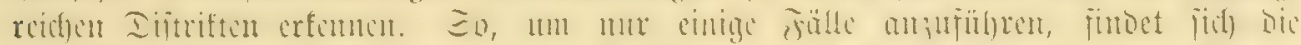

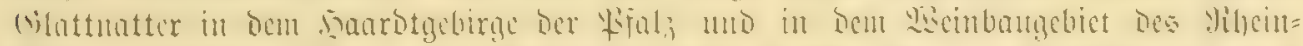

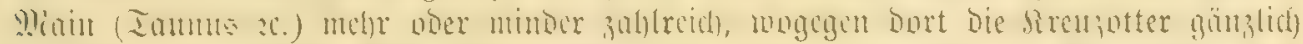

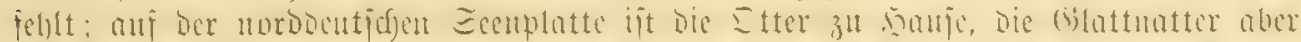

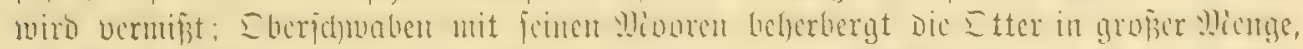

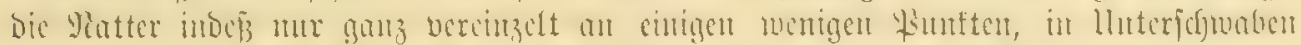

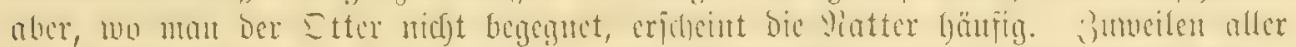

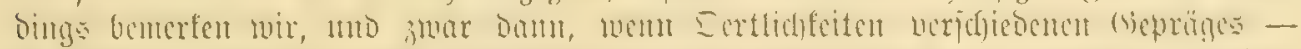

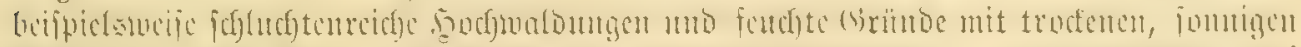

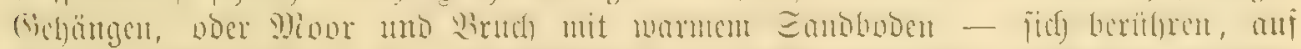

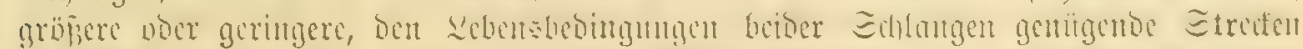

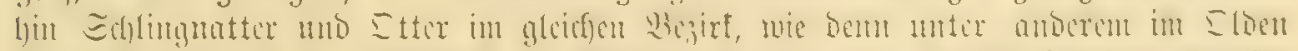

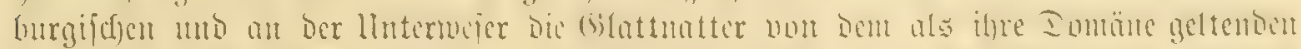

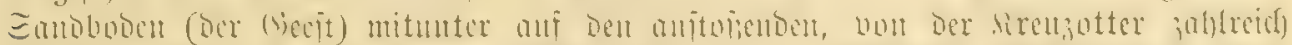

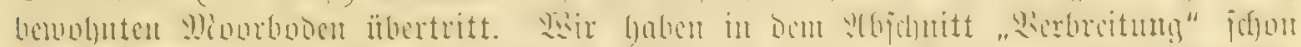

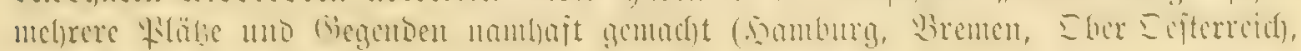

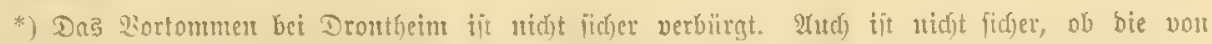

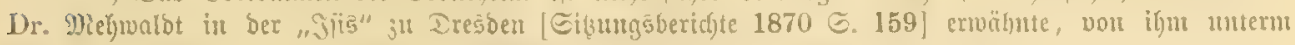

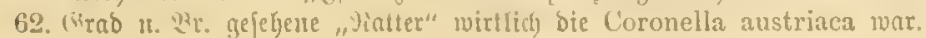




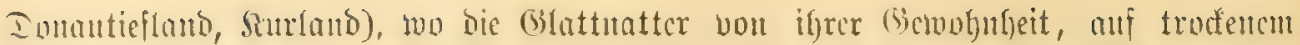

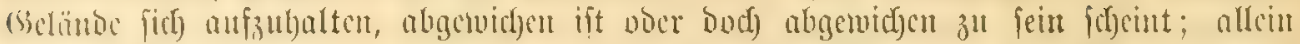

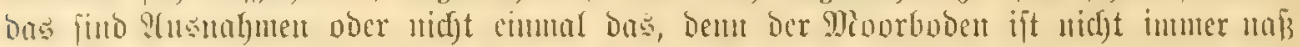

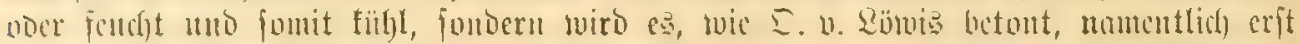

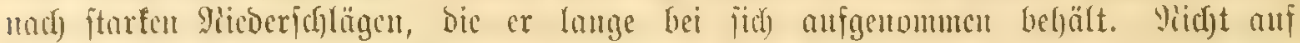

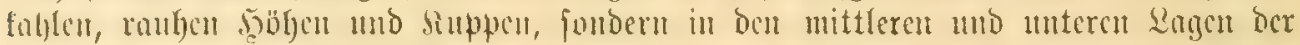
(vebirge bezm. Dent Thalfentungen uns Thalfümmen berfelben fïblt fidf unjere Siatter

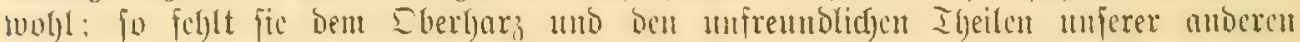

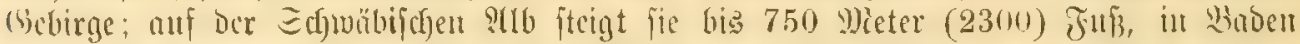

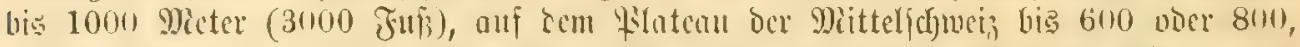

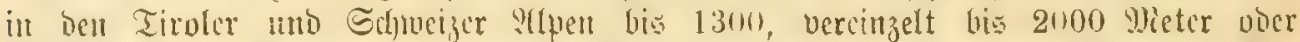

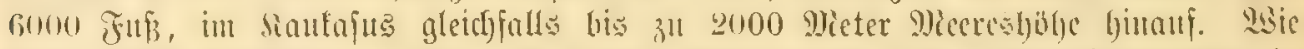

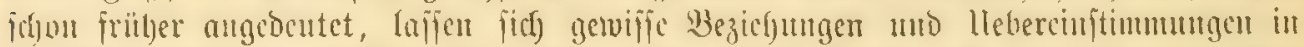
Deu Lebensbedingutugen Der (Blattnatter mit unferer 3aun= noer auth) ber Emarago=

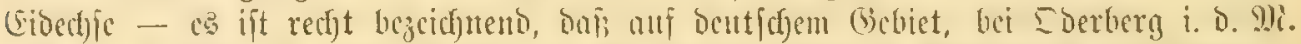

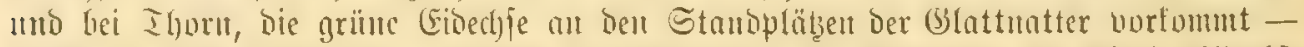

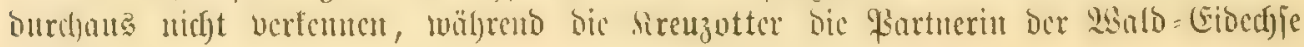
Daritellt.

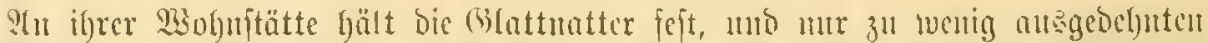

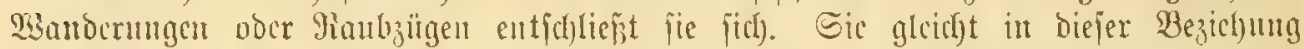
weit mely Der Sircuzotter als Der gingelnatter, cbenfo in Der Fortbetuegung, weldye

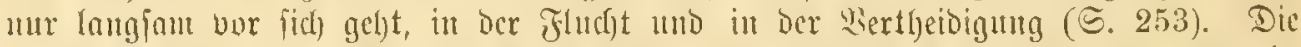

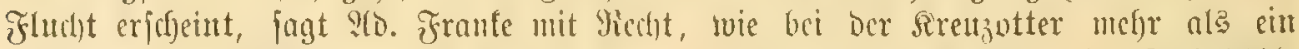

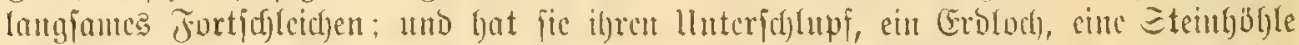

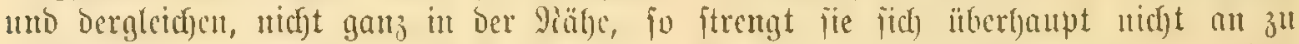

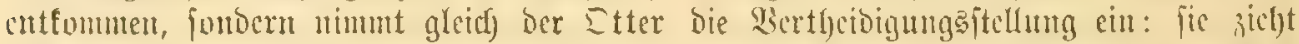

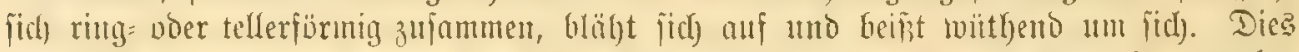

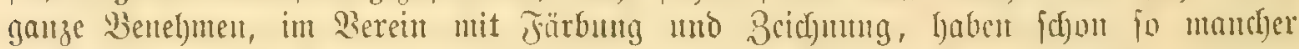

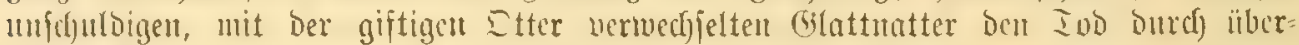

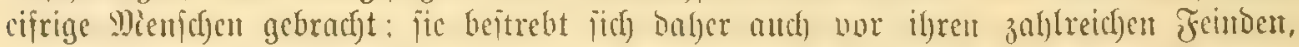
aber gleidlzeitig aud bor if)ren Epfern, zu verbergen, indem fic fidh unter Etcinen,

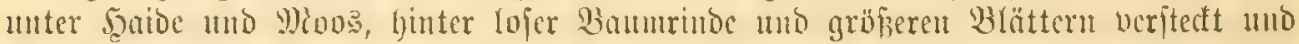

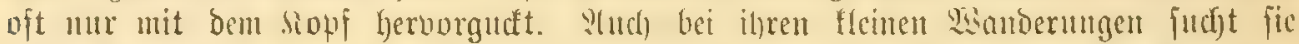

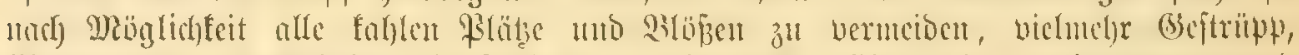

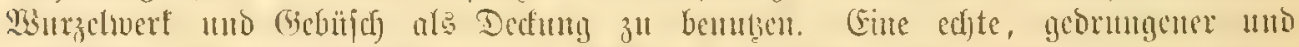

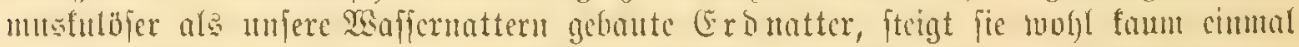

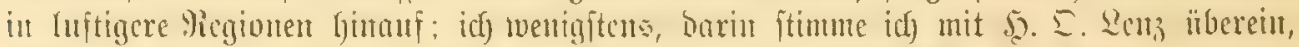

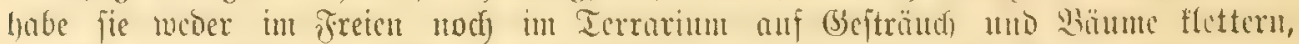

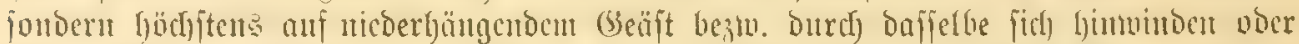

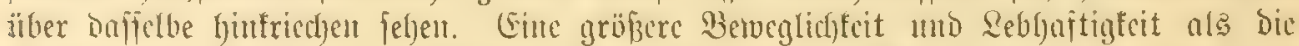

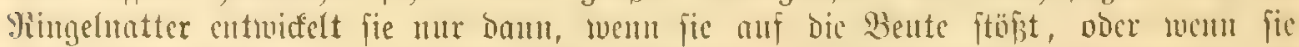

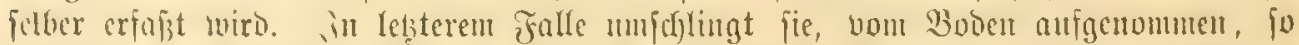

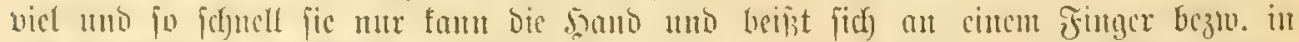

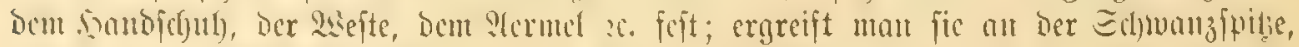

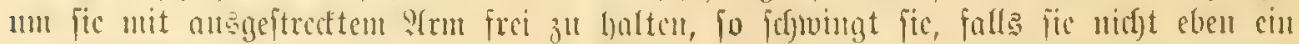

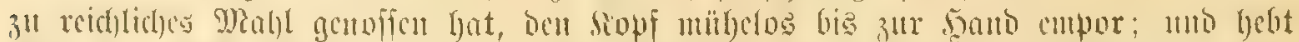

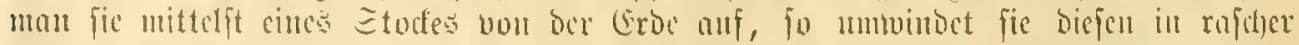

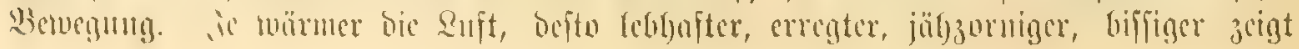




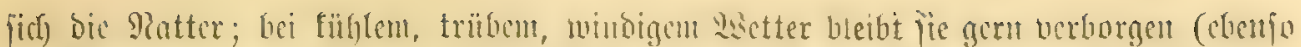

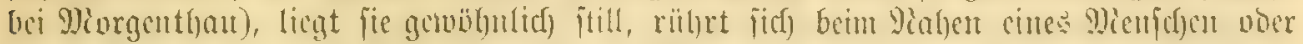

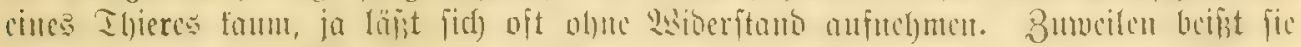

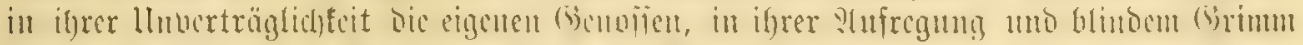

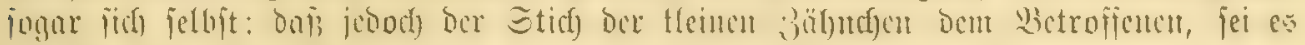
Mienfid) ober Thier, nichts fdjabet, bedarf faum Der Betomung.

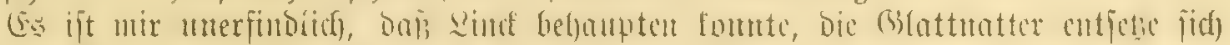

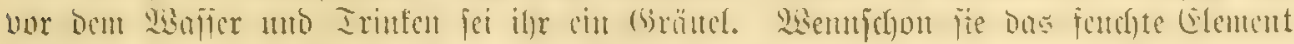

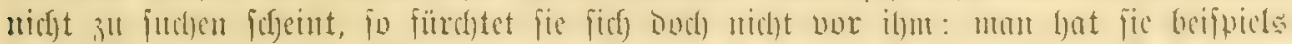

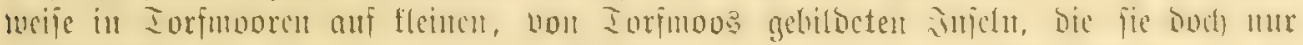

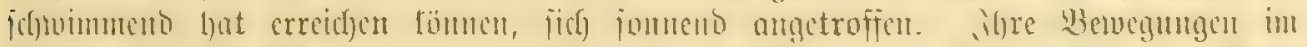

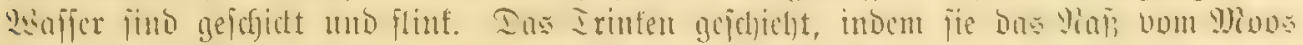

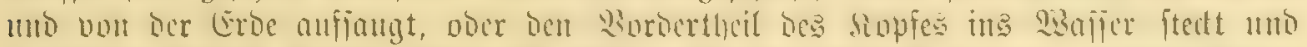

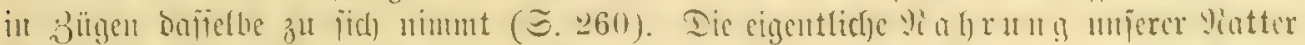

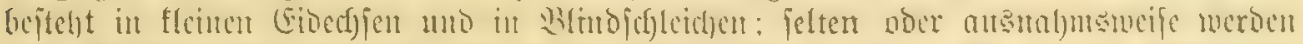

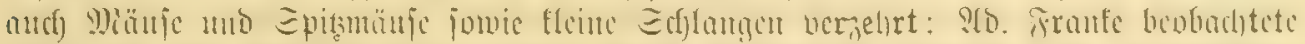

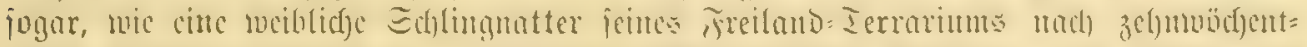

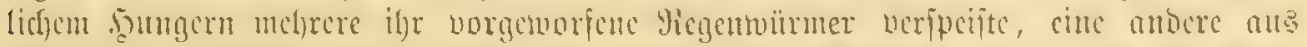

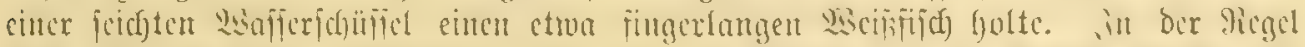

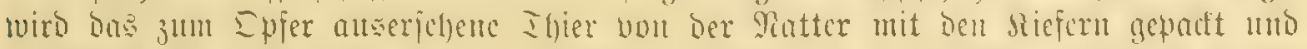

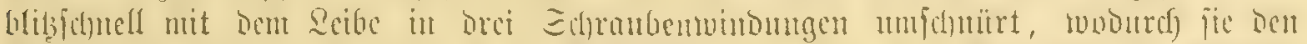

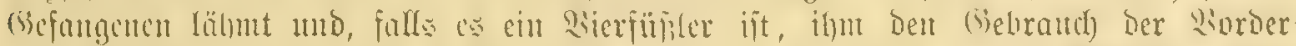

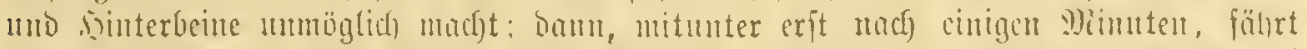

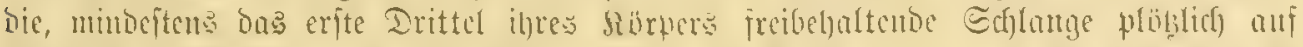

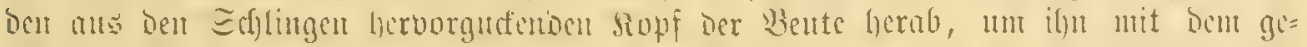

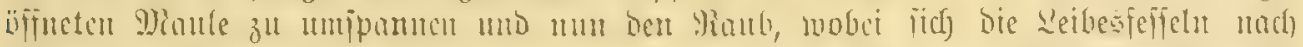

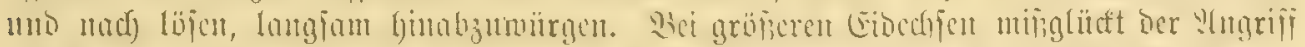

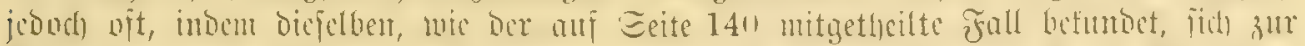

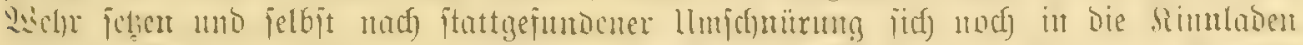

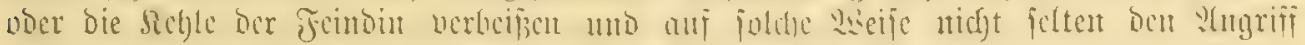

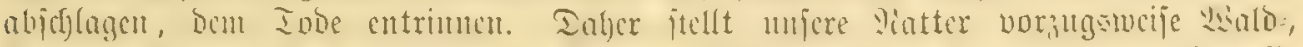

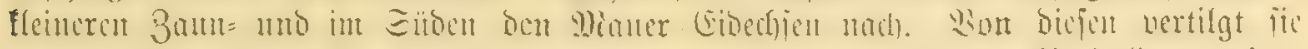

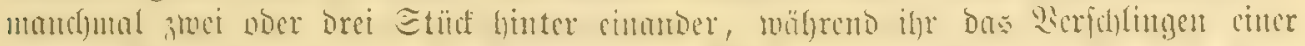

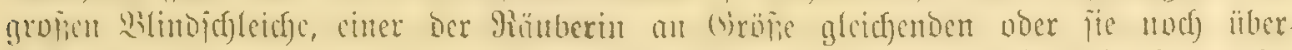

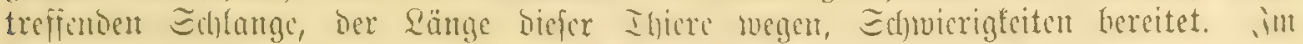

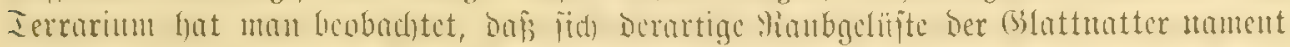

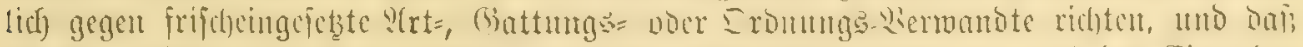

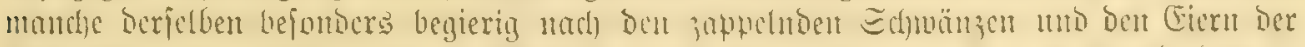

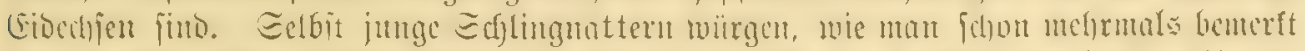

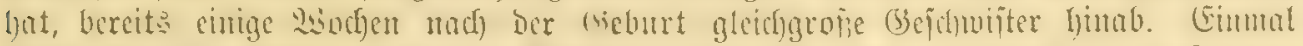

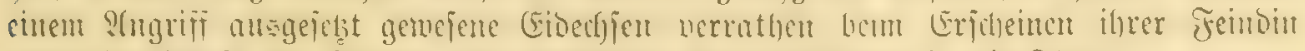

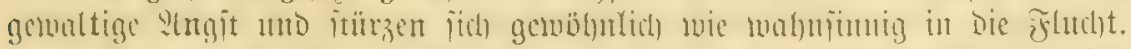

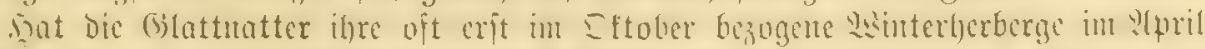

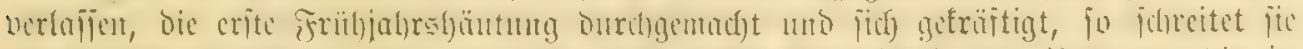

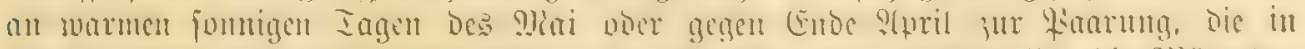

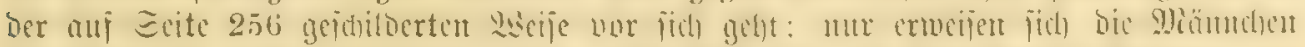

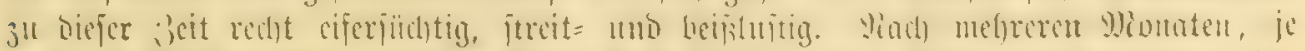

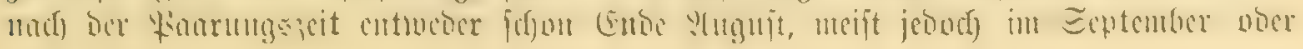


wit in Eltuber, crfolgt bie Beburt ber im Minterleibe böllig intwidelten Iungen,

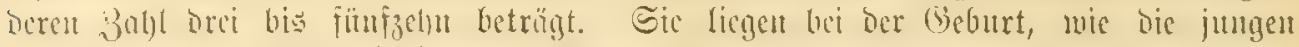

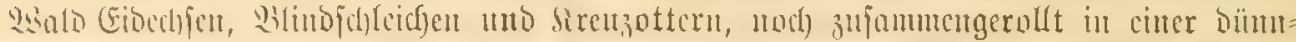

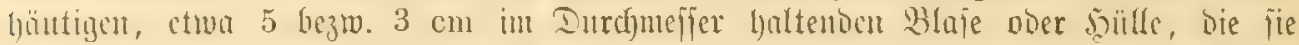

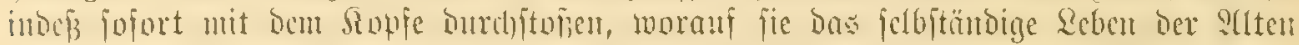

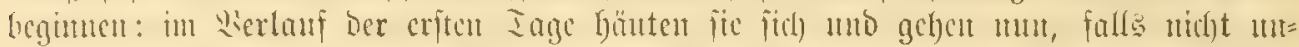

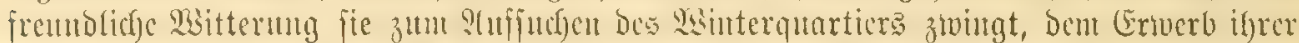

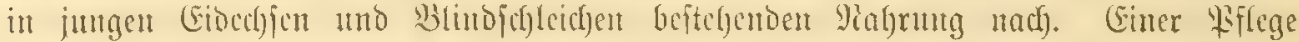
feiten Der Mintter werben fie, trokbem Dies Dr. Setturi beobacftet haben will and

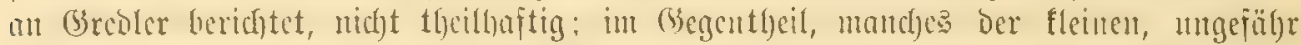

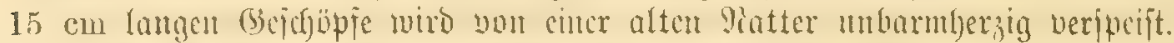

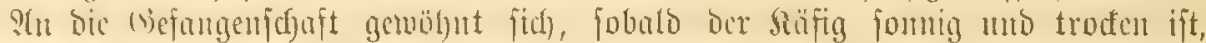

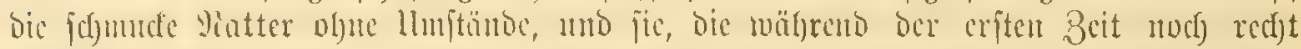

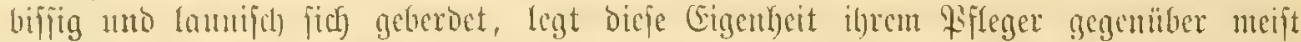

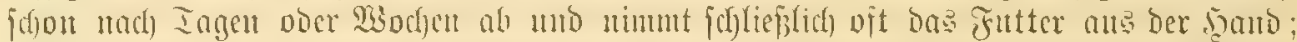

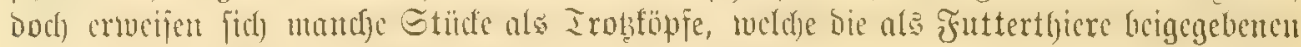

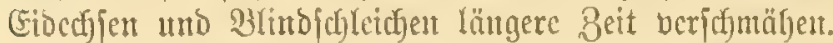

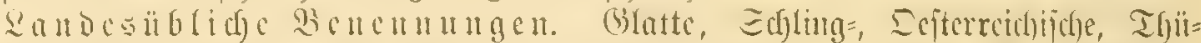

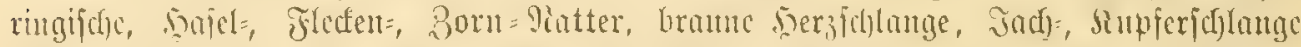

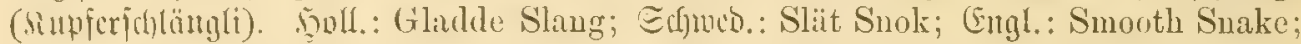

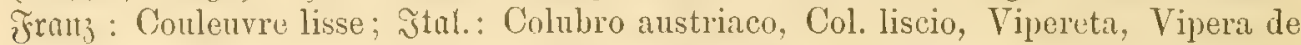

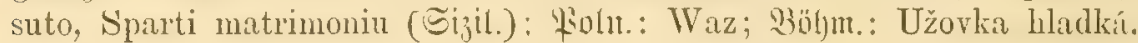

Coronella austriaca, Laurenti 1768. - Coluber laevis, Lacep. 1788. - Col. versicolor, Razoum. 1789. - Col. coronella, Bonnaterre 1789. - Col. austriacus, Gmelin (Limué) 1790. - Col. ferrugineus, Syarmum 1795. - Natrix Coronilla, Seleranek 1798. - Col. thuringiacus, Becthstein 18mo - Col. tetratgonus, Lutreille 1800. - Col. cupreus, Georgi 1801; I'allas 18:31. - Natrix litevis, Merrem 18211. - Coronella laevis, Buie 1827. - Zacholus austriacus, Wughler 1830. - Col. cancasicus, Pullus 18:31. - Natrix anstriaca, Reider und IIahn 1832. Col. puedera, Durigmbsky 18:32. - Natrix Dumfrisiensis, Fleming 18:38. - Zacholus Fitzingeri, Bonay. 183\%. - Zacholus latevis, Eibherdd 184\%. Tropidenotus austriacus, Gimmerthal 1845. - Trop. thuringicus, Merkel 1845.

\section{2. familic: Mibcru, Viperidae.}

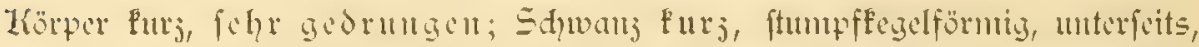
wenigftens bei den curopäifhen 2lrten, mit sincr Doppelreihe, Baud bazgen ftets

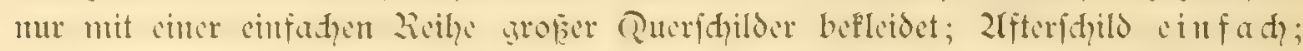

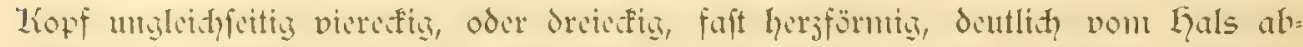

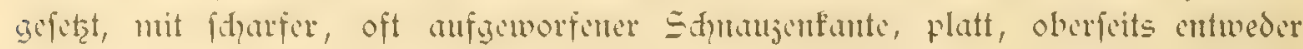

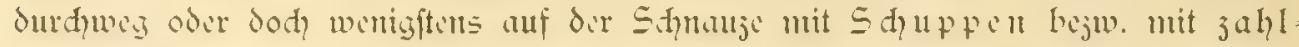

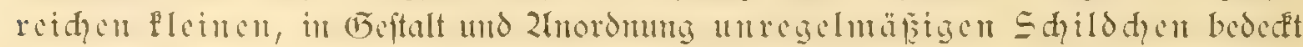

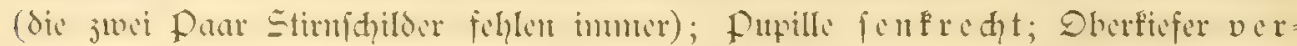

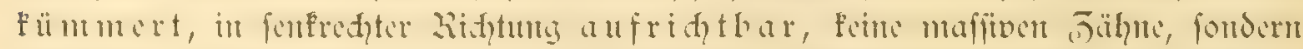

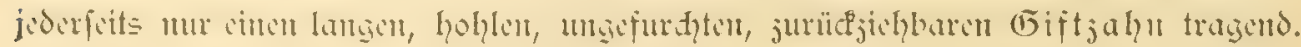
In Dentict)land unt einc Battung: 


\section{4. (5)attung: עiџcr. Vipera, Laur.}

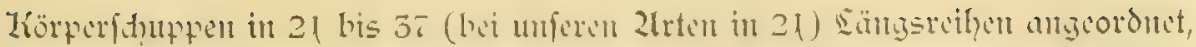

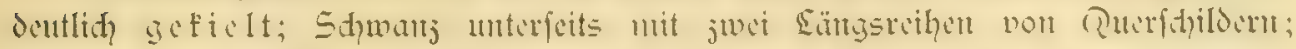

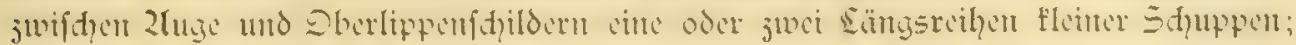

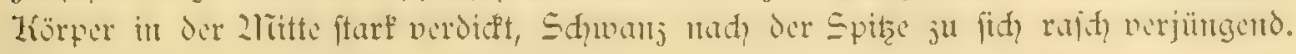
Int Uebrigen Kenmeithen der familie.

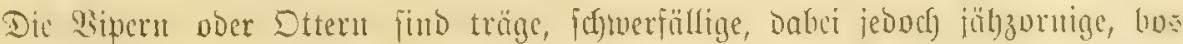

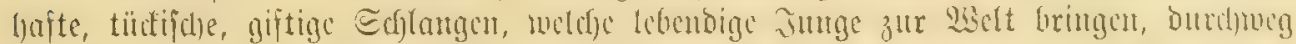

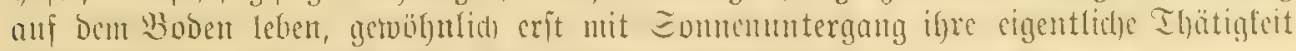

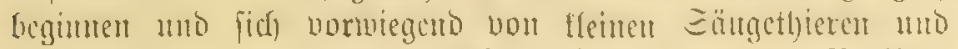

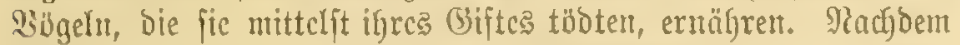
uvir auf Seite 243 und 244 über bic Berberben bringende $2 u$ :

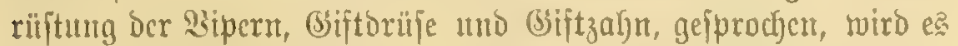
gentügent, jene Mrittheilungen fier Durff eine 2(66ildung, weldyc (Biftbatcu jammt (sifttunal (b) powic bie cijiftoriffe (a) veran=

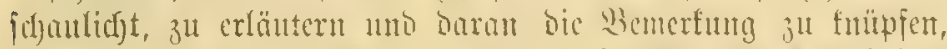

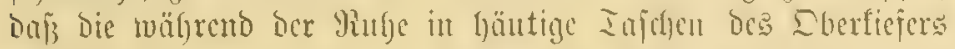

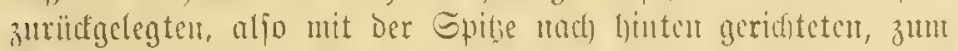

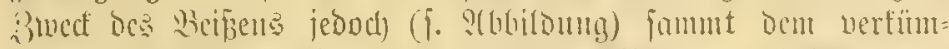

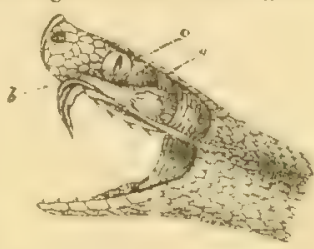

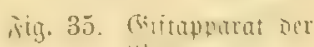
vitipet.

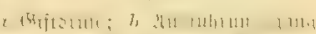
Dot

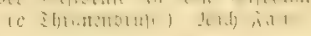

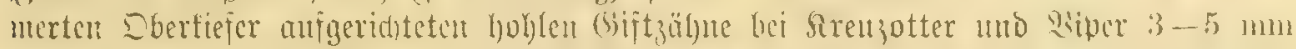

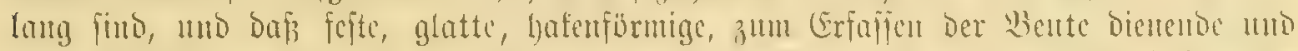

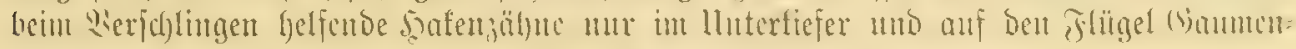

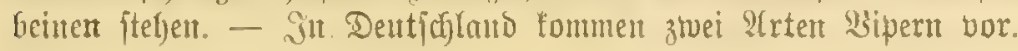

\section{9rt: Ireujotter. Tipera berus $(L$.$) .$ Trbbitsungen: Tajel IX.}

Jై

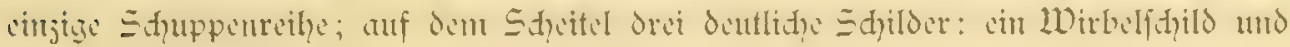
3wei Ginterhaupt:S đ̧ilder; Sdnaujenfpitze abgerundet.

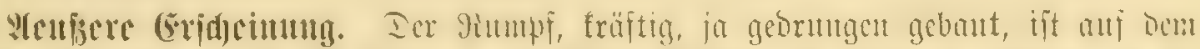

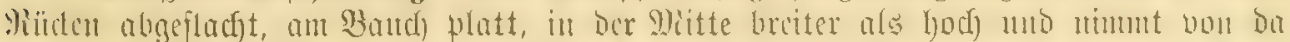

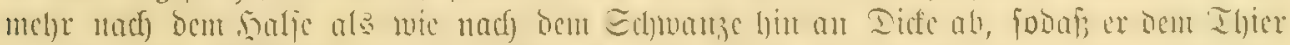

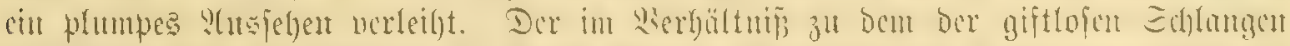

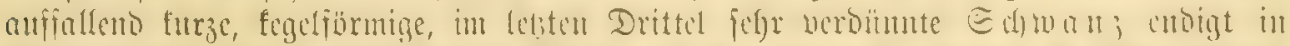

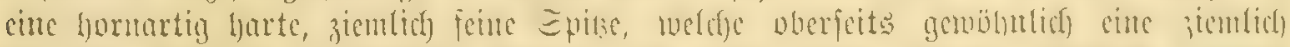

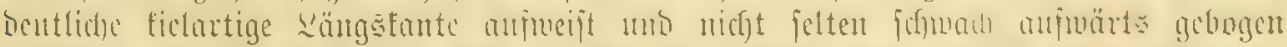

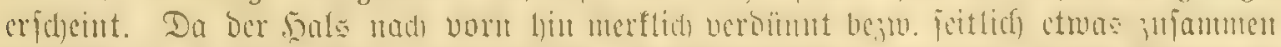

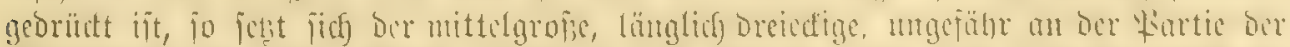

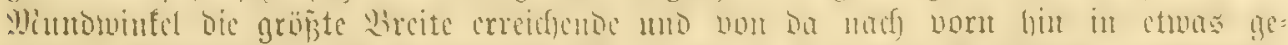

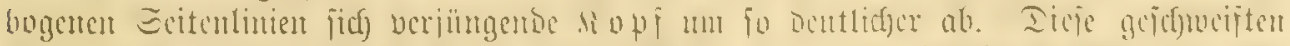

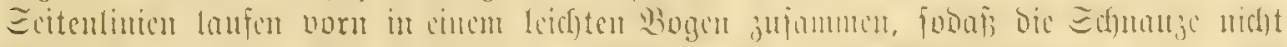

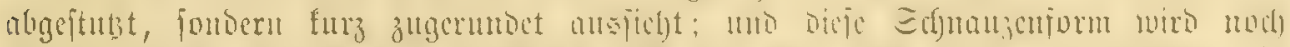

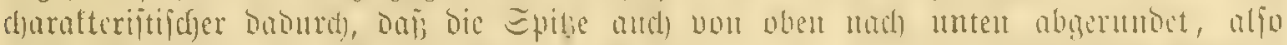

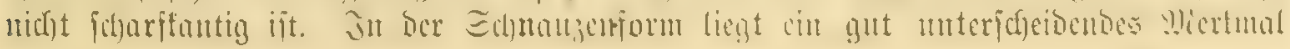




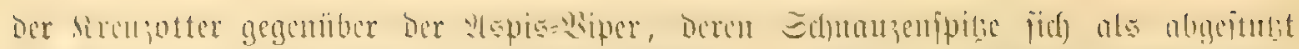

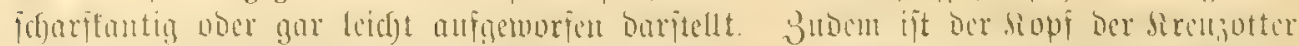

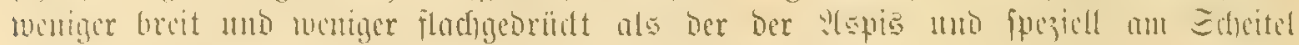

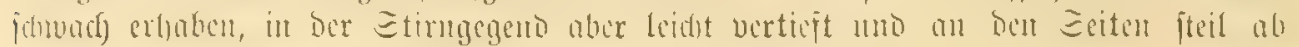
falleno; die Bügelgegeno vor ben ?lugen ift faum mertbar cingeoritdt.

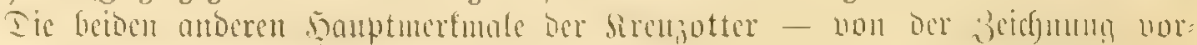

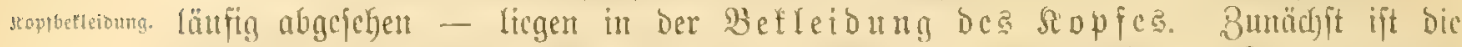

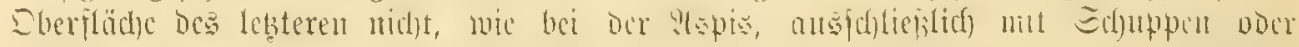

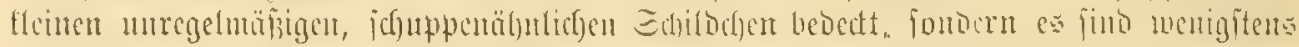

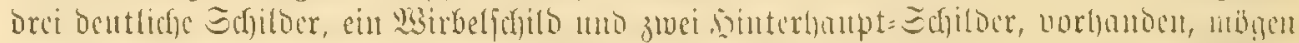

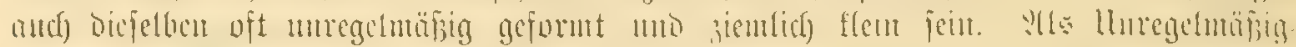

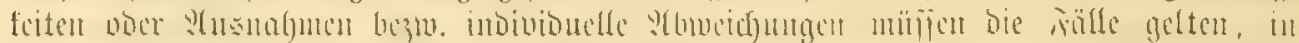

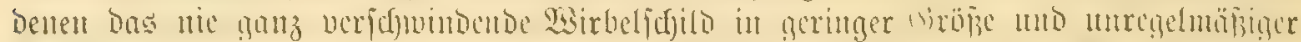

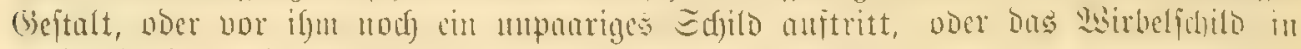

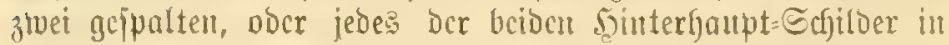

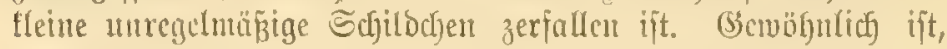
wie 2tbbilbung 2 auf Tafel IX veranfdyanlicht, bas Wirbel=

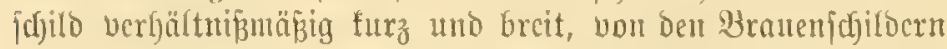

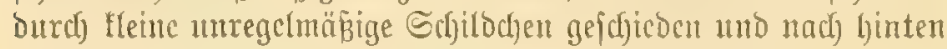

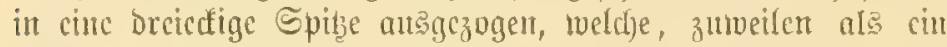

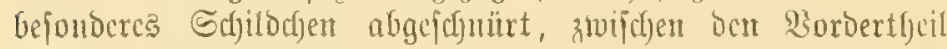

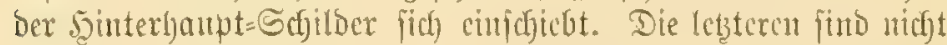
jo lang anggezogen toie bei mipcru Yattern, fdyäler als bą

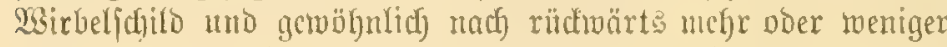

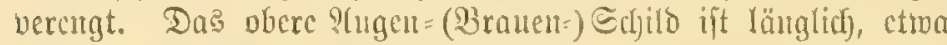

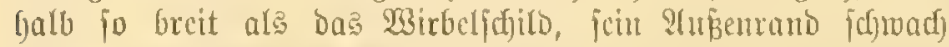
gehogen uno äher bas ?luge vorfpringento, moburef bas lebtire cineıt tïdifden :(4sorud exhält (vergl. Evite 34\%). int llebrigent

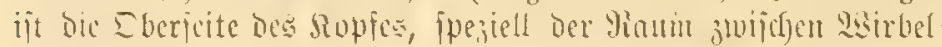

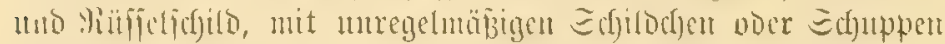
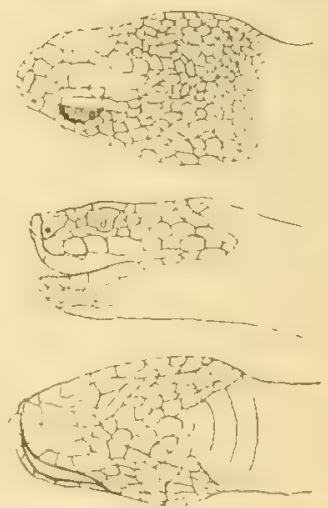

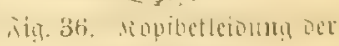
nteulnttr.

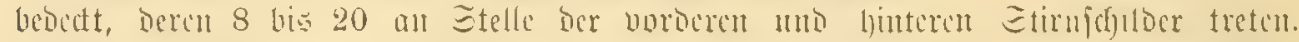

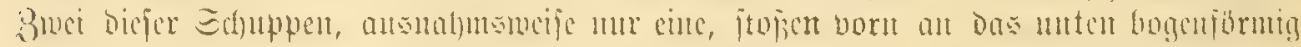

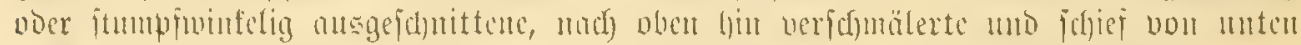

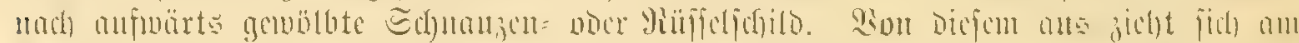

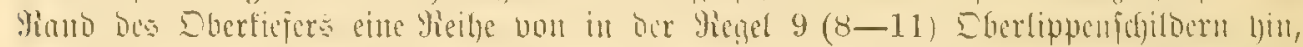

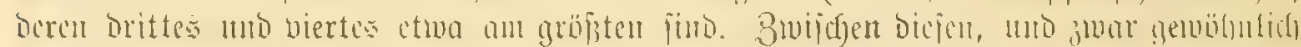

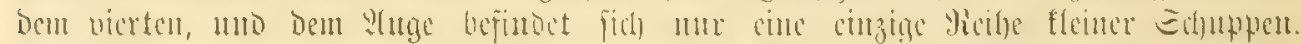

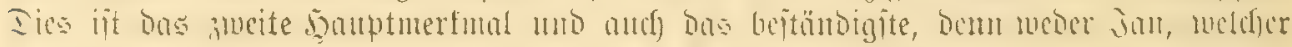

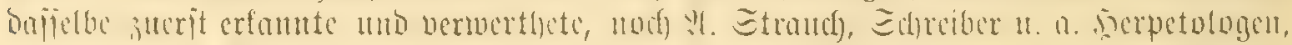

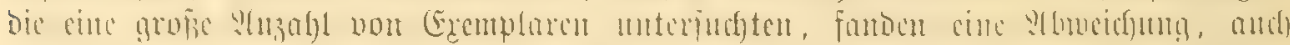

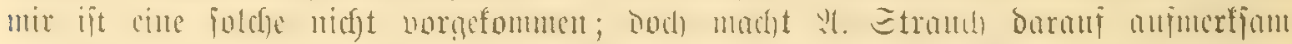

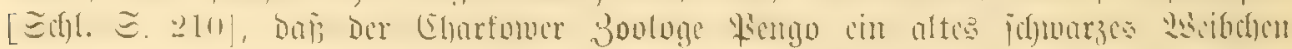

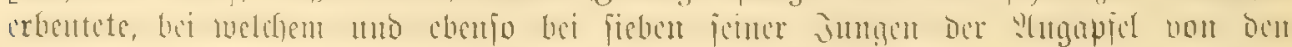

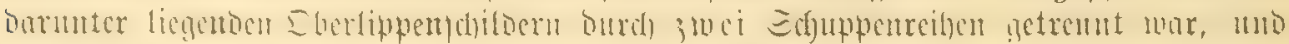

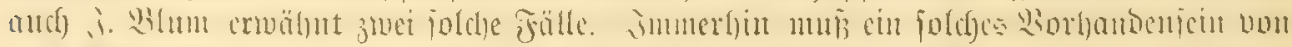

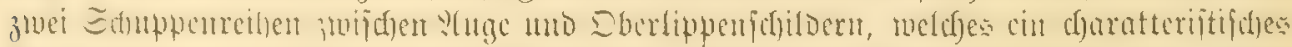

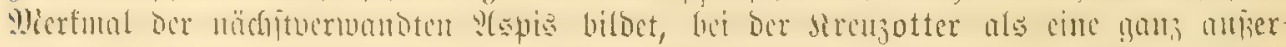

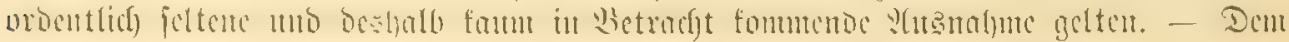




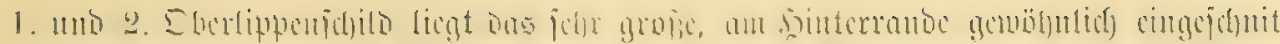

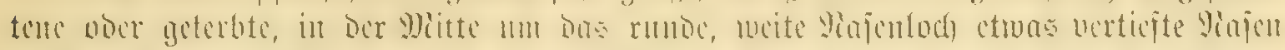

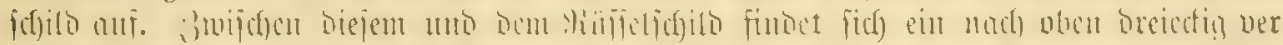

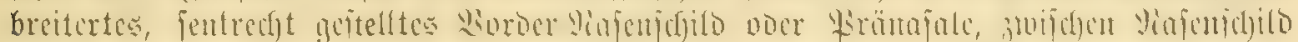

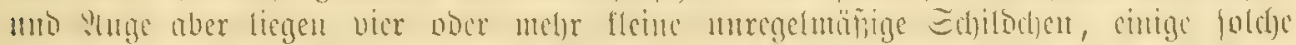

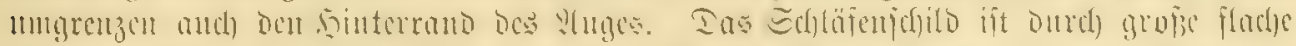

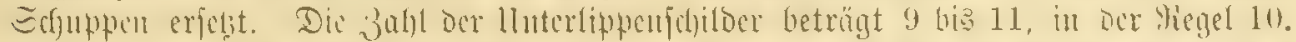

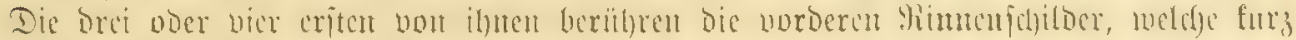

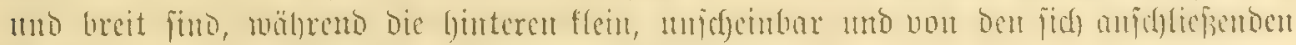

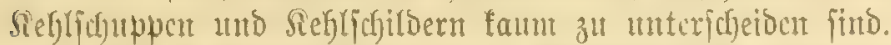

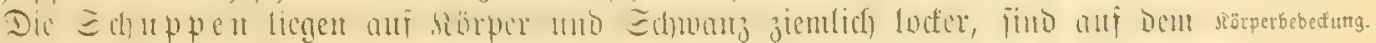

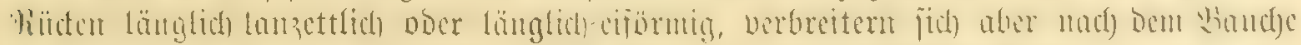

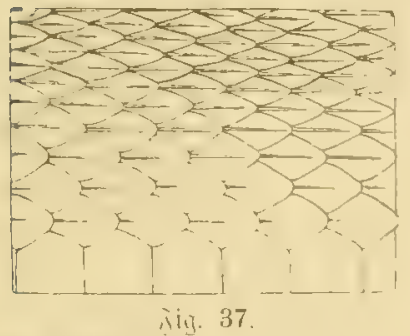

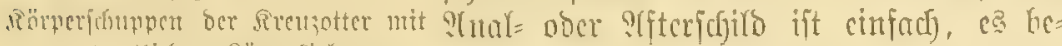
Dentlichent Qüngstiel. Doppelt jo groß̧ als bic ber vorforgebenden cridjeinen, find mit fararfem, beutlichen Rängsticl, Der jebod auf Denen Der unteriten Reife uur noch autgedeutet ift, berjeljen uno in 21 Rängsrciljen geftellt. Dic Babl

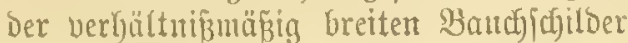
beträgt 132 bis 158, Die Der Sctuanz=

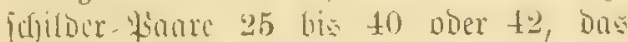
fteht alfo, im Gegentab zu Dem Der fdjon Gin, fodafi die der Iebeten, unterjten Sicifyc

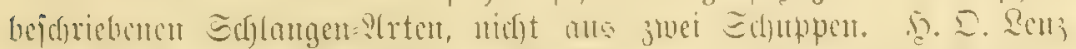

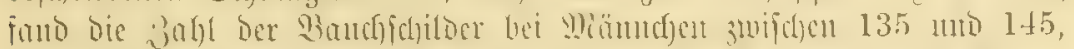

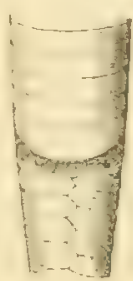

ivig. 38. vinter leibsgegentio but Lipex mit beut Den 2lfter Defent ben cilltalla ?tatolibila

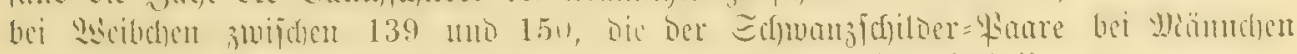
3)

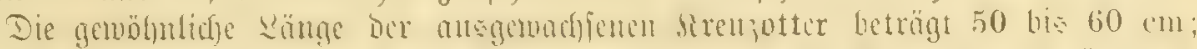

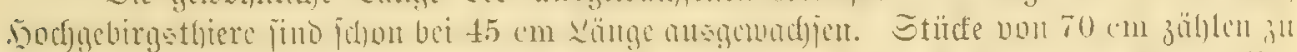

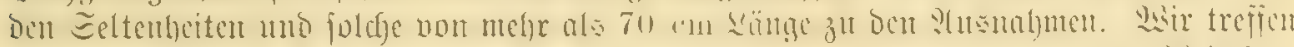

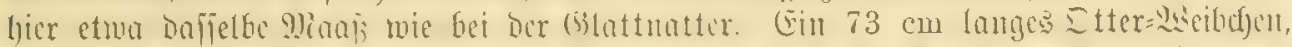

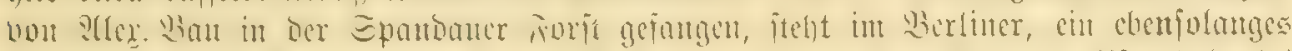

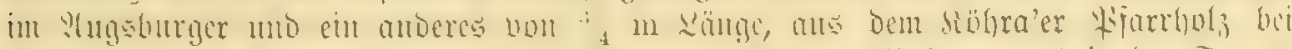

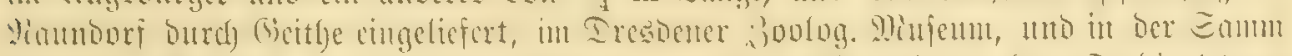

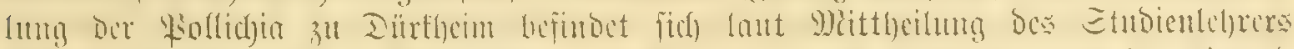

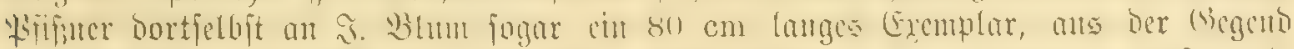

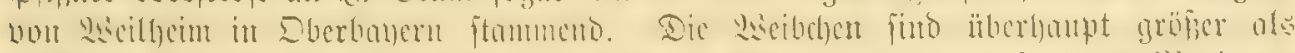

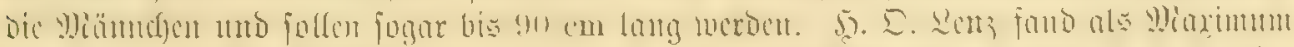

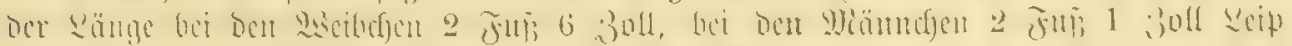

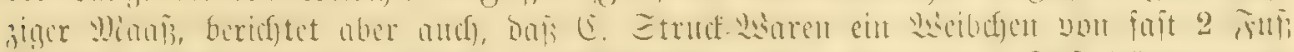

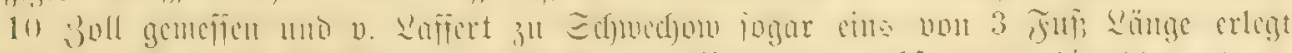

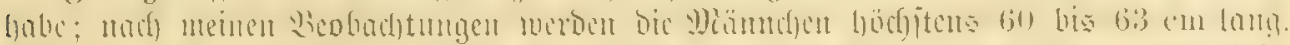

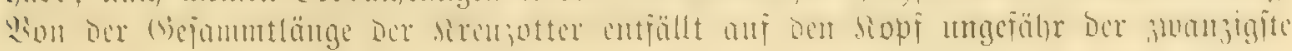

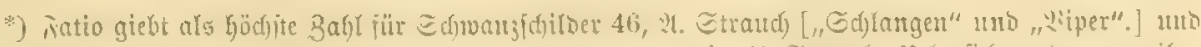

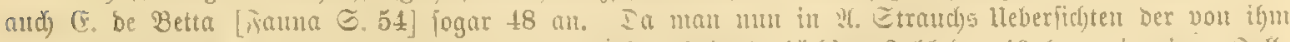

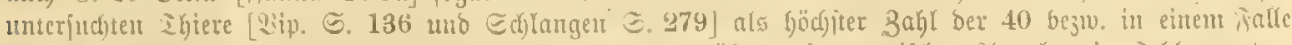

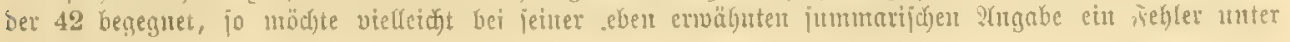
lautent feirt. 


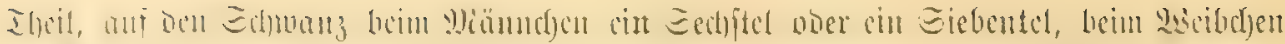

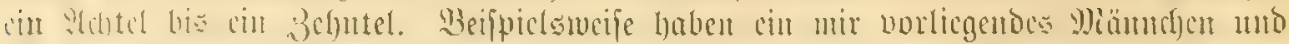

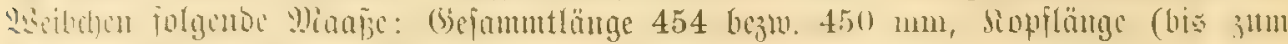

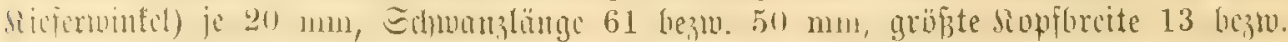

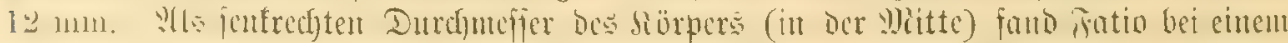

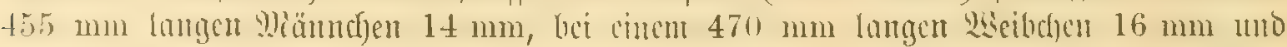

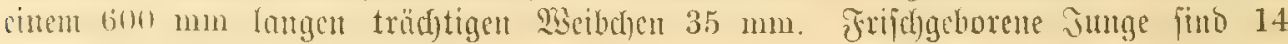
bỉ $21 \mathrm{~cm}$ lang.

îärbung. Stammiorm.

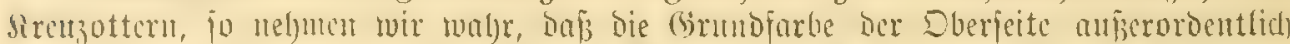

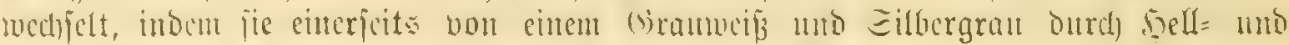

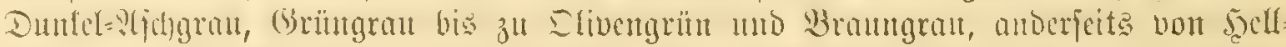

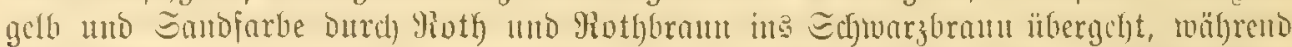
bie 3cid)nung wenigftens in ifrem incjentlichen Theile bejtänoig bleibt. Wian findet

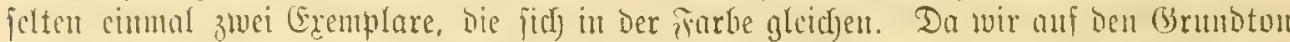

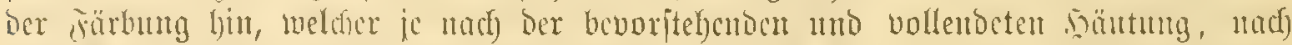
Dem S(ujentfult*) Des Ibieres abündort uno Durdh bie Thätigfeit ber berveglichen

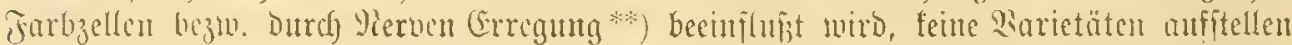

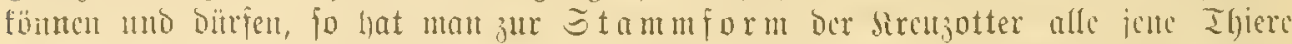

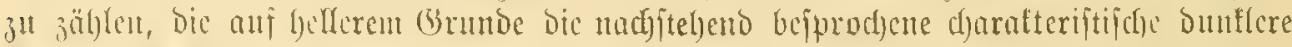

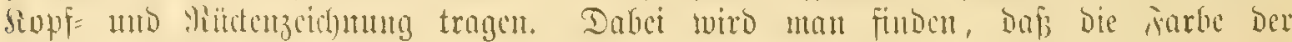

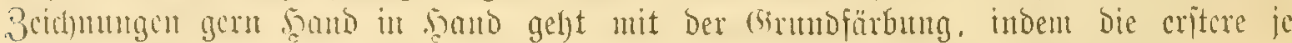
Itad) Dem (Grunoton beller oocr Dunfler cricheint: io zcigen bräunfid) = gethe Ettern

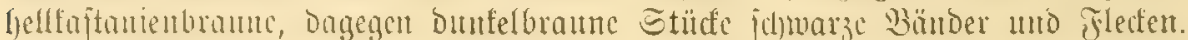

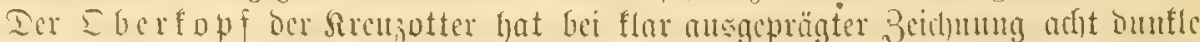

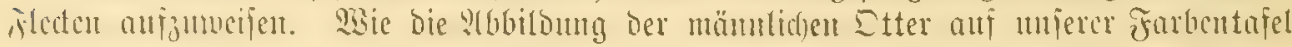

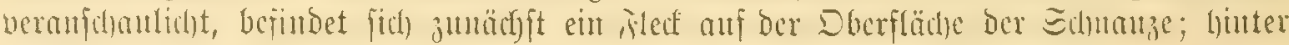

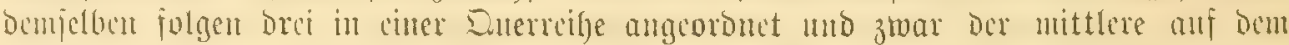

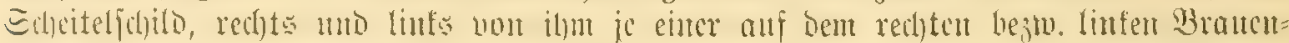

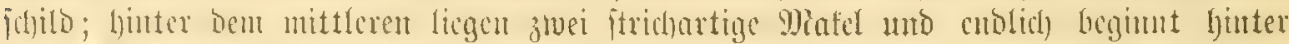

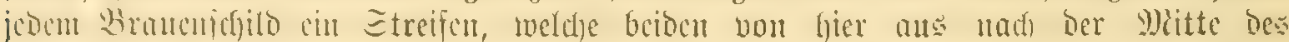

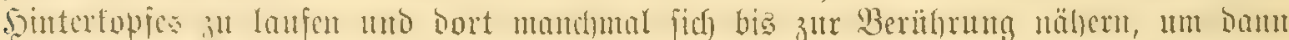

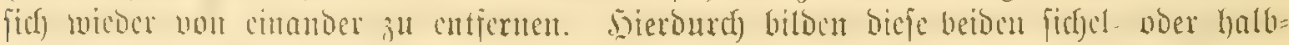

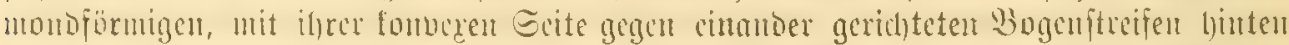

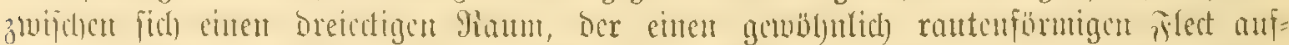

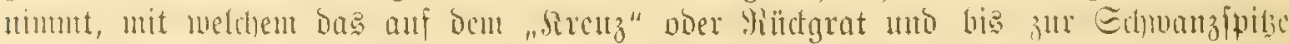

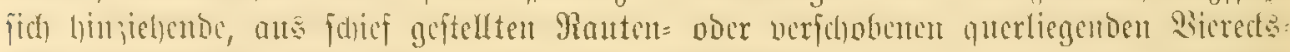

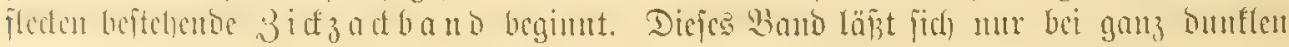

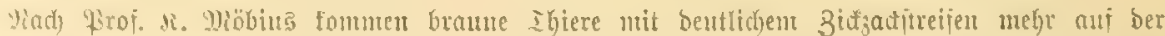

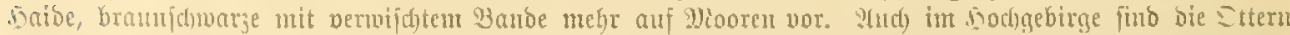

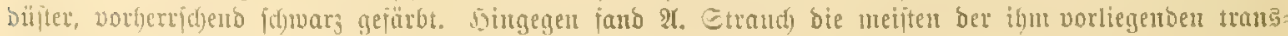

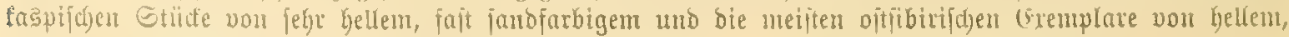
jtat ins (sitünliche fpiełenden Grunoton.

*) Bscifpiels̆veife werben frifd)gefangene hellgrane IGiere in siäfig bunfelgran ober jagl braun=

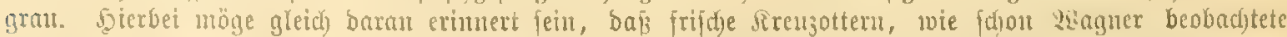

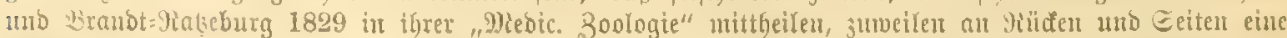

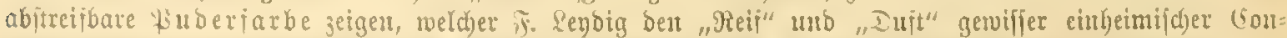

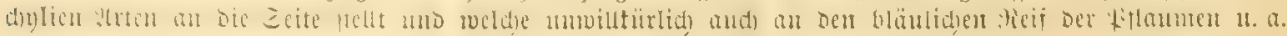
Fridgte gemahnts. 


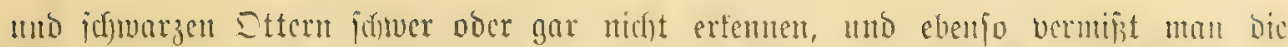

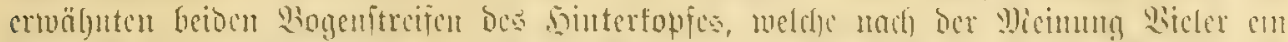

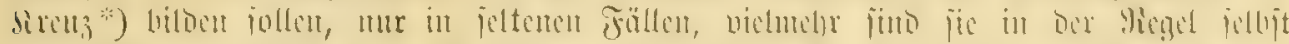

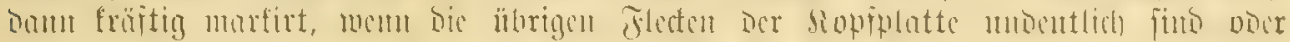

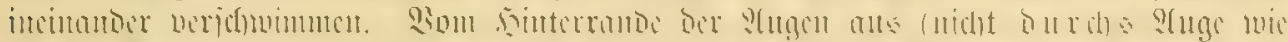

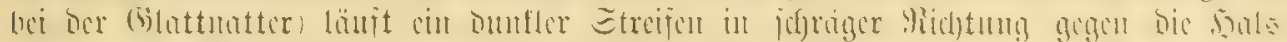

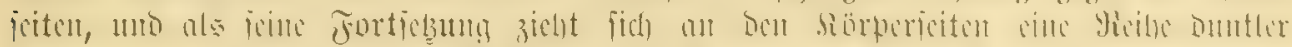

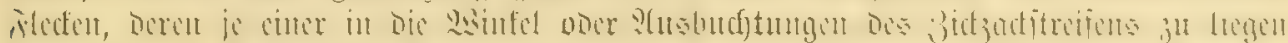

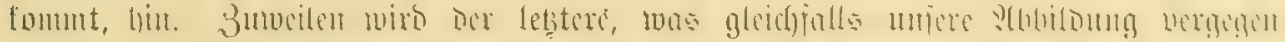

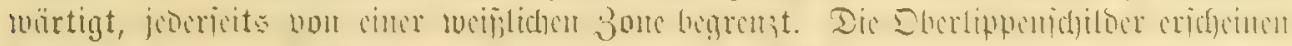

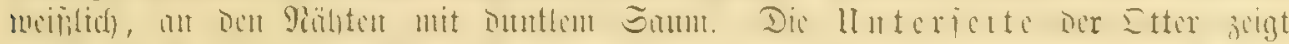

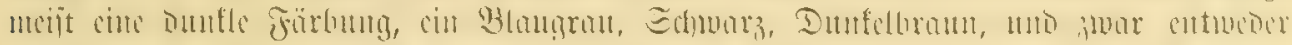

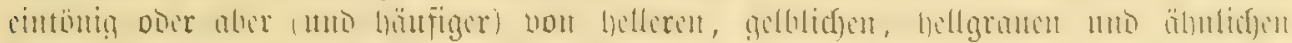

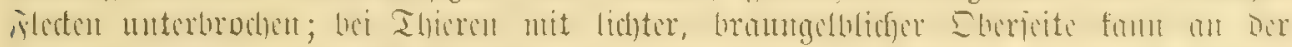

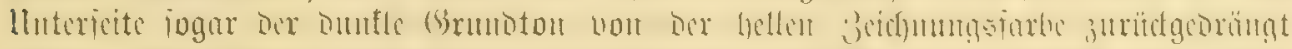

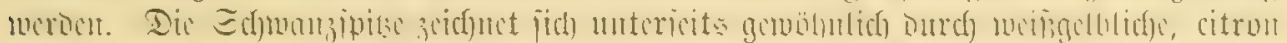

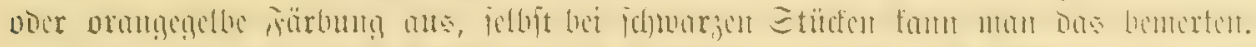

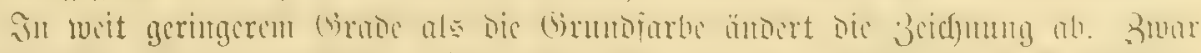

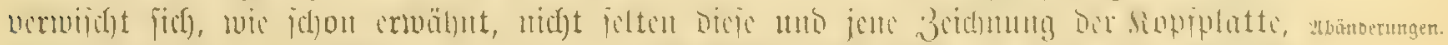

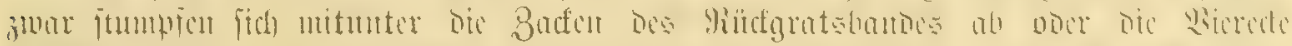

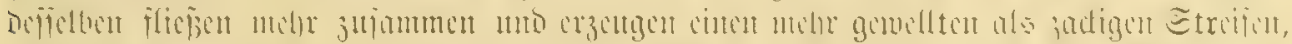

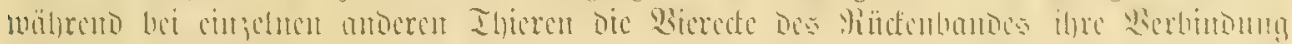

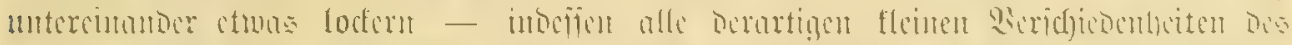

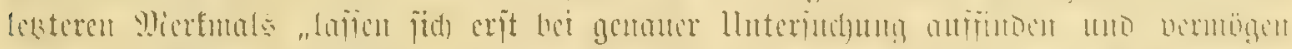

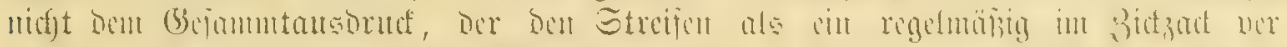

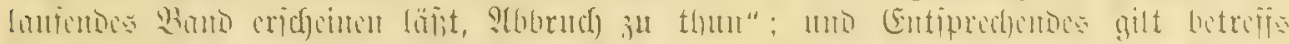

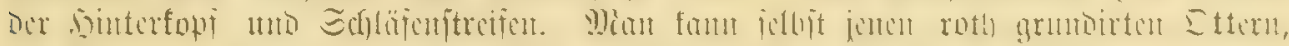

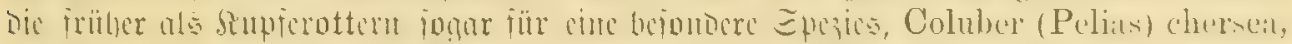

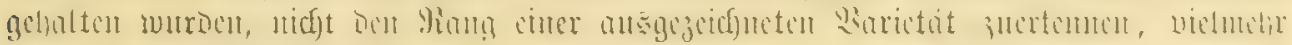
mur eine foldie auffitellen:

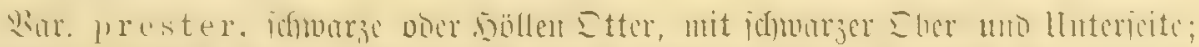

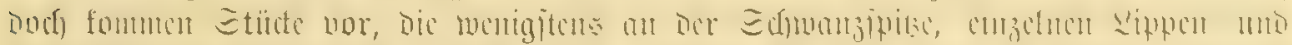

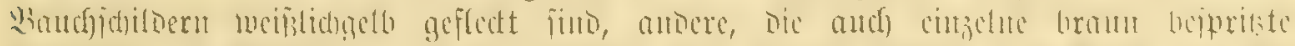

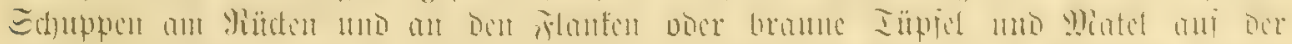

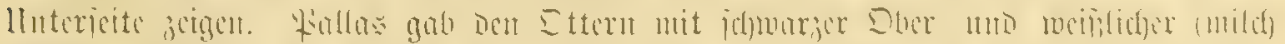

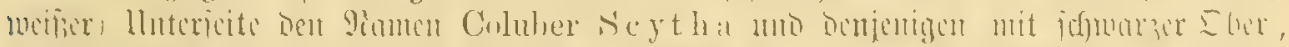

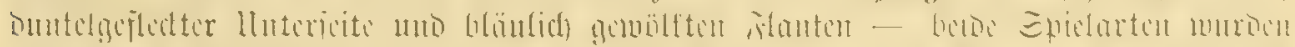

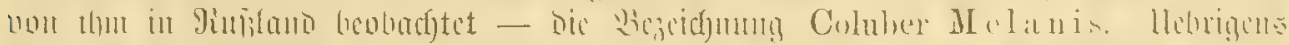

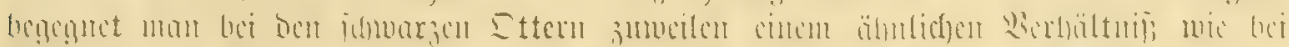

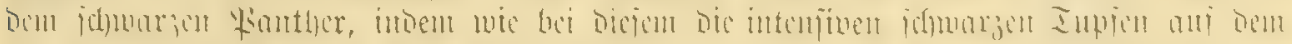

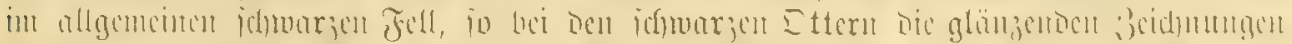

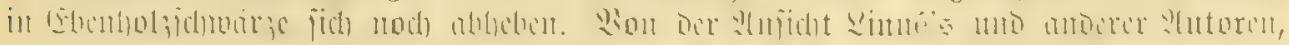

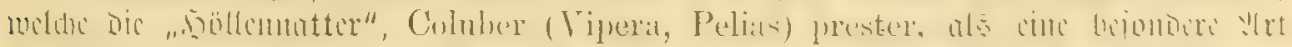

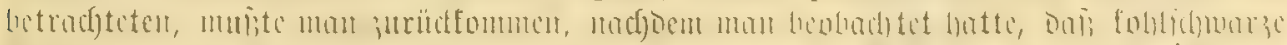

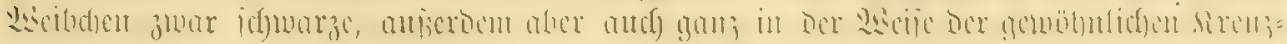

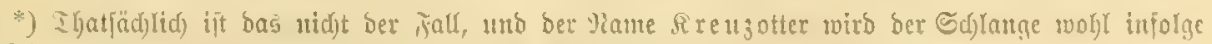

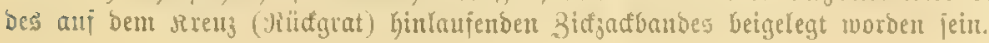




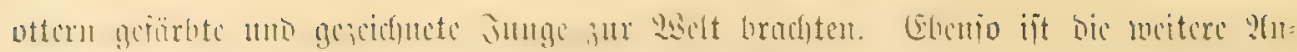

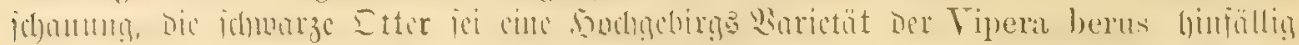

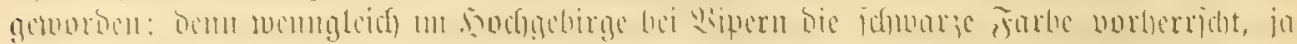

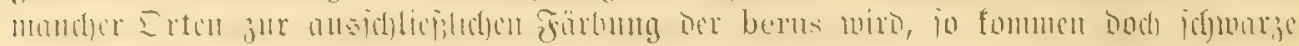

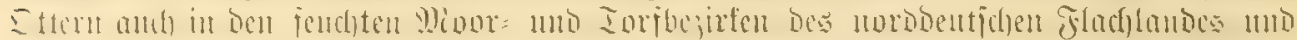

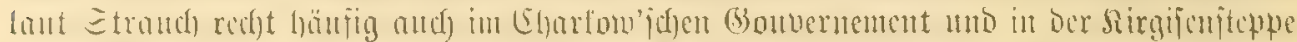

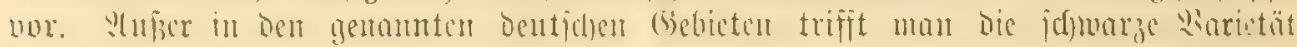

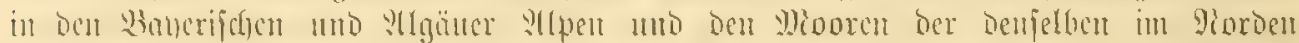

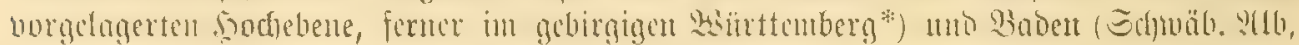

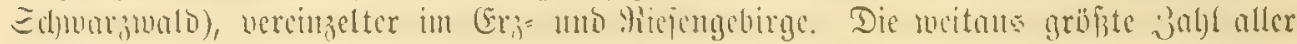
\{djwarzen Dttern ift meiblidjen (Bejd)ledyte.

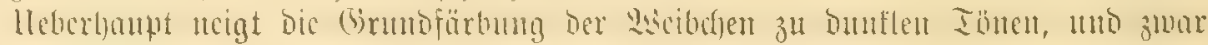

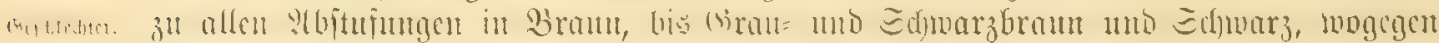

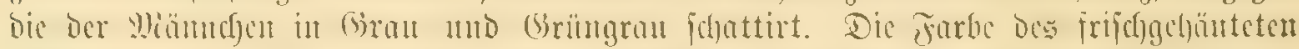

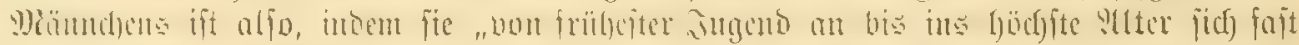

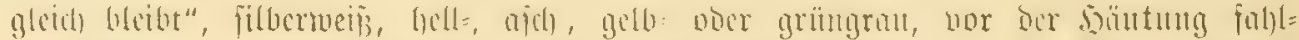

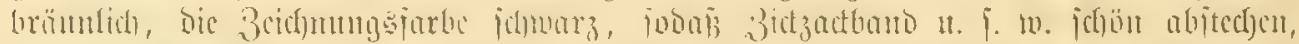

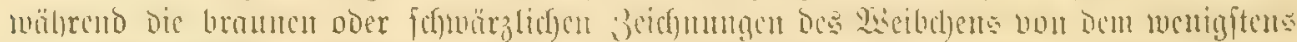

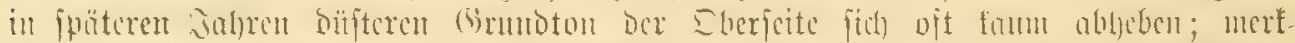

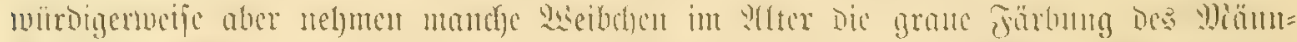

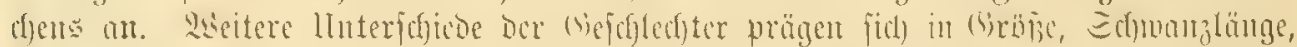

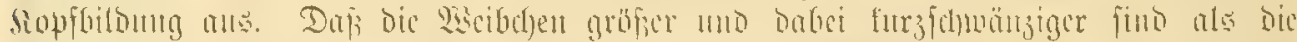
9)

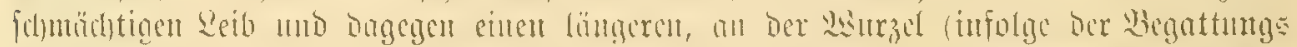

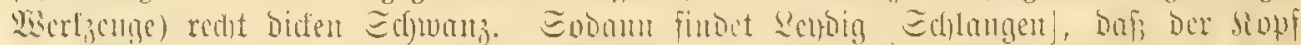

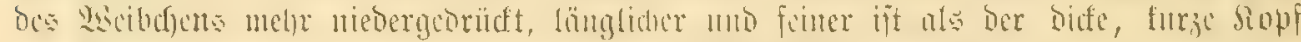

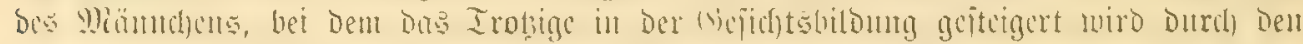

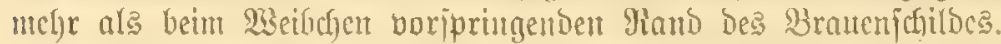

Dicic, bereits anf Ecitc $3: 38$ bermertte (vicitaltmu mo Zagermb bes oberen

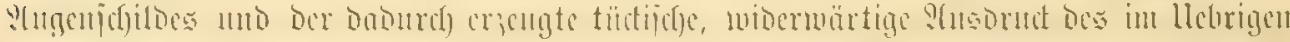

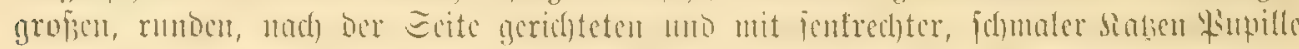

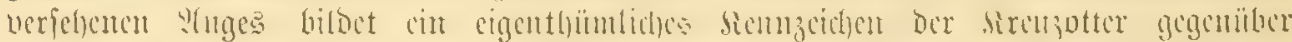

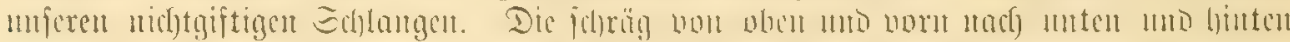

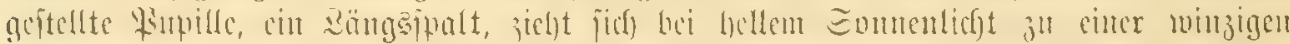

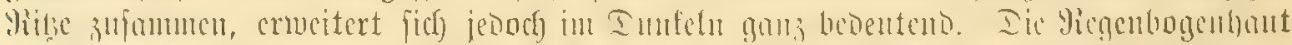

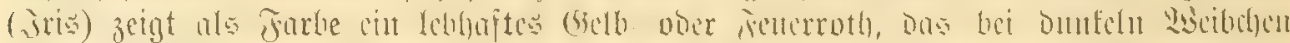

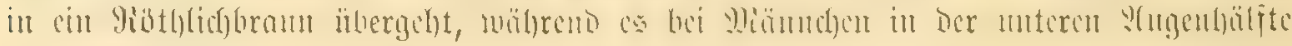
gern ourd) Sdywarz erjebt wird.

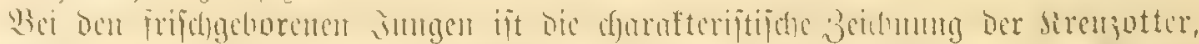

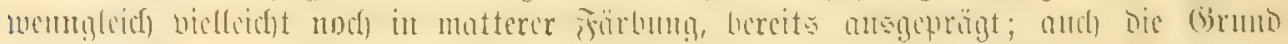

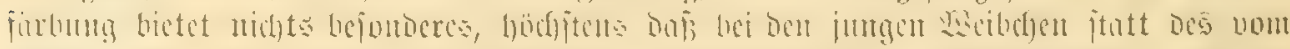

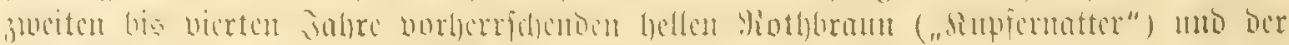

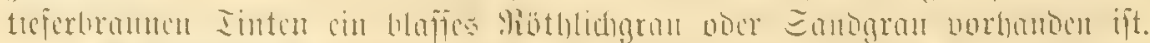

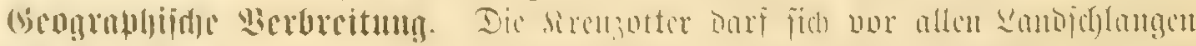

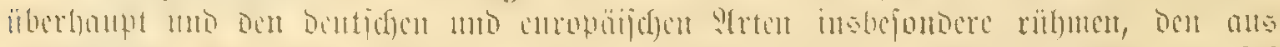

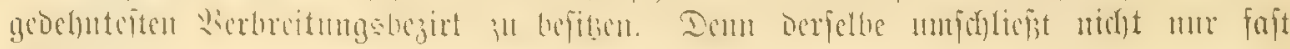

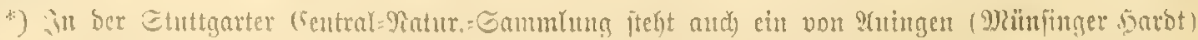
itammendes excuthlar ber var. seytha. 


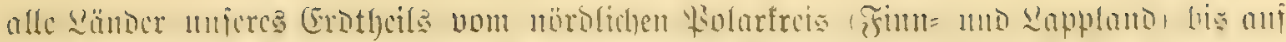

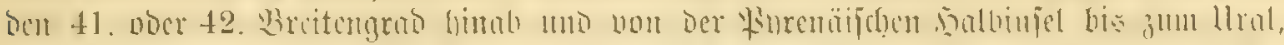

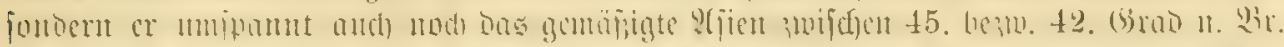

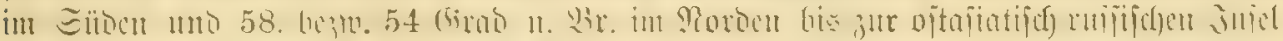

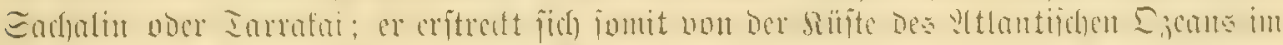

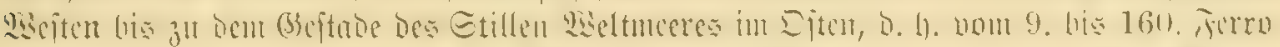

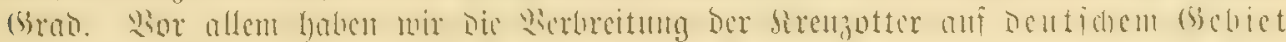

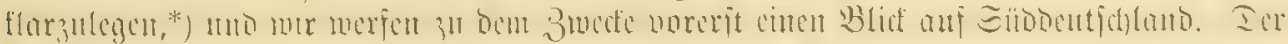

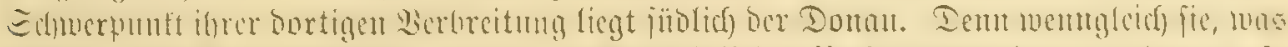

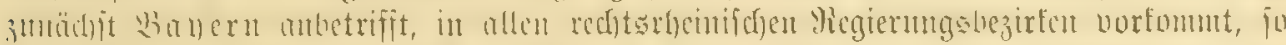

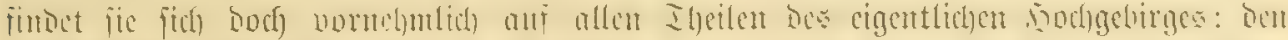

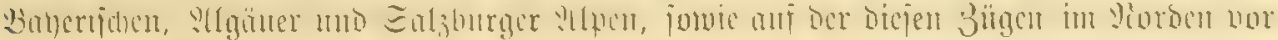

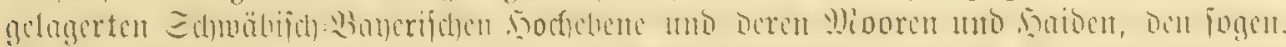

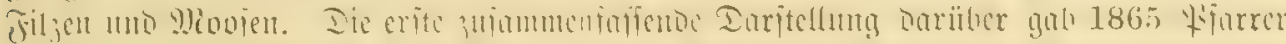

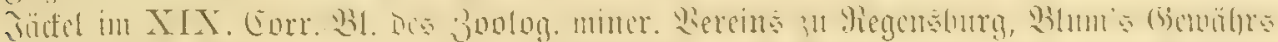

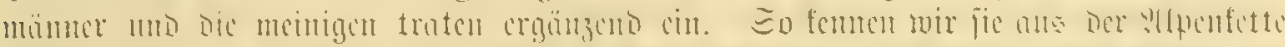

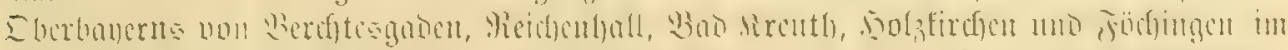

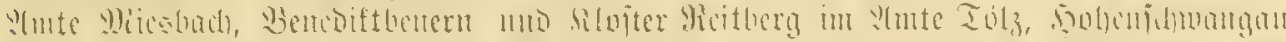

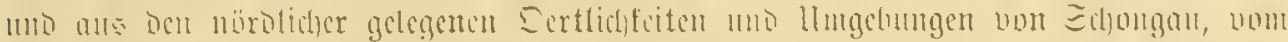

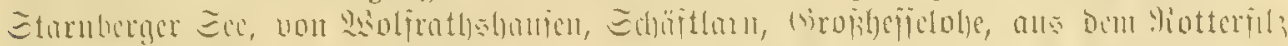

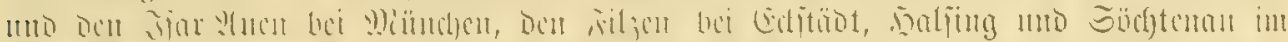

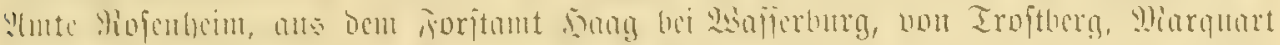

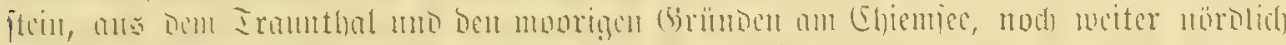

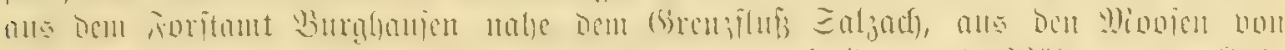

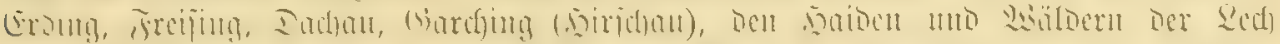

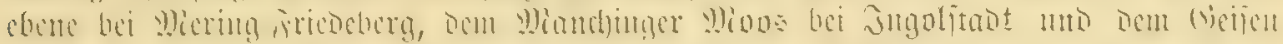

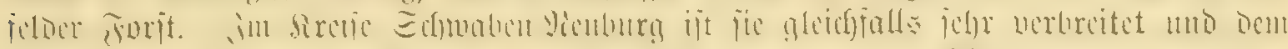

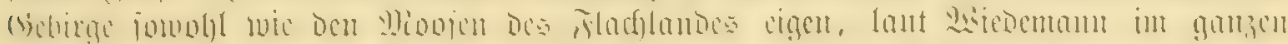

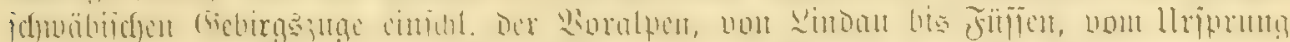

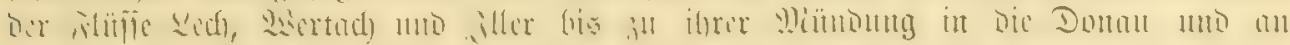

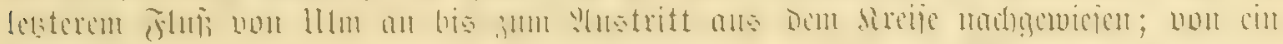

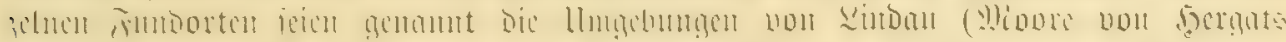

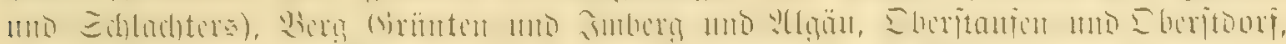

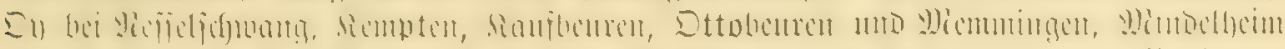

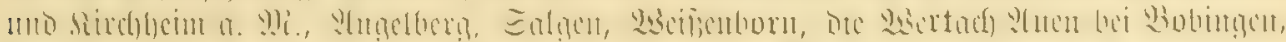
Dic Ved :

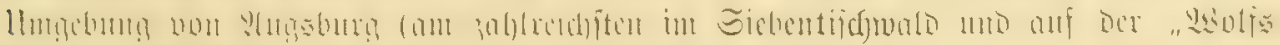

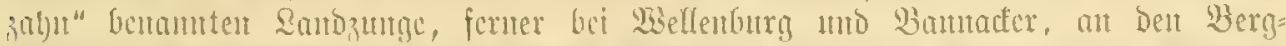

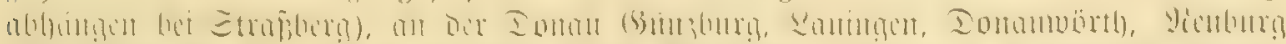

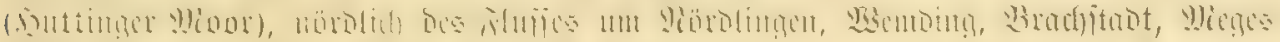

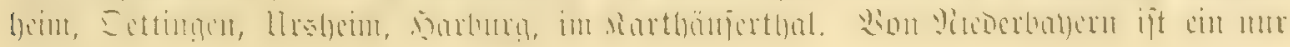

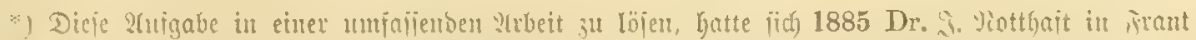

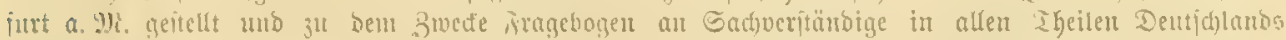

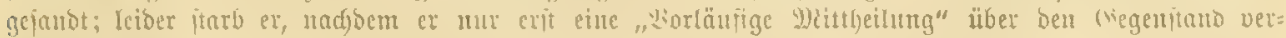

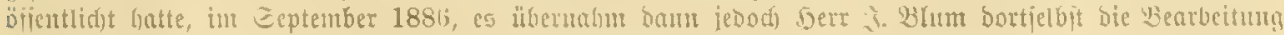

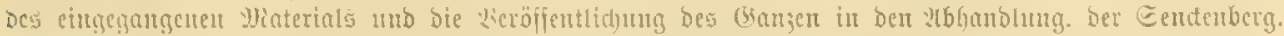

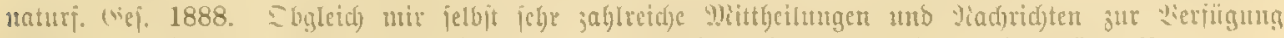

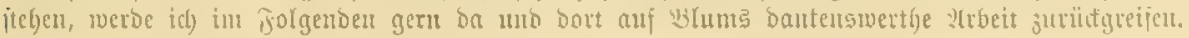




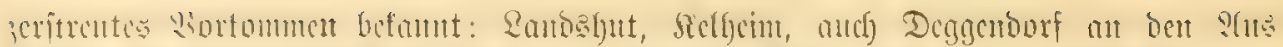

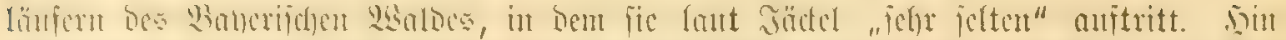

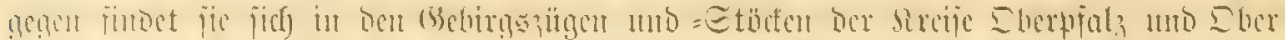

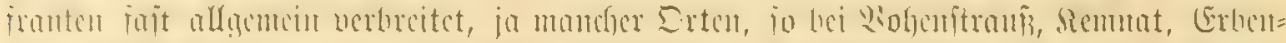

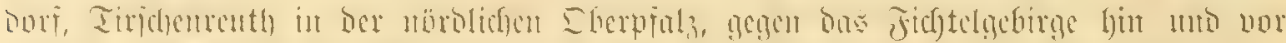

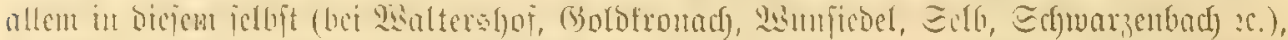

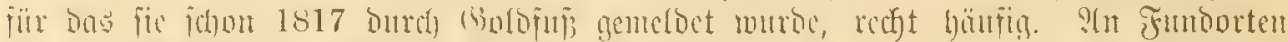

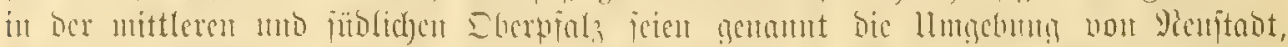

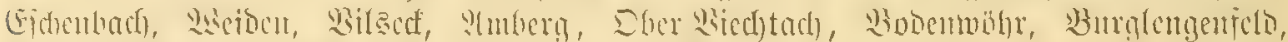

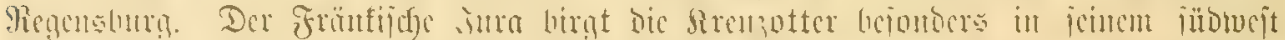

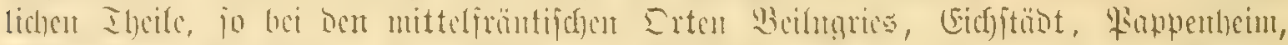

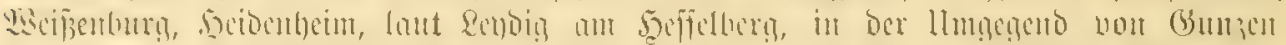

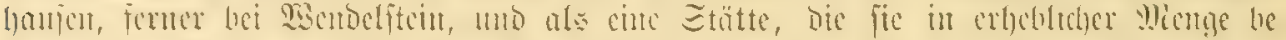

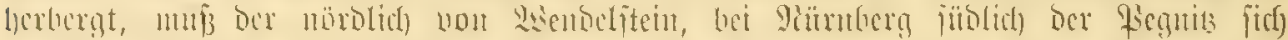

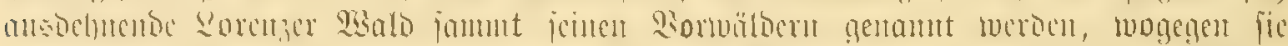

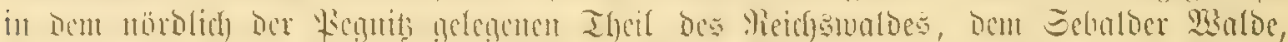

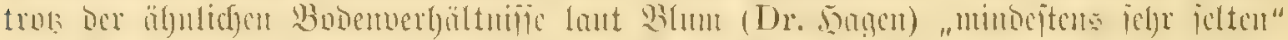

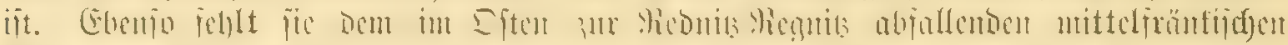

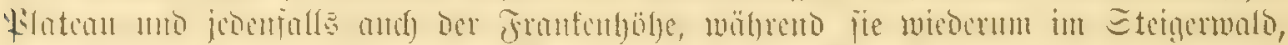

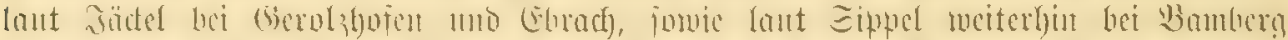

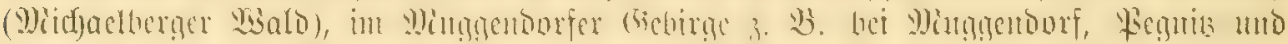

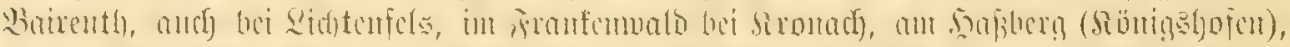

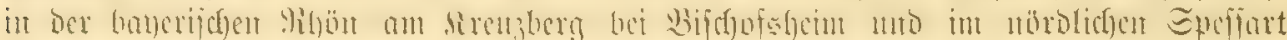

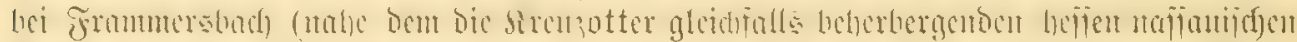

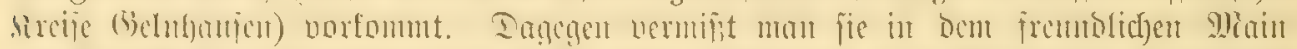

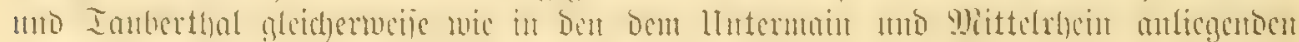

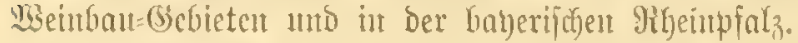

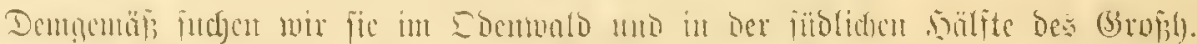

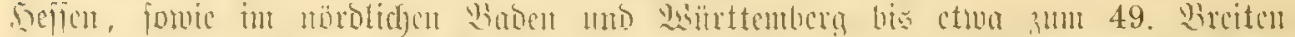

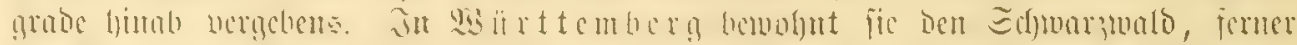

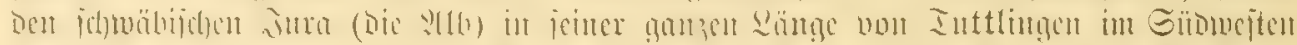

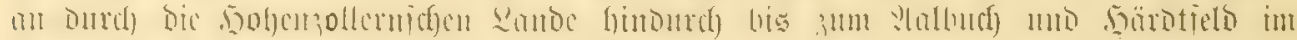

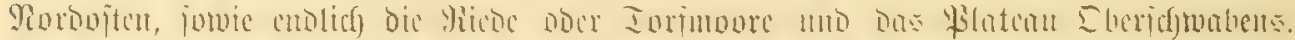

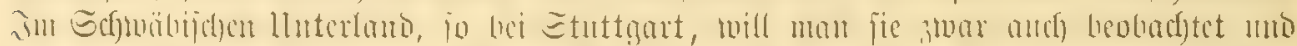

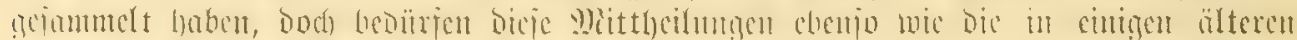

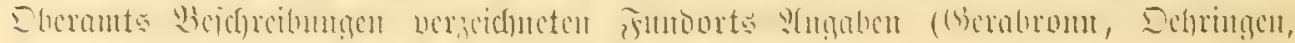

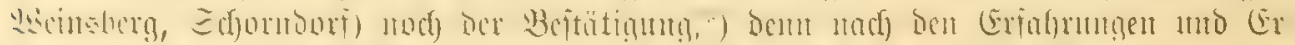

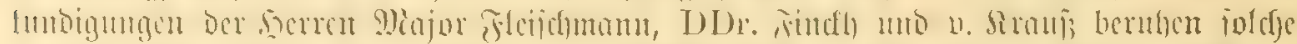

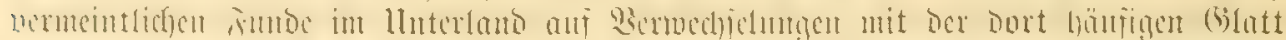

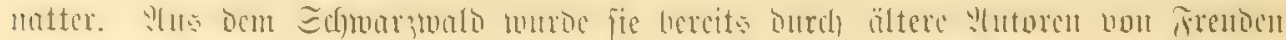

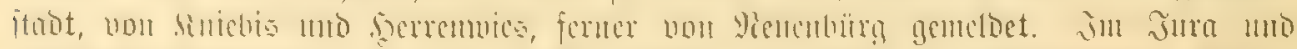

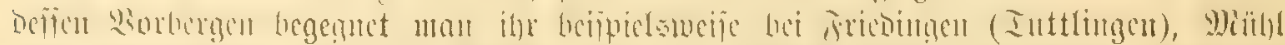

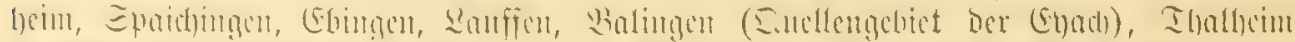

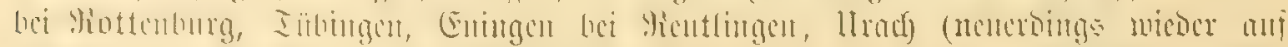

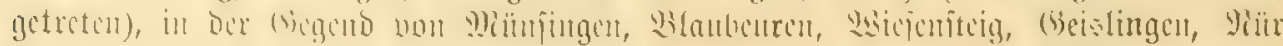




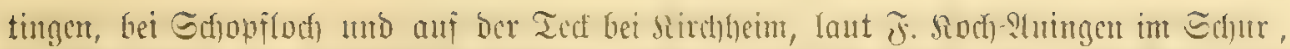

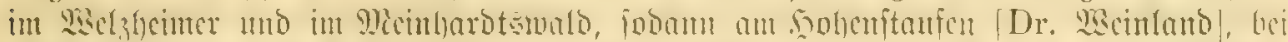

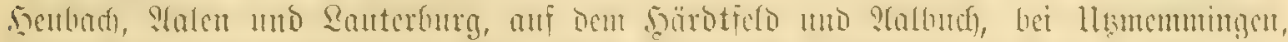

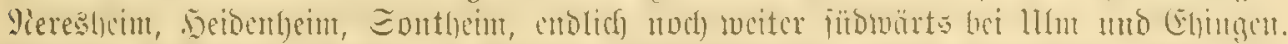

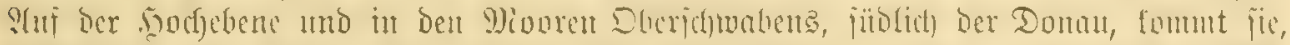

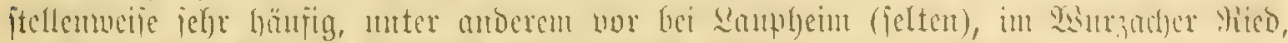

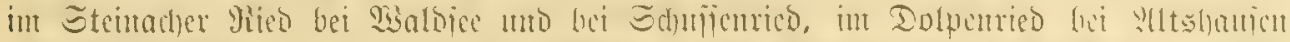

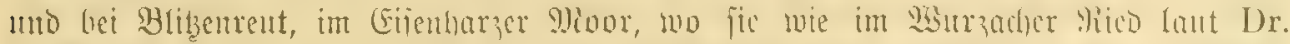

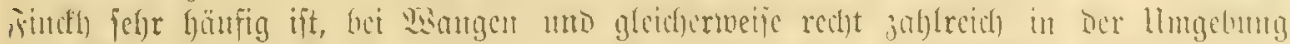

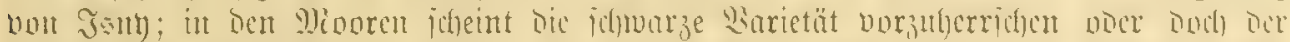

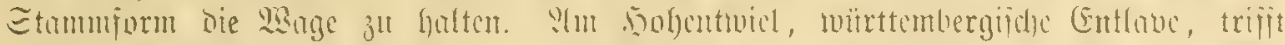

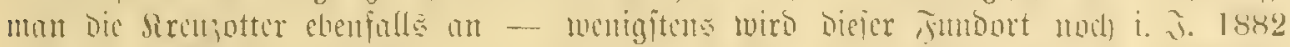

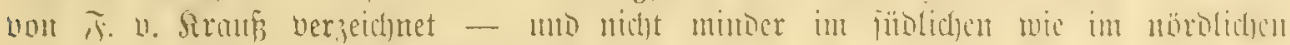
Soobenzollern (Ditractithal, Berg Soljenzollern).

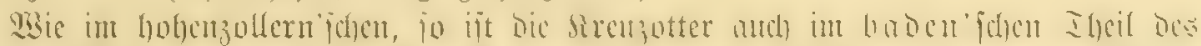

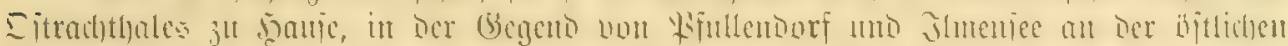

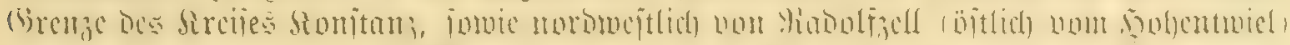

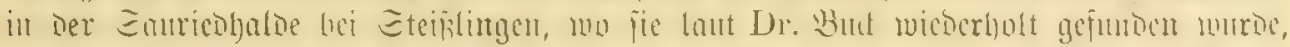

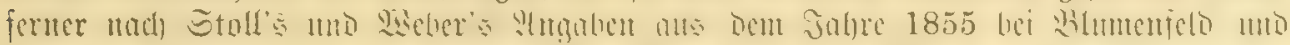

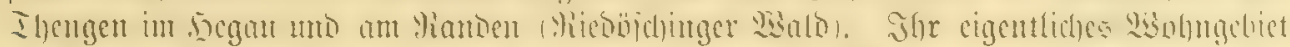

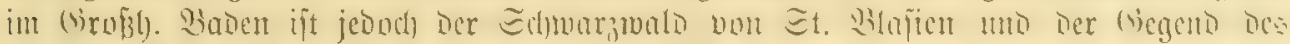

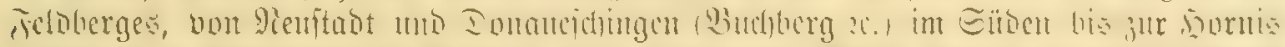

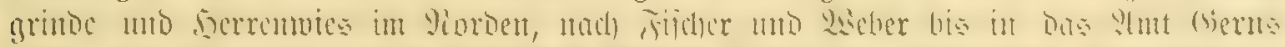

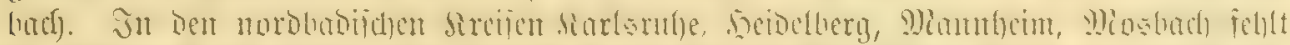

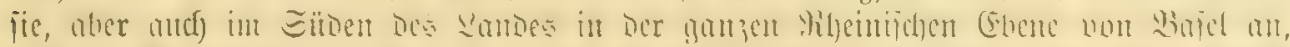

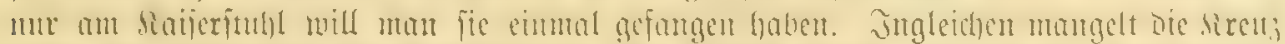

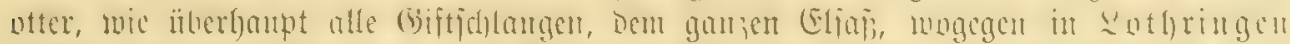

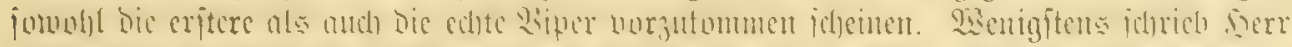

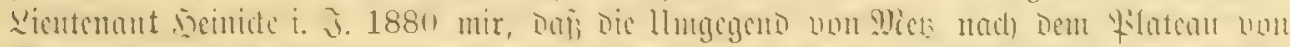

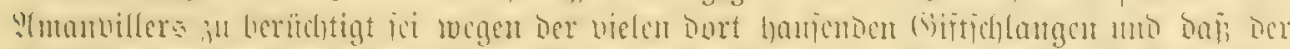

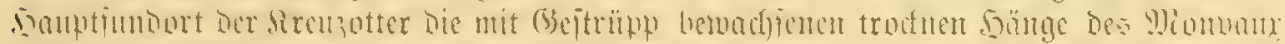

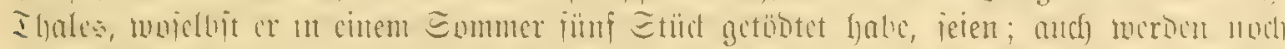

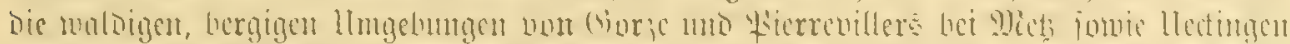

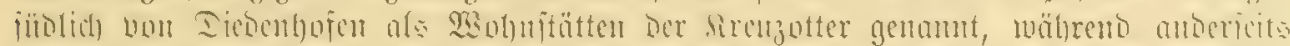

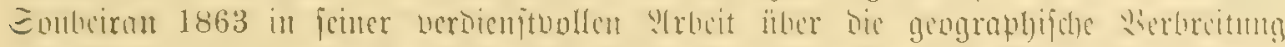

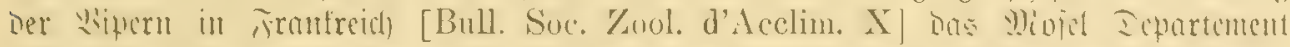

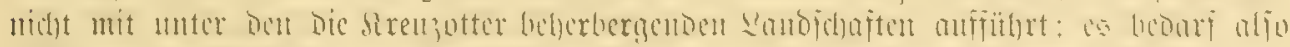

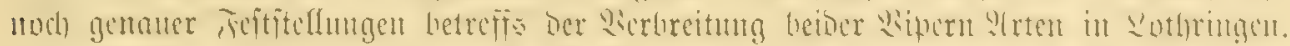

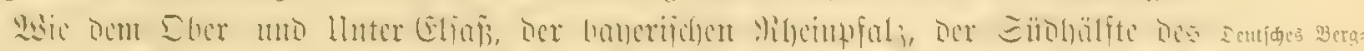

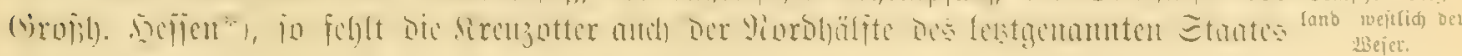

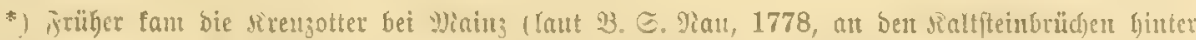

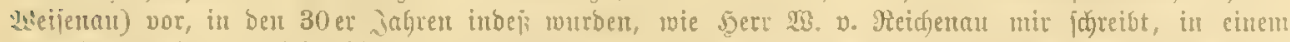

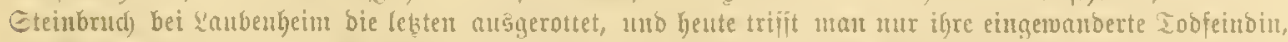

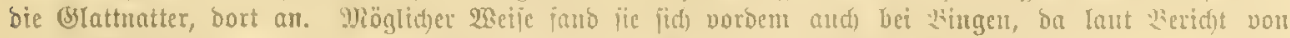

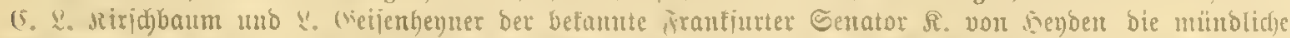

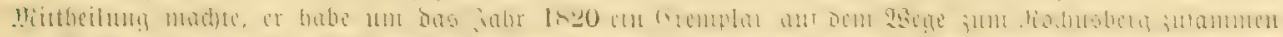

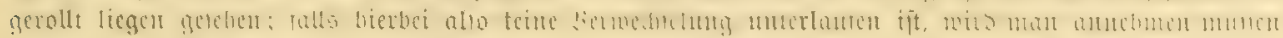

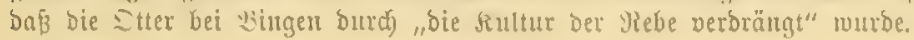




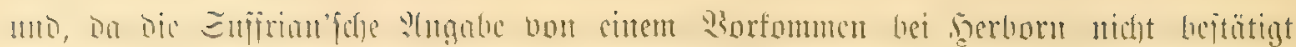

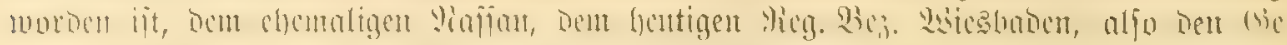

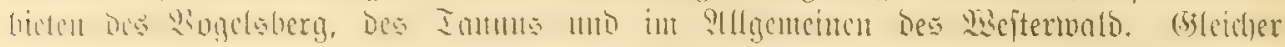

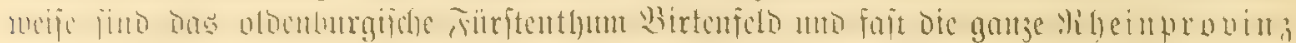

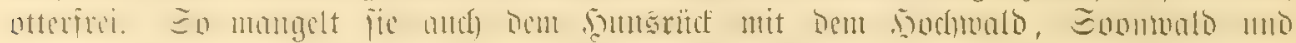

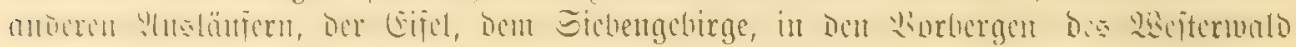

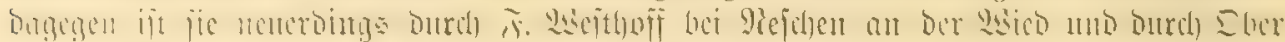

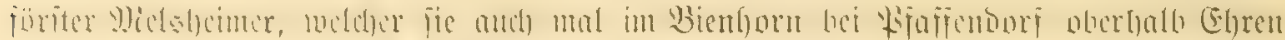

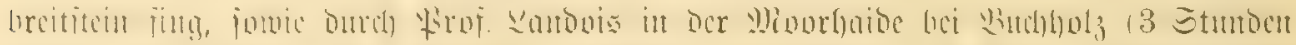

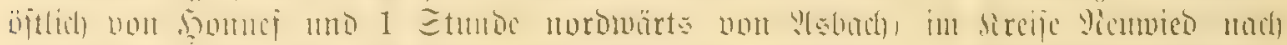

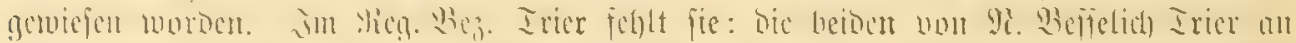

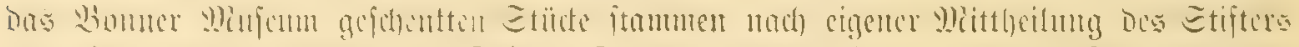

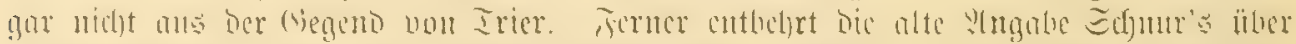

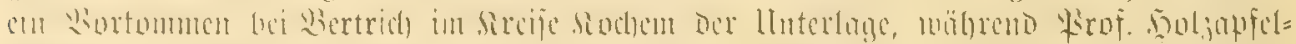

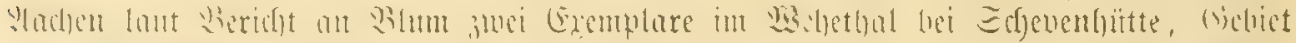

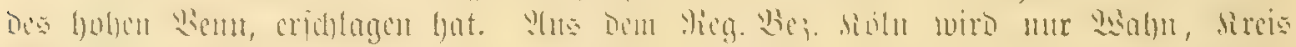

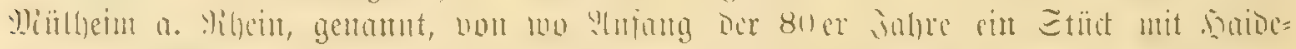

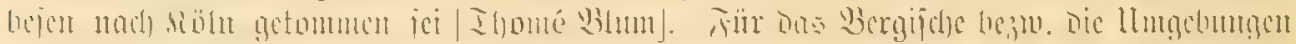

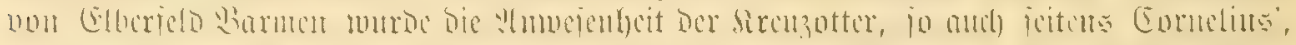

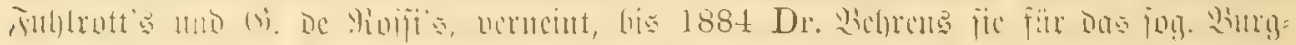

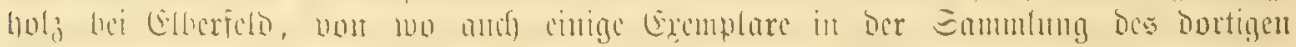

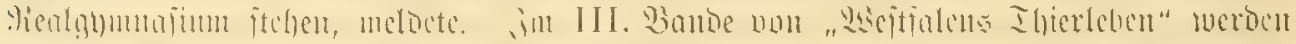

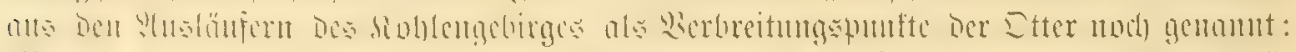

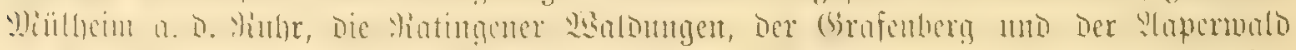

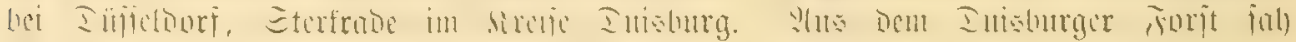

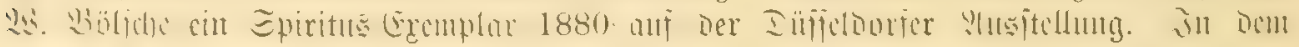

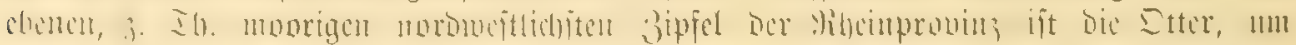

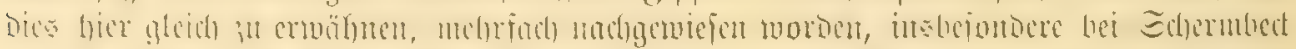

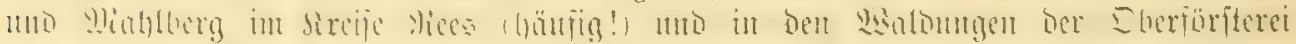

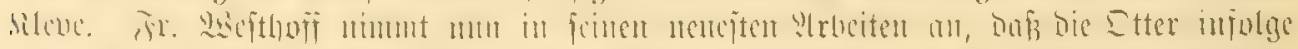

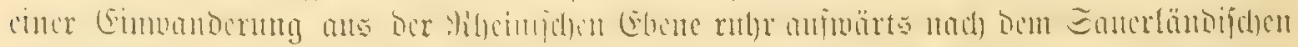

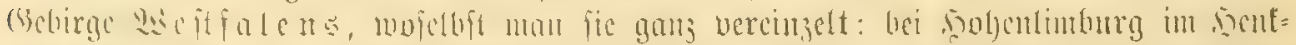

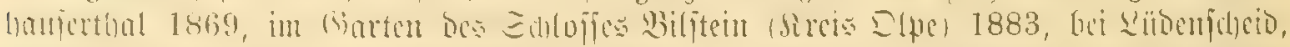

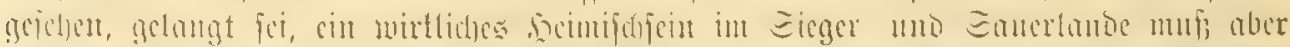

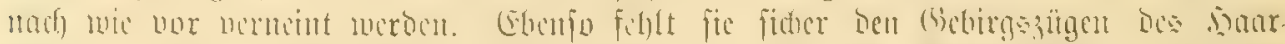

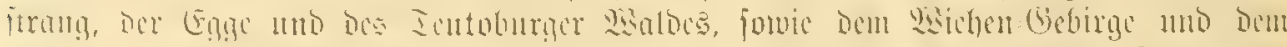

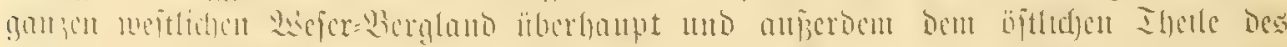

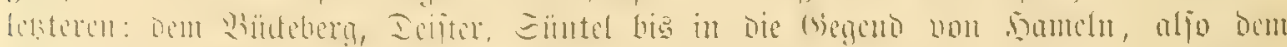

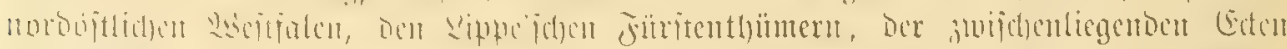

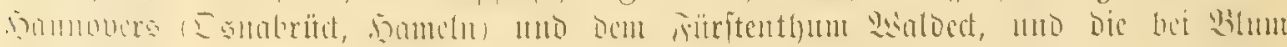

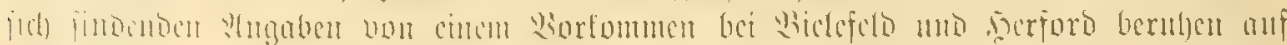

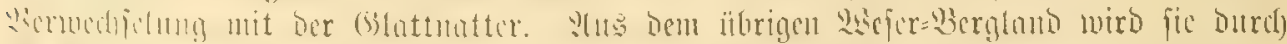

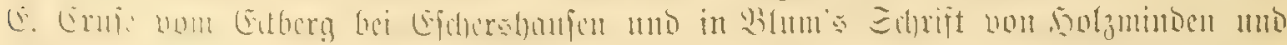

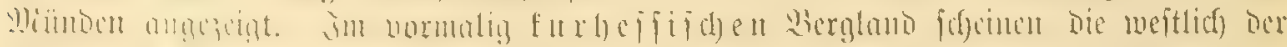

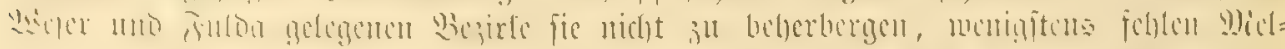

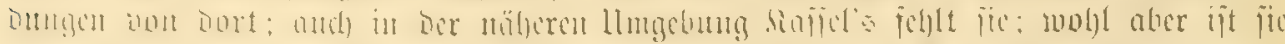

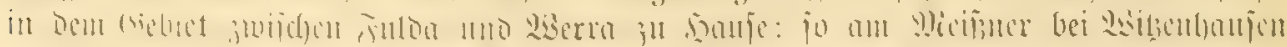

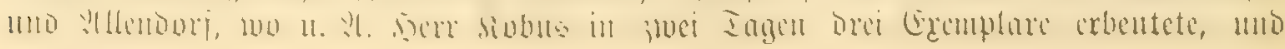




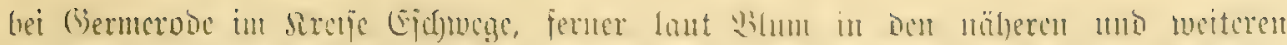

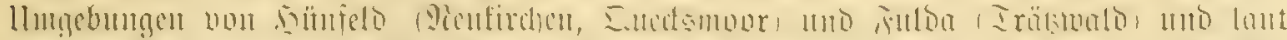

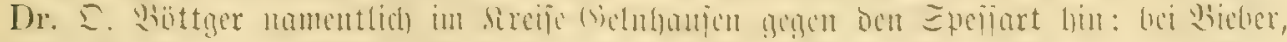

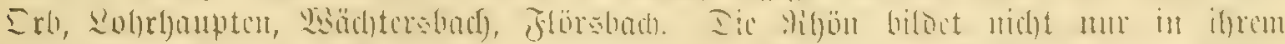

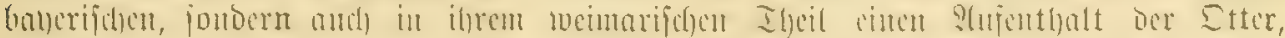

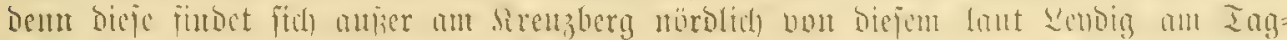

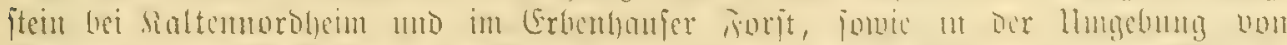

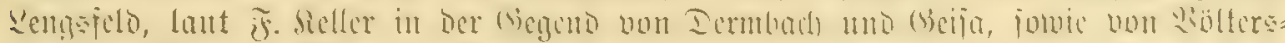

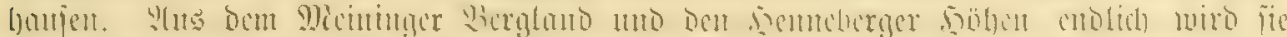

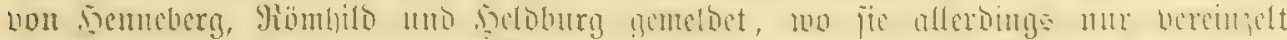

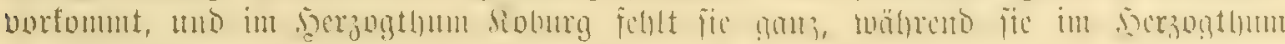
Gotlja an melyerent Drten auftritt.

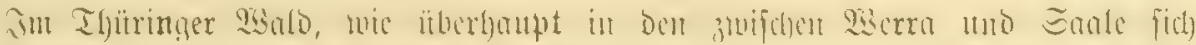

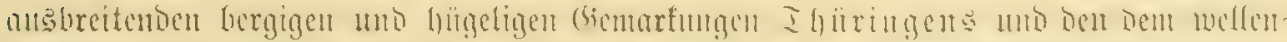

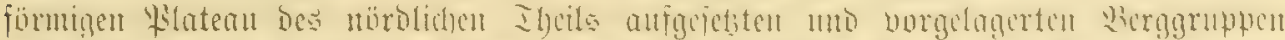

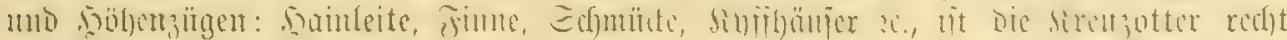

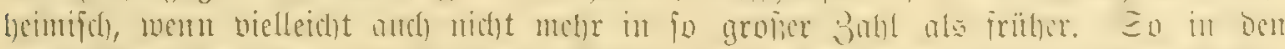

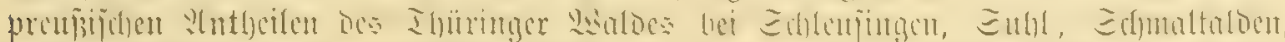

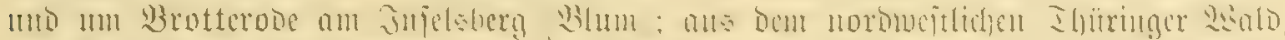

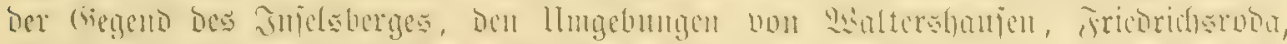

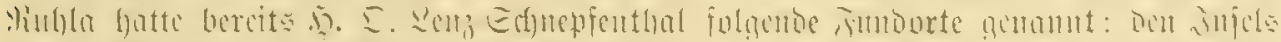

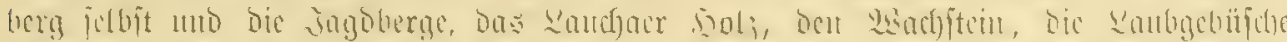

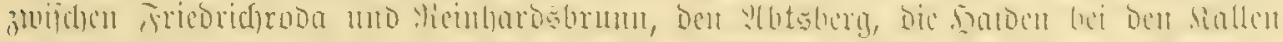

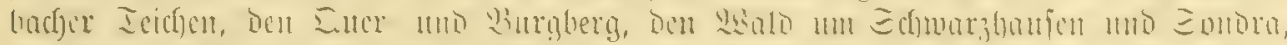

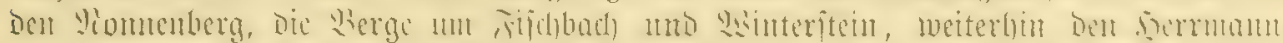

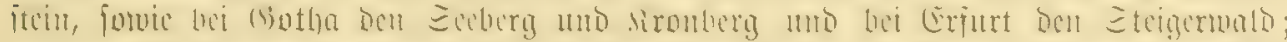

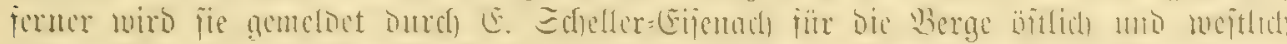

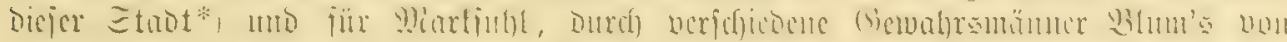

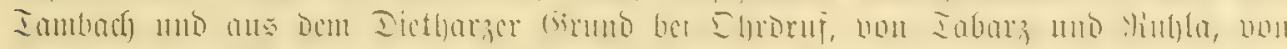

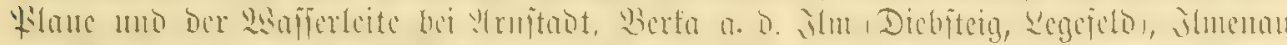

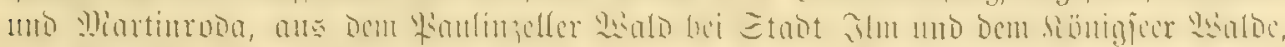

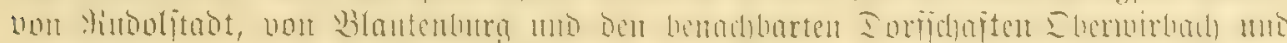

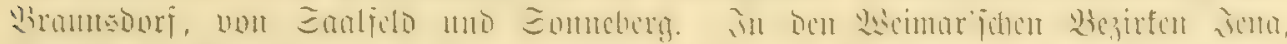

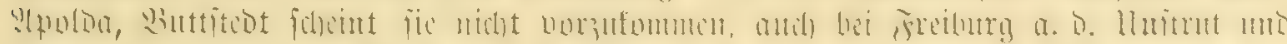

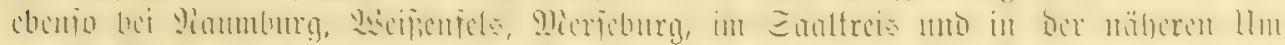

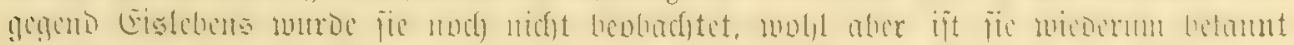

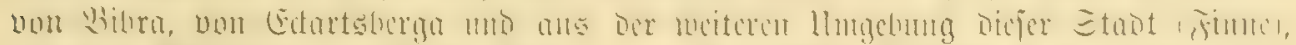

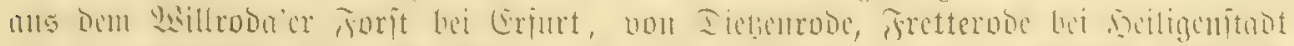

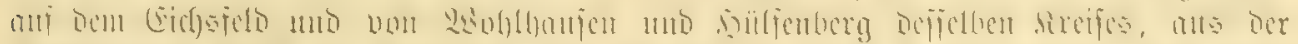

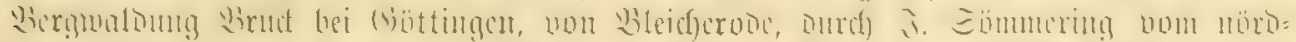

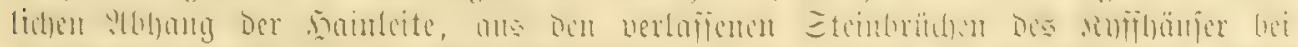

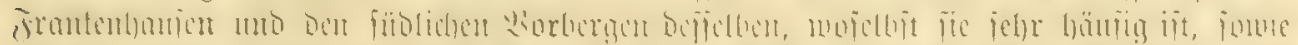

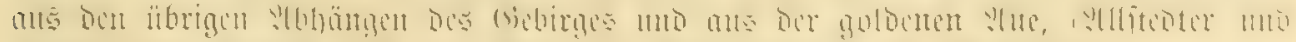

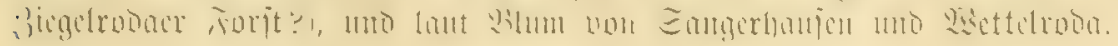

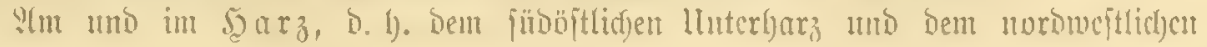

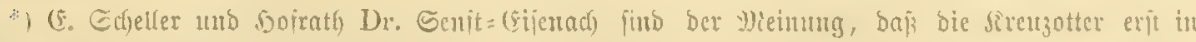

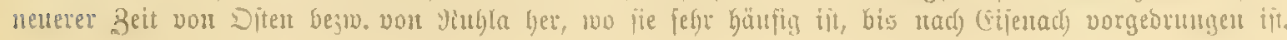




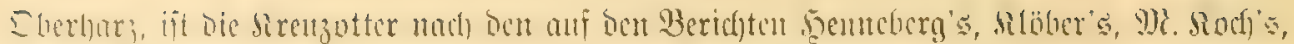

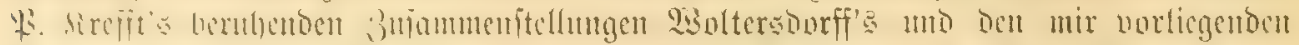

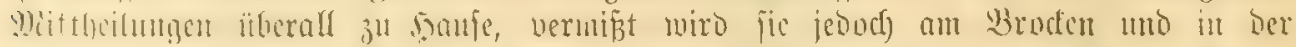

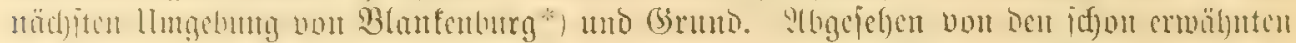

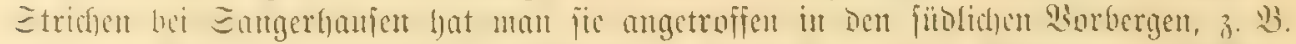

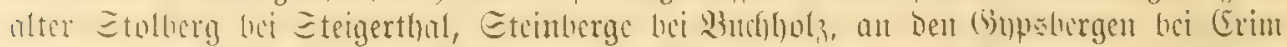

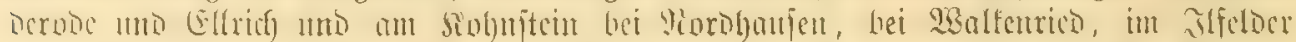

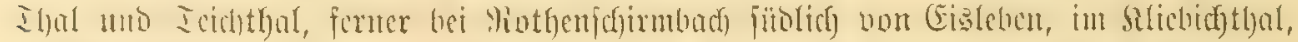

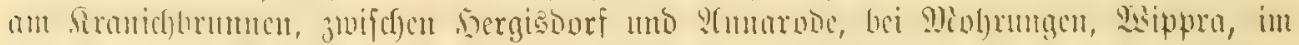

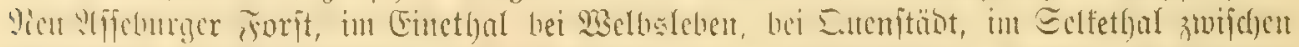

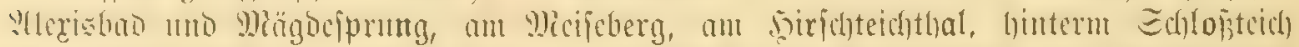

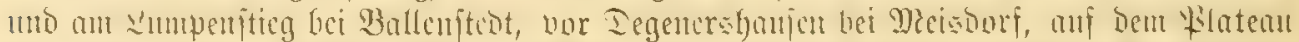

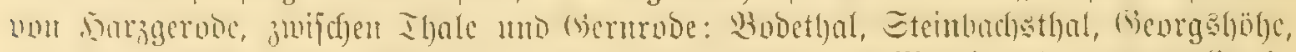

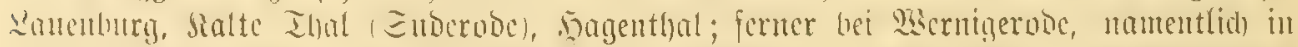
ient :

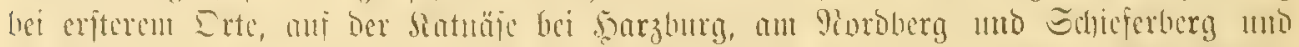

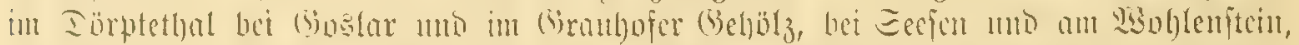

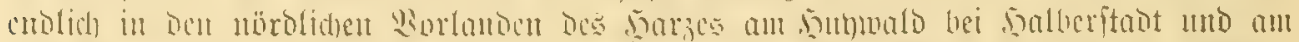

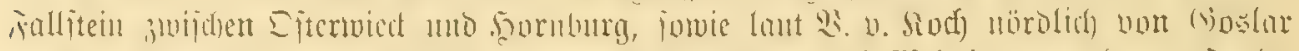

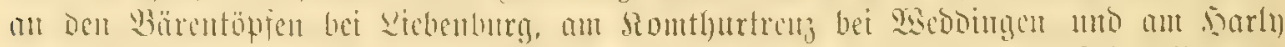

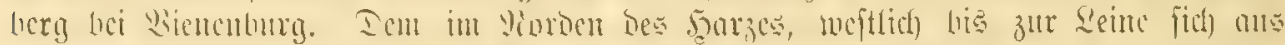

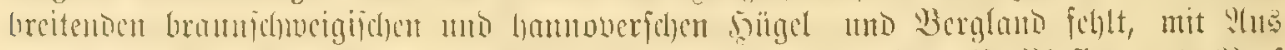

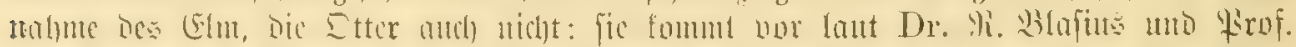

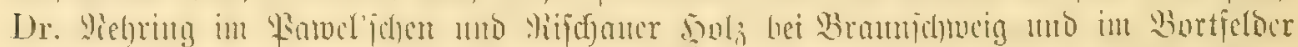

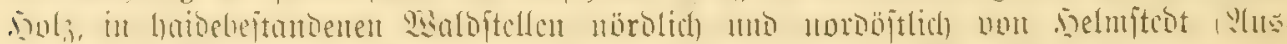

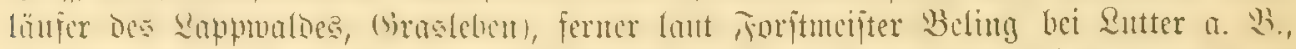

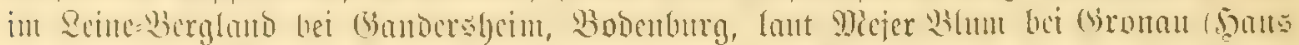

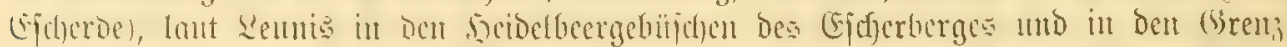

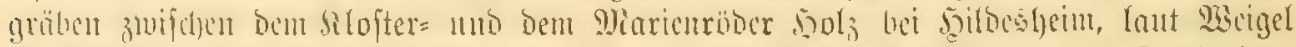

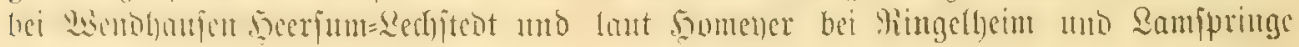
[W̉lım].

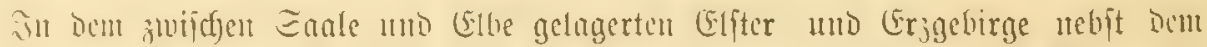

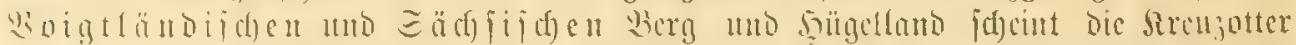

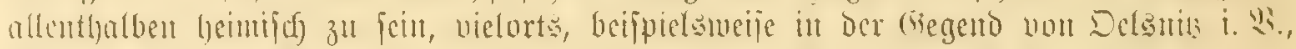

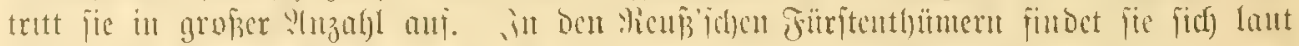

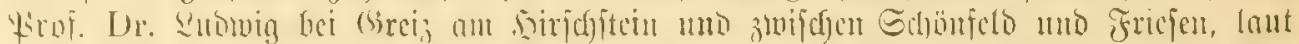

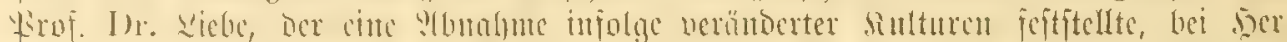
mams

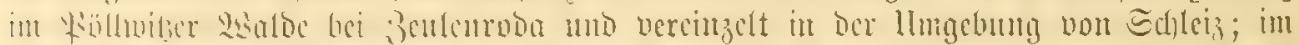

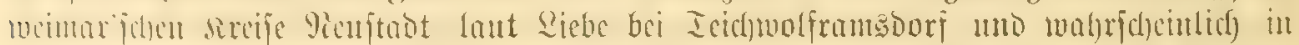

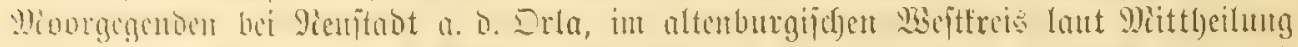

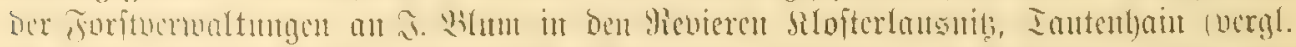

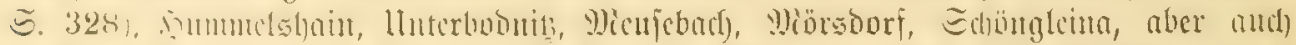

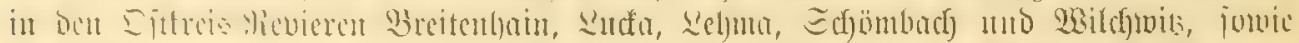

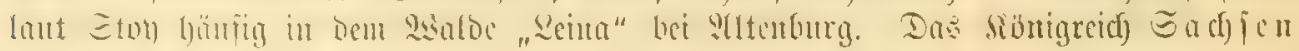

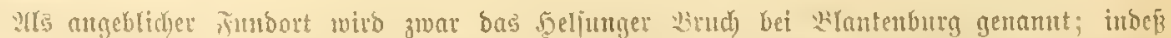

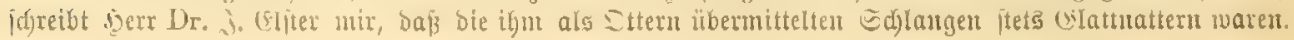




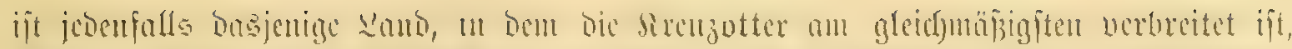

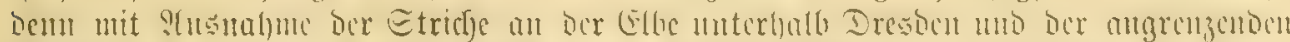

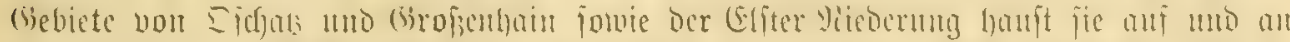

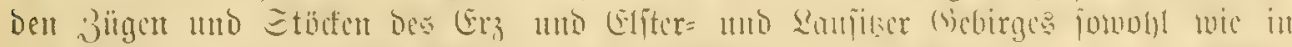

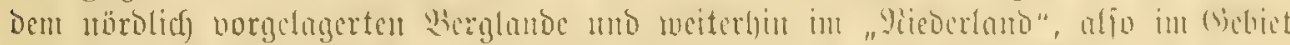

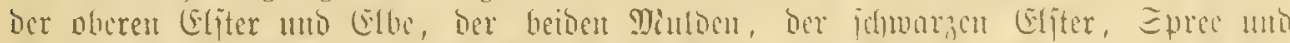

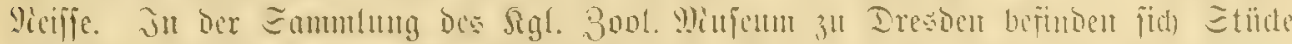

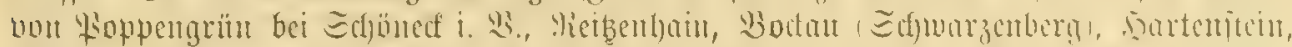

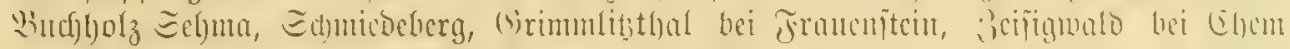

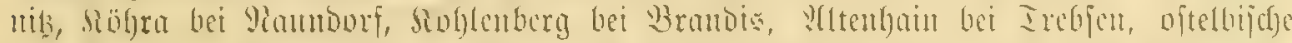

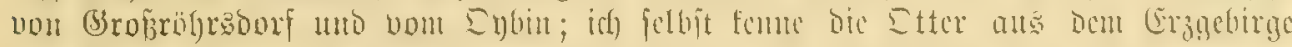

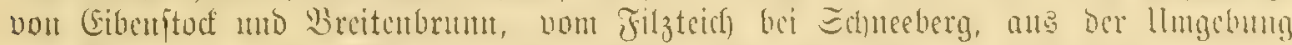

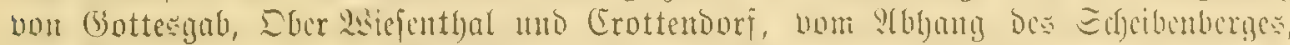

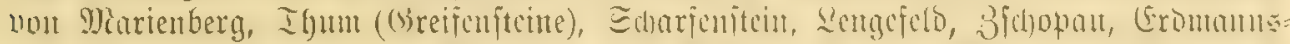

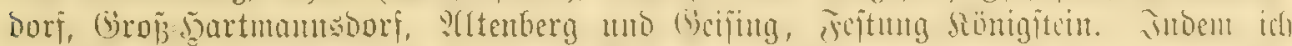

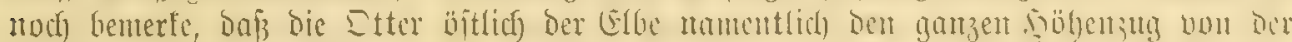

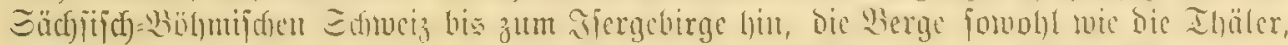

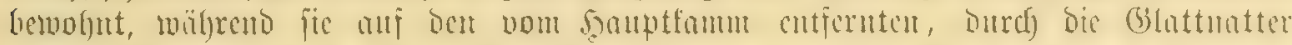

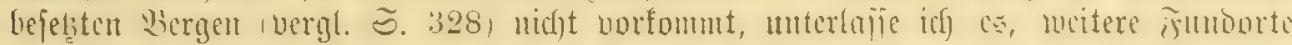

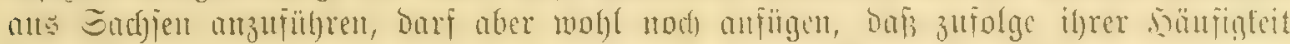

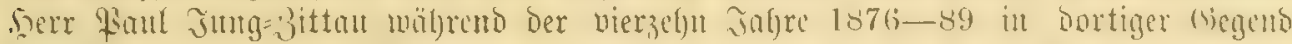

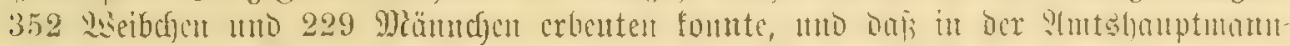

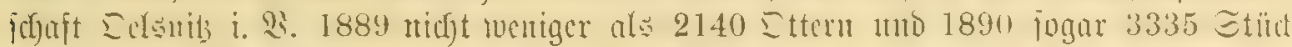

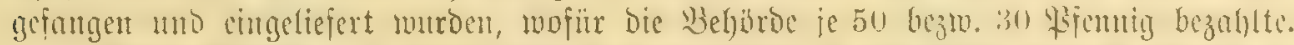

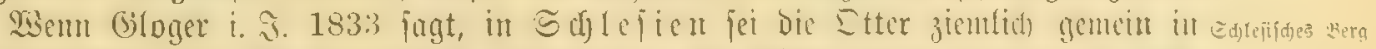

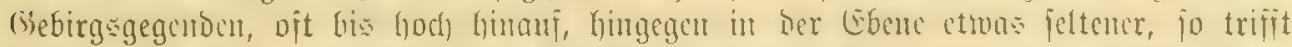

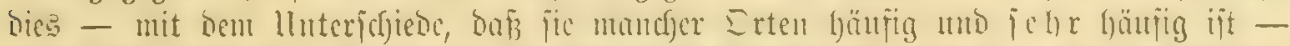

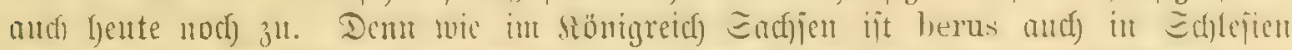

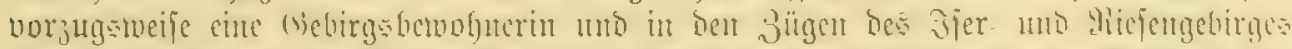

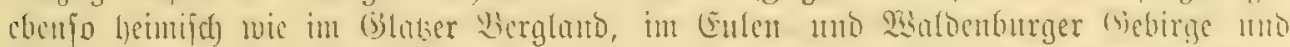

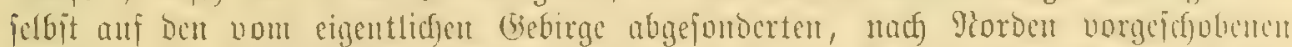

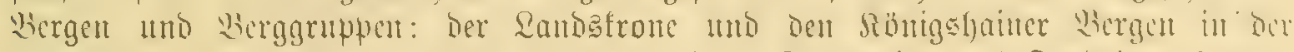

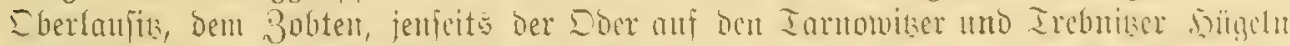

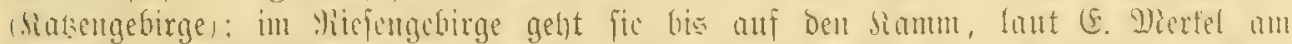

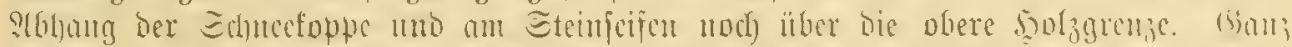

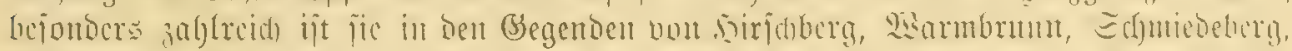

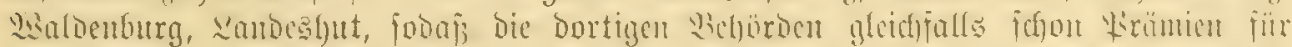

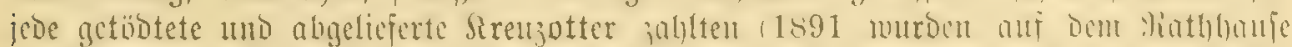

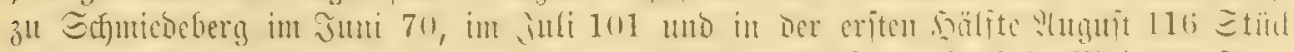

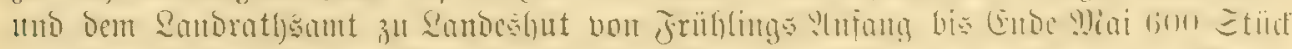

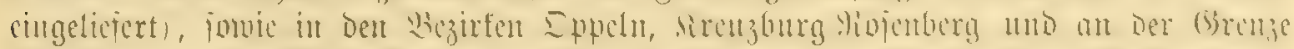

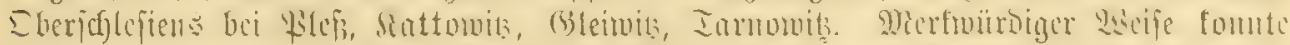

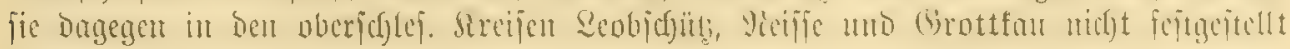
toerdont.

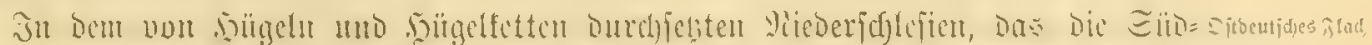

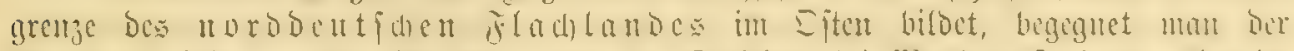

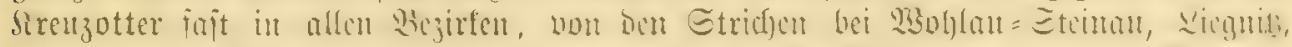

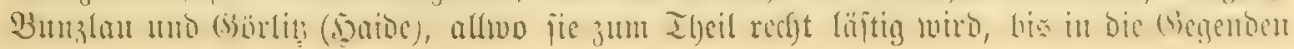




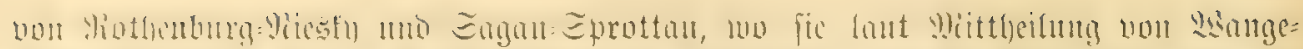

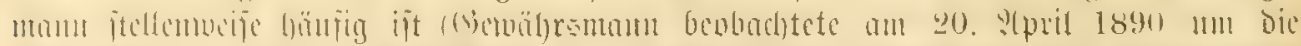

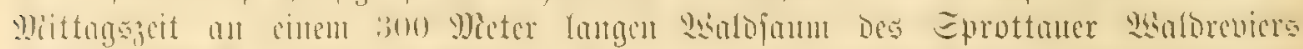

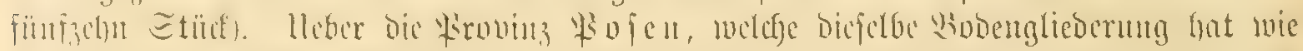

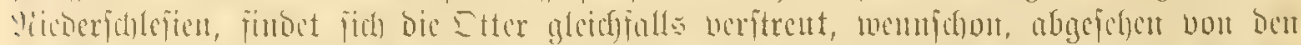

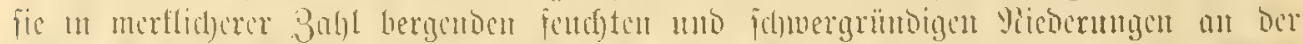

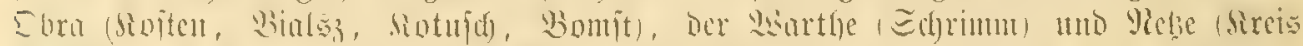

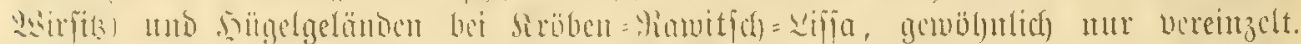

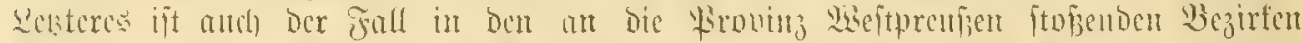

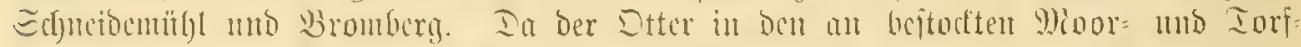

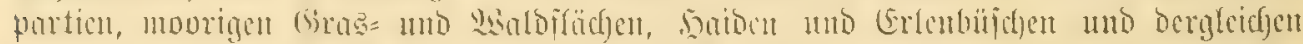

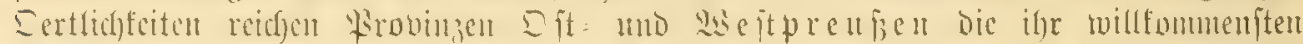

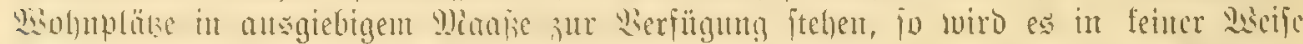

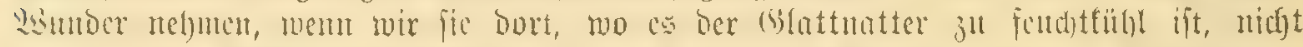

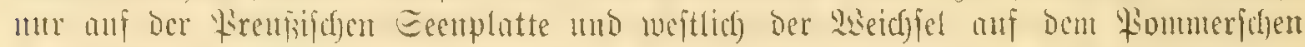

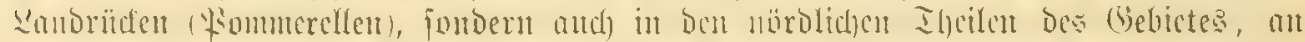

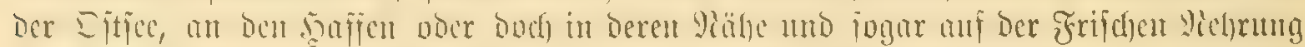

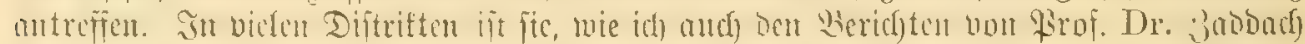

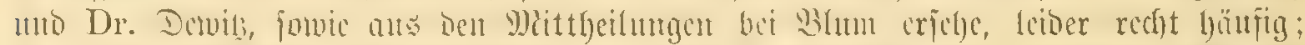

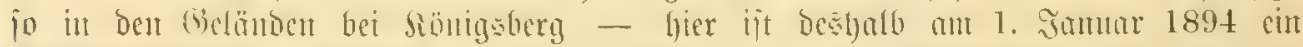

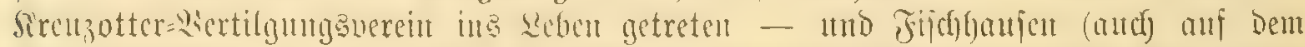

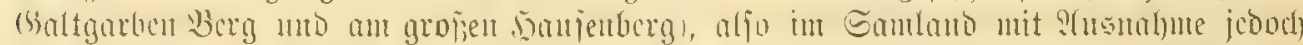

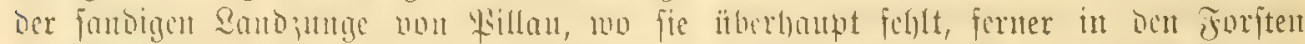

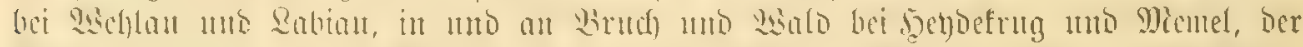

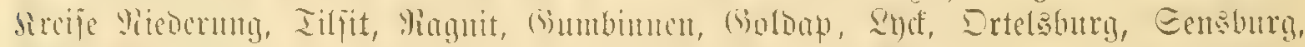

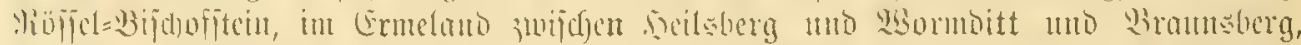

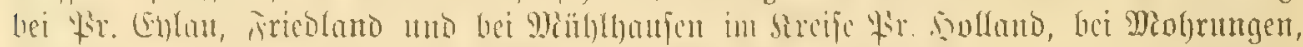
Piouldatubry=

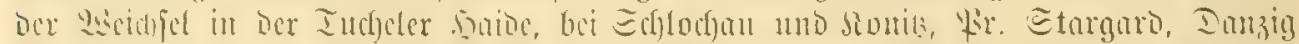

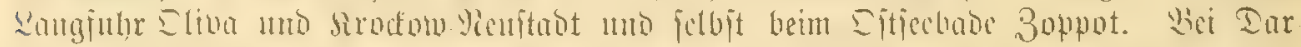

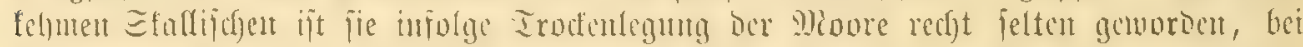

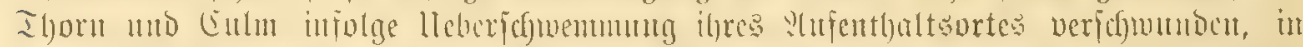

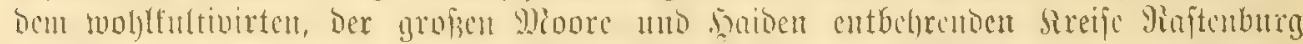

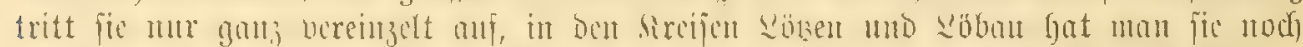

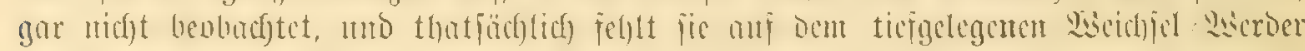

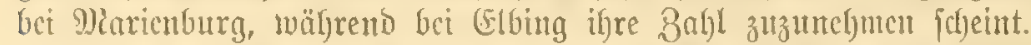

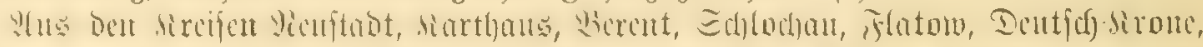

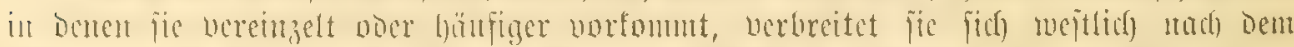

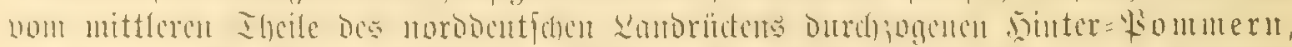

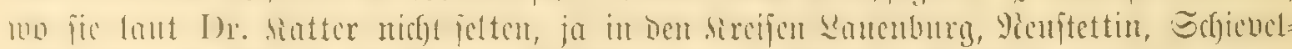

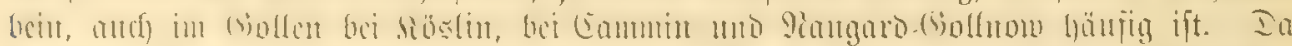

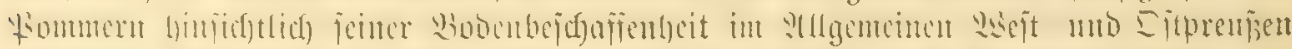

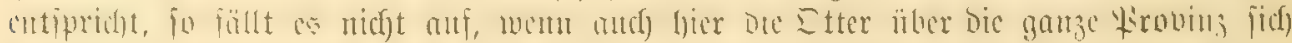

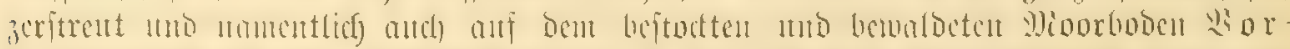

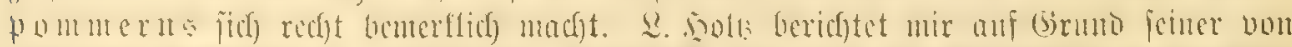

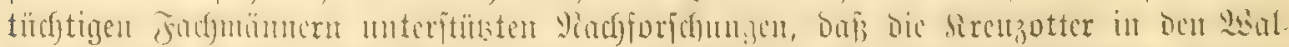

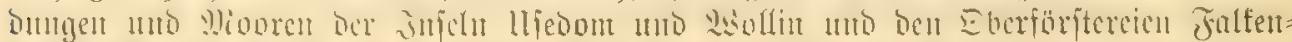

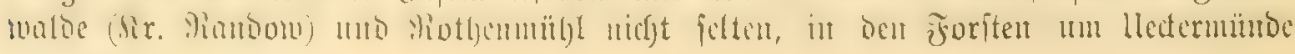




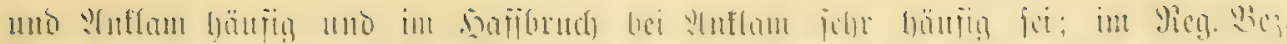

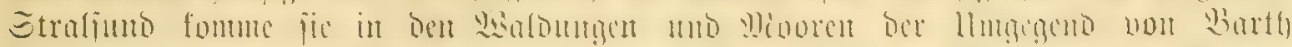

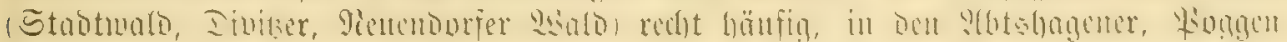

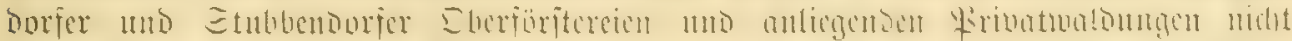

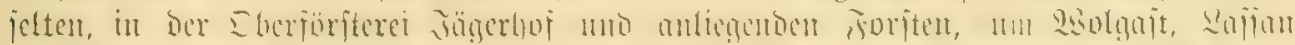

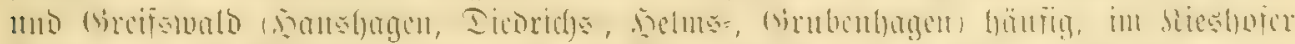

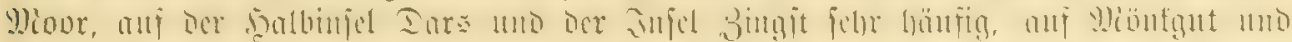

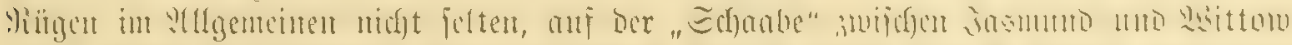

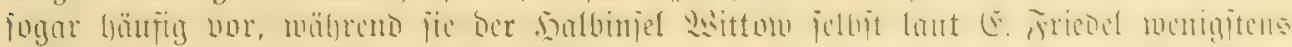

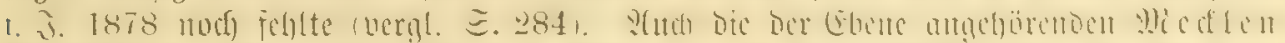

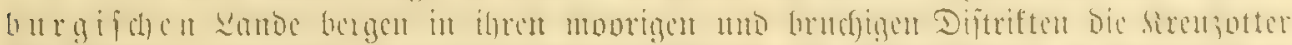

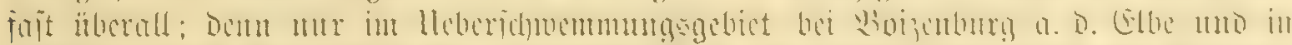

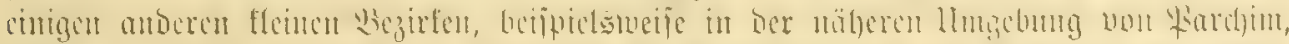

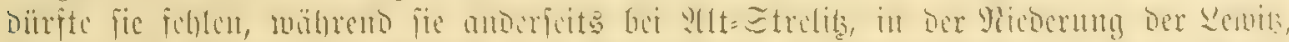

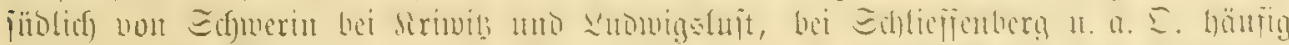

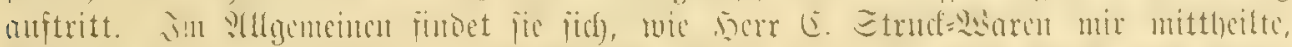

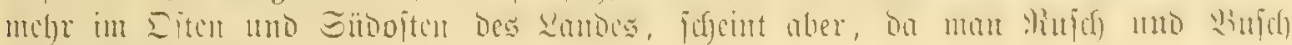
mukr bejeitigt, feltener zu werber.

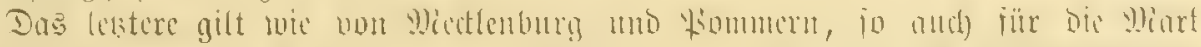

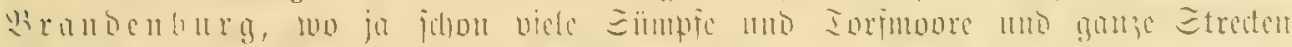

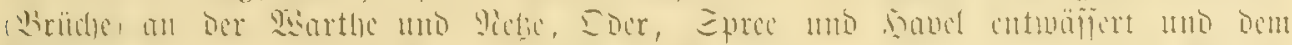

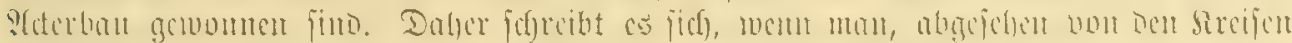
um Werlin, Die Dtter nur vercinzelt und zerftrent antrifft. Dem von Doer und

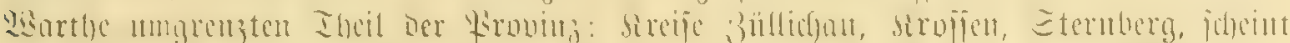
jie

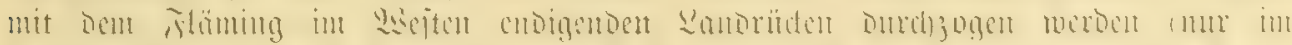

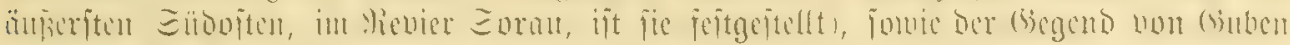

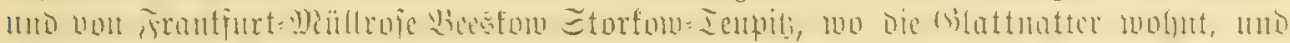

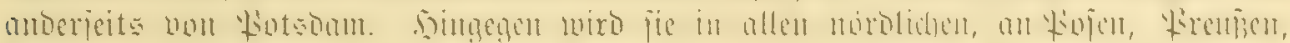

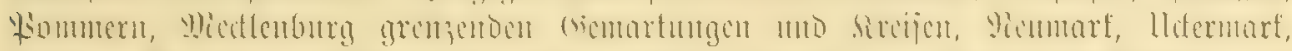

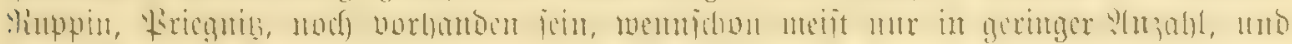

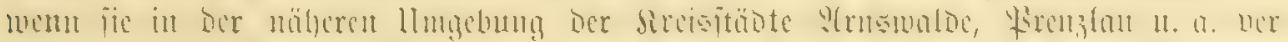

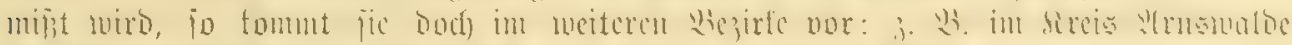

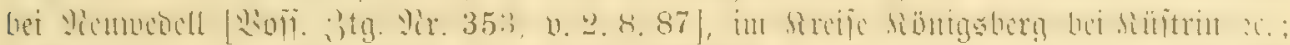

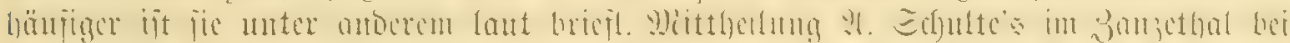

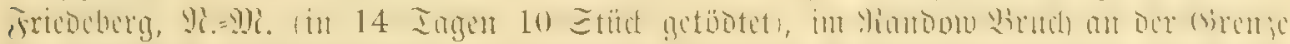

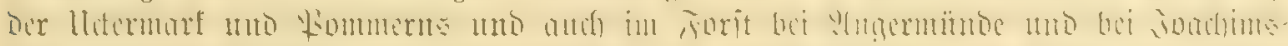

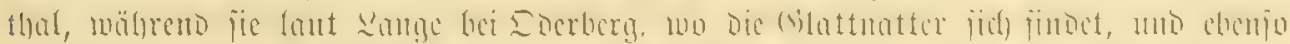

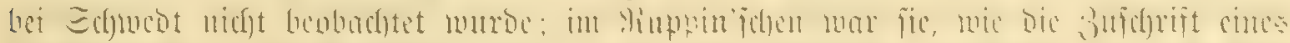

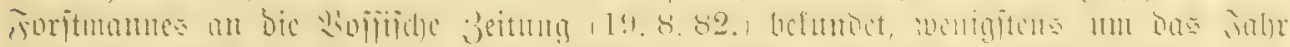

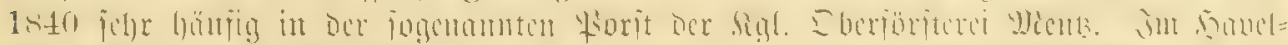

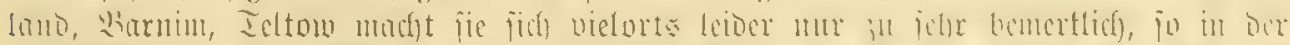

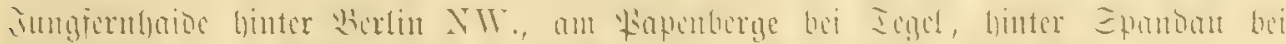

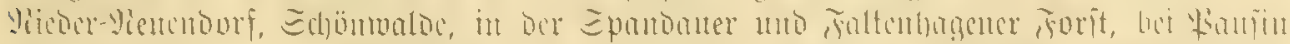

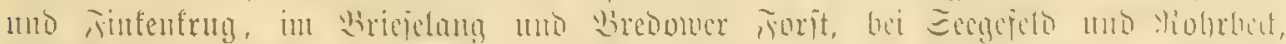

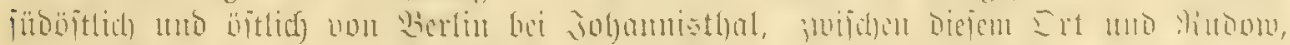

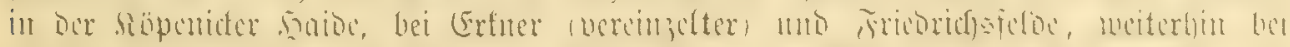

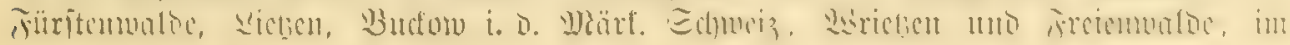




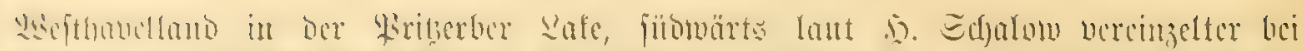

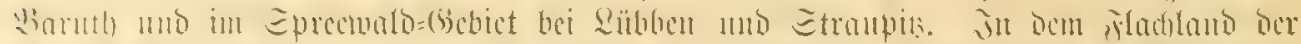

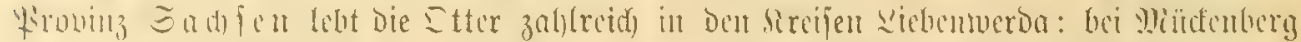

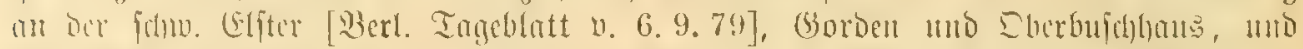

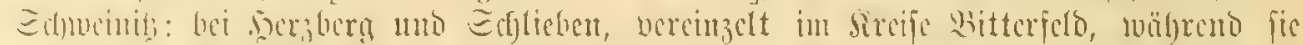

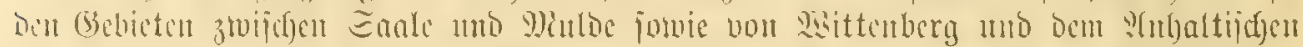

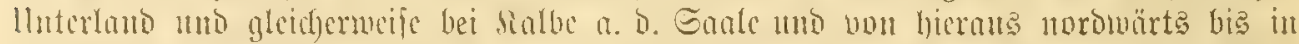

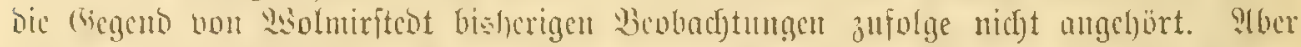

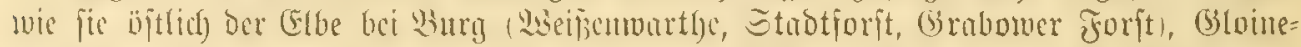

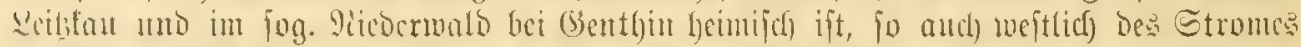

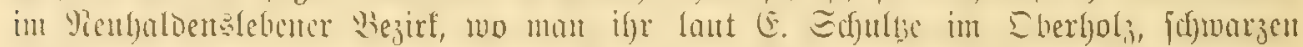

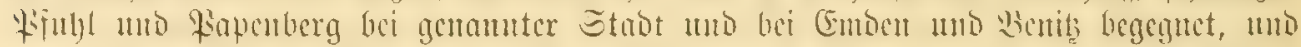

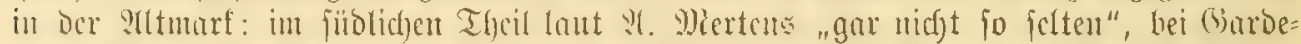

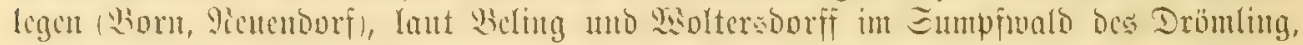

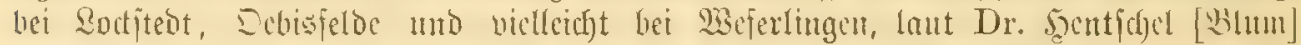

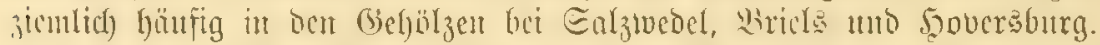

).

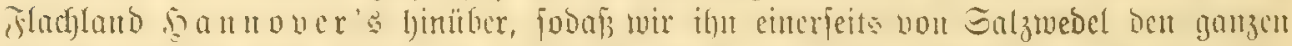

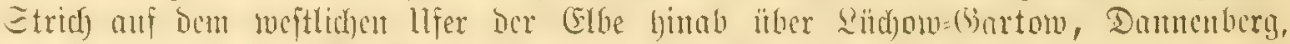

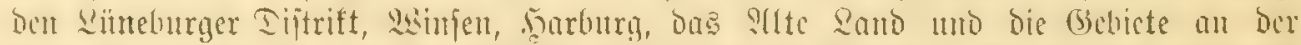

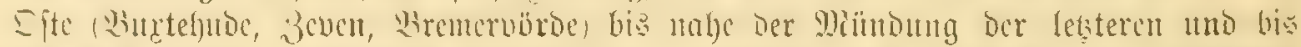

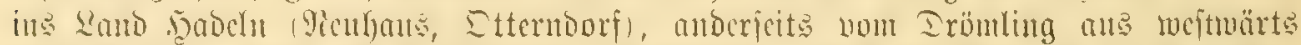

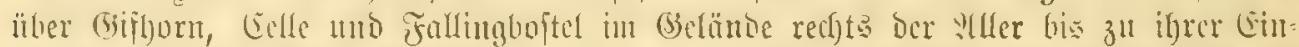

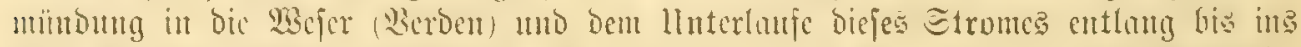

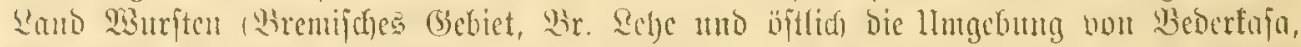

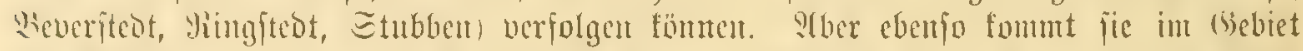

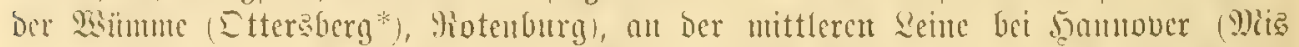

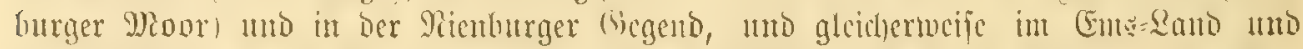

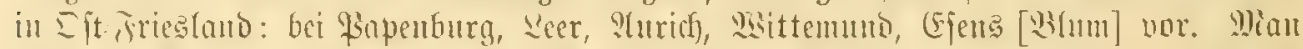

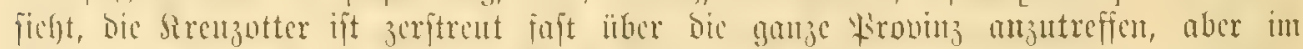

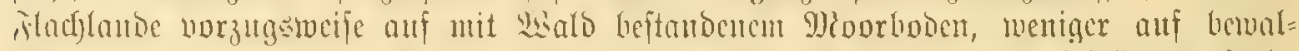

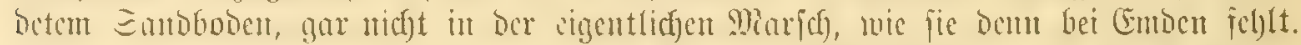

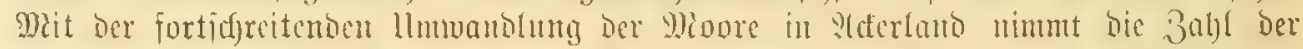

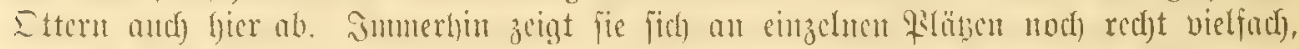

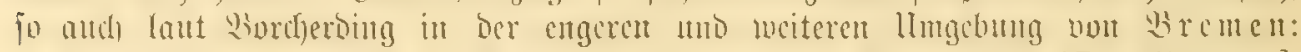

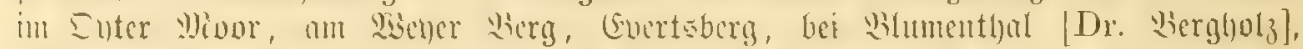

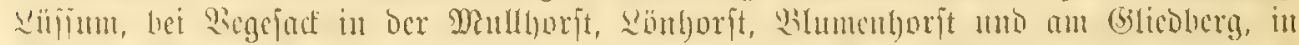

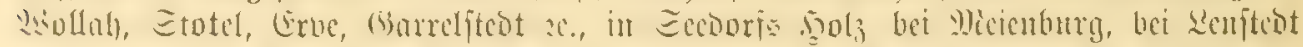

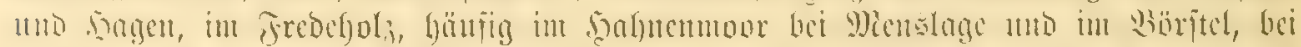

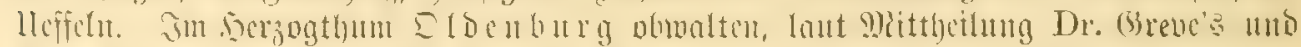

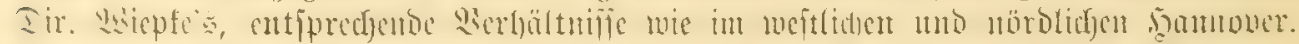

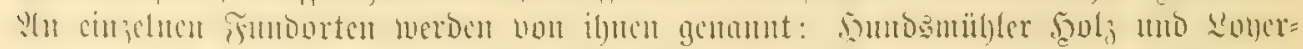

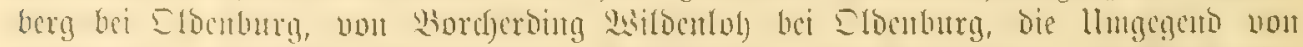

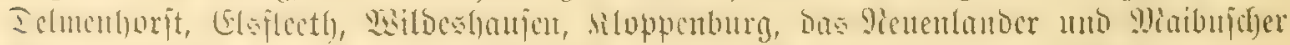

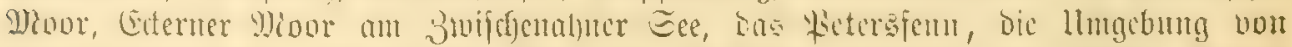

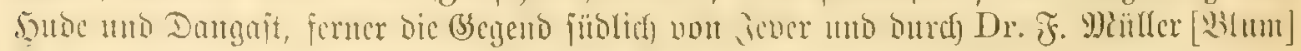

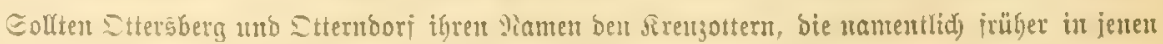
(Biegenton bäuftg gewejen jeit modjten, verbanten? 


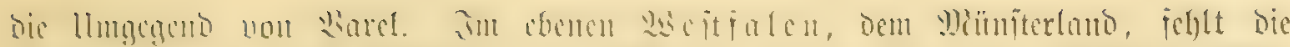
Ettre, wic uir bur(f)

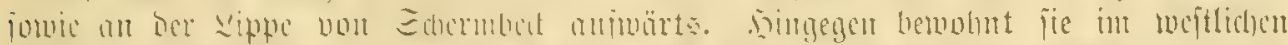

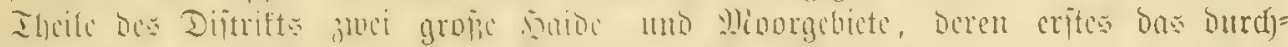

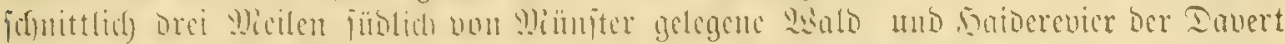

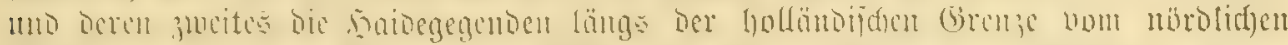

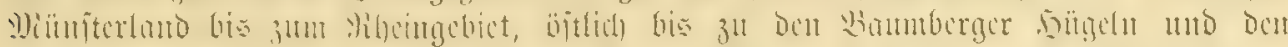

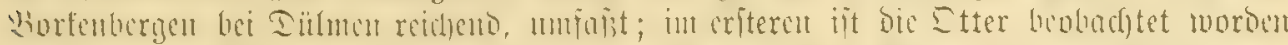

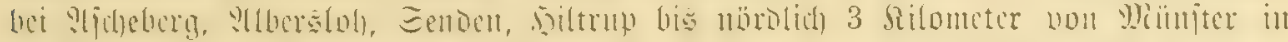

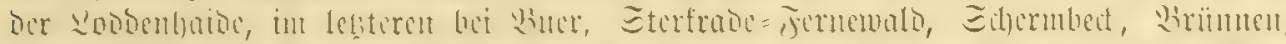

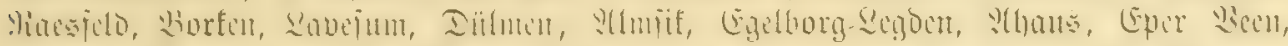

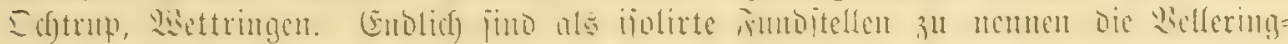

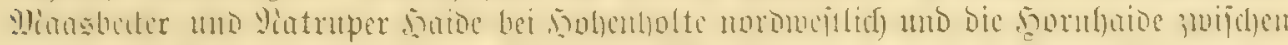

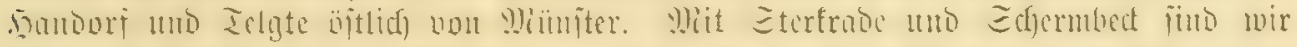

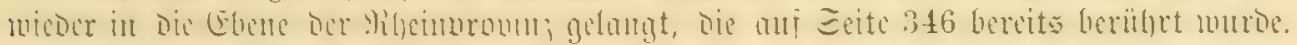

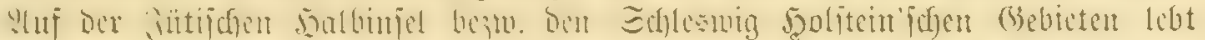

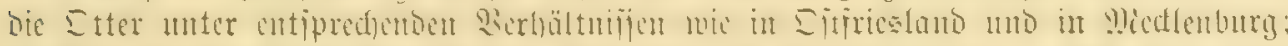

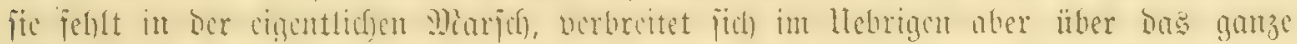

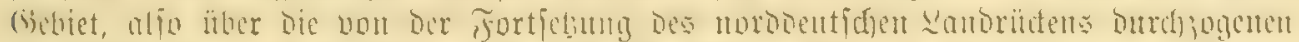

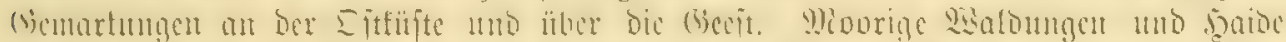

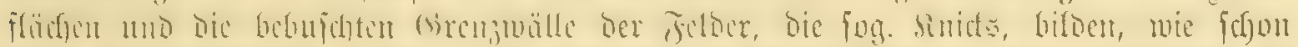

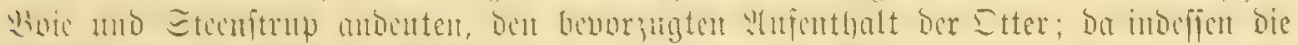

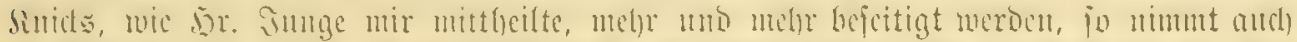

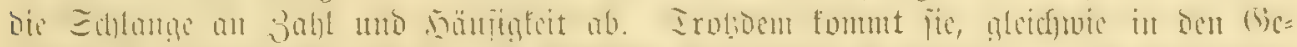

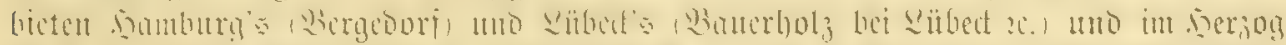

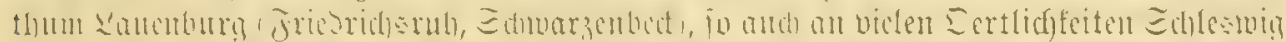

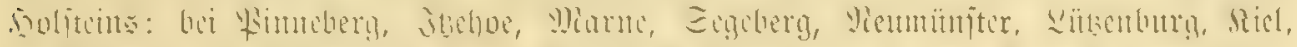

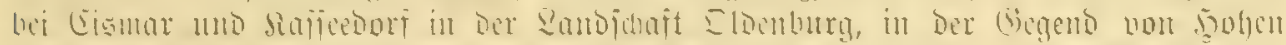

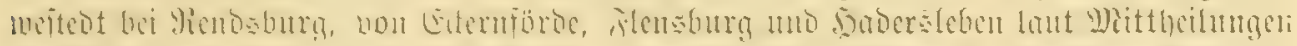

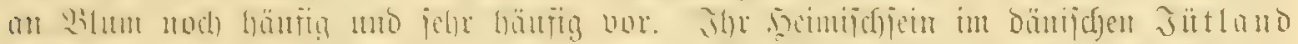

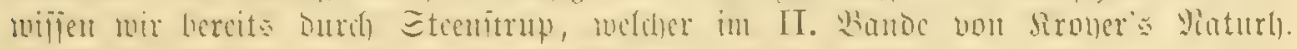

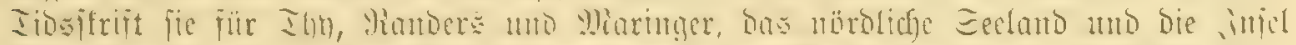

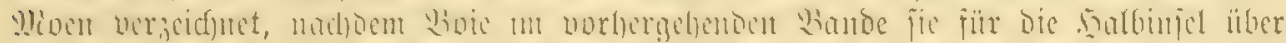

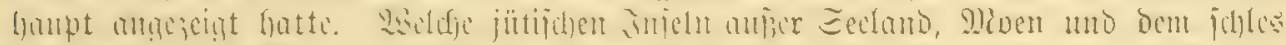

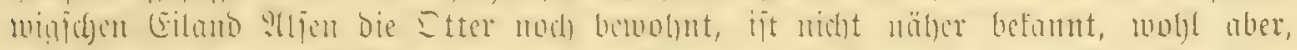

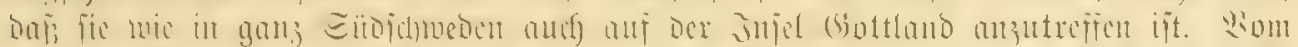

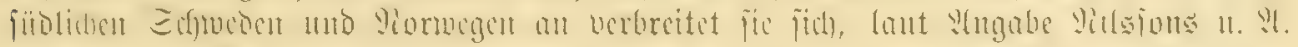

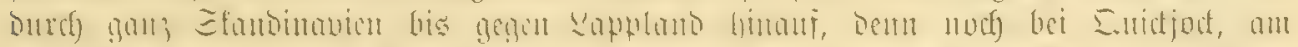

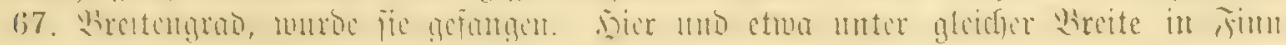

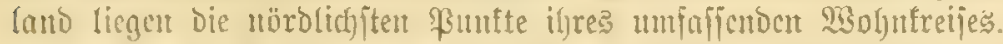

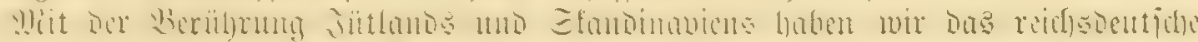

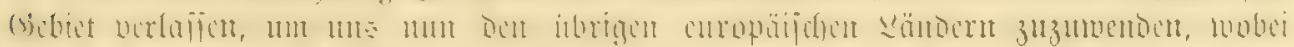

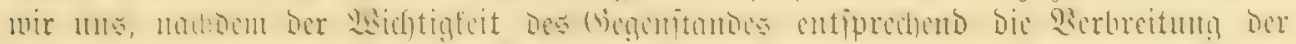

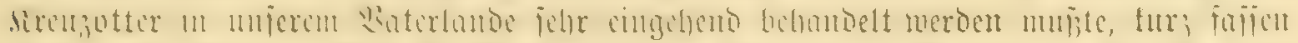

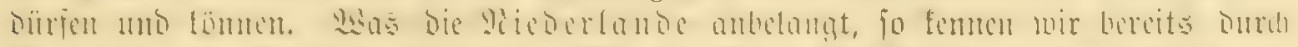

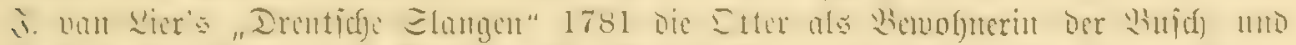

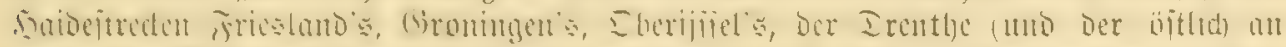

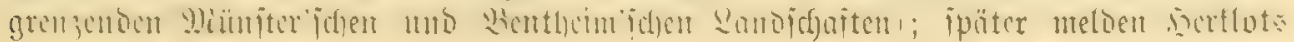




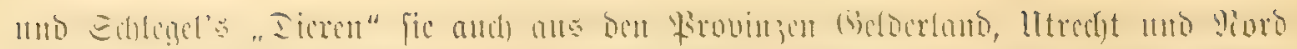

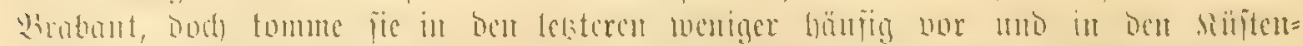

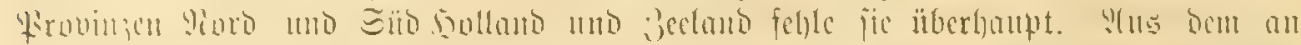

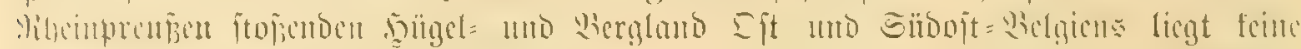

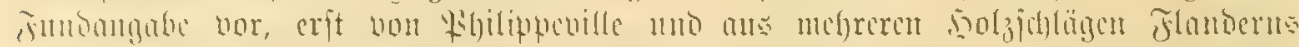

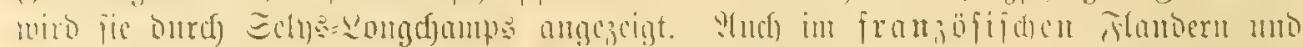

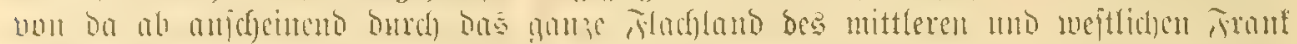

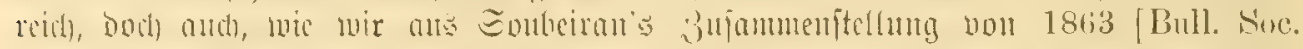

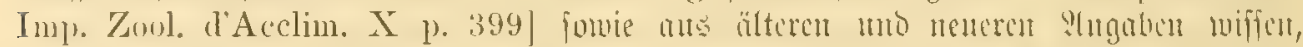

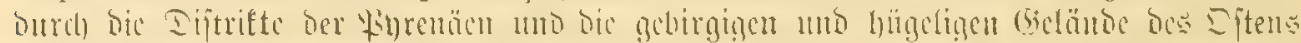

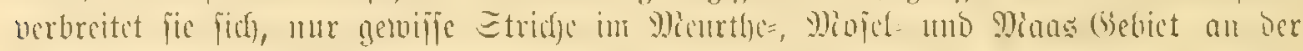

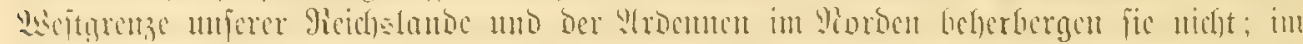

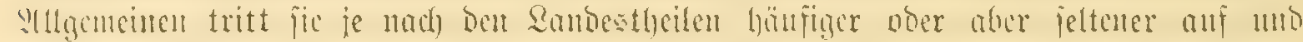

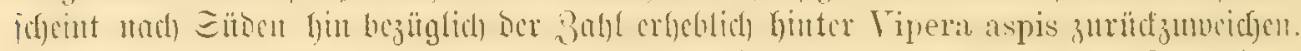

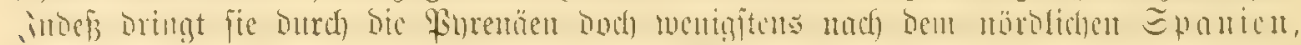

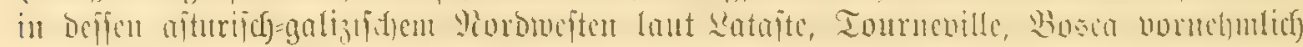

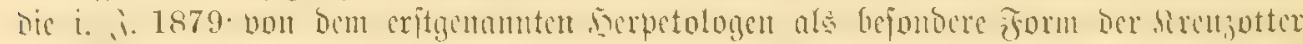

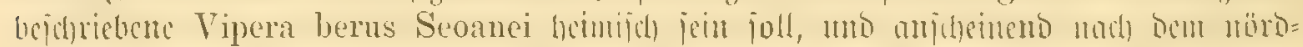

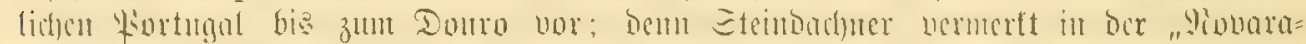

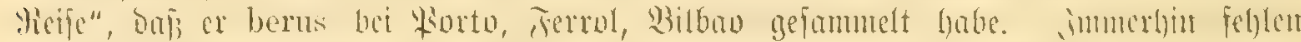

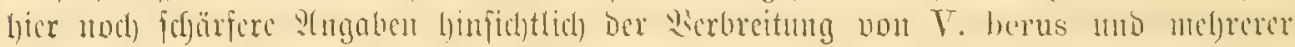

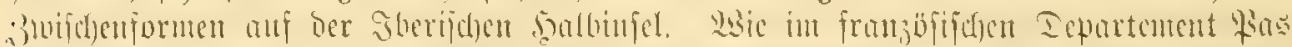

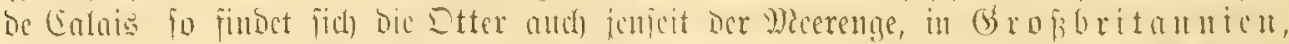

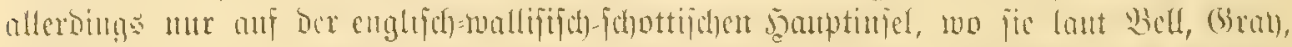

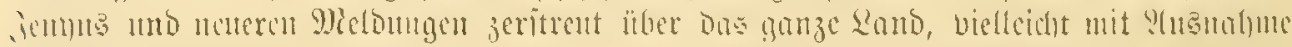

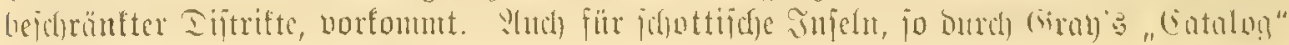

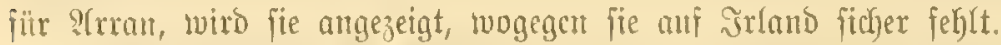

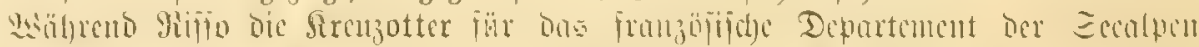

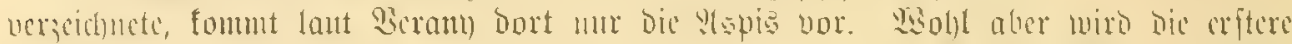

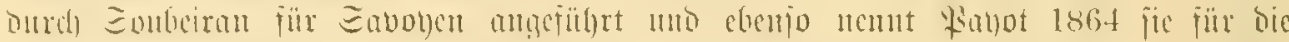

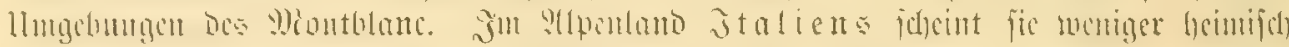

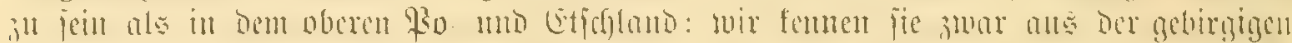

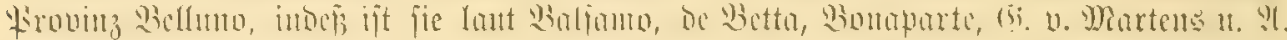

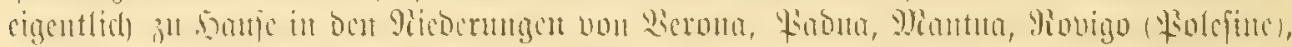

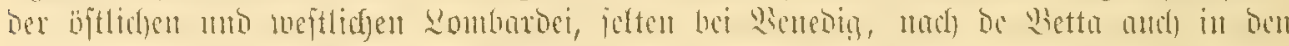

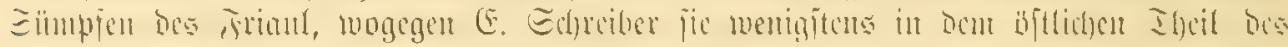

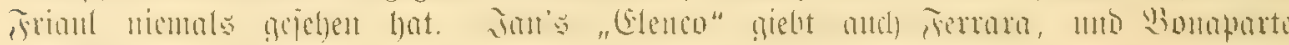

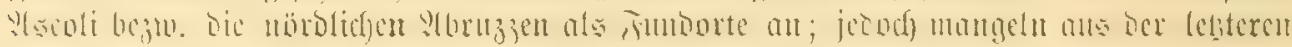

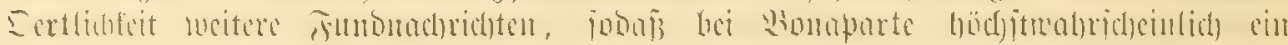

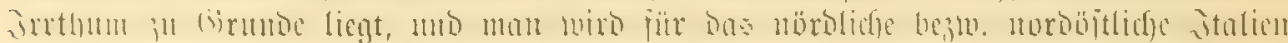

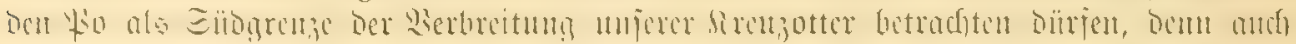

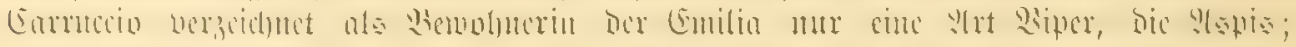

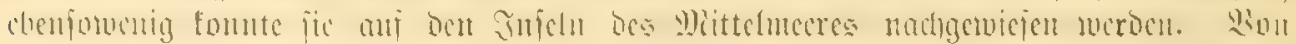

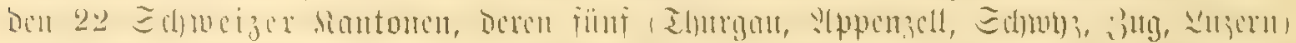

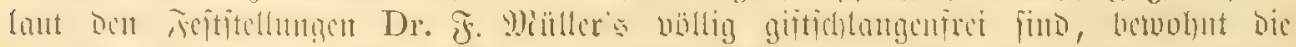
Sirugutex

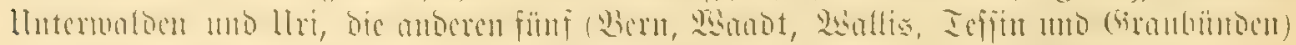

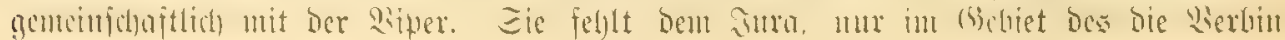




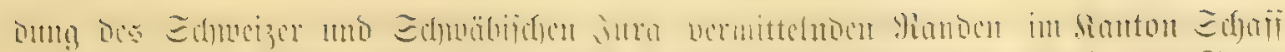

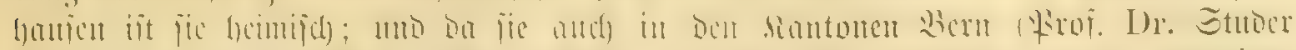

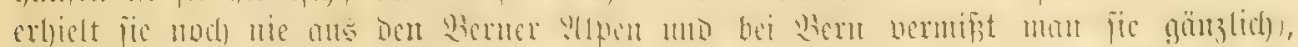

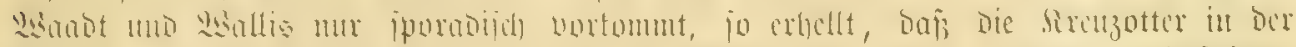

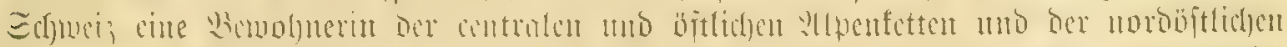

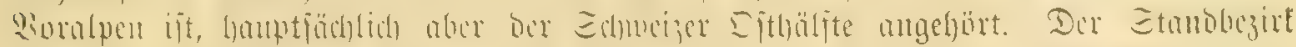

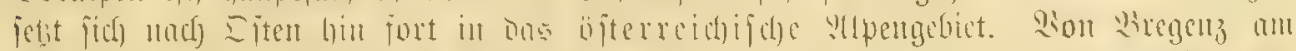

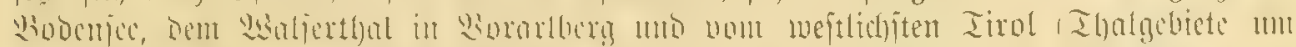

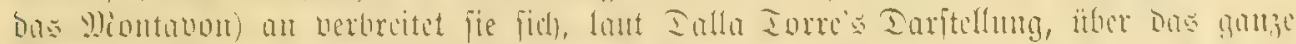

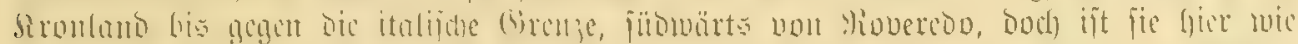

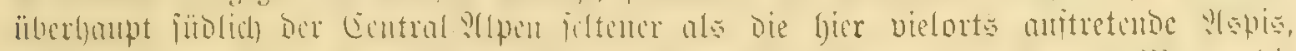

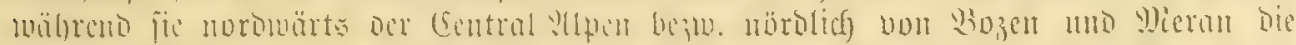

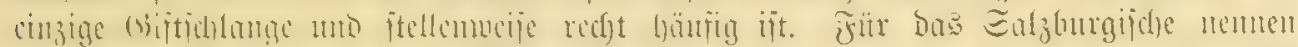

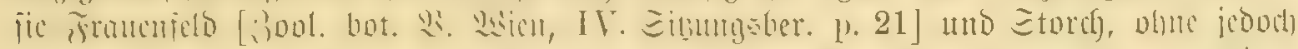

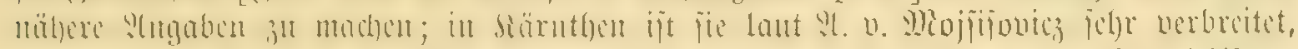

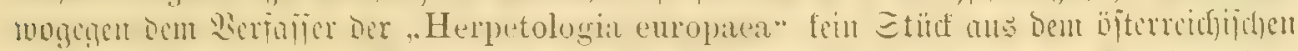

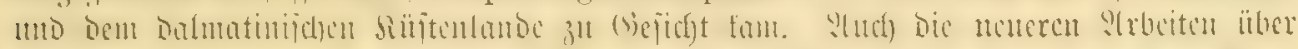

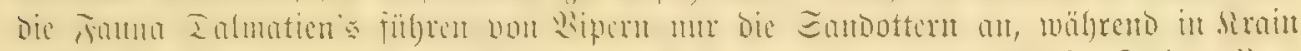

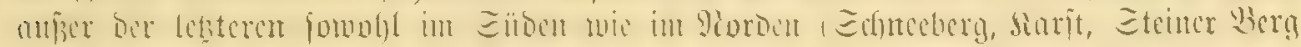

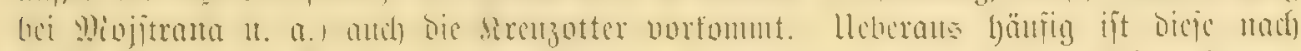

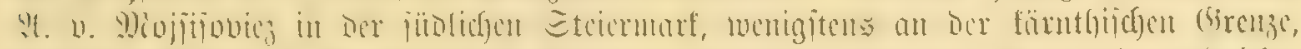

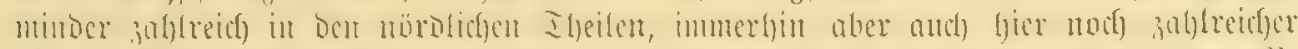

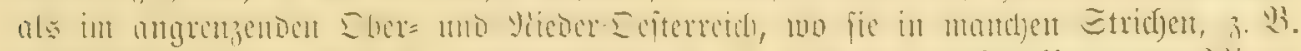

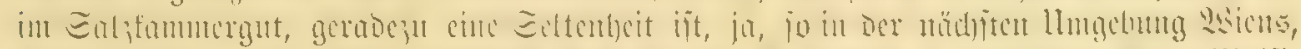

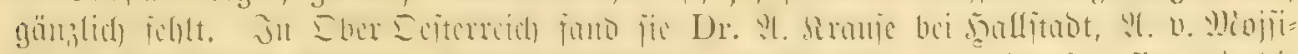

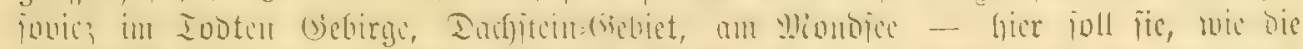

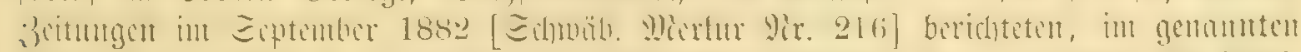

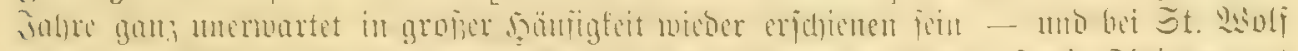

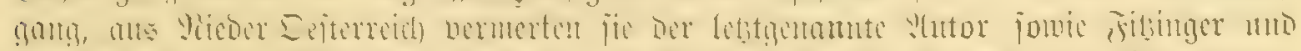

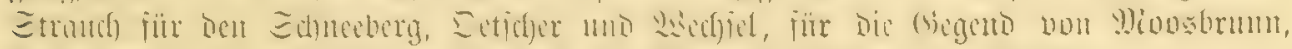

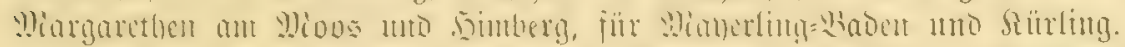

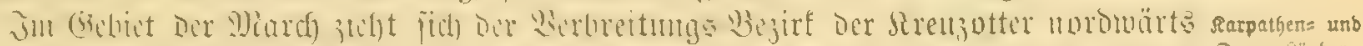

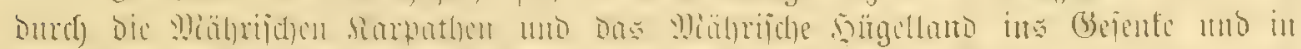

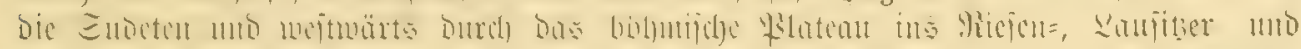

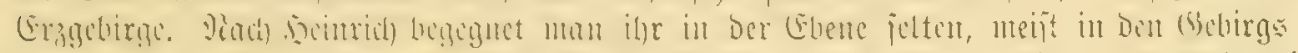

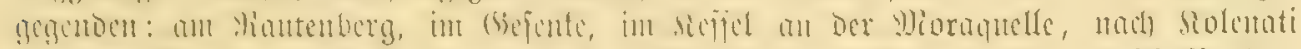

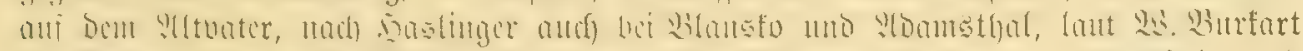

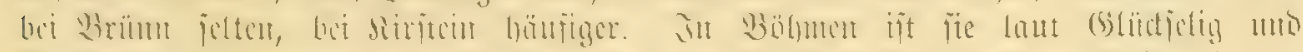

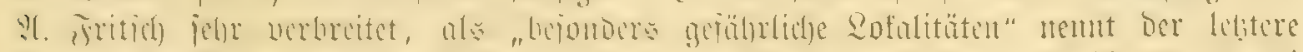

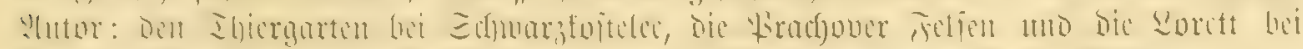

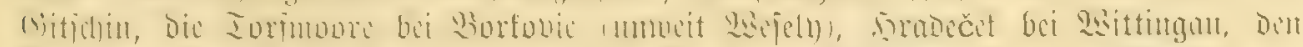

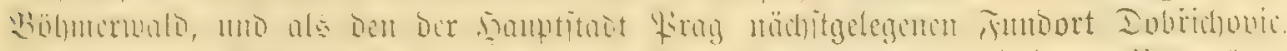

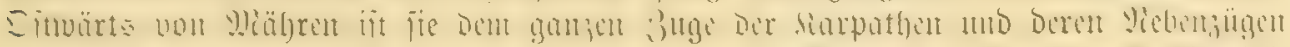

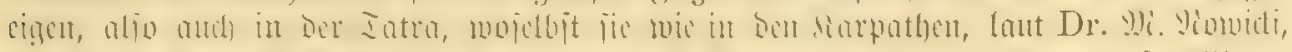

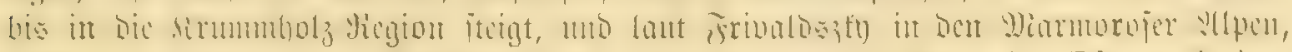

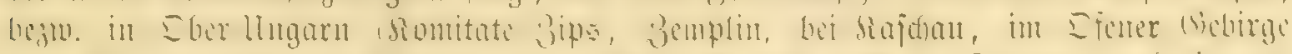

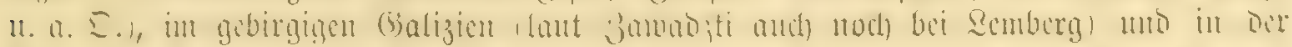

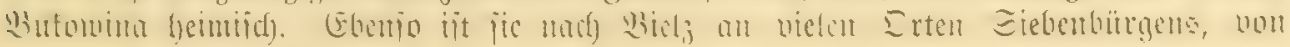




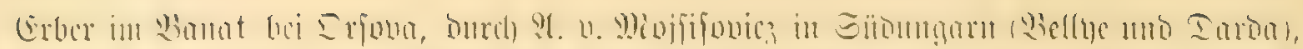

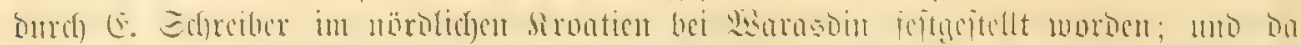

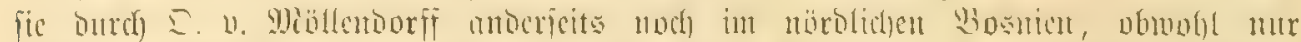

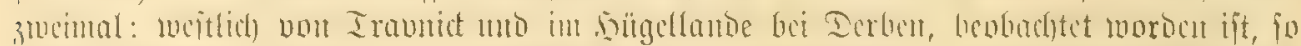

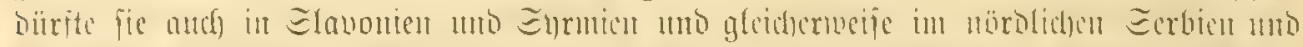

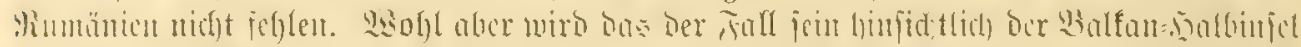

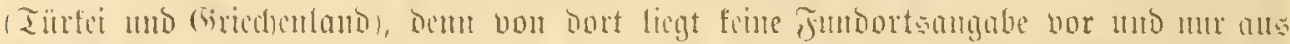

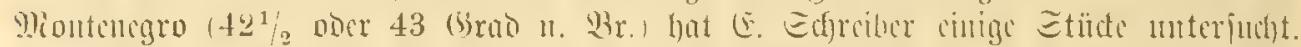

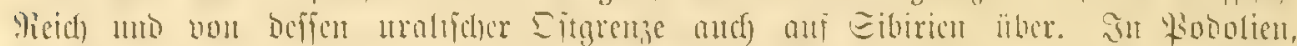

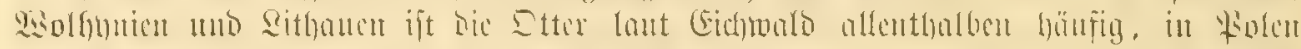

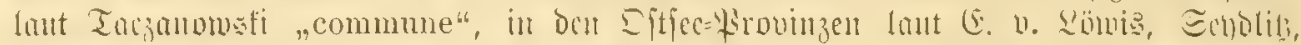

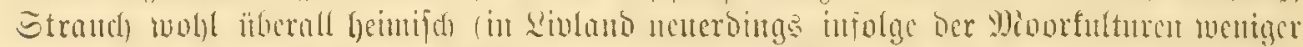

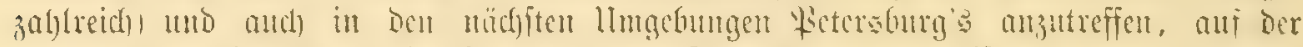

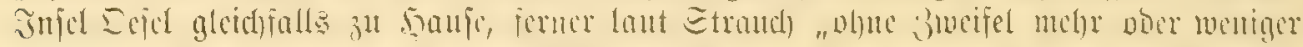

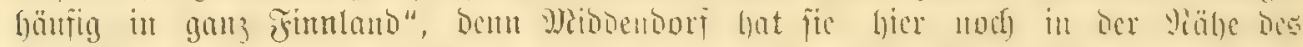

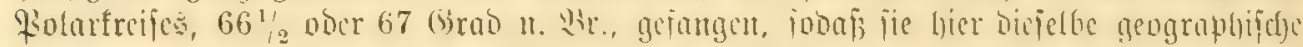

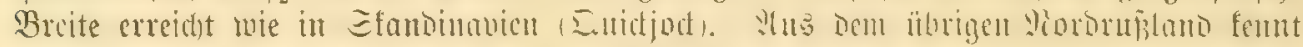

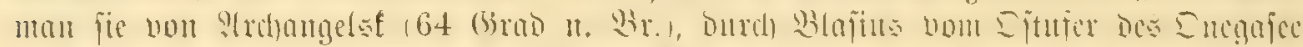

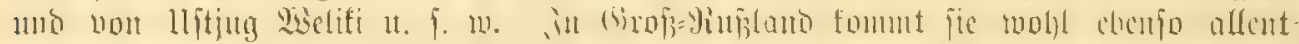

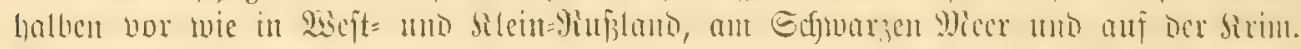

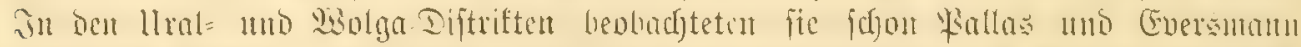

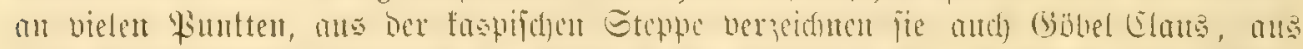

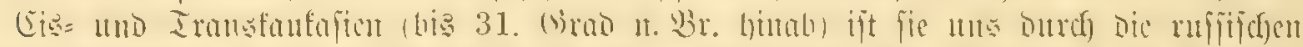

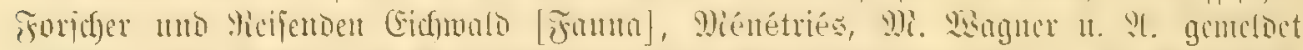

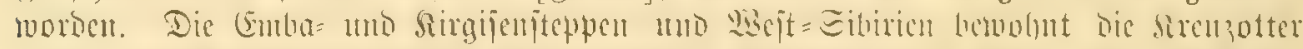

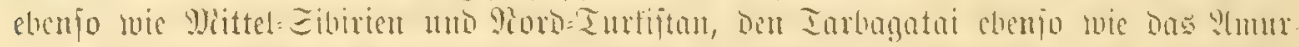

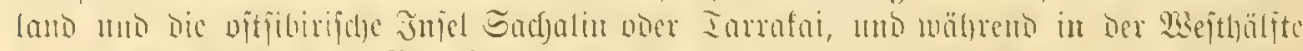

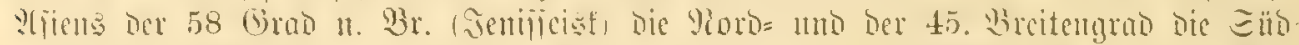

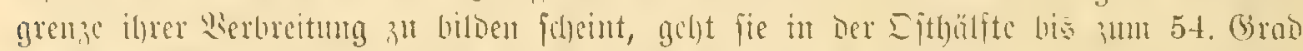

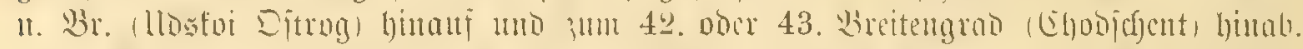

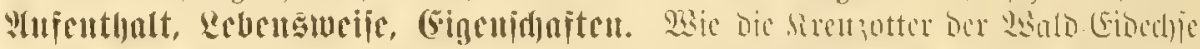

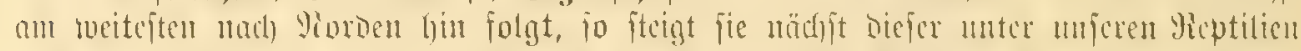

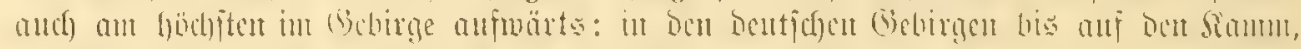

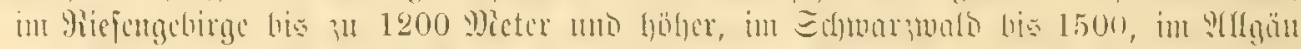

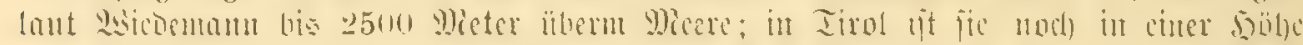

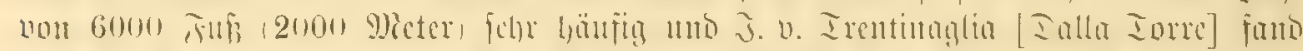

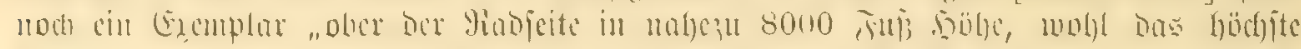

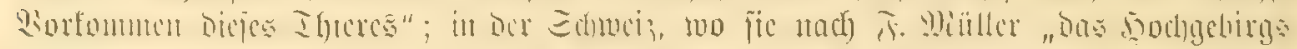

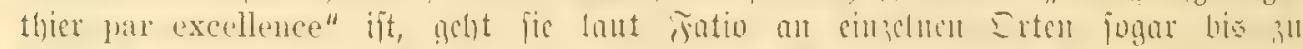

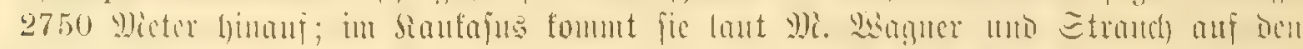

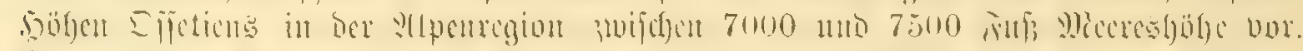

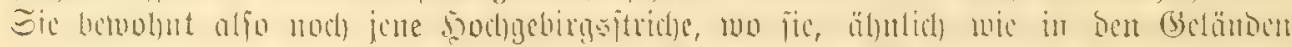

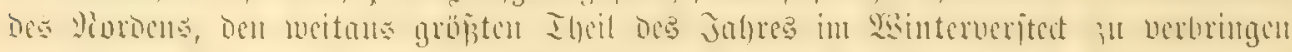

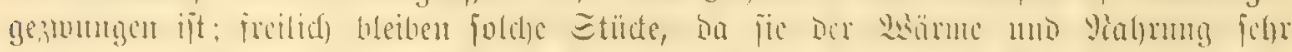

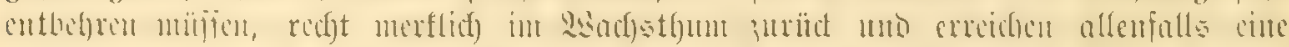

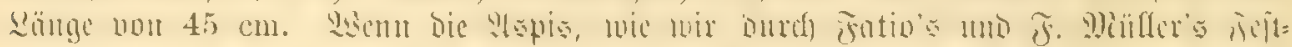

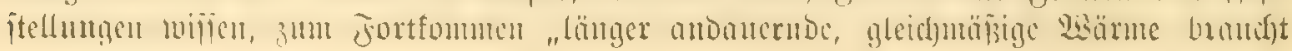




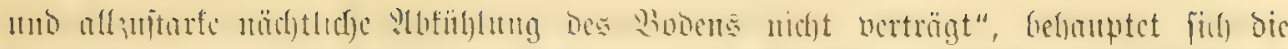

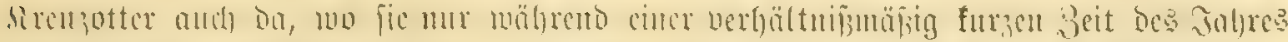

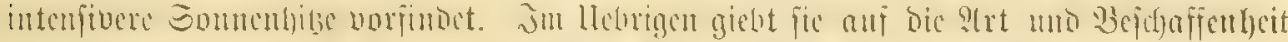

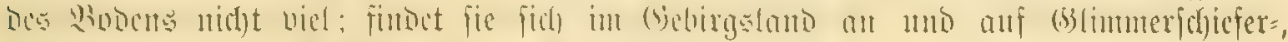

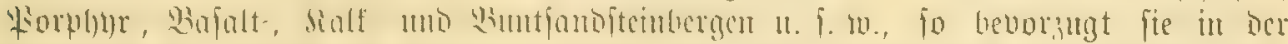
(E) Mture

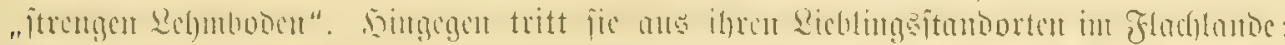

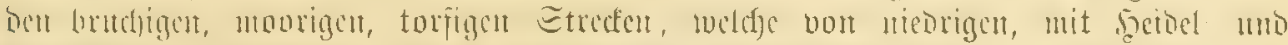

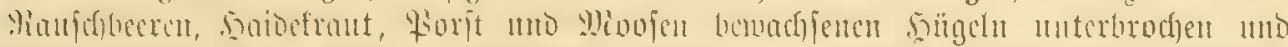

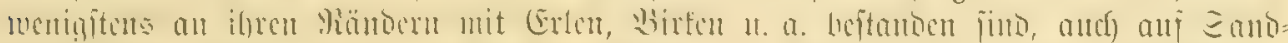
boon

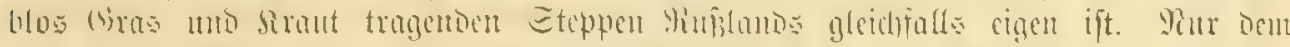

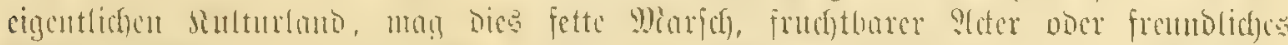

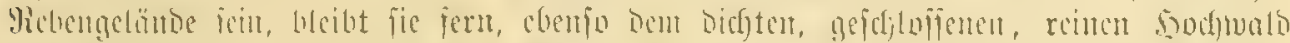

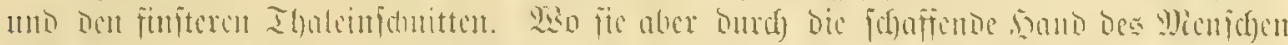

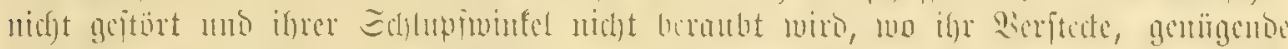

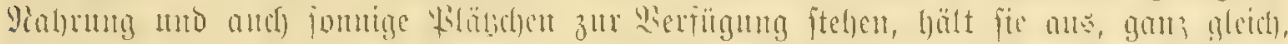

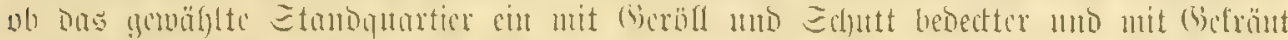

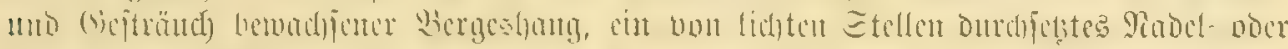

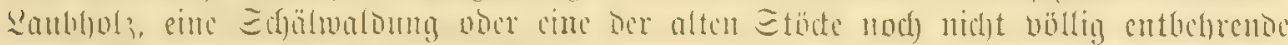

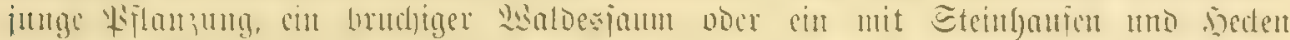

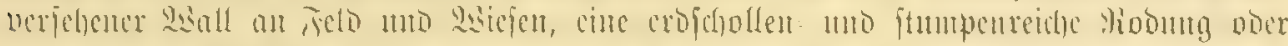

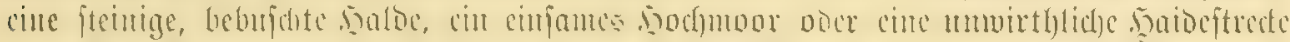

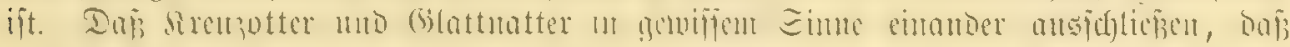

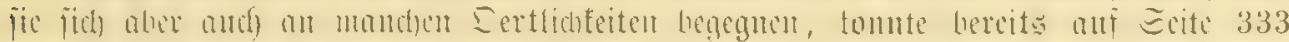

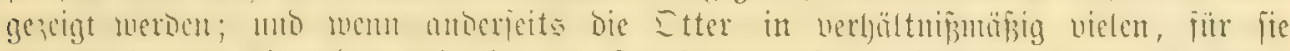

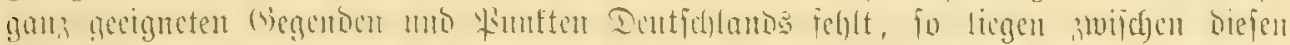

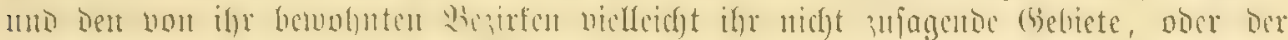

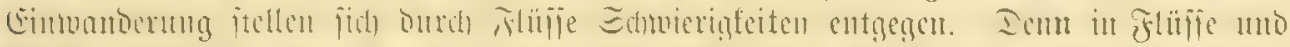

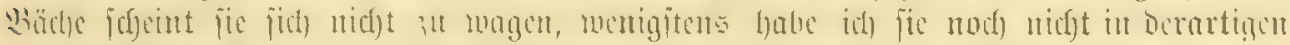

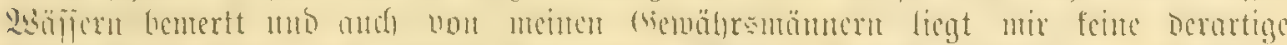

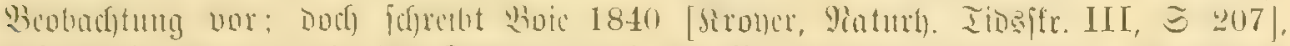

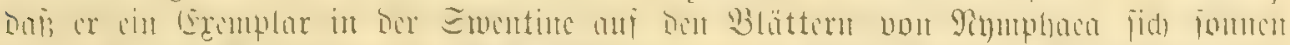

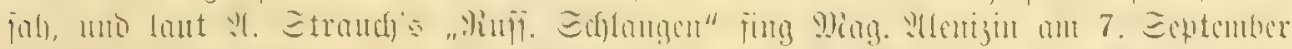

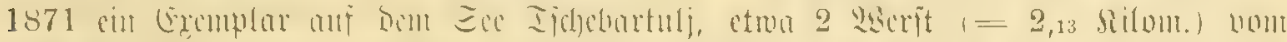

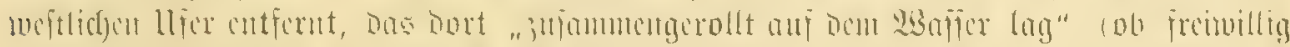

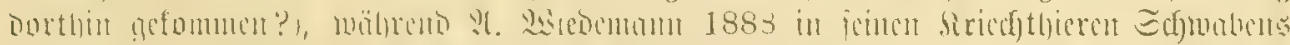

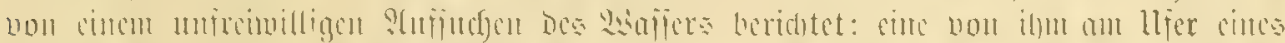

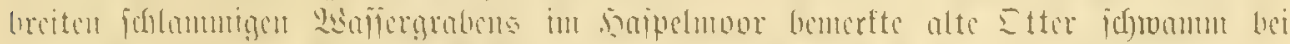

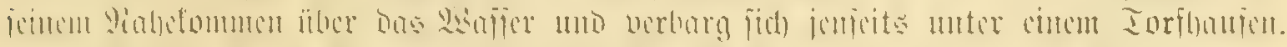

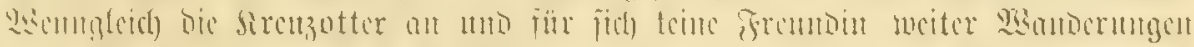

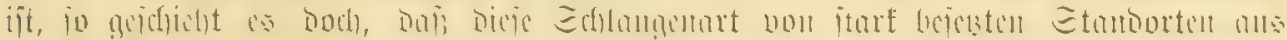

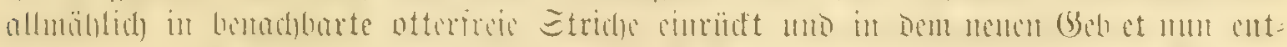

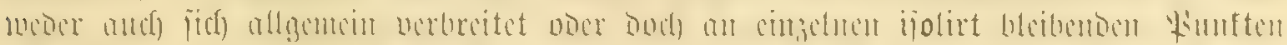

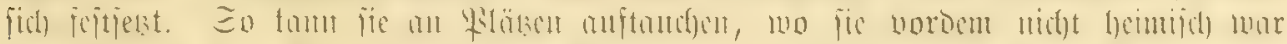

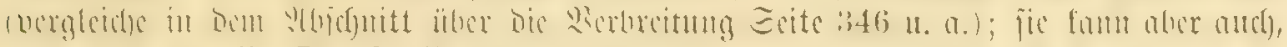

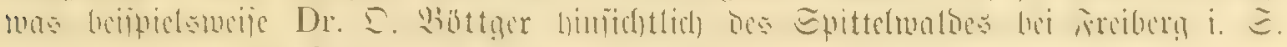

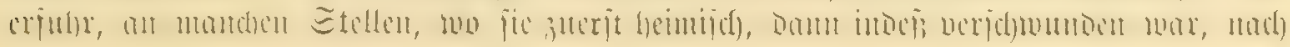




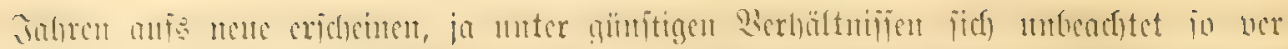

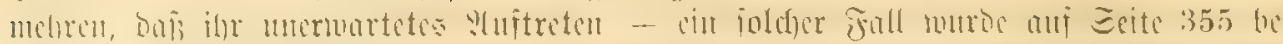

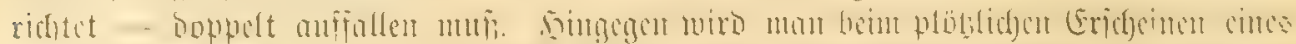

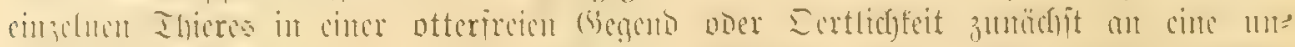

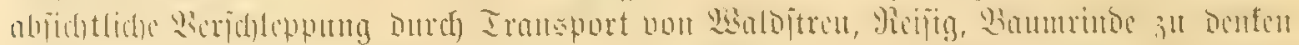

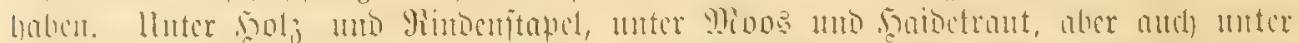

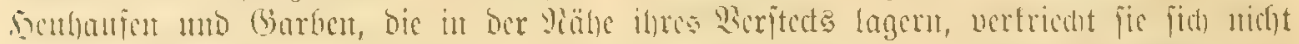

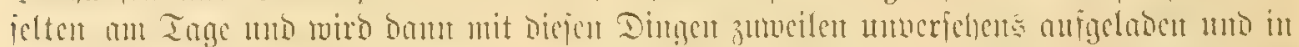

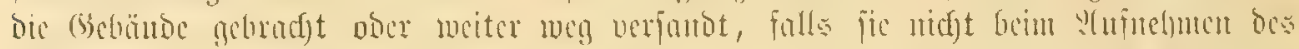

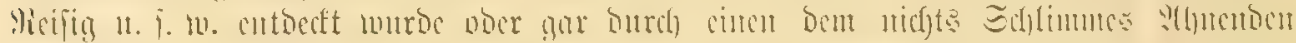

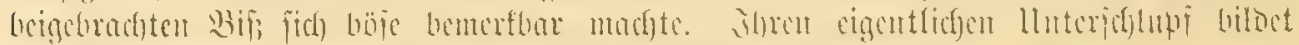

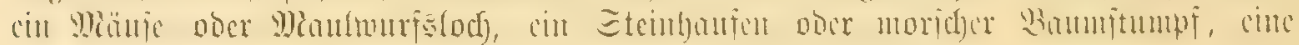

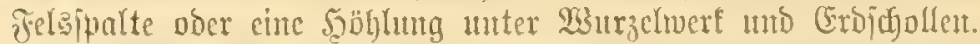

kimteridjtaf.

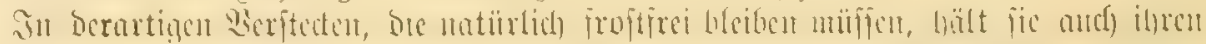

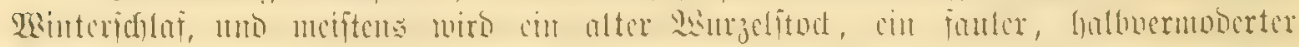

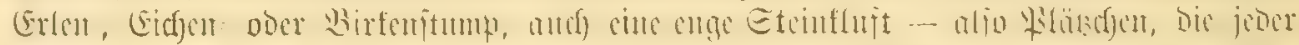

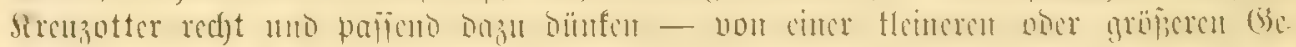

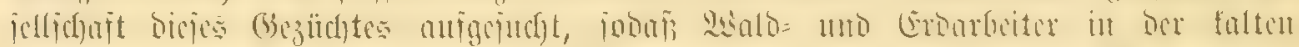

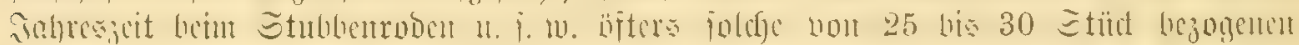

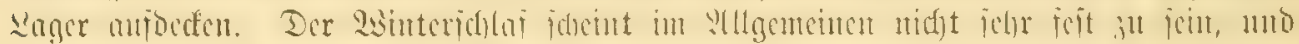

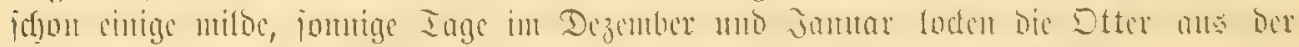

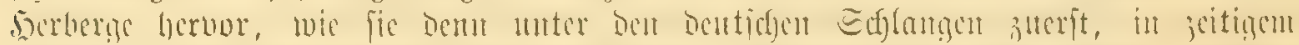

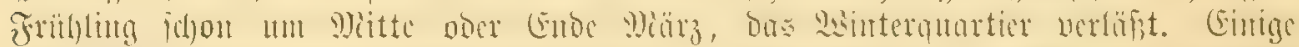

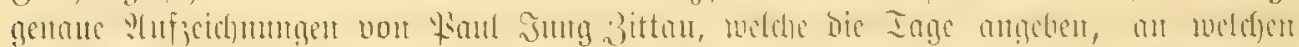

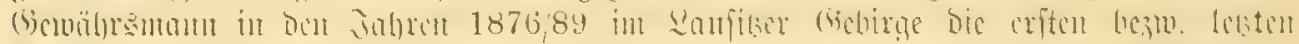

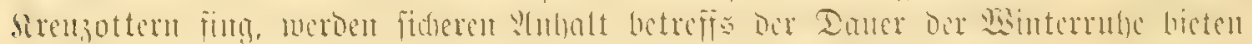

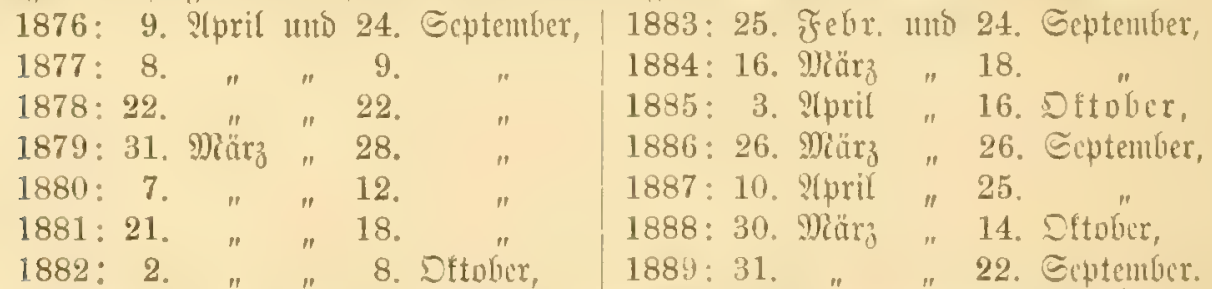

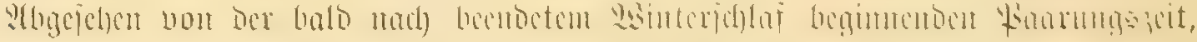

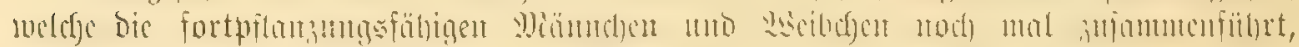

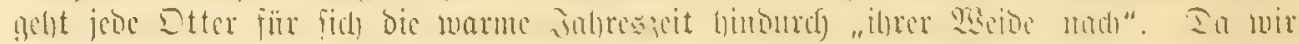

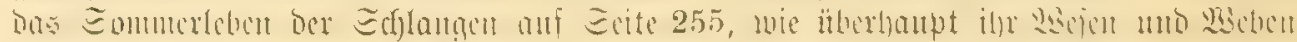

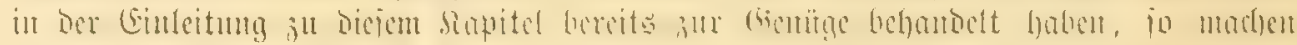

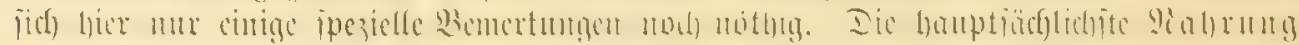

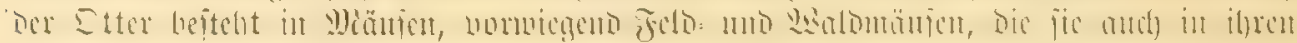

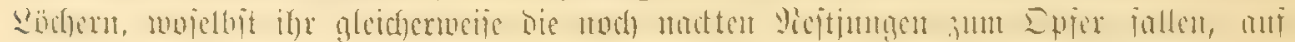

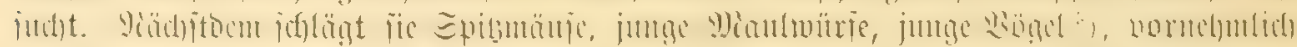

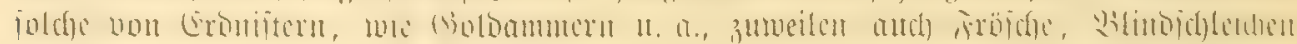

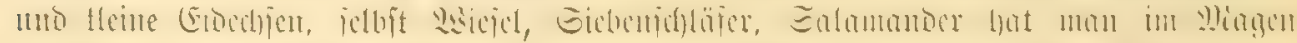

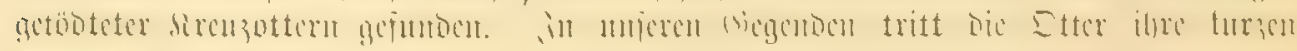

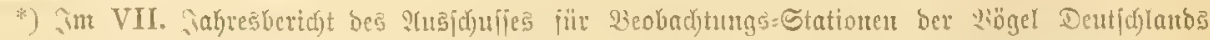

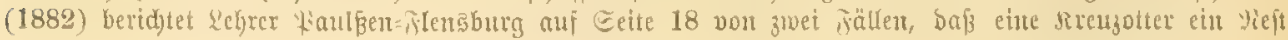

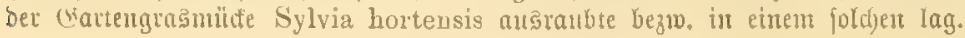




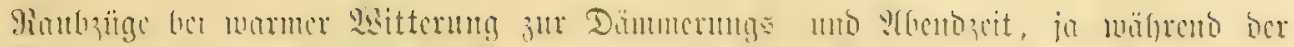

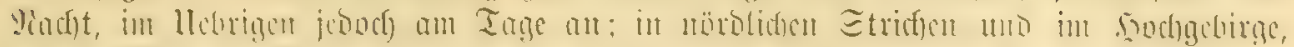

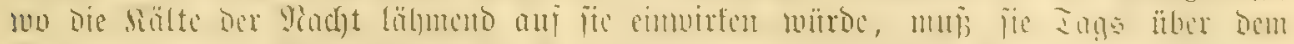

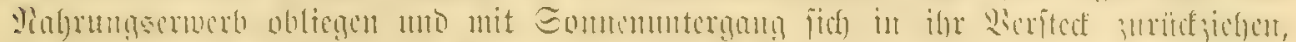

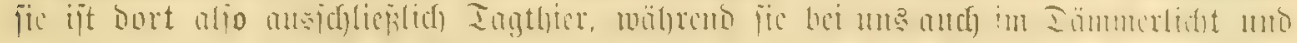

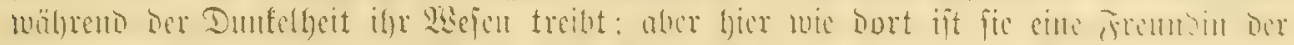

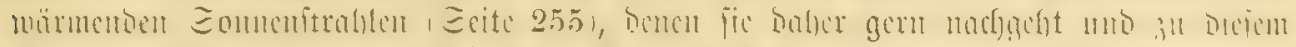

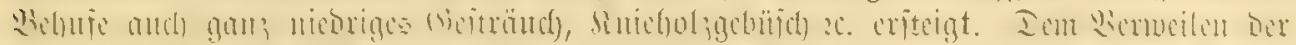

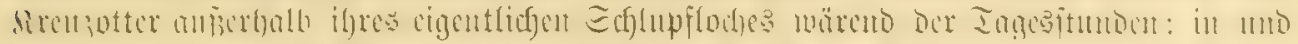

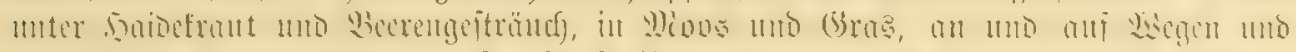

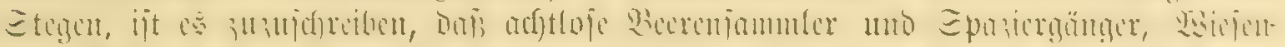

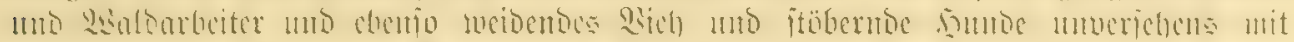

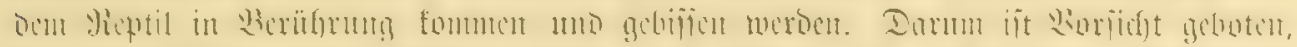

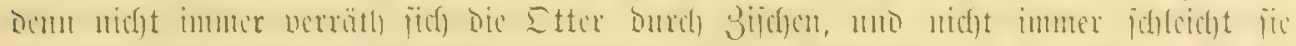

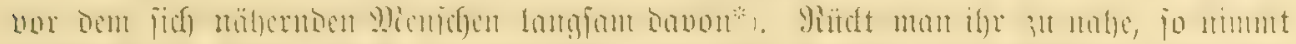

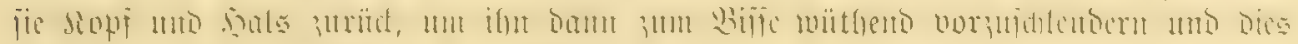
unter llmitünden blitjódtell zu toiederfyolent.

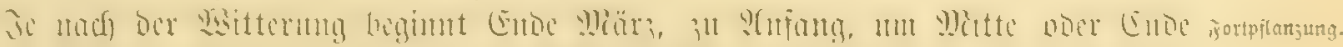

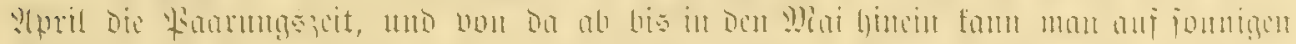

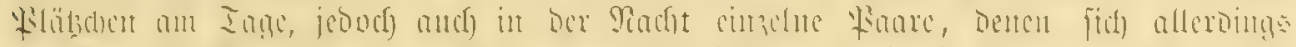

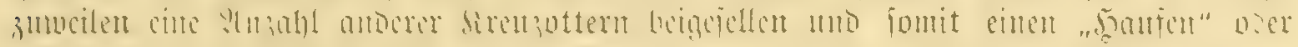

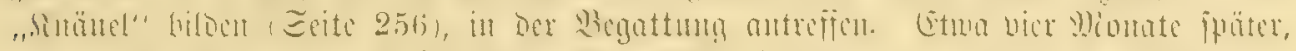

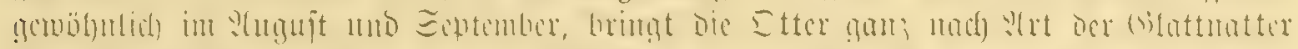

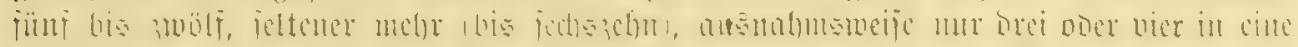

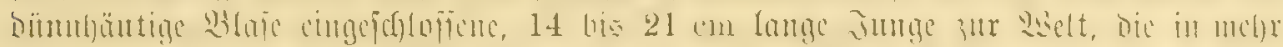

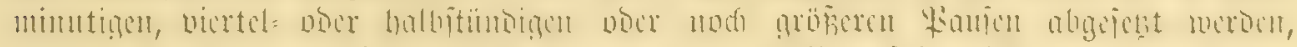

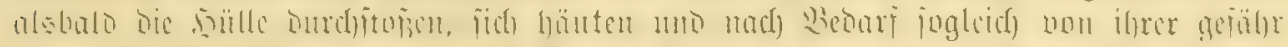

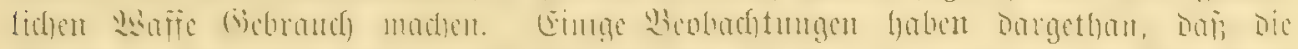

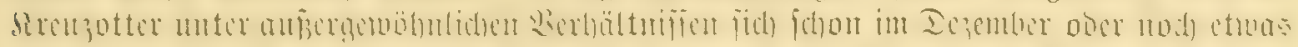

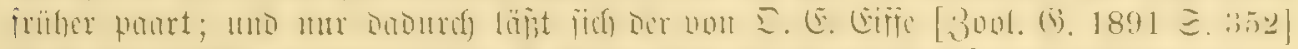

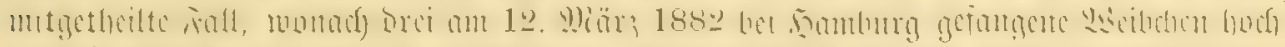

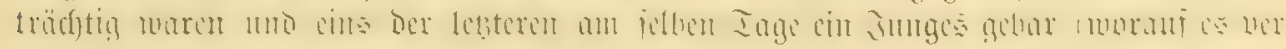

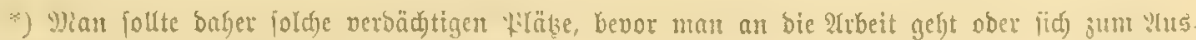
ruhen Ginlegt, immer erit möglicjit getrau befidtigen uno abjuchen uno fie nie betreten, ohne frätity

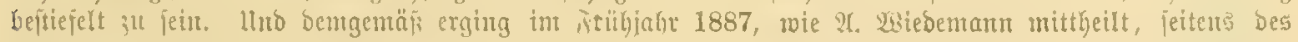
("eneral=sionmanto an bas 3. infanterie=9egiment ju ?tugsburg ber Bejehl, bab Jicberliegen ber Wiant=

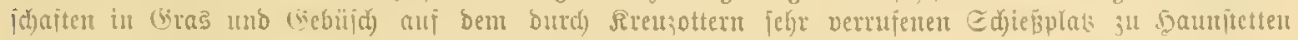

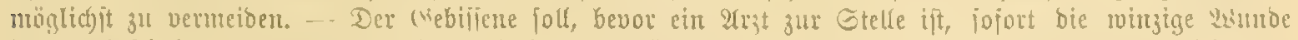

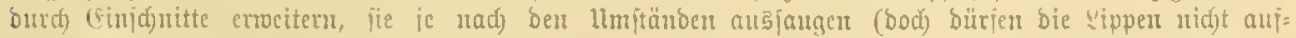

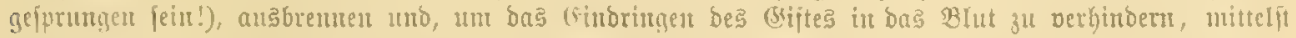

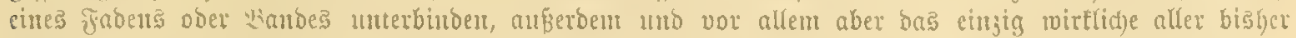

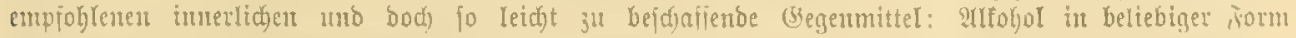

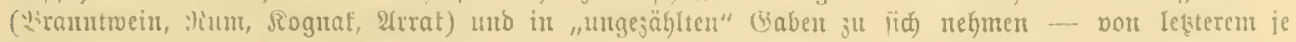

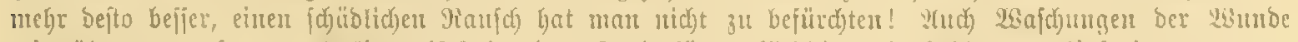

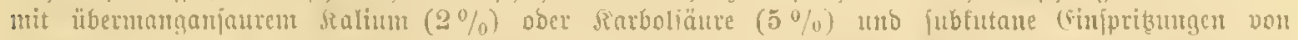

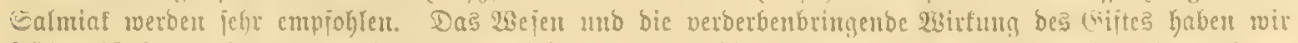

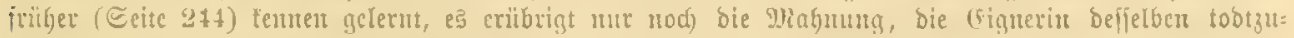

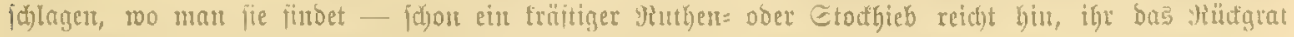

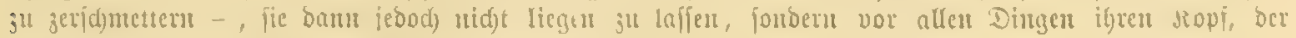

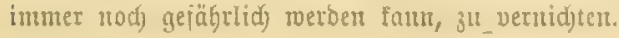




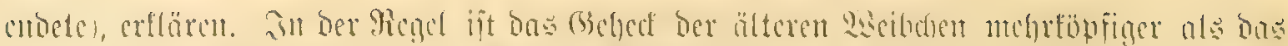

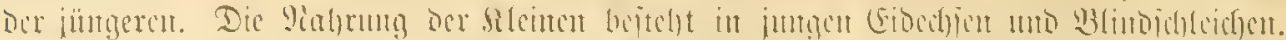

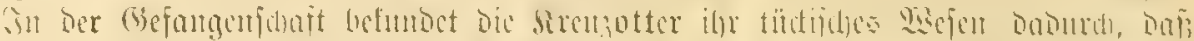

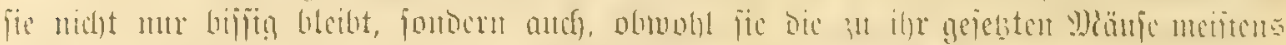

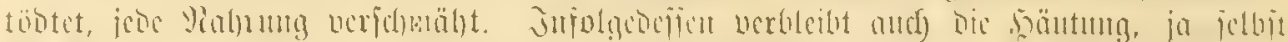

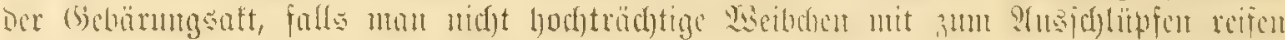

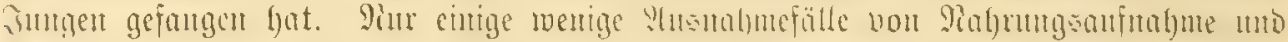

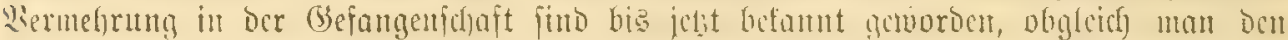

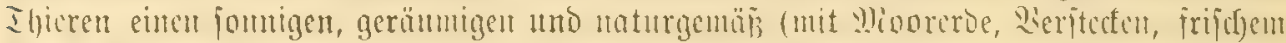

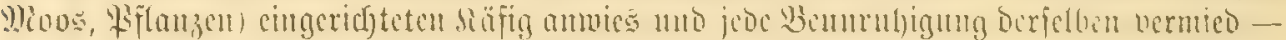

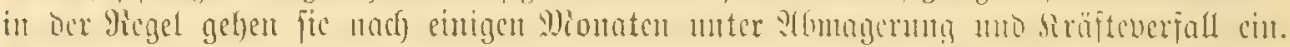

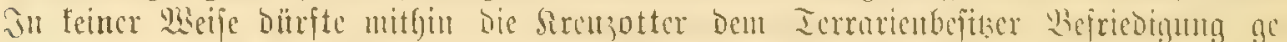

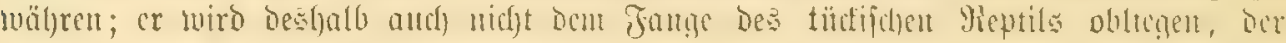

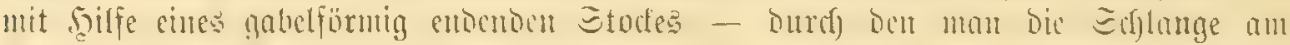

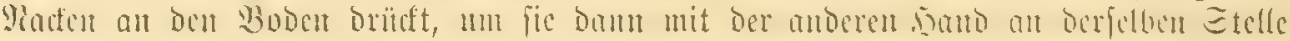

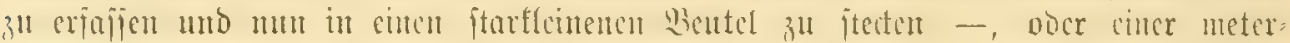

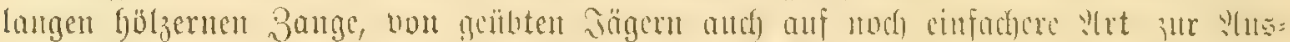

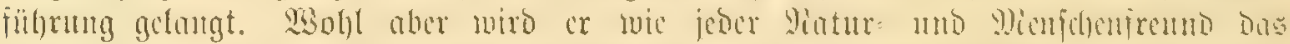

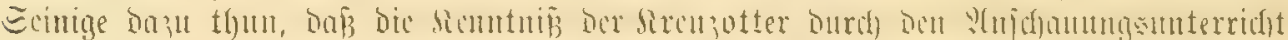

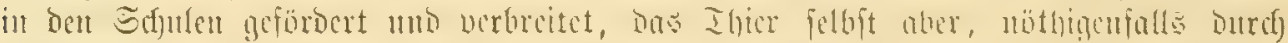

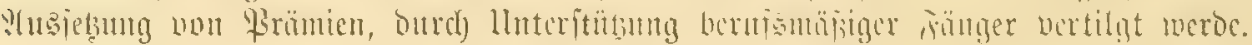

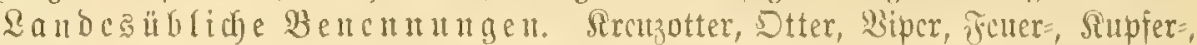

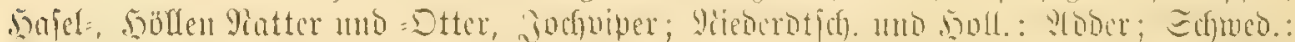

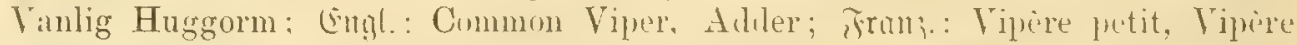
a trois plaques un Peliaule; ital. Marasso, Viperil rossa: Epan.: Vibora; Vhij.

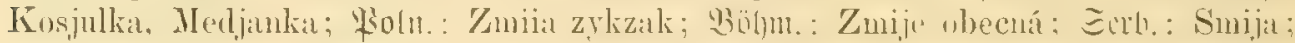
Qettiff): Ohdse (Tschuska); đ̈nn.: Kyy-kärme, Musta-kärme.

Vipera ceilonica, V. squamosa, V. orientalis, Echis americanus, Coluber Tlehna, Seba 1734. - Coluber chersea, Liuné 1749. - Col. Berus, Linné 1758. - Col. prester, Linné 1761. - Col. vipera anglorum, Laurenti 1768. - Col. Melanis et Col. Scytha, Pallas 1771. - Col. niger, Lacep. 1788. - Col. schytha, Bonnaterre 1789. -- Vipera vulgaris, prester, melanis, schytha, Latreille 1802. Vipera Berus, V. prester et V. trigonocephala, Jaudin 1803. -- Col. coeruleus, Sheppard 1804. - Pelias berus, Merrem 1820. - Vip. limnaea, Bendise. Pelias chersea, Wagler 1830. - Pelias dorsalis, Gruy 1831. - Vip. torva, Lenz

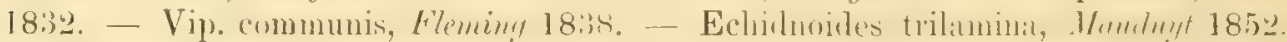

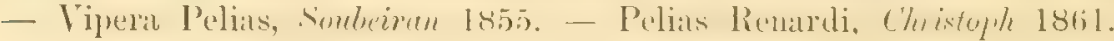

\section{Yrt: 2lspis=Liper. Vipera aspis $\left(I_{\text {. }}\right)$. wbbilsung: Zajel X yir. 1.}

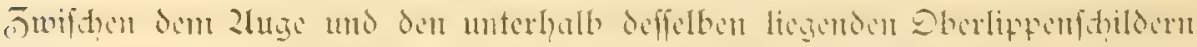

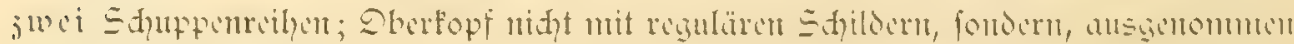

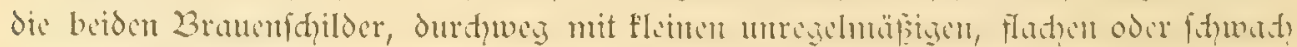

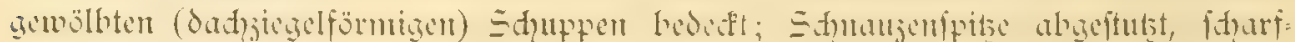
fantig und deutlid aufgeworfen.

Interiqiebe 310 \$reusotter unb Bipet.

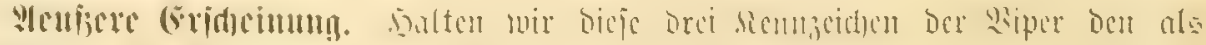

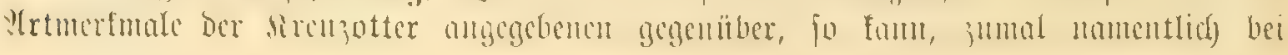




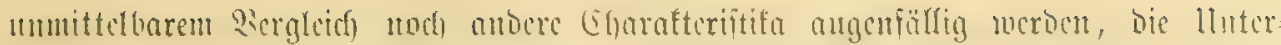

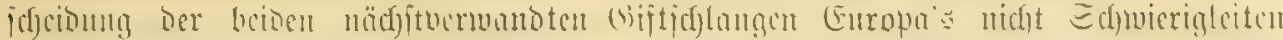

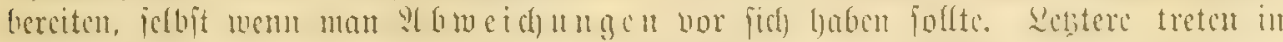

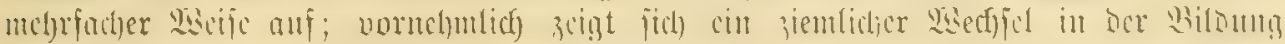

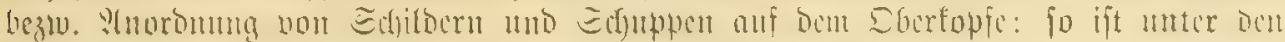

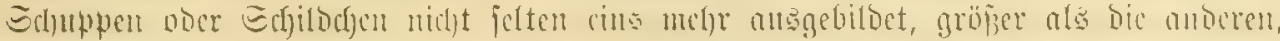

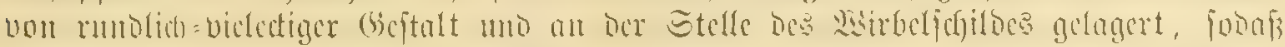

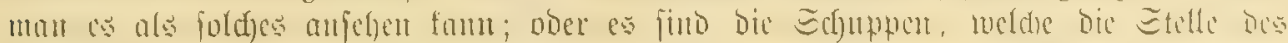

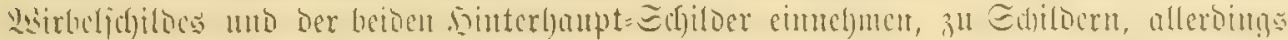

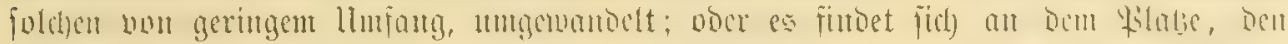

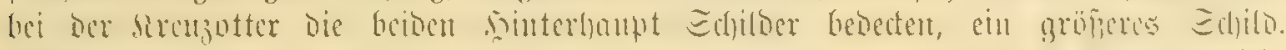

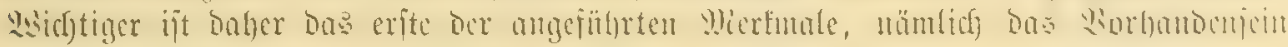
won zwei Sdfuppenreifen zrwifden Dem ?tuge und ben unter ifm liegenden Dberlippenjd)ildern; Denn Fälle, tvie ocr von F. Mäller [Baj. Siat. 5. 695] mitgetheilte, daj cin ibm vorlicgendes (Exemplar linferjeits zovijchen Ituge und viertem Dberlippenforils nur cinc Sdjupe zeigt, ftefon Durdjaus vereinzelt Da. - 34 don ferneren unter idjeibcnocn Mertmalen Der 9 apis gefjören: Der jeljr Dent=

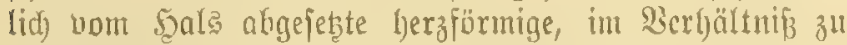
Dem ber Sircugotter viel Greitcre mo audi flachere Sip Das rimfichtrich Der (Sejtalt von Dem ber Ichteren $a b=$ weidjende Iafenfdjild, in Dem bas Iajenlody twetter nady vorn an bie Sdynauzenfante geridft mo melyr offen, aljo gröber crjacint, forner bas etroas fleincre Brauenjchild, cin nac) aboärţ gefrünmter, beim Männdicn ctruą längerct Stadjel an Dcr Sdywanzipiţe *) mo entich bie Beidjung, in weydyer ein anf bem 9üden hinlaufendes

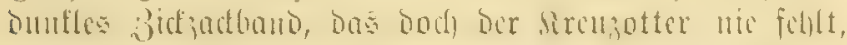

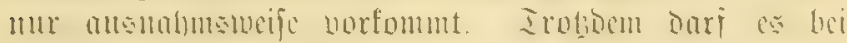
ocm fritheren Stanoc Der Schlangenfunde nidft befremben,
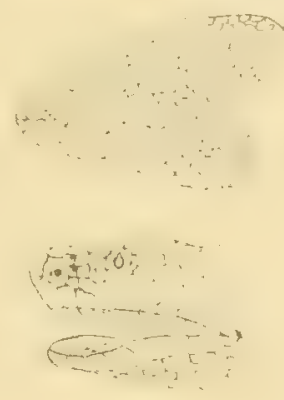

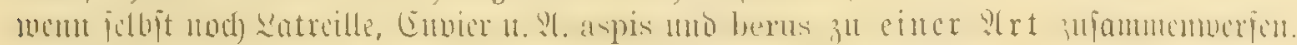

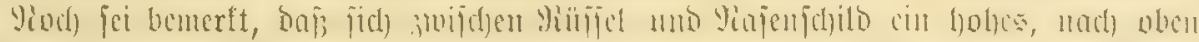

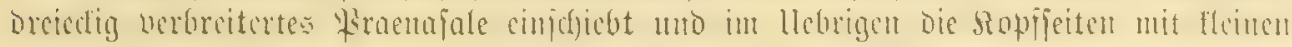

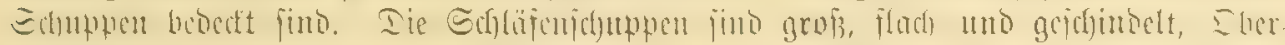

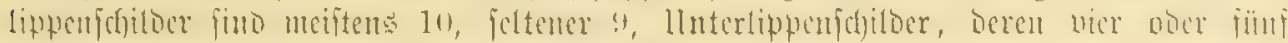

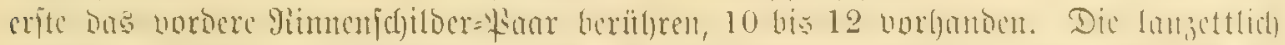

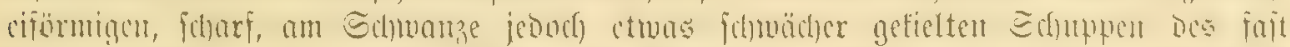

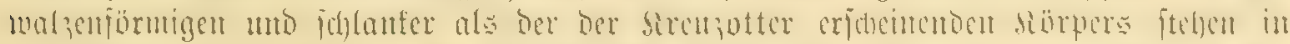

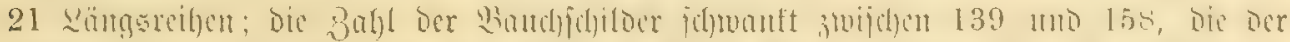

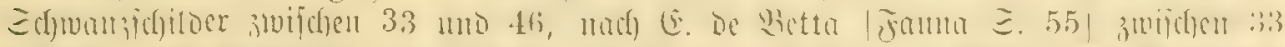

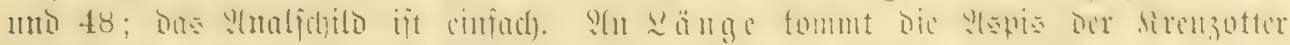

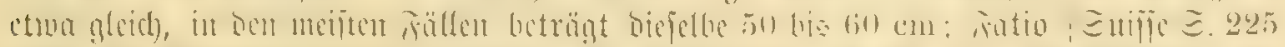

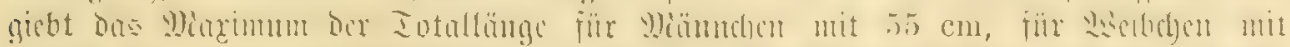

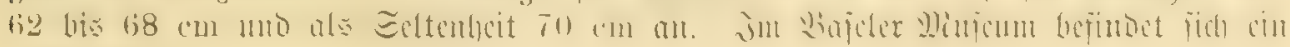

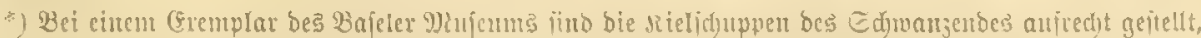
woburd) bas lebtere, äfulicl) twie bei ber Iobesotter :(ujtralens, Acanthophis antaretica, cir morgen

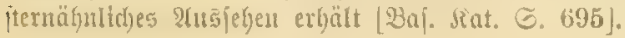




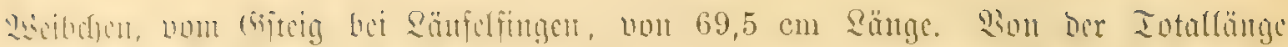

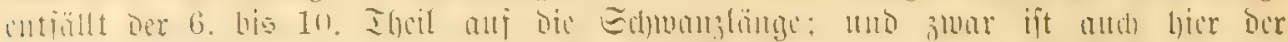

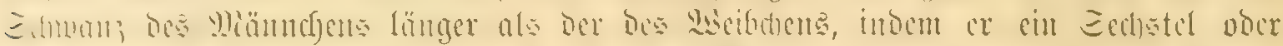

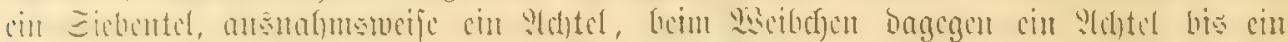

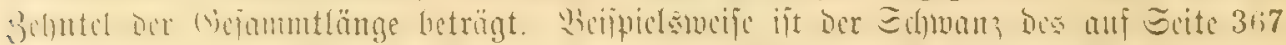

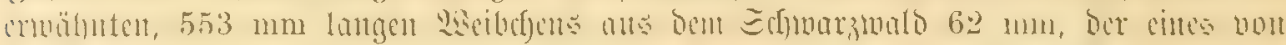

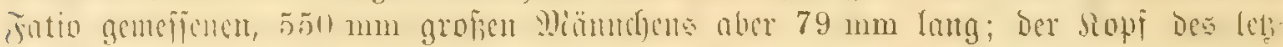

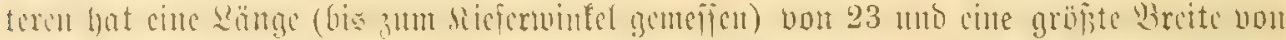

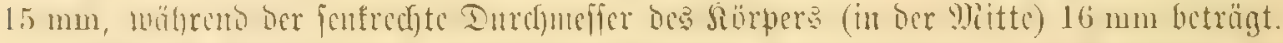

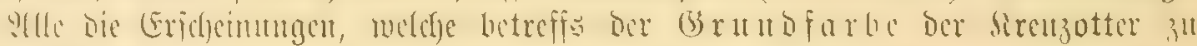

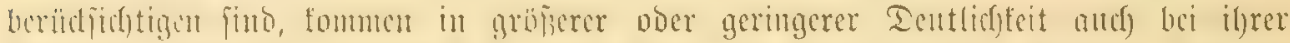

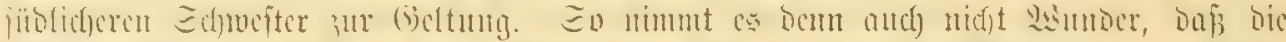

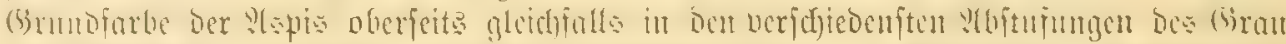

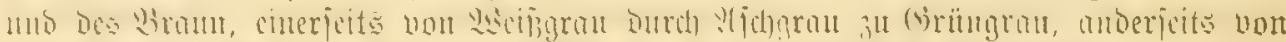

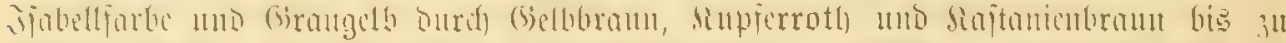

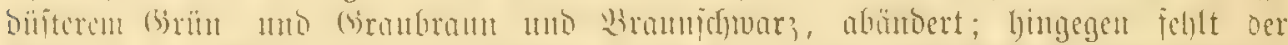

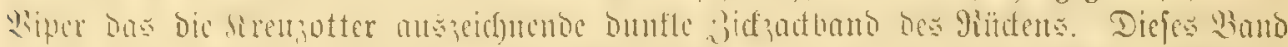

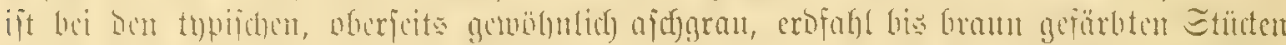

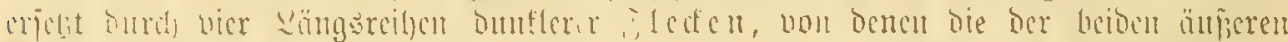

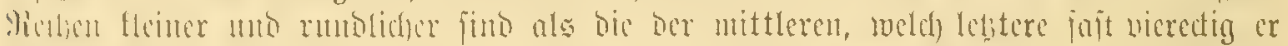

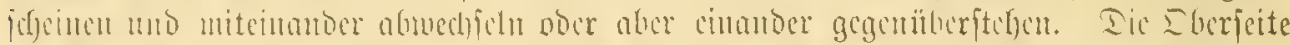

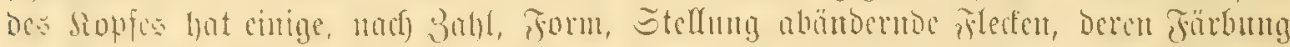

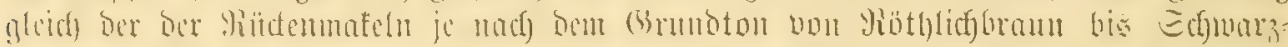

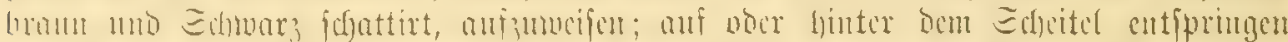
juci furie bunte

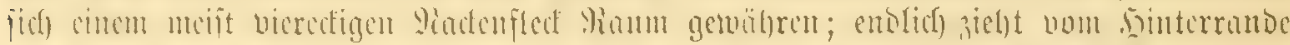

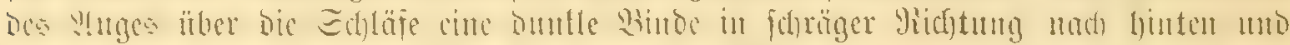

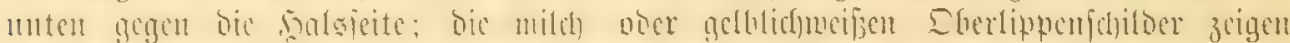

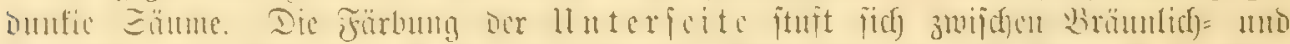

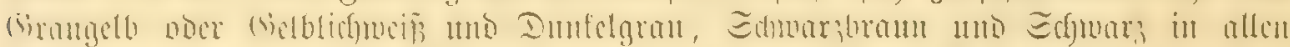

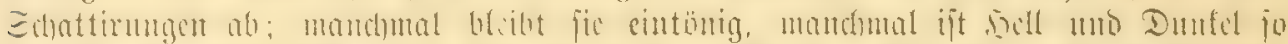

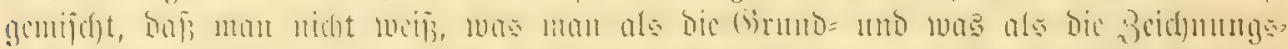

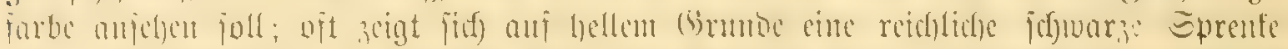

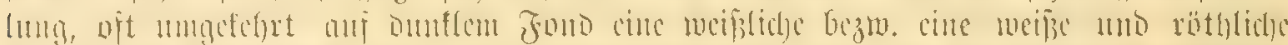

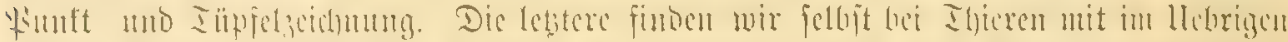

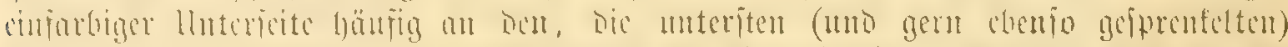

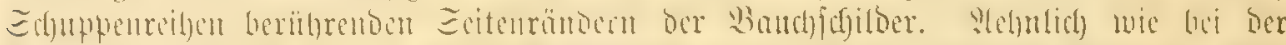

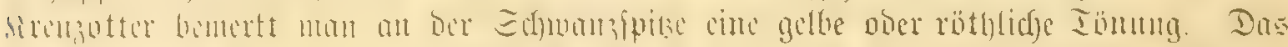

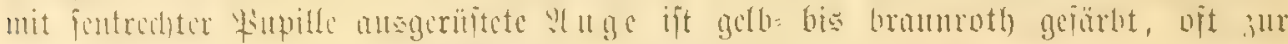
vberen 5älfte roth, zur unteren beälfte fchun̈rzlidyoraun.

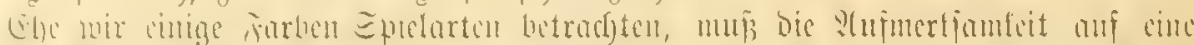

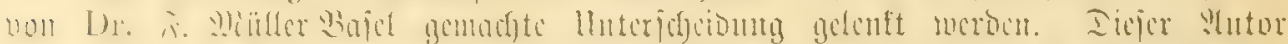

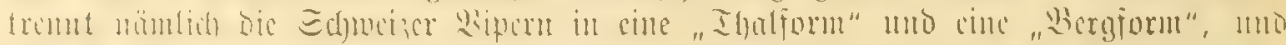

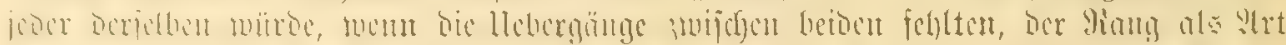

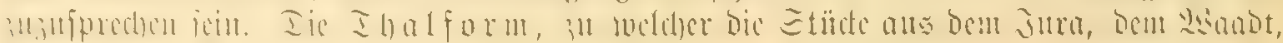

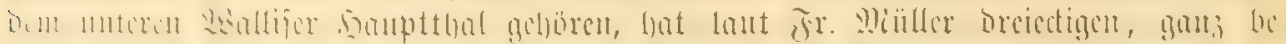

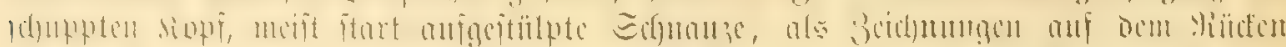

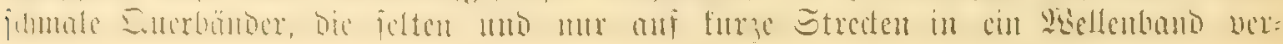




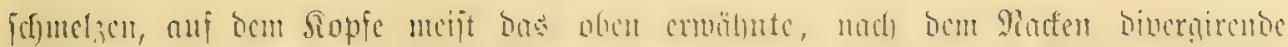

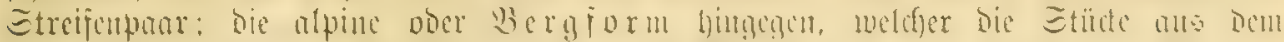

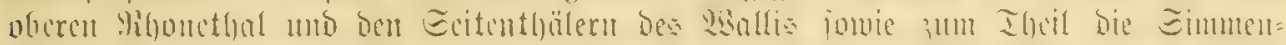

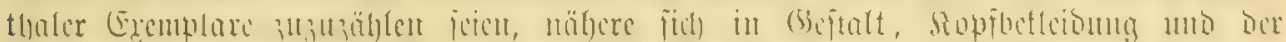

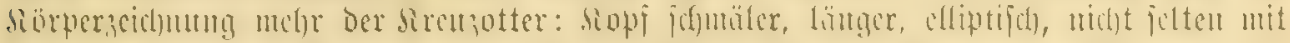

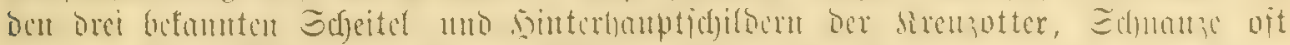

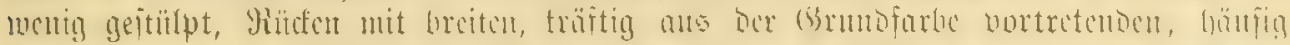

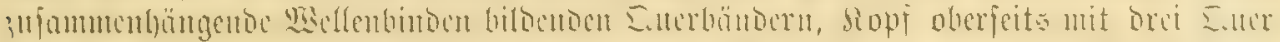

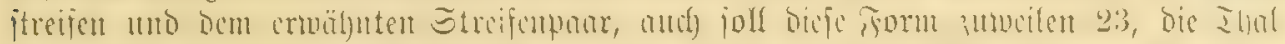

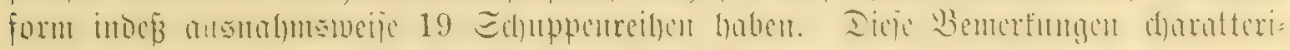

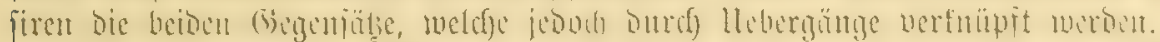

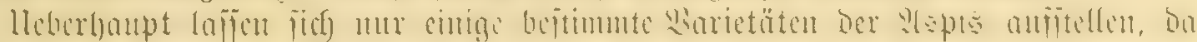

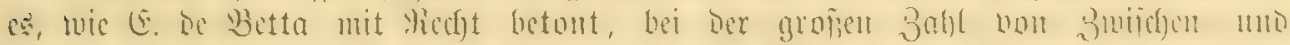

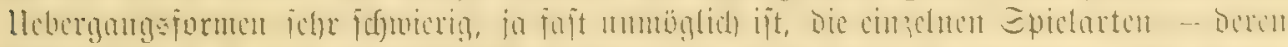

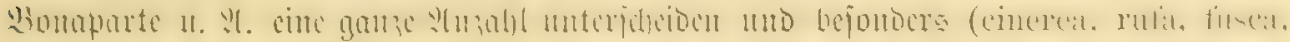

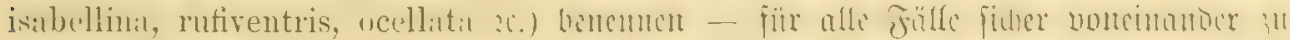
untericheiden.

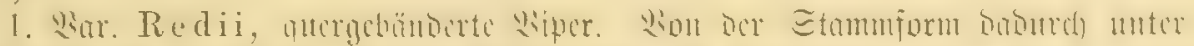

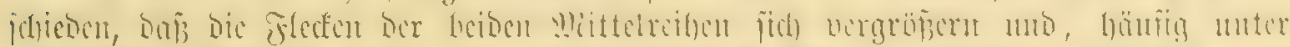

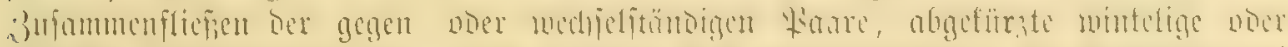

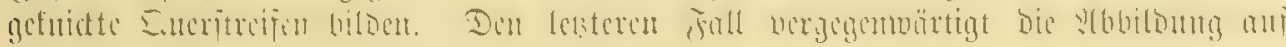
Iafel X. (Vipera Redii, Laur, Metara.)

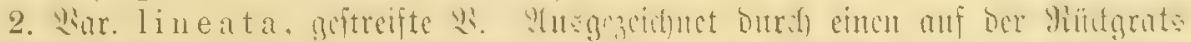

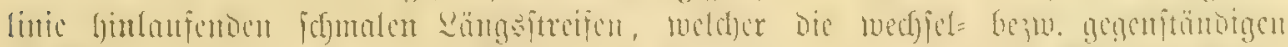

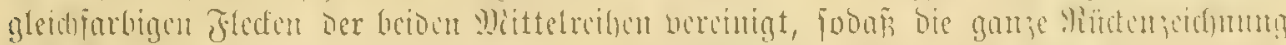

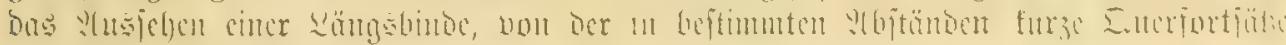
Docr Plepte abgeljen, gewinut. (Vipera chersea, Latr.; Sdjrciber var. m.)

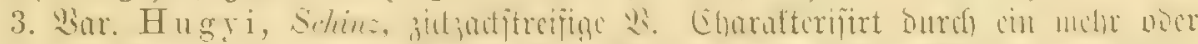

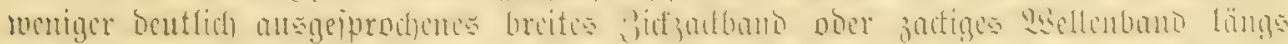

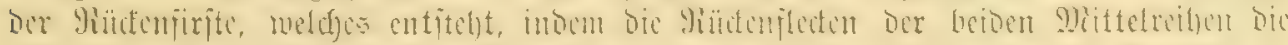

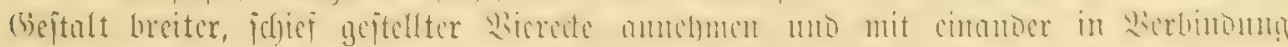

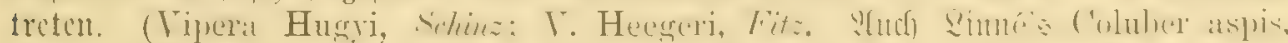

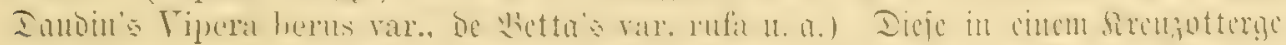

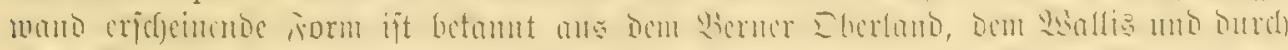

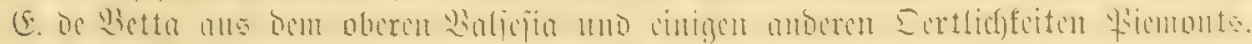

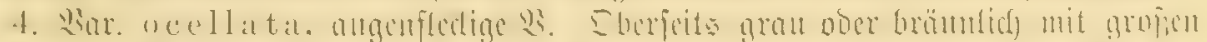

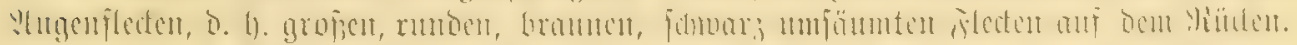

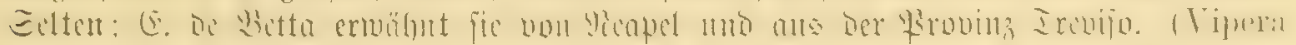
ocellata, Latr.; Aspis ocellata, Fitz.)

5. Sar. isabellina, de Betta. Sberfeite vout beller sfabelffarbe, un mit

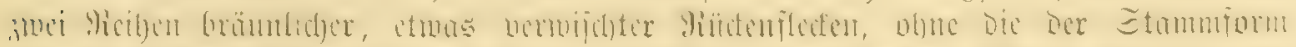

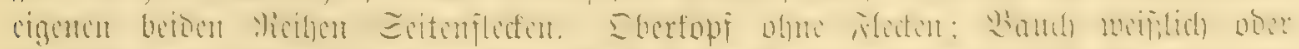

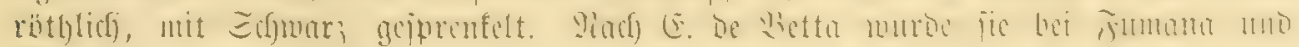
Darcellife in ber Wirovinz Berona gejammelt.

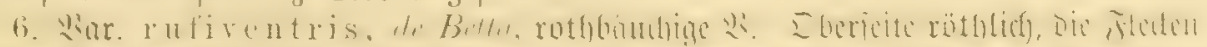

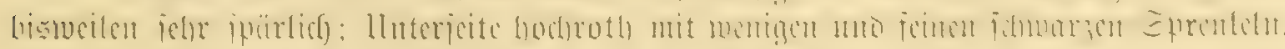

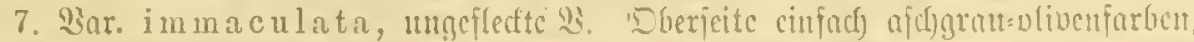

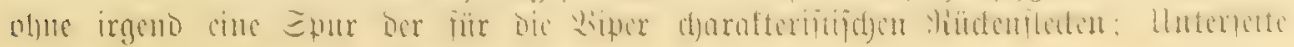




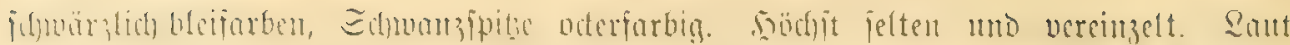

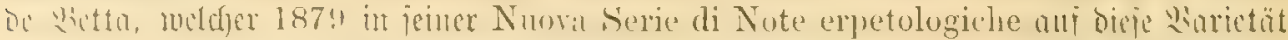

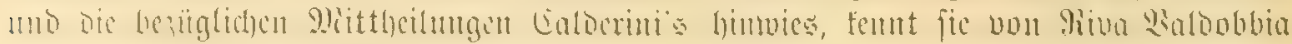
int oberen Baljefía in 'Picmont.

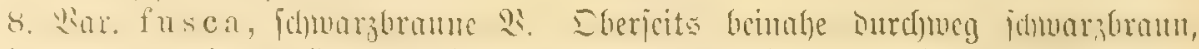

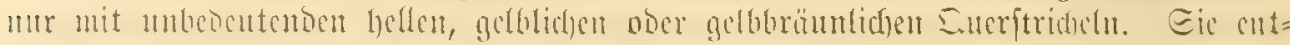

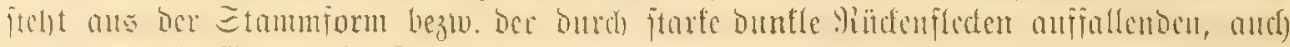

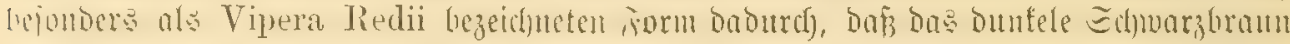

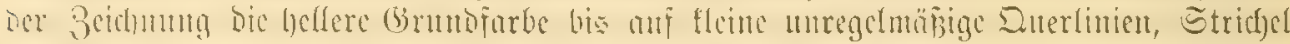

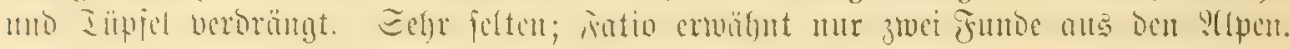

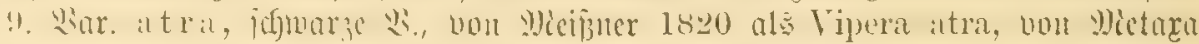

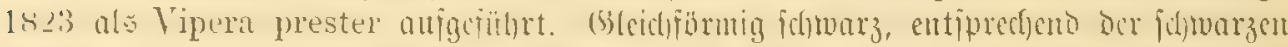

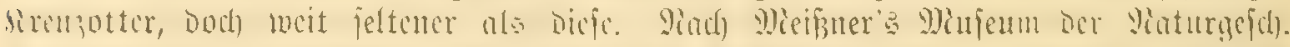

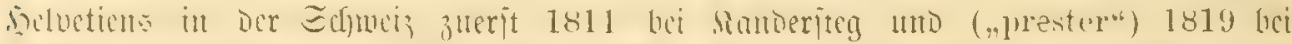

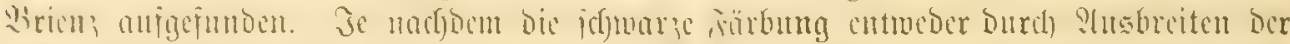

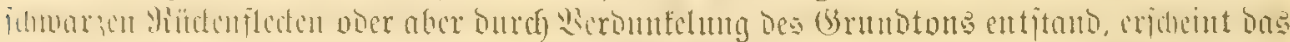

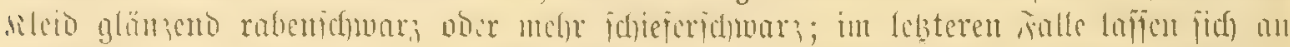

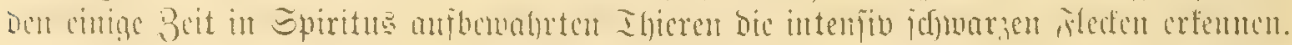

10. Sar. infernalis, $F$. Müller, Seöllenbiper. Ganze Dberjeite ichuorst

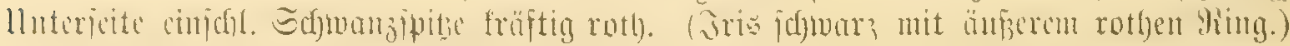

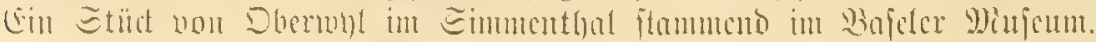

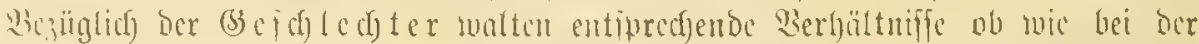

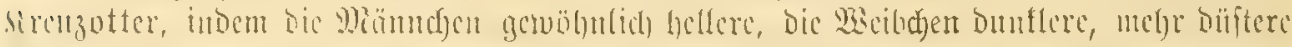

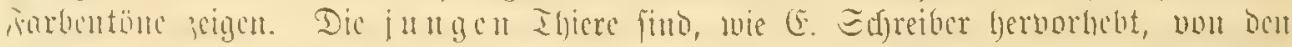

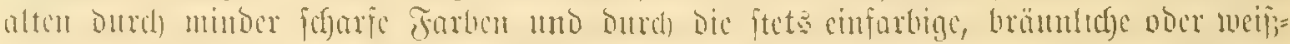

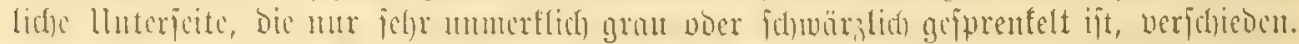

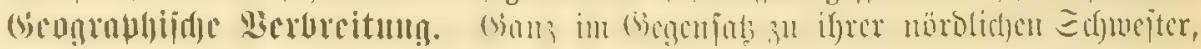

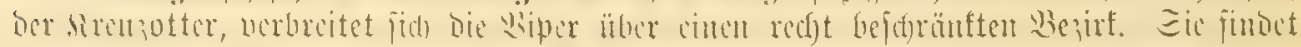

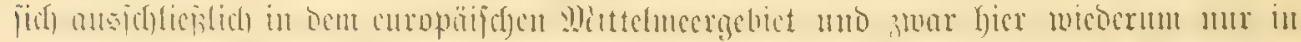

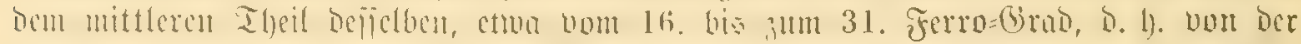

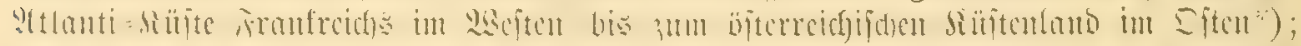

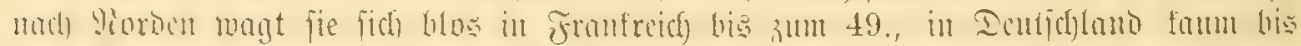

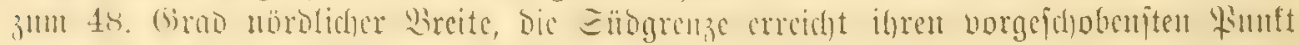

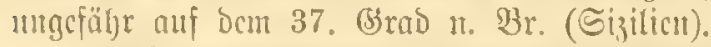

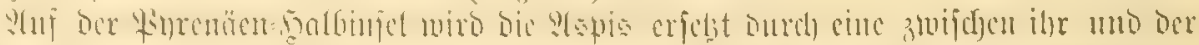

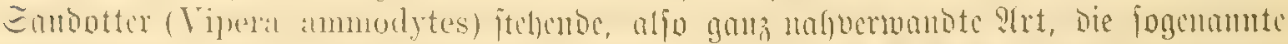

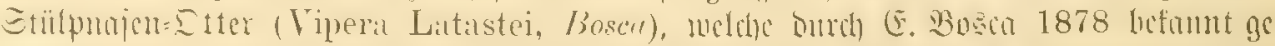

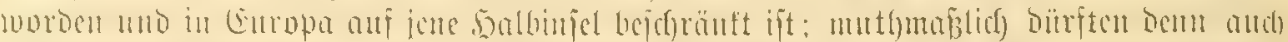

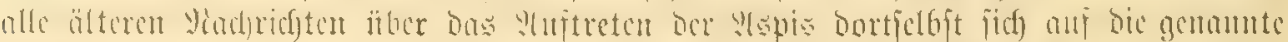

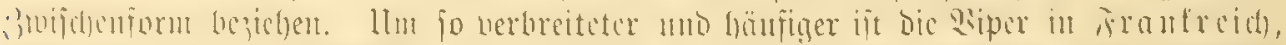

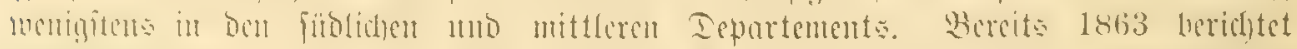

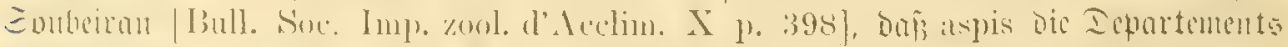

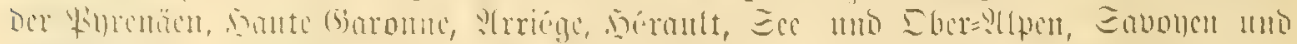

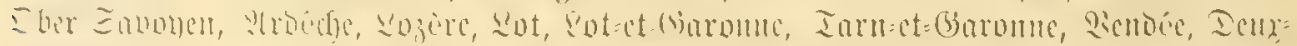

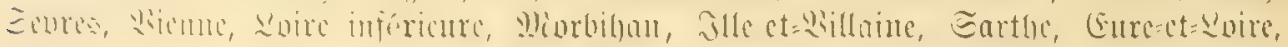

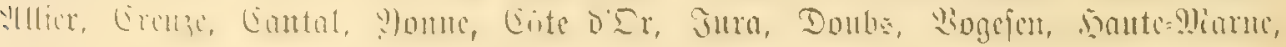

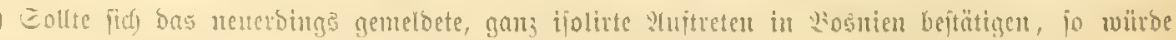
die Sitgrenze un 5 Grabe, bis zant 36. Ferro=ctirad oftwärts rüdteu. 


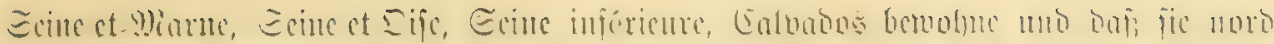

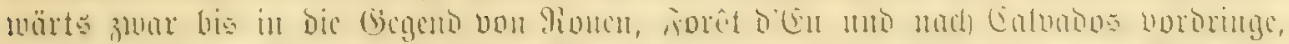

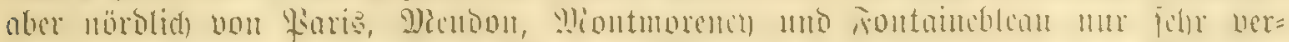

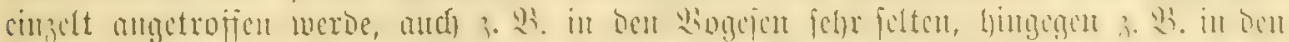

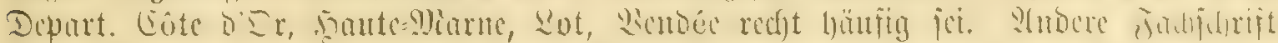

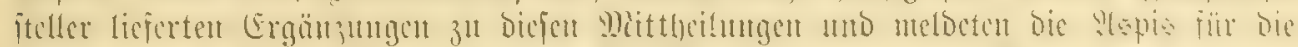

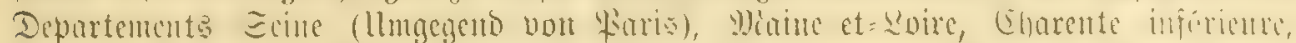

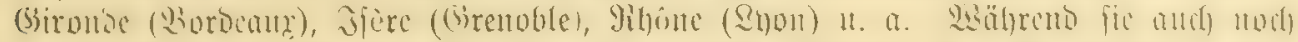

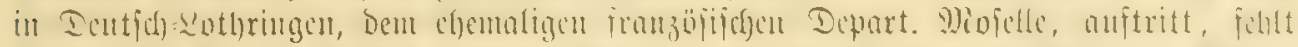

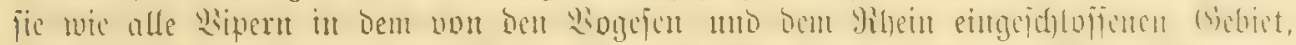

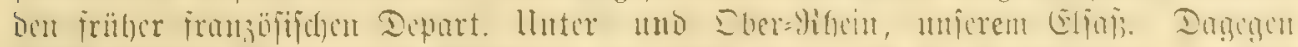

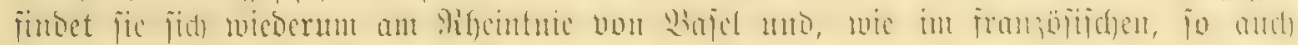

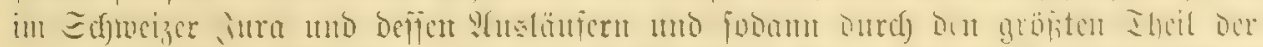

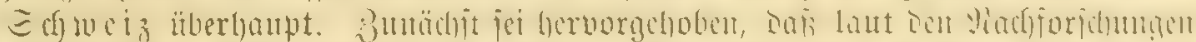

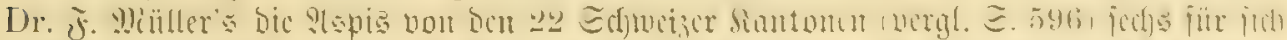

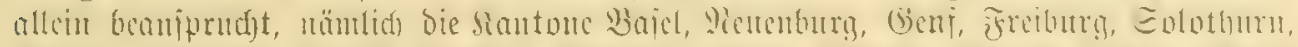

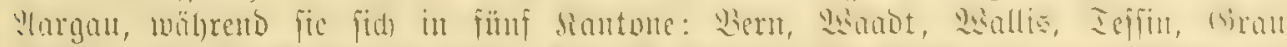

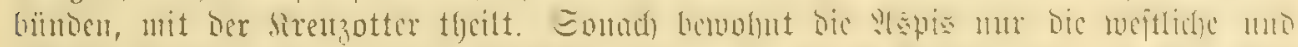

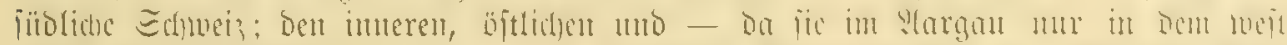

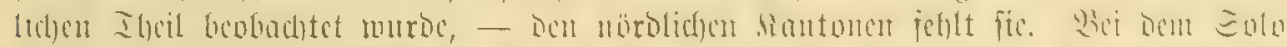

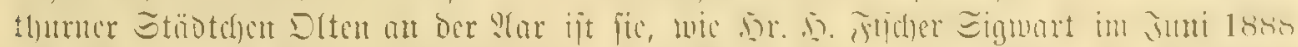

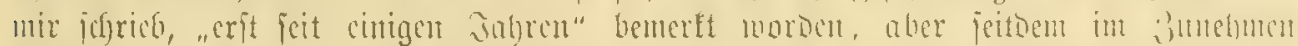

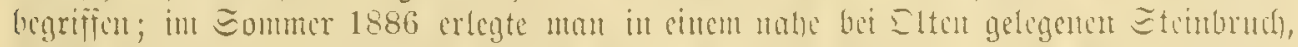

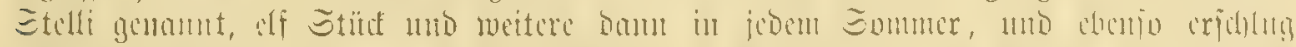

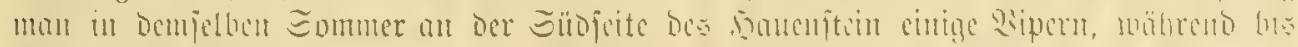

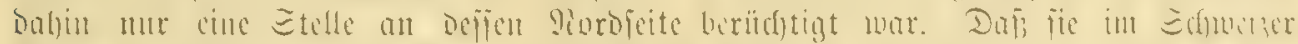

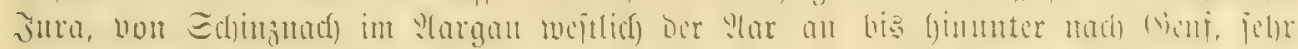

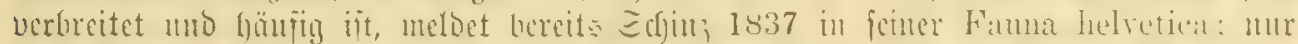

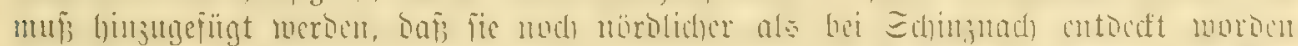

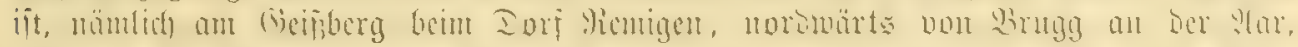

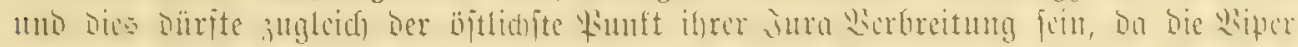

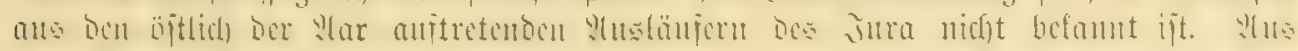

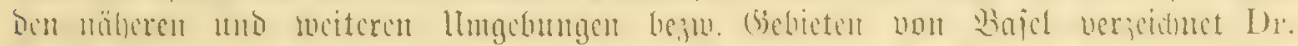

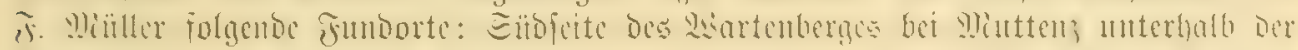

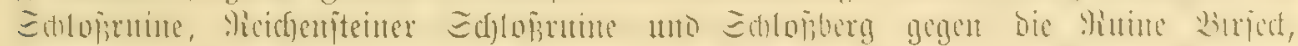

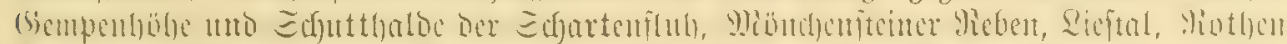

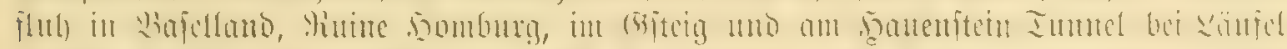

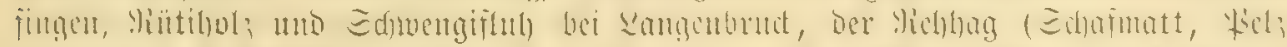

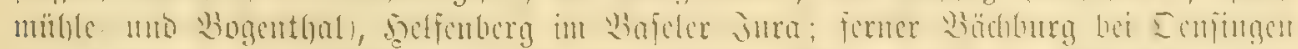

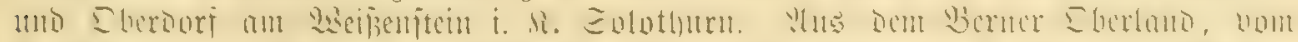

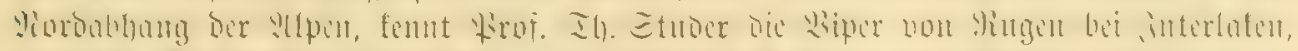

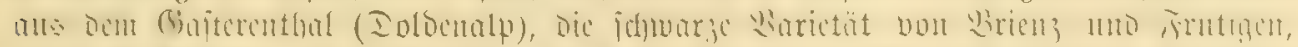

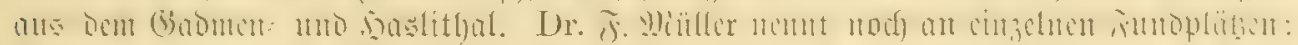

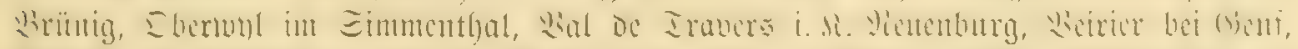

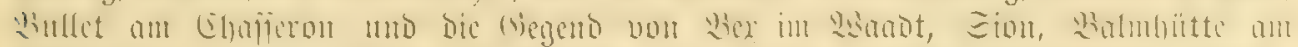

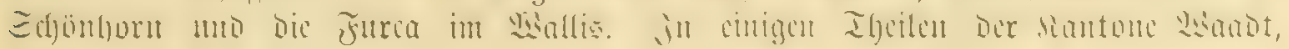
Walliz uno Siid= Zejîu foll jic rect)t bäufig foin.

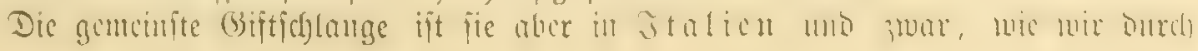


(6.) De

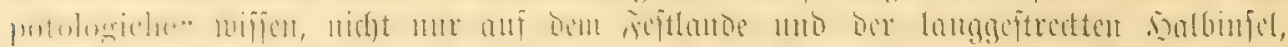

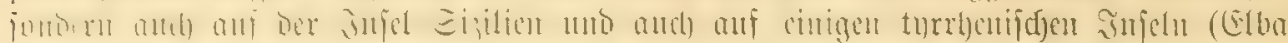

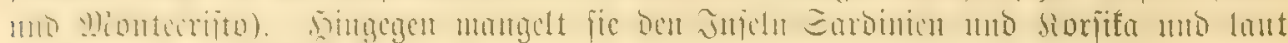

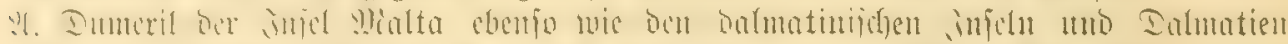

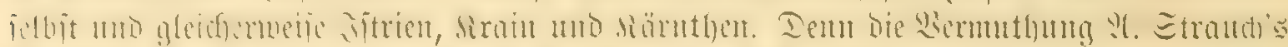

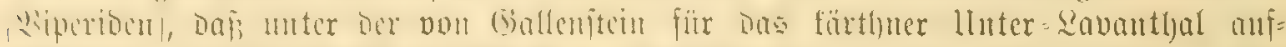

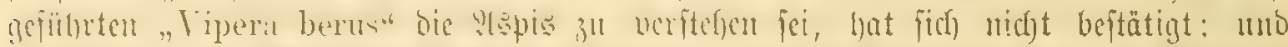

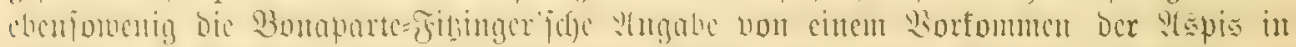

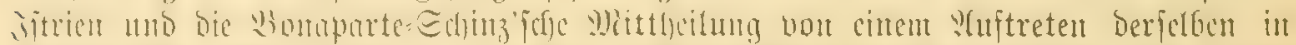

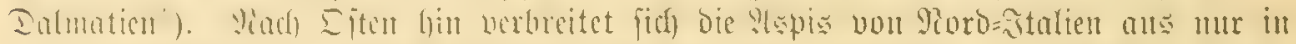

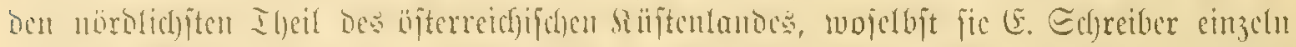

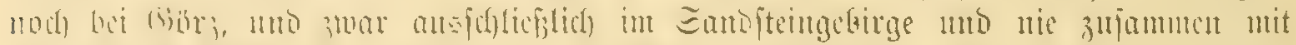

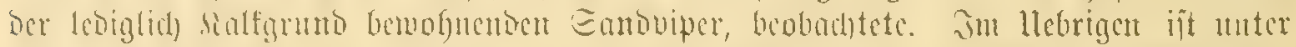

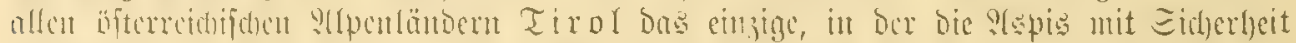

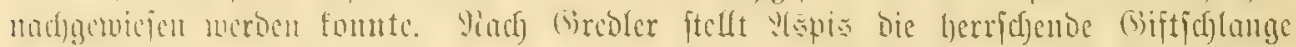

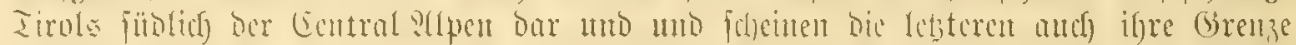

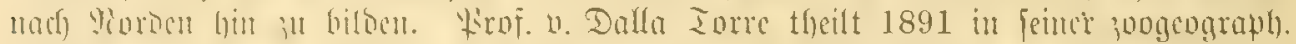

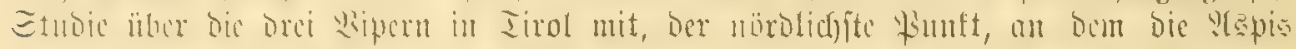

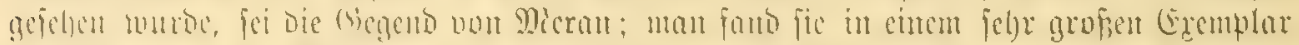

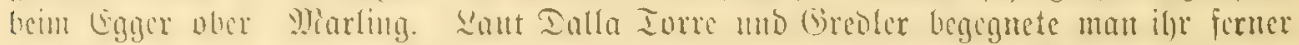

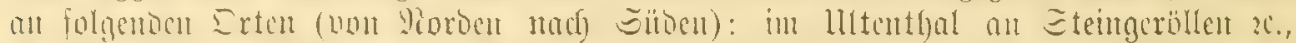

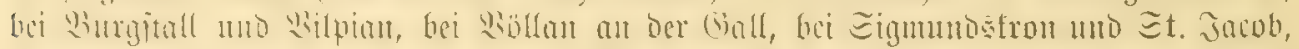

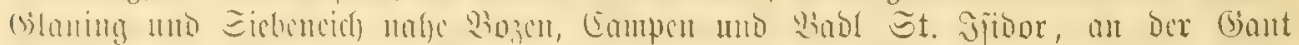

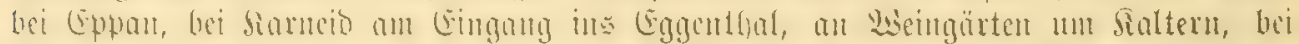

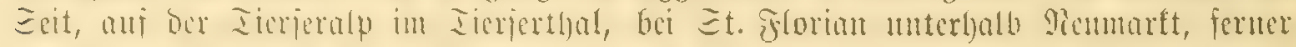

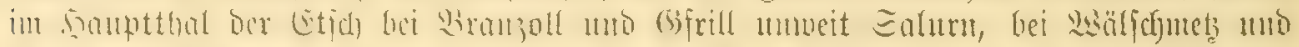

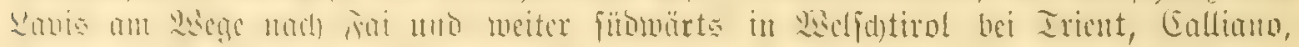

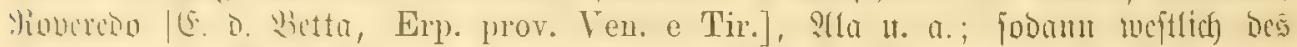

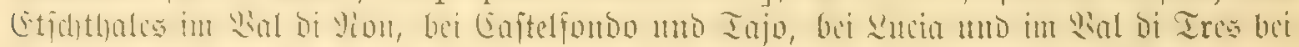

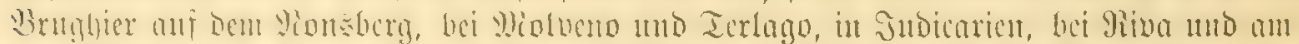

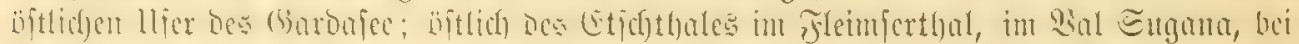

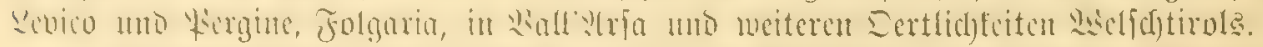

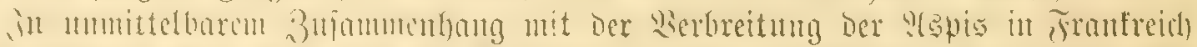

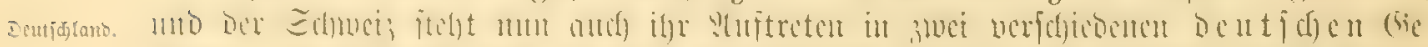

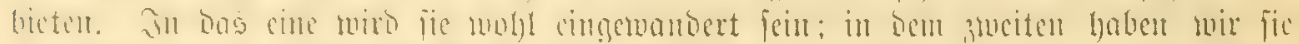

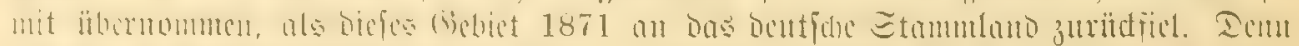

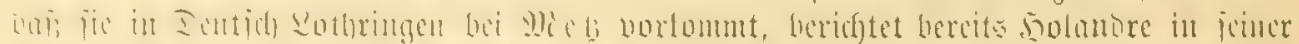

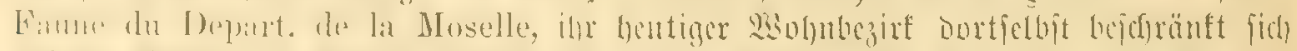

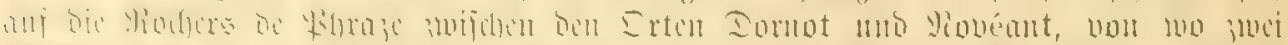

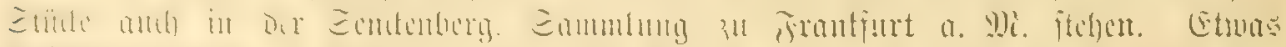

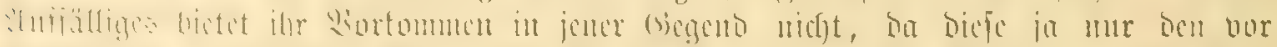

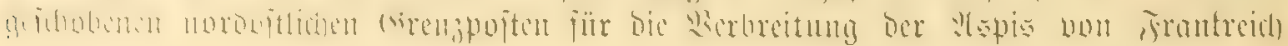

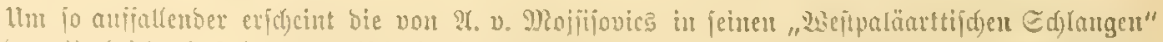

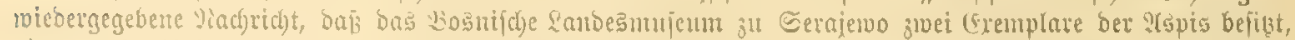

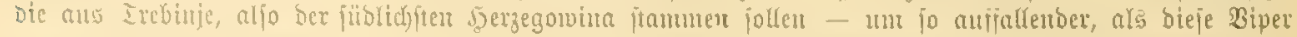

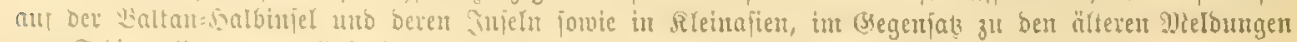

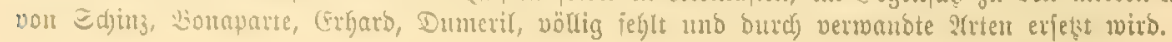




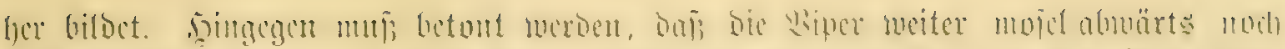

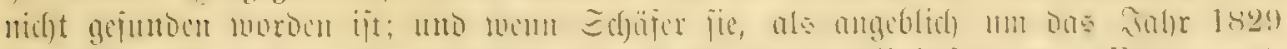

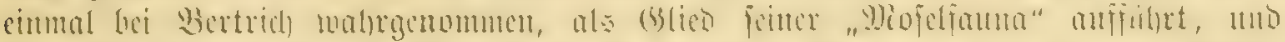

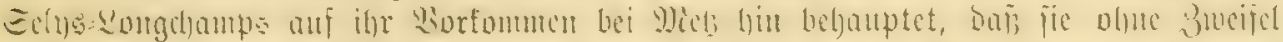

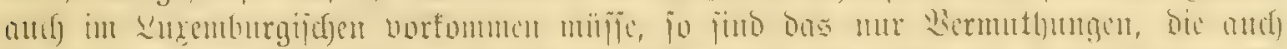

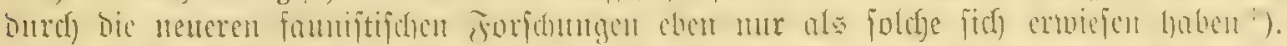

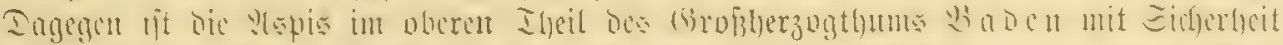

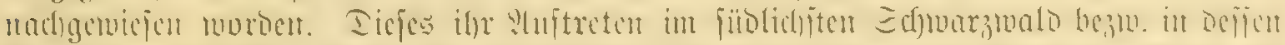

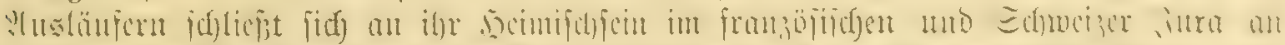

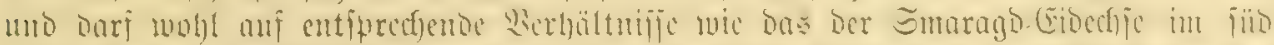

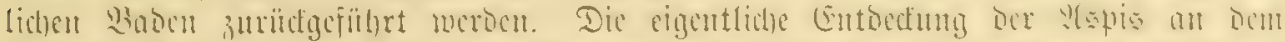

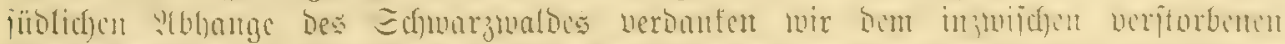

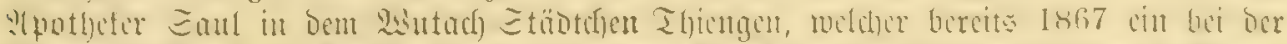

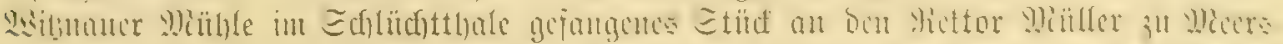

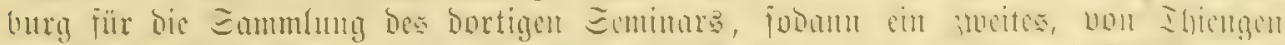

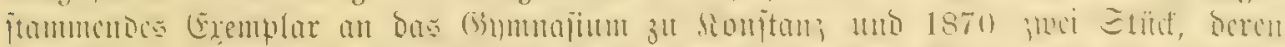

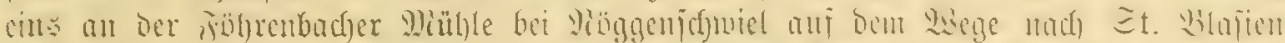

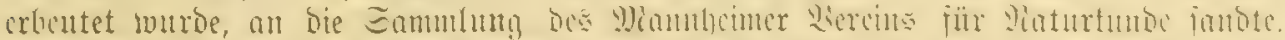

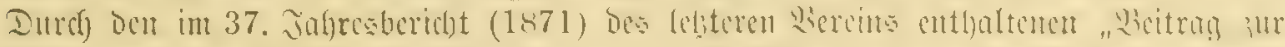

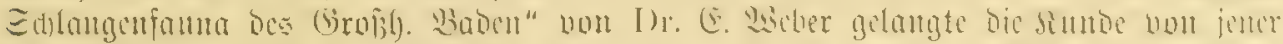

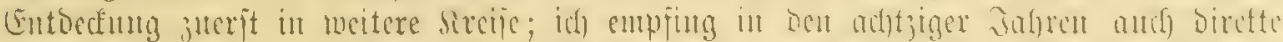

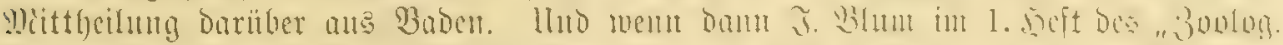

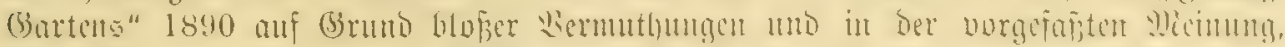

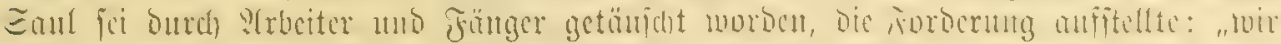

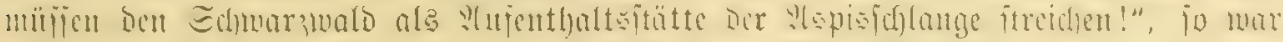

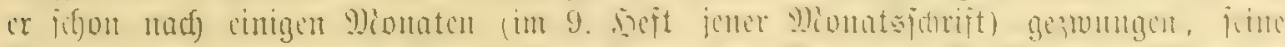

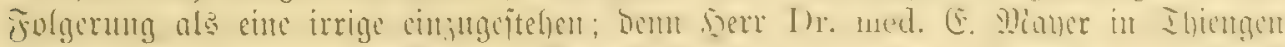

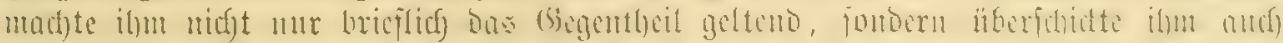

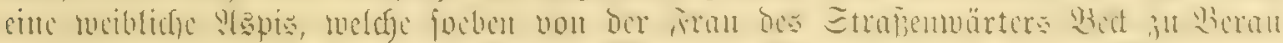

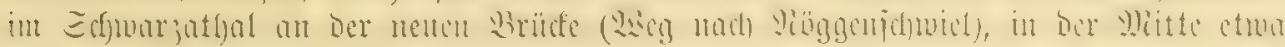

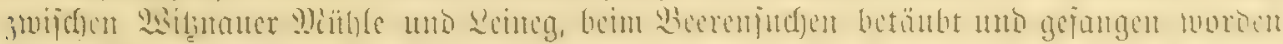

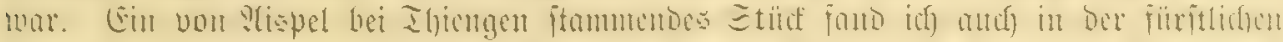

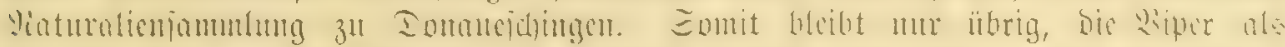

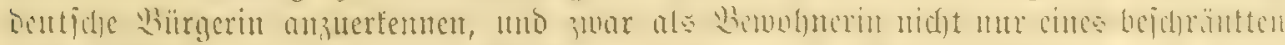

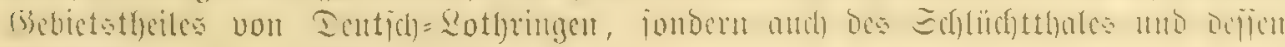
Slefonthäler in babijajen Sberlanto.

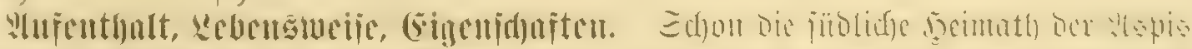

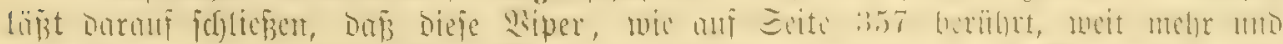

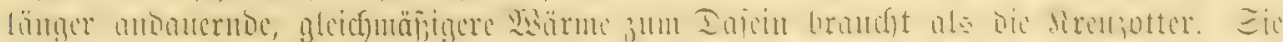

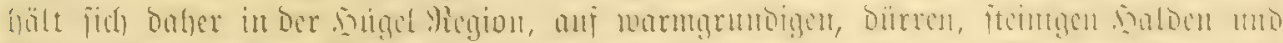

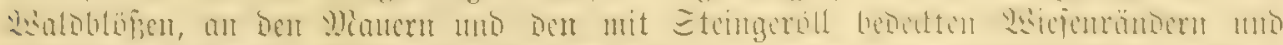

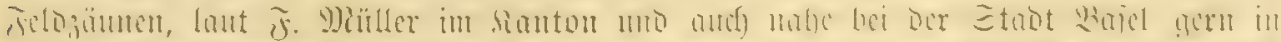

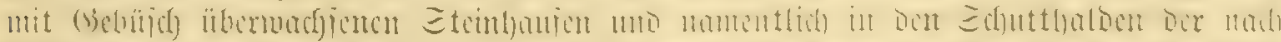

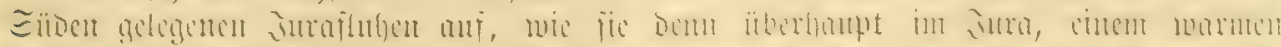

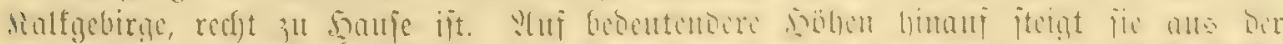

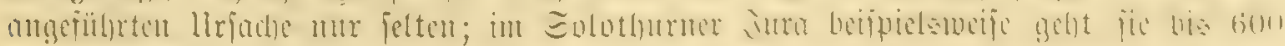

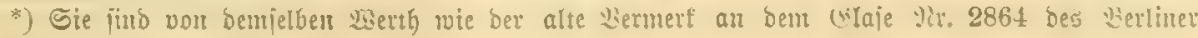
3ool. Wujeun: "Wayern, burdj Wagler". 


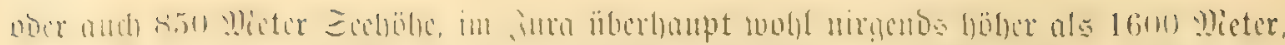

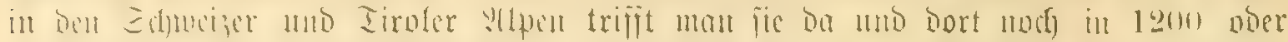

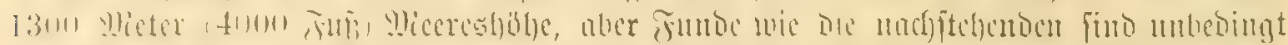

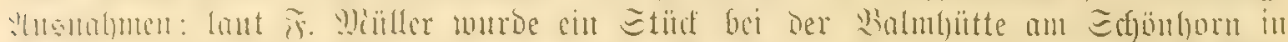

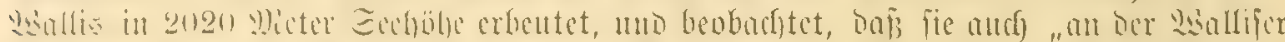

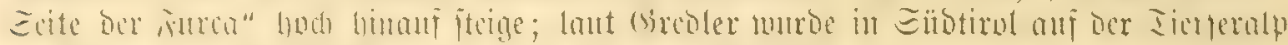

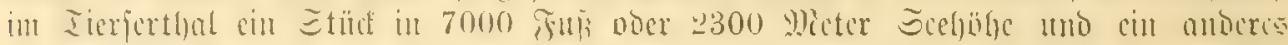
in Dericlben Soblje auf ber oberen Sardialp gefangen [Serp. Beob.].

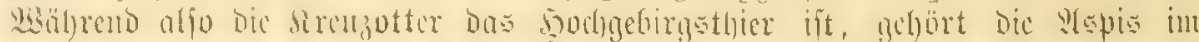

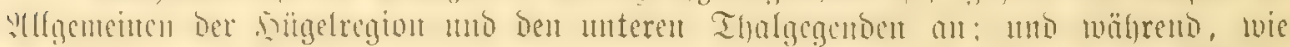

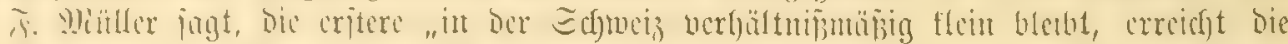

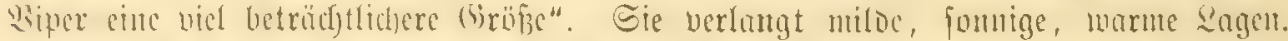

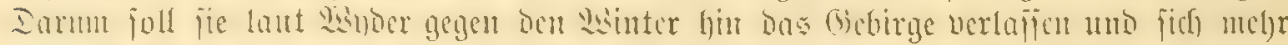

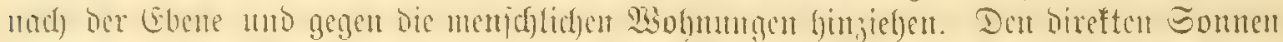

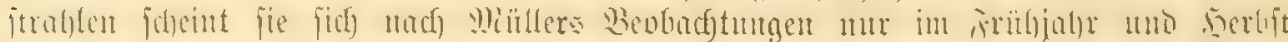

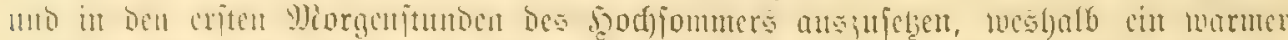

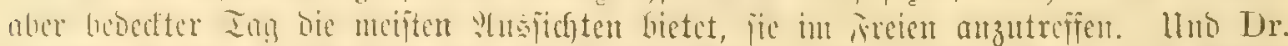

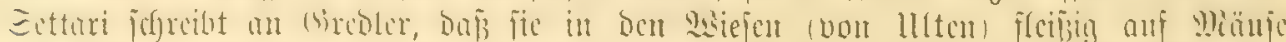

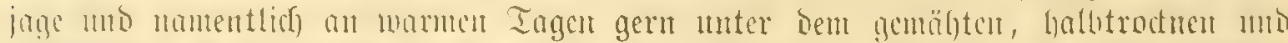

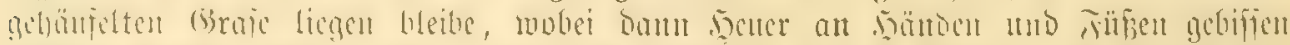

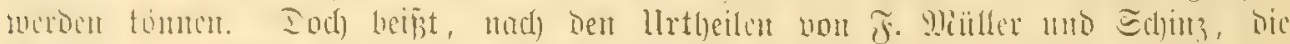

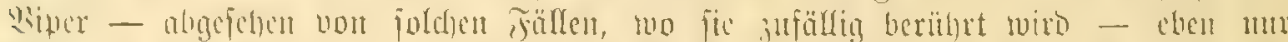

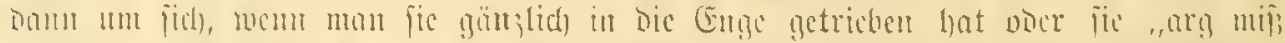

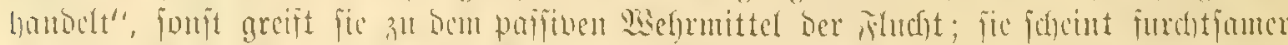

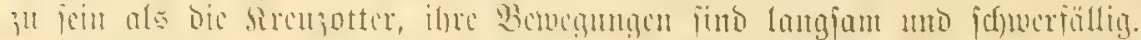

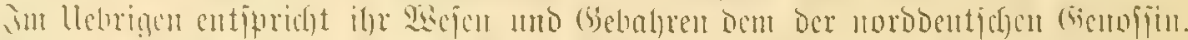

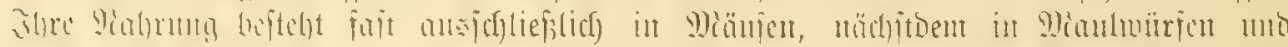

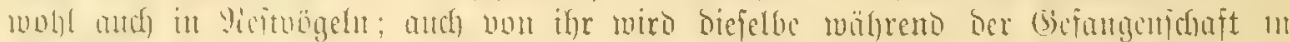

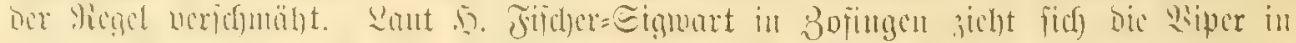

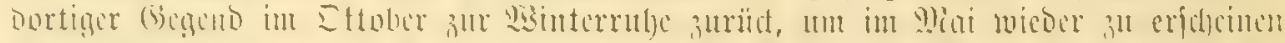

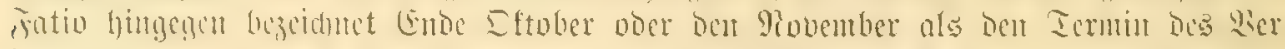

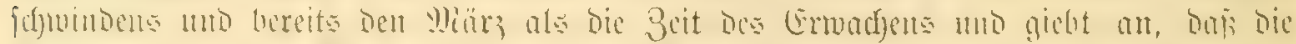

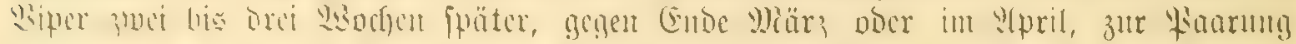

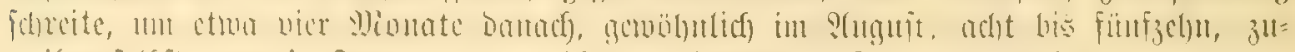
tweilen felgit zwanzig Santge vou 14 bis 19 Eentimeter \&änge zu twerfent.

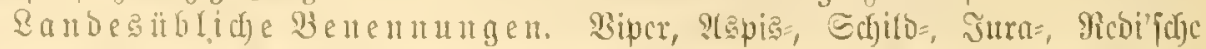

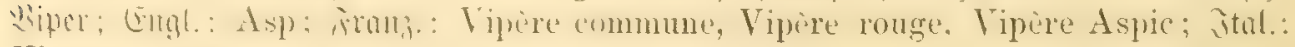
Vipera commune, Aspide, Lipara; Span.: Vibora.

Coluber aspis, Limné 1758. - Vipera Francisi Redii et V. Mosis Charas, Laurenti 1768. - Coluber berus et Col. Chersea, Razoum. 1789. - Col. berus (partim), Bomat. 1789. - Col. Redii, Gmelin 1790. - Col. vipera, Latreille 1800.

Vipera rulgaris, ocellata, chersea et Redii, Latr. 1802. - Coluber Charasii, Shan 1802. - Vip. berus var. 5, Dautin 1803. - Vipera (Echidna) Aspis, Merrm 1820. - Vip. Redii et V. aspis, Metaxa 1823. - Aspis ocellata, Fitzinger 1826. - Pelias aspis, Boie 1827. - Lachesis Redii, Hempr. - Vip. berus, Cuvier 1829. - Vip. Hugyi, Schinz 1833. - Vip. communis, Mauduyt 1852. 


\section{Südeuropäijh̨e Sळ̧langen.}

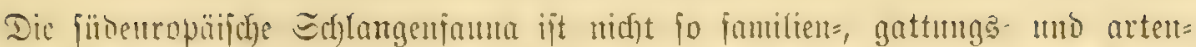

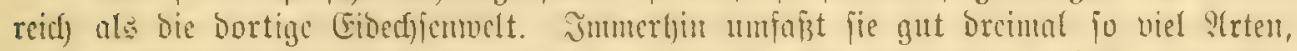

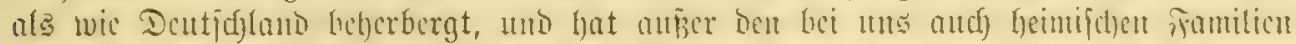

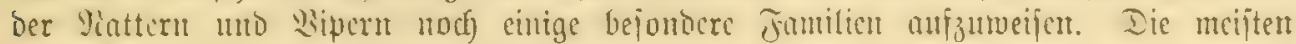
Acrten gefjörcn ber f(f)on früher gefcumzeidjneten

Familie Der Miattern an. Sion Der un befannten Gattung Tropidonotus

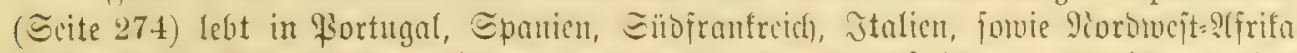

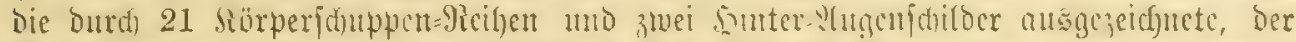

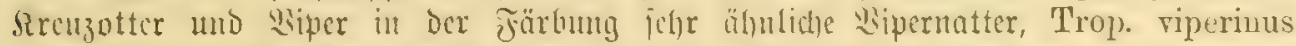
Latr. (Ecite 300). Wion ber Gattung Coluber (Eeite 308) finden wir in Entouropa

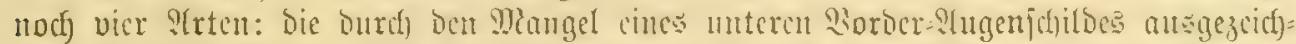

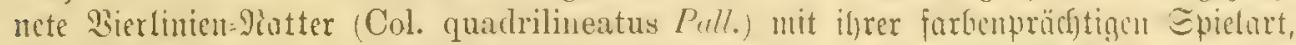

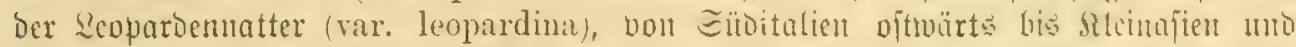
bie Serm, ferner bie mäd)tige, bis 2 m lange, mit ber vorigen ungefäf)r bie seimath

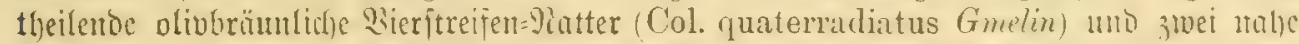

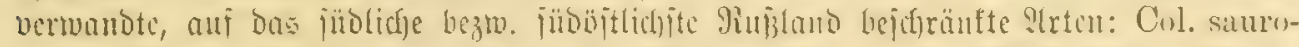

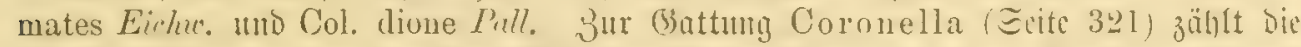

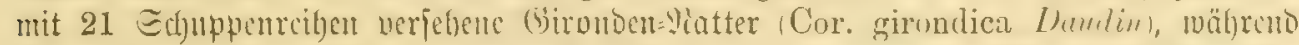

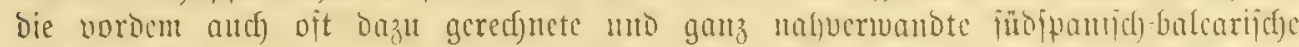

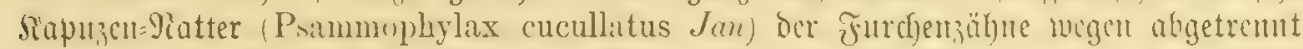

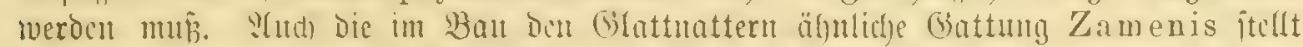

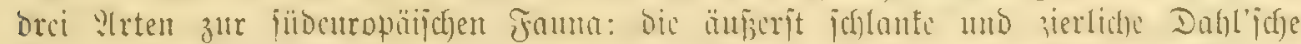

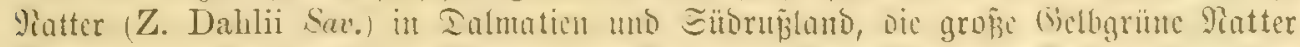

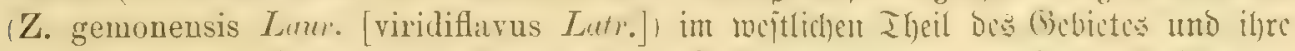

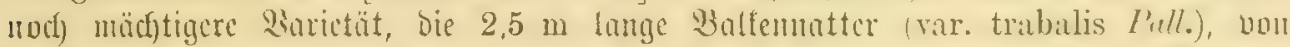

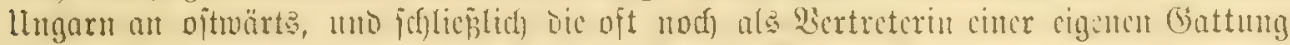

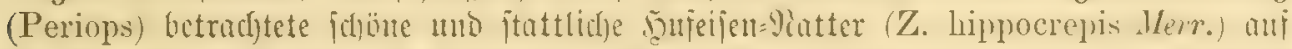

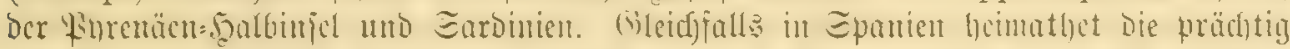

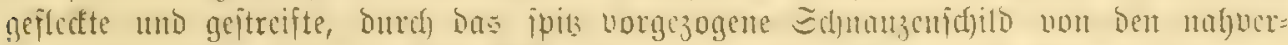

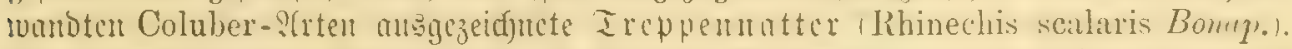

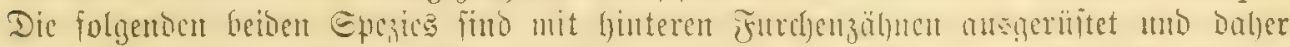

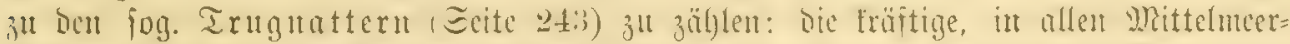

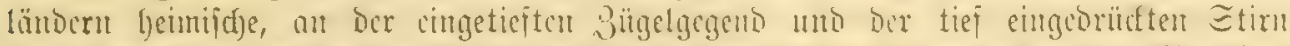

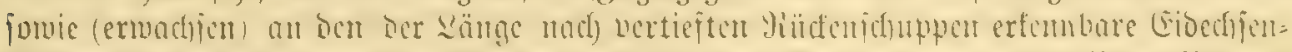

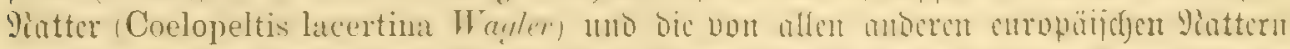

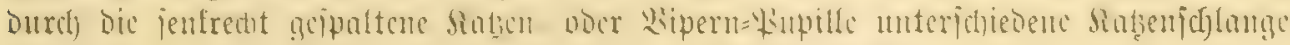
(Tarbophis vivax Fitz.) Dalmatiens mo Der Baltan=5calbiulch.

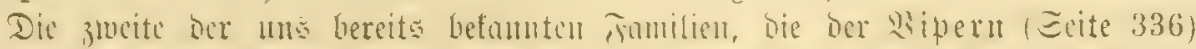

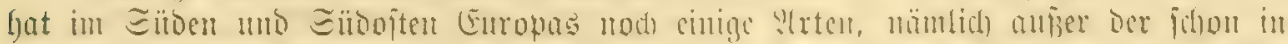

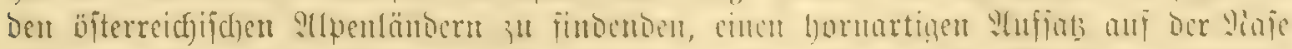

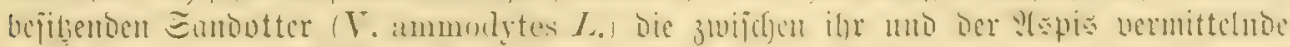

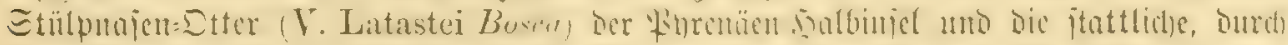

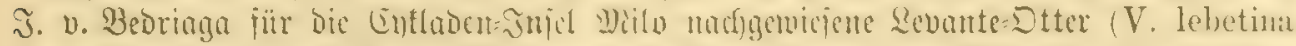

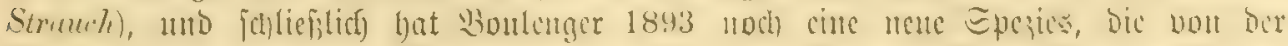

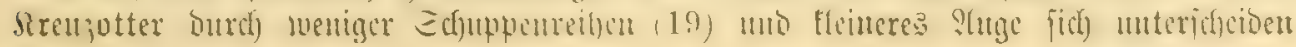




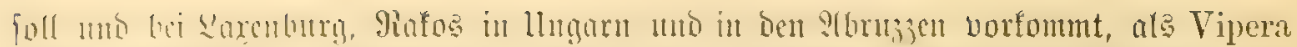

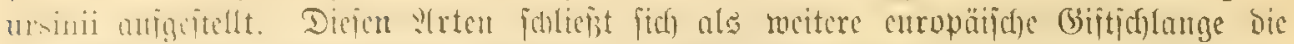

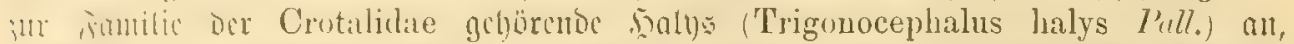

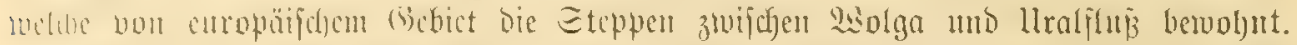

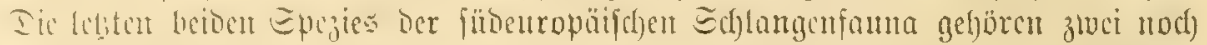

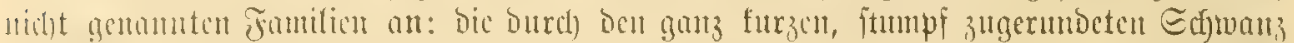

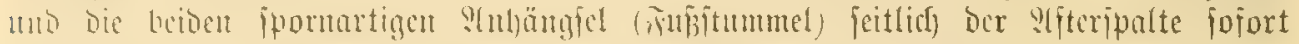
crtembure Eambid)longe (Eryx jaculus /.o) Den Etummelfäfacrn vocr Peropodidae,

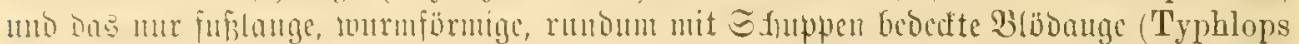

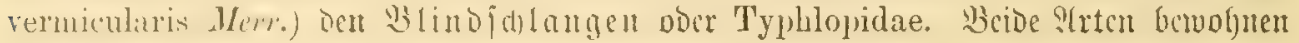
(Briedfenlano. 


\section{Jucite Amphibien oder sutratie. Amphibia (Batrachia).}

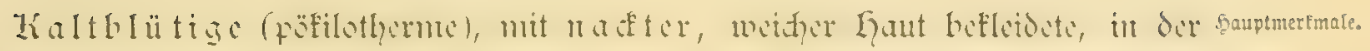

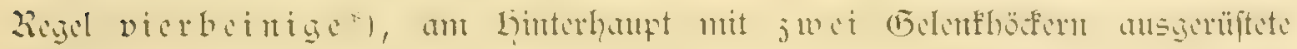

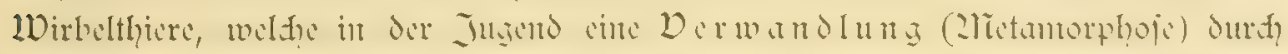

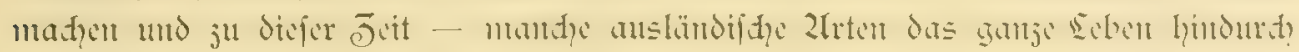
- vermittelift Kiemen athmen.

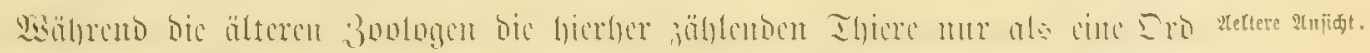

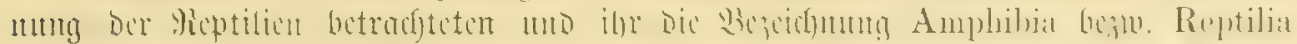

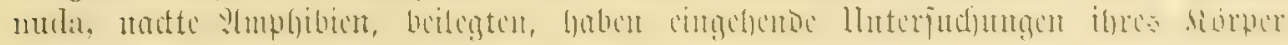

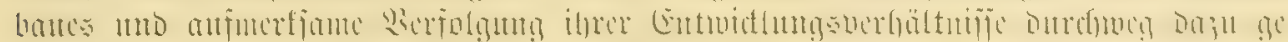

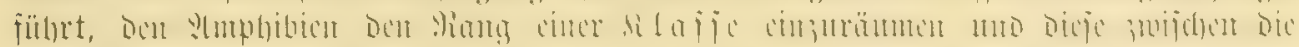

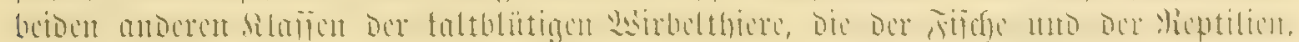

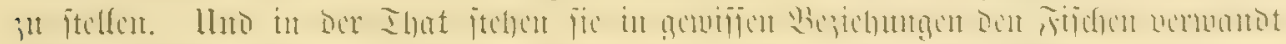

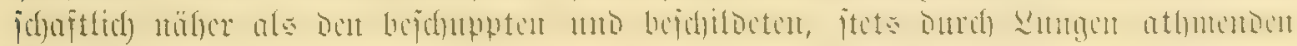
Meptilicn.

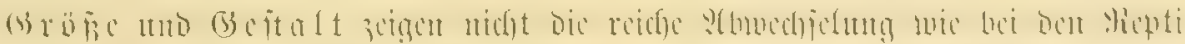

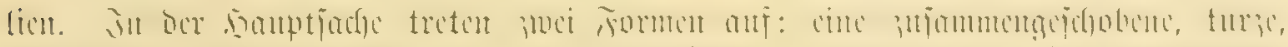

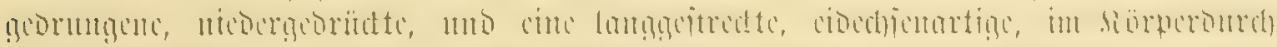

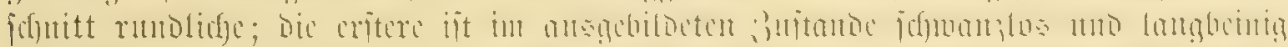
(a)

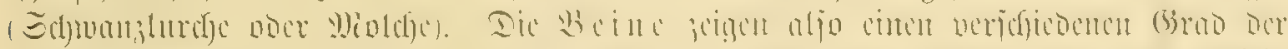

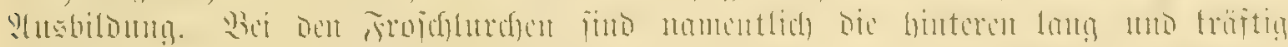

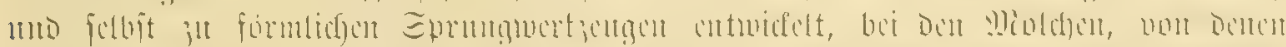

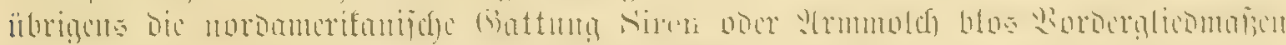

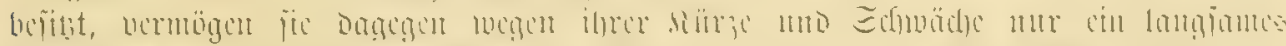
Sirmente

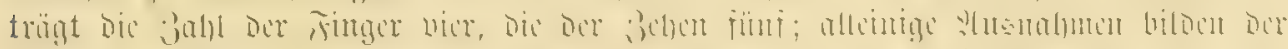

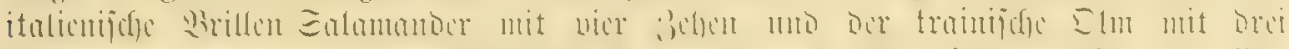

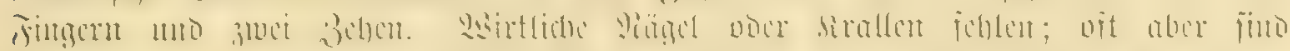

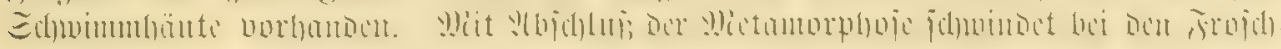

*) Die fuğlofen, mutmartigen, fdjienenartig verbiđte நautringe mit Gdjüpdjen befilsenden

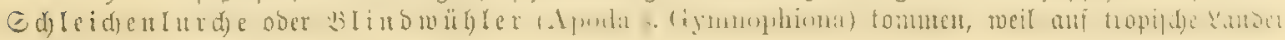
bejäräuft, Gier gar nidjt in Betradjt. 


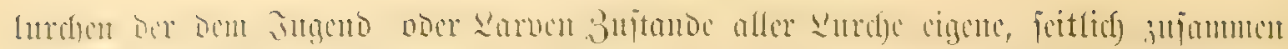

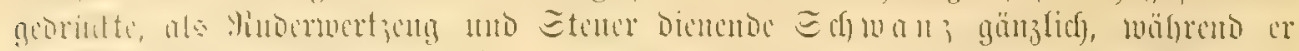

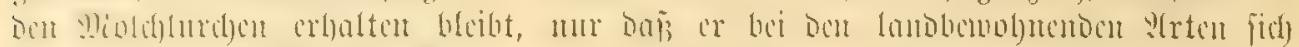

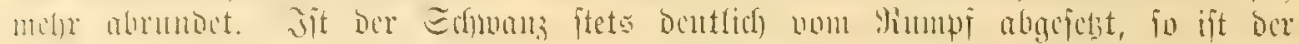

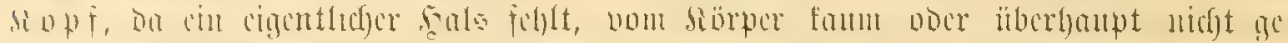

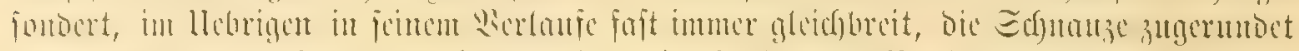

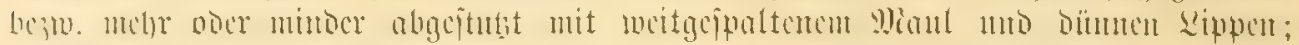

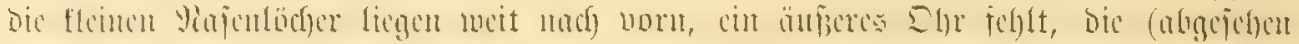

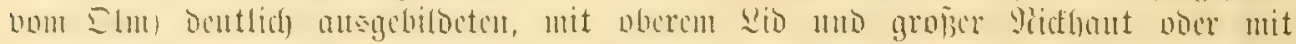

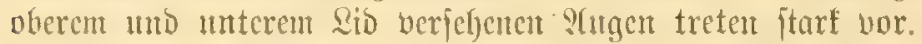

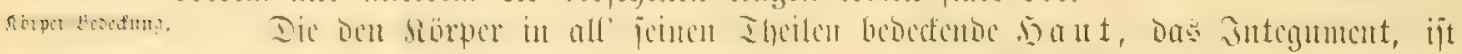

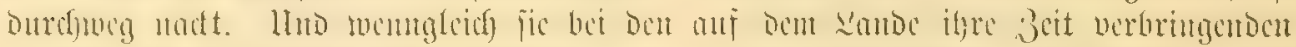

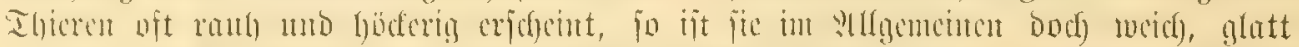

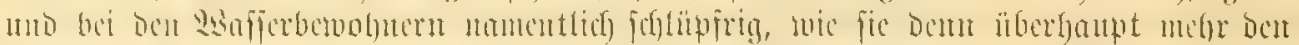

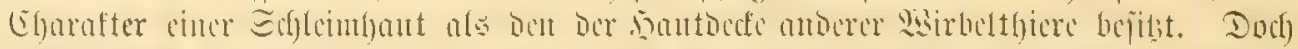

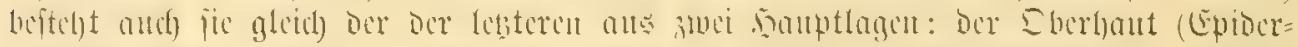

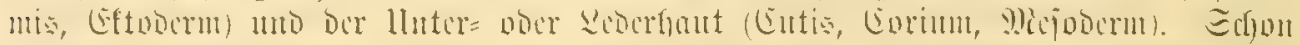

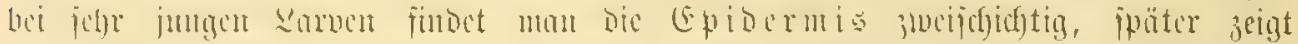

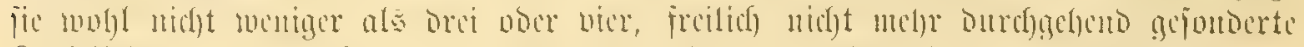

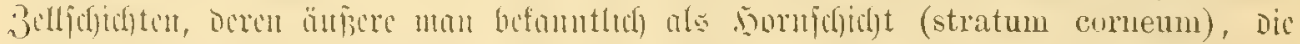

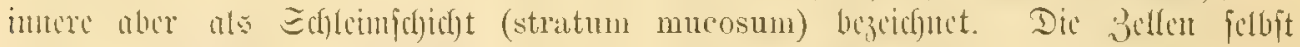

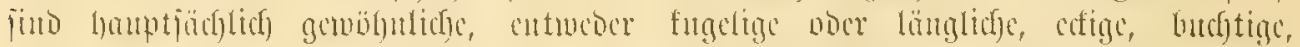

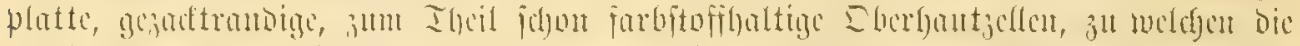

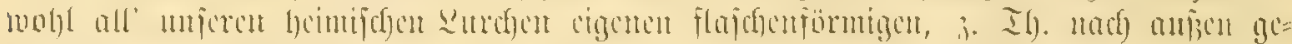

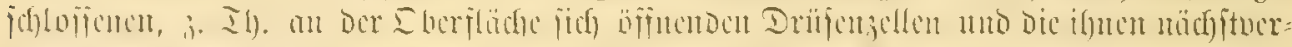

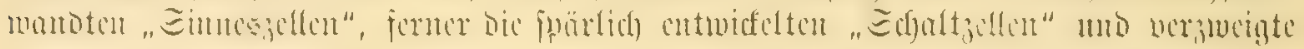

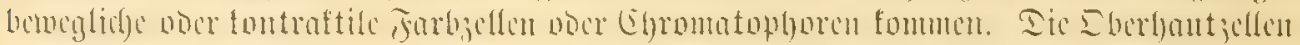

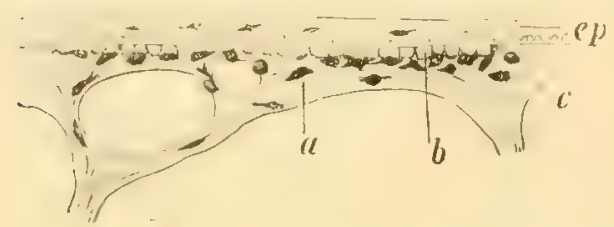

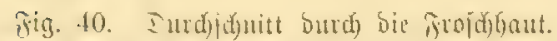

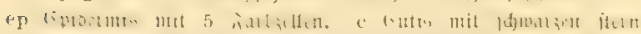

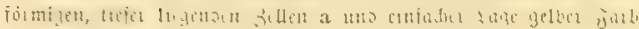
zellert b bidst unter ber (Fpibermit.

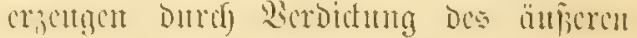
Syeile ifyrer feinen Bellwand (\$)cmbran) cin fetucs Däutchen, cine jogçanute Cuti= cula, mb Dic freic Flädje bicjer bie ganze Siöperfant nodh hberzichenton Euticula bleibt cntweder, wie lluterjudjungen mittelit

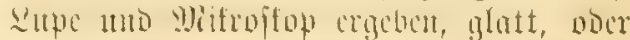
aber fite ift, and jum bäurig, mit viclicf bildunger oder Sfulpturen bezı. mit 5öder=

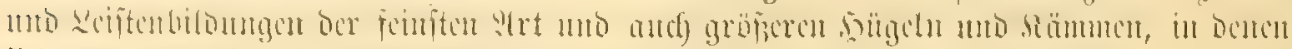

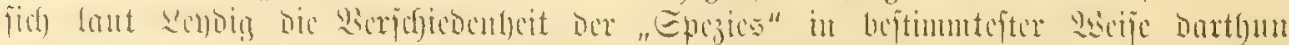

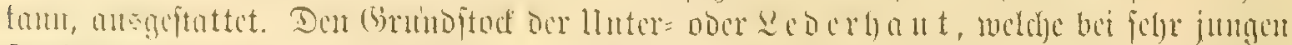

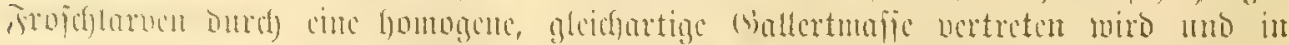

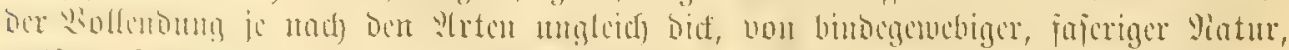

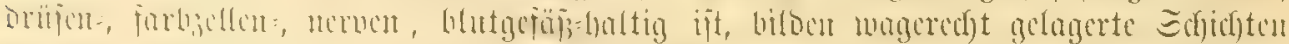

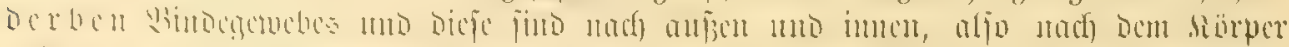

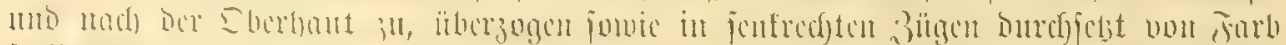
ftofi,

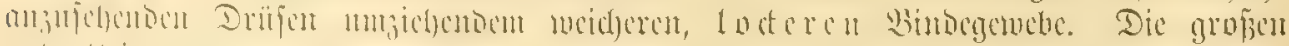

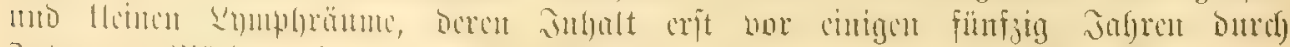

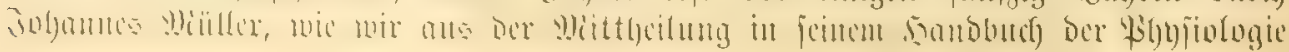




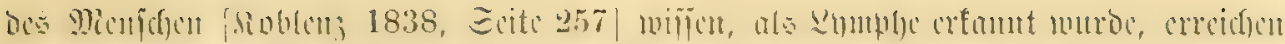

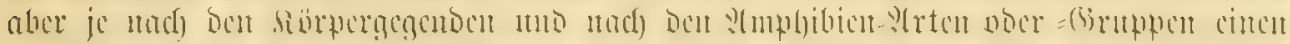

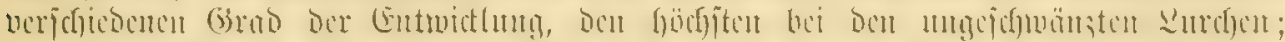

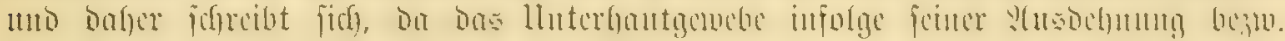

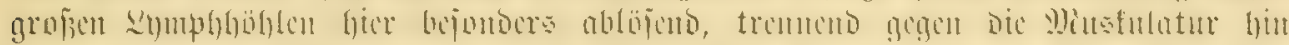

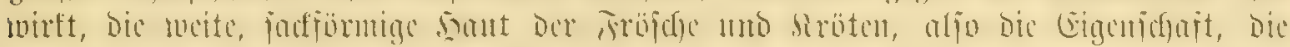

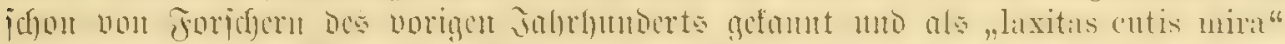

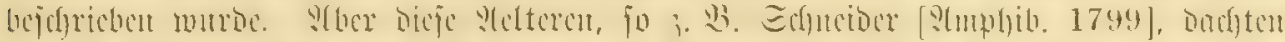

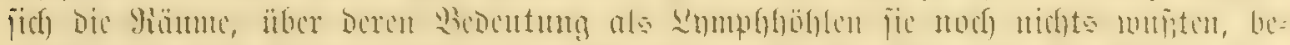

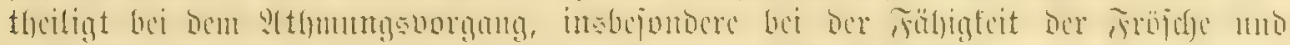

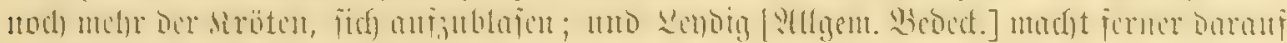

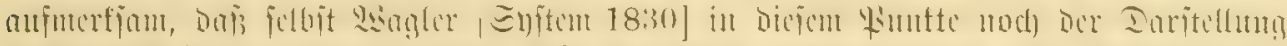

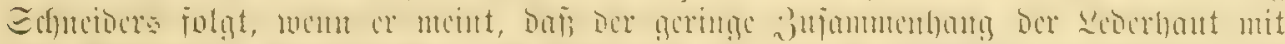

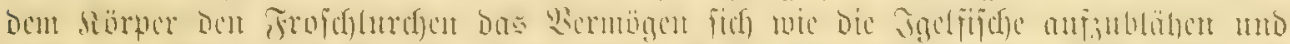

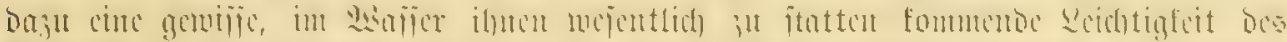

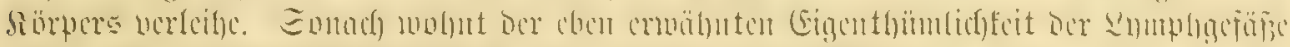

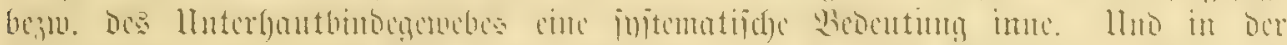

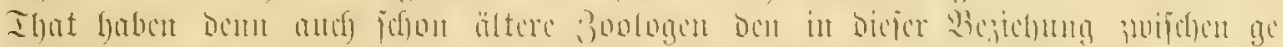

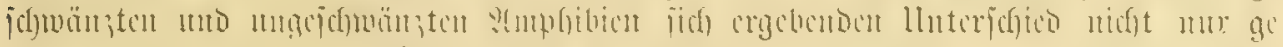

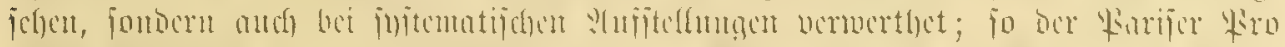

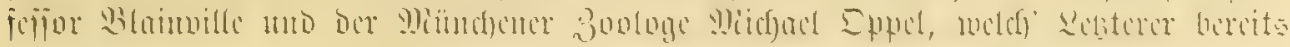

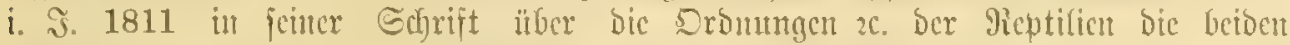

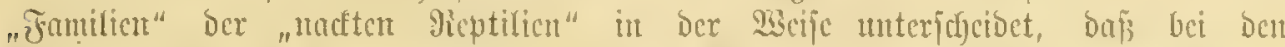

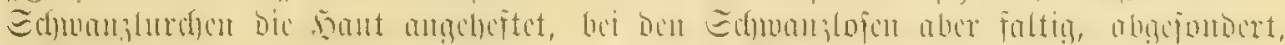

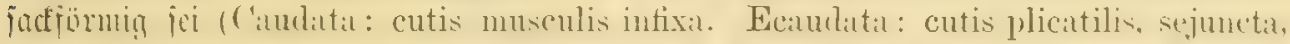

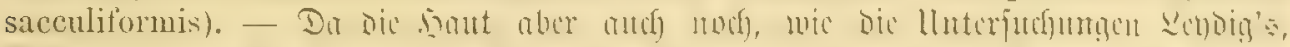

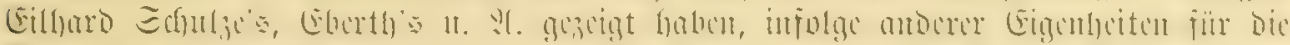

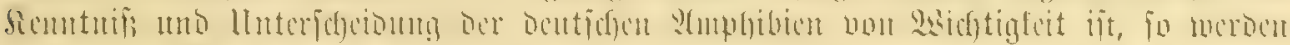

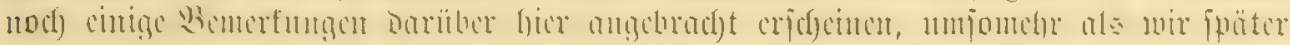
imuter, voieber barauf zuritgefeifen milffen.

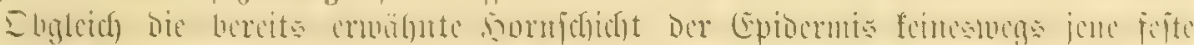

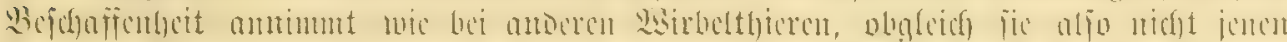
(i)

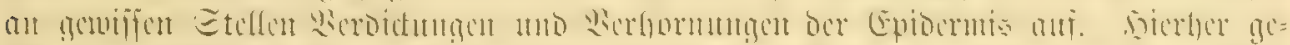

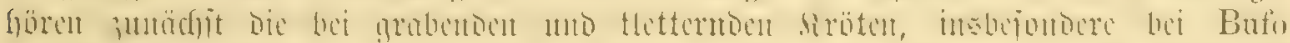

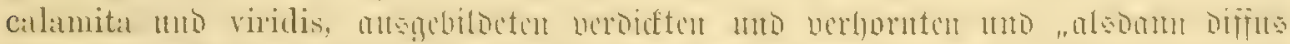

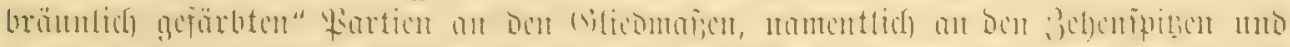

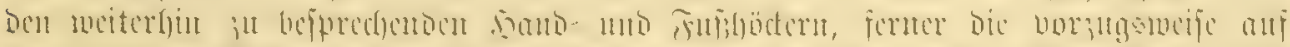

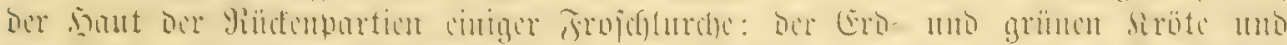

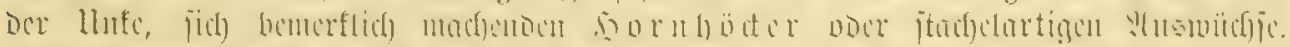

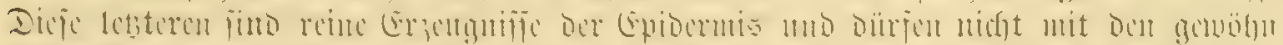

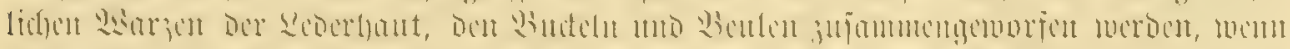

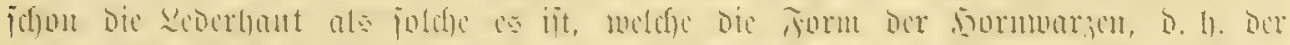

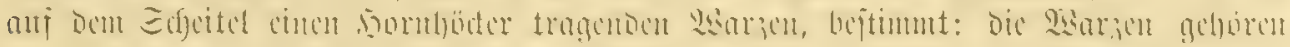

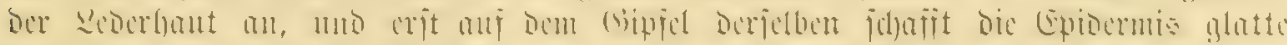

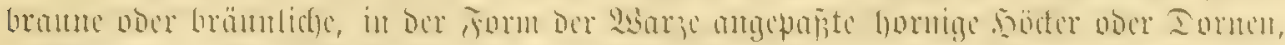

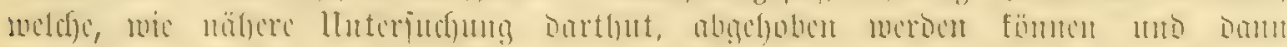

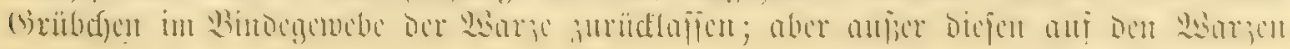




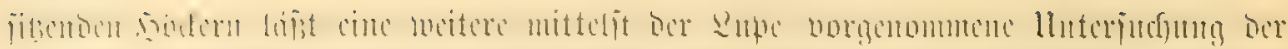

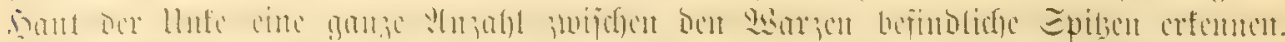

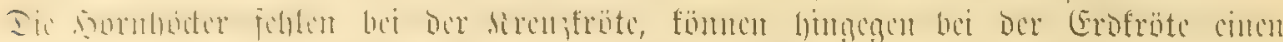

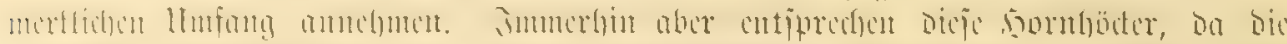

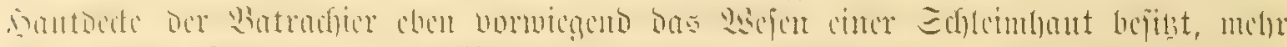

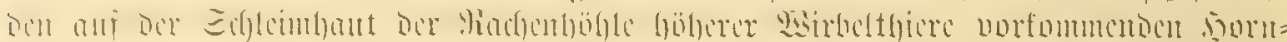
jübut.

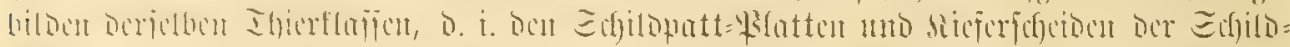

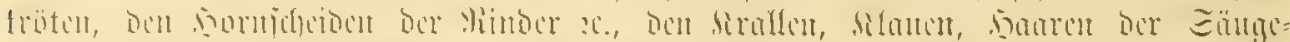
there, och Federn Dex

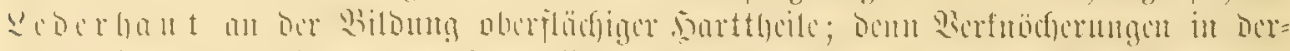

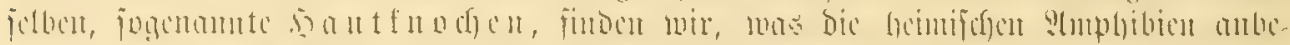

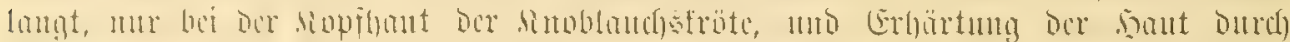

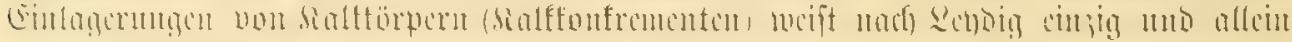

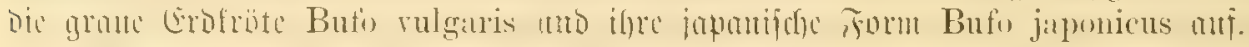

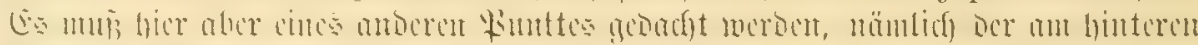

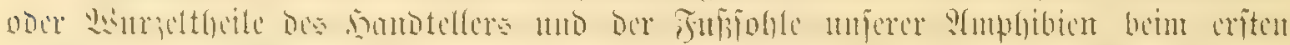

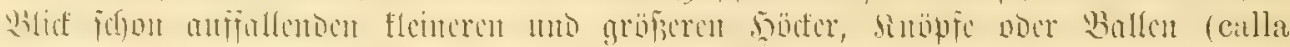

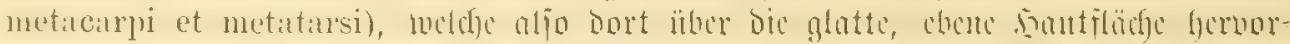

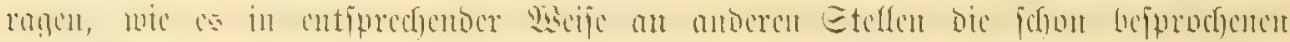

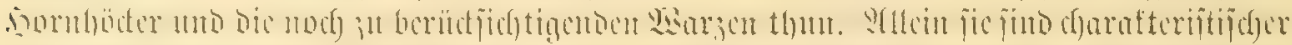

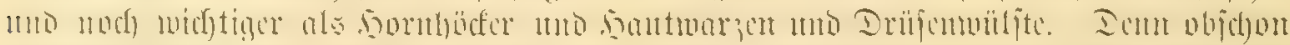

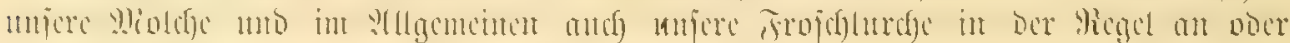

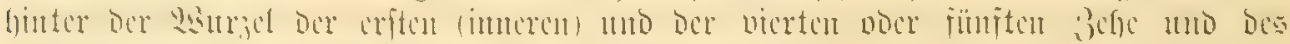

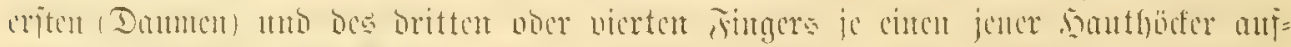

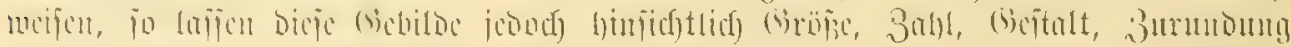

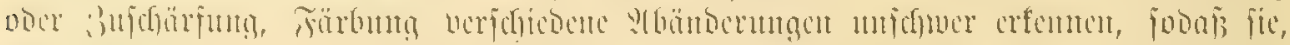

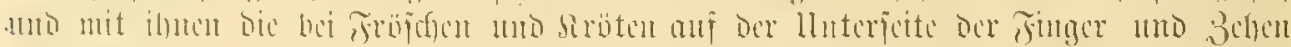

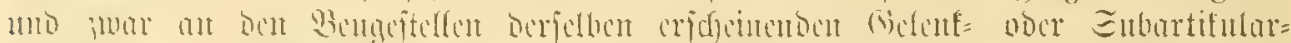

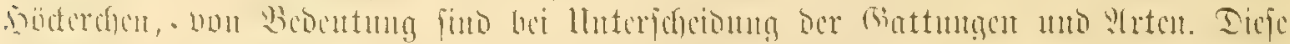

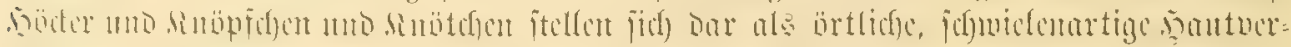

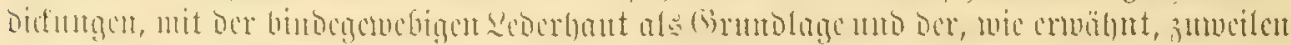

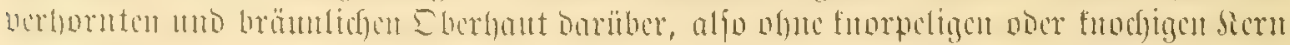

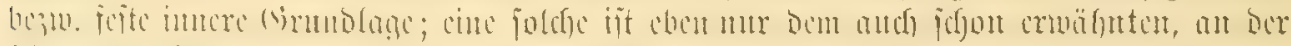

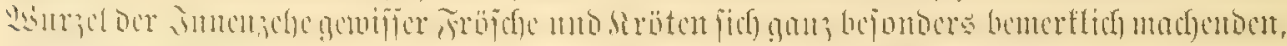

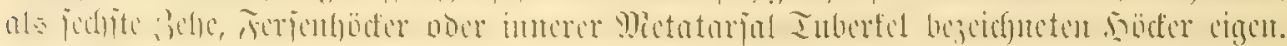

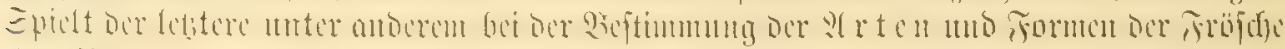

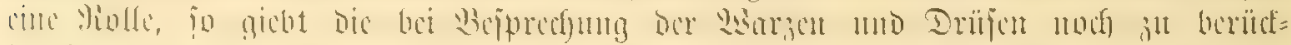

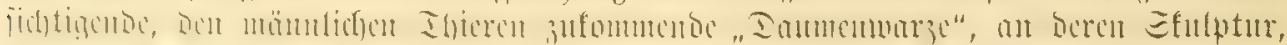

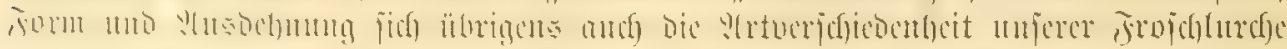

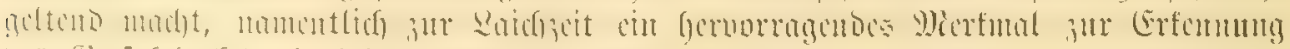

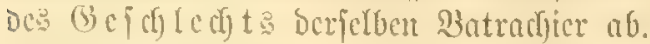

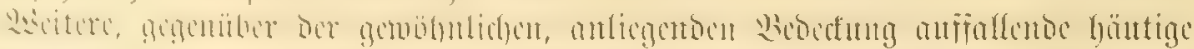

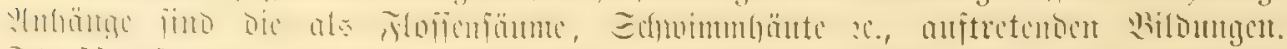

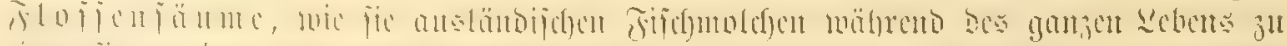

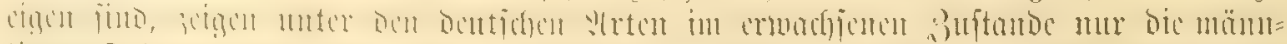

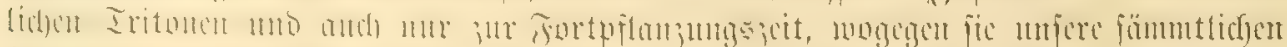

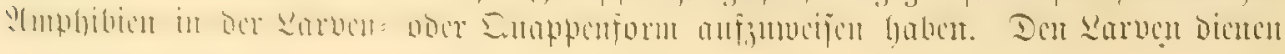




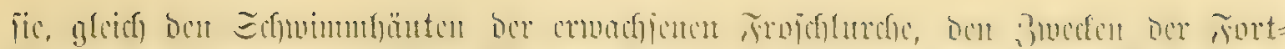

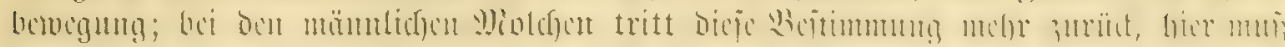

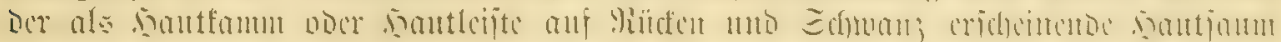

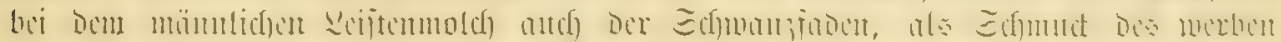

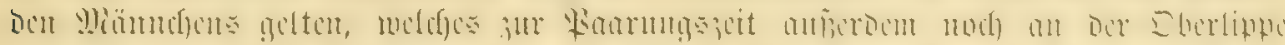

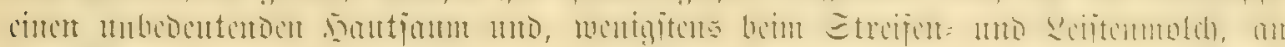

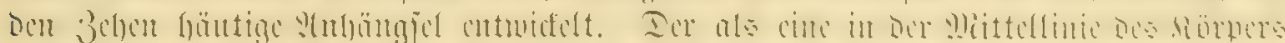

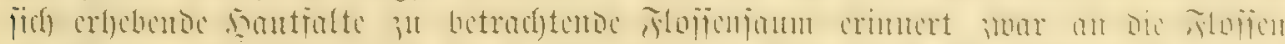

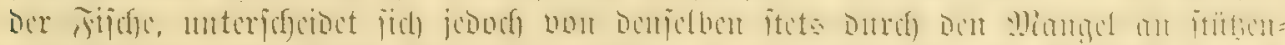

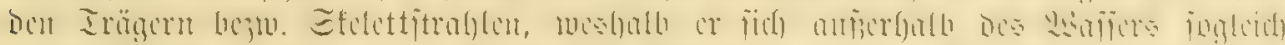

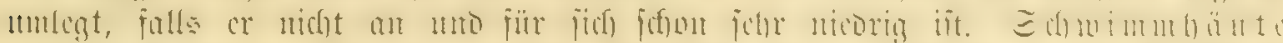

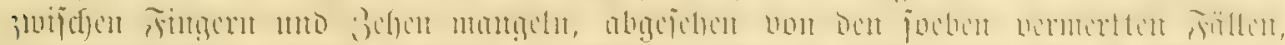

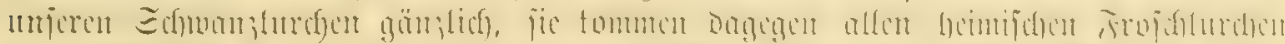

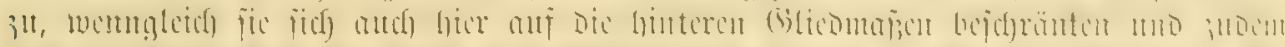

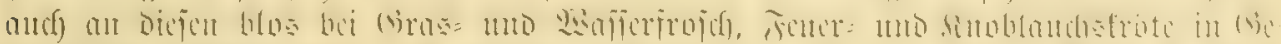

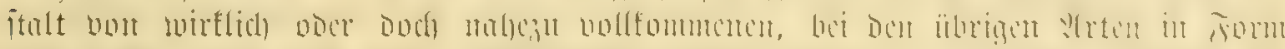

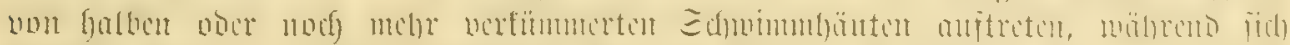

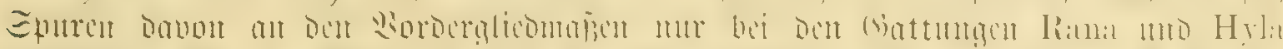

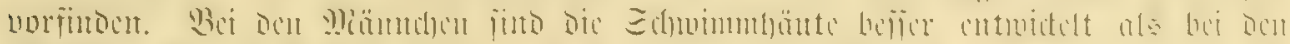

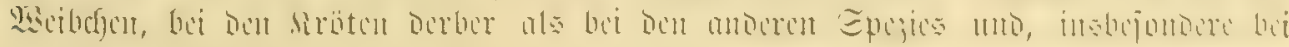
Der Sreuzfrötc, am Jiande geferbt und berbict.

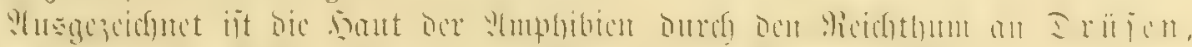

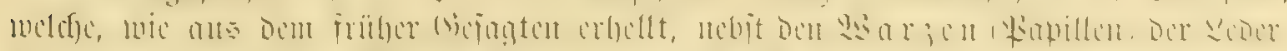

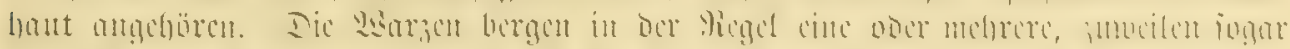

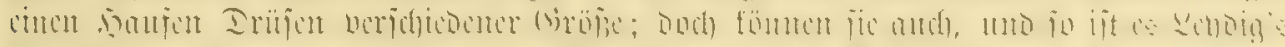

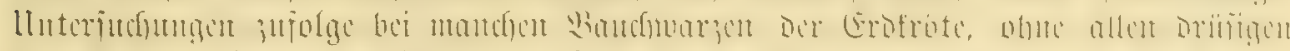

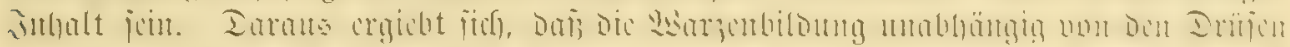

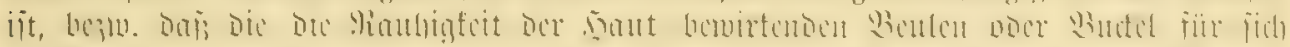

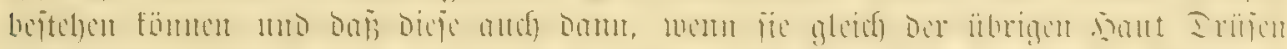

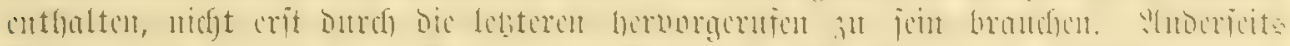

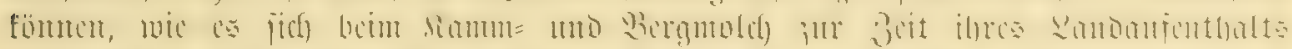

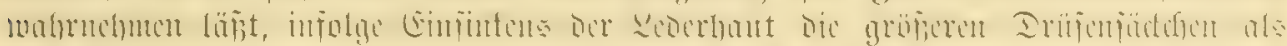

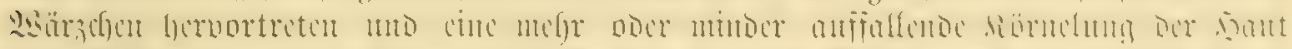

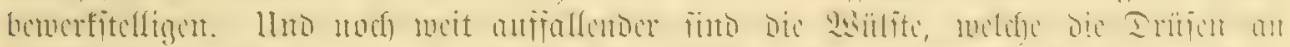

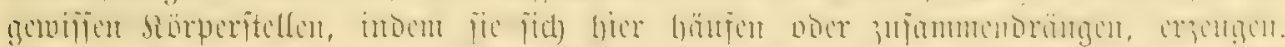

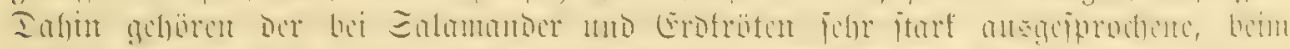

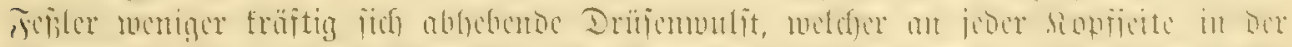

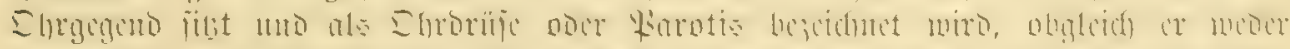

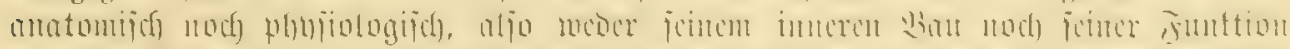

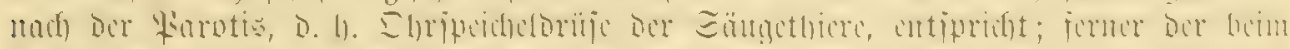

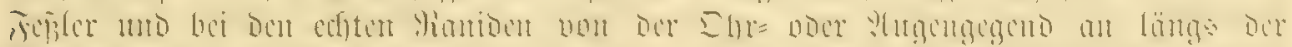

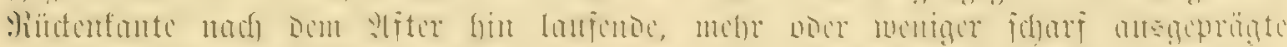

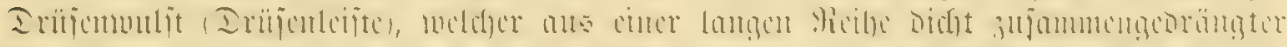

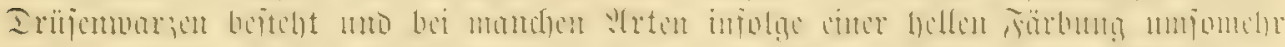

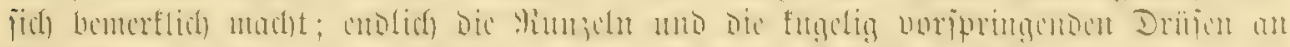

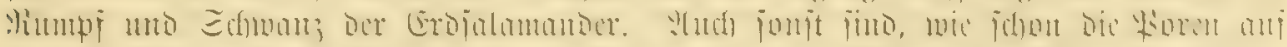

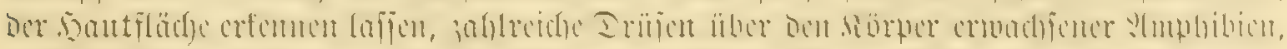

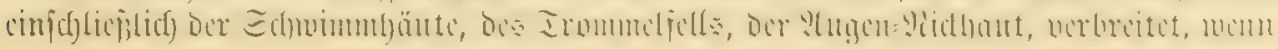




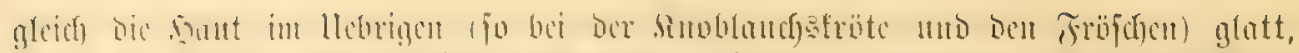

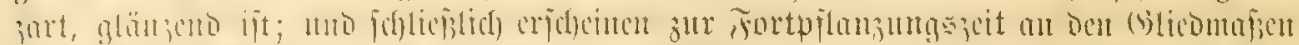

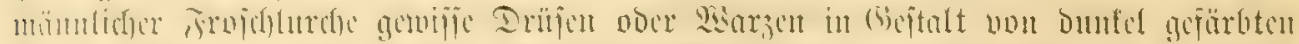

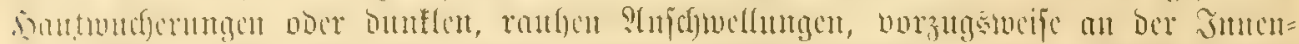

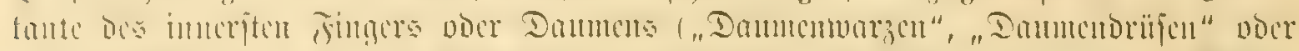

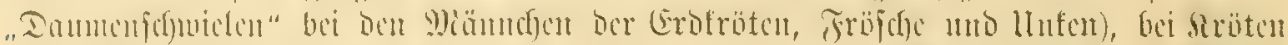

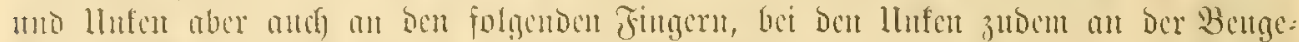

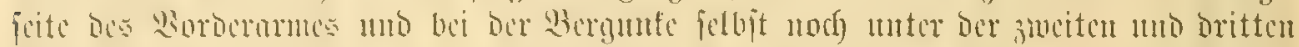

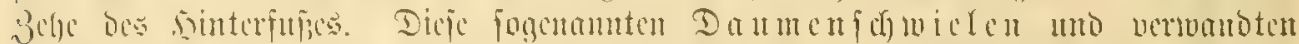

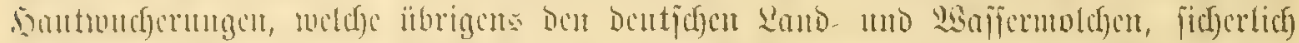

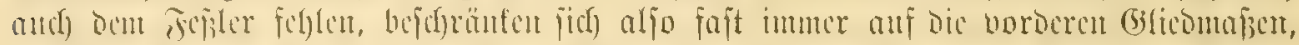

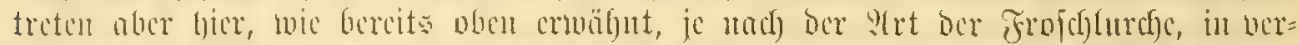

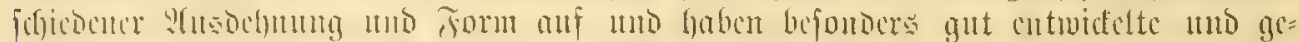

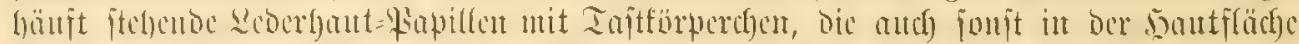

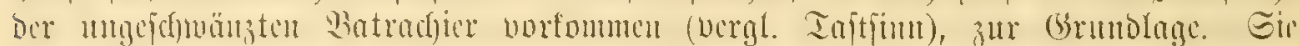

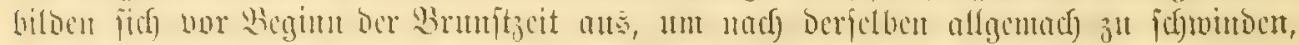

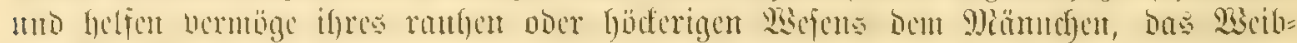

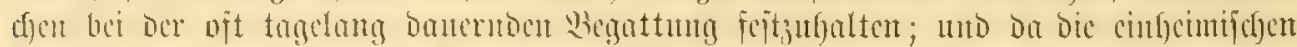

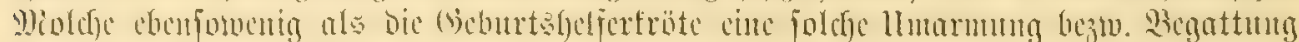

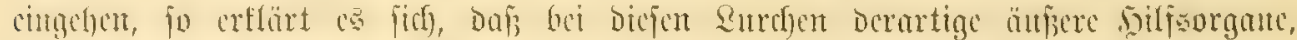

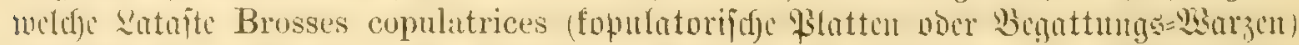

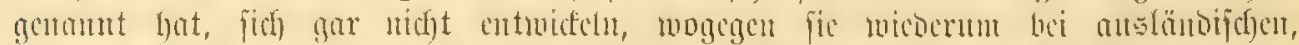

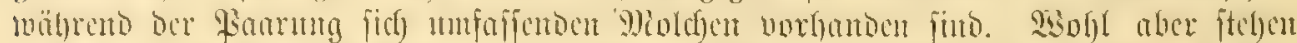

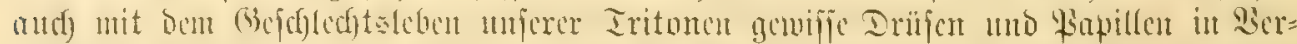

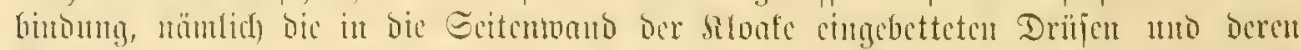

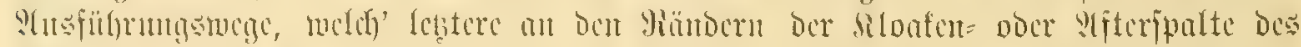

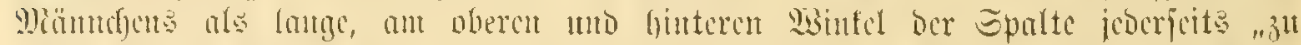

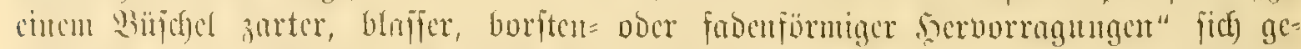

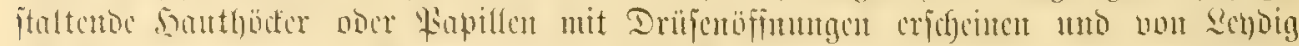

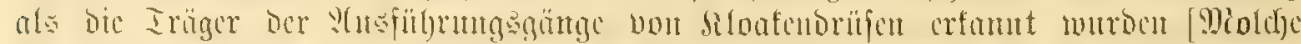

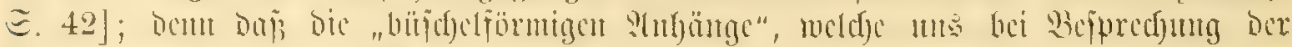

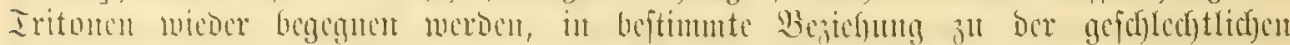

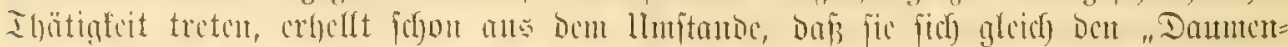

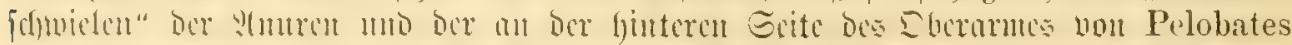

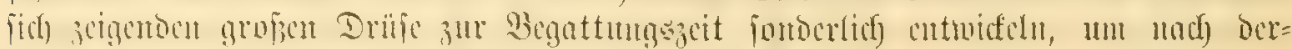
jelben cine ganz bebentende Buidfbildung zit erleiben.

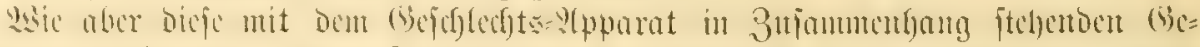

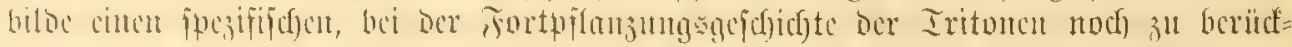

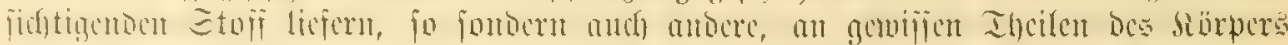

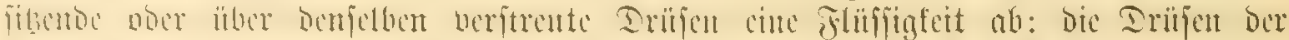

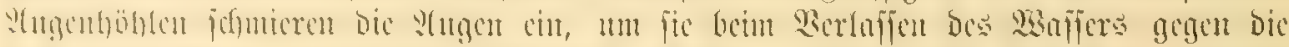

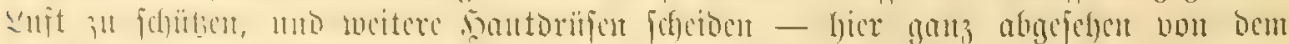

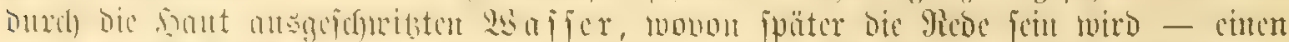

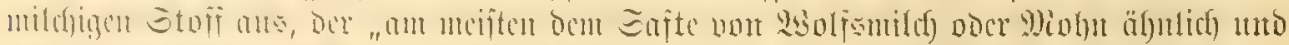

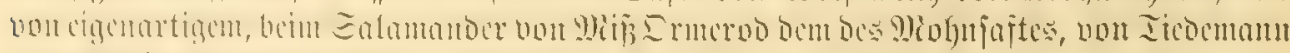

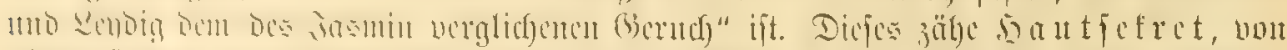

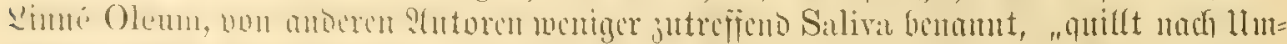

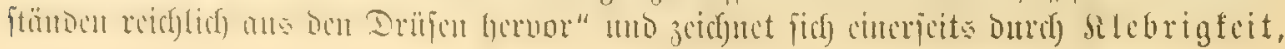




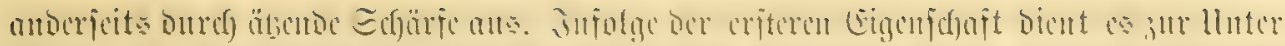

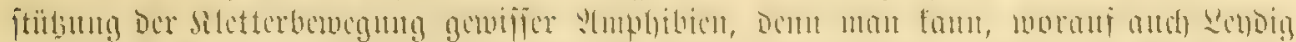

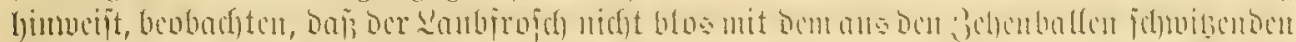

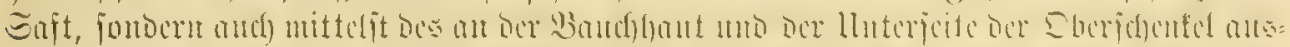

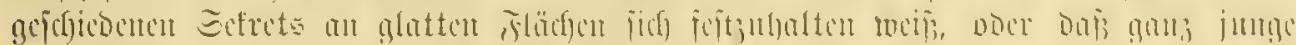

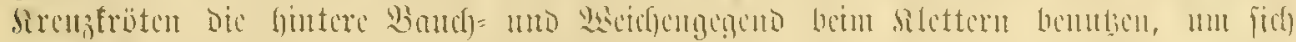

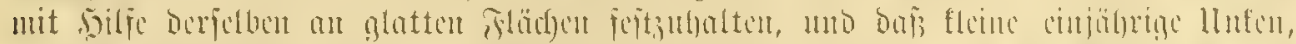

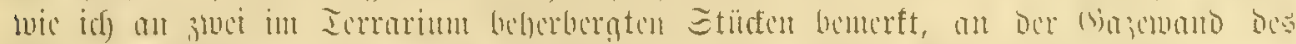

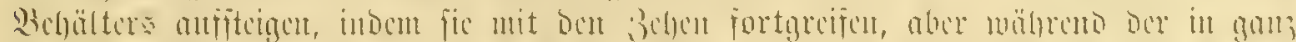

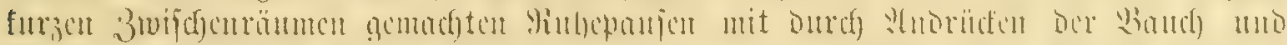

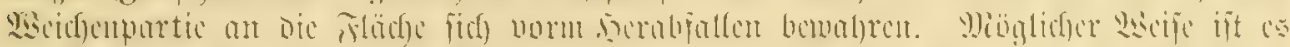

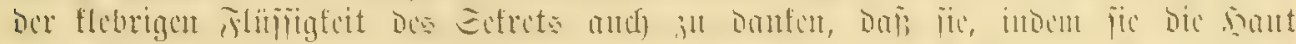

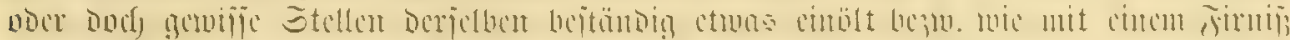

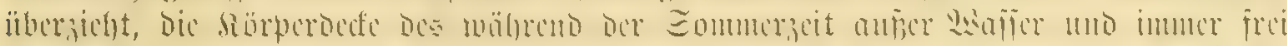

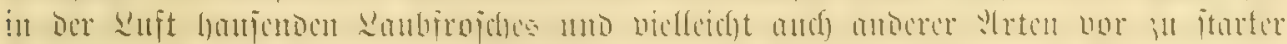

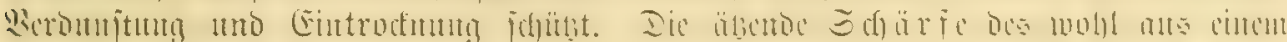

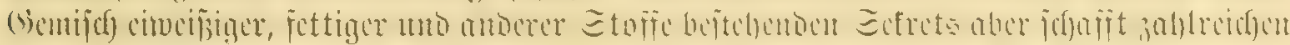

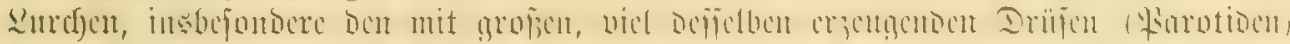

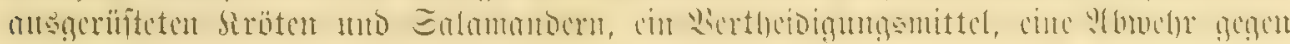

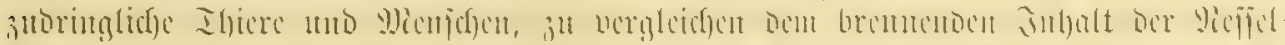

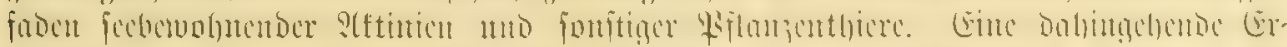

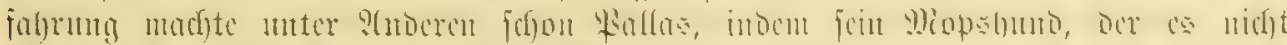

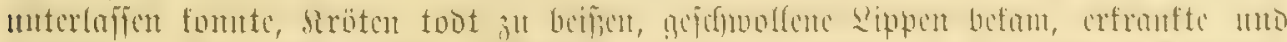

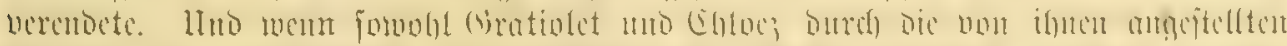

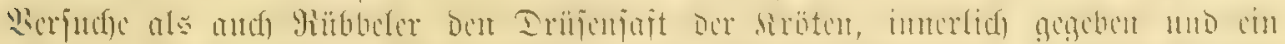

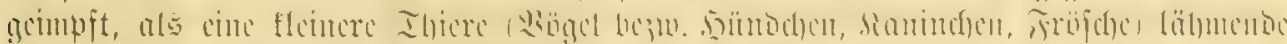

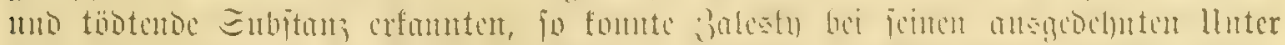

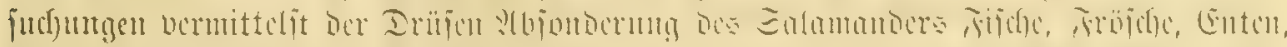

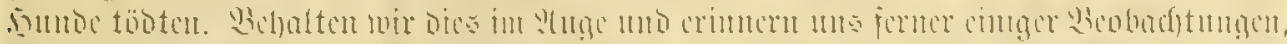

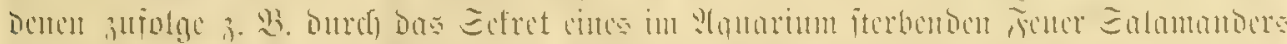

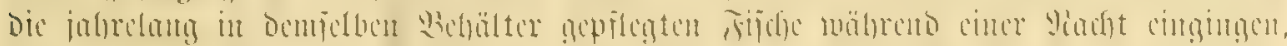

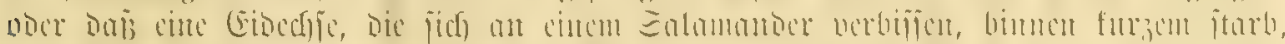

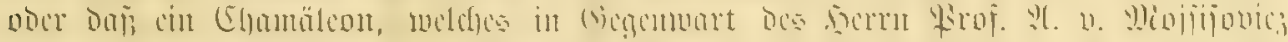

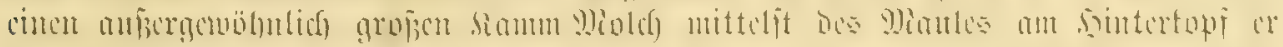

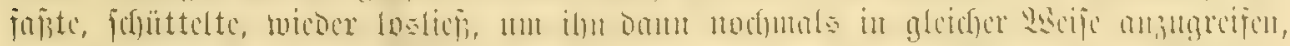

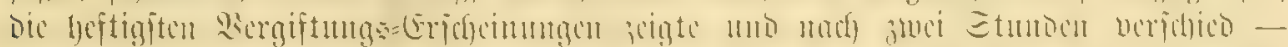

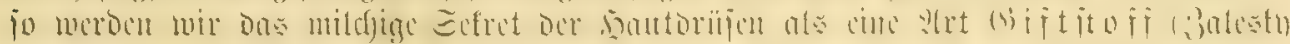

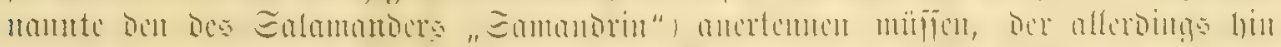

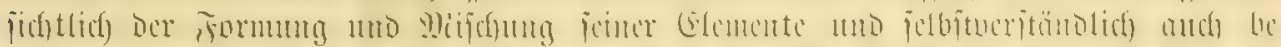

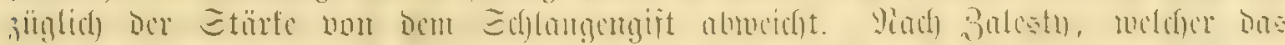

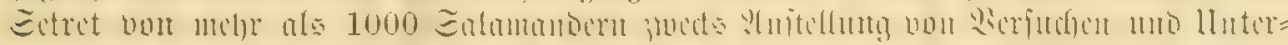

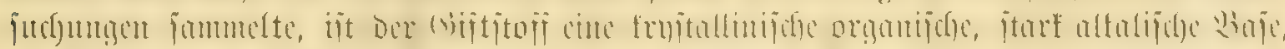

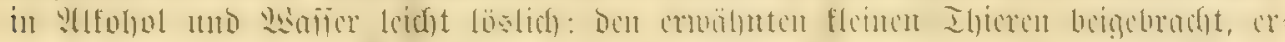

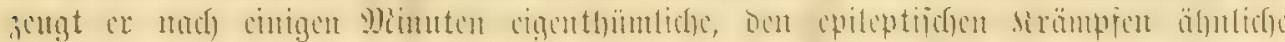

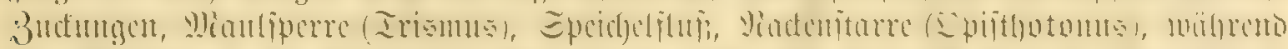

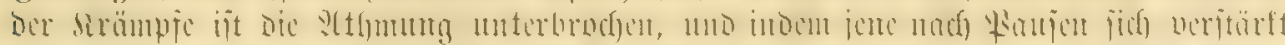

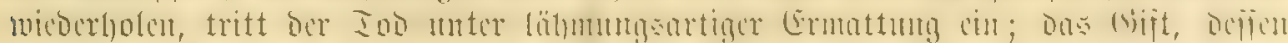

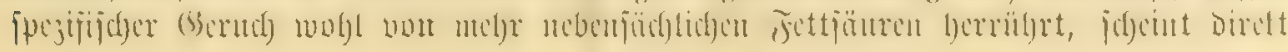




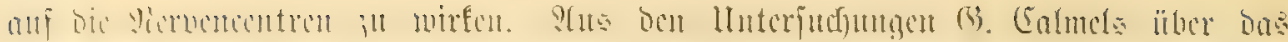

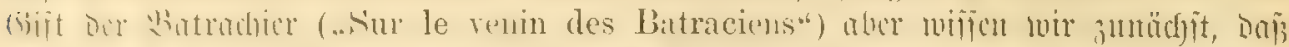

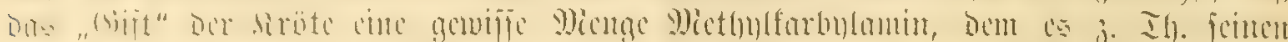

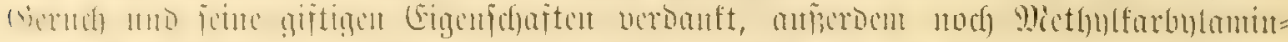

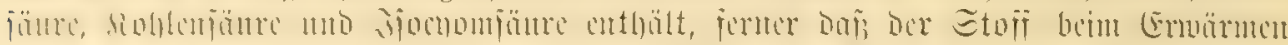

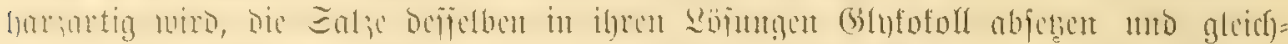

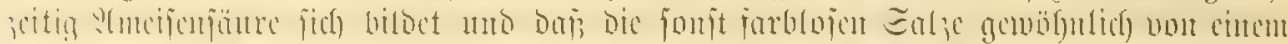

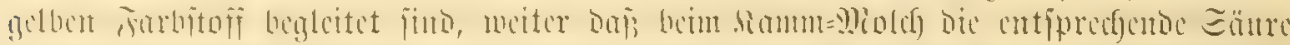

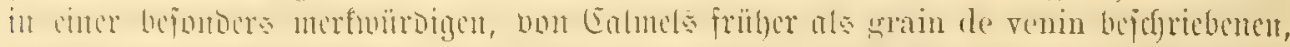

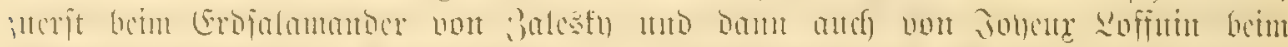

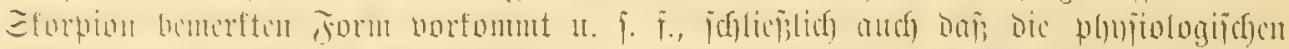

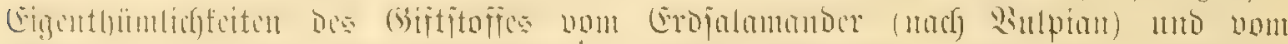

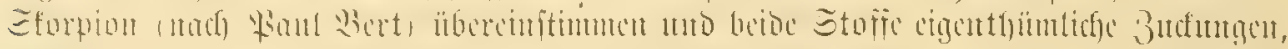

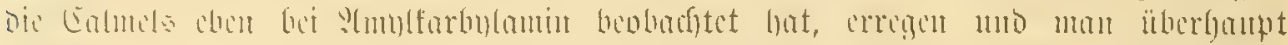

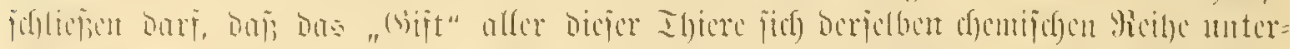

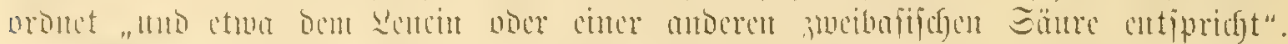

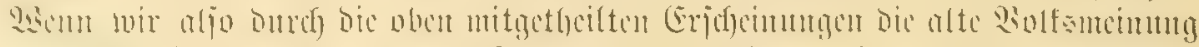

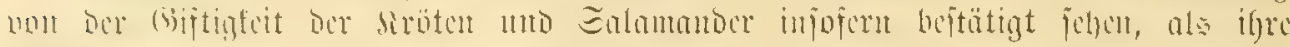

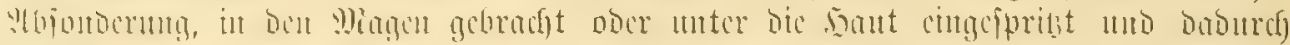
ins

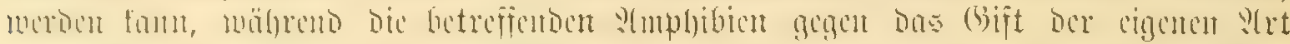

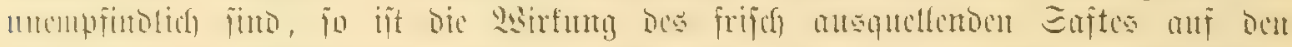

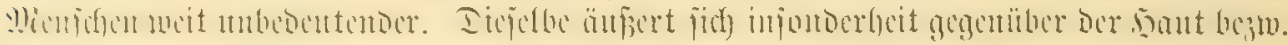

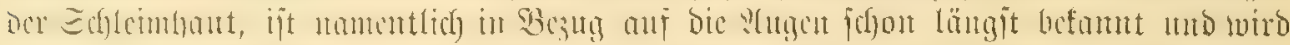

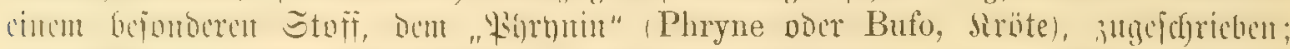

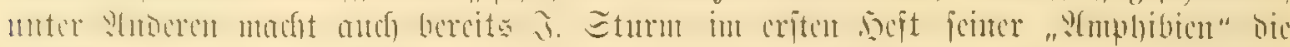

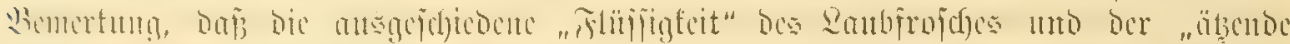

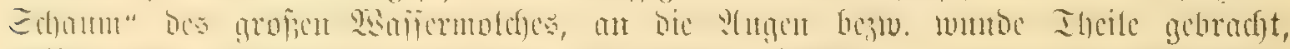

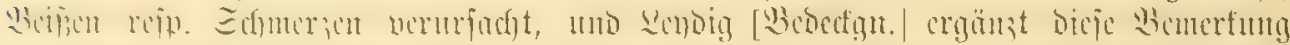

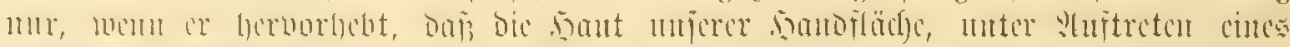

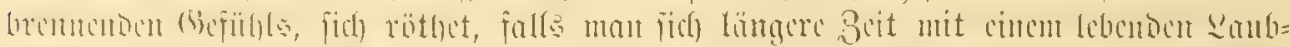

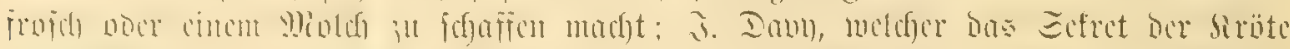

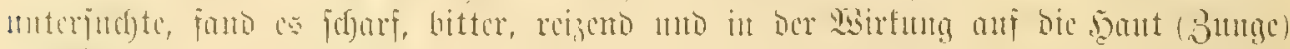

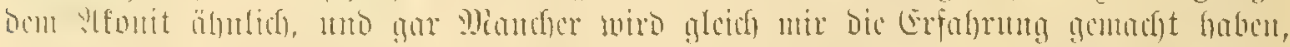

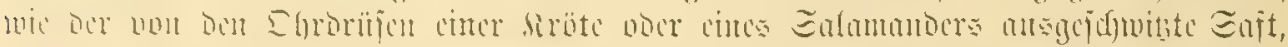

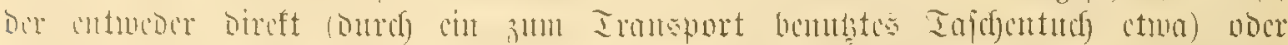

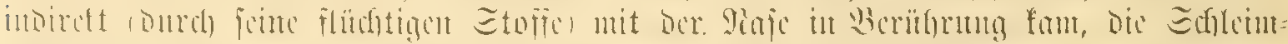

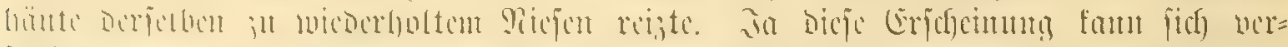

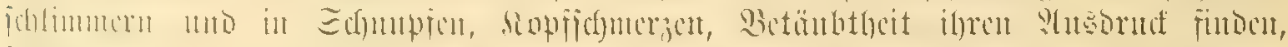

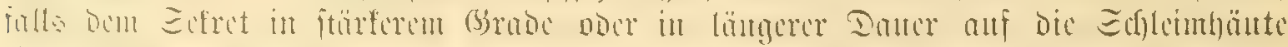

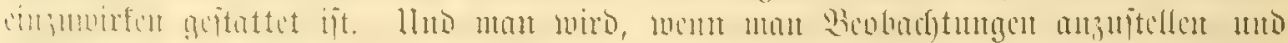

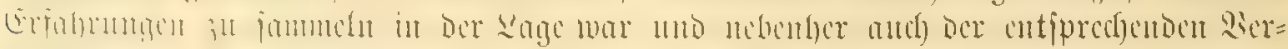

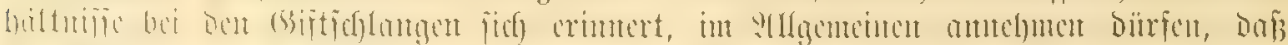

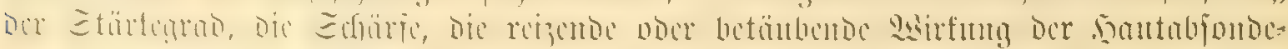

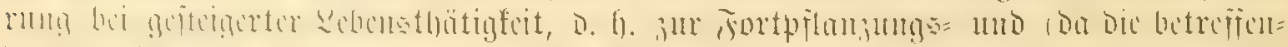

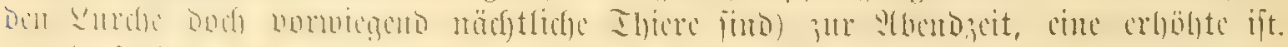

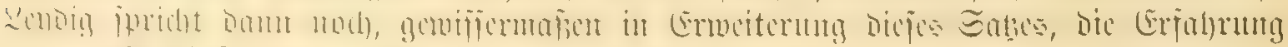

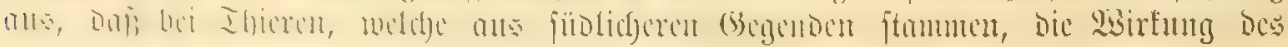




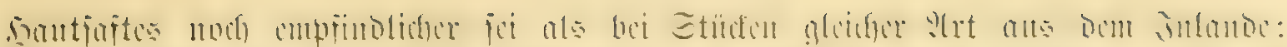

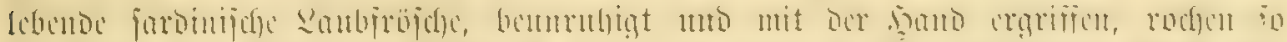

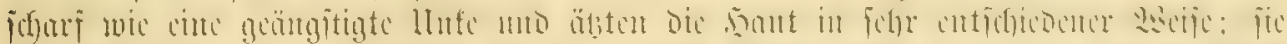

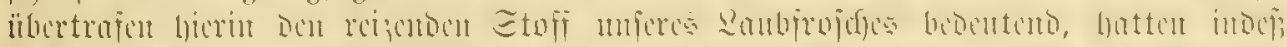

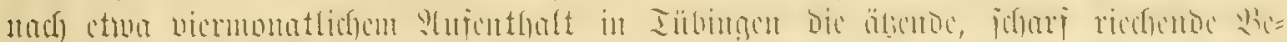

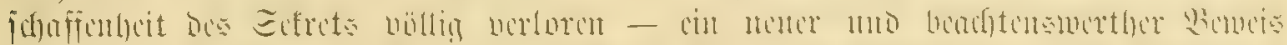

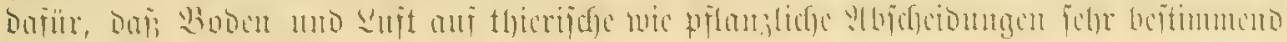
cim\}แ

E.

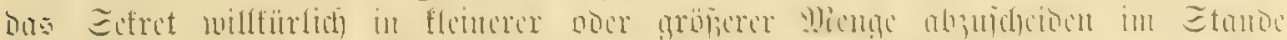

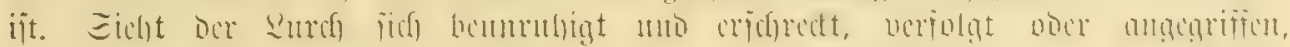

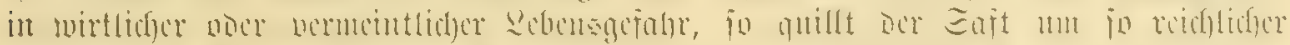

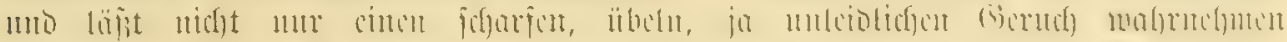

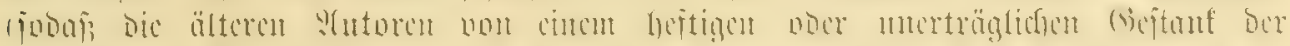

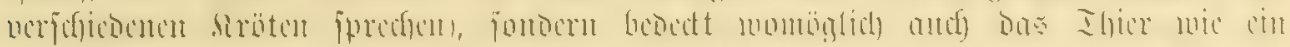

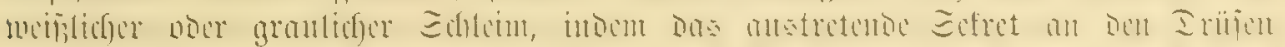

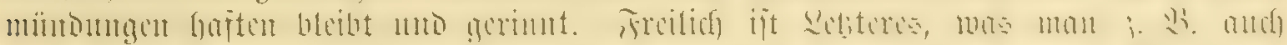

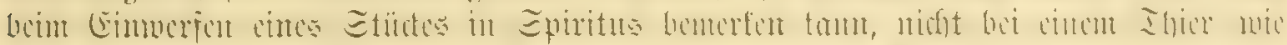

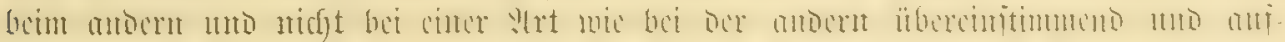

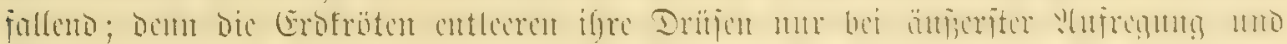

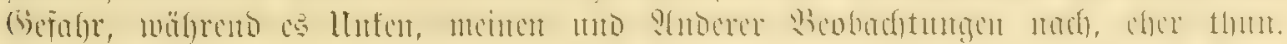

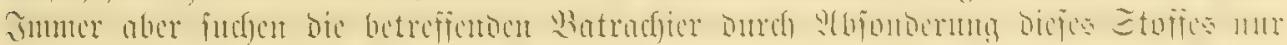

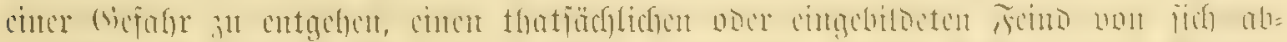

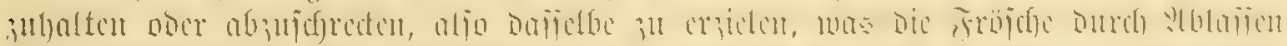

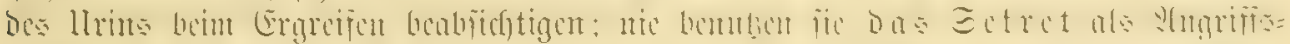

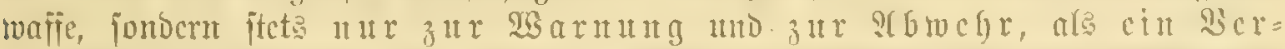

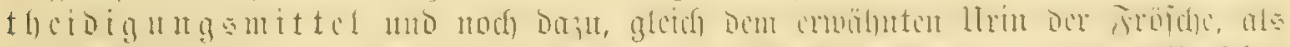

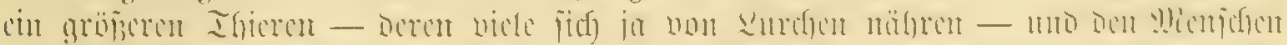

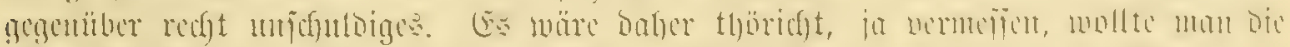

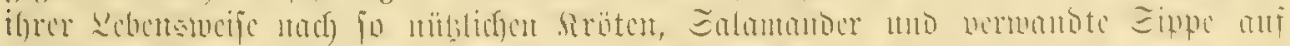

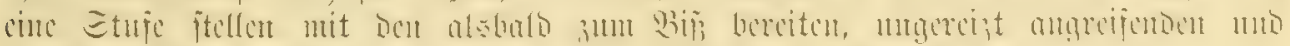

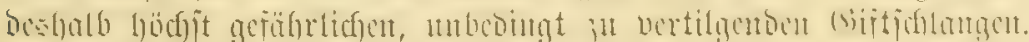

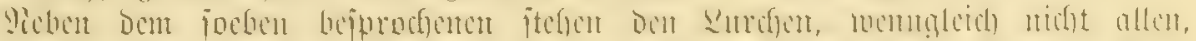

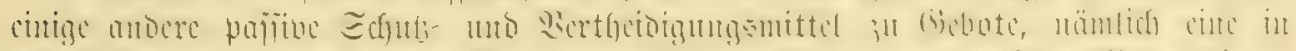

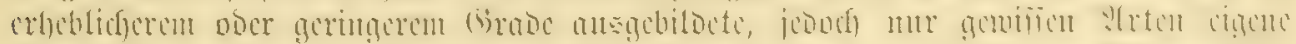

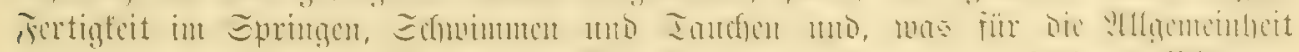

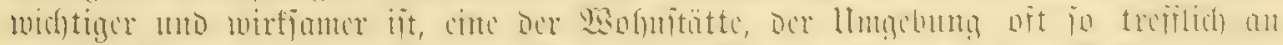

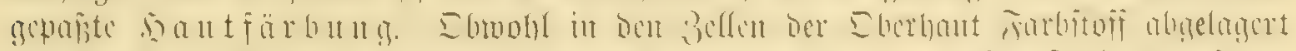

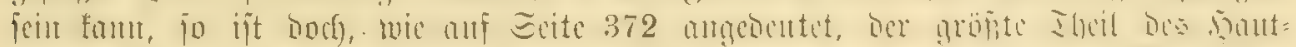

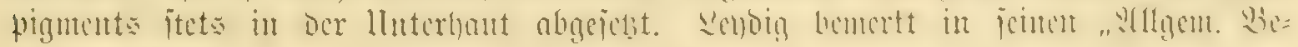

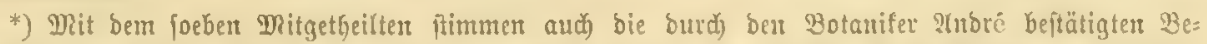

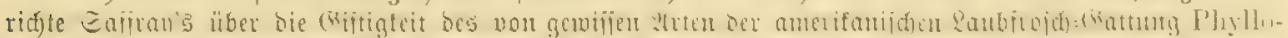

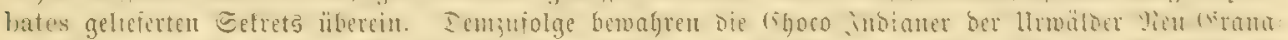

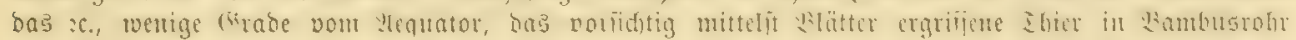

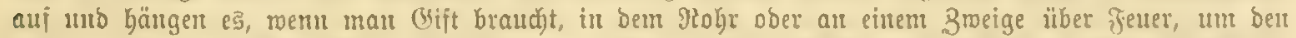

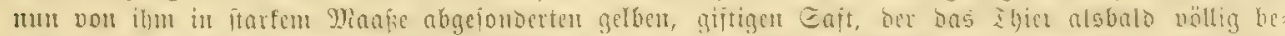

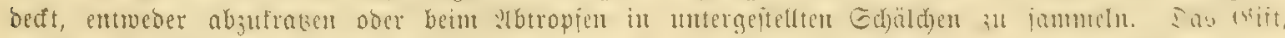

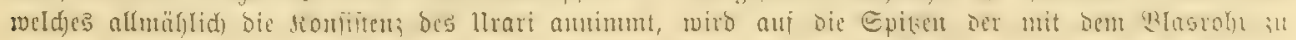

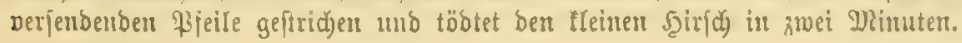




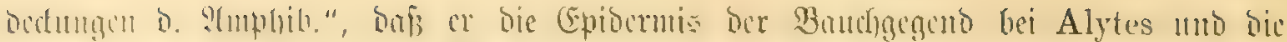

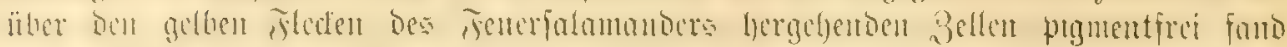

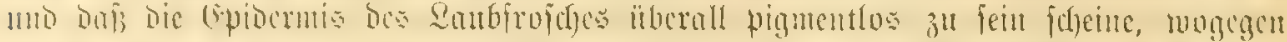

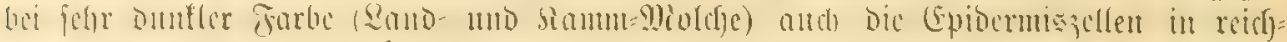

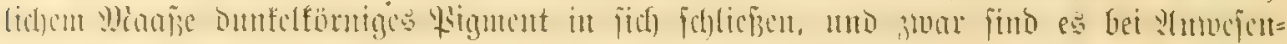

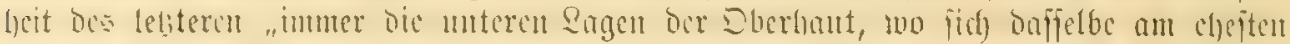

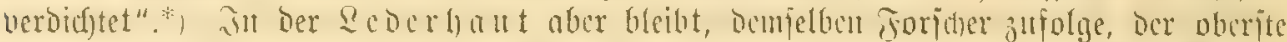

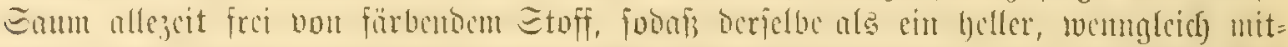

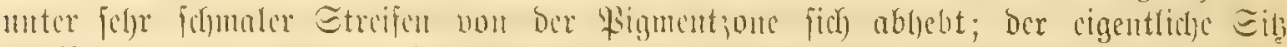

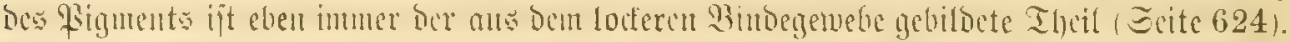

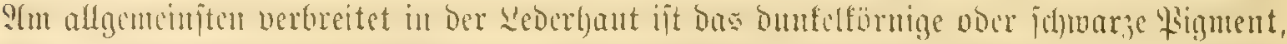

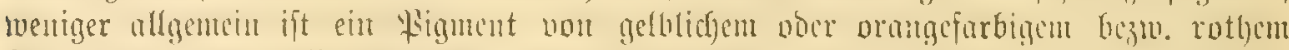

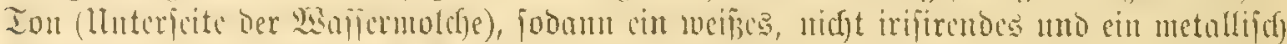

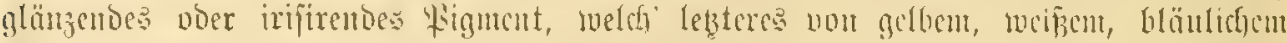

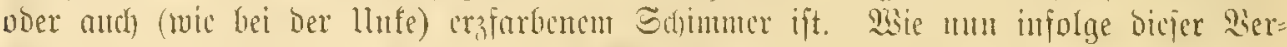

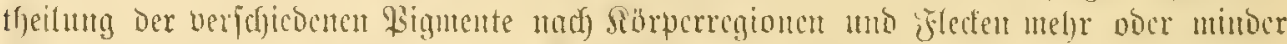

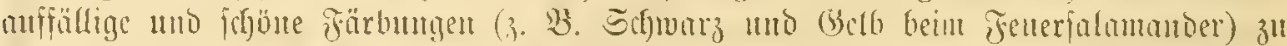
Etmose tommen, fo beruben antere Färbungen, numentlidg gritue mo blanc, mno

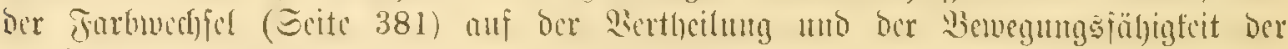
veräftelten fontraftilen Farbzellen ober Chrontatophoren.

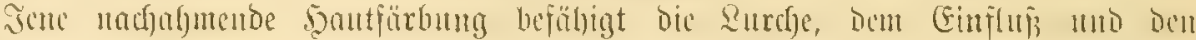

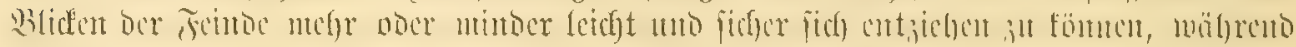

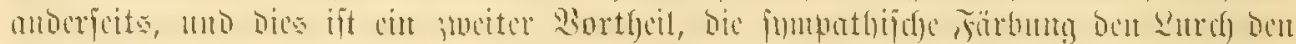
")

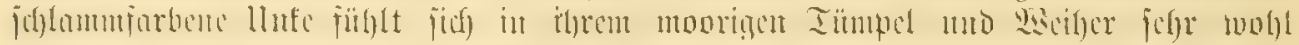

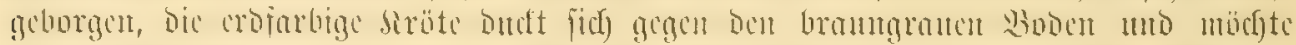

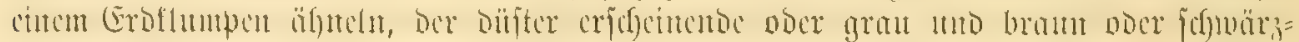

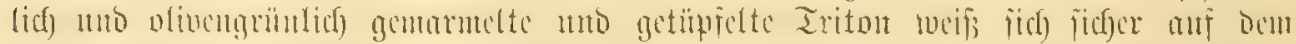

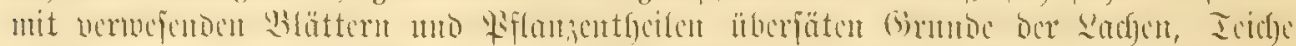

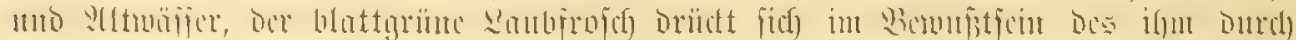

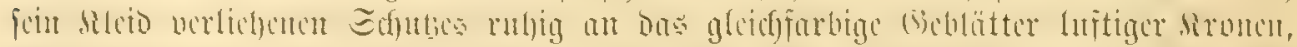

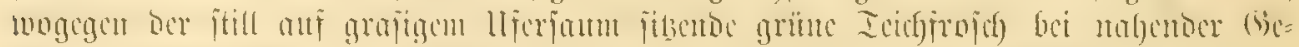

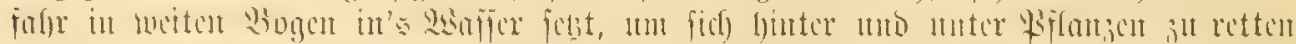

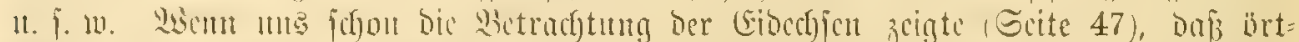

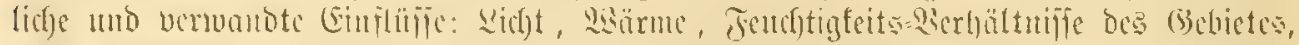

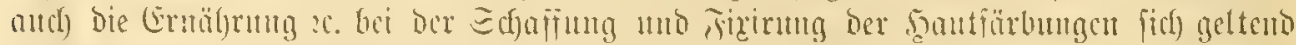

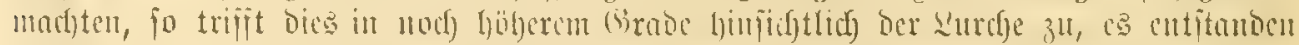

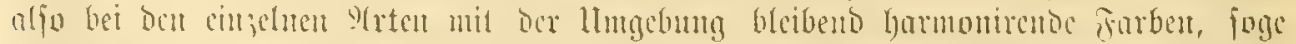

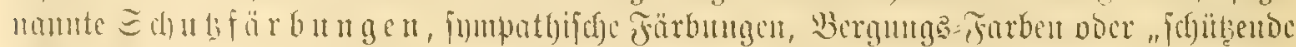

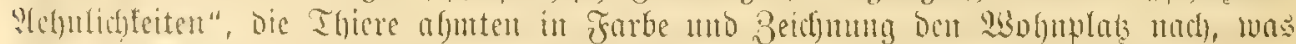

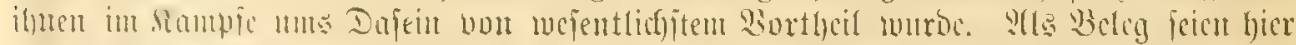

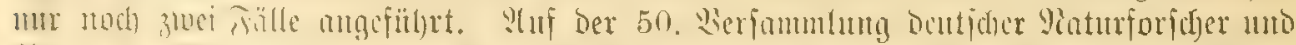

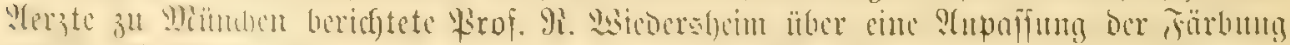

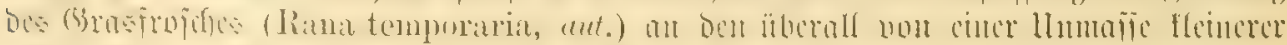

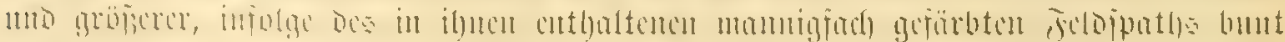

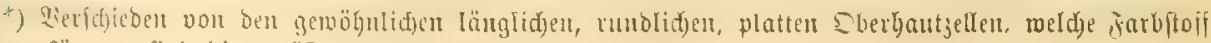
enthalten fömen, finto bie veräftelten beroeglidjen Ggromatopgoren. 


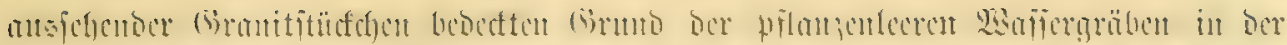

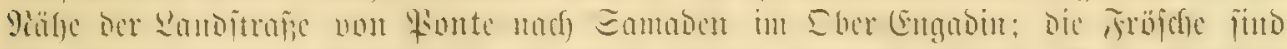

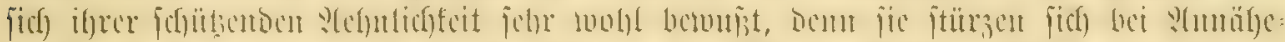

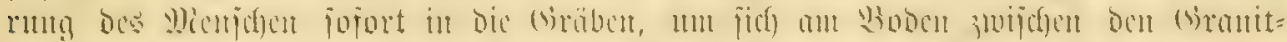

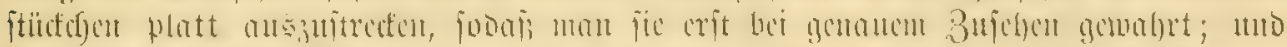

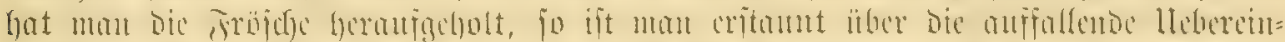

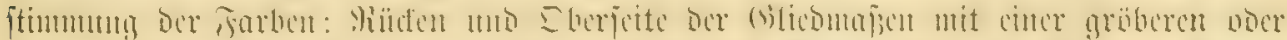

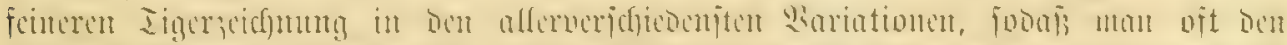

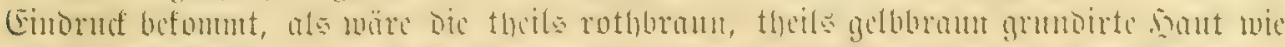

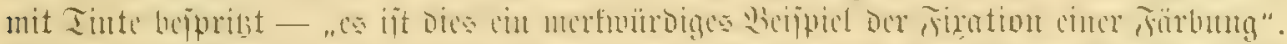

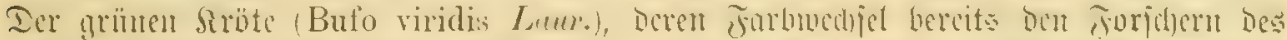

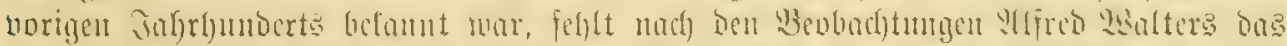

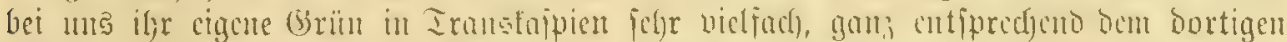
hänfigen ?tuftreten cines hellen

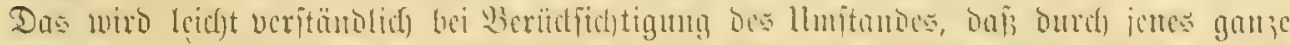

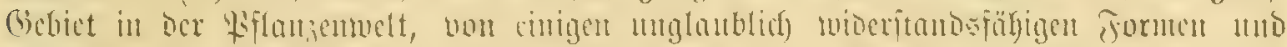

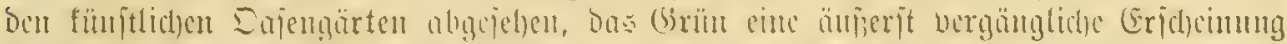

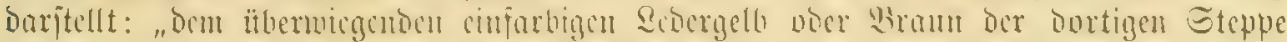

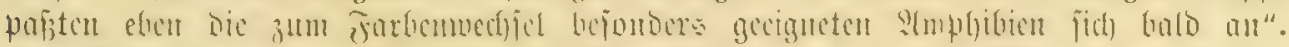

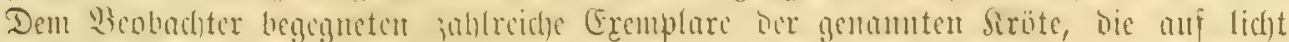

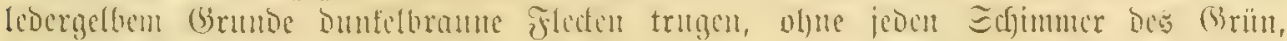

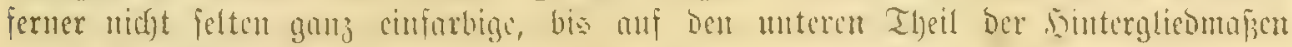
ungcfledte Gtüde u. \%. w.

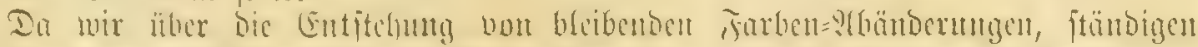

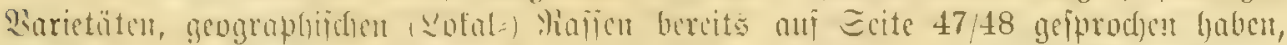

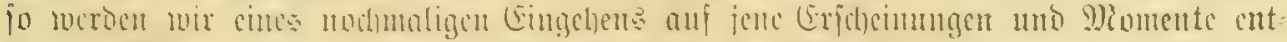

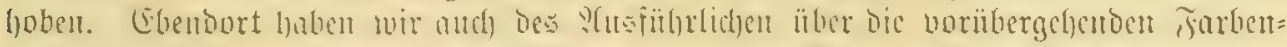

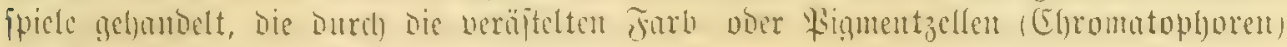
ber Saut bebingt tocrocn, toclche auf ge= เviffe Yicize Giu, bezu. unter Den Eutfup Deg 9erveninftems fici) zufammenzuzichen แnD aแรzubriten, höhor gegen bie Soaut= obcrfläctje zu itcigen ober in dic Ticfe [idf zurürtłuziehen bermögen. So wirs, menn alle Chromatophoren auzgebehnt fins, (Fig. 41), Braun oder Edjwarz vorfjerrfdjen mo an Stcllen, wo helle Efromatoplyoren gebäuft ftchen, bie Farbe Der leb̨teren ab= änDern; jieben fid) icne zufamun (Fig. 41a und e), wäbrent dic belfct ausgedcbnt blcibcn, fo twiro bic Farbe Der Ielzterent

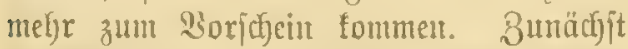

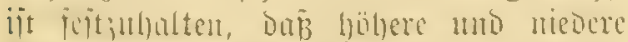
Iemperatur, griperc noer geringere Jeurly=

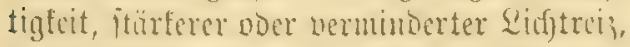

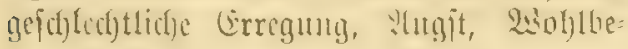
bagen, Utregung Die Stimmug Des

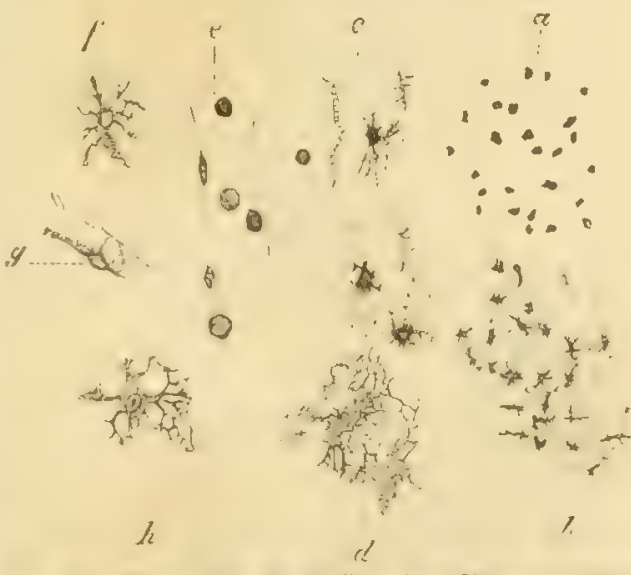

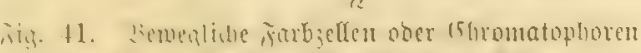

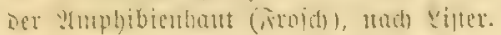

a uns e ut ans :

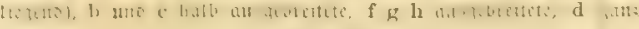
ant?, il tillute.

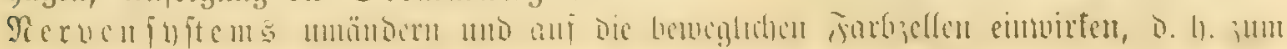




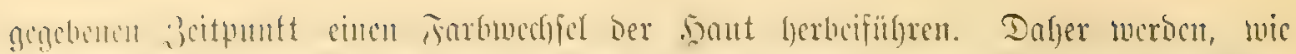

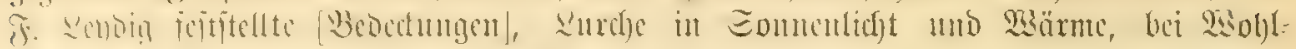

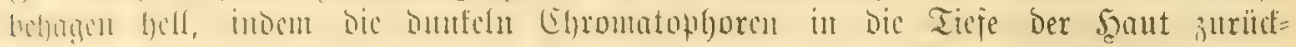

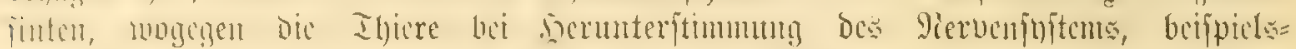

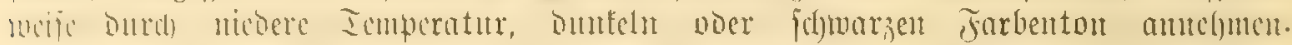

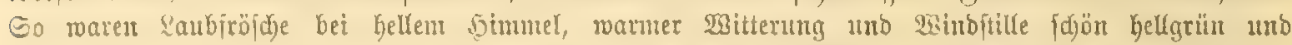

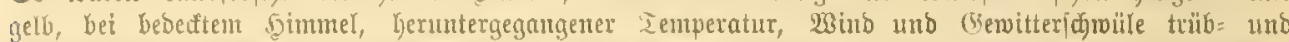

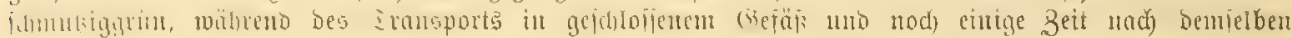

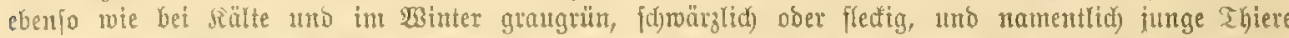

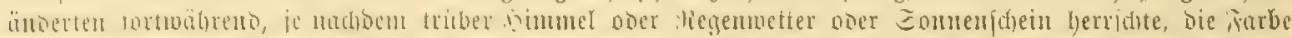

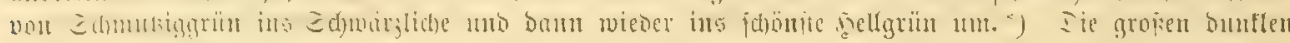

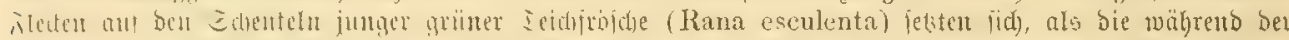

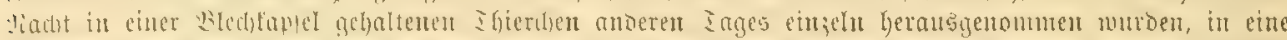

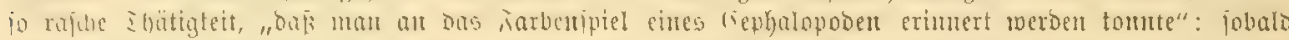

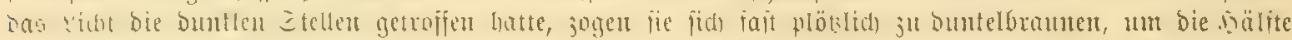

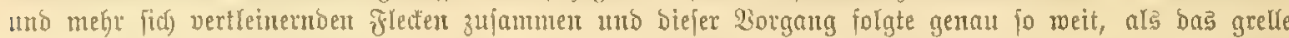

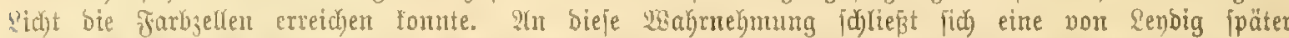

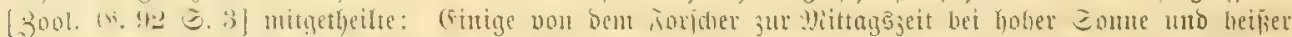

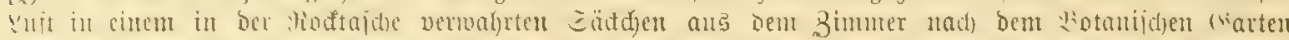

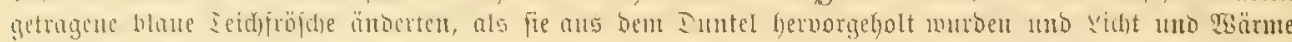

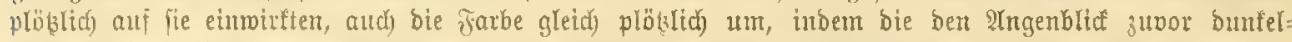

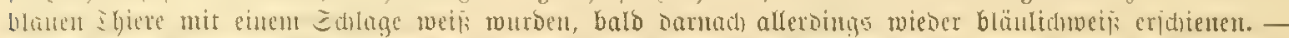

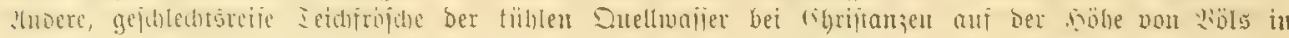

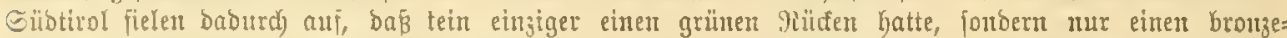

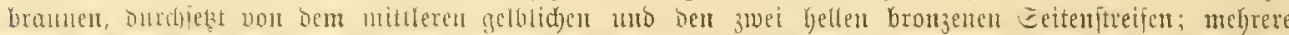

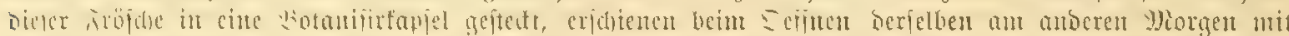

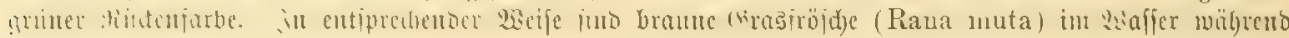

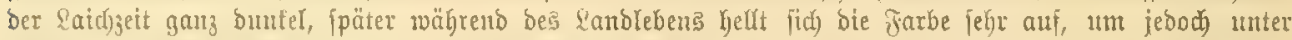

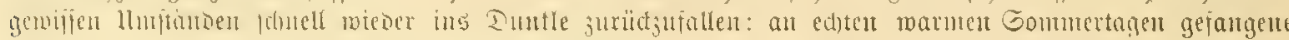

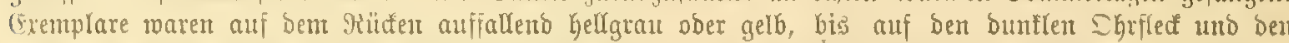

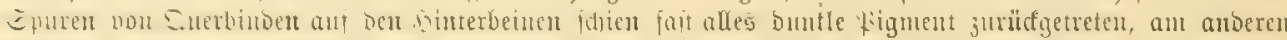

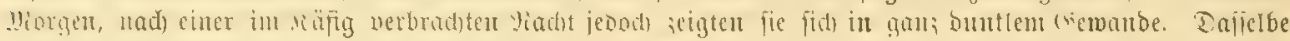

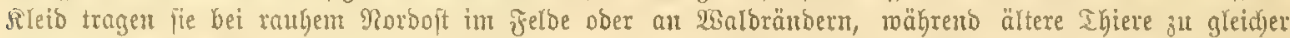

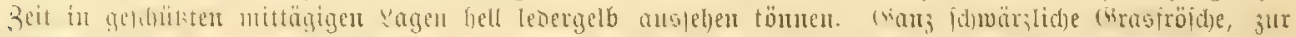

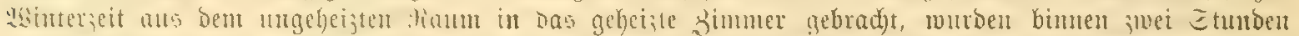

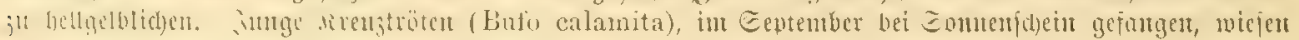

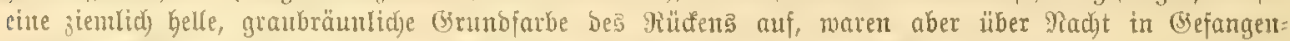

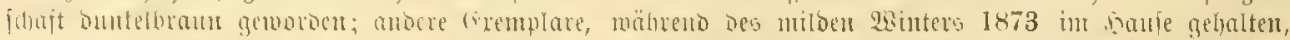

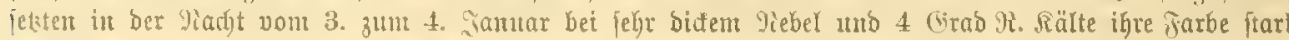

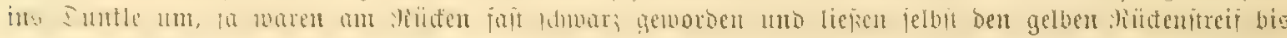

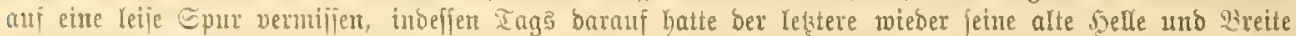

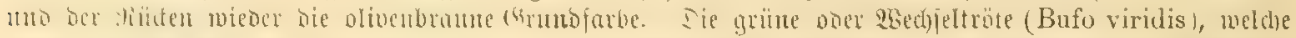

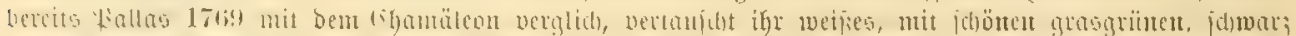

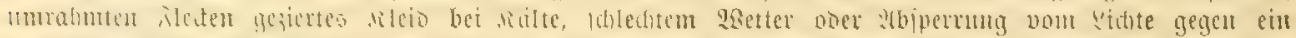

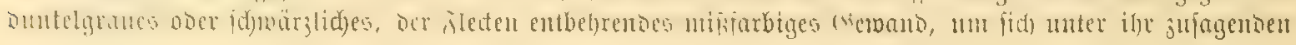

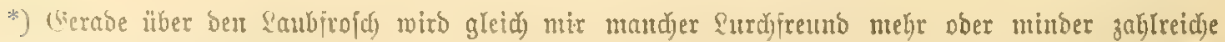
uno auffallenbe Beobadiungen gemadjt baben. (Eine bet abfonberlidjten ift bie non Dr. E. Bubbe

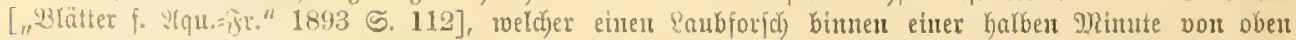

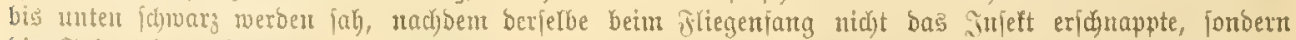

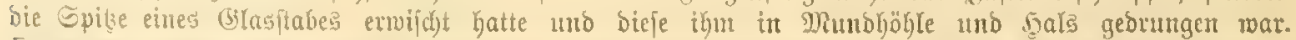

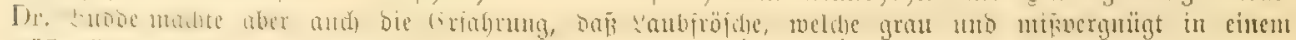

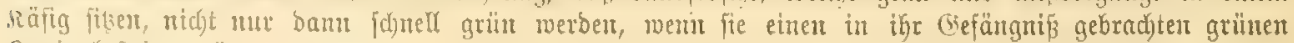
3wetig befteigen tönnen, fonbenn and ban, weln fie auf bem 3weige herumffettem fömen, ohne ifn

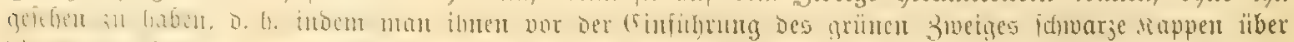

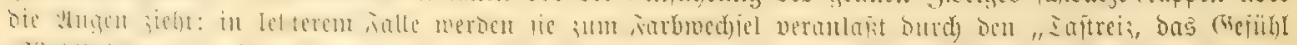

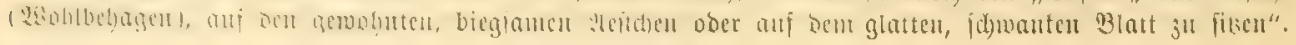




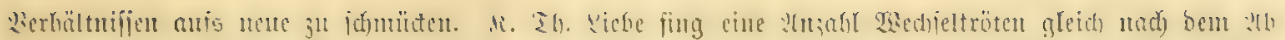

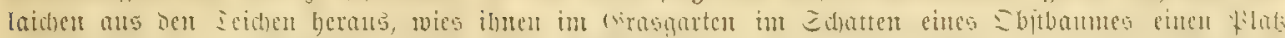

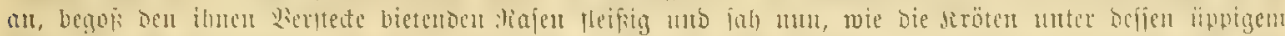

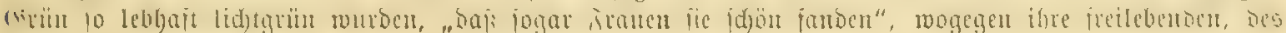

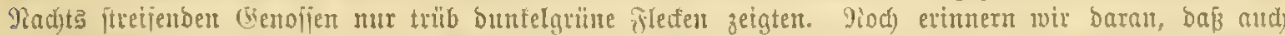

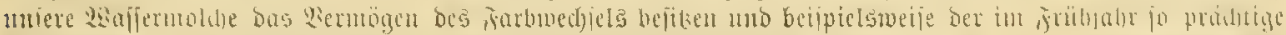

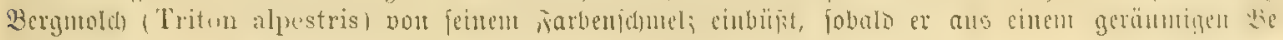

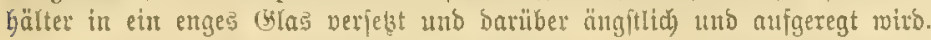

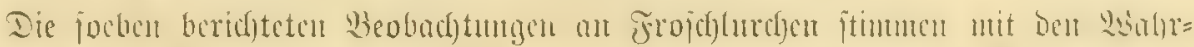

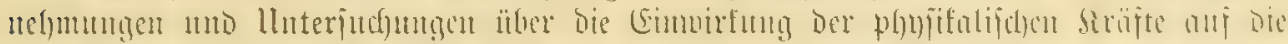

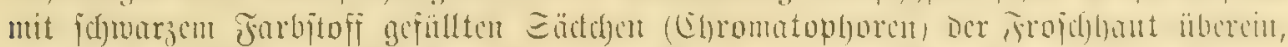

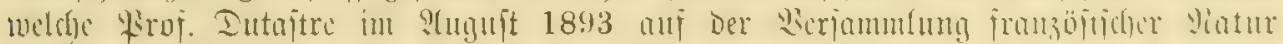

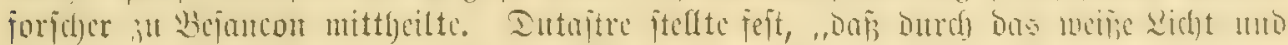

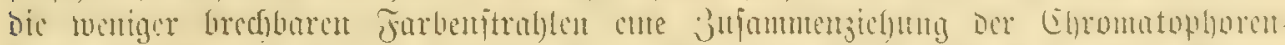

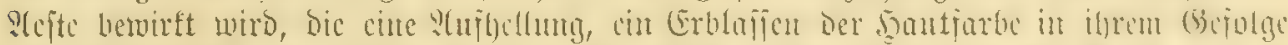

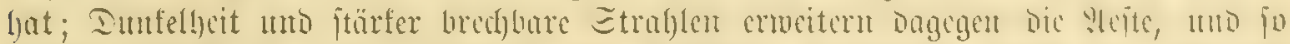

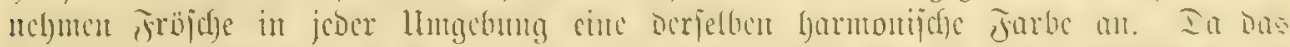

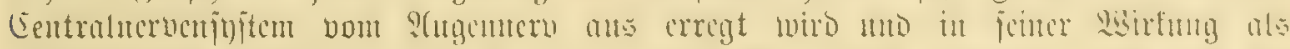

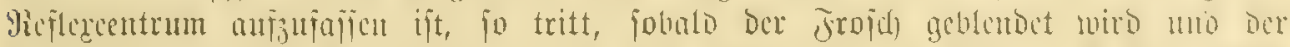

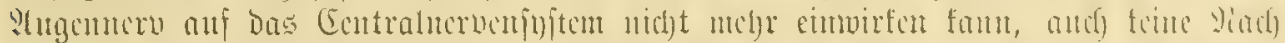

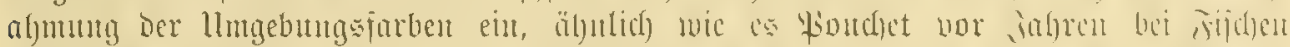

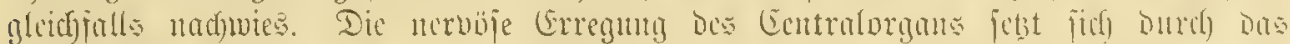

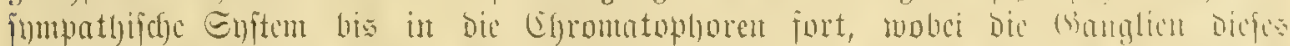

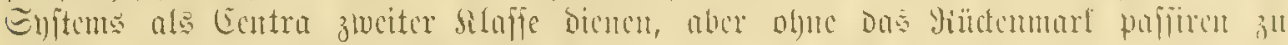

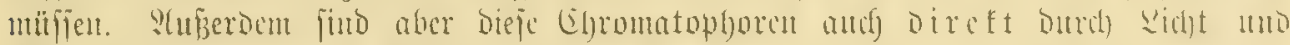

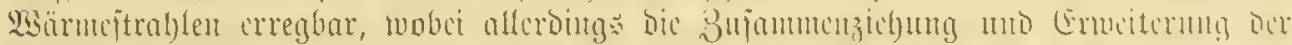

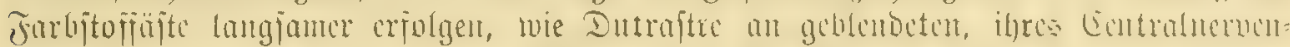

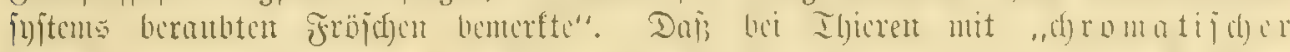

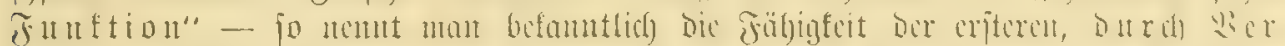

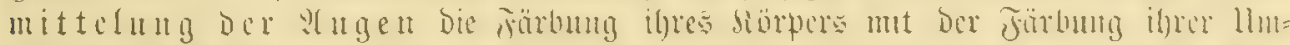

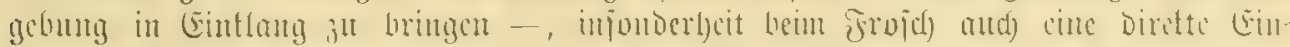

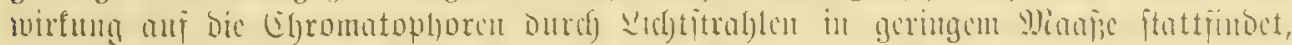

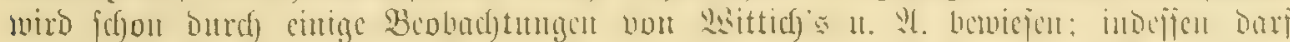

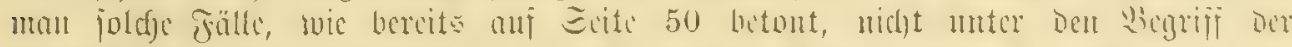

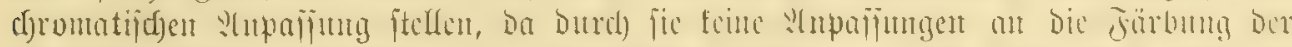

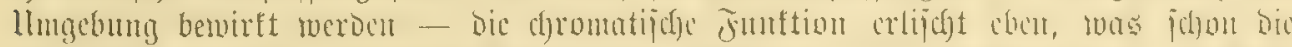

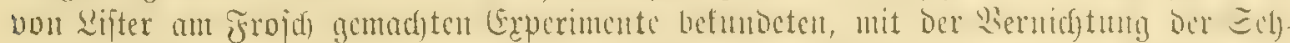

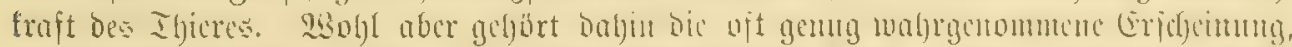

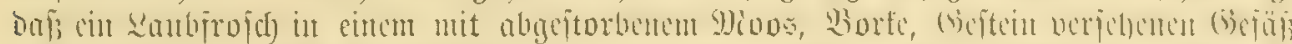

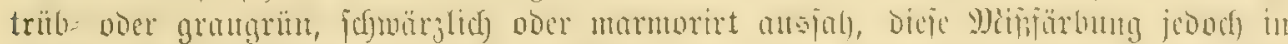

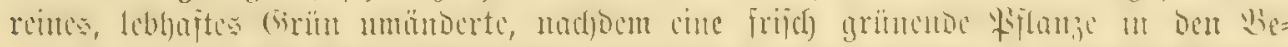

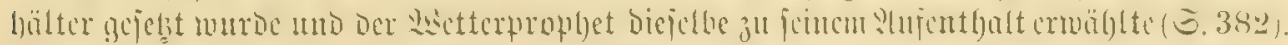

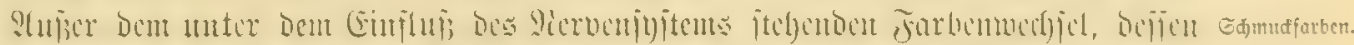

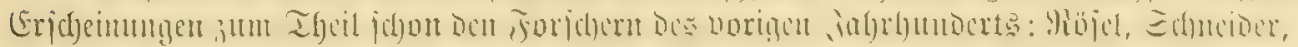

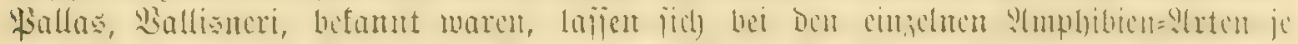

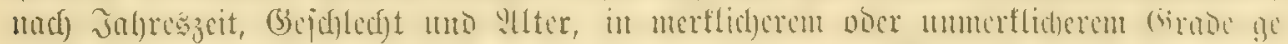
svijfe förbungs:

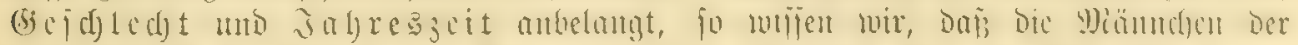

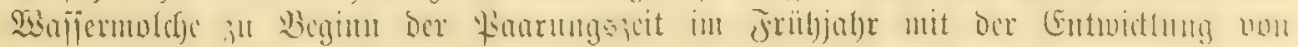




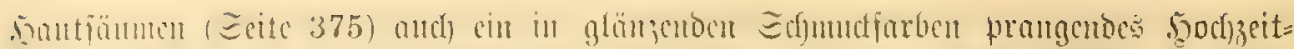

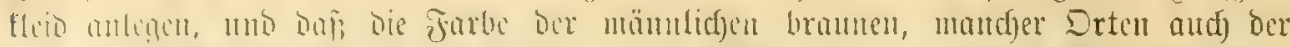

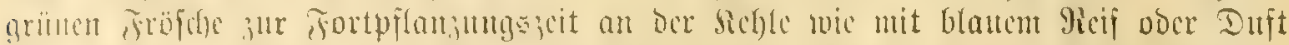

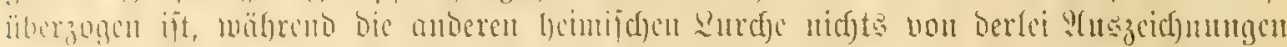

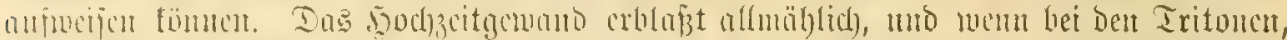

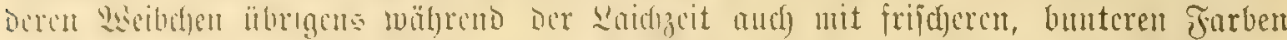

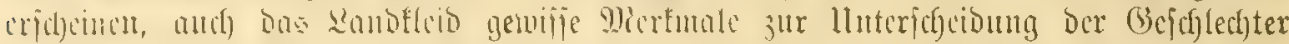

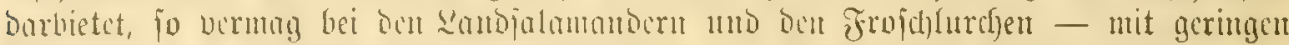

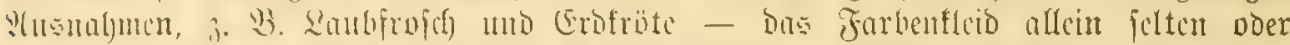

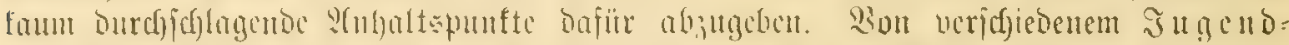

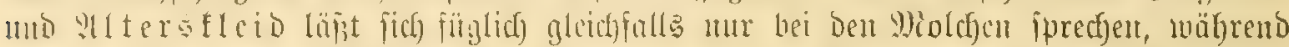

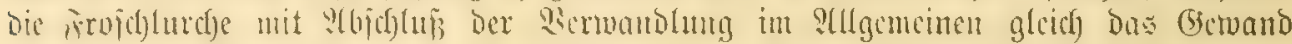
ber erwadfenen Thicre anthun.

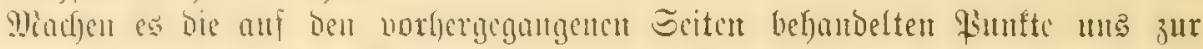

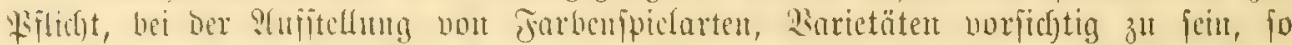

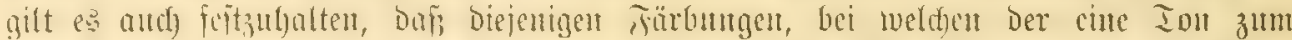

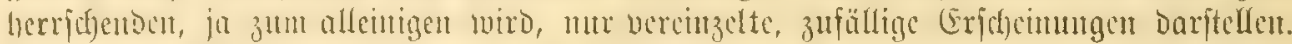

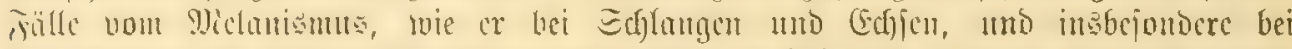

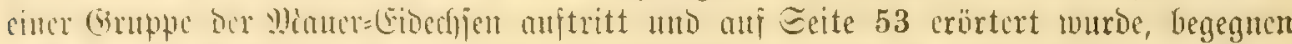

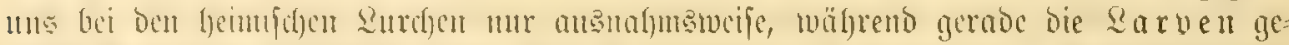

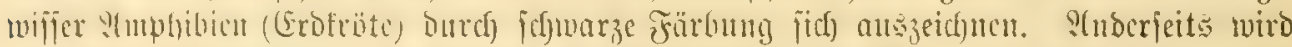

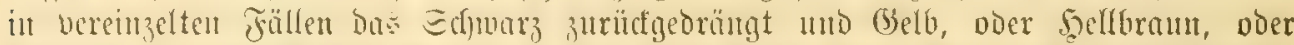

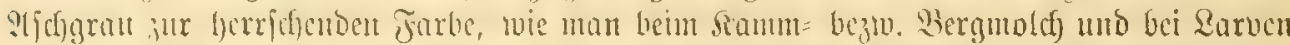

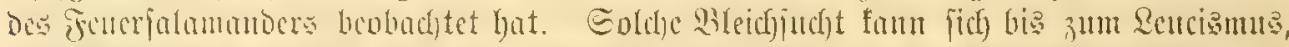

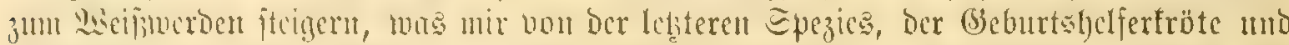

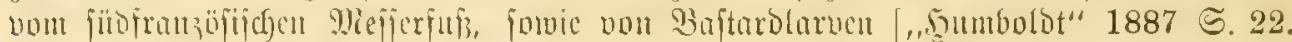
168] befaunt gerworden ift.

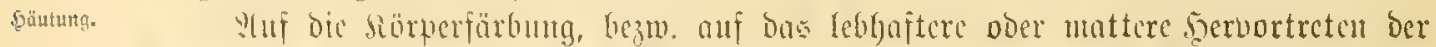

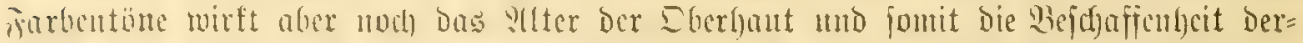

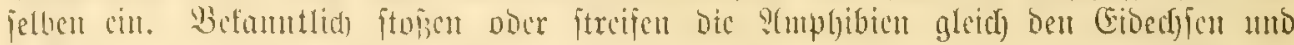

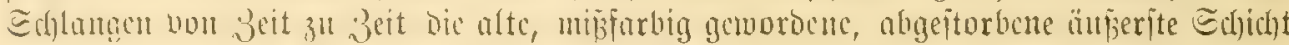

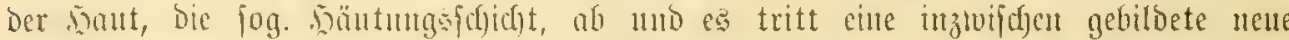

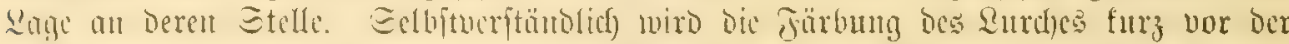

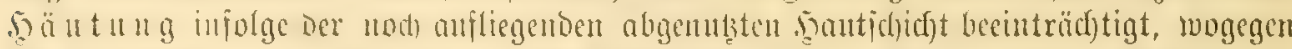

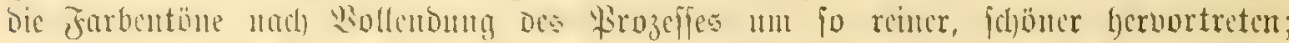

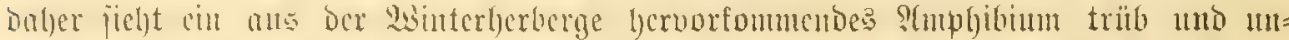

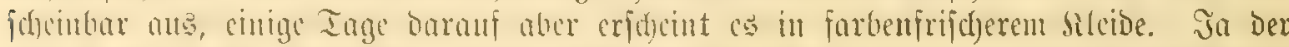

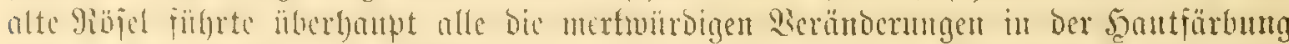

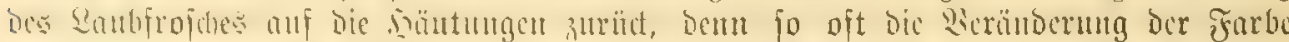

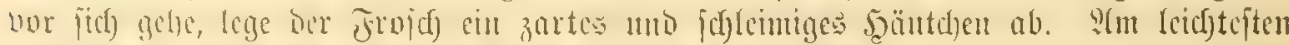

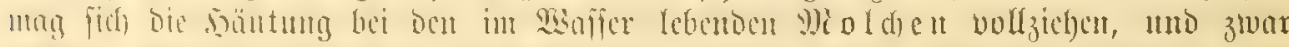

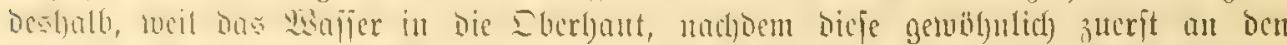

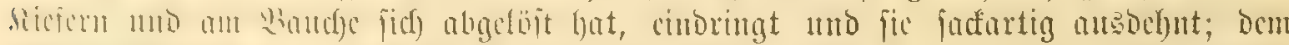

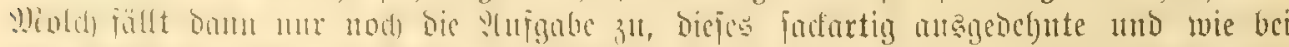

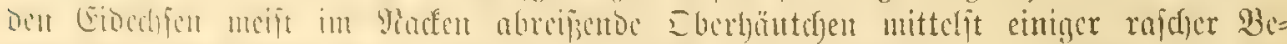

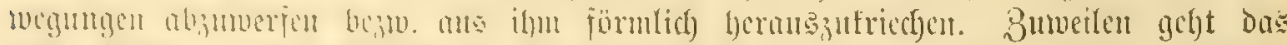

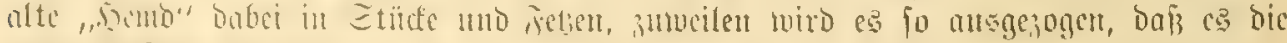

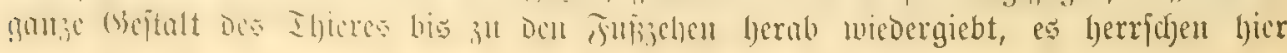




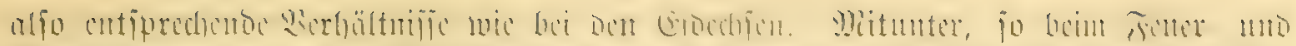

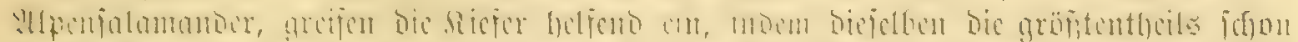

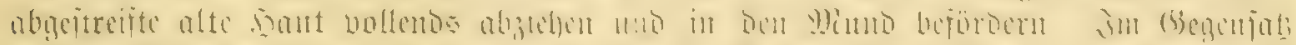

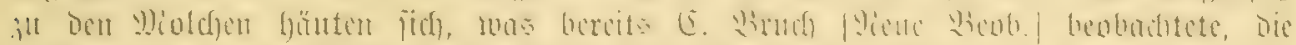

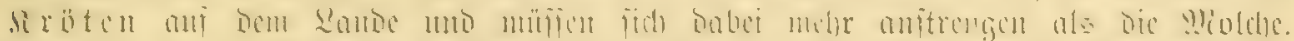

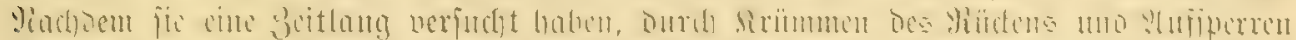

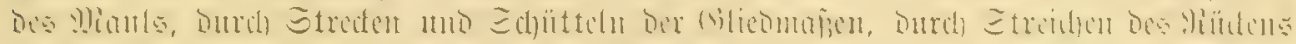

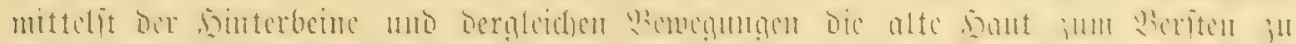

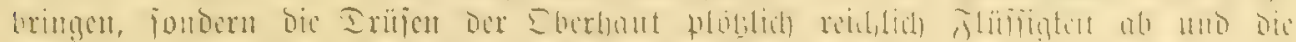

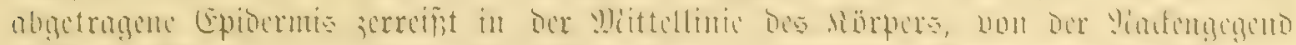

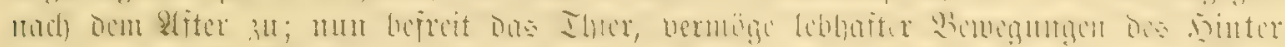

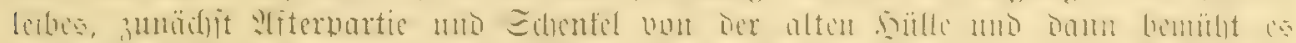

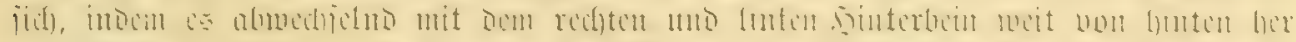

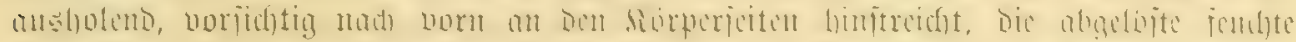

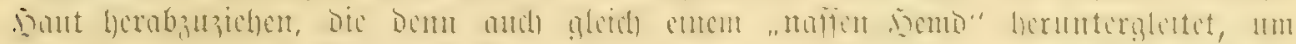

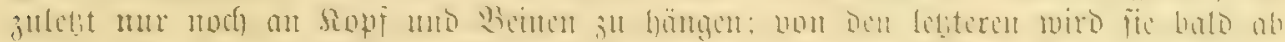

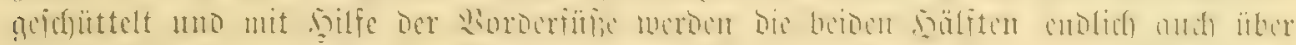

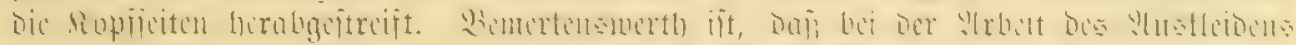

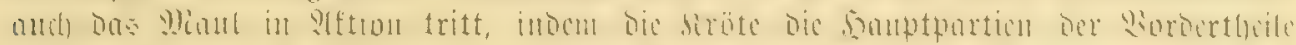

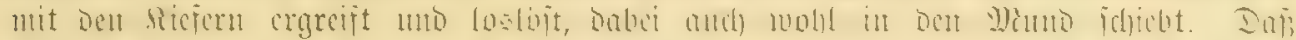

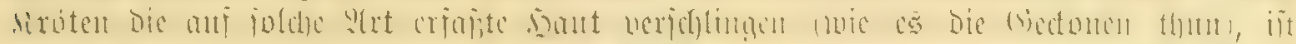

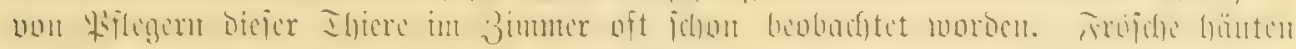

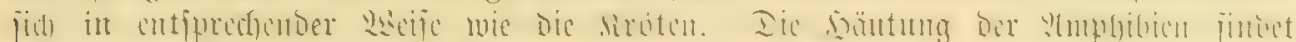

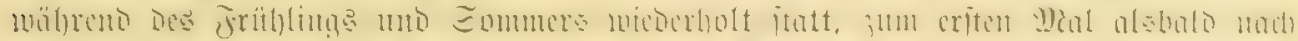
Dem gebert cin.

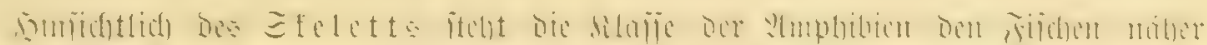

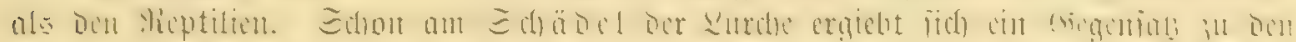

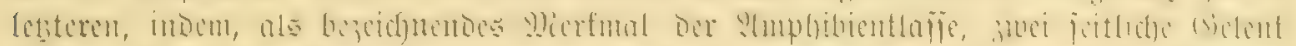

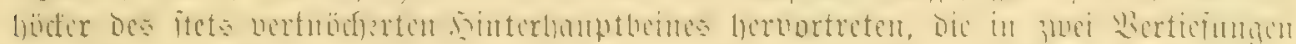

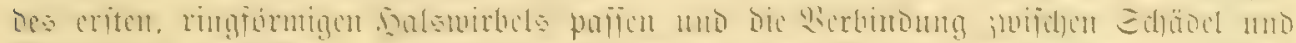

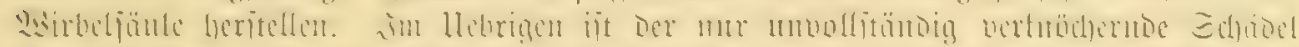

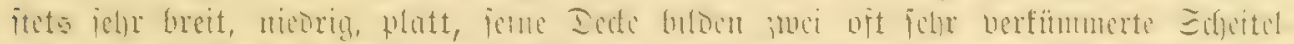

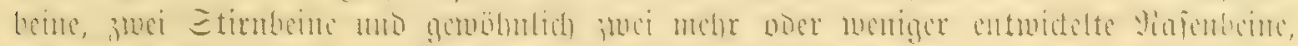

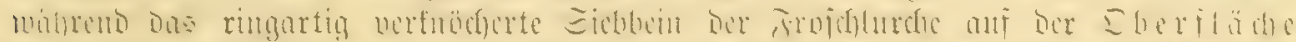

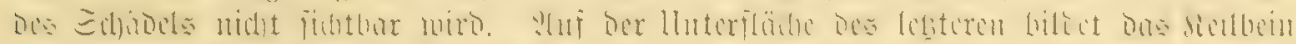

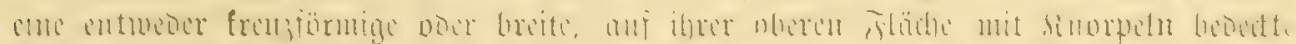

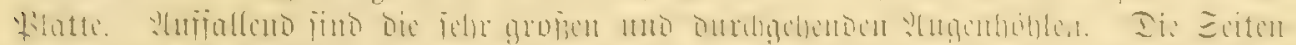

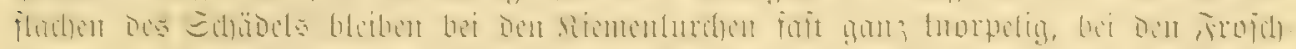

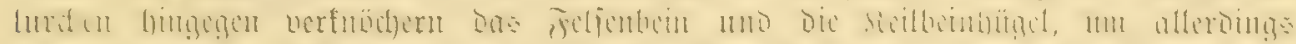

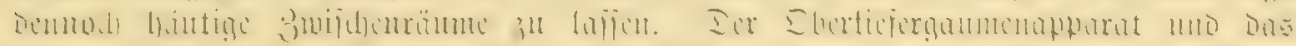

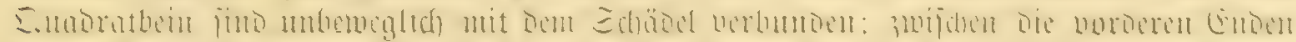

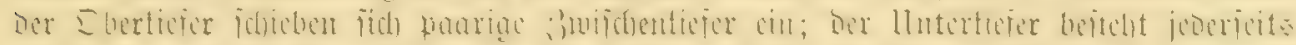

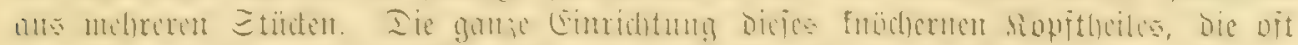

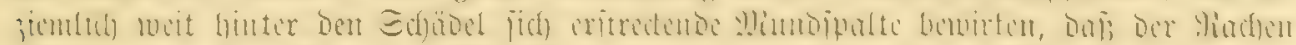

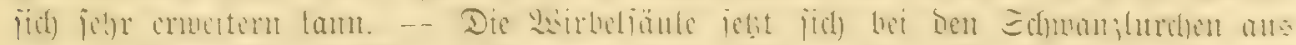

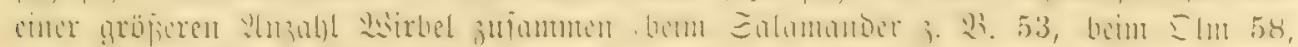

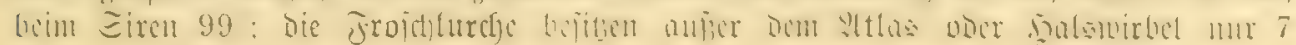




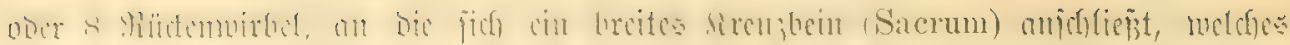

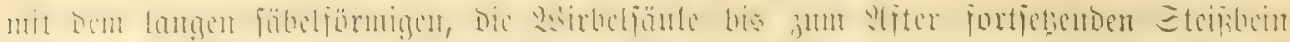

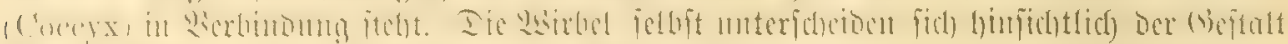

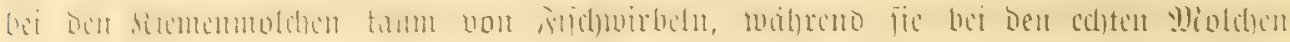

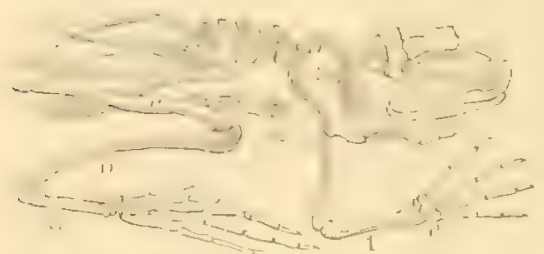

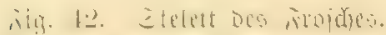

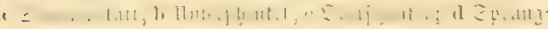

uto Secjentein; e sanbiurzel; f llnterazm. bercita völige :Awbildung cxjafyrent baben, vorn cinen rumben Gielentfopf, Gunten eine Pुfamme auf= tweifcu und oaburch mitcinander gelenten. Die Duer= fortfäłc Der ख̉irbel find bei allen !mphibien gut ausgebildet, ja zutweilen aubcrorbentlid) lang, fodaî fie in getwiffem (Srade die Mippen, dic bet Den

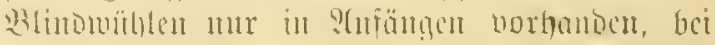

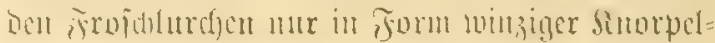
anbänge angebentet futb, erjetzen tönnen uno

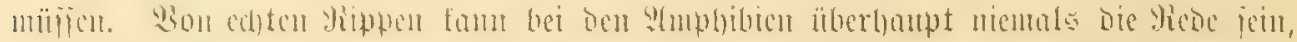

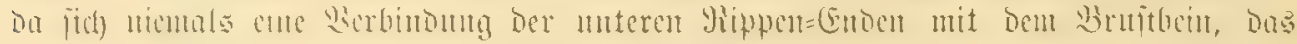

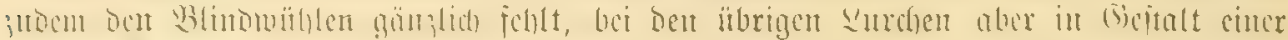

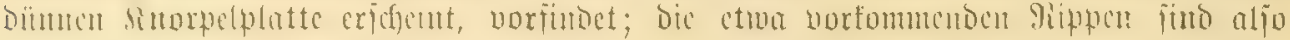

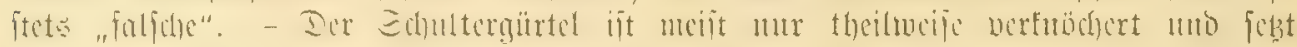

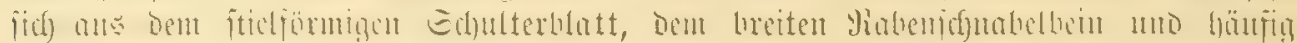

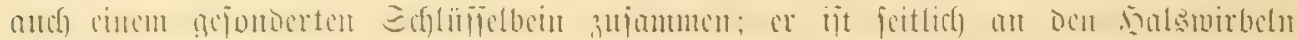

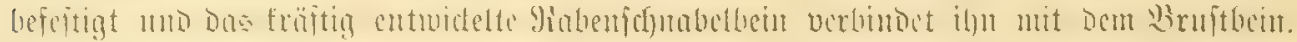

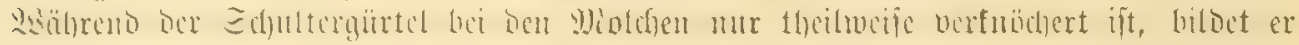

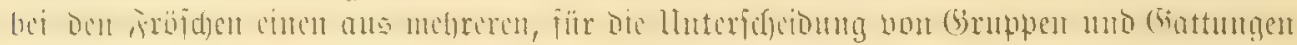

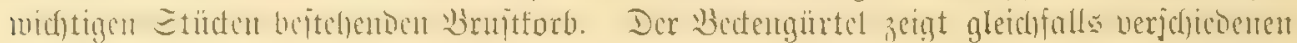

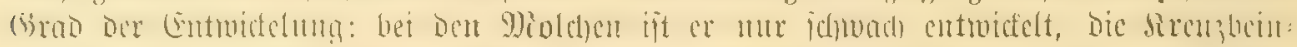

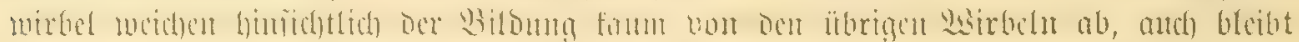

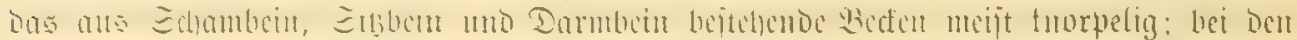

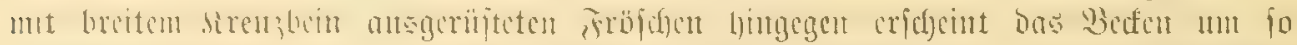

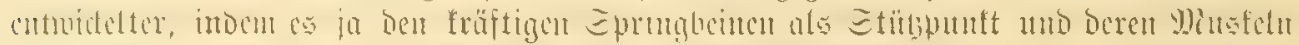

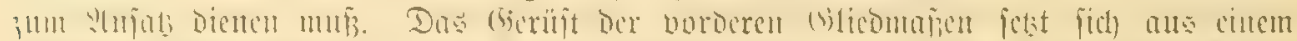

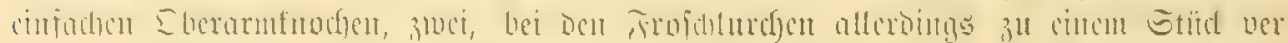

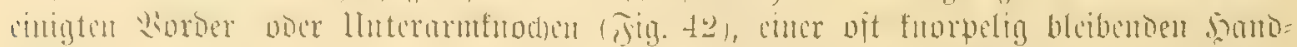

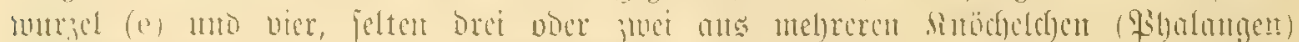

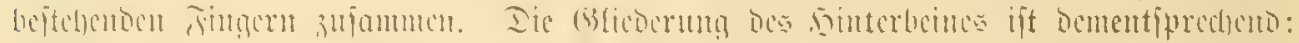

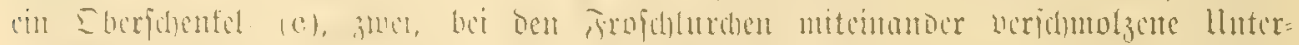

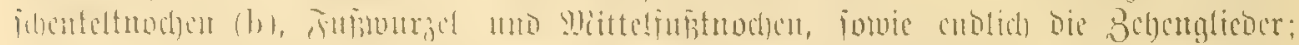

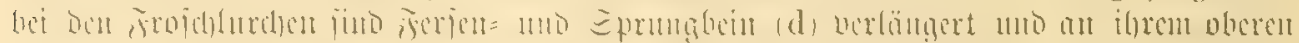

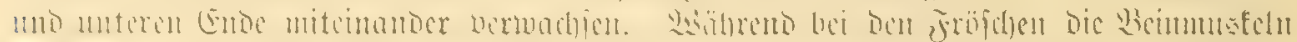

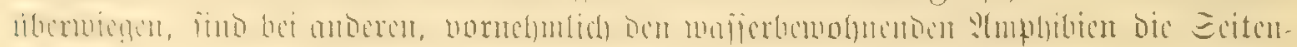

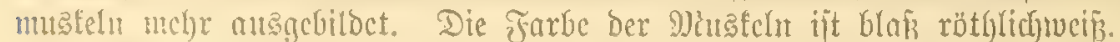

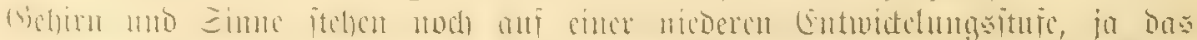

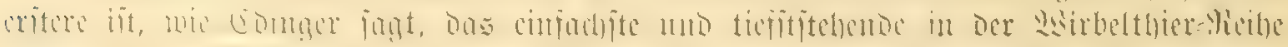

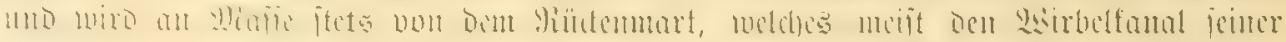

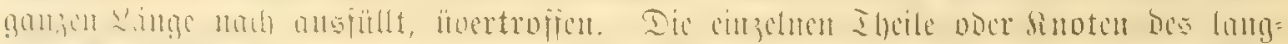

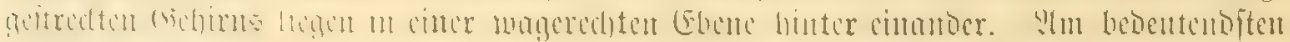

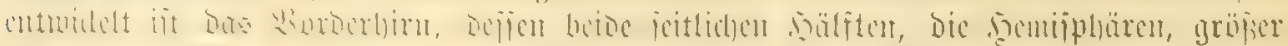

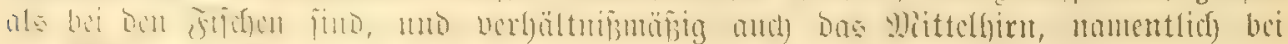

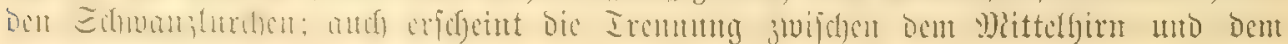




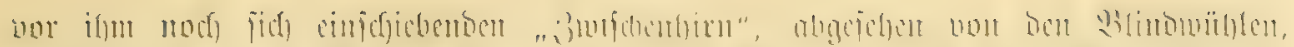

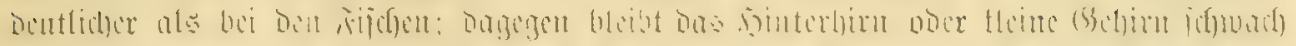

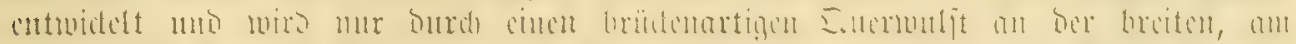

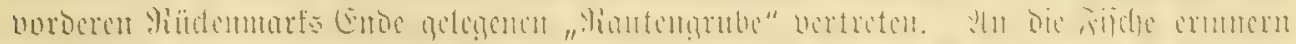

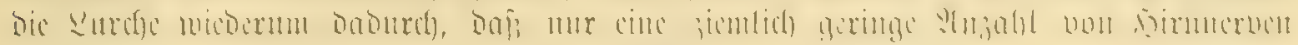

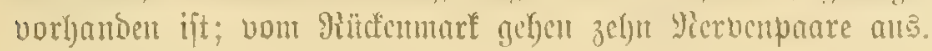

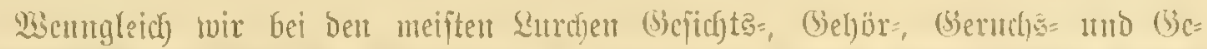

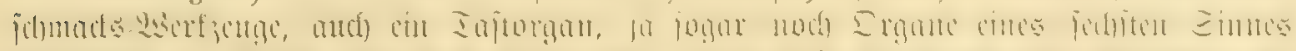

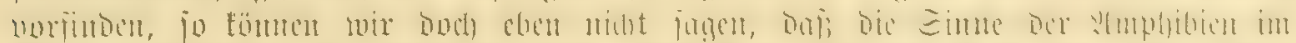

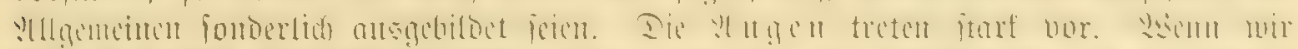

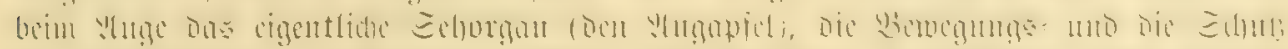

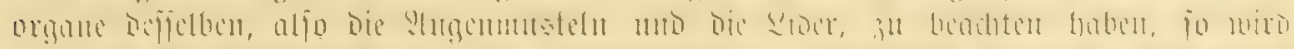

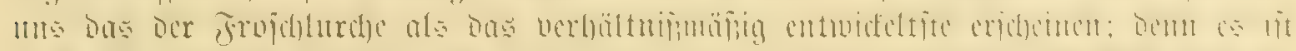

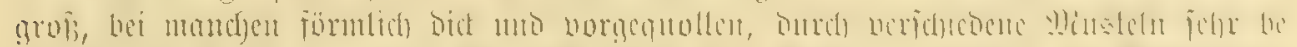

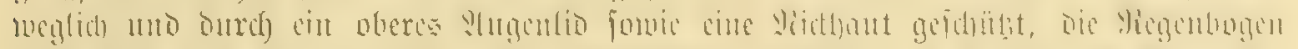

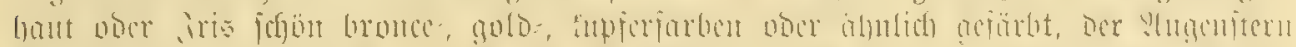

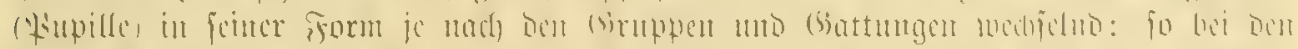

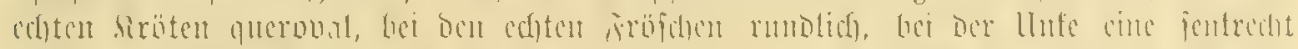

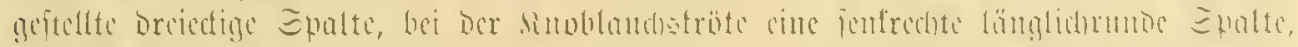

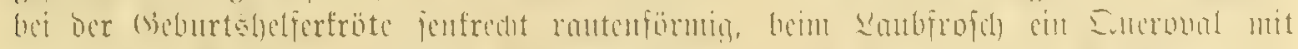

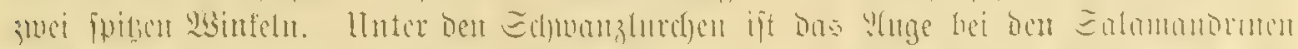

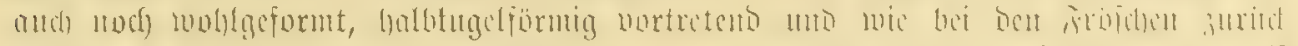

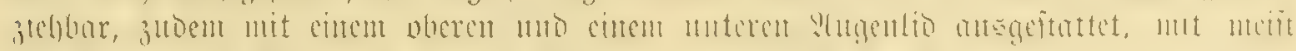

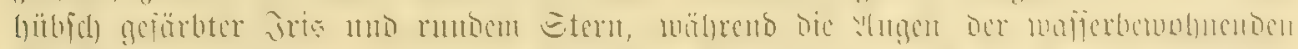

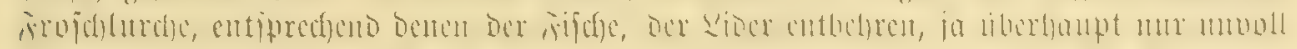

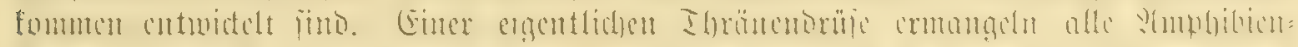

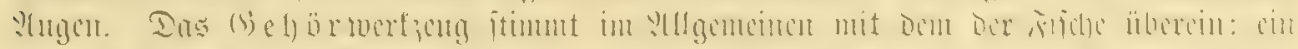

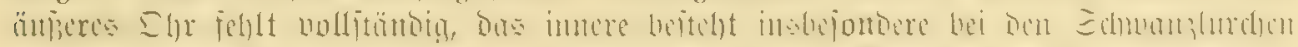

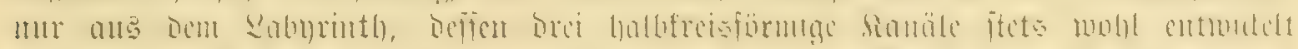

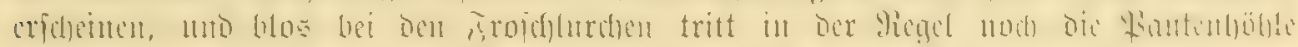

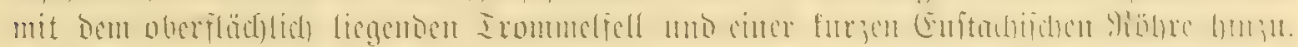

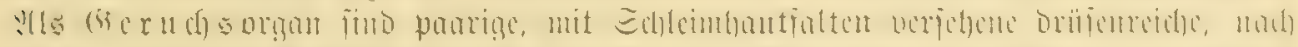

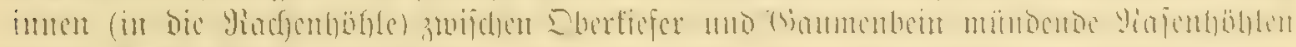

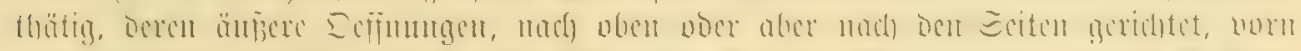

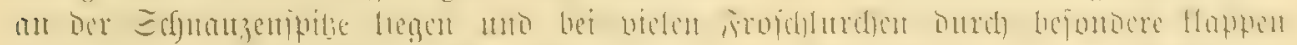

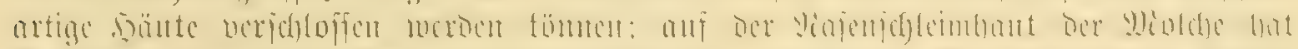

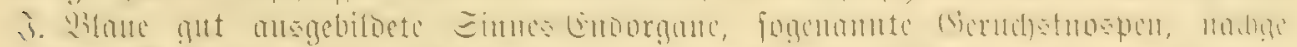

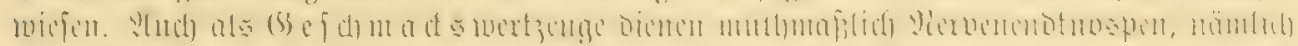

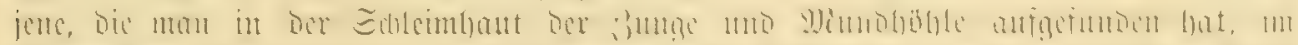

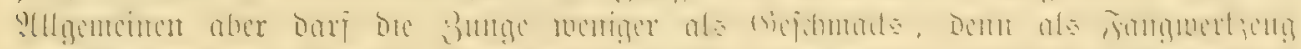

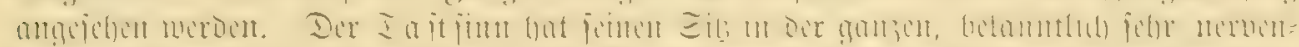

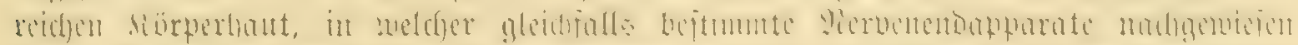

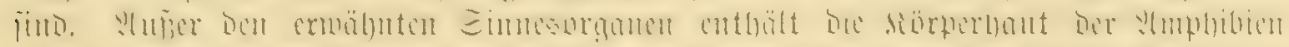

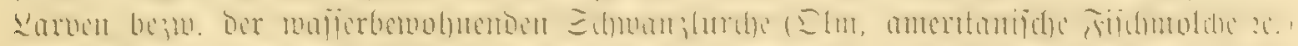

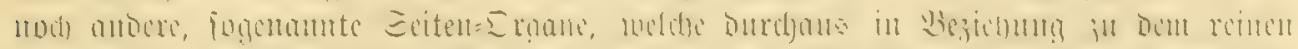

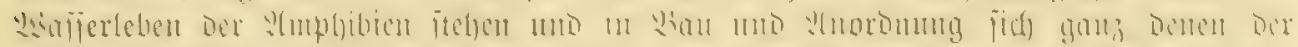

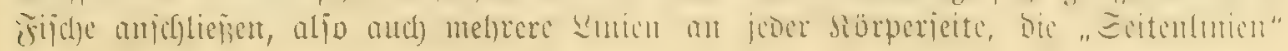




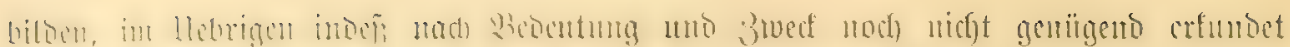

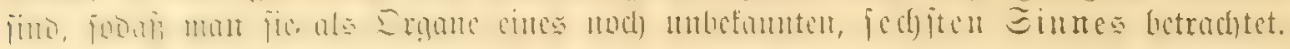

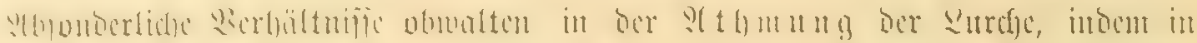

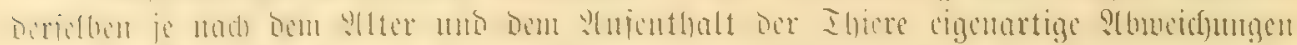

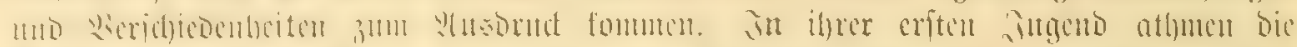

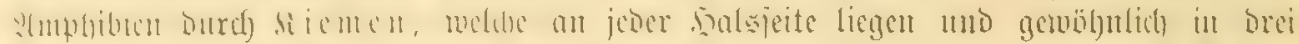

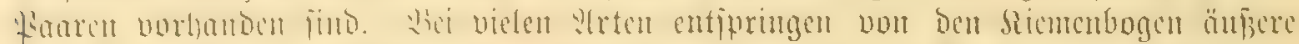

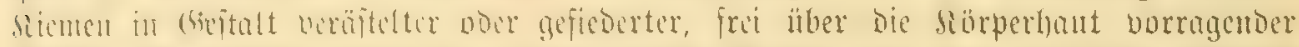

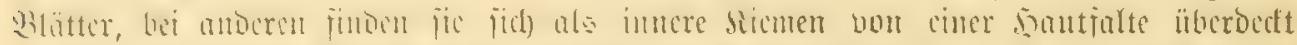

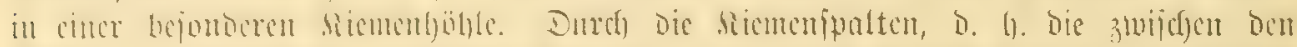

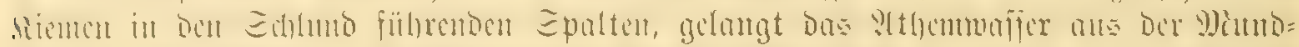

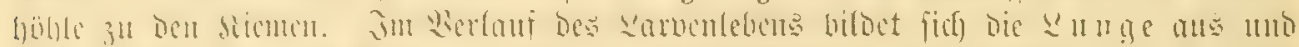

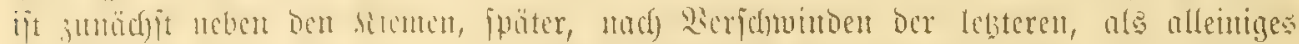

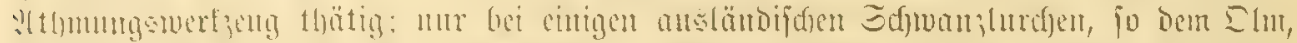

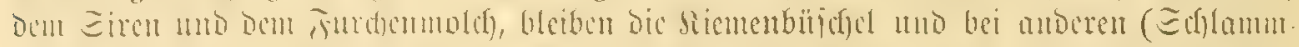

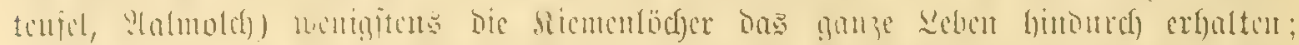

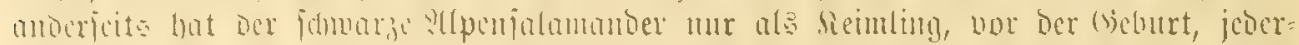

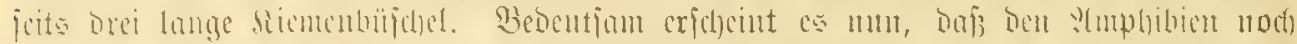

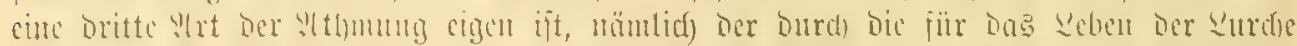

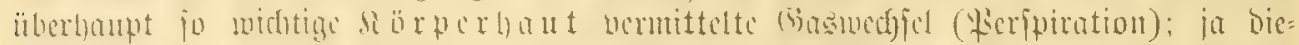

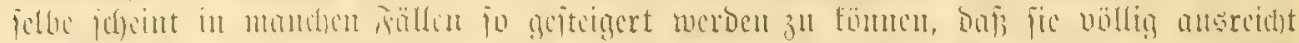
ille

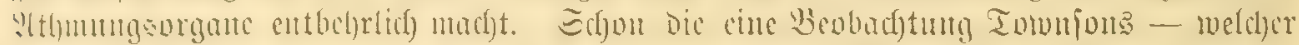

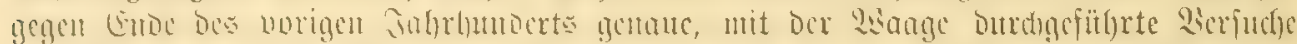

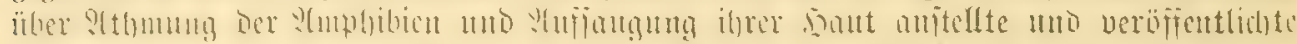

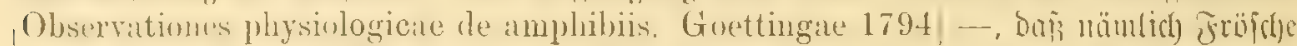

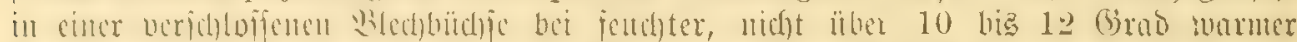

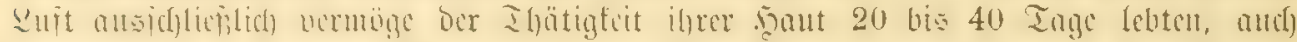

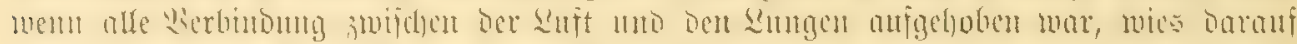

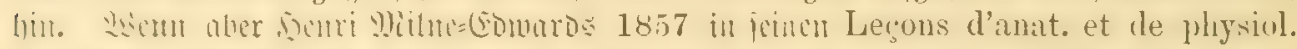

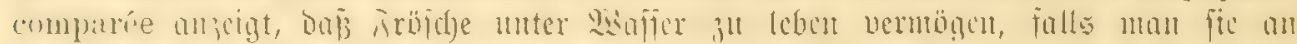

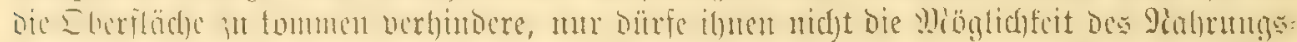

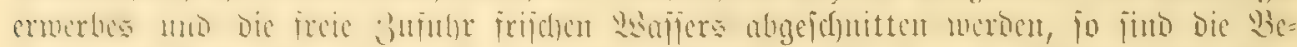

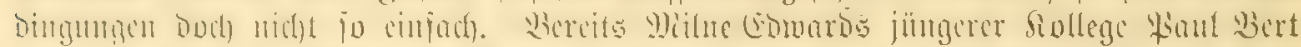

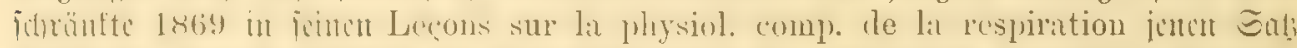

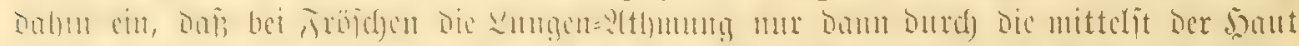

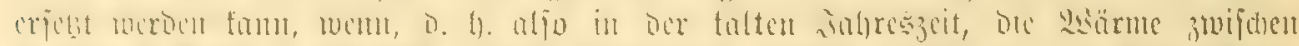

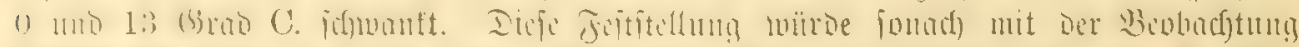

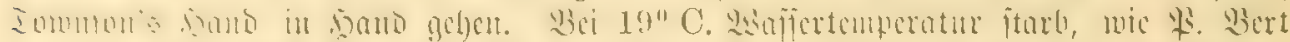

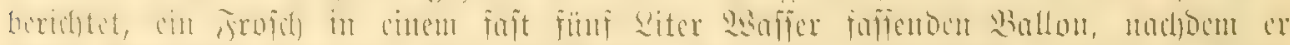

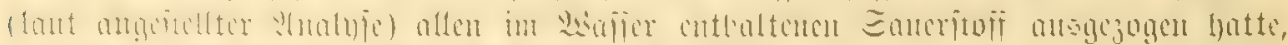

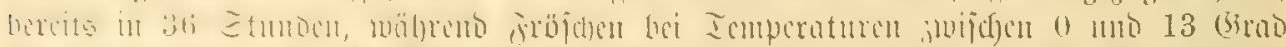

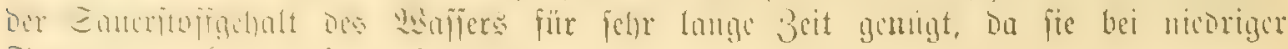
Tempcratur cben wenig verbraudjen.

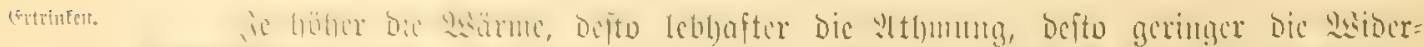

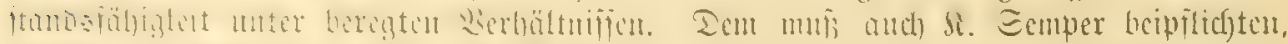

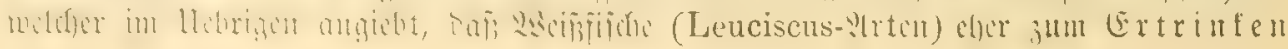




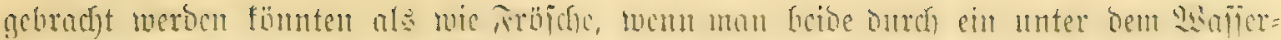

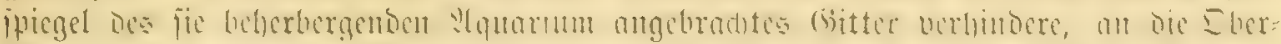

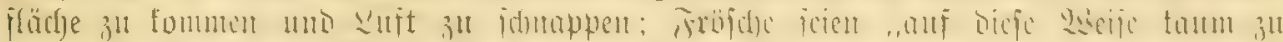

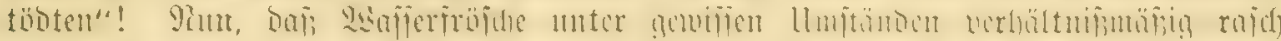

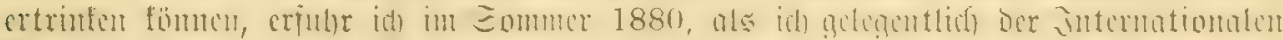

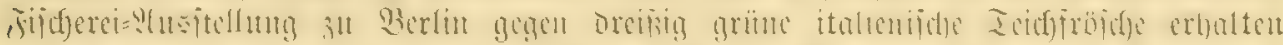

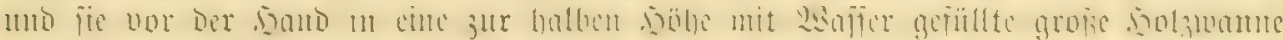

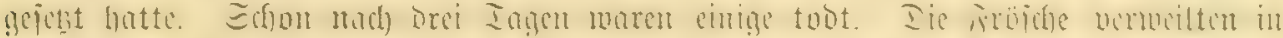

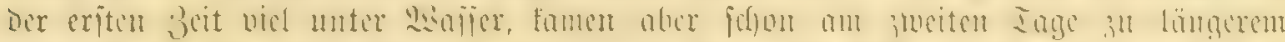

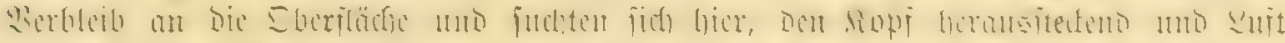

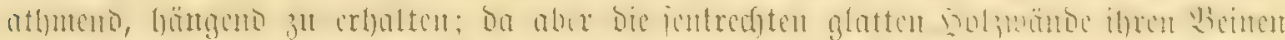

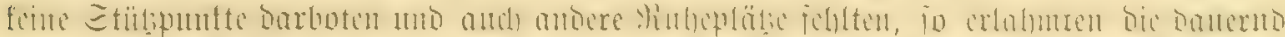

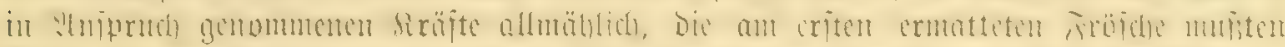

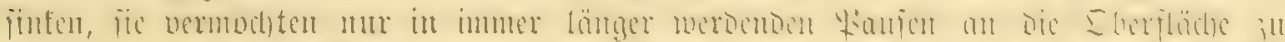

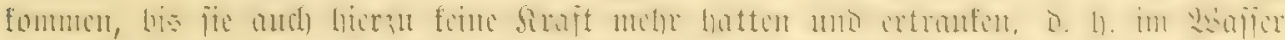

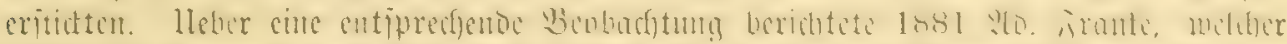

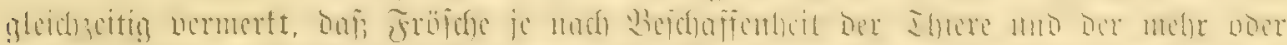

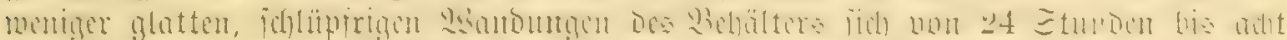

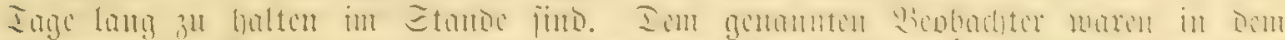

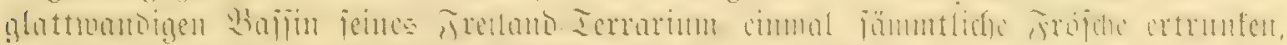

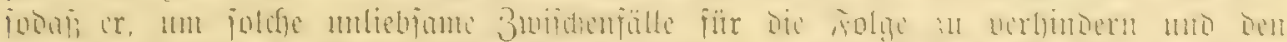

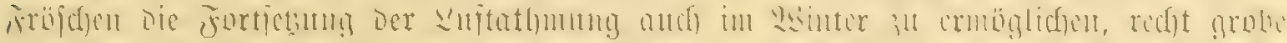

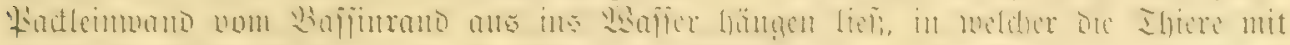

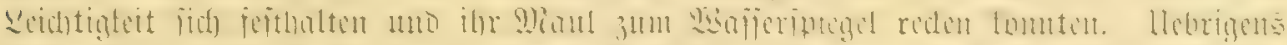

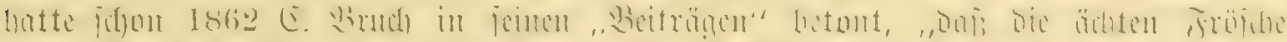

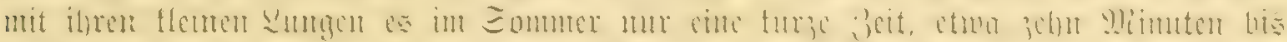

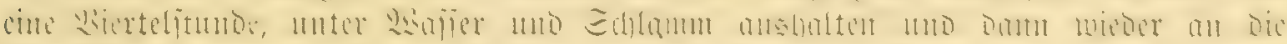

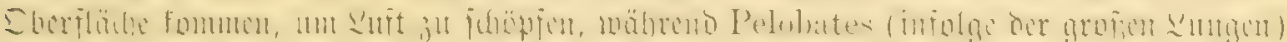

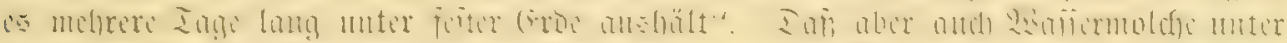

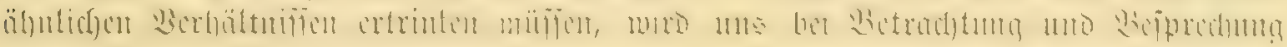
Diefer (5)attung flar werben.

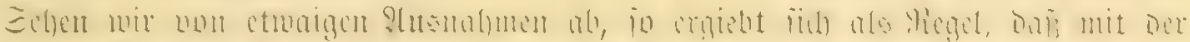

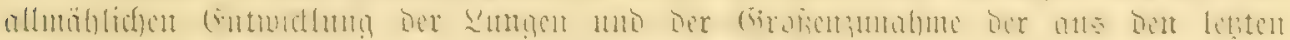

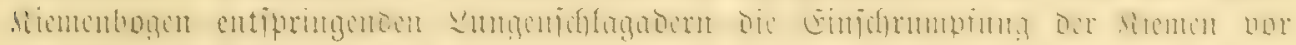

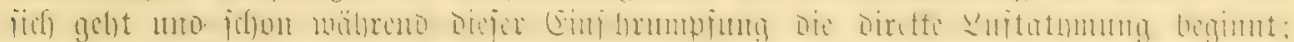

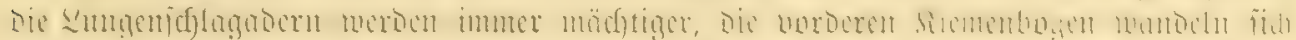

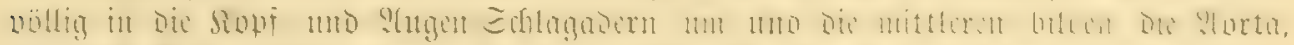

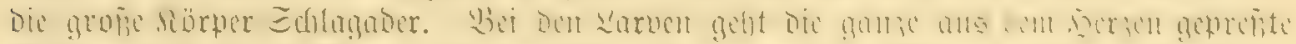

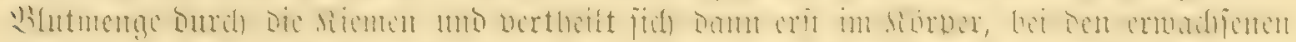

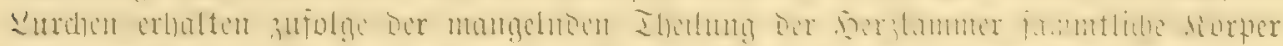

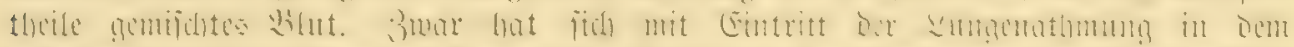

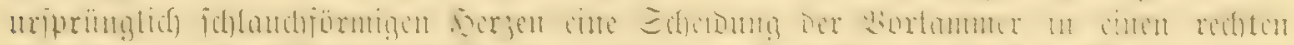

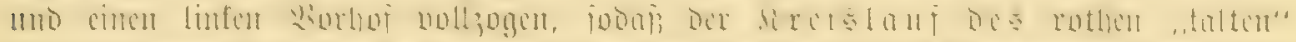

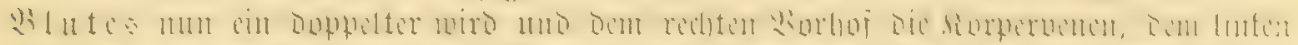

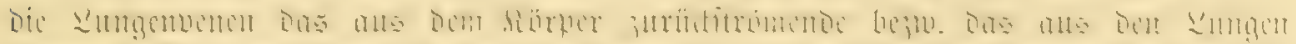

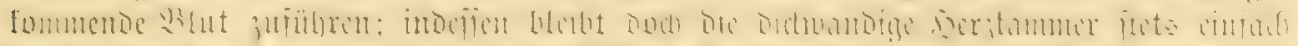

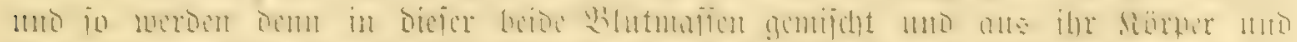

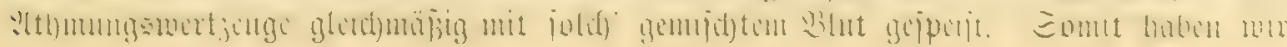


Rument 1:tto zurnge.

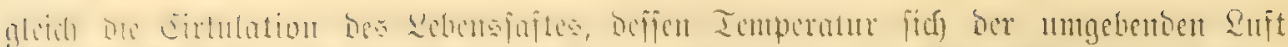

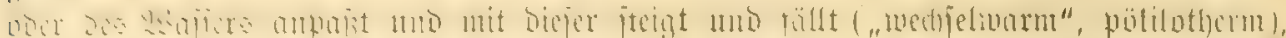

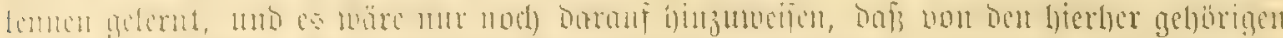

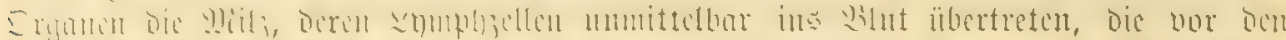

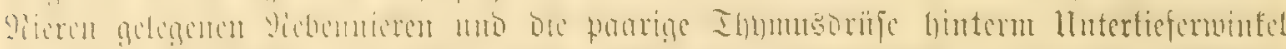

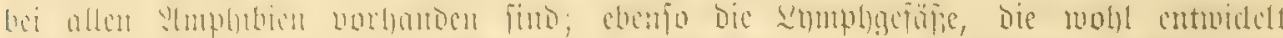

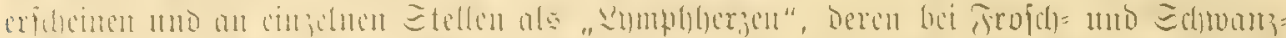

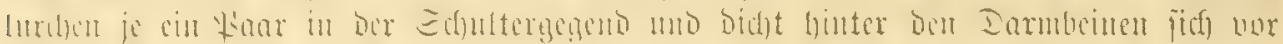
findet, rluttunificy putfiren fömen.

然m bा

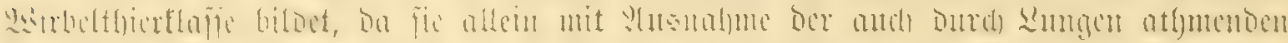

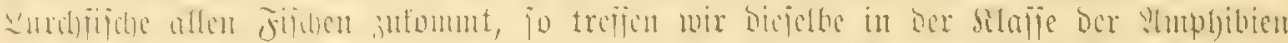

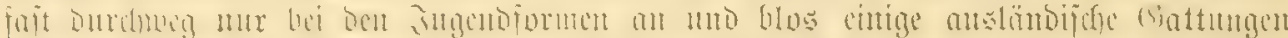

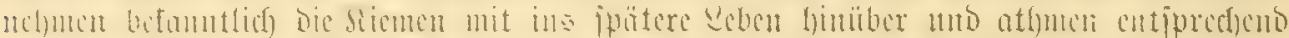

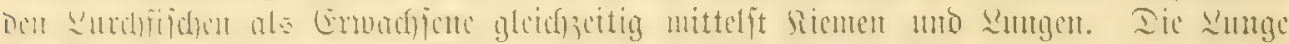

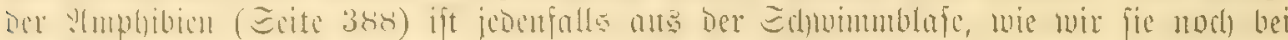

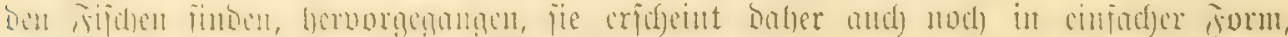

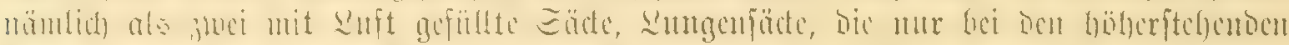

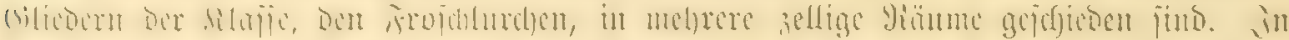

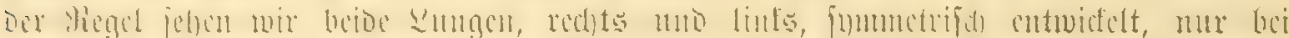

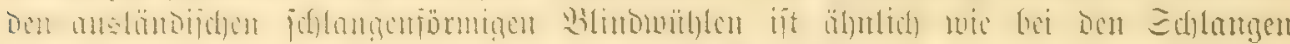

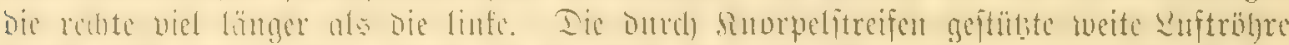

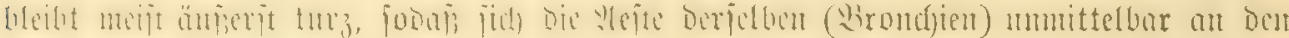
Sicl)【topf anfdylicficu.

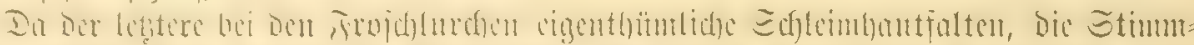

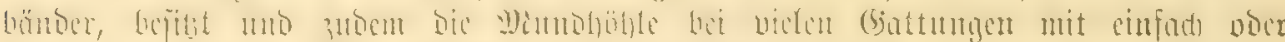

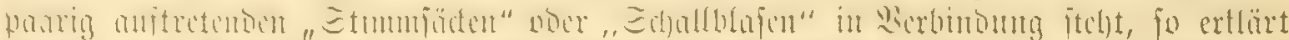

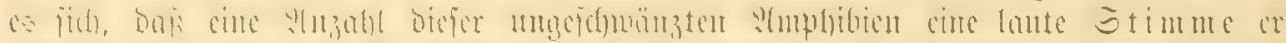

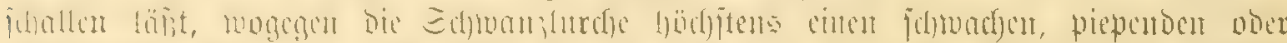

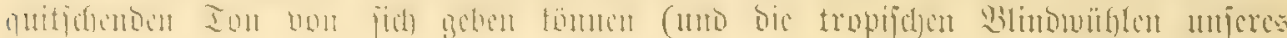
Libifen

Eex 果e

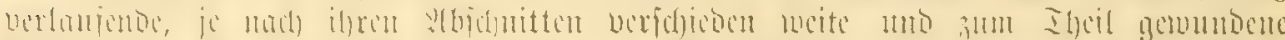

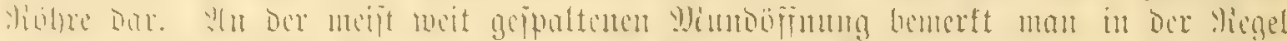

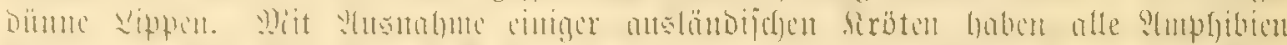

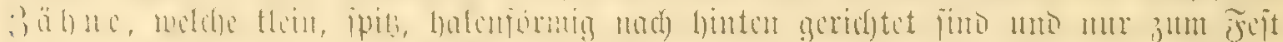

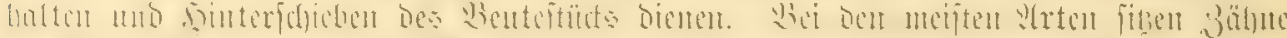

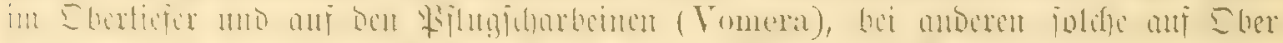

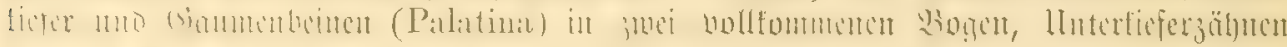

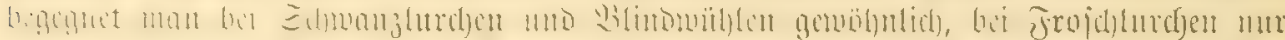

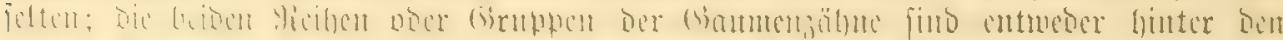

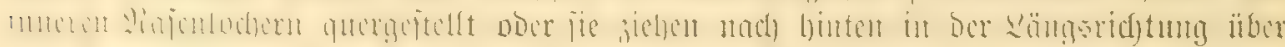

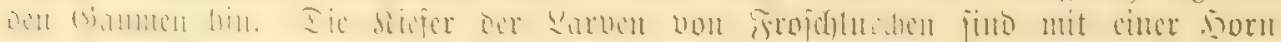

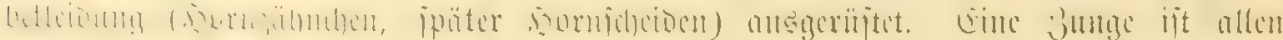

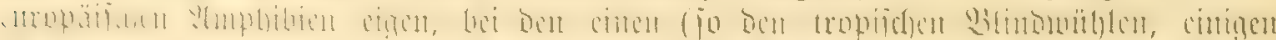

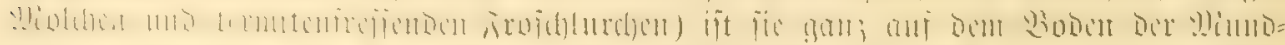

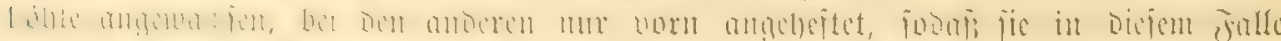

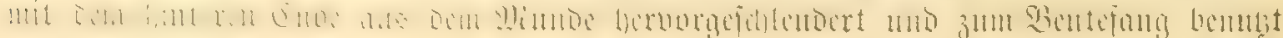




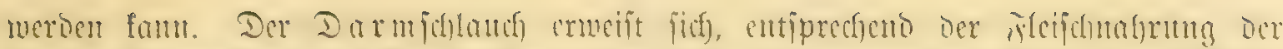

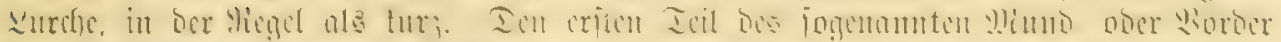

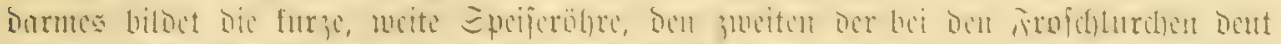

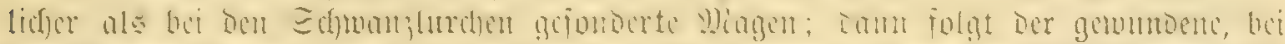

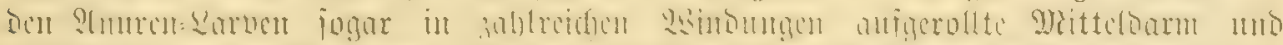

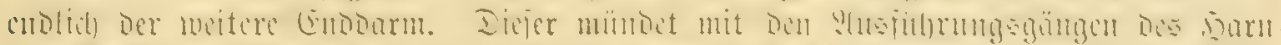
mat (b)

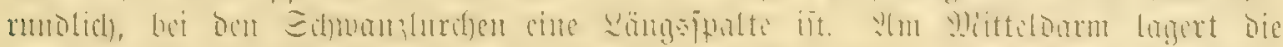

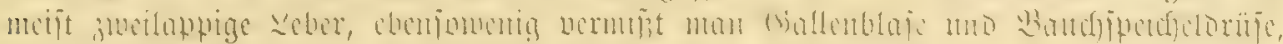
twobl aber feblert bie eigentlidjen Epcidjelbriffen am Sitcfer 1t. a.

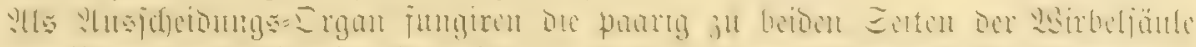

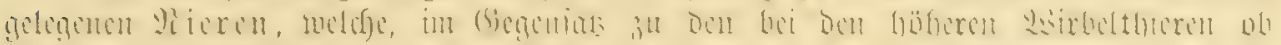

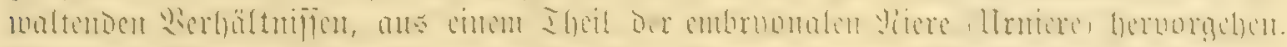

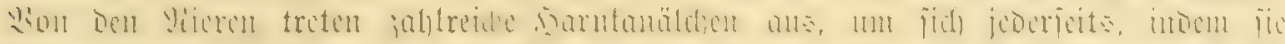

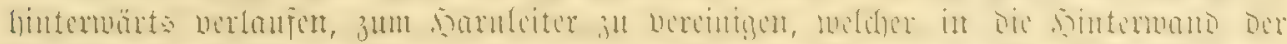

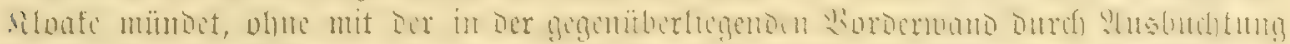

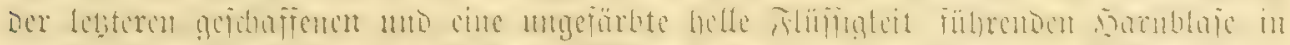

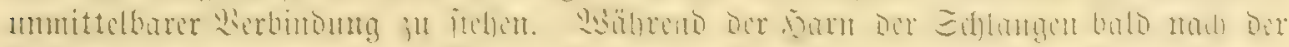

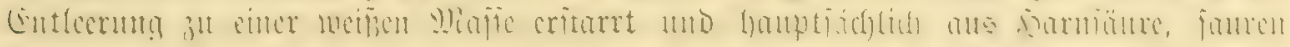

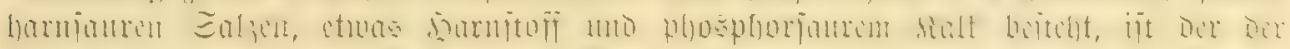

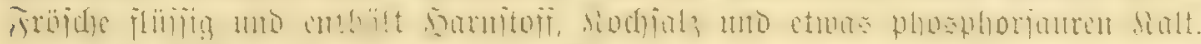

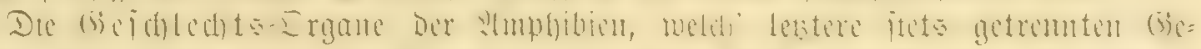

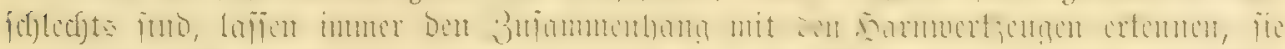

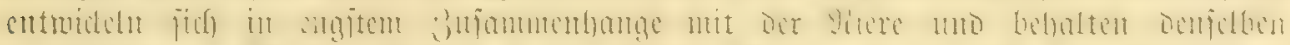

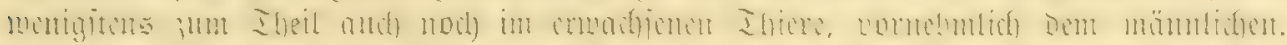

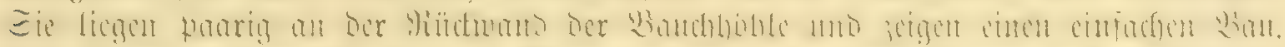

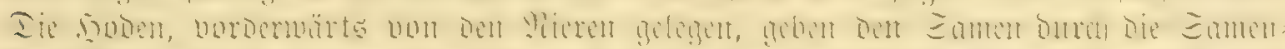

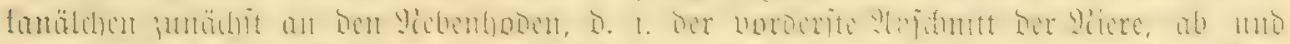

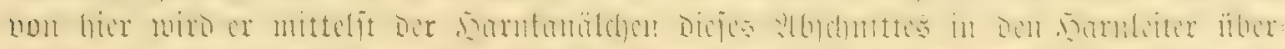

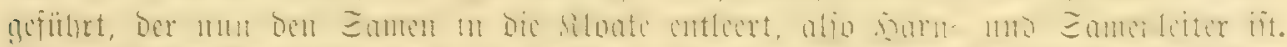

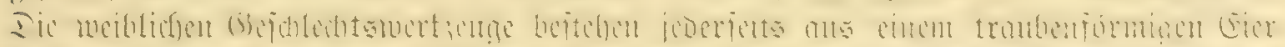

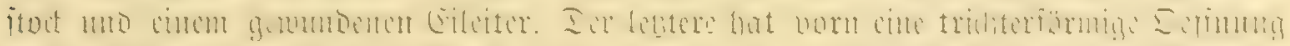

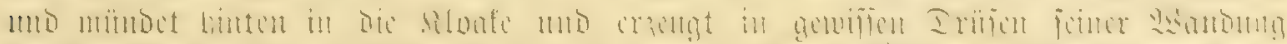

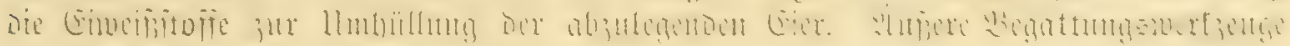
F(t)len Den Frof

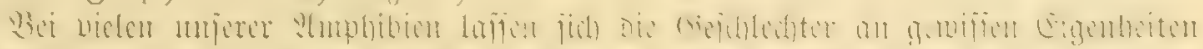
Gefitredect.

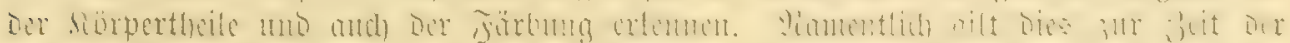

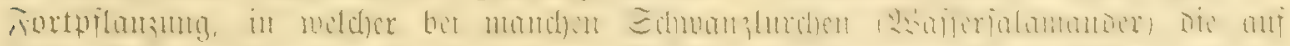

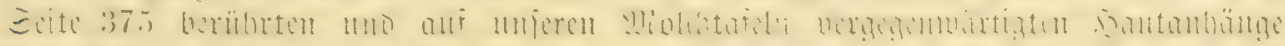

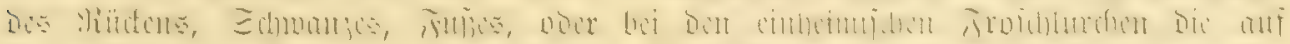

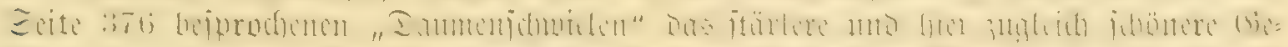

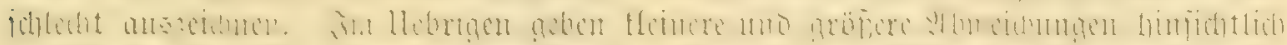

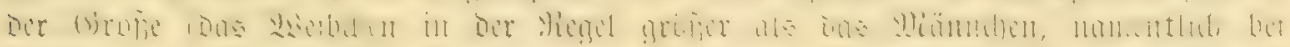

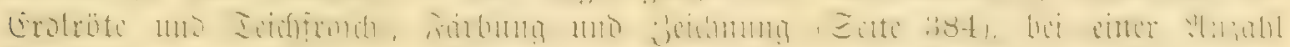

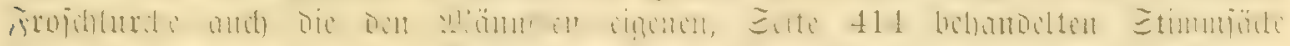

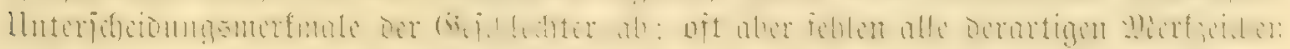

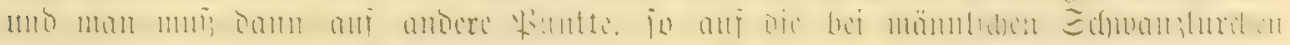
jtärter Gervortretendon Stbatenuillite แ. a. adjten. 


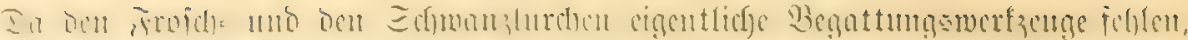

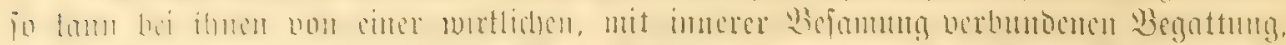

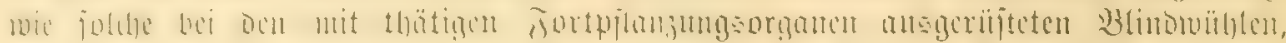

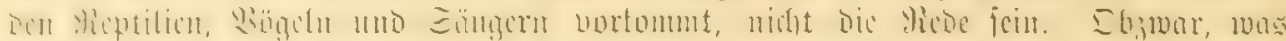

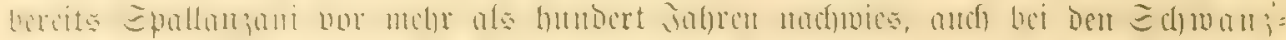

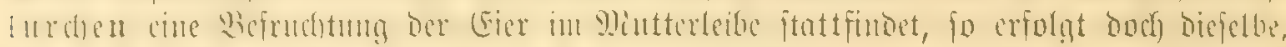

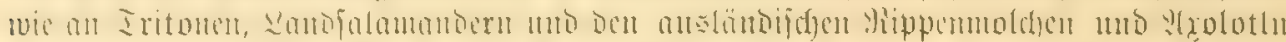

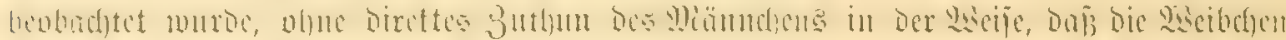

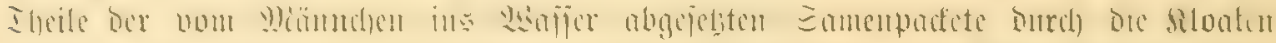

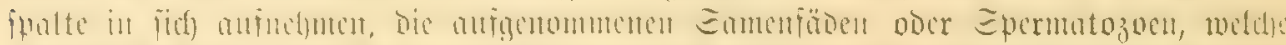

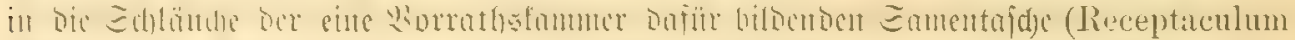

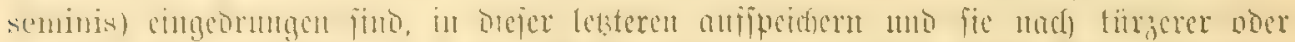

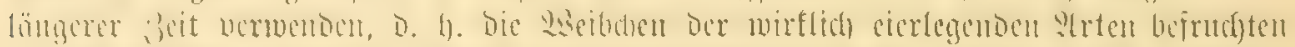

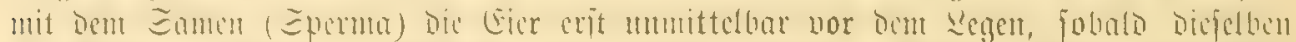

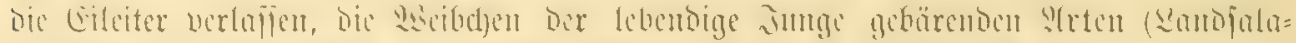

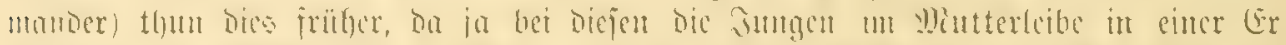

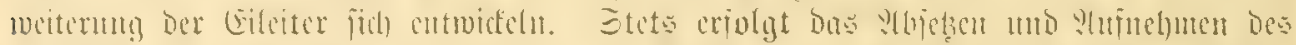

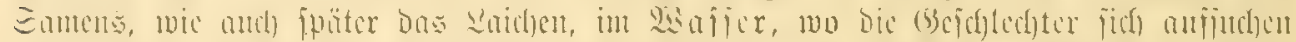

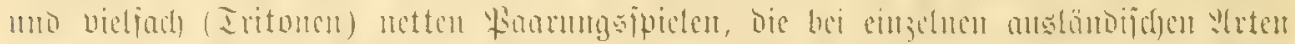

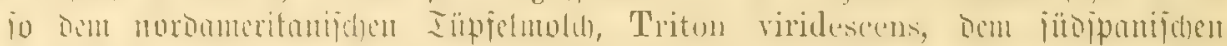

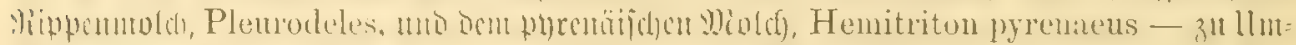

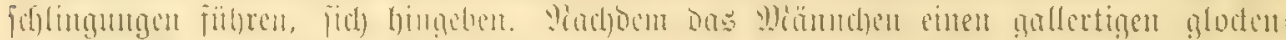

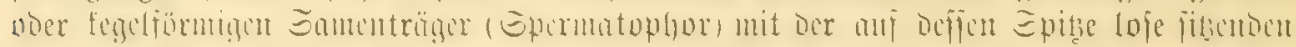

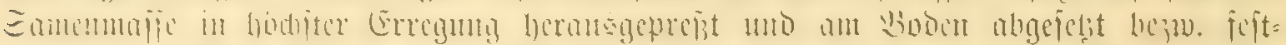

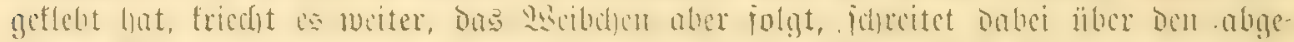

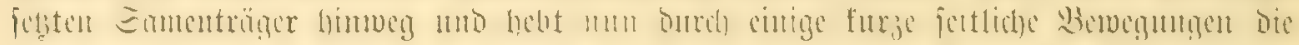

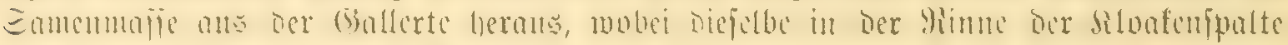

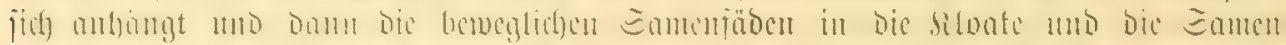

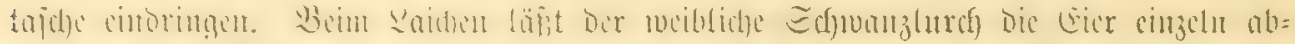

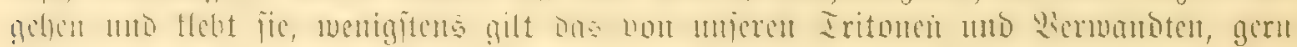

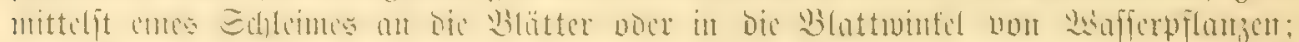

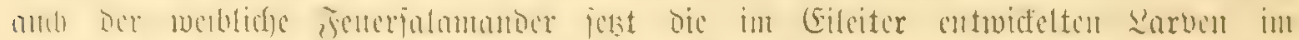

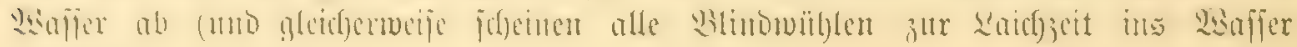
(3) ge(jen).

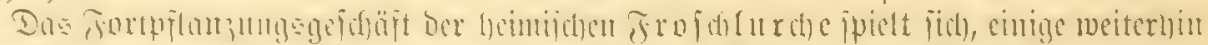

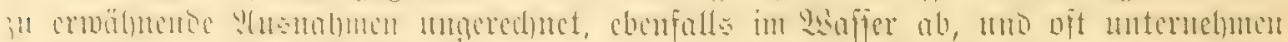

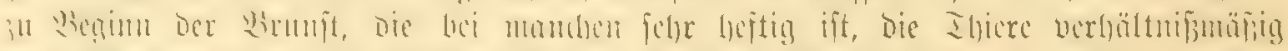
weite

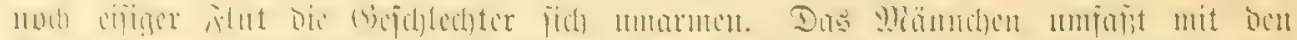

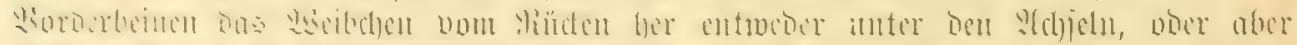

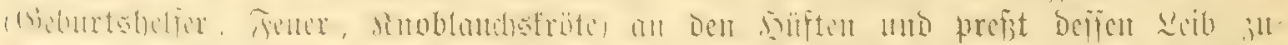

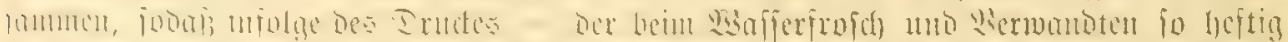

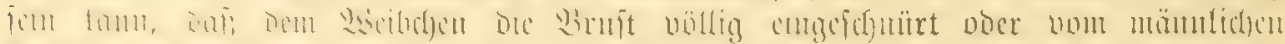

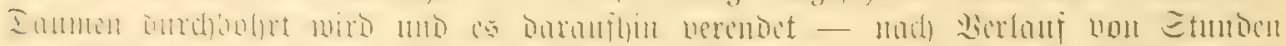

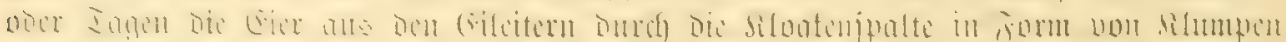

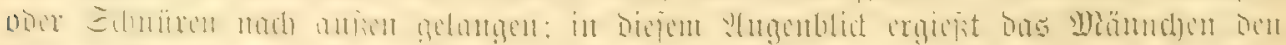

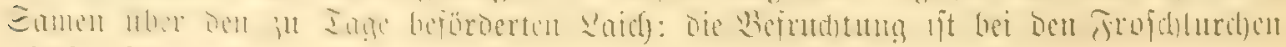

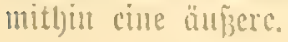




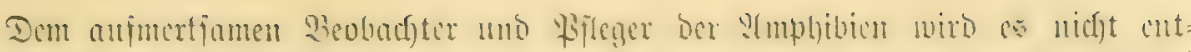

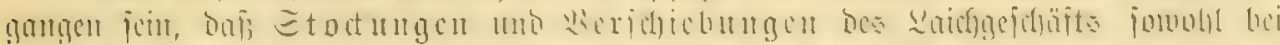

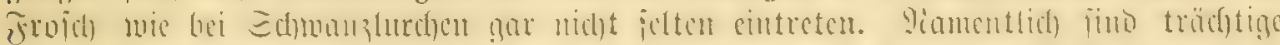

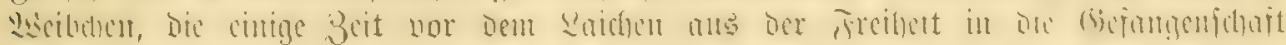

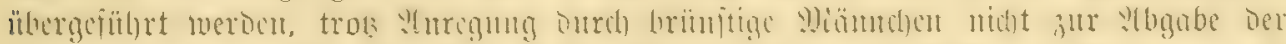

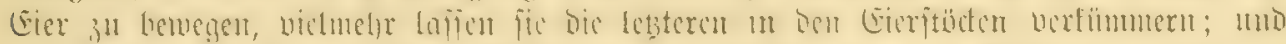

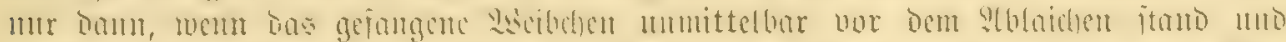

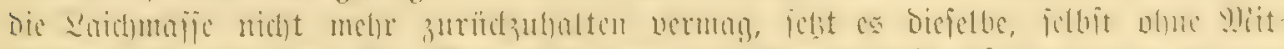

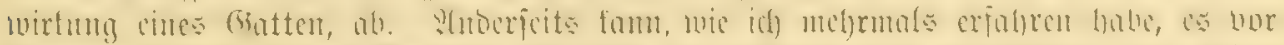

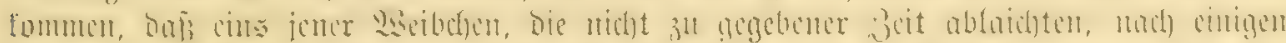

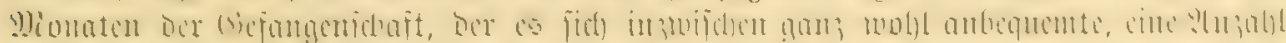

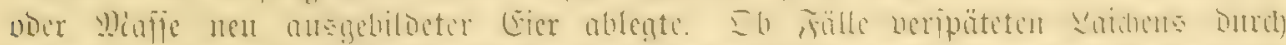

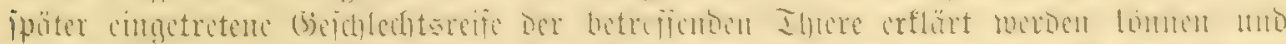

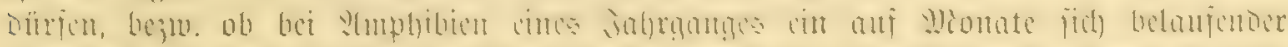

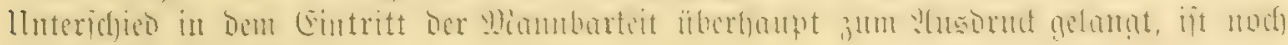
nidjt ficher fejtgeitellt.

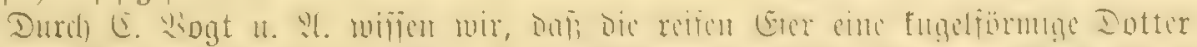

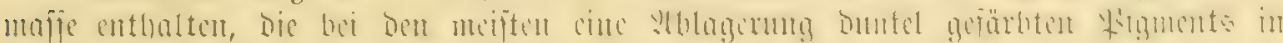

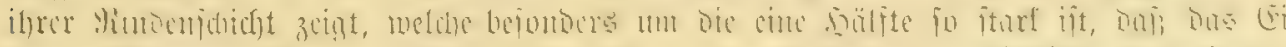

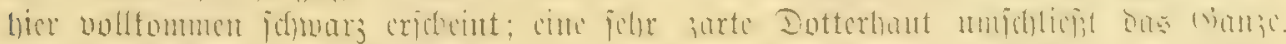

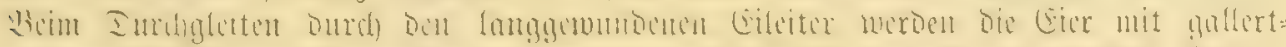

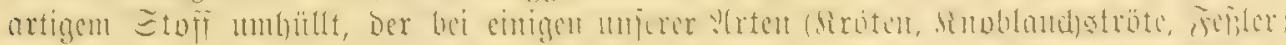

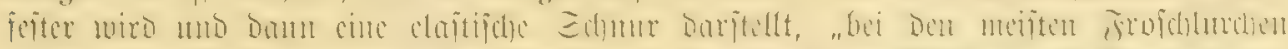

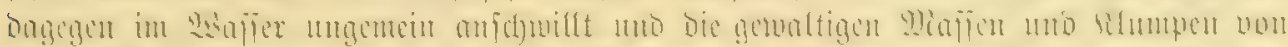

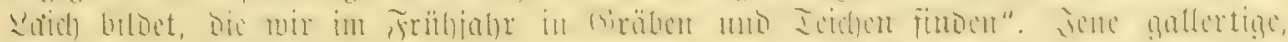

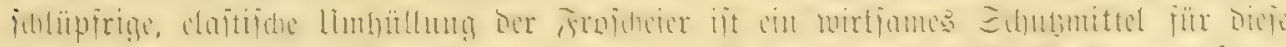

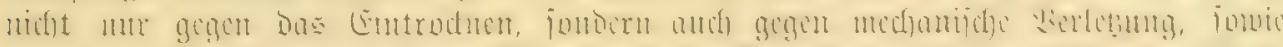

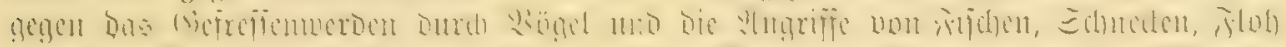

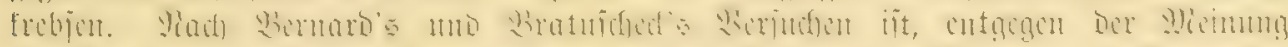

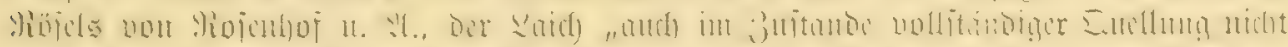

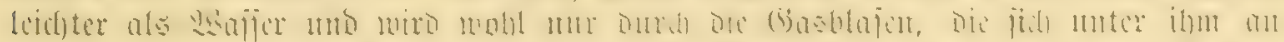

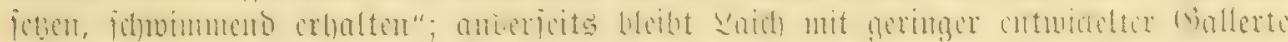

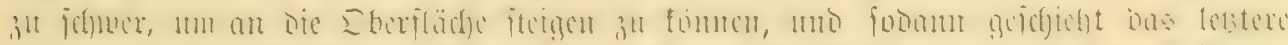

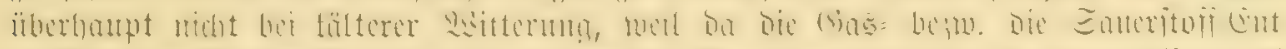

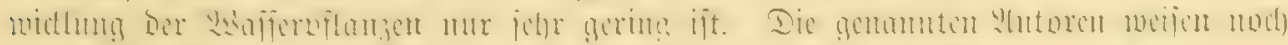

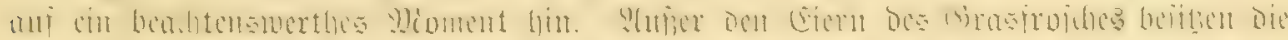

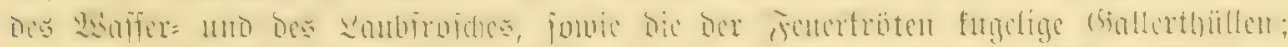

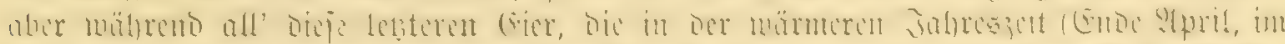

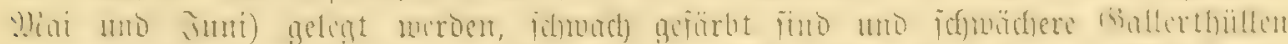

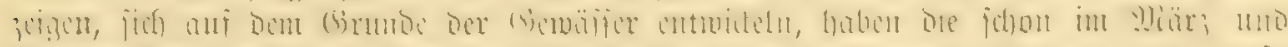

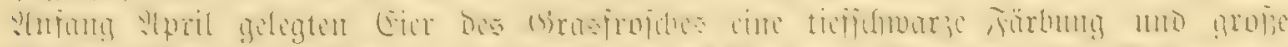

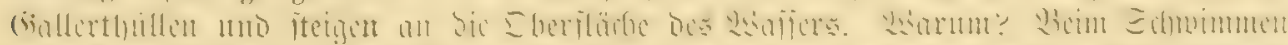

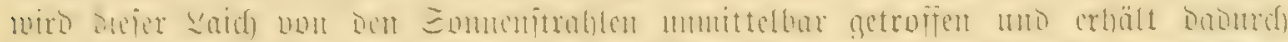

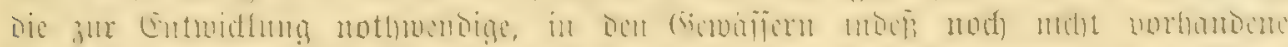

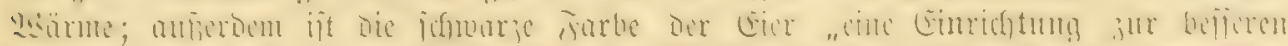

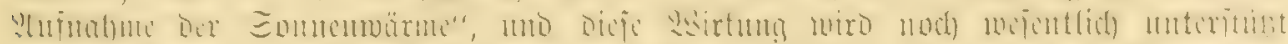

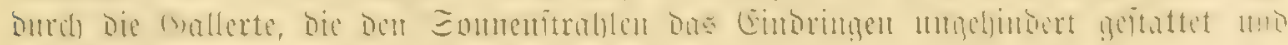

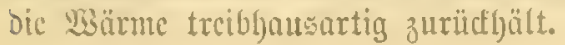




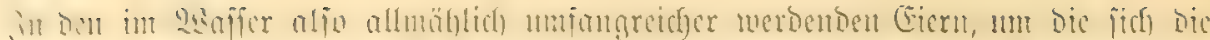

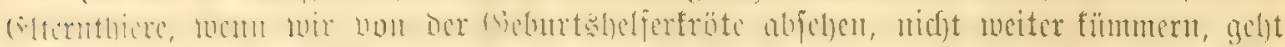

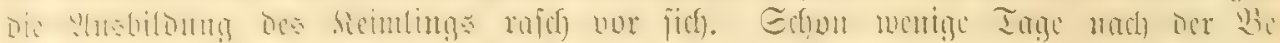

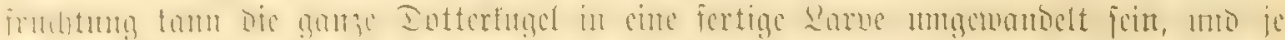

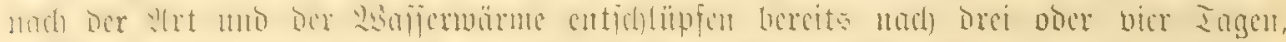

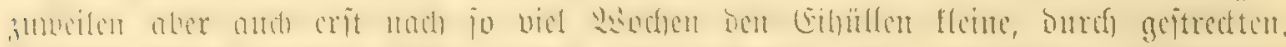

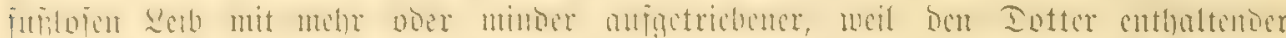

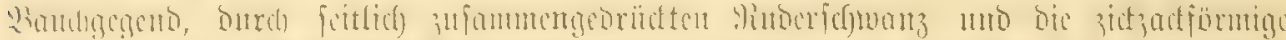

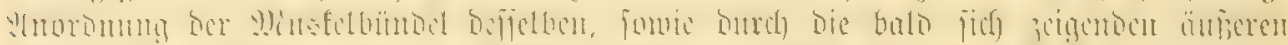

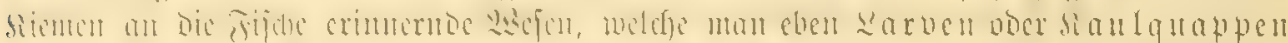

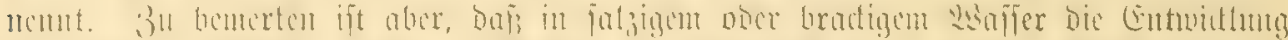

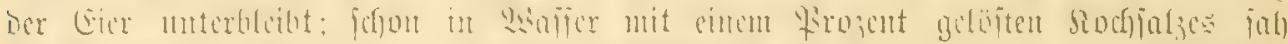

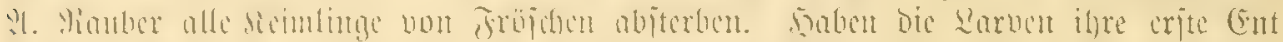

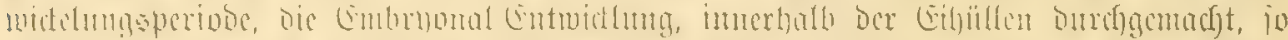

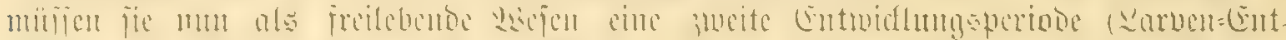

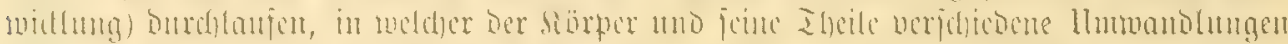

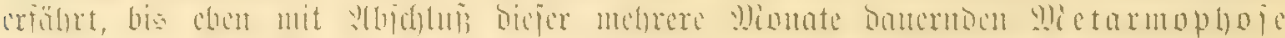
Die blëbento Form Der Celterntljere erreicht ift.

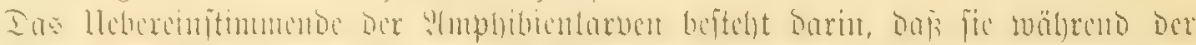

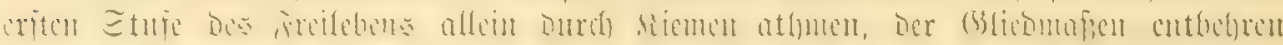

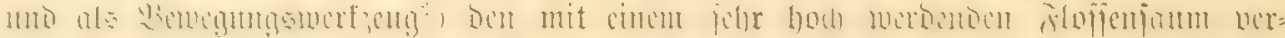

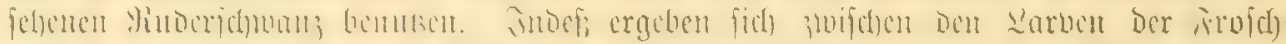

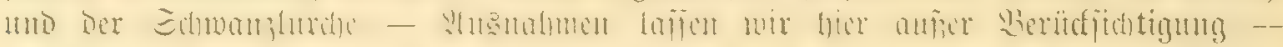

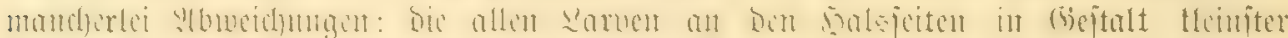

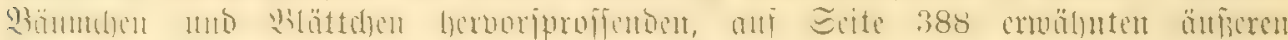

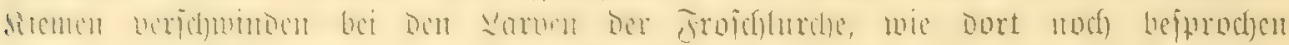

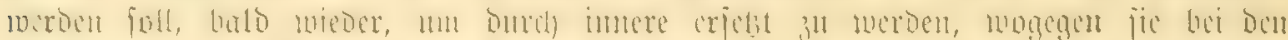

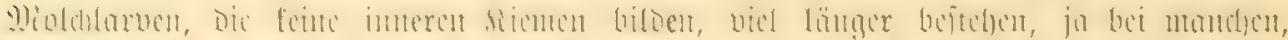

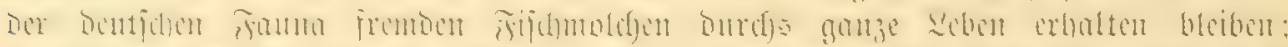

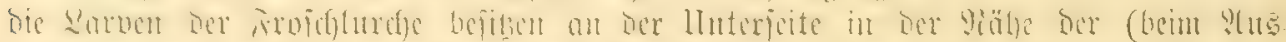

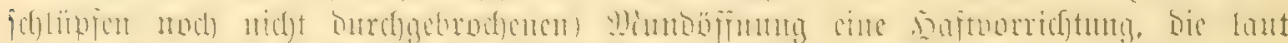

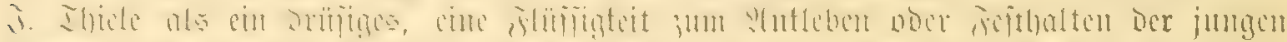

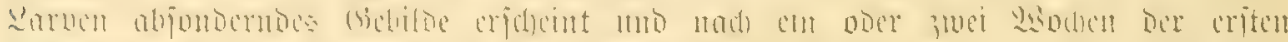

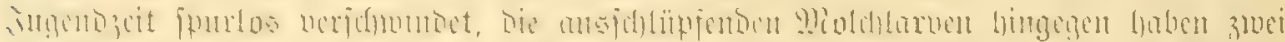

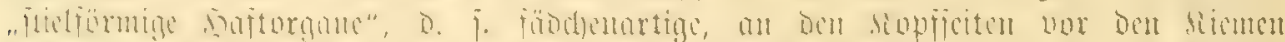

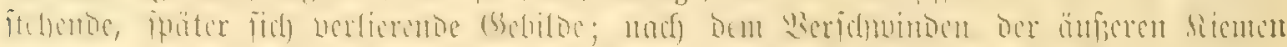

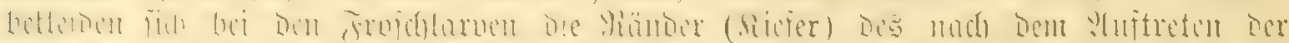

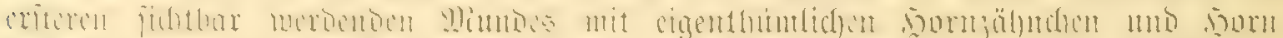

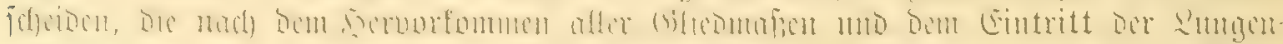

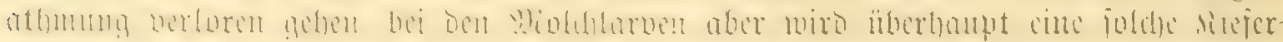

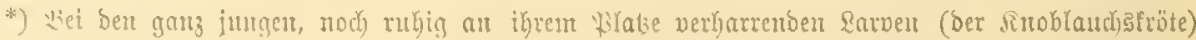

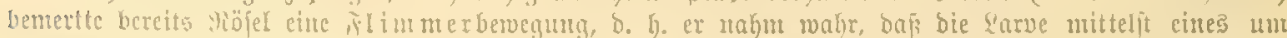

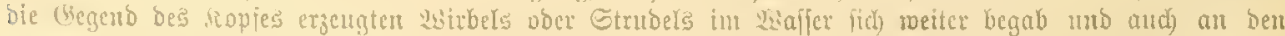

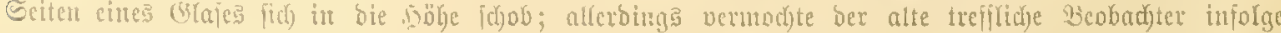

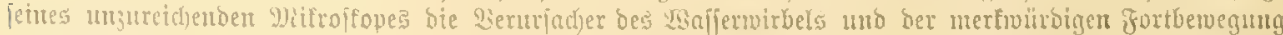

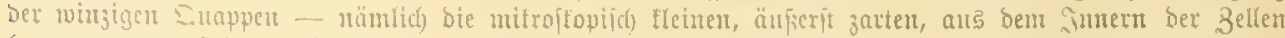

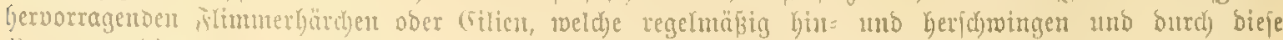

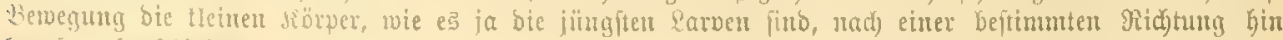

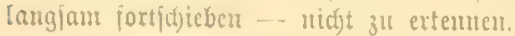




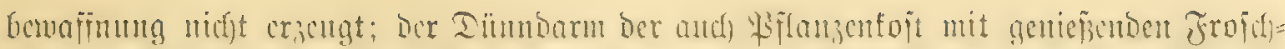

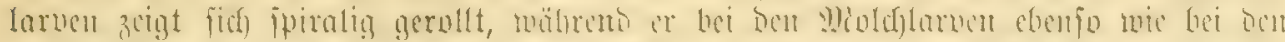

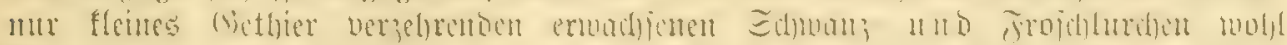

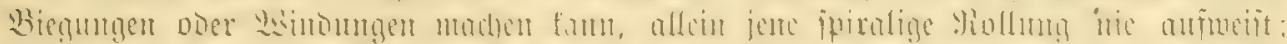

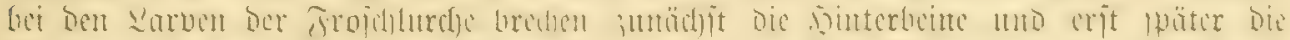

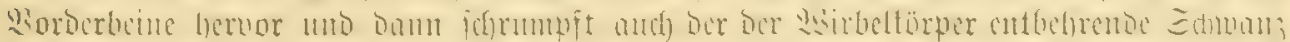

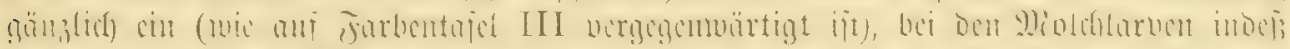

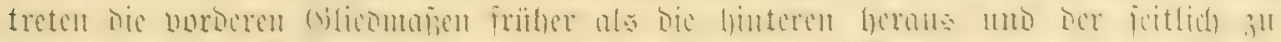

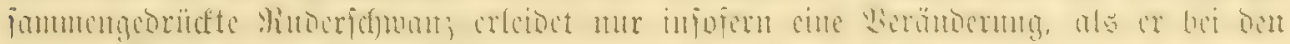

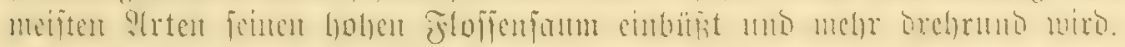

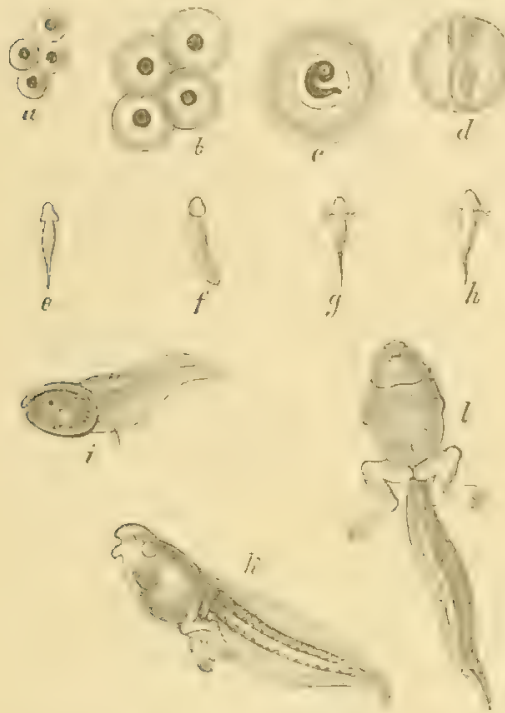

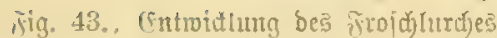
im uno altpern (Fi.

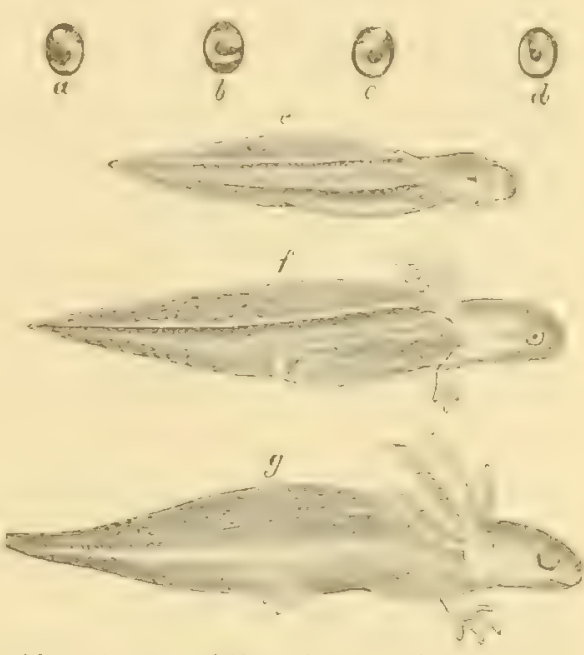

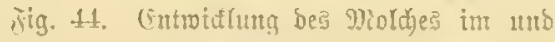
aulierm (si.

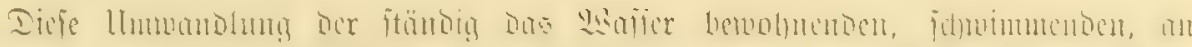

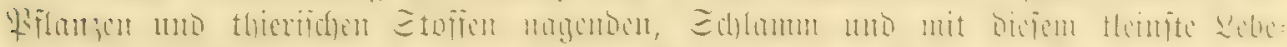

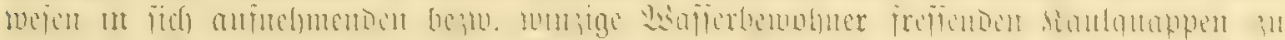

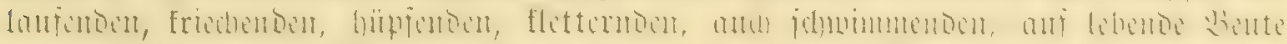

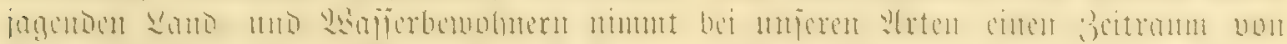

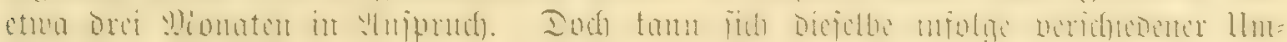

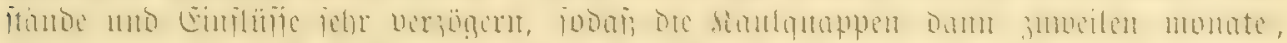

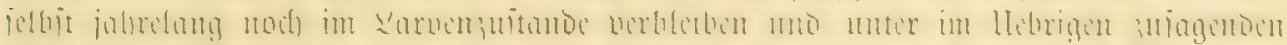

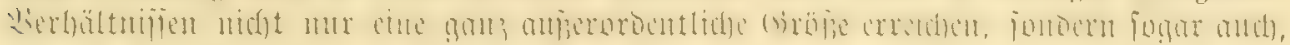

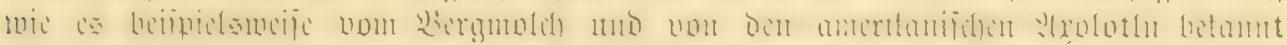

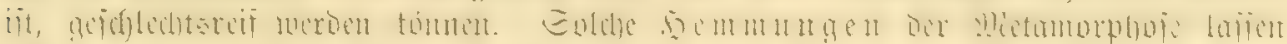

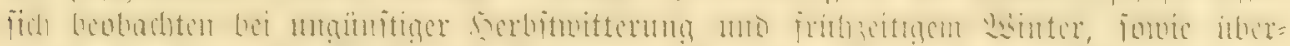

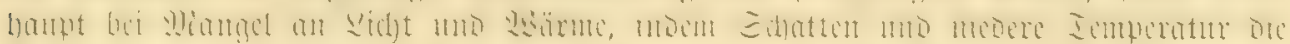

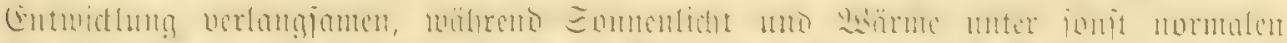

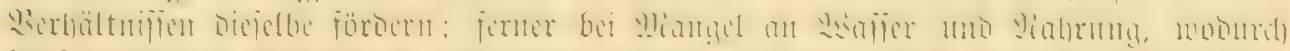

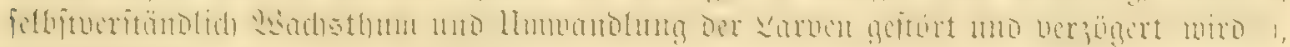

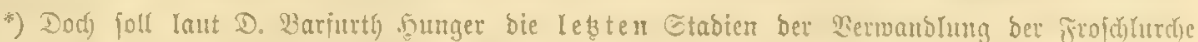

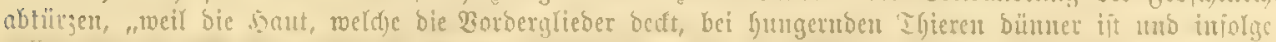

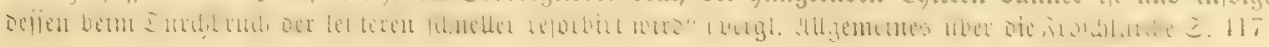




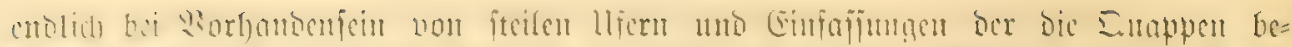

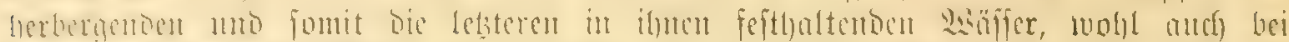

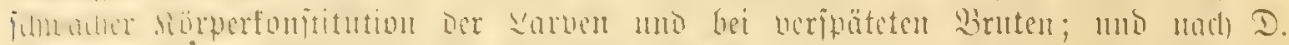

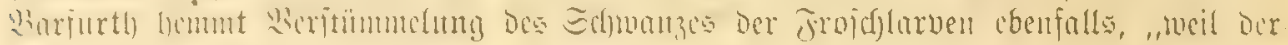
qelbe regencrirt wiro".

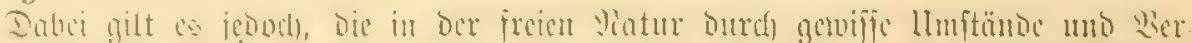

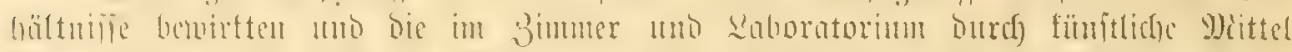

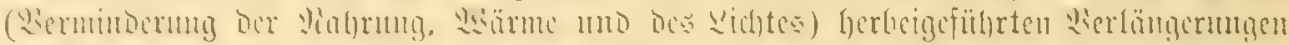

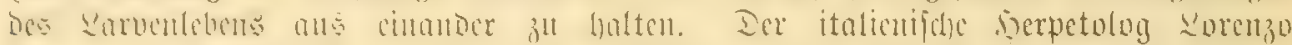

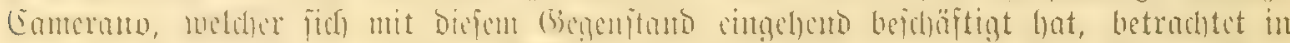

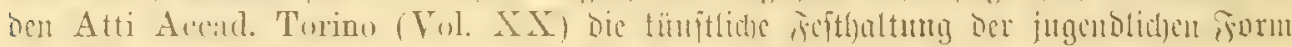

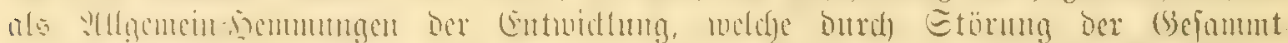

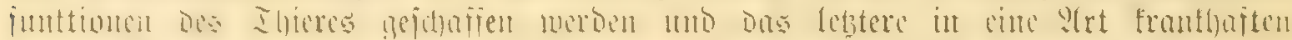

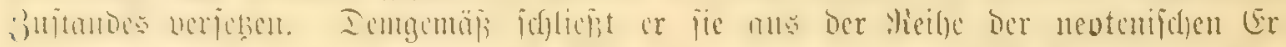

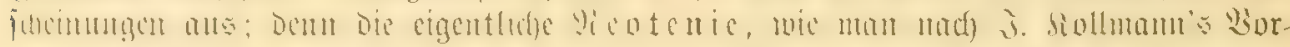

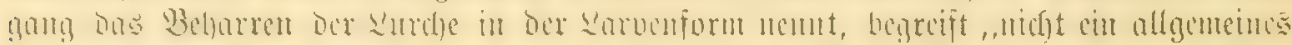

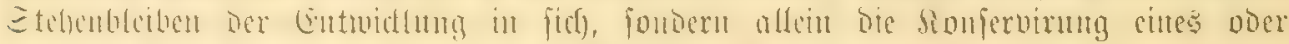

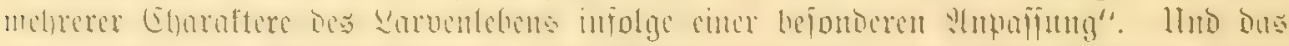

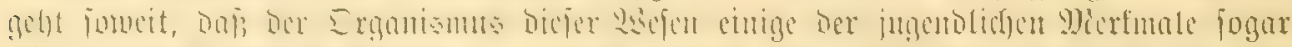

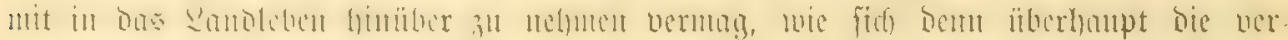

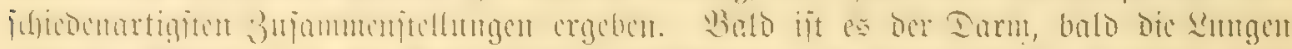

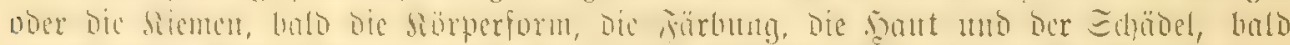

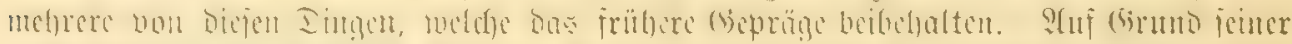

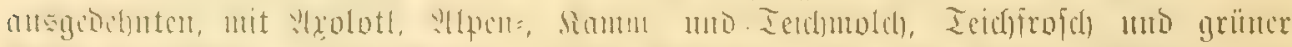

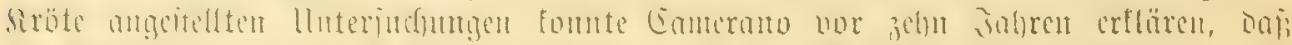

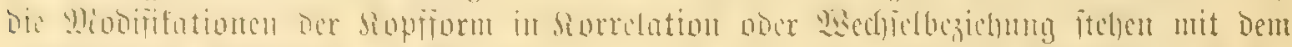

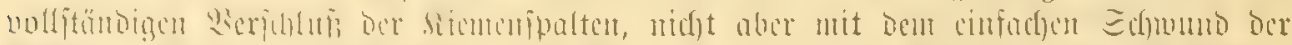

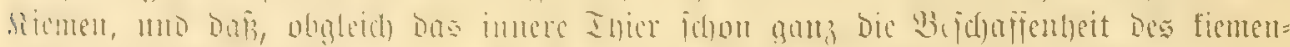

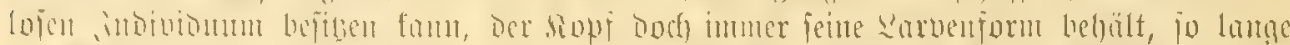

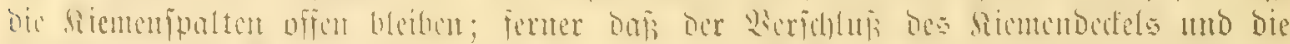

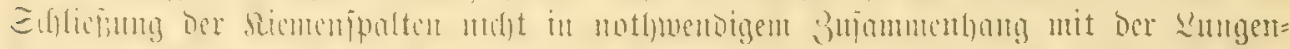

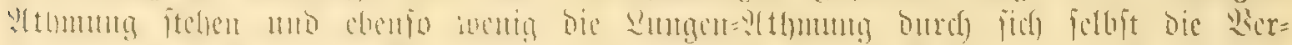

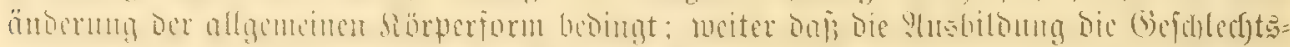

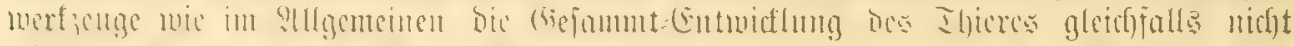

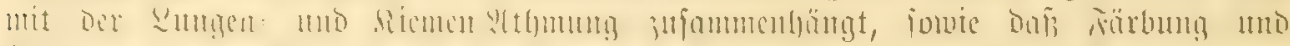

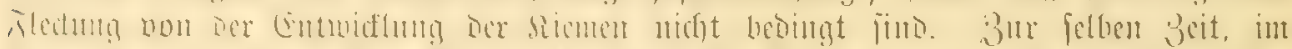

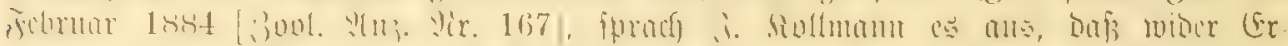

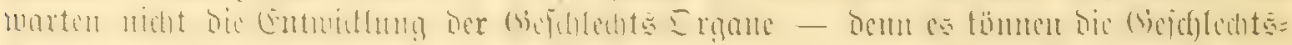

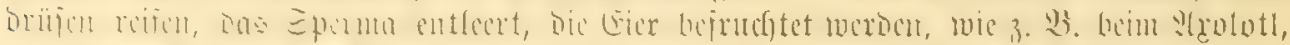

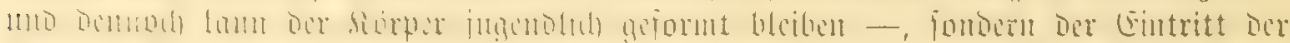

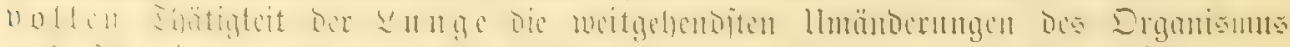

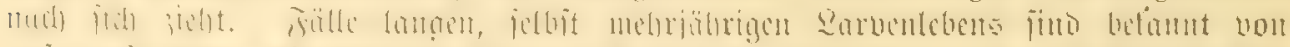

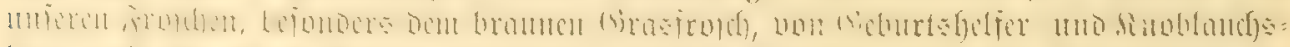

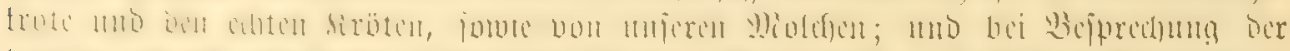

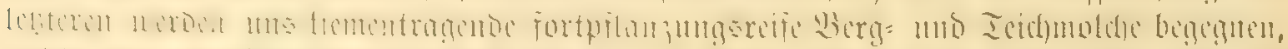

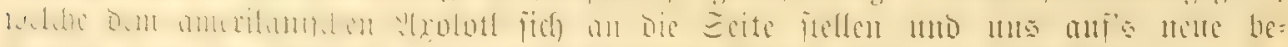

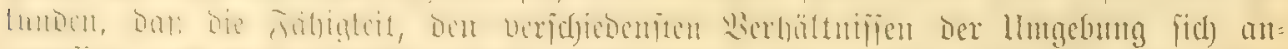

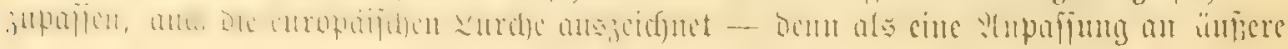




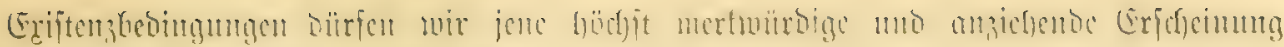
oer Meotenie jedenfalls betrad)ten.

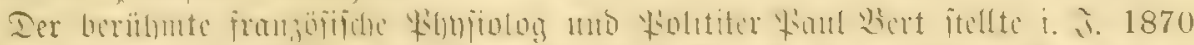

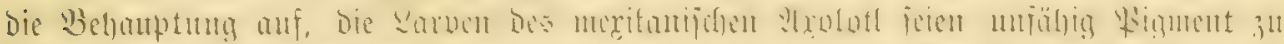

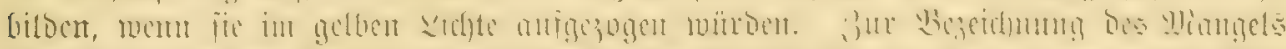

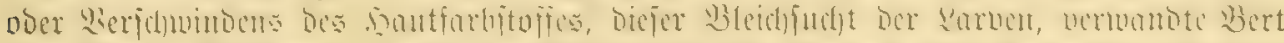

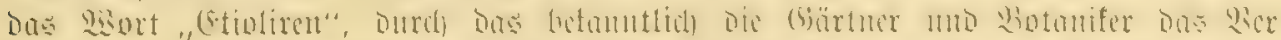

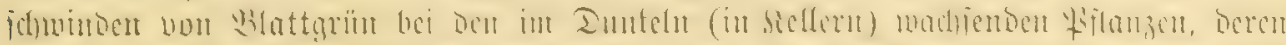

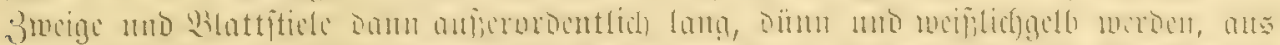

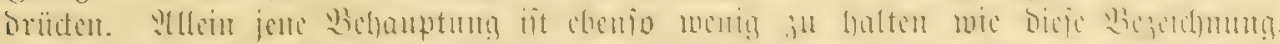

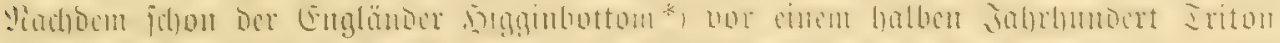

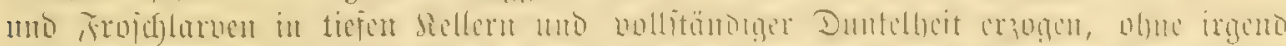

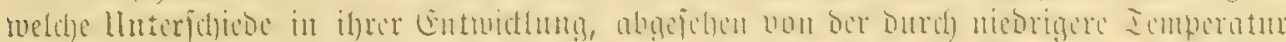

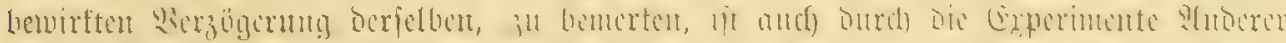

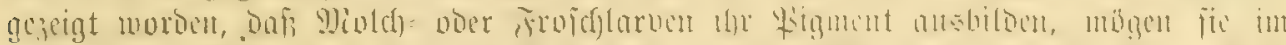

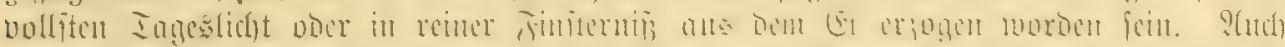

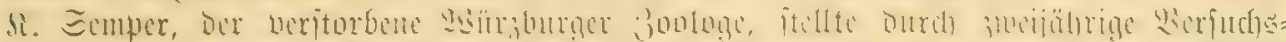

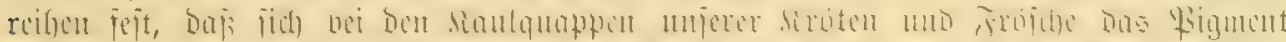

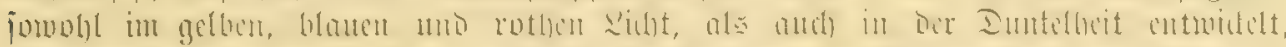

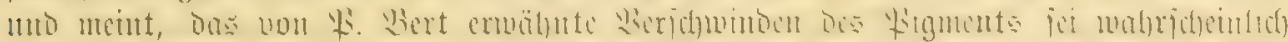

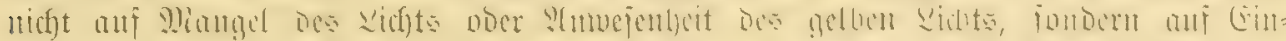

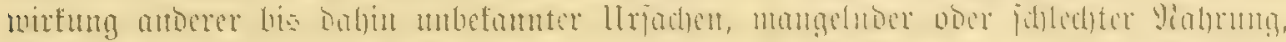

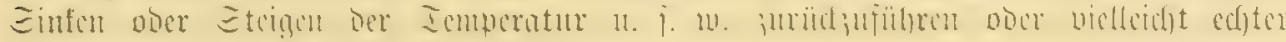

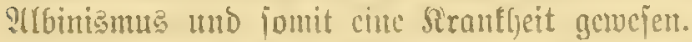

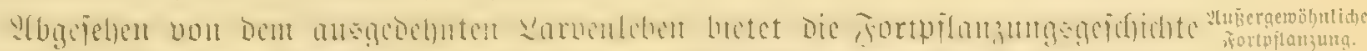

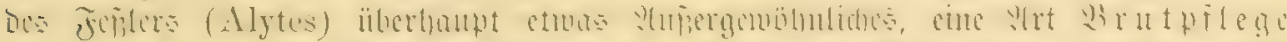

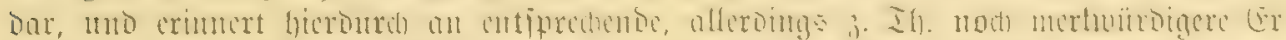

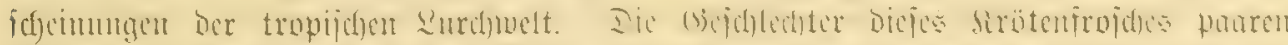

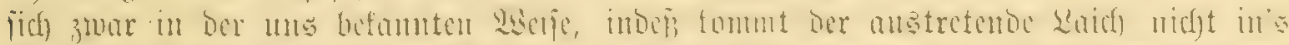

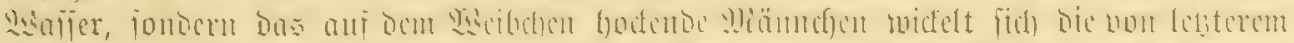

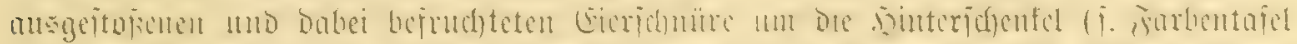

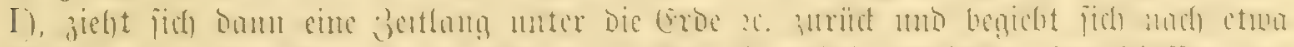

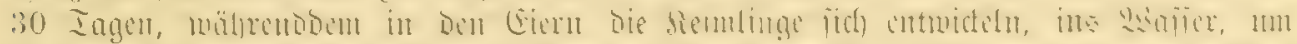

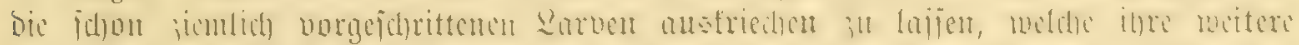

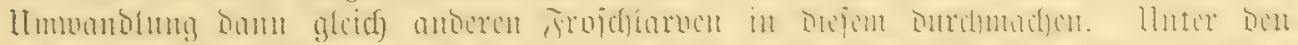

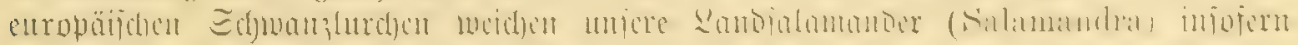

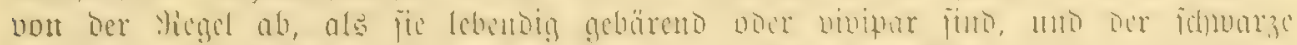

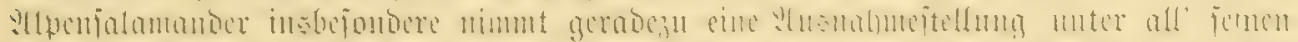

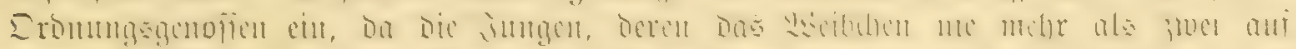

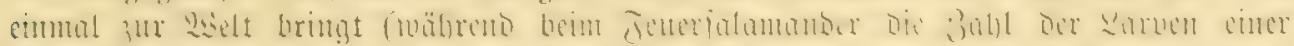

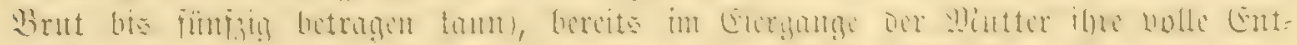

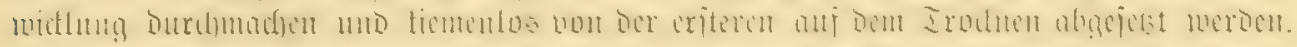

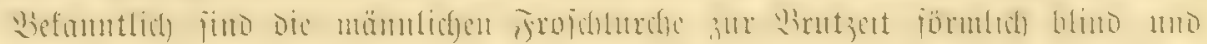
Haitarbe.

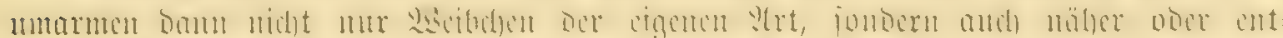

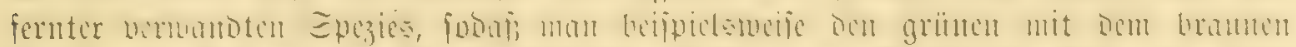

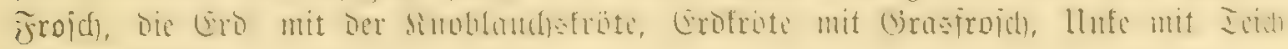

*) Influence of Physical agents etc. in: Philosophical Transactions 1850 S. 431. 


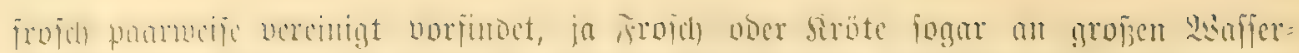

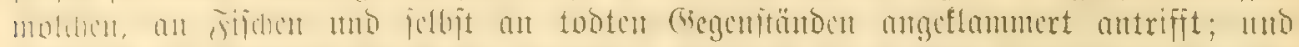

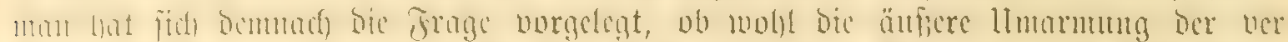

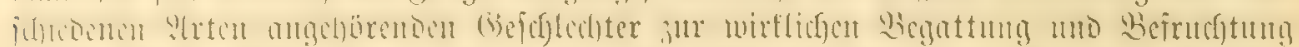

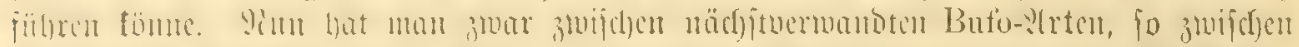

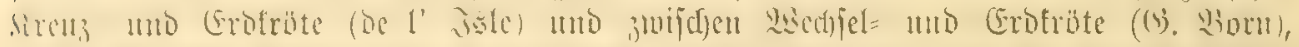

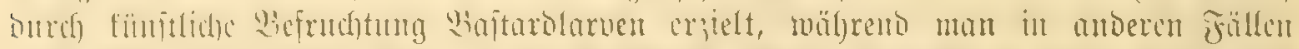

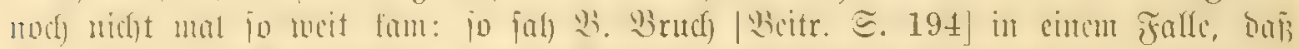

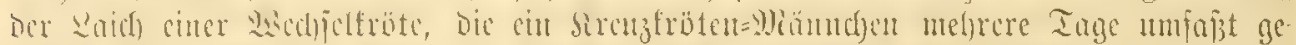

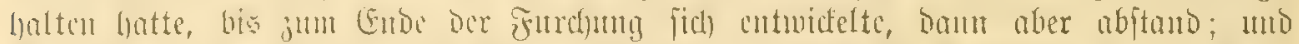

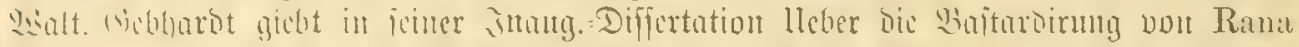

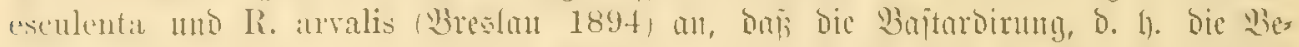

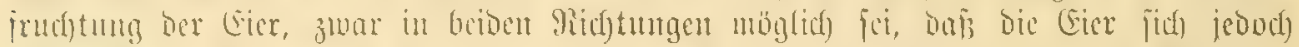

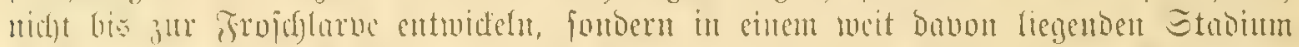

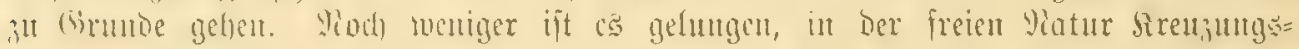

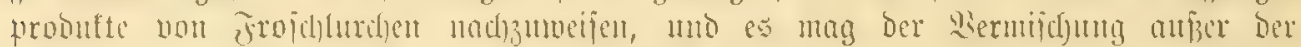

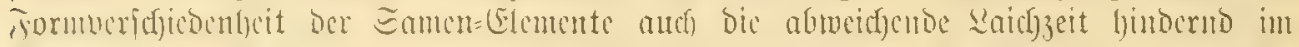

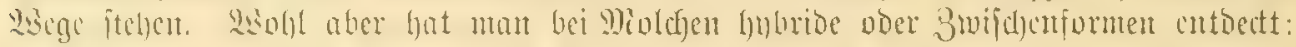

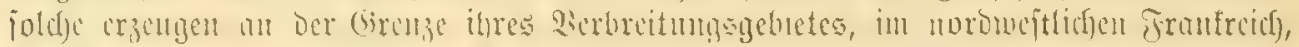

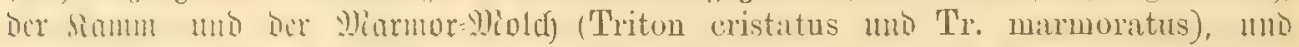

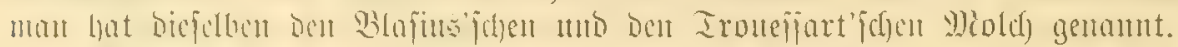

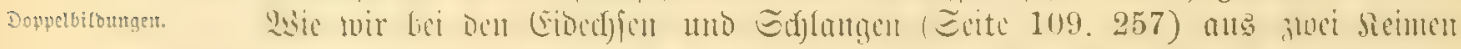

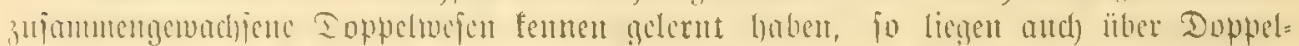

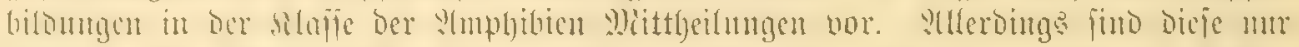

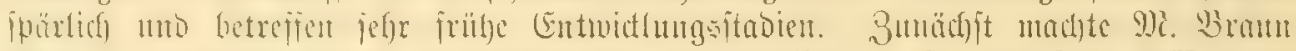

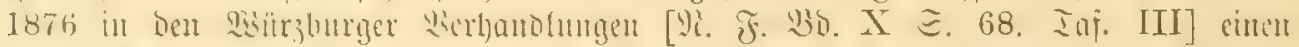

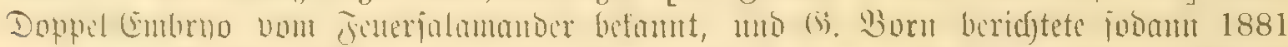

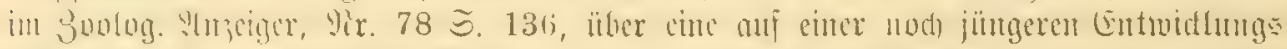

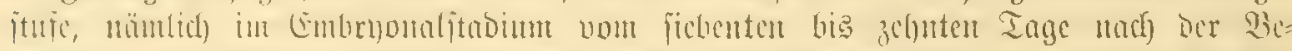

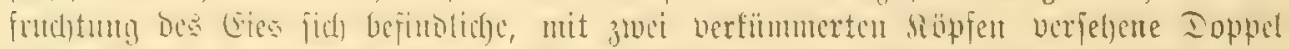

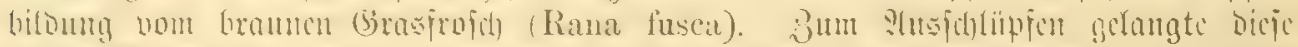

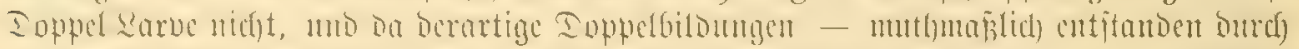

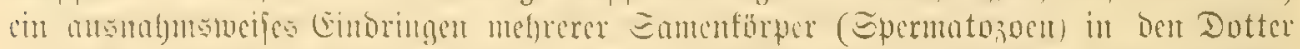

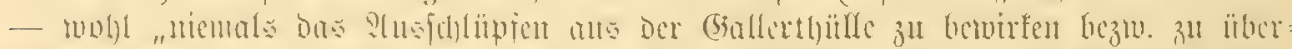

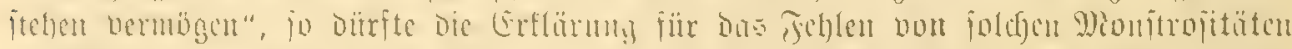

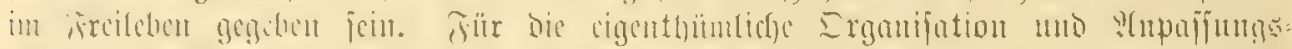

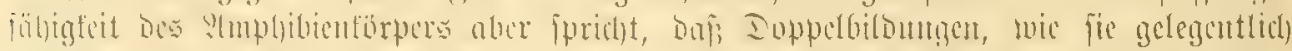

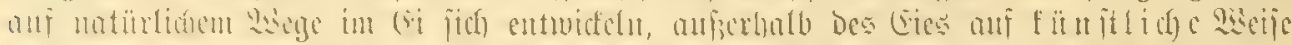

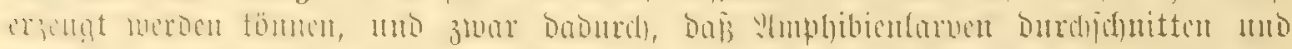

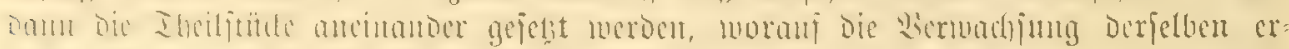

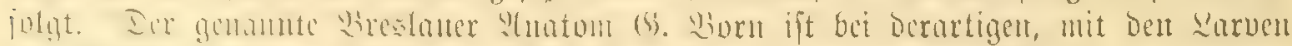

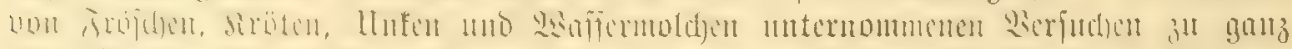

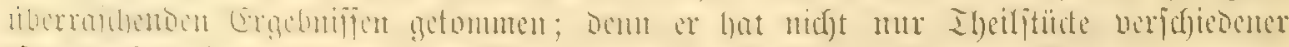

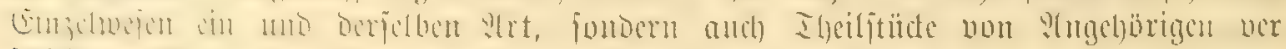

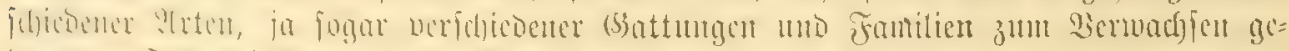

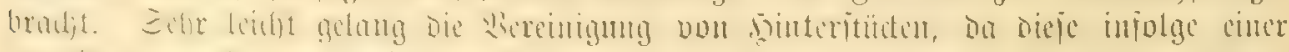

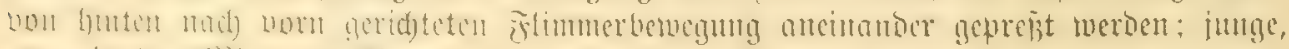

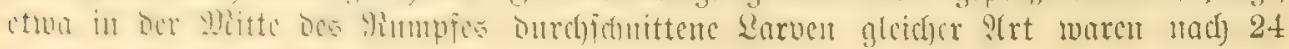




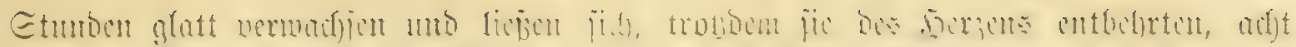

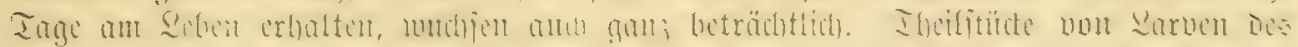

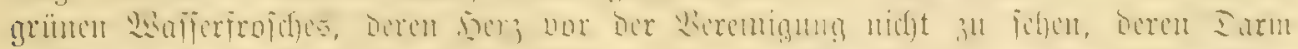

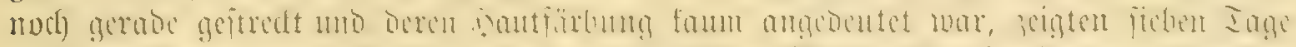

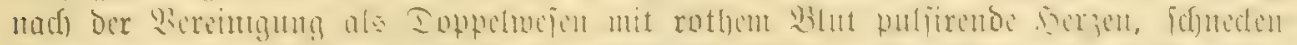

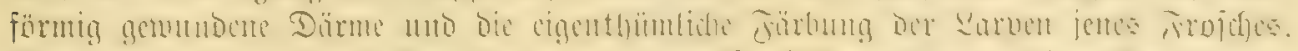

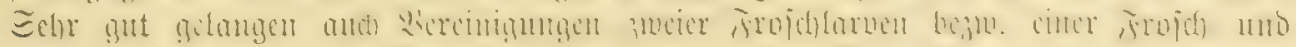

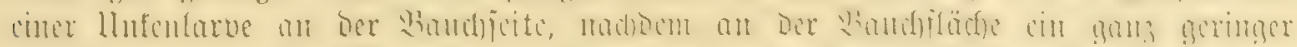

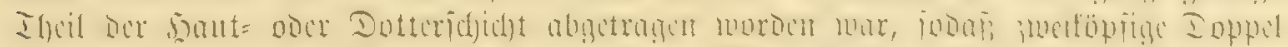

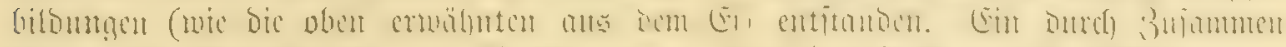

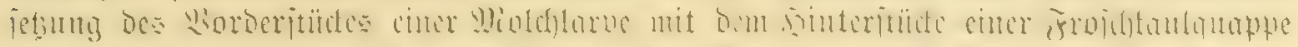

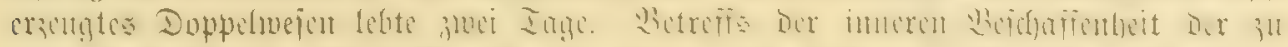

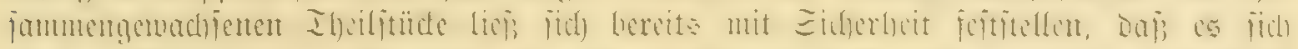

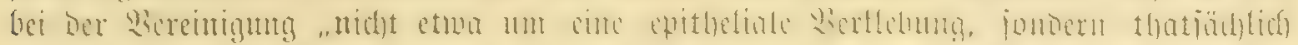

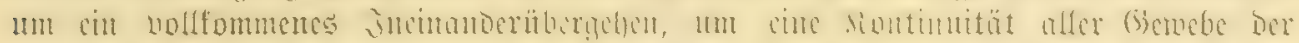

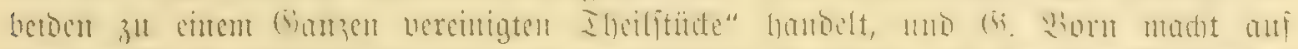

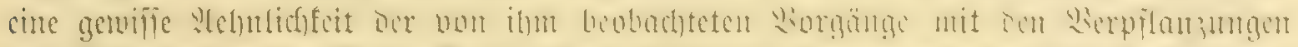

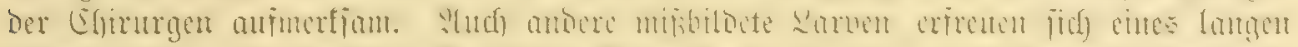

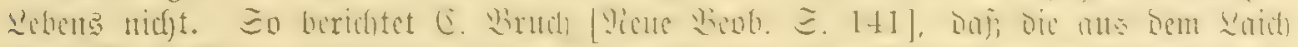

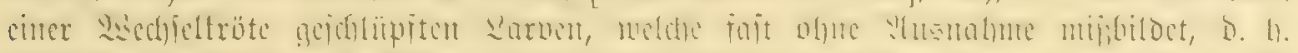

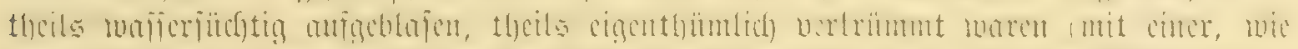

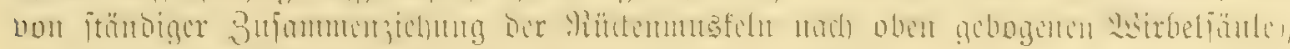
trots jorgföltiger Pffrcge in turzer Beit zu Girutbe gingen.

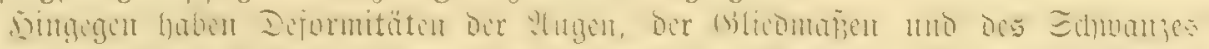

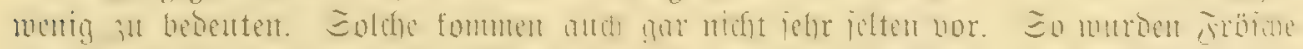

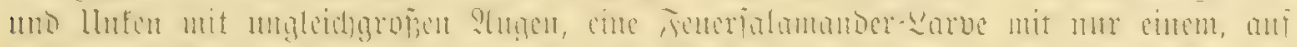

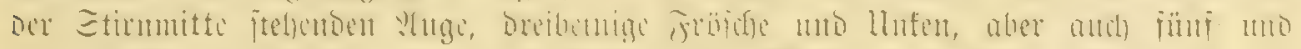

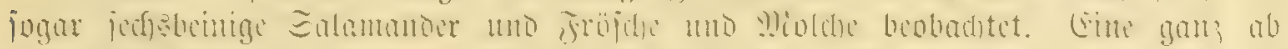

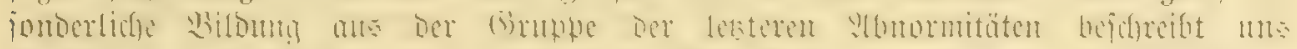

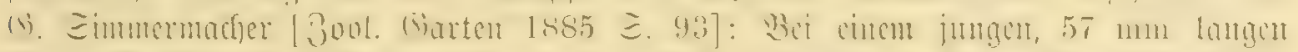

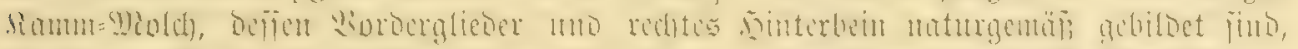

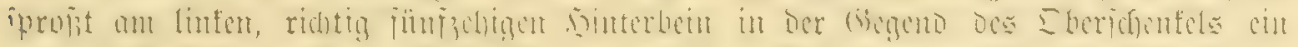

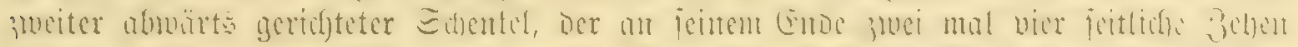

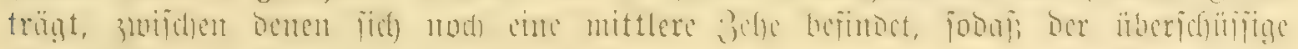
(uลntud)s neut Beljen bejibt.

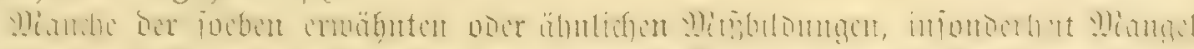

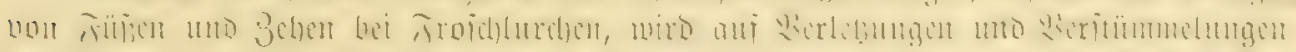

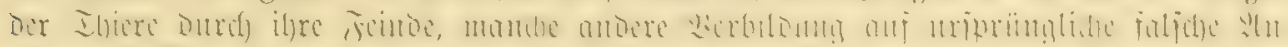
lage mo

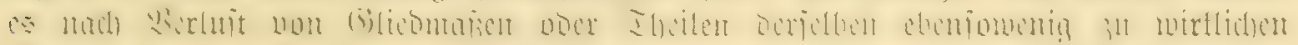

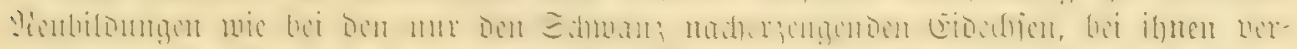

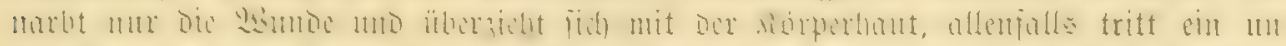

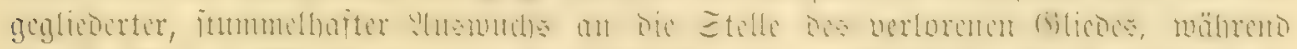

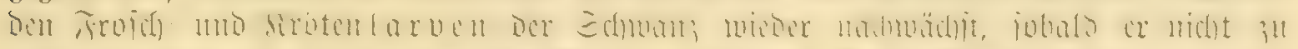

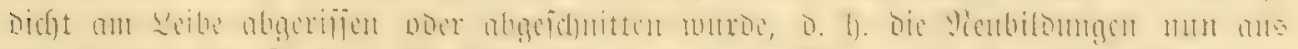

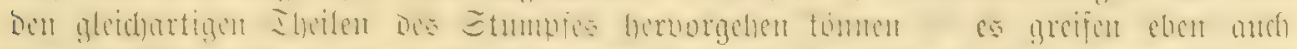

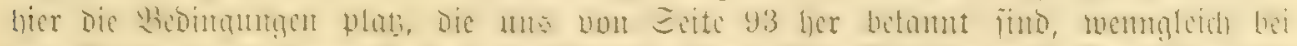

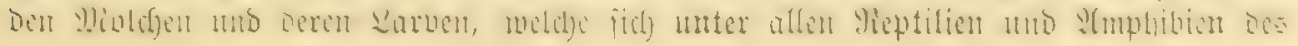




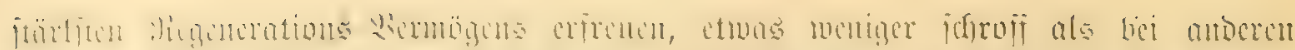

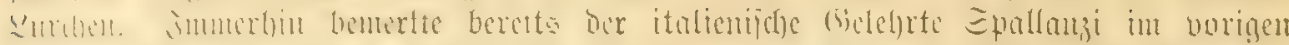

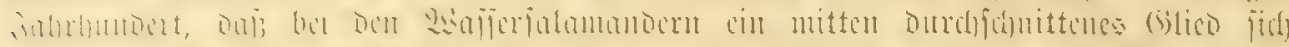

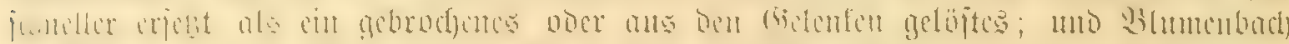

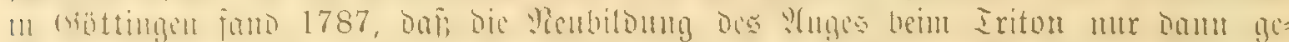

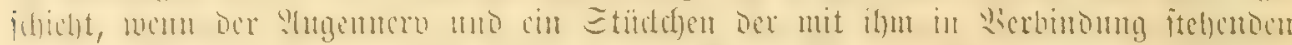

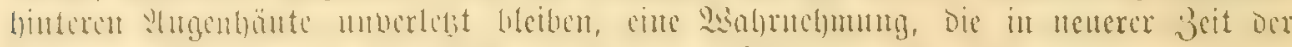

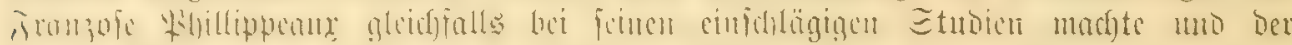

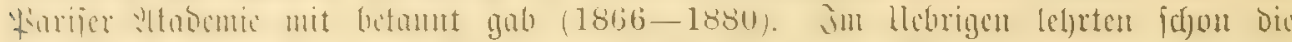

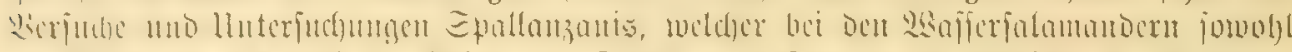

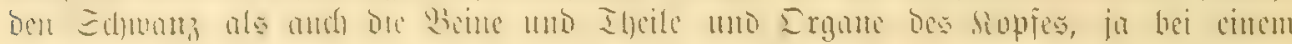

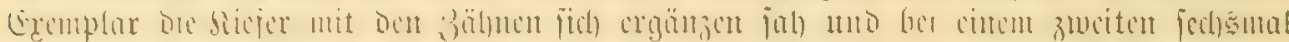

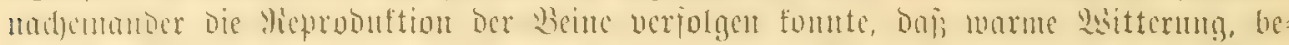
lougliche

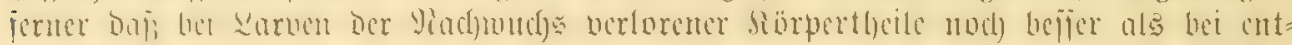

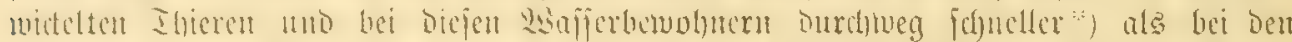

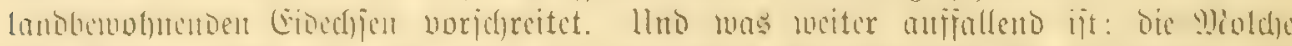

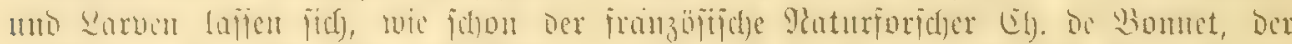

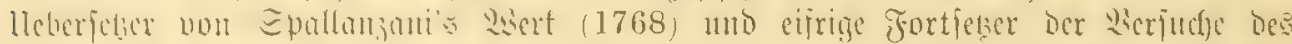

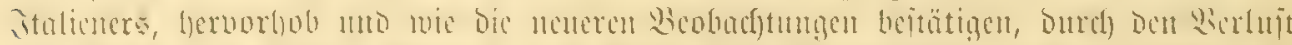

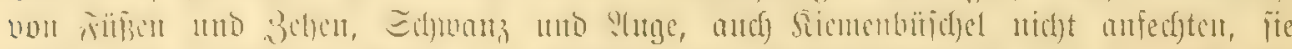

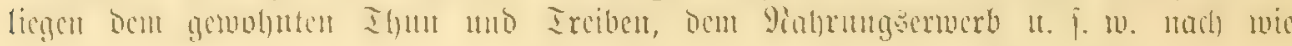
vor of.

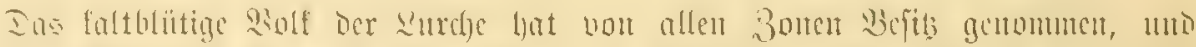

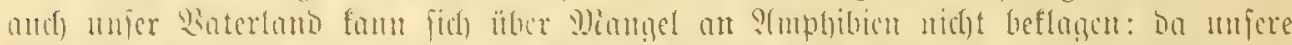

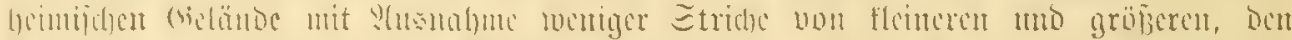

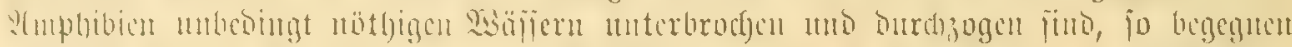

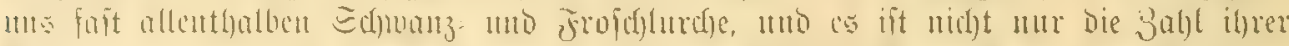

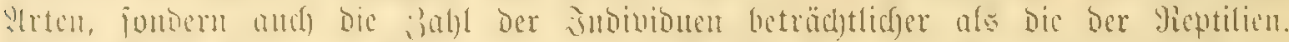

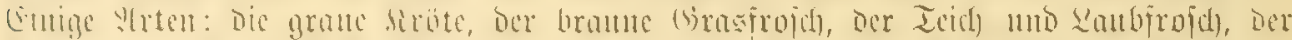

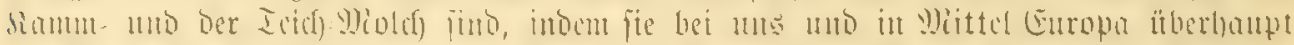

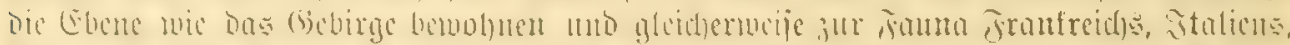

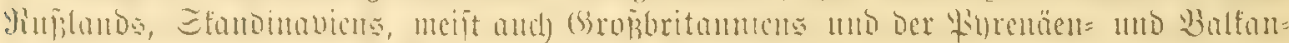

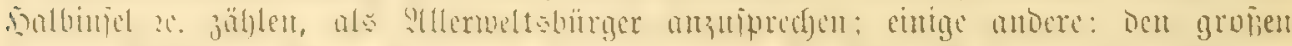

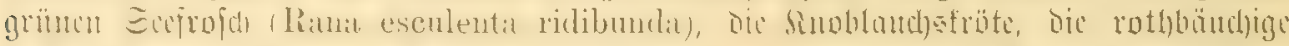

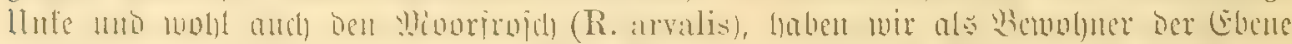

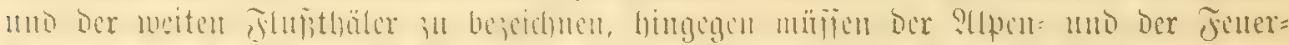

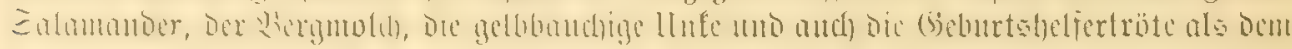

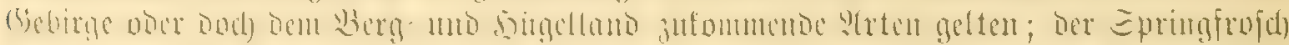

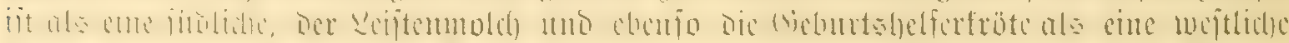

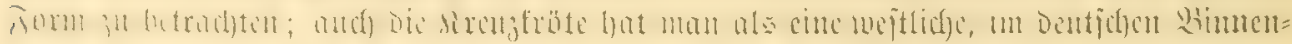

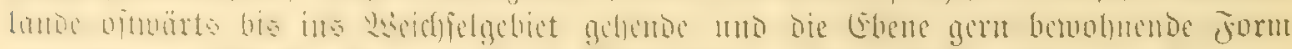

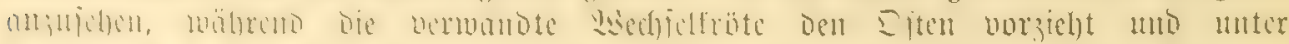

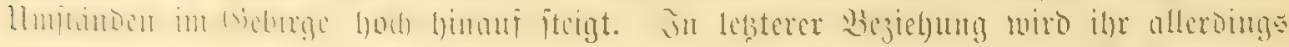

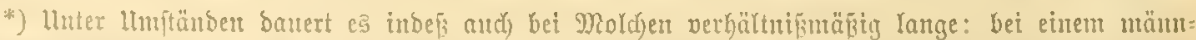

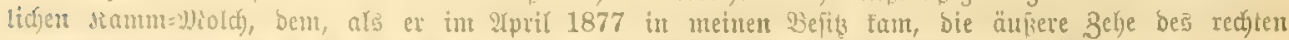

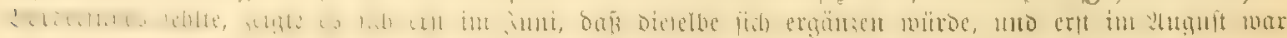

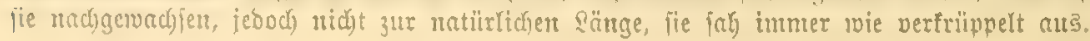




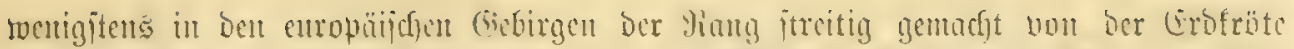

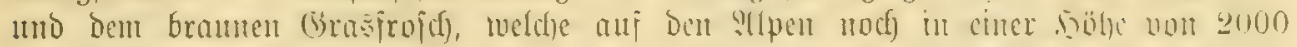

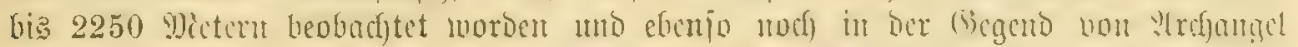

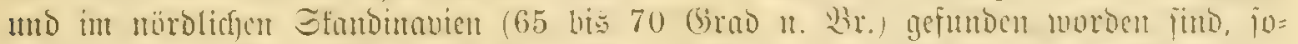

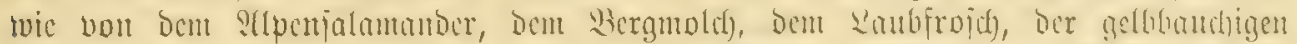

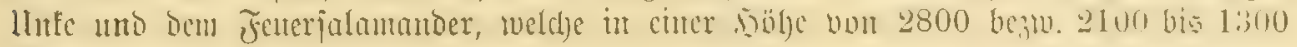
Mictern angetroffen burden.

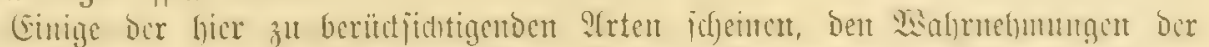

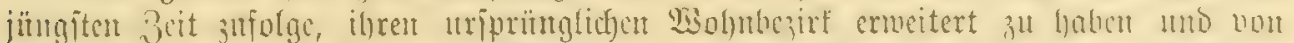

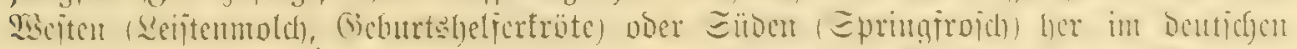

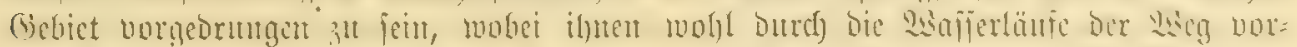

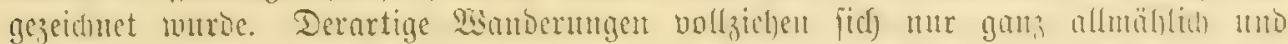

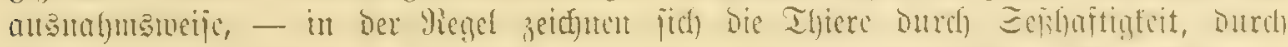

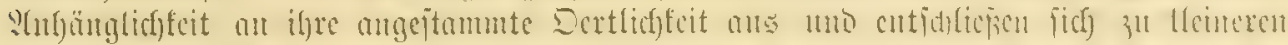

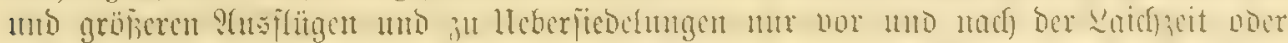

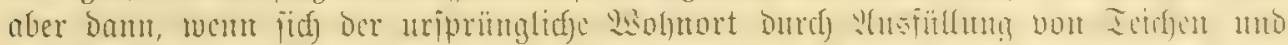

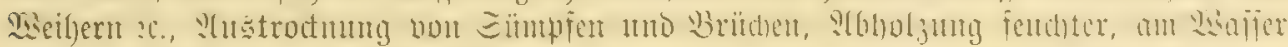

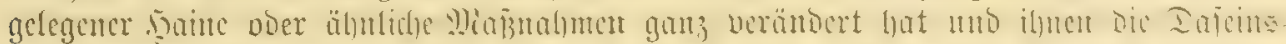

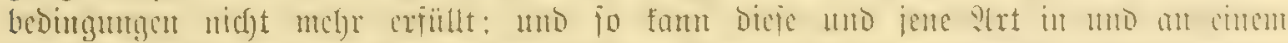

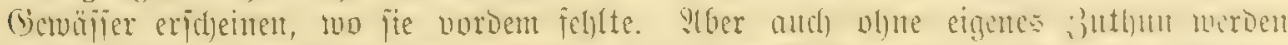

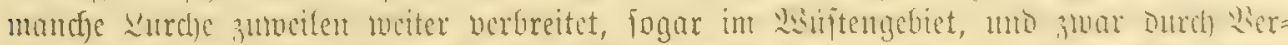

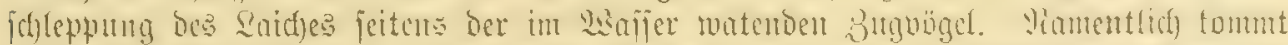

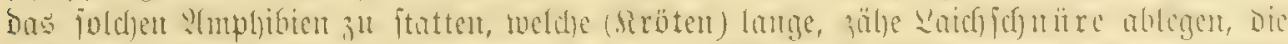

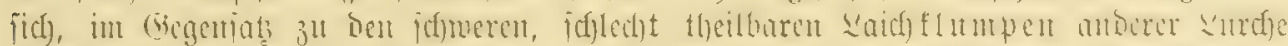

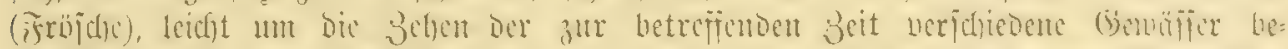

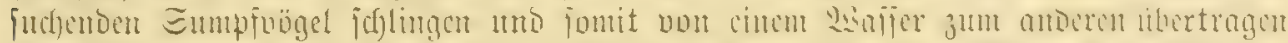

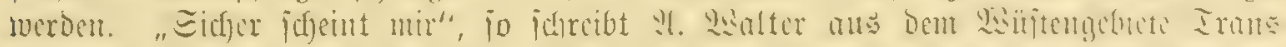

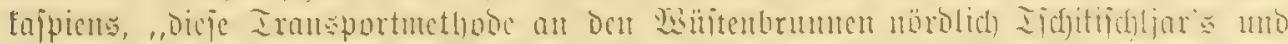

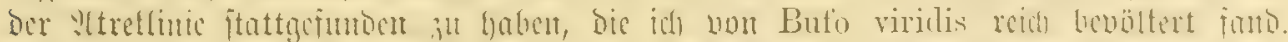

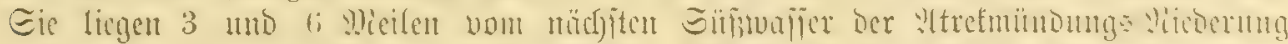

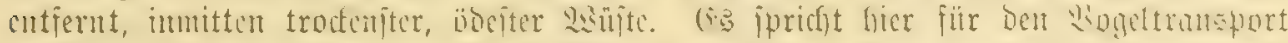

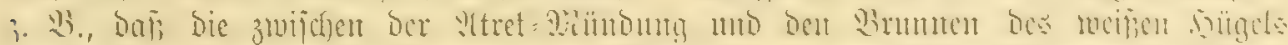

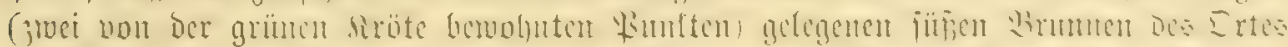

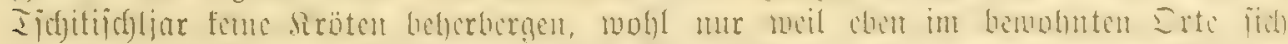

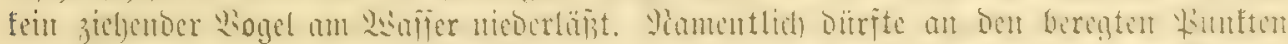

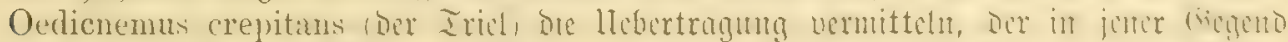

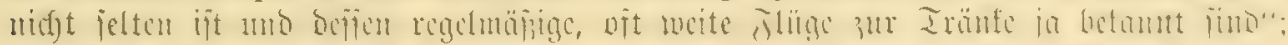

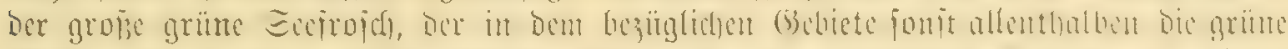

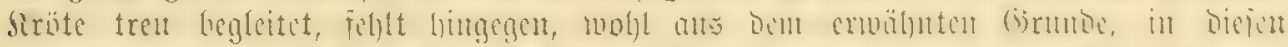
sinjenbrumen.

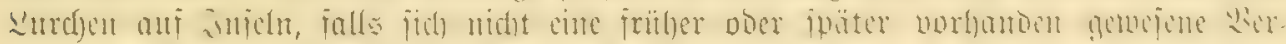

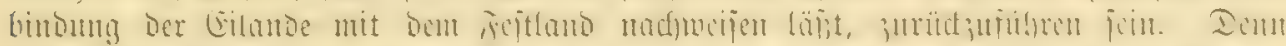

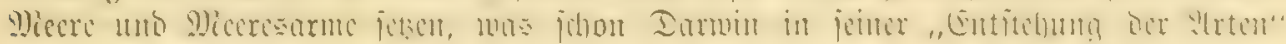

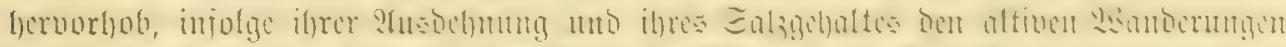

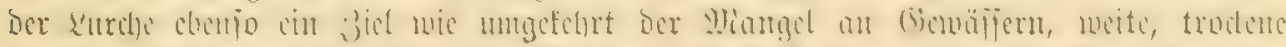

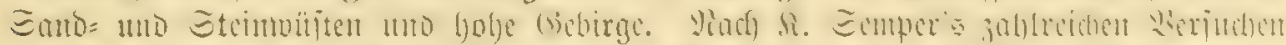

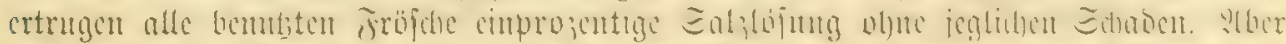

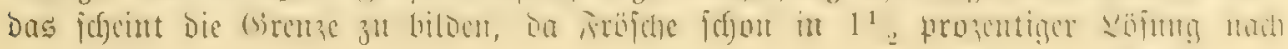




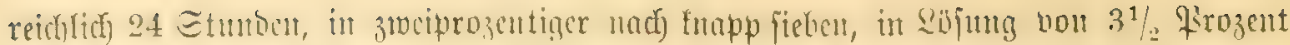

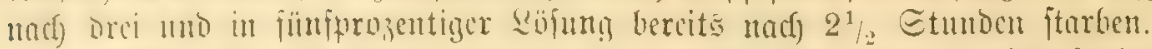

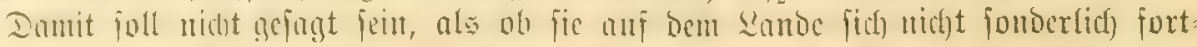

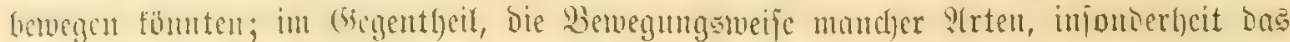

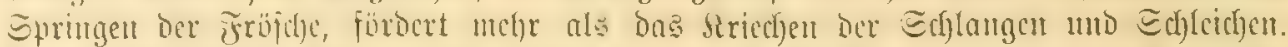

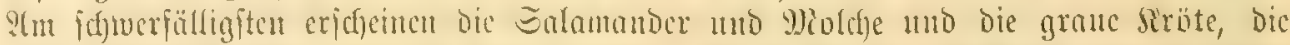

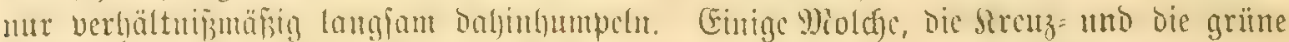

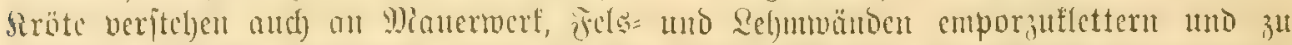
flimmen, unD ber L̈mbjrofd) ftcigt in bic luftigen Sironen von Bamm und Straud)

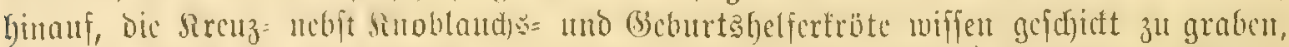

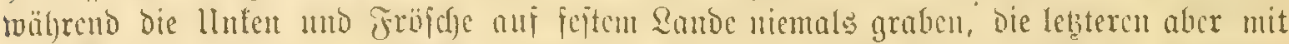

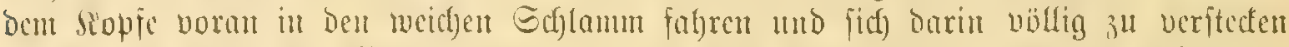

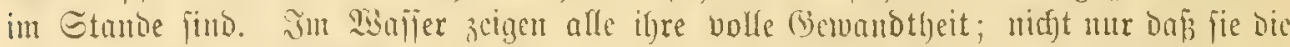

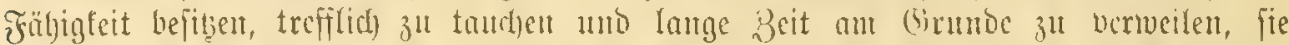

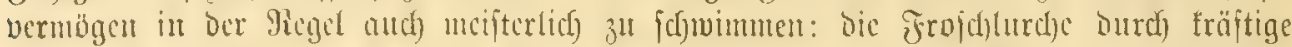

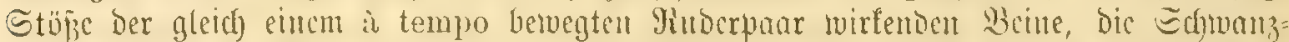

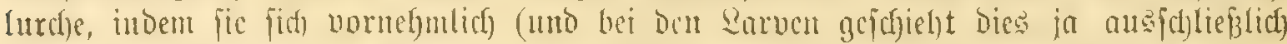

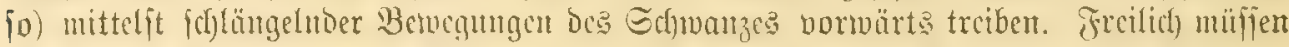

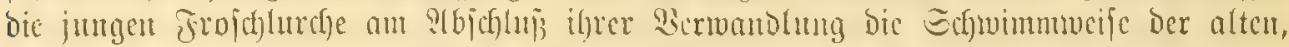

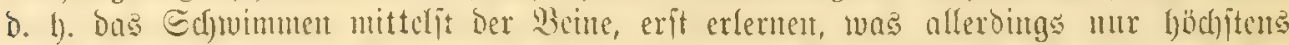

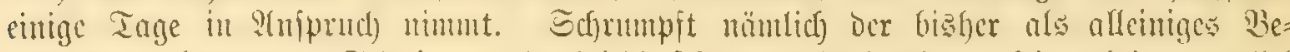

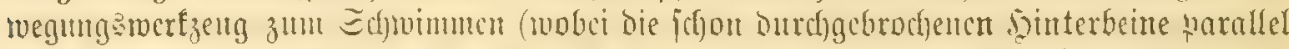

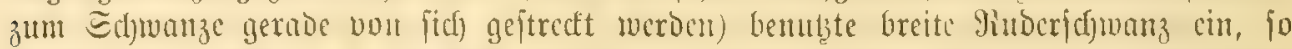
beginut Der junge Zurch bie Bene nad) ?

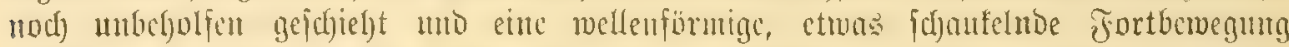

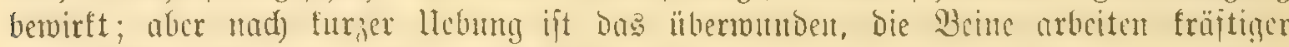

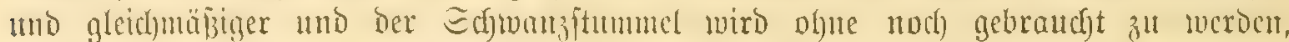
gerabeweg nod) hinten getragen. (b)anz brollig ficht es and) ats, wem bie nod) mit

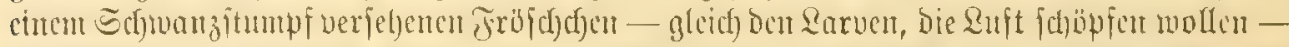

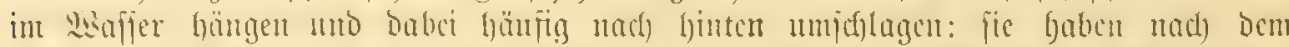

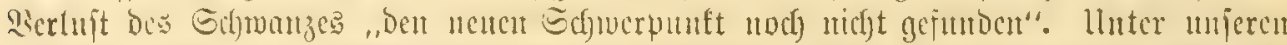

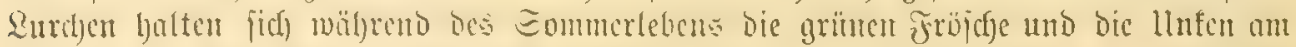

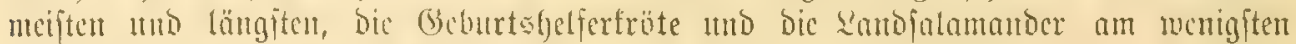
und utidjt gern im Bajaficr jelbit anf.

Wuferthalt.

Bon Den jocben erwäluten, "2bajierfremben" abgejehon, gehen unfere suphibien

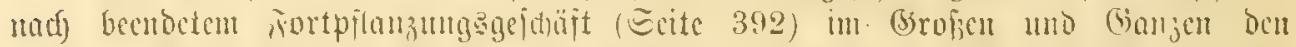

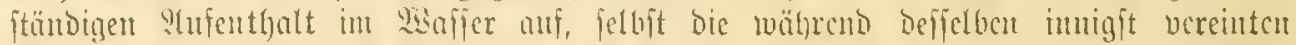

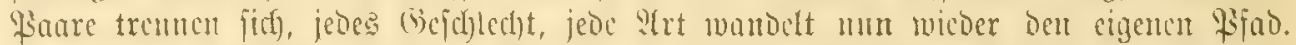

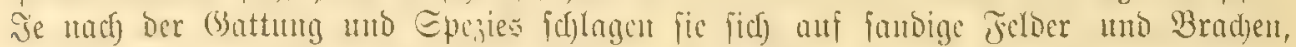

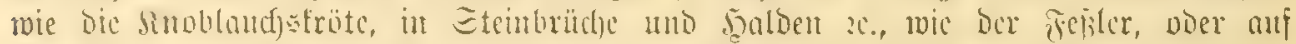

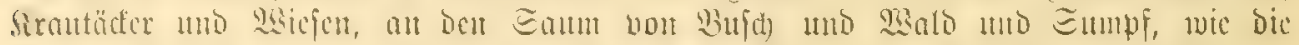

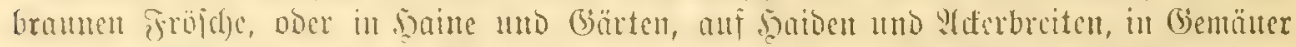

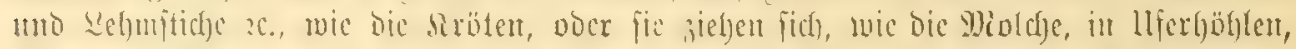

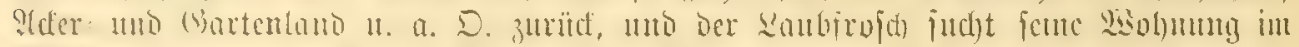

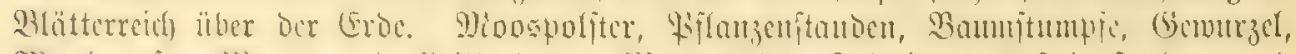

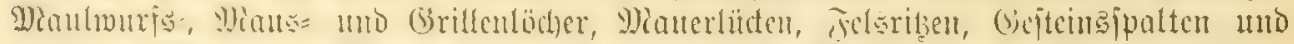

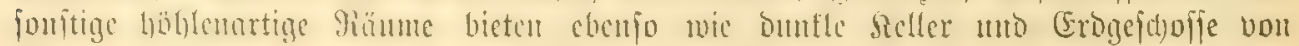

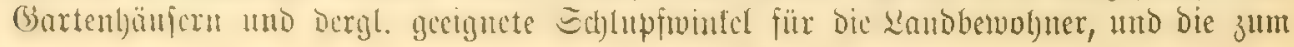




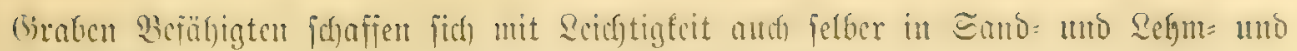
2Ađerboben einc vorïbergefocnde oder bleibende llnterfunft.

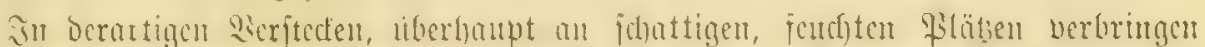

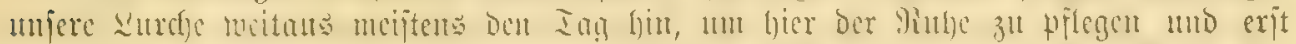

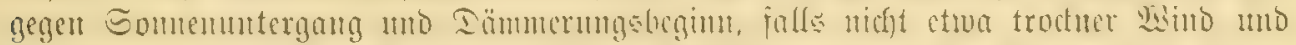

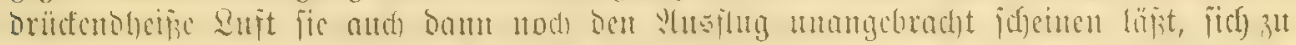

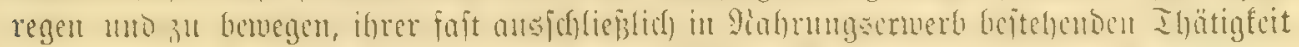

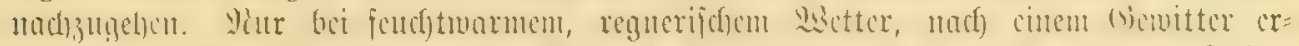

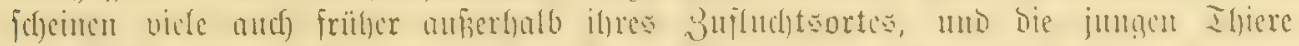

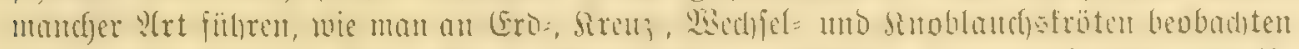

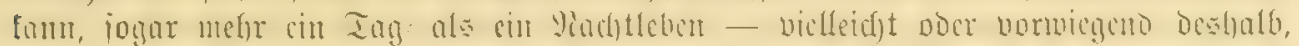

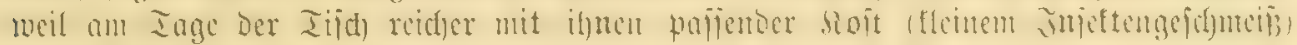

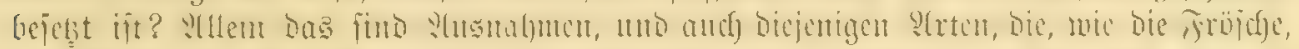

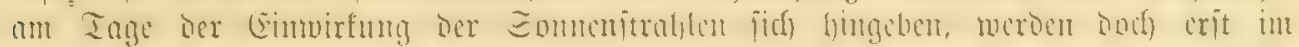

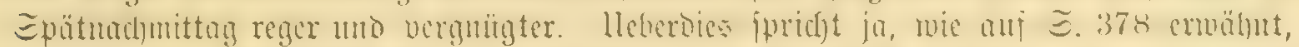

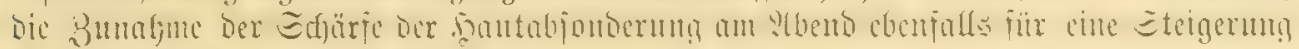
Der Qebenstjätigteit zu biejer Beit.

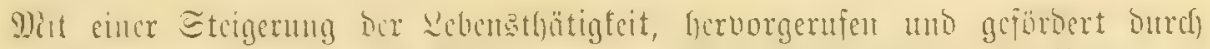

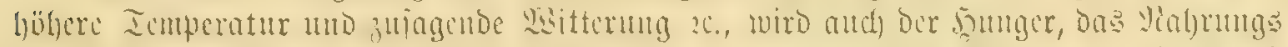

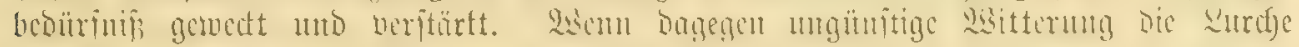

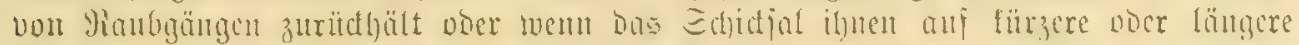

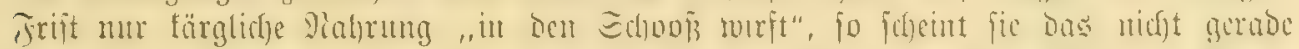

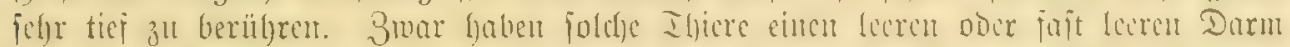

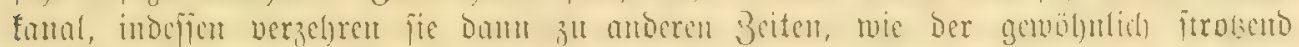

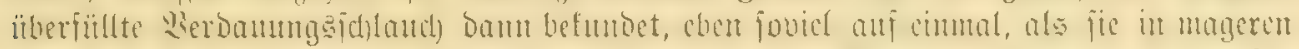

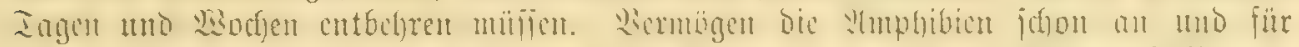

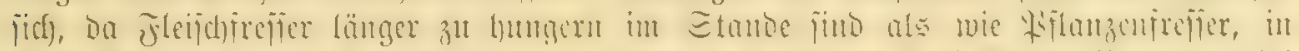

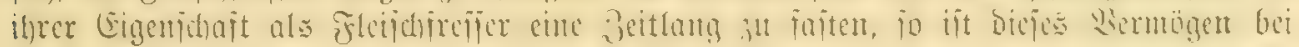

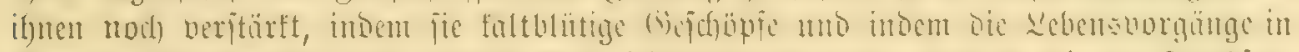

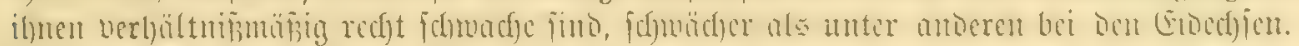

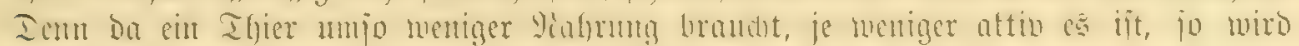

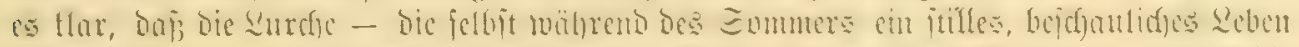

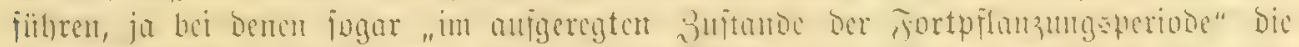

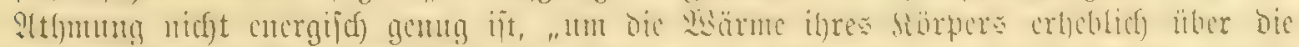

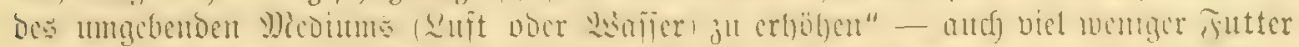

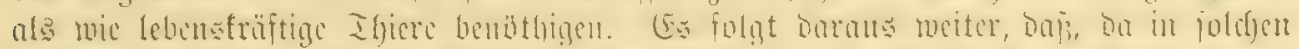

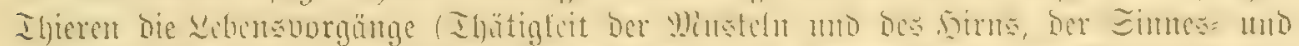

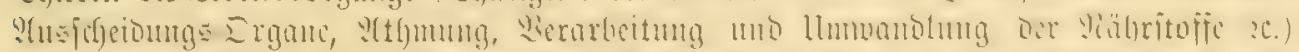

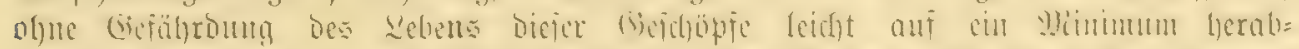

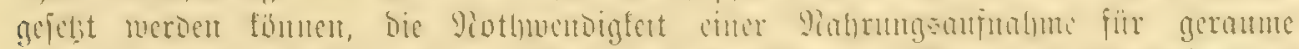

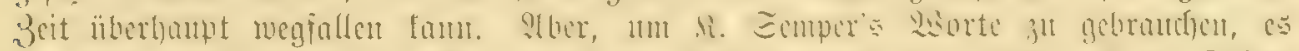

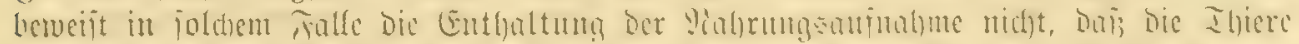

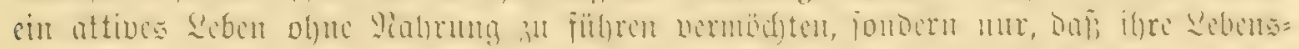

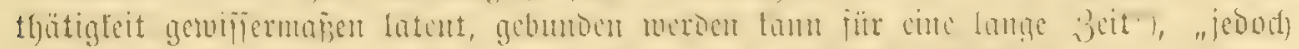

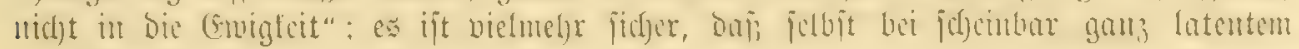

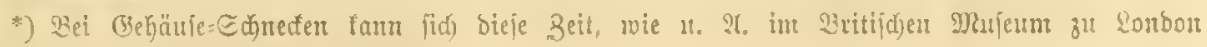
erviejen murbe, auj Jofre bium erjtreden. 


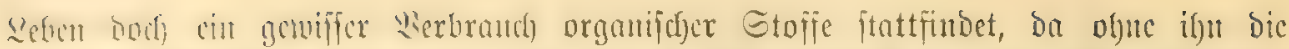

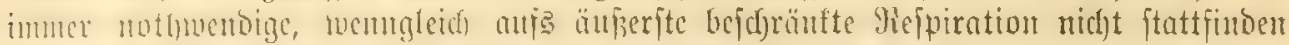

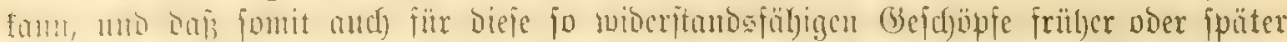

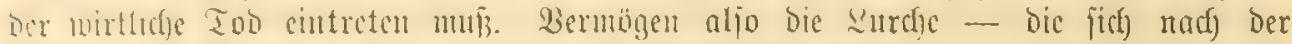

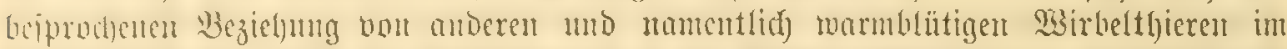

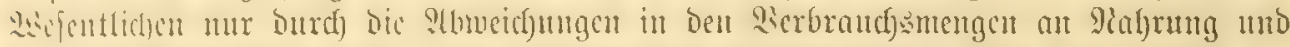

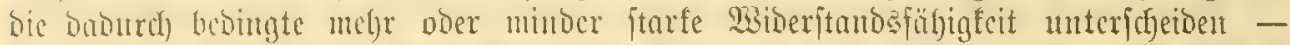

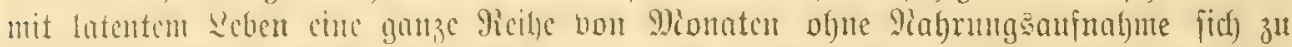

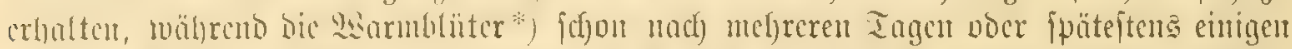

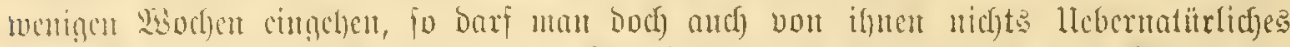

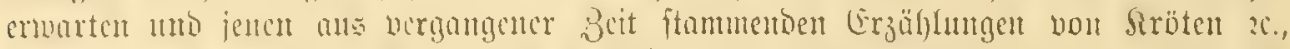

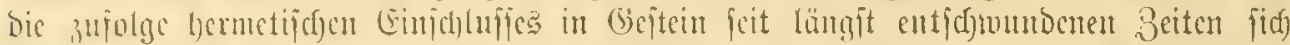

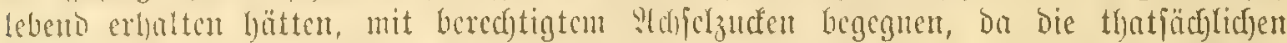

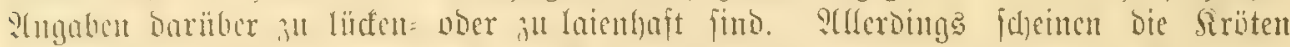

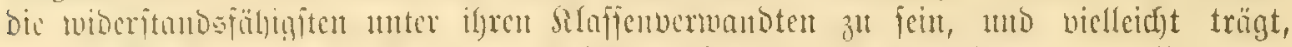

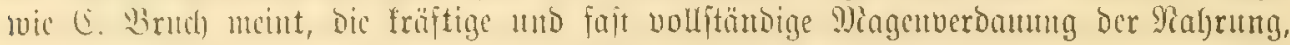

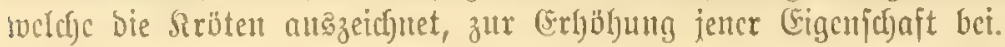

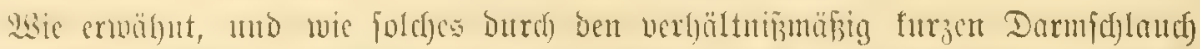

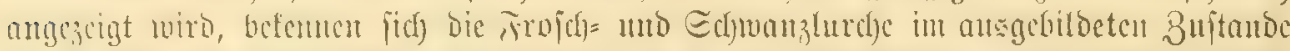

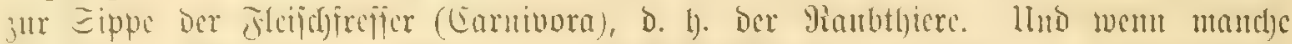

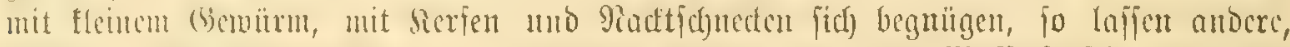

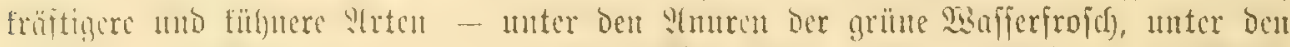

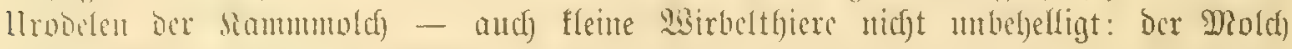

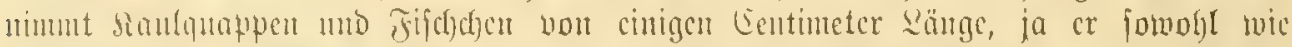

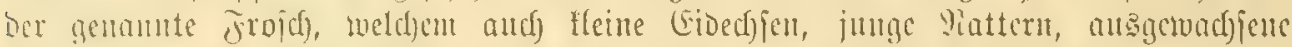

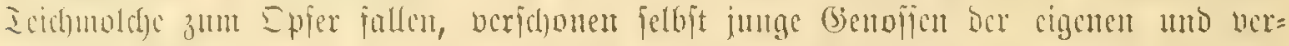

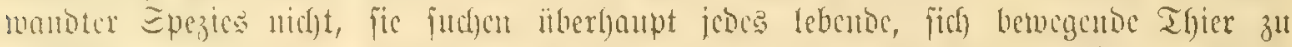

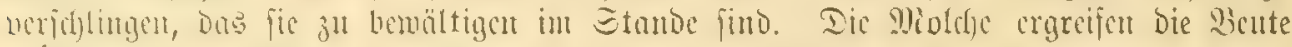

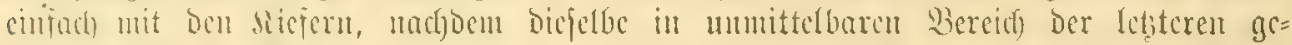

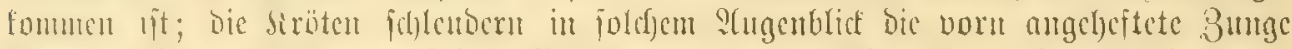

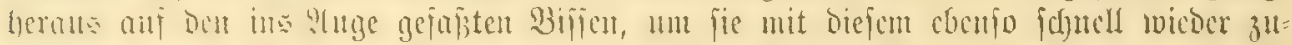

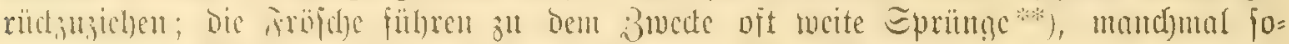

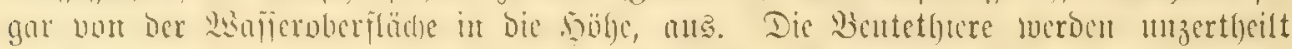

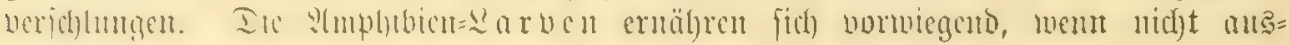

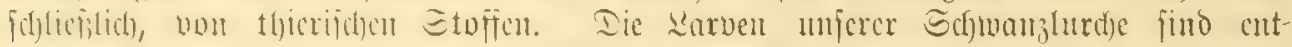

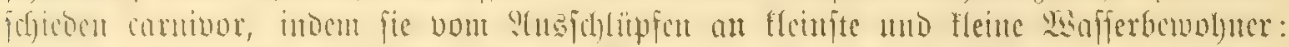

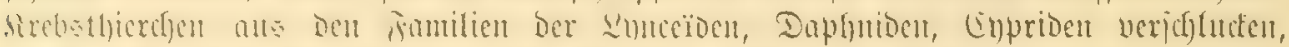

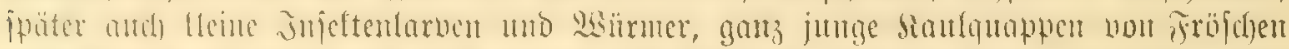

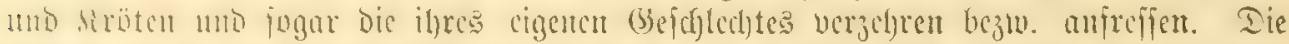

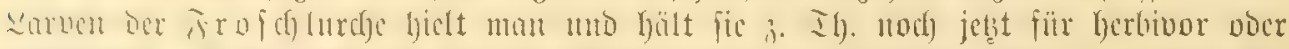

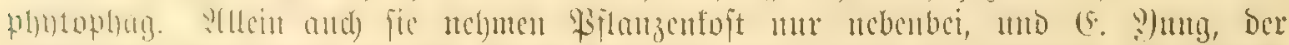

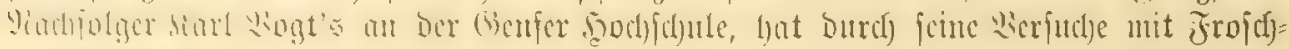

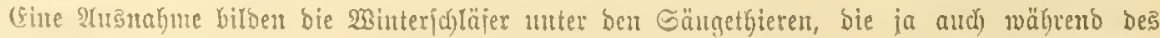

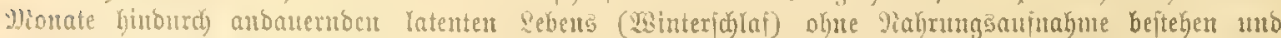
Daber zu biejer seit ben 9 (mphibien und Yieptilien gleidgettellt roerben bürfes. - **) 2senu ber frojd)

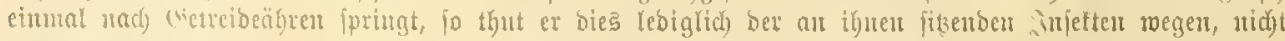

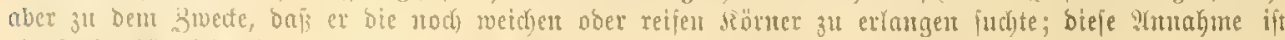

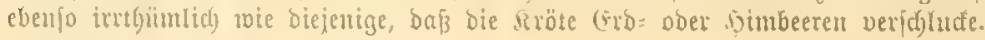




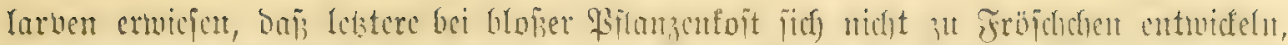

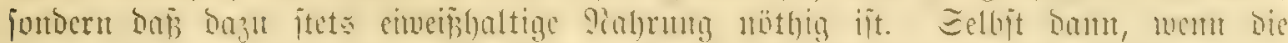

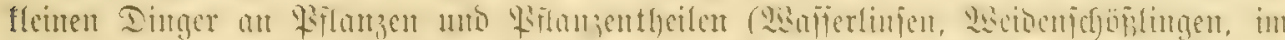

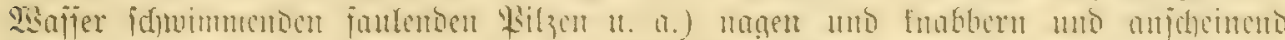

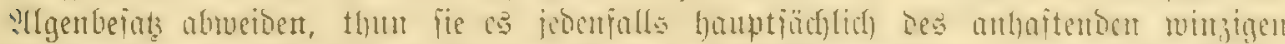

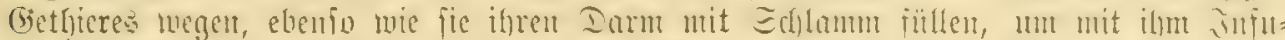

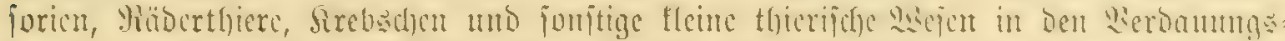

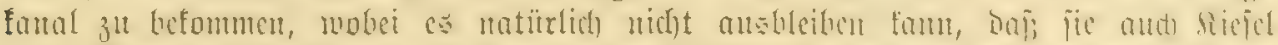

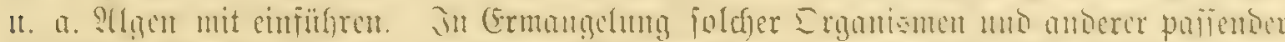

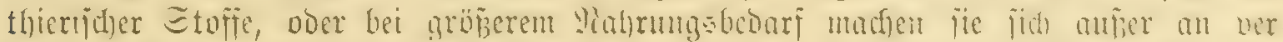

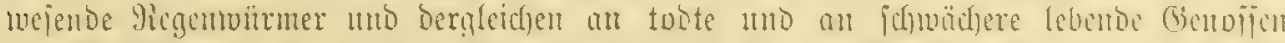

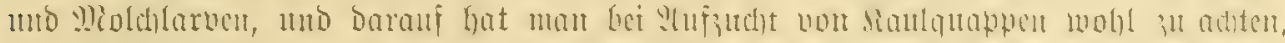

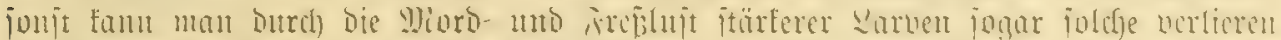

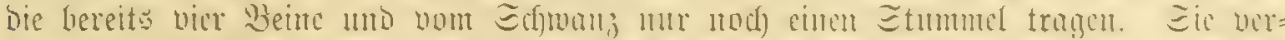

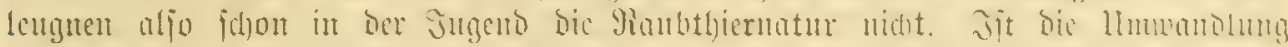

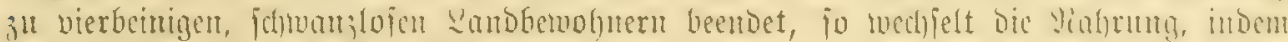

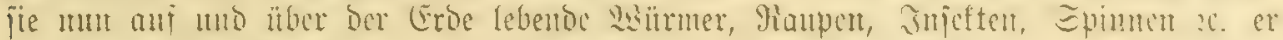

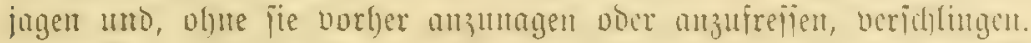

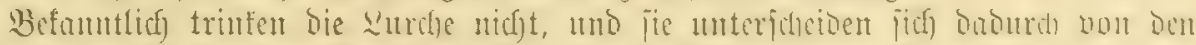

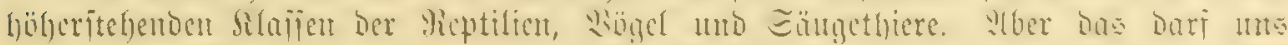

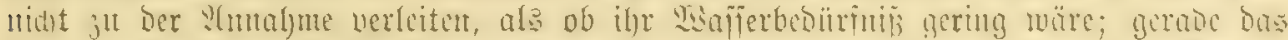

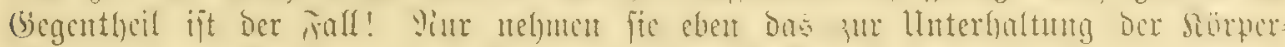

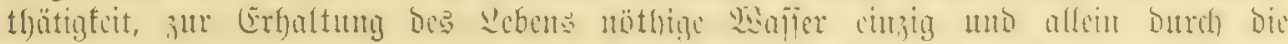

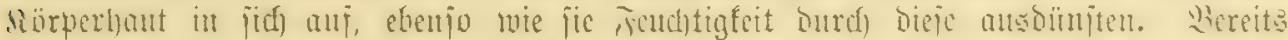

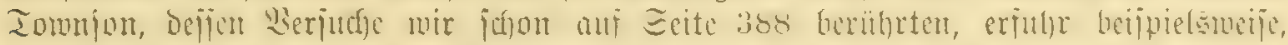

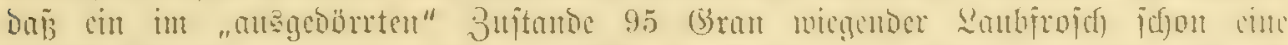

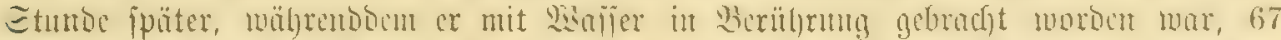

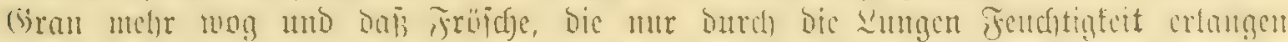

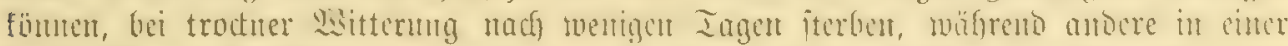

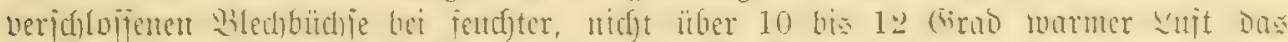

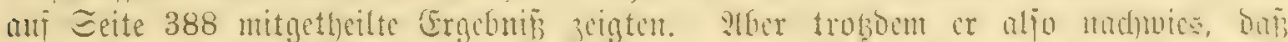

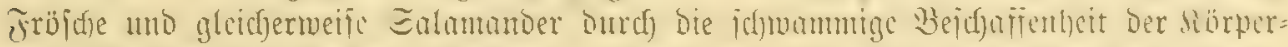

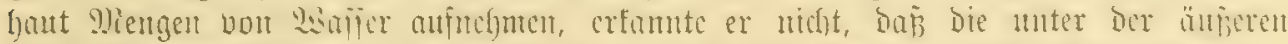

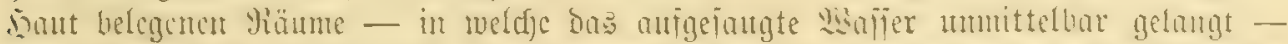

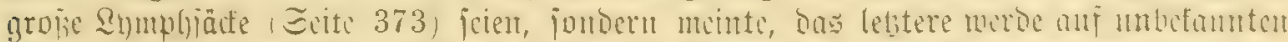

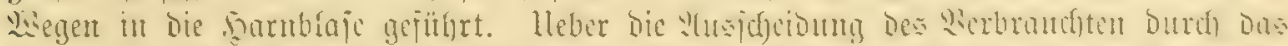

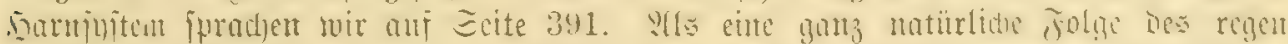

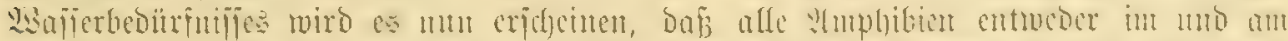

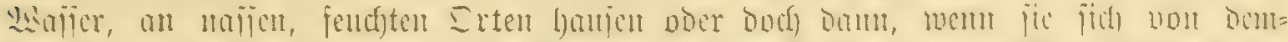
juben cutjernt foben, blos bei rognerijoger

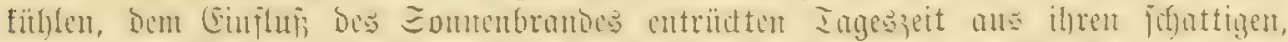

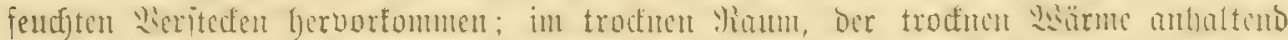

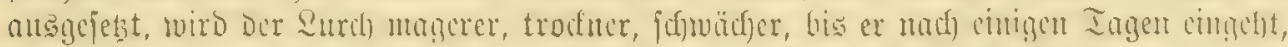

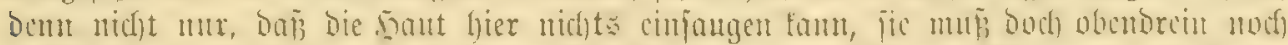

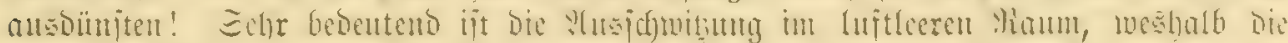

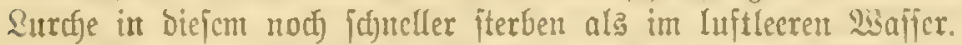

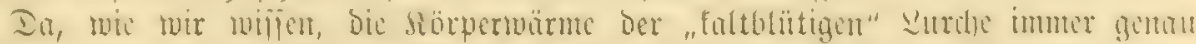
Wintelidglai.

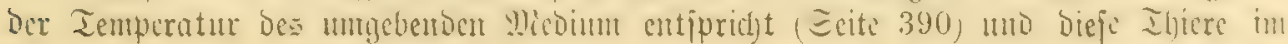




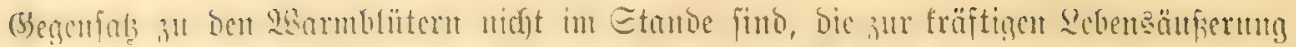

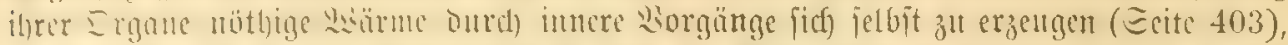

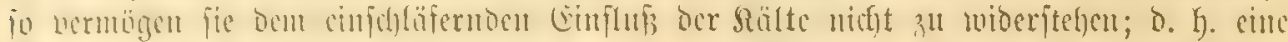

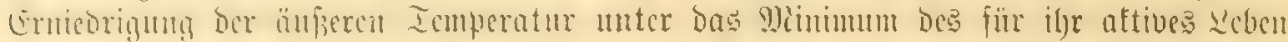

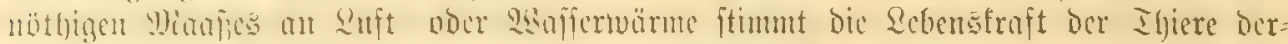

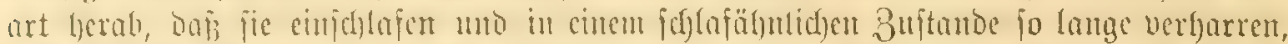

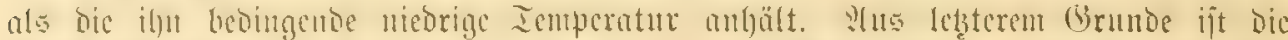

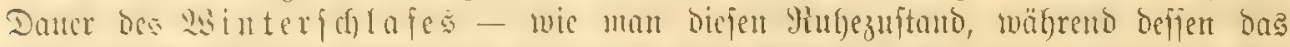

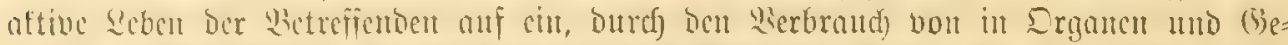

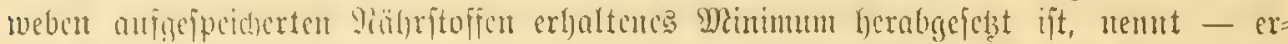

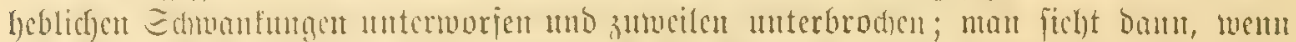
zur 2sinterseit plibslich cinge warme Iage cintreten, nicht felten ocu cinen ober

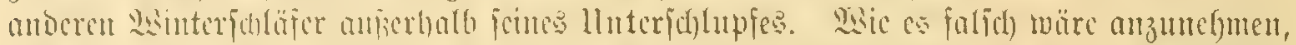

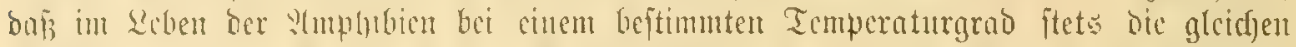

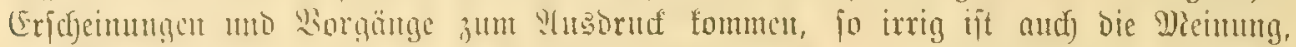

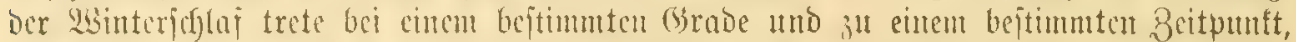

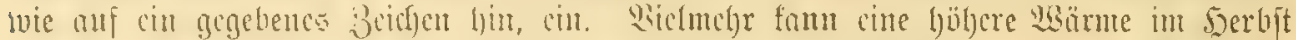

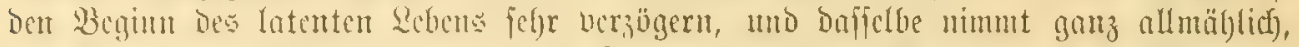

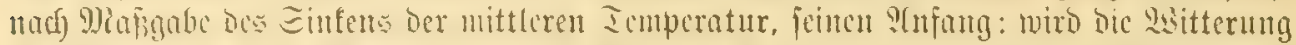

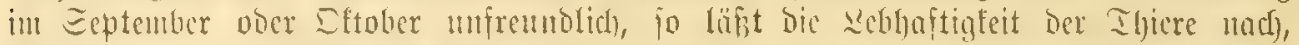

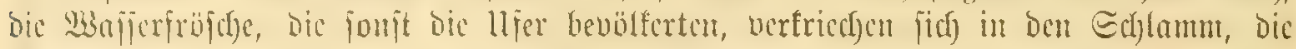

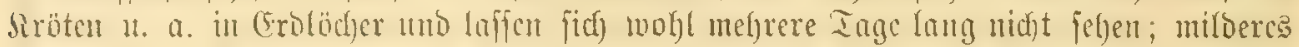

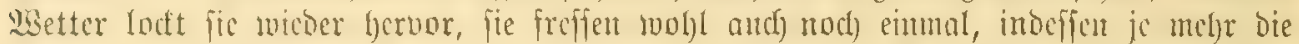

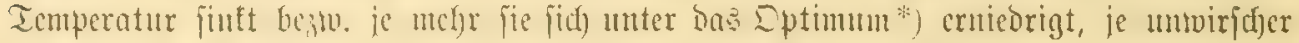

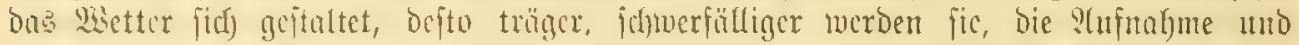

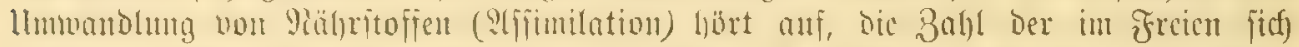
zeigenden Ibier fdrumpit immer melje sufammen, fie graben fidf tiefer cin und fommen

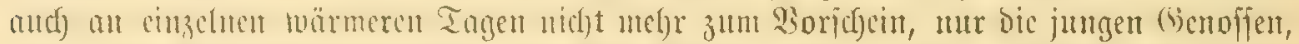

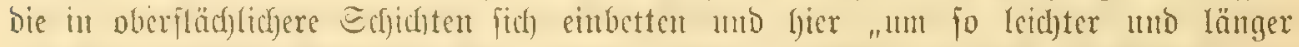

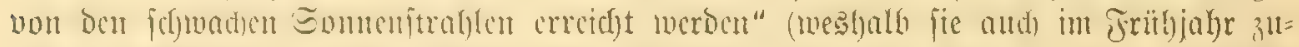

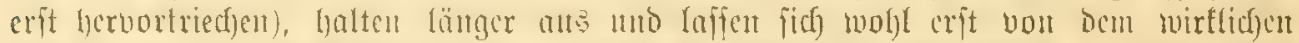

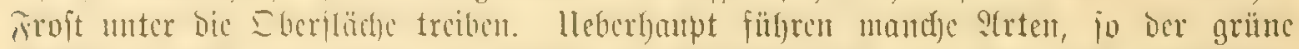

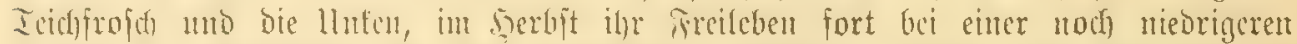

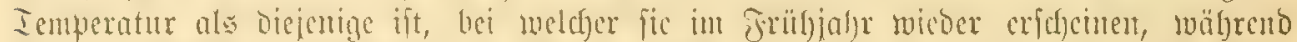

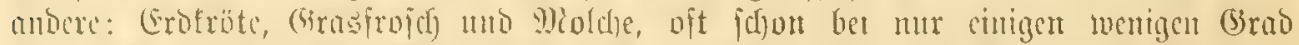

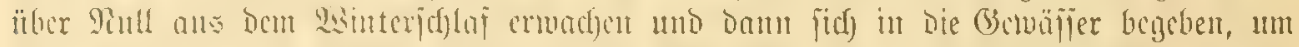

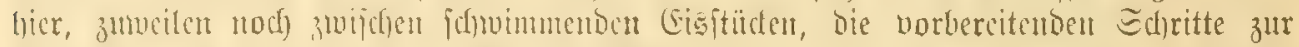

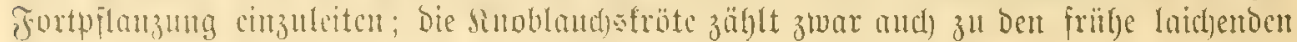

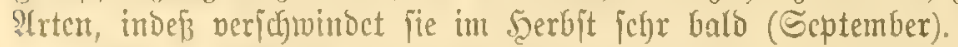

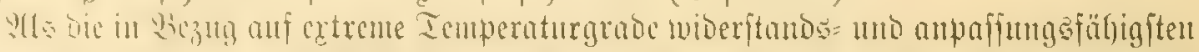

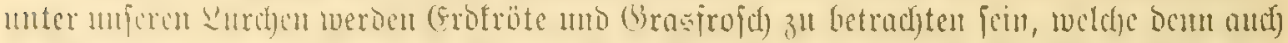

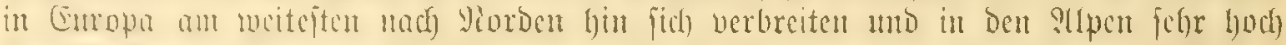

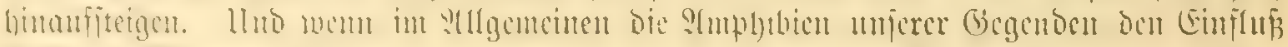

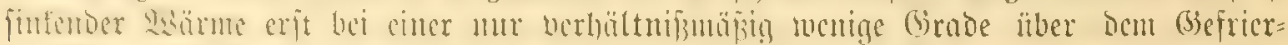

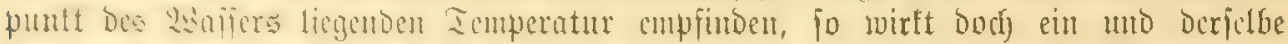

*) arc Temperatur=Dptimun bezetounet mon ben für bas Thier günjtigiten, feinem Gebeihen förberlidyizen zemperaturgras. 


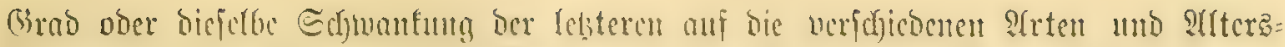

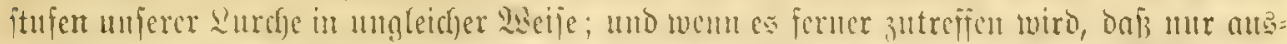

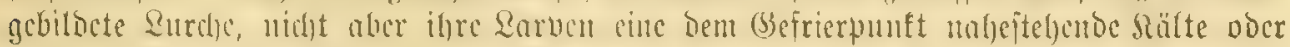
gar bas Einfricren felbit ertragen fümmen, fo tarf man bod and bent erferen nicht

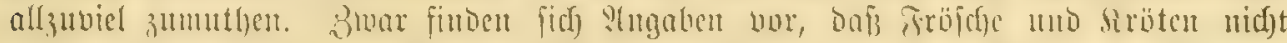

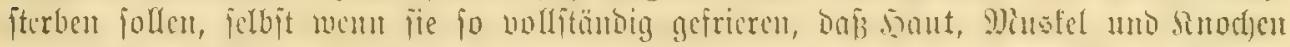

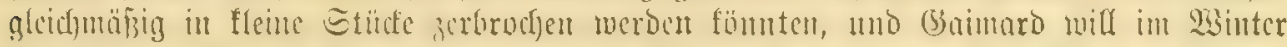
1828.9 anf Jotand beobachtet haben, wic Siröten jo gefroren, "Daß alle ibre flitfligen

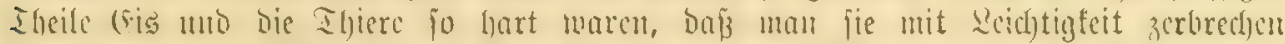

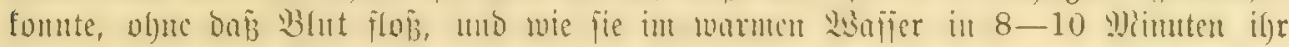

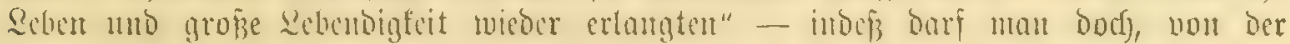

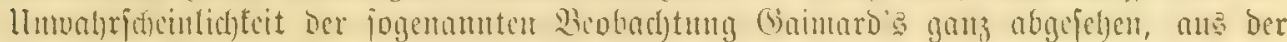

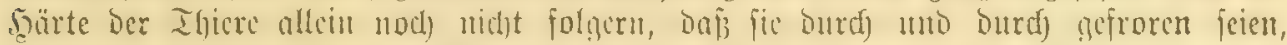

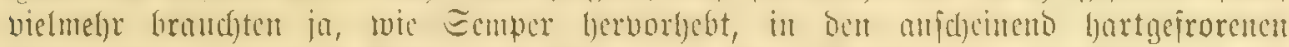

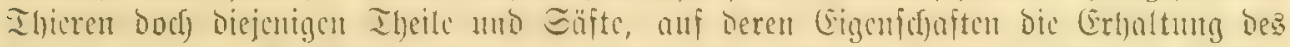

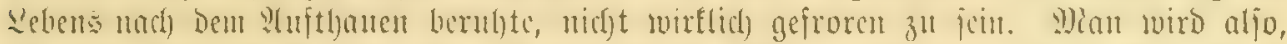
che man berartige :!ngaben wic bie ermälntutu mad)t, mafaficube, foufequent burd)=

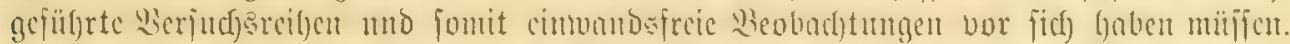

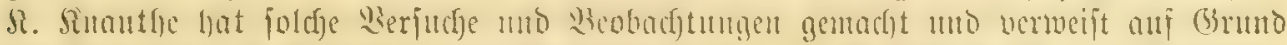

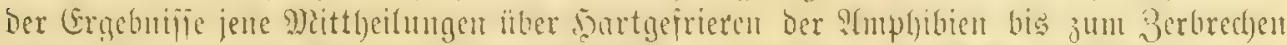

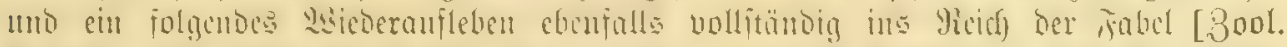

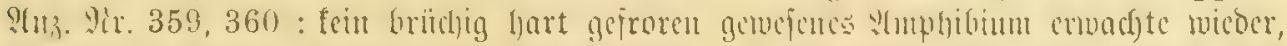

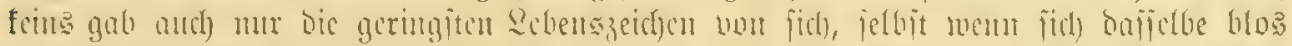

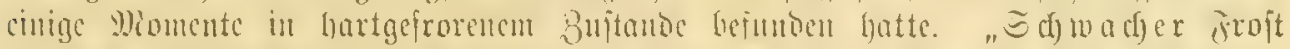

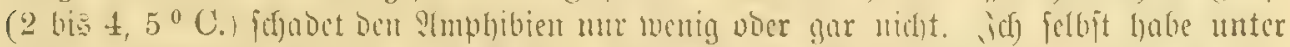

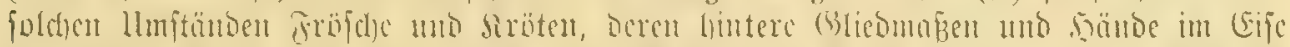

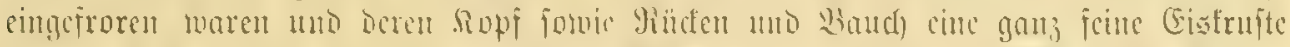

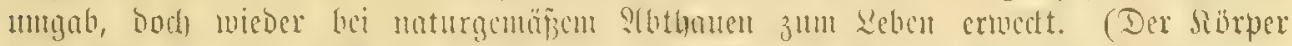

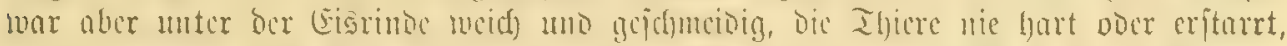

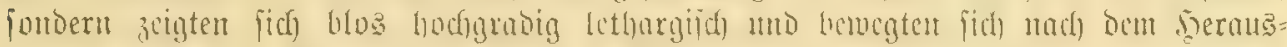

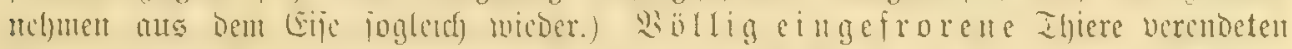

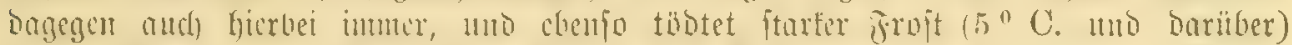

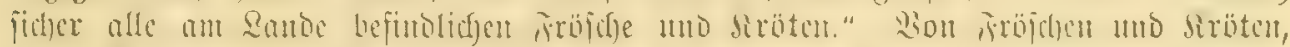

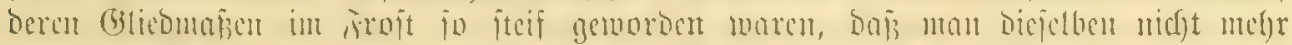

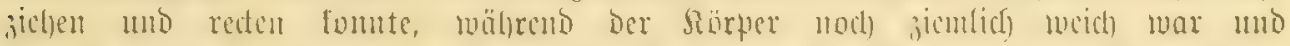

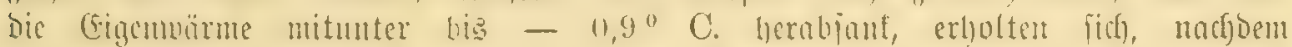

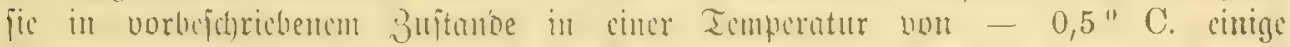

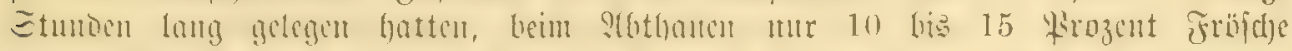

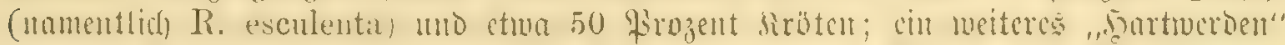

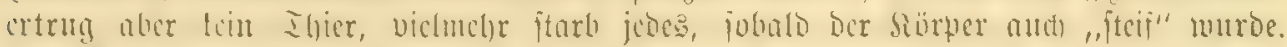

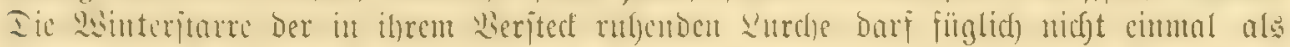

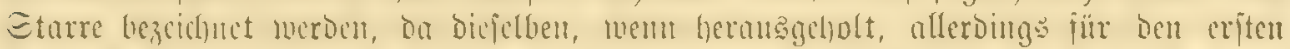

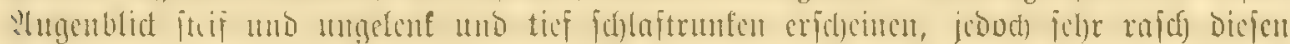

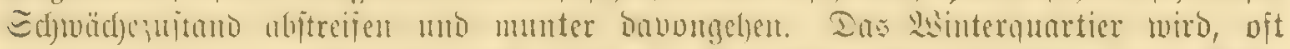

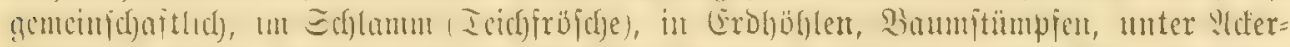

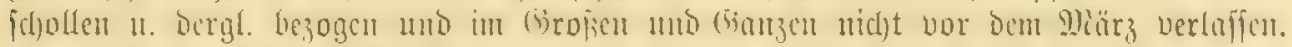

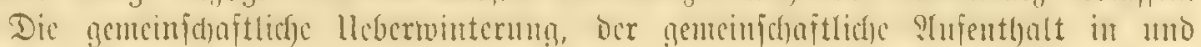

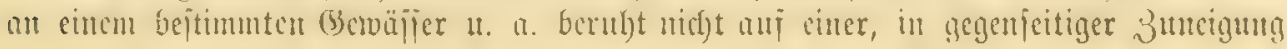




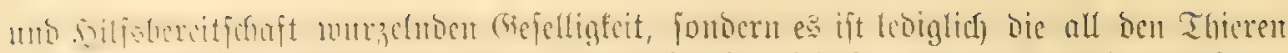

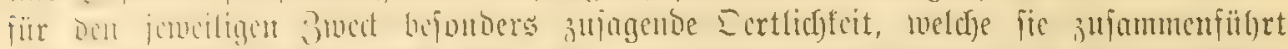

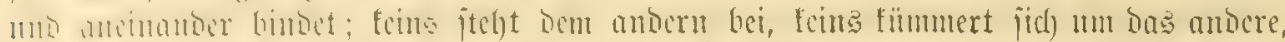

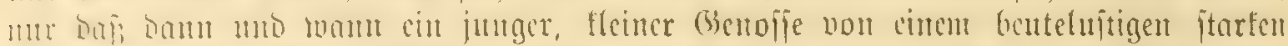

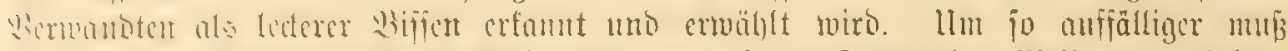

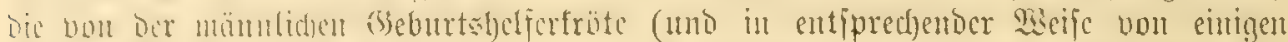
nil:

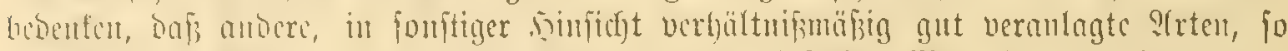

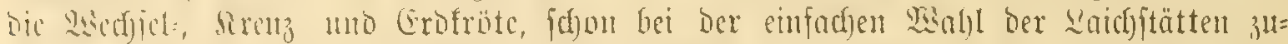

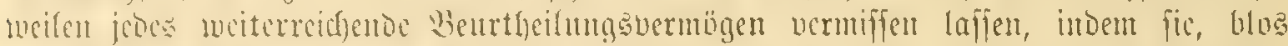
um bie llnterbringung unt. allernächite Beriorgung Der Eier befümuncrt, biejelben in

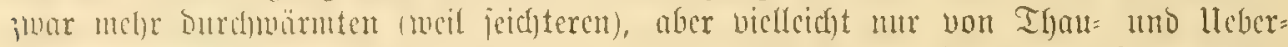

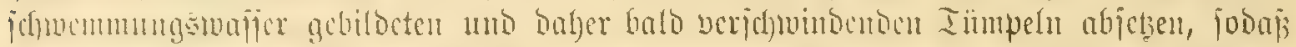

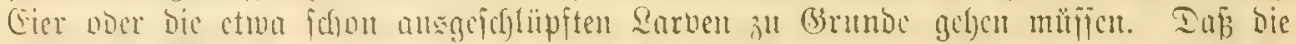

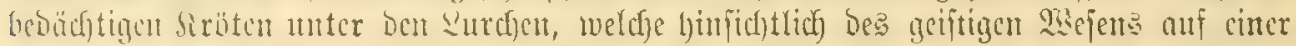

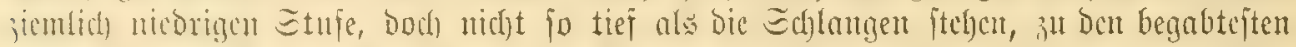

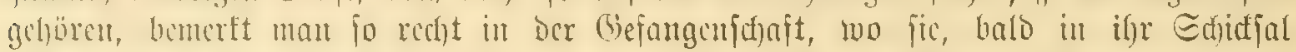

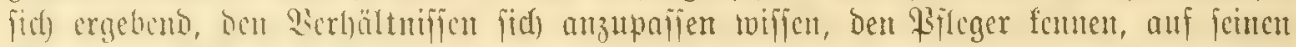

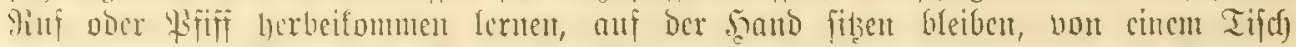

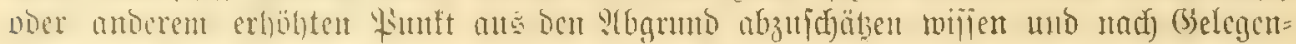

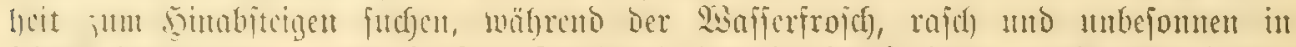

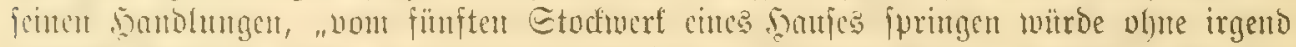

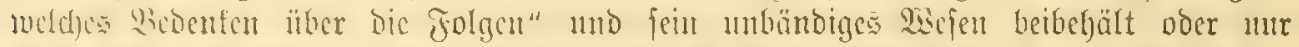

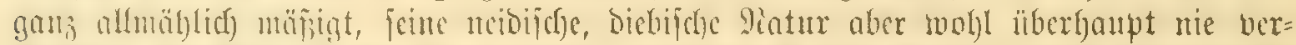

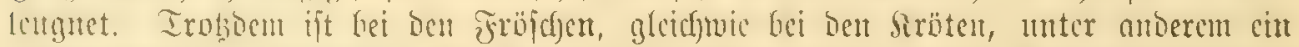

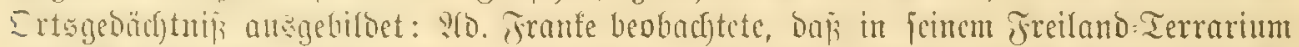

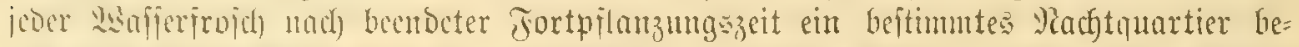

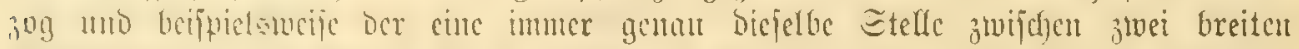

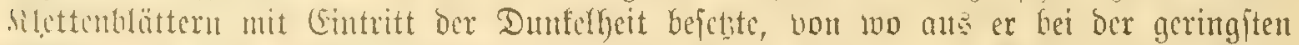

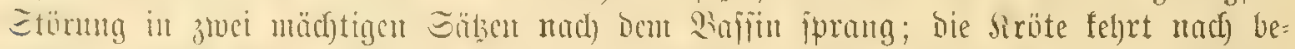

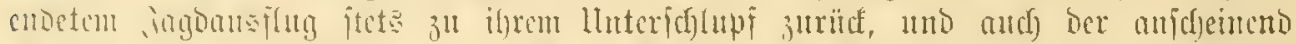

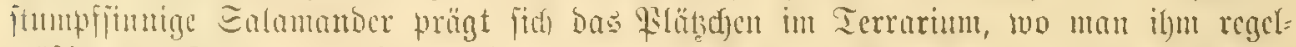
mâjig Dos jutter verubfolgt, ein mo fucht es jeden Iag zur genifien Beit altf.

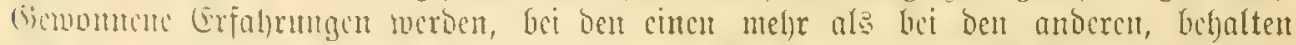

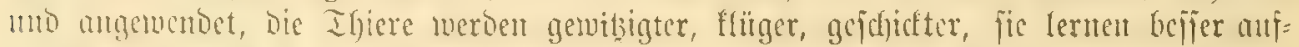

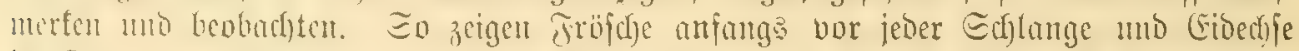

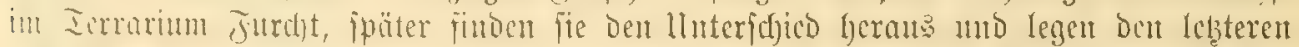

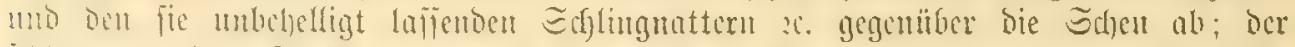

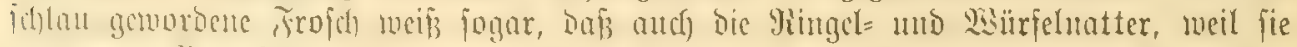

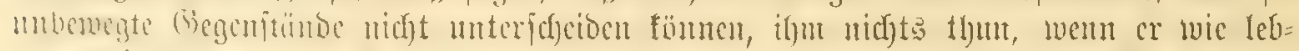

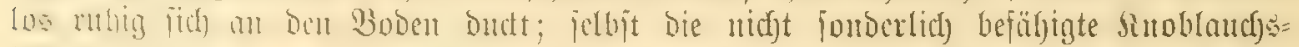

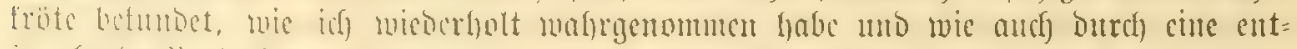

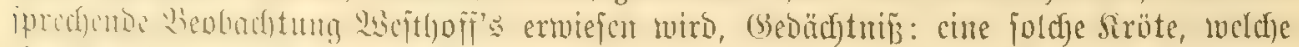

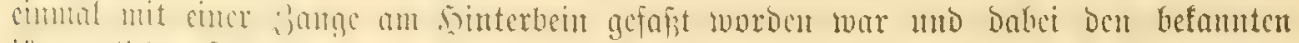

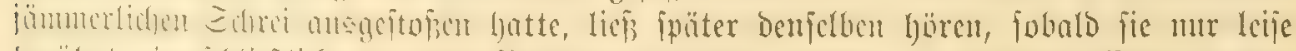

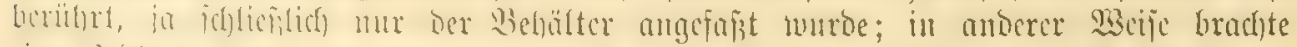

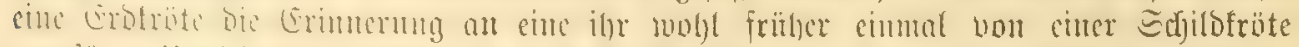

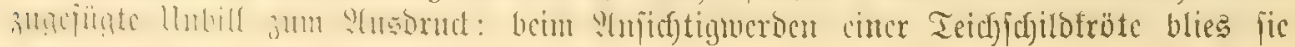




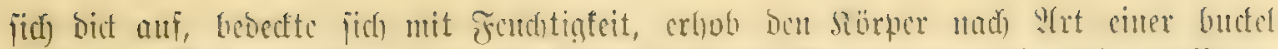

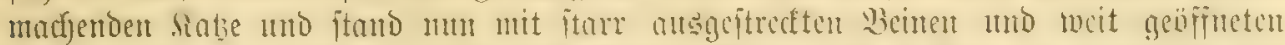

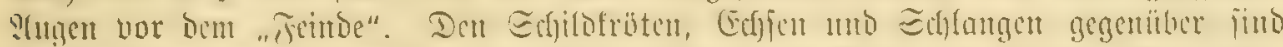

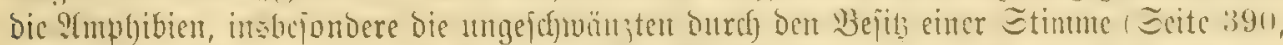

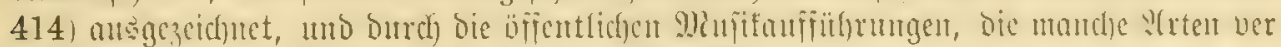

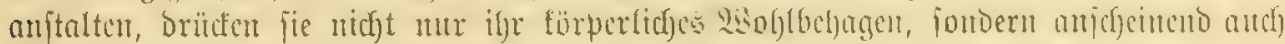

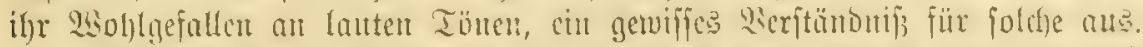

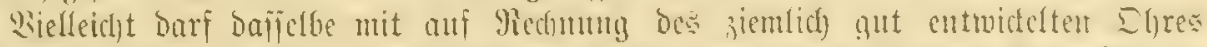

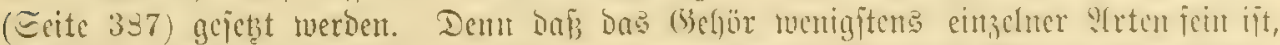

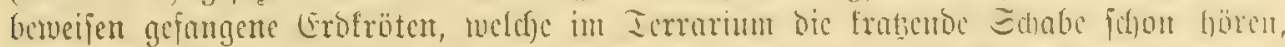

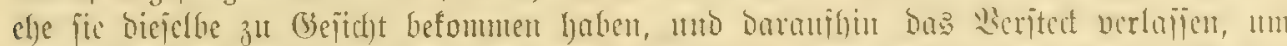

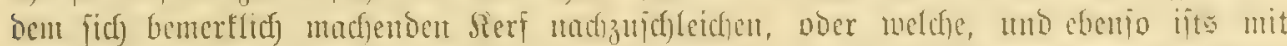

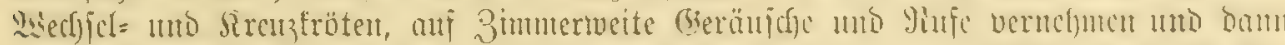

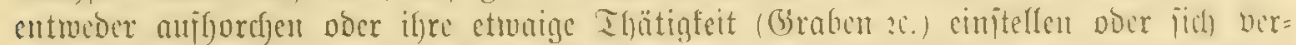

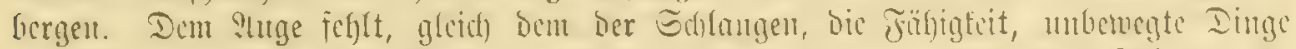

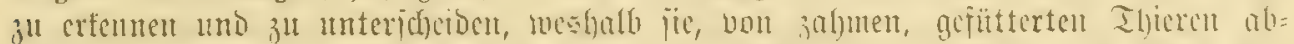

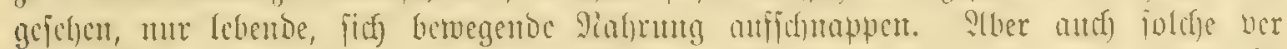

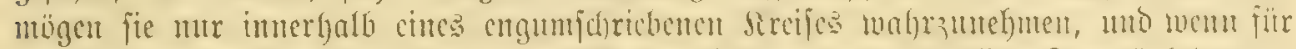

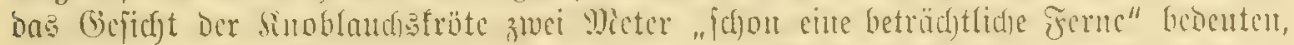

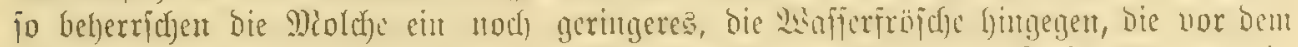

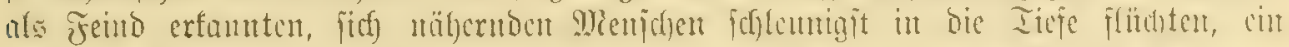

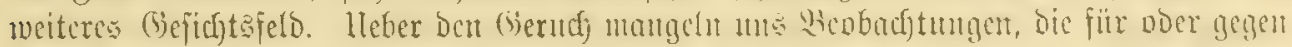

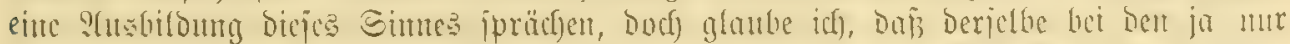

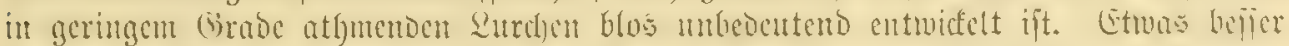

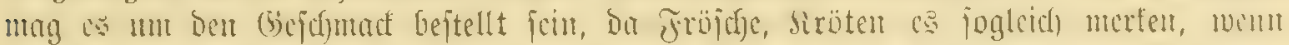

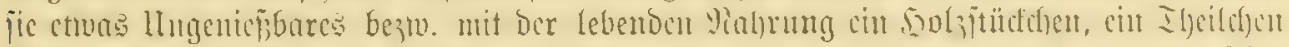

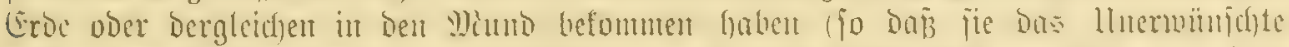

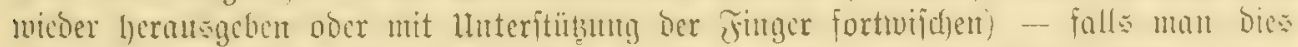

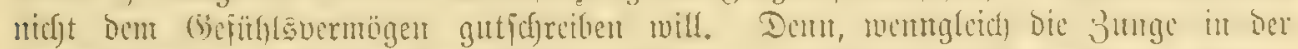

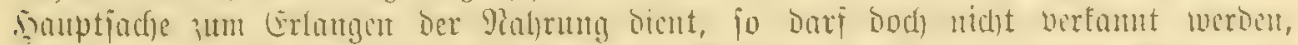

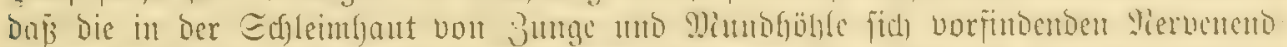

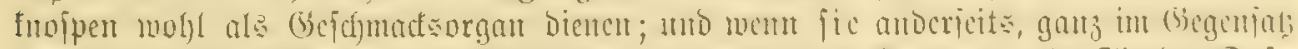

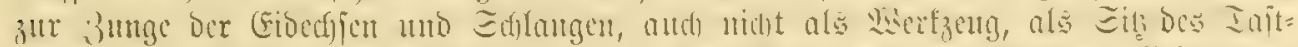

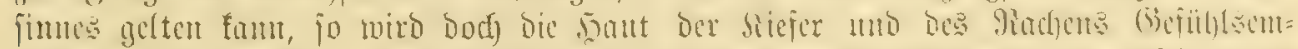

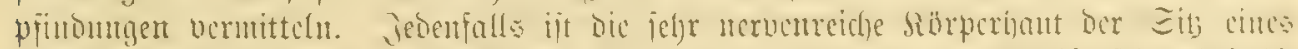

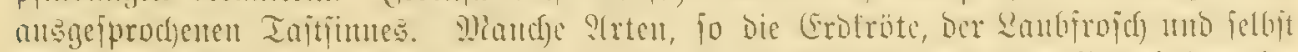

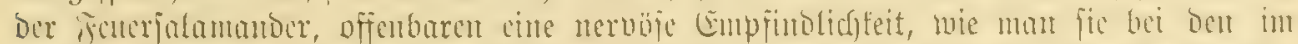

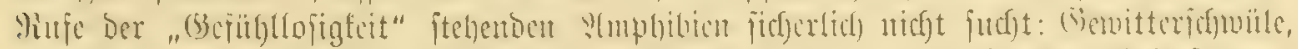

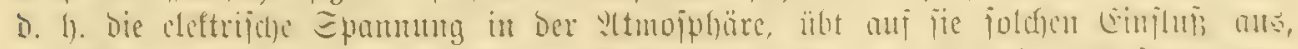

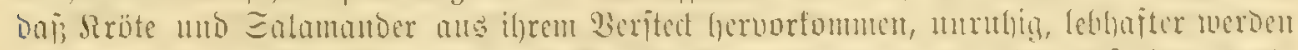

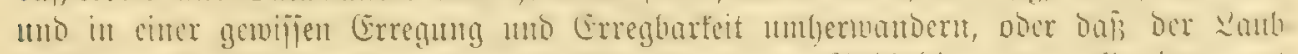

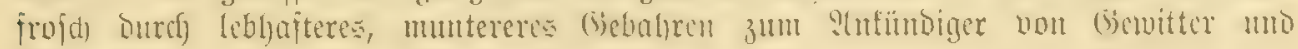
Siegent wirb.

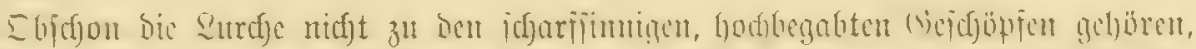

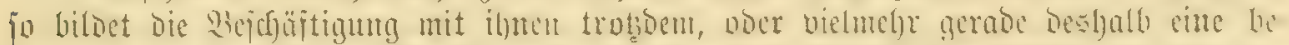

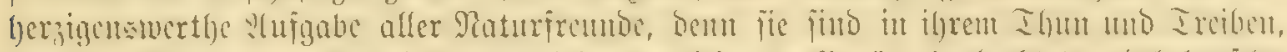

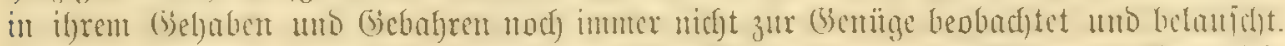

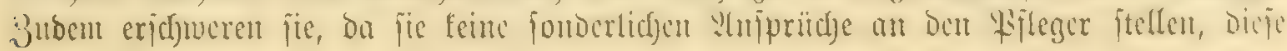




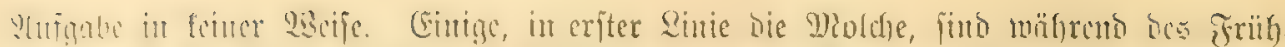

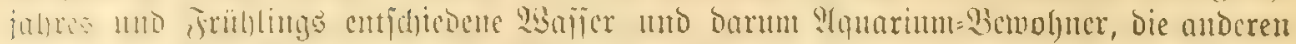

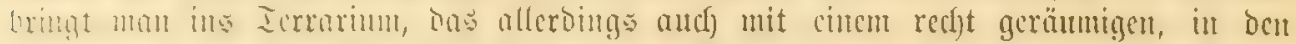

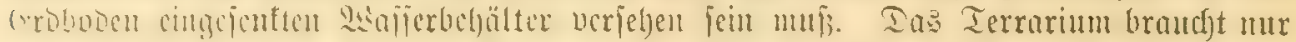

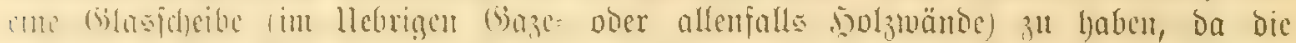

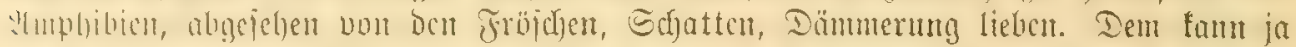

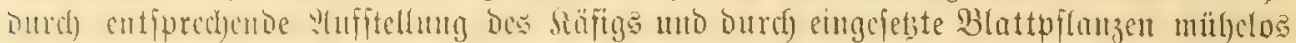

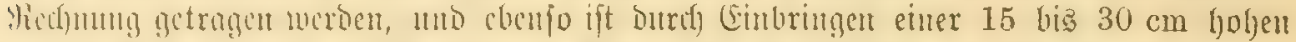

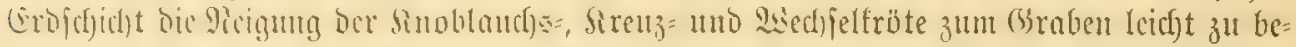

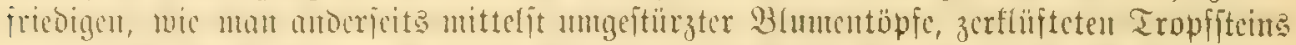

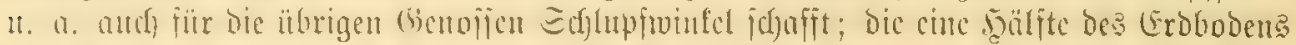

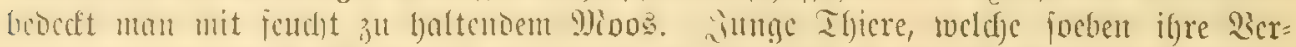

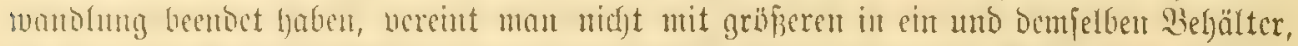

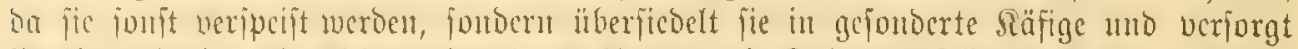

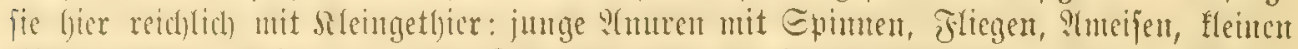

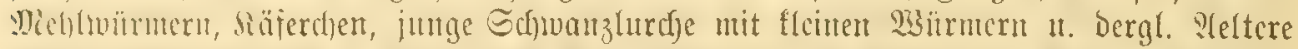

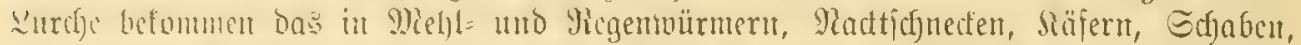

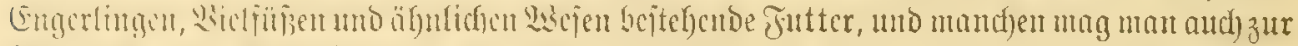

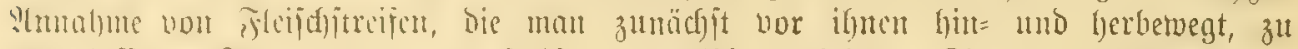

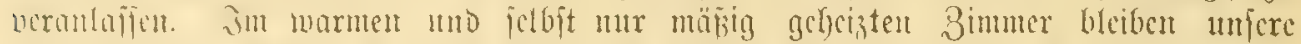

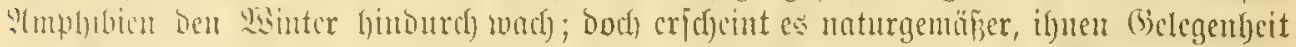

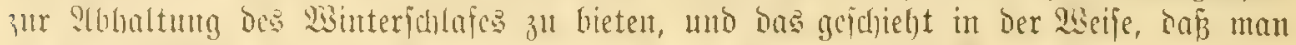
fic in mit Liroc, Eteincu, Bhummurgch, Dions, Saul gefülte Ripten bringt und bicje in falte, abcr froftfreic Sieller $2 c$. Ftellt.

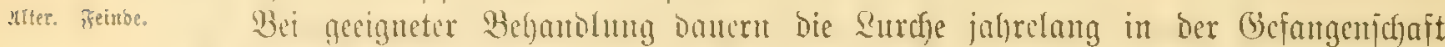

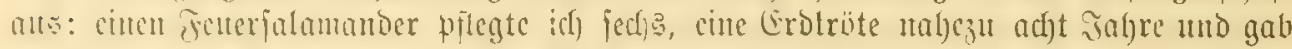

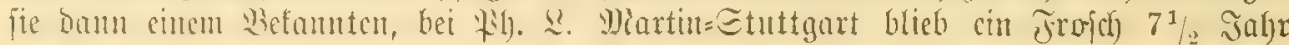

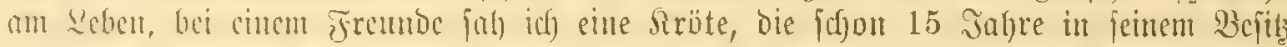

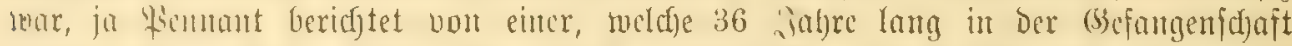

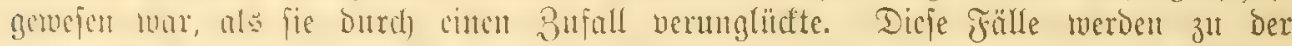

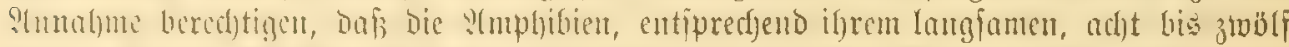

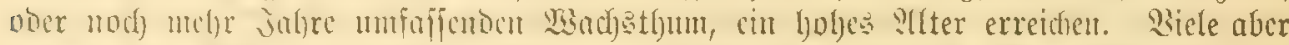

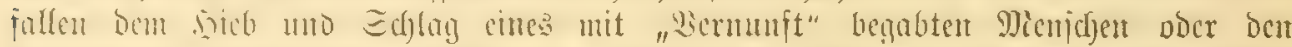

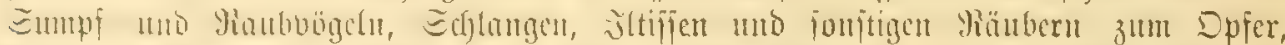

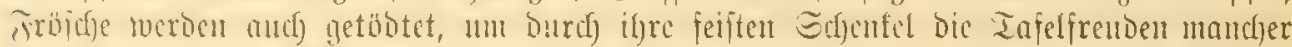

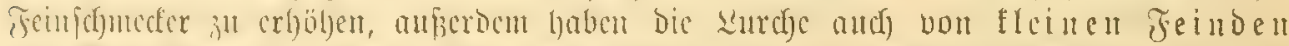

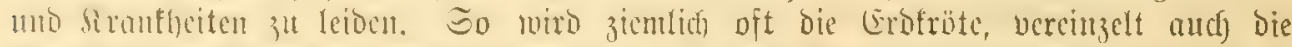

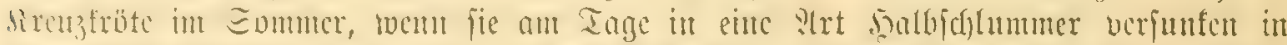

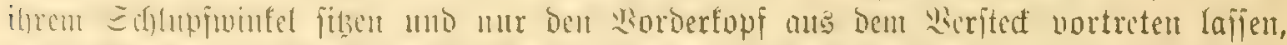

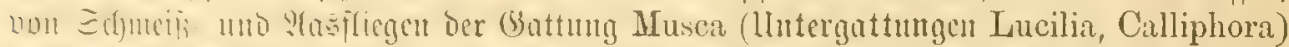

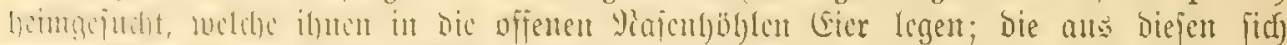

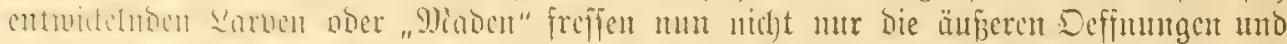

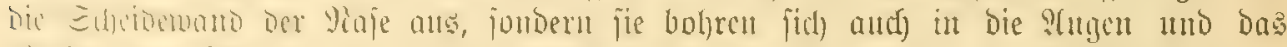

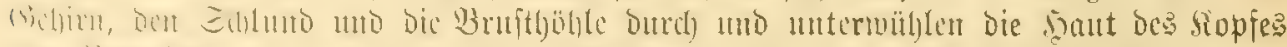

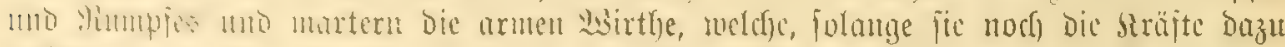

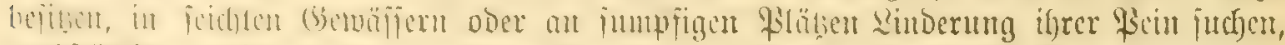

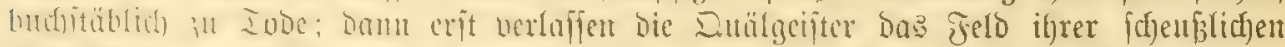

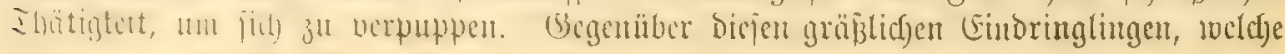




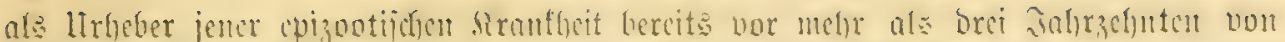

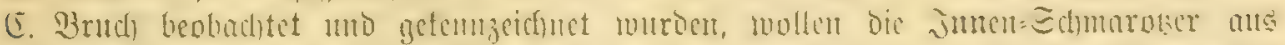

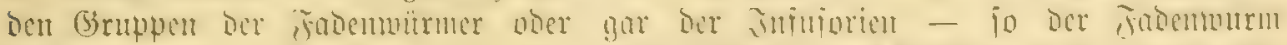

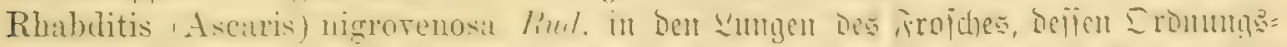

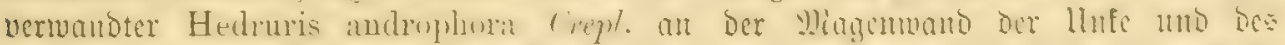

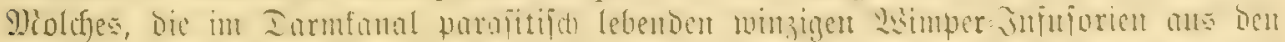

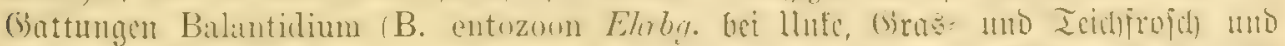

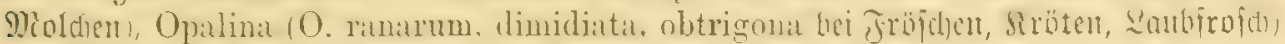
11. a. - twenig ober nidjts bcjagen.

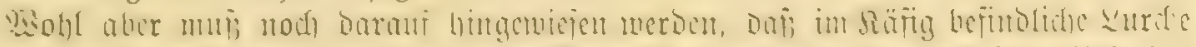

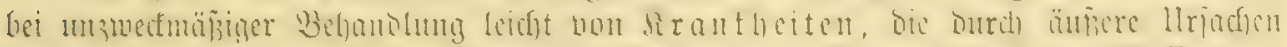

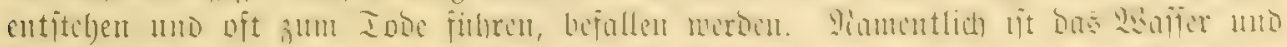

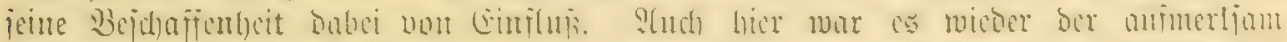

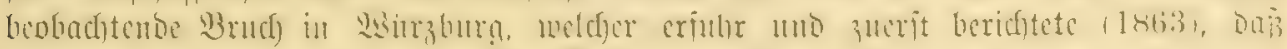

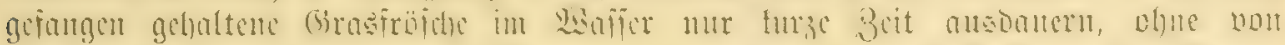

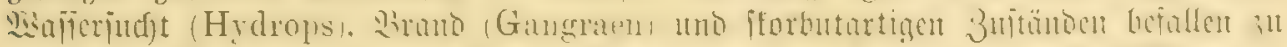

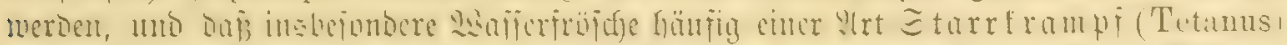

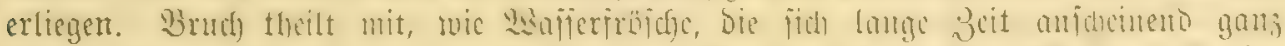

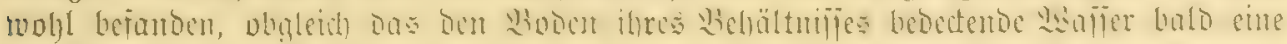

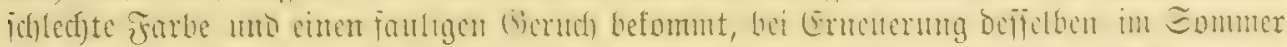

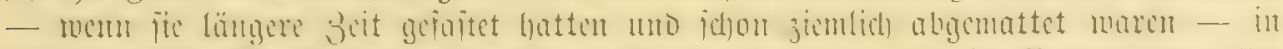

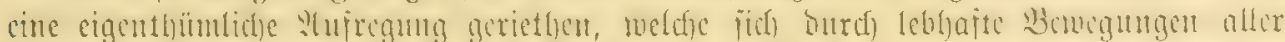
QI r

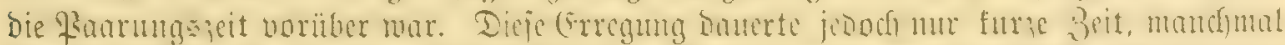

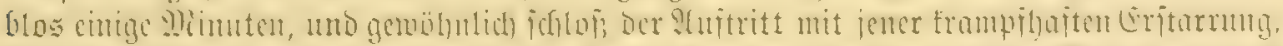

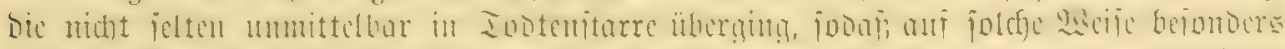

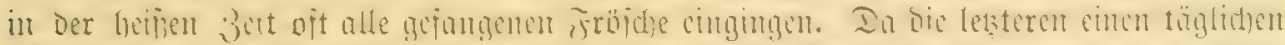

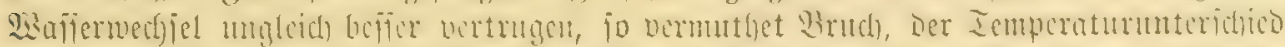

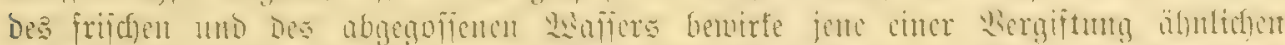

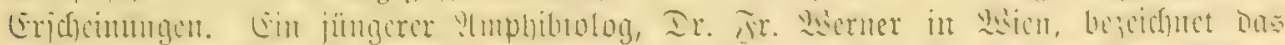

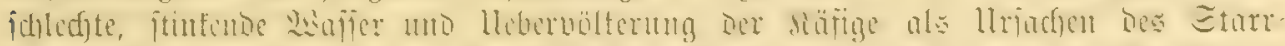

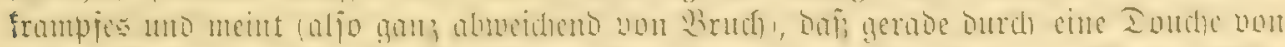

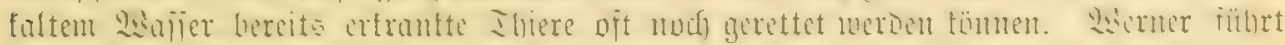

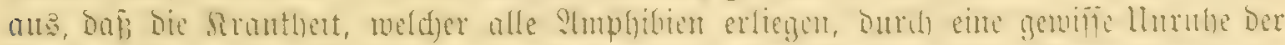

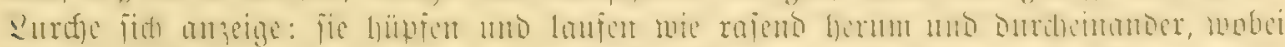

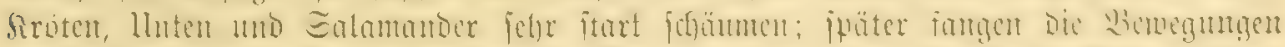

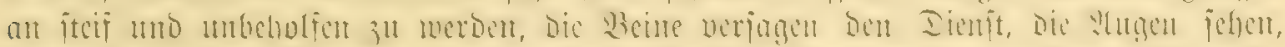

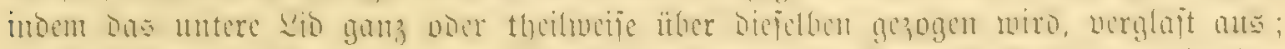

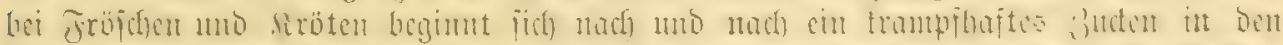

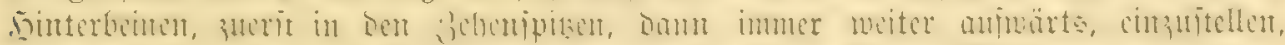

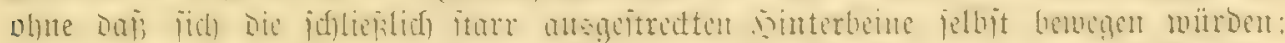

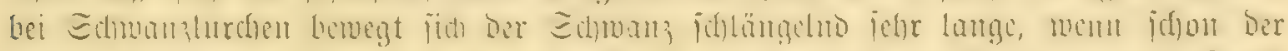

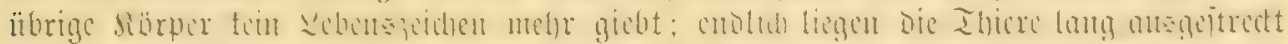

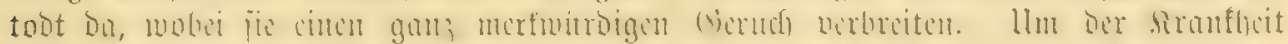

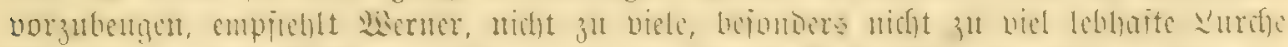

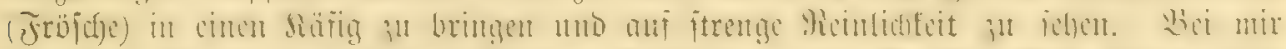

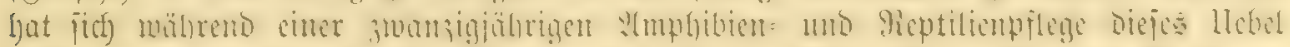

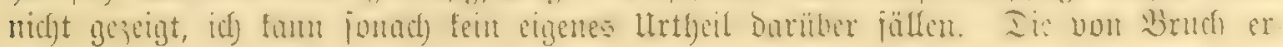




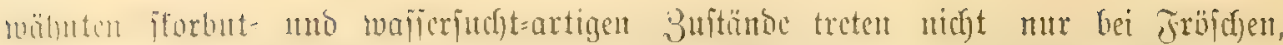

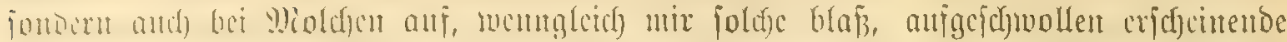

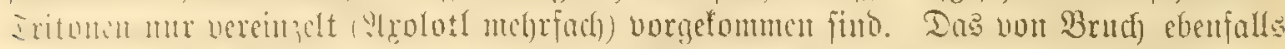

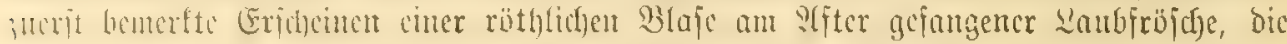

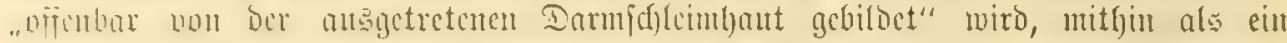

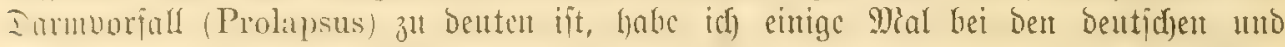

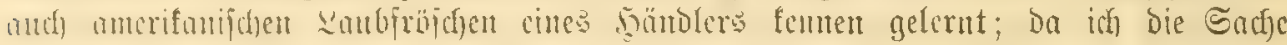

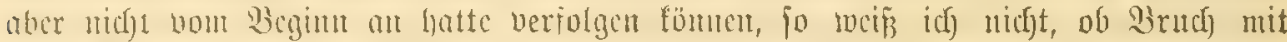

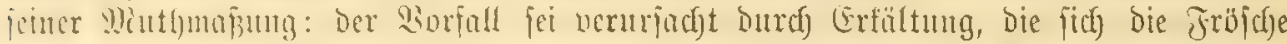

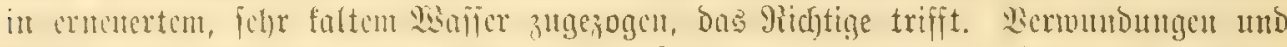

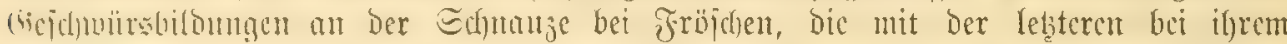

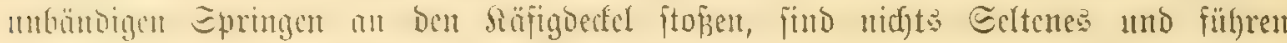

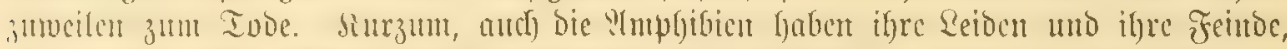

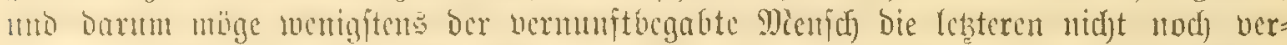

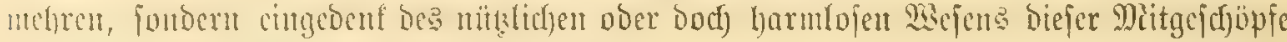
dab 93 ort befjerzigen: Sefuts Den Surchen!

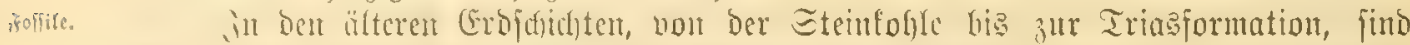

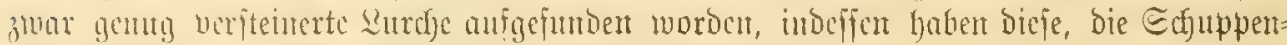

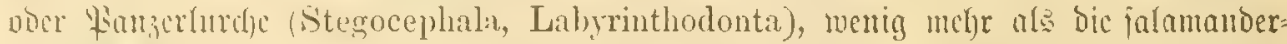

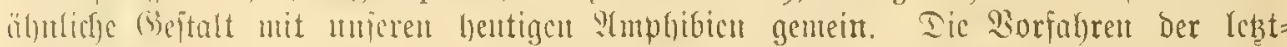

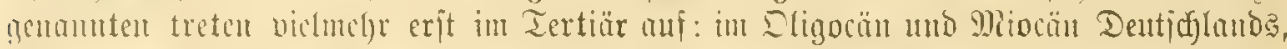

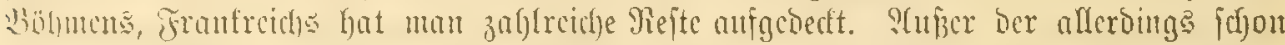

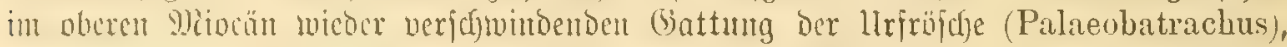

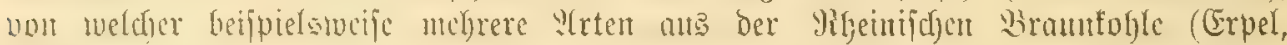

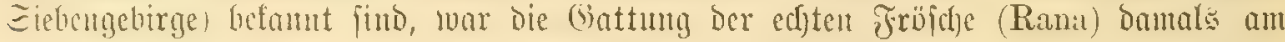

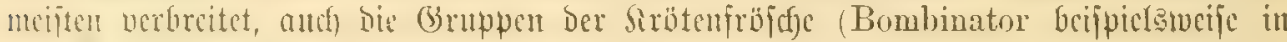

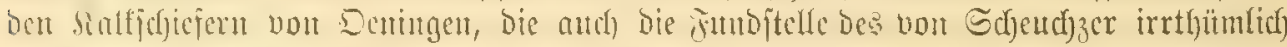

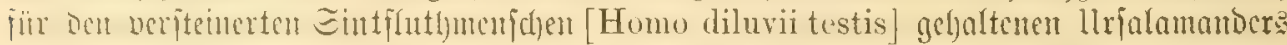
[Andrias Seheuchzeri Tsehudi; Cryptobranchus primigenius riur.] Giloeten) 1 ono

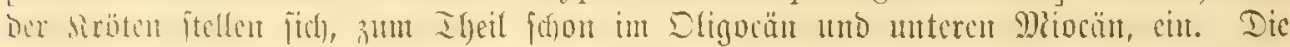

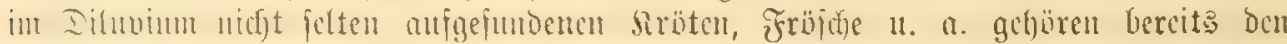

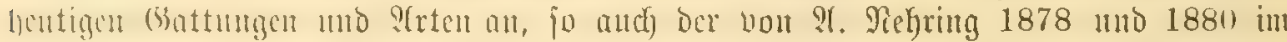
Diluvium von $23 e f t e r c g e l n$ umb Igiede cntbecfte Pelobates.

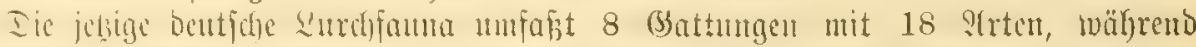

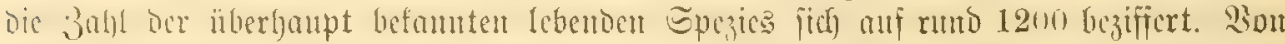

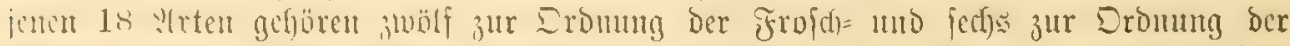

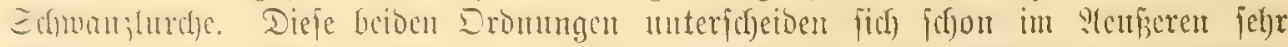

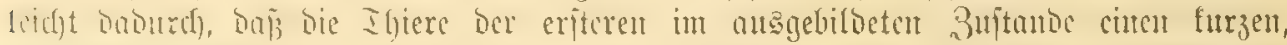

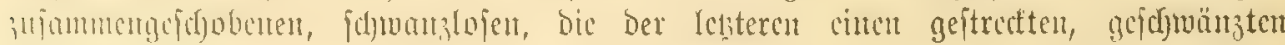
siörper bejizent. 


\title{
I. (1)ronming.
}

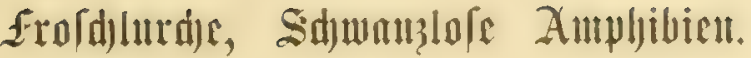

\author{
Anura (Ecaudata. Batrachia salientia).
}

Ziörpir fll

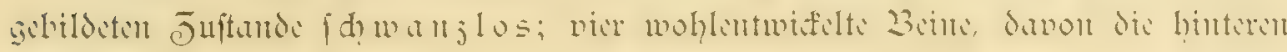
verlängert.

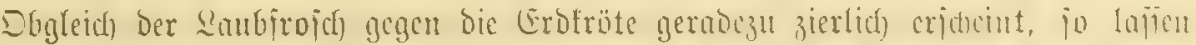

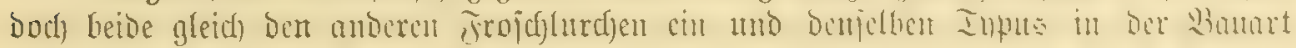

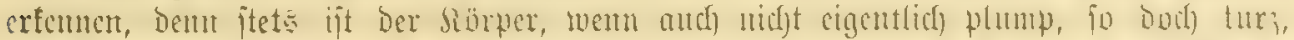

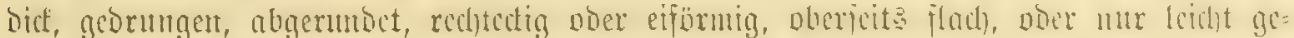

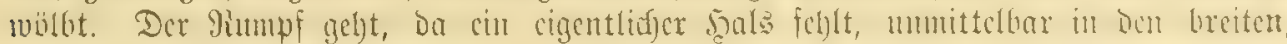
mcitmäuligen, im Edhanzmtlycil bogig zugerutocton Siopf über. Dic :!ngen haben Ivir Ecitc 387 befmodjen; Das Irommelfell tritt bei allen mujeren Battungen, ans

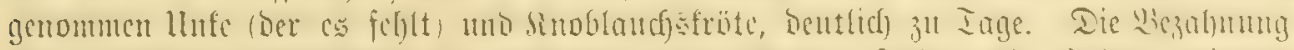

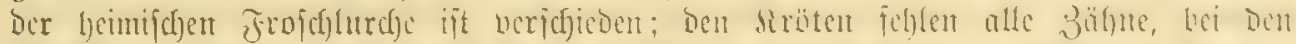

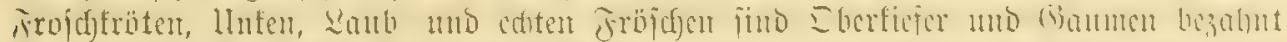

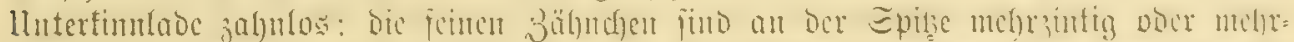

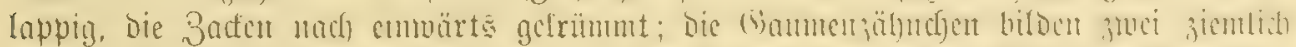

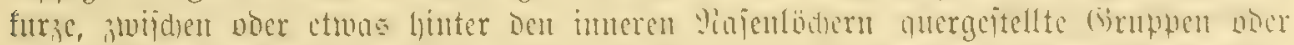

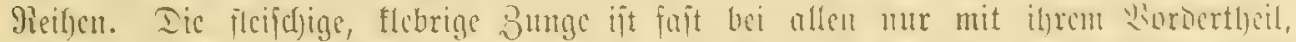

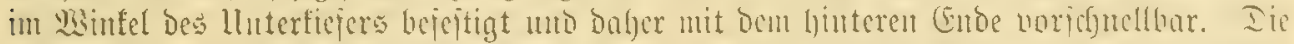

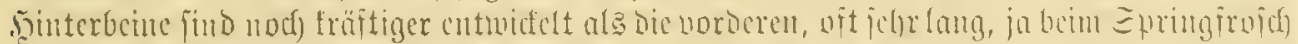

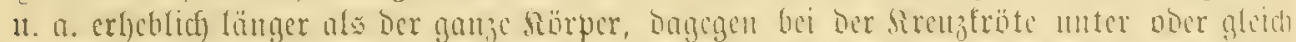

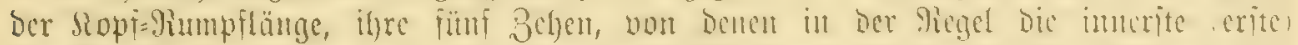

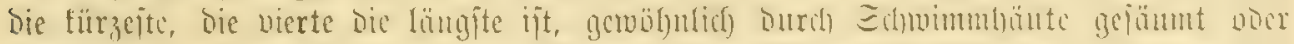

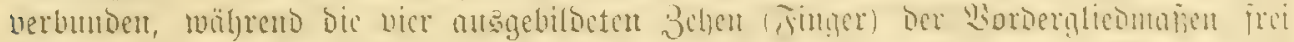

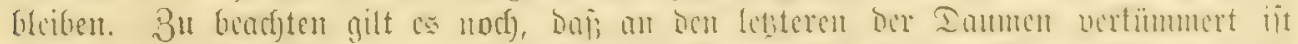

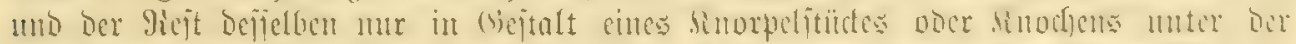

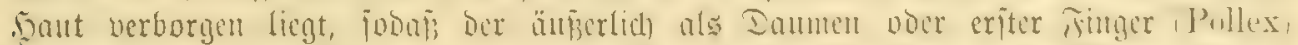

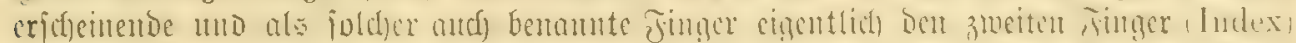

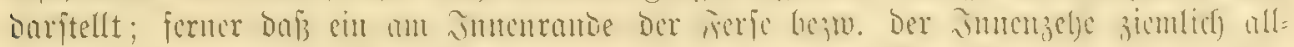

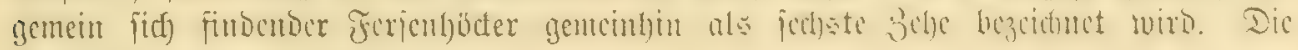
Sloatenöffnung ift runblich.

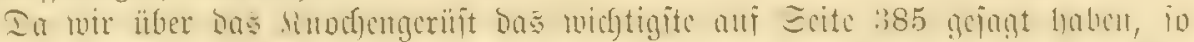

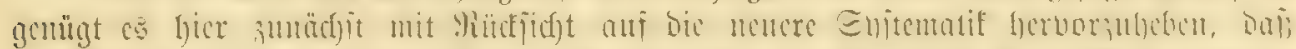

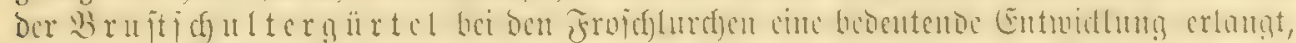

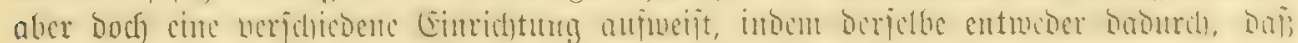

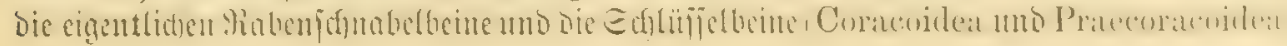




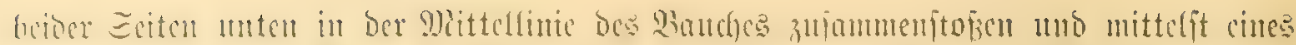

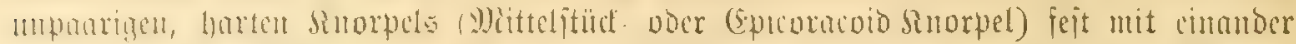

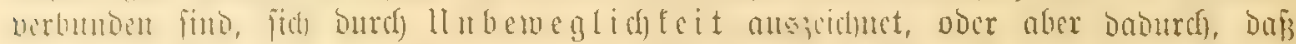

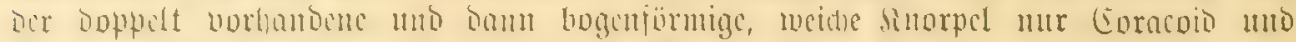

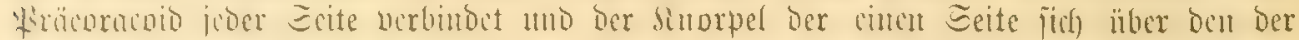

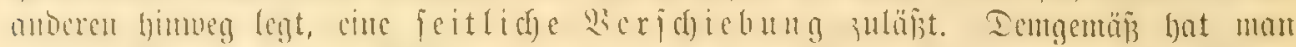

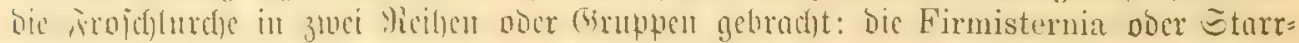

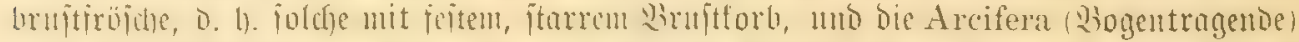

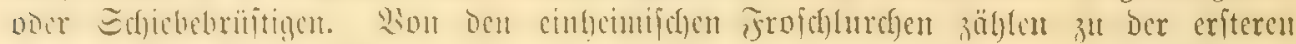

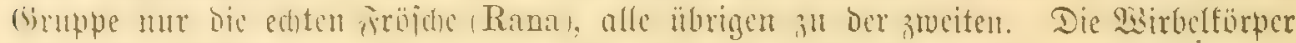

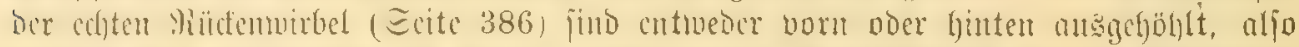

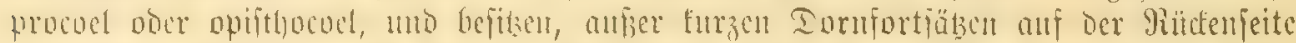

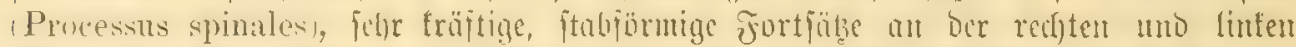

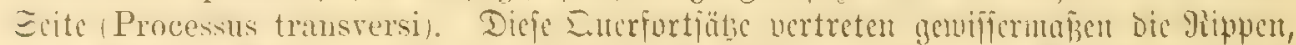

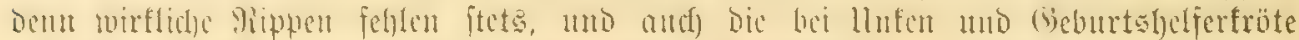

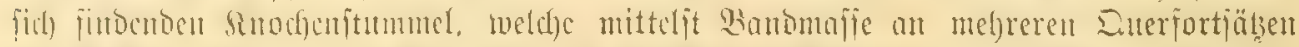

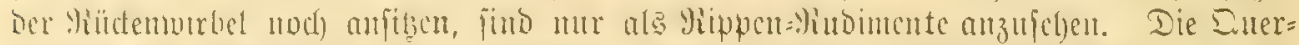

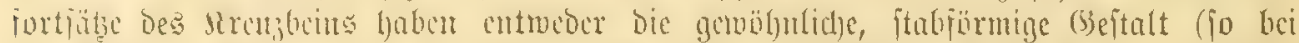

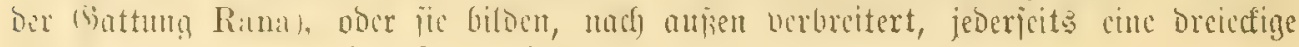
Sinodjenplatte (jo bei Qaubfrofd), Cros= und Feuerfrötc).

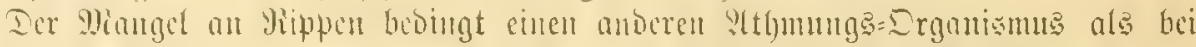

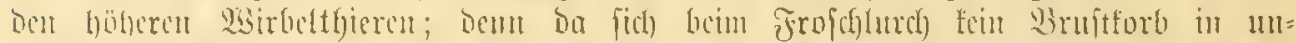

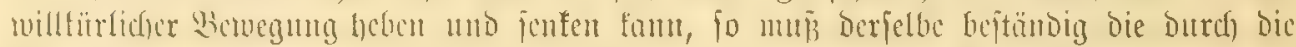

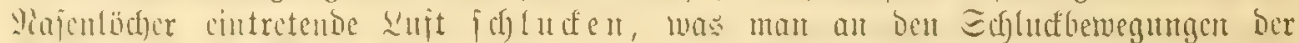

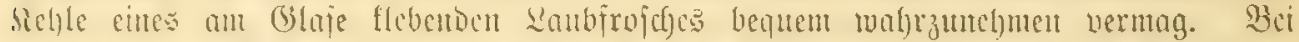

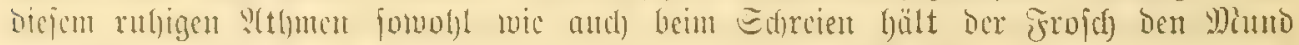

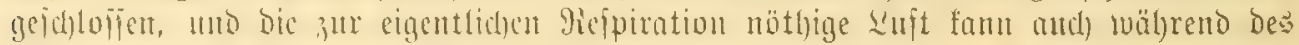

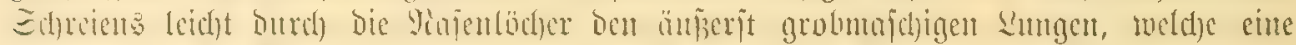

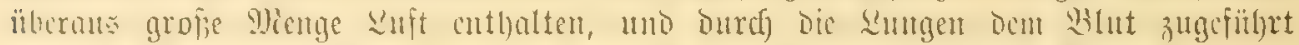

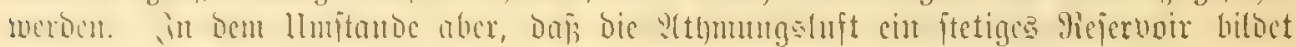

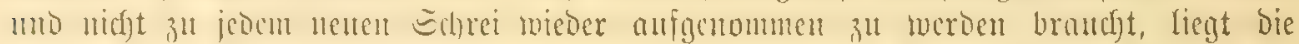

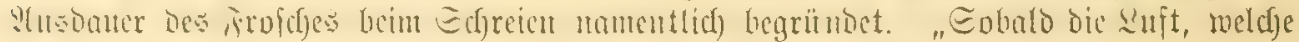

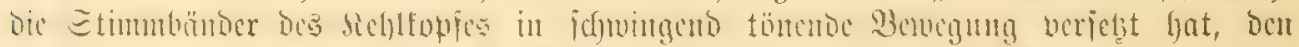

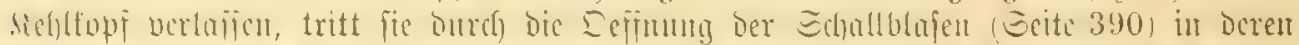

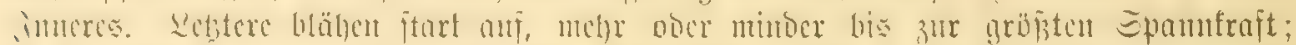

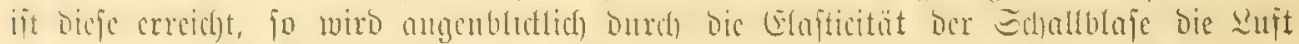

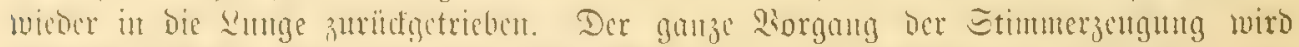

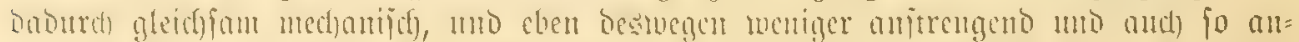

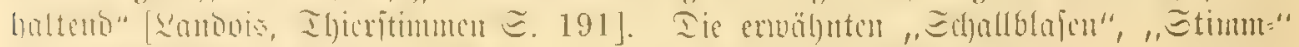

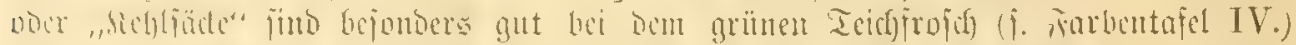

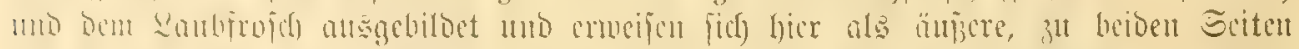

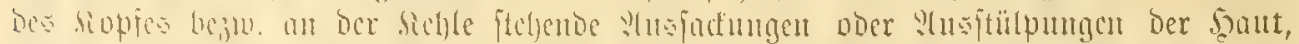

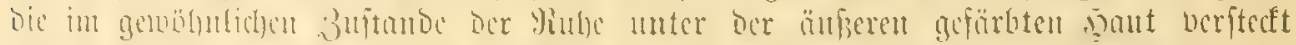

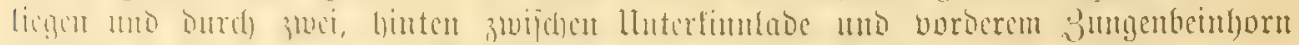

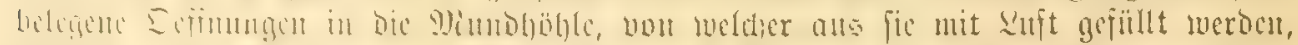

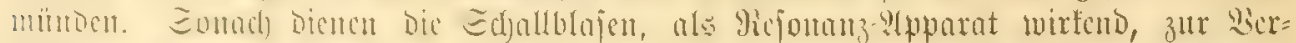

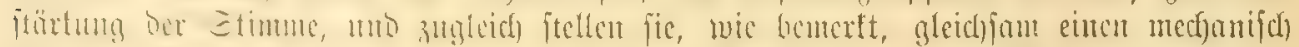

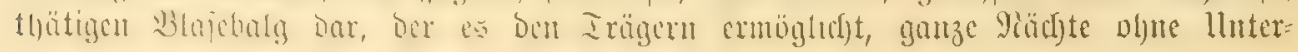




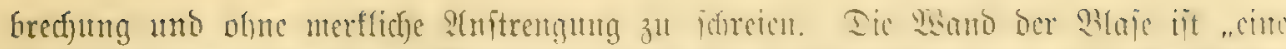

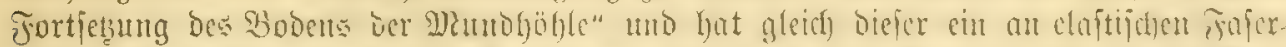

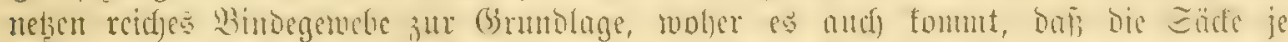

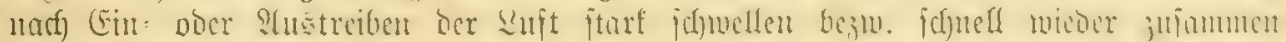

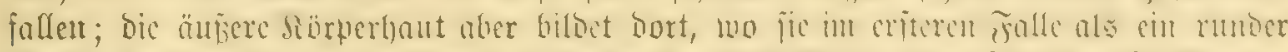

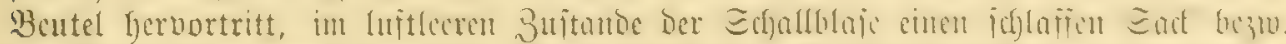

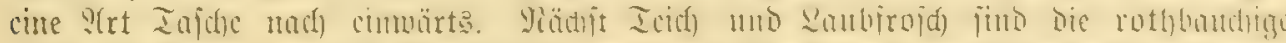

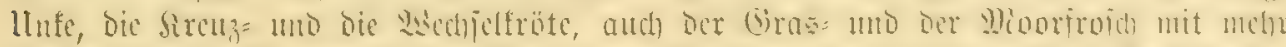

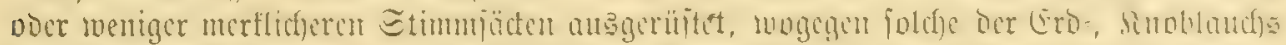

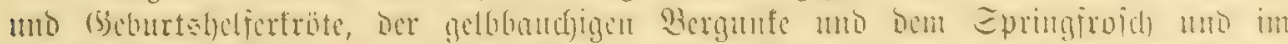

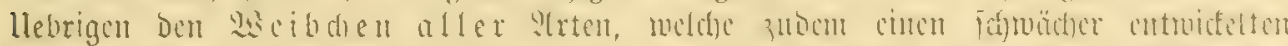

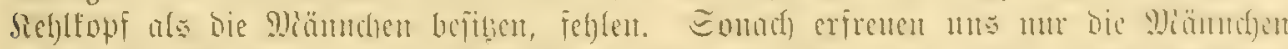

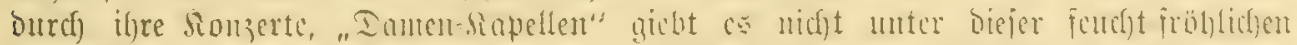

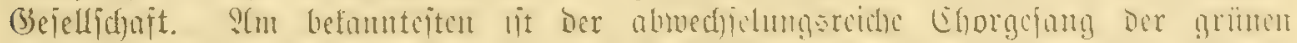

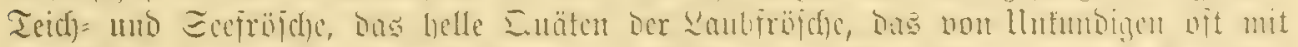

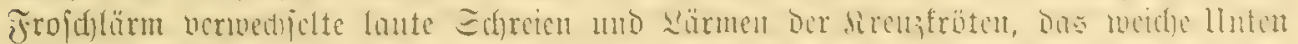

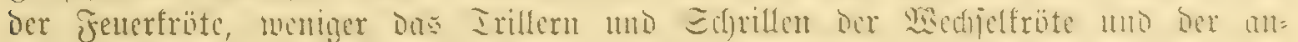

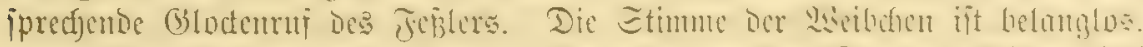

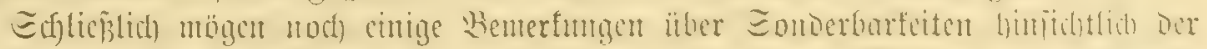

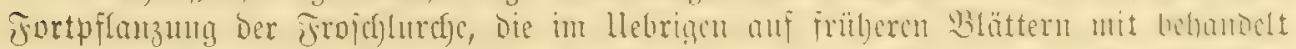

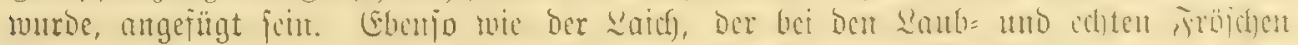

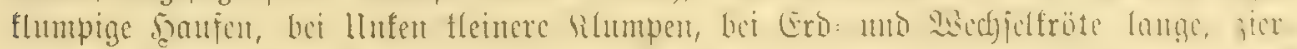

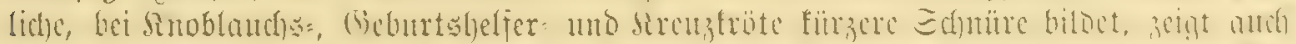

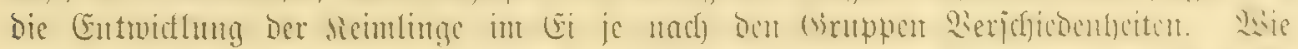

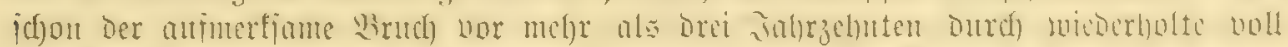

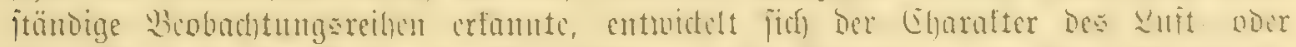

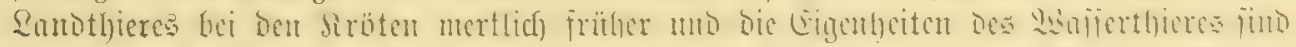

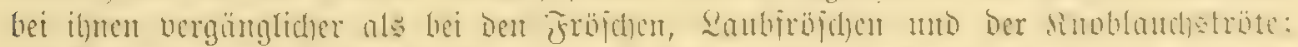

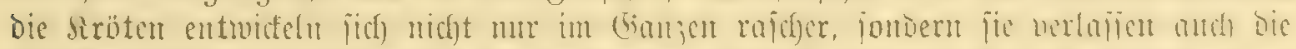

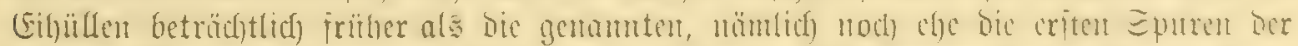

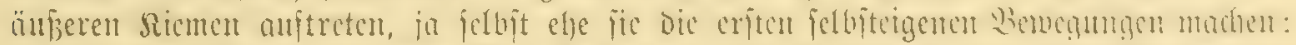

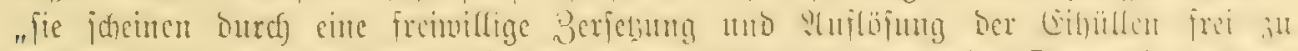

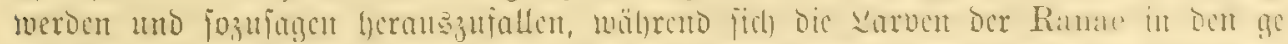

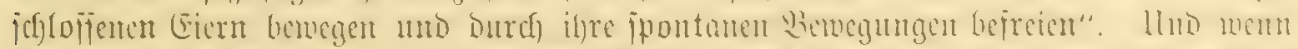

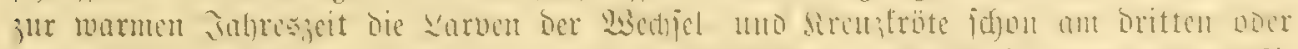

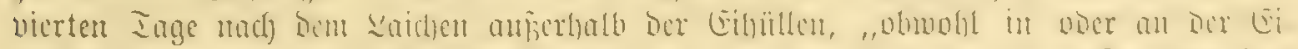

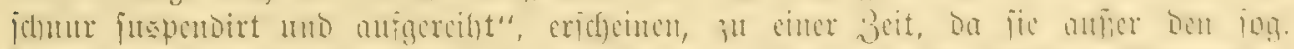

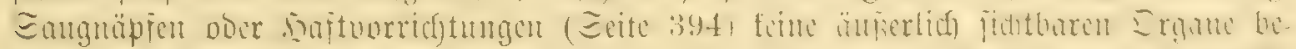

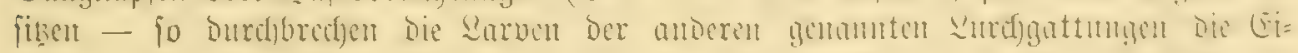

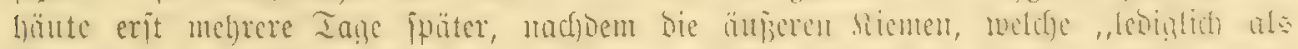

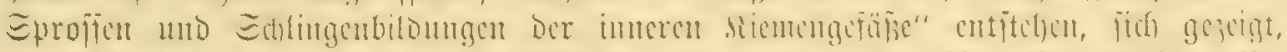

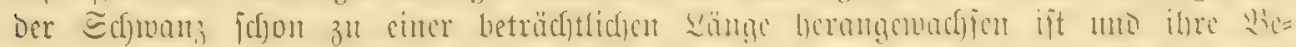

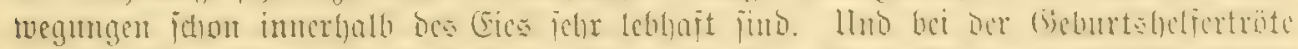

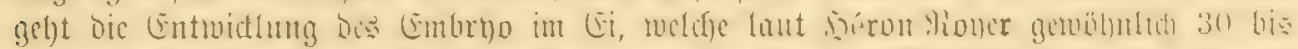

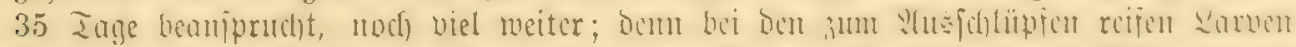

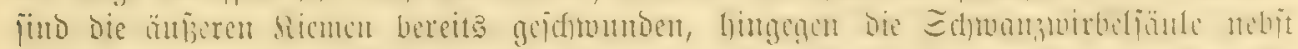

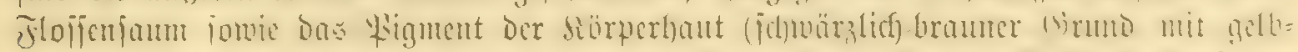

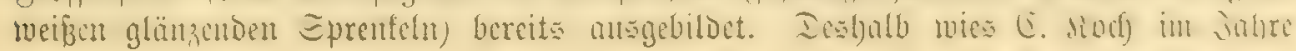




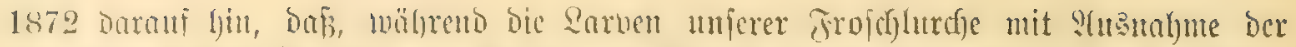

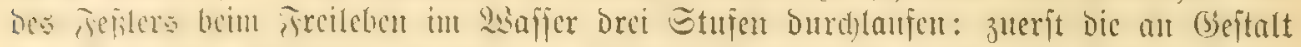

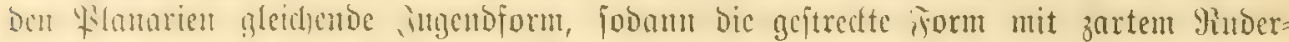

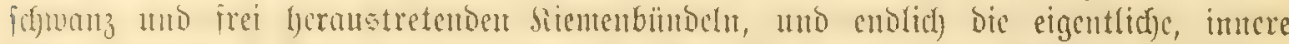

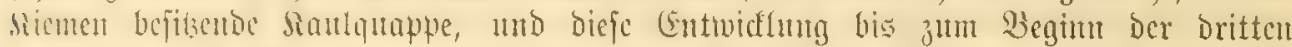

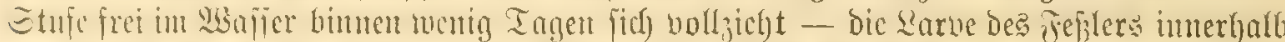
Der (Eibülle burdh bie beiben crften Etnbien anf bem Iroducn in längerer Beit fich) entruidelt.

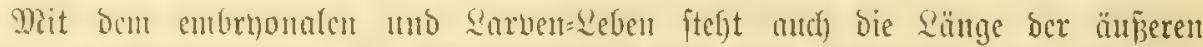

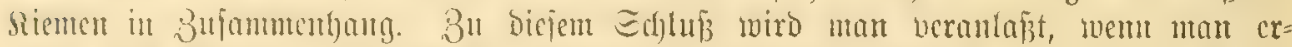

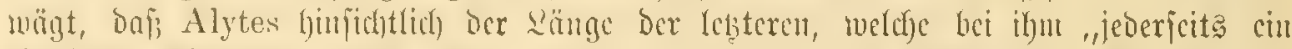

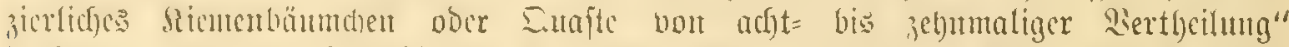
Durjtcllen, alle unjere Frojd)lurche ïbertrifit, währeno bie ämperen Siemen bei Der Darve

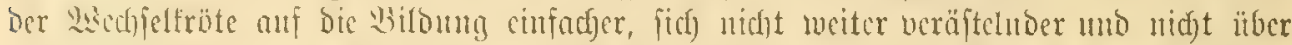

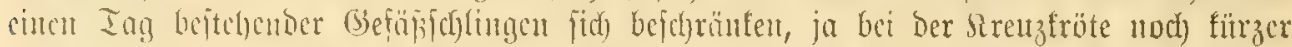

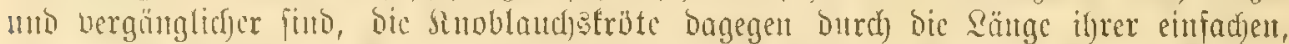

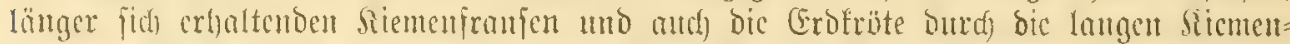

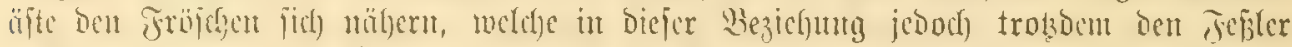

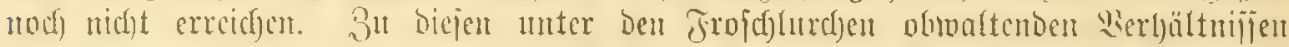

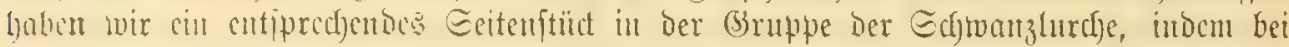
ben Ichend=gebitrenden ober wiviparen Sanbjalamantorn (Ecite 397) bic Siemen and)

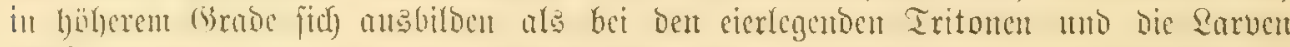

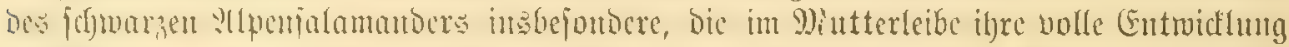

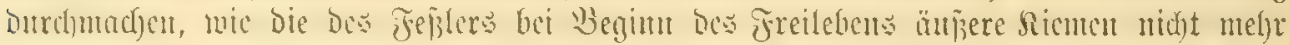

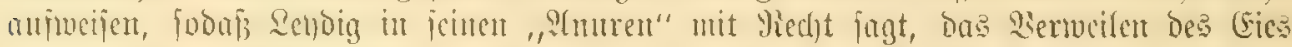

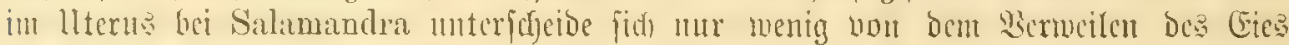

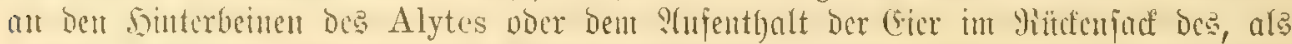

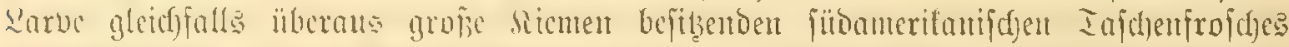

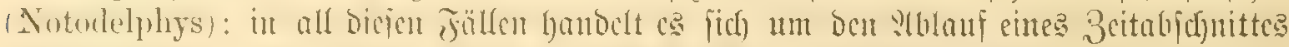

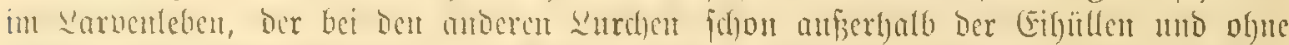

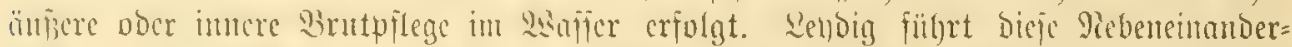

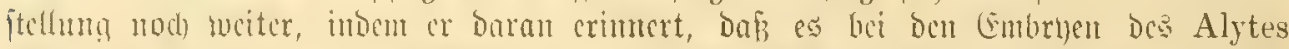
Ivic aucf bei bencu bes Notodelphys unb Der Gattung Salamandra zur Fervor= bilbung eines cigenttidjen Iotteriates fommt, ber unjern moern Zuthen abgefprodjen twerbent mí.

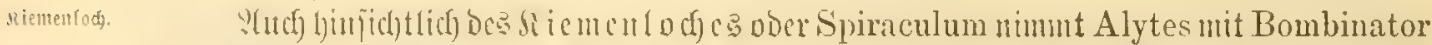

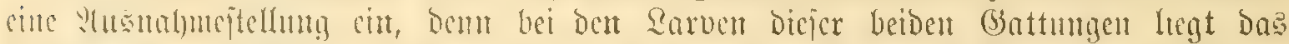

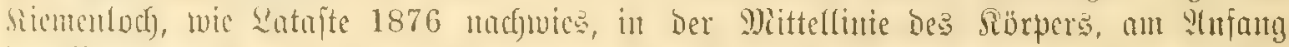

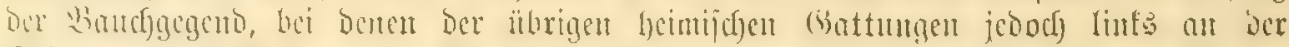

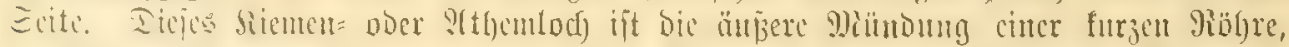

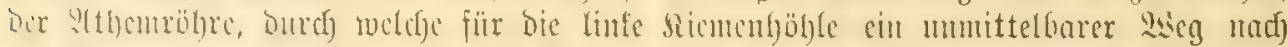

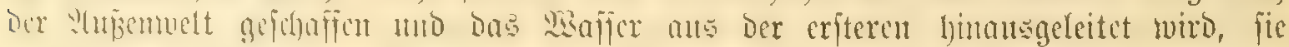

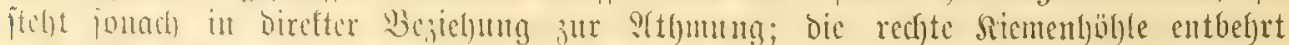

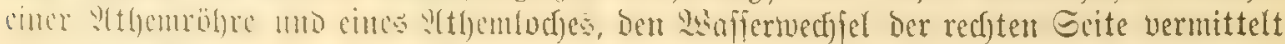

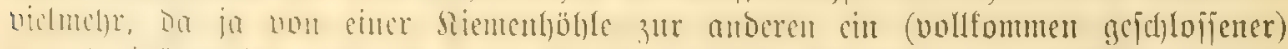

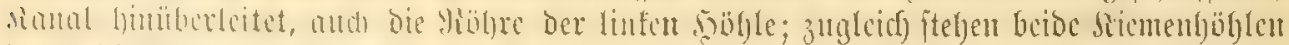

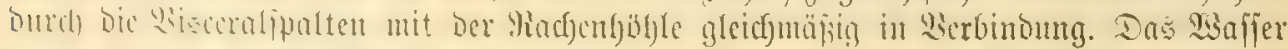

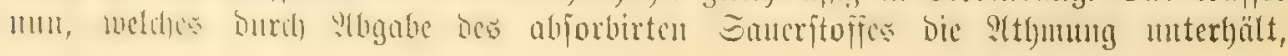




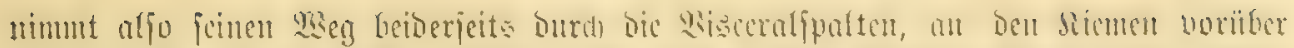

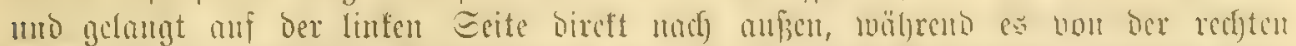

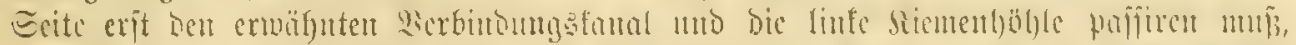

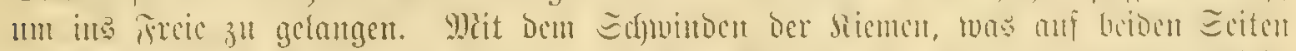

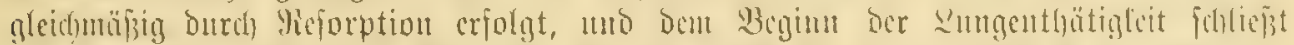

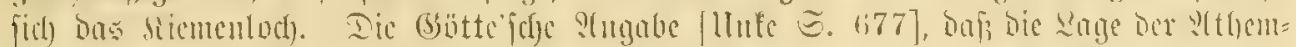

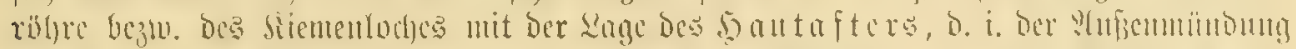

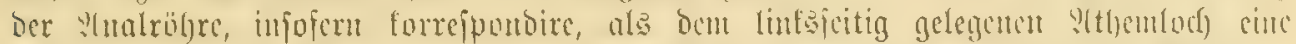

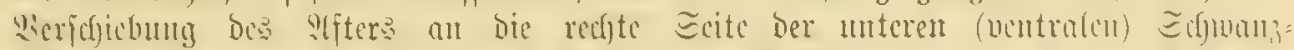

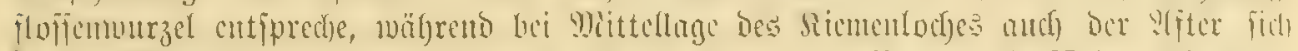

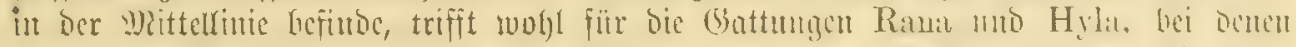

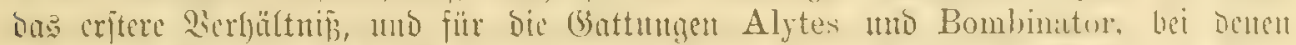

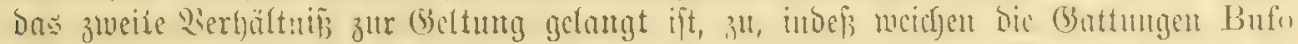

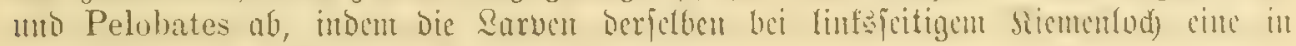

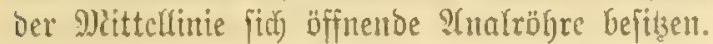

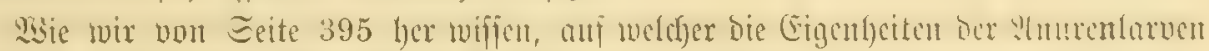
Durdjorud bec Hointe.

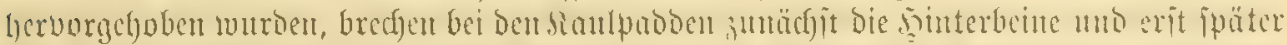

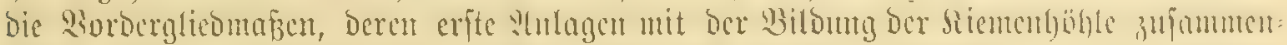

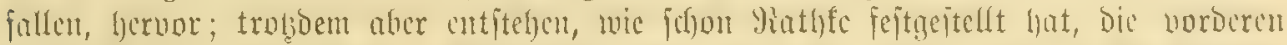
gleidyeitig mit ben hinteren (Bilicomajen un fic halten bann and in ber weiteren

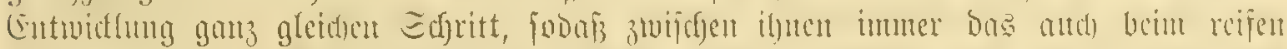

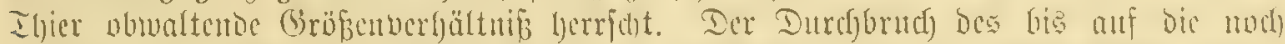

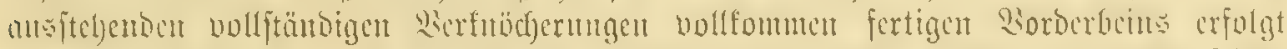

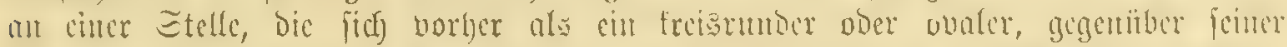

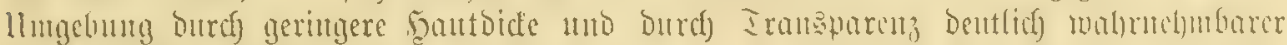

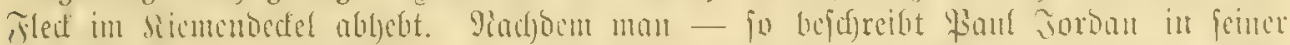

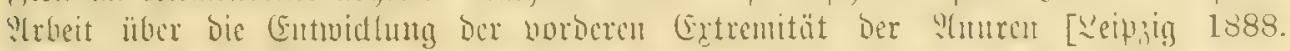

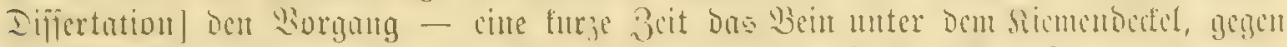

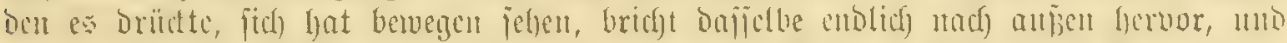

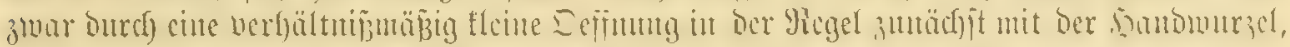

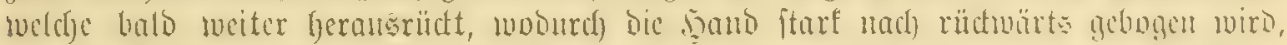

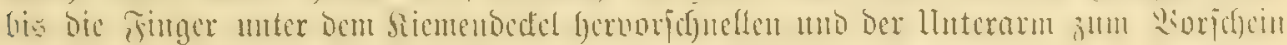

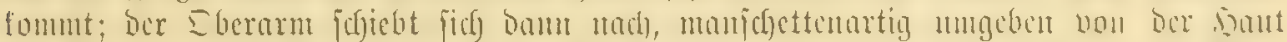

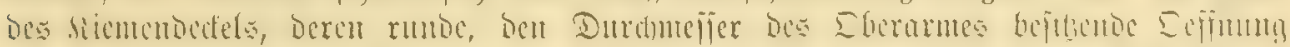

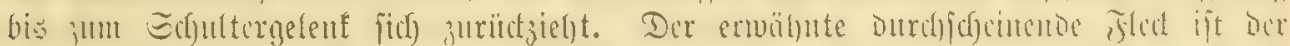

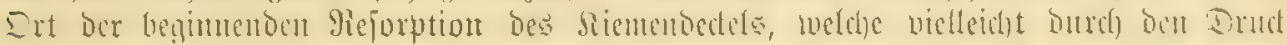

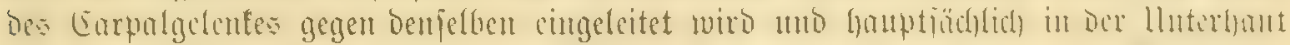

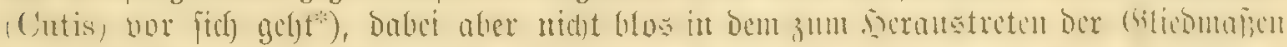

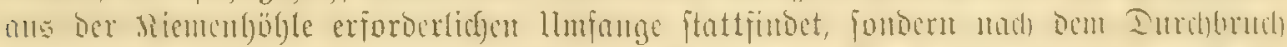

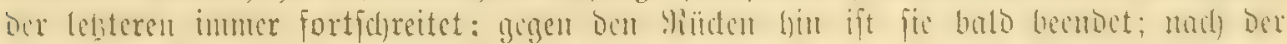

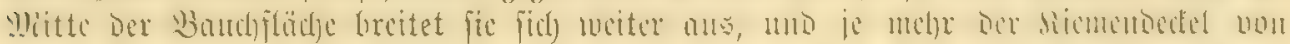

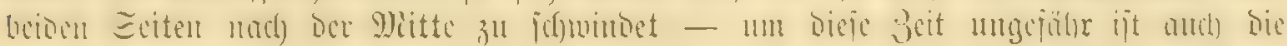

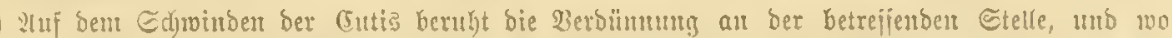

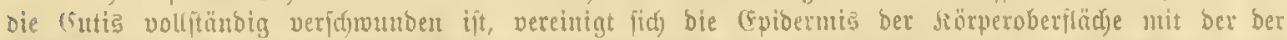

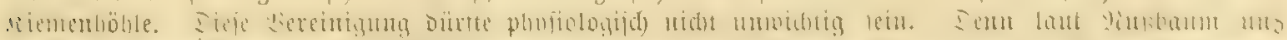

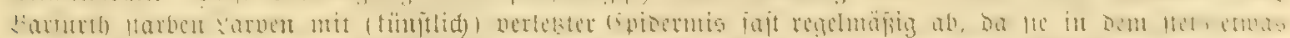

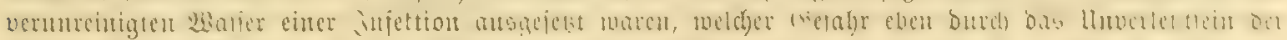

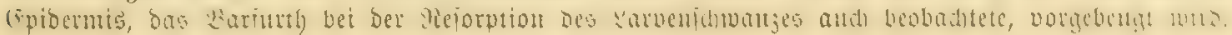




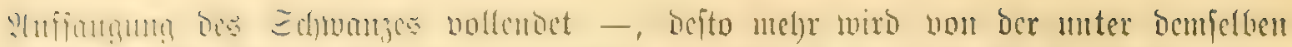

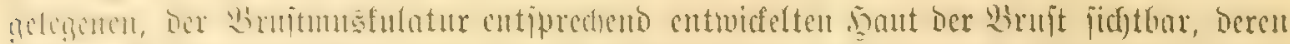

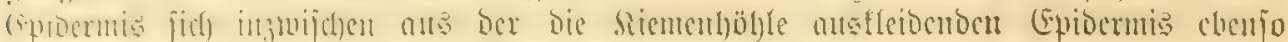

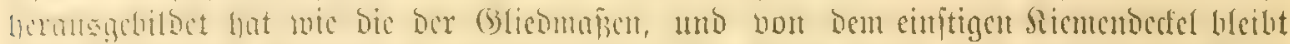

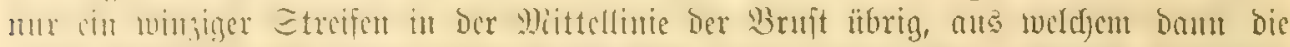

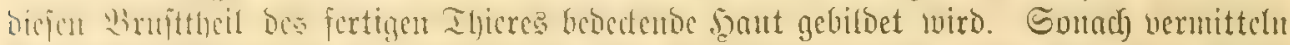

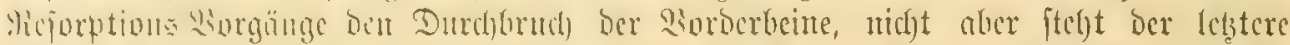

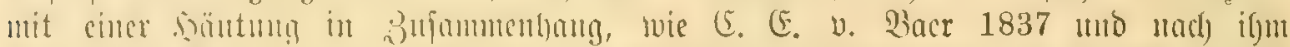

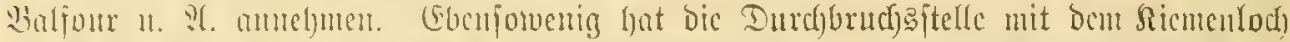

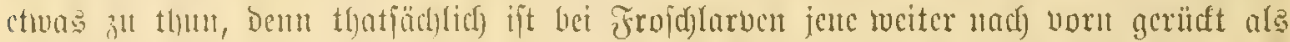

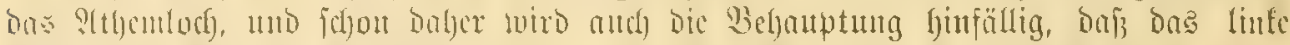

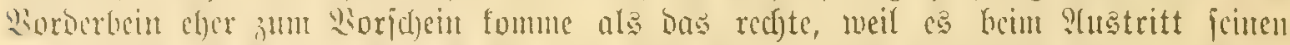

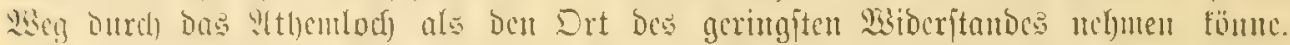

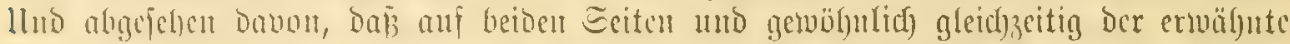

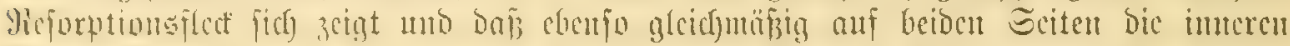

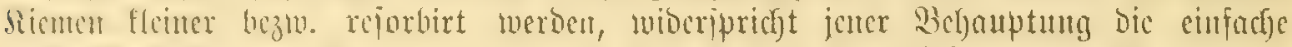

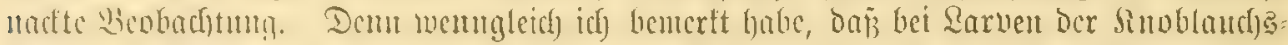

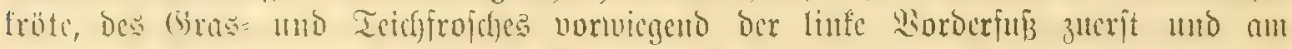

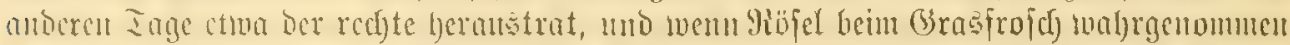

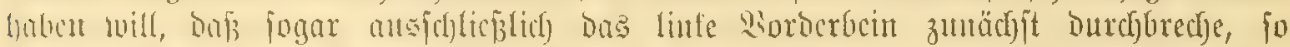

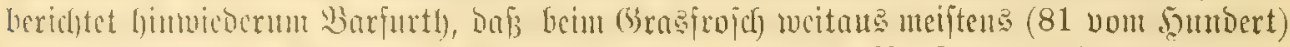

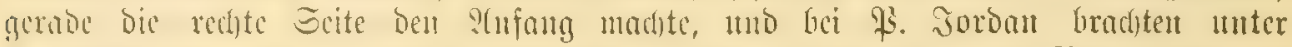

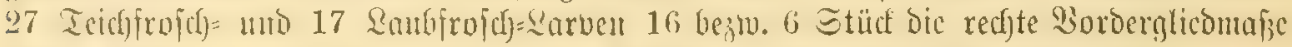

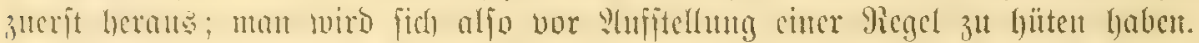

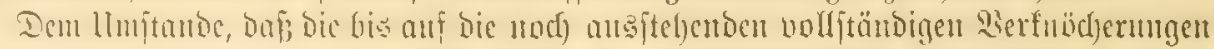
firtigen

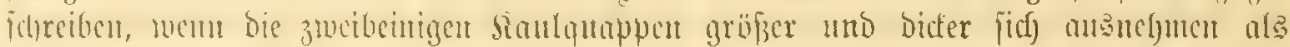

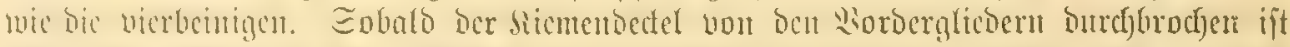

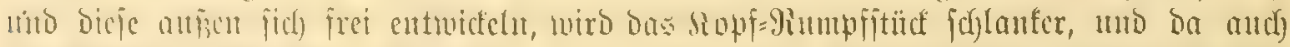

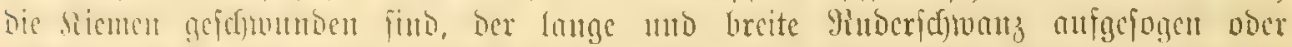

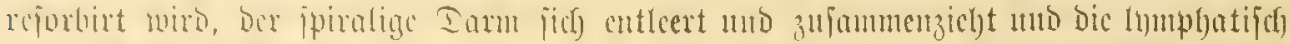

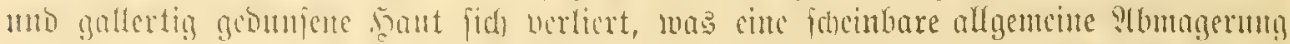

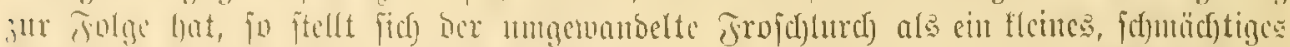

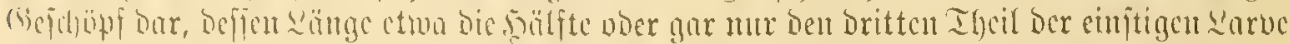

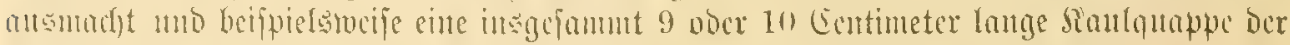

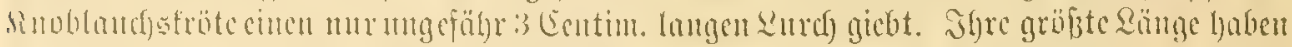

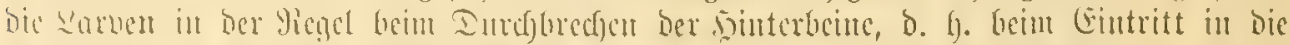

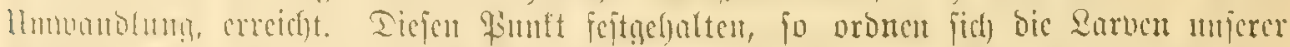

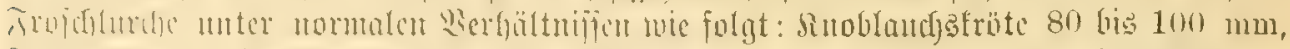

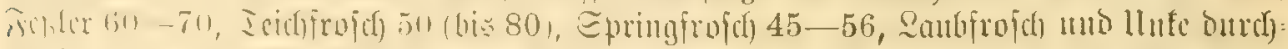

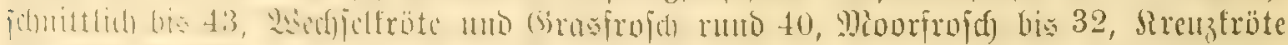

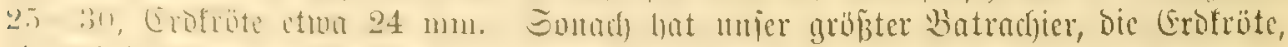

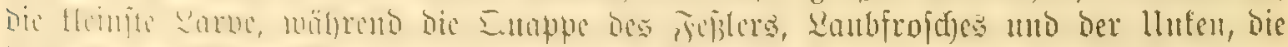

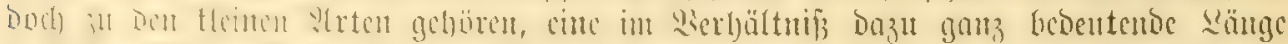

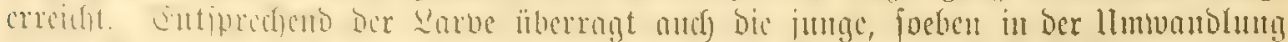

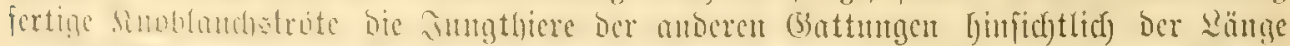

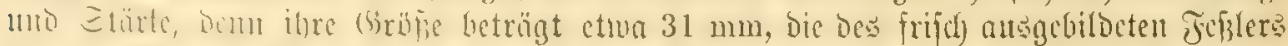

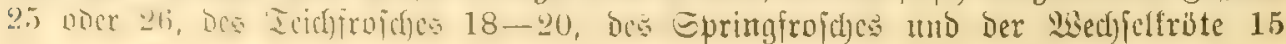




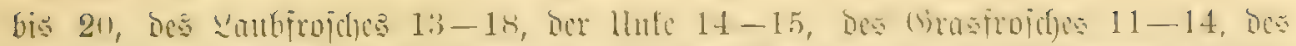

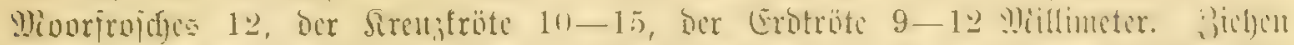

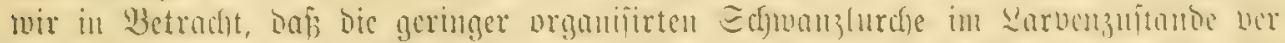

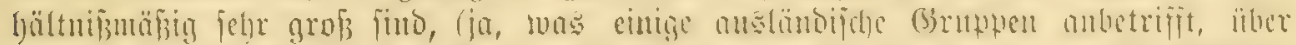

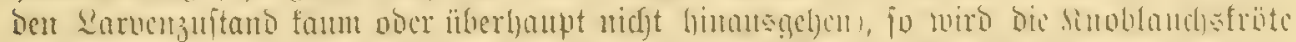

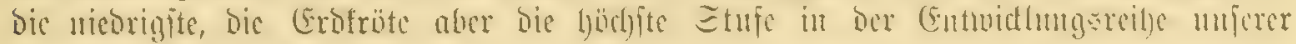
Jroich)(urdje einnegment.

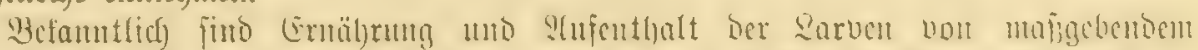

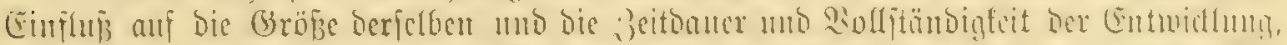

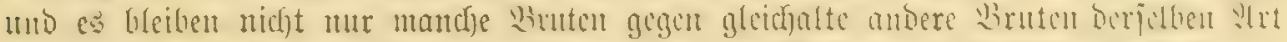

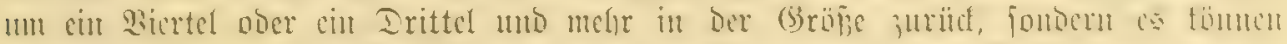

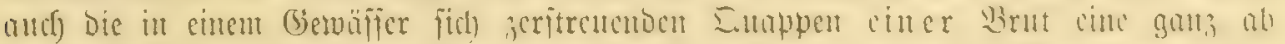

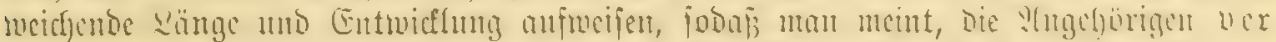

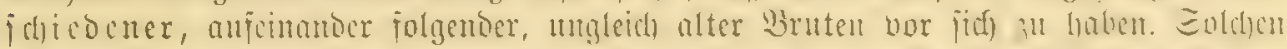

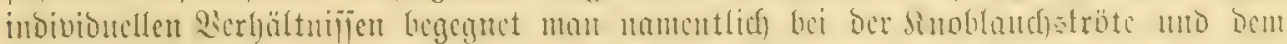

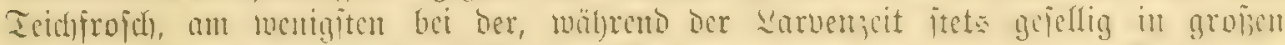

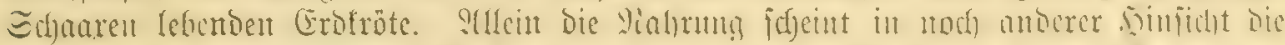

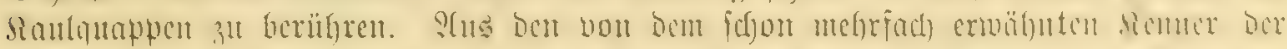

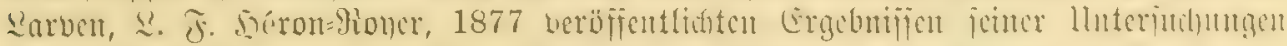

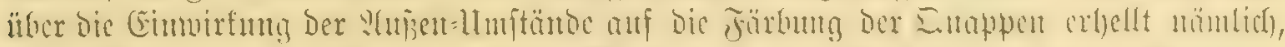

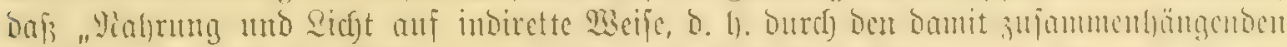

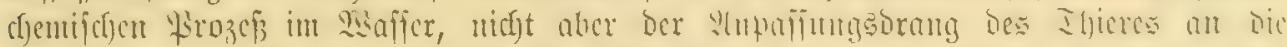

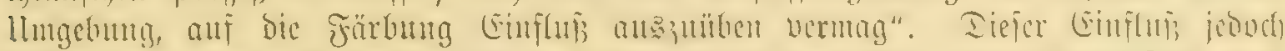

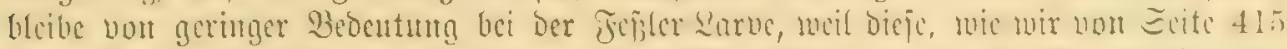

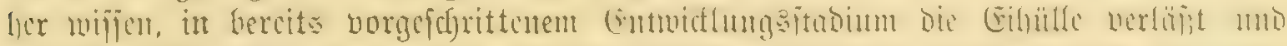

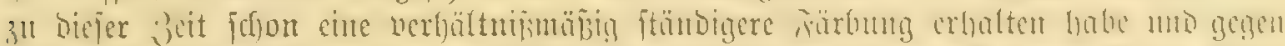

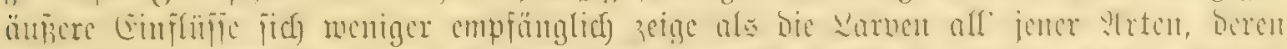

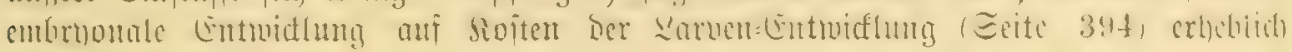
vertürzt iit.

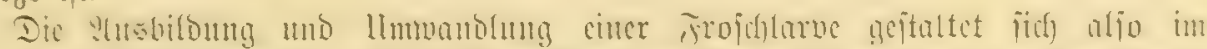

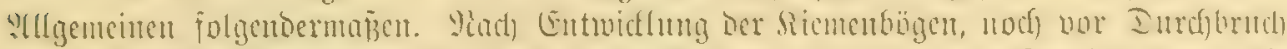

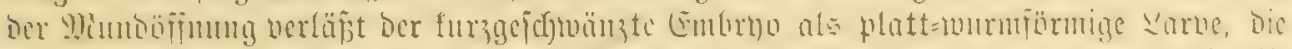

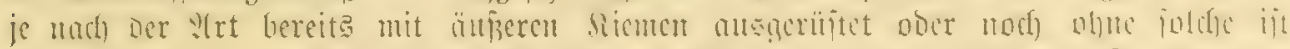

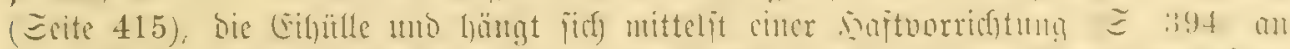

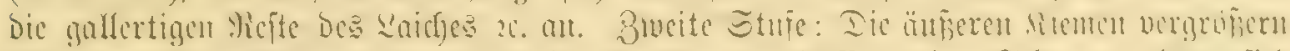

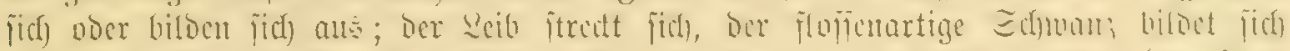

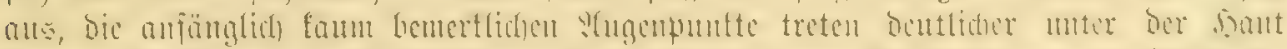

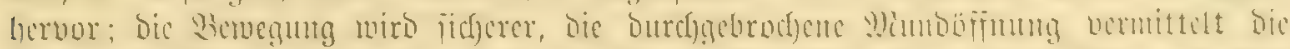

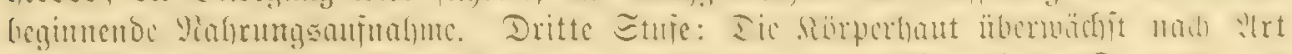

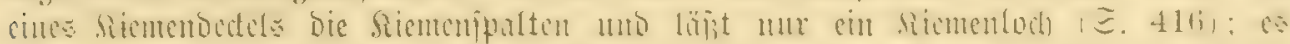

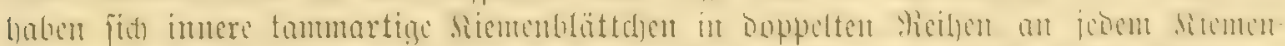

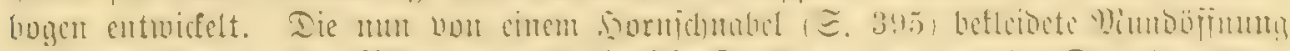

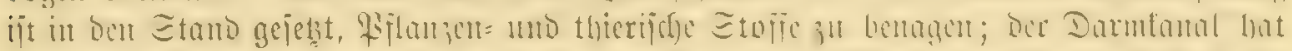

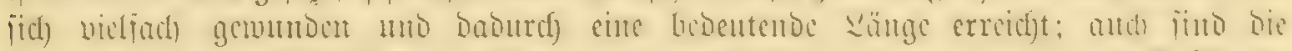

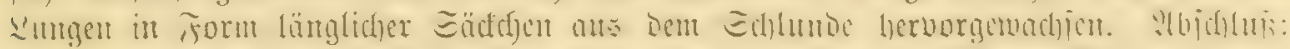

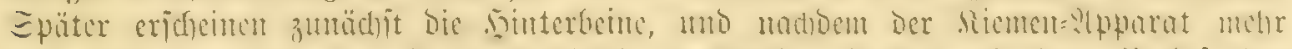

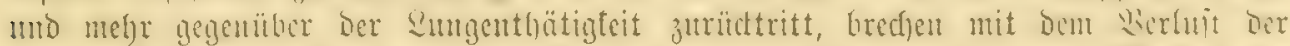

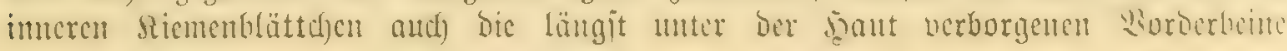




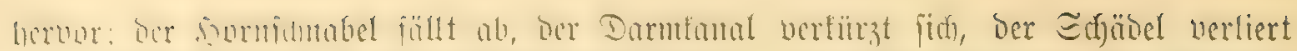

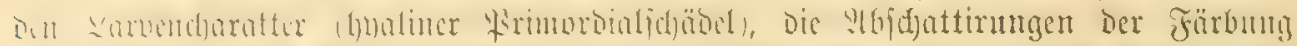

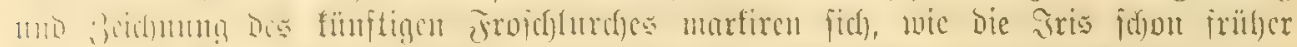

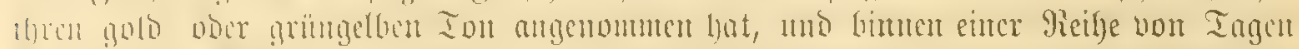

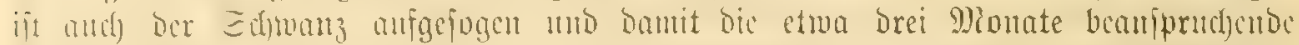

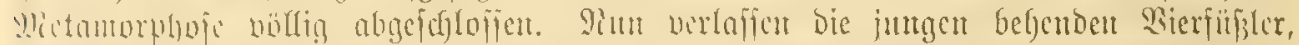

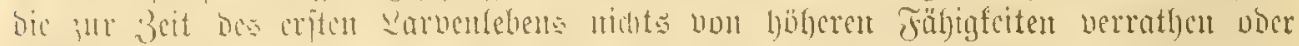

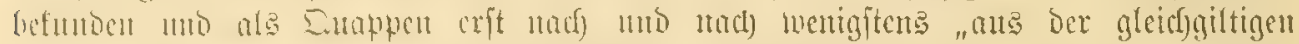

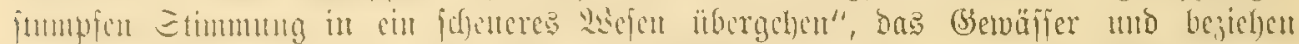

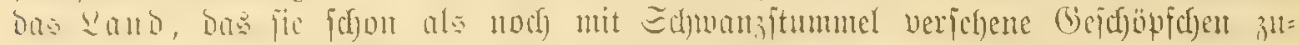

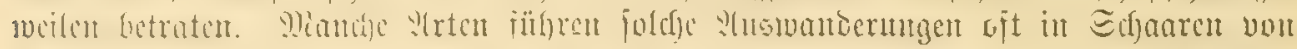
Sumberten

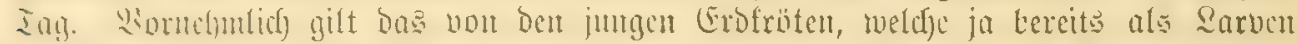

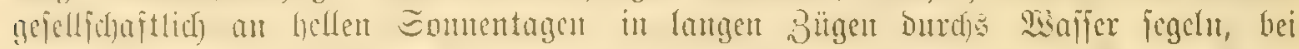

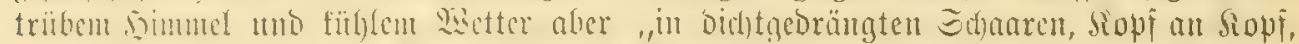

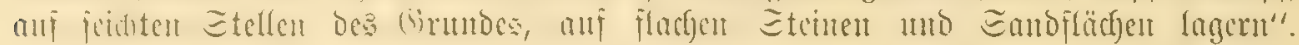

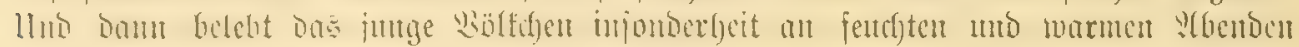

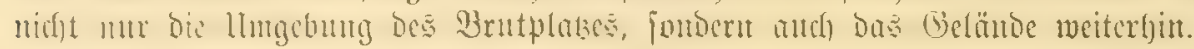

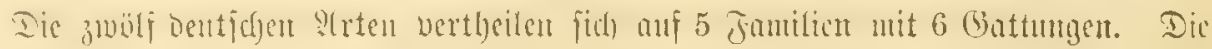
fünf Familien fülyrt nadjfebende lleberficht vor.

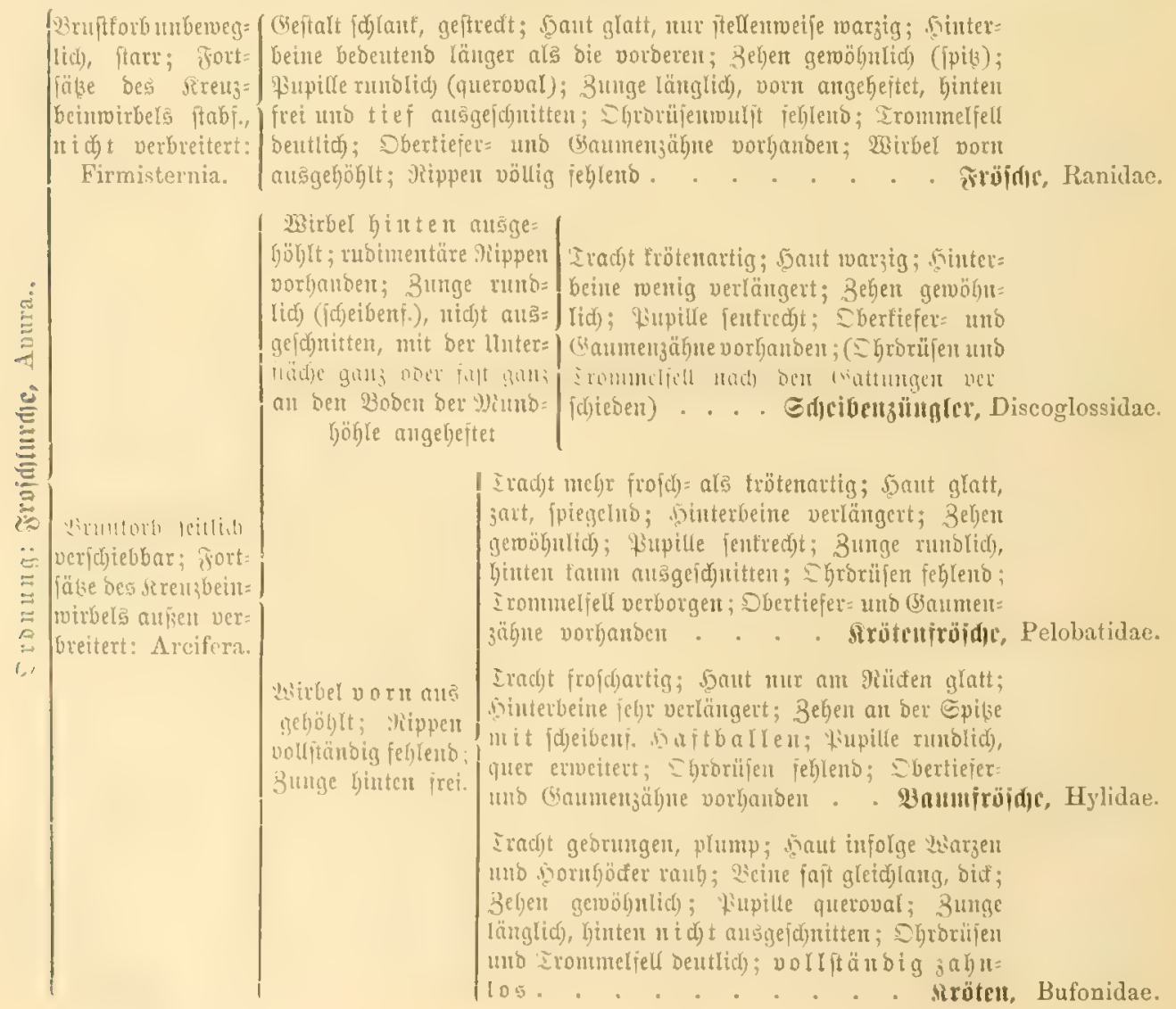


1. Reibe: Ctatrbuit= Tröjde, Firmisternia.

\section{Familie: (Gd)te Gröid)e, Ranidae.}

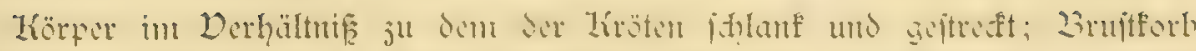

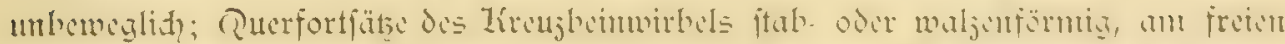

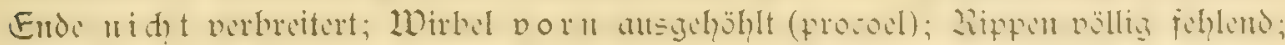

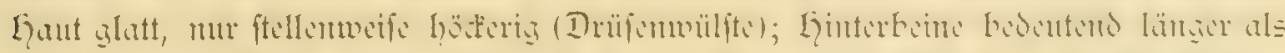

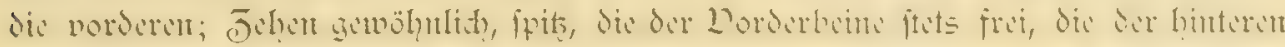

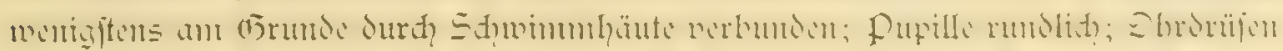

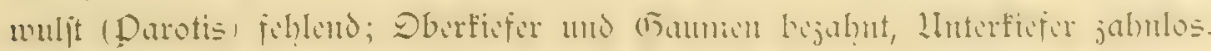

in Doutichland mur eime Battung:

\section{1. (5attung: Froid. Raua, $L$.}

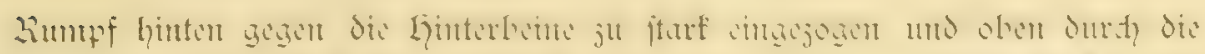

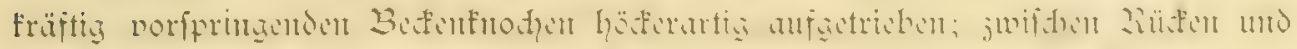

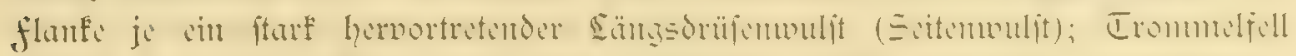

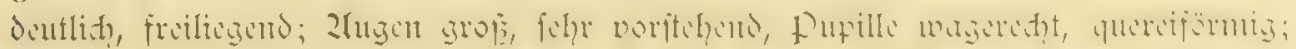

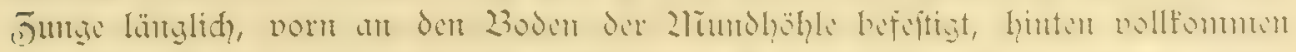

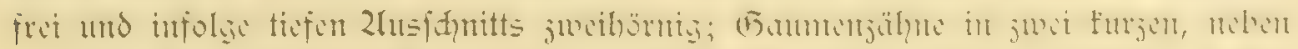

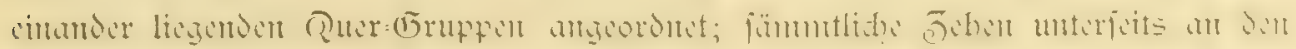

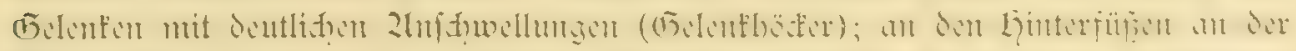

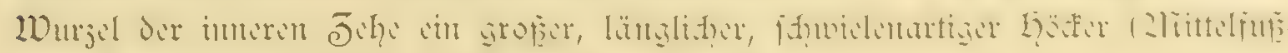

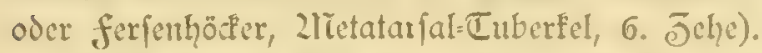

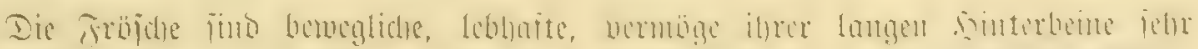

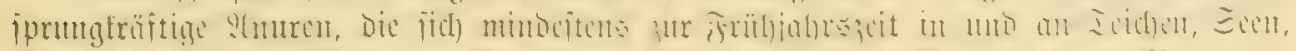

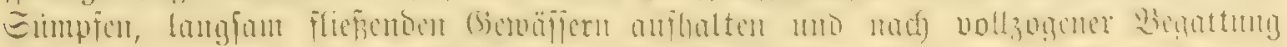

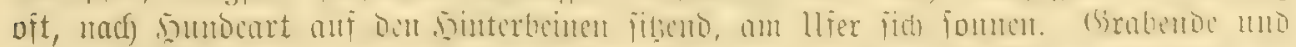

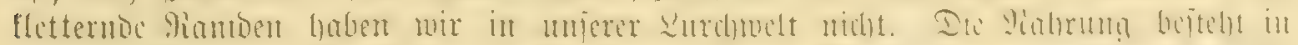

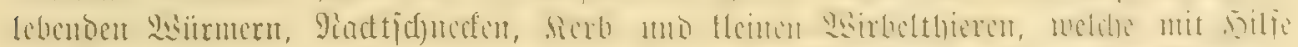

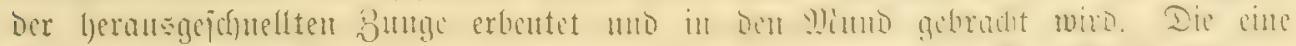

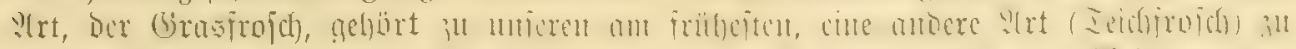

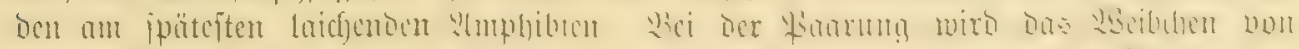

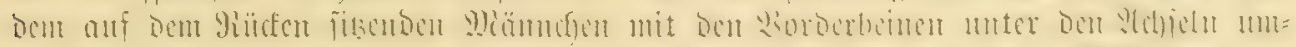

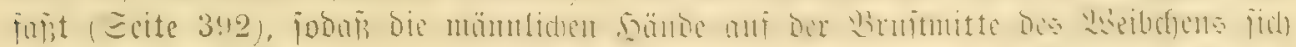

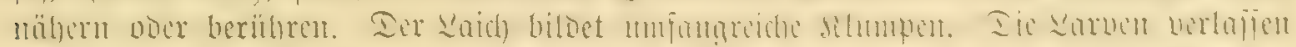

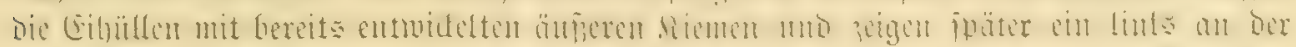

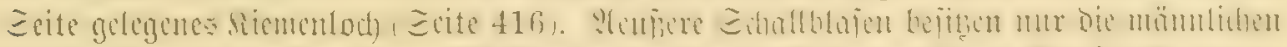

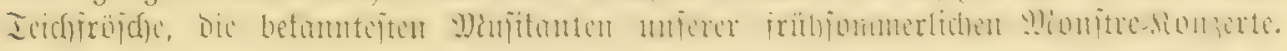

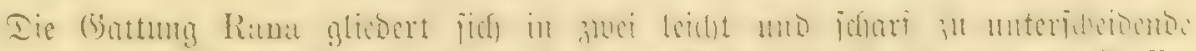

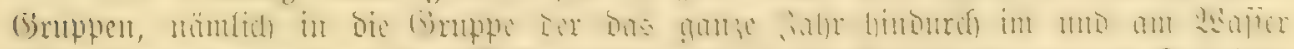

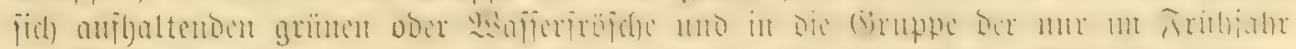

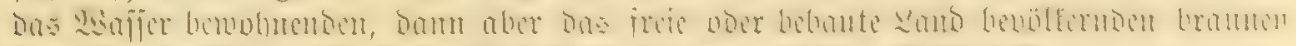

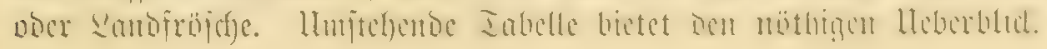


A. Mücfen grïn ober grïnlid); Sberid)enfel bezm. Jinterbaden ftets fdyvarg uno bell (gelblid))

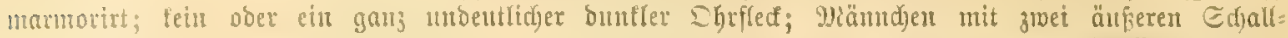

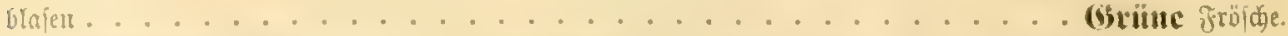

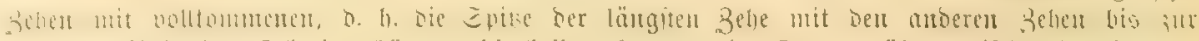

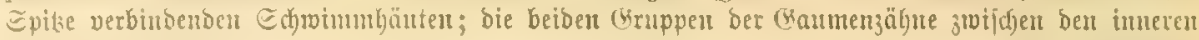

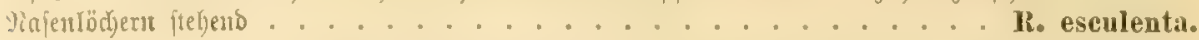

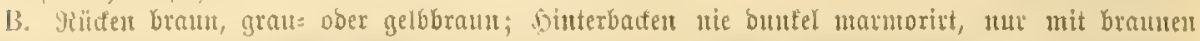

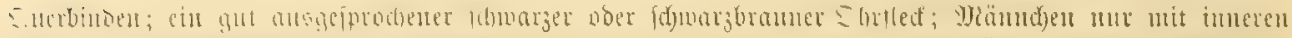

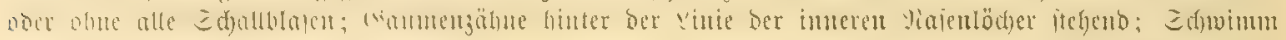

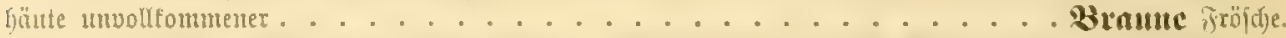

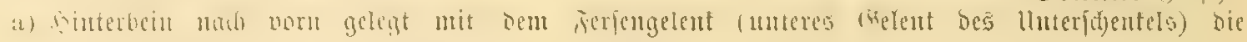
Echnausenfpise entidjieden liberragend; an ber wsurgel ber längiten Zehe ein tleiner roarzenartiger

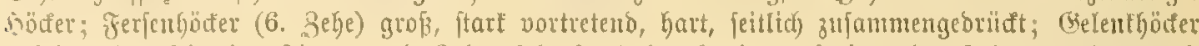

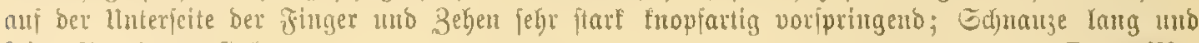

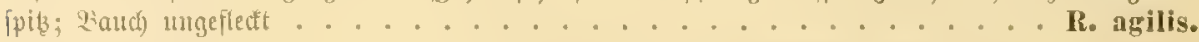

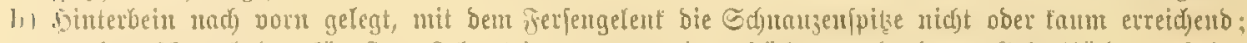

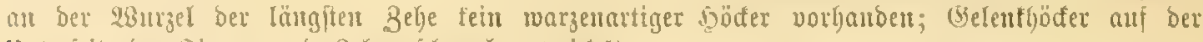
Unteripe ber jituger mo Behen fdrwad entwitelt:

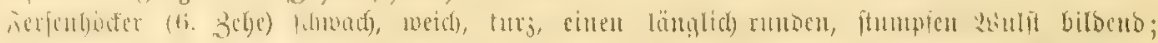

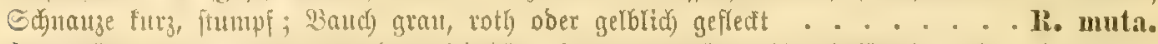

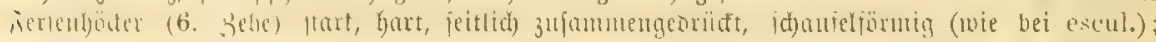
Cd)nauze zugefpitit, Oberlippe vorgezogen; Đaud ungefledt . . . . . . . . R. arvalis.

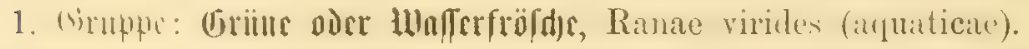

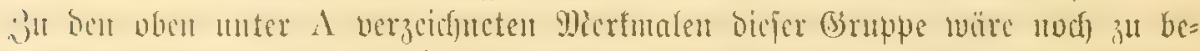

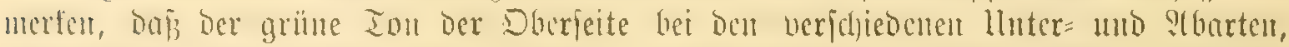

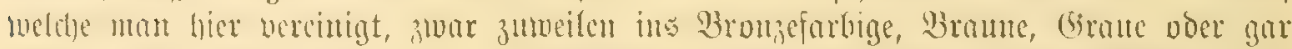

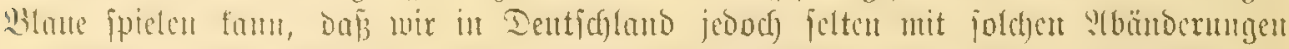

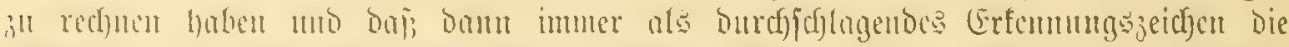

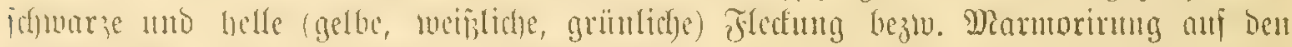

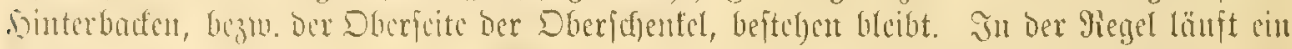

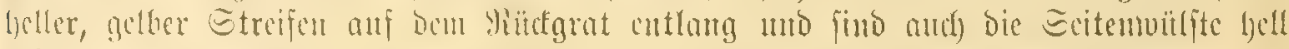

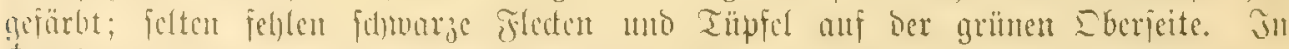

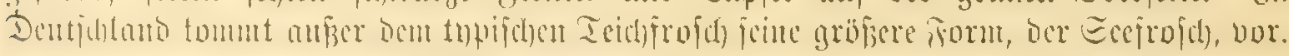

1. Int: Wafferfrofd). Rana esculenta, $L$.

:Ibbiloung Tafel IV, gir. 1.

:trleutuzeldent.

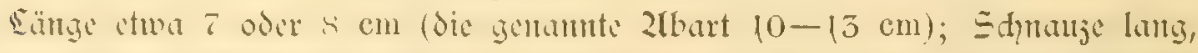

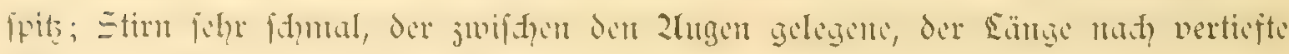

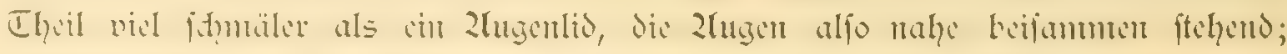

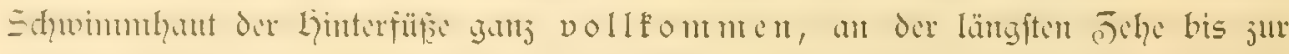

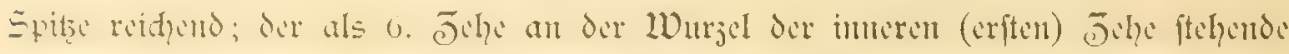

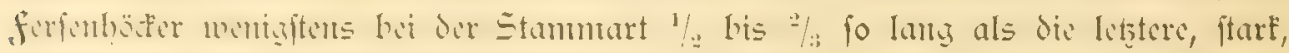

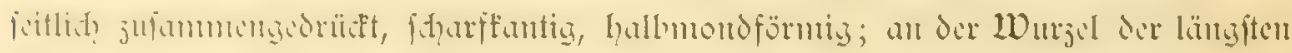

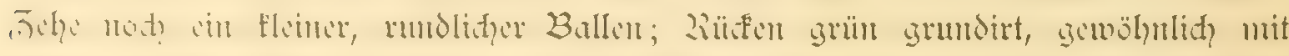

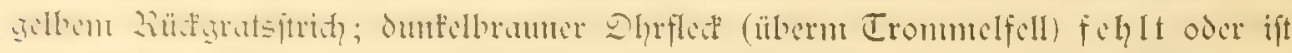

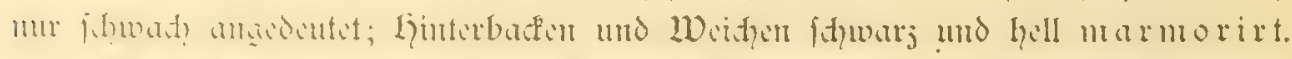

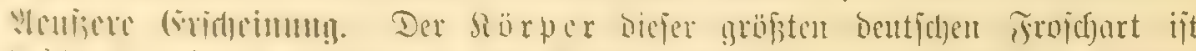

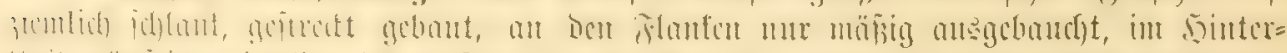

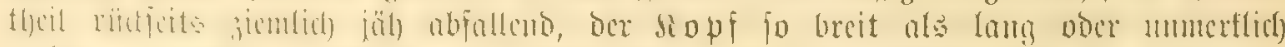

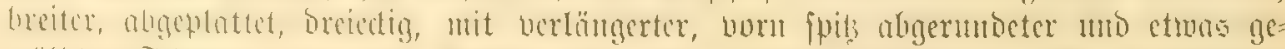

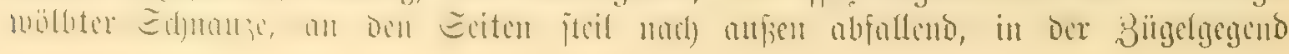




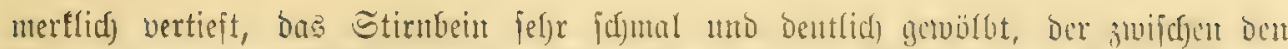

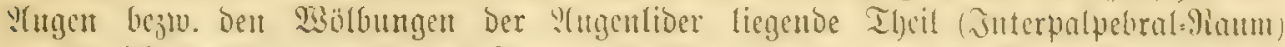

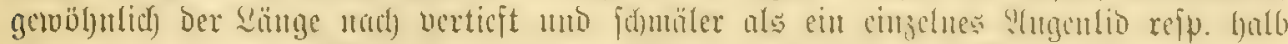

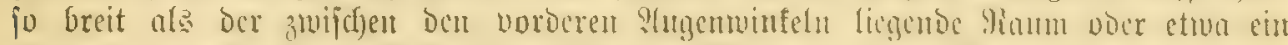

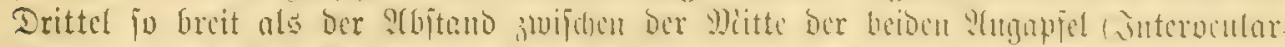

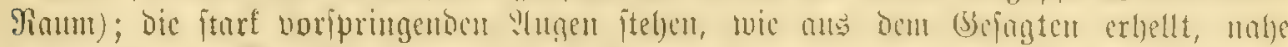

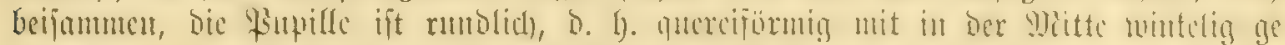

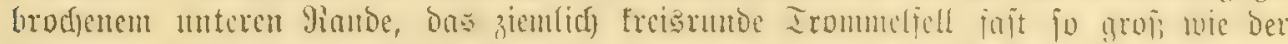

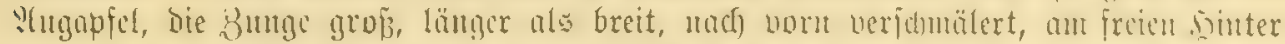

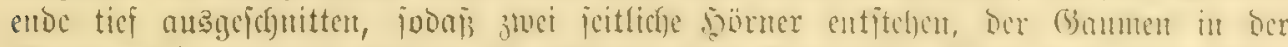

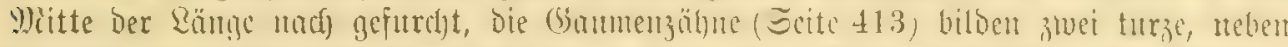

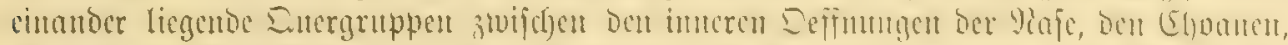

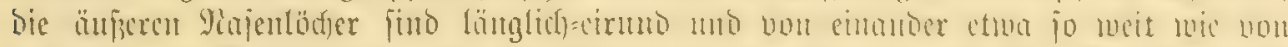

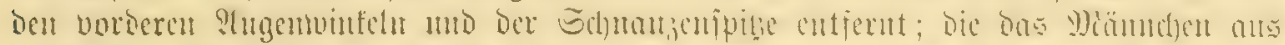

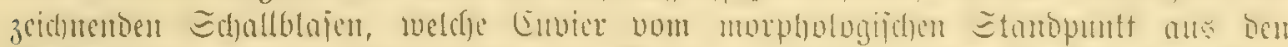

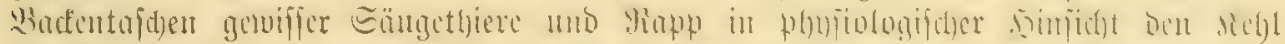

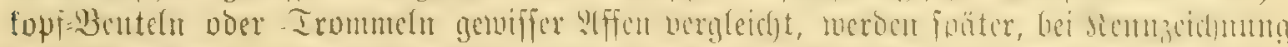

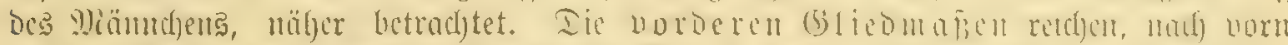

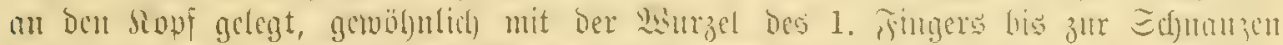

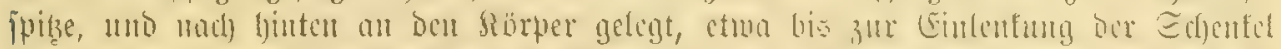

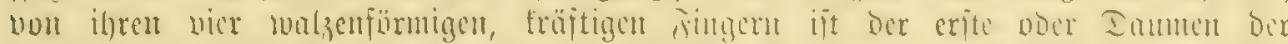

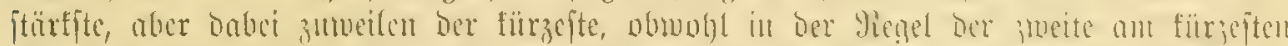

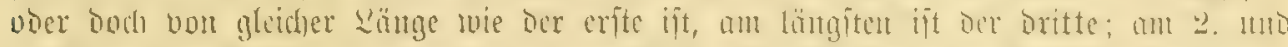

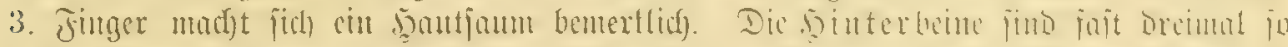

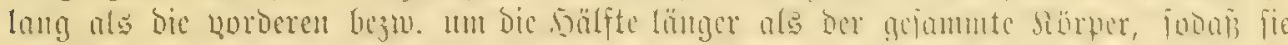

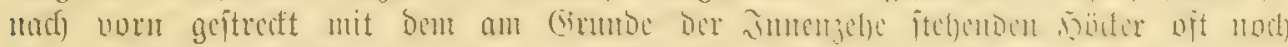

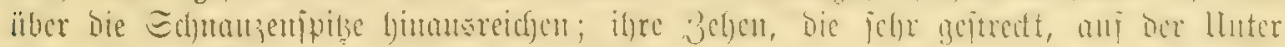

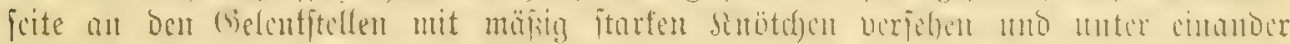

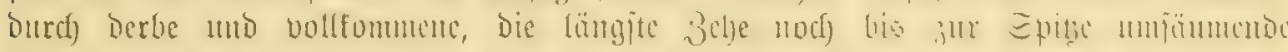

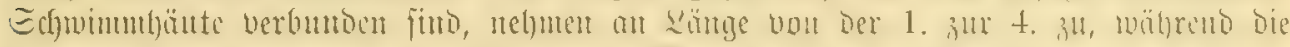

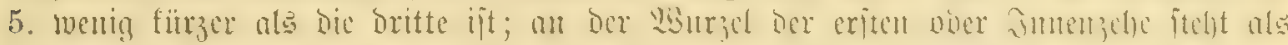

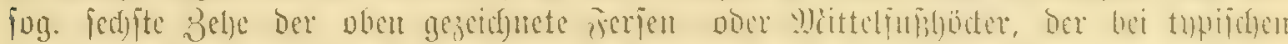

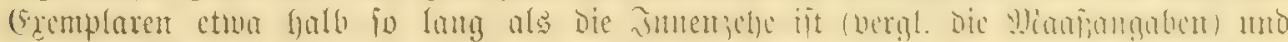

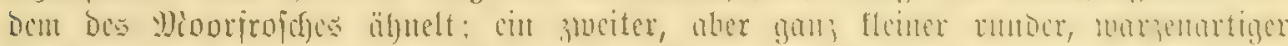

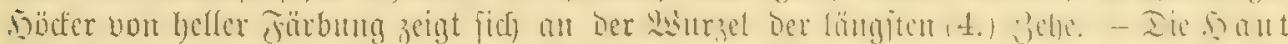

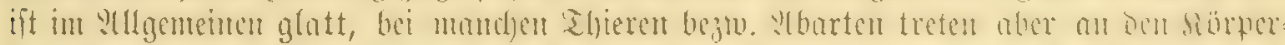

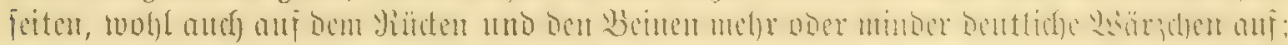

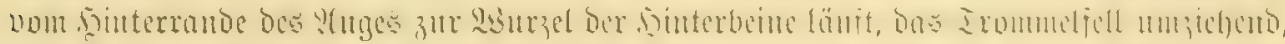

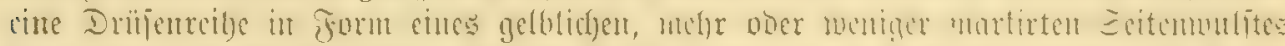

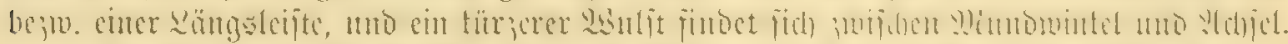

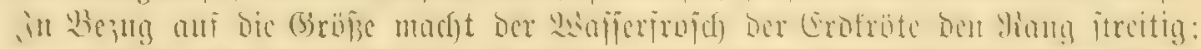

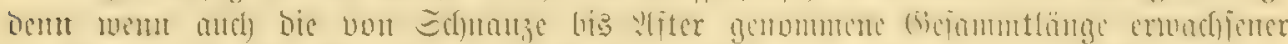

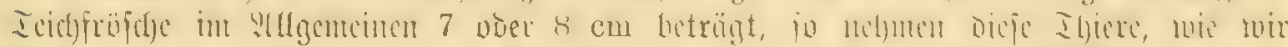

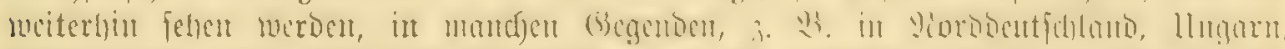

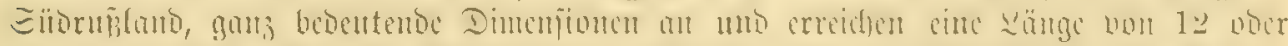

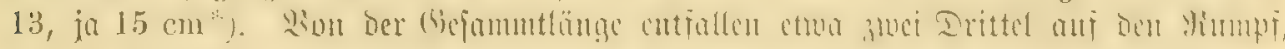

*) Go jtegen and in wiener Minfenm, Eteinbadnets strgabe zujolge |Yovara S. 17|, aus llngant, sroatten :c. (Exemplare "von 6 Boll dörperlänge uto barüber". 


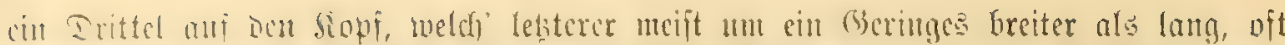

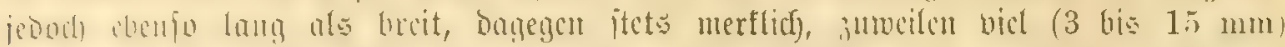

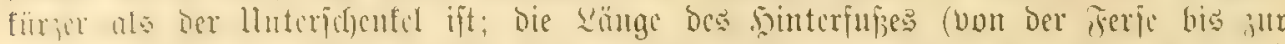

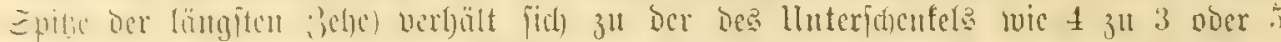

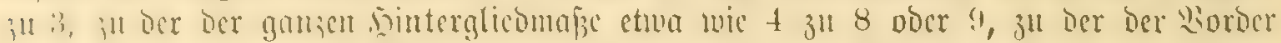

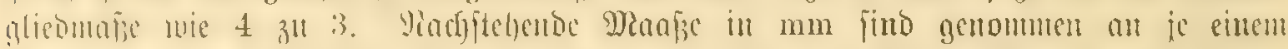
weciblyen

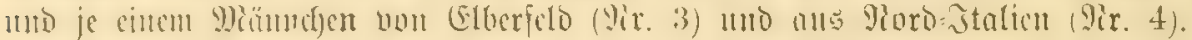

\begin{tabular}{|c|c|c|c|c|c|c|c|c|c|c|}
\hline Yit. & $\begin{array}{l}\text { (fejammit: } \\
\text { sänge. }\end{array}$ & $\begin{array}{l}\text { Borbet: } \\
\text { gliedm. }\end{array}$ & $\begin{array}{l}\text { Sinters } \\
\text { glisout. }\end{array}$ & $\begin{array}{l}\text { Dbel: } \\
\text { jusulet. }\end{array}$ & $\begin{array}{l}\text { linter: } \\
\text { fdjentel. }\end{array}$ & Ropilänge. & $\begin{array}{l}\text { Gröbte } \\
\text { Sopibr. }\end{array}$ & 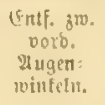 & 6. Sebe. & Snnenjelye. \\
\hline 1 & 50 & 29 & 83 & 20,5 & 21 & 18 & 18 & $7_{\text {, }}$ & $3_{12}$ & h \\
\hline 2 & 51 & 30 & 85 & 21 & 22 & 19 & 20 & 8 & 4,3 & 7 \\
\hline 3 & 57 & 33 & 93 & 22,8 & 23 & 20 & 20 & 7,8 & 4 & 8,3 \\
\hline 1 & 71 & 40 & 111 & 33 & 33 & 23 & 23,5 & 9 & $4 . s$ & 0 \\
\hline 5 & 112 & 58 & 163 & 46 & 48 & 33 & 34 & 11,5 & 4 & .11 \\
\hline
\end{tabular}

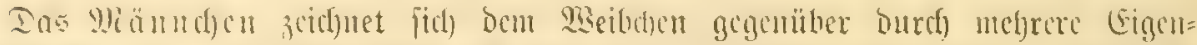

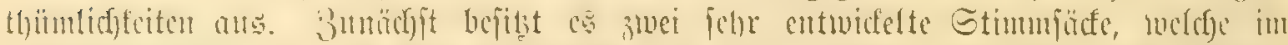

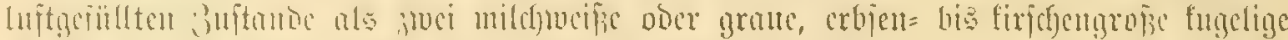

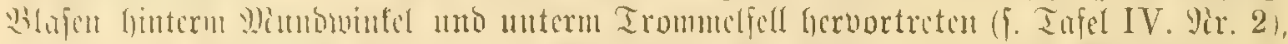

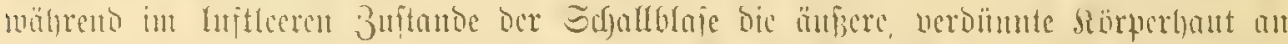

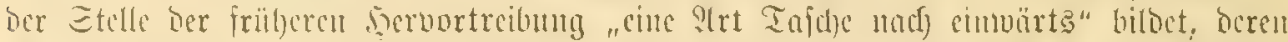

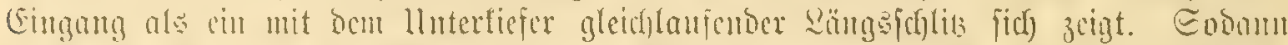

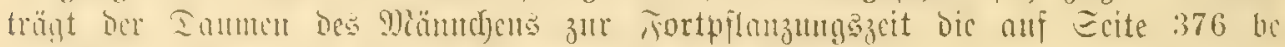

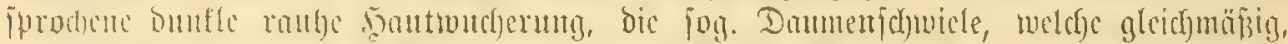

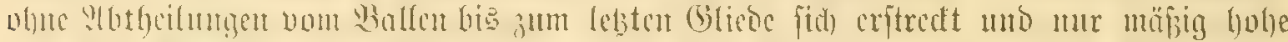

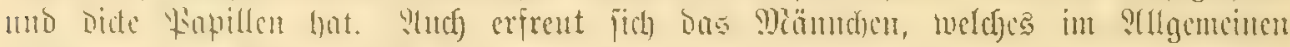

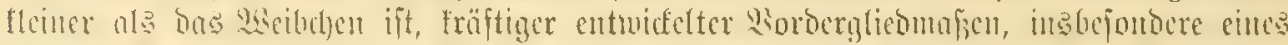

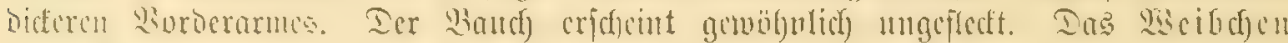

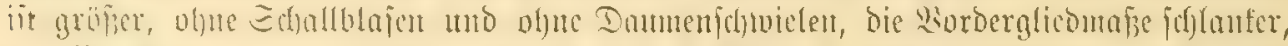

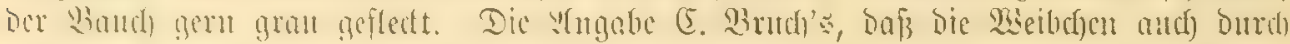

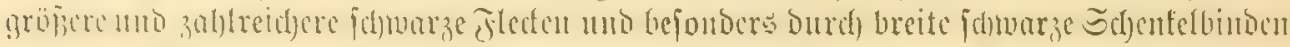
won Den 9läuntden fich untericheiden, trifft nicht burchueg zu.

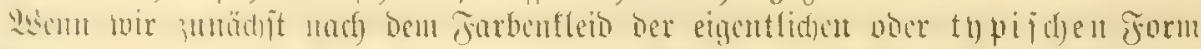

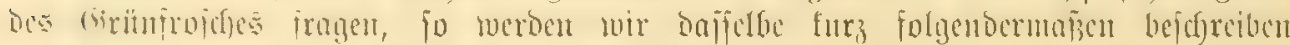

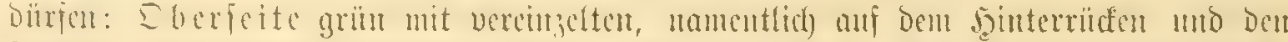

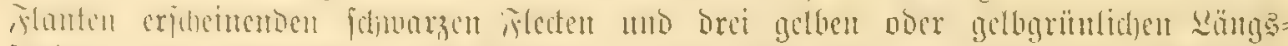

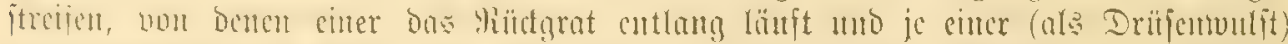

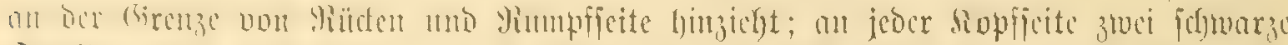

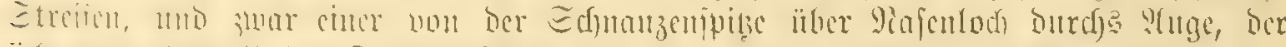

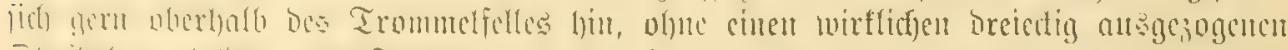

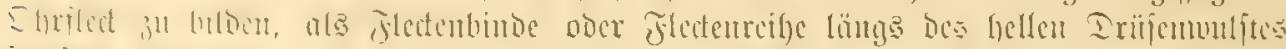

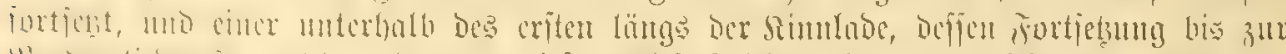

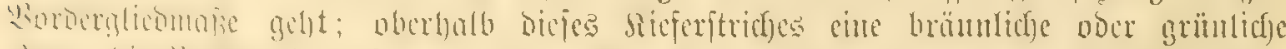

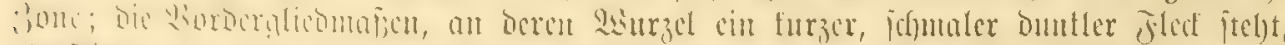

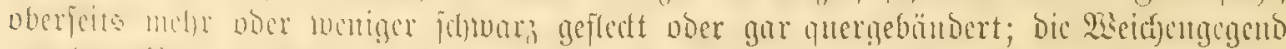

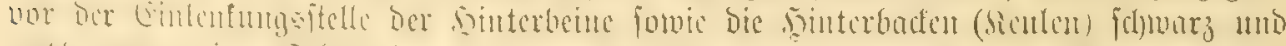

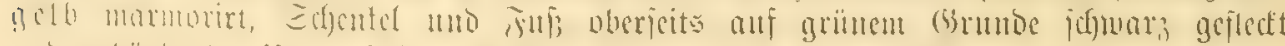

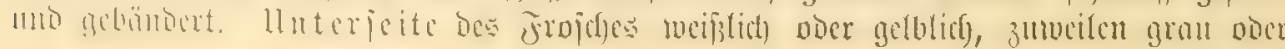




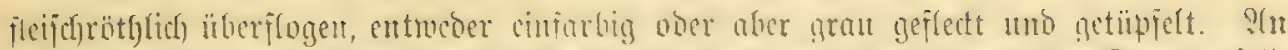

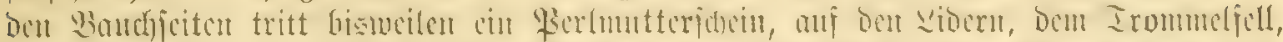

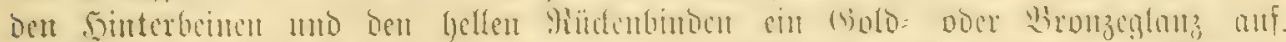

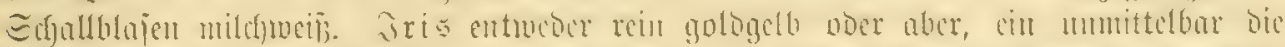

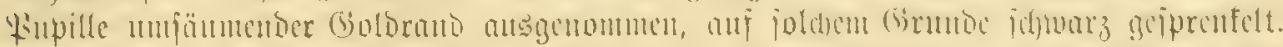

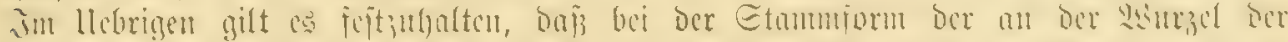

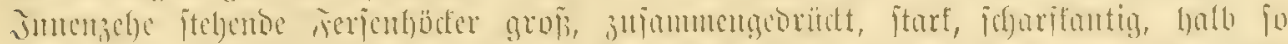

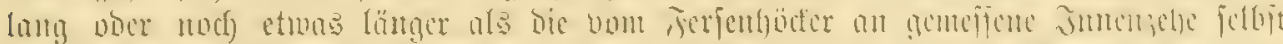

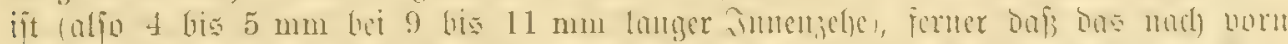

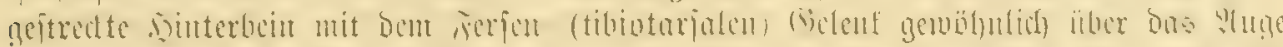

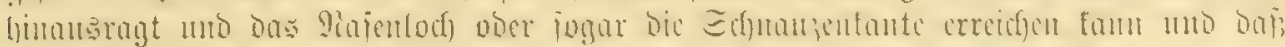

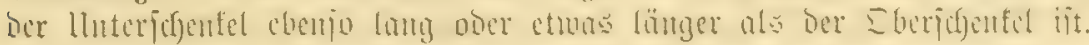

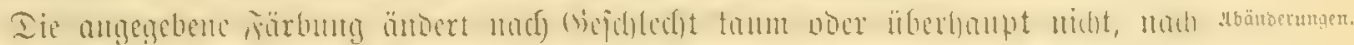

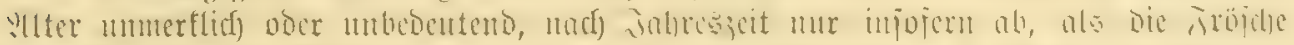

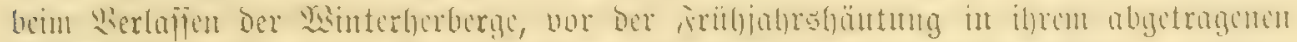

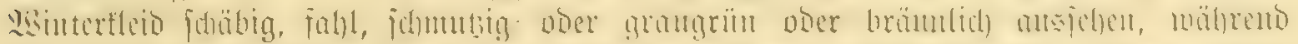

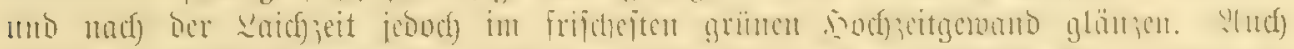

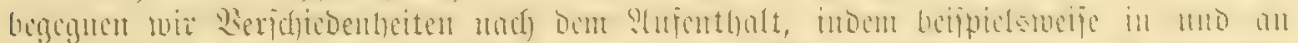

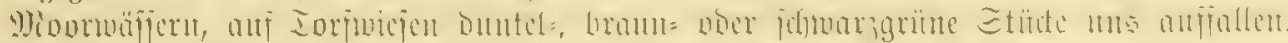

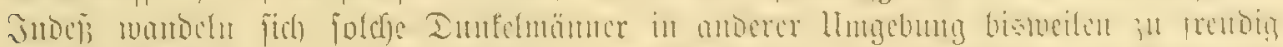

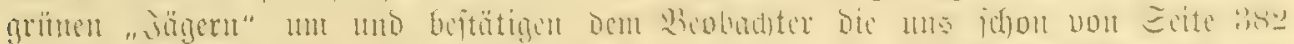

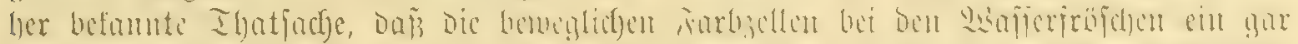

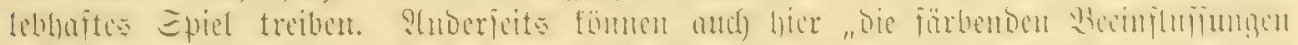

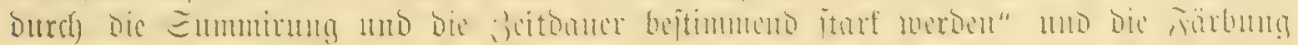

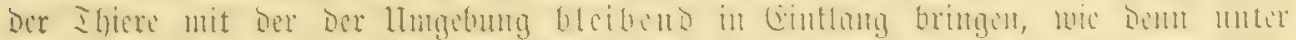

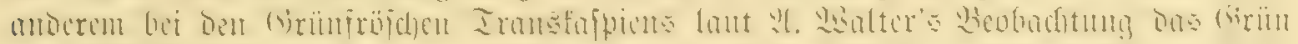

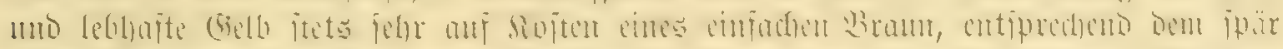

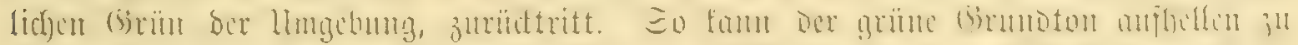

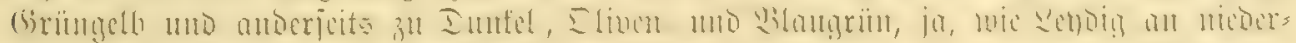

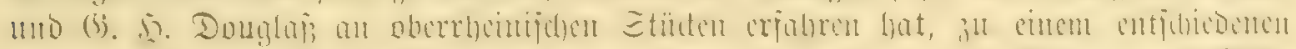

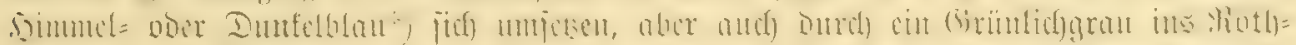

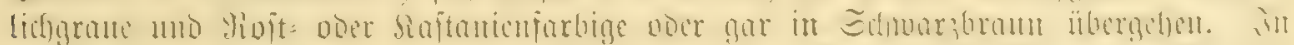

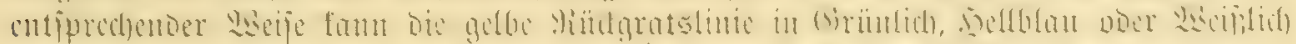

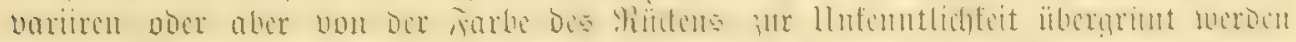

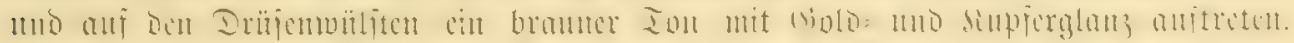

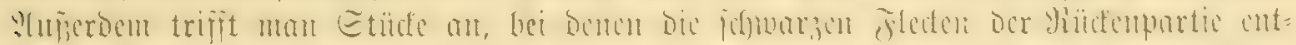

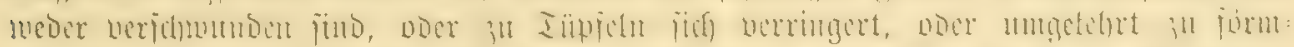

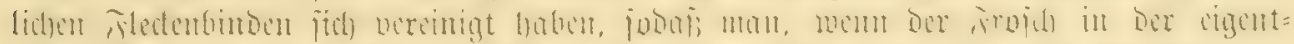

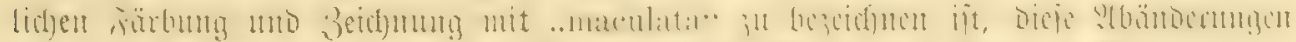

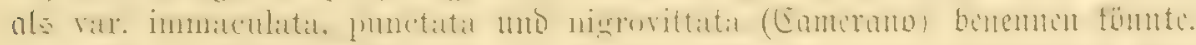

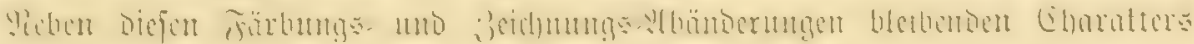

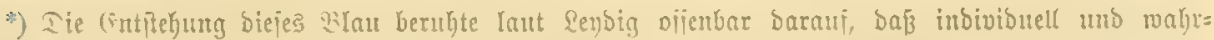

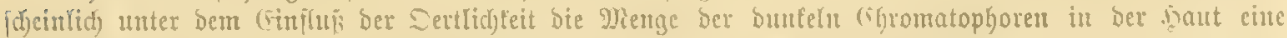

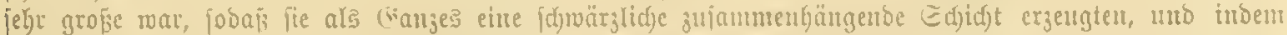

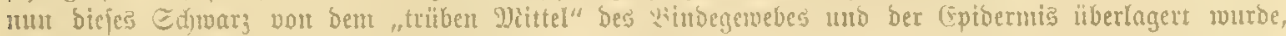

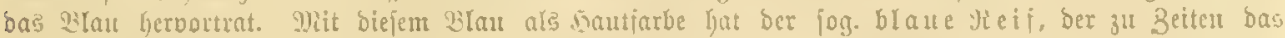

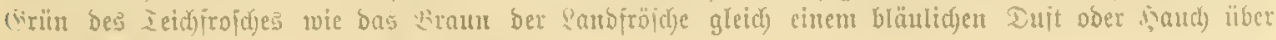
3ielft, nidjts 3u thut. [300l. (45. 92 S. 4]. 


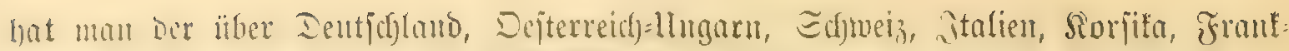

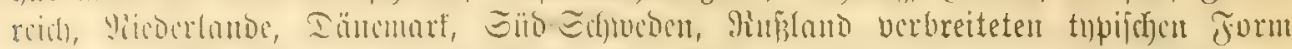

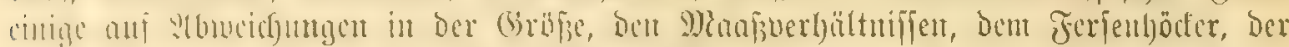

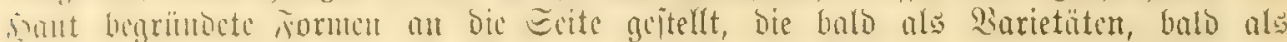

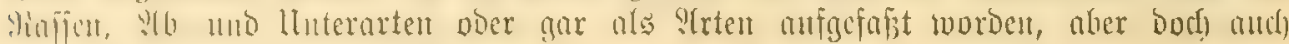
burd) llcbergänge verbunden find.

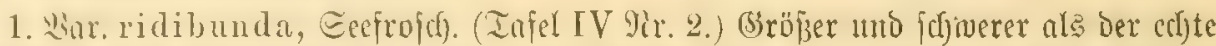

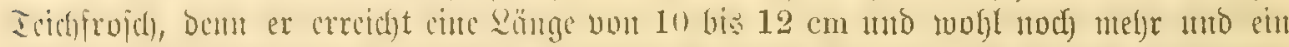

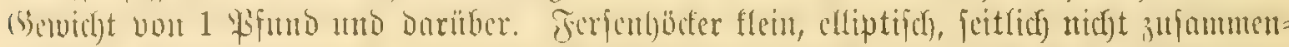

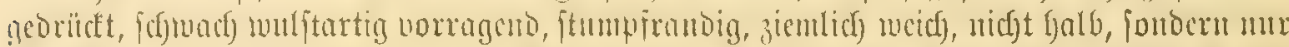

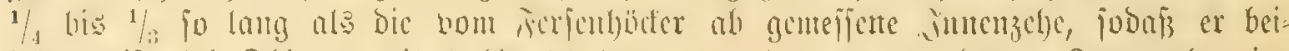

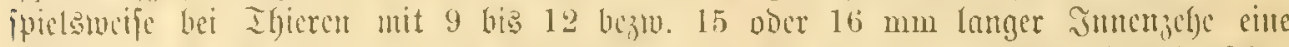

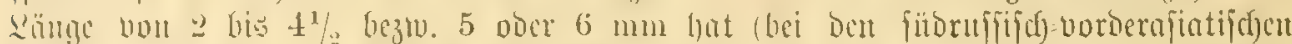

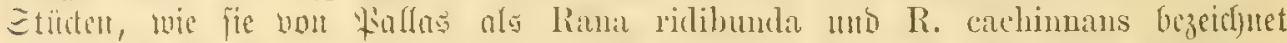

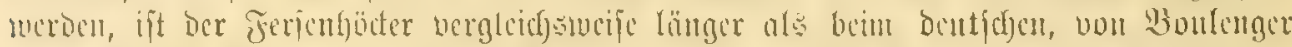

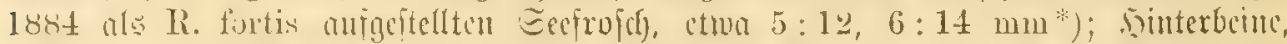

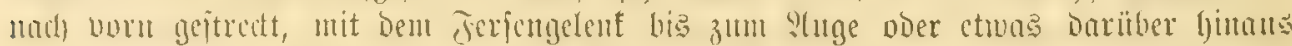

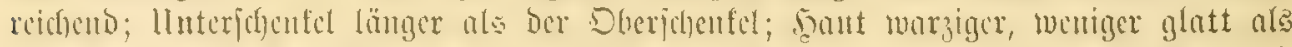

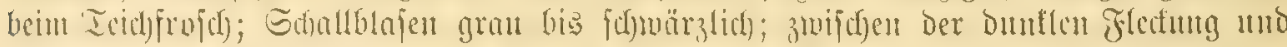

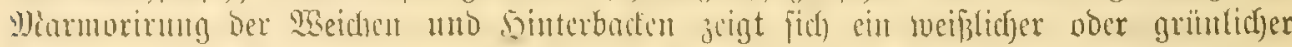

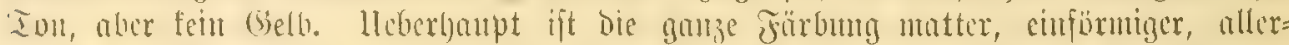

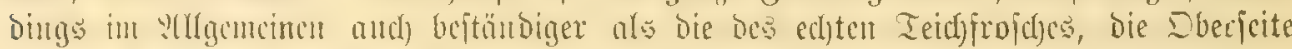

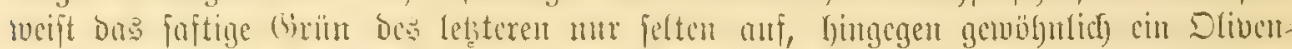

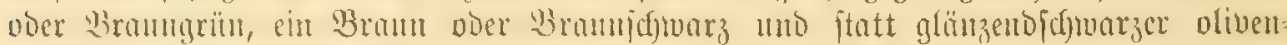

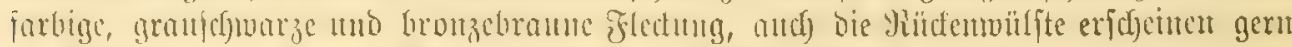

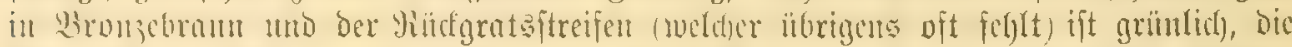

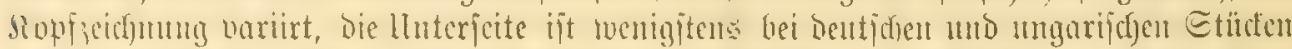

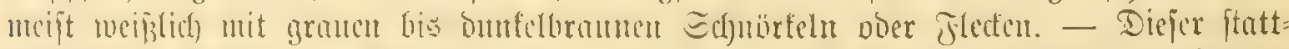

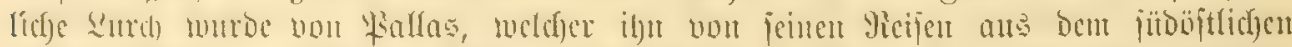

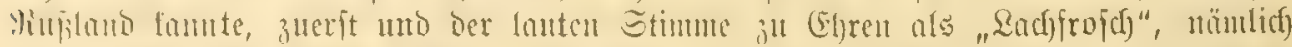

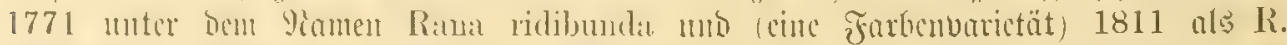

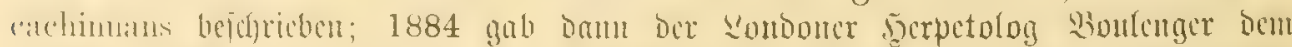

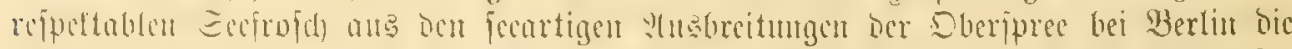

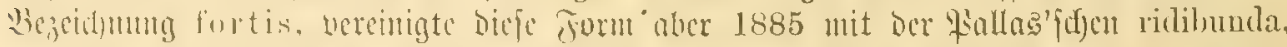

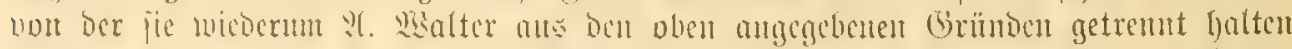

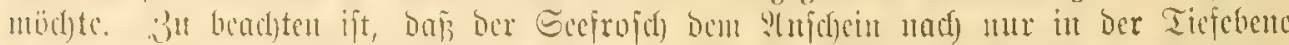

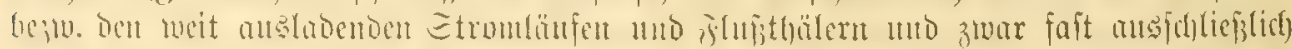

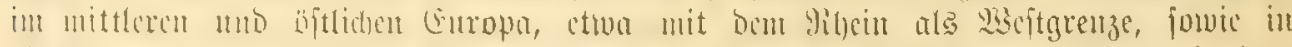

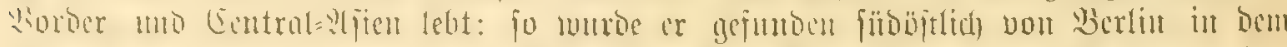

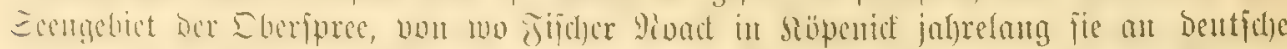

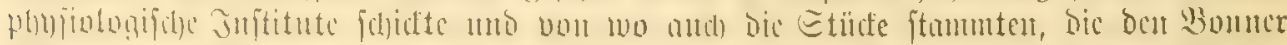

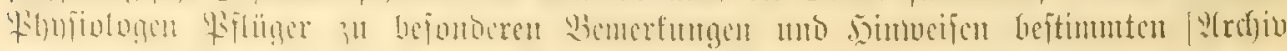

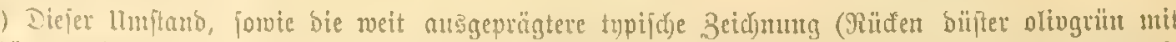

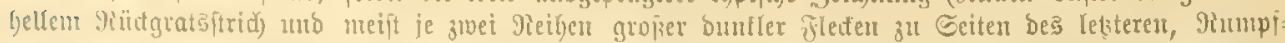

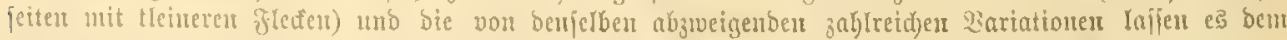

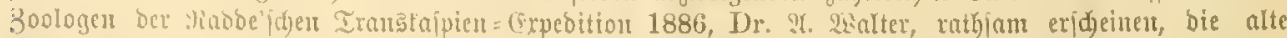
Hallas'id)e var. ridibunda-cachinnans von ber beutfden var. fortis getrent ju balten; bie 2hiaten pollen aud eite abveidenbe Stimuse baben. 


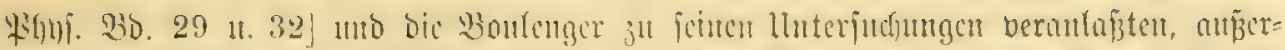

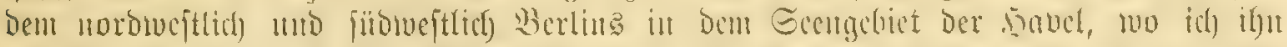

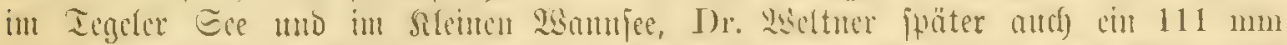

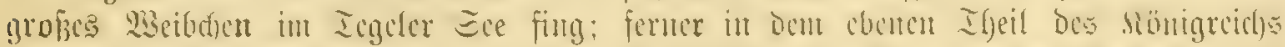

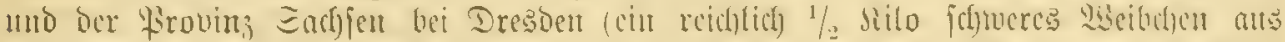

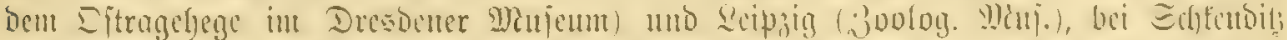

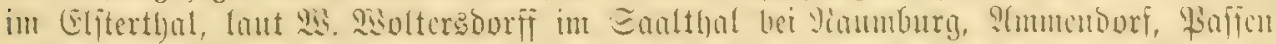

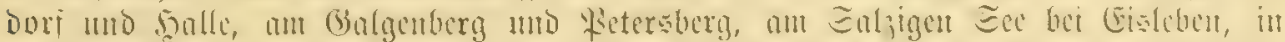

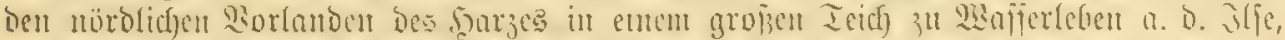

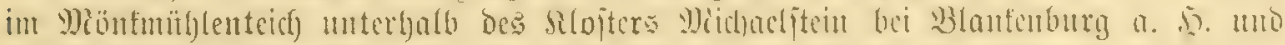

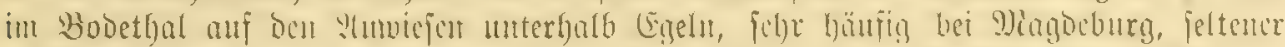

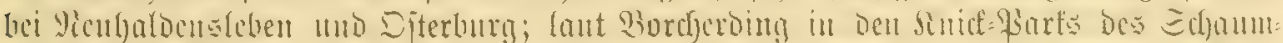

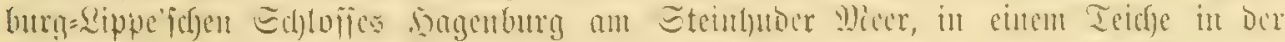

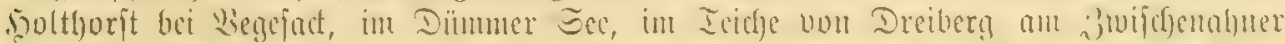

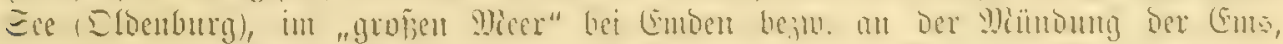

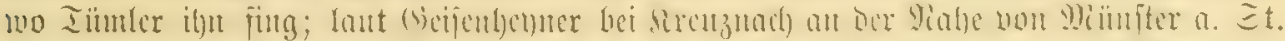

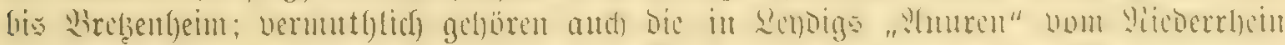

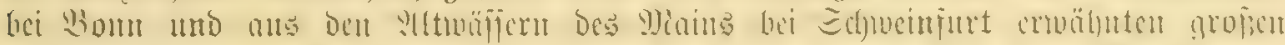

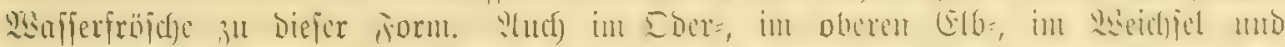

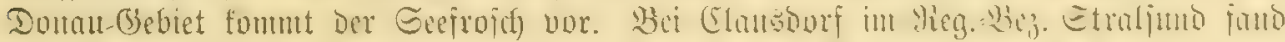

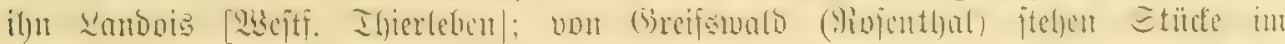

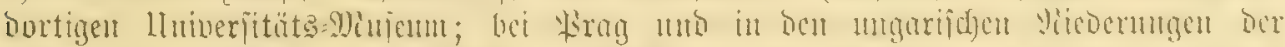

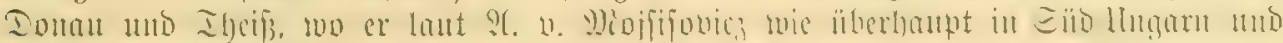

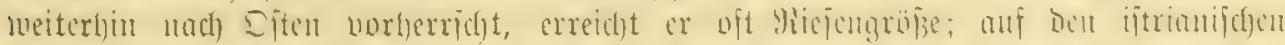

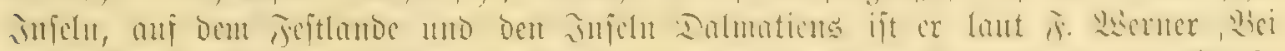

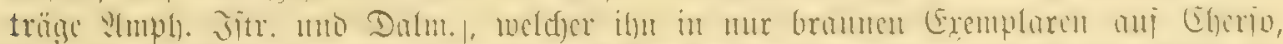

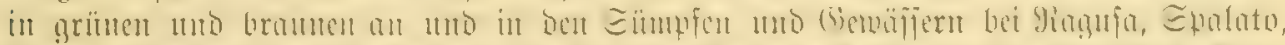

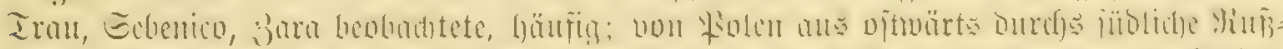

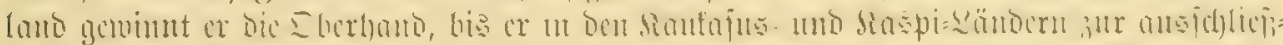

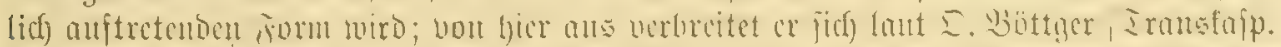

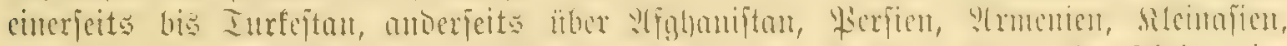

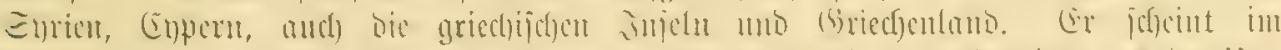

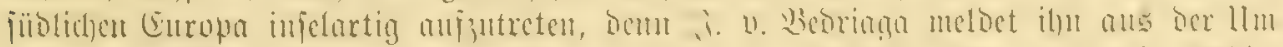

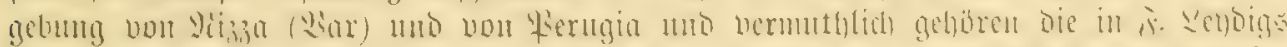

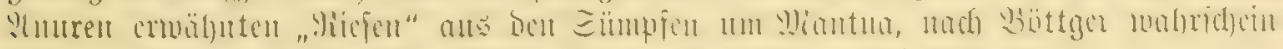

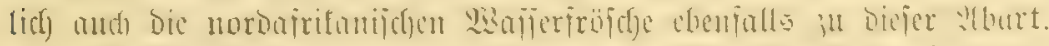

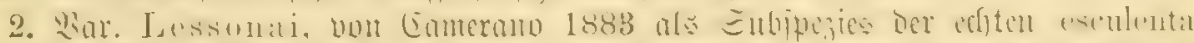

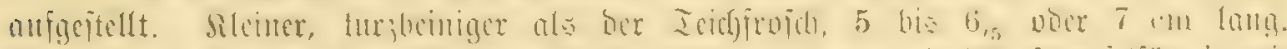

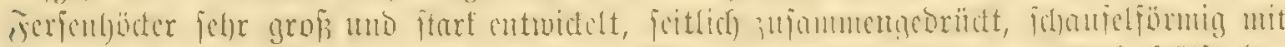

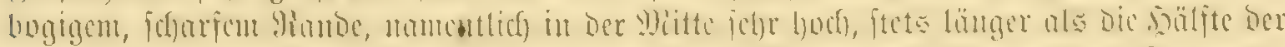

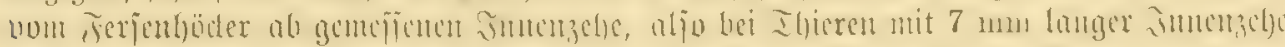

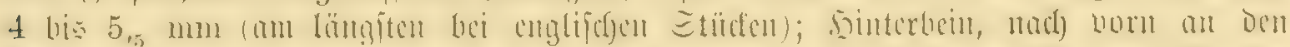

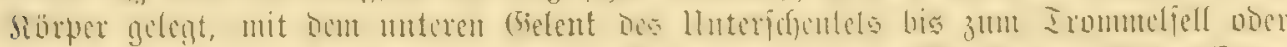

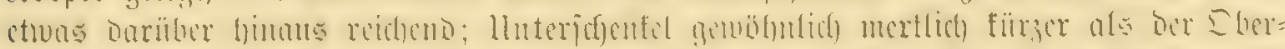

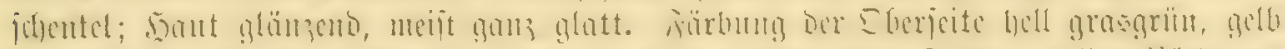

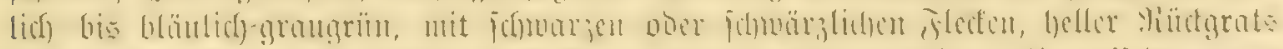

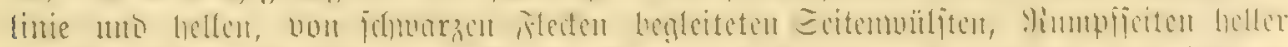

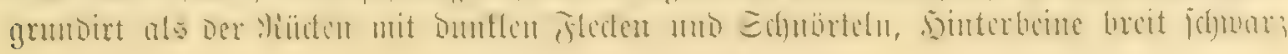




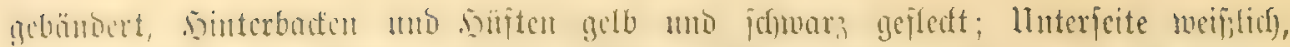

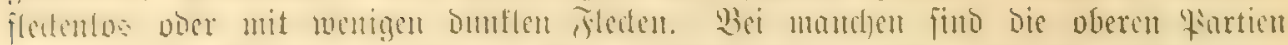

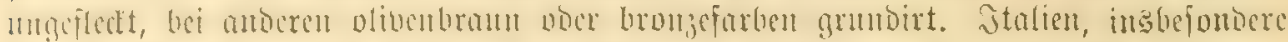

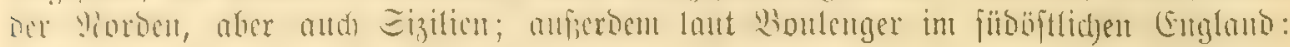
(sambriogeflice mo शorfolf, nad)getviefen.

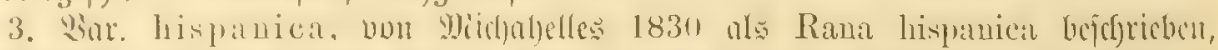

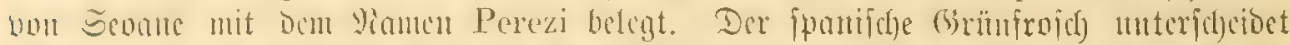

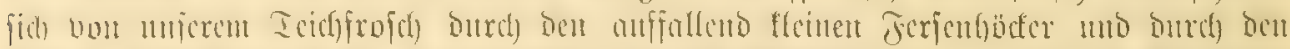

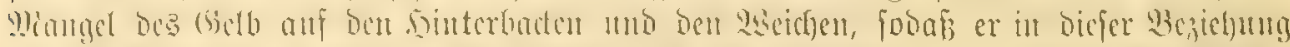

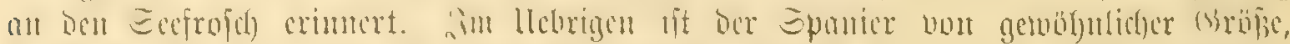

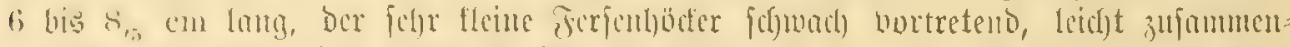

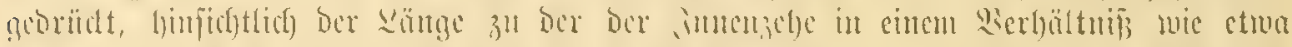

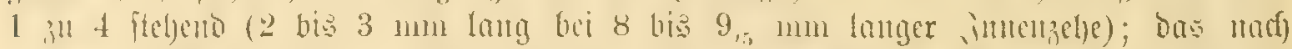

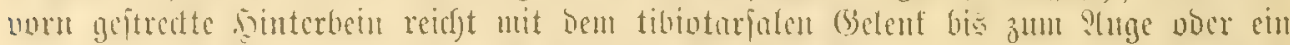

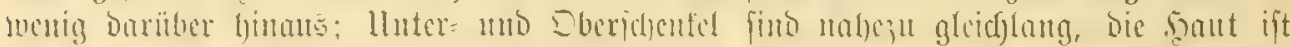

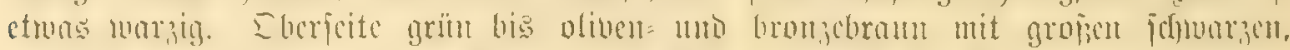

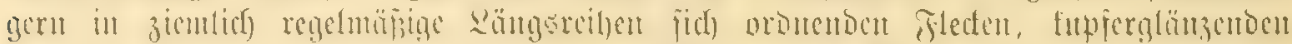

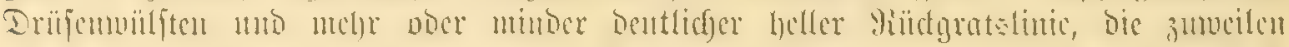

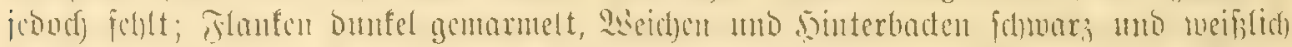

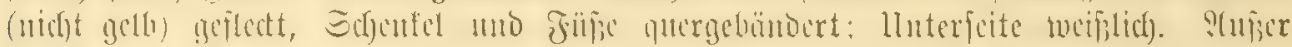

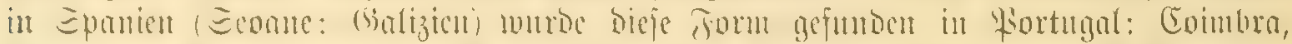

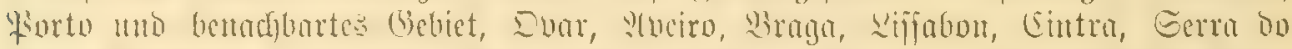

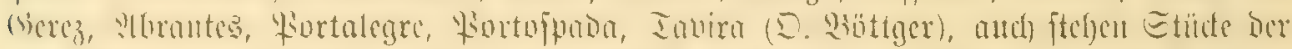

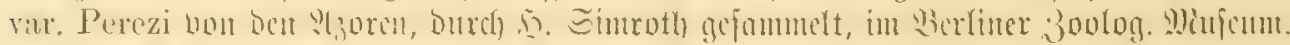

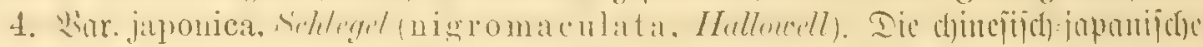

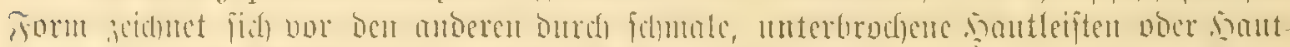

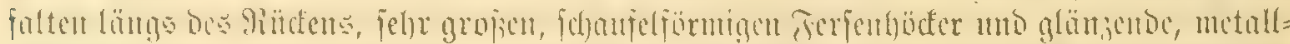

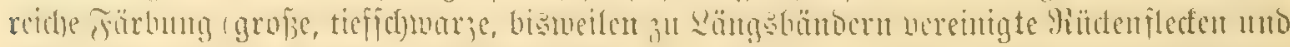

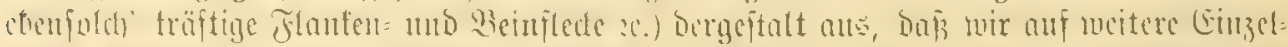

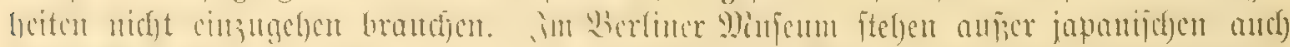

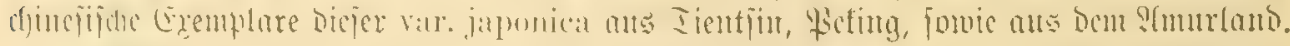

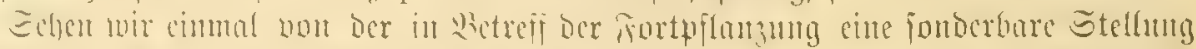

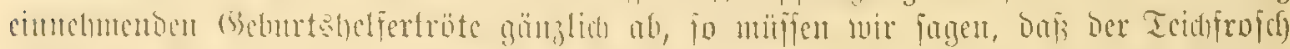

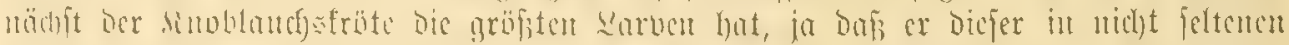

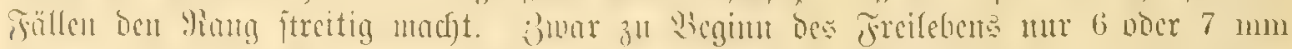

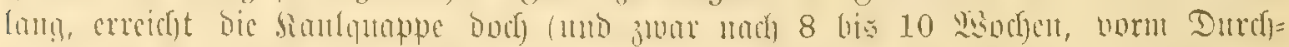

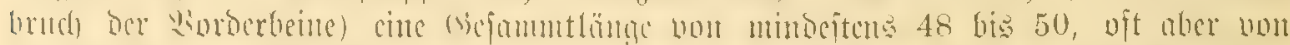

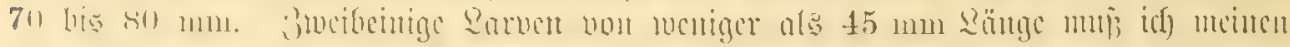

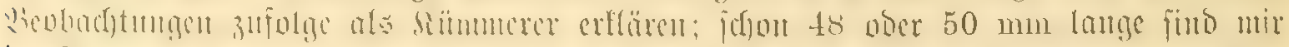

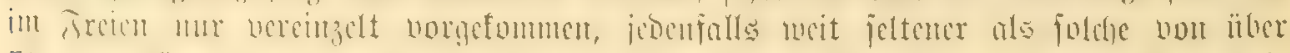

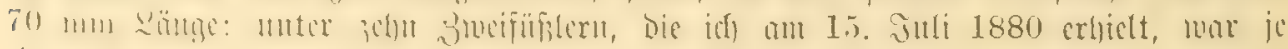
citte $62 \mathrm{~mm}, 65 \mathrm{~mm}, 67 \mathrm{~mm}, 70 \mathrm{~mm}$, vier 75 bis $78 \mathrm{~mm}$ und zwci je 85 bezw.

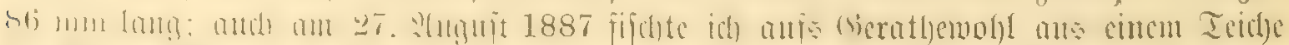

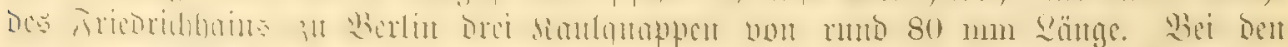

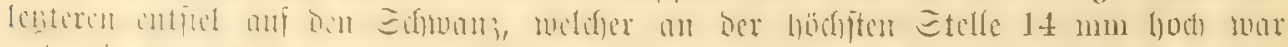

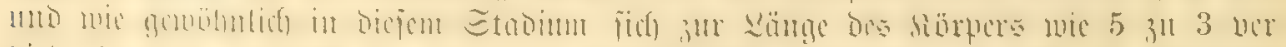

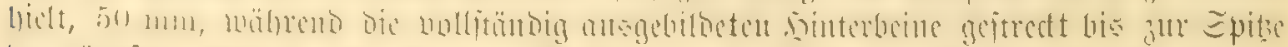

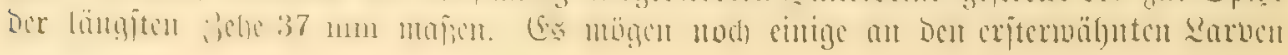




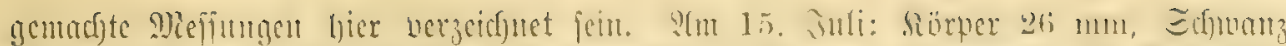

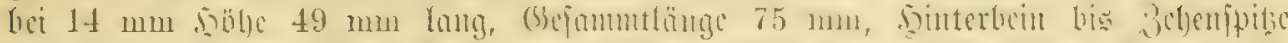

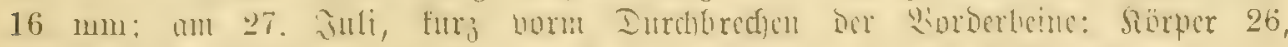

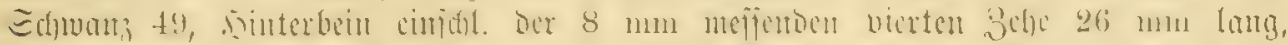

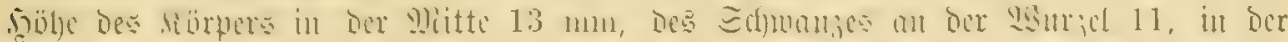

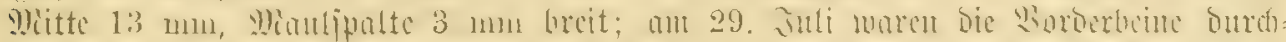

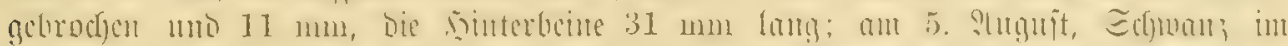

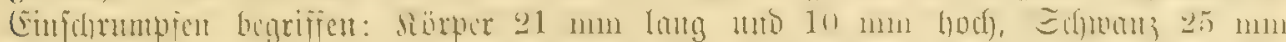

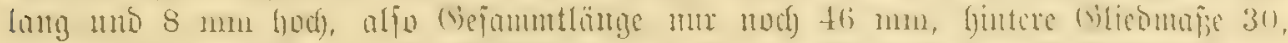

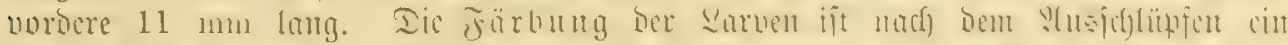

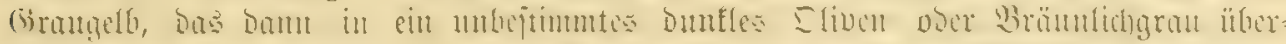

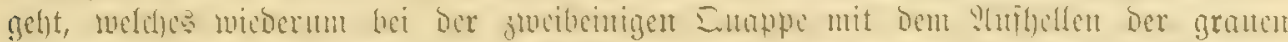

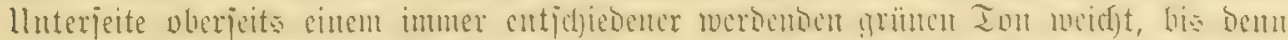

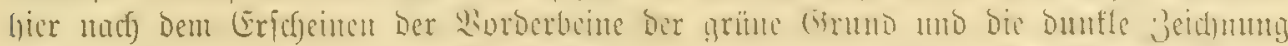

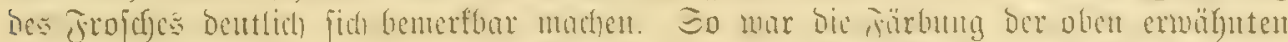

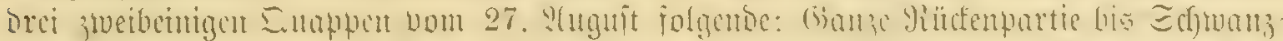

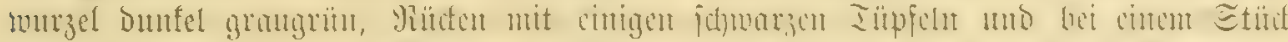

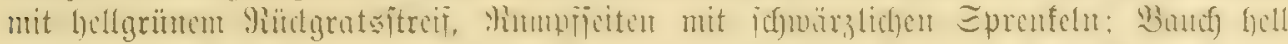

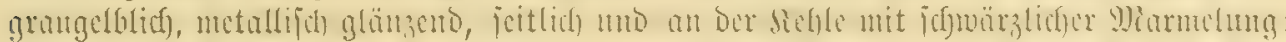

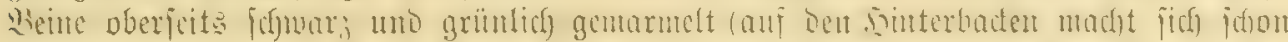

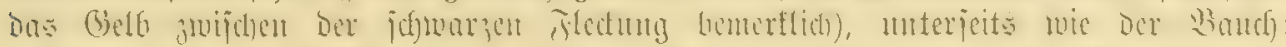

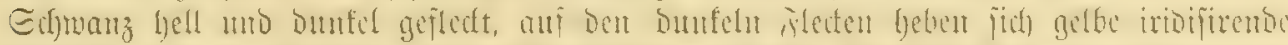

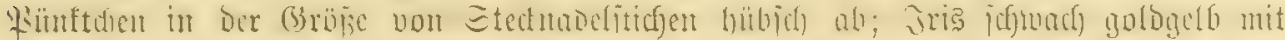

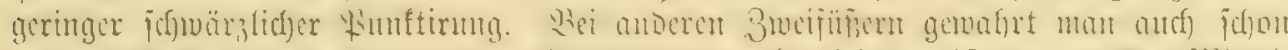

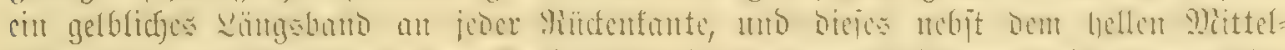

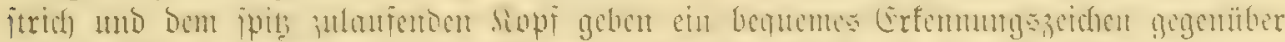

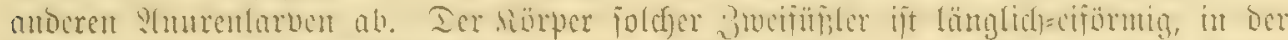

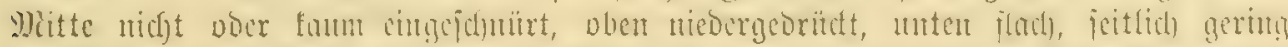

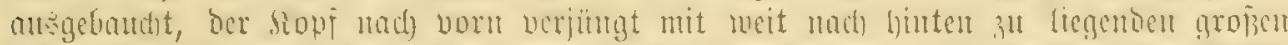

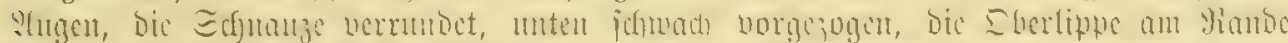

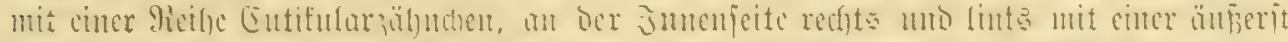

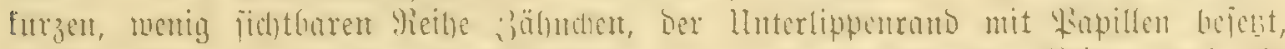

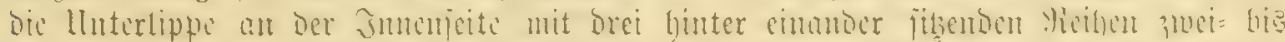

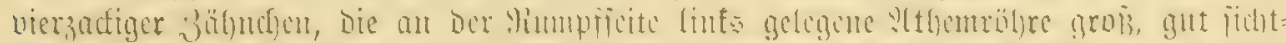

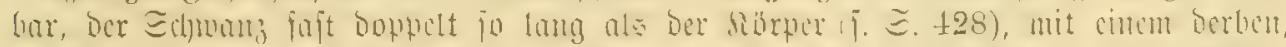

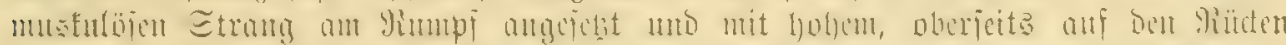

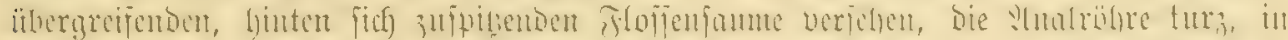

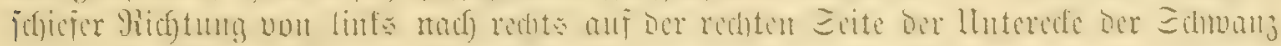
flofie fid) öffnend; Dic jog. Geitenlinien futb Deutlid) anggcprägt.

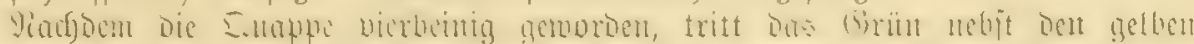

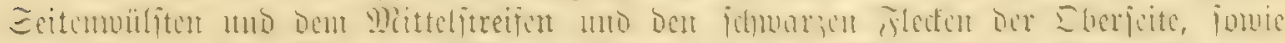

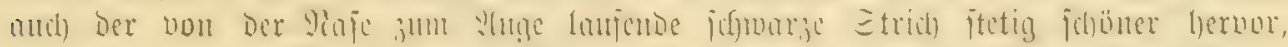

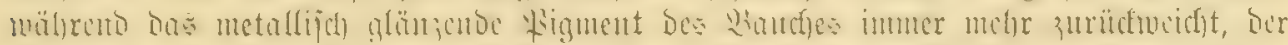

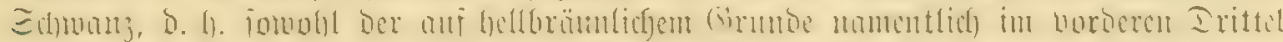

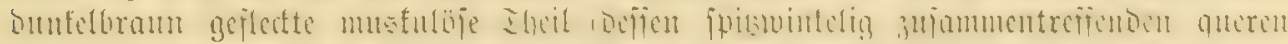

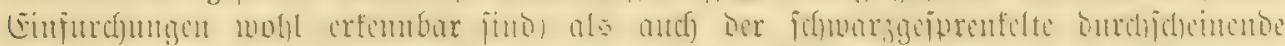

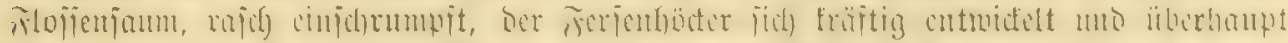

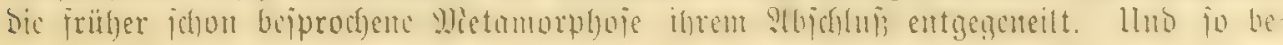




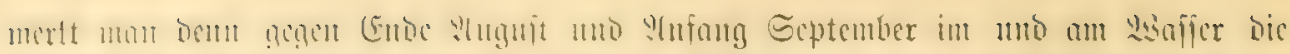

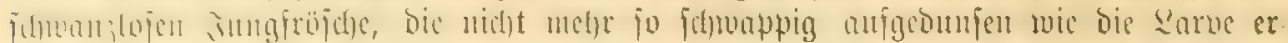

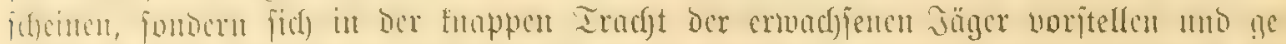

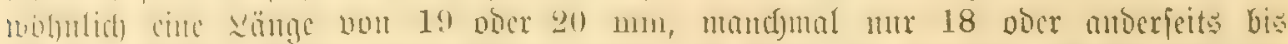

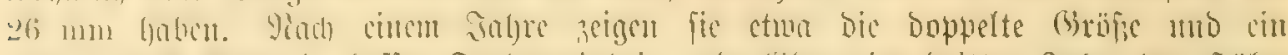

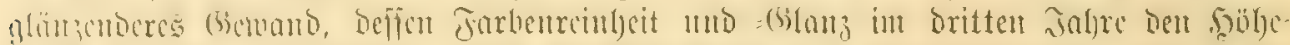

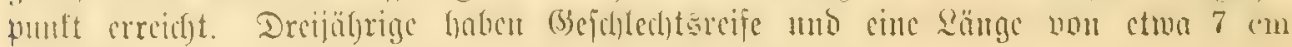

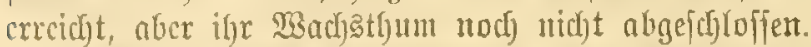

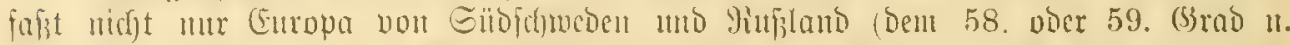

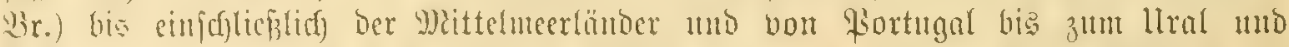

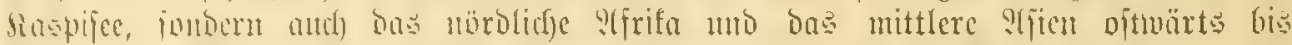

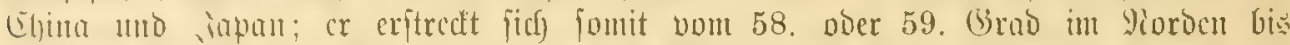

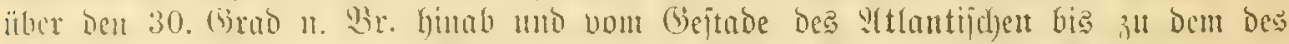

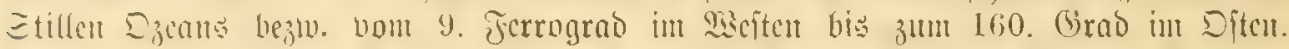

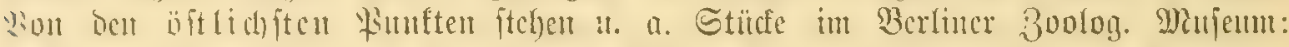

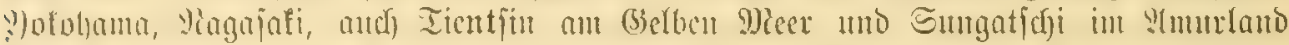

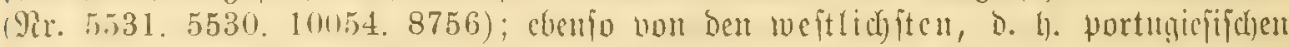

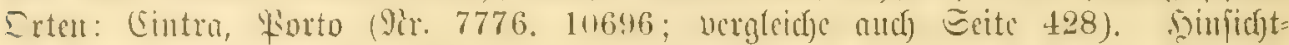

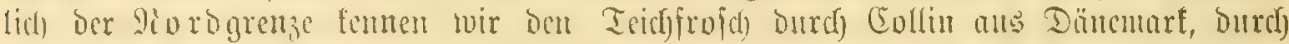

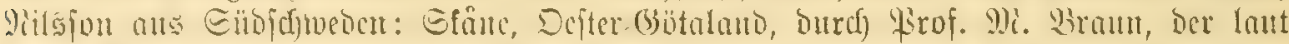

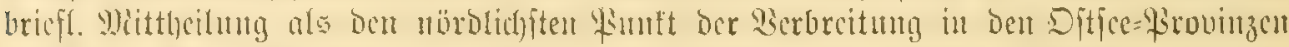

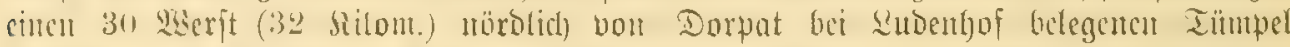

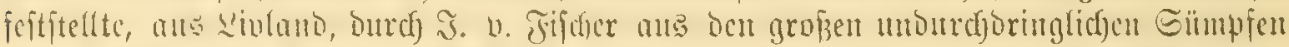

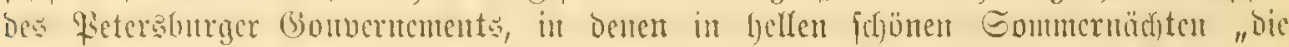

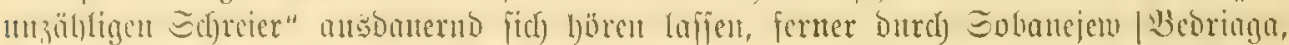

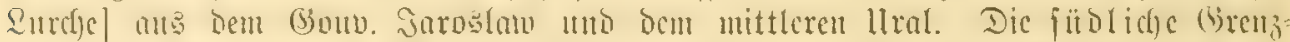

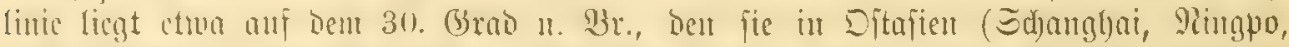

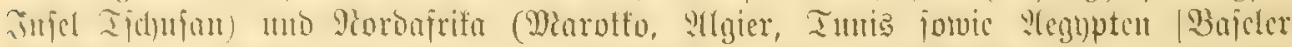

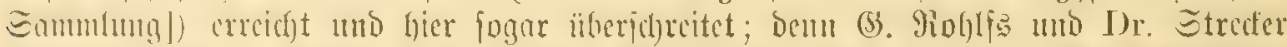

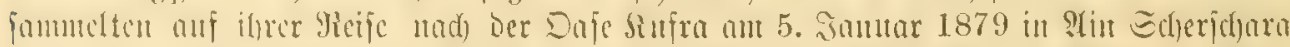

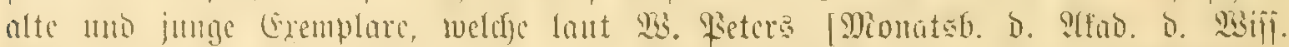

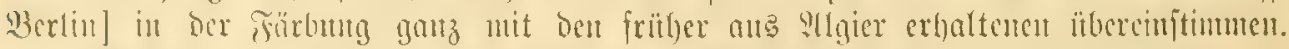

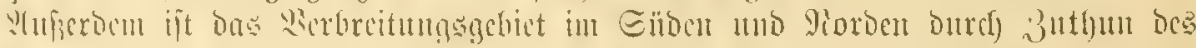

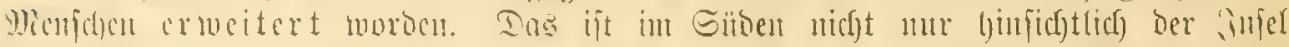

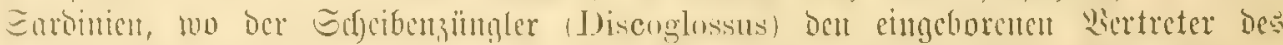

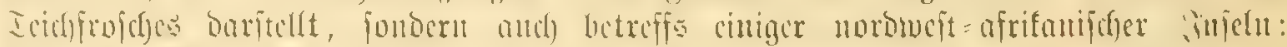

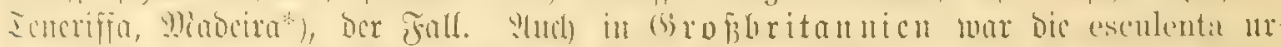

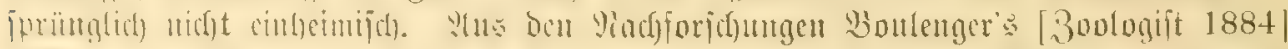

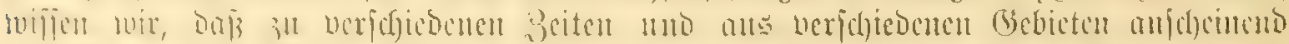

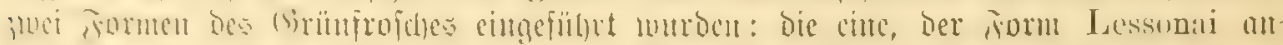

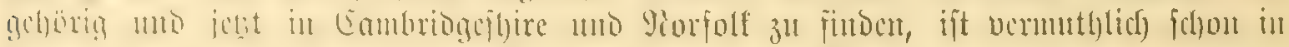

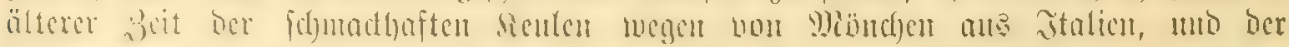

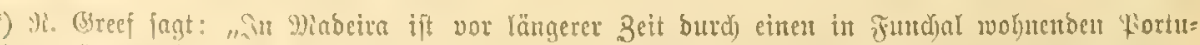
giefen Der grüne 23afferjtojch (Rana esculcnta) aus 2aute ober Borliebe füt bieje Thiere aus Guropa

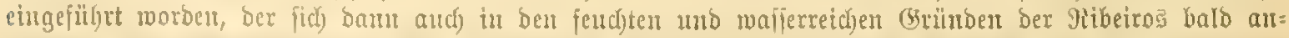

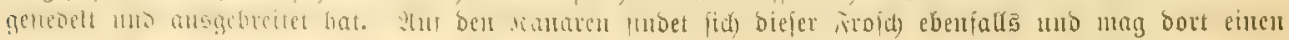
äfutlichen ltrprung als nuf Miabeita haben." 


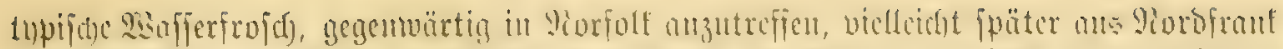

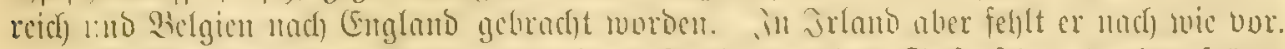

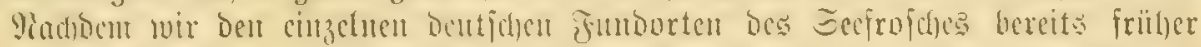

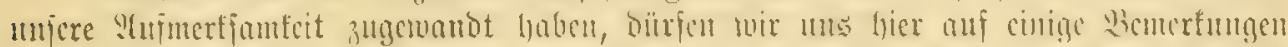

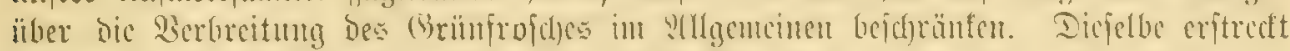

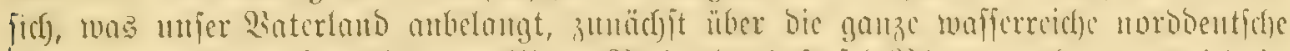

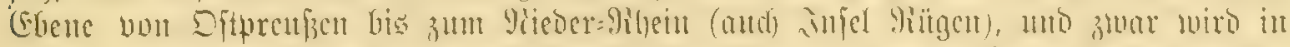

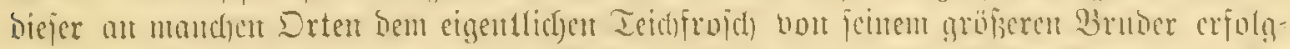

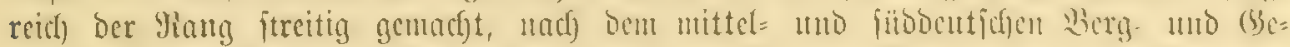

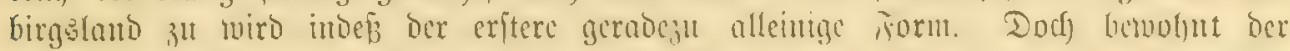

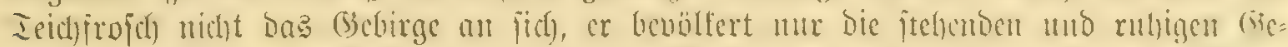

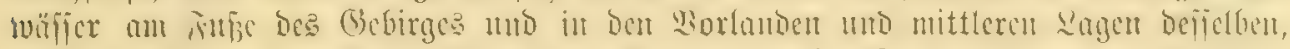

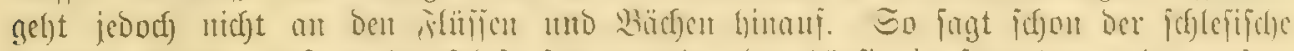

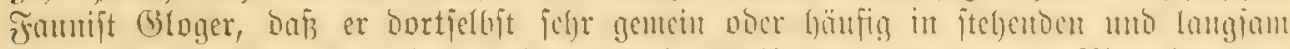

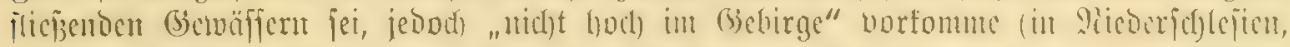

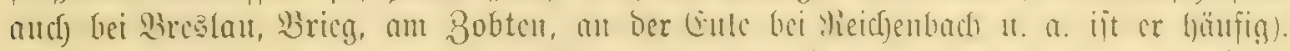

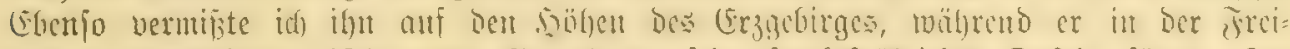

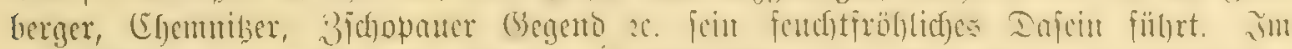

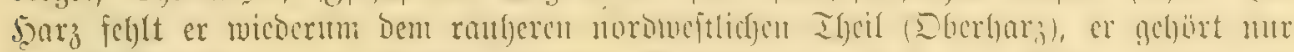

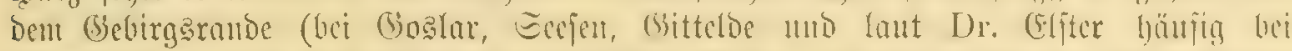

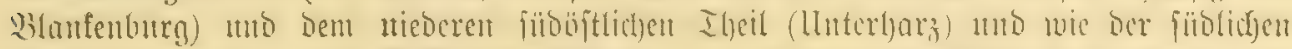

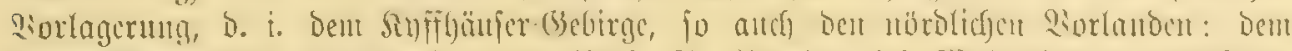

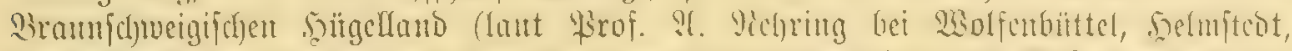

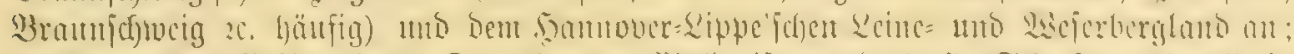

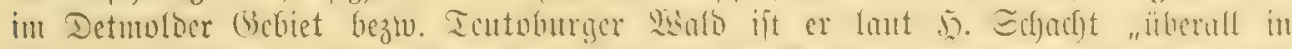

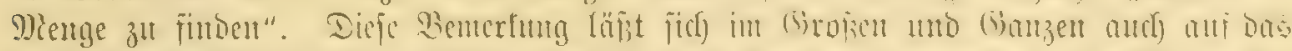

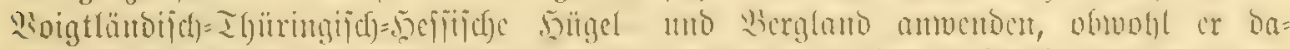

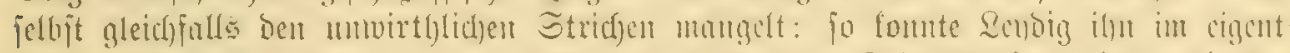

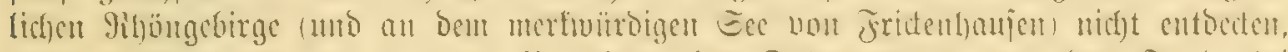

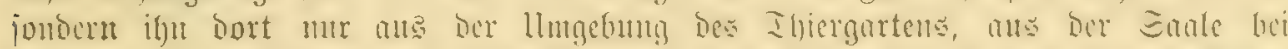

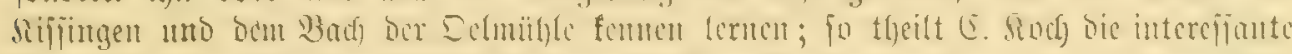

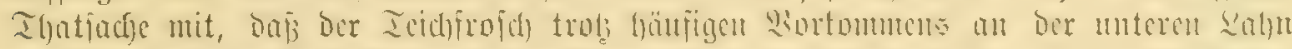

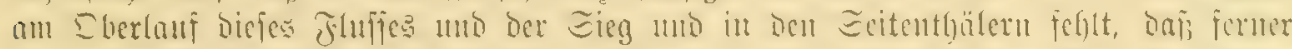

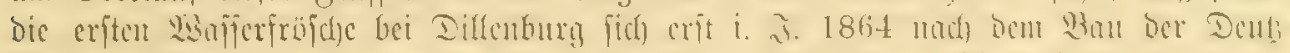

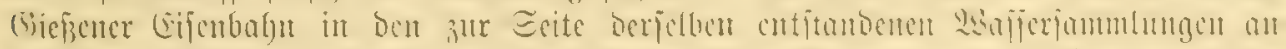

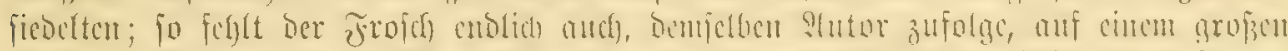

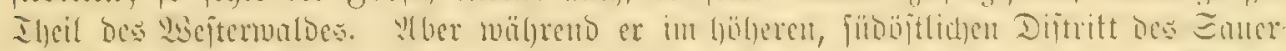

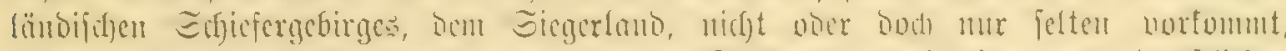

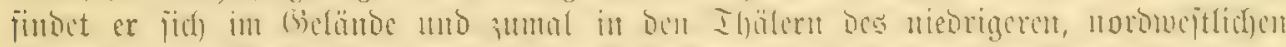

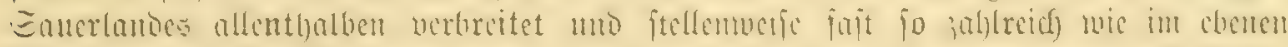

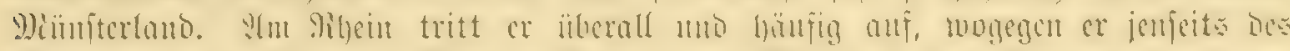

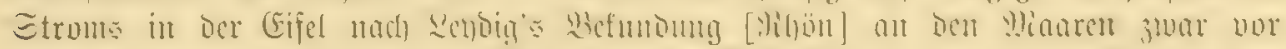

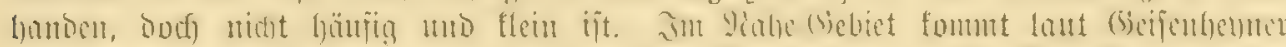

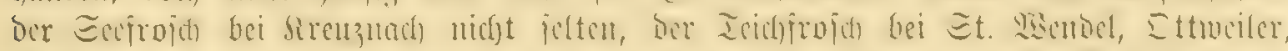

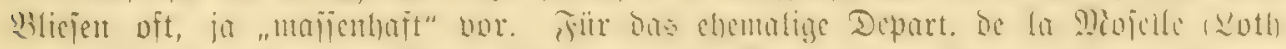

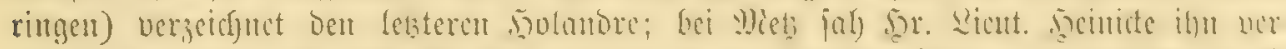

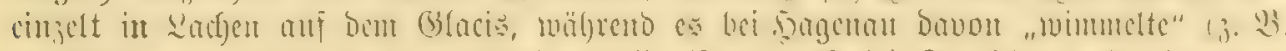

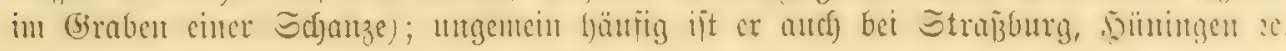




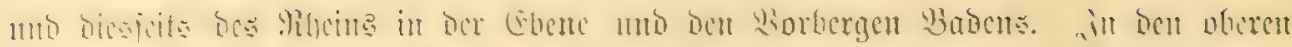

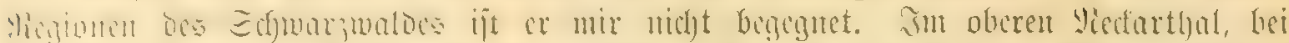

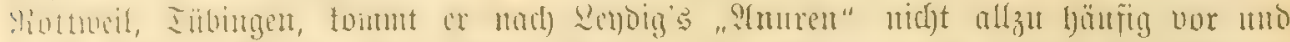

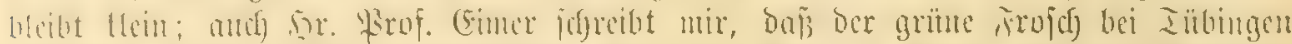

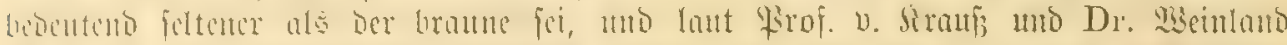

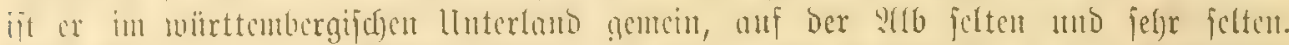

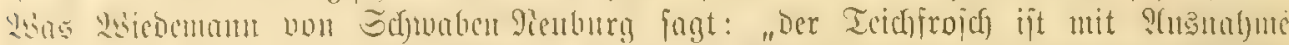

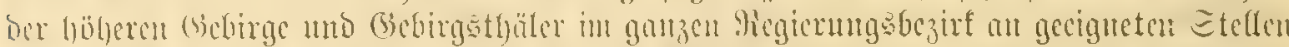

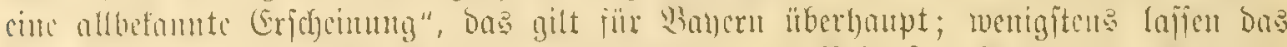

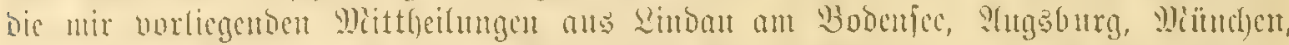

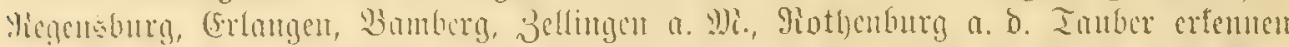

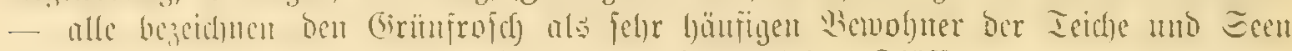

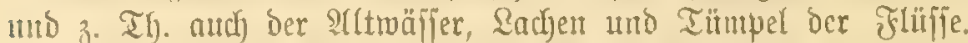

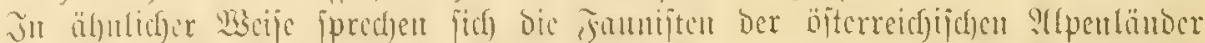

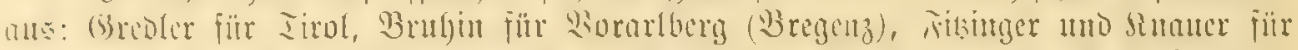

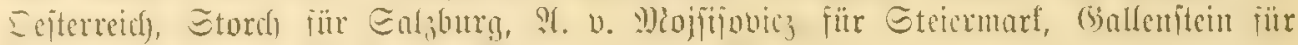

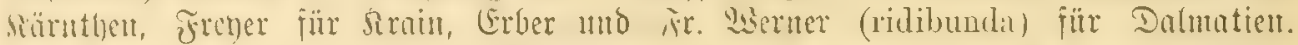

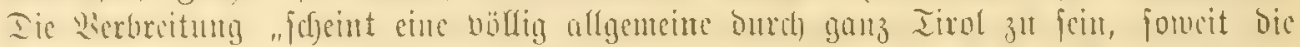

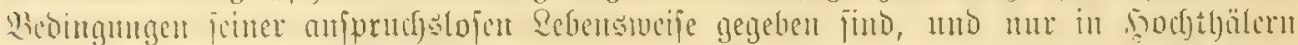

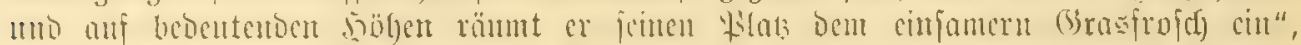

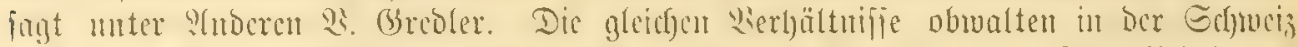

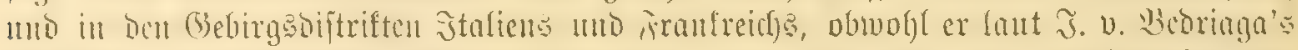
"Anura" int Iepartement ber Eeculpen recht folten jein foll. Jnt llebrigen jagt be

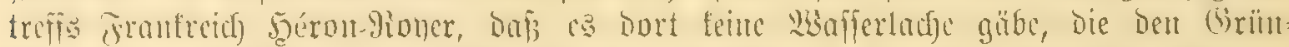

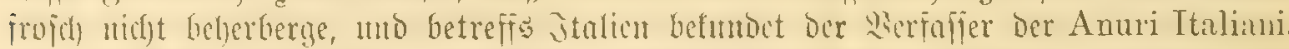

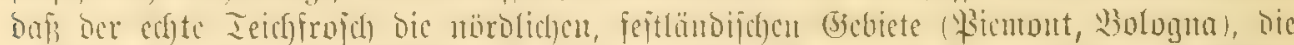

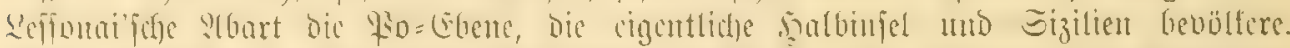

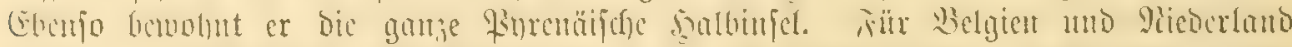

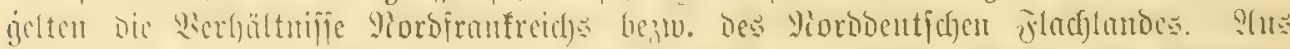

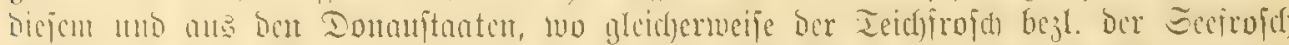

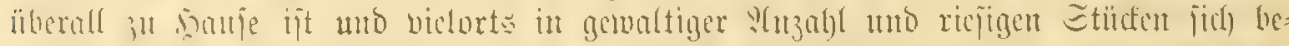

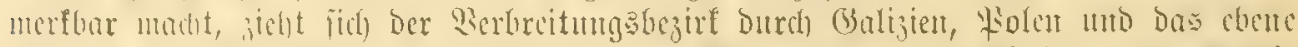

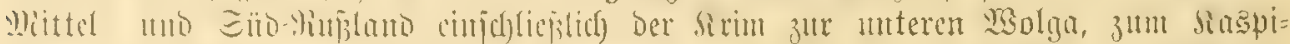

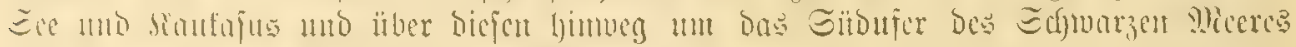

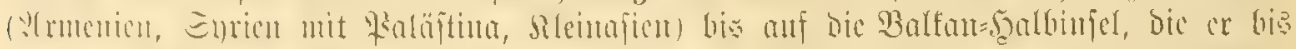

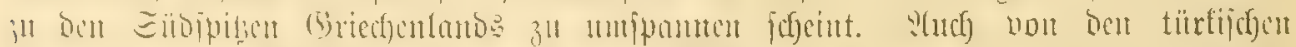

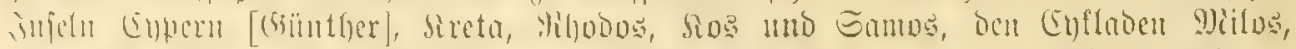

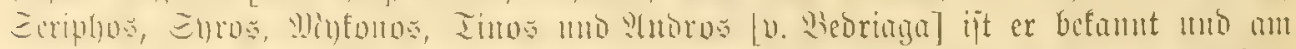

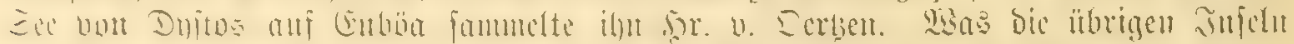

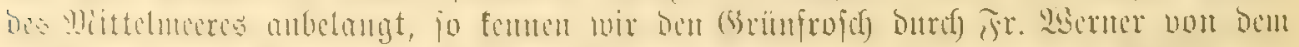

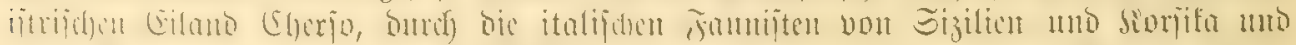

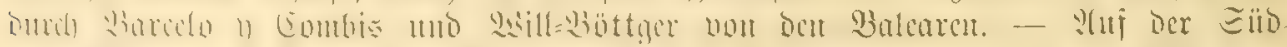

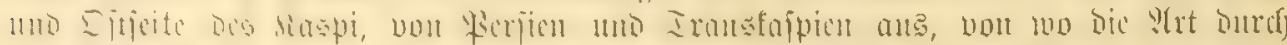

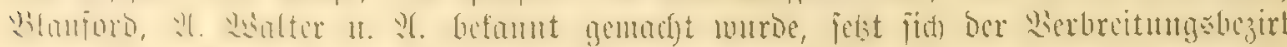

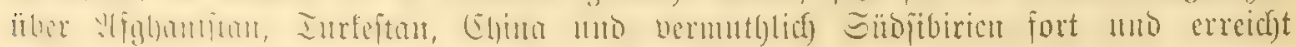
mit Jopan bic vorn angegebene Ditgrenze.

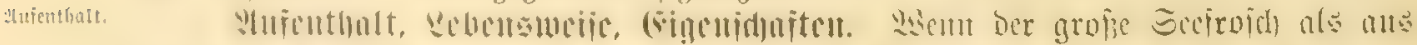

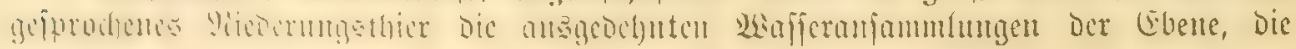




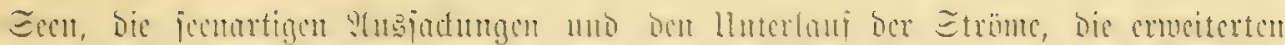

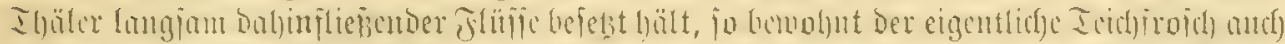

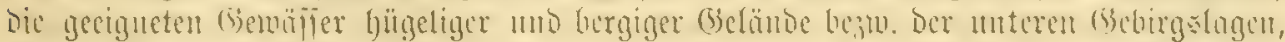

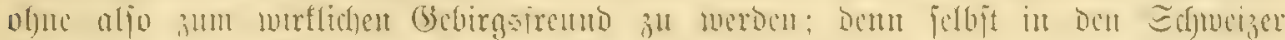

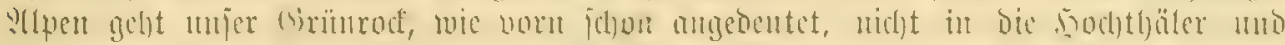

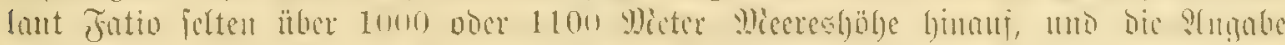

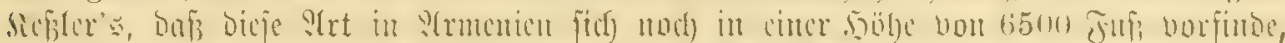

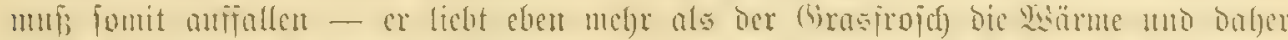

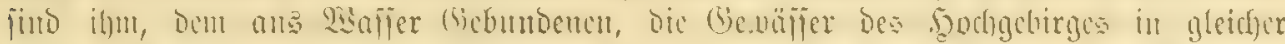

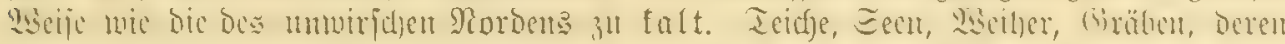

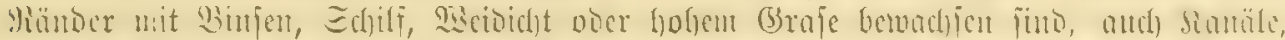

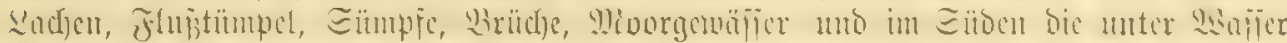

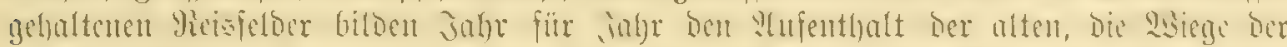

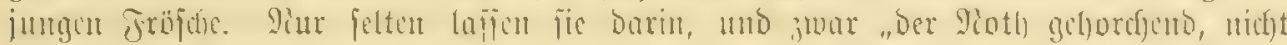

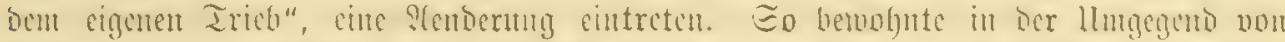

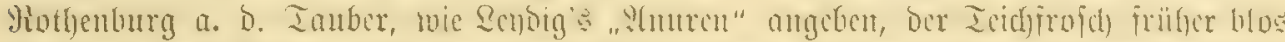

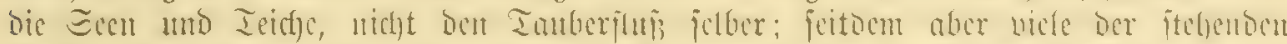

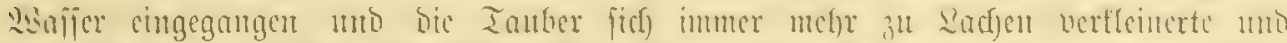

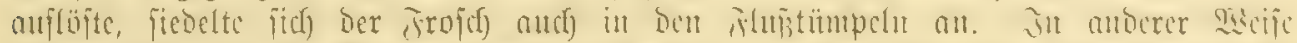

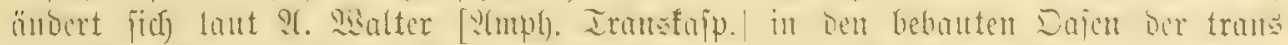

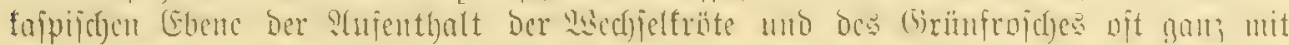

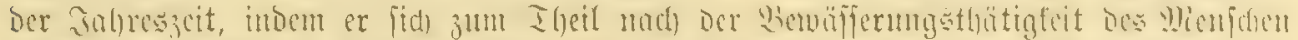

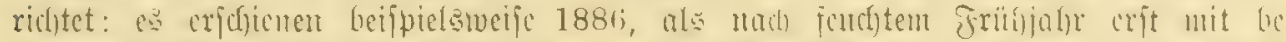

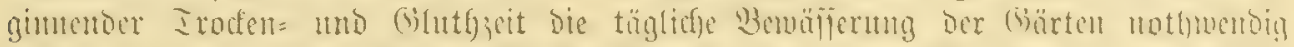

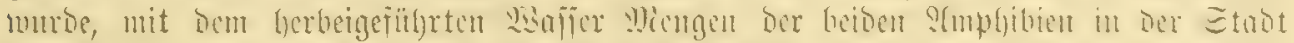

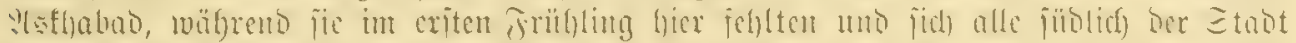

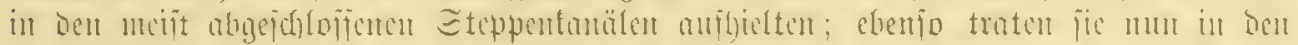
regelmäpaig überflutfycten \&uzernefelbern auf.

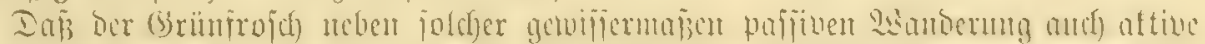

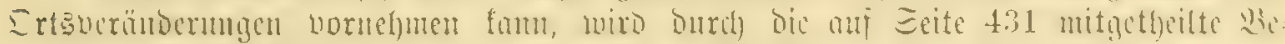

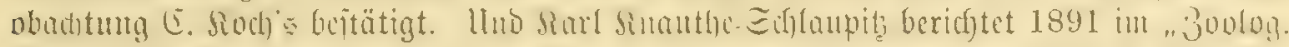

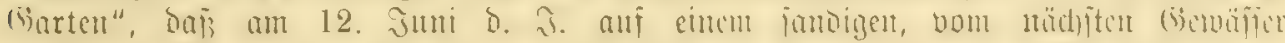

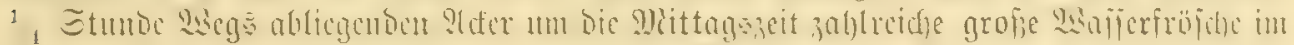

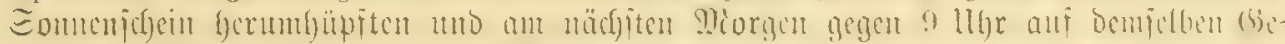

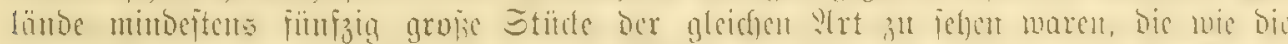

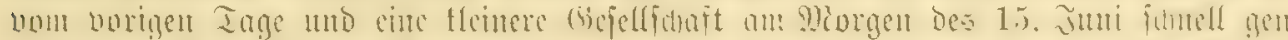

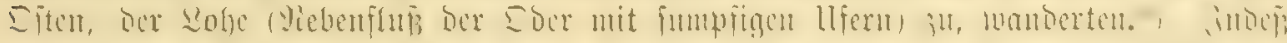

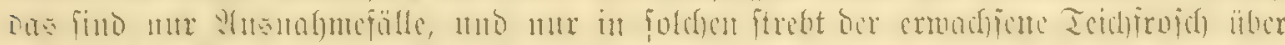

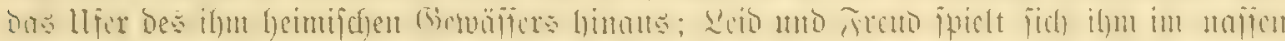

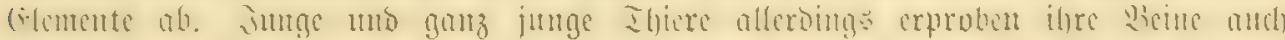

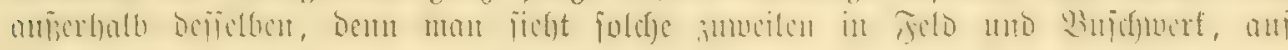
Wicien uno Bracten fid Gerumtrciben.

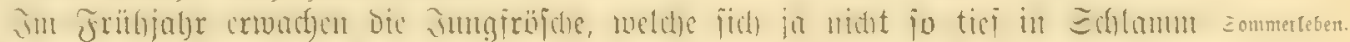

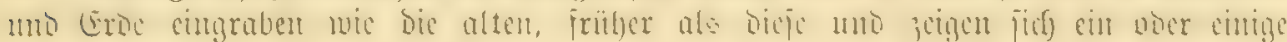

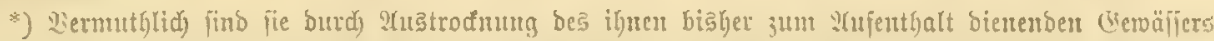

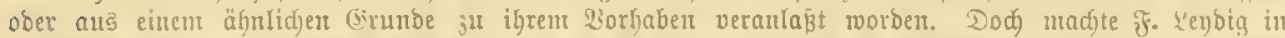

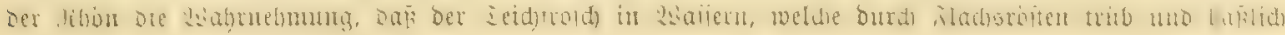
geroorben marest, nod ausbauert. 


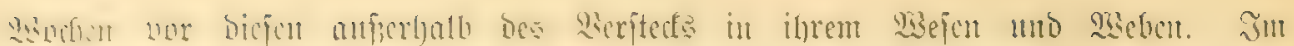

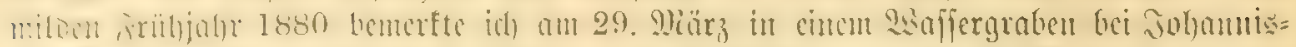

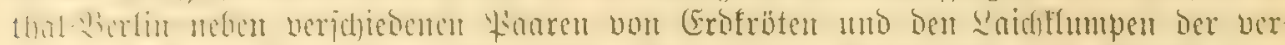

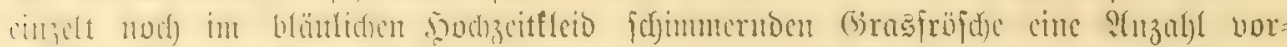

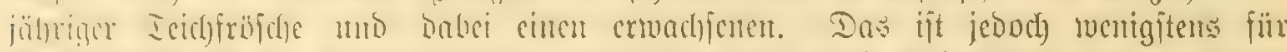

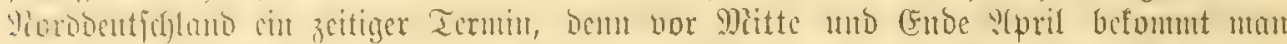

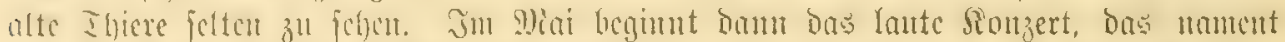

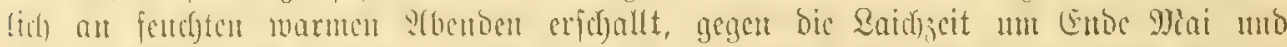

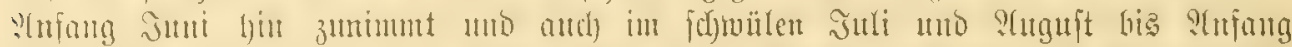

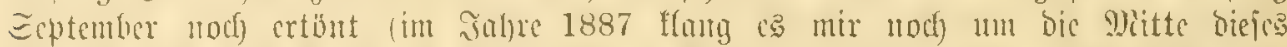
Wionats an bon fianal bei Sethanim in Werlin entgegen.) ?(m Tage liegt voer

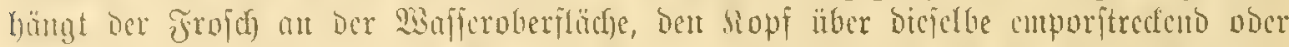

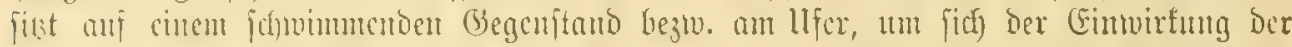

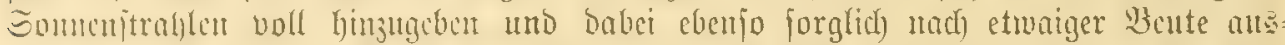

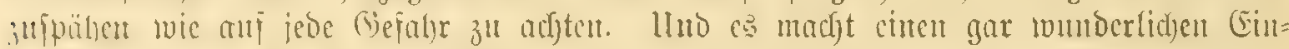

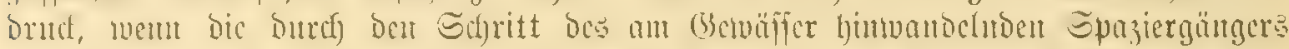

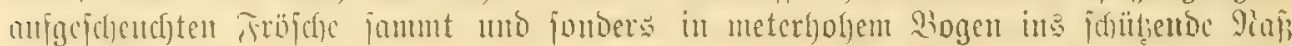

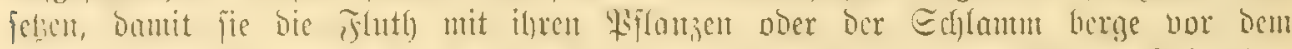

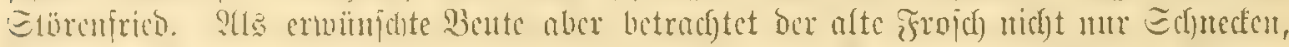

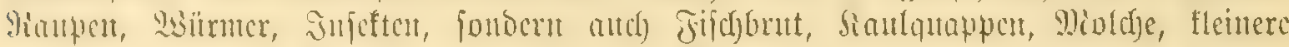

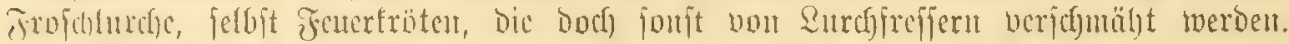

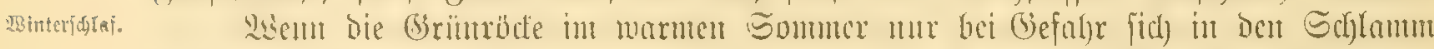

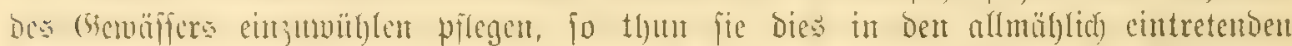

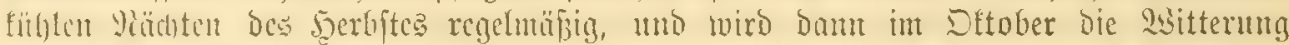

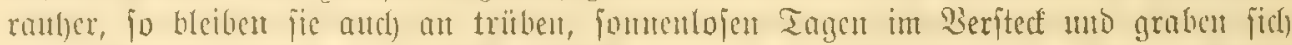

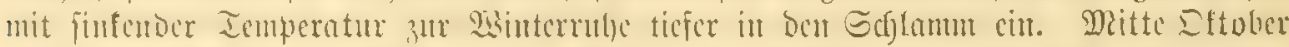

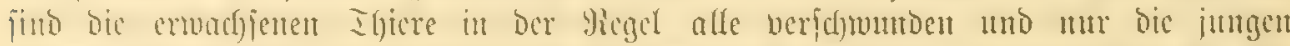

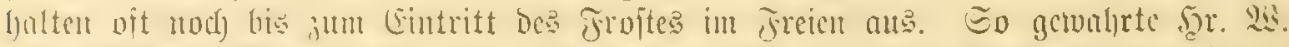

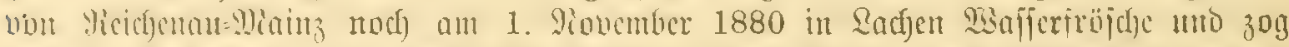
an 11. Dejentber 187! vier friffe Stint ans bem Siropfe cines Fiffreibers herwor.

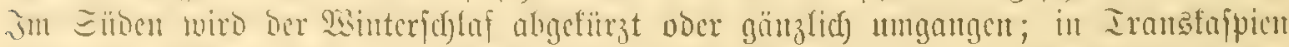

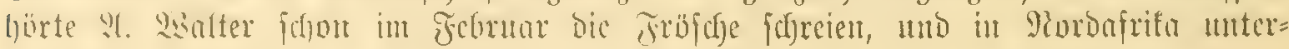
Fdycibet fidf dą 93 inter= faum vom Sommerlebent.

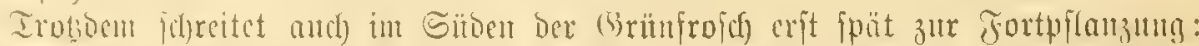

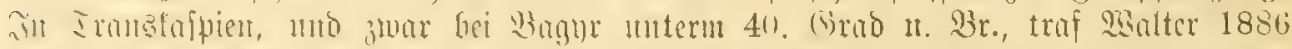

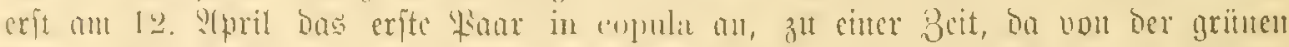

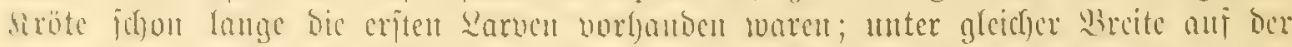

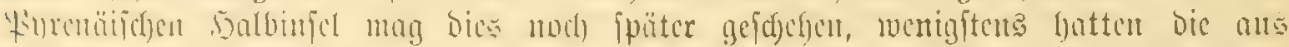

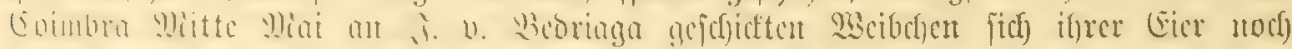

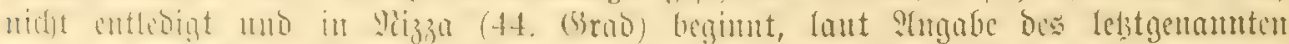

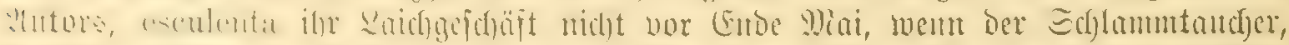
Det

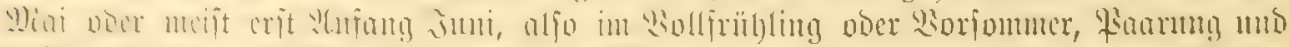

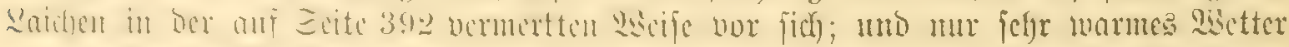

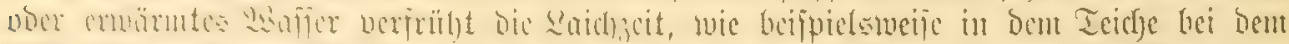

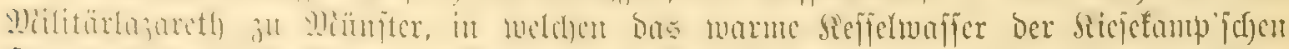

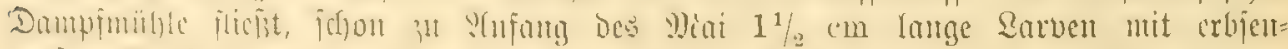

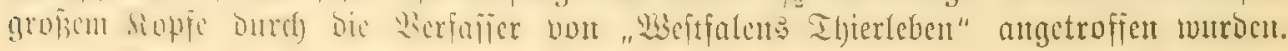




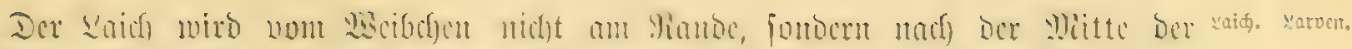

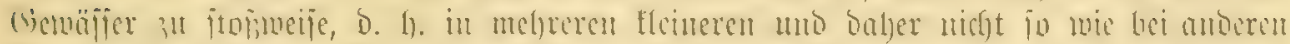

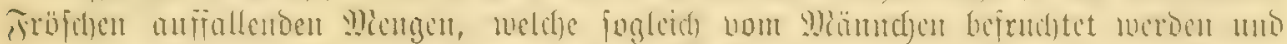

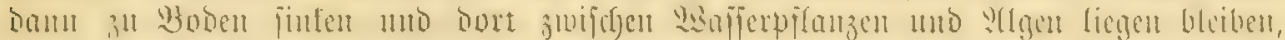

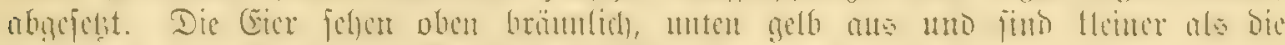

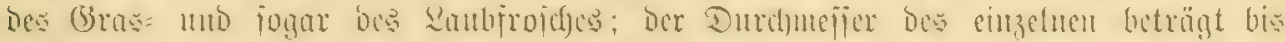

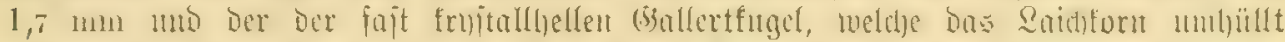

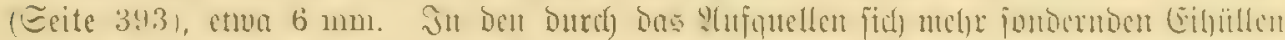

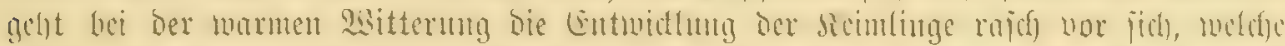

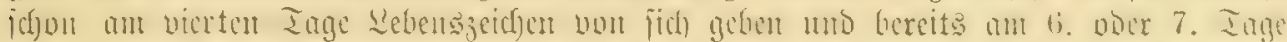

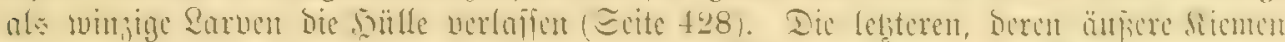

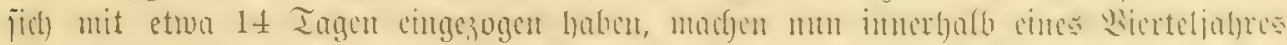

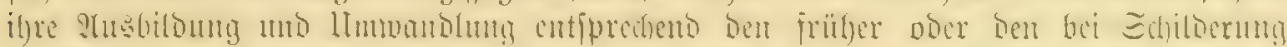

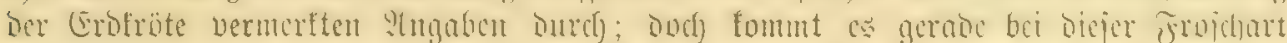

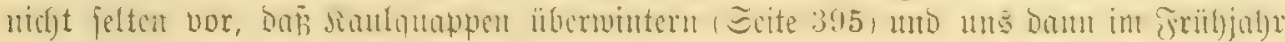
als Sicjenlarven entgegentretent.

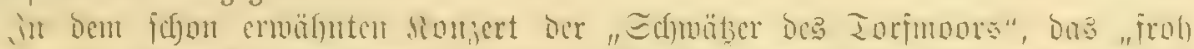

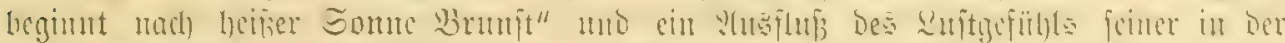

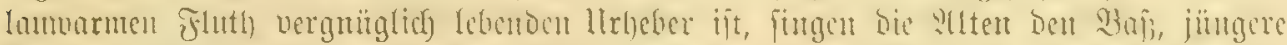

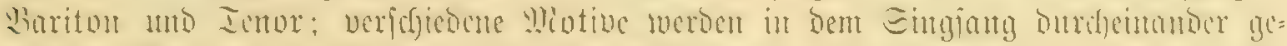

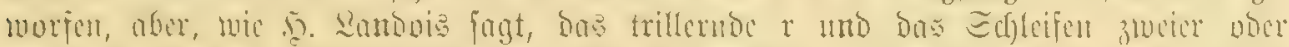

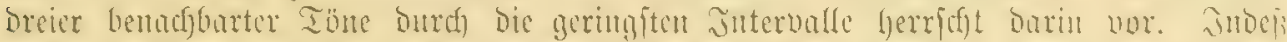

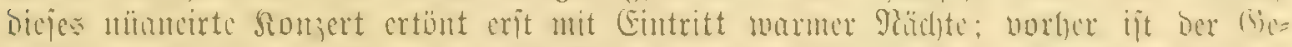

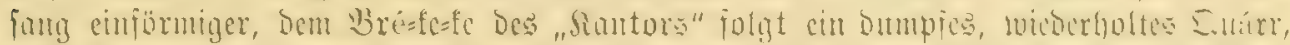

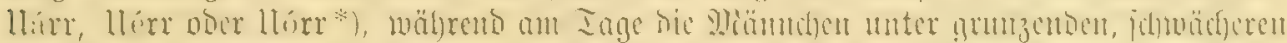

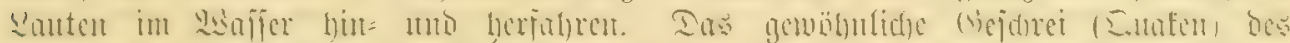

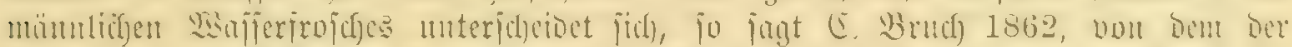

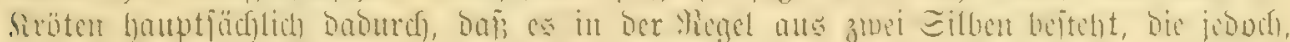

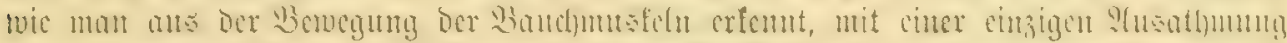

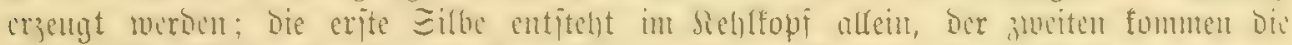

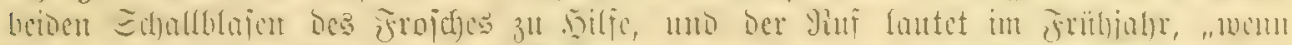

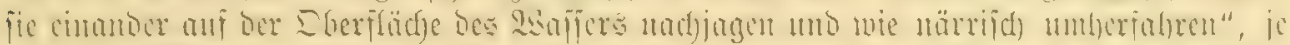

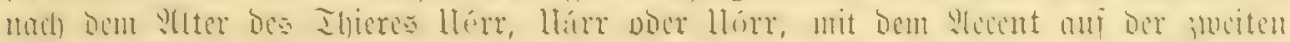

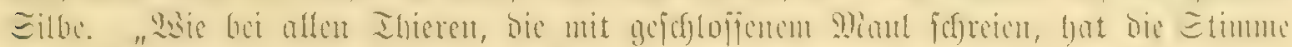

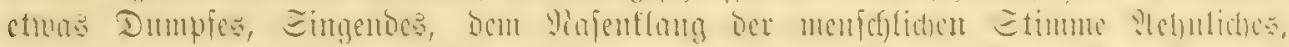

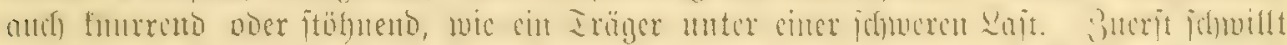

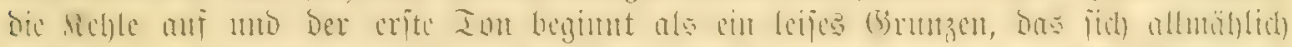

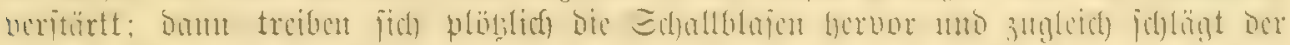

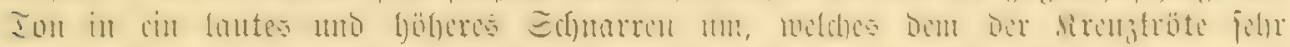

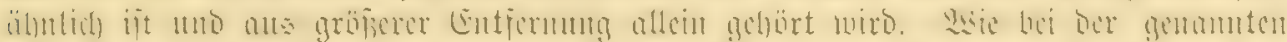

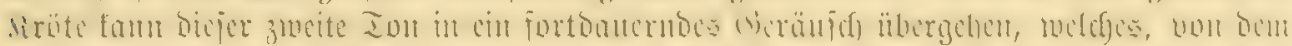

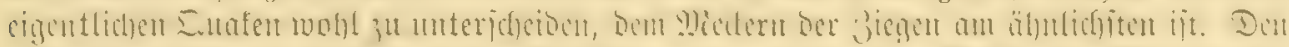

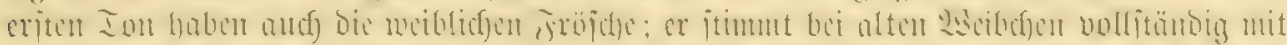

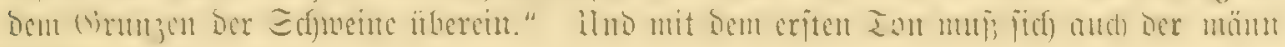

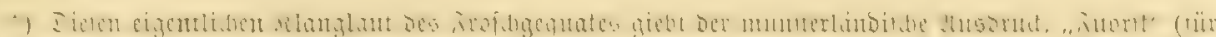

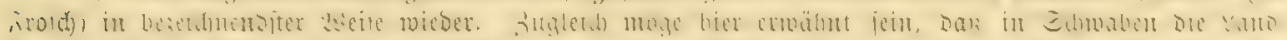

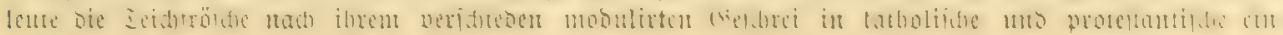

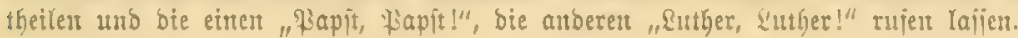




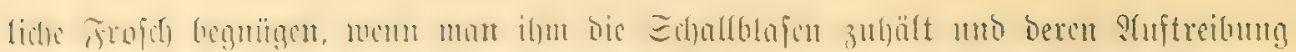

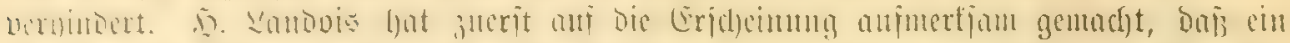

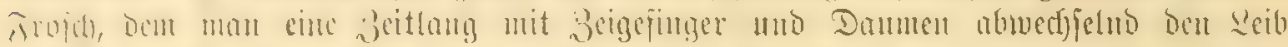

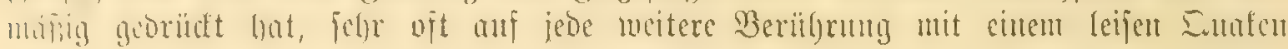
antivortet.

whepert.

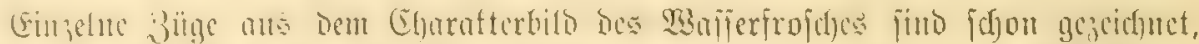

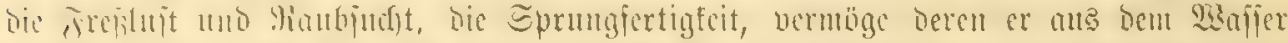

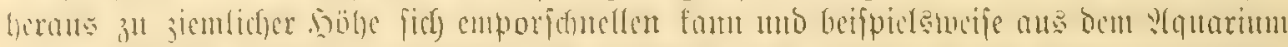

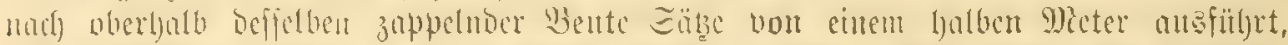

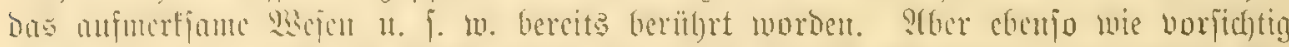

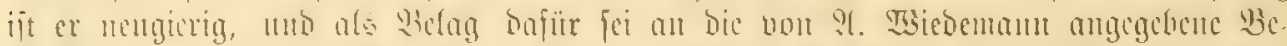

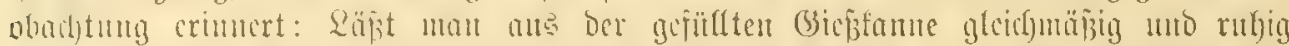

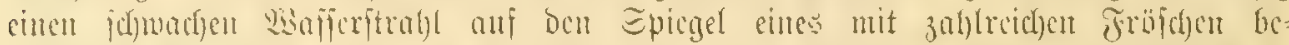

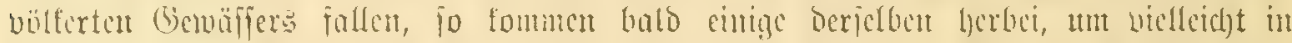

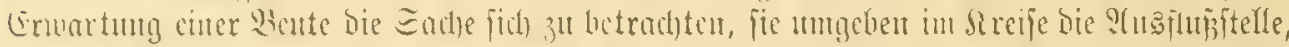

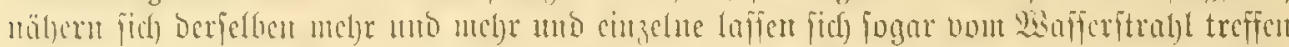

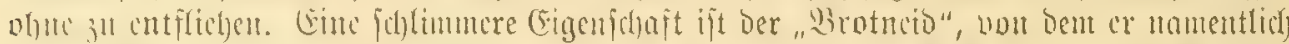

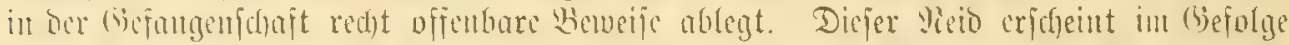

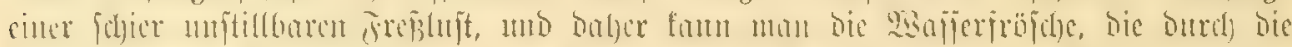

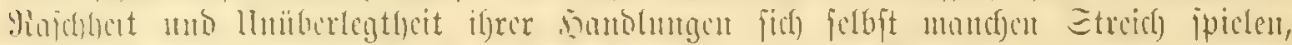

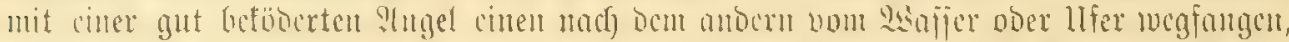

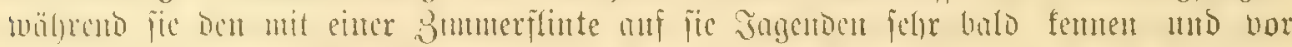

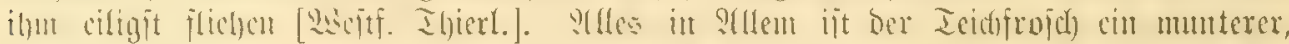

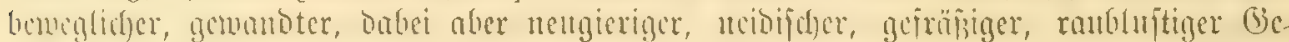

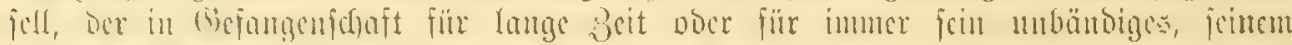

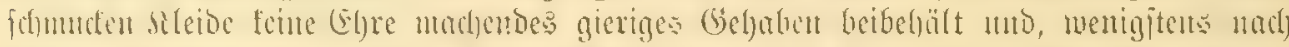

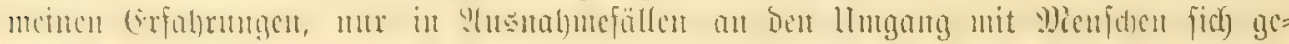

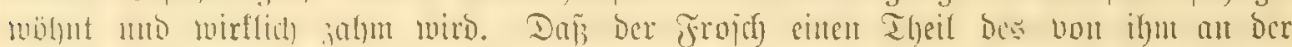

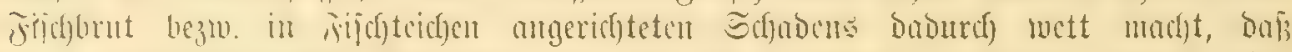

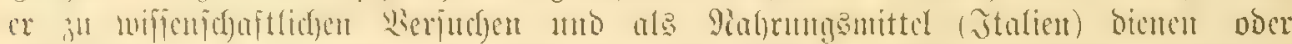

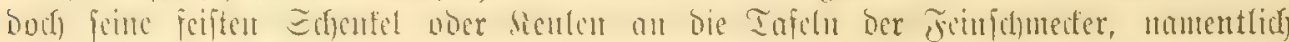

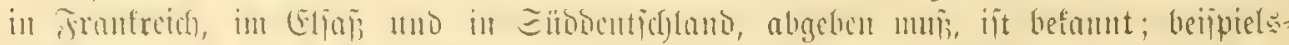

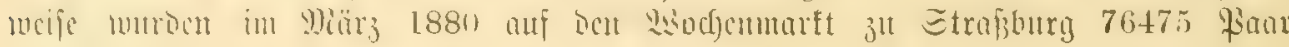
Jrofdifichenfel gebradit!

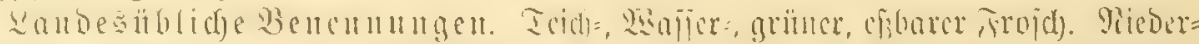

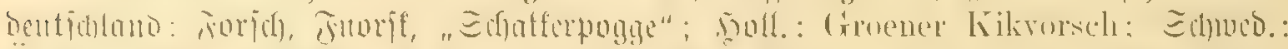

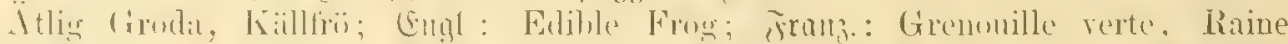

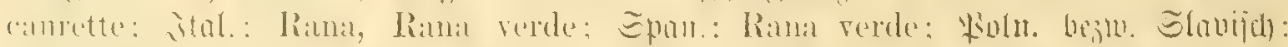

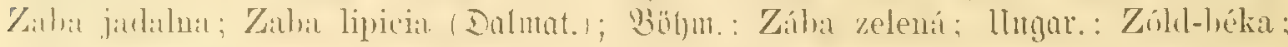
Jiıff.: Ljagúschka; J̛imı.: Konna; Japan.: Kairo.

Rana fluviatilis, Ronclel 1554. - Rana aquatica citrina et R. aqu. viridis, Schwenclef. 1605. - Rana edulis, Aldrovandi 1663. - Rana aquatica, Ray 1713. - Rana viridis, Rösel 1758. - Rana esculenta, Linné 1758 [S. N., Edit. X, I p. 212]. - Raua vulgaris, Bonnaterre 1789. - Rana palmipes, Spix 1840. -

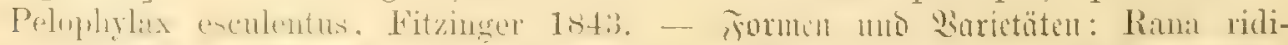

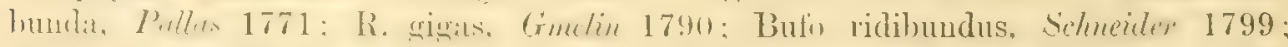

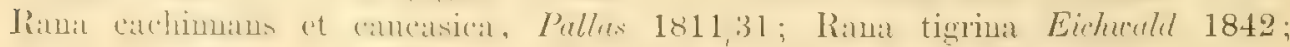
Palophylax ridibundus. Fitzinn' 1853 [Alenag.]; Rana fortis, Bonlenter 1885. - 


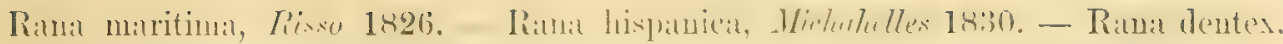
Krynicki 1837. - Rana scotica, Bell 1839. - R. Perezi, Seoane 1885.

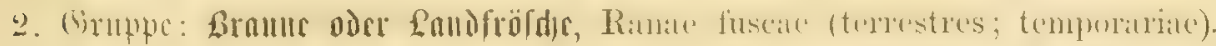

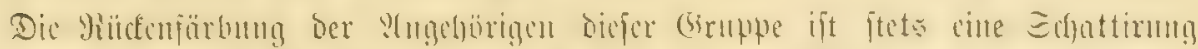

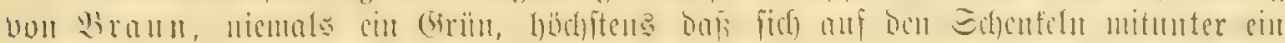

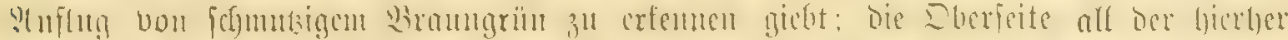

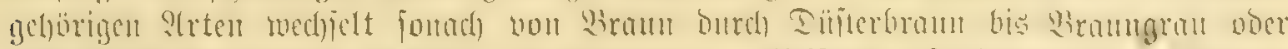

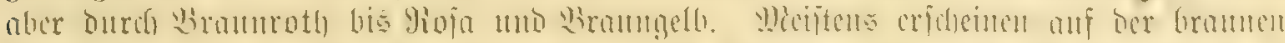

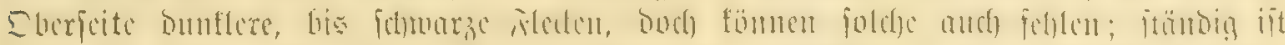

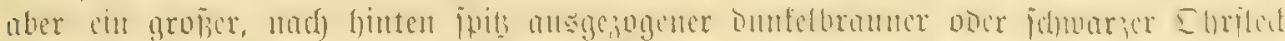

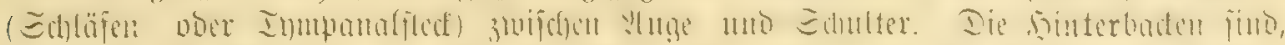

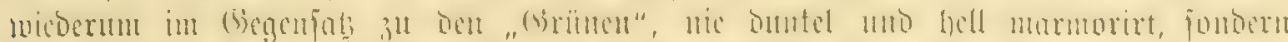

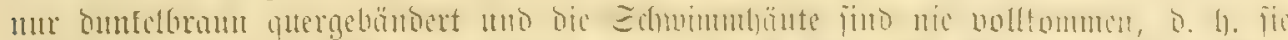

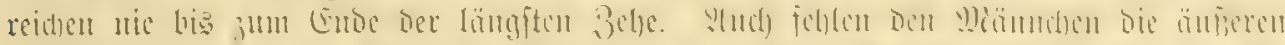

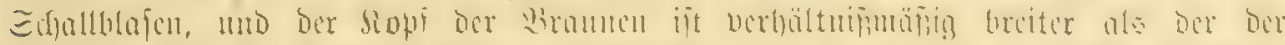

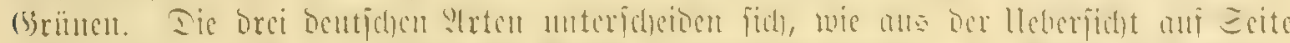

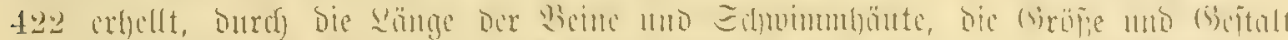

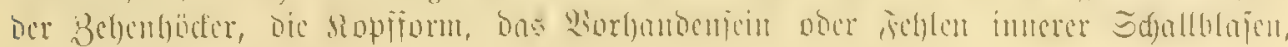

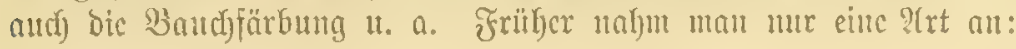

\section{2. !rt: Grasfrofd. Rana muta, Laur. arbilbung: Tafer III Yir. 4.}

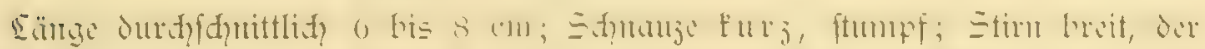

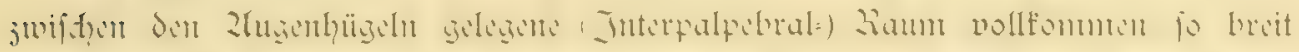

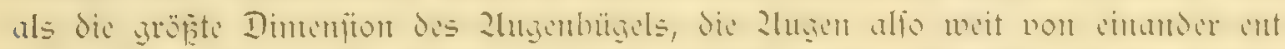

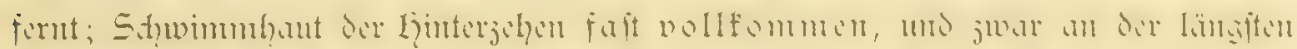

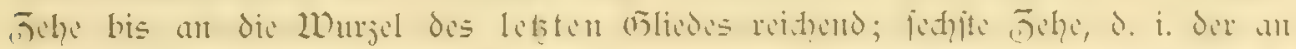

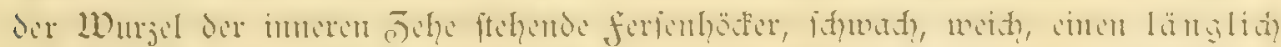

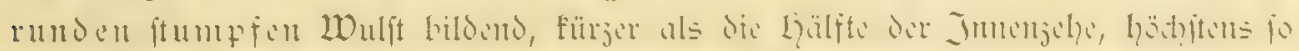

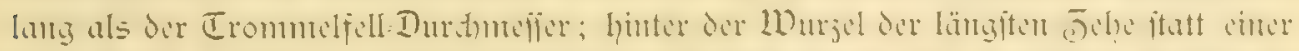

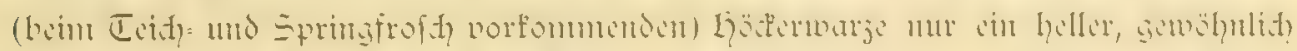

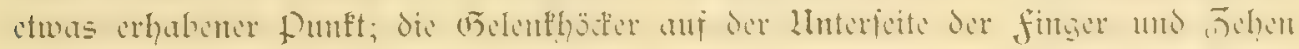

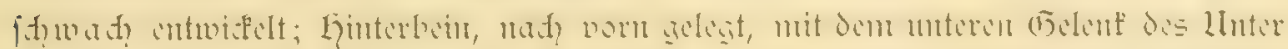

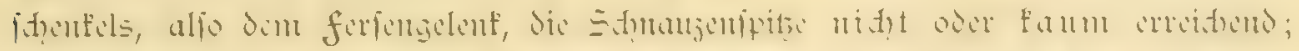

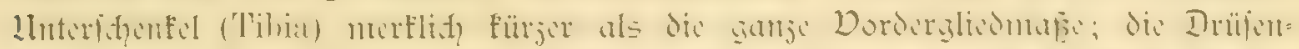

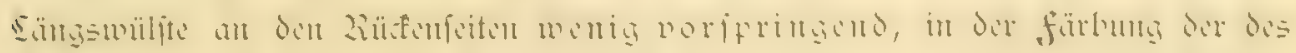

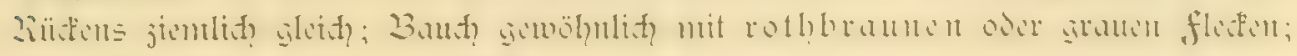
2ränndien mit imeren Sdhallblaien.

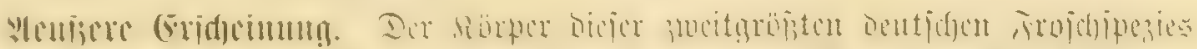
Rorperban

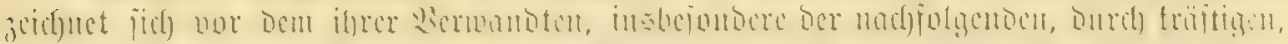

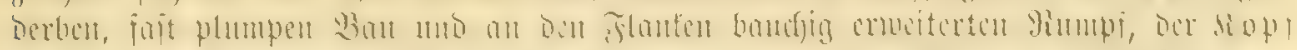

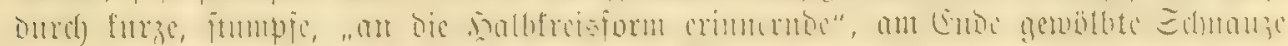

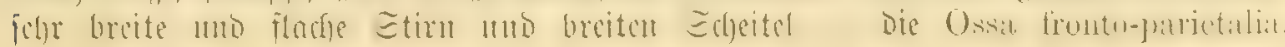




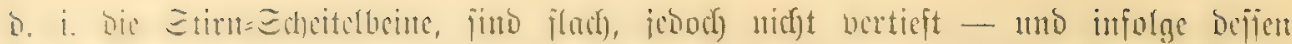

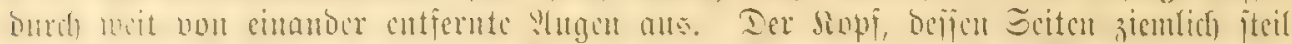

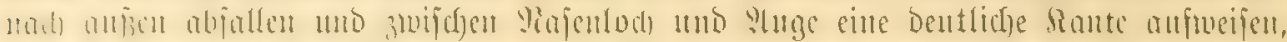

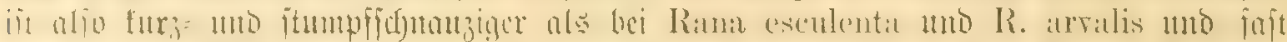

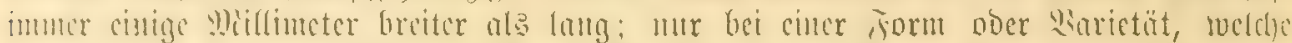

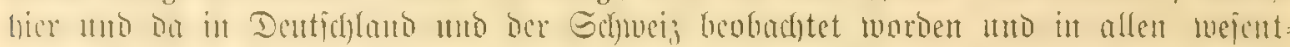

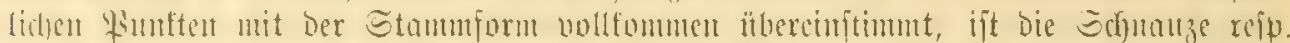

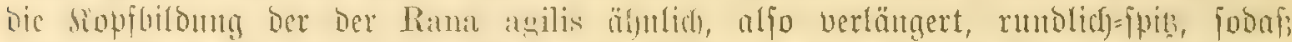

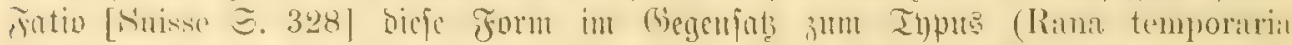

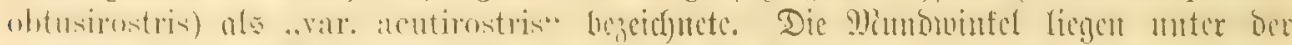

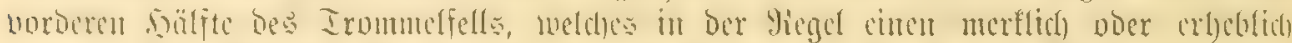

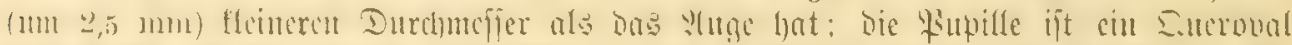

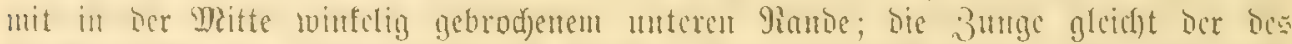

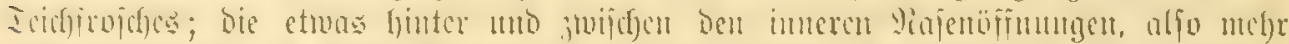

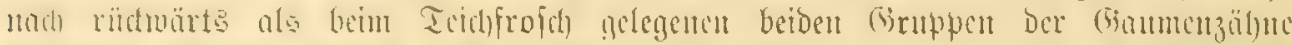

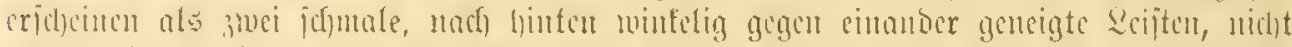

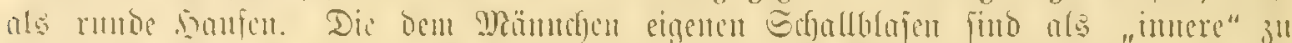

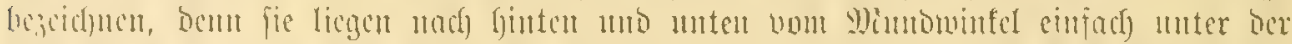

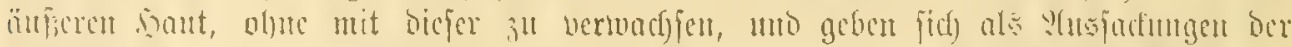

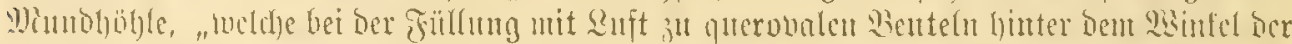

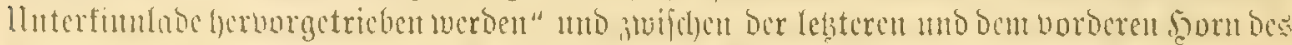

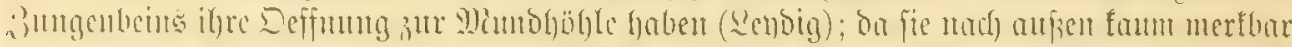

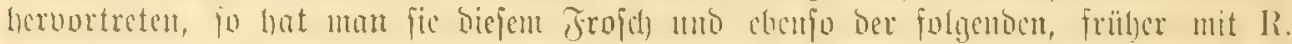

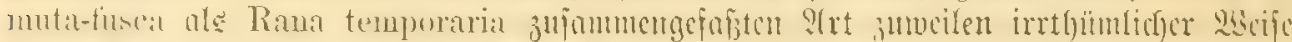

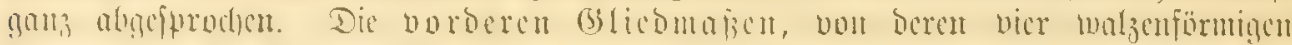

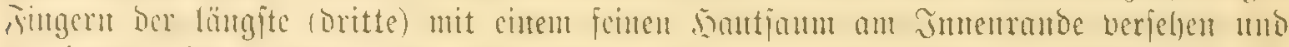

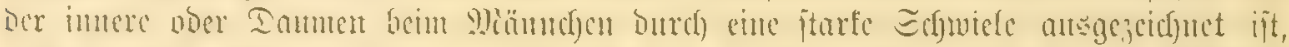

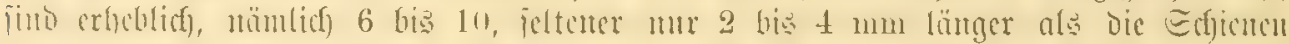

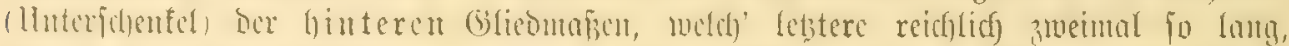

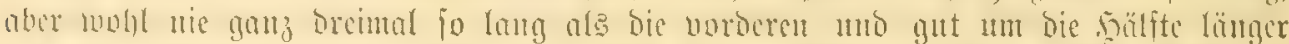

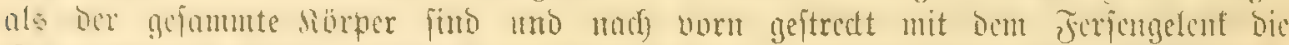

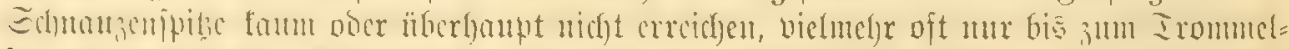

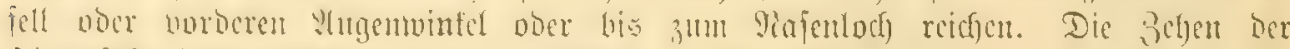

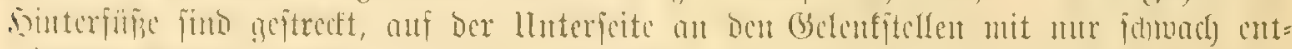

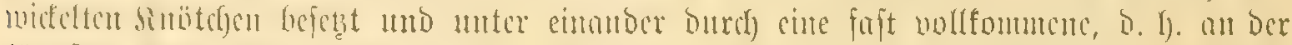

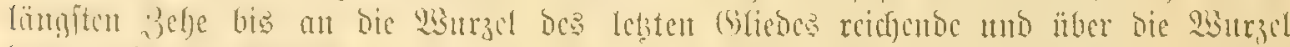

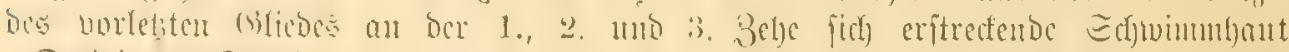

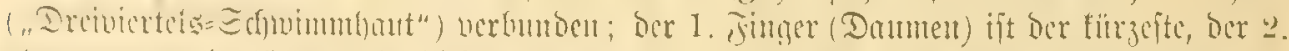

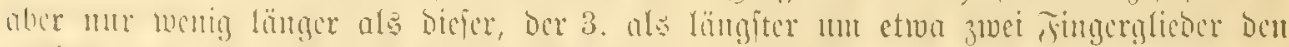

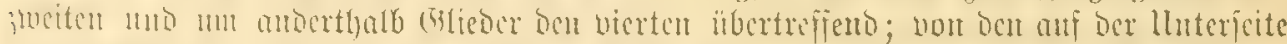

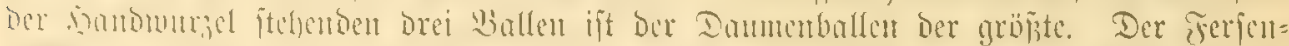

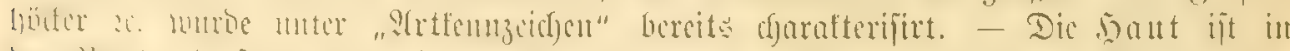

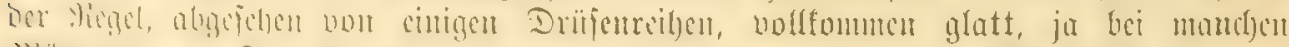

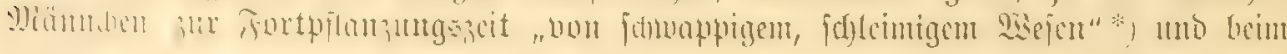

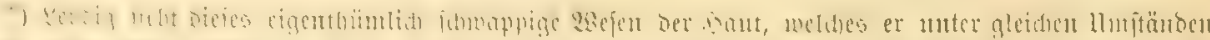

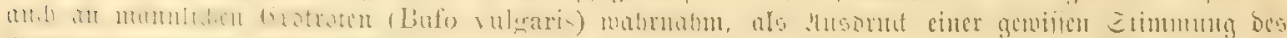

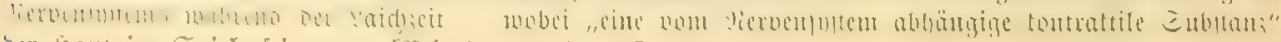
ber saut im Gpiele jei — an [Bededungen ๔. 88]. 


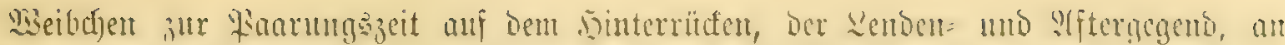

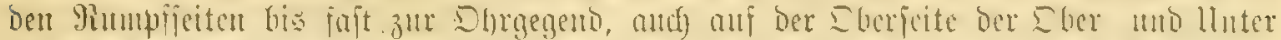

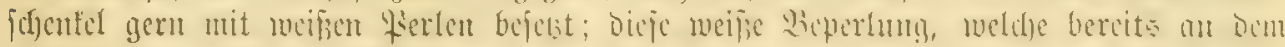

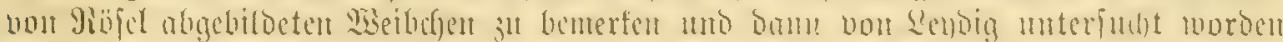

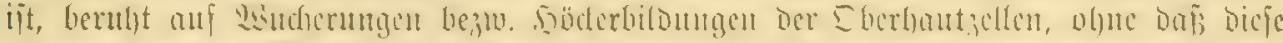

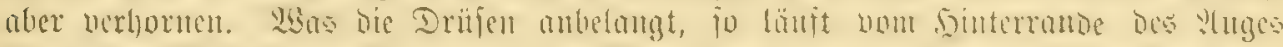

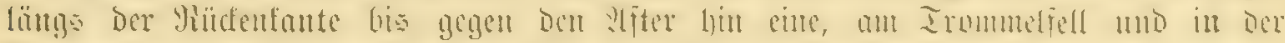

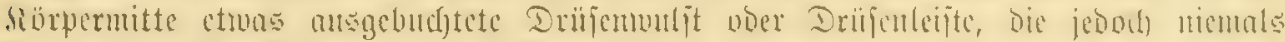

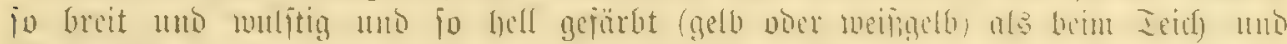

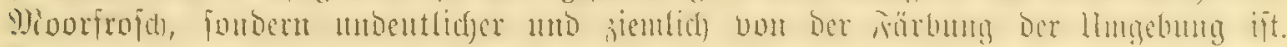

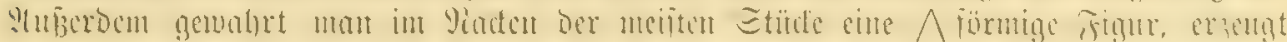

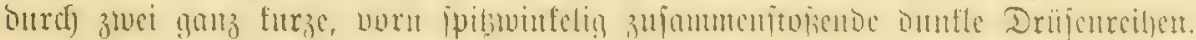

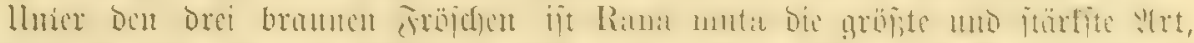

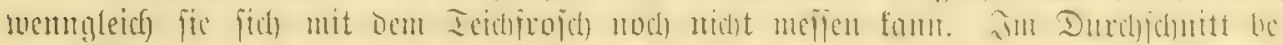

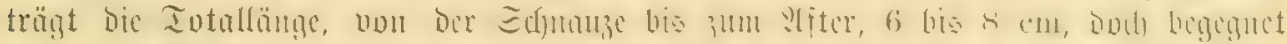

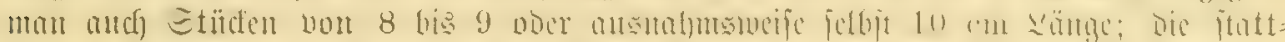

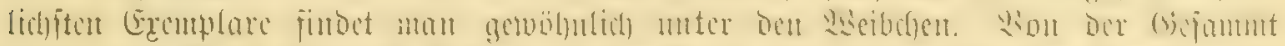

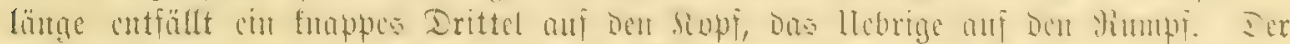

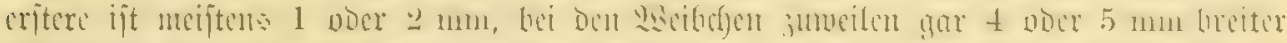

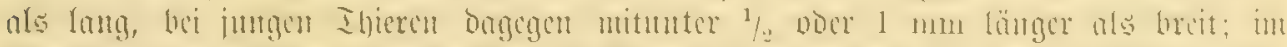

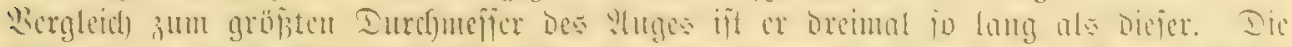

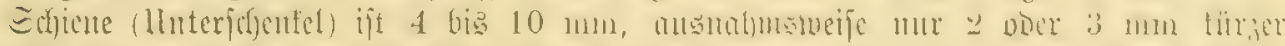

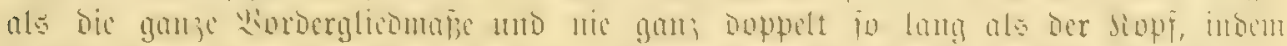

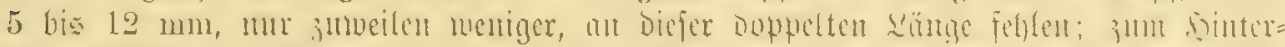

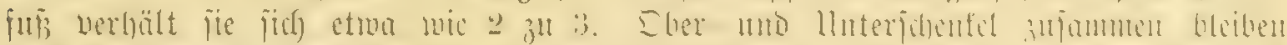

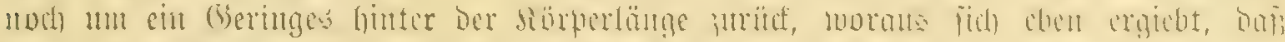

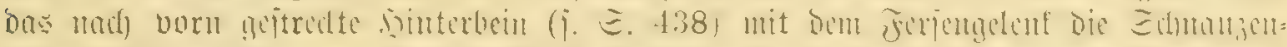

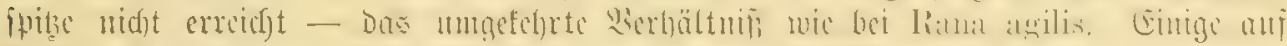

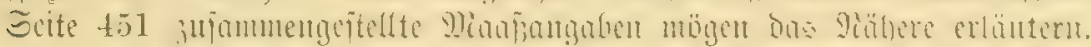

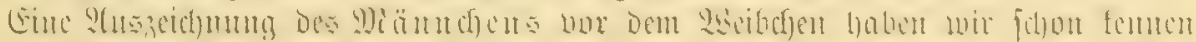

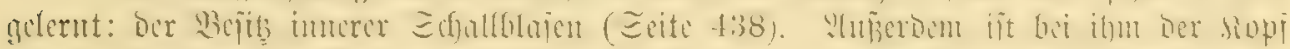

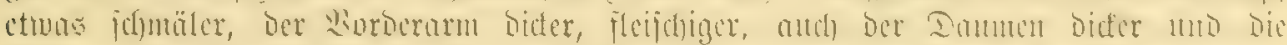

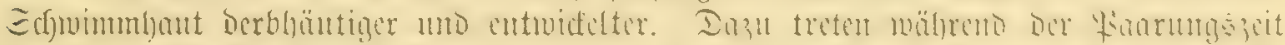

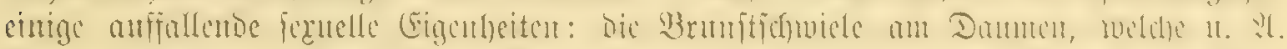

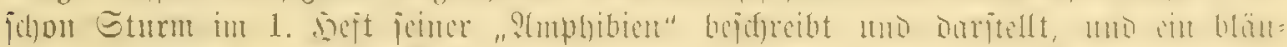

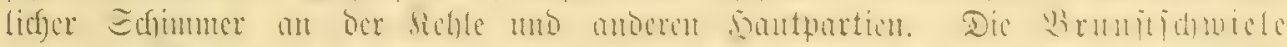

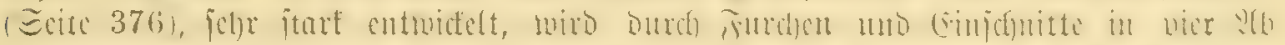

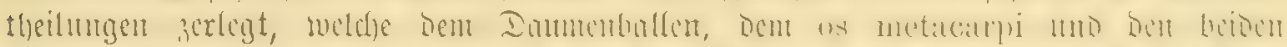

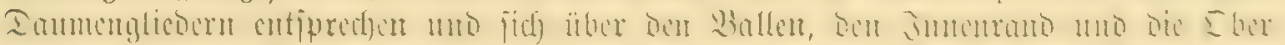

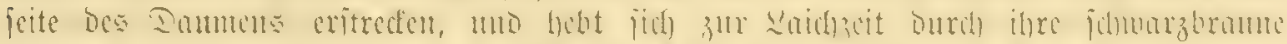

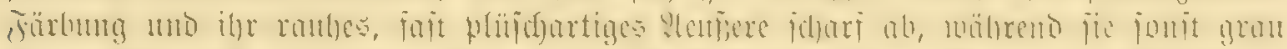

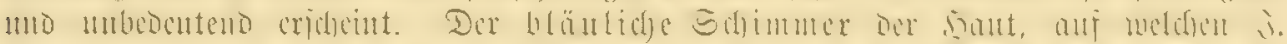

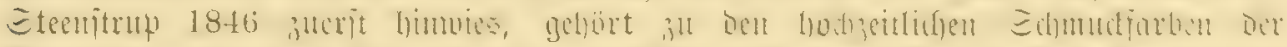

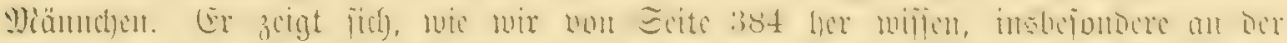

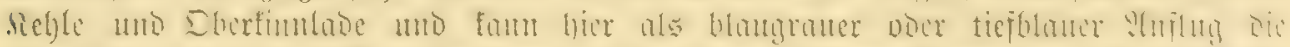

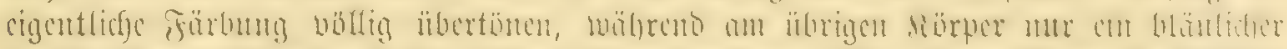

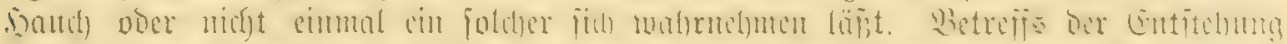

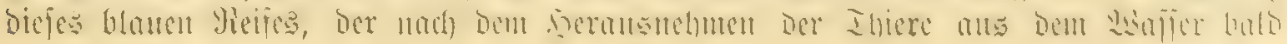




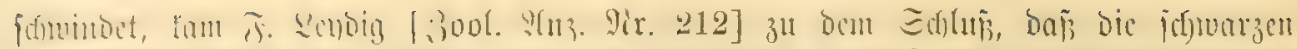

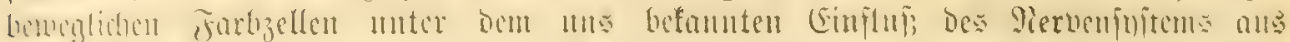

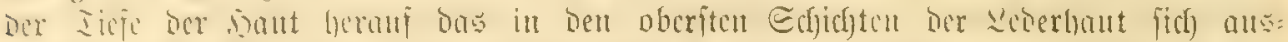

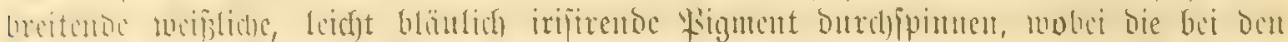

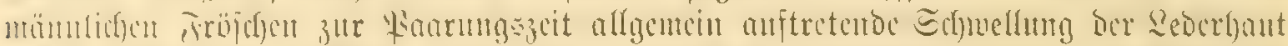

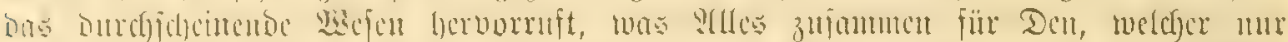

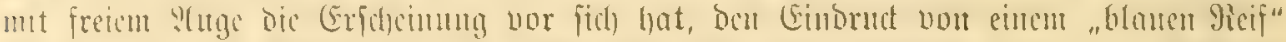

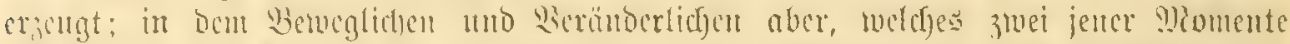

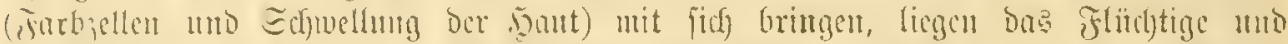

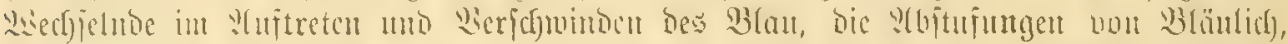

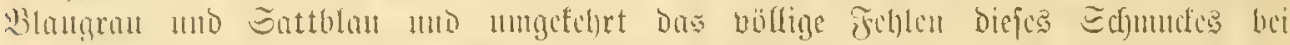

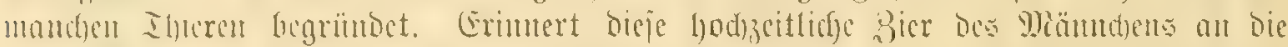

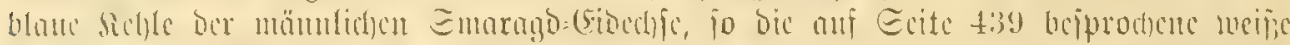
Weprantug bes

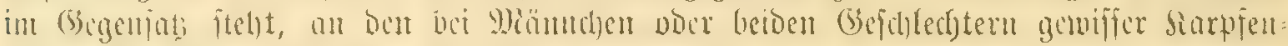

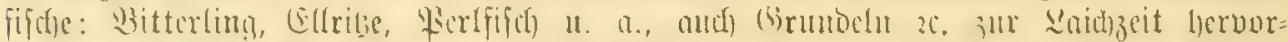

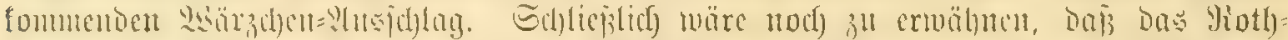

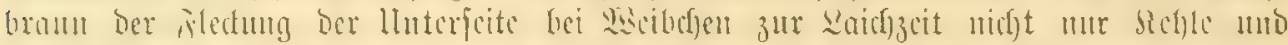

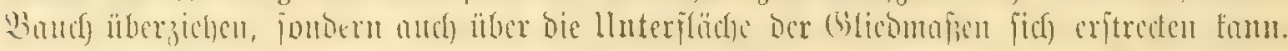

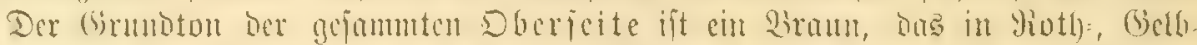

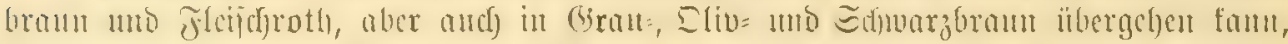

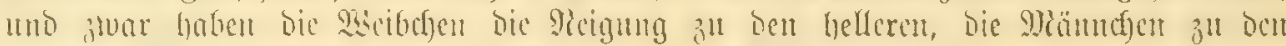

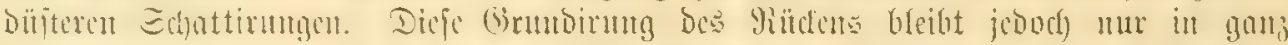

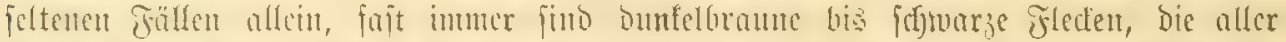

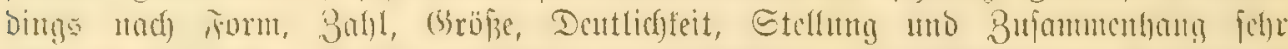

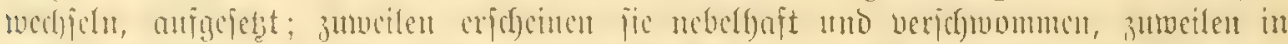

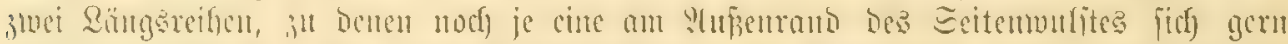

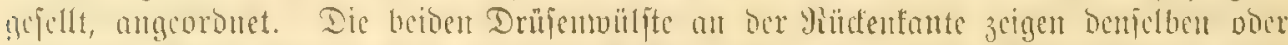

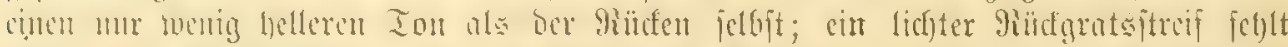

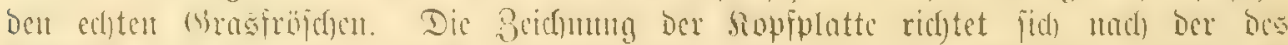

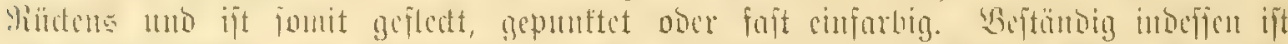

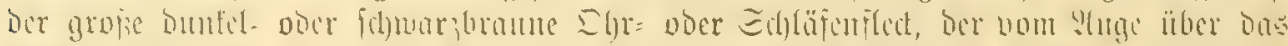

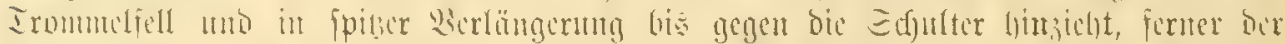

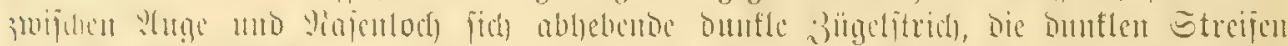

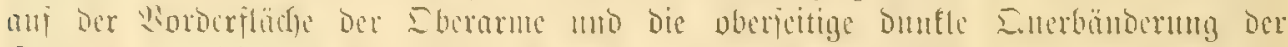

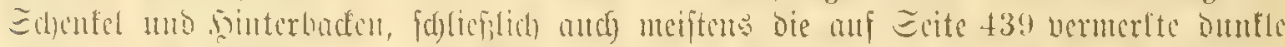

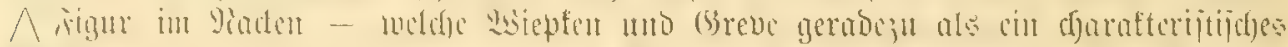

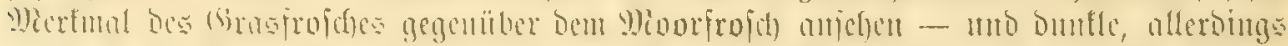

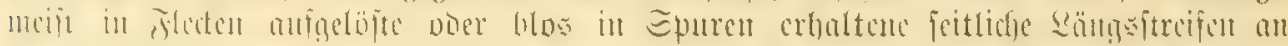

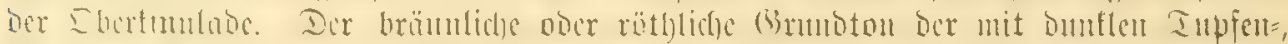

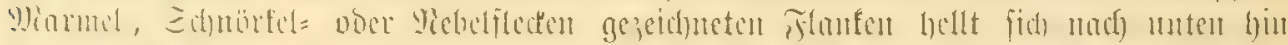

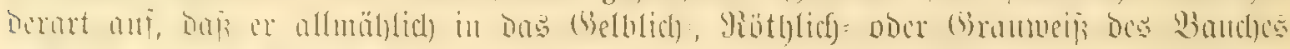

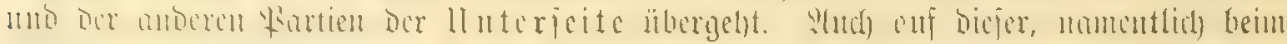

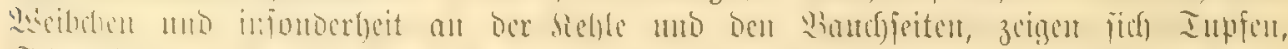

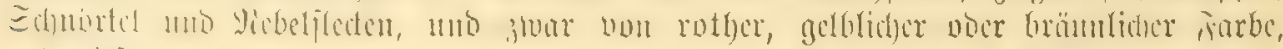

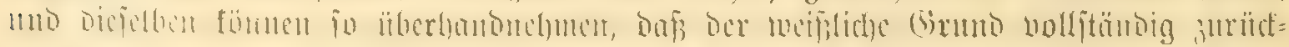

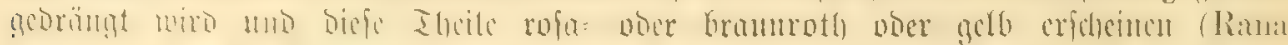

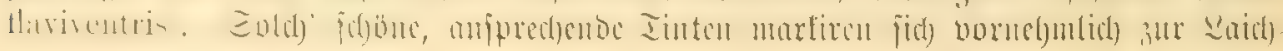




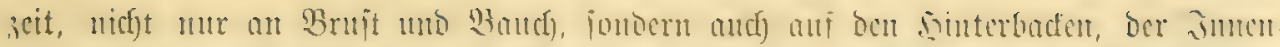

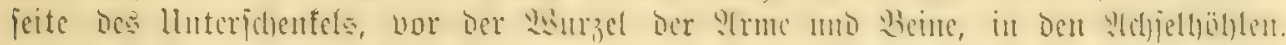

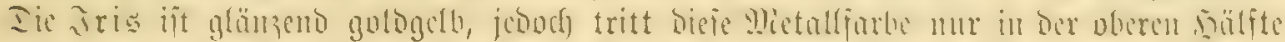

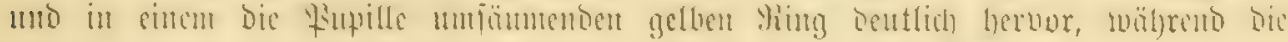

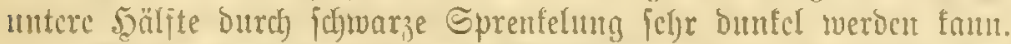

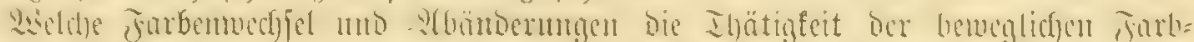

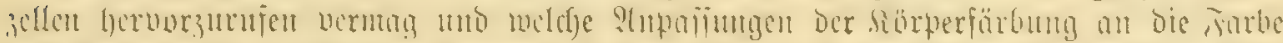

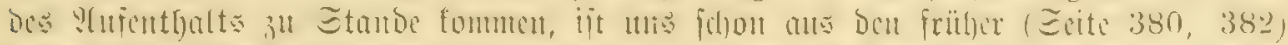

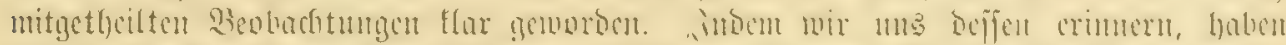

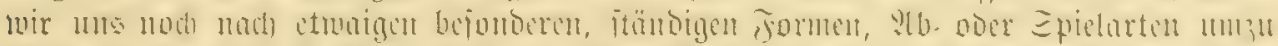

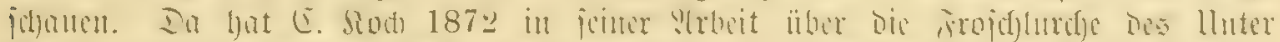

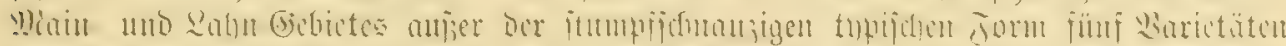

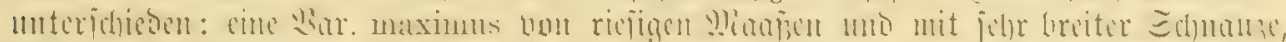

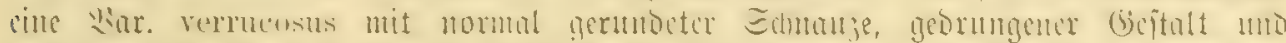

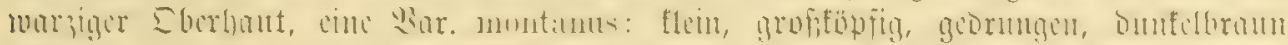

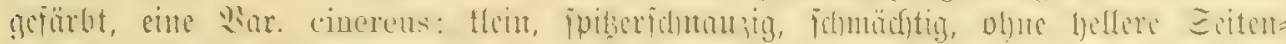

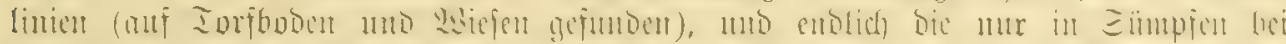

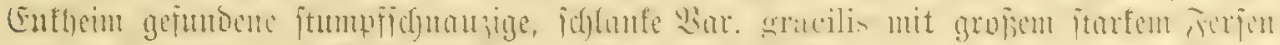

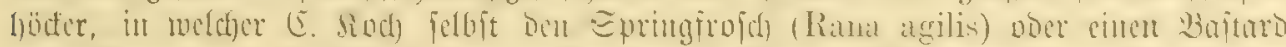

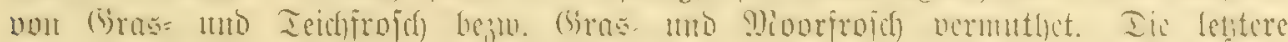

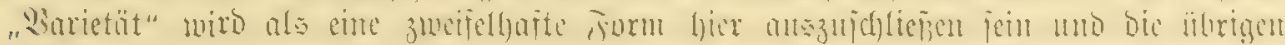

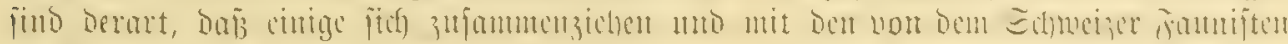

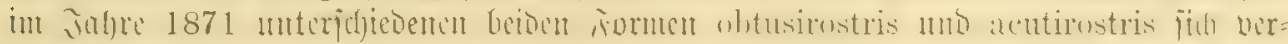
cinigert taffert.

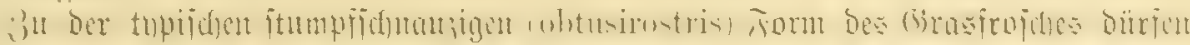

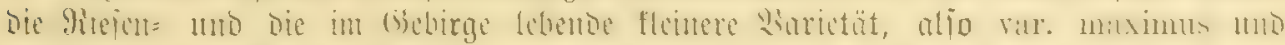

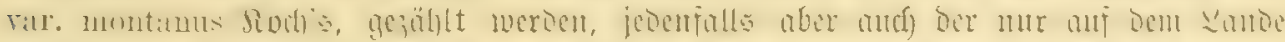
gefundus ... Wha

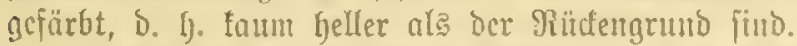

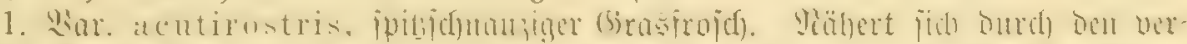

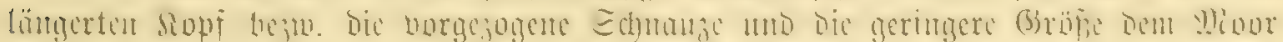

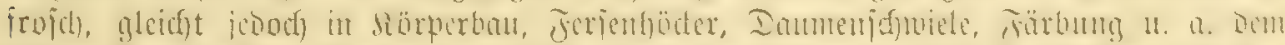

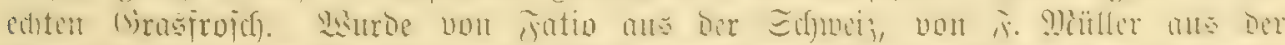

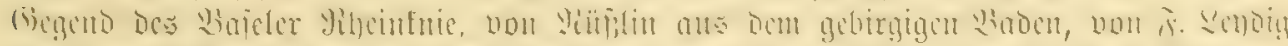

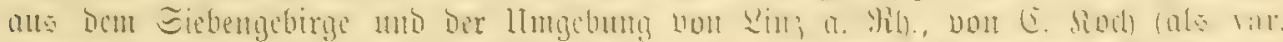

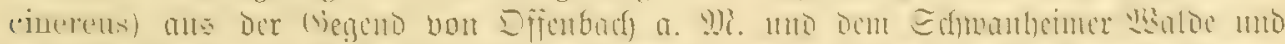

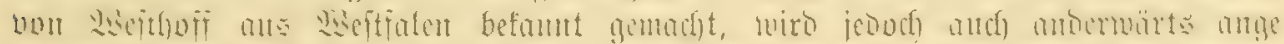

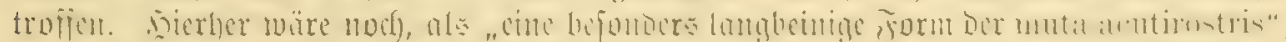

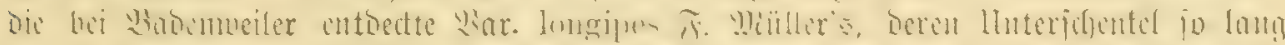

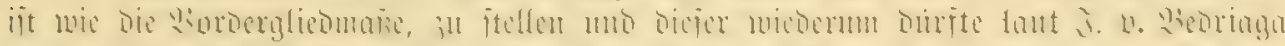

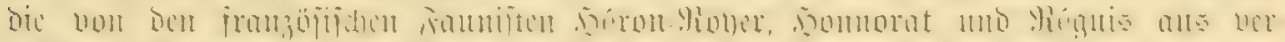

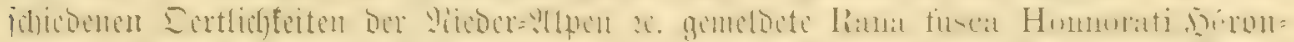

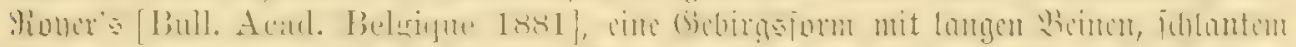

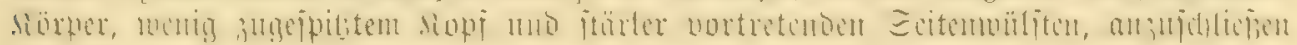
jein. (?)

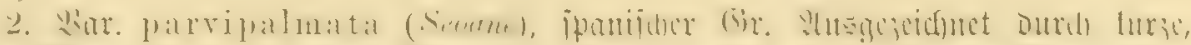

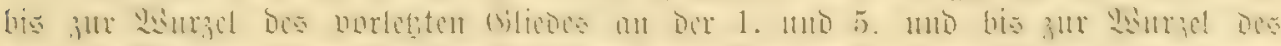

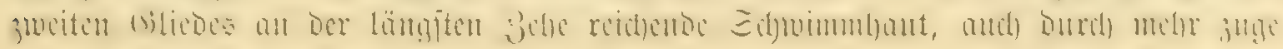




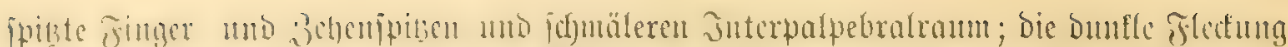

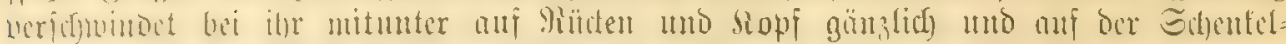

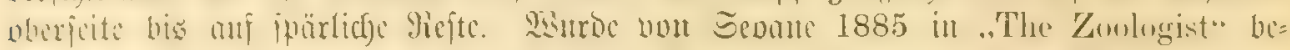

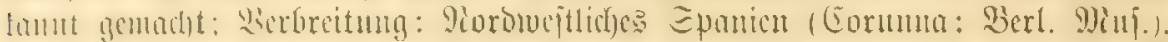

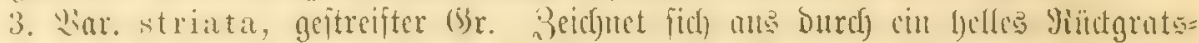

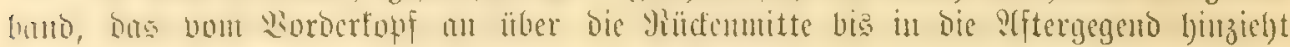

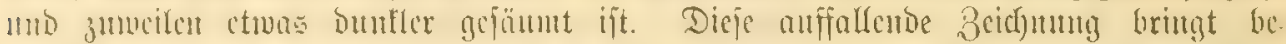

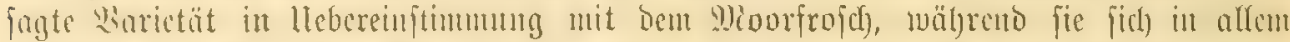

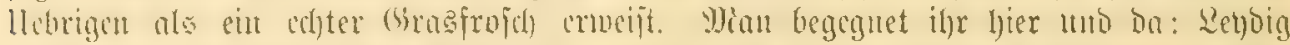

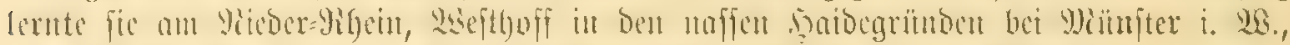

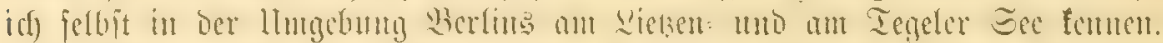

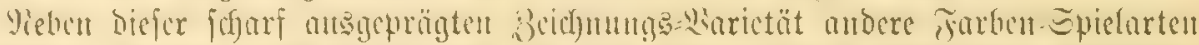

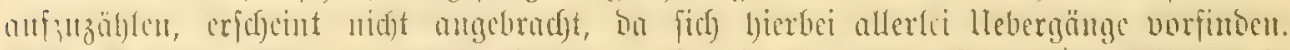

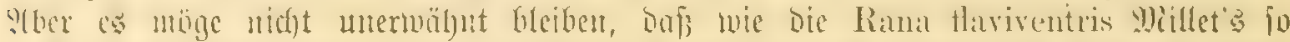

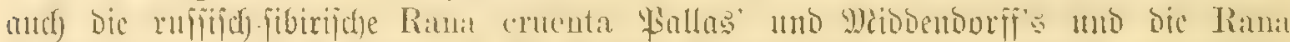

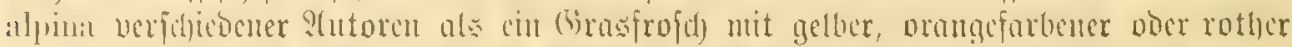

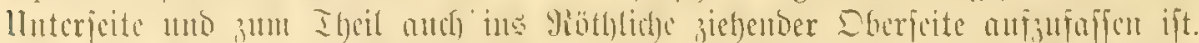

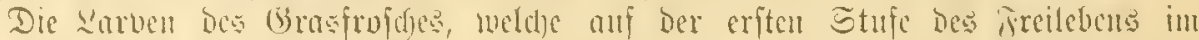

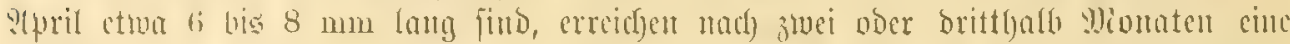

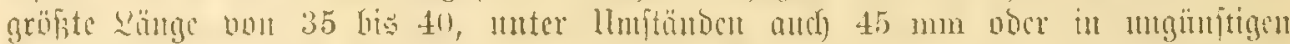

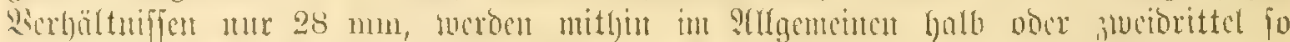

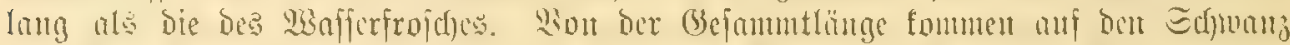

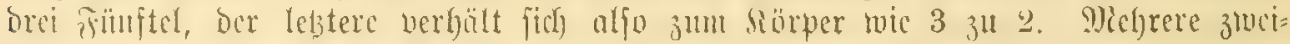

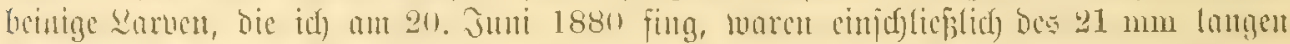

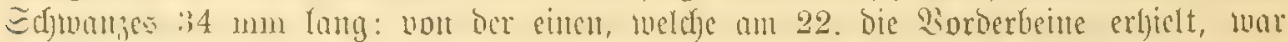

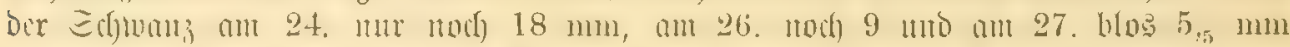

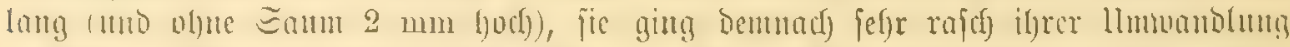

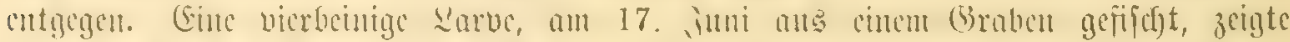

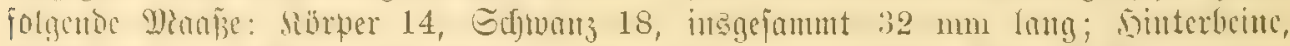

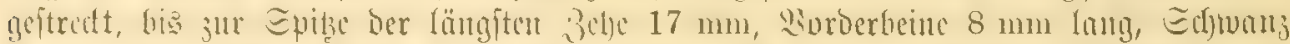

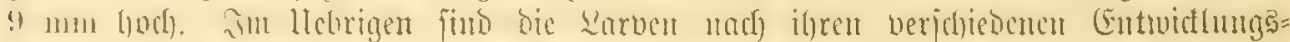

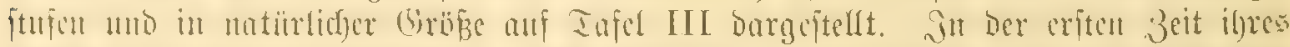

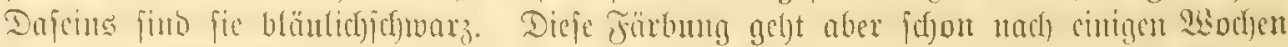

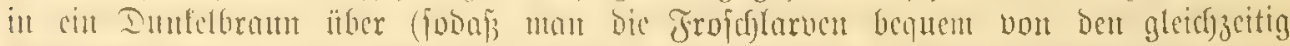

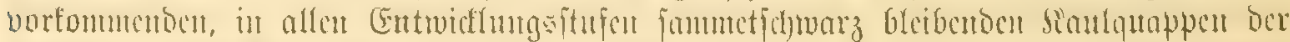

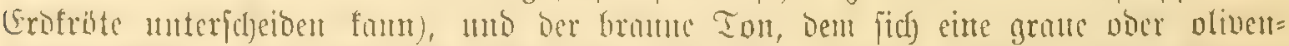

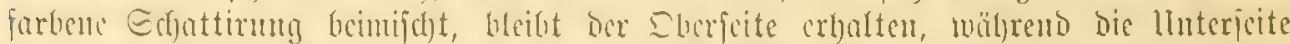

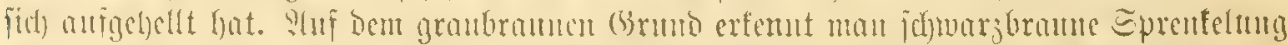

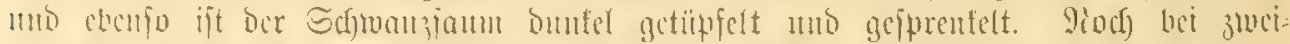

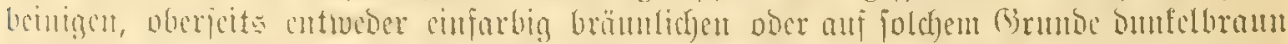

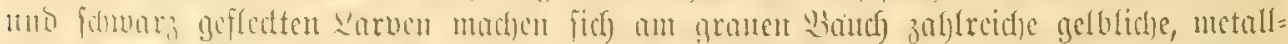

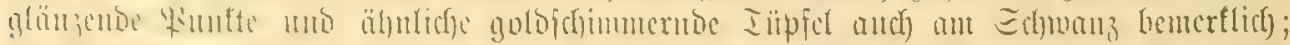

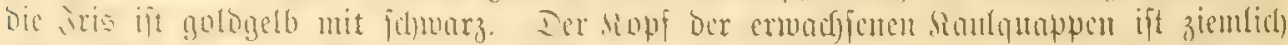

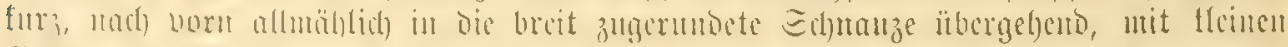

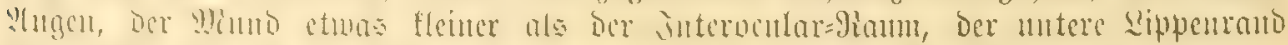

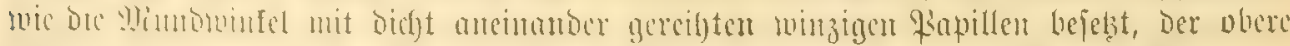

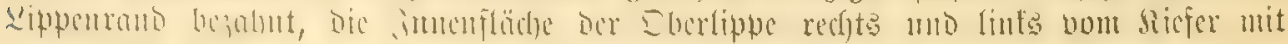

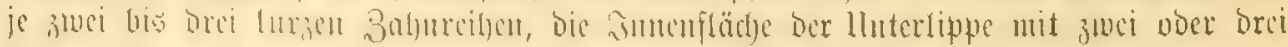




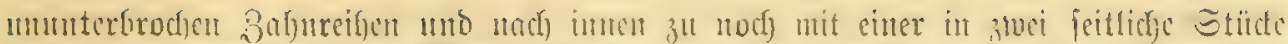

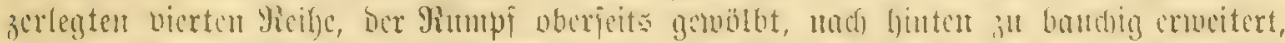

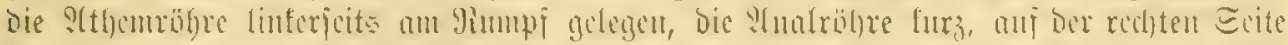

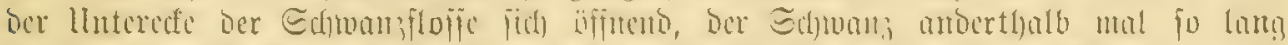

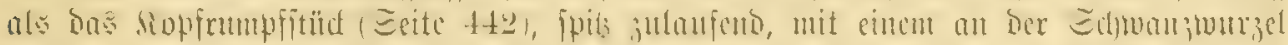

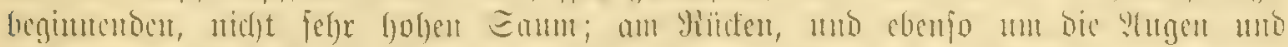

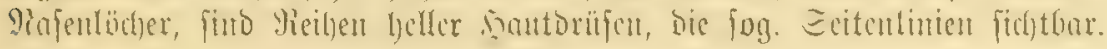

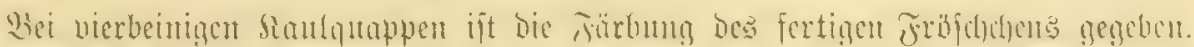

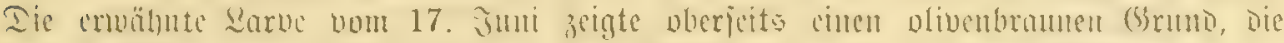

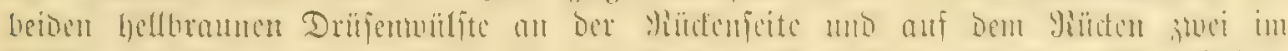

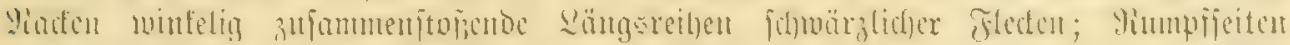

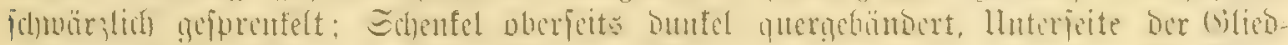

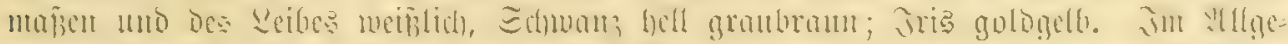

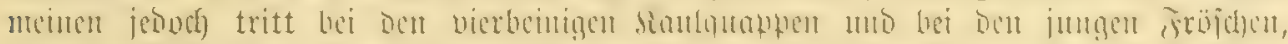

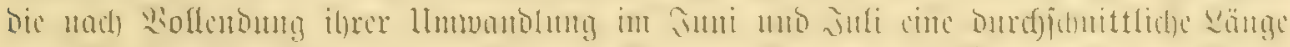

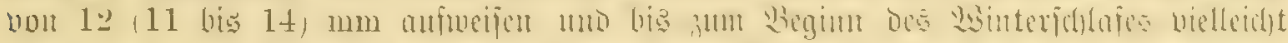

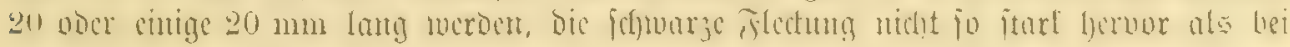
melyrjägrigen Fröfdjen. Diefe finto mit brei Jangren gefdjectjtsreif.

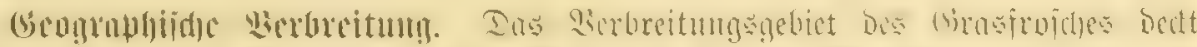

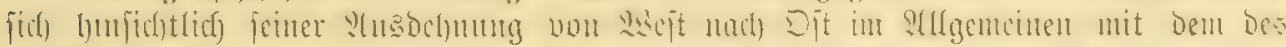

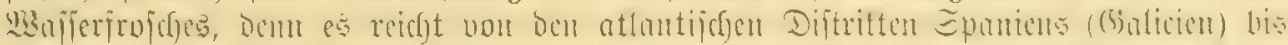

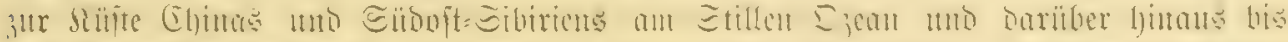

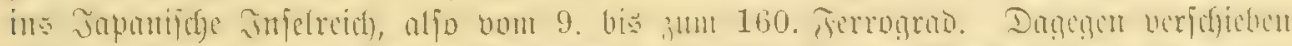

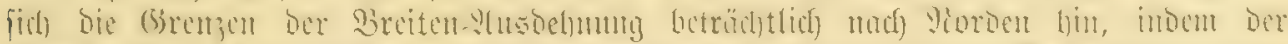

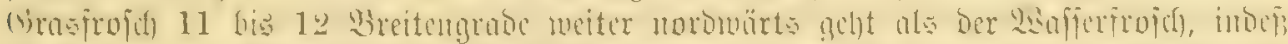

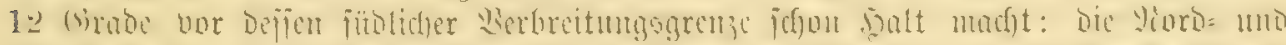

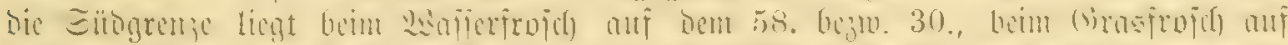

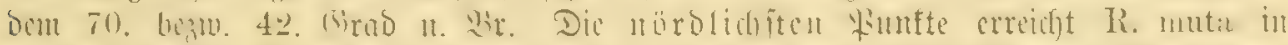

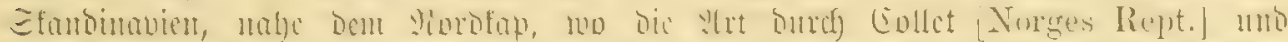

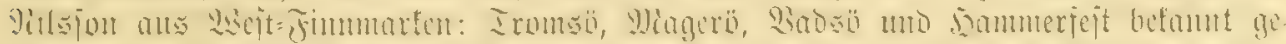

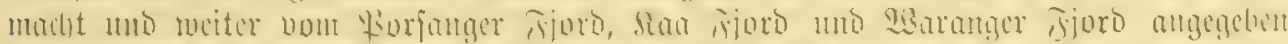

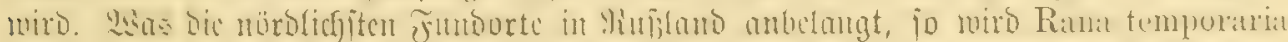

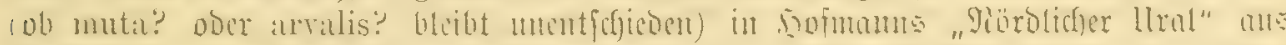

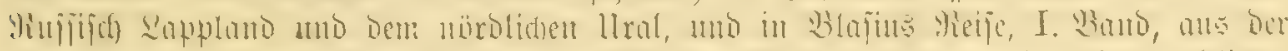

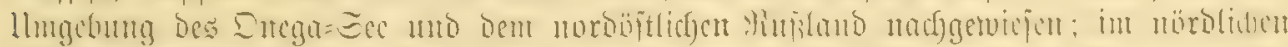

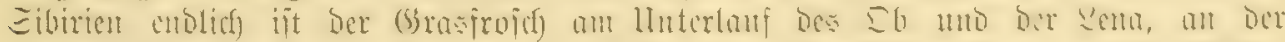

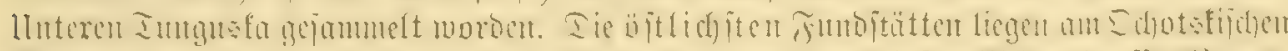

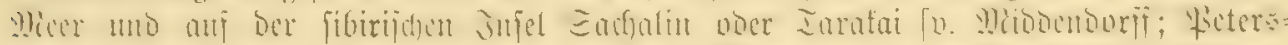

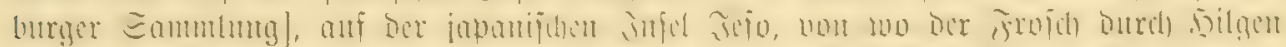

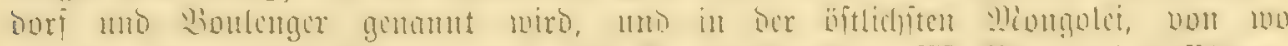

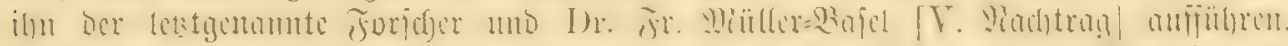

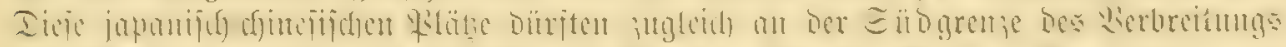

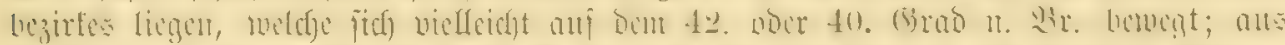

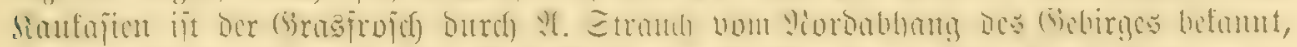

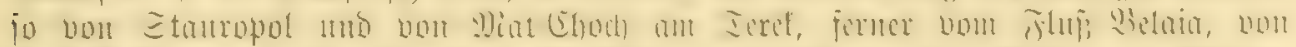

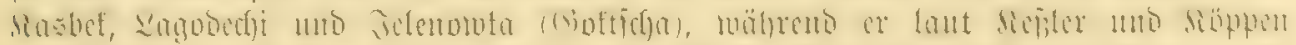

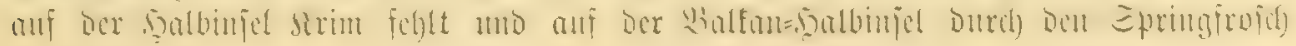




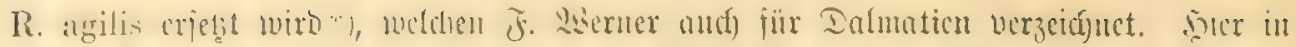

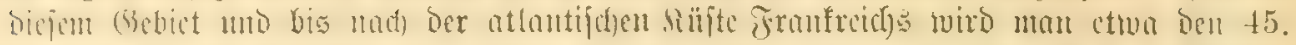

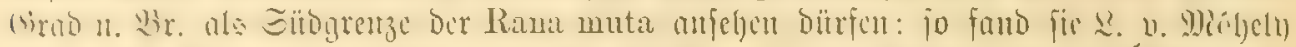

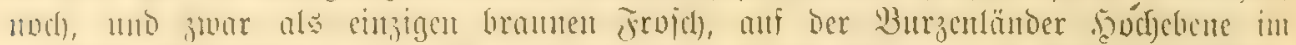

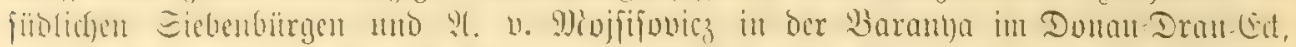

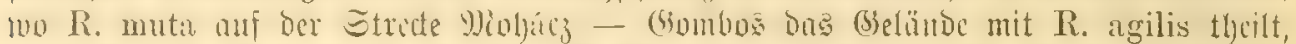

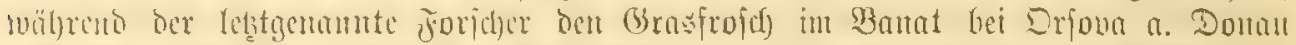

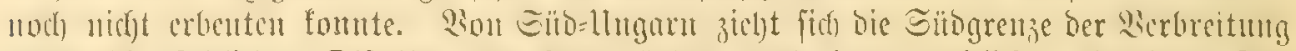

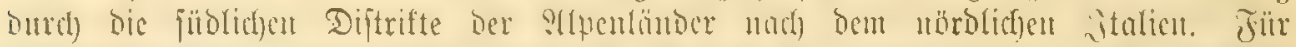

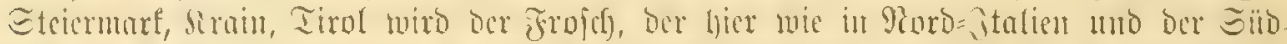

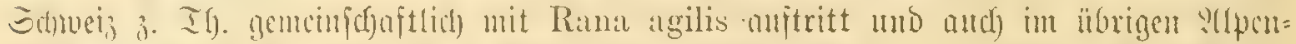

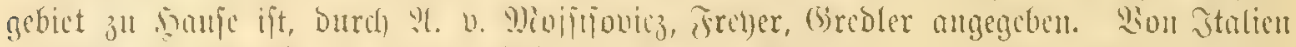

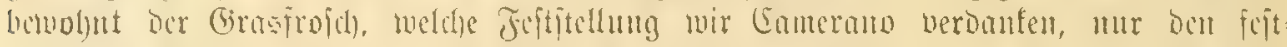

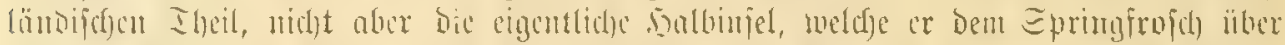

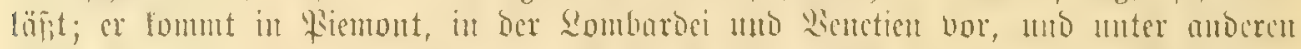

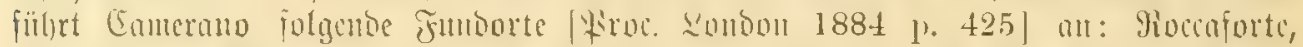

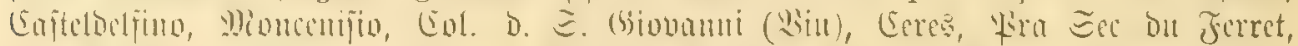

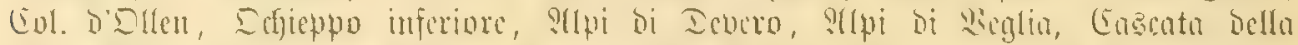

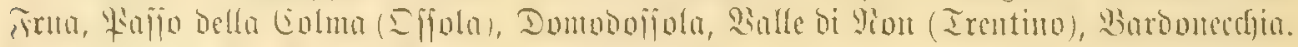

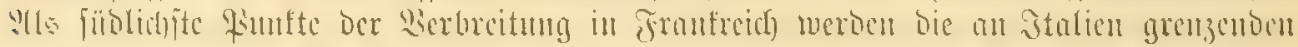

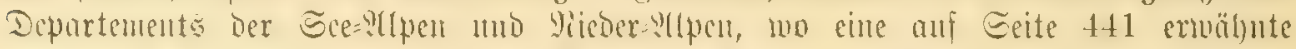

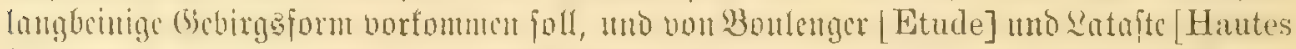

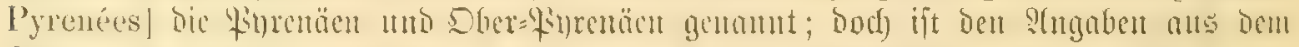

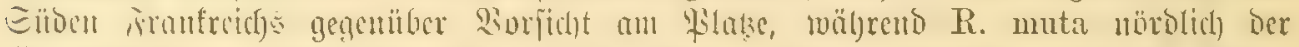

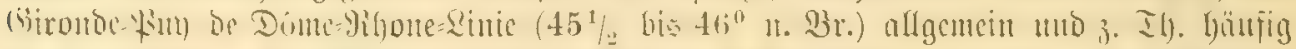

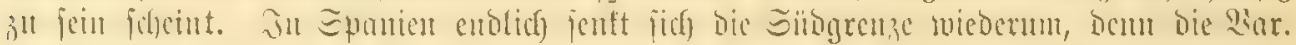

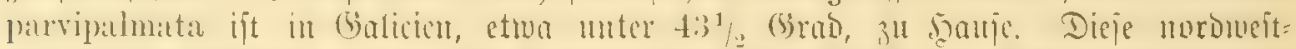

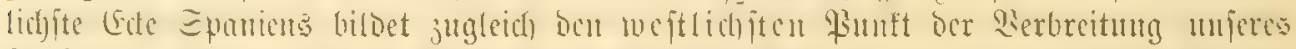

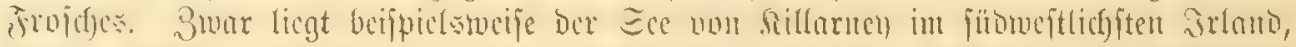

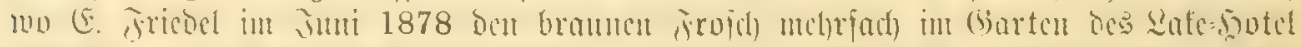

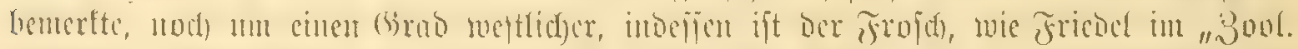

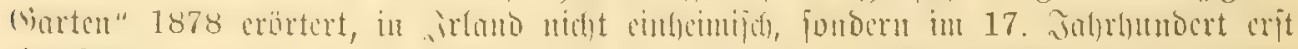

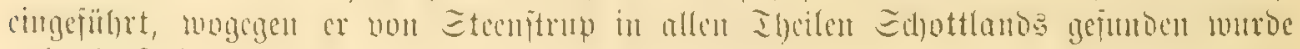
uno ebcuffels in Englanto angetroffen biro.

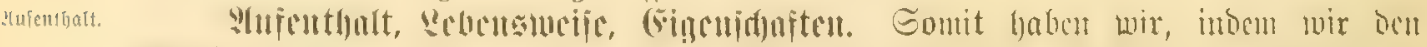

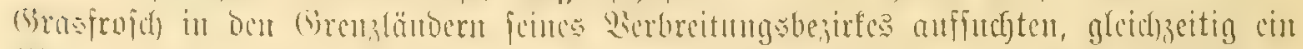

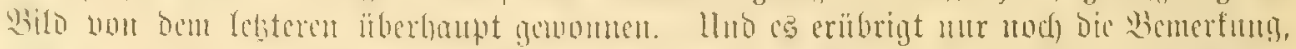

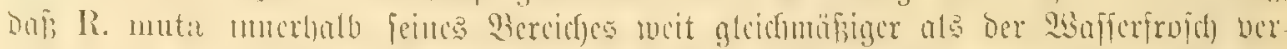

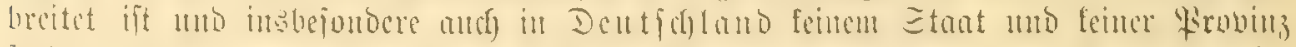

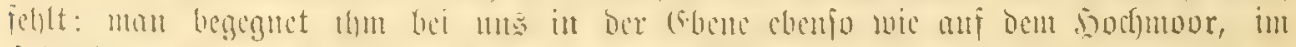

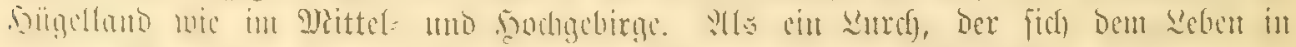

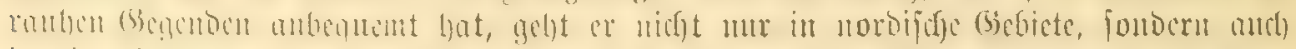

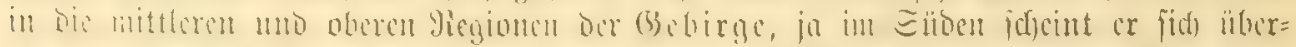

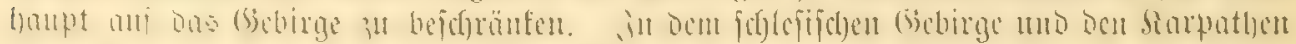

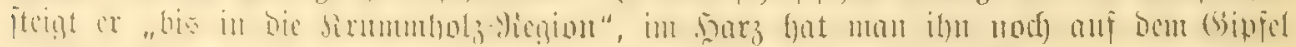

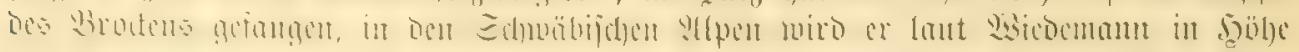

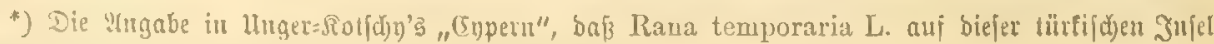
vortomme, bedari baher nod) Der mäheren 2tuftlärung. 


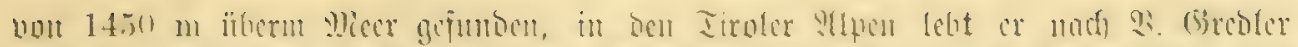

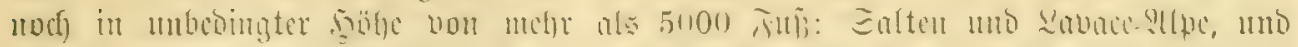

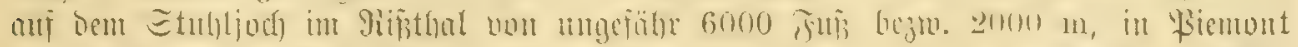

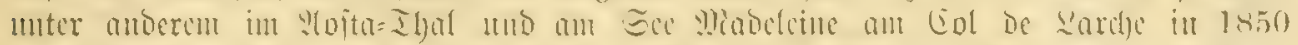

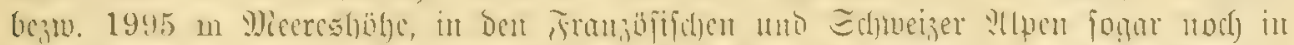

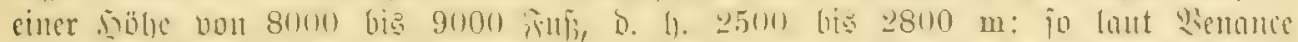

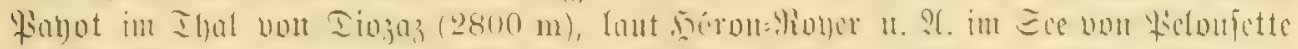

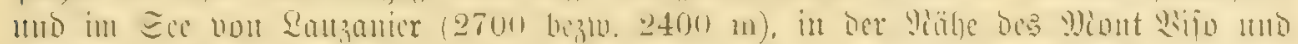

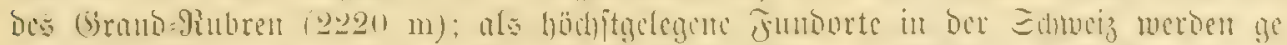

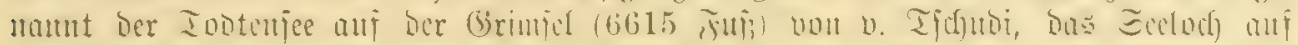

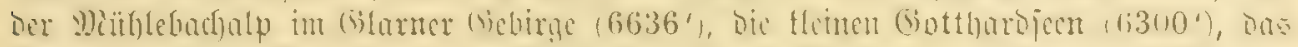

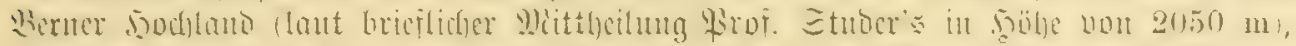

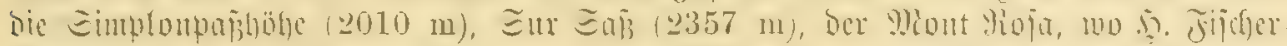

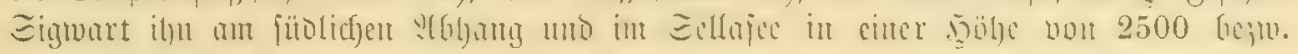
$2231 \mathrm{~m}$ beobachtete.

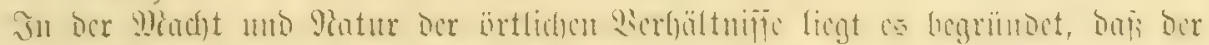

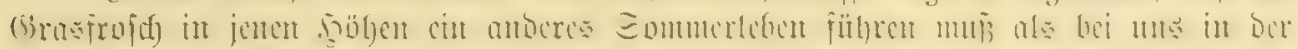

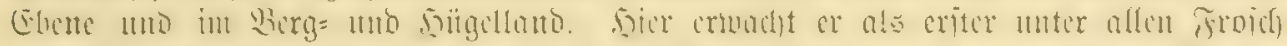

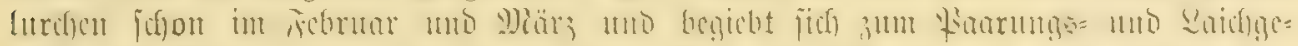

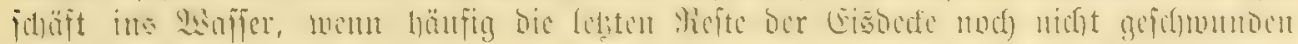

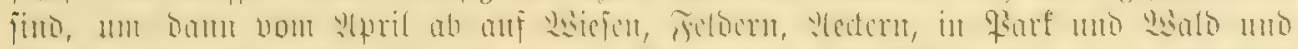

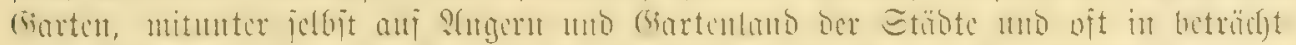

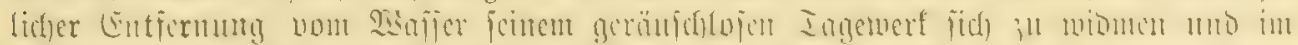

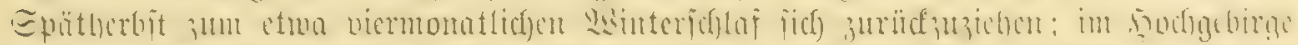

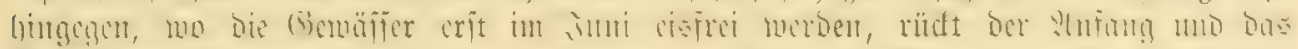

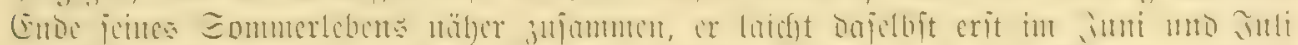

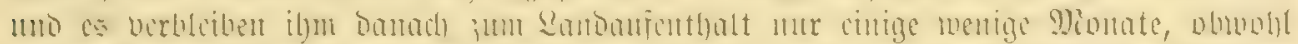

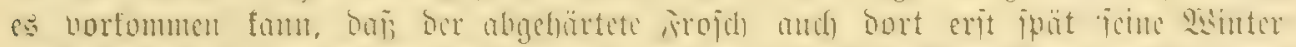

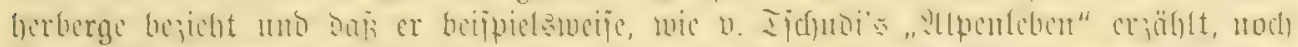

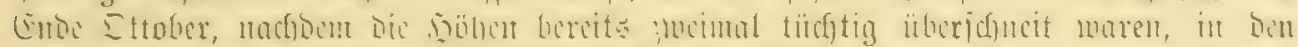

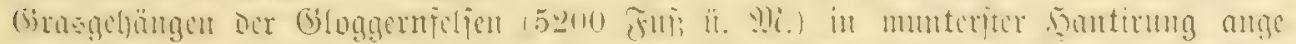

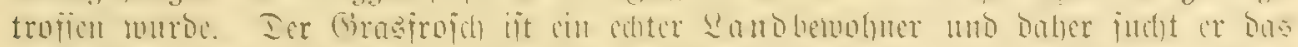

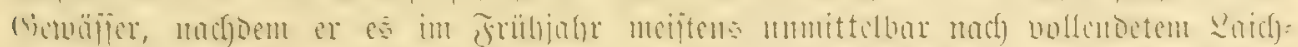

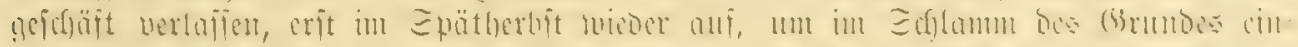
genuilst 3 in

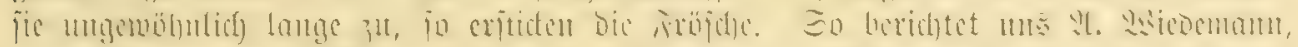

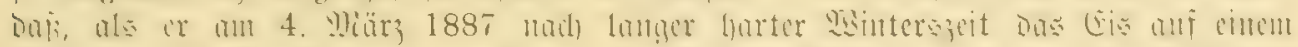

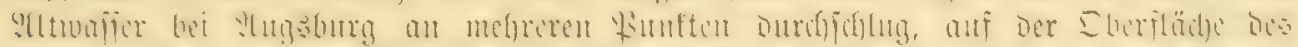

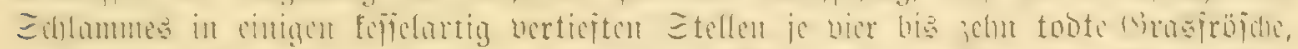

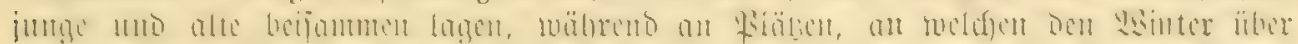

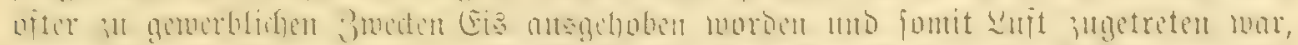

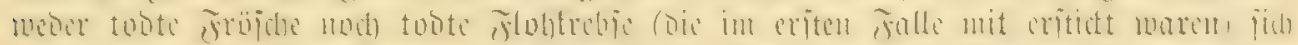

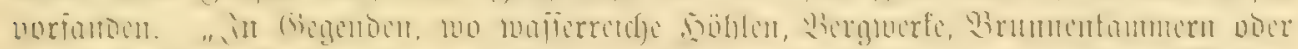

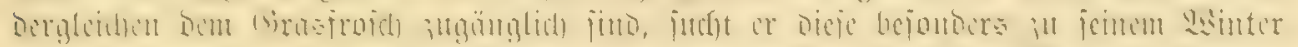

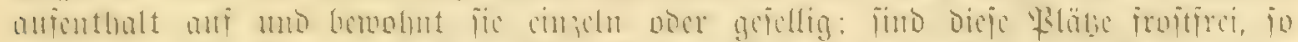

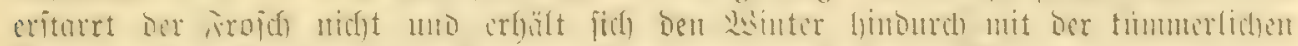

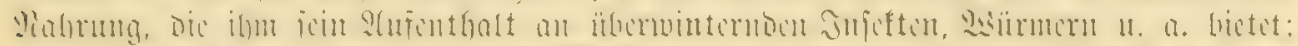

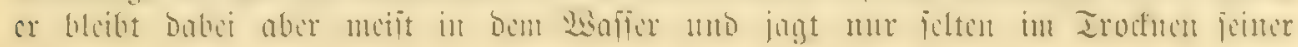




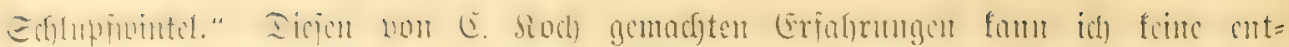

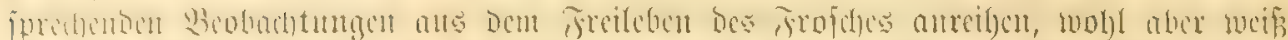

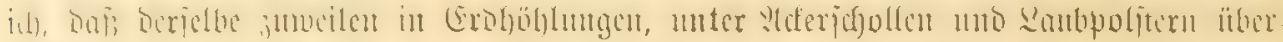
wintert.

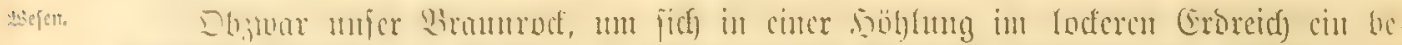

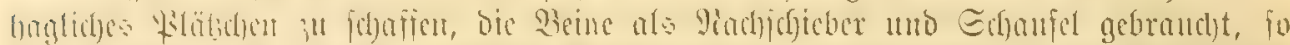

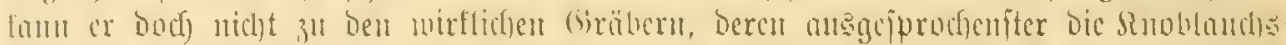

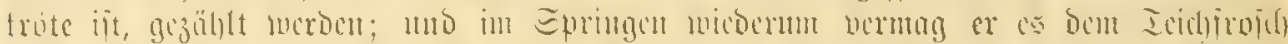

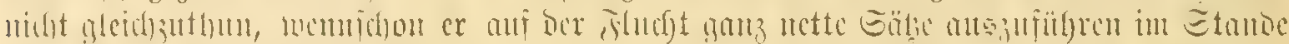

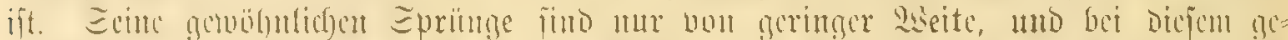

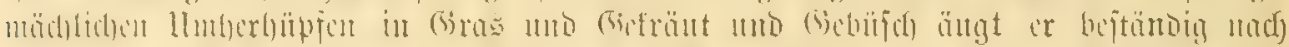
Flingemben

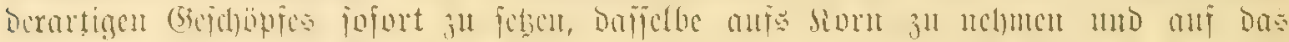

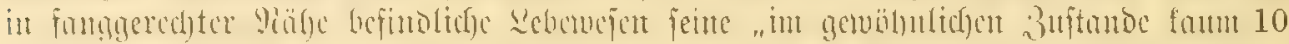

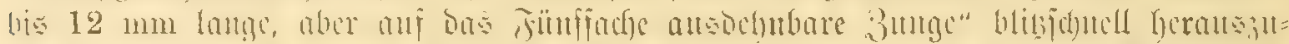

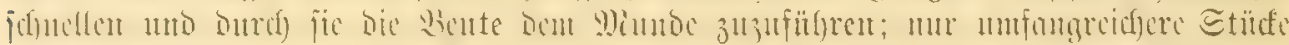

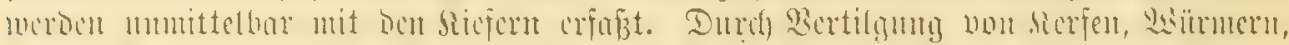

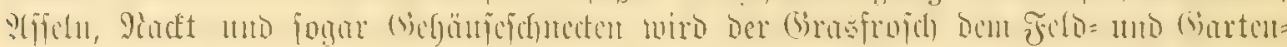

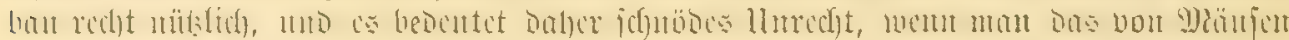

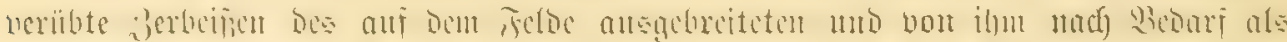

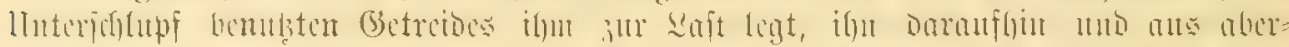

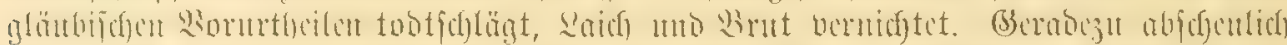

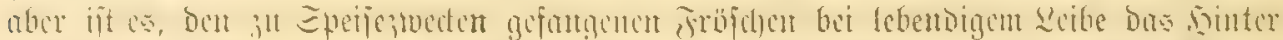

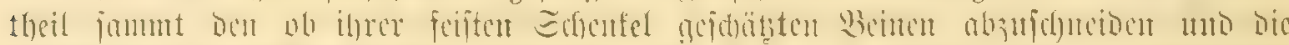

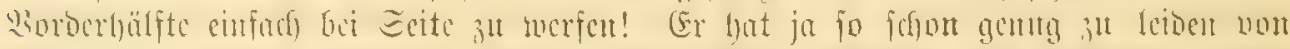

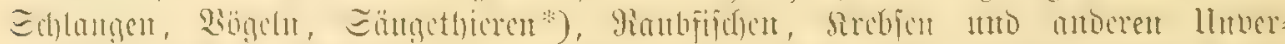

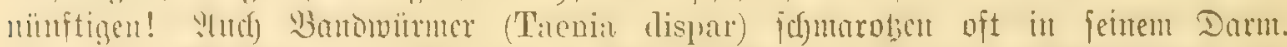

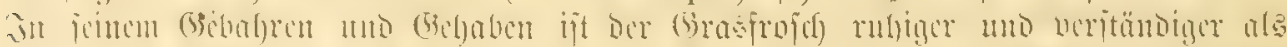

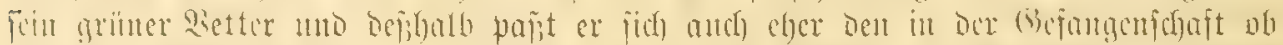

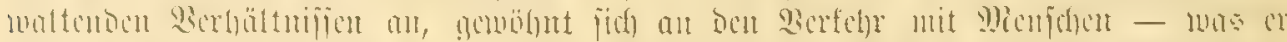

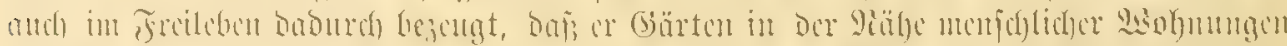

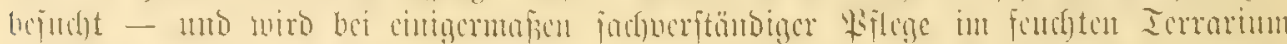

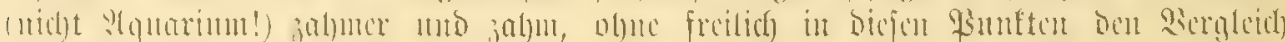

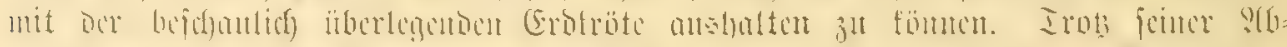

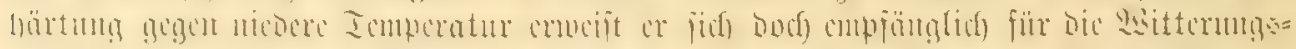

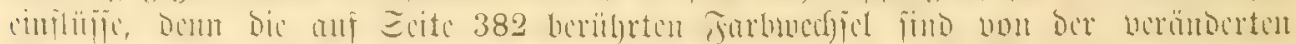

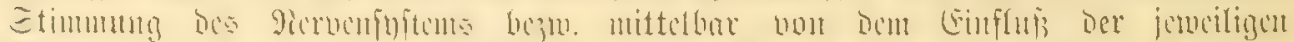

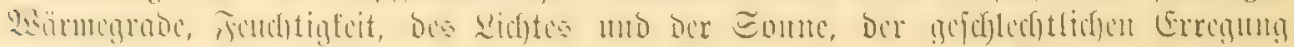
11. ถ. bedingt.

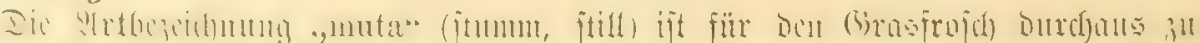

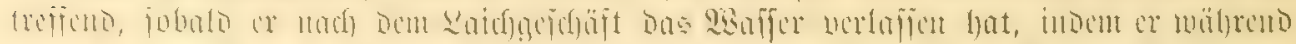

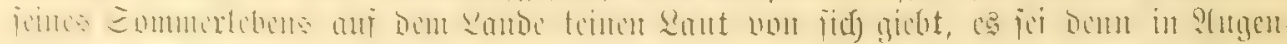

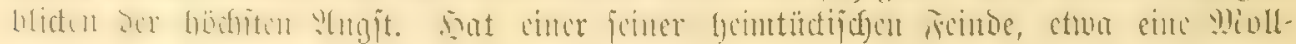

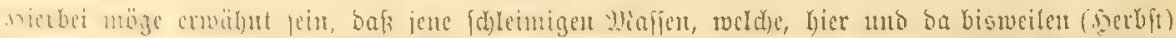

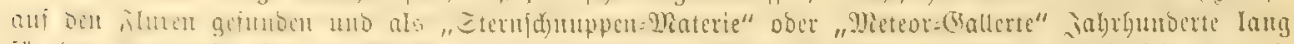

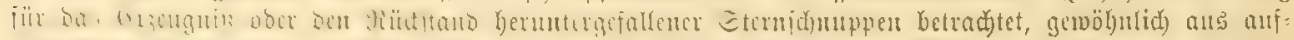

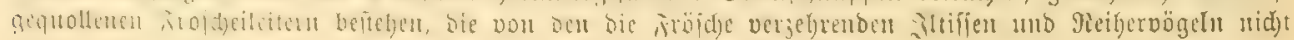
mit gefrefien bezw. nac) Trt ber (Beroöle mieber ausgerwitrgt murben. 


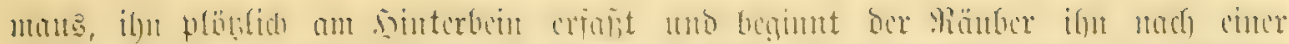

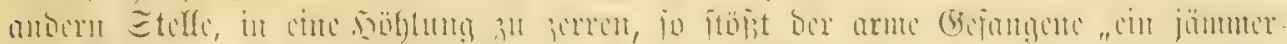

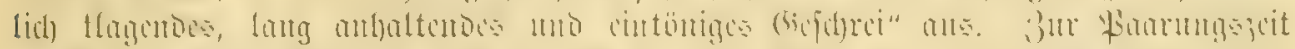

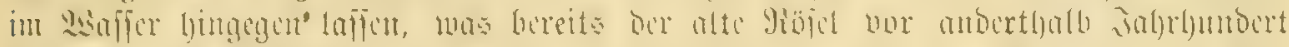

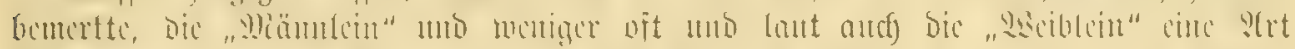

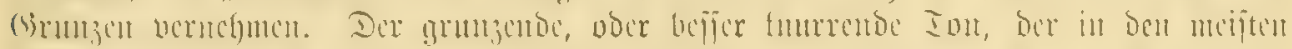

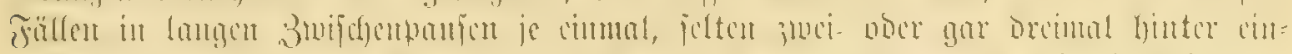

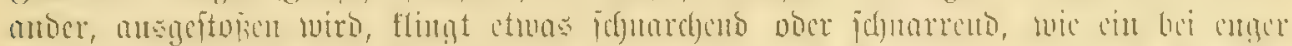

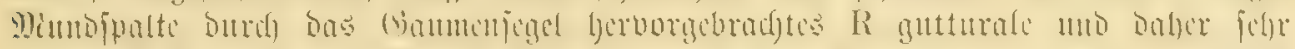

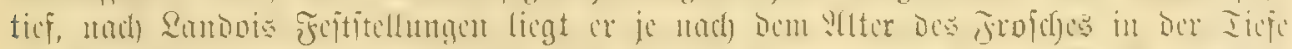

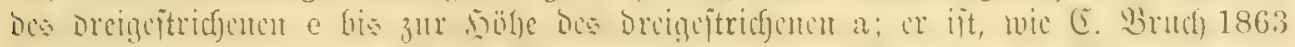

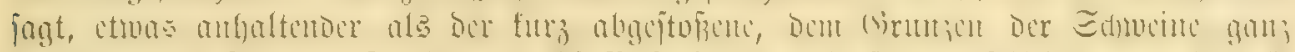

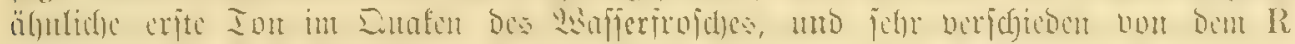

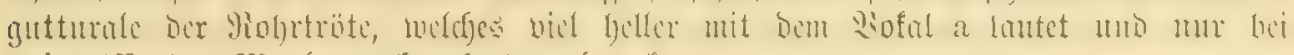
weitgeoffuctem Munto nadjgcalynt werden faut.

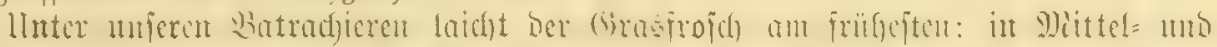

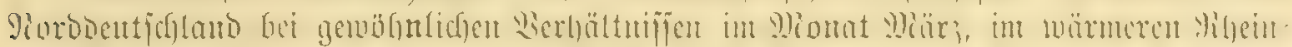

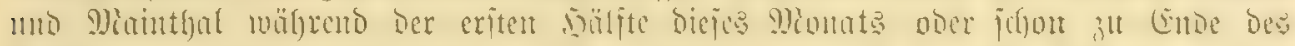

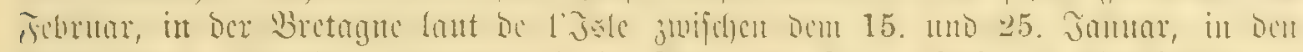

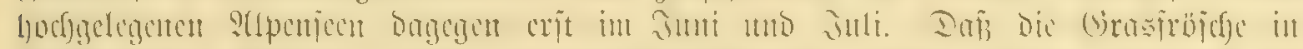

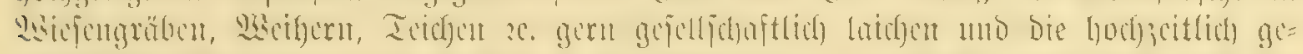

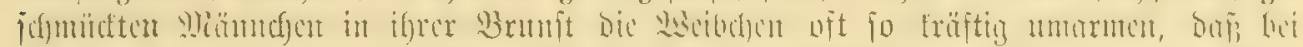

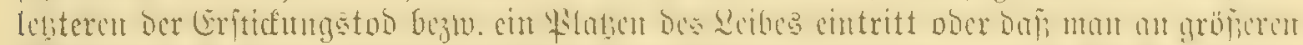

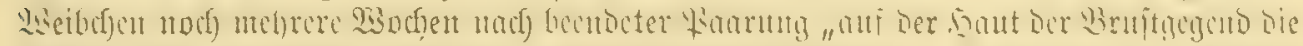

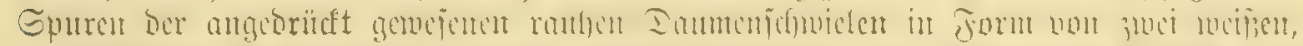

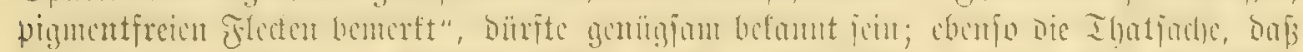

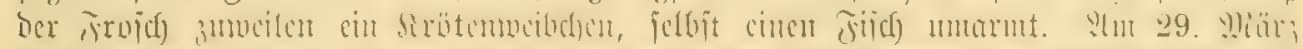

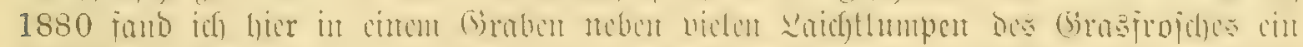

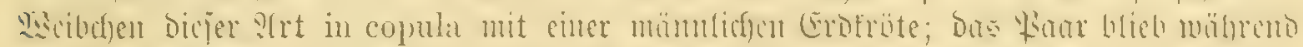

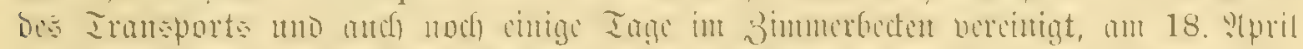

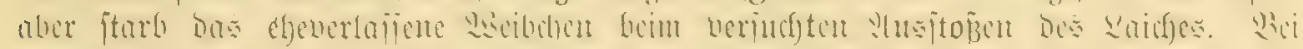

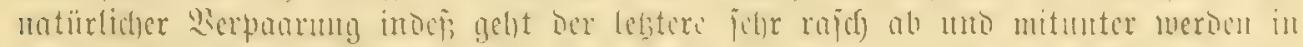

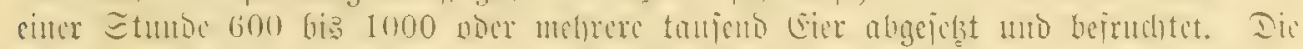

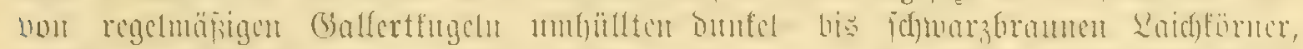

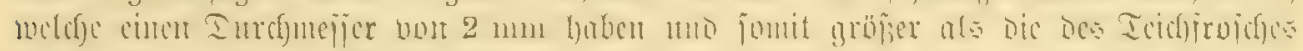

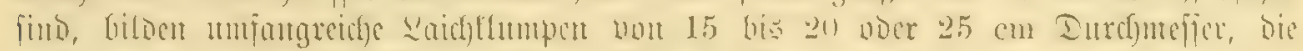

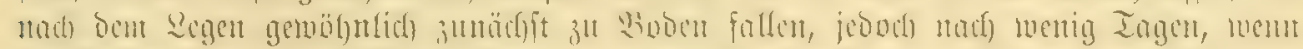

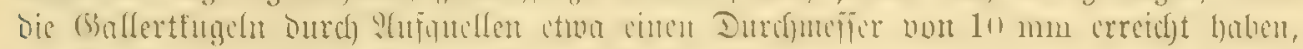

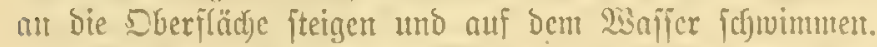

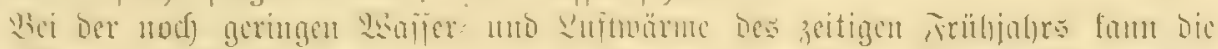

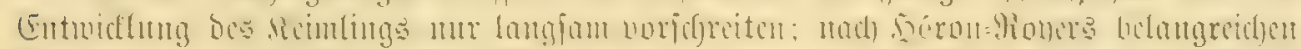

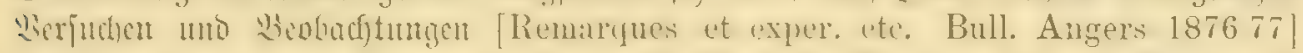

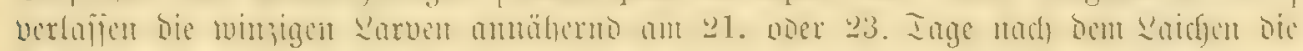

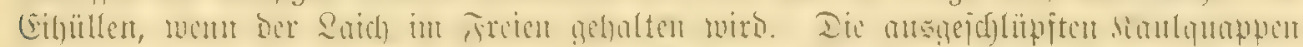

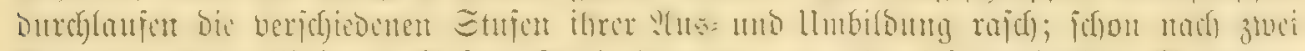

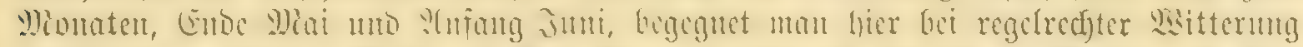

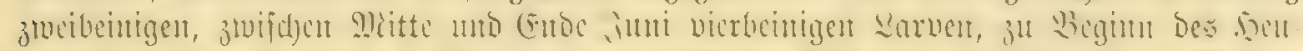

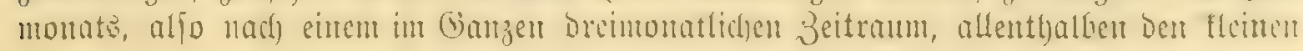




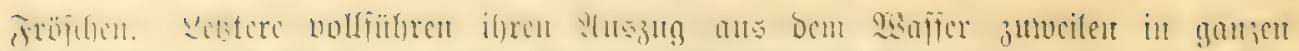

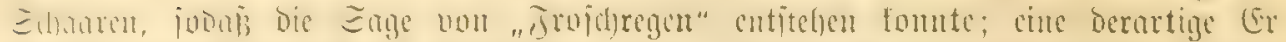

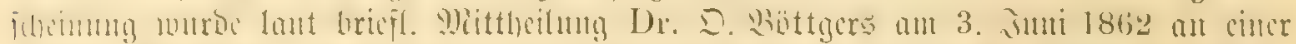

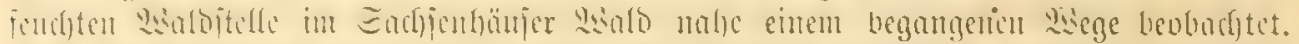

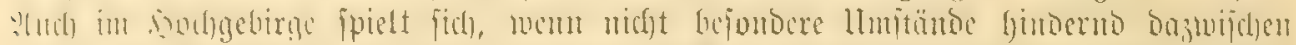

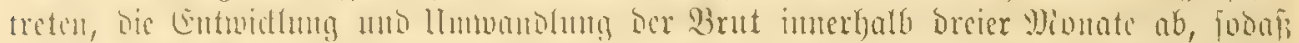

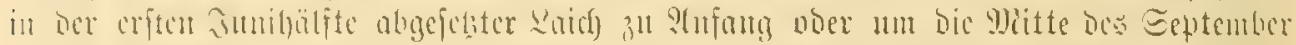

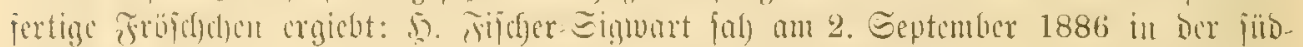

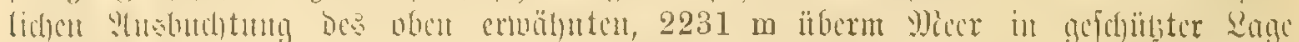

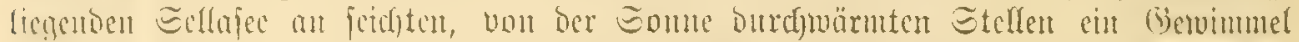
unu 41) $45 \mathrm{~mm}$ langen, ansgawad)jentu Sarven fovie junge, nod) mut Euman\}:

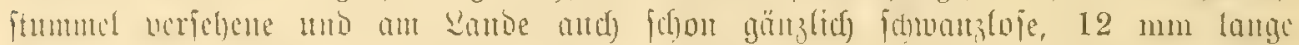

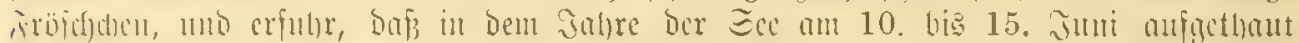

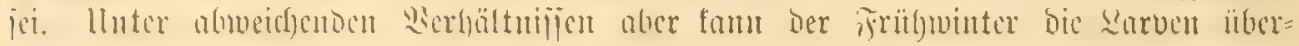

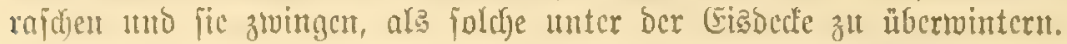

Za

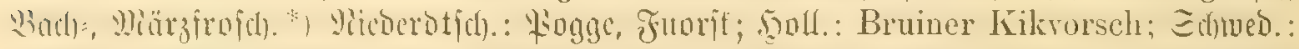
Groulal, Vanlig Groclat, Frö, Klossal: Engll: Common Frog: Framz.: Gremouille rounse, Rathe; Ital.: Rana rossa, Campee, Pissacan; Enan.: Ramal roja; folu.

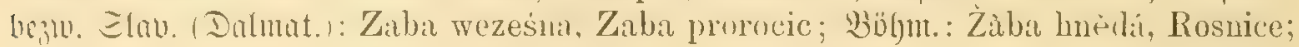

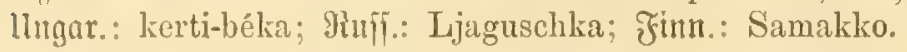

Rana s. Rubeta gibbosa, Gesner 1617. - Rubeta gibbosa, Aldrov. 1663. Rana temporaria, Charlet 1677. - Rana fusca terrestris, Rösel 1758. - Rana muta (et R. alpina) Laurenti 1768. - R. atra, Bonnat. 1789. - R. temporaria,

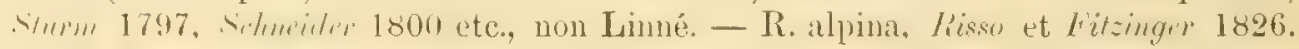
- R. Haviventris, Millet 1828. - R. cruenta, Pulles 1831. - R. platyrrhinus, Steenstrup 1846. - R. Dybowskii, Gïnther 1876.

3. Ylrt: 2lioorfrofh. Rana arvalis, Nilsson. 2rbbilbung: Tafel III Mr. 3.

Eänge 4 bis 5, ausnahmsweife $6 \mathrm{~cm}$; Sdnauje 3 ug fipitst, Oberlippc

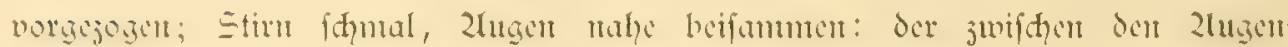

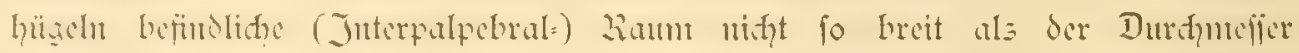

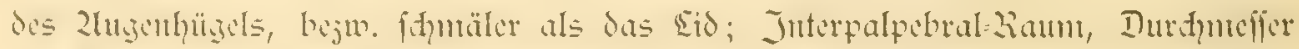

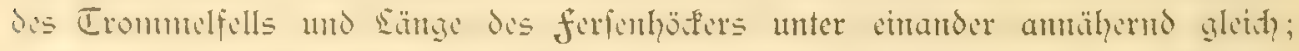

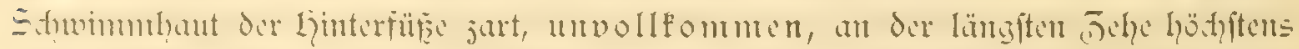

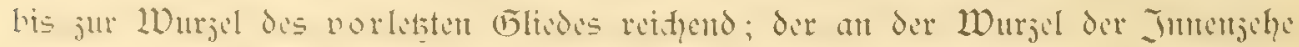

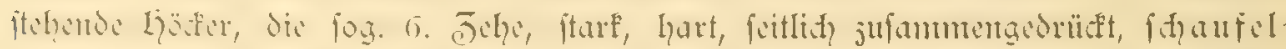

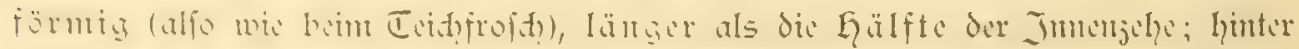

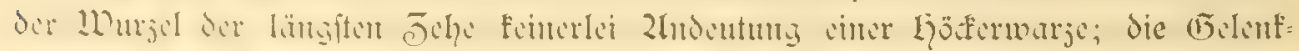

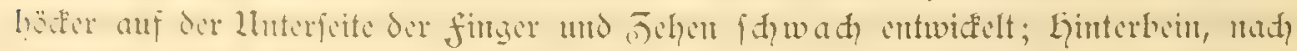

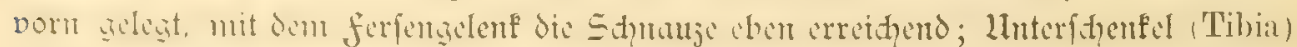

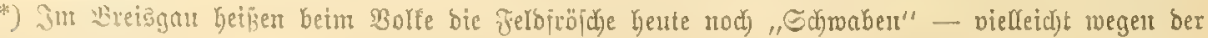

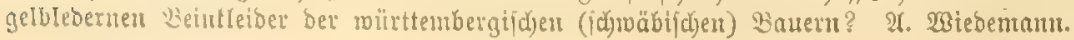




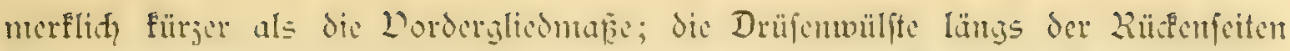

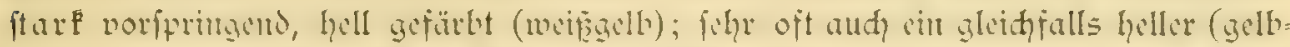

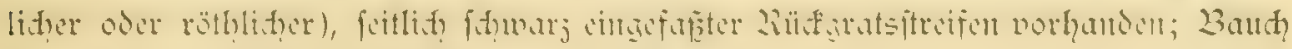

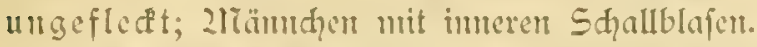

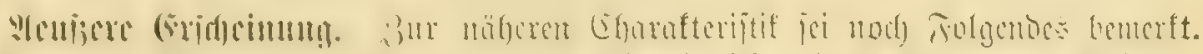

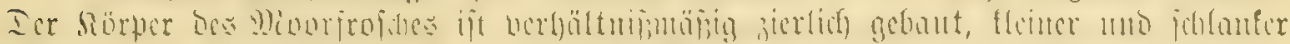

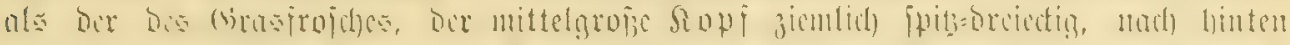

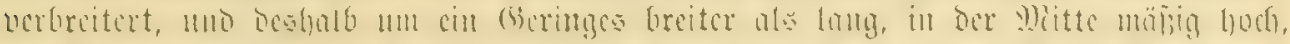

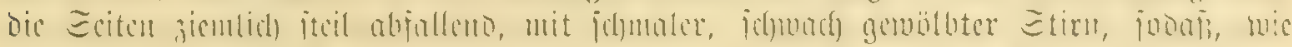

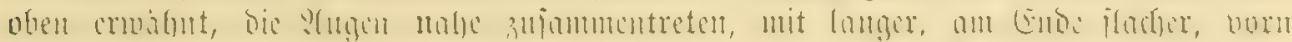

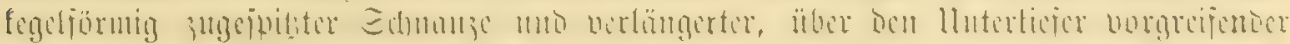

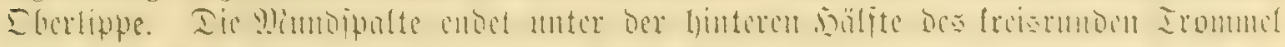

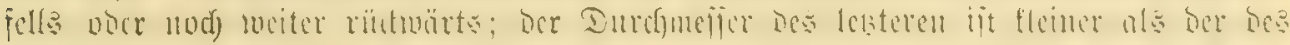

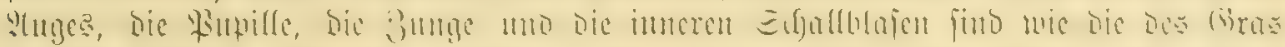

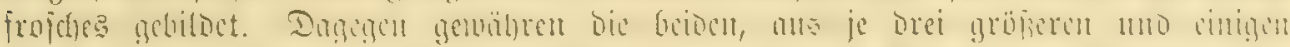

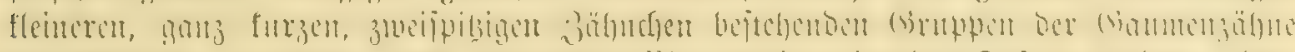

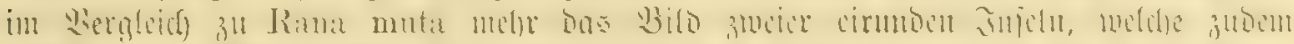

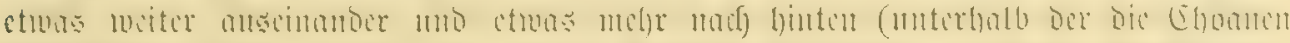

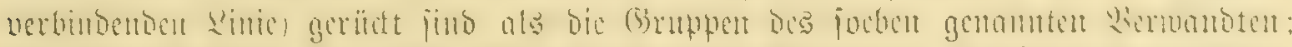

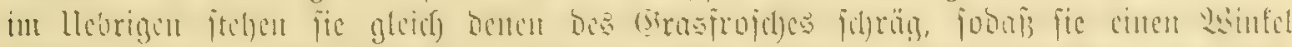

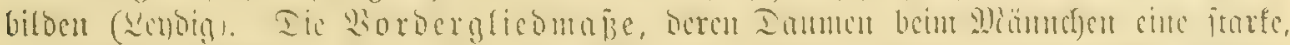

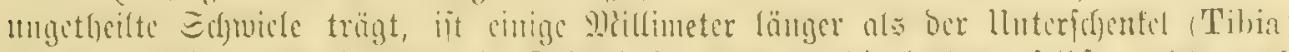

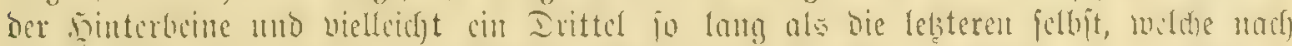

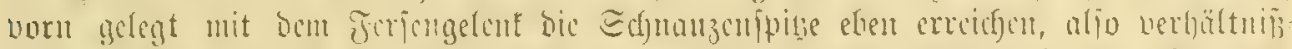

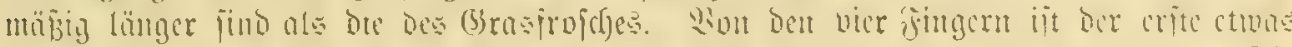

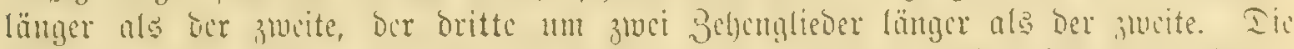

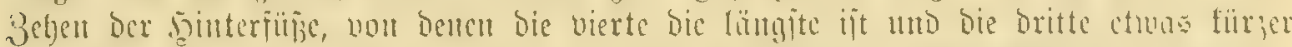

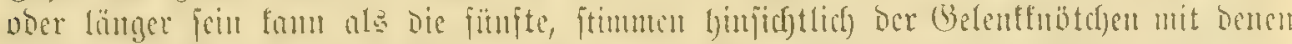

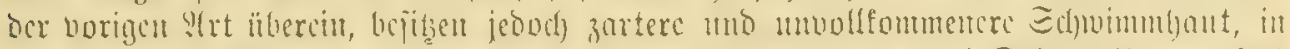

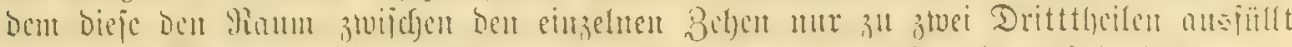

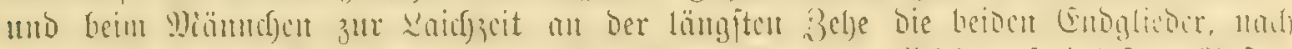

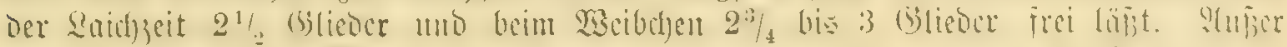

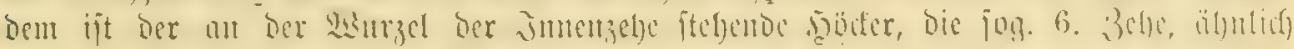

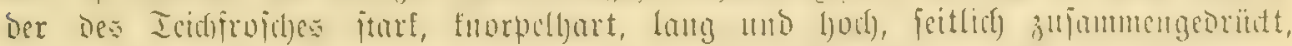

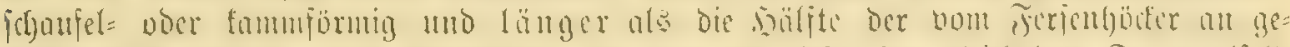

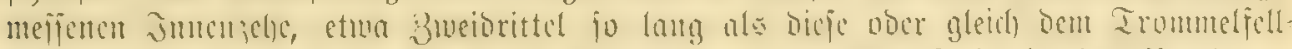

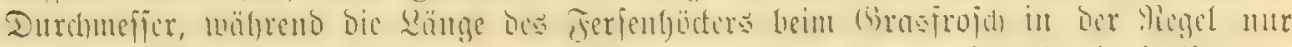

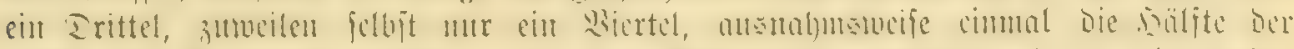

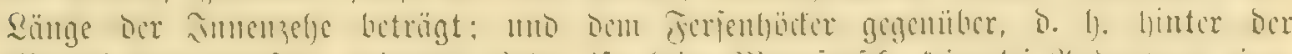

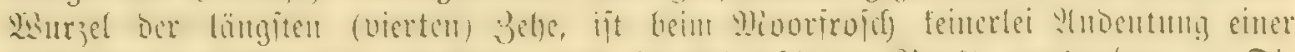

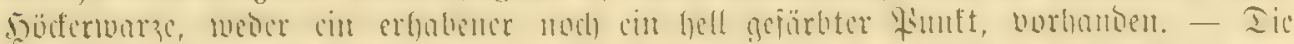

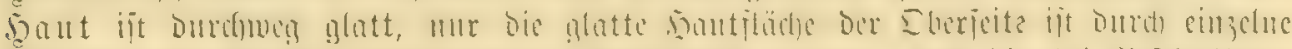

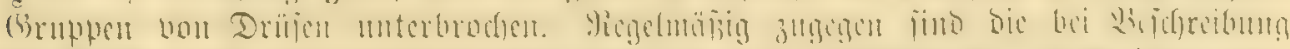

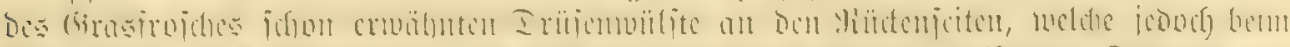

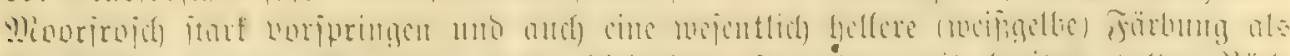

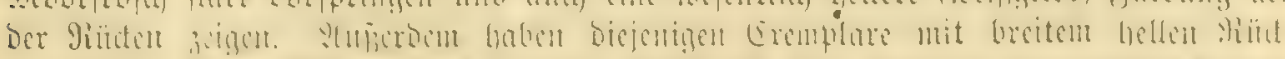

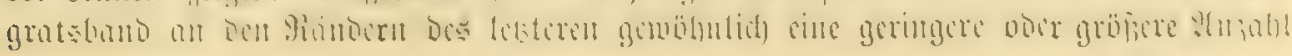




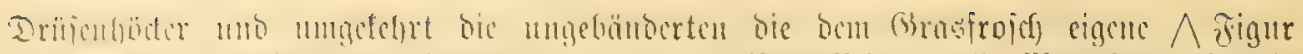

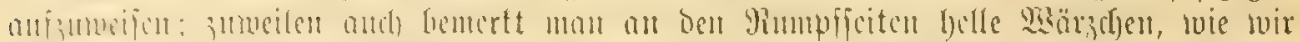

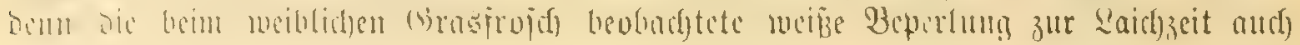
bei arvalis midjt vermiffent.

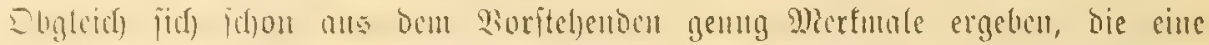

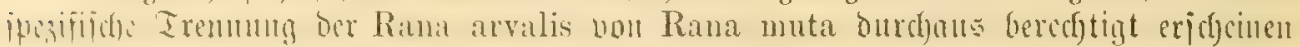

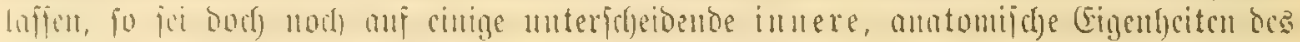

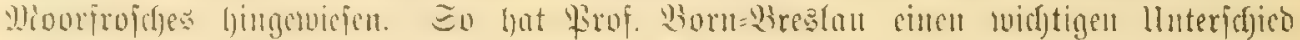

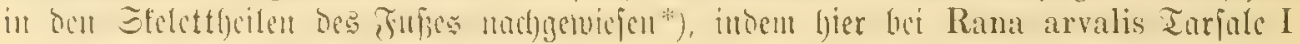

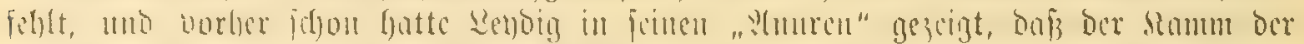

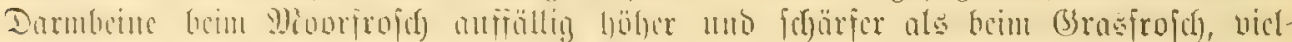

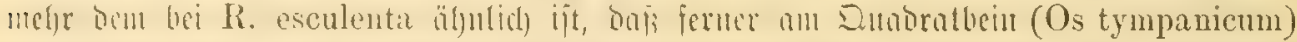

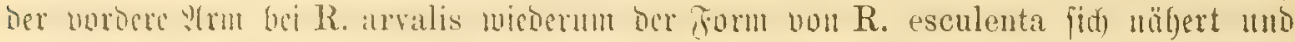

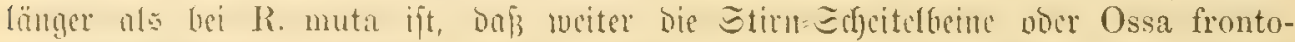

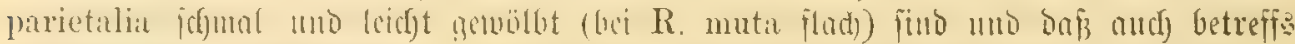

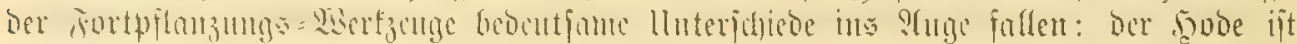

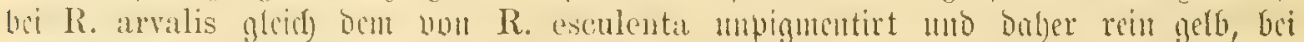

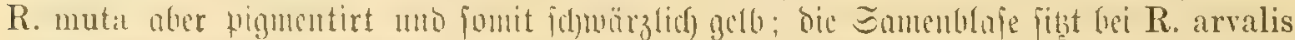

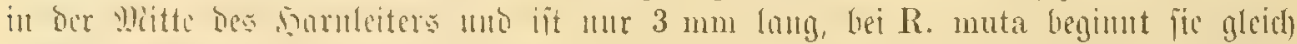

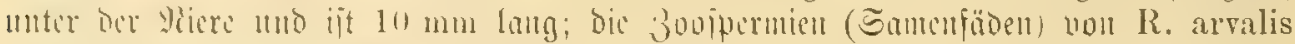

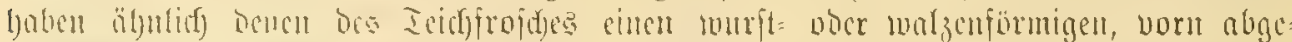

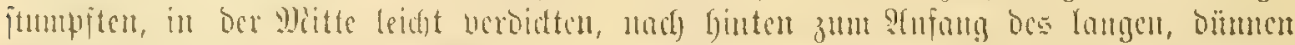

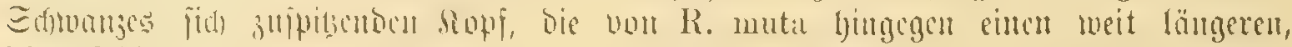

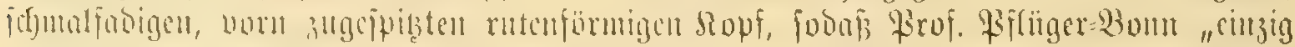

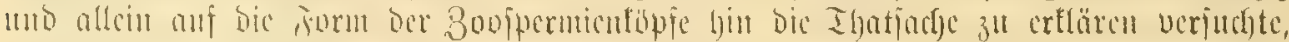

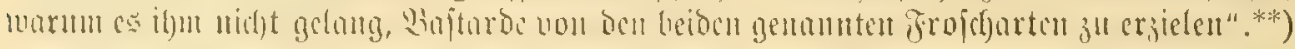

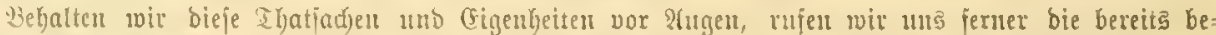

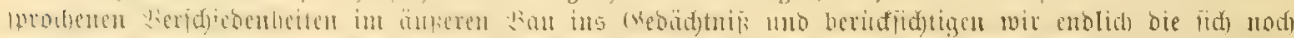

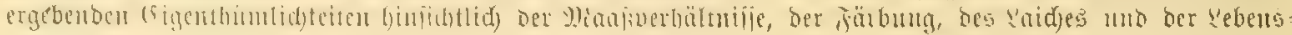

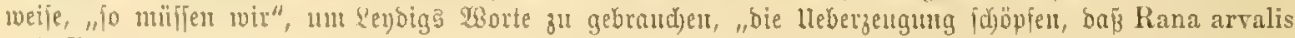

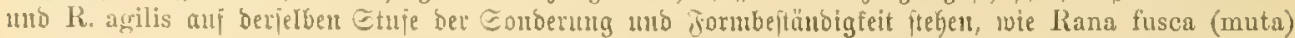
mo R. esculenta", baj aljo jomogr Rana arralis als audj R. agilis bie Bebentung einer vollen Speziez

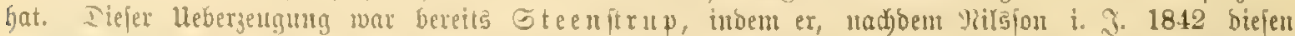

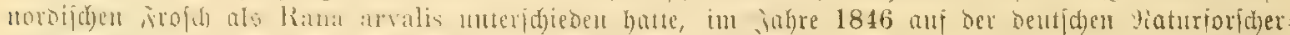

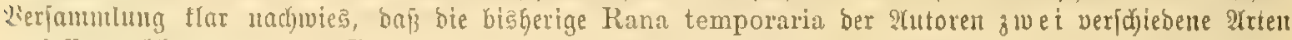

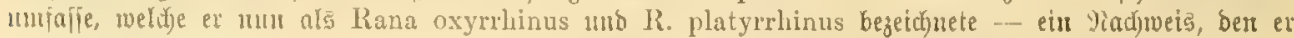

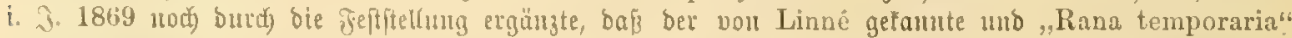

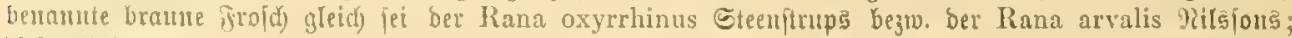

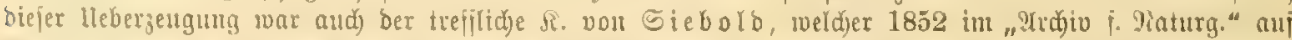

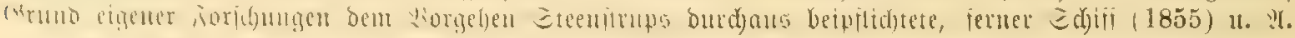

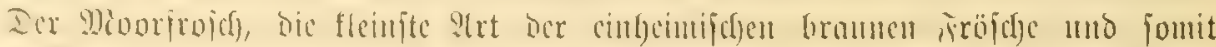

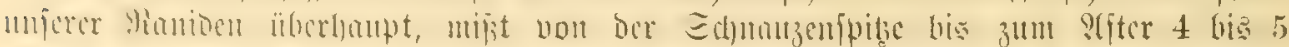

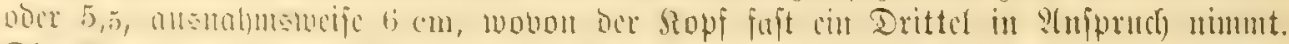

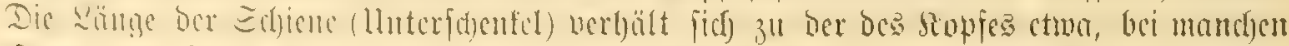

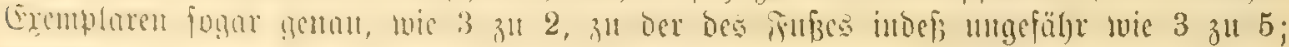

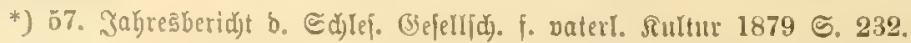

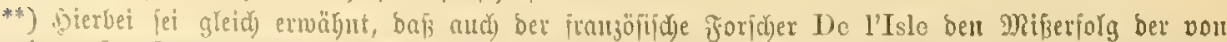

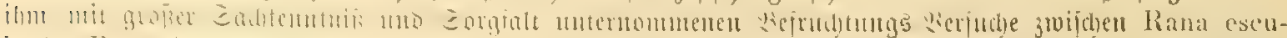

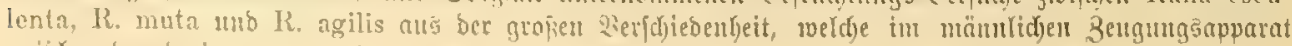
jwidjen ben brei genanuten ?trten beftegt, fid erflärt [Ann. d. sciene. natur. $1872 \mathrm{~N} .17$ ]. 


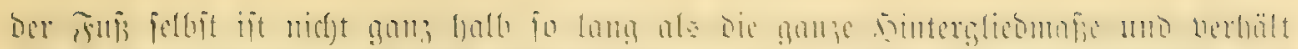

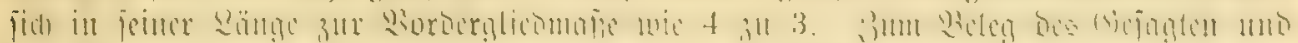

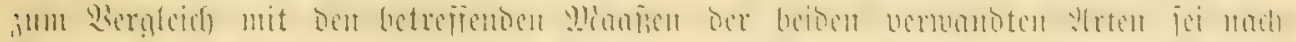

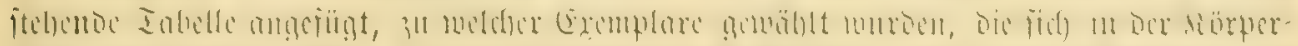

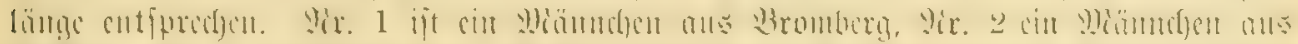

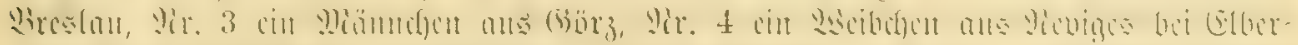

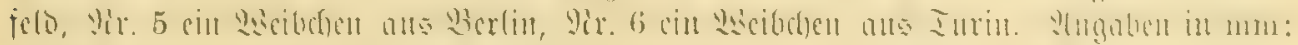

\begin{tabular}{|c|c|c|c|c|c|c|c|c|c|c|}
\hline $\begin{array}{l}\text { Rörver= } \\
\text { lärnge } \\
\text { (tolaf) }\end{array}$ & $\begin{array}{l}\text { Borber= } \\
\text { gliebm. }\end{array}$ & $\begin{array}{l}\text { finter: } \\
\text { glicom. }\end{array}$ & $\begin{array}{l}\text { Scinter= } \\
\text { f11B }\end{array}$ & $\begin{array}{l}\text { Intet: } \\
\text { lfenfet }\end{array}$ & $\begin{array}{l}\text { frop }= \\
\text { tänge }\end{array}$ & $\begin{array}{l}\text { Gröbte } \\
\text { Stopfbr. }\end{array}$ & 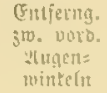 & $\begin{array}{l}\text { ?lugets } \\
\text { surd)m. }\end{array}$ & 6. $3 \mathrm{erge}^{\mathrm{r}}$ & $\begin{array}{l}\text { Jumen: } \\
\text { selle }\end{array}$ \\
\hline 56 & 36 & 100 & 45 & 28 & 17 & 19 & 10 & 5 & 2,9 & 7 \\
\hline 56 & 34 & 101 & 44 & 28 & 16,3 & 18 & $T_{1 .}$ & 5,5 & 3,8 & ij \\
\hline 56 & 35 & 105 & 46 & 36 & 19 & 20 & $9^{\prime \prime}$ & 5,5 & 2,0 & (i) \\
\hline 47 & 30 & 83 & 38 & 23 & 16 & 17 & 8,5 & 5 & 2,2 & 6 \\
\hline 47 & 28 & 87 & 38 & 21 & 15 & 16,5 & 7 & 4,5 & 3, & $5_{15}$ \\
\hline 47 & 28 & 93 & $39^{\circ}$ & 30 & 16 & 17 & 7,5 & 4,8 & 2,5 & 5,5 \\
\hline
\end{tabular}

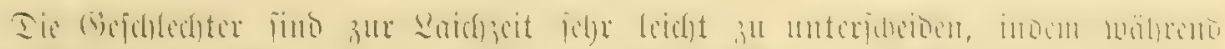

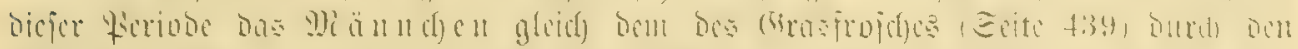

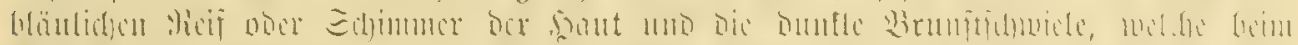

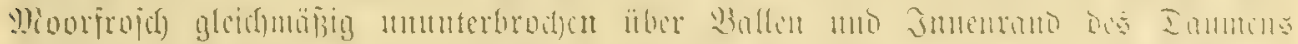

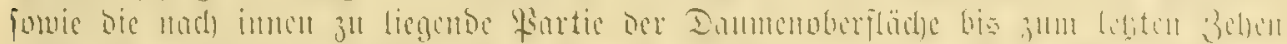

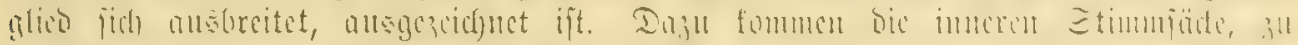

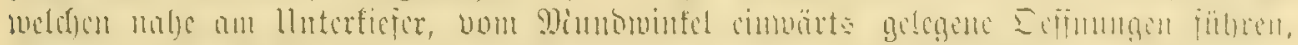

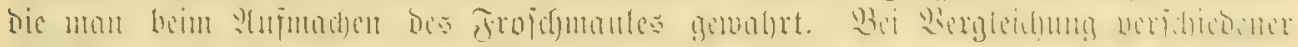

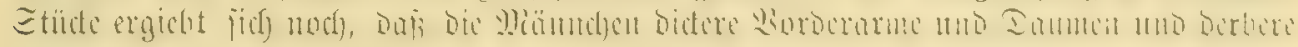

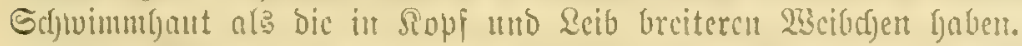

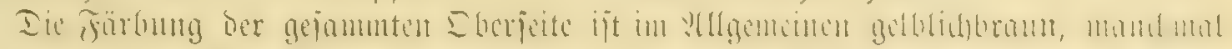

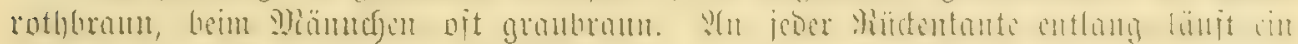

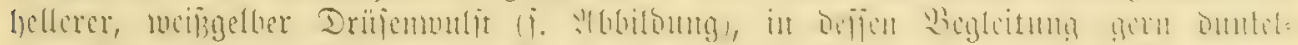

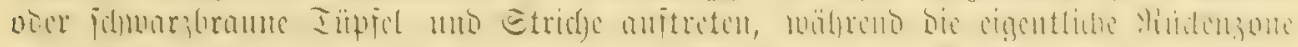

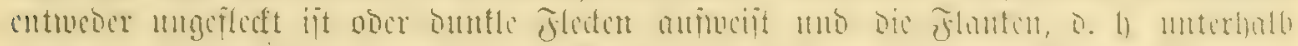

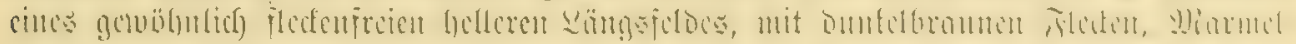

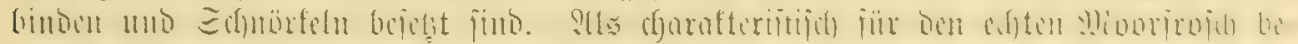

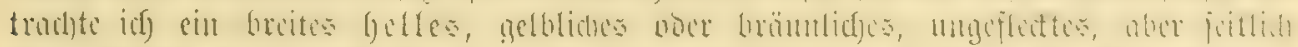

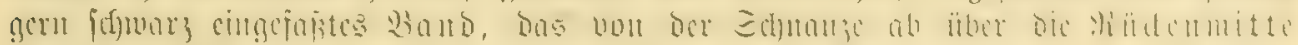

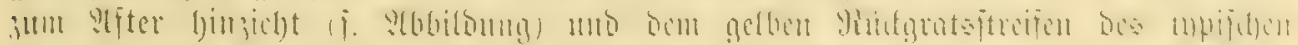

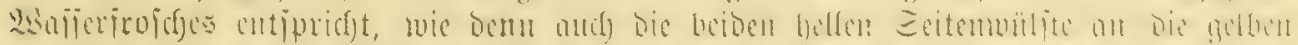

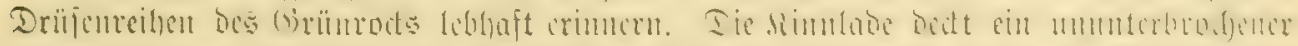

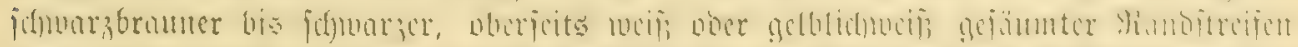

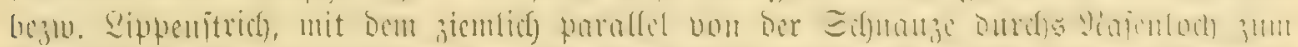

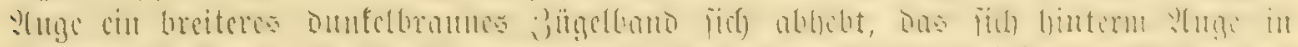

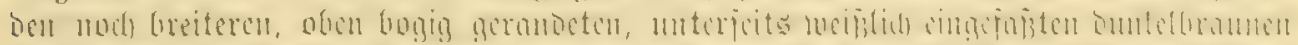

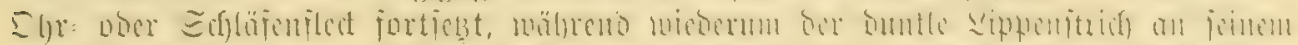

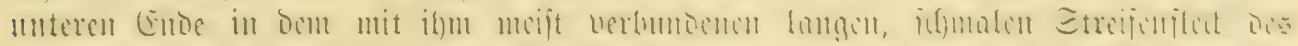

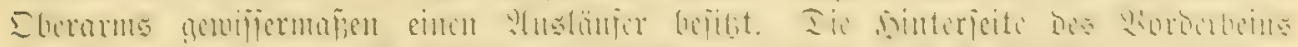

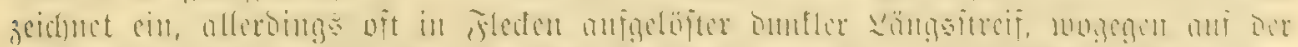

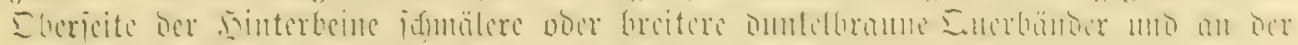

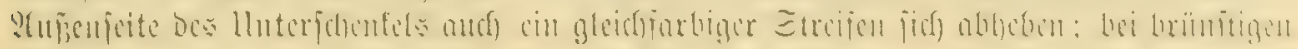

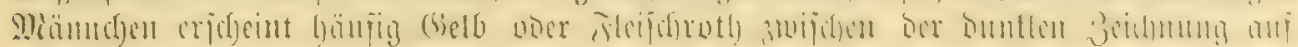




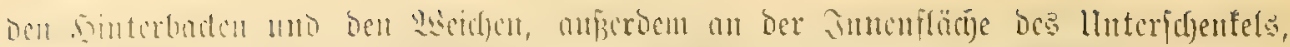

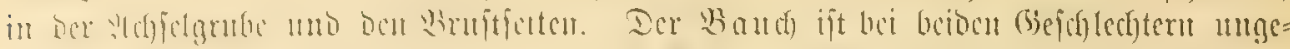

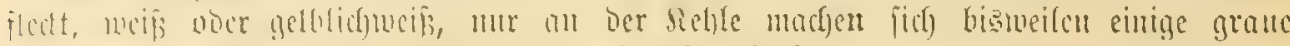

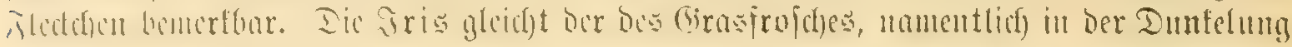
ber linteren Sälffte.

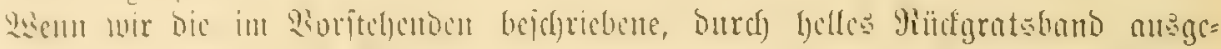

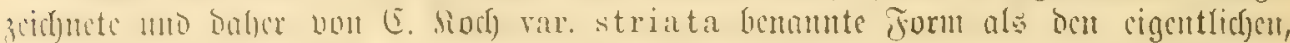

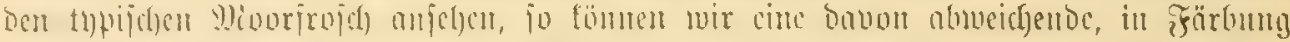

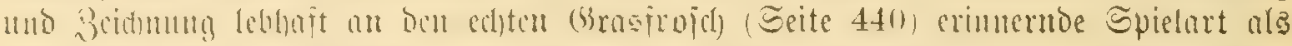

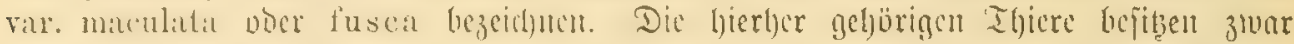

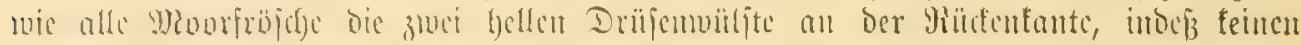

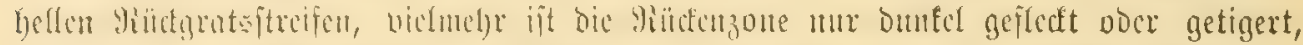

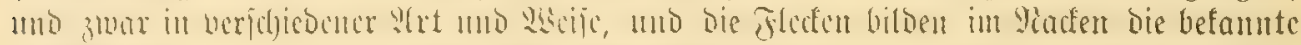

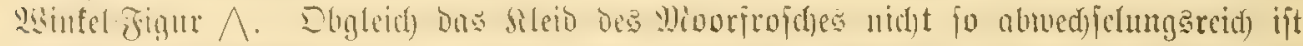

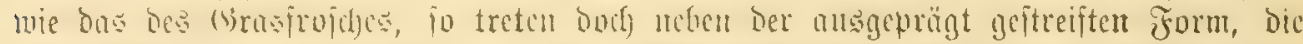

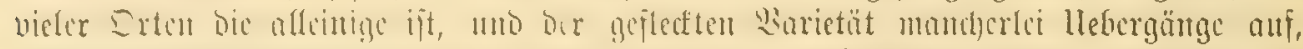

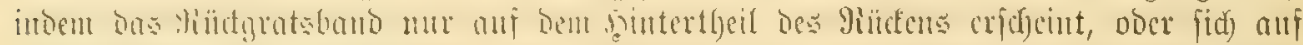

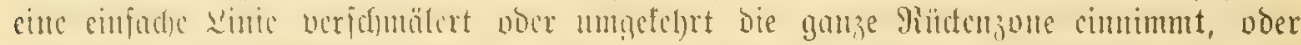

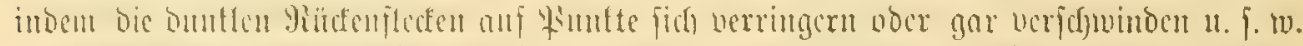

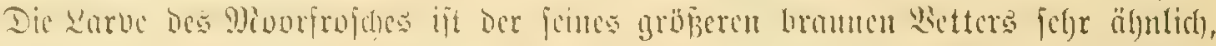

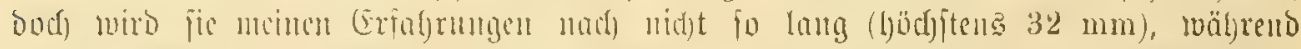

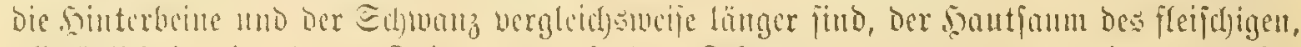

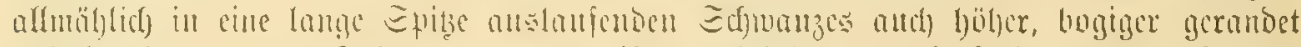

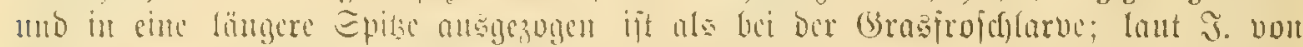

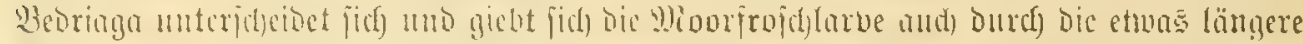

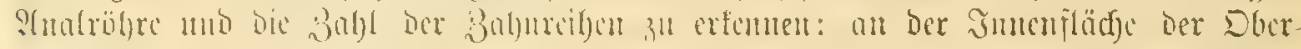

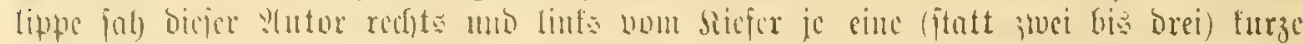

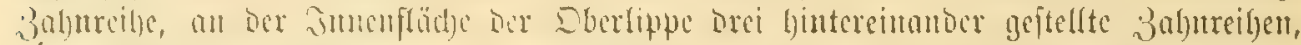

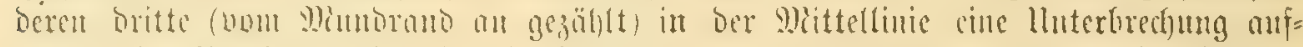

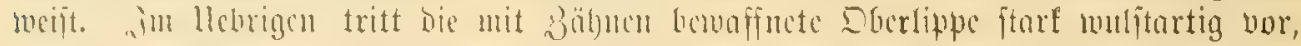

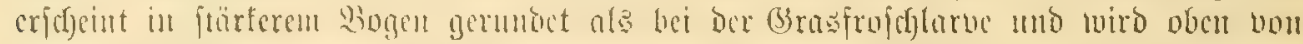

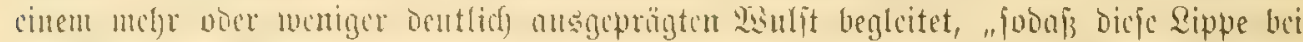

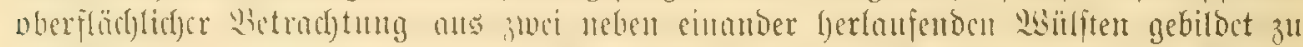

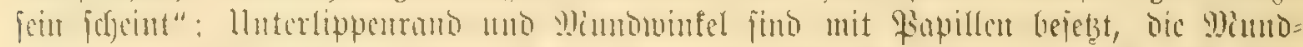

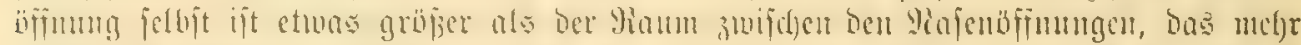

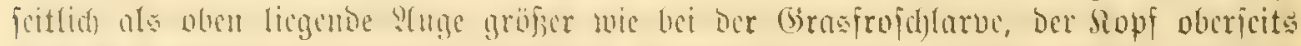

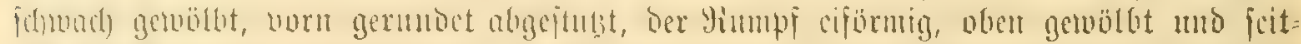

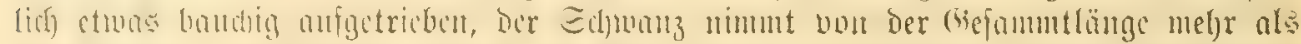

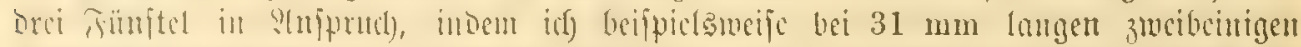

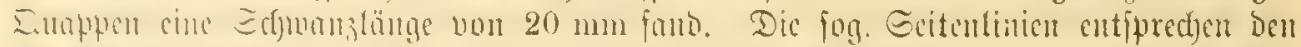

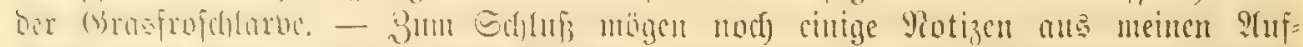

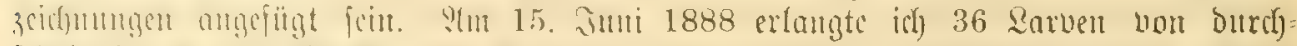

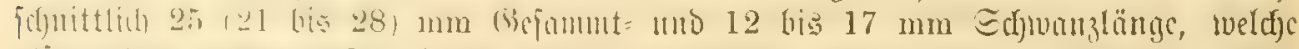

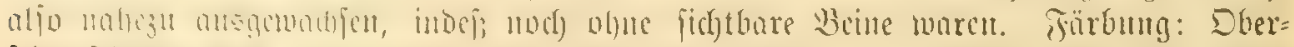

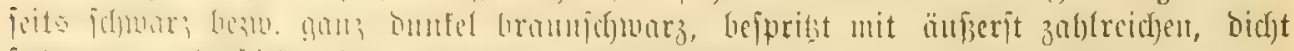

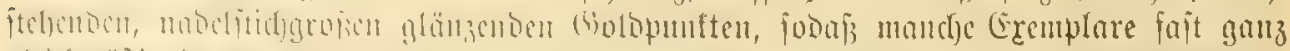

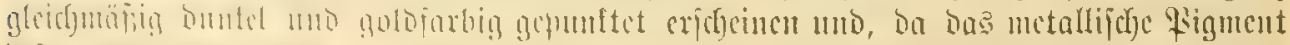

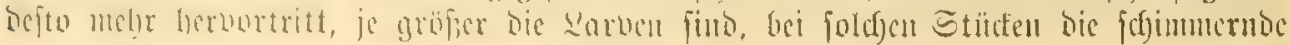




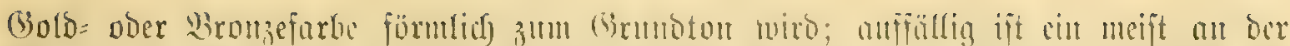

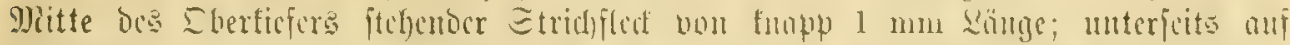

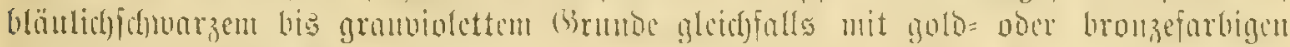

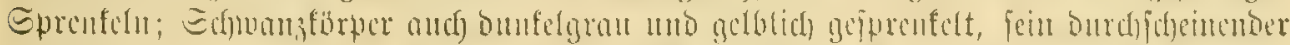

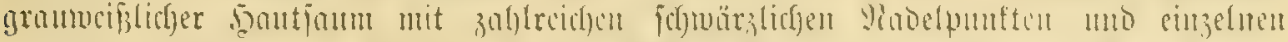

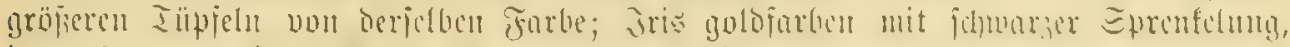

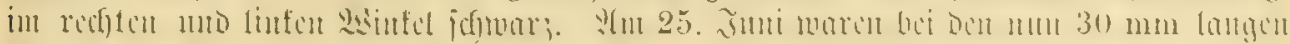

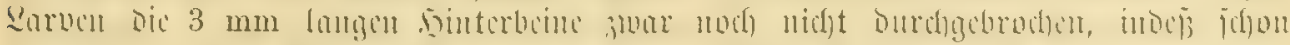

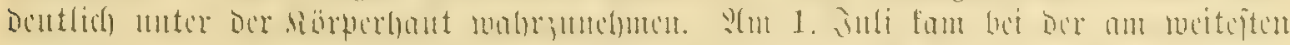

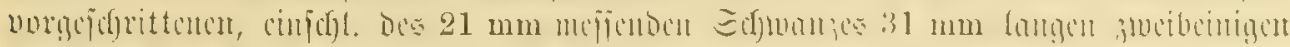

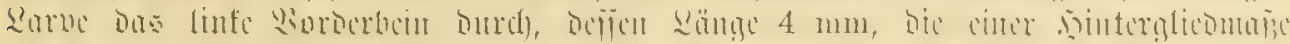

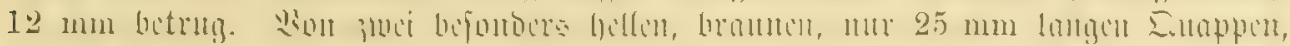

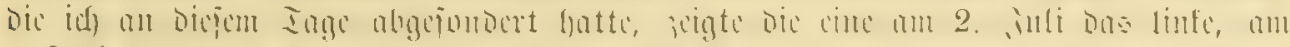

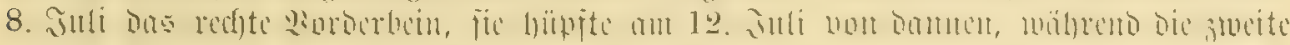

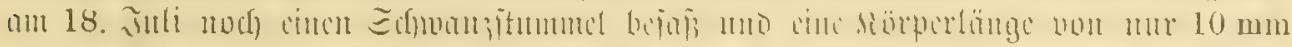

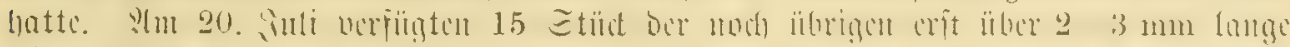

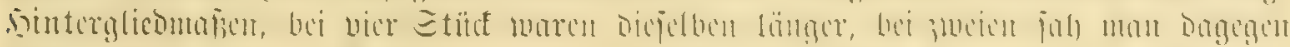

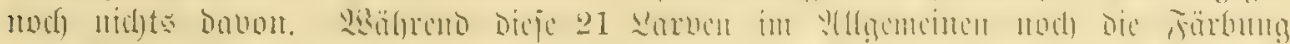

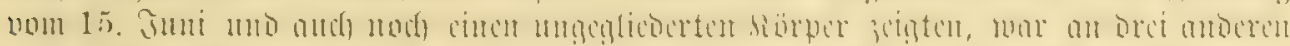

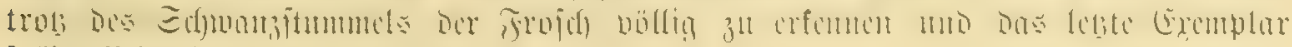
itellte fich it berbaut als fertiges

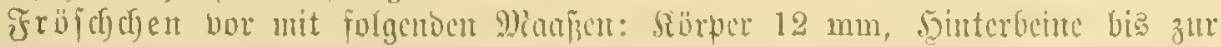

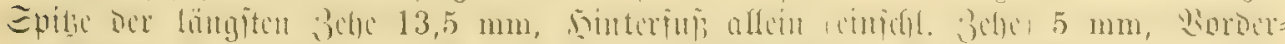

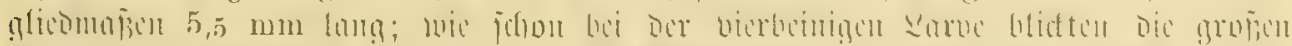

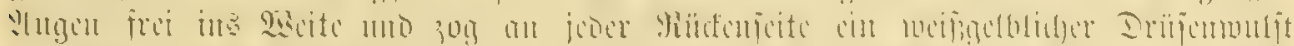
1)

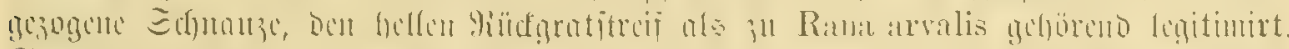

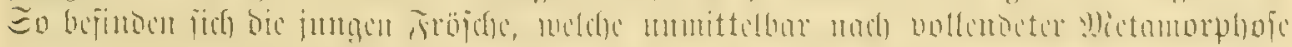

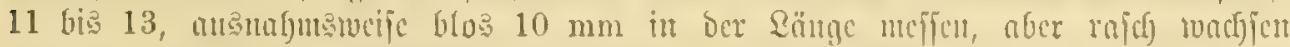

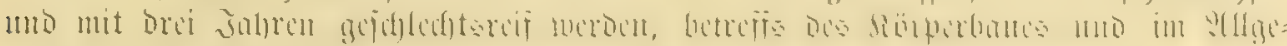

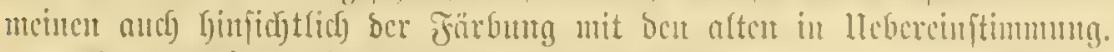

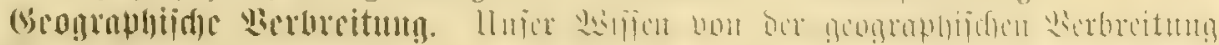

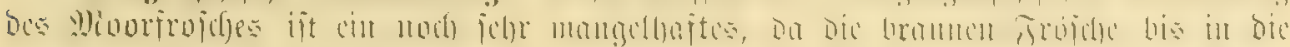

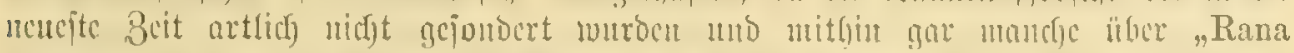

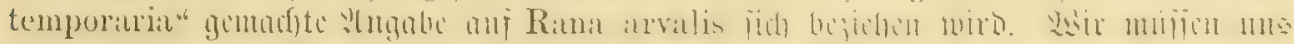

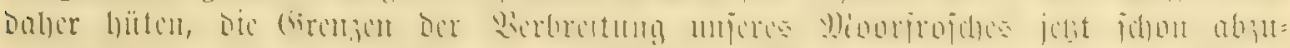

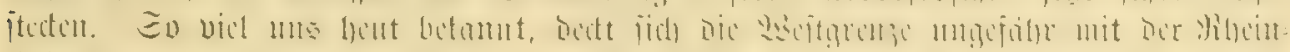

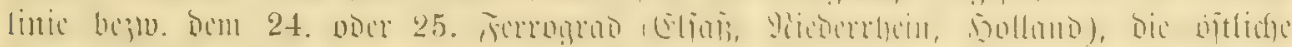

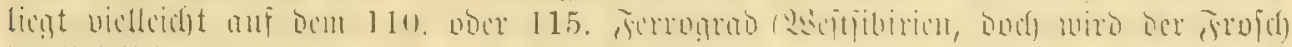

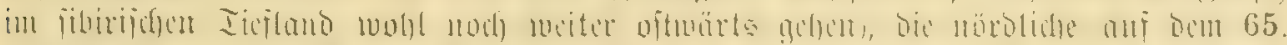

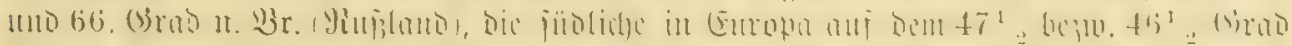

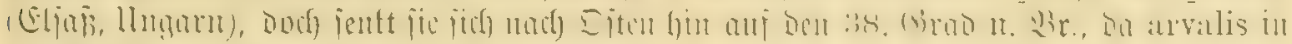

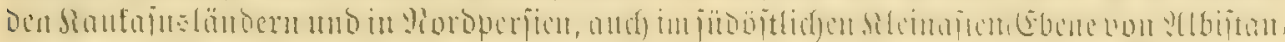

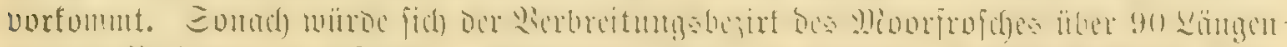

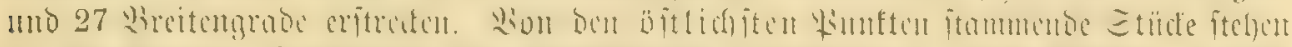

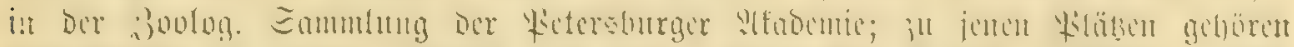

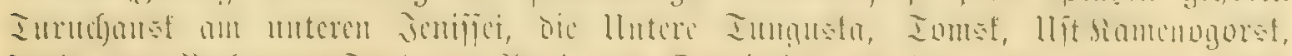

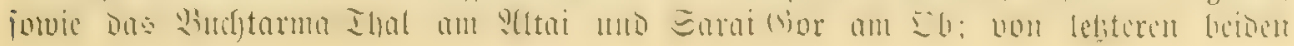




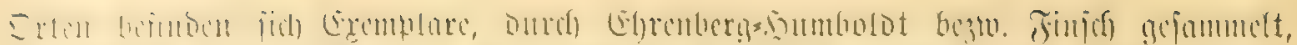

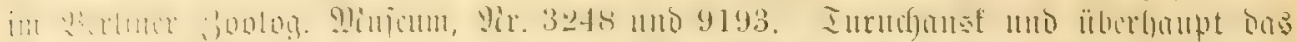

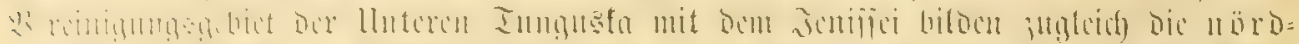

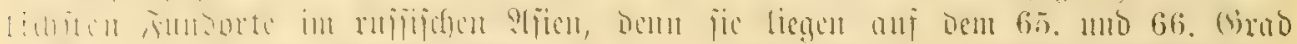

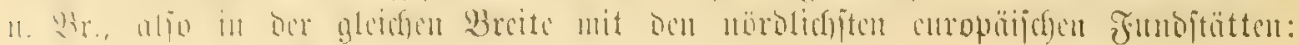
D)eicn, 9trdyangel, Muffifd Sapplanto [Riljeborg].

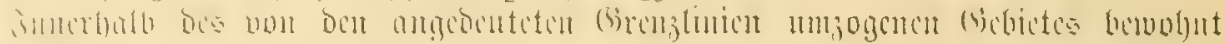

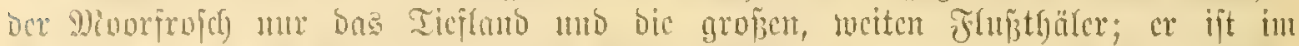

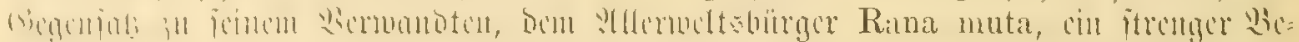

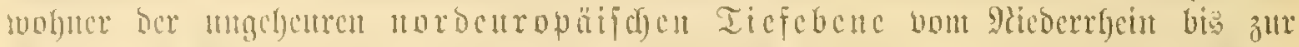

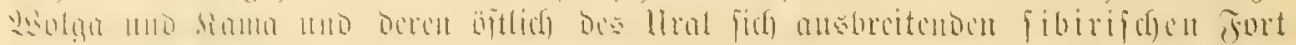

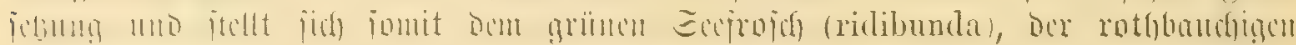

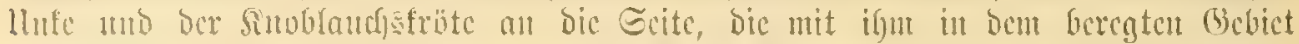

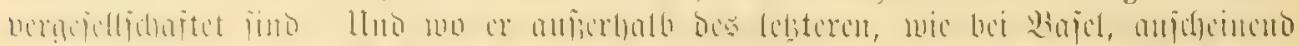

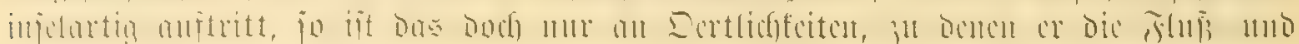

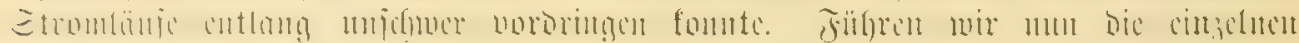
Jumborte ant.

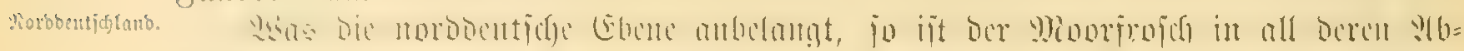

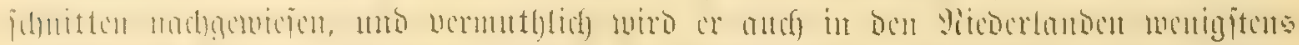

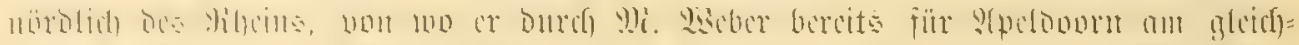

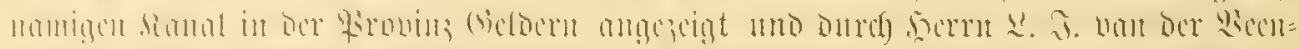

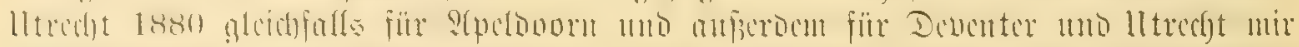

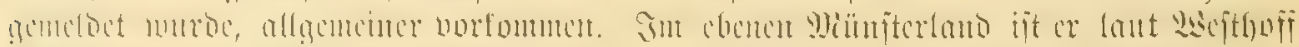

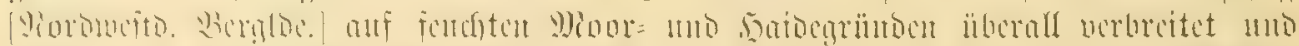

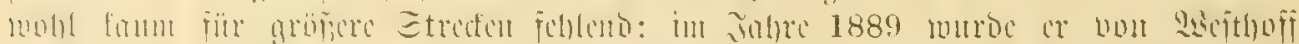

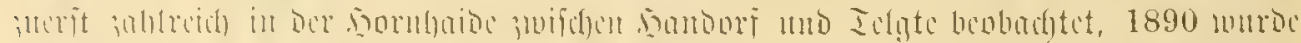

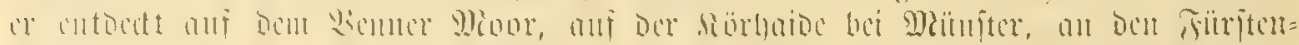

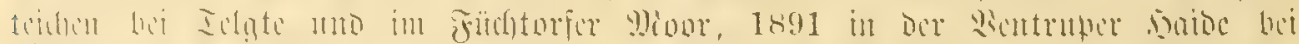

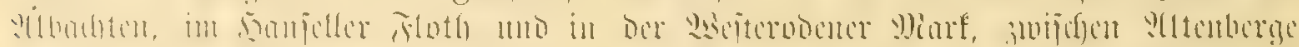

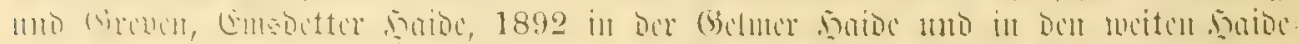

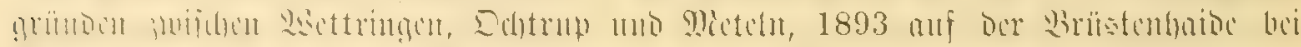

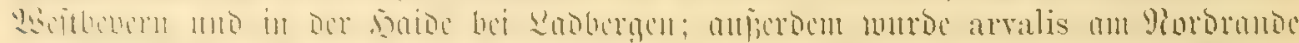

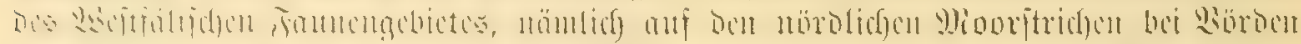

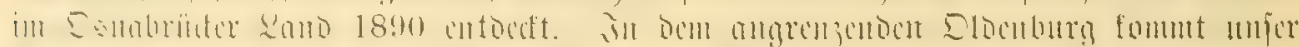

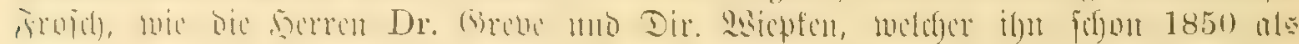

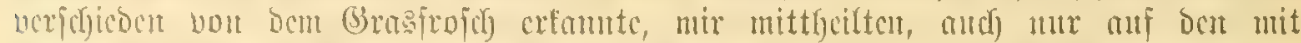

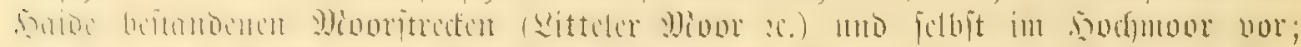

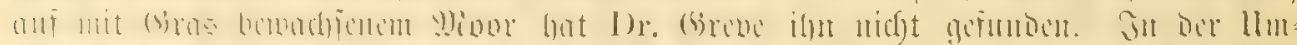

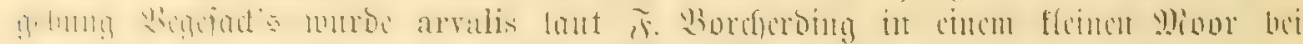

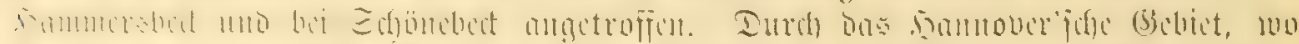

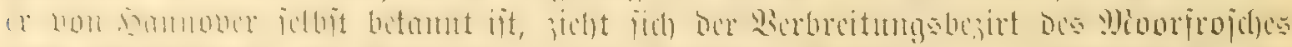

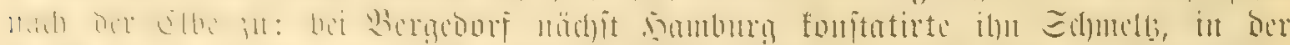

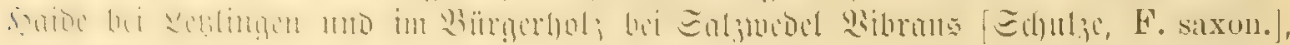

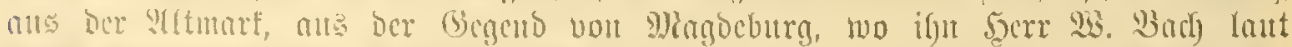

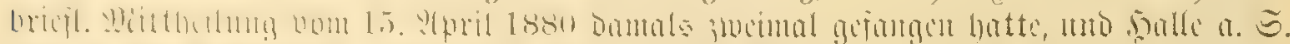

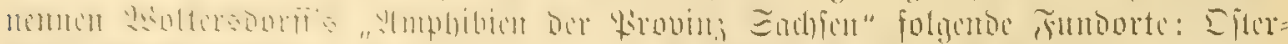

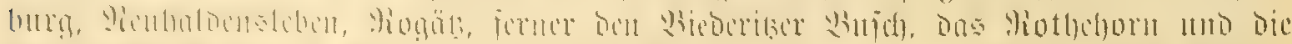

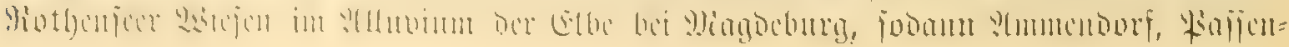




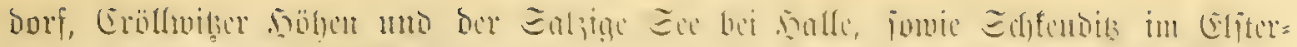

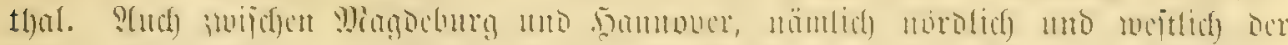

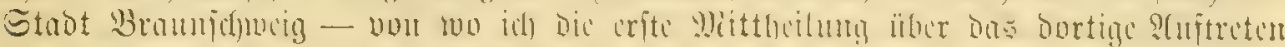

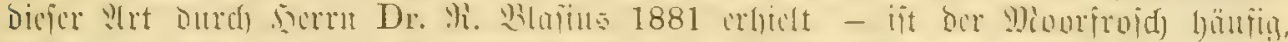

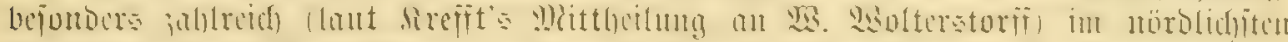

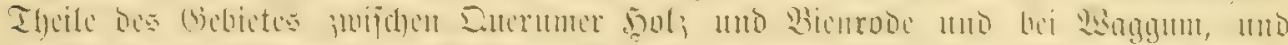

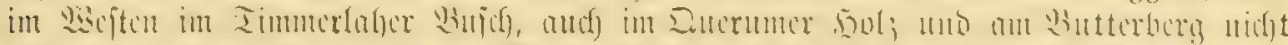

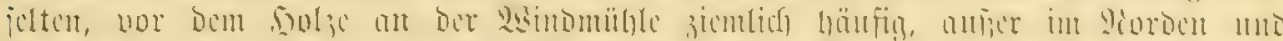

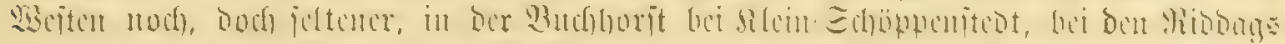

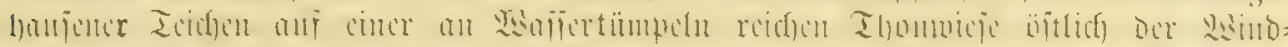

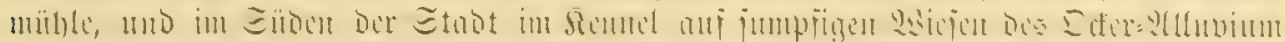

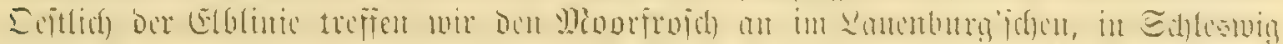

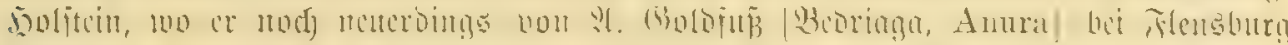

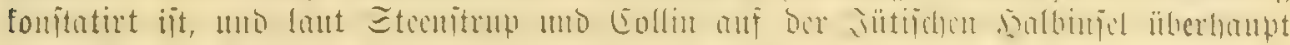

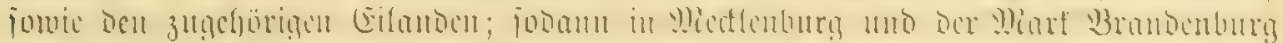

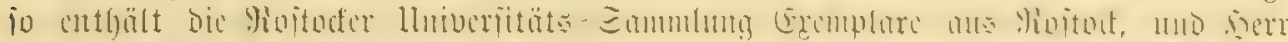

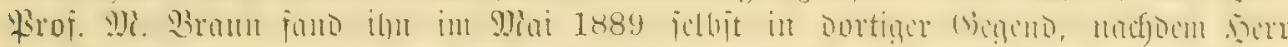

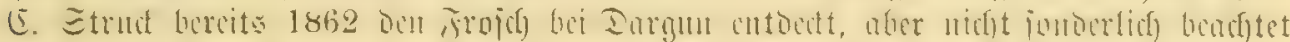

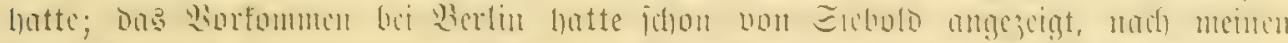

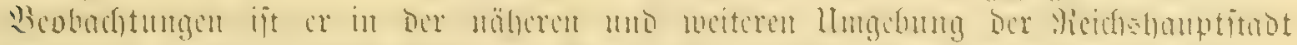

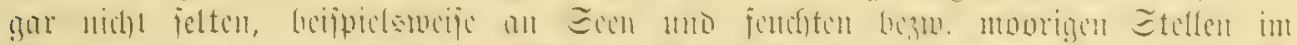

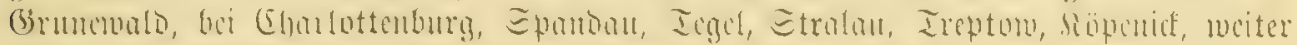

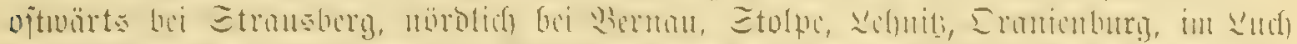

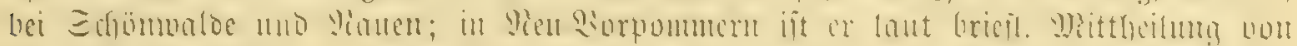

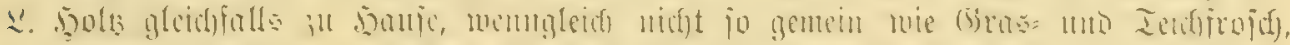

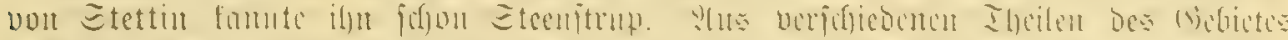

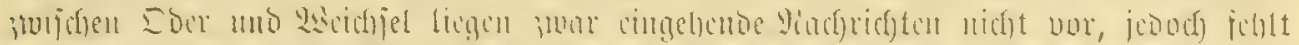

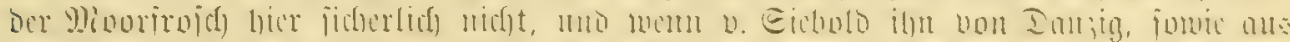

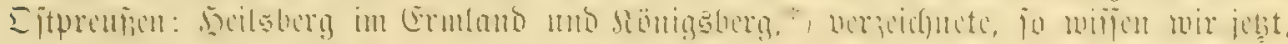

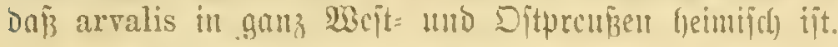

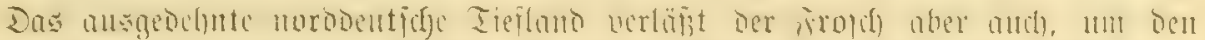

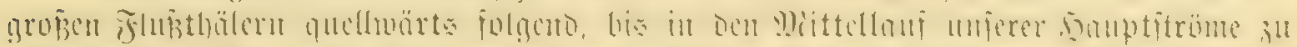

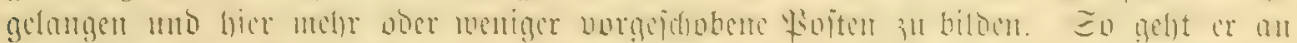

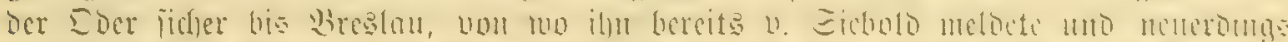

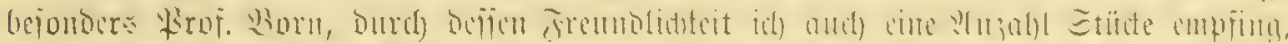

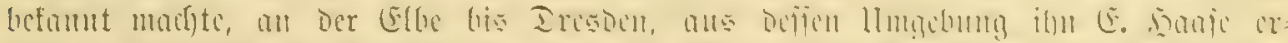

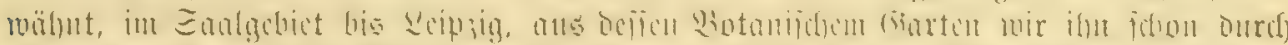

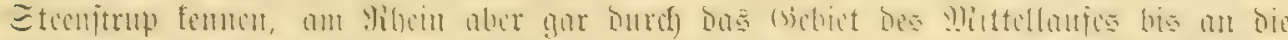

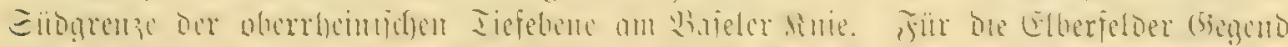

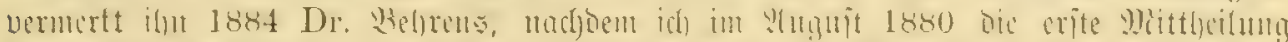

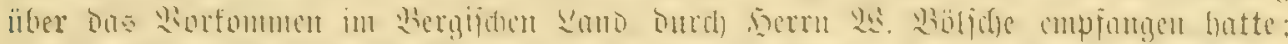

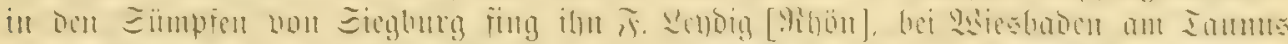

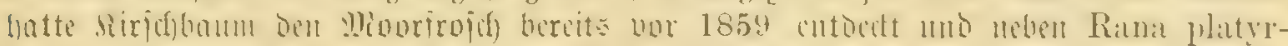

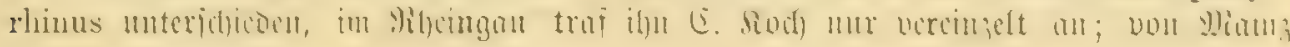

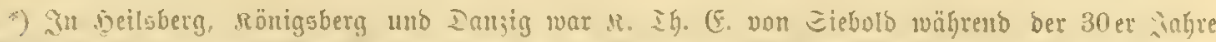

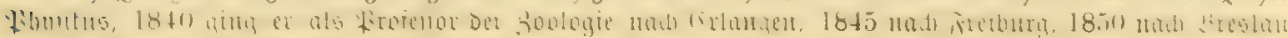

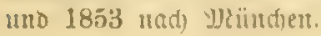




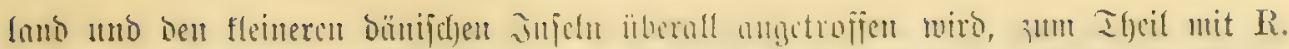

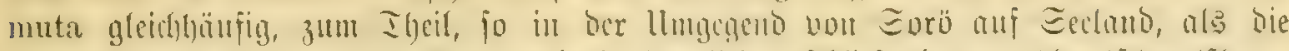

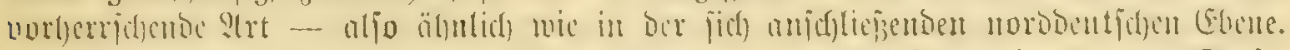

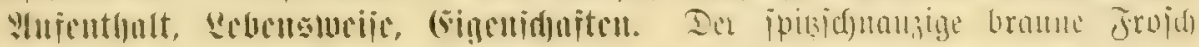

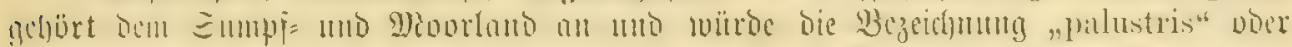

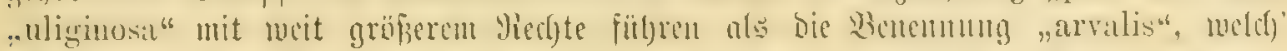

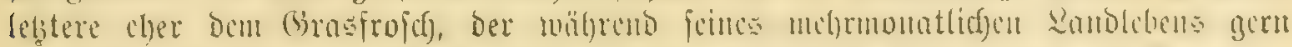

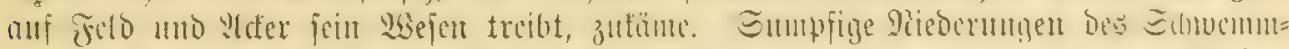

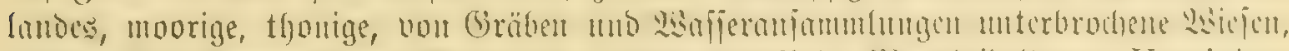

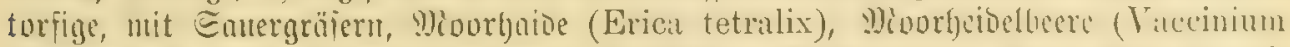

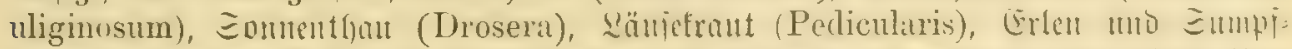

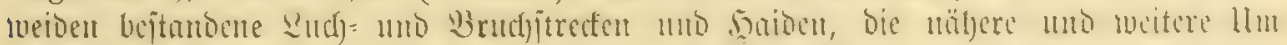

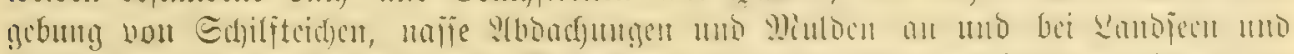

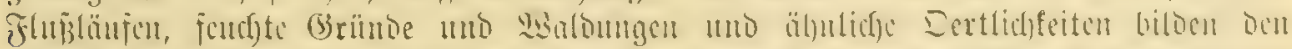

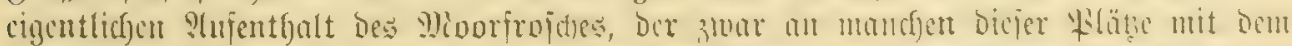

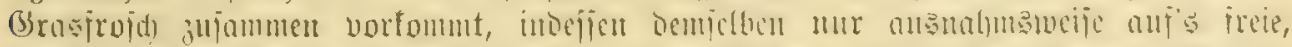

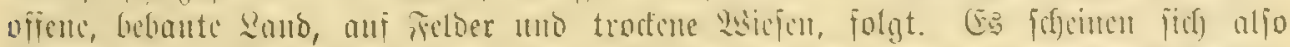

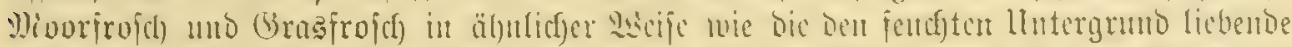

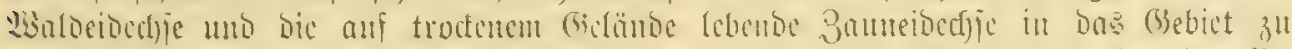

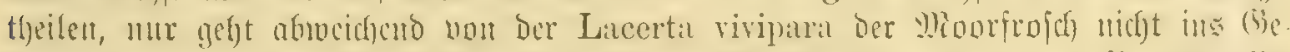

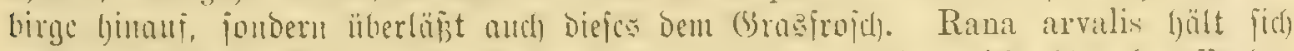

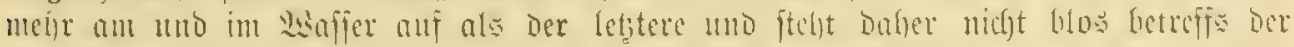

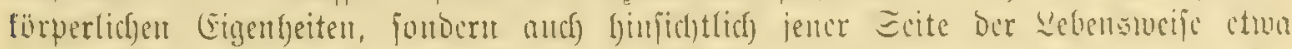

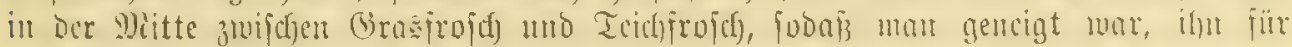
eine Bajtardjorm biejer beidon Irten anzujelen.

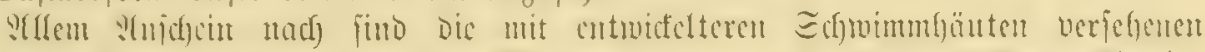

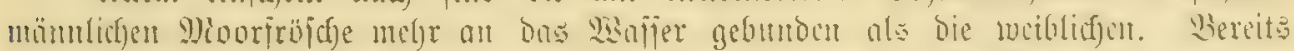

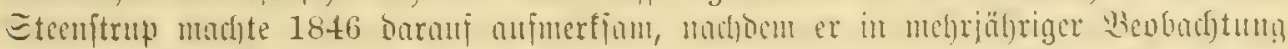

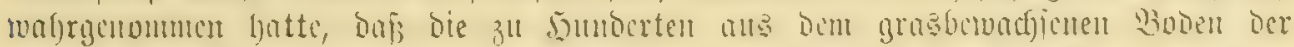

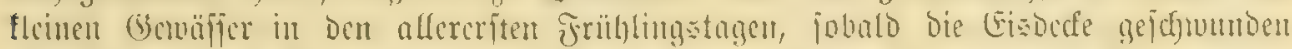

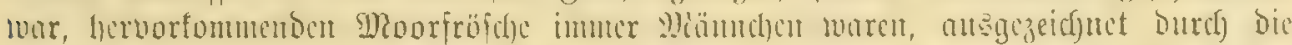

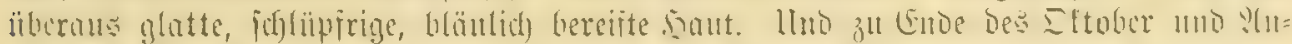

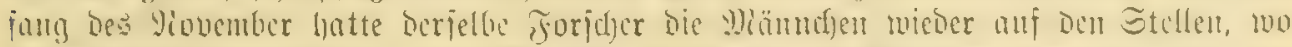

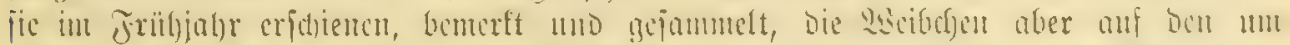

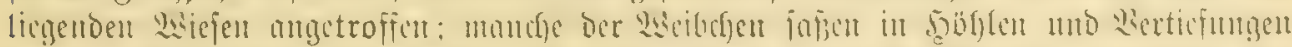

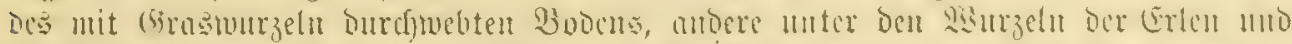

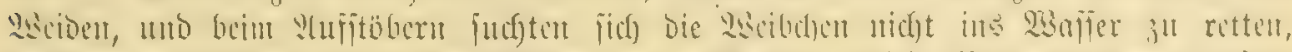

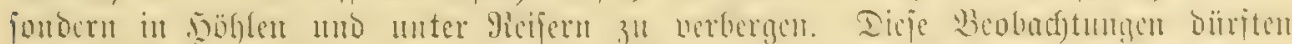

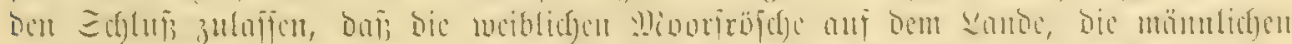

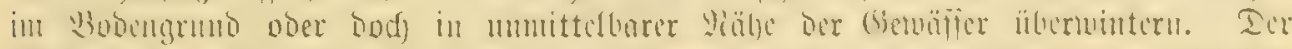

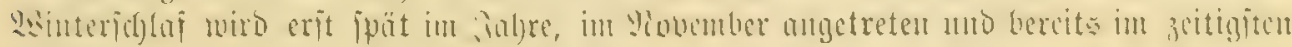
Jrübingr, im Jebruar obcr Miärz, Geendet.

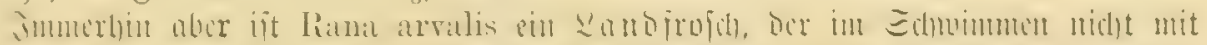

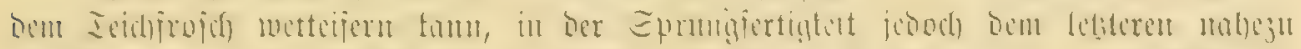

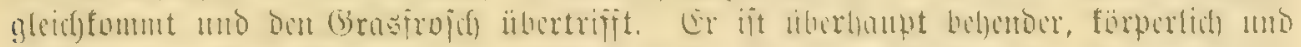

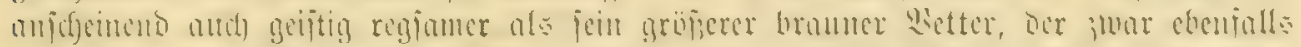

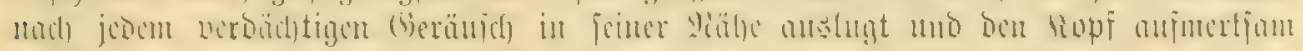

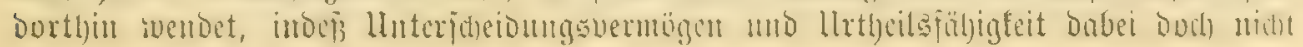




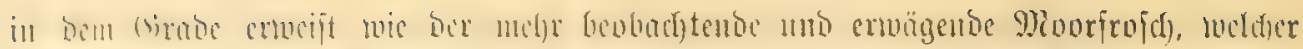

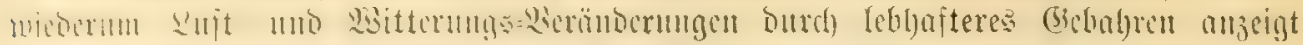

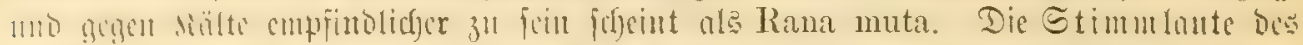

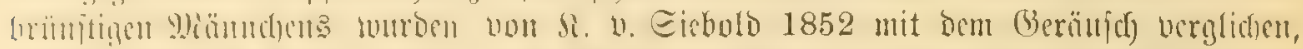

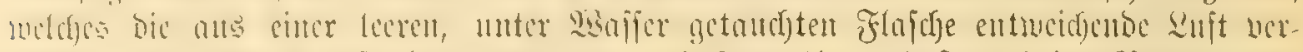

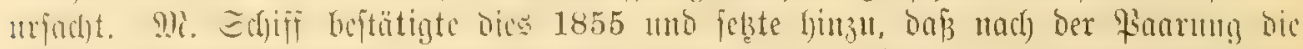

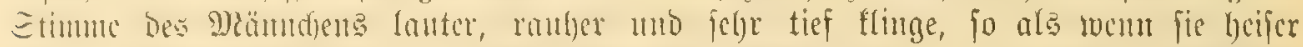

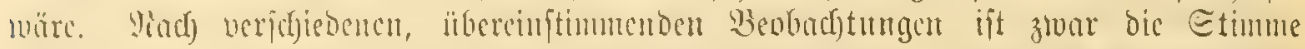

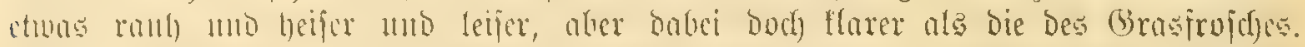

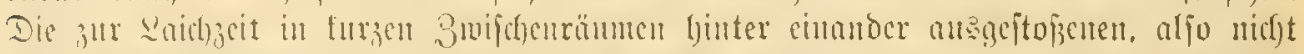

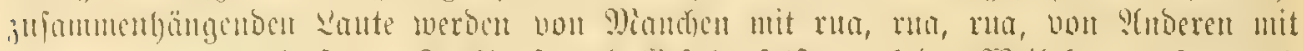

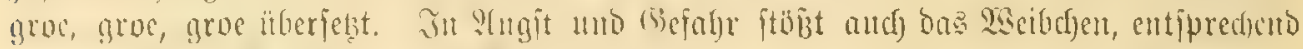

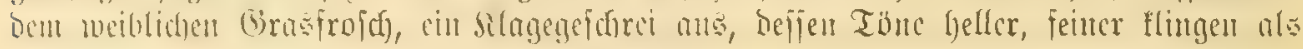

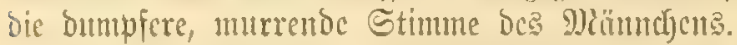

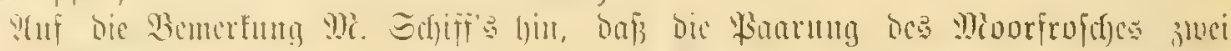

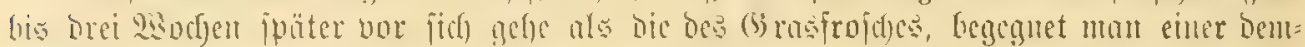

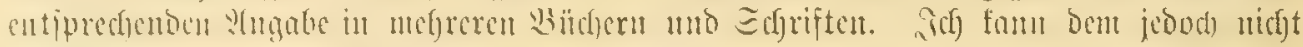

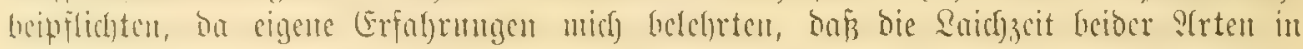

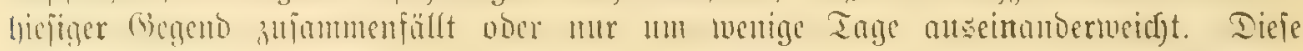

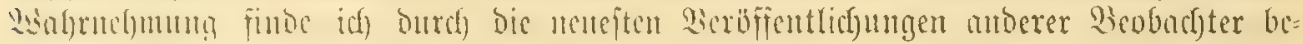

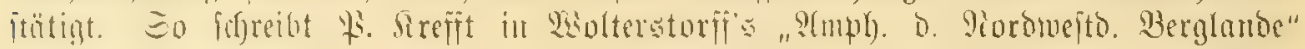

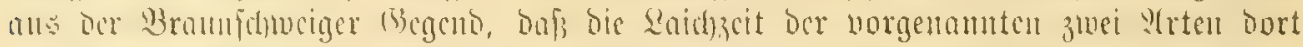

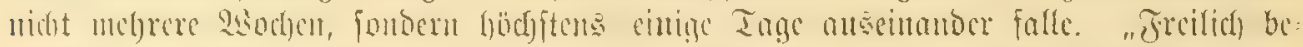

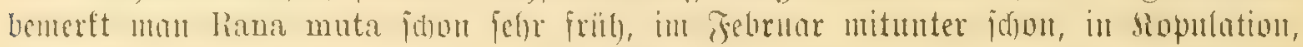

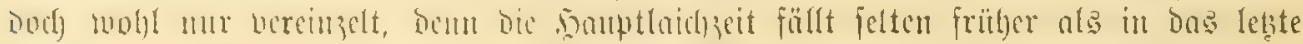

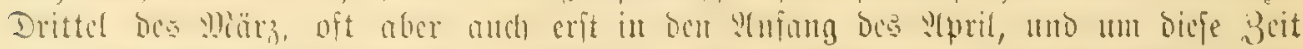

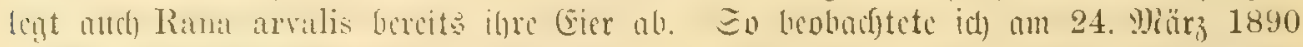

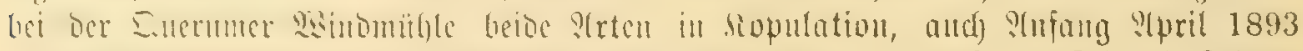

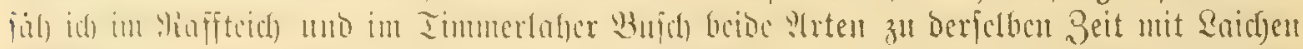

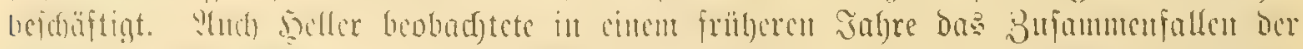

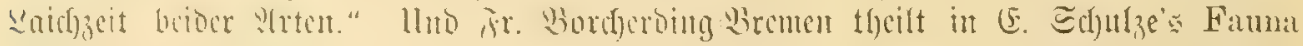

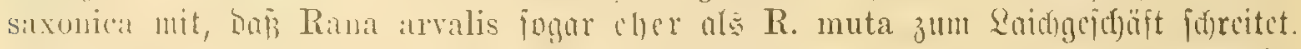

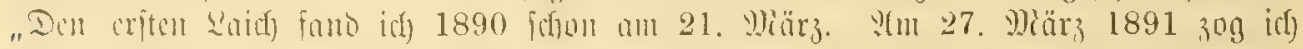

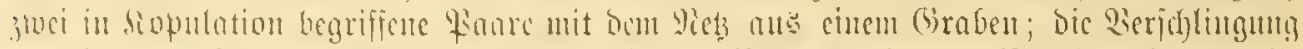

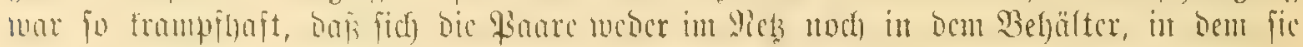
แad) Scatte gebradjt tourocn, uod in Spiritus trennten."

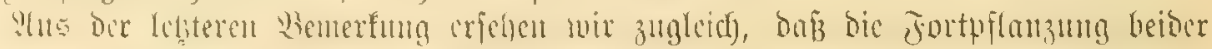

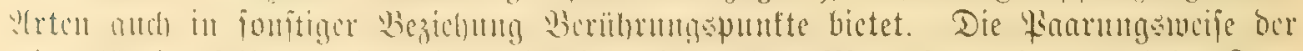

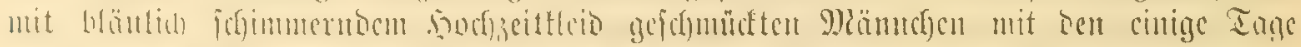

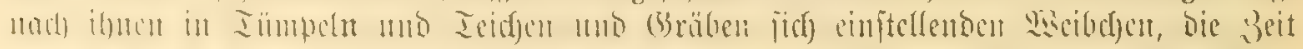

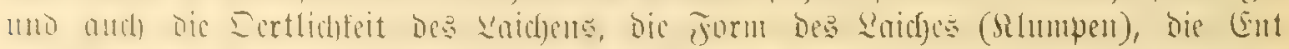

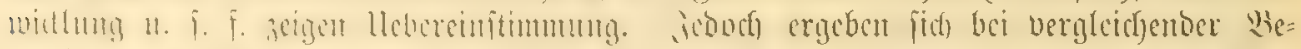

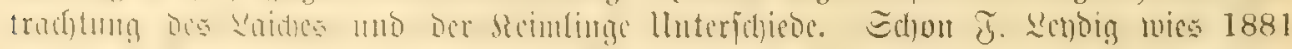

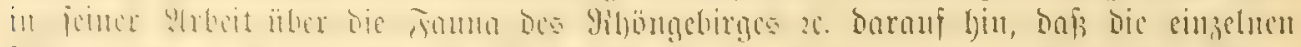

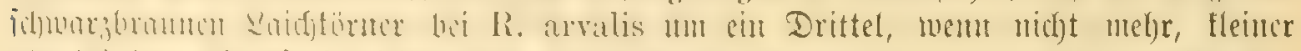

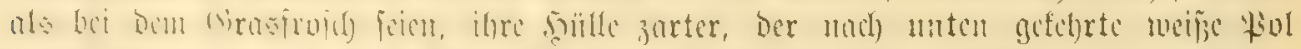

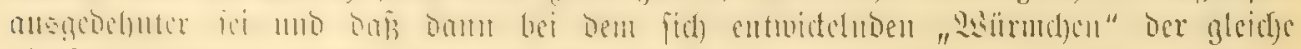

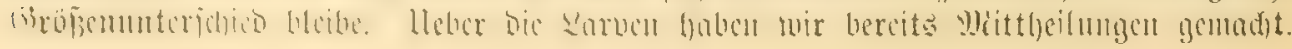




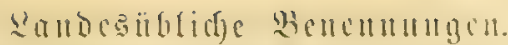

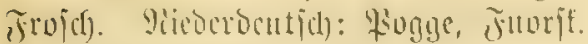

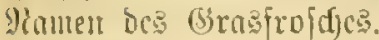

Rana temporaria, Jimué 1761 (non autorum!). - Rana arvalis, Nilsson 1842. - Rana oxyrrhinus, Steenstrup 1846.

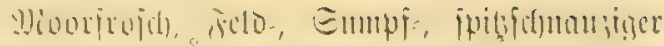

\section{Irt: Springfrof(5). Rana agilis, Thomas.}

9bbildurg: Tnjel III 9R. 2.

Eänge 5,5 bis $7 \mathrm{~cm}$; Sthuang Iang, am Ende rundlidg:fpits, nit vorge

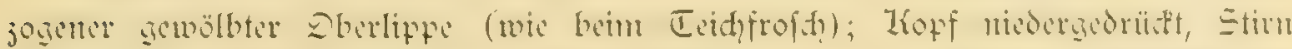

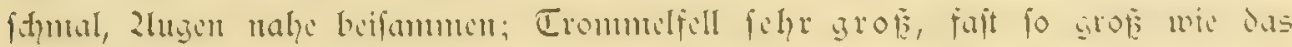

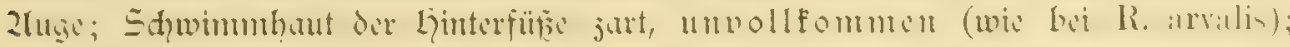

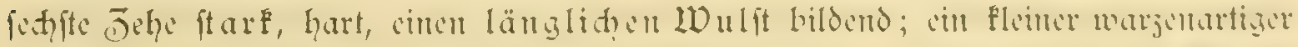

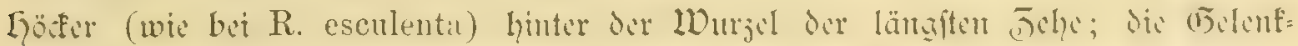

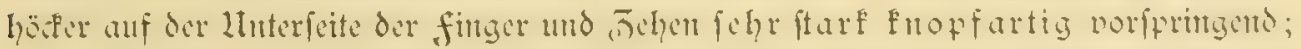

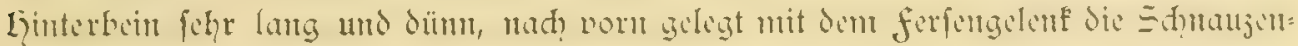

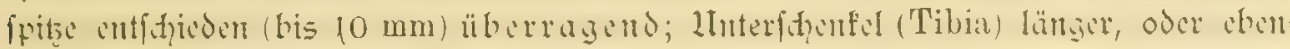

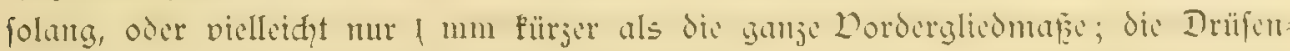

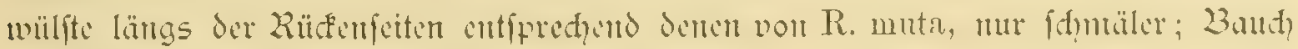
ungefledt; 2hännhen ohne jede Shallblafen.

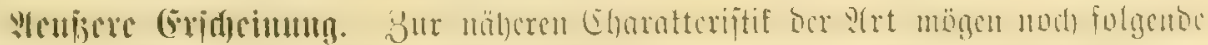

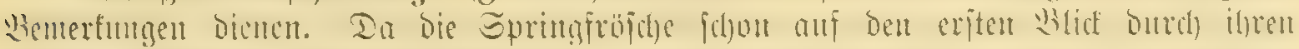

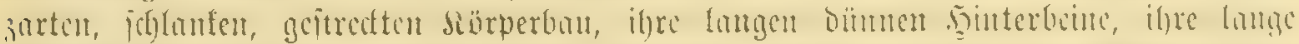

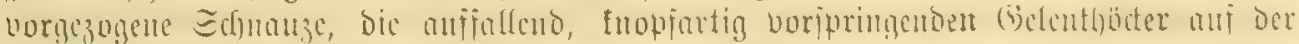

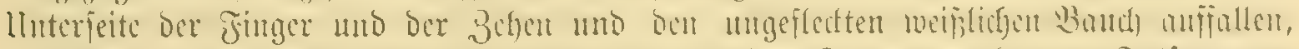

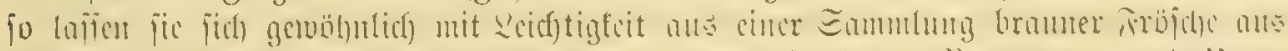

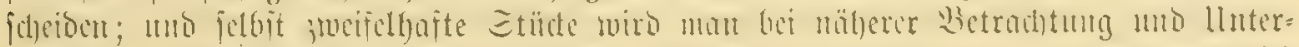

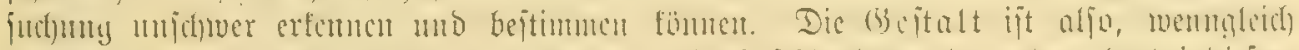

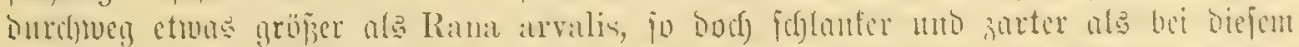

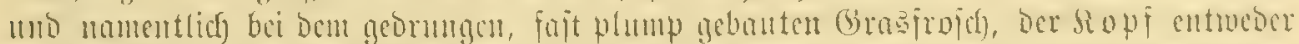

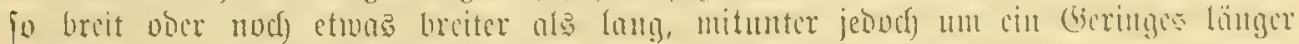

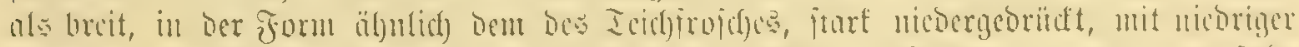

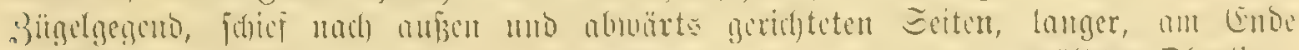

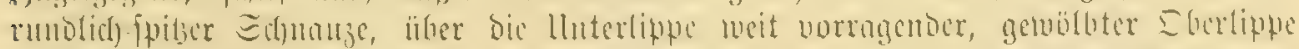

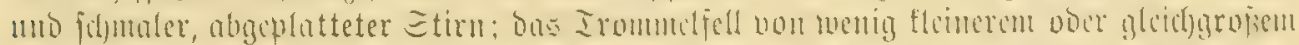

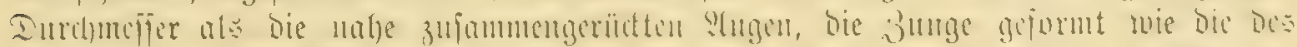

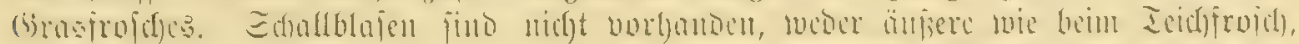

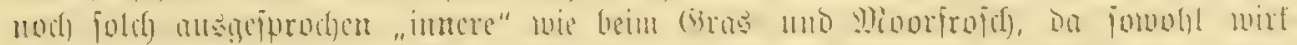

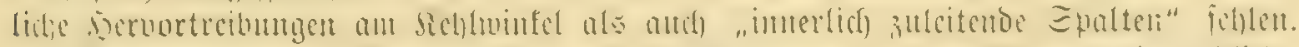

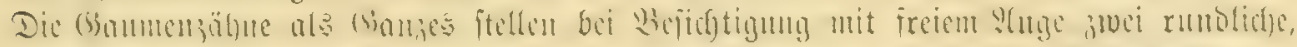

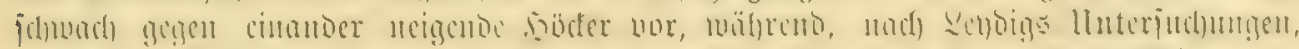

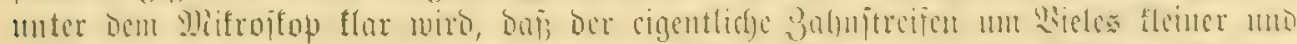

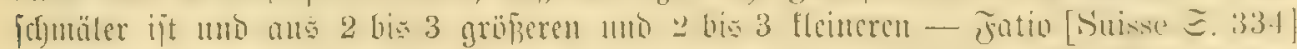

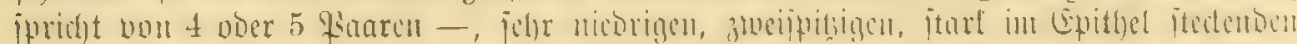

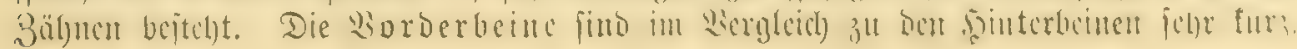




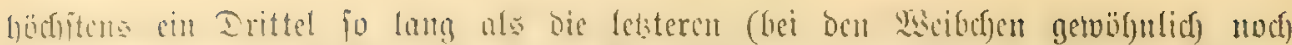

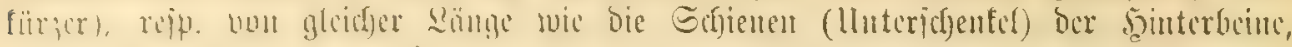

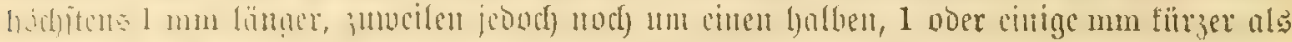

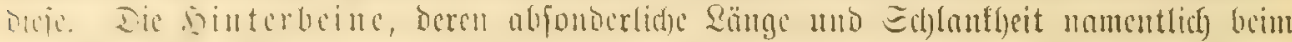

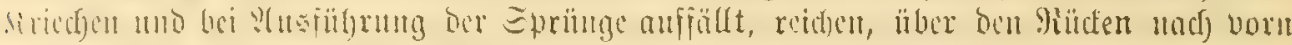

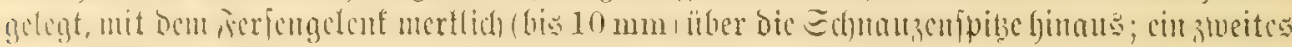

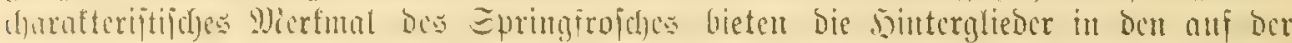

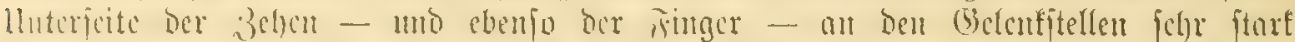

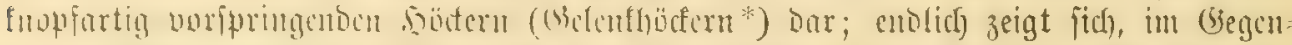

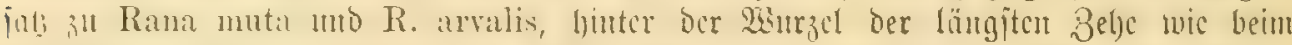

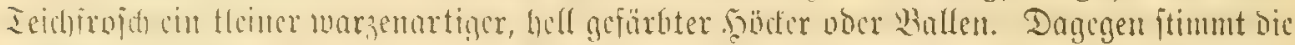

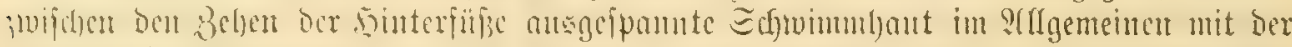

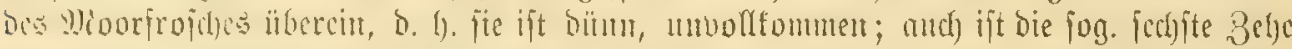

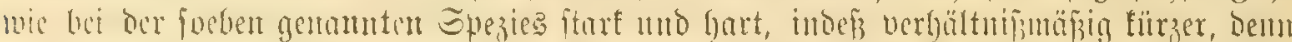

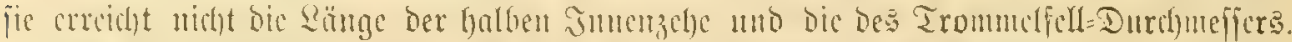

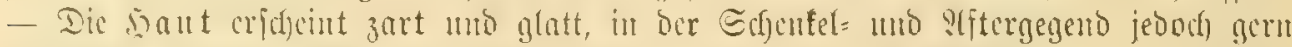

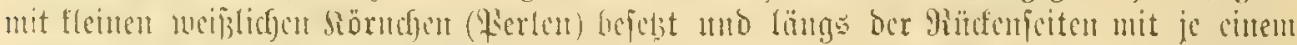

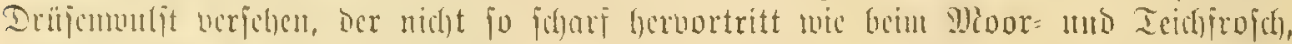

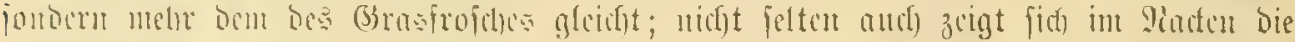

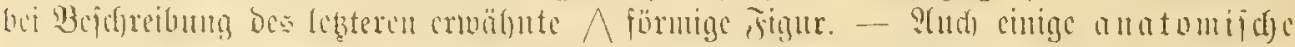

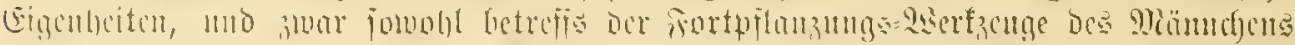

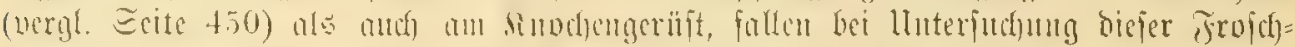

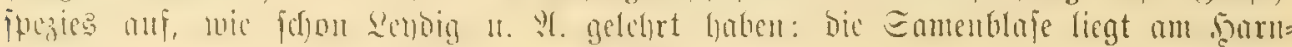

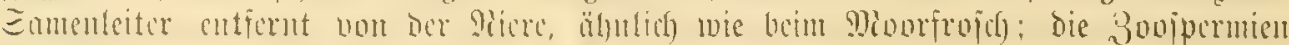

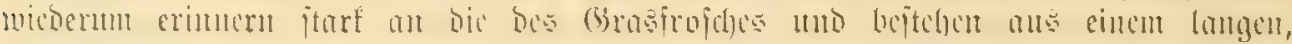

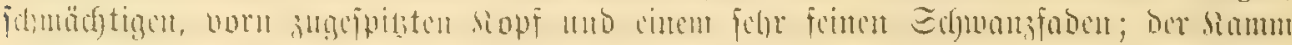

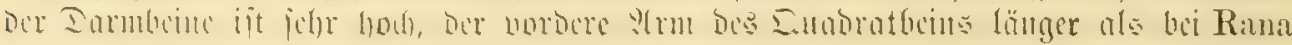

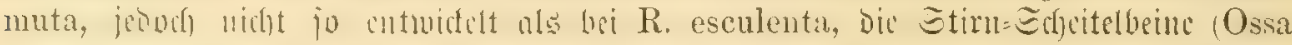

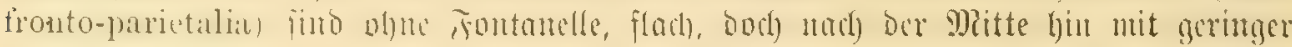

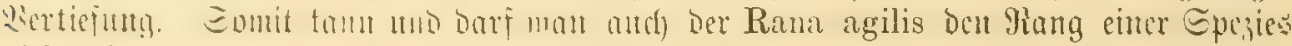
uicht abjpredjeut.

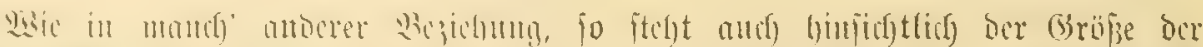

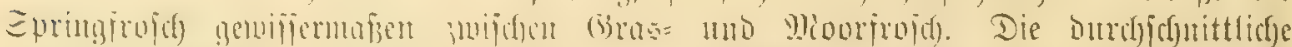

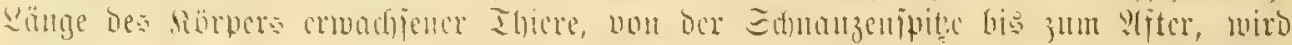

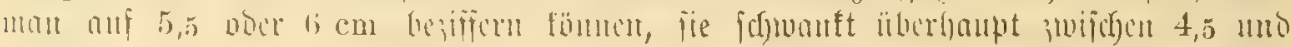

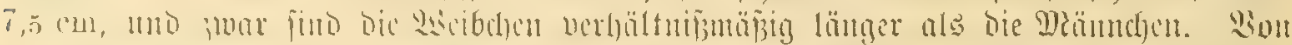

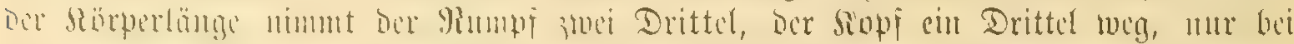

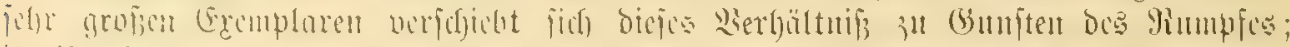

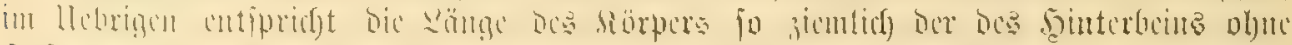

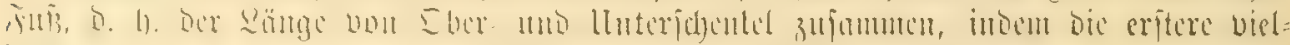

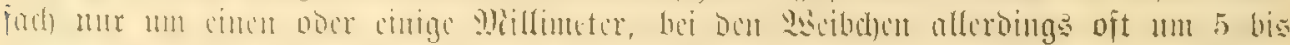

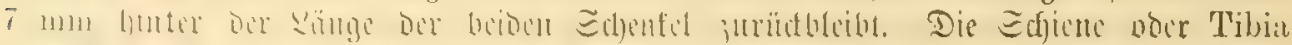

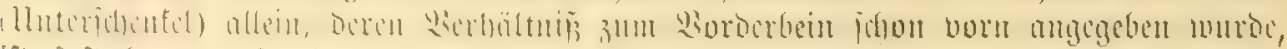
ift faift boppelt fo lang -

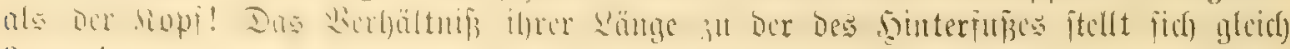
3 , $31 \mathrm{ll}$. 


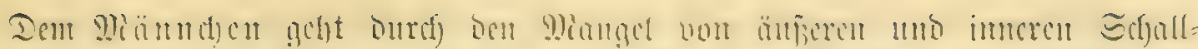

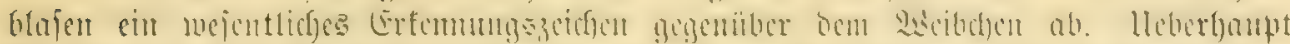

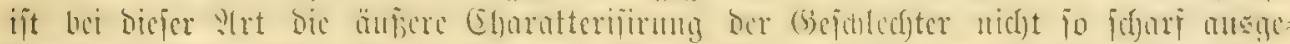

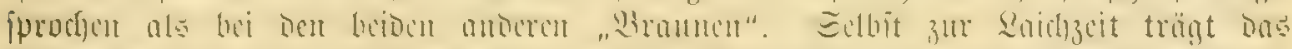

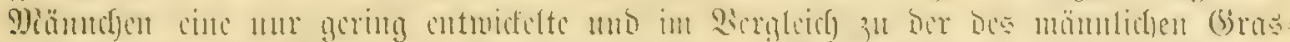

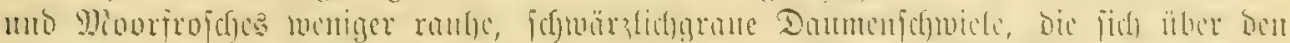

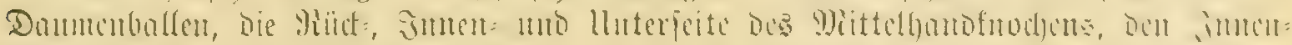

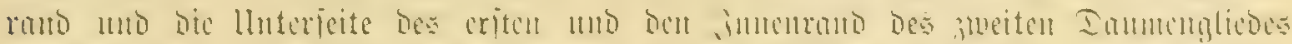

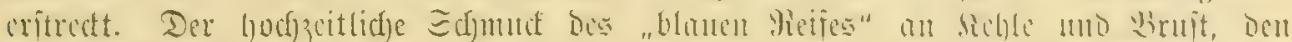

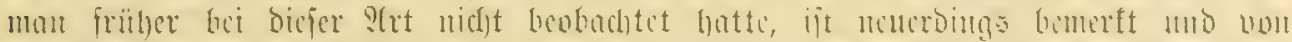

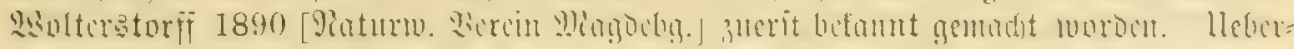

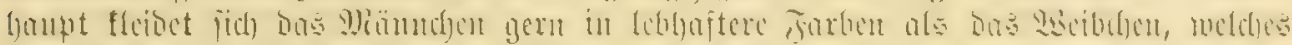

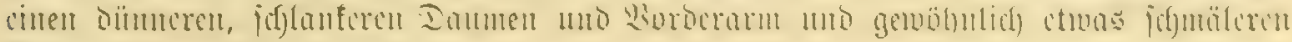

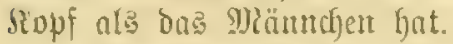

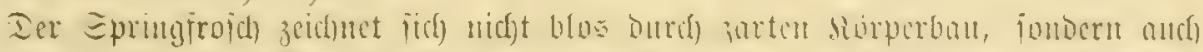

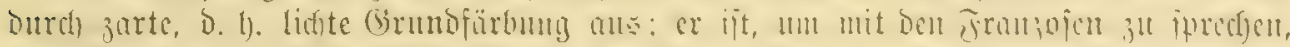

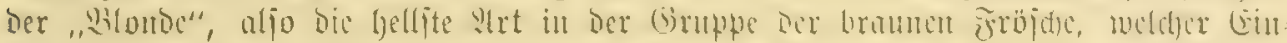

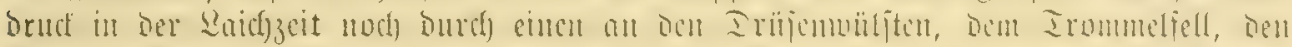

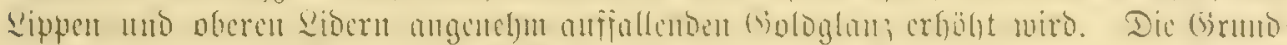

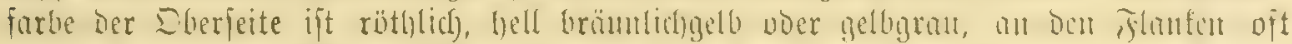

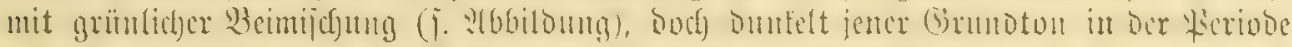

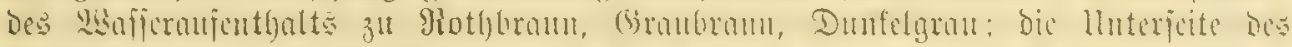

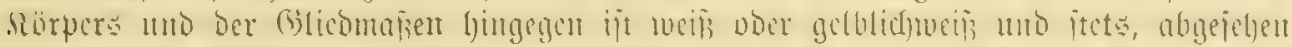

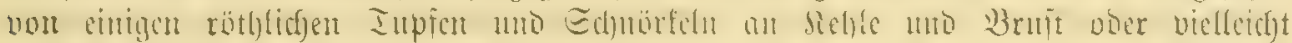

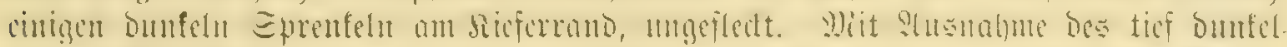

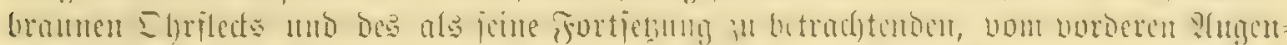

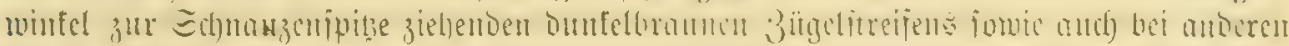

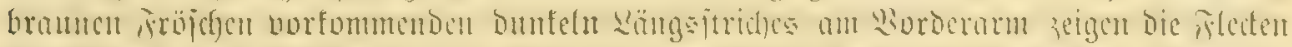

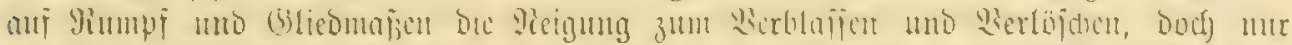

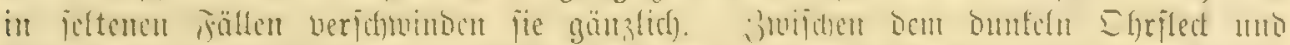

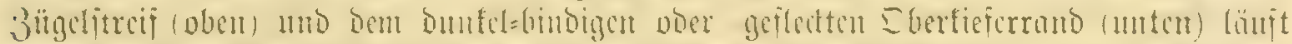

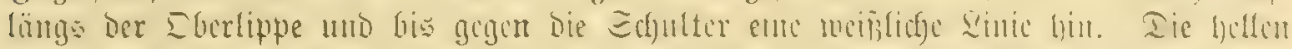

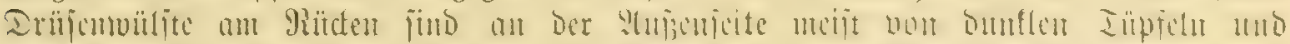

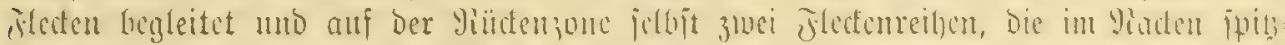
wintelig ,

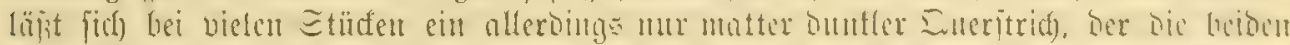

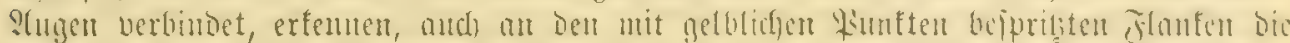

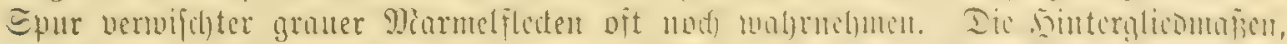

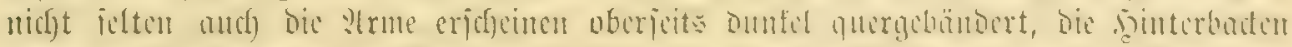

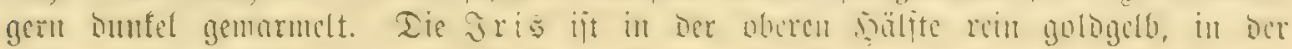
unteren, "ïtuerfdywärzt".

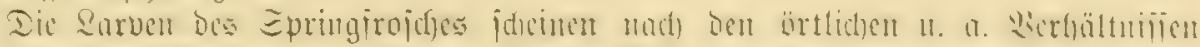

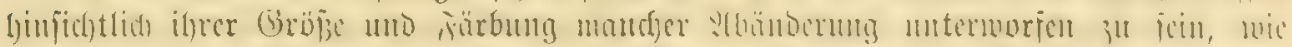

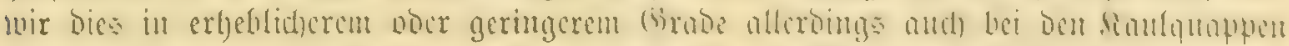

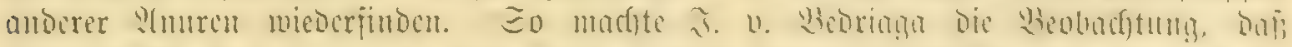

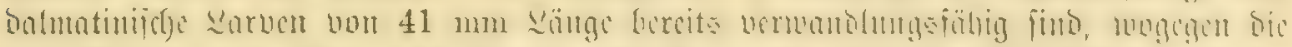

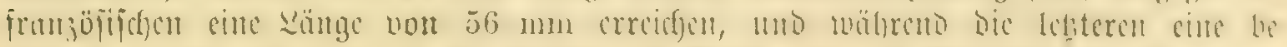

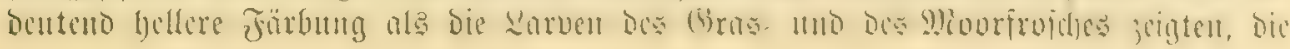




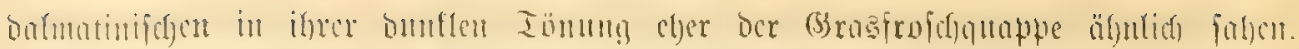

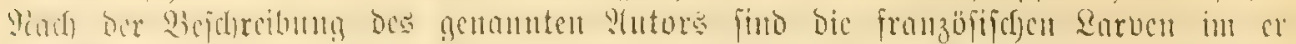

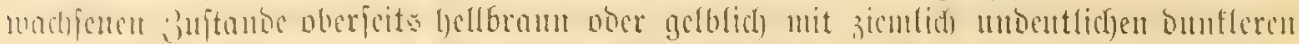

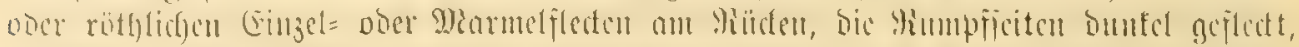

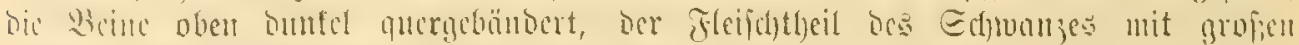

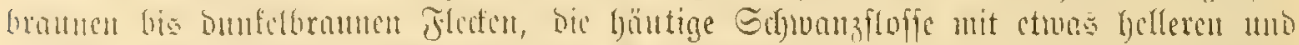

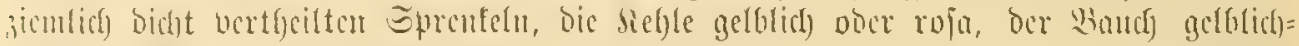

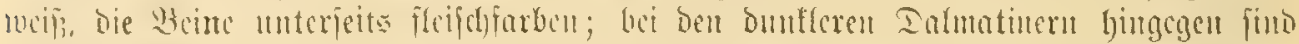

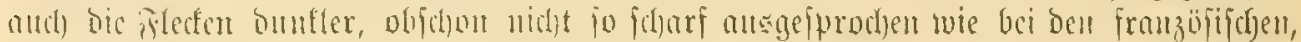

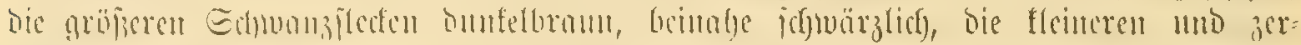

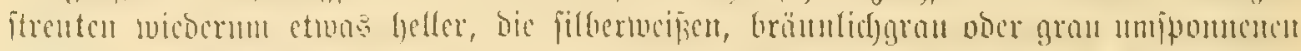

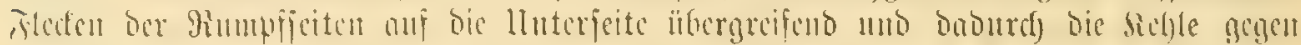

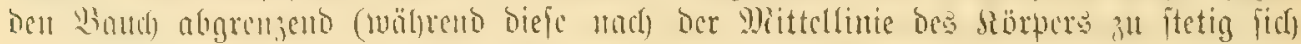

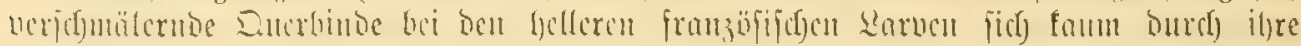

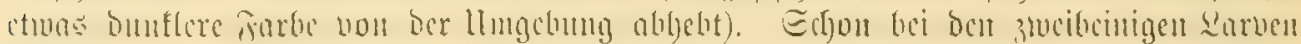

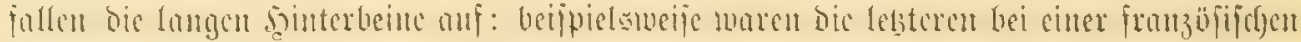

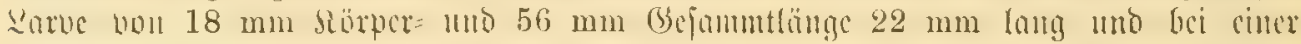
Datmatinifacn bon $41 \mathrm{~mm}$ (Scjammtlänge $16 \mathrm{~mm}$ lang. Der oben flad) genublbte,

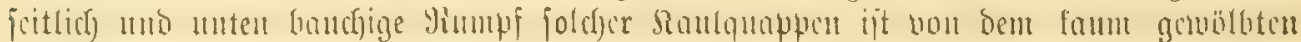

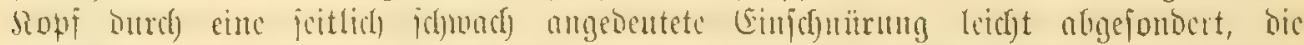

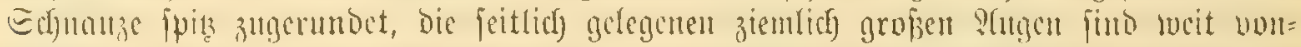

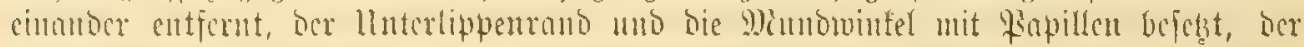

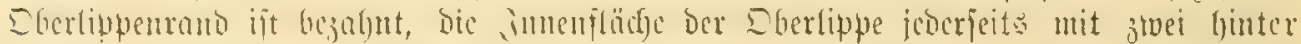

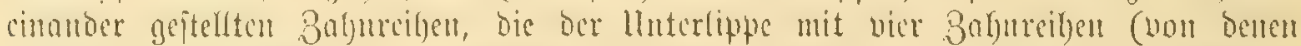

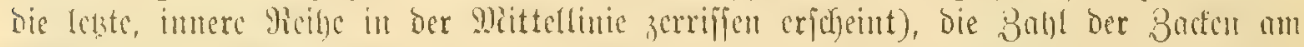

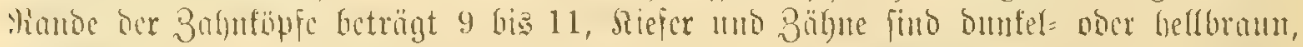

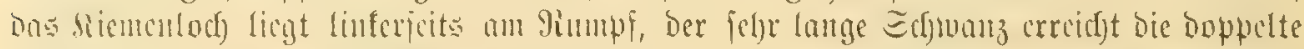

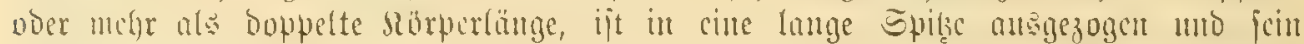

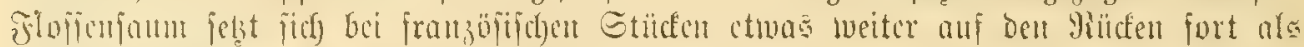

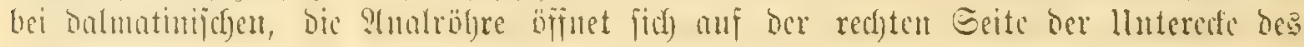
Floficujaumes.

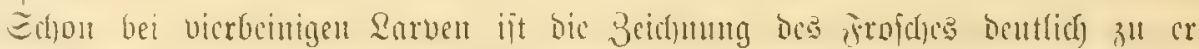

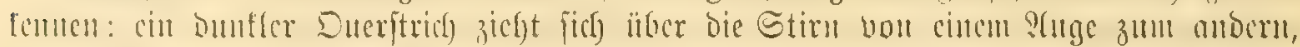

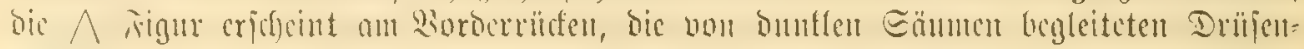

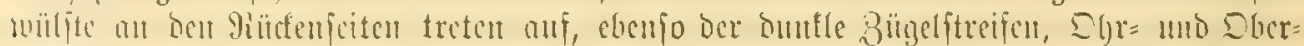

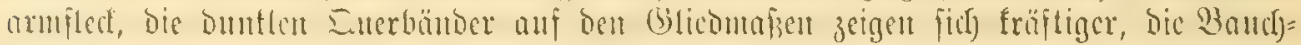

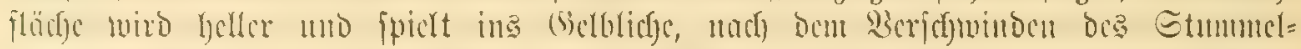

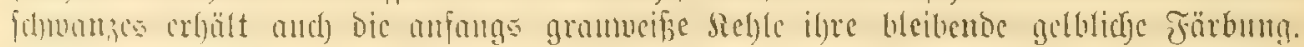

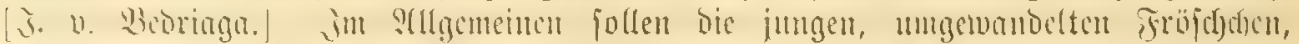

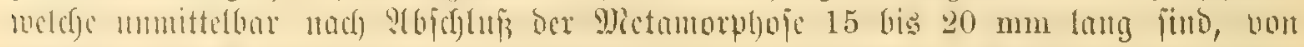

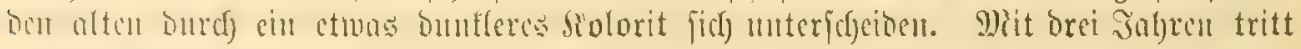
dic (3icjolechtercife eir.

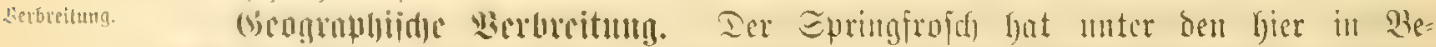

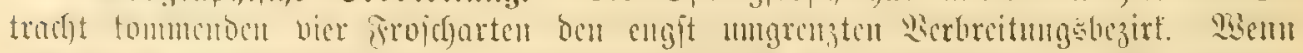

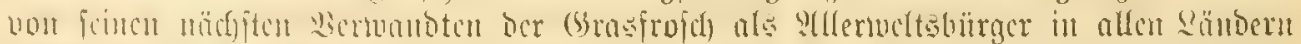
(5mx)

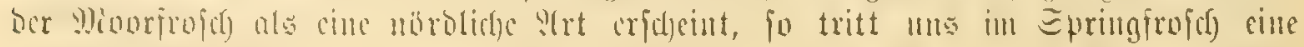

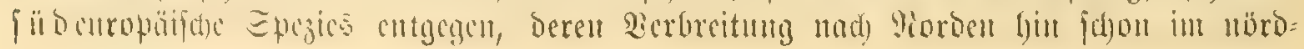




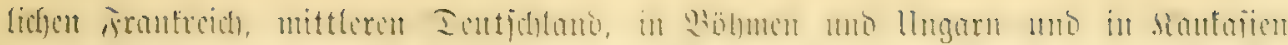

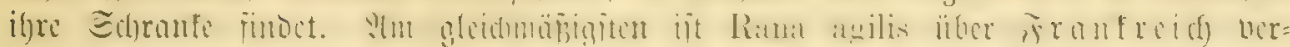

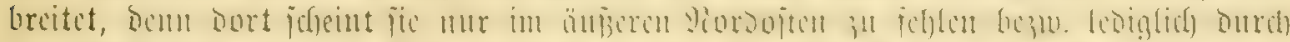

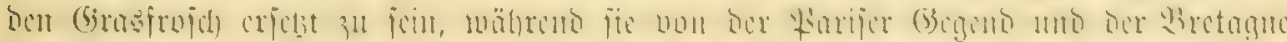

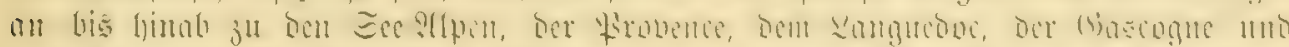

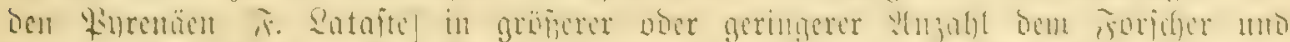

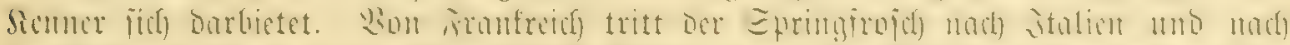

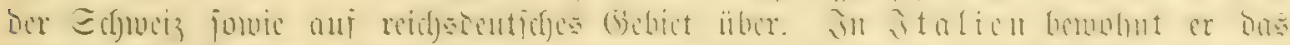

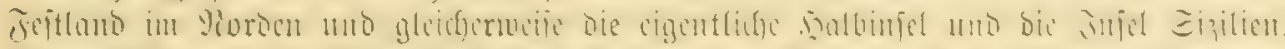

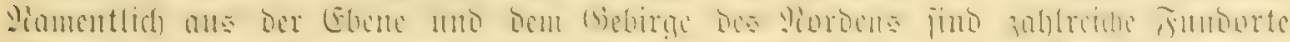

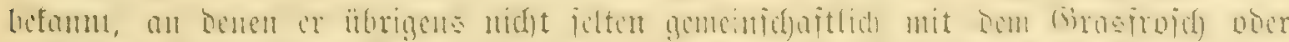

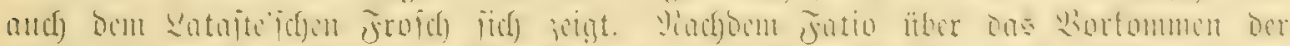

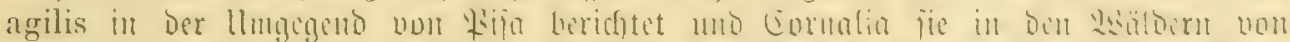

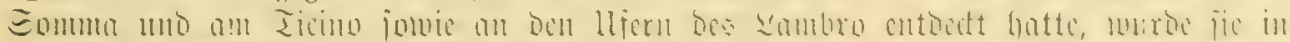

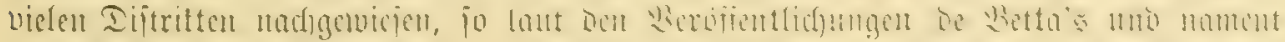

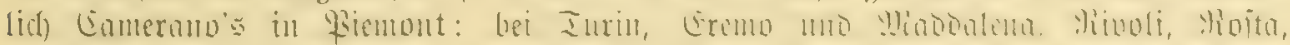

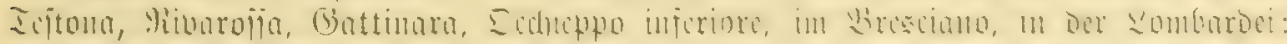

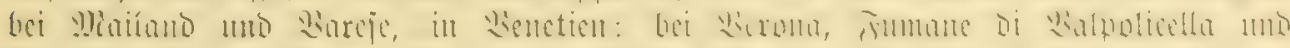

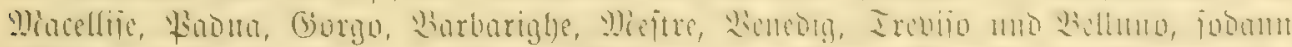

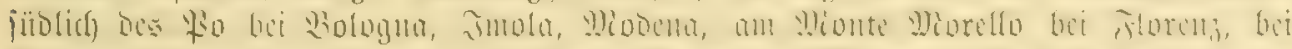

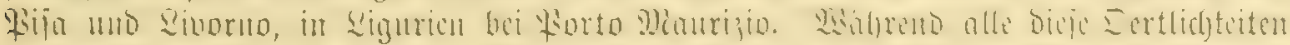

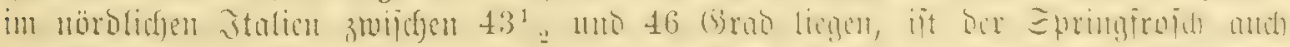

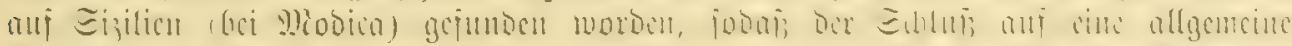

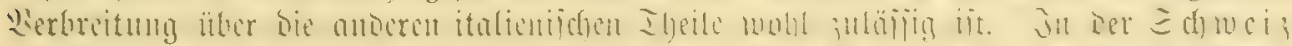

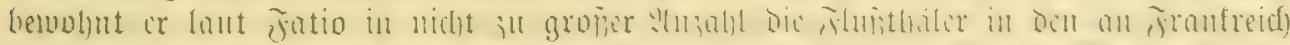

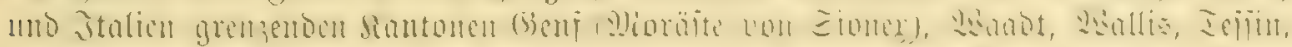

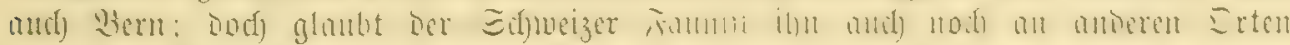

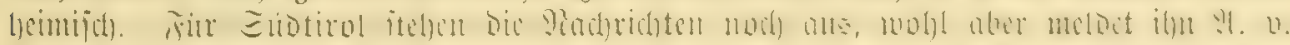

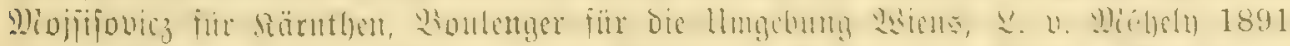

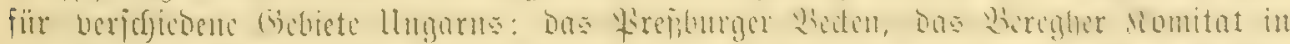

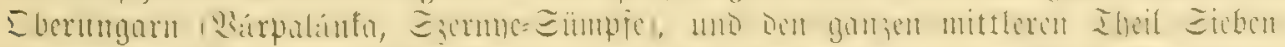

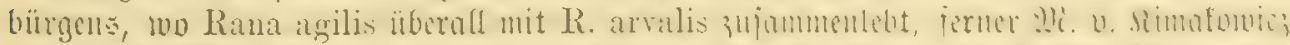

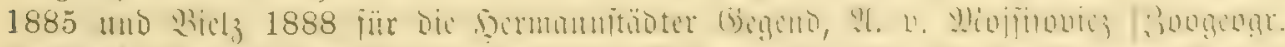

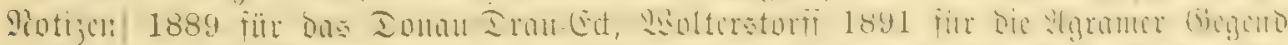
in srontion, ist.

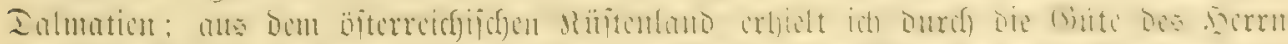

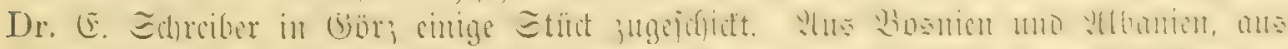

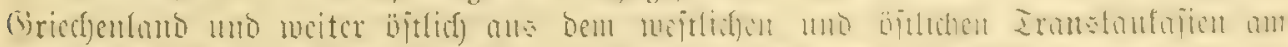

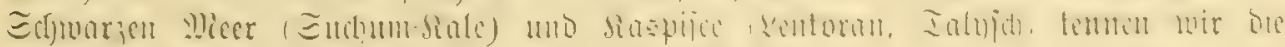
Irt burch) D. Böttger, Boulcuger und כ. v. 2̧edriagn.

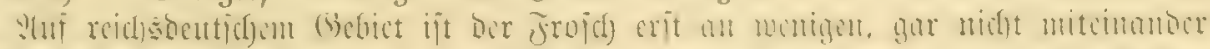

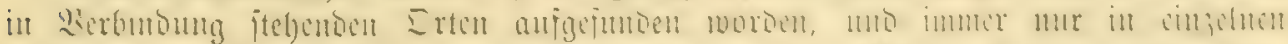

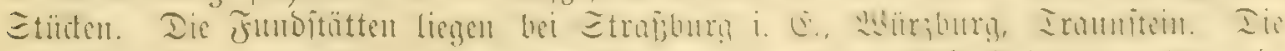

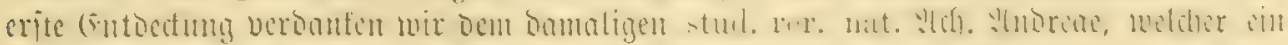

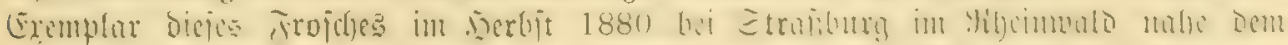

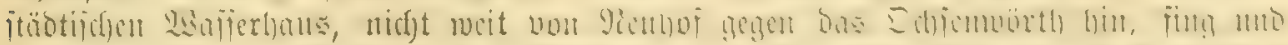

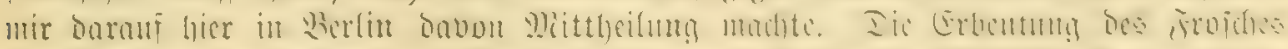

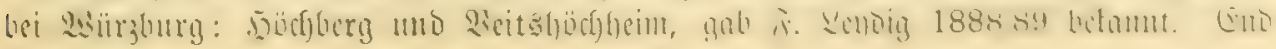




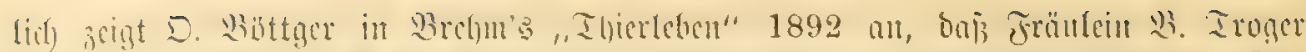

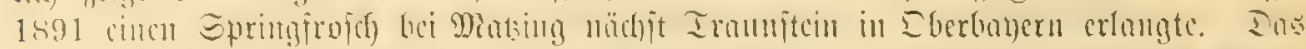

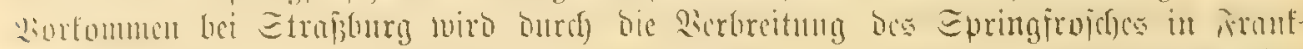

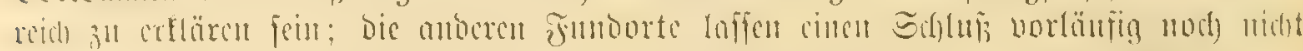

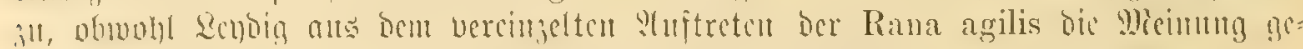

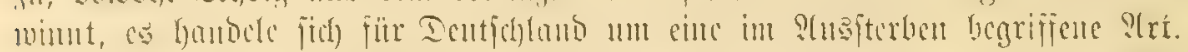

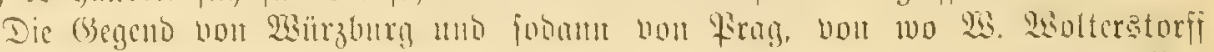

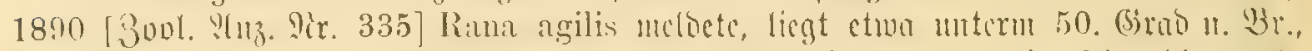

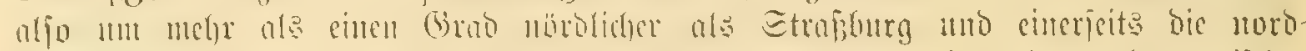

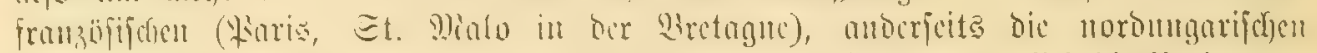

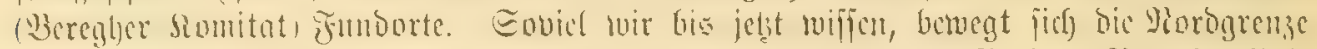

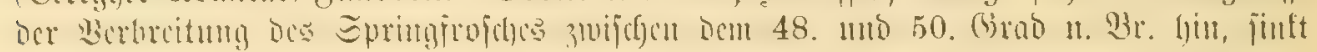

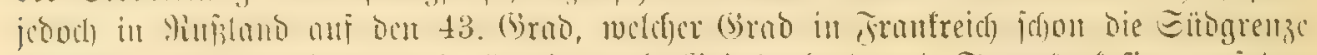

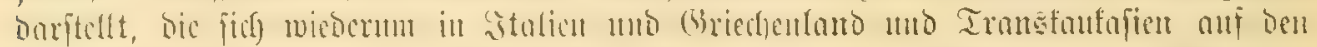

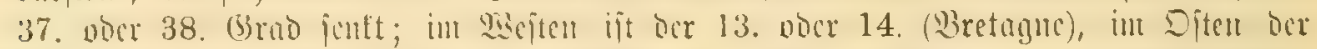

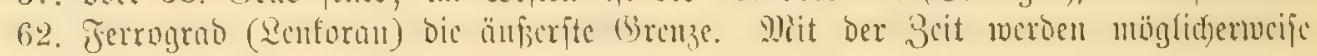
die Grenzen anders gcitectt tverben milffen.

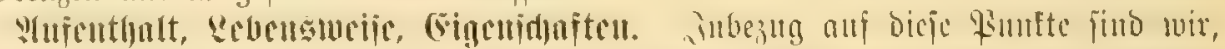

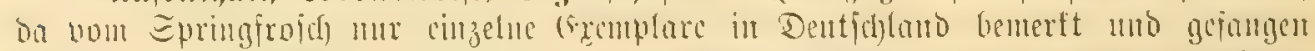

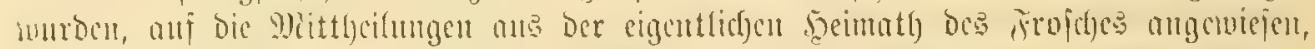

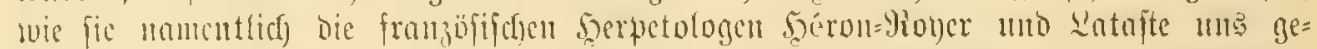

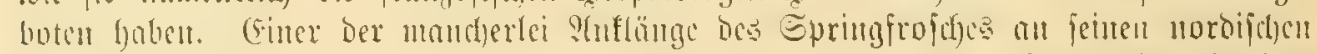

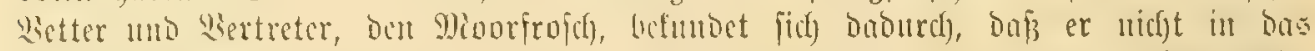

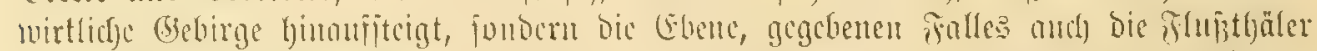

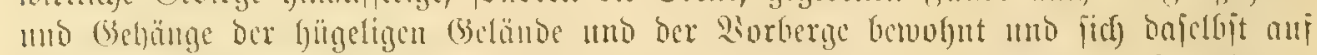

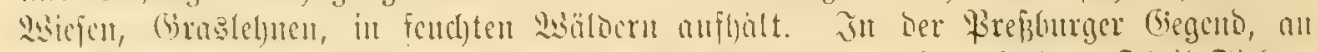

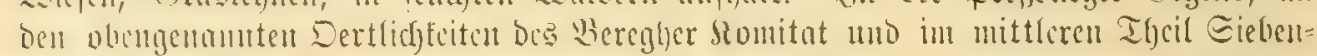

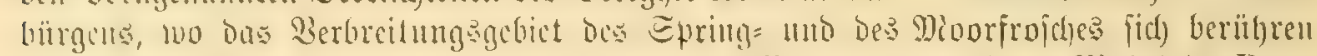

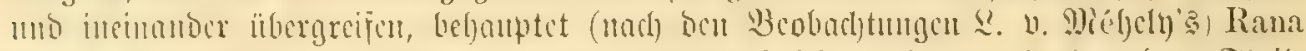
agilis, trotiocu fie mit Rana arralis gemeinjonftlidf vorfomm, bod andere Ilyeile

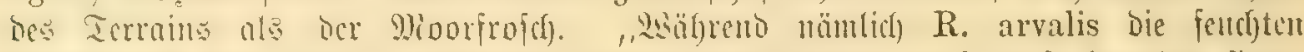

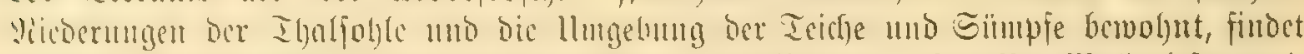

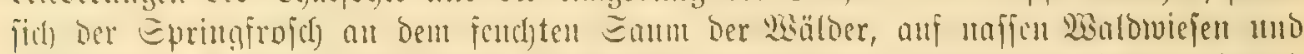

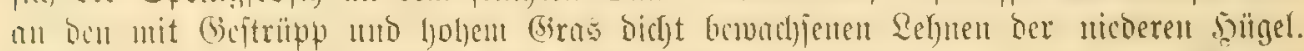

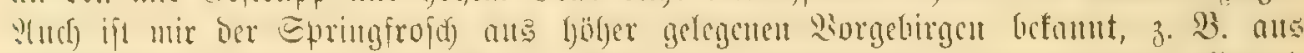

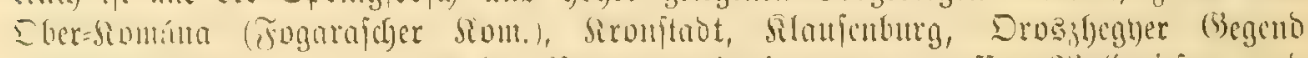

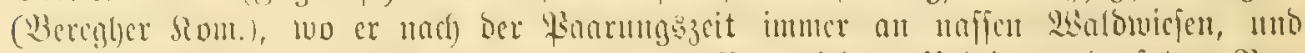

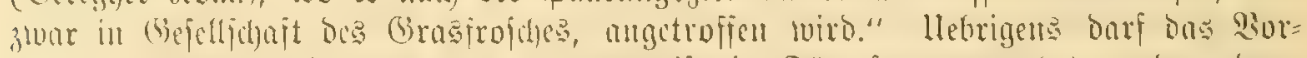

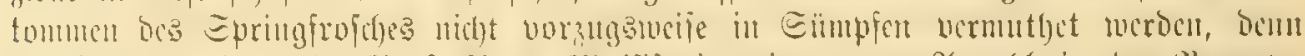

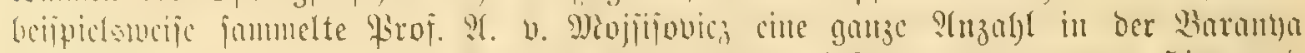

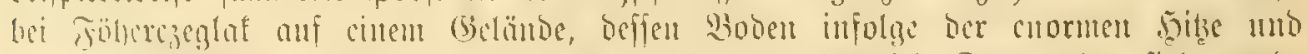

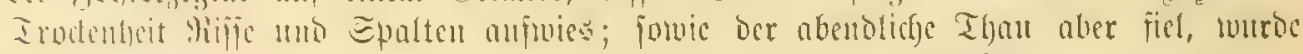

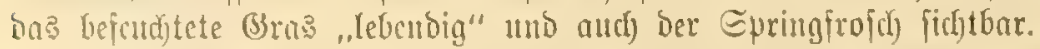

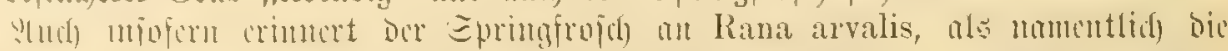

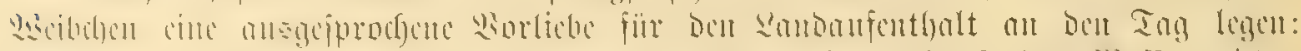

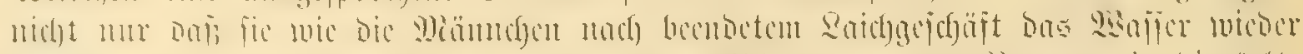

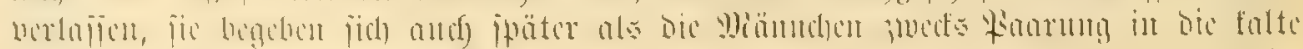

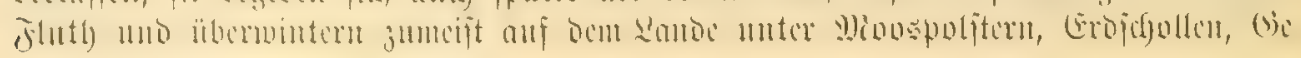




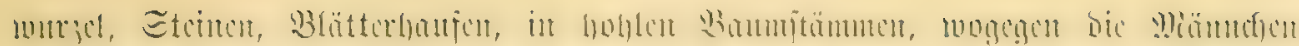

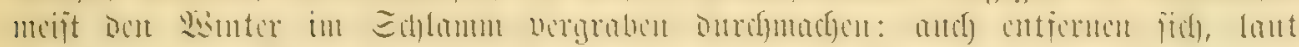

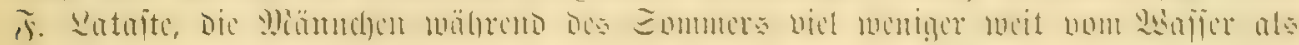

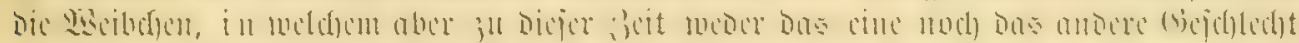

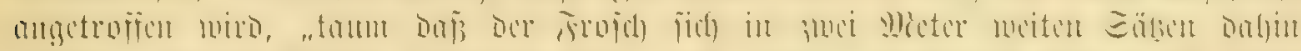

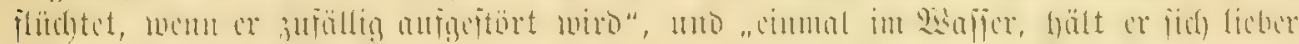

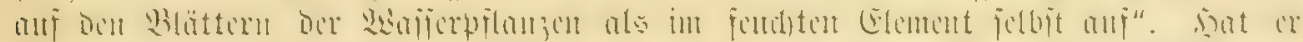

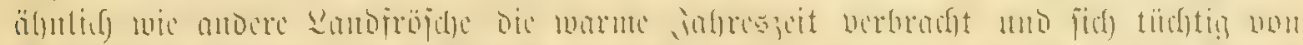

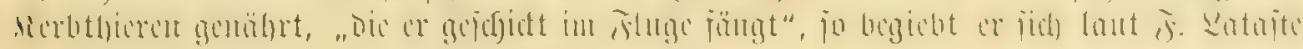

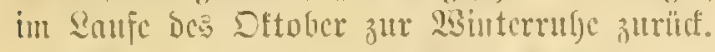

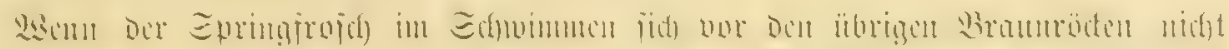

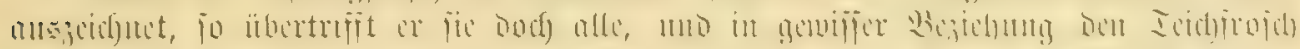

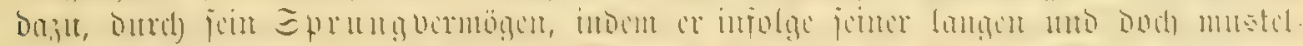

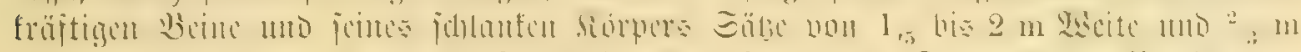

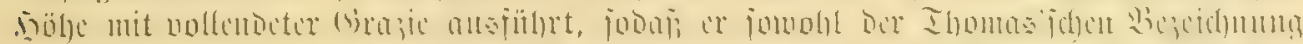

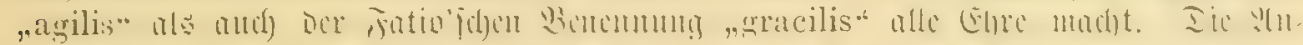

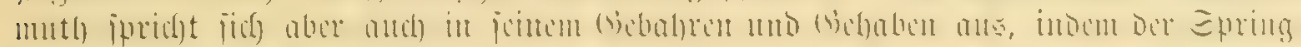

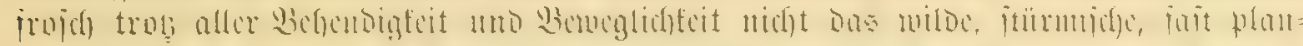
10. Ingcitume

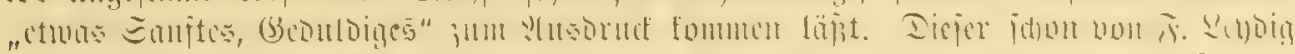

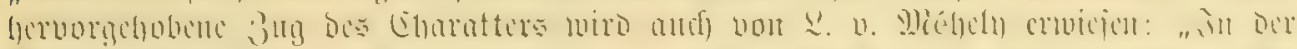

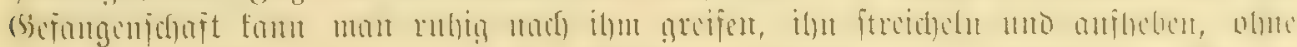

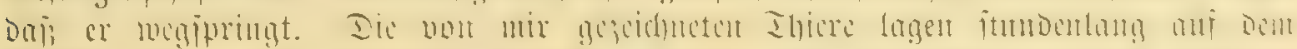

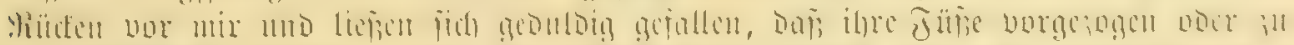

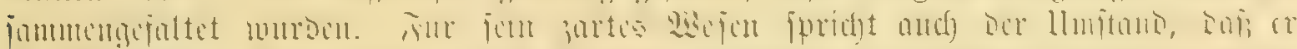

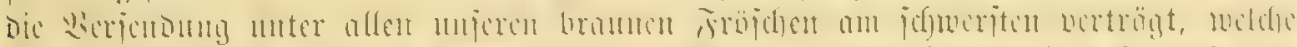

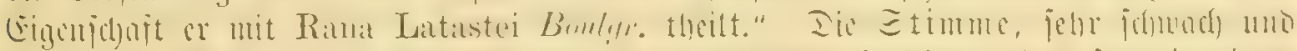

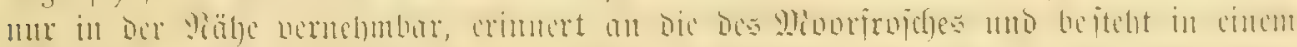

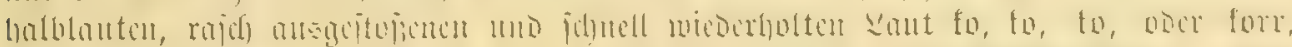

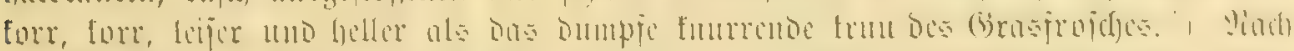

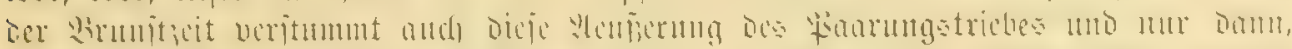

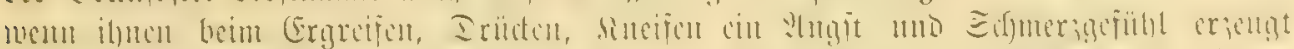

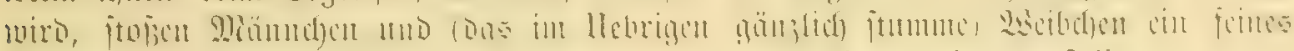

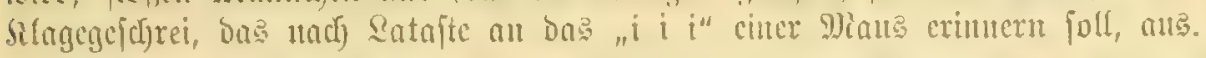

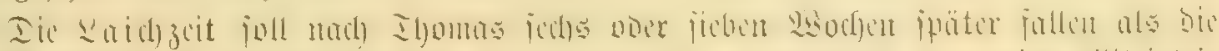

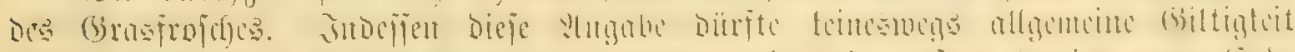

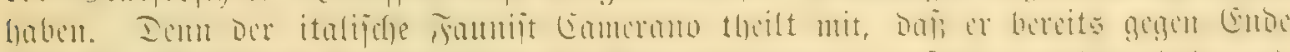

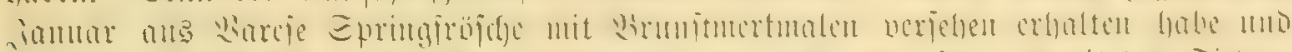

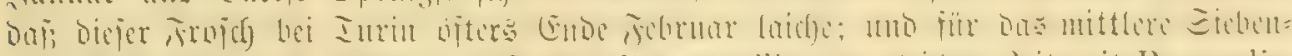

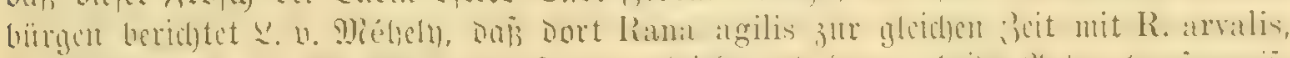

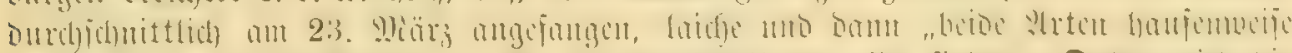

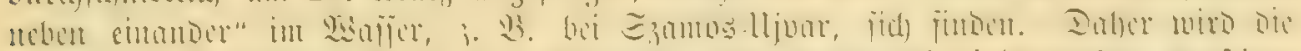

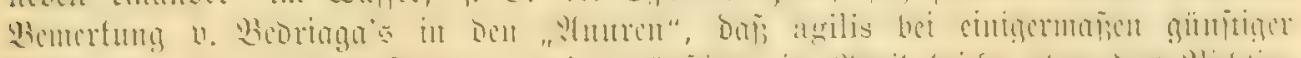

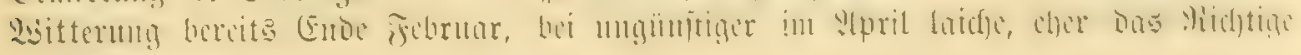

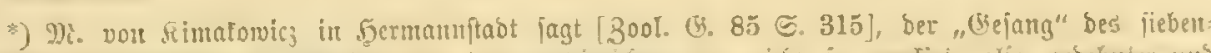

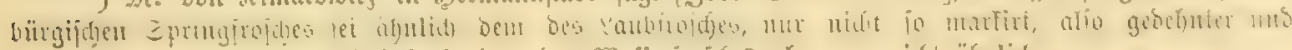

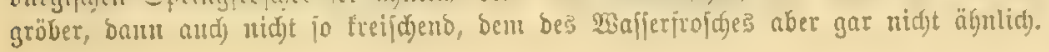




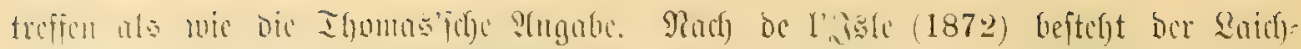

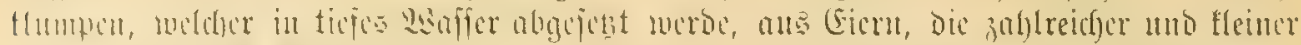

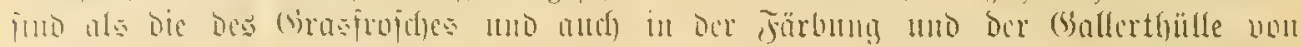

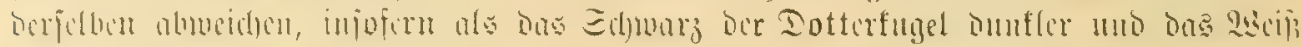

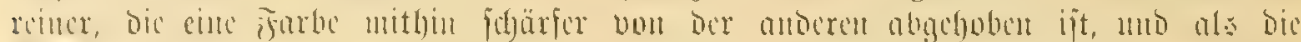

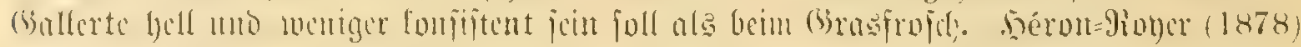

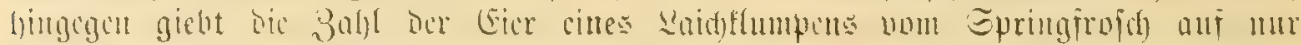

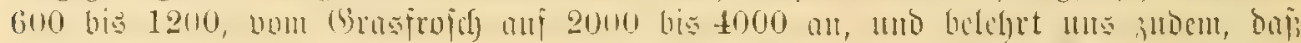

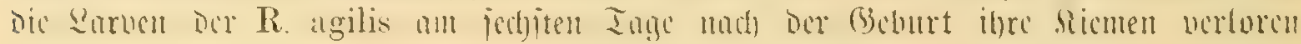

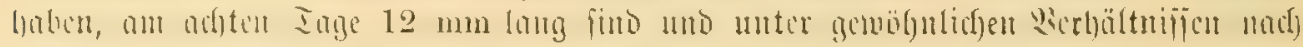

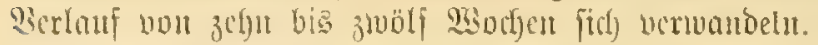

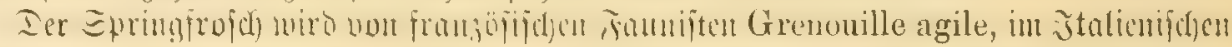
Rana agile, Saltafossi voer Saltaguazzo, in Srontif(h) Plavke modrake (Wloufrofín) genamt.

Rana temporaria, Millet 1828. - Rana agilis, Thomas 1855. - Rana gracilis, Fatio 1862.

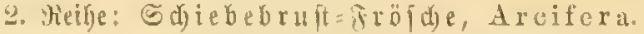

\section{2. familie: Ströten, Bufonidae.}

Körper dict, jufammengeftyoben, Traḑt überhaupt plump; Gant durd Warjen und hornhöker $r$ a uh; Bane dick, die norderen faft fo lang als die hinteren;

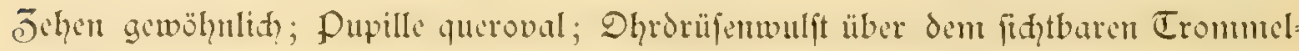
fell deutlid hervortretend; Junge länglith, etwa doppelt fo lang als breit, mit freiem, ganjrombigen Limterthet; voll tändig jahnlos; Brufterb feit= lid verfdicbbar; Querfortfätze des Zrenjbeinwirbels an freiell Ende orcictig verbreitert; Wirbel vorn msgehöhlt; Bippen vollftündig fehlend.

Sin Deutjolano mur eine Battung:

\section{Gattung: Grofröte. Bufo, Laur.}

Rumpf rundlich jufammengefhoben, oberfets gewölbt; Riopf flady, aber dic

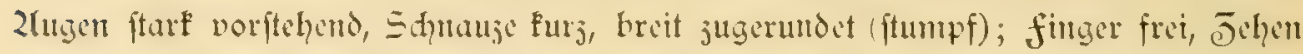
mit Spann oder atwa halken Sthwimmbäuten; auf dem Gandteller und der fupfohle je cin an der Wurgel des Daumens hejw. der Jnmengehe und cin mehr nad?

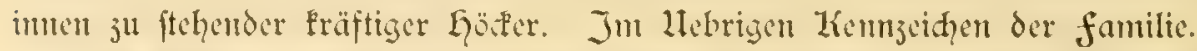

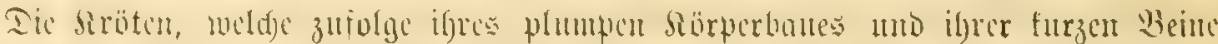

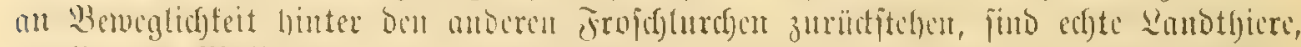

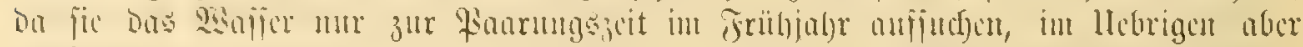

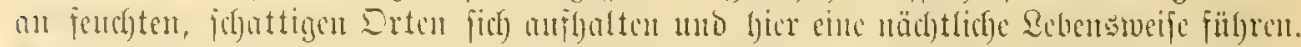

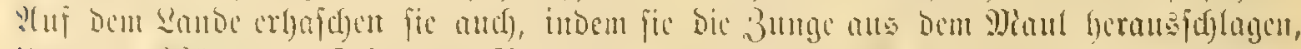

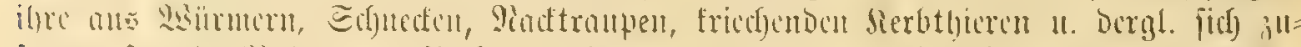

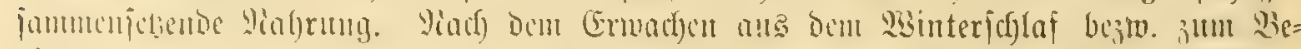

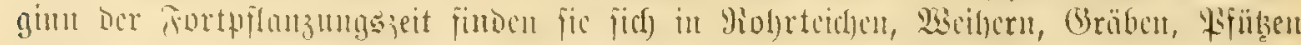

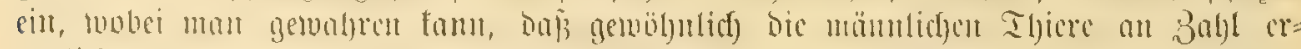

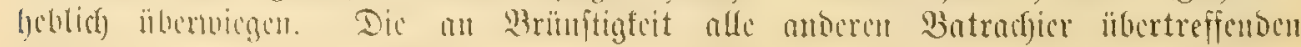

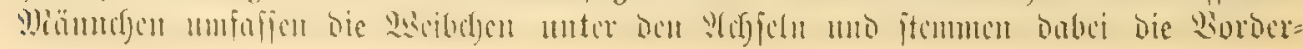




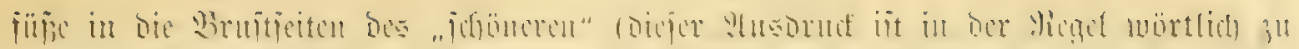

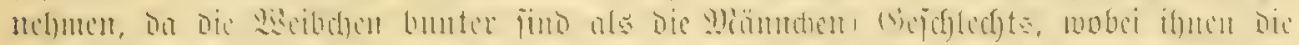

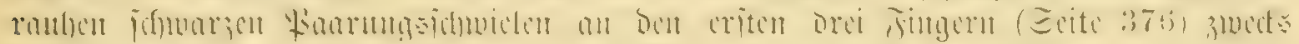

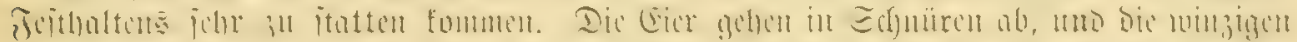

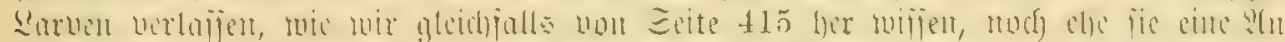

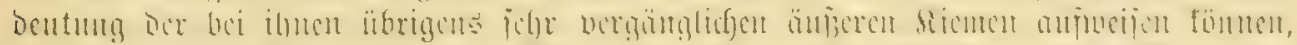

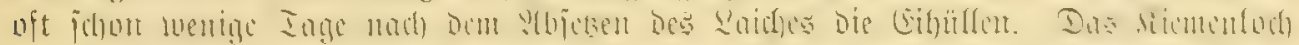

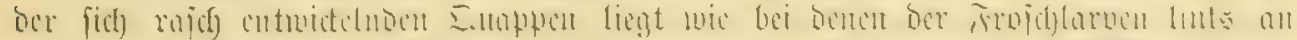

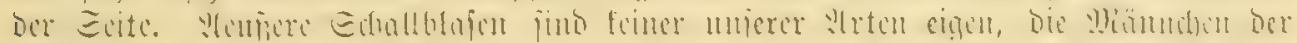

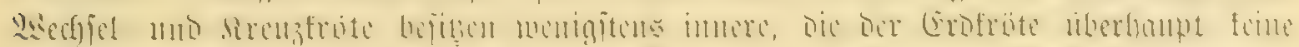

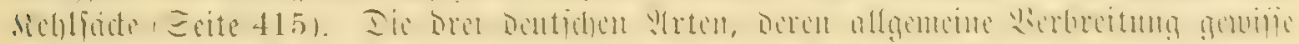

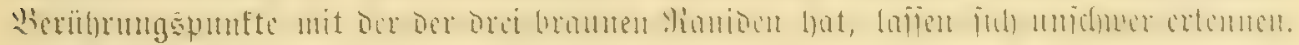

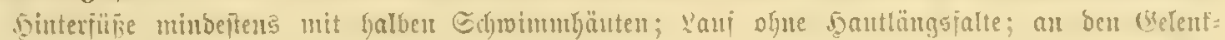

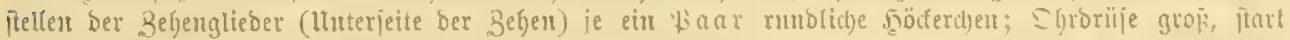
Gervortretent, ehwa halbmonbjürnig; Dberjeite ber setöte brau, grau, ober olivenjarbig, zuveilen butufler gefledt

13. rulgaris.

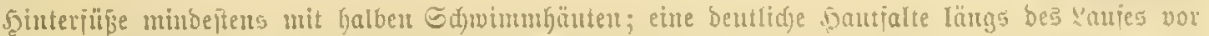

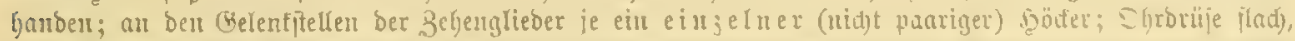

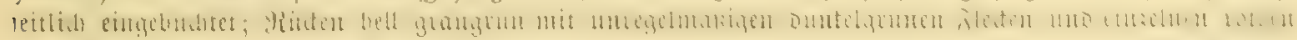
Läräd)en

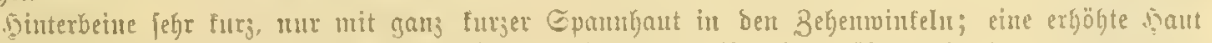

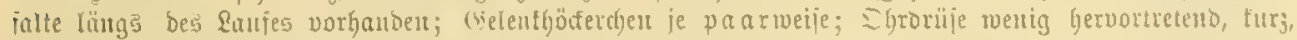

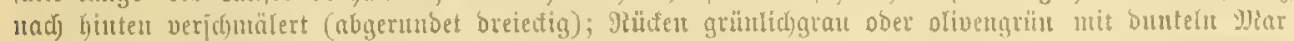

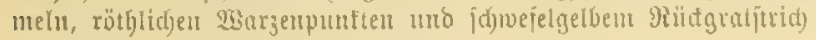

B. calamita.

\section{9.rt: (5) aue liröte. Bufo vulgaris, Laur.}

qrbilbung: 'รajel I Tir. 1.

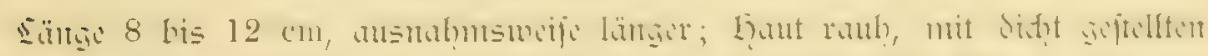

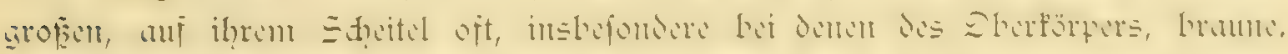

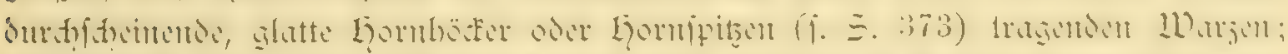

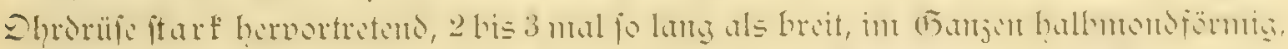

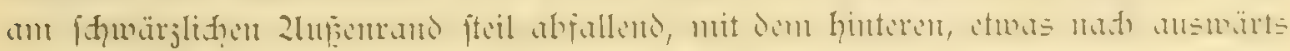

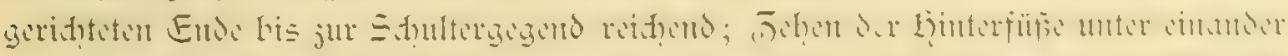

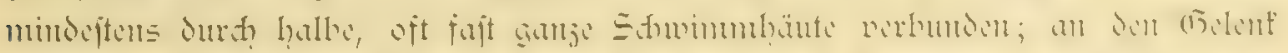

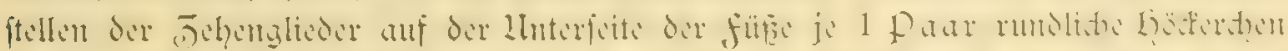

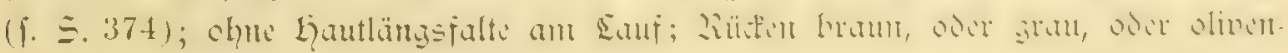
farben, juveilen mit dunfleren fledten.

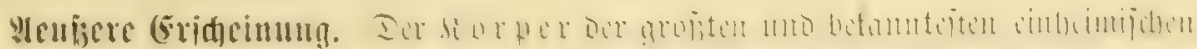
Rerperbau.

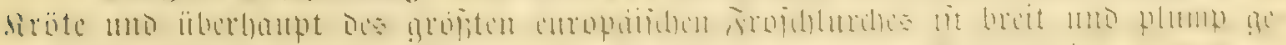

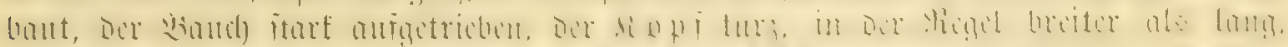

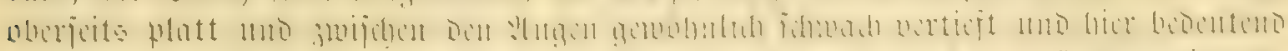

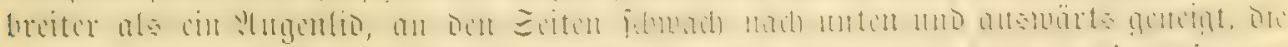

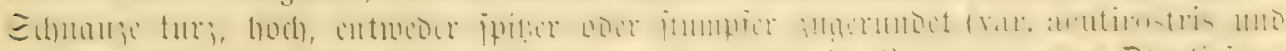

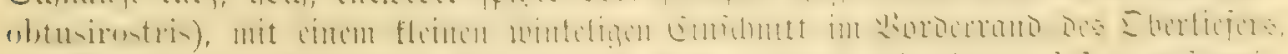

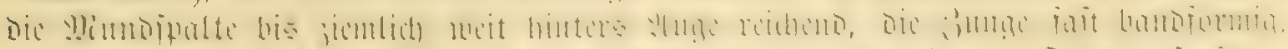

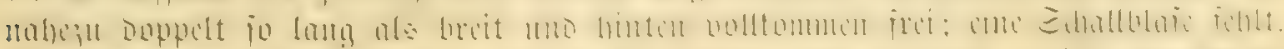

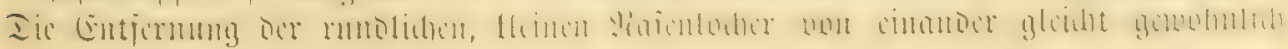




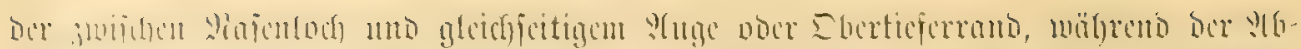

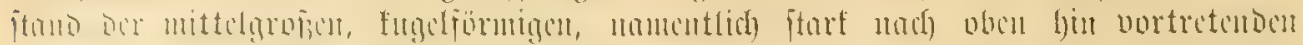

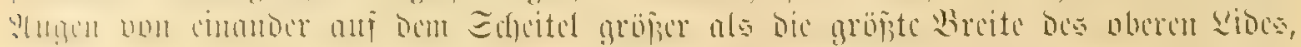

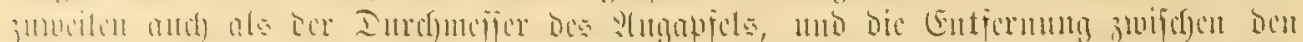

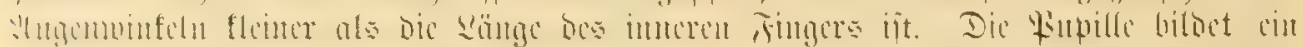

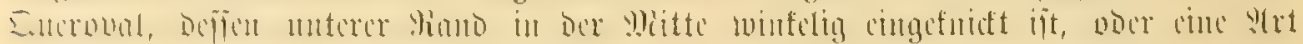

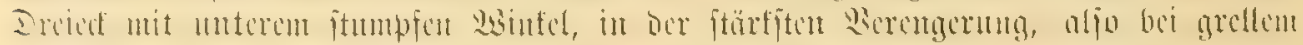

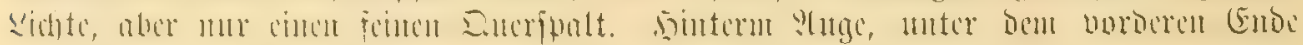

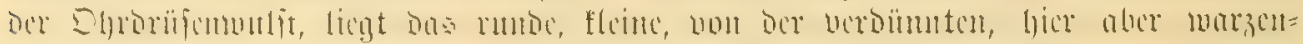

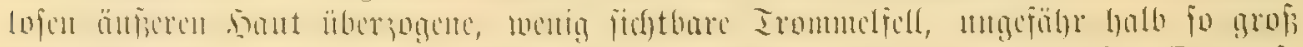

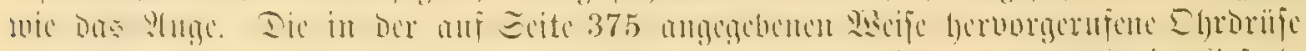

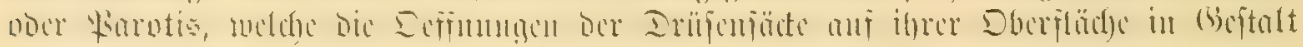

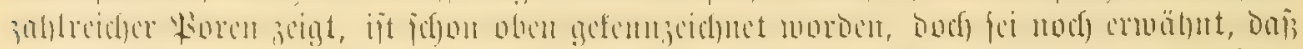

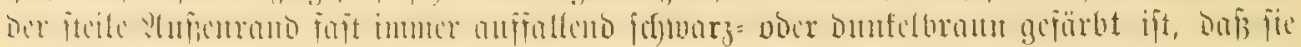

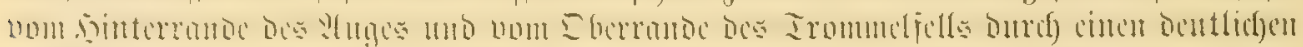

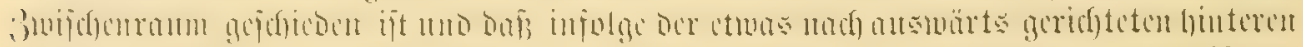

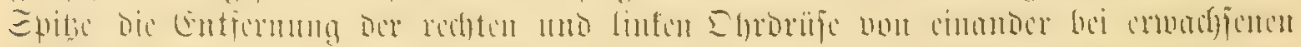

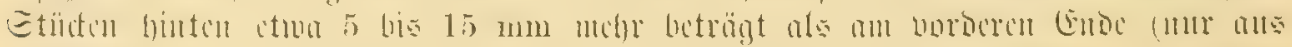

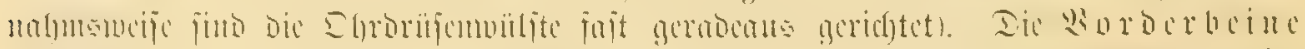

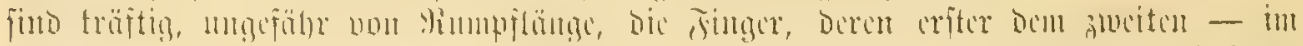

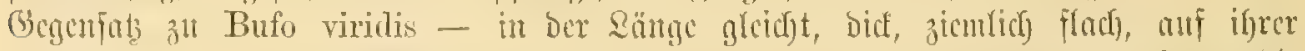

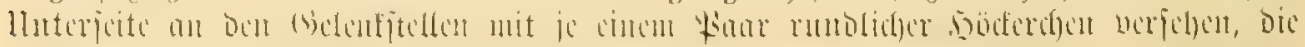

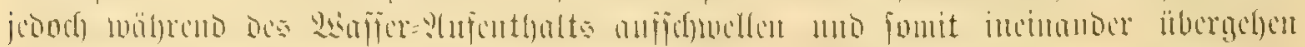

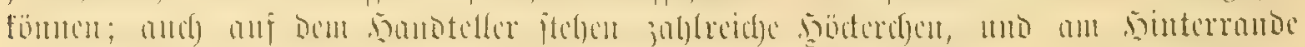

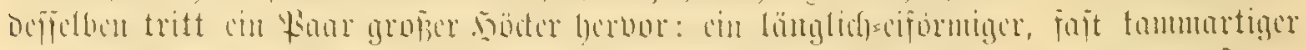

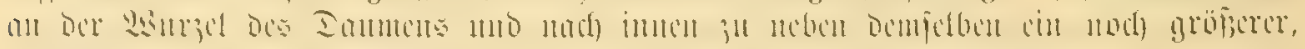

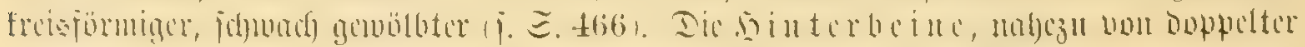

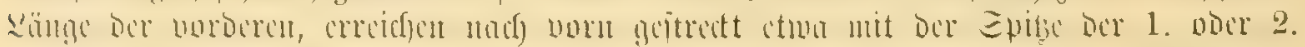

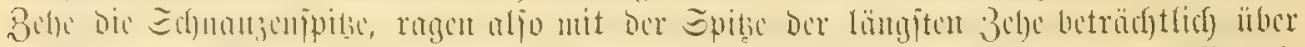

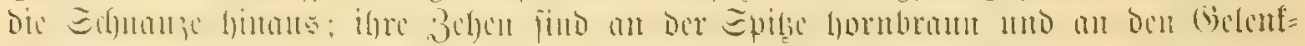

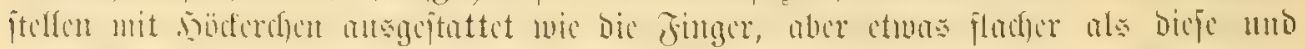

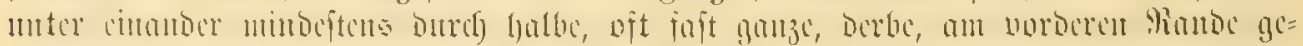

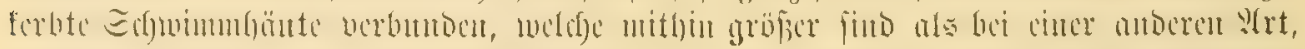

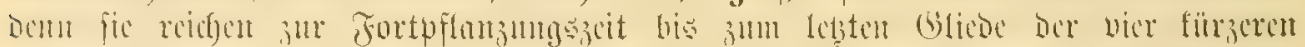

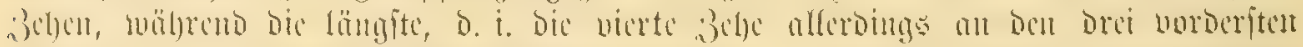

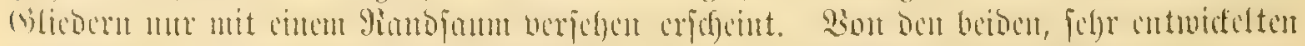

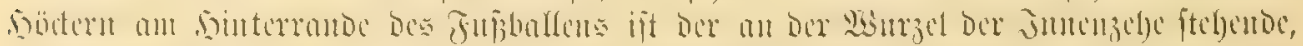

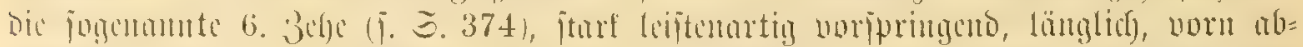

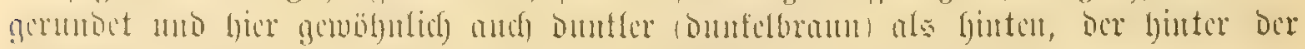

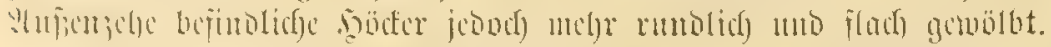

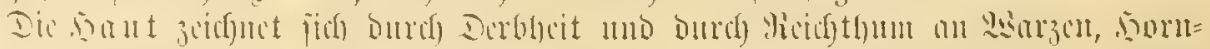

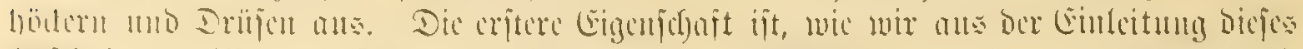

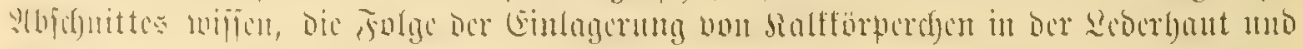

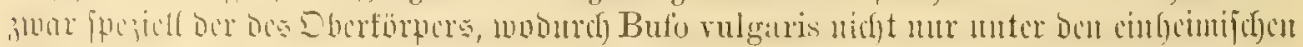

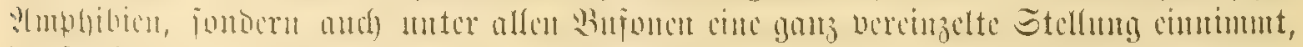

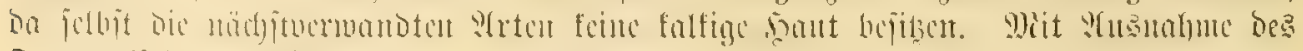

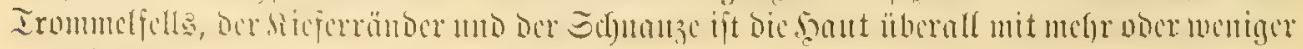

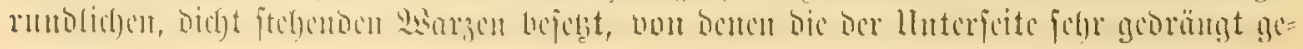




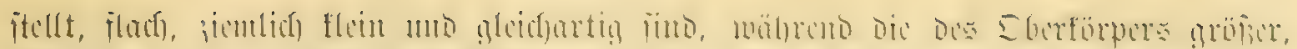

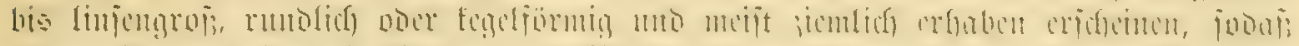

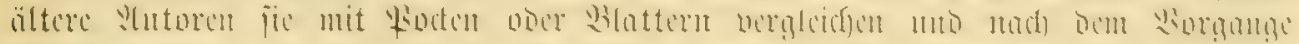

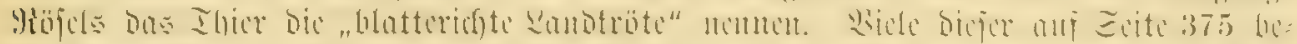

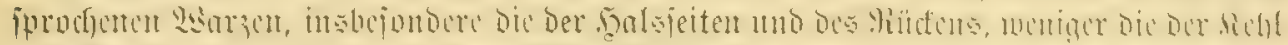

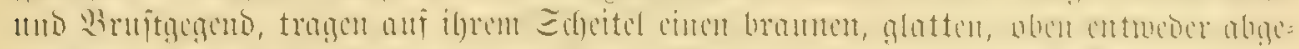

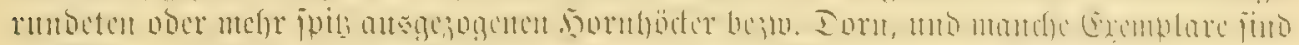

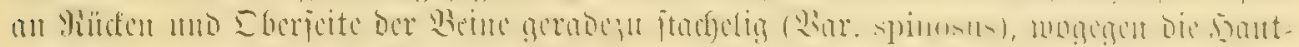

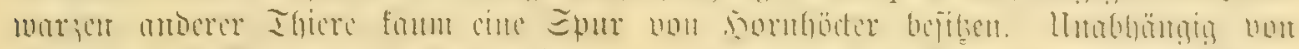

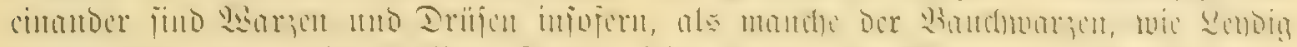

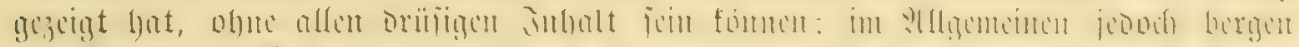

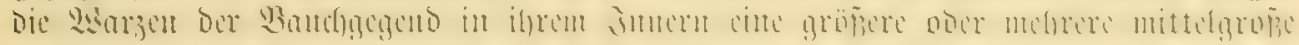

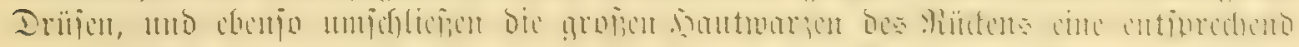

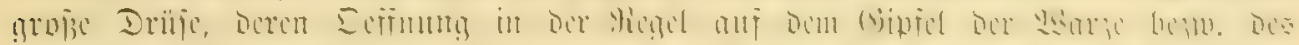

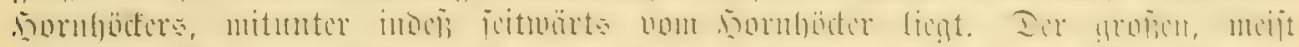

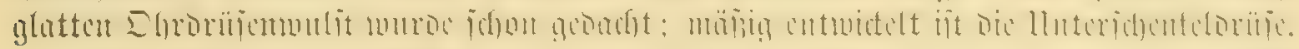

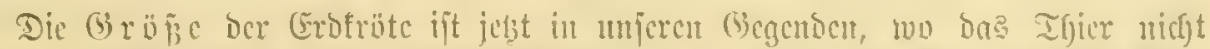

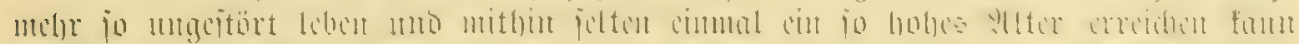

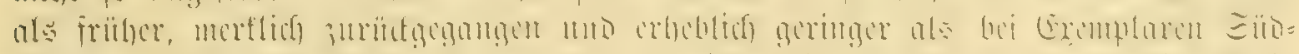

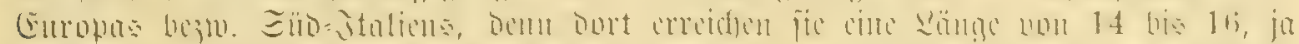

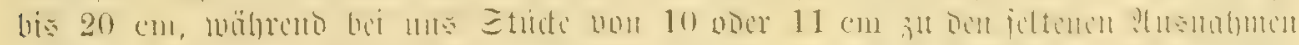

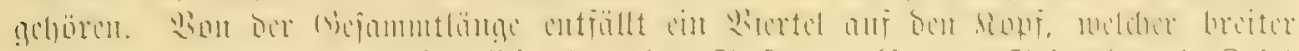

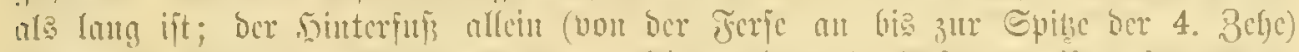

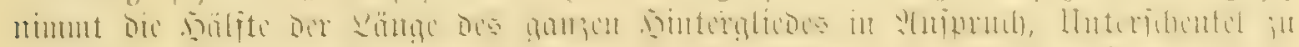

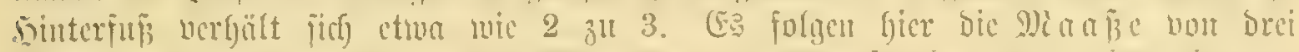

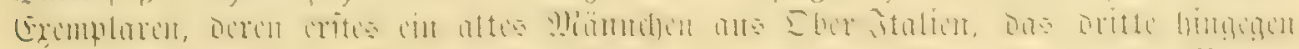

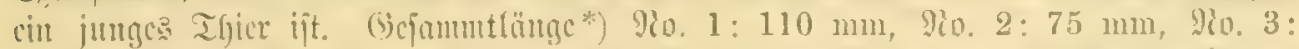

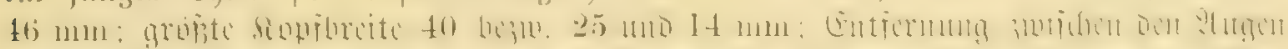

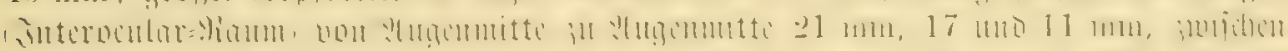

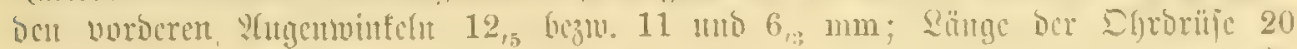

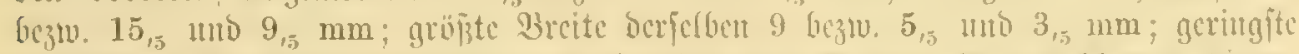

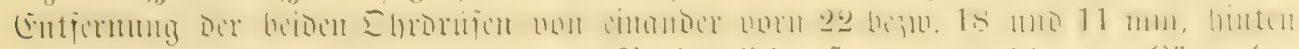

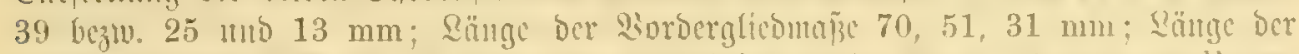

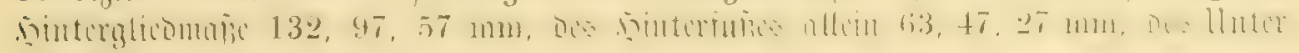

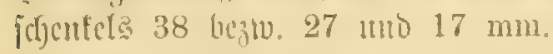

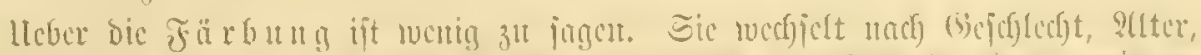

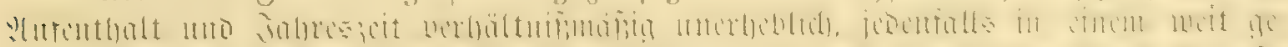
rimgeren simos ab ats $\mathrm{i}$.

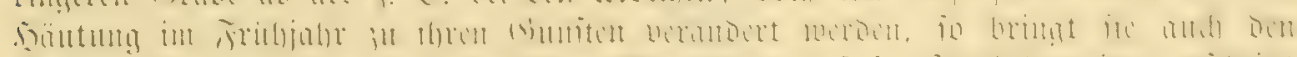

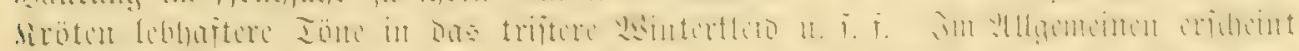

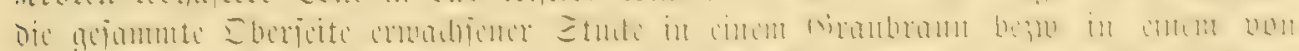
ber :lidforbe bis

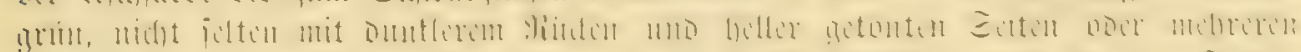

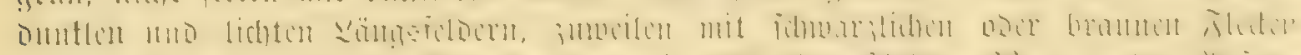

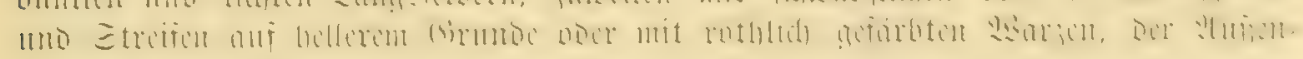

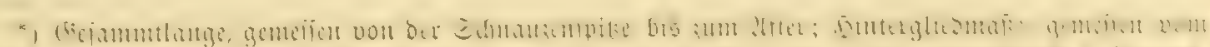

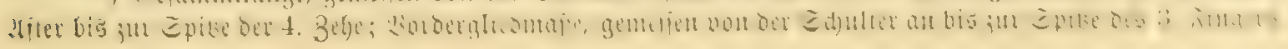




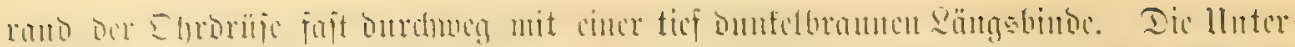

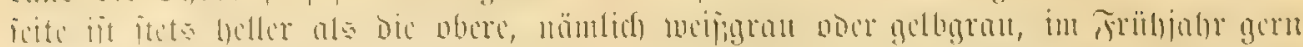

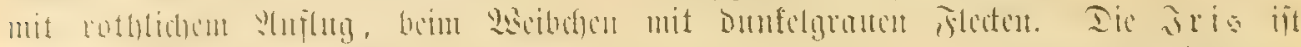

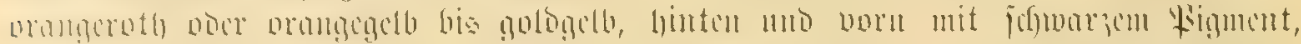

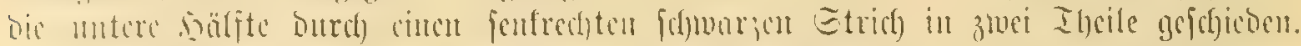

Ins

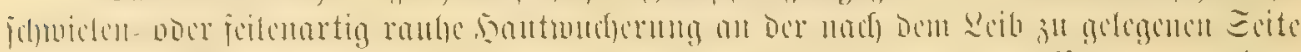

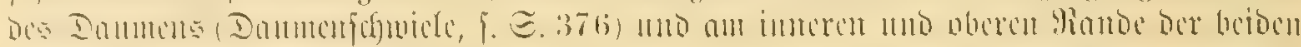

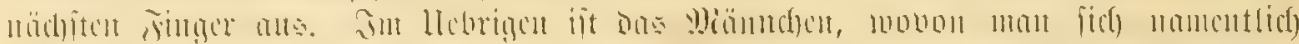

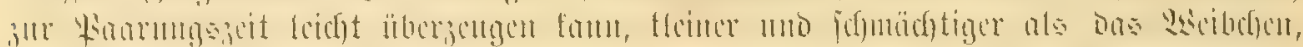

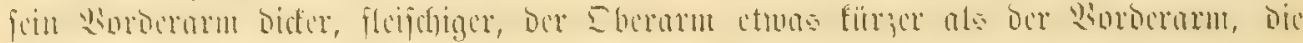

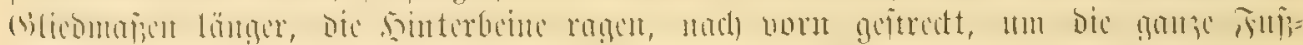

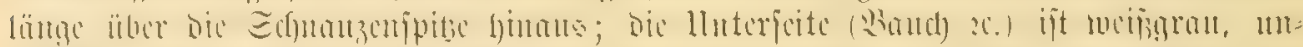

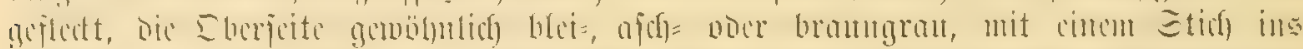

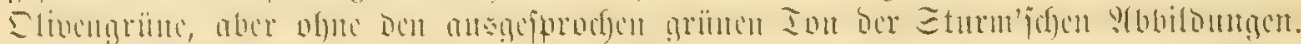

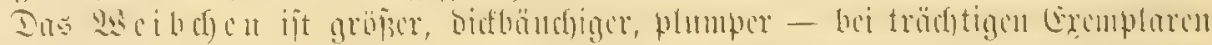

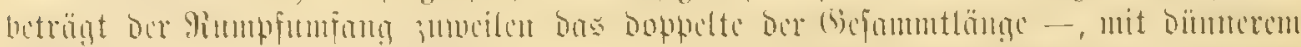

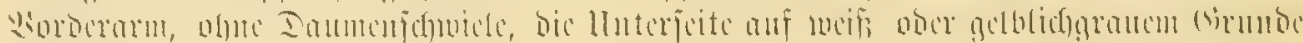

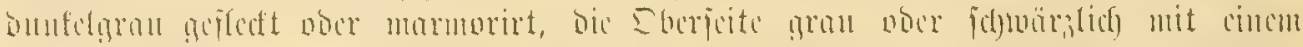

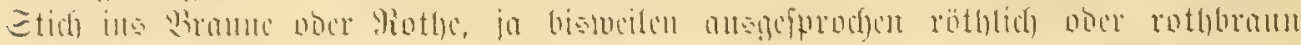

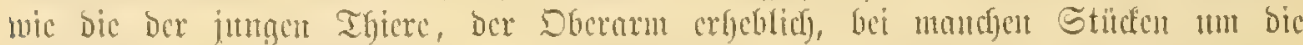

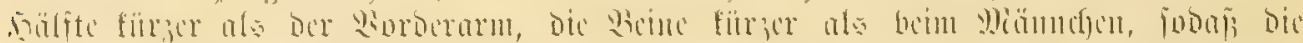

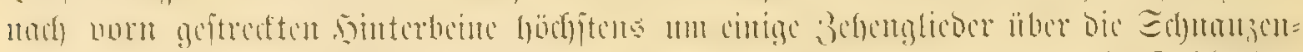

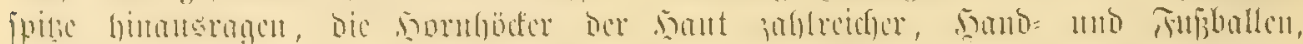

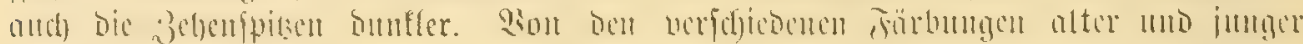

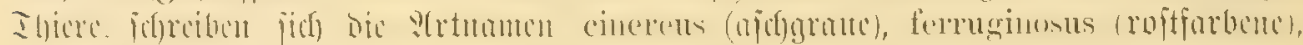
rubeta (rothe firite) her.

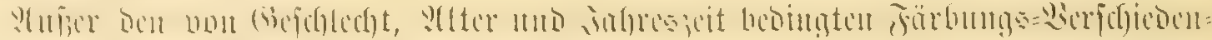

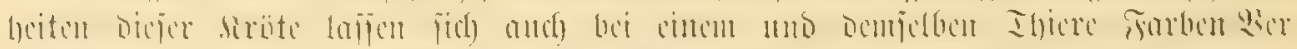

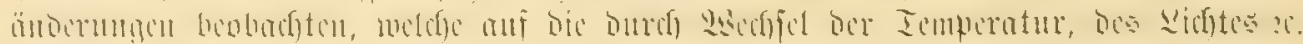

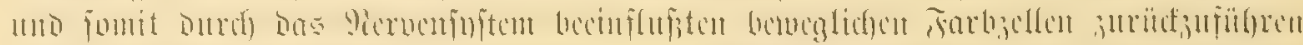

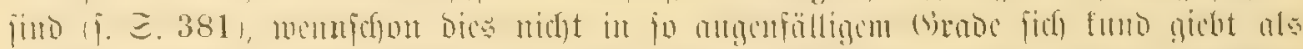

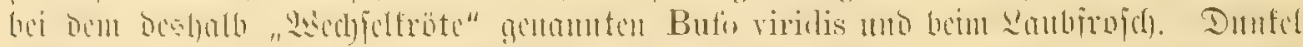

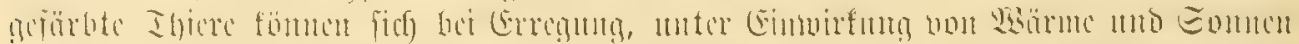

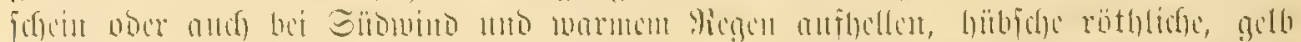

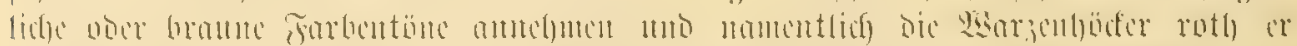

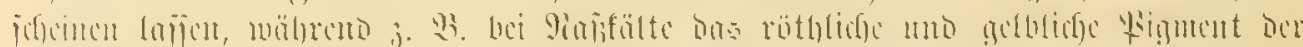

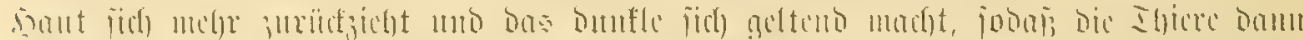

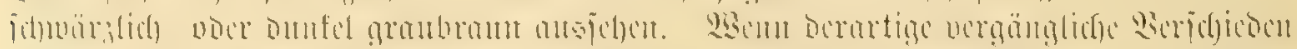

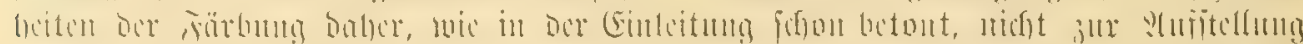

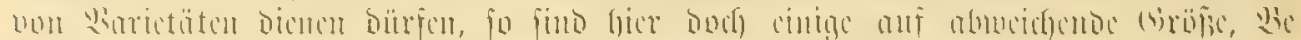

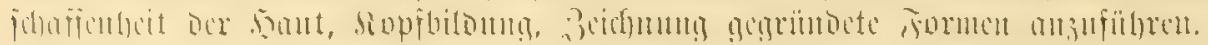

Zar. spinosus, Dornigc Crofrute, Lou Dandin 1803 als Bufo spinosus

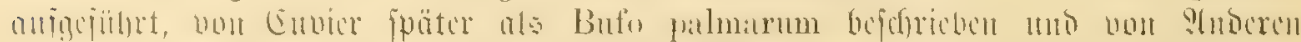

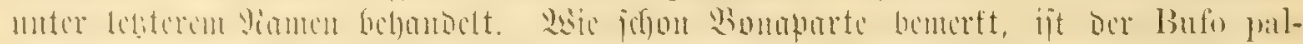

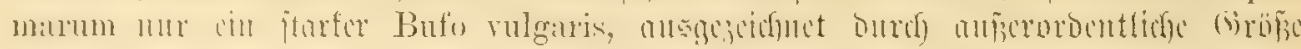

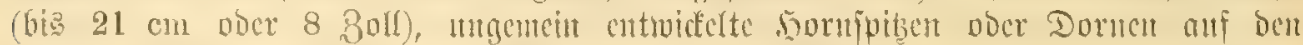

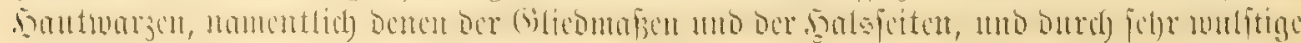




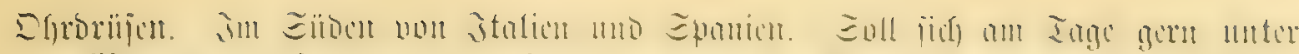

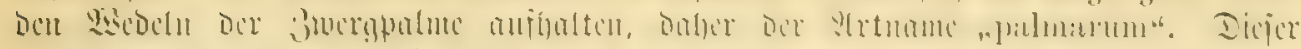

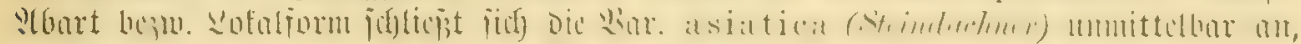

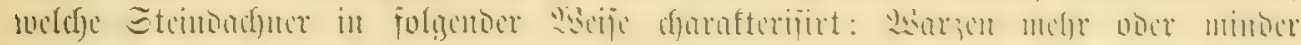

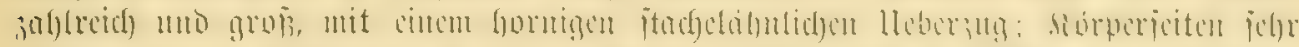

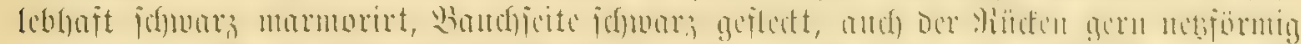

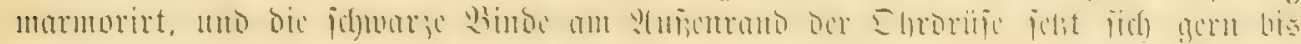

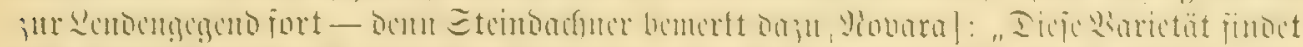

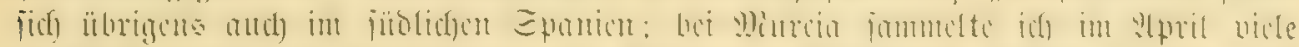

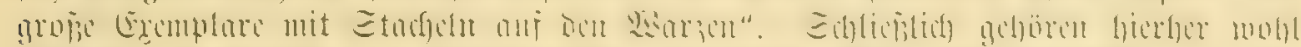

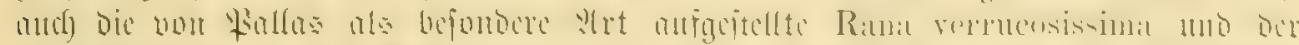

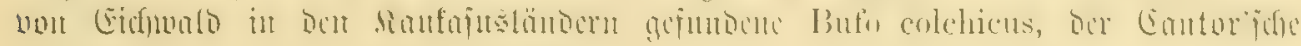
Bufo gargarizans unb dic japanifde form Bufo japonicus (Schlegel).

Bar. commutatus (Steenstr.) = War. medius (C. Koch), mittlere Ero=

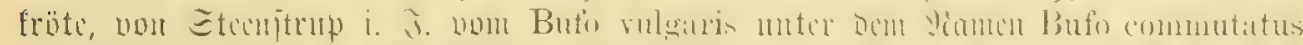

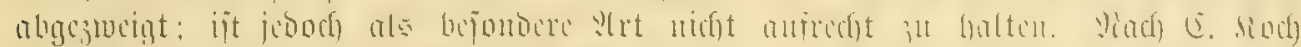

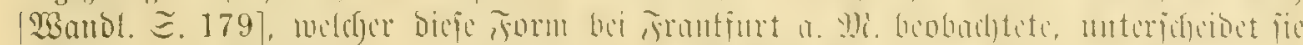

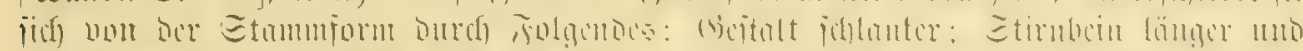

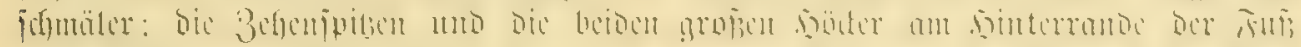

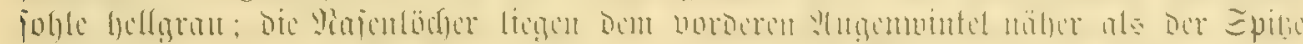

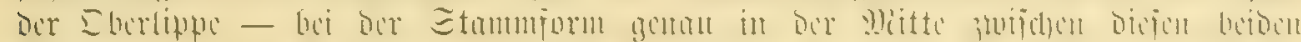

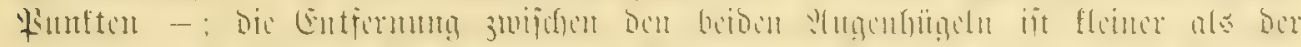

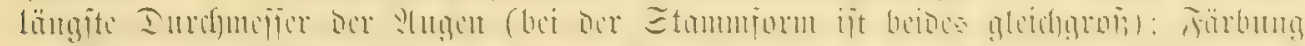

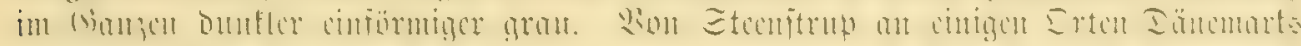

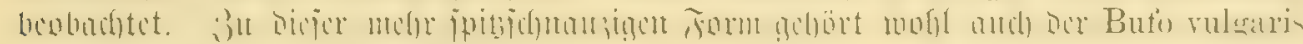

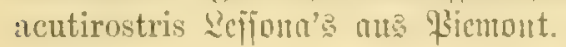

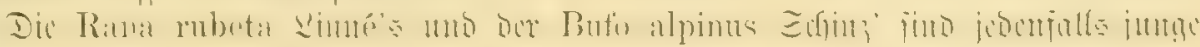
Tlicer.

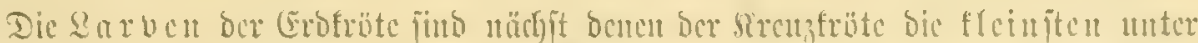

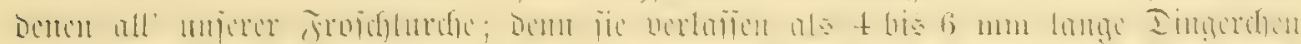
dit (E)

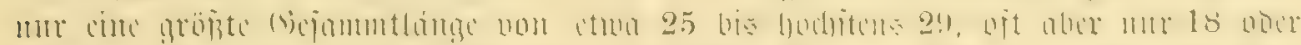

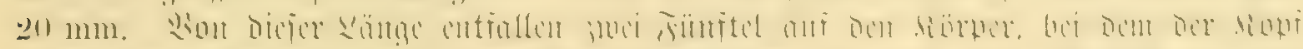

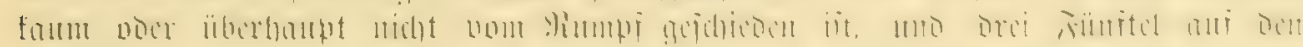

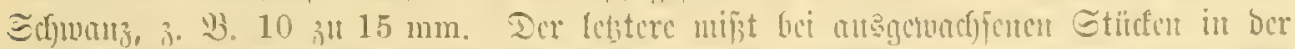

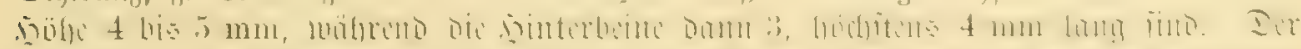

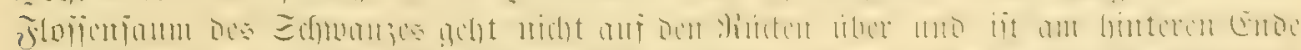

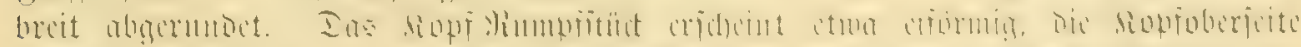

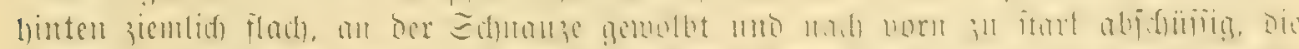

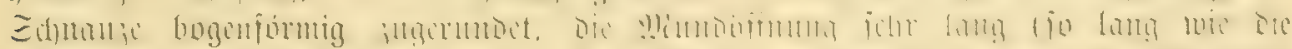

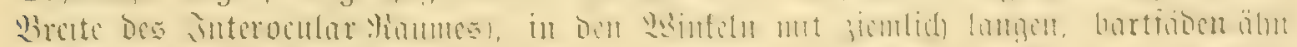

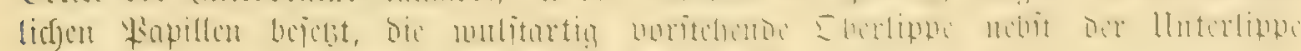

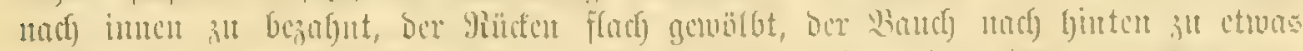

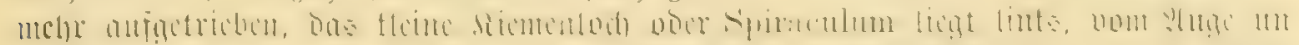

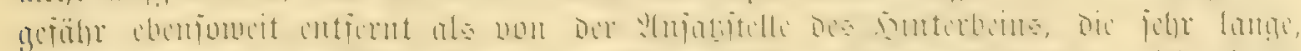

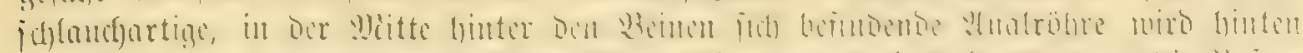

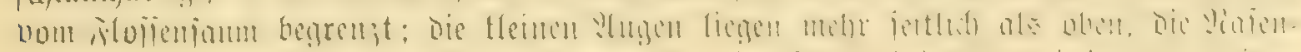

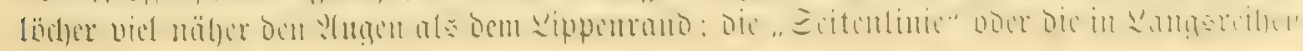




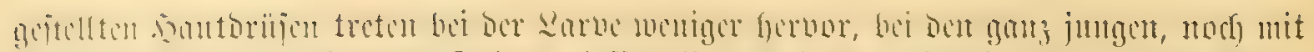

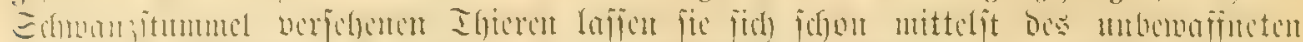

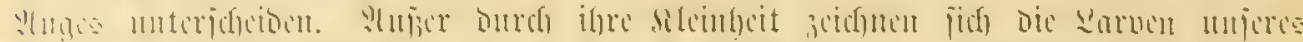

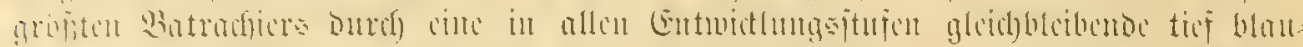

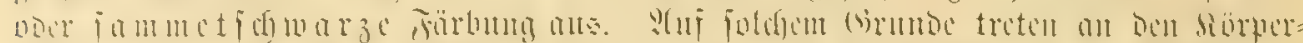

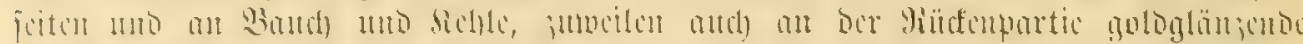

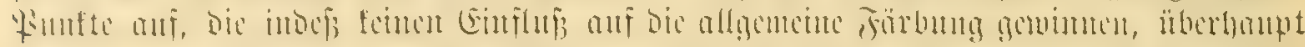

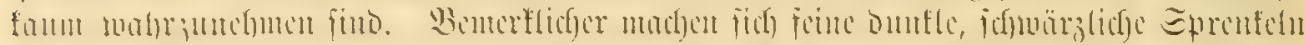

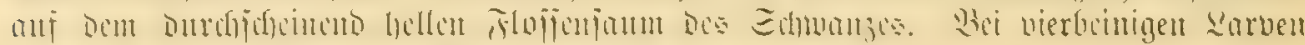
Ém fich der Grumbton ju Braun auflucllen.

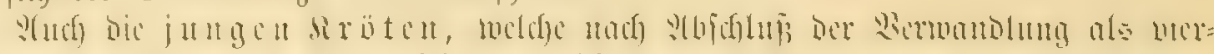

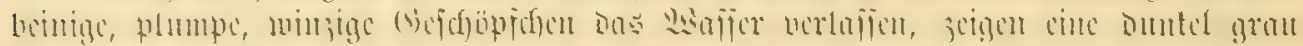

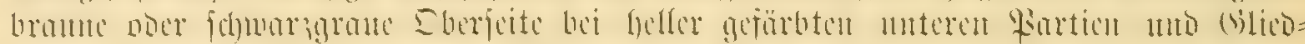

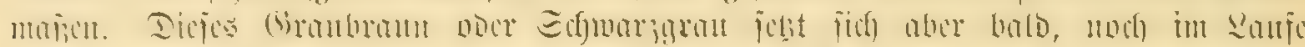

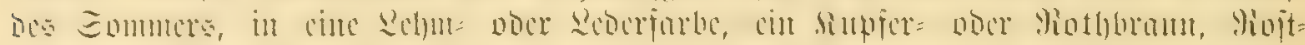

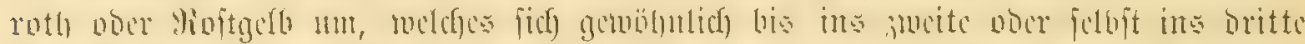

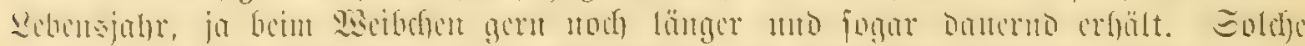

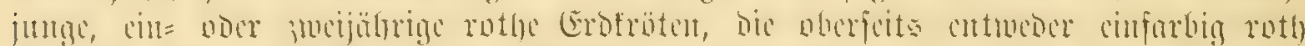

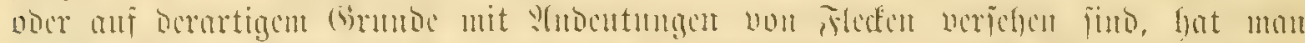

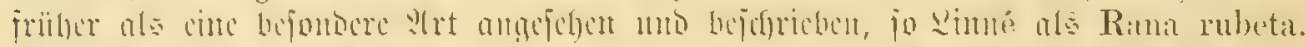

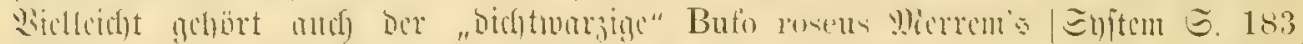

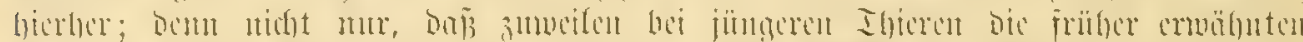

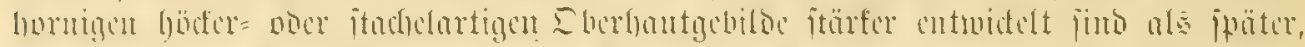

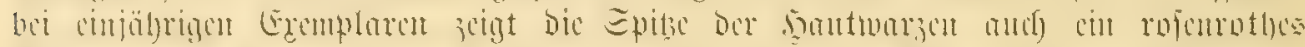

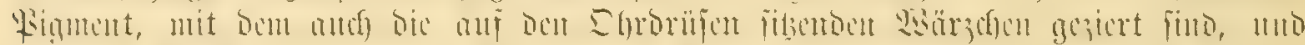

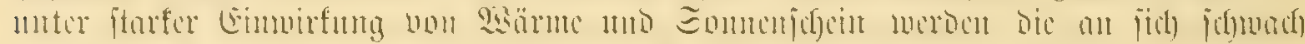

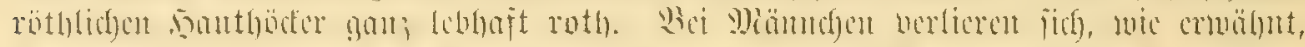

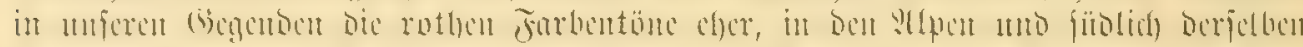

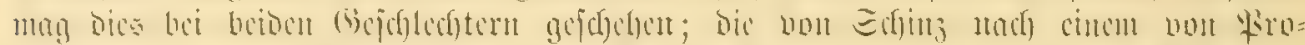

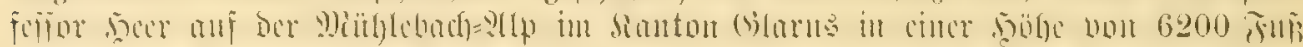

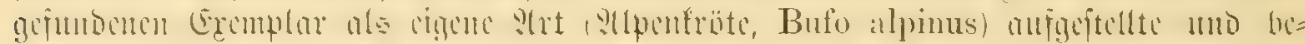

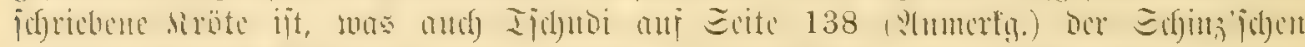

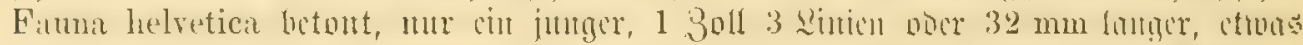

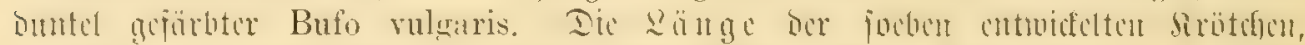

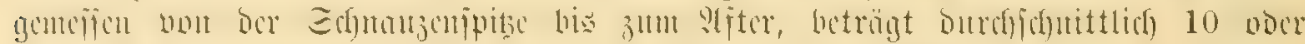
$12 \mathrm{~mm}$. Sä̆feres

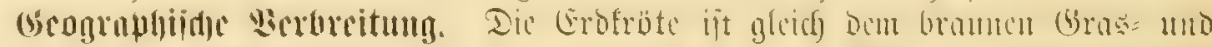

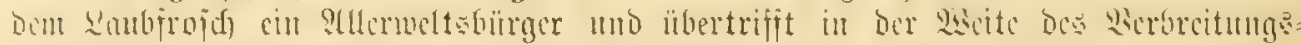

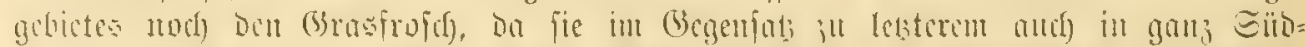

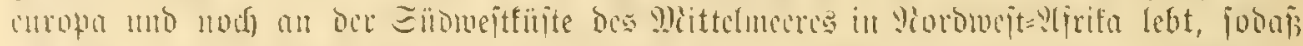

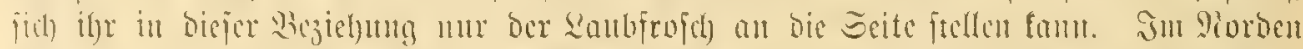

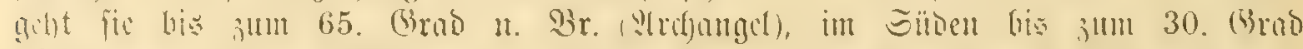

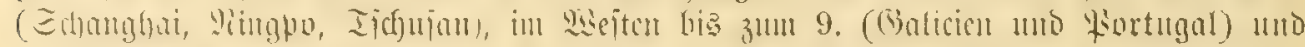

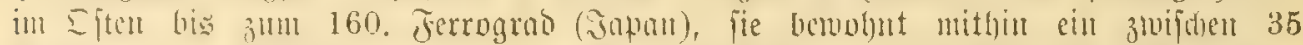

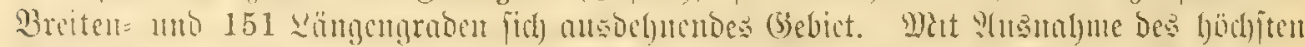

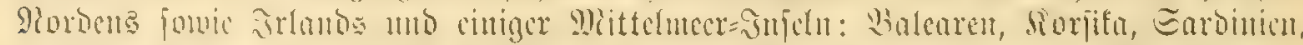

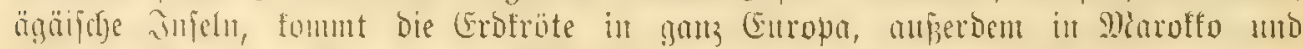

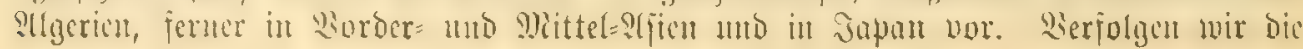




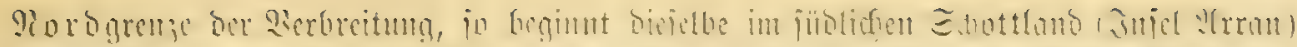

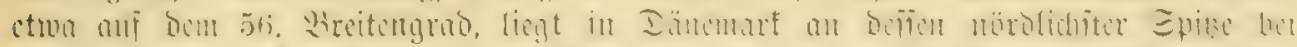

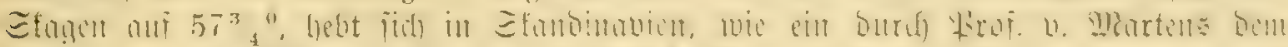

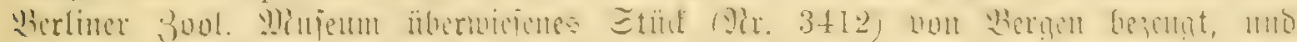

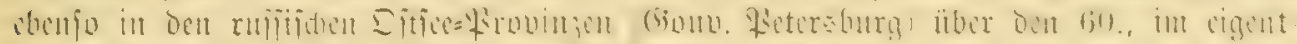

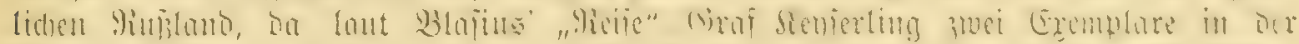

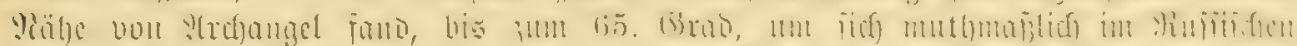

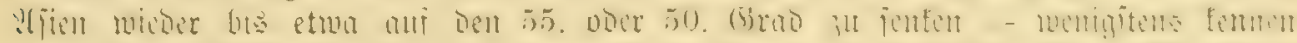

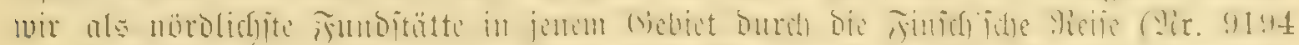

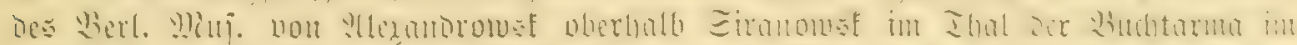

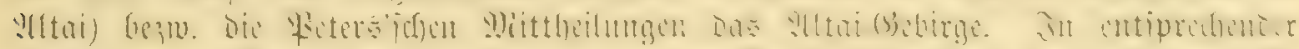

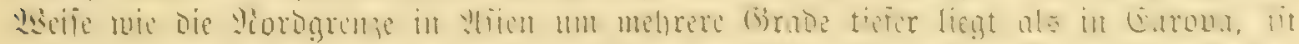

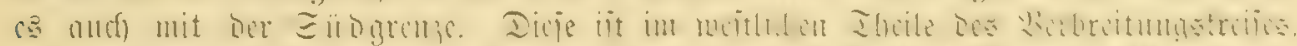

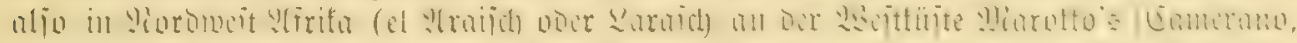

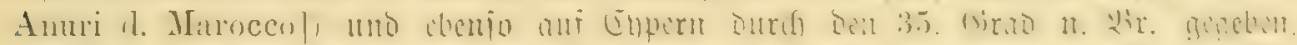

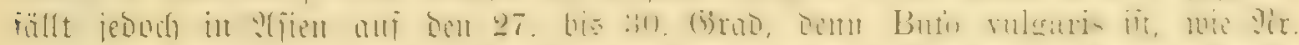

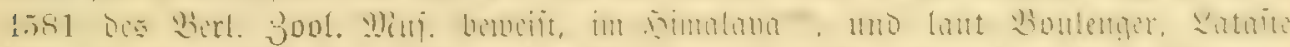

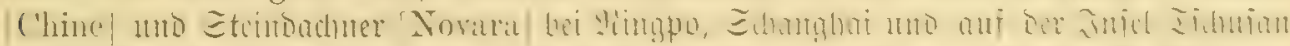

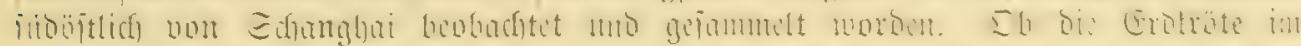

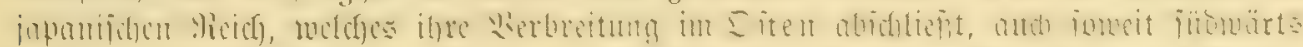

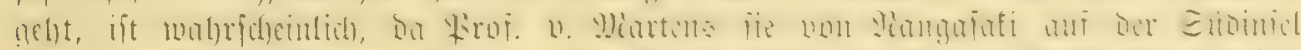

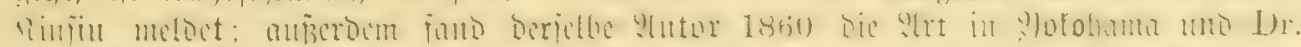

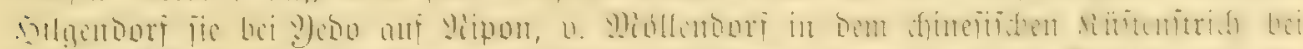

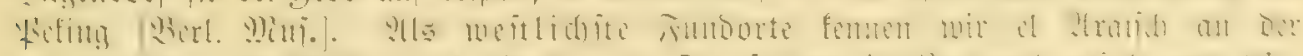

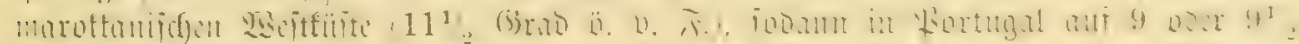

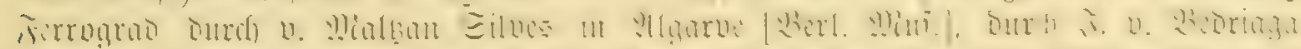

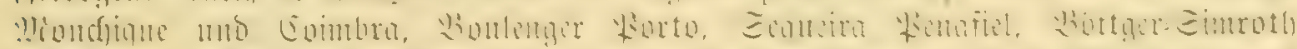

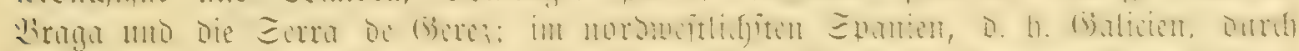

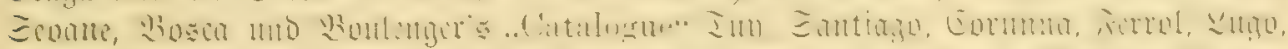

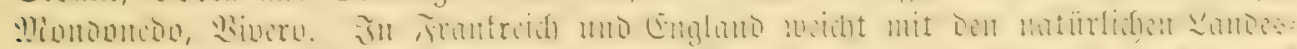

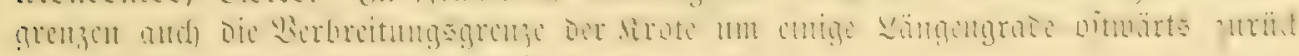
bis alf betr 12. bie 14. Jerrograd.

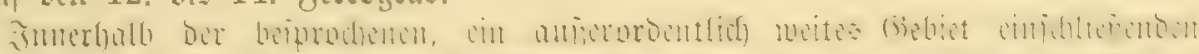

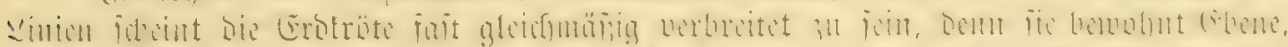

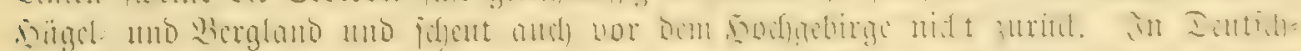

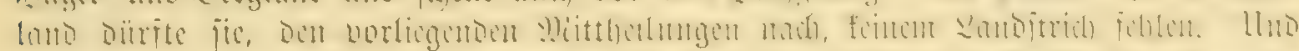

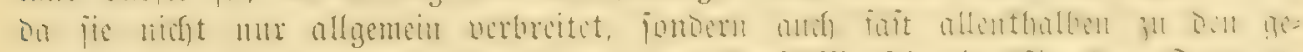

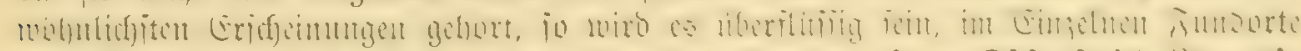

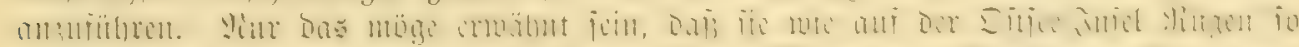

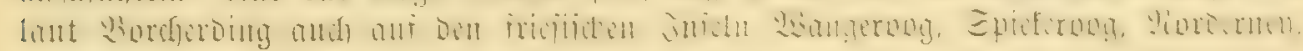
Suijt, Bortum vorfonmt.

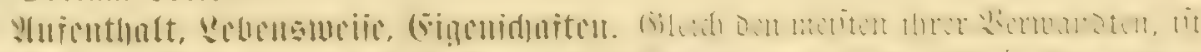
Dic Eretrute cint

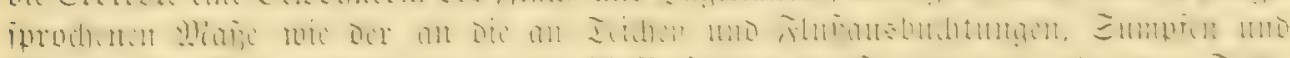

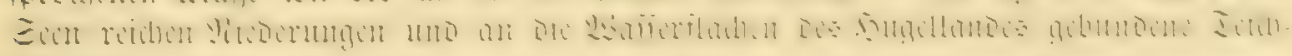

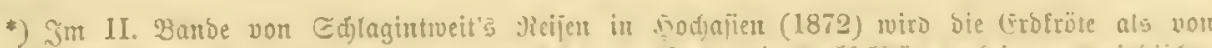

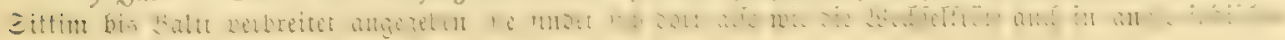
Ërrident. 


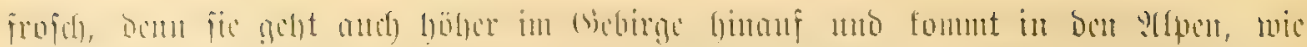

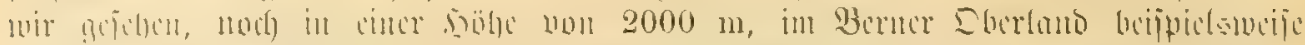

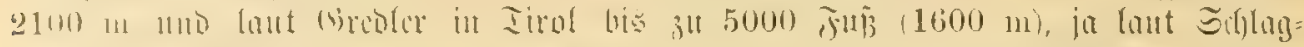

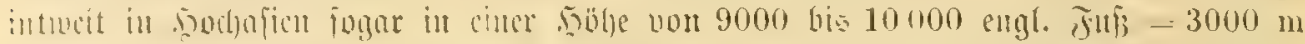

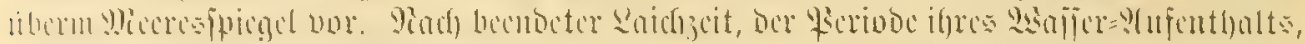

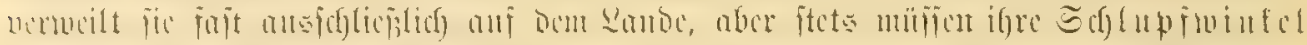

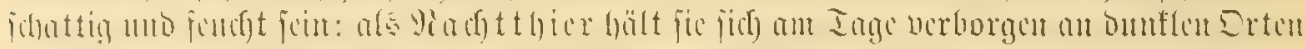

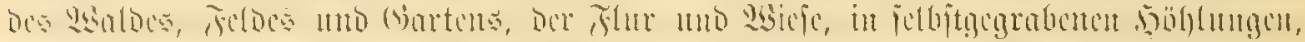
mater (b)

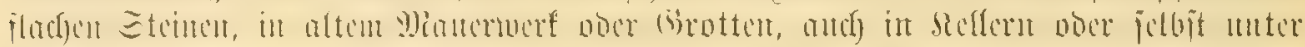

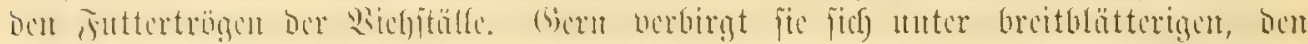

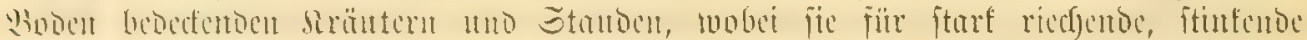

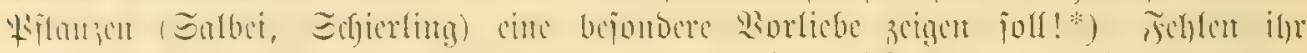

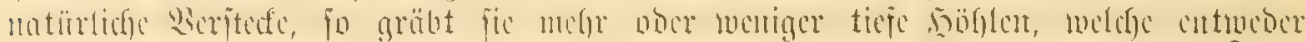

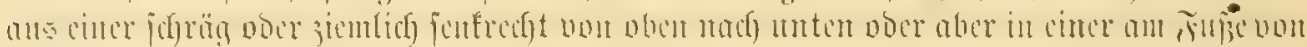

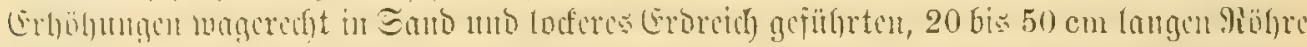

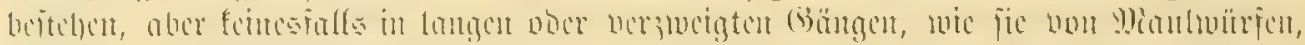

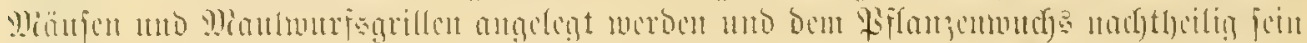

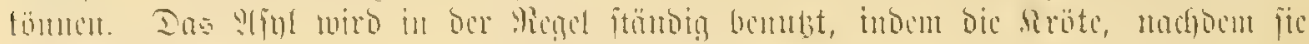

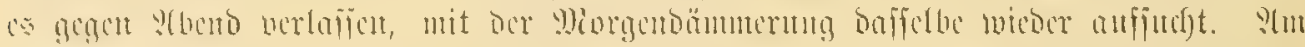

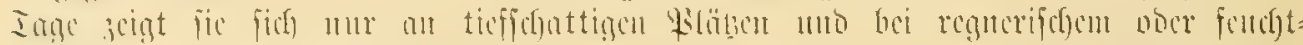

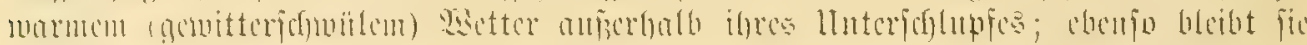

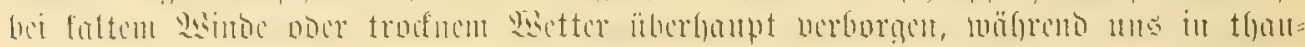

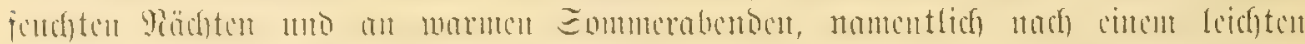

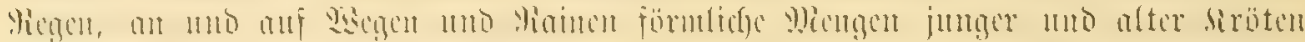

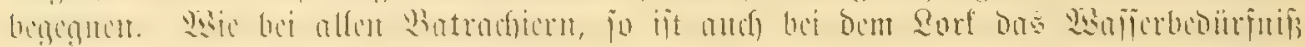

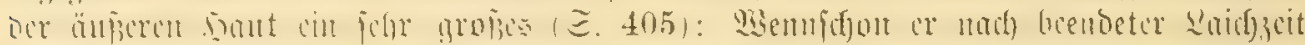

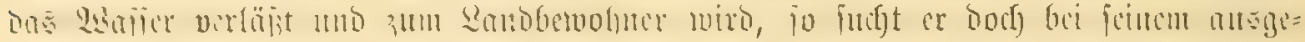

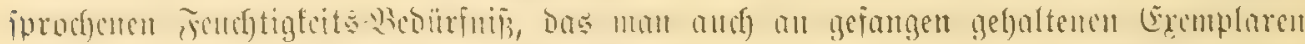

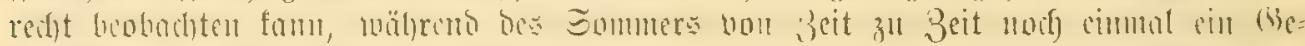

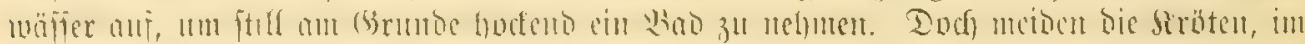

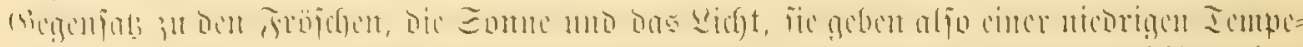

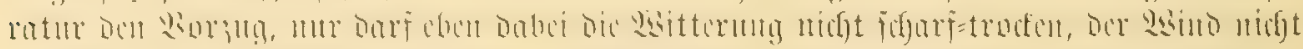

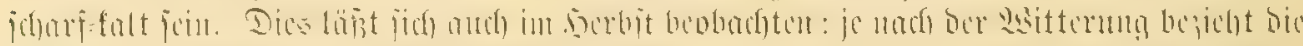

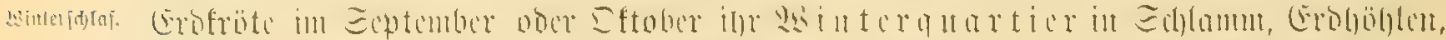

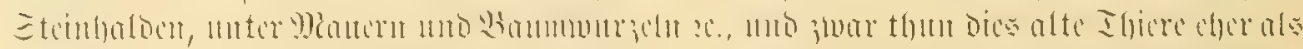

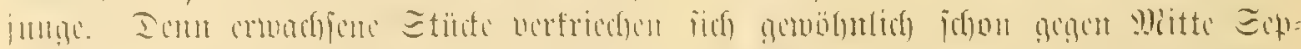

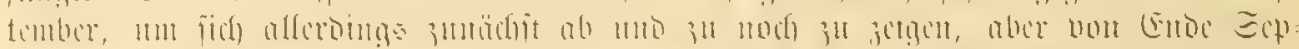

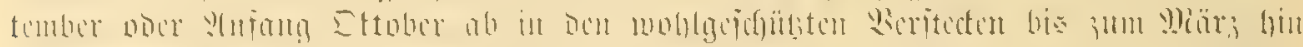

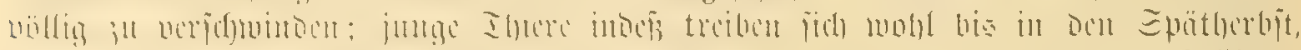

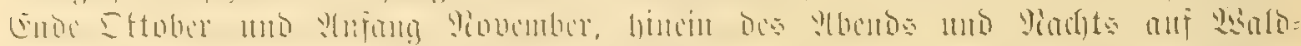

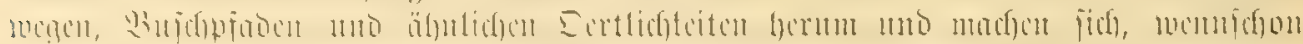

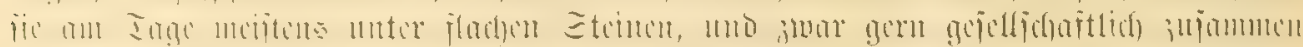

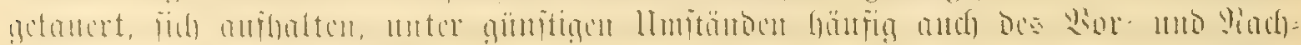

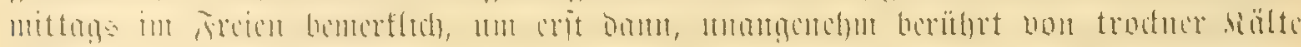

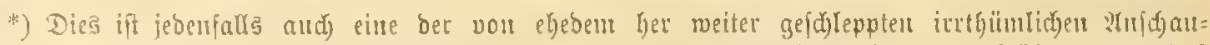

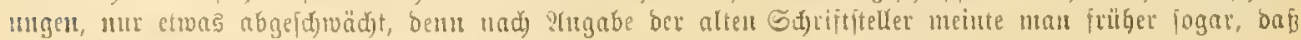

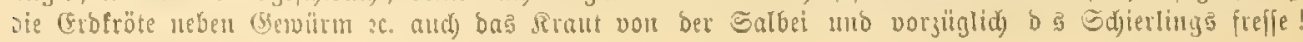




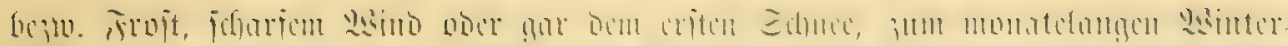

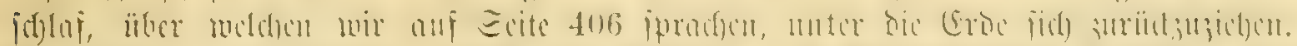

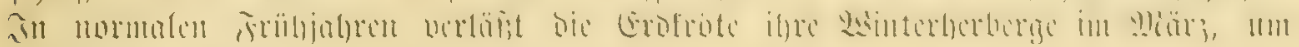

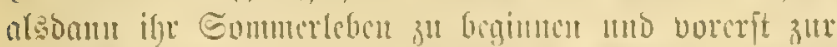

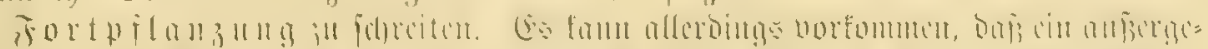

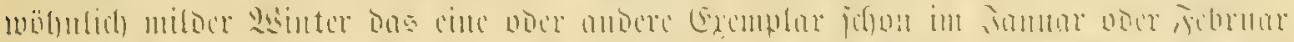

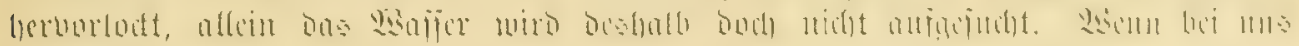

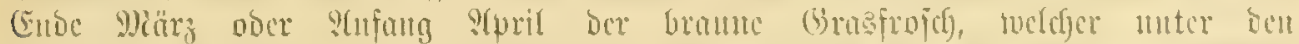

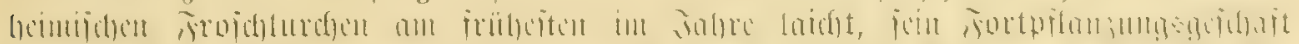

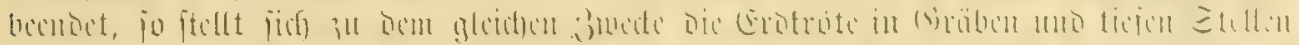

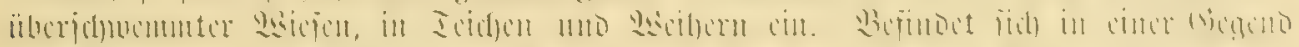

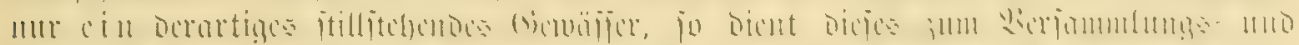

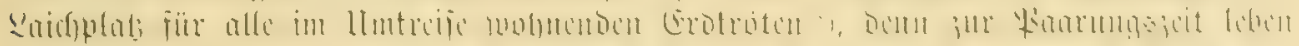

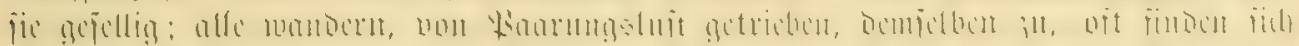

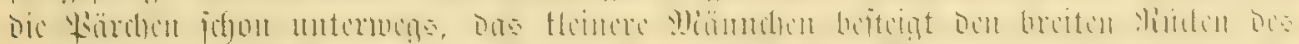

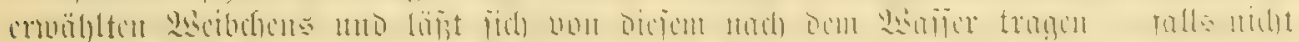

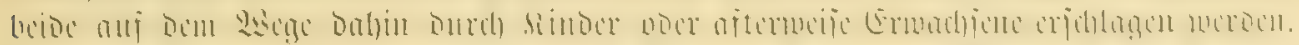

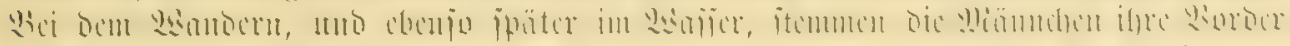

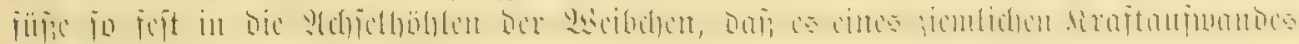

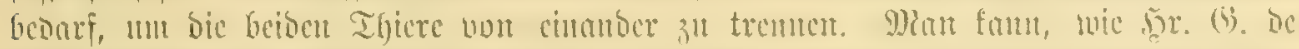

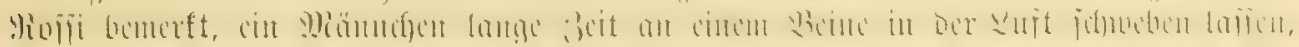

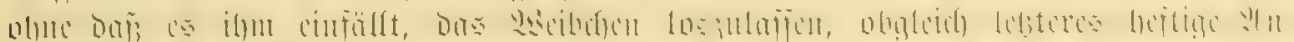

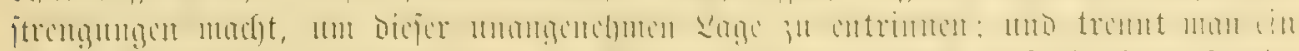

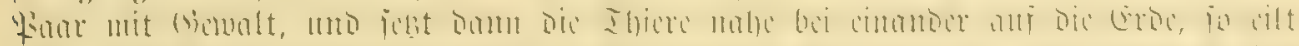

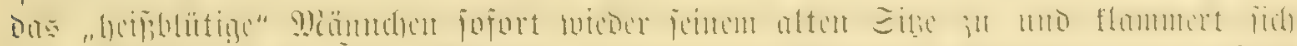

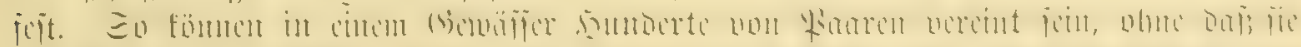

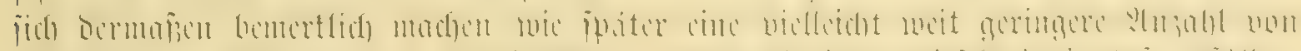

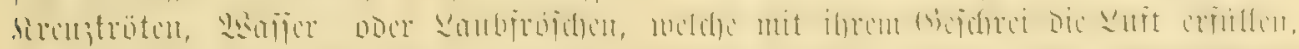

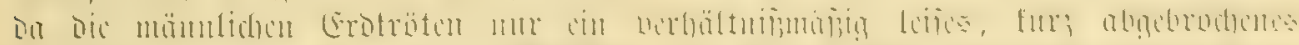
Dumplos

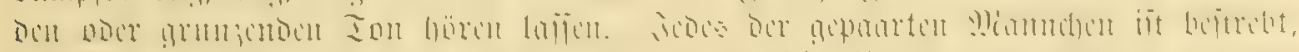

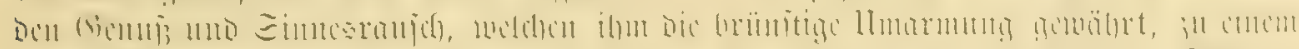

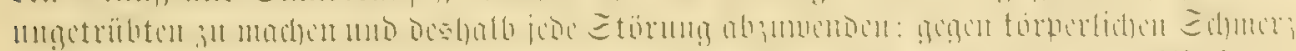

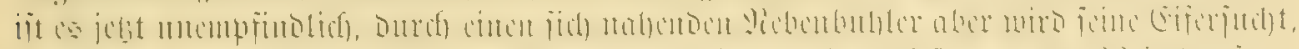

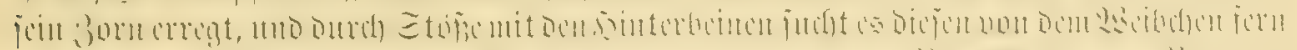

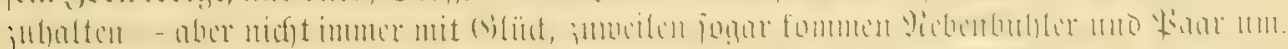

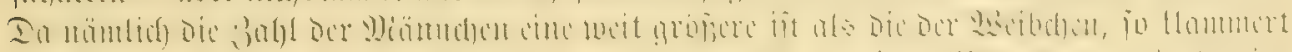

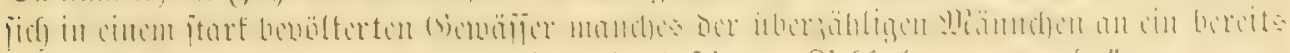

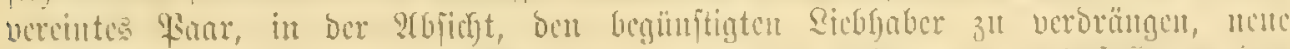

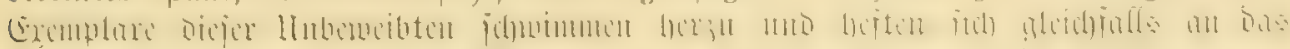

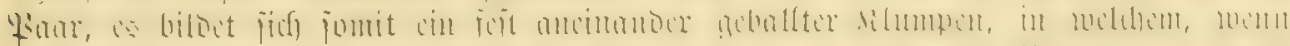

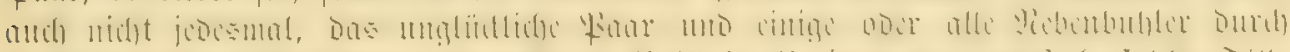

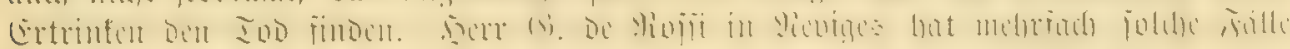

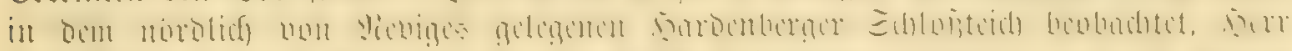

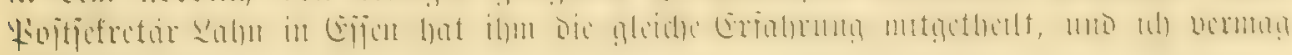

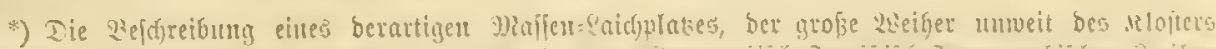

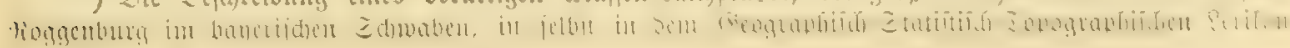
Edjuabers vom Sabre 1791 jul finden. 


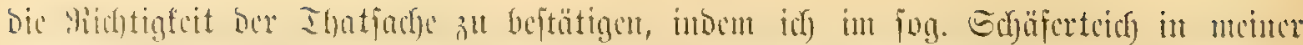

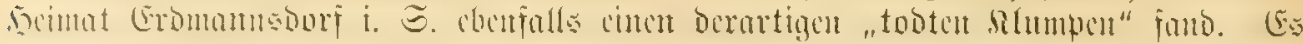

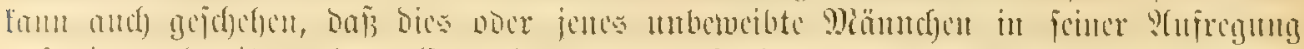

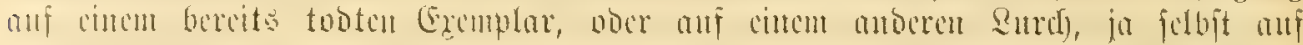

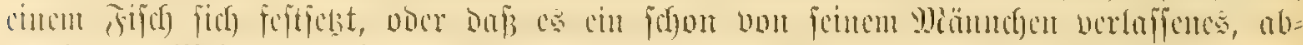

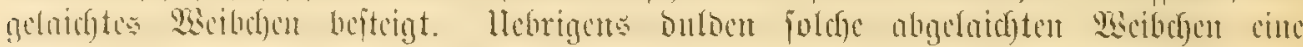

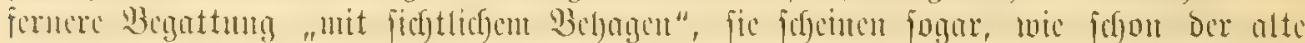

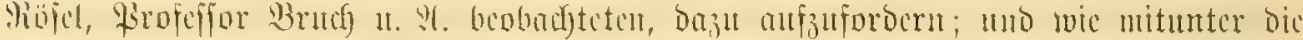

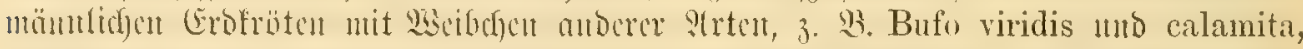

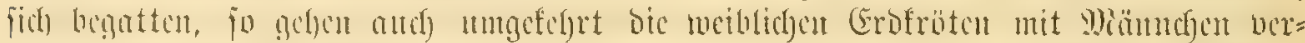

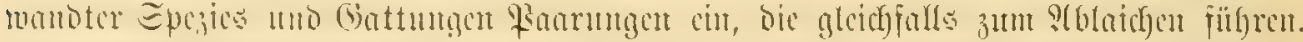

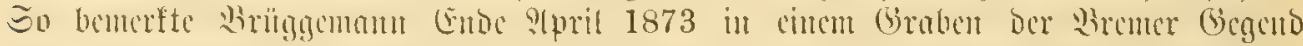

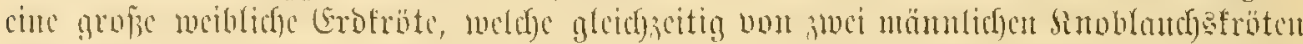

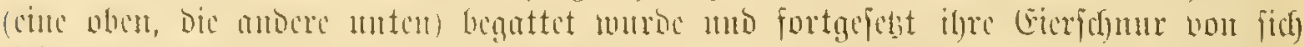

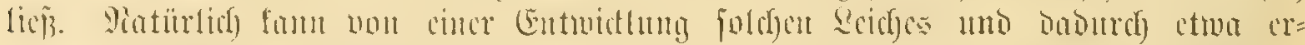

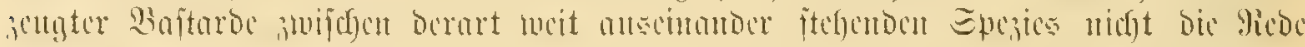

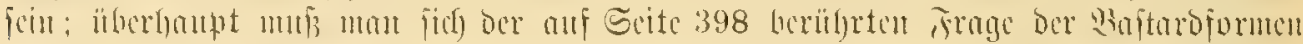

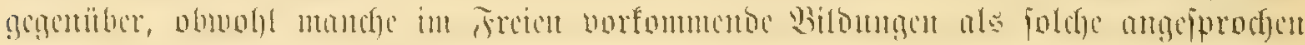
werden föntent, fiib)l berfalten.

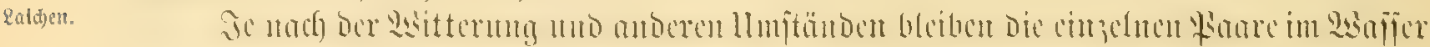

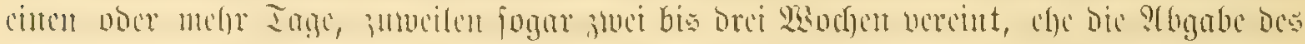

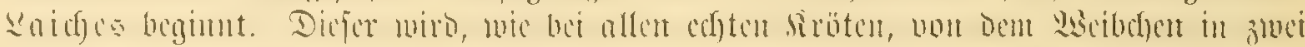

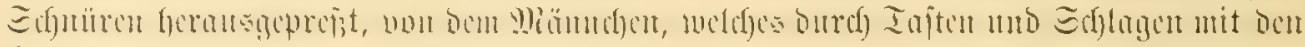

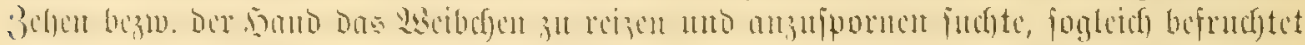

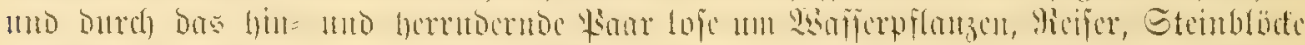

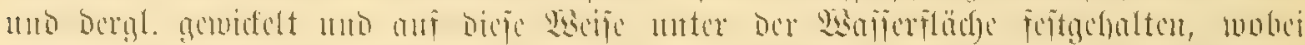

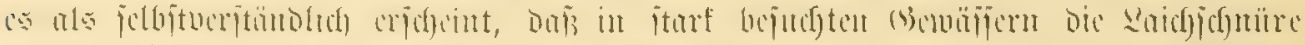

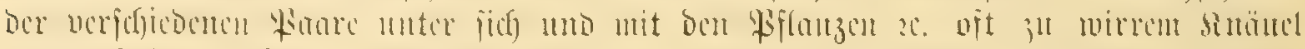

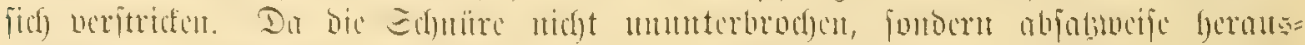

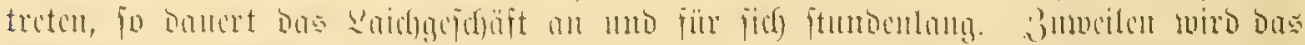

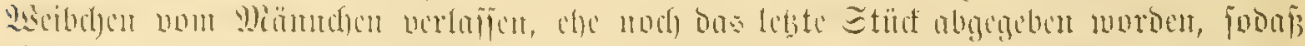

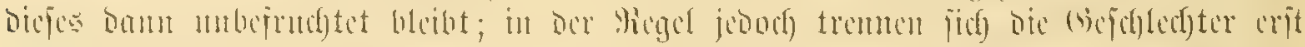

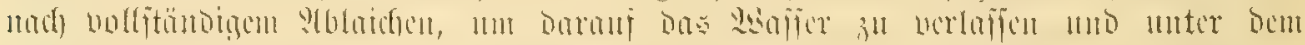

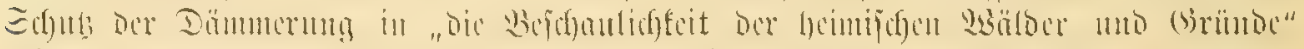

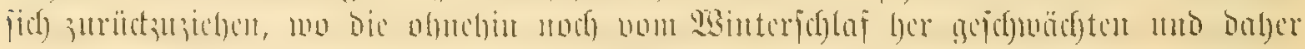
mu Doppelt abgefpanten Thicere fich allgemad) crljoleut.

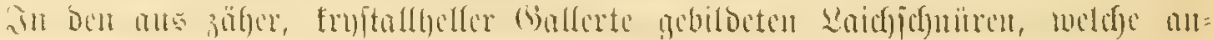

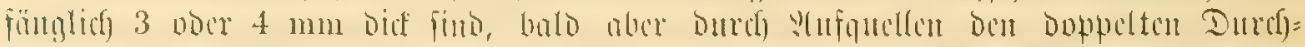

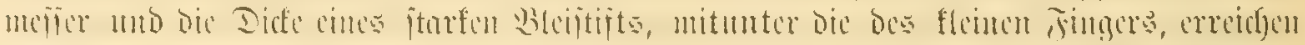

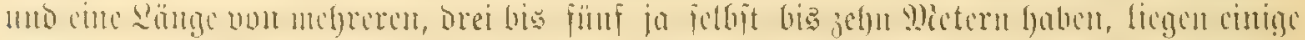

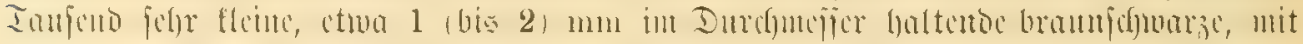

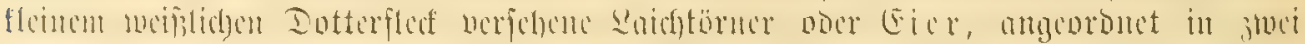

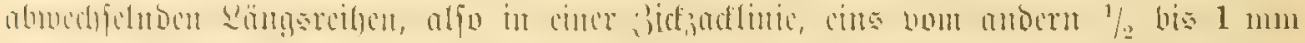

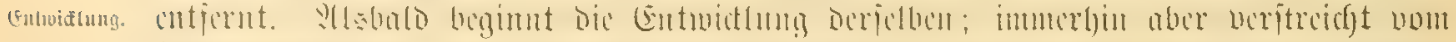

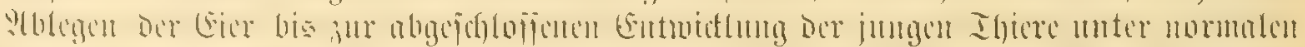

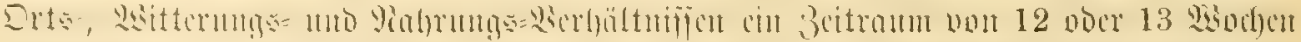

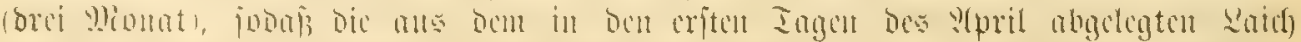

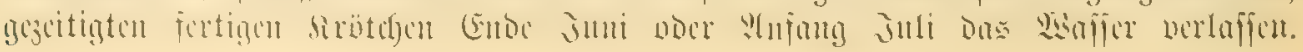




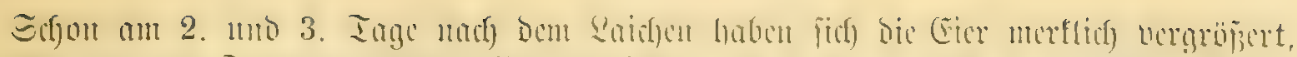

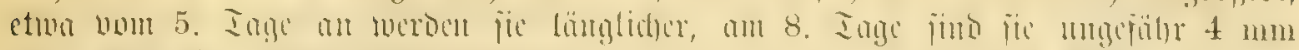

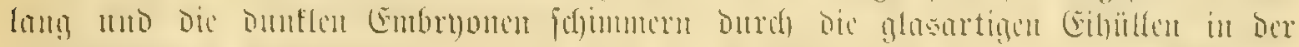

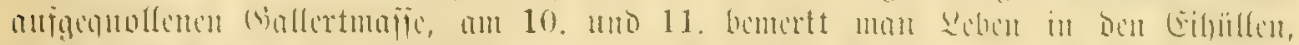

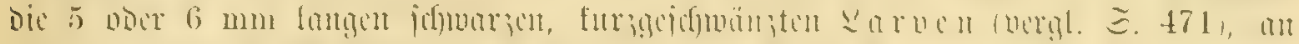

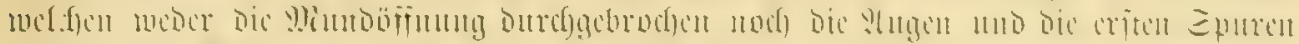

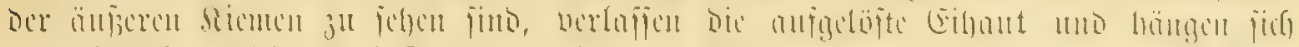

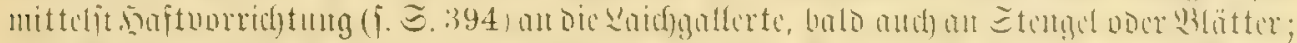

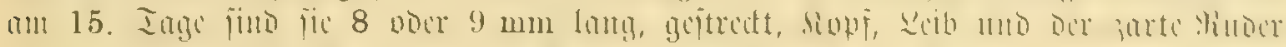

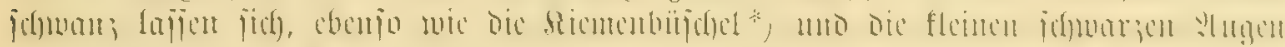

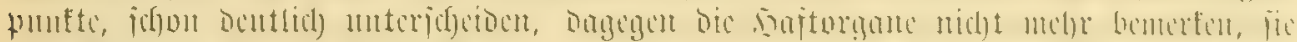

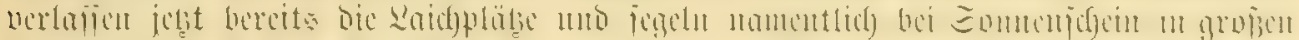

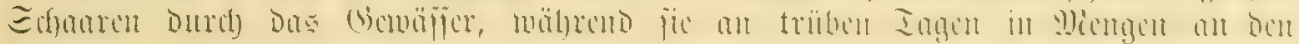

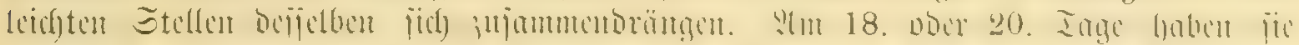

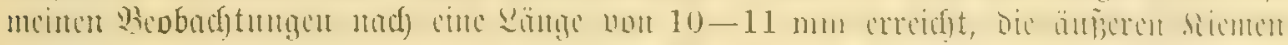

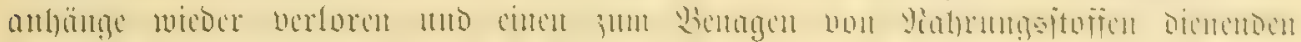

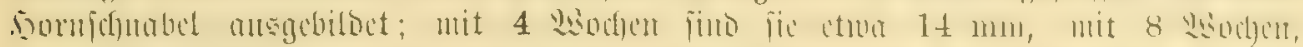

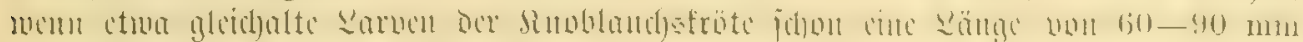

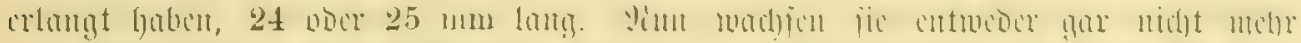

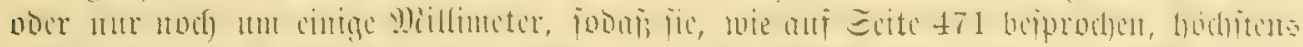

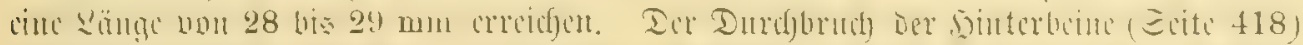

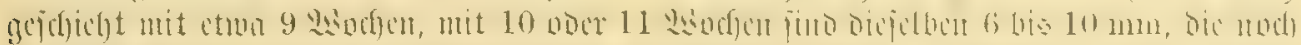

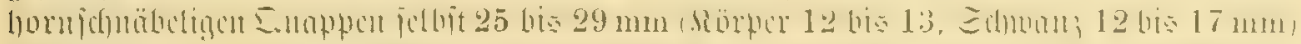

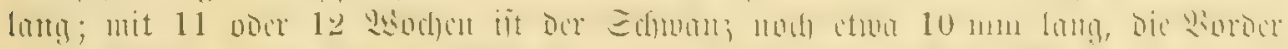

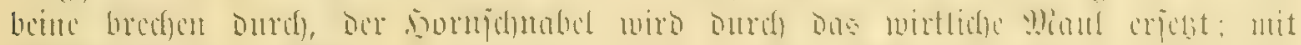

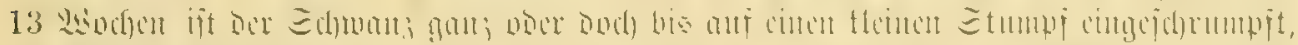

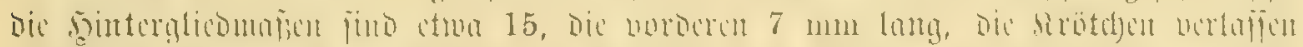

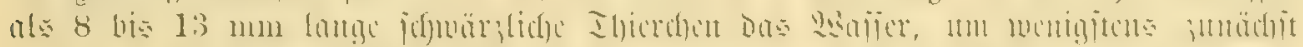

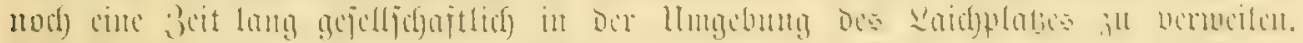

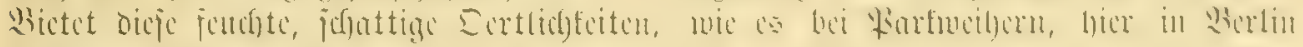

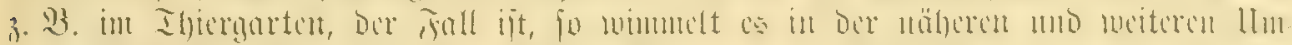

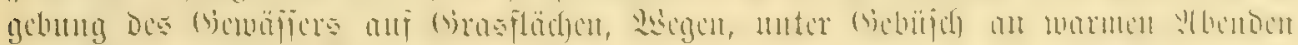

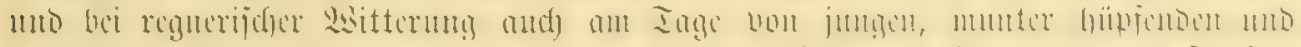

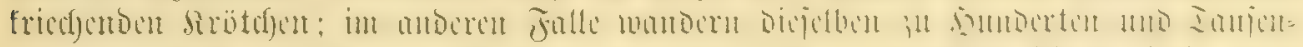

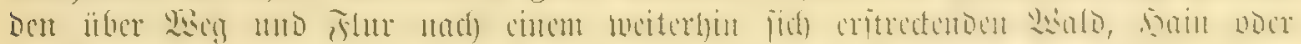

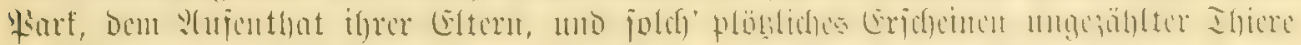

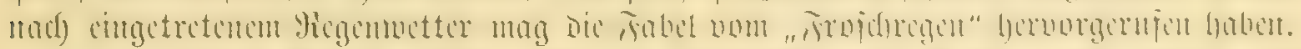

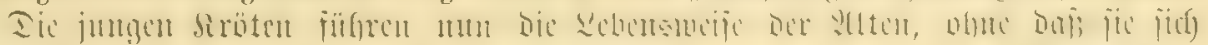

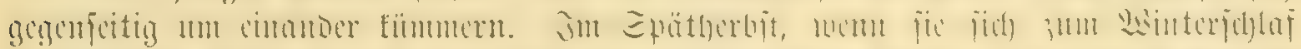

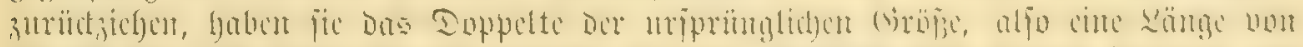

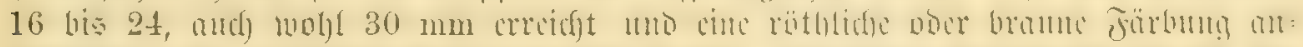

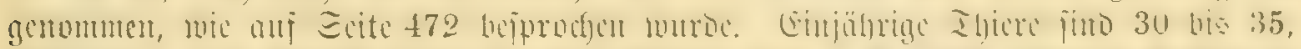

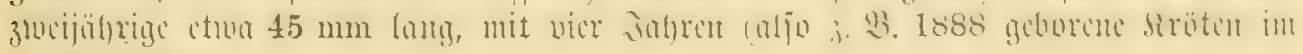

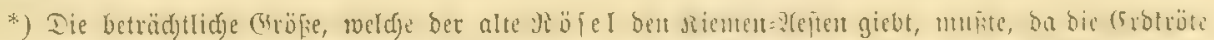

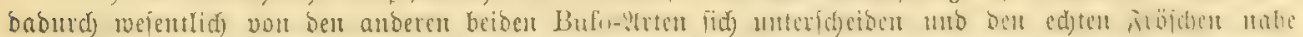

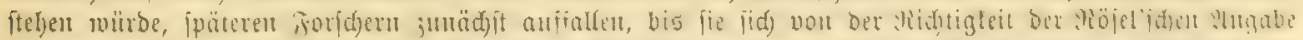

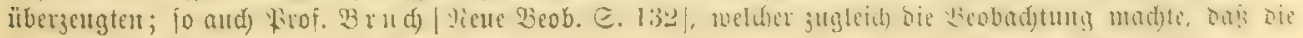

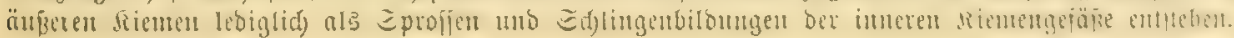




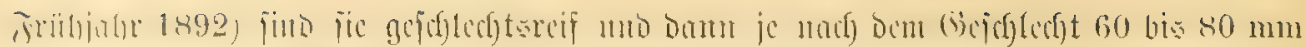

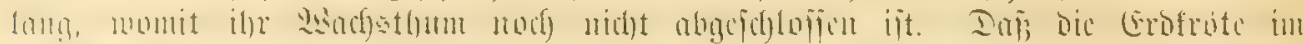

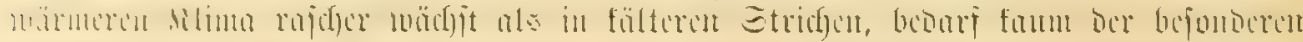

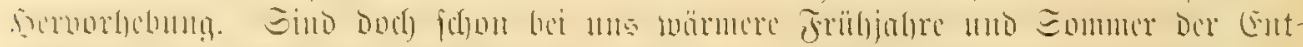

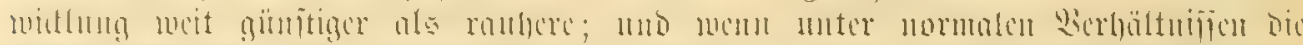

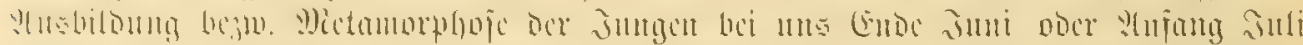

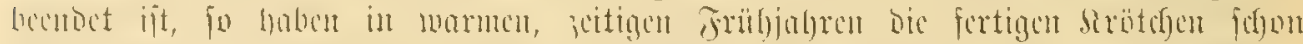

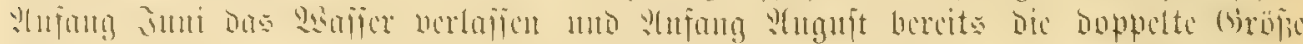

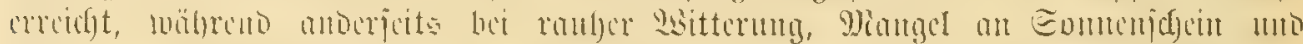

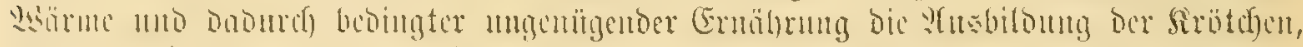

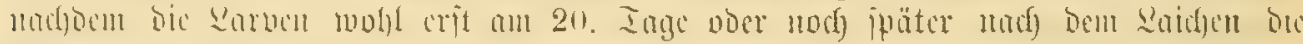

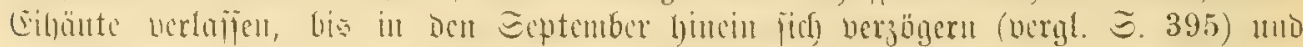

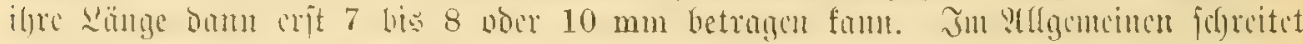

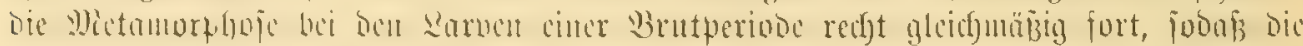

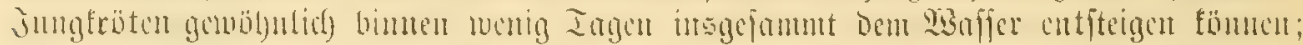

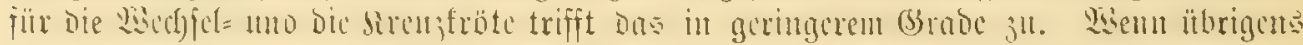

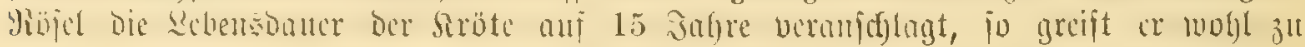

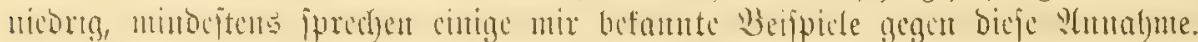

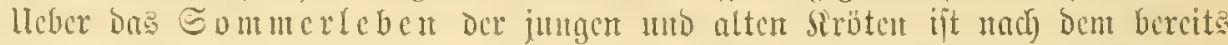

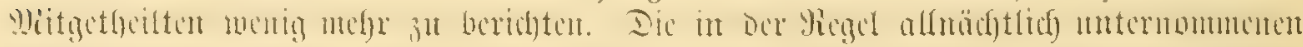

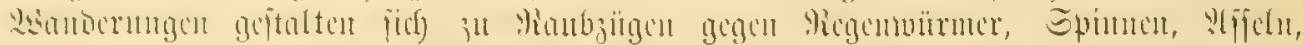

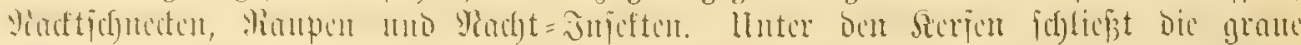

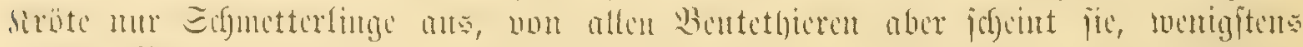

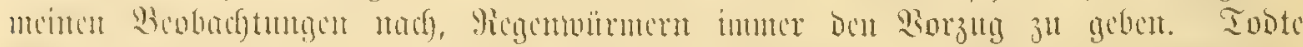

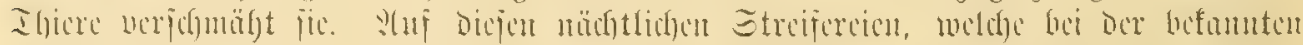

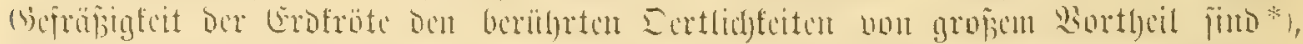

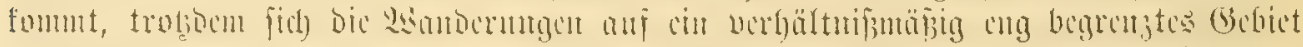

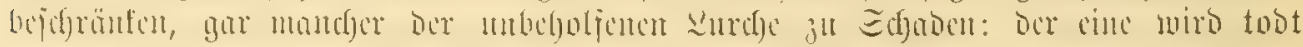

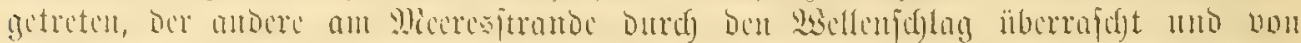

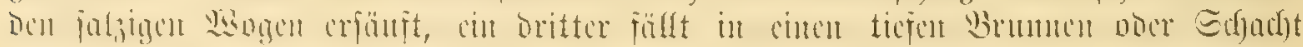

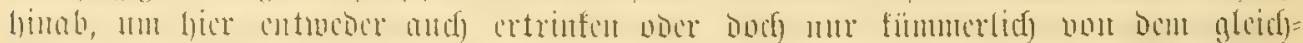

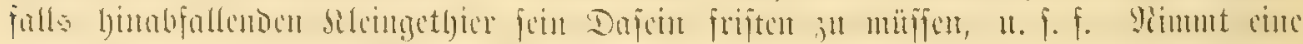

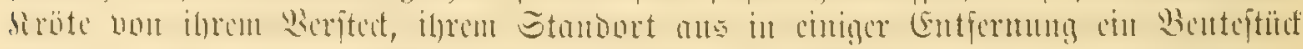

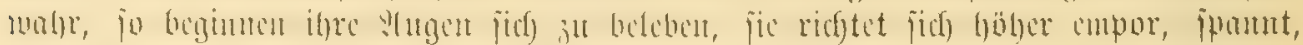

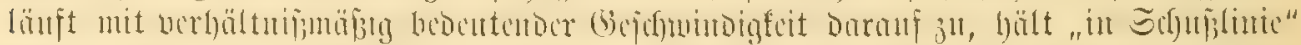

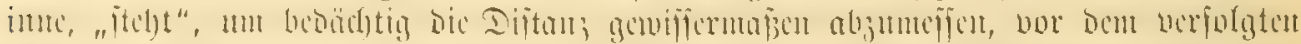

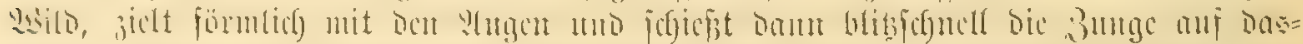

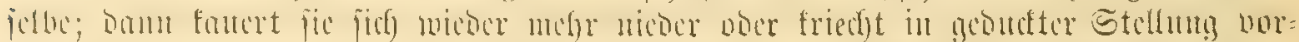

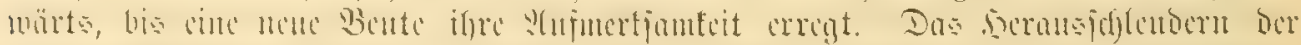

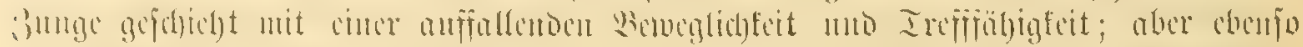

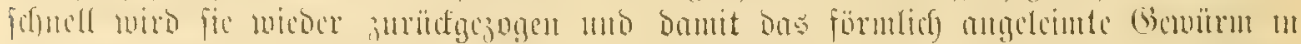

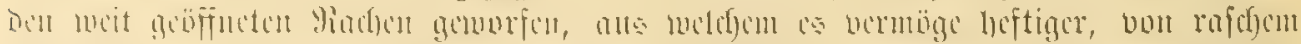

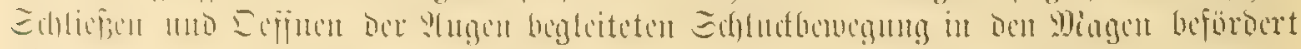

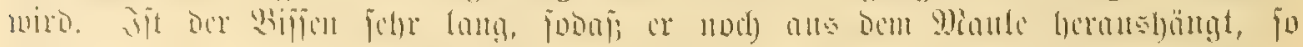

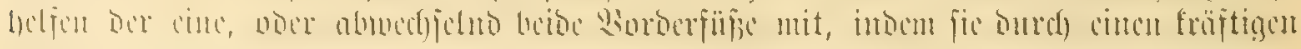

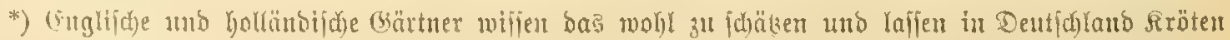

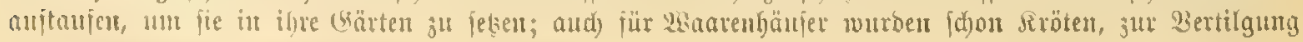

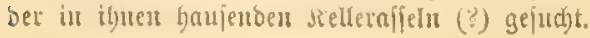




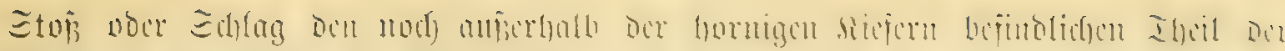

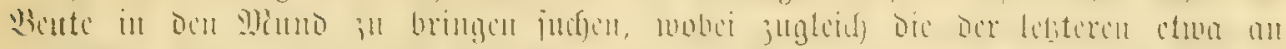

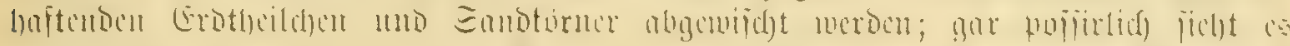

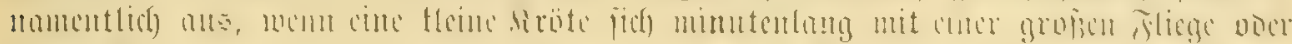
cimcm

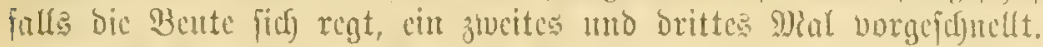

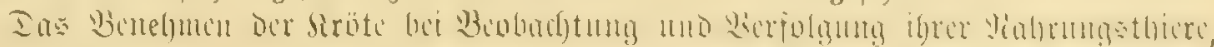

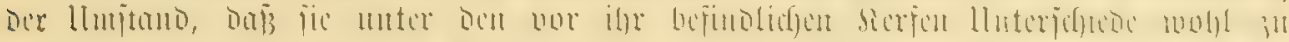

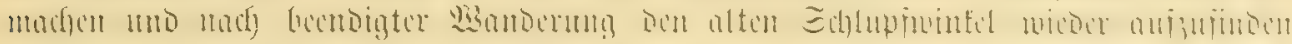

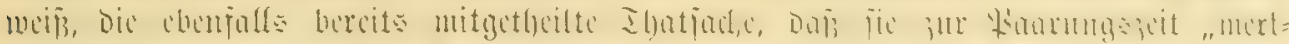

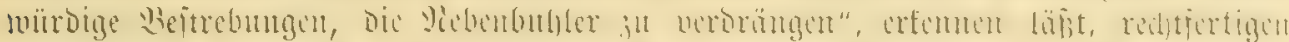

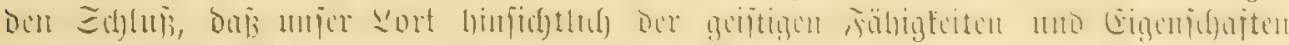

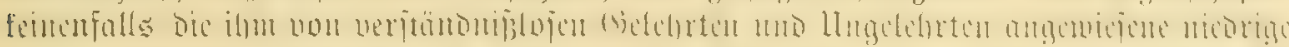

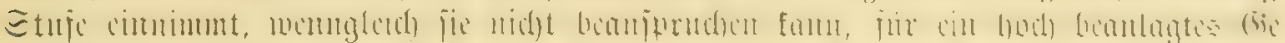

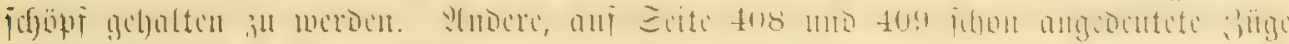

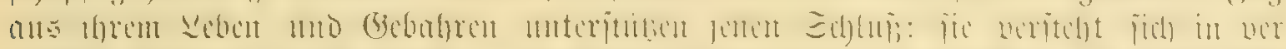

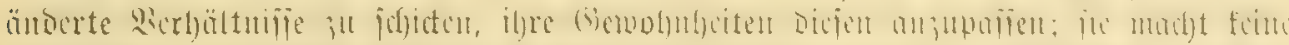

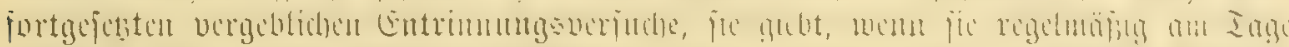

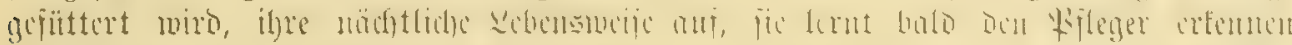

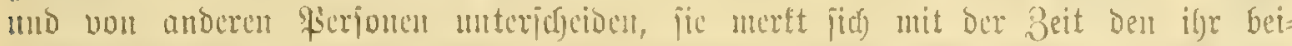

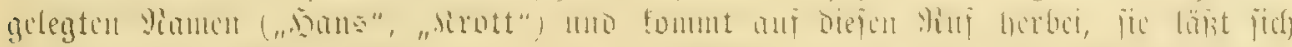

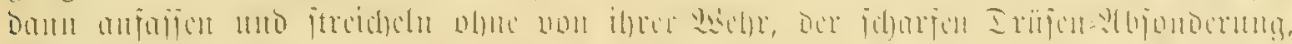

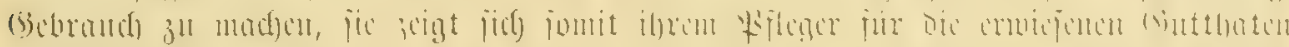

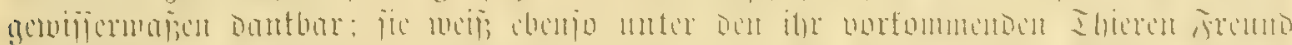

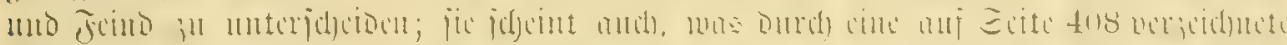

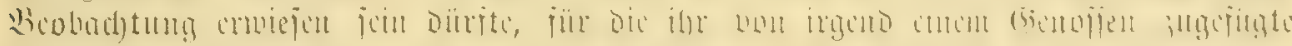

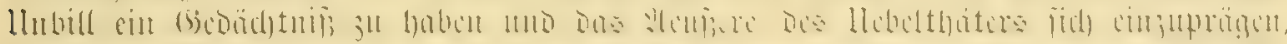

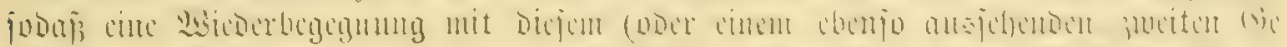

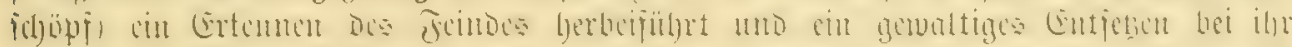

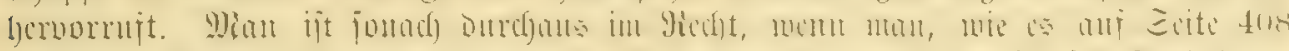

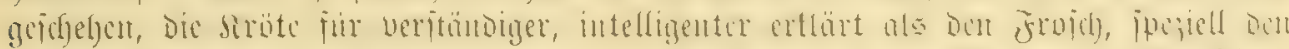

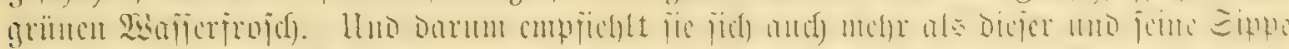

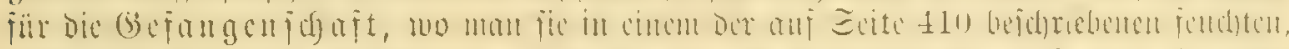

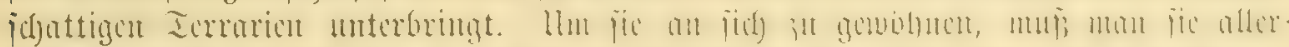

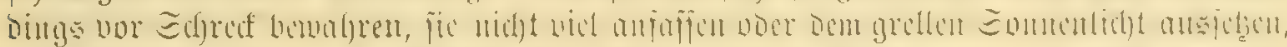

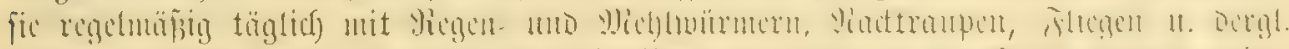

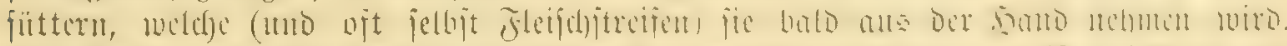

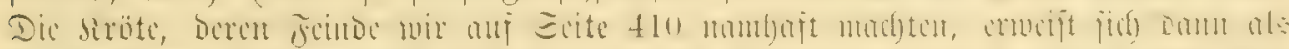

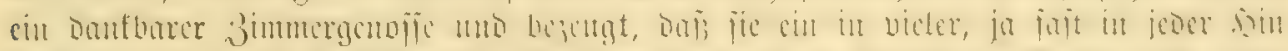

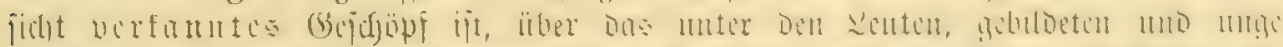

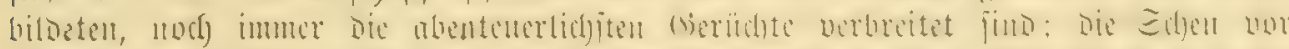

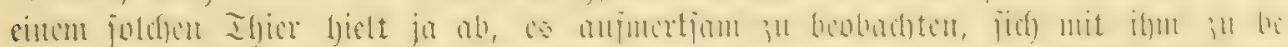

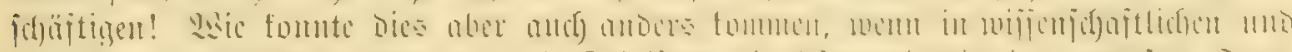

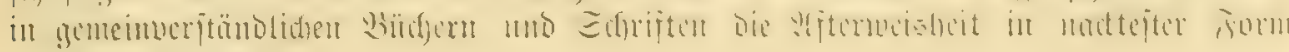
aufgctij(jt sourde! *)

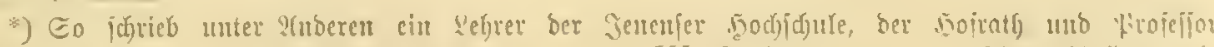

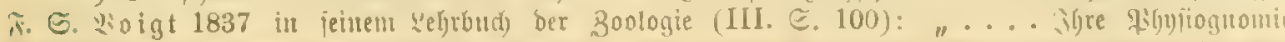

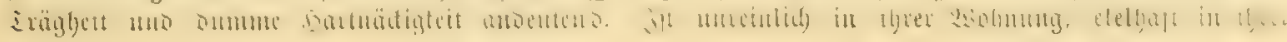




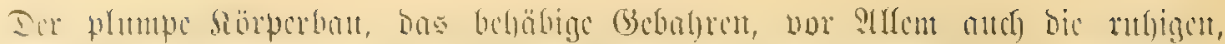

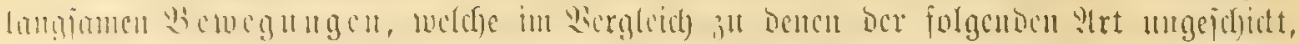

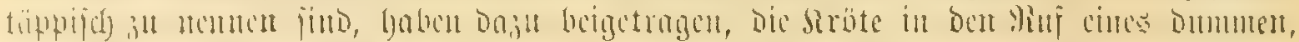

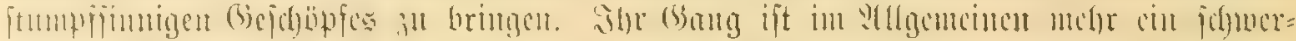

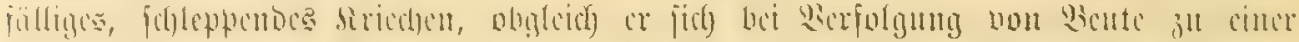

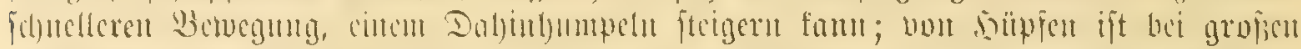

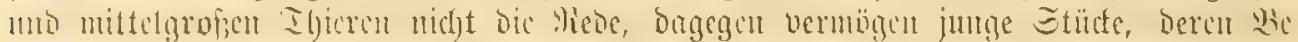

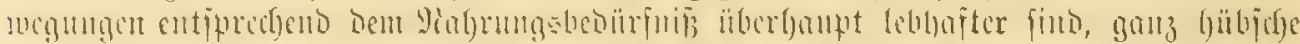

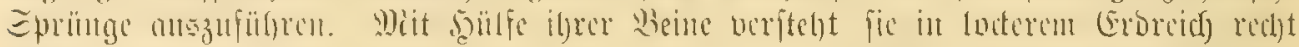

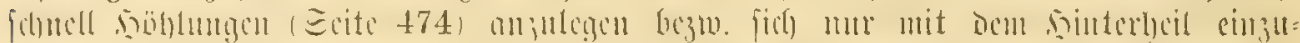

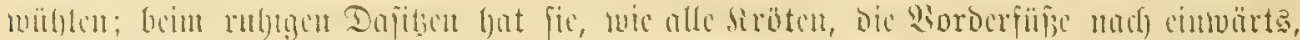

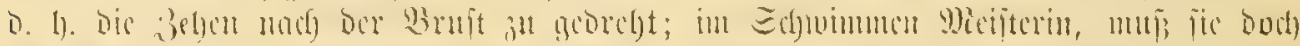

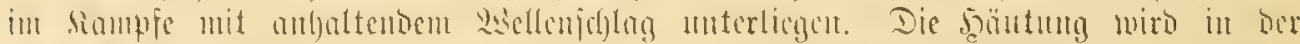

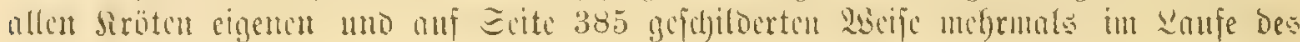
Jahres vollzagent.

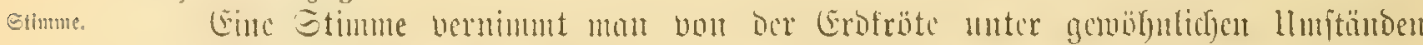

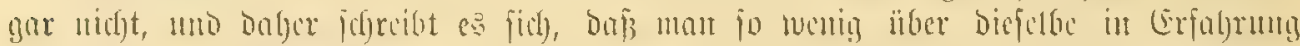

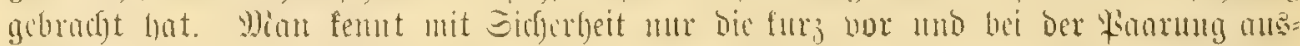

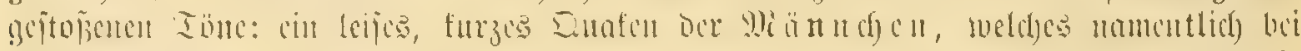

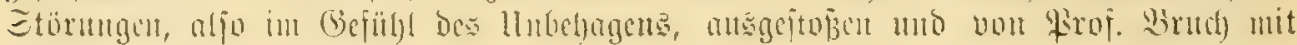

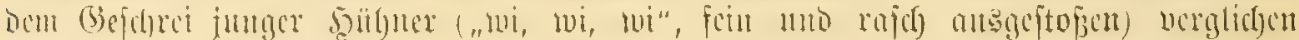

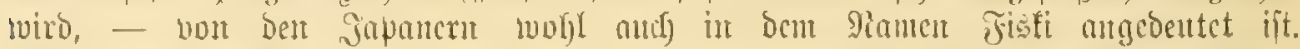

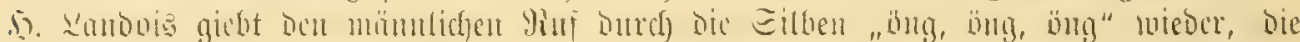

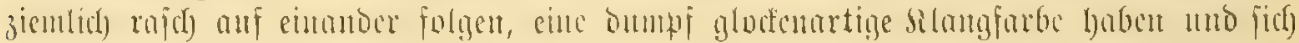

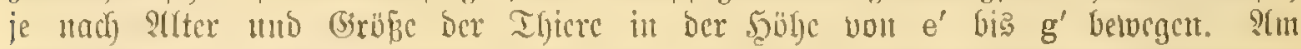

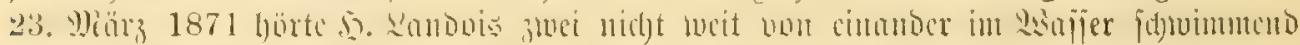

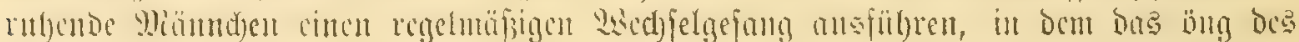

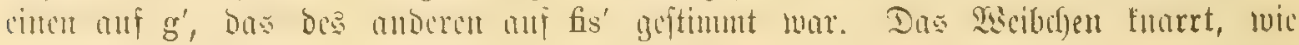
eruälynt, noch feltcucr wub in ticferen sagen.

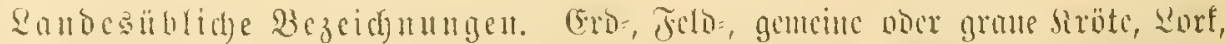

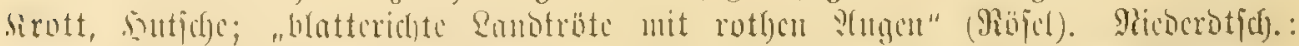

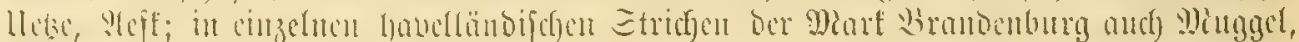

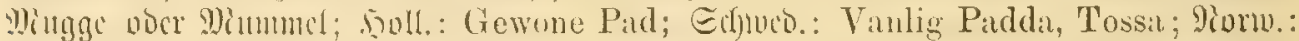
Gre; Engl: Common Toad; Frm, ,: Crapaud commun Crapaud brun, Cr. cendré); Stul.: Rospo comme, Botta, Sciatt; Epan.: Sapo comun; finlu.: Ropucha popiclatı; Rỉbur.: Ropucha obecná; Dalmnt.: Zaba zabuaca, Z. krastavica; llug.: varas beka; Jcut.: Konna; Iiuff.: Shába.

synonyma. Bufo terrestris major, Sclivenkfeldt 1603. - Rana Bufo, Limné 1754. - Bufo terrestris, liösel 1758. - Bufo vulgaris, Laur. 1768. - Bufo cinereus et B. salsus, Schneider 1799. - B. Roeselii, Latreille 1800. - B. ventricosus, /handir 1803. - I3. ferruginosus et B. tuberculosus, Rieso 1826. li. Hratextatus, Bric [Isis $1826 \approx .224$ ). - Phryne vulgaris, Fitzinger 1843. -

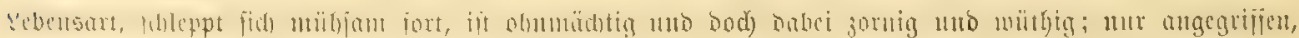

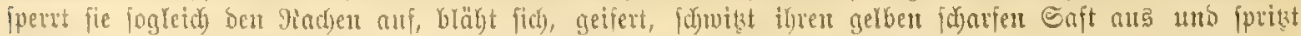

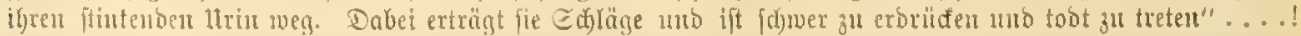

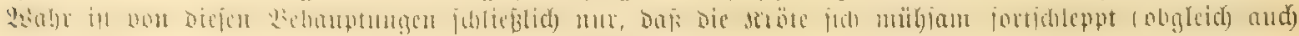

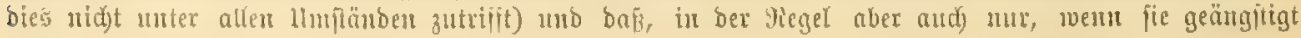

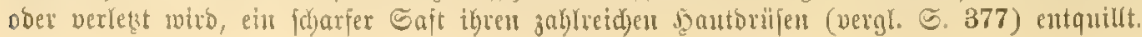




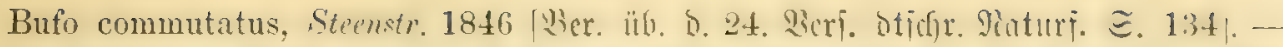

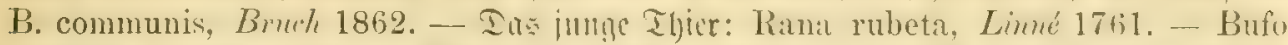
alpinus, Sihnz 1833. - 2inrictüt: Bufo spinosus, Imudin 1803: Ramar verrucosissima, Pulles 1831; Bufo colchicus, Fichereld 1831: Bufor vulgaris jalponicus. Solegel 1838; B. palmarum, r'uvier 1829; B. gatrgarizans, rimem LAn. of nat. hist. 1842, ऽ. 483].

\section{2(rt: Grünte Iröte. Bufo viridis, Laur.}

26bilbung: Tajel I פir. 2.

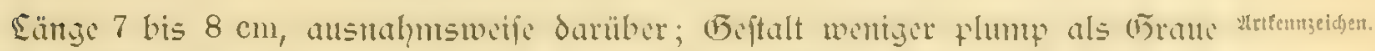

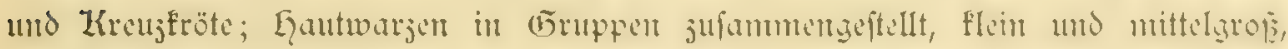

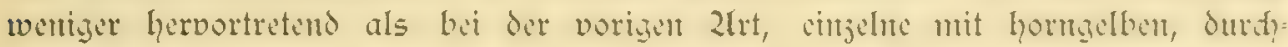

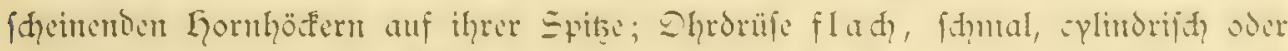
nierenfürmig, das hintere Ende cinmäts geriłtet (daber redpte und linfe Dhrorüfi nad) hinten etwas fid nähernd) unt mit dicfem bis hinter dic 2f dyfol reifhillo, alfo

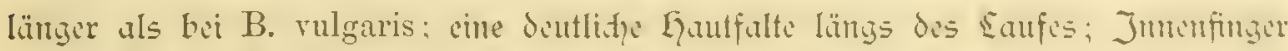

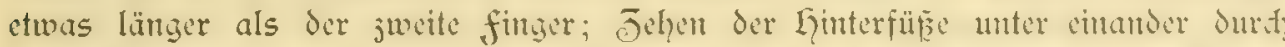

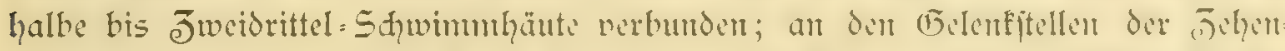

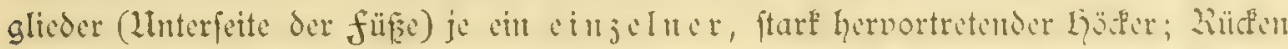
grammets mit unegelmäpigen oun rothen Warzen.

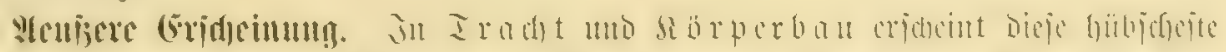

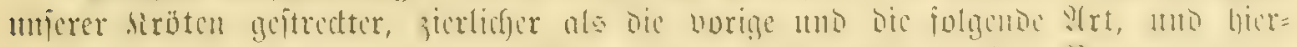

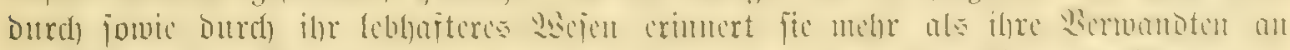

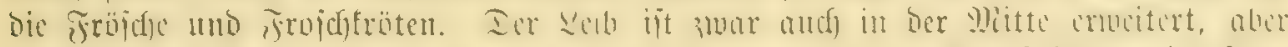

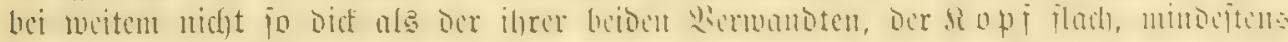

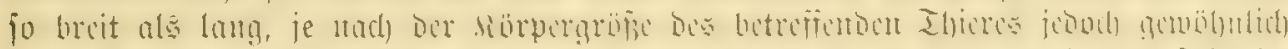

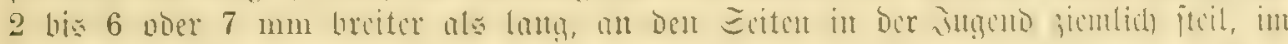

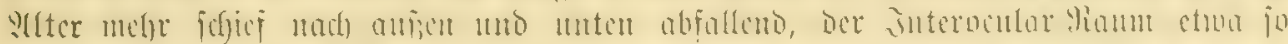

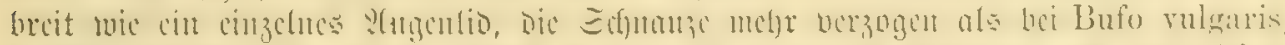

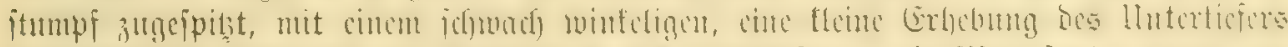

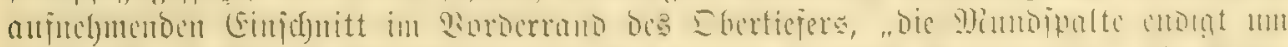

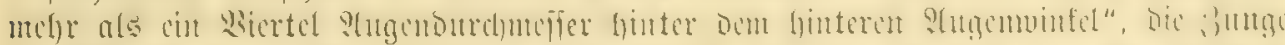

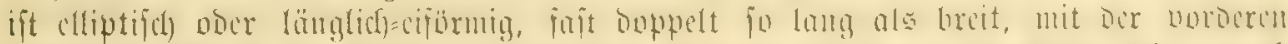

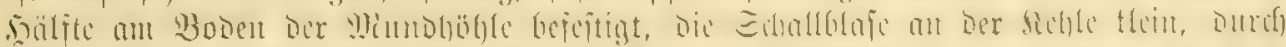

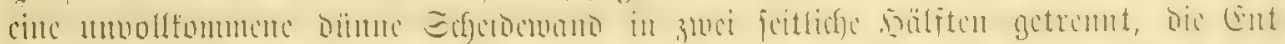

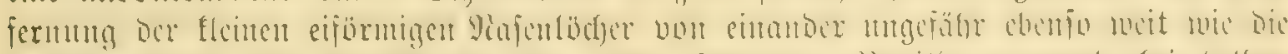

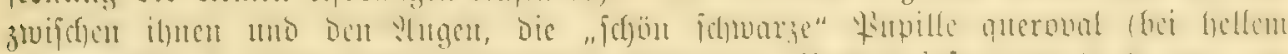

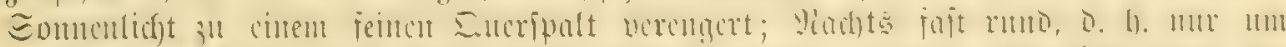

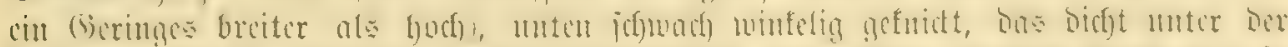

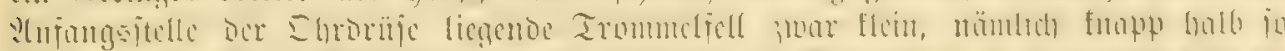

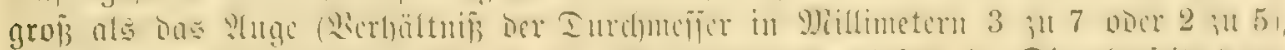

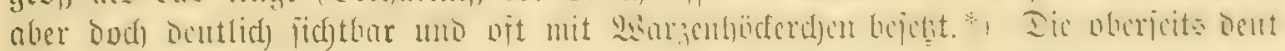

*) Pet Der balecrifden form ber grünen Sröte, bie fidj oud burd) andere (Eigentheitcu vor ber

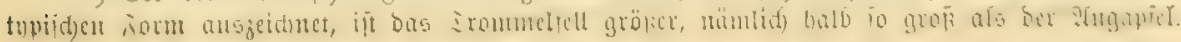




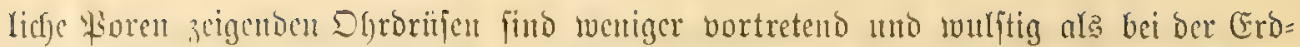

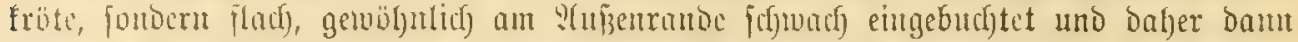

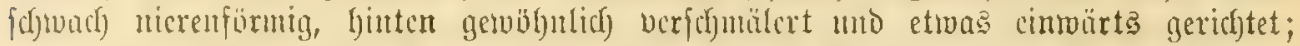

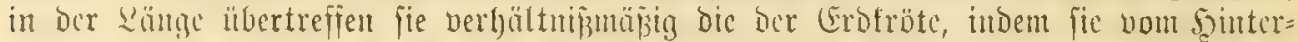

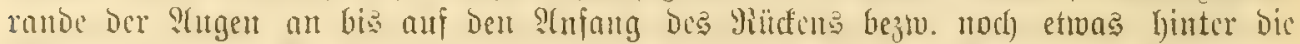

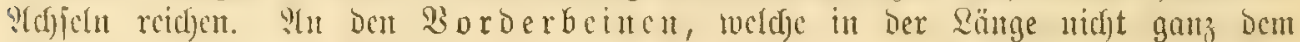

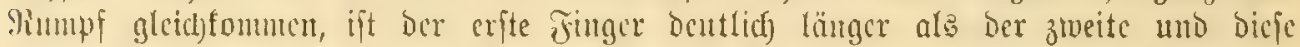
beiben cbenjo wic bie andocrn Finger anf ifjer llntericite an bent belentfteflen mit je

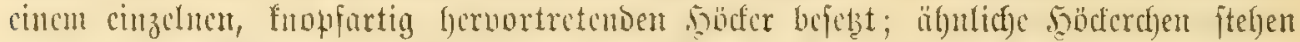

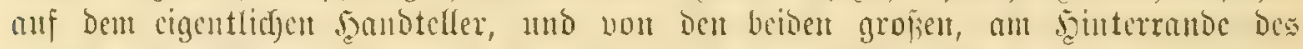

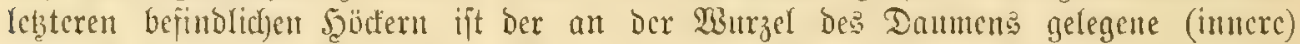

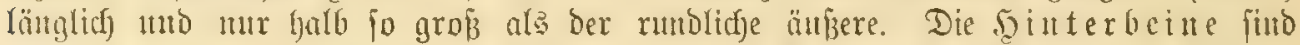
foflanter alz bie ber Erofröte und lä̈nger alo bei B. calamita, etwa boppclt jo lang

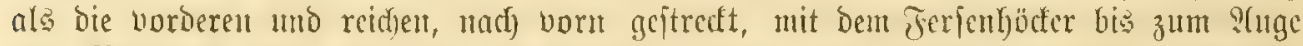

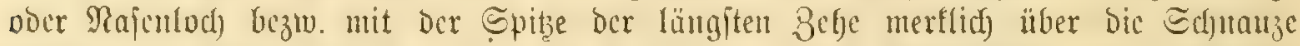

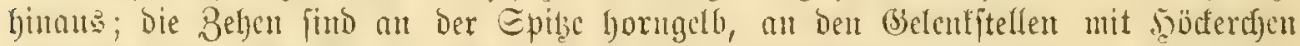

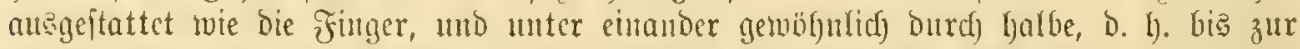

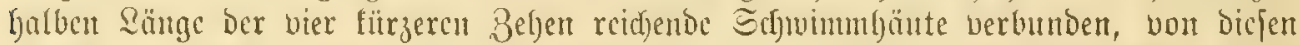
an bis zur Epitze nber nod mit cinem nautfaum verjeben; bie vierte Bélge ijt bie läugite, dic britte faum läuger ale bie fünftc, ant fitrzejten ift bic erfte; Der finter

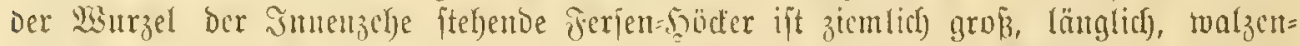
förmig, zmucilen fantig, lünger, hähger und härter als bei Der Sirenztröte, Der igm gegeniltber licgende rumblidh, fladjer. Die bei Der (Erd = und Der Sircuzfröte woht cut=

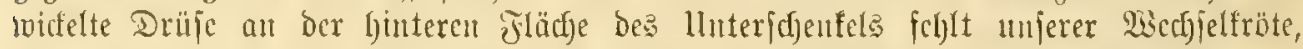

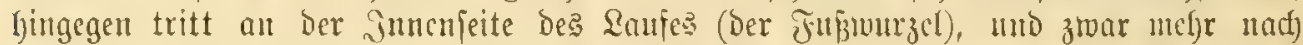
innell zat, eine Şautleifte ober Sautfalte auf.

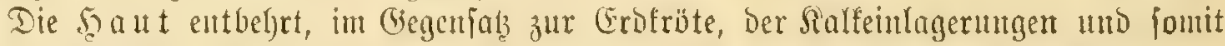

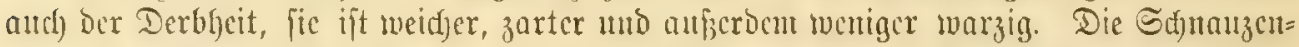
gegend und Siopffeiten bis an Das Trommelfell, zumeilen aud fajt ber ganze Ober= fopf find, mo cbenjo Der Ilnterarm uno bie Edfienen, ïberfaupt glatt, ja bci fel)r

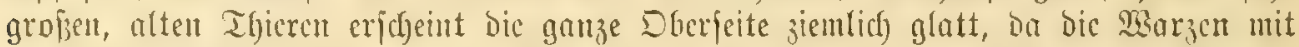

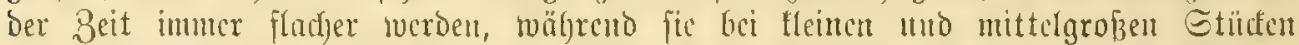

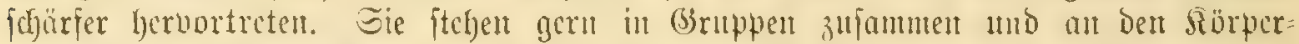

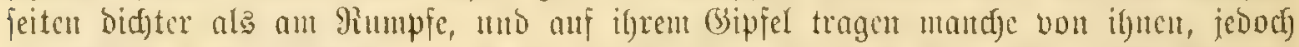

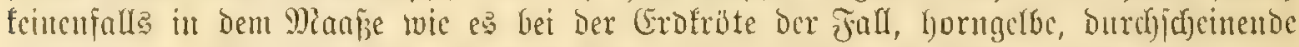

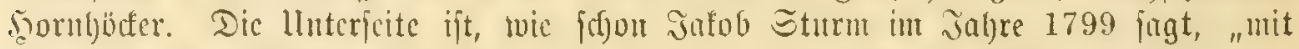

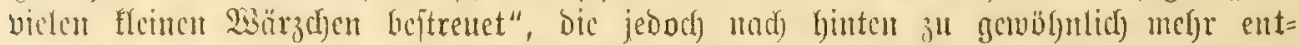

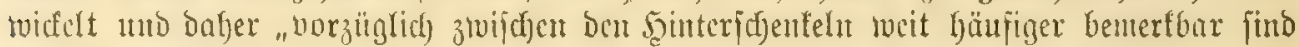
ale auf Dem Dberk̈nrper".

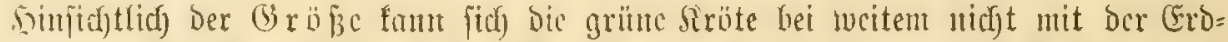

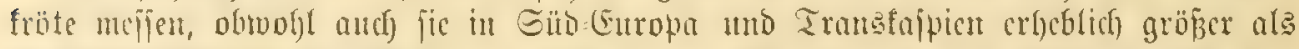
in unjern Breiten, nümlid) bis 10 pDer 12 , ja bis $133_{5} \mathrm{~cm}$ lang wiro, bet uns hin= gegen unr eite Bepannutlänge vout 6 bis 7 , allenfalls autch $8 \mathrm{~cm}$ erreicht, wobei bic

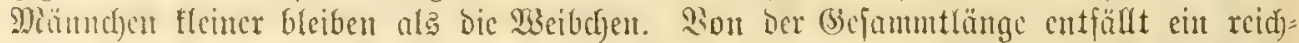

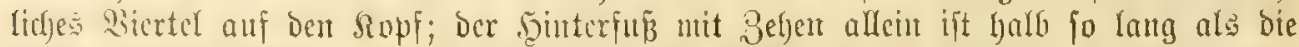

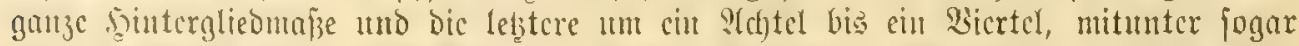

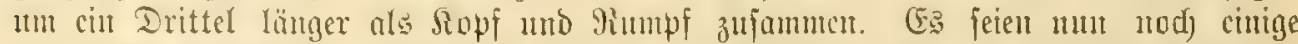

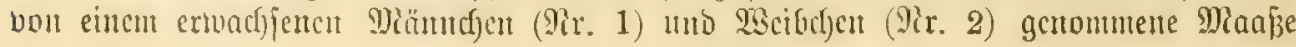




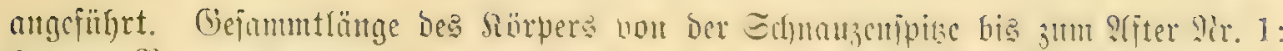

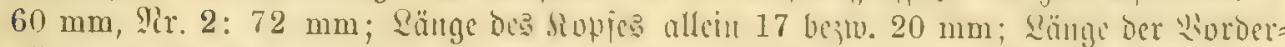
glicomaje 34 bezw. $41 \mathrm{~mm}$; Qünge ocr ninterglicomapic $8: 2$ bezw. $94 \mathrm{~mm}$, bes lluter=

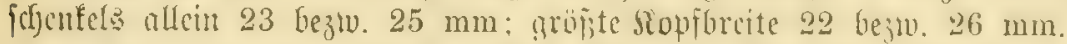

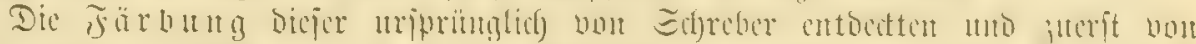
isătbung.

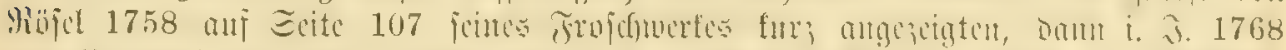

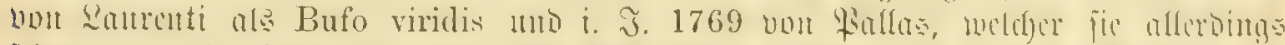

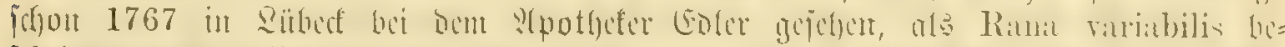

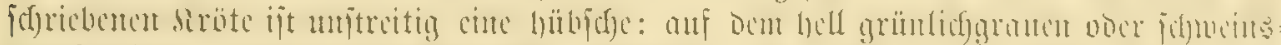

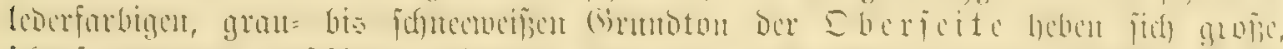

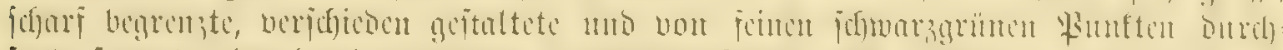

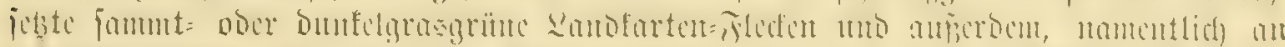

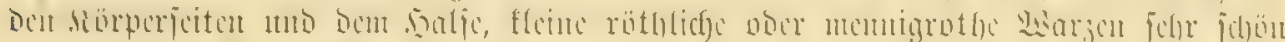

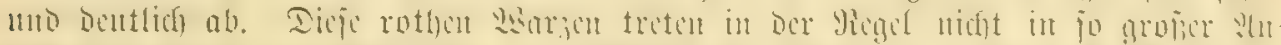

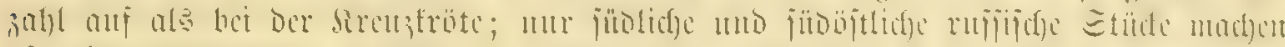

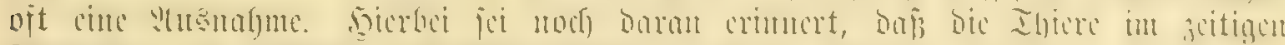

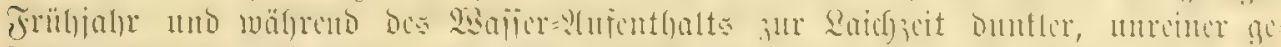

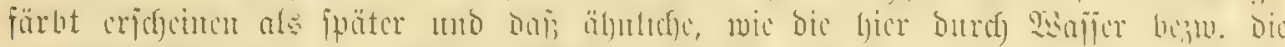

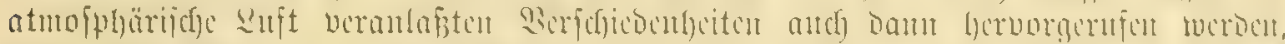

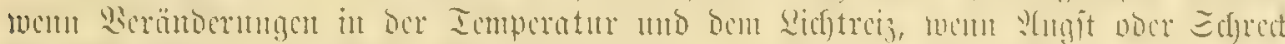

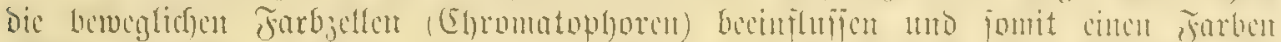

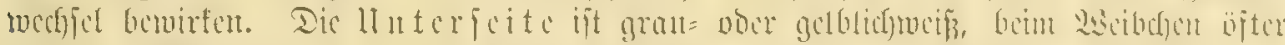

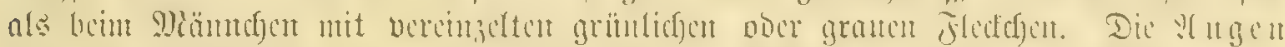

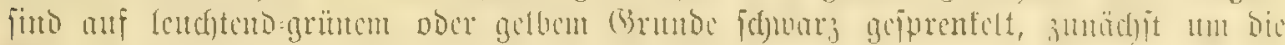
Psupille aber mit cinem fdjmalen Golbjantm verjehent.

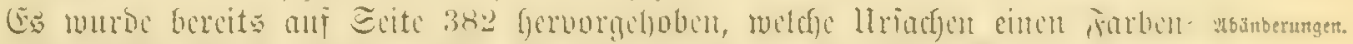

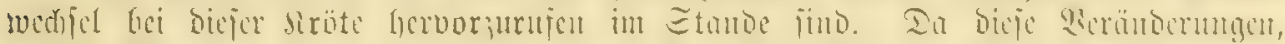

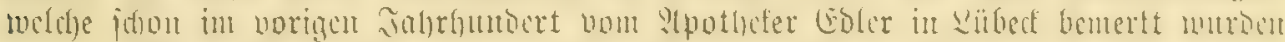

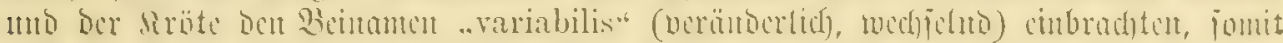

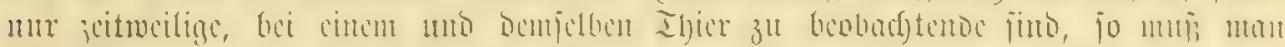

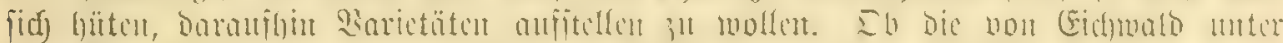

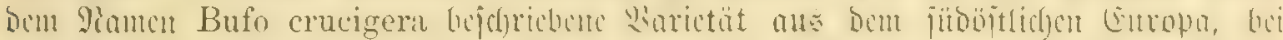

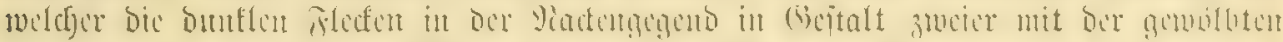

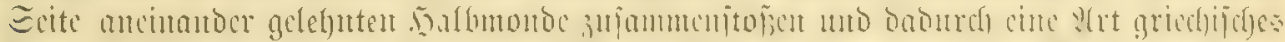

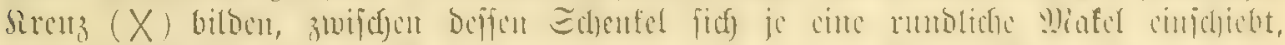

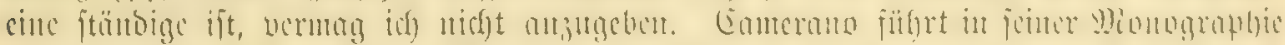

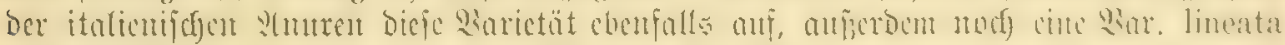

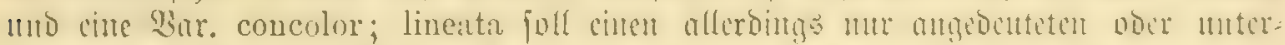

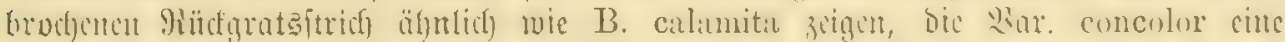

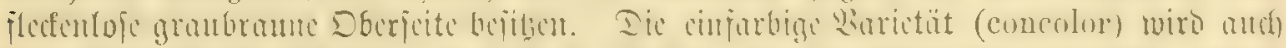

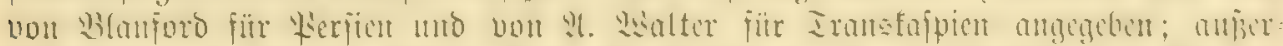

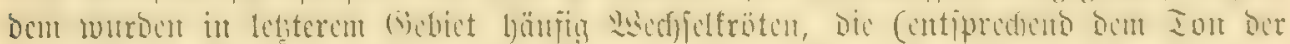

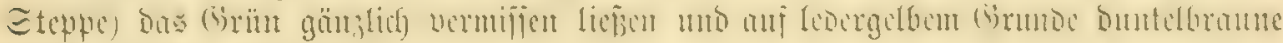
Flecfer trugen, beobadftet.

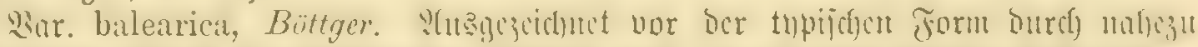

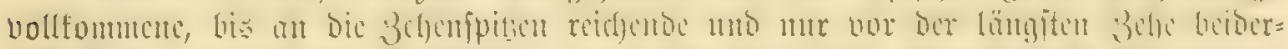

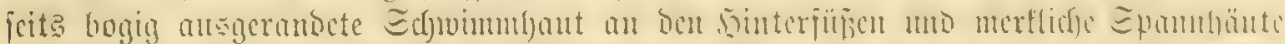

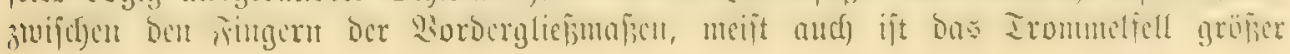




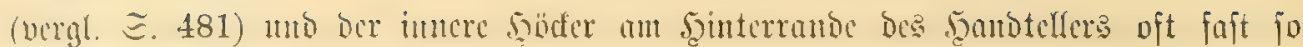
groß̧ alङ ocr äupere. Balcaren.

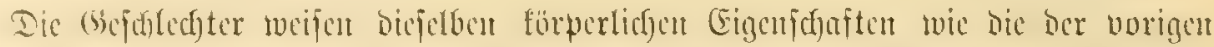

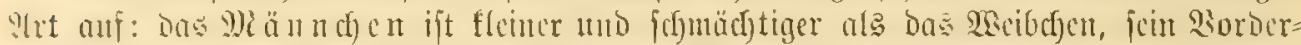

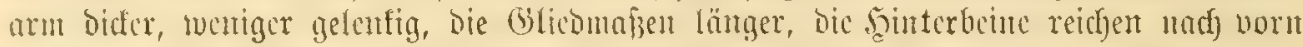

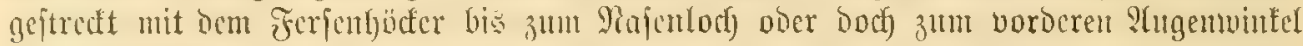

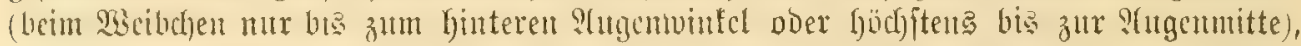

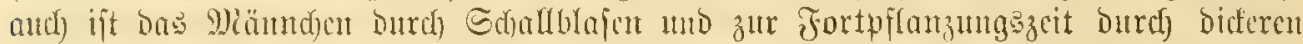

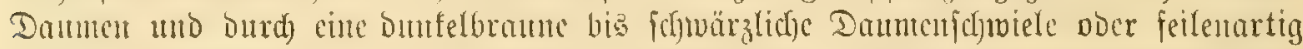

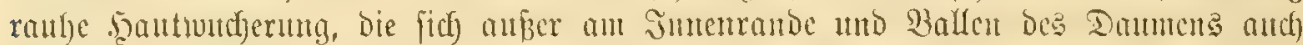

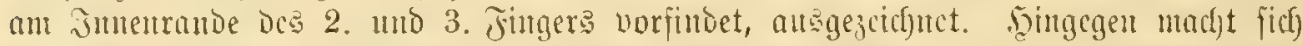

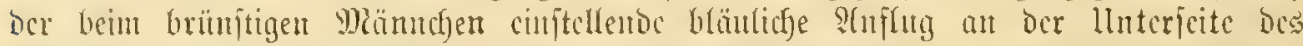

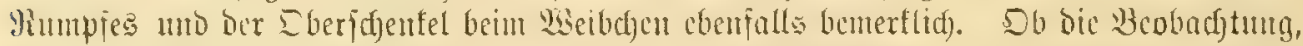

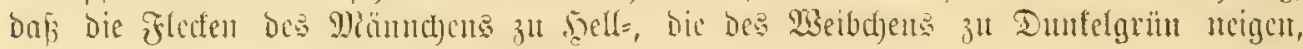
Durd)gängig zutrifft, Gedarf nod) ber Auftlärung.

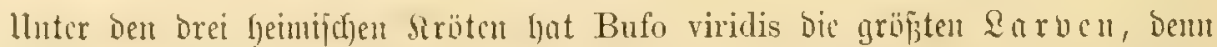

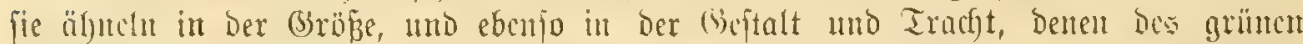

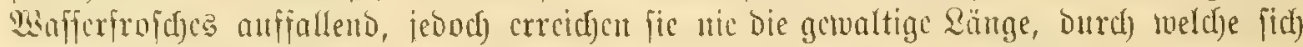

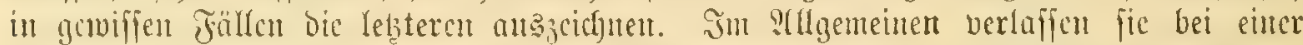

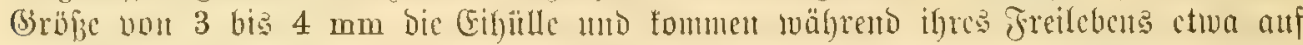
bas 3ehufudje bicfar \&üstge, o. i. 35 oocr 36 bie 40 oder $44 \mathrm{~mm}$, und von dicfer cutfallen

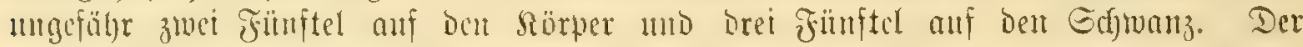

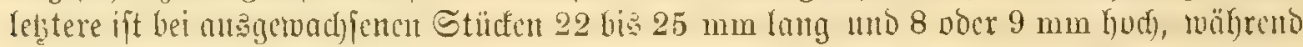

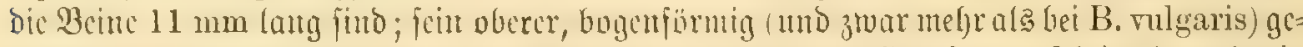

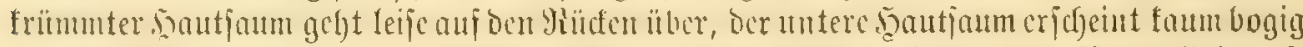

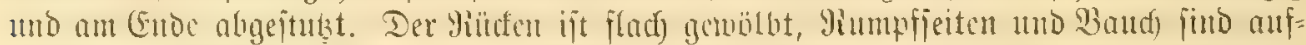

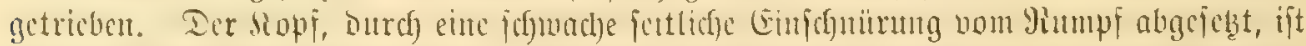

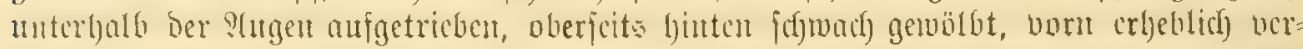

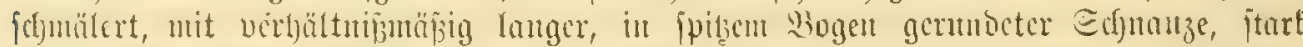

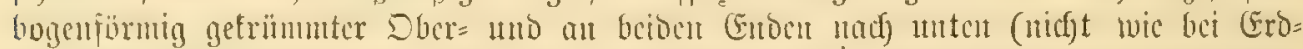

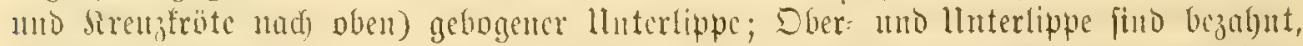

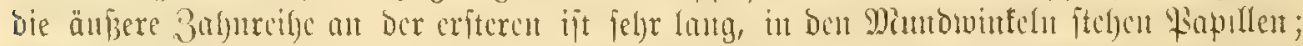

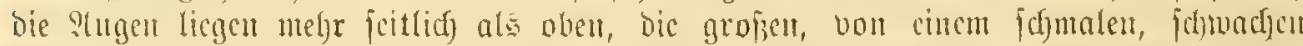

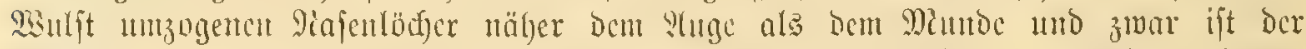

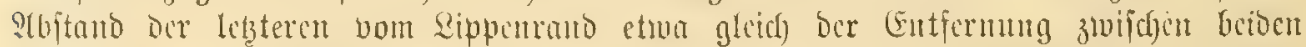

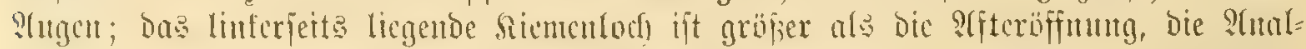

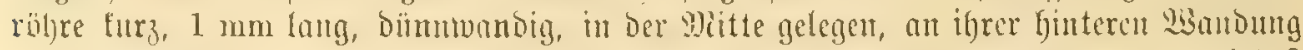

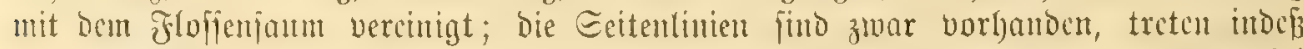
nutr wentig fervor; bie langen seinterbeine madjen fid bet etwa 30 ober fdyon bei

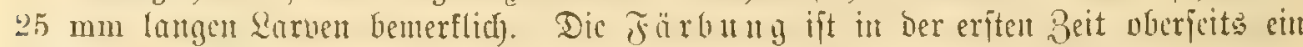

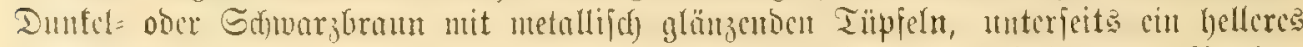

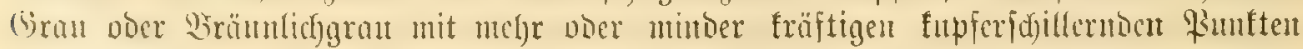
und Tüpfilu, ber vbere Edywanzfaum zeigt Dentlidje butufle Fledtug, ber untere ba= gegen mur an Exfwanzende einige menige Dunfle Eprizer. Radh Dem Sorrvorbrechen

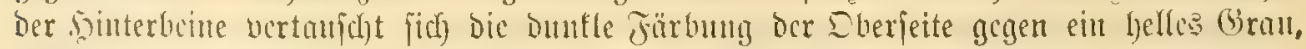

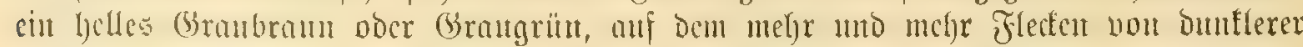

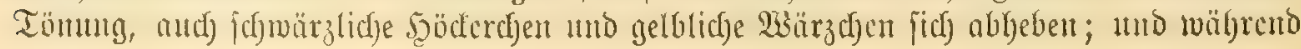




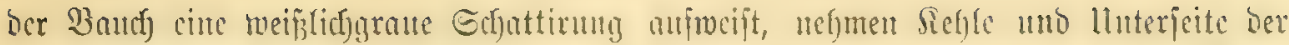
Beine cintent gelblichen Tout an.

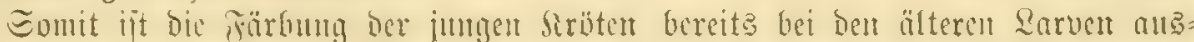

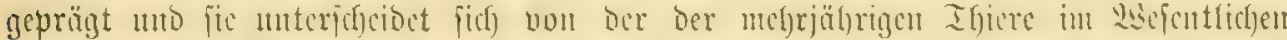

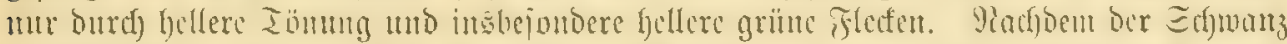

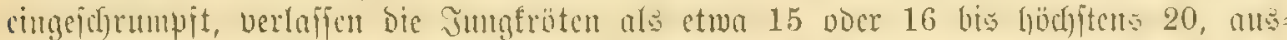

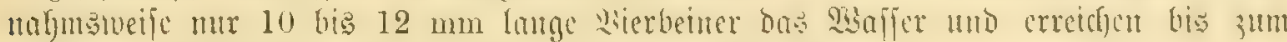

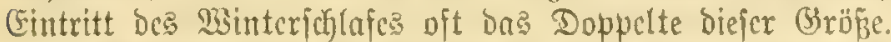

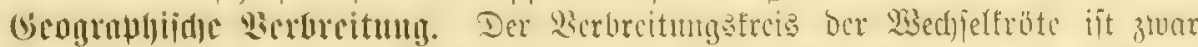

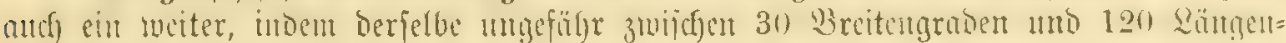

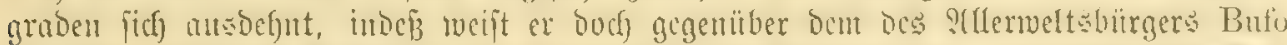

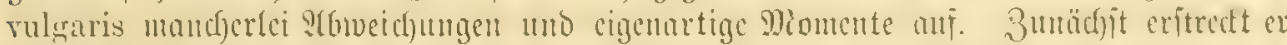

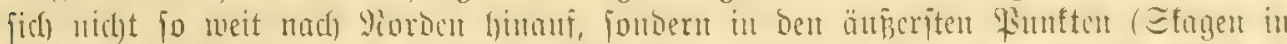

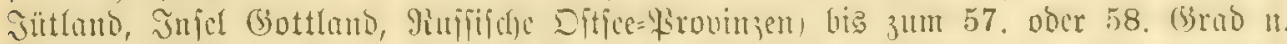

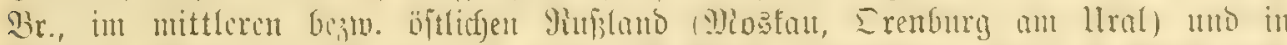

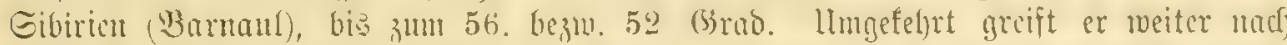

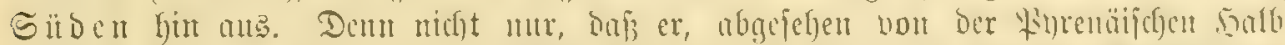
injel, in (Europa bis zu Den fïblidfiften Epitsen Des Feftlandes (Jitalien, Griechenland)

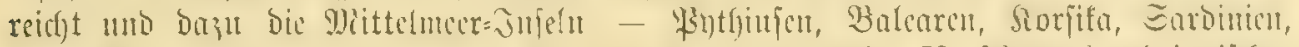

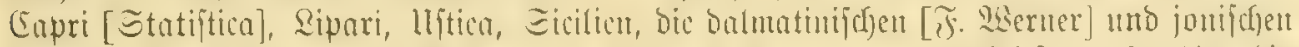

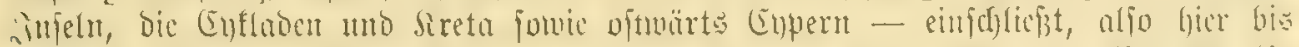

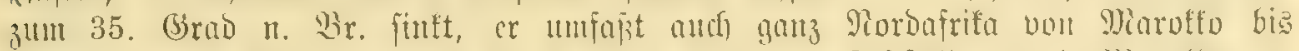

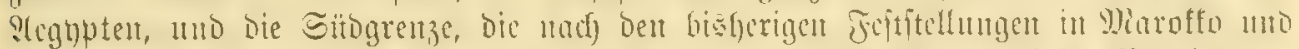
in Tripolis (Wengafi in Barta) viclleidst anf bem 32. (Sirad (Winie Miognobr-

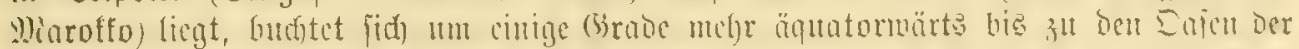

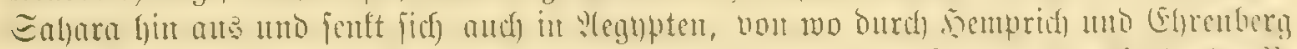

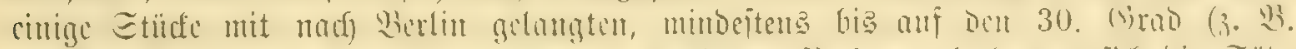

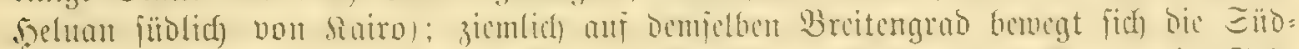

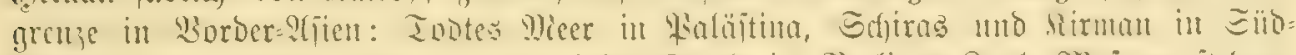

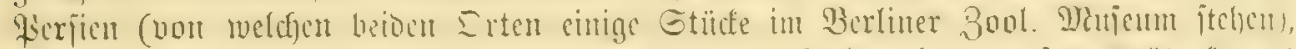

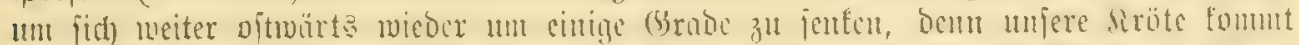

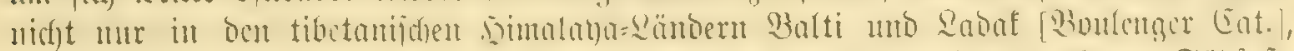

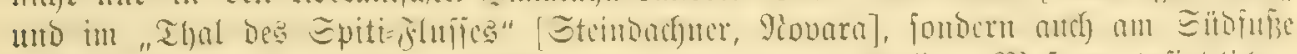

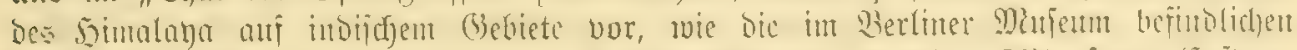

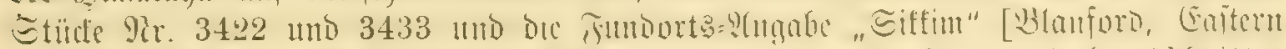

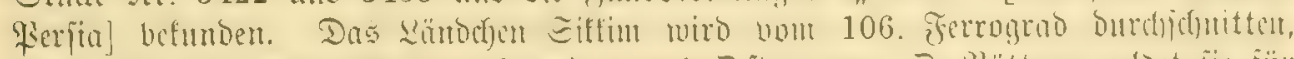

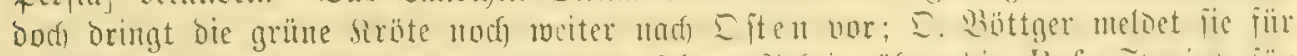

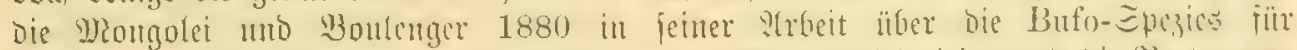

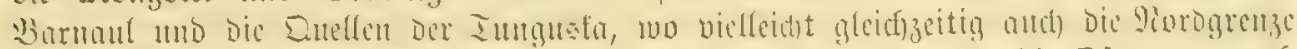

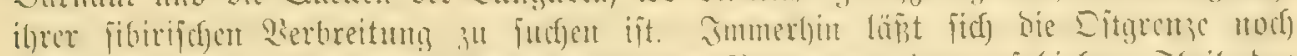

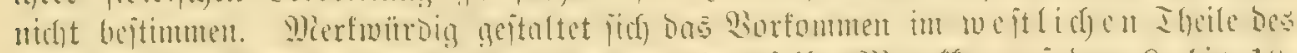

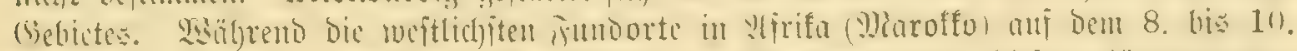

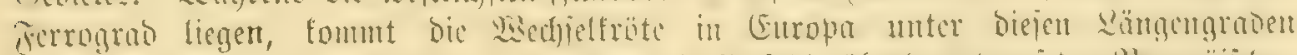

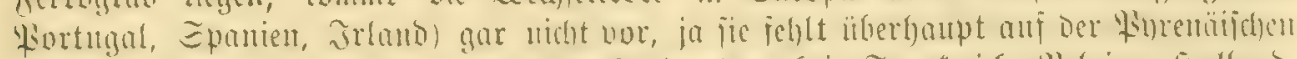

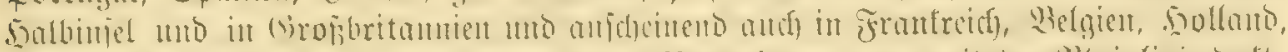

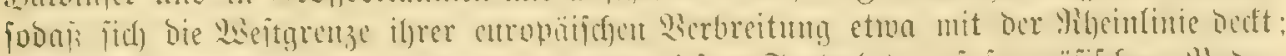

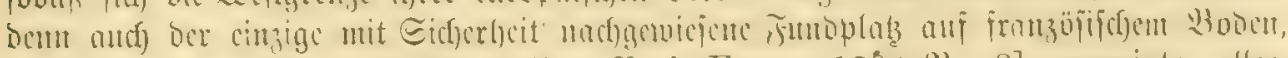
nümlid) ber von Blandaro [Bull. Suse. Zoul. France 1888 9ir. 2] angezcigte, aller= 
Dings mur cinige fumbert Micter von Der italienifd)en Brenze in Tepart. Daute

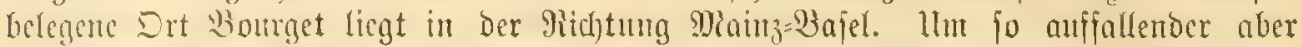

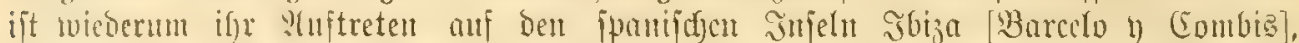

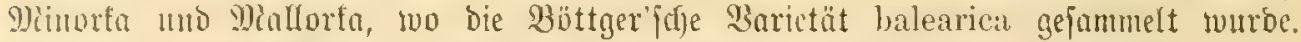
23ien alfo die 2iseftgrenze in ?lfrifa Durch den 8. ober 9. Ferrograd gegeben ijt, jo für bic fübeuropäifchen imfelu burch) ben 19. und fïr bas feftländijcfe Guropa un= gefäbr burd ben 24. Birao.

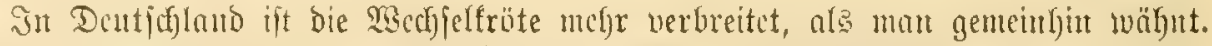
Freilid) vermag fic fid) barin nod) bei wcitem nicht mit Der Erotribte zu meffen; Denn

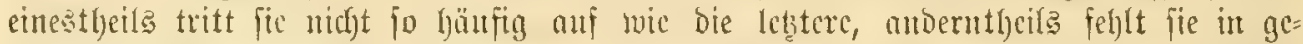
mif̂̃en Etrichen gänzlich, obwohl fie mandyer Drten noch itberichan fein bürfte. W3as

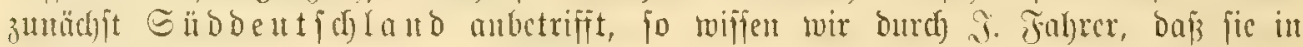

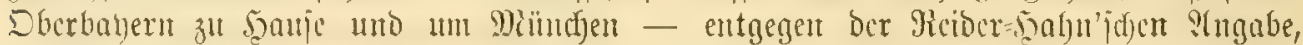

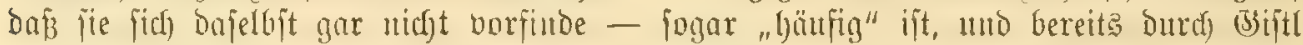

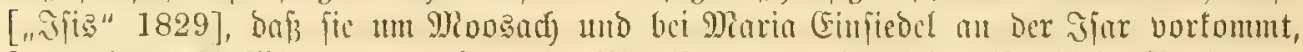

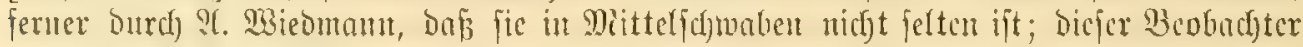

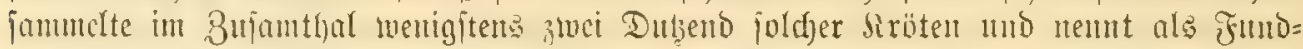

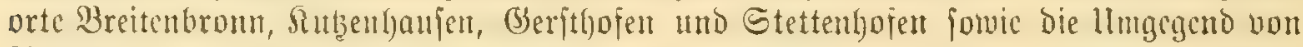

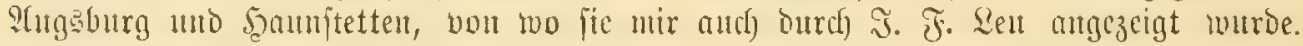

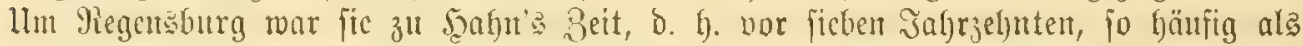
bie gemeine Siröte; Dericlbe "Yiaturbiftorifer" hat fie andh einigemal in uno bei

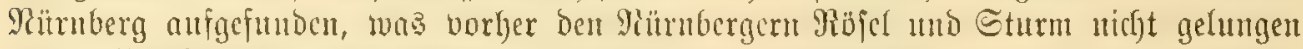
mor. Bhei Erlongent uno Bamberg fonnten mene Diturbeiter fie nod) nicht cntbecfen,

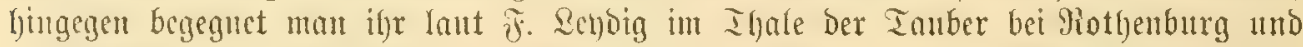

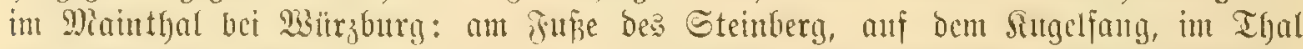

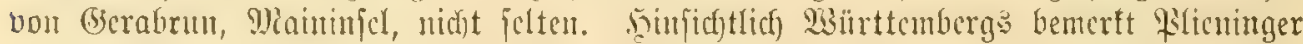

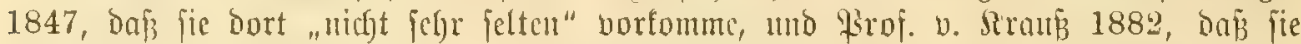
im lluterlano nid)t hä̈nfig fei, in Sbcrichwaben foble; Damit ftimunt bic Mittreilung

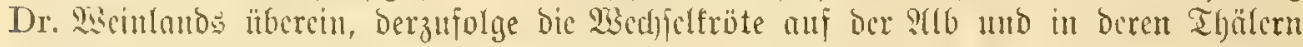
nirgenda beobadftet worben ift; ala Fumborte nenten bereits (3). v. Martens 1830

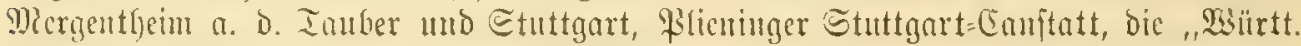

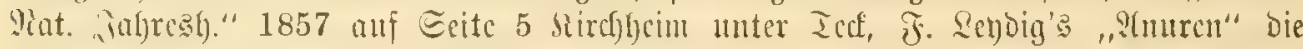

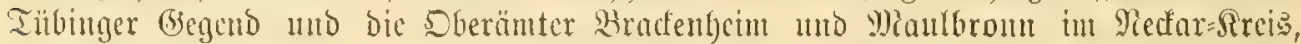

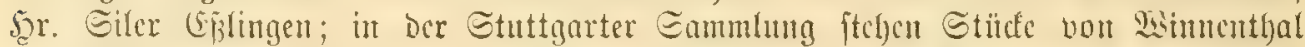

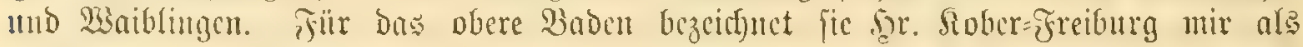

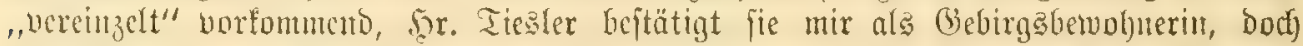

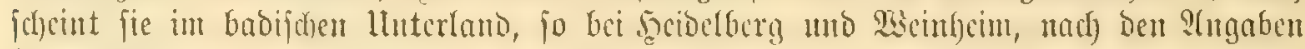

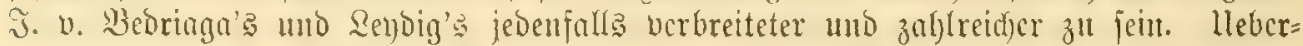

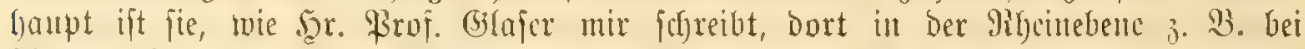
Wisorms eine gemöhnlidje Eridycimmg; bei Epcicr fammelte fie of. Lenbig, bei Deibeas=

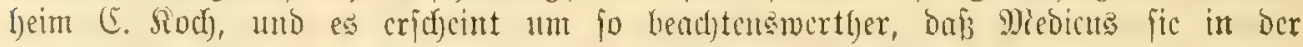

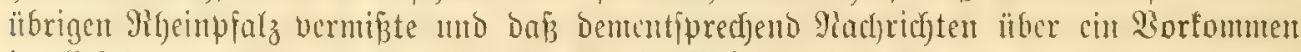

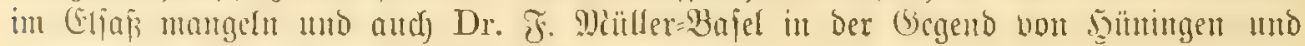
Sendorf im Dher=Elją nur Sircuzfröten erlangte.

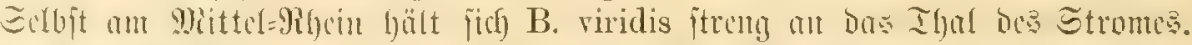

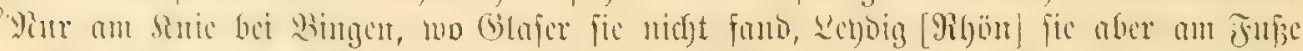

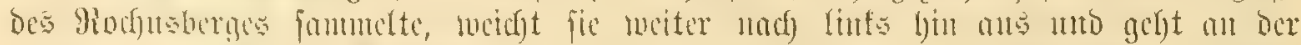

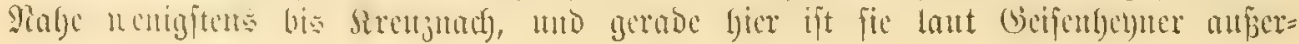




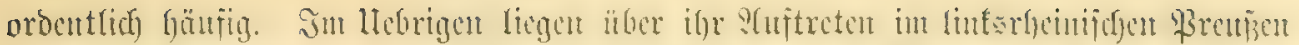

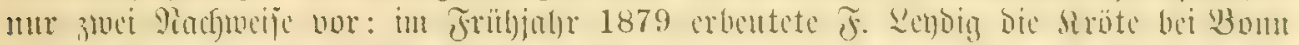

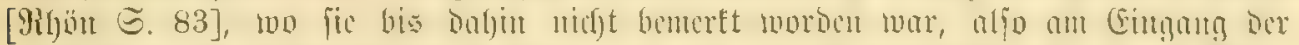

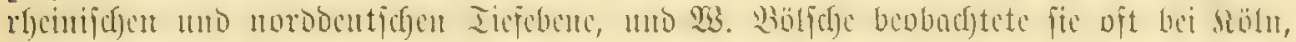

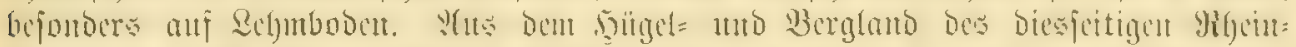

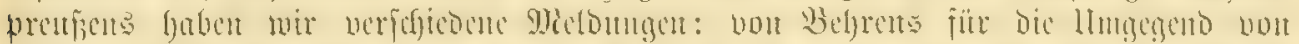

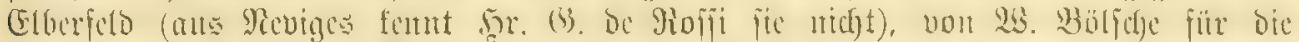

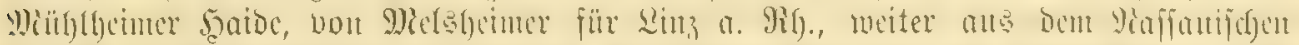

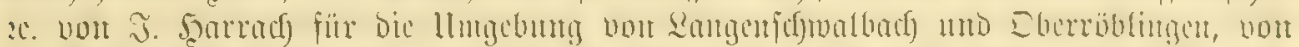

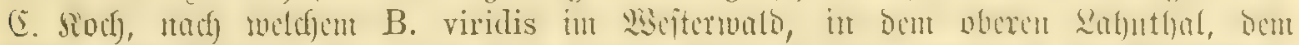

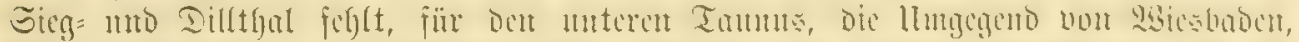

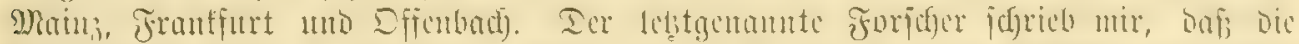

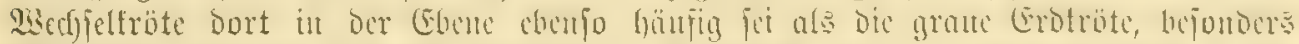

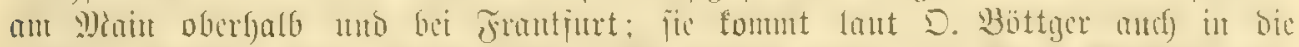

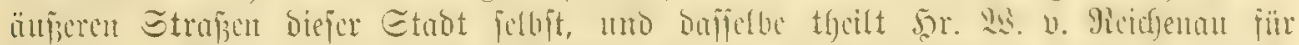

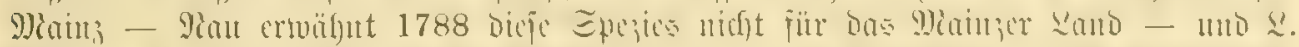

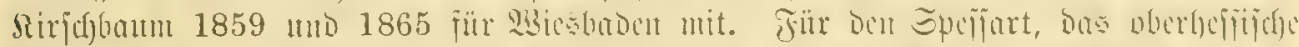

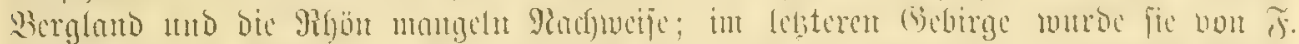

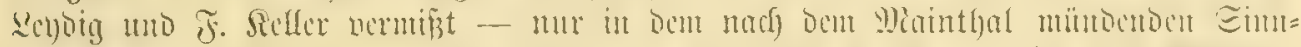

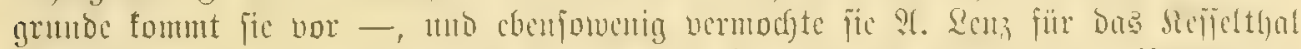

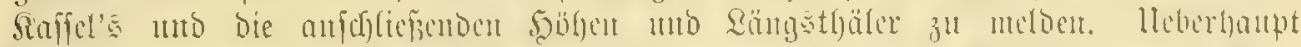

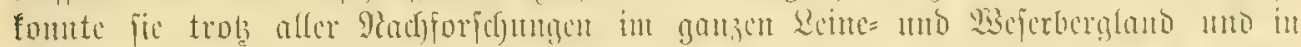

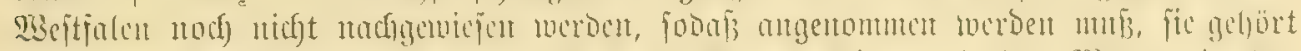

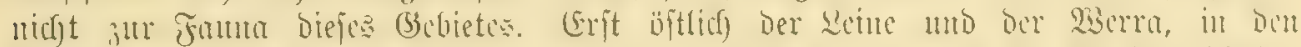

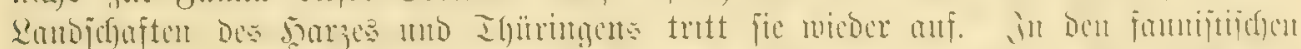

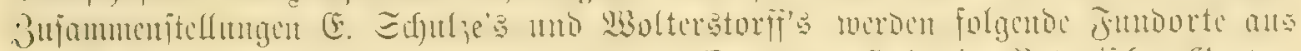

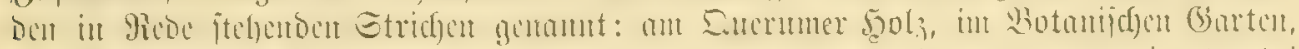

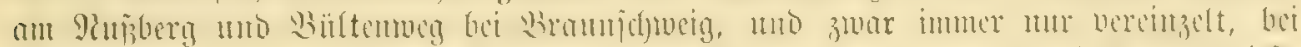

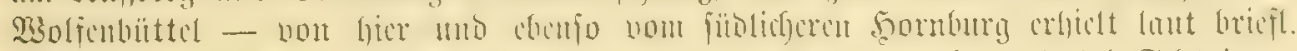
פ)

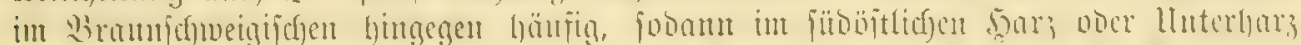

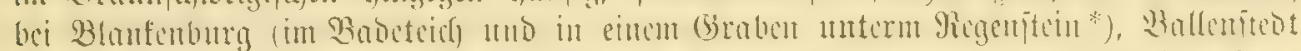

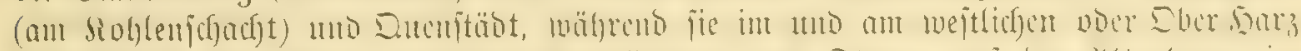

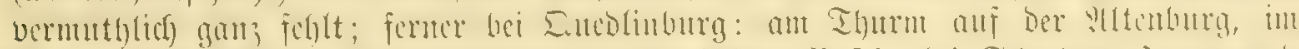

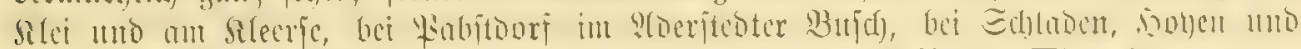

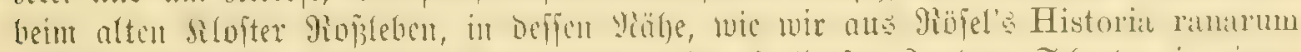

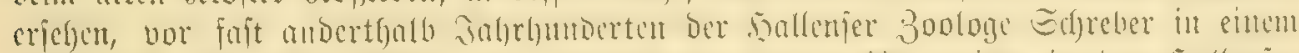

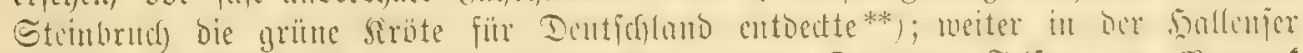

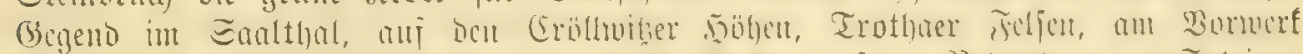

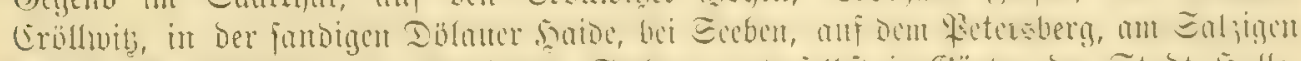

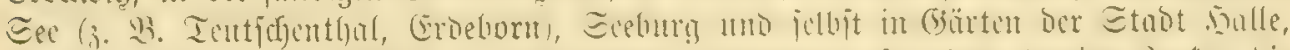

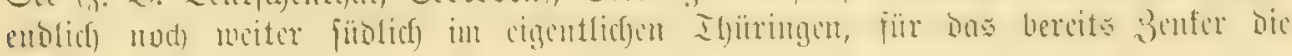

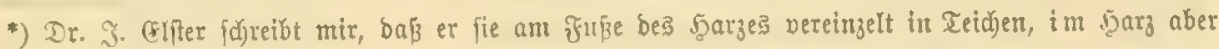
nux eimual in Bobetgal fing.

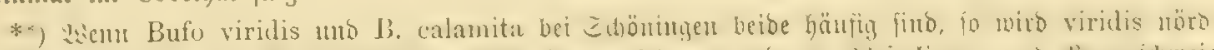

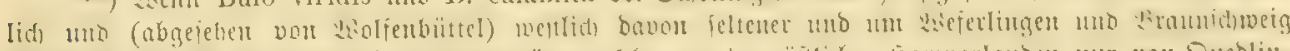

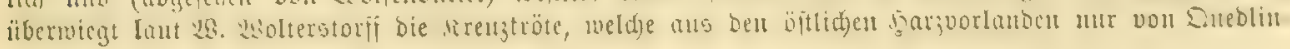
burg angezeigt ift. 


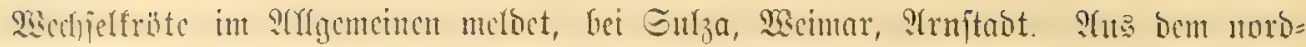

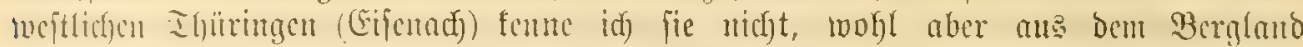

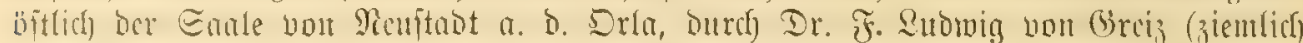

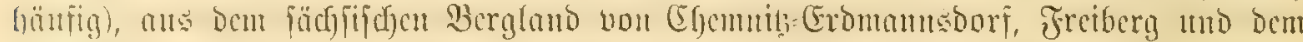

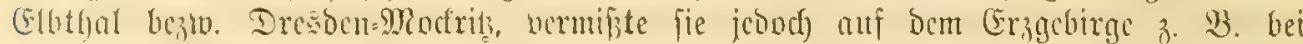

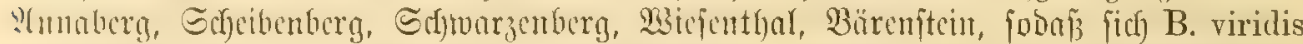

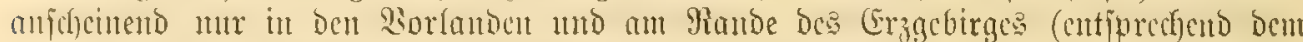

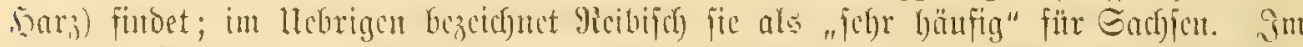

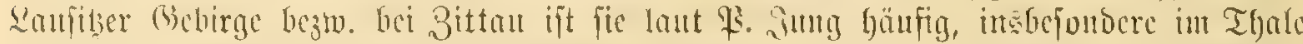

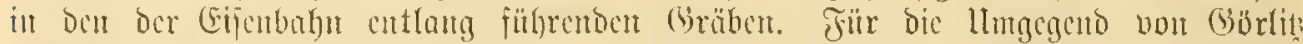

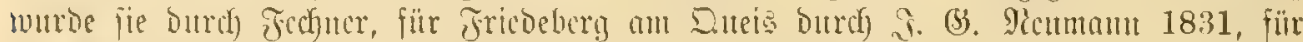

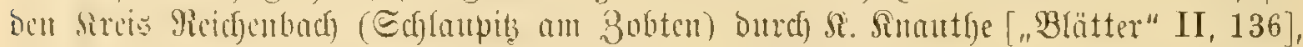

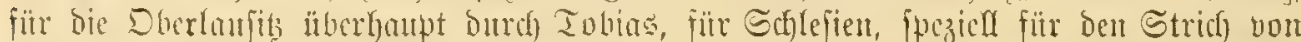

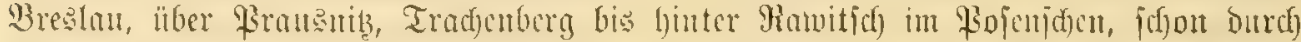

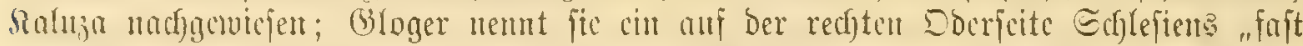

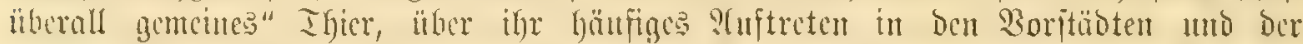

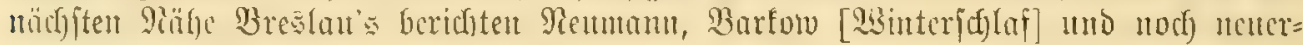
binge \$rof. (3. Błorn.

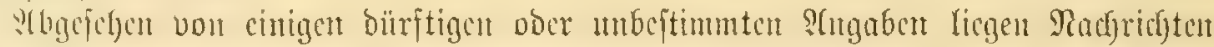

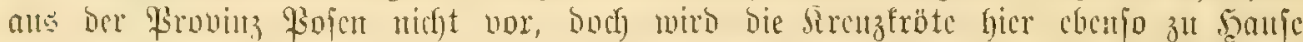
feit wie im autgrenzenocn Folen (,commun partout" jagt Taczanowefi) und Branben=

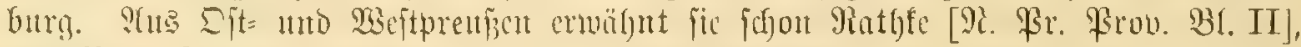

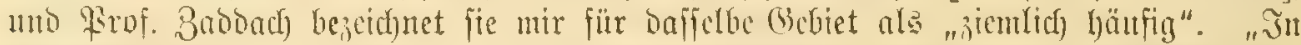

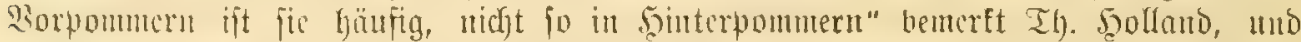

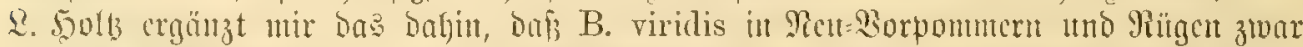

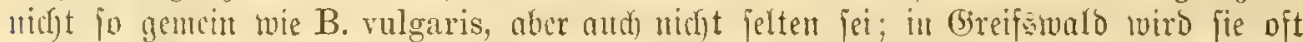
in aften Seflern gejchen. In Medfenturg, wou wo bercits Jafob Sturm im nerbit

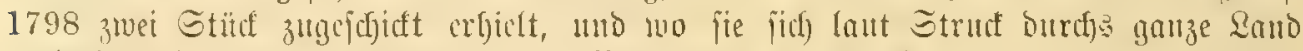

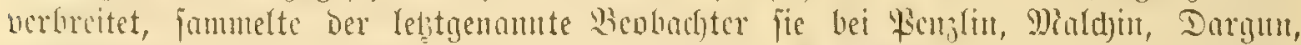

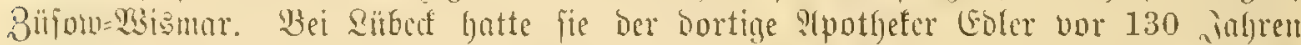

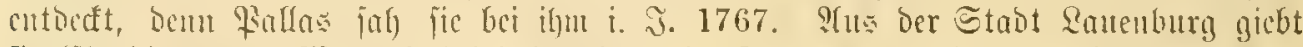

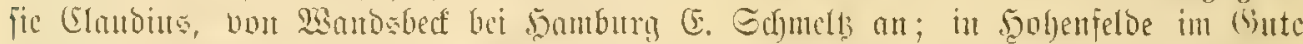

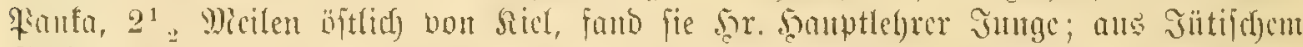

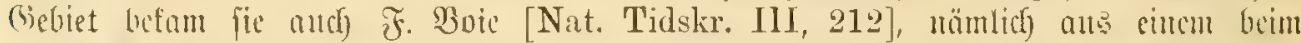

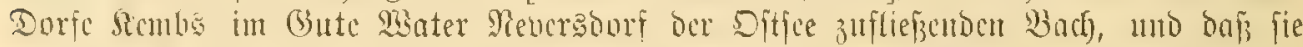

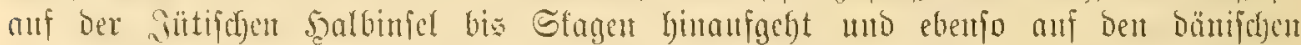

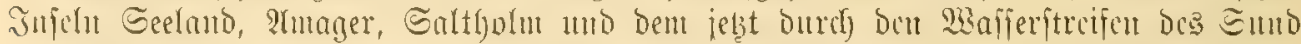

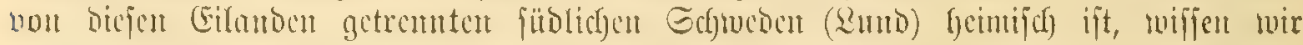

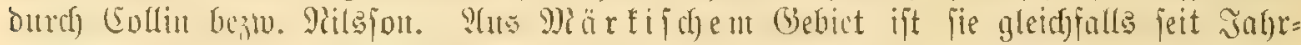

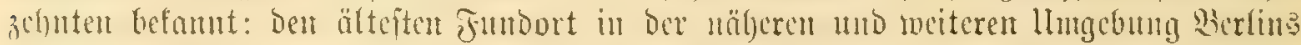

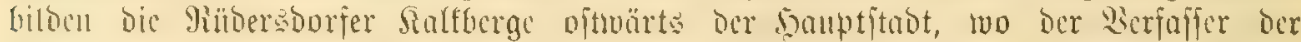

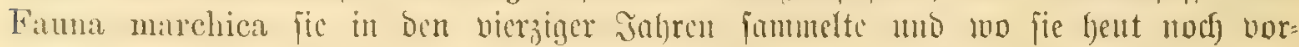

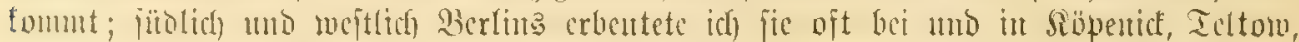

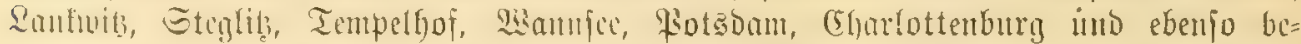

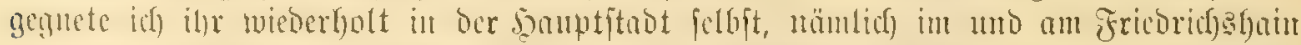

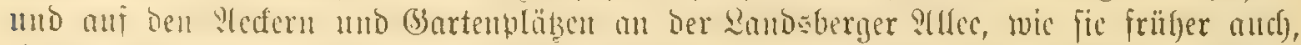

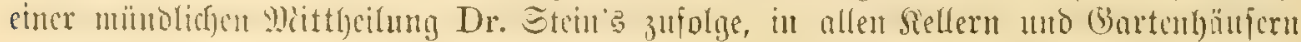

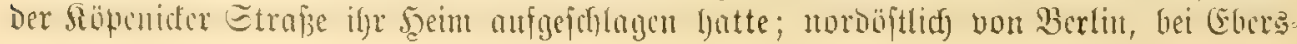




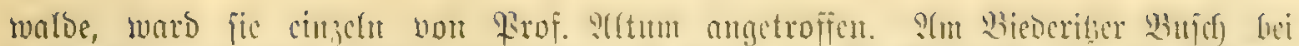

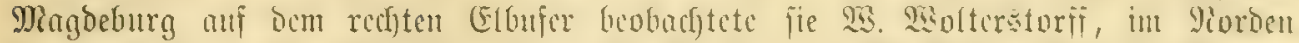

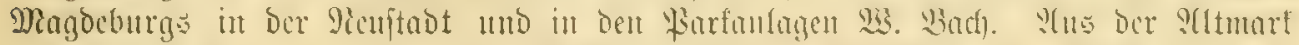

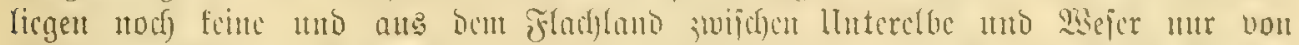

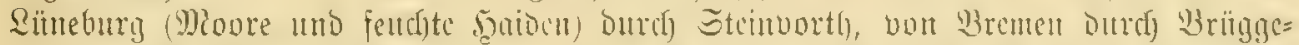

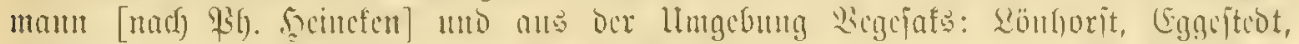

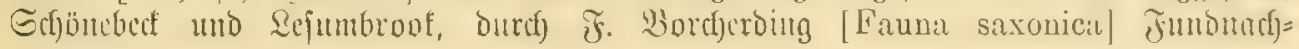
tocije vor.

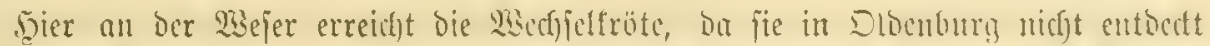

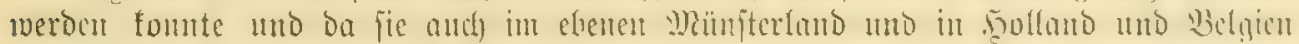

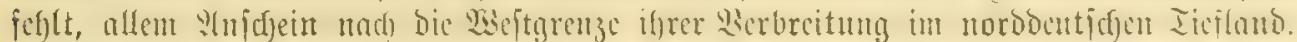

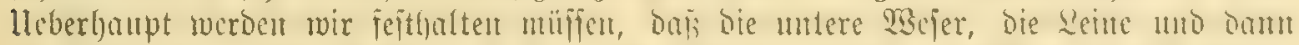

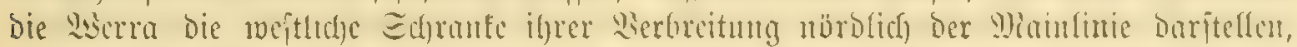
D. 1). Daj bie

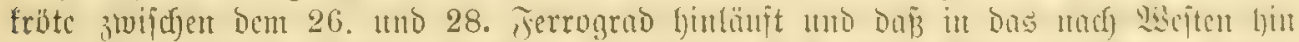

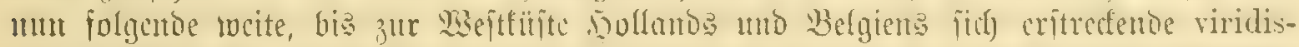

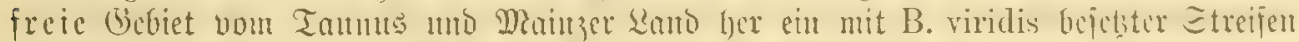

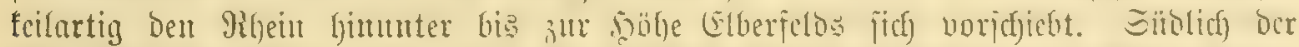

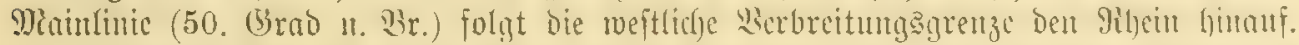

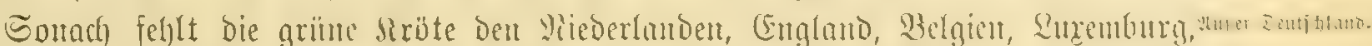

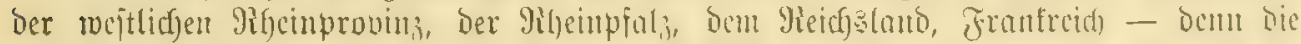

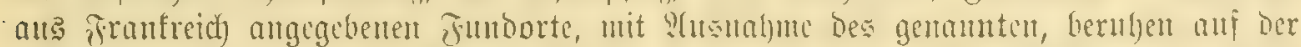

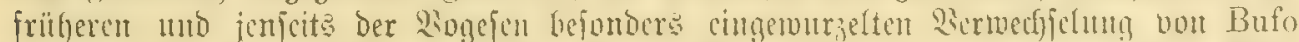

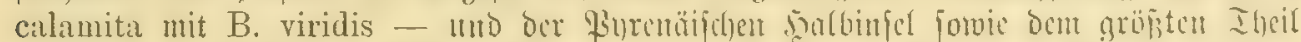

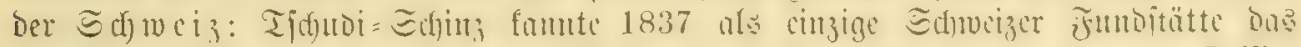
Ieffin, wo Dr. Dtth bie Siröte cutbedt hatte; Fatio nent 1872 Das untere Iefiü,

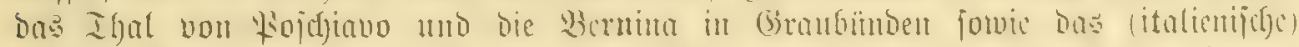

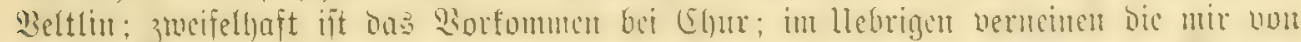

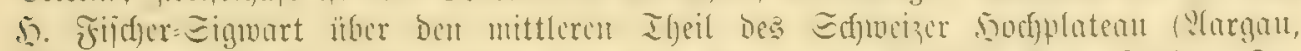

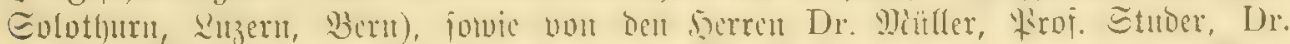

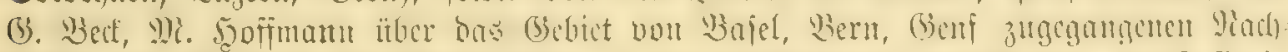

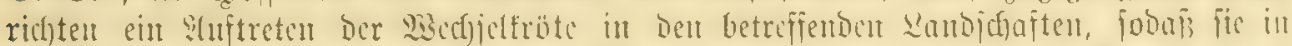

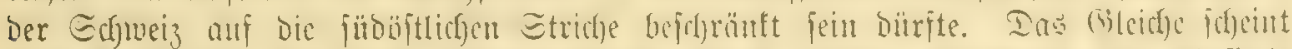

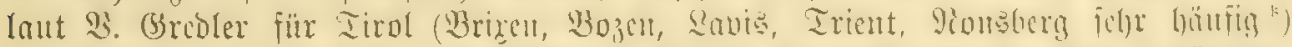

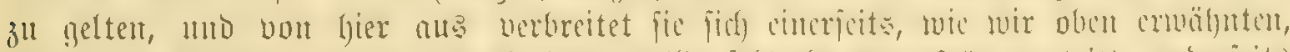

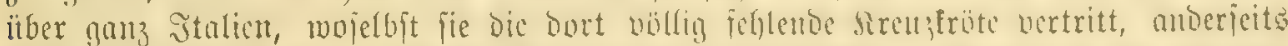

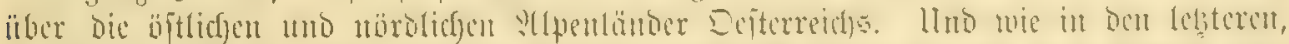

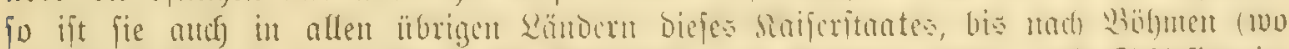

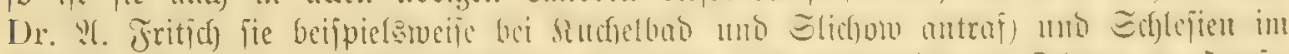

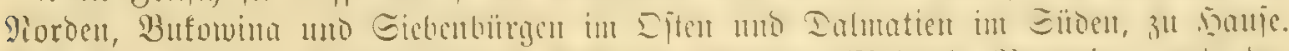

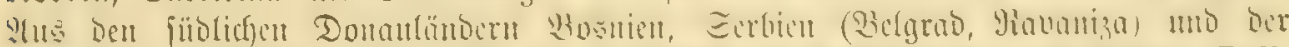

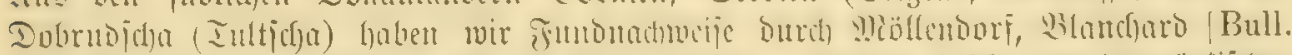
Soc. Zuol. France 1888 p. 67| umb Eteinondfuer. Ebivar foldfe ats ben türfifden

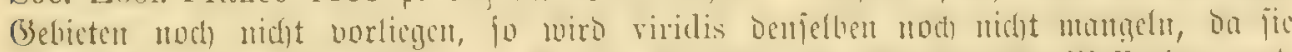

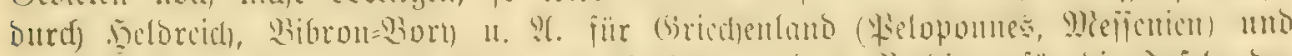

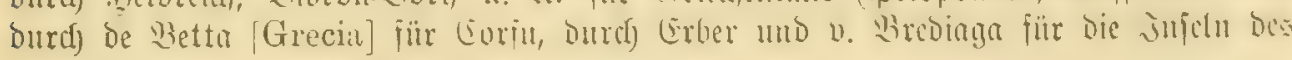

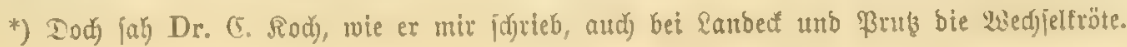




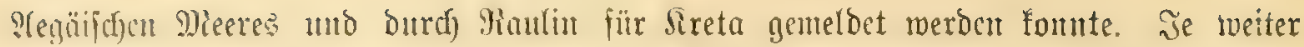

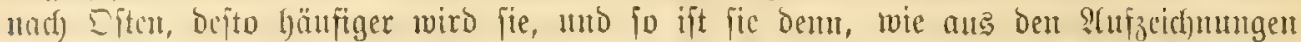

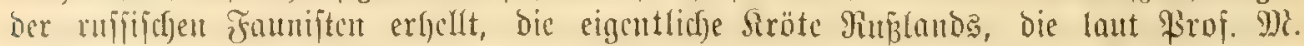
Siraut auch in ben Eitjee Provinzen Surland, Sivland - woic auf Gottland, in

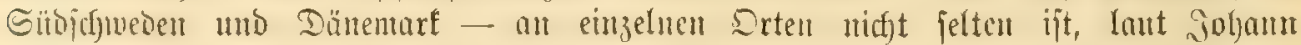

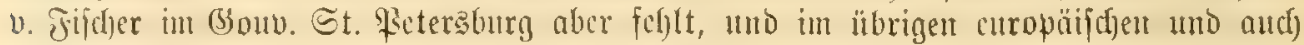
aftatifdyen Mupland etwa an 52. Breitengrad Dic Rorogrenze ifrer Serbreitung zu erreichen icheint. Machbem wir bereits anf Seite 485 bie (3rundzinge ifjrer anfiser=

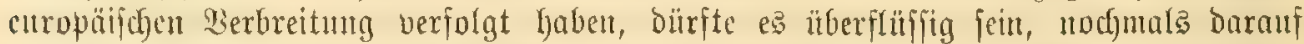

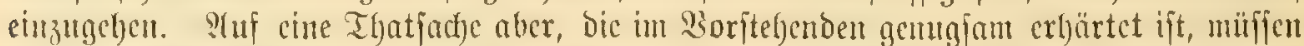

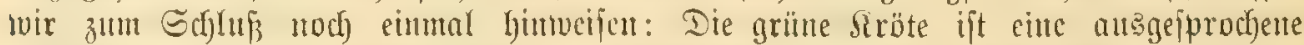

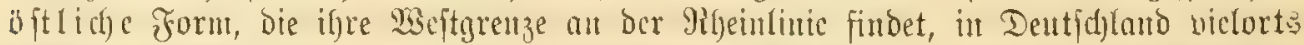

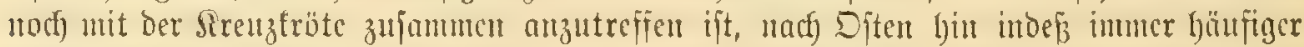

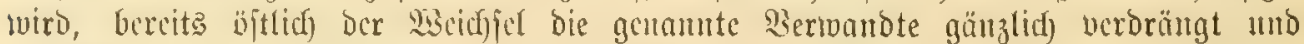

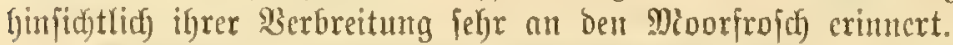

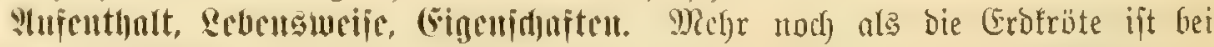

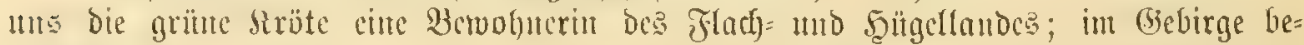

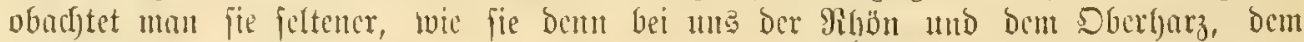

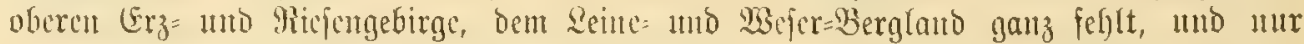
Damu, twcun weite Thäler ftchende wäffer bieten, im Gebirge bie vielfeidjt zul 600 voer $1000 \mathrm{~m}$ über bem Mecresfpicgel cmporfteint; in Den ?tlpen Tirole unt ber

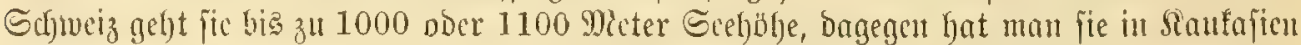

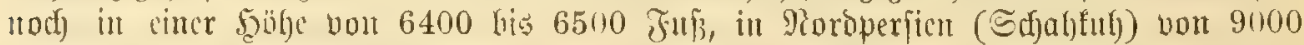

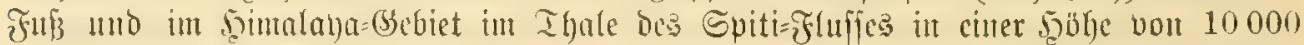

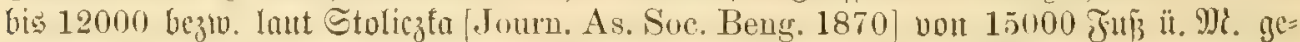

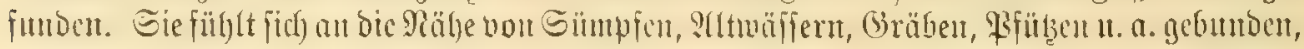

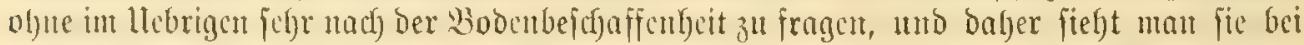

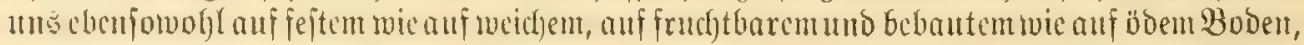

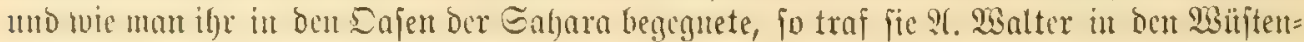
brunucu ber transfojpifdyen Stcppe (f. S. 401) ant. Sie hält fich uicht mur zur Raidzeit,

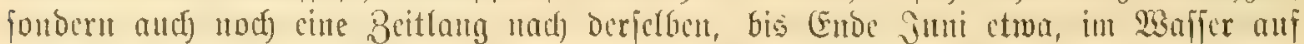

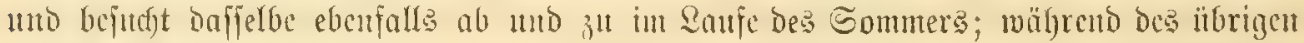

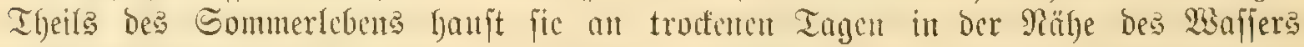

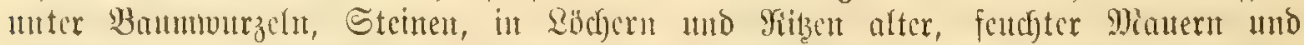

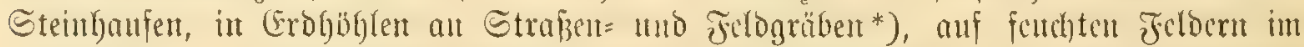

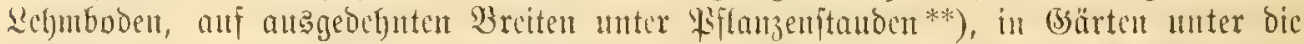

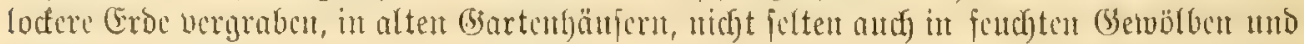

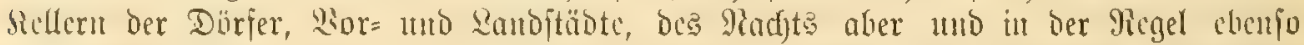

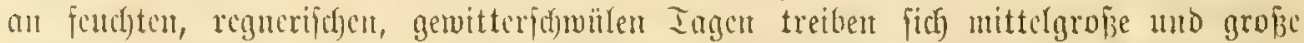

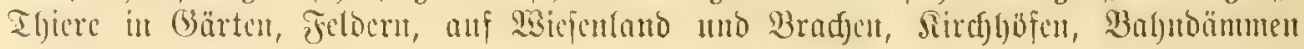

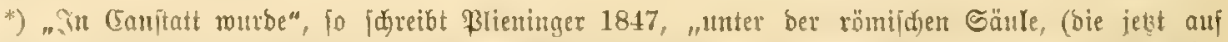

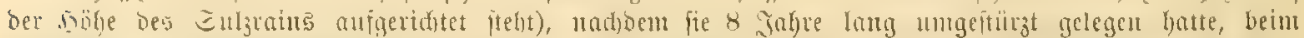

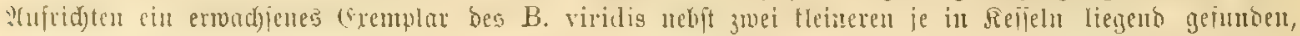

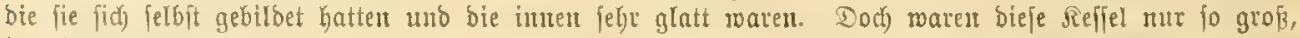

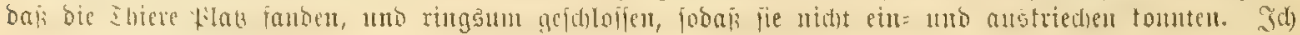
Gatte jie nuchrere Gabre lang im (SYas am Reben".

**) So fano fie 5r. 2B. Bölidje wieberbolt auf ber jogen. MRülgeimer 5aibe bei Röln, mo bie

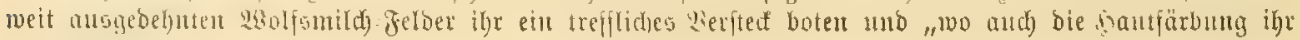
зu fatter faun". 


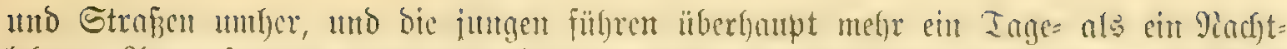

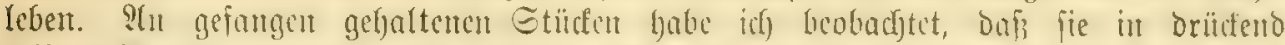

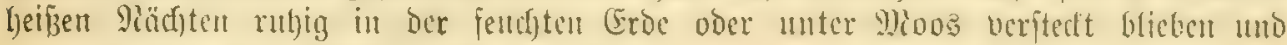
nur mit Ropf und Qugen etwas vorguetert.

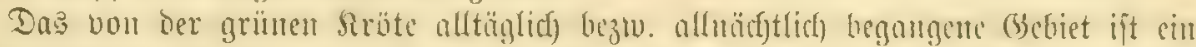

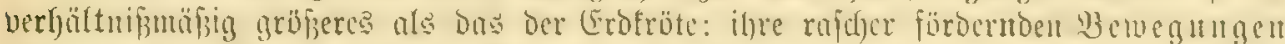

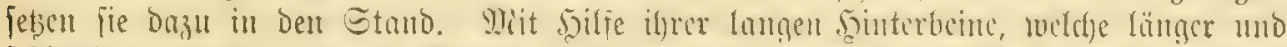

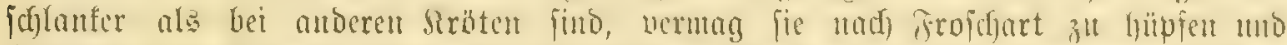

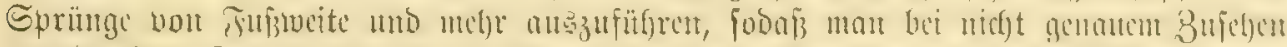

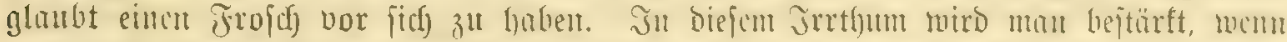

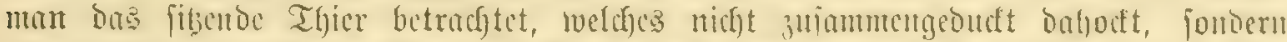

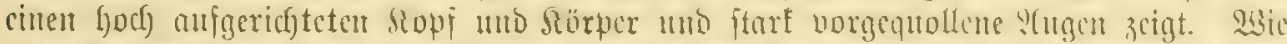

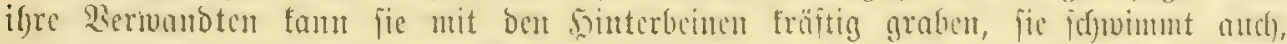

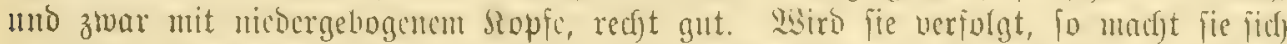

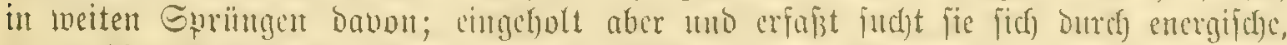

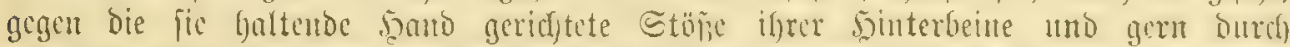

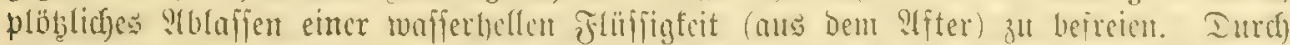

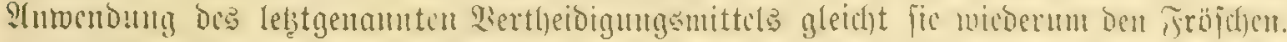

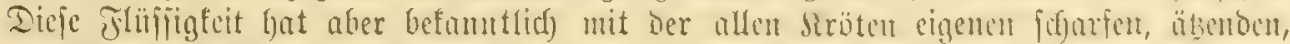

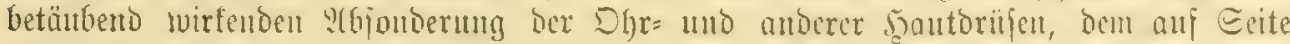
377 bciprodjenen Sautiefret, nichts zu thut.

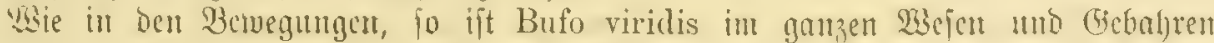

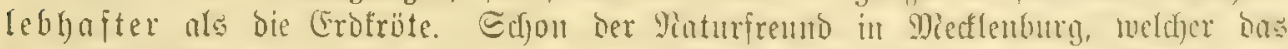

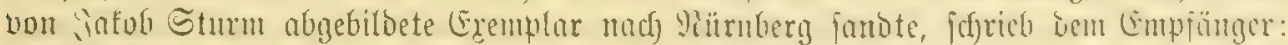
"Dieje Sröte ijt gegen Das Iomperament aller Siröten fefre munter mo lehhajt,

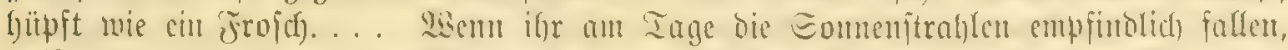

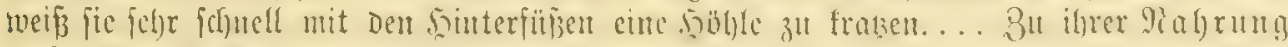

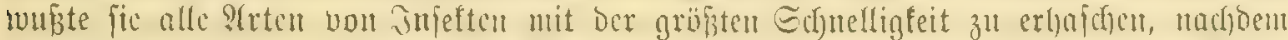

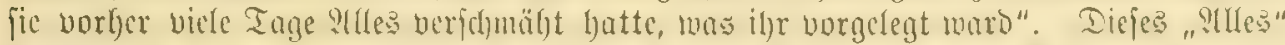

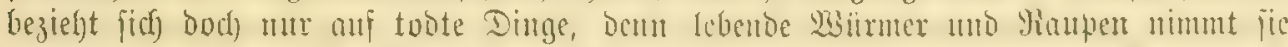

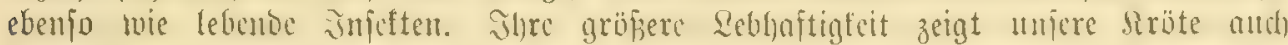

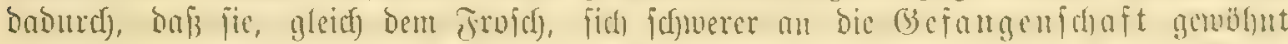
al B Bufo rulgaris, Dic erften Iage unrutgig herumfüpft, an Dex Sichtjeite Des Siäfigs

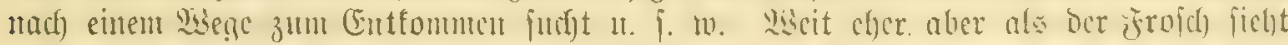

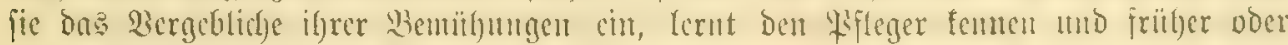

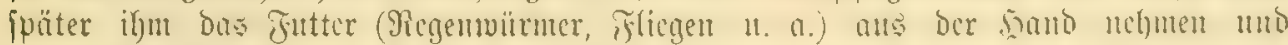

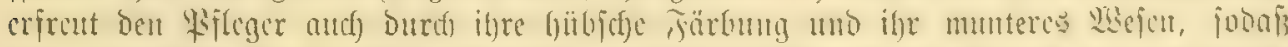

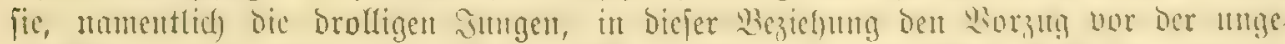

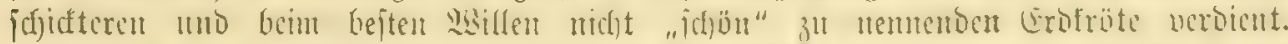

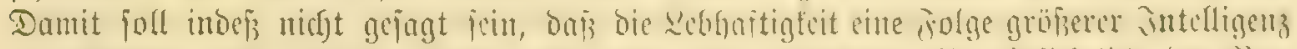
[ei, Deweife enter joldjen liegen nicht vor. Jut llebrigen gilt hinficftlid) ber Wier=

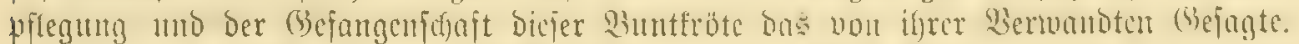

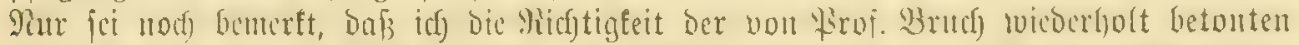

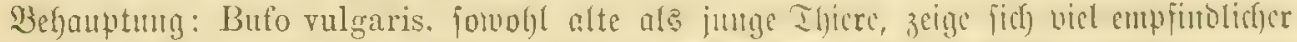

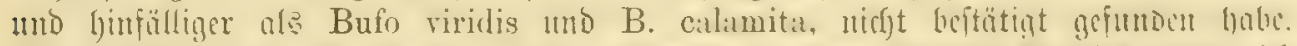

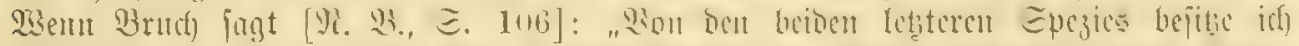

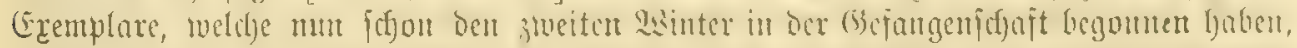

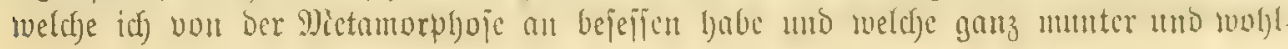




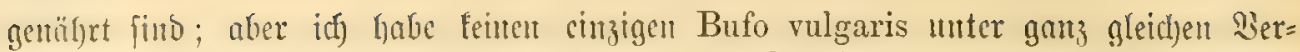
hältuiffen länger als cintge Mionate erbalten. Sic fränfeln fozulagen bom criten

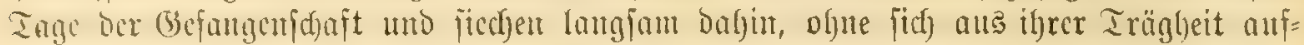

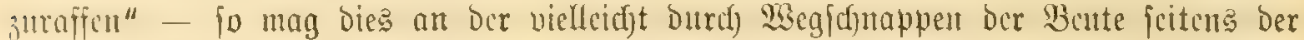

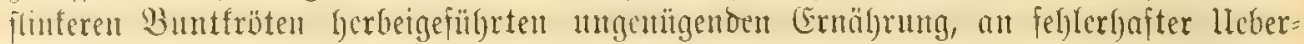
minterutg :c. ober an Dabci zu Tage getretener Eorglofigfeit ocr Evrofröten gelegen baben.

In lebterer beziefuntg mutiste id) atth cine (5rfahrung madjen: Sm Jabre 1880

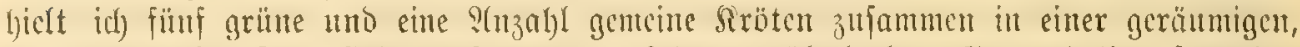

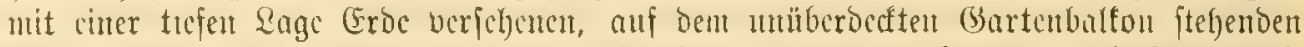
Sijte, weldje idf), nuchoem bic Shicre alle eincn vergun̈gten Sommer uno Frühherbit

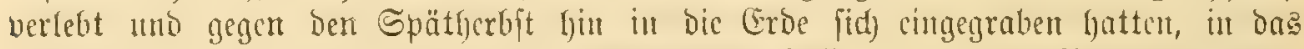

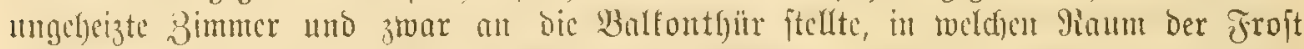

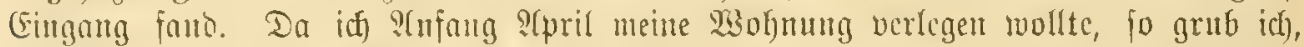

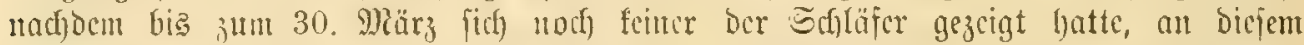

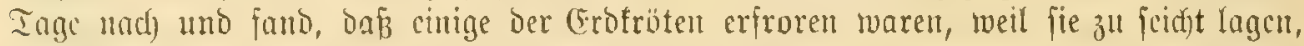

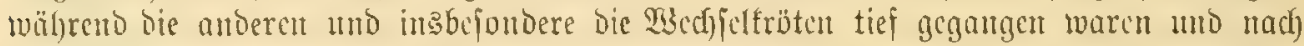
Dem Errwadjen in warmen Bimuter munter weiter lebten. (Semöhnlid) Dantert ber

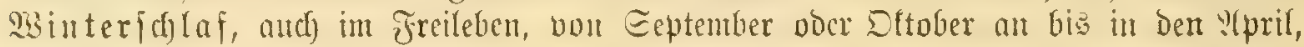

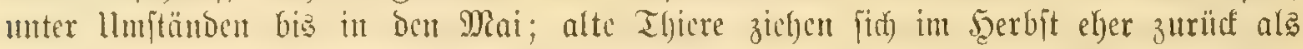

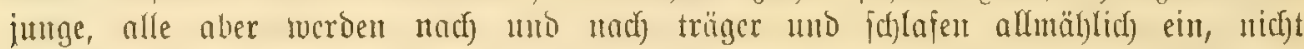

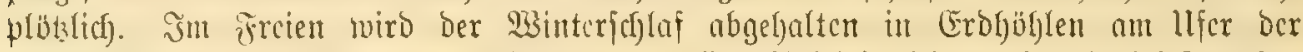

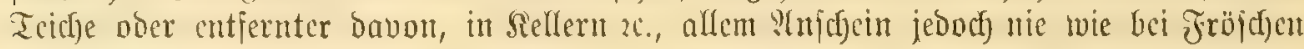
in Sdjlamm der Teidje und Sïmpje.

Etimme. Dic Stimme ber grümen Siröte zeidyut fich bor ber aller unjerer anderen

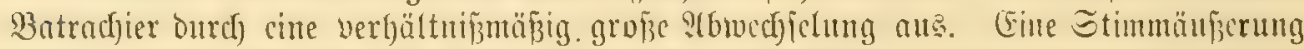

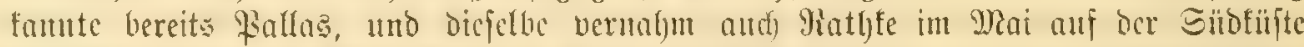

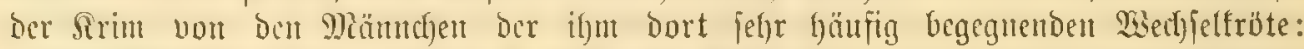

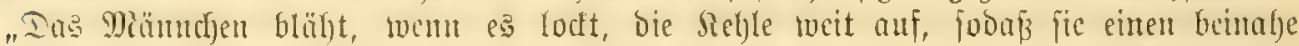

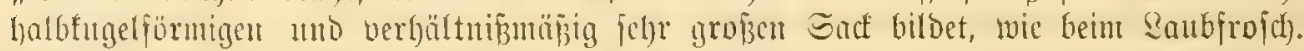

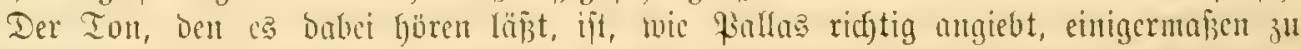

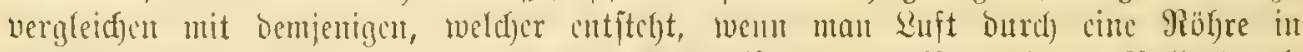

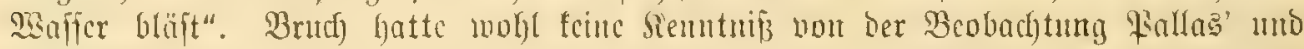

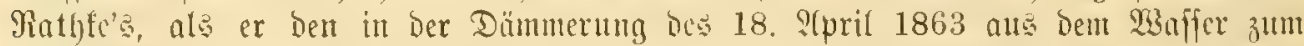

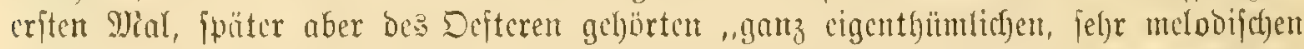

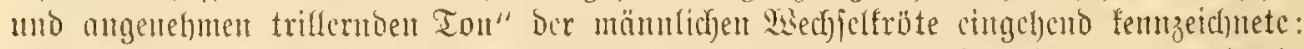

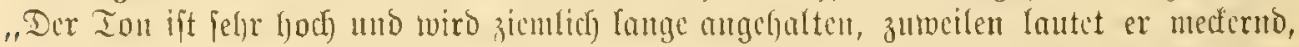

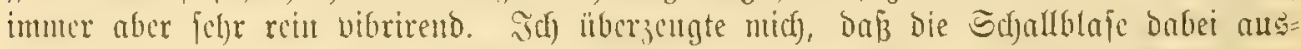

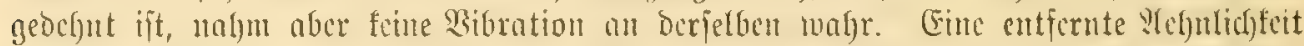
bamit im Mifnthmus, aber nicht im Silang, hat Das befannte Mecfern Der 2̧ajier=

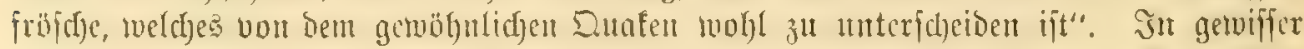

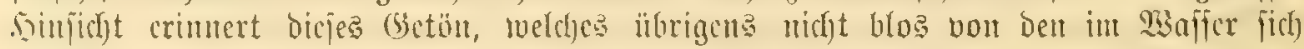

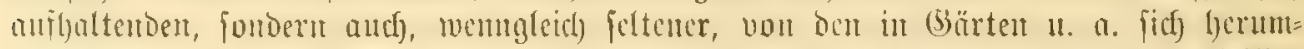

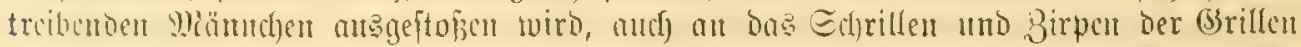

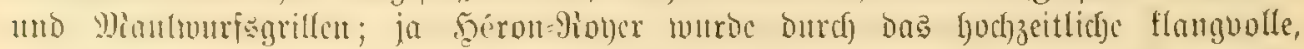

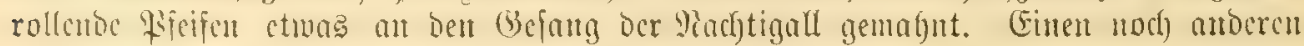

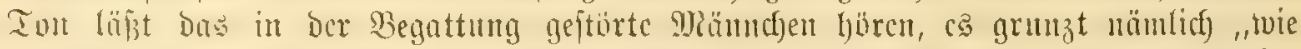

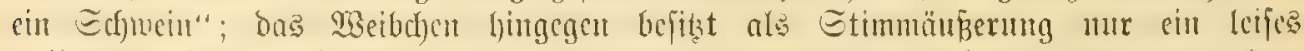

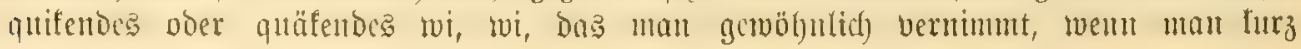




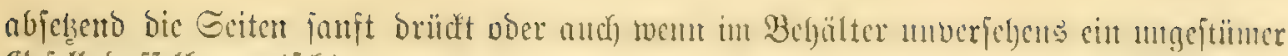
(Bejell Dafielbe quetjcht.

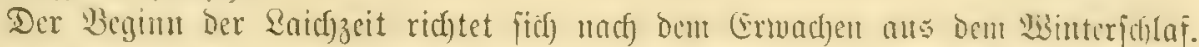

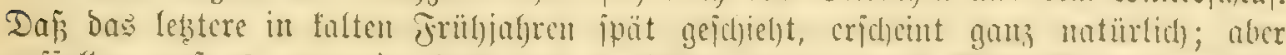

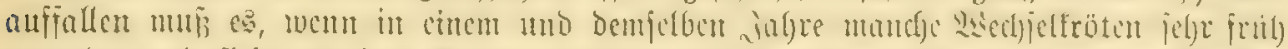

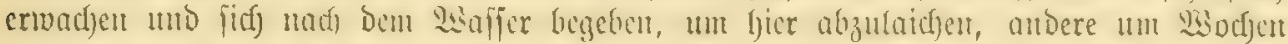

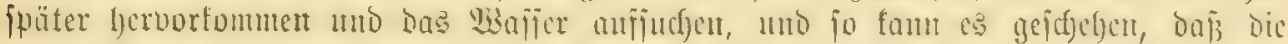
criten Haare fichon im ?(pril, ummittelbar mad) Bufo rulgaris, fid) begatten unb ab=

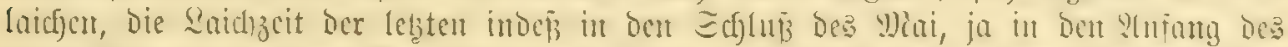

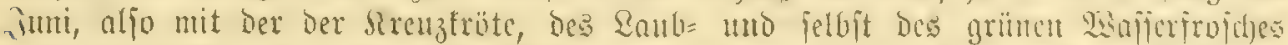

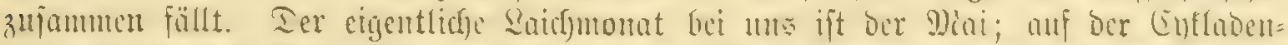

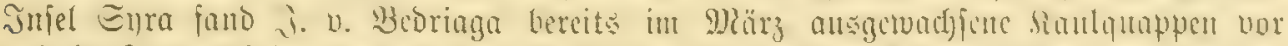

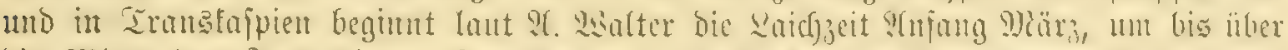

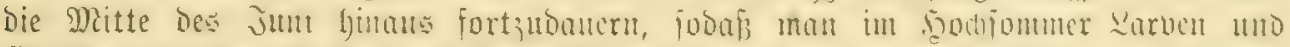

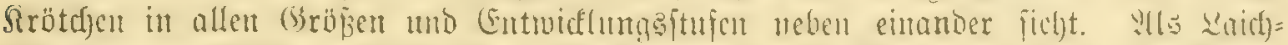

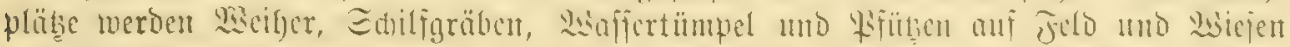

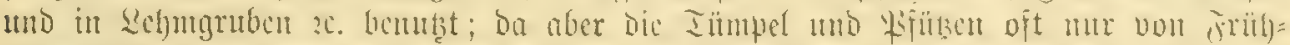

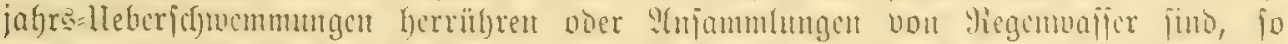

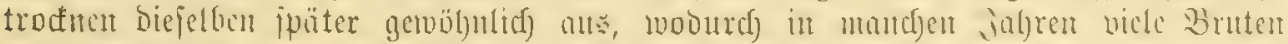

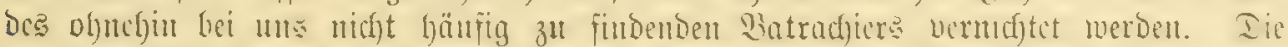

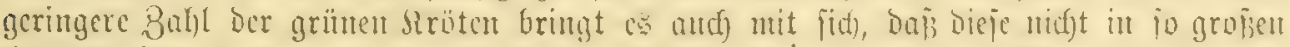

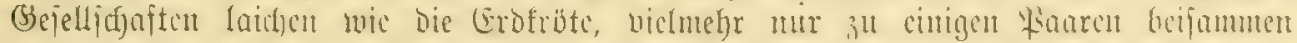

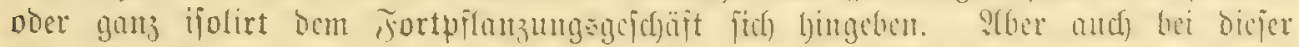

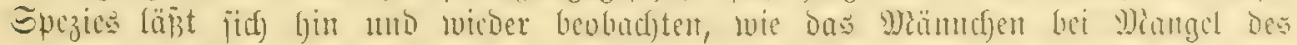

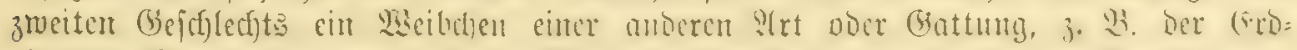

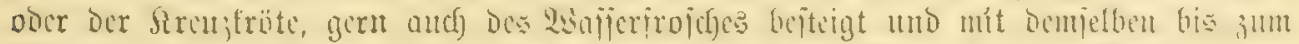

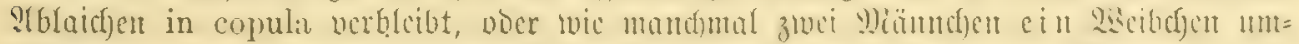

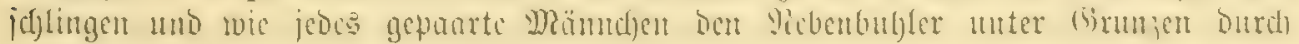
Stöpe mit Den Sinterbeincr abzumeifen fudt.

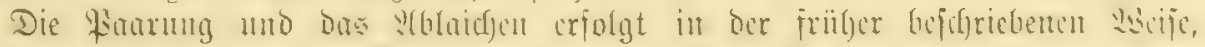

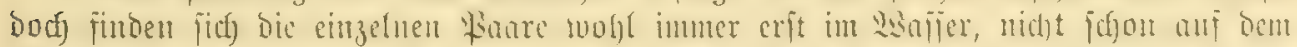

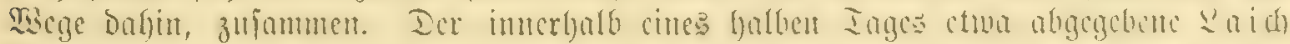

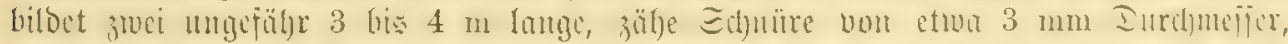

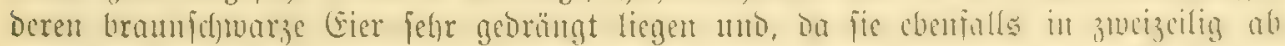

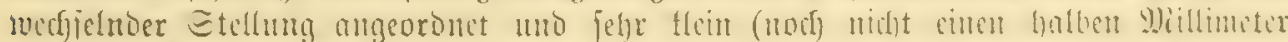

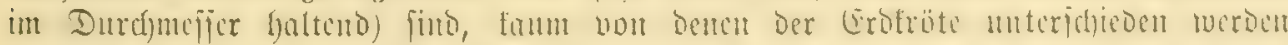
fömen. Sie wout cincm 2.

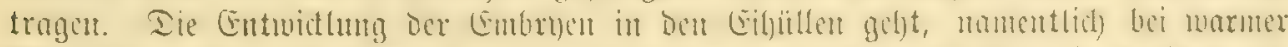

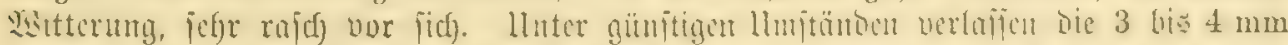

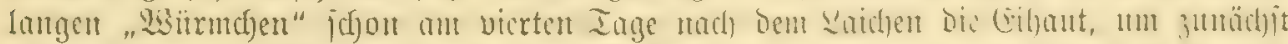

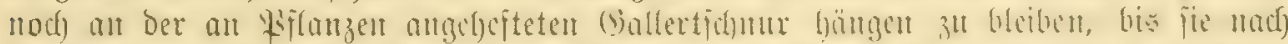

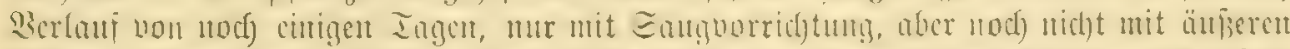

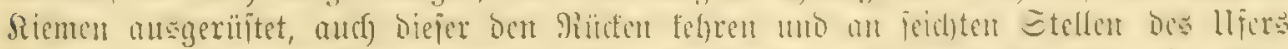

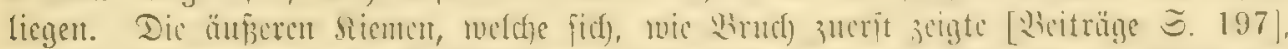

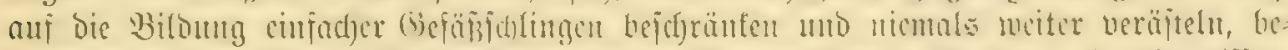

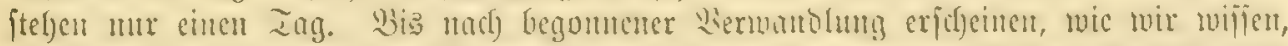

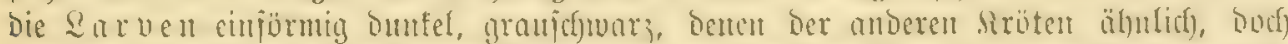

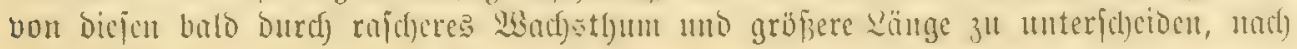




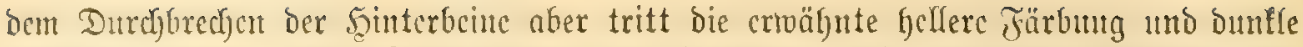
Flectung bervor. Beim Durdbrecten Der Jenterbeinc finto bie baun ungefülyr adjt= wöd)entlidfu Sarven 25 bis 30 bis $35 \mathrm{~mm}$ lang, mandfe, je nadj ben mefr ober

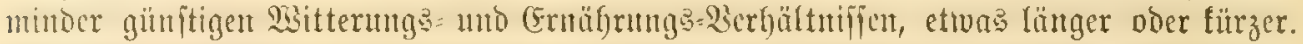

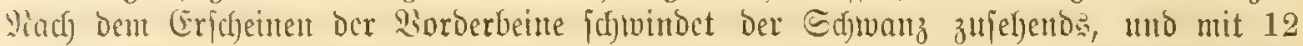

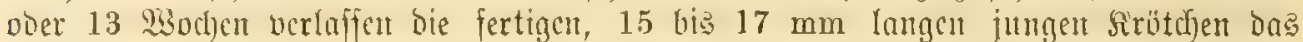
Waffer. Dice gefdicht mithin ?(nfang 3ult, twent ber betreffende \&aich im erften Drittel bes STprif abgejelit war; im stuguit aber tam man neben bicjen aus ber Frübbrut ftammenden, auf weißz= ober perlgratem (3rumbe bübid) grün geffecten

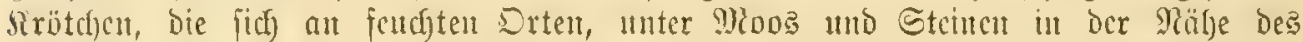

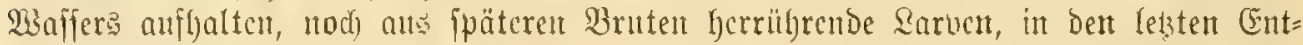

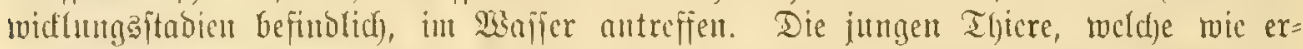

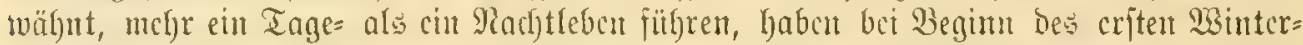

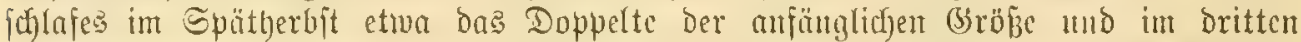

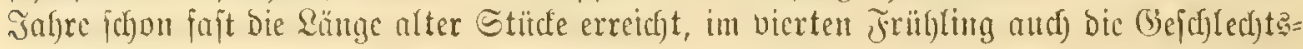
rcife erlangt.

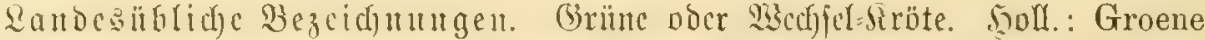

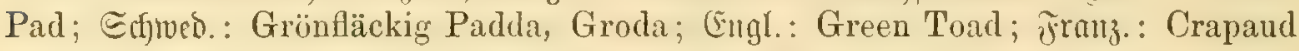
vert ou Crapaud variable; Ital.: Rospo smeraldino; Span.: Sapo verde: \$Folı.: Ropucha zmienna; Bbłym:: Ropucha pestrá (mènivá).

Bufo viridis et B. Schreberianus, Laur. 1768. - Rana variabilis, Pallas 1769. - Rana sitibunda, Pallas [9ieife I] 1771. - R. bufina, Müller 1776. R. Bufo, Gmelin 1790. - Bufo sitibundus, Sclmeider 1799. - Rana viridis, Shav 1802. - Bufo variabilis, Merrem 1820. - Bufo arabicus, Rüppel 1827. - ?Rana picta Pallas 1831. - Bufo crucigera, Ëichuereld 1831. - B. variab. var, balearica, Böttger [80ol. 9.n?. 1880 S. 642].

\section{Art: KreujFröte. Bufo calamita, Laur.} Abbilloung: Tajel I $\Re$ ir. 3.

Sänge 5 bis $8 \mathrm{~cm}$; Gqutwarjen veremzelt ftehend, ohne Gornhöcfer (Dorten); Jehen der Ginterfüre ohnc eigentlidge $S$ h wimm haut, mux mit ganj furjer Spannhat in den Jehenwinkeln; Ginterbeite fehr Furj, nad vorn an den Körper gelegt, mit der Spitze der längiten (4.) Jẹhe hödftens bis jum Sdntauzen= Ende retąend; einc crhöhte Gautfalte längs des Saufes ftets fohr dcutlid, an den

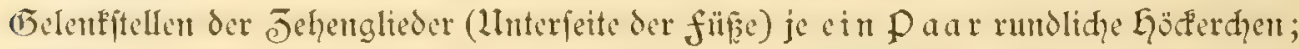

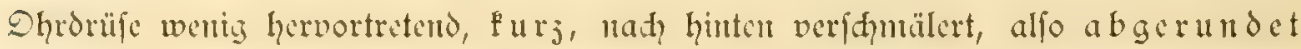

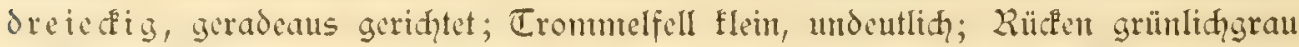

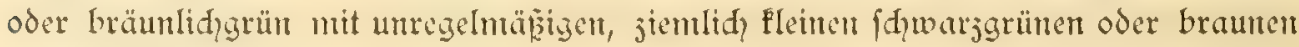

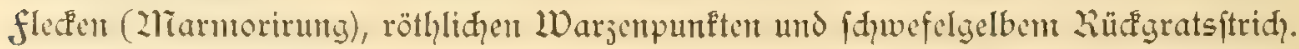

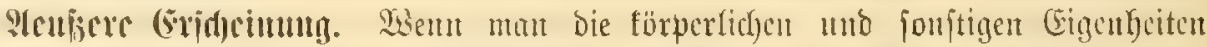

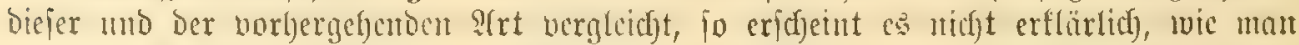

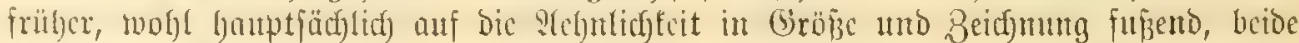

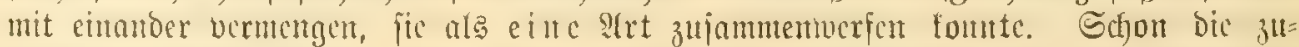

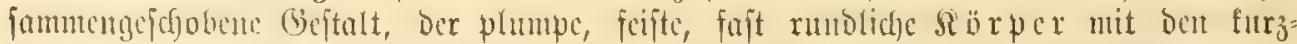

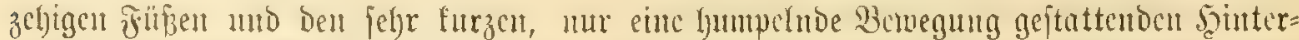

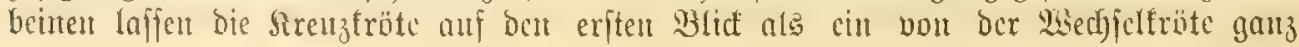




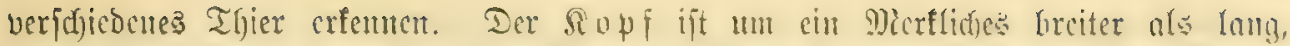

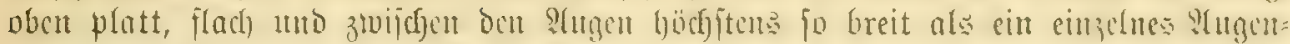

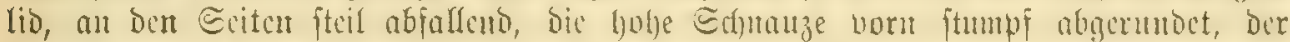

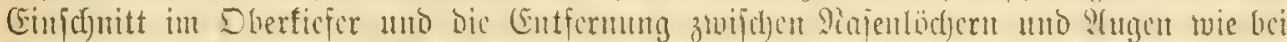

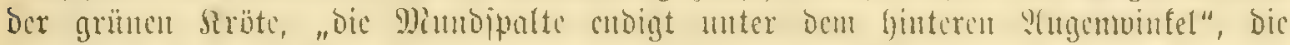

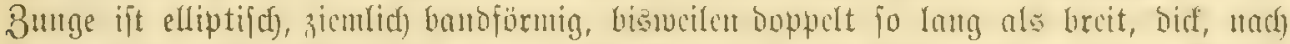

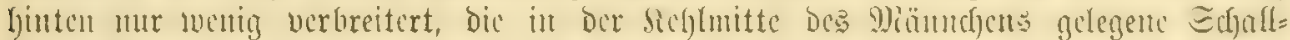

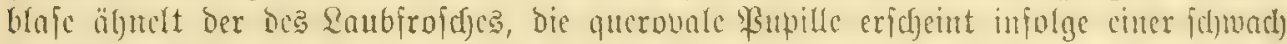

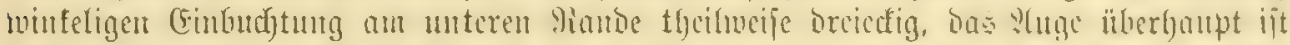

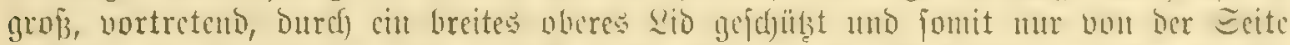

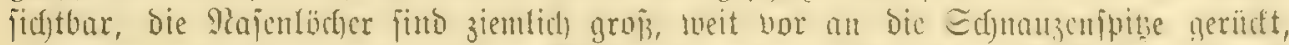

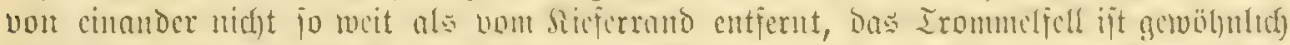

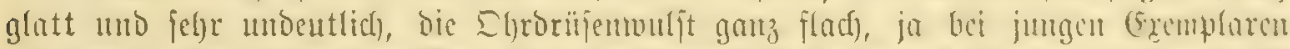

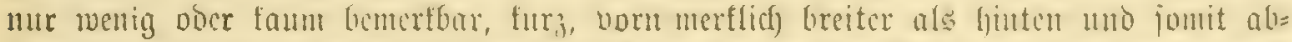

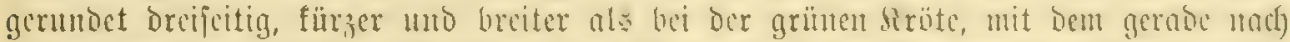

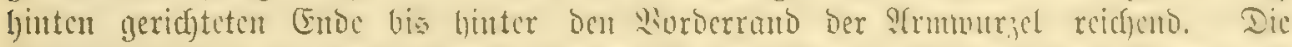

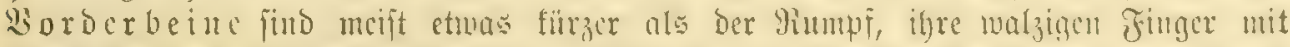

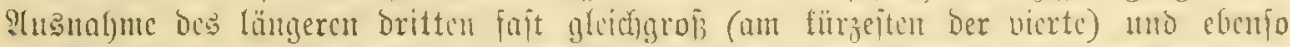

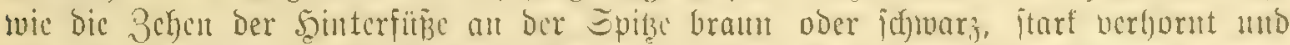

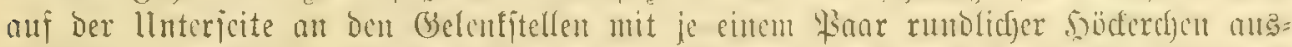

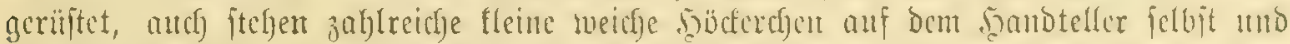

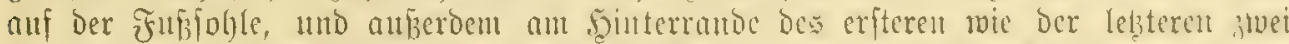

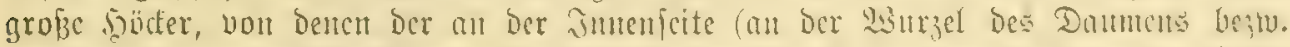

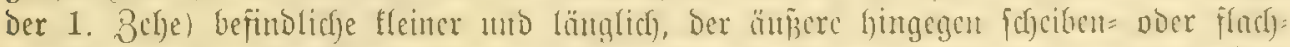
fegelfümig ift. Die ninterbeine finto nidgt me fürger als bei ben anderen beiden

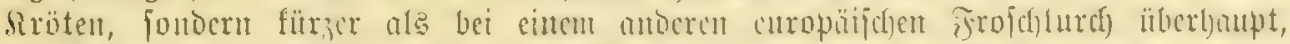

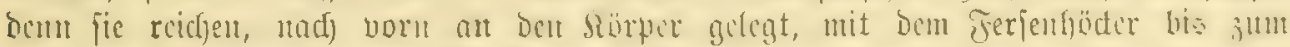

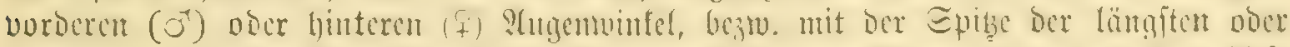

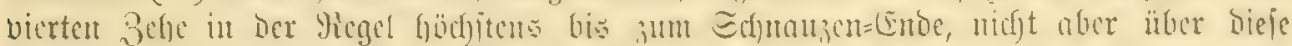

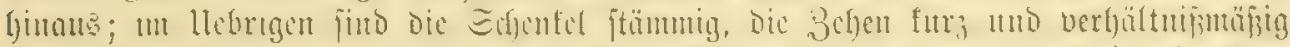

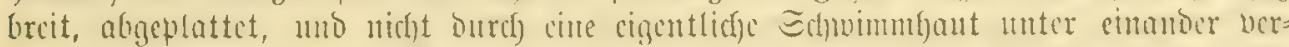

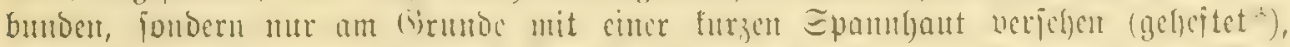

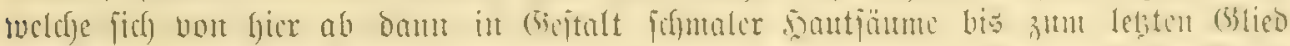

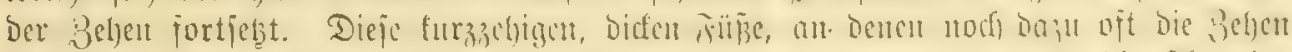

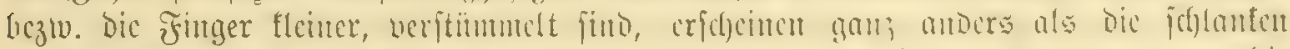

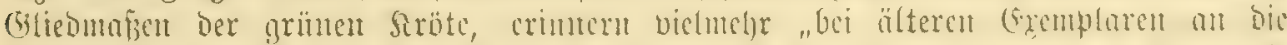

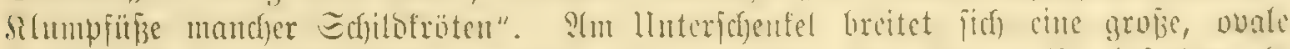

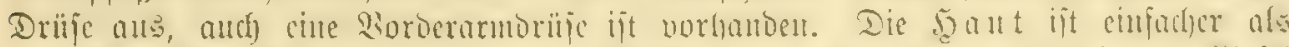

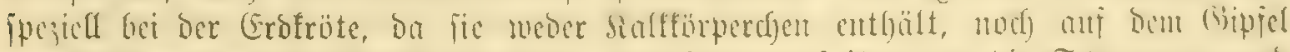

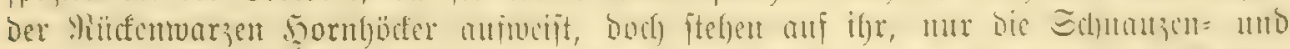

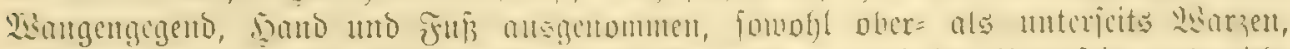

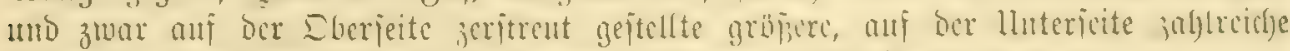

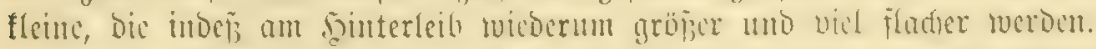

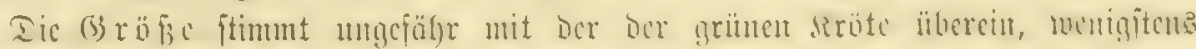

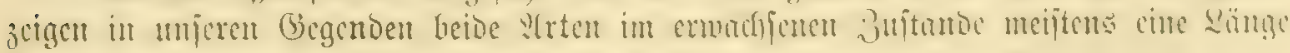

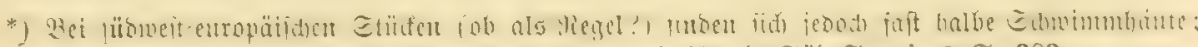

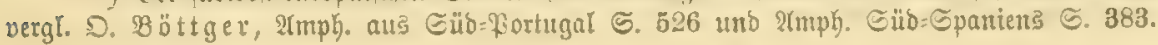


von ctwa $6 \mathrm{~cm}$; wäbrento aher B. viridis erbeblich griffer weroen fant, wiro mant

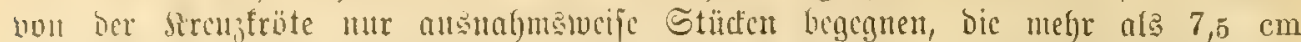

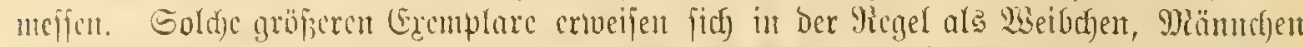

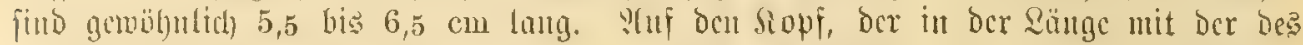

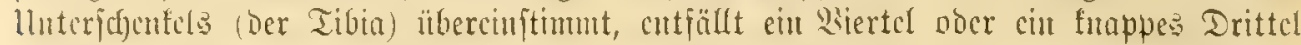

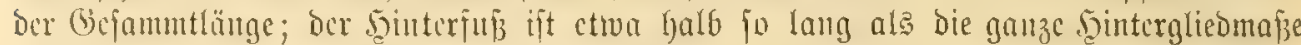

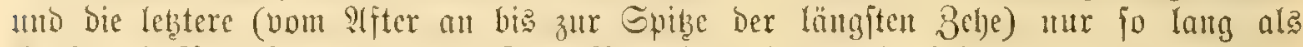

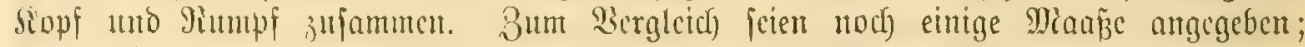

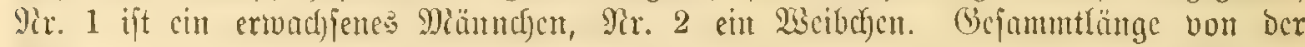

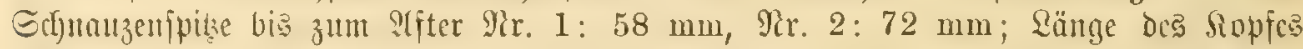

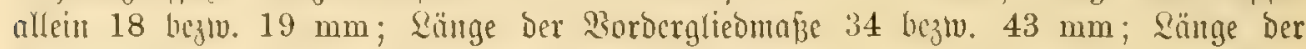

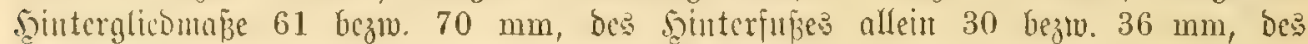

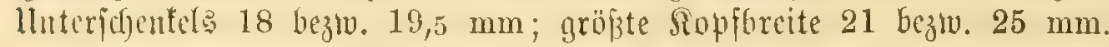

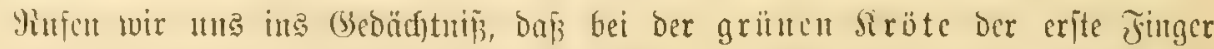

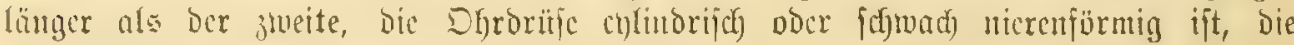

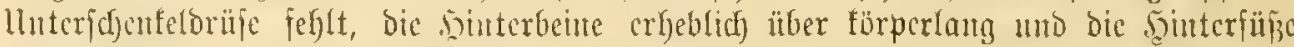

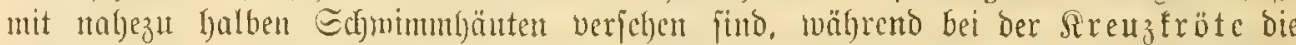

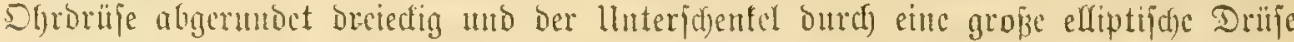

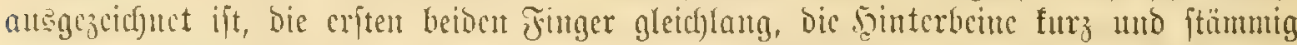

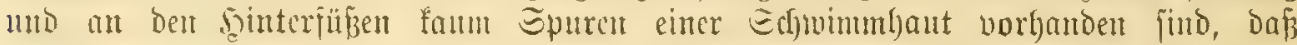

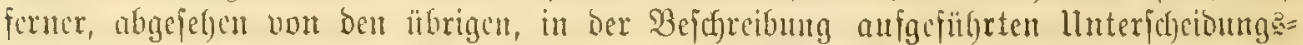

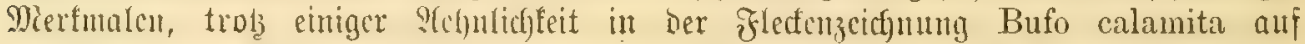

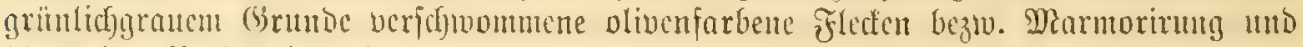
längs bor Yitidfenmitte cincu fohar abgegrenzten gelfen Strich, Bufo viridis hingegen

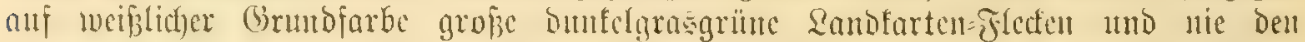

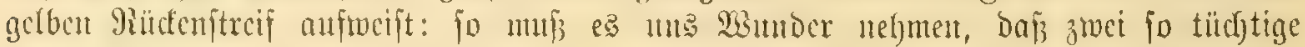

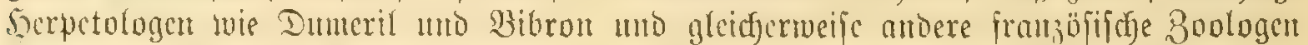

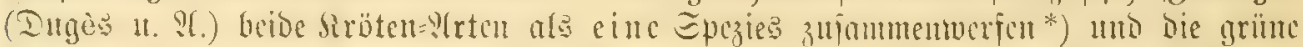
Siröte mur als ,un calamita sans rail jaune sur le dos", cine SBarietït bor Sireltz=

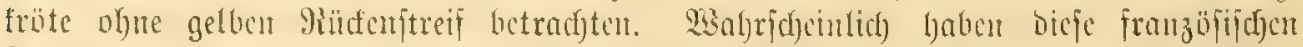

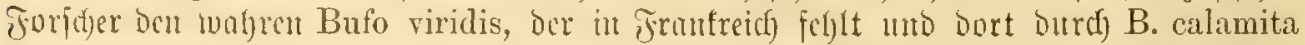

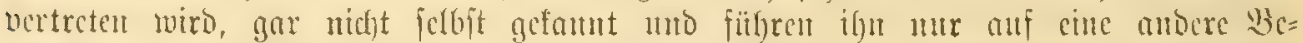

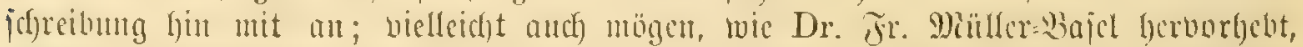

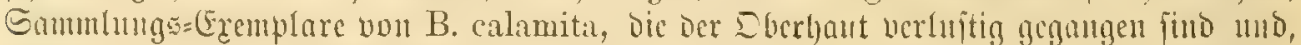

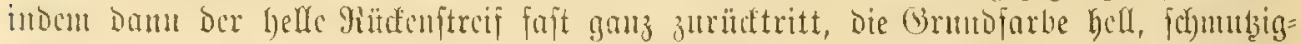

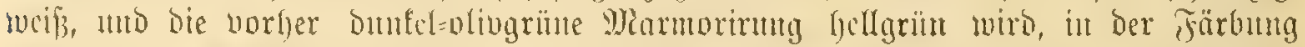

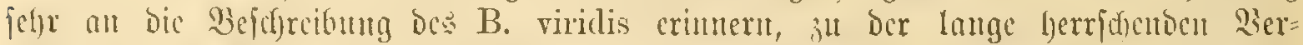

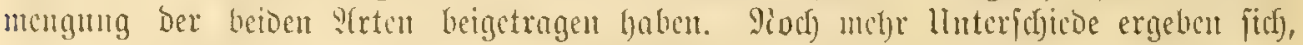

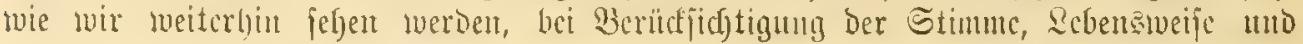
Fortpflanzung.

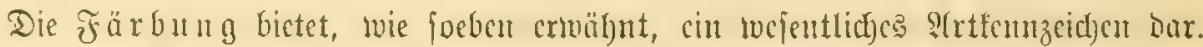

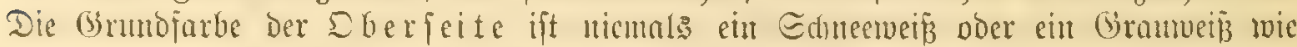
bei ber grünen Sirbte, jondern bübfyiten ein griunliches vier gelbliches Grau, oft aber

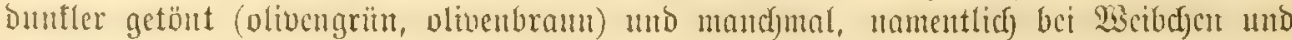

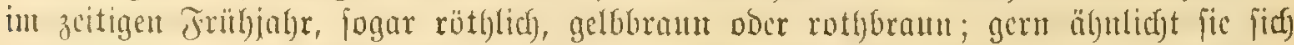

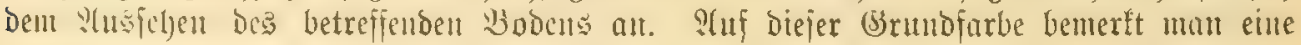

*) Satreille [Sal.] und (Guvier jeboch behanbeln fie aโs verjajiebene strtent. 


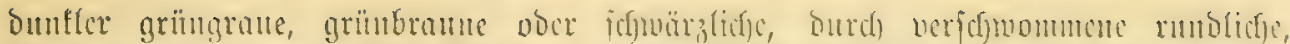

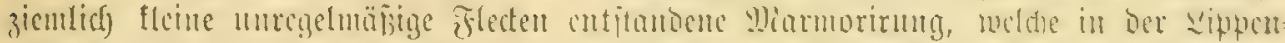

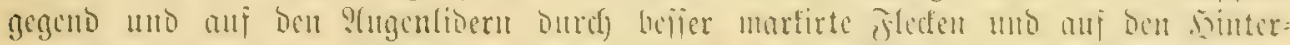

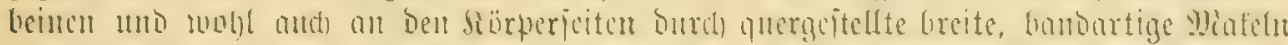

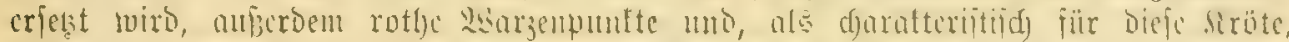

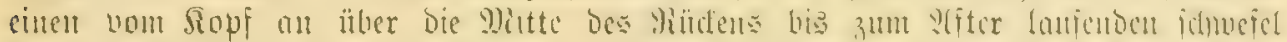

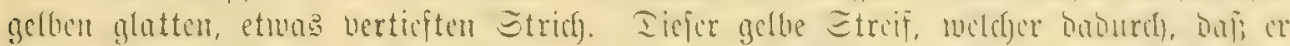

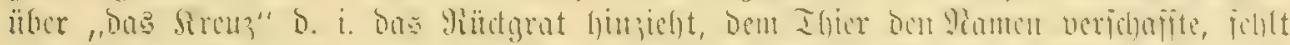

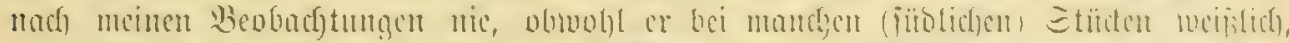

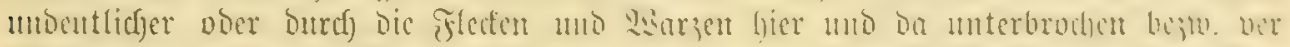

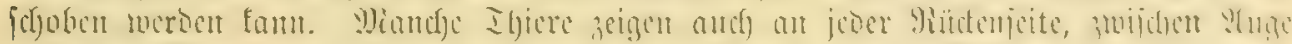

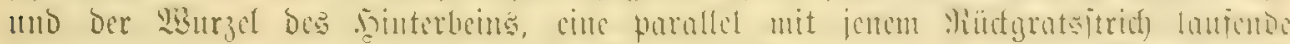

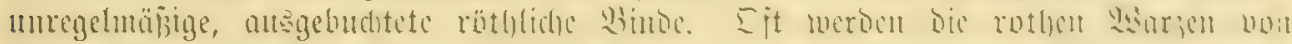

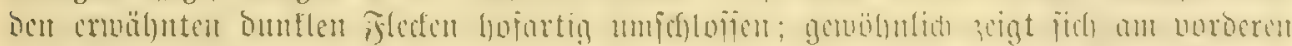

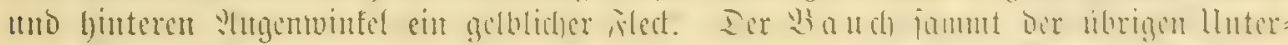

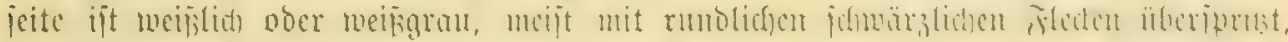

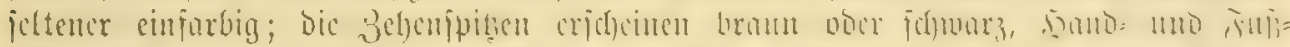

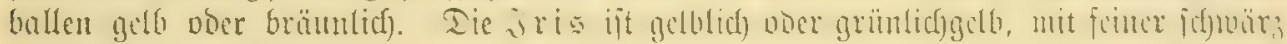
lidjer Sicjprentelung.

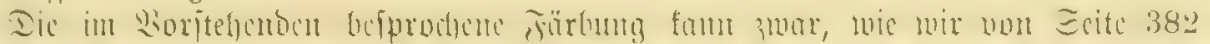

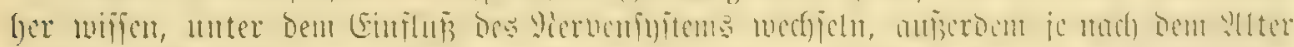

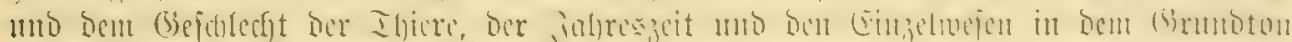

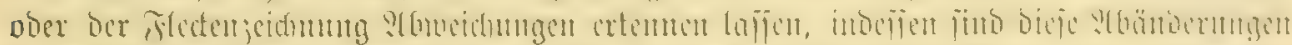

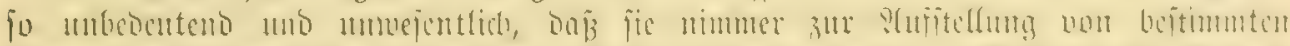

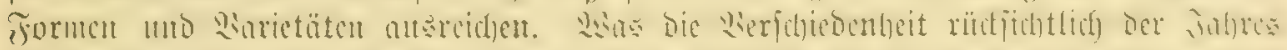

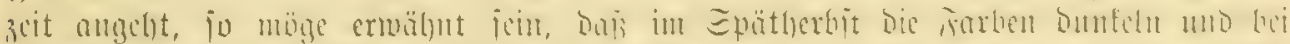

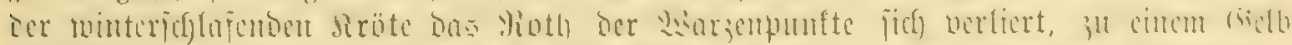

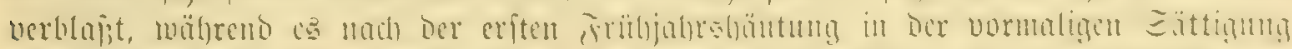

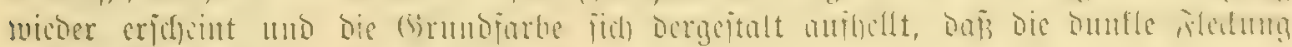
fräftig bervortritt.

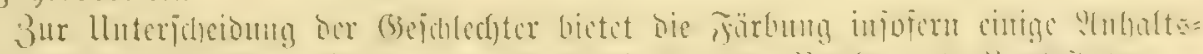
peiflefiter.

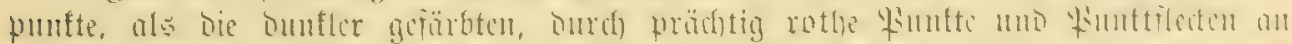

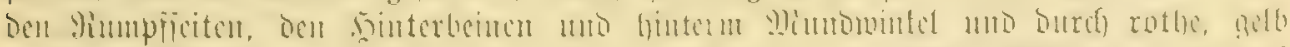

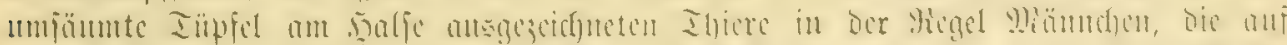

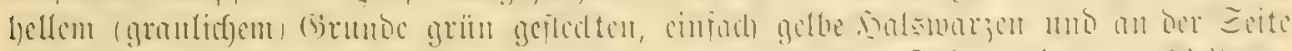

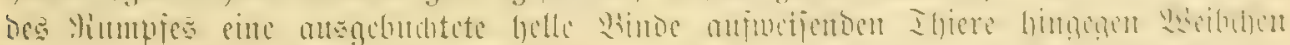

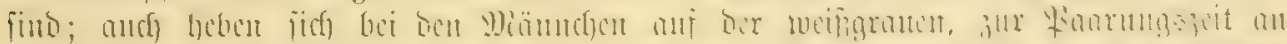

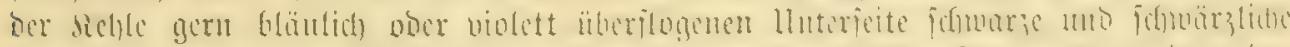

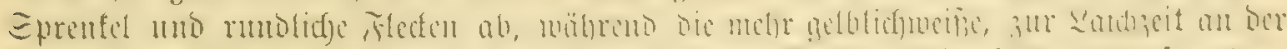

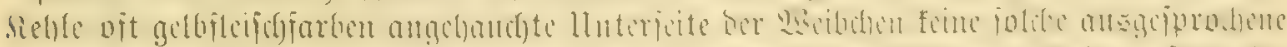

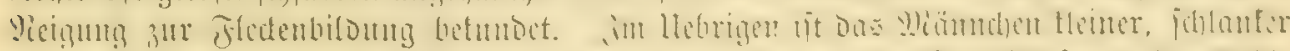

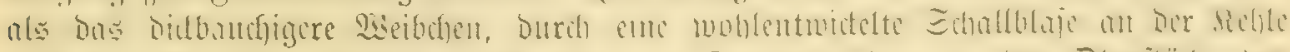

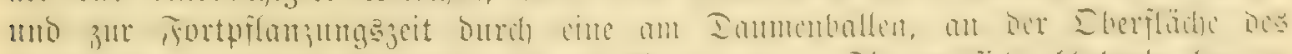

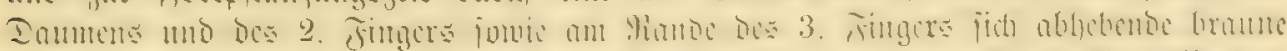

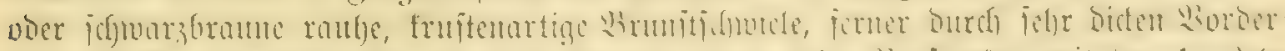

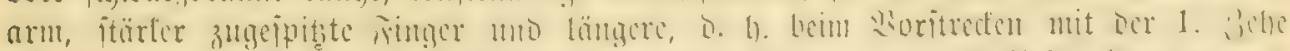

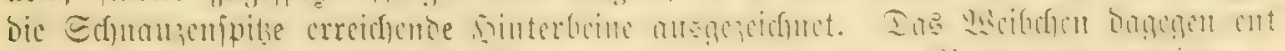

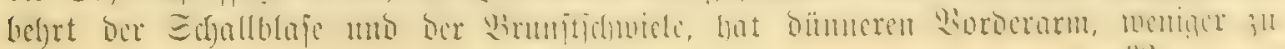




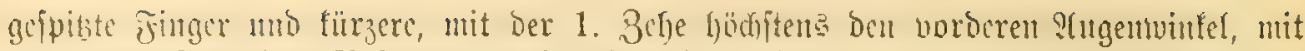

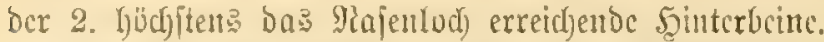

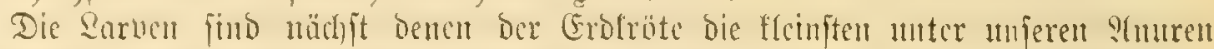

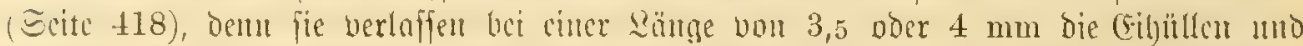

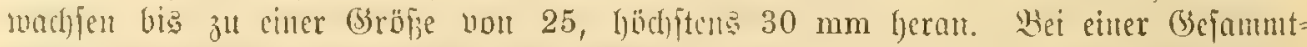

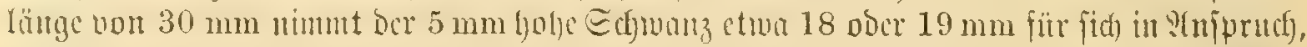

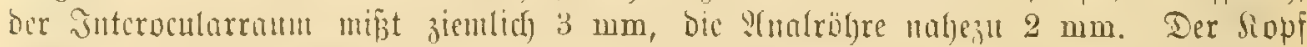

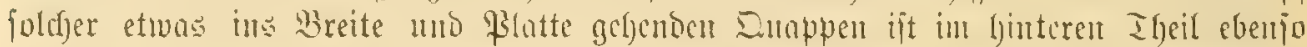

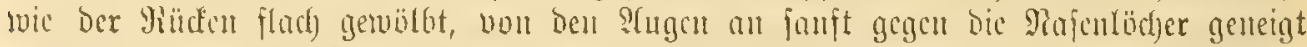

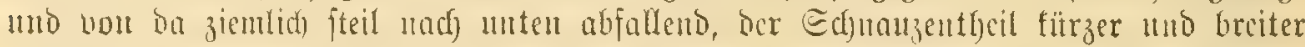

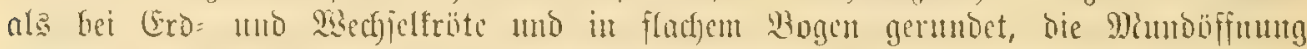

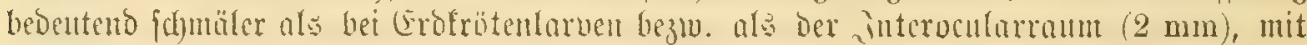

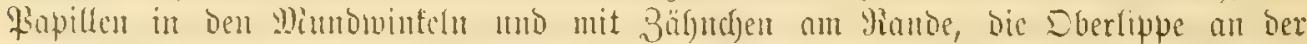

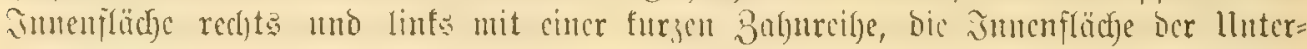

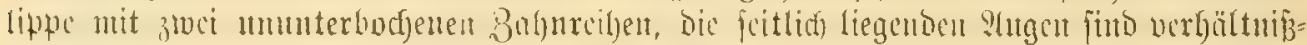

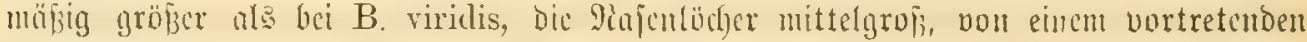

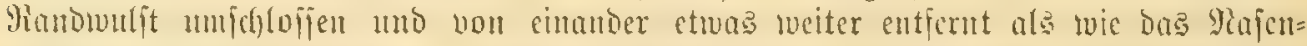

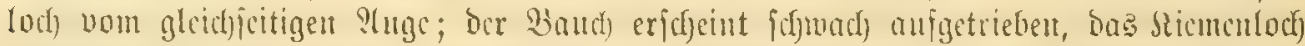

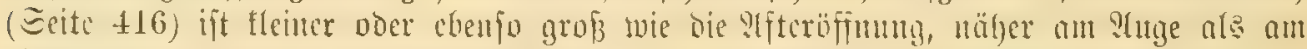

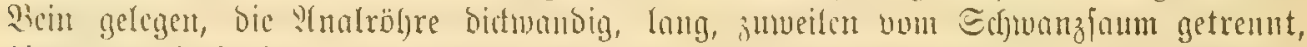

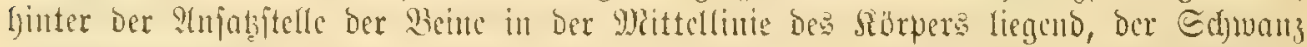

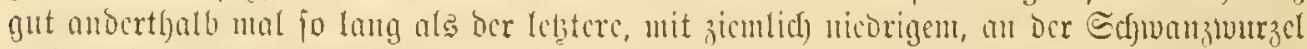

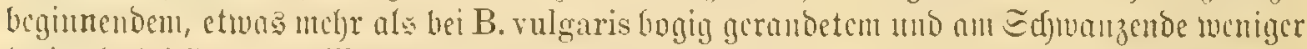

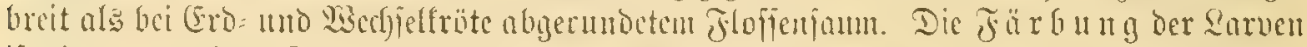

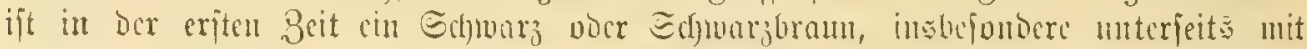

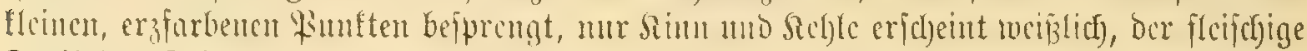

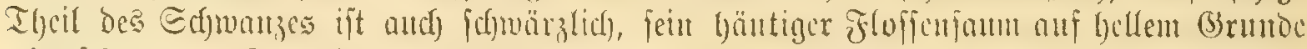

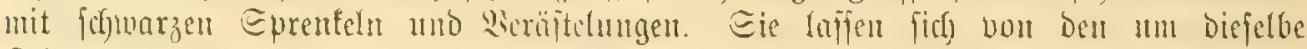

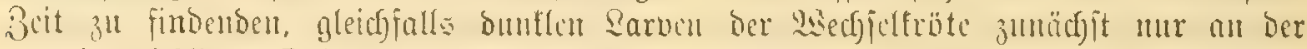

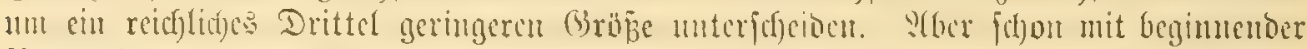

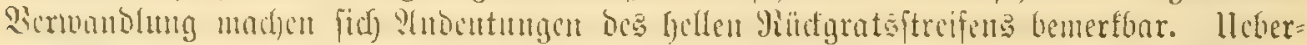

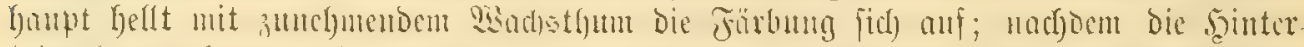

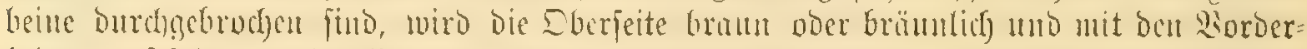

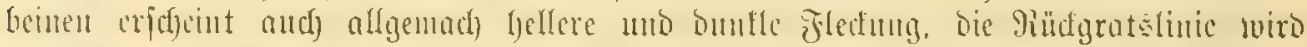

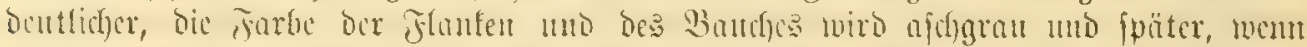

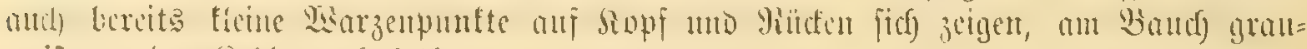
weî̉, an ber Siegle trody geller.

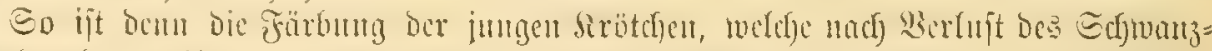

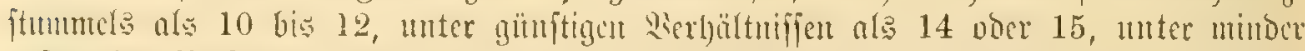

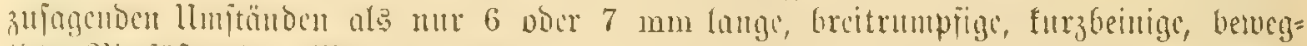

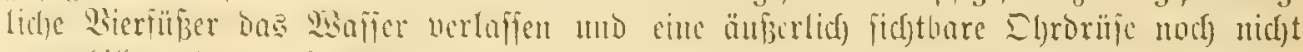

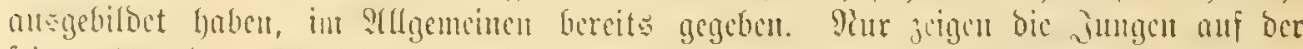

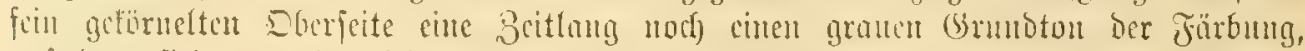

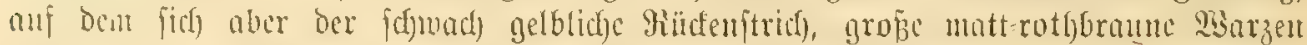

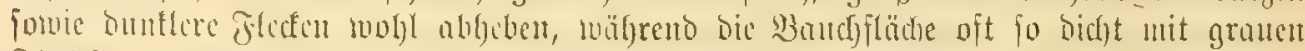

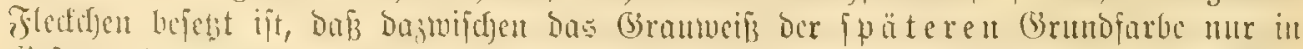

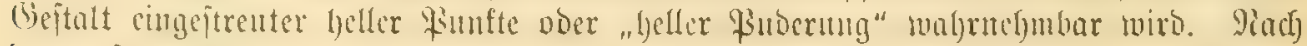

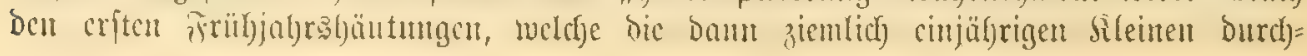




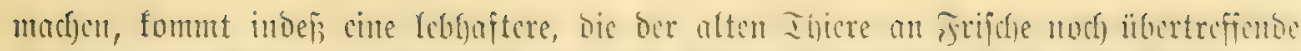

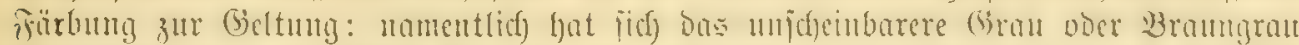

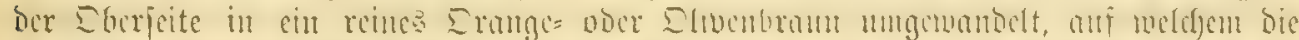

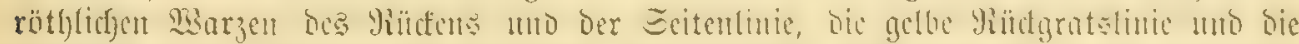

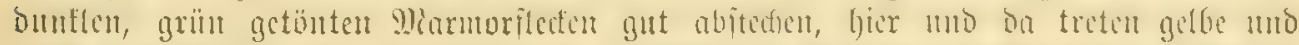

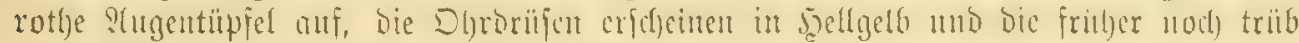

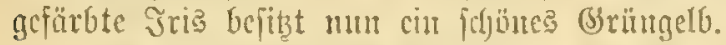

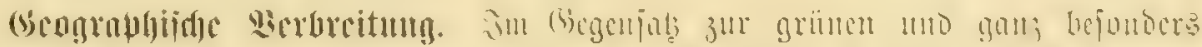

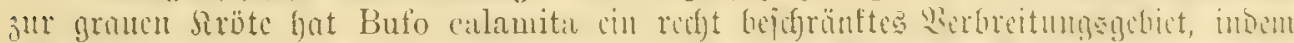

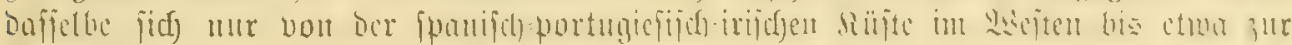

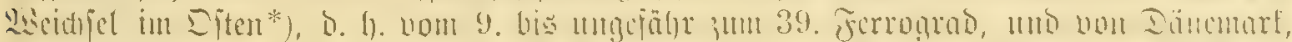

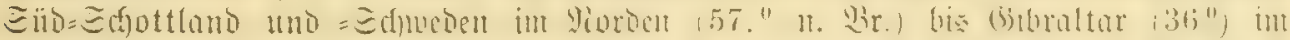

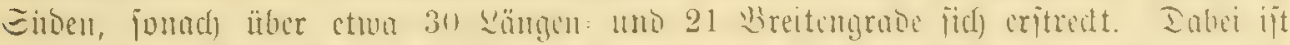

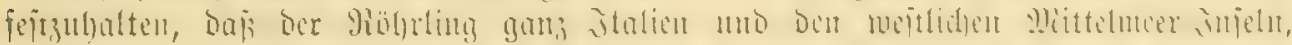

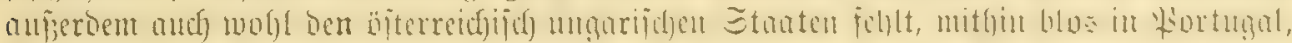

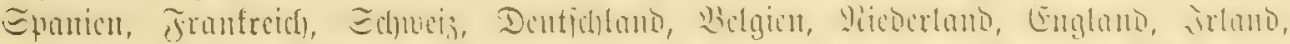

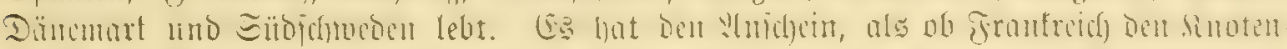

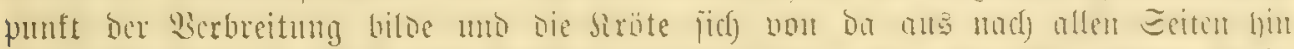

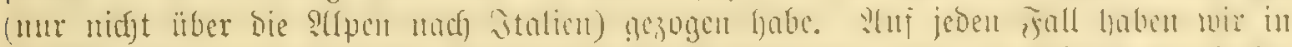

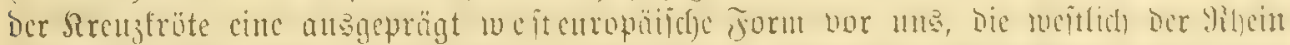

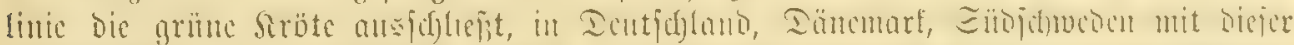

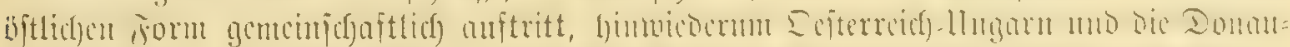

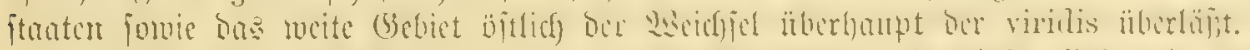

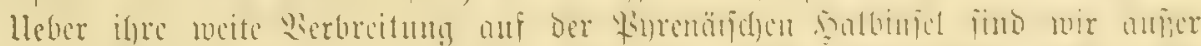

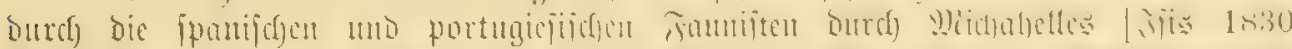

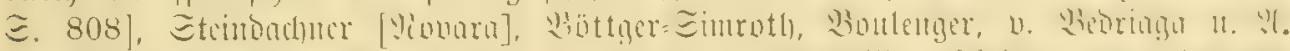

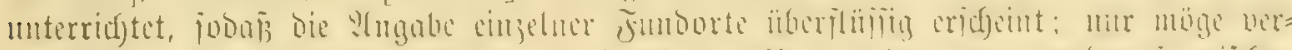

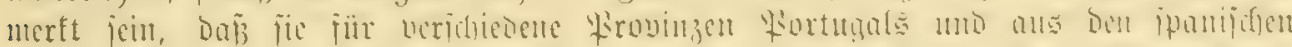

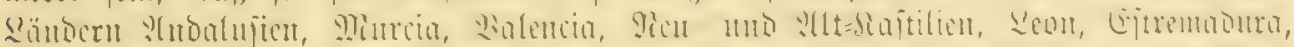

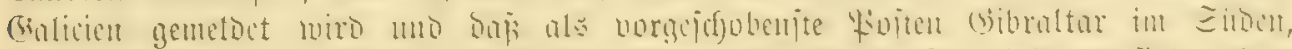

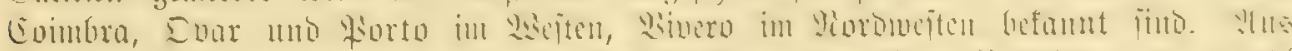

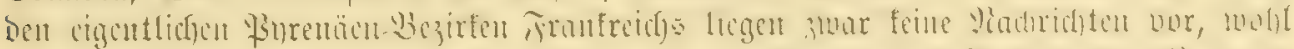

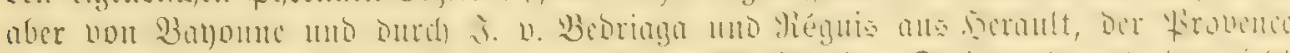

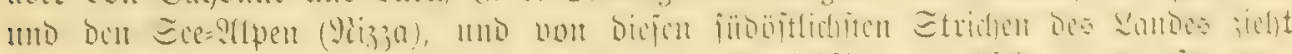

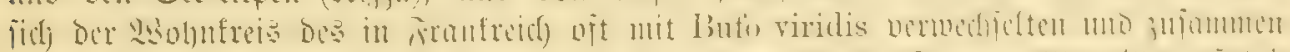

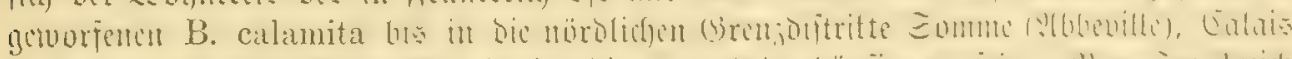

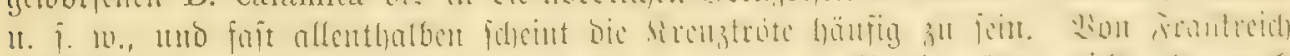

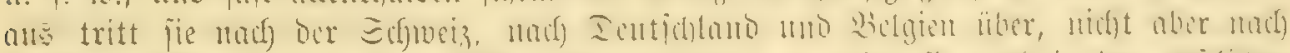

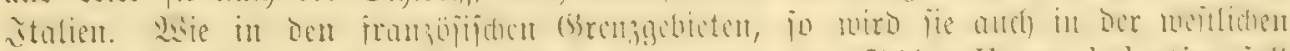

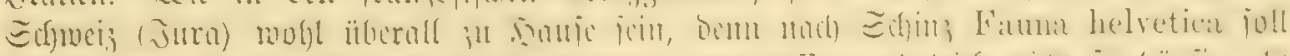

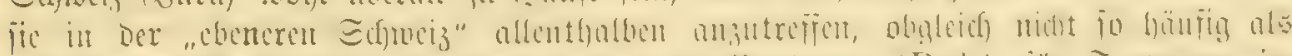

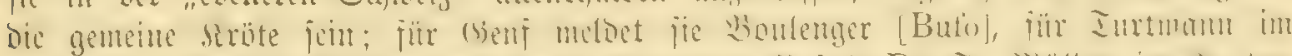

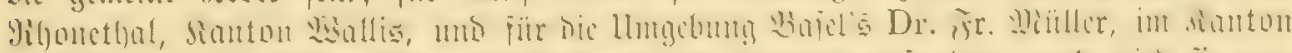

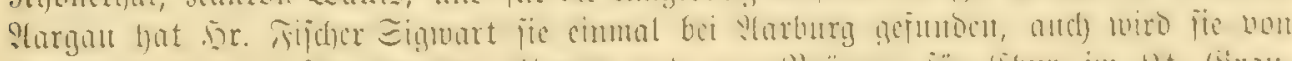

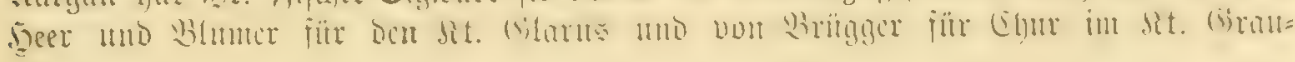

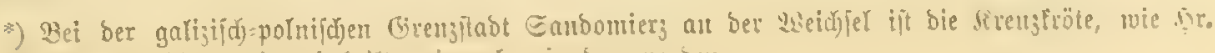
frof. 92. Lomid́ 1880 mir miktgeilte, einnal gejunben voroen. 


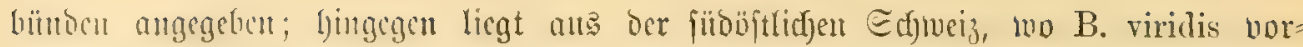
fommt, teine ?!nzeige vor, fic fiblt alfo wohl bort, mo ebenjo vermijst man fie lant

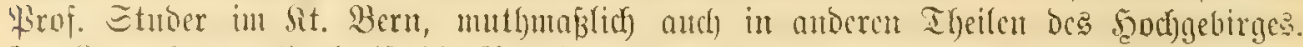

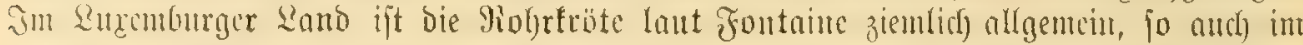

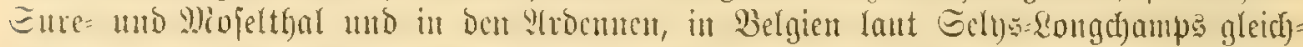

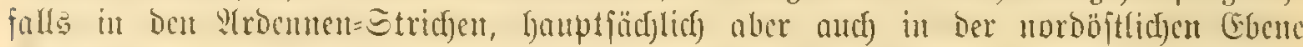

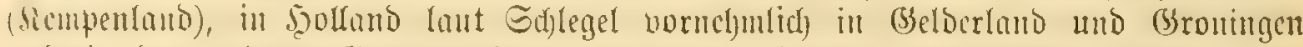

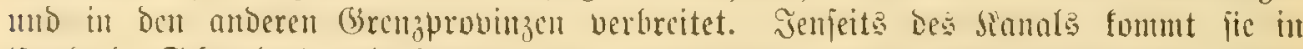

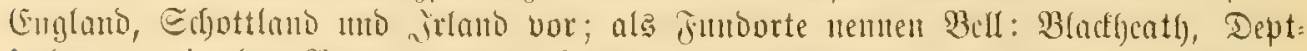

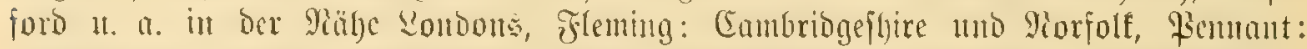

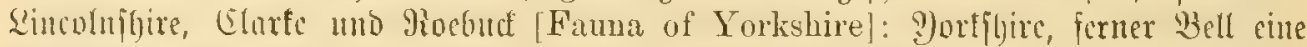
Eortlichteit an llfer bes Evlwat) Firtl) im füblicfen Edjottlnm, (E. Jriedel mad) 2.3. Tontpious Natural History uno :. (3. Wiorc [Journal of Botany 1877 ङ. 350]

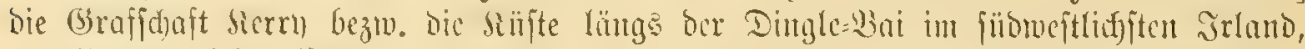

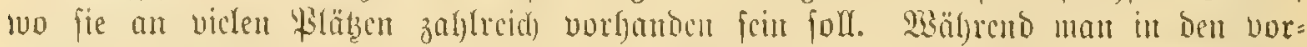

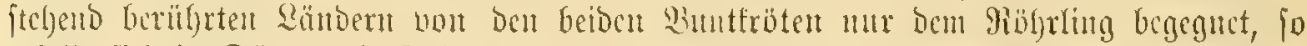

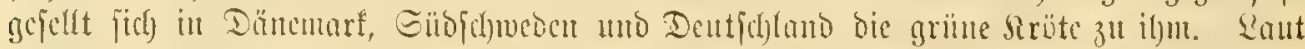

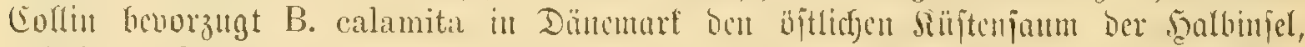

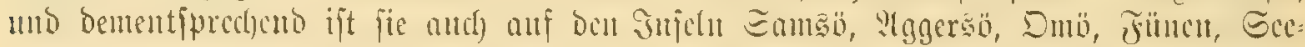

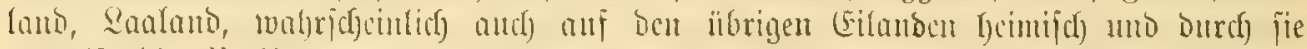

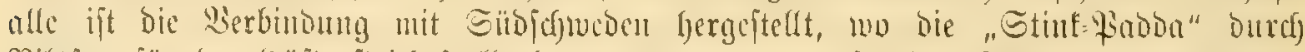

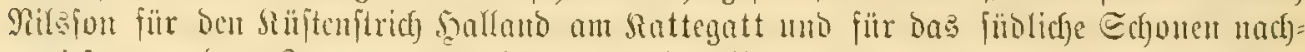

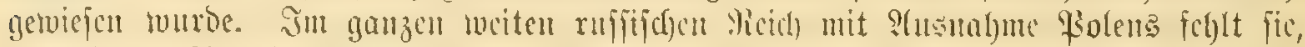

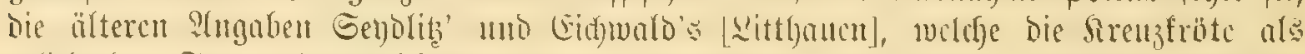

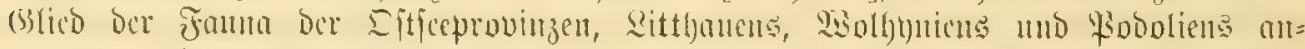

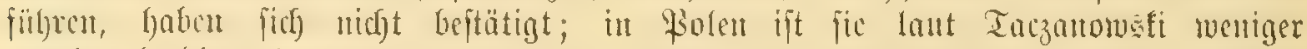

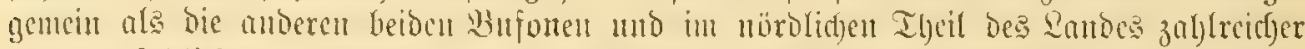

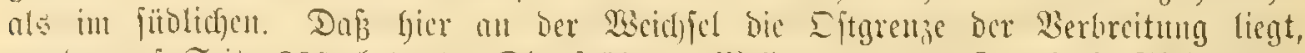

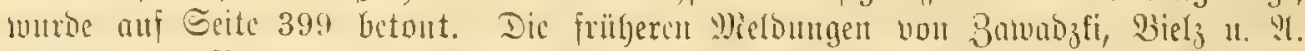

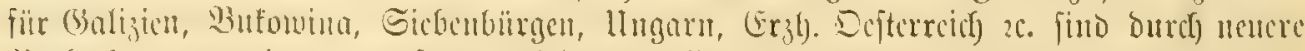

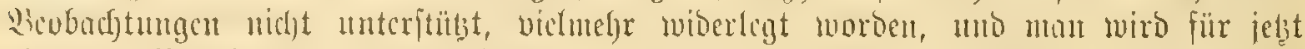

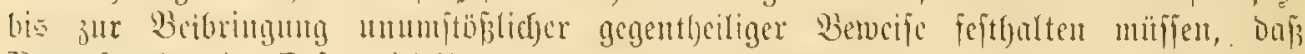

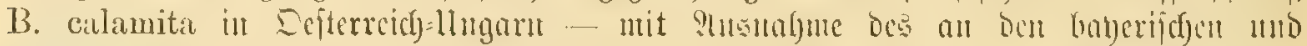

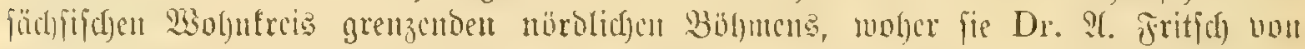

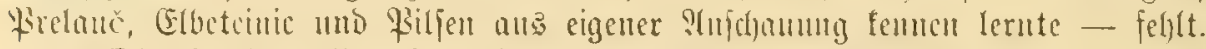

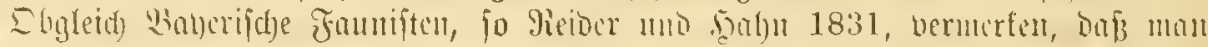

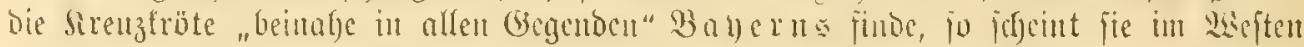

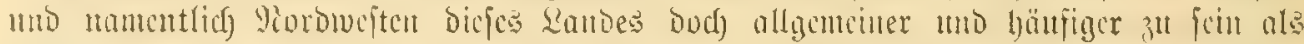

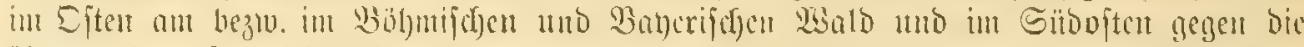

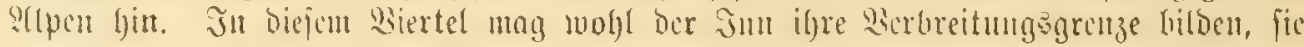

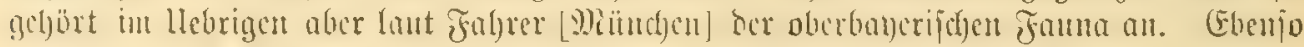

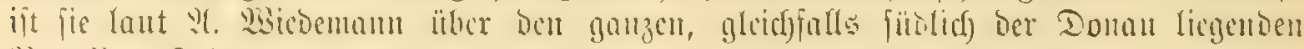

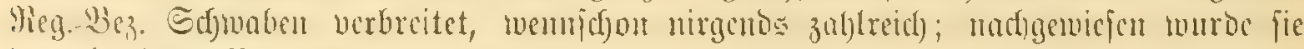

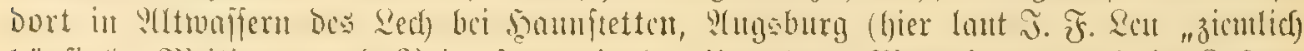

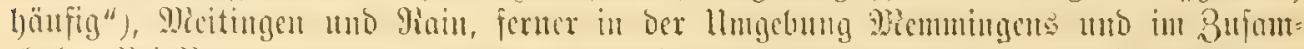

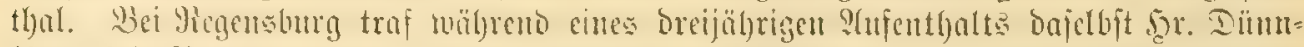

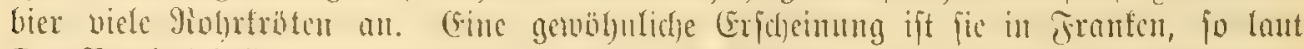

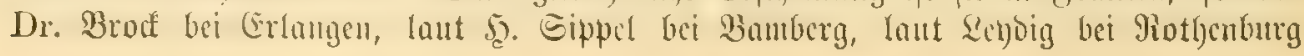




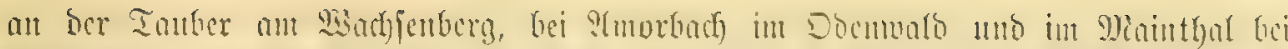

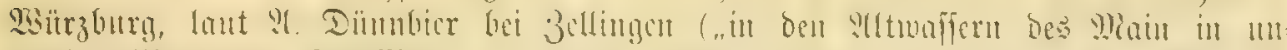

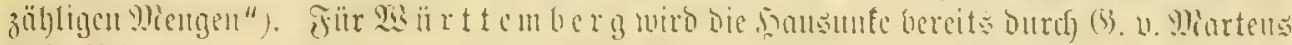

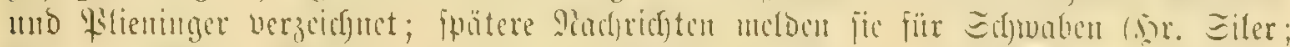

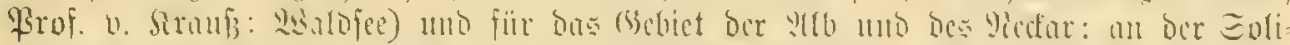

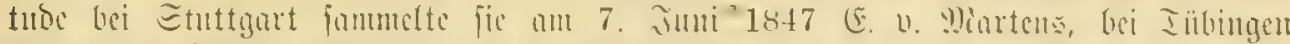

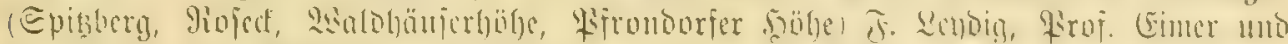

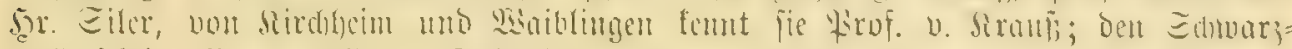

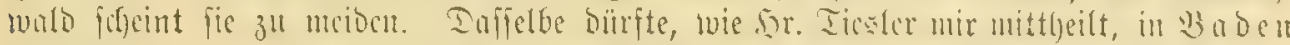

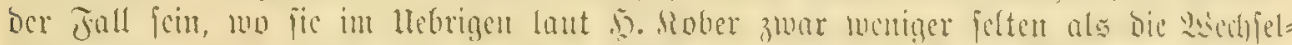

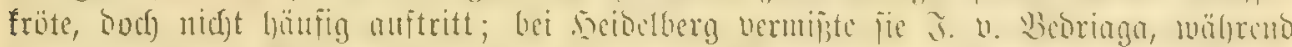

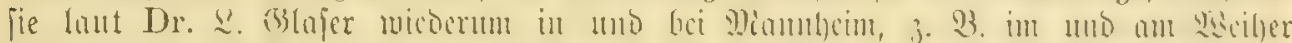

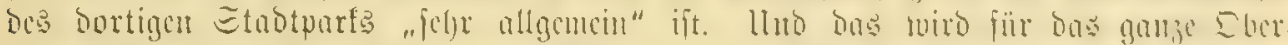

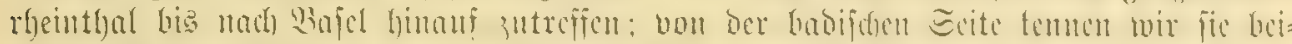

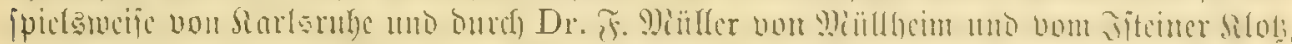

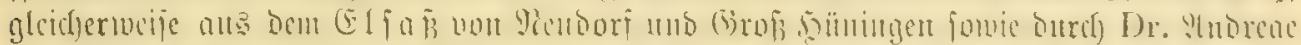

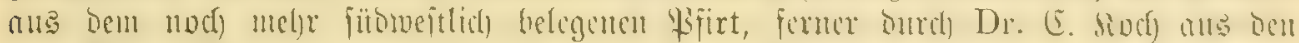

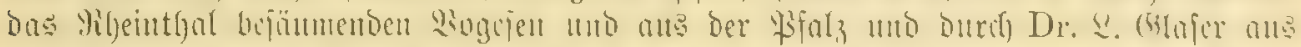

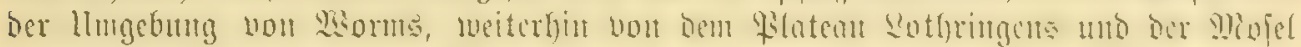

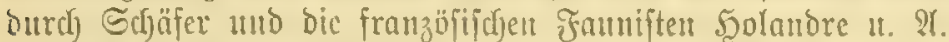

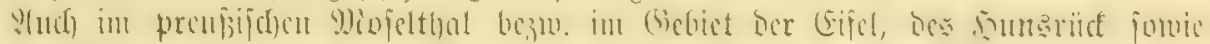

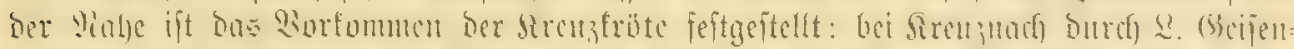

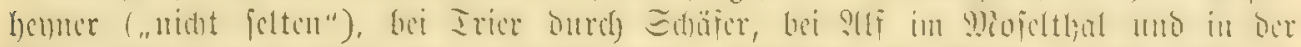

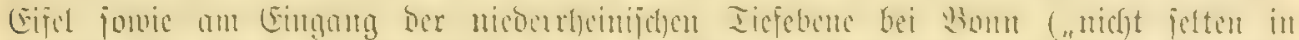

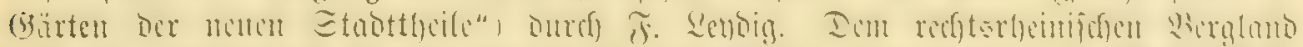

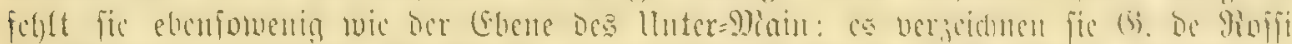

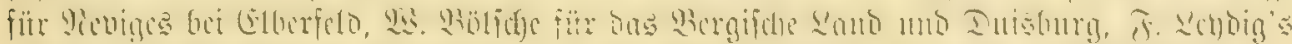

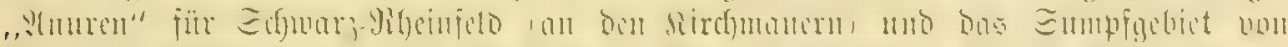

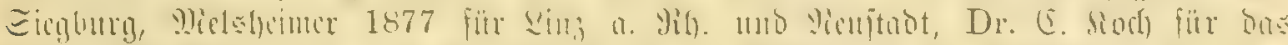

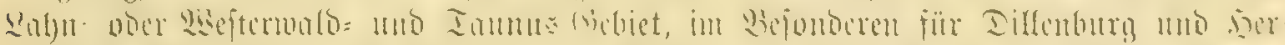

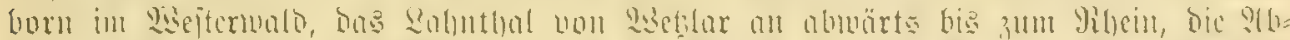

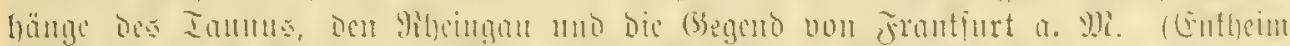

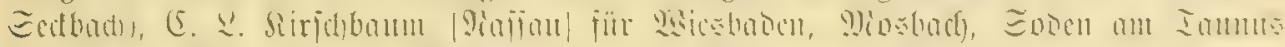

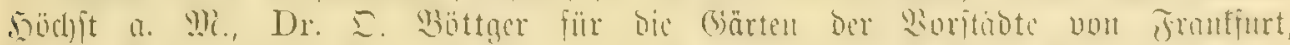

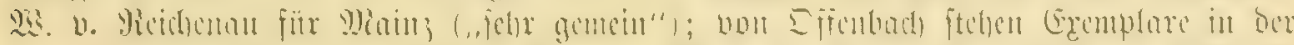

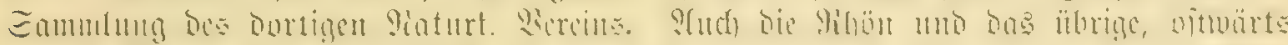

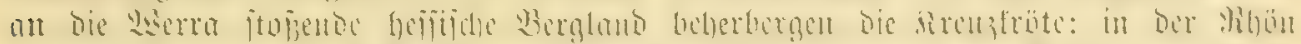

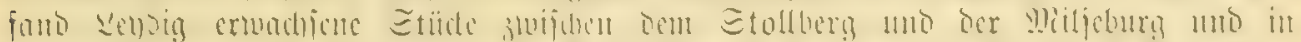

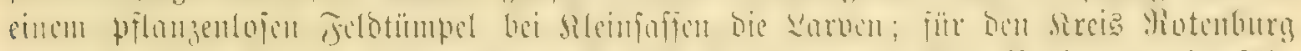

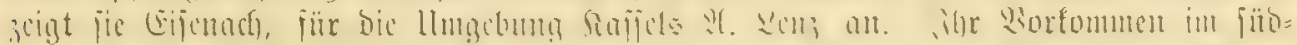

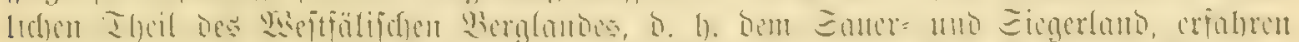

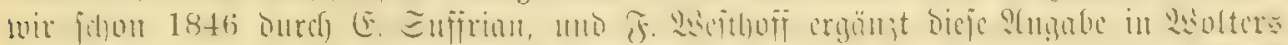

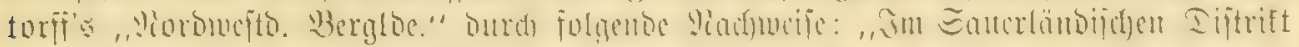

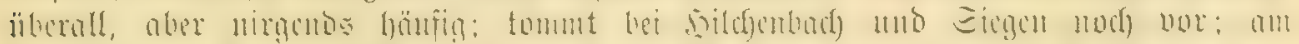

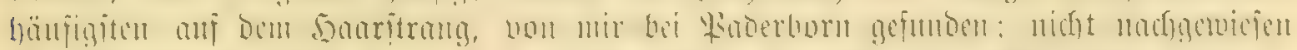

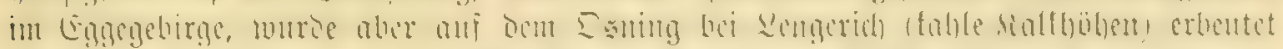

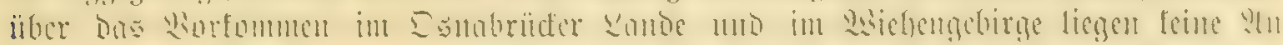

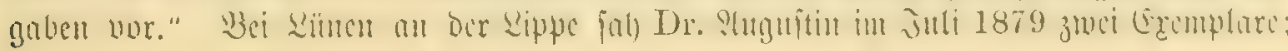




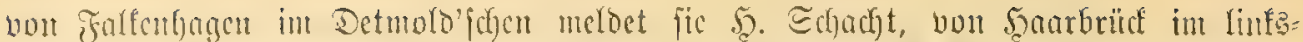

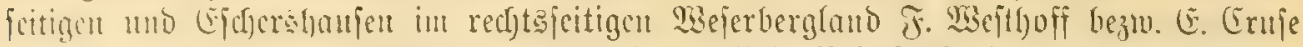

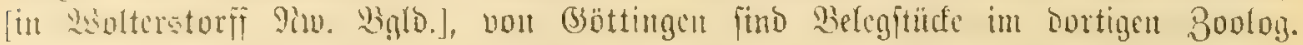
Matieum.

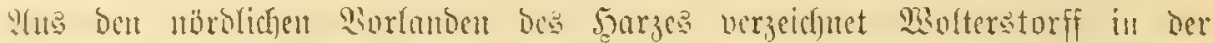

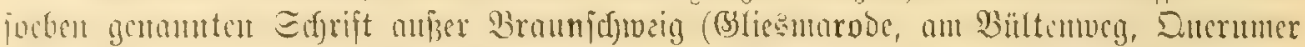

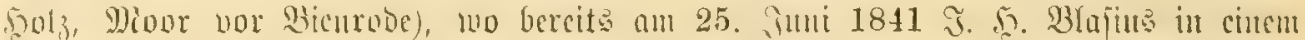

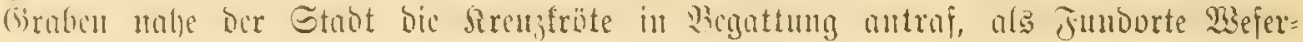

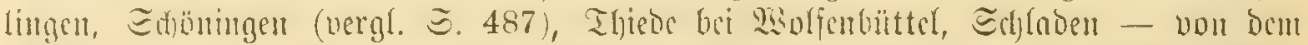

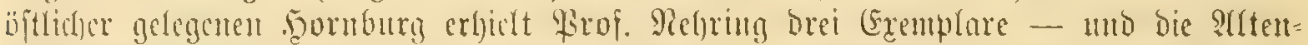

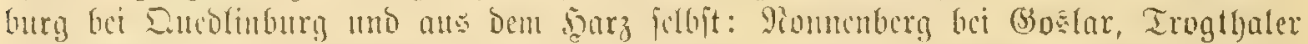

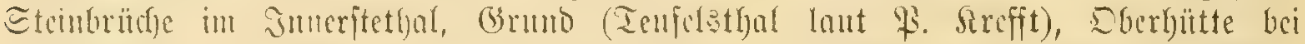

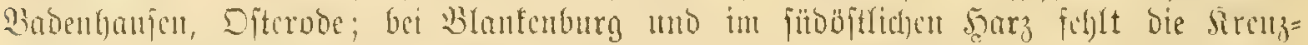

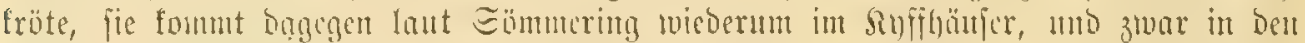

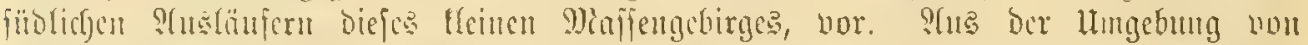

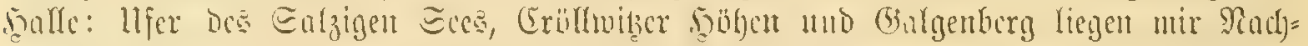

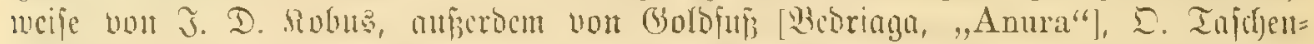

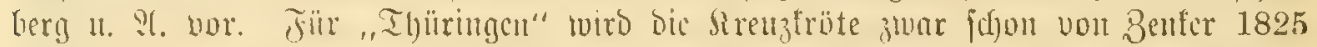

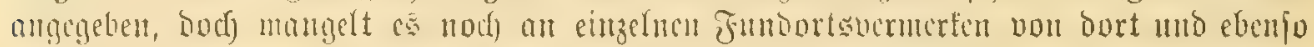

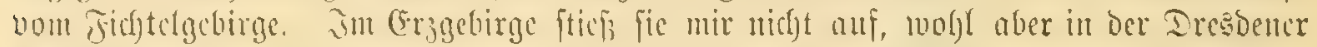

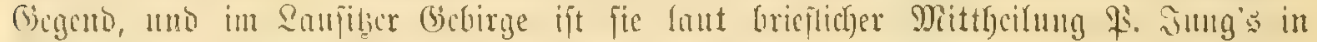

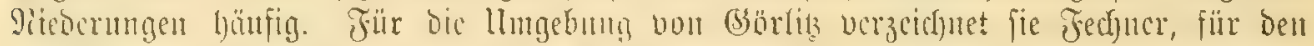

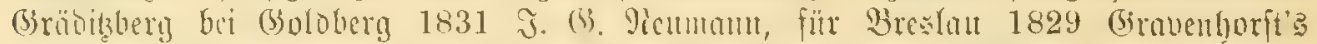

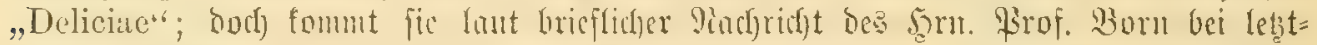

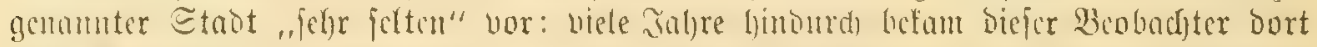

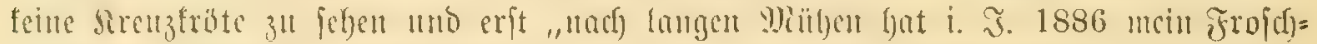

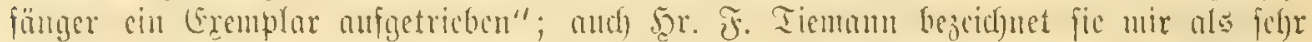

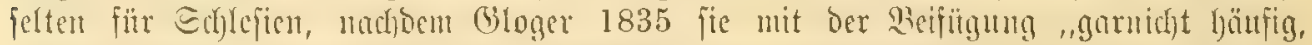

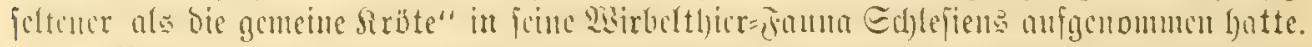

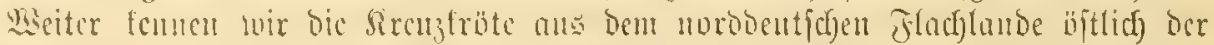

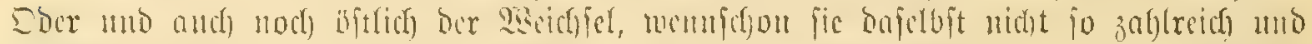

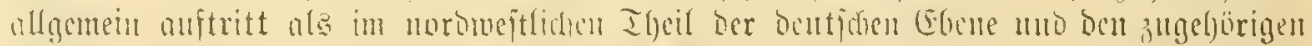

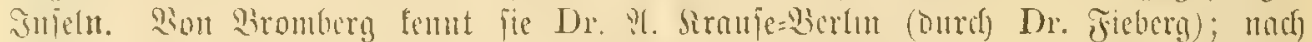

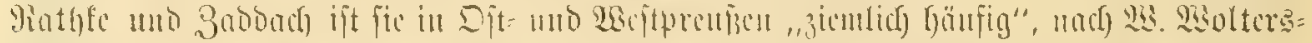

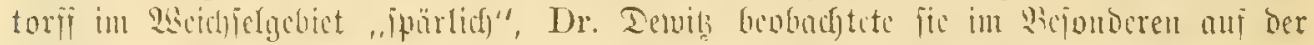

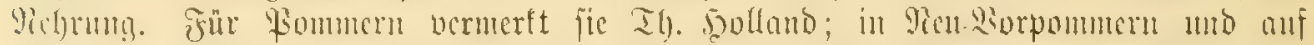

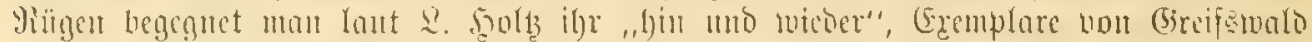

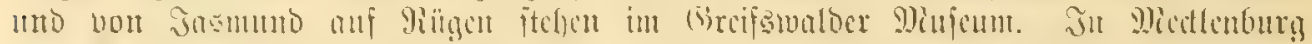

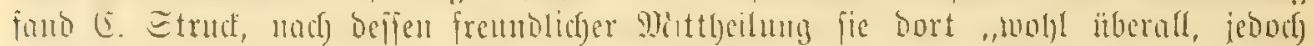

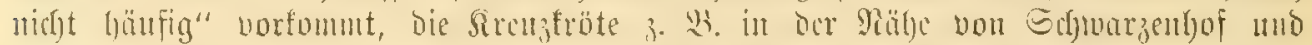

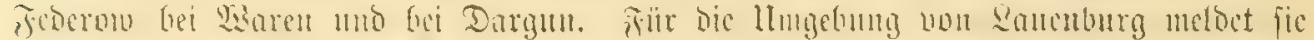

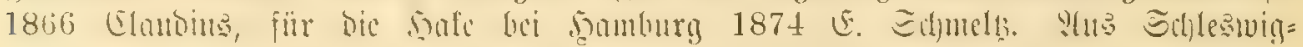

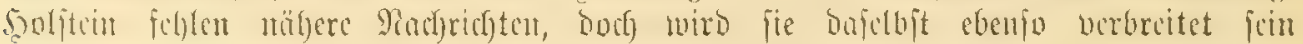

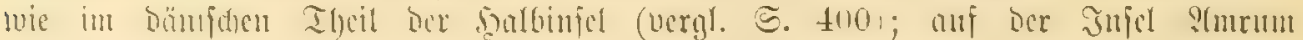

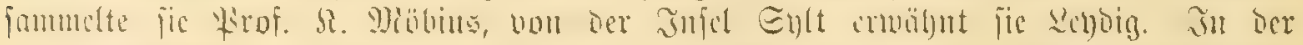

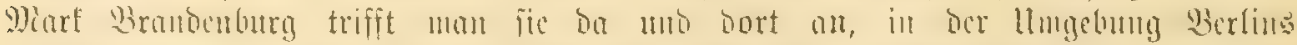

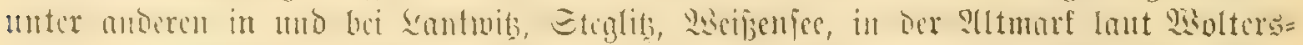

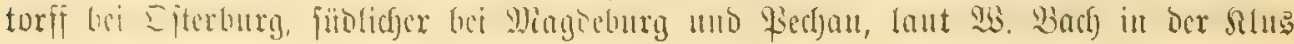




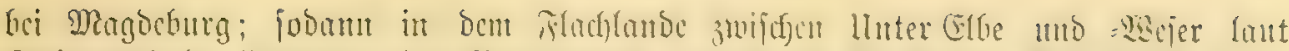

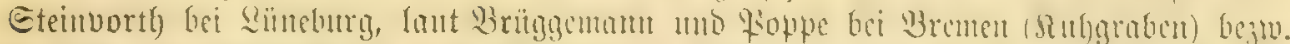

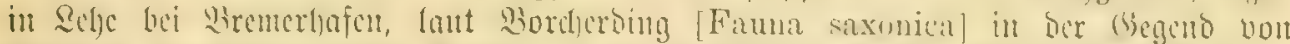

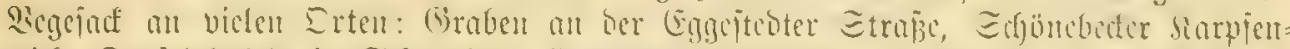

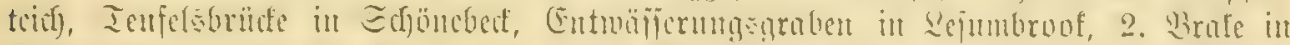

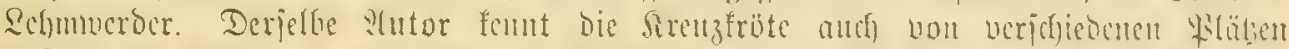

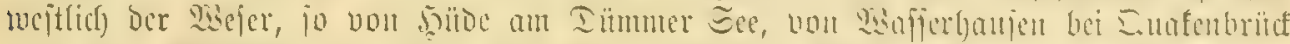

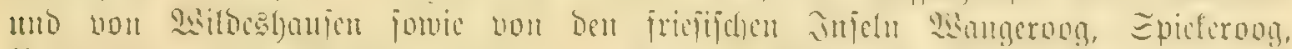

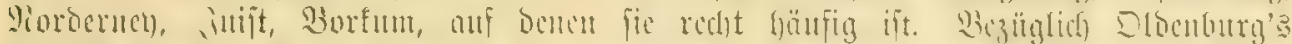

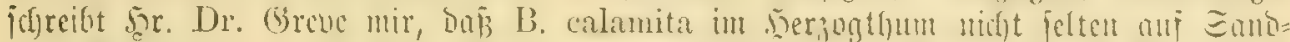

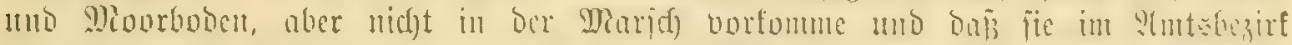

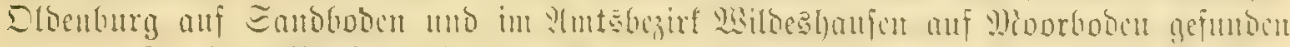

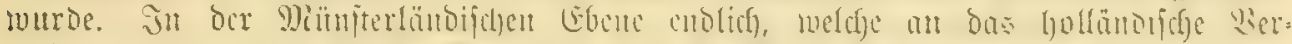

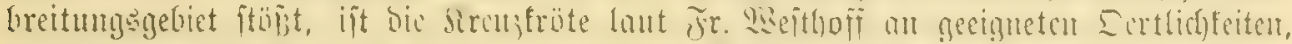

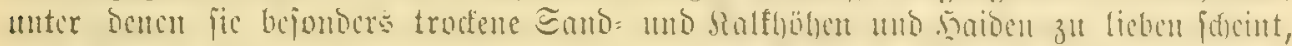

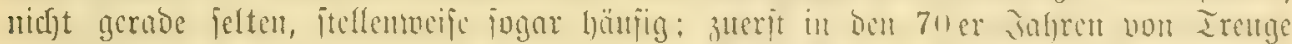

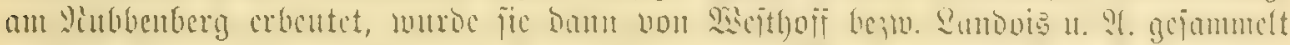

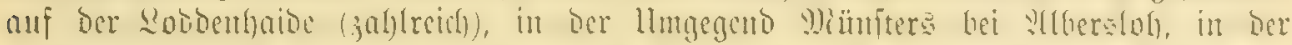

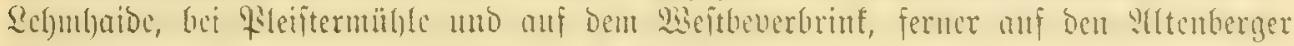
Ralfïblen und im Steveder Scm bei Coçfeld.

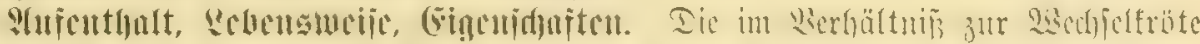

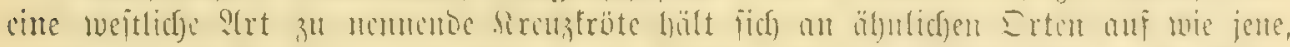

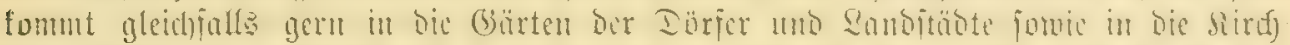

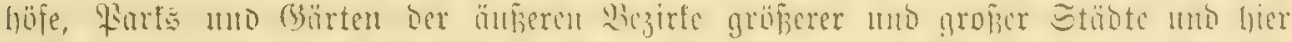

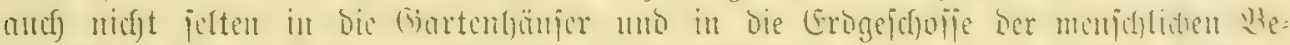

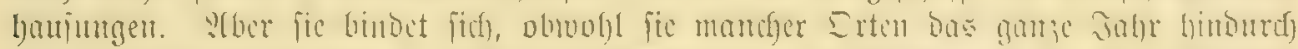

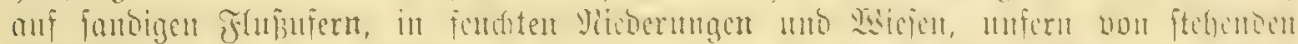

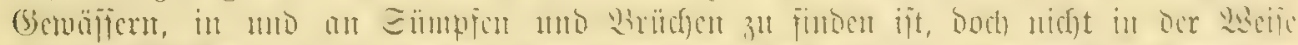

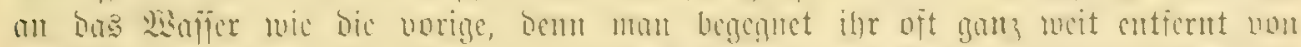

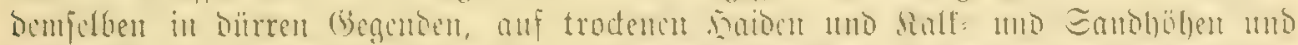

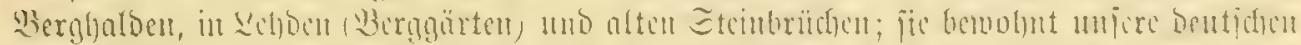

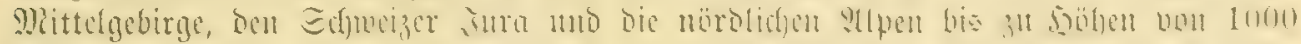

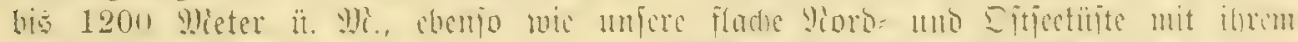

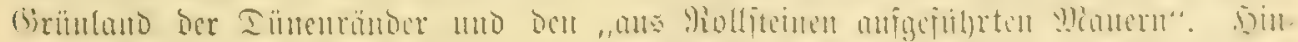

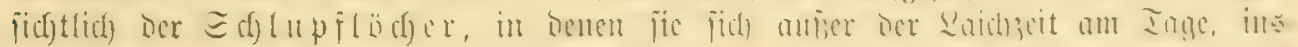

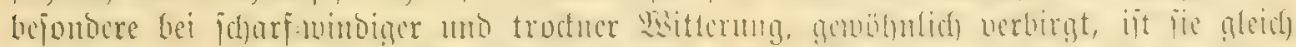

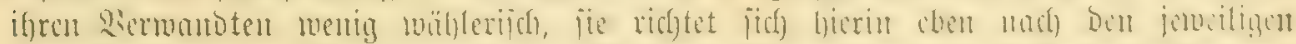

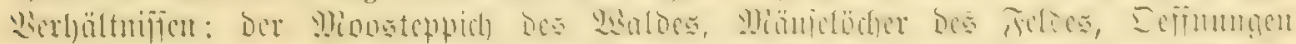

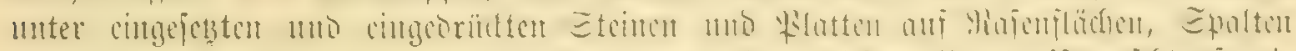

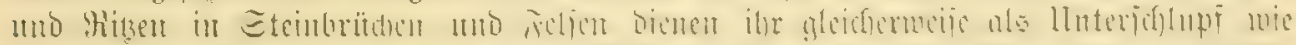

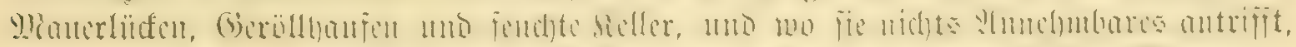

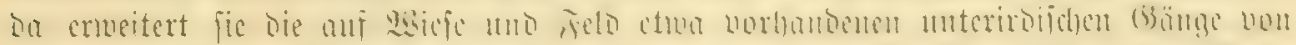

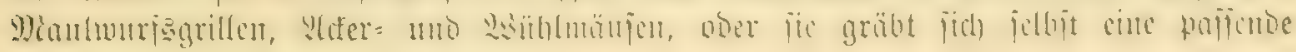

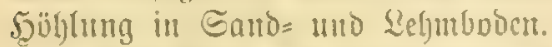

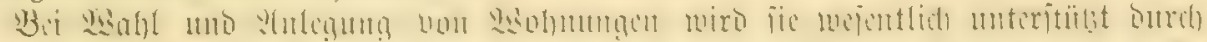

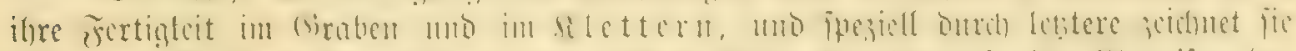

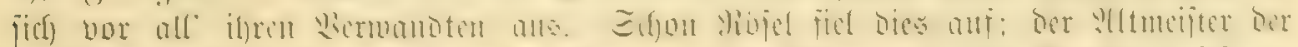

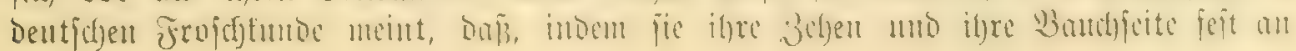




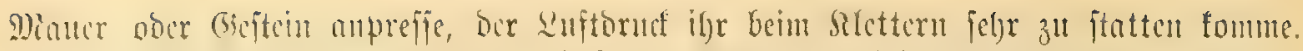

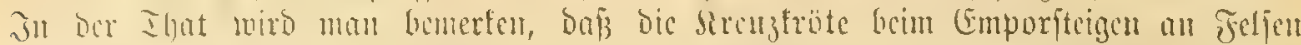

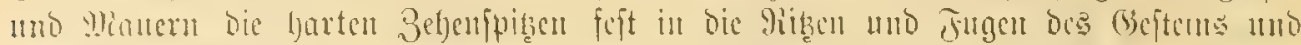

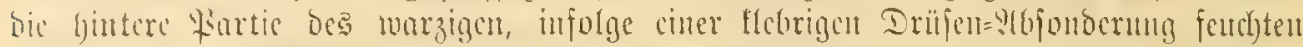

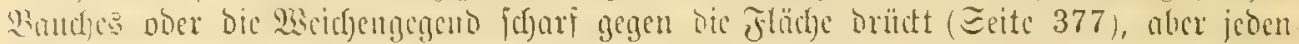

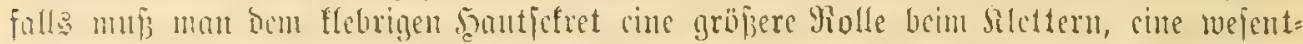

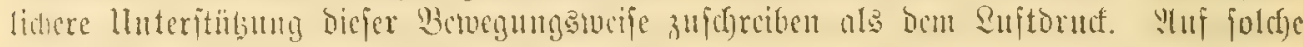

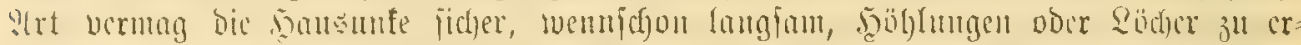
flimman, dic melorere Jub

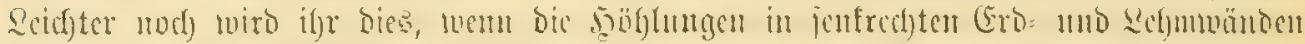

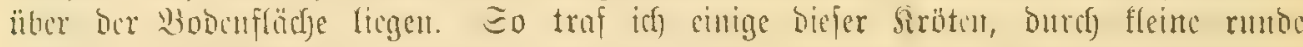

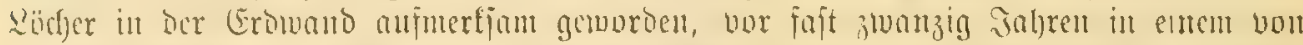

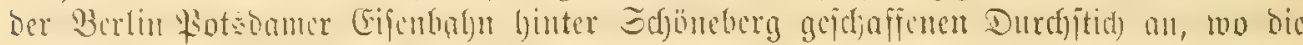

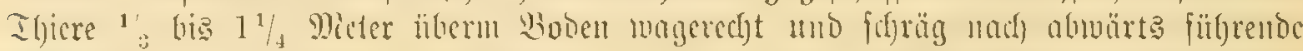

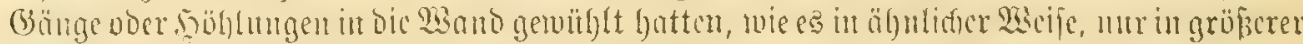

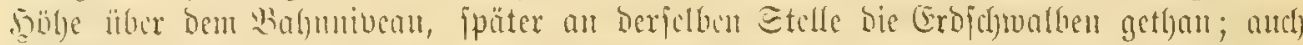

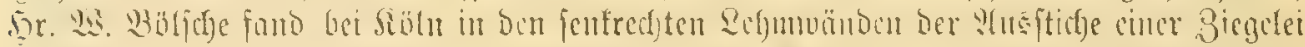

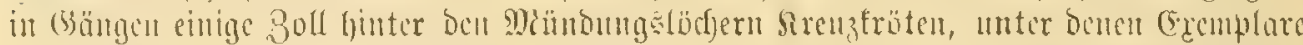

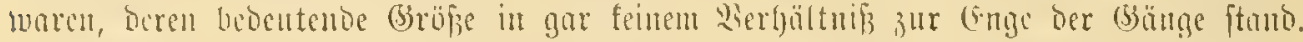

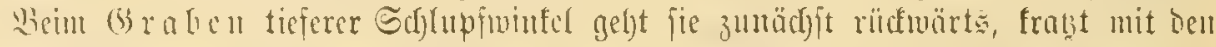

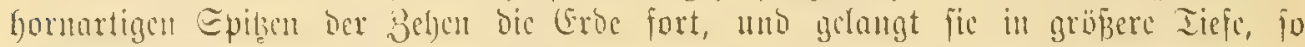

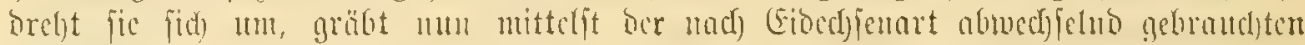

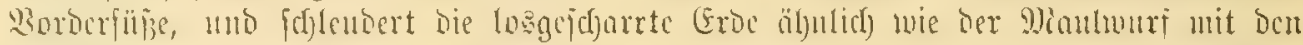

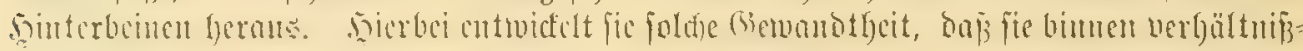

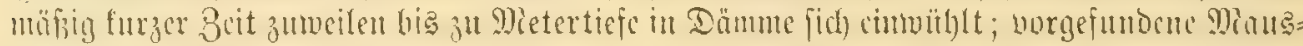

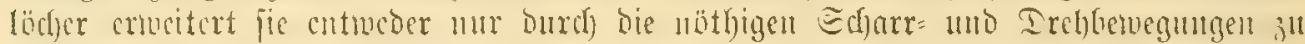

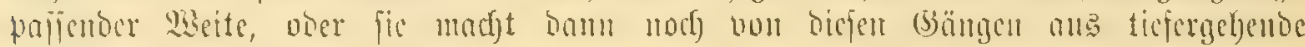

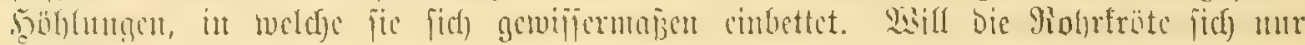

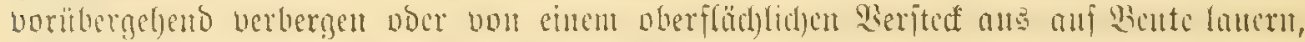

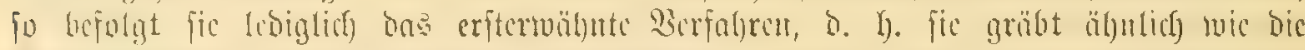

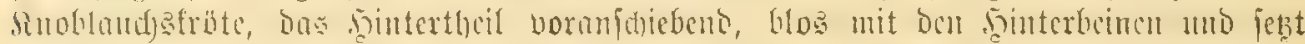

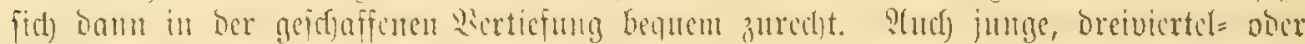

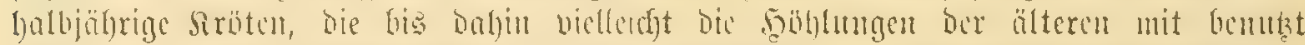

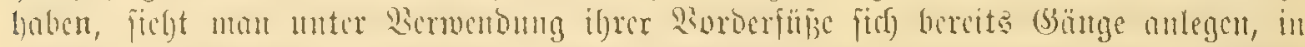

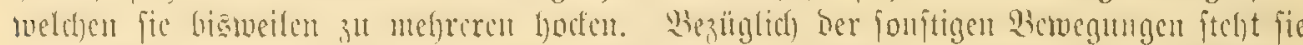
monigftes in cinct ninfift binter Bufo virilis zuribl: fie vermag fcinc Epringe

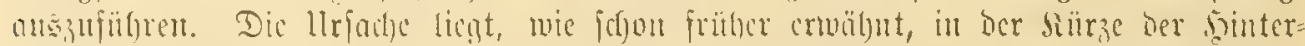

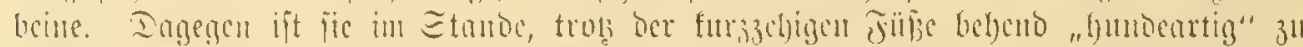

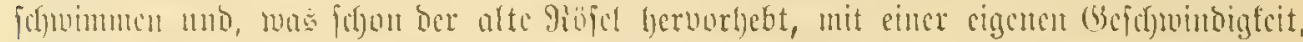

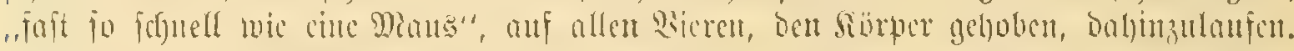

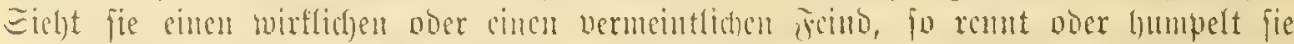

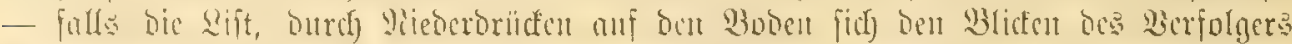

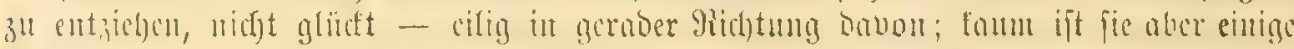

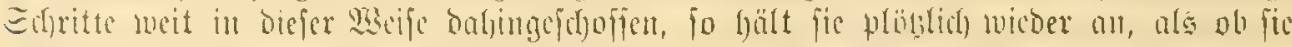

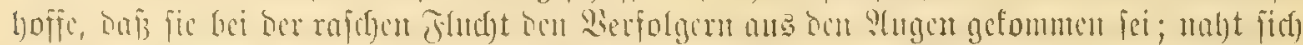

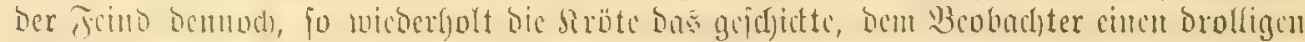

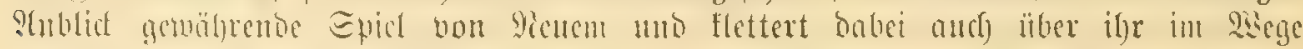

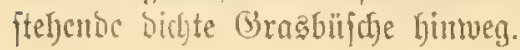




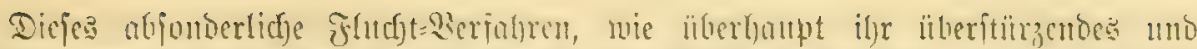

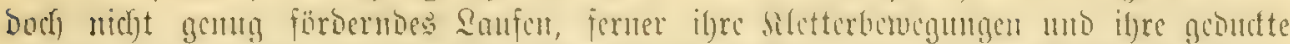

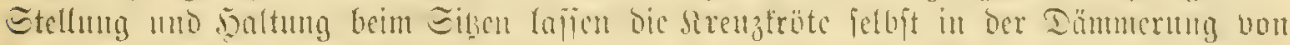

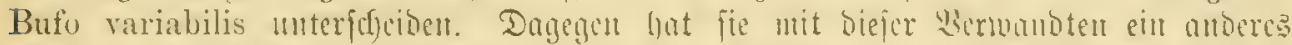

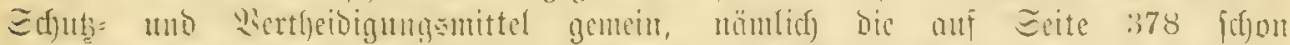

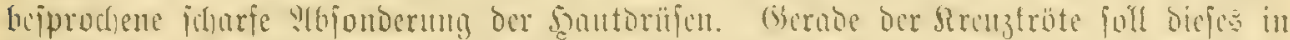

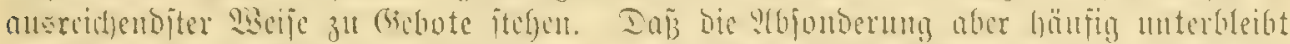

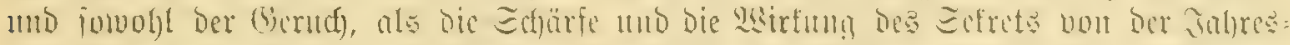

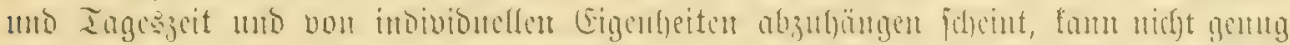

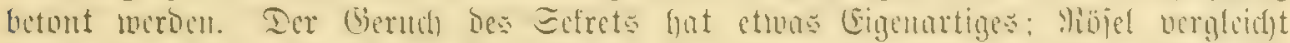

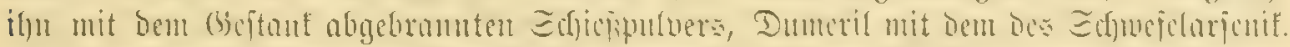

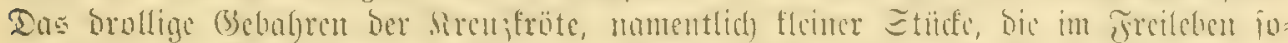

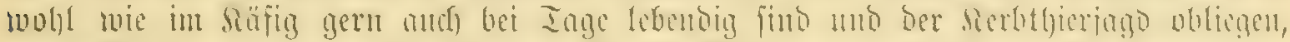

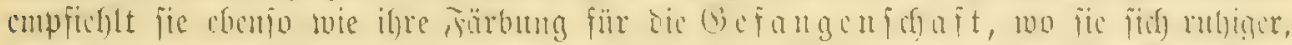

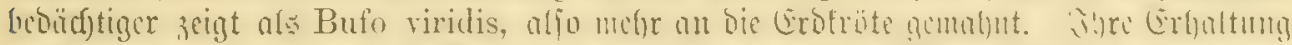

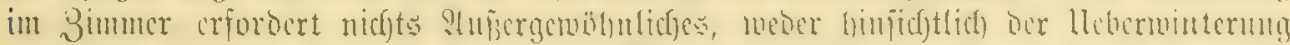

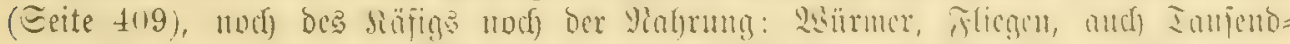

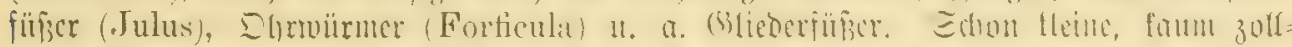

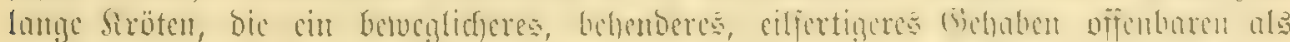

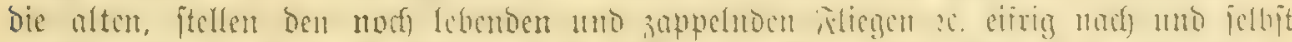

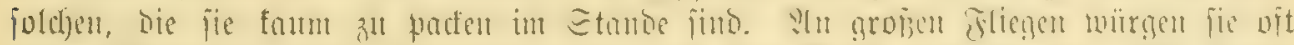

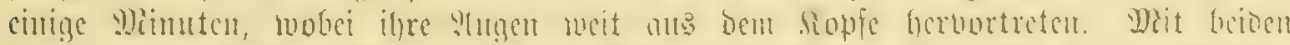

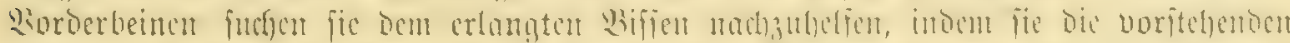

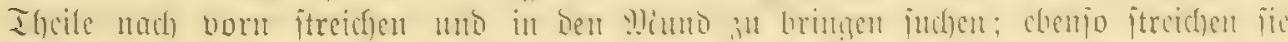

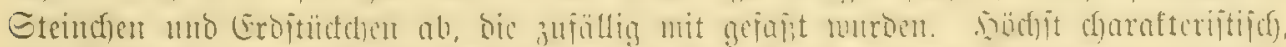

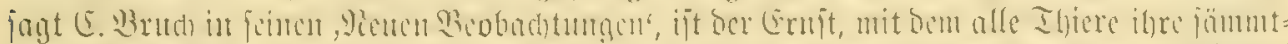

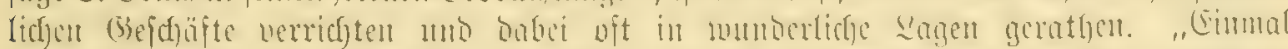

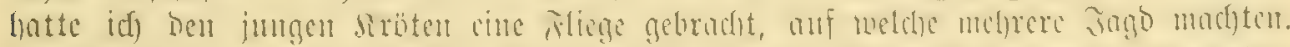

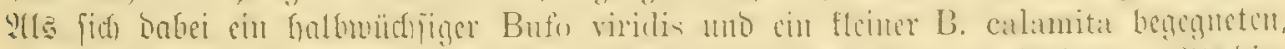

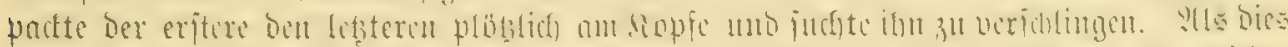

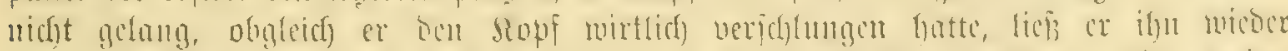

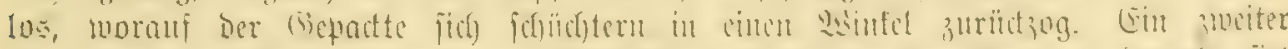

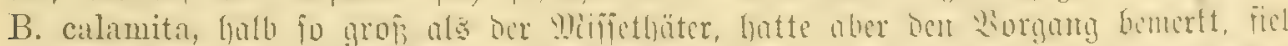

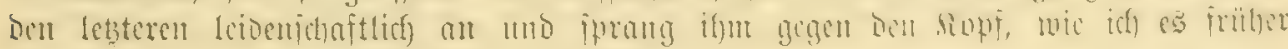
idjon von eincr jungen Erotrbte bemertt lyatte."

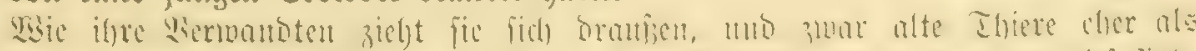

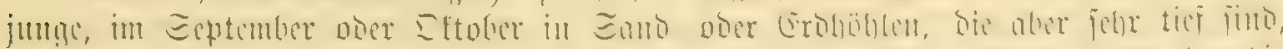

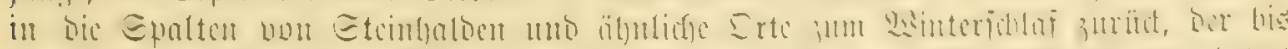

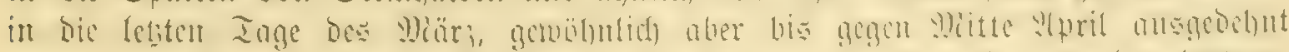

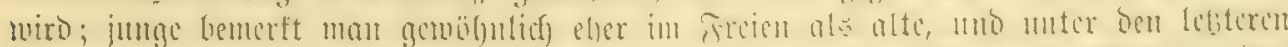

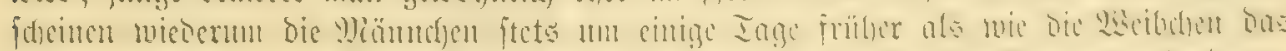

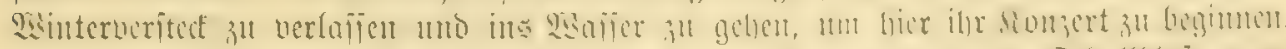

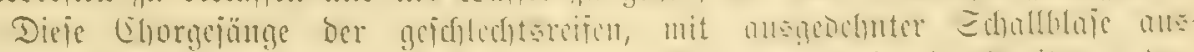

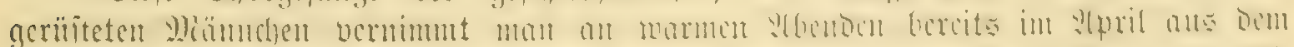

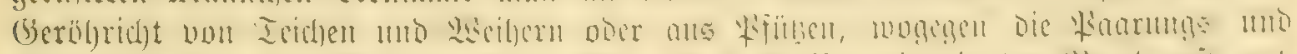

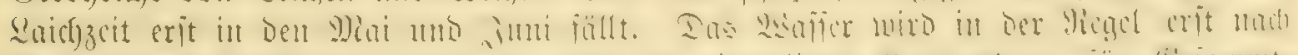

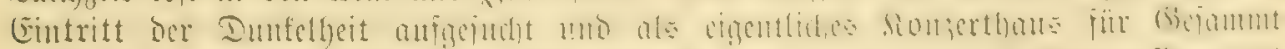

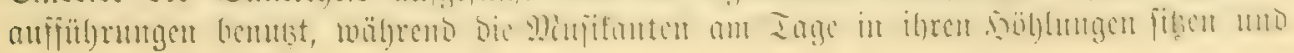




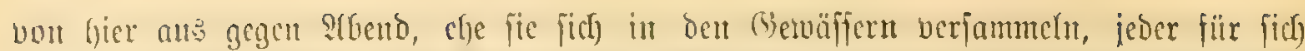

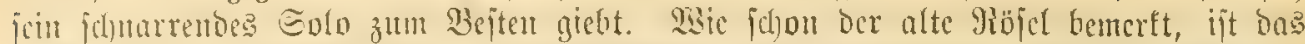

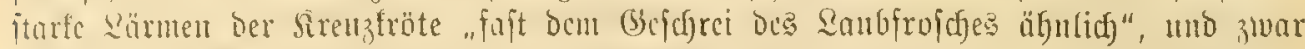

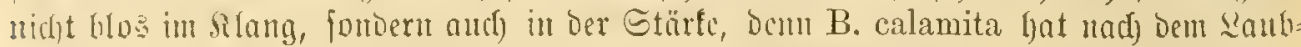

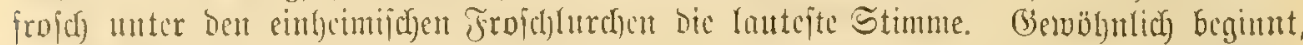

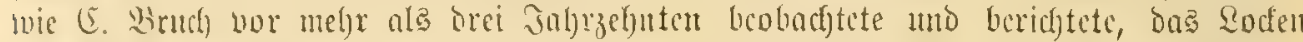

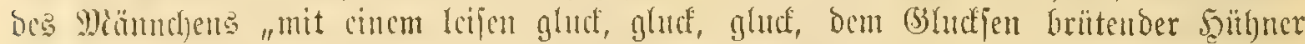

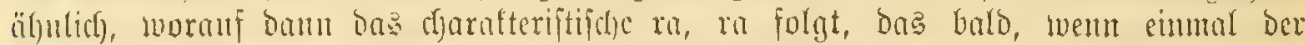

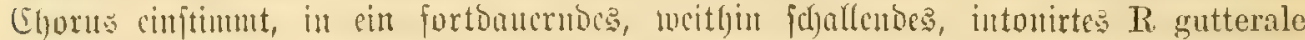

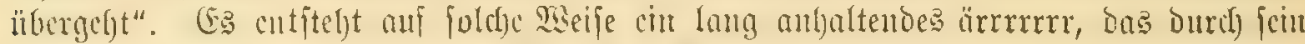

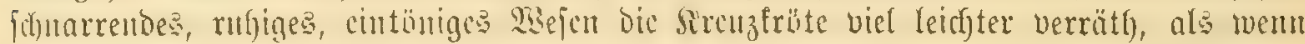

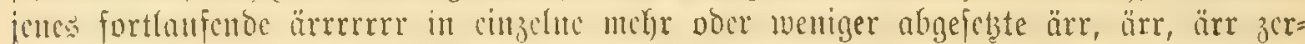
legt wirb; in lekterem falle licgt bam cine \$strwedjelung mit ben aus furz hervor=

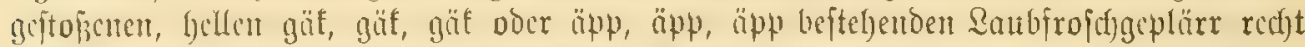

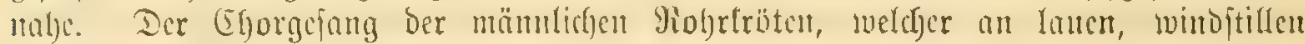

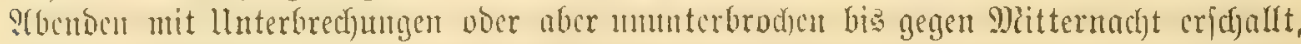

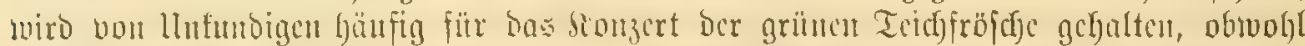

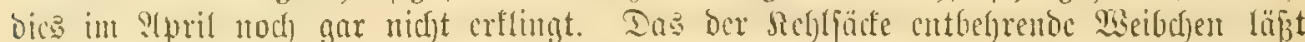
nur ciu zartce, medfernbes toi bo oder toü toẩ vernelymen.

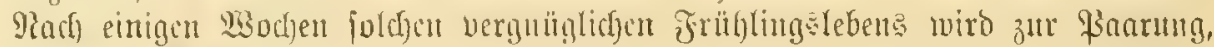

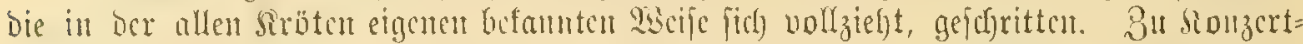

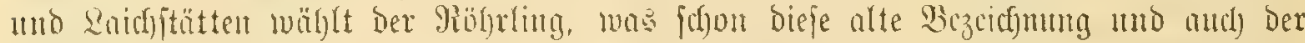

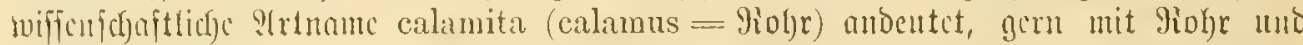

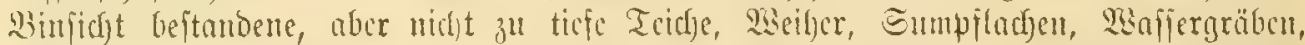

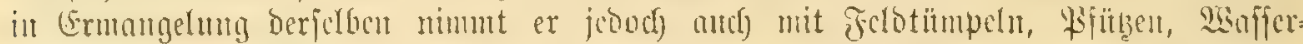

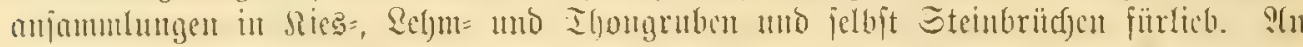

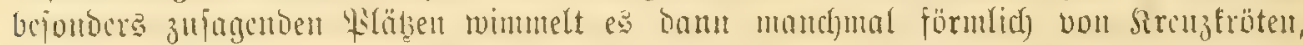

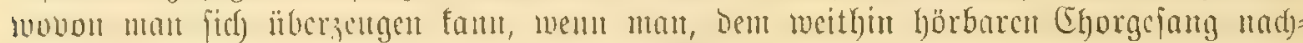

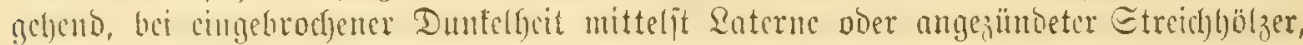

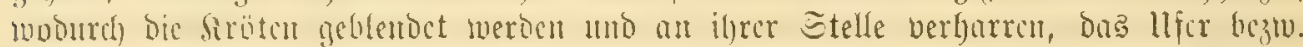

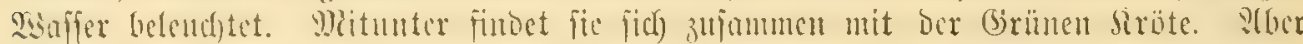

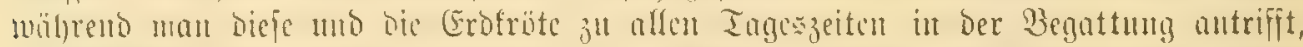

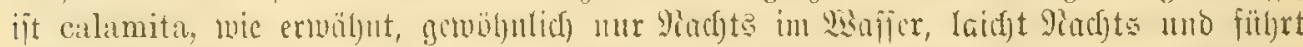

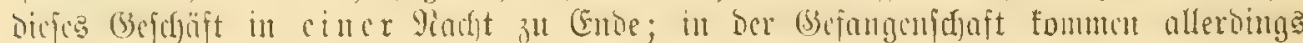

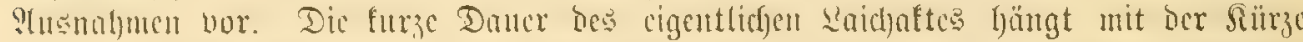

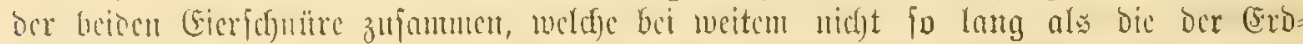

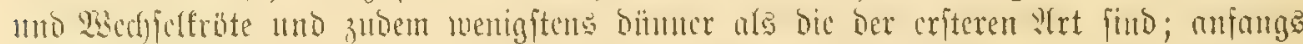

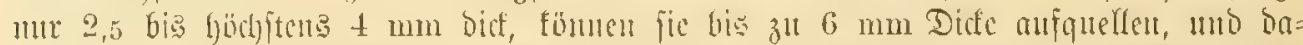

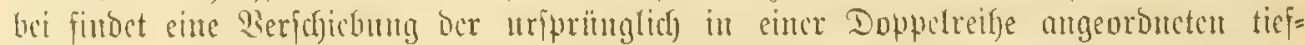

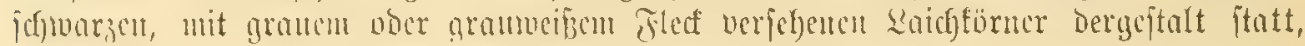

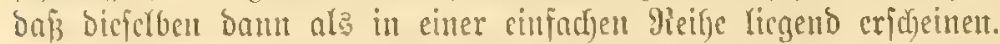

Ju ben bon (Sallerte engejuloffenen Eiern regt ca fid) febr balo und bi ber

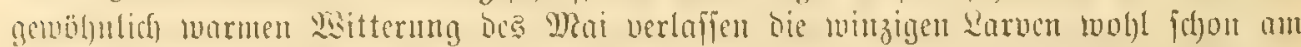

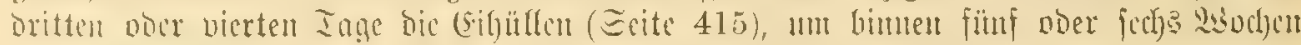

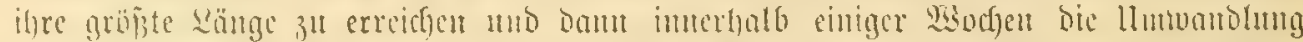

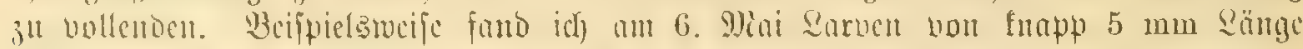

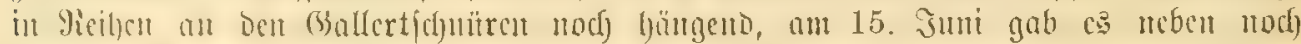

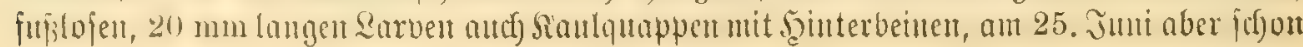




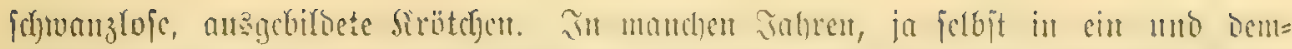

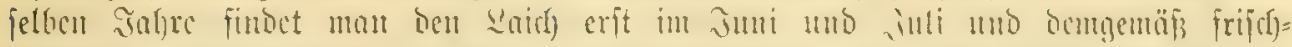

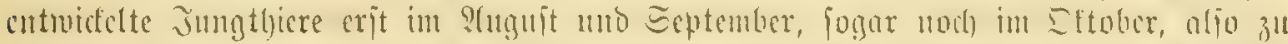

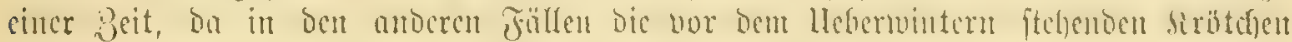

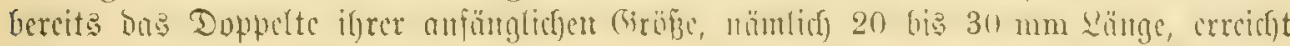

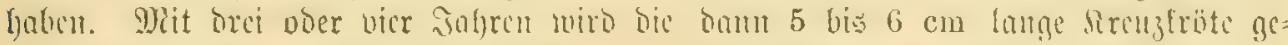

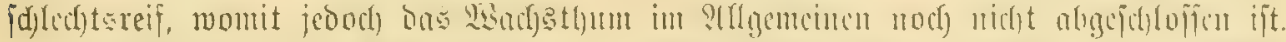

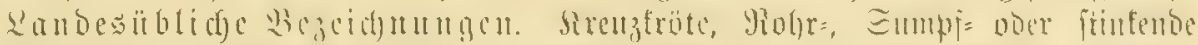

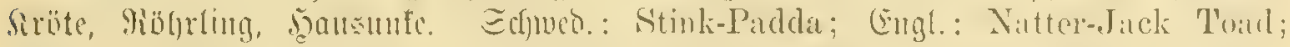
Fronz.: Crapand calamite ou Crapaud des jones; itnt.: Rospo pralustre; Folm: Ropucha krzyzowa; Ribum.: Rinpucha bachratí; Fum.: Rupi Sammakis.

Bufo terrestris foetidissima, Rösel 1758. - B. calamita, Laur. 1768. Rana foetidissima, Hermann 1783. - Rana bufo et R. salsa, Gmelin 1790. Rana portentosa, Stum 1797. Bhomenturh. - Bufo cruciatus, Srlmeiler 1799. Rana mephitica, Shan 1802. - Bufo cursor, Imudin 1803. - Bufo purtentosur, Schinz 1837. - Bufo viridis (partim), I). B. [Frp, gen. TIII S. 681] 1841.

\section{3. fantilic: Bammiröid), Hylidae (Calamitne).}

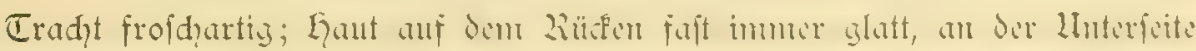

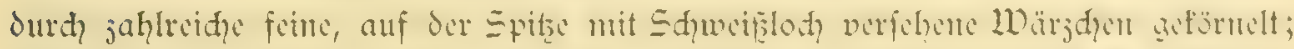

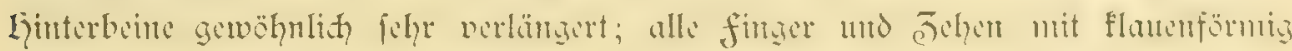

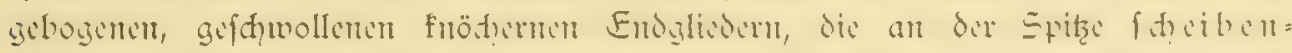

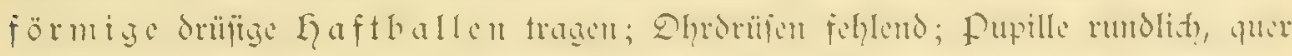

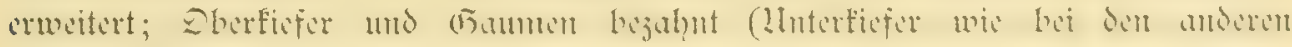

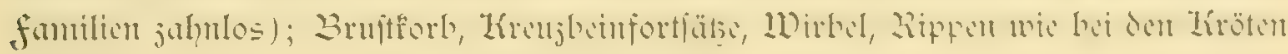
In Deutfdylano mur cinc Battung:

\section{Gattung: Rnubiroid). Hyla, Laur.}

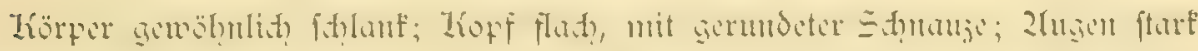

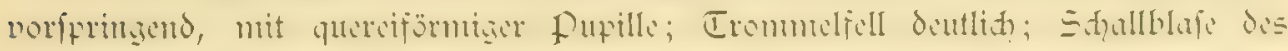

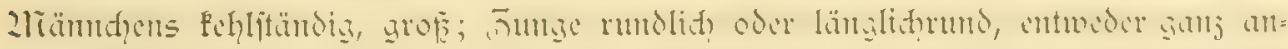

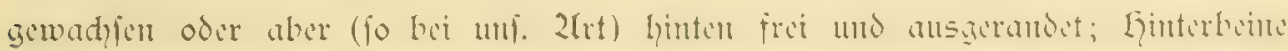

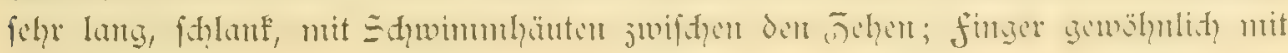
Gautfaum.

Jn Deutjdyland mie überljant in Europa mur cine ?(rt:

8. 9irt: Europäifher Saubfrofd. Hyla arborea, $I_{\text {s }}$ 26bilbung: Tajel IV gir. 3.

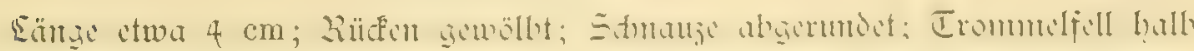
Ittlensugeidjets.

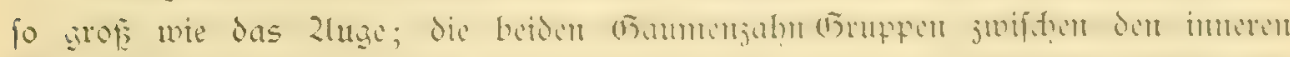

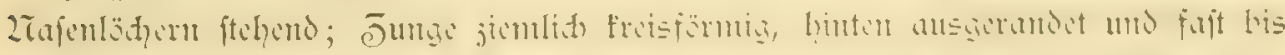

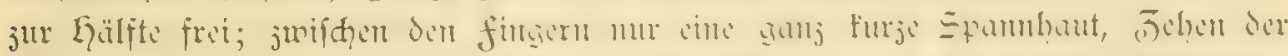

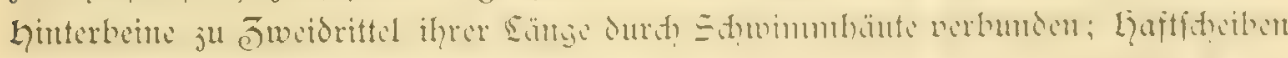

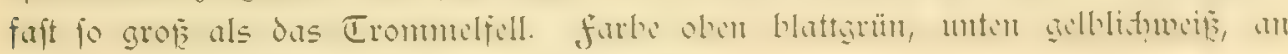
jeder Seite gewöhnliđ ein fđ̧warger Eängsftreif. 


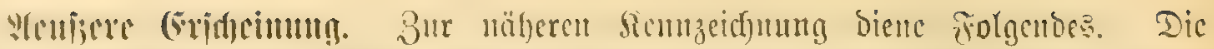

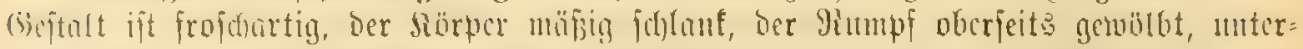

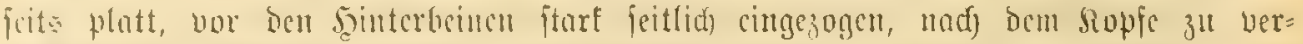

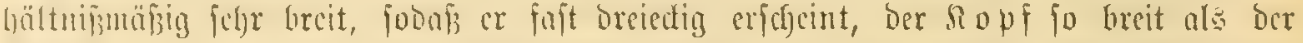

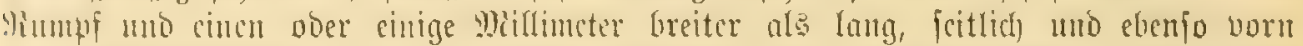

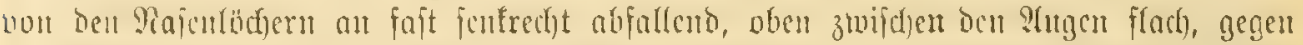

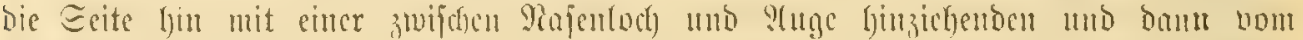

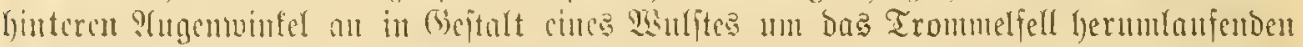

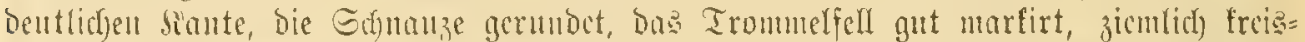

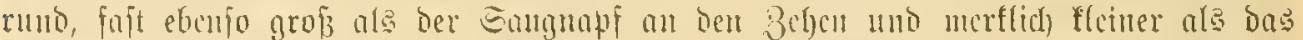

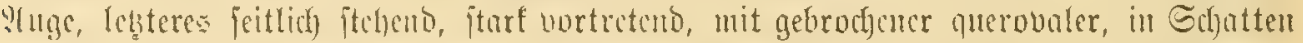

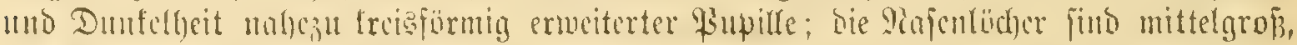

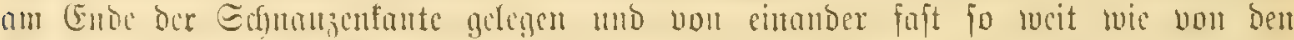

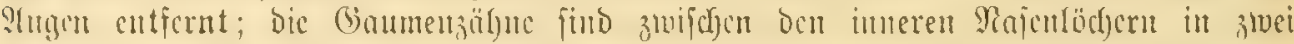

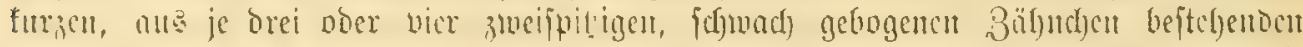

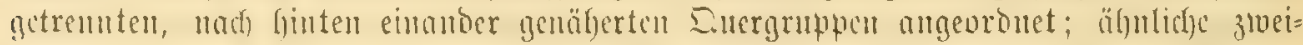

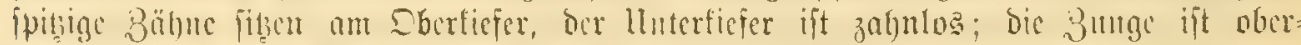

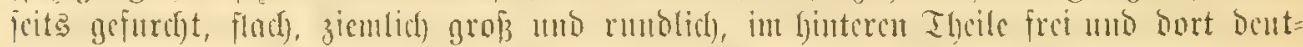

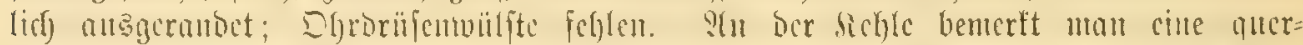

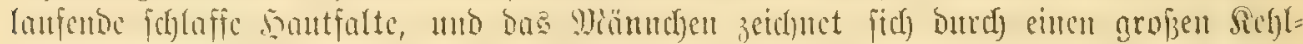

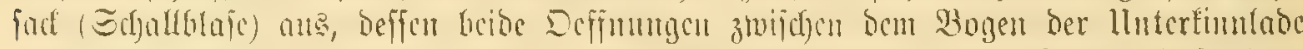

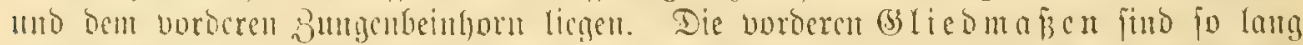

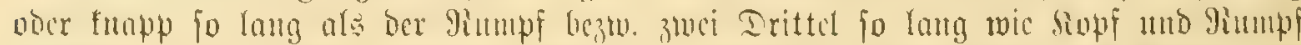

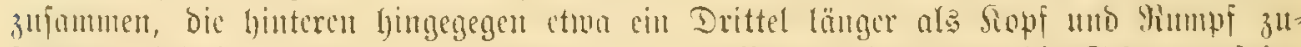

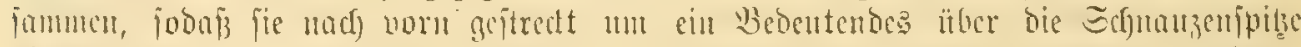

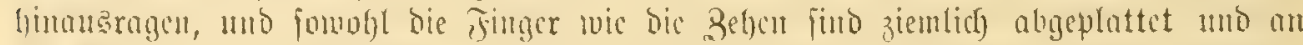

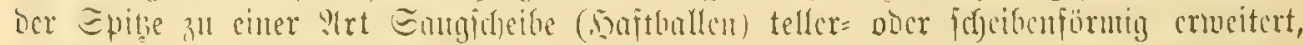

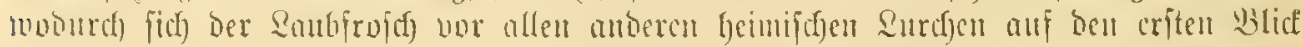

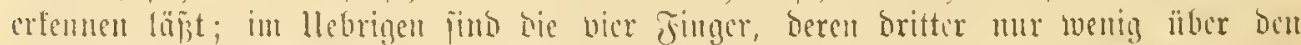

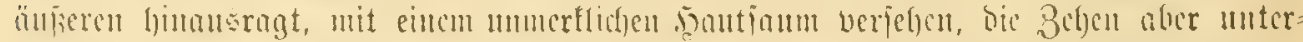

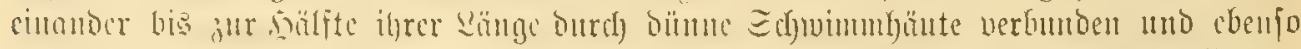

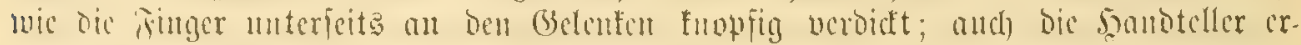

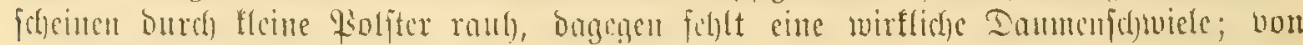

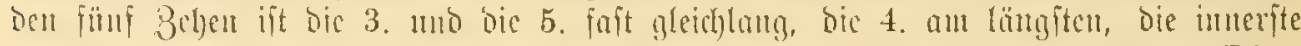

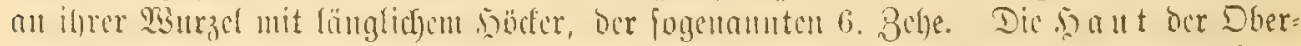
jeite ift glatt, dic to

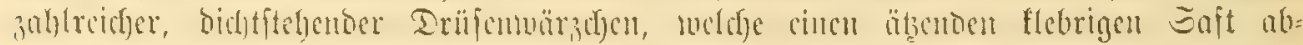

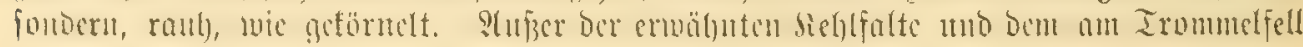

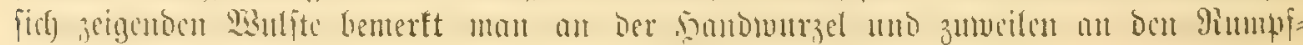
jeitert Jautfaltent.

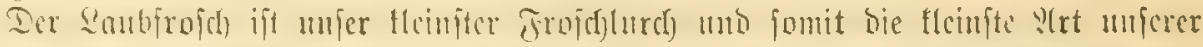

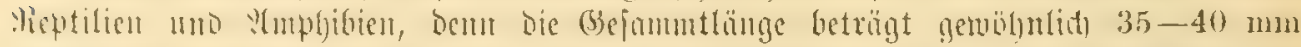

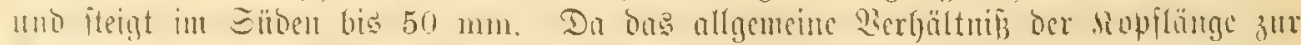

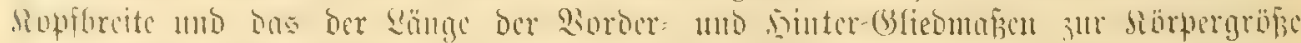

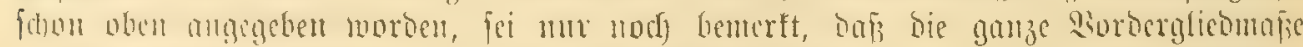

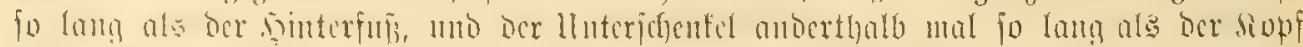

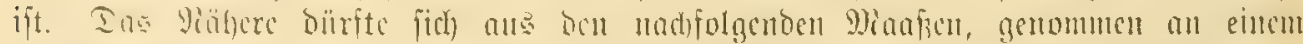

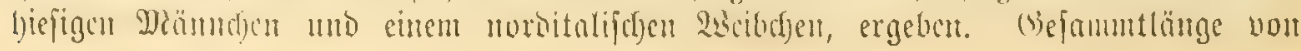




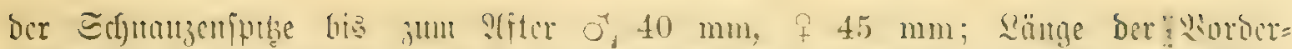

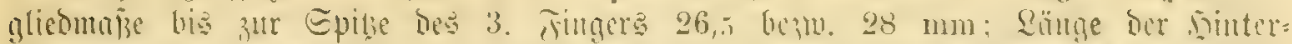
glicontafic bis zu Evilse ber 4.

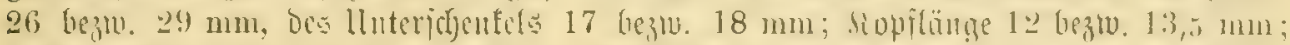

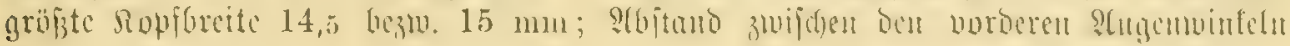
7 безเи. $7,5 \mathrm{~mm}$.

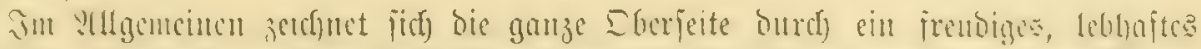

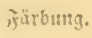

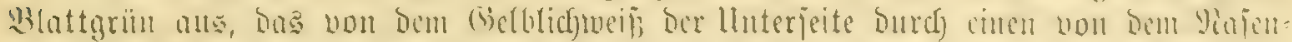

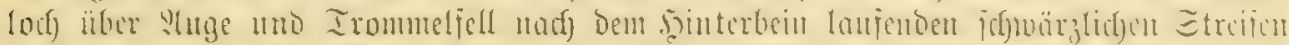

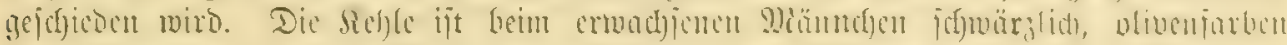

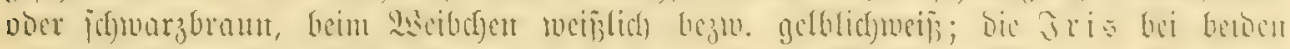

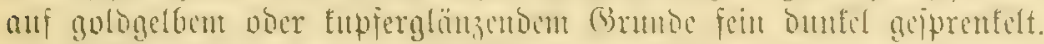

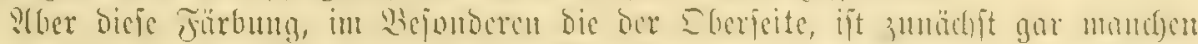

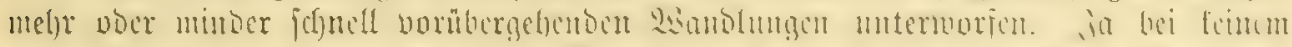

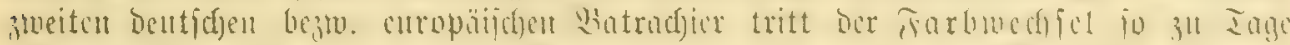

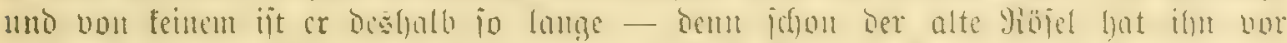

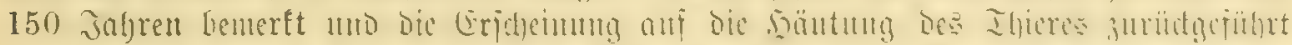

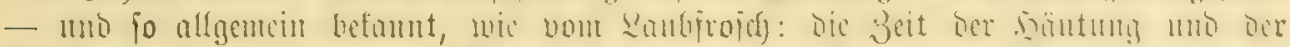

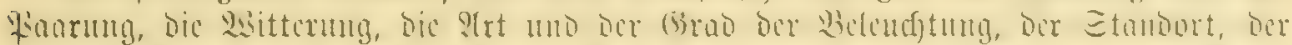

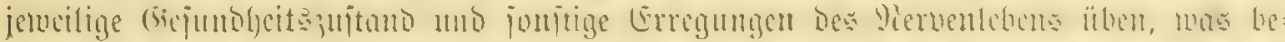

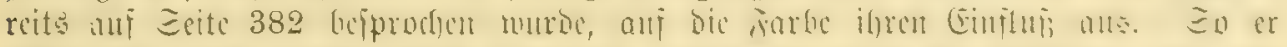

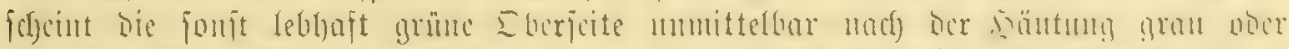

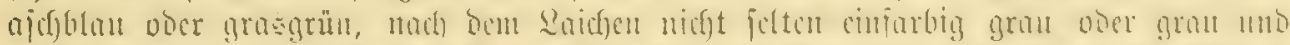

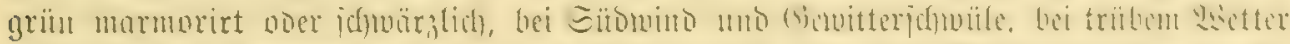

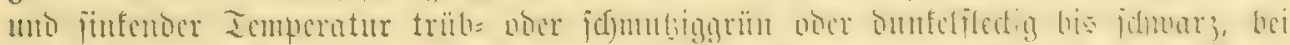

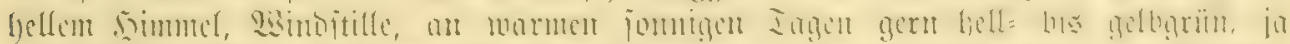

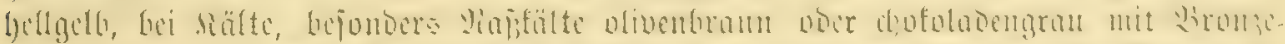

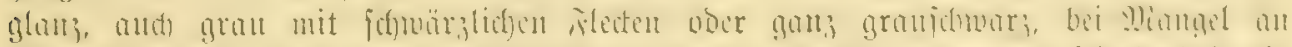

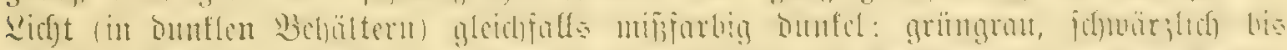

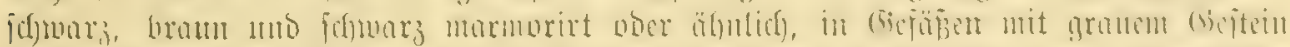

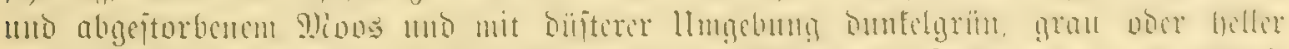

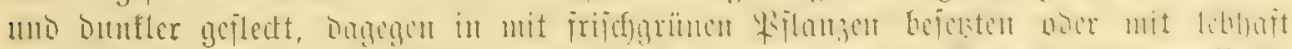

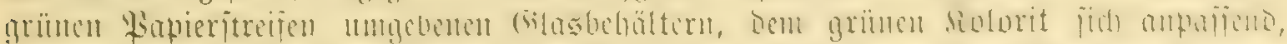

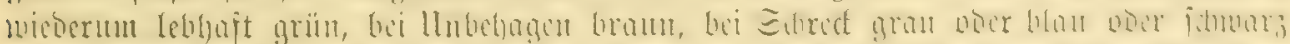

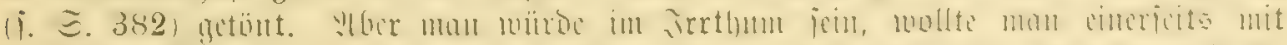

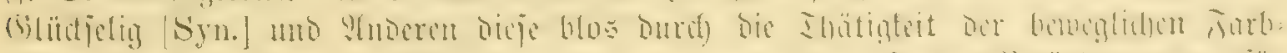

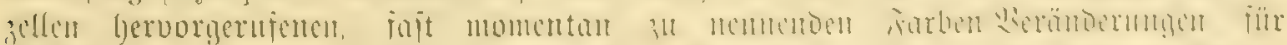

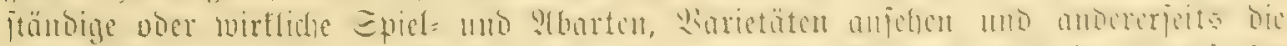

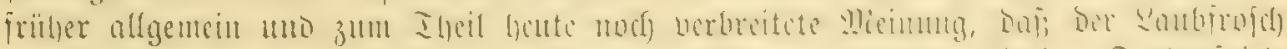

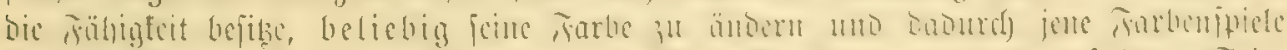

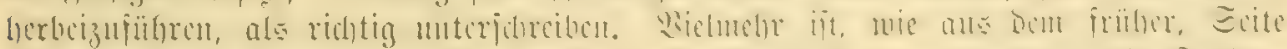

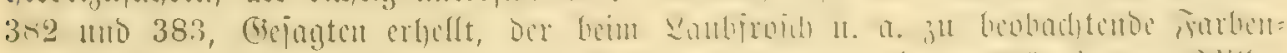

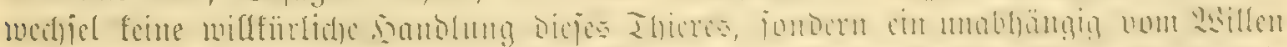

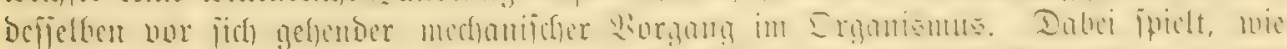

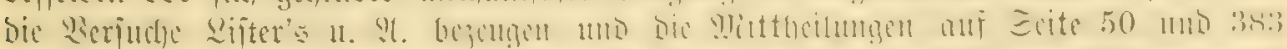

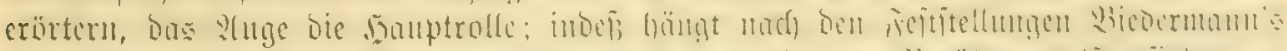

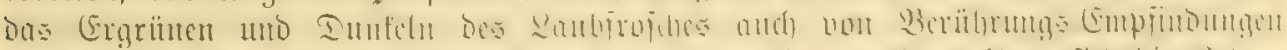

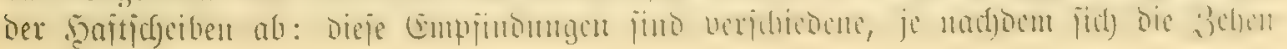




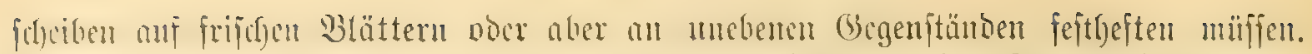

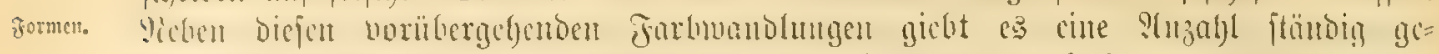

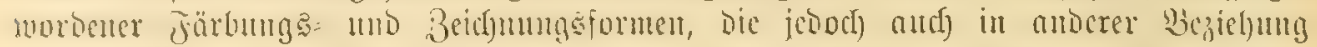

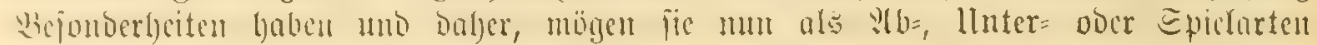

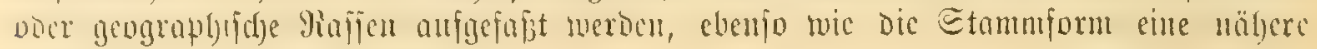
Wetractitumg verbiencut bitrften.

Die Stamminrm, Hyla arborea typica, als welde wir bic in Deutfdilano

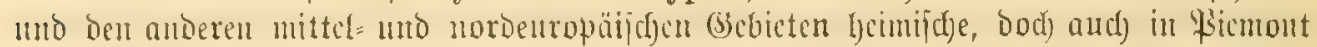
und Tosfana noch wertretene jorm betrad)tin, wurbe bercits oben furz getemizecdenet

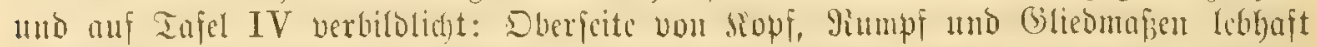

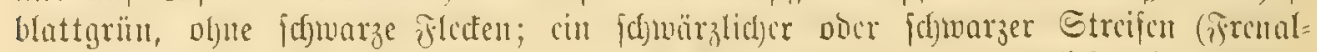

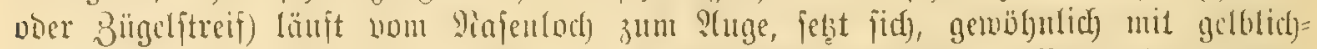

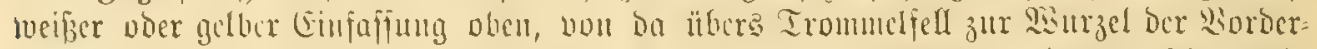

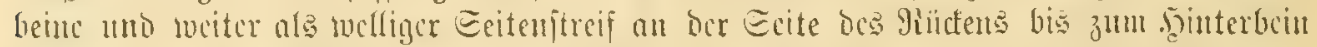

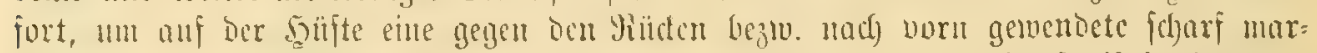
tirte baten= noer joflingenförmige 3eidyunt zu biloen; Dicjer Eeitenjtreif idjecioct Das

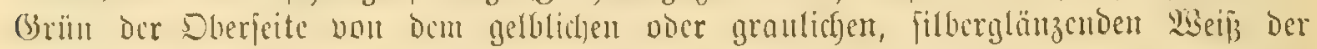

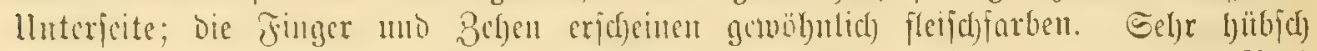

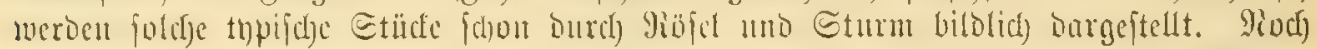

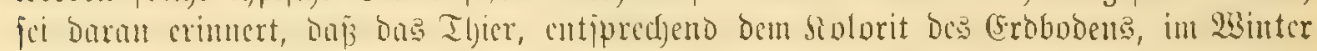

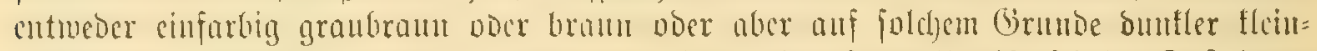

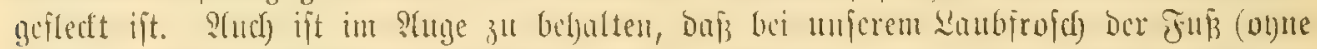

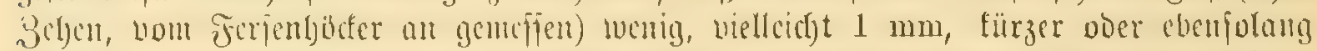

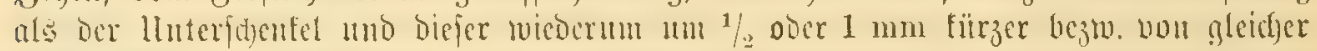

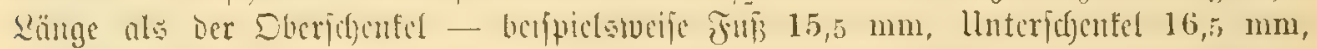

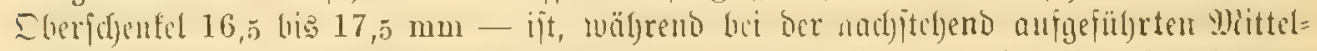

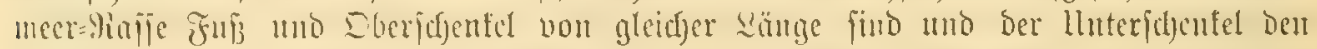
cincn wic ben anderen un einige MRiflimeter in Der Sänge übertrifft.

Je mef)r wir nadh Eilden tommen, Defto hänfiger zeigt fidf bic bei unferem

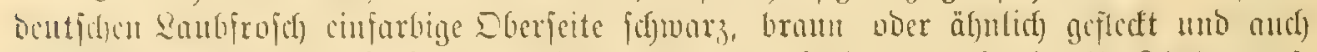

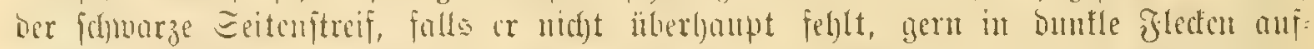

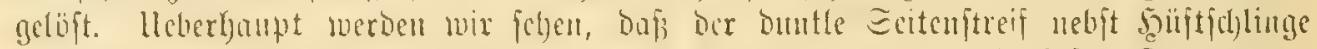

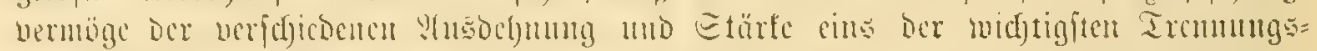

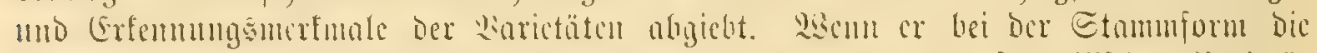

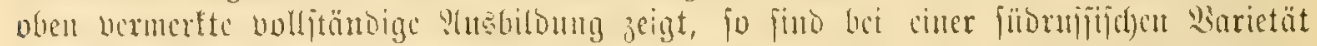

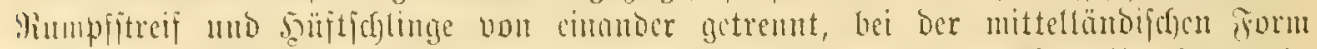

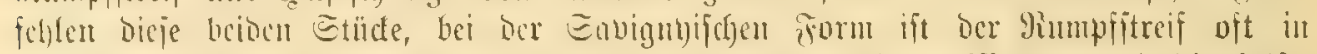

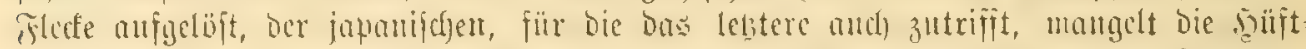

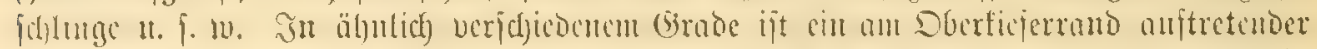

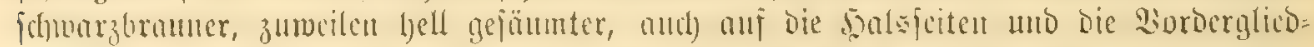

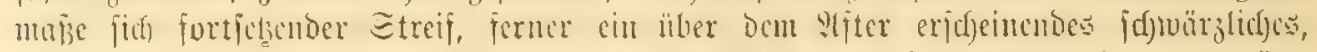

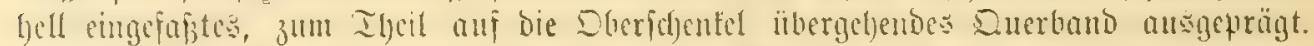

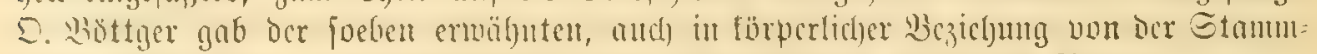

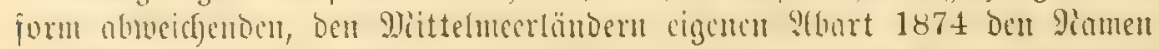

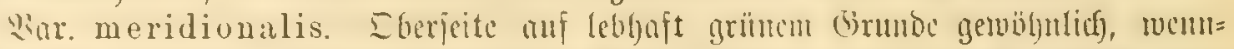

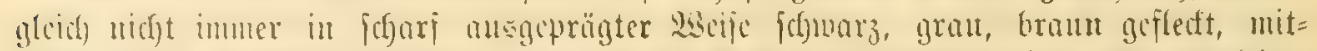

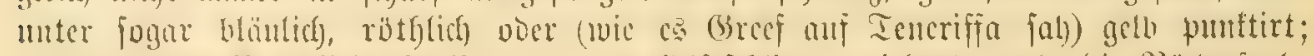

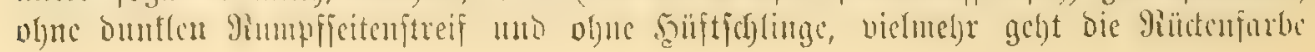




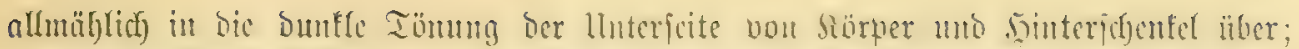

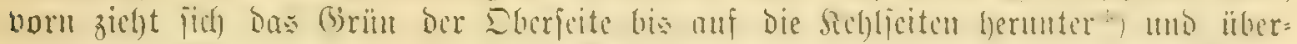

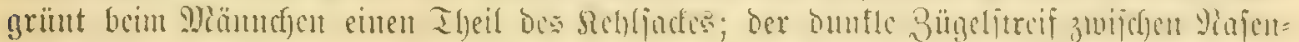

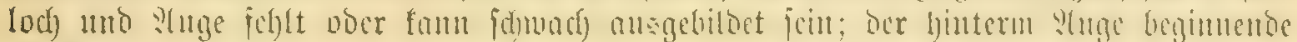

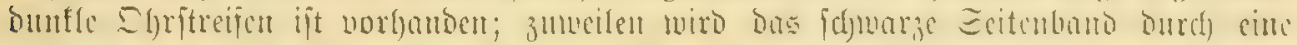

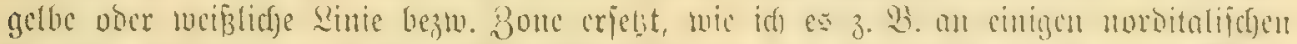

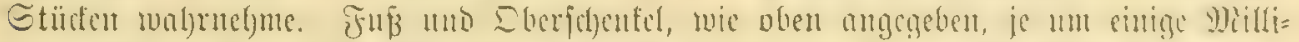
meter fürzer als ber llnterichentel; Sichlfat grifger ale bei ber benticfen Etumminum

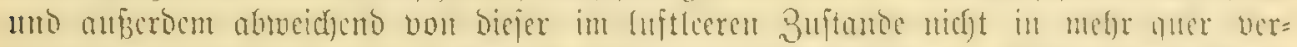

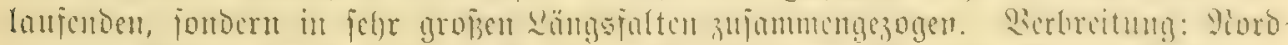

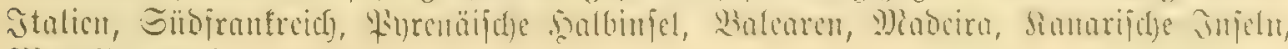
Mtarotto, MIgier, Tuni̧.

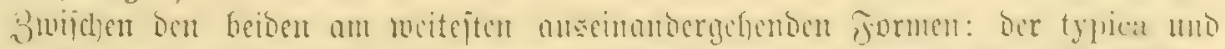

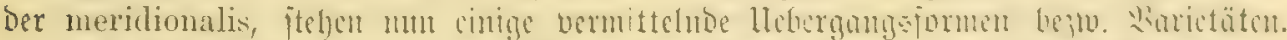

2. Sor. internedia, non Whoulenger 1882 in jemem "Catalogne" jo Gemmint.

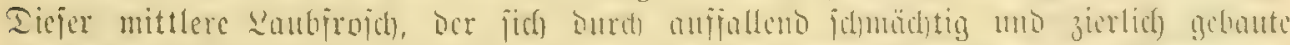

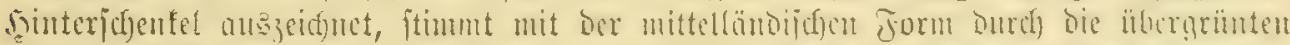

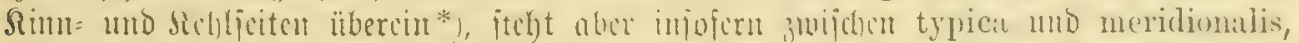

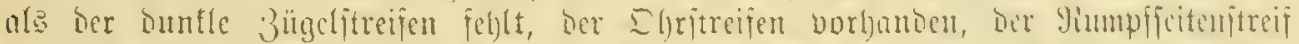

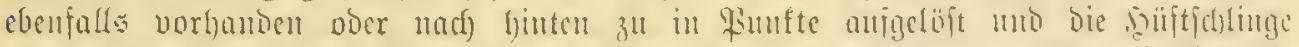

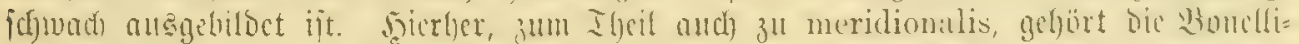

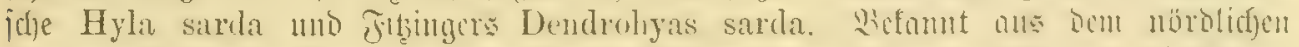

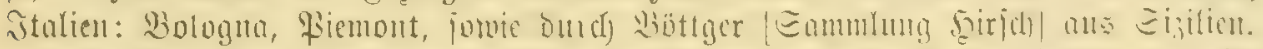

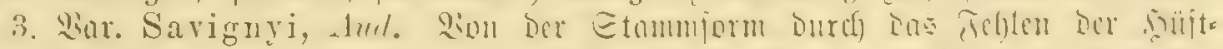

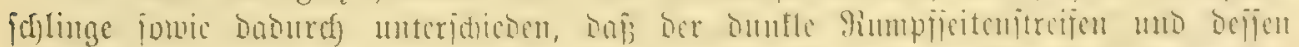

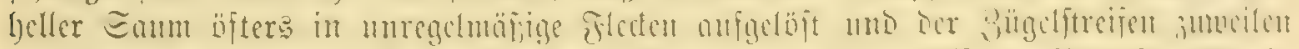

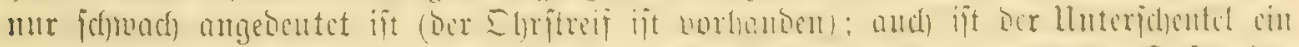

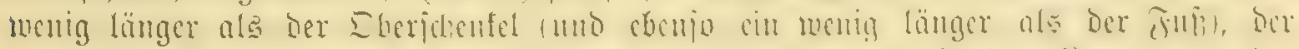

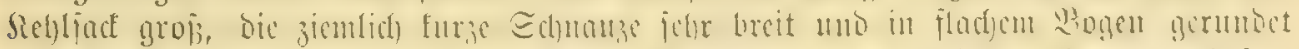

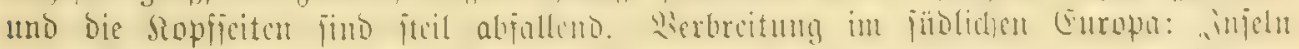

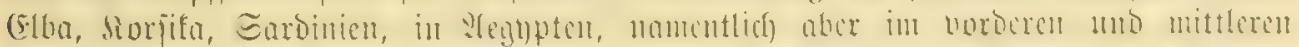

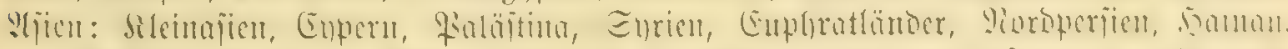

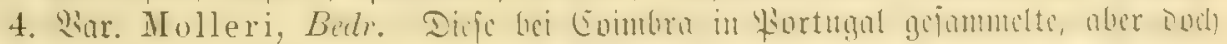

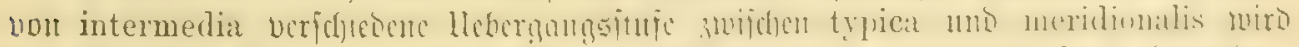

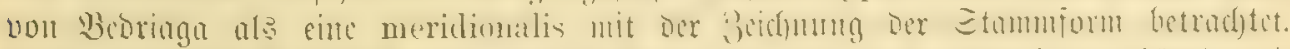

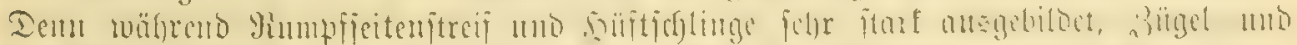

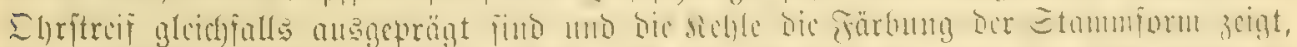

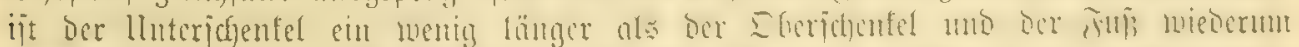

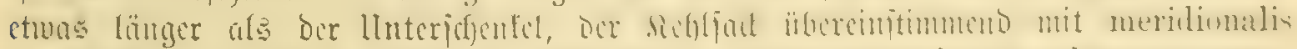

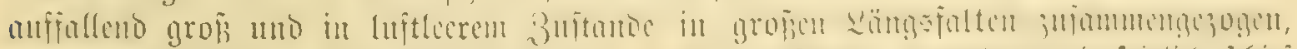

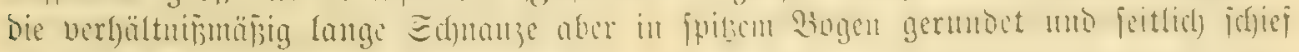
mach) auber abfallend.

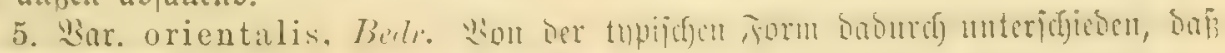

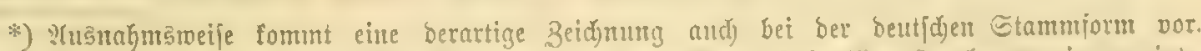

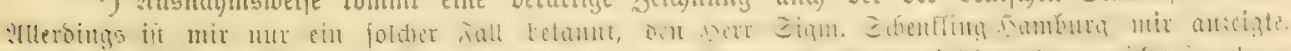

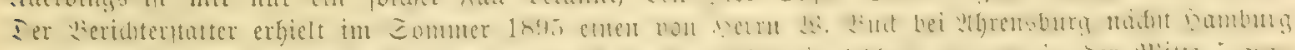

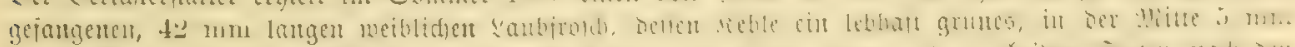

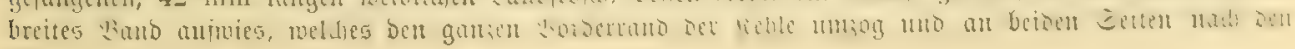
Diunowinteไn hin ipis zulię. 


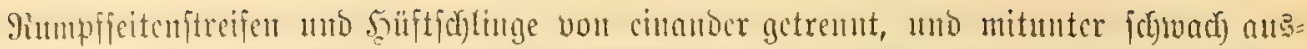

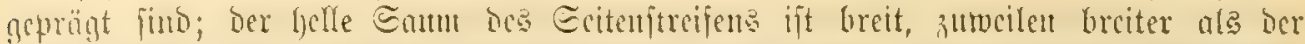

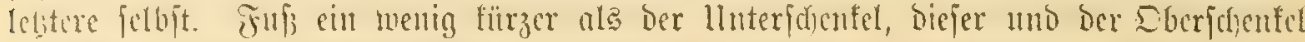

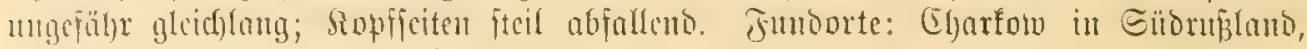
Tulticha an ben Donaumitudumgent.

6. Sar. japonica. Dicfe japaniffje Sarictät gat ben Bügelftrcifen wic bic

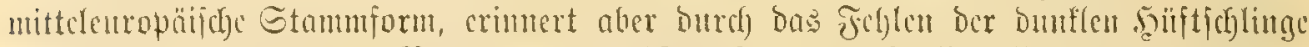

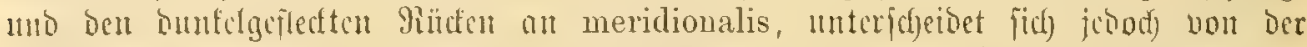

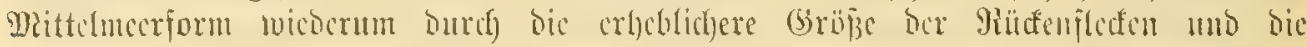

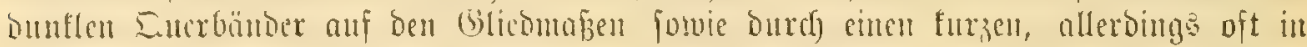

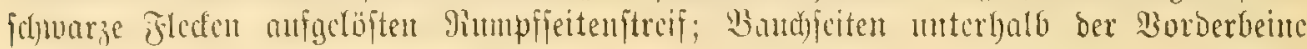
unto 2(ftcrgegcto fajwarzgrau. Sapan.

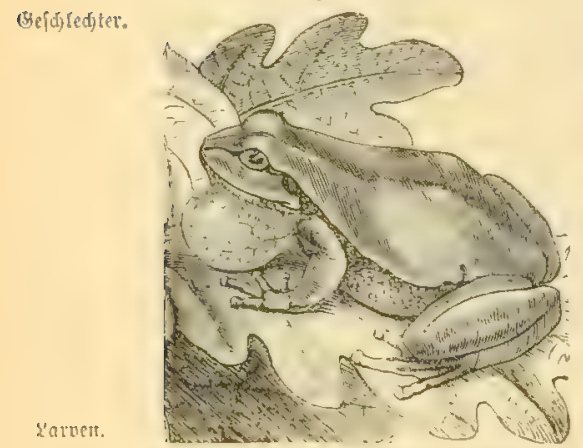

Das befomutefte Picrfzeichen unjercs Saubfrojich=

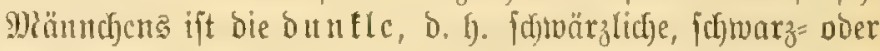
graulbrame Sieflthant, tocldye, im lufflecren 3uitande in

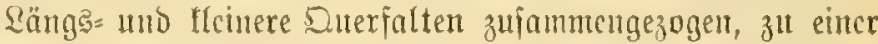
anjehnlidjen fugcligen Sdjallbraje anfgebläht uverocu faun, twäl)rend das ftattlicherc aber Elcinerföpfige MSeibchen eine

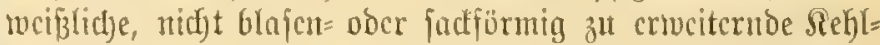

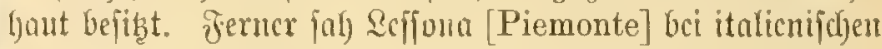

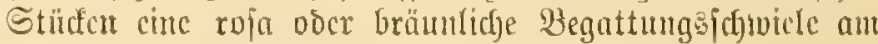
Daumeıt dç Mlämuchenı̉.

Die nad) Dem Bcrlaffen Der Ciffüllen eincn halben

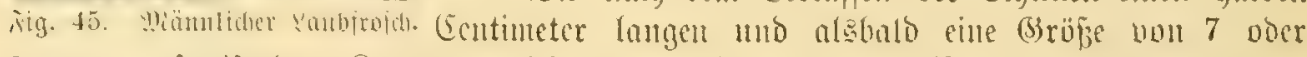

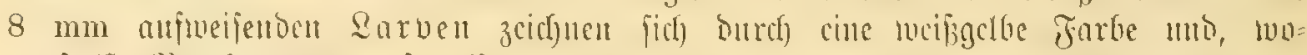

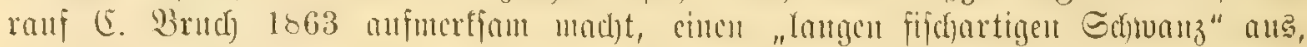

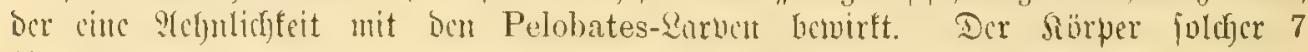

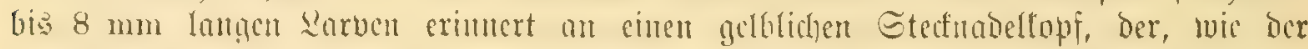

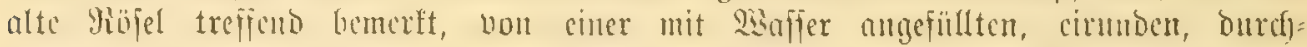

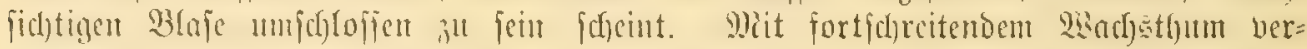

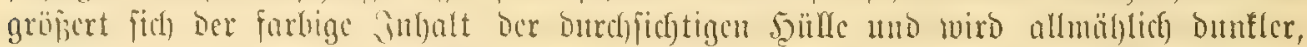

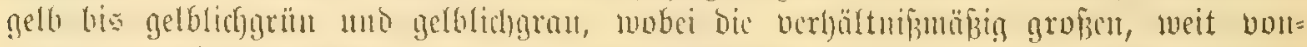

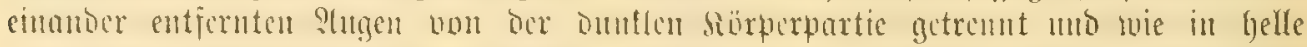

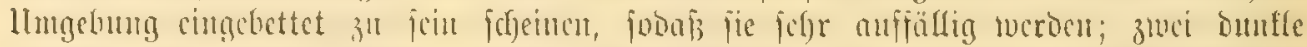

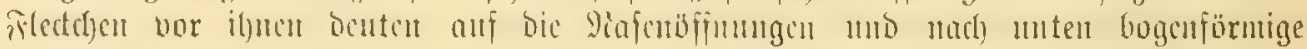

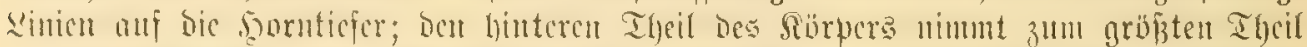

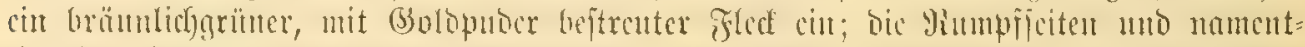

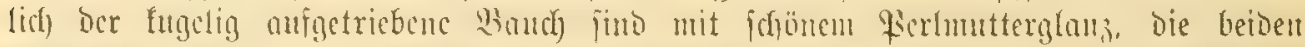

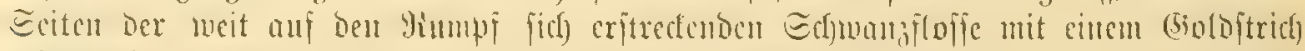

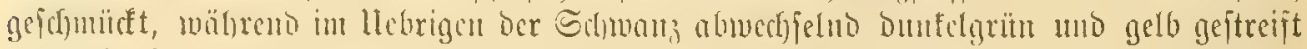

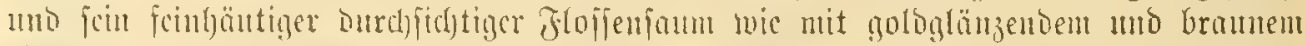

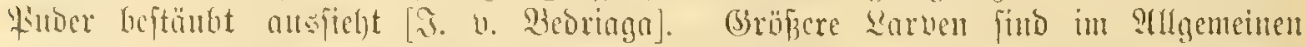

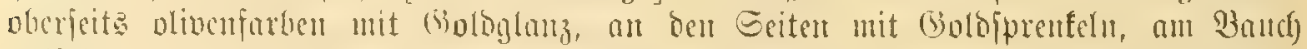
weifilicl) mit perlmutterfarbigen ober golocmen Eprenfeln, im mutalbian Theil bes

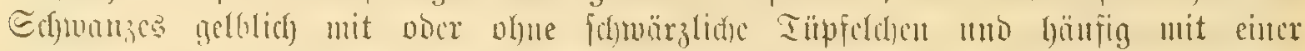

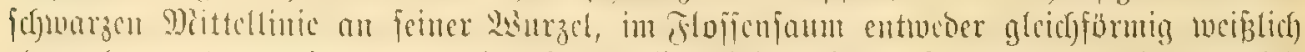

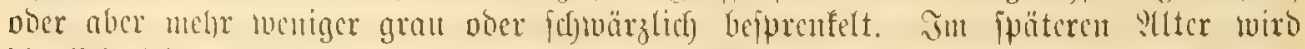

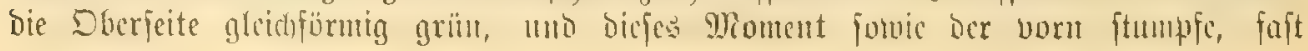




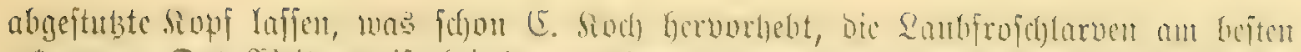

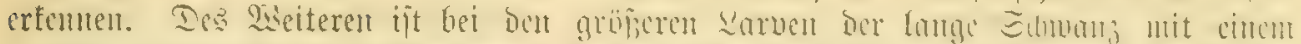

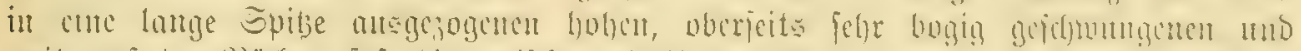

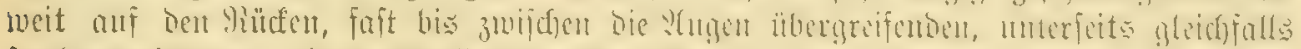

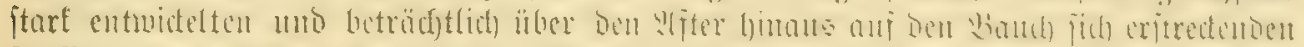

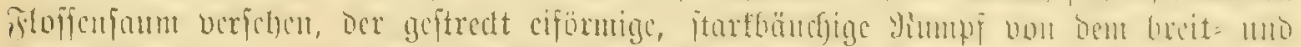

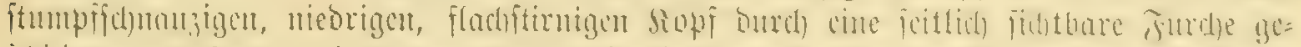

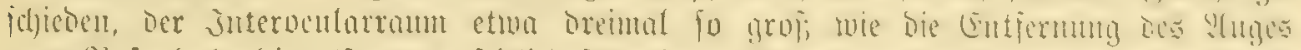

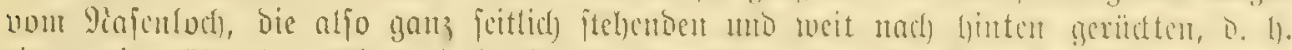

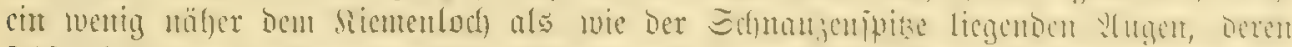

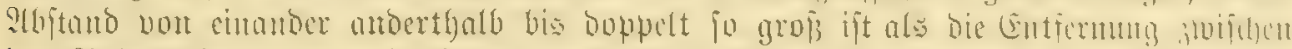

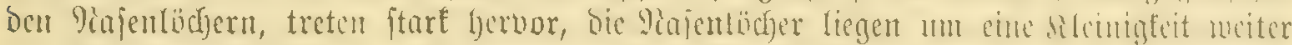

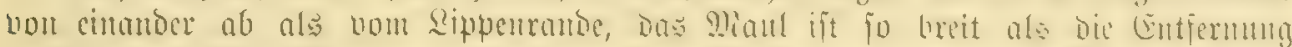

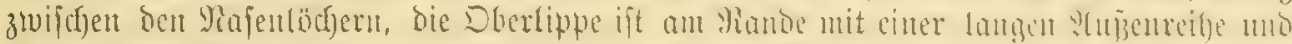

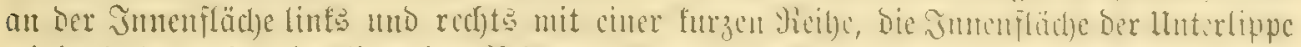

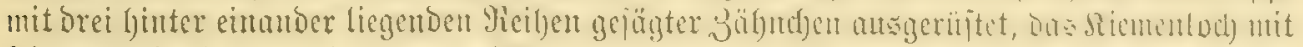

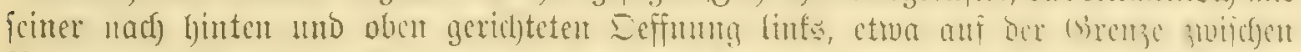

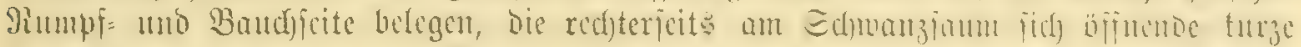

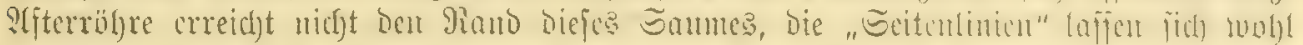

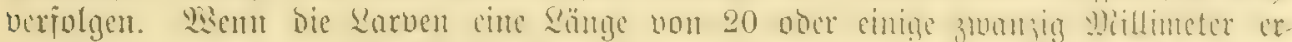

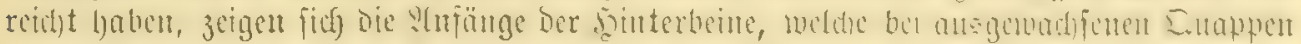

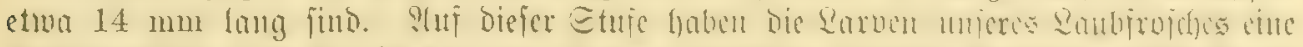

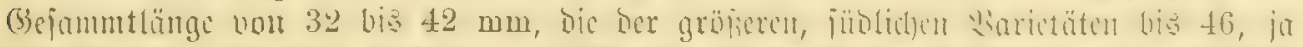

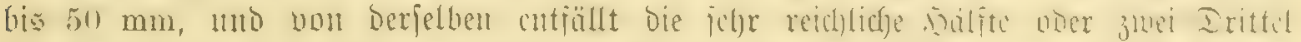

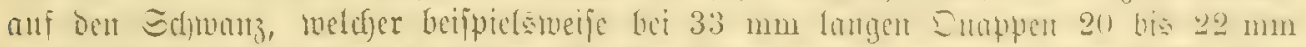

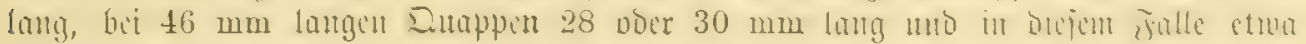
$14 \mathrm{~mm}$ fod ift.

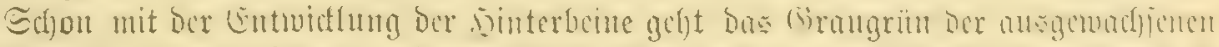

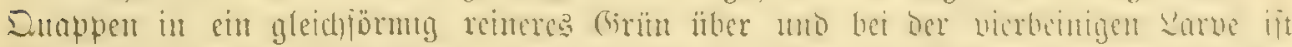
Dic ganze Dherfeite frifd llatt= voer gelbyrän grumbirt, whe bei bem firtigen, bon ber

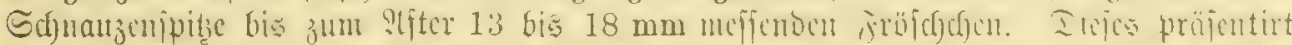

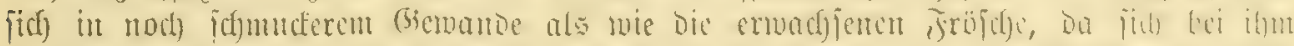

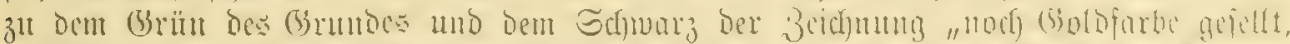

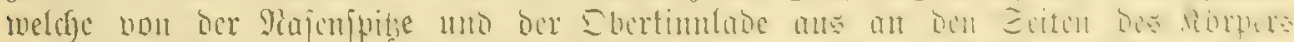

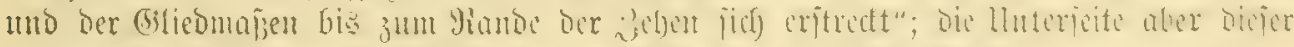

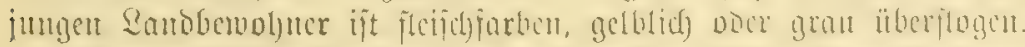

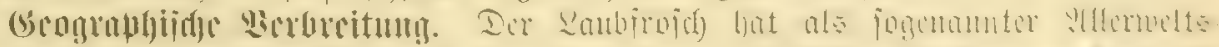

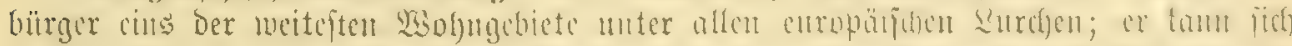

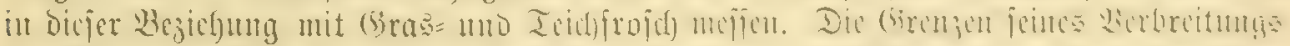

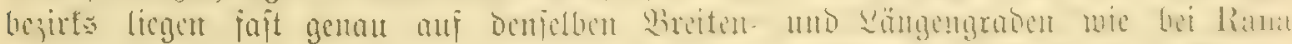

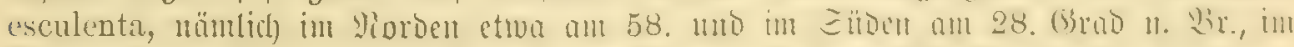

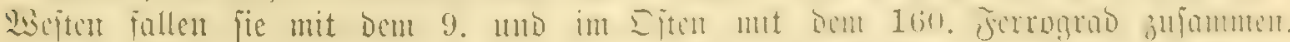

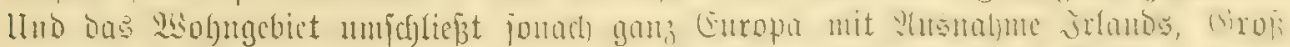

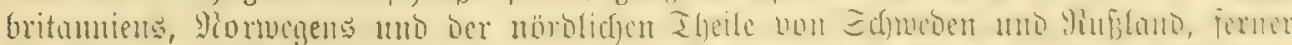

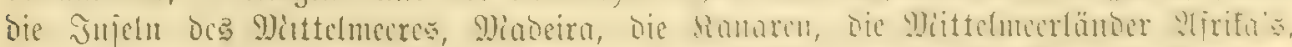

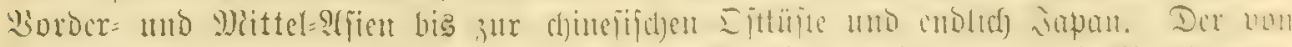

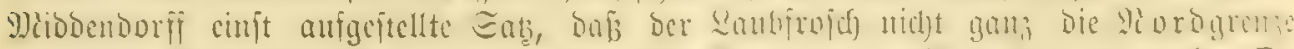

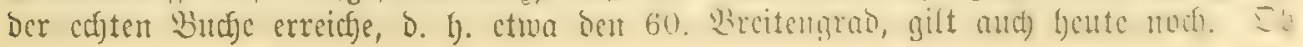




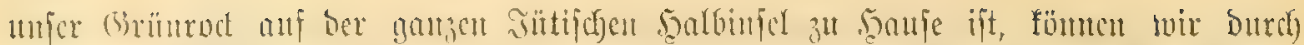

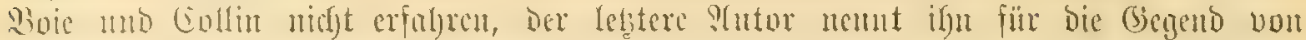

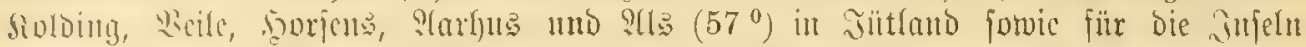

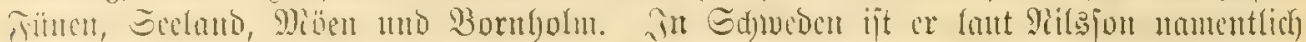

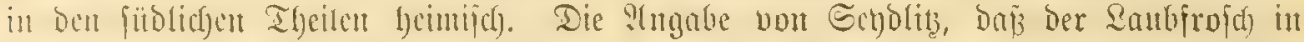

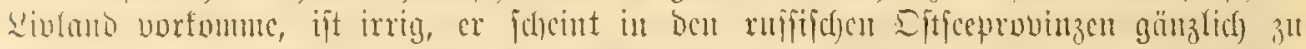

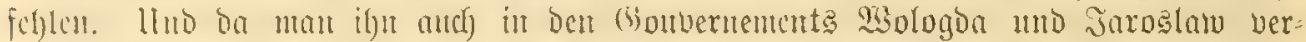

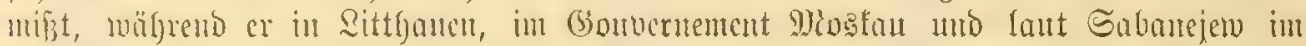

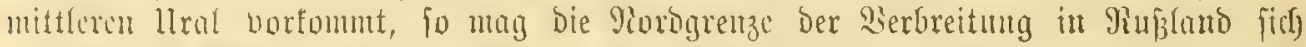

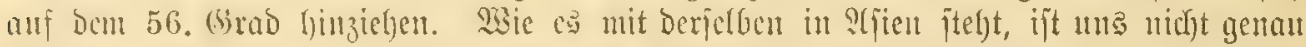

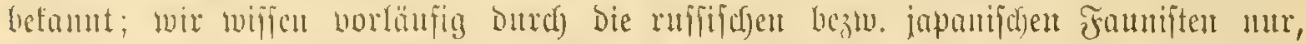

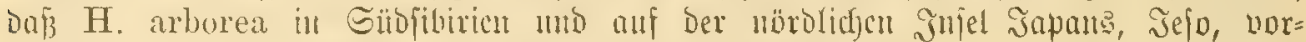

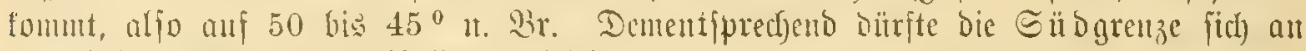

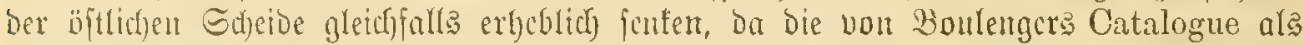

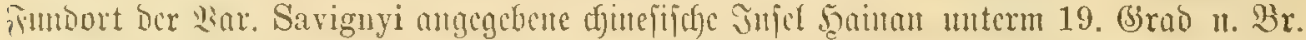

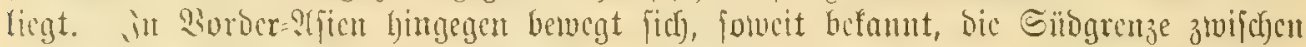

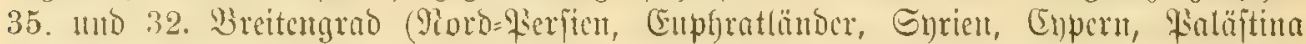

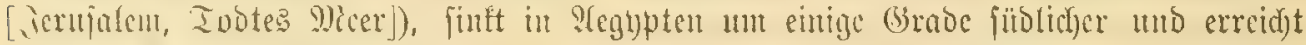

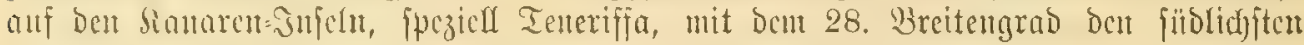

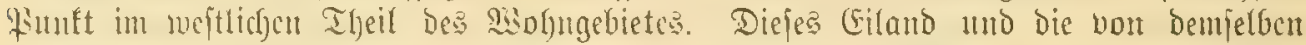

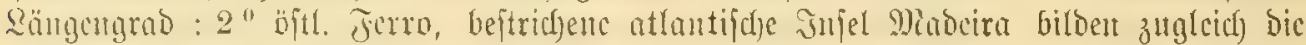

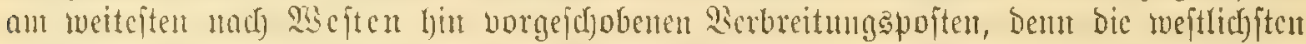

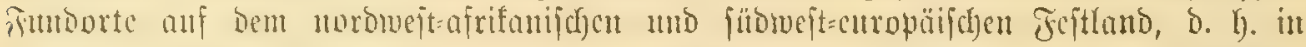

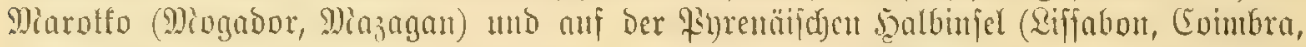

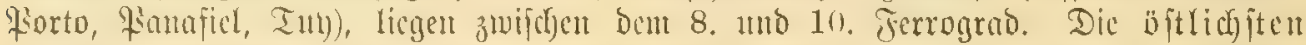

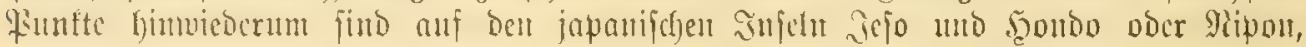
158. bie 162. Ferrograb, zu jucter.

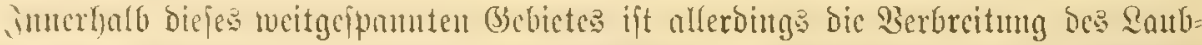

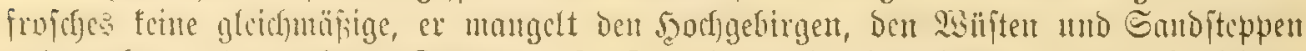

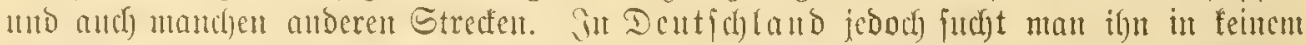

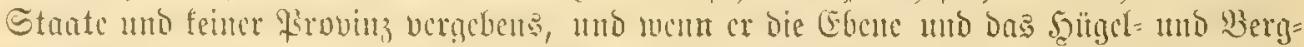

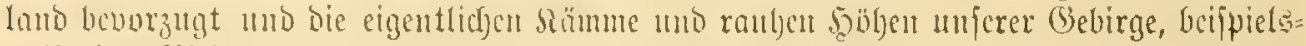

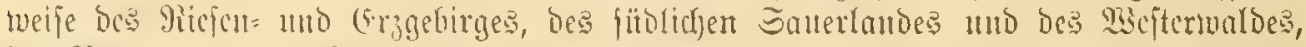

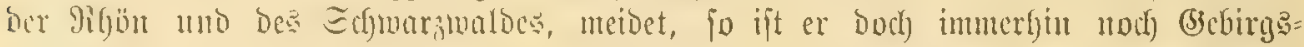

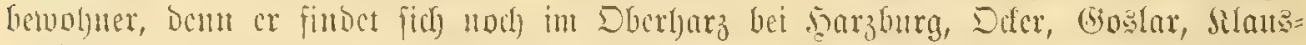

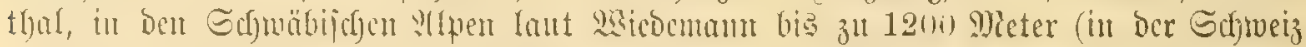

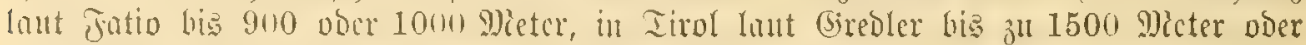

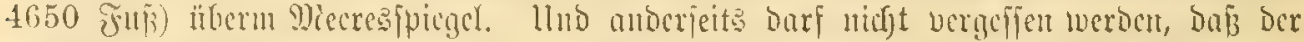

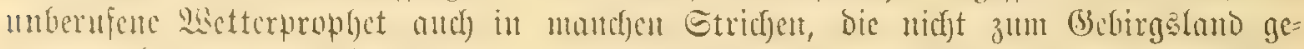

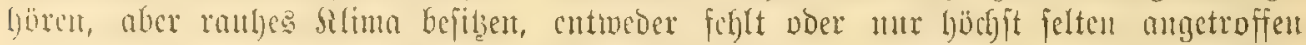

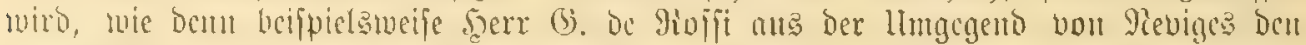

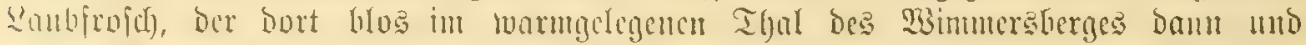

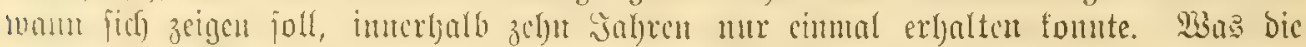

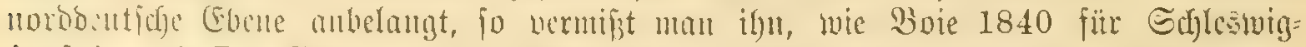
Sholfteit uno Dr. Grene mir für Dlbenburg mittgeilt, in ber malolofer Marjaj.

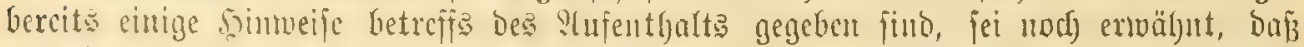

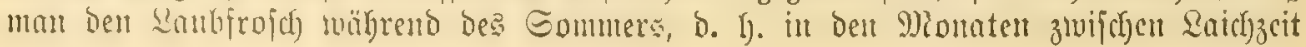




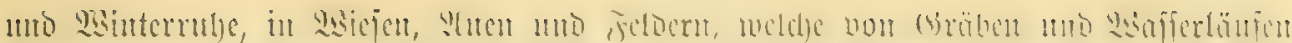

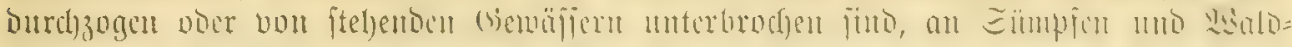

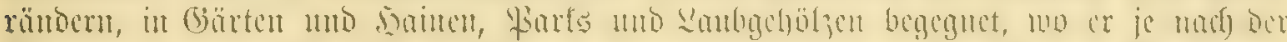

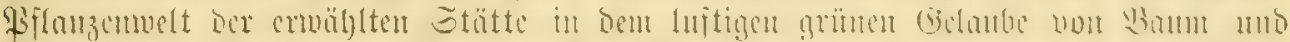

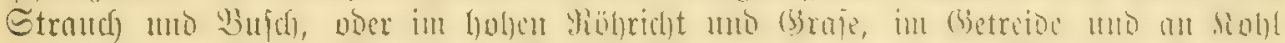

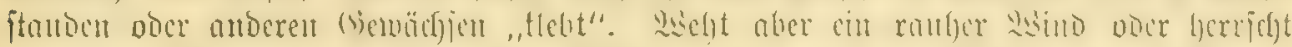

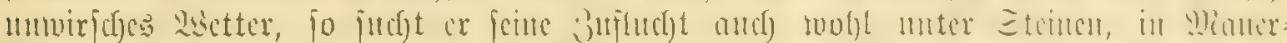

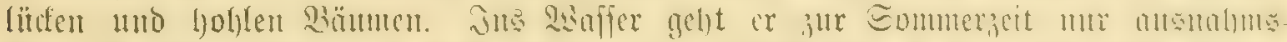

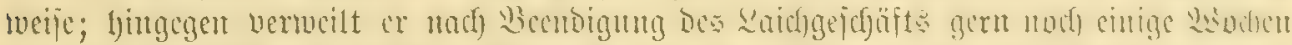

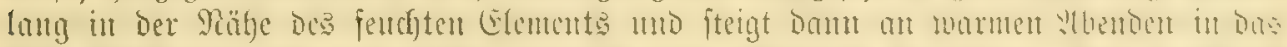

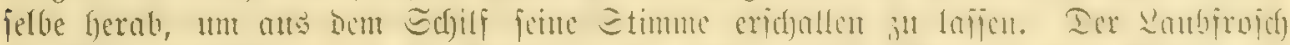

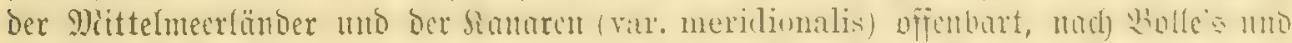

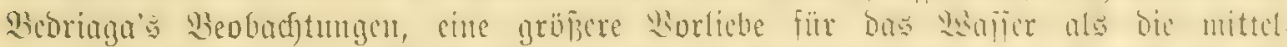

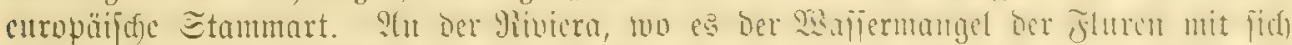

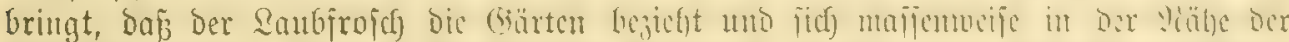

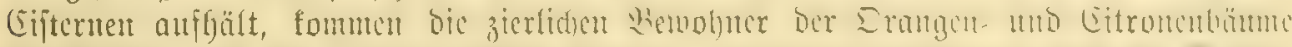

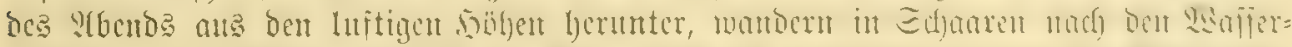

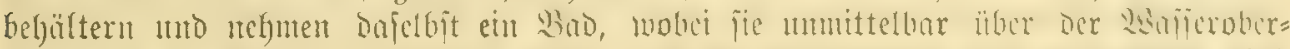

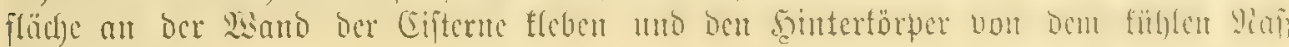
befpillen rajien.

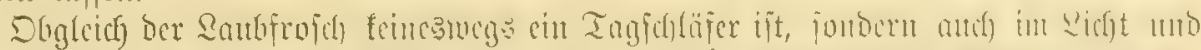

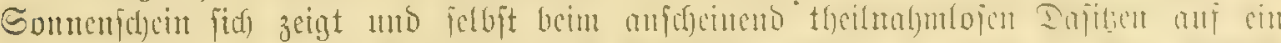

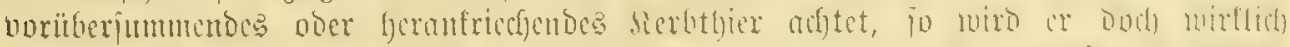

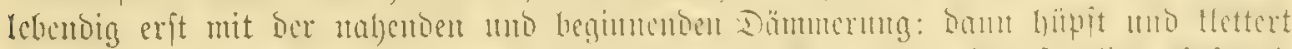

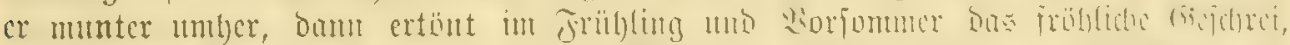

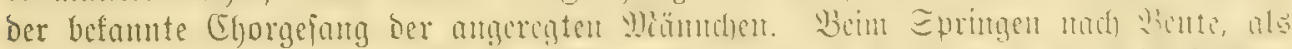

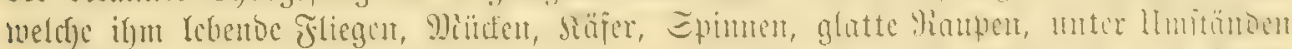

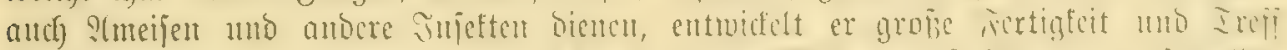

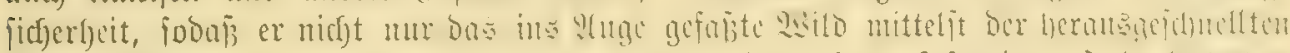

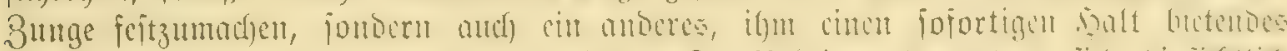

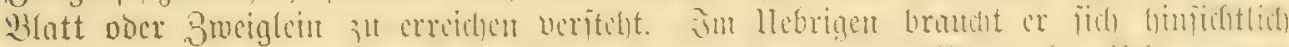

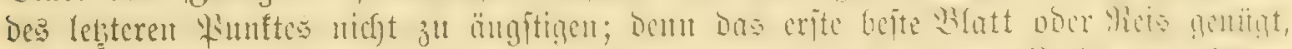

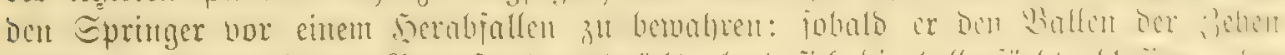

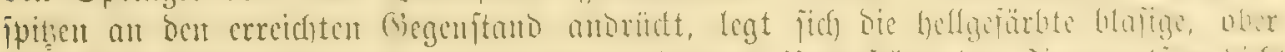

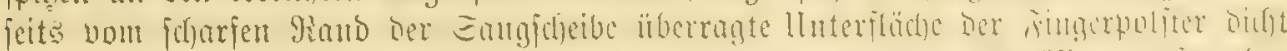

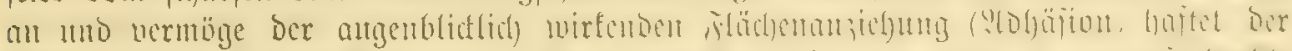

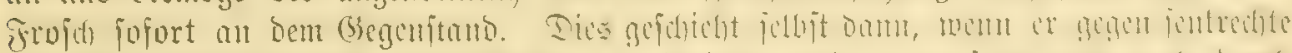

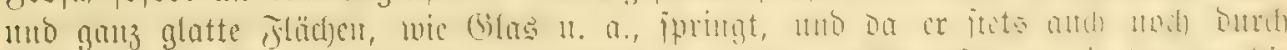

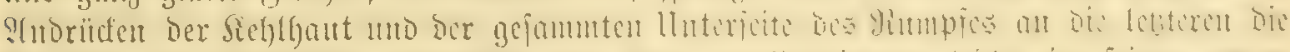

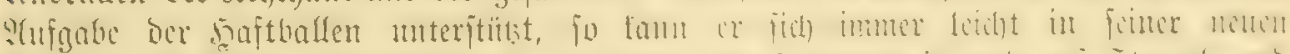

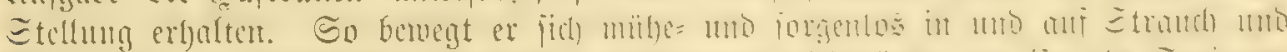

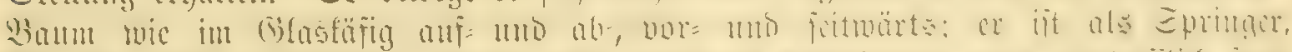

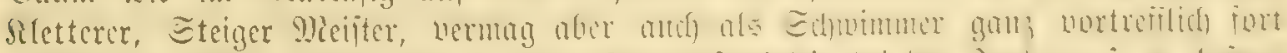

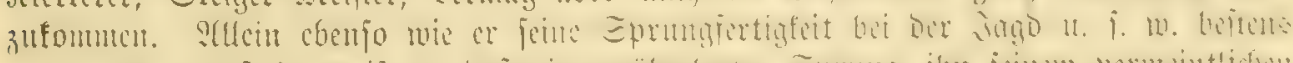

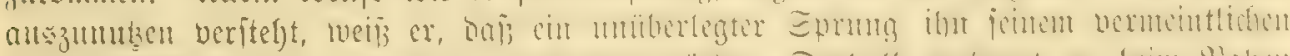

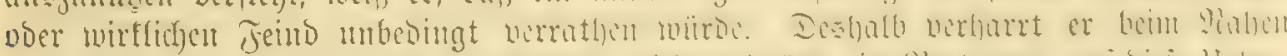

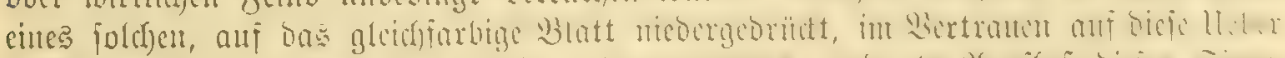

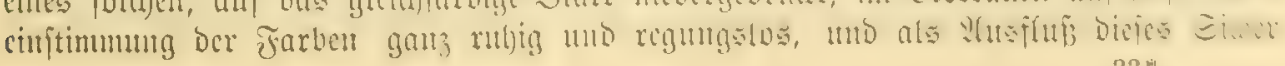




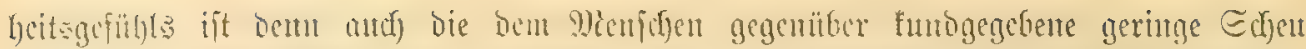

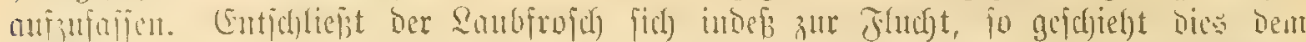

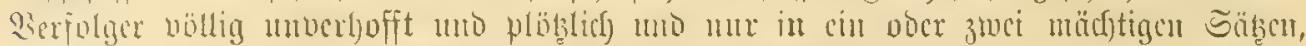

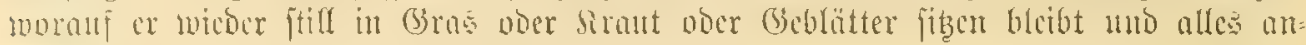
geftrengte Suchen nach) ifm gewölynlidf bercitelt.

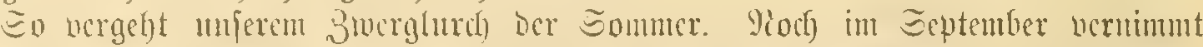

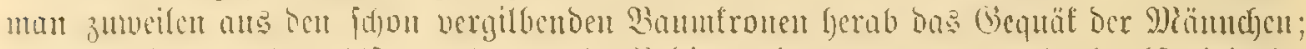

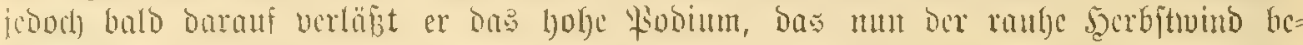

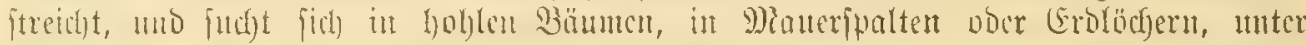

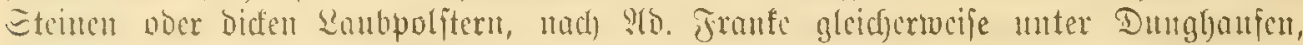

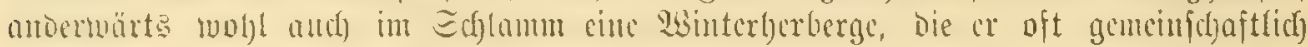

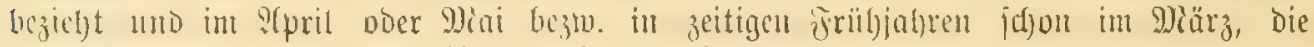
Mämuduen früfer ale bie $233 e$ eibchent, wicoer aufgiebt.

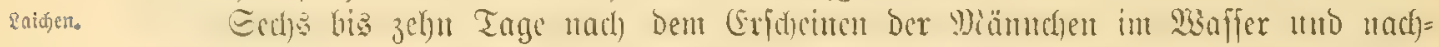

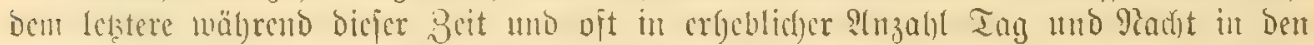

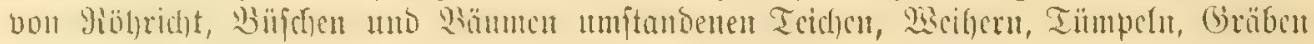

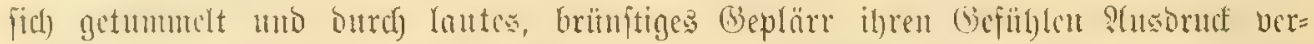

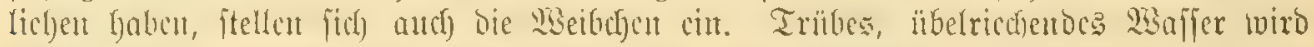

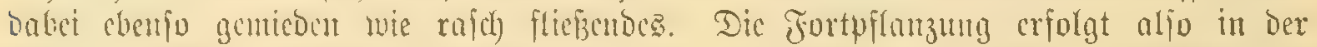

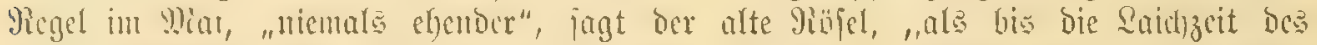

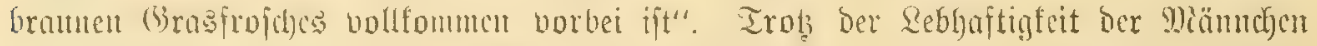

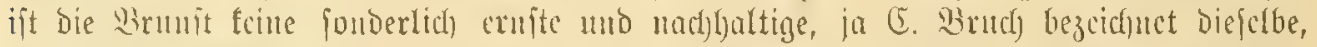

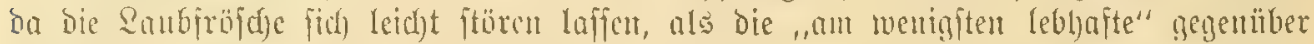

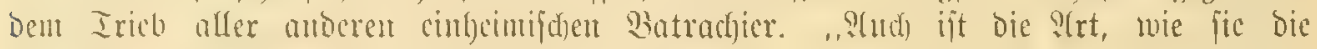

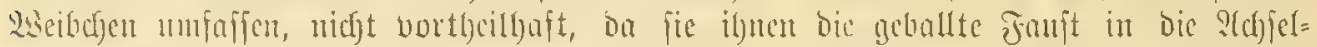

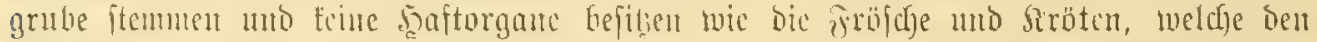

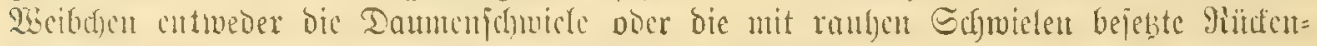

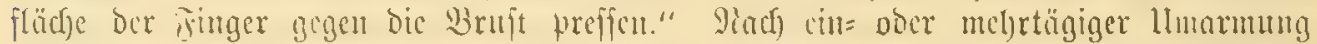

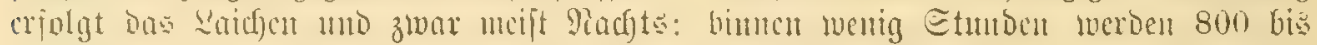

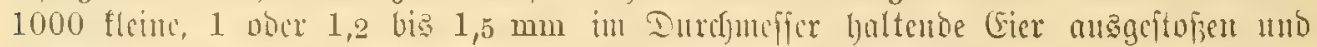

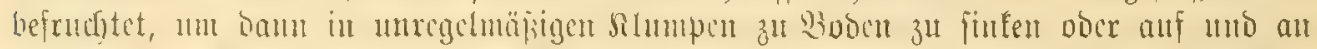

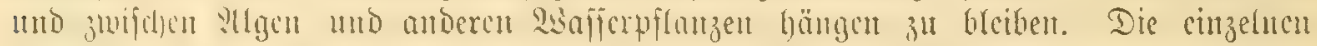

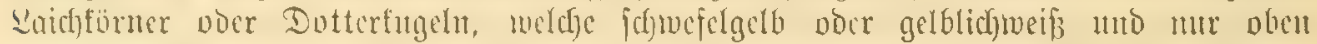

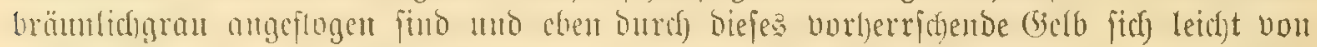

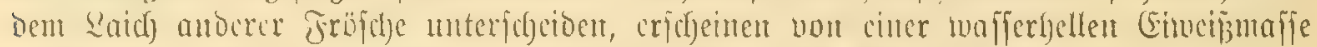

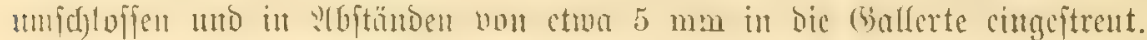

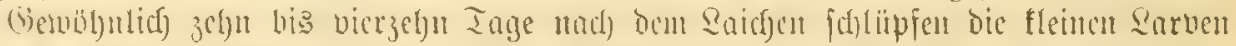

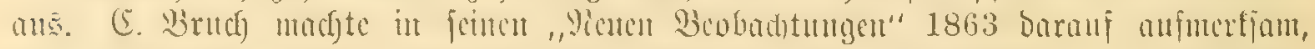

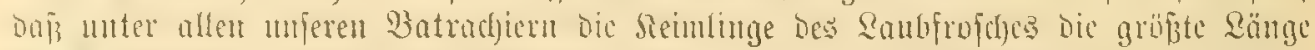

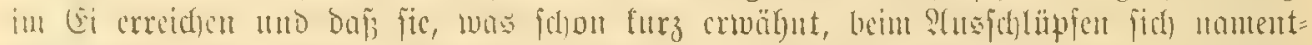

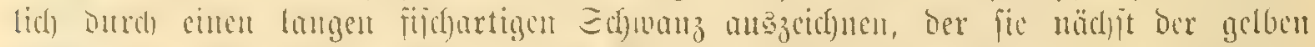

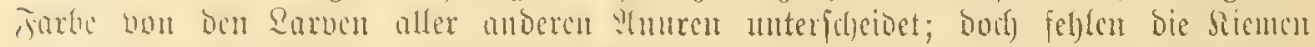

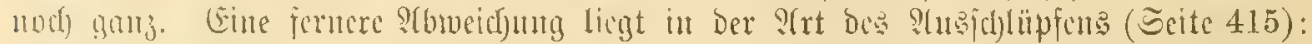
Die (sibunt be Hyla, ijt nänlich viel berber mo bejtent ans brei bifintenten Edjichten,

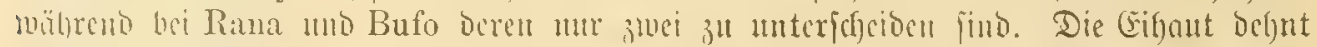

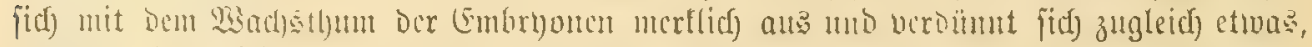

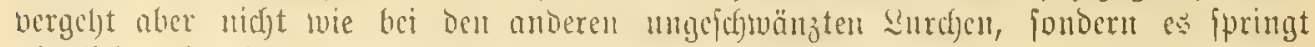

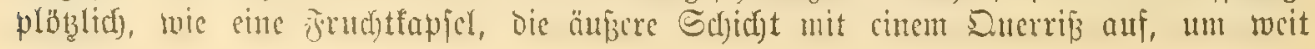




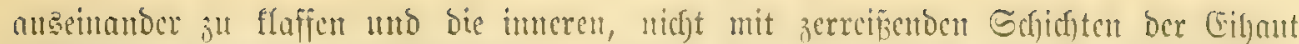

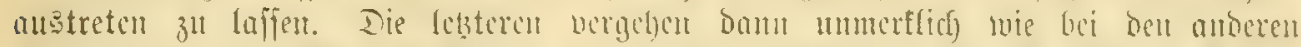

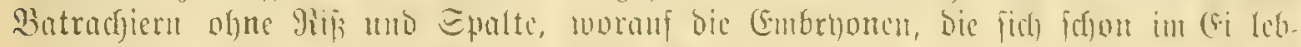

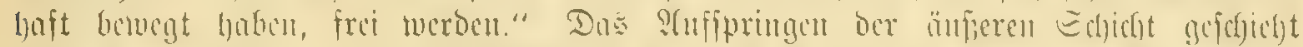

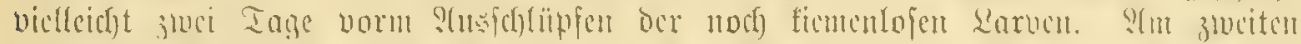
Inge des jreitebens, ment die ?(ugen nod) nidjt pigmentirt, bie jogen. Enugnäpfe (Ecite 394) legelfärmig mo rabiär acitreift finto, der Eiffunang halb fo lang als bie

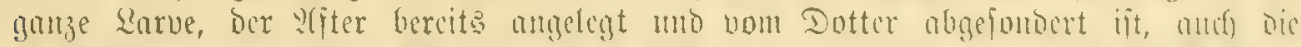

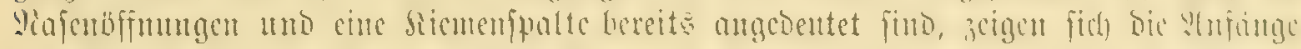

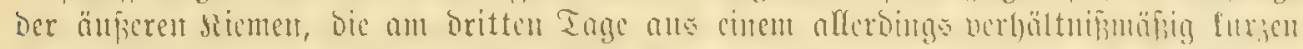

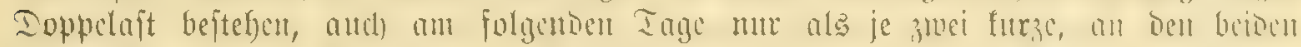

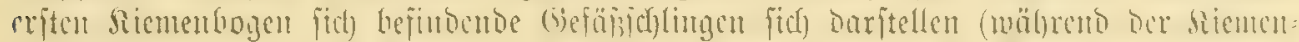

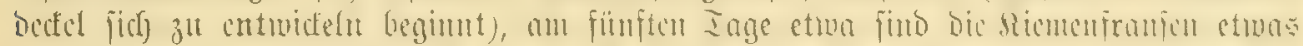

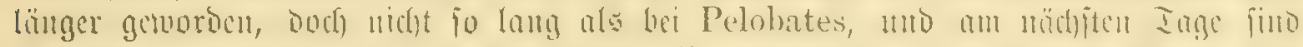

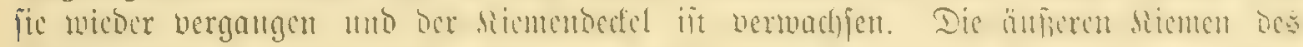

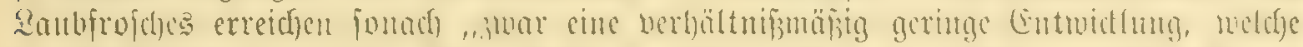

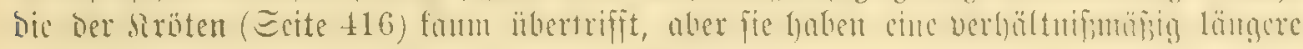
Daucr, wefdyer ber Der echten Fröfdre nabefommt".

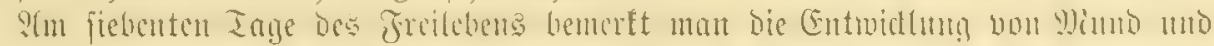

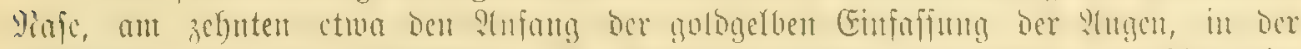

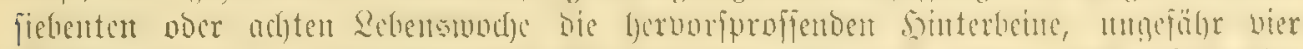

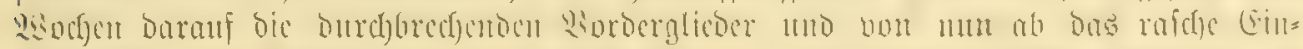

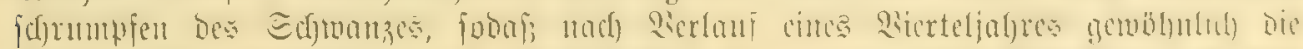

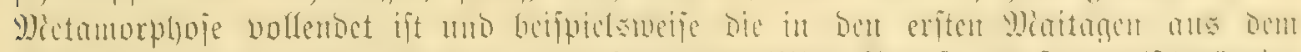

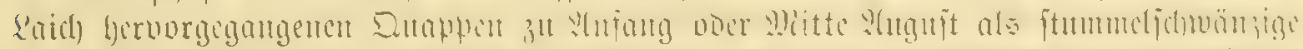

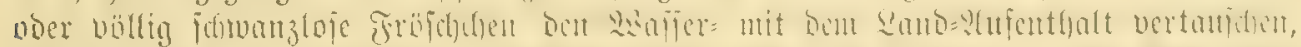

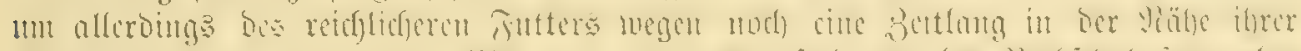

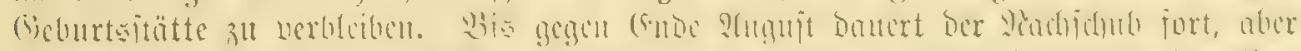

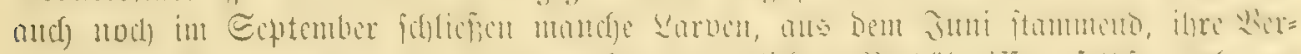

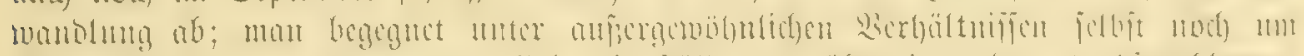

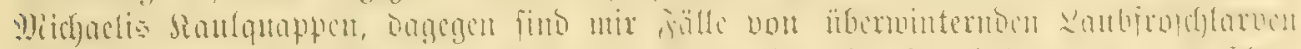

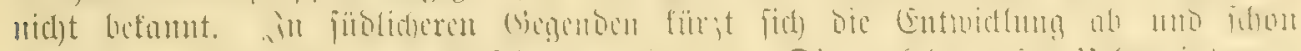

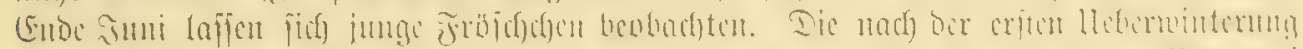

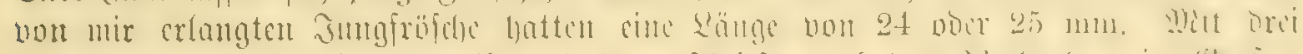

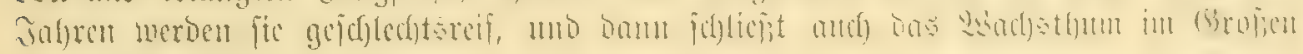
und (3anzen ab.

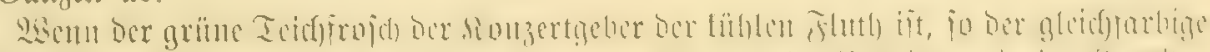

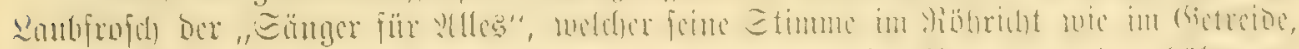

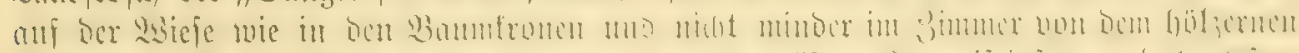

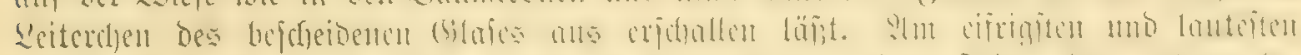

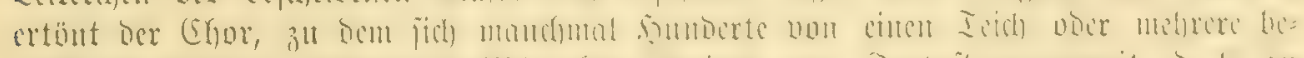

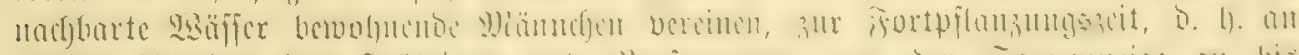

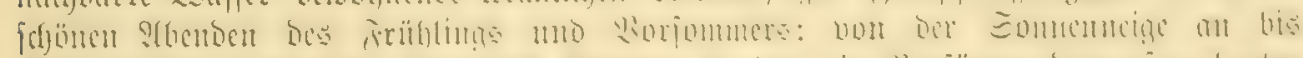

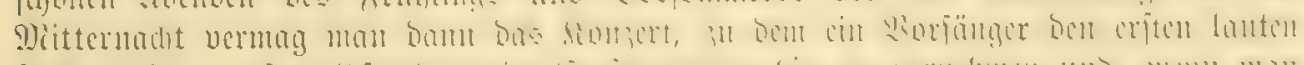

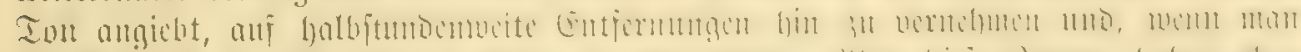

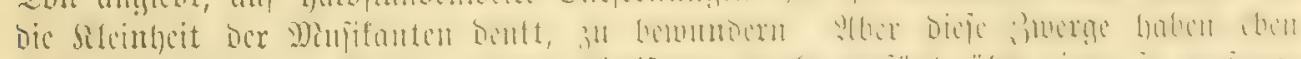

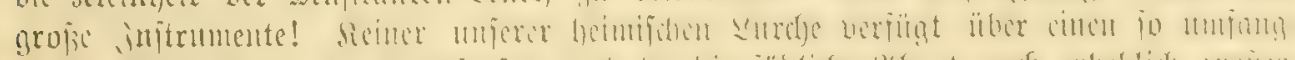

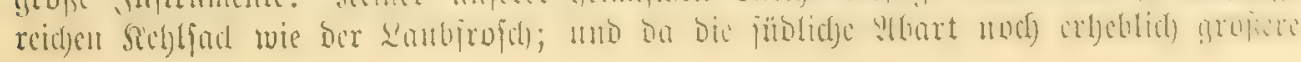




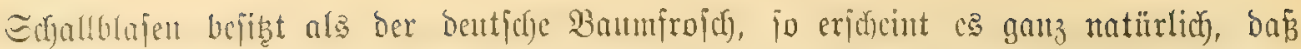

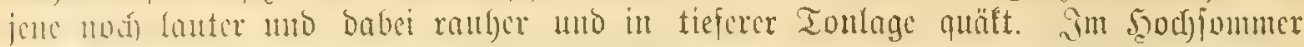

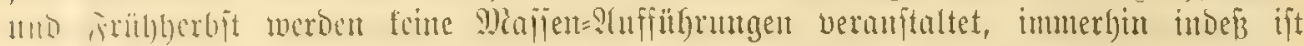

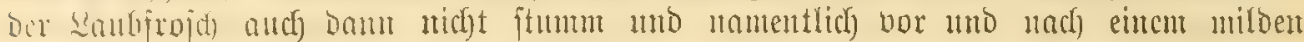

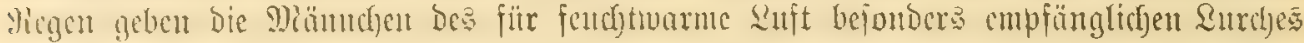
ans

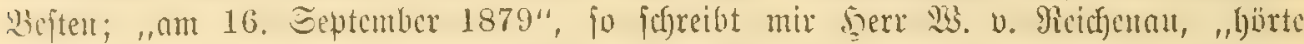

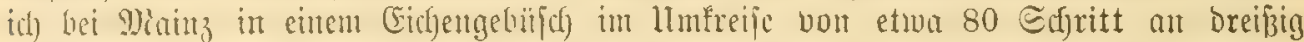

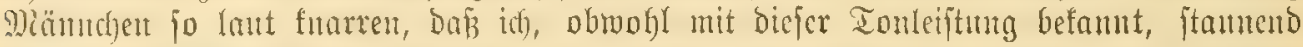

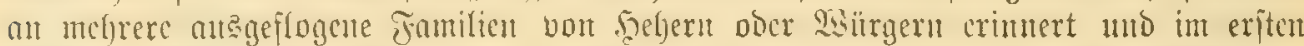

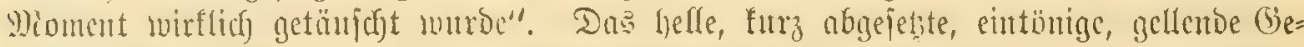

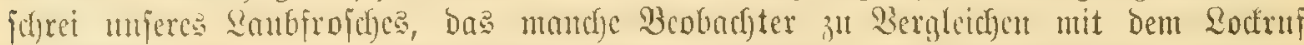

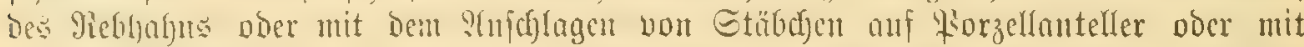
ciutem Echellengelünte angeregt hat, flingt wic äpp äpp äpp ober gä́f gäf gäf uno

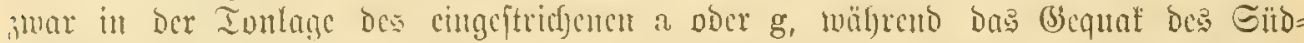
länocrs cinem tieferen, wolleren rab rab rab ober frua frua frua zu vergleidfen feis

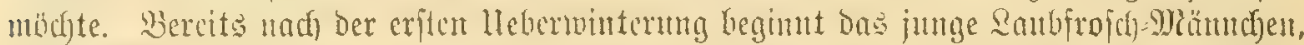

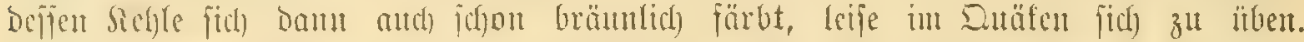

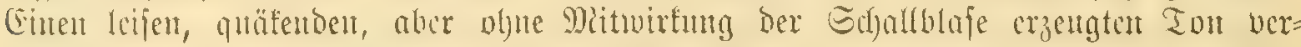

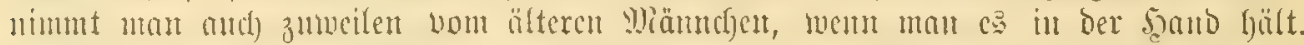

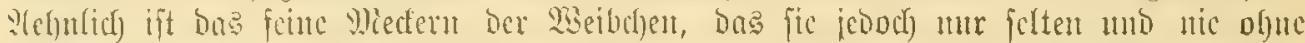

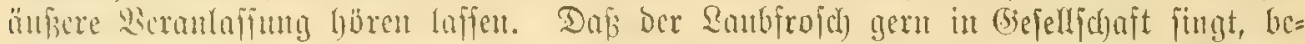

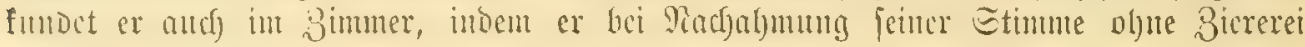
cinfällt zum Duett.

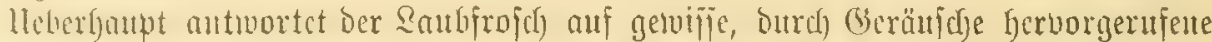
Eimenreize gern mit feincm (Geplärr; beifpiclsweife anf antoltendes giajdeln mit

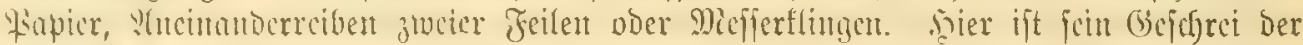

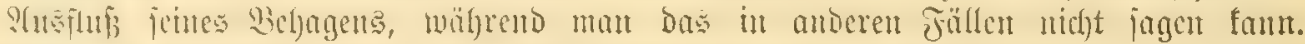

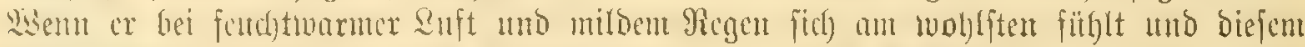

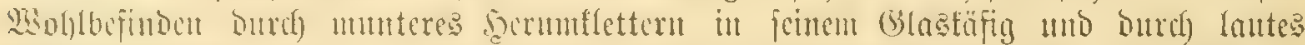

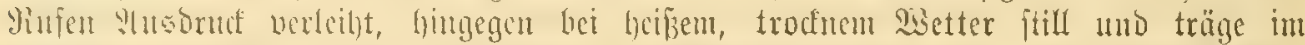

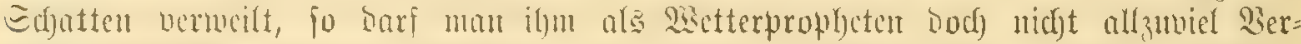

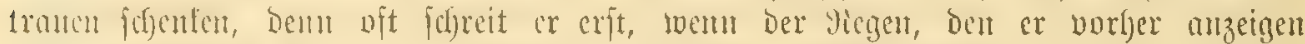

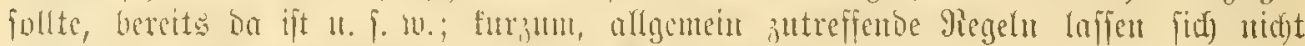

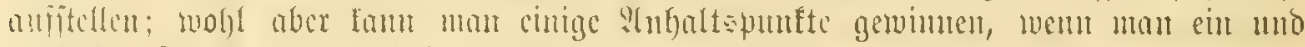

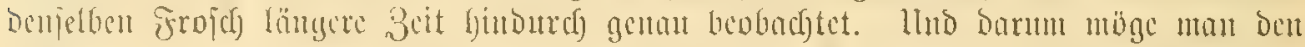

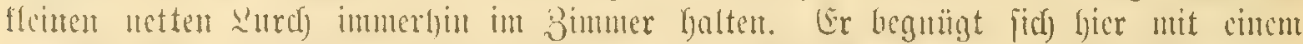

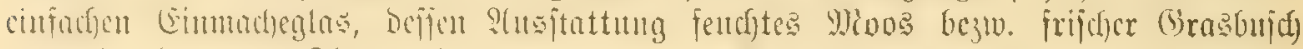

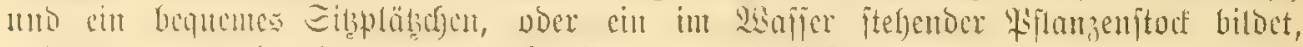

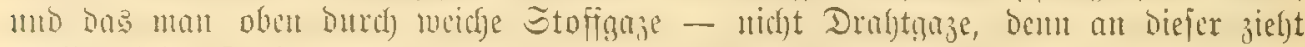

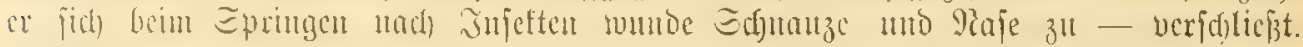

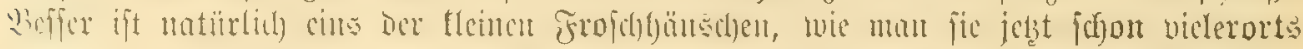

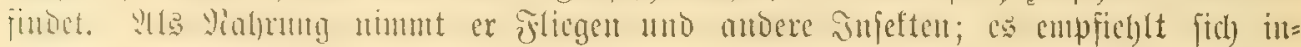

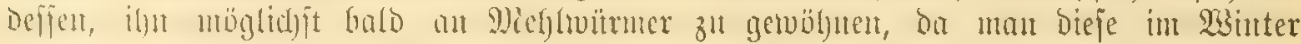

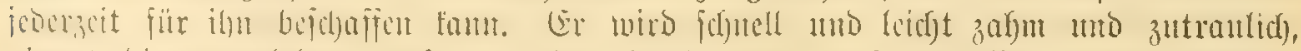

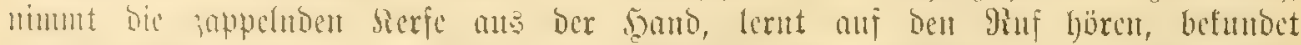

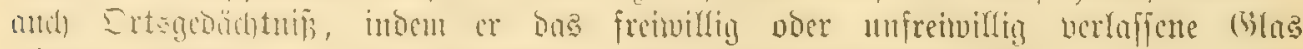

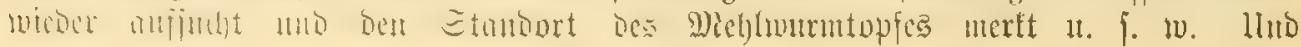




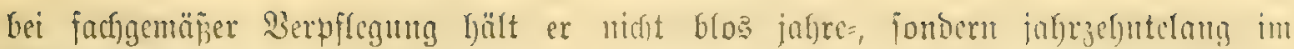
ภäfig aนs.

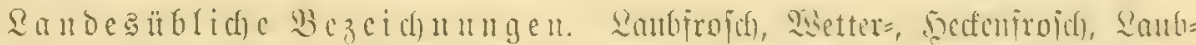

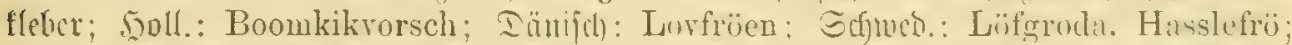

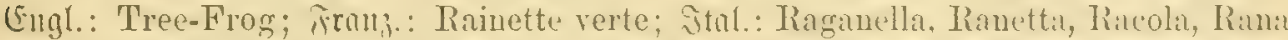
de S. Giovanni; Epant: Ranilla verde; Soln.: Zabka drzewna: Dulmat.: Prorocic

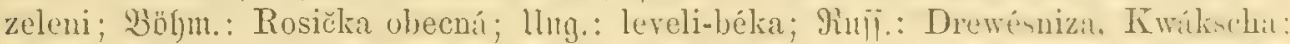
Fint: Lebto-Rupsale.

Rana arborea, Schuenkfild 1605. Limé 1761. - Ranunculus riridis, Gevm 1617. - Rana viridis, Linné 1746 [F. S. ed. I]. - Rana Hyla, Linné 1758, Hyla arborea, Linné 1766. - Hyla viridis, Lumrenti 1768. - Calanita arhoreun.

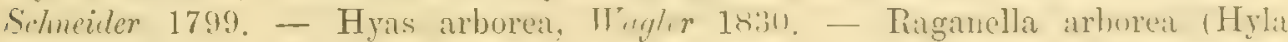
viridis), Bomip. [Icon.]. - Dendrohyals athorea, Tachudi 1839. - Demlrohyas viridis, Fitzinger 1843.

\section{4. familie: Froidhtötct, Pelobatidae.}

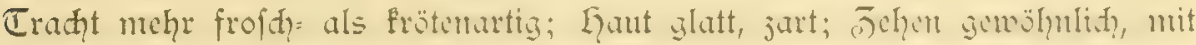

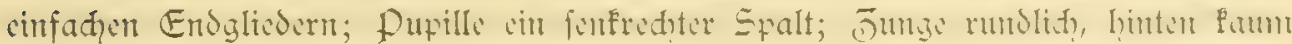

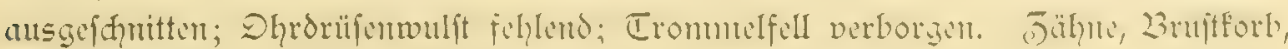
Zreujbeinfortfäzze, Wirbel, Rippen wie bei den Saubfröjhent.

Sin Deutichlano nur che Battung:

\section{Gattung: Rand=llnfe. Pelobates, Wagler.}

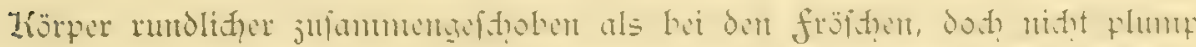

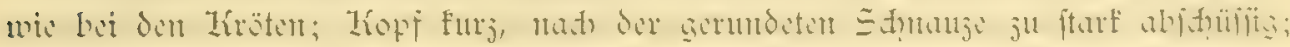

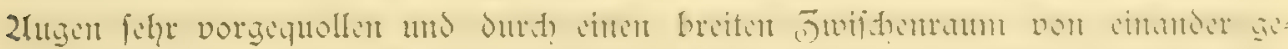

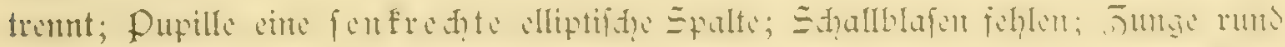

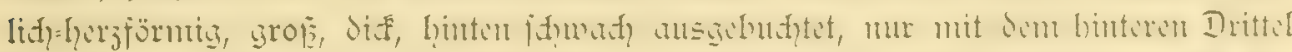

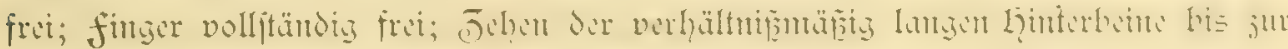

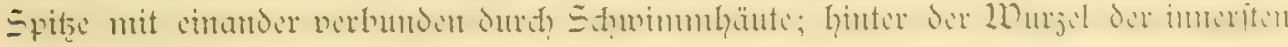

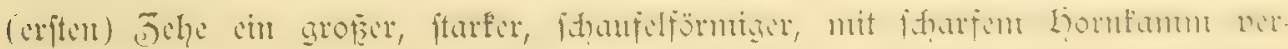

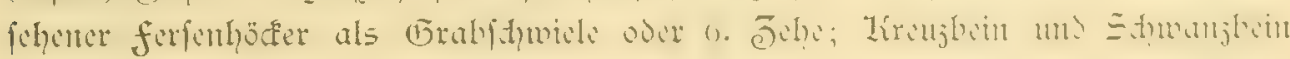
verwadfer.

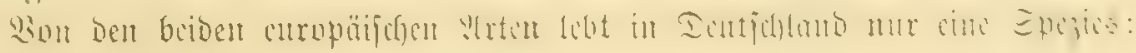

\section{9(rt: Kroblauḑskeöte. Pelobates fuscus (Taur.). 2tbbildungen: :afel III gir: 1 , zajel II Mir. 7.}

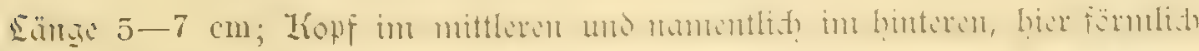

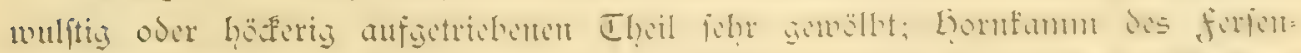

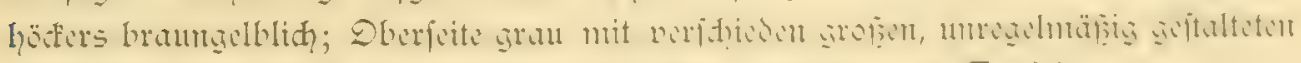

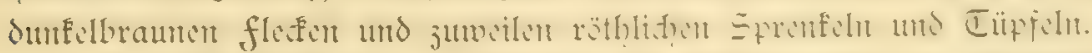

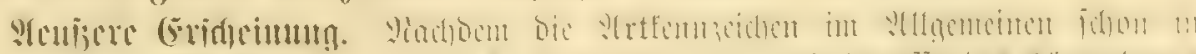

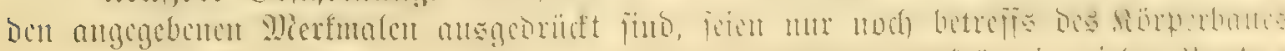

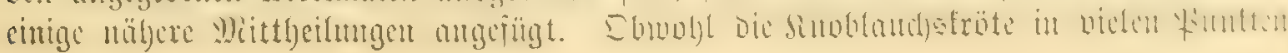




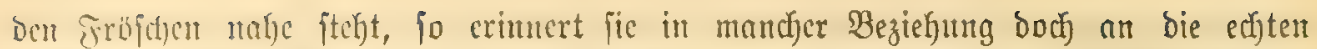

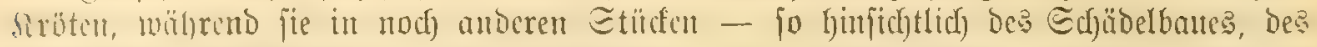

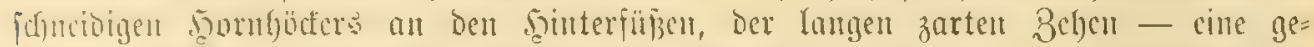

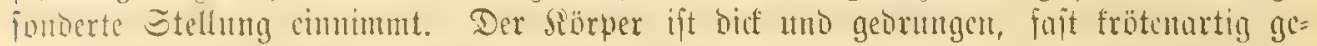
haut, ohericits gewölbt, Der Siopf Deutlich) fürzer als im binteriten Theile brcit, bon

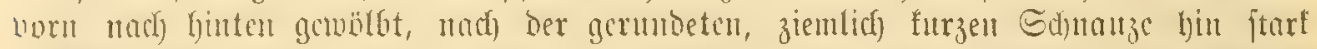

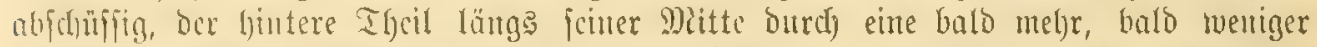

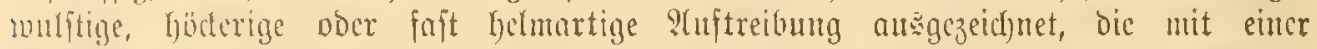
felgr Dïntuen und fraff anlizgenten, bei altu Thicren gowöhnlich rauben obor ge

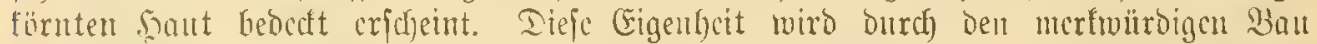

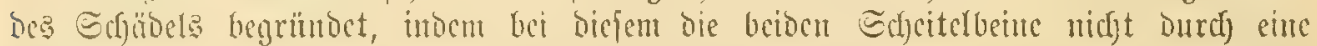

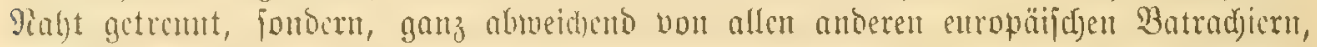

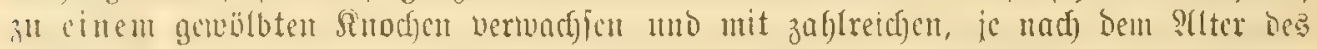
hetreffenden Ihieres mef)e ober minder fturf entwidfelten barzigen finod)envorfpringen

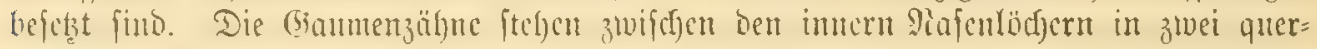

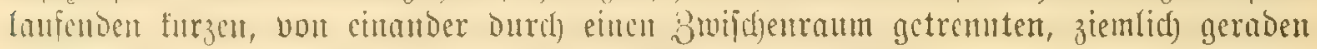

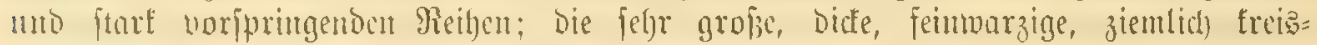

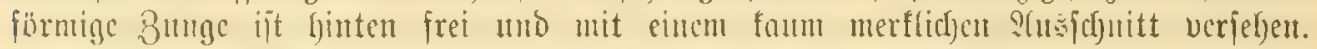

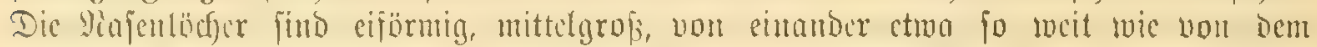
vorderen ?lugentwitfel cutfernt, bic :1ugen fef)r ftorf vorigequollen, bou einanocr burch

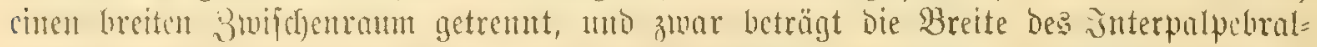

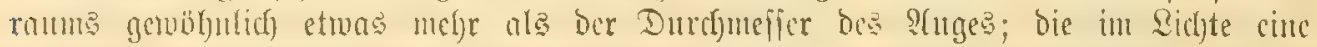

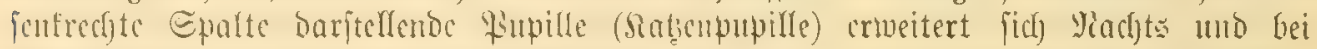

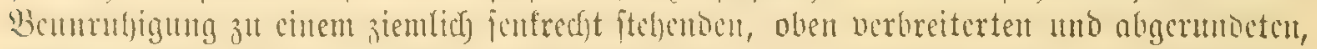

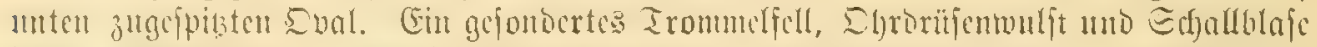

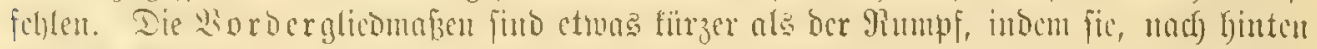

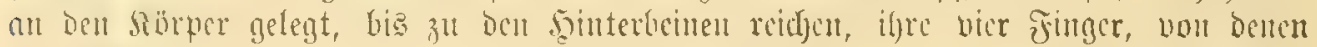

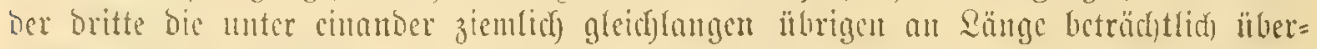

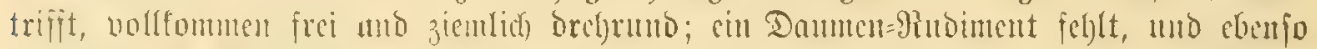

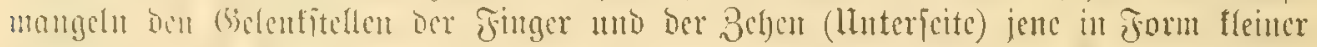

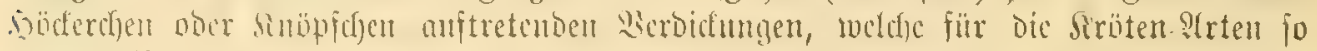

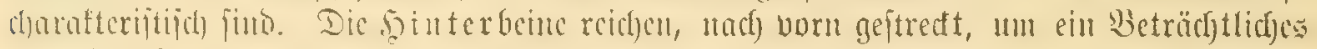

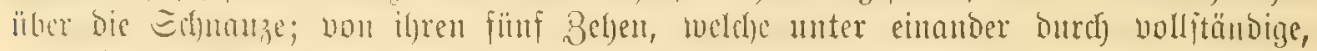

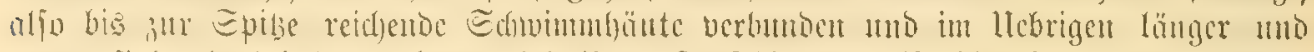

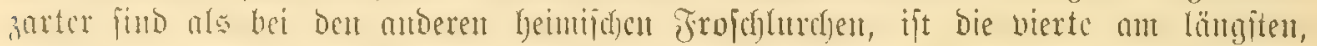

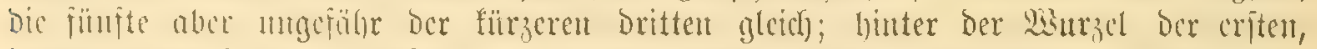

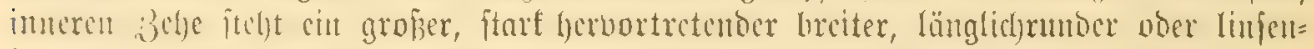

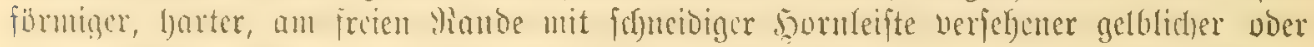

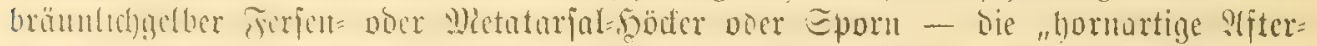

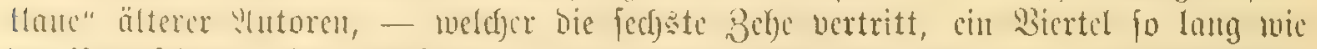

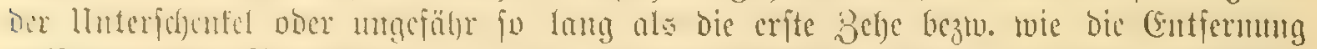

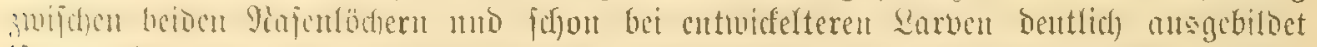

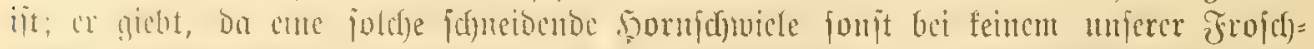

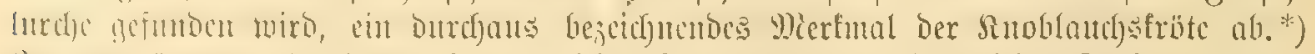

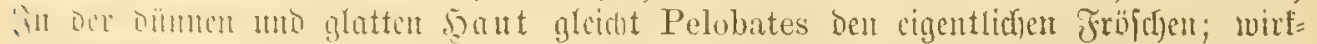

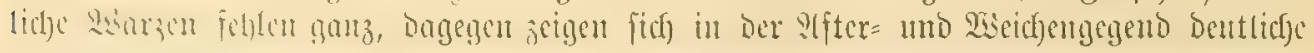

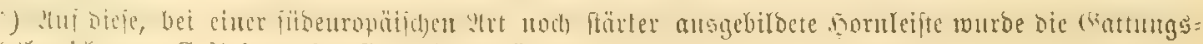
bezw. Artbezeid)untg Cultripes (Mefjerfufi) gegrünbet. 


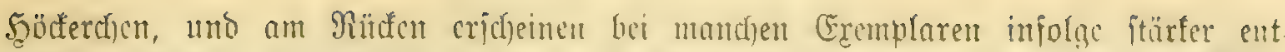

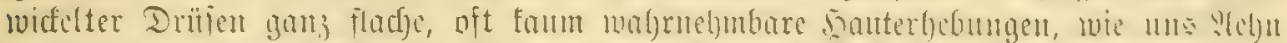

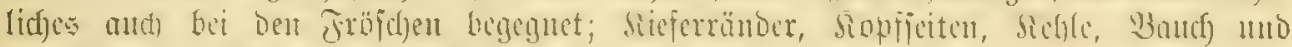

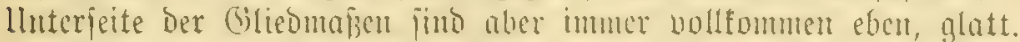

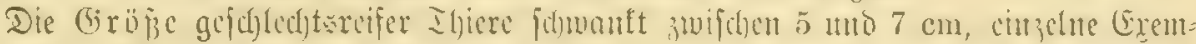
plare mögen bis $8 \mathrm{~cm}$ lang merbon, antore find mur $4,5 \mathrm{~cm}$ lang. Der llntericfentel

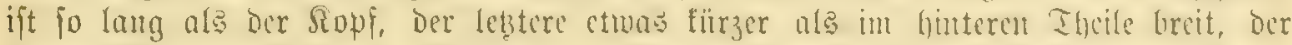

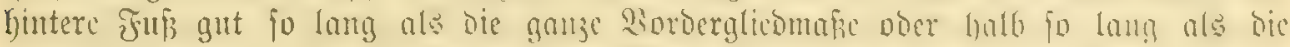

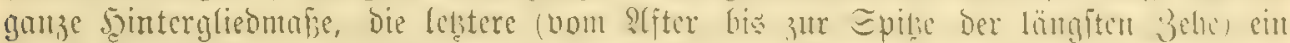

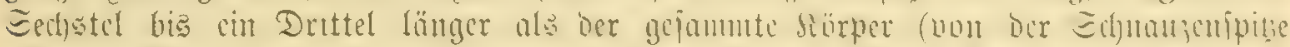

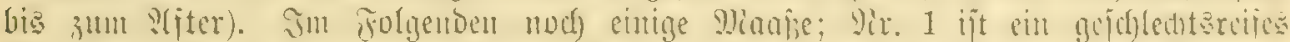

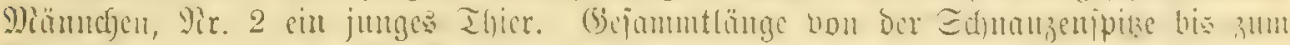

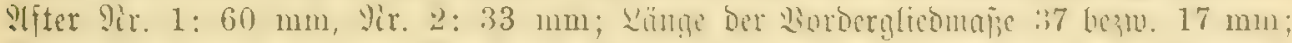

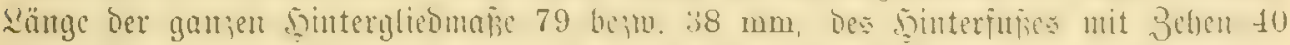
bezm. $18 \mathrm{~mm}$, der Sibia 22 hejm. 9 $\mathrm{mm}$; Siofflünge 20 hezum. 10,5 mm, grbigte

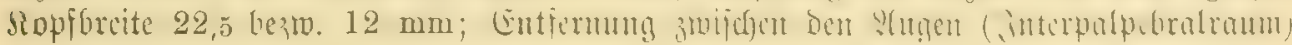
6,8 beżm. $4,5 \mathrm{~mm}$.

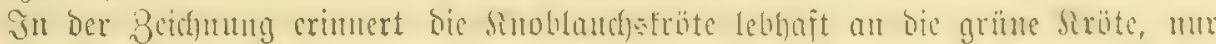

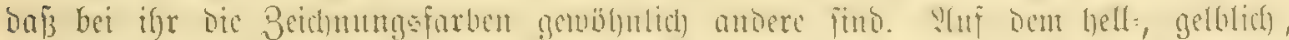

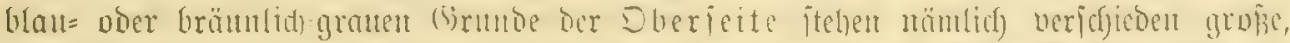

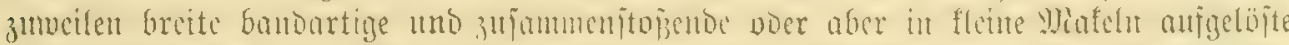

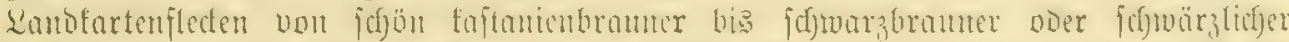

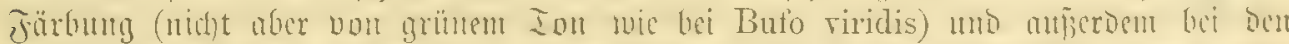

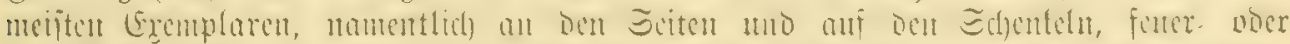

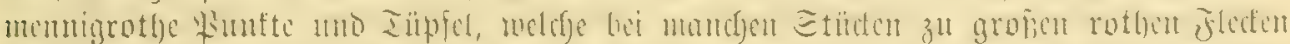

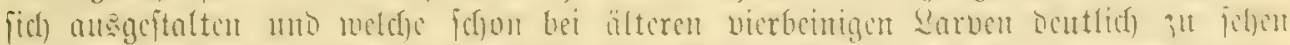

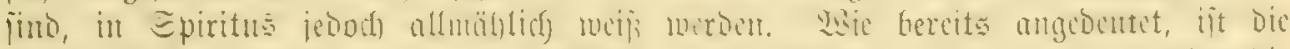

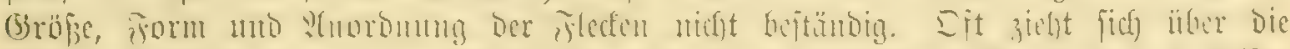

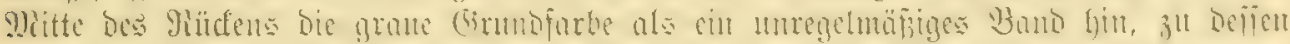

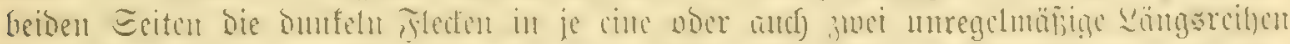

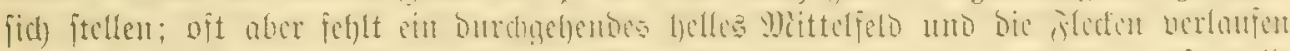

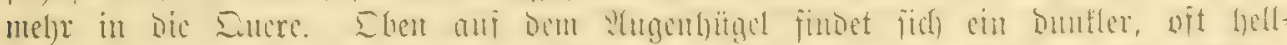

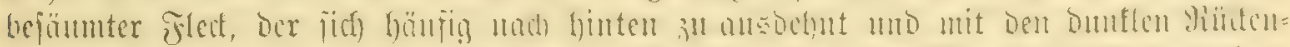

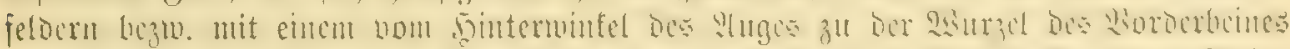

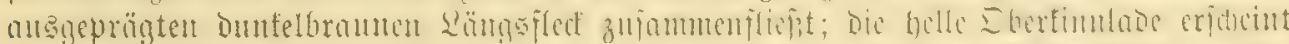

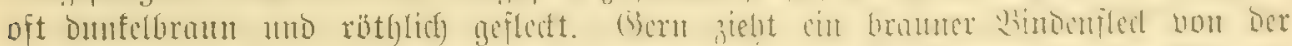

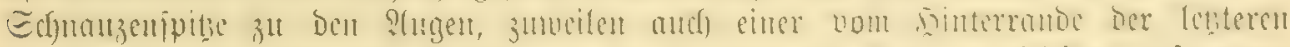

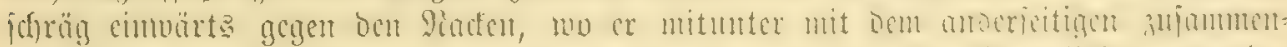

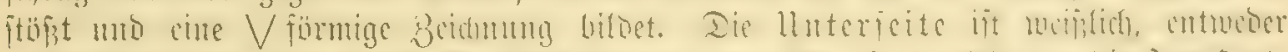

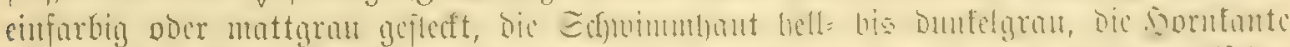

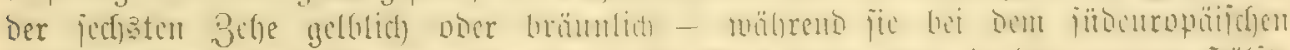

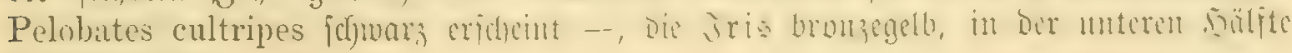
burtel geäbert.

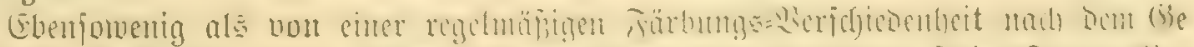

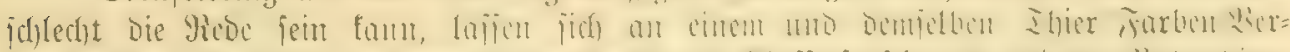

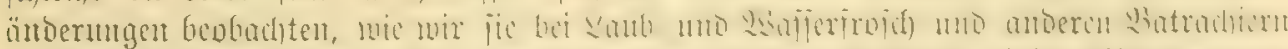

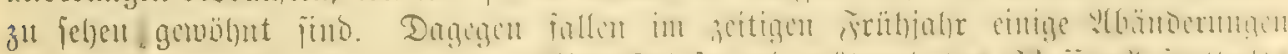

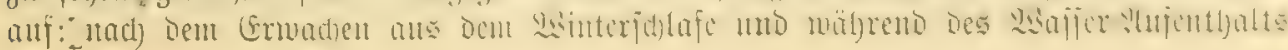




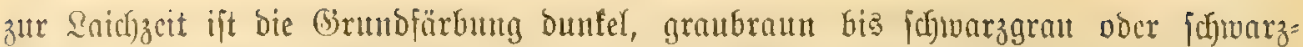

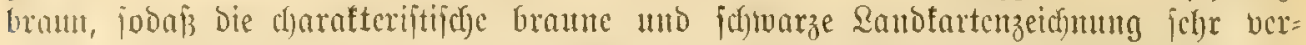

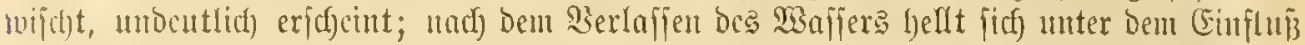

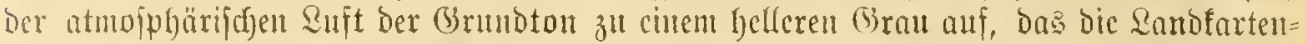

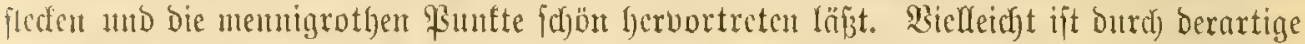

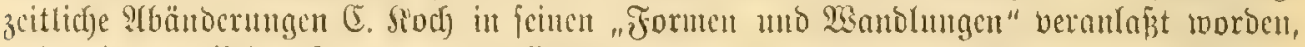

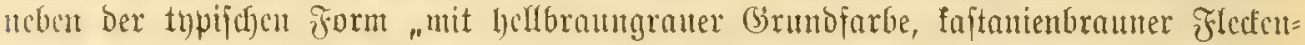

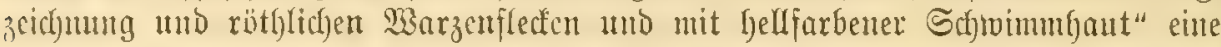

Barictät lividis "mit Dunfel bleigrauer Brutudarhe, Dic beutlich) Blan

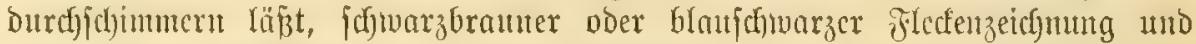

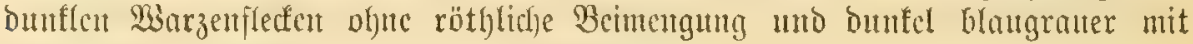

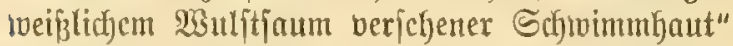

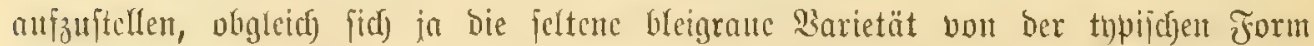

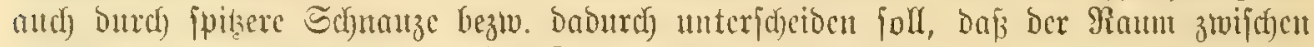

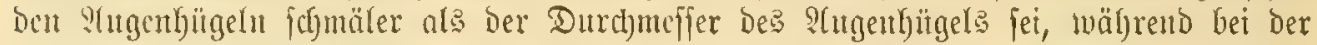

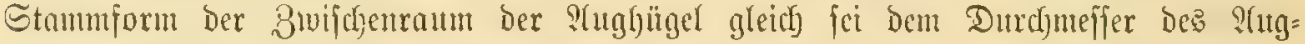

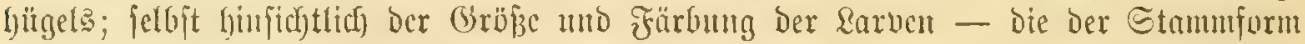

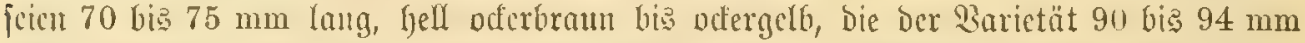

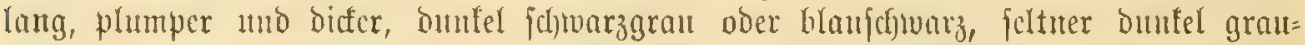

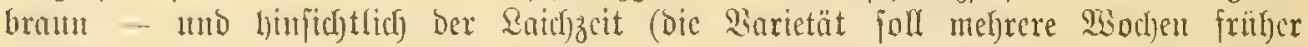

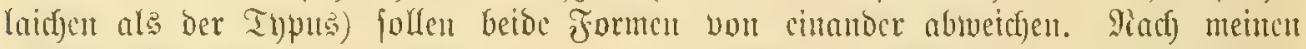

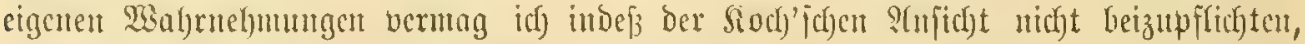

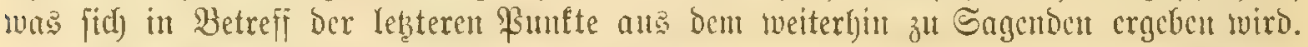

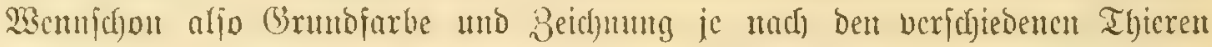

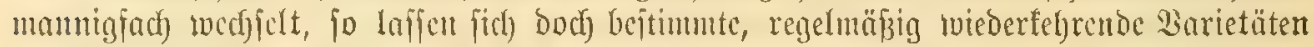

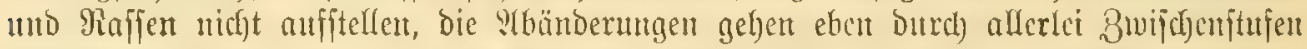

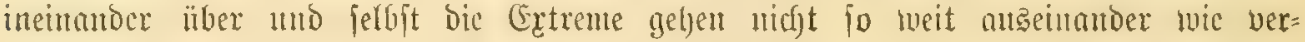
gleid)

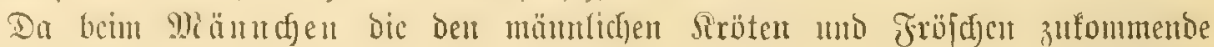

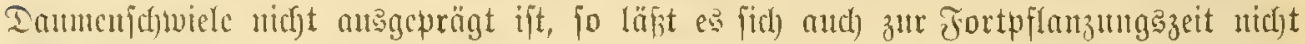

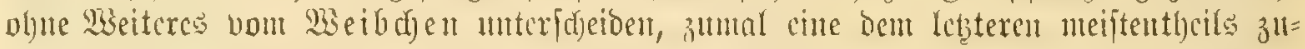

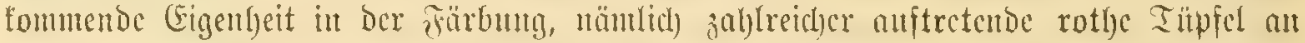

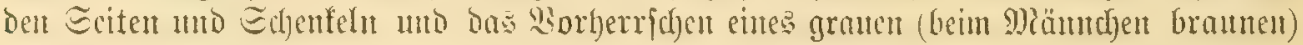

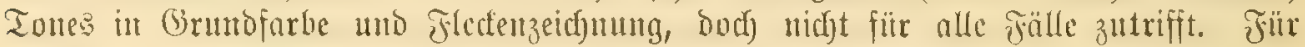
Den Sienter ausfdylaggeheno ift eritens cine zur Begattungazzeit an ber linteren Seitc

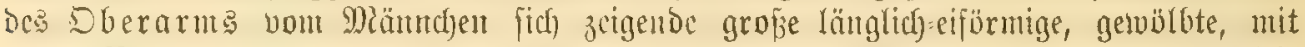

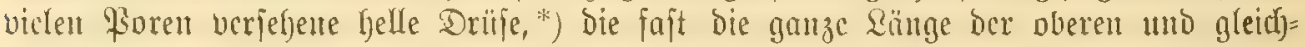

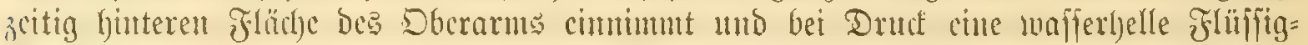

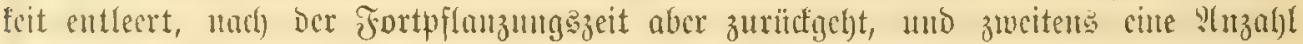

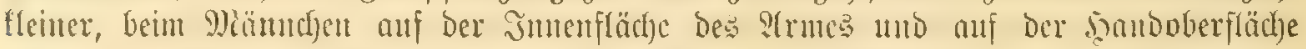

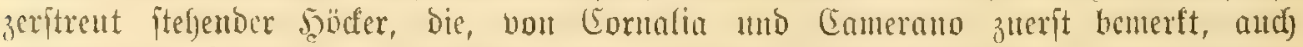

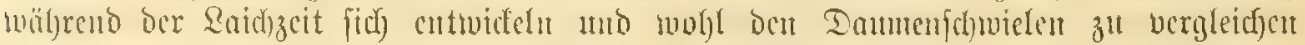

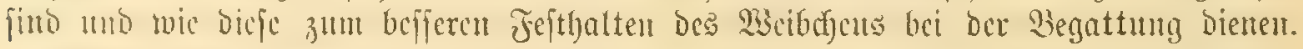

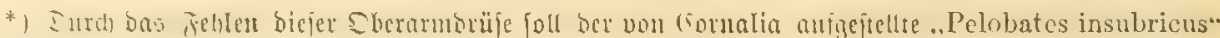

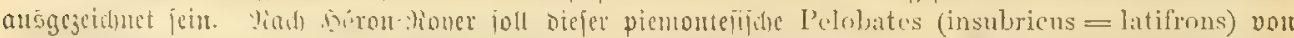

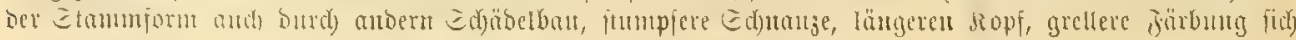

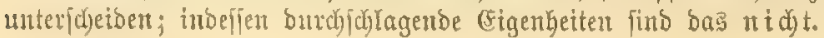




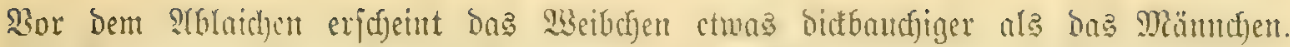

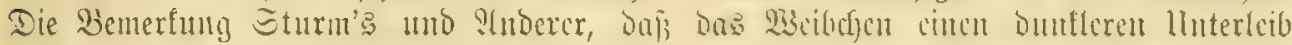
Gabe als bas Mlämucticu, hat nicht allgemeine Bectung.

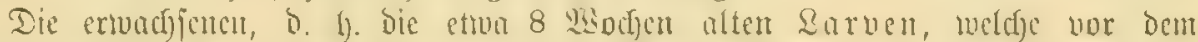

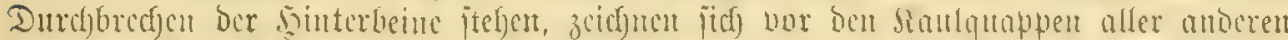

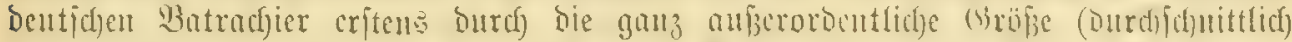

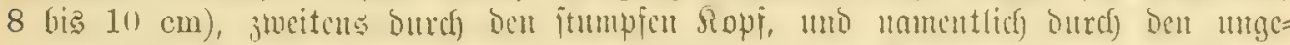

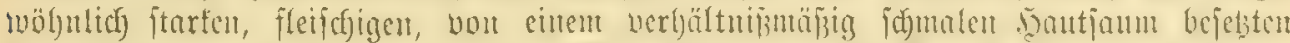

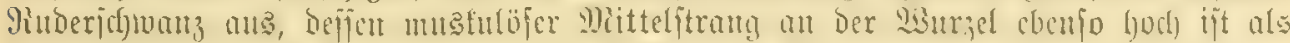

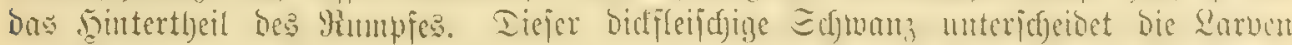

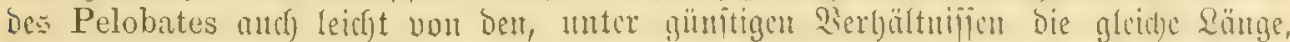

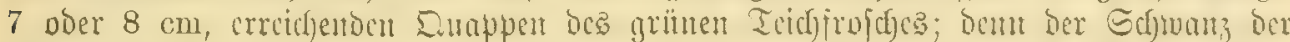

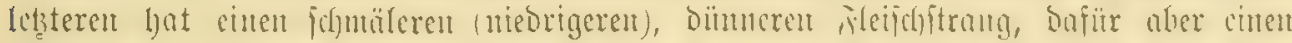

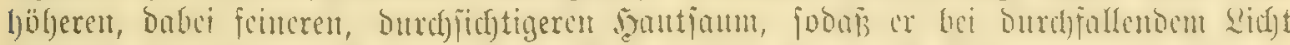

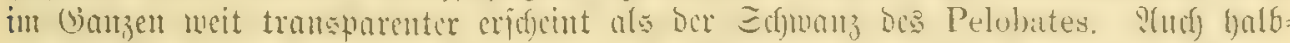

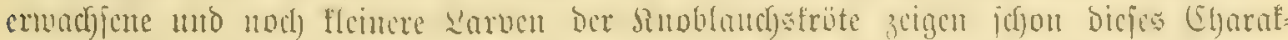

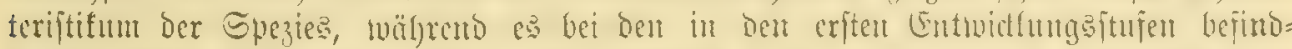

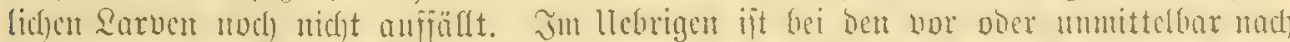

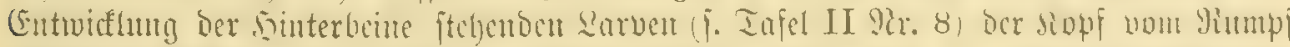

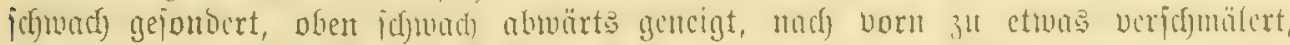

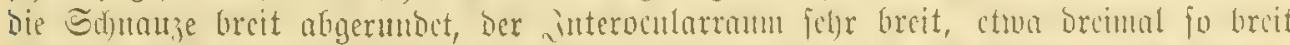

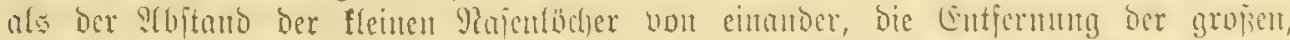

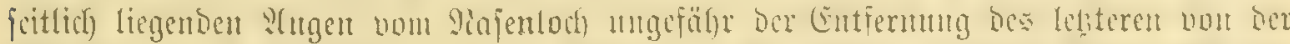

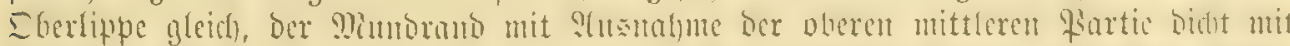

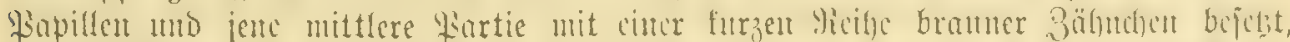

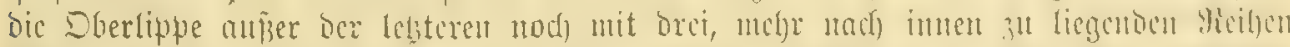

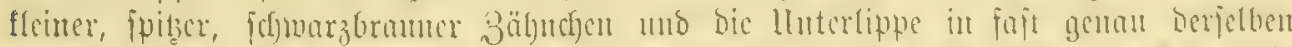

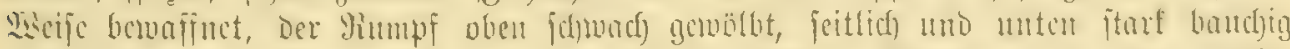

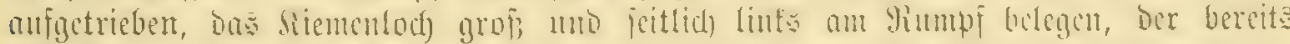

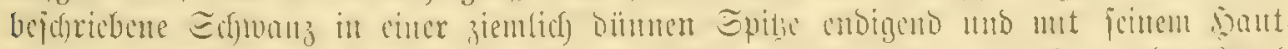

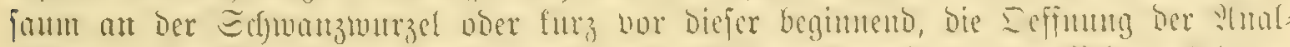

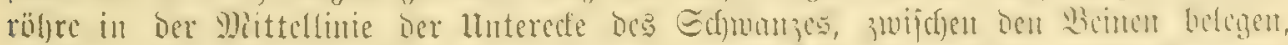

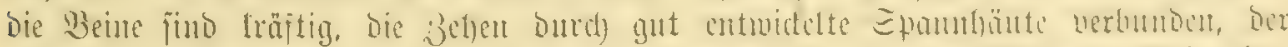

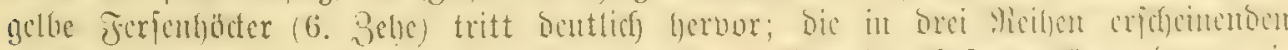

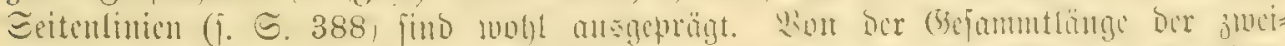

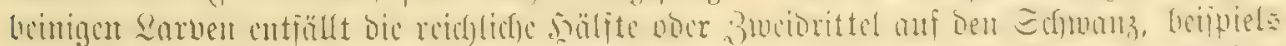

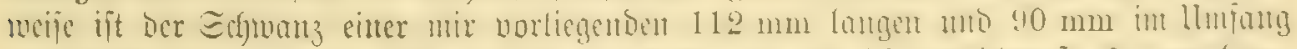

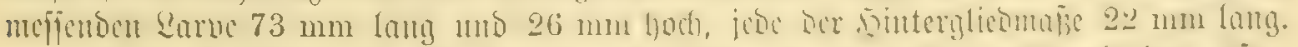

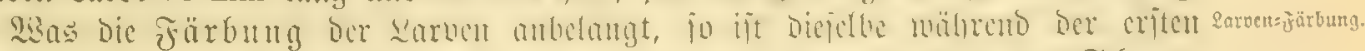

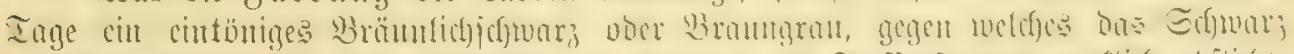

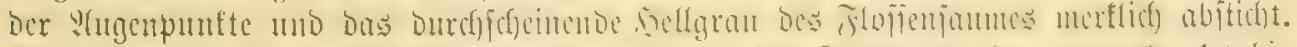

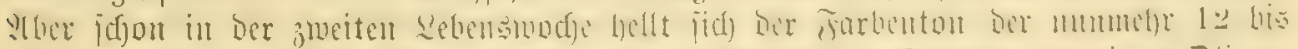

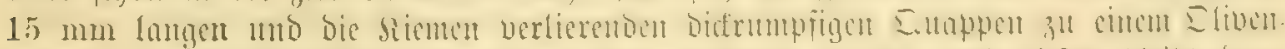

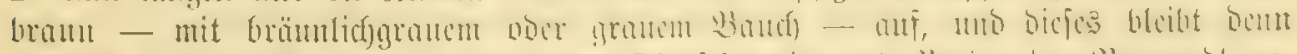

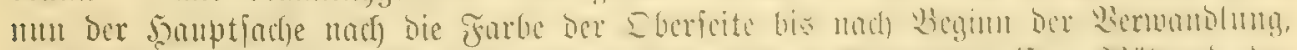

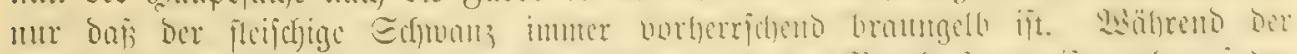

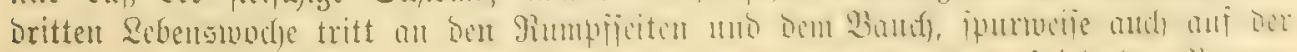

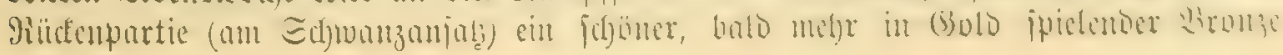




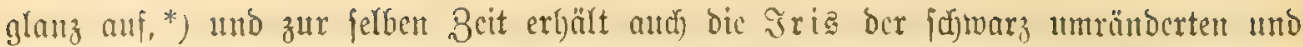
mit fidwarzer (jek̨t roic ein feiner fdjwarjer Rabelitid) fid) atsnef)menter) Bupiffe wer=

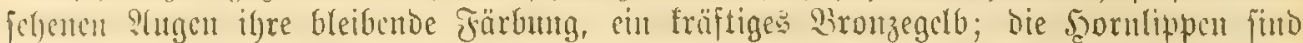

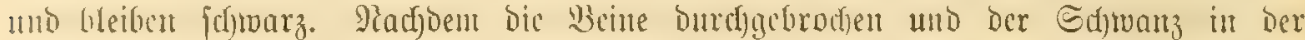

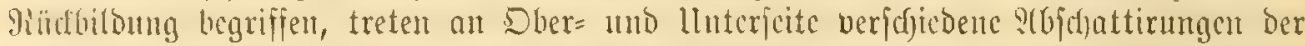
irarbe fdjon merflid) hervor. Die folgenten siotizen, an einer $109 \mathrm{~mm}$ langen, nod)

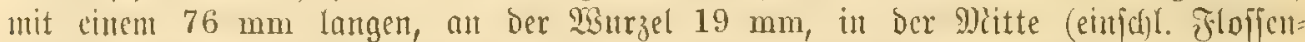

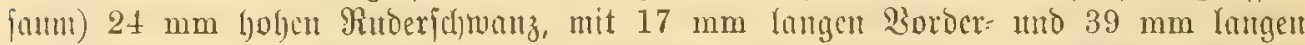

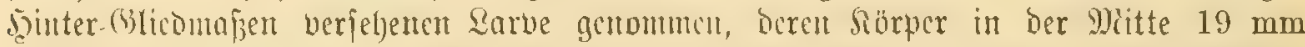

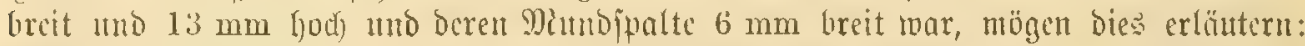

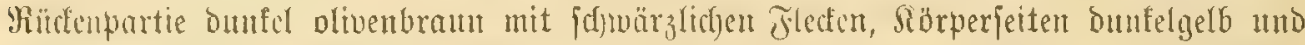

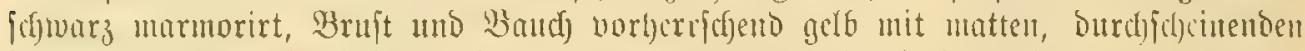

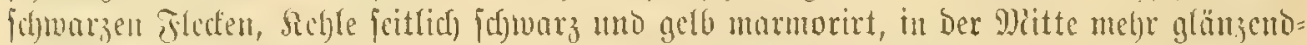

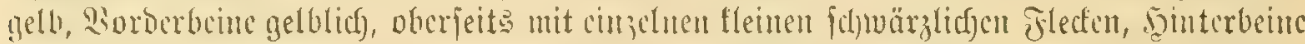

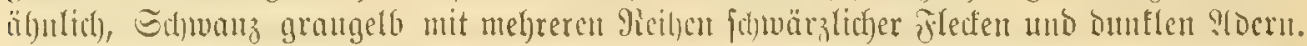

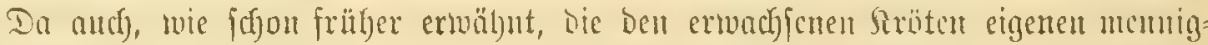

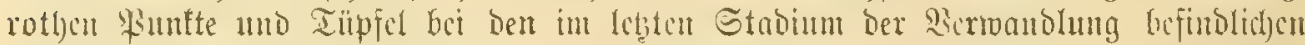

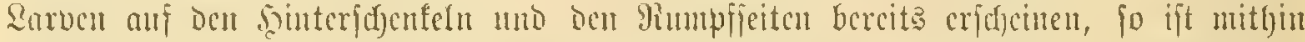

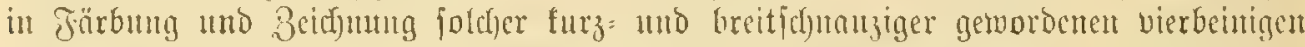

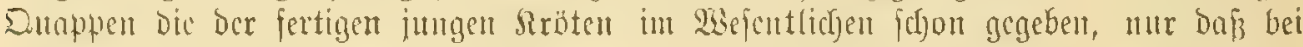

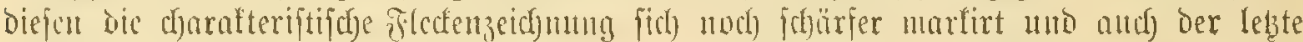

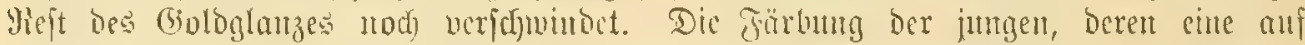
Iafel II abgebildet ift, entfpricht aber wicherum ber ber alten Siröter. Die jungen

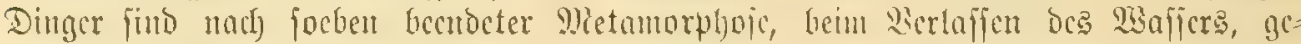

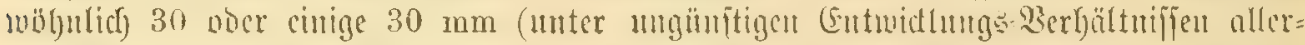

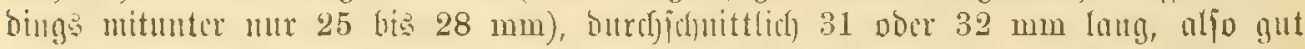

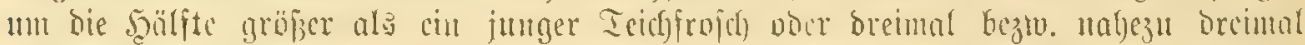

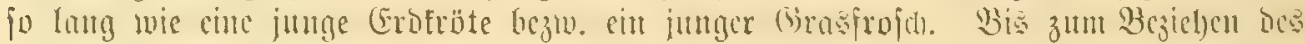

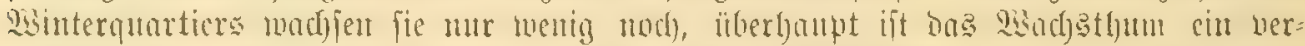

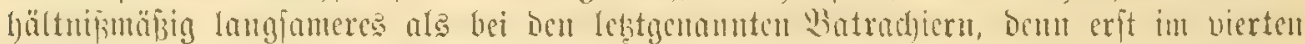

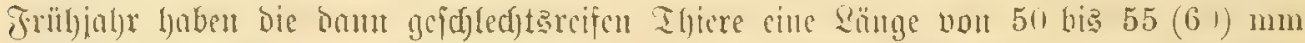

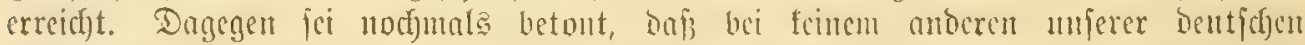

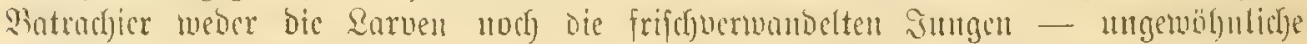

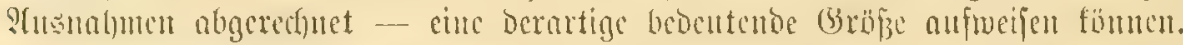

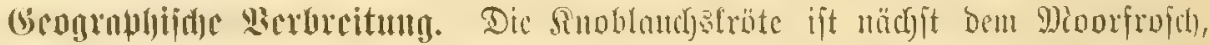

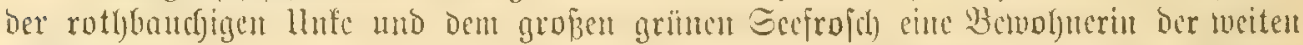

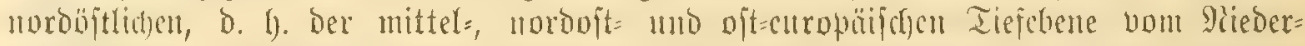

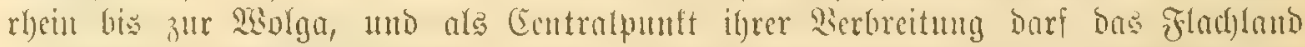

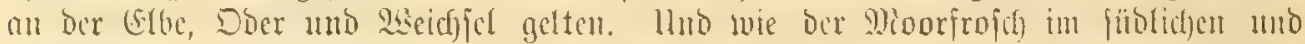

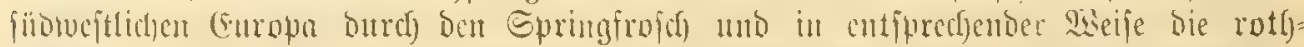

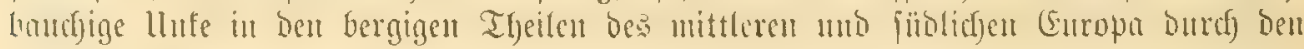

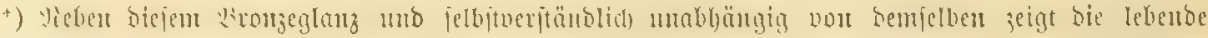

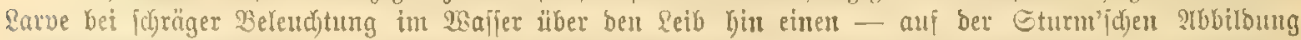

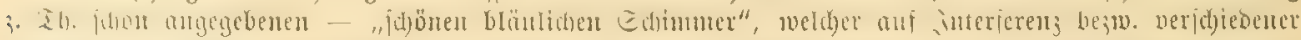

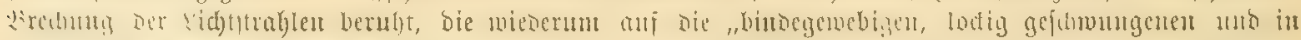

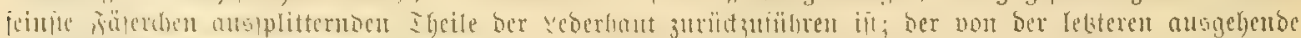

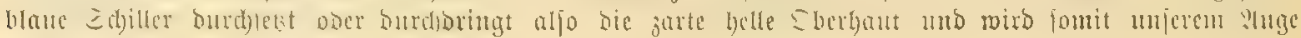
wahnthmbar [vergl. Revbig, 3ool. 2tnzetger 1885, ธ. 753]. 


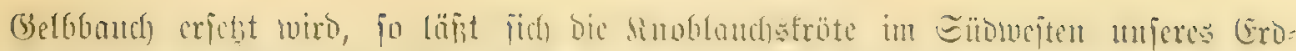

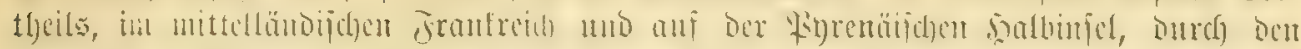

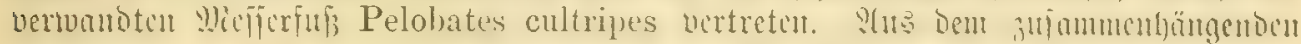

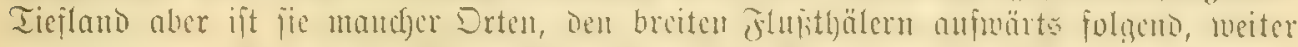

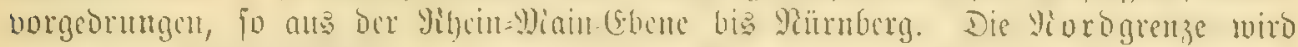

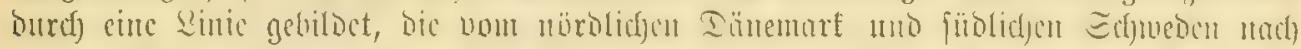

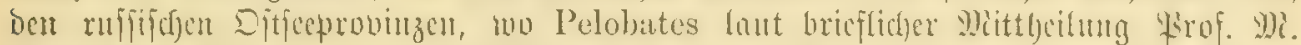

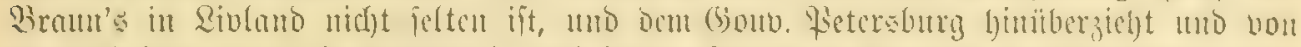

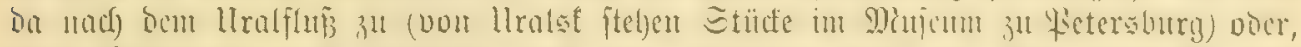

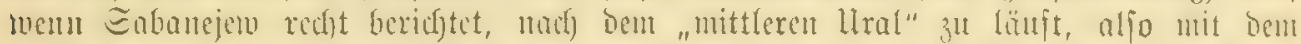

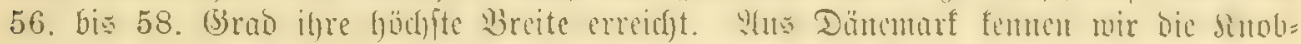

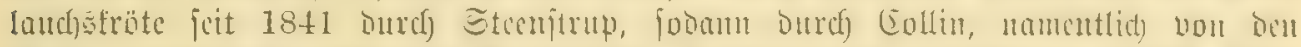

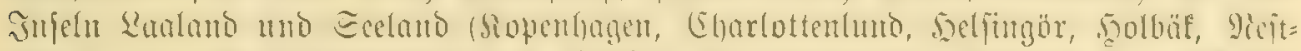

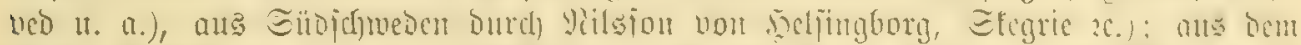

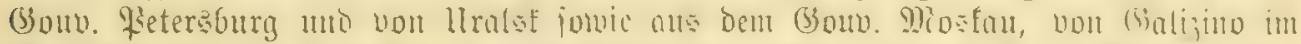

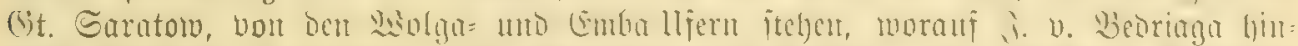

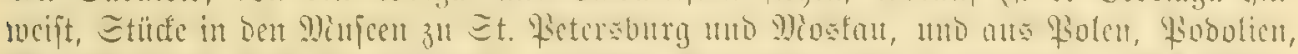

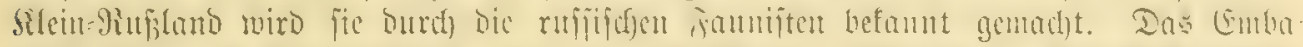

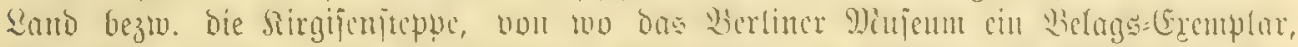

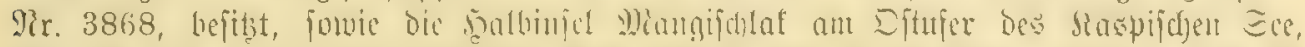

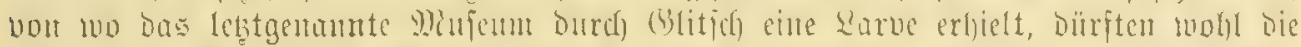

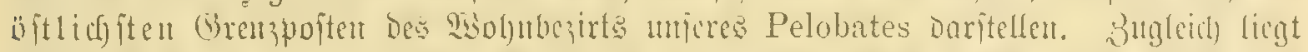

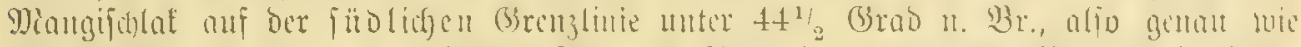

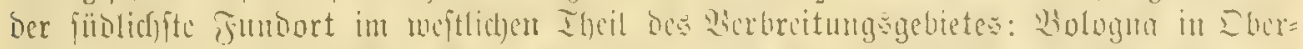

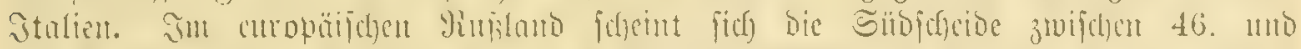

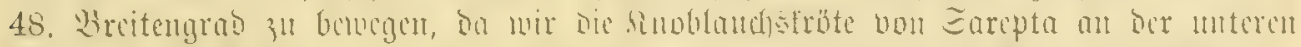

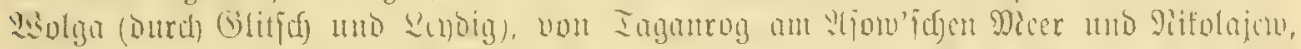

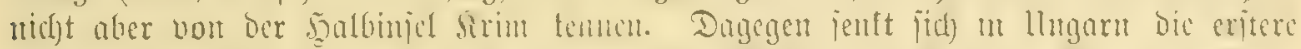

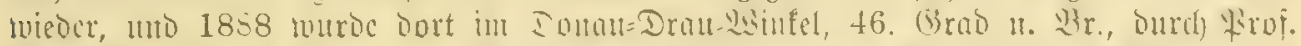

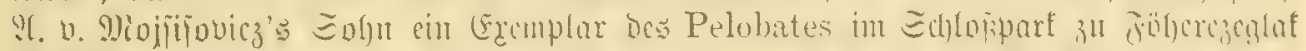

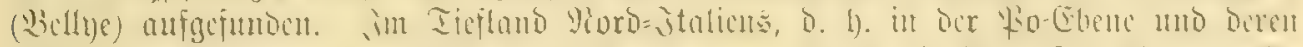

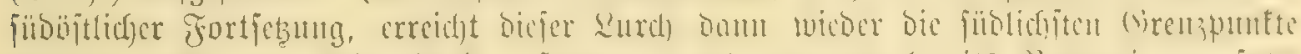

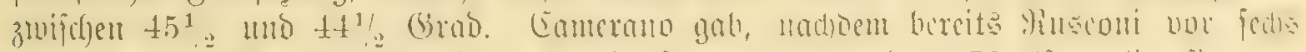

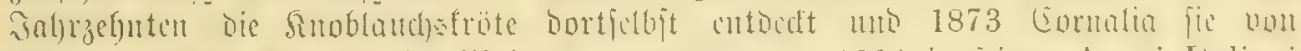
Vonerasco und Whirajole he Whinilano gentunt hatte, 1883 in jement Anuri Italiani folgenoc Funnorte an: ans

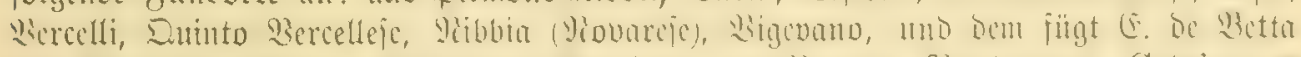

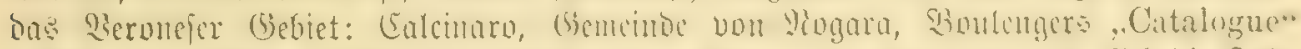

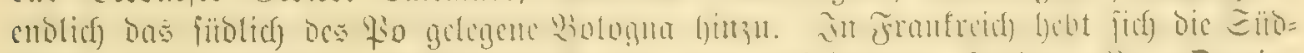

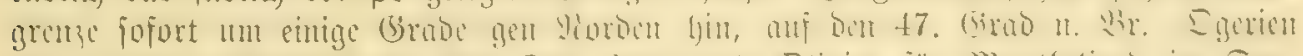
hat mineren Pelobates für Das Dep. Jun mo Elivicr für Mentueliaro im Tep.

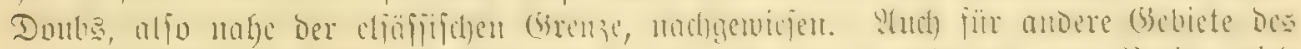

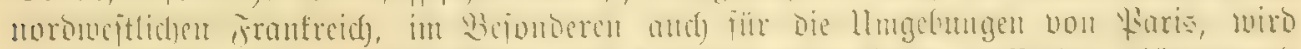

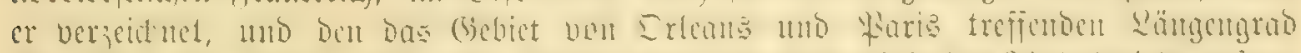

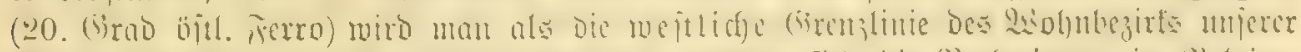

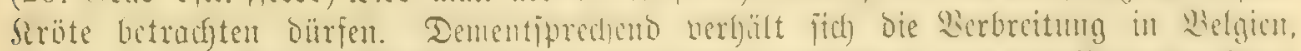
wober mir fic ourd) Sely)

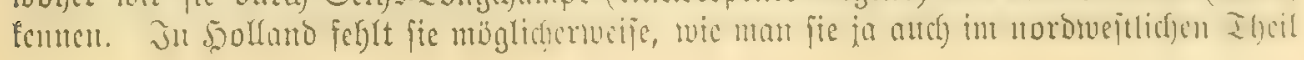




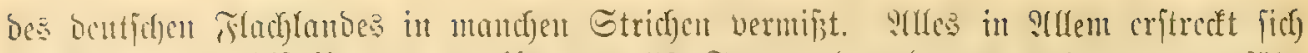

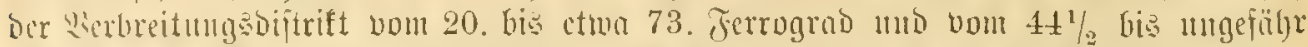
58. (3rad $11.3 \mathrm{r}$. , mithin über viclfcicht $5: 3$ \&ängen= mo 13 bis 14 3reitengrabc.

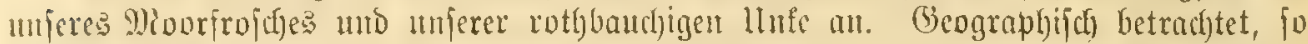

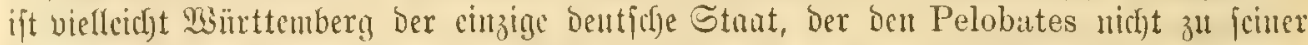

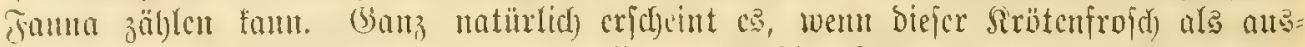

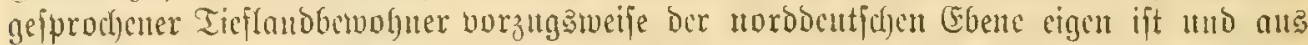

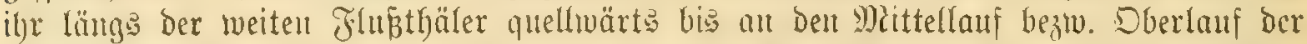

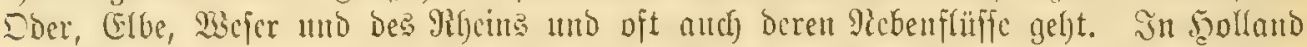
nod) nidjt anjgefunden, ijt fie aud) im Dloentung'idjen bis jebet crit cumal, in der Pläfe von Jever, und ztwar als Sianlquappe, Dic Der Sammlung Des (Grofil). Wiufeum in Dloenburg einverleibt worben, bou Dr. (Grebe gejammelt. Thut) aus

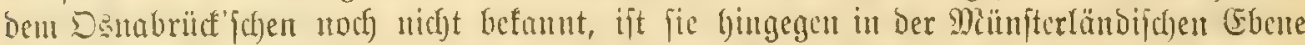

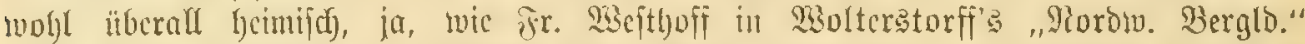

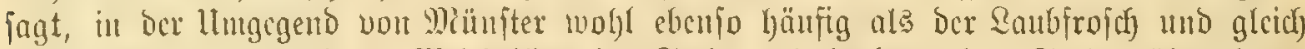

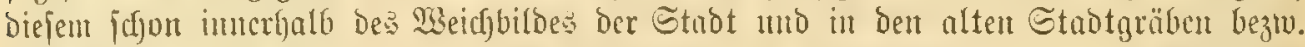

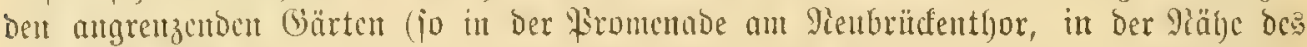

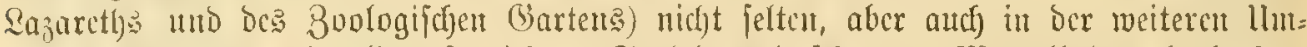
gebung Whiunters iiberall auf leidjtem Sentel= mid fidwerem Miergelboden beubachtet

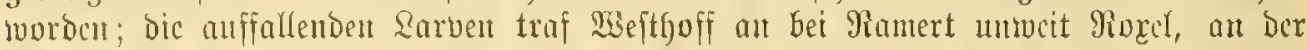
Gisuenteder Sifule, auf Dor Sibrbnibe im Graben ber Ricbesimpel, einem alten Guten= fang (116 mm lange Stïcle), het stngelmobde nörolid) vom Dorfe und in Sinnat

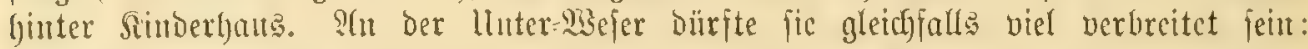

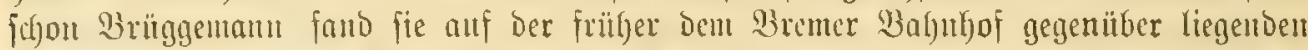

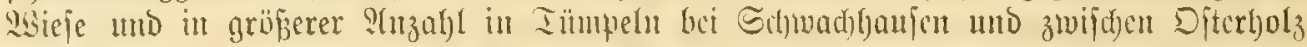

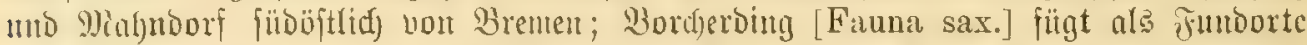

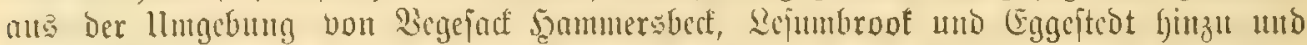

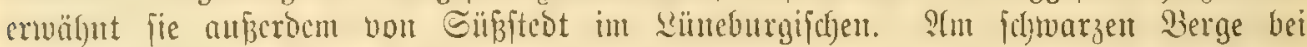

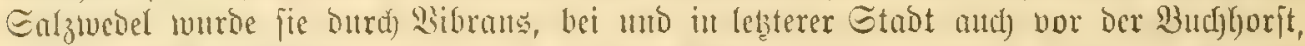

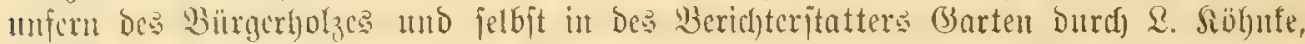

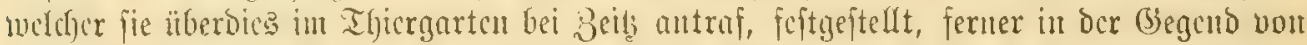

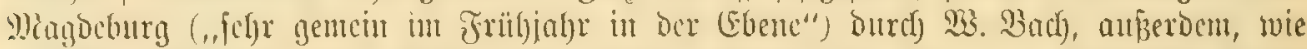

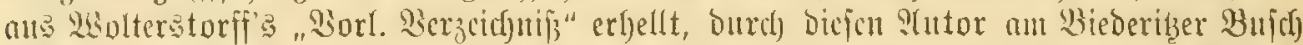

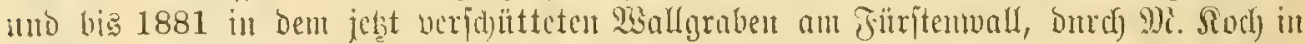

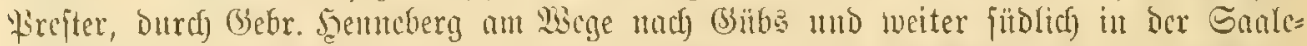

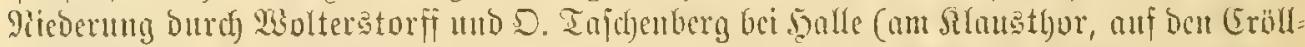

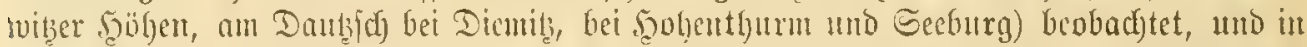

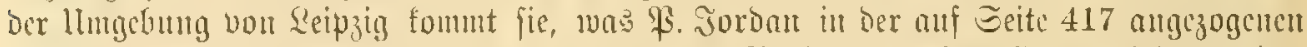

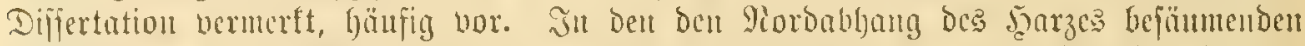

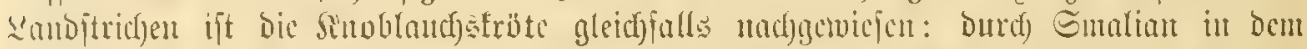

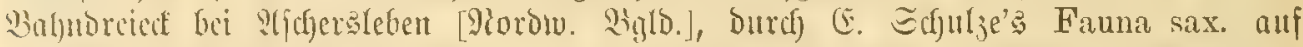

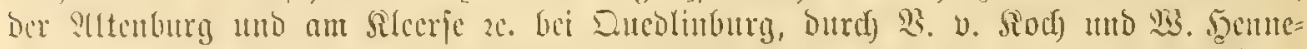

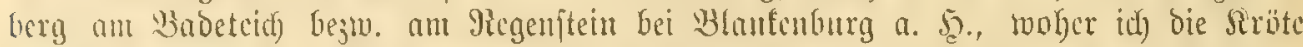

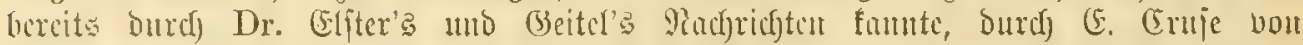

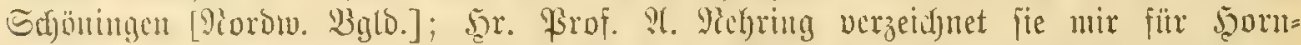

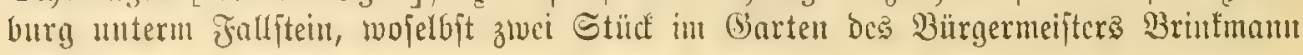




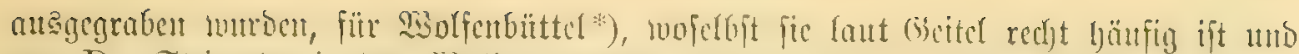

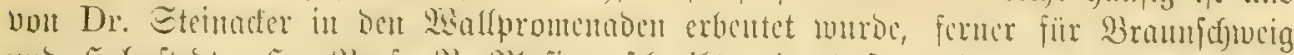

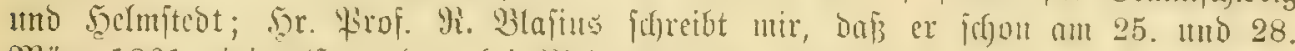

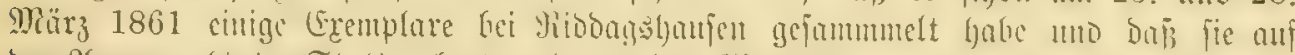

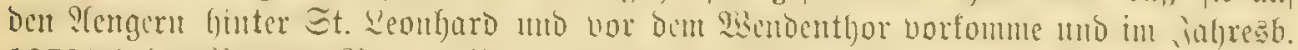

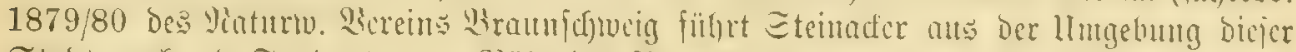

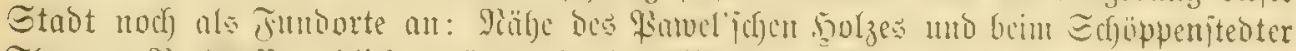

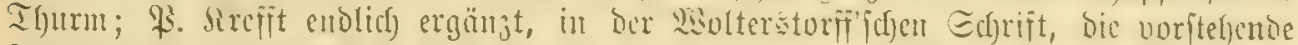

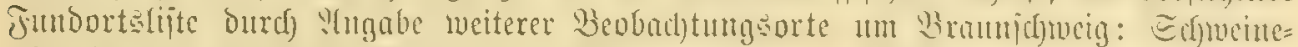

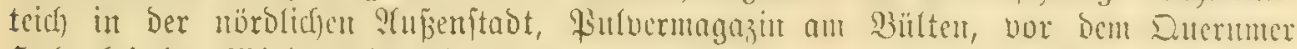

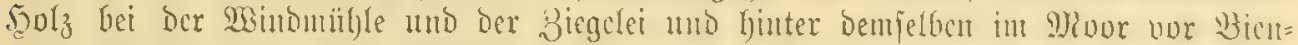

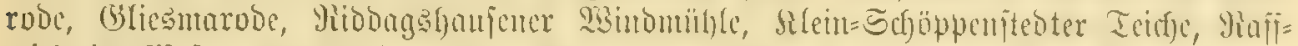

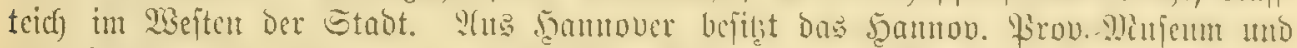
laut Boulenger's Catalogne Das Britifche Diufeum einge Etüde.

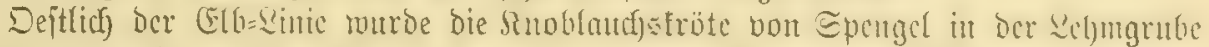

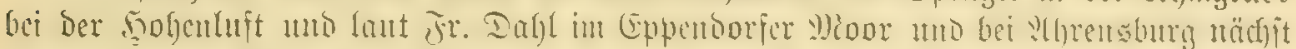

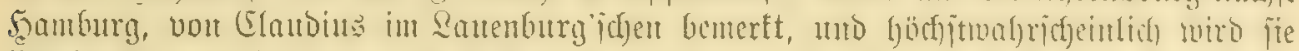

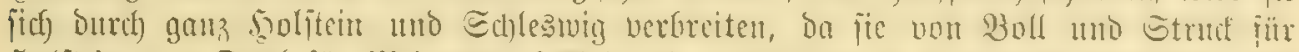

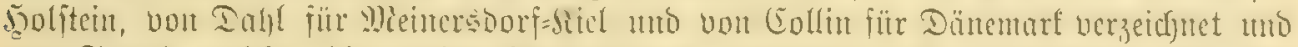

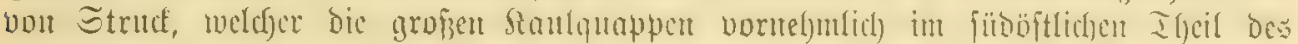

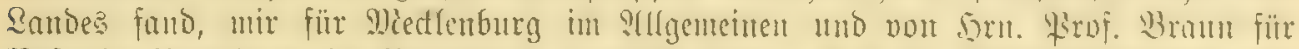

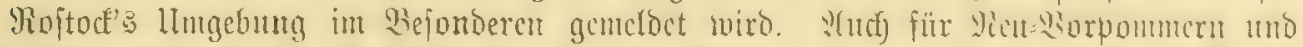

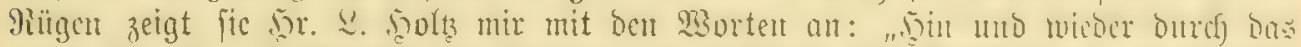

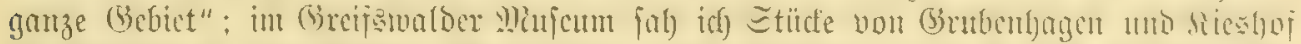

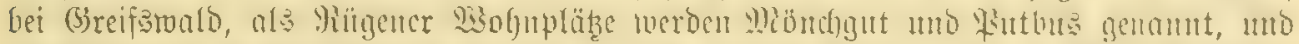

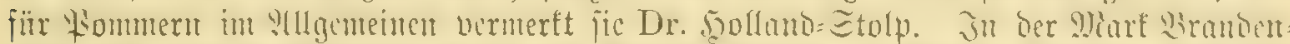

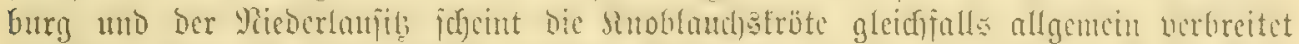

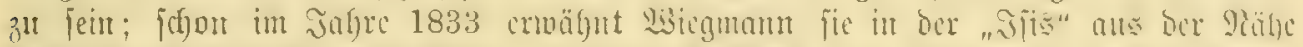

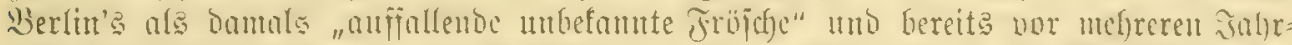

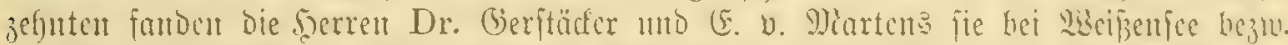

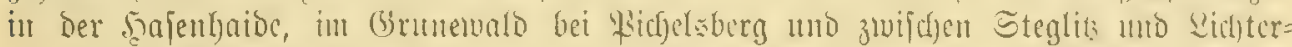

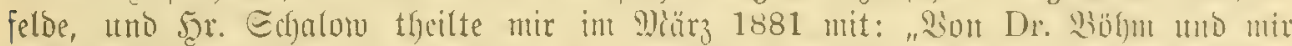

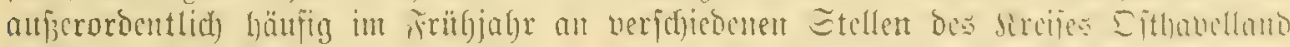

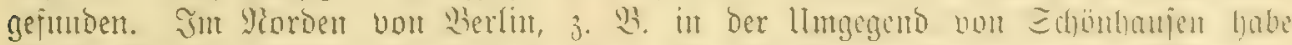

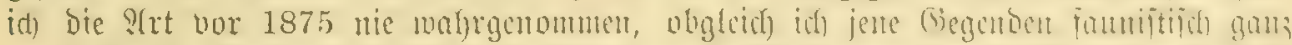

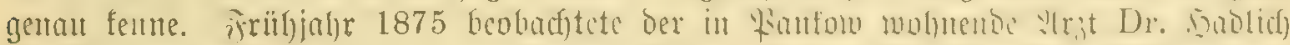

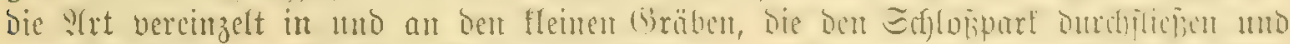

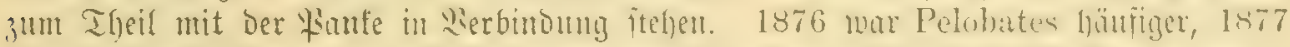

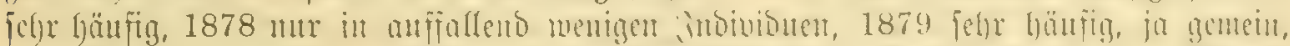

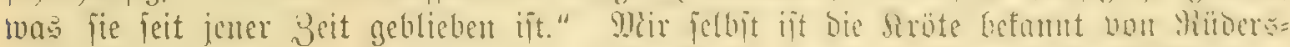

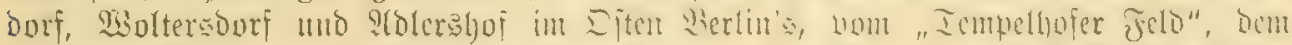

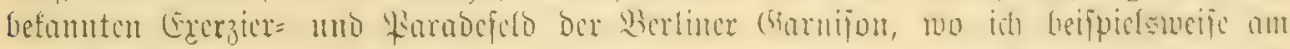

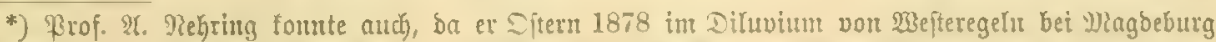

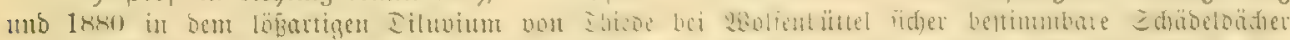

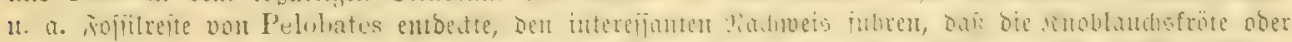

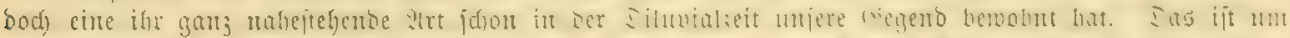

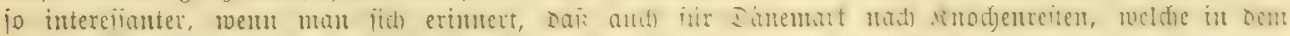

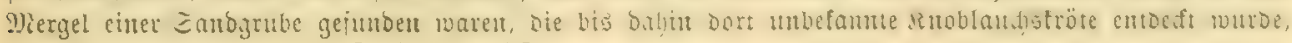

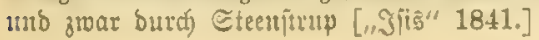




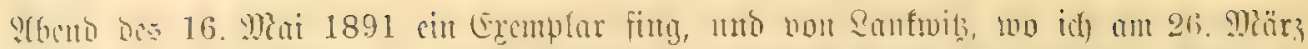

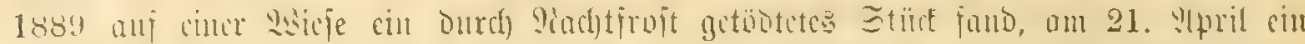

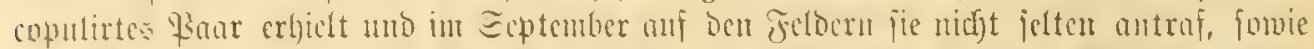

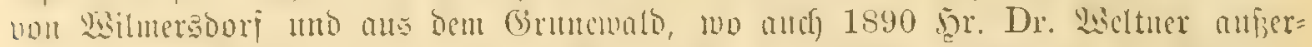

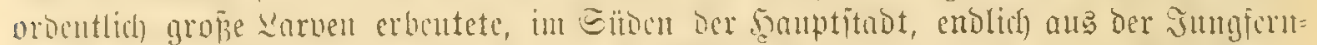

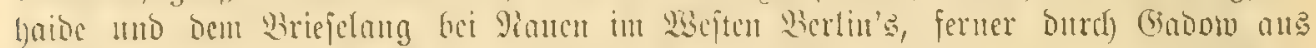

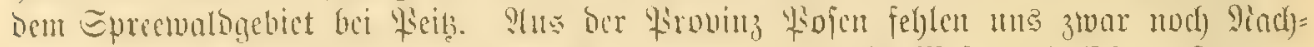

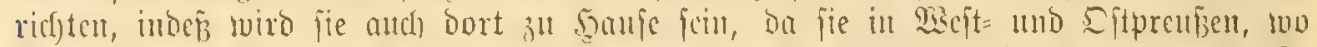

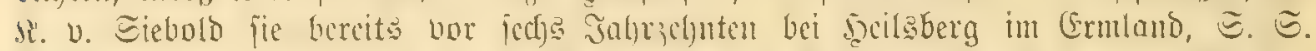

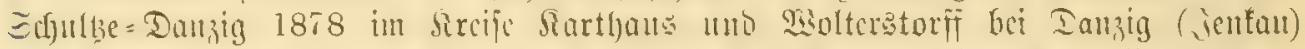

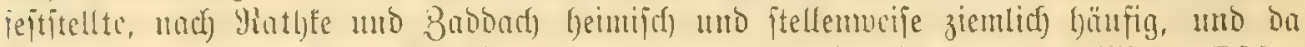

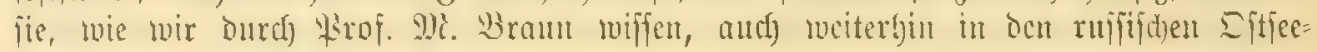
Provinzen "niclit filten" ift.

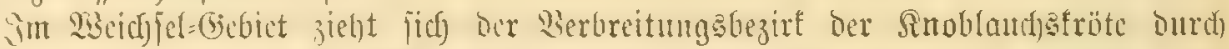

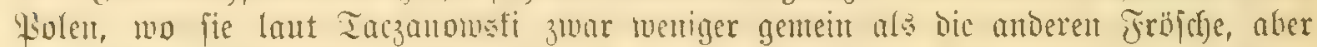

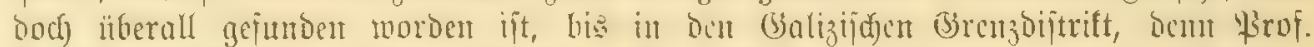

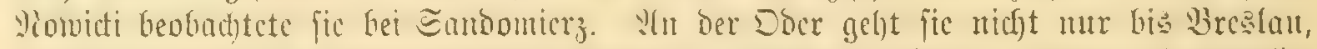

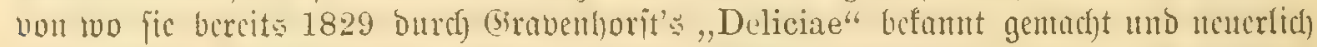

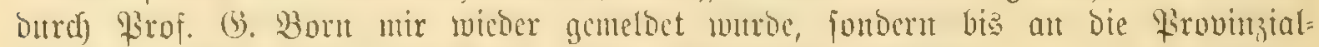
grenze - menigftenz gicbt Saluza 1815 als Funtoort Matrbor an - Int aud in

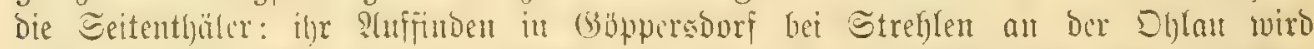

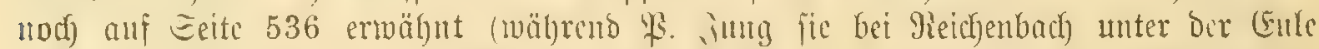

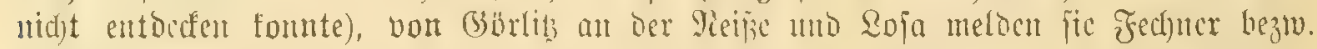

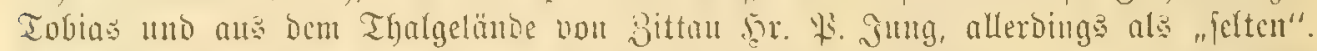

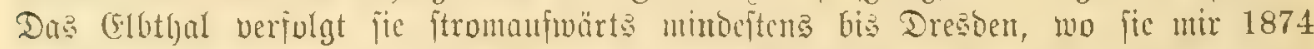

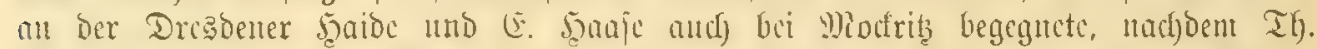

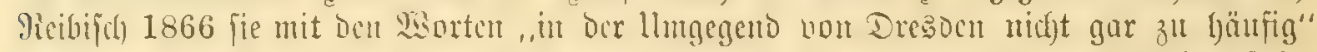

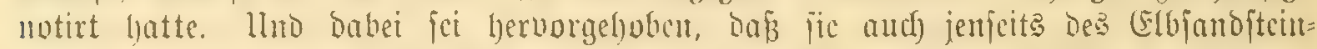

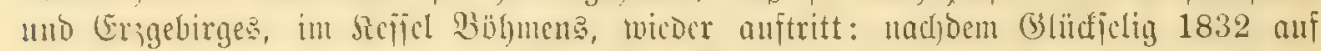

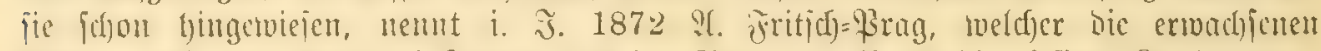

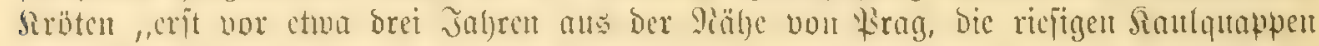

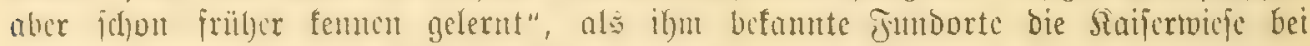

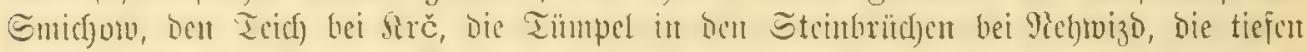

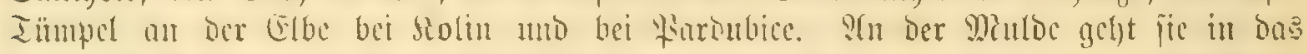

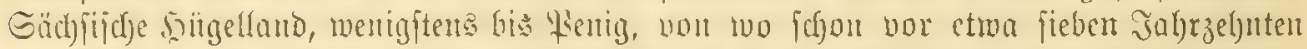
3)

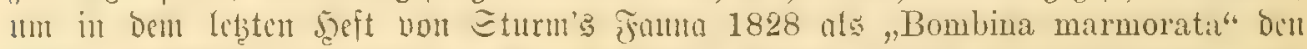

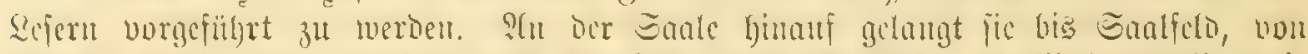

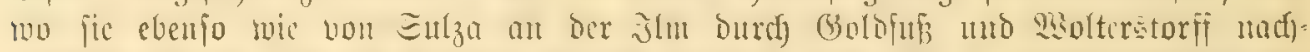

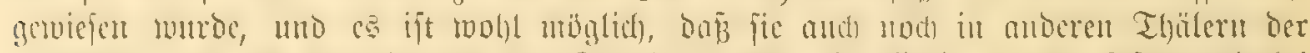

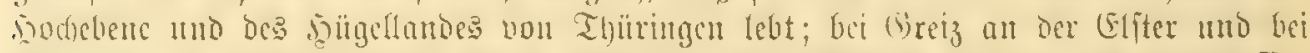

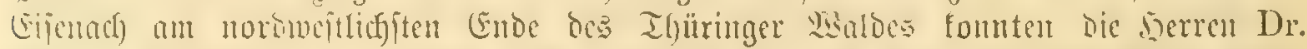

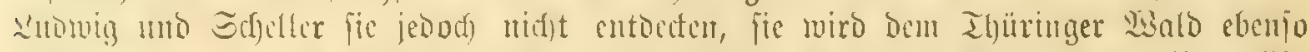

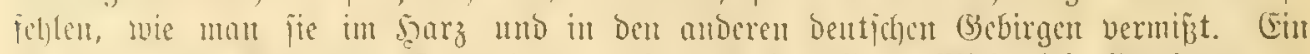

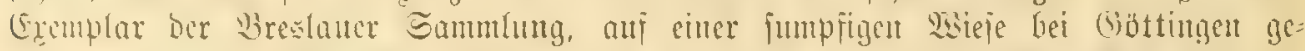

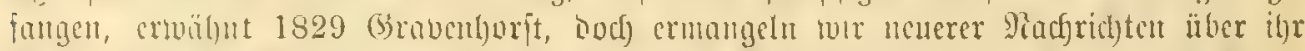

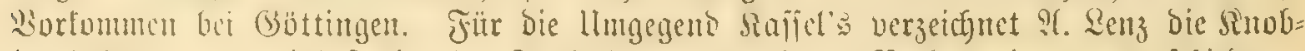

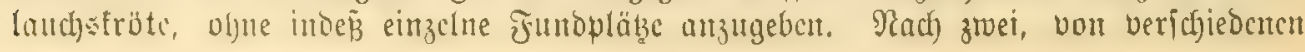




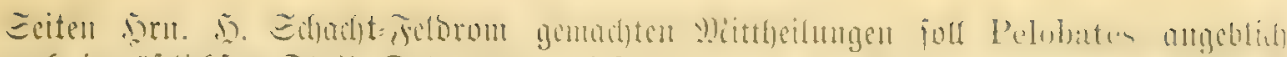

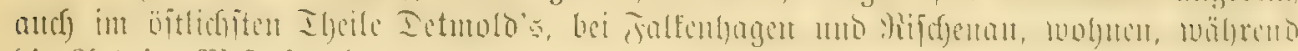

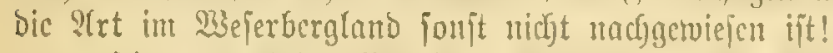

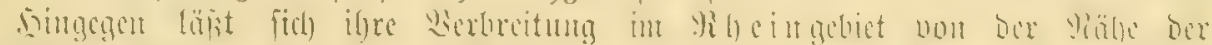

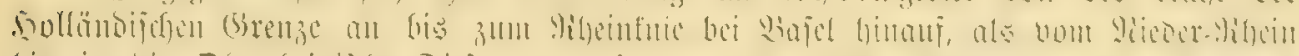

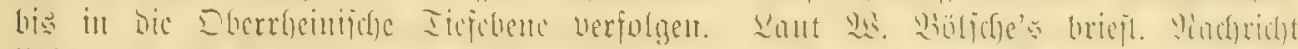

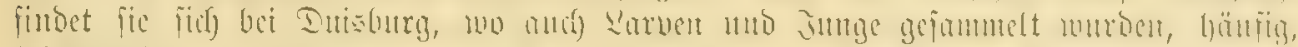

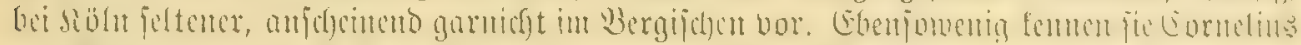

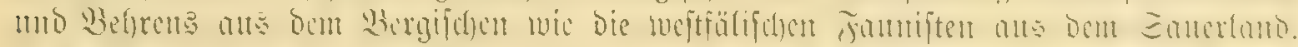

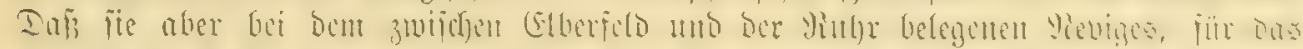

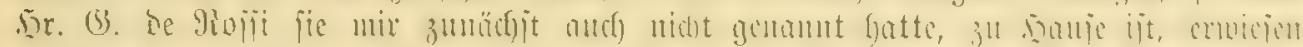

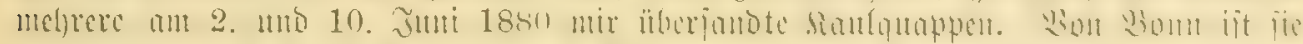

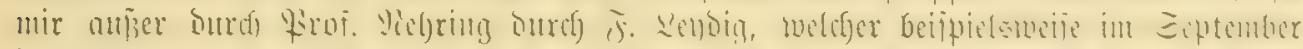

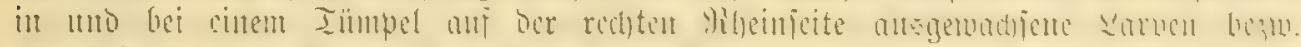

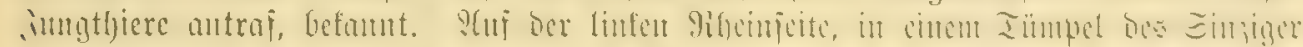

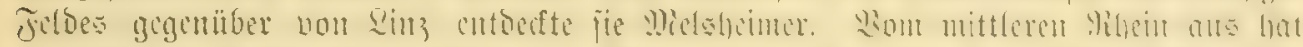

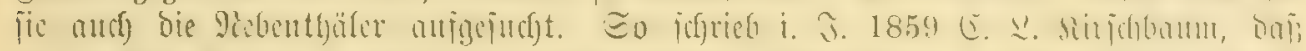

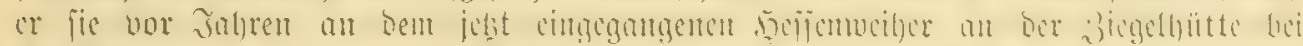

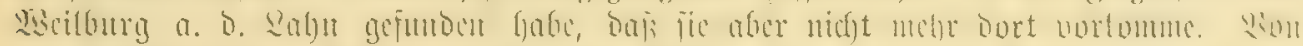

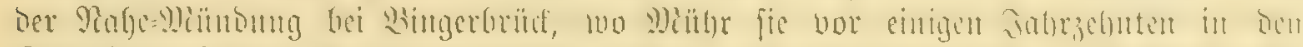

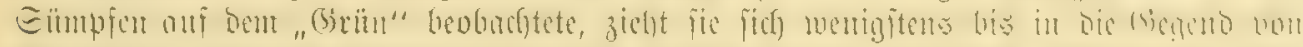

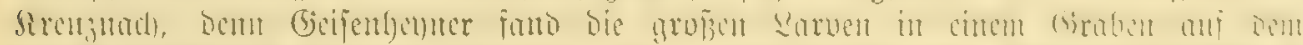

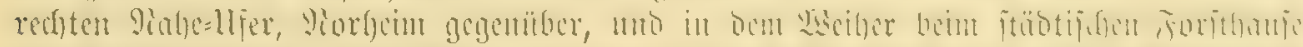

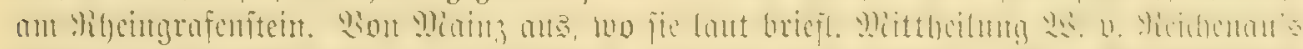

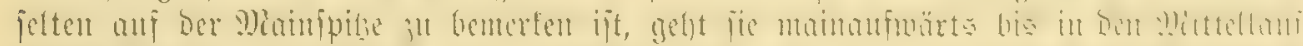

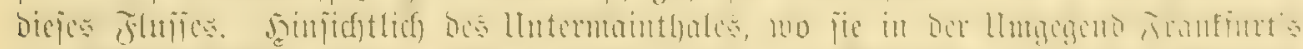

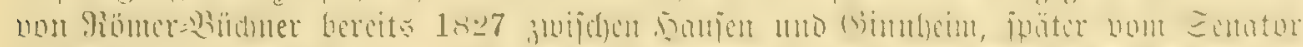

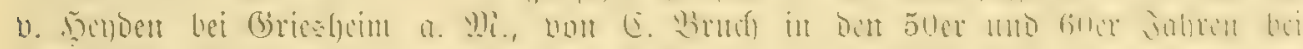

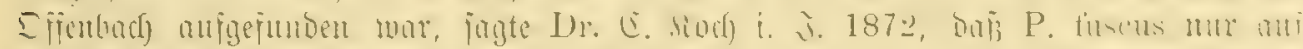

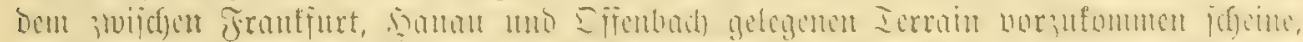

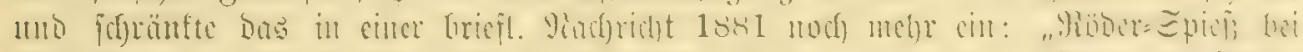

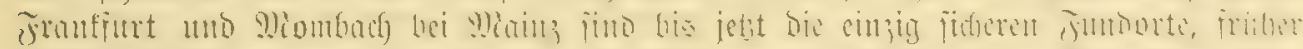

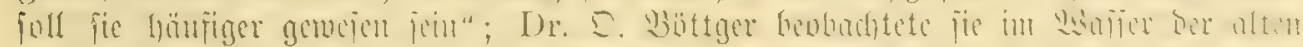

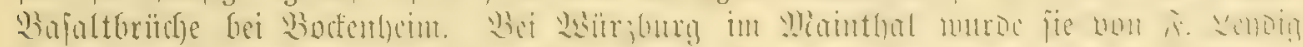

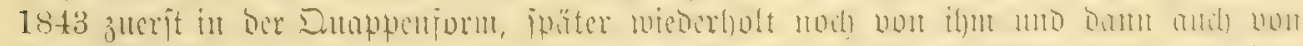

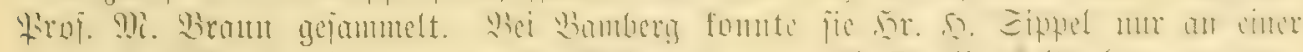

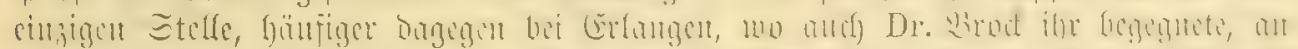

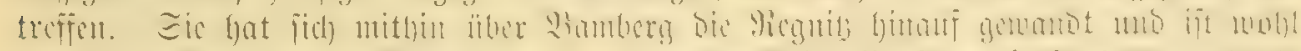

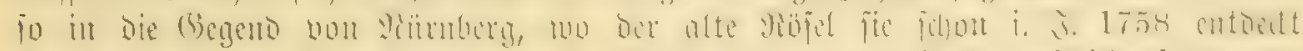

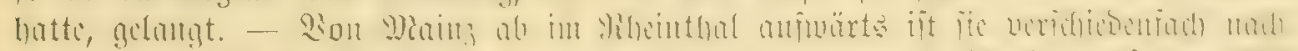

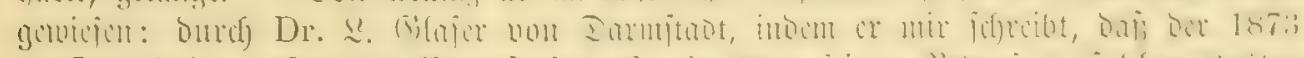

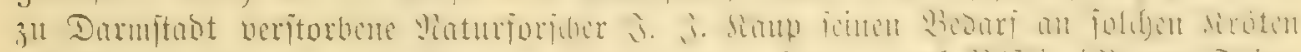

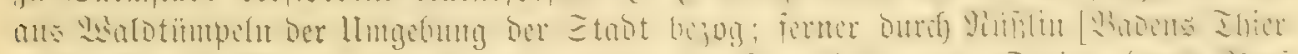

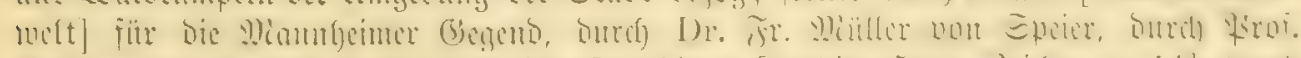

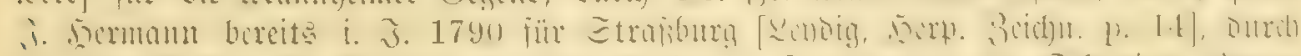

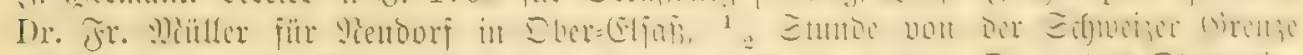

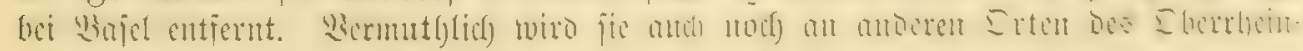
tgales aufgefunden tuerben. 


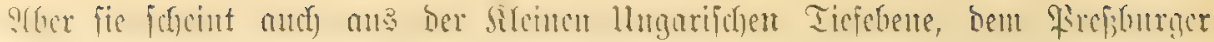

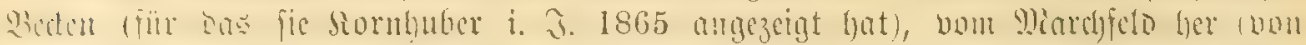

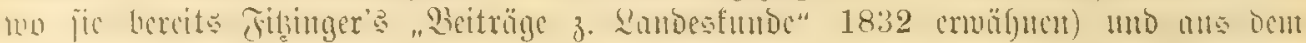

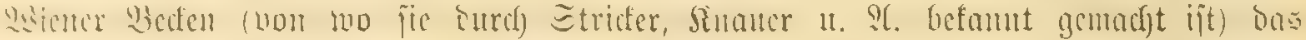

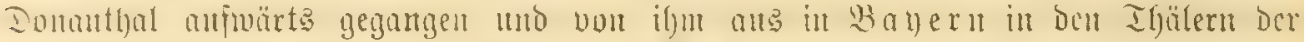

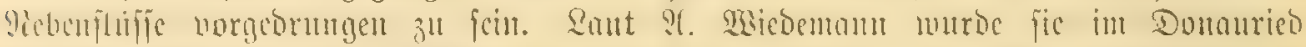

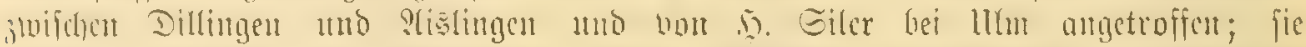

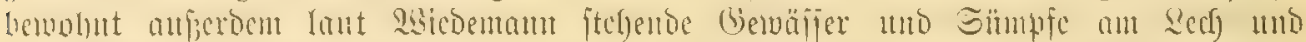

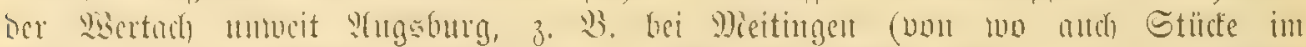

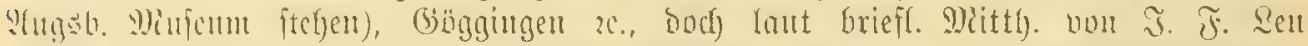

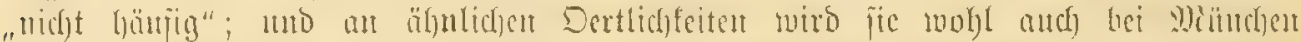

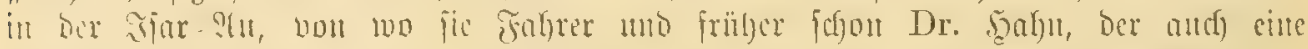

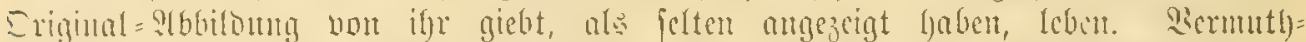

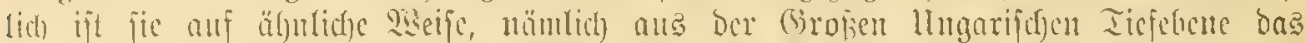

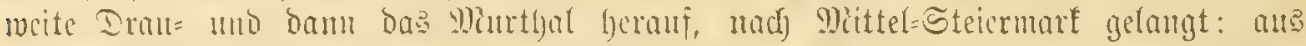

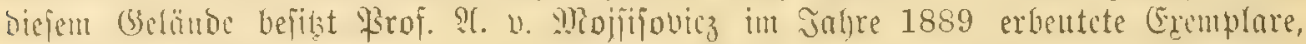

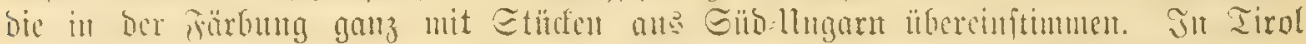

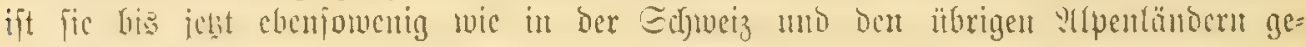
funden morden.

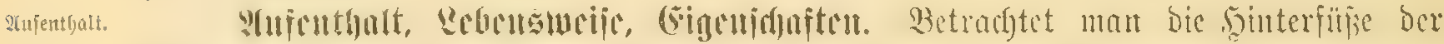

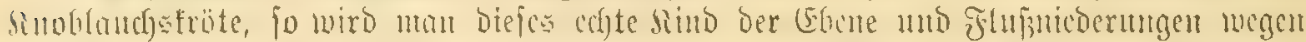

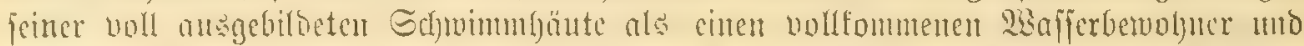

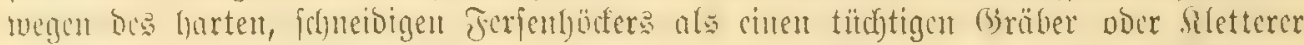

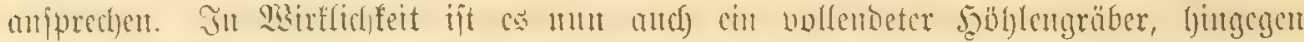

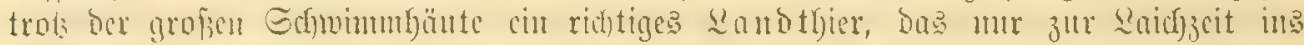

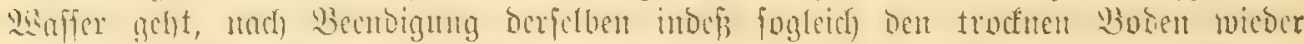

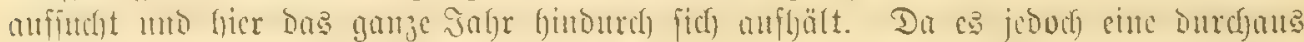

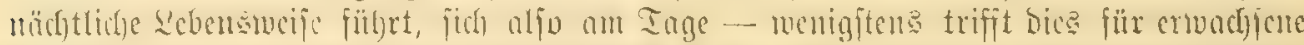

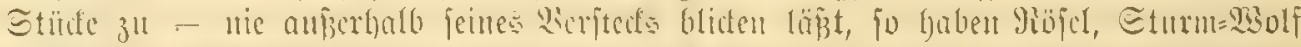

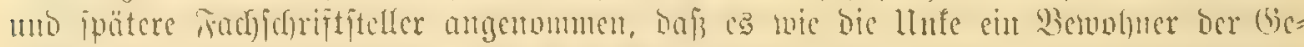

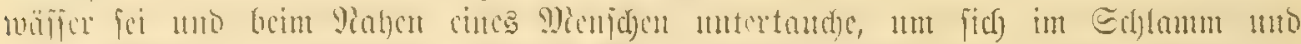

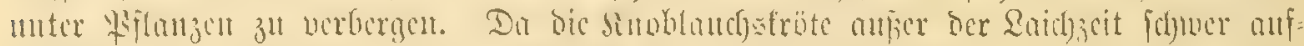

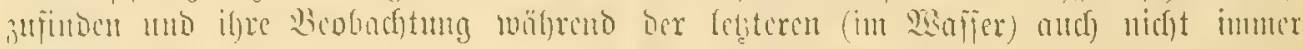

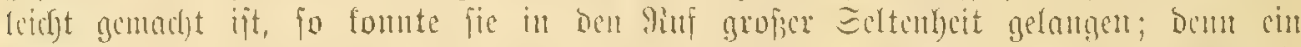

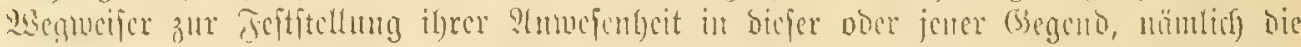

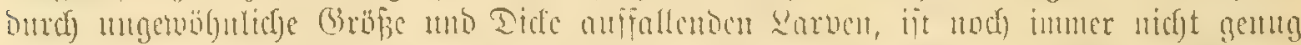

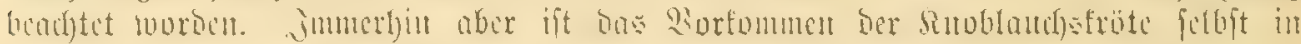

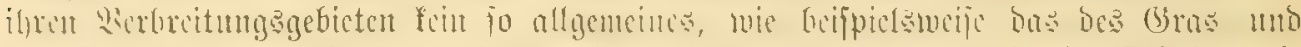

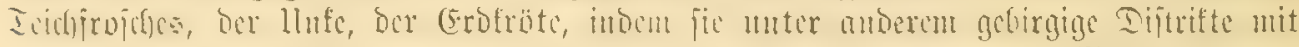

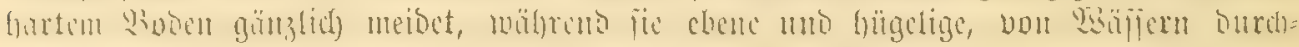

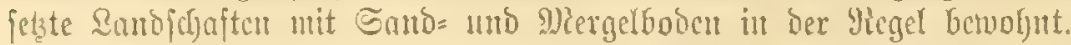

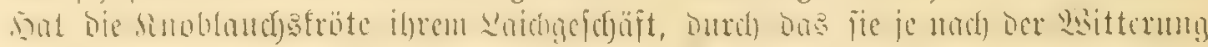

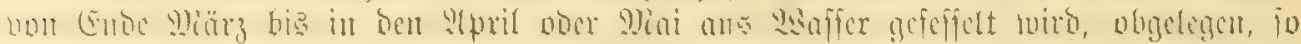

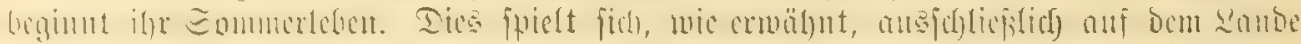

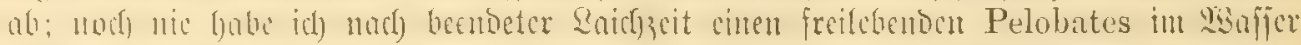

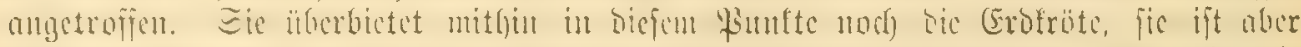

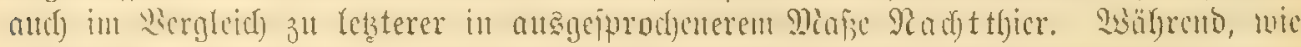

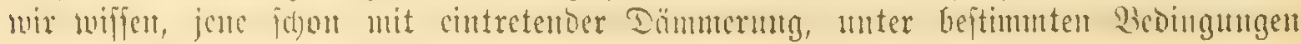




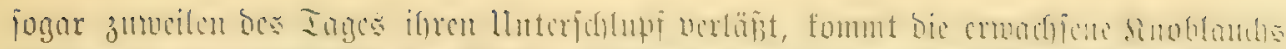

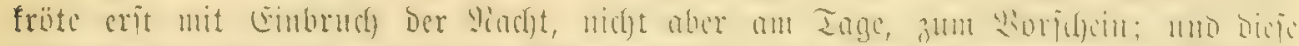

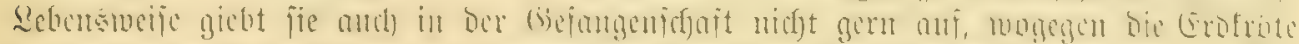

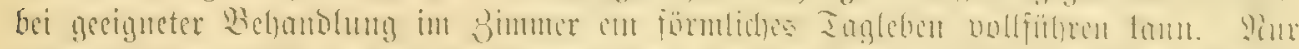

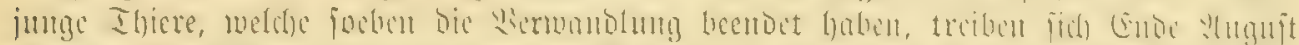

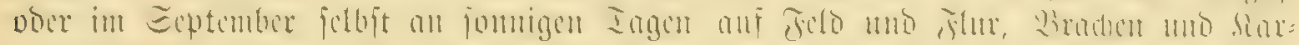

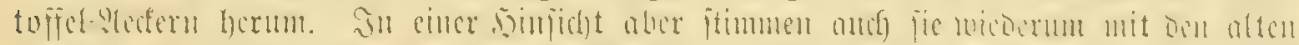

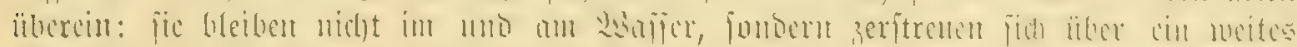

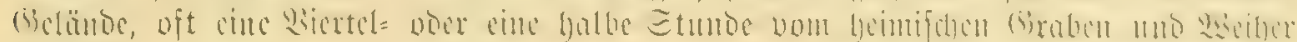
cuticrut.

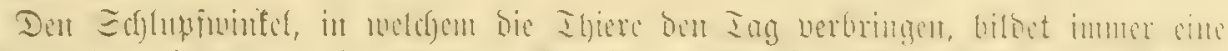

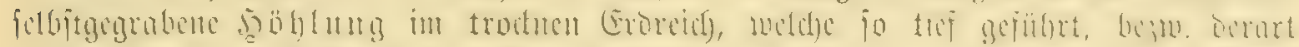

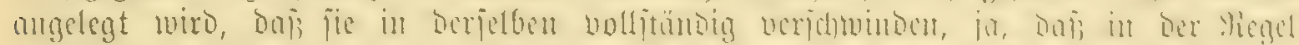

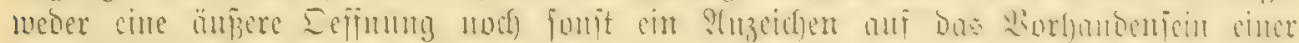

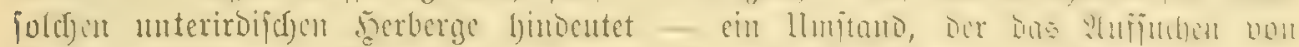

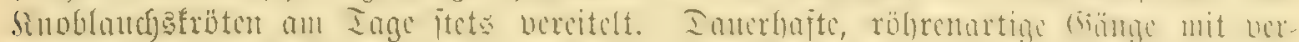

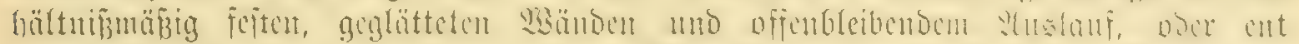

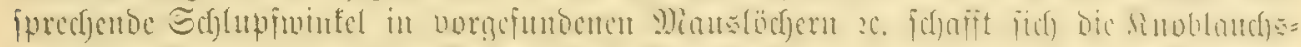

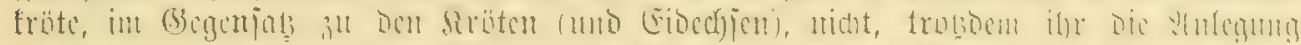

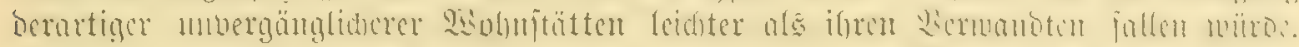

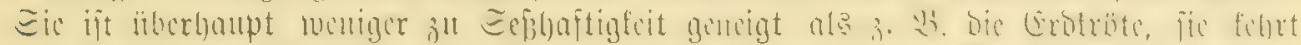

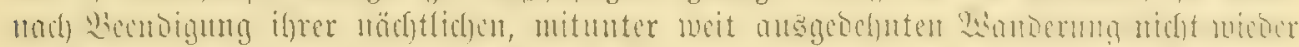

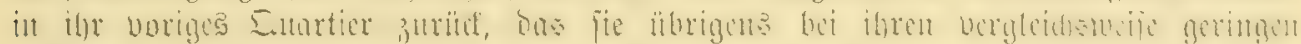

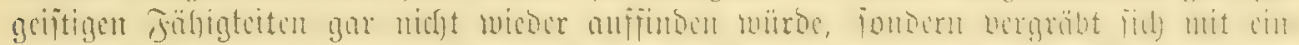

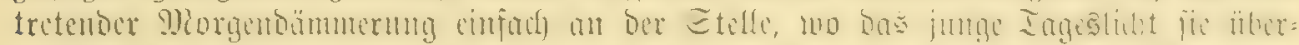

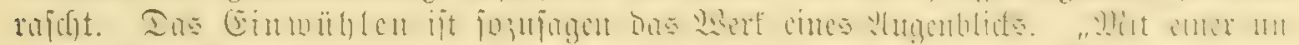

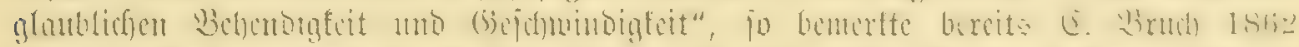

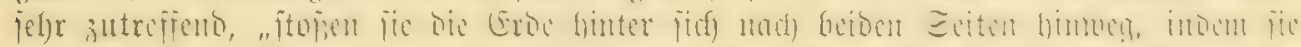

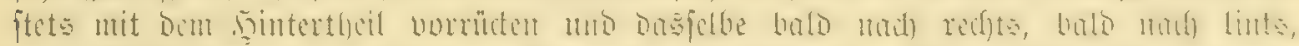

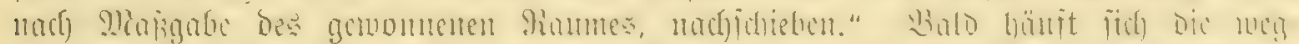

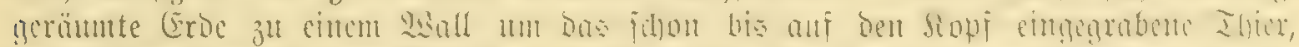

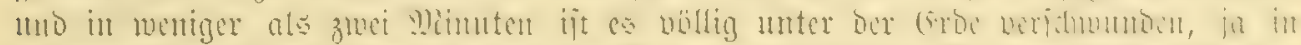

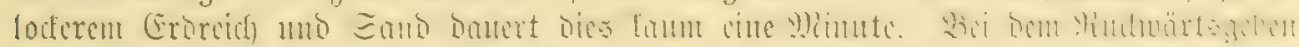

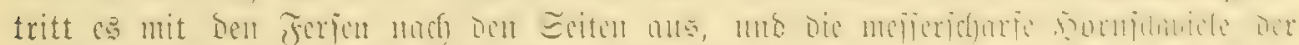

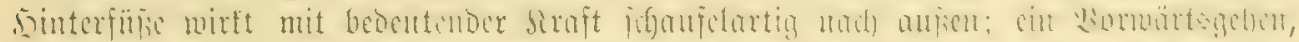

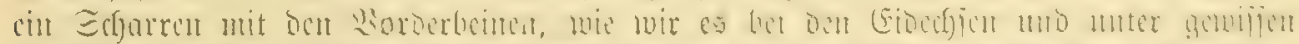

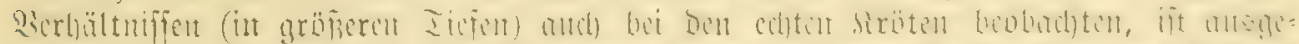

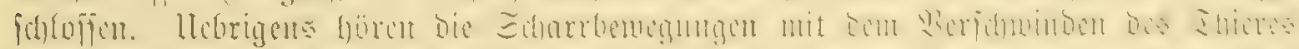

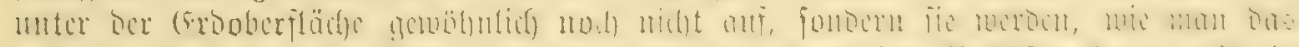

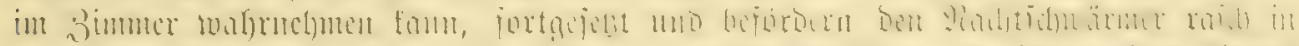

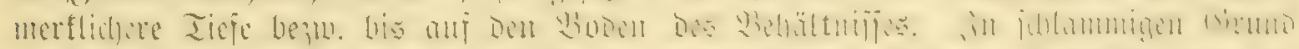

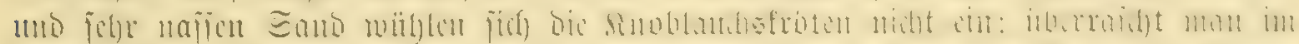

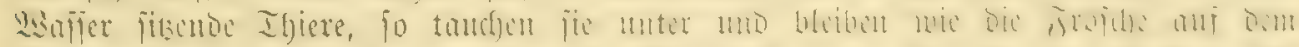

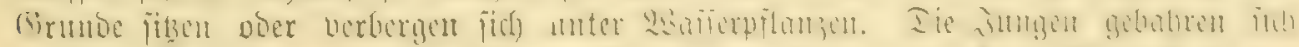

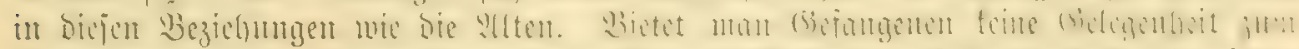

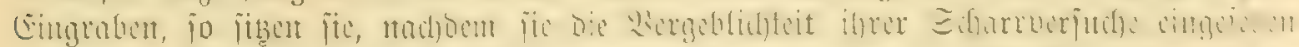

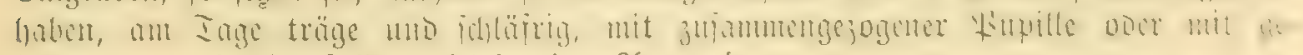
joblofientu, toic eingefallen erjd) 


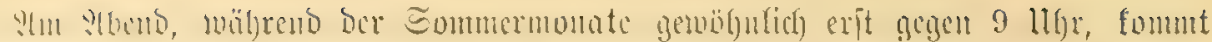

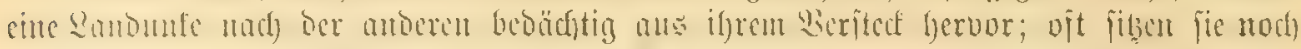

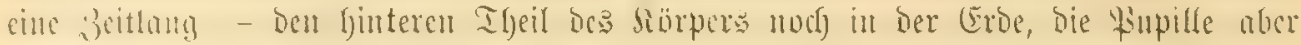

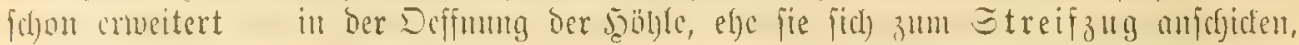

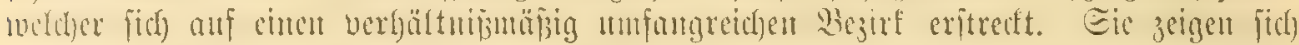

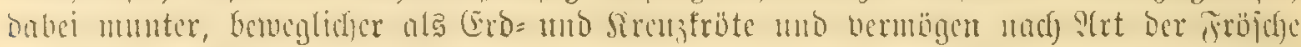

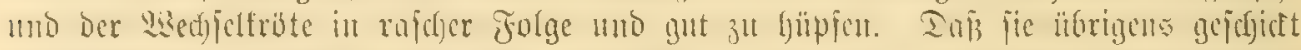

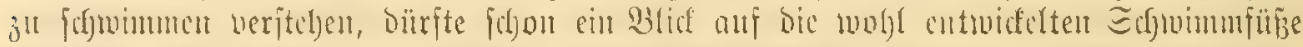

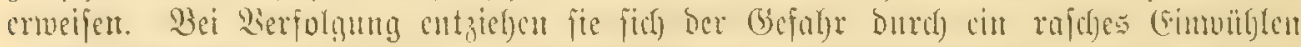

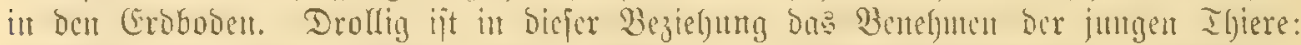

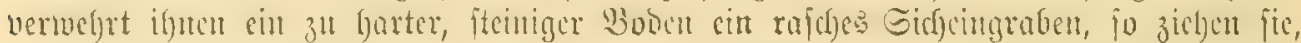

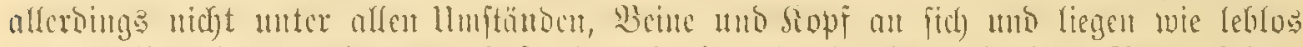

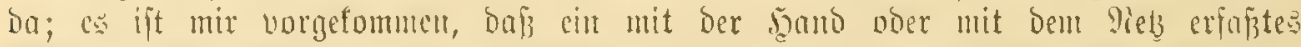

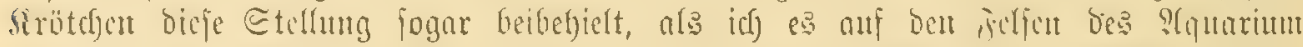

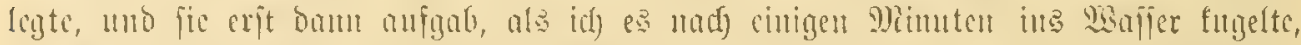

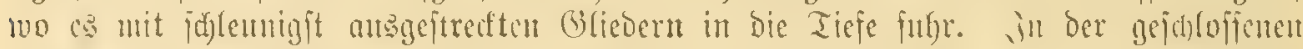

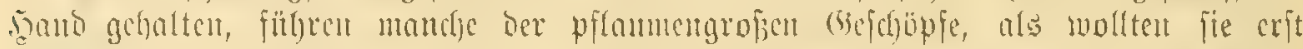

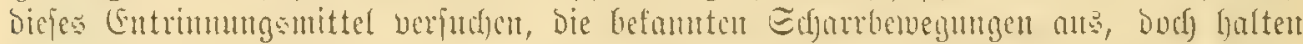

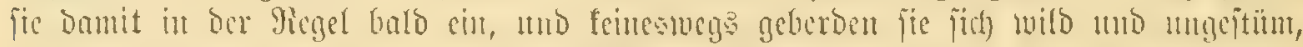

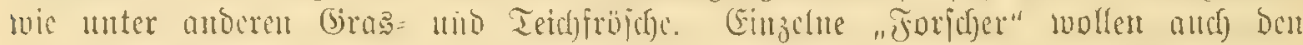

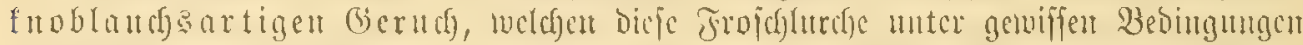

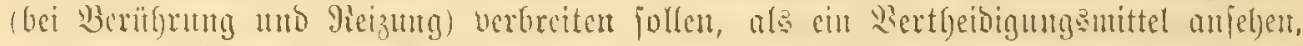

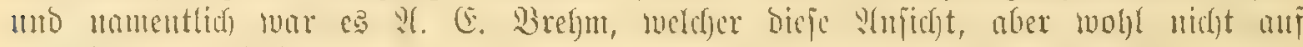

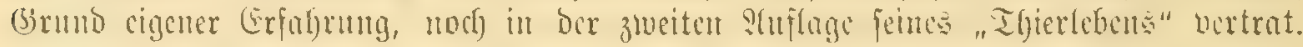

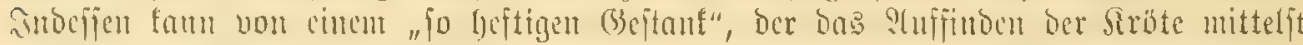

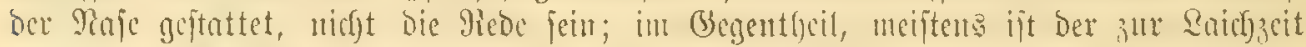

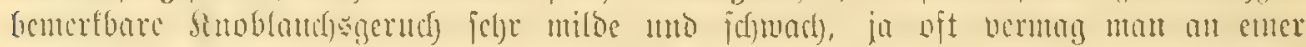

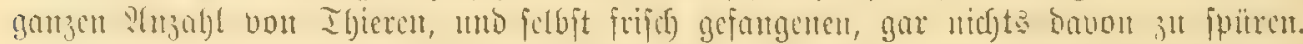

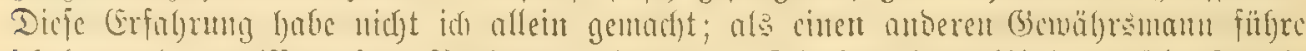

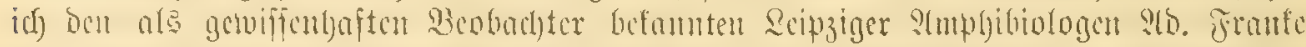

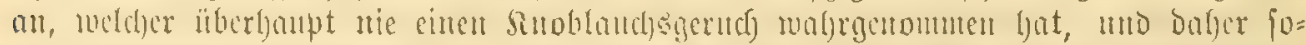

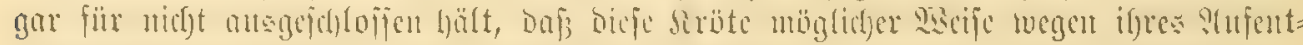

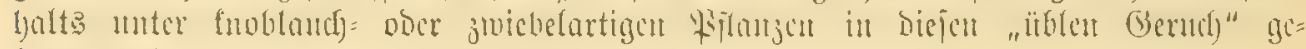
fomment ift.

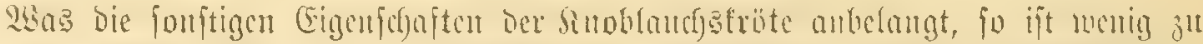

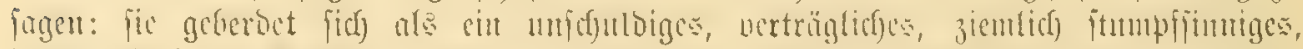

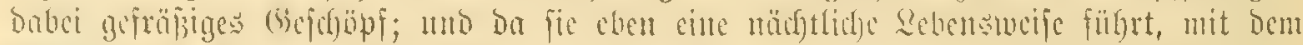

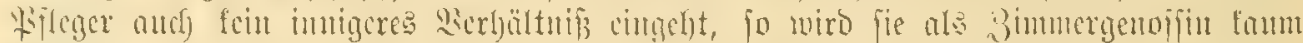

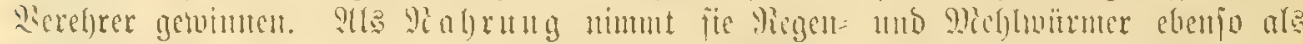

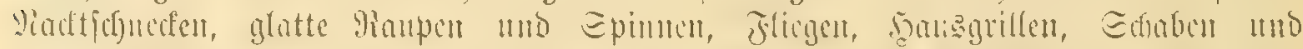

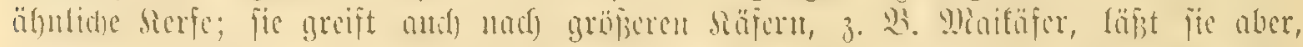

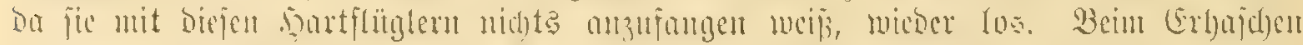

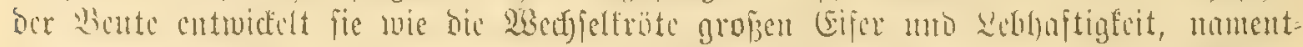

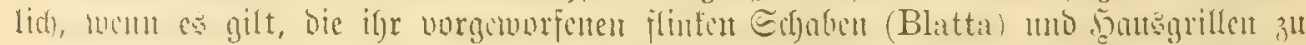

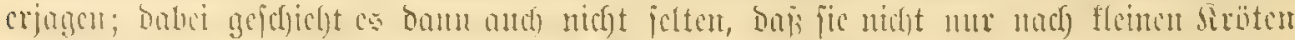

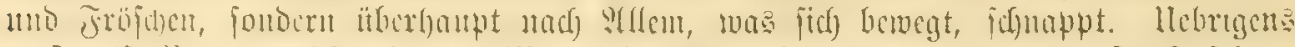

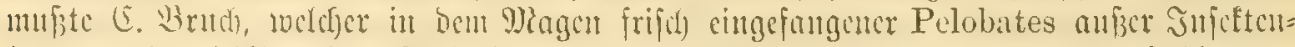

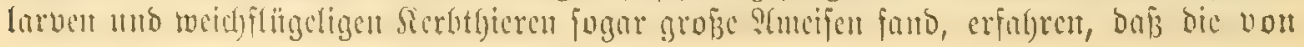




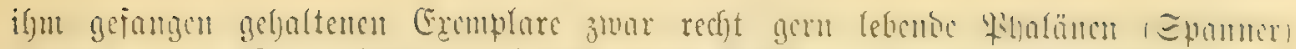

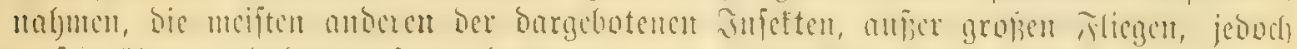

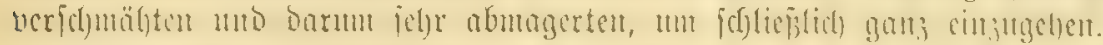

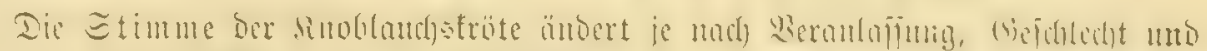

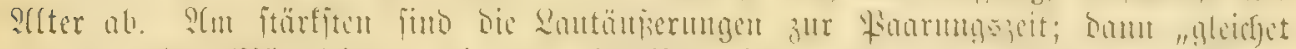

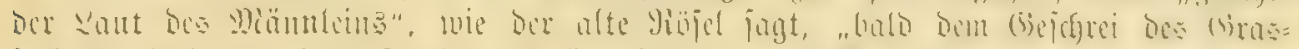

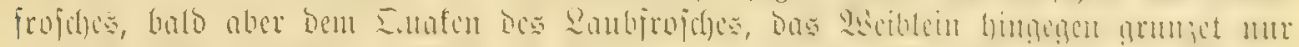

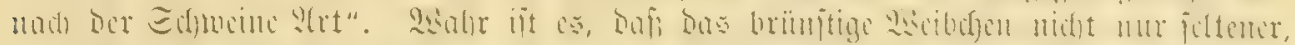

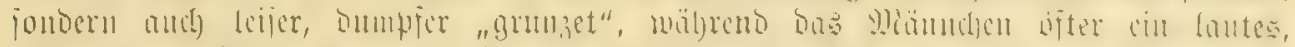

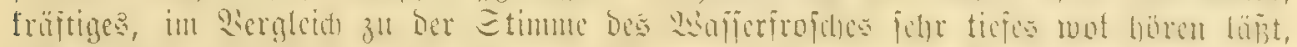

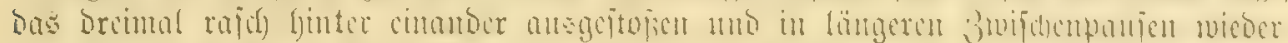

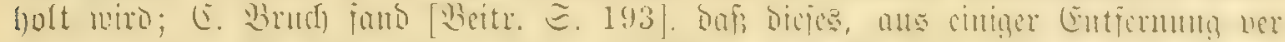

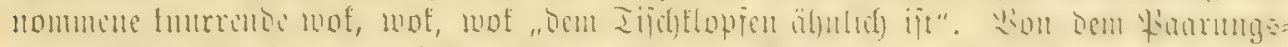

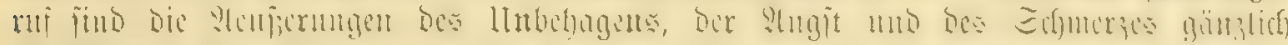

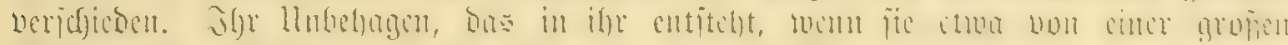

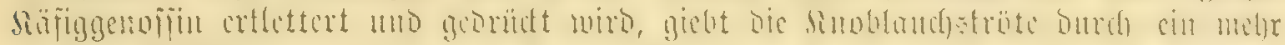

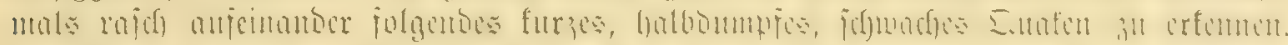

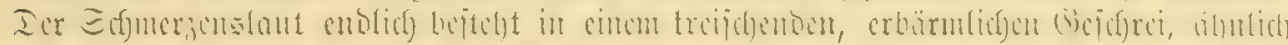

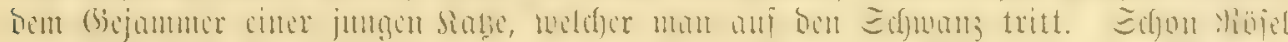

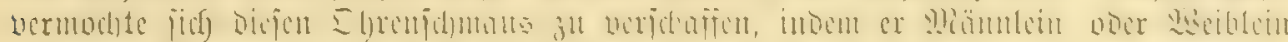

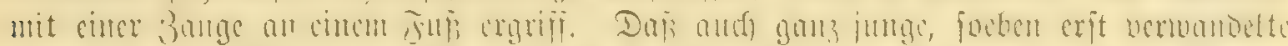

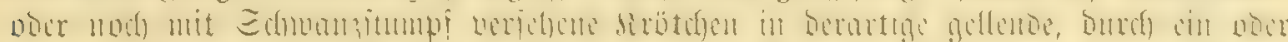

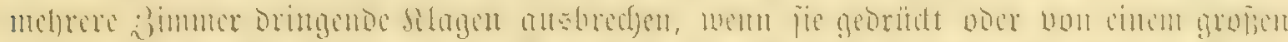

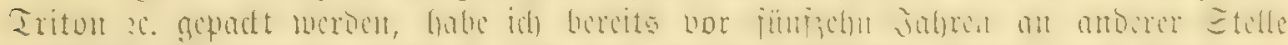

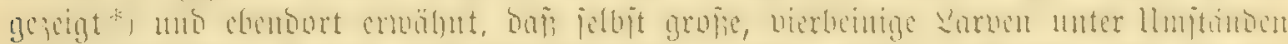

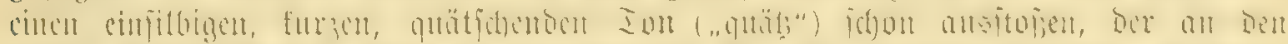

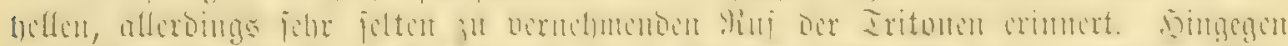

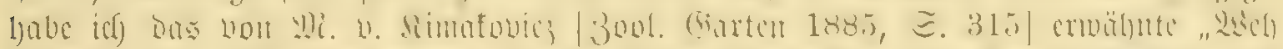

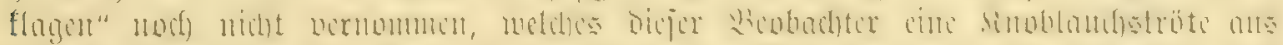

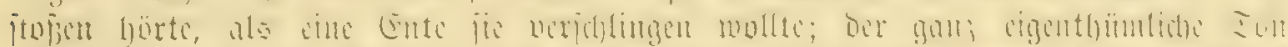

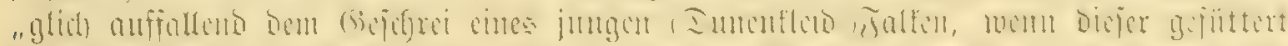

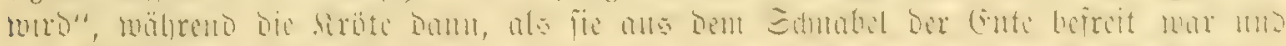

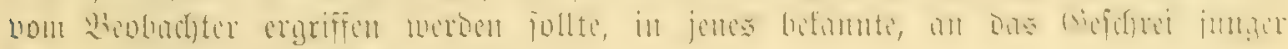
Saben gemalymenoc Sireijdjen ansbrach).

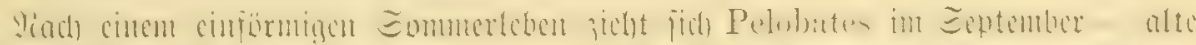

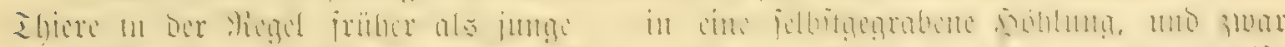

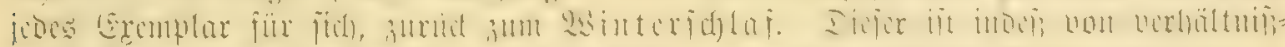

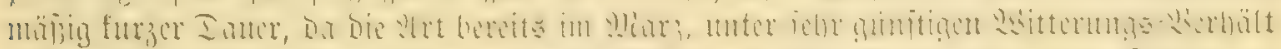

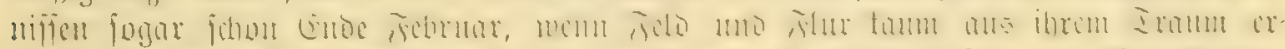

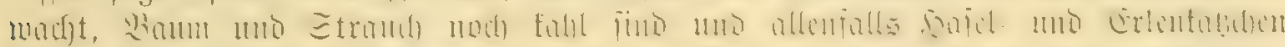

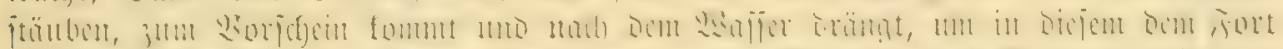

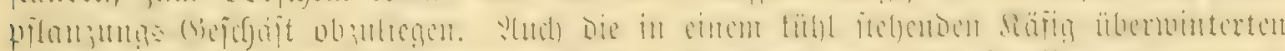

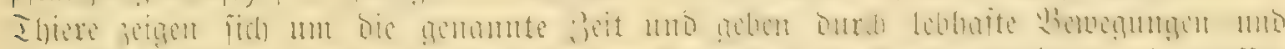

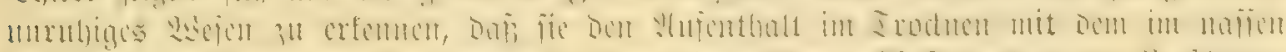

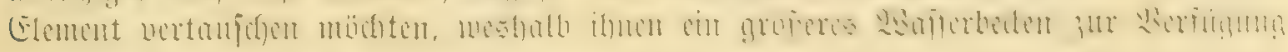

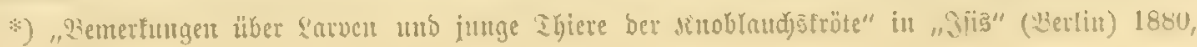
9ir. 3130111037. 


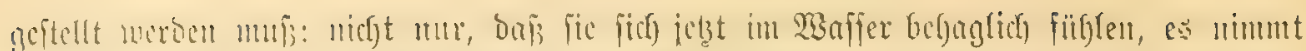

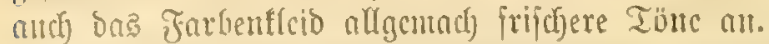

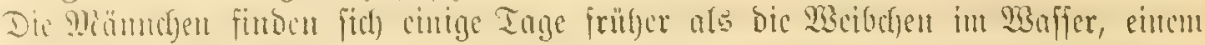

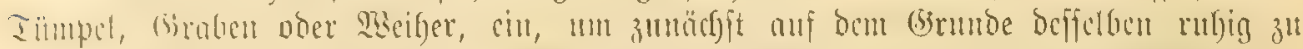

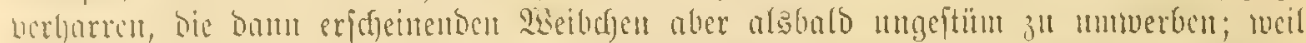

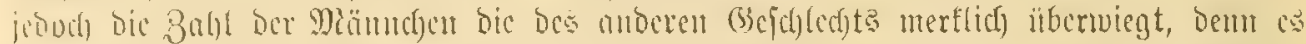

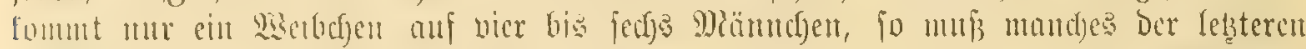

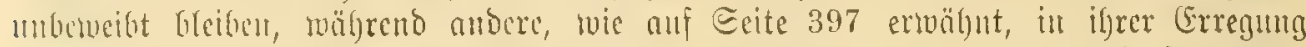

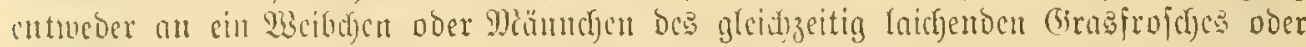

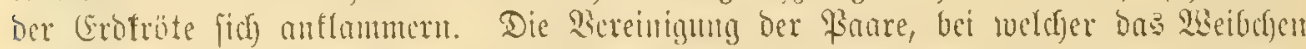

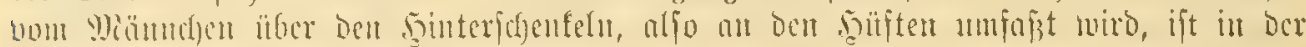

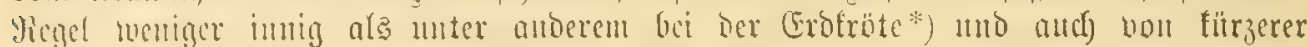

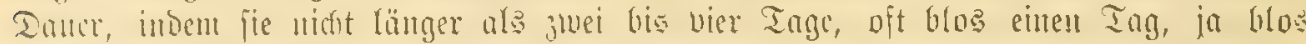

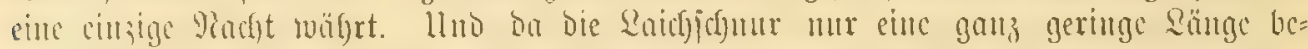

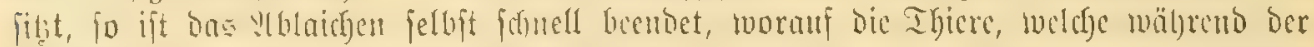

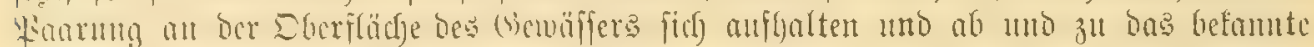

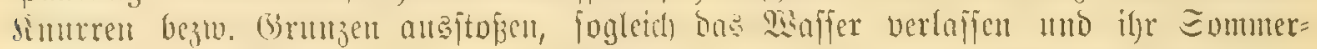

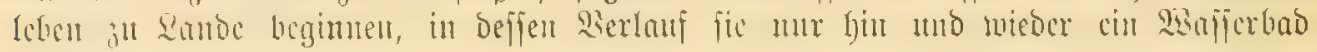
nelyment.

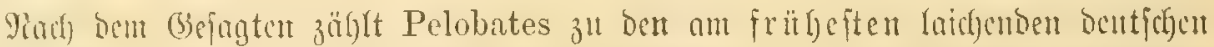

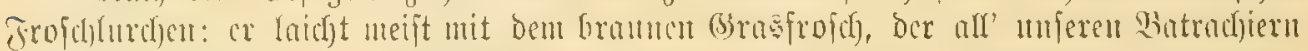

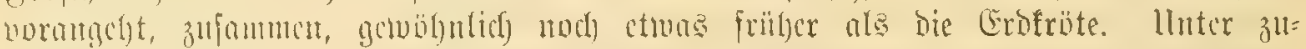

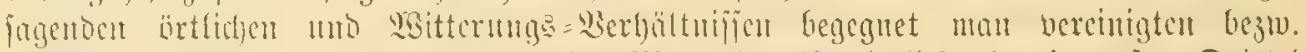

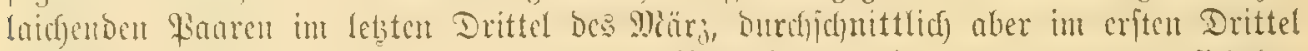

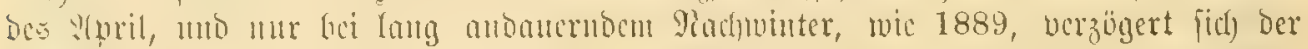

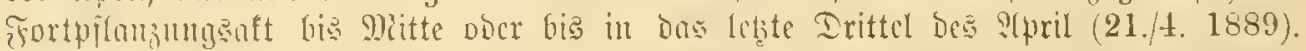

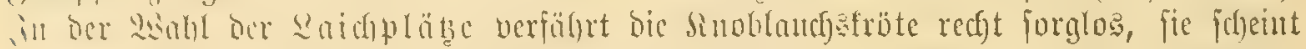

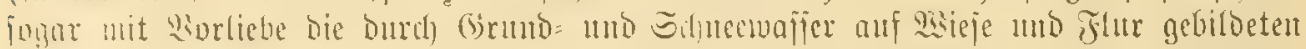

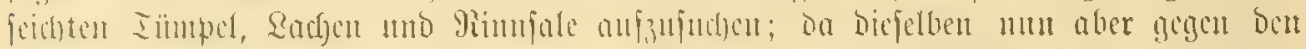

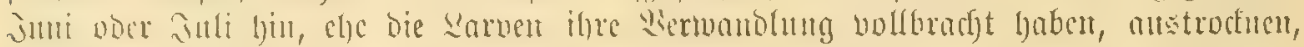

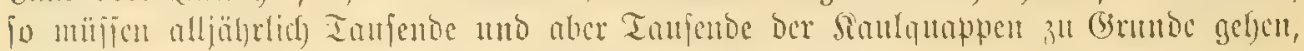

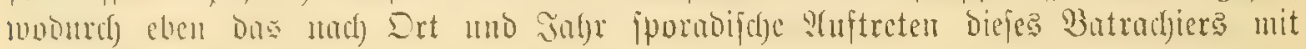
bedingt wirb.

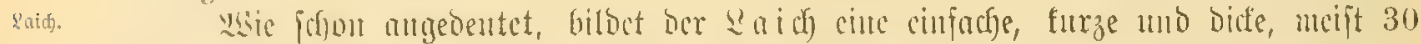

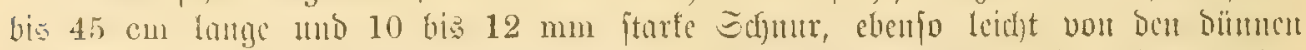

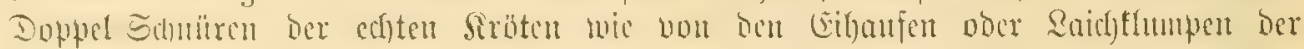

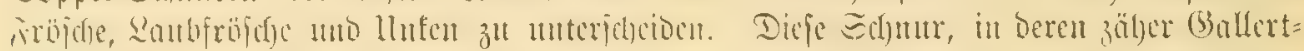

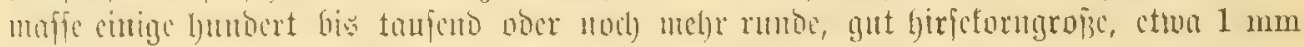

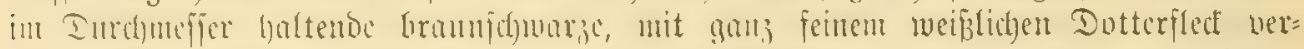

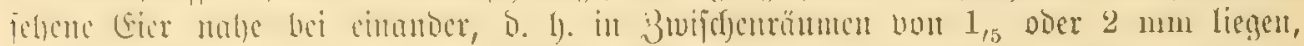

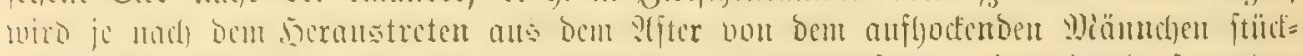

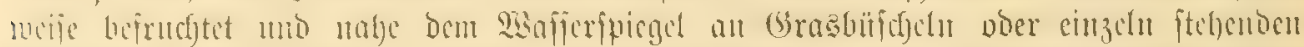

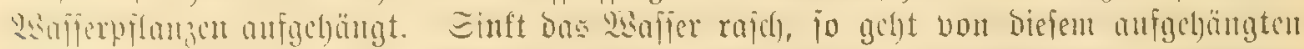

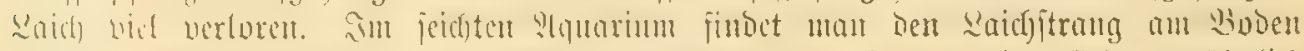

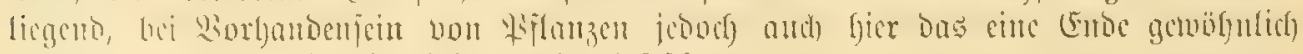
an cinem Etengel bocr in S3lattgenirr befeftigt.

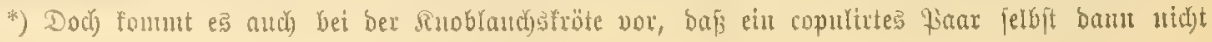

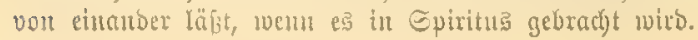




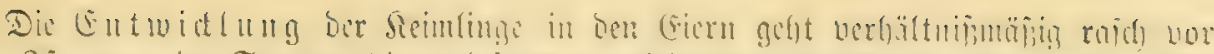

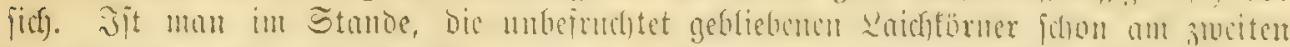

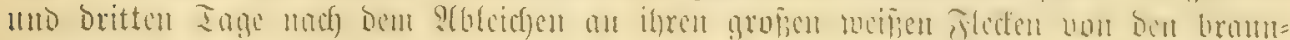

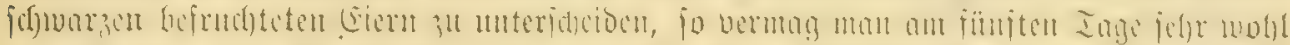

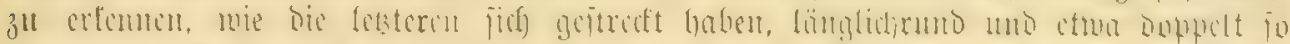

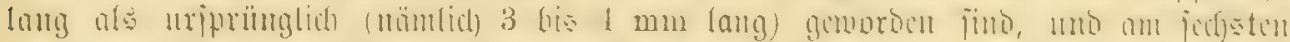

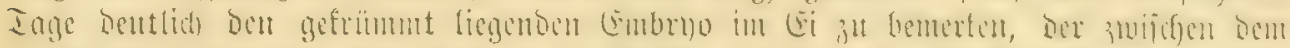

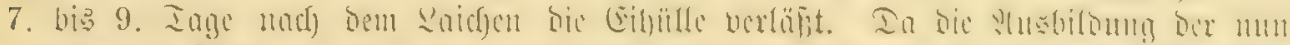

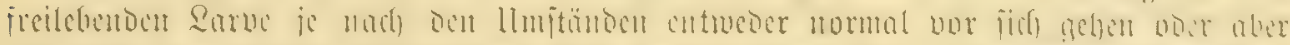

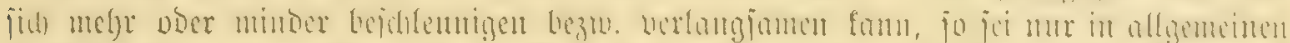

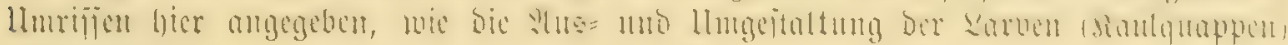
ficli) abipielt.

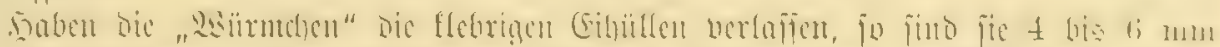

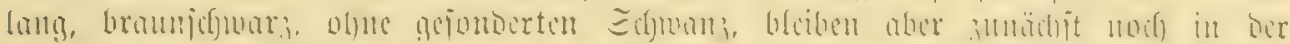

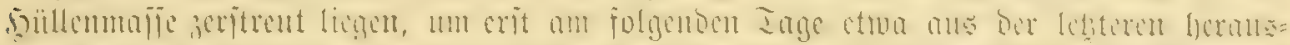

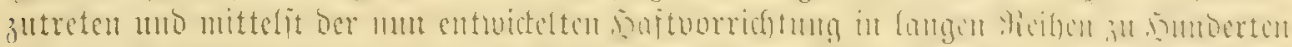

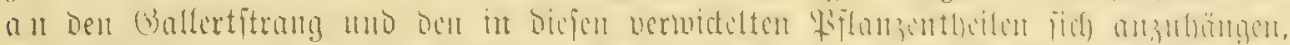

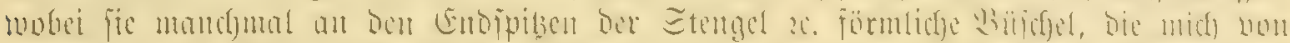

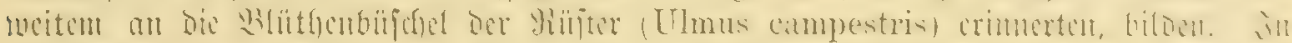

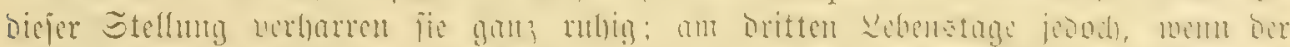

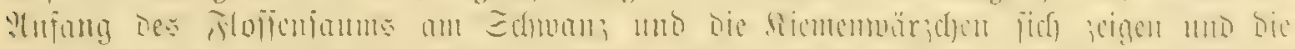

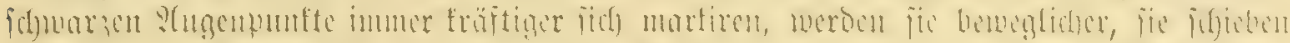

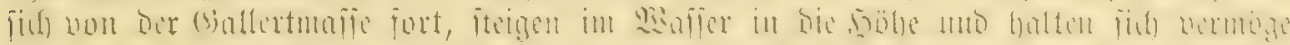

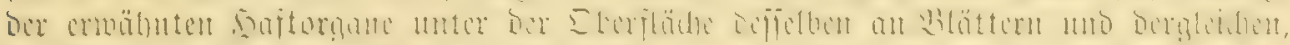

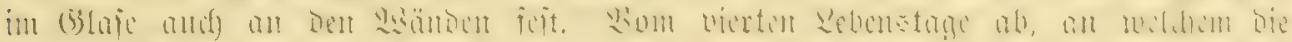

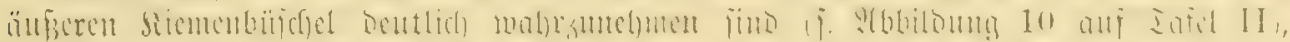

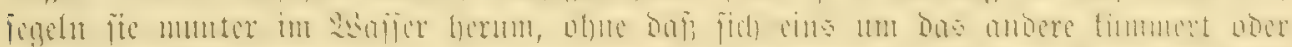

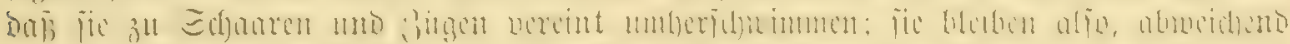

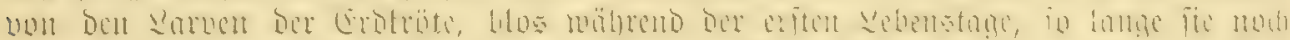

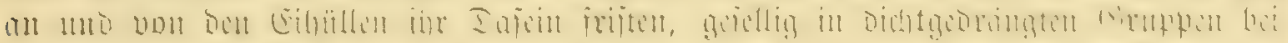

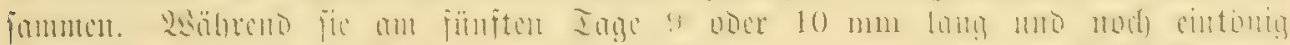

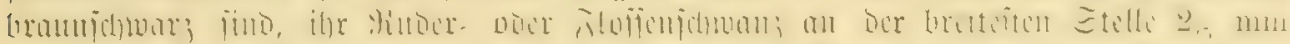

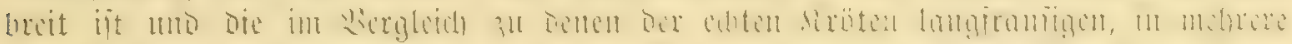

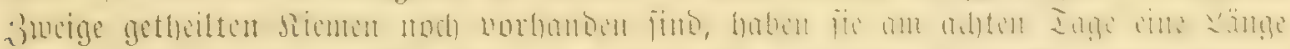

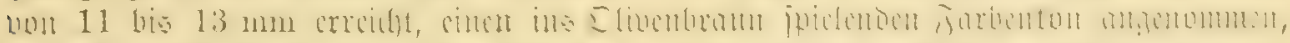

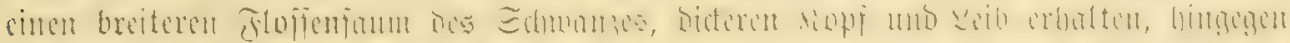

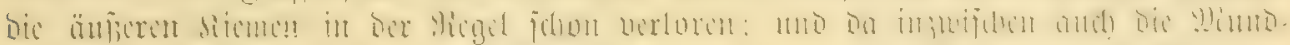

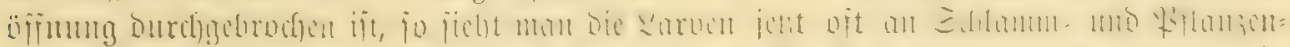

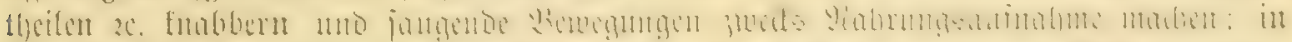

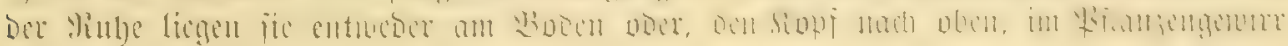

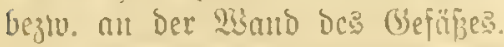

I

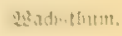

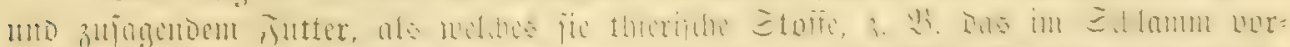

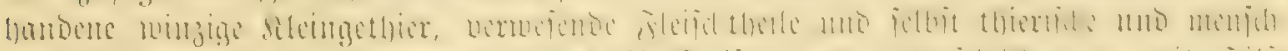

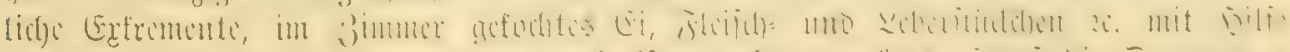

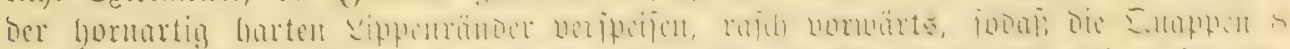

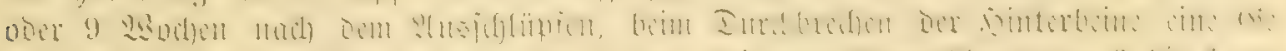

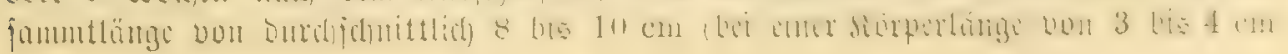




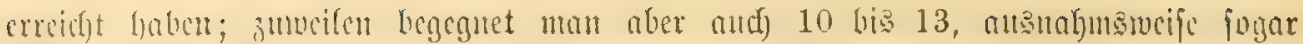

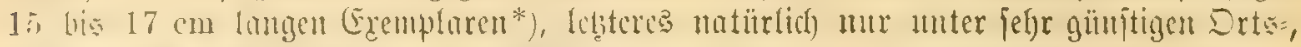

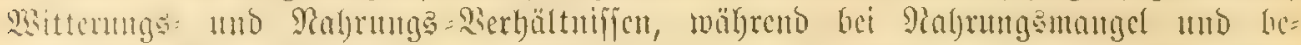

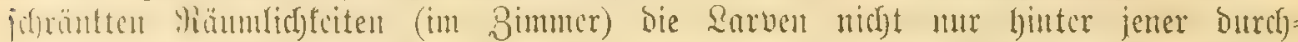

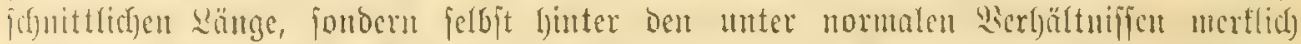

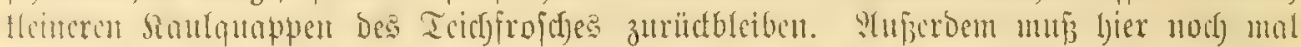

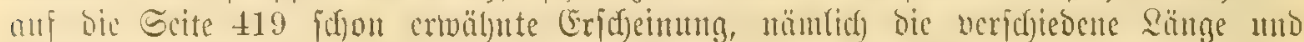

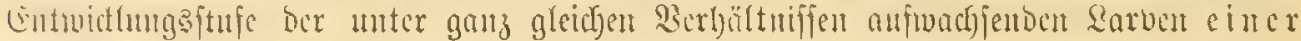
Brut Gingerviejen werben.

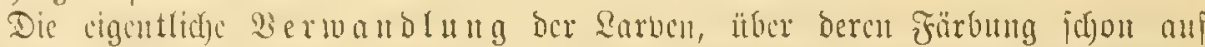

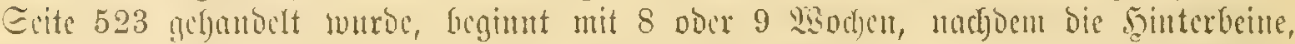

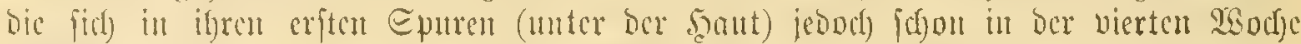

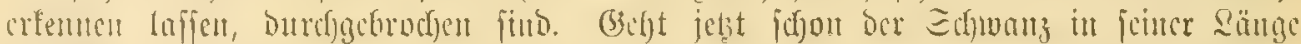

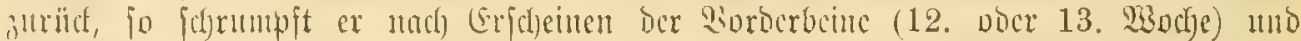

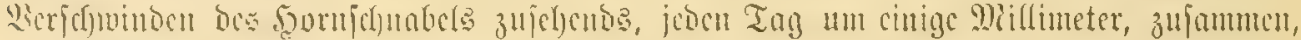

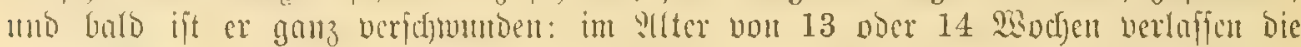

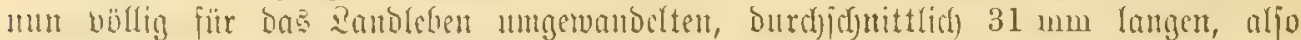
etma pflammengrofien, anf Grite 524 befdrichenen und anf Iafel IT abgebildeten

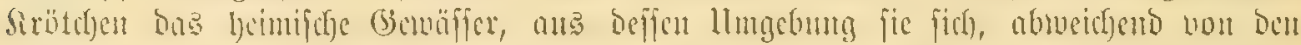

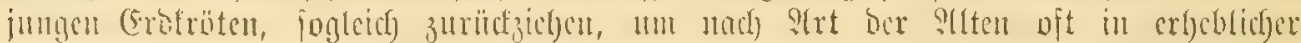

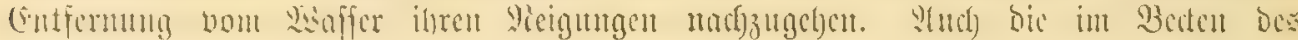

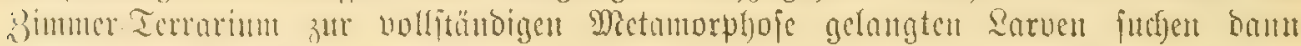

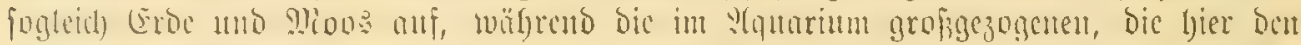

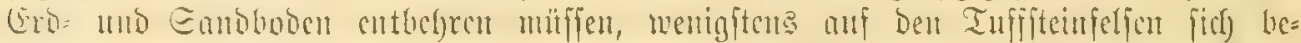

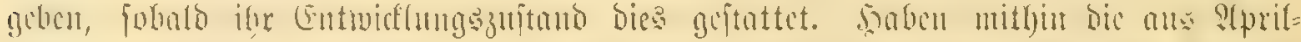

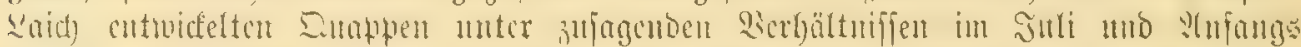

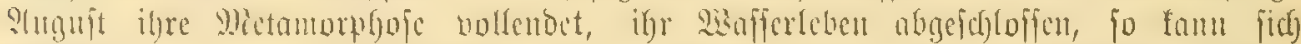

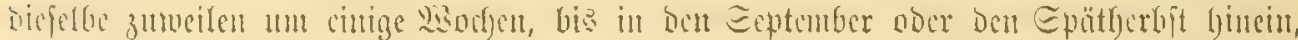

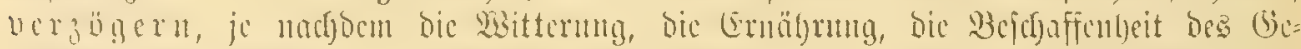

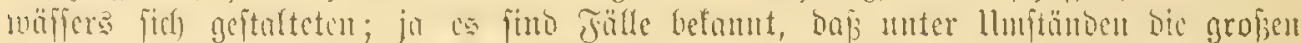

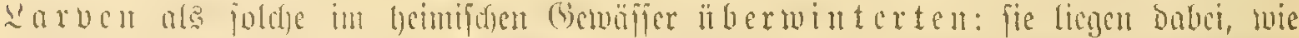

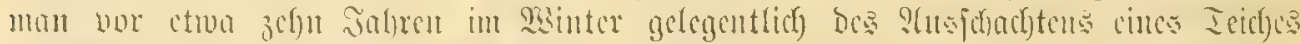

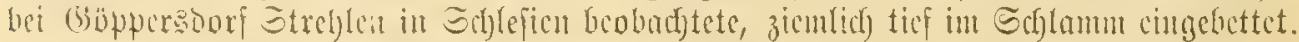

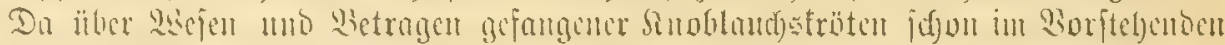

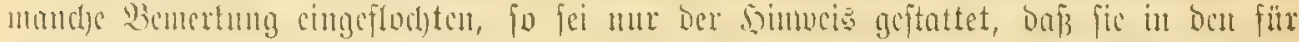

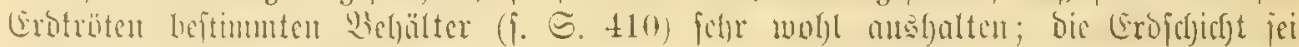

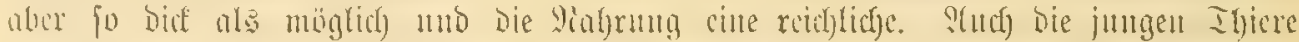

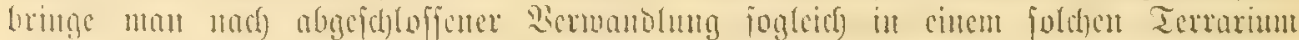

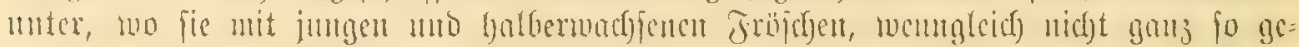

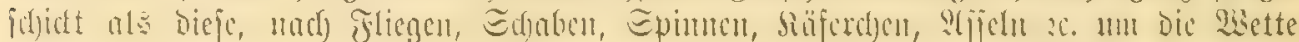
ipringen.

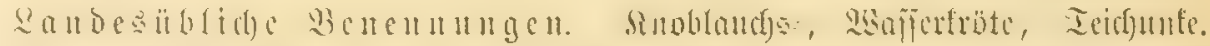

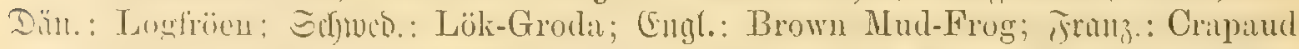

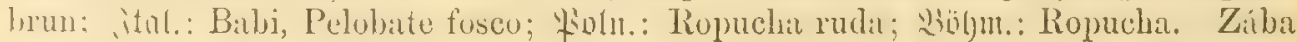
smrdutí.

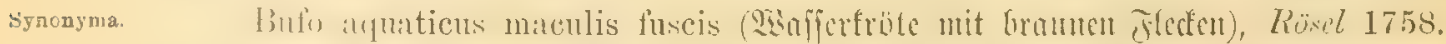
- Bufo fuscus, Laurenti 1768. -- Rana vespertina, Pullas 1771. - Rana fusca,

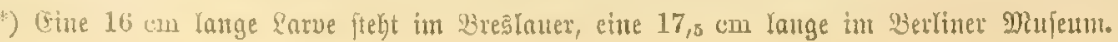


Meyer 1795. - Bufo respertinus, Schurder 1799. - Rana alliaccia, Shum 1802. Rana seorolosma, Hermen 1804. - Bumbiuator fuscus, Fitziner 1826. - Bumbinal marmorati, Stmm 1828. - Pelolates fuscus, Wingle 1830. - Tombina fusca. Inlen 1831. - C'ultriper minor, J. Mälle 1832 [Isis XIY S. 538]. - Polubiter insubricus, Comalic 1873. - Pelob. latifrons, Heron-Royer 1888.

\section{5. famtilic: Ed)cibcuzünglcr, Discoglossidae.}

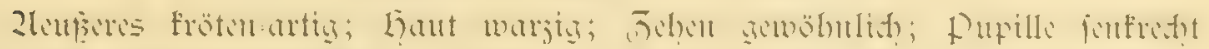

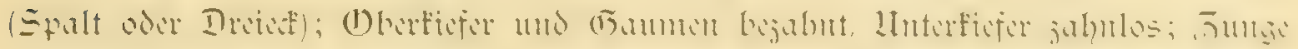

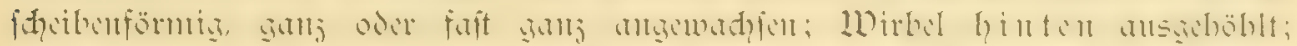
rudims tä mirtal vorla a forb feitlid verfdicbbar.

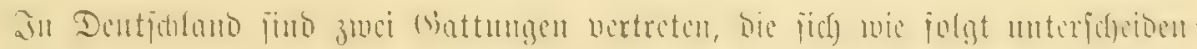

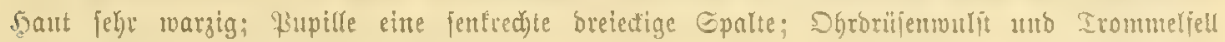

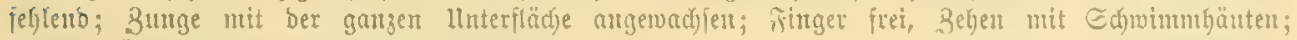

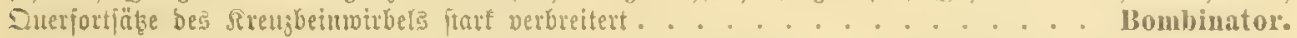

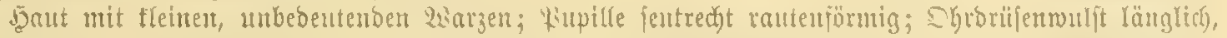

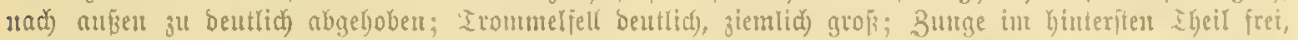

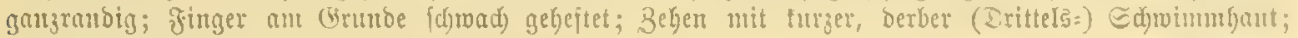
Suevortäłse bes streubein mäßig verbreitert.

Alytes.

\section{5. (5)attung: Maffer=llute. Bombinator, Merrem.}

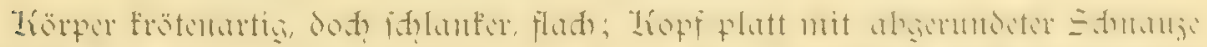

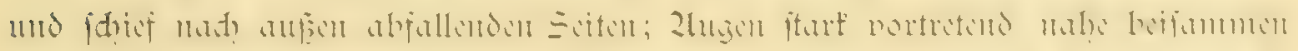

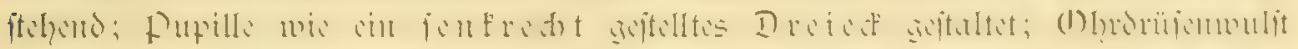

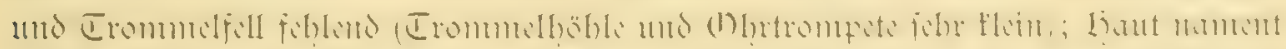

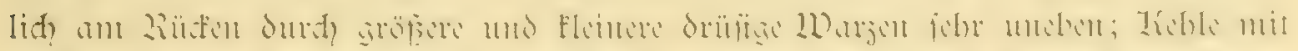

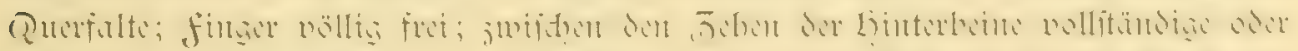

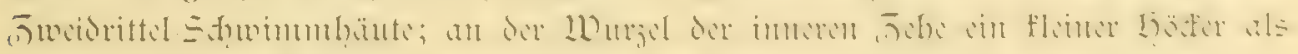

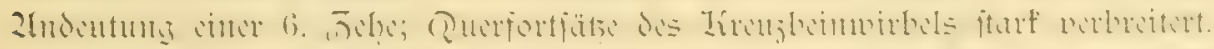

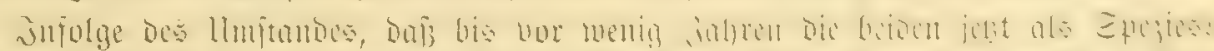

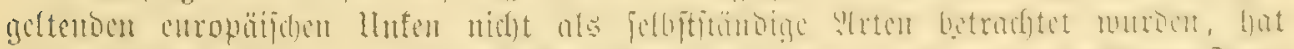

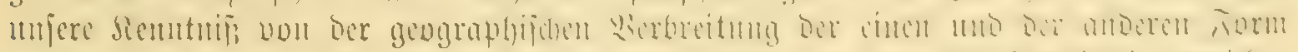

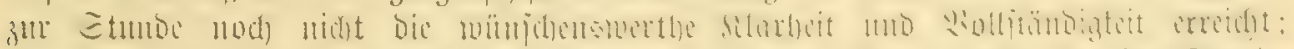

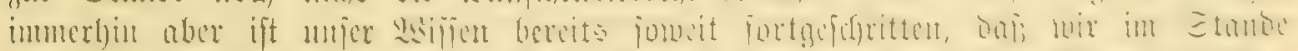

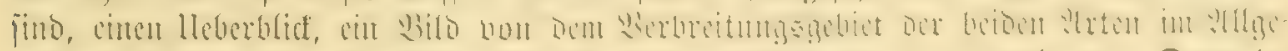

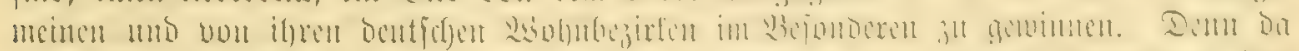

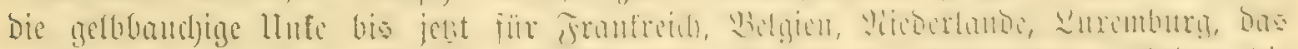

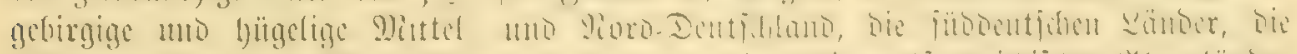

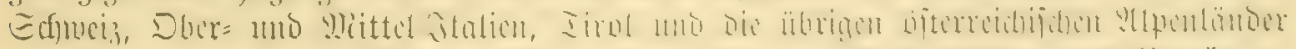

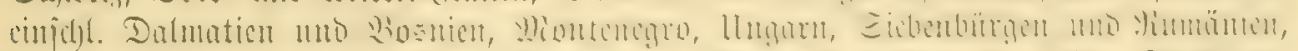

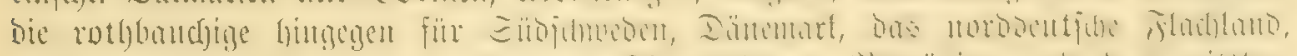

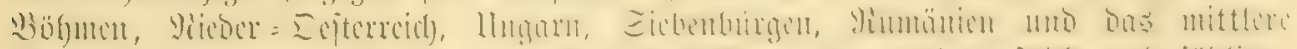

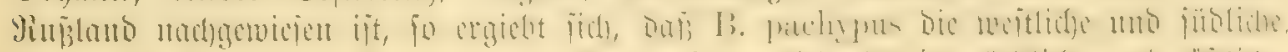

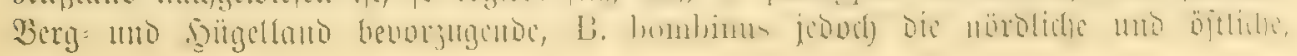




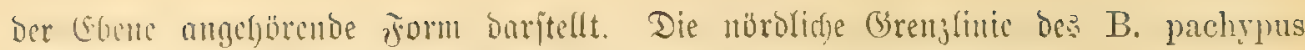

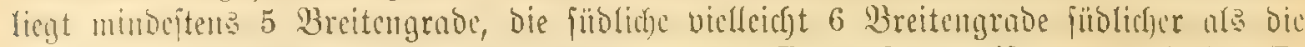

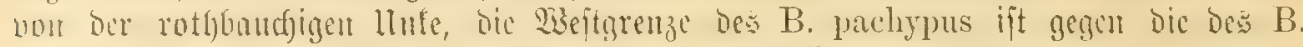

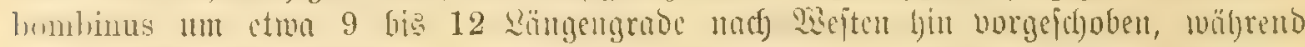
Dic Ditgrenze ber bergunfe um 12 bis 15 së̈rgengrabe weftlidger bletht. Dabei ift

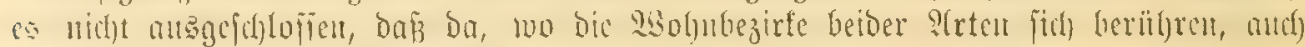
beibe gemeinlichaftlich vorfonment fönncr.

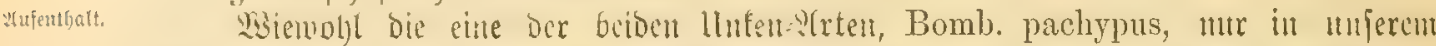

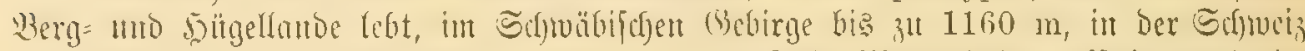

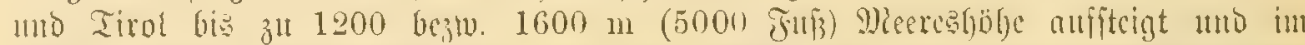

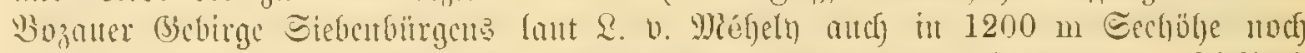

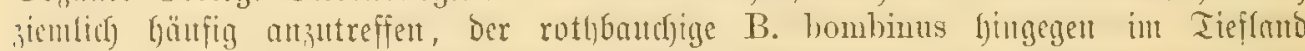

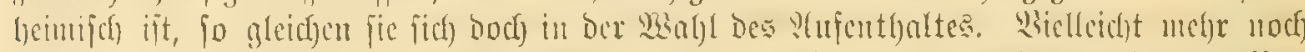

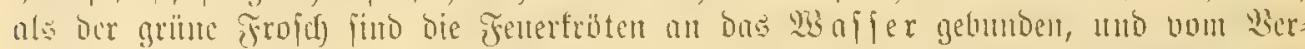

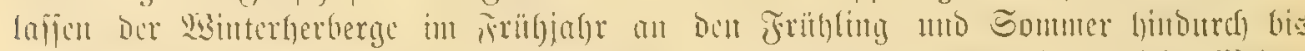

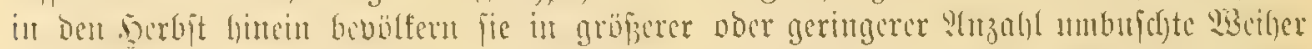

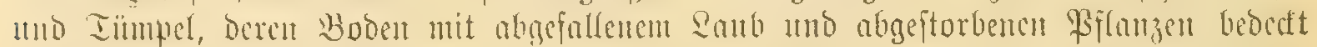

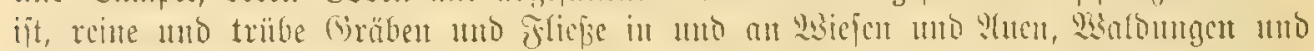

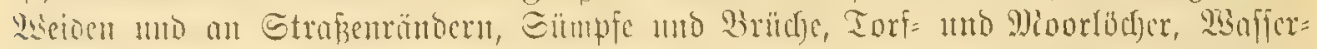

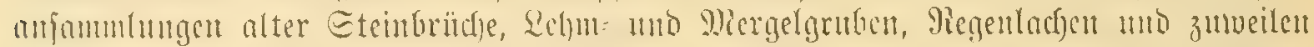

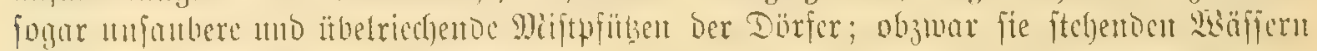

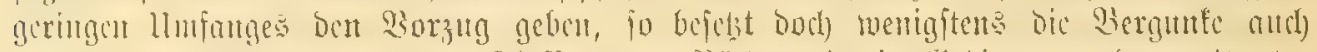

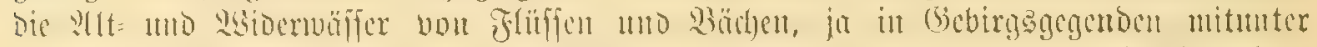

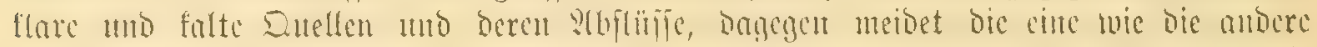

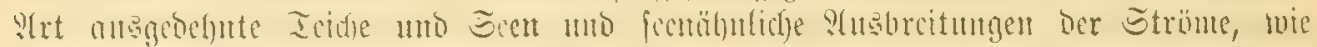

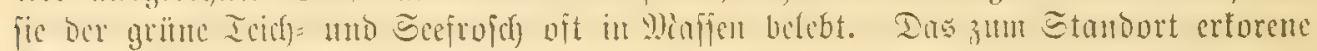

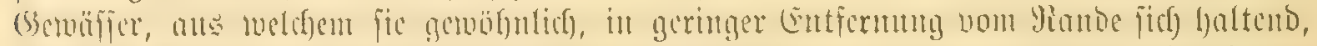

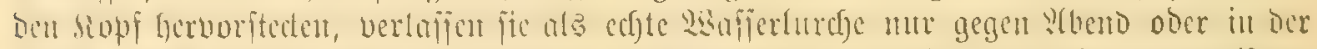

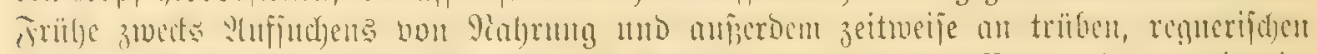

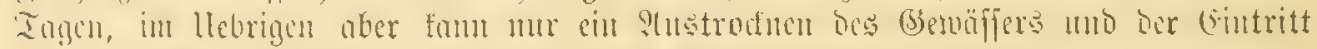

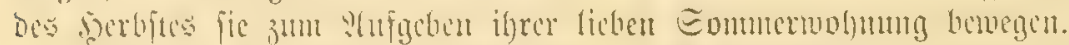

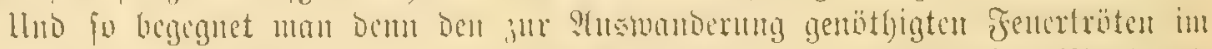

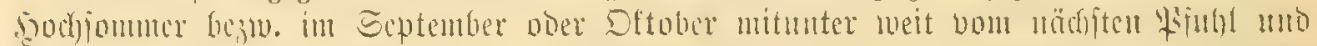

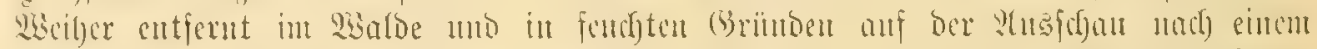

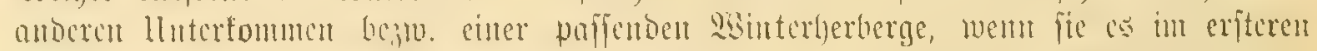

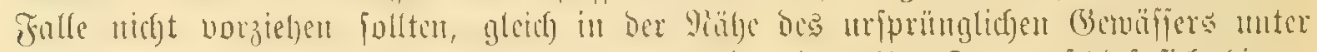

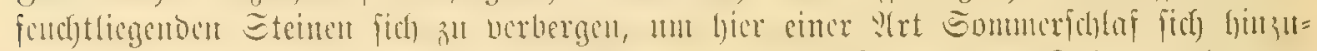

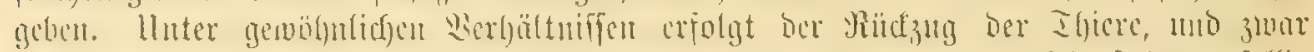

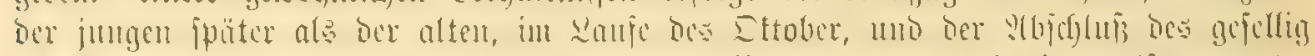

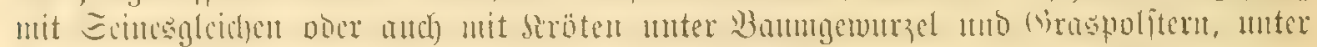

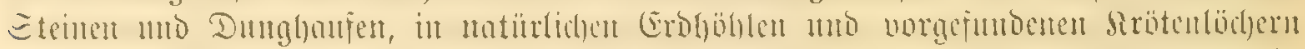

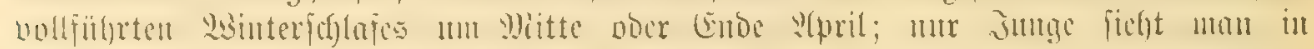

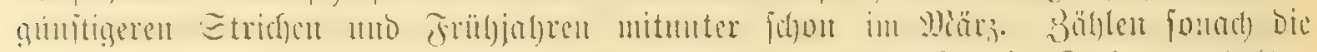

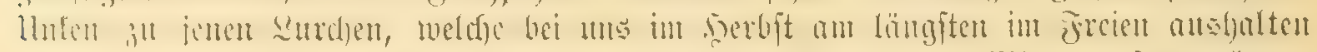

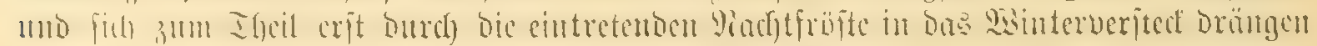

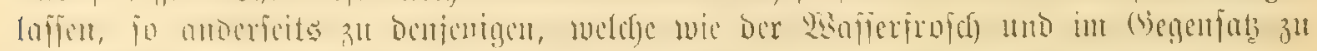

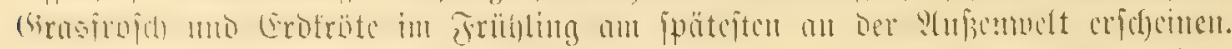

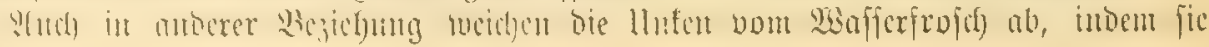




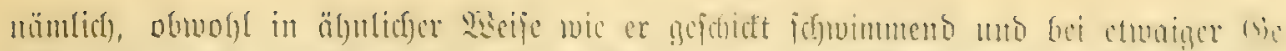

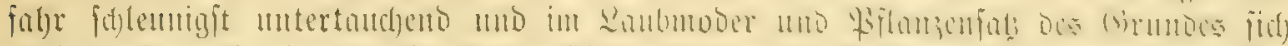

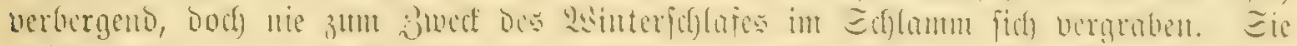

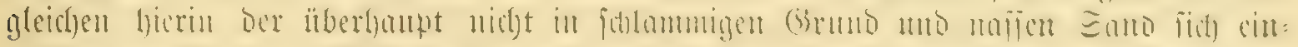

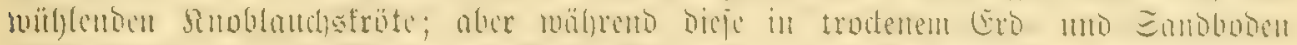

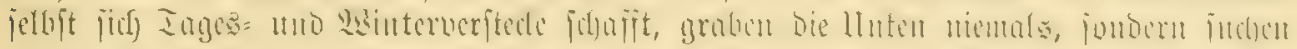

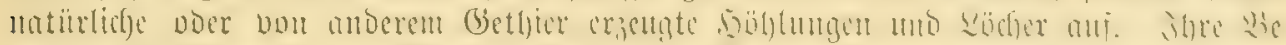

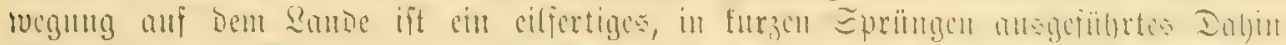

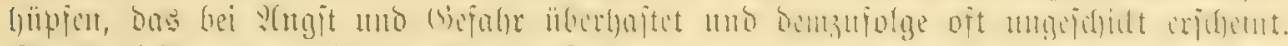

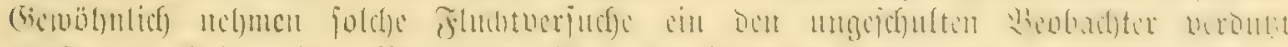

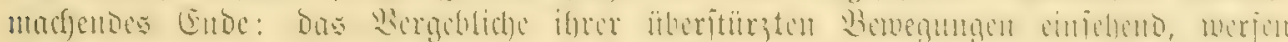

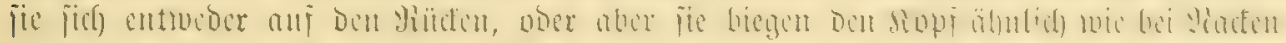

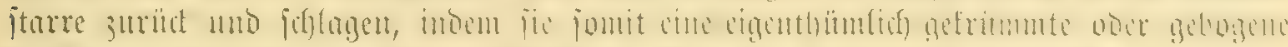

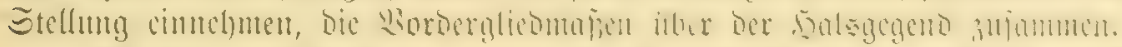

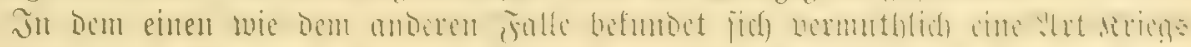

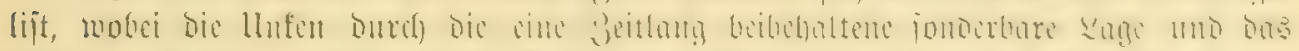

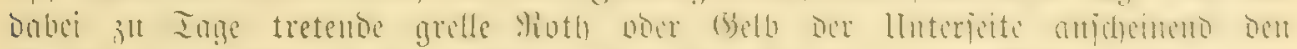
(b)

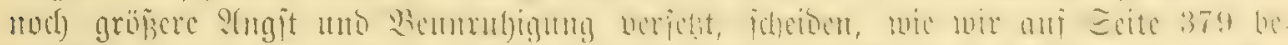

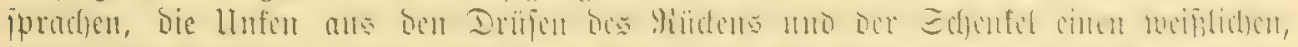

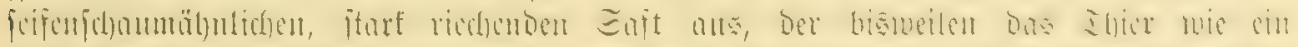

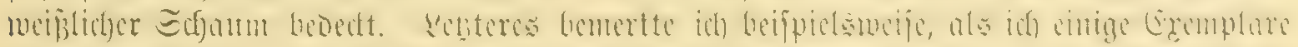

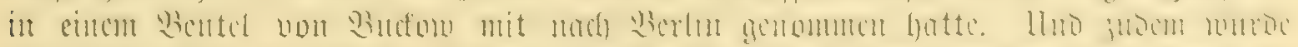

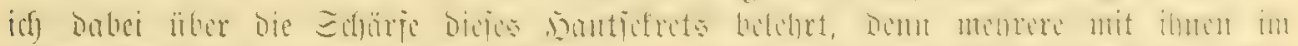

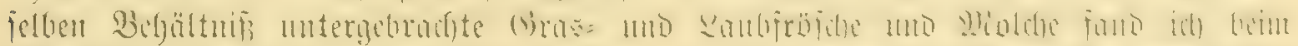

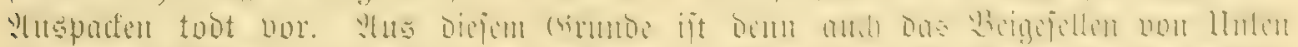

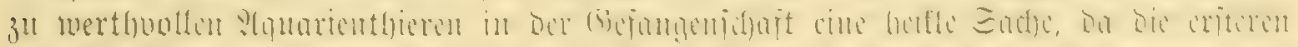

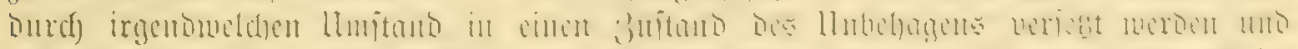

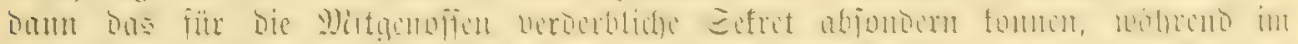

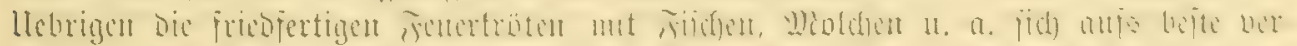

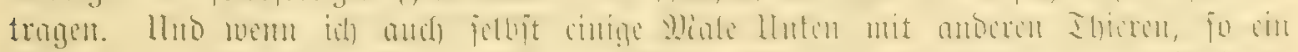

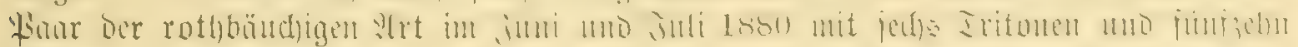

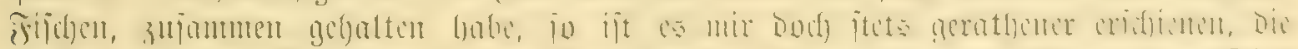

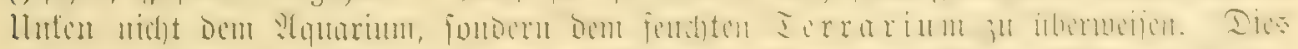

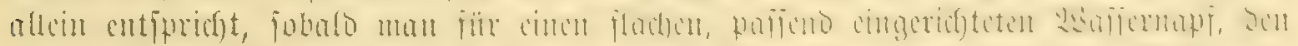

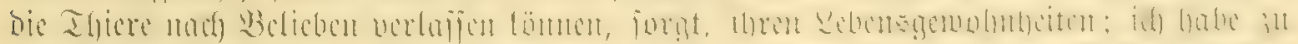

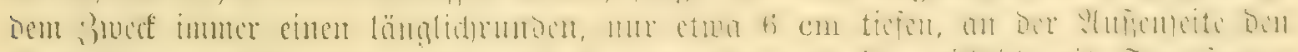

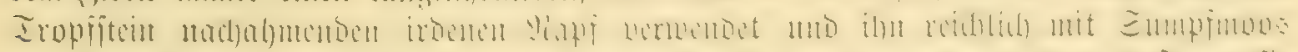

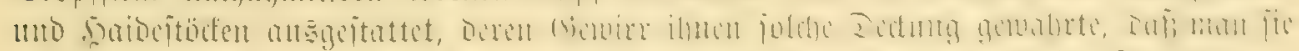

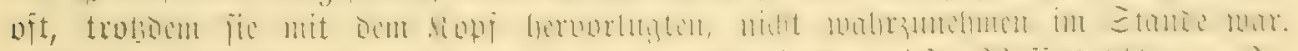

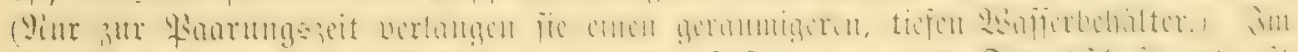

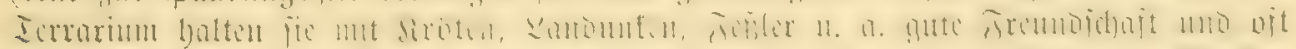

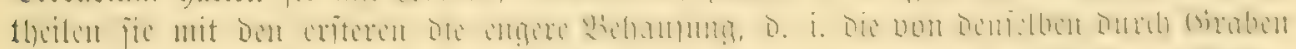

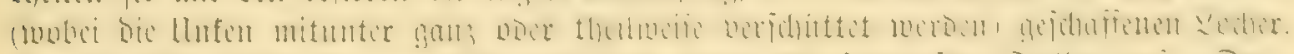

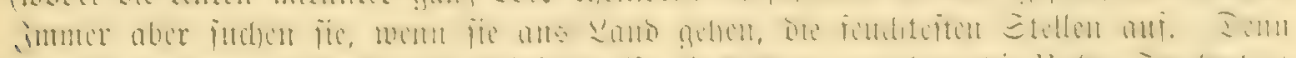

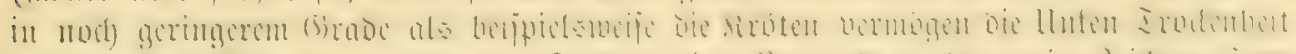

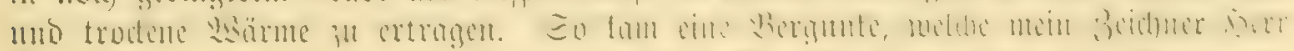

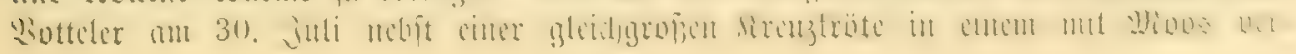




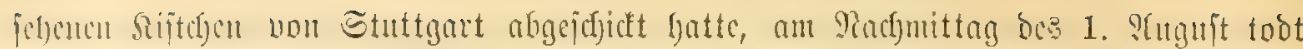
uno 3ufanmengetrochet in Berlin an, wäluteno calamita nod) lebte; cin Exemplar ber

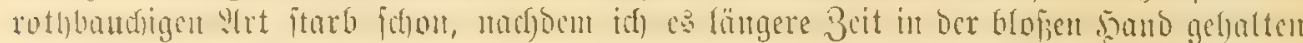

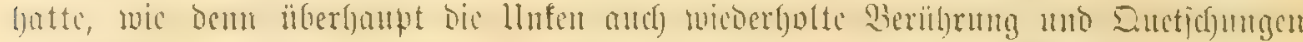

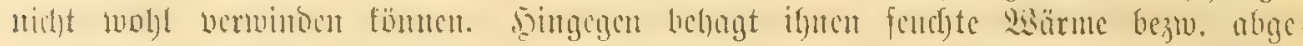

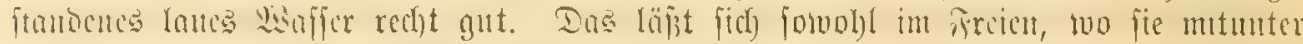

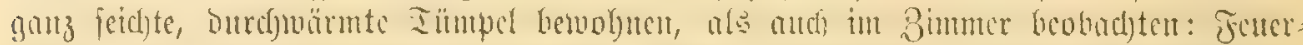

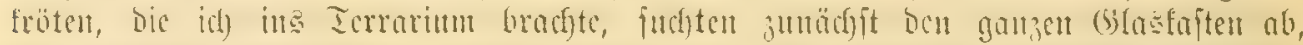

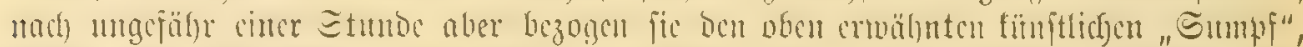

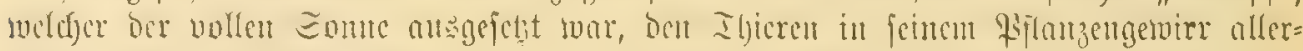

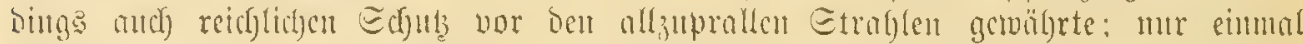

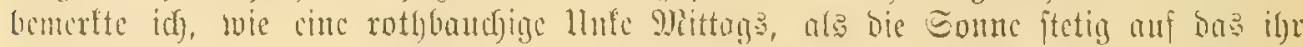

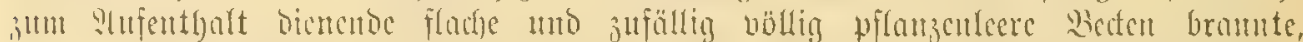

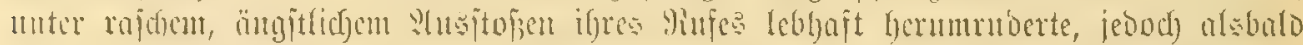

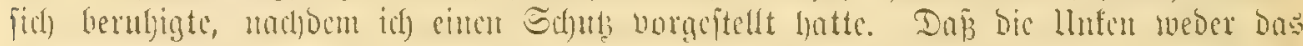

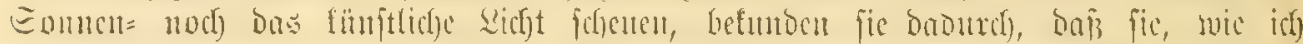

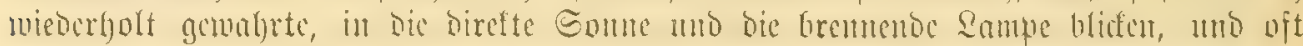

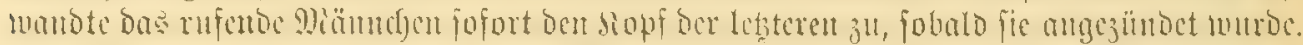

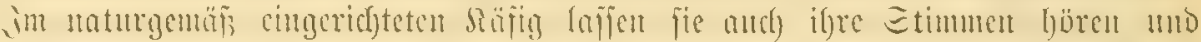

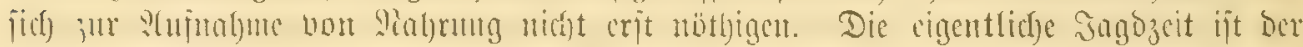

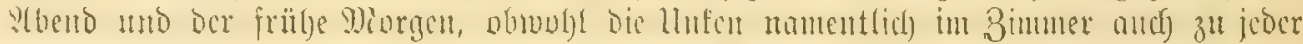

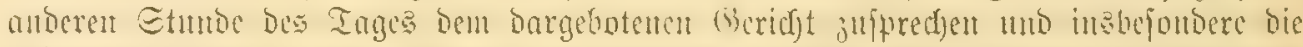

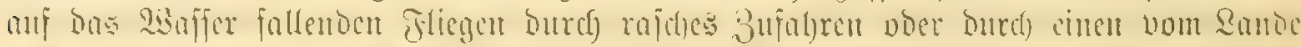

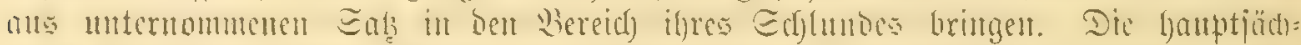

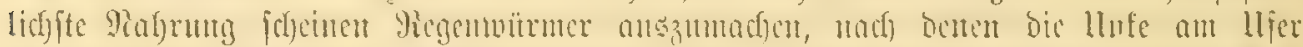

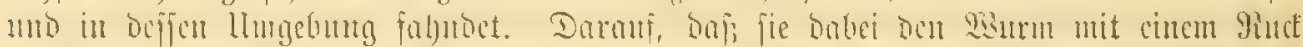

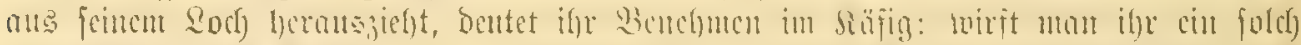

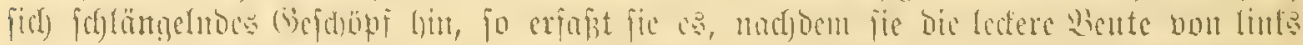

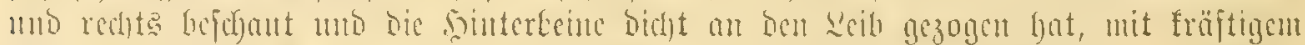

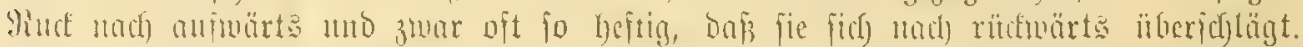

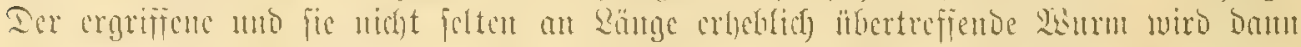

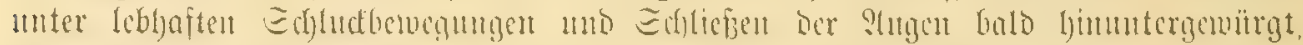

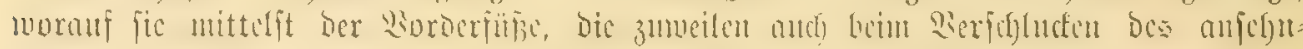

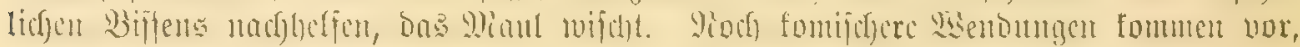

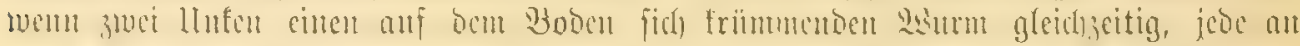

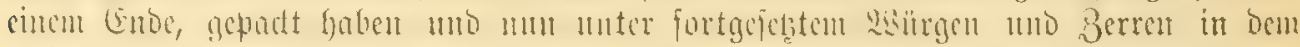

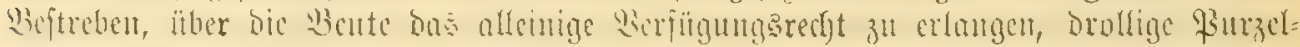

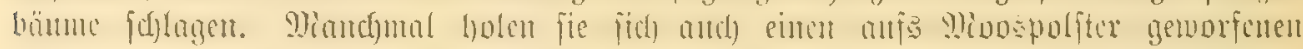

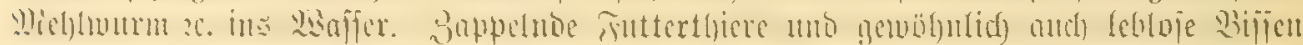

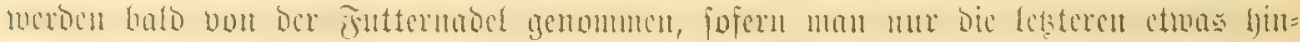
anis herberwegt.

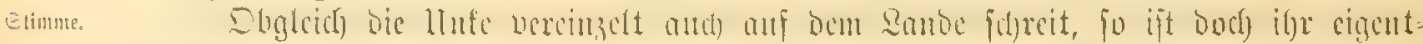

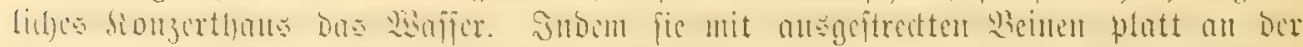

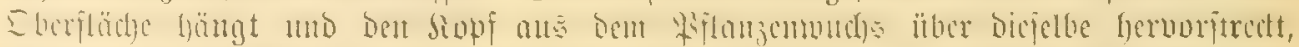

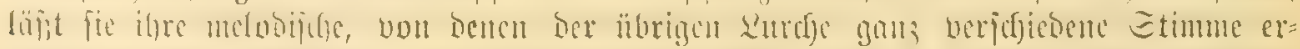

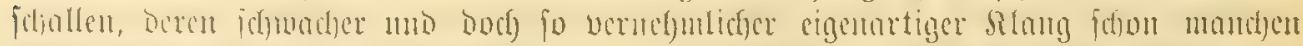

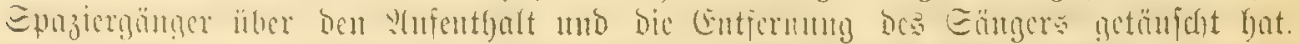

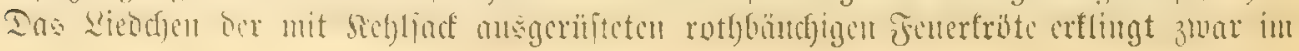




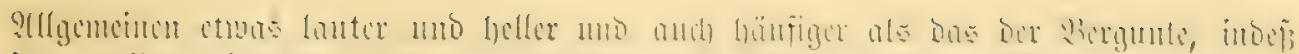

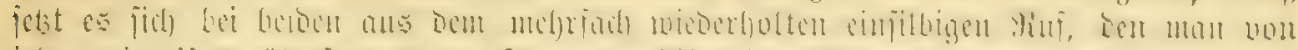

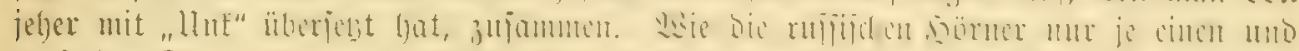

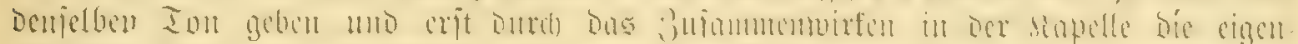

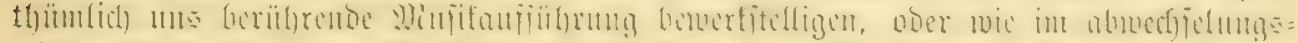

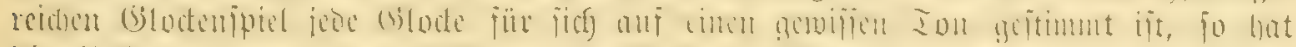

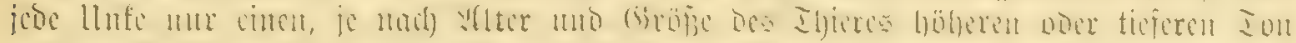

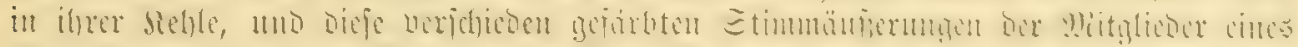

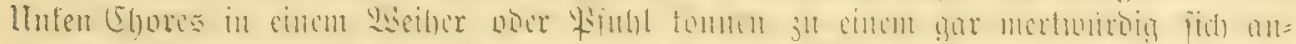

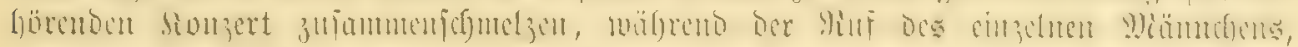

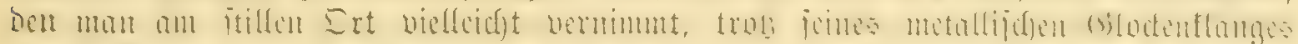

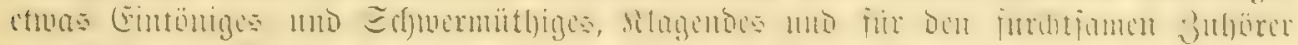

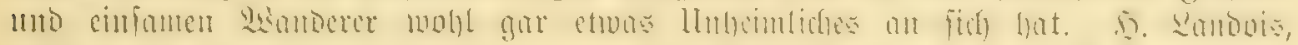

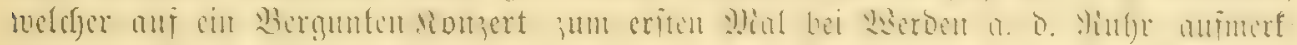

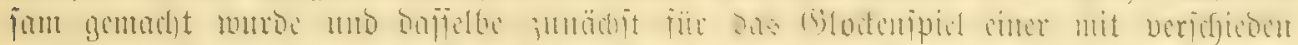

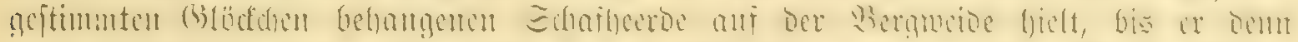

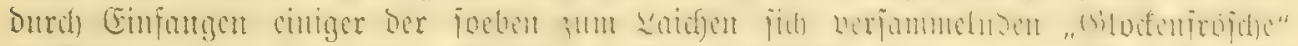

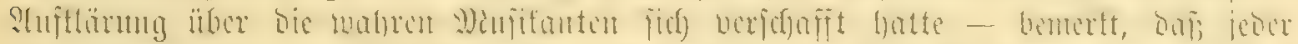

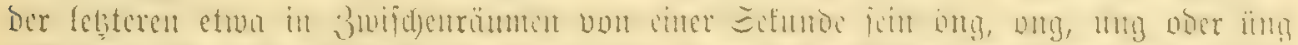

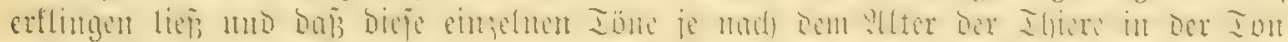

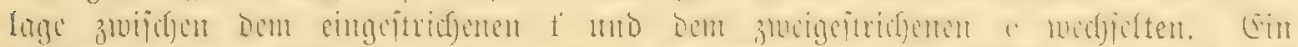

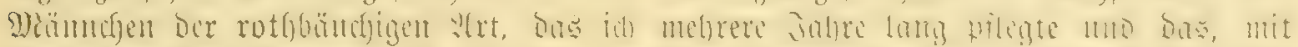

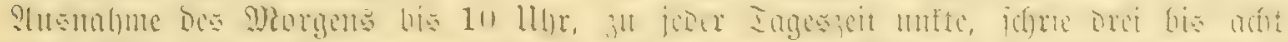

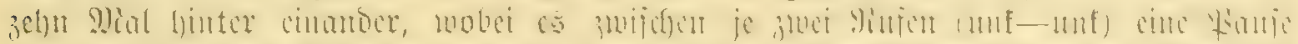

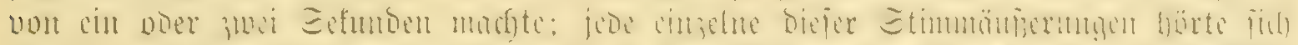

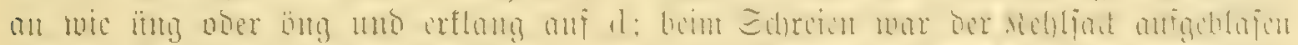

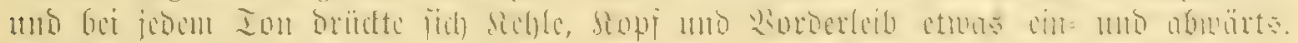

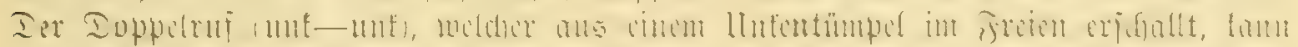

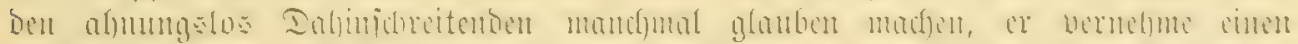

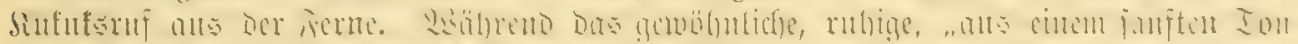

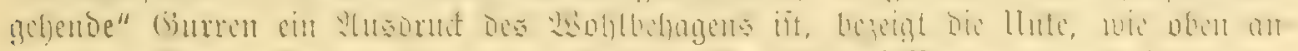

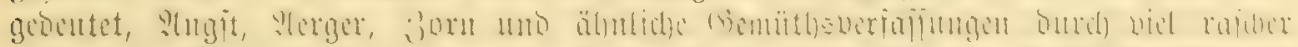

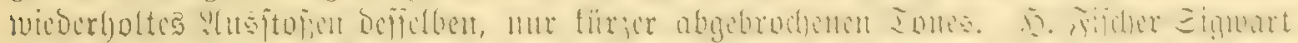

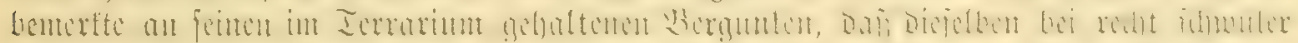

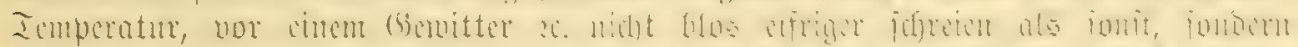

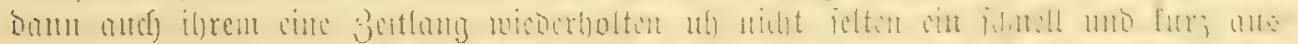

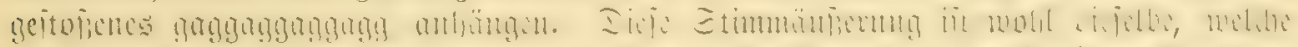

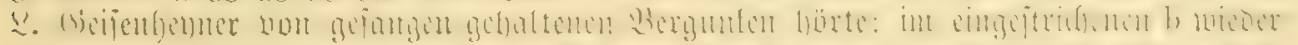

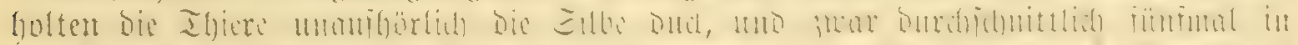

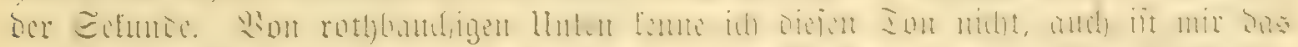

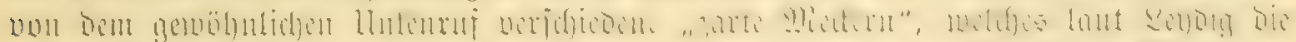

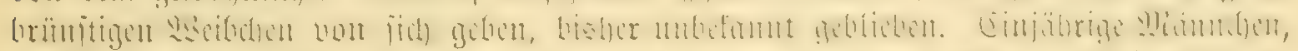

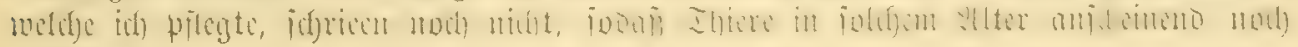
ftumun find.

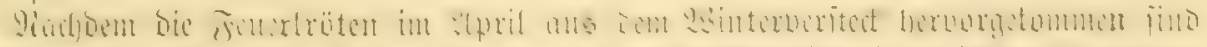

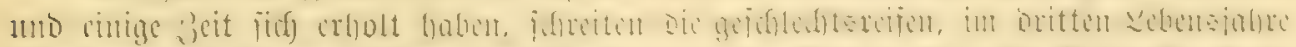

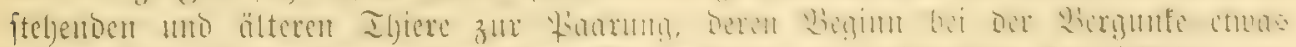

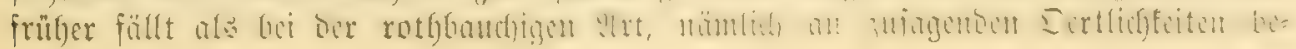




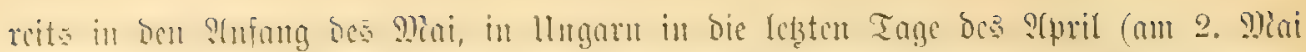

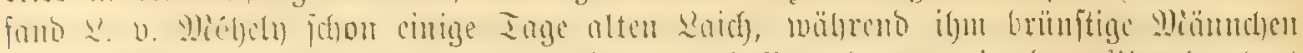

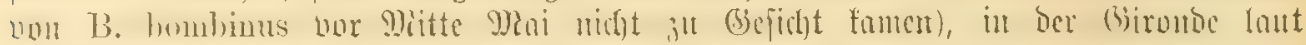

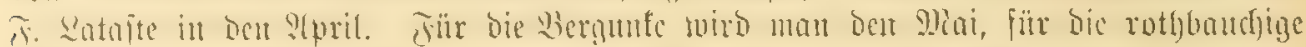

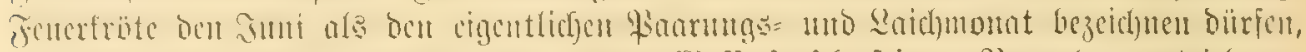

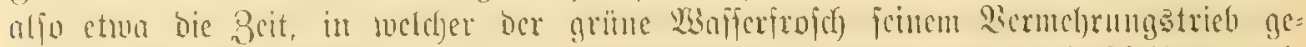

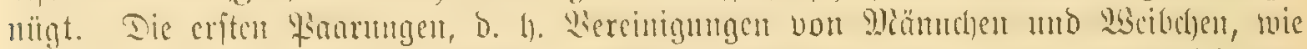

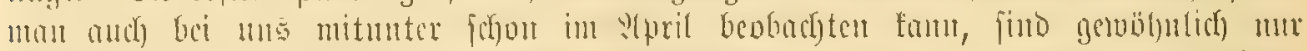

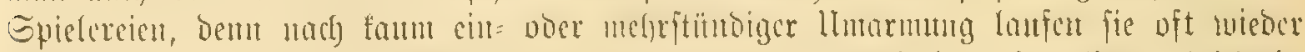

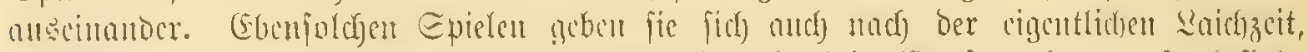

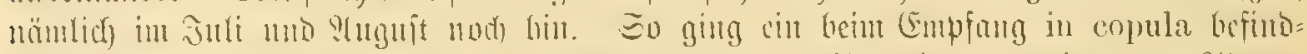

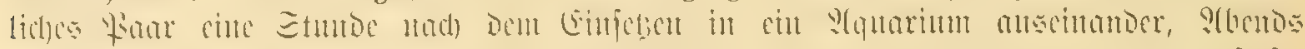

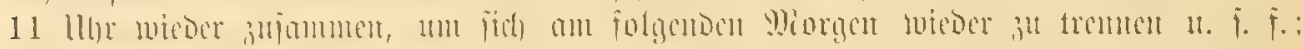

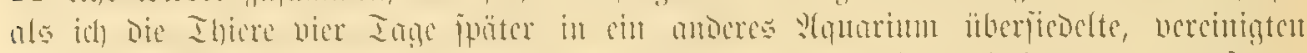

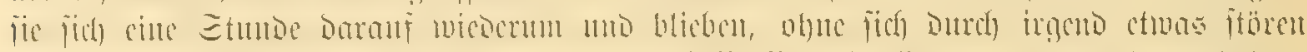

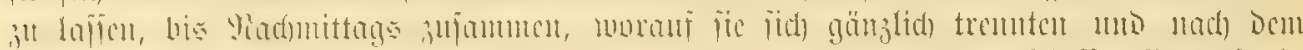

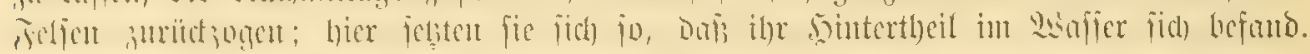

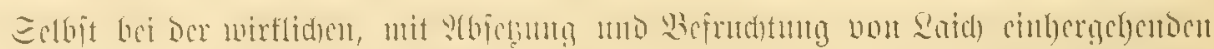

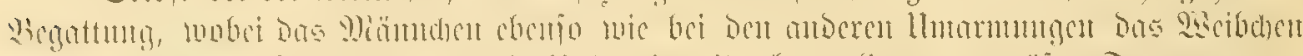

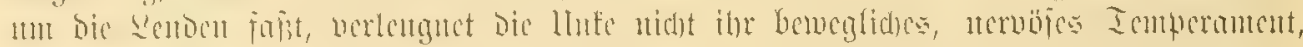

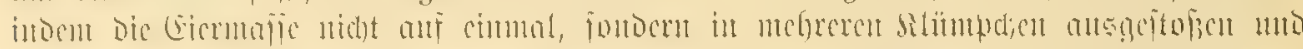

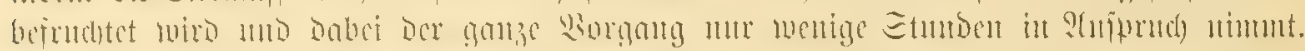

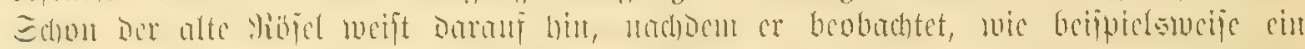

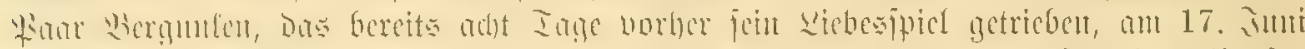

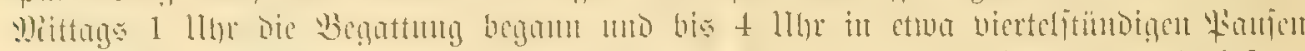

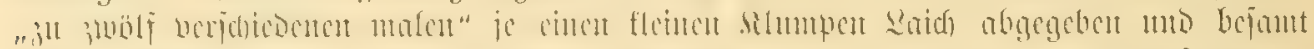

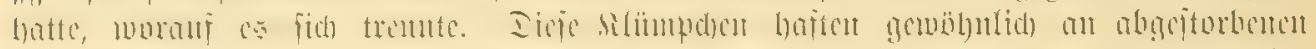

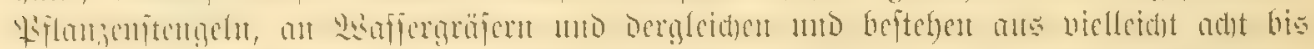

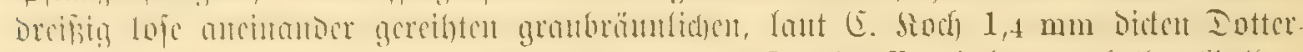

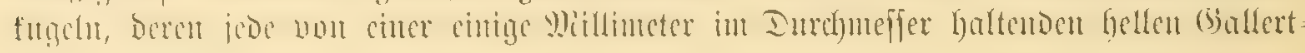
bülle umforloffert wirb.

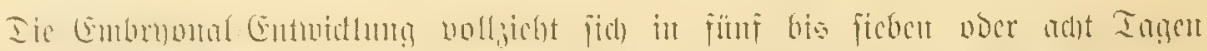

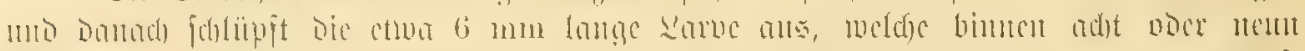

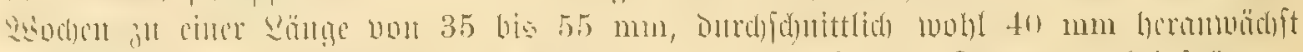

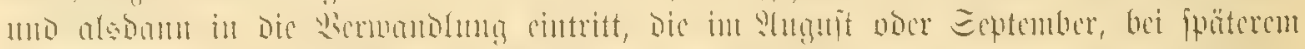

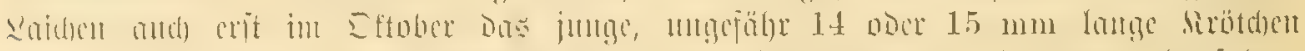

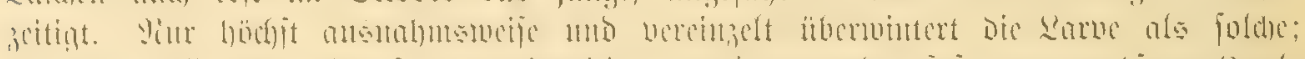

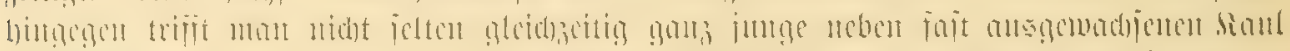

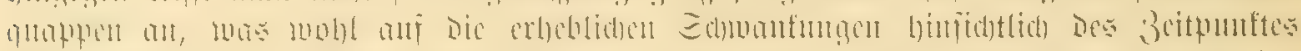

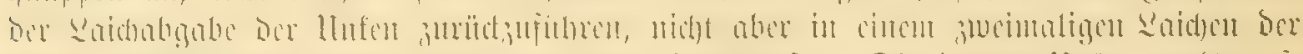

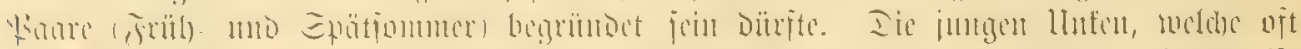

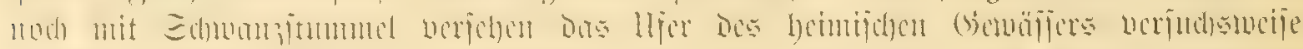

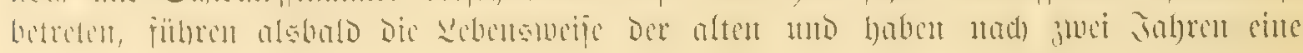
Säutge vou ctroa $35 \mathrm{~mm}$ erreididt.

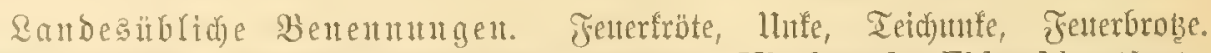

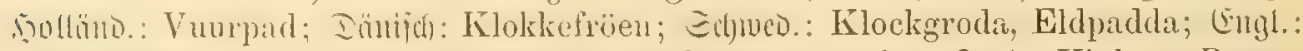
Fire-hellied Toad; îrans.: Sonneur igné, Somneur en feu; ìtal.: Ululone, Rospo, 


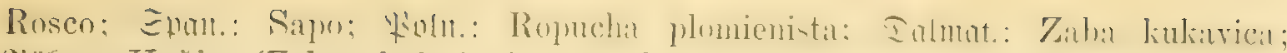

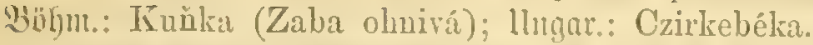

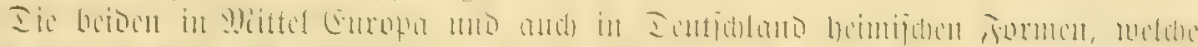

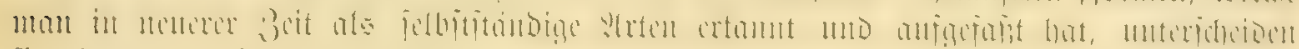
fid) leicht in folgender greife:

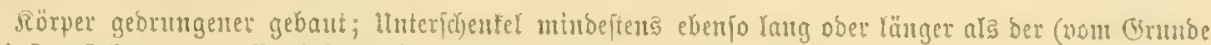

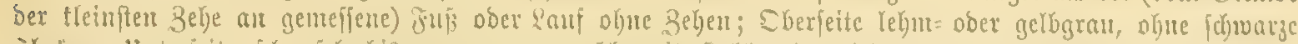

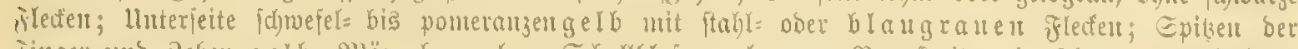

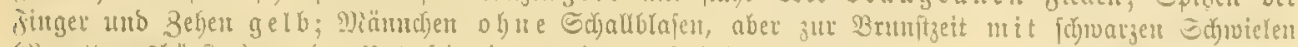
(begattungaburiten) an ber lnterjeite ber zweiten uno britten Behe.

B. pachypus.

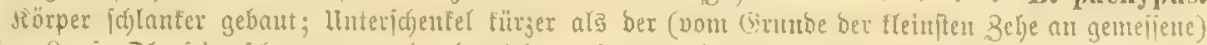

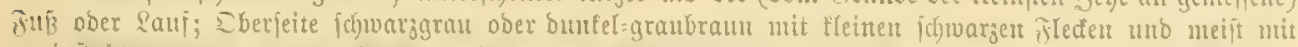

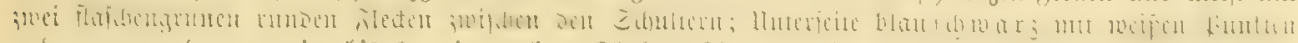

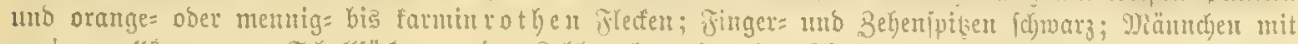

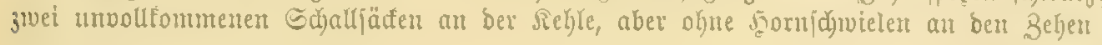

B. bombinus (igneus).

10. Irt: Gelbbaudjige Bergunfe. Bombinator pachypus, Bonap.

:bbildung: Tajel II, Tir. 1, 2.

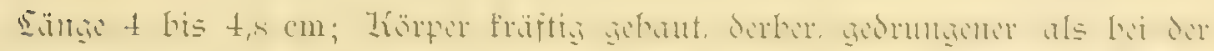

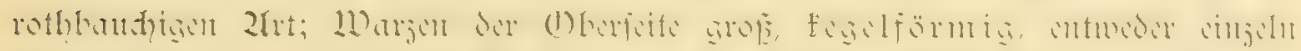

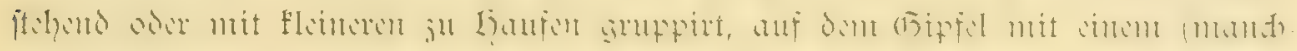

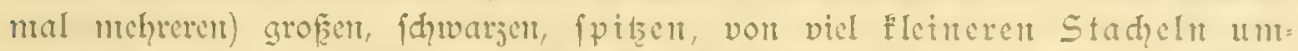

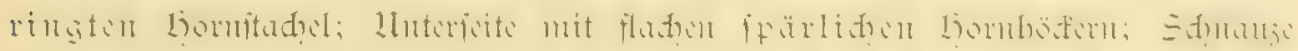

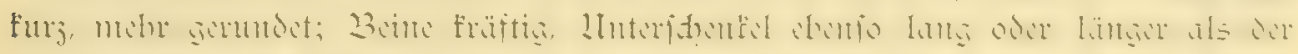

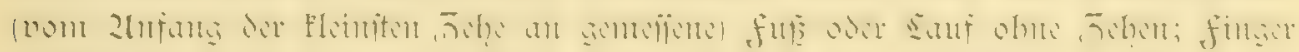

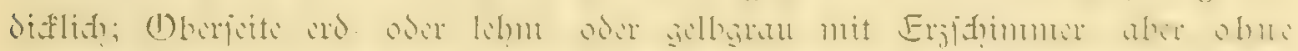

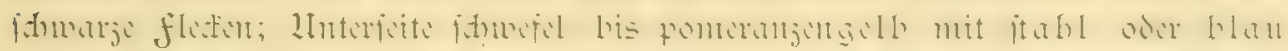

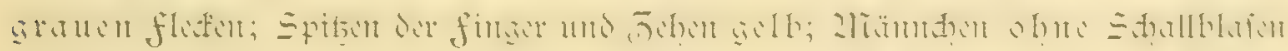

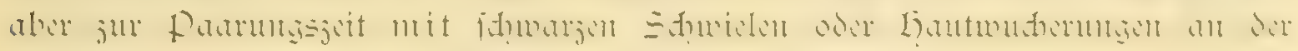
Unterfeite der jweiten und dritten อ̈che der Lintergliednafisen.

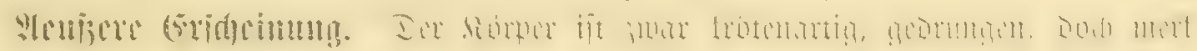

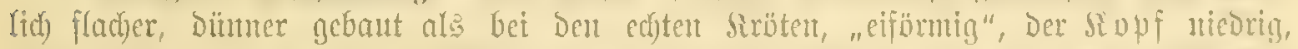

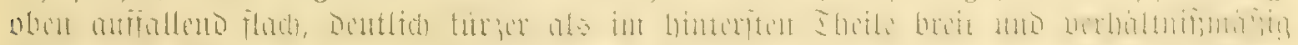

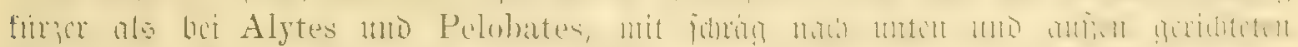

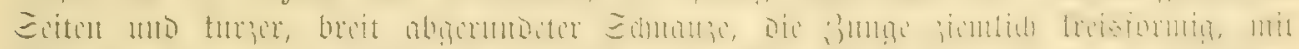

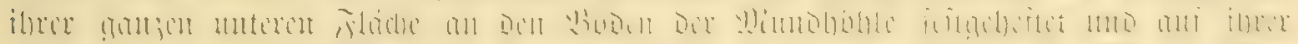

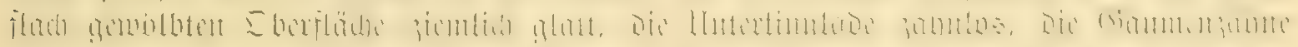

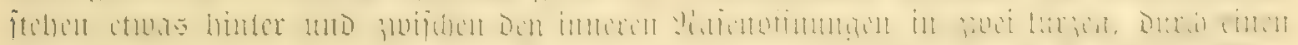

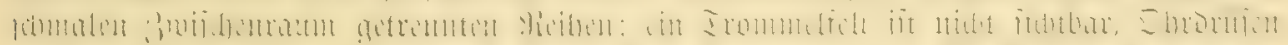

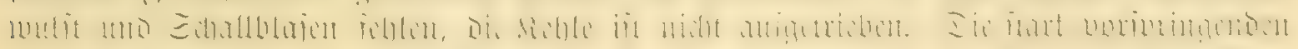

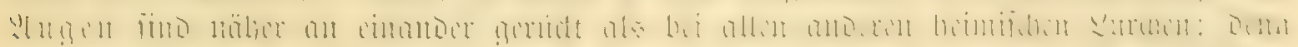

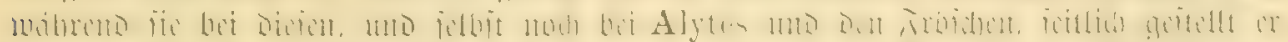
f(t)

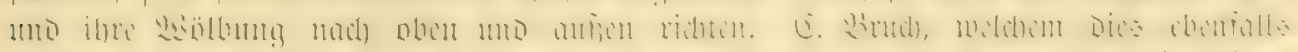

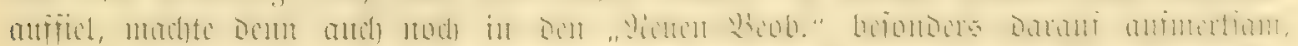

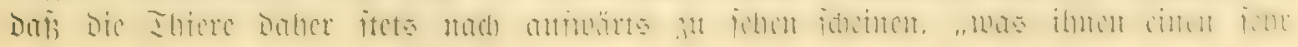




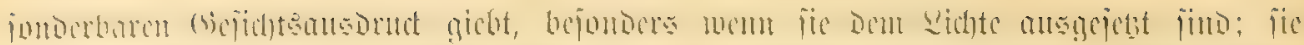

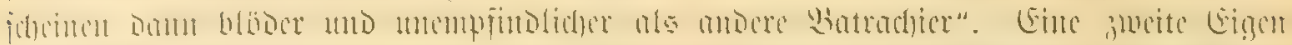

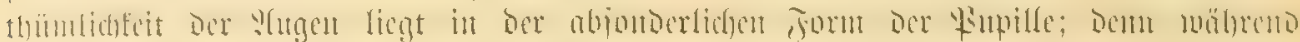

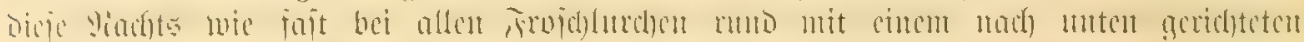

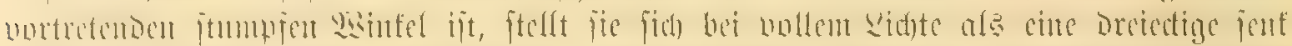

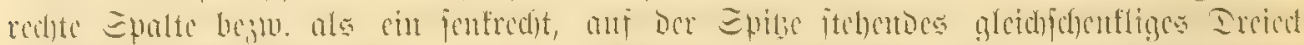

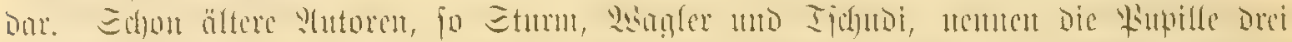

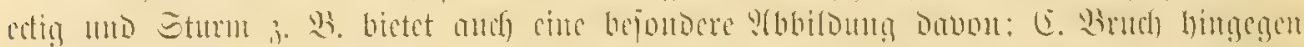

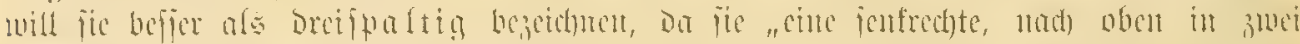

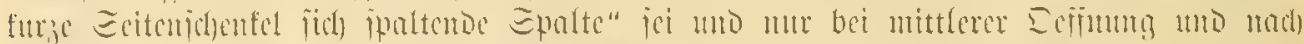

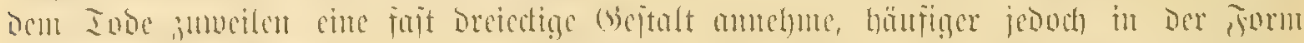

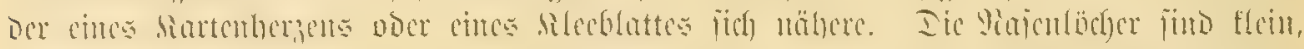

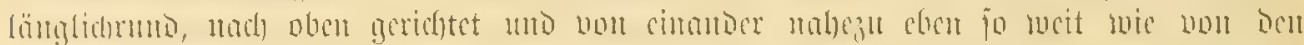

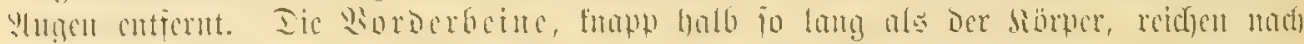

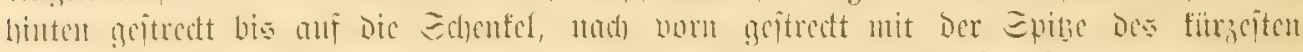

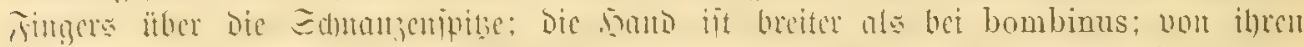

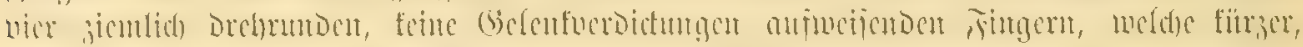

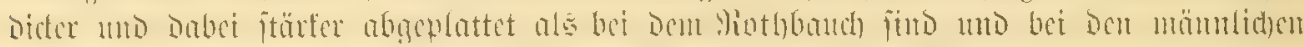

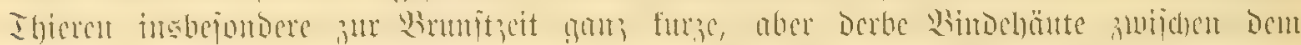

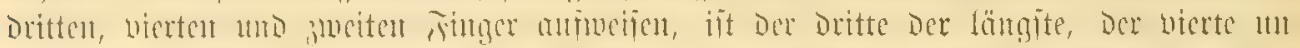

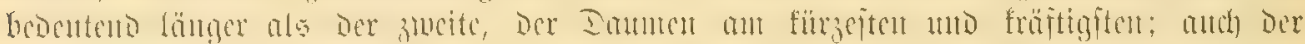

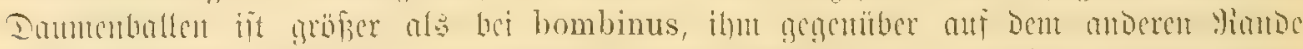

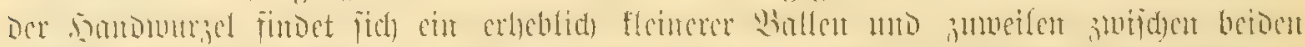

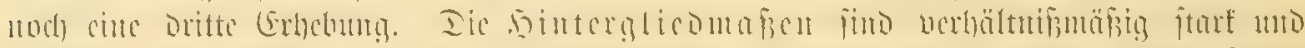

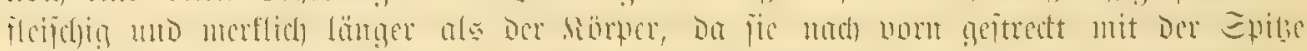

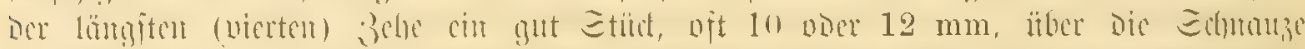
h)

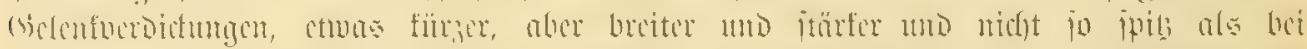

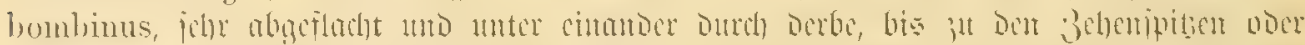

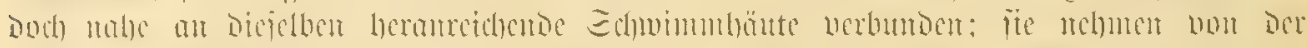

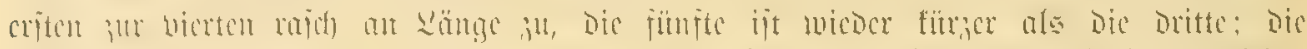

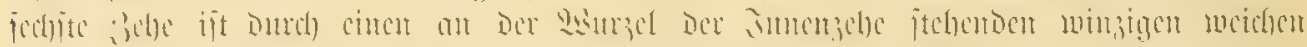

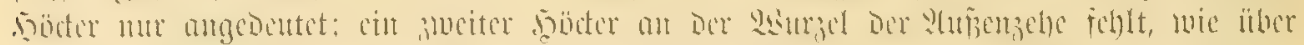

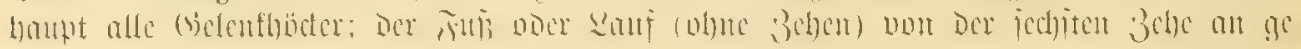
mefien, ift finzer oder cbenjo long ala Der llnteridjentel.

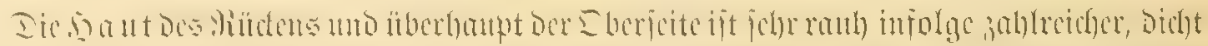

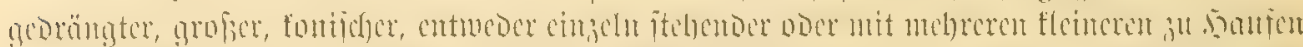

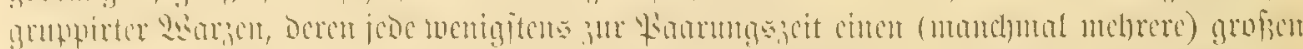

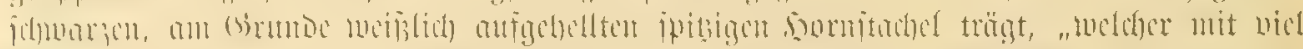

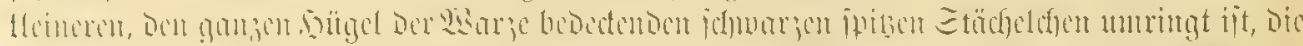

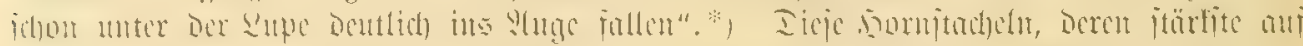

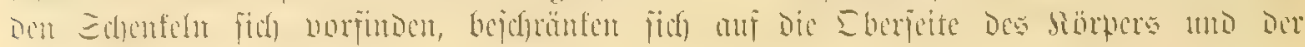

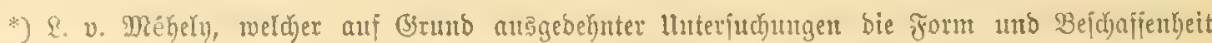

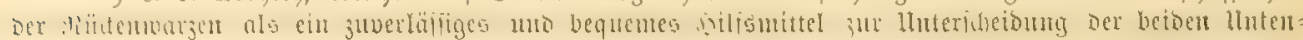

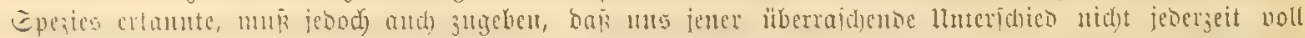

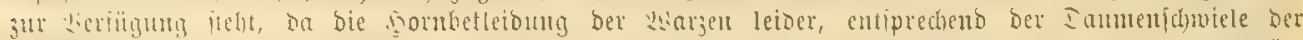

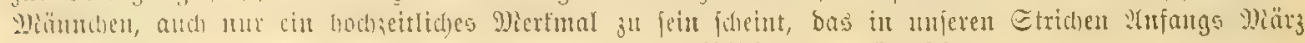

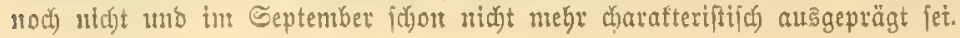




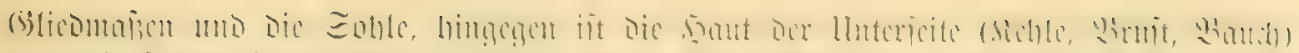

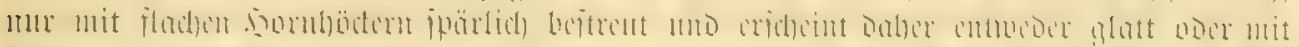

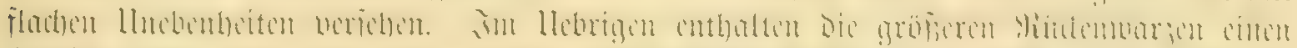

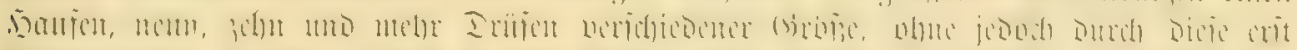

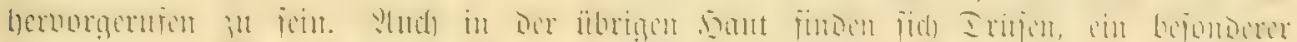

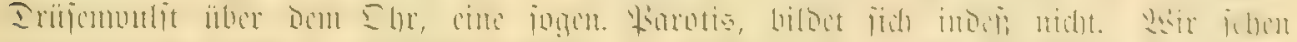

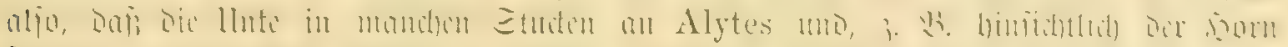

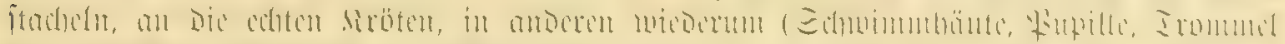

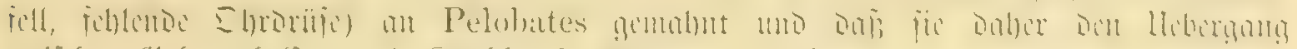

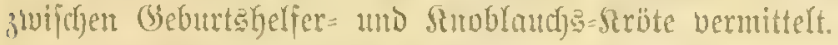

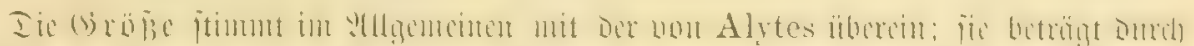

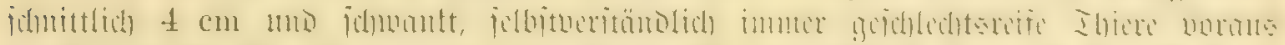

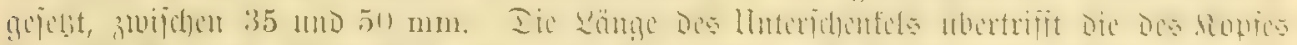

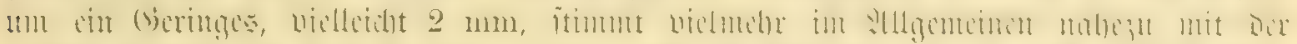

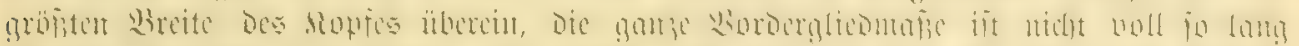

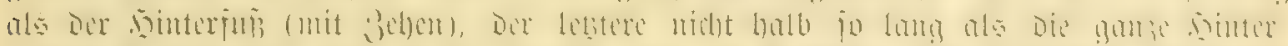

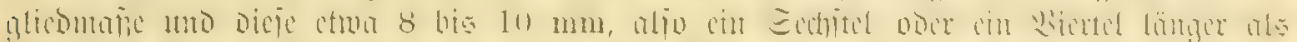

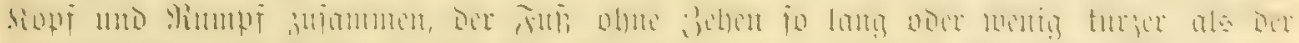

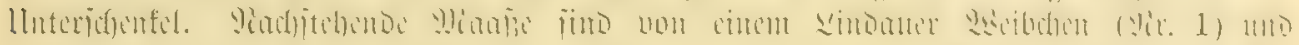

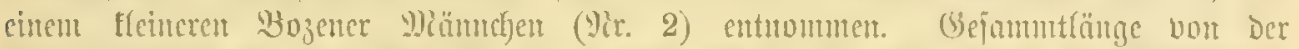

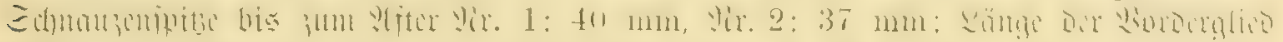

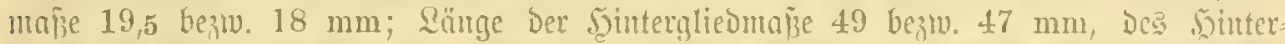
funs mit

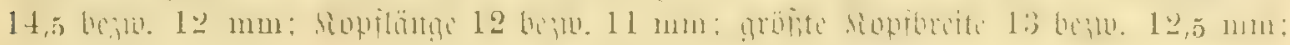

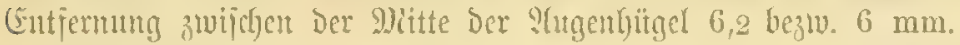

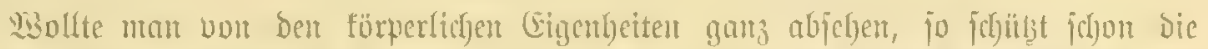

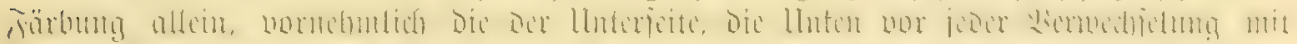

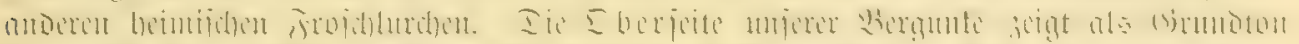

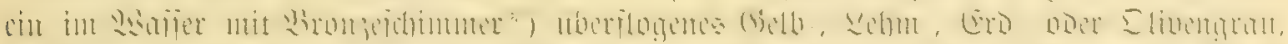

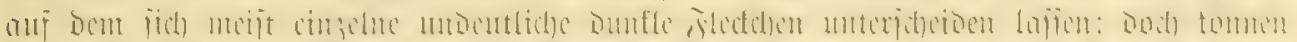

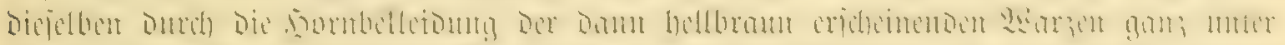

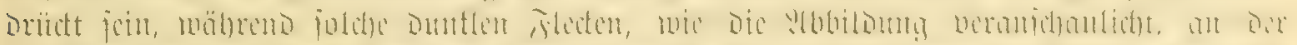

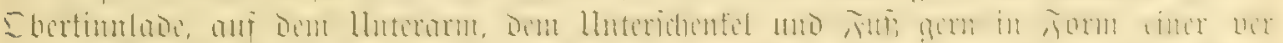

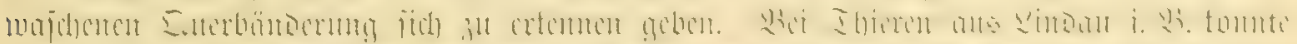

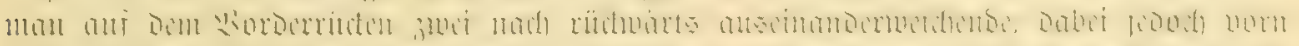

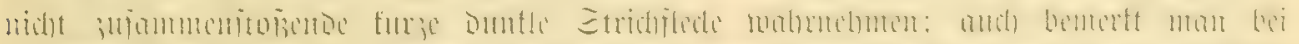

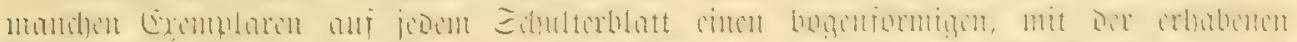

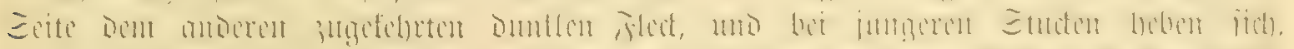

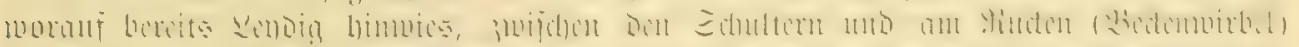

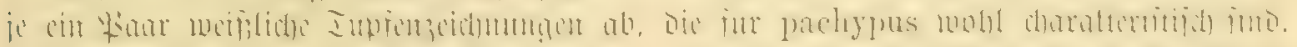

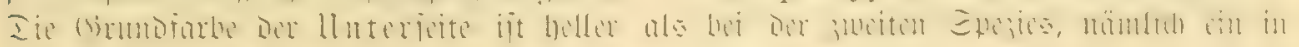

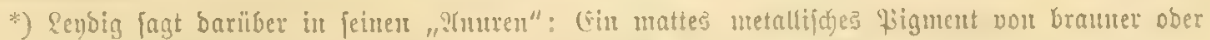

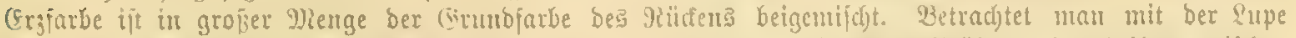

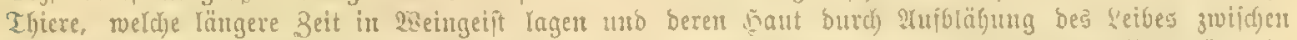

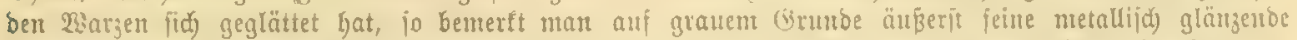

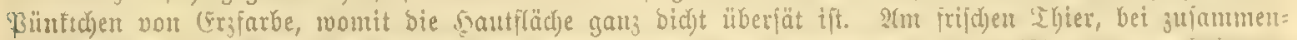

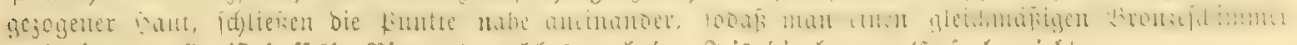
wahtminmt. (Es if baffelbe Pigment, meldyes audj ber Sris bie braune Ergiarbe giebt. 


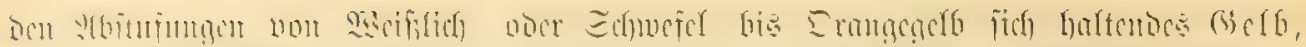

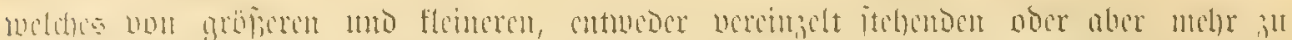

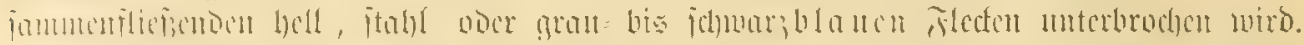

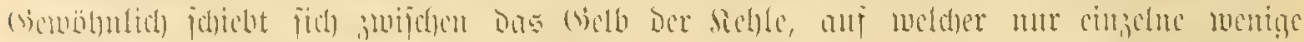

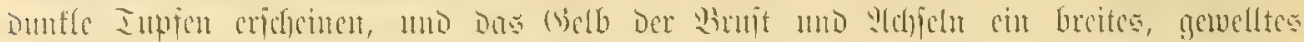

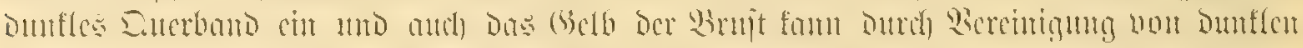

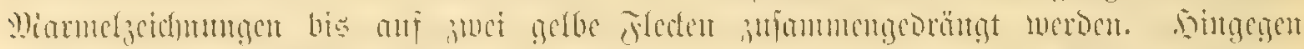

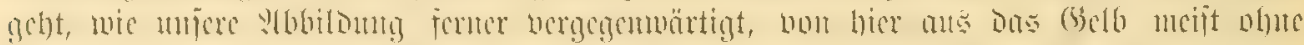

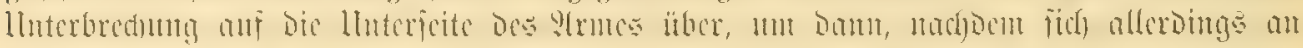

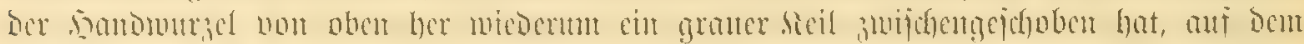

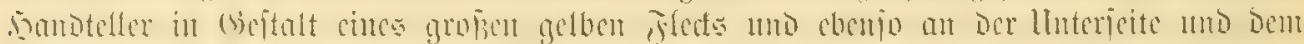

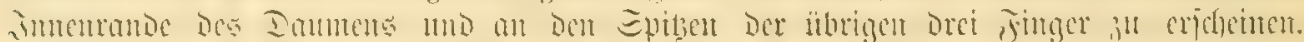

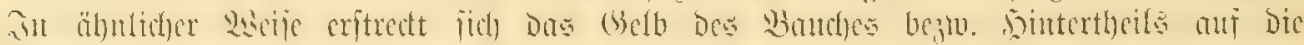

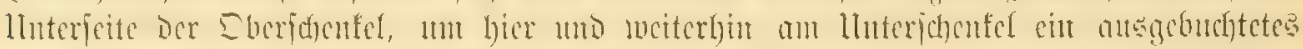

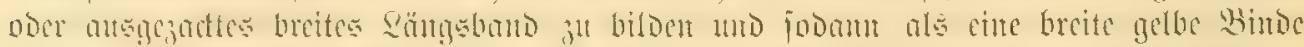

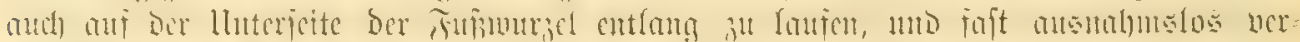

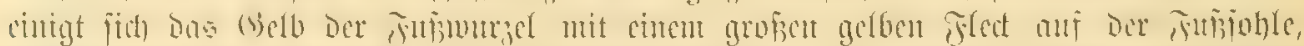

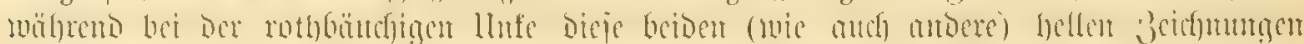

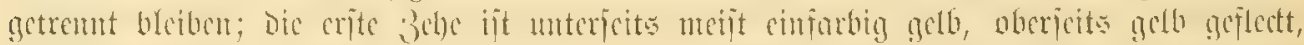

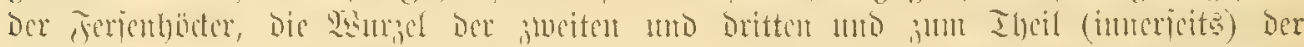

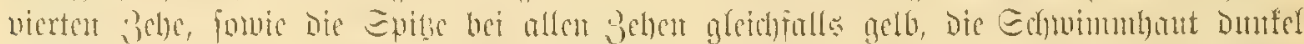

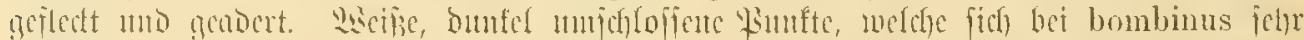

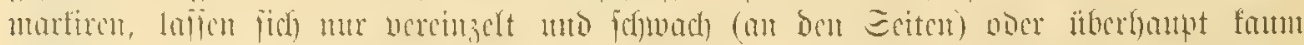

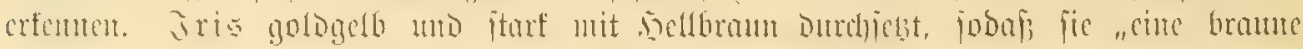
Erzfarbe" zeigt, bie obere Sälfte etwas Dunfler als bie untere.

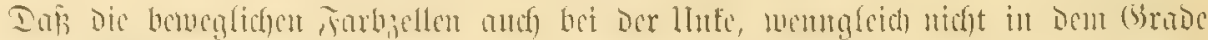

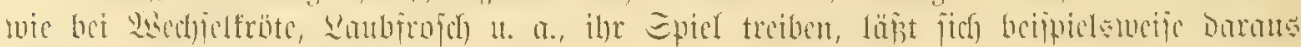

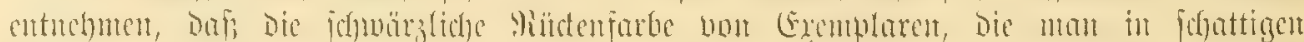

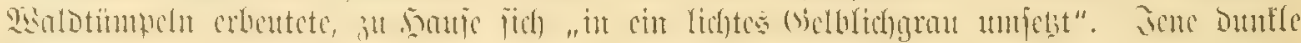

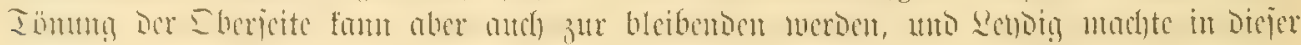

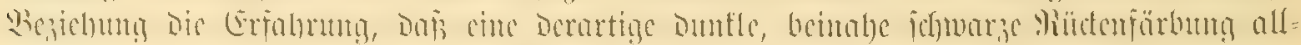

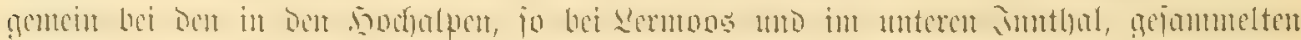

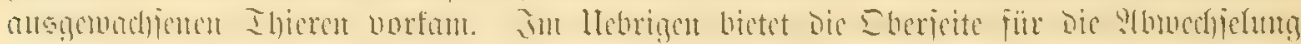

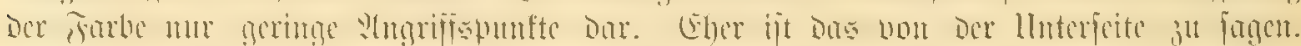

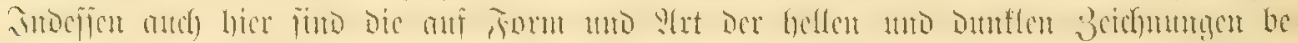

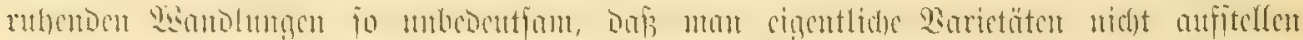

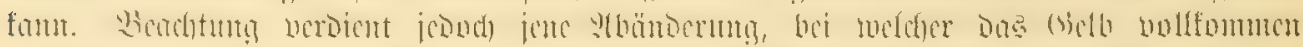

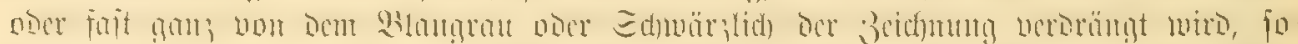

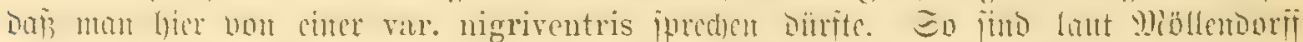

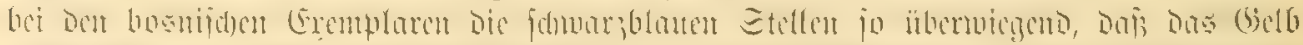

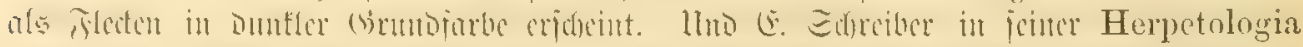

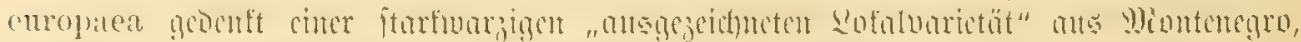

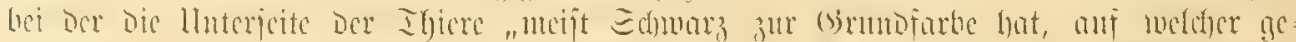

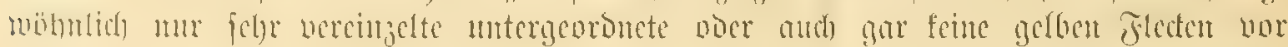
fontment".

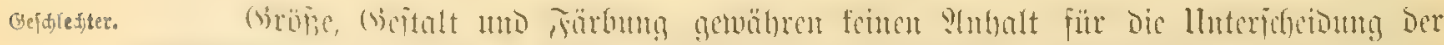

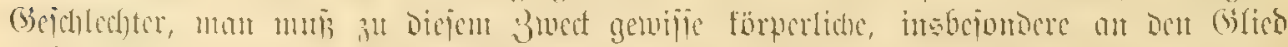

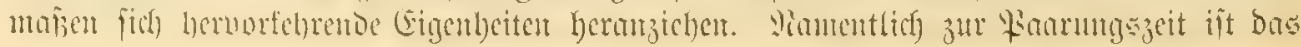




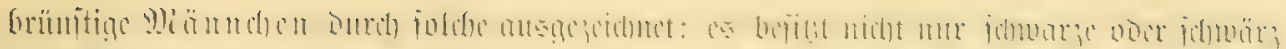

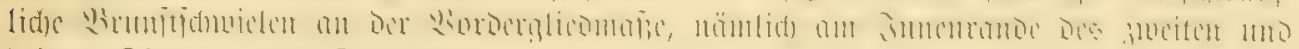

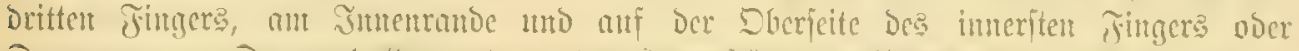

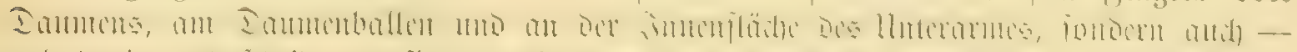

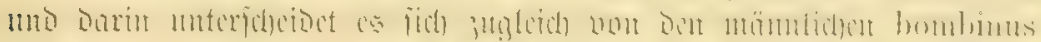
mim in intiv

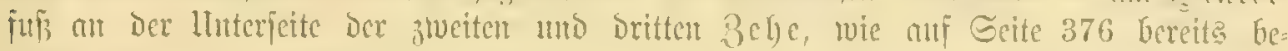

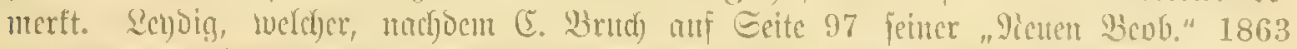

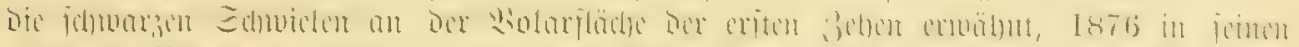

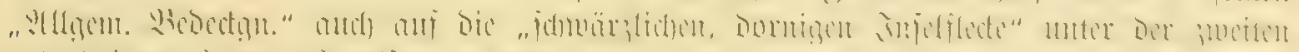

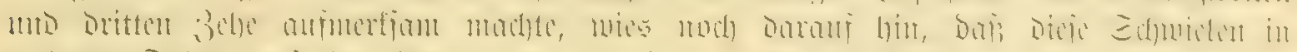

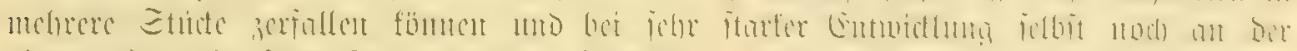

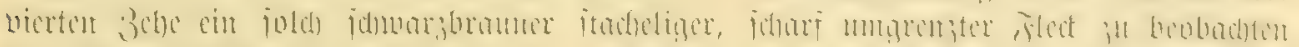

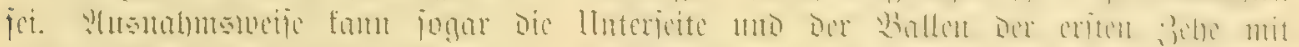

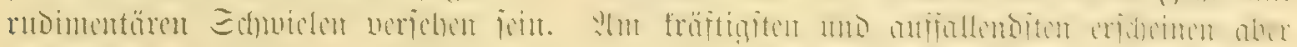

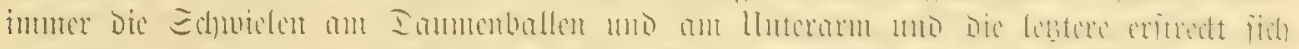

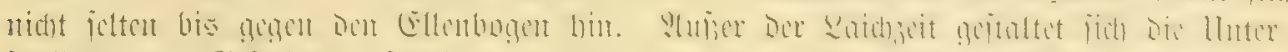

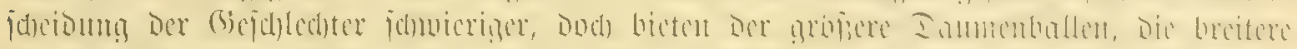

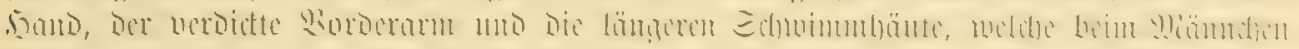

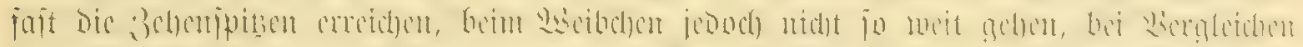

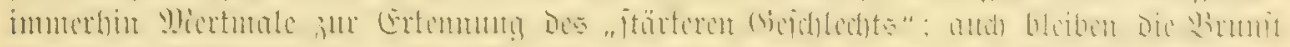

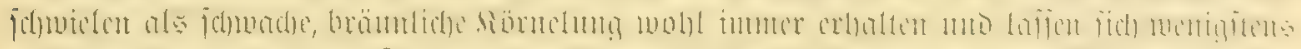

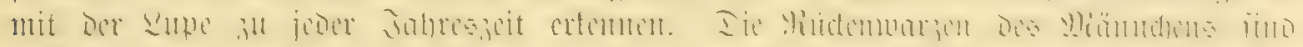

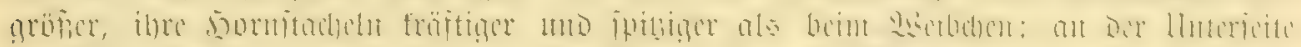

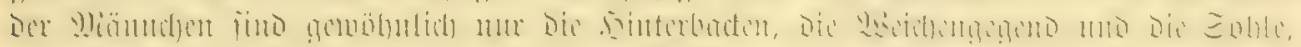

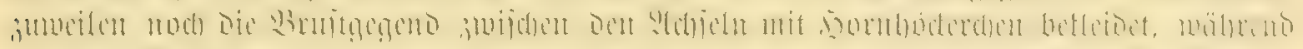

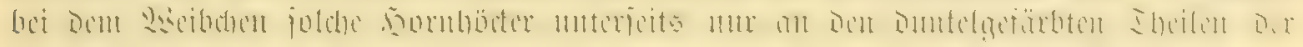

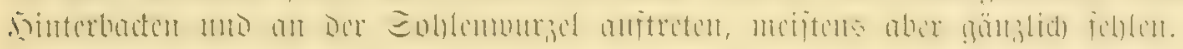

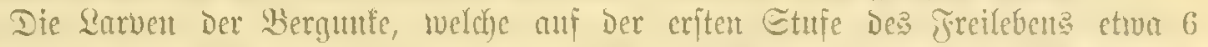

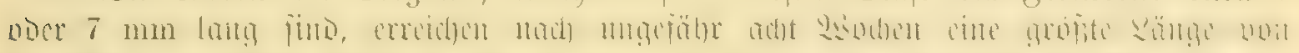

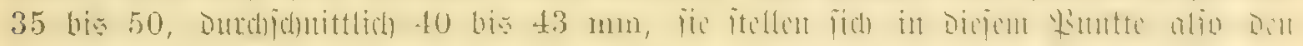

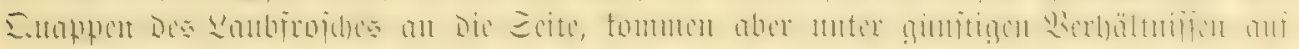

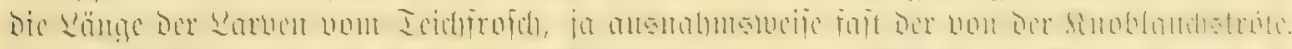

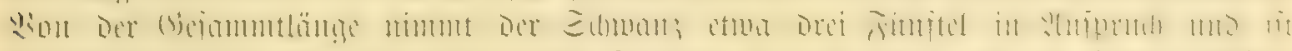

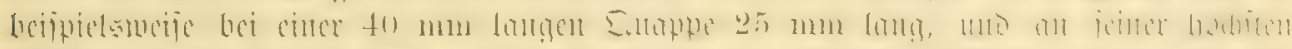

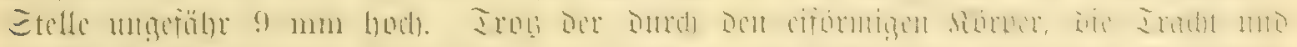

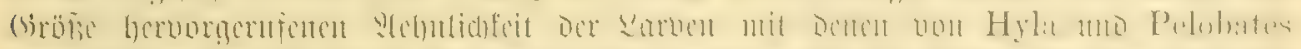

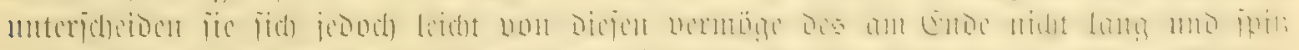

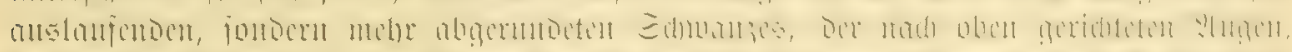

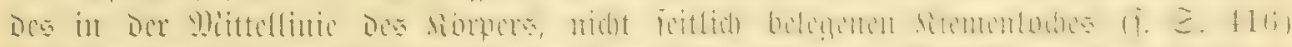

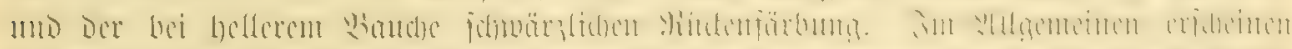

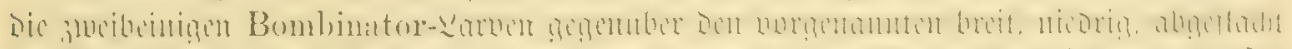

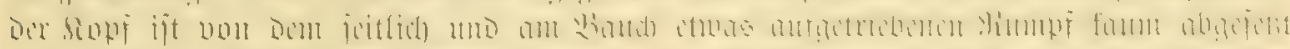

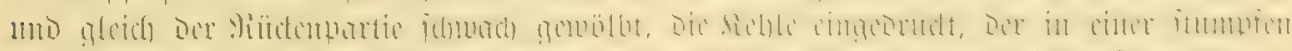

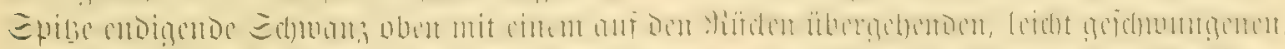

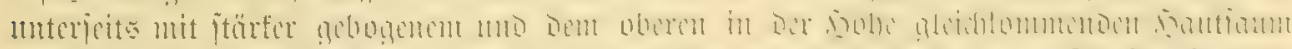

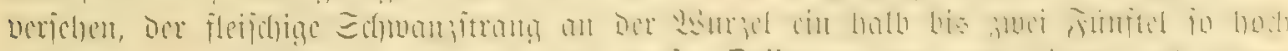

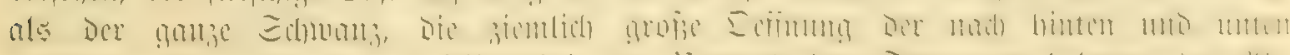

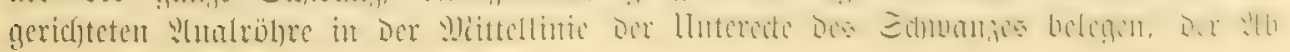




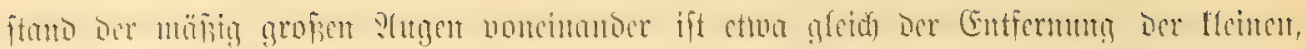

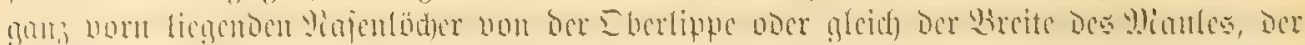

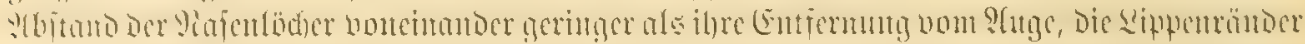

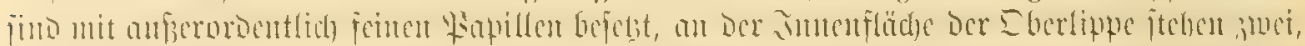

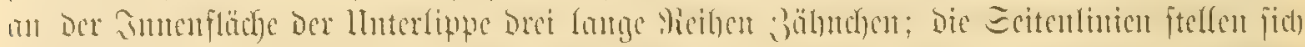

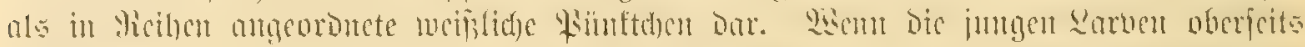

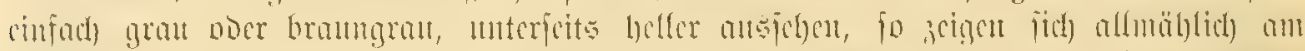

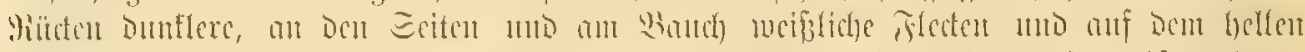

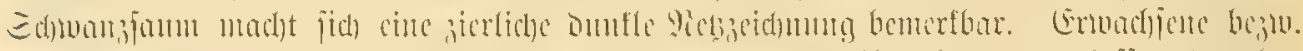

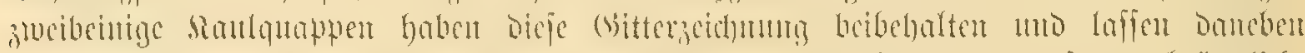

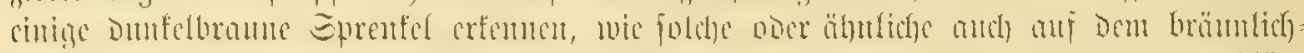

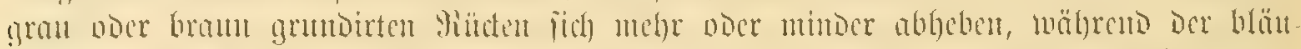

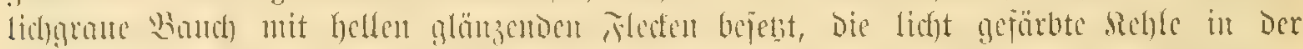

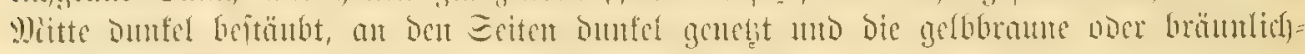
gelbe Sdfuanzuitte gleidffalle braun befitrent eridjeint.

Jurtge.

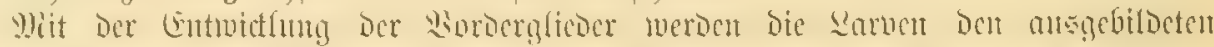

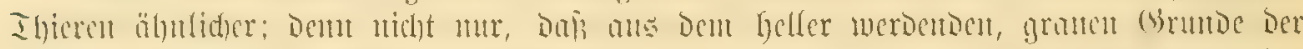

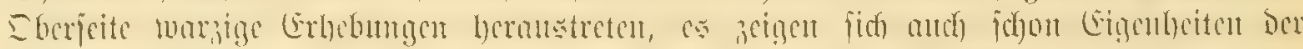

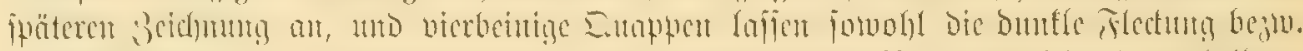

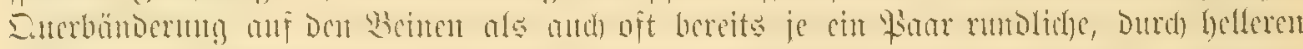

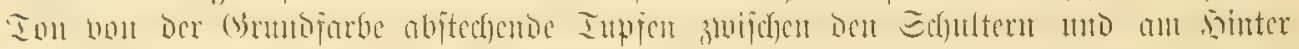

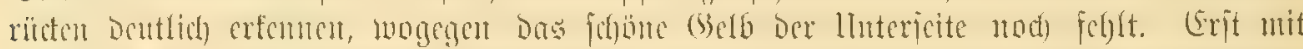

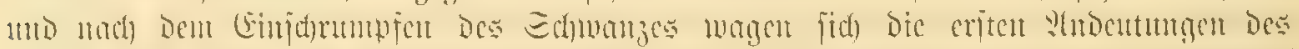

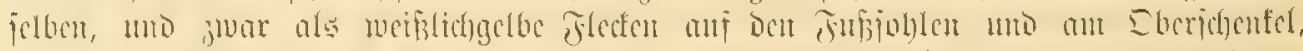

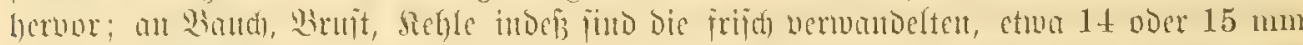

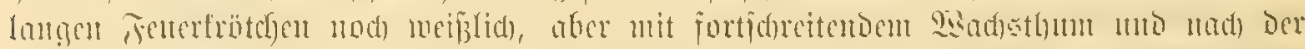

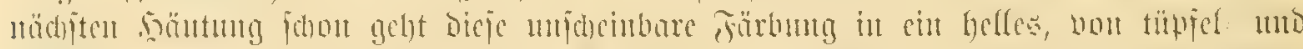

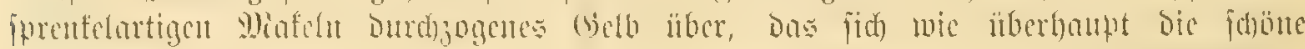

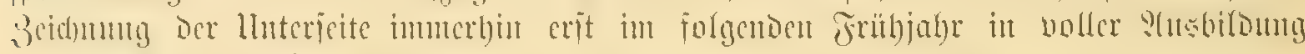
IInd Sättigung giebt.

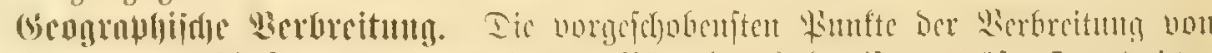

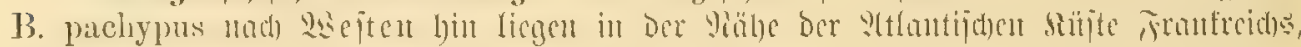

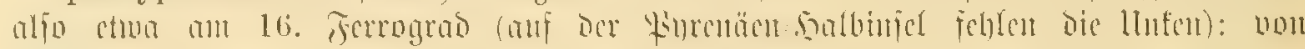

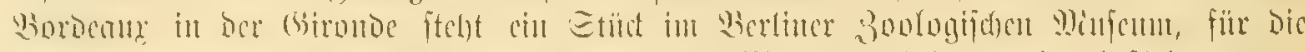

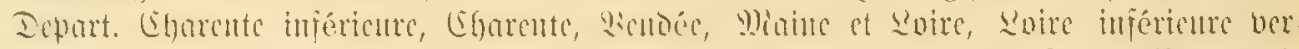

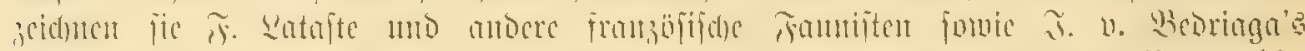

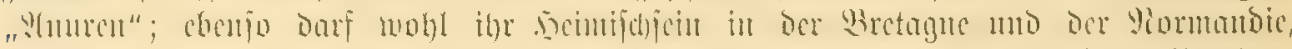

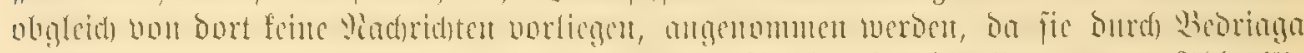

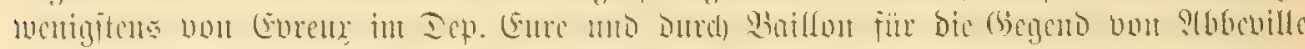

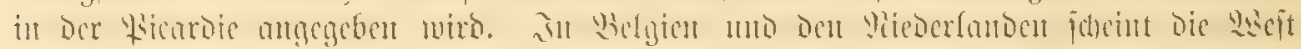

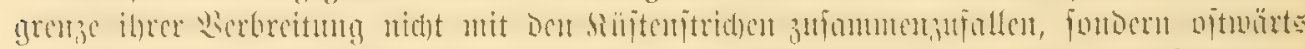

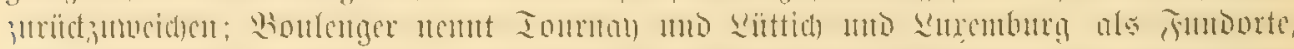

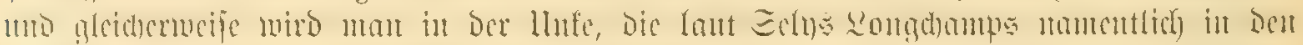

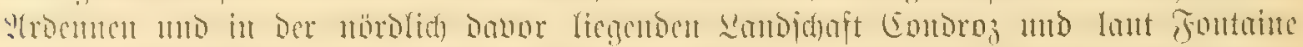

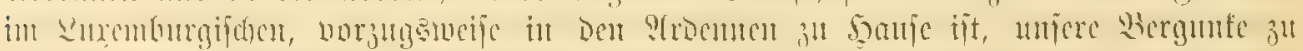

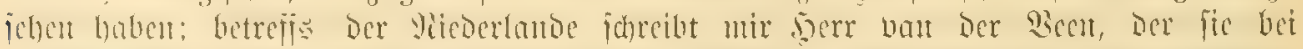

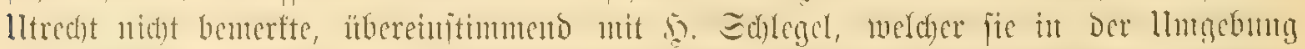

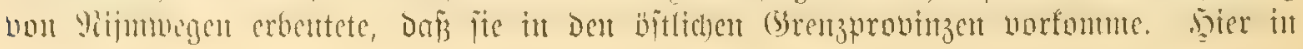




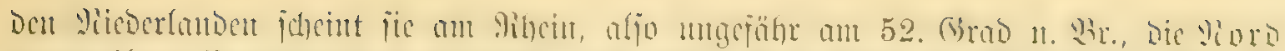

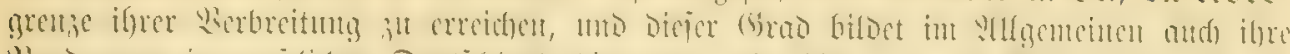

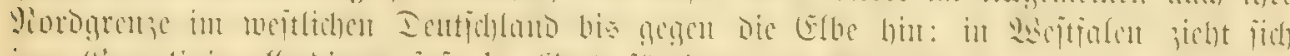

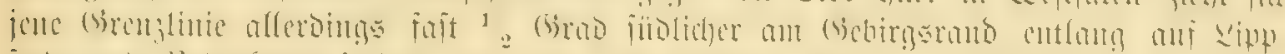

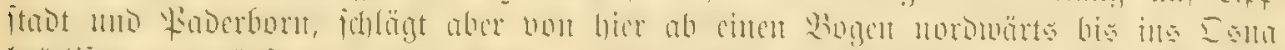

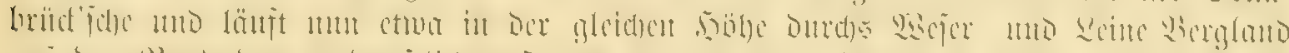

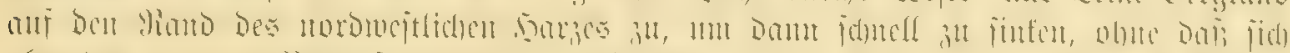

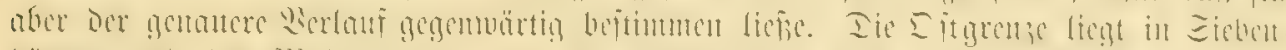

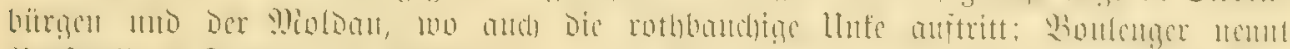

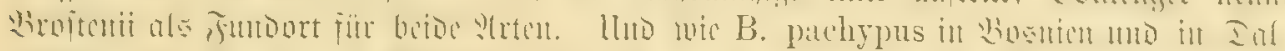
mation, wo thu Dr. $\bar{x}$.

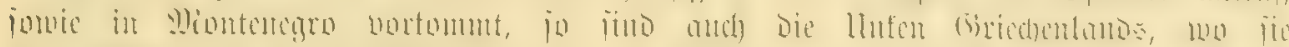

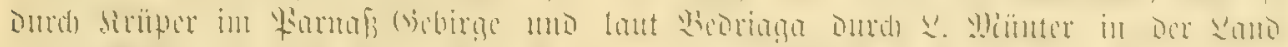

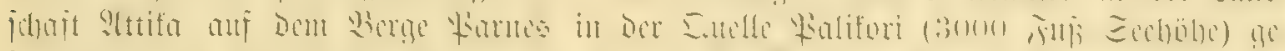

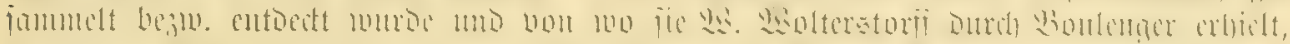

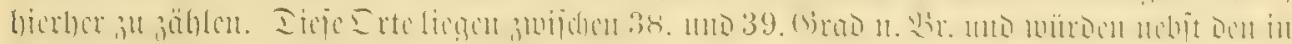

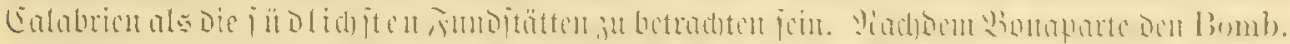

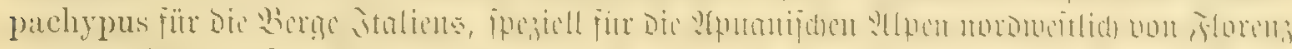

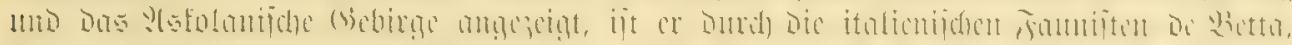

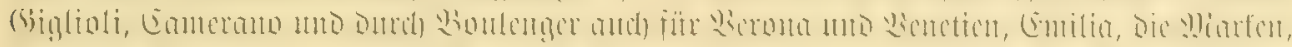

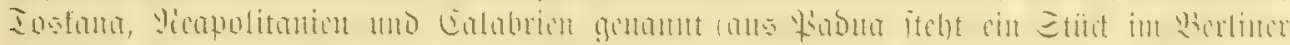

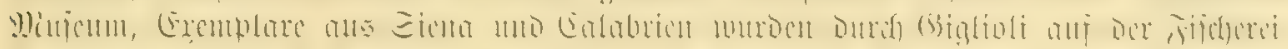
Y)

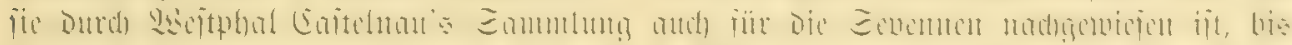

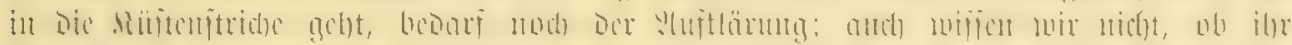

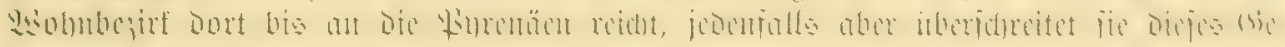
birge nicht.

然施 in bo

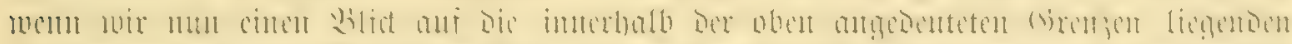

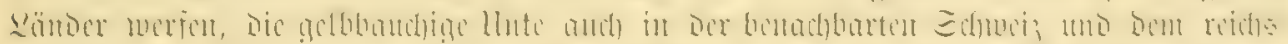

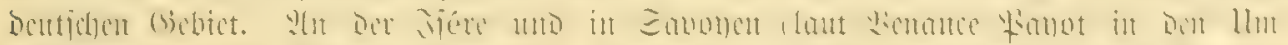

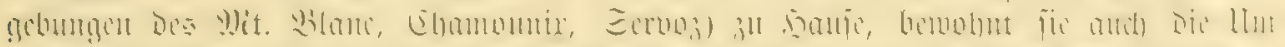

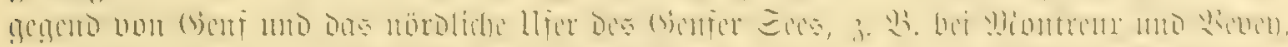

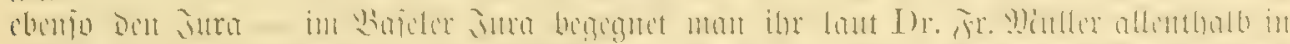

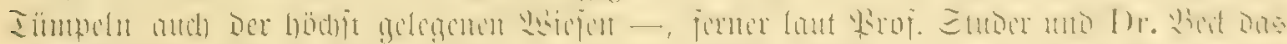

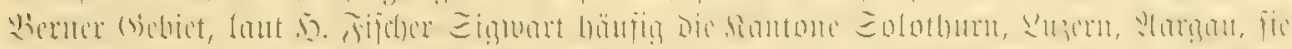

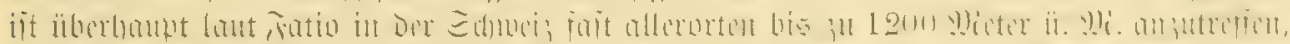

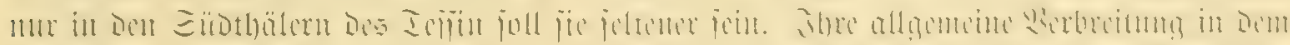

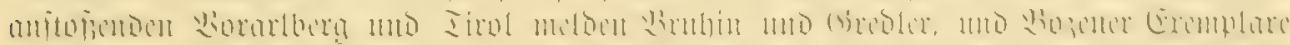

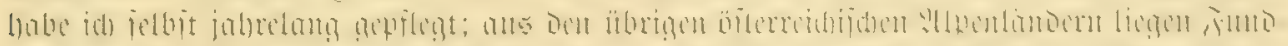

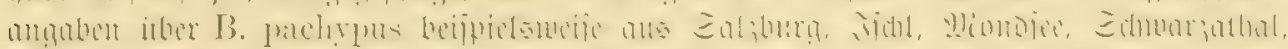

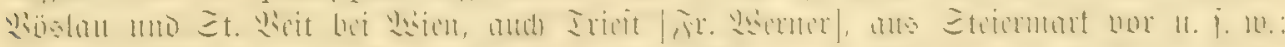

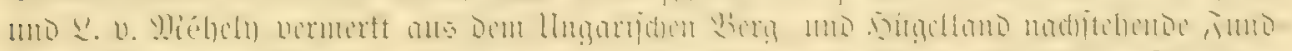

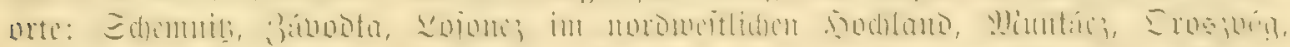
3)

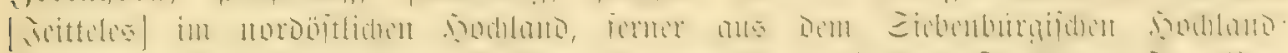

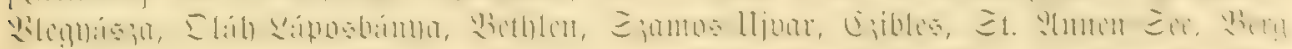

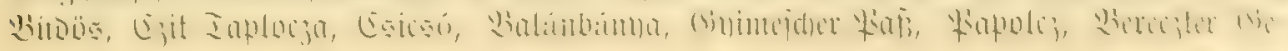




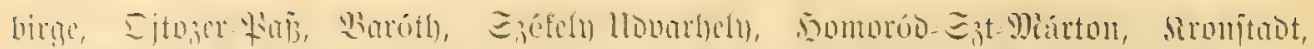

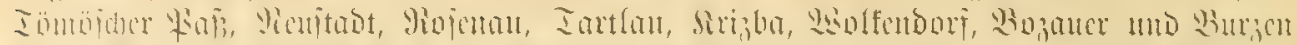

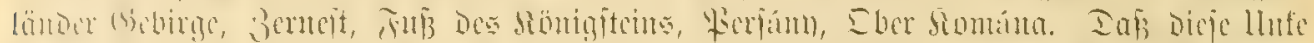

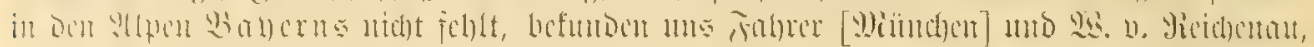

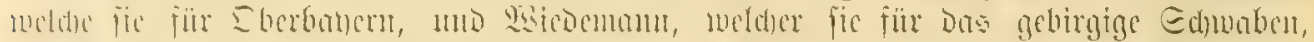

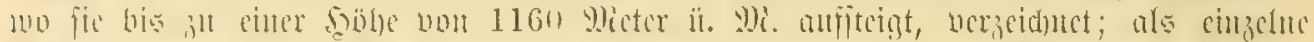

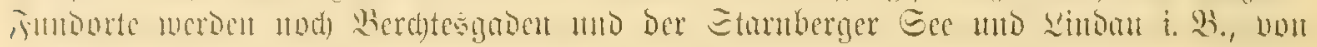
wo idj) rebentie Etïdfe exhielt, nambajt gemadit.

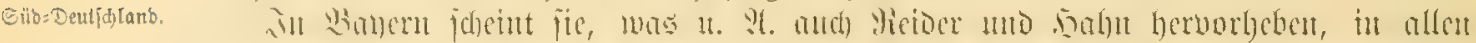

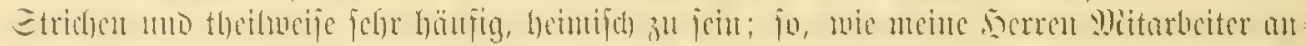

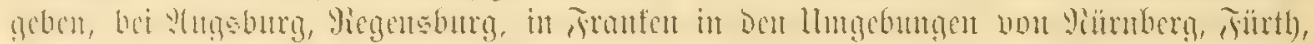

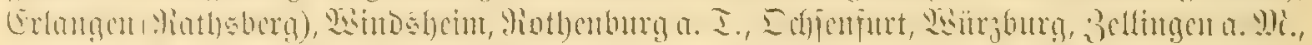

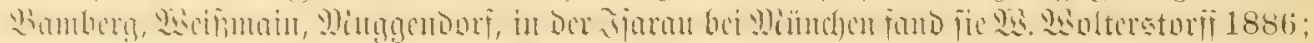

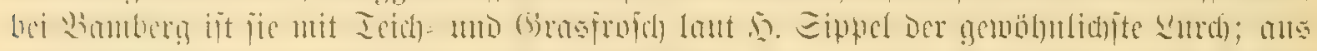

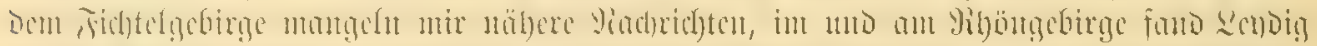

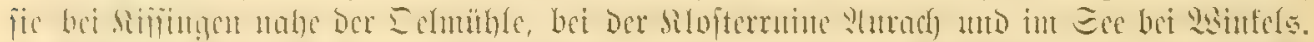

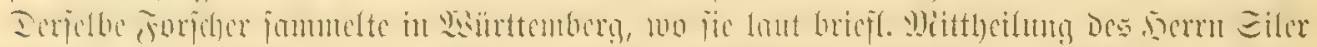

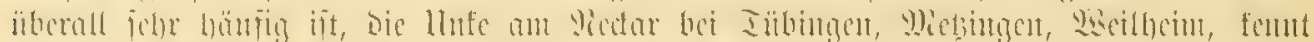

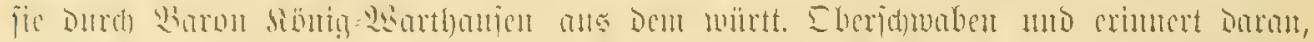

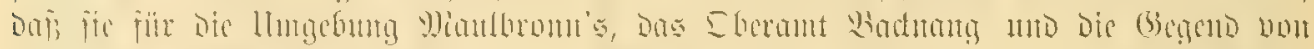

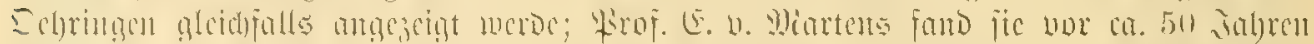

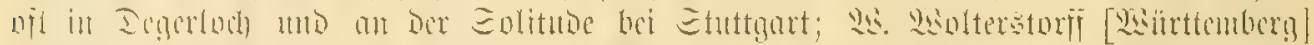

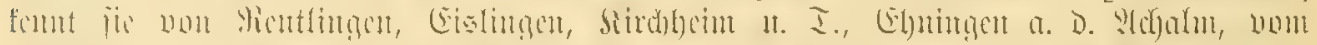

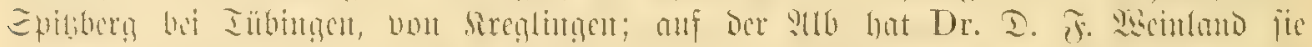

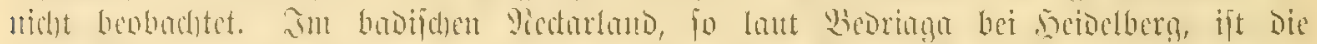

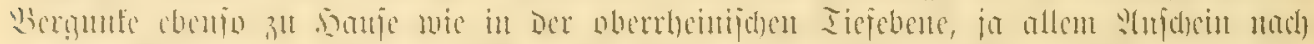

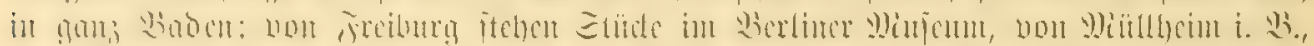

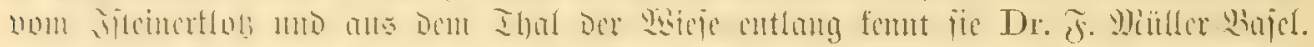

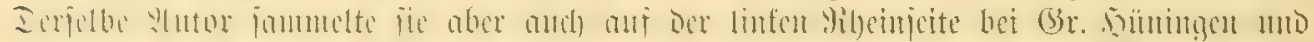

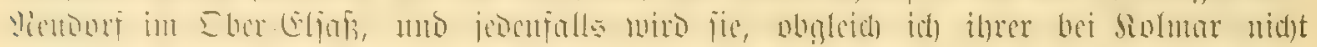

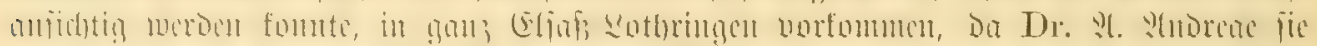

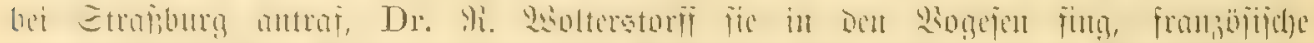

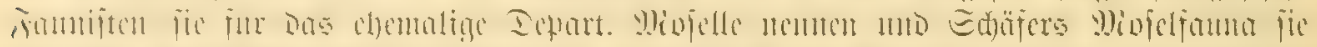

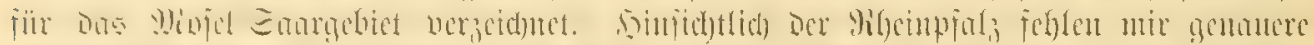

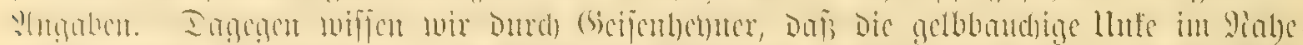

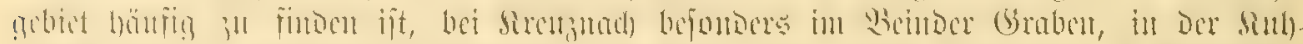

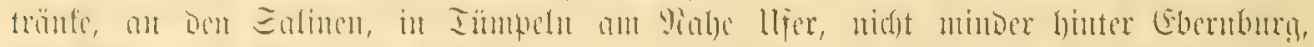

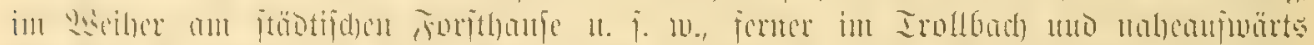

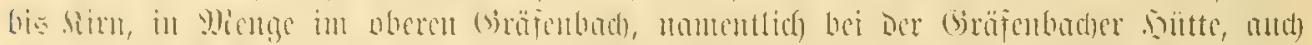

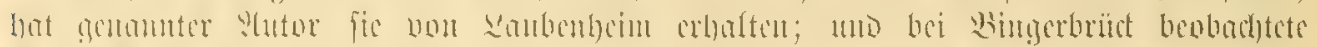

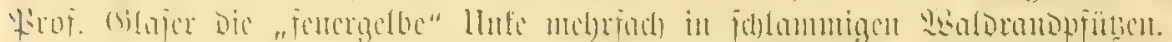

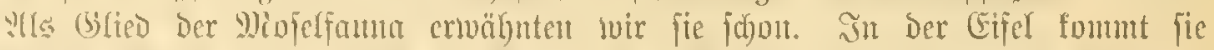

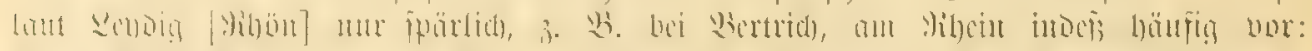

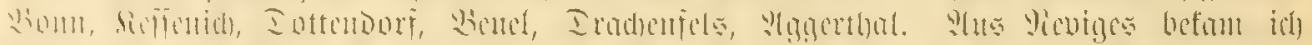

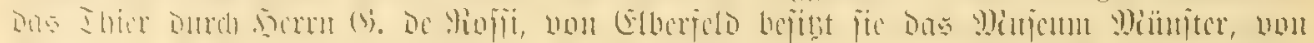

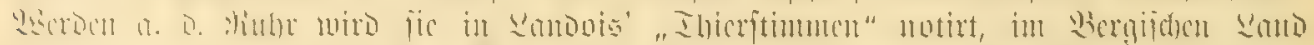

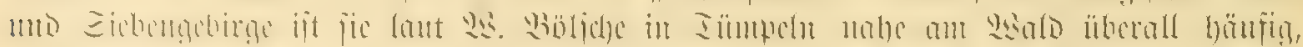

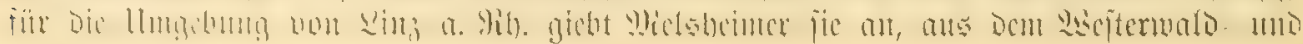




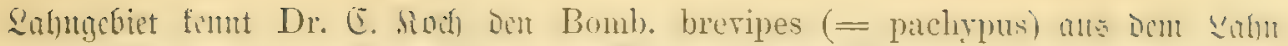

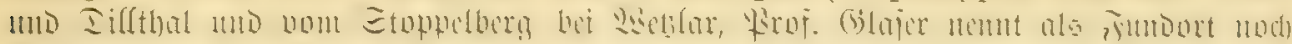

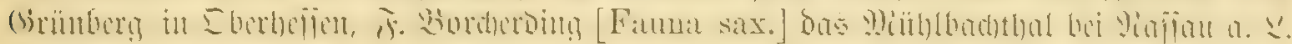

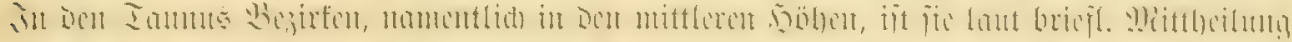

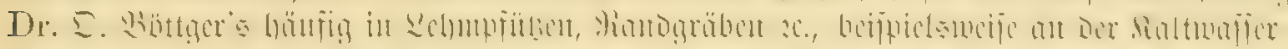

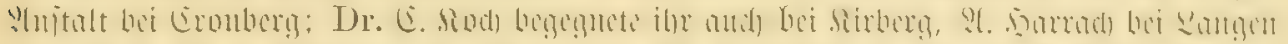

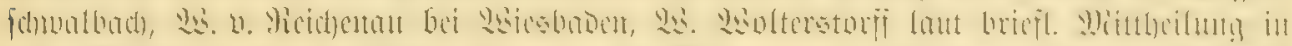

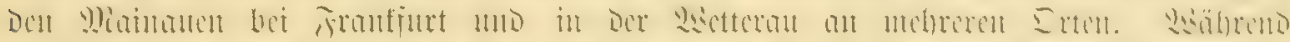

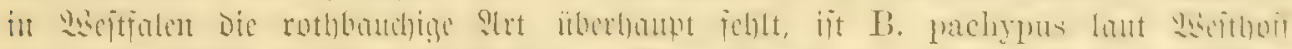

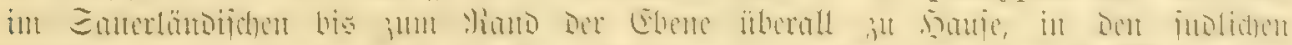

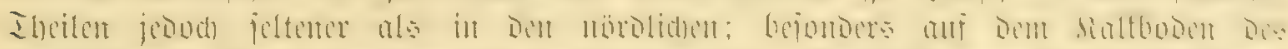

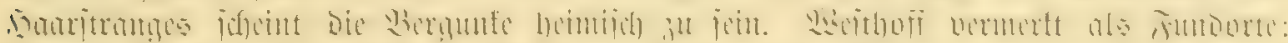

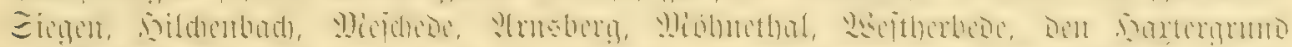

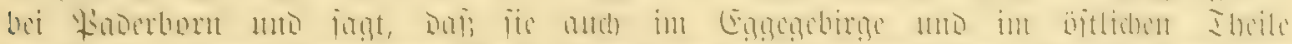

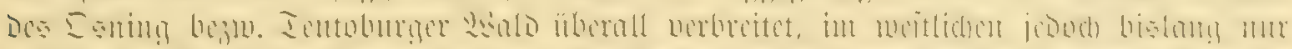

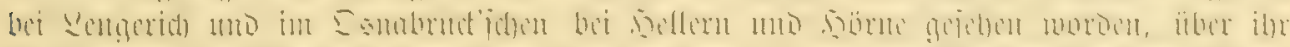

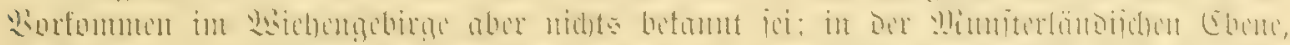

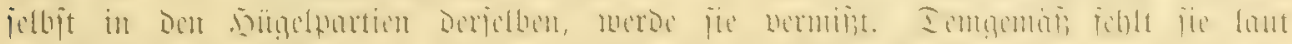

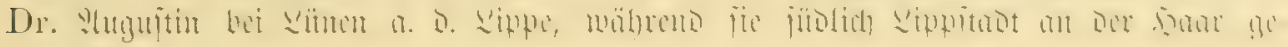
pammelt suroe.

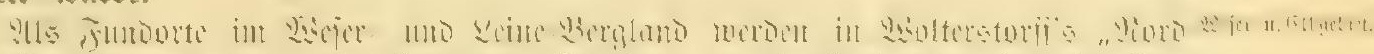

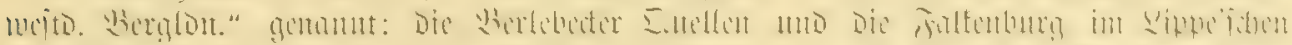

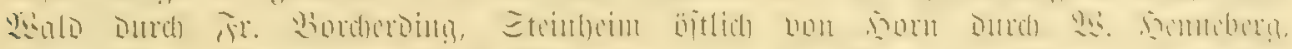

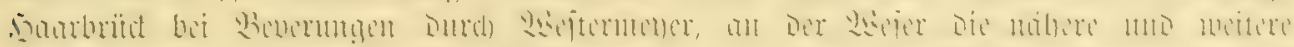

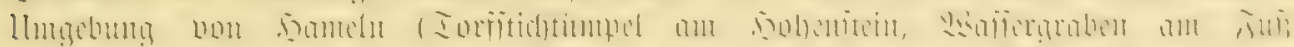

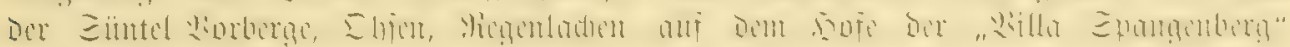

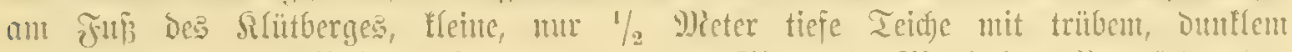

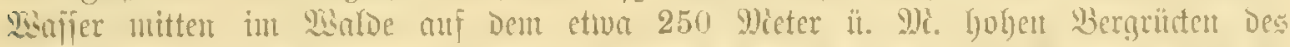

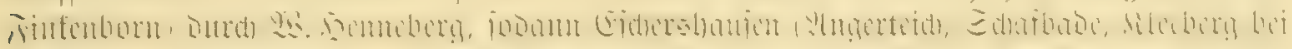

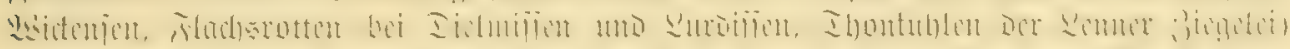

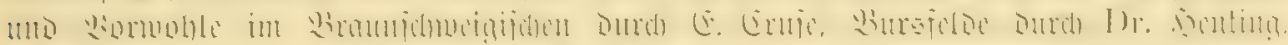

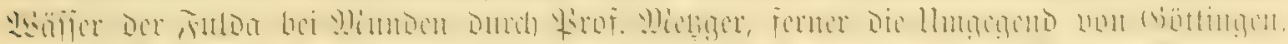

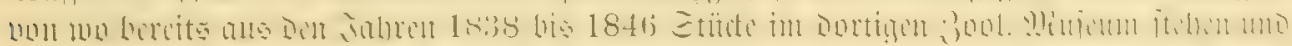

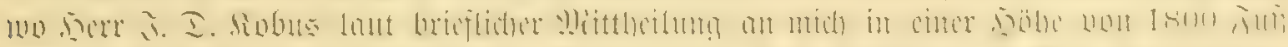

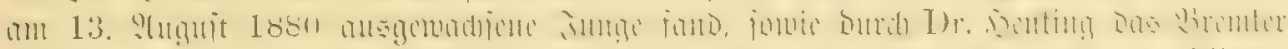

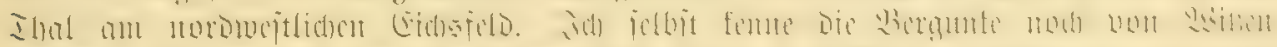

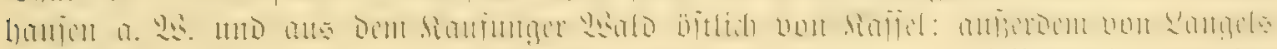

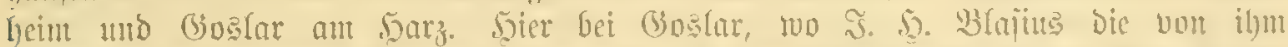

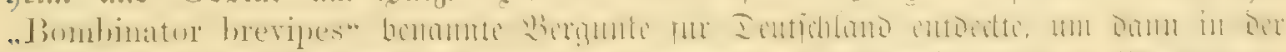

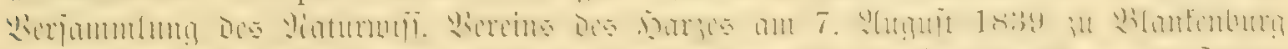

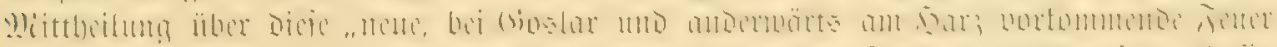

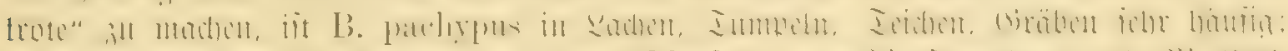

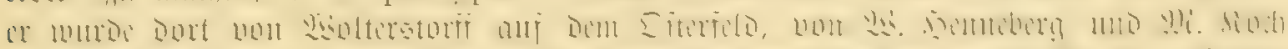

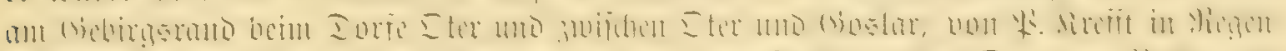

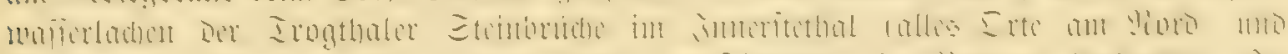

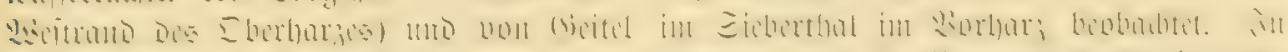

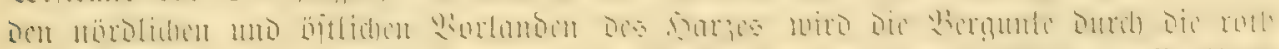

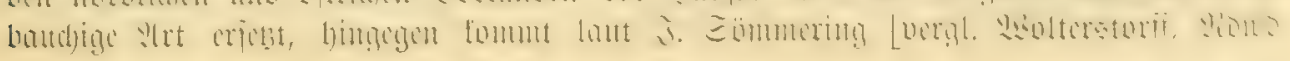




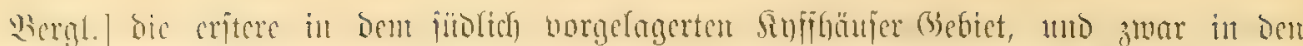

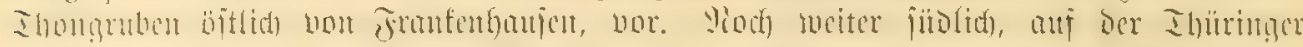

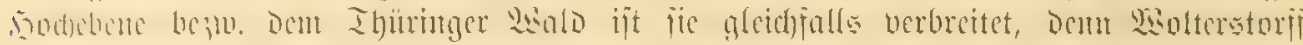

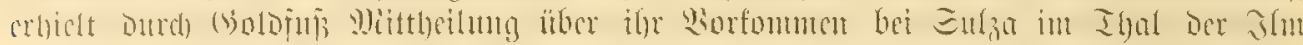

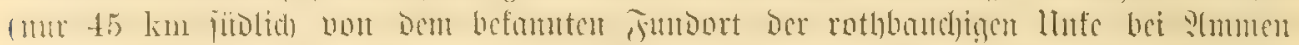

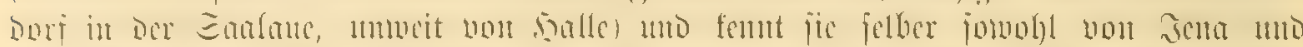

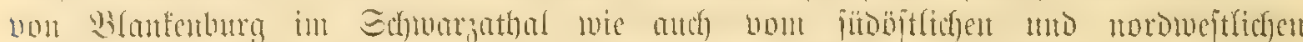
Ende de Ihum

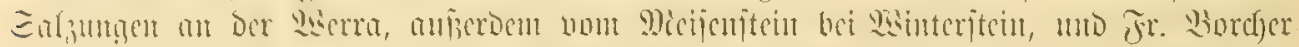

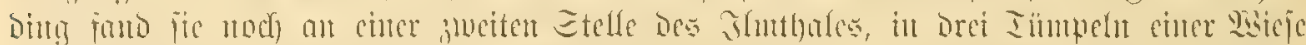

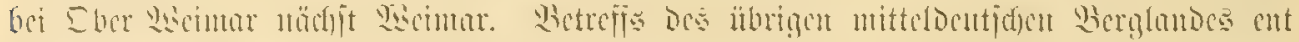

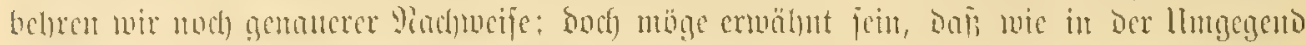

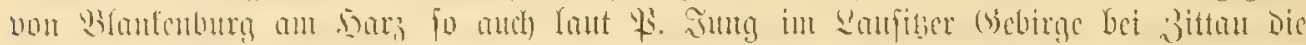
llutent gäuţ lich felylent.

Bombinator pachypus, Bonaparte 1838. - Bombinitor brevipes, Blasins 1839. - B. bombinus, Boulenger 1886.

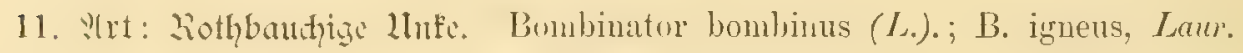
2rbb. Tufer II, Iir. 3. 4.

Eänge 4 bis 4,5 kn; Körper jicntión fhlanf gebaut; Warjen Ser Eberfate flintil und wentiger gedringt beifammenfthend als bat B. pachypus. abgeflaht=

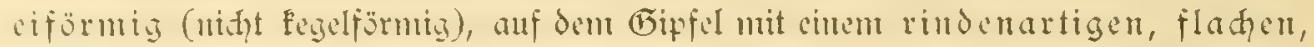

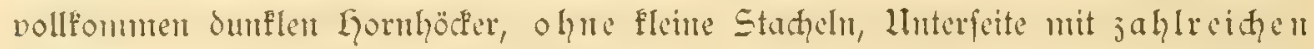

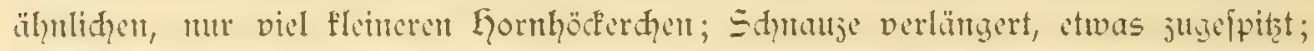

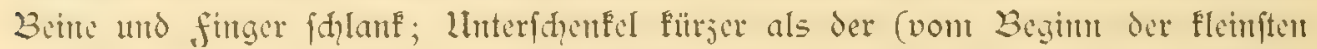

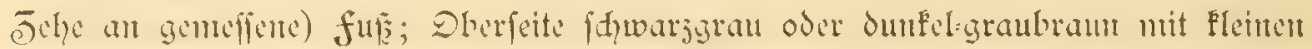
grïnthwarjen fleken und meift mit jwa flafhengrünen runden flecken jmifhen

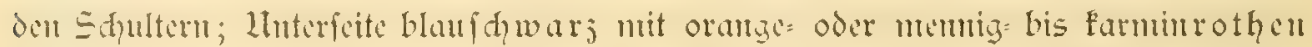

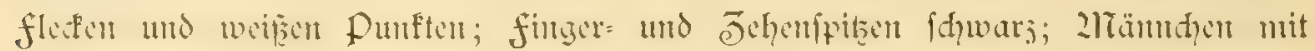

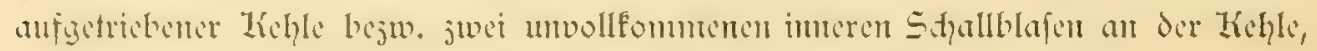

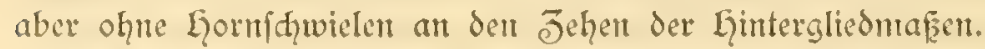

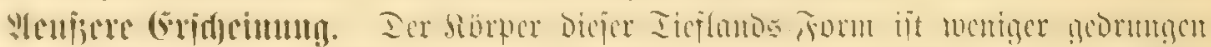

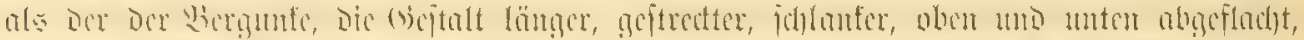

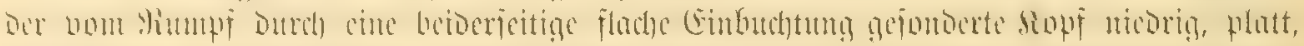

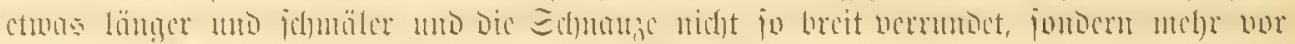

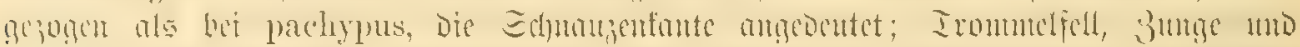

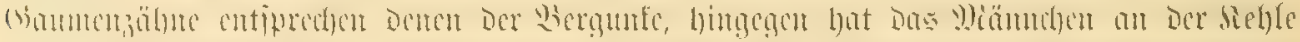

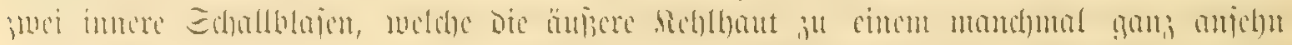

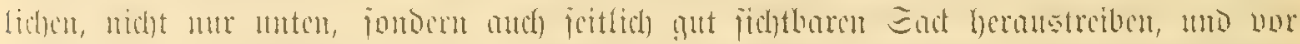

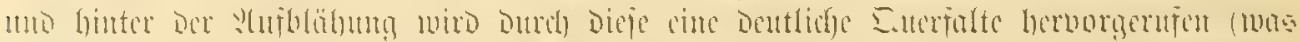

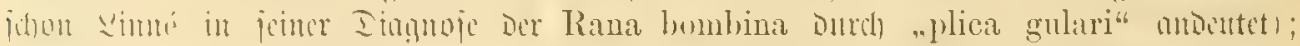

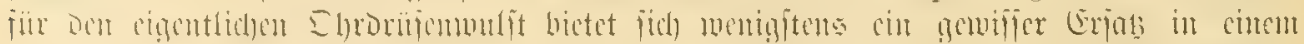

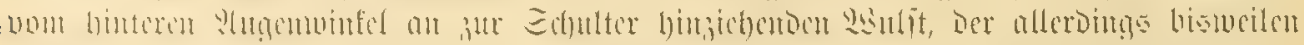

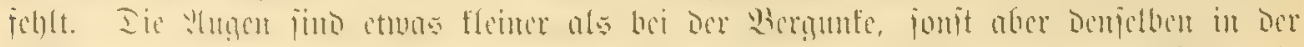

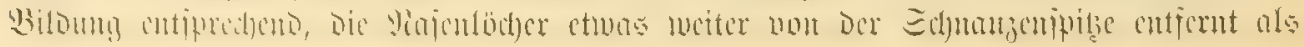




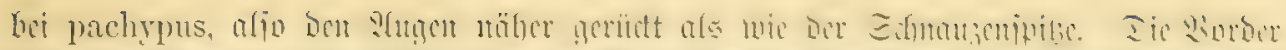

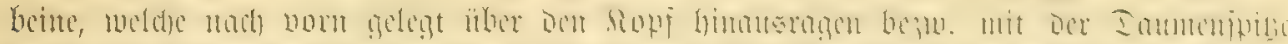

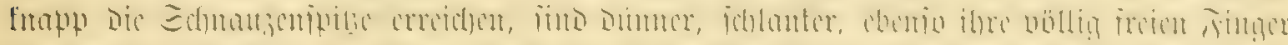

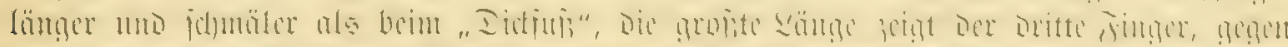

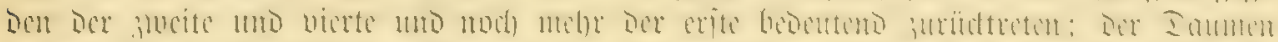

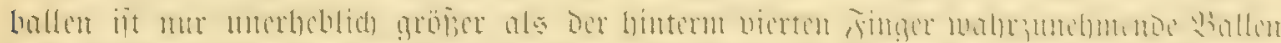

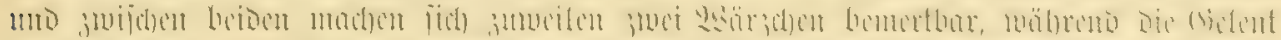

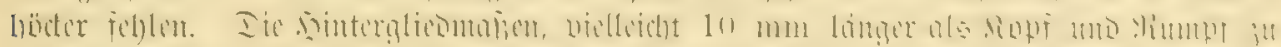

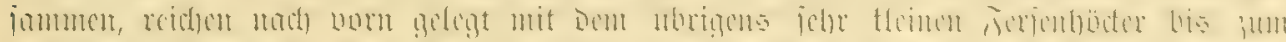

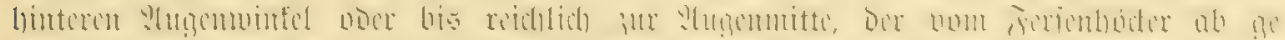

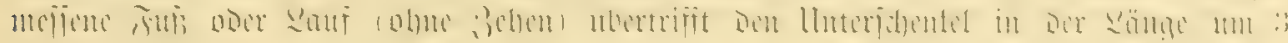
Doer $4 \mathrm{~mm}$; wie Die finger find and Die 3ehen, bie von ber eriten zut vierten an

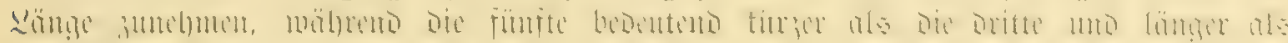

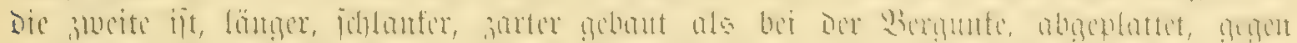

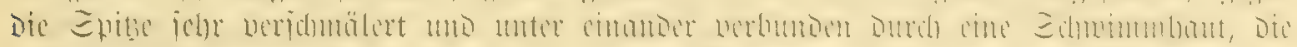

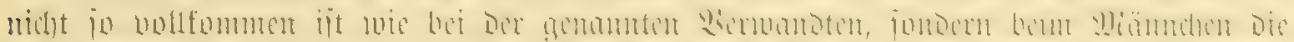

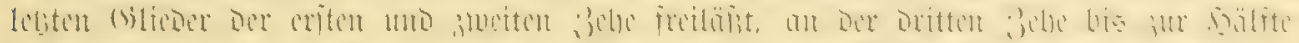

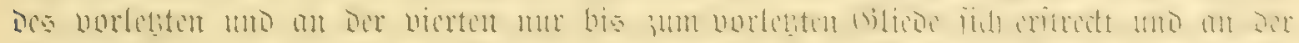

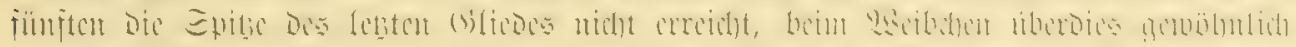

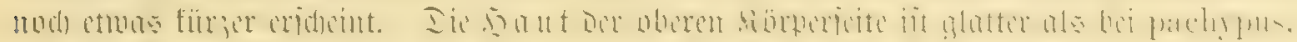

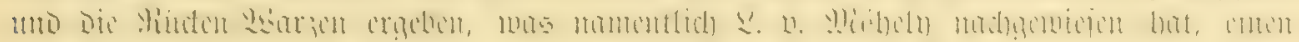

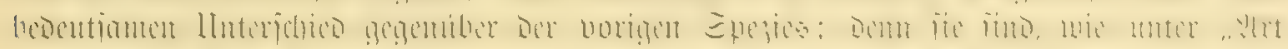

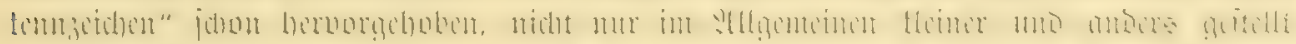

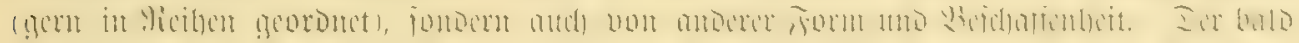

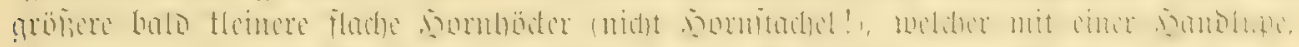

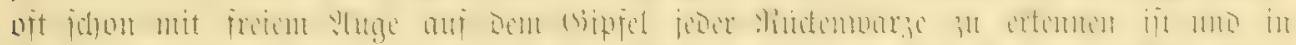

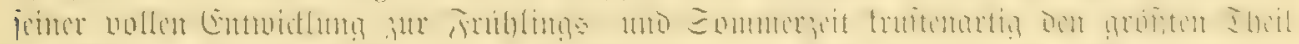
Des

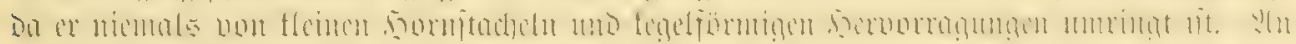

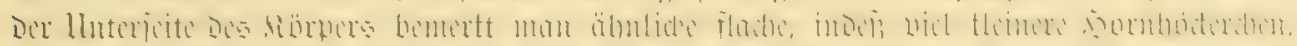

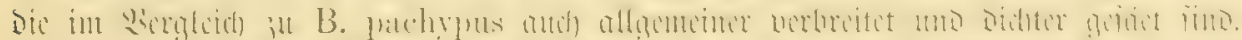

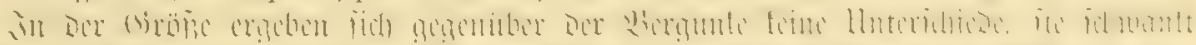

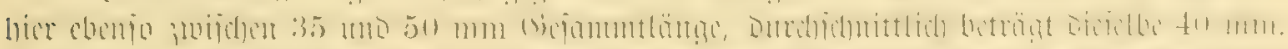

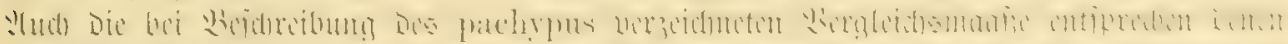

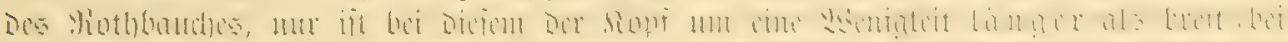

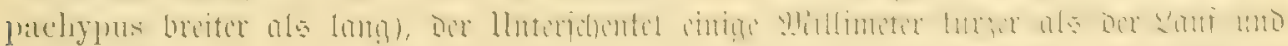

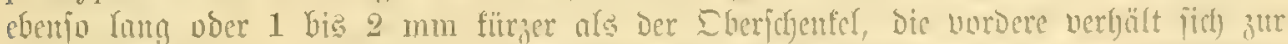

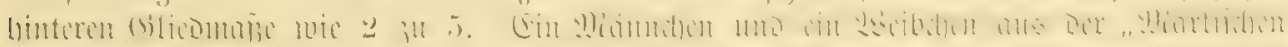

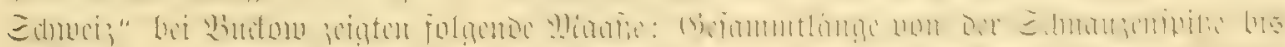

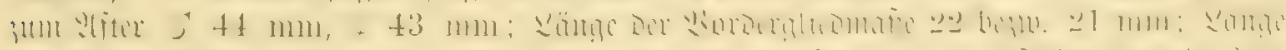

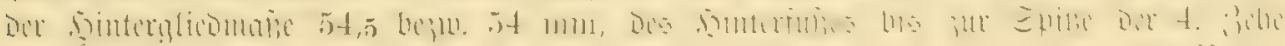

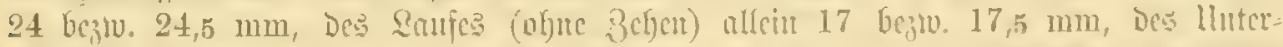

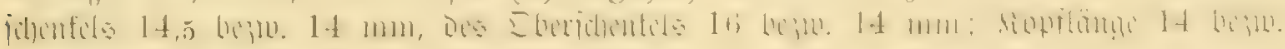
$13 \mathrm{~mm}$; gröfite Sinpforcite 13 begtw. $12,5 \mathrm{~mm}$.

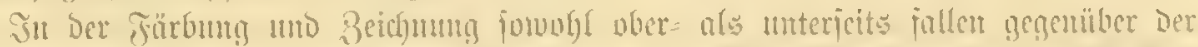

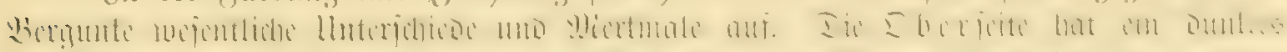

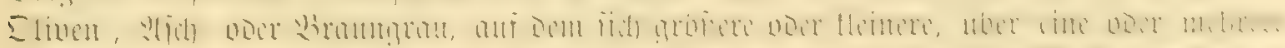

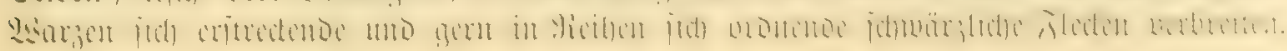




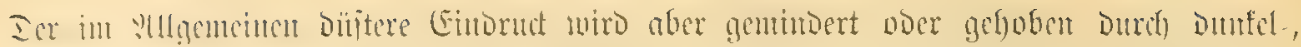

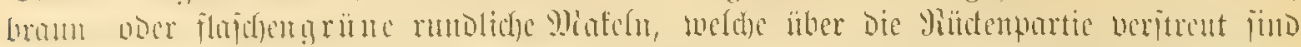

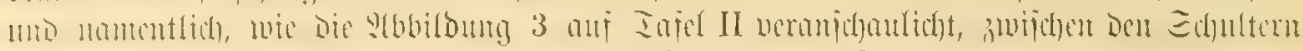

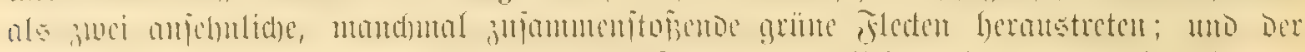

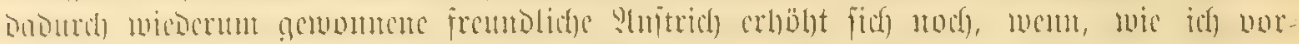

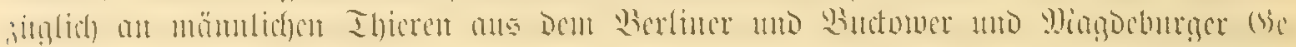

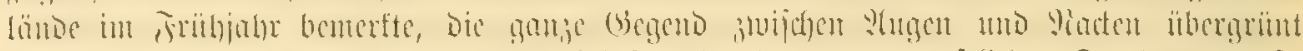

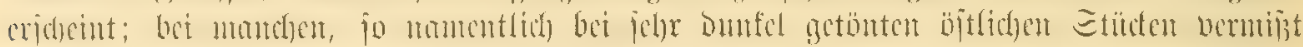

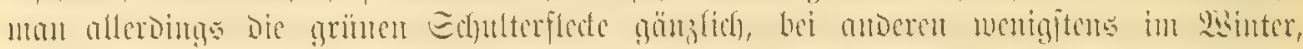

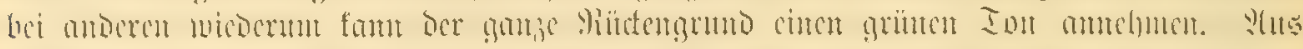

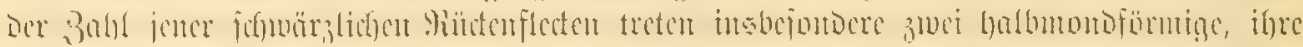

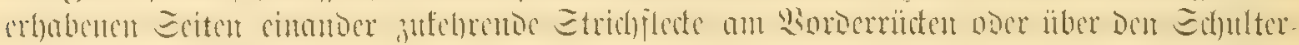

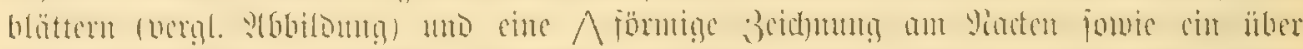

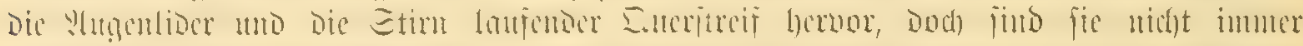

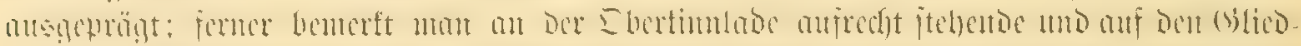

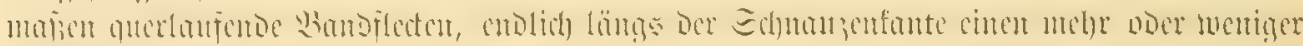

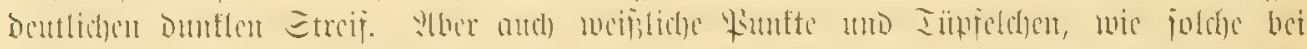

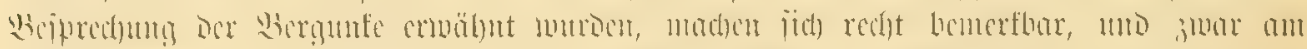

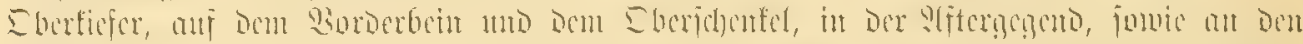

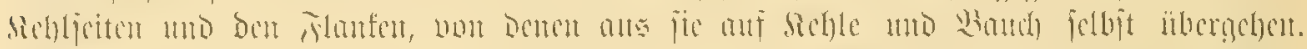

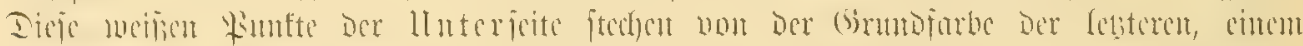

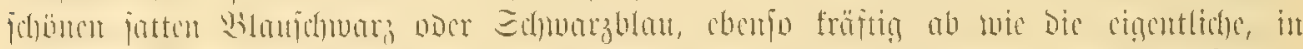

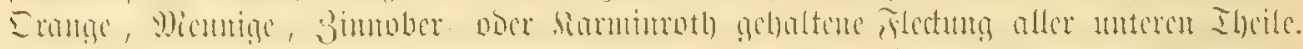

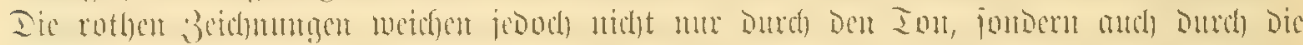

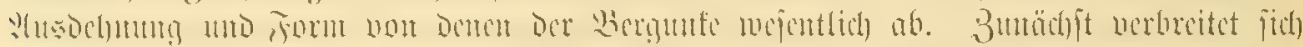

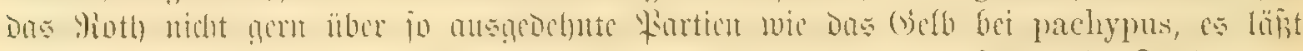

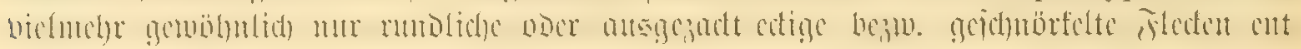

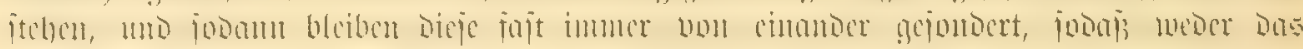

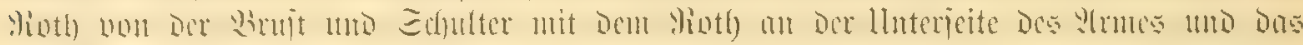

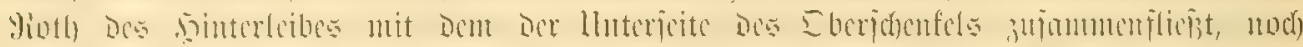

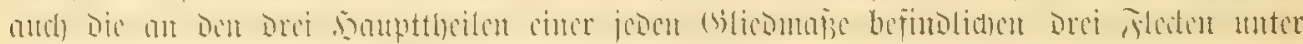

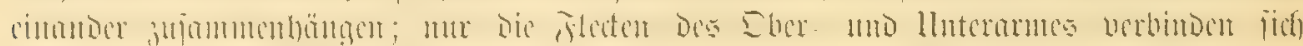

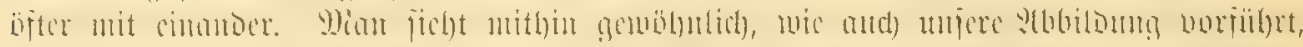

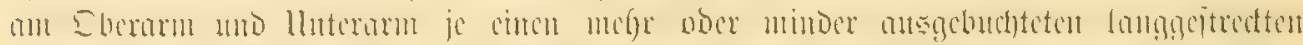

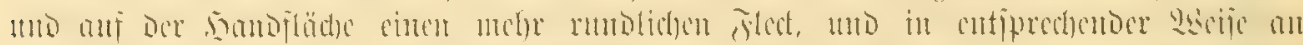

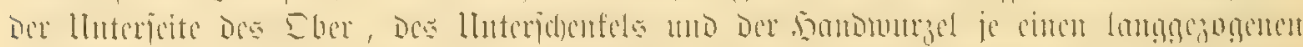

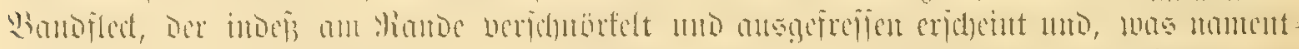

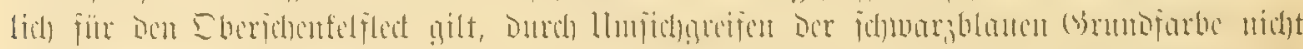

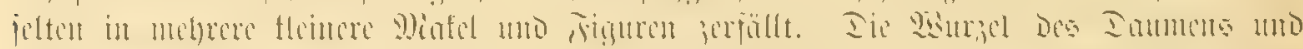

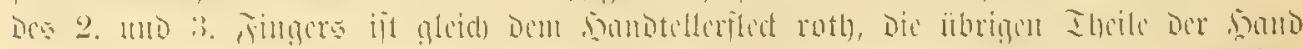

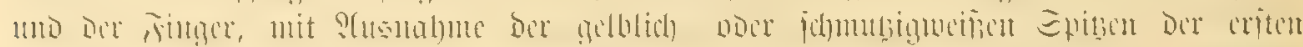

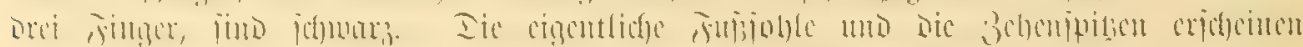

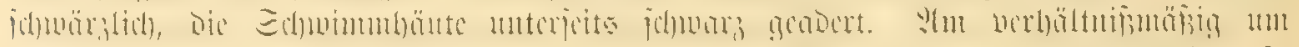

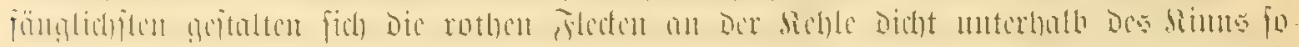

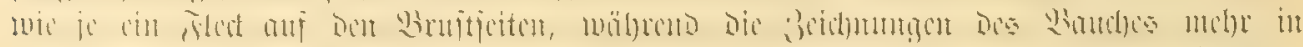

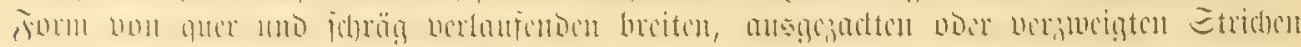

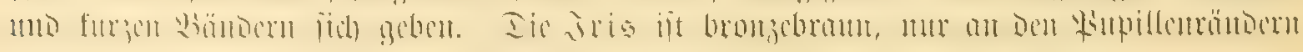
wben wat wutest zeigt fich ein Goldogelb. 


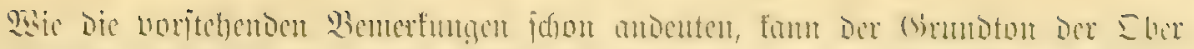

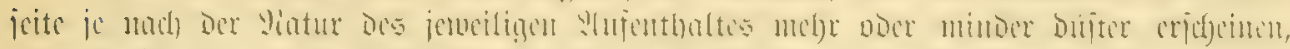

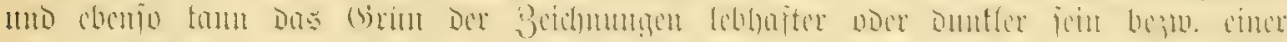

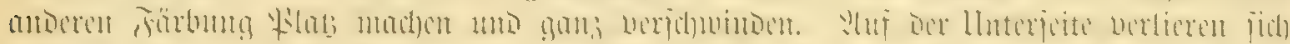

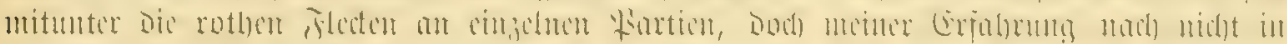

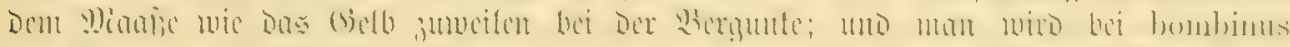

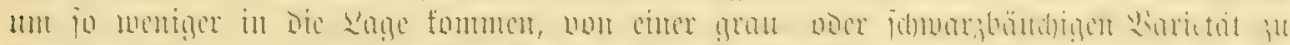

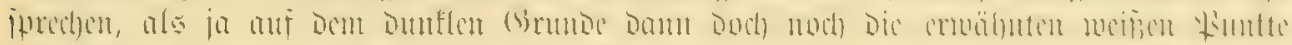

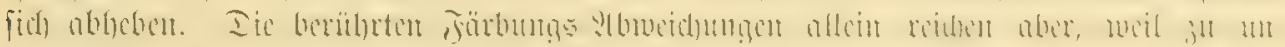

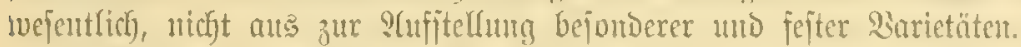

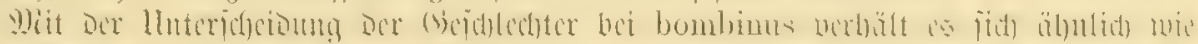

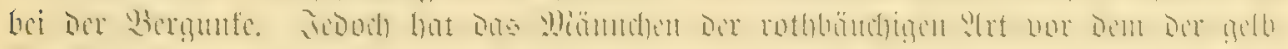

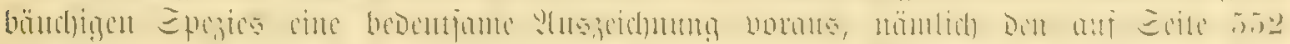

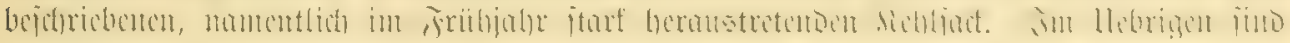

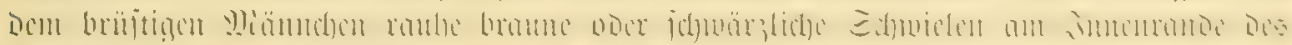

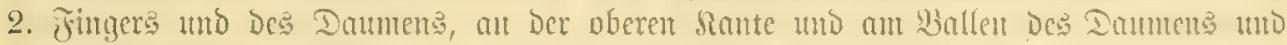

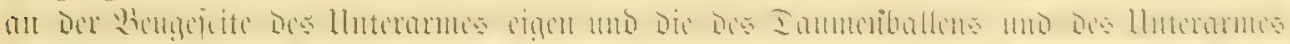

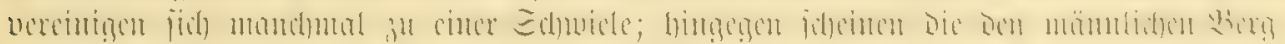

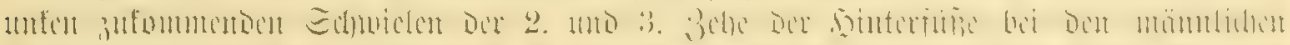

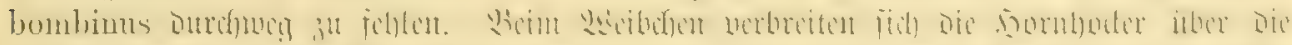

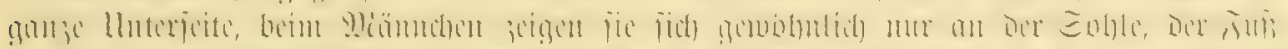

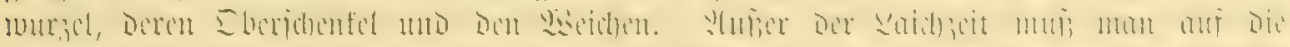

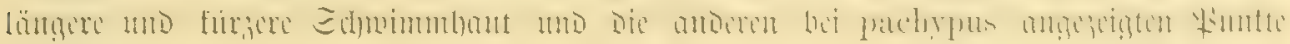
adjent.

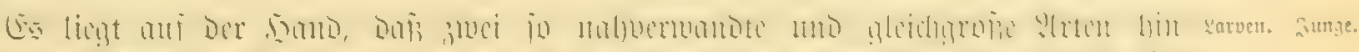

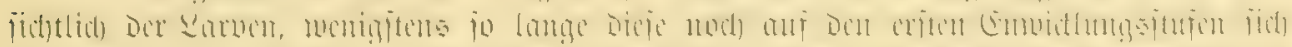

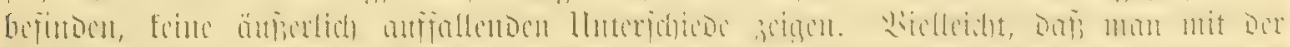

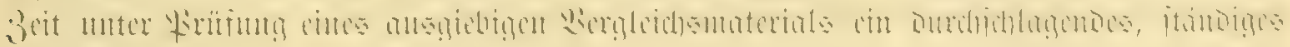

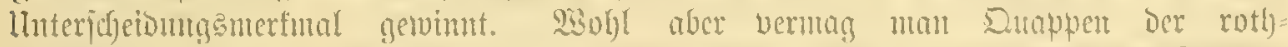

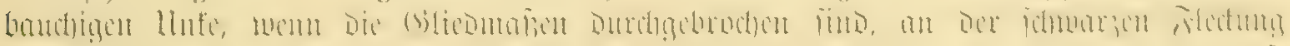
anf Der Dunfel gefärbten und twentiger ranfycu giüdfant un an Den junädjit

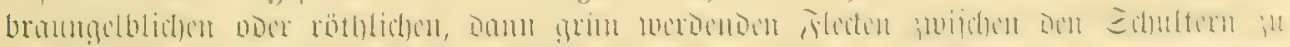

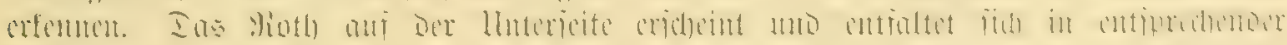

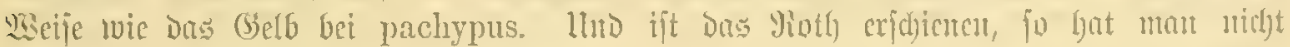

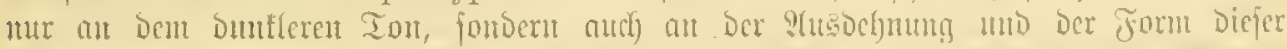

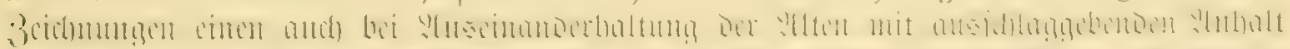

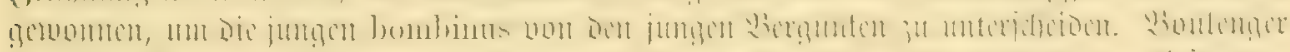

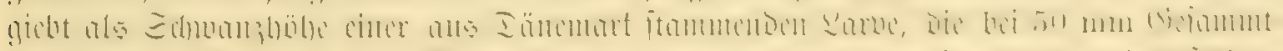

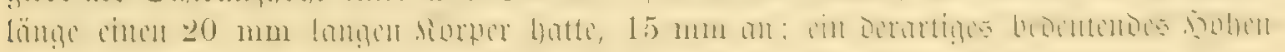
manis habe idy noch nicht finden föment.

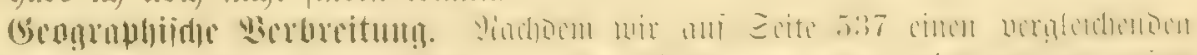

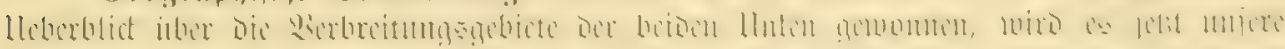

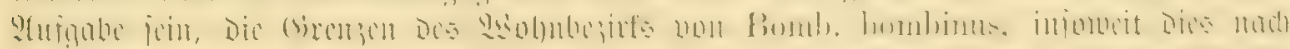

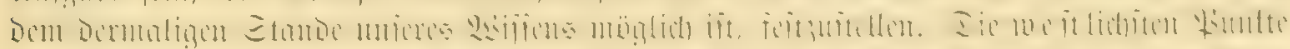

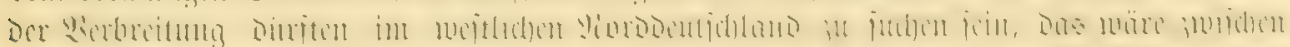

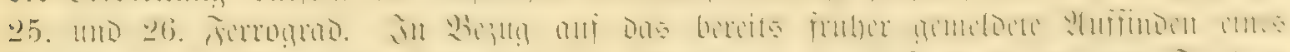

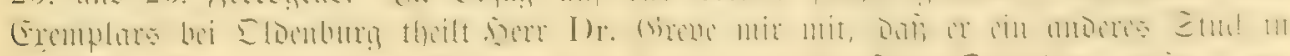

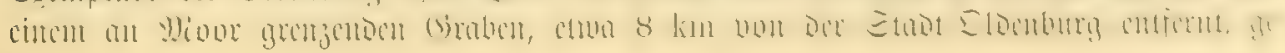




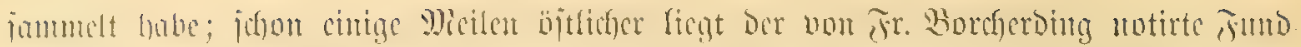

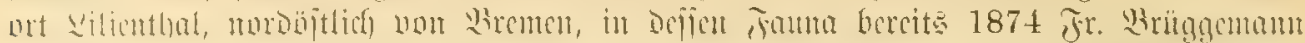

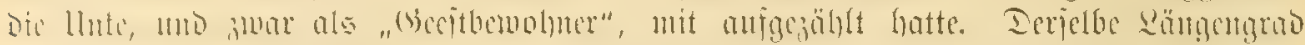

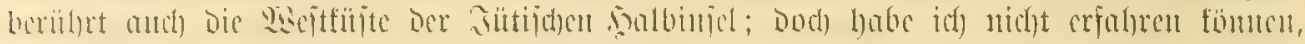

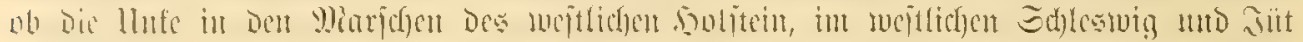

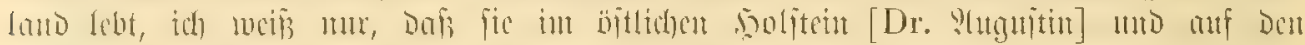

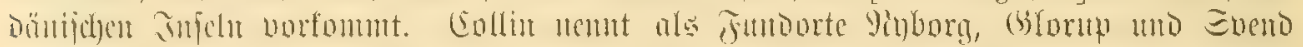

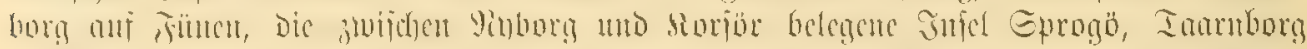

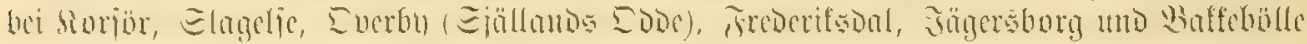

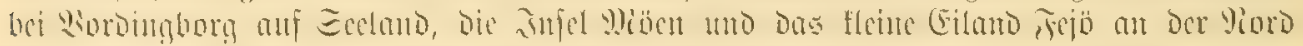

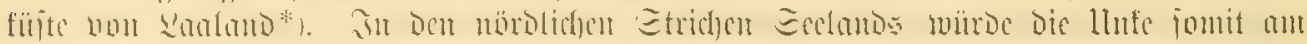

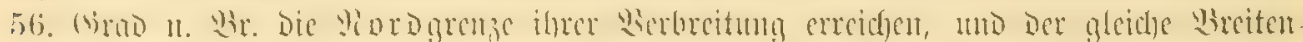

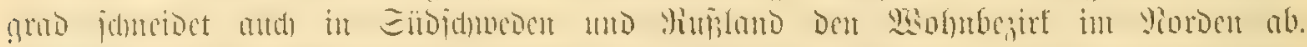

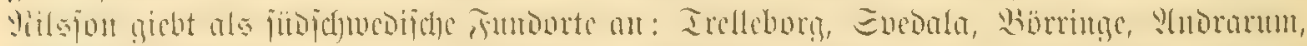

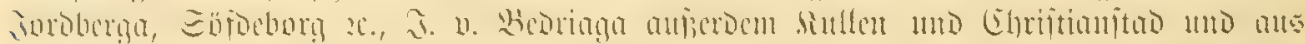

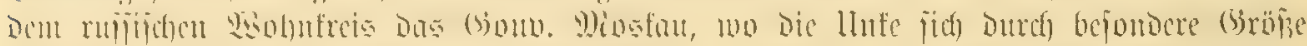

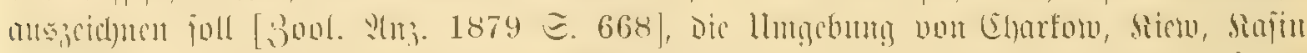

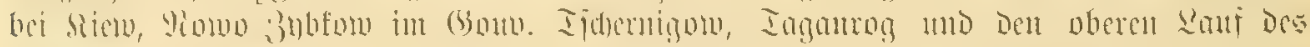

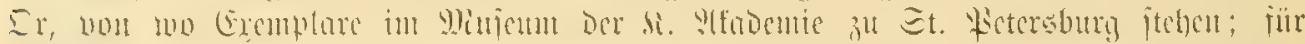

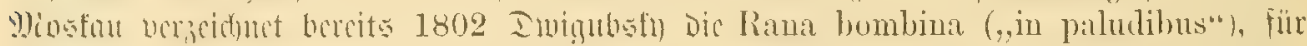

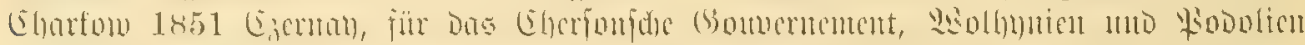

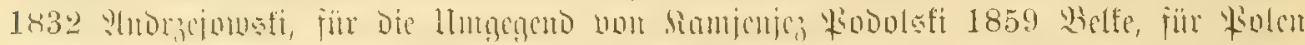

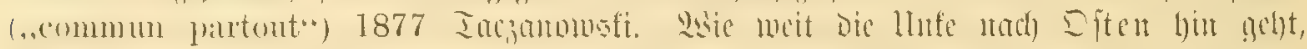

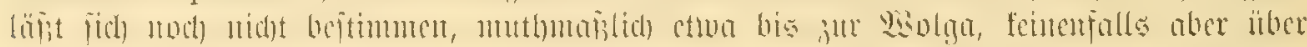

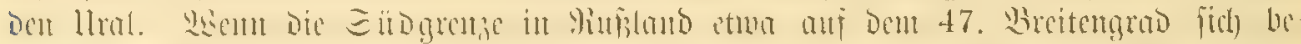

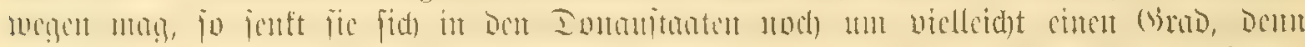

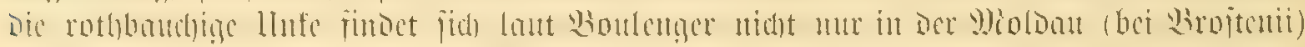

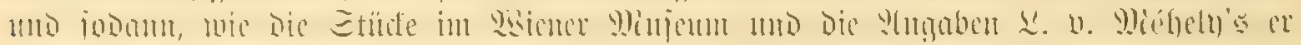

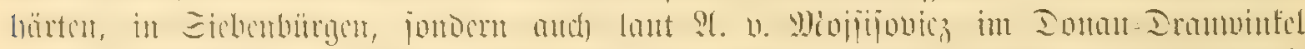

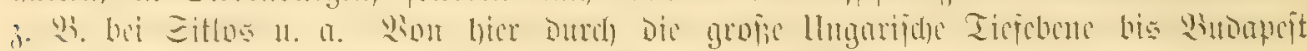

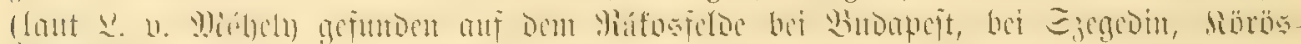

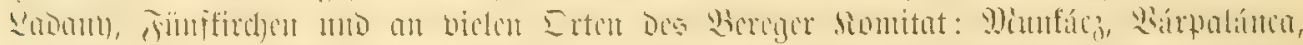

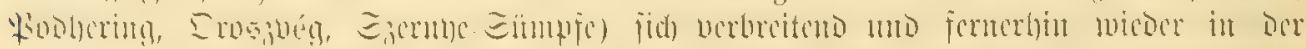

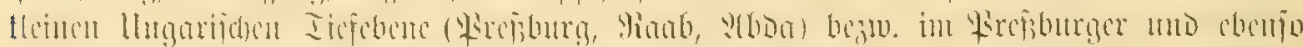

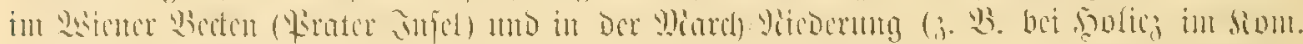

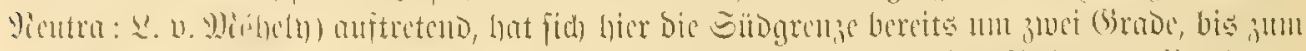

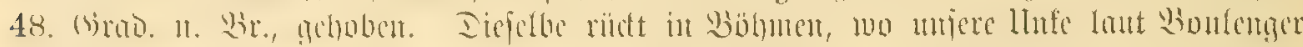

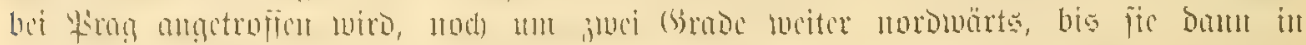

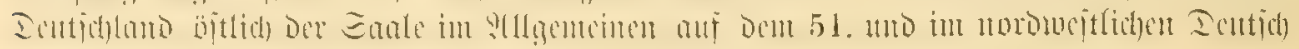
Laulo auf 52 nder $52^{1} / 2$ (Grad fid) hinzichen Dürfte.

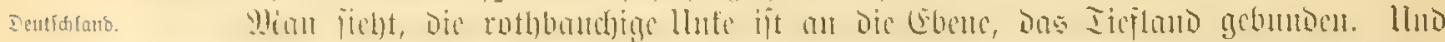

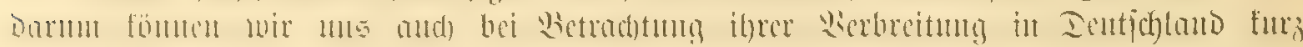

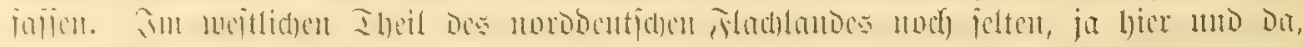

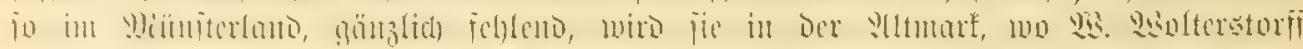

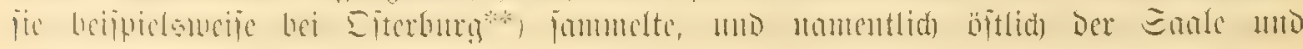

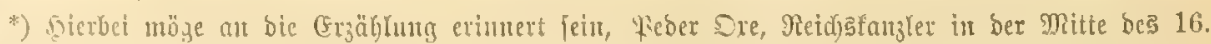

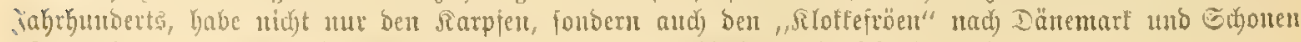

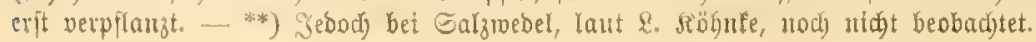




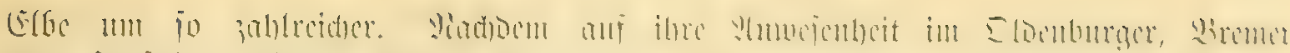

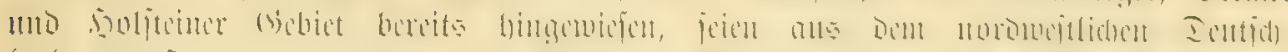

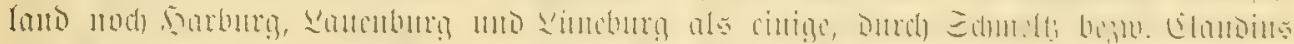

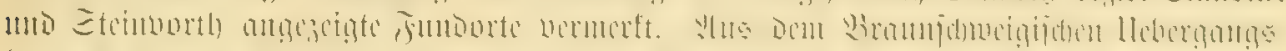

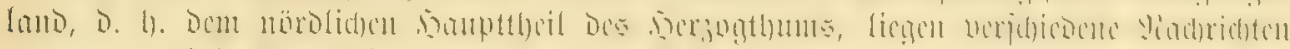

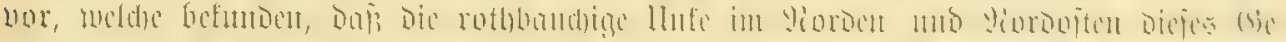

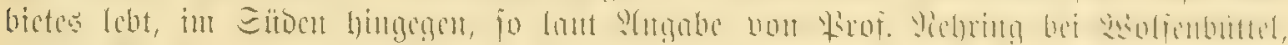

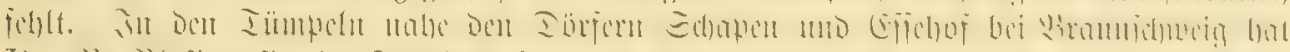

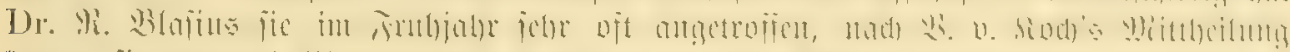

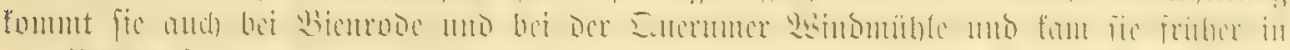

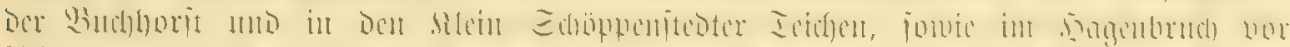

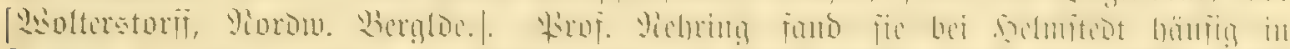

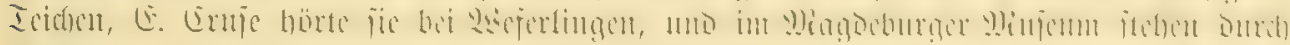

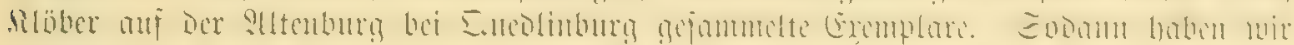

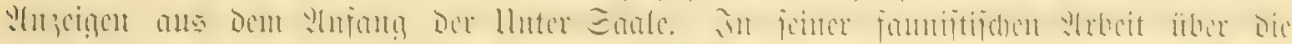

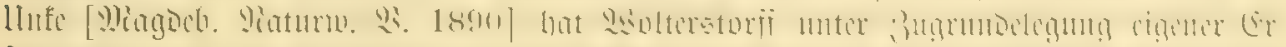

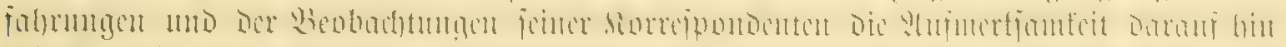

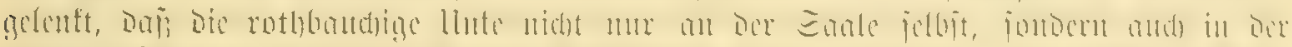

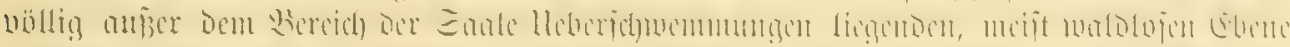

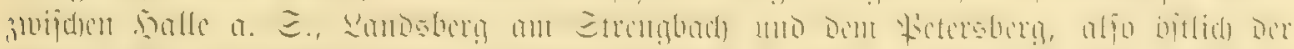

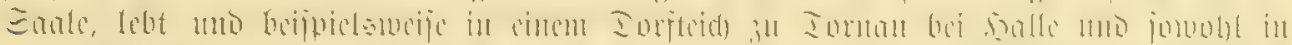

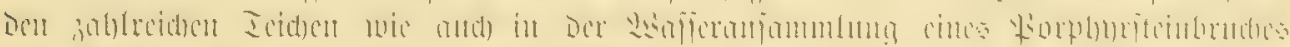

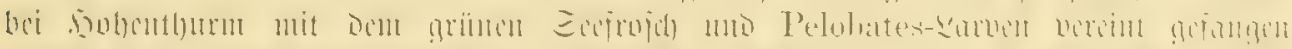

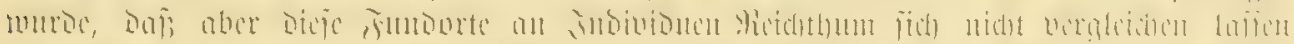

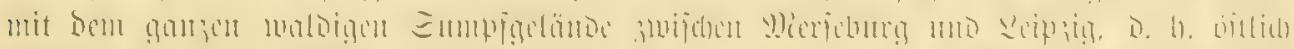

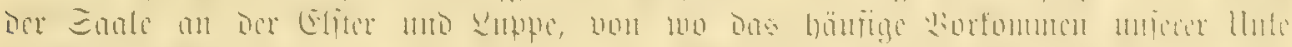

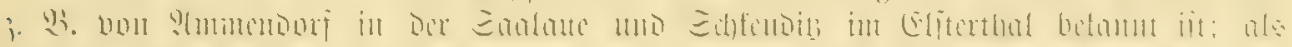

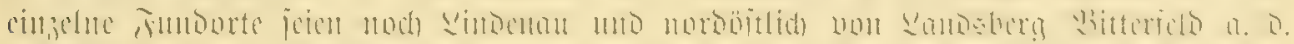

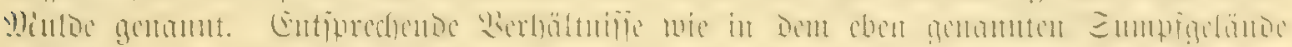

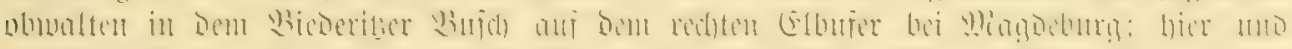

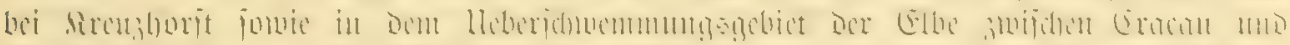

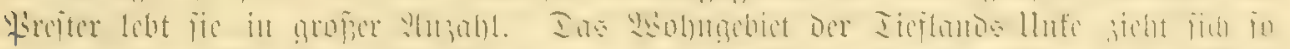

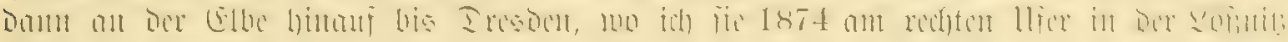

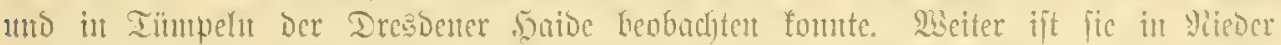

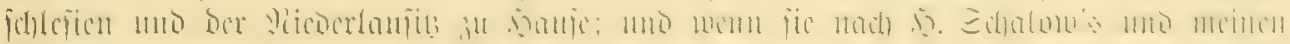

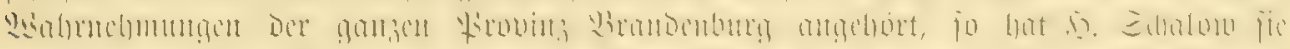

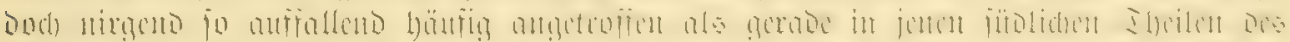

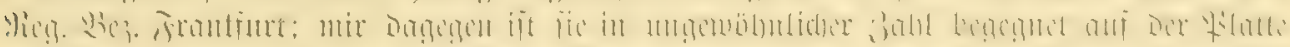

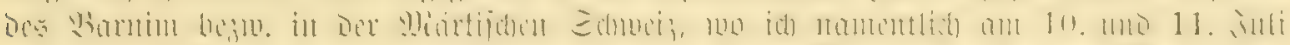

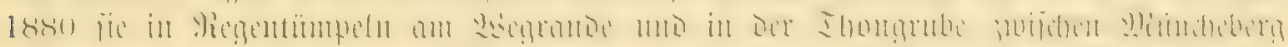

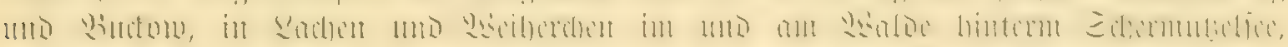

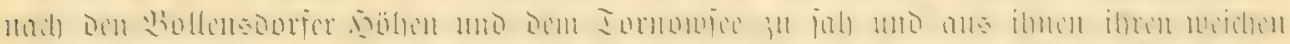

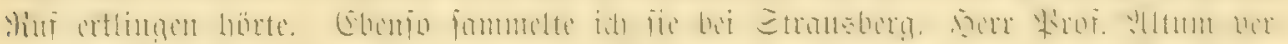

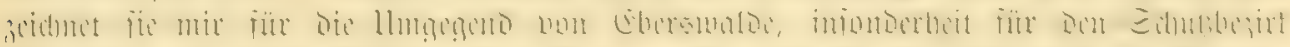

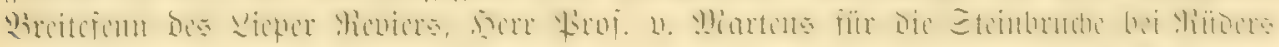
Dorf (1879); Iant Dr. E. Dlüller beztv. Dr. Etein toar fie fribfer in Iümpeln um

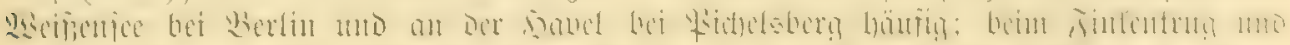

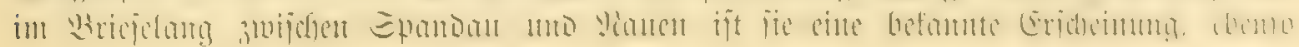




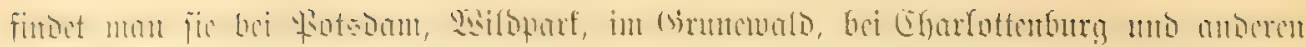

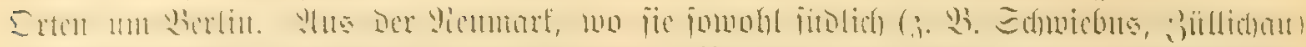

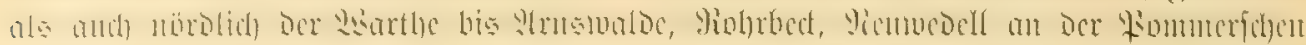

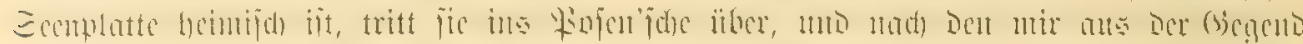

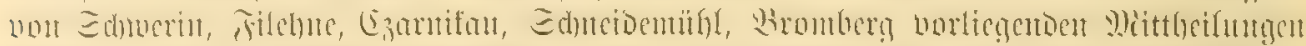

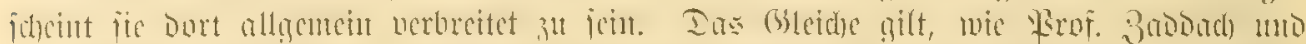

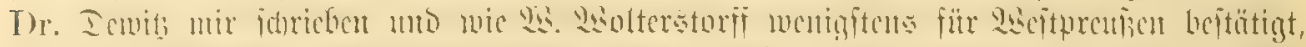

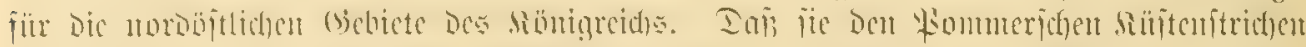

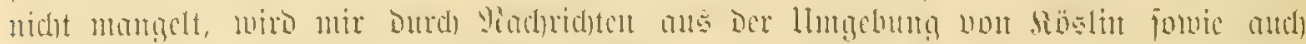

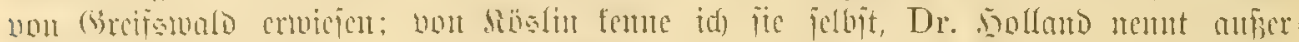

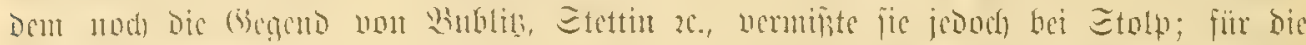

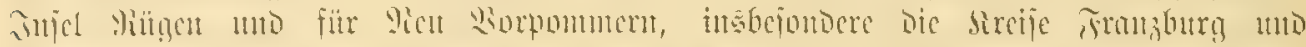

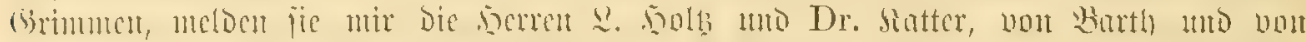

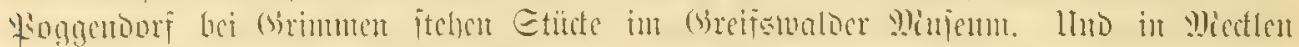

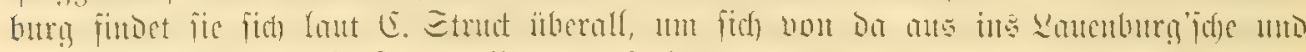

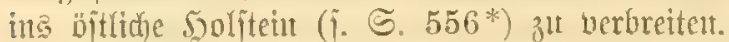

Rana bombina, Linné 1761. - Bufo igneus, Laurenti 1768. - Bombinator igneus, Merrem 1820.

\section{Gattung: Fejiler. Alytes, Wagler.}

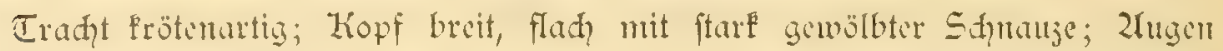

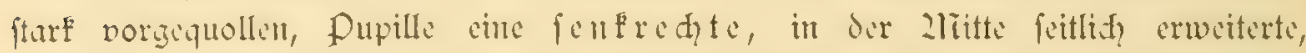
bifonvere Epalt; Dhrorufenmulit länglid; Tronmifill rumblid, jicmlid, grofs,

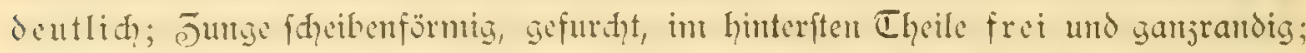

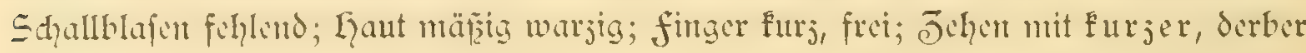

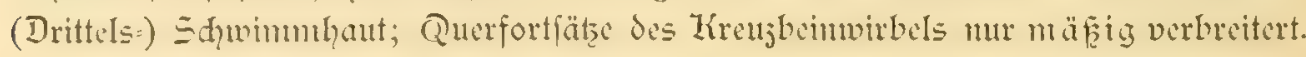

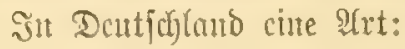

\section{SGrt: (5eburtshelferfröte. Alytes obstetricans (Laur.).}

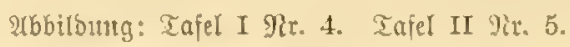

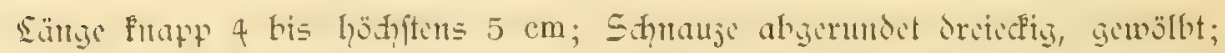

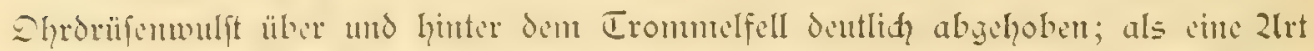

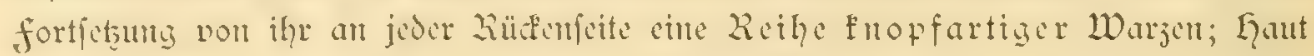
des Rüdens mit jicmlid fleinen, rundidhen Warjen, aber obne fornjtadyeln,

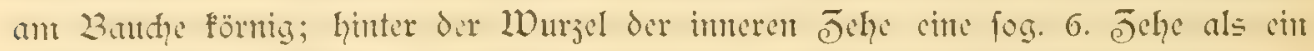

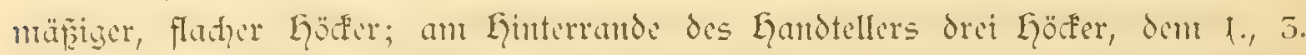

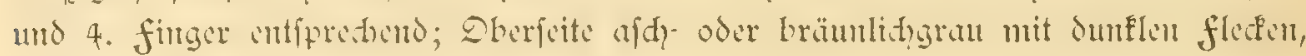
Ulnterfeite weifilid.

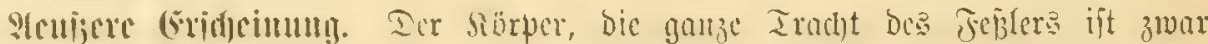

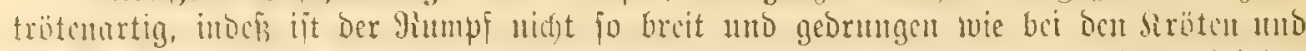

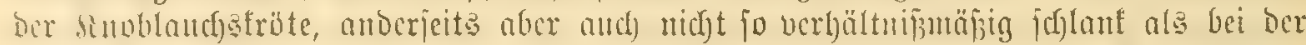

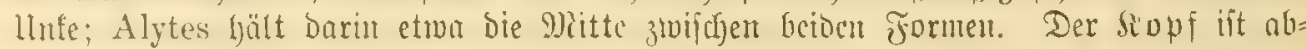

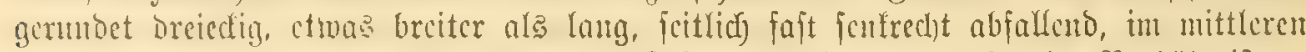

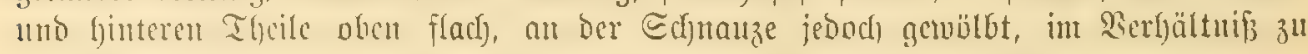

*) Dr. Fr. Dahl ift fein Jutu aus Gdylesmig= Jolftein befannt gemorbent. 


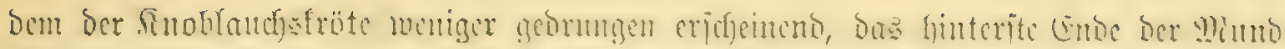

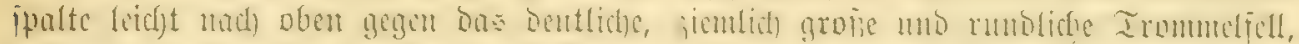

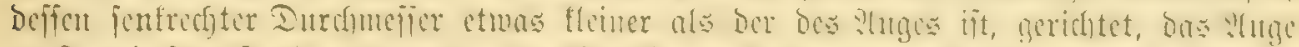

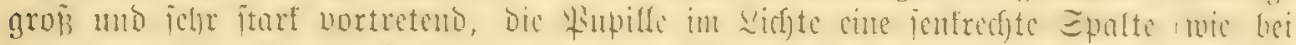

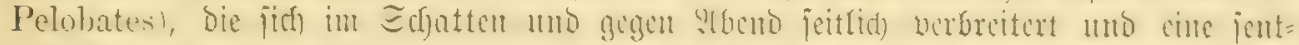

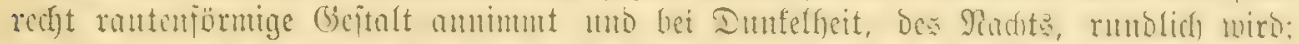

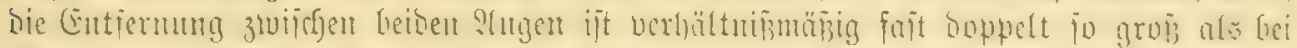

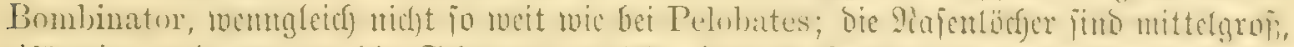

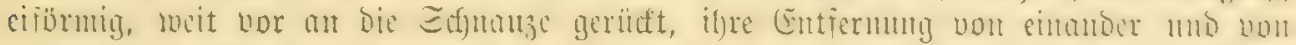

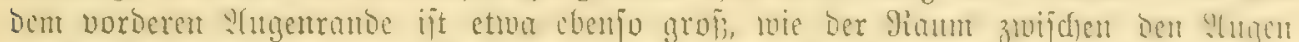

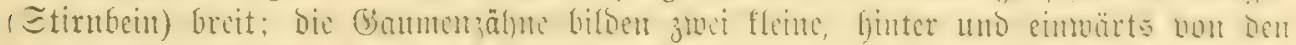

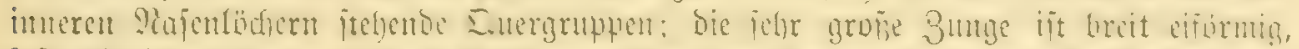

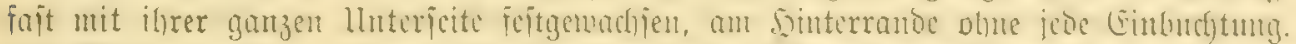

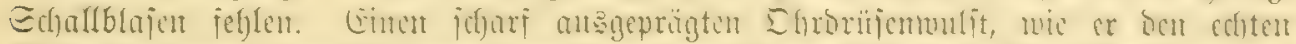

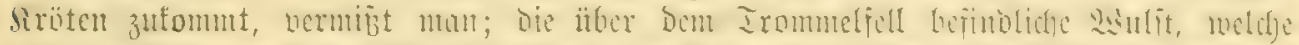

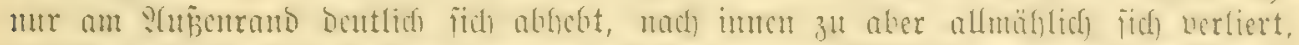

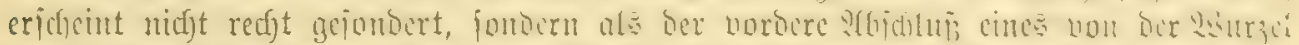

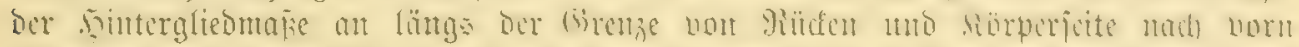

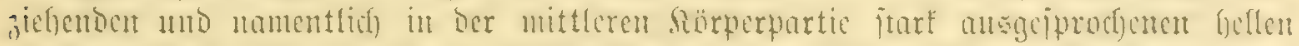

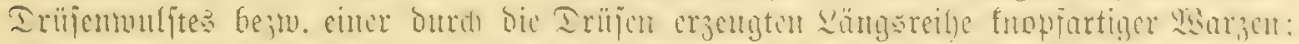

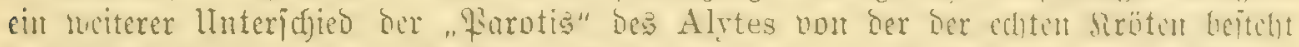

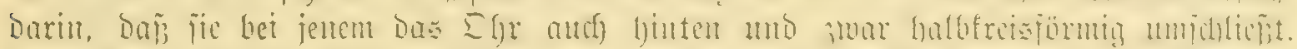

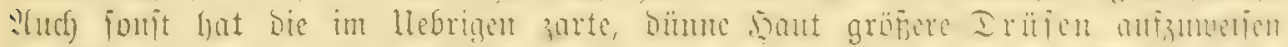

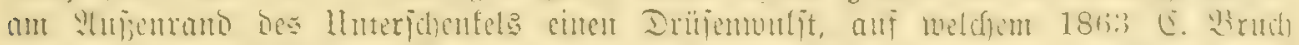

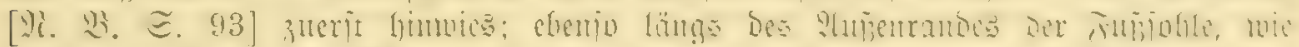

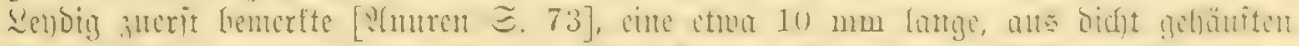

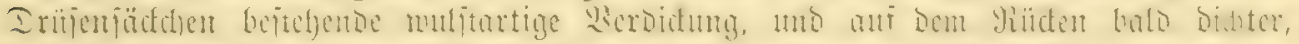

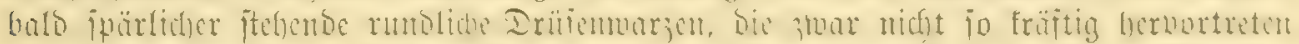

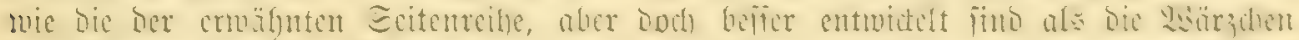

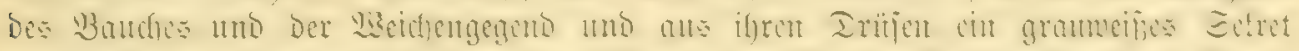

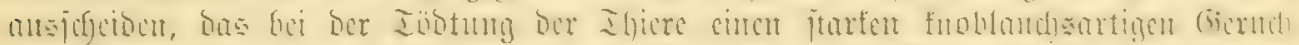

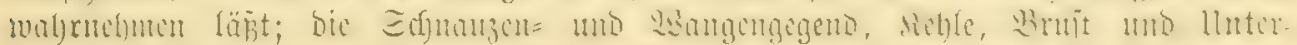

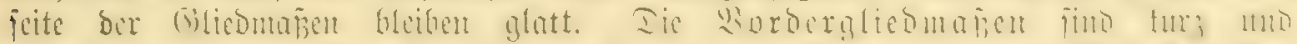

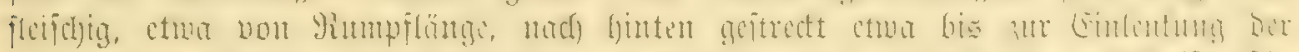

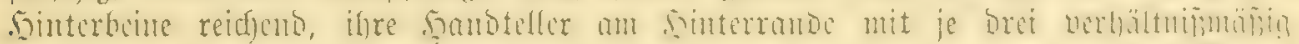

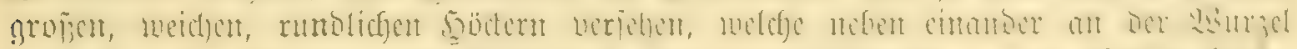

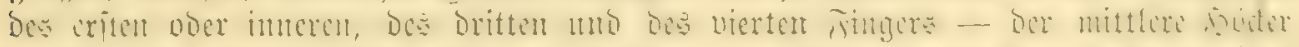

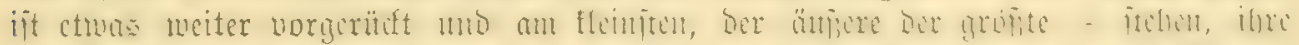

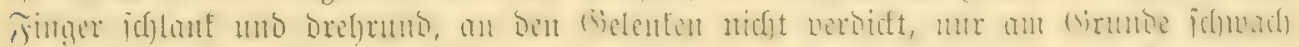

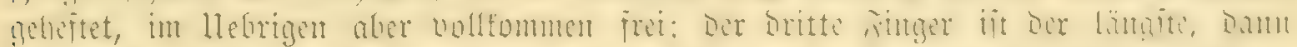

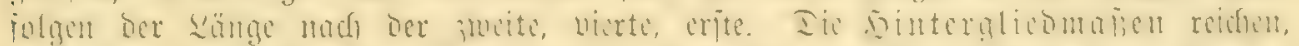

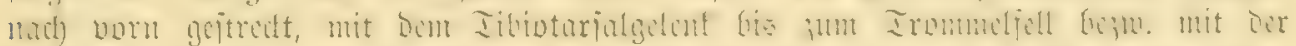

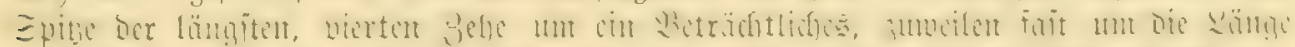

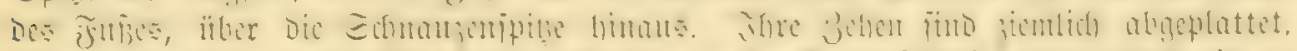

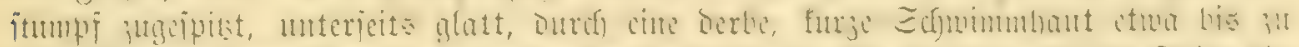

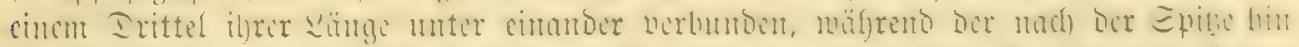

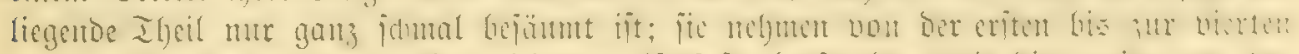

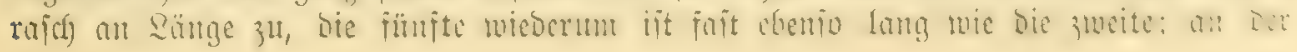




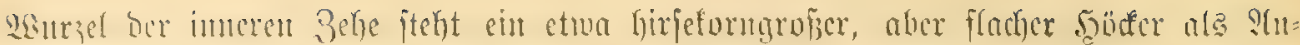

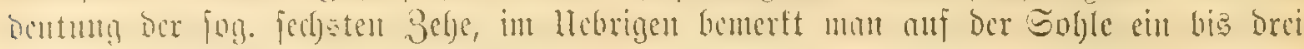
winzige Tuberte!n.

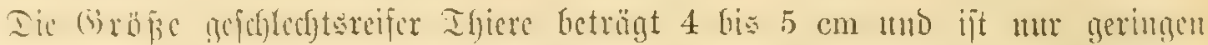

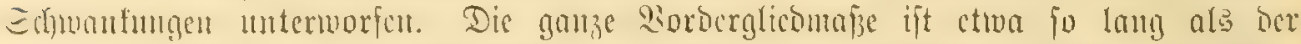

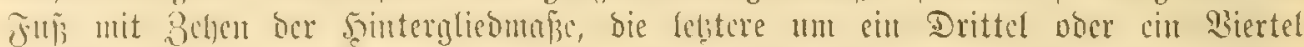

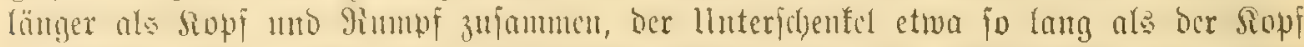

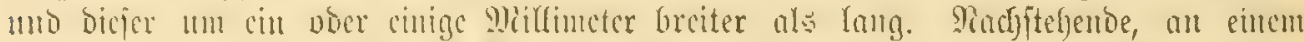

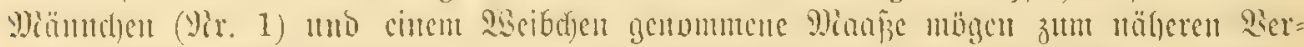

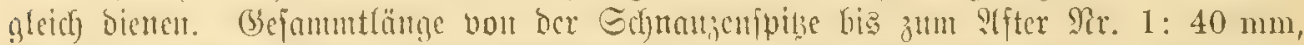

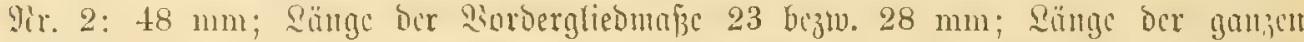

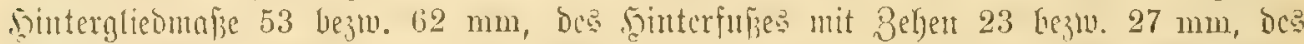

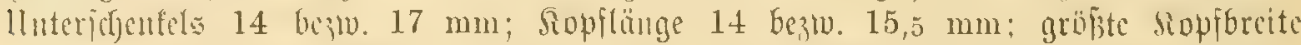

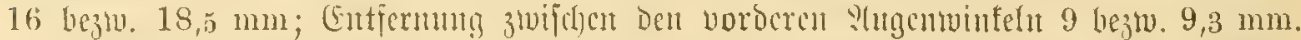

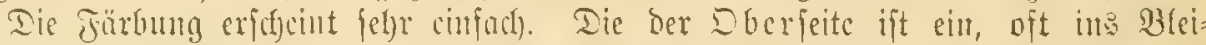

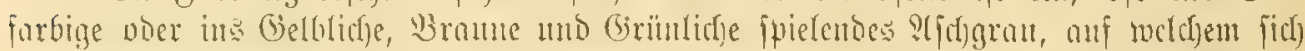

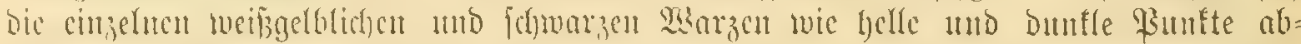

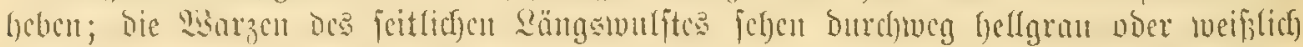

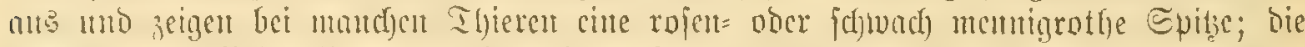

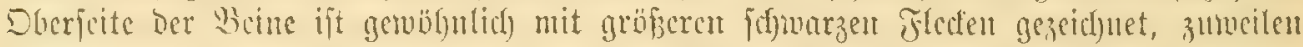

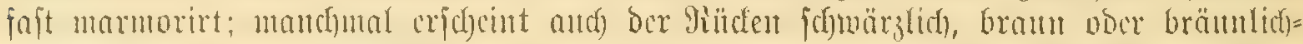

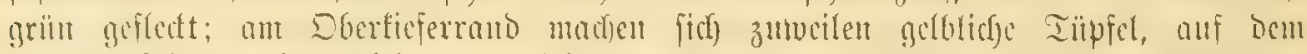

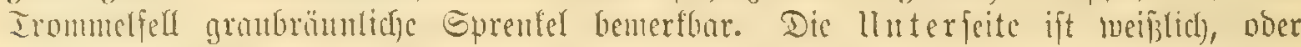

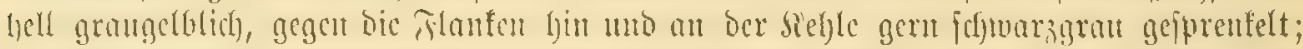

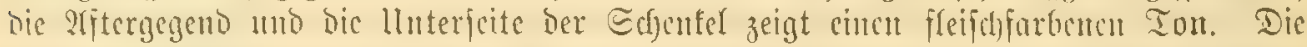

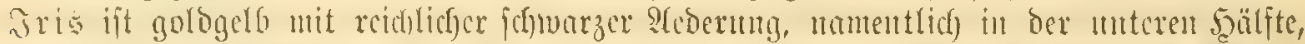

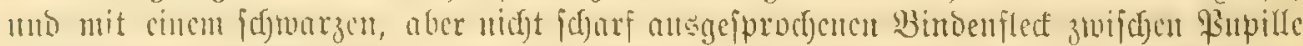

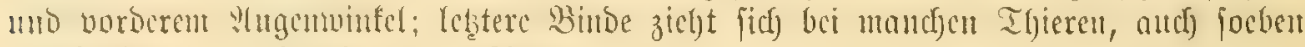
entroidelten, quer Durchje ganze Pluge.

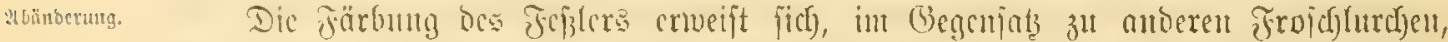

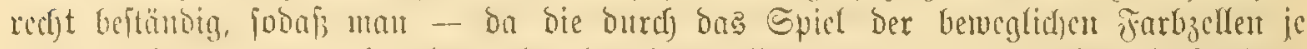

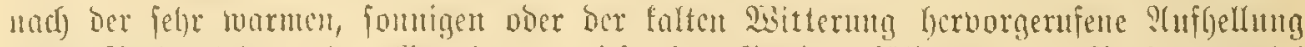

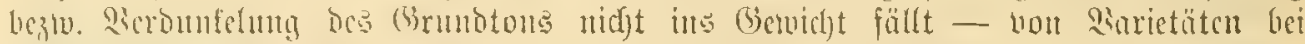

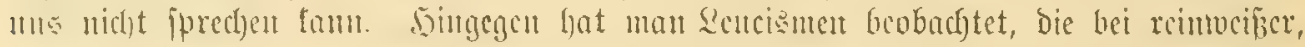

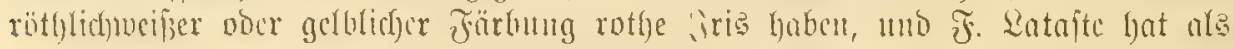

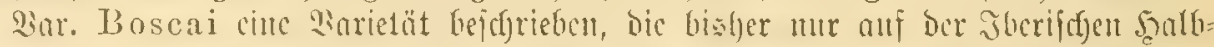

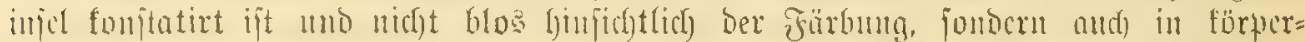

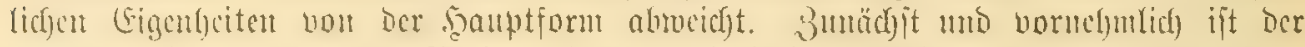

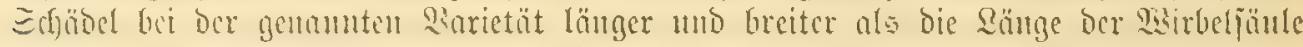
(bef ber Etommform fitraer und elonjo breit wie bic libtere), ihre sibrperbant feiter

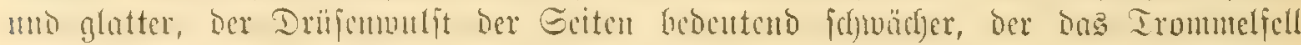

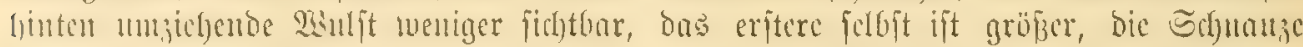

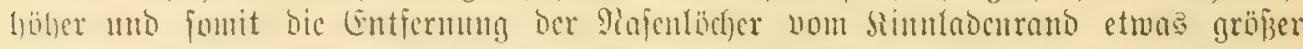

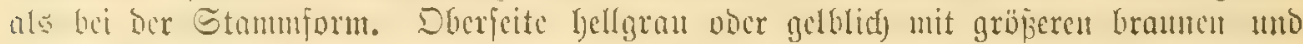

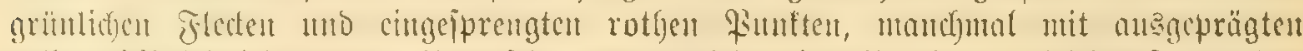

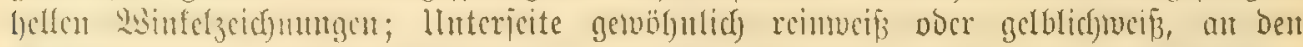

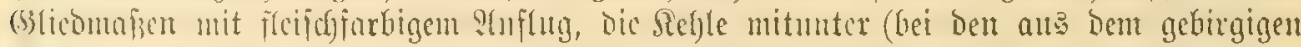

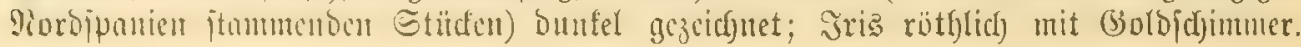




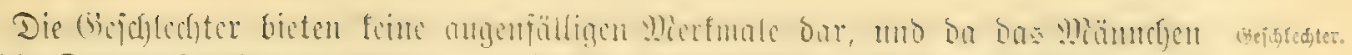

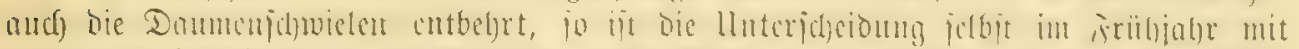

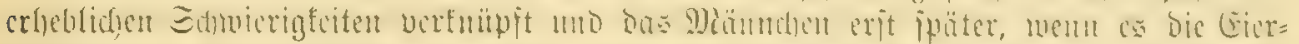

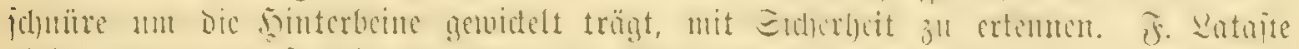

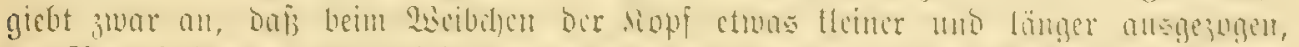

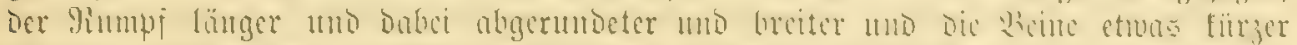

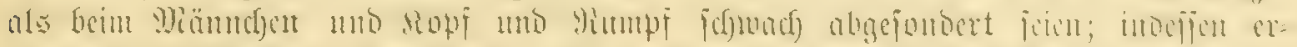

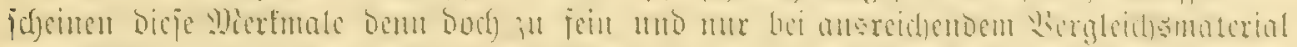

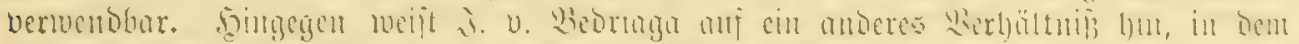

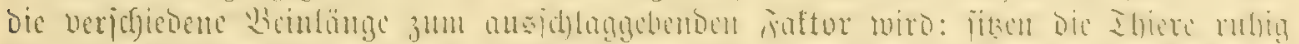

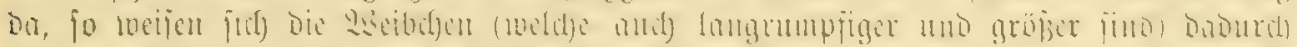

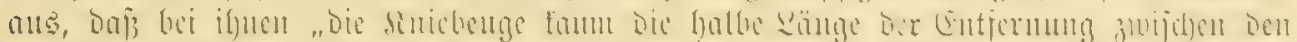

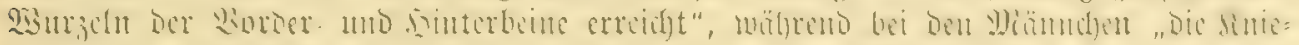

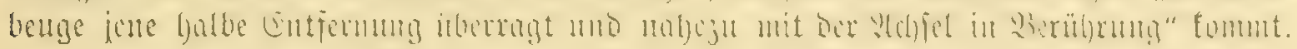

Die Barven verlajicu, wie auj Eeite 415 betont, Die Eibullen in eintent viel

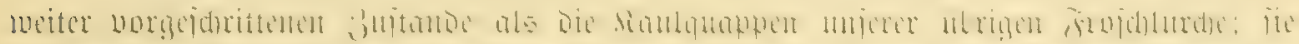

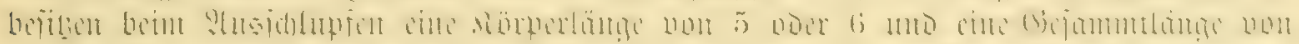

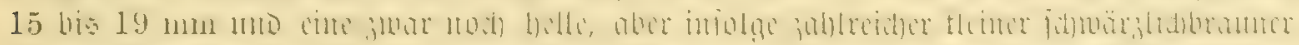

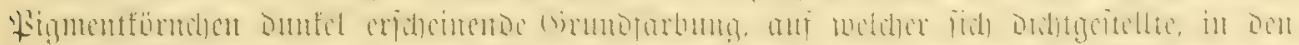

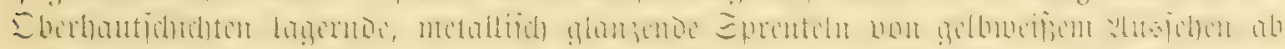

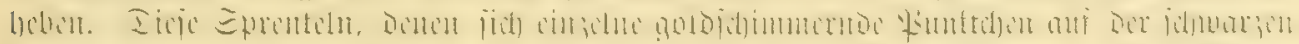

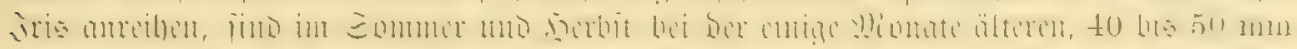

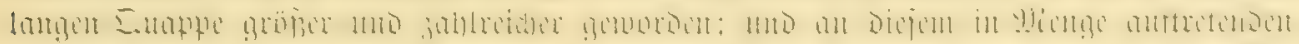

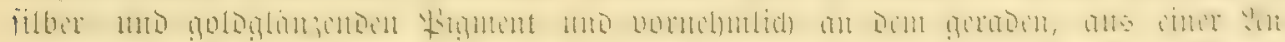

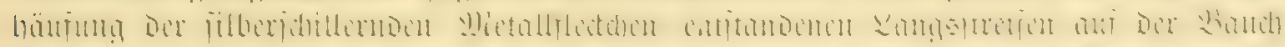

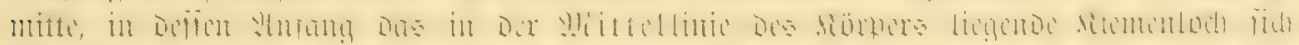

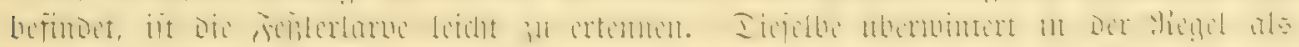

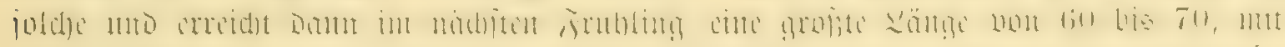

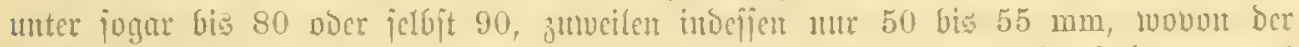

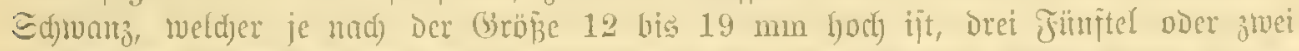

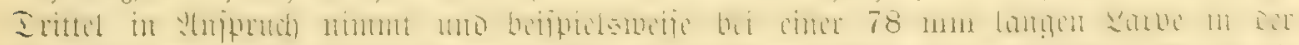

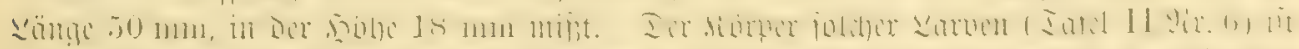

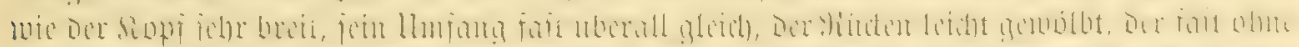

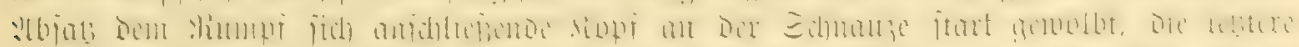

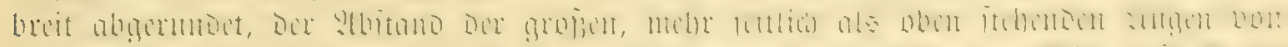

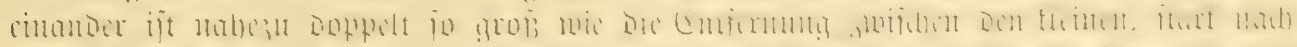

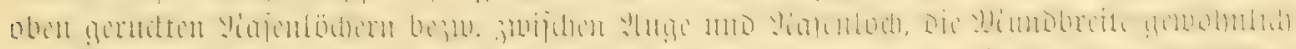

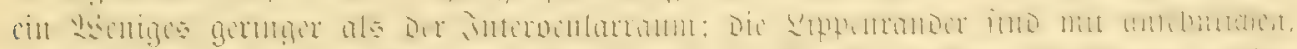

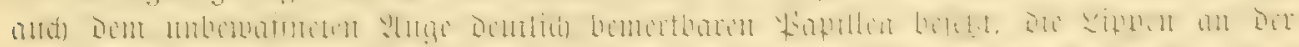

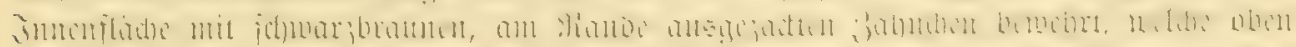

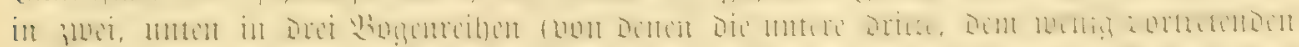

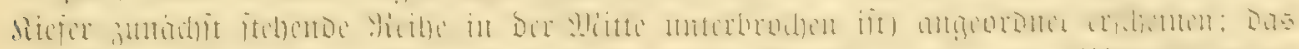

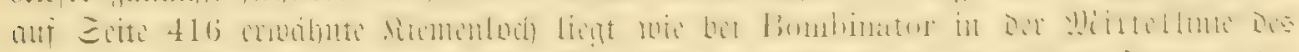

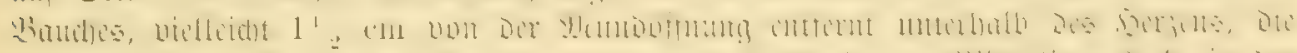

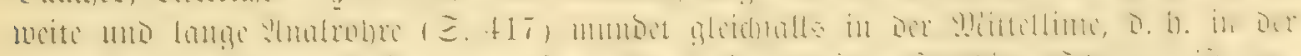

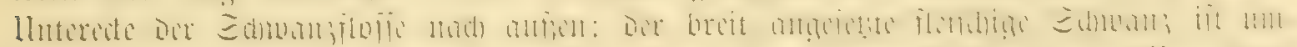

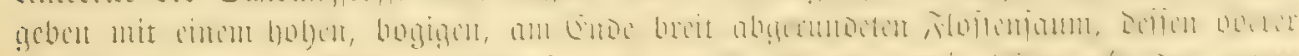

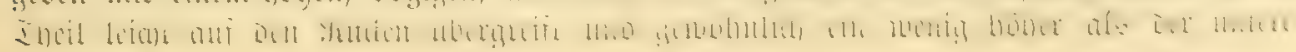




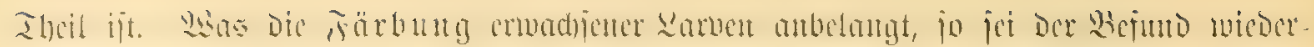

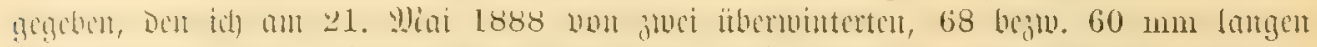

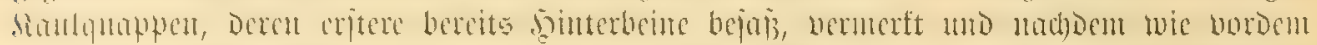

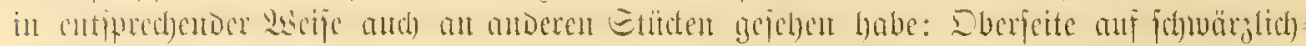

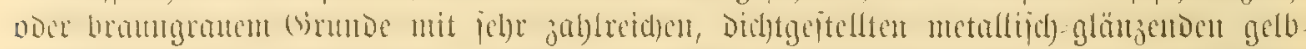

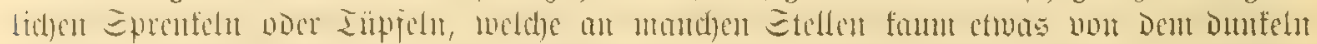

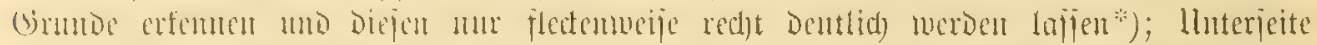

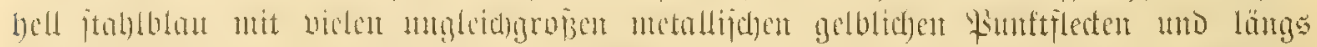

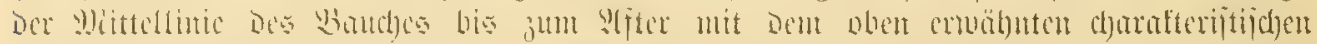

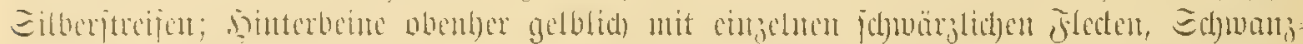

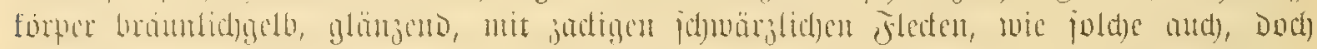

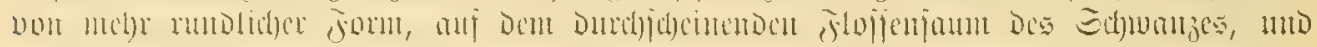

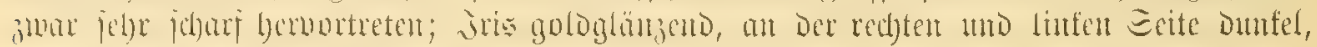
fodaß Das Ange cine :Irt Dumfler Duterbinde erfält.

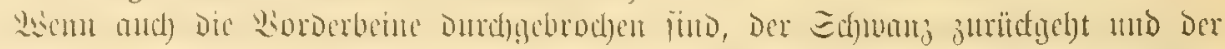

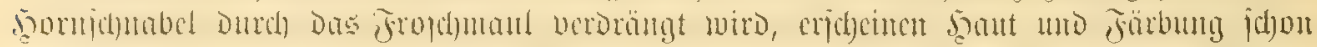

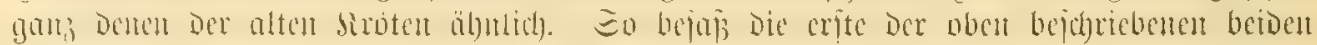

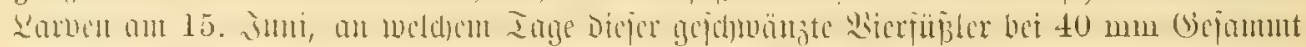

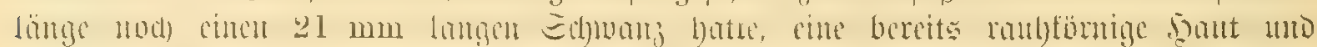

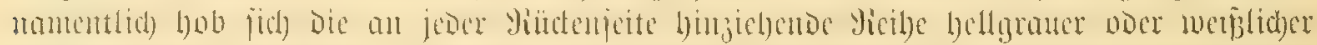

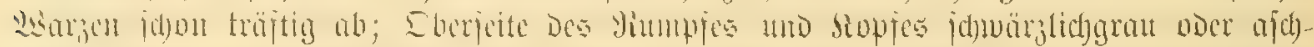

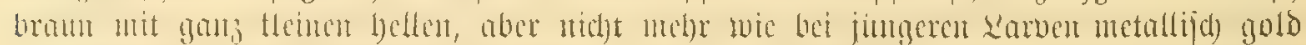

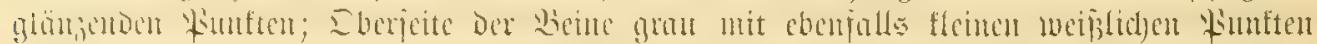

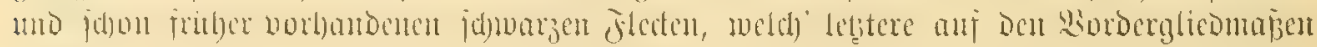

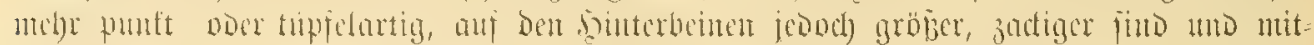

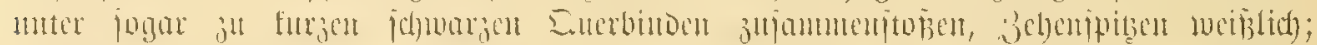

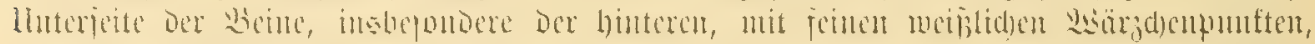

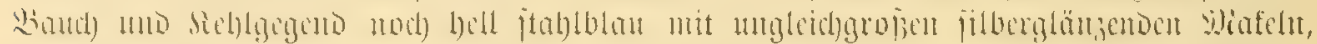

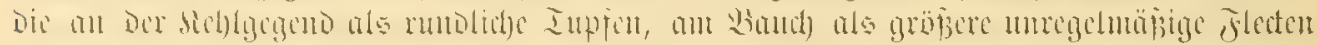

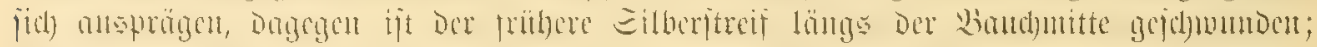

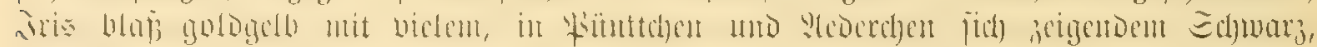

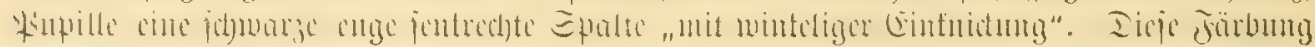

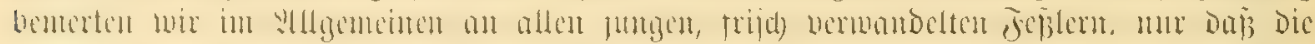

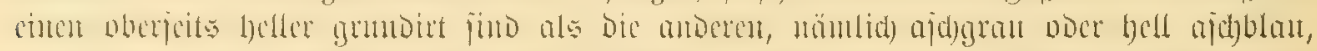

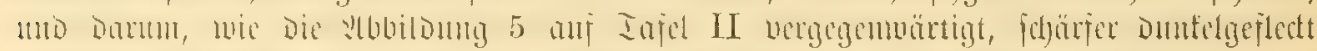

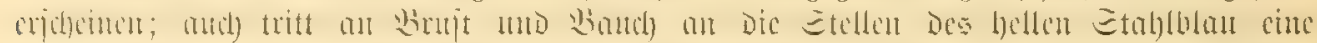

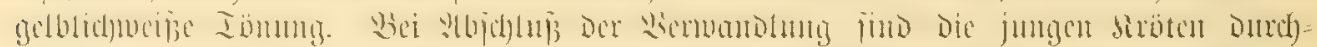

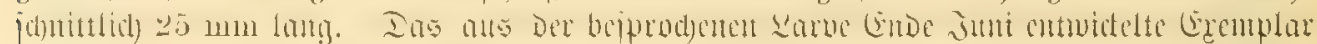

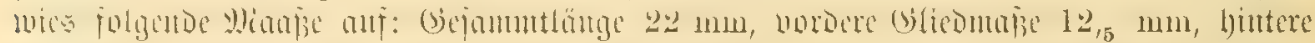

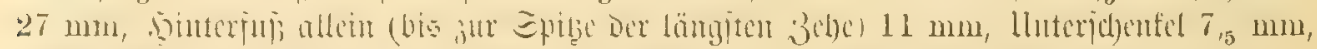

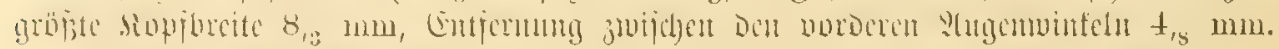

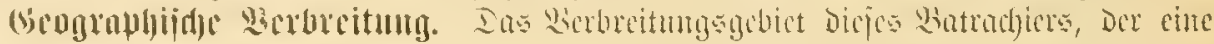

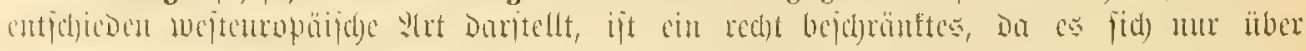

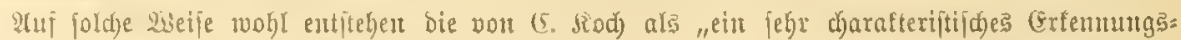

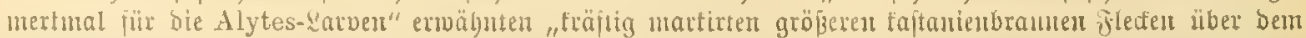

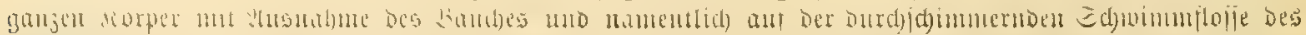

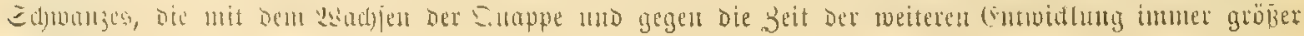
uno Dentlidjer merden". 


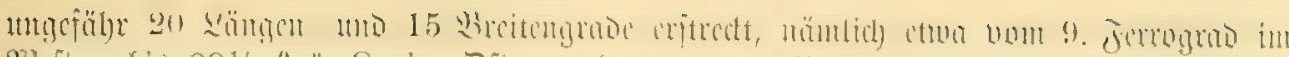

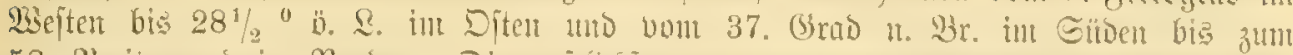

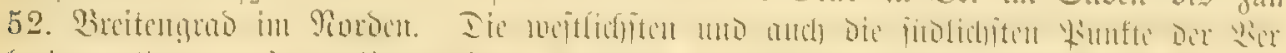

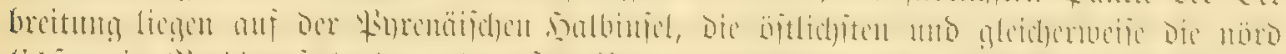

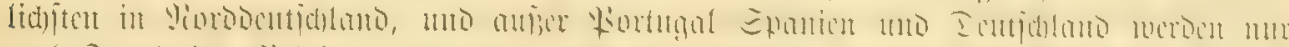

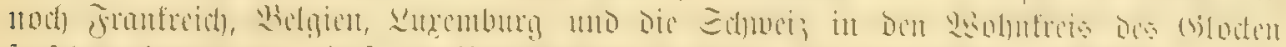

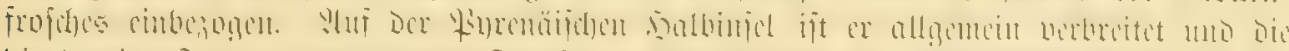

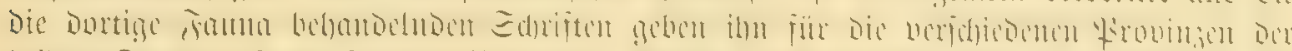

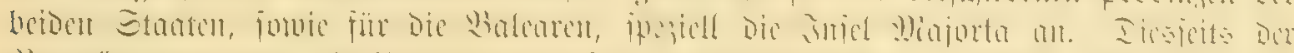

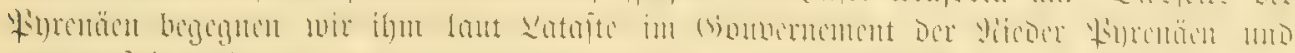

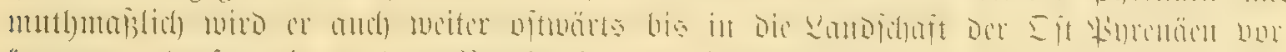

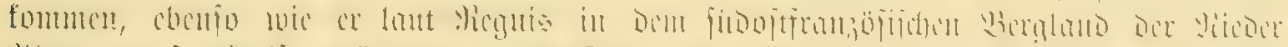

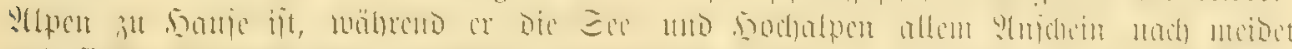

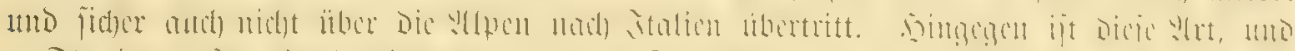

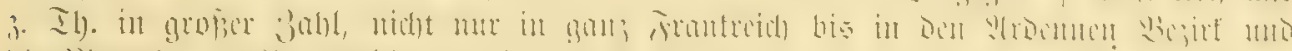

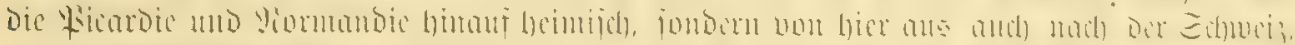

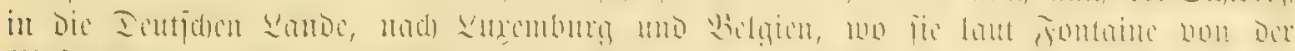

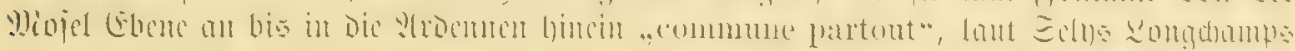

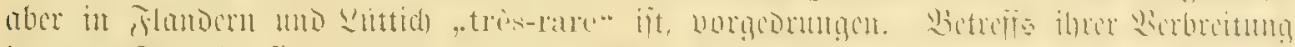

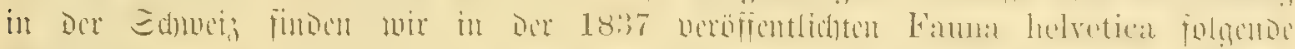

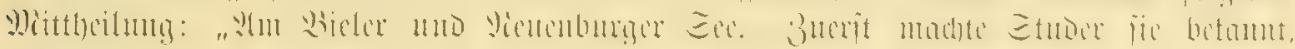

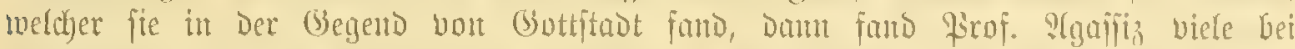

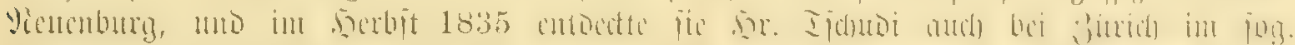

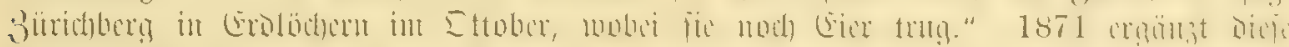

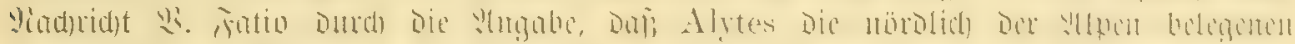

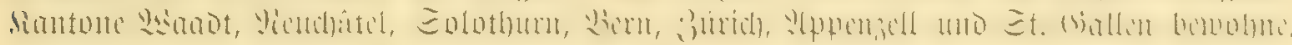

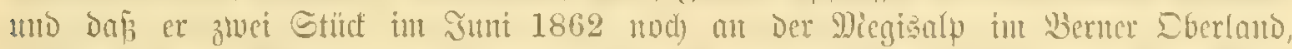
1500 an Dittheilnng an mich fie in bener Dberland nidyt beobantet hat. Da Die Jemen

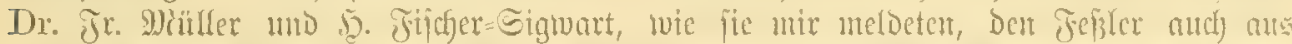

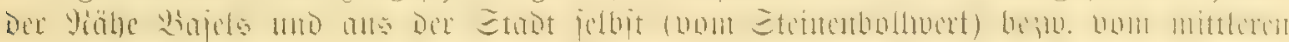

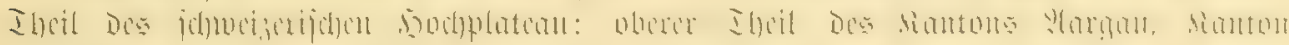

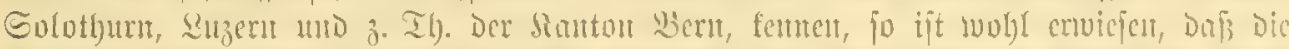

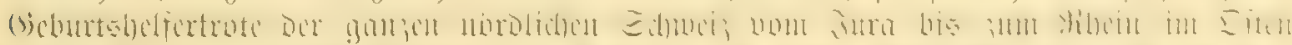

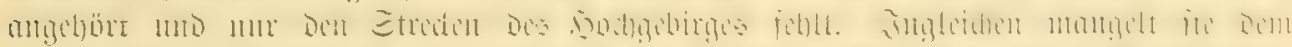

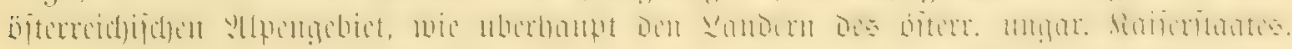

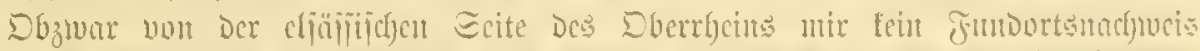

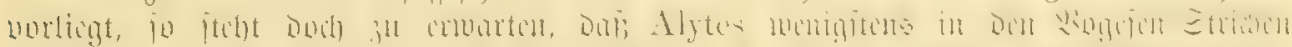

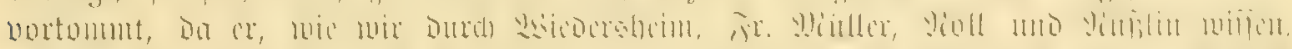

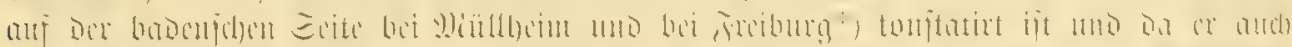

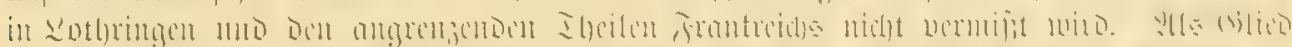

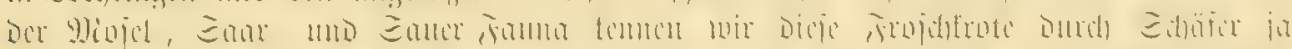

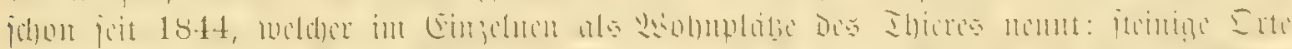

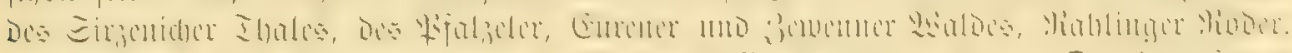

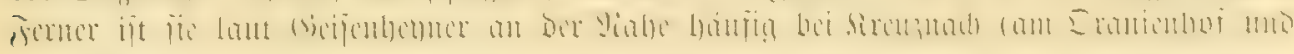

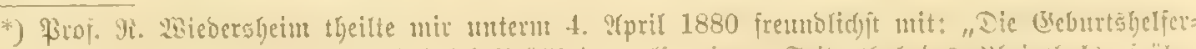

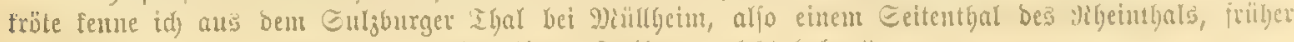
foll fie aud in ben Bergen umnittelbat binter ijteiburg gelebt baben". 


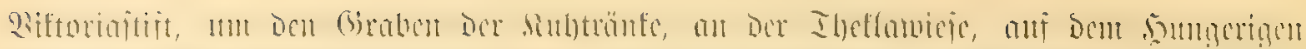

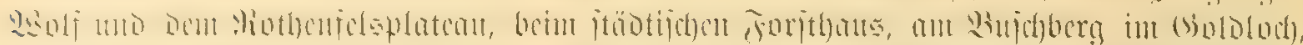

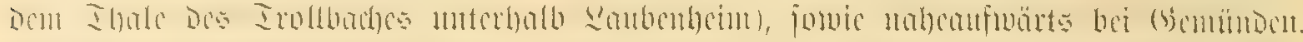

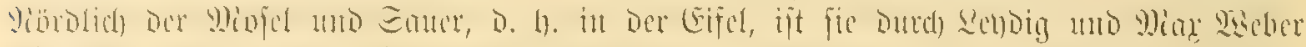

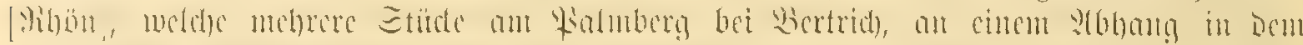

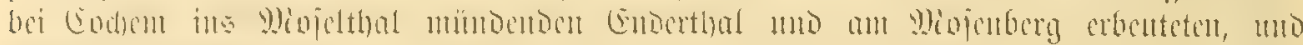

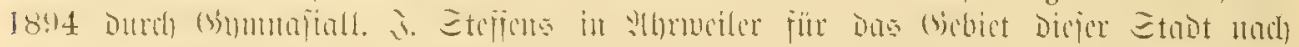

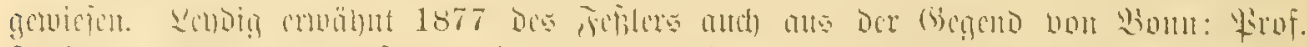

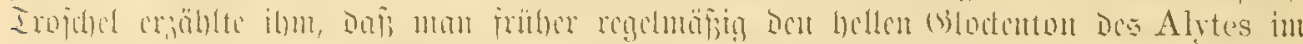

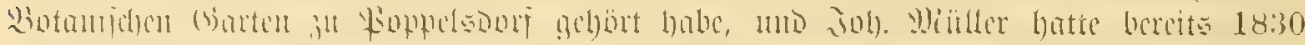

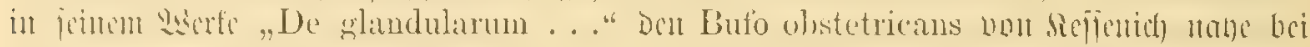

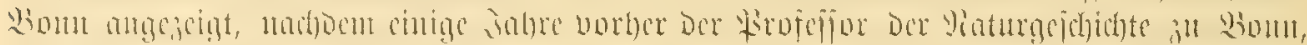

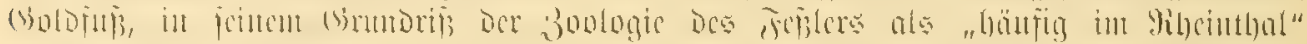

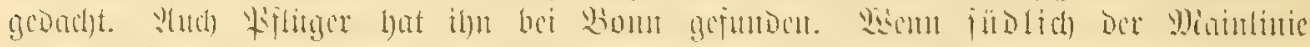

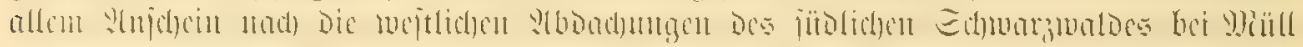

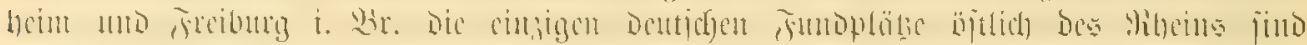

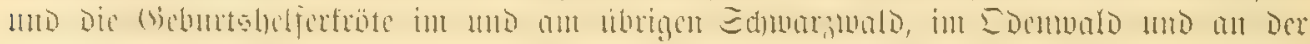

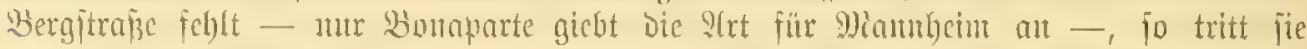

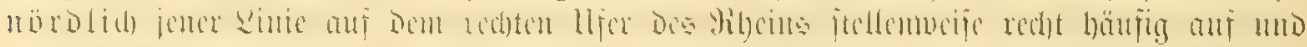

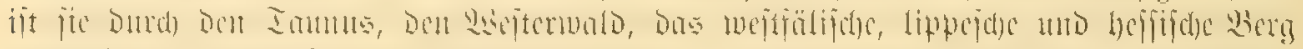

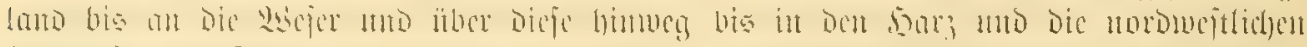

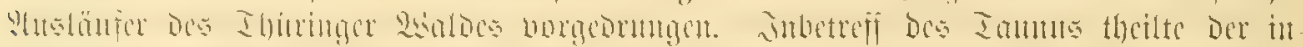

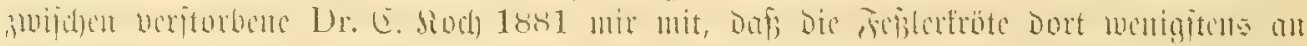

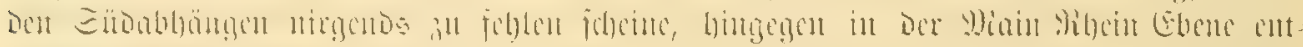

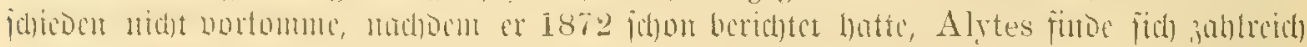

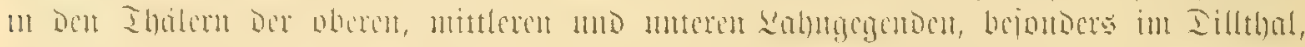

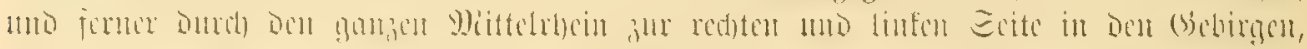

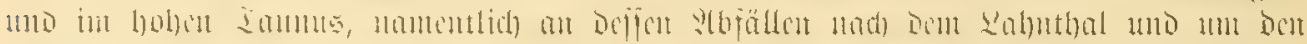

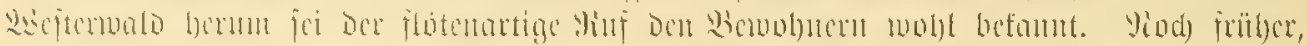

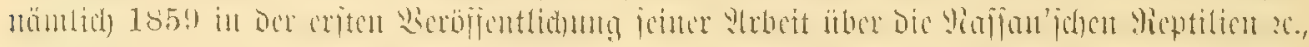

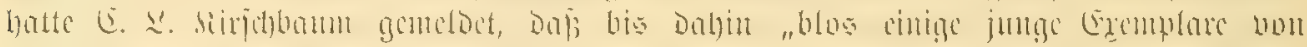

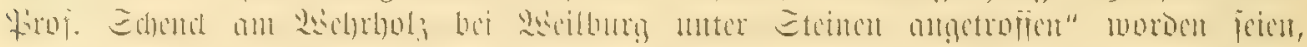

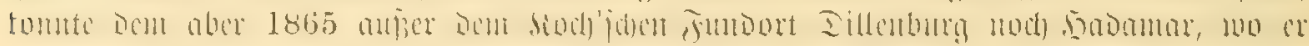

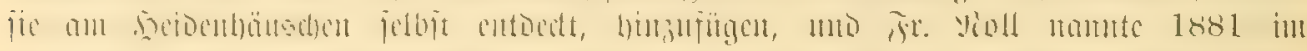

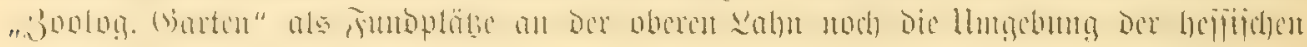
Erte Sicbentopf nut Miarbitrg.

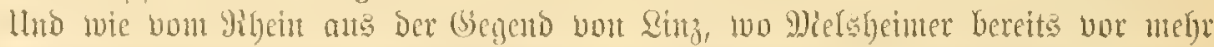

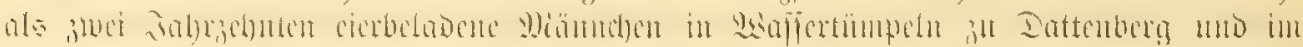

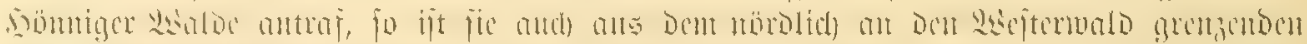

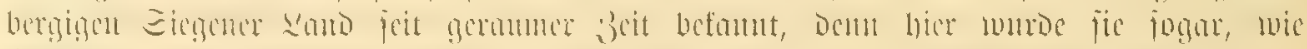

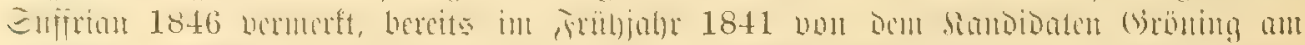

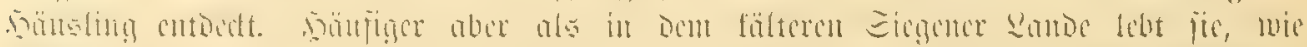

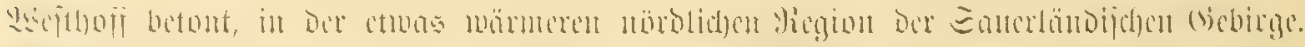

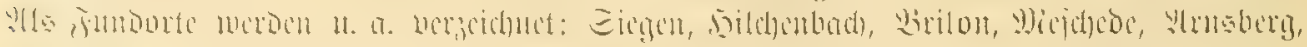

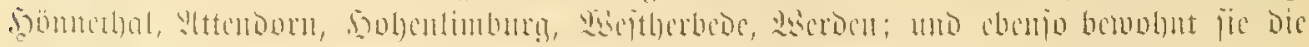

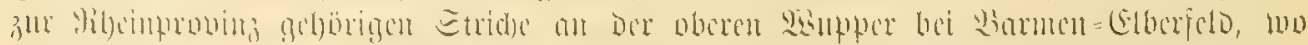

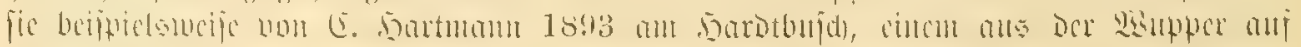

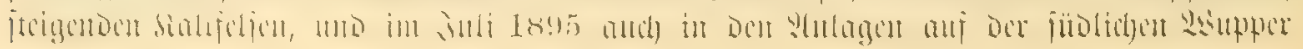




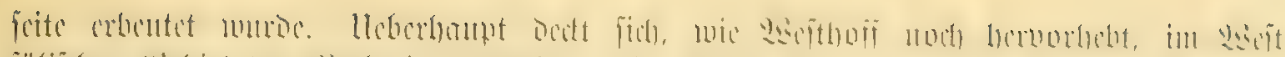

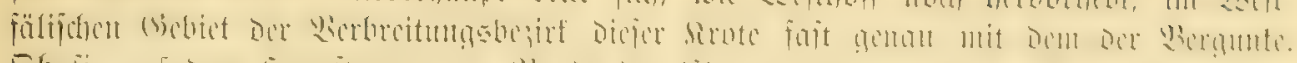

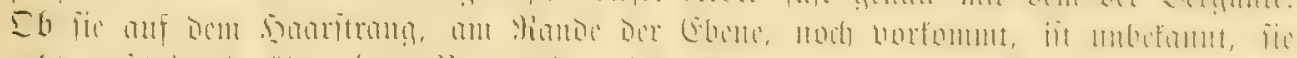

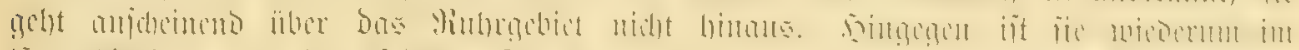

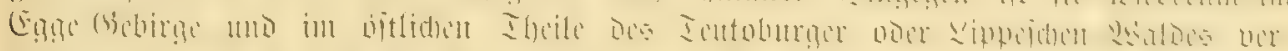

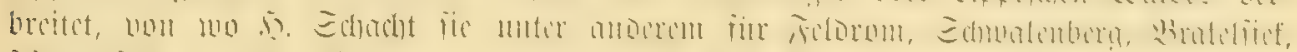

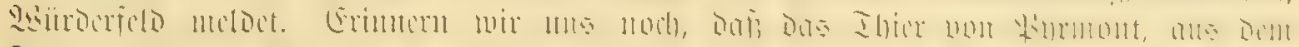

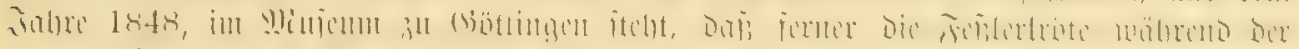

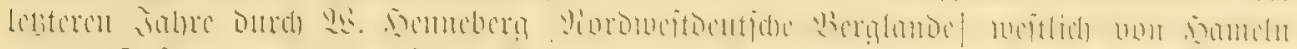

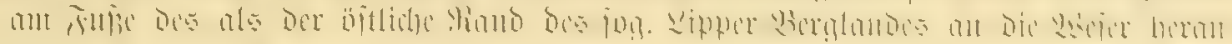

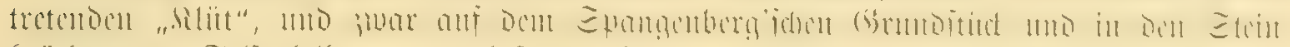

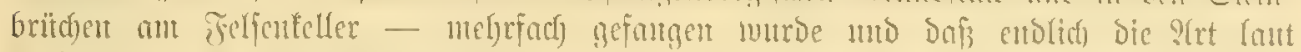

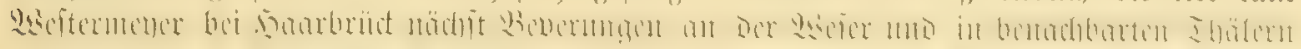

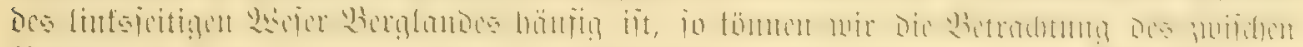

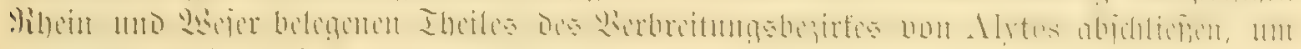

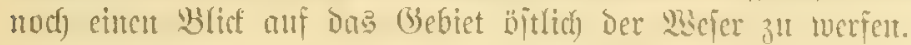

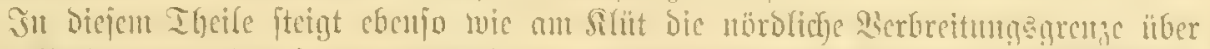

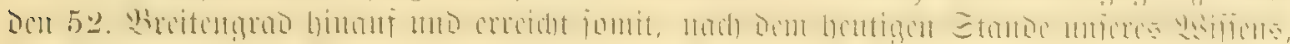

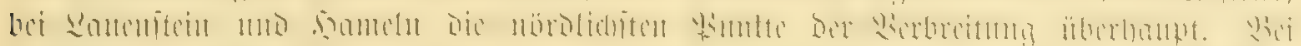

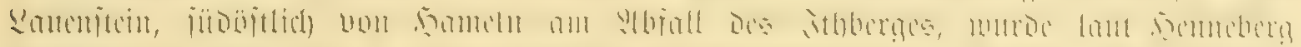

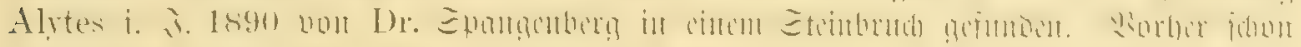

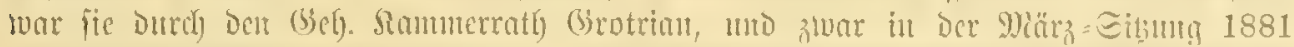

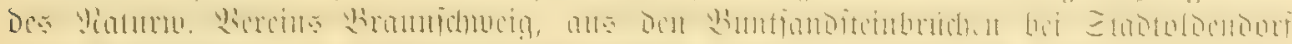

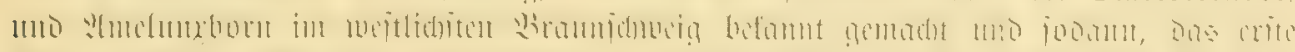

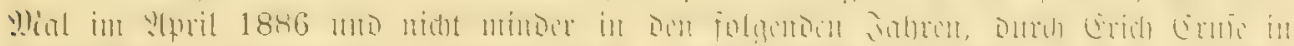

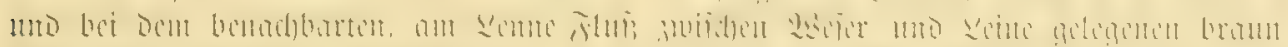

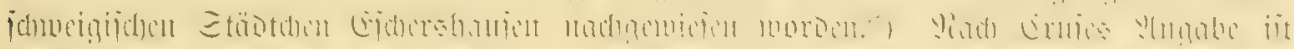

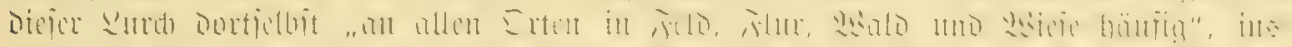

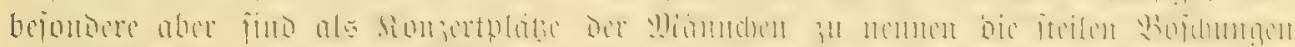

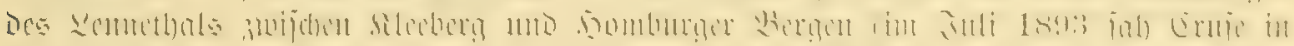

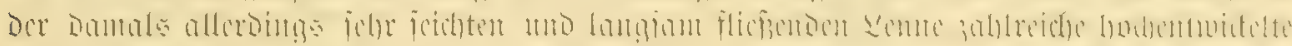

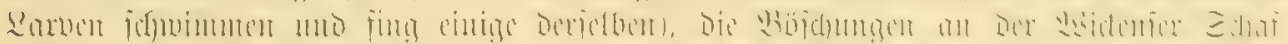

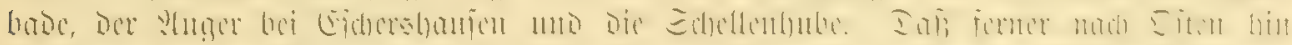

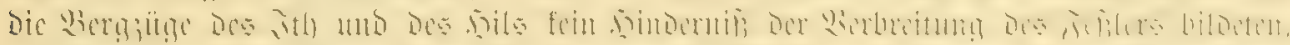

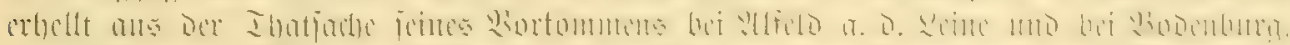

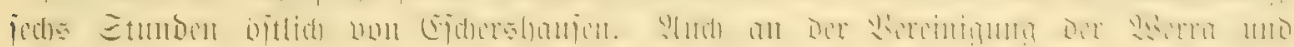

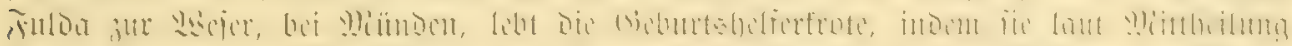

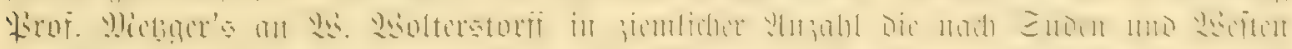

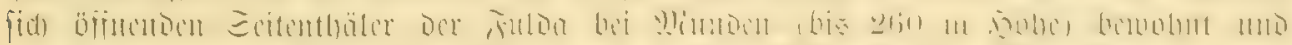

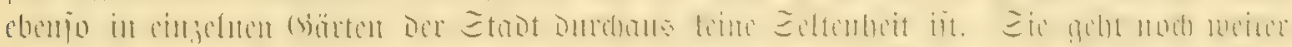

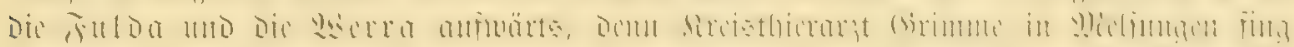

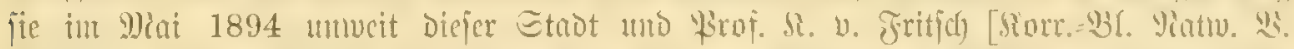

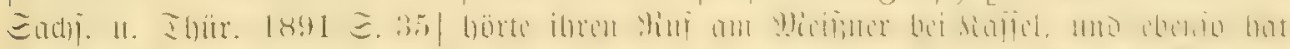

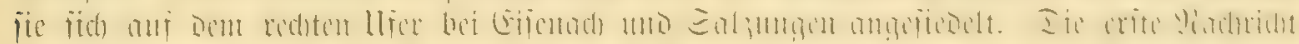

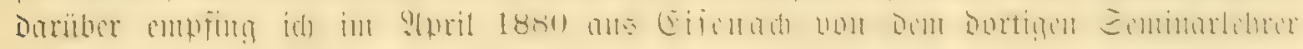

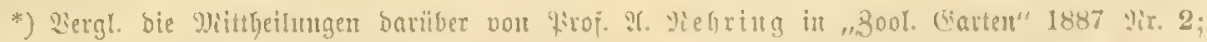

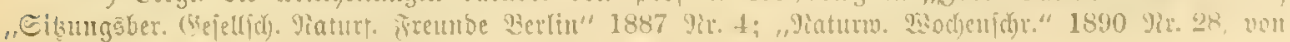

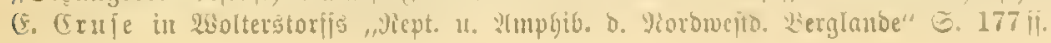




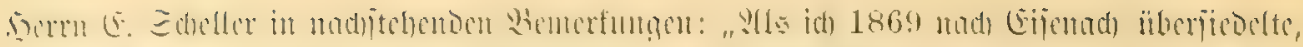

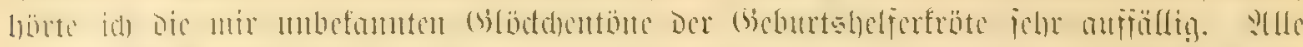

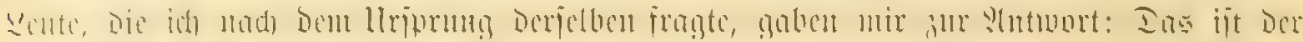

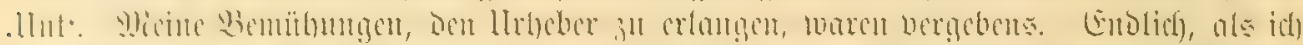

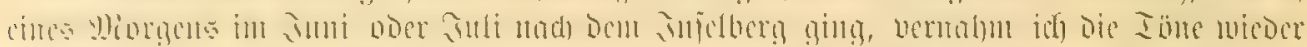

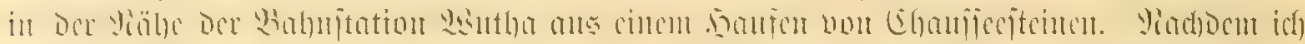

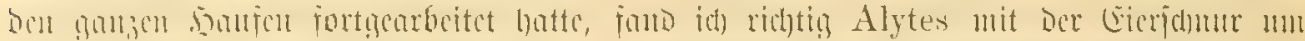

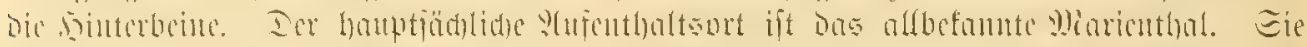

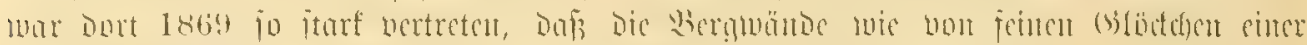

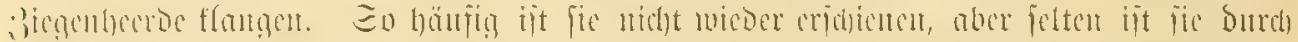

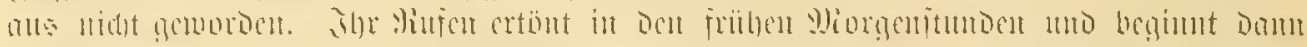

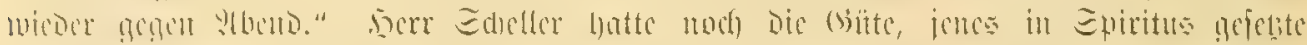

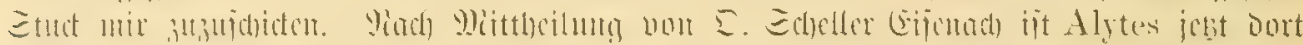

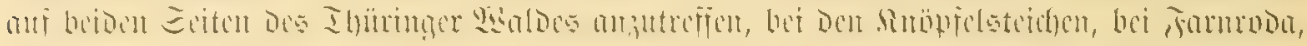

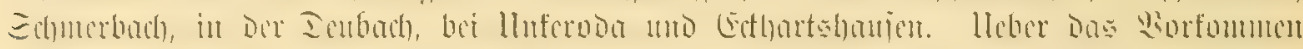

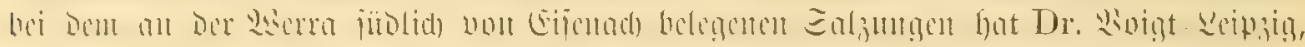

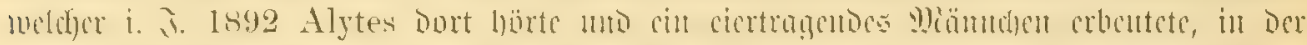

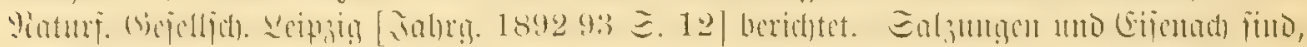

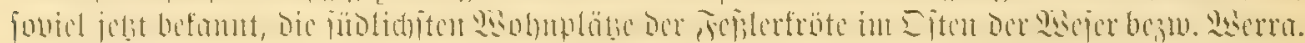

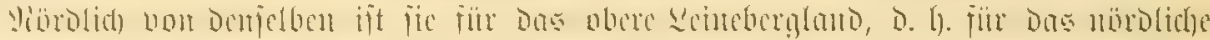

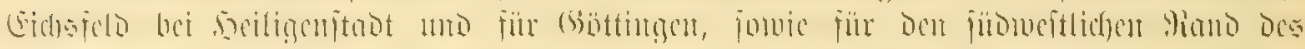

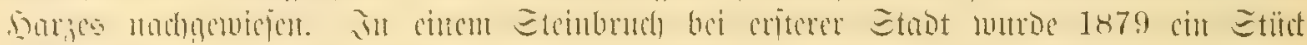

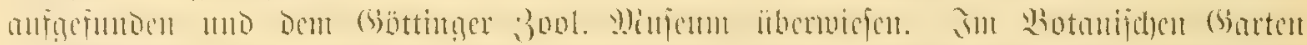

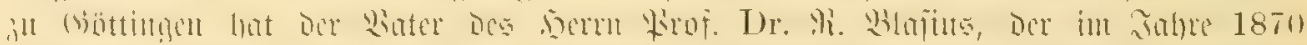

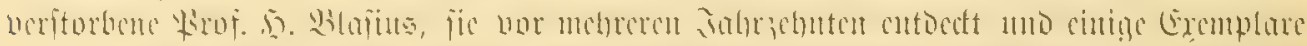

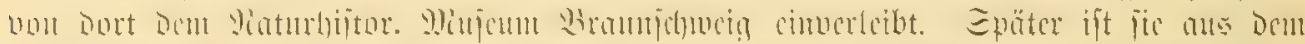

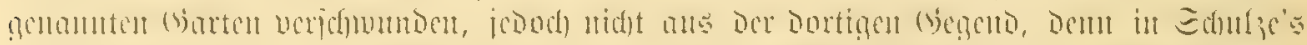

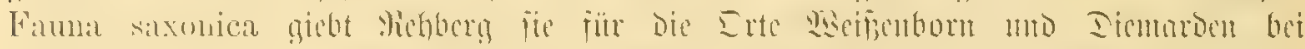

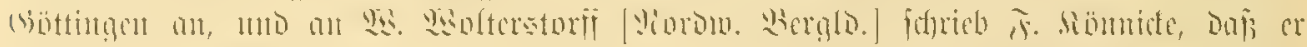

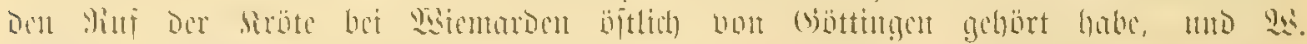

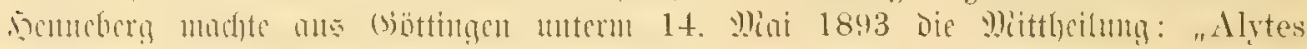
obstetricans rittgosmu".

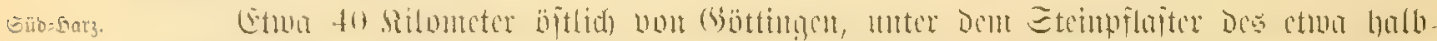

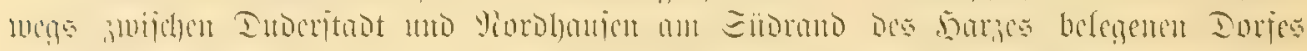

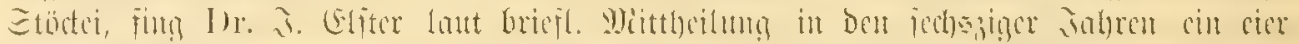

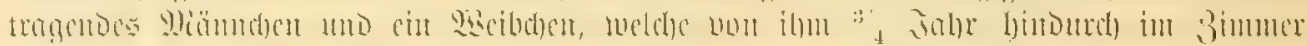

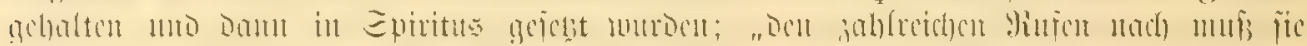

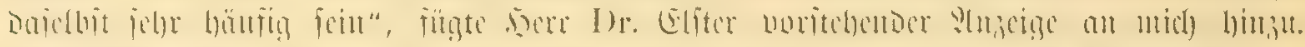

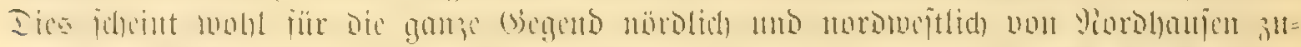

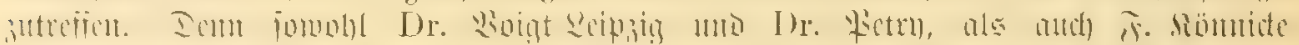

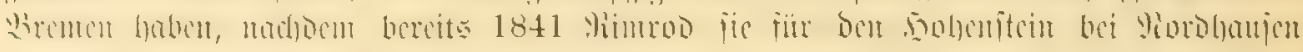

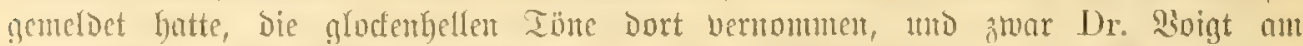

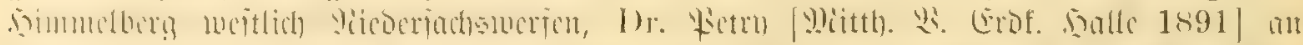

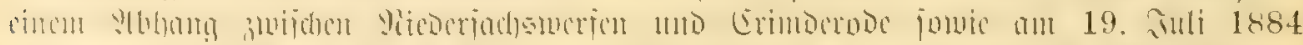

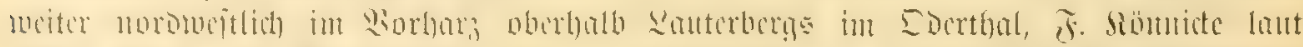

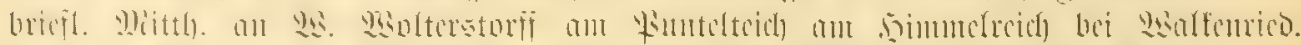

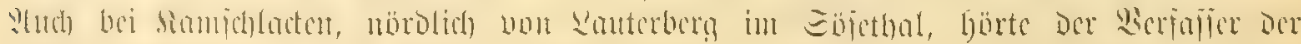

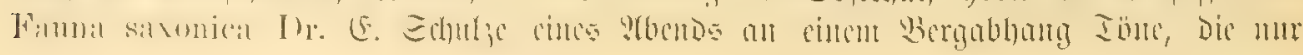




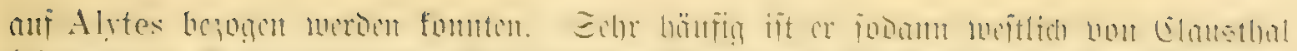

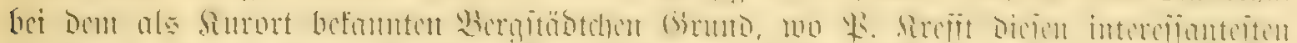

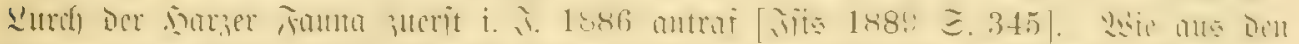

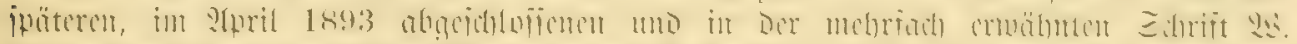

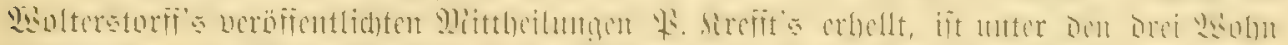

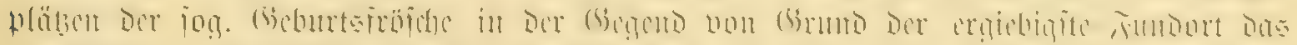

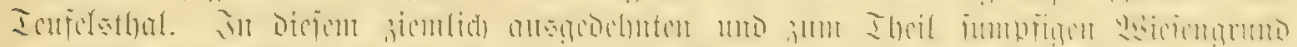

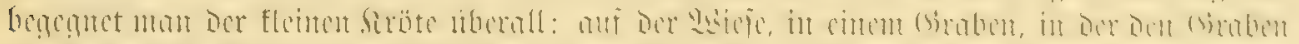

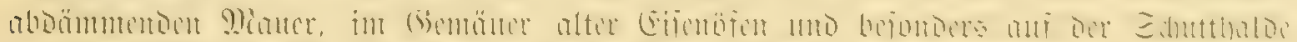

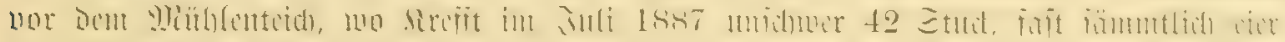

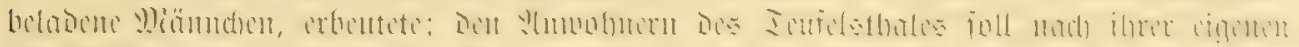

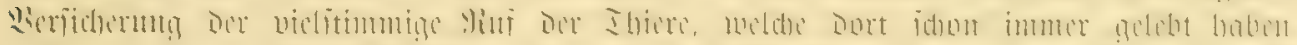

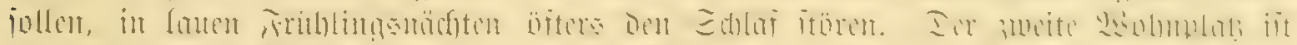

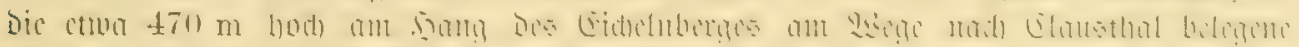

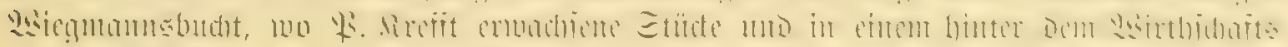

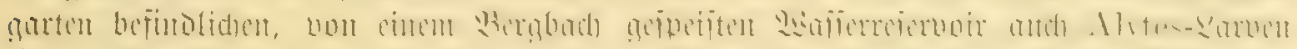

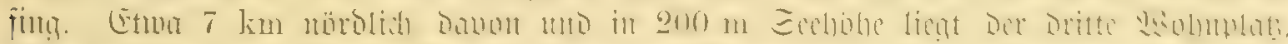

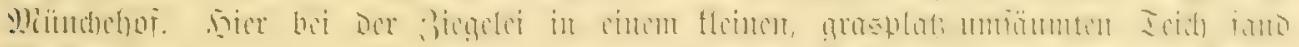

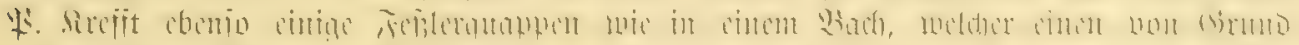

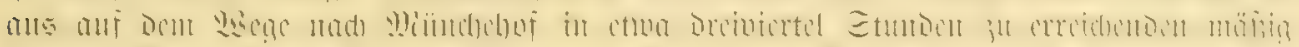

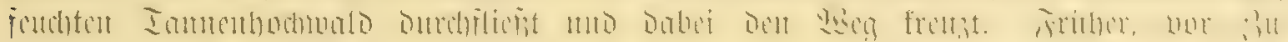

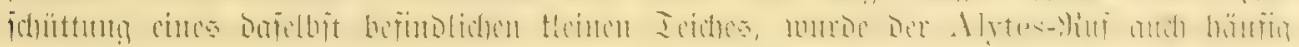
in Drte Girutud jelfit bei Der jogentanten Becfje verntumutent.

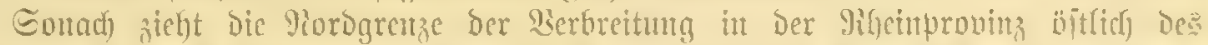

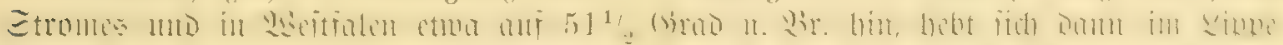

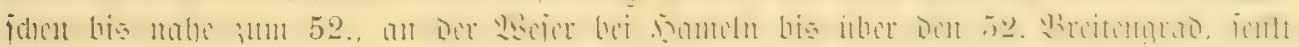

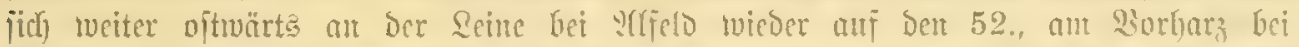

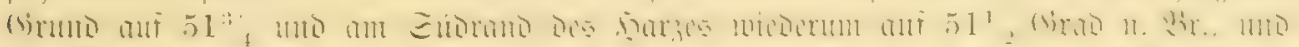

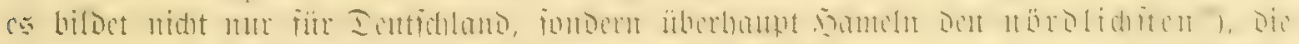

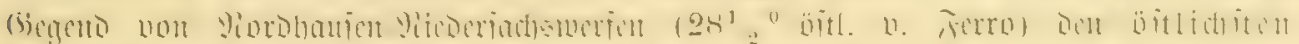

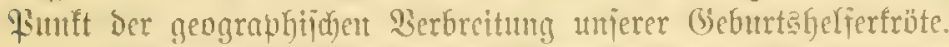

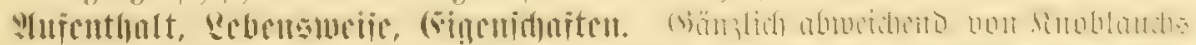

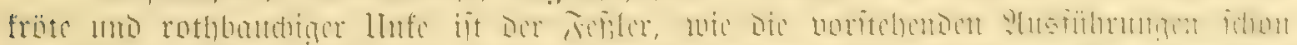

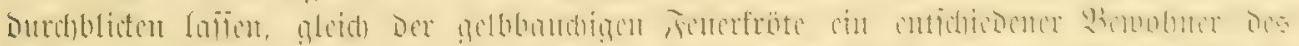

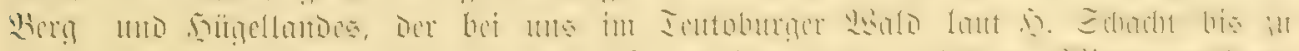

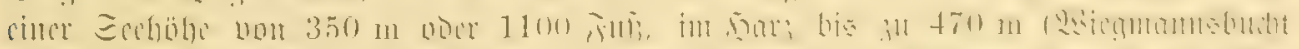

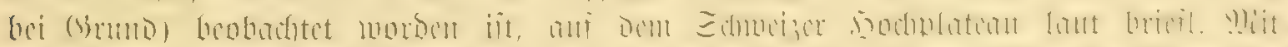

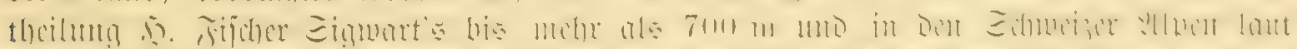

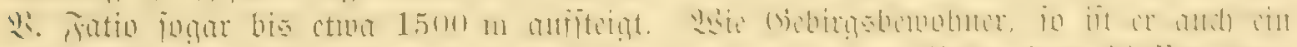
rotes

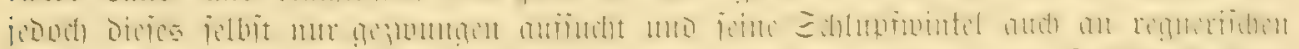

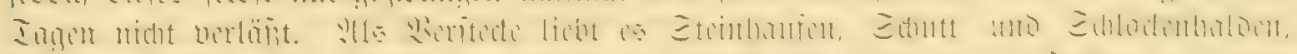

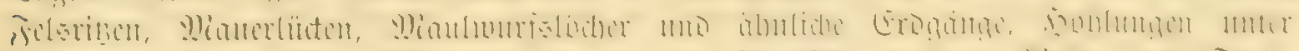

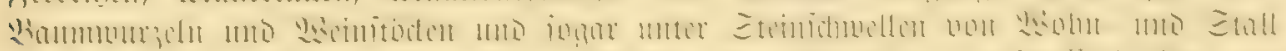

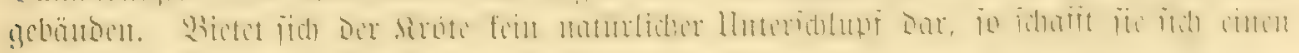

*) Bei einent in ben 70 er Sahren angejeigten funb mehrerer (Exemplare bes Alytes in ber tiähe von

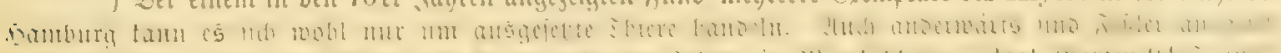

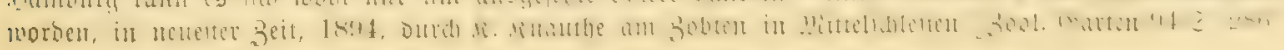




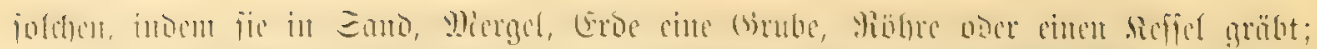

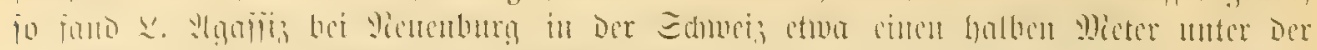

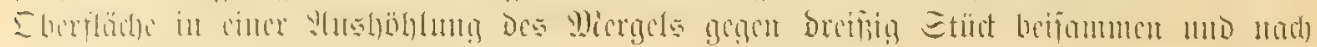

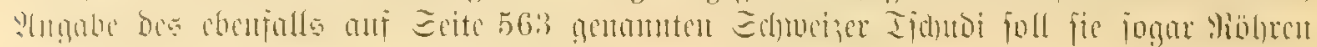

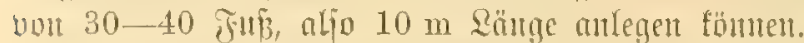

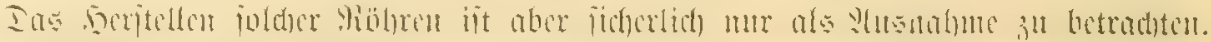

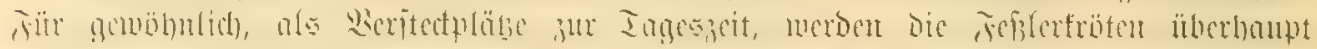

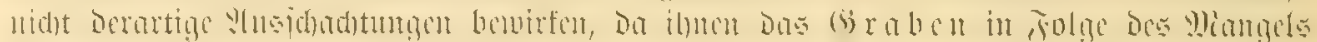

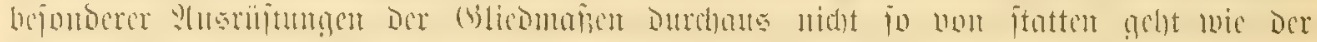

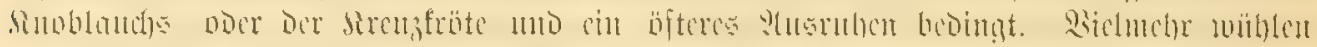

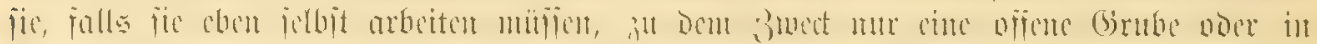

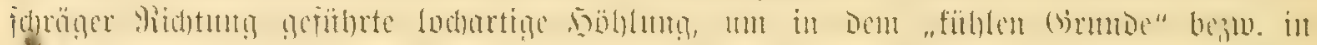

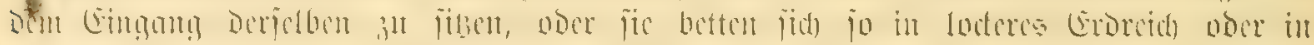

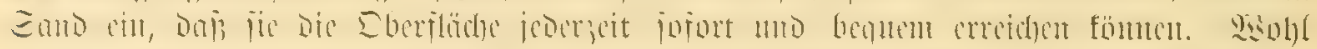

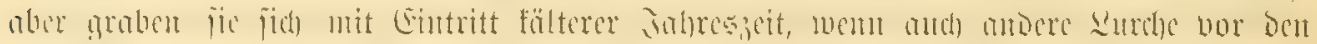

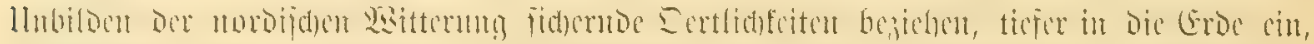

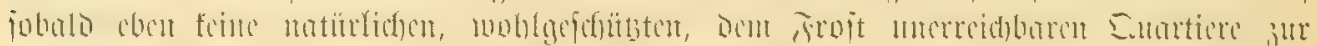

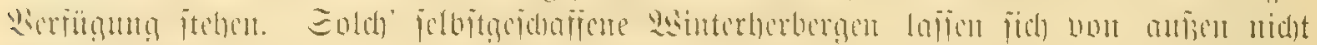

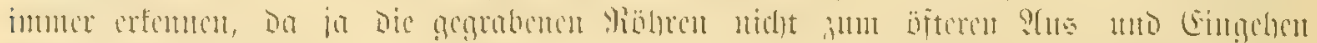

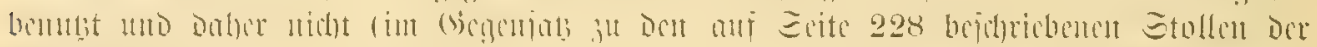

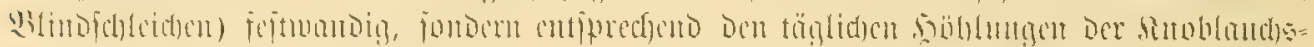

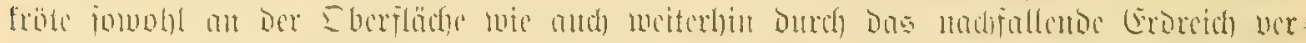

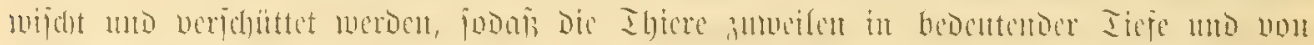

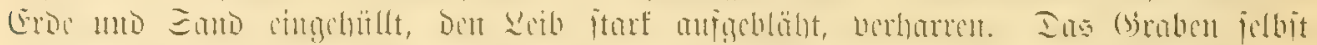

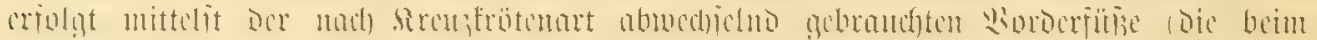

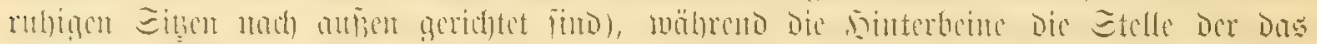

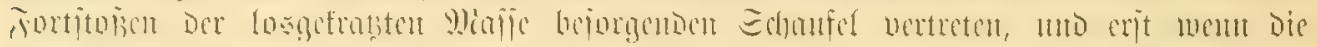

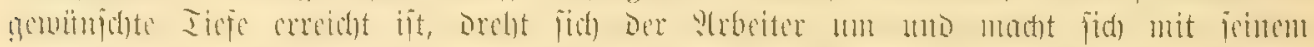

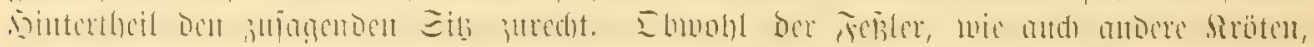

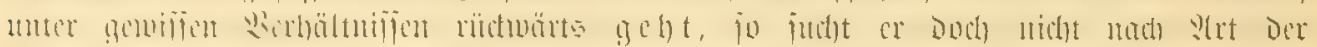

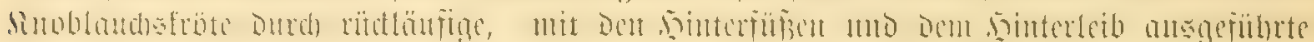

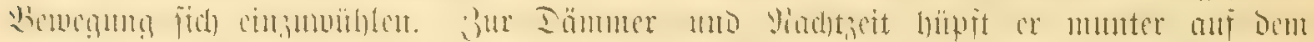

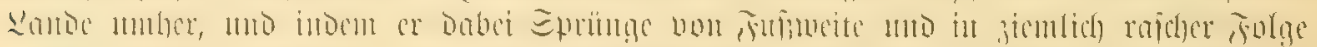

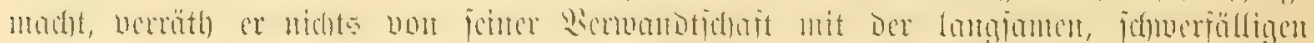

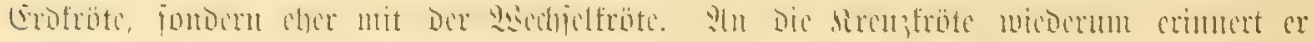

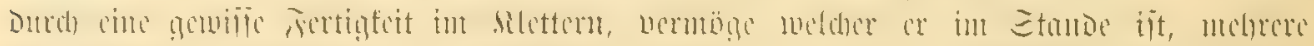
Fili;

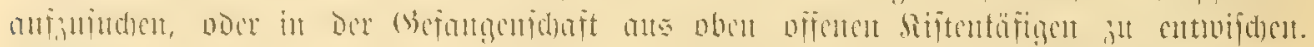

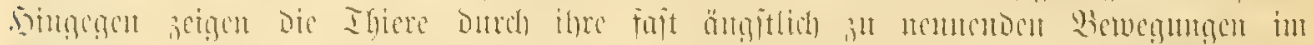
鵕

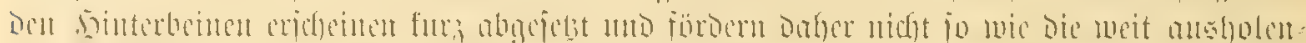

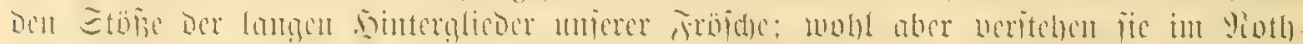

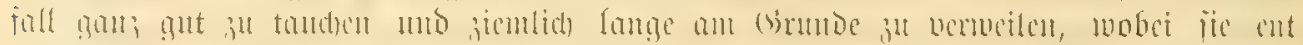

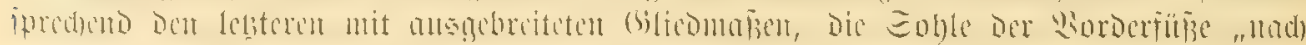
ausbürts and binten gerichtet", ftill am Boben liegen.

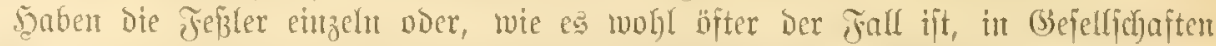

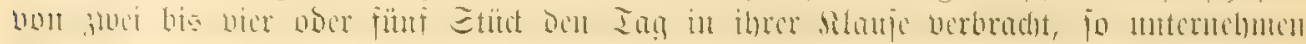

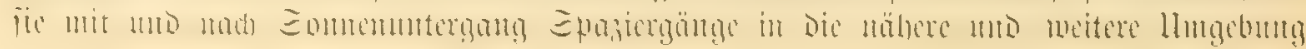




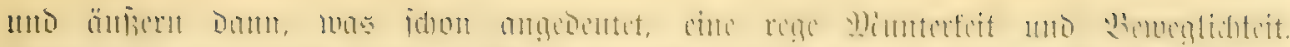

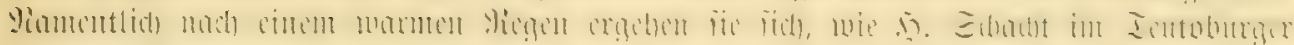

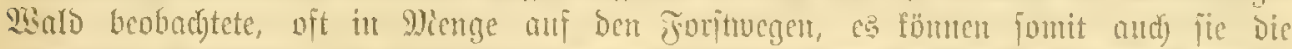

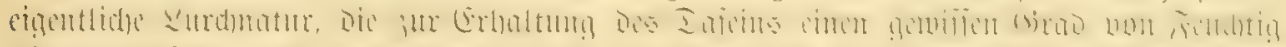

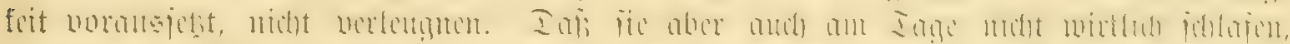

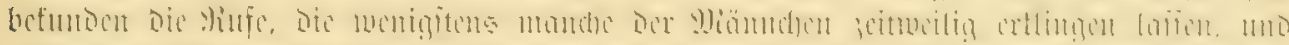

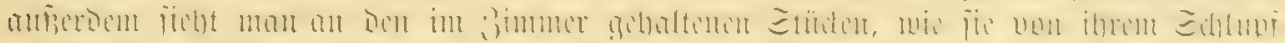

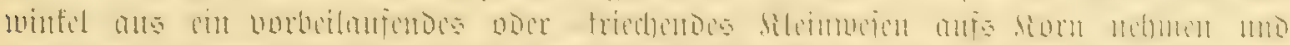

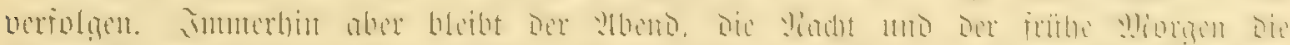

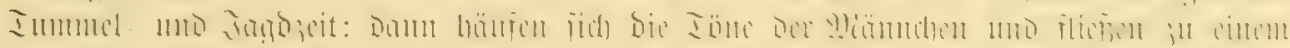

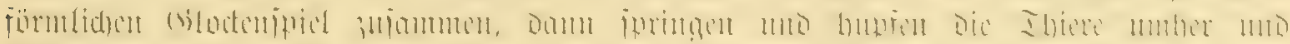

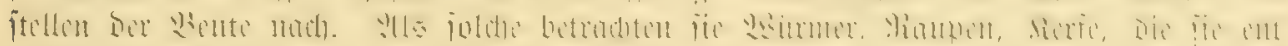

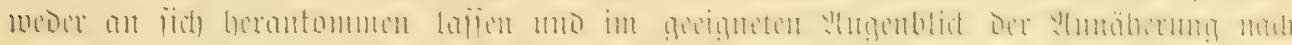

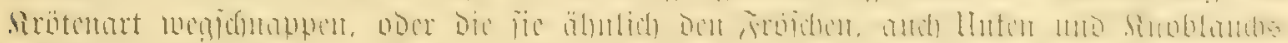
fröten im Eprunge erbajefte. Sn Den 45 Elmoratueter Bobenflädje Dectenden

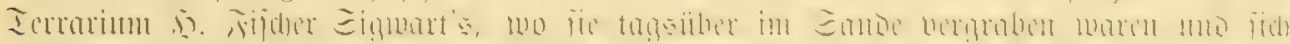

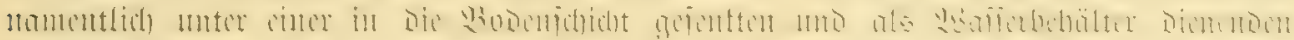

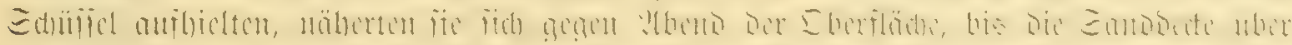

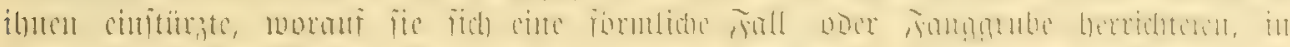

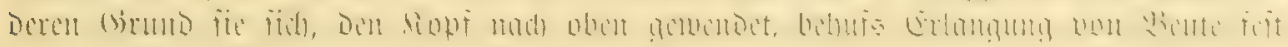

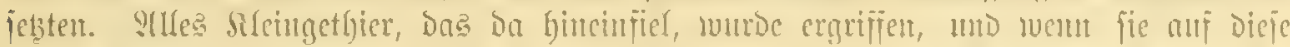

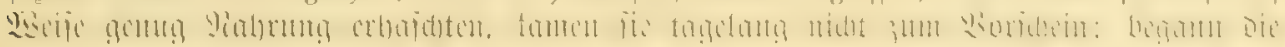

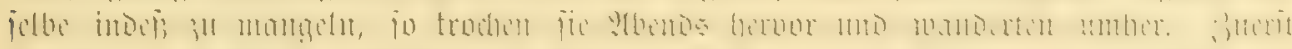

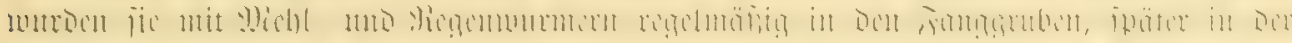

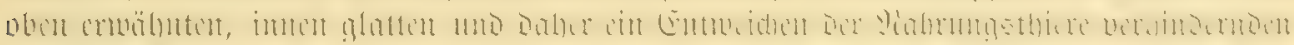

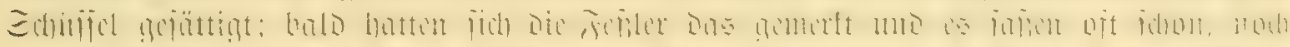

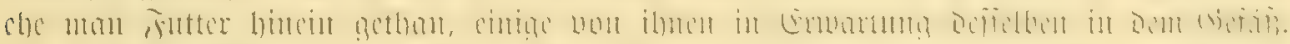

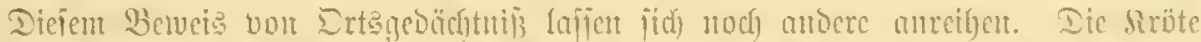

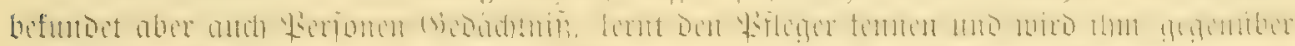

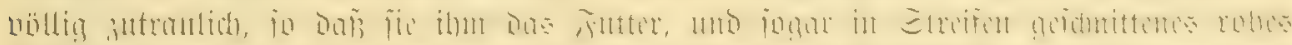

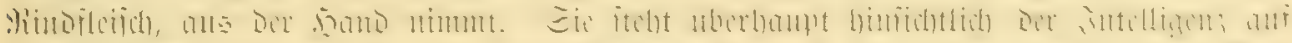

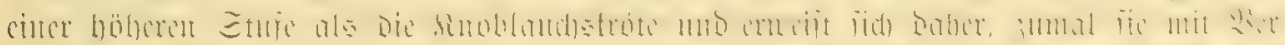

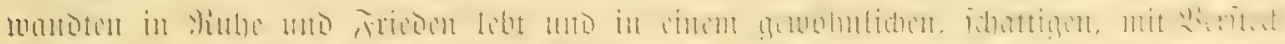

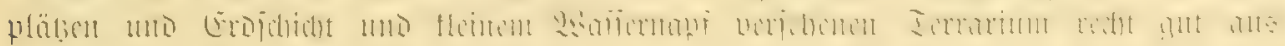

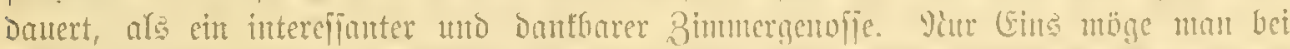

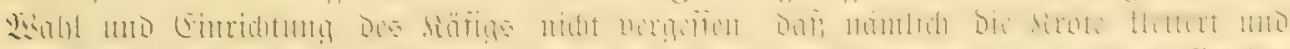

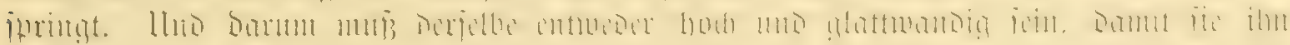

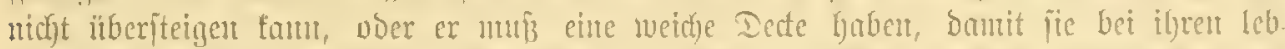

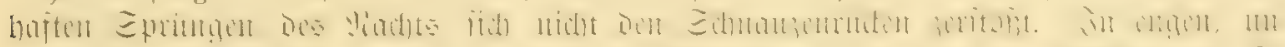

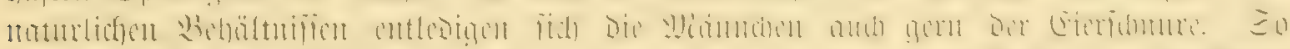

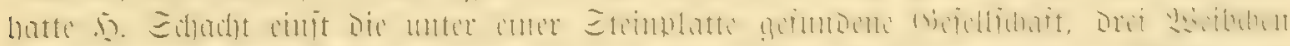

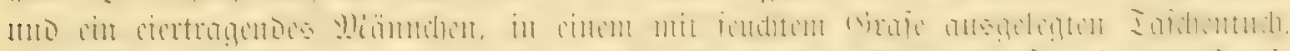

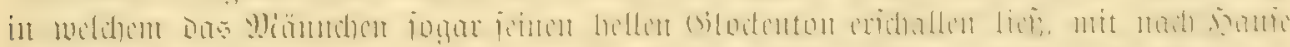

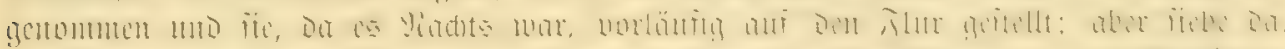

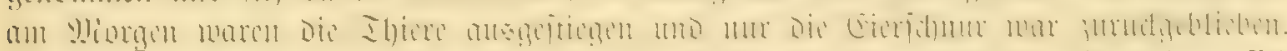

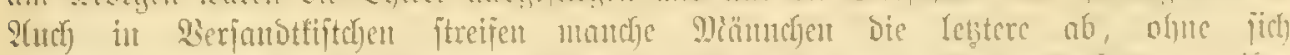

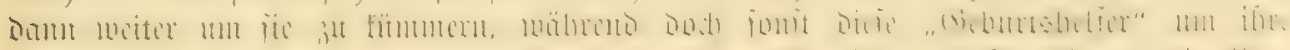

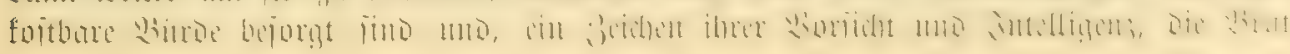




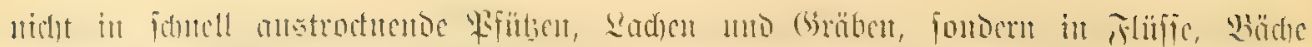

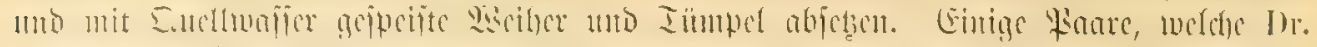

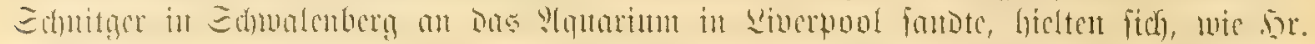

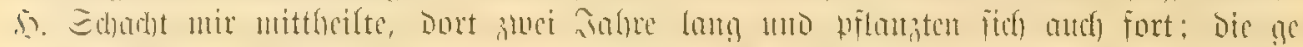

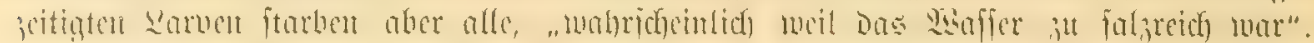

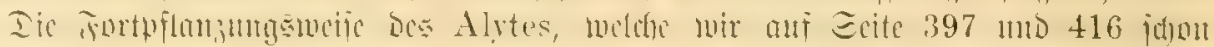

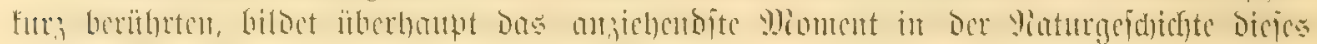

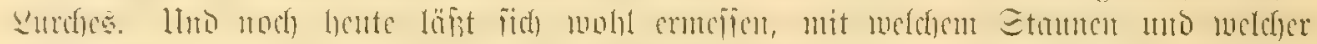

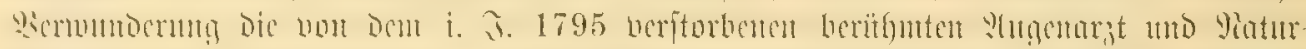

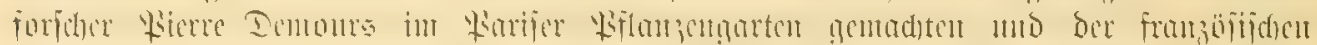

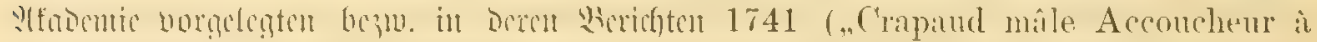

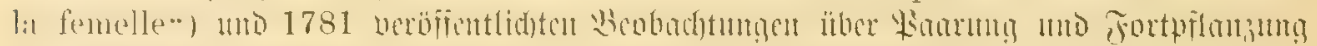

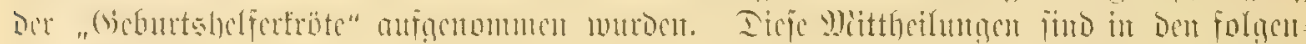

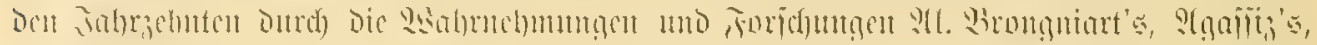

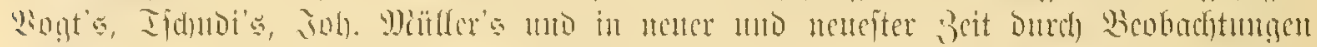

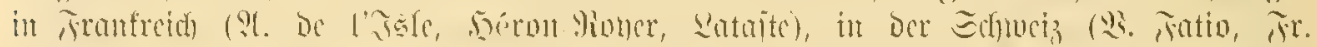

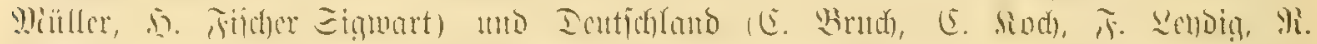

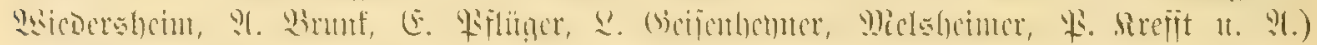

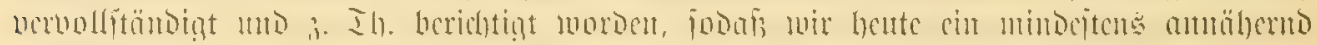

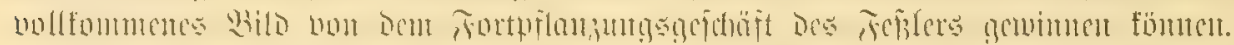

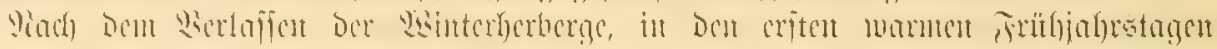

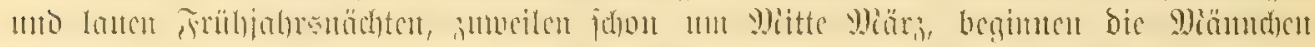

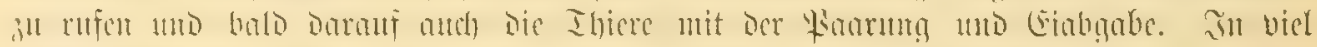

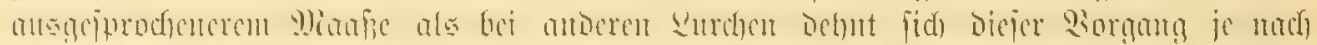

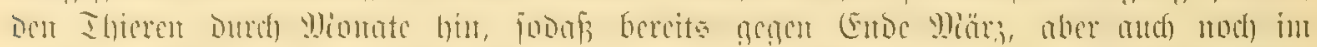

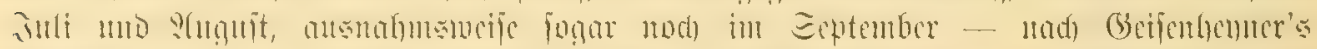

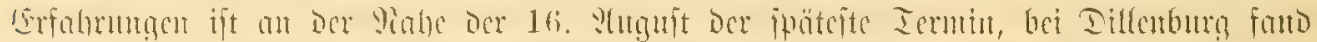

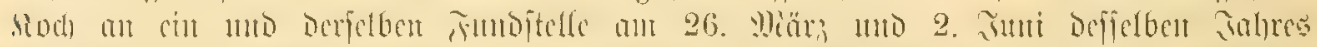

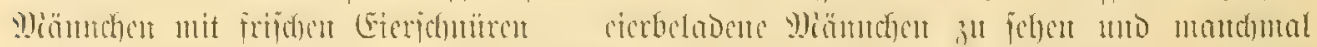

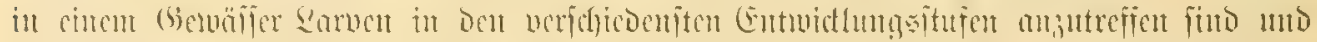

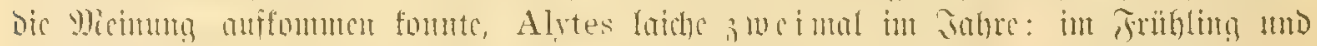

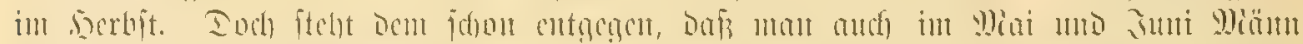

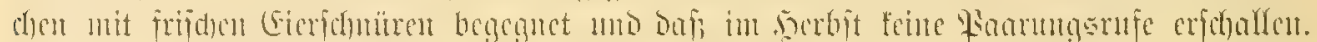

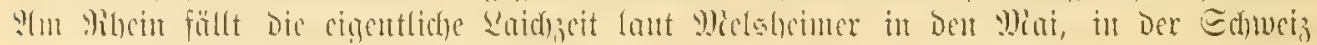
laut Tifubi in dent Quril.

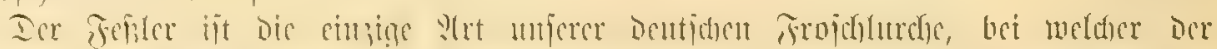

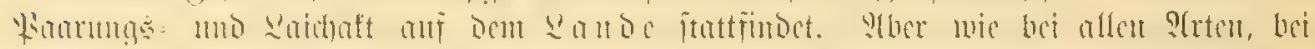

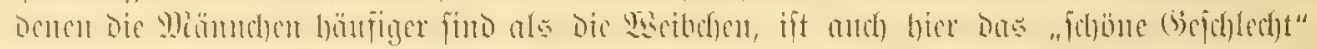

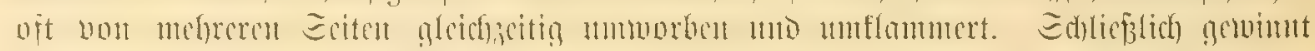

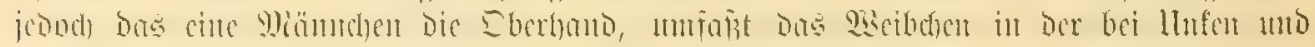

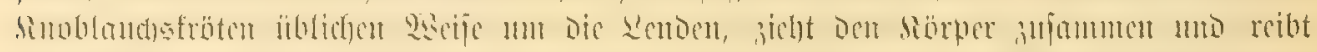

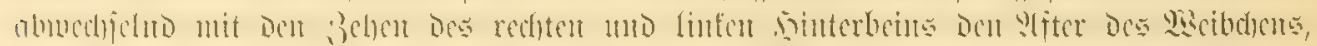

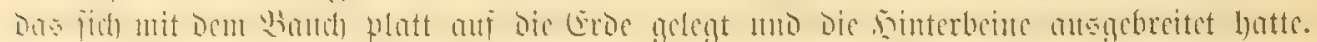

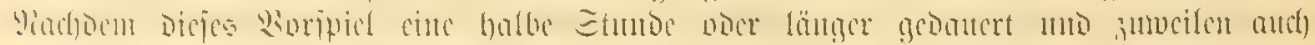

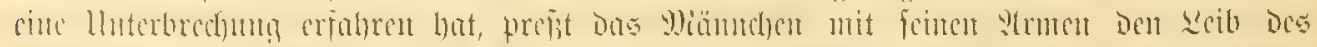

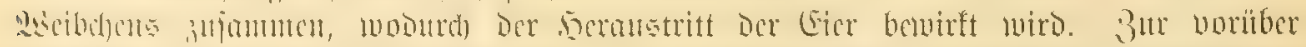

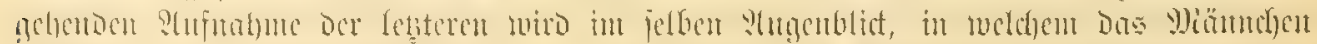

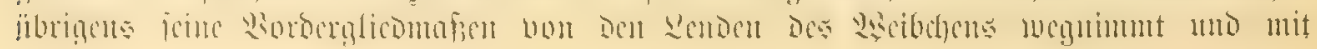




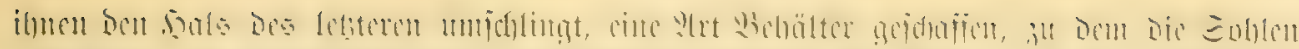

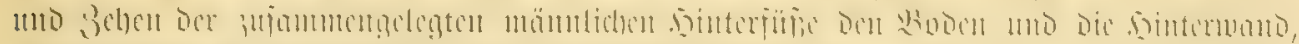

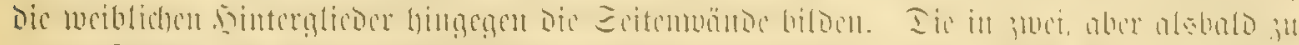

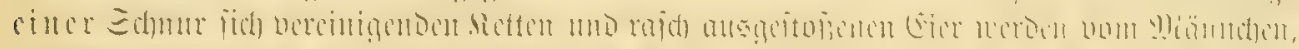

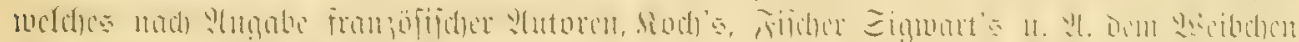

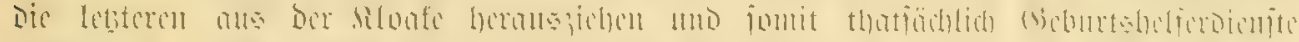

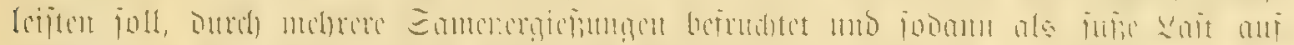

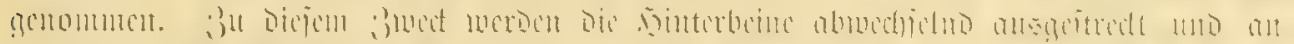

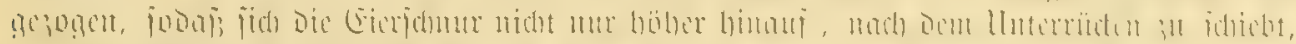

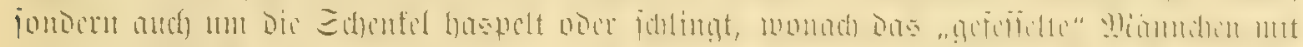

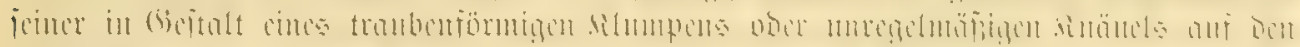

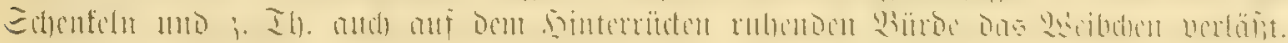

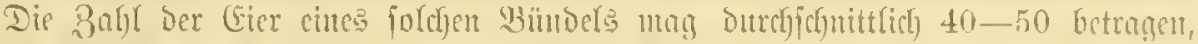

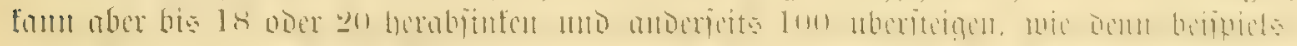

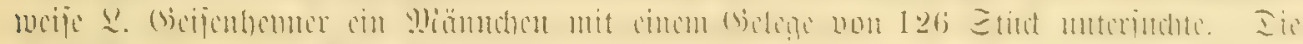

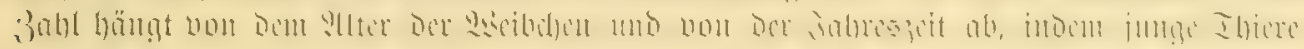

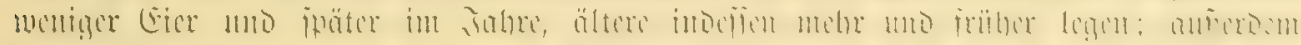

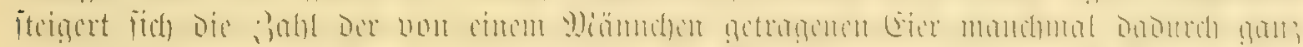

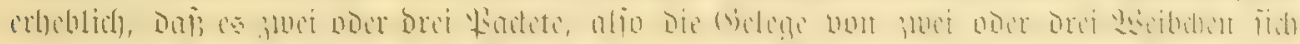

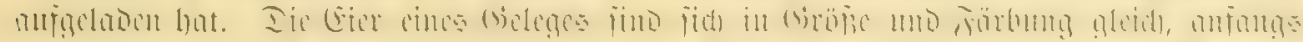

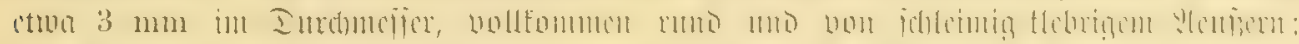

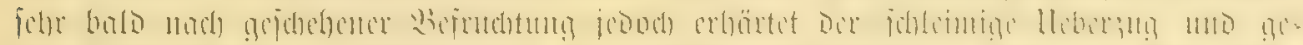

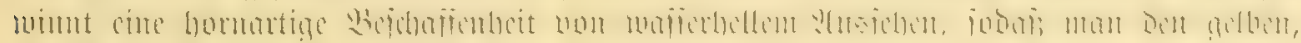

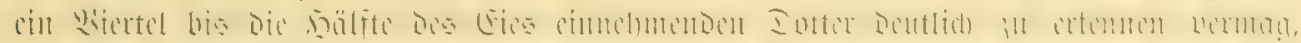

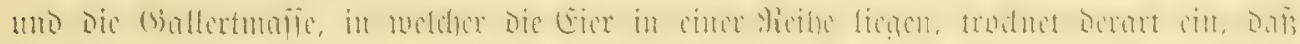

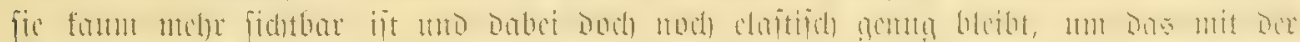

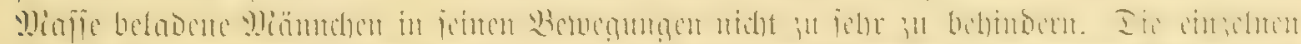

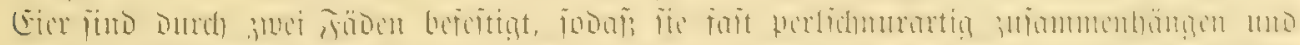

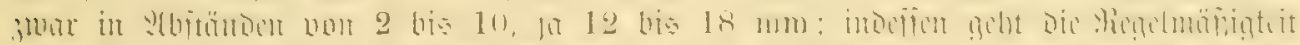

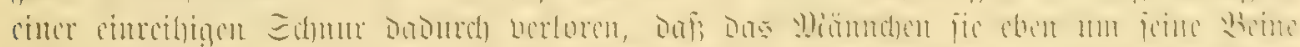

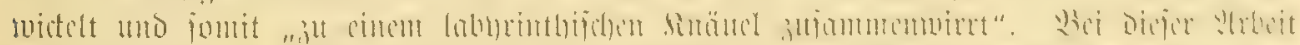

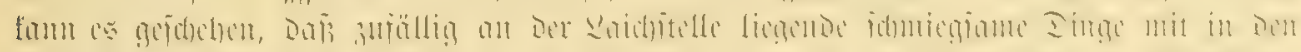

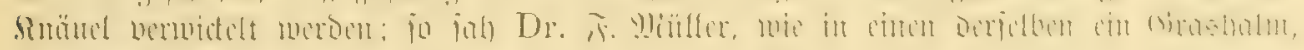
in einen zweiten cin langes Franenfour nach allen Yiditutgen eingeflodjen war.

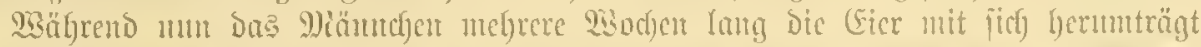

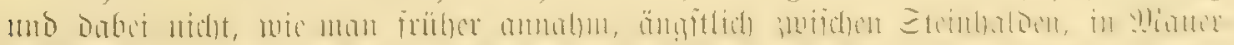

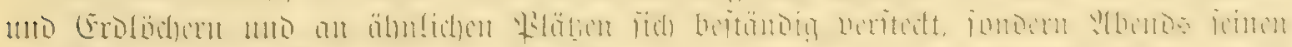

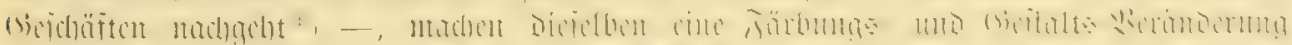

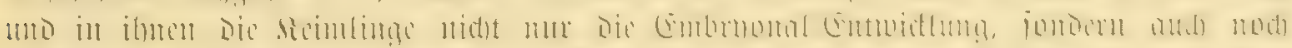

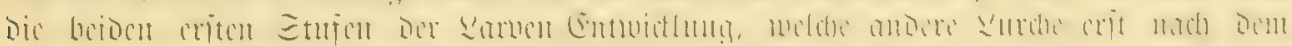

*) A. de l'Isle hatte vor zuvei Gahrzebuten [MI $\mathrm{em}$. sur les moeurs et l'accouchement de l'Alytes obst. in ben Ann. d. Sc. nat. VI u. a.] im (iegenjab zu irïgeren 2:eobnd)tern hervorgehoben, onfi bns

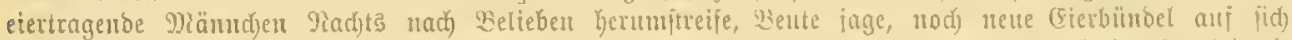

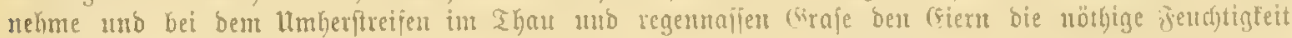

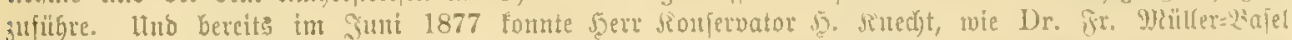

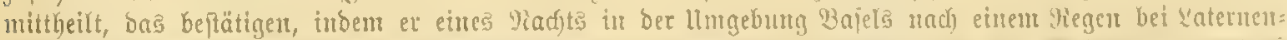

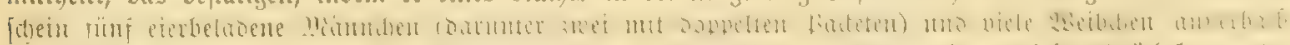

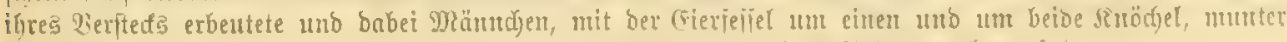

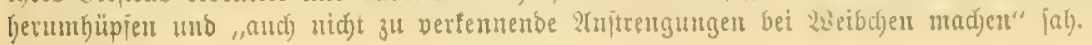


Whatam Dit (E)

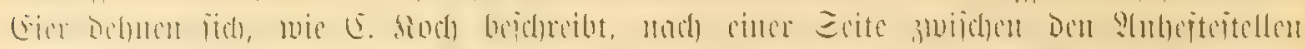
De.

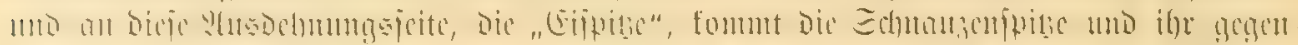

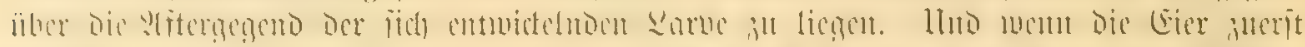

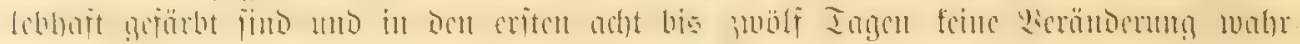

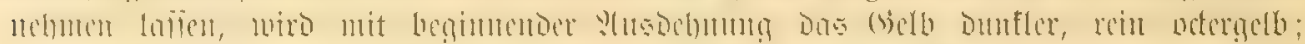

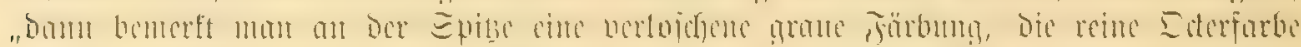

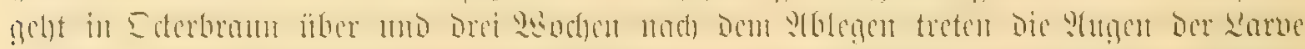

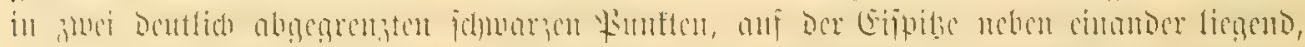

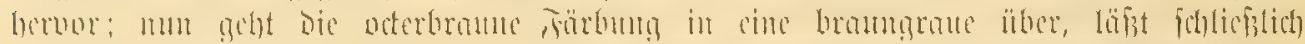

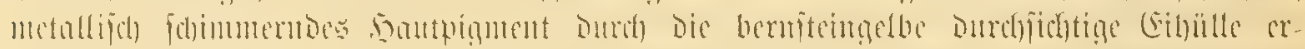

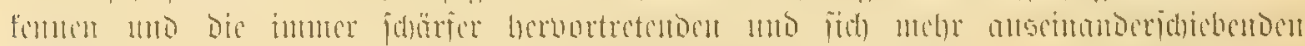

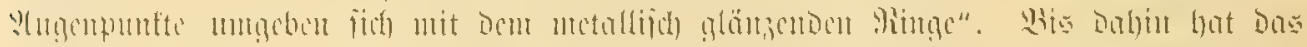

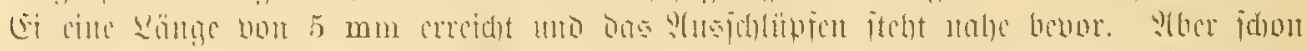

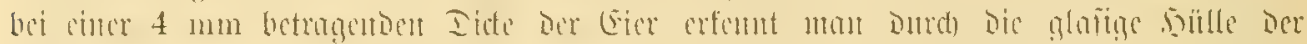

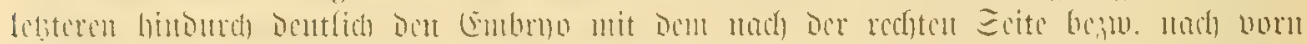

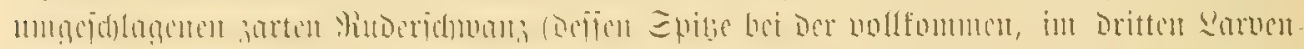

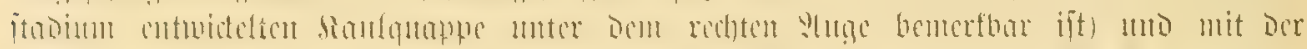

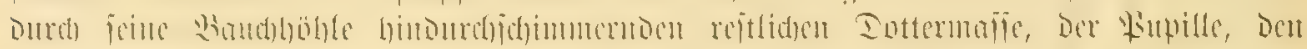

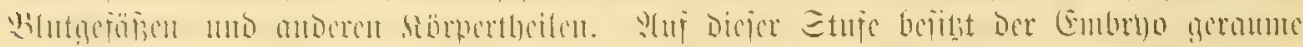

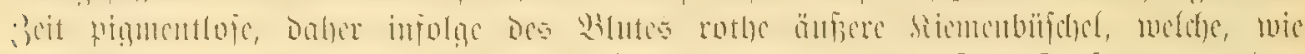

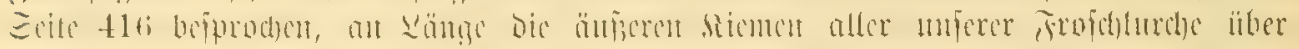

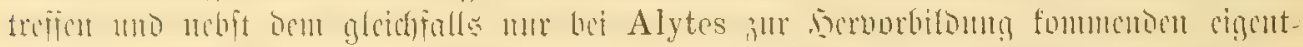

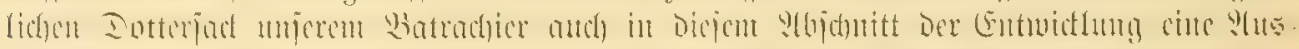

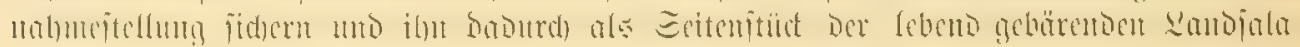
nuander erfictiement rafien.

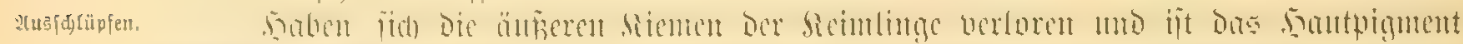

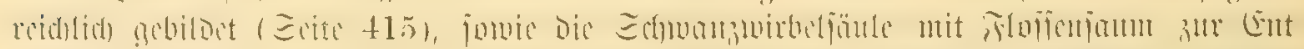

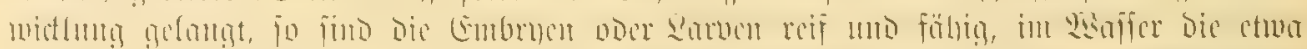

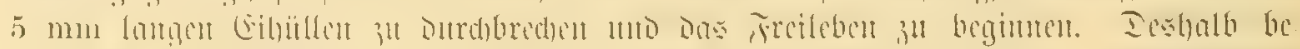

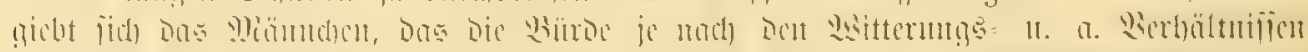

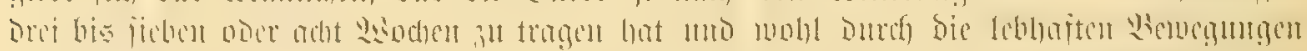

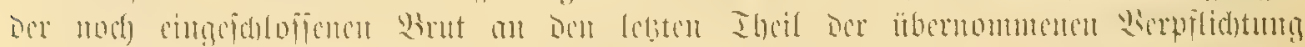

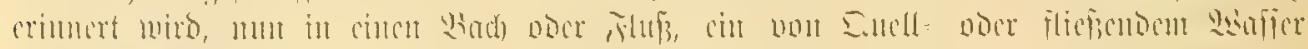

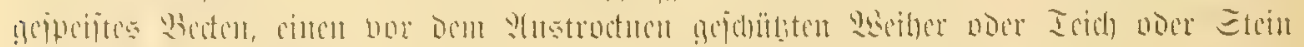

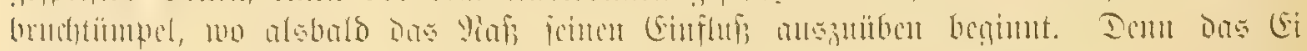

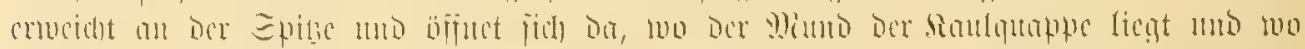
formfalls De ;

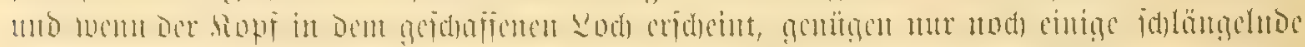

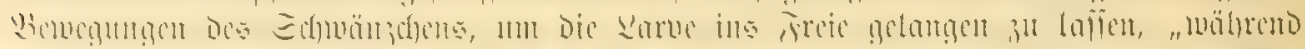

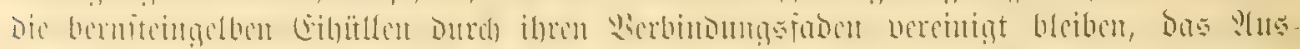

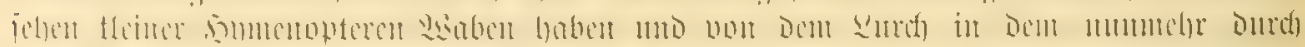

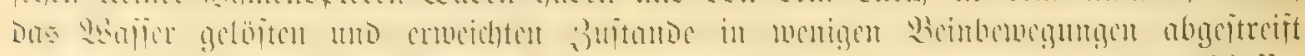

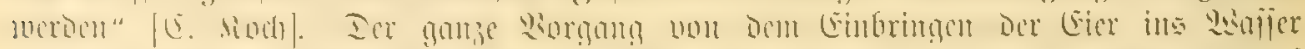

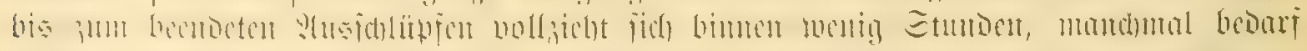

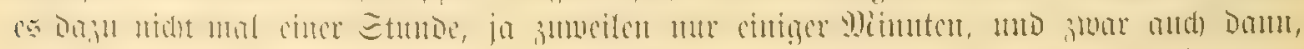

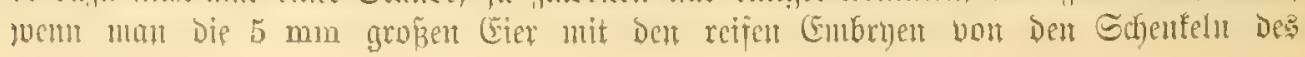




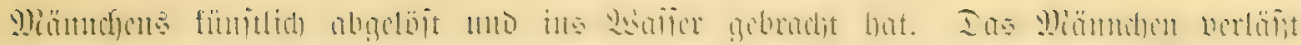

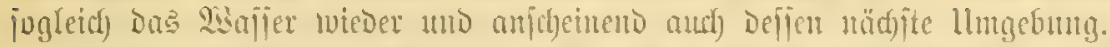

Iic as

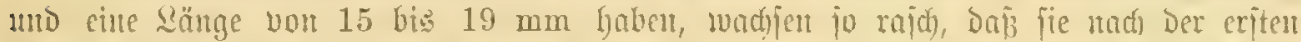

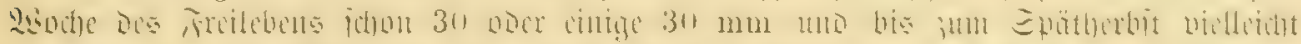

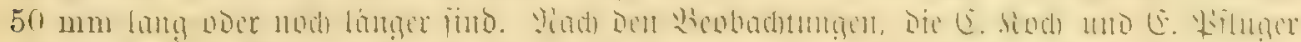

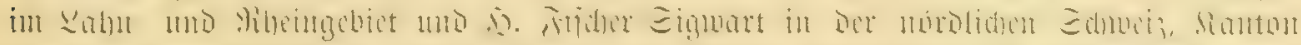

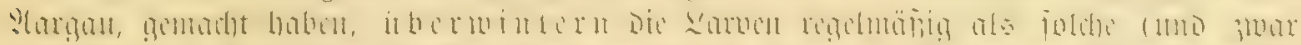

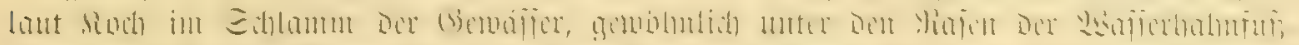

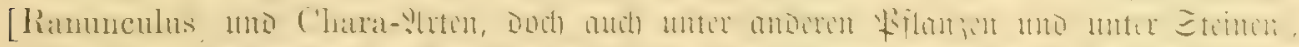

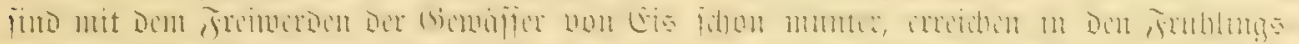

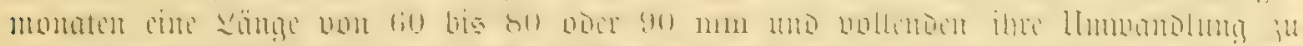

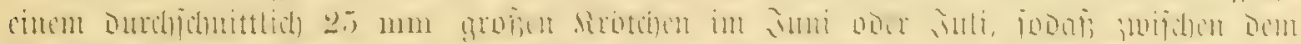

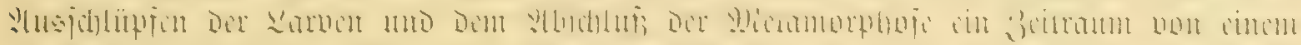

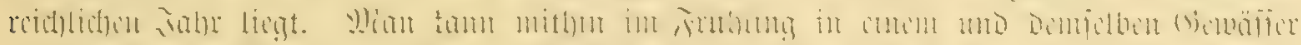

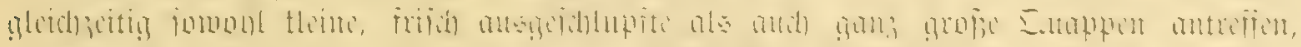

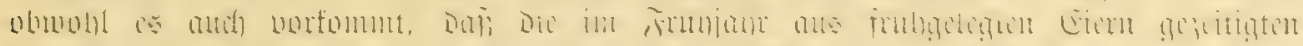

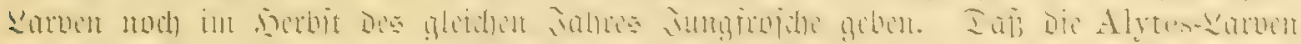

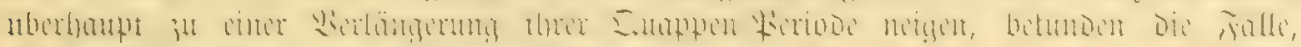

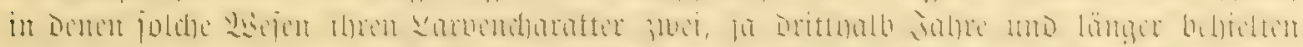

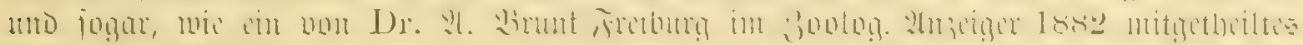

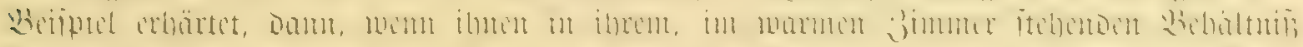

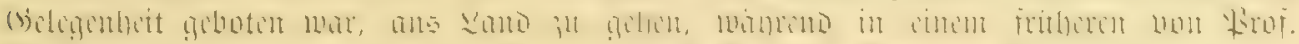

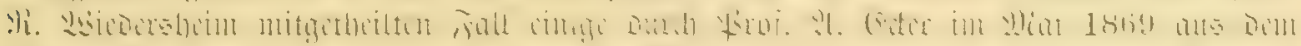

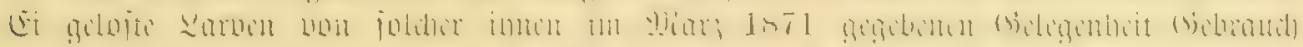

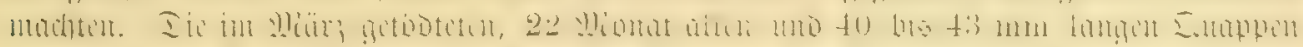

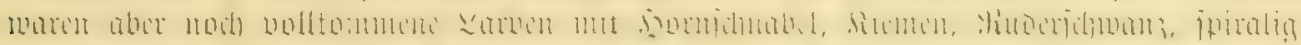

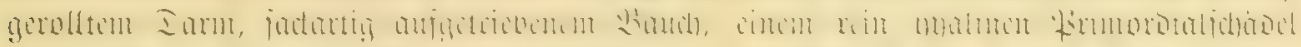

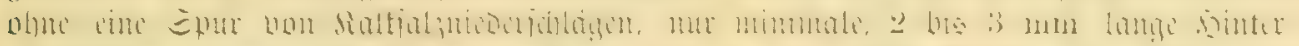

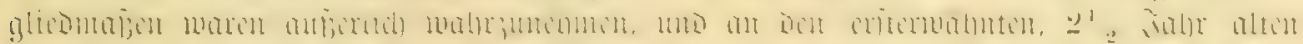

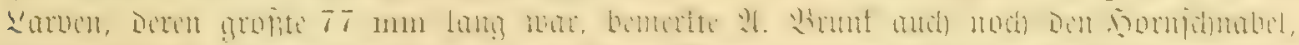

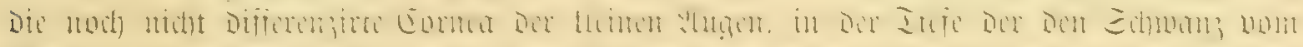

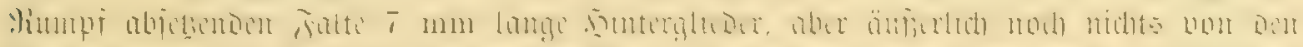

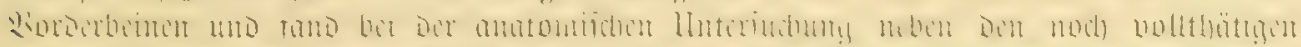

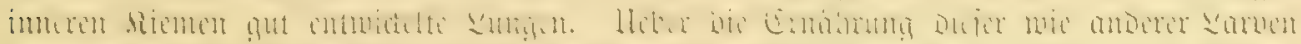

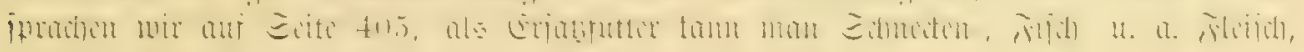
gelochte und geljucte బeber, D̃erz und Dergl. reidgen.

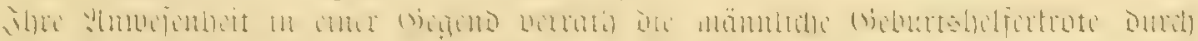

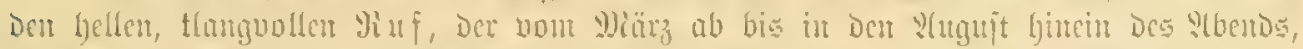

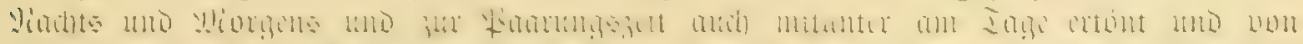

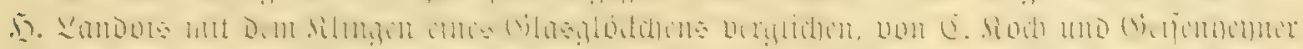

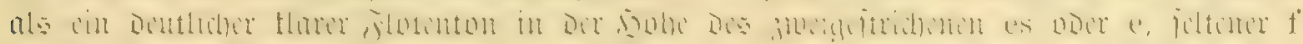

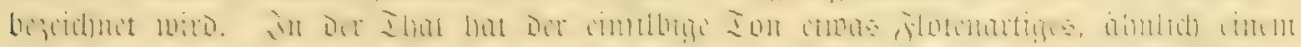

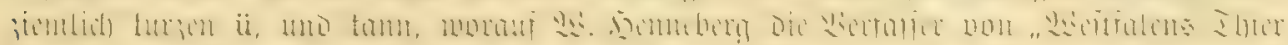

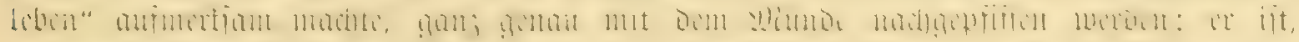

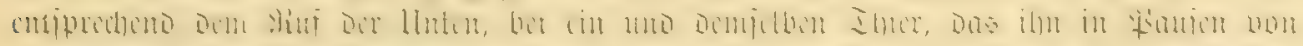

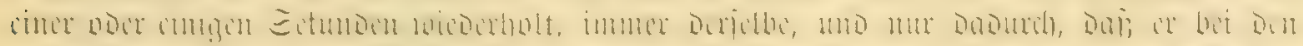

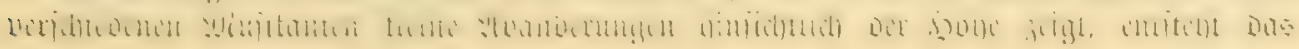




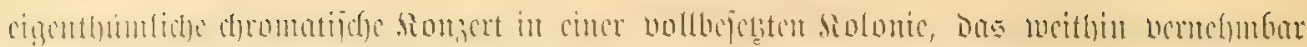

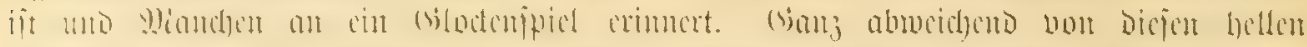

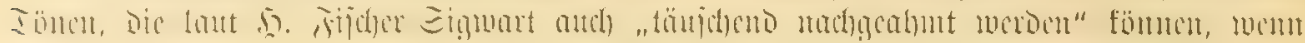

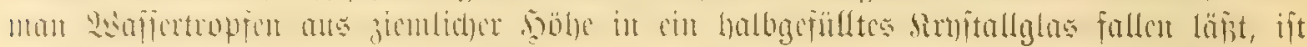
Der Silageluut cin furzes Duäfent.

Vumer.

Zando Jistir. Engl.: Midwite Toad; Frouz.: Crapand acenchemr; Span.: Sapro cubridor; Holu.: Ropucha Ikronosz.

Synonyma

Bufo obstetricans et Rana campanisona, Laurenti 1768. - Rana Bufo var. d, Gmelin 1790. - Bufo vulgaris var., Bechstein 1800. - Rana obstetricans, Sturm-Wolf [frauta, 4. Sgeft] 1805. - Bufo companisonus, Goldfuss 1820. Bombinatur ohstetricans, Merem 18:0. Alytes obstetricaus, Wingler 1833. Obstetricans vulgaris, Dugès 1834.

\section{II. (1)roming. Alold)e, Sidjwnแżlurdee.}

\section{Urodela (Caudata. Batrachia gradientia).}

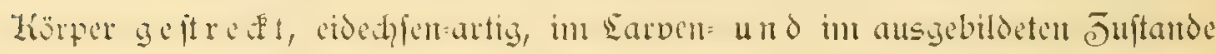

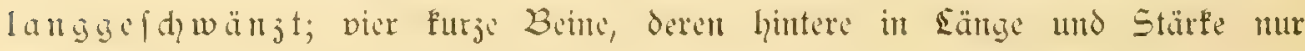
wenig von den vorderen verfitieden.

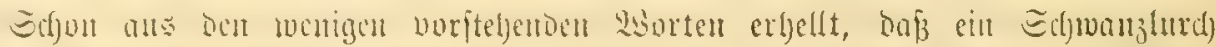

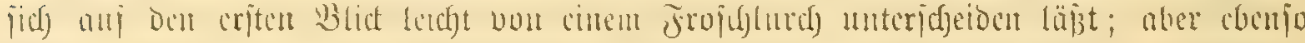

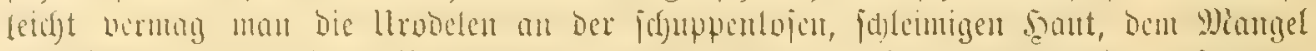

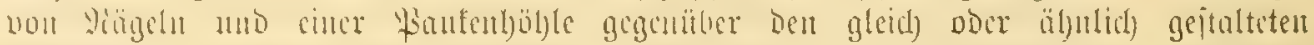

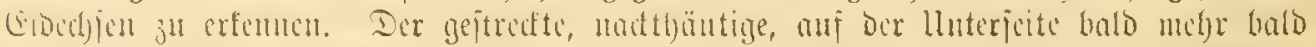

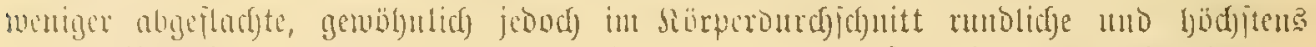

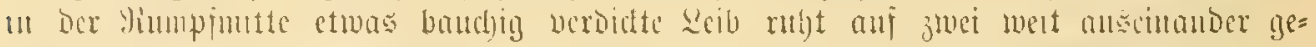

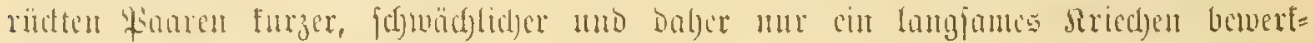

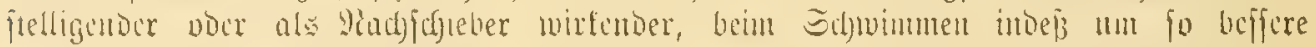

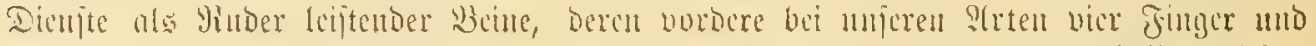

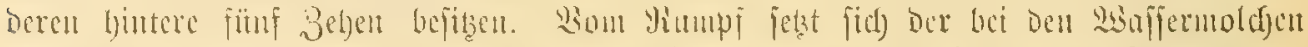

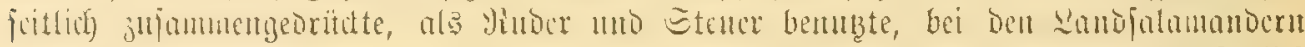

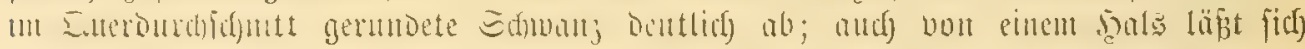

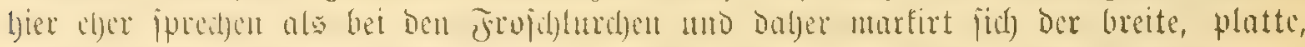

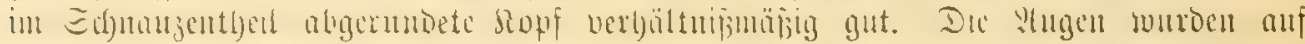

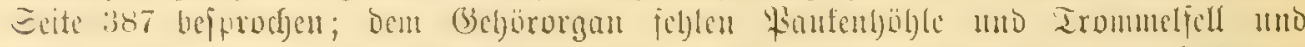

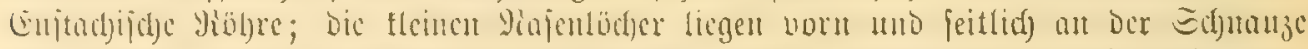

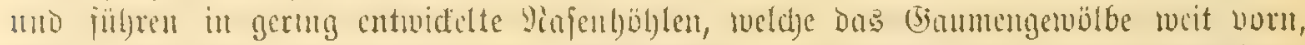

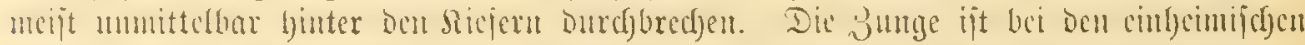

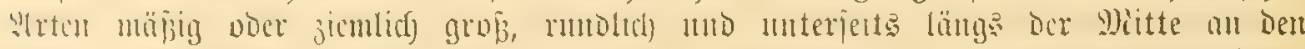

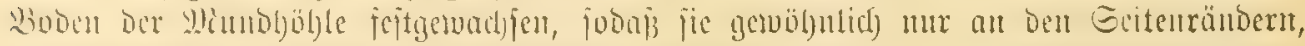

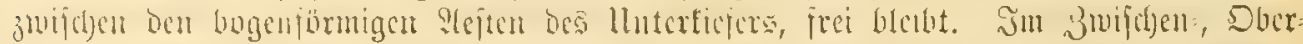

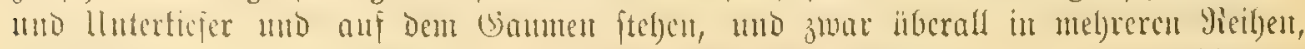

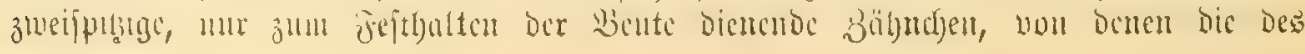




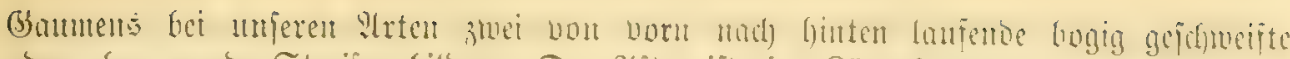
Doer aber gerado Streifut bilden. Der slftur ift eine Rämgsipaltc.

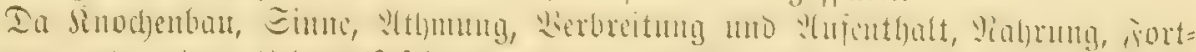

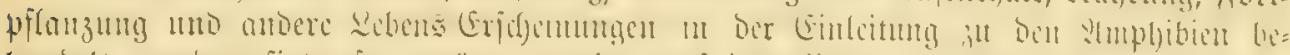

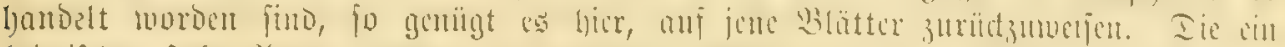

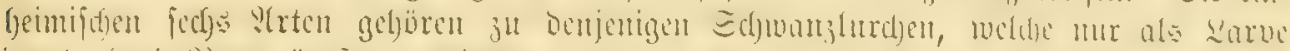

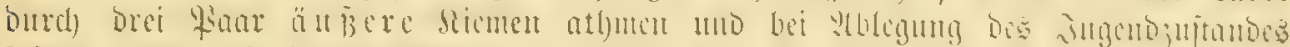

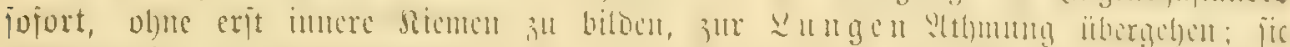

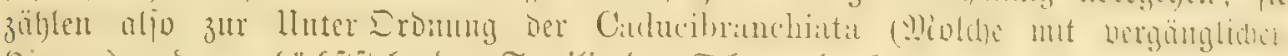

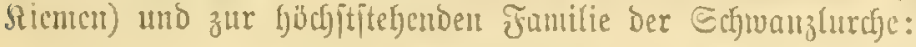

\section{familie: Salamantcr, salamandridae.}

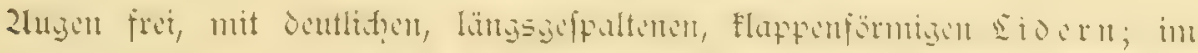

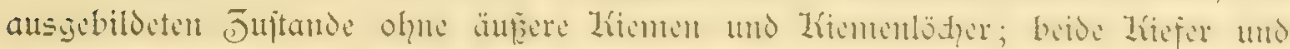

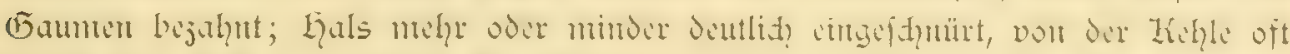

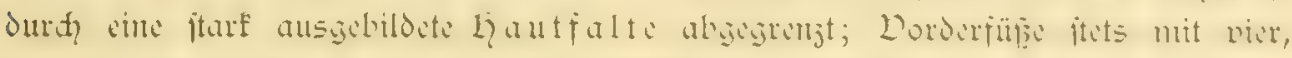

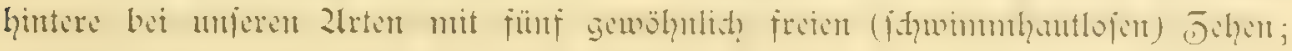
Sđqwanz von Runnflänge oder etwas länger.

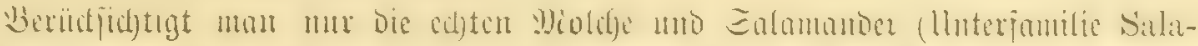

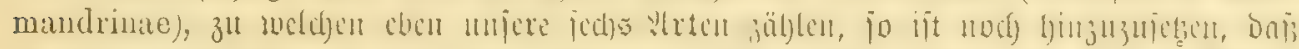

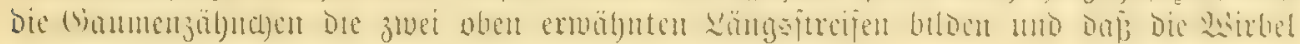
auf ifrer Seinterjeite ausgchöblt pDer opijtljocoel find.

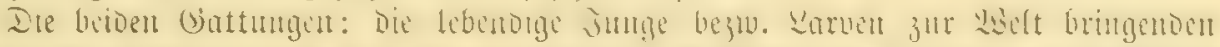

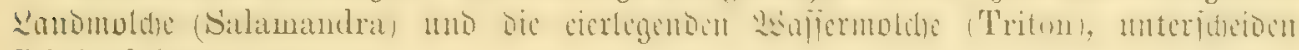
ficl) in folgentoer weife.

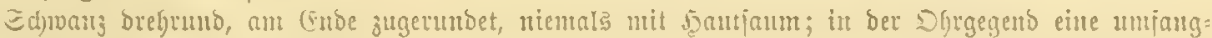

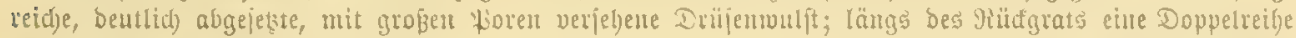

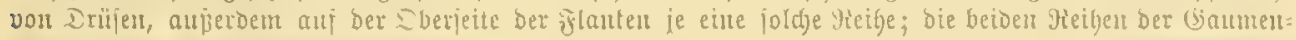

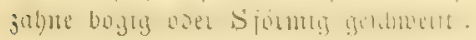

Salamiandra.

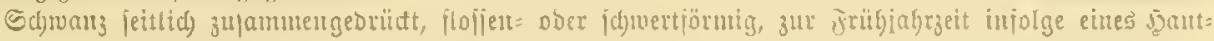

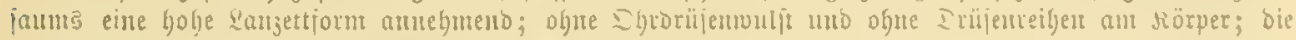

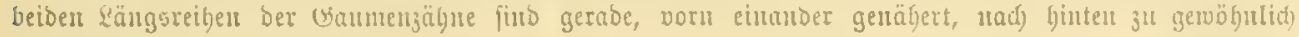

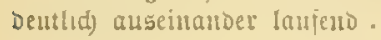

'liton.

\section{Eattung: Eambunold). Salamandra, Laur.}

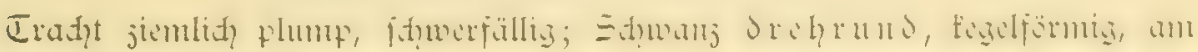

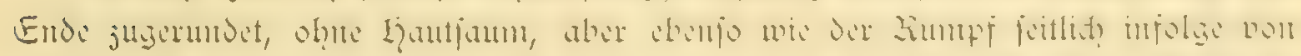

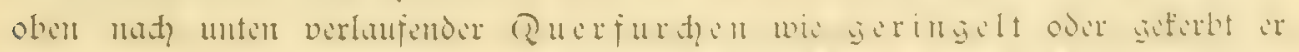

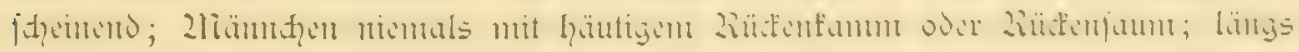

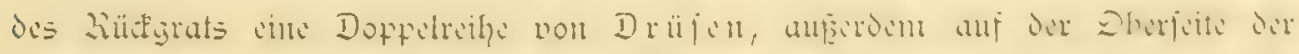

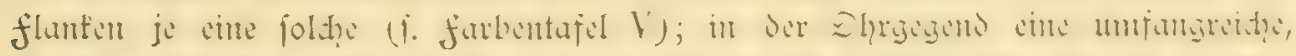

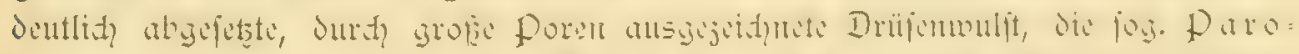

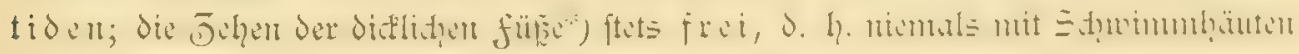

*) Don ben 5 Beben Der 5intergliebnajen füb bie oritte unt bie viette bie lütgitn unb cinntuer

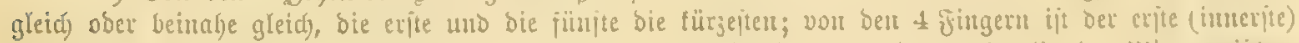

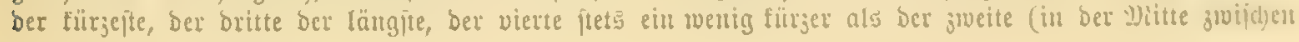
Dem 1. uno 2. jefenti). 


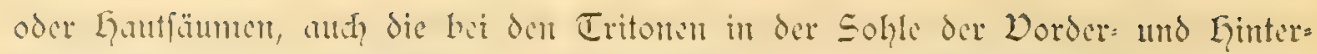

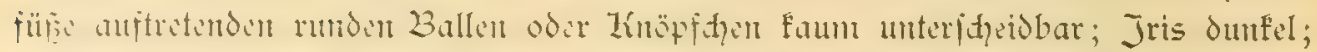

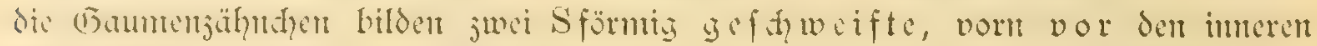

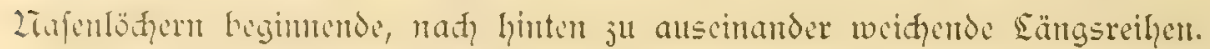

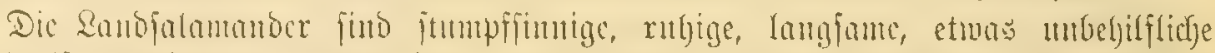

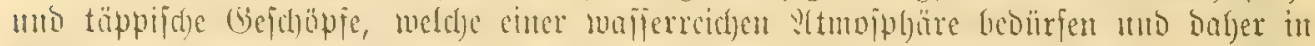

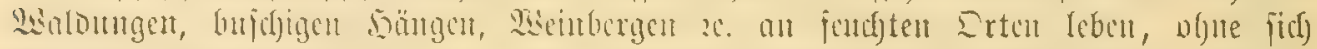

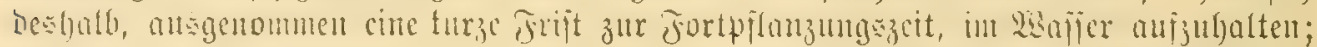

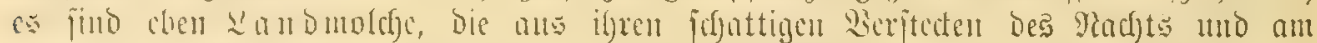

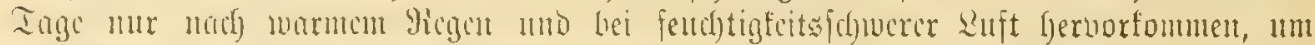

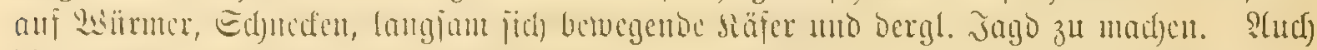

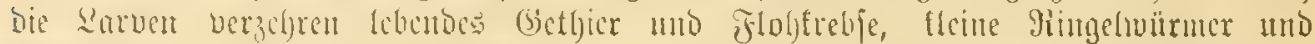

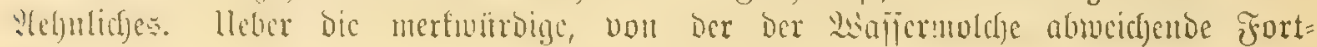
pflantungasucife lyaben wir auf Seite 392 แnd 397 gefprod)cn.

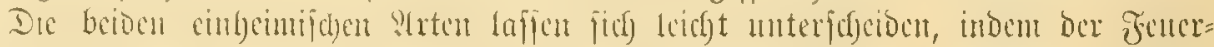

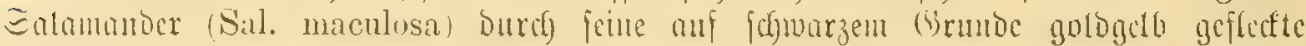

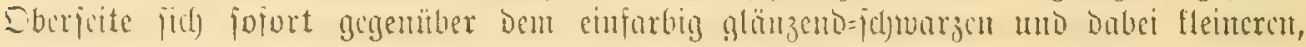
weniger biden s!lpent-Salamander (Sal, atra) z" ertennen gicbt.

\section{Irt: feuer=Salantander, Salamandra maculosa, Laur.}

\section{2tbbitoung: Tajel V Tir. 1-4.}

Sänzi $1+$ bis $25 \mathrm{~cm}$; ticffipwarz mit goldgelben fleften über den ganjen

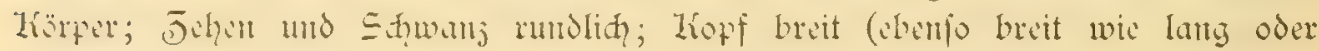
hödyftens un \& Diertel länger als breit).

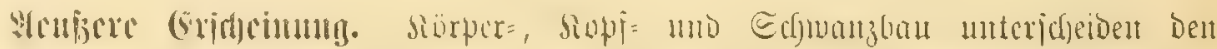

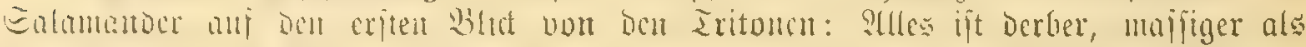

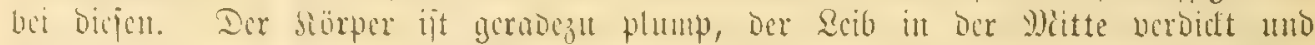

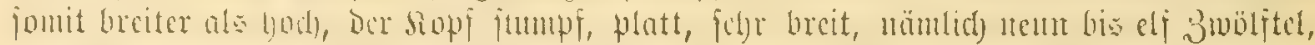

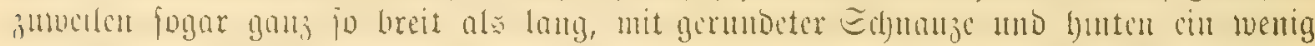

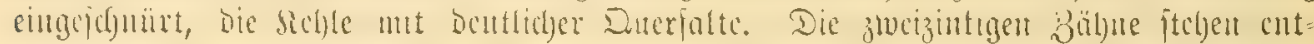

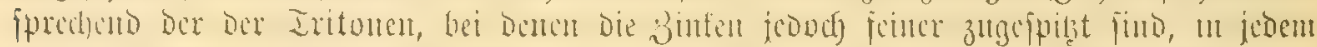

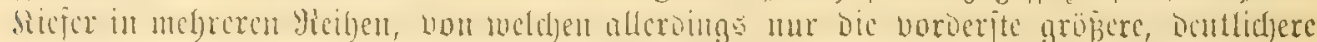

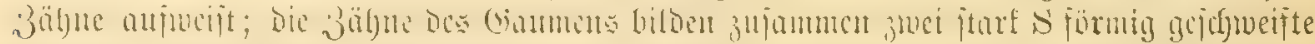

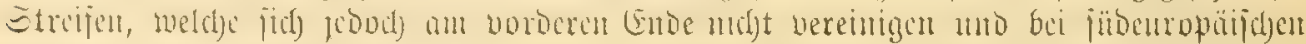

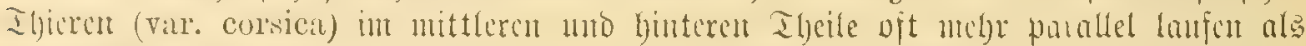

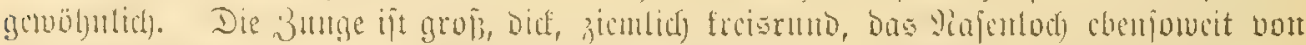

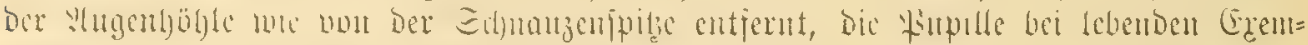

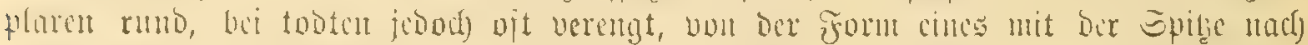

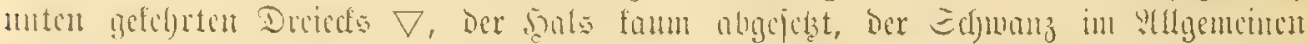

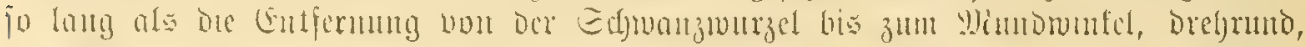

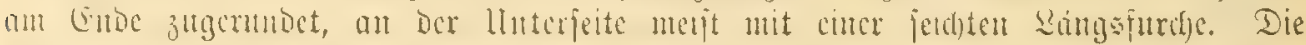

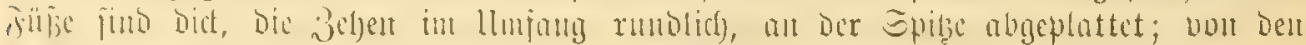

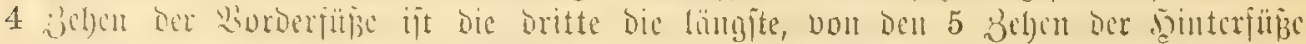

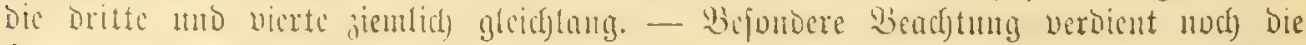

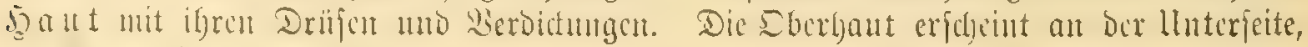

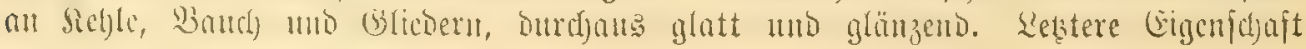




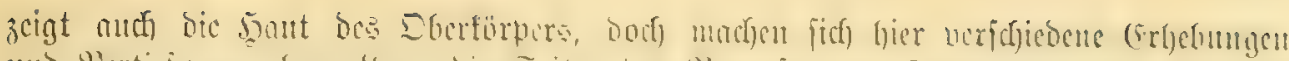

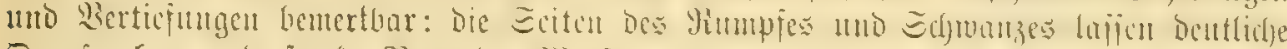

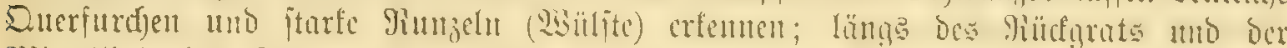

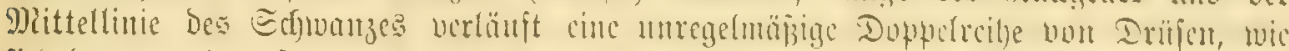

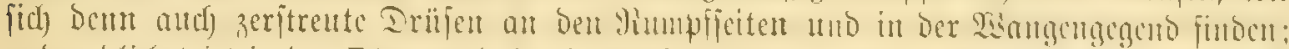

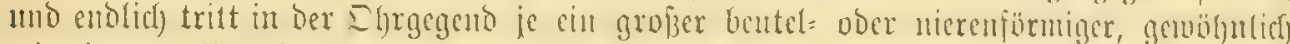

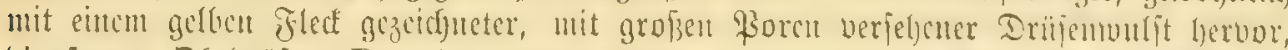

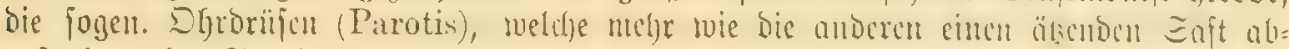
zujondern im Stande find.

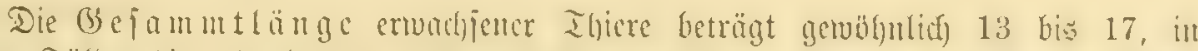

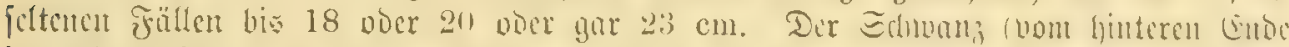

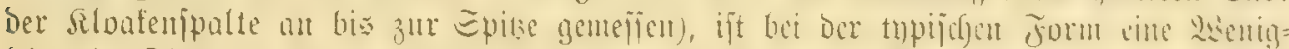

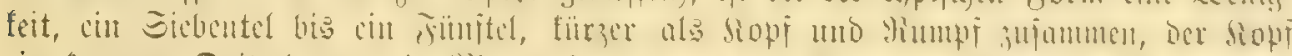

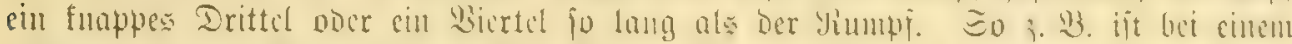

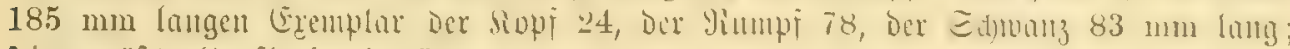
fine grüßstc Sopfbrcite bcträgt $22 \mathrm{~mm}$.

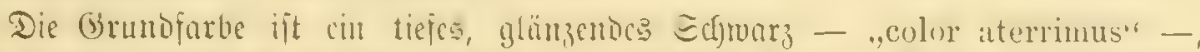

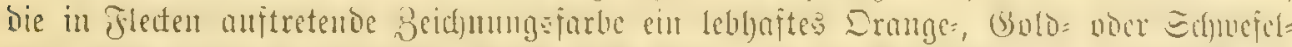

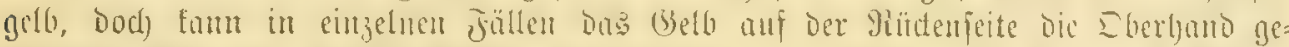

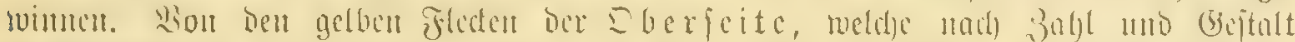

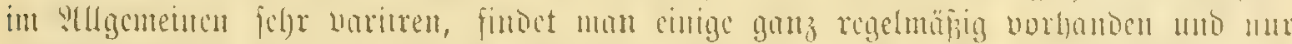

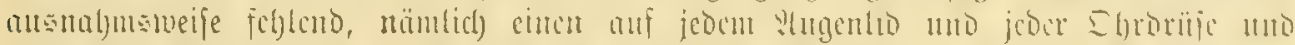

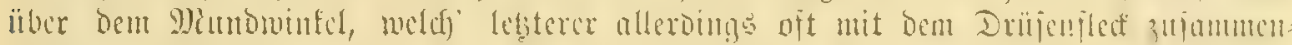

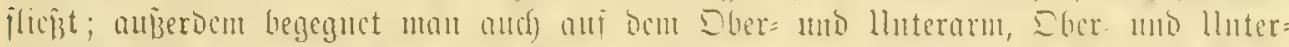

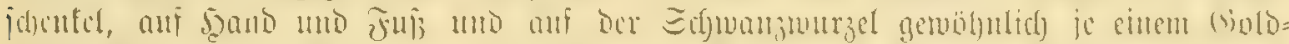

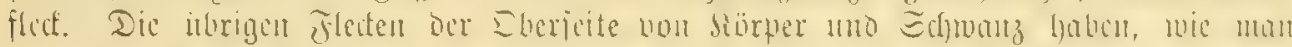

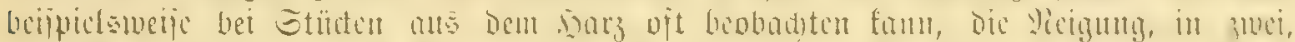

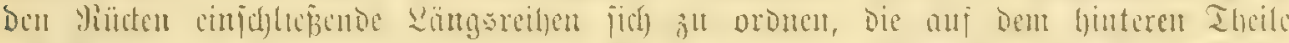

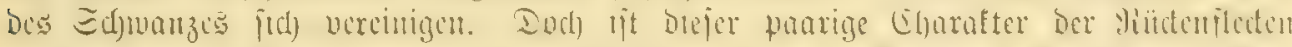

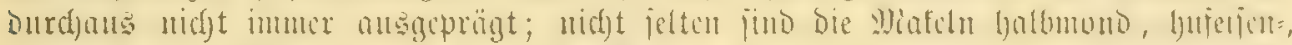

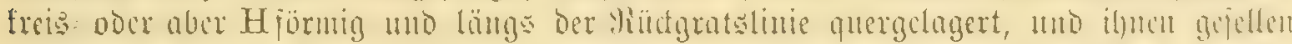

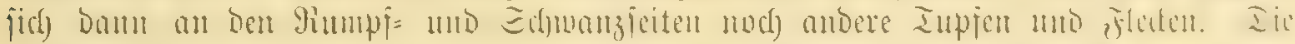

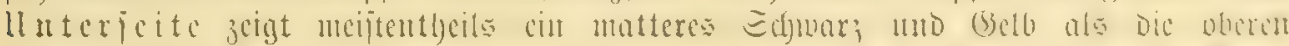

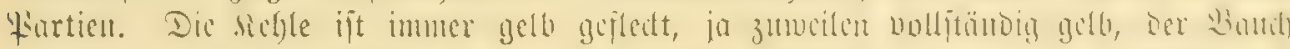

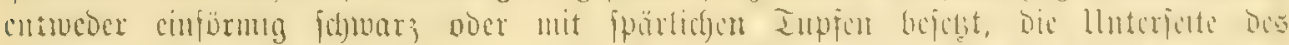

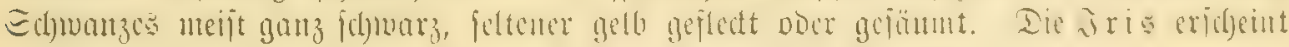
bumtel (nid)t roth, wie man es bei Siojel mo feinen 2lad)abmern fiel)t).

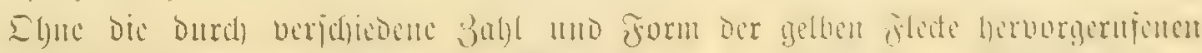

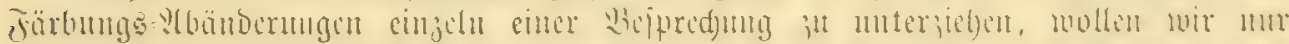
emige red)t angejprodgen

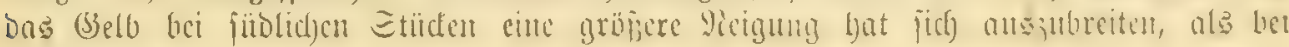
nủrolidjen.

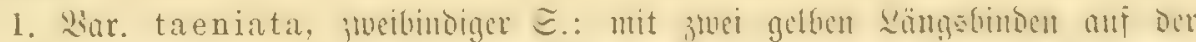

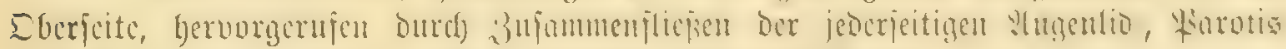

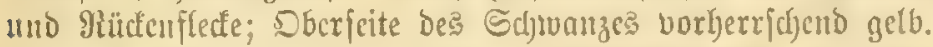

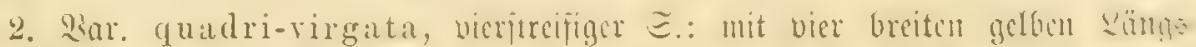

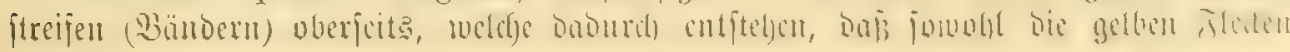




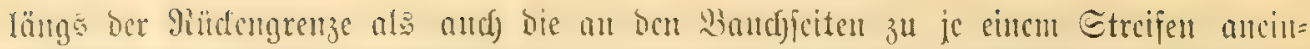

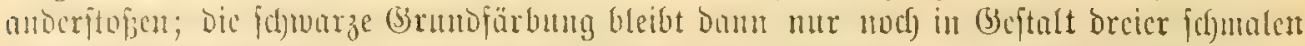

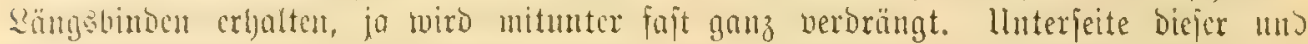

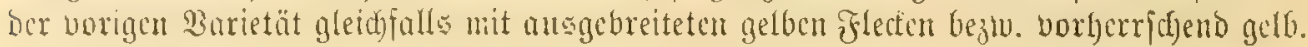
(5) fummen aud völlig gelbbauthige Spielarten vor.

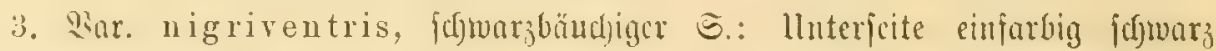
(infra immaculata), Eberieite mit frärlichen gelben Flecter. Total fdywarze Eala-

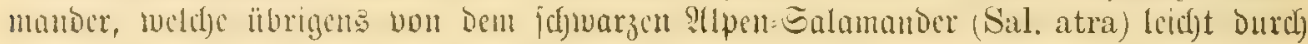
il)re grö̈zere uno phunpere (Gejtnlt, Den breiten sopf, bic Dentlicfer fich zeigenden

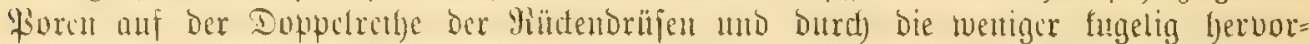

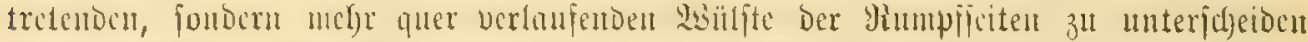

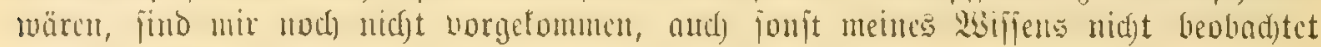
worbent. פun folgen nuch einige befondore Formen:

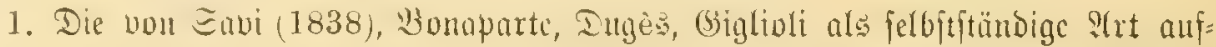

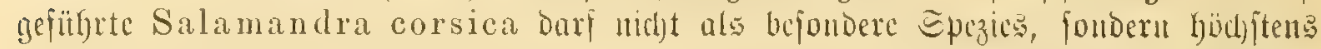

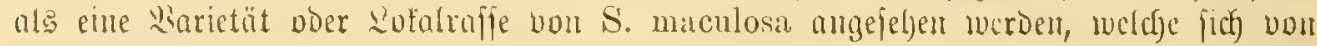

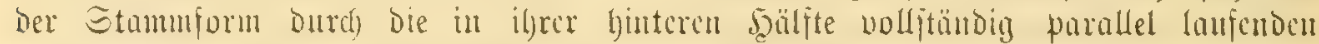

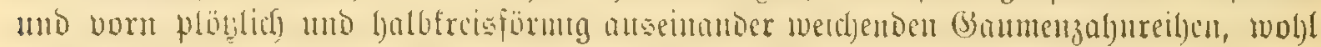

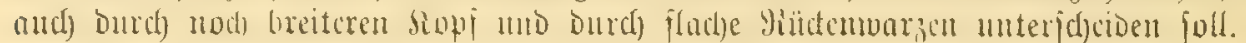

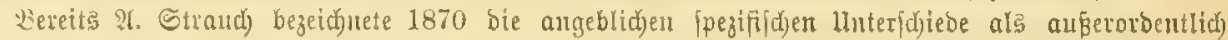

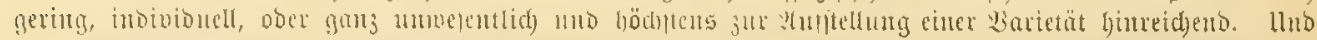

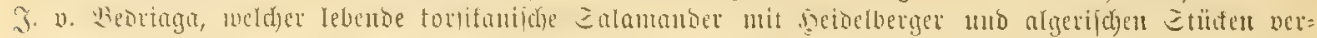

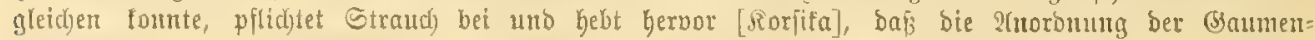

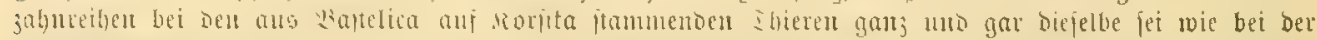

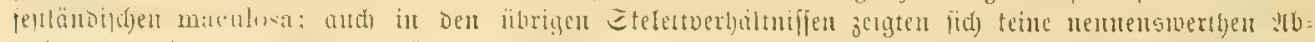

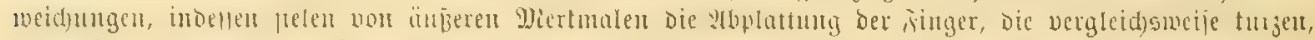

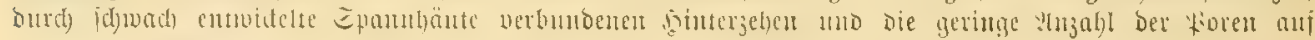

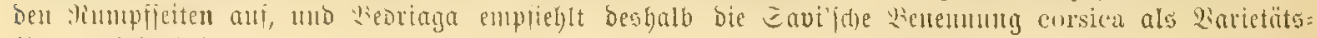
Nianten betzubehaltest.

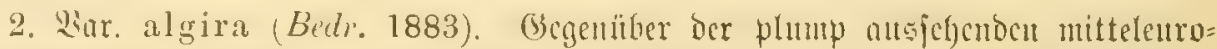

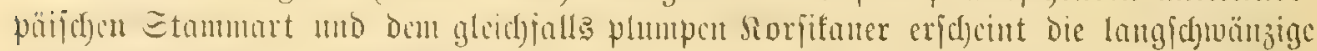

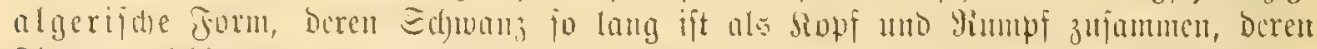
Finger gleichfalls länger fimb als be bor Etanmart und bie ferner cinch platten siopf

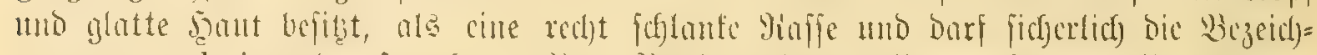

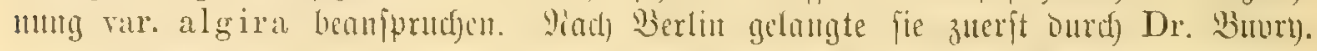

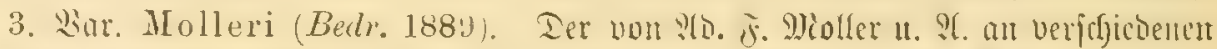

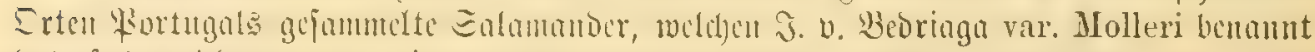

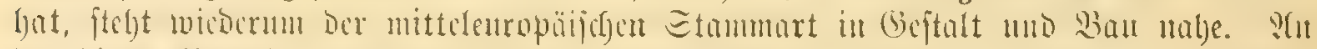
Den bidcut Siumpf febt fidf ein turzer uno gleidjfalle biffer, an Enoc abgeftumpftur

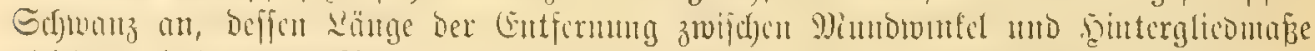

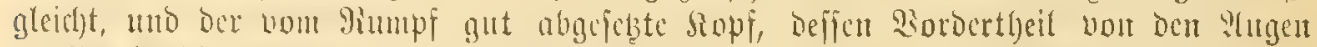

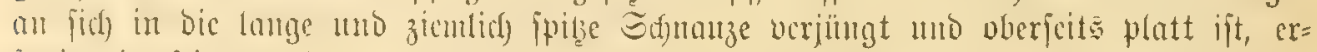

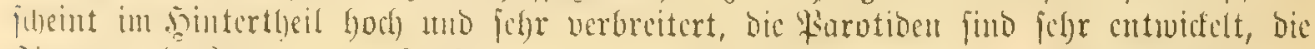

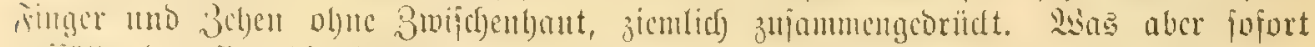

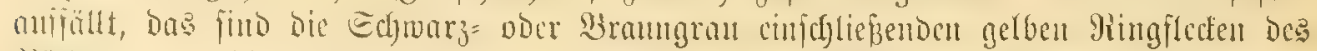

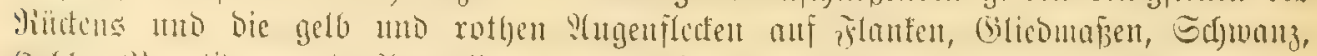

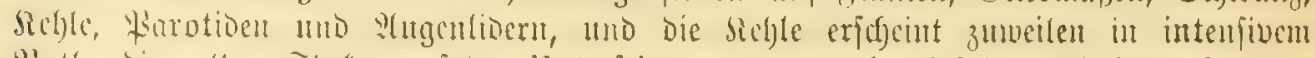

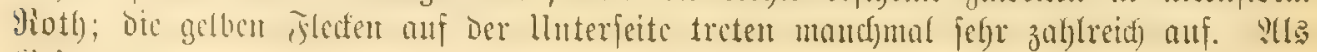

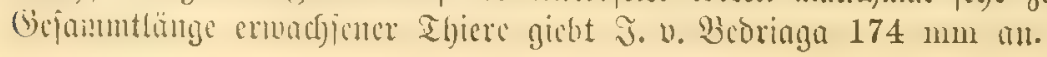




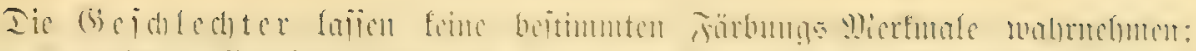

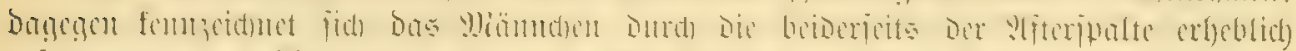

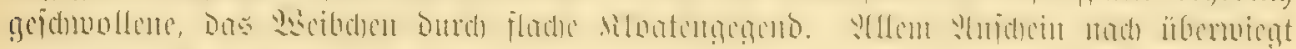

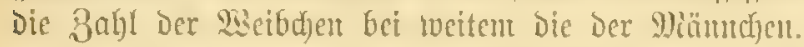

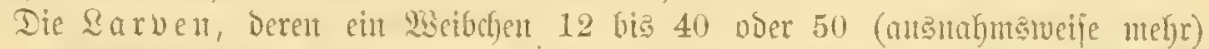

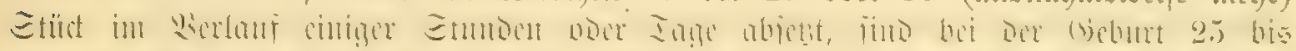

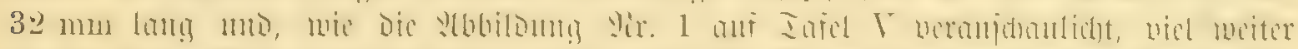

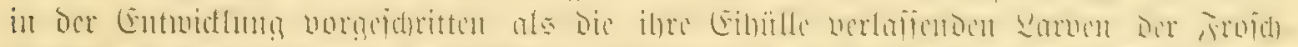

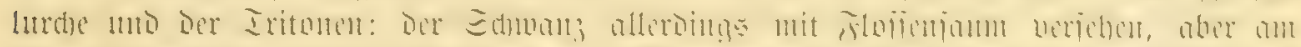

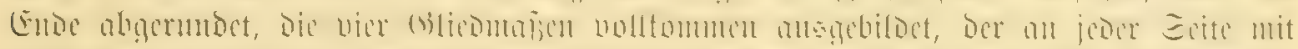

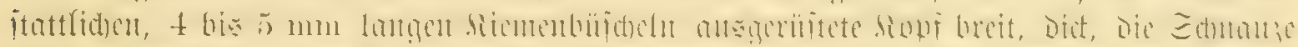

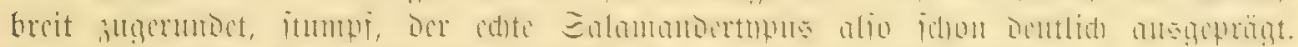

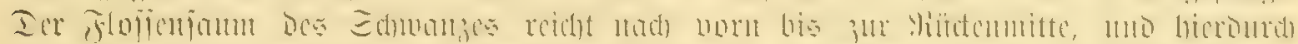

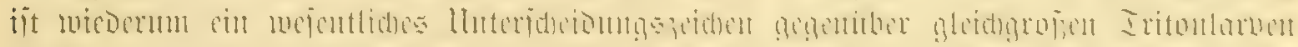

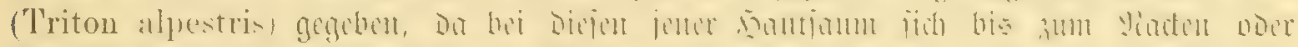

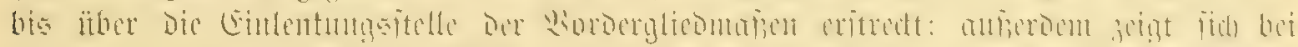

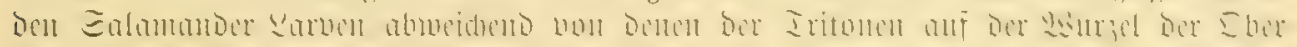

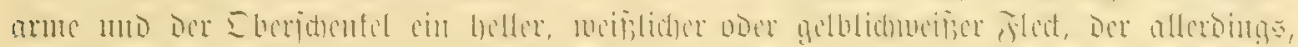

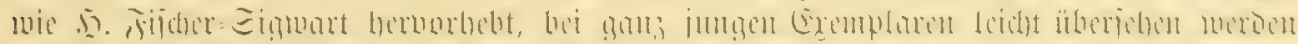

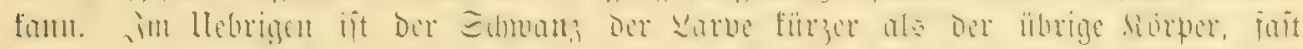

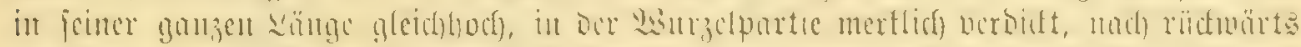

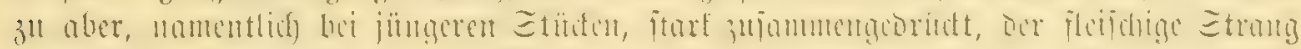

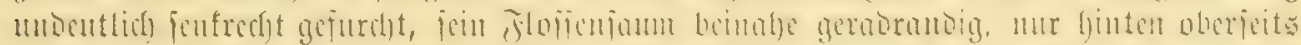

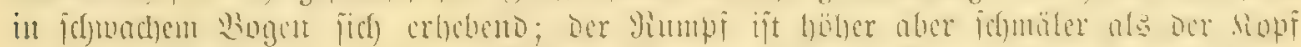

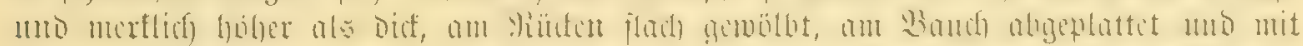

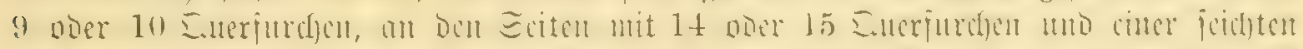

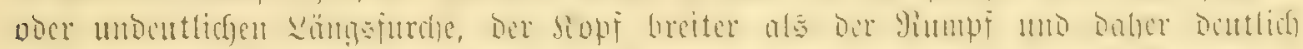

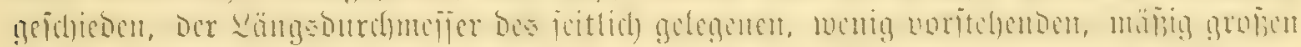

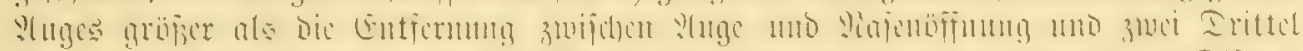

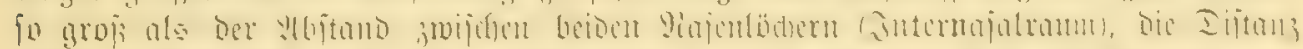

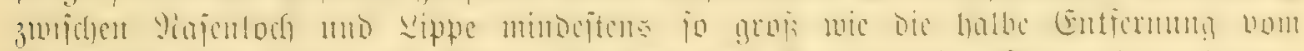

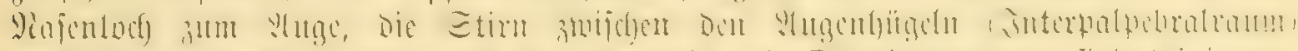

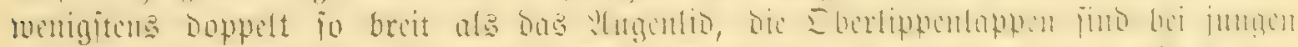

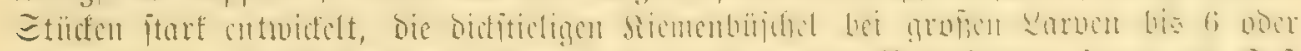

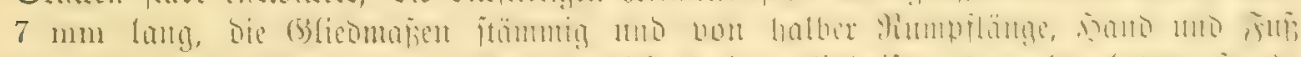

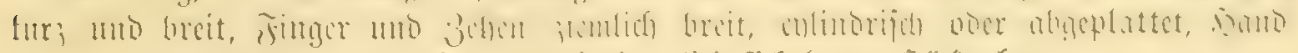

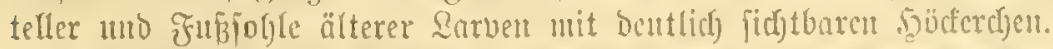

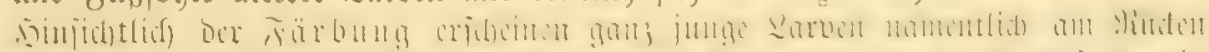

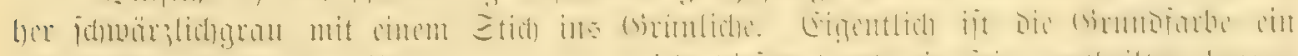

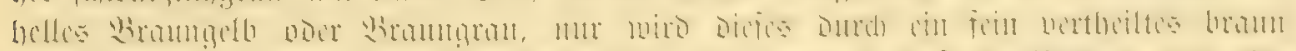

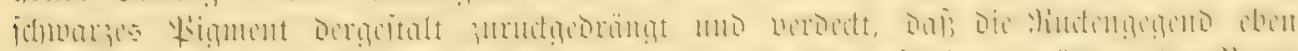

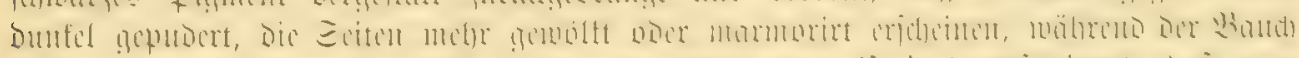

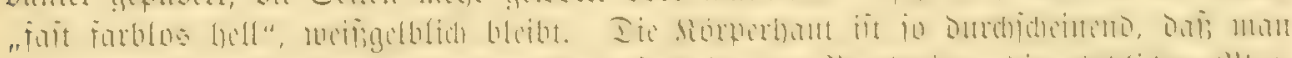

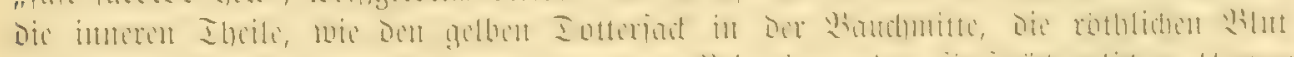

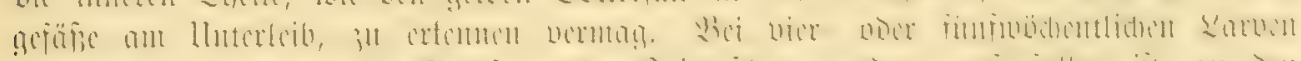

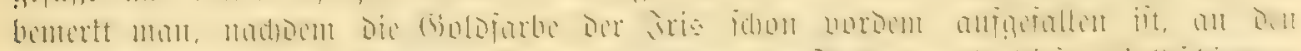

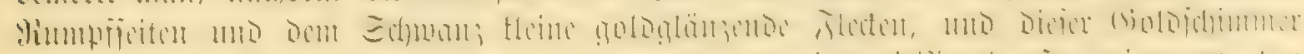

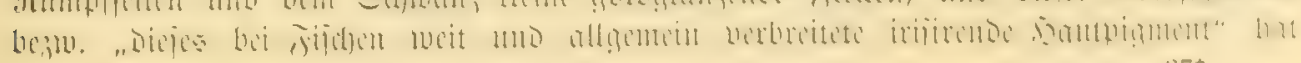




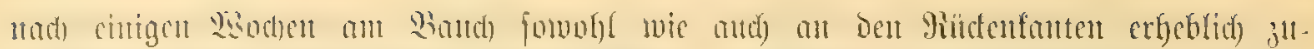

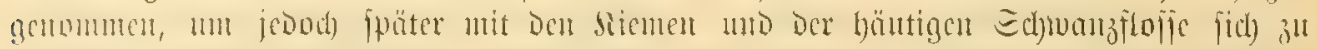

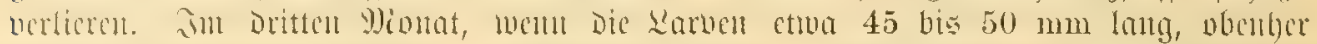

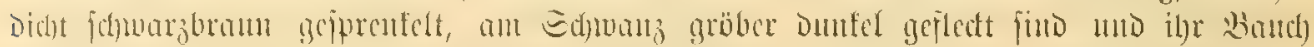

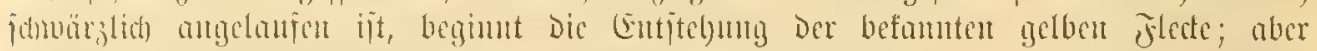

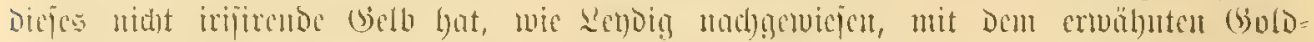

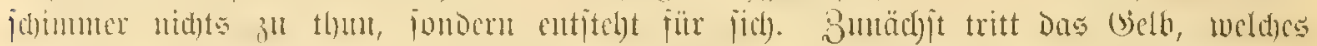

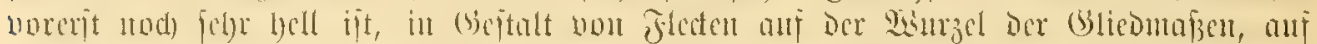

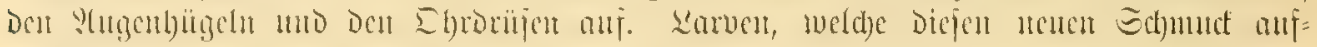

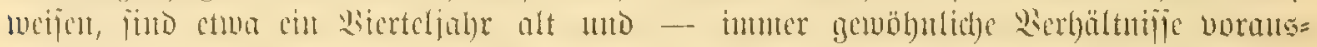

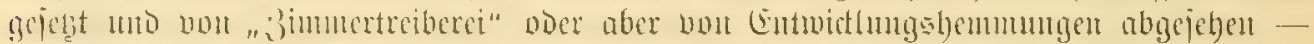

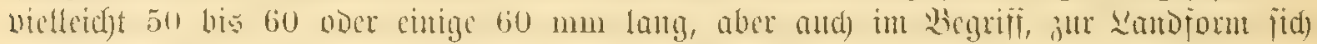

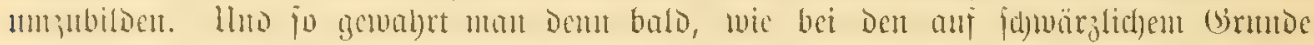

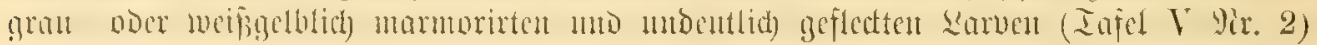

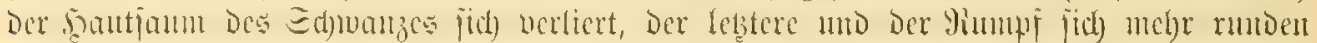

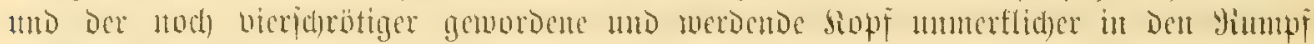

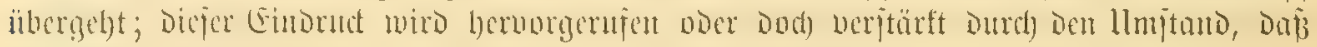
die Sienenbiajdel bis auf furze Stummel eingejdrumpft futb.

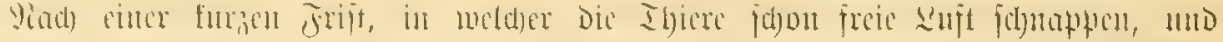

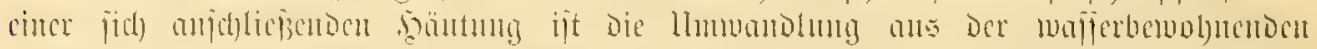

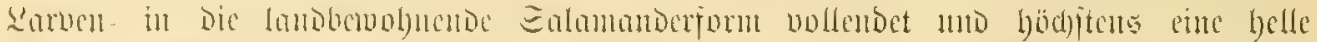

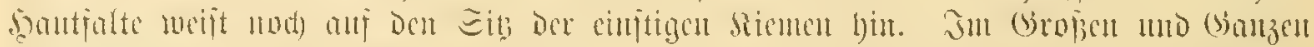

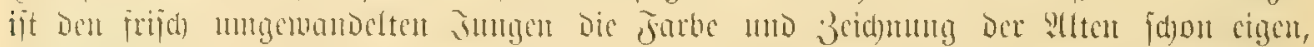

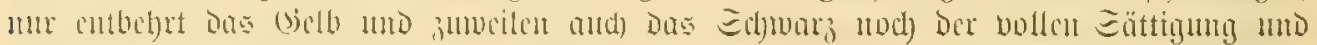

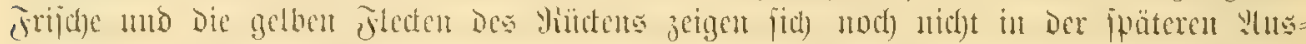

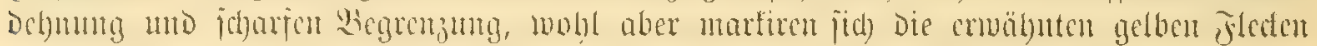

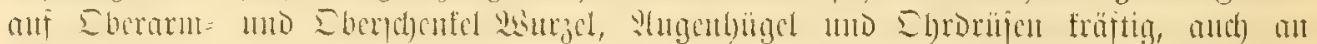

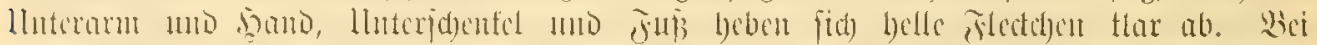

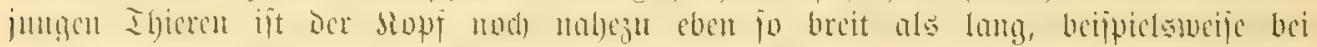

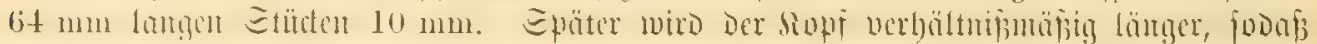

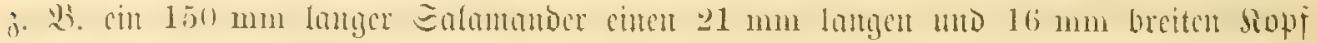

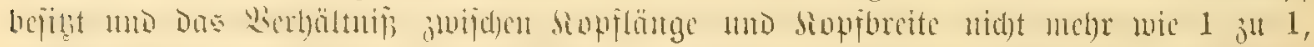

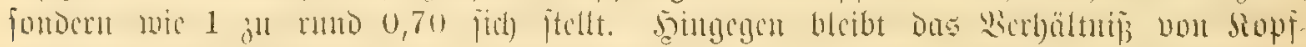

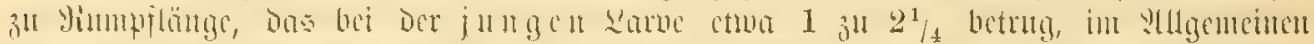

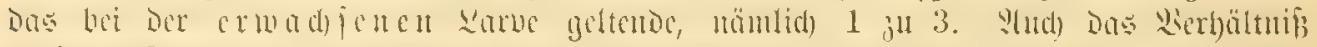

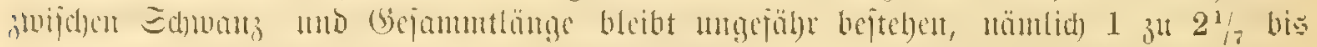

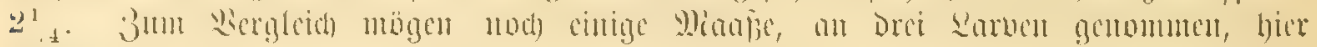
wievergegeben feil. Iotallänge Jir. 1:64 mm, Jir. 2:45 mm, 2ir. 3:25 mm;

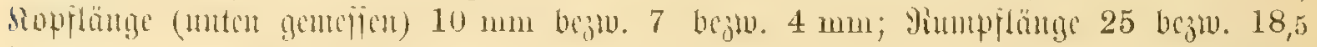

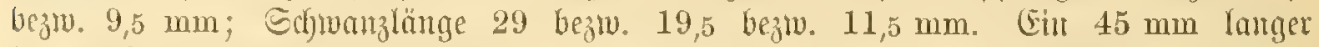

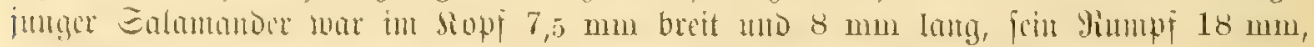

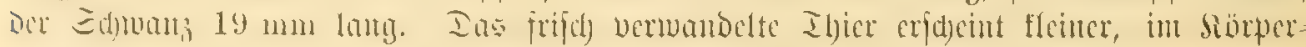
Iluffang geringer, als es die Sarve auf der rebten Entwidfungätuje war.

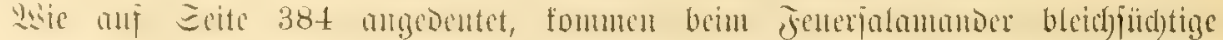

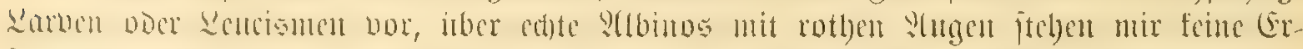

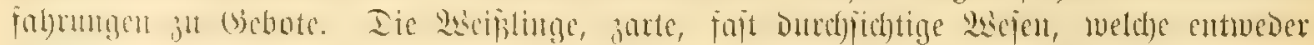

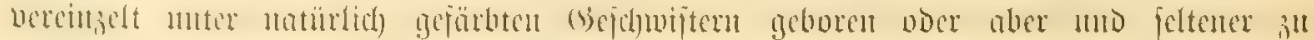

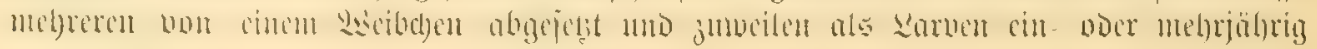




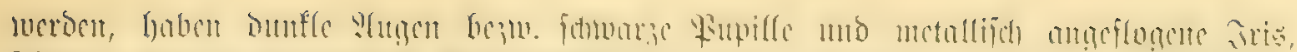

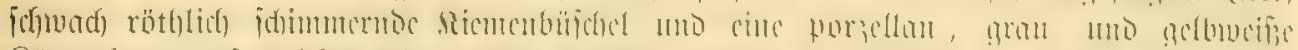

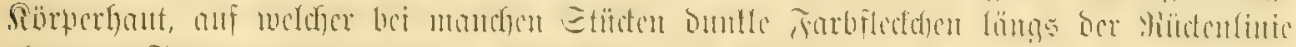

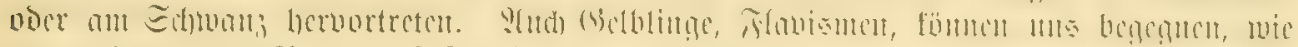
Deren einer Imter Sir. 3 auf Iafel $V$ vergegentuärtigt iit.

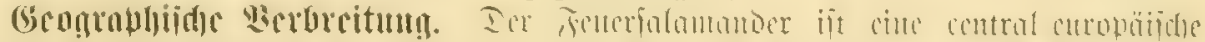

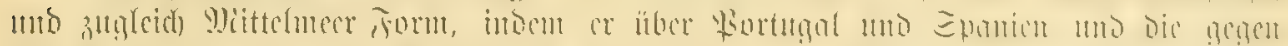

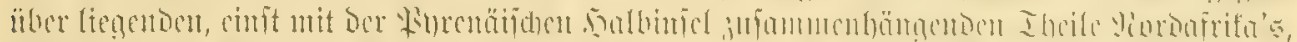

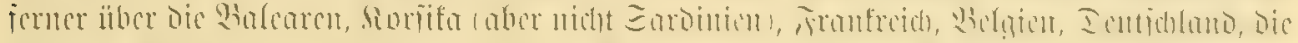

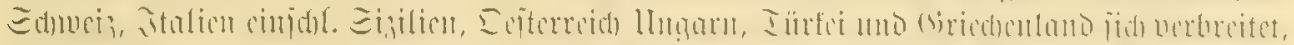

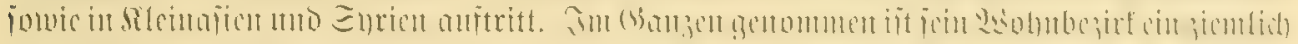

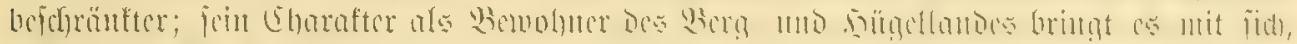

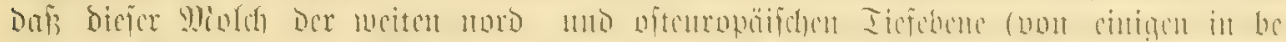

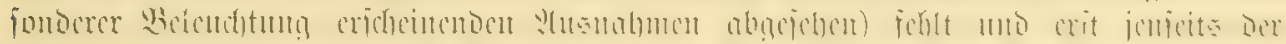

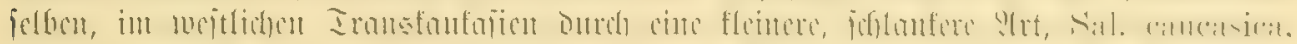

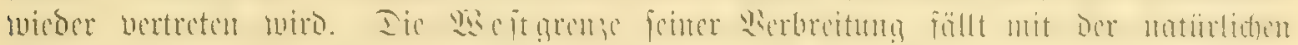

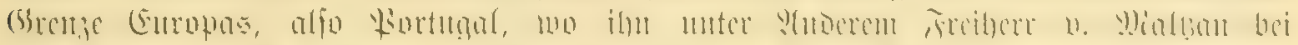

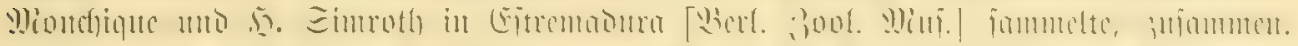

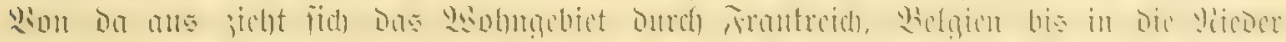

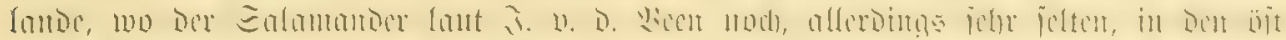

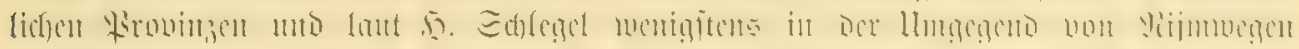
angetroffon moto. Ets a

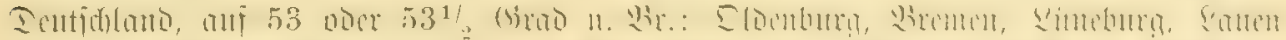

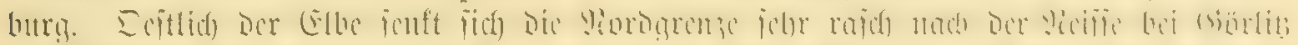

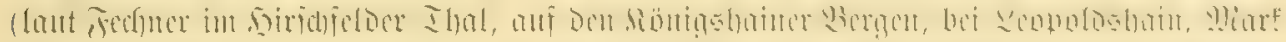

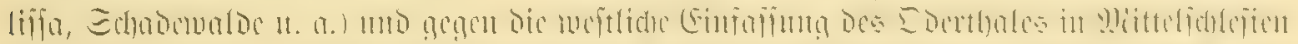

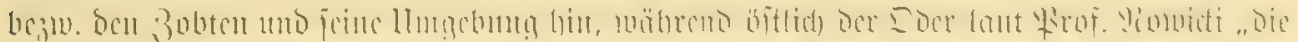

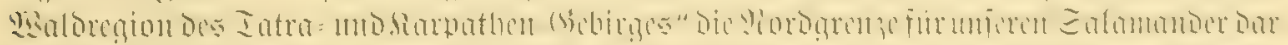

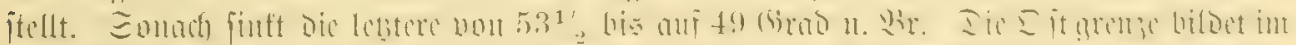

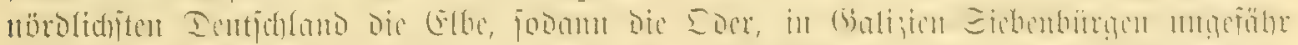

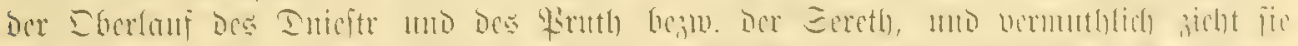

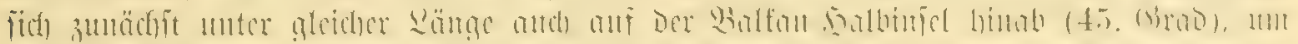

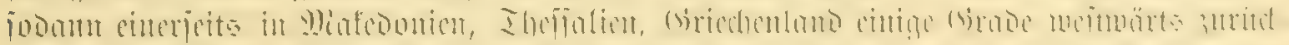

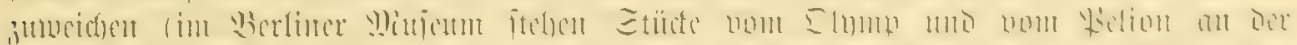

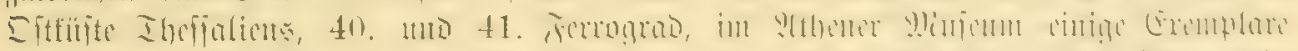

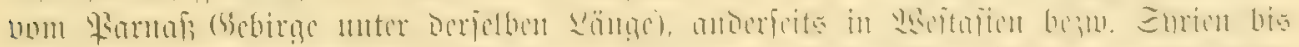

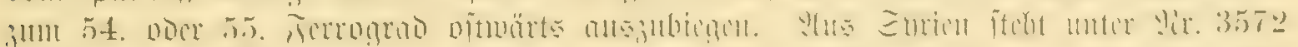

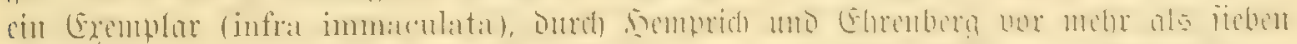

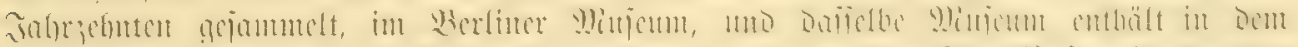

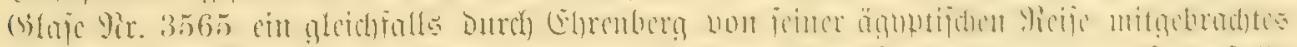

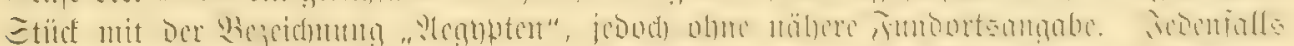

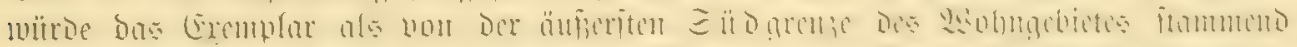

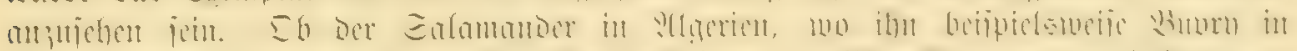
Eforbel (E)

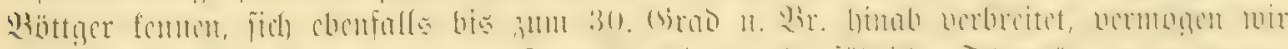

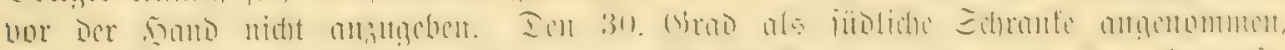

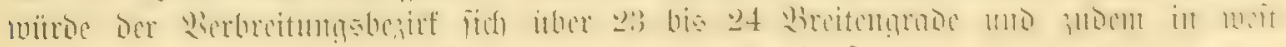
bifllicher glid)tung über vielleidyt 45 bis 46 sängengrabe fpanten. 


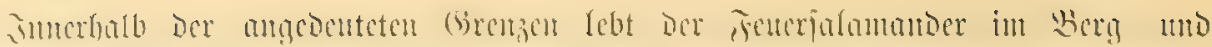

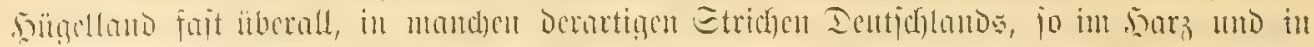

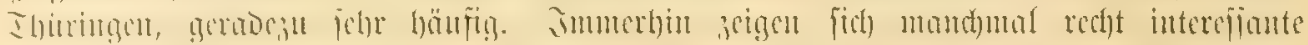

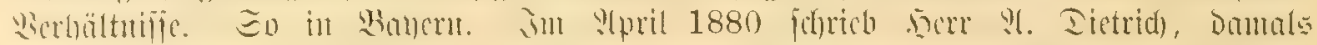

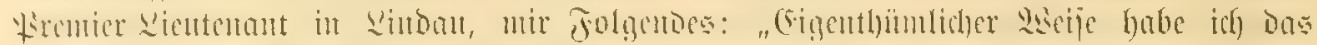

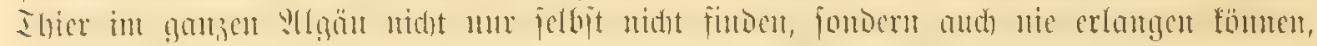

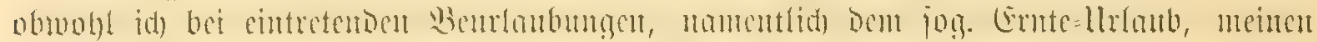

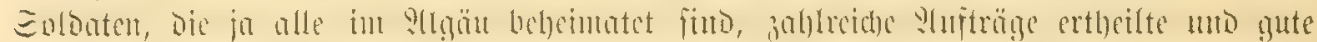

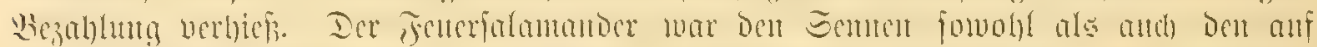

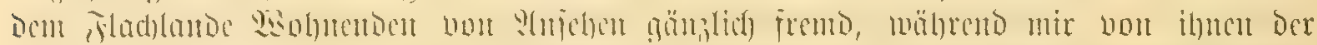

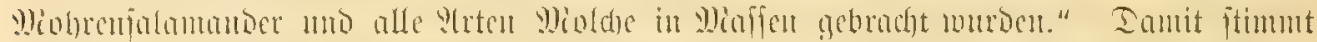

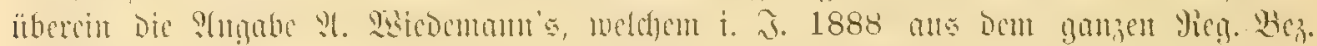

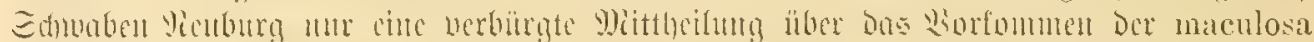

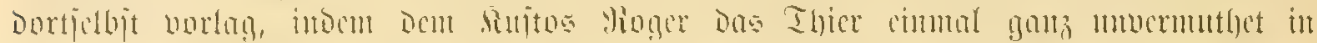

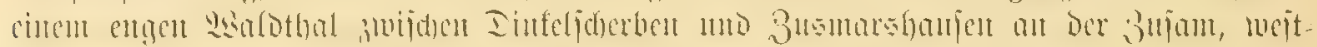

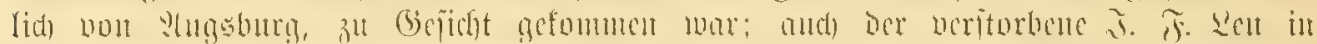

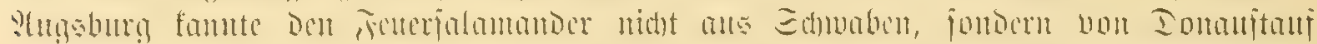

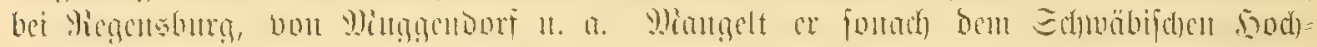

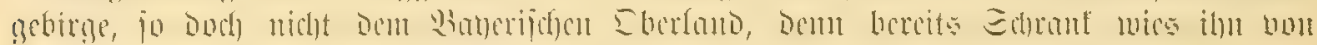

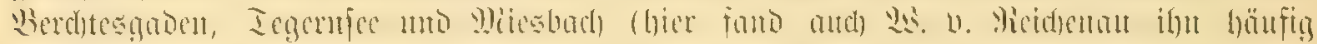

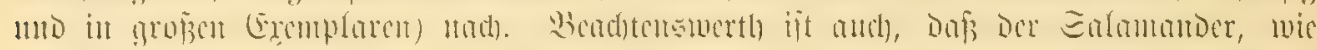

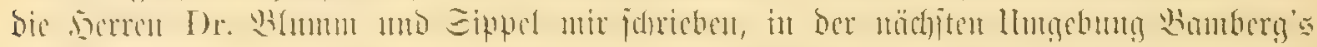

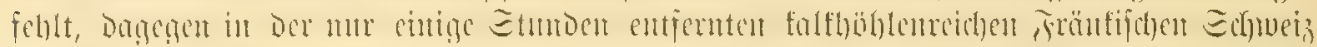

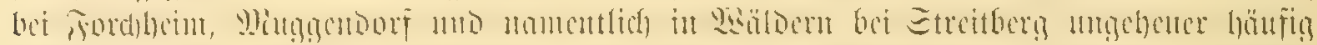

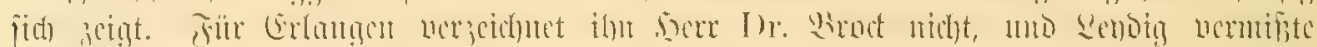

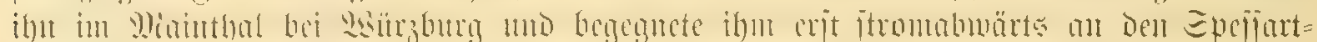

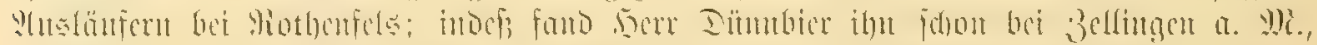

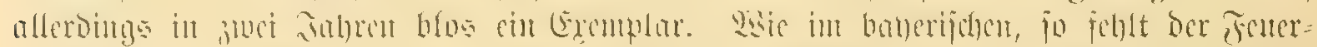

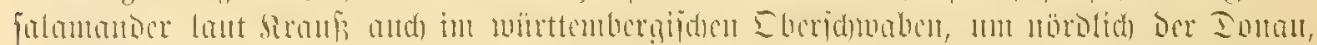

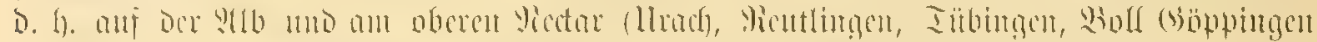

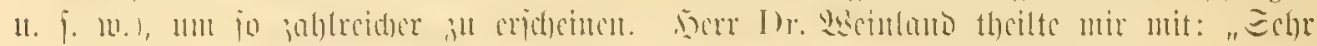
gemein auf Der sub, and oben anf Den Silatent; felten in Dent bergen des lluter=

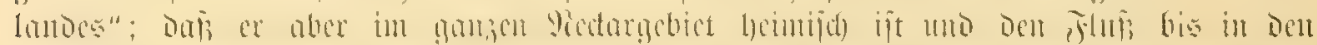

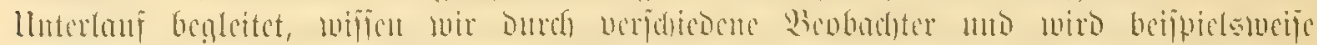

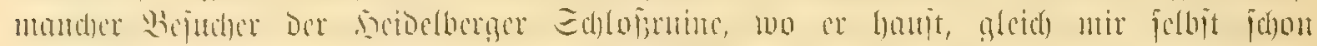

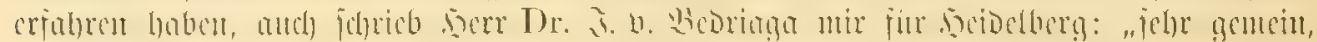

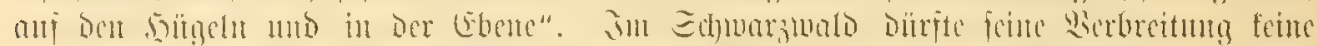
gletdmäfige feit. En benad)

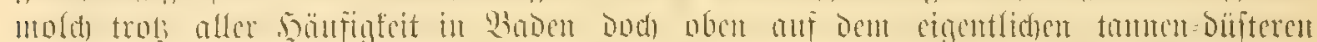

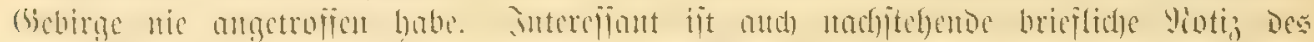

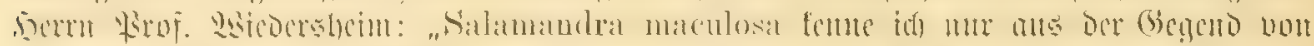

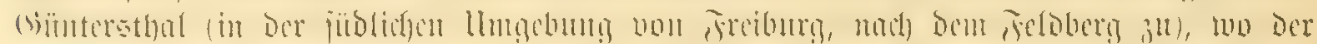

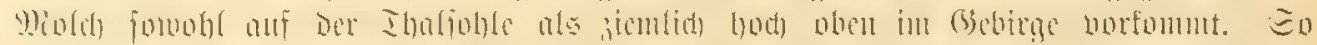

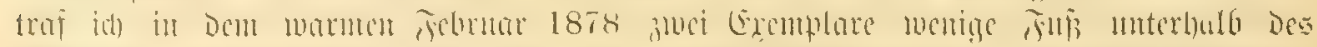

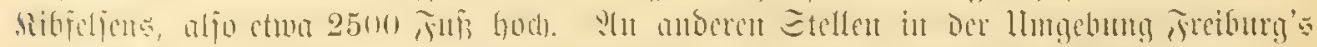

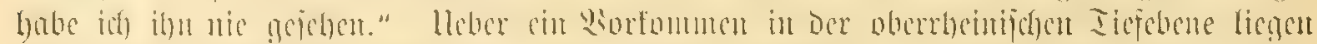

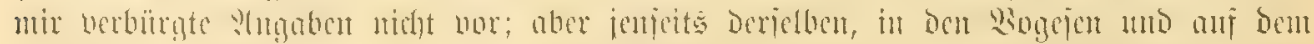

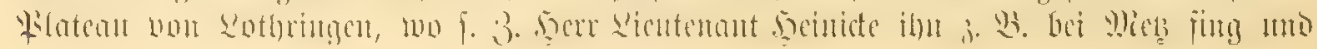




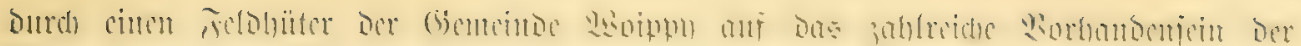

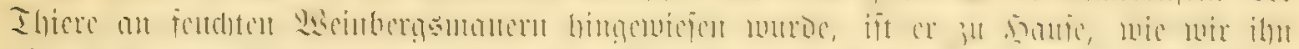

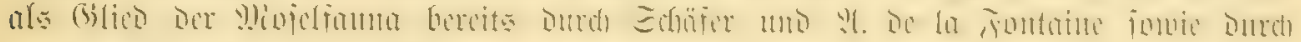
Ret)dig (Trarbady, (Ëffel) feumen.

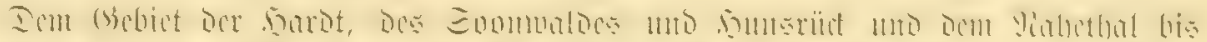

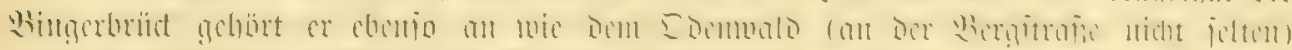

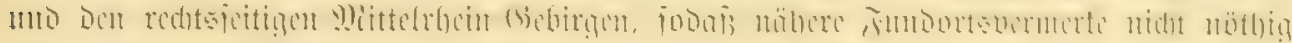

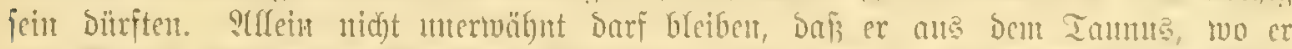

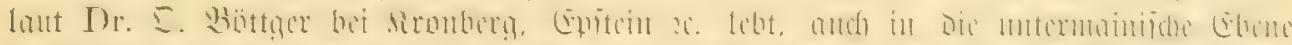

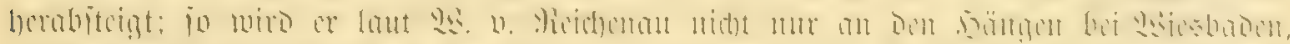

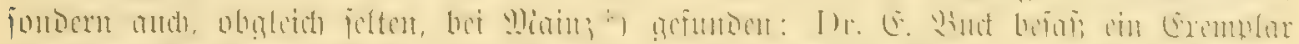

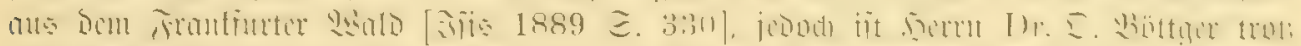

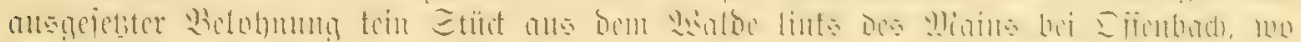

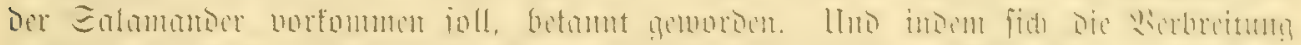

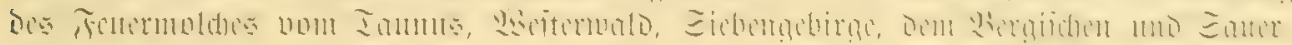

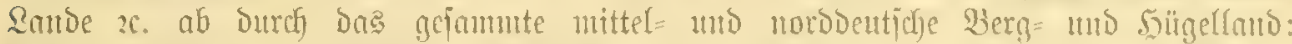

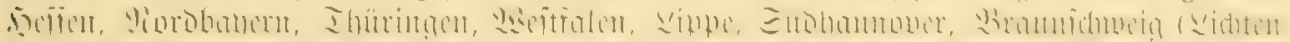

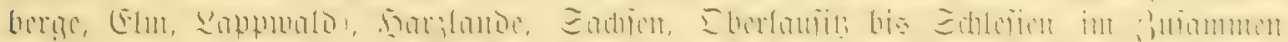

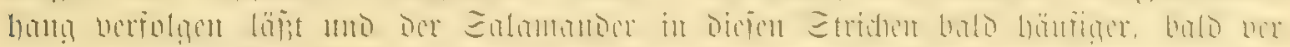

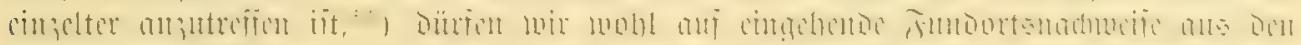

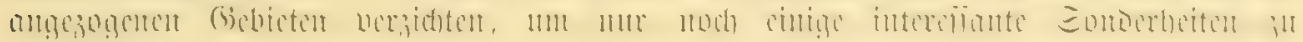
beriaffichtigert.

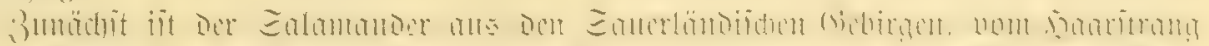

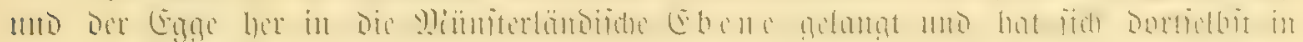

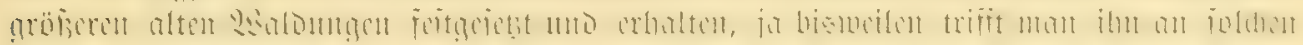

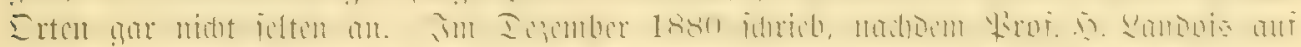

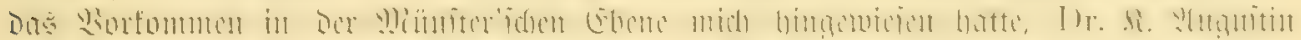

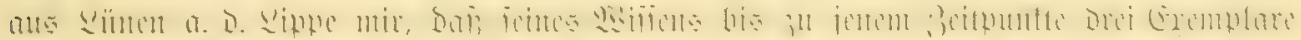

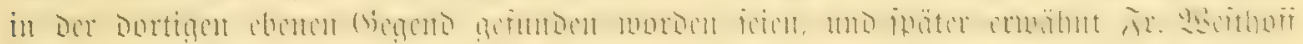

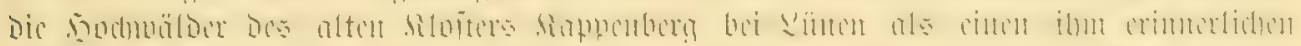

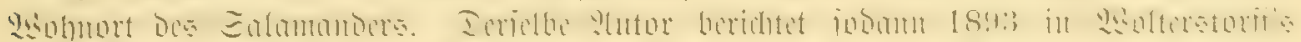

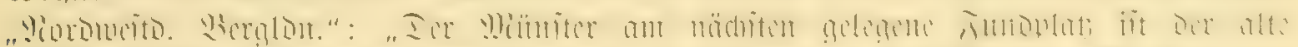

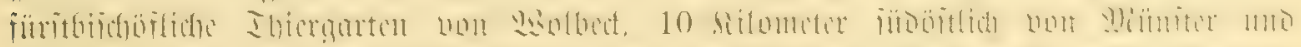

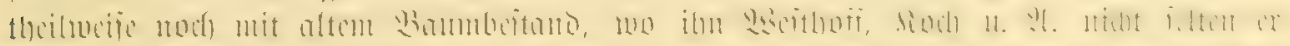

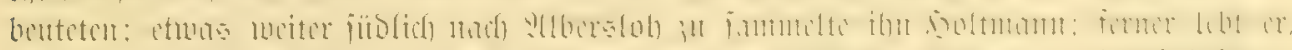

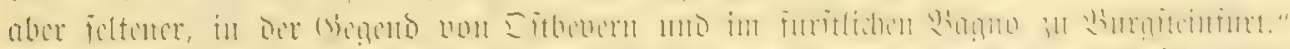

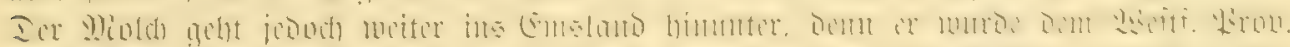

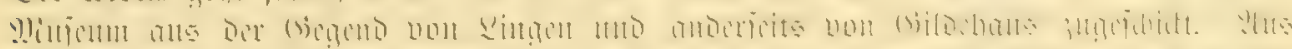

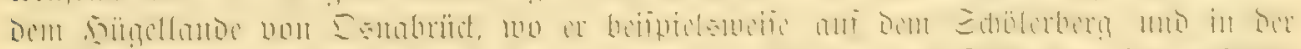

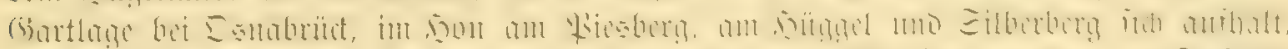

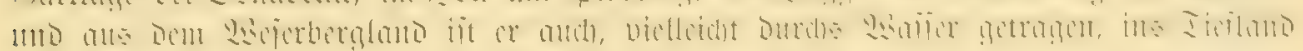

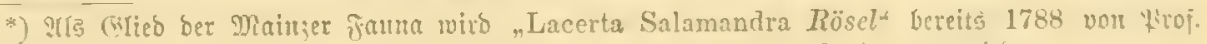

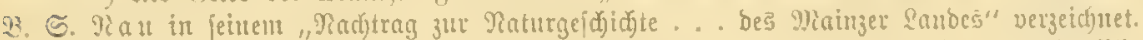

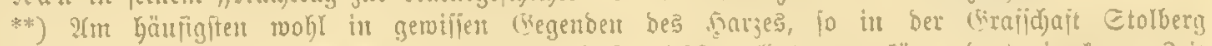

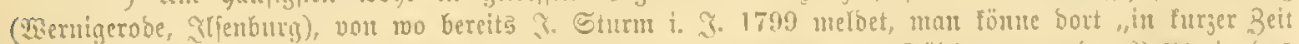

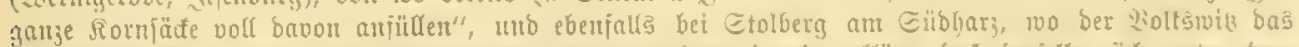

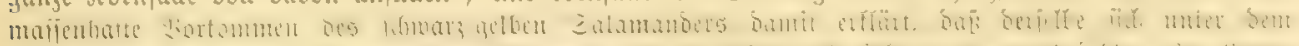

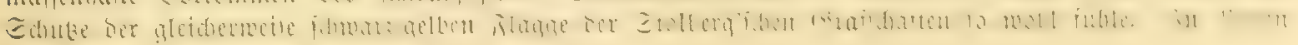

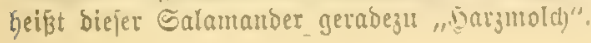




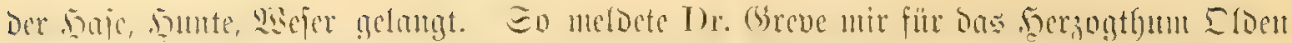

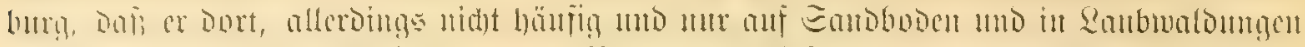

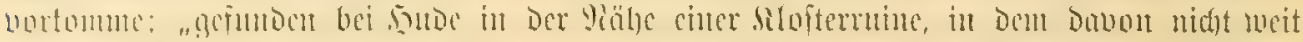

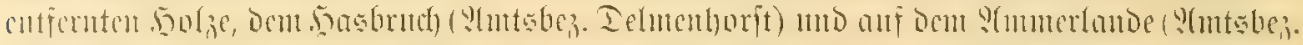

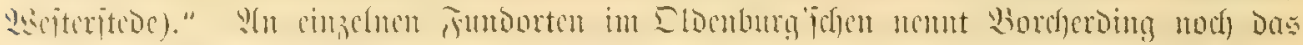

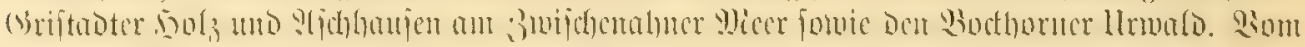

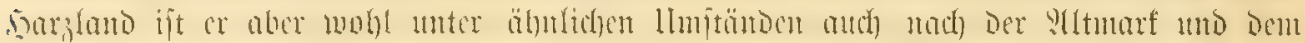

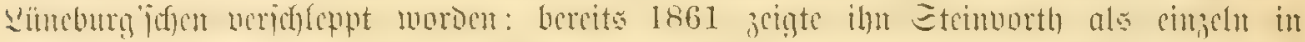

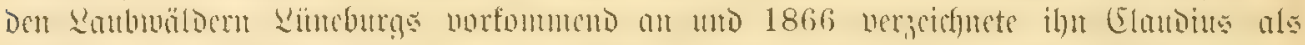

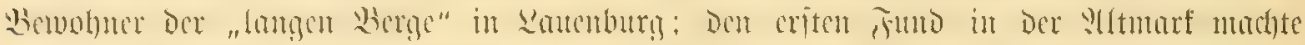

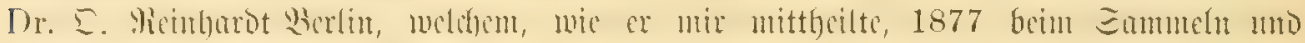

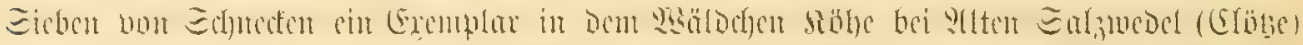

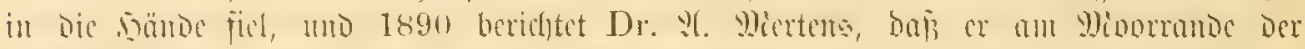

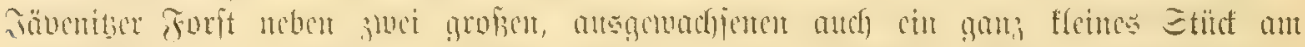

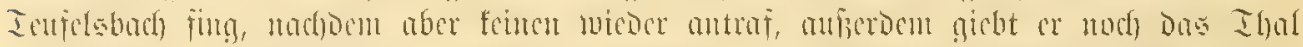

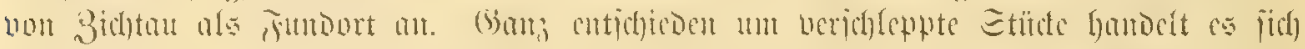

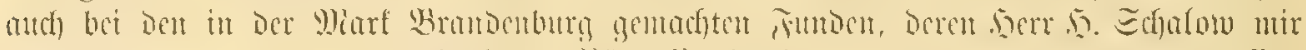

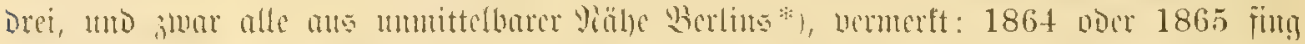

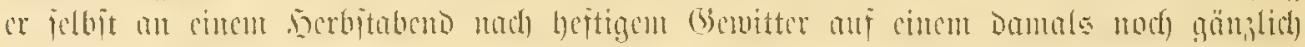

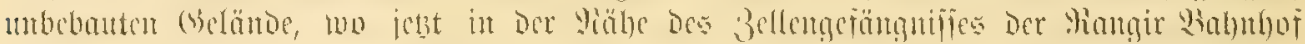

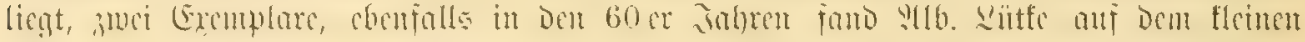

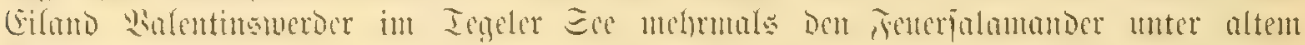

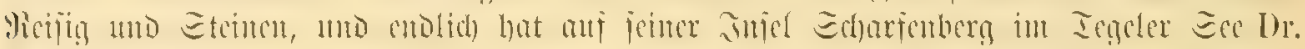

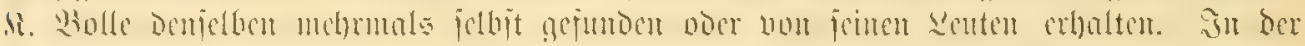

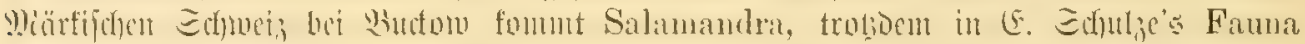

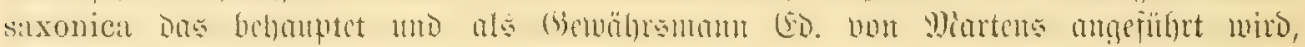

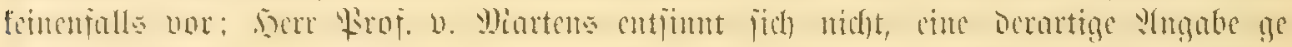

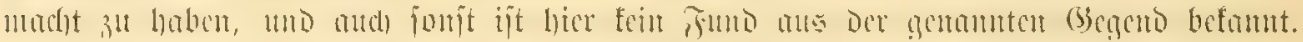

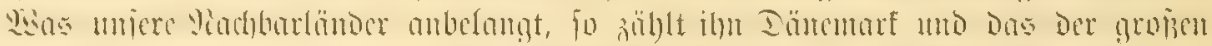

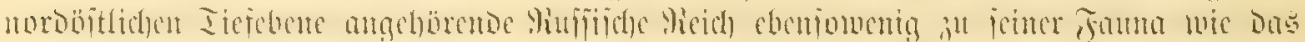

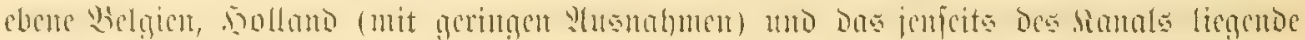

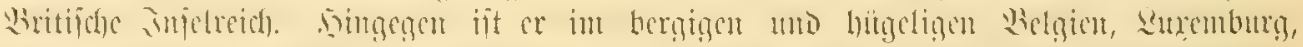

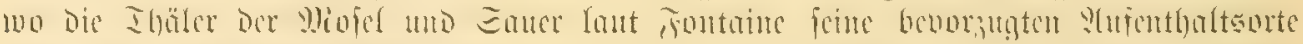

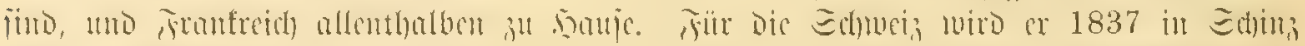

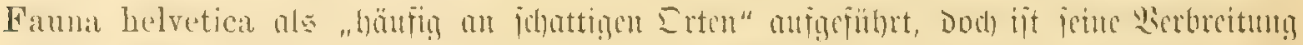

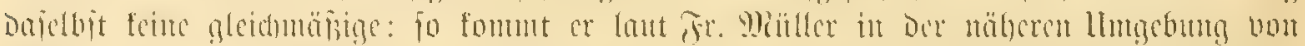

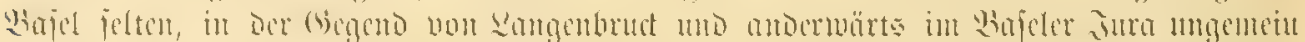

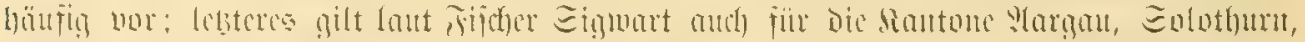

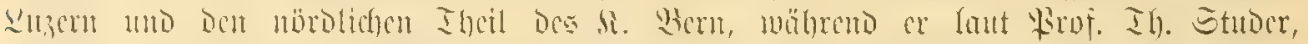

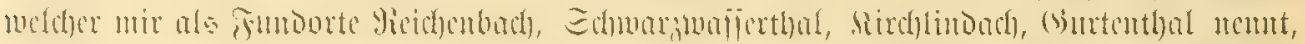

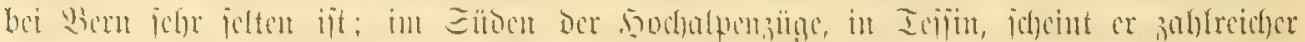

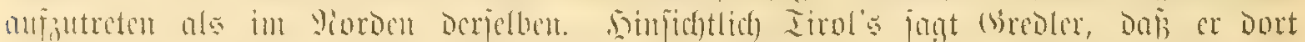

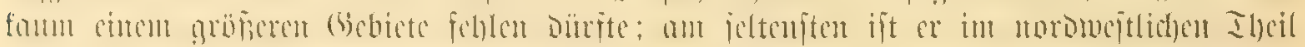

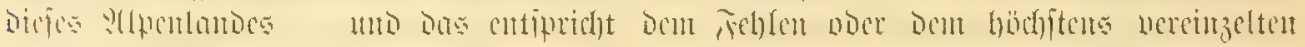

*) Sogar in ber Stabt felbft - und bas fommt and anberwärts vor - futo fojon entwijate

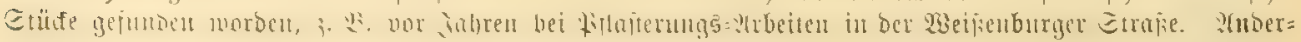

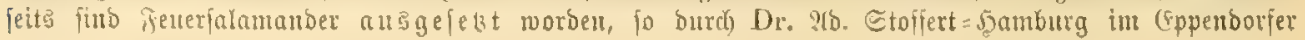

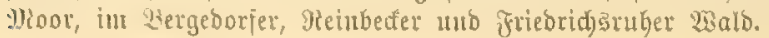




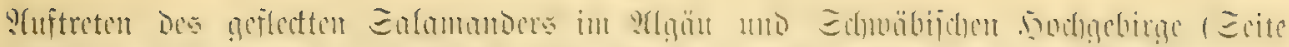

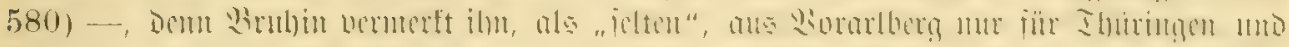

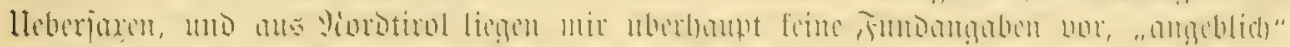

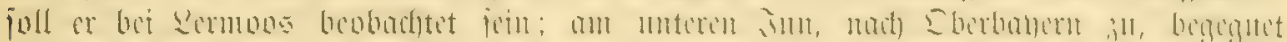

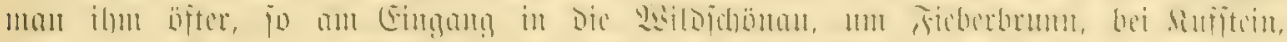

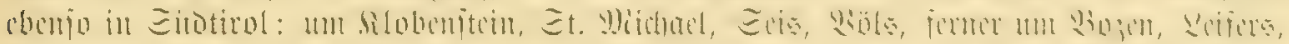

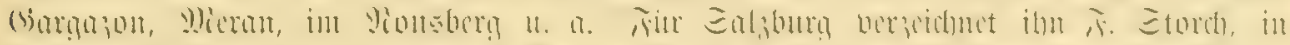

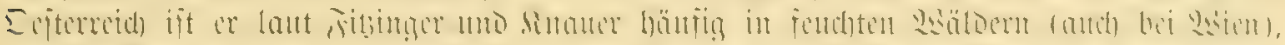

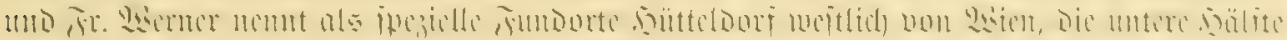

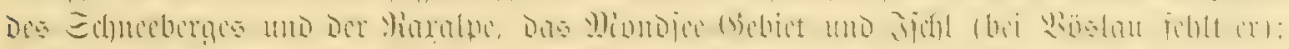

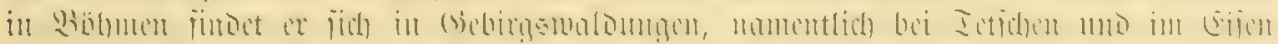

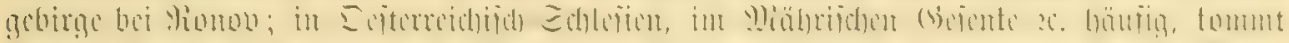

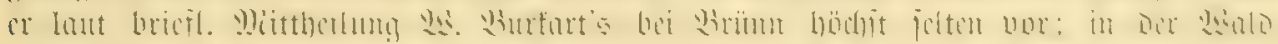

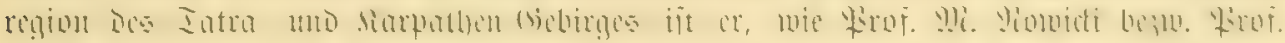

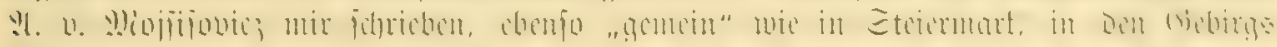

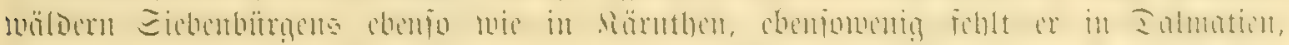

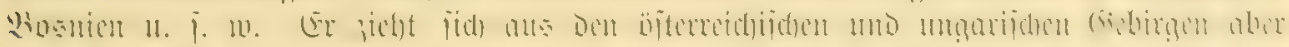

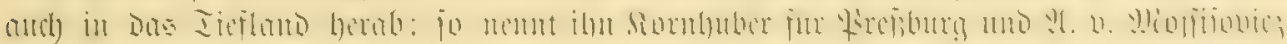

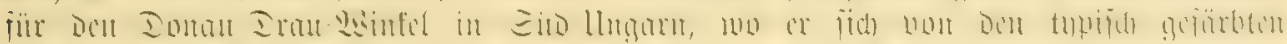

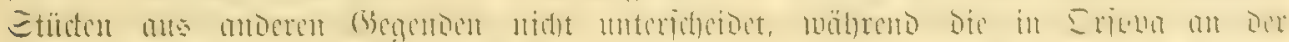

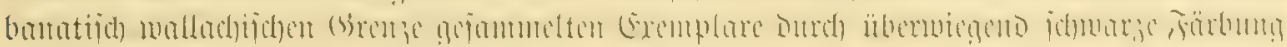
nutD Sileinheit Der gelben Mlateln fich ansjeidfneten.

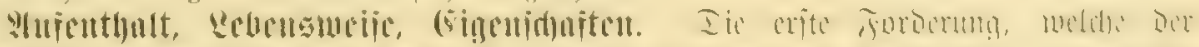

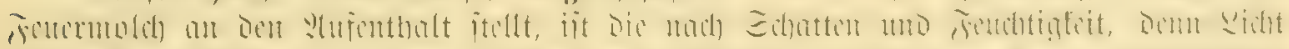

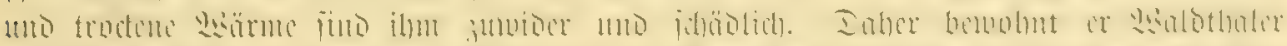

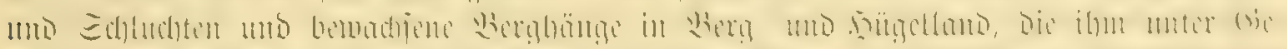

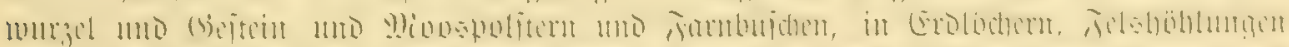

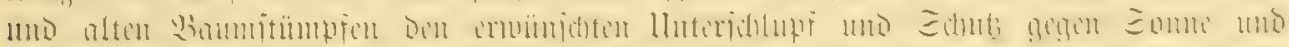

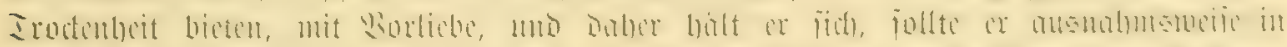

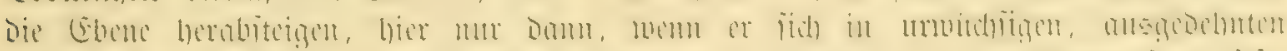

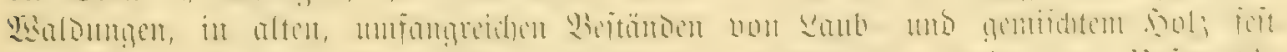

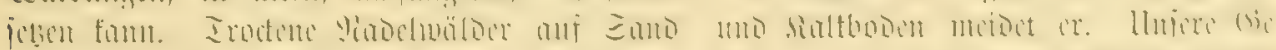

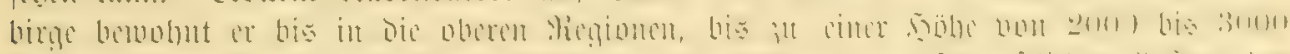

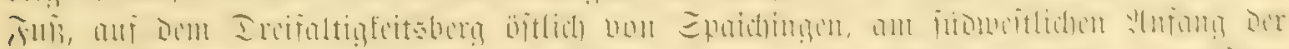

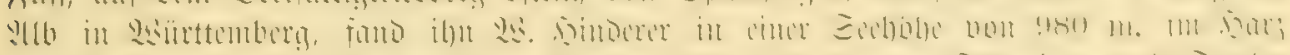

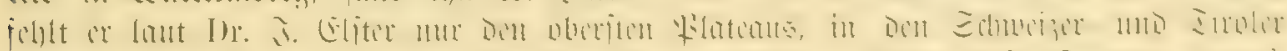

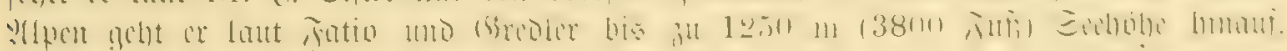

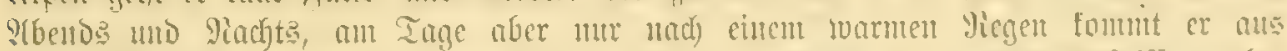

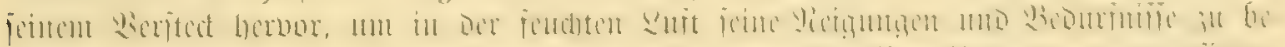

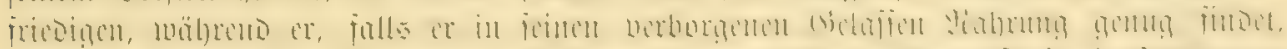

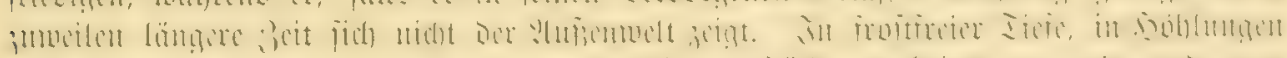

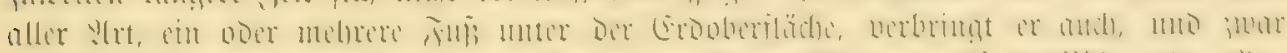

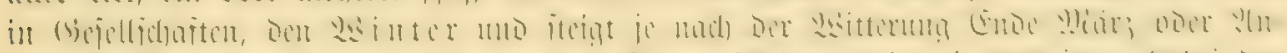

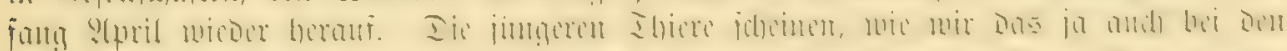

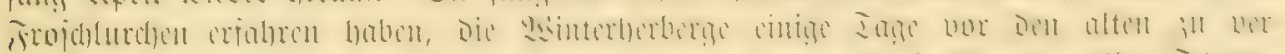

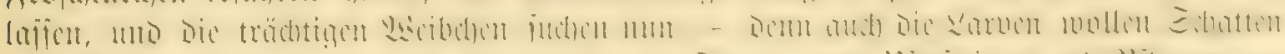

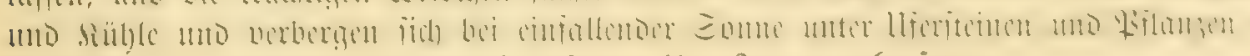

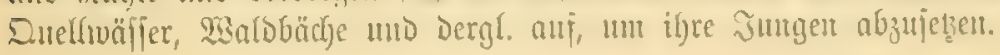


jortpfranzung (Gijdidite.

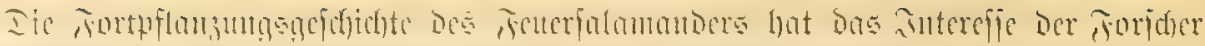

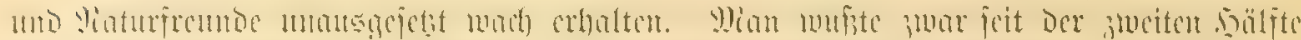

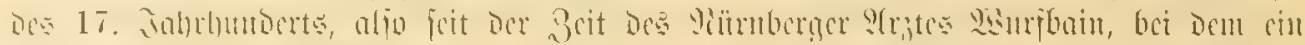

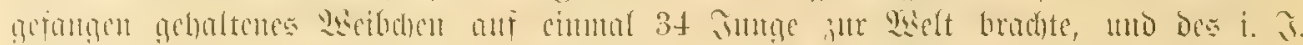

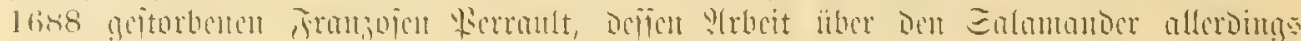

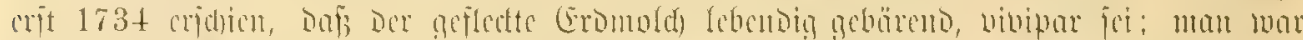

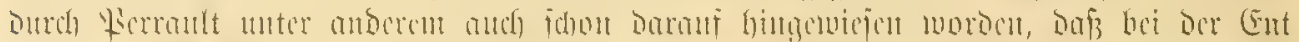

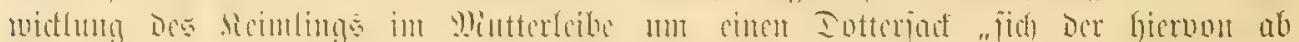

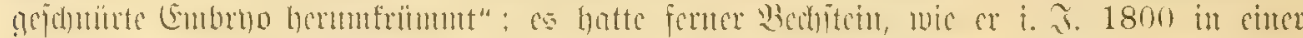

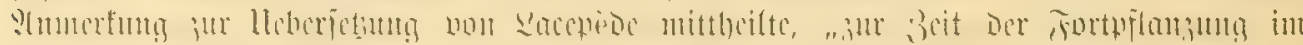

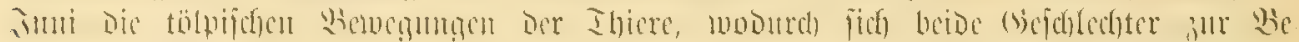

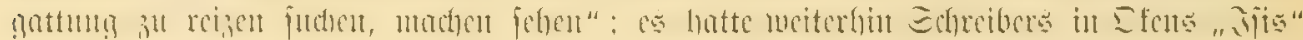

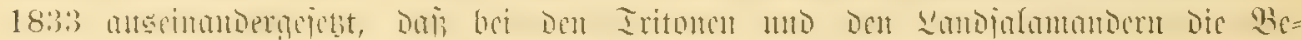

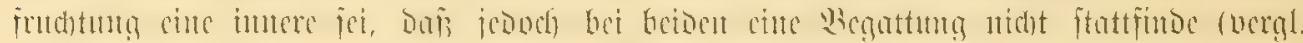

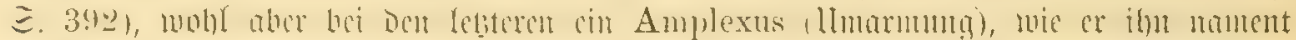

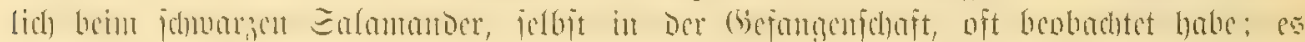

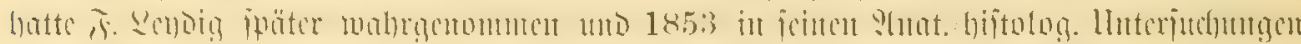

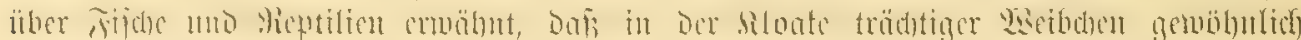

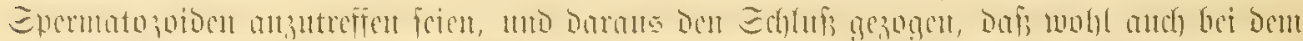

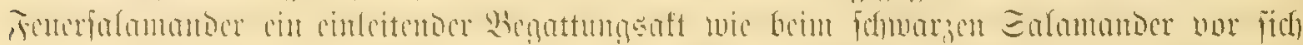

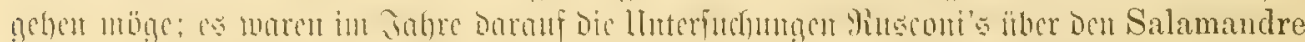

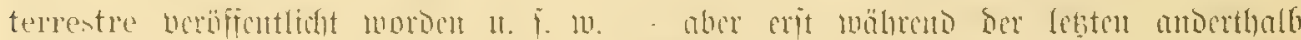

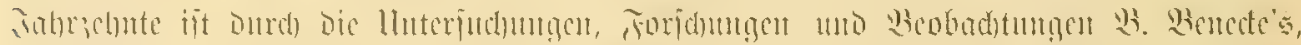

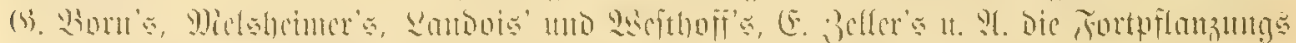

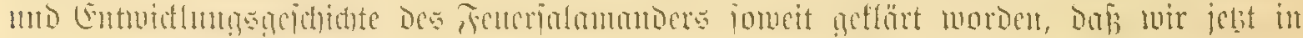
furzen Strichen folgentee Bild unt Derielben entwerfen lömen:

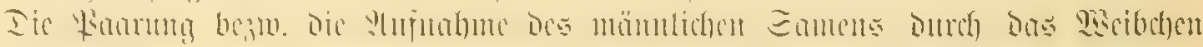

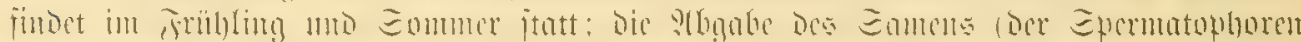

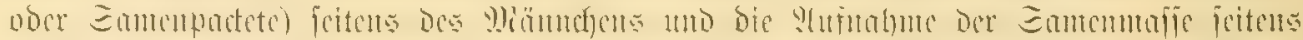

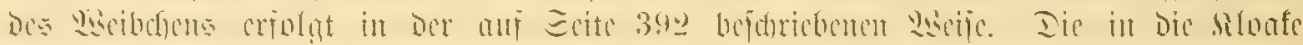

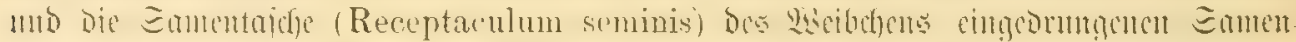

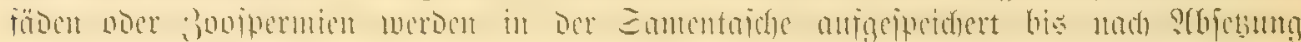

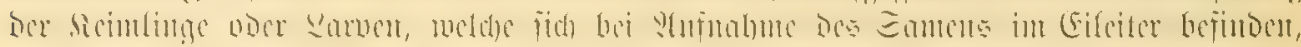

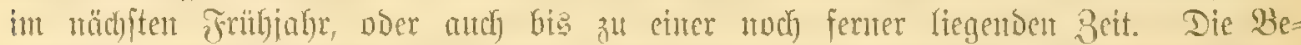

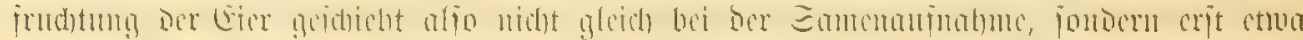

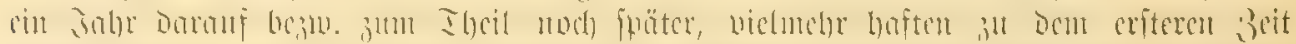

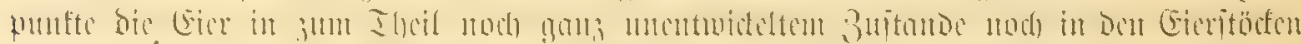

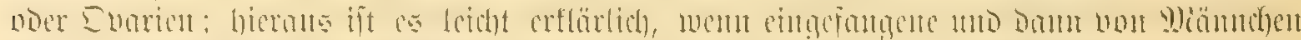

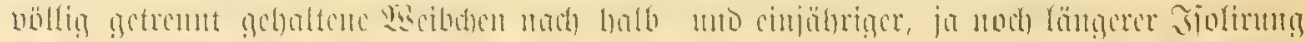

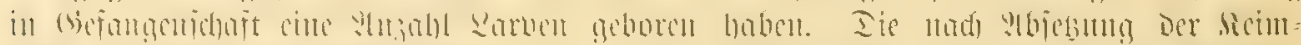

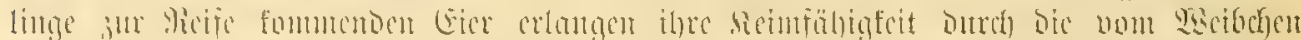

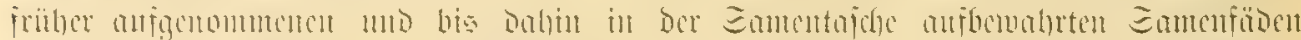

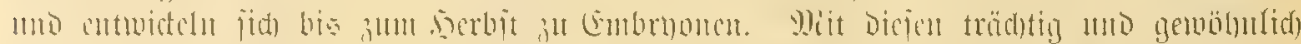

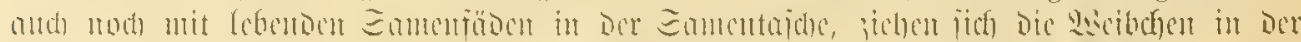

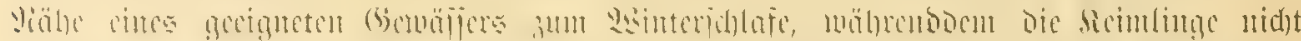

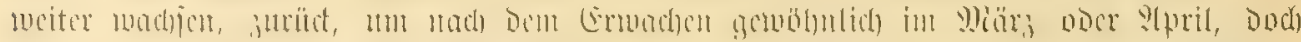

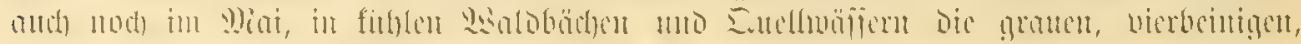

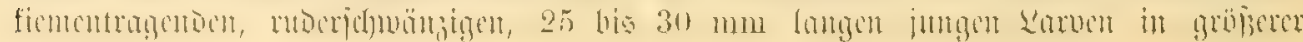




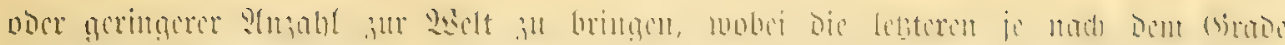

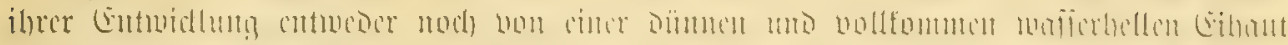

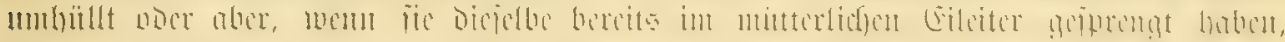

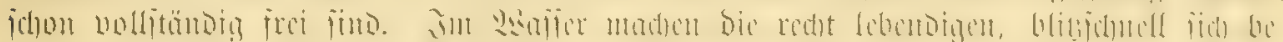

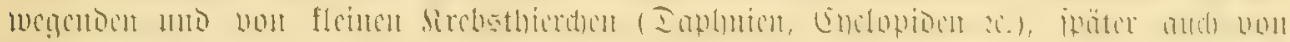

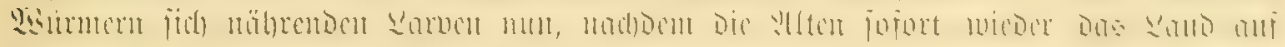

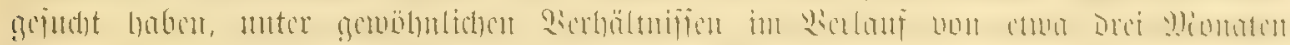

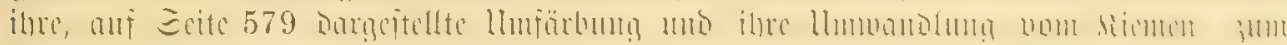

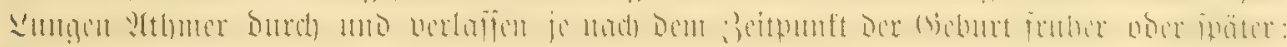

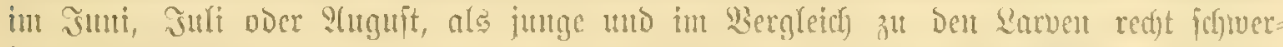

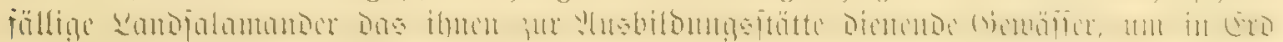

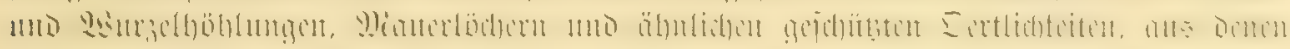

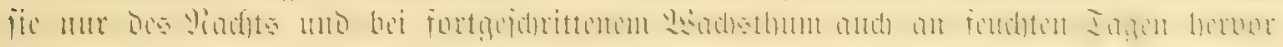

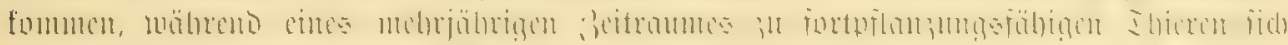

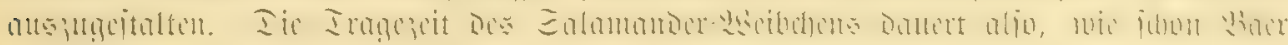

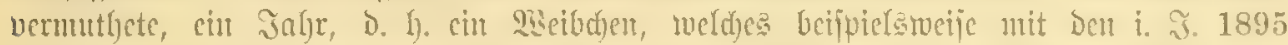

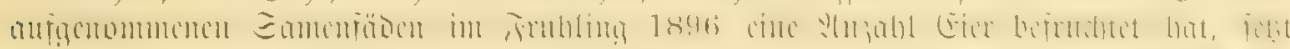

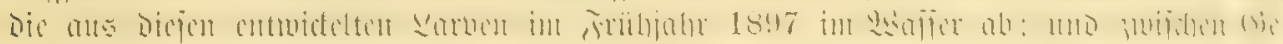

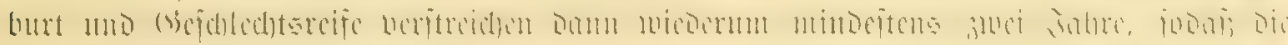

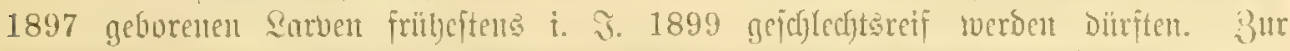

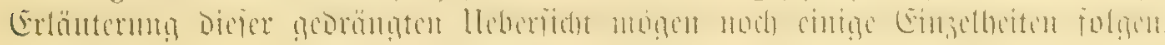

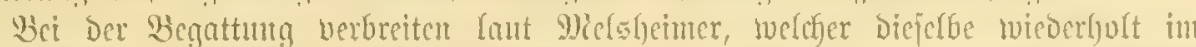

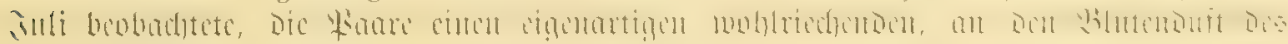

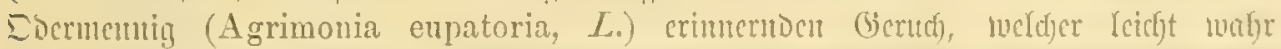
, .

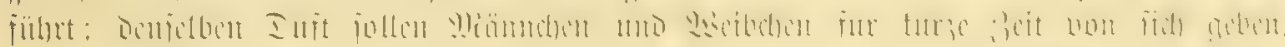

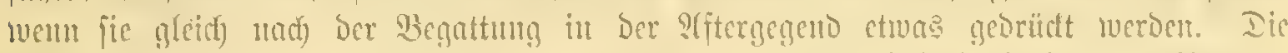

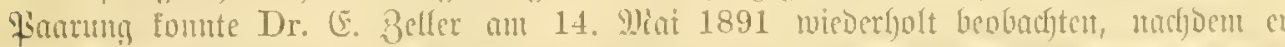

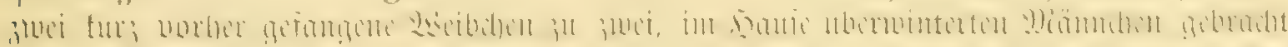

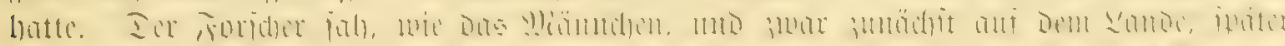

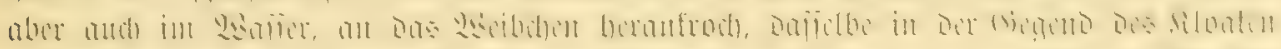

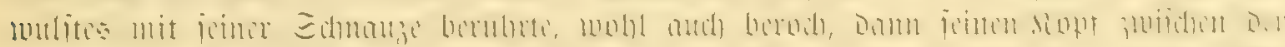

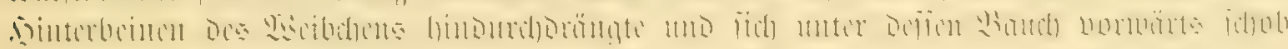

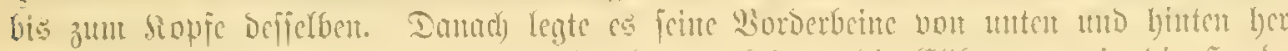

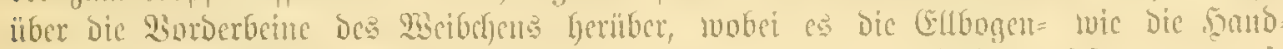

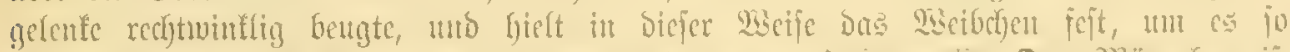

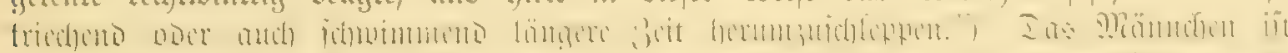

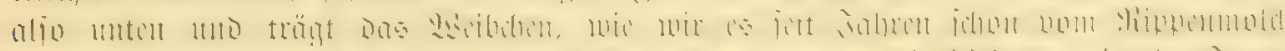

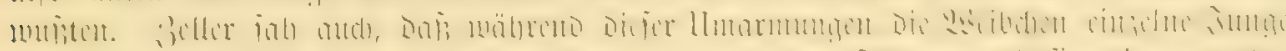

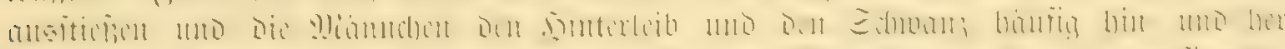

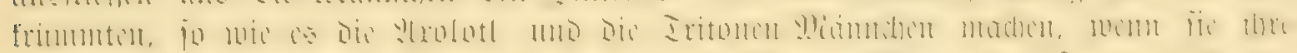

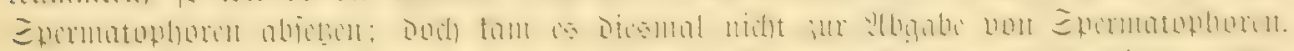

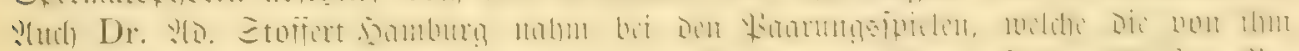

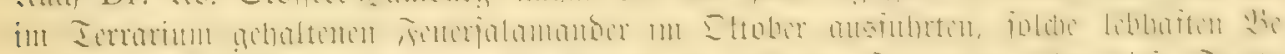

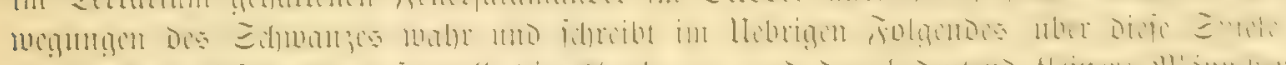

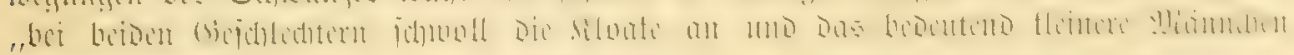

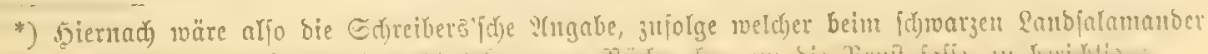

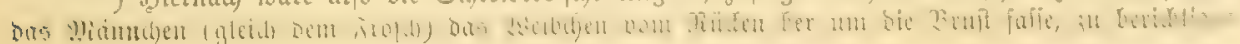




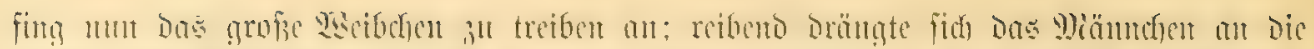

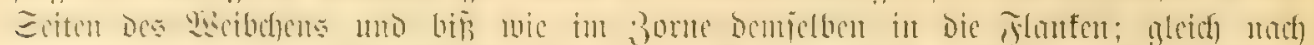

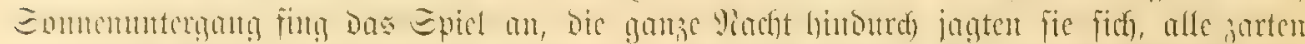

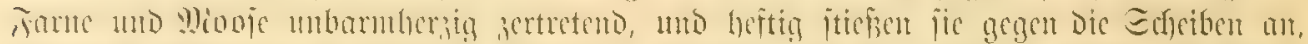

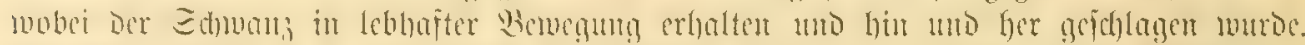

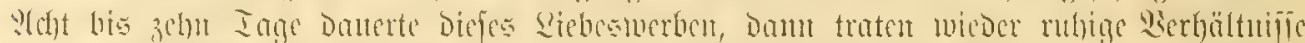

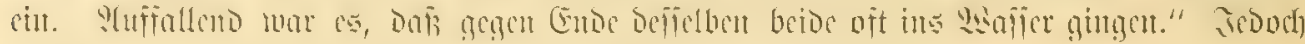
fomnte Dr. Etofiert nie eine eigentide Begattung beobachten.

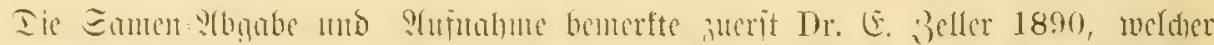

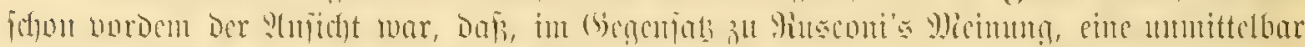

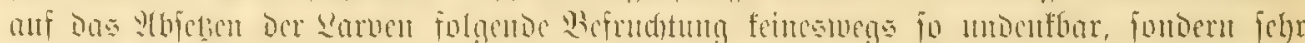

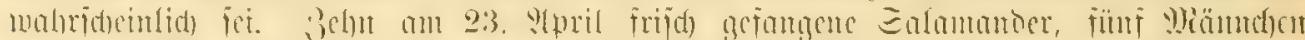

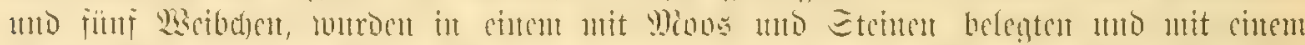

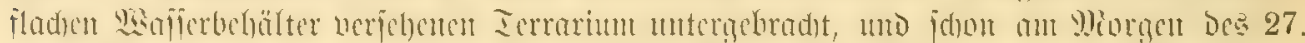

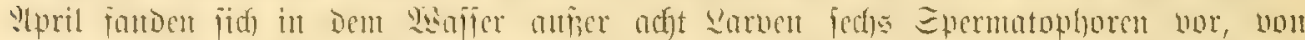

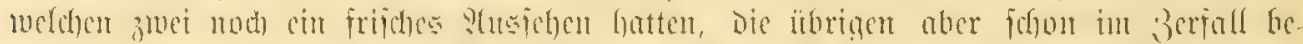

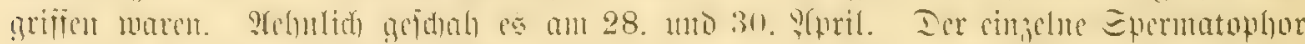

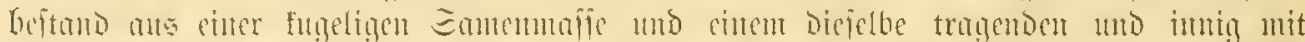

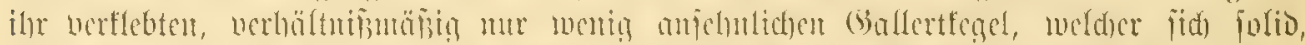

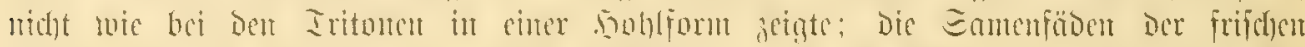

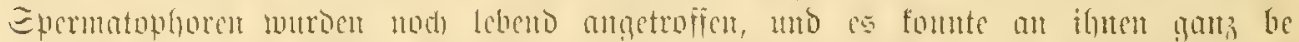

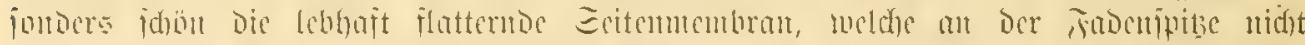

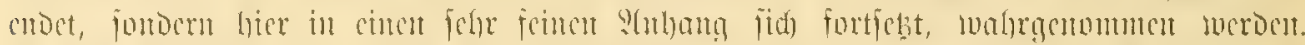

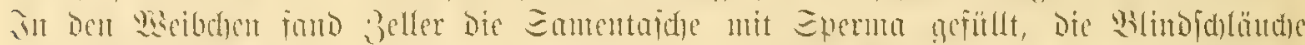

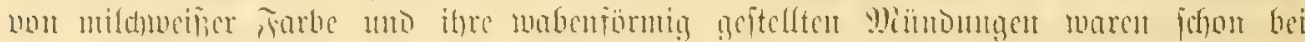

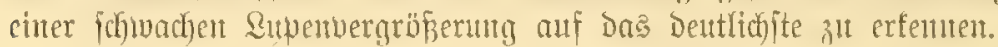

(Y)mbrnonat: Entwialung.

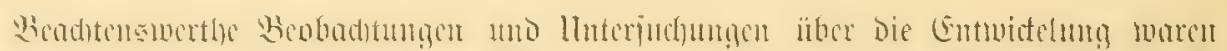

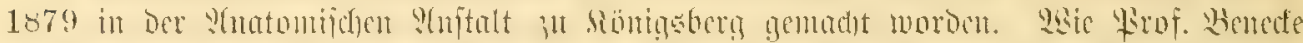

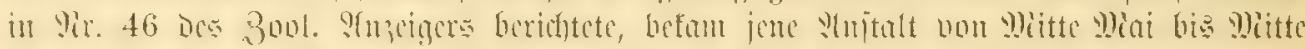

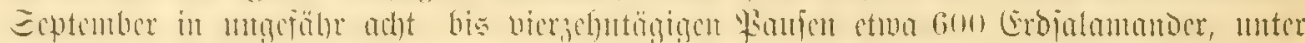

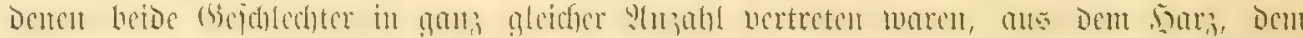

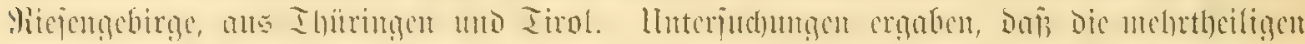

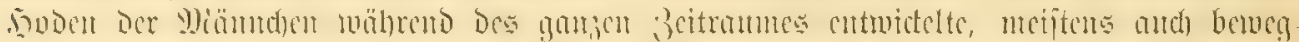

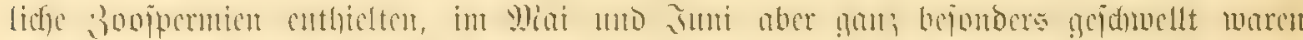

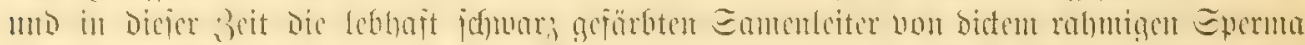

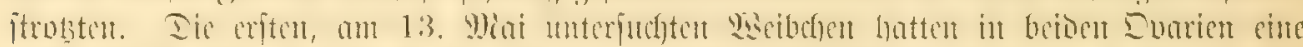

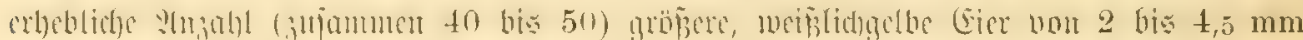

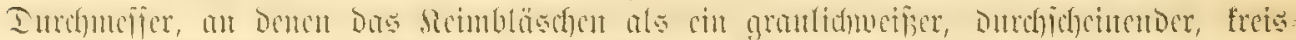

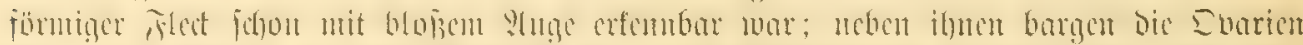

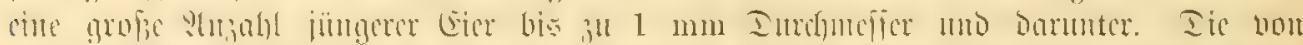

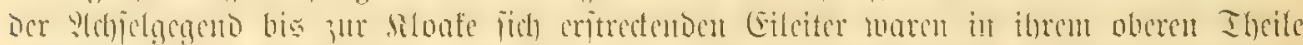

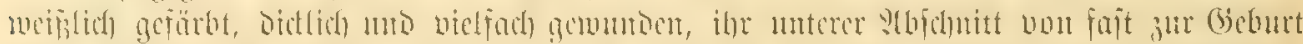

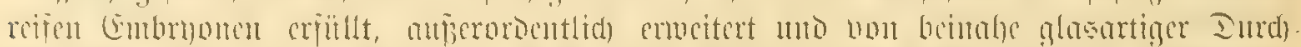

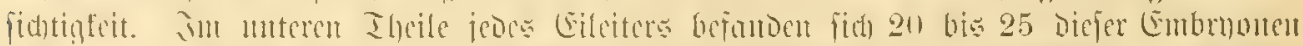

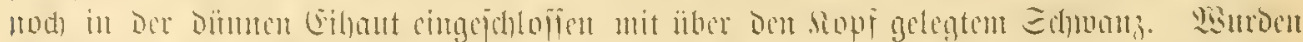

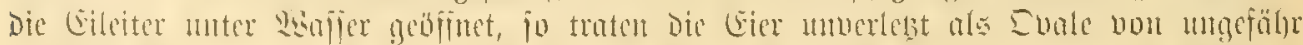

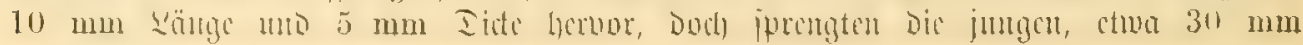




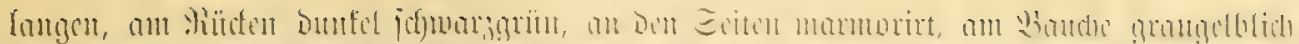

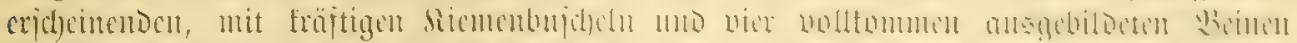

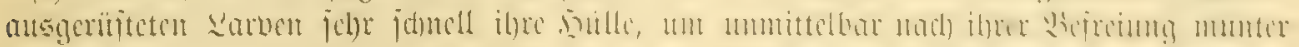
แmble,

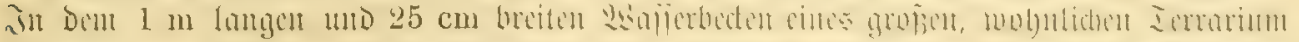

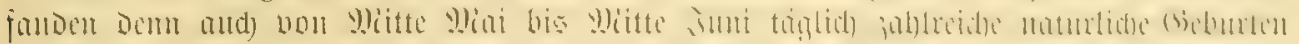

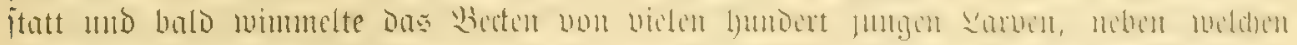

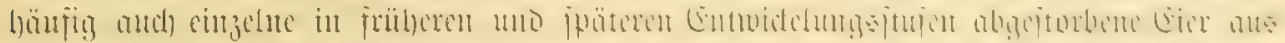

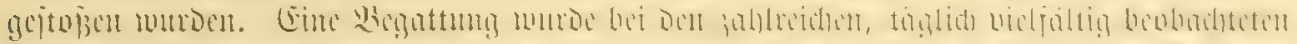

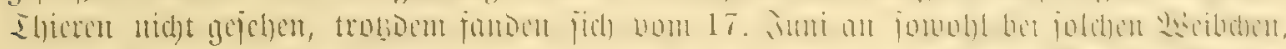

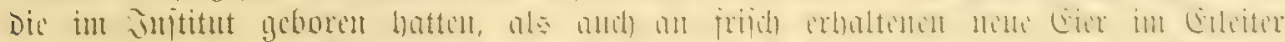
mährend be anderen (E)

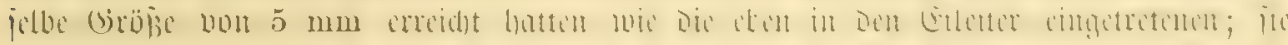

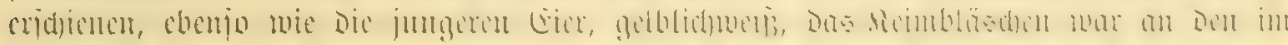

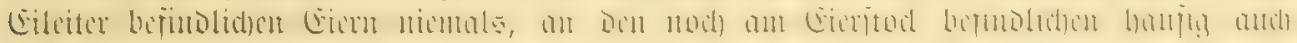

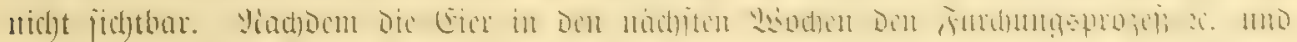

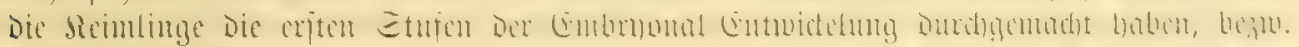

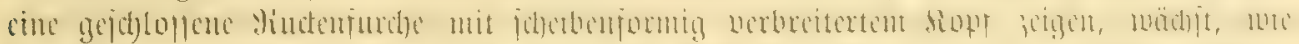

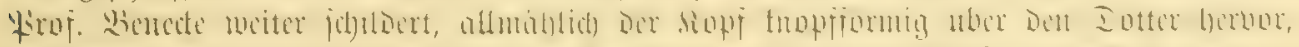

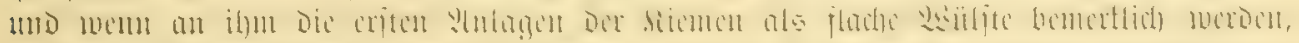

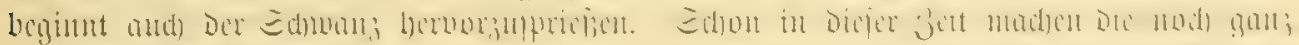

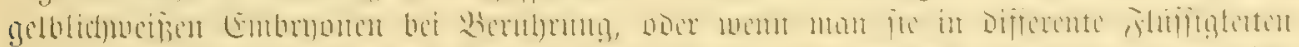

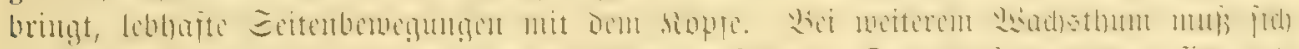

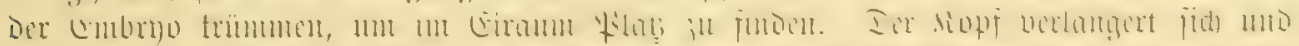

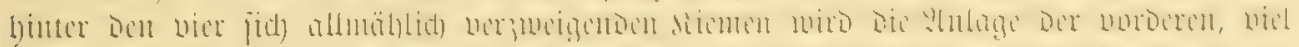

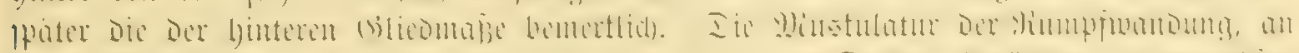

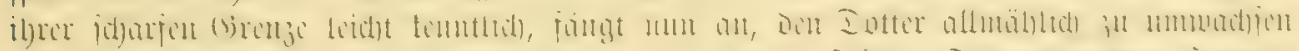

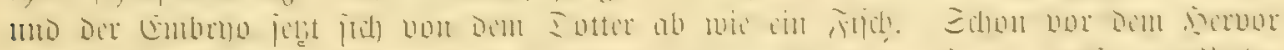

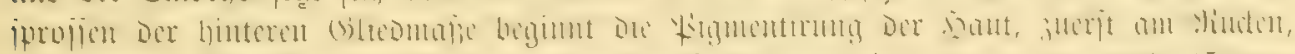

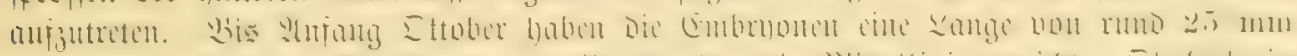

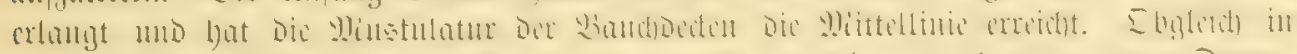

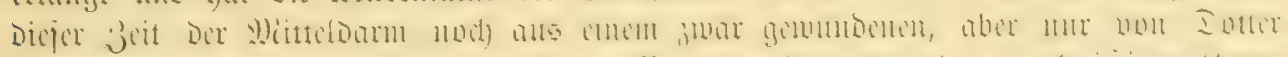

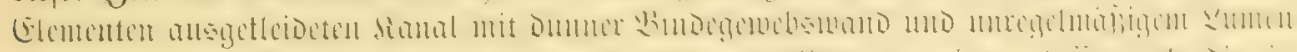

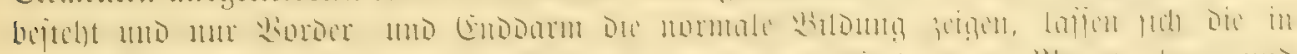

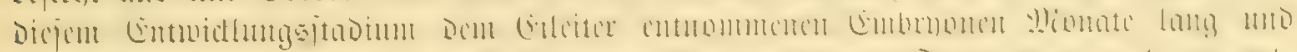

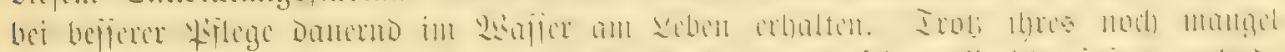

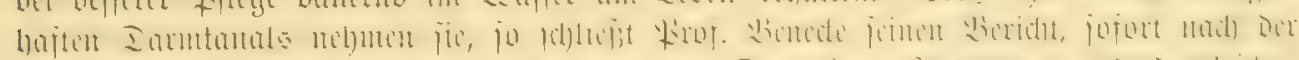

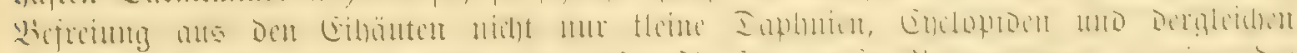

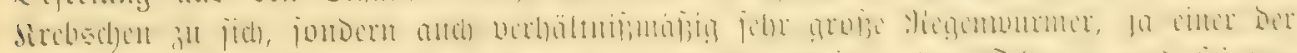

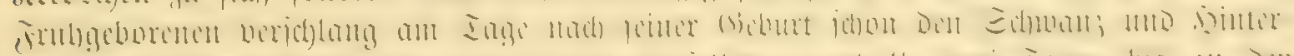

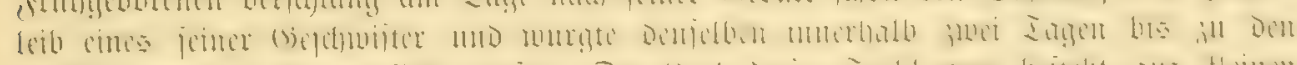

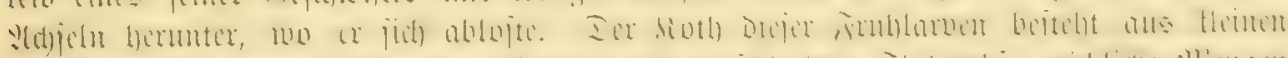

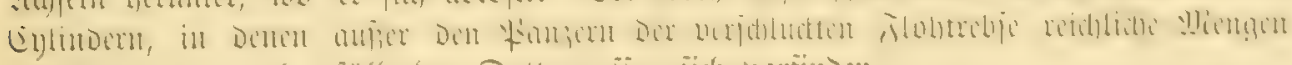
Der Den Durm noch expïllendest Dottermajien fidh vorfindent.

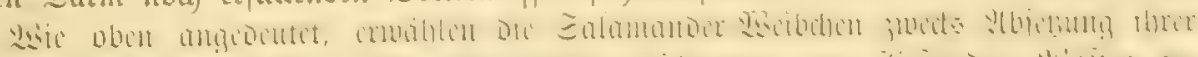

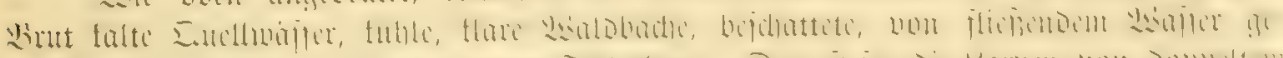

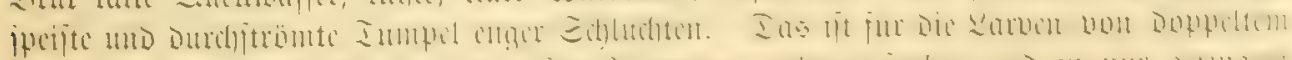

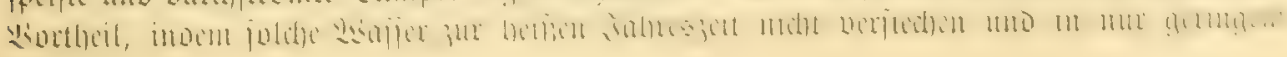




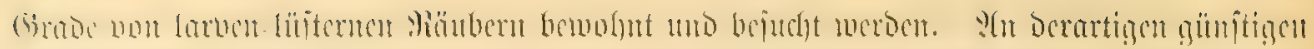

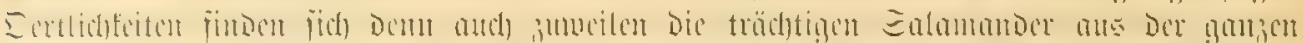

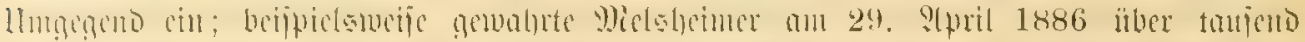

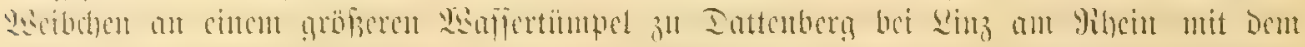

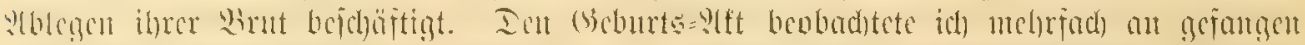

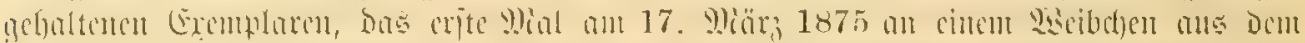

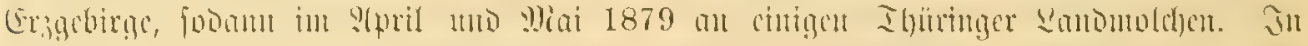

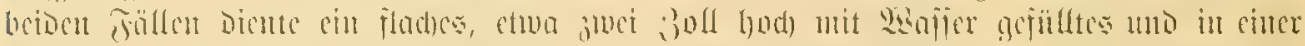

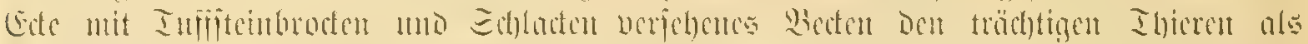

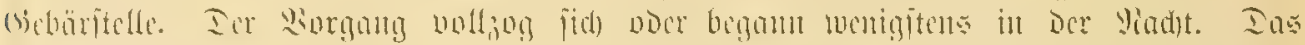

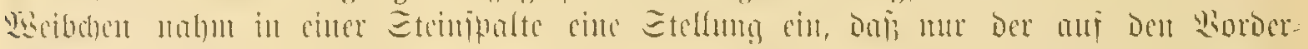

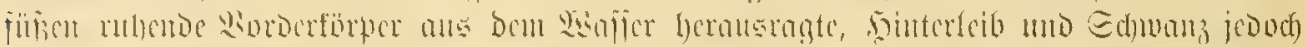

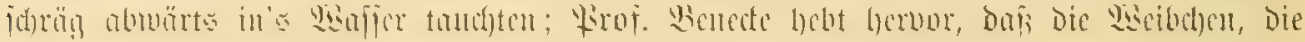

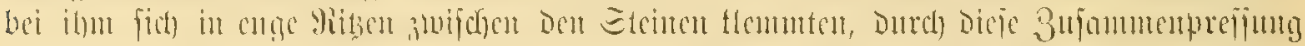

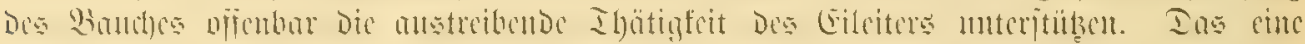

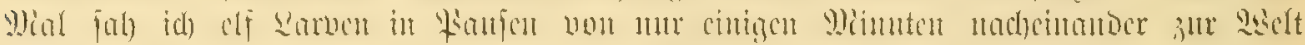

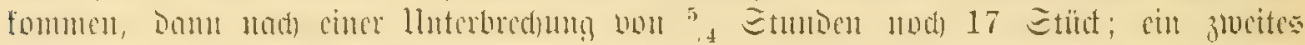

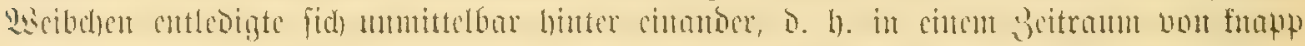

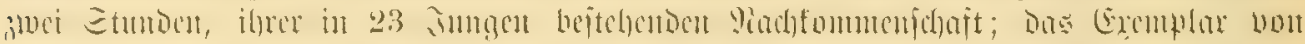

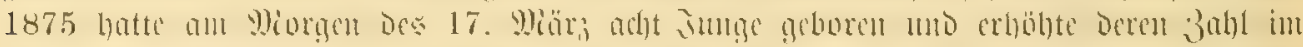

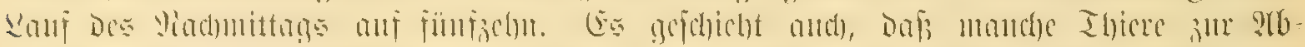

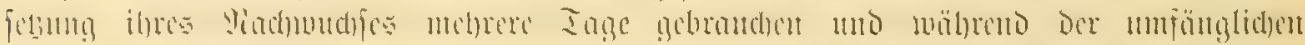

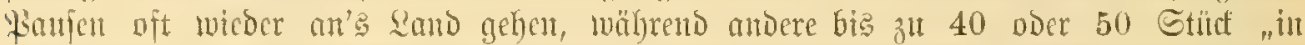

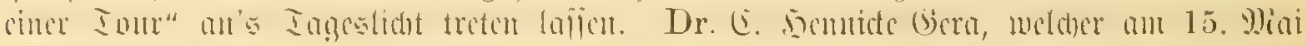

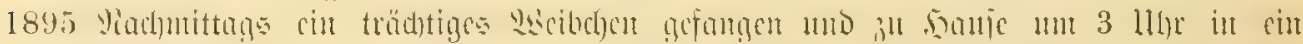

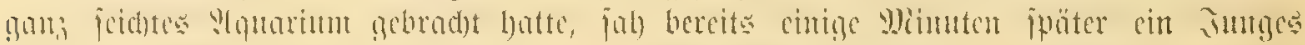

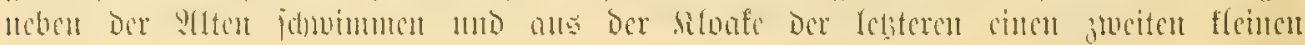

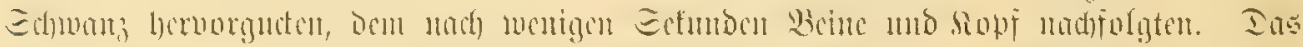

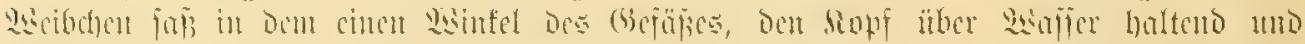

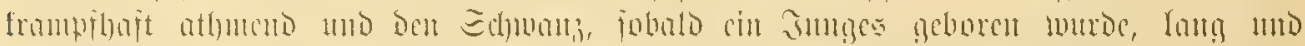

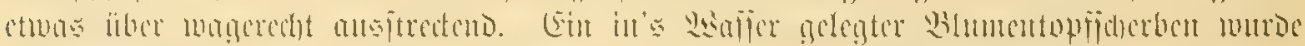

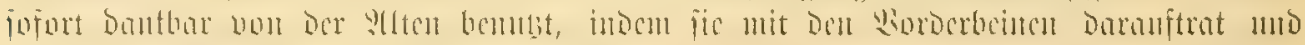

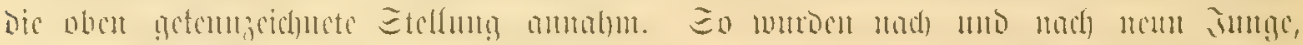

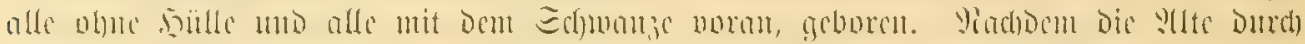

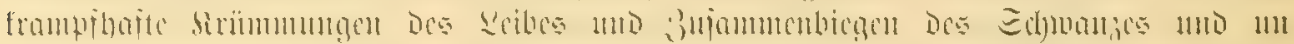

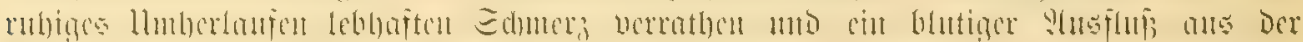

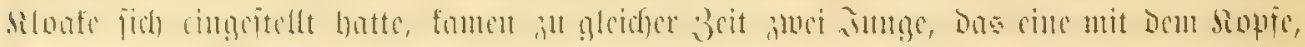

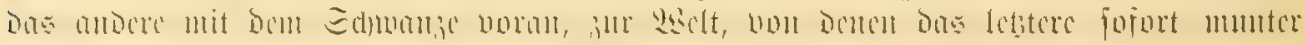

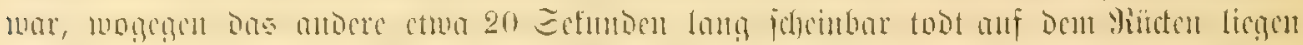

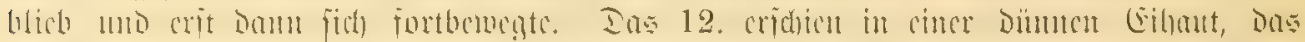

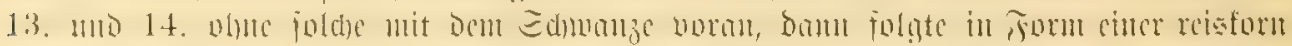

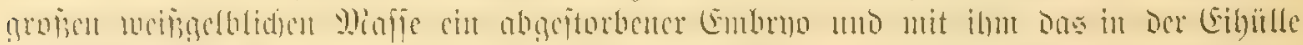

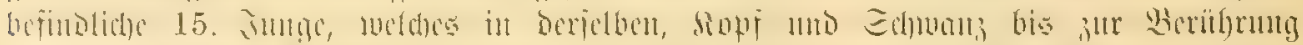

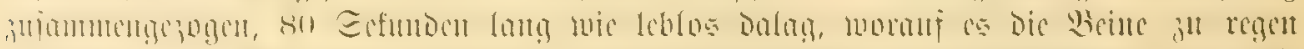

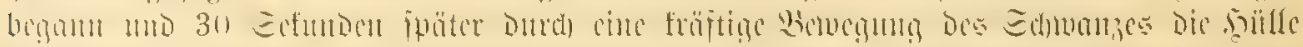

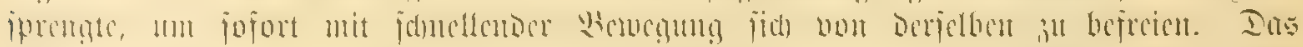

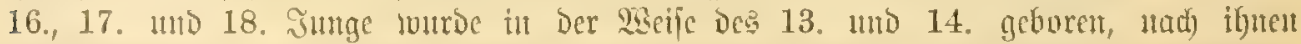

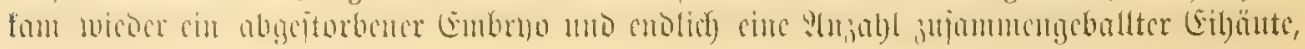




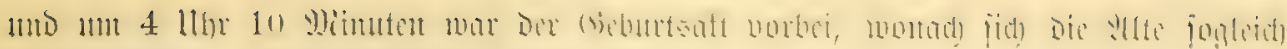

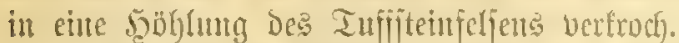

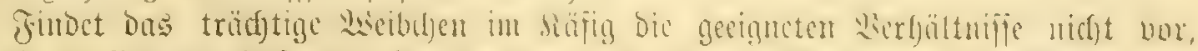

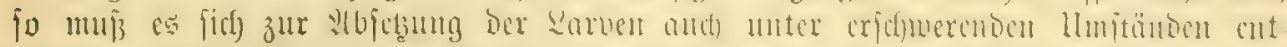

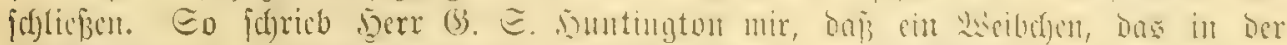

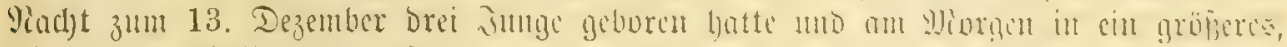

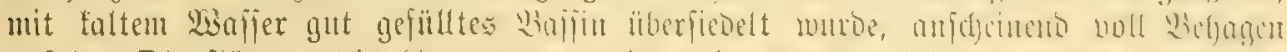

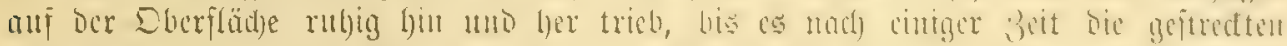

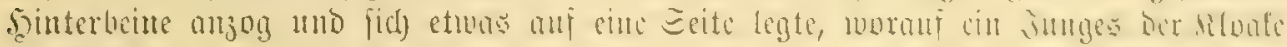

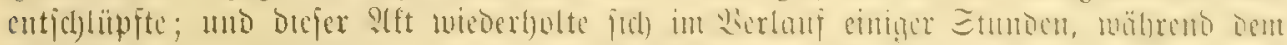

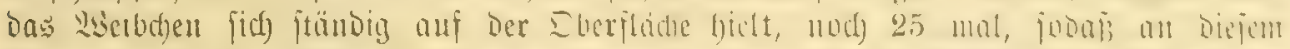

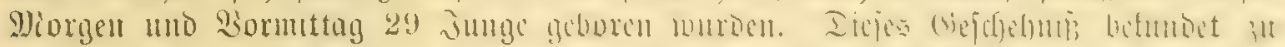

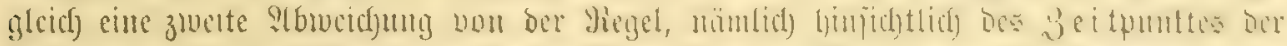

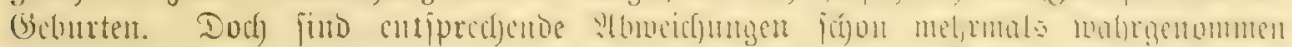

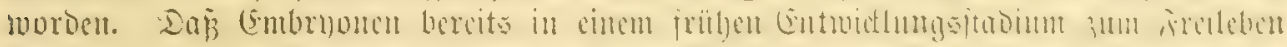

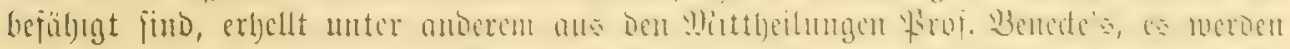

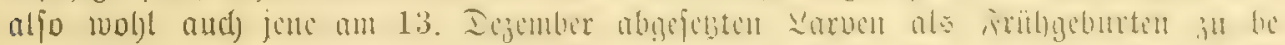

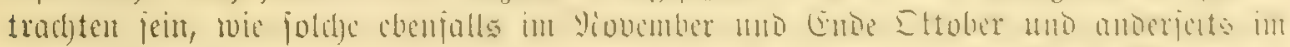

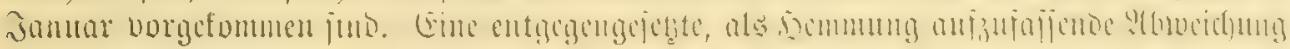

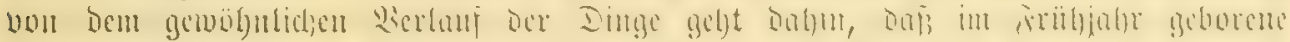

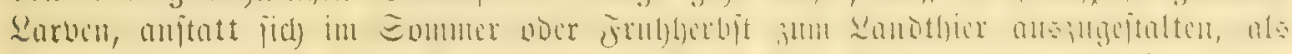

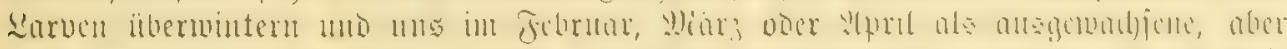

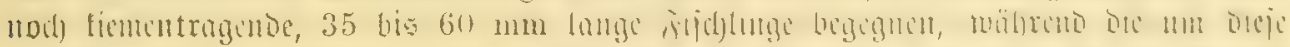

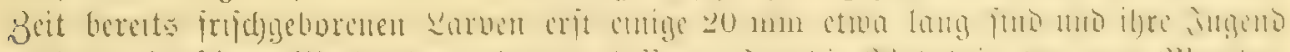

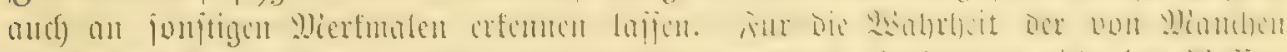

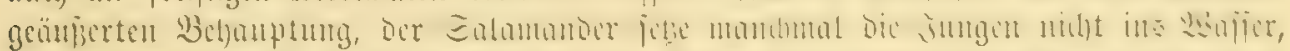

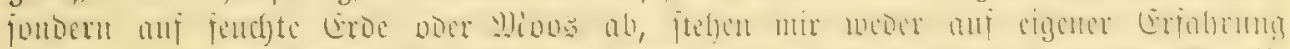

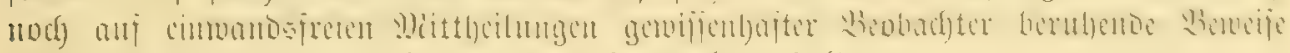
3u (Sebote; id muß mid) foutad) nocly ablebucnd verbalten.

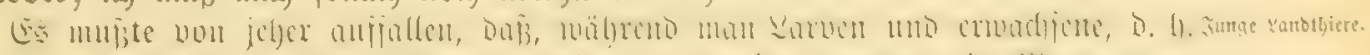

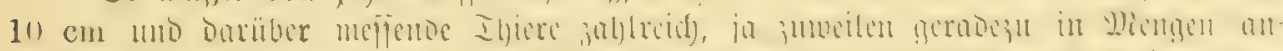

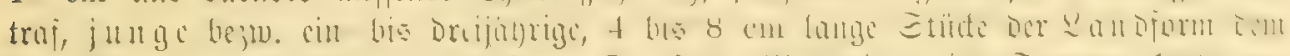

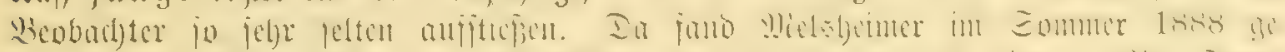

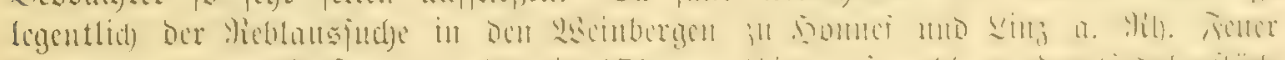

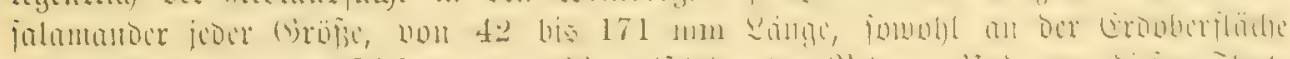

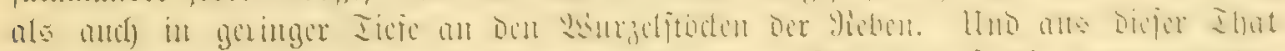

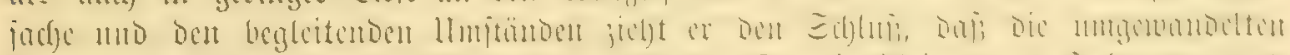

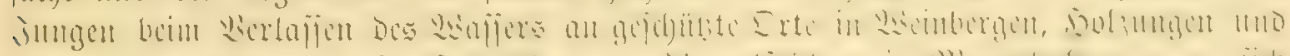

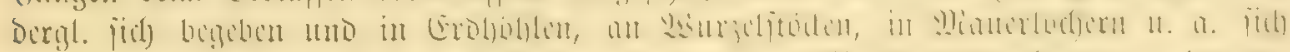

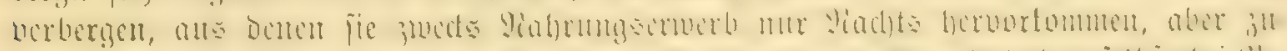

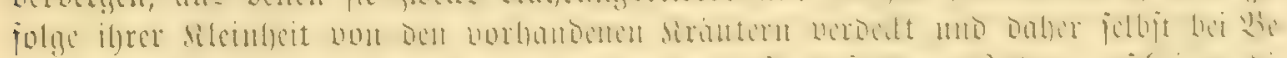

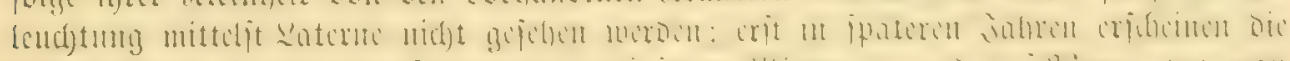

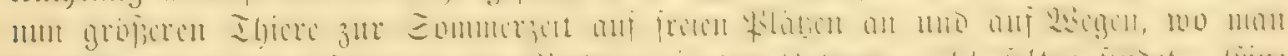

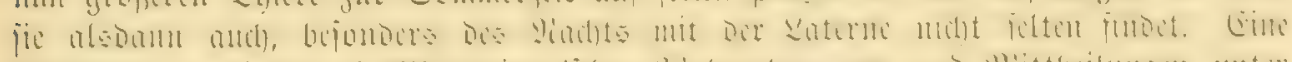

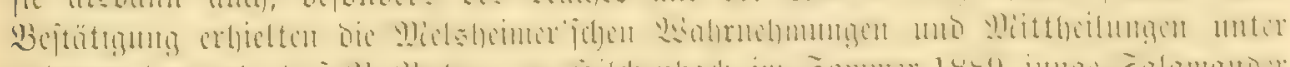

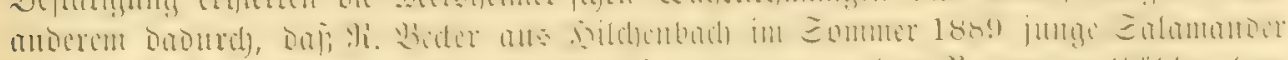

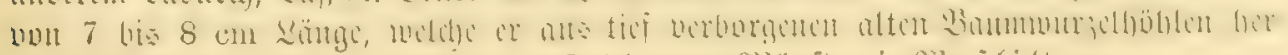

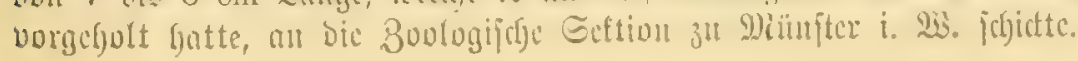




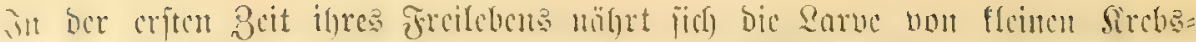

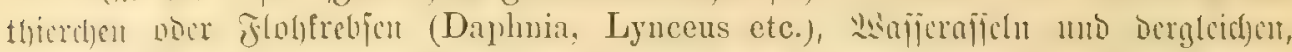

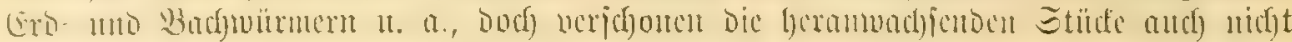

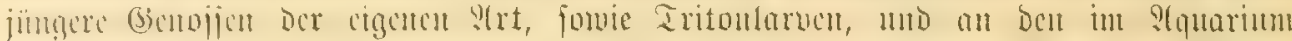

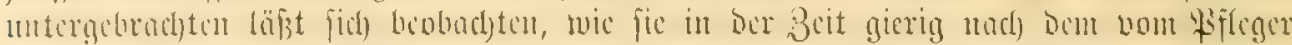

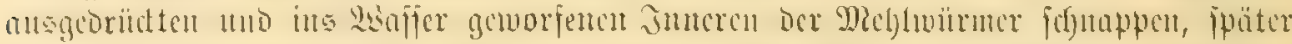

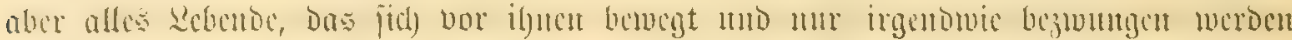

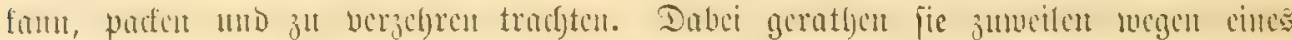

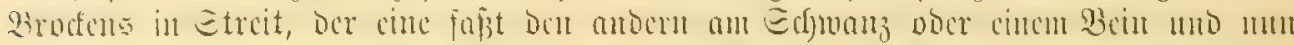

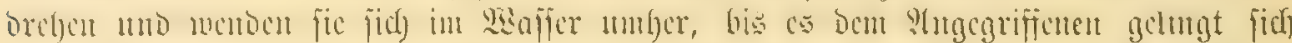

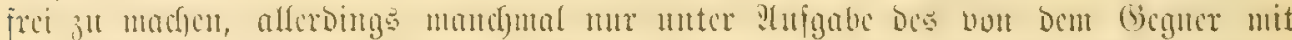

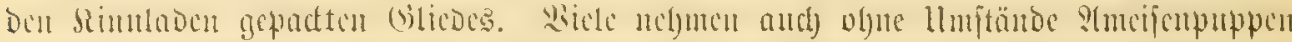

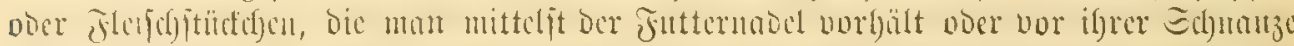

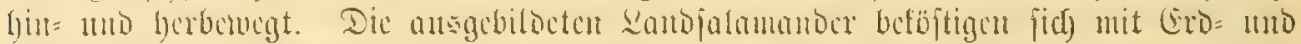

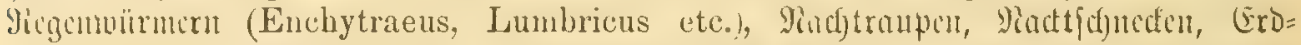

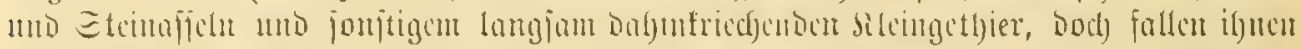

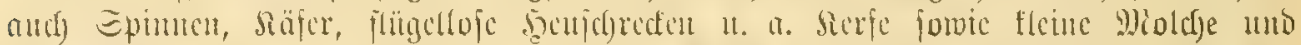

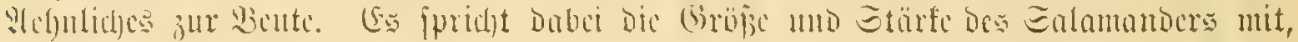

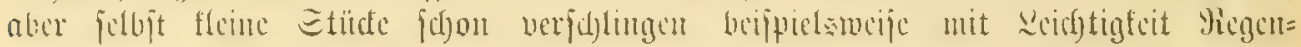

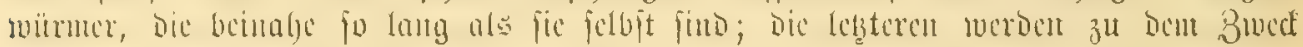

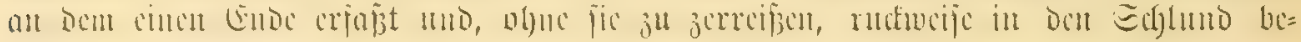

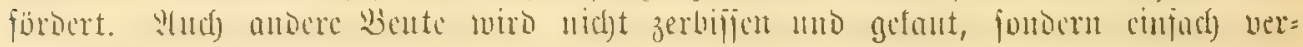
idjluct ober butabgenürgt.

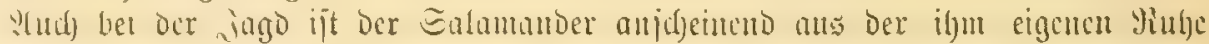

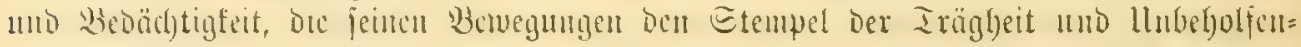

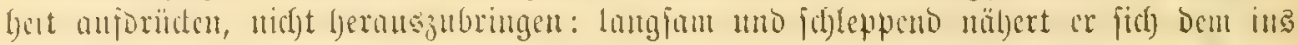

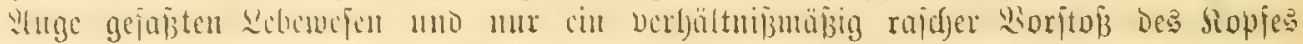

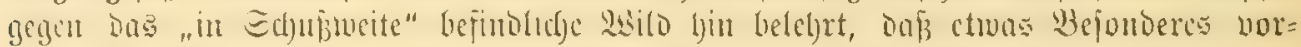

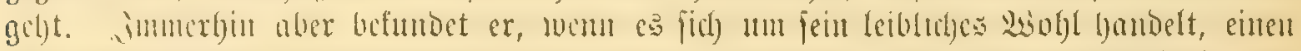

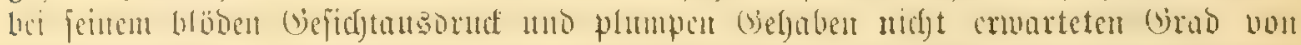

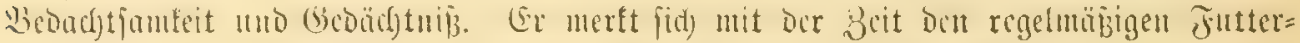

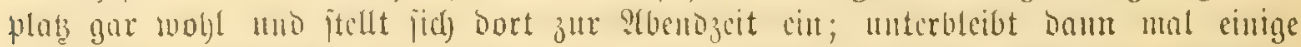

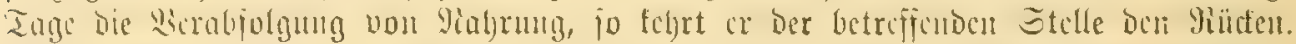

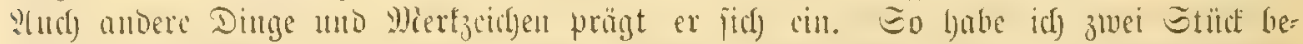

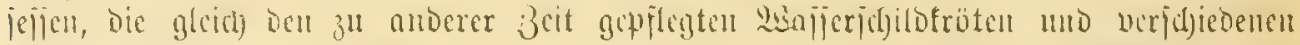

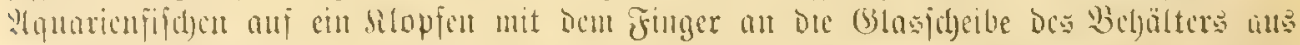

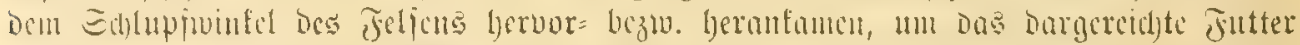

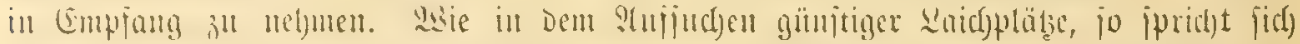

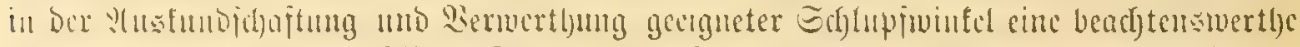

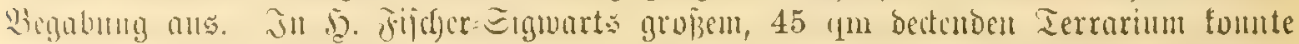

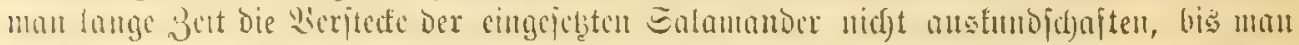

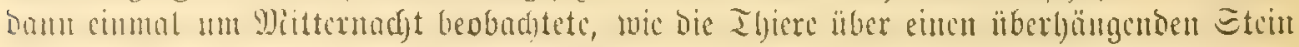

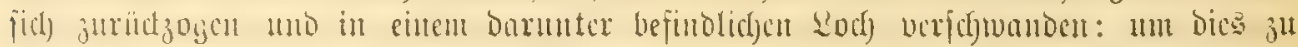

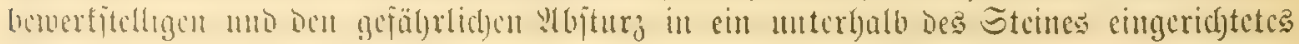

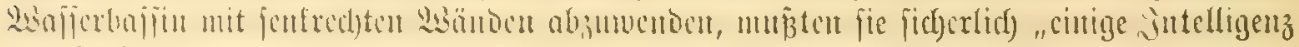
chtruidelu".

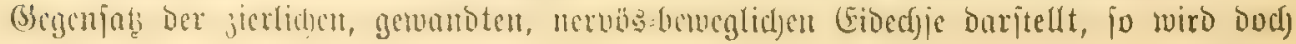




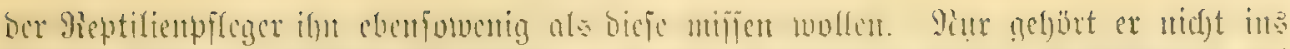

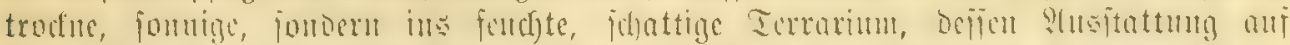

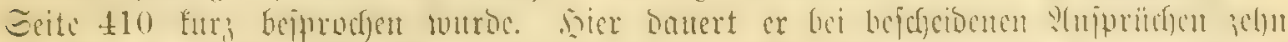

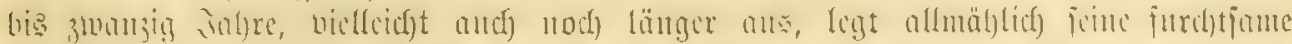

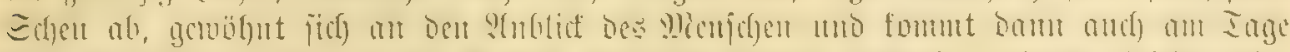

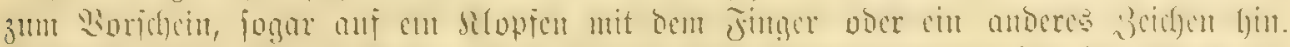

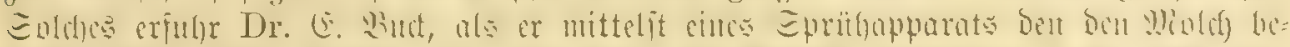

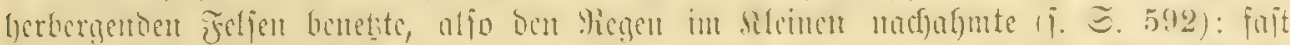

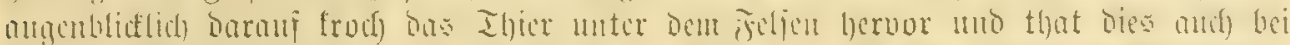

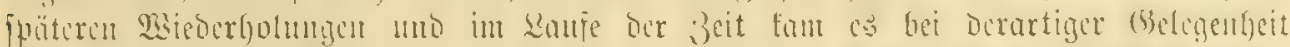

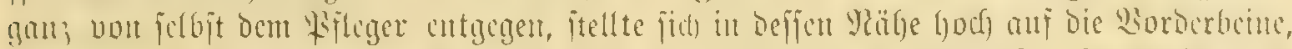

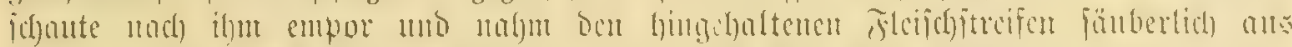

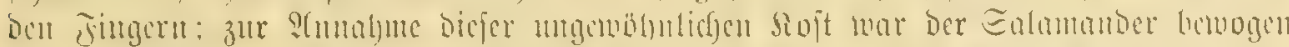

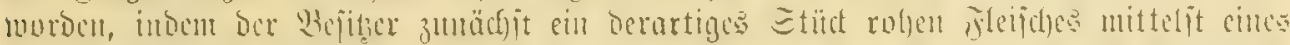

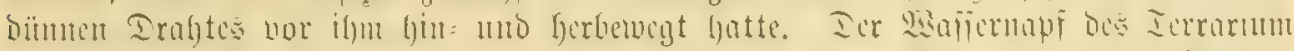

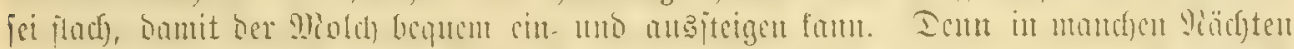

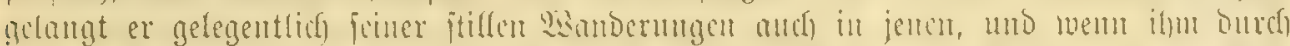

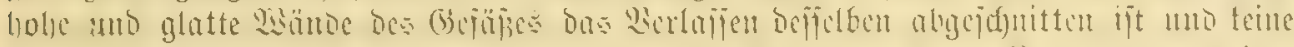

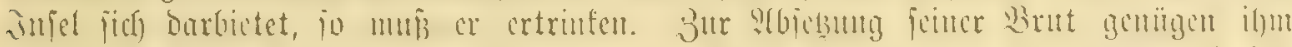

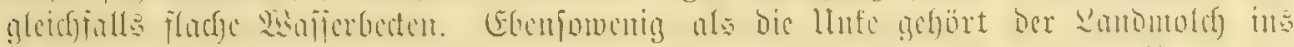

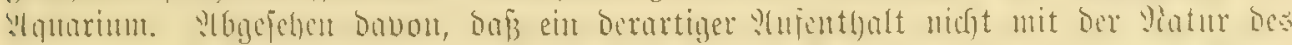

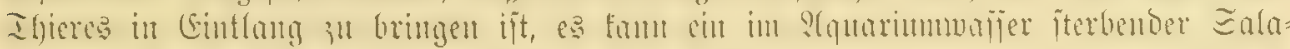

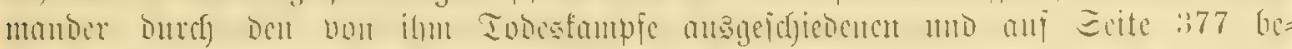

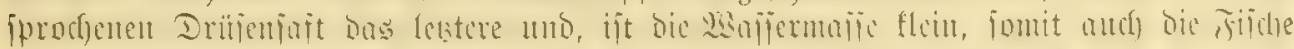

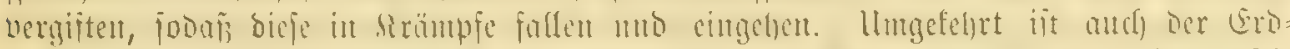

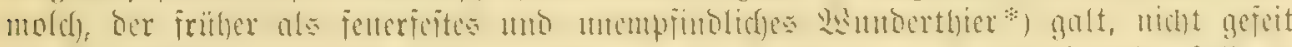

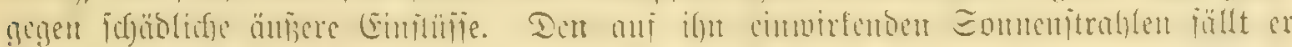

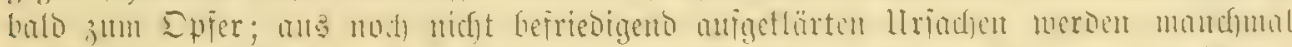

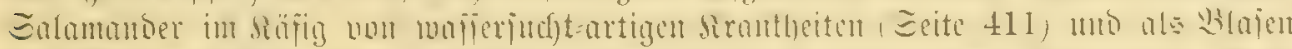

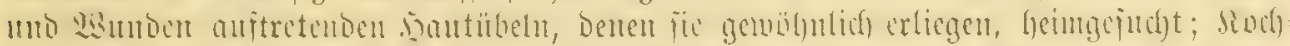

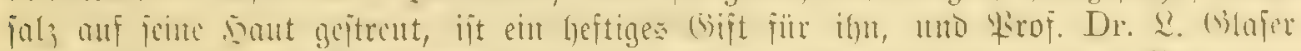

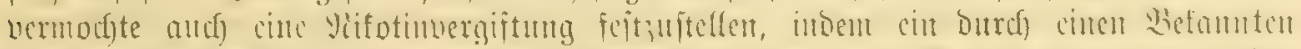

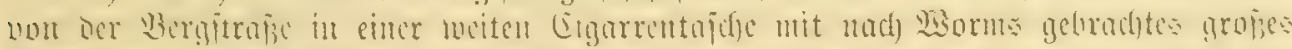

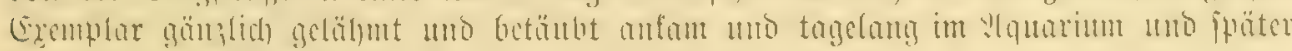
anf (Sartentand fid) nicht bout ber Stelle ritforte.

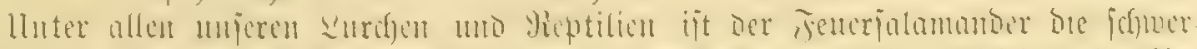

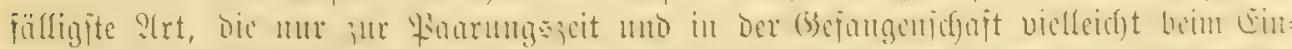

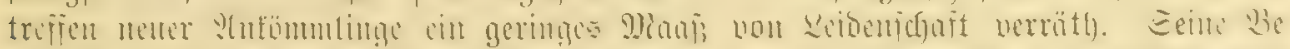

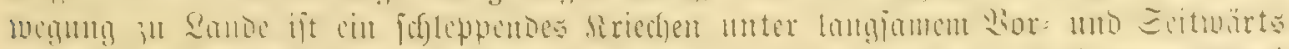

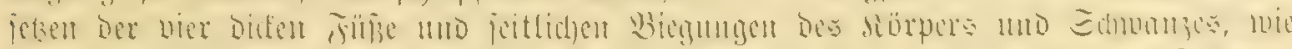

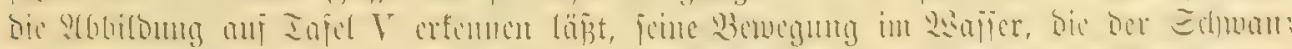

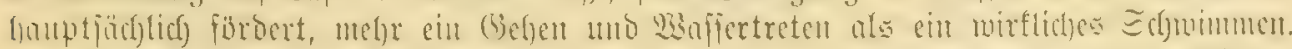

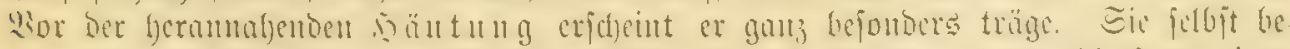

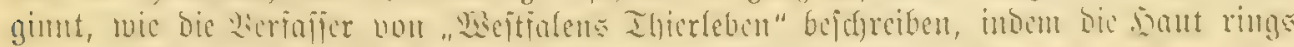

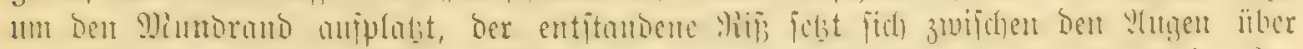

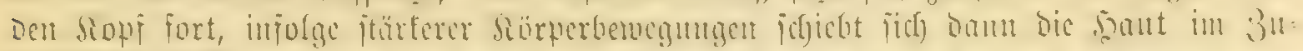

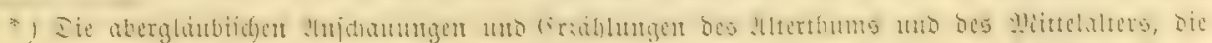

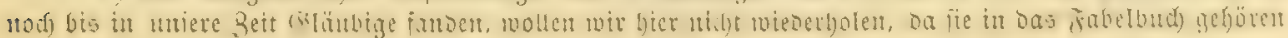




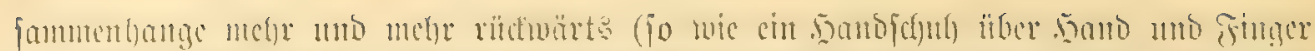

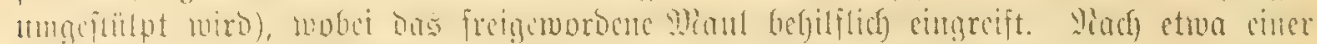

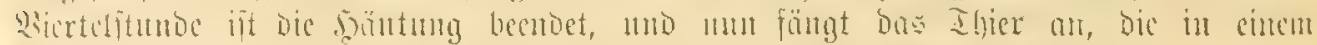

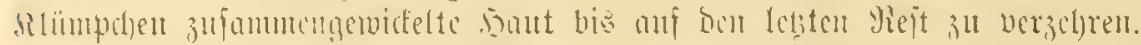

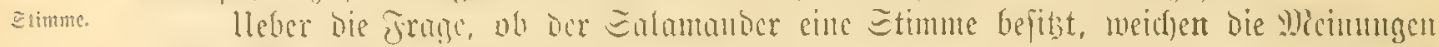

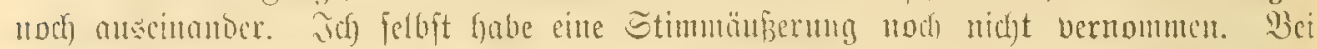

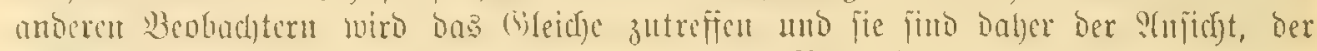

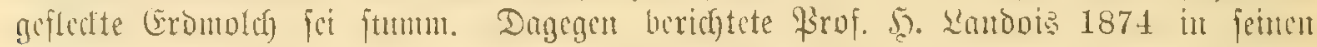

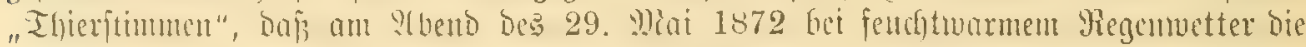

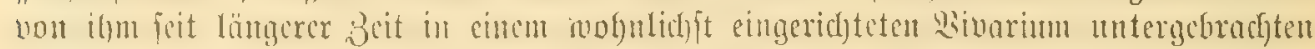

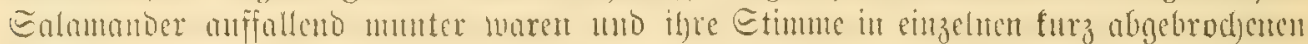

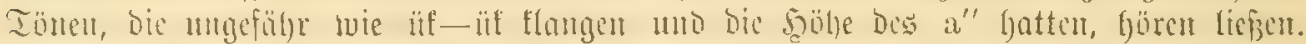

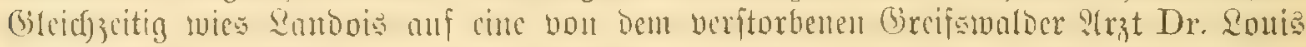

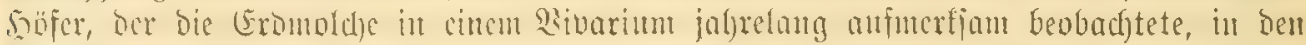

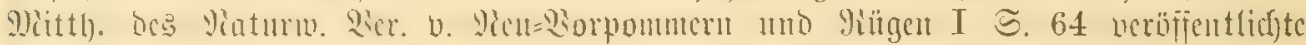
Totij bin: "Salamandra maculosa ift uicht ftumm, fondern giebt lö̈lfig, felbft im

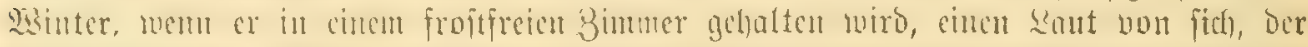

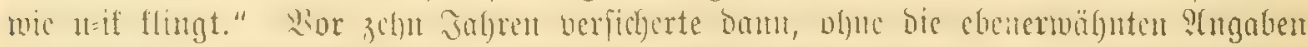

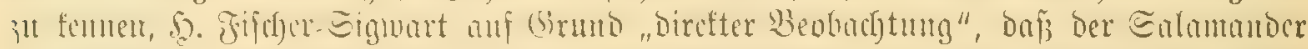

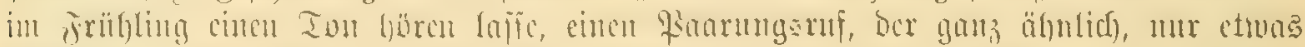

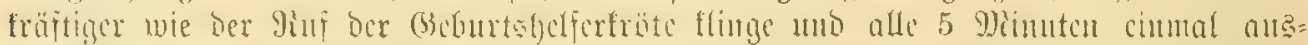

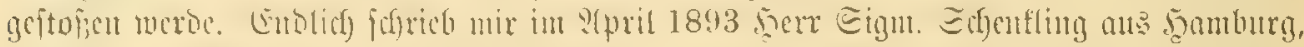

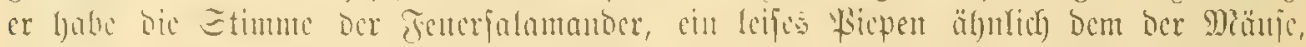

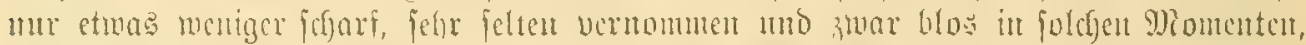

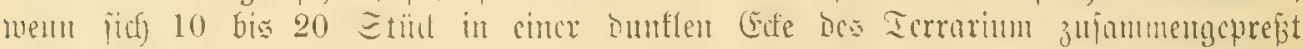

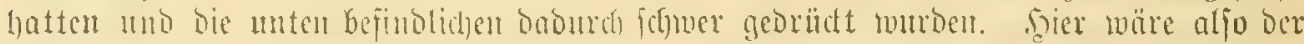

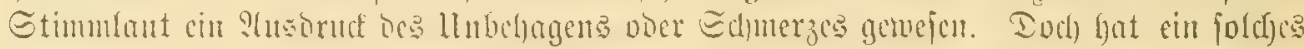

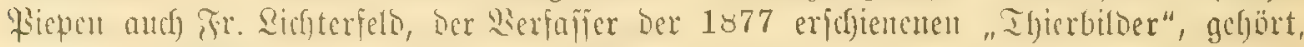

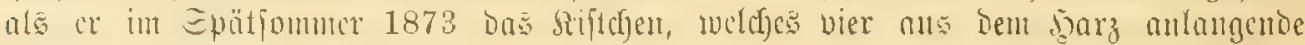
Feuerjalamander barg, Dfffucte.

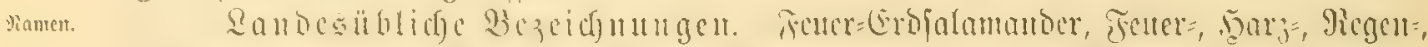

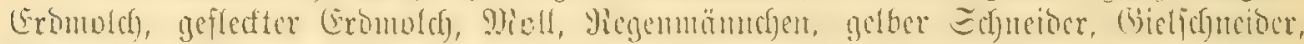

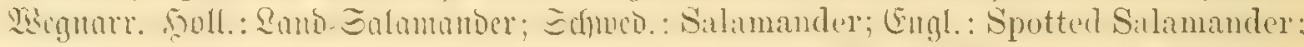
Frans.: Salamandre commune, terrestre (tachetée); Stal.: Salanandla terrestre, Sil. de terra, Sammandola: Epun.: Salamandra manchada: Folut: Salamandre ognista; llıg.: tüz-gyek; Błölyn.: Mlnk obecny; Dalm.: dazdenjak.

Salamandri, Gesner 1617. Salamandrat terrestris, Lldroe.166i3. - Wurfluin 1683. Sill, terr. maculis lutuis distincta, Chemlet 1677. Sill. 1naculusa nostrats, Silue 1734. - Lacerta Salanantra, Limm [Mus. Ar. Frid. I. ¿.45] 1754. - Salamandra

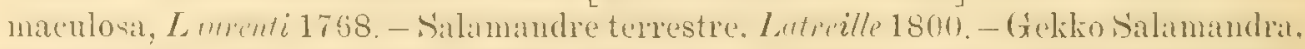

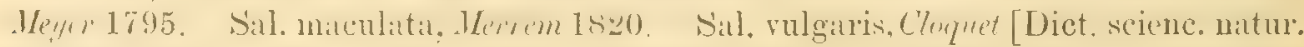
XLVIT, こ.50] 1827. - Dic 2arve: Proteus tritonius, Lanenti 176s. - Triton corthyphorus, Wagler 1820.

2. Art: Zlpen=Salamander. Salamandra atra, Laur. \{bbilsurg: Tafer V, Mir. 5.

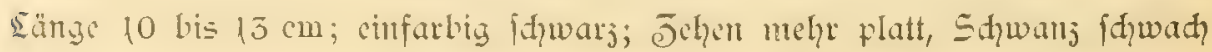
vierfantig; Kopf ctwa um die Gälfte länger als breit. 


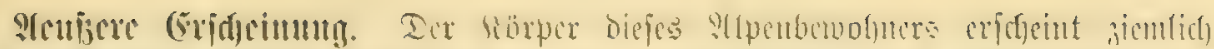

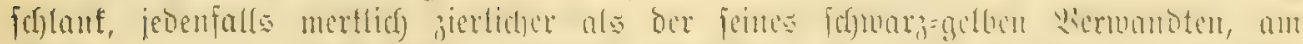

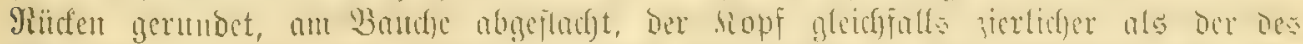

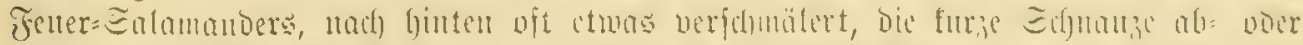

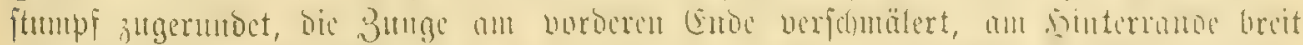

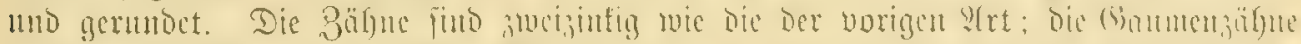

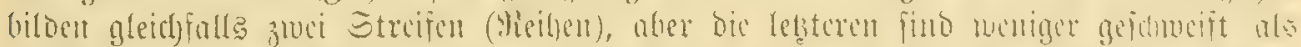

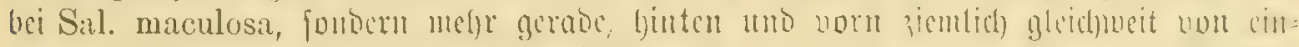

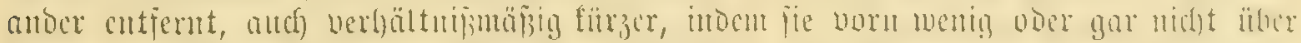

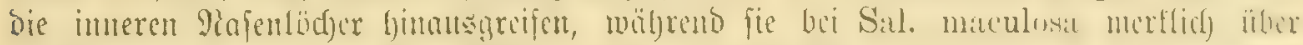

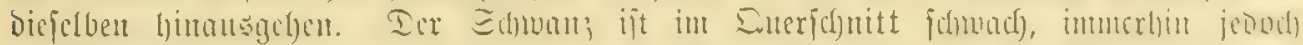

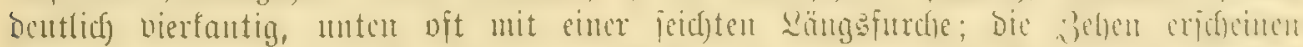
breiter mo platter als beim vorigen. - Die jo a 1 zeigt bie exigenteitur ber Dis

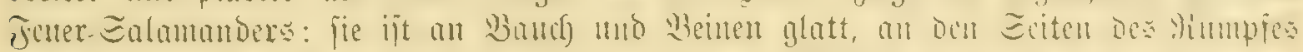

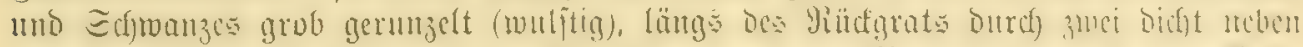

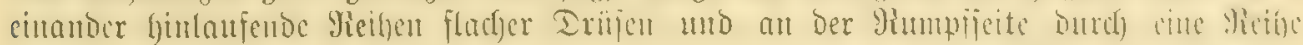

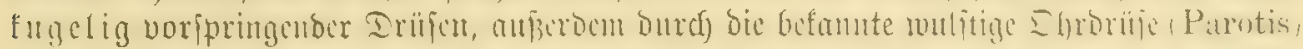

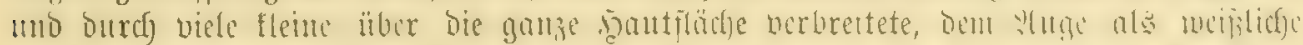

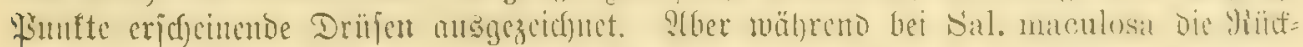

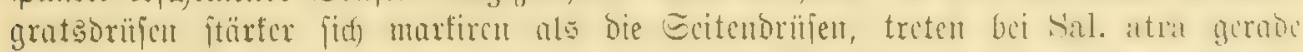

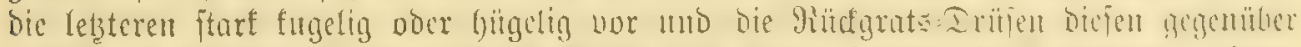
zurüd; im llebrigen ift bei atra Dic sichle nicst glatt, fondern fturf gerungelt, hinten aucf) oft mit eincr Duerfalte verjefjen.

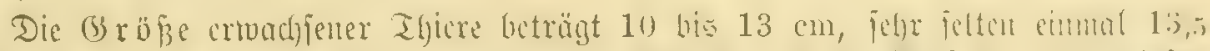

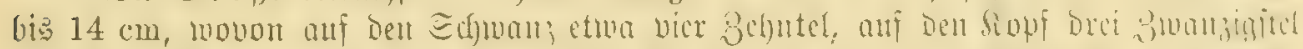

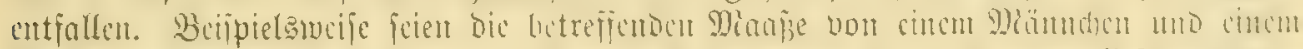

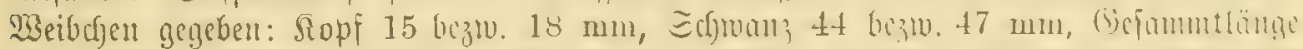

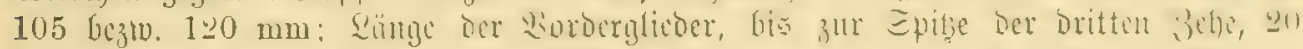

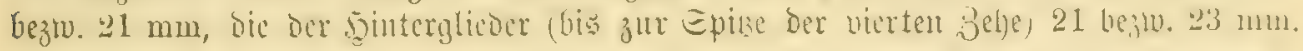

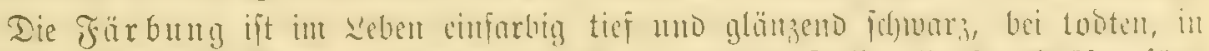

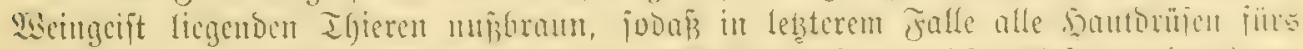

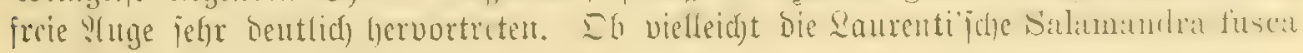
eit foldjes Excmplar bezcidjutet?

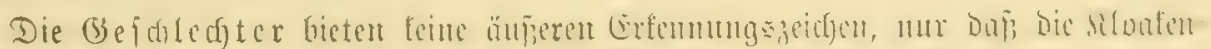

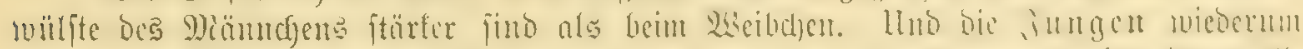

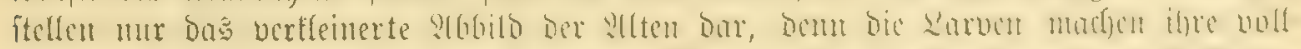

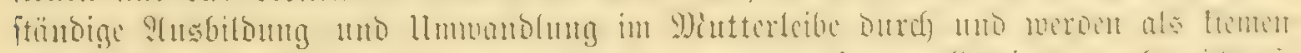

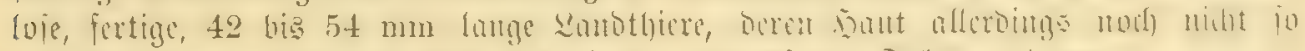

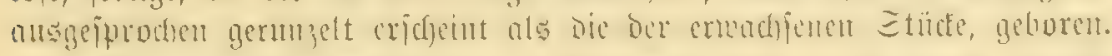

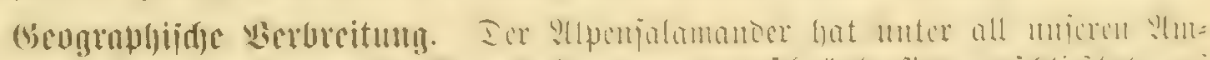

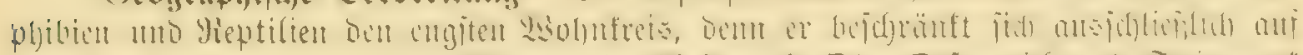

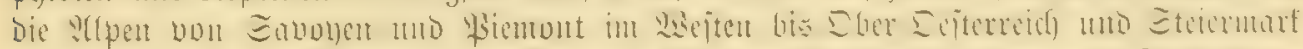

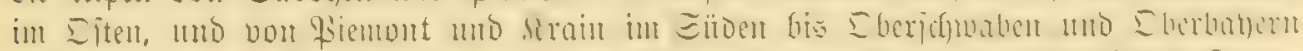

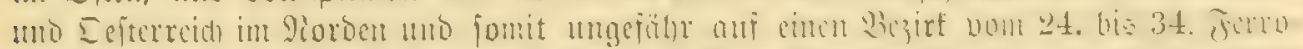

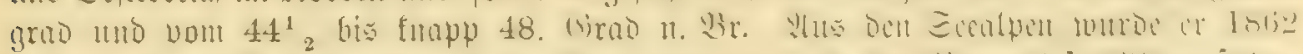

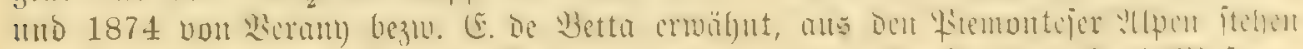

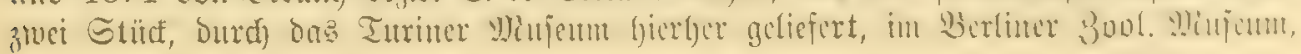




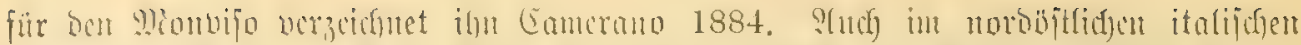

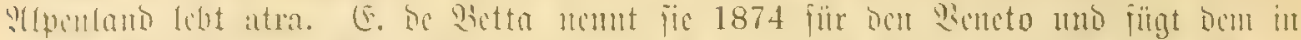

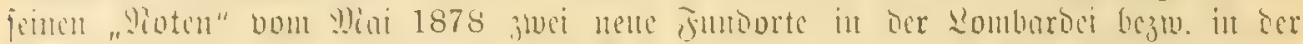

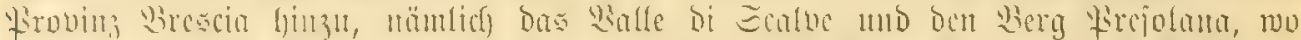

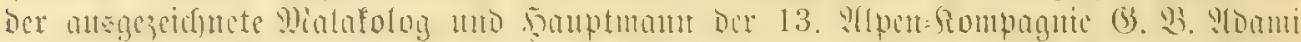

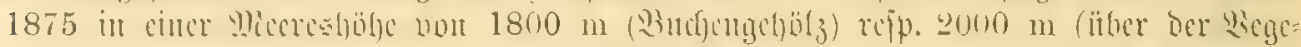

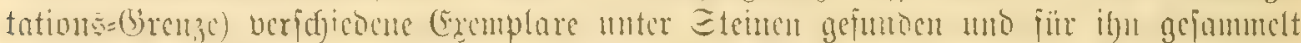

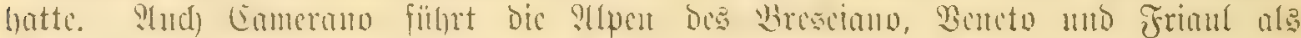

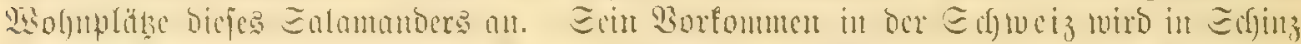

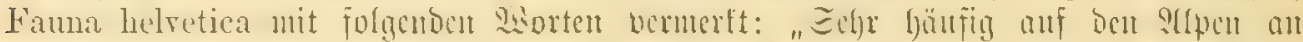

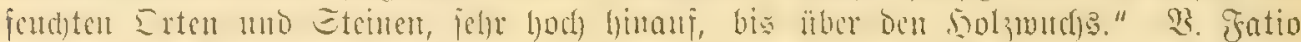

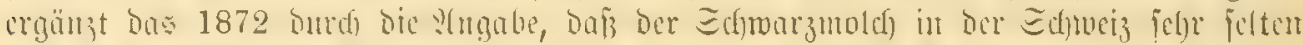

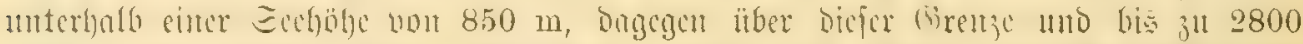

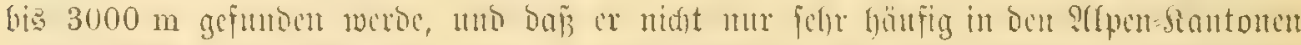

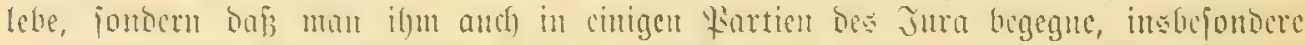

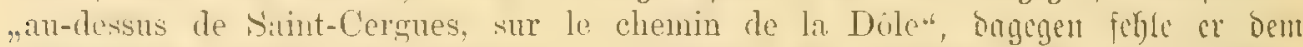

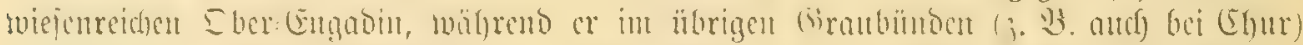

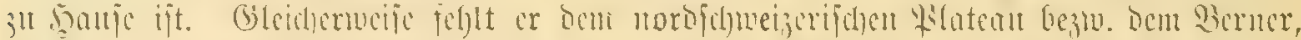

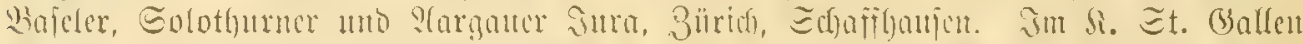

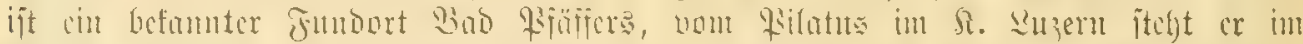

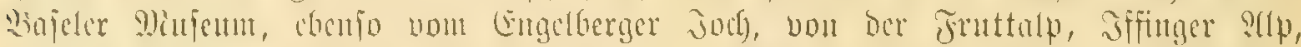

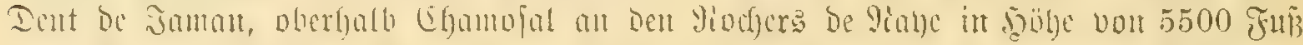

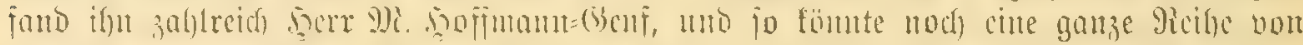

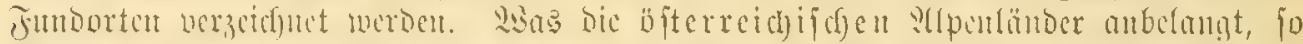

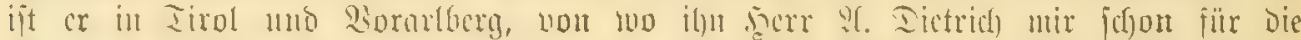

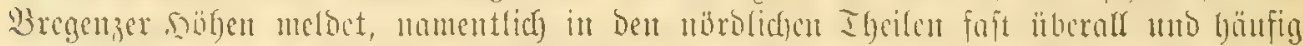

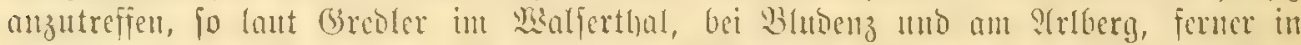

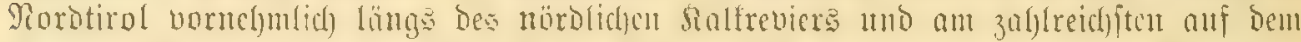

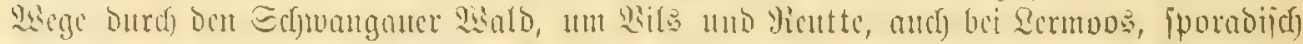

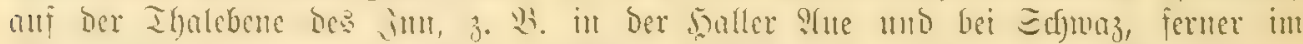

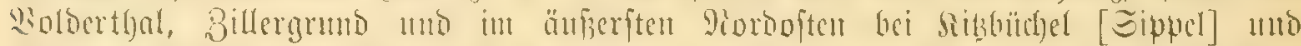

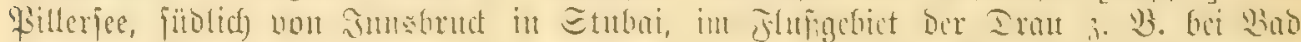

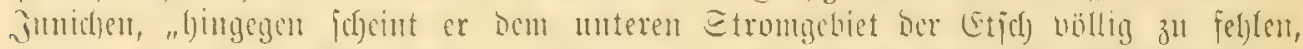

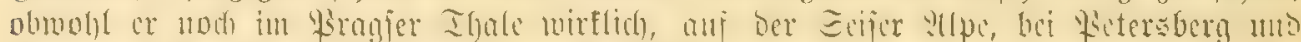

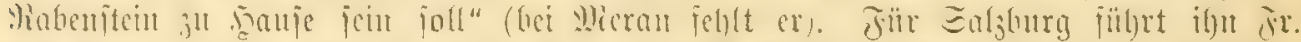

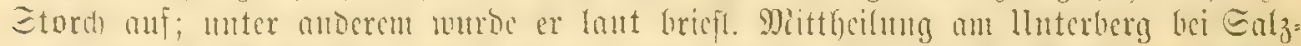

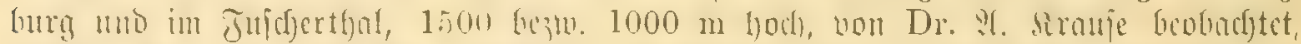

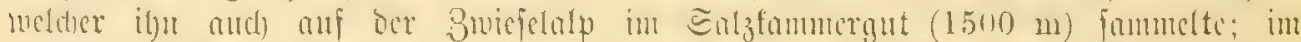

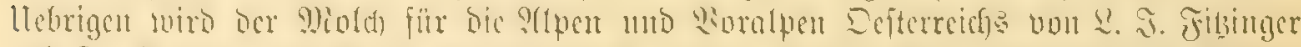

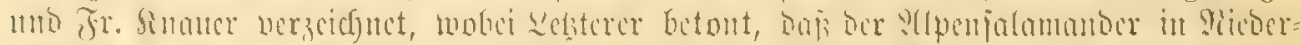

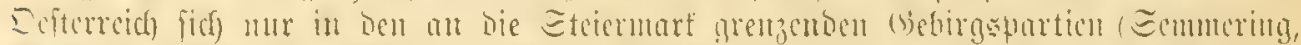

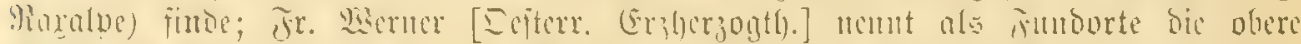

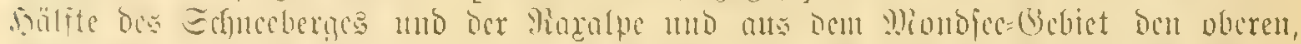

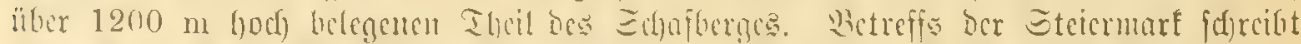

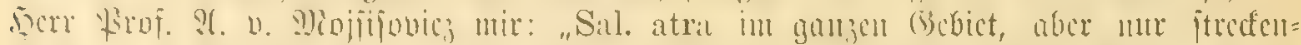

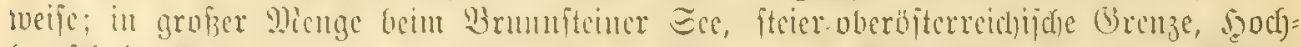

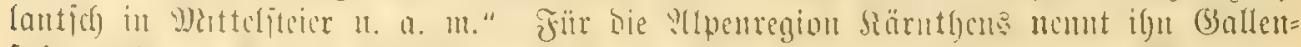

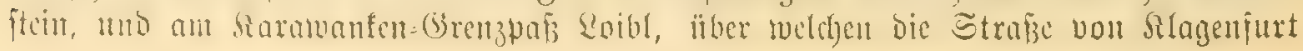




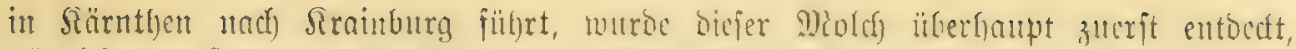

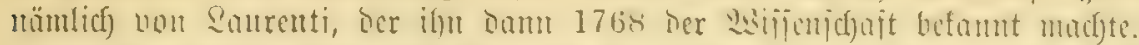

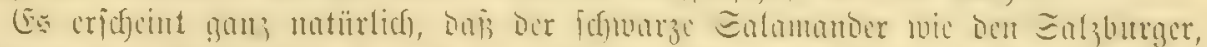

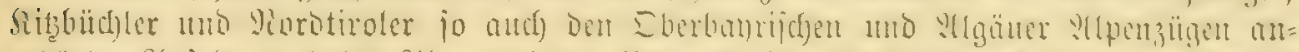

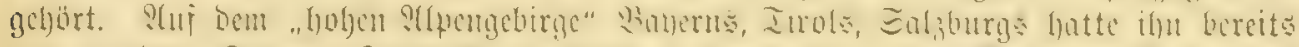

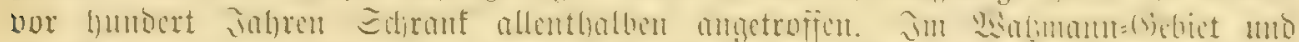

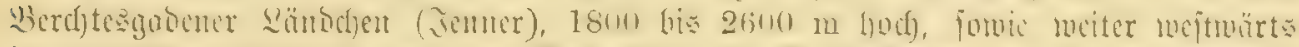

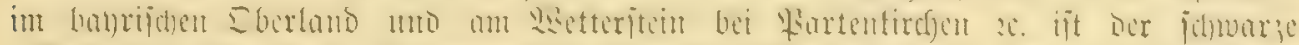

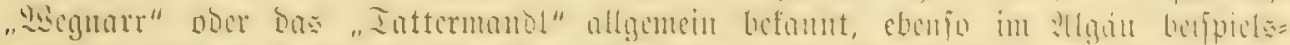

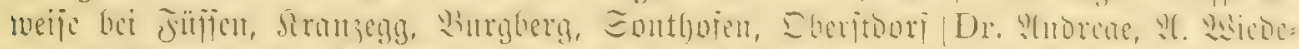

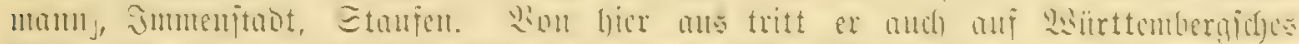

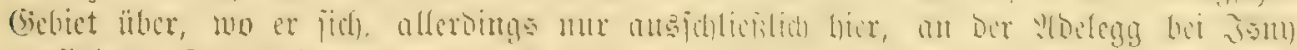

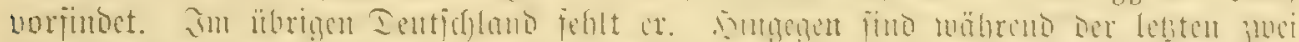

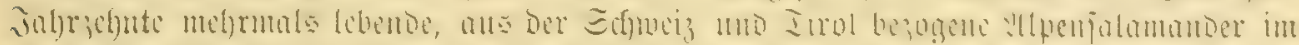

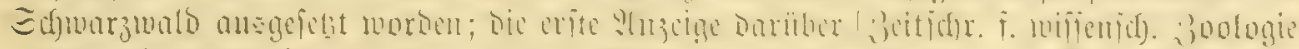

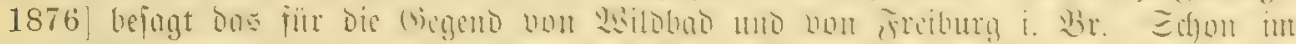

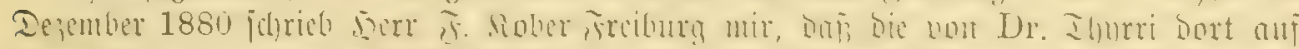

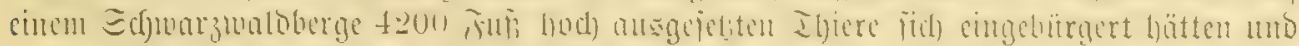

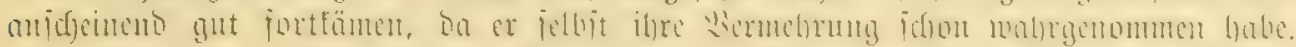

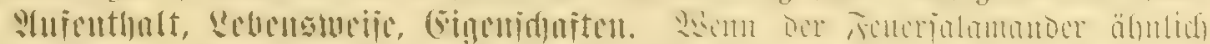

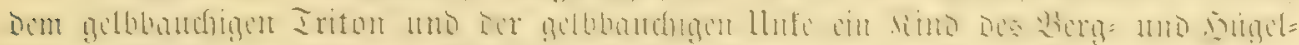

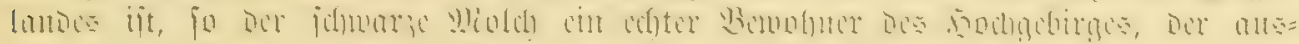

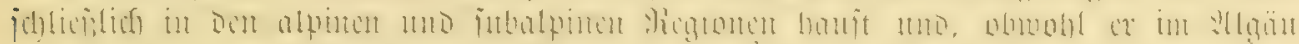

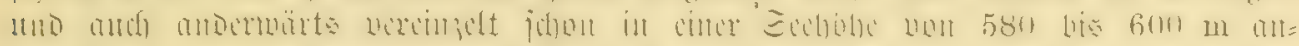

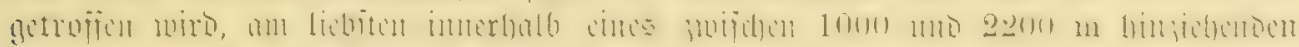

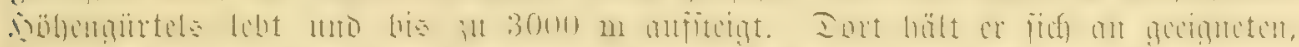

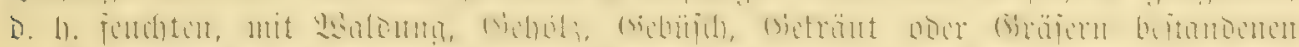

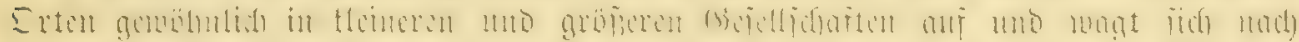
Bu regntridam

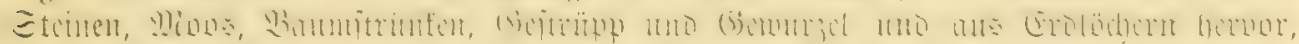

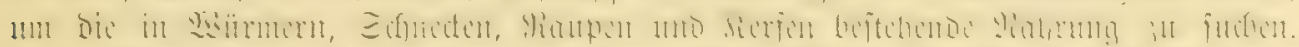

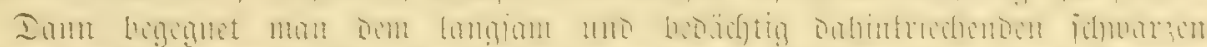

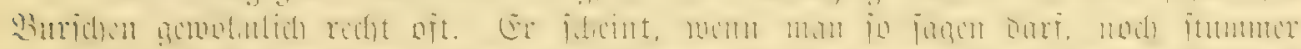

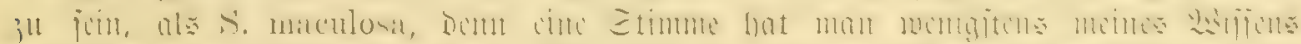

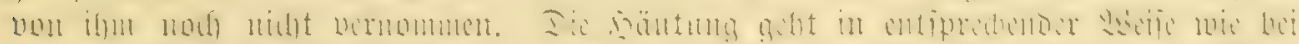

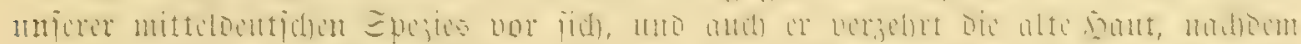

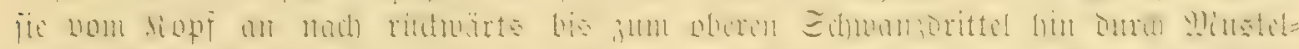

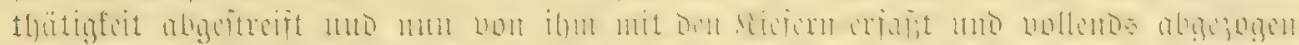

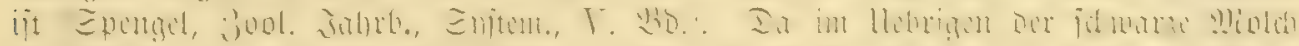

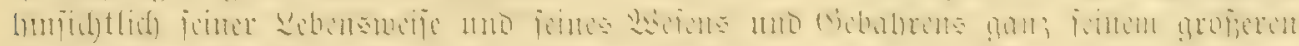

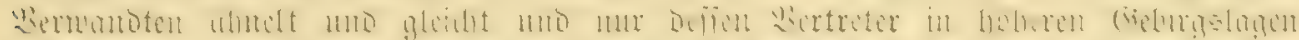

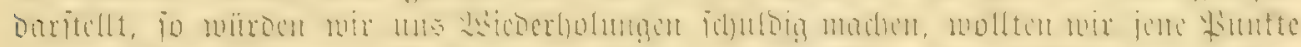

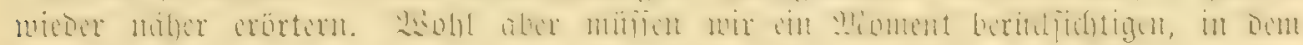

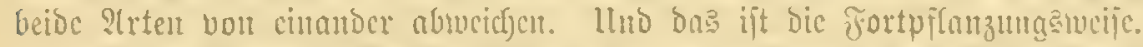

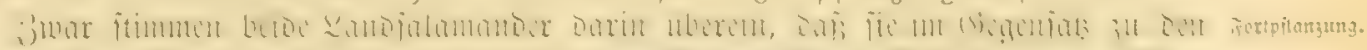

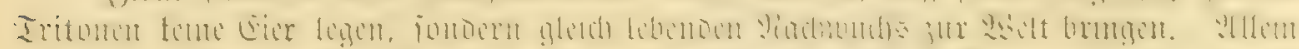

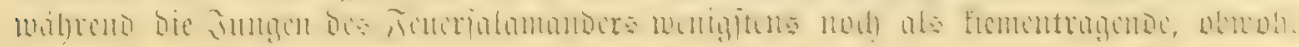




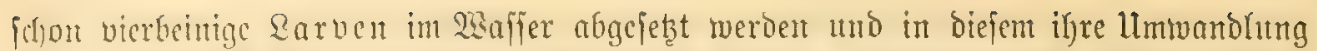

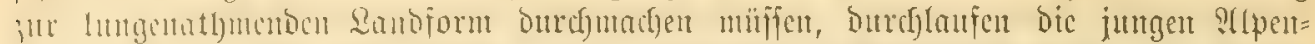

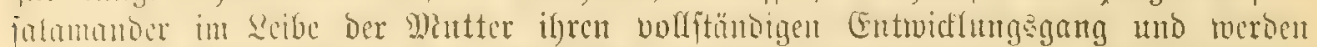
non biefer als bercits gän,

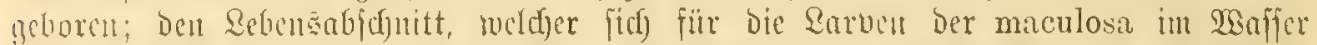

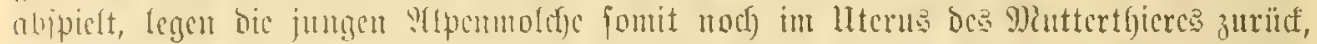

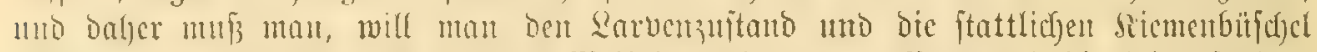

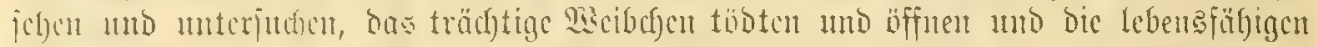

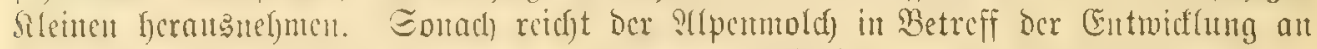

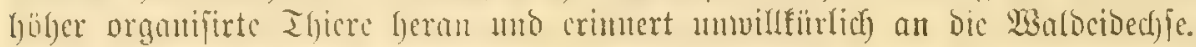

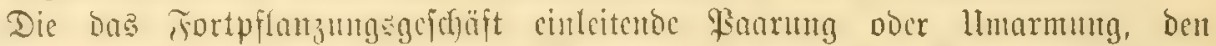

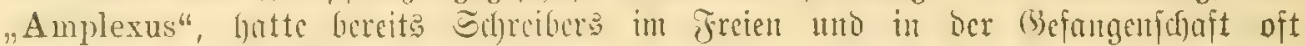

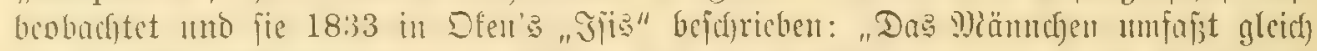

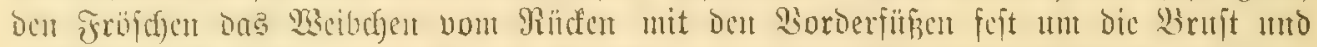

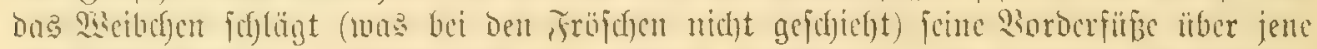

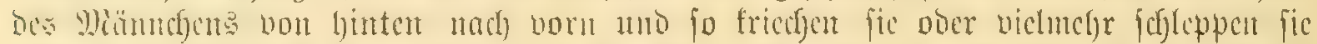

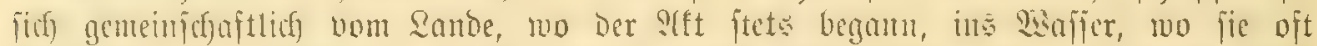

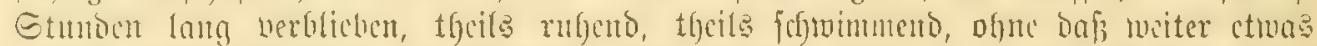

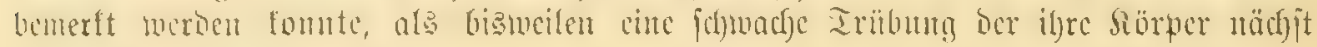
umigebenocn Maffermaffe."

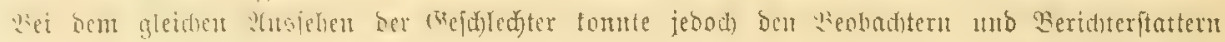

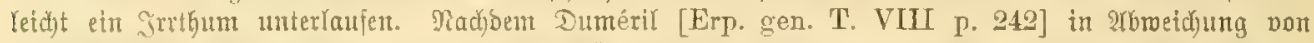

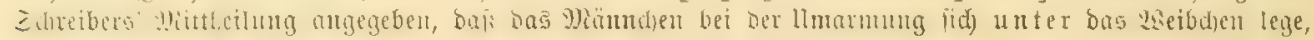

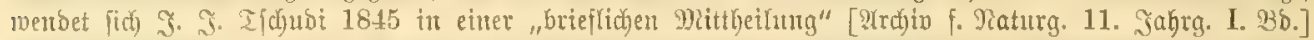

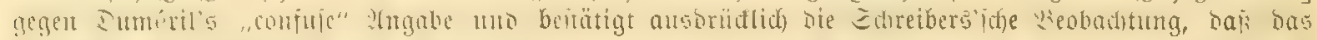

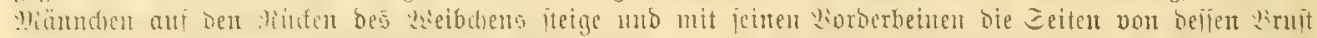

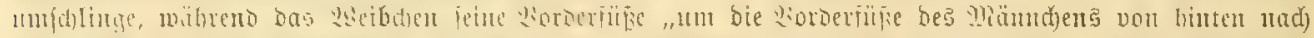

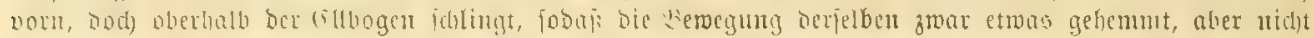

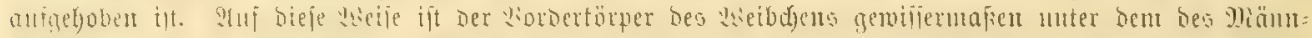

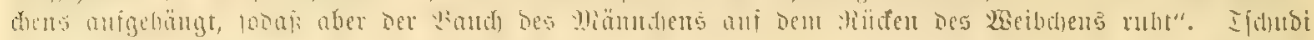

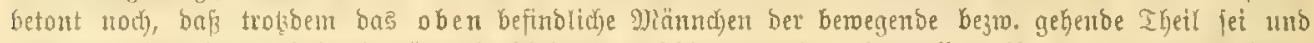

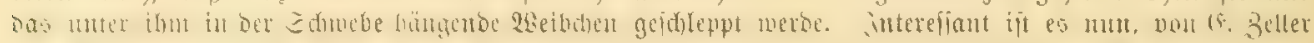

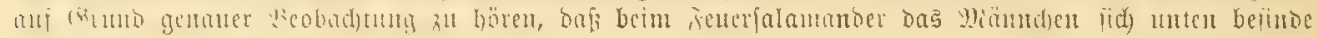

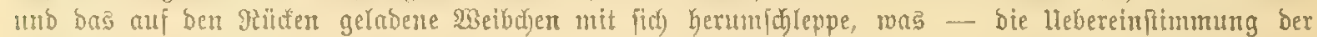

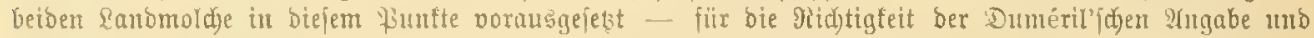

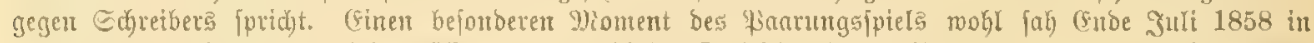

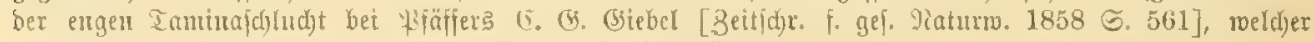
benerfte, baß bie weibchen auf ben gï̈ten uno bie Miäund)en fie untamen batauf Ingen.

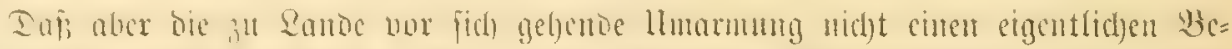

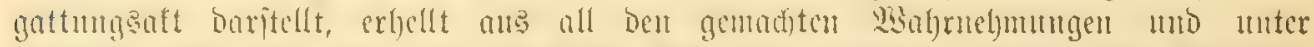

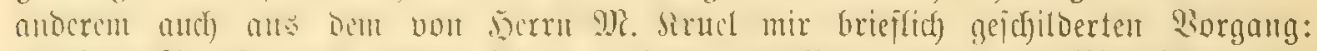

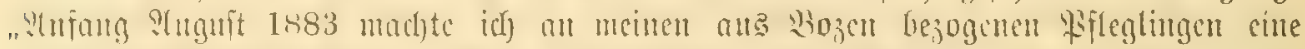

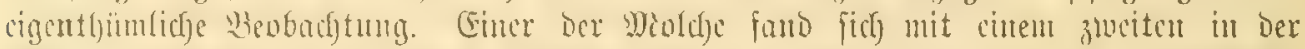

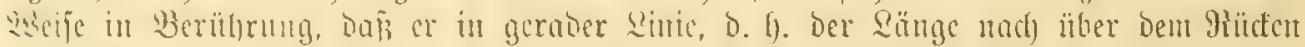

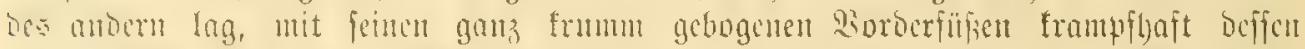

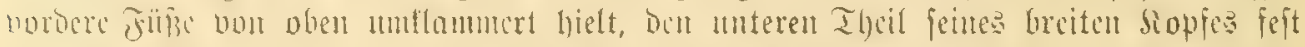

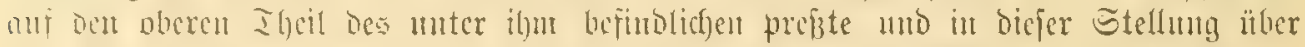

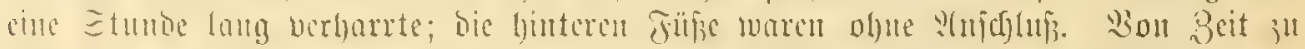

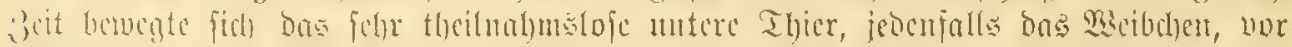

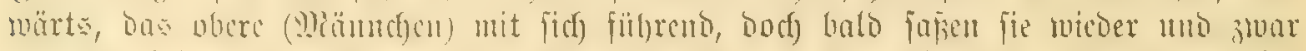

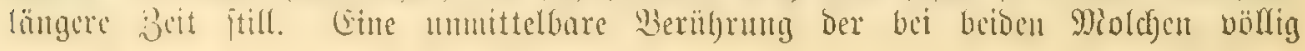




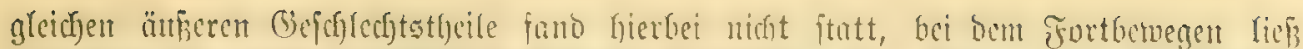

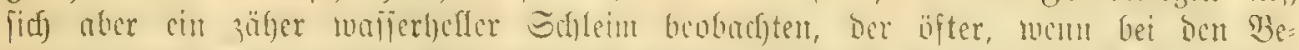

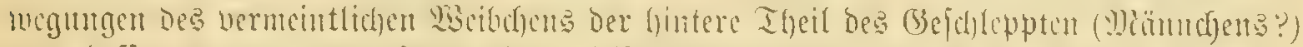

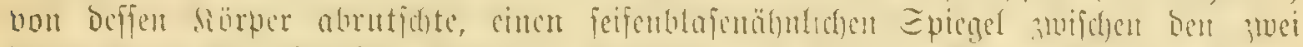

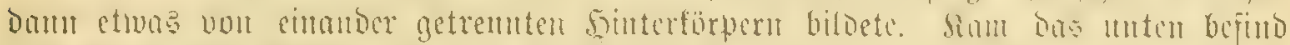

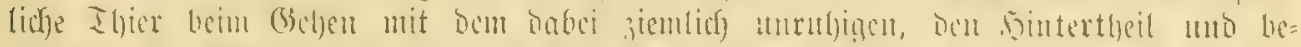

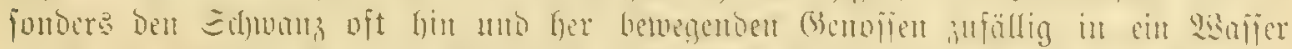

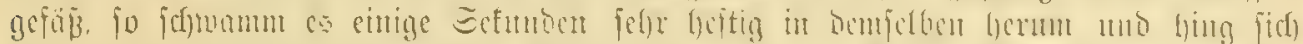

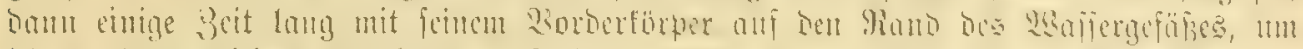

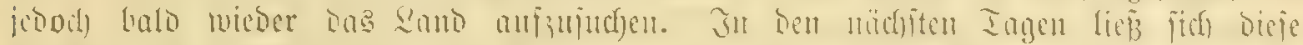

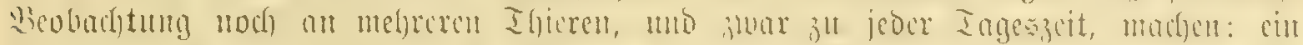

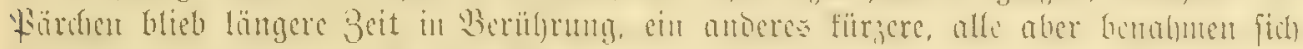

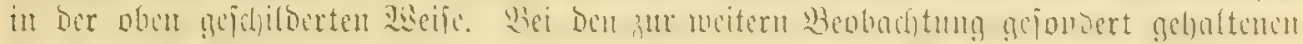

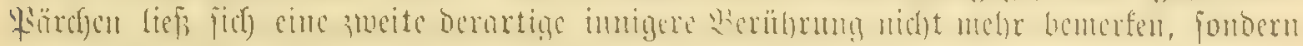

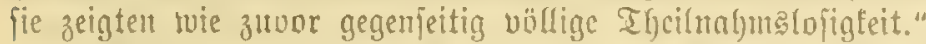

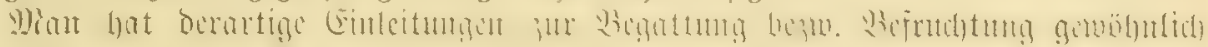

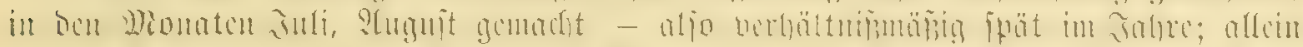

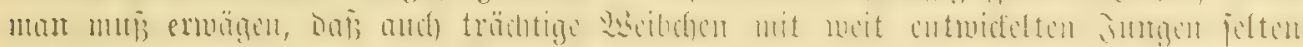

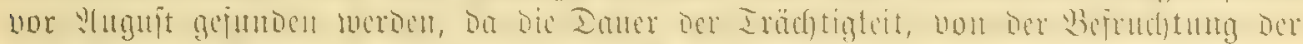

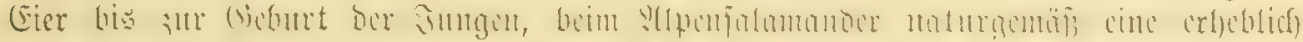

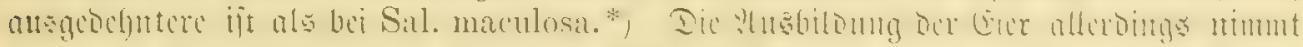

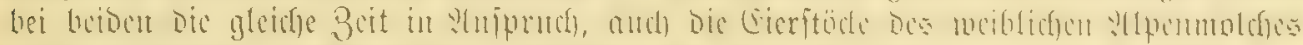

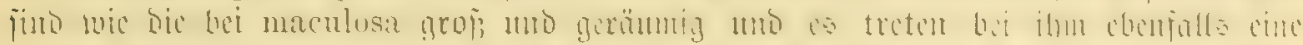

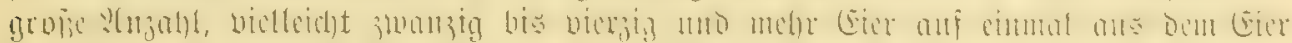

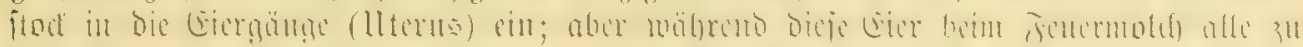

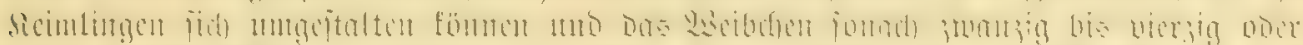

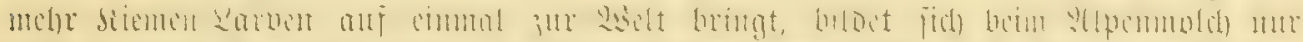

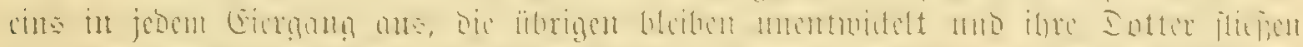

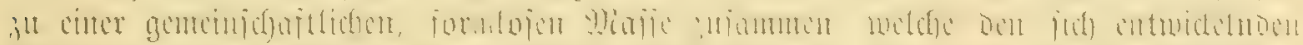

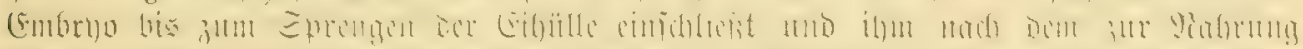

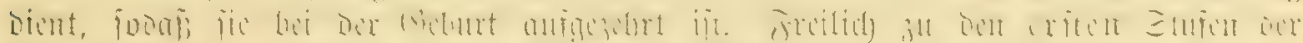

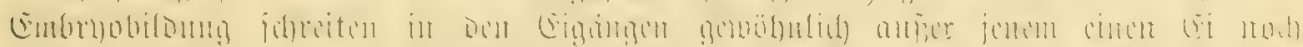

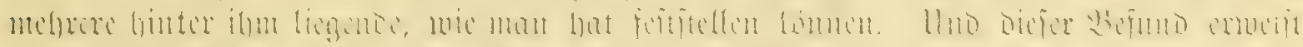

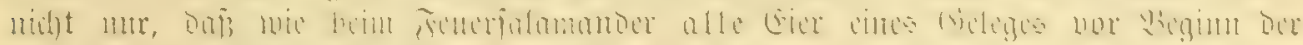

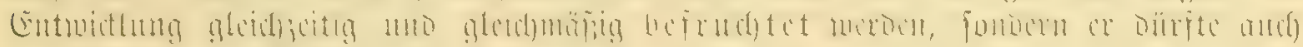

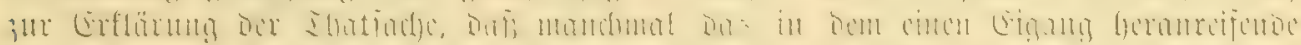

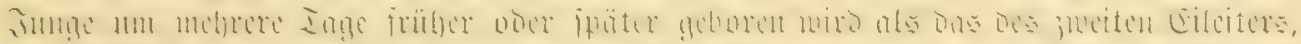

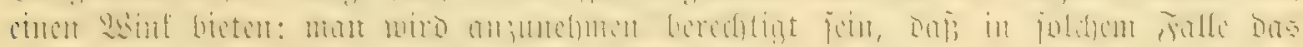

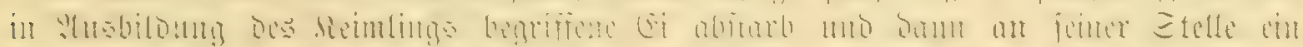

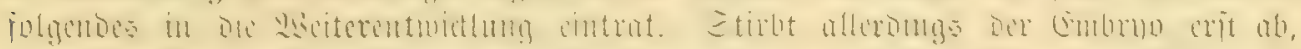

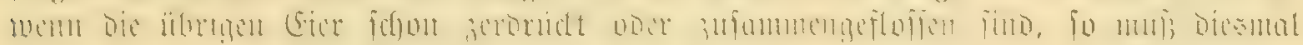
Dor cine Eiergang ofjue Ergebnis blcibent.

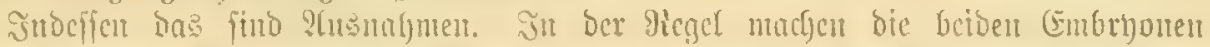

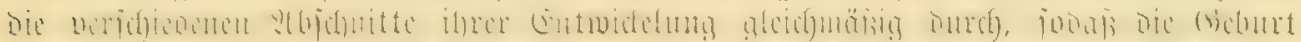

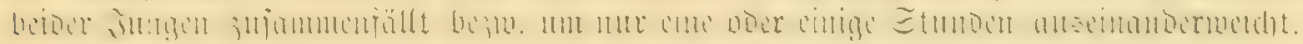

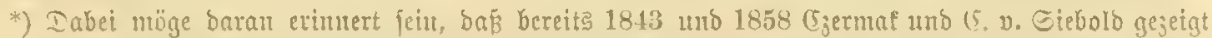

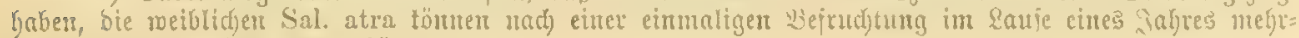
mals träcjtig voerben uno gebären. 
Es möge faflichlich nodjmals betont fein, Daps bas Junge alle Stabien Der Embryo=

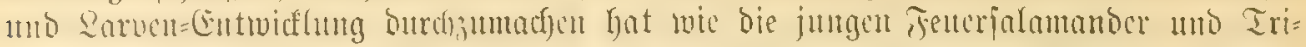

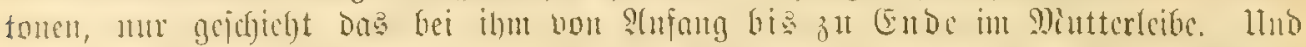

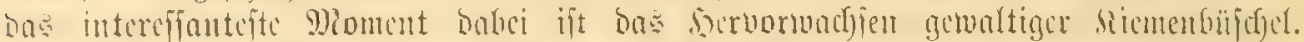

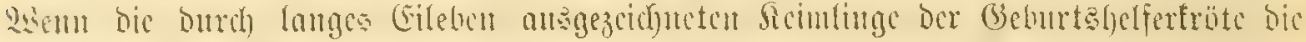

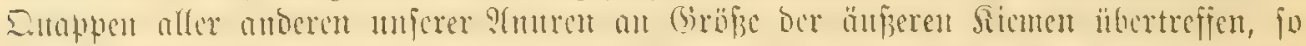

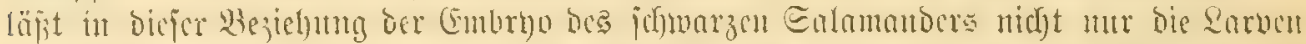

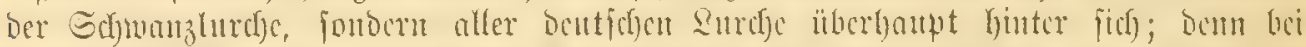

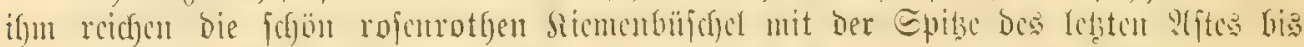

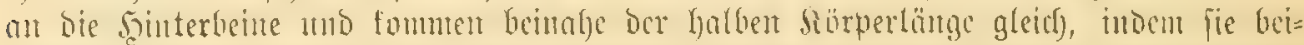

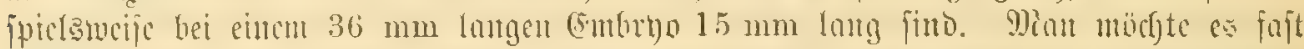

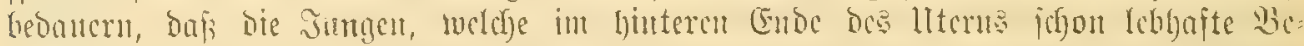

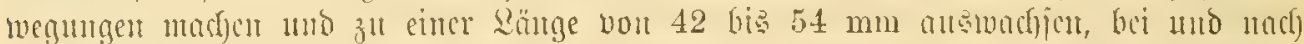

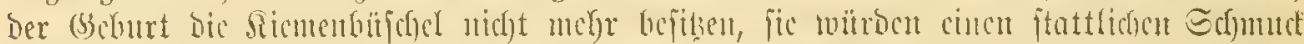

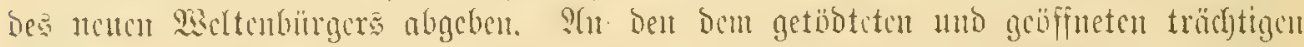

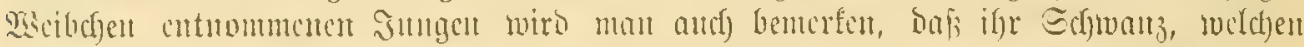

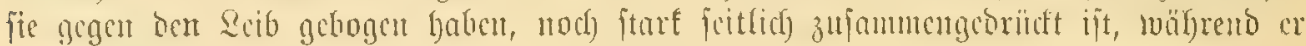

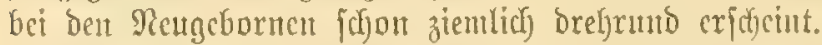

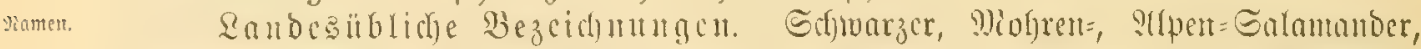

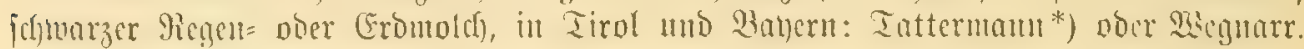
Engl.: Black Salamanter; Jranj.: Silamandre noire; Jtul.: Salamandra nera; Polu.: Salamander czarna.

Salamandra atra, Laurenti 1768. - Lacerta atra, Wolf [Gitrm 4. \$eft] 1805, - Lacerta Salamandra $\beta$, Gmelin 1790. - Salam. nigra, Gruy 1850.

\section{Battung: Minifrutuld). Triton, Laur.}

Geftredter, im 2llgemeinen folanfer Körper mit sünnen vicrjehtgen Dorder=

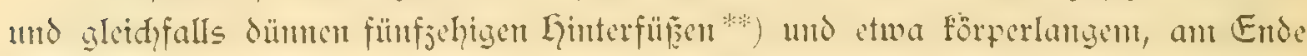

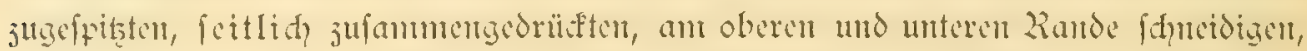

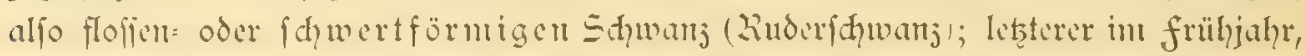

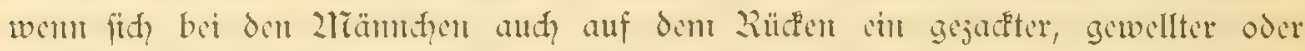

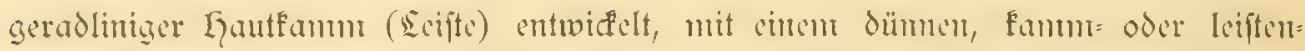

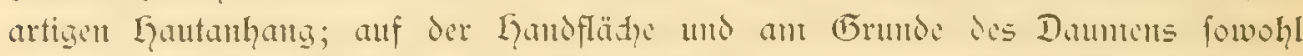

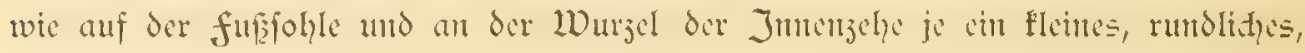

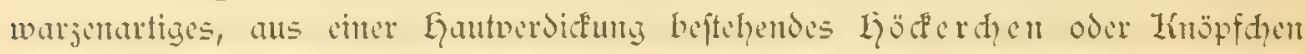
(23allen); Laut entweder vollfonmten glatt oder abat mibr oder minder (im Eand.

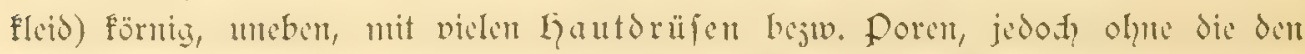
Eandalamandern jufonmende Ehroriffmmulft (Parotis) und ohne durd das unbe=

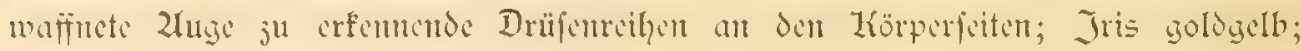

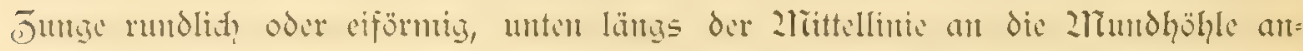

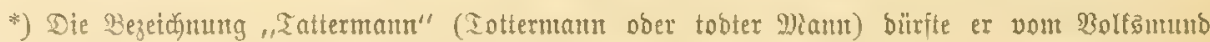
jebenfalts jeines trägen siseients megen befontmen baben.

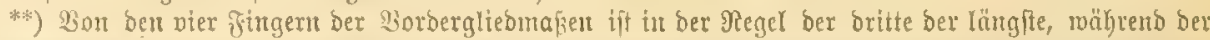

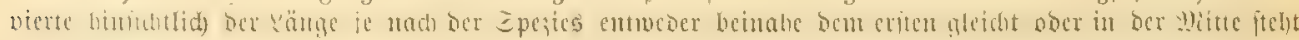

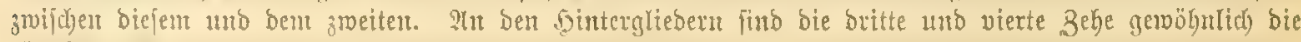

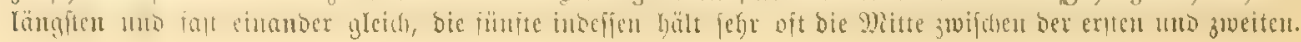


gemadien, fomit şemöhnlid mur an don Sciten frei bleifents; Gaumenjähne

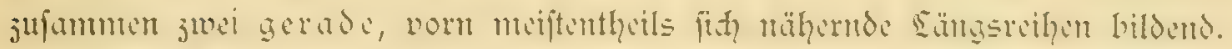

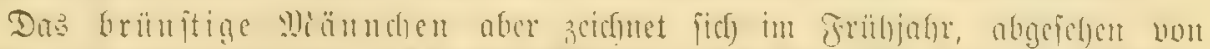

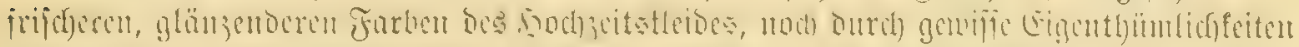

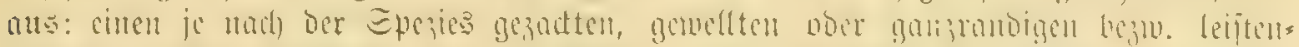

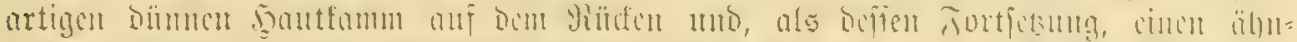

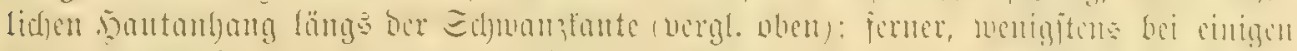

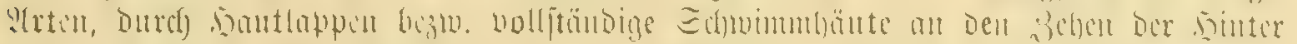

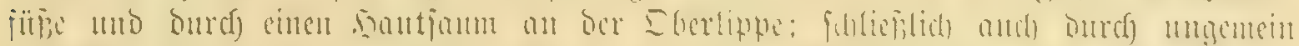

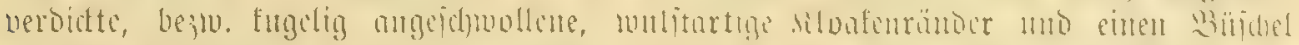

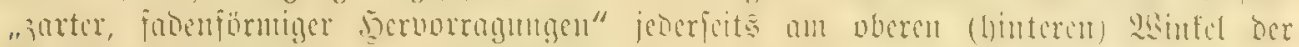

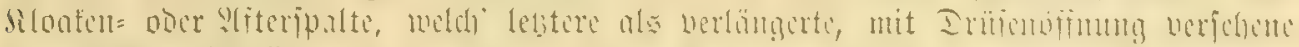

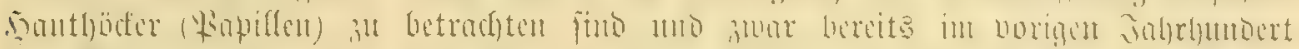

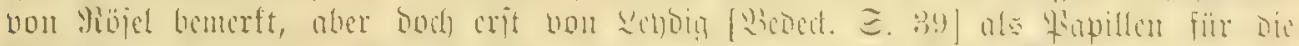

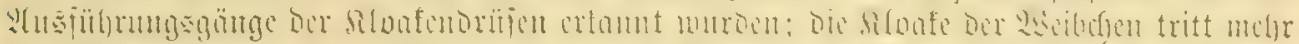

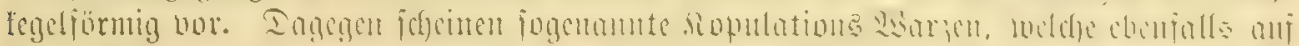

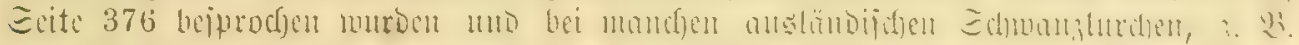

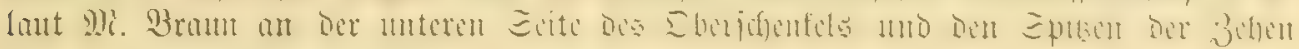
bç nordamerifanij(jelt Triton viridescens, Raf. umb laut Beoriagna an Dem obcren und mittlcren Thcil Des Dbernrmb vom Miippennold) (Pleurodeles Waltlii, Lichah.), fick ent=

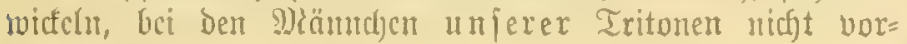
zutoument.

Mertwitrbiger M3eife trifft man unter Den Tritonen auf 3rotiterbilbutgen, twic foldbe uts allerbings auth bet Siröten und Fröfchen begeguen. Eine fierfer getjörige

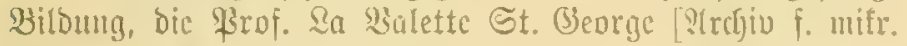

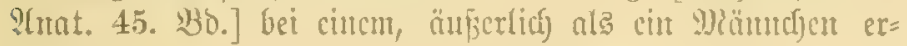
fincinendent Streifenmold Triton vulgaris fant, beront= ichanlicht die nebenftelyende stbbildung 46 , anf weldyer $\mathrm{E}$

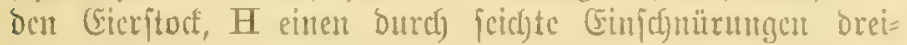
theiligen 5roden mo Sl bie Samenleitcr bezeid)net; Eilciter

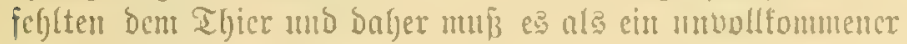
Britter betradjtet werbet.

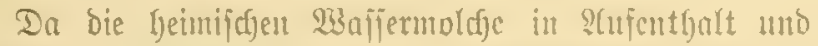

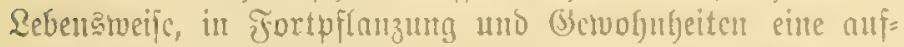
fallonde llebcreinftimnung zeigen, wie toir fie bei feiner anberen (Bruppe unjerer ?tmphibien bvieberfindent, jo Dürfte

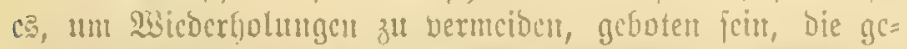

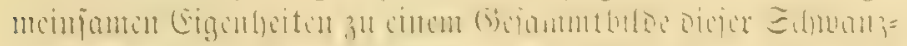

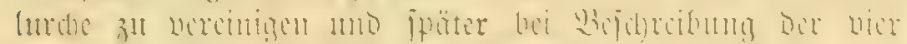

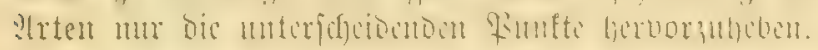

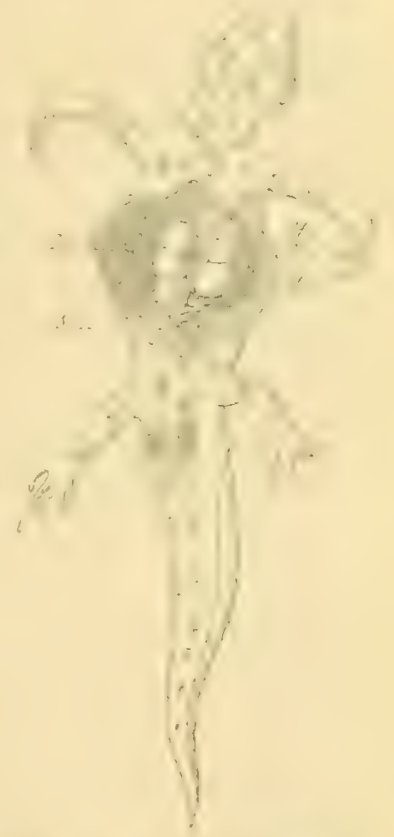

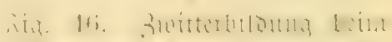
Emitumats. 1: rit:16.d

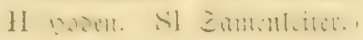

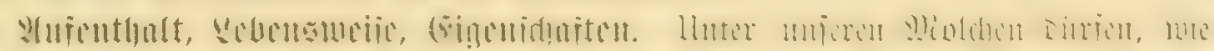

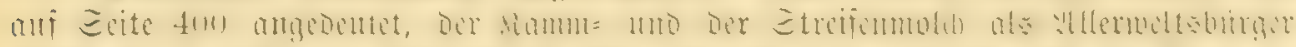

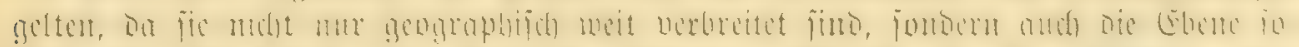

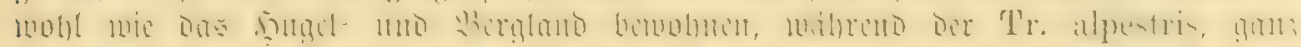

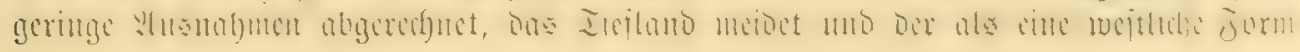




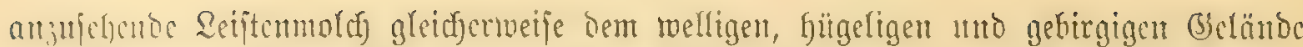

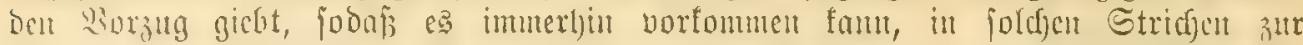

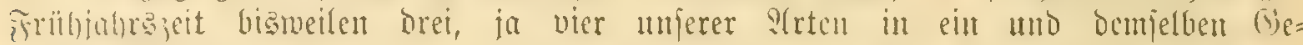

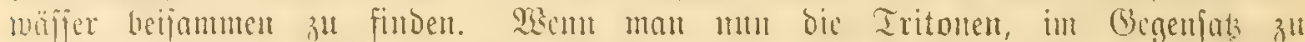
Den cigentlichen Ealumandern, "2isaffermoldye" nenut, io bat man infofern

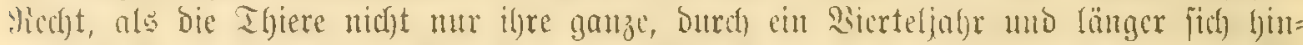

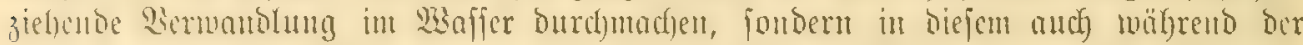

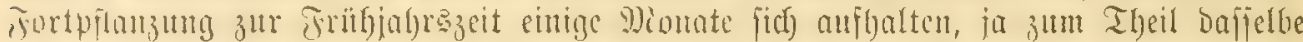

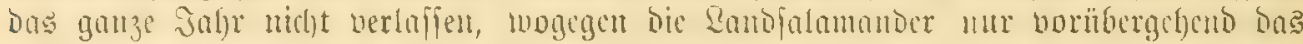

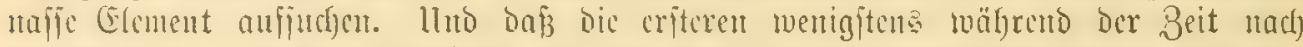

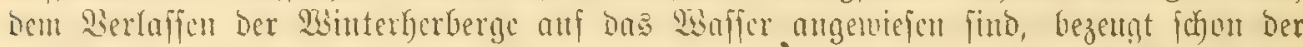

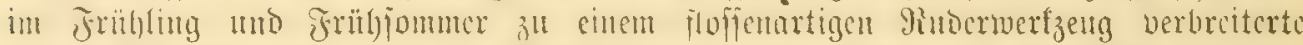

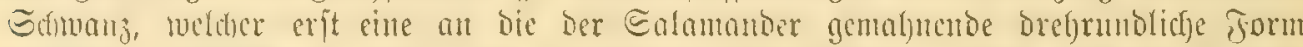

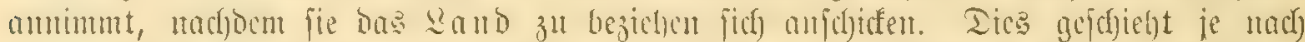

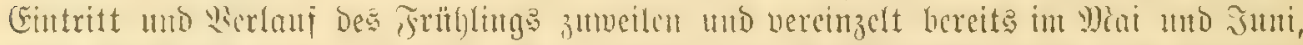

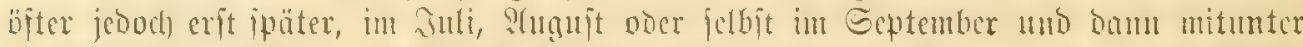

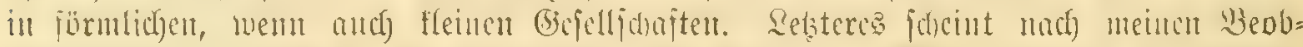

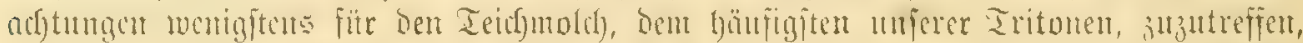

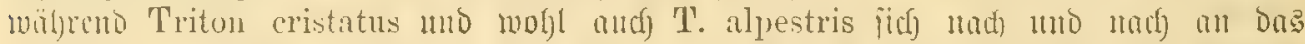

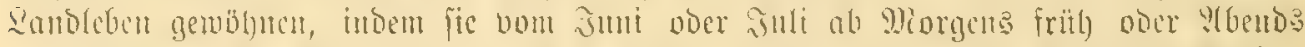

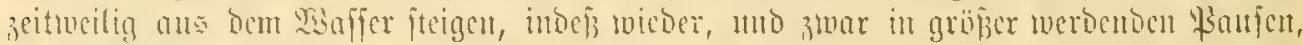

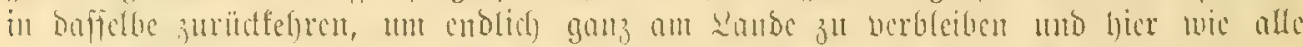

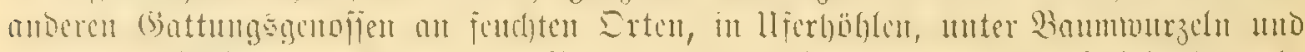

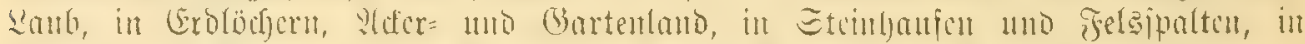

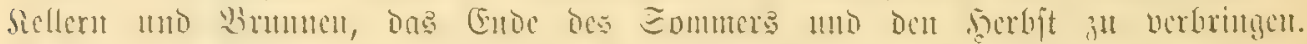

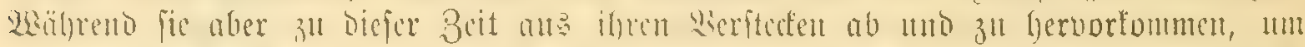

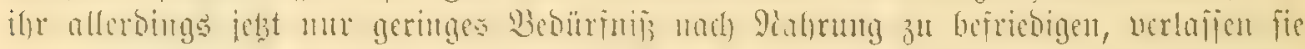

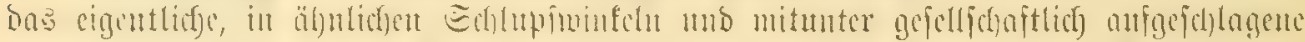

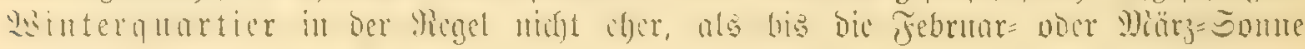
an bic Igür bejijelben flopit.

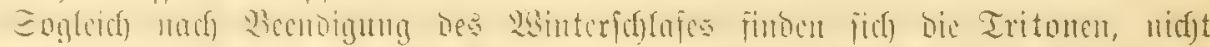

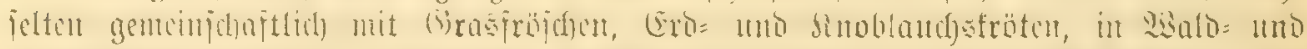

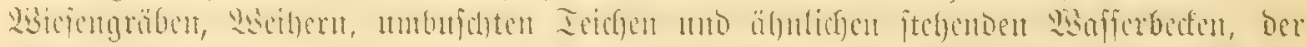

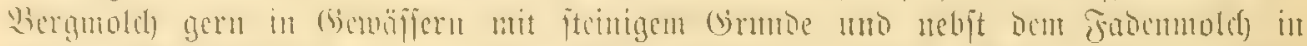

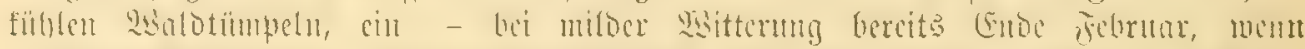

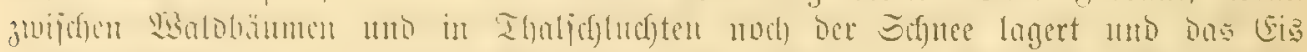

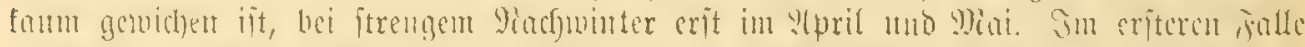

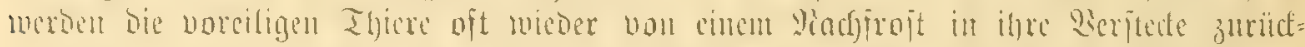

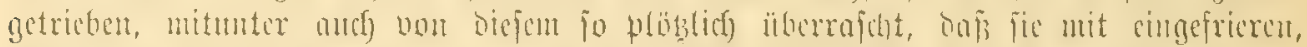

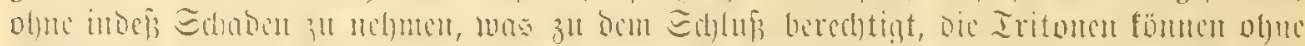

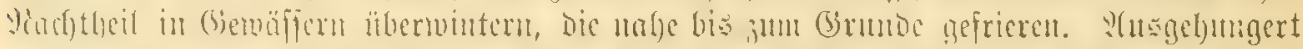

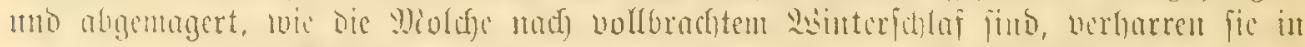

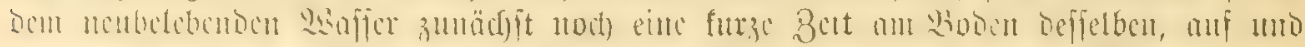

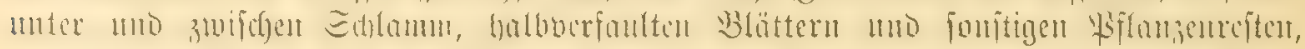

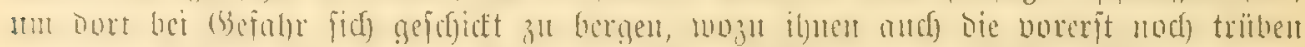

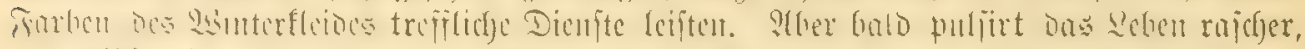

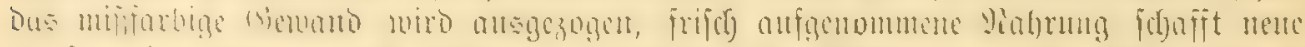

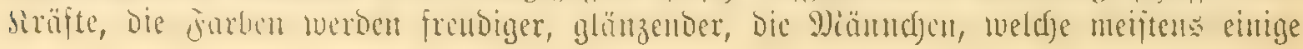




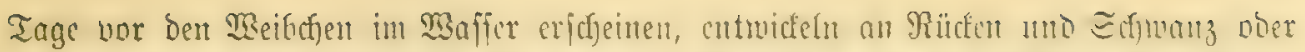

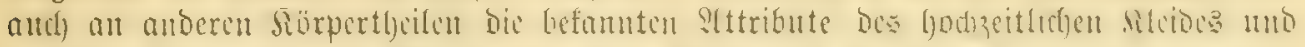

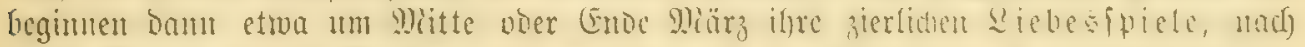

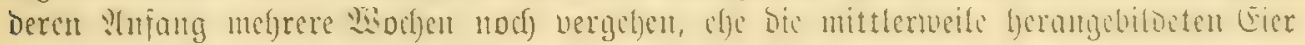
bom $\mathfrak{3} 3$ eibchent abgejețt merden.

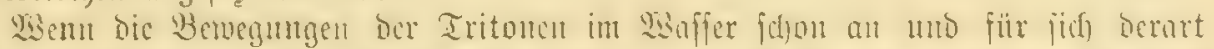

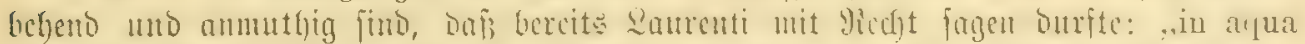

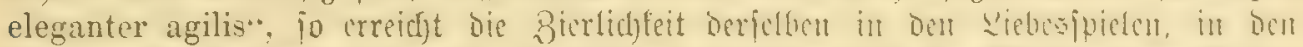

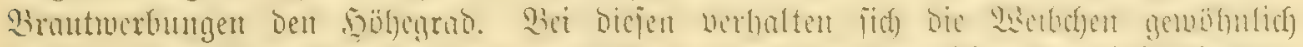

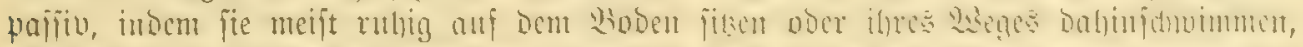

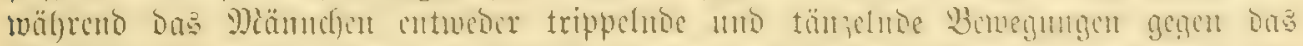

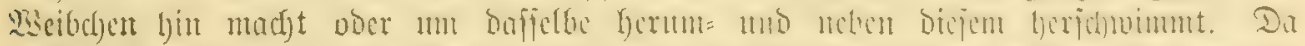

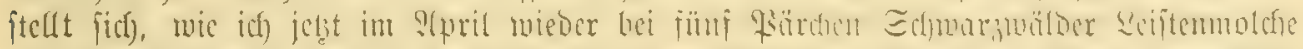

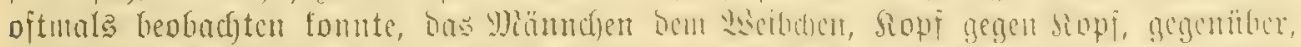

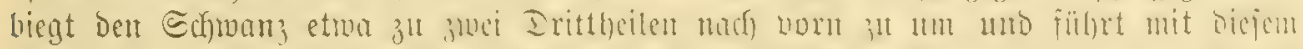

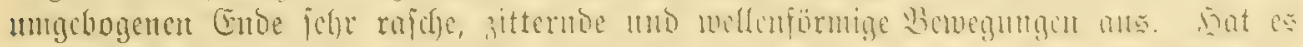

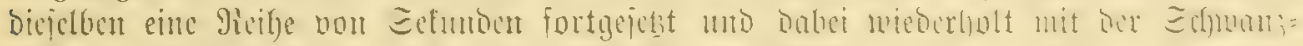

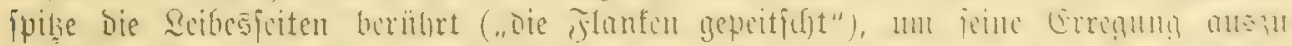

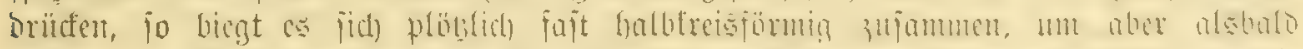

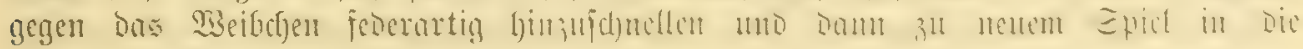

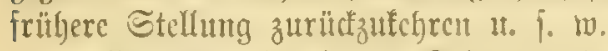

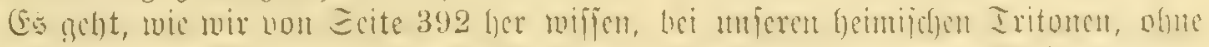

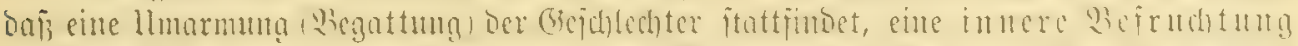

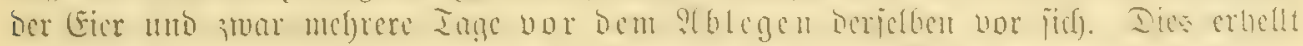

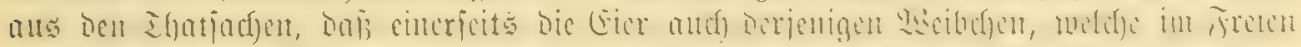

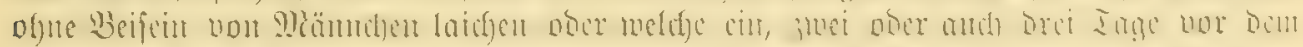

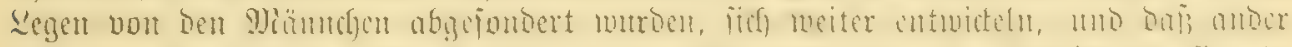

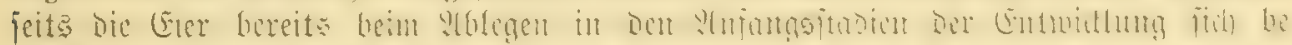

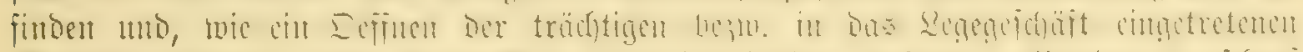

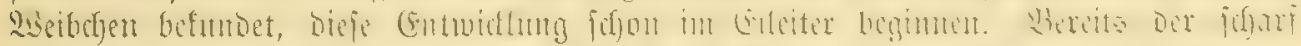

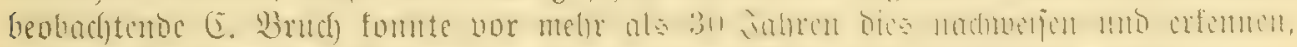

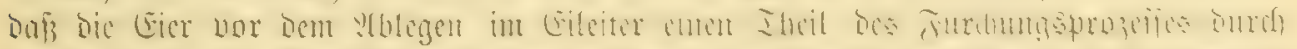

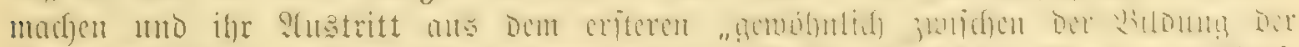

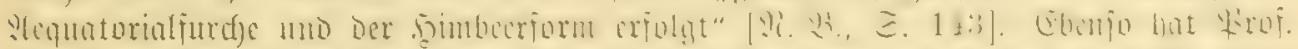

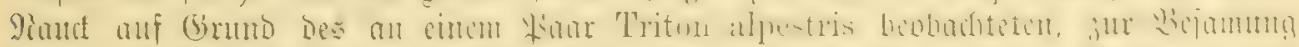

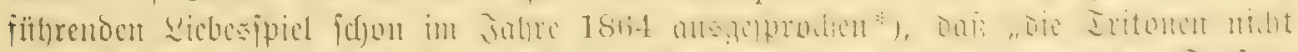

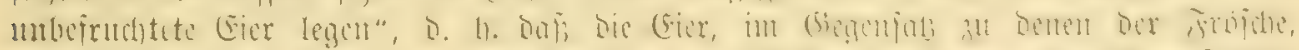

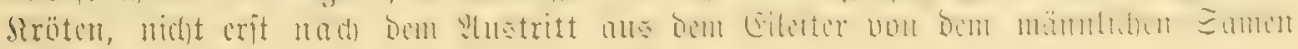
bcirudjet werden.

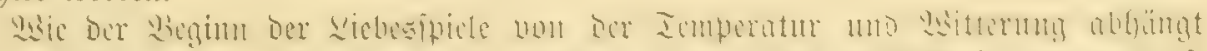

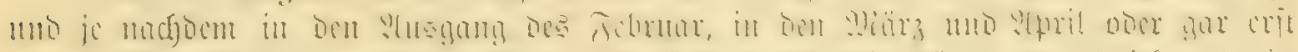

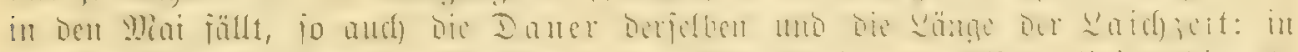

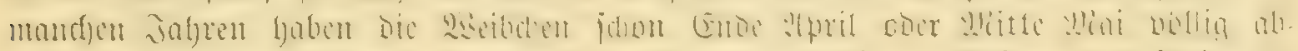

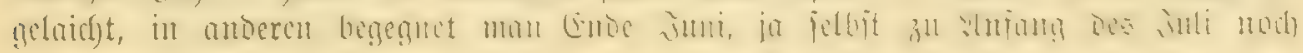

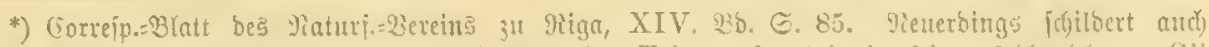

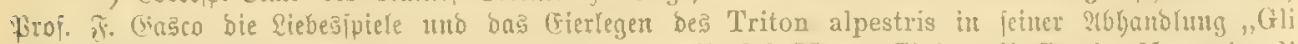
amori del Tritone alpestre - " (Estr. degli Aunali del Museo Civico di Storia Naturale di Genova, Vol. XVI. 1880.) 


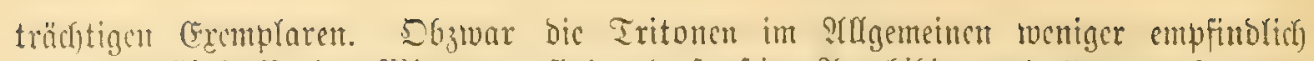

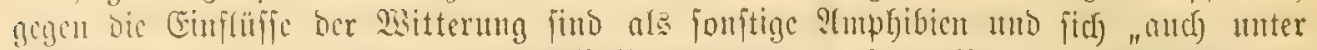

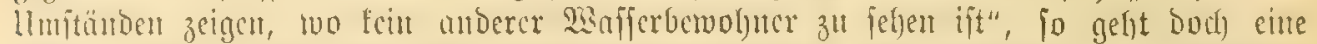

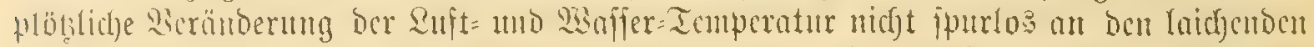

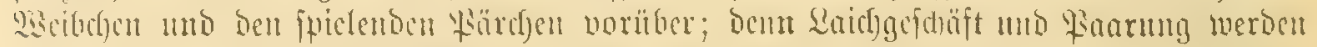

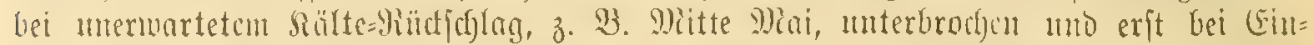

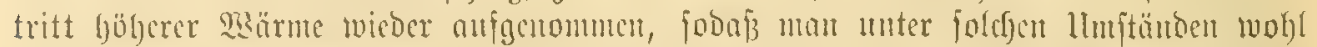

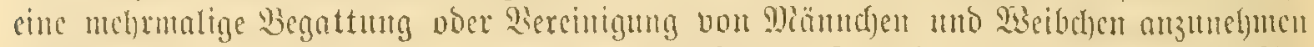

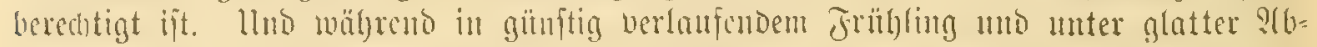

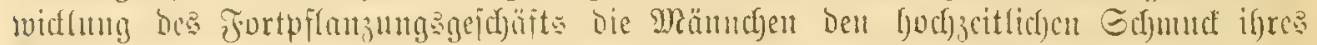
sileides f(f)on in Juni ahgelegt baben, trifit man in anderen Jabren noch im Julli

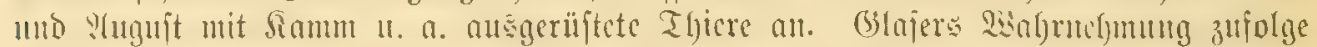

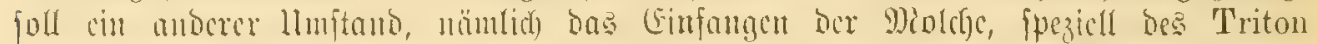

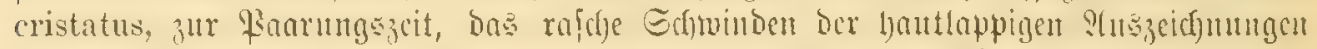

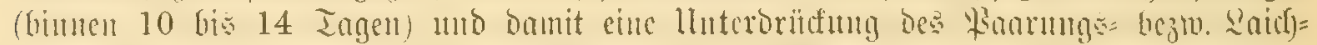

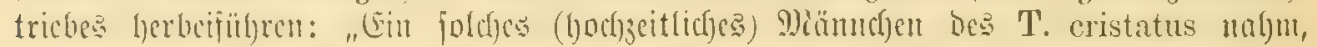

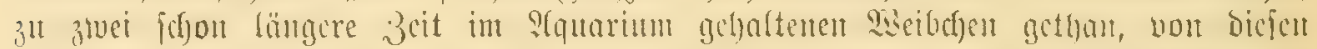
Burchan feine 2ioti, uno legte, viellecht nor ?llterntion ilber bas sinfangen, alle

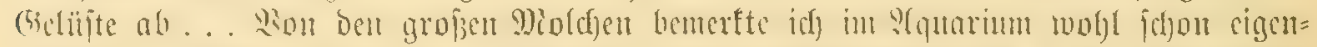

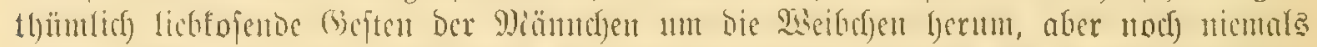

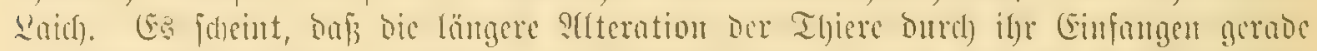

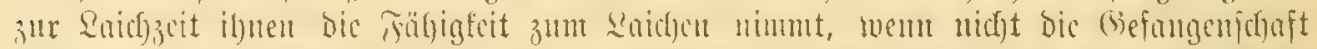

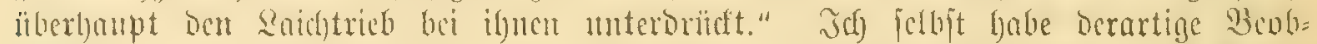

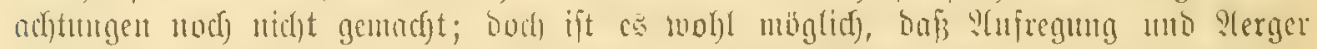

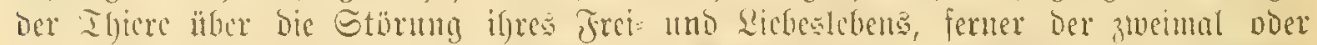

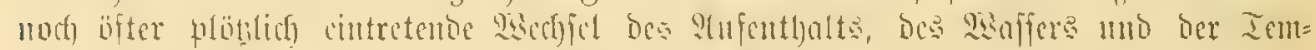

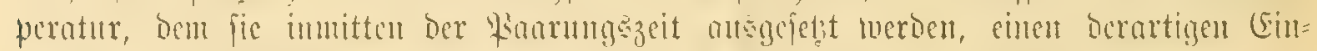

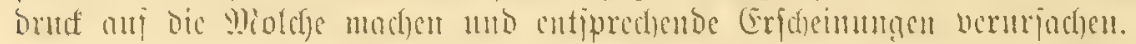

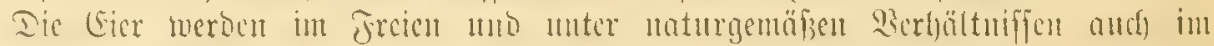

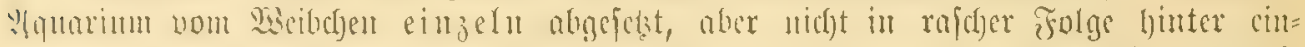

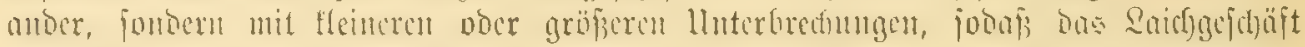

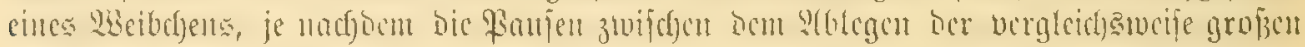

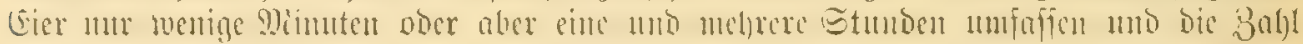

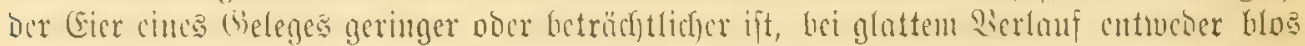

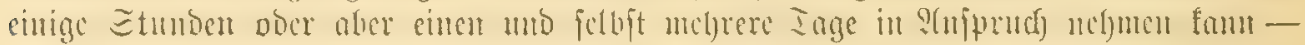

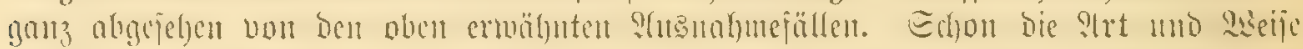

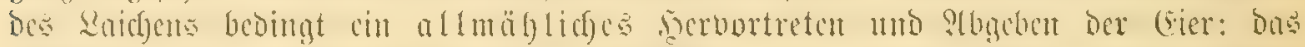

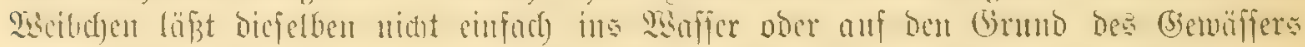
bezw. Bebülters gleiten, pondern flebt jebcs cinzelne an ein Sifonzenblättchen, énen

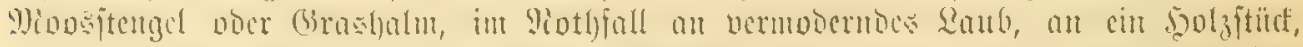

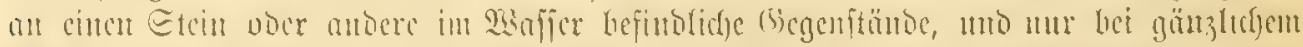

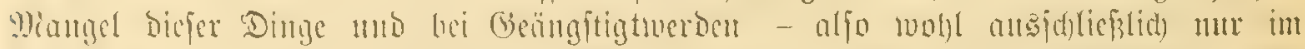

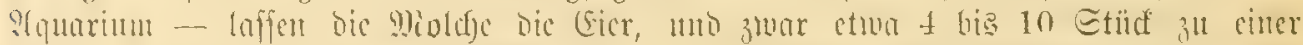

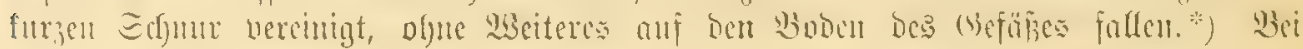

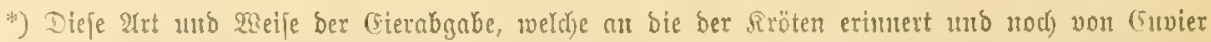
[Regne an., 2. edit.] für bie jontule gehalten murbe, ift mitbint als eine abutorme anzupegen; bent

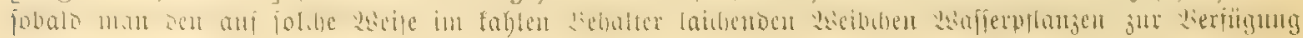
frellt, fo gekeat fie an bieje. 


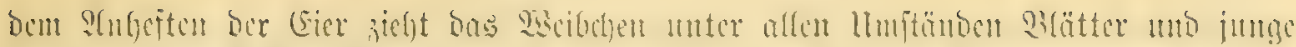

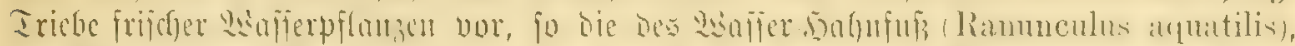

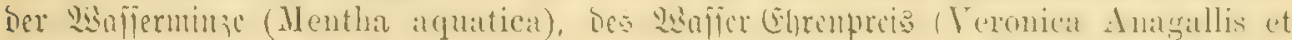

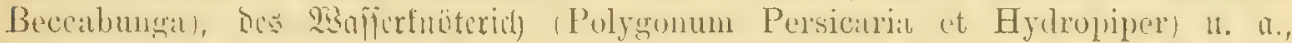

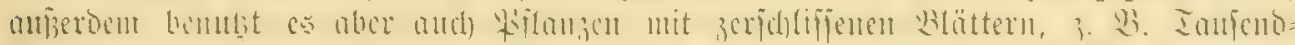

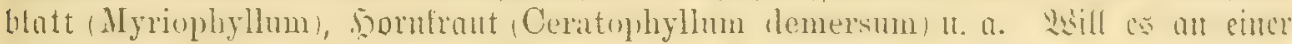

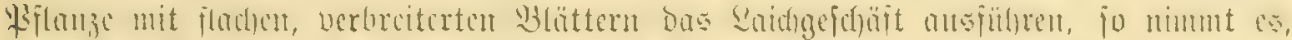

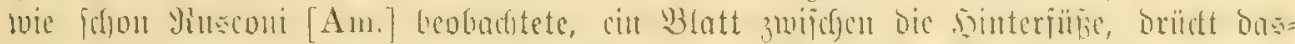

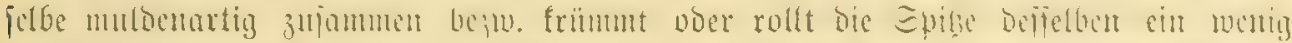
3.)

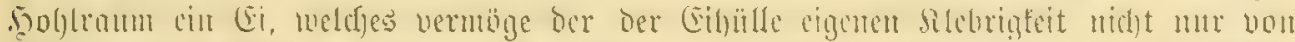

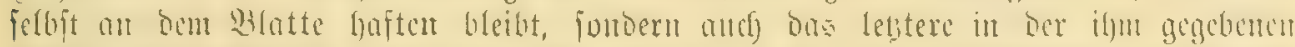

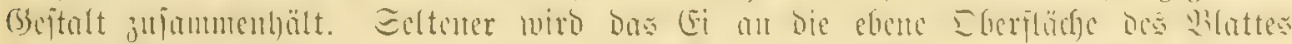

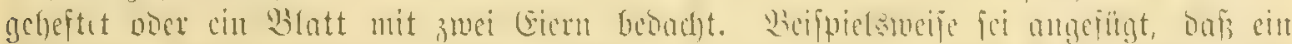

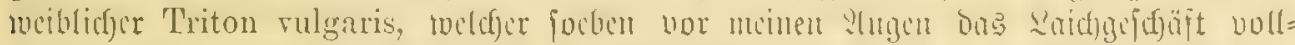

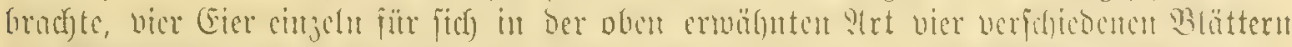

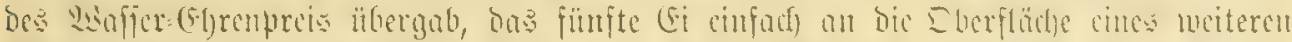

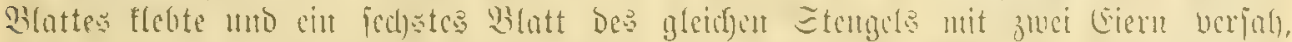

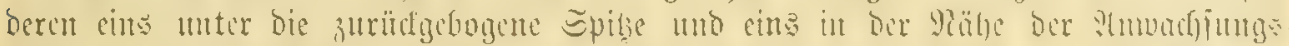

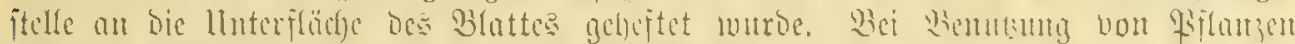

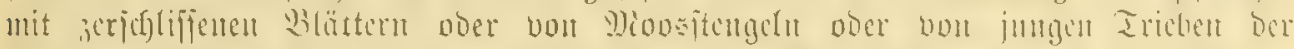

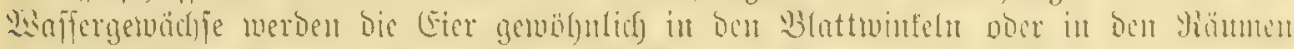

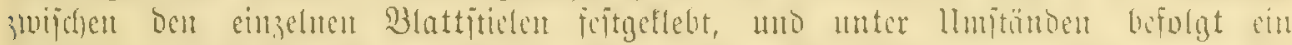

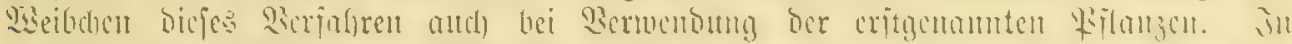

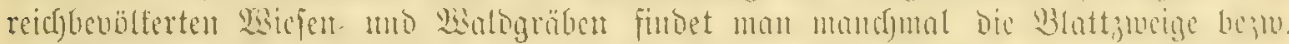

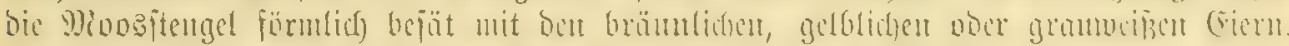

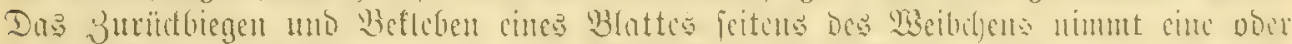

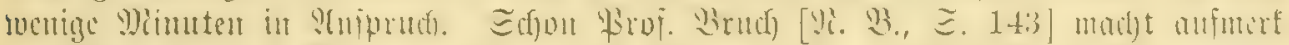

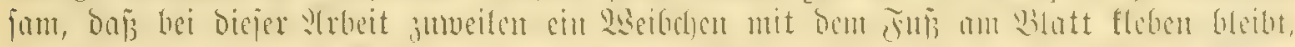

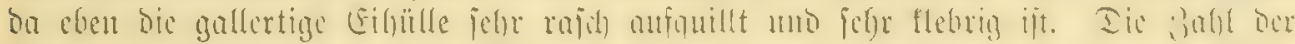

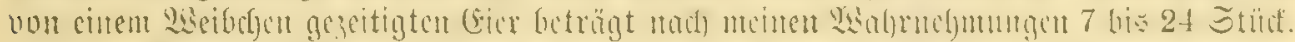

Sic 2 se it er

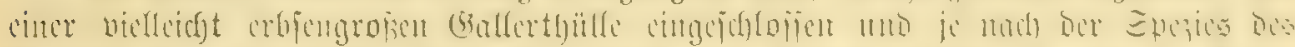

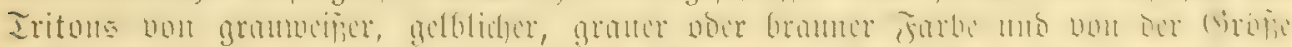

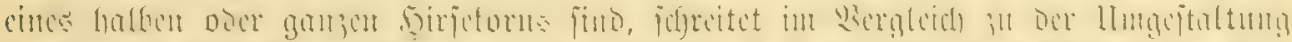

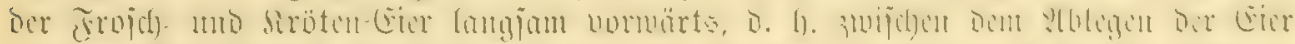

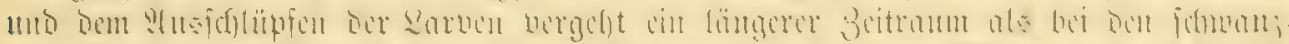

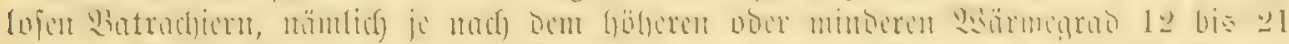

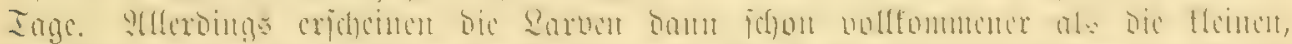

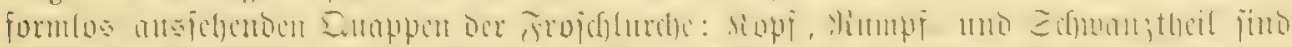

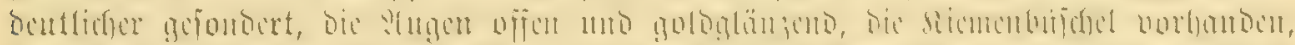

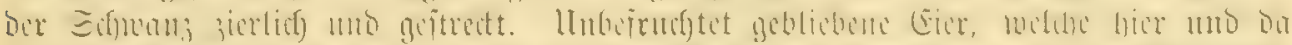

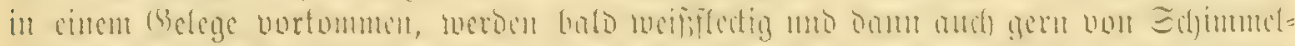

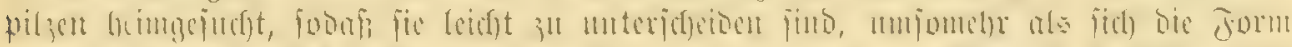

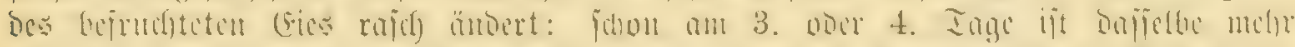

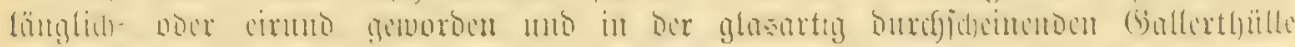

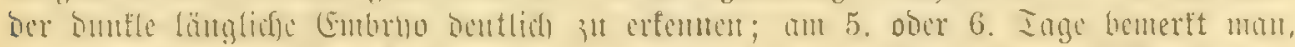

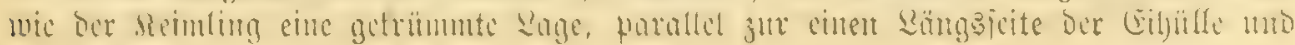




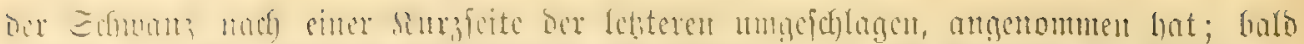

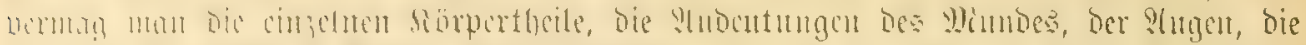

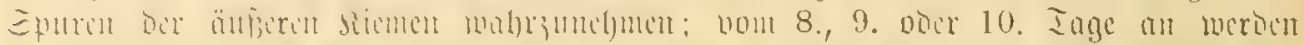

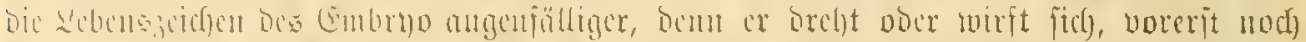

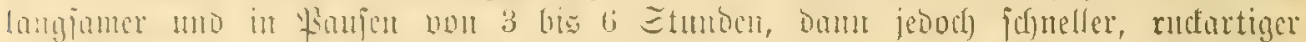

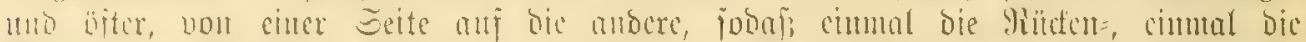

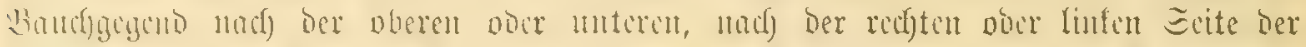

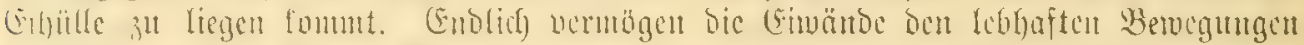

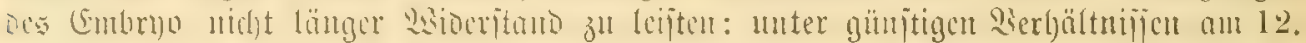

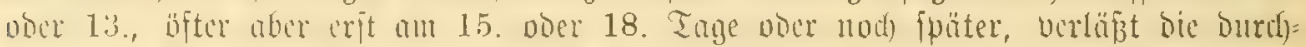

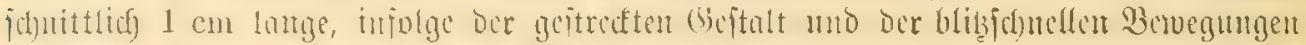

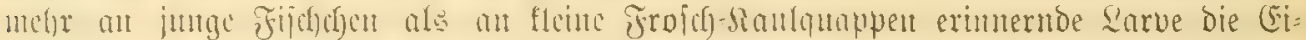

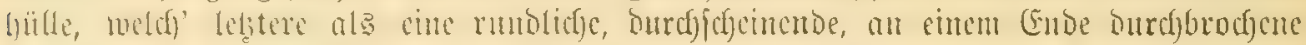

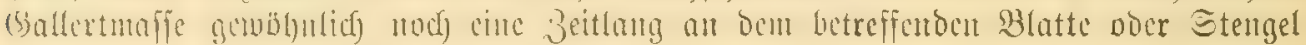
baftent blcibt, bis fie zerfüllt odcr tveggeipullt wiro.

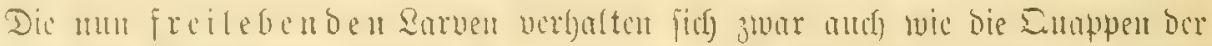

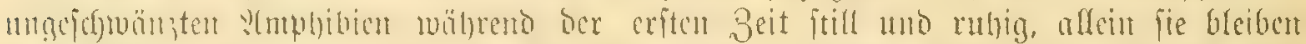

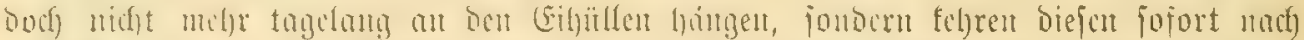

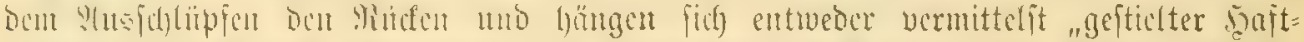

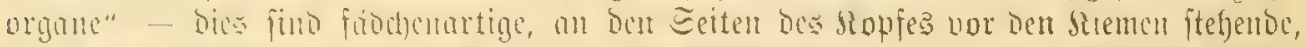

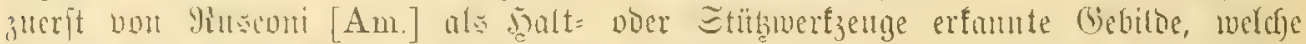

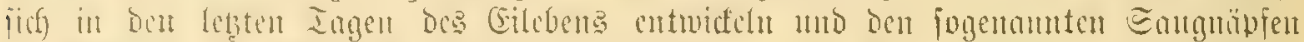

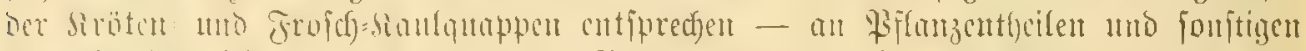

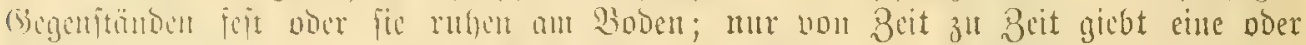

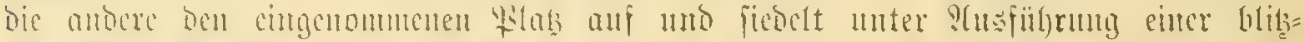

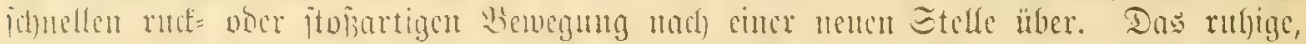

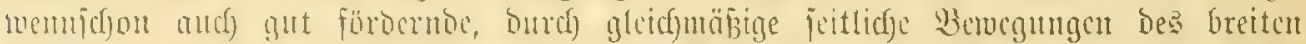

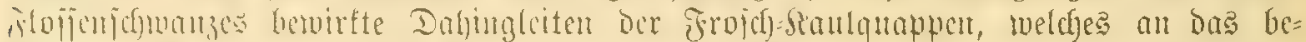

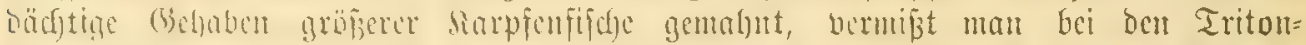

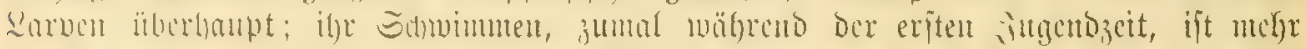

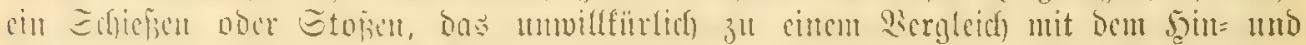

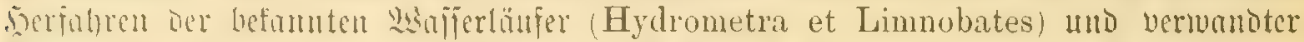

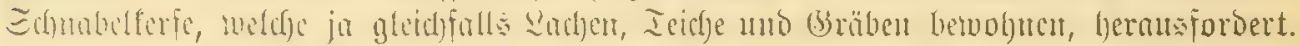

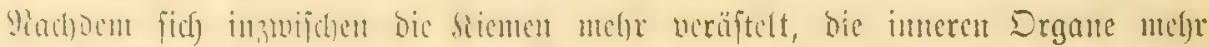

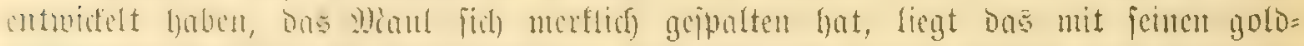

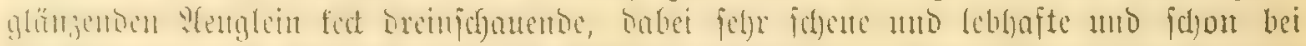

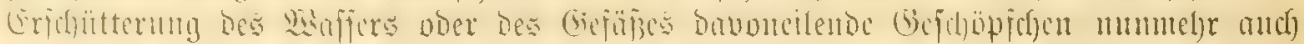

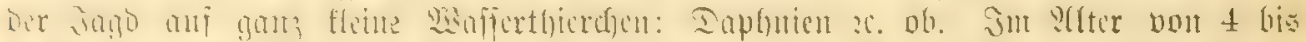

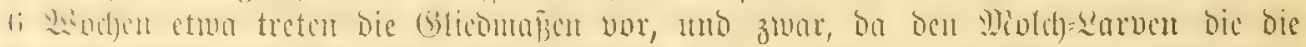

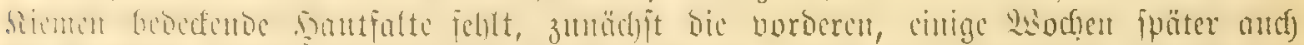

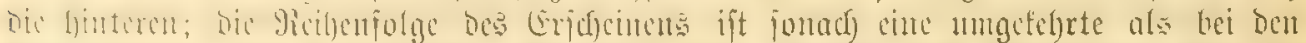

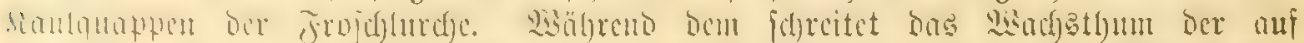

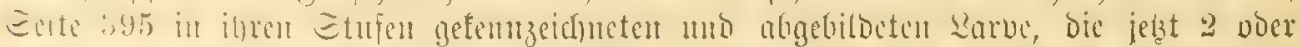

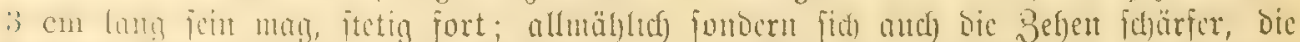

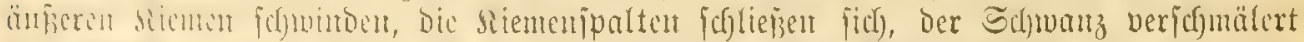

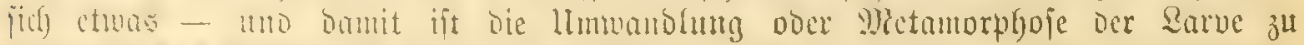

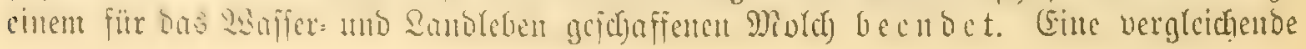




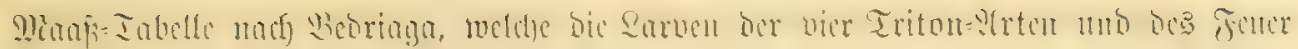
falamanders berïditchtigt, möge bicr folgen.

\begin{tabular}{|c|c|c|c|c|c|c|c|c|c|}
\hline \multirow[b]{2}{*}{ 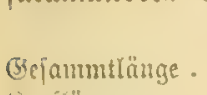 } & \multirow[b]{2}{*}{ 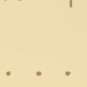 } & \multirow[b]{2}{*}{. $\mathrm{mm}$} & \multirow{2}{*}{$\begin{array}{l}\text { parad. } \\
29\end{array}$} & \multirow{2}{*}{$\begin{array}{l}\text { vulgr. } \\
31\end{array}$} & \multicolumn{2}{|c|}{ alpestris } & \multicolumn{2}{|c|}{ cristatus } & \multirow{2}{*}{$\begin{array}{c}\text { Sal. mac } \\
4 H^{3} / 2\end{array}$} \\
\hline & & & & & $\overline{57}$ & 41 & $\overline{5+1 / 3}$ & 82 & \\
\hline siopflänge . & . . & . " & 5 & $5^{1 / 3}$ & 9 & 8 & $10 \%$ & 15 & $81 / 2$ \\
\hline sopitöge. . & . . & . $" 1$ & 3 & 3 & $31 / 2$ & $3 \% / 3$ & 5 & $71 / 3$ & $4^{1 / 3}$ \\
\hline Ropfbreite . . & - & . " & 4 & 4 & $61 / 2$ & $5^{2} / 3$ & $7^{1 / 3}$ & 7 & $6^{2} 1 / 3$ \\
\hline Sänge ber oberer & Siente & . $"$ & $31 / 2$ & 4 & $2^{1 / 2}$ & $4^{1 / 2}$ & $7 \%$ & 7 & 4 \\
\hline গumpflänge. . & . . & - " & 9 & 11 & 21 & 14 & 10 & 15 & 15 \\
\hline geumplgöhe. . & . . & . & 4 & 4 & $53 / 4$ & 5 & $7 \%$ & 10 & $5^{3 / 4}$ \\
\hline Mumpfunfang . & . . & . " & $11^{1 / 2}$ & $12 \%$ & 29 & $17^{1 / 3}$ & 23 & 31 & $18^{1 / 2}$ \\
\hline Worberbein . . & . . & " & 5 & $51 / 2$ & $91 / 2$ & $71 / 3$ & 10 & 15 & 7 \\
\hline Dinterbein . & & $"$ & $4^{1} / 4$ & $51 / 3$ & 10 & $71 / 3$ & $10^{1 / 2}$ & 16 & $71 / 2$ \\
\hline Ed)manjlänge. & . . . & . " & 15 & $14^{1 / 8}$ & 27 & $2 \cdot 2$ & 29 & 40 & 21 \\
\hline Sdinnangähe. & & " & 4 & 4 & 5 & $51 / 8$ & $7^{1 / 2}$ & 11 & 6 \\
\hline
\end{tabular}

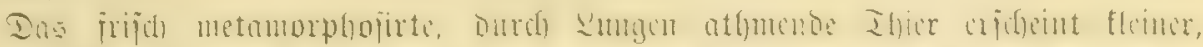

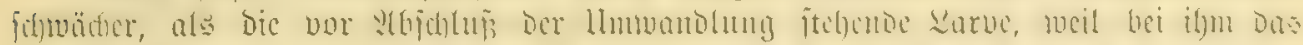

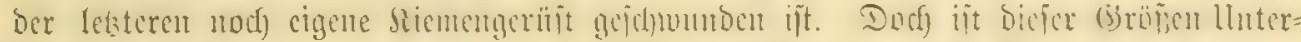

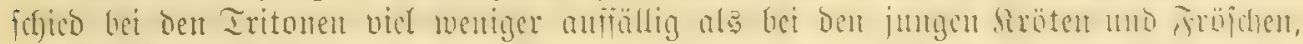

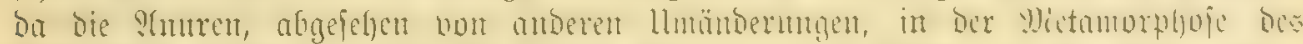

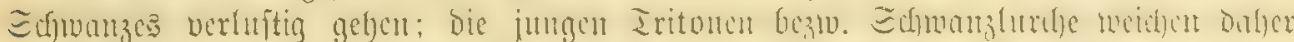

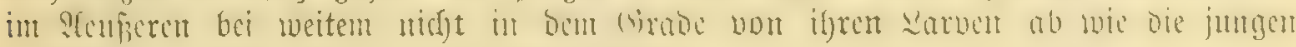
Frofduturdje von ifgen faulquappen=8uitänden.

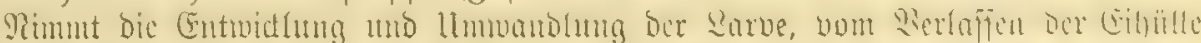

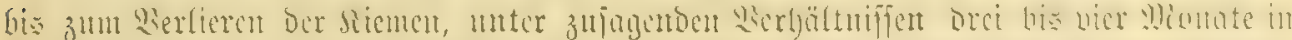

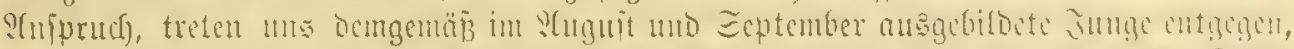

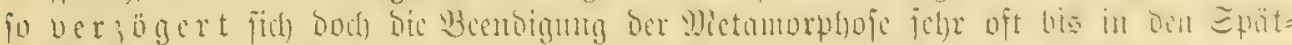

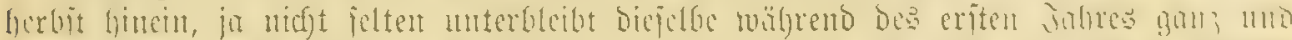

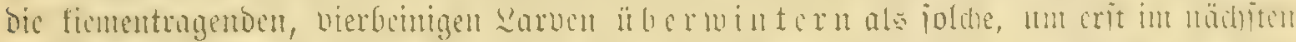

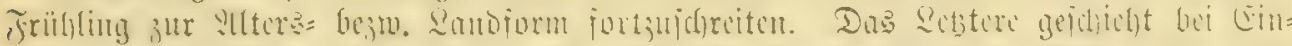

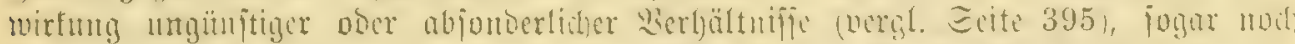

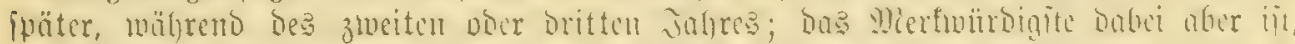

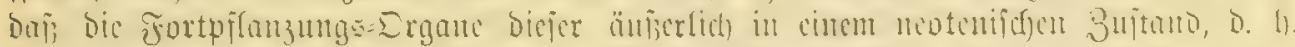

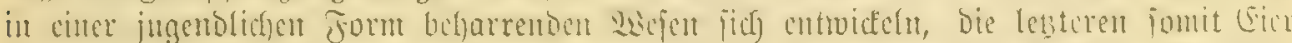

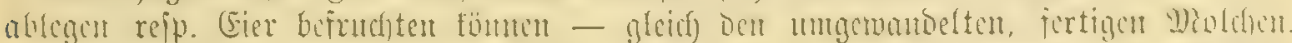

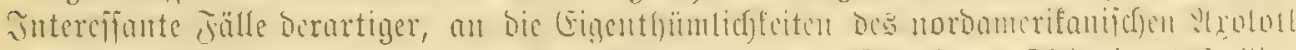

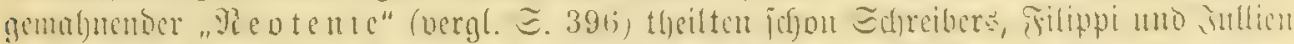

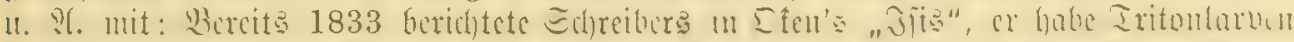

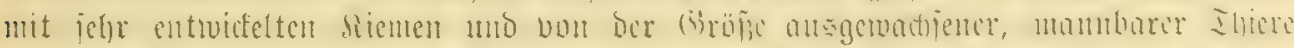

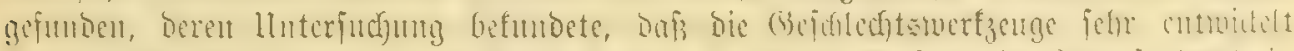

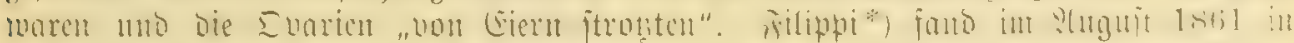

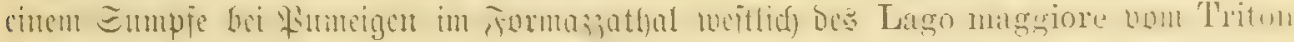

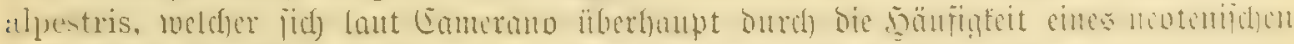

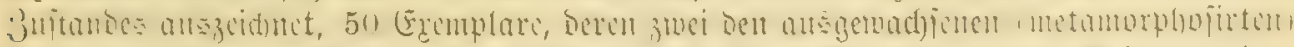

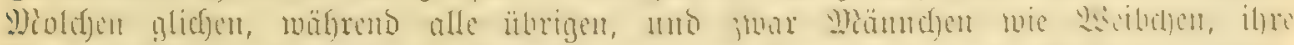

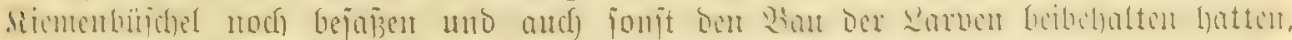

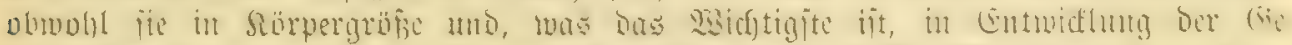

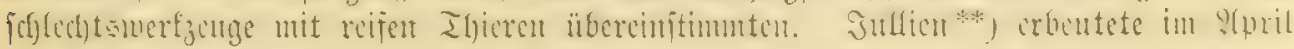

*) Archivio per la Zoologia. Genora 1861 Vol. I p. 206-211.

**) Compt. rend. de l'Acad. de Paris LIVIII (1869) pag. 938. 


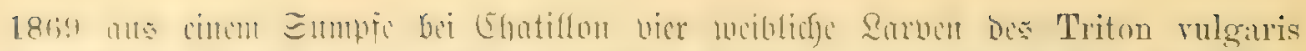

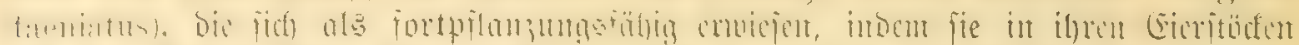

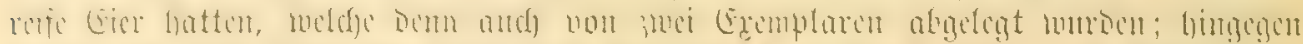

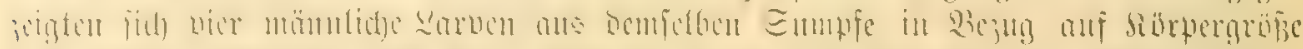

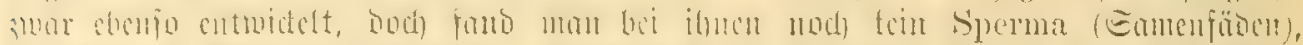

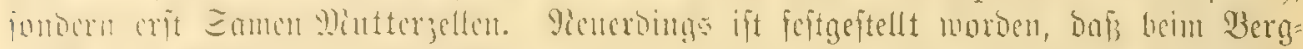

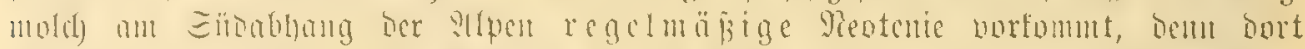

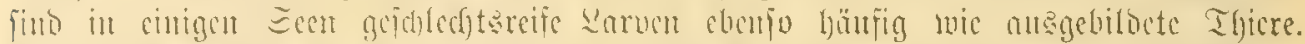

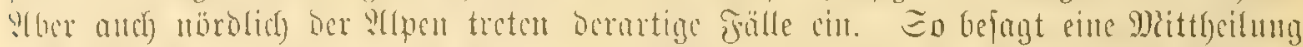

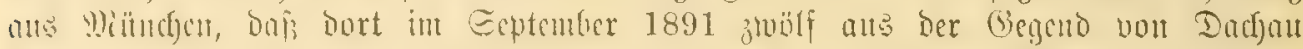

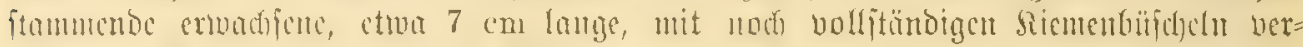

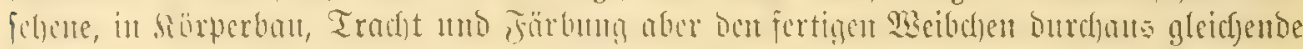

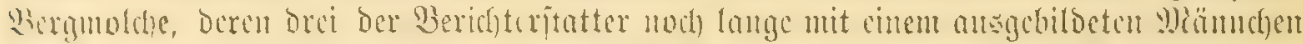

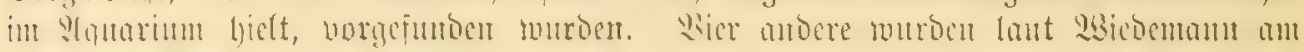

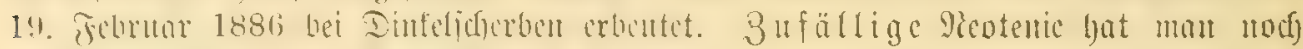

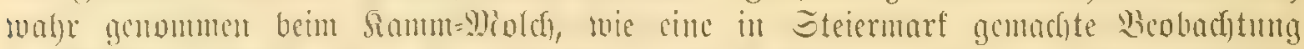

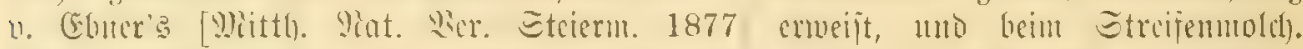

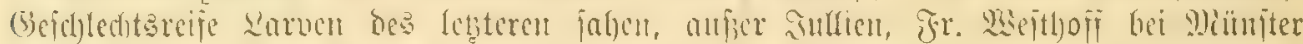

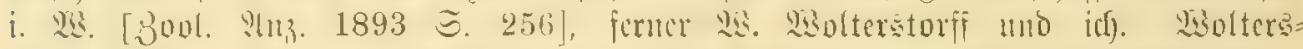

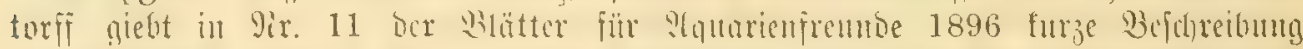

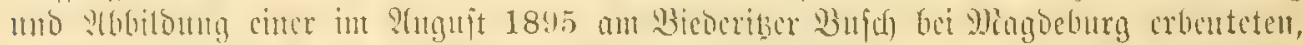

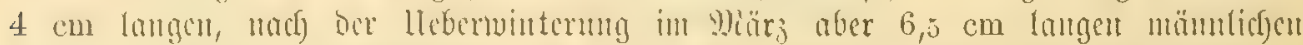

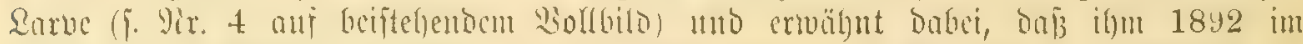

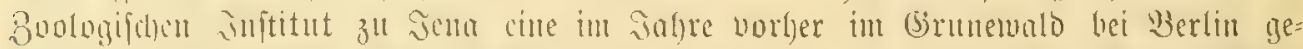

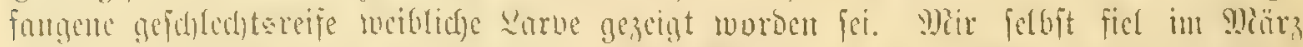

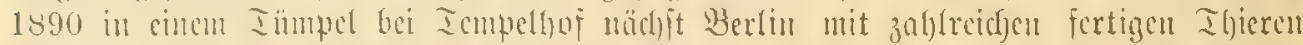

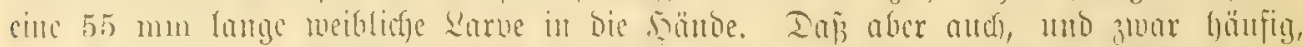

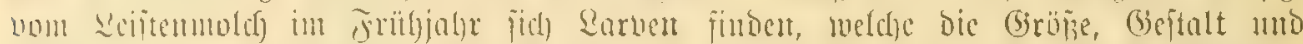

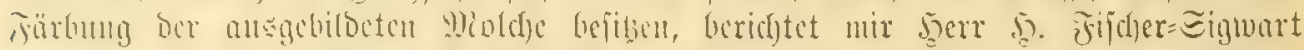

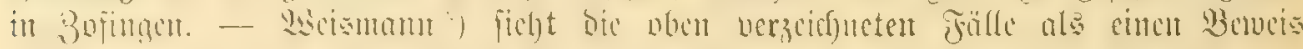

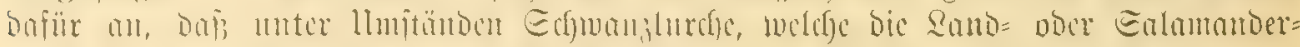

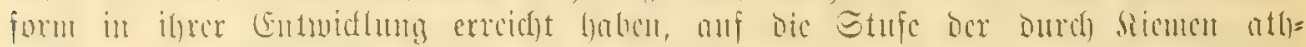

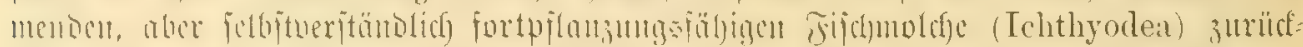

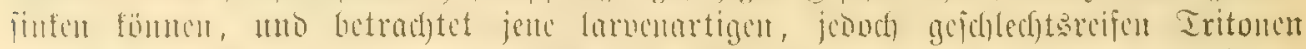

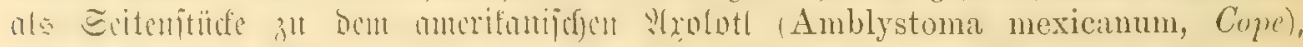

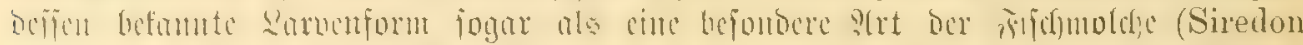

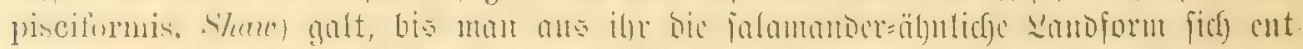

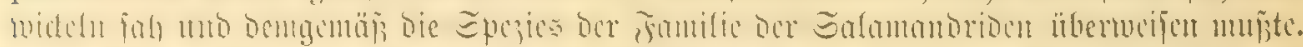

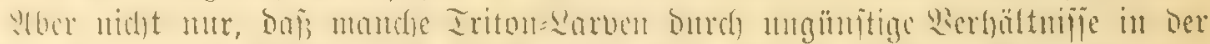

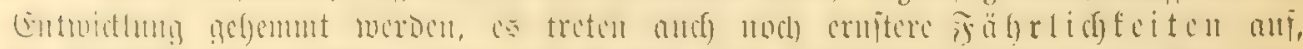

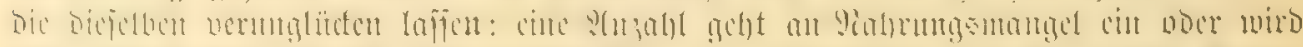

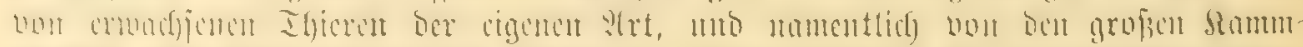

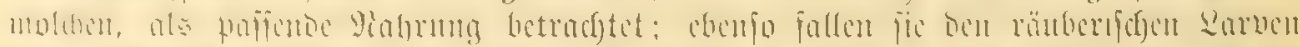

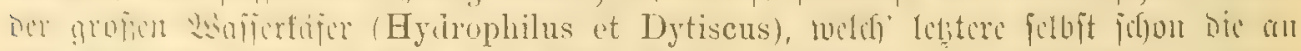

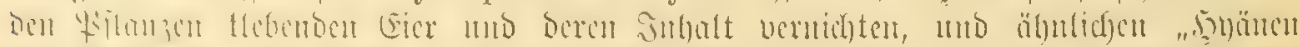

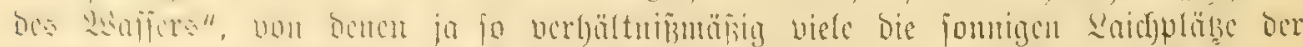

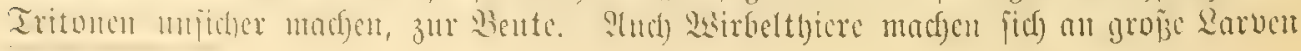

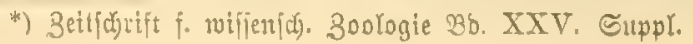




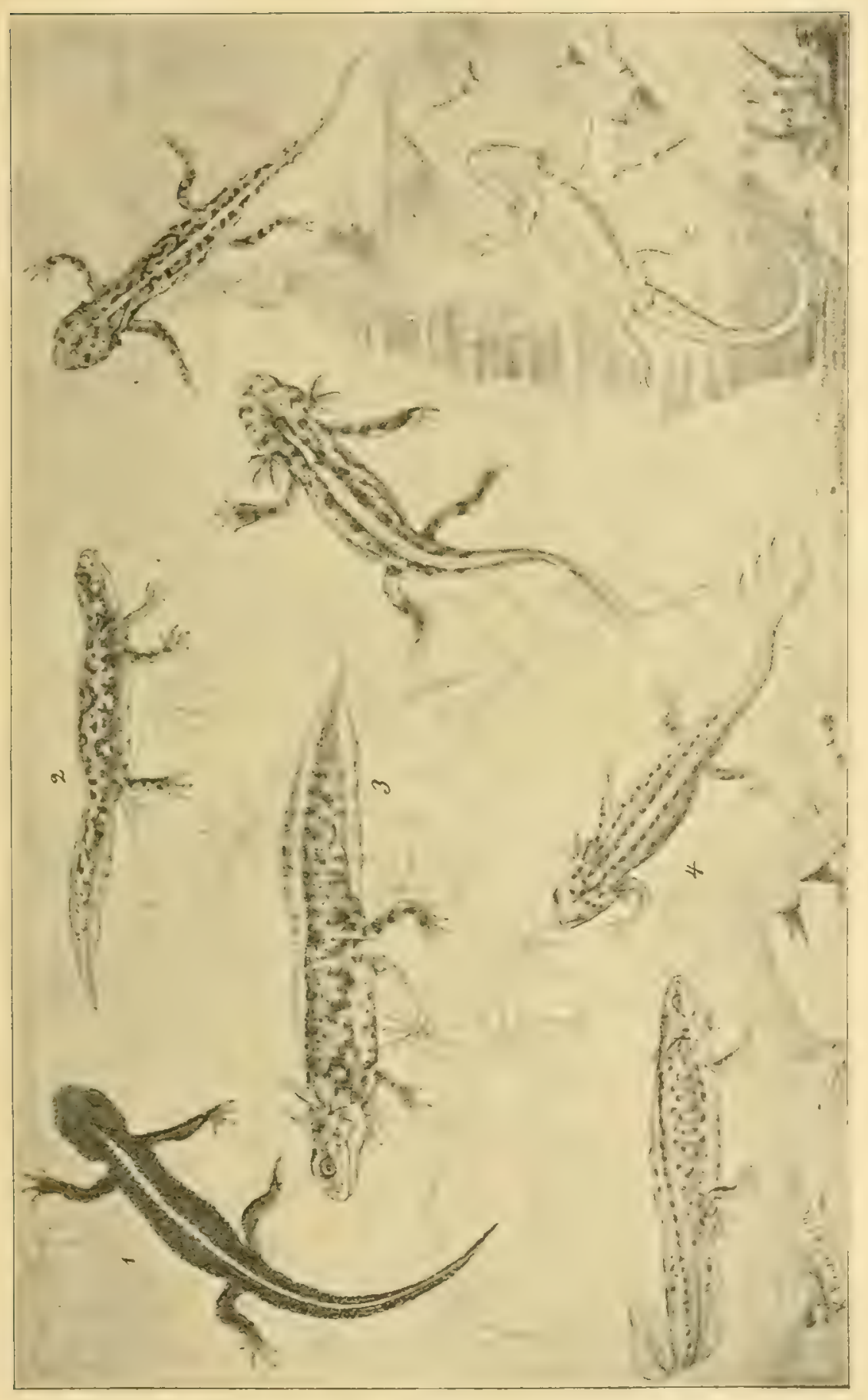

0

要

$\bar{z}=$

$\equiv$

在

$\ddot{\vec{E}}=$

-

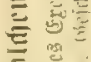

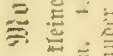

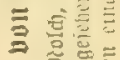

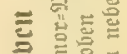

芯芯范

을 突

范

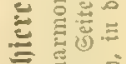

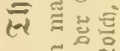

层

总总范

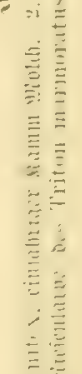

$\equiv$

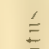

事

:

三” 


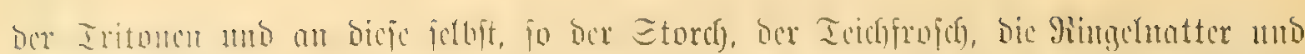

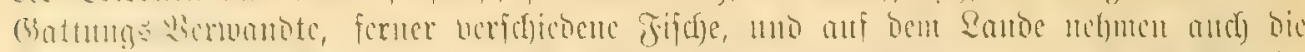

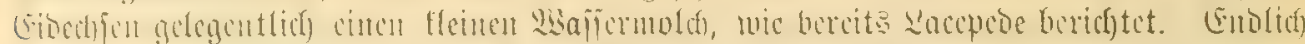

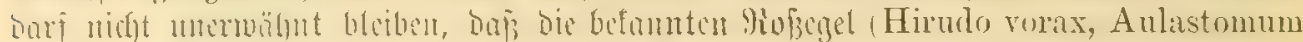

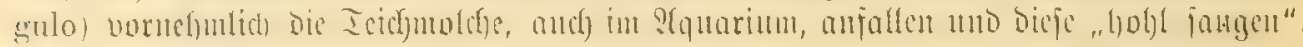

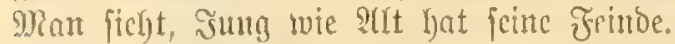

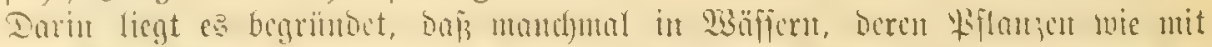

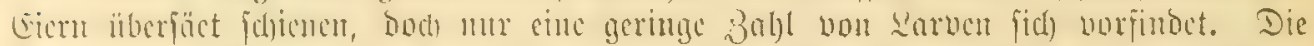

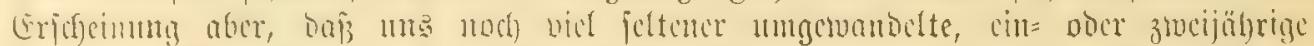

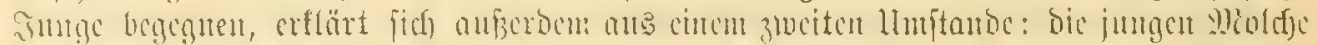

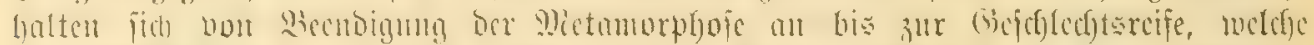

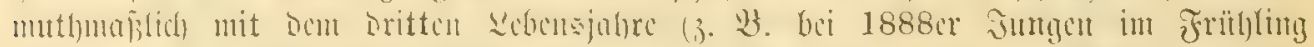

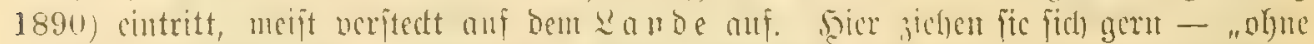

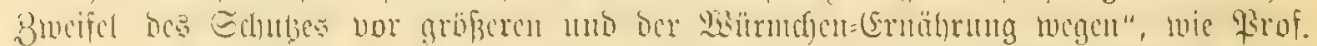

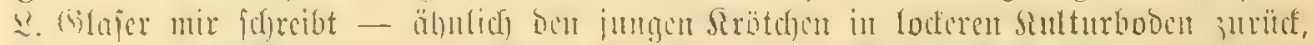

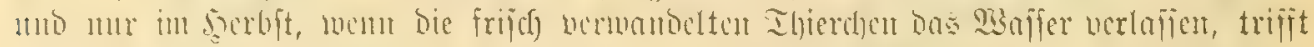

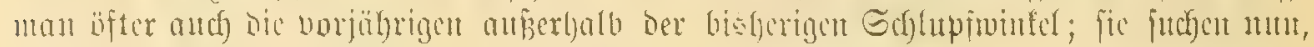
gleich) den ?uten, cin ficheres $\$ 3$ interquarticr auf.

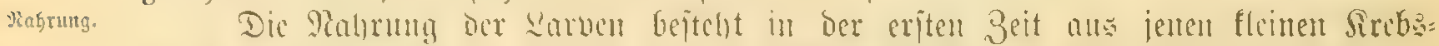

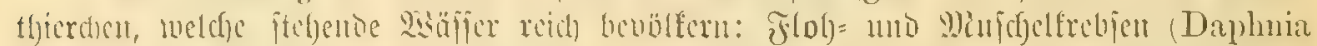

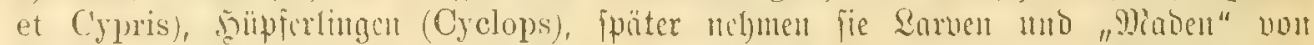

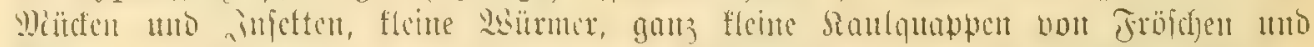

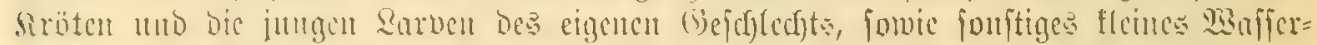

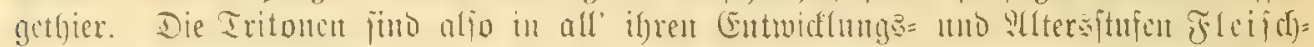

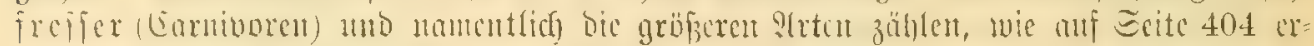

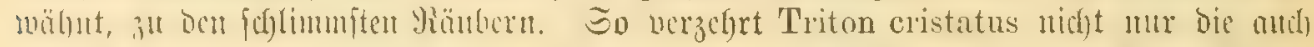

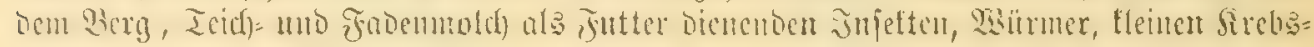

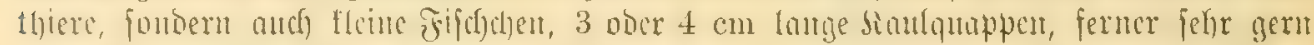

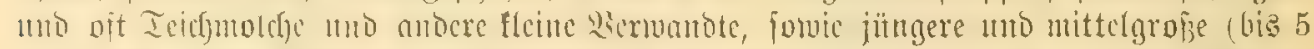

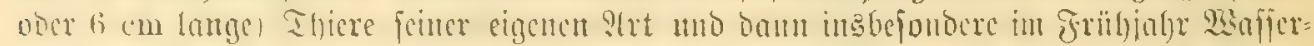

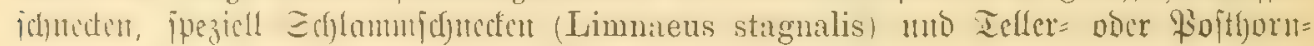

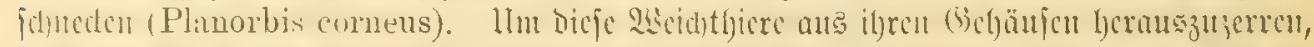

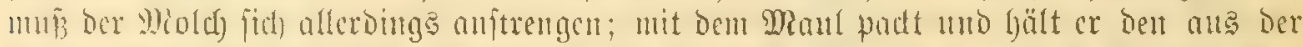

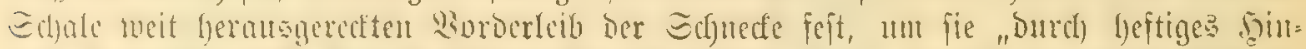

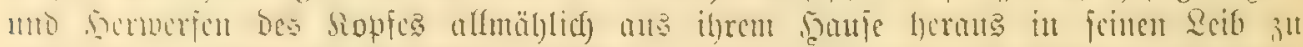

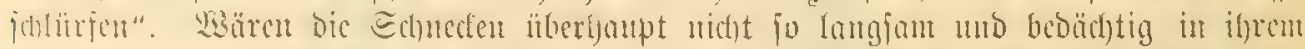

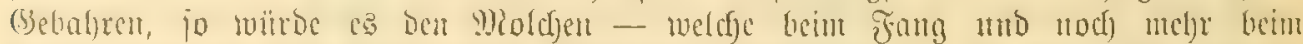

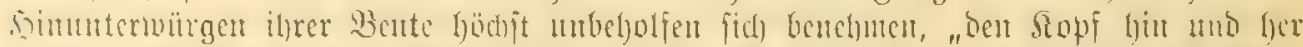
werfen,

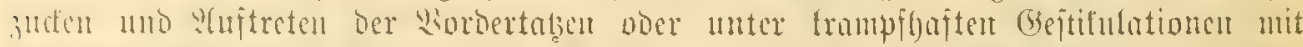

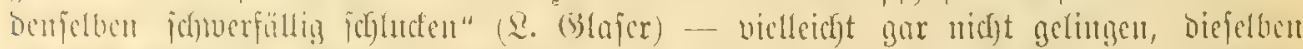
itt iffet

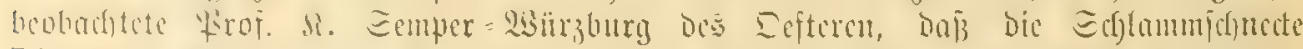

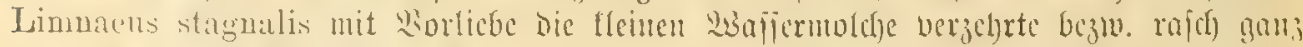

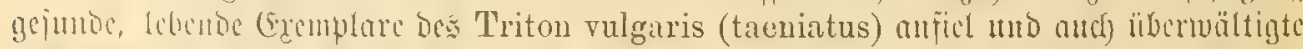

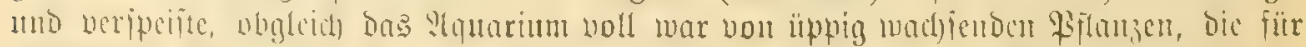

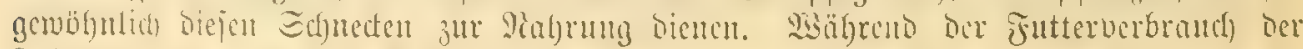

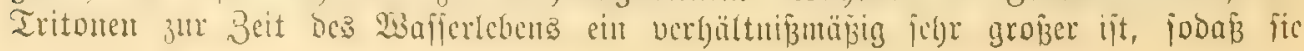




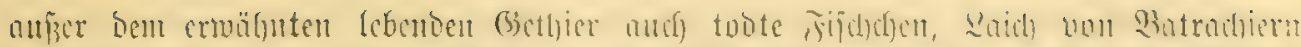

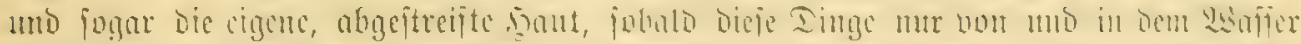

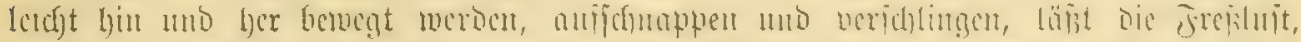

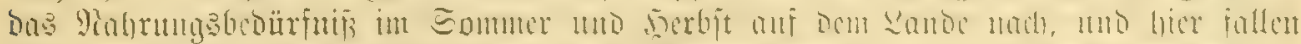

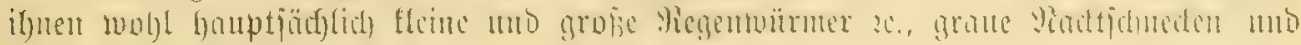
Derglcidfen zut: Beute.

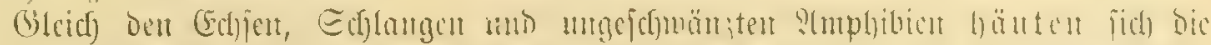

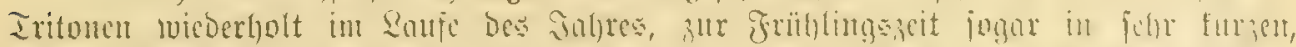

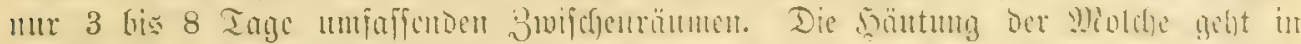

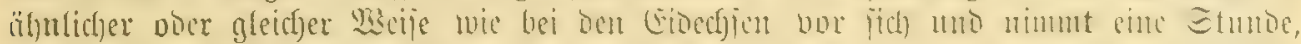

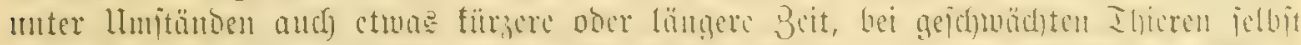

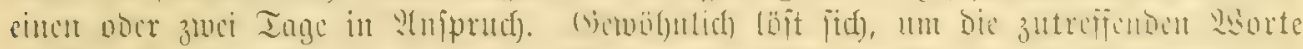

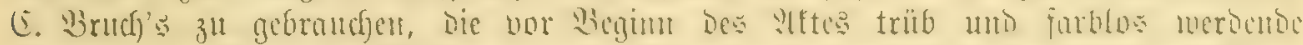

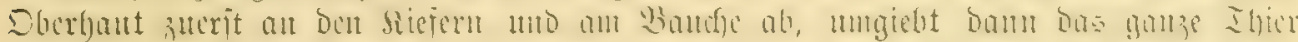

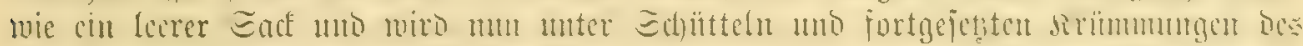

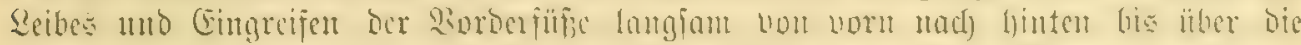

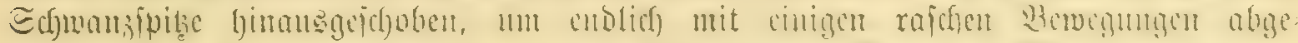

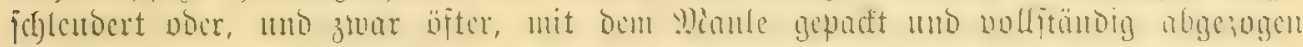

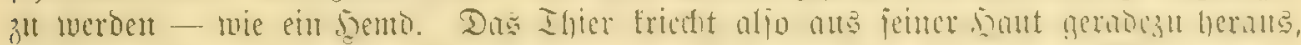

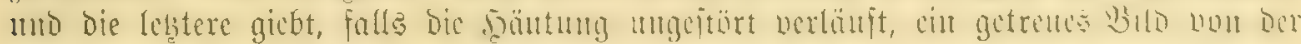

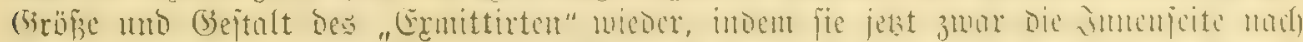

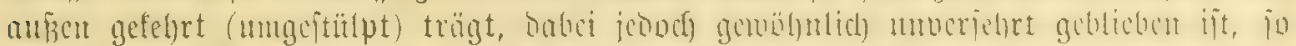

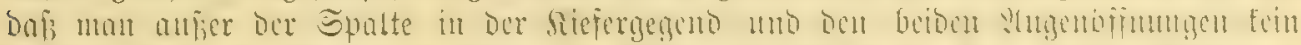

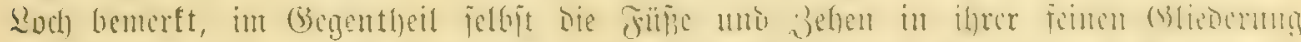

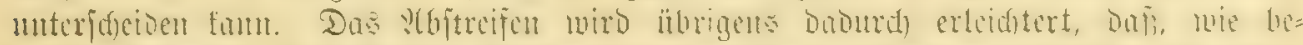

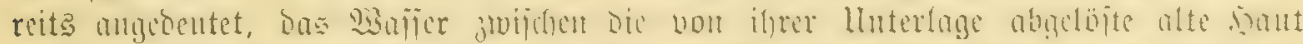

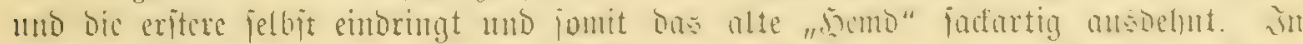

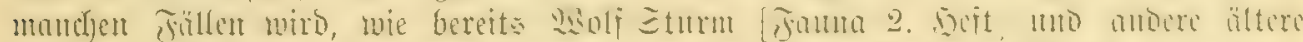

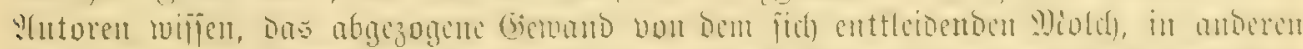

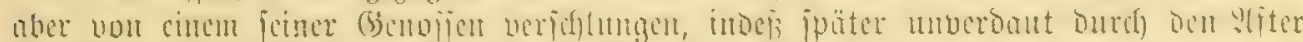

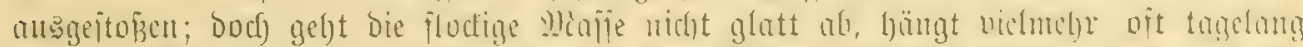

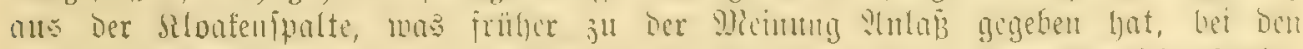

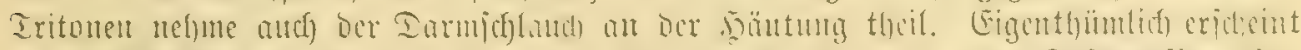

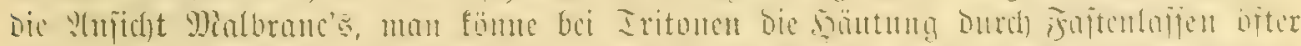

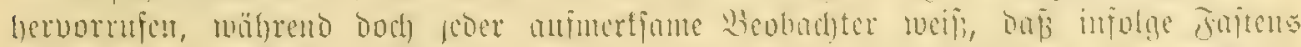

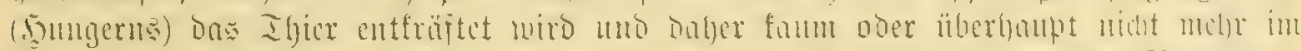

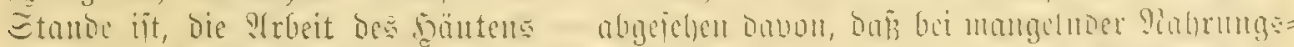
3)

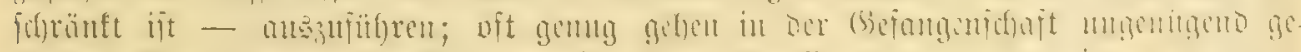

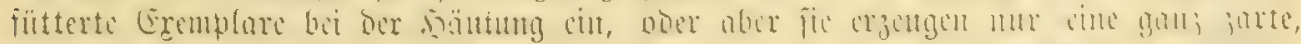

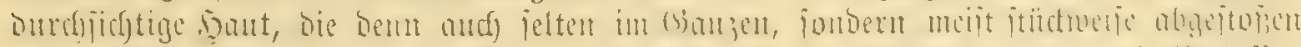

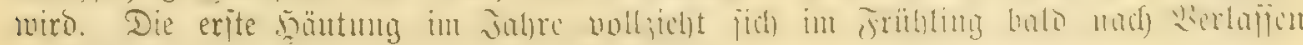
Der Minterberberge uno Begint Des 23ajerlebens.

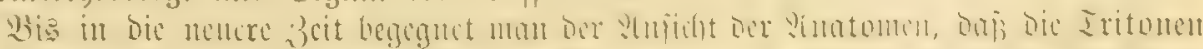

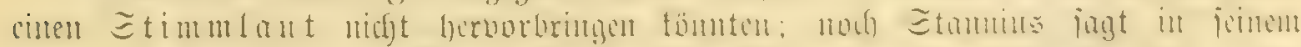

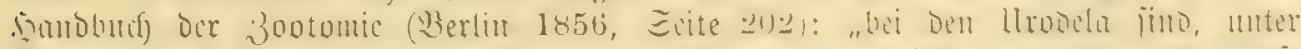

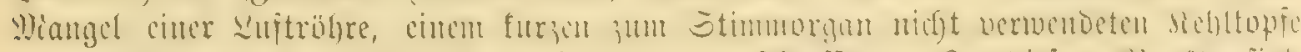

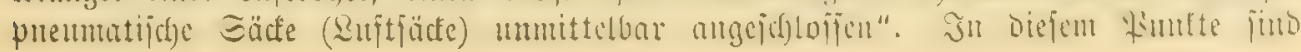




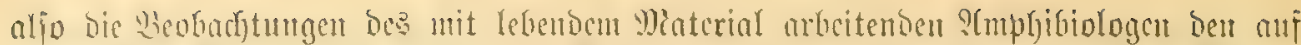

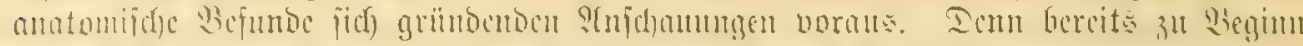

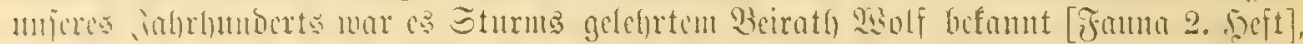

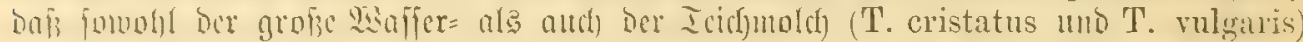

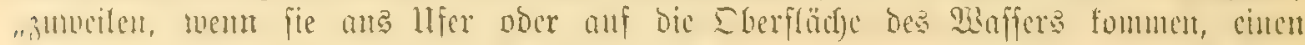

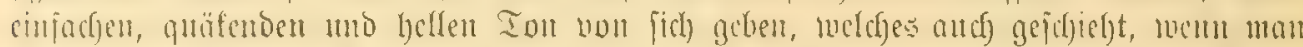

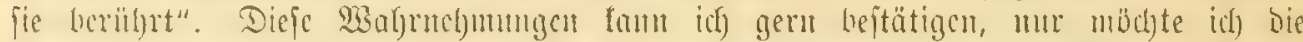

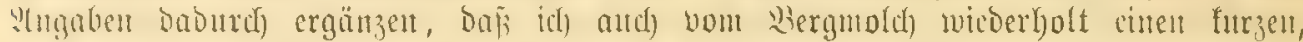

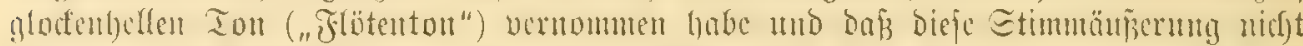

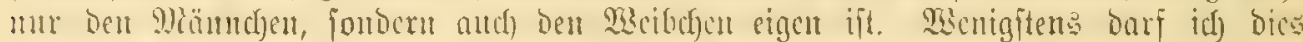

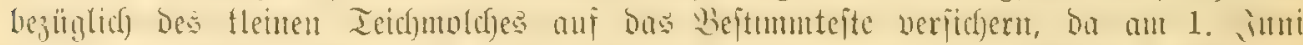

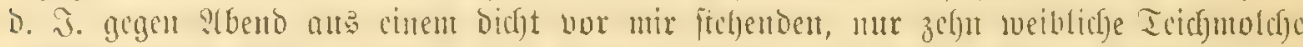

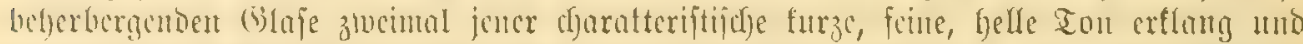

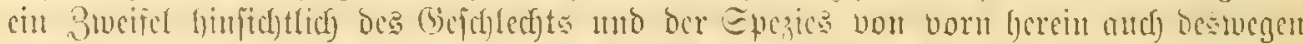

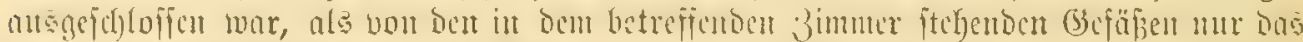

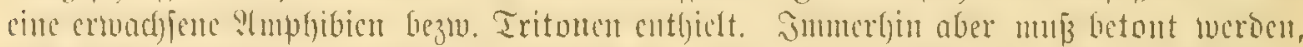

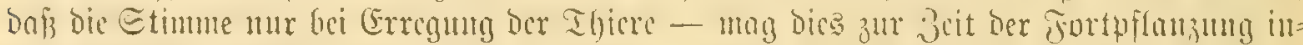

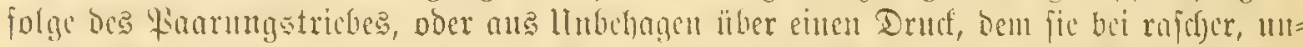

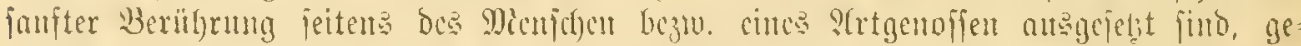

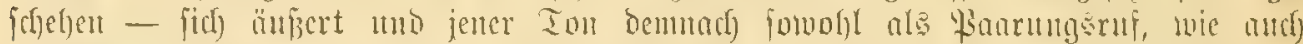

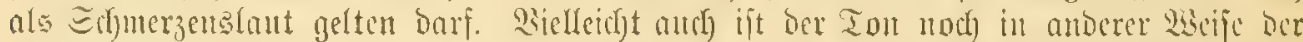

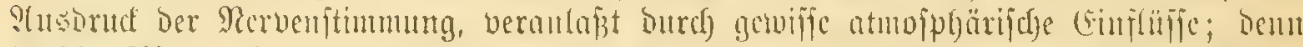

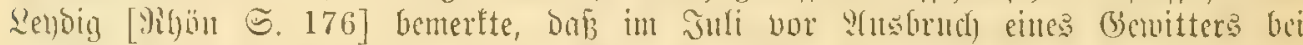

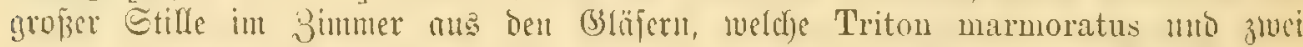
meitue fïbcuropäifche llrobclen: Euproctus Rusconii und Pleurodeles Waltlii cut.

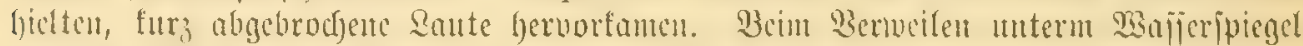

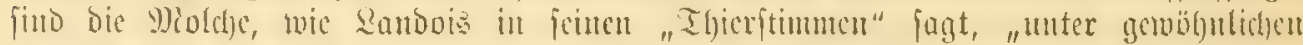

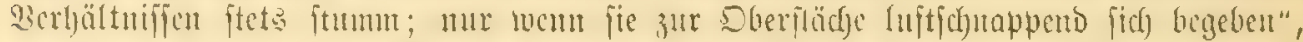

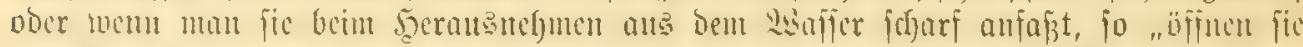

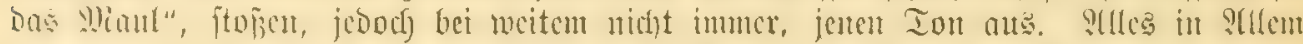

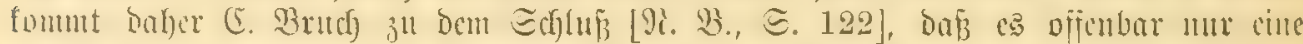
Jolge ber Lebmoneije und Getwohnheit biejer Ifjere jei, wenn man von iljnen felten

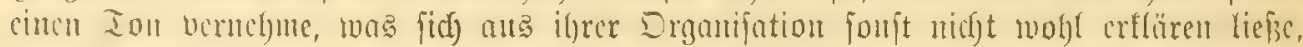

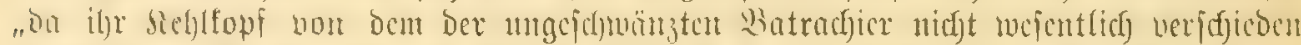

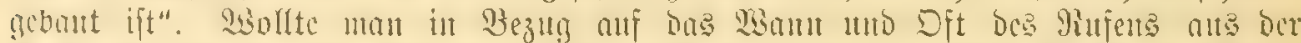

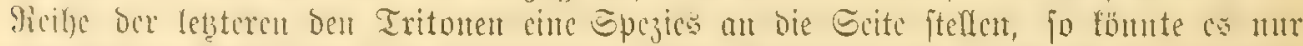

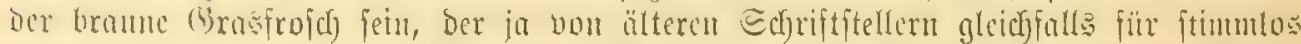

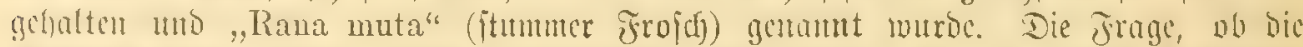

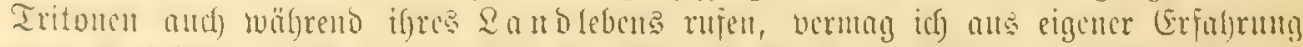

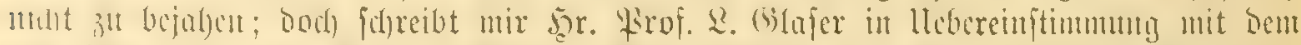

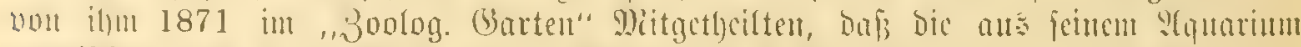

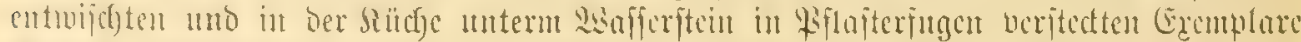

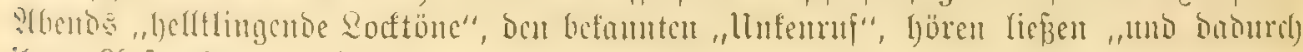

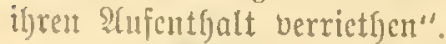

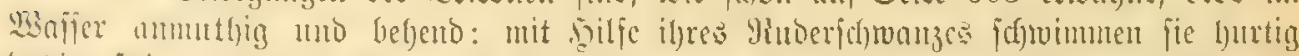

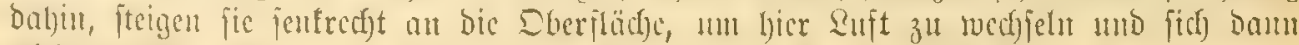

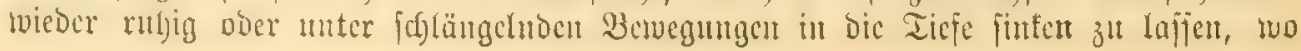




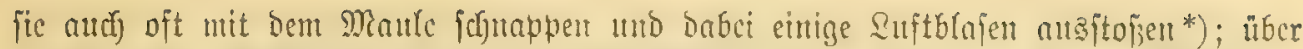

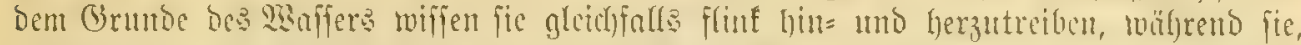

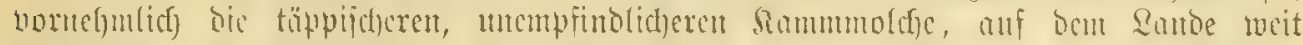

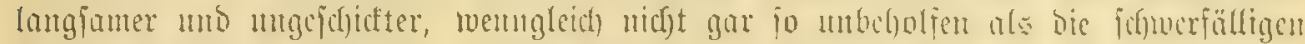
Erofalantanoer, fortfommen. Dafjer fallen fii bemn antd bier ben fie verfolgenden

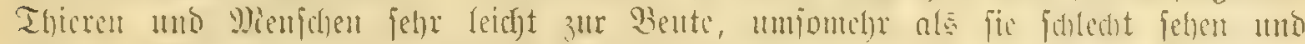

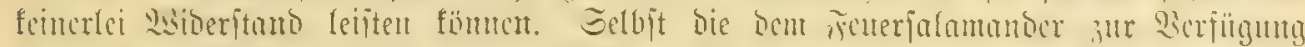

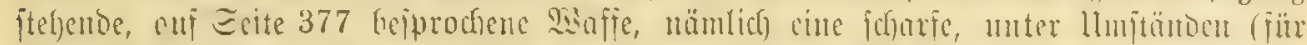
Sileirgetficr) giftige soutabjouberung, ift ben Molden mur in wentiger zur

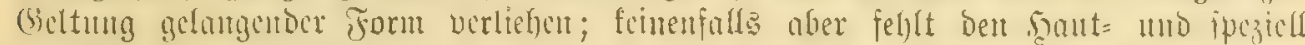

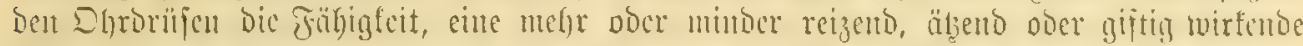

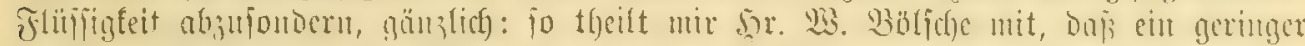
Incil bicfes Eefrets nom 'Triton cristatus mo T. alpestris bet cinem jeiner be=

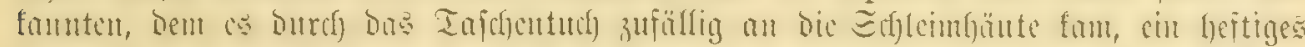

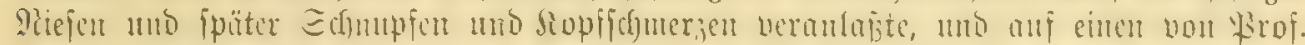

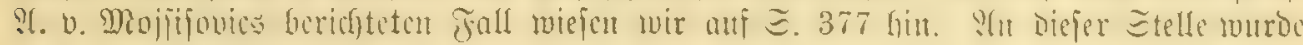

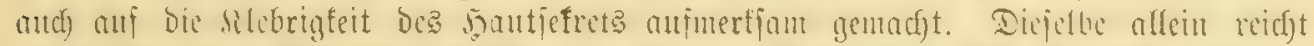

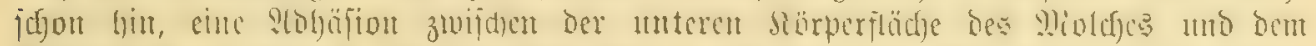

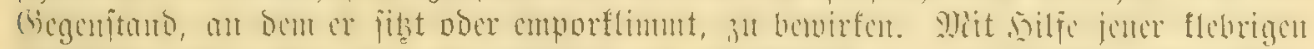

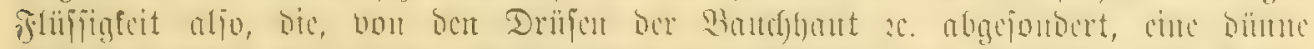

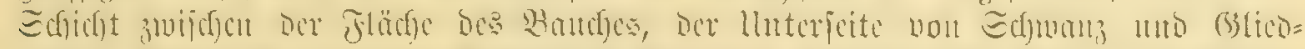

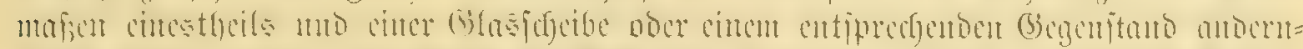

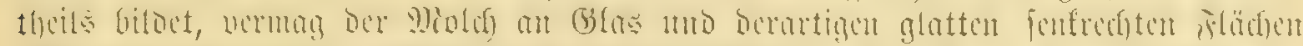

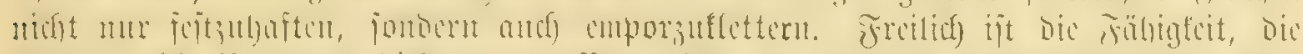

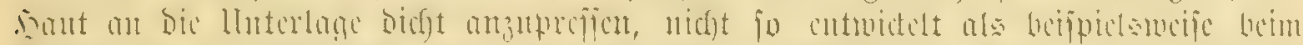

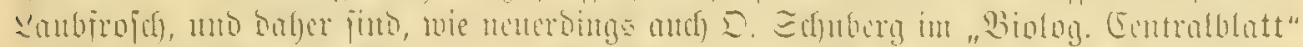

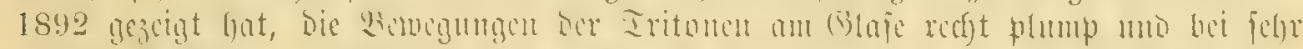

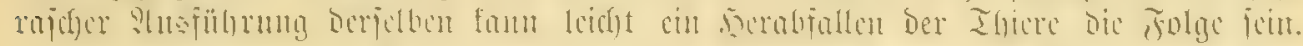

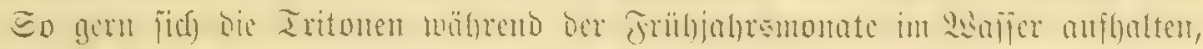

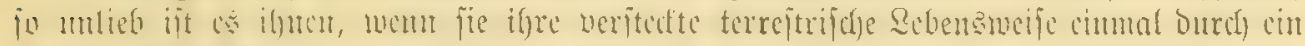

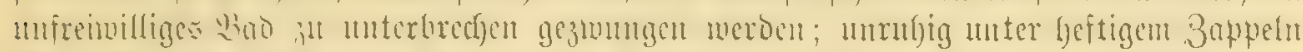

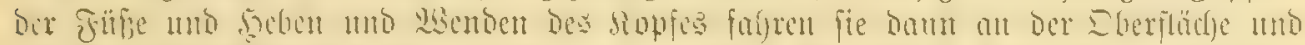

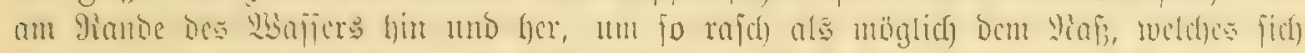

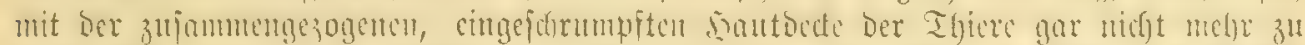

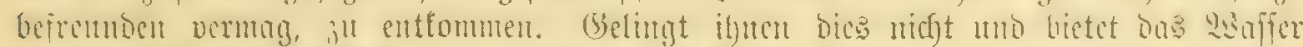

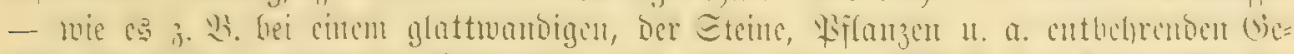

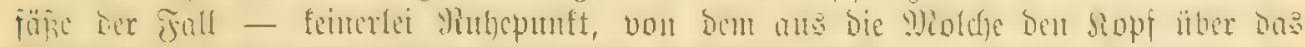

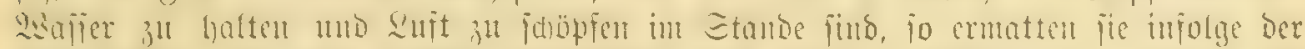

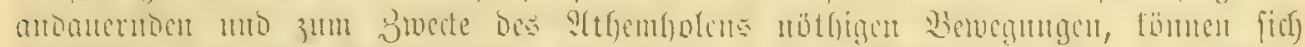

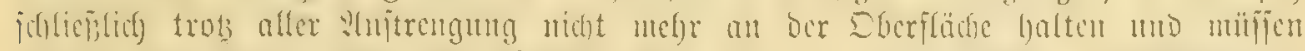
(infad) ertriuten, mas, mie anf Ecite 389 crörtert, unter gleidfen llnitänben and)

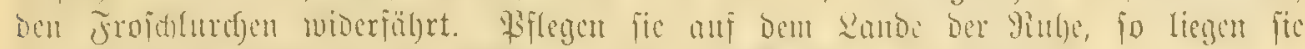

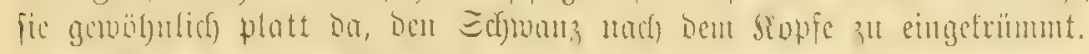

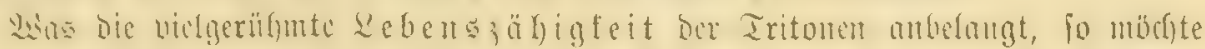

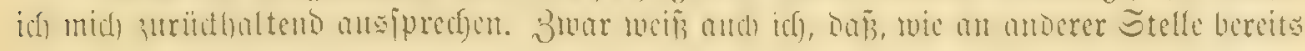

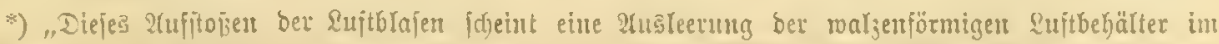

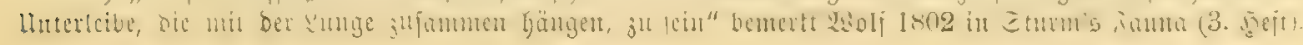




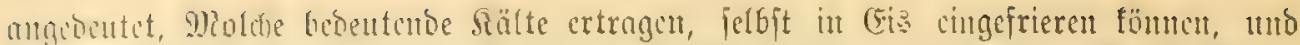

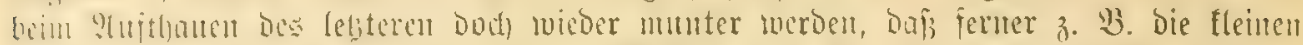

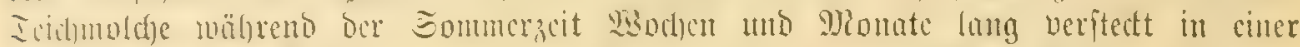

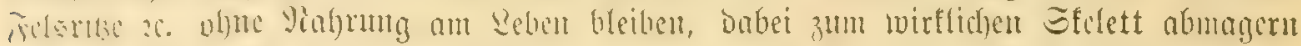

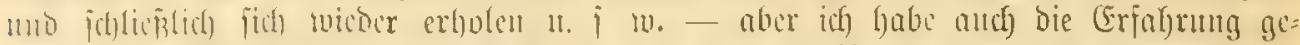

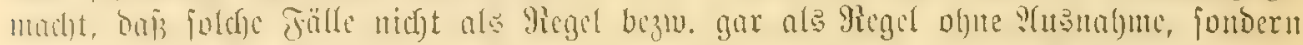

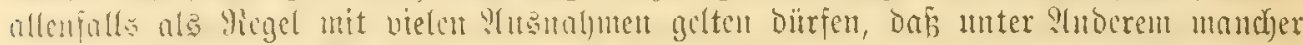

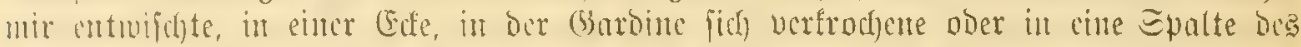

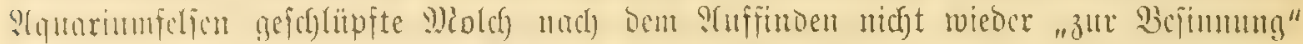

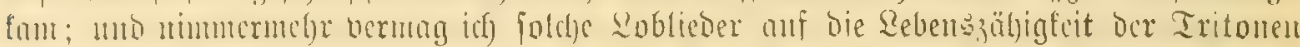

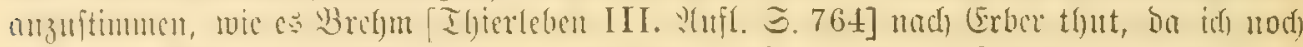

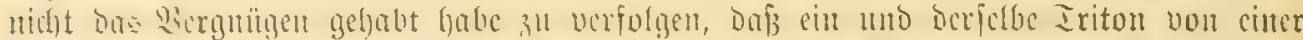

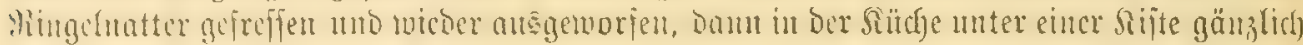

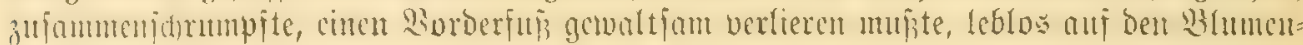

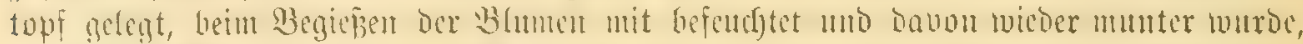

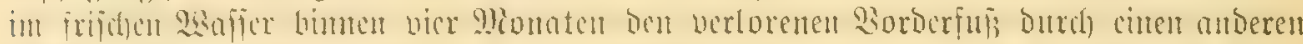

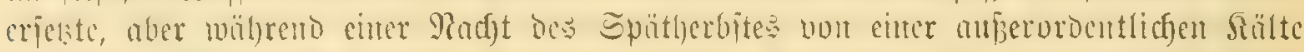

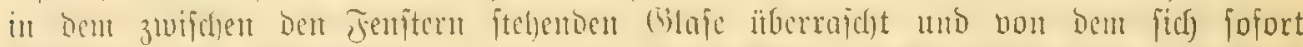

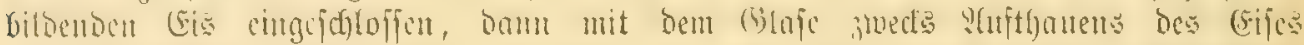

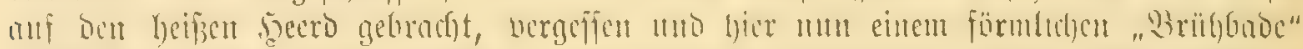

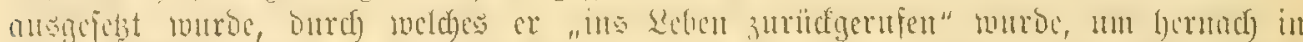

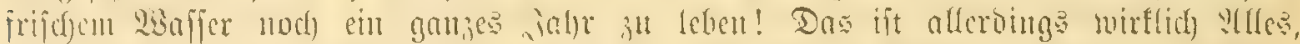

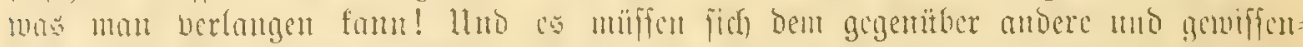

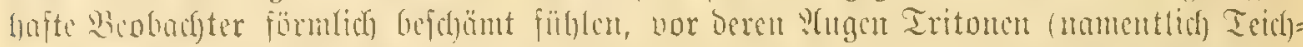

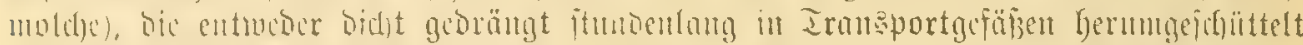

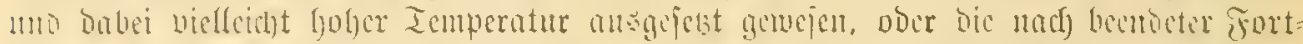

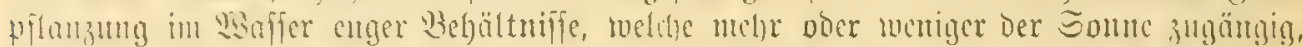

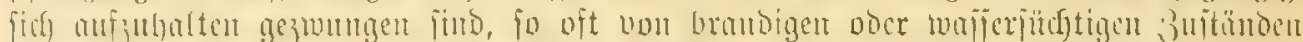

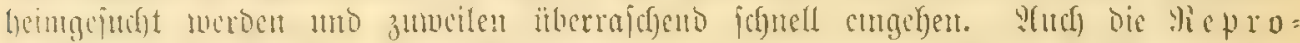

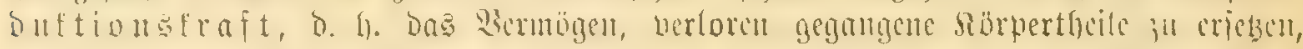

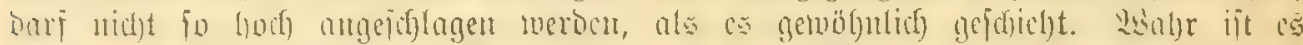

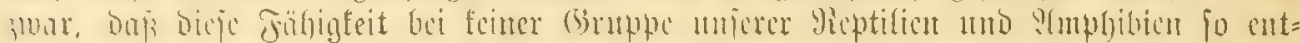

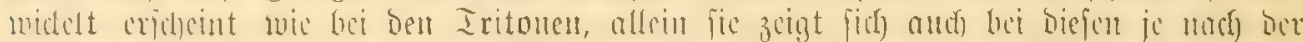

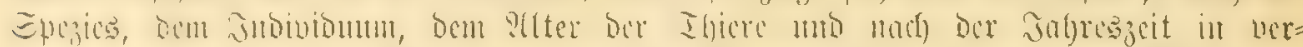

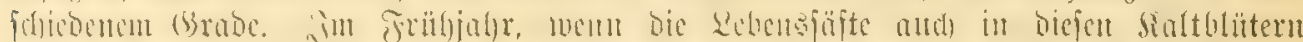

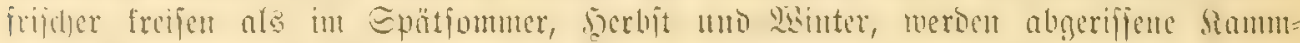

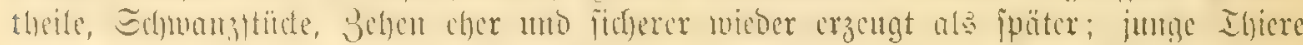

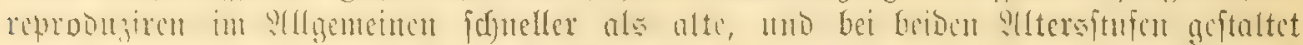

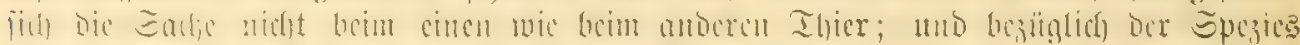

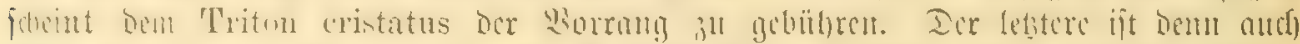

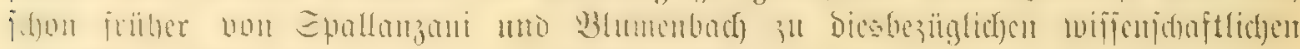
23 crijuchen bentigt worden, bie suir anf Scite 400 bereite bciprochen.

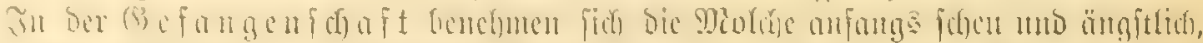

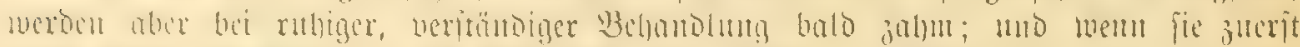

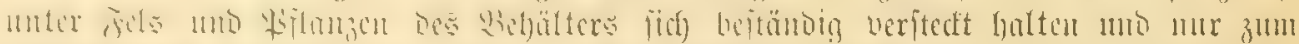

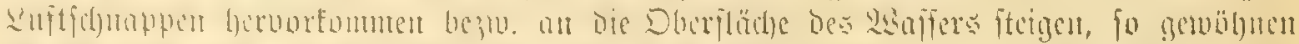

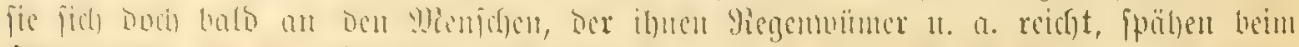

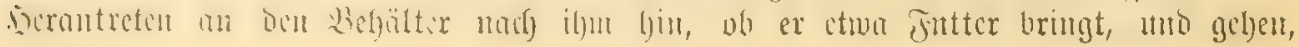




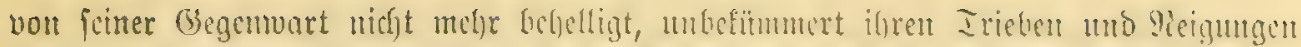

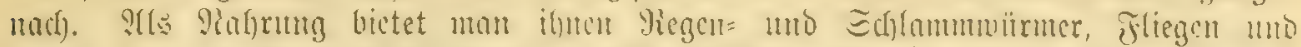

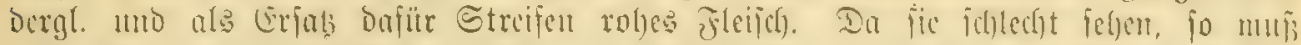

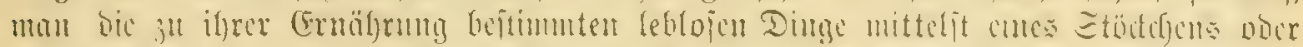

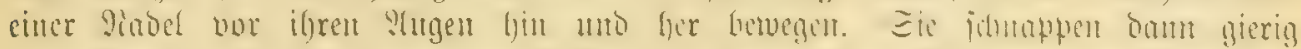

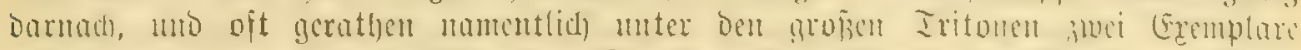

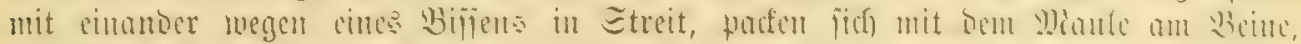

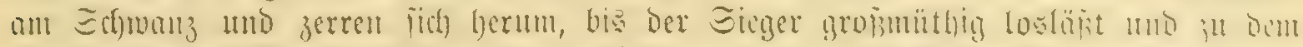

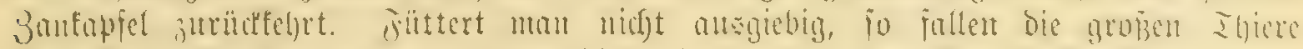

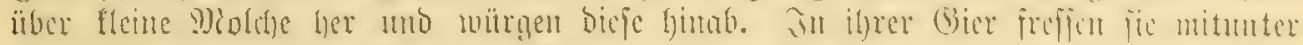

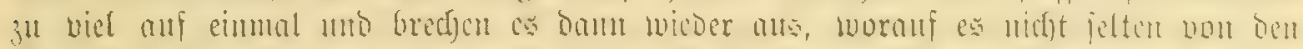

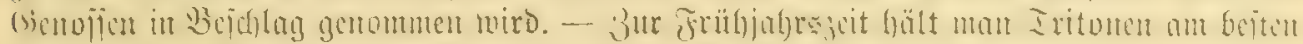

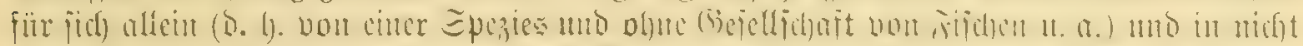

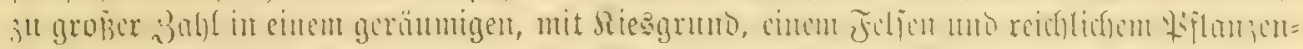

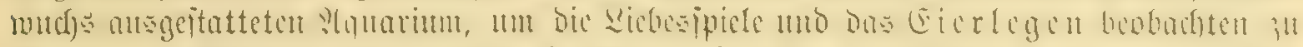

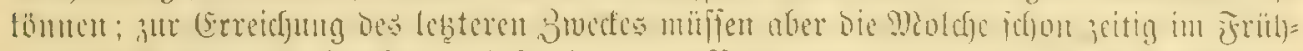

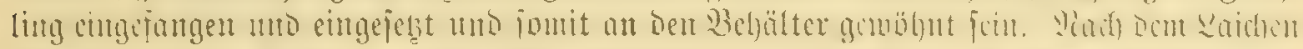

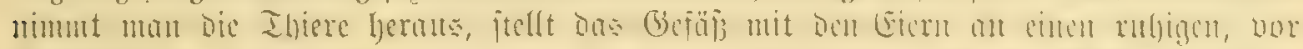

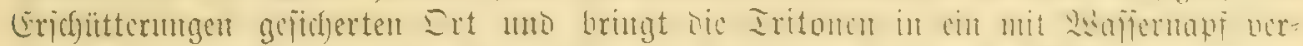

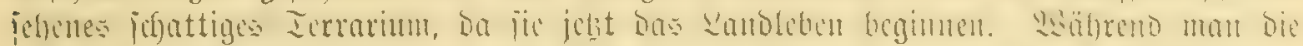

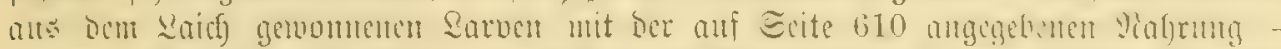

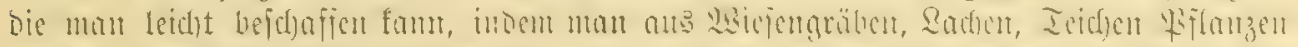

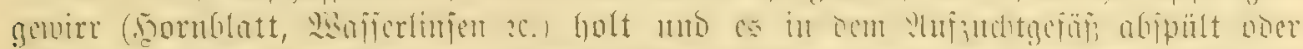

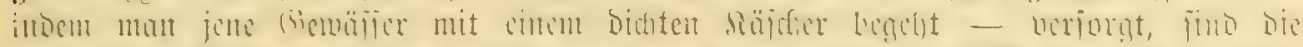

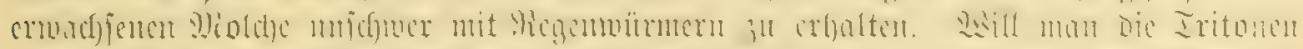

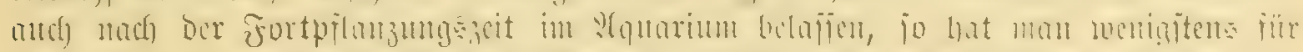

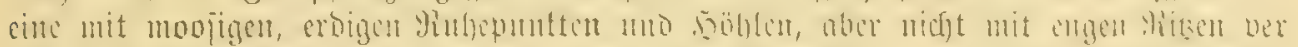

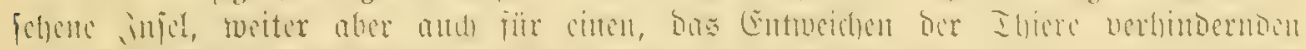
oberen

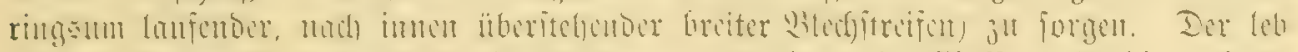

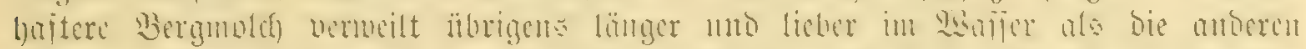

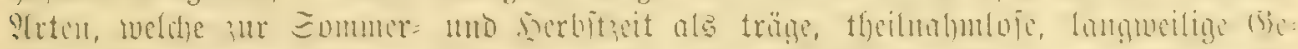

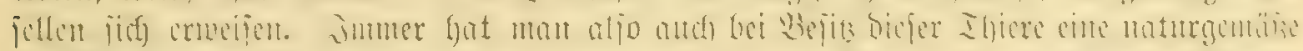

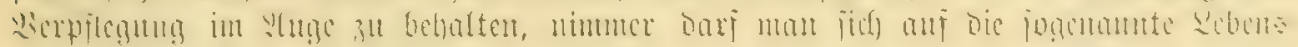
zäligfeit (vergl. S. 615) Dericlfar verlaficn!

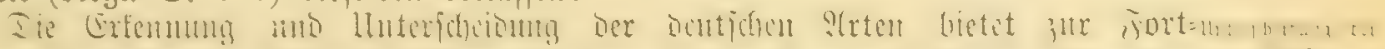
film,

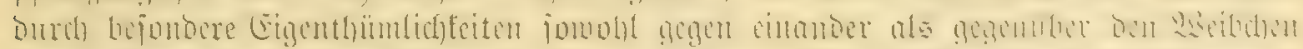

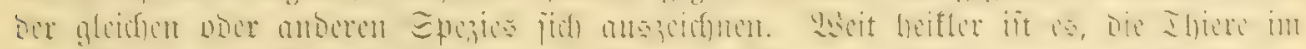

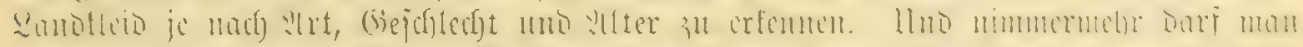

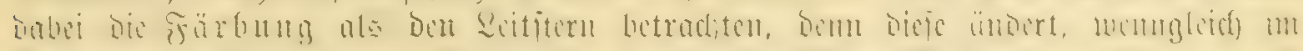

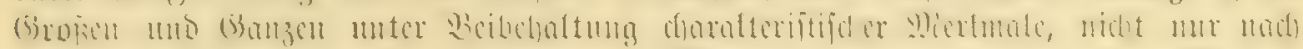

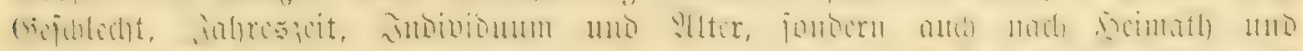

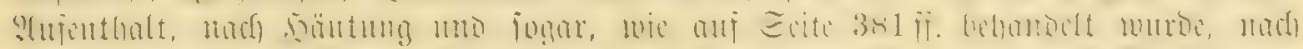

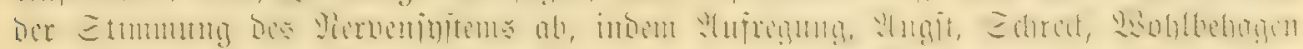

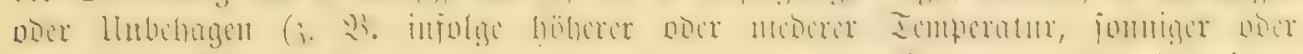

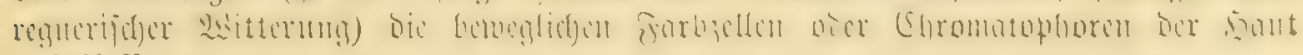
becinfluifen. 


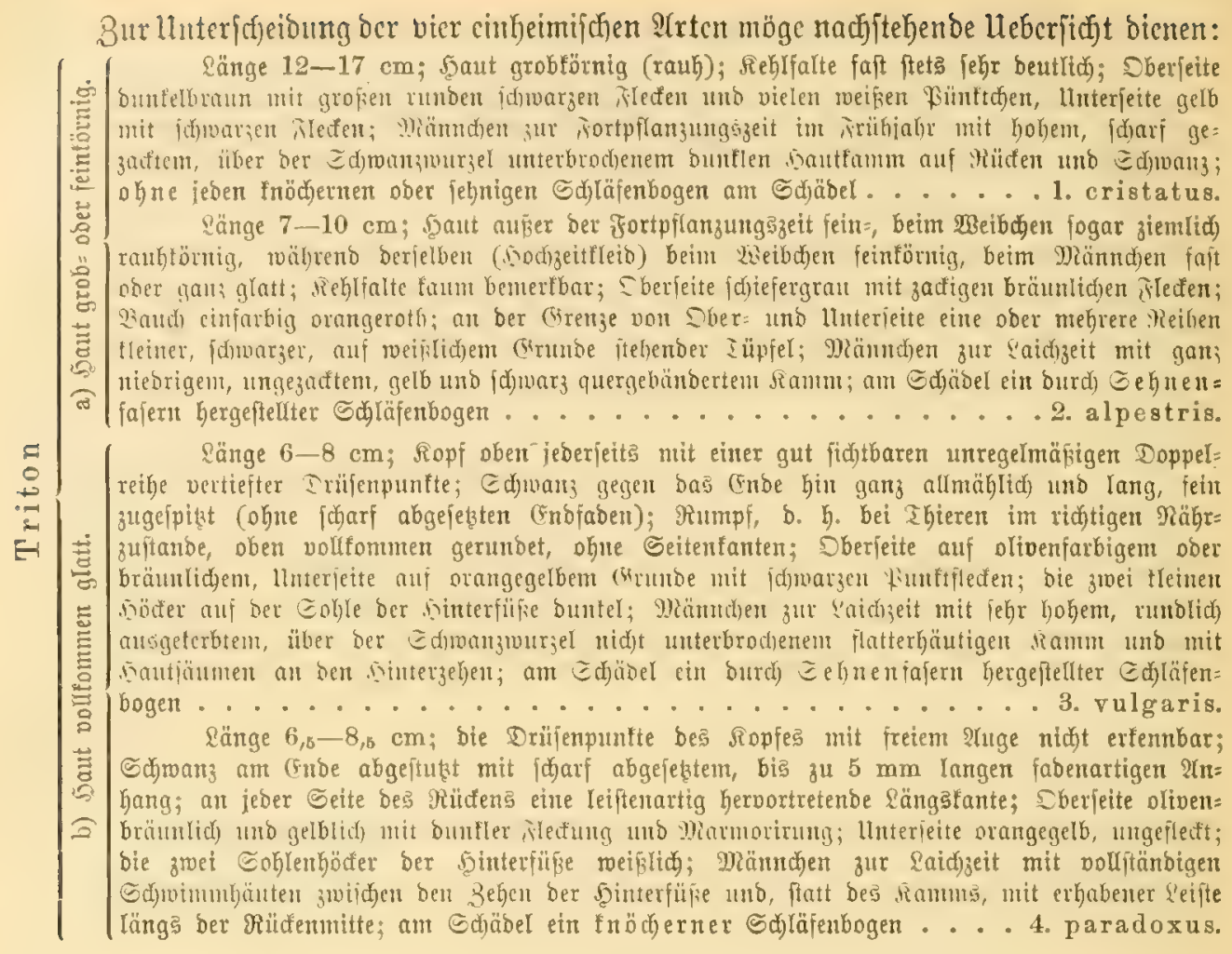

3. Irt: Kamm=21Tolh. Triton cristatus, Laur.

פbbilbung: Tafel XTI, 9ir. 3. 4.

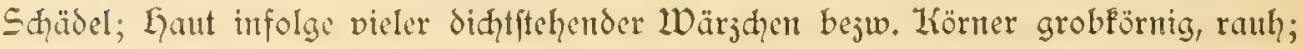
Keblfalte faft inmer fehr deutlid ausgeprägt; Dherfeite dunfelbraun mit grof̧en runden fhwargen flecken und zahlreiden weisen pünțhen, Ltnterfeite gelb nit fawarjen fleden; Zluge (Jris) goldgelb mit einem von der Pupille fenfreḑt nad) abwärts gehenden fhwarjen Striđ; liömdhen jur fortpflanjungszeit (frühjahr) mit hohen, fharf gejadtem, über ber Sđwanzwurzel unterbrodyenem dunflen Lqut= fanm auf Rüden und Sdwanj.

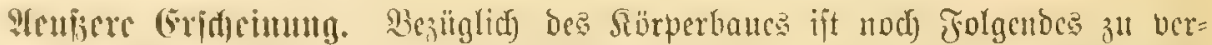

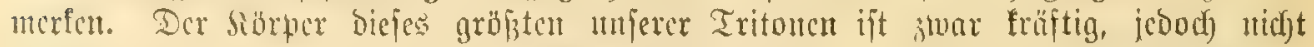

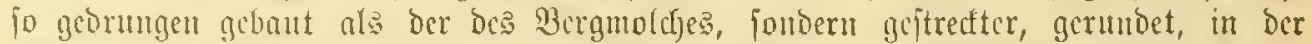

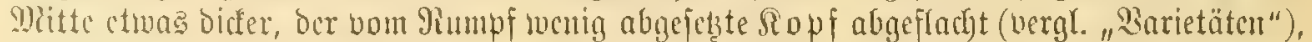

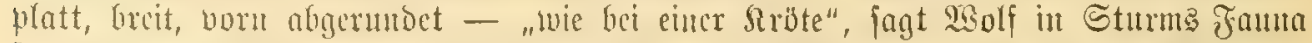

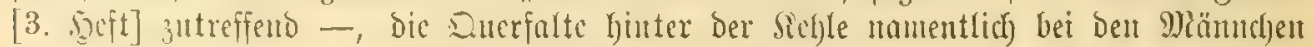

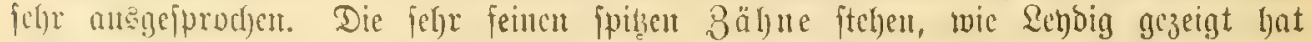

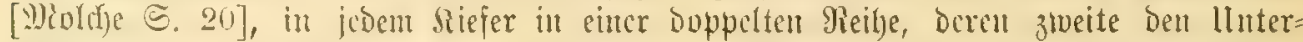
fudfonden fonft immer entgangen ijt; dic bes Ganmens bilden - cin mejentlides

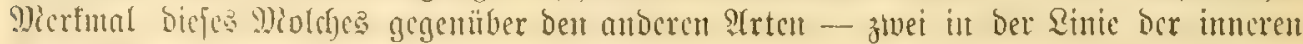
Tajenlibfer beginncube paralfele, nux binten ein wenig madj anben biu geridjtete 


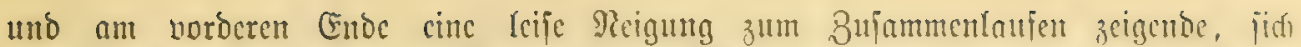

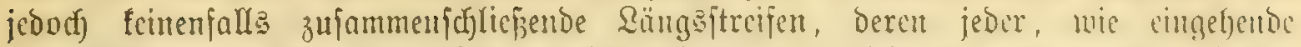

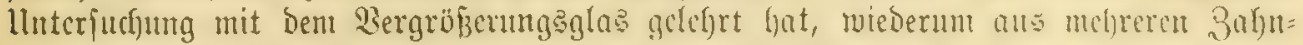

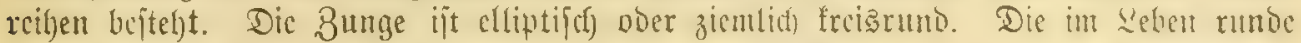

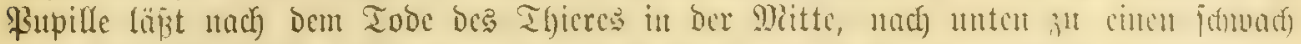

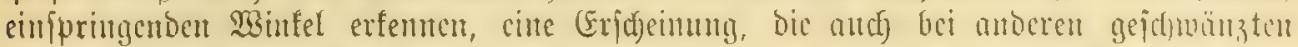

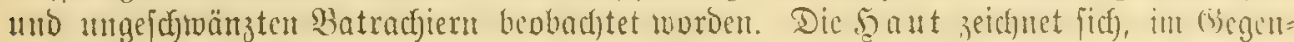

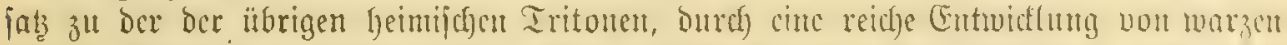

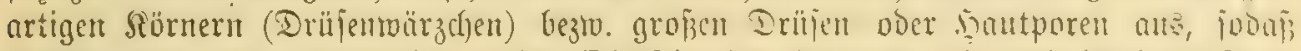

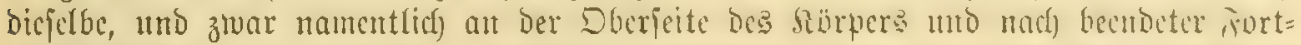
pffanzungezcit (im Randfleio), grobtörnig cricheint. Eine eigentlic)e Driffcumulit in

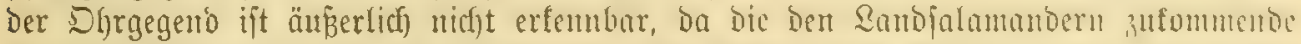

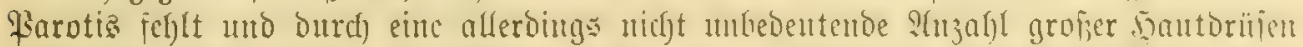

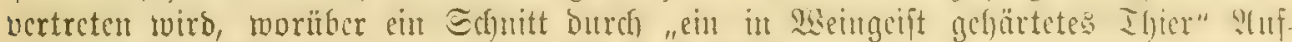

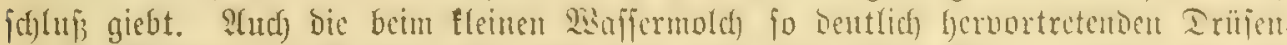

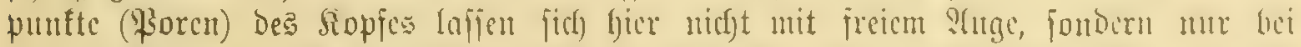

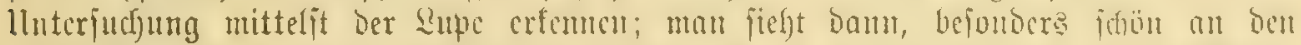

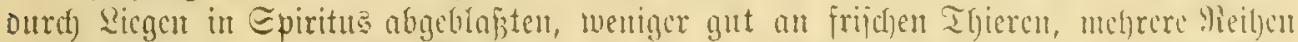

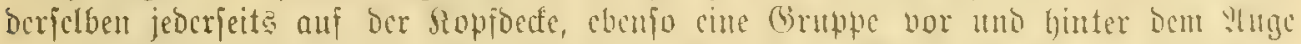

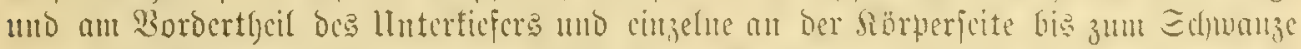
fin. Die (Scjammtlänge crmadjentr. Thicrc Grträgt gemöbnlich 13 bis $15 \mathrm{~cm}$, in

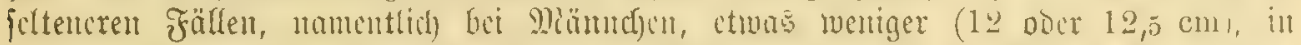

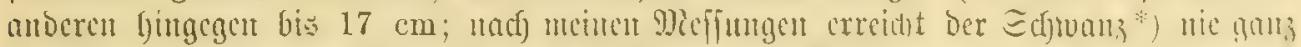

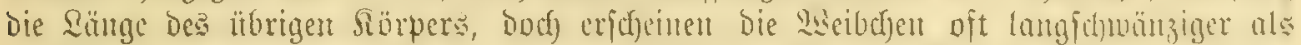

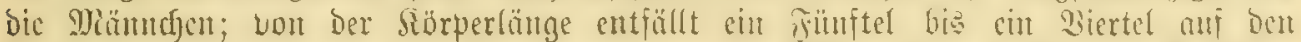

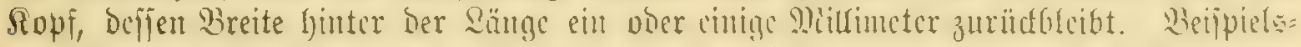

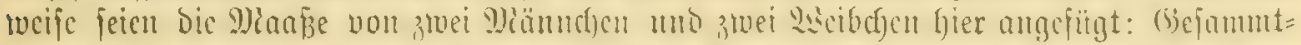

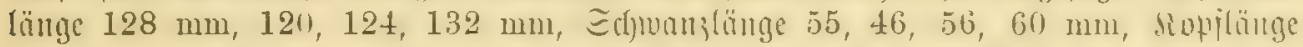

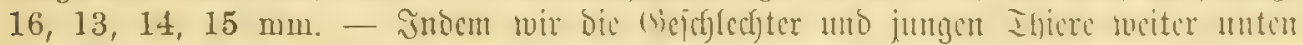

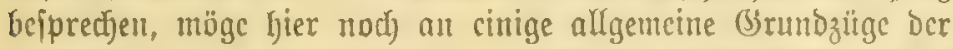

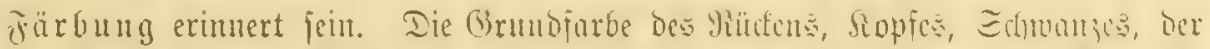

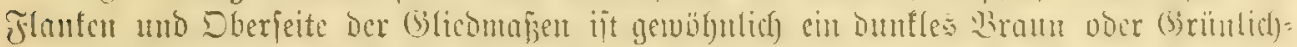

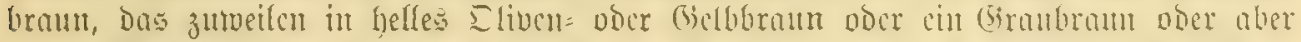

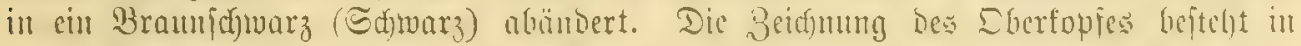

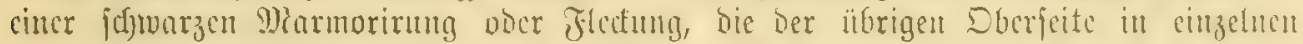

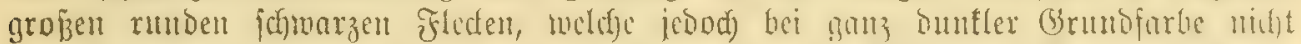

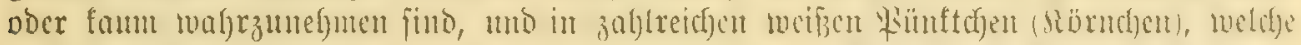

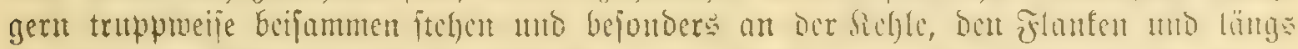

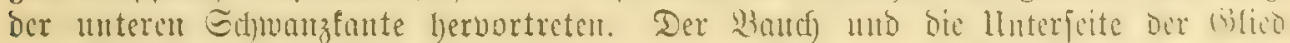

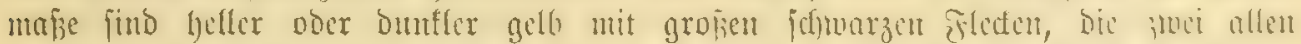

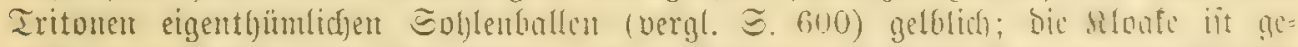

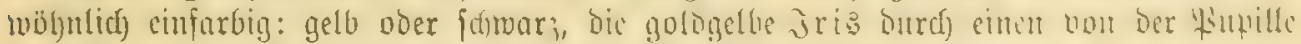

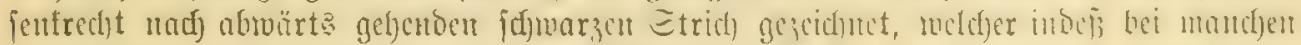

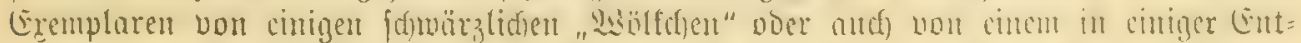

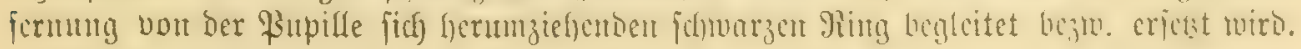

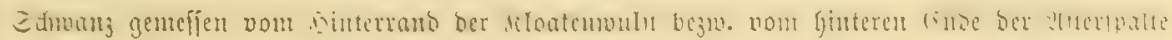
an bis วur Spiţe. 


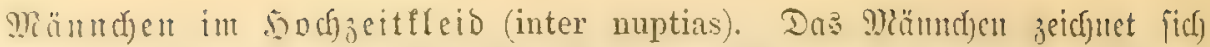

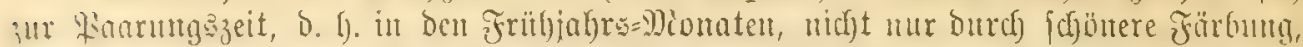

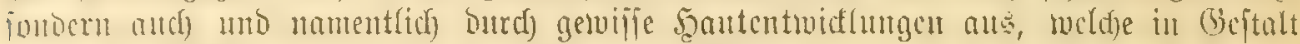

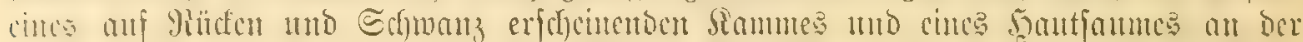
Ebcrlippe auftreten. Ier eigentlidsc (jofarfzadige) Samm hegimnt als nicorige Leijtc

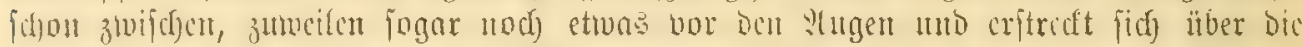

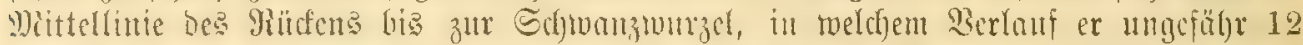

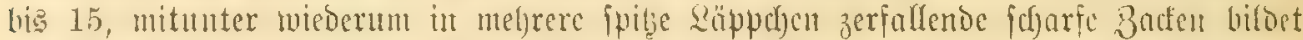

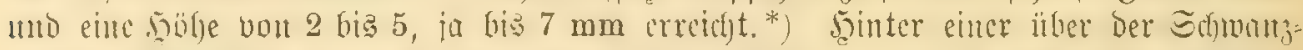
Imuracl befindichen, 4 bis $6 \mathrm{~mm}$ langen fahlen Stelle - mur in ganz foltenen frällen

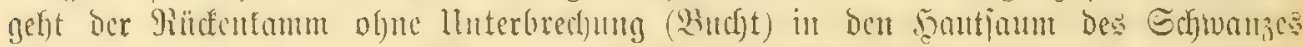

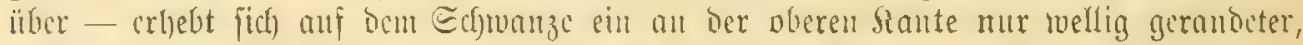

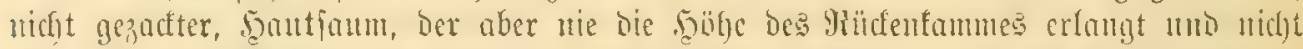

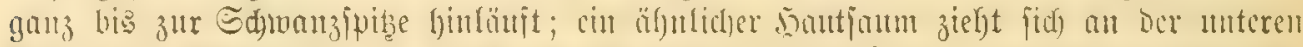

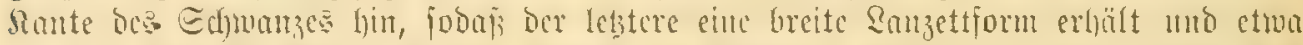

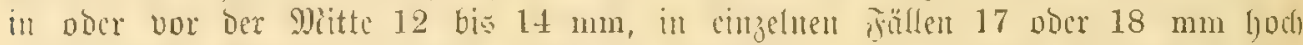

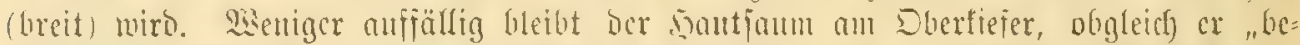

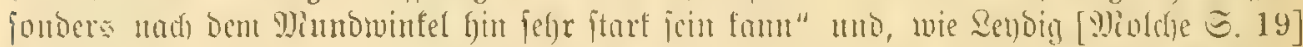

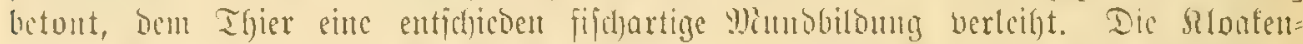

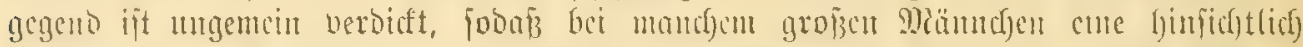

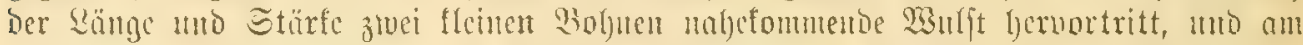

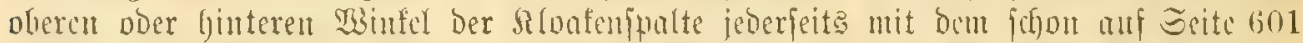

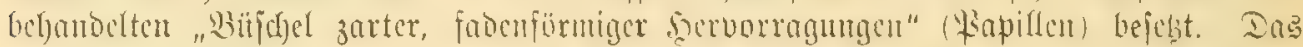

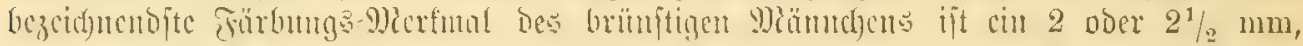

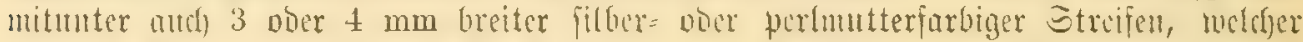

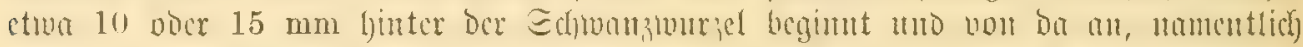

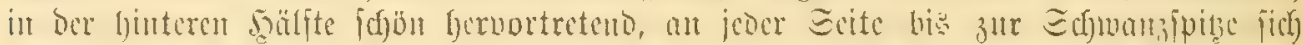

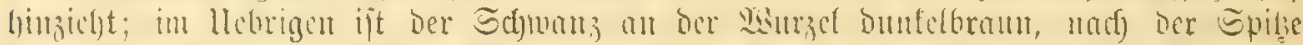

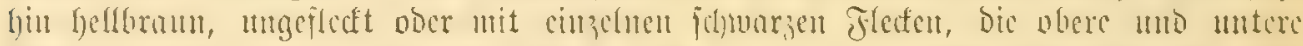

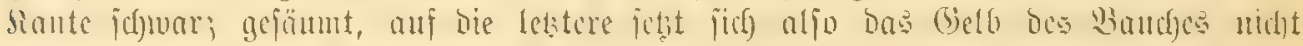

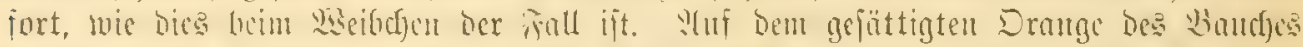

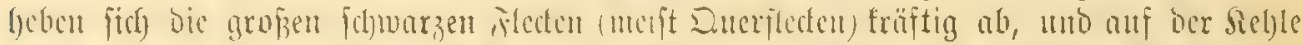

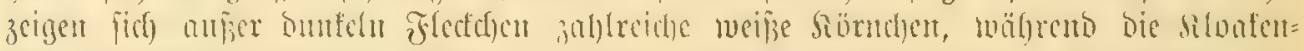

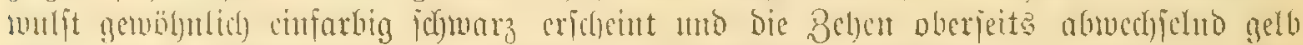

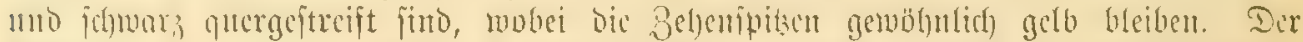

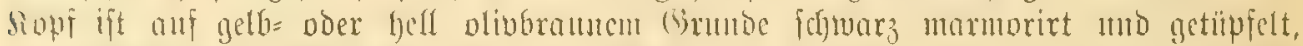

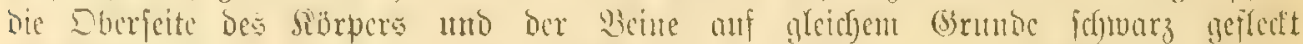

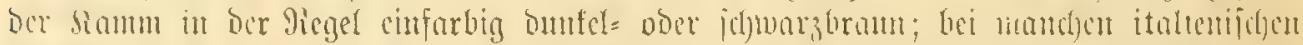

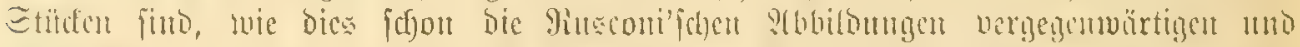

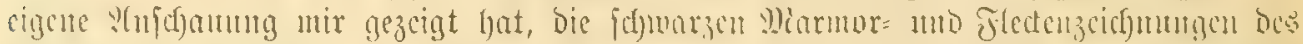

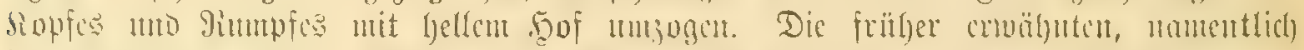

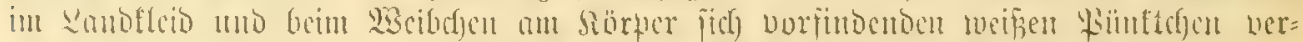

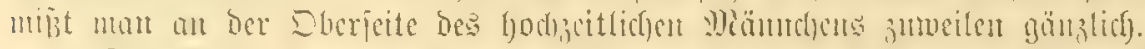

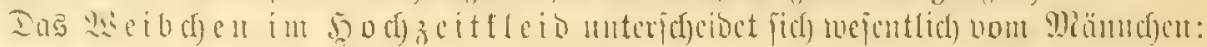

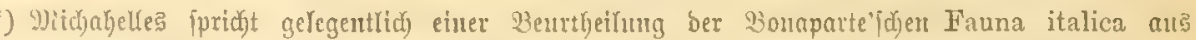

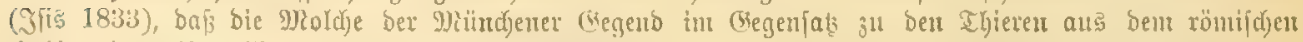
(bebiet emen bis 6" - aljo $12 \mathrm{~mm}$ ! - Gohen Samm crhalten tömten; mir if eir berartiges Gxentplar ute 3u (3efidgt gefomment. 


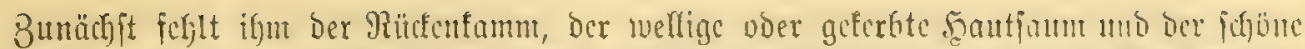

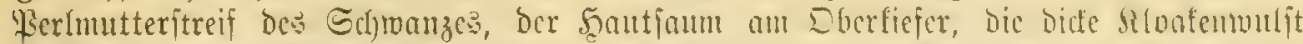

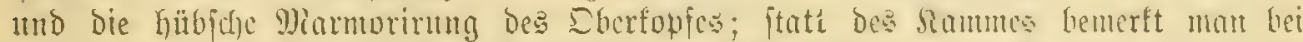

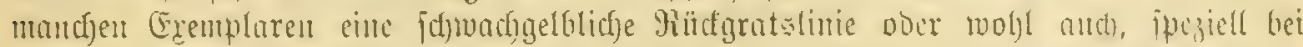

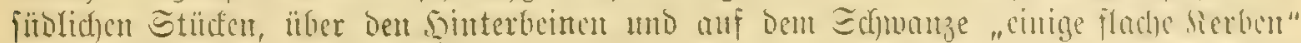

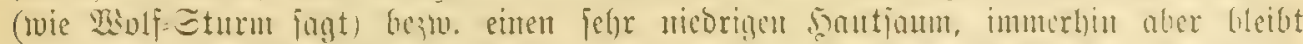

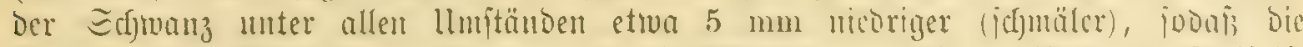

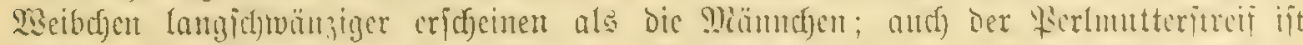

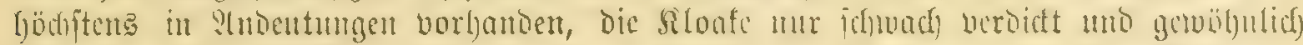
cinfarbig geth, Die Siehle blos Dunfel getïpfit, im llibrigen glatt, onne Wiseib, der

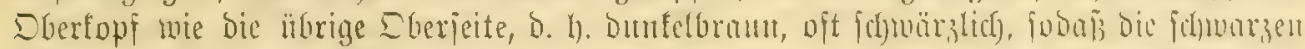

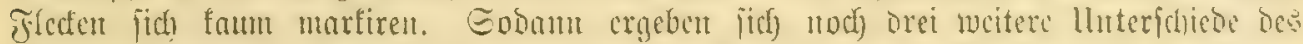

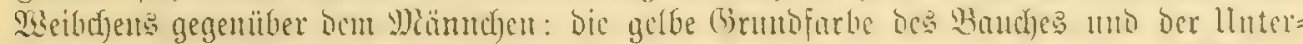

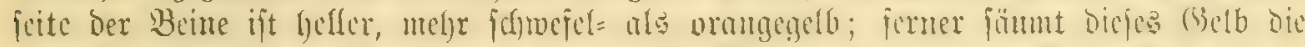

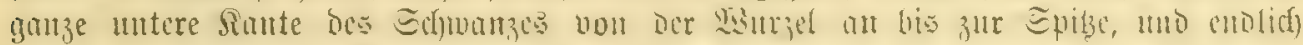

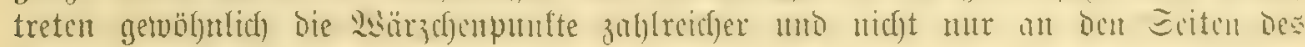

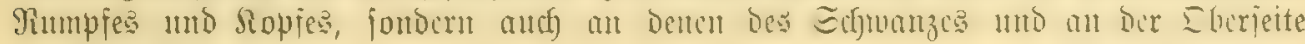
ber Bcine auf.

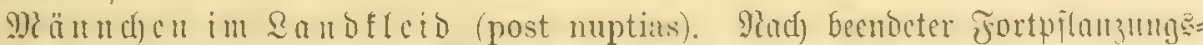

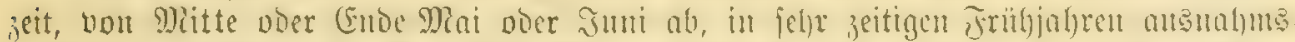

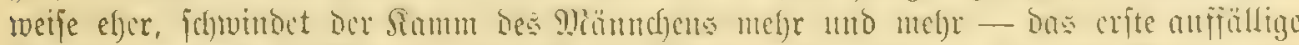

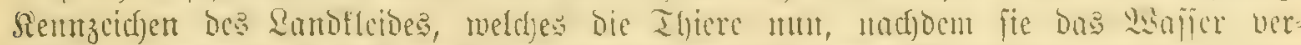
laffen, antegen แnd bis nadf Dem (ermadfen aus Dem wisinterfolof trangen. Der

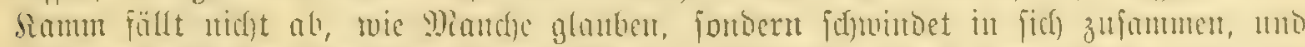

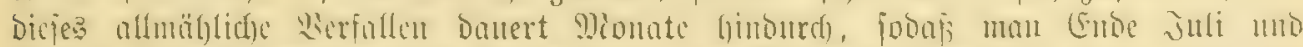

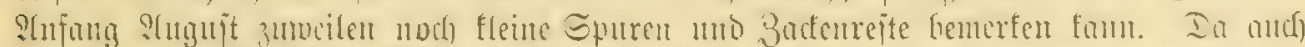

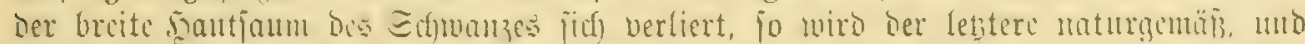

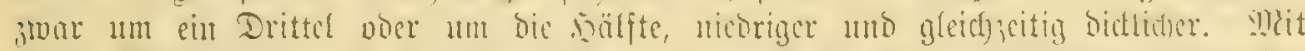

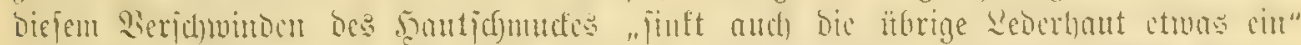

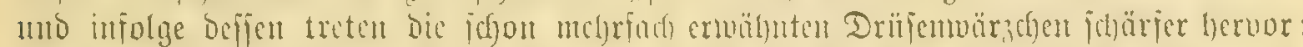

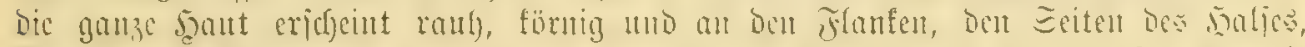

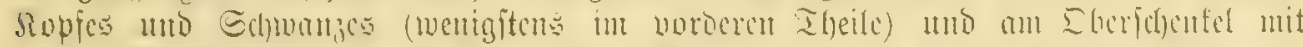

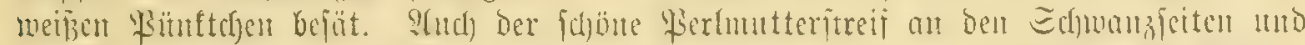

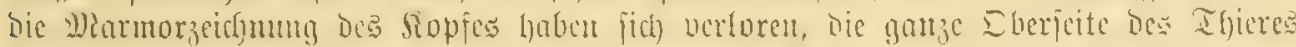

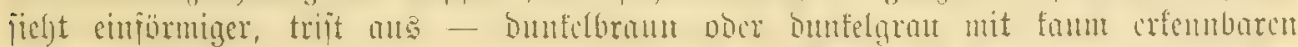

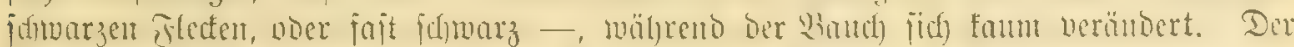

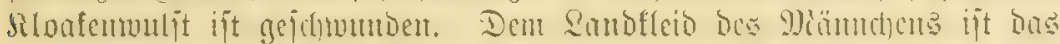

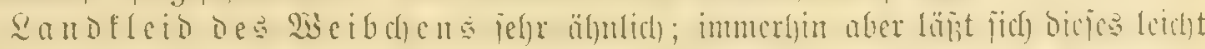

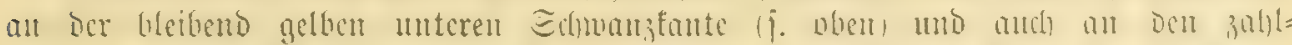

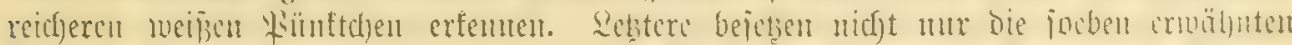

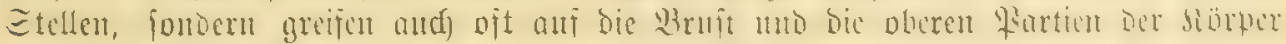

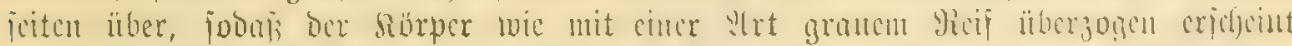

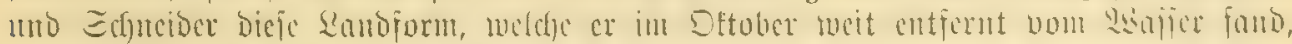

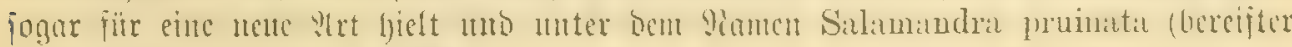
Ealamander i. Э. 1799 bejdyrieb.

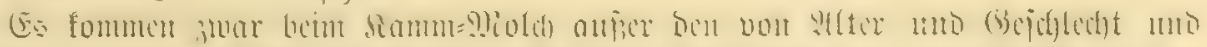

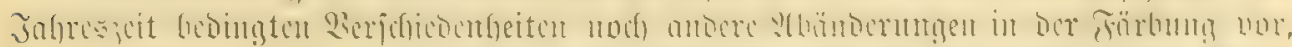

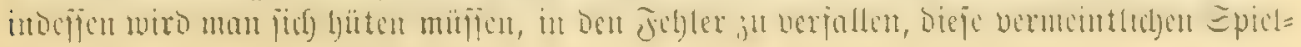




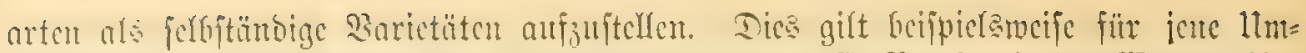

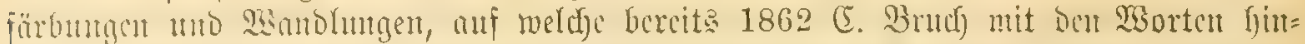

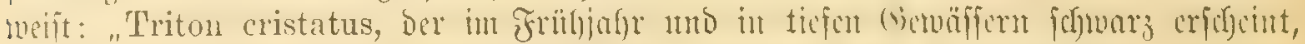

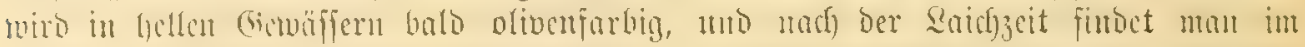

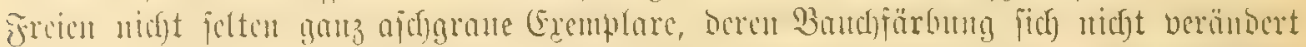

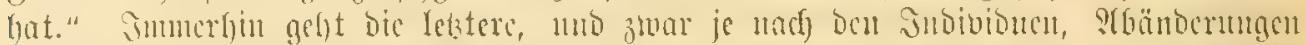

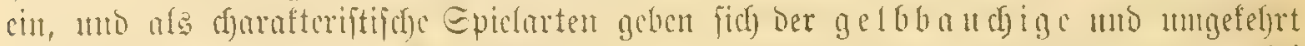

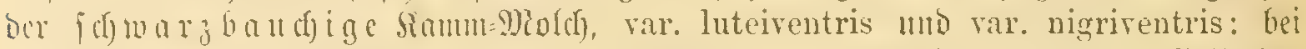

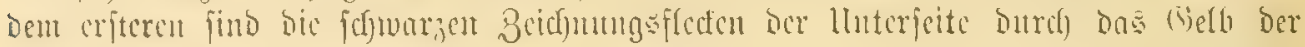

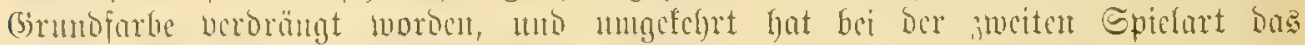

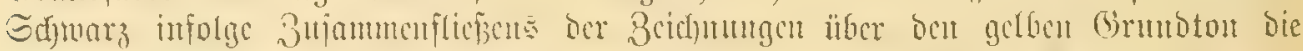

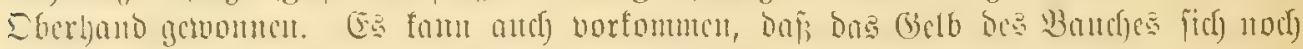

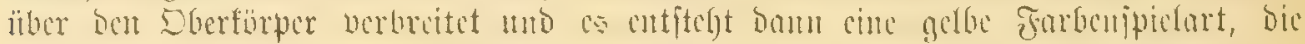

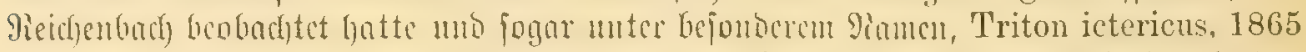

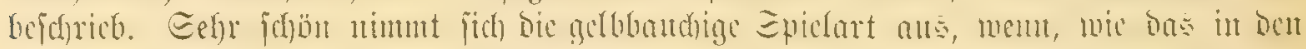

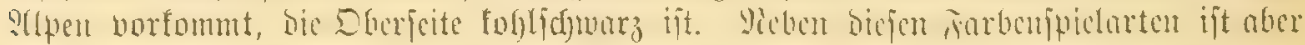

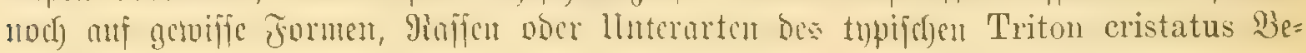
Docht z̆l nefmen.

Tin jeiner, 1872 erjujienenen Histoire Nat. des Reptil. et des Batraciens ber Faune suisse

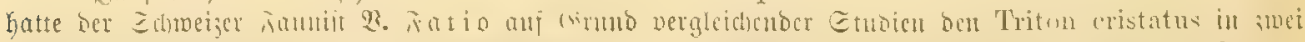

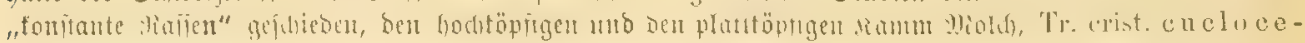

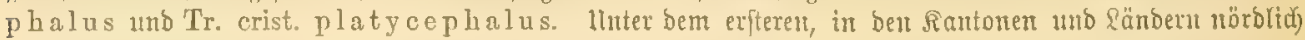

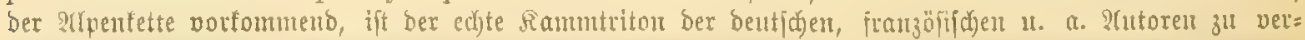

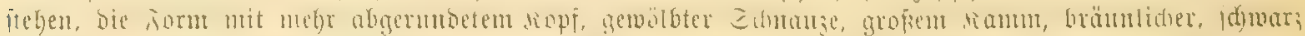

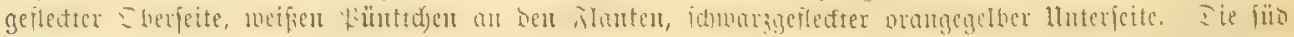

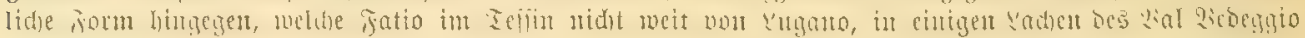
beobachtet Gatte, wurbe von ifm bes breiteren uno platten Siopjes megen platycephalus benannt

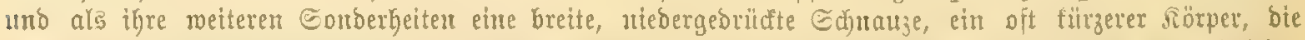

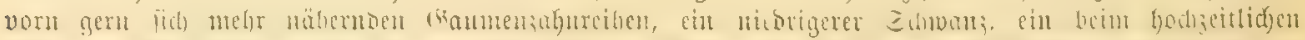

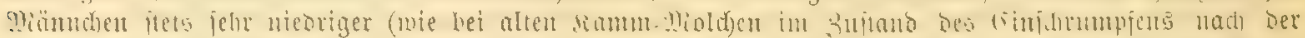

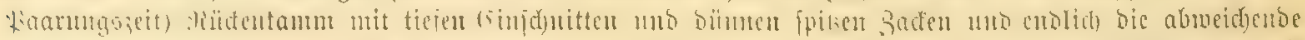

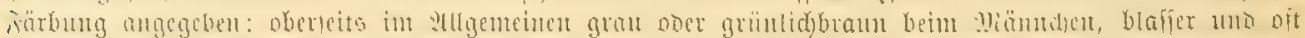

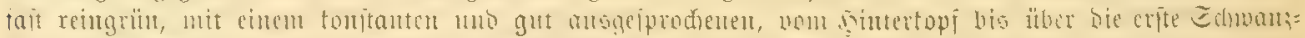

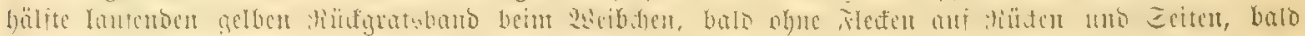

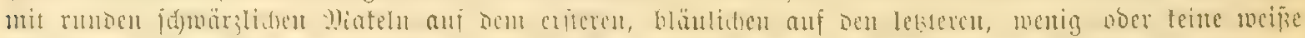

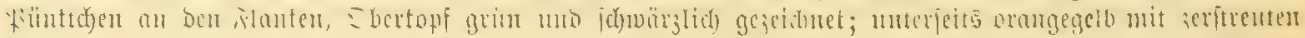

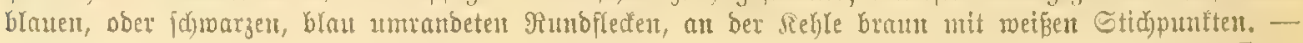

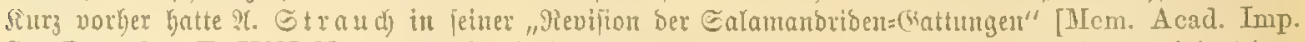

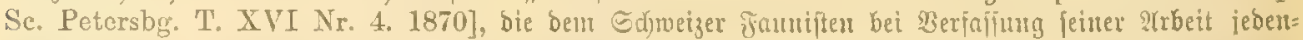

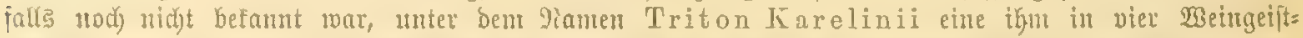

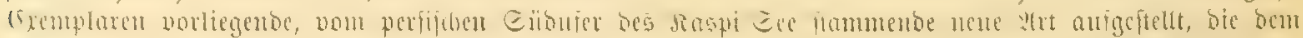

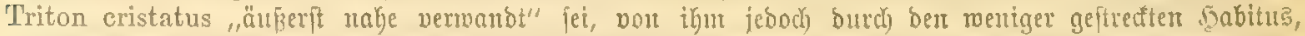

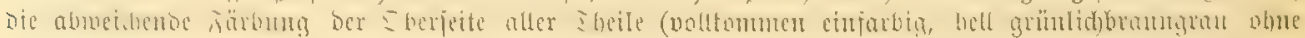

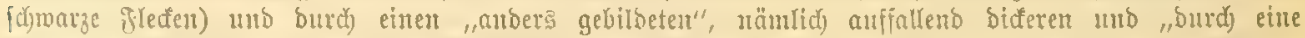

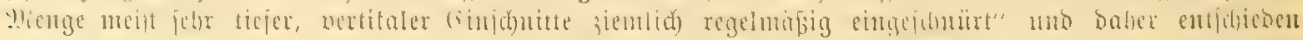
geringelt erfdjeinenton Sdywanz unterfdyetoe. Boulenger hat baun 1882 im "Catalogue" Den Triton

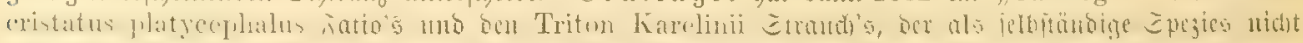

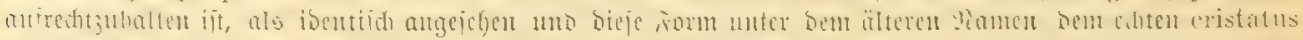

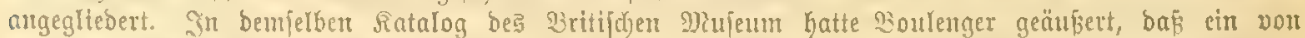

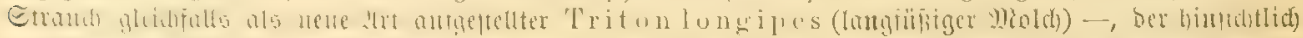

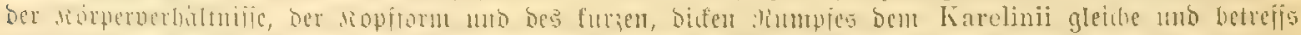

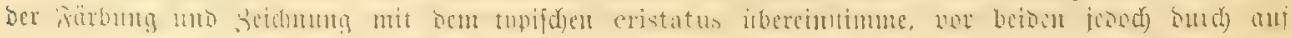

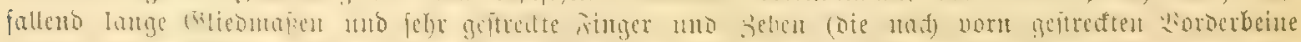

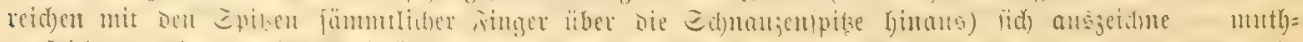

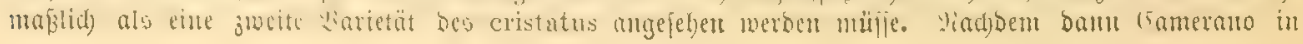




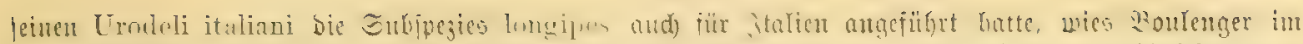
Februarheft 1892 bes Ann. and Jagazin of Nat. Hist. auf (junt ber von ifm an zablreiden, ans

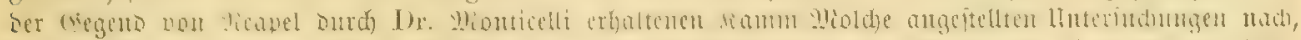

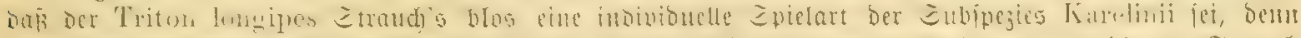

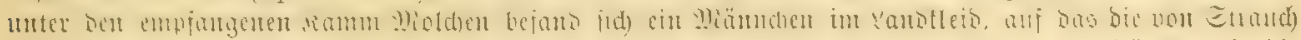

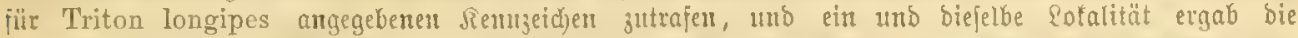

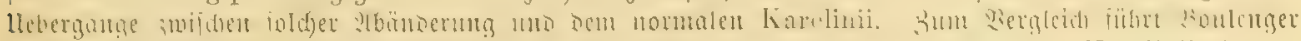

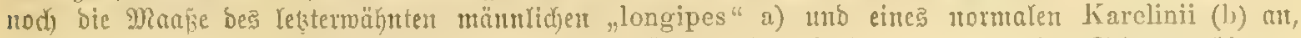

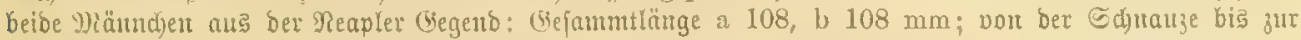
Rloale a 60, b $56 \mathrm{~mm}$; Ropflänge (Echäbel) a 14 , b $14 \mathrm{~mm}$, Sopfbreite beỉe $11 \mathrm{~mm}$; vorbcre (Glied: maje a 25, b $22 \mathrm{~mm}$, hintere a 28, b $22 \mathrm{~mm}$; vierter Finger a 8, i) $6 \mathrm{~mm}$; vierte 3ege a $10, \mathrm{~b} 7$

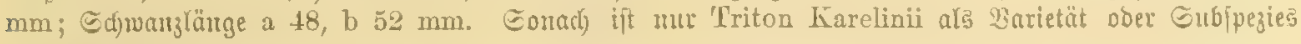
auived)(3uthaltert.

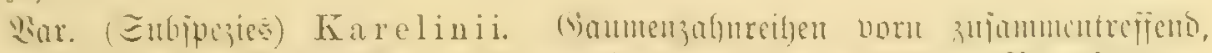

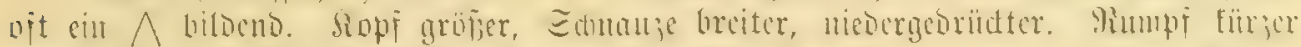

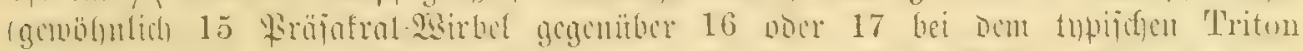

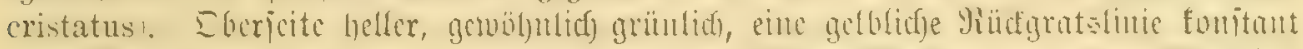

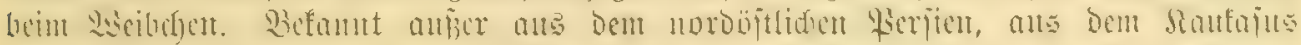

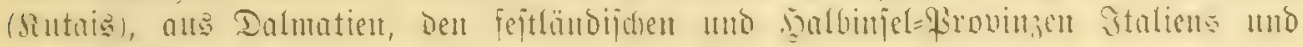
aแe ber italtenifdjen Sayweiz.

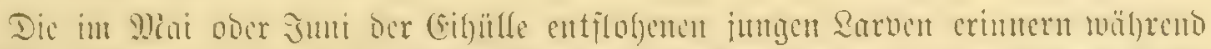

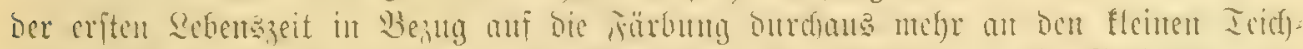

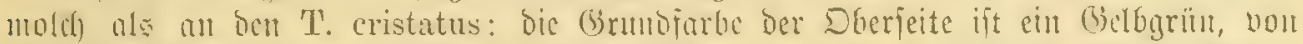

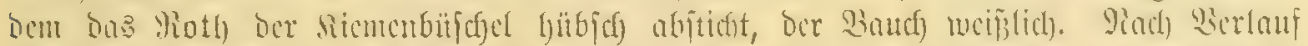

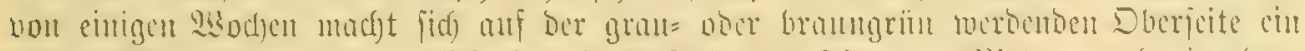

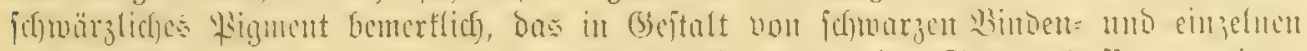

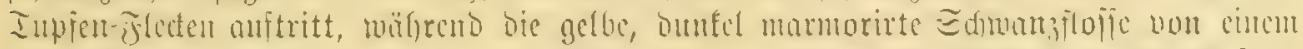

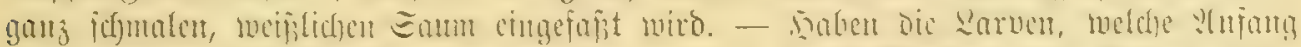

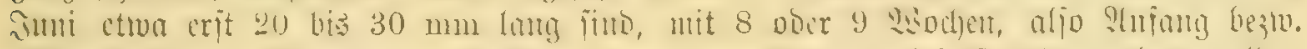

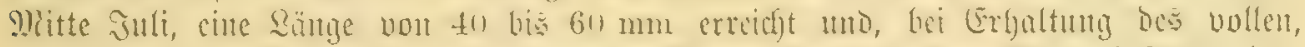

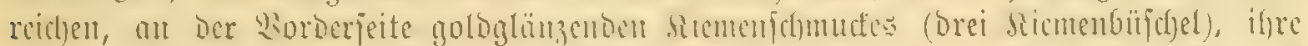

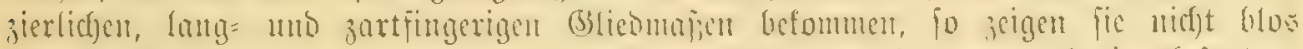

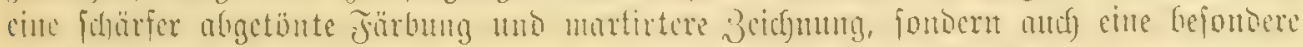

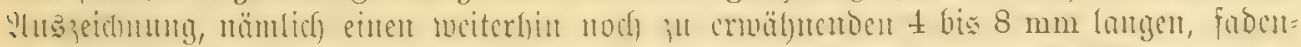

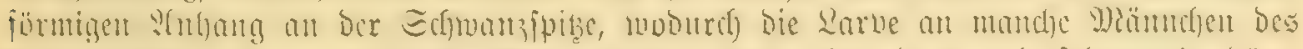

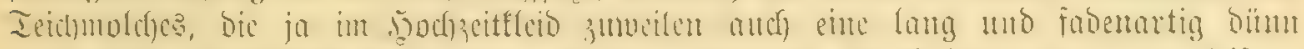

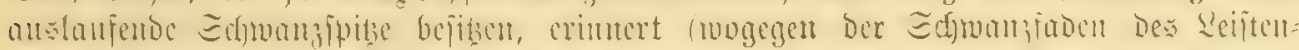

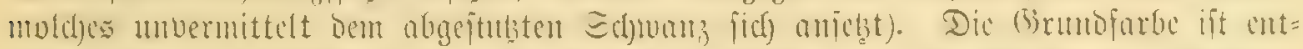

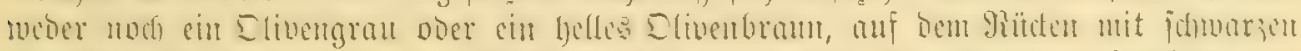

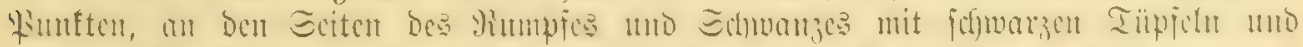

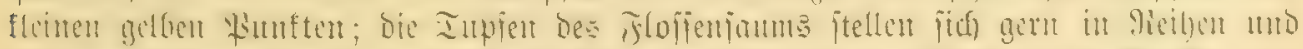

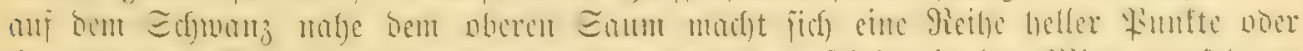

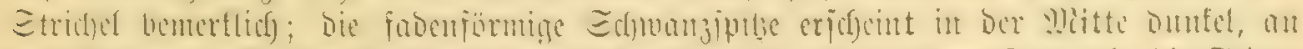

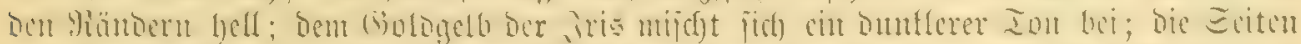

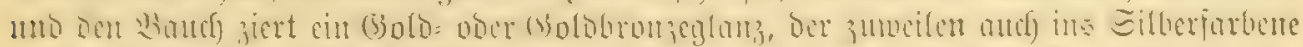

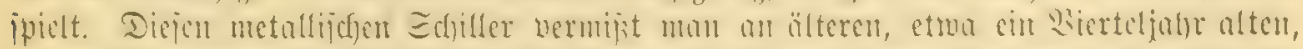

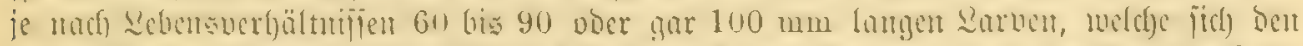

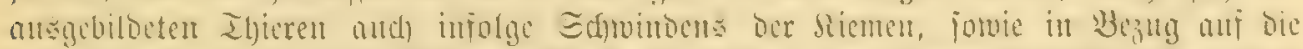

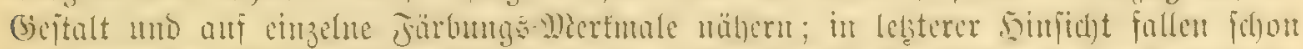

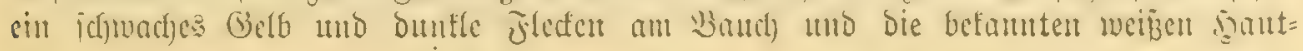




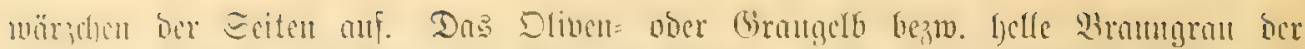

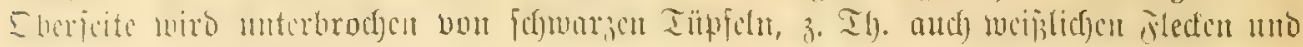
ciutcr mattgerben 9lürfgratatinte.

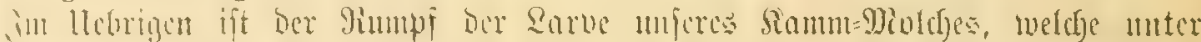

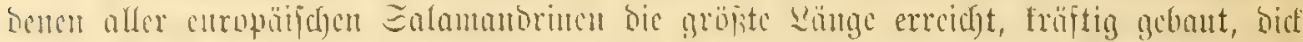

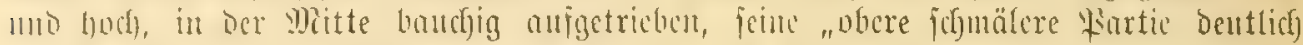

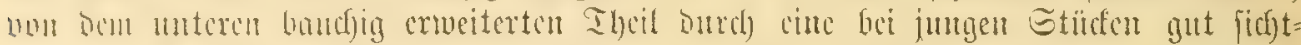

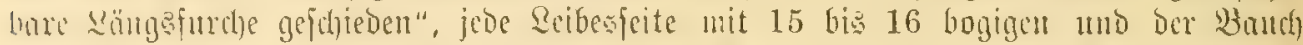

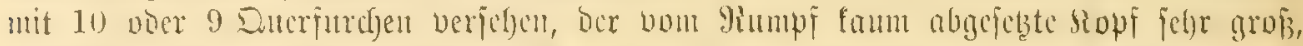

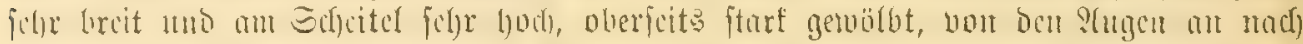

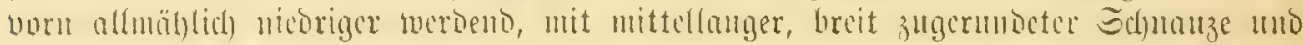

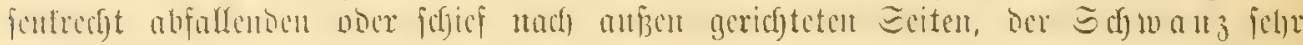

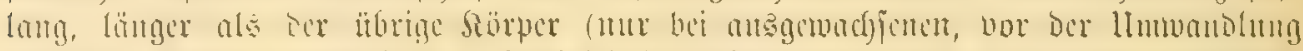

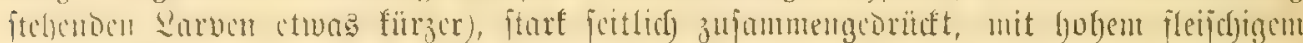

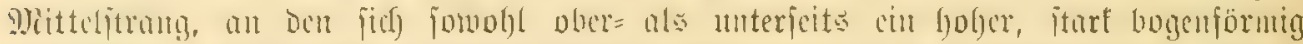

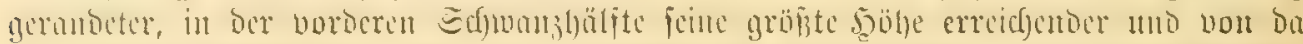

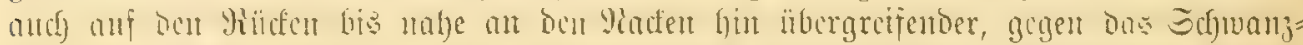

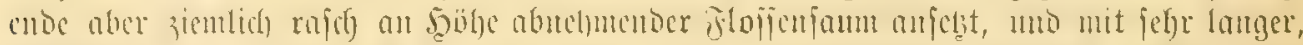

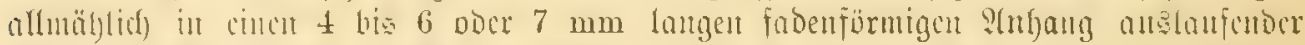

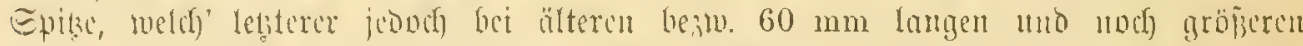

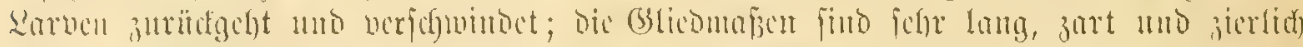

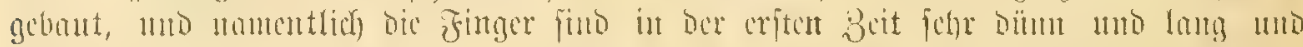

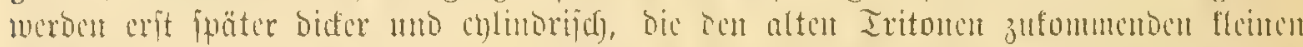

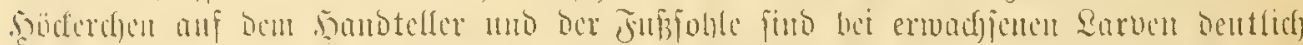

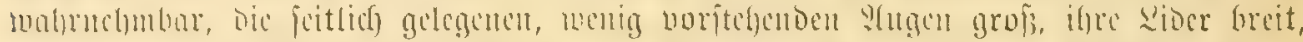

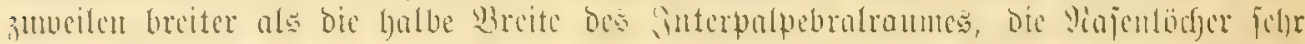

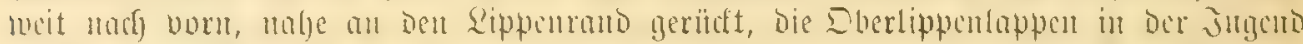

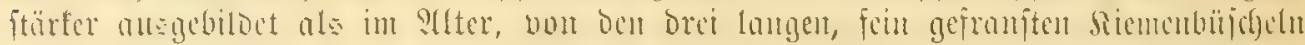

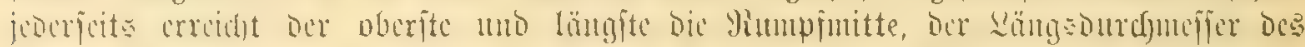

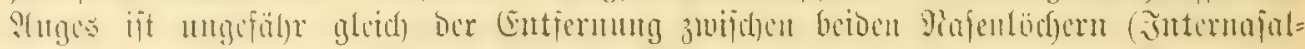

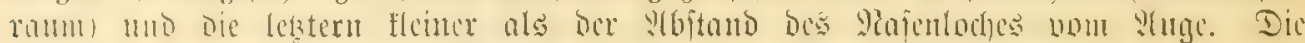
Dinaje twurbon auf Scite 607 angegebent.

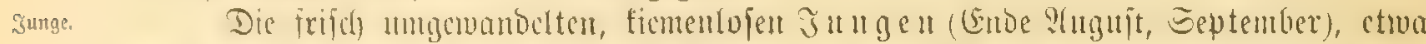

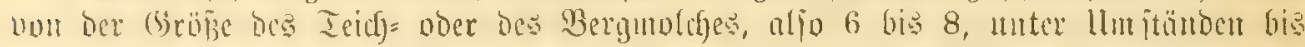

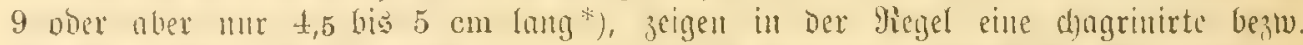

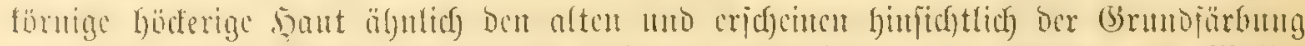

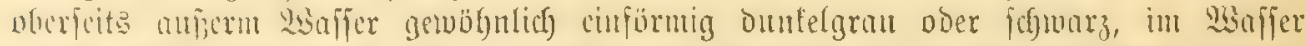

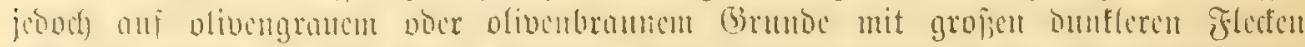

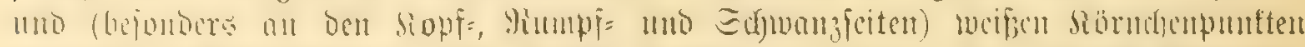

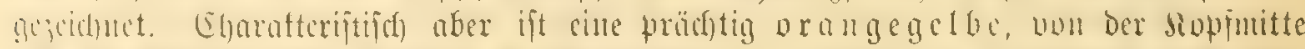

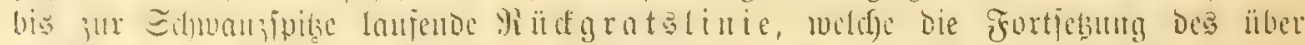

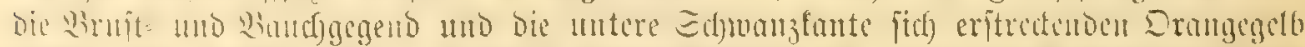

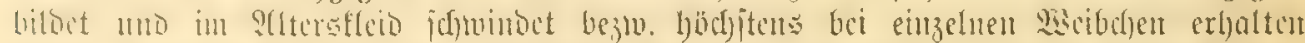

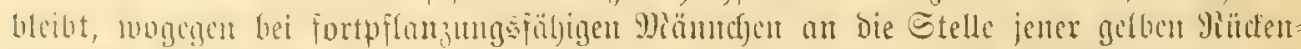

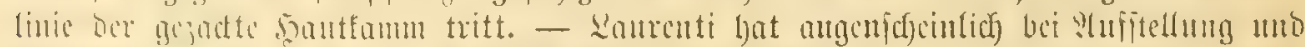

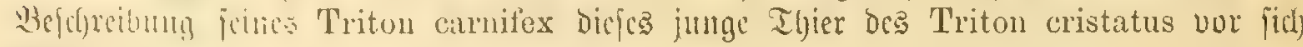

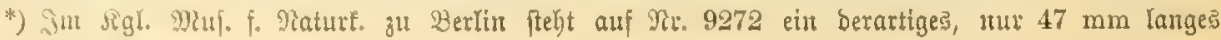

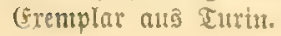




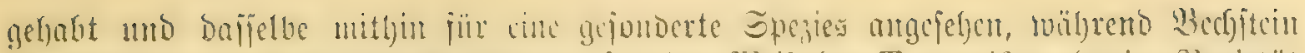

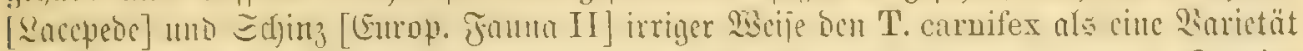

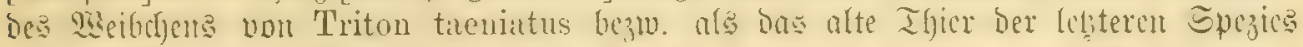

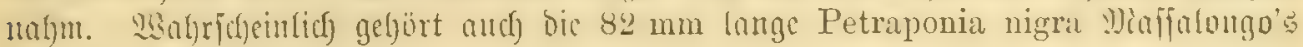
[Nuovo gen.] Gierfer.

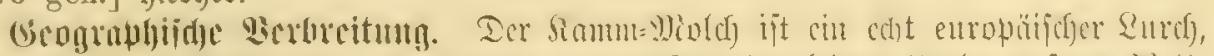

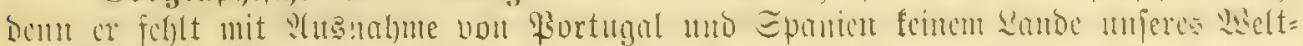

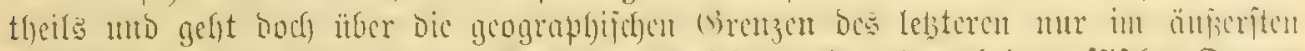

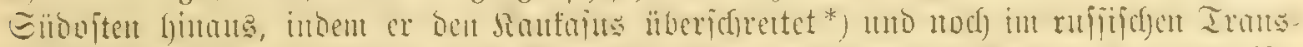

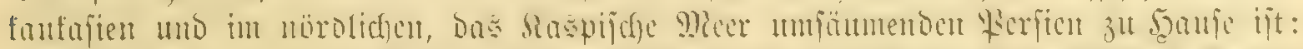

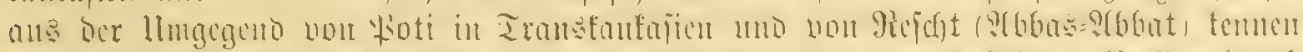

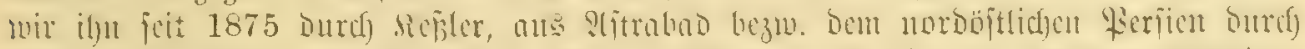

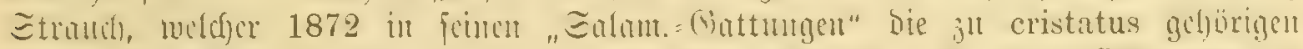
Triton Rilrelinii uno Tr. longipes wont borther bejohreibt. Sn Dicicr Este, etwa an

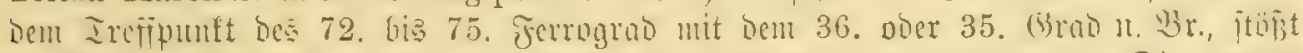

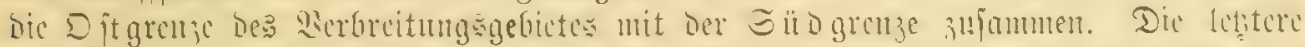

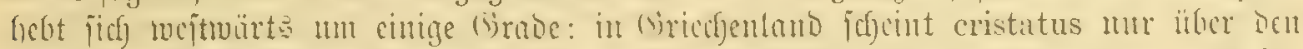

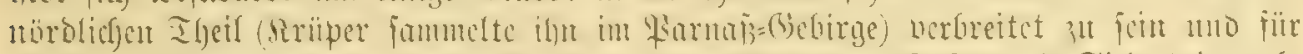

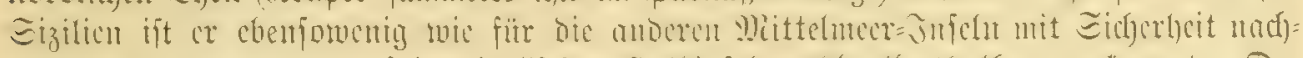

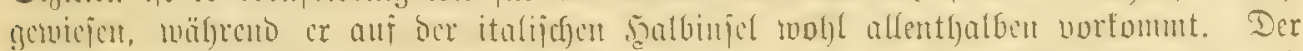

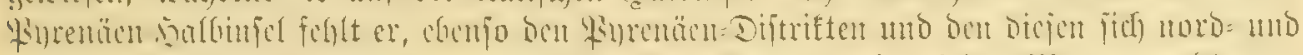

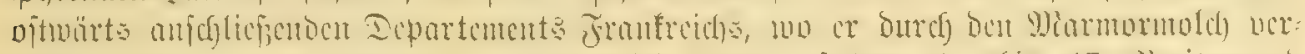

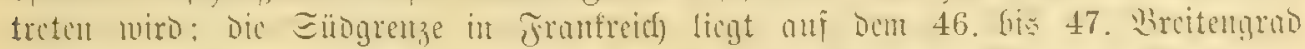

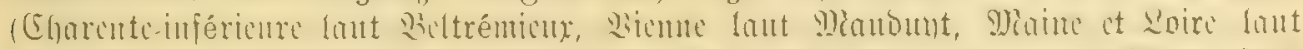

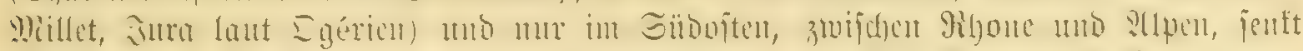

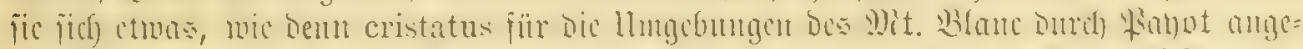

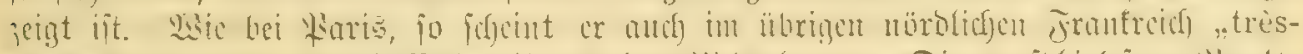

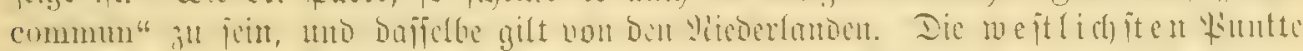

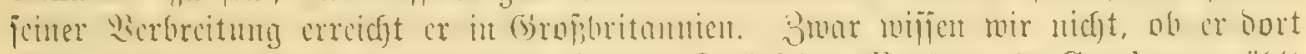

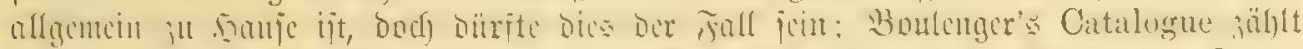

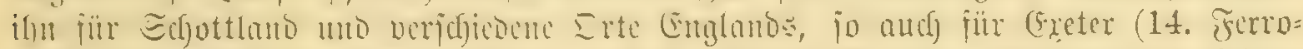

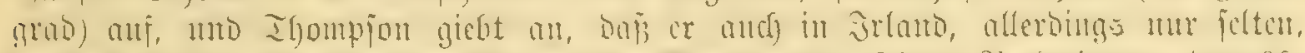

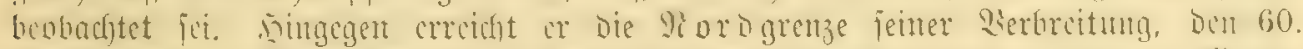

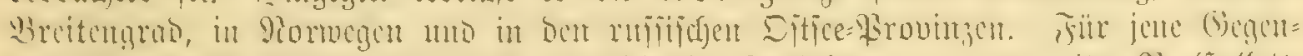

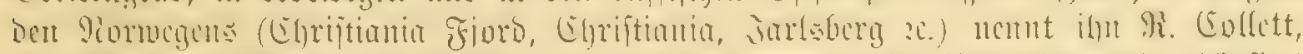

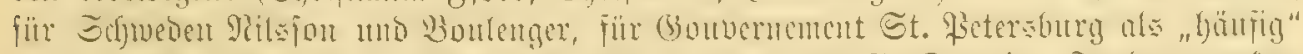

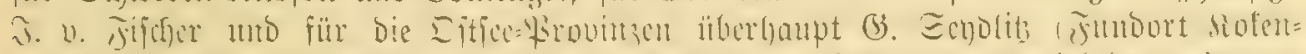

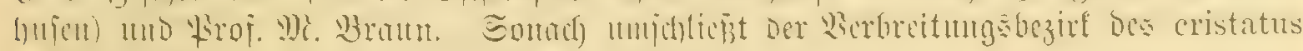
ctrua 25 Breitengrabe uno 60 biz 62 Qängentrube.

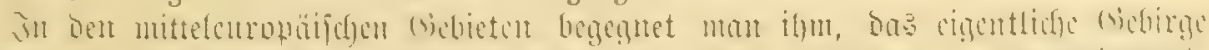

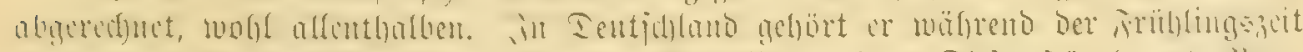

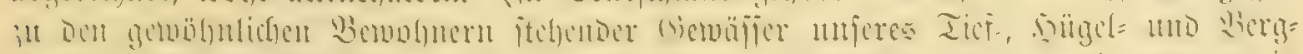

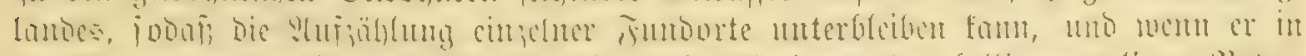

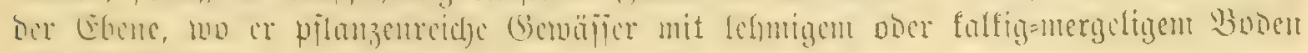

*) Die 2ermutbung Sd)reiber's, baỉ cristatus in Rußlanb oitmärț ben Injepr nicht zu über=

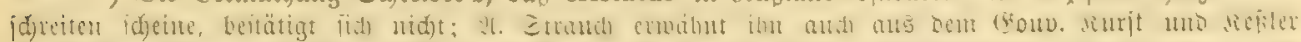

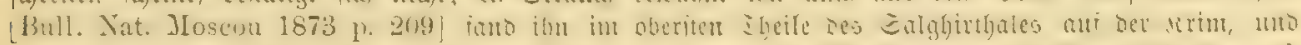

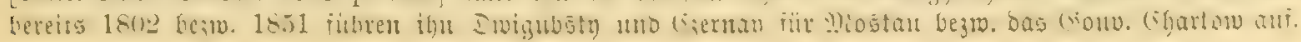




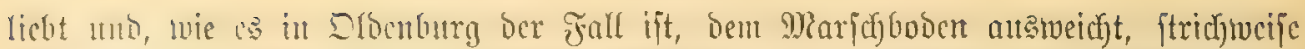

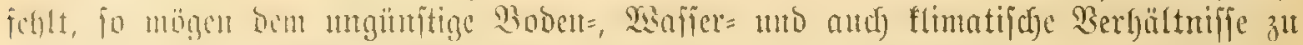

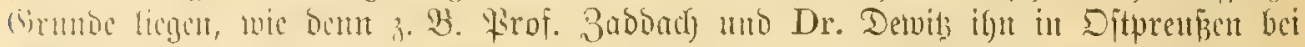

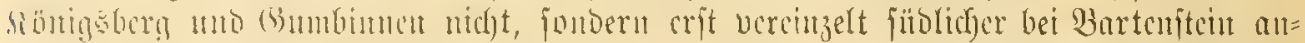

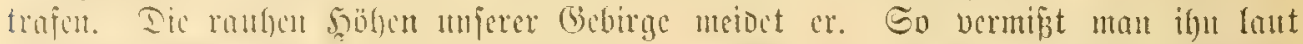

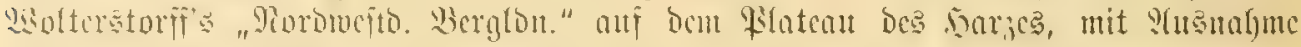

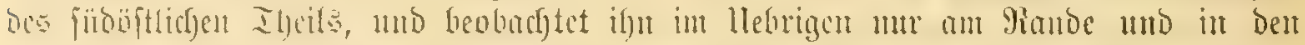

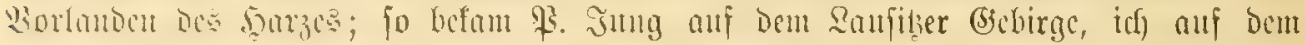

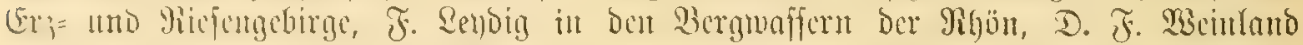

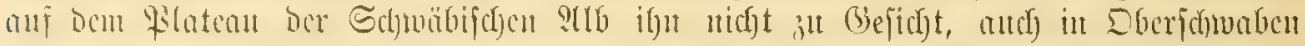

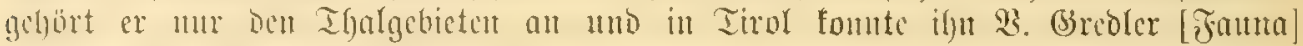

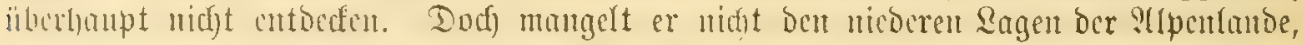

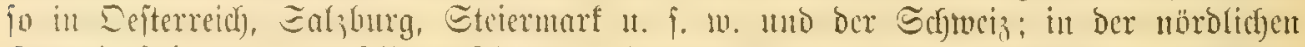

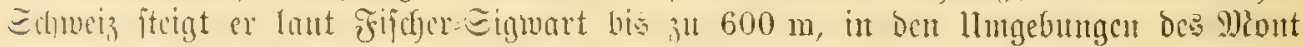
Blanc laut Finjot bis zu 1000 noer $1500 \mathrm{~m}$ Mecreşöhe alt, 3 . Fatio fanto ifu

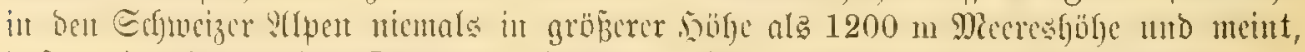

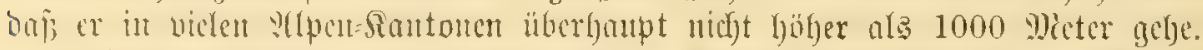

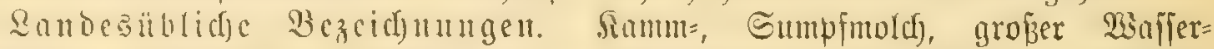
Enlamanoer; Tieberotidy.: Erafrup; Fell.: Water=Salamanocr; Scfwed.: Watten-

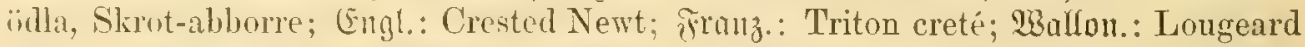
d'Yau; Ital.: Tritone crestato, Luserta d’aqua; Ruff.: Wodjanája Jístscheriza; Wuln.: Tryton wielki; Elaw. (Inlmat.): Guscerika vodarica; llugar.: toi-gyék; 3ibm.: Colek velky; Fent.: Jalkakala.

Lacertus aquaticus, Ge:ner 1554. - Salamandra aquatilis, Cumerarius 1590. - Salamandra aquatica, s. Batrachon rera, Wurfbain 1683. - La grosse Salamandre noire, Dufay 1729 [Mém. de l'Acad. de Paris p. 190]. - Lacerta atricana et Salam. aupatica, Sebn 1734. - Lacerta palustris, Linné [S. n. I]*) 1766. - Triton cristatus et T. americanus, Laurenti 1768. - Salamandra alepidota verrucosa .... Gronov 1781. - Sal. laticauda, Bonnaterre 1789. Iac. aruatica, Gmelin 1790. - Gekko palustris et aquaticus, Meyer 1795. Sialim. cristata et S. pruinata, Scheider 1799. - Lacerta porosa, Retzius 18100. - Salamandre cretée, Latreille 1800. - Molge palustris, Merrem 1820. Iacerta lacustris, Blumenbuch 1821. - Salam. platycauda, Rusconi 1821. [Amours Ioj. 1 it. 2]. - Triton palustris, Fleming 1838. - Hemisalamandra cristata, Inegie [Cimdiles] 185\%. - Sus junge Thier: Triton camifex, Luur. 1768; Gekko "aruifex, 14yer 1795: Sal, carnifex, Schneider 1799; Triton nycthemerus(?), Michuh. [viju 18:30, こ. 806]; T. Bibroni, Bell 1839; Petroponia nigra, Massulongo 1854.

\section{Art: Bergmold. Triton alpestris, Laur.}

abbilbung: Tajet V ir. 6. 7.

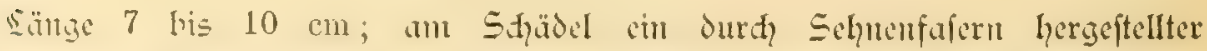
Estlafutrogen; Lout auper der fortpflanjungsjeit (im Sandfleid) feins, bem

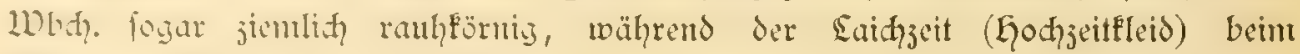

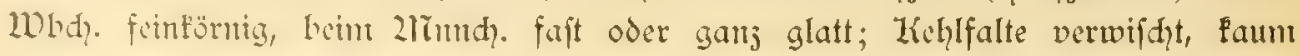

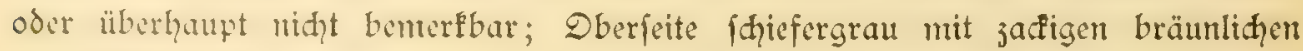

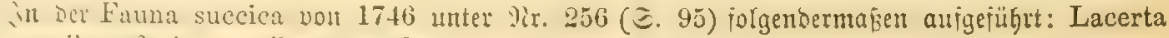
pedibus inermibus fissis, manibus tetradactylis, plantis pentadactylis, cauda ancipiti. 


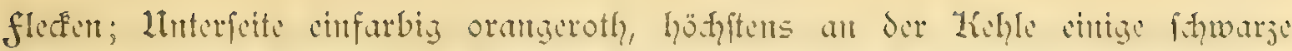

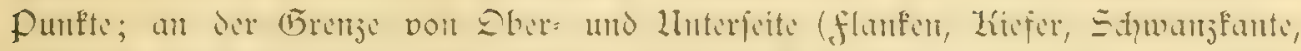

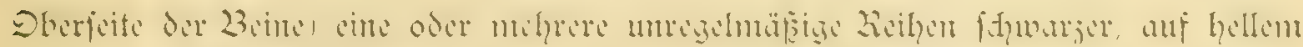

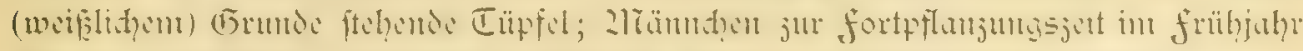

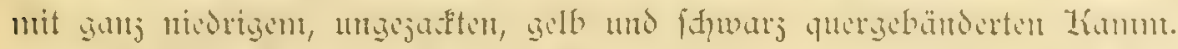

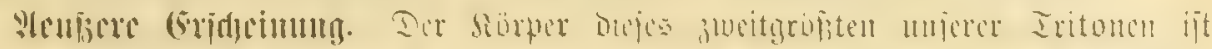
triffiger, georungencr gebunt als Der ber anderen

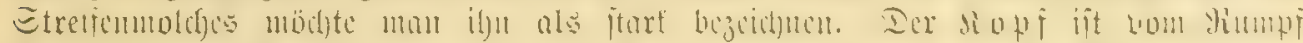

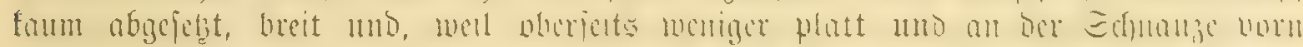

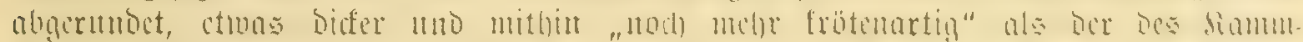

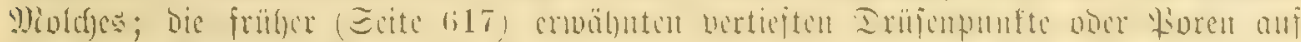

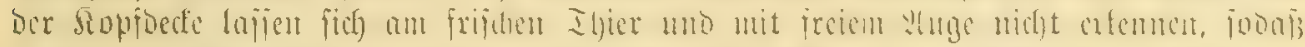

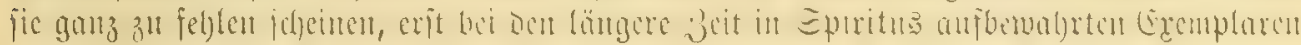

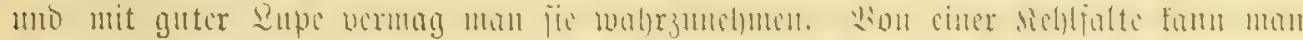

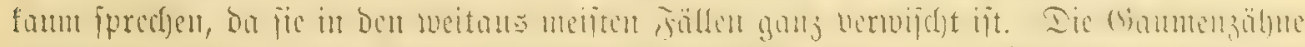

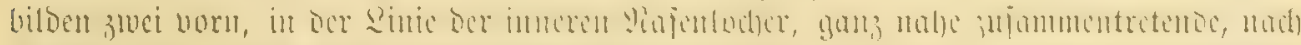

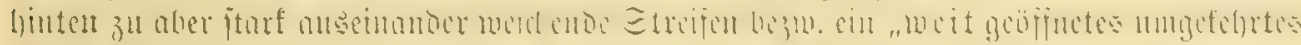

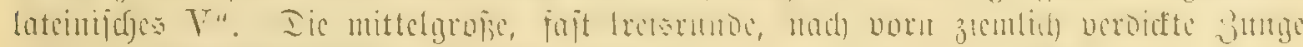

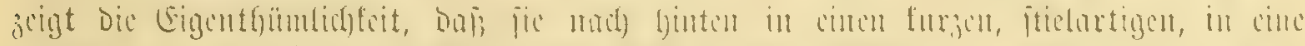

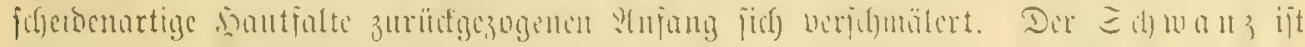

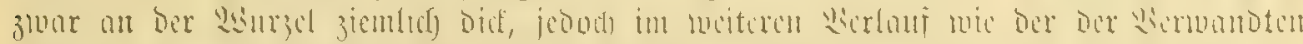

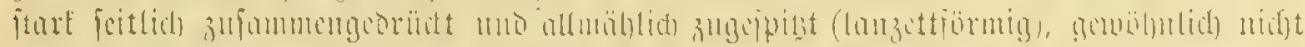

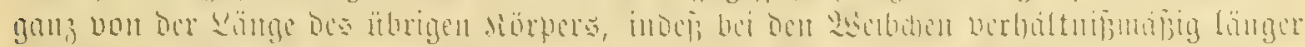

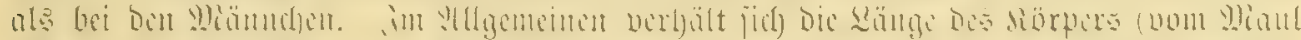

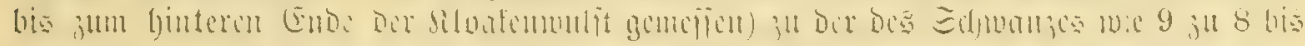

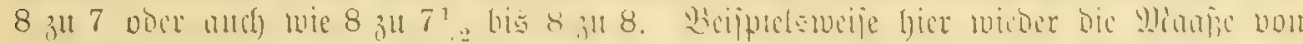

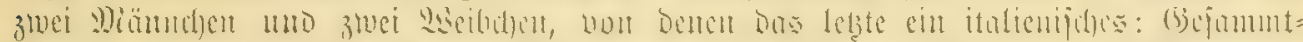

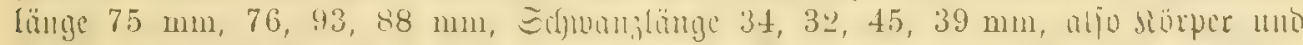

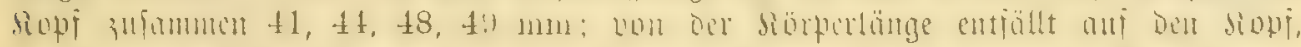

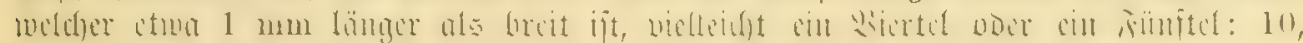
$9^{1} / 2,11,9 \mathrm{~mm}$. Ein (Exemplar von mel)r ala $10 \mathrm{~cm}$ (Bejamntlänge ift mir nod)

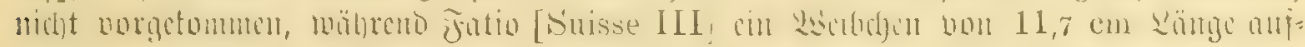

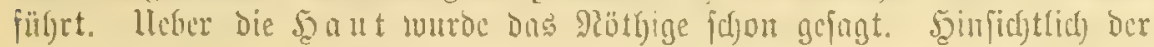

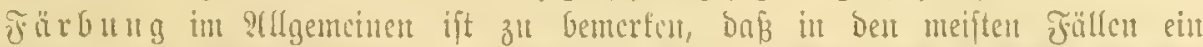

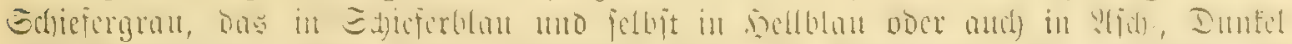

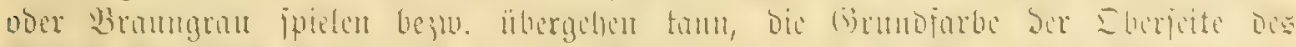

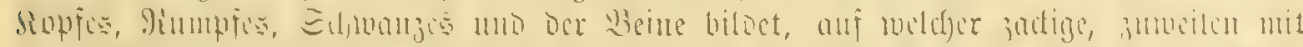

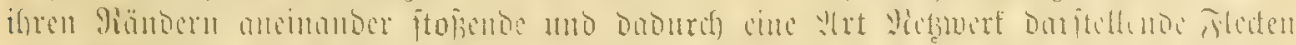

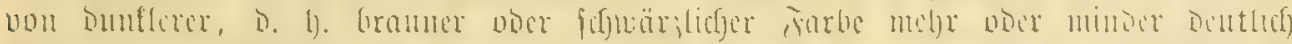

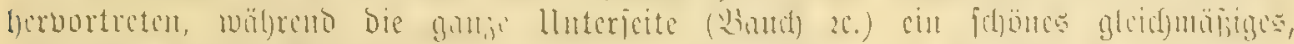

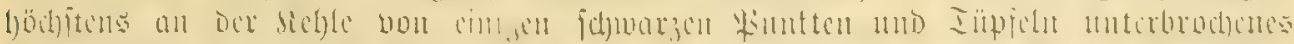

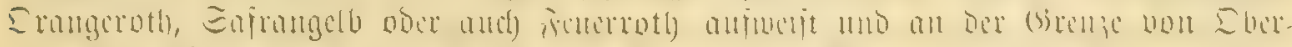

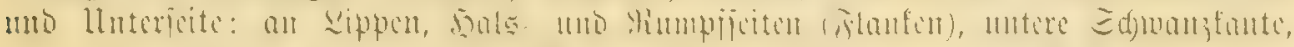

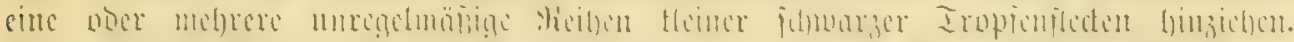

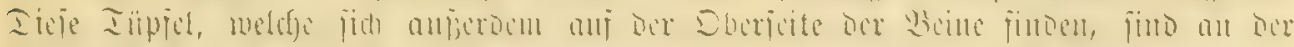

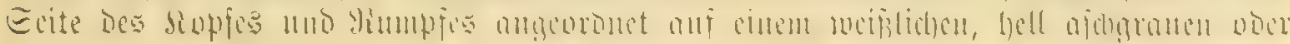

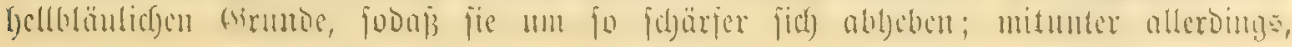




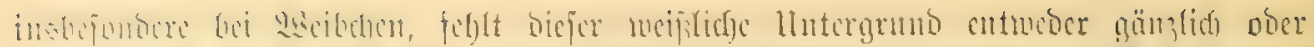

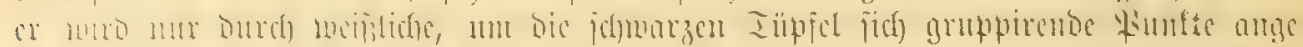

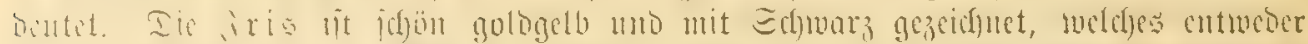

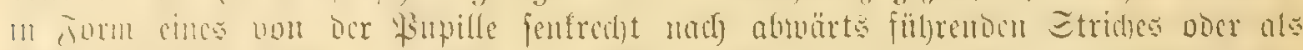

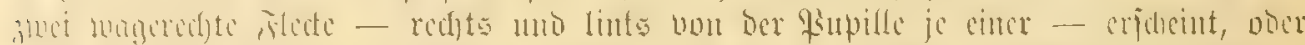

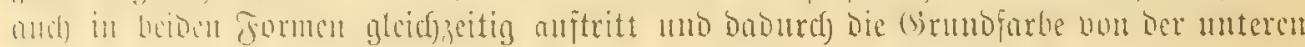
Seälfte bor Jris verbrängt.

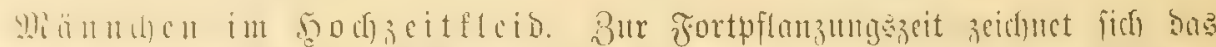

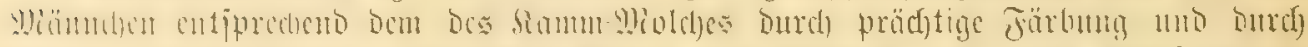

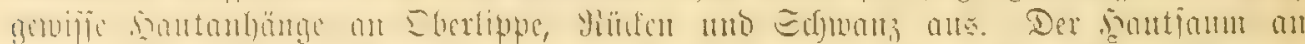

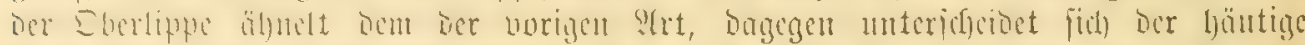

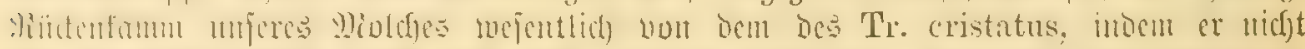

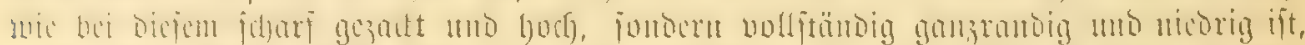

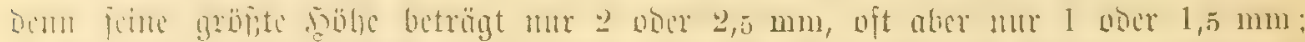

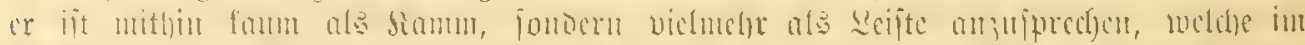

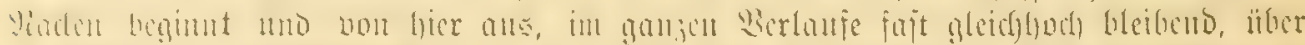

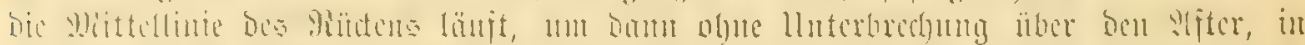

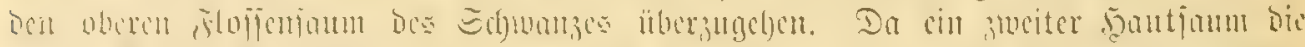

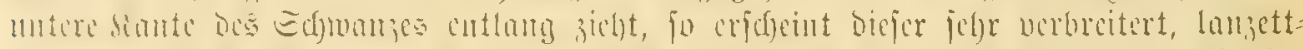

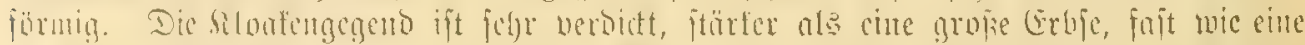

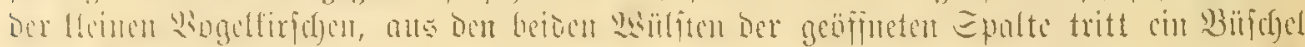

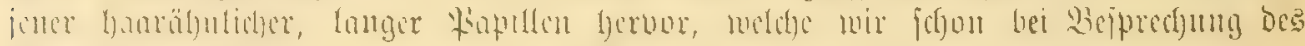

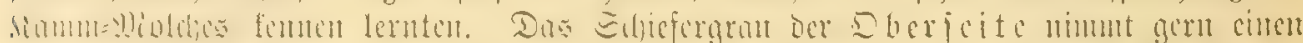

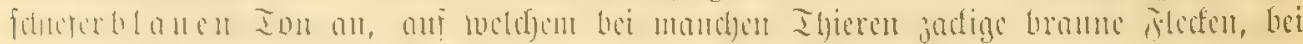

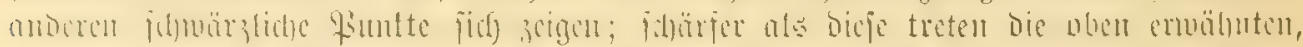

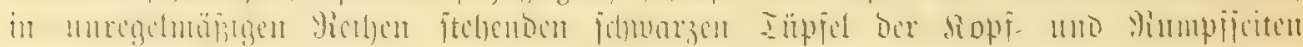

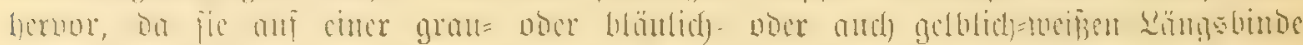

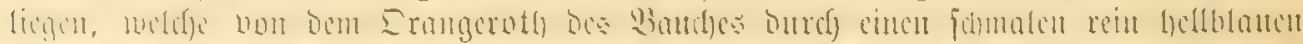

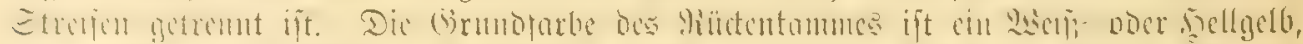

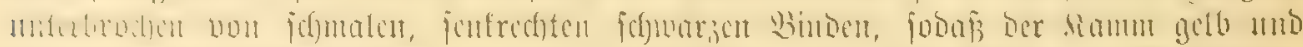

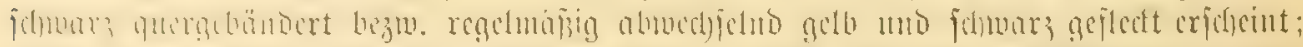

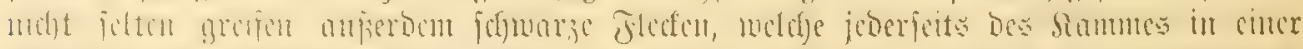

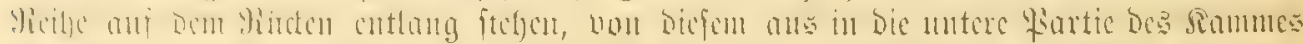

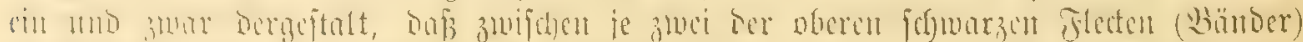

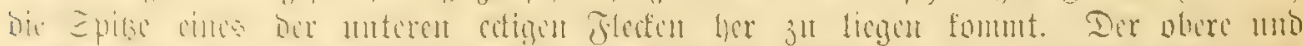

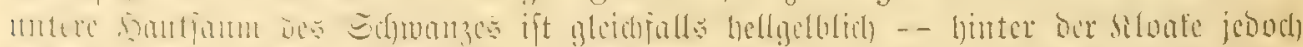

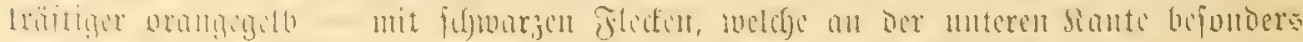

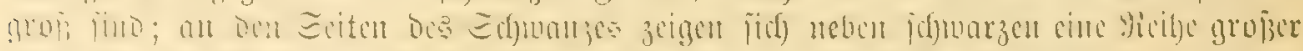

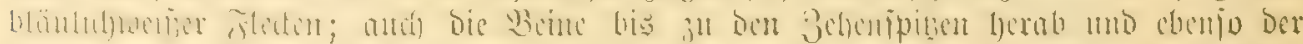

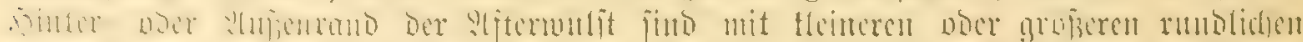

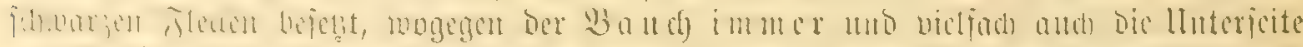

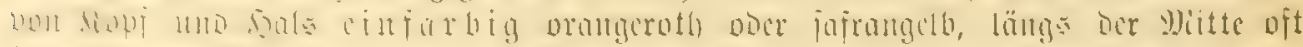

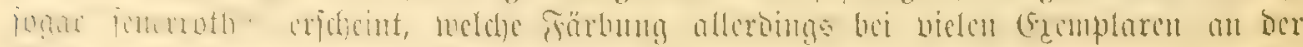

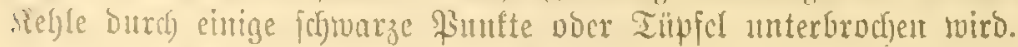

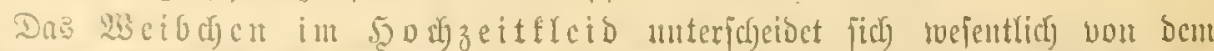

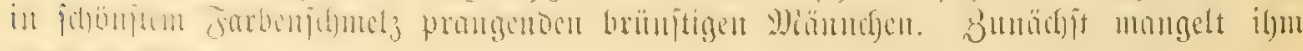

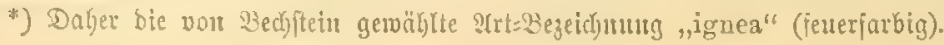




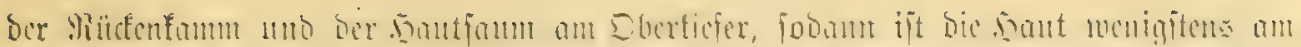

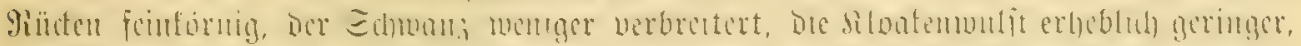

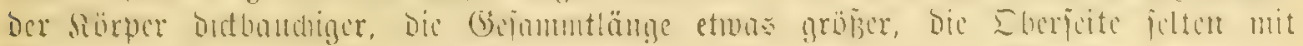

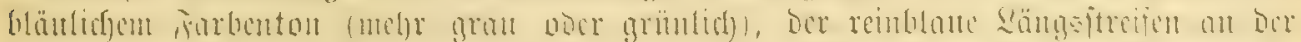

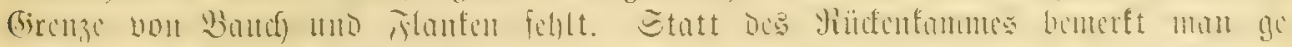

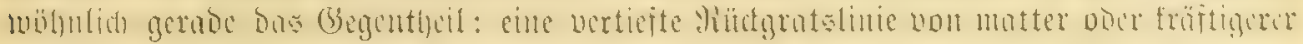

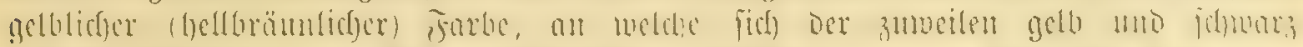

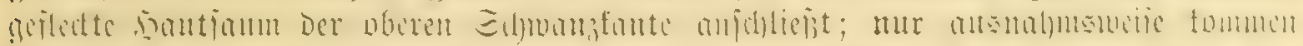

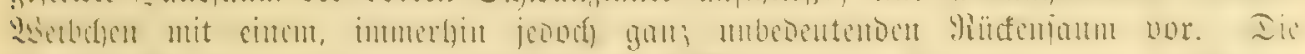

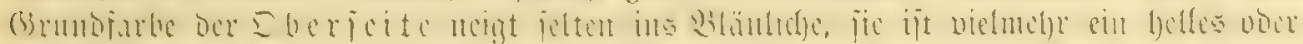

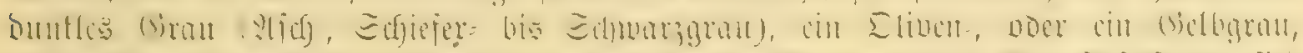

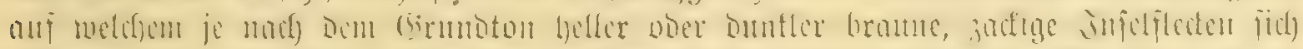

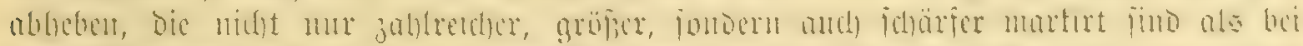

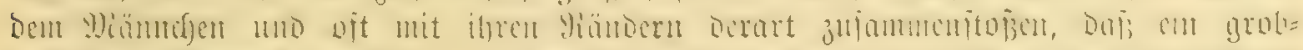

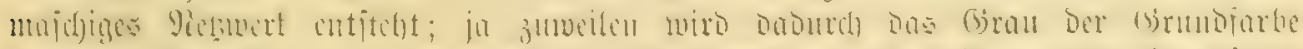

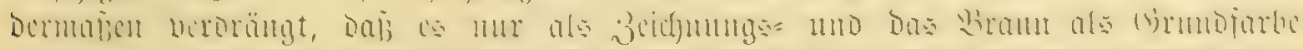

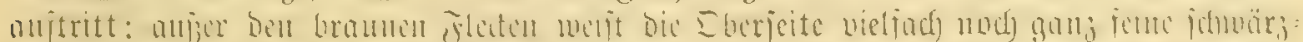

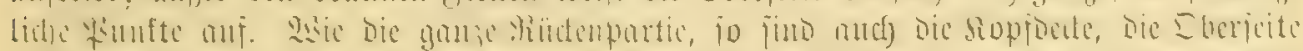

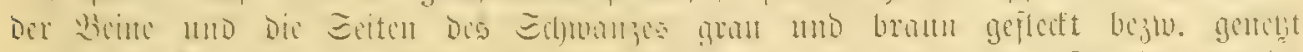

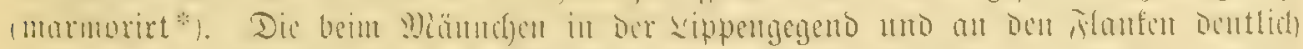

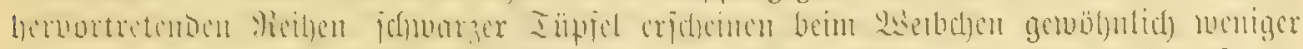

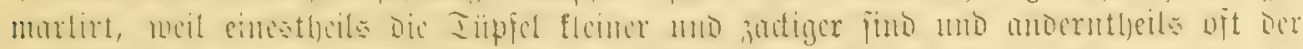

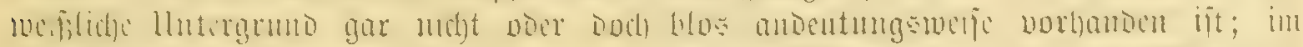

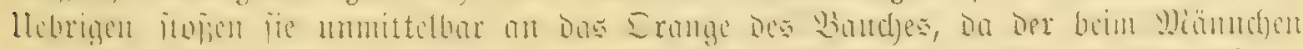

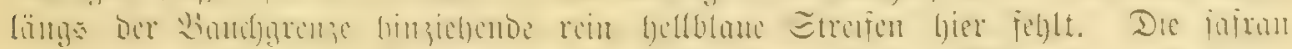

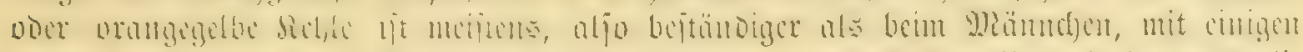

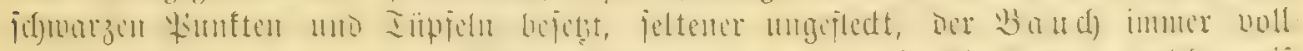

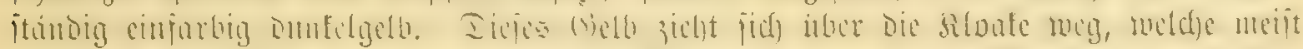

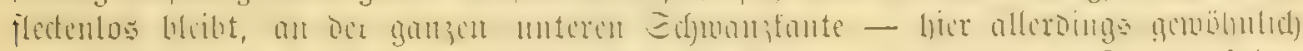

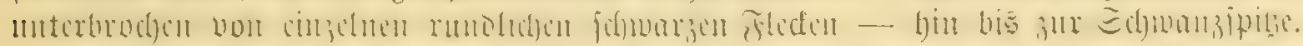

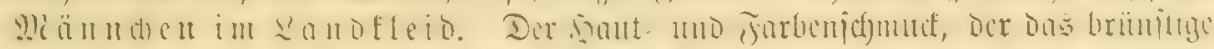

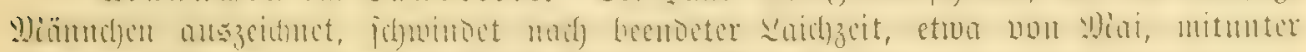

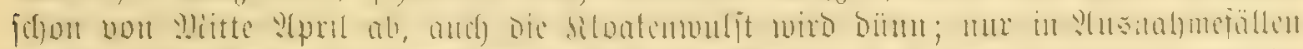

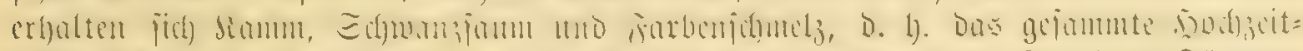

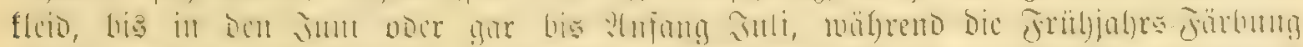

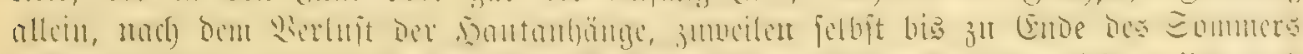

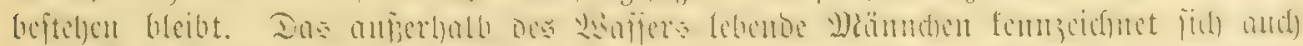

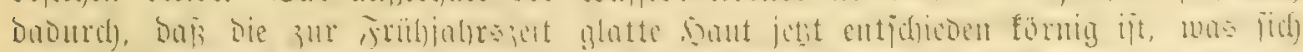

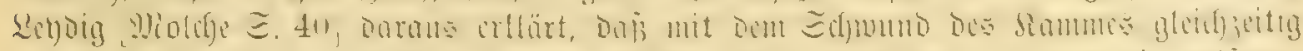

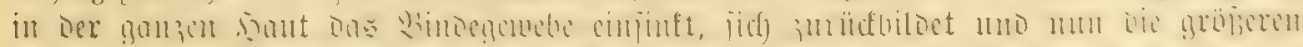

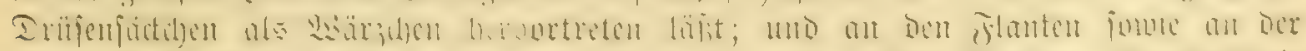

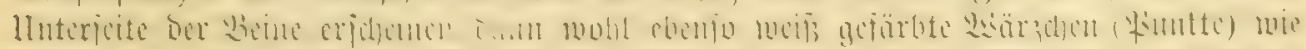

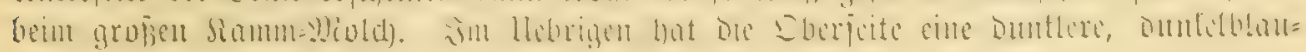

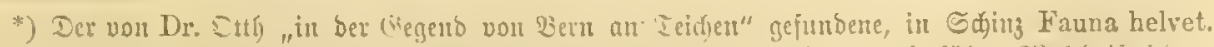
unter bem Yiancu "(iefiedter Miold), Triton marmoratus, Triton marbre" augejüfrte Ploldy ijt jeben=

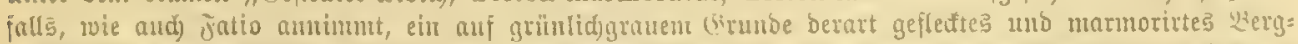

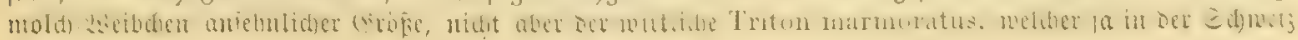
gänglid) jeร̧โt. 


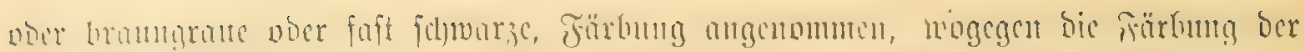

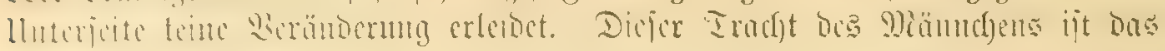

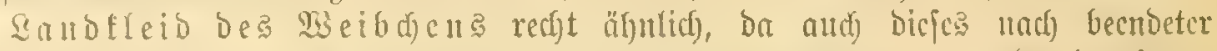

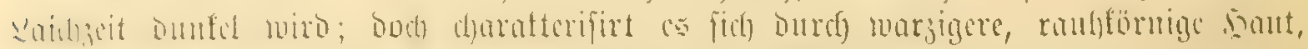

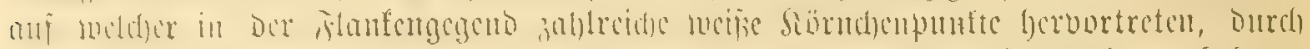

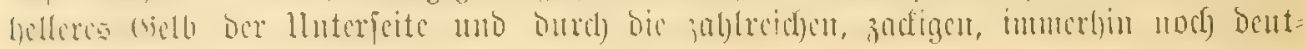
lidjeu grö̈en brauten Fledten auf Der Sberfeite.

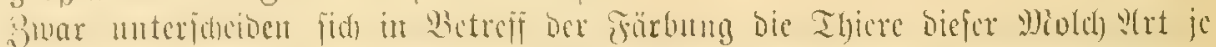

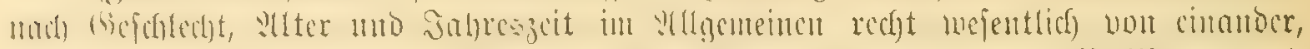

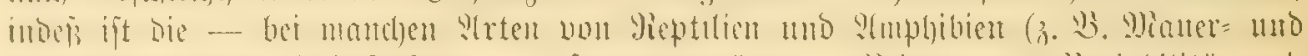

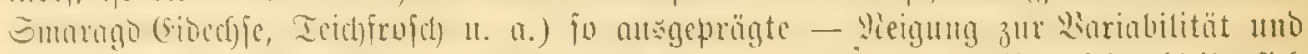

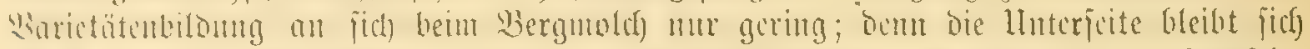

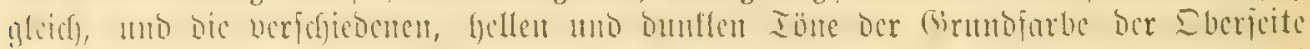

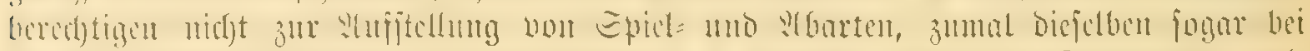

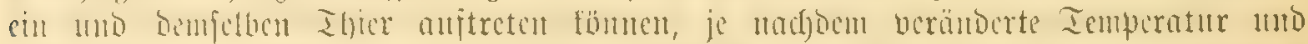

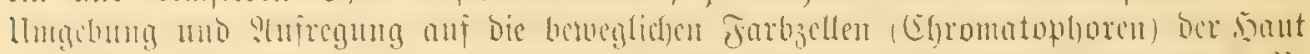

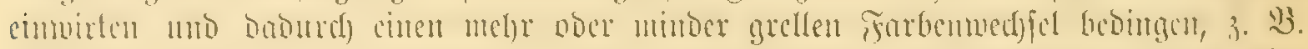

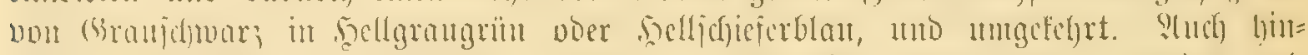

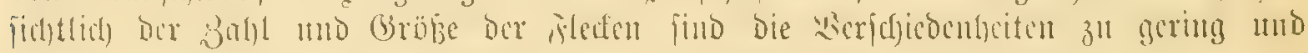

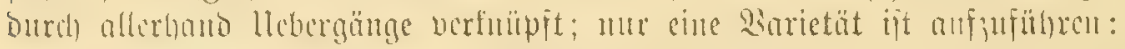

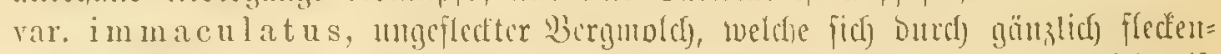

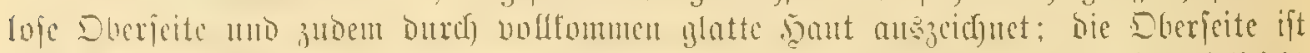

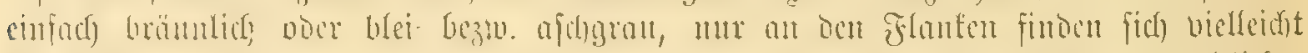

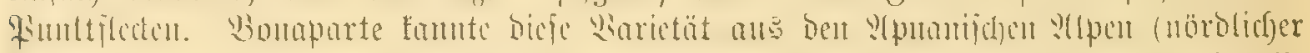

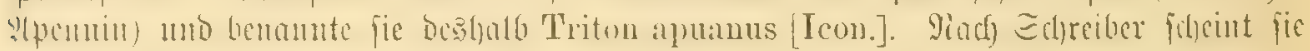

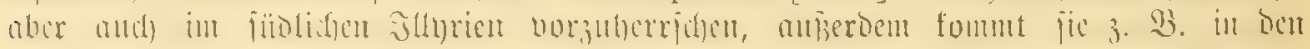

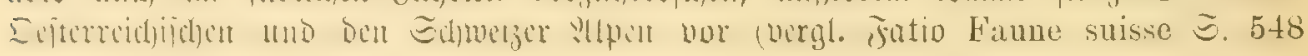
11. Tafel III Jig. linf:

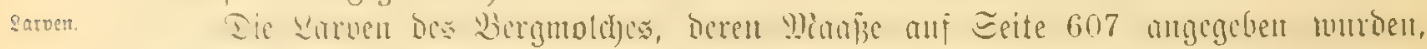

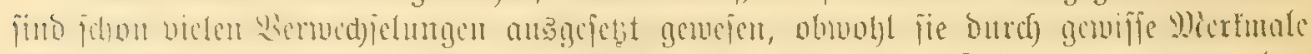

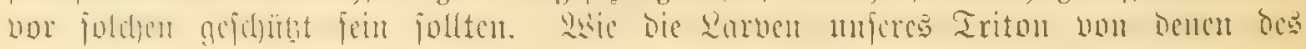

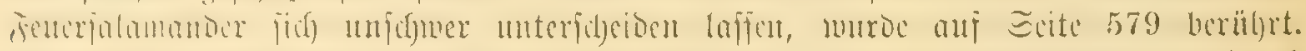

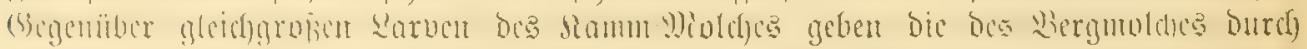

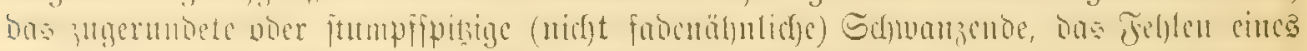

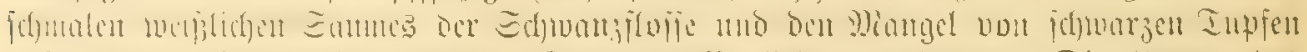

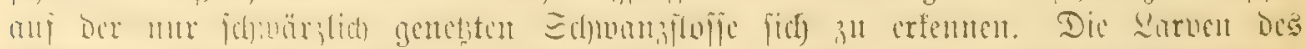

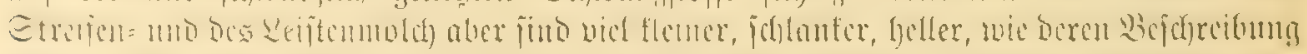

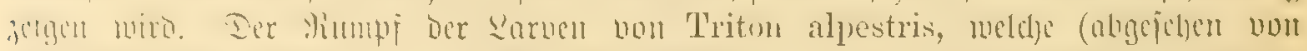

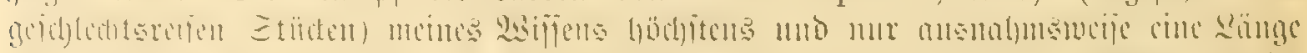

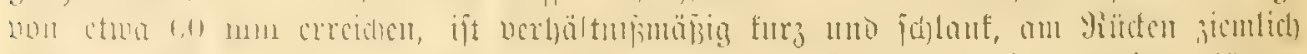

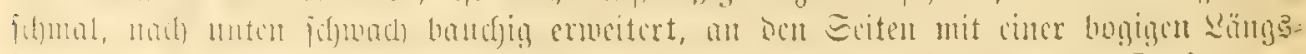
furche und 12 b13 13 mo an Baud mit 7 bis 8 Sucrfurchen, ocr Sropf etmas

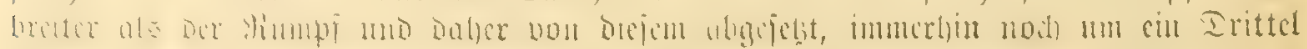

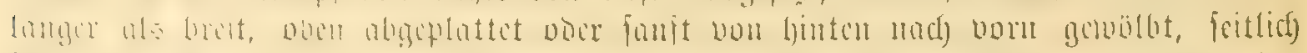

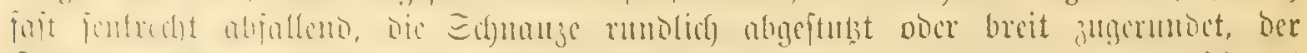

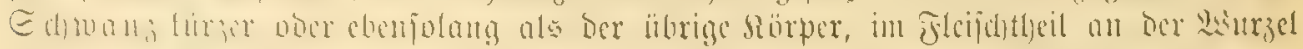

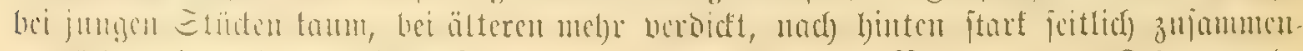

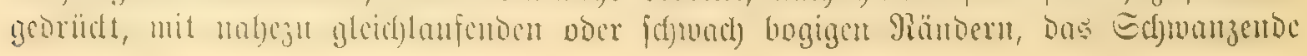




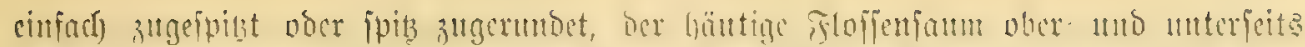

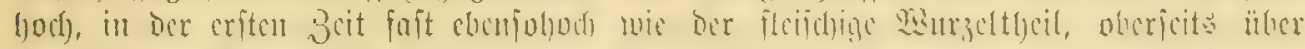

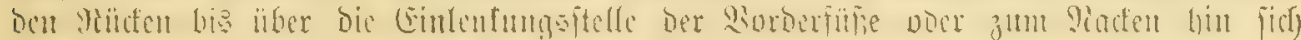

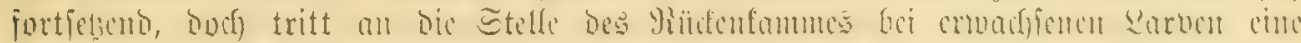

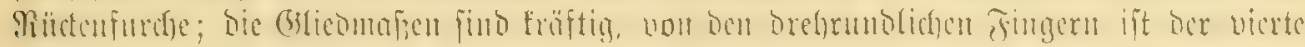

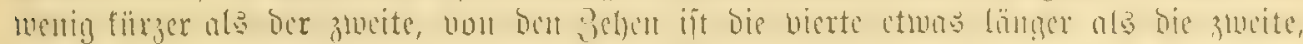

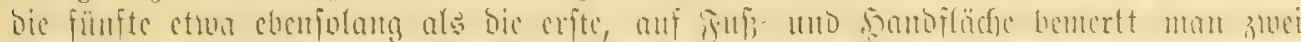

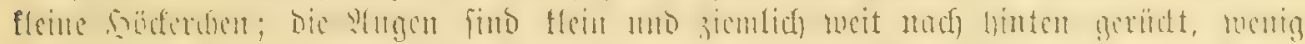

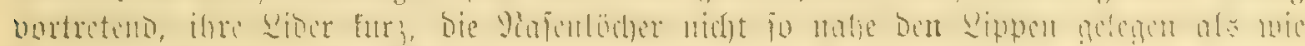

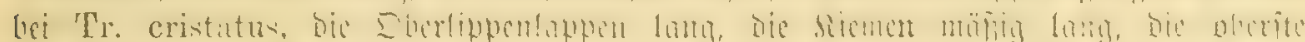

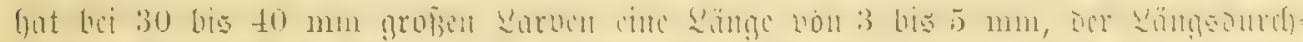

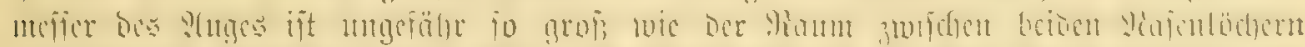

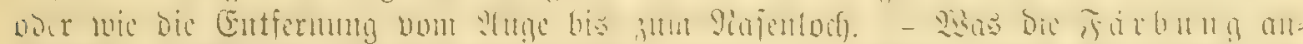

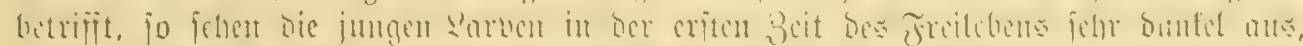

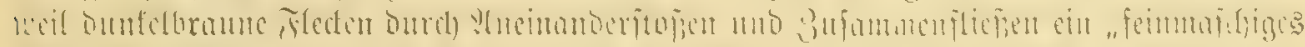

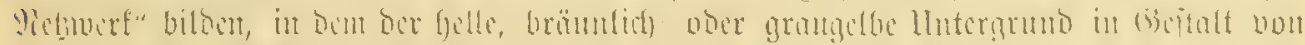

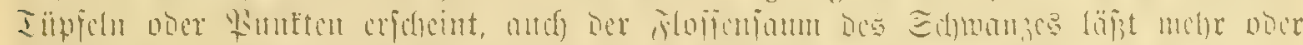

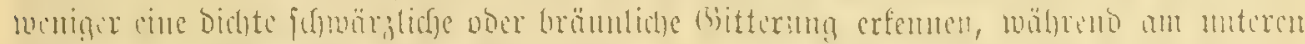

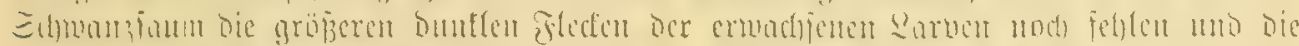

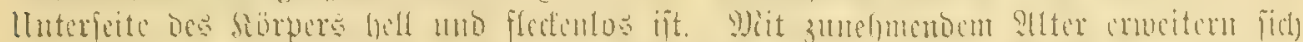

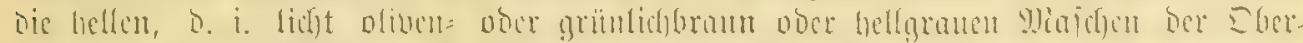

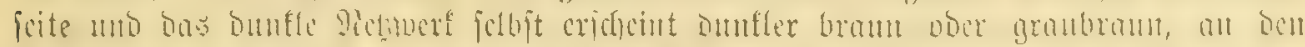

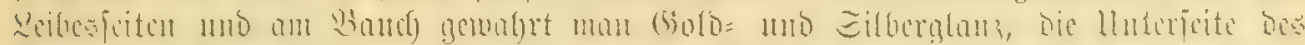

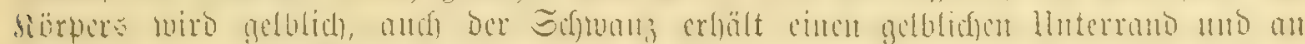

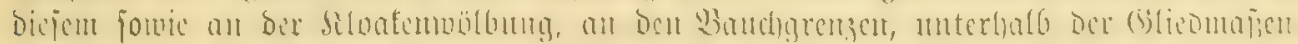

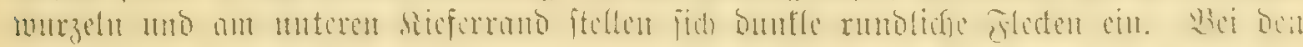

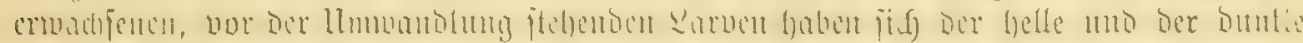

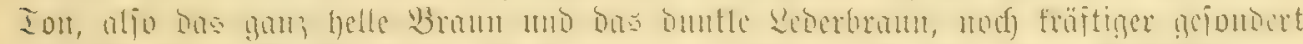

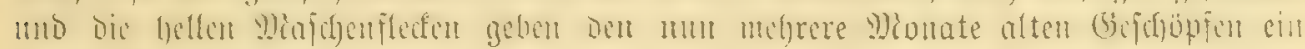

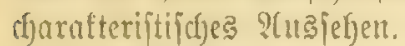

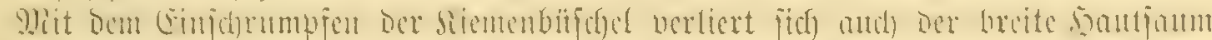

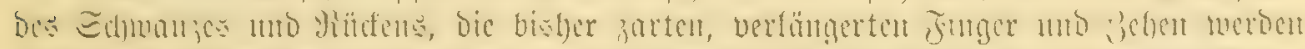

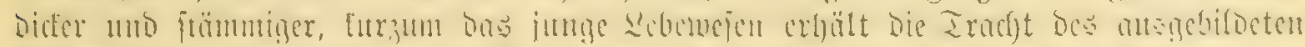

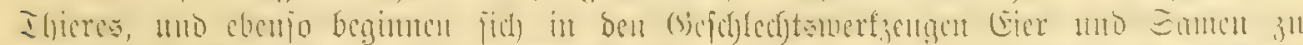

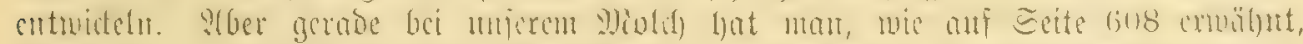

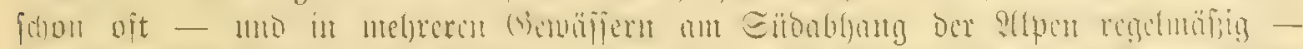

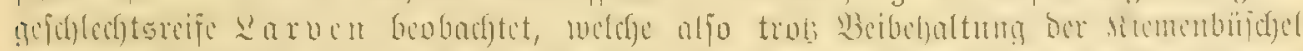

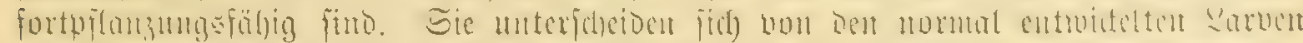

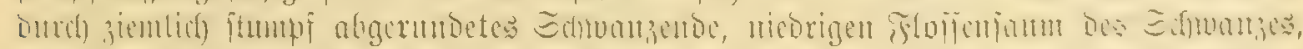

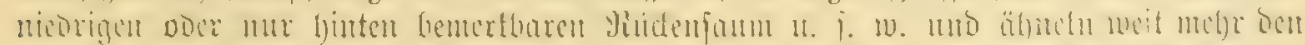

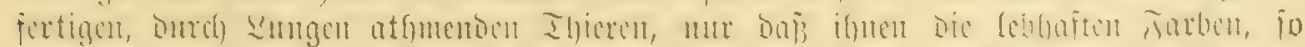

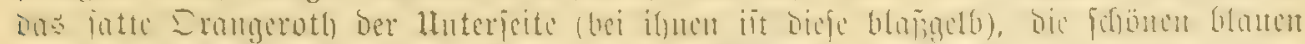

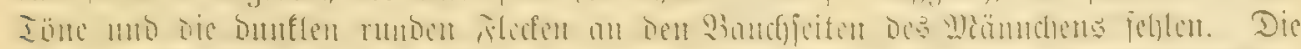

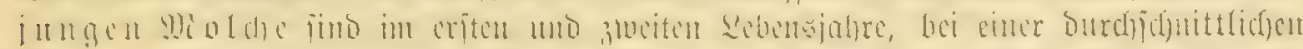

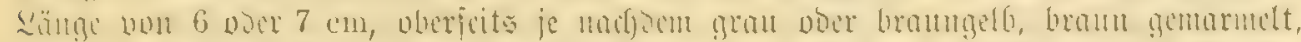

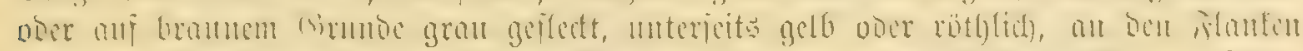

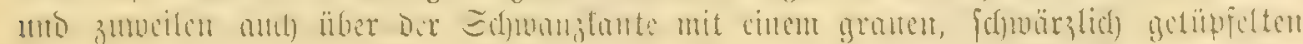

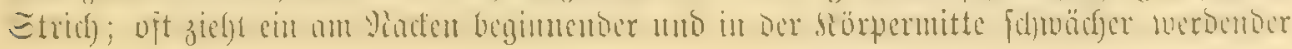




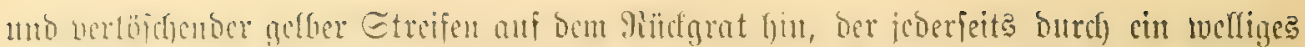

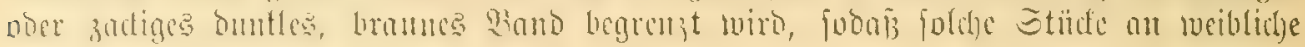
Strcifumoldhe crimern.

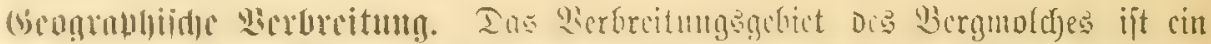

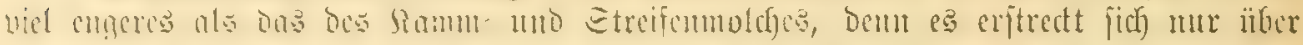

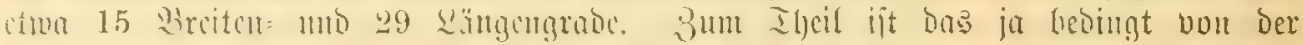

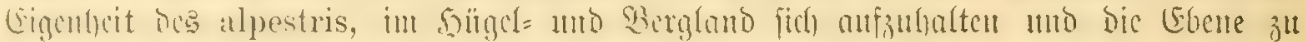

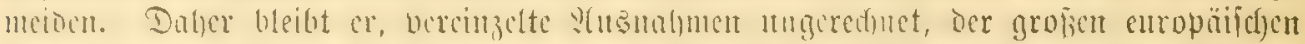

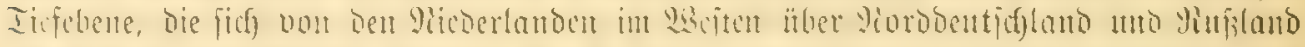

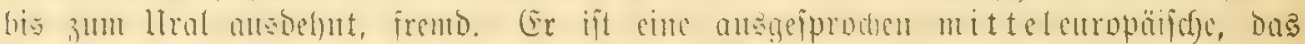

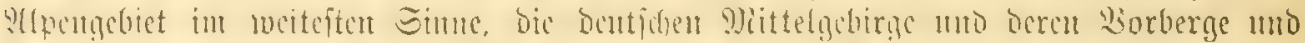

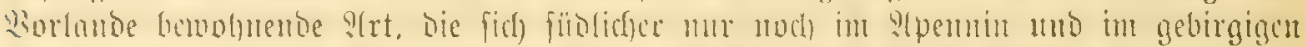

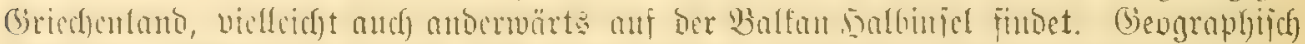

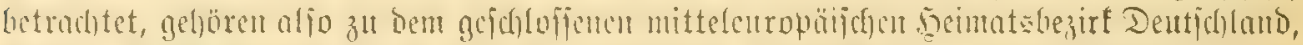

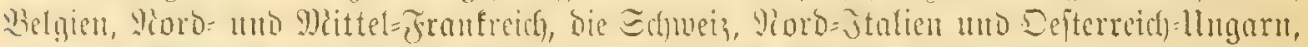

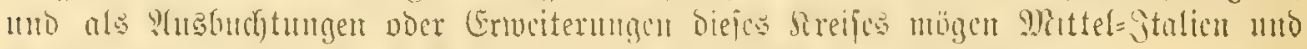

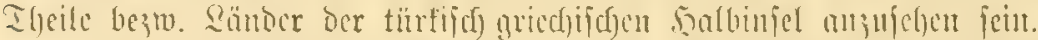

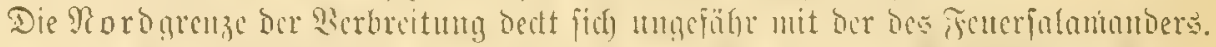

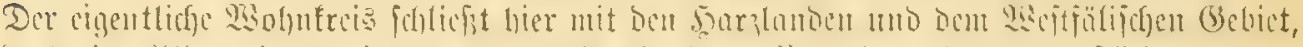

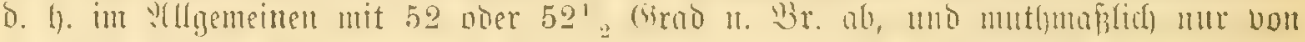

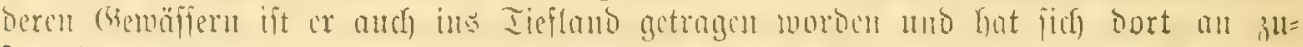

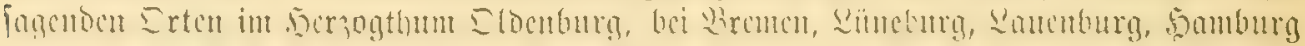

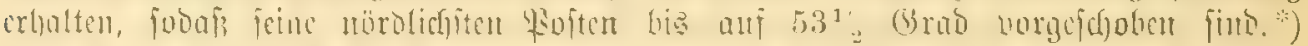

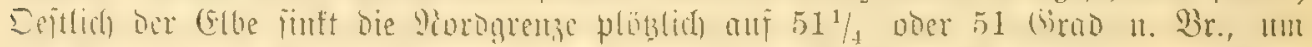

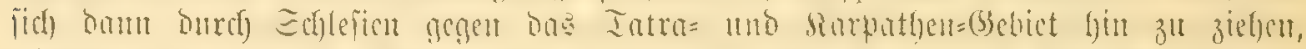

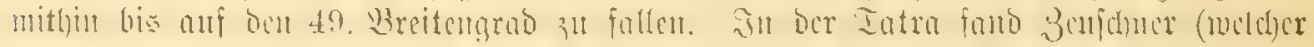

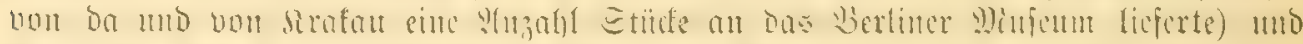

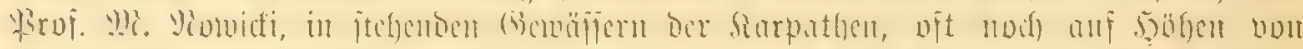

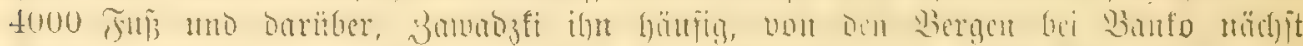

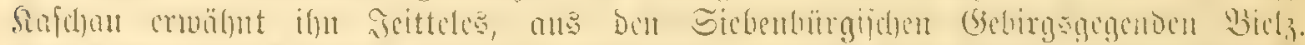

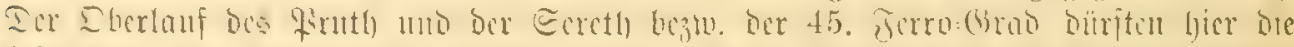

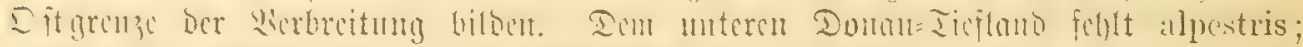

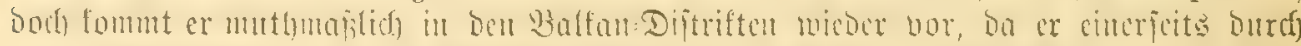

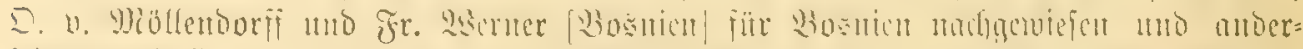

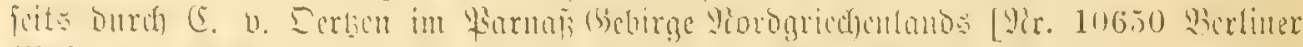

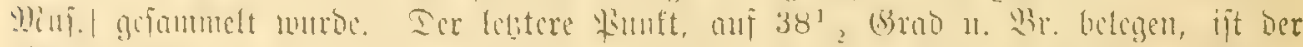

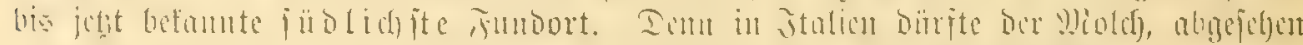

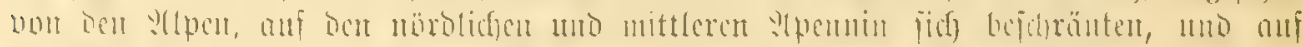

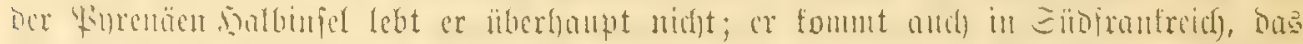

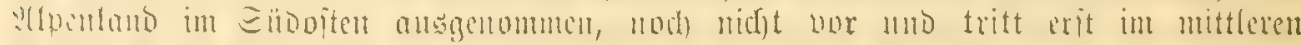

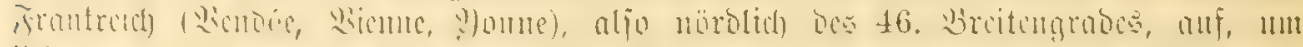

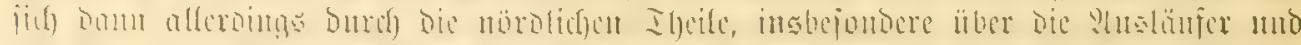

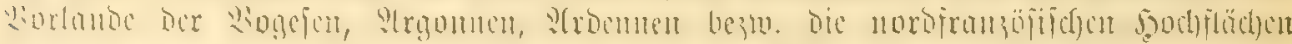

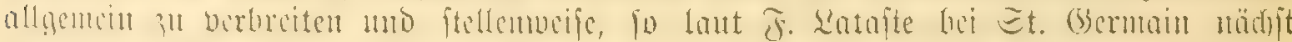

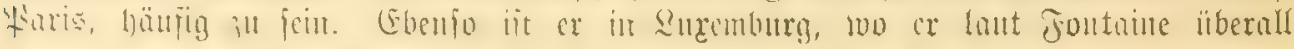

*) Titsjout giebt Triton alpestris aud für Sandstrona im jïbridjen Cdyweben an. Da biejer

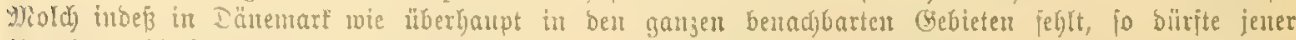
Ltugabe wogt ein Jirthut zut Grunbe Yiegen. 


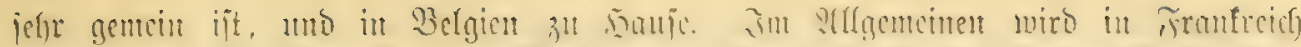

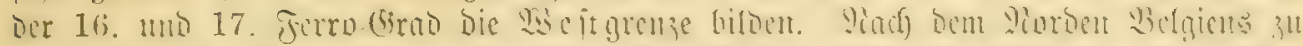

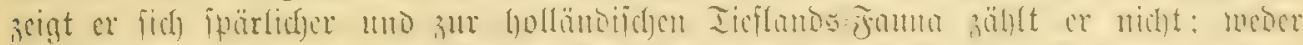

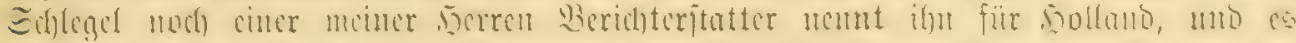

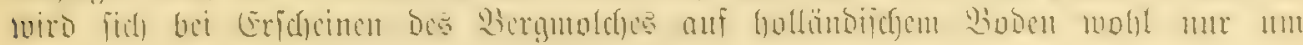
vertragenc แnb verjdjleppte Stüde gehandelt haben.

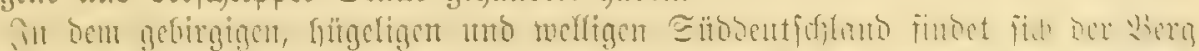

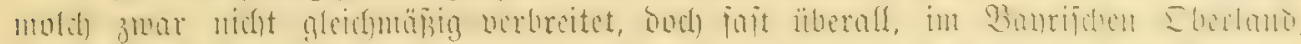

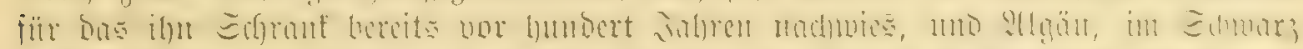

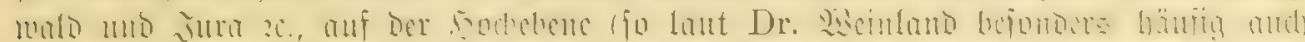

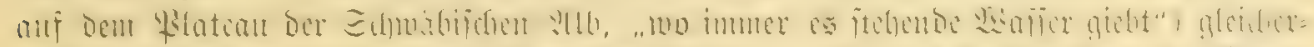

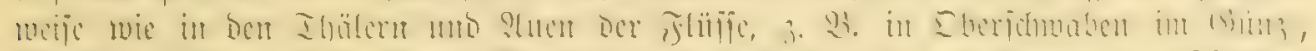

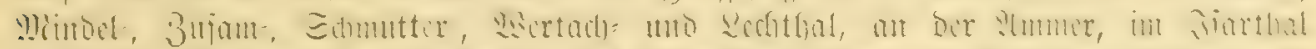

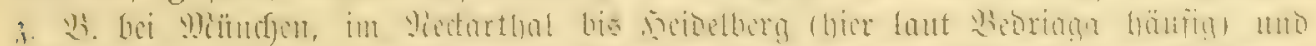

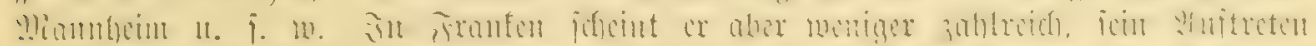

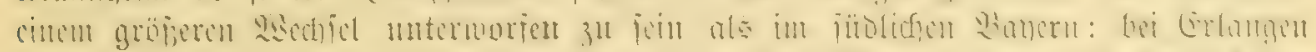

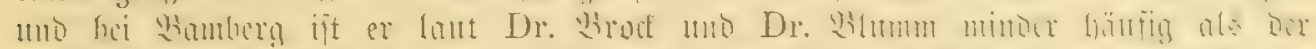

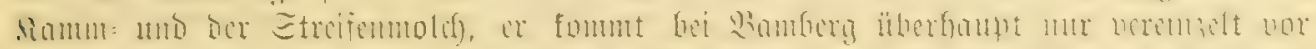

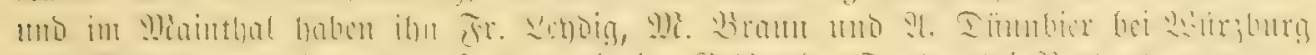

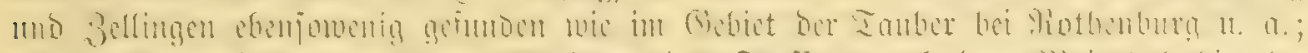

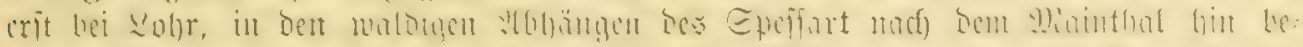

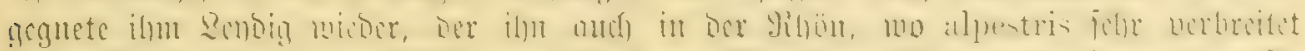

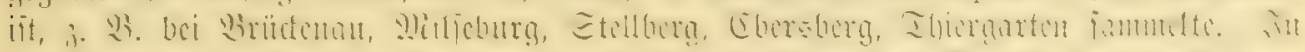

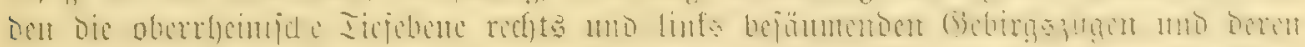

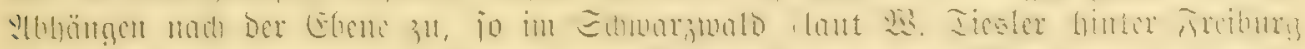

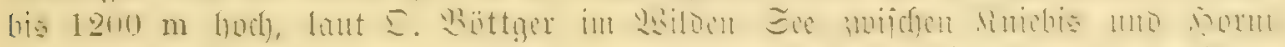

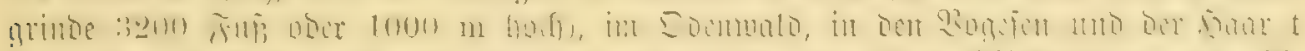

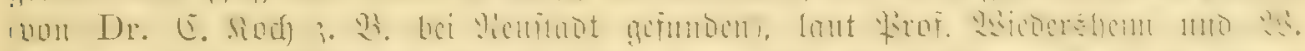

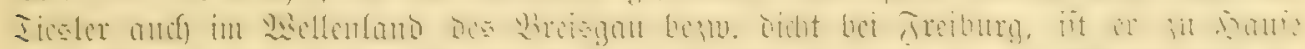

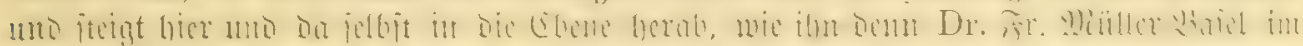

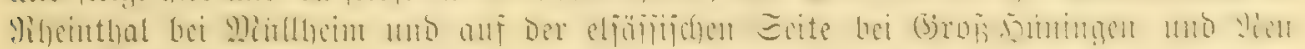
Dorf fommeltc.

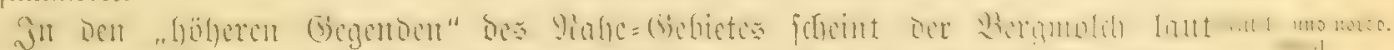

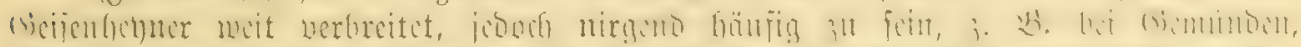

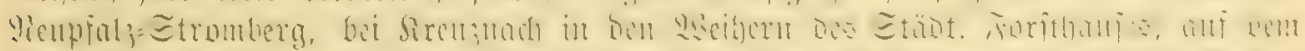

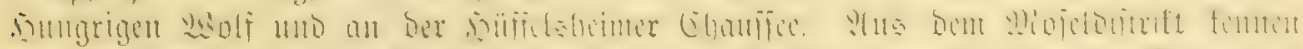

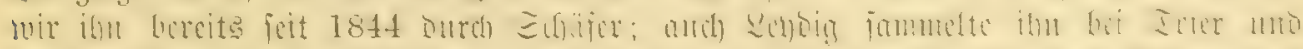

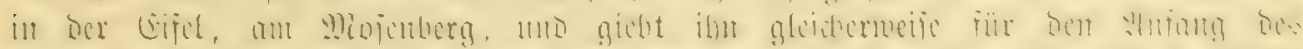

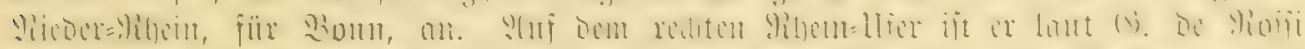

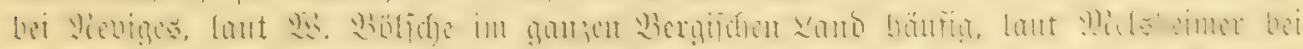

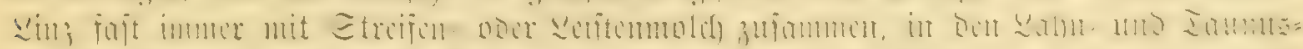

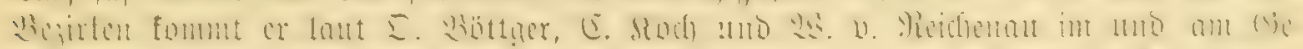

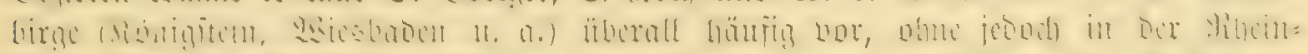

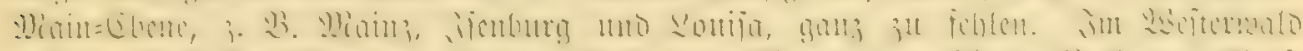

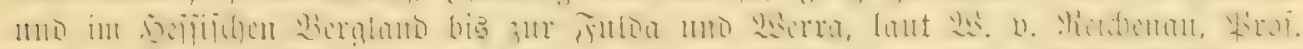

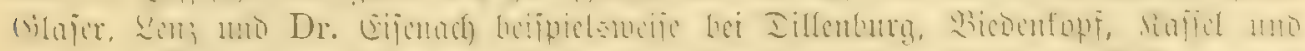

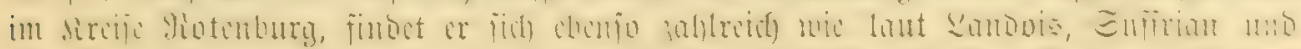

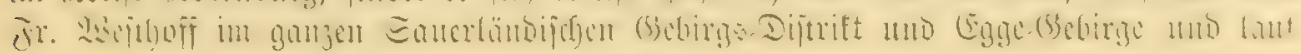




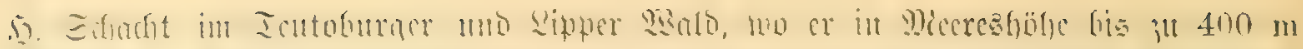

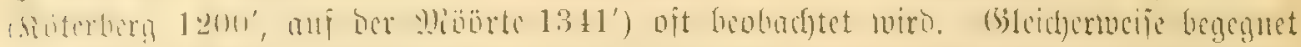

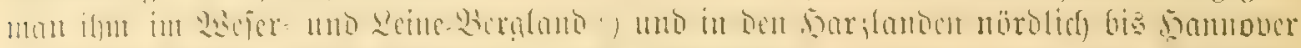

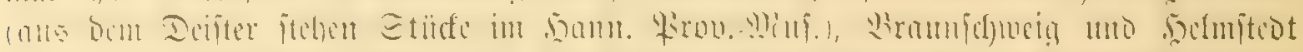

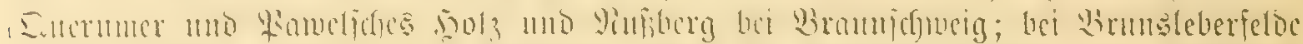

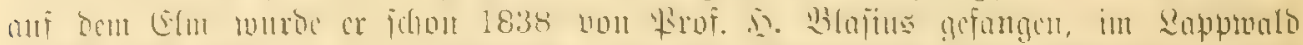

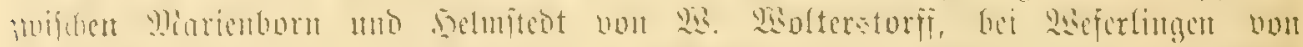

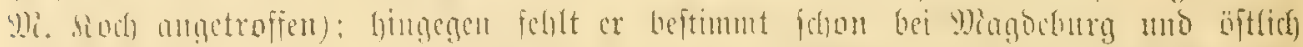

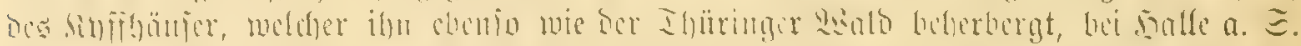

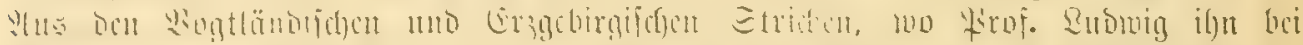

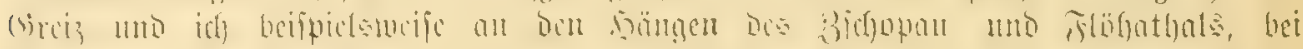

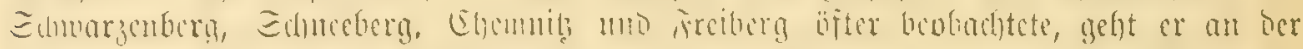

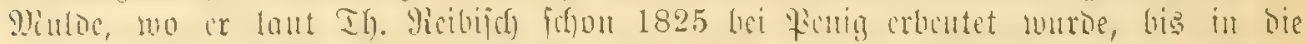

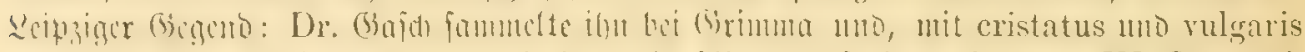

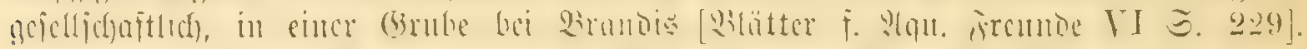

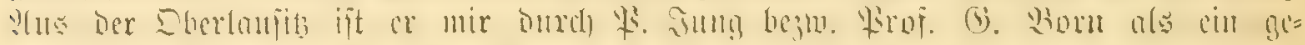

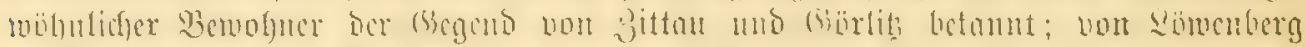

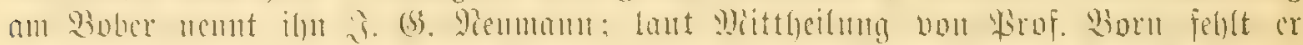

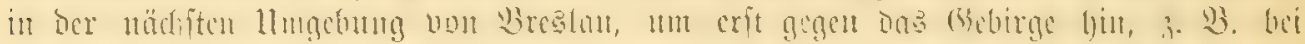

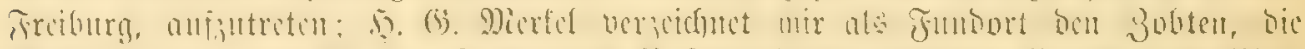

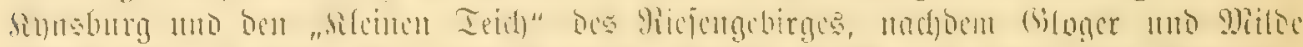

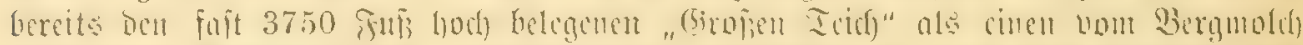

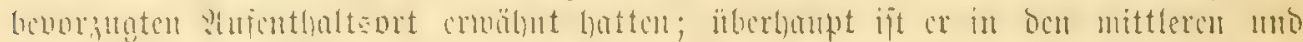

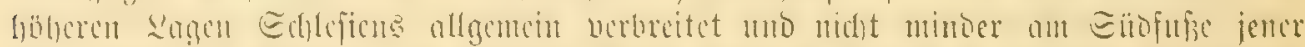

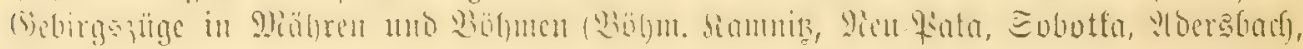
\$aroubils 4. a.).

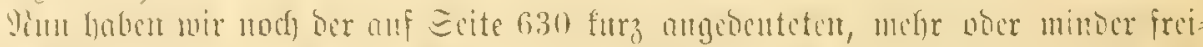

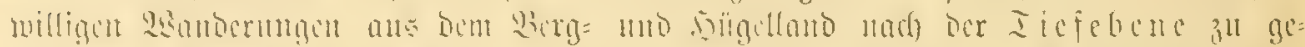

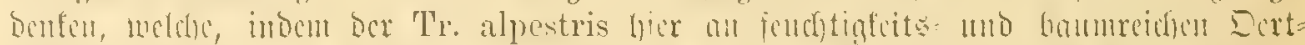

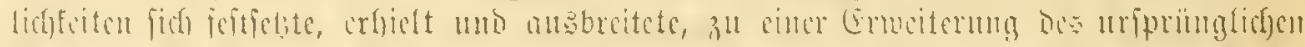

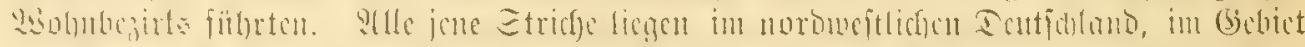

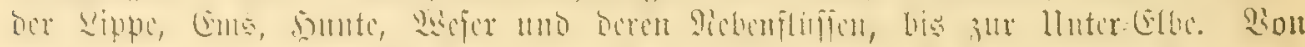

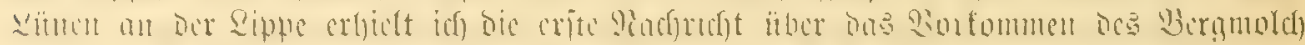

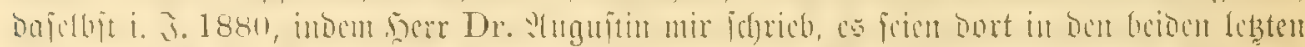

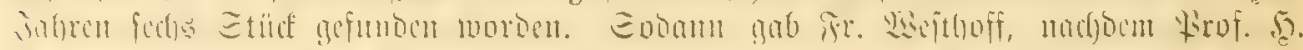

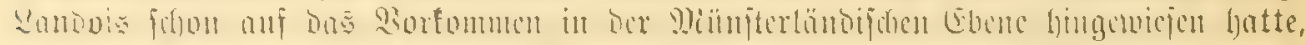

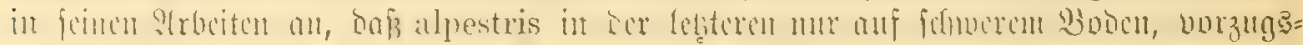

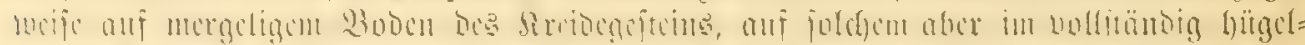

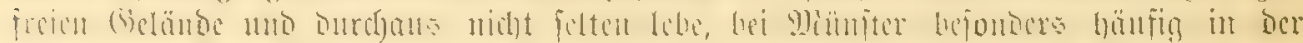

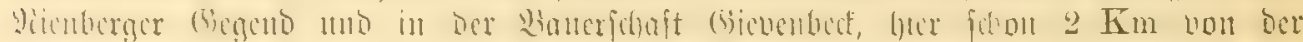

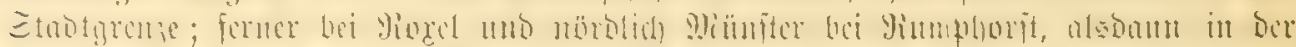

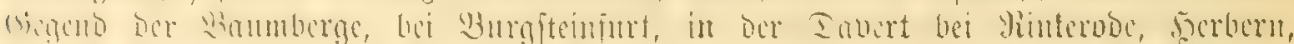

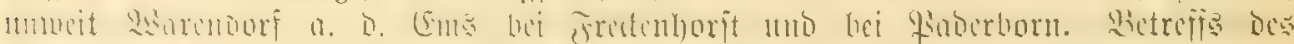

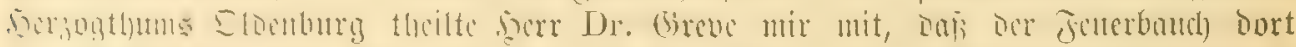

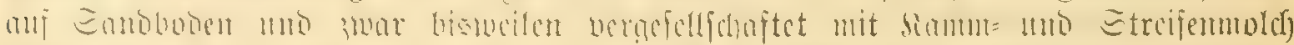

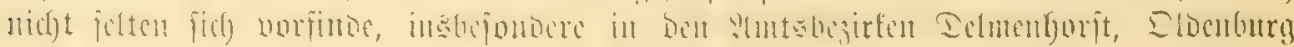

*) Suts ber (Gegeno von (Söttingen wirb Triton alpestris bereits 1789 im IX. Banbe ber

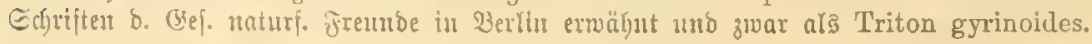




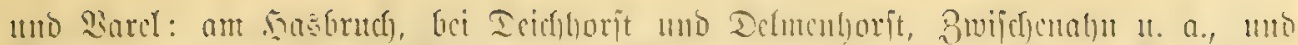

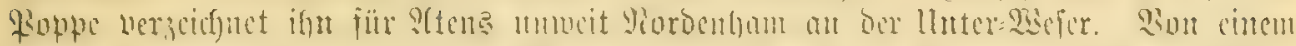

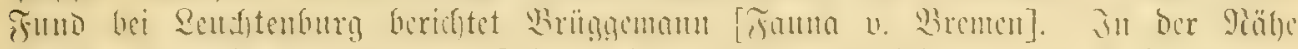

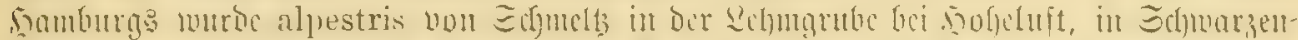

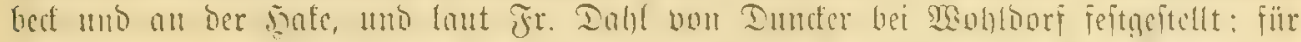

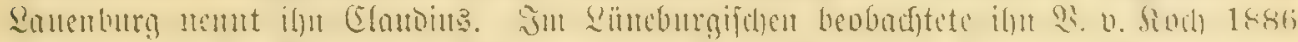

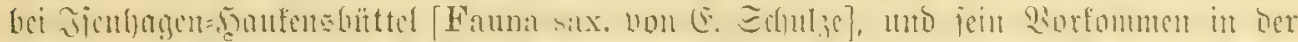

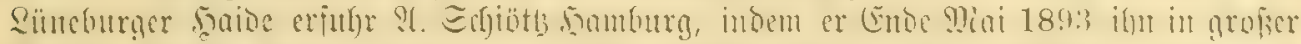

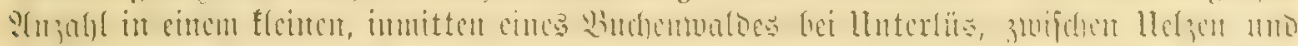

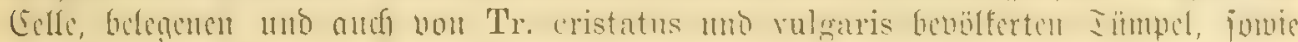

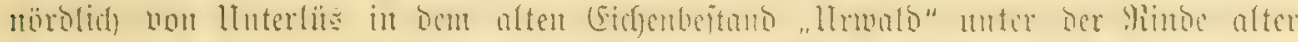

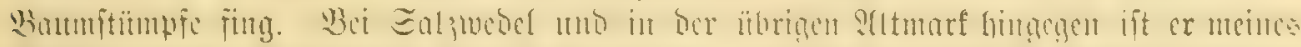

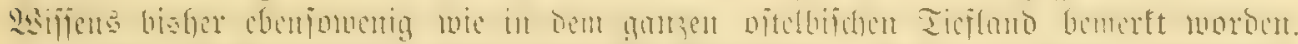

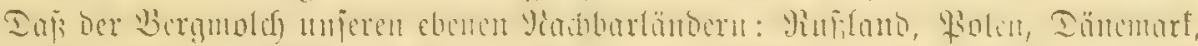

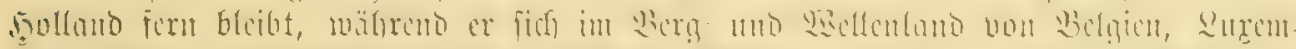

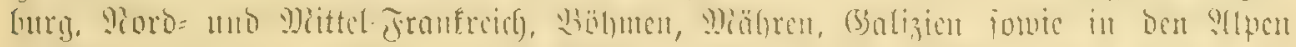

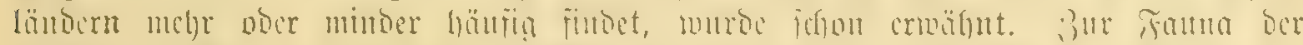

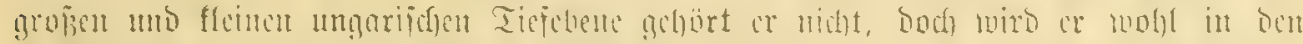

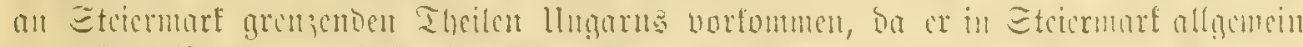

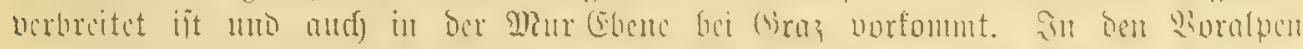

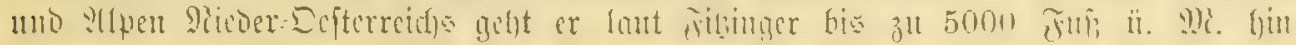

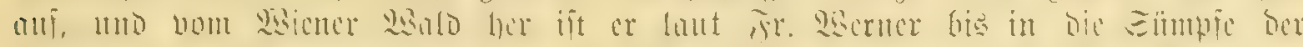

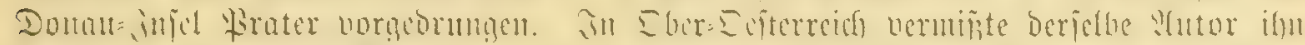

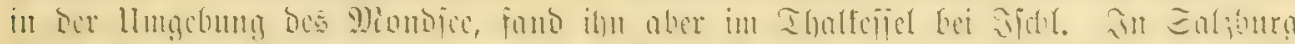

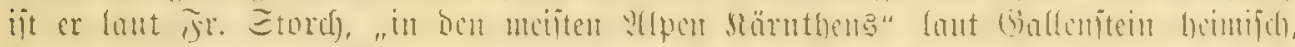

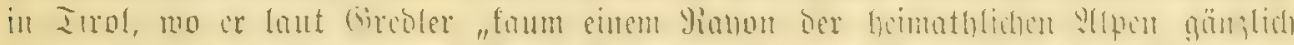

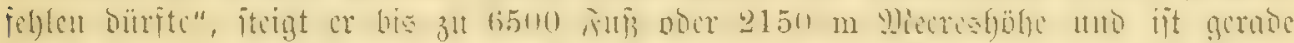

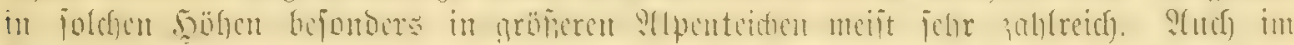

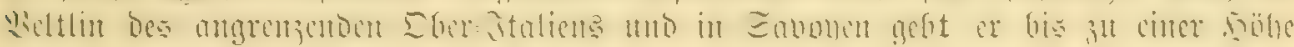

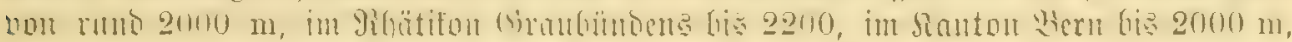

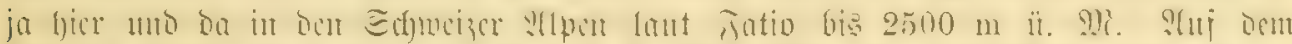

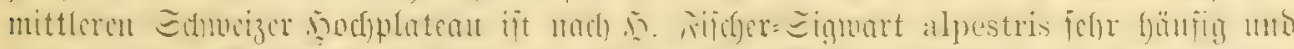

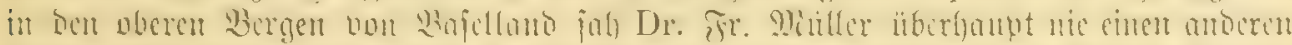

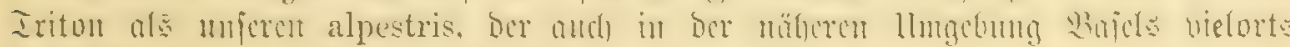
vorfommt.

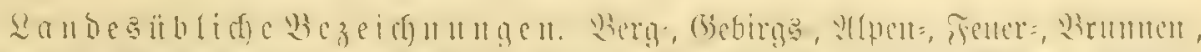

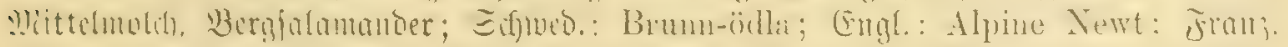

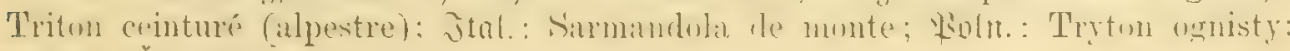
(Bör)m: Čolek horni.

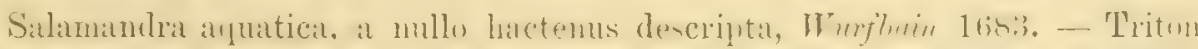
alpestris. Wurfhainii et salamamdroides. Lomenti 1768. - Lacertat palustris

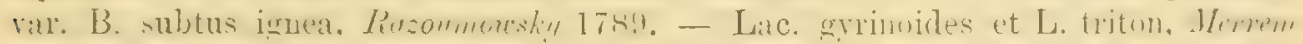

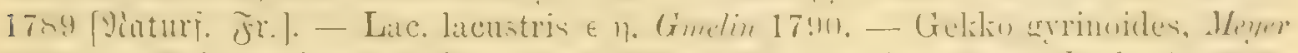

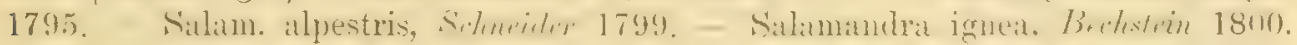

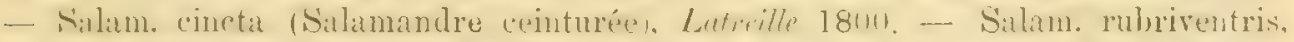

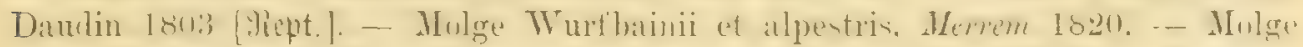

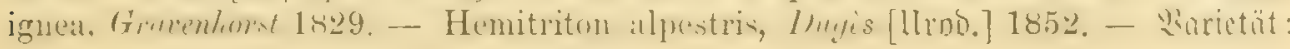
Triton apuanus, Bonap. [Icon. tab. Fing. 3] 1841. 


\section{Q(xt: Streifenmold). Triton vulgaris $\left(J_{\text {. }}\right)$. Mbrilbung VI, Tajer 9ix.2.3.}

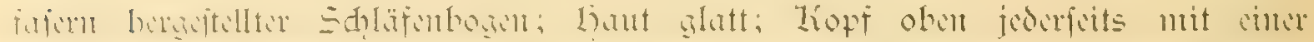

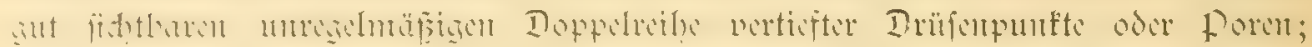
Sdywanz gegen das Ende lin allmälplid und lang, fein jugefpitst (ohnte

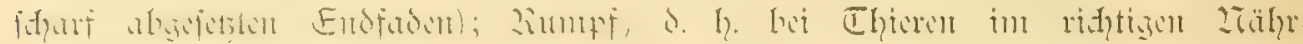

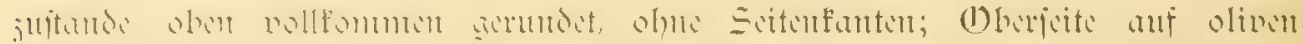

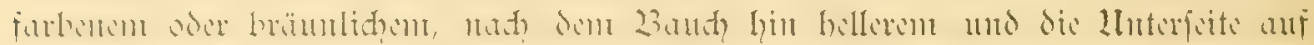

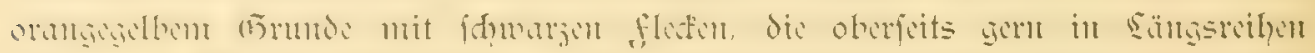

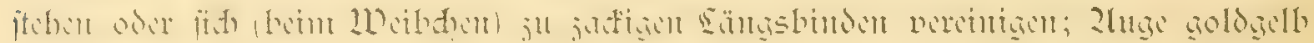

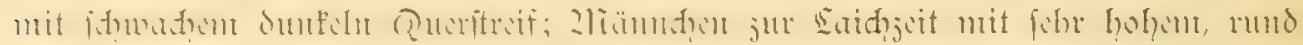

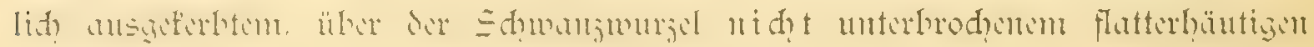
Ifamm nus mit Б)antfäment an den Liuterjehen.

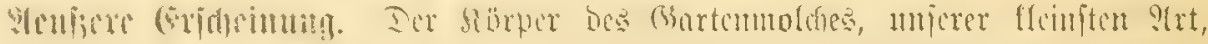

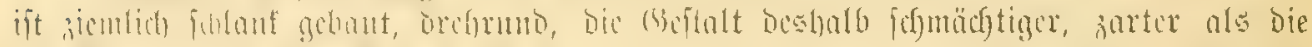

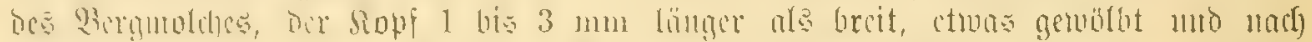

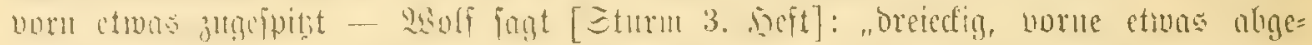

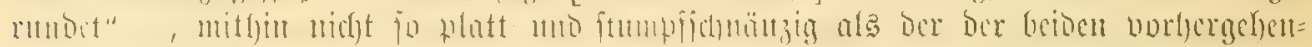

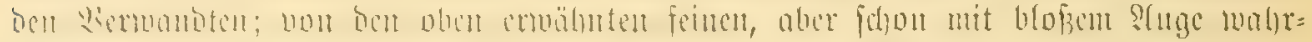

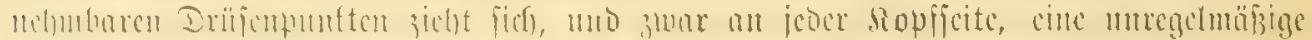

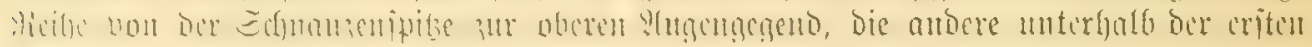

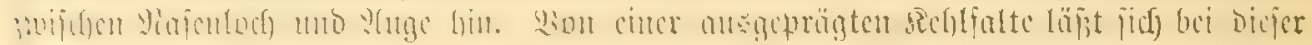

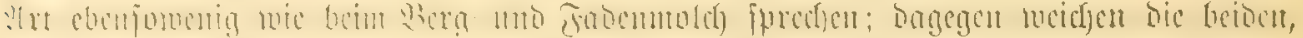

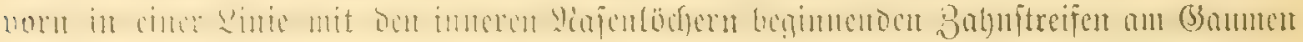

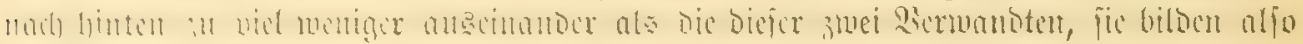

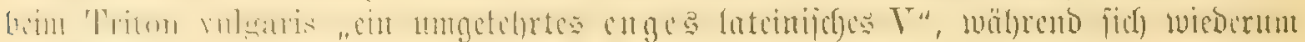

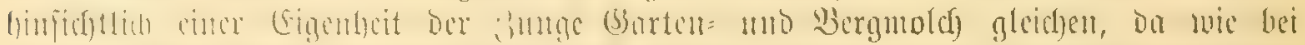

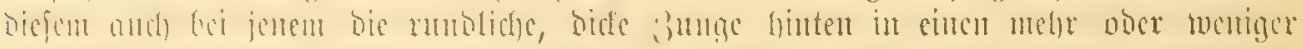

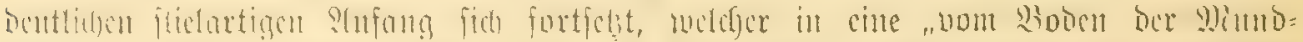

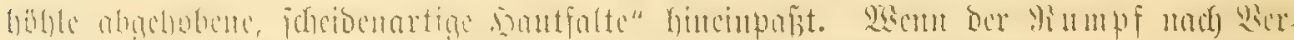

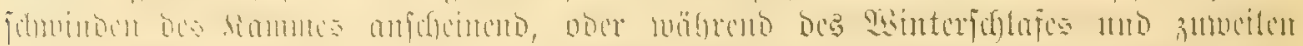

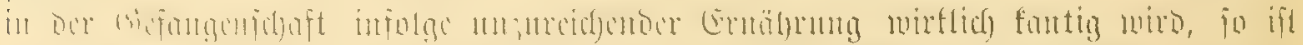

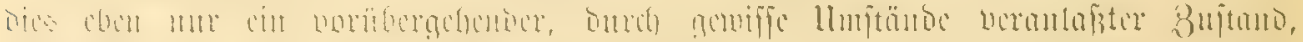

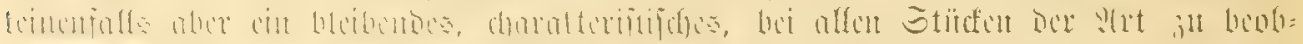

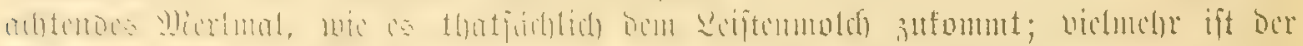
施m

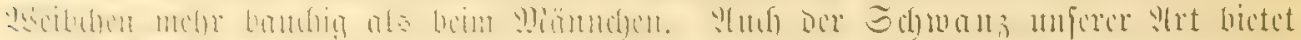

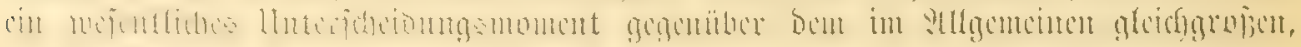

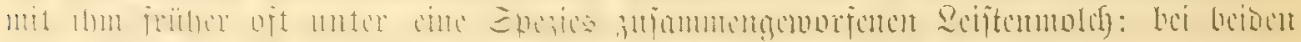

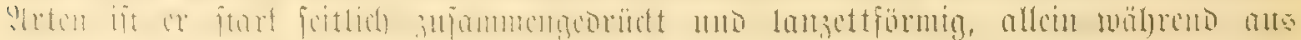

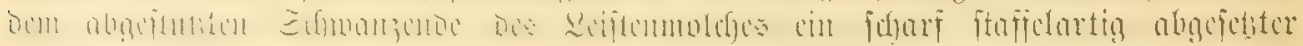

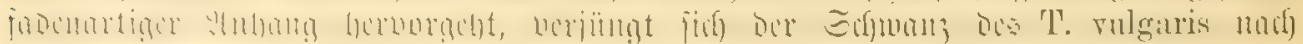

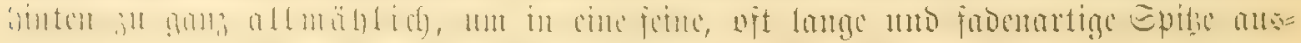

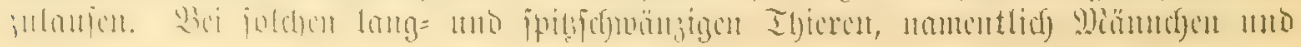




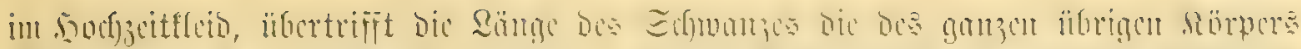

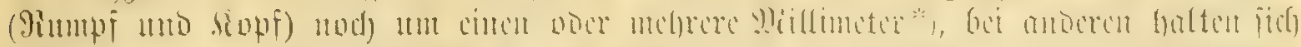

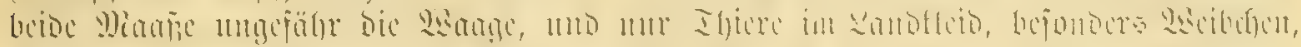

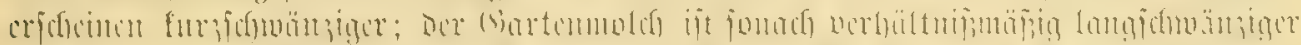
als bie

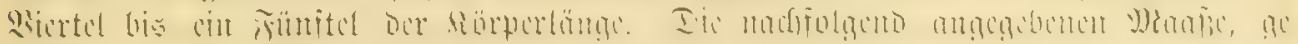

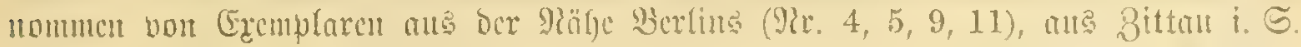

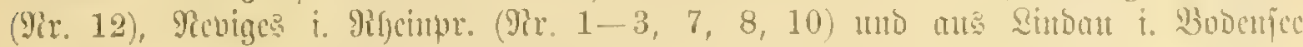

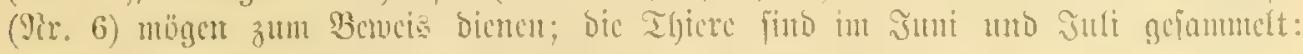

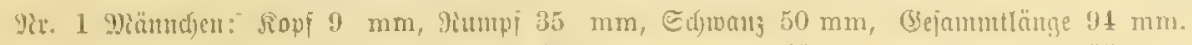

\begin{tabular}{|c|c|c|c|c|c|c|c|c|c|c|c|c|}
\hline 2 & " & $"$ & 8,5 & $"$ & " & $333_{, 5}$ & $"$ & " & 43 & " & $"$ & 85 \\
\hline 3 & " & $"$ & 8,5 & $"$ & $"$ & 34,5 & " & $"$ & 42 & $"$ & $"$ & 85 \\
\hline+ & $"$ & " & 9 & $"$ & $"$ & 31 & $"$ & $"$ & 40 & $"$ & $"$ & 80 \\
\hline 5 & $"$ & $"$ & 3,5 & $"$ & $"$ & 35,5 & $"$ & " & 45 & " & $"$ & 90 \\
\hline 6 & $"$ & $"$ & 7 & $"$ & $"$ & 29 & $"$ & $"$ & 32 & " & $"$ & 68 \\
\hline 7 & & $"$ & 8 & $"$ & $"$ & 31 & $"$ & $"$ & 35 & " & $"$ & 74 \\
\hline 8 & 2keibutjen & $"$ & 7 & $"$ & " & 31 & " & $"$ & 35 & " & 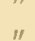 & 73 \\
\hline 9 & $" 1$ & $"$ & 8 & $"$ & $"$ & 35 & $"$ & $"$ & 33 & $"$ & $"$ & 76 \\
\hline 10 & " & $"$ & 8,5 & ", & ", & 32,5 & " & " & 40 & $n$ & " & 80 \\
\hline 11 & " & " & 6,5 & " & $"$ & 21,5 & " & $"$ & 25 & " & , & 56 \\
\hline 12 & " & " & 8,5 & $"$ & " & 32 & " & " & $37_{15}$ & " & " & 78 \\
\hline
\end{tabular}

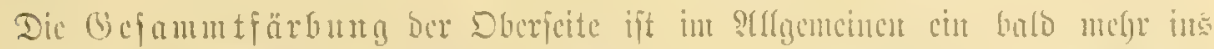

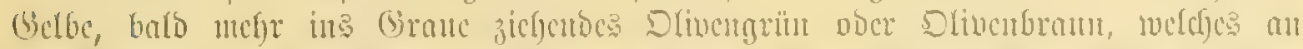

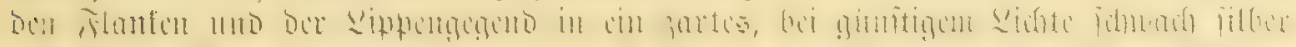

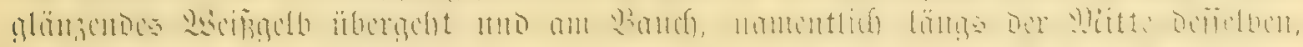

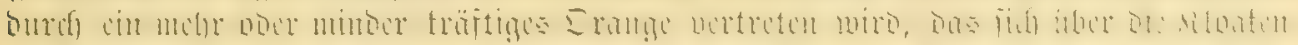

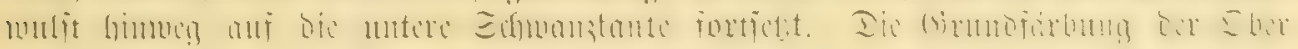

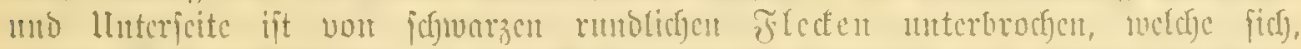

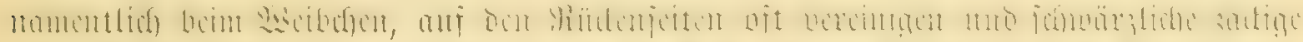

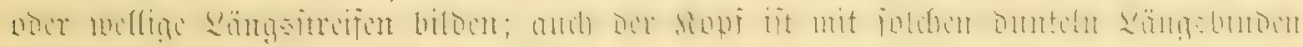

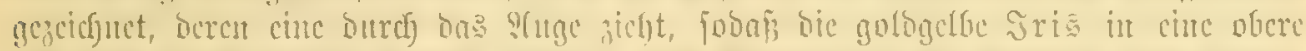

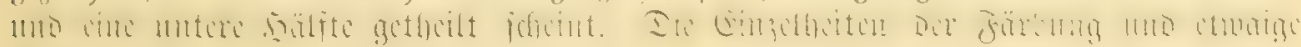

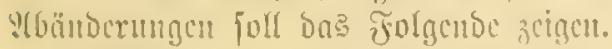

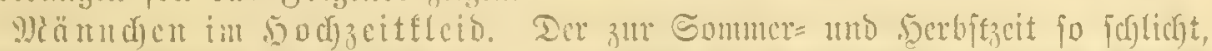

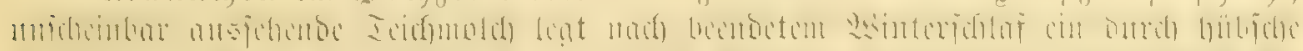

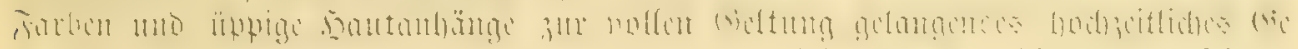

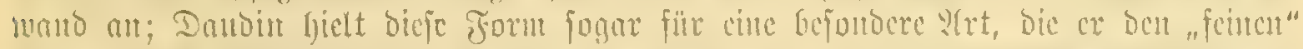

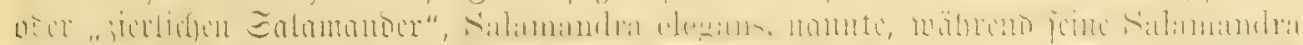

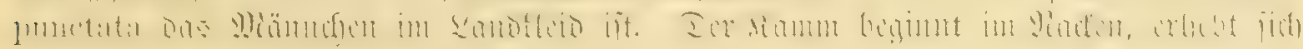

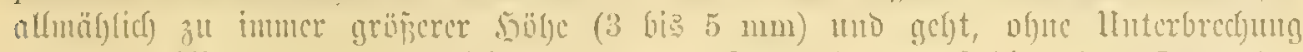

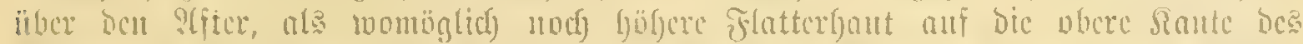

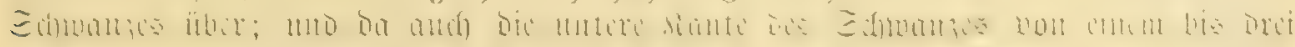

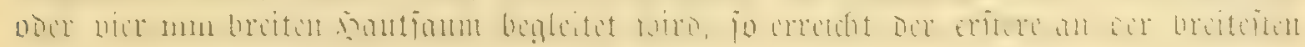

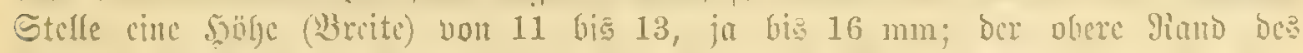

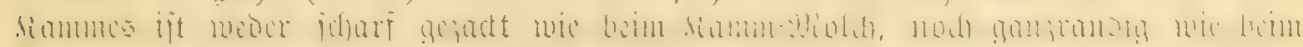

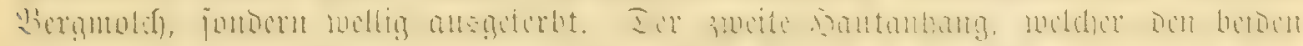

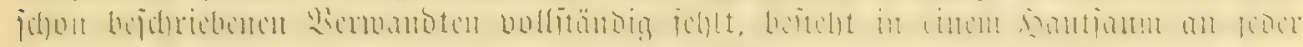

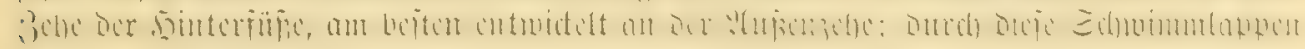

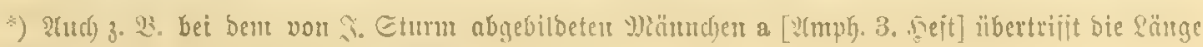
bes Ergwanzes bie bes ganzen übrigen sörpers un etwa $1 \mathrm{~mm}$. 


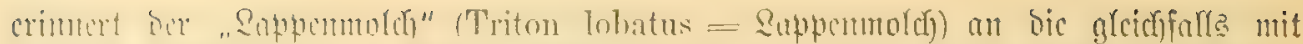

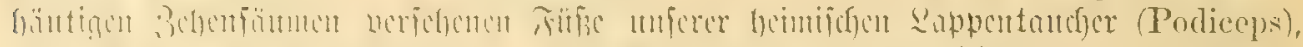

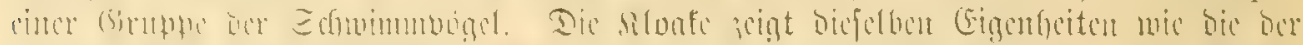

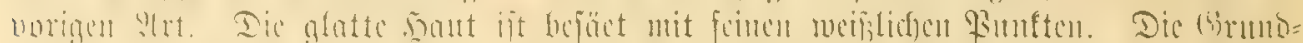

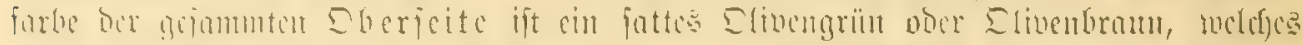

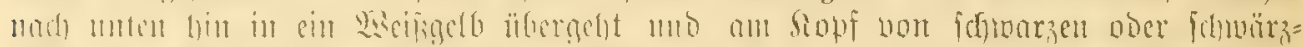

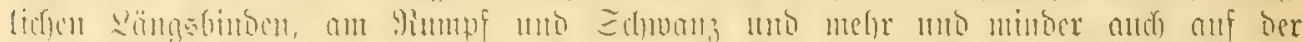

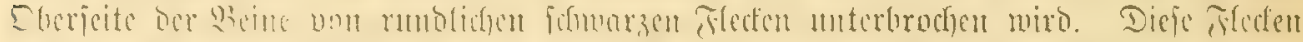

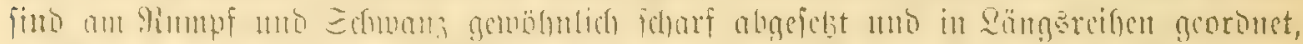

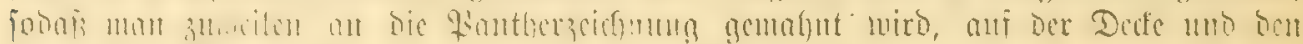

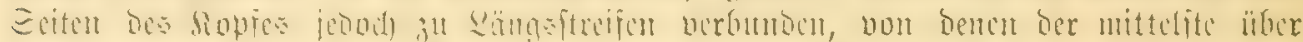

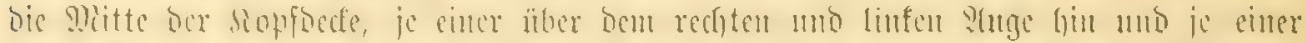

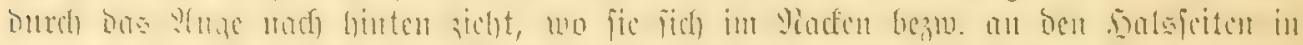

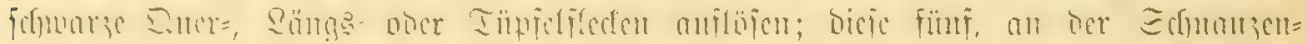

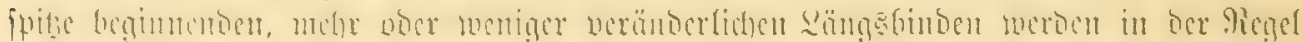

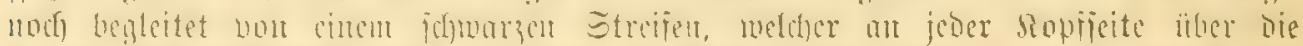

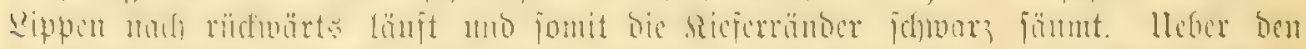

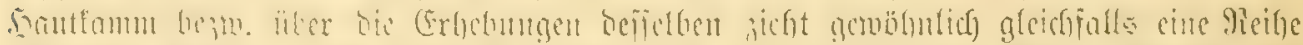

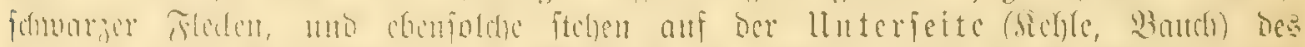

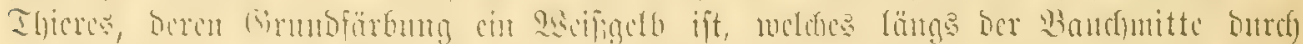

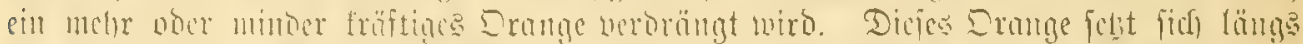

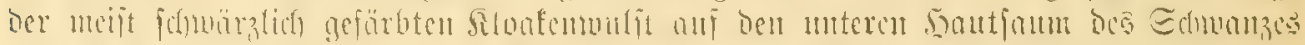

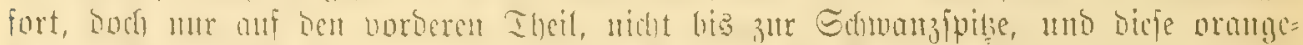

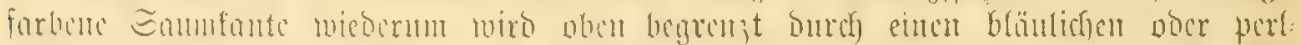

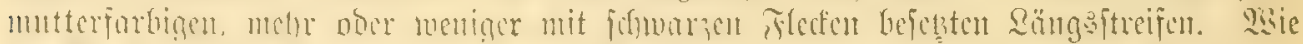

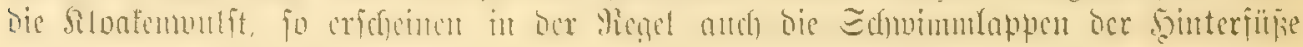

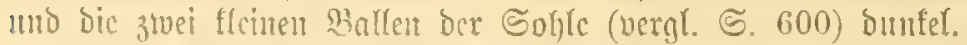

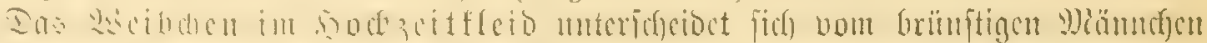

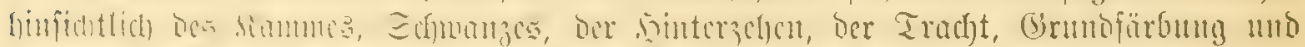

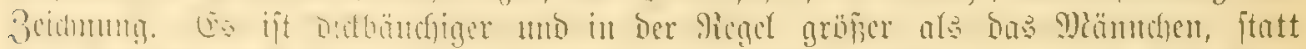

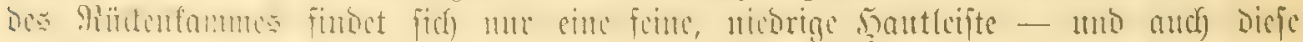

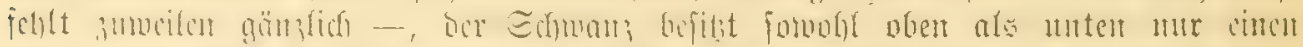

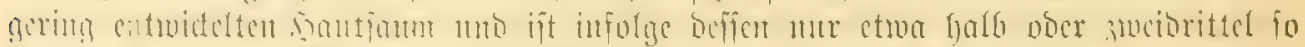

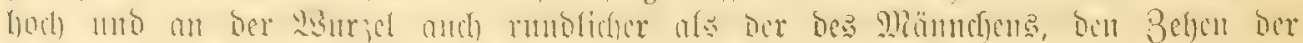

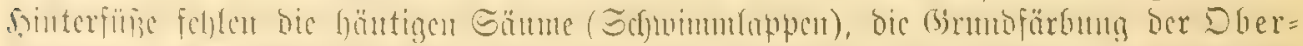

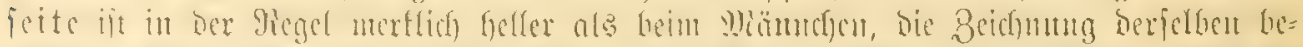

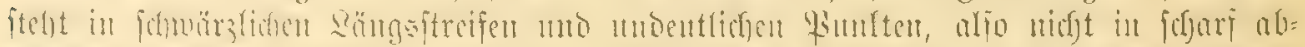

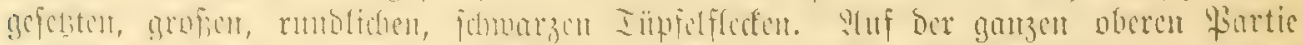

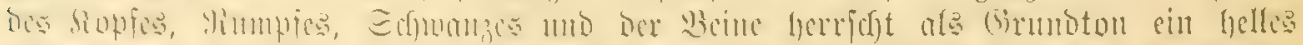

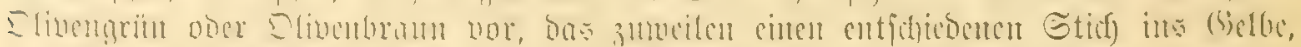

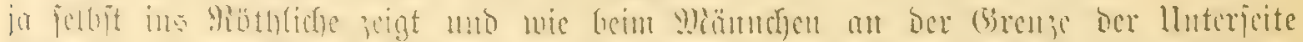

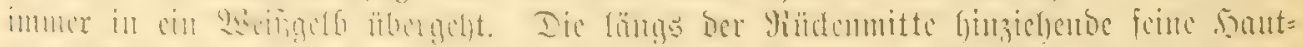

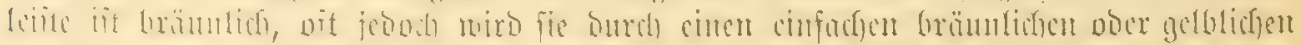

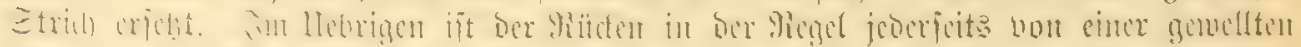

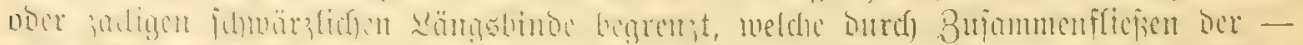

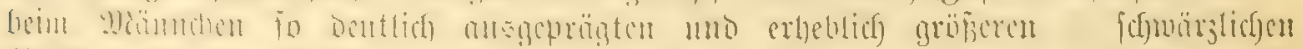

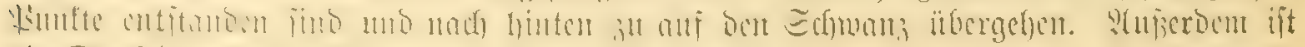

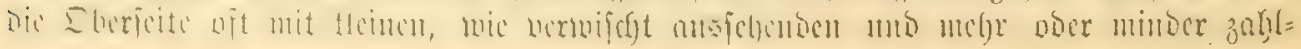




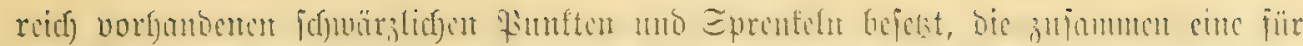

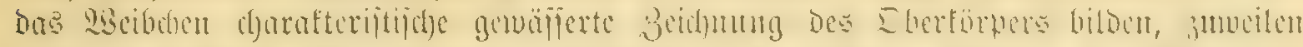

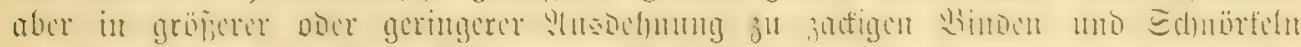

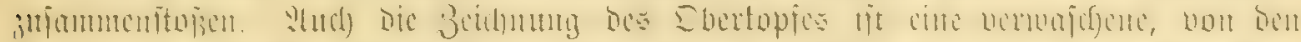

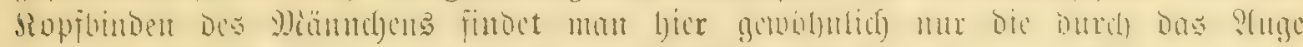

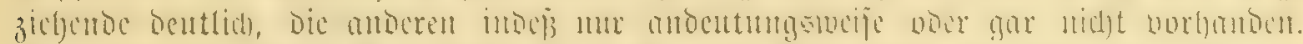

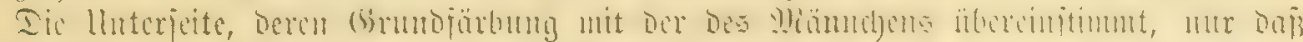

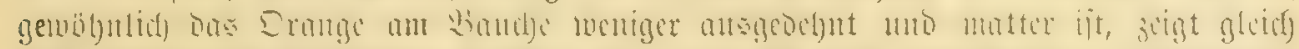

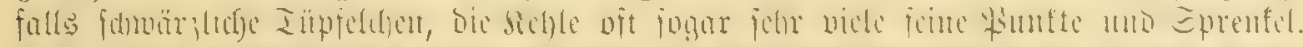

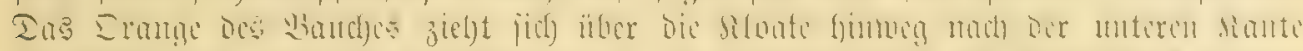

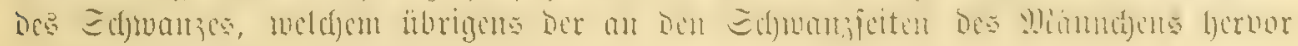
tretenoc blänliche Sängsittreifen nangelt.

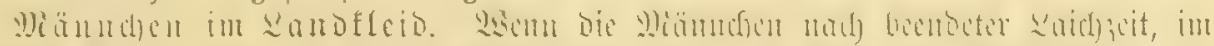

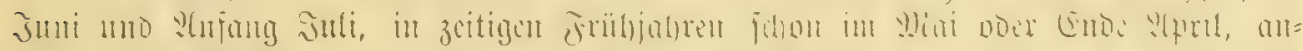

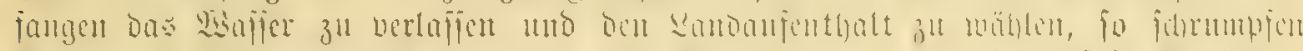

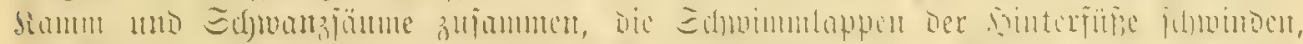

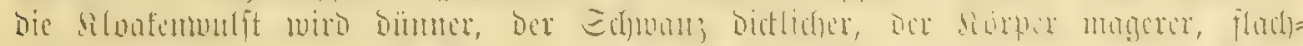

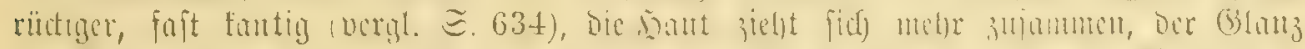

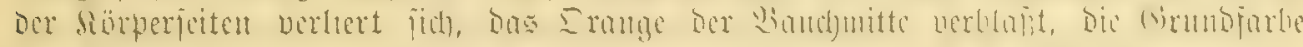

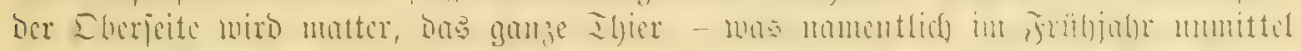

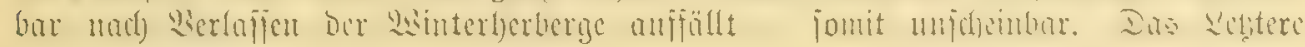
gilt in nod) bibferen Grabe vou dem

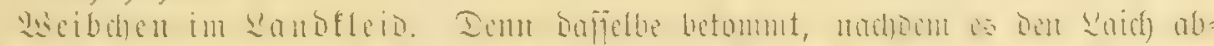

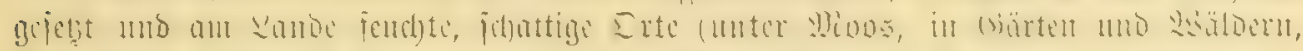

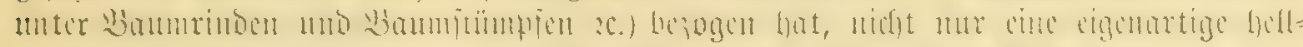

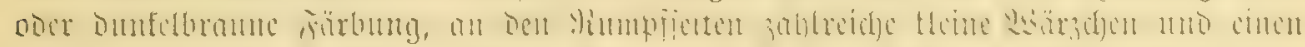

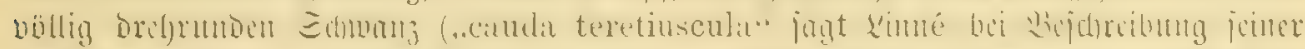

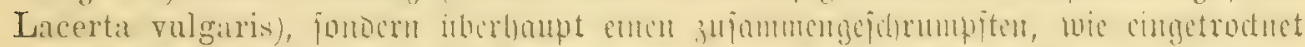

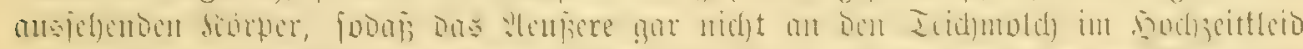

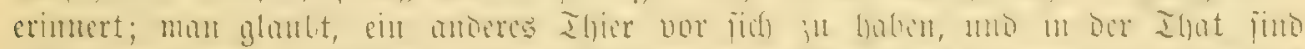

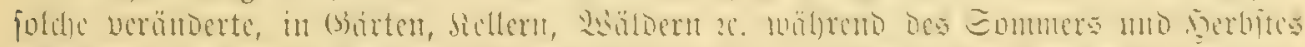

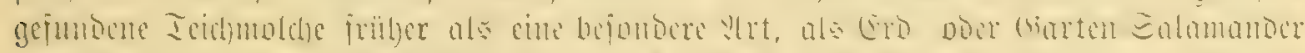

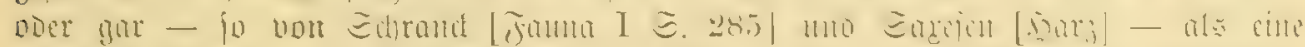

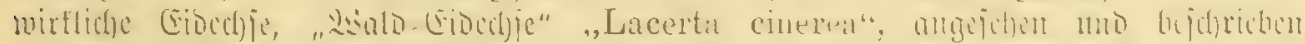

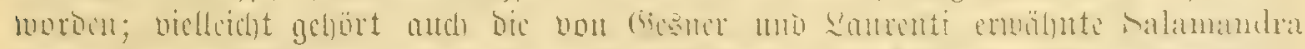

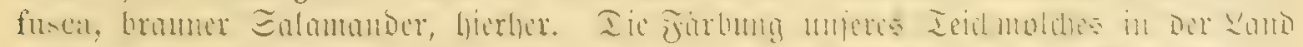

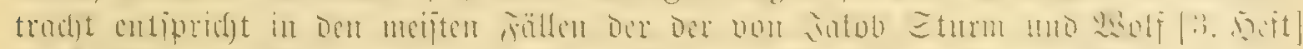

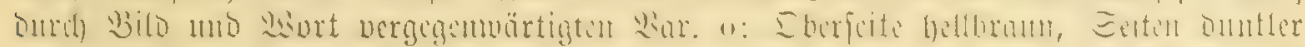

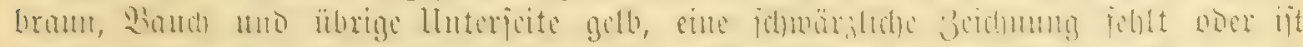

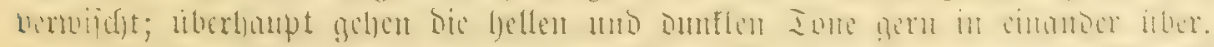

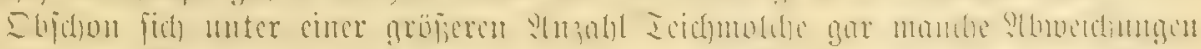

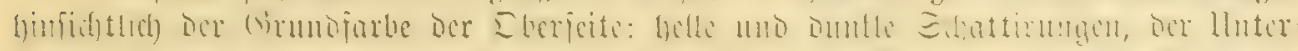

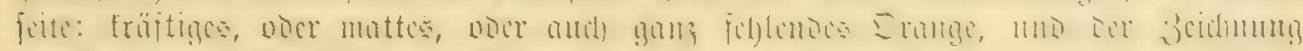

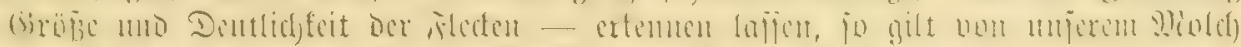

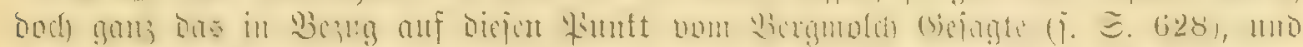

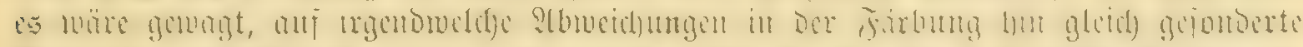

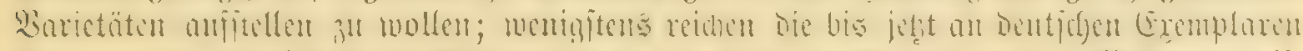

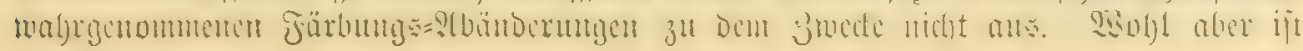




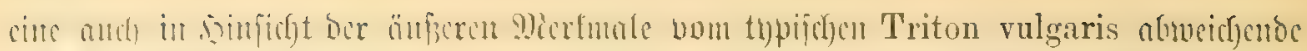

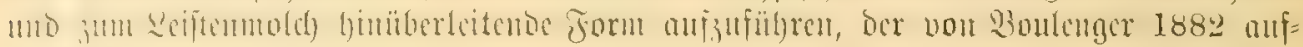
geftellte

Triton vulgaris meridionalis, meldyer in ben Mittefmcerlünorn: Italion,

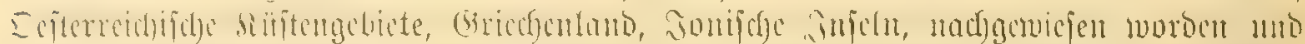

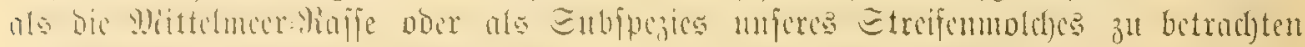

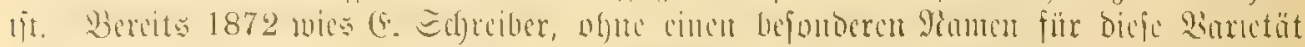

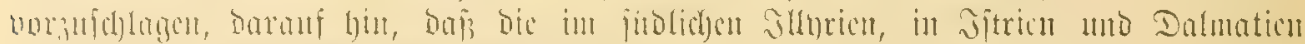

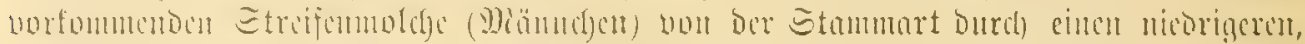

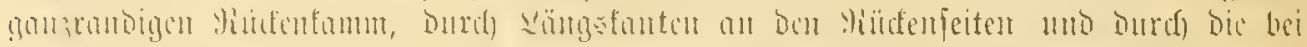

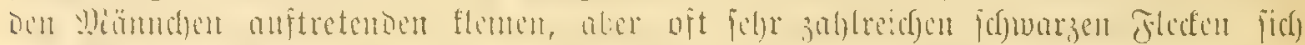

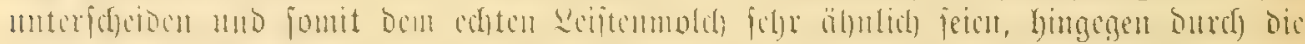

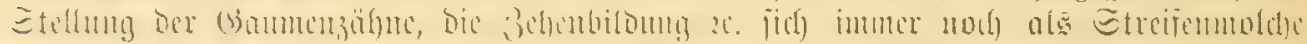

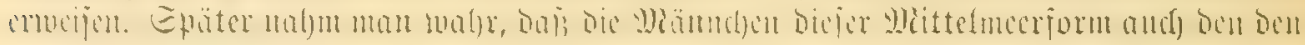

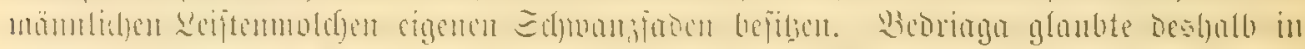

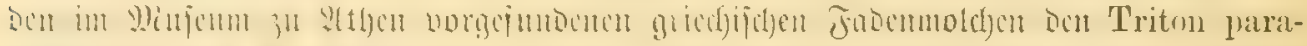

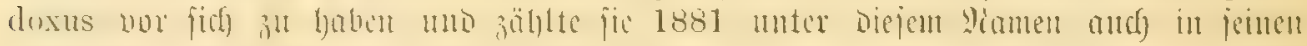
"YMpribient mo Mieptilien Bricchenlando" anf.

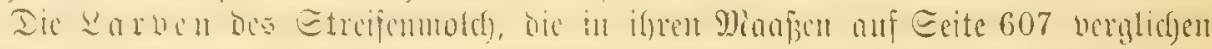

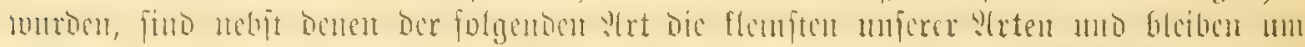

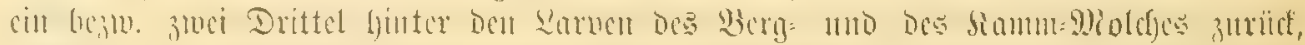

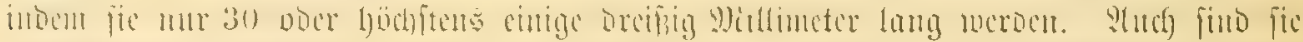

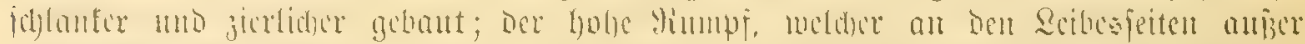

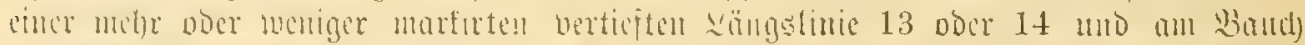

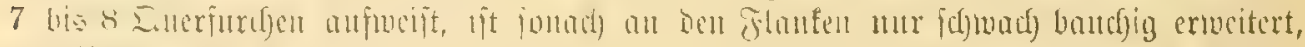

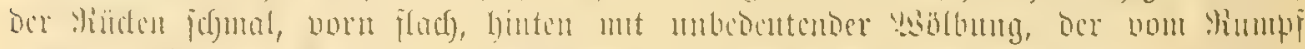

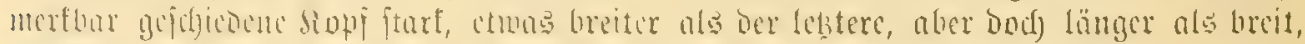

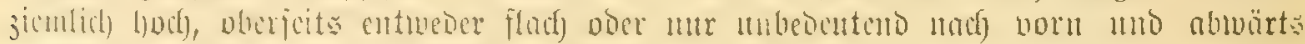

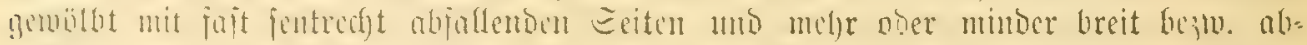

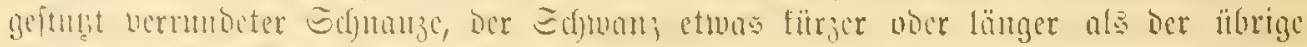

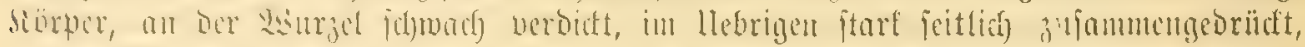

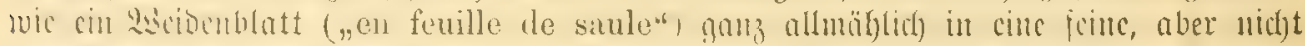

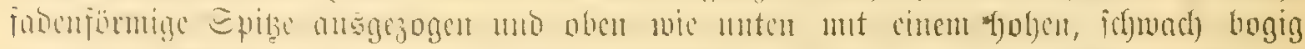

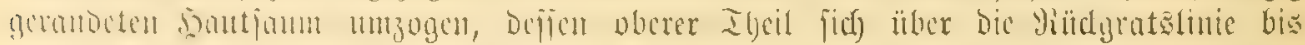

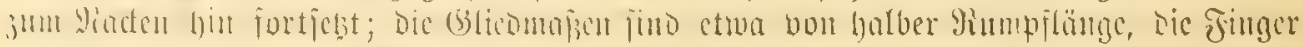

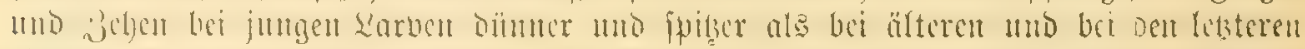

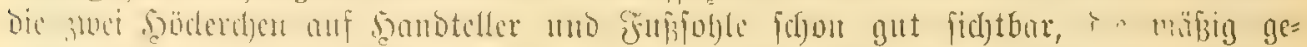

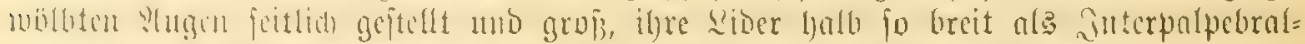

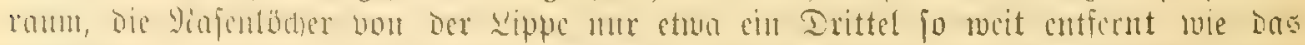

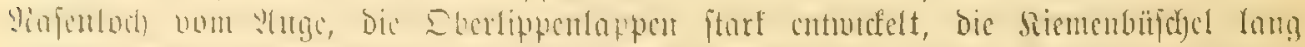

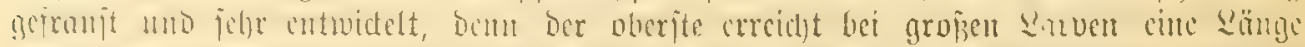

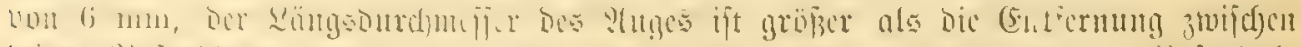

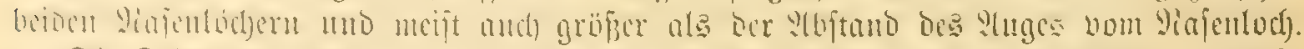

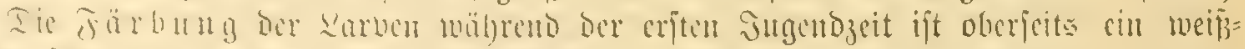

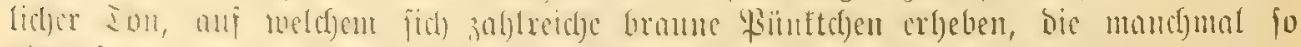

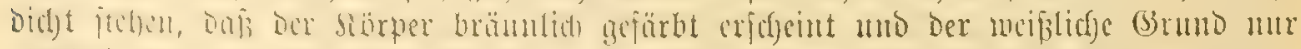

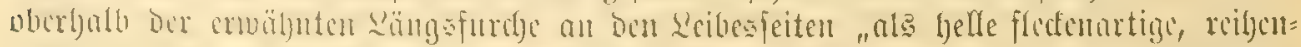

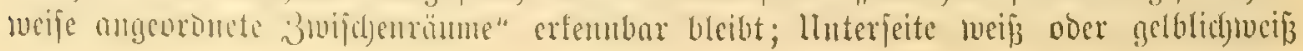




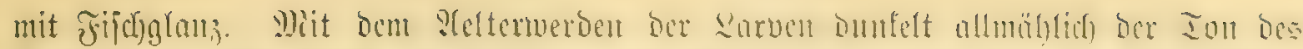

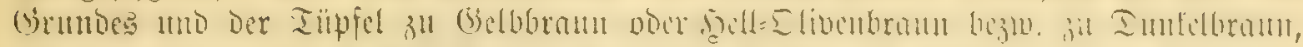

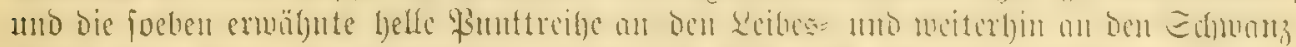

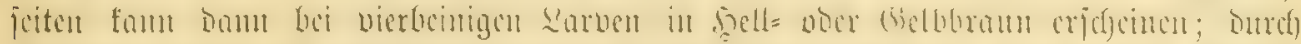

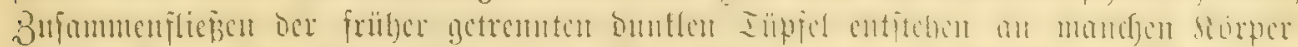

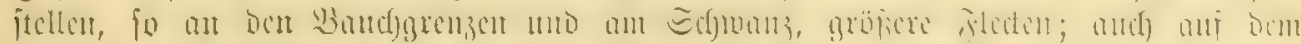

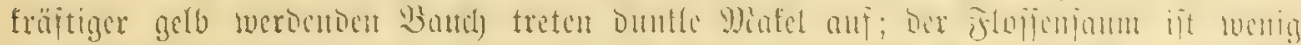

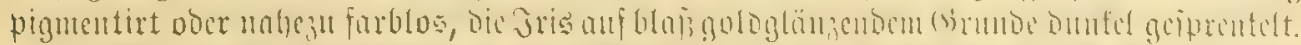

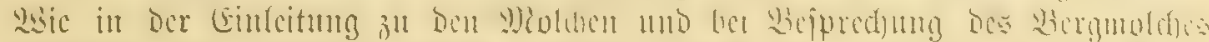

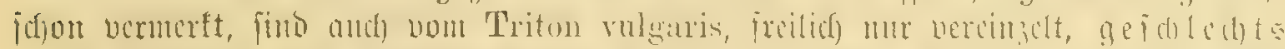

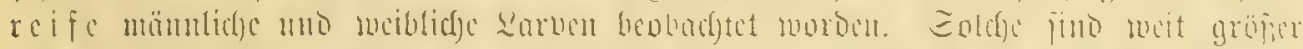

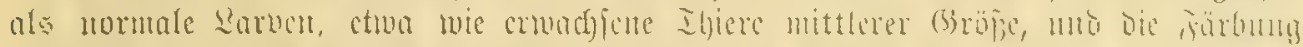

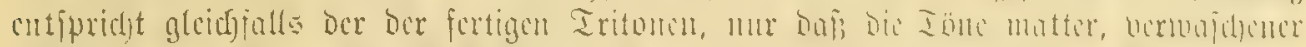

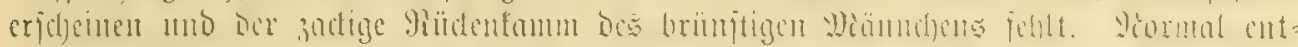

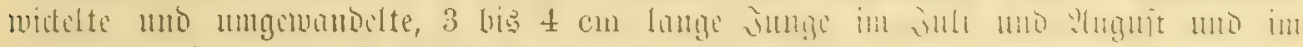

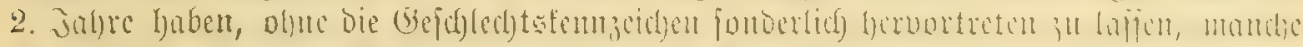

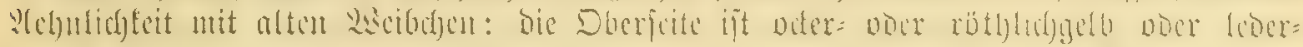

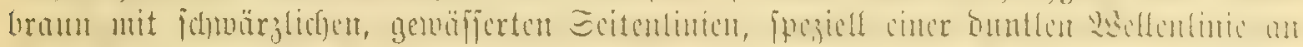

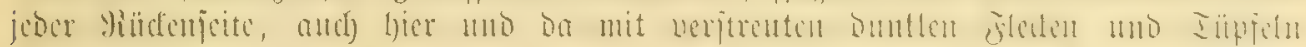

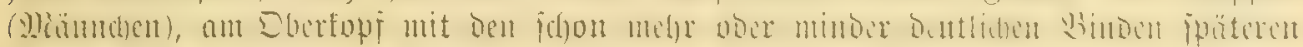

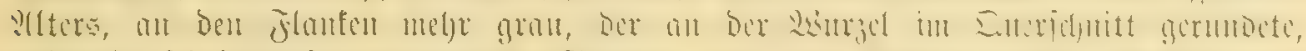

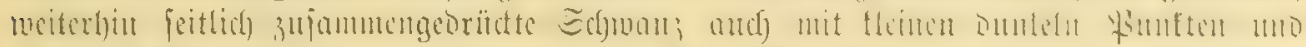

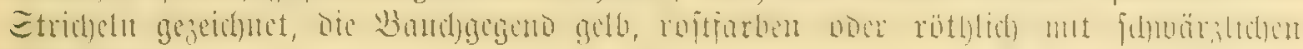
\$ituntten.

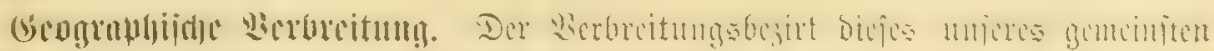

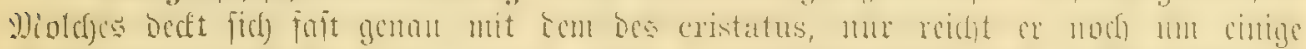

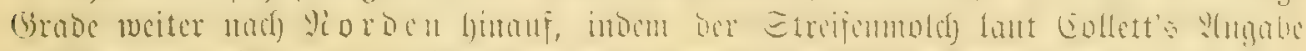

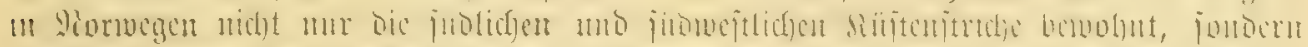

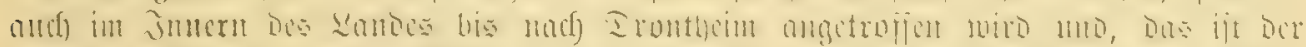

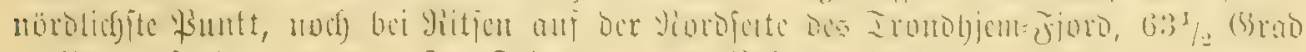

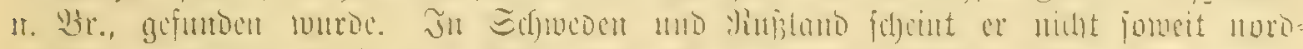

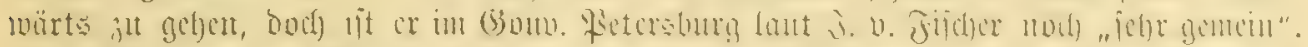

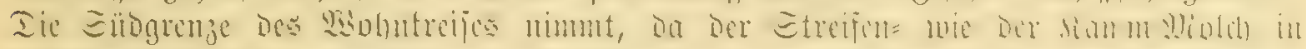

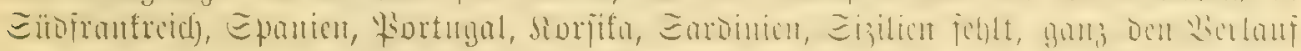

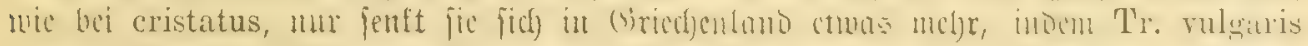

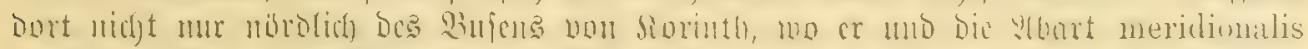
Durdi Dr. Siriper im firmajj=

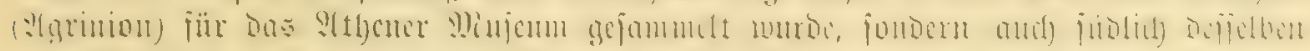

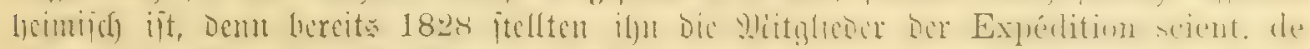

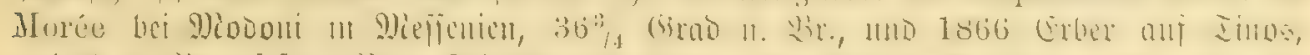

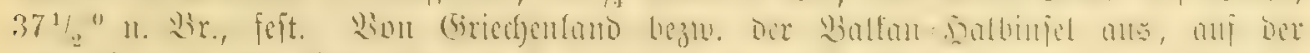

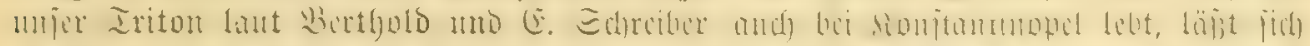

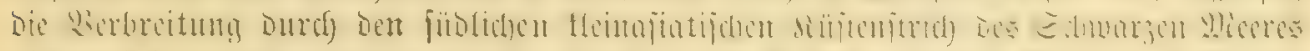

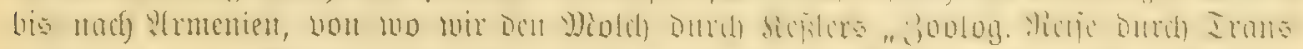

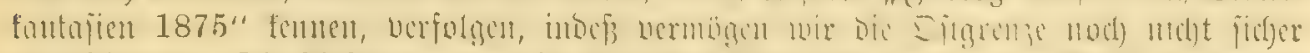

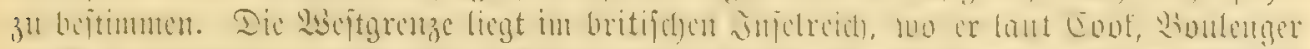

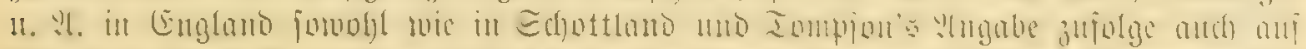

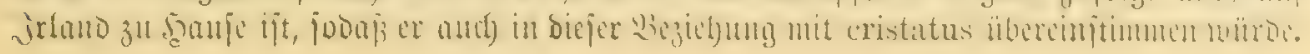




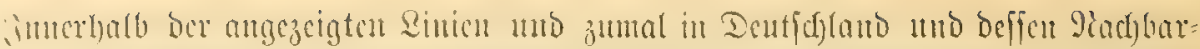

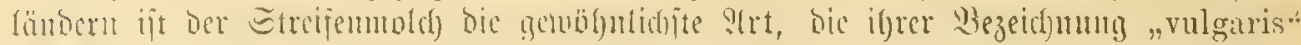

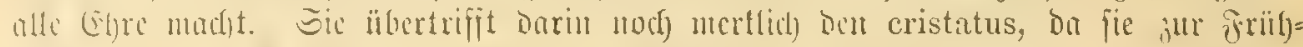

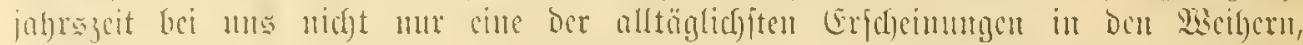

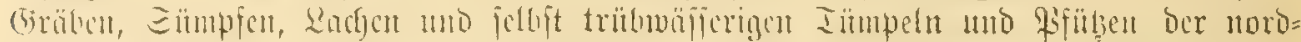

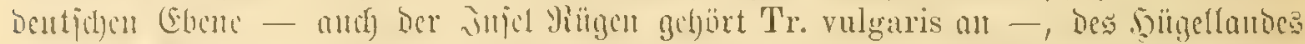

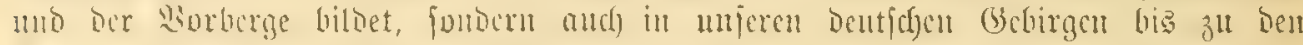

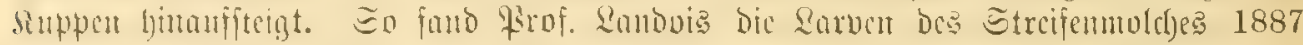

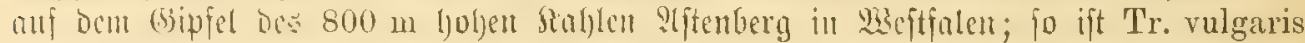

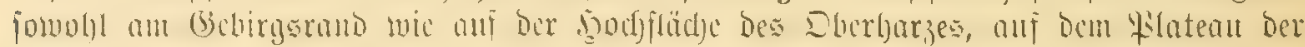

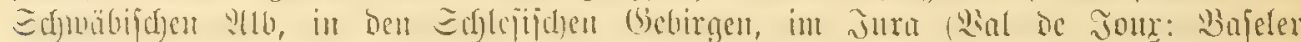

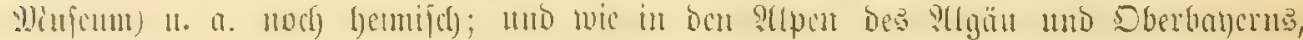

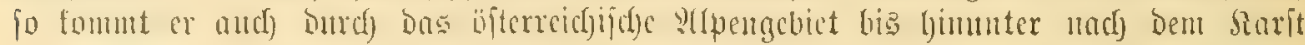

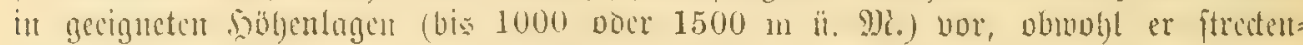

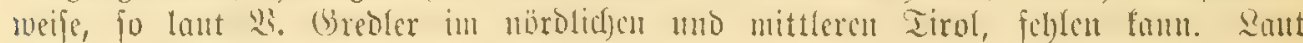

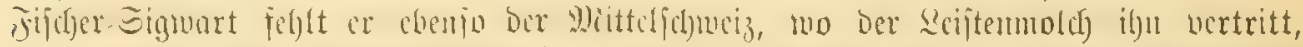

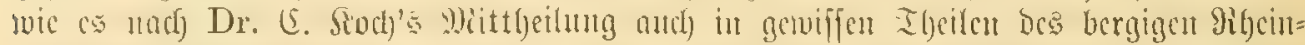

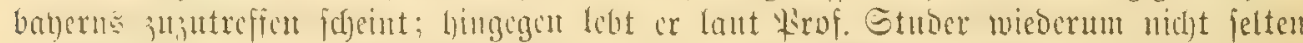

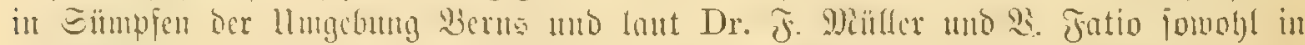

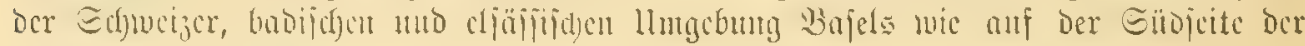
?ִpen, 3. 23. in Telfut.

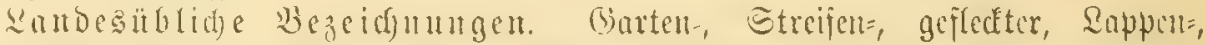

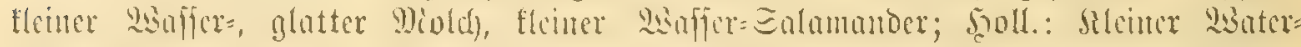
Eafunanocr; Edfwio.: Mindre Vatteu-iilla; Engl.: Smooth or Common Newt; Jranj.: Triton punctué (lolé), Petite Salamandre; Jtal.: Tritone punteggiato, Sarmandoletta; Hinff.: Wodjamája Jístscheriza; Woln.: Tryton pstry; Wiúlum.: Coleli tečkovaný.

Petite Salamandre, Jufay 1729 [Mem. de l'Acad. de Paris 1729]. -

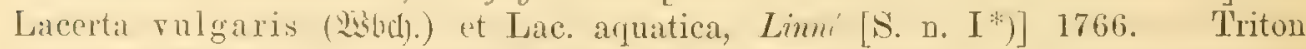

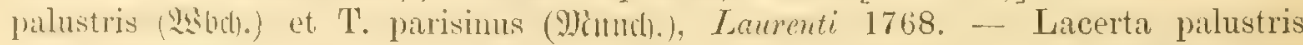
A.: subtus lutea, Razoum, 1789. - Gekko triton, Meyer 1795. - Salamandra

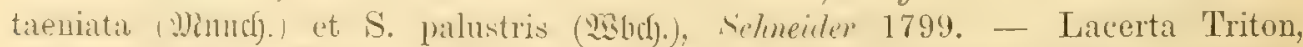
Retziu: 1800. S'alam. punctata (Mind).) et S. abdomiualis (2iso(f).), Latreille 1810. Lacerta seu Salanandra treniata, Bechstein 1800. - Salam. punctata,

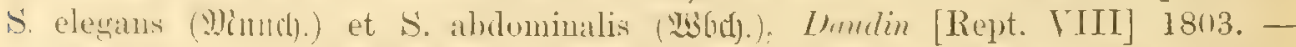

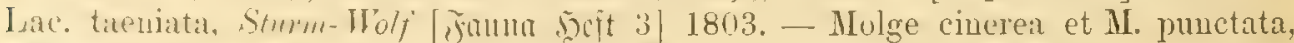
Merrem 1820. - Salam. exigua, Rusconi [Amours Iaf. 1] 1821. - Molge taeniati, Grmwel. 1829. - 'Triton abdominalis, Bilmon Bory [Exp. Morea] 1832. - Nial. Lacepulii. Aulrajoushy 1832. - 'Triton hobatus, Oth-Schinz [Famma helr.] 1837. Tritou lobatus et 'T'r palmatus. Bemaquete 1839. - Tr. aruaticus et Tr. vulgaris. Fleming 1838. - I isisotriton punctatus, Bell 1839. - Lophinus punctatus, Grom [Ciatal.] 1050. - Tritun puretatus, Dum. Bibr. [Erpet. IX] 1854. - Pyronivia punctata, Gruy [Pruc. 'Loul. Soc.] 1858. - Triton taeniatus, Jeydiy 1867. - Dä ふuıgc: Salamandra exigua, Laurenti 1768.

3n ber Fauna suecica vou 1746 unter Nx. 254 mus Tir. 257 nod) ohue beionbere Gpezieș=

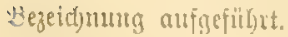




\section{2(rt: Eciftemmolf). Triton paradoxus (Razoum.). \\ 9bbiloung zatel VI 9it. 4.5.}

Länge 6,5 bis $8,5 \mathrm{~cm}$, felten cinice 2rillimeter darunter oder darüber; ant nttemzeidem.

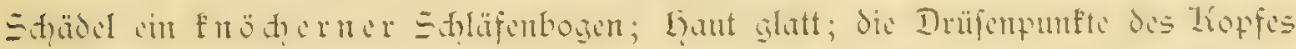

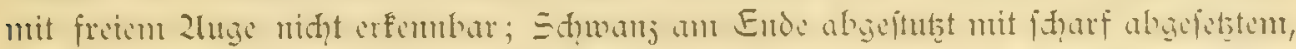

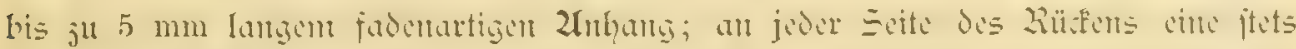

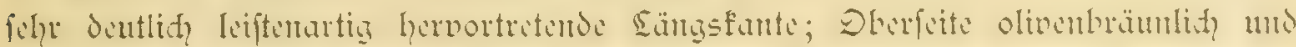

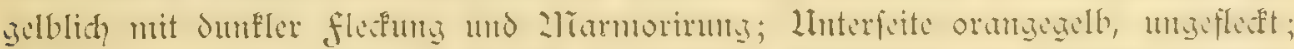

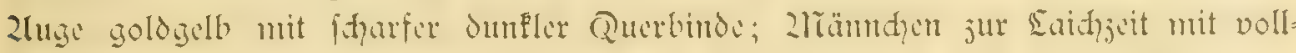

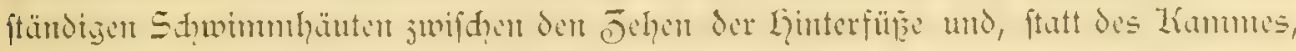
mit erhabener Seifte längs der Rüdenmitte.

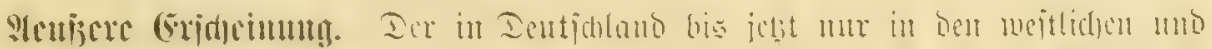

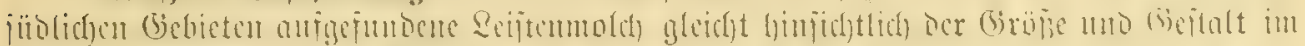

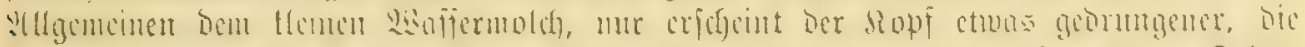

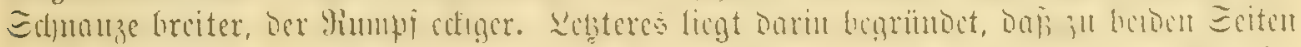

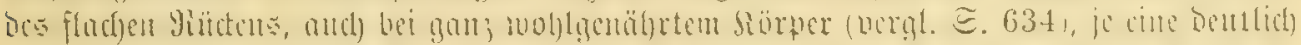

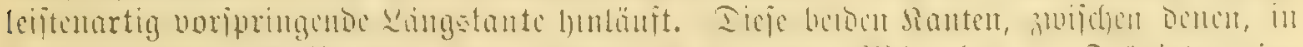

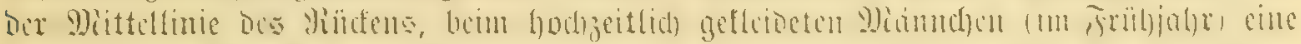

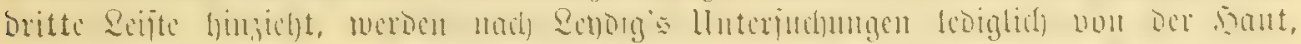

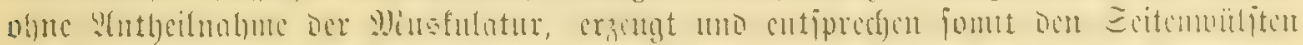

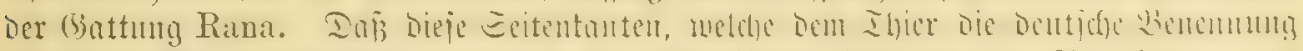

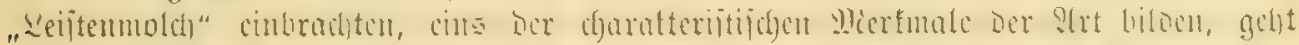

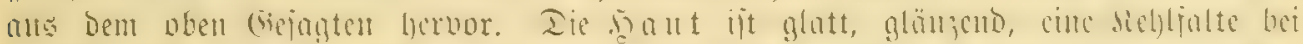

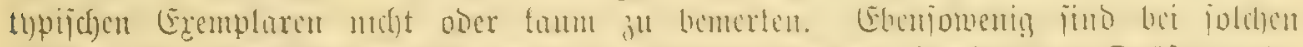

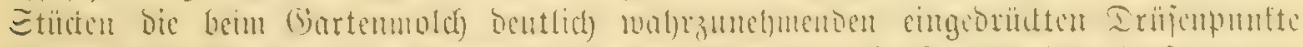

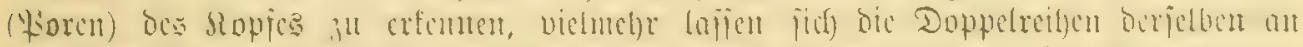

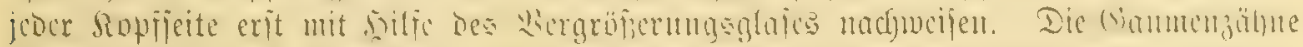

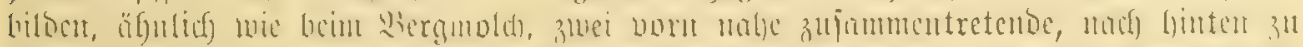

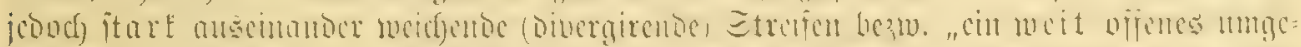

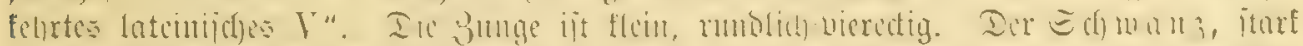

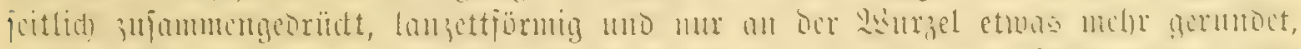

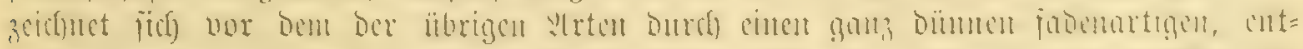

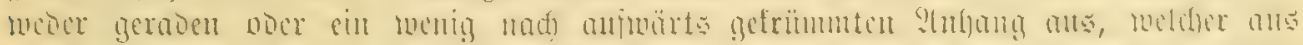

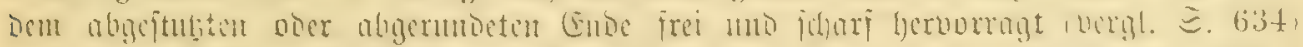

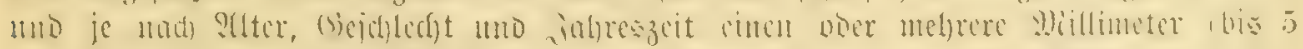

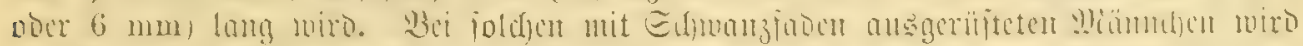

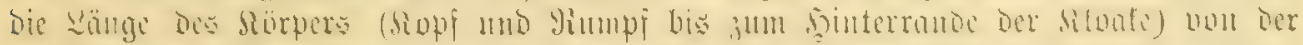

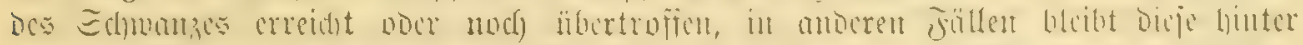

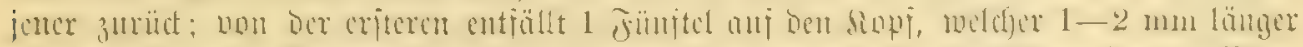

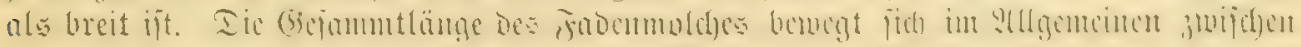

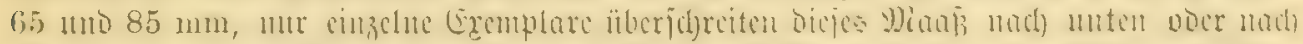

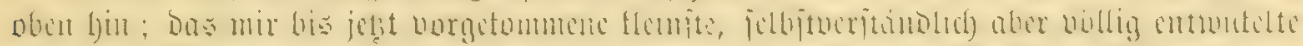

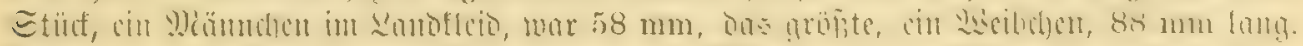

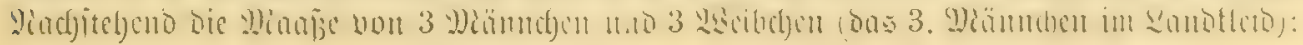


Sinf $7,5,7,5,7 ; 7,8,9 \mathrm{~mm}$; Vimup $28,5,28,5,29 ; 32,31,39 \mathrm{~mm}$; Ecfmunz 30 , 33,$30 ; 31,37,40 \mathrm{~mm}$; (Şcjantmtlünge $66,69,66 ; 70,76,88 \mathrm{~mm}$.

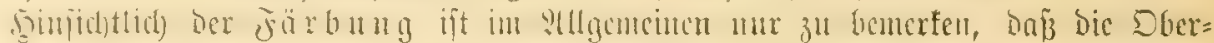

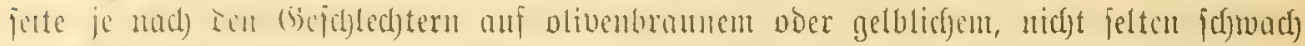

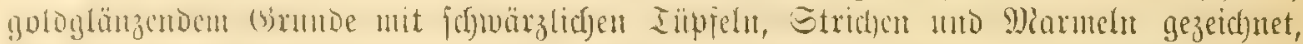

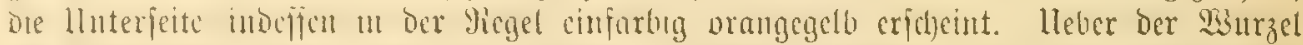

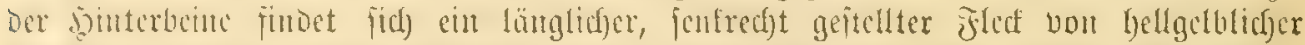

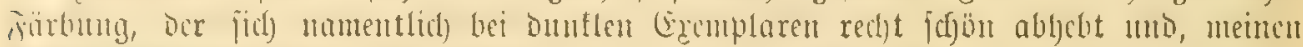

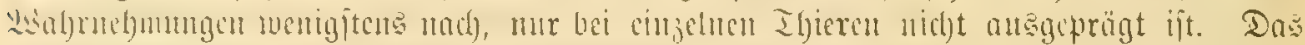

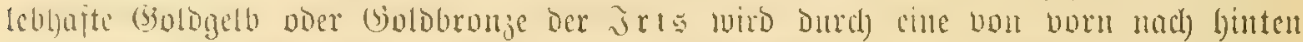

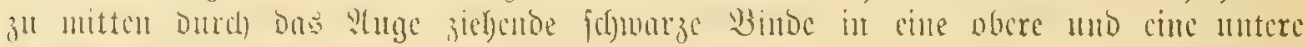

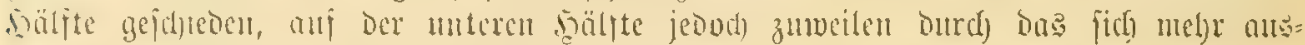
brentende Gdywarz fajt ober gänzlid) beroringt.

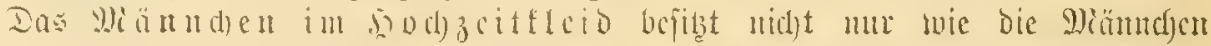

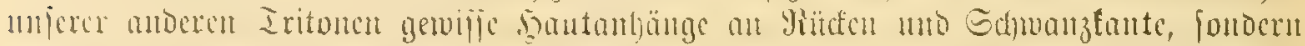

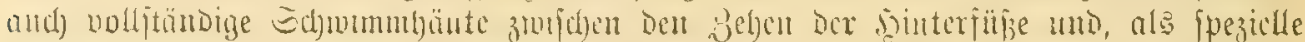

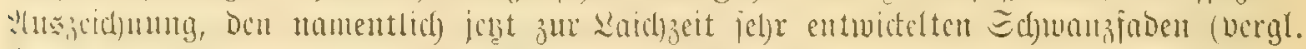

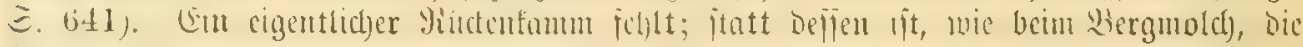

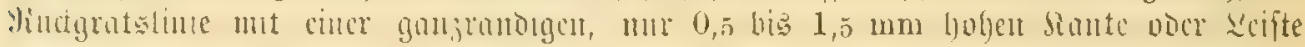

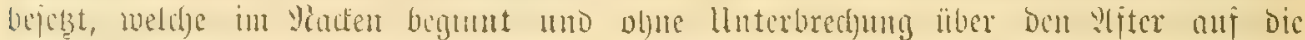

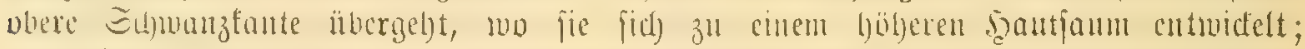

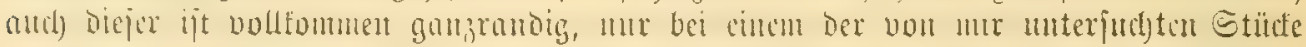

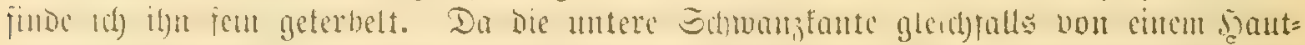

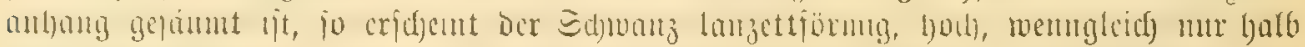

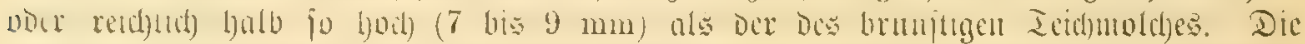

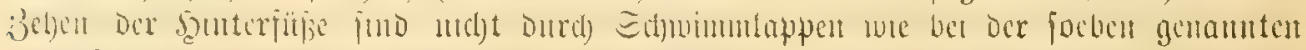

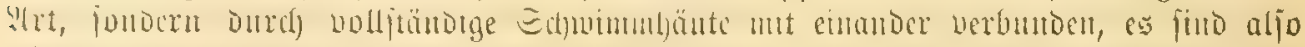

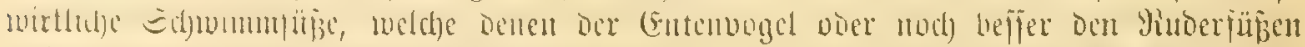

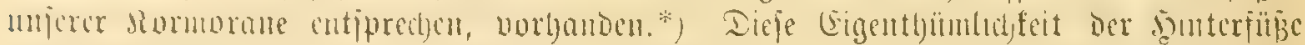

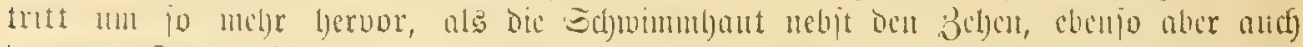

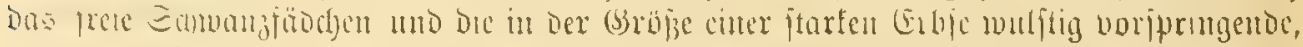

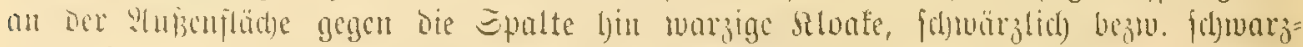

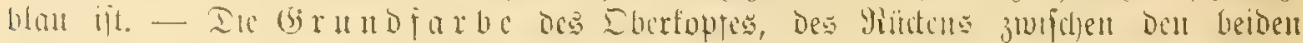

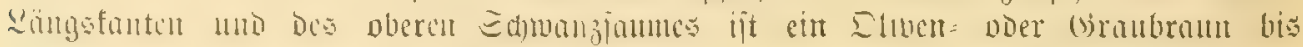

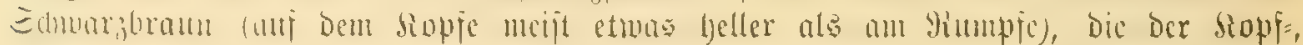

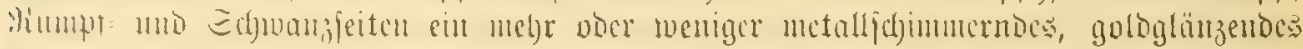

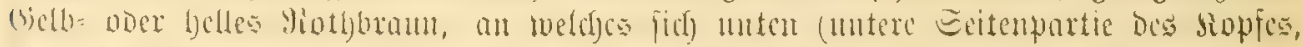

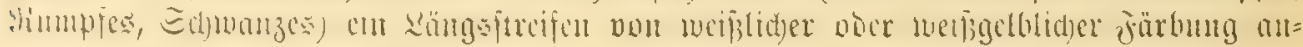

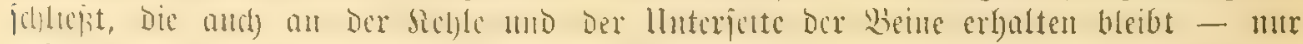

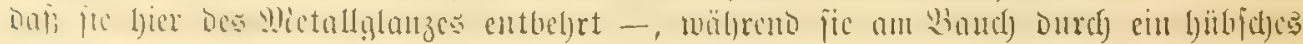

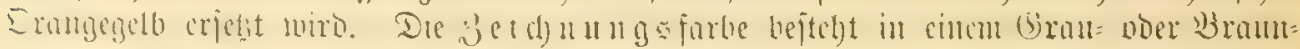

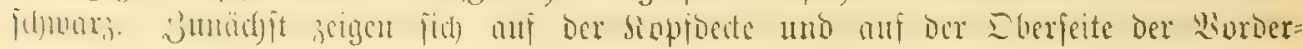

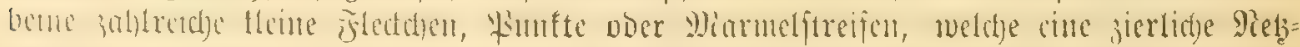

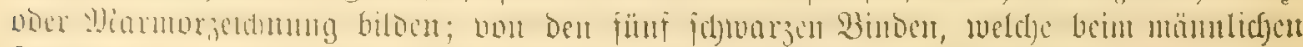

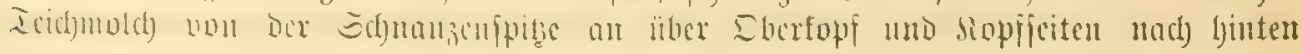

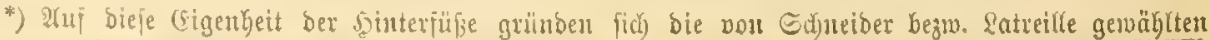

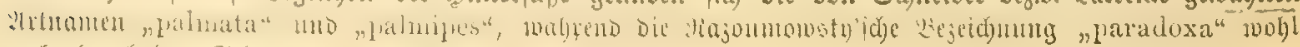

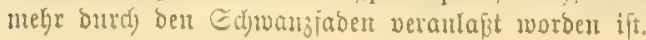




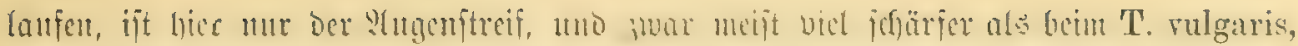

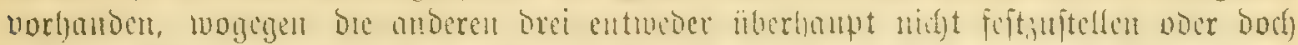

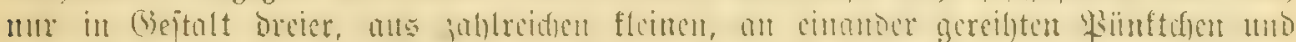

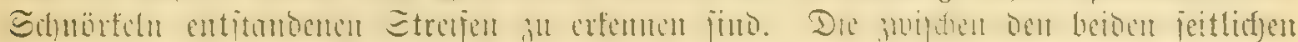

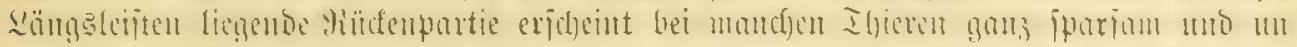

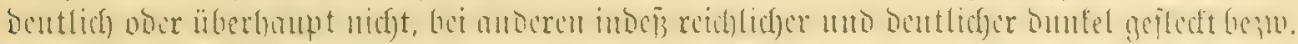

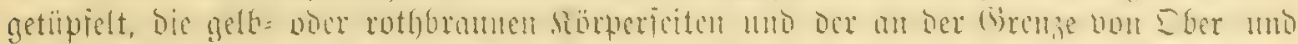

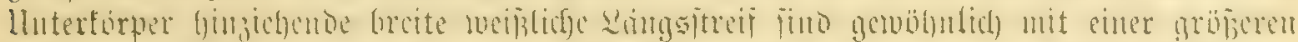

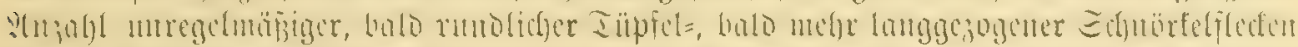

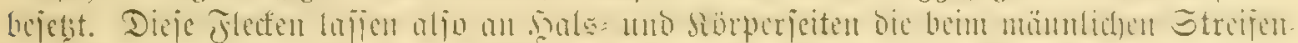

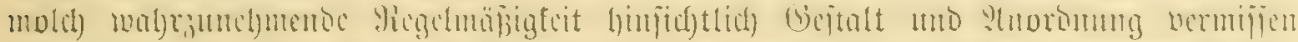

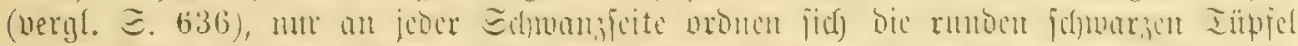

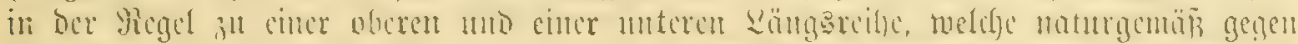

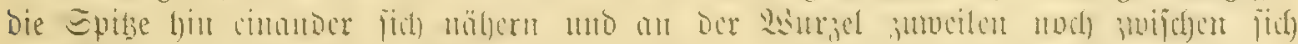

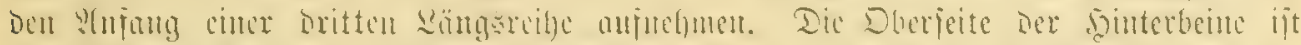

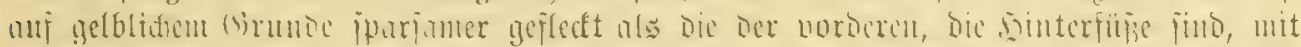
Y)

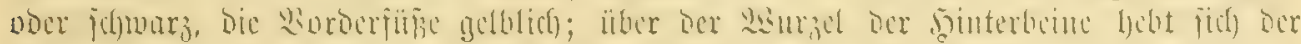

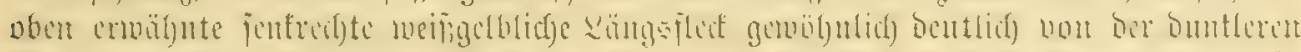

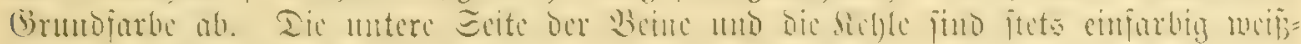

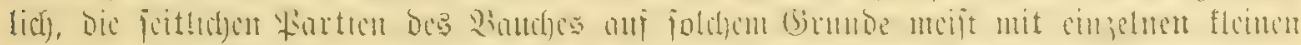

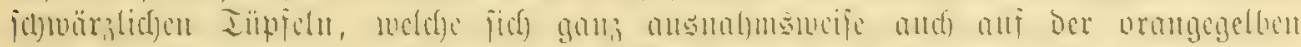

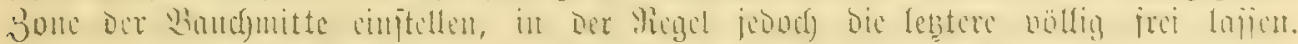

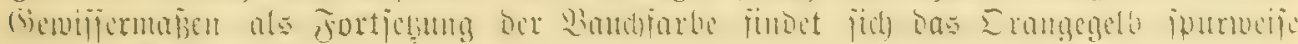

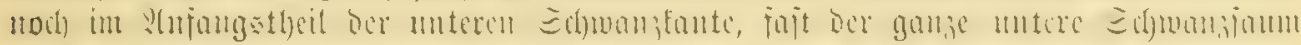

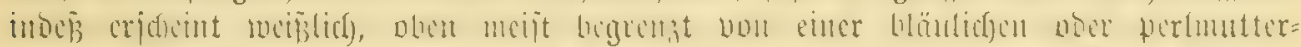

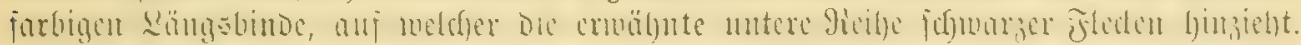

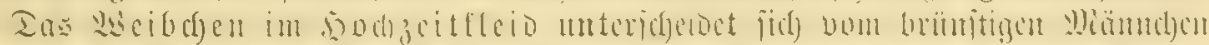

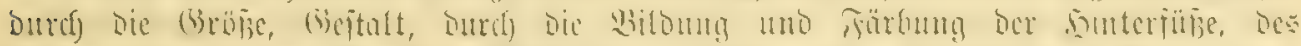

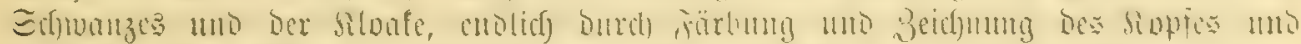

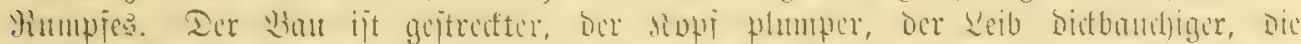

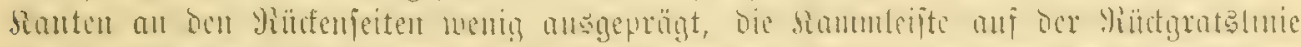

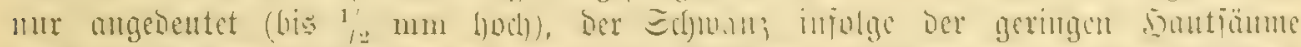

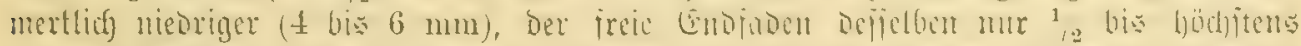

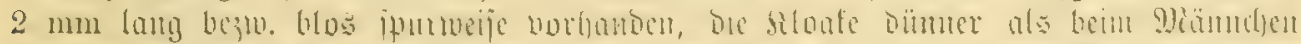

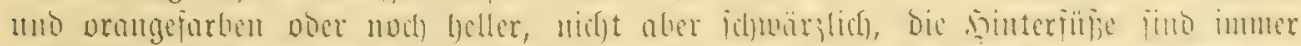

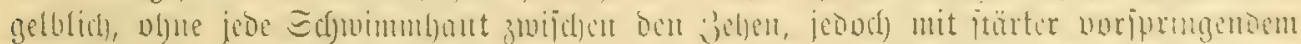

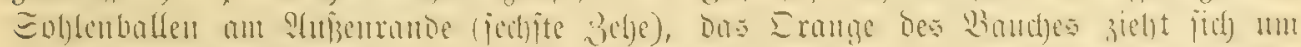

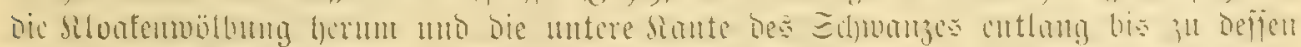

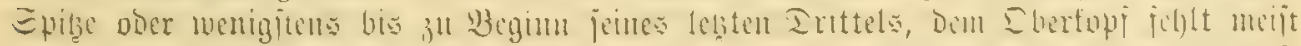

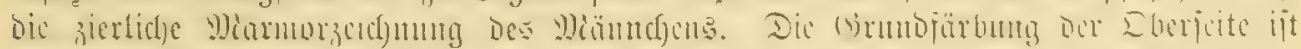

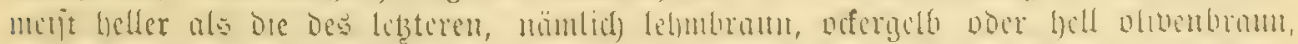

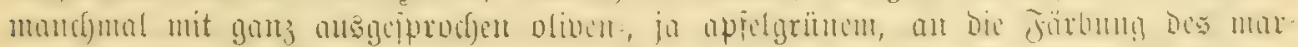

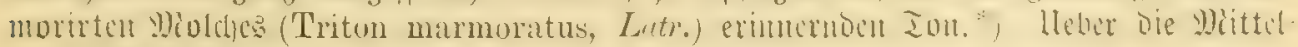

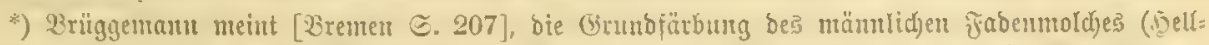

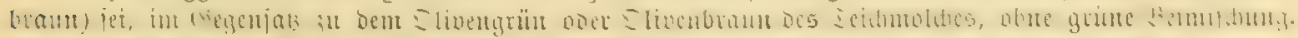

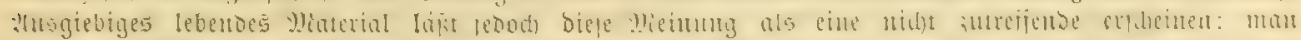

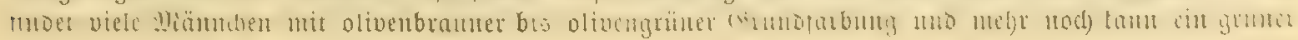

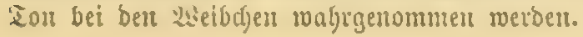




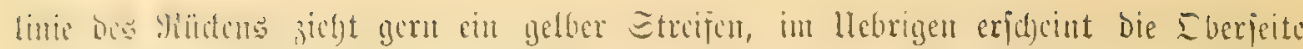

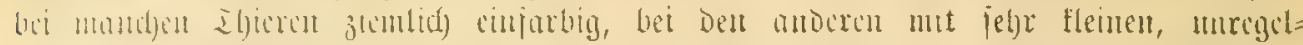

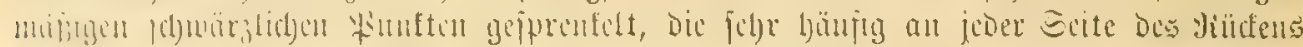

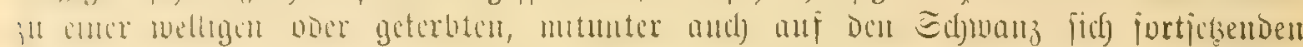

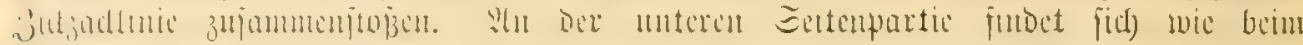

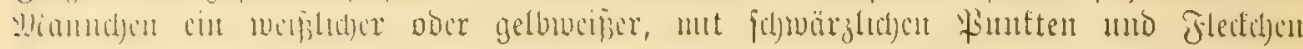

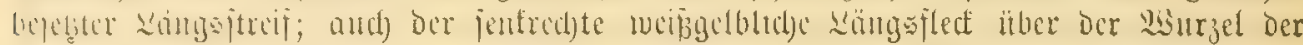

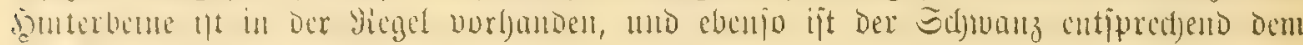

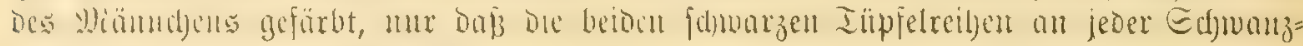

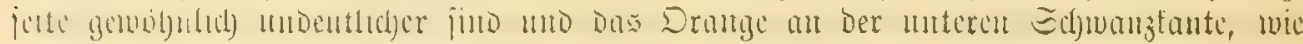

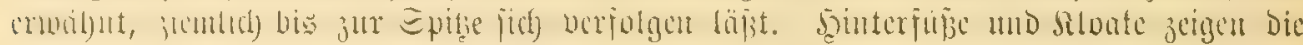

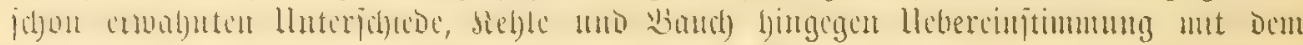

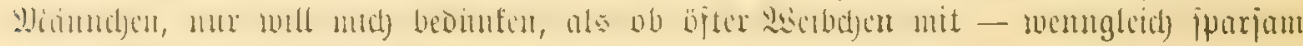

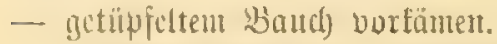

iul 2 แ

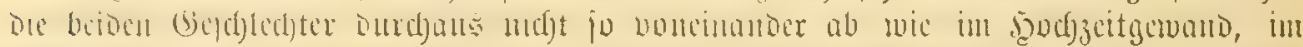

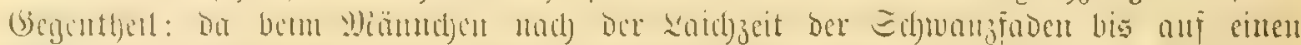

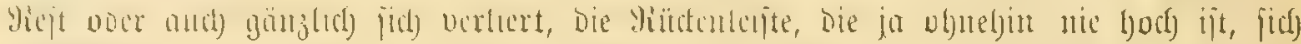
zuritutulot, ("iu winter the dorsal crest is diminished by about onethird, although

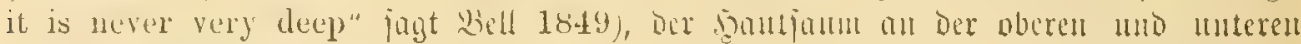

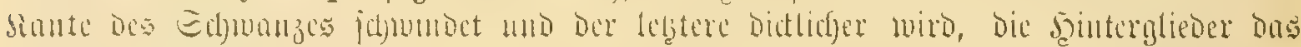

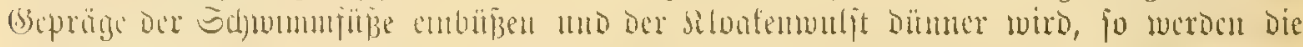

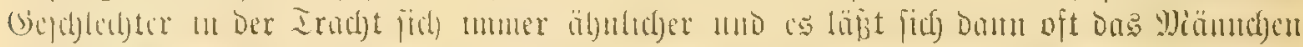

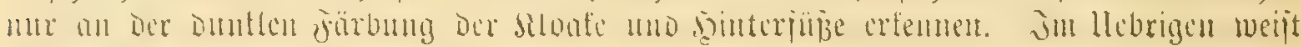

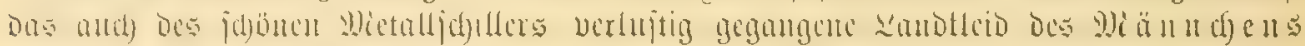

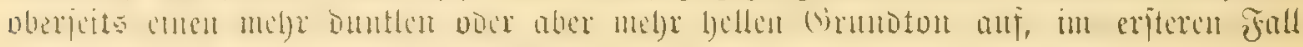

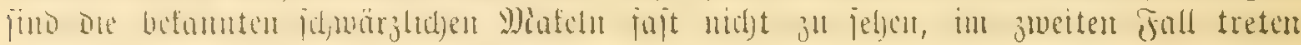

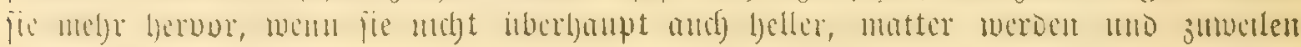

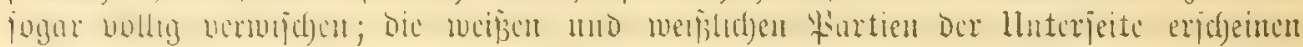

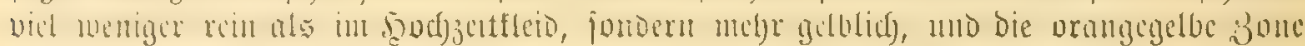

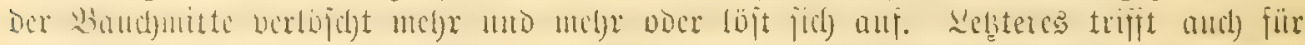

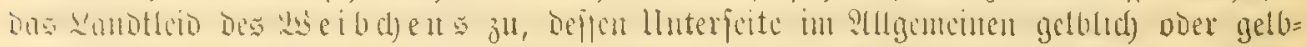

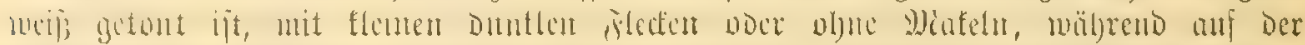

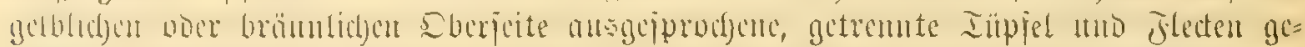

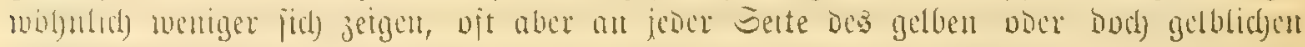

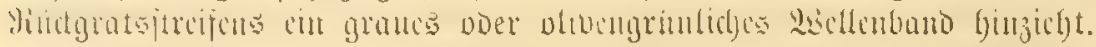

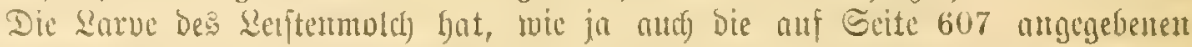

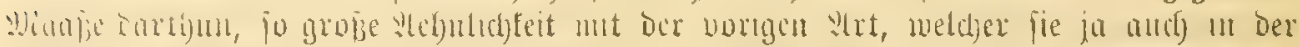

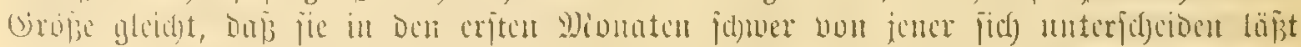
$11 n 0$ i.

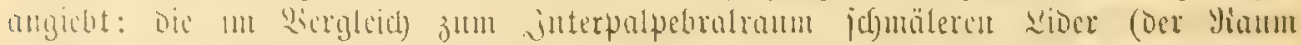

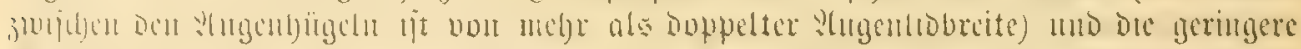

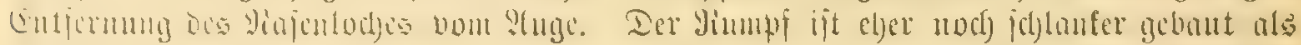

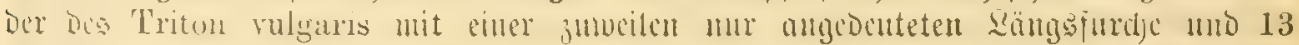

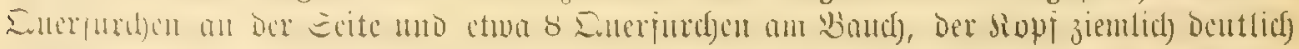

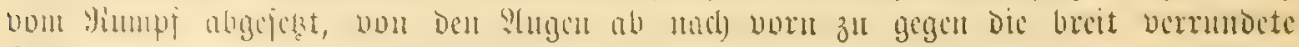

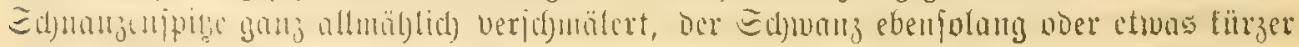

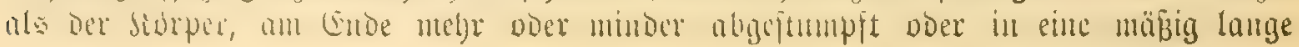




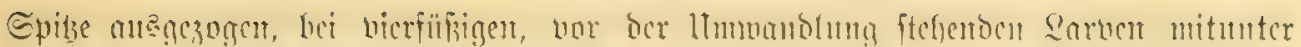

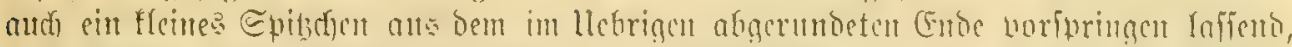

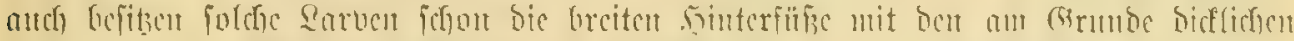

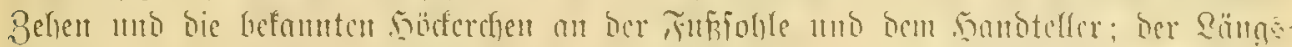

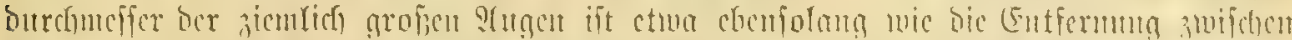

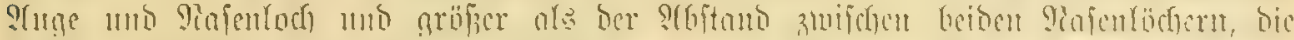

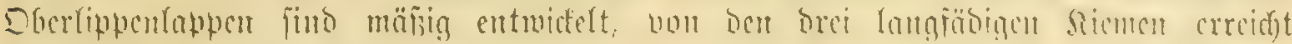

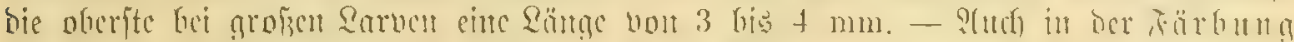

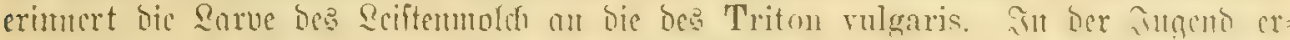

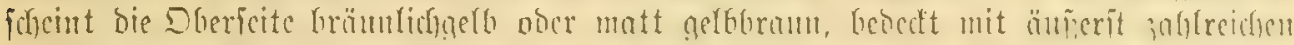

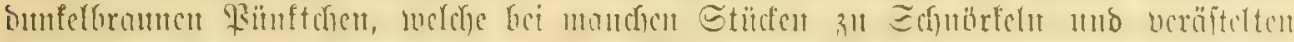

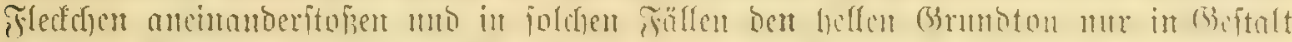

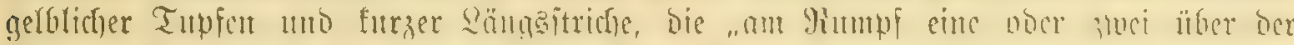

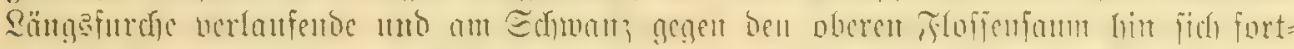

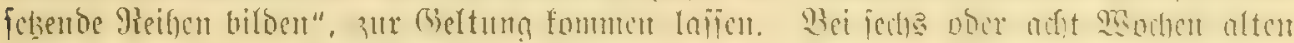

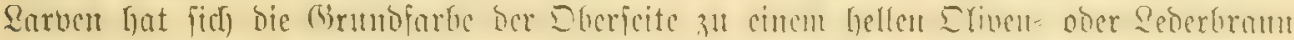

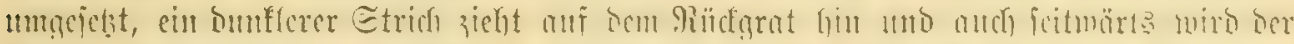

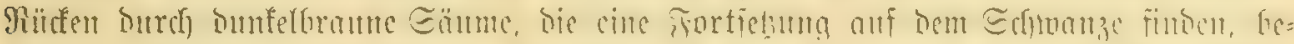

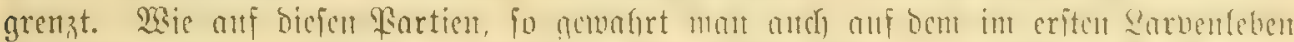

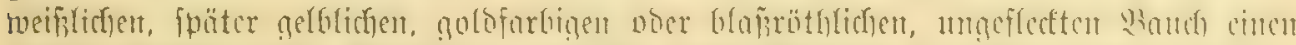

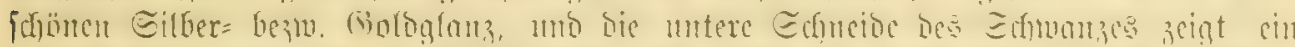

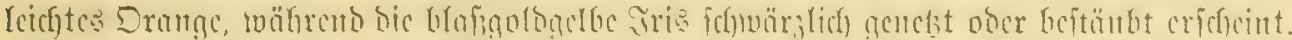

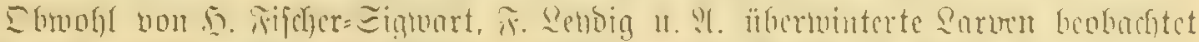

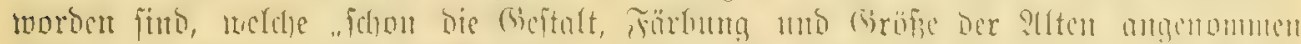

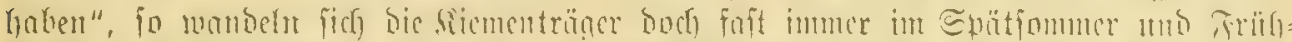

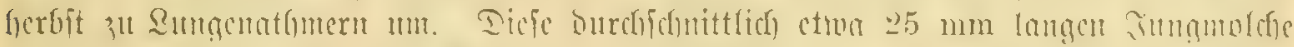

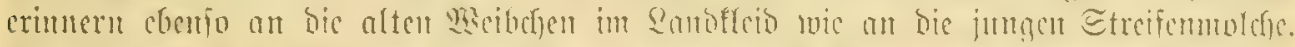

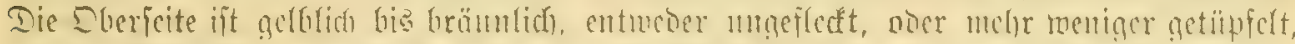

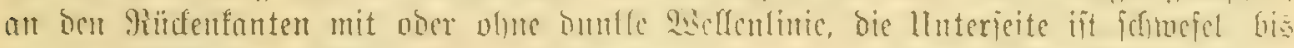

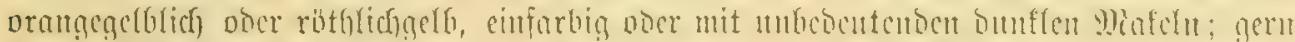

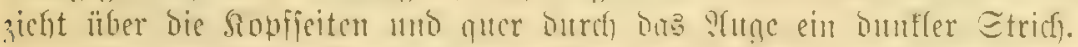

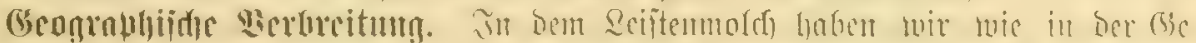

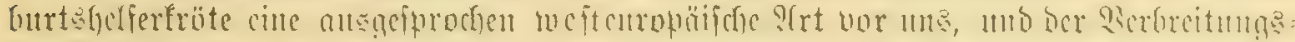

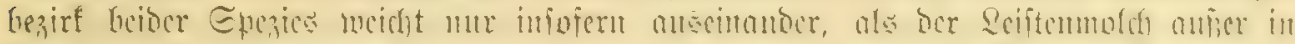

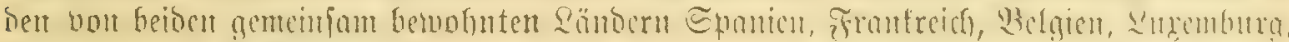

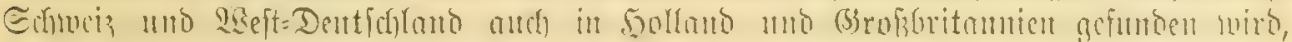

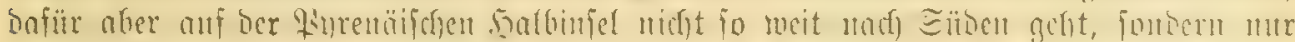

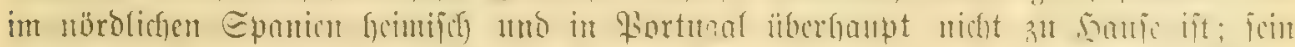

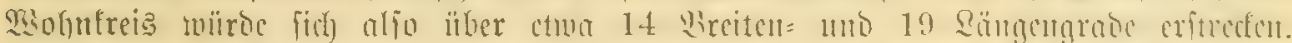

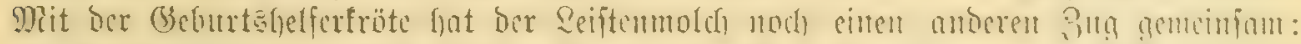

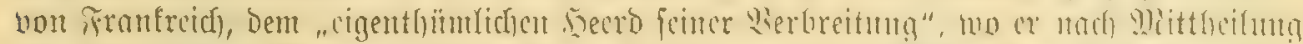

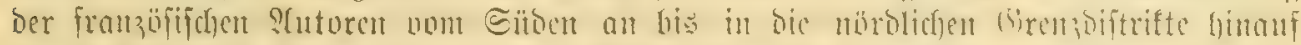

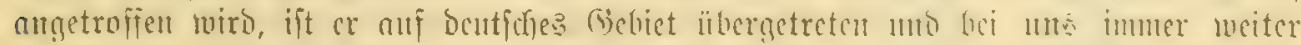

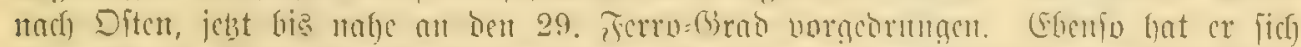

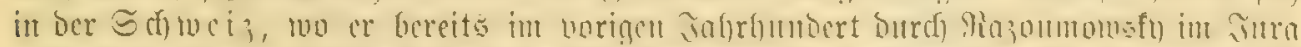

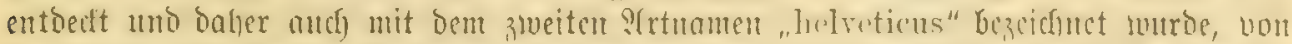

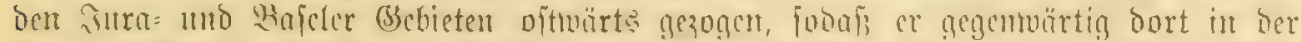

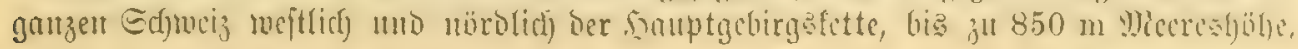




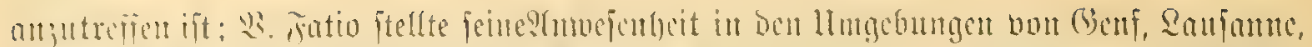

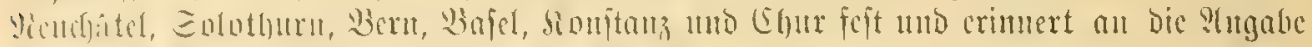

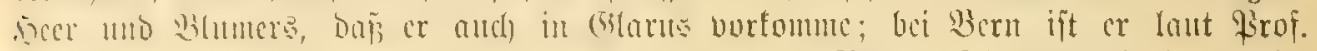

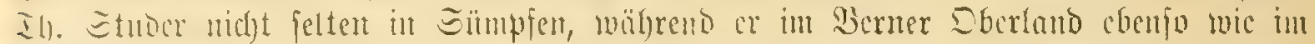

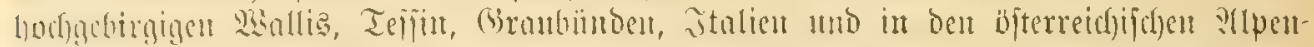

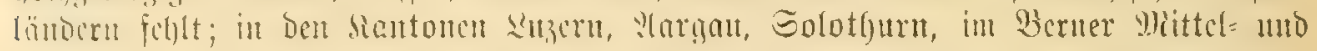

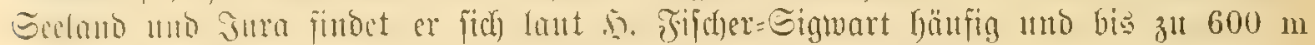

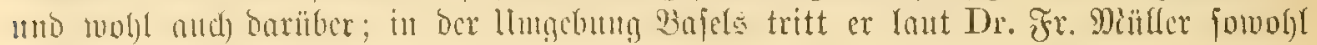

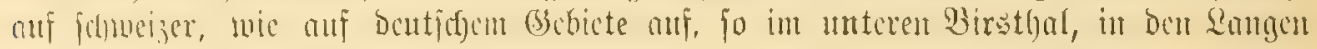
Errtcu, an Ettinger Blauen und bei Reuborf.

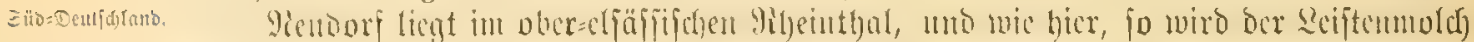

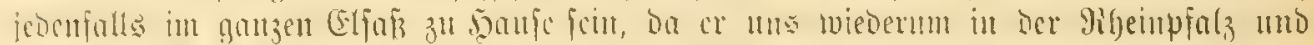

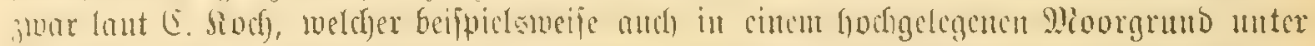

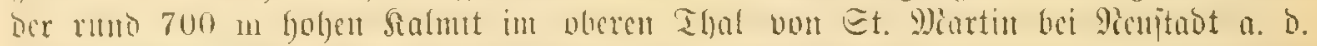

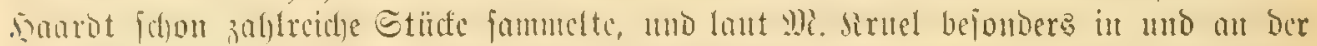

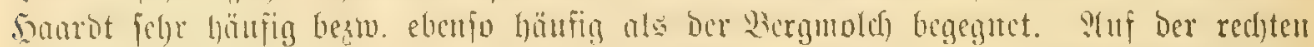

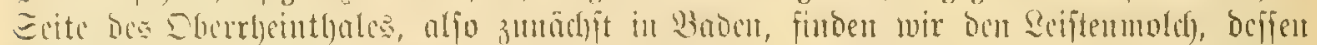
2)

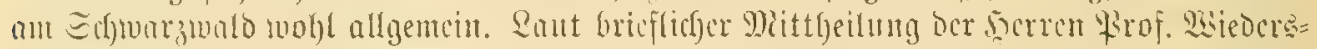

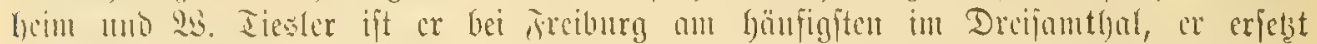

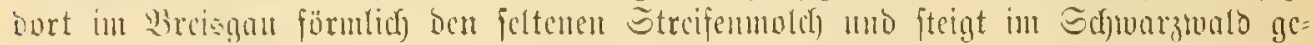

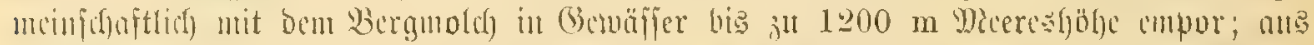

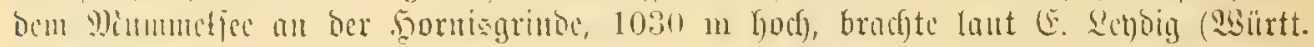

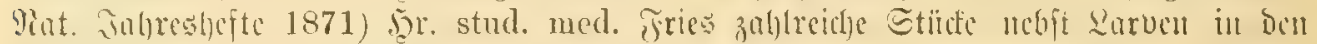

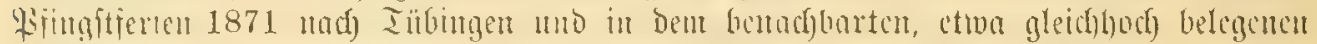

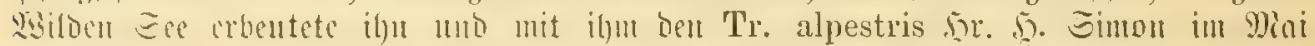

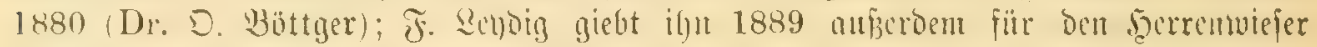

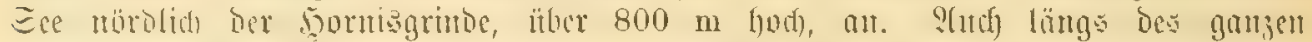

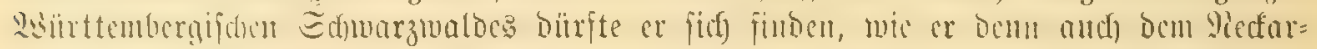

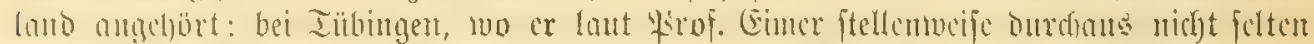

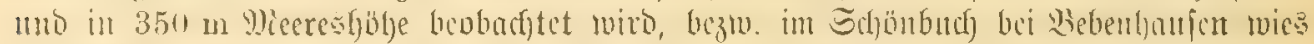

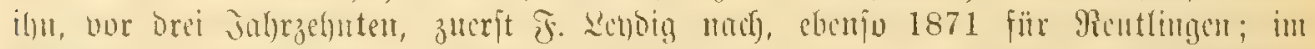

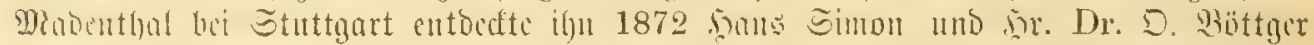

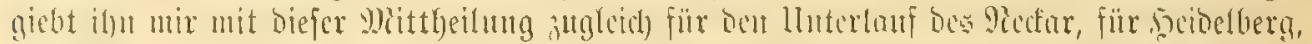

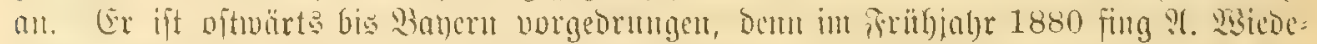

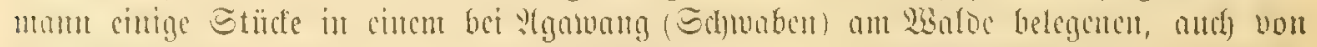

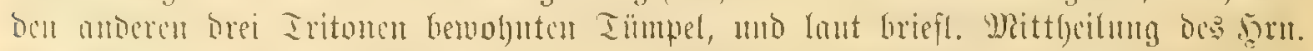

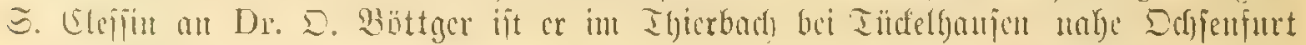
a. 9). häufig.

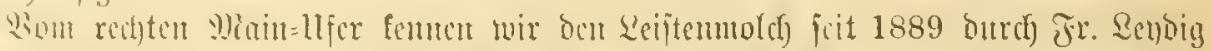

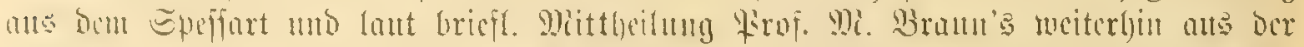

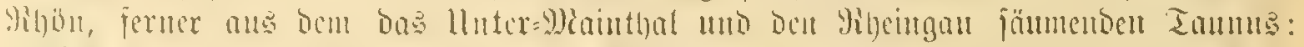

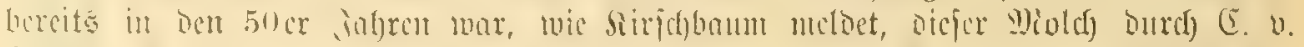

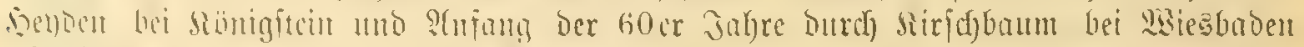

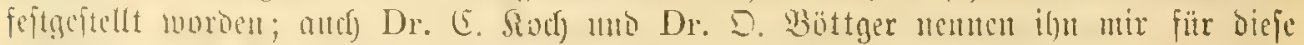

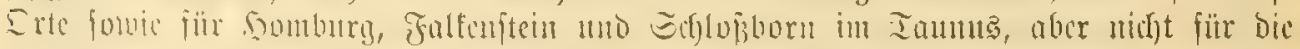

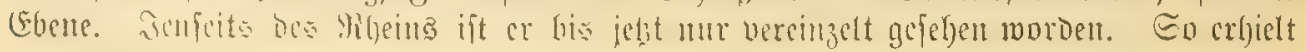

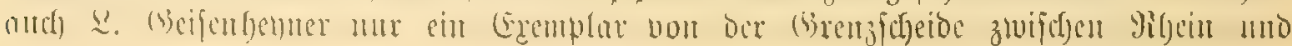




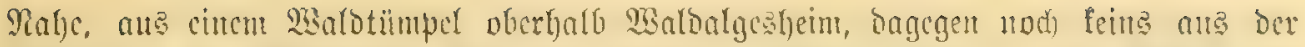

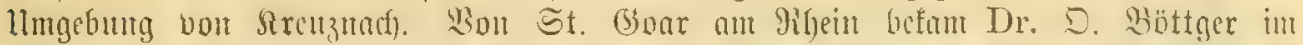

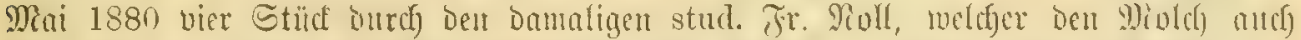

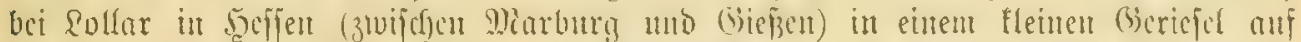

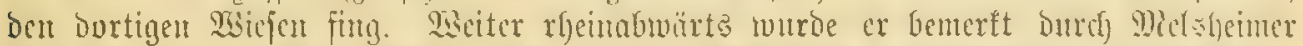

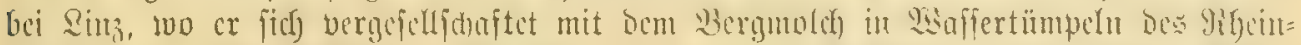

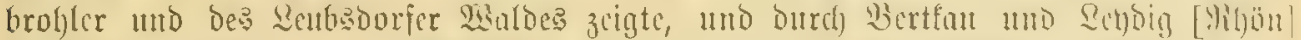

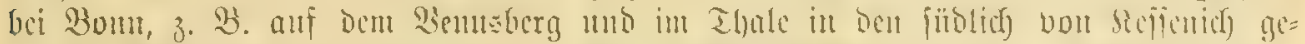

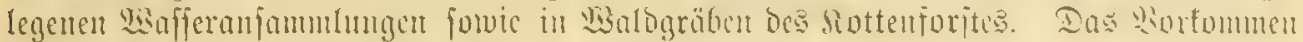

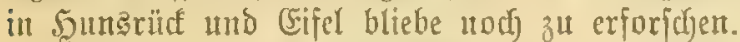

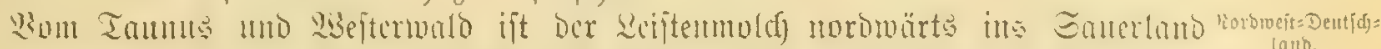

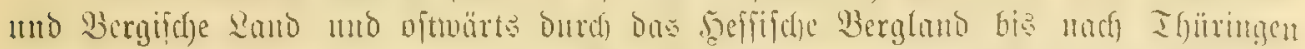

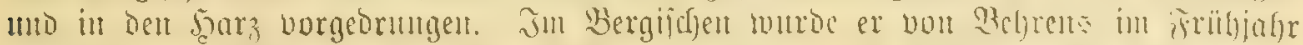

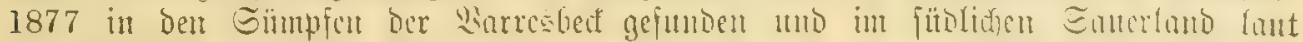

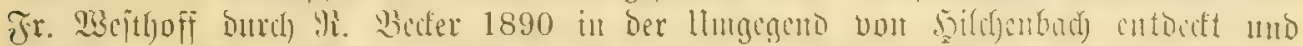

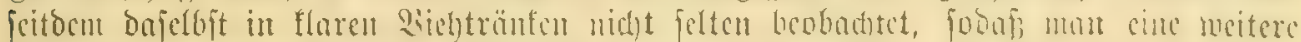

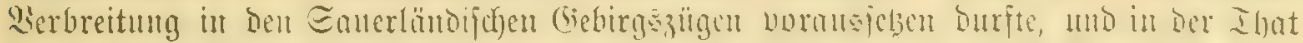

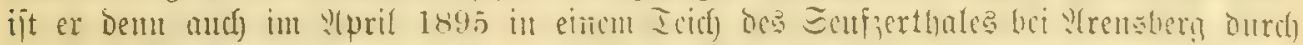

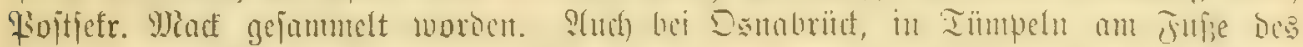

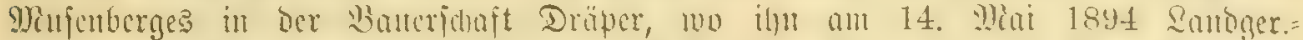

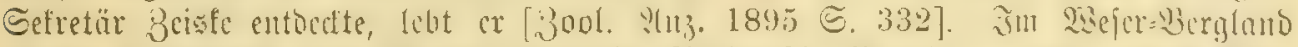

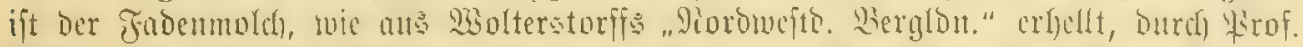

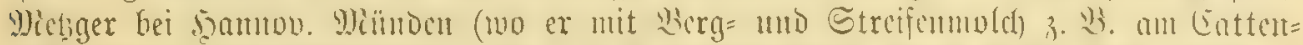

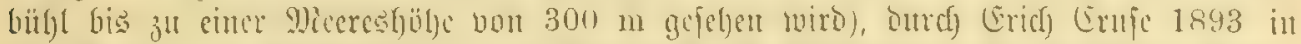

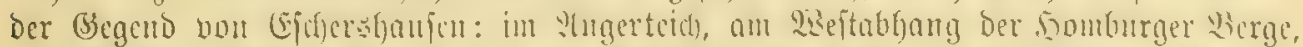

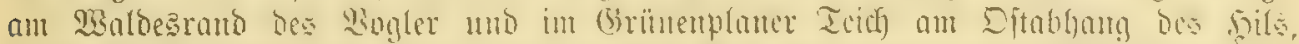

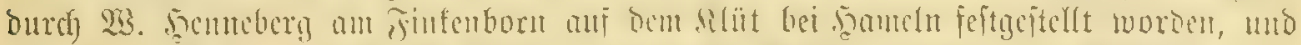

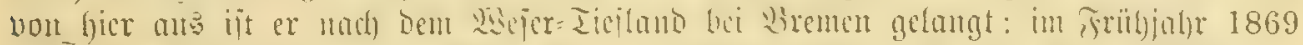

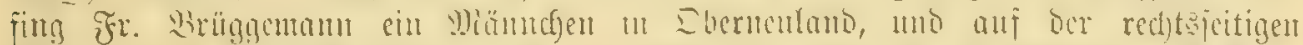

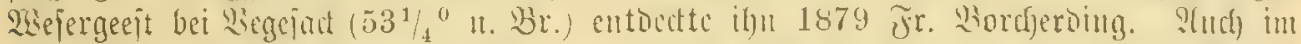

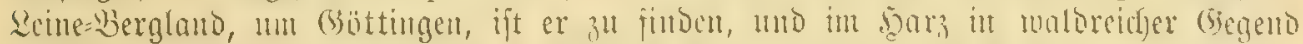

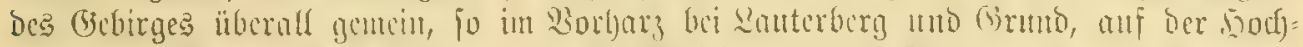

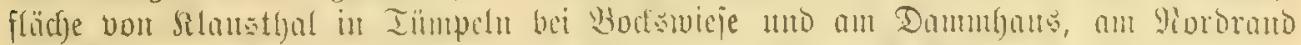

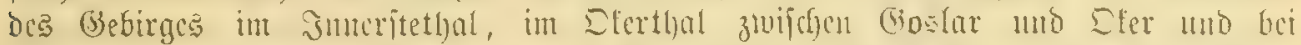

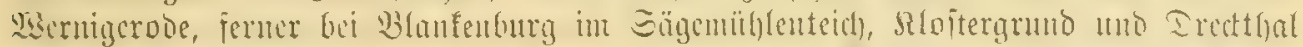

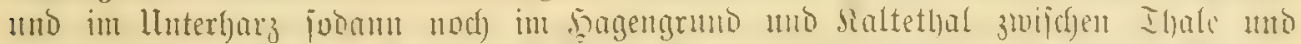

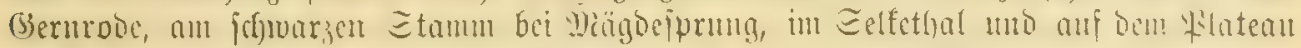

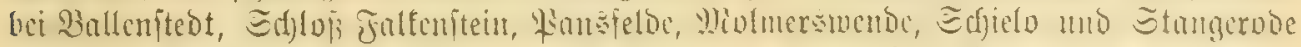

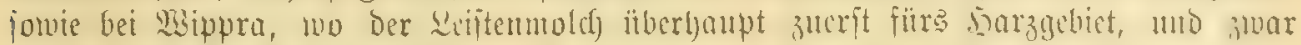

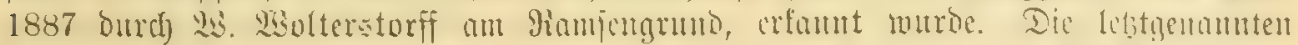

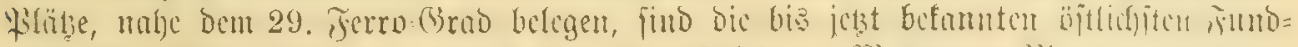

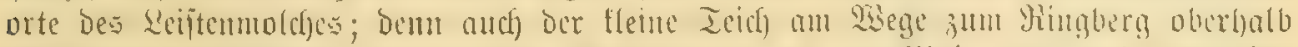

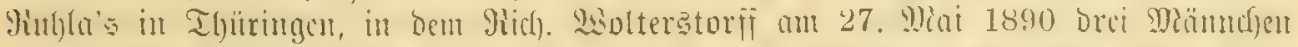

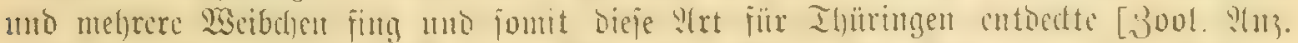

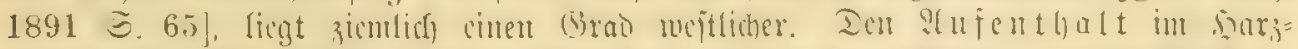

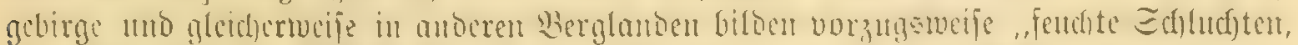

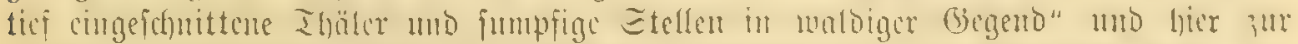

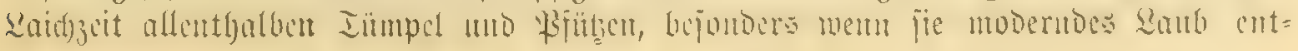




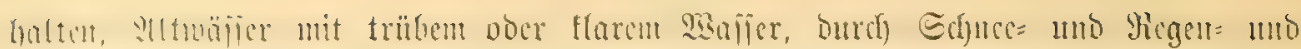

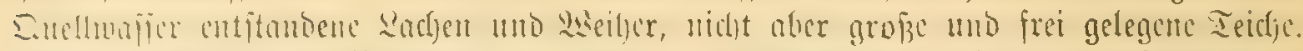

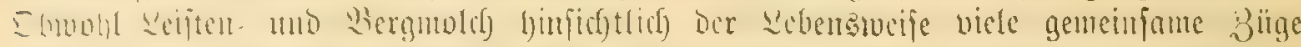

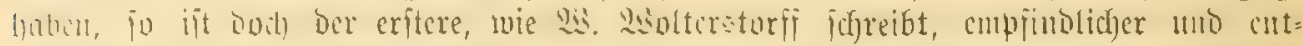

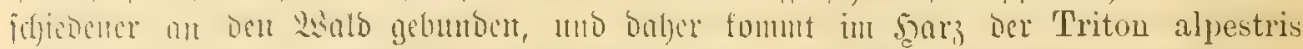

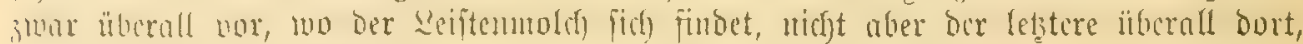
top alpestris beimiicl) ift.

Zan Des Palmated Newt; Franz.: 'Triton palmé.

Lacerta paradoxa s. helvetica, Razoumowsky 1789. - Salamandra palmata, Sclneider 1799. - Sal. palmipes, Latreille 1800. - Molge palmata, Merrem 1820. - 'Triton palmatus, T'schudi [Butr.] 1839. - Dugès 1852. - Lissotriton

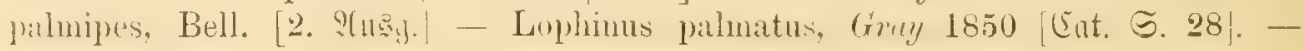
'Triton helveticus, Leydig [M](d) 1867.

\section{Siideuropäifde Surdie.}

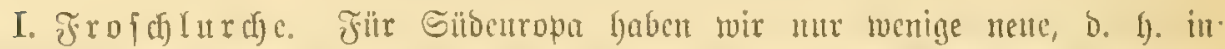

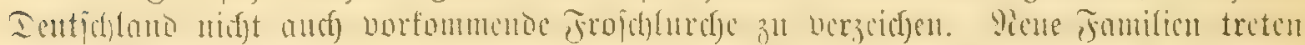

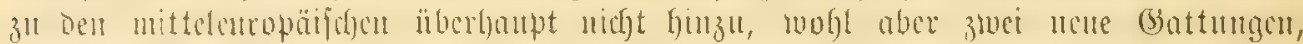

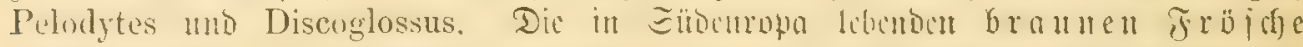

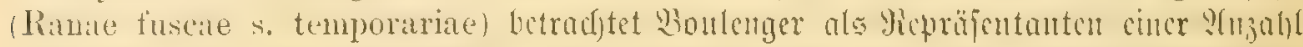

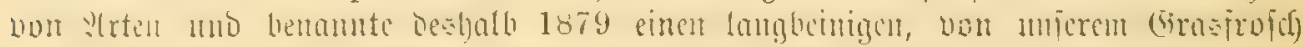

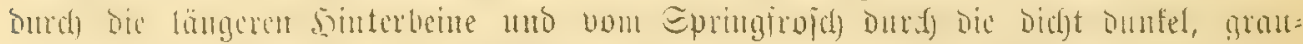

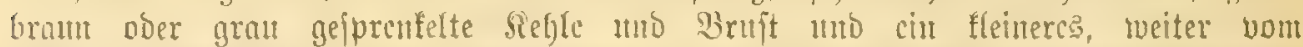

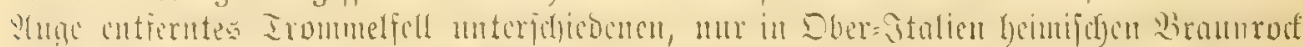

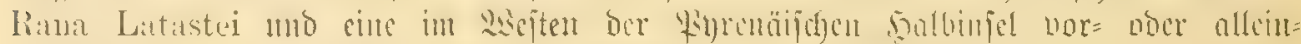

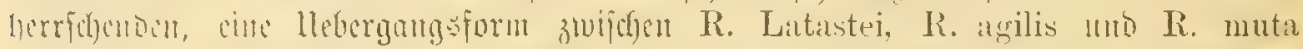

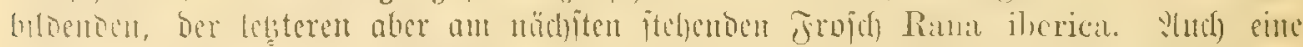

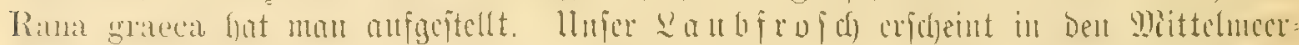

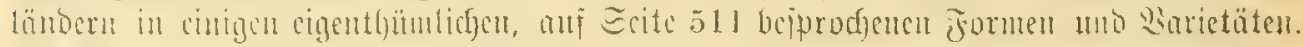

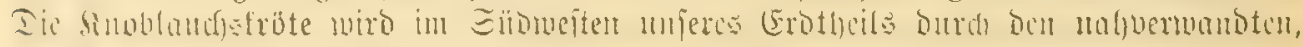

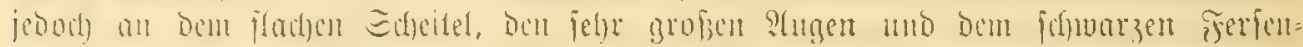

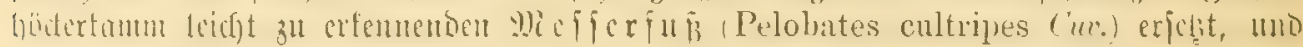

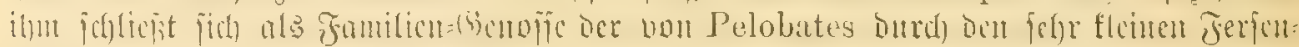

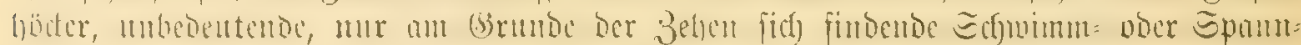

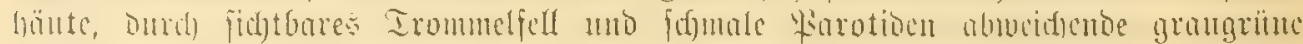

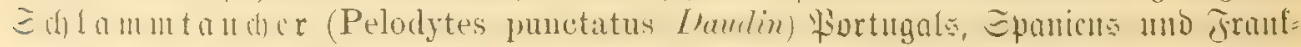

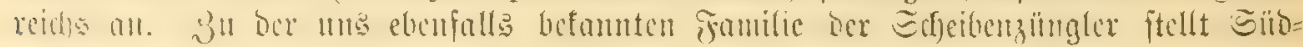

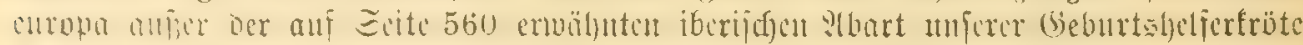

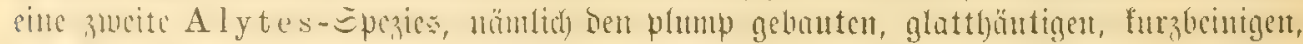

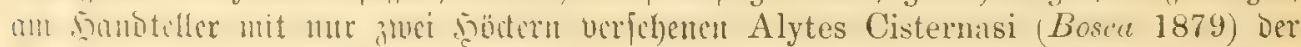

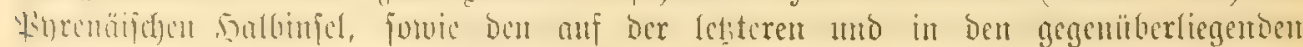

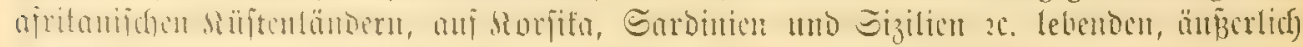

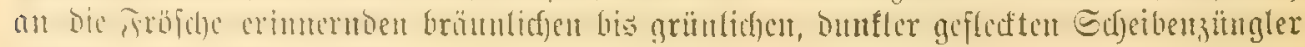
Discoglossus pictus Otth.

I1. E (f)

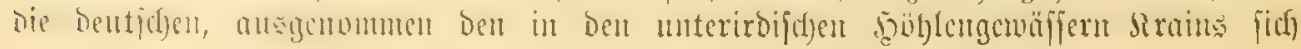




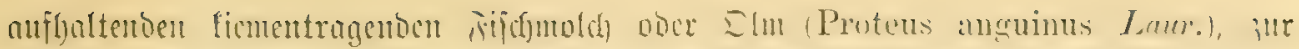

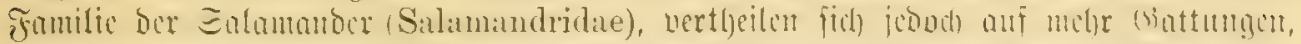

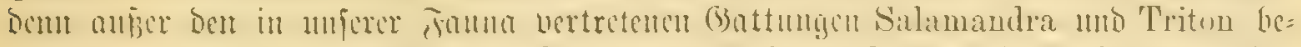

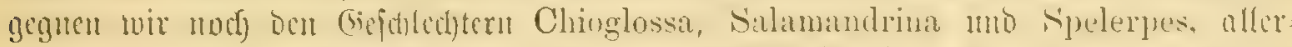

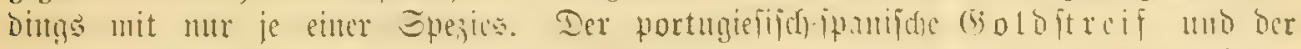

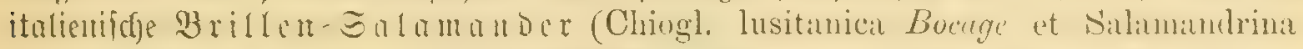

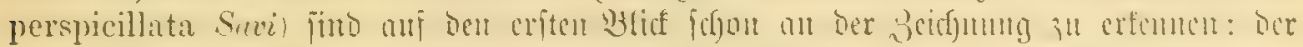

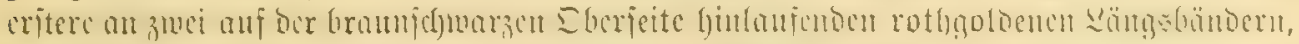

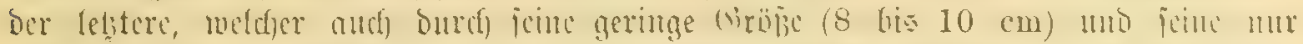

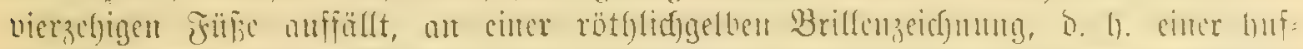

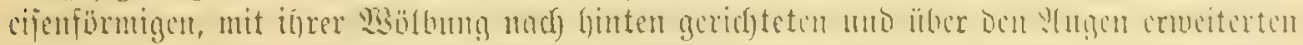

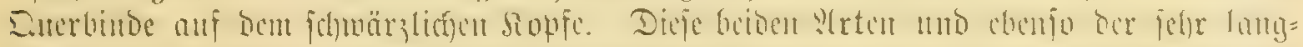

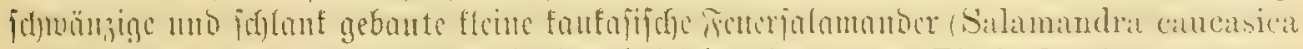

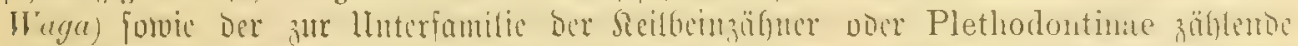
flcime hromte Erotriton (Spelerpes [Geotriton] fuscus Bonap) ìtuliens und oce

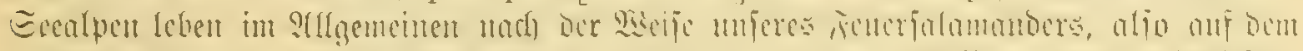

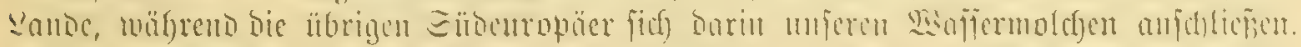

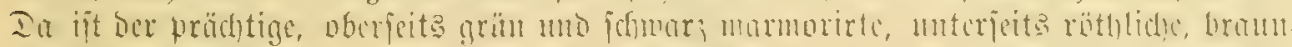

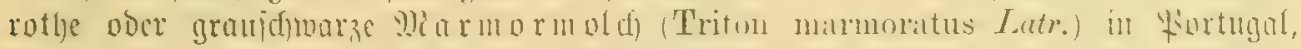

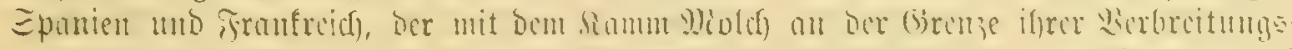

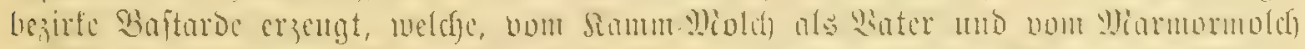

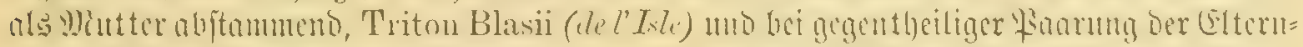

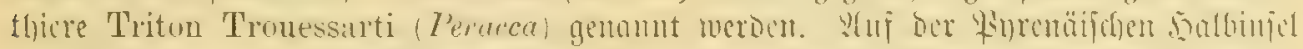

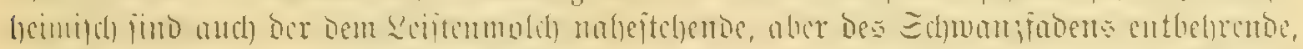

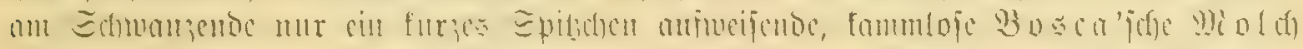

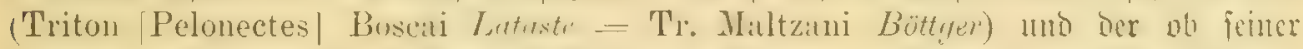

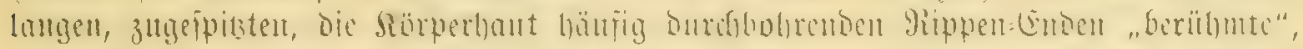

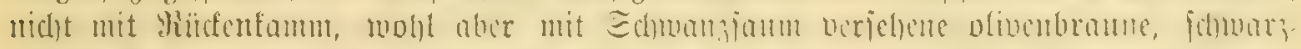

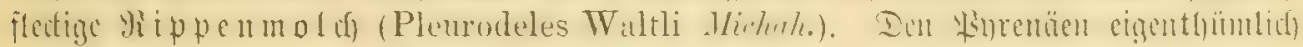

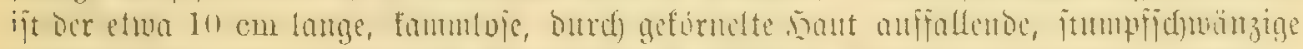

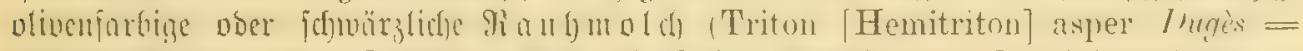

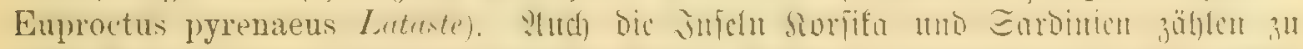

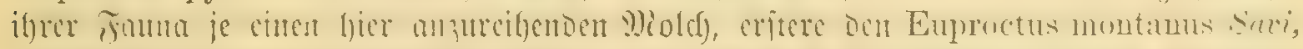

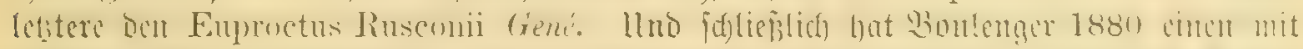

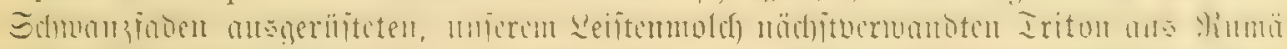

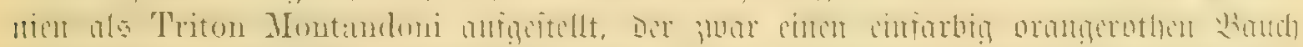

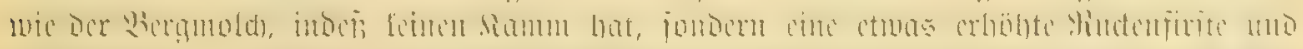

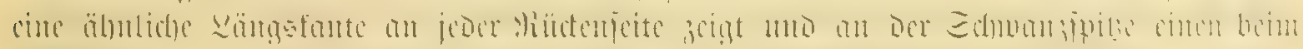

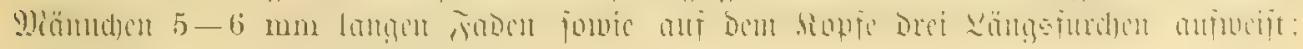
er foumut and) in Siebenbürgen bor. 


\section{כెulätşe.}

1. But Emys europaea, Sumpffutrofrötc (Seitc 14-28). Die alf

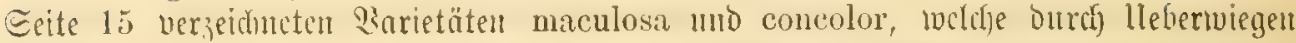

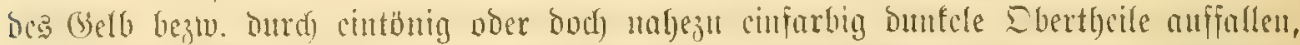

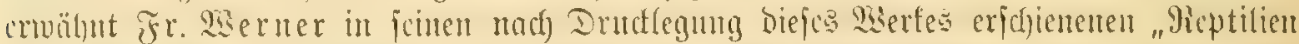

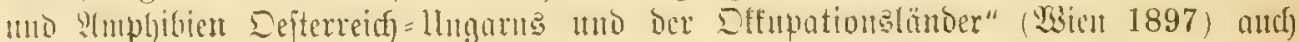

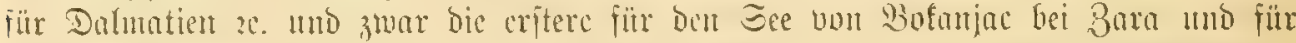

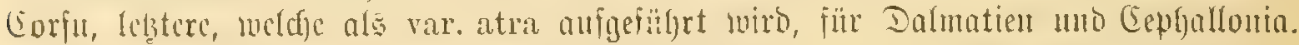

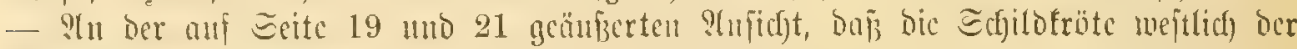

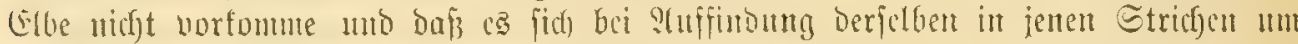

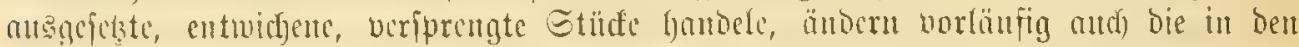

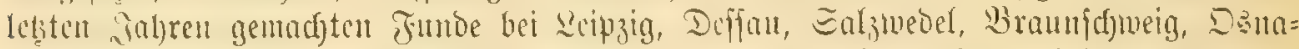

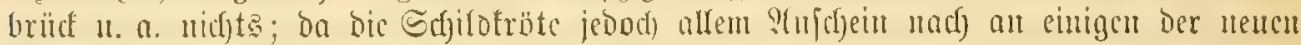

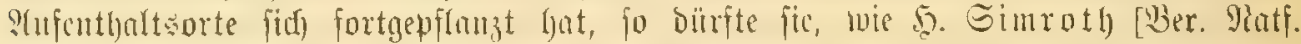

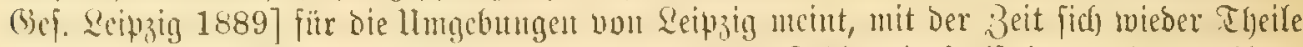

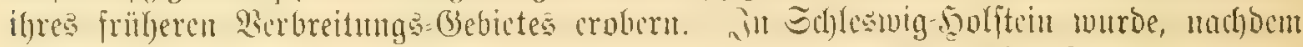
Etelettititde in Torfmooren bei 9icujtudt, Eegeherg uno Ellerbef gefanmelt merocu

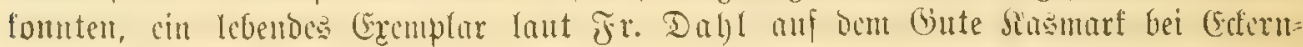
förbe gefangent.

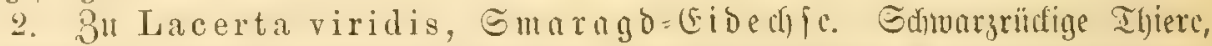

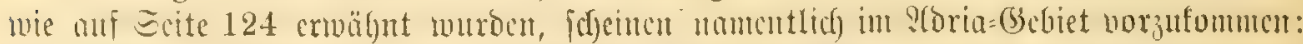

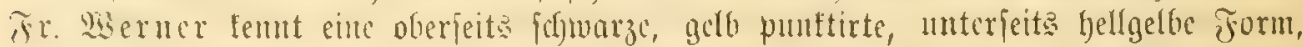
bit or vatr. istriensis benemt, ans iftrien mo von beffen Jnjeh, und eine ober= und

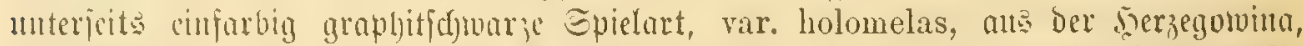

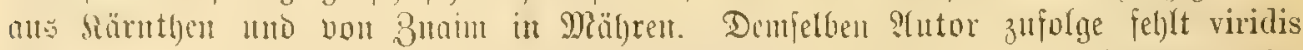

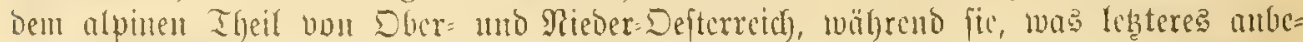

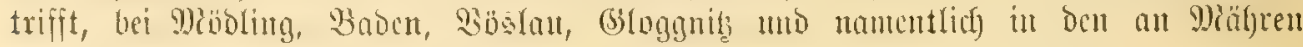
grenzenten Theilen jehr häufig ift. (ঙ. S. 132.)

3. 3 Lacerta agilis, $8 a u n=$ (Fidedfie. Finc Spiefort, Wuebchent,

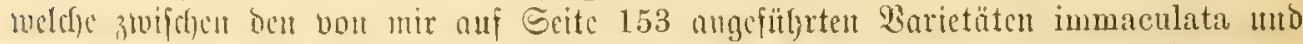
melanonotit etwa in ber Meitte fteht, crmähnt 4 S. Secfit anf E. 131 bon Wolters=

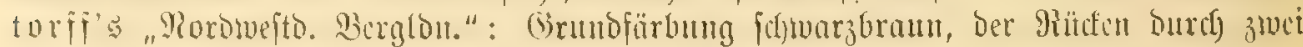

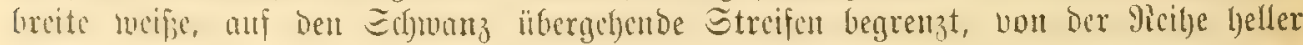

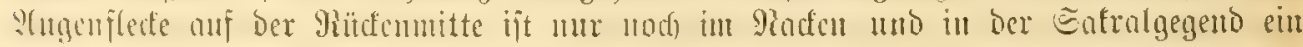

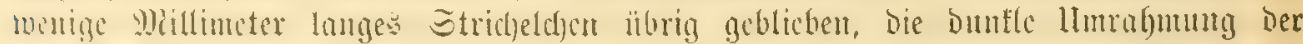

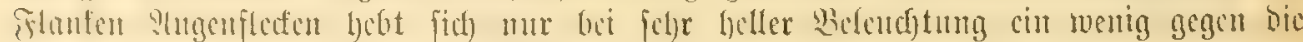

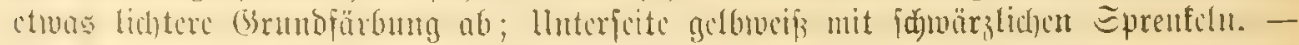

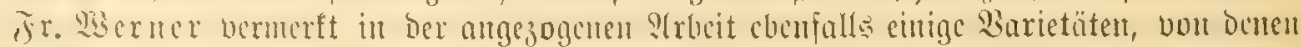
bic var. .spinalis" mit mcincr "albolineata" zujummonjällt uno bic var. "aunulata",

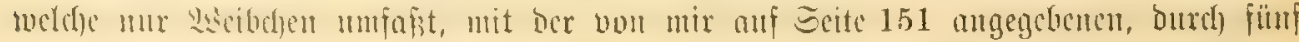

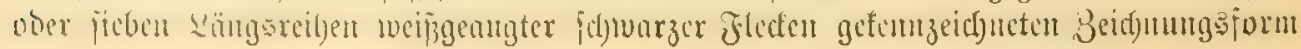




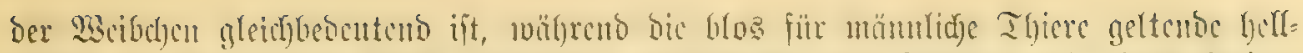

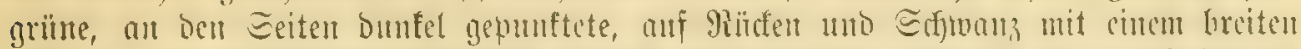

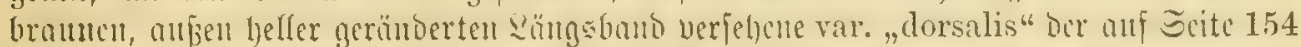

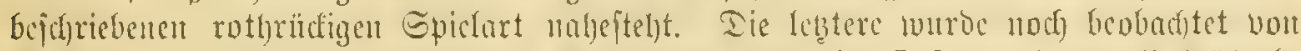

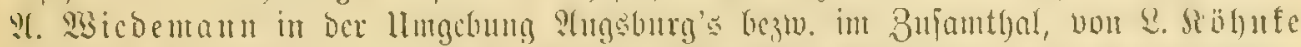

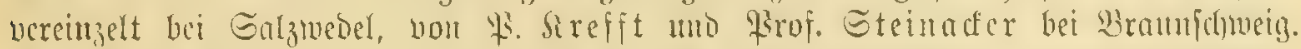

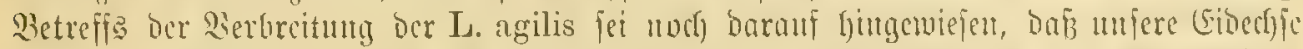

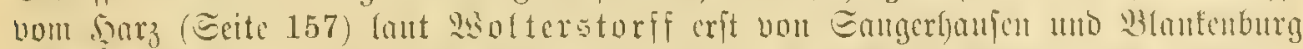

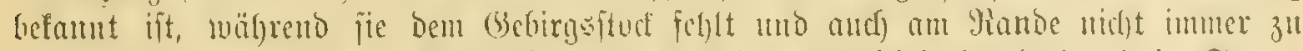

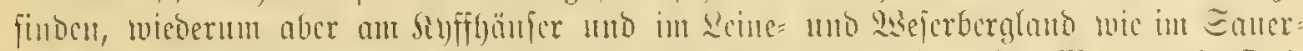

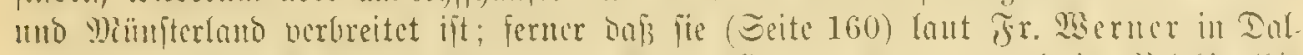

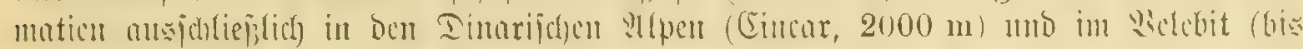

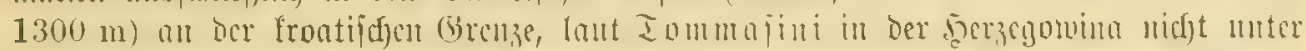

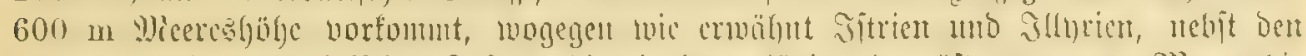

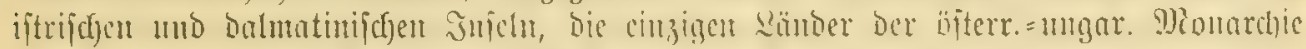

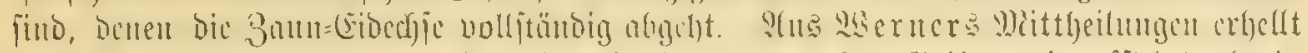

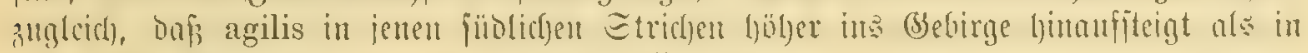
Den cigentlicben ?(lpen und don beutjugen Bicbirgen.

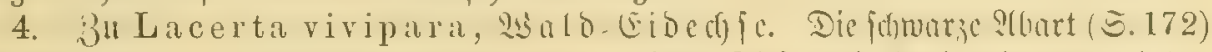

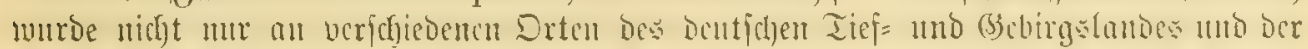

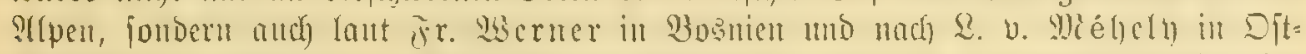

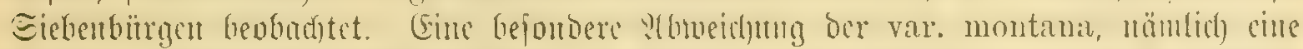

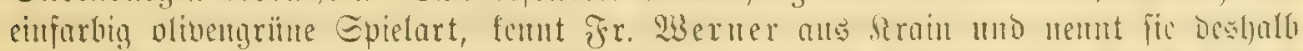

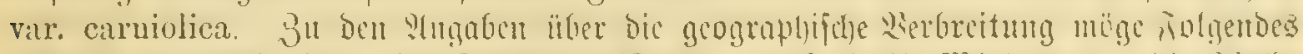

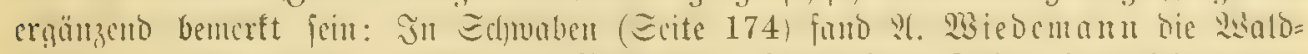

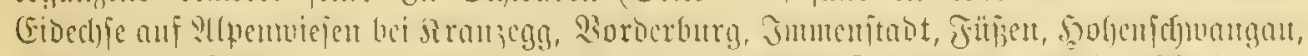

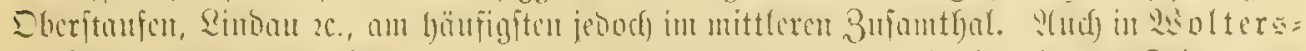

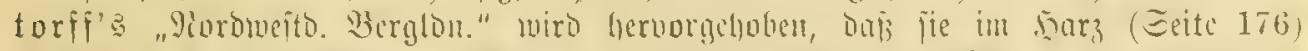

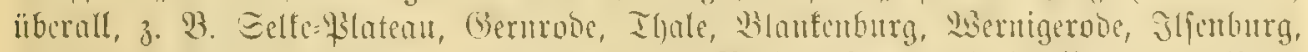

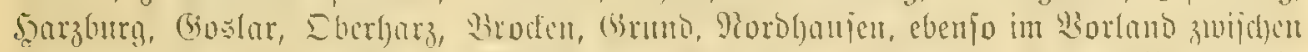

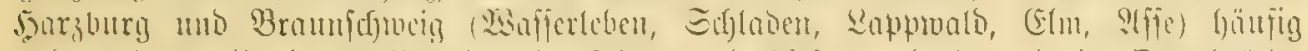

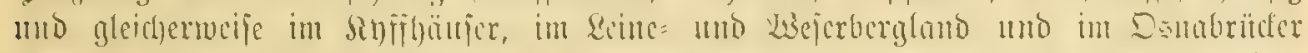

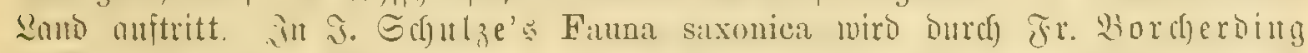

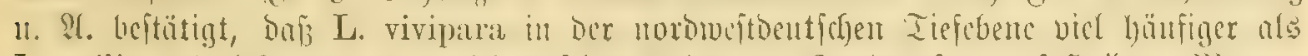

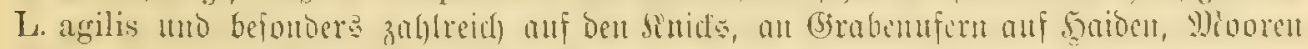

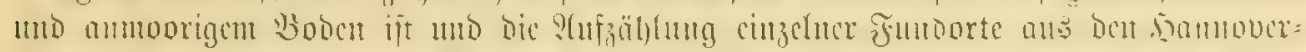

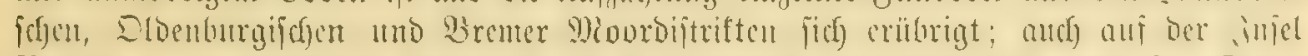

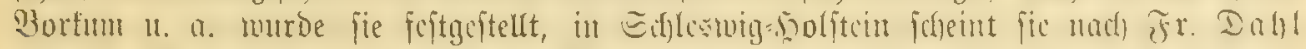

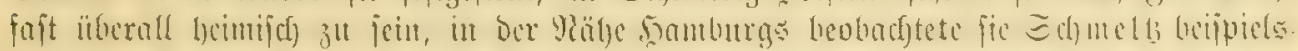

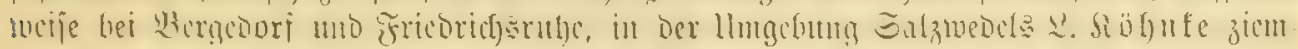

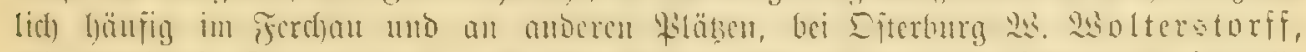

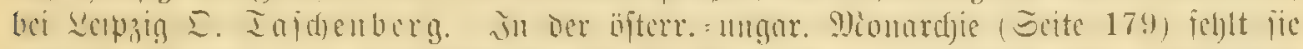

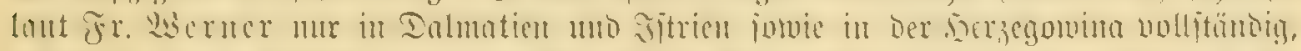

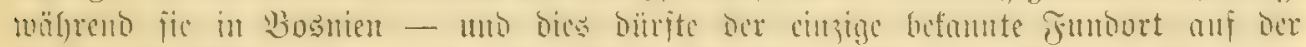

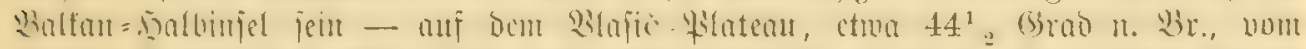

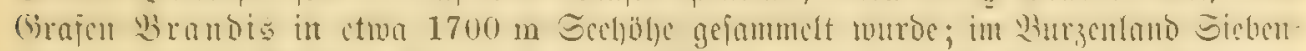

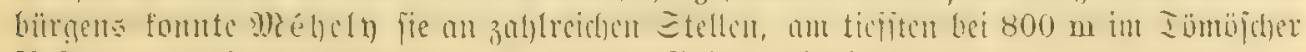
Faß̧, an bödjften bei $2400 \mathrm{~m}$ im Bucjeç=(Gebirge, beobact)ten. 
5. 3uLacerta muralis, Maucr=(Fibed)fe. Fr. Werucr brimnt bie

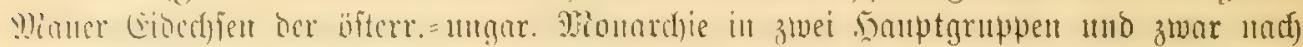

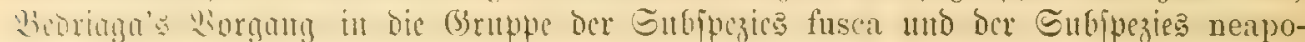

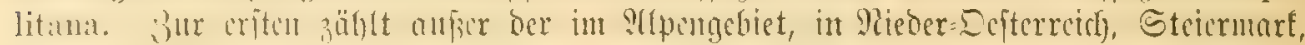

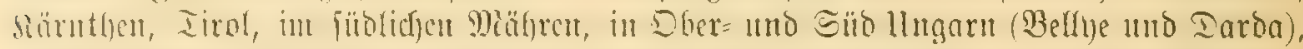

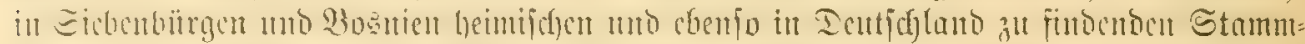

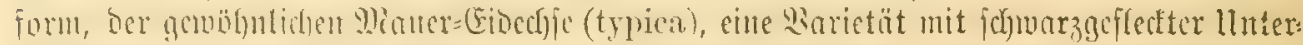

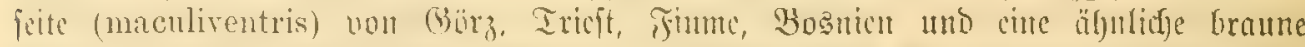
Q

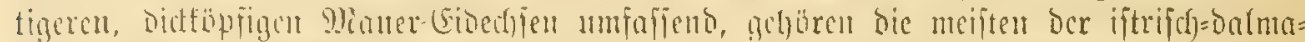

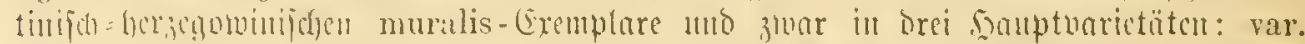

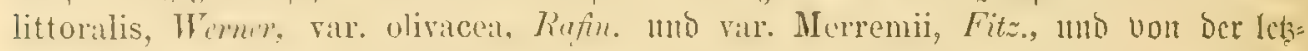

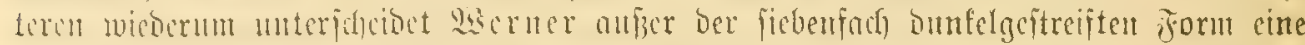

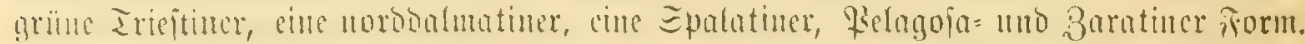

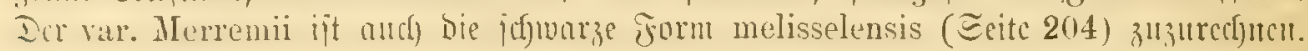

6. 3n Tropidonotus natrix, gingelnatter (Scite 278 ff.) In

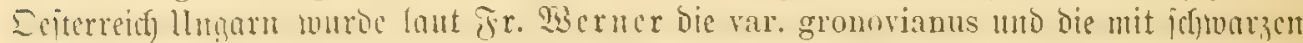

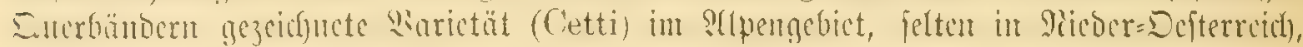

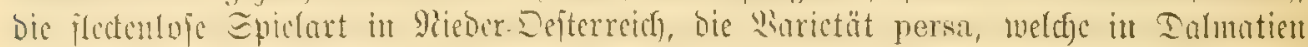

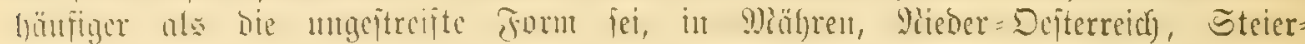

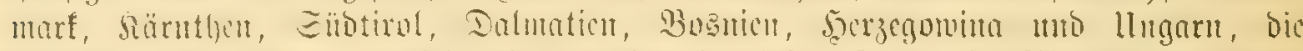

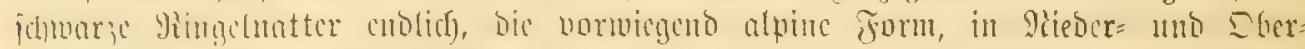

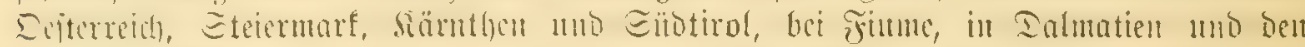
Ettupationständern nadgervicicu. Derjelbe

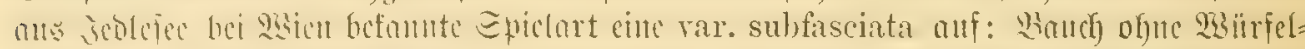

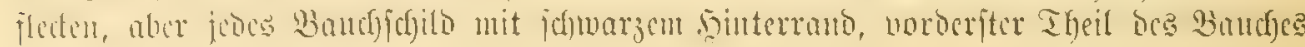
ganz weiß;, Sd)wanzunterjcite fdywarz.

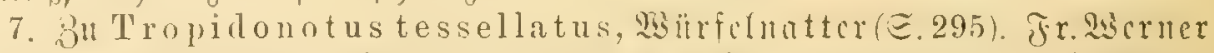

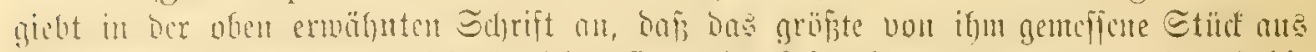

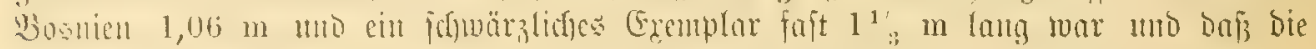

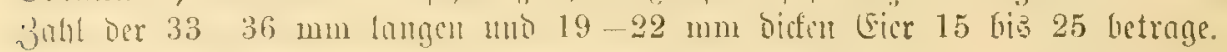

8. 3 Coluber Aesculapii, Açfulap= Ratter. Die von Fr. Werner

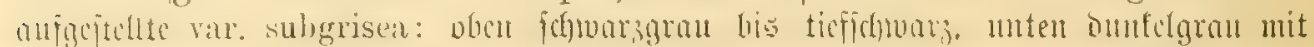

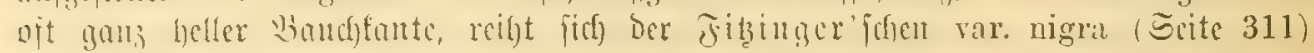

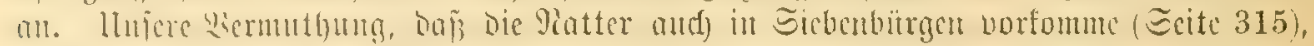

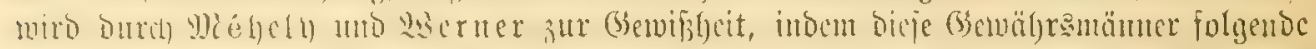

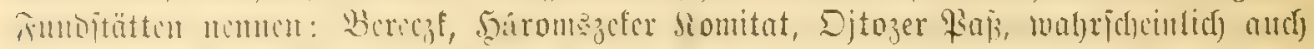

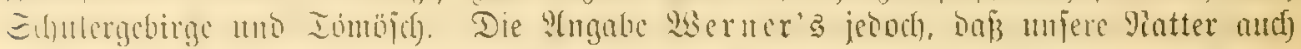

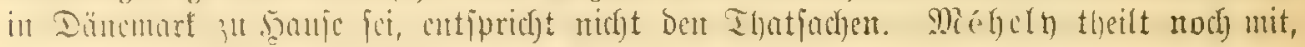
Dnî̉ Aesculapii bis adjt Cicr, jebcs von $5-5,5 \mathrm{~cm}$ \&änge, legge.

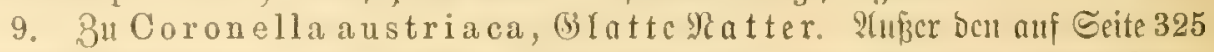

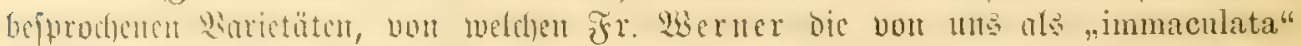

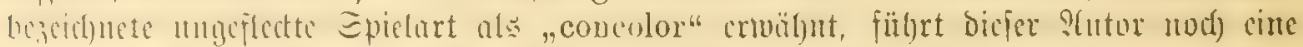

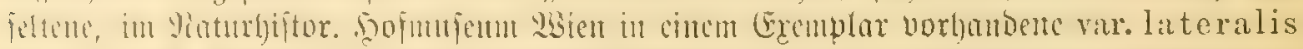

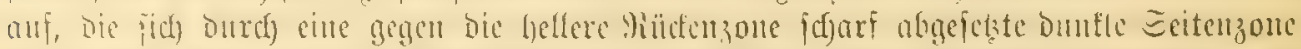

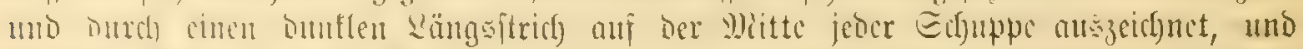

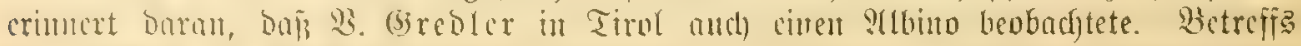

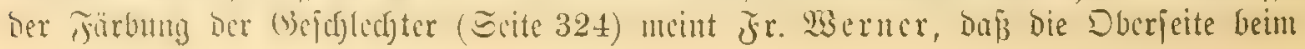




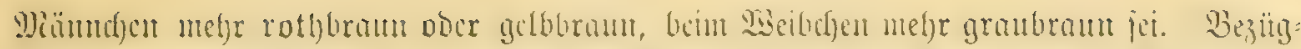

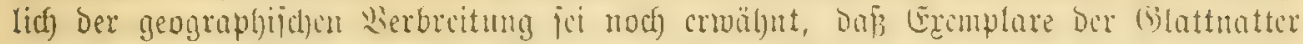

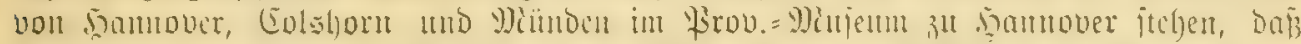

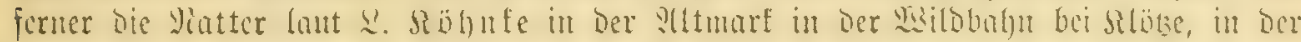

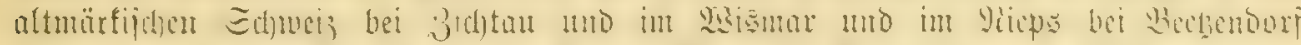

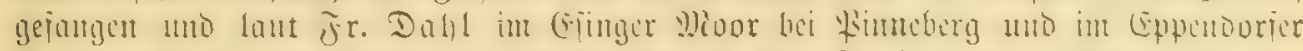

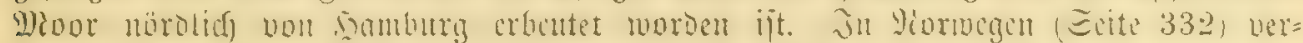

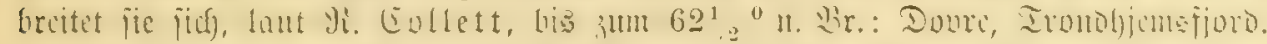

10. 3u Vipera berus, sireuzotter. Gine felgr beacftmincrtge, in megr=

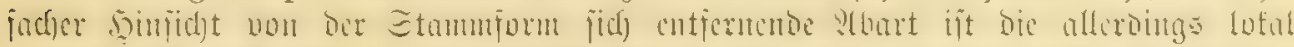

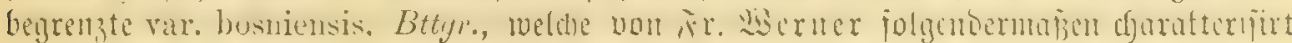

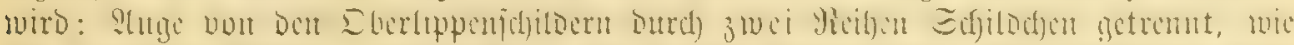

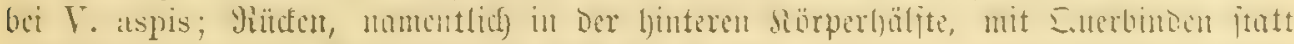

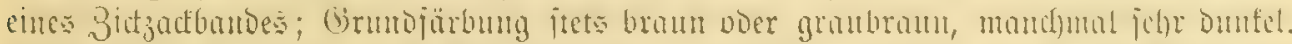

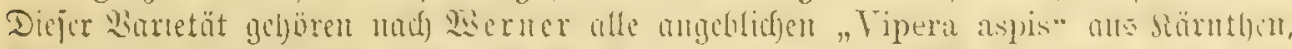

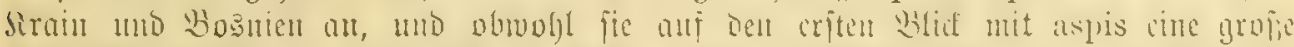

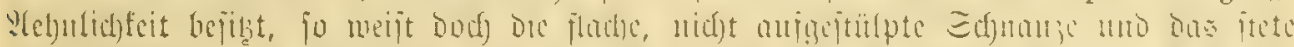

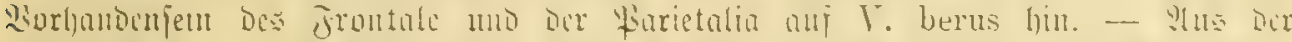

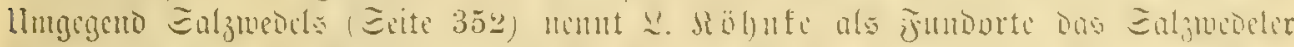

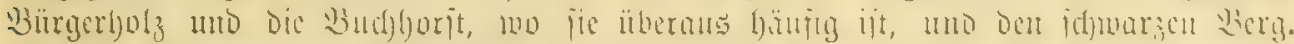

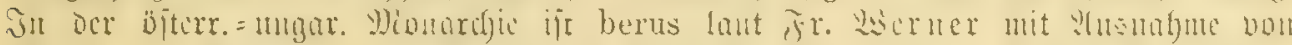

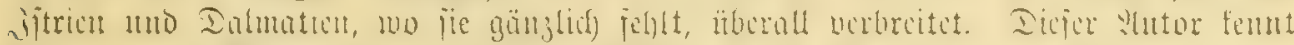

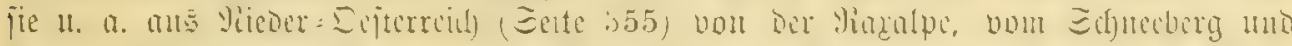

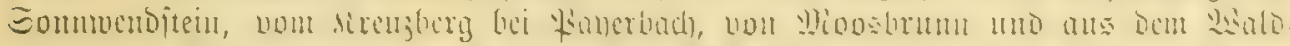

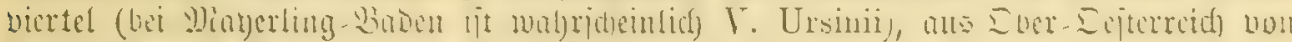

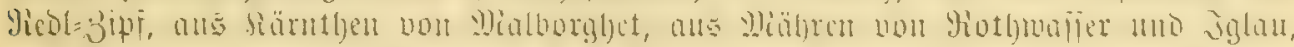

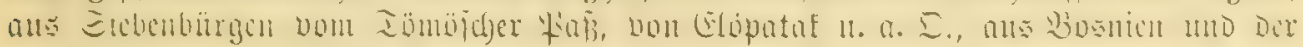

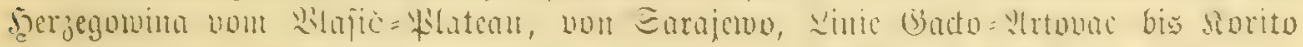

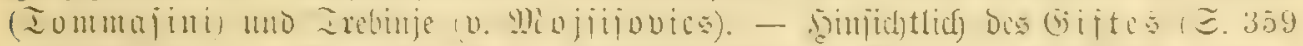

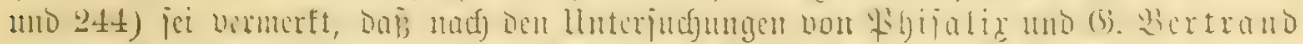

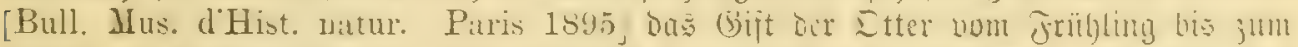

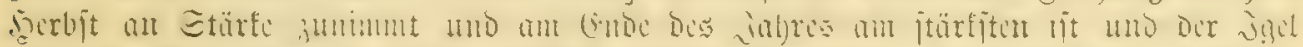

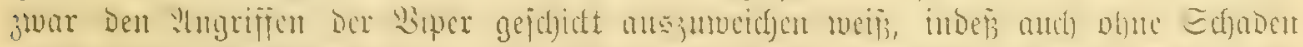

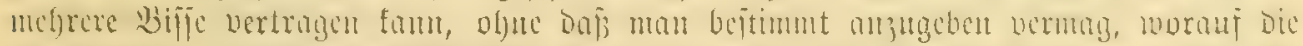

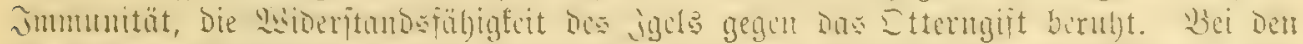

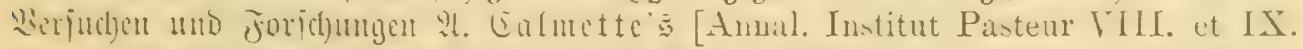

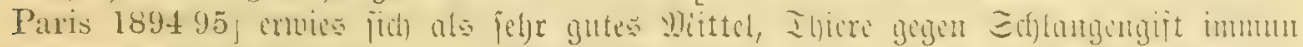

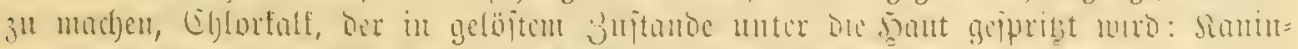

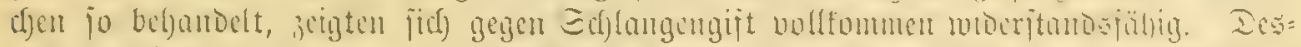

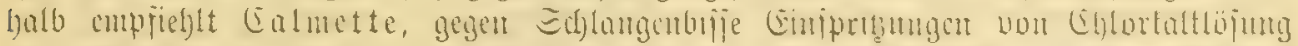

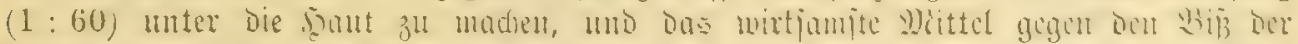

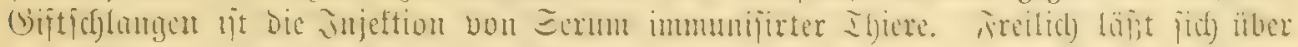
bie Erjolge bei Mienjalt nod) nidjta fagen.

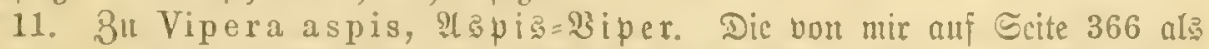

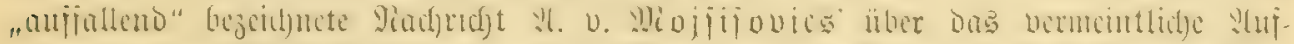

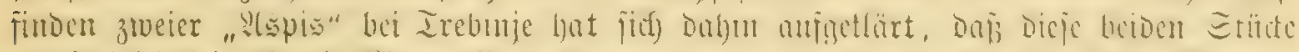

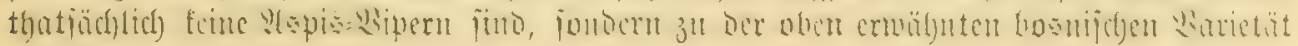
Der Siruzotter geljüren. 
12. 311 Ecite 369. Die Viperal Ursinii murbe bereits 1835 non 2ionaparte in ittalion cutbett, ging afor ban in bie Enmommie ocr Vipera berus ïfor uno

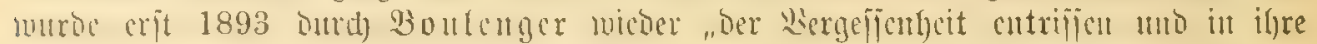

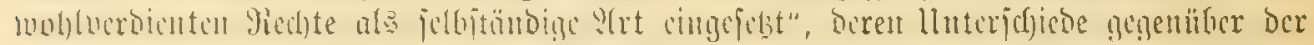

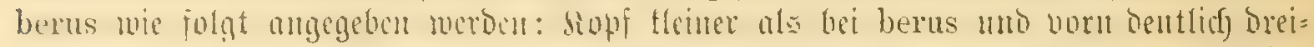

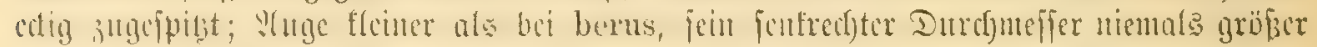

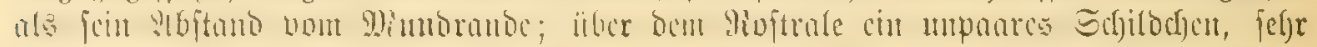

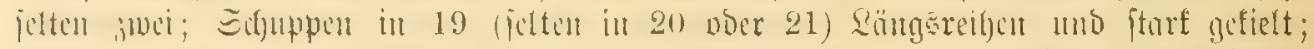

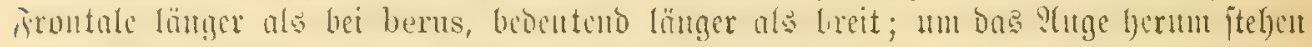

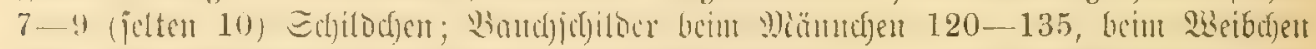

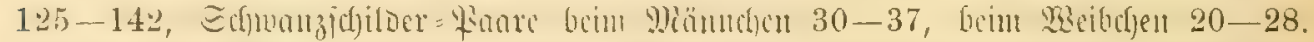

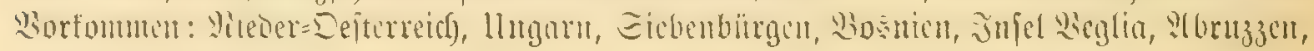
Depart. Siteder $=2$ llpent.

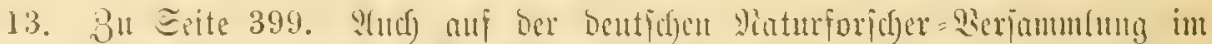

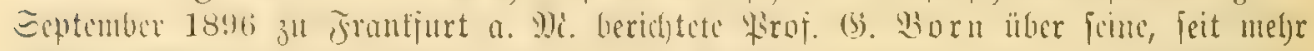

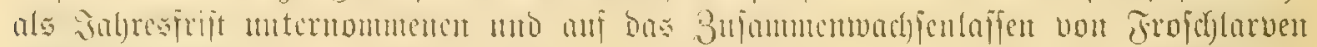

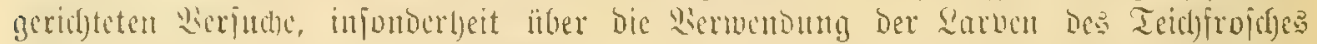

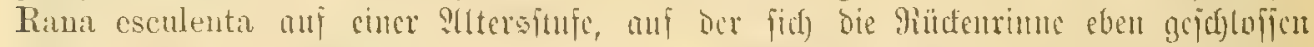

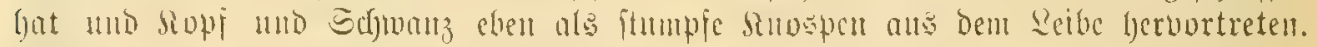

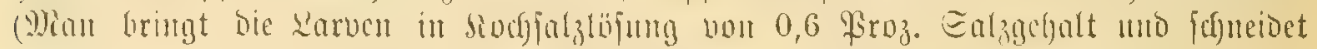

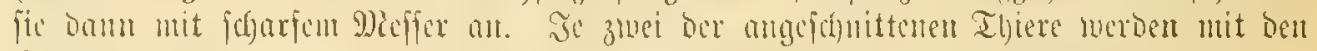

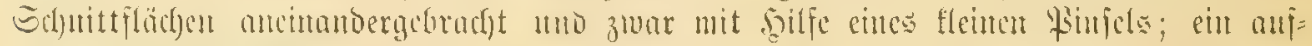

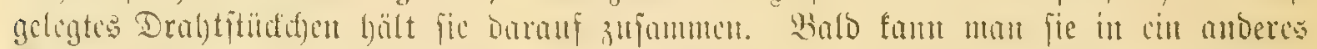

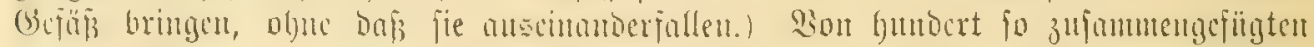

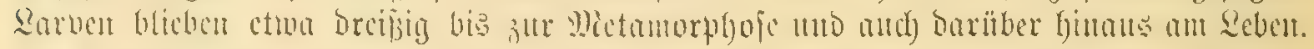

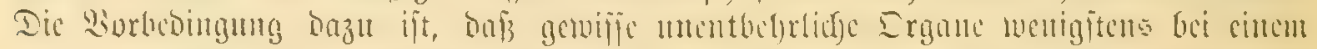

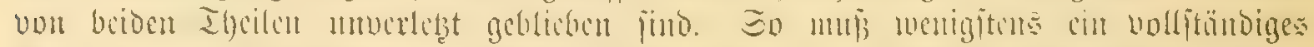

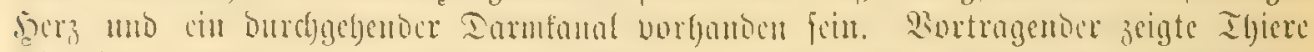

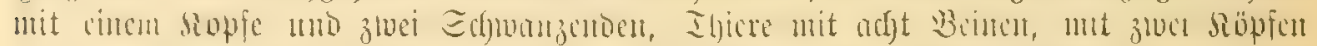

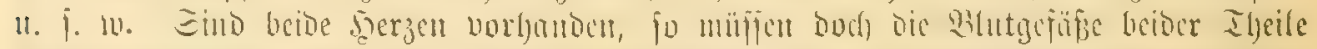

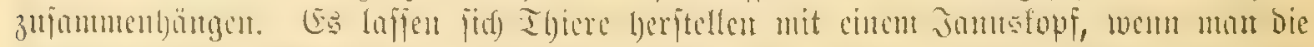

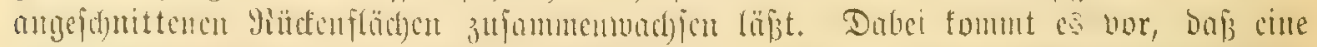

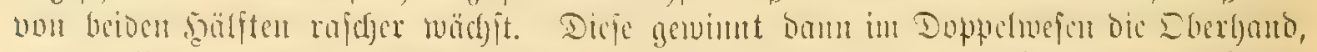

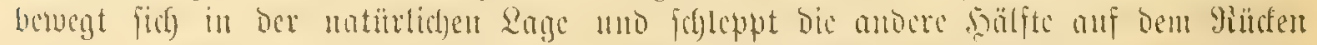

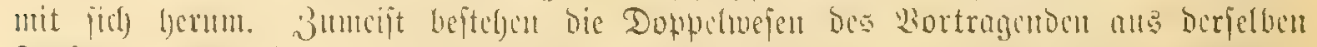

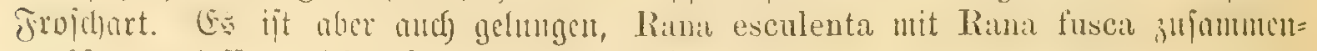

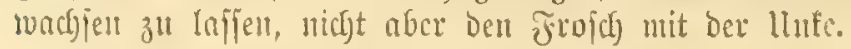

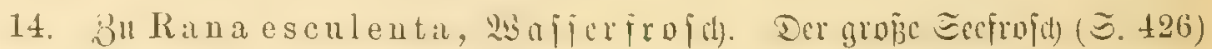

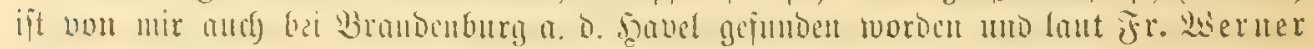

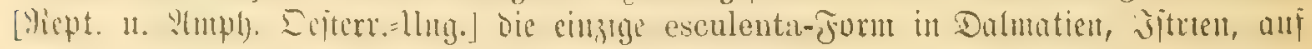

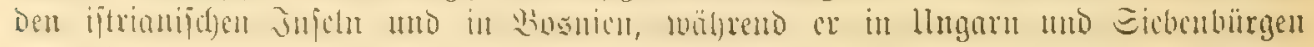

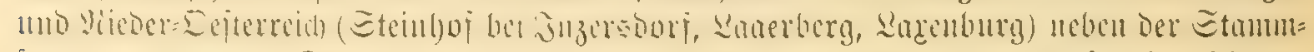

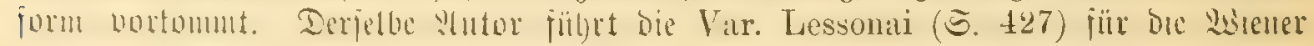

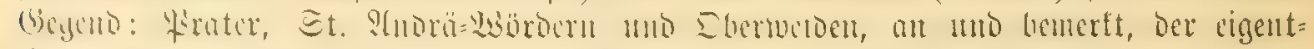

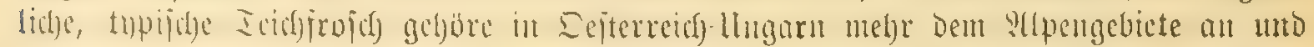

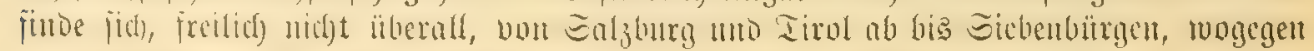

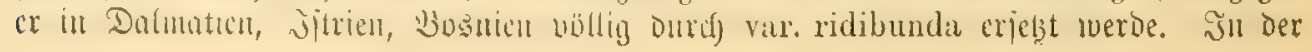




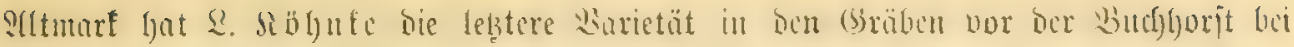
Ealzucoel feftgeitellt.

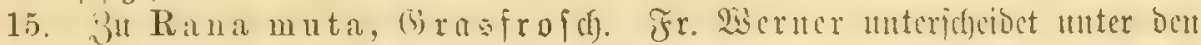

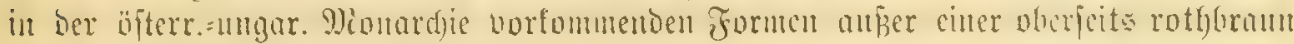

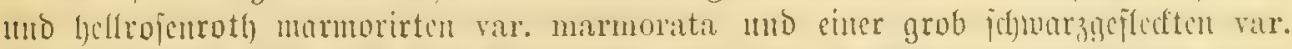

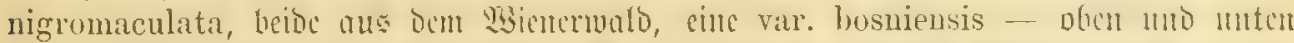

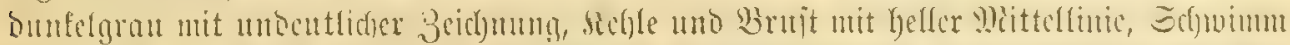

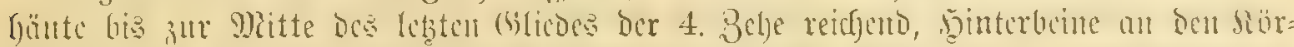

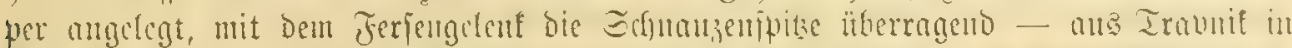

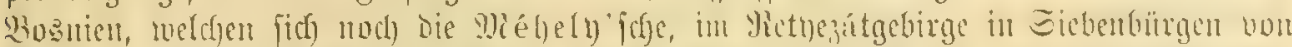

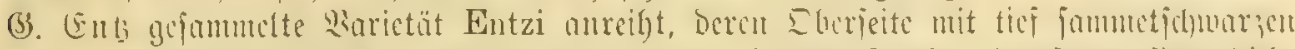

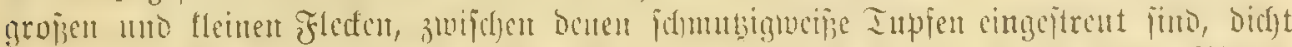

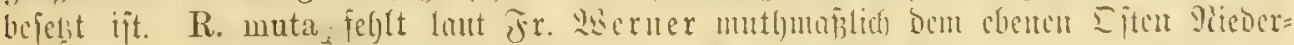

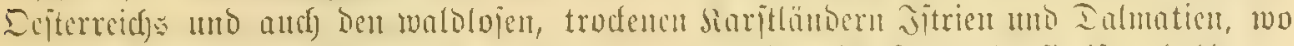

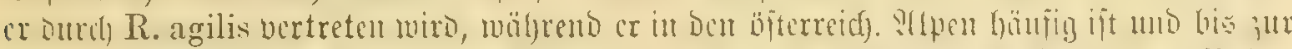

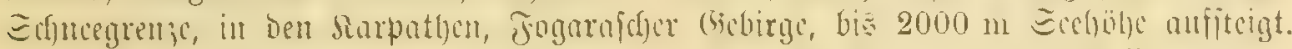

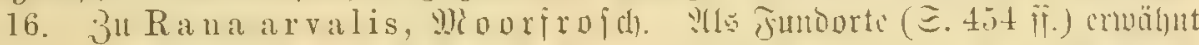

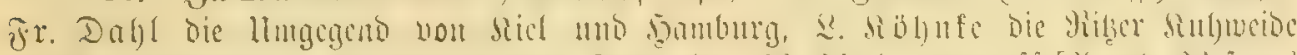

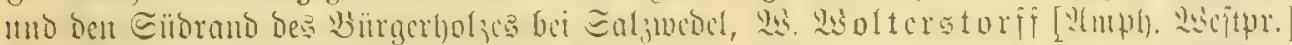

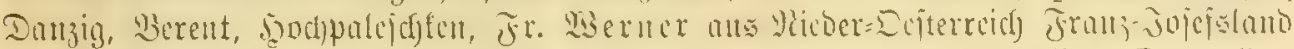

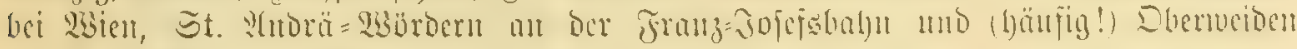
in Mardffeld, auberbem nody Fimme nahe Dent 45. Brcitengrad.

17. Bu Rana agilis, Spritgfrof(l). Die anf Scite 461 verzciducte

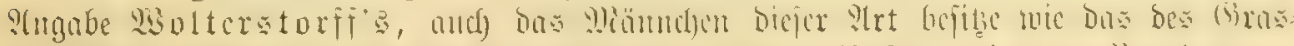

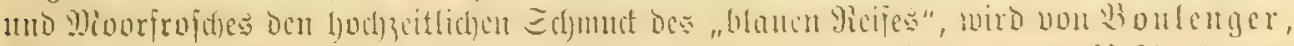

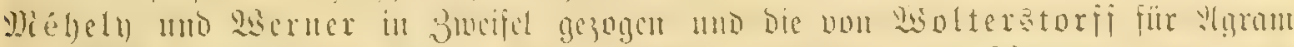

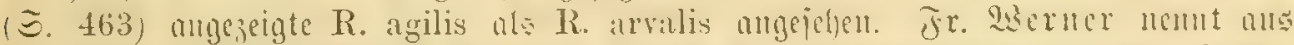

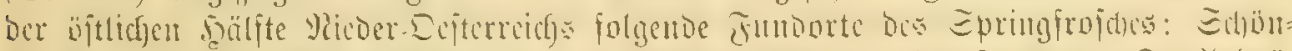

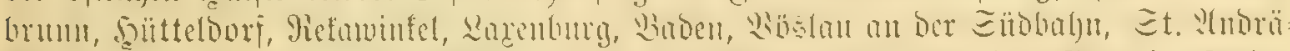

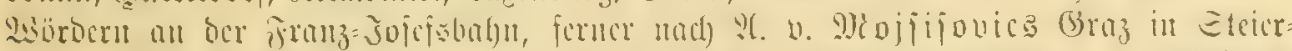

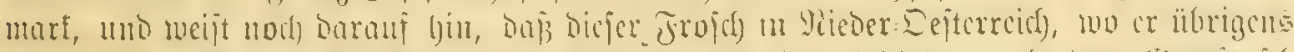

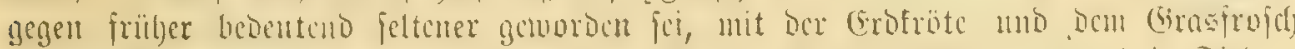

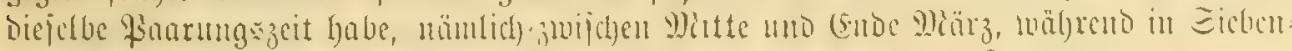

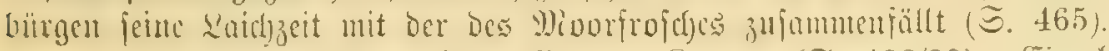

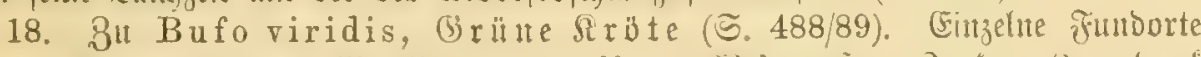

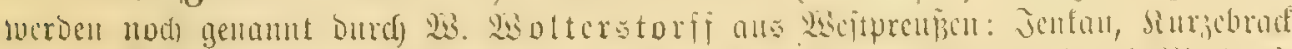

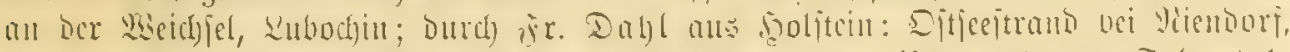

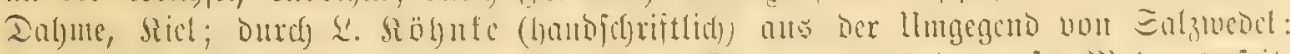

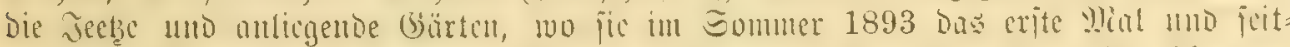

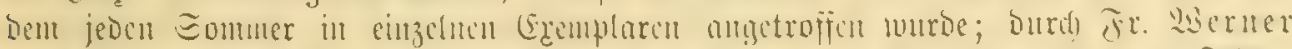

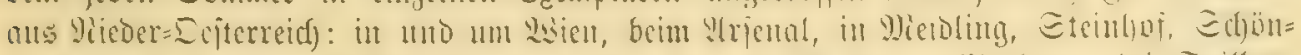

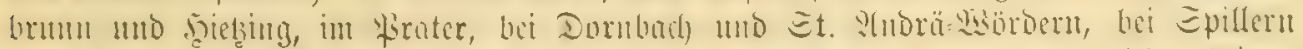

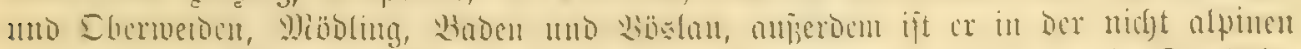

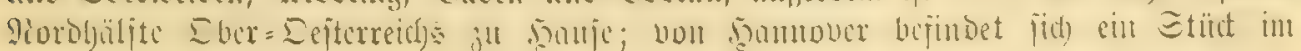

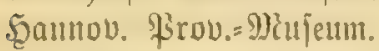

19. Bu Bufo calamita, Rreuzfrötc (ङ.500-502). Dicfe Siöte ift

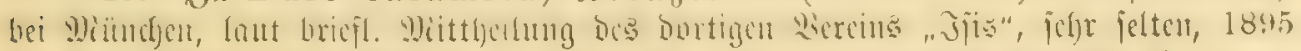

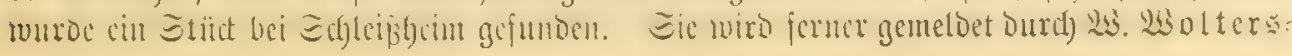




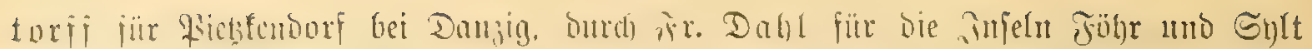

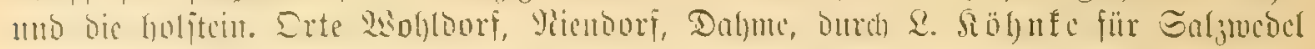

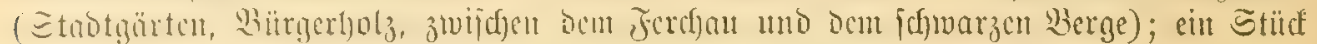

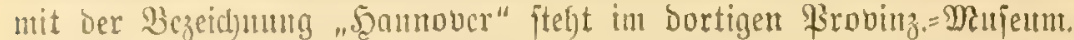

20. Bu Pelobates fuscus, Sinoblaud)

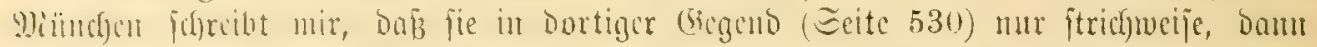

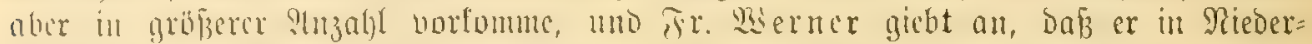

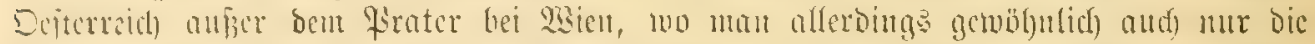

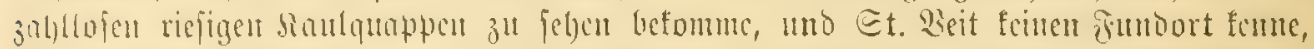

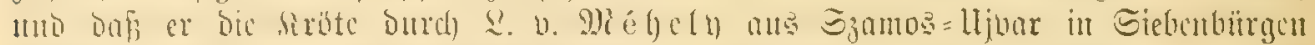

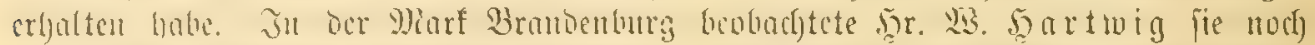

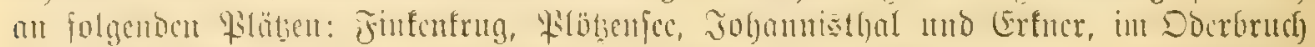

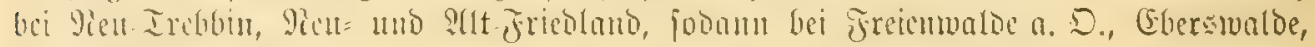
Bicjenthal.

21. \$u Bombinator pachypus, Bergute. Fr. Weirner, welcher beruorbed, Daj unitunter bort, wo beibe llufen:

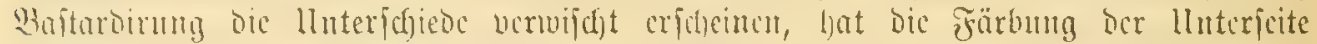

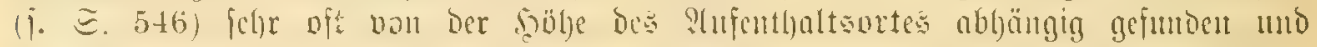

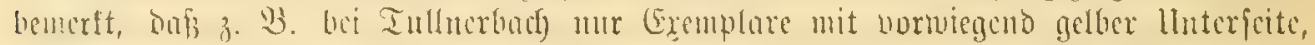

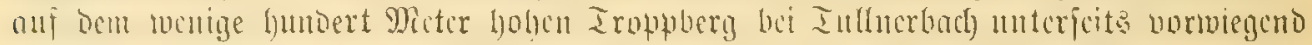

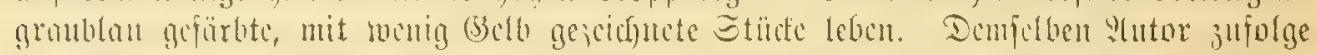

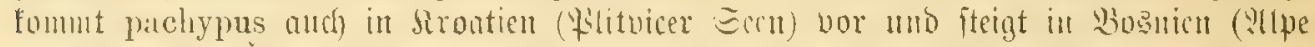

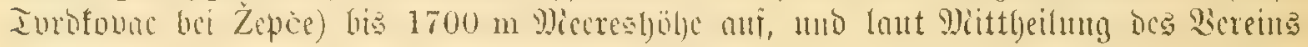

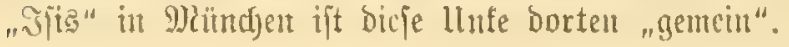




\section{Siteratur.}

Aldrovandi, Serpentum et draconum historia. Bononiae 1640.

- De quadrubedibus digitatis oviparis. Bononiae 1663.

Anlrzejowski, Amphibia nostrantia, seu enum. saurorum, ophidiorum nec non sireniorum in exc. p. Volhyniam, Podoliam guberniumrque chersonense etc. observ. (Nouv. Mém. Soc. Imp. Natur. Jloscou II, 1832).

Indonin et Sarigny, Reptiles de l'Eoypte (in: Description de l'Egypte. Hist. nat. T. I. Suppl. Paris 1820).

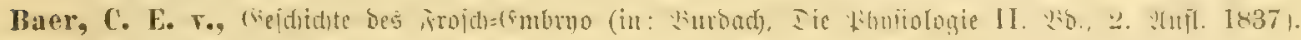

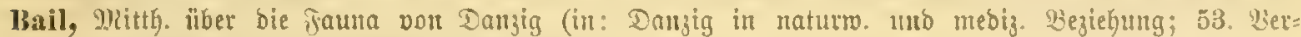
[aumulutg bentider Yaturiprid)er 1880).

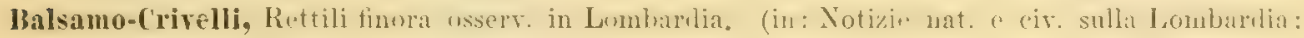
[herausgeg. v. C. Cattaneo]. Milano 1844, vol. I).

Barbosa du Bocage, Liste des Mammiferes ot Reptiles olscreius en Portugal (Rerue ut mag. Zool. par Guérin-Meneville XVI, 2. ser. 1863).

Barcelo y Combis, Catalogu de lis Reptiles ete. obs. ('n las Baleares. I'alma de Malloria 1876.

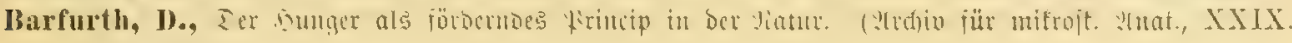
औื. 1887).

- Berinde über bie ummanolung ber jrojdjlarwen. (Dajelbjt.)

Barkow, Der birterfdilaj. Wertin 1846.

Bechstein, Lacépebe's Yinturgeldidite ber 2(mphibten. 2seimar 1800-1802.

Bedriaga, J. To, lleber bie Entitefung ber Frarben bei ben (Eibedjen. Jena 1874.

- Die Faraglione=(Fibed)fe. Ђetbelberg 1876.

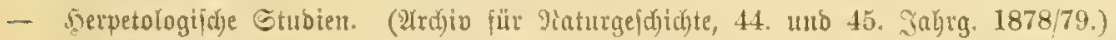

- Bergeidnißß ber Reptilien und Impfibien 2orber=21ients. (Bull. Soc. Imp. Nat. Mloscou 1879.)

-- Die geograph. Berbreitung ber europ. Eurdje. (Bull. Soc. Imp. Nat. Moscou 1879 Nr. 4.)

- Sie 2Imphibient uno Mieptitien (sriechenlanos. (Bull. Nat. Moscou LVI. 1881.)

- " " " " " Beridytigumgen. (Bool. Mng. 1883 Nx. 137.)

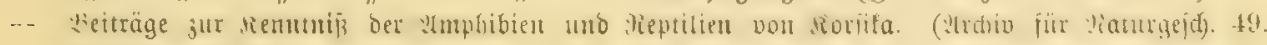
Sabrg. 1883. Bo. I.)

- Beiträge zu Renntuiß bet Eacertiben=ร̃amilie. Frantjurt 1886.

- Die Surdjauna (Furopas, I. Inura. (Bull. Nat. Мoscou 1889 Nr. 2. 3.)

- Amphibiens et Reptil. rec. en Portugal p. Ad. F. Moller. (Coimbre 1890.)

- Mrittheilungen über bie Larven Der Mtold)e. (Bool, Anzeiger 1891.)

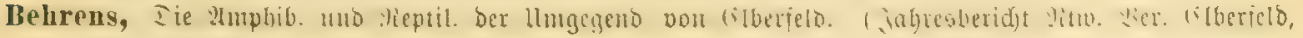
230. 6 188.4.)

Belke, Sur le Climat et la Faune de Kamieniec-Podolski. (Bull. Nat. Mloscou 1853 Nr. 2.)

Bell, A Jonograph of the Testudinata. London 1836-1848.

A History of British reptiles. London 1839.

- A History of British reptiles, 2 ed. London 1849.

Beltrémieux, Faune du Dep. de la Charente inférieure. La Rochelle 1864.

Bert, P., Catalogue méth. d. Animaux rertébrés du Depart. de l'Yonne. Paris 1864.

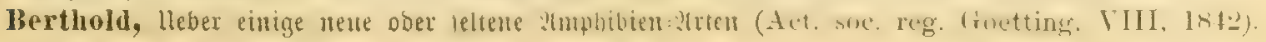


Betta, F. de, ratalogo dr.i Rettili d. Val di Xom nel Trento merid. (2ierh. Bool.:23. Wien 1852.)

- Erpetologia delle Provincie Venete e del Cirolo merid. Verona 1857.

- Monogr. degli Anfibi Urodeli Italiani (Memor. R. Istit. Veneto XI. Venezia 1864.)

- Materiali per una Fauna Veronese. Mem. Accad. Agricoltura XLII. XLVII. Verona 1863-70).

- Rettili ed Anfibi del Regno della Grecia. Venezia 1868.

- Fauna d'Italia: IV. Rettili ed Anfibi. Milano 1874.

- Alcune Note erpetologiche ['I'ropid., Aspis, Salam., Triton, Bomb.]. (Atti R. Istit. Ven., Ser. V, T. IV. Venezia 1878.)

- S. 'Iiliguerta o Caliscertula Cetti. (Ibidem.)

- Nuova Serie di Note erpetol. [Lac. mur., Vip. aspis etc.]. (Ibidem Ser. V, T. V. 1879.)

- S. Vipera ammodite nell'Italia. (Ibidem, Ser. V, T. V. 1879.)

- Distribuzione geogr. dei Serpenti velenosi in Europa. (Ibid., Ser. V, T. VI. 1880.)

- III. Serie di Note erpetol. (Ibidem, Ser. VI, I. I.)

- S. Questione delle Rane rosse d'Europa. (Ibid., Ser. VI, T. V. 1887.)

Bibron et Bory de St. Vincent, Expedition scientifique de Morée III, Paris 1832.

Bielz, Jauna Der Lisirbethiere Gicbenbürgen. Soemanuftadt 1856.

Blanford, Zoology and Geology in "Lastern Yersia", Vol. II. London 1876.

- Rept. a. Amph. of the 2. Yarkand Mission based up. the collect. a. notes of F. Stoliczka. Calcutta 1878.

Blasius, J. H., Meije im europ. Mufland 1840/41. Braunjaneig 1844.

Blejer-Hejden, G., ๔d)langenfanna Deutidlanos. 2ieimar 1891.

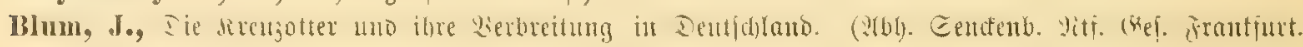

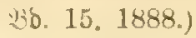

Blumenbach, 5anobuch ber Taturgeidjichte. Böttugen 1821.

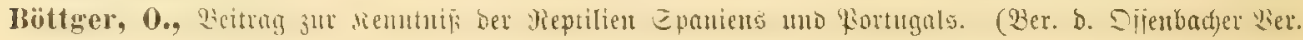
für Viaturf. X, 1869.)

- Heber Meptilien von Gried)enland unt (56ios. (15. 16. Effenbadyer Ber. 1873.)

- Meptitien vos Miarntfo. I. Il. (26band. Gendentb. Jranffurt 1874 u. 83.)

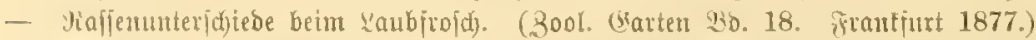

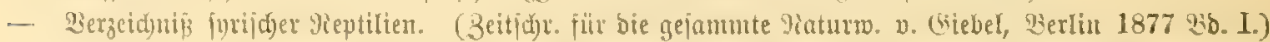

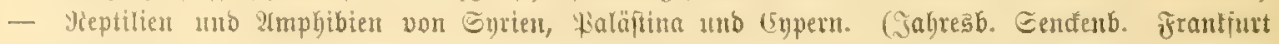
$1879,80$.

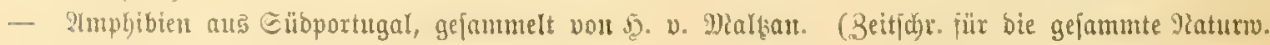
3erliu 1879, wל. IV.)

- Stubien an paläartt. Rept. 1. Imph. (19./21. Ber. Sffenbadjer 3. f. Tat. 1880.)

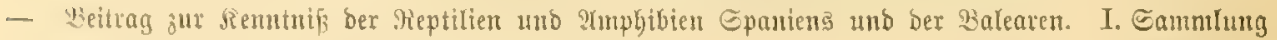
von 5. Einton in Gübpanien. IT. Gammlung von F. Wsill auf ben Balearen. (Mbhanblutg Sendent. XU. Jrantiurt 1881.)

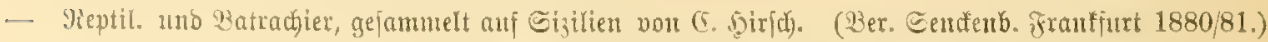

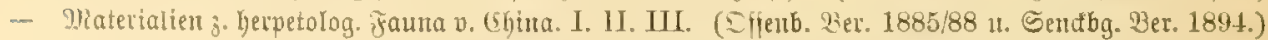

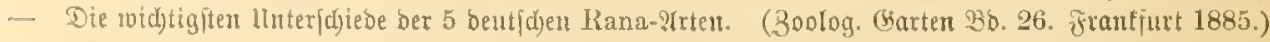

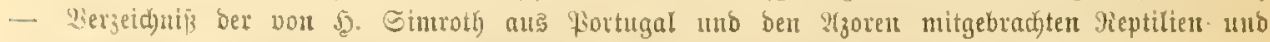

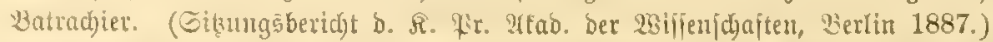

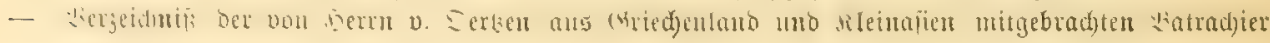
unb Meptilien. (Dajelbit 1888.)

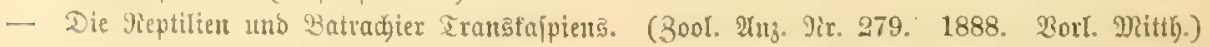

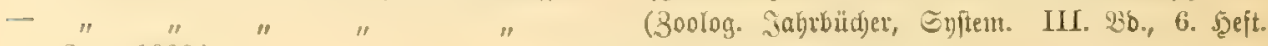
Jent 1888.)

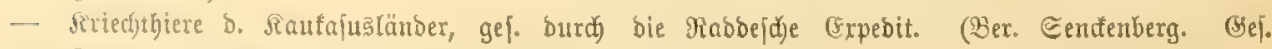
Grantjurt 1892.)

Boie, Generalslleberfidgt ber Familien unb Gattungen ber Sphibier. (Sjī̇ XIX, 1826.)

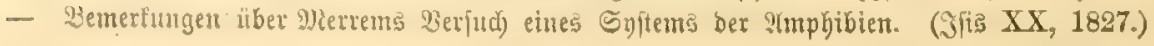




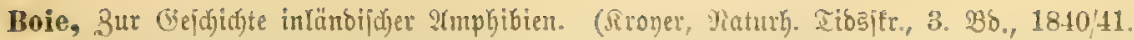

Bonaparte, Iconografia della Fauna italica. 'I'. II. Anfibi. Roma 1832-1841.

- Amphibia europaea. (Mem. R. Accad. Sc. Torino, Ser. 2, T. II. 1839.)

Bonizza, Enum. sistem. dei Rettili ed Anfibi ... Modenese. (Eco d. Universita 1870. Modena.)

Bonnaterre, Erpetologic. Paris 1789.

Bonnet, Cli., Oeurres d'Histoire Nat. Neuchâtel 1779-83.

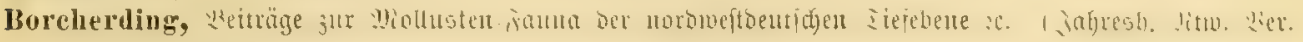
२üнеburg 1887.)

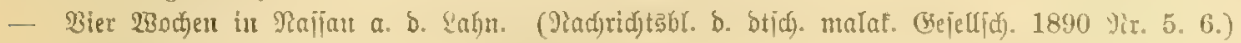

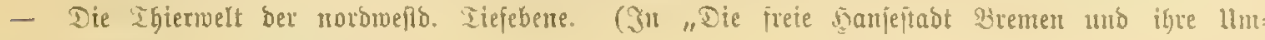
gebungen". Brenten 1890.)

Bosea, Cat. de los Reptiles y Anfibios en España, Portugal é Islas Baleares. Iladrid 1877.

- Las Viboras de Espana. (An. Soc. Esp. Hist. Nat. Bd. 8. Madrid 1879.)

- Cat. des Reptiles et Amph. de la Pcninsule Ibérique et des Iles Baleares. (Bull. Soc. Zool. France, V., Paris 1880.)

- Correcciones y Adiciones al Cat. d. 1. Rept. y Anf. d. España etc. (An. Soc. Esp. Hist. Nat., Bd. 10. Madrid 1881.)

- Exploracion herpetol. de la Isla de lbiza. (Ibidem Bd. XU. 1883.)

Bonlenger, G. A., Etude sur 1. Grenonilles rousses, Ranae temporariae. (Bull. Soc. Zool. France IV. 1879. Paris 1880.)

- On the Palaearctic a. Aethiop. Species of Bufo. (Proc. Zool. Soc. London 1880.)

- Catalogue of Batrach. gradientia in Brit. Museum. London 1882.

- Catalogue of Batrach. salientia in Brit. Museum. London 1885.

- Catalogue of Lizards in Brit. Museum. London 1885-87.

- On the existence of two Kinds of Aquatic Frogs in North Germany. (The Zoologist, june 1884.)

- Description of the German Riverfrog R. escul. v. ridibunda. (Proc. London 1885.)

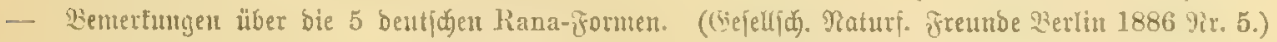

- On two Europ. Species of Bombinator. (Proc. London 1886.)

- Sur la Synonymie et la Distrib. geogr. des deux Sonneurs européens, Bomb. ign. et pach. (Bull. Soc. Zool. France Vol. 13. 1888.)

- Synopsis of the Tadpoles of the Europ. Batrach. (Proc. London 1891.)

Brandt u. latzeburg, Mebiginifd)e 30ologie I. Vievin 1829.

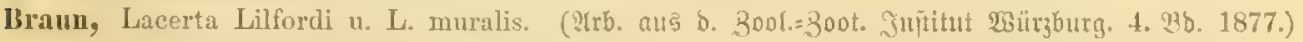

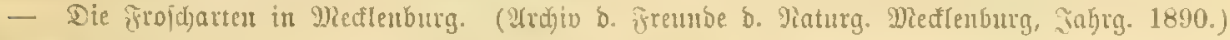

Brehm, 3luptrtes Thierteben, V. Seipzig 1878; 3. Tuft. 1892.

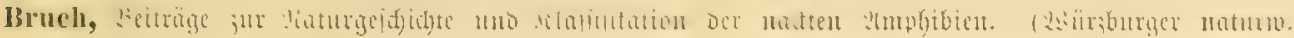
3eitidrijt Ш, 1862.).

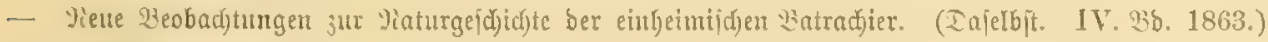
Die Geburtahelferfiöte. (5. Beridjt D. nat. Wer. Effenbad) 186t.)

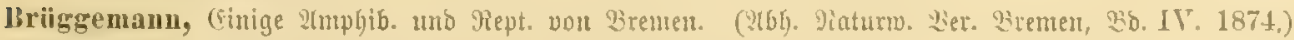

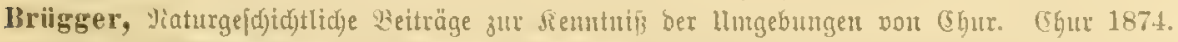

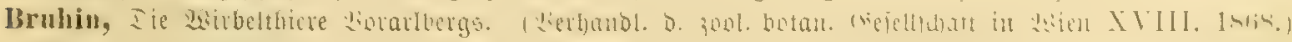

Bujack, Viaturgefojidjte ber böheren TGiere, befonber ber Fauna Prussica. Röniggberg 1837.

Camerauo, Considerazioni sul genere Lacerta. (Atti della R. Acad. delle Scienze di Torino, Vol. III.)

- Monografia degli Anfibi anuri Italiani. Torino 1883.

- Jonogr. d. Anfibi urodeli Italiani. Torino 1884.

- Monogr. dei Sauri Italiani. Torino 1885.

- Nuove osserr. int. alla Neotenia d. Anfibi. (Atti Acc. Torino XX. 1884.)

Camerarius, Joachim (Nürnberg), Symbola et emblemata, Cent. IV. 1590.

Campeggi, Cat. d. Rettili e Anfibi di Milano. Mil. 1883.

Cara, Monogr. della Lucertola comune di Sardegna. Cagliari 1872. 
Canestrini, Intorno alla Fauna del Trentino. (Atti soc. Veneto-Trent. Sc. nat. Padora. Vol. IV. 1875.)

Carruccio, A., Importanza ... Fauna del'Emilia. (An. Soc. Nat. Modena XV. 1881.)

Cattaneo, Notizie naturali su la Lombardia, Vol. I. Milano 1844. (Vgl. Balsamo- Crivelli.)

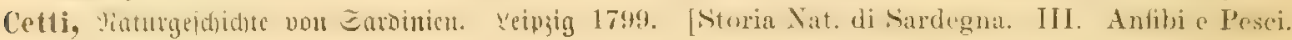
Sassari 1777.]

Charas, Nouv. expér. sur la Vipère. I'aris 1836.

Clarke and IRoebuek, Fauna of Yorkshire. London 1881.

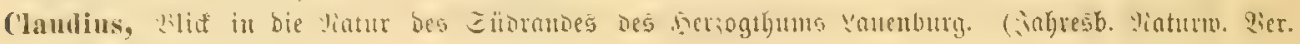
Sünerurg 1866.)

Clermont, Guide to the Quadrupeds and Reptiles of Europe. London 1859.

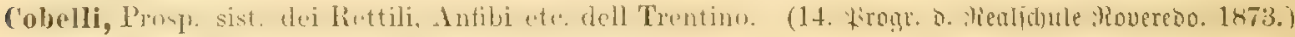

Cucteau, Etudes sur les Scincoides. Paris 1836.

- Sur un genre peu connu de Lezards vivipares (Guerin's Mag. de Zool.; Paris 1835.)

Collet, Norges Reptilier og Batrachier. (Forhandl. i Vid.-Selsk. Christiania. Nr. 3, 1878.)

Colliu, Danmarks Fröcr og Tudser. (Naturh. Tidsskrift, 3. R., Bd. VI. Kopenkagen 1870.)

Collin de Plancy, Cat. des Rept. et Batrac. de l'Aube. (Bull. Soc. Sc. nat. Semur, 1877.)

- L'accouplement et la ponte chez les Lézards de firance. (Bull. Soc. Zool. Firance pour 1877. Paris 1877.)

Cooke, Our Reptiles. London 1865.

Cope, 1)., Sketch of the Primary Groups of Batr. Salientia. (Nat. Hist. Review, rol. V, Nr. XVII, 1865.)

Cornalia, Eu., Osserrazioni sul Pelob. fuscus e s. Rana agilis, trov. in Lombardia. (Atti Soc. ital. sc. nat. Vol. XVI. 1873.)

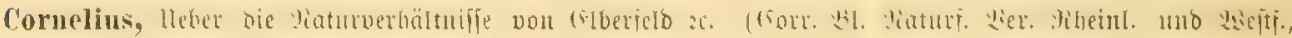
35. 3. 1878 9ir. 2. *iom.)

Costa, 0. G., Statist. fisicn ed econom. dell'Isola di Capri. (Eserc. acc. d. Asp. nat. etc. Vol. II. Napoli 1840.)

Crespon, faune meridionale. Nimes 1814.

Cuvier, Règne Animal, II. Paris 1829.

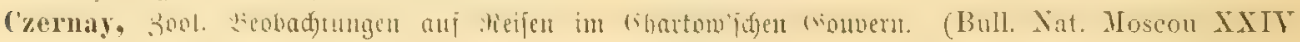
Nr. 1. 1851.)

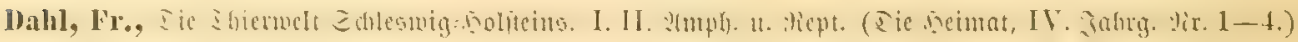

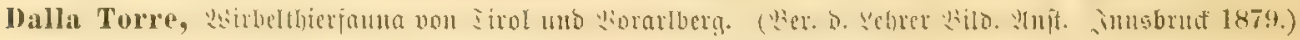

- P. berus, Vip. Aspis 11. Ammodytes in Thol nub 2orarlberg. Smisbrud 1891.

Daubenton et Inuduyt, Hist. nat. des Animanx, Paris 1782-87.

1)audiu, Hist. nat. des Rainettes, Grenouilles et Crapauds. Paris 1802.

- Hist. nat. des Reptiles. Paris 1802-1804.

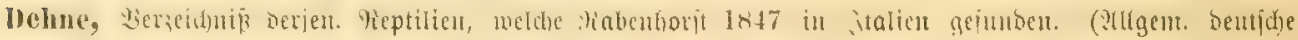
naturh. 3tg. II, 1856.)

Demiloff, Yoyage dans la Russie meridionale et la Criméc. Paris 1841.

Doderleiu, Alcune gener. int. la Fauna Sicula dei Vertebrati. (Ann. Soc. Nat. Modena VI. 1872. .)

- Rivista dei Vertebrati della Fauna Sicula. (Nuove Effem. Siciliani XI. Palermo 1881.)

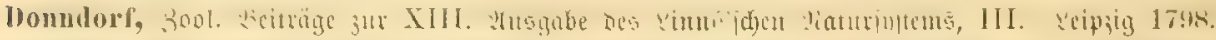

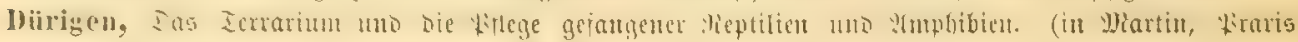
ber Taturg. UI, 2. Wietmat 1882.)

Duges, Ant., Memoire sur les espèces indigènes du genre Lacerta. (Ann. scienc. nat. XVI, 1829.)

- Recherches sur l'osteol. et la myol. des Batraciens. (Mem. Mus. d'Hist. Nat. Paris 1835.) AIfr., Urodèles de France. (Ann. se. nat., III. ser. XVIII. Paris 1852.)

Duméril, C. et A., Catal. méthodique des Reptiles du MIuseum d'hist. naturelle de Paris. Paris 1851 .

Daméril, C.g Prodr. de la classification d. Reptiles Ophidiens. Paris 1852. 
Duméril et Bibron, Erpítologie générale. 10 vols. Paris 1834-54.

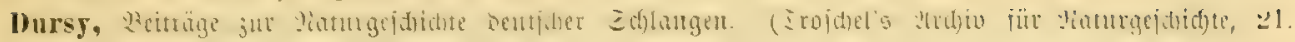
iabrg. I. 30.)

Duvernoy, Hist. nat. des Reptiles (Règne Animal de Curier). Paris 1850.

Dwigubsky, Primitiae Faunae Mosquensis. Moskau 1802.

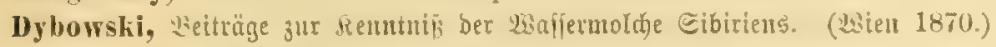

Ecker, A., Tie Inatomie Dę Frofdes̀. Braunfdueig 1864.

Eichwalı, Zoologia specialis Rossiae et Polonize, III. Vilnae 1831.

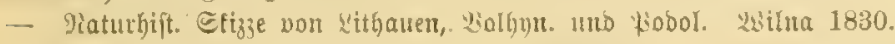

- Meije auj bem Gajp. Mleere und in b. Jantajus. I. Etuttgatt 1834.

- Fauna caspio-cancasica. Mosquae 1841.

Eimer, 3ool. Etubien nuf (capri, II. Lacerta mur. cacrulea. Veip3ig 1874.

- Interfud)ungen über bas Lariiren ber Mauers(sibedfe. Werlin 1881.

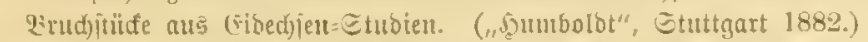

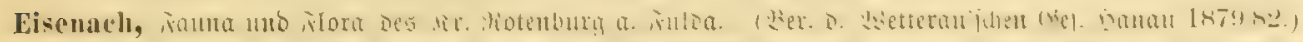

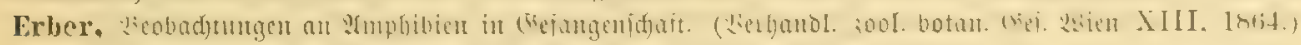

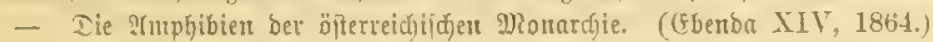

- Crgebniffe einer Meije nad) (bried)enlanb. ((Ebenba XVI, 1866.)

— Beridyt über eine Tieife ntad) Mhobus. ((ङbenda XVII, 1868.)

Erhard, Fauna ber (Enclaben. I. Eeipjig 1858.

Erersmann, Retipe vou Etenburg nady Budjata. Wierlin 1823.

- Lacertac Imperii Rossici. (Nour. mém. Soc. Imp. Moscou III, 1834.)

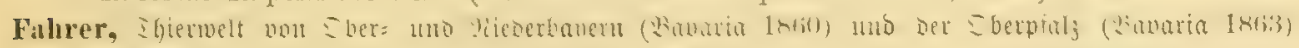

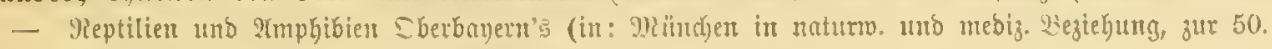
Werfammlutg heuticher Yiaturj.), Mänd)en 1877.

Fatio, Faune des Vertébrés de la Suisse, III. Reptiles. Genève 1872.

- Reptiles et Batrac. d. 1. Haute-Engadine. (Arcl. Sc. phys. nat. XXI. Genève 1864.)

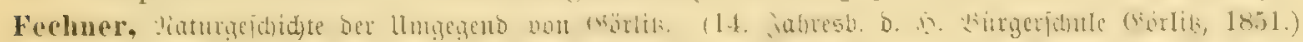

De Filippi, Note de un viaggio in Persia 1862. Milano 1865.

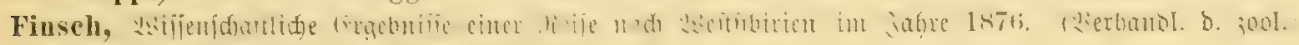
bot. (Ge . Wiert, XXIX. Witert 187\%.)

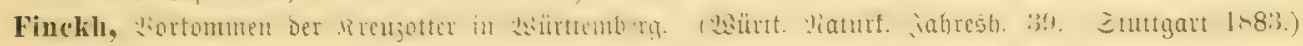

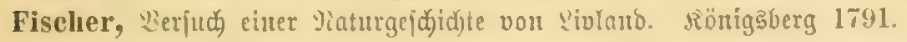

- J. T., Die Meptilien und Ymphibien Des Wetersburger Gouv. (马ool. (Garten 1873.)

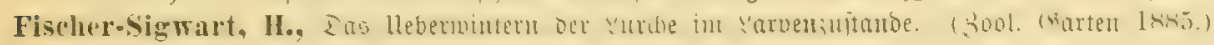

- Das Thierleben im Terrariun. Bofingen $188 \%$.

Fitzinger, פeue Rlafinfation ber Mieptilien. 23ien 1826.

- Meiträge sur Eanbesfunde Eefterreid)s unter D. (sns. I. 1832.

- Systema reptilium. I. Amblyglossae. Vindobonae 1843.

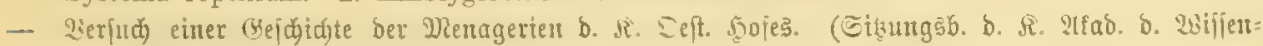
ifhaiten X. 2Bien 1853.)

Fleischmann, Dalmatiae nova serpentum genera. Erlangae 1831.

Fleming, History of British animals. Edinburgh 1838.

Fontaiue, de la, Faune du Pays de Luxembourg; Reptiles. Luxernb. 1870.

Fontana, F., Ricerche fisiche sopra il reneno della Vipera. Lueca 1767. (Deutif́n non Jecben= itreit. 'eipsig 1785.)

Francke, H. G., Die Rreusotter. Dresben 1889.

Franke, Ml., Die Mept. uto Ampfit. Deutidlands. Leipjig 1881.

Freyer, Jauna ber in Jirain beobad)teten Cängetfiere, 3ögel, Mieptil. x. Zaibad) 1842.

Fritsch, A., Die 2Sirbelthiere 330 bmens. Hrag 1872.

Frivaldsky, Monographia serpentum Hungariae. Pestini 1823.

Friedel, E., IGierlebent uno Thierpflege in italien. (Bool. (3arten 1874 गit. 9.)

- IGierTebent und Igierpllege in 3tlano (Daj. Tr. 12. 1881.) 


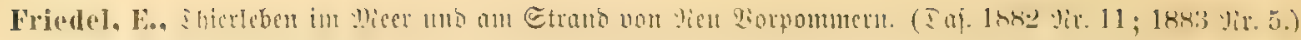

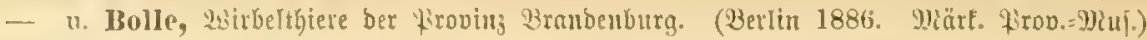

Funk, A. F., Salamandrae terr. vita, evolut., format. Berolin. 1827.

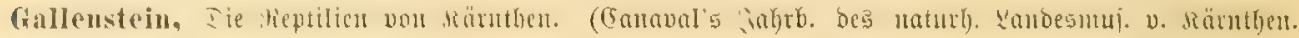
W3b. II. 1853. Rlagenfurt.)

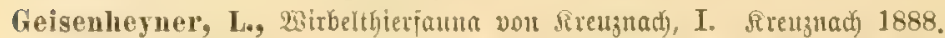

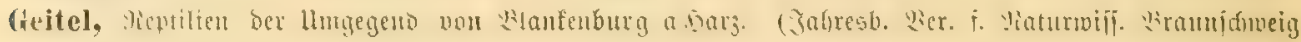
ๆüเ 1880;81.)

Gené, Synopsis reptilium Sardiniae indigenorum. (Mem. d. reale acad. d. scienze di Torino, ser. 2, I, 1839.)

- Sulla Tiliguerta di Cetti.

Gentil, Erpétologie de la Sarthe. (Bull Soc. Agr. Sarthe 188t.)

(Hervais, Animaux vertébrẻes de l'Algerie (Ann. scienc. nat. 3, ser. $\mathbf{X}, 1818$ ).

Gesner, De Serpentium natura. Francofurti 1621.

- De quadrupedibus oviparis. Francofurti 1617.

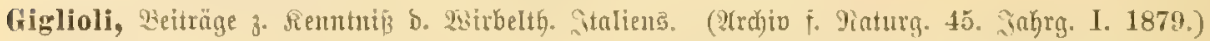

Giglioli, Elenco dei Mammiferi degli Uceelli e dei Rettili ittiofagi d. fauna ital. . . Firenze

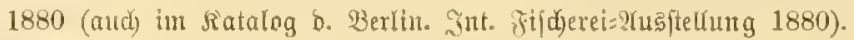

Girod-Chantrans, E'ssai sur l' geogr. phys. et l'hist nat. Doubs. I. Paris 1850.

(Yistl, Bemerfurgen ïber enige Surdue. (Jï 1829.)

Glaser, Itmphibien um siorms. (Bool. (Garten 1870.)

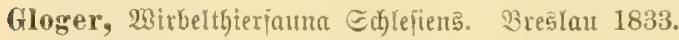

Gliickselig, Synopsis Reptilium et Amph. Bohemiae. Prag 1832.

Gmelin, Linnei Systema naturae 1. 1788.

- Maturgefdidyte ber Implibien. 2. Muft. Mannbeim 1839.

Godron, Zoologie de la Lorraine. Nancy 1862.

Göbel и. Claus, Teife in bie Steppen bes füblidjen Mußlaut, II. Iorpat 1838.

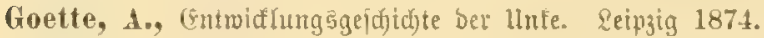

Goldfuss, Jombouch ber 3oologie. Teünberg 1826.

Gravenhorst, Deliciae musei zoologici rratislaviensis. I. Reptilia. Lipsiae 1829.

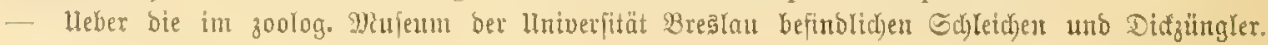
B̀ręłau 1847.

Gray, Spicilegia zoologica. London 1828.

- Monographic Synopsis of the Vipers. (Zoolog. Miscell. London 1831.)

- Catalogue of Slender-tongued Saurians. (Jardine's Ann. of. nat. hist. London 1838.)

- $\quad$ of Isizards in the Brit. Museum. London 1845.

- . of Snakes in the Brit. Museum. Isondon 1849.

- " of the Batrachia gradientia. London 1850.

- $\quad$ of the specimens of Amphibia. London 1850.

- $" \quad$ of Shield Reptiles in the Brit. Museum. London 1855. Suppl. 1870. Appendix 1872 .

Gredler, Fanta ber Sirechthiere uno Purche Tirols. Bozen 1872.

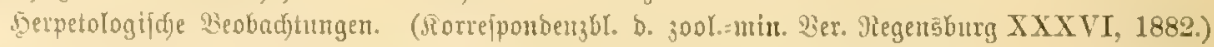

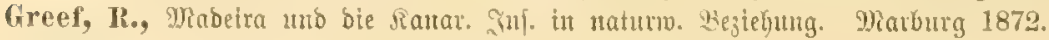

Griffith ete., The Animal Kingdom. IX. London 1831.

Gronorius, Zoophylacium. Lugd. Batar. 1781.

Guérin-Menéville, Iconographie du Regne animal de G. Cuvier; Reptiles. Paris 1838,39.

Giinther, Catalogne of the Batrach. salientia in the Brit. Mus. London 1858.

- Catalogue of the Colubrine snakes in the Brit. Mus. London 1858.

- Report on a collect. of Reptiles f. Palestine. (Proc. Zool. Soc. London 186t.)

Guichenot, Reptiles et poissons (in: Explorat. de l'Algérie, Zoologie, T.) Paris 1850.

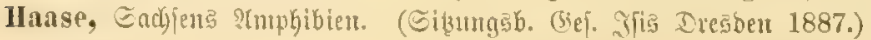

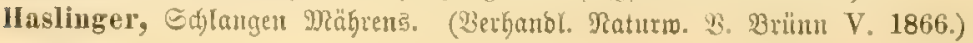




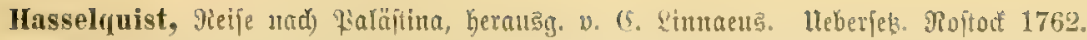

Hast, B. R., Amphibia Gyllenborgiana. (Dissert, Praes. C. Linnaco.) Upsaliac 1745.

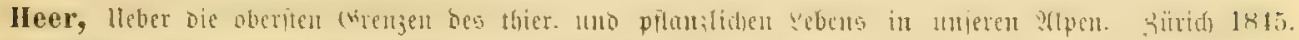

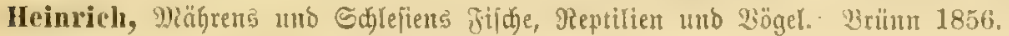

Heldreich, Fanno Grèce. Athènes 1878.

Heller, lleber bie Werbreitung ber Thiernelt im Tiroler jodhgebirge, I. 23 ien 1881.

ILller, Tmphibiologijo Tiotizen. (Bool. (Garten 1888.)

Iermann, Tabulae affinitatum animaliam. Argentorati 1783.

Heron-Royer, Les nuances diverses des tetards de Batraciens anoures. (Bull. Soc. zool. de France. Yaris 1878.)

- Sur les têtards et l'hybridation des Batrac. anoures. (Paris 1881-84.)

- Notices sur 1. moeurs d. Batraciens. (Bull. Soc. d'Et. Se. Angers 1885. Angers.)

v. Ileyden, Gorfonmen vou Callop. Harescens Sdjlangenbab utb vou Trop. tessellatus bei ("mis. (Gabrb. D. Ber. F. Tatutt. Maffau, Jeft 16. 2siesbaben 1861.)

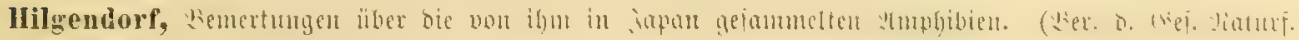
Freunde Ber(in 1880 Pir. 8.)

Hofmanu, Der nörbliche Ural, II. Getersburg 1856.

Holandre, Animaux rert. d. Départ. de la Hoselle. (Bull. Soc. Nat. Moselle VI. Mietz 1851.)

Holland, Die wirbetthiere Wommerns. Ctolp 1871.

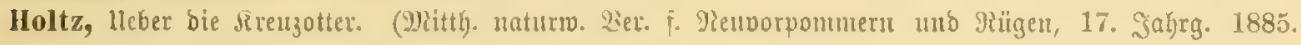
(ireirsmalb.)

Host v. Jaquin Collect.

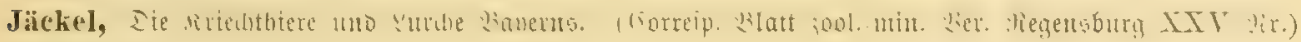
6 uा 7. 1871.)

Jan, Cenni sul museo civico Milano ed indice sist. d. Rettili ed Anfibi esposti nel medesimo. Milano 1857.

- Iconographie générale des Ophidiens. Paris 1860-82.

- Elenco sistem. degli Ofidi. Milano 1863.

- Enumerazione sistem. degli Ofidi, Coronellidac. (Arch. p. la Zool. Genua, Vol. II. 1865.)

Jacolbens, Ranis et Lacertis.

Jaquin, Collectanea ad Botanicam etc. Yol. IV. Tindobonae 1790.

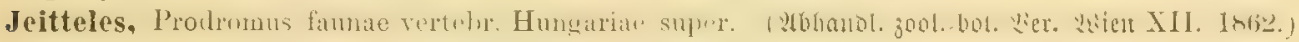

Jenyus, Manual of british vertebrate animals. Cambridge 1835.

Jonston, Hist. natur. de Serpentibus. Heilbronn 1757.

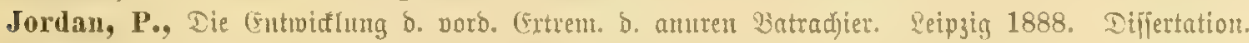

Jumean, Synopsis Rept. et Batrac. du Dẹp. d. Hérault. (Bull. Soc. d'Et. Sc. nat. Béziers 1879.)

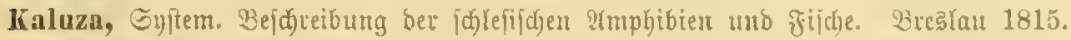

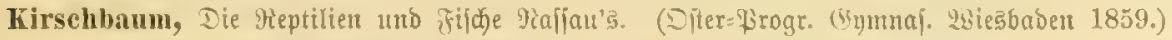

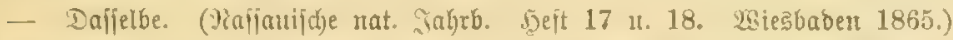

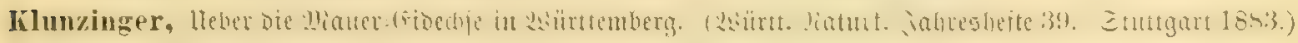

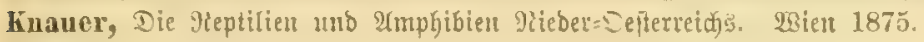

Ḱnauthe, 3ur Biologie ber Batrachier. (30ol. 2nj. 1892 Mr. 381.)

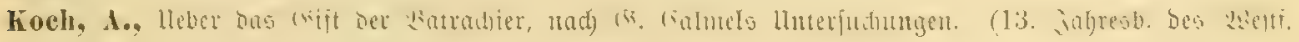

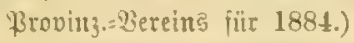

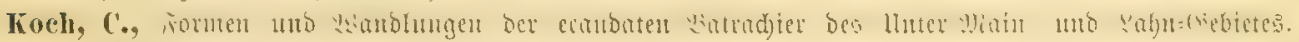
(2:er. Eendentb. nat. Bef. Frantfut 1872.)

Koeh, F., Fie Gdjlangen Deutidglands. Ctuttgart 1862.

Koch u. A., Fauna Ratisbonensis. Regetaburg 1840.

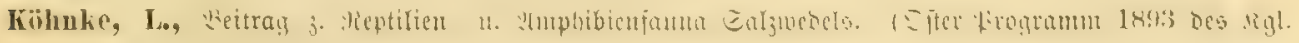
(Gynuna्. Calzmede!.)

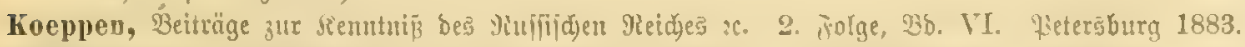

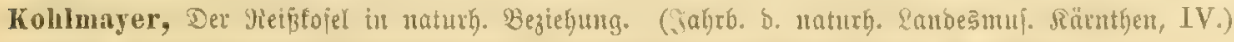

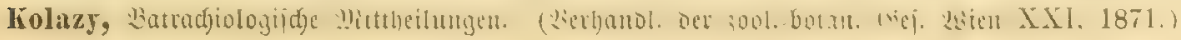


Kolombatovic, Mammiferi, Rettili ed Anfibi della Dalmatia. Spalatu 1882. Catal. vertebratorum dalmaticorum. Spalato 1888.

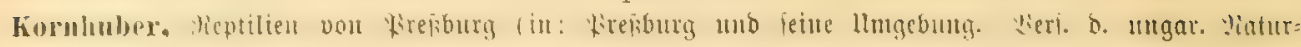
jorjacter, lireşurg 1865).

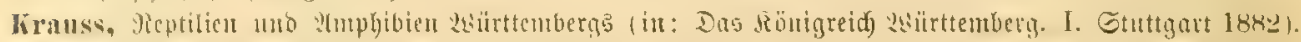

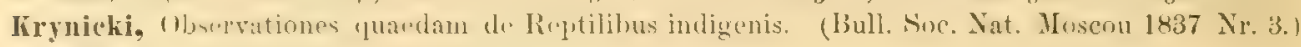

Kuhl, Seiträge zur Soologie. Frantiurt 18:0.

Lacépède, Histoire naturelle des quadrupèdes ovipares et des serpents. Paris 1787/88.

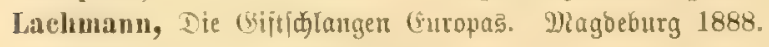

Landois, II., Die Wiefffär. Mioldartent. (Werf. Miat. Wer. D. Mheint. uno vseftf. 1872.)

- IGieritimment. Freiburg i. 13.1874.

- Rade u. Westhoff, Weftiatens TGierleben, 3. 230. Faberborn 1892.

Lataste, Faune herpetol. de la Gironde. (Act. Soc. Lin. Bordeaux, XXX, 1876.)

- Catalogue des Batrac. et Rept. de Paris. (Ibidem.)

- Accouplement des Batrac. anoures. (Bull. Soc. Zool. France 1877. Paris 1877.)

- Tentatives d'llybridation chez les Batrac. anoures et urodèles. (Ibidem 1878.)

- Etudes élément. S。 la faune herpetol. francaise. (Bull. Soc. d'Et. Sc. Nat. Nimes 1878.)

- Observations herpetol. dans 1. Hautes-Pyrenées. (Revue intern. Sciences. Paris 1879.)

- Batraciens et Rept. recueillis en Chine par Collin de Piancy. (Le Naturaliste 1880. Paris.)

Latreille, Hist. nat. des Salamandres de France. Paris 1800.

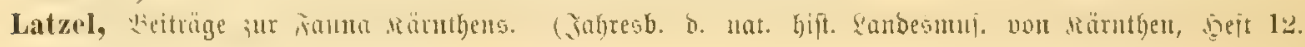
Rlagenfurt 1876.)

Lanrenti, Synopsis Reptilinm. Viennae 1768.

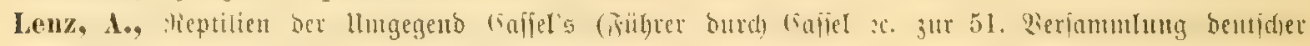
Yaturforider; (safiel 1878).

Lenz, H. 0., Gdylangentunde. (5otha 1832.

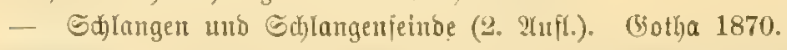

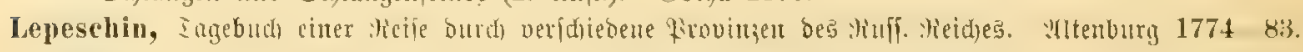

Lesson, Cat. Faune Charente Inférieure. (Act. Soc. Lin. Bordeaux 1876.)

Lessona, Studi s. Anfibi anuri del Piemonte. (Atti d. Accad. Torino 1877.)

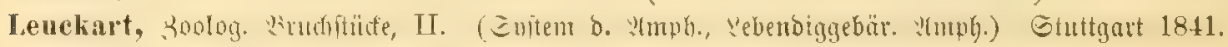

Lennis, Synopfis des Thierveid). Dannower 1875; 3. 2ufl. 1883.

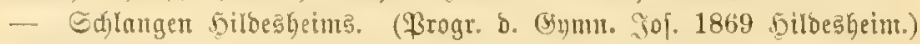

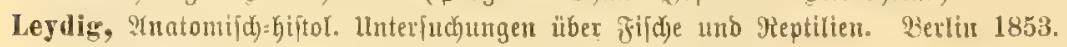

- Etigje zu einer Fauna Tubingensis. Stuttgart 1867.

- Die Mioldje Der mürttemberg. Tauna. Berlin 1868.

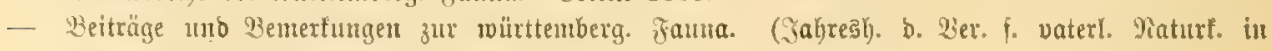
württ., XXVU. Stuttgatt 1871.)

- Die in Dentidano rebenden Irten ber Santer. Tübingen 1872.

- Neber bie Jant einheimif(d)er Ophibier. 2onu 1873.

- Die affgemeinen Bebedungen ber Tmphibien. $230 u n 1875$.

- Die mutren Batrabiter ber beutidgen Fauna. Bonn 1877.

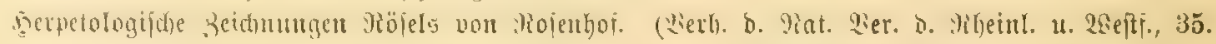
马ałrg. 1878, Bontr.)

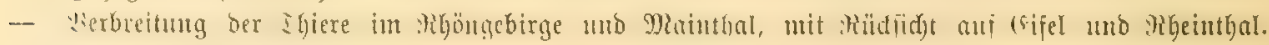
(Dajo, 38. Jahrg., 1881.)

- lleber bie einhetunijont Gajlangen. Frantiurt 1883.

-- T'riton helv. u. Rana agilis. Wiürzurg 1888.

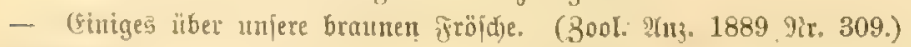

Lichtenstein, Nomenelator Rept. et Amph. Mus. Zool. Berol. Berlin 1856.

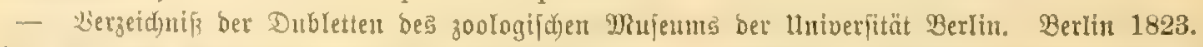

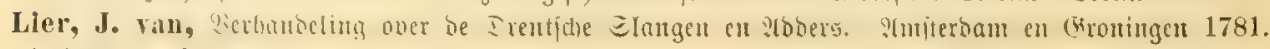

I.lljeloorg, Bidrag till Corra Rysslands ech Norriges Fauna. (Kigl. Vet. Acad. Handl. 1850.) 


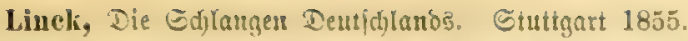

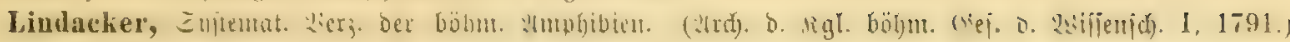

Linné, Oelïndska och Gothländska Resa 1741. Stockholm u. Upsala 1745.

- Wäsgötha Resa. Stockholm 1747.

-- Systema naturac I. Editio VI Holmiae 1746; ed. X 1758; ed. XII 1766/67.

- Fauna suecica. Stockholm 1746. Edit. II: 1761. [Retzius 1800.]

- Museum Adolph. Frideric. Holmiae 1754.

- Amocnitates academicae, s. Dissertat. variae. Erlangae 1785-90.

Löwis, 0. r., Die Reptilien Rur=, Qiv= 11. (Ffthlanbs. Mitga 1884.

Lopez Vieira, Catalogo dos Amph. e Rept. de Portugal. Coimbra 1887.

Lorek, Fauna Prussica. Röntģ̄berg 1834.

Lortet, Poissons et Reptiles du Lae de Tibériade. (Arch. Mus. d'hist. nat. Lyon III. Lyon 1883.)

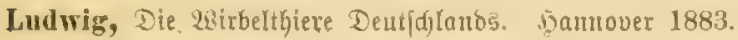

Lüneburg, Betträge jur fauna bes Jïnftentfums. (\&üneburg 1861.)

Machado, Erpetologia Hispalensis. (Revista Cienc., Lit. y Artes [Serilla] VI. Madrid 185y.

Malherbe, Zoologie de la Moselle. (Statist. d. 1. Moselle. Metz 1854.)

Marcotte, Les animaux rertébrées de l'arondiss. d'Abbeville. Abbeville 1861.

Marcgrar, s. Piso.

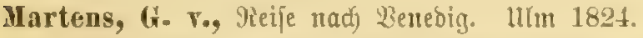

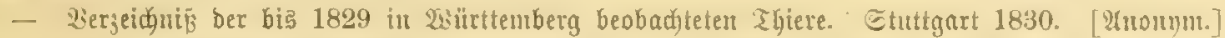

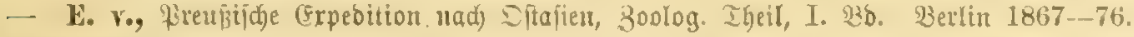

Massalongo, Nuovo genere di Rettili della Prov. Padovana. (Ann. Sc. Natur. Bologna 1853.)

-. Saggio di un'Erpetologia veronese. (Mem. Accad. Agric. Verona 1854.)

- Catal. dei Rettili delle Prov. Venete. (Atti R. Ist. Venete. Venezia 1859.)

Matthioli, Commentarius in libros sex Dioscoridis. Venetiis 1558.

Manduyt, Herpet. de la Vienne. Poitiers 1844.

Medicus, Thiembelt der Rhetuplal3 ('心avaria 1867.)

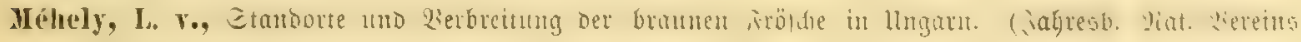
Magbeburg 1890.)

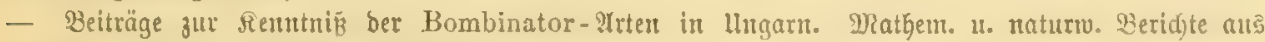
Itngart, BB. X. Butoapeît 1892.

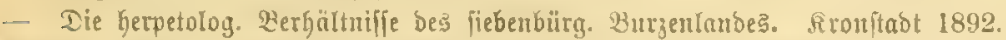

Meissner, Minfeum. Dex Tiaturgejdytde Jelvetients I. Sern 1820.

Mejakofr, Observ. sur 1. Rept. d. Gour. Wologda. (Bull. Soc. Nat. JLoscou XXX, 1857.)

Méla, Vertebrata Fennica. Helsingissae 1882.

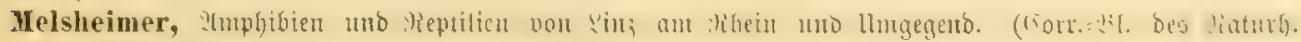

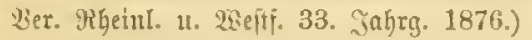

- 3ur Maturgejdidfte des Salam. maculosa. (2ajelfit, 44. unt 46. Jahrg.)

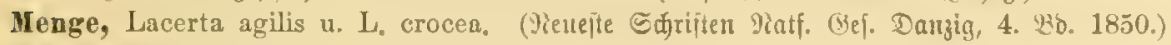

Menétriès, Catal. raisonné des objects de Zoologie recueilles dans un voyage au Caucase. Petersburg 1832.

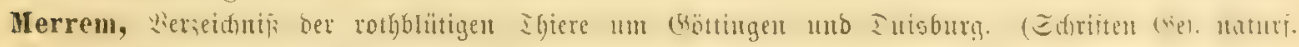
Freunbe. IX. Berlin 1789.)

3eriud) eines Єnjtems ber 2Impgibien. Mrarburg 1820.

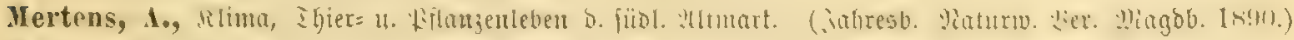

Metaxa, L., Monografia dei Serpenti di Roma. Roma 1823.

Meyer, Synopsis Reptilium. Göttingae $\mathbf{1 7 9 5 .}$

- 2orjellung aflerbano Thiere. Märıberg 1749.

Michahelles, Jieue fïbeurop. 2mmbibien. (צis XXIII. 1830.)

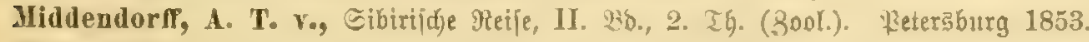

Milde, Heber Zootoca vivipara. (Serh. zool. = bot. Gef. Wisten XX. 1870.)

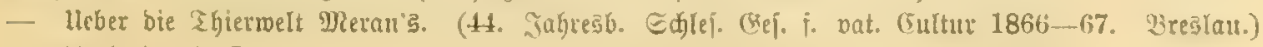

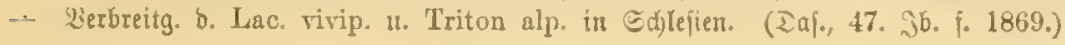


Millet, Faune de Maine-ct-Isoire II. Angers 1828.

Milne-Edwards, Recherelers pour survir al l'histoire des leczards. (Ann. sciene. natur. XV1. 18z?.)

Miua-Palumbo, Studi sui Rettili Siciliani. Palermo 1863-66.

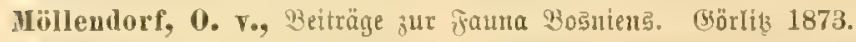

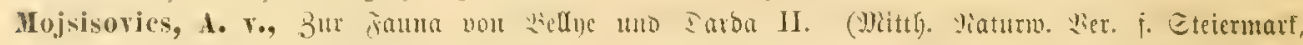
Jahrg. 1883. (Wraz 1884.)

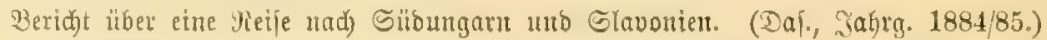

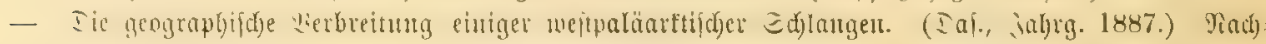

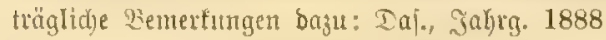

- 30ogeogr. Trotizen über Sïb=llugarm. (Daf., Jahrg. 1888.)

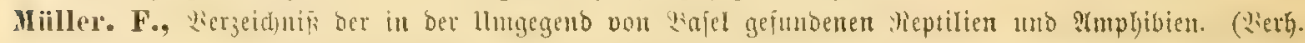
แatur. (6ер. Bajel, 38. VI, 3. 5. 3ajel 1878.)

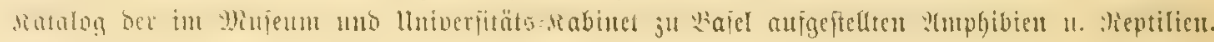
(Daj., Bbo. VI, 4. hejt. 1878.)

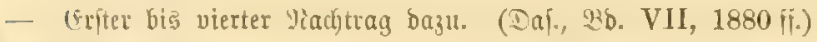

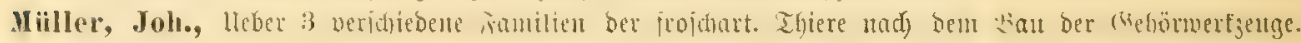
(3)is 1832.)

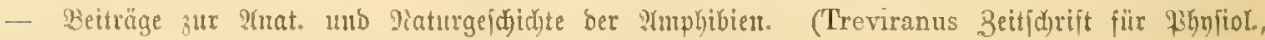
Tom. IV. 1832.)

Miiller, 0. F., Zoologiae Damicae prodromus. Havniae 1776.

Nardo, Dom., Prospetti sistem. d. Animali d. prov. Venete. I. (Atti R. Ist. Veneto. Venezia 1860.)

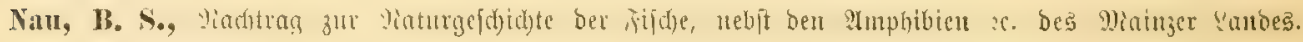
Miàilz 1787.

Nelıring, Cinige Notigen über D. Sorf. v. Lae. vir., Alytes, Pelobates. (Boor. (Garten 1880.)

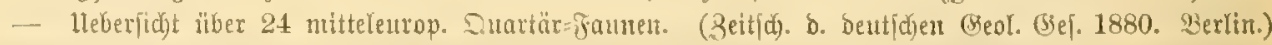

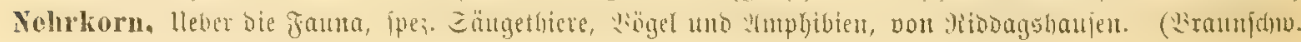
¿agebl. $187292 x .12$.

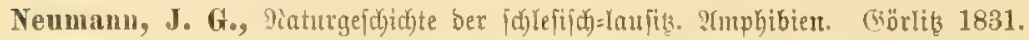

Nilsson, Skandinarisk Fauna, III. Amfibierna. 2. Aufl. Lund 1860.

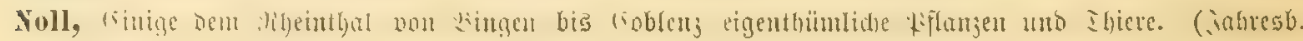
JrantF. 2:. F. Geogr. 1876.)

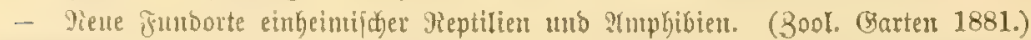

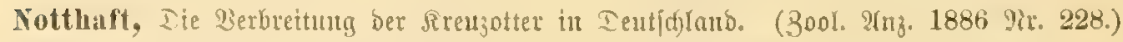

Niisslin, Das Grokg. Baben I: TGiermelt. Rarłambe 1883.

Ogerien, Hist. nat. du Jura. Zoologie viv. t. III. Paris 1863.

Oken, Sugemeine Naturgeididite, VI. Etuttgart 1836.

Olirier, Faune du Doubs. (Mem. Soc. d'Emul. Doubs. Besancon 1883.)

- Faune de l'Allier I. (Bull. Soc, d'Emul. Allicr 1880. Moulins-Paris.)

Oppel, Oromurgen, famitien uno Battungen ber Meptitien. München 1811.

I’agenstecher, Janobucly D. Soologie. Berlin 1881.

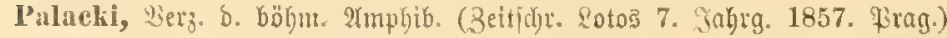

Pallas, Spicilegia zoologica. Berolini 1767.

Meije burd) veridjiebene ßroviuzen bes xuffild)en Meidhes. I. Reters̆burg 1771/72.

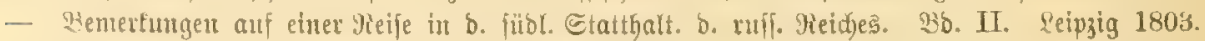

- Zoogranlia rosso-asiatica. III. Petropoli 1831 (1811 gedruckt).

Pavesi, P., Materiali p. una Fauna d. Cant. Ticino. (Atti Soc. Nat. Milano XVI.) 1873.

Payot, Veuance, Erpetologie, Malac. et Paléont. d. env. du Montblanc. (Ann. Sc. phys. et nat. Lyon. VIII. Lyon 1864.)

Penmant, British Zoology, II. Warington 1776.

Petiver, J., Opera histor. natural. spect. Londin 1764.

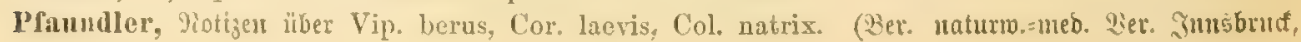
3alfrg. 17. 1887.) 
Piso et Marcgrar, De Indiac utrinsque re naturali et med. Amstelod.; 1658.

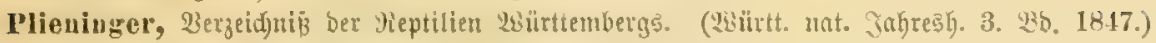

Poiret, Meife in bie Barbatey. I. Ctraburng 1789.

Radde, Franta uto flora bes fïbr. (5ajpigebietes. S'eipzig 1886.

Rafinesque Schmalz, Caratteri ... Sicilia. Palermo 1810.

Ramys y Ramys, Specimen animalium etc. in Insula Minorea frequentiorum. Magone 1814.

Rathke, 3ur Jaun D. Krmm. 1840. (Jem. Acad. Imp. Sc. U. Petersburg 1837.)

- Sftpreußs. Frovingialbl. $1848 \mathrm{ff}$.

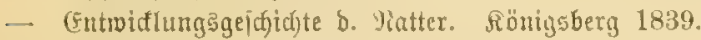

- Heber bie Entridflutg ber Gdjilsfröten. Braunjdmeig 18.18.

Ray, Synops. meth. anim. quadr. et serp. 1713.

- Catalogue de la Faune de l'Aube. Paris 1813.

Raulin, Descript. phys. ... de Crète. II. (Act. Soc. Linn. Bordeaux 1869.)

Razoumorsky, Hist. nat. du Jorat. I. Lausanne 1789.

Réguis, Hist. nat. d. Vertébrés d. I. Provence. Poissons et Batraciens. Marseille 1882.

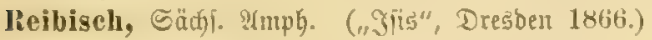

Reider Halin, Fauna boica. Nürnberg 1837.

Retzins, Fauna suecica I. 1800.

Riegler, Die Türtei mo igre Beroohner. I.

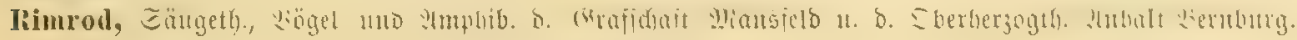
(3er. D. naturm. 23er. D. Şarges fïr 1840/41.)

- u. Saxesen, Tiaditrag baju. (Dof., f. 1841/42.)

Risso, Hist. nat. de l'Ẻurope meridionale III. Paris 1826.

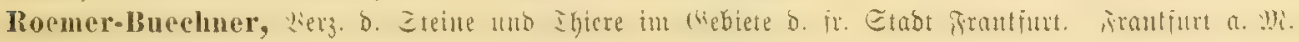
1827.

Roesel, Hist. nat. ranarum nostr. Norimbergae 1758.

Rochebrune, Cat.d. animaux d. 1. Charente. (Act. Soc. Linn. Bordeaux XIL.)

Rondelett, Libri de piscibus marinis. . . Lugduni 1554

Rosenhauer, Die Thiere Intontuftents. Ertargen 1856.

Rozet, Voyage dans la régence d'Alger. I.

Rusconi, Hist. nat., développ. et metam. de la Salamandre terrestre. Paria 1854. (Onvr. posthume.)

- Amours des Salam. aquatiques. Jilan. 1821.

- Déreloppement de la Grenouille comune. Milan. 1826.

Sabanejew, Uralijge 2tmphibier. (Bull. Nat. Moscou XLIV. Nr. 2. 1871.)

Sadelin, Fauna Fennica. Aboe 1819.

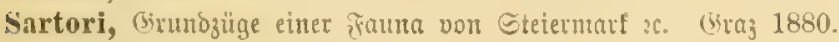

Savi, Descriz. d'alcune nuove spec. di Rett. ital. (Giorn. lett. Pisa Nr. 102. 1839.)

Saviguy, Reptiles de l'Egypte. (Paris 1818.)

Saxesen, s. Rimrod.

Searpa, Cat. di Rettili ed Anfibi del Trivigiano. (Atti Soc. Ven.-Trent. Padova, Vol. II. 1874.)

Schäfer, Mtofelfama. Trier 1844.

Schifr, M., Remarques inédites (in: Thomas, Note s. denx. espèc. d. grenoull. 185̃5).

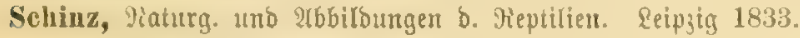

- Europäliche Jauna, II. Stuttgart 1840.

- Fauna helvetica. I. (Dentfdifrt Gdyreiz. Gej. f. 2atum. I., 1837. Bafer.)

schlegel, H., Essai sur la physion. d. serpens. Amsterdam 1837.

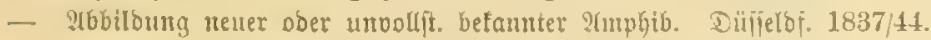

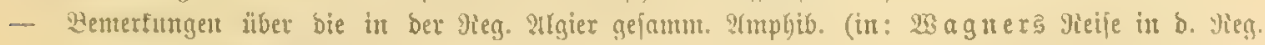
t(tgier, I. Leipjig 1841).

- De Dieren tan Nederland, I. De Kruipende Dieren. Amsterdam 1875.

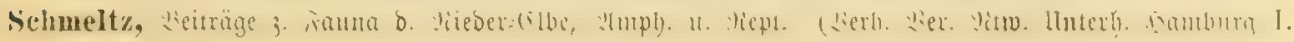
1875.) 


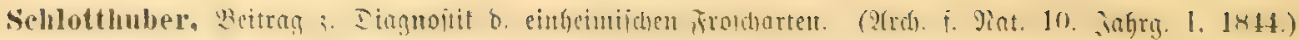

Schneider, Hist. amphibiorum natur. Jena 1799-1801.

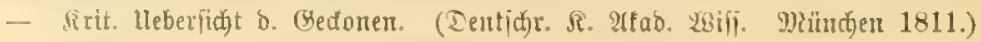

- stugem. Taturgein. ber Sdjilbfröteu. Seipsig 1783.

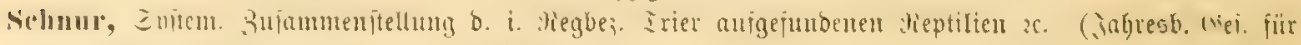
แï(3. Jorid). Trier 1857 . Trier 1858.)

Schöpf, giaturg. ס. Gojilbtröten. Erlangen 1792.

Schrank, Naturbiftorifde Briefe ïber Seiterr., Salzbg., Bafiau sc. I. Galjburg 1785.

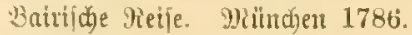

- Fanna boica. 1. Nürnberg 1798.

Schreiber, Herpetologia europaea. Braunschweig 1875.

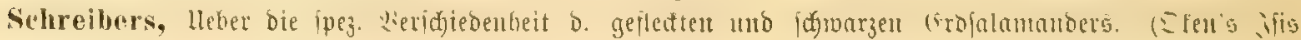
1833.)

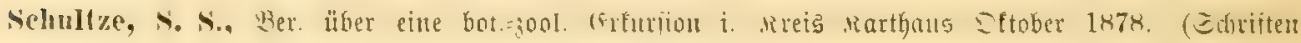

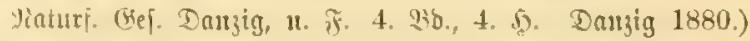

Schulz, J. H., Fruna marchica. Berlin 1845.

Seliulze, E., Amphibiorum europ. enumeratio. Ed. II. Lipsiae 1892.

- u. Borcherding, Fanna saxonica. Tmphib. U. Meptilient. Jena 1893.

Sehwenckfeld, Theriotropheum Silesiae, Lignicii 1603.

Scopoli, Iter tirolense (in: Scopoli, Annus historico-naturalis. Vol. II. Lipsise 1769.

Seba, Thesaurus rerum naturalium locupet. 1734.

Seetzen's Reijen burd Snrien, Faläitina zc., Kerausg. v. frr. Rruje. 1859.

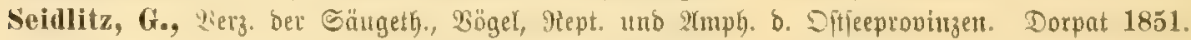

Selys-Longehamps, Faune belge. I. Liège 1842.

Semper, Die natît. Exiftenjbebingungen D. TGiere. I. Seipłig 1880.

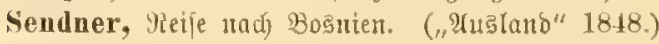

Seoane, Reptiles y Anfibios de.Galicia. (Anal. Soc. Esp. Hist. Nat., T. VI. Madrid 1877.)

Sequeira, Distribucao geogr. d. Rept. em Portugal. . (Bol. d. Soc. Geogr. Lisboa VI. ser. Nr. 6. Lisboa 1886.)

Shaw, General Zool., III. Amphibia. London 1802.

Sheppard, Descr. British Lizards u. new Brit. Viper. 1804.

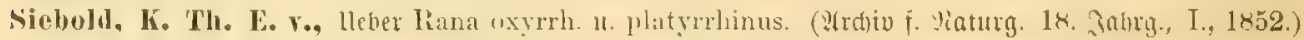

- Observat. de Salamandris et Tritonibus. Berolin. 1828.

Siebold, Ph. F. v., Fauna japon., Reptil. Lugd.-Batav. 1838.

Spallanzani, lleber b. thieri|d)e Meproduttiontônermögen. 1768.

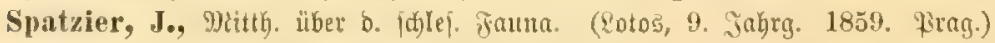

Spix, Species novae Ranarum. Jonachii 1840.

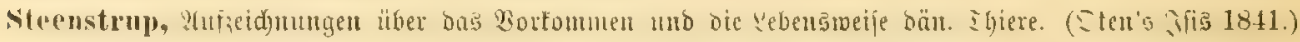

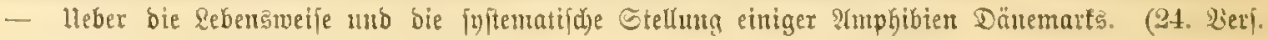
beuticy. Maturf. Riel 1846.)

- Bidrag til Bestemmelsen af de nordiske Arter af Rana og Bufo. (Videnskab. Meddelser f. d. naturhist. Fos. i. Kjöbenhavn 1869.)

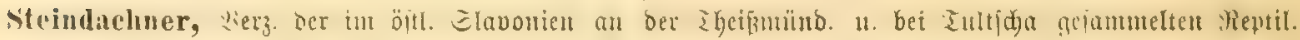
(Werf. zool.=bot. (Ge Le Lien, XII. 1863.)

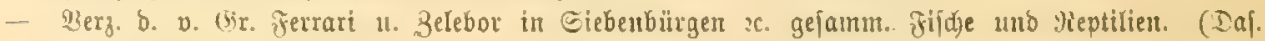
XIII., 1863.)

- Werg. ๖. v. 5. Manu bei Brufja gejamm. Rept. (Daj.) Meptilien แ. Amphibien in llnget u. Rotjdy's "Ynfel (Syperu". Witen 1865.

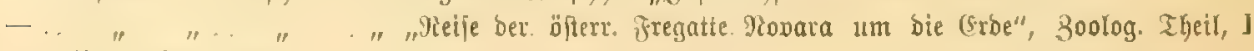
H. Whitent 1867.

Steinheim, Die (intwifelung ber Fröldye. Jamburg 1820.

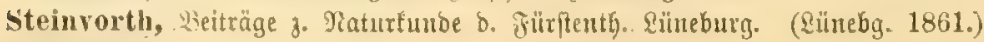

Storeh, Catal. Faunae Salzburgensis. (Mitth. Gef. f. Galjb. Eanbest. VII. 1867.) 
Stranch, Essai d'une Erpetol. de l'Algirie. (Mem. Acad. Inp. Sér. Petersbourg, 7. ser.. 'T. IV. 1862.)

- (5helonologifde Stubien. (Daj., V. 1862.)

- Vertheilung ber Echitbtröten ïber ben (Erbball. (Dof., VII. 1865.)

- Ennopfis ס. Wiperiber. (Daf., XIV. 1869.)

- Mevilion bet Salamanbriben=Grattungen. (Daj., XVI. 1870.)

- Die Edjlangen bes 9iulf. Reidjes. (Daf., XXI. 1873.)

Stricker, Beiträge 3. Wiologie §. Batradjiex. (Berb. zool.bot. (Gef. WBien XVL. 1866.)

Studer, Theophil, Reue Gpegies von Tropidonatus. ('ienner Mittheilungen 1869.)

Sturm, Jac., Deutidje Tauna, II. Die Qmphibien, 6 befte. Tiümberg 1797-1828.

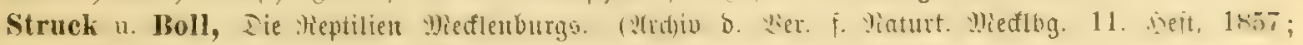
Tactitrag im 13. Steft, 1859.)

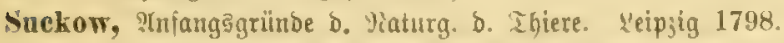

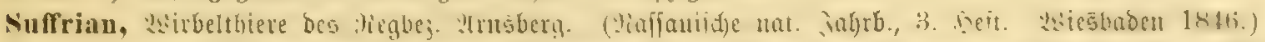

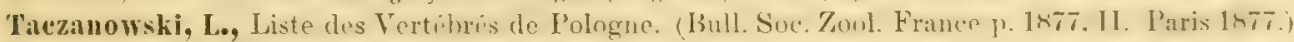

Tappe, Fie einheimijden (Eibed)fen. (Difert. Bonut.) Dberhaujen 1868.

Taslé, Cat. đ. Jammif., Ois. et Reptiles d. Dép. đu JIorbihan. Tannes 1869.

Tehihatcheff, Faune de l'Asie Yineure. Yaris 1856.

Thomas, Note sur deux espèc. de grenouilles. (Ann. Sc. Nat., 4. Serie, Zool. T. IV, 1855.)

Thompson, Additions to the Fauna of Ireland. (Ann. a. Jag. Nat. Hist. VII. London 1841.)

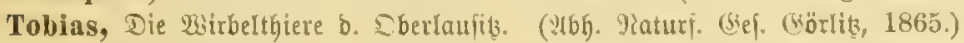

Tourneville, Etude s. les Vipères. (Bull. Soc. Zool. France p. 1881. VT.)

Tomnson, Observationes physiol. de amphibiis. Göttingae 1794.

Tsehudi, (STafiffitation ס. Batrabier. (Mem. Soc. Nat. Neuchatel 1839.)

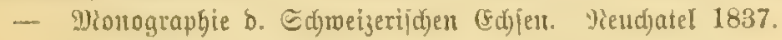

- TGierTeben §. Alpembelt. Seipsig 1865.

Verany, Zoologie des Alpes marit. (Statist. d. Alpes mar. p. MI. J. Roux. Nice 1862.)

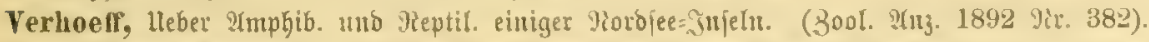

Viand-Grand-Marais, A. Etudes mid. sur Lu serpents de la Vendéc et d. l. Luire-Intirienre. St. Germain 186769 .

Vieillot, Faune francaise, Paris $1820-30$.

Vinciguerra, Rettili e Batraci di Eugano racc. da Modigliani. Genova 1892.

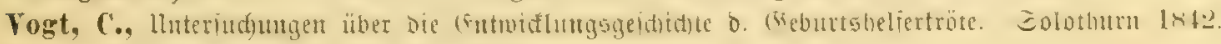

Wagler, Die 2tmphibien. Deit 1. 1820.

- Matürlides Eyftem b. Imphibien. Mündjen u. Guttgart 1830.

- Descriptiones et icones amphibiorum. München u. Stuttgart 1833.

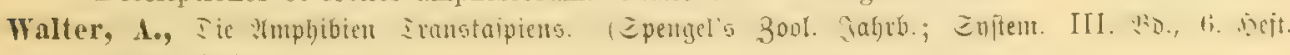
รenเ 1880.)

Weber, Ed., Babijaje Edylangen. (21. Jahteş. MRannfeimer 2ier. f. Raturf. 1855.)

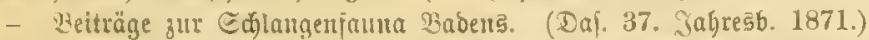

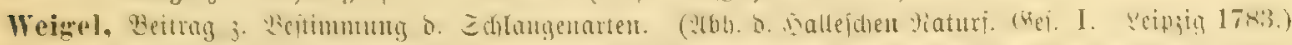

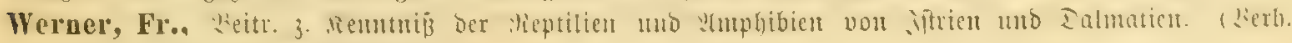
D. zool. =bot. (iej. Wien 1891.)

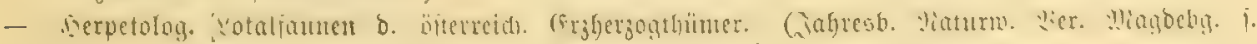
1891.) Taătrag Dazu baj. 1892.

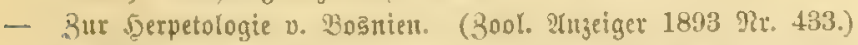

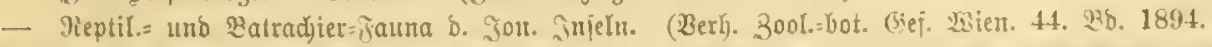

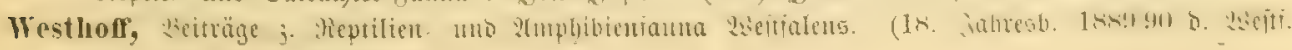
Prov. 2er. Maunjter 1890.)

- Die geogr. Berbr. von P. berus in zieitiaten «c. (Daf., 19. Ber., 1891.)

- Neigung gu Rafiebiloungen bei Rana arvalis æc. (Eof., 20. Ber., 1892.)

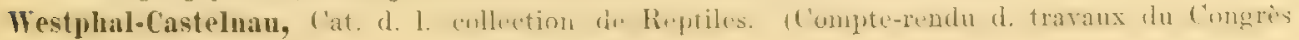
S'e. de France 1868. Montpellier 1870.) 


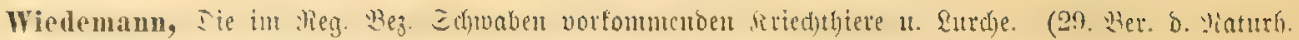
Wer. आugฐ̆butg 1887.)

Wiedersleim, IR., Salamandrina perspic. u. Gentriton fuscus etc. Genua 1875.

Wiegmann, Herpetol. mexicana. I. Berlin 1834.

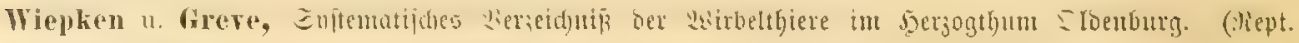
แ⿰丿丶⿱⿴囗十丌

Wolf F. Stum.

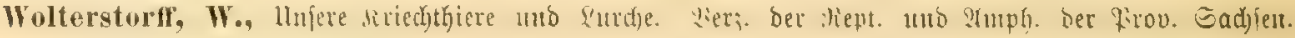
balle a. b. G., 1888.

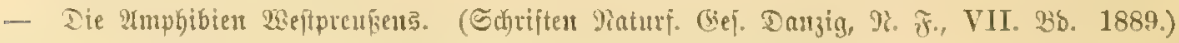

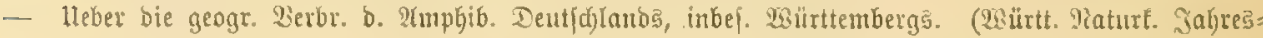
hefte 1890.)

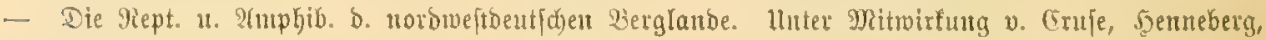

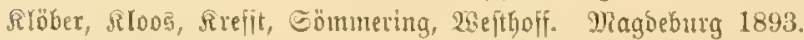

Wulf, Ichthyol, cum amph. regni Borussici. Regiomonti 1765.

Wurfbain, Salamandrologia. Nïrnberg 1683.

Wyder, Essai s. Hist. nat. des serpens de la Suisse. Genève 1826.

Zawadzki, Fauna d. galiz=butouv. 23irbeltgiere. Stuttgart 1840.

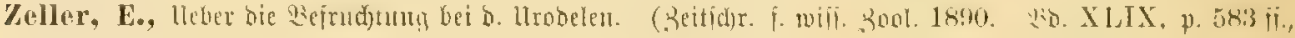
Bertddtigung p. 737 fi.)

Zenker, Batrachomyologia. Jena 1825.

\section{Drucfęler: Beridtigungen.}

\begin{tabular}{|c|c|c|c|c|c|}
\hline ite 5 & zile $t$ & lies: & $b 0$ & ftat & \\
\hline 55 & "24 & " & Geberolepiooten & " & Gederoboten. \\
\hline 66 & " 31 & " & ausgejtatteten & " & ausgeftatter. \\
\hline 233 & " 45 & $"$ & 1828 & " & 1428. \\
\hline 238 & 1146 & "I & Phrynocephalus & , & I'hynocephalus. \\
\hline 290 & " 28 & " & b活 & $" \prime$ & 9iti. \\
\hline 304 & " 21 & " & jujagentoex & " & љијаmmen々ängenben. \\
\hline 327 & 1140 & $"$ & ober & ", & uाb. \\
\hline 330 & ", 21 & " & dumfrisiensis & " & dumfriensis. \\
\hline 343 & , 33 & , & im शgăı & ", & 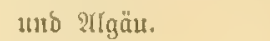 \\
\hline 356 & 1124 & $"$ & 41. (5ixab & " & 31. (5rad. \\
\hline 500 & $11 \quad 29$ & $"$ & 499 & " & 399. \\
\hline 470 & " 6 & & . & Gert. & \\
\hline
\end{tabular}




\section{Derjeichnis der 2lbbildumtgen.}

\section{a. จuf Torbentuicli.}

Iajel 1. 1. Graue Grbfröte; 2. Girine Rröte; 3. Jiteuztröte; 4. Geburtaheliertröte.

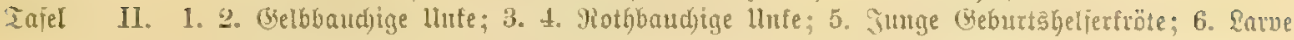
derjelben; 7. Sunge Sinoblaudjströte; 8-10. Sarven berjelben.

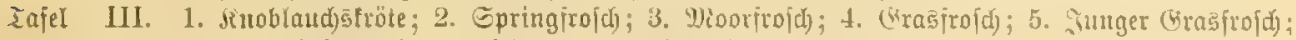

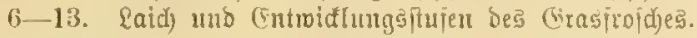

Tafel IV. 1. 2kafferfrofd); 2. Seefrofd (Rana escul. ridib.); 3. Raubfrofd.

Tafel V. 1-3. Earven 4. 4. erwadjentes Thier bes Fenterfarmanbers; 5. Ilpen=Ealamander; 1 .

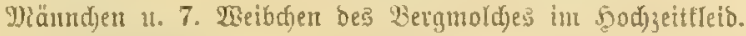

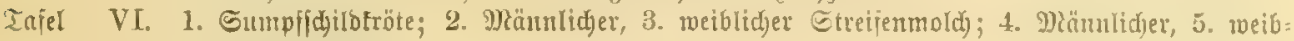
(icher Reifteumold).

zajel VII. 1. Bäriflututter;2. Mingelnatter.

Tajel VIU. 1. Tesfulap: Fatter; 2. Glattnotter.

Tafel IX. 1. Beibdjen, 2. Miämdhen, 3. fdjwarze Gpielart ber Rrenzotter.

Tajer X. 1. 2iper; 2. Niännlidge Snaragb=(Eibedje im 5oodjeittleib; 3. Wieibdjen uno 4. junges EGier berjelbent.

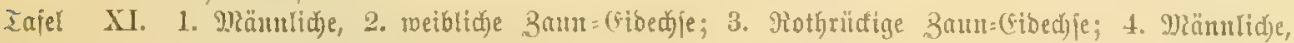
5. weiblidje 9)iauer=(sibechje.

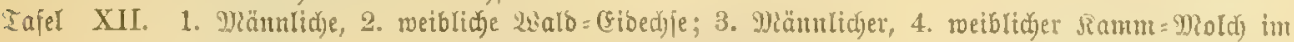

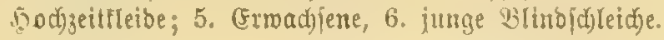

Fighur

1. Rnodhengetüft ber Єdjilofröte.

2. Müuferidjale b.

3. Rautchidjale b.

4. (jriedjijfe Edjilbfröte.

5. Farbzellen ber irrofdhant

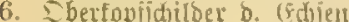

7. Ropfletterticjilber b. (6djert . . . . . 59

8. Unterfopfichilder b. " . . . . 61

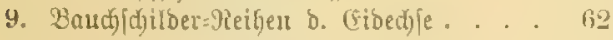

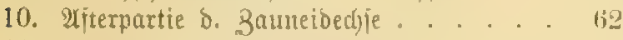

11. Mopiplatte b. Emarago=(50ed)je ... 115

12.

13. Ropilieite

14. Sopfunterfeite b.

$"=0.0118$

16. Ropriditber b. Bauneibedje .... . . 147

17. Afterpartie b. " . . 148

18. నoplidjilder ber 2Ealbeibed\}\{e . . . 168

19. Sopiplatte D. Diautereibedje . . . . 189

20. Ropifeite b. " . . . 190

21. Reglgegeno b. "

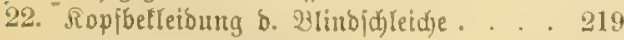

23. Efelett b. Sdi)lange. . . . . . 241

24. Sđuppenreifen \$. Jatter . . . . . . 246 b. Sin Tcrt.

Site | Figur Eeite

7 25. Ropjplatte ber Reŝtulap= Matter . . . 247

$8 \mid$ 26. Siopfieiteajidilber b. Yatterm . . . . 248

$9 \mid 27$. Interfopfidjiloer b. Aestulap=92. . . 248

28. Waudjilfilber o. gelbytüneat Patter . . 248

29. 3ud)tuapi (Tatteru=(fier) . . . . . . 670

30. Jopffdilber b. Ningeluater . . . . 275

31. " "2iüfelmatter . . . . 296

32. Wipermatter . . . . . . . . . . 300

33. sopfiffilder 8. Nesfulap=ข2. . . . . . 309

34. " " (3) ". . . 322

35. (3iftapparat §. Biper . . . . . . . 337

36. sopibefleibutg o. Streujotter . . . . . :3.;

37. siörperjoluppett " " . . . . 339

38. Titerpattie 8. Wiper . . . . . . . . 339

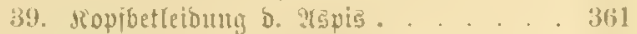

40 Durdjidjutift D. Erojdhaut . . . . . . 372

41. (5hromatopforen o. ifrojdhant . . . 3N1

42. Sfelett bes jroldes . . . . . . 3865

43. (Futudufung be jtofdjlurd)es. . . . 395

44. ". . . 37olches . 395

45. Jiäunlidjer Iaubirojd . . . . . . 512

46. Broitterbildung bein 9):oId) . . . . 601

47. Sefajledtitetie 9holdjlarven . . . . 609 


\section{Regifter.}

$\%$

Ahlepharus 40.237.

- pannonicus 237.

Acanthodactylus 57, 234.

- Savignyi 237.

- Schreiheri 237.

- vulgaris 237.

Acrodouta 41

2tobet 360 .

2tcoculavuatter 259, 271, 272, 308. 652.

Agama sanguinolenta 238.

A panidae 238.

Aglyphodonta 243, 273

Algiroides Fitzingeri 235.

- moreoticus 235.

- nigropunctatus 235

Ulpermolff 6.33 .

\section{शนpenfalauattoer 397.594.}

Ruestriton 633.

Alytes 537. 558.

Alytes Cisternasi 648 .

Aytes obstetricans 397.416 .558$.

Ameiva tiliguerta 216.

Amphibia 371 .

$2 m b$ jibien 371.

Amphisbaenidae 56, 238 .

Angiostomata 241.

Anguis 217.

Anguis Aesculapii 320 . Grecis 320

- Besseri 223. 233.

- licolor 223. 233.

- cinerea 224.233.

- clivica 233.

- eryx 233.

Anguis rragilia 53. 218. 233.

- incerta 226.233

- lineatia 220.233.

Allura 413 .

Areifera 420.

Aspis ocellati 363.368 .

Revietbiver 360.653.

Atropis nigra 188.

b.

Batrachia 371.

Batrachia gradientia 574 . salientia 413 .

Watratrier 371 .

2daunituidie 420.507.

Werg= Eibedie 187.

thernuold) (5:24.

Blanus cinereus 238.

- Sitrauchi 238

Kiafius'idter 9)(old 398.

WLattinnet 239.

Hitudituletue $47,52,64,218$.

Wlinbidhlangen 370
Bomhina fusca 537.

- marmorata 537.

Bombinator 412. 537 .

Hombinator bombinus 543.552 . 656 . Bombinator brevines 552 .

- filecus 537.

- igneus 543. 552.

- ohstetricans 574 .

Bombinator pachypus 543. 656 .

Brachyglossi 216.

Hraune Ir Tijide 422.437.

Brevilingua 68.226 .

Brudjidjlange 233.

virumesmoldi 633

Hudeluale 230.

B $u f 0 \quad 4$ tit $t$.

Bufo, alpinus 472. 481.

- arahicus 494.

- aquaticus mac. fuseis 536 .

Bufo calamita $382.467,494,655$.

Bufo cinereus 480 .

- colehicus 481 .

- eommunis 481 .

- commutatus 481 .

- companisonus 574 .

- cruciatus 507.

- crucigera 494 .

- cursor 507.

- ferruginosus 480 .

- fuscus 536 .

- gargarizans 481 .

- japonicus 481. ohstetricans 574 .

- jalmarum 481.

- portentosus 507.

- praetextatus 480.

- Reeseli 480.

- ridibnndus 436

- roseus 472 .

- salsus 480.

- Schreherianus 494.

- sitihnndus 494.

- sininosus 481 .

- terrestris 480 . - foetill. 507. - major 480.

- tuherculosus 480 .

- variahilis $\$ 94$.

- Fentricosus 480 .

- vespertinus 537 .

Bufo virisls $381,382,401,467,481$. $4913,507,655$.

Hufo vulgaris 467.480 .

Bufo vulgaris var. 574.

Bufonidae 420,466 .

\section{6.}

Caducihranchiata 575.

Caecilia typhlus 233.
Caecilia typhlus graecis 233.

- vulgaris 233.

Calamitil arhoreus 519 .

Calamitae 507.

('aliscertula 200

Callopeltis flavesceus 320 .

Caudata 574 .

Chalcides 237.

- Bedriagai 237.

- limentus 237.

- ocellatis 23r.

- tridactylus 237.

Chamäleon 55. 239

Chamaeleo vulgaris 240 .

Chelonia 6 .

Chersidae 10

Chioglossa Insitanica 649 .

Cistrido eurowaea 37.

- hellenica 15. 37.

- lutaria 37.

Clemmys caspica 37. - lutaria 37.

Coelopeltis 273. 369 .

Coluber 308 .

Coluber Aesculapii 308, 320, 652.

Coluber arabicus 278. 294.

- asclepiadeus 320.

- Aspis 308.

- austriacus 336.

- Berus 360. 368.

- bicephalus 257.

- bilineatus 294.

- bipes 294.

- caucasicus $325.33 t$.

- Charasii 368.

- Chersea 341, 36n. 368.

- coeruleus 360.

- coronella 330.

- cuprens 325. 330.

- dione 369.

- elaphoides 298, 308.

- ferrugineus 336.

- Havescens 320.

- frgax 311.

- Gabinus 308.

- griseus 308.

- Gronovianus 278

- helveticus 294.

- hydrophilus 308.

- hydrus 293. 308.

- laevis 332. 336.

- leprosus 311.320 .

- longissimus 320 .

- melanis 341.360.

- $\operatorname{minax} 279$.

- minutus 294.

- murorum 279

- natrix 294.

- _ var. $\beta 320$. 
Coluber niver :

- paeilera 336 .

pannouicus 320. mapyre

- persa 204.

pouticus 224, 30s.

Prester $3 \nmid 1,360$.

yuadrilineatus 332, 349.

quaterrauliatus 369 .

Reti 3 ris.

reticulatus 308 .

lomanus 311 .

- sillumates 369.

- Scopolianus 294.

Scopoli $310,320$.

- sentatus 294. 308.

seut abil. 225, squam, cant. p. 78. 320 .

Sertua $341,360$.

- Vellmanui 32u.

siculus 279,294

tesspllatus 298.

retragonle 336.

thuringiacus 336 .

-. Tlejua 360.

-. torquatus 294.

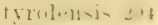

rersicolor s3ii.

Vipera $30 \mathrm{~s}$

- anglorum 360

viperinus $294,30 \%$

-. Fulgaris 204.

folubrislae 271 .

Coronella 321.

Coronelln anstrinca 321, 336 . 15:2.

Coronella grrondica $3 \pm 6.369$.

- italica 32.

- lievis 33i.

- tecmpllatia 30x.

Cultripes minor 537.

\section{i.}

Dendrobyas arborea 519.

- sardir 511.519

- viridis 310.

Discoglossidae $420.53 \%$.

Biscoglossus nictus 648 .

Iormidumang 239 .

\section{(5.)}

Futadata 413 .

Echidna Aspis 368 .

Echidnoiles trilamina 360 .

Echis americamus 3 fio.

U⿺ d)

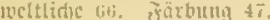

(E) te (Fidedien 50. Gs.

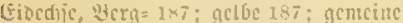

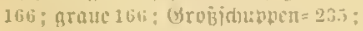

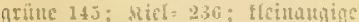
$16 t ;$ lebendabuarenc 187 ; y) a uset: 18 ; iajranbaudiqe 187; Etenven= $230 ; \sin a x a n D=114 ; 2 b a 1 b=$ 167: wicien=187; $3 a n n=145$.

Ciochient=Vinter 369.

Elaphis Aesculapii 320.

- thavescens :20.

Emydae 10.

Emys 11.

Enys caspica 37.

Emys enropaea 10. 950

Emys hellenica 15, 37.

- Inftmami 15.37.

- leprosia 37.
Emvs lutaria 37.

- pulchella 16. 37.

- Sigriz 37.

- titrfia 29.

Erolrete 40 b.

(Fromold) 594.

Erojalamumoer 594.

Erotritolt 649.

Eremias arguta 236 .

- Telos 230 .

- variabilis 71.230

Eryx plivicus 233.

- jaculus 370.

(Exzichleide 237

Euproctus montants 649 .

- pyrenaens 649

- Rusconii 012.

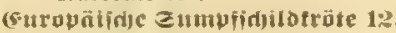
Eurystomata 241 .

\section{is.}

Fademold 64 s.

Fraraglionte (Fidedic \&4.

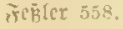

Fetserbrotse 542

jevertröte 542

Fetcrmold) 594.633

Fenerstter 3 bio.

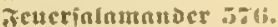

Firmisternia 421 .

Fissilingua 67 . 68 .

Frumjentruger 237.

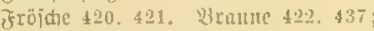
(srüne 122: 20110 $=437$

Enthic februft $=464 ;$ Etarrbruit $=421$; inaiīer $=422$.

îroid) (orattulg) 49.50,421.

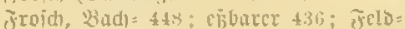
459 ; (1) $x a=437$; grümet 43 . becfent=519; $2 a 11 b=507 ; 92 \ldots$;

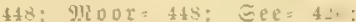

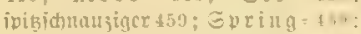

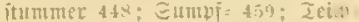

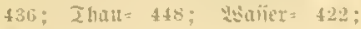
Lietter $=519$.

îrojitifröten 51 ?

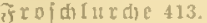

(1).

(Hartermoldt) bito.

\section{(Seuatrteficliferfoute 415.538.}

(i)edortet $5.5,239$

Geckonidae 23.1

(ircifedter yiold) 534.

(iekko aquaticus 624.

- carnifex 624.

- gyrinoides 633.

- palustris 624.

- Salamanima 594.

$$
\text { - Triton bitu. }
$$

(Hetvonatdine tute 543. G5\%.

Geotritoll 649.

(b) atte 9latter 141. 200, 272. 3:21.052.

(ionerylus 237 .

(Hrasfroid) $3 \div 0,3 \times 2,435.6135$.

(brane ströte 4 it:-

(brine Früide $4 * 2$.

(i)rüncอย 145.

(B)rüls=(Fidedric 145 .

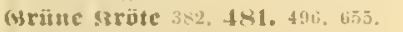

(brïuer firtoid) 436 .

(mrïlt: 14:

tiymnodactylus 239.

(iymmojhthalmus 92.
5.

Duitiefer 239

shatsand =( Sibedien 68 .

50atna 370

5atoun 238.

Sartiourm 233.

5urzmo[d 5:33. 594.

Grajelotter 3 เі0.

Snajelturm 233

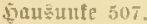

befeniroidg 519

Hemidactylus turcicus 239.

Hemisalamandra 624

Hemitriton 633 .

berzidilange 336.

5öllenotter 360 .

5ujeijen= Matter 369 .

Hyas arborea 519.

Hylas 507.

Hyla arborea 507.

Hyla. sarda 511

- ririlis 519.

- Marictaten 510.

Hylidae 420. $50 \overline{\text {. }}$

\section{งิ.}

Jachidtange 336.

3odbiner 300 .

\section{i2.}

Rammt=2iold) 399, (B1(i.

Hapuzent=Yiatter 369.

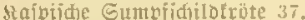

stakenjolange 369 .

Siel-eibedie 236.

Miclridten=Uattern 274

(xnoblnudiotröte 519.65\%.

itrautfialn 145.

Srreu3tröte 38. 40 4. 507. 65.3.

(ireusotter $259,260,324,33 \% 6.33$.

siriectithicre 1 .

siräte, aiduraus 574 ; ficrtragentbs 574 :

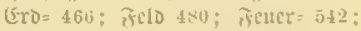

(ife burt helfer = 5.5. gement

450; graue 467; gritne 4.5);

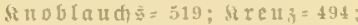

Hant $=480$; Viohr $=507$; finlente

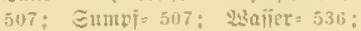

Whediel $=494$.

hàrioten 420 . 4titi.

Sirötcniräidc $\$ 20,519$

STrötenfont 238.

sirott 480

Supicrnatter 360 .

siunierntter 360 .

Aluvierictlange 336 .

Aur3jïagler $6 \mathrm{k}, 216$.

\section{i?}

Quburinthaonuten 66.

Idacerta 68 . 72 .

lacerta aedura 107 .

- atricana 624.

Lacer ta agil is 53. 113. 145. 157, 21ti, - var. $\gamma 18 \overline{7} .651$.

Lacerta aquatiea 624. 640 . arenicols $151,267$.

atra 600.

Bedriagae 234.

bifasciata 200.

hilineata 121. 145.

bistriata $121,145$.

Bronguarti $21 \%$.

- caliscertula $200,216$. 
Lacerfa chalybaea 208 .

- chersonensis 126, 155, 147.

- chloronotia 124. 145.

- elrysogastra 187. cinerea 637.

- colchica 155. 167

- communis 166 .

- crocea 187.

- eyanolaema 121, 145.

- de Jaquin 173.

- Dugesi 102.

- Fidwarsiana 65.

- elegans 123. 154.

- erythronatus 154.

- emropaea 166.

- exigua 167.

- Galotti 87. graeca 234.

- gyrinoides 633.

- helretica 648.

- indigena vir. 166.

- lacustris 624. 633.

- Lanrenti 167.

- Lilfordi 52, 203. major 145.

- Merremi 199.

- montana 172. 158 - mosorensis 234.

Jacerta muralis 113, 188, 652 Lacerta nigra 172.

- ocellata 234.

- olivacea 198.

- oxycephala 198. 234.

- palustris 624.

- pal. var. subt. ignea 533.

- - subt. luter 640.

- praxadoxa 048.

- peloponnesica 235.

- porosia b24.

- praticola 235

- puccina 198.

- pyrrhogaster 187.

- rubra 167

-. quinquevittata 125,145 .

- Salamaurira 583. 594. 600.

- saxicola 197.

- Schreilieri 127.

- Selireibersiana 174.

- sepium 166.

- sericea 167.

- serpa 124. 145. 198

- sicula 124. 145.

smaragdina 123. 145

- stellata 167.

stirpium 151. 166.

- strigata 125. 145.

- sylvicola 155. 167.

- taeniata 640.

- taluríca 52.199. 235.

- tiliguerta 145, 198, 216.

triton 633. 040.

- unicolor 188.

- viridissima 123. 145.

Lacerta firidis 113. 114. 145. 151 155. 187. 650 .

visipara 53.113,156,158,167,651.

Lacerta vulgaris $193.216,640$.

Inacertilae 68 .

Lacertus aruaticus 628.

- pardus 160.

- terrestris vulg. 187.

Lachesis lierli 368.

Lanbutold] 397, 575, 594.

Laubjdilofrïten 10. 38; brcitrandige 39 : griedijote 38 ; maurifitie 39. 2)amentmold 640 .

Lanounte 519.

yaubiroid) (bafturn) 507

Enubiraidl $382.50 \%$.

Laubleber 509.

Leiodactylia 70 .

seiftemoint 641 .

Reoparber $=9$ iatter 369 .

Retante= Etter 369 .

Eilforo= Sibechie 84

Lissotriton palmatus 648 .

- palmipes 648.

- pumetatus 640 .

Lophinus palmatus 648.

- punctatus 640 .

Sort 480.

urche 371 ; fübeuropiaighe 648 .

y).

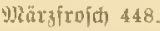

Dtaucre(sidenic 47,52,54, 76,80 . 44. $87,108,18 \times, 652$. - Marictätèt 54, 194 ff.

Miaucrgedo 51.

Wheїетїв̈ 648.

Wicteor=thallerte 446.

y) o $\{$ (f) 5 - 54 .

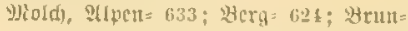
nen $=633 ; \quad$ Ero $=594 ;$ Baobel $=648$; Fener $=594$; (B)arten $=640$; (Sebirg $=$ 633; geflecfte: 594; glatter 640 :

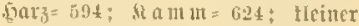

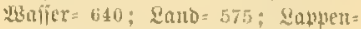
640; Leiftelt= 041; Mittel= 633; diegen $=594$; Sdhucizer 649 ; Strei= $f(1)=634 ; \quad$ Eumpf $=624$; Wafijer(ioi).

Holge alpestris 633.

- cinerea dito.

isnea 633 .

palmata 648

yalustris 624

- punctata 640.

taeniata fito.

Wurthaini 633 .

gliolf 594.

Dlooriroit) 48.653 .

yi.

Viadtfinger 239.

Natrix anstriaca 336

- Cetti 279. 295.

- Coronilla 336.

Dumfrisiensis 336 .

Gabina 308 .

- (ironoviana 278. 294.

hylridus 294

- hydrus 308.

laevis 331 .

longissima 320 .

rubetaria 294.

tessellata 304

torquata 279. 294.

- minax 27!.

- vulgaris 294.

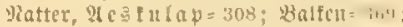
Ialyl'jue 369 ; Eibediett= :H, Fedf $=336$; gel ggrine 369 ; viron= ben $=369$; (blatt $=321$; (b) a t te 321 ;

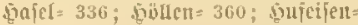
369; stapu $3 \mathrm{en}=369$; hielriden= $274 ;$ Sand $=308 ;$ Seoparbeli $=369 ;$

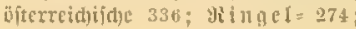
Ed) Linn $=330$; Ed)uintm $=294$
Treppen $=369 ;$ Trup= 369; SierLinient= $369 ;$ Wieritreifen= 369 :

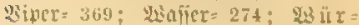
feI $=295 ; 3$ orm $=331$.

Matterti 271.

giestuiffle 238.

Notopholis 235 .

\section{E.}

Obstetricans vulgaris 574.

Defterreich. Shatter 330.

Drm 649 .

Ophidia 240.

Ophiomorus punetat. 237.

Ophiops elegans 236.

- Schlueteri 23ri.

Ophisaurus apus 238.

Opistoglypha 243.

Otophis 220 .

- eryx 223.

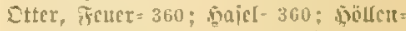
$360 ;$ Areuz $=337 ;$ Hแ⿰亻е $=360$; Lebunte $=369$; Eano $=369$; Etilly $=$ rajen $=369$

Ettern 272 .

\section{3.}

Palaeobatrachus 412

Paludites 10.

Pelias aspis 368.

- Berus 360.

- chersea 360.

- dorsalis 360 .

- Renardi 360.

Pelobates $412,519$.

Pelobates eultripes 521, 648

Pelohates fitseus 519. 656.

Pelohates insubricns 522. 537 .

Pelobatidae 420,519.

Pelodytes muctatus 64s.

Pelonectes 64?.

Pelophylax esculentus 430 .

- ridihundus 436 .

Periops 369.

Lierleidedife 234.

Peropodidae 370.

Petraponia nizra 6.23.

yifuflichilofrite 36 .

Phryne vulgaris 480 .

Phrynocephalus helioscopus 239

- mystacinus 230.

Phyllodactylus europ, 43. 239.

Plagiotremata 240 .

Platydactylus manit. 239.

Plenrodeles Waltli 612. 049.

I'leurodonta 41.

Podareis cupreiventris 198.

- cyanolaema 145

- Merremi 199.

- muralis 216.

- nigra 188.

- tiliguerta 198. 200.

Fogge 448

Pristidactyles 70.

Proteroglypha 243.

Proteus anguinus 649 .

- tritonius 594

Provipera 271

Psammodromus hispan. 65. 236. Psammophrlax cucull, 273, 369. Psammuros 236.

Pseudopus apus 93.238.

I'tychopleurae 2:38.

Pyronicia punctata 640. 
M.

Raganella arborea 519.

Ii all a 412,421 .

land agilis $422,451,456,459.406,655$.

Kana alliacea 537.

- alpina 448 .

- aquatica 436.

- aqu. citrina 436 .

- - viridis 4315 .

- aruorea 519

IRana arralis 422.448 .655$.

Rana atra 448.

-- bombina

-. bufina 494.

- Buto 480. 494, 507.

- - var. d 574.

- cachimans 426. 436 .

- eampanisona 574.

- caucasiea 436.

- cruenta 448

- dentex 437 .

- Drbowski 448.

- edulis $430^{\circ}$.

Rana esculenta 382.422 .651$.

Rana Haviventris 448.

- fiuriatilis 436 .

- foetidissima 507.

- fortis 426.436.

- fusca 531 .

- - terrestris 448 .

- gibbosa 448 .

- gigas 430 .

- gracilis 466.

- hispanica 428. 437.

- Hyla 519.

- iherica 648.

- Latastei $64 \mathrm{H}$.

- Lessonai 427.

- maritima 437.

- mephitica 507.

Kana muta $382,422.437,448,450,655$.

Rana obstetricans 574 .

- oxyrahinus 450.459.

- palmipes 430 .

- Yerezi 428. 437.

- picta 494.

- platyrrhinus $\mathbf{4 1 8}$

- portentosa 507.

- ridibunda $420,436.655$.

- rubeta 472. 481.

- salsa 507.

- scotica 437.

- scorodosma 537.

- sitibunda 494.

- temporaria 380. 448. 459. 466.

- tigrina 436.

- Tariabilis 483.494.

- verrucosissima $\$ 81$.

- respertina 536.

-. viridis 430.494 .519$.

- vulgaris 430.

Jamile firseae 437 .

- virides 422 .

Ranifae 420,421.

Rammeulus viridis 519 .

Jiedijo Biper 368 .

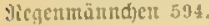

itegermold 591.

Heptilia 1.

lievtilien 1.

Rhinechis scalaris 369.

Rlipiptoglossa 239.

Dhingel=(5djen 238.

Mimgelnattex 259, 260. 267. 272. 274.652.
Diofyrling 507.

Jiofrtröte 507.

9kothunudine Itufe 5.52.

Rnlieta gribbosa 448

\section{$\Xi$.}

Eägetunger 237.

Eafamatioer $5 \%$ is.

Ealamantber, II pen $=494$; 2ierg= 633; Briflen $=649$; Feuer $=576$; groß̄er Whafier $=624$; fleiner walict $=640$; Mlofjen $=600$; idjwarzer 600 .

Salamandra 397.416 .575$.

Salamandra abdominalis 640 .

- alepid. verme. 624.

- alpestris 633 .

- aquatica li24. 633.

- aquatilis 624.

Salamaudra atra 604. 600 .

Salamandra Batrachon vera 624 .

- carmifex 624.

- eausasica 649 .

- cincta 633.

- corsica 578.

- cristata 624.

- elegans 635. 640.

- exigua 640.

- fuser 637.

- imnea 633.

- Lacepedi 640.

- laticauda 624.

- marulata 594.

Salamandra maculosa อัด 6. 594, 607.

Salamandra nigra 600 .

- palmata 648.

- palmipes 648 .

- palustris $6 \pm 0$.

- platycauda 624.

- pruinata 619.624. juuctata 635, G40.

- rubricentris 633.

- taeniata 640.

- terrestris 594.

- terr. mac. luteis 594.

- vulgaris 594.

Salamandridae 575 .

Salamandrina perspicill. $6 \notin 9$.

Eamanbrit: 377.

Eanปtäuโ̣ 236.

Eanootter 309.

Eandid)latige 370.

Sauria 39.

Edeiveniึinger 239.

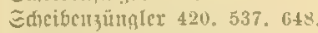

Edieltoyujit 238.

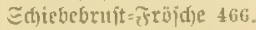

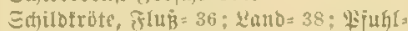
36; Echlamm = 36; Eumbf = 36 ; Teidi $=36 ; 2$ aliner $=36$.

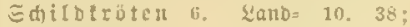

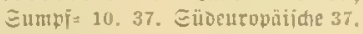

Edjilbuiper 368 .

Schistoglossi 67 .

Ed)

Edinumutauticr 648 .

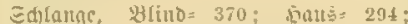
hices $=336 ;$ Jact $=336 ;$ : At algen $=369$; supjer $=336 ;$ Eano $=370$.

Edlangen 240; vortveltiche 271.

Zdrangent-2tuge 236 .

S̈blangeujthleidje $68,217$.

छd) feidien 68, 216.

Eकletberidivan 238.

Et)lingnatter 33 t;

Ednale 294 .
Echuprent=Cenicn 21 .

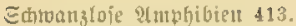

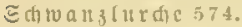

Sđtoinmutter 294.

Seincoidne 21 ti.

Eeerroith 426

Eeitemaltier 56, 238.

Seps argus 152. 167.

- chalciles 237.

- coerilescens 166.

- erythronotis 151

- muralis 193. 216.

- ruber 154, 167.

- stellatus 154.167.

- terrestris 125. 145.

varius $123,145$.

- virillis 123. 145

Serpentes 240.

Zmarapo=(sioed)ic $32.85,88,89$. 104. 114. 6.50.

Solenoglypha 243.

Enaltiüitgler 67 .

Speleryes tuscus 649 .

zpristatroid) 454. 6.5.

Srqumata 39.

Etarrbenitroithe 421 .

Stellio vulgaris 238 .

Stenostomata 241.

Etepuen=(EtDedie 236.

Etreifenntold) (334. 640.

Etreifematter 369.

Etülprajent=5tter 369 .

Stummelíüber 370.

Eumpfiroi(f) 459.

Eitmpitröte 507.

ङumpintulá) 624 .

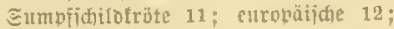
taipijde 37.

ミumpịithilofröten $10,3 \bar{\gamma}$.

\section{T.}

Tarbophis vivax 369 .

Tarentola maurit. 239.

Tatterntaun buo.

Icictirojid $\$ 30$.

Tcictimolth

Ieichichilof röte 36.

รcichut:๋ 536. 542.

Terrapene euromaea 37 .

Testudo campanulata 38.39.

- europaea $3 \overline{7}$.

- tlava 37.

- graeca 38.

- jhera 39.

- Jutaria 15. 37.

- marginata 39.

- meleagris 37.

- orbicularis 37.

- pulchella 16. 37.

- pusilla 39.

Ihauịujal 44 k.

Ifuring. Yiatter 33 ti.

Iifigugu 238

Irepuenatter 369 .

Trigonoeephales halys 370 .

Triton 575. 1300.

Triton abdominalis 640 .

Triton alpestris 383, 607, 616, 624.

Triton apuanus 633 .

- americanus 624.

- aquaticus cs0.

- asper $6 \$ 0$.

- Bibroni 624.

- Blasii 649.

- Boscai 449. 
Triton earuifex 1.2. 1,2t

- cortyphorus 594.

Triton cristatus 607,1316

- Farelini 620

- lonripes 620

- helveticus 648.

- ictericus 620.

- lobatus 640.

- Maltzani 649.

- marmoratus 627. 649 . Montandoni 649.

- nycthemerus 624

- palmatus 640.648.

- palustris 624, 640.

Triton paradoxus $607,616,6 \pm 1$.

Triton parisinus 640 .

- punctatus 640

- Rusconi 649

- Salamandroides 633.

- Taeniatus 640.

- Tronessarti fi49.

Triton vulgaris 601. 607, 616, 634. - merid. 638

Triton Wufhaini 633

Tropidonotus 272. 2

Tropodinotus ater -4 ;

- alstriacus init.

- Cetti 279.24.

- elaphoides 2 in. :3ir.

- fallax 280.

- gracilis 300.308.

- hybridas 294.

- hydrus 308.

Tropidonotus natrix 274. 652

- - D'aristätcn 278.653.

Tropidonotus Oplili 294.

- persa 295.

- persicus 295. seutatus 295

- Tantalus 308

Tropidonotus tessellatus $245 \%$

Tropid. thuringicus 336 . viperinus 300.369.

Tropidosaura 57, 230,

- algira 236.

Iroutefiart'fice 9Rold 398 .
Truguattern 369

Iupfeligleide 238

Typhloys rermicularis 370 .

Typhlus fragilis 233.

\section{1.}

Llnt 294.

Unte 537. Werg=543; getbbaudige 543 ; Lanto $=519 ;$ rothball ige $552 ;$ reid $=530 ;$ शisanier $=537$.

Urodela 574.

Uromastix spinipes 5,233

ㄴ.13.

Wiertiuien=yintter 369

Wieriftripen=liatter 369 .

Vipera 272.337.

Vipera aminodytes 364.369 .

Vipera aspis 360. 368.653 .

Vipera atra 364.

Vipera berus 387, $360,368.653$.

Vipera leerus var. 5 368. 65.5

- ceilonien 360.

- chersea $363,36 x$

- communis 361).368.

- Francisci Rerdii 368

- Heegreri 363.

- Hugyi 363. 368

- Latastei 364. 369

- leluetina 369.

- limnara 360.

- melanis 360

- Nosis Charas 308.

- ocellata 363,308

- aritntulin : Inliks ates,

- prester 341, 360 .

- Rerli 363. 364. 368

- schytha 360.

- siluamosa 360

- torva 360.

- trigonocephala 360 .

- Ursimi $:-U_{1}, 1 \cdot 4$

- vulgaris is, : in

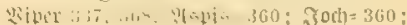

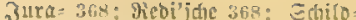
$36 \mathrm{~s}$.

Viperidae 272. 336.

Bipern 261.272, 336.

wipernatter 360 .

w.

Qualo=(ctoed)ic 47, 64, 16\%. 451. Waijerfröjdie 422.

Lafiferiroint $382,389,408,422.654$ פgafierfröte 536

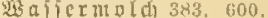

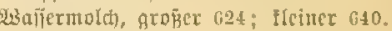
igalfernatter 274.

Wajperfalamanoer, grok̄er 624; Ifeiner 640.

23anjerichiloftöte 36 .

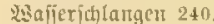

wanter $=$ llute 537 .

wasedjiclfrüte 494

wisegnare 594. 600

Wisetteriroid) 519

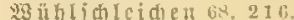

W6irficlnatter 208.272 . 245. 052

ํำ

\section{8.}

Zacholus anstriacus 336.

- Fitzingeri 325, 33ij.

- laevis 336.

- italicus 325

Zamenis Aesculapii 320 .

- Iahlii 369

- gemonensis 369.

- hippocrepis 360 .

- viridifiavis 369 .

3oun=(cibedic $47,52,76,-2,1$ 108. 14.5, 0.51 .

Zootoca 167.

Zootoca crocen 188 .

- Lilfordi 203

- montana 185.

- inuralis 188, 216.

- jyrrhogastra 1 -8.

- vivipara 187.

Buitterbiloung 601. 


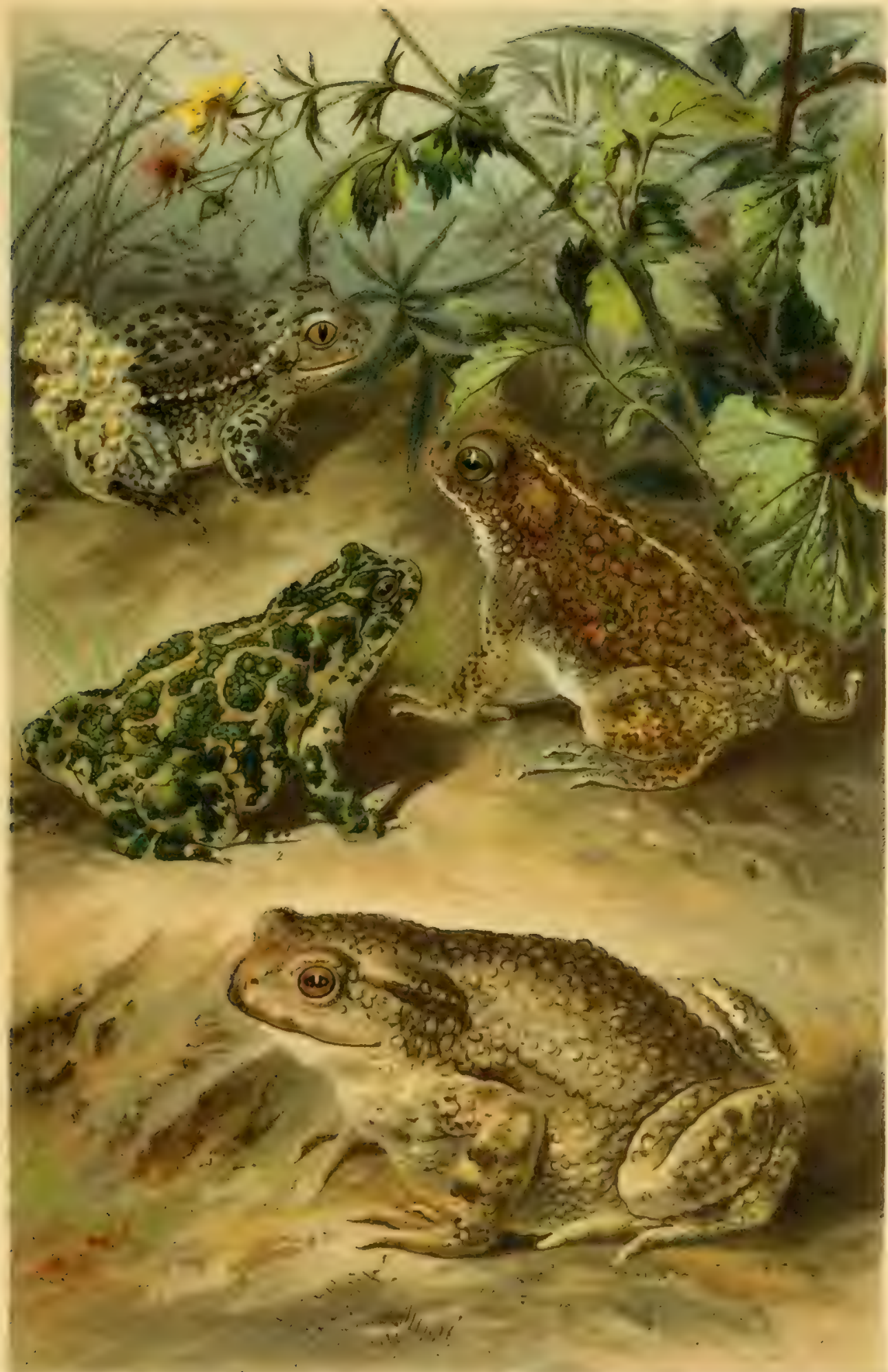

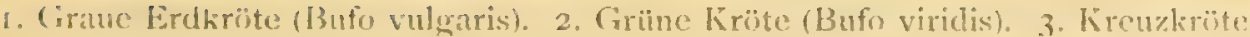
(I3ufo calamita). \&. (ieburtshclferkrïte (Alytes of)stetricans). 



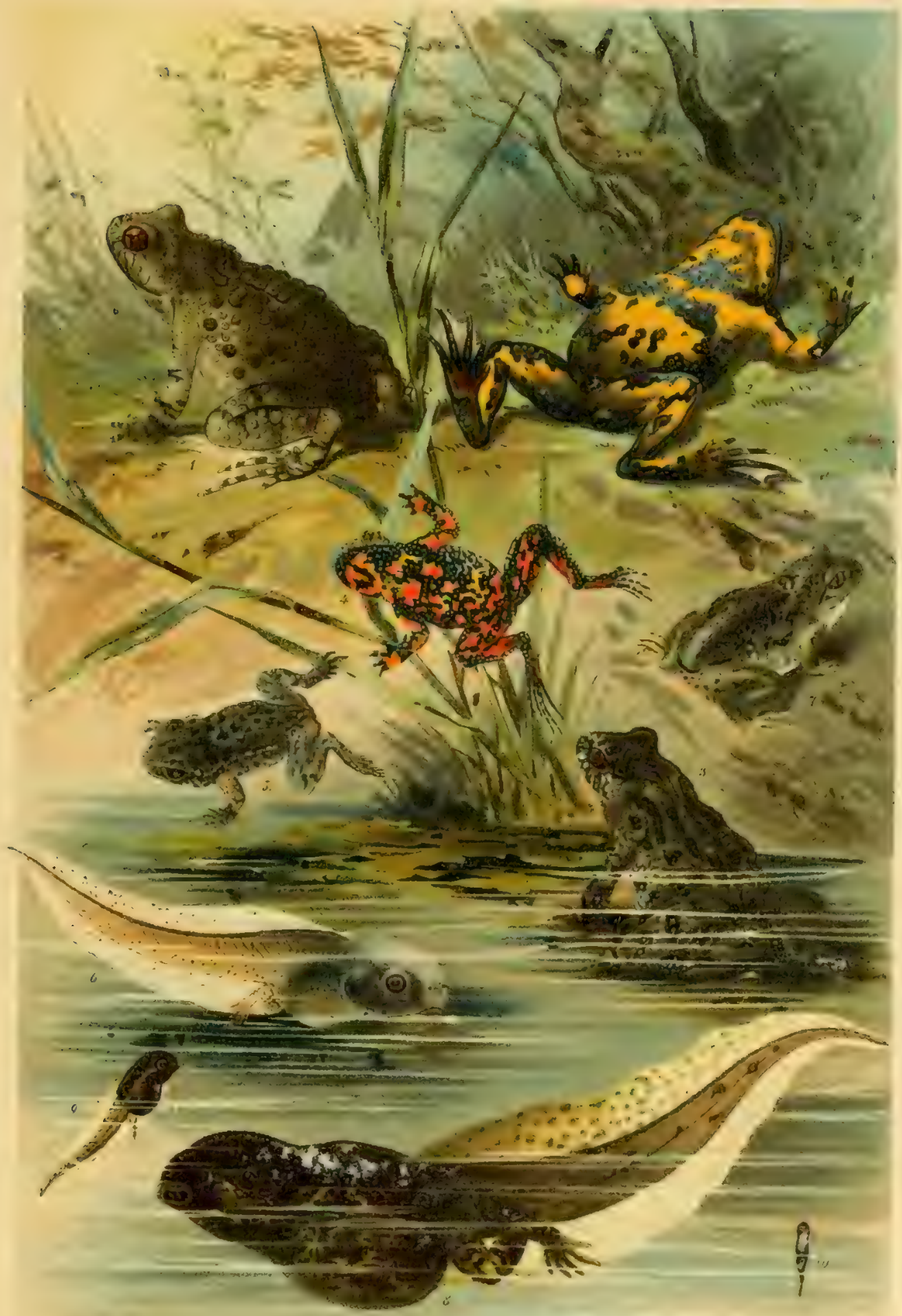

I. 2. Gelbbauchire Bergunke (Bombinator pachypus), 3.4. Rothbauchige Link. (I3cumb. bombinus). 5. Jumge Geburtshelferkröte (Alvtes nbst.). 6. I.arve derselben - Junge Knoluduchskröte (Pelobates fuscus). \&-Io. Tarven derselben 



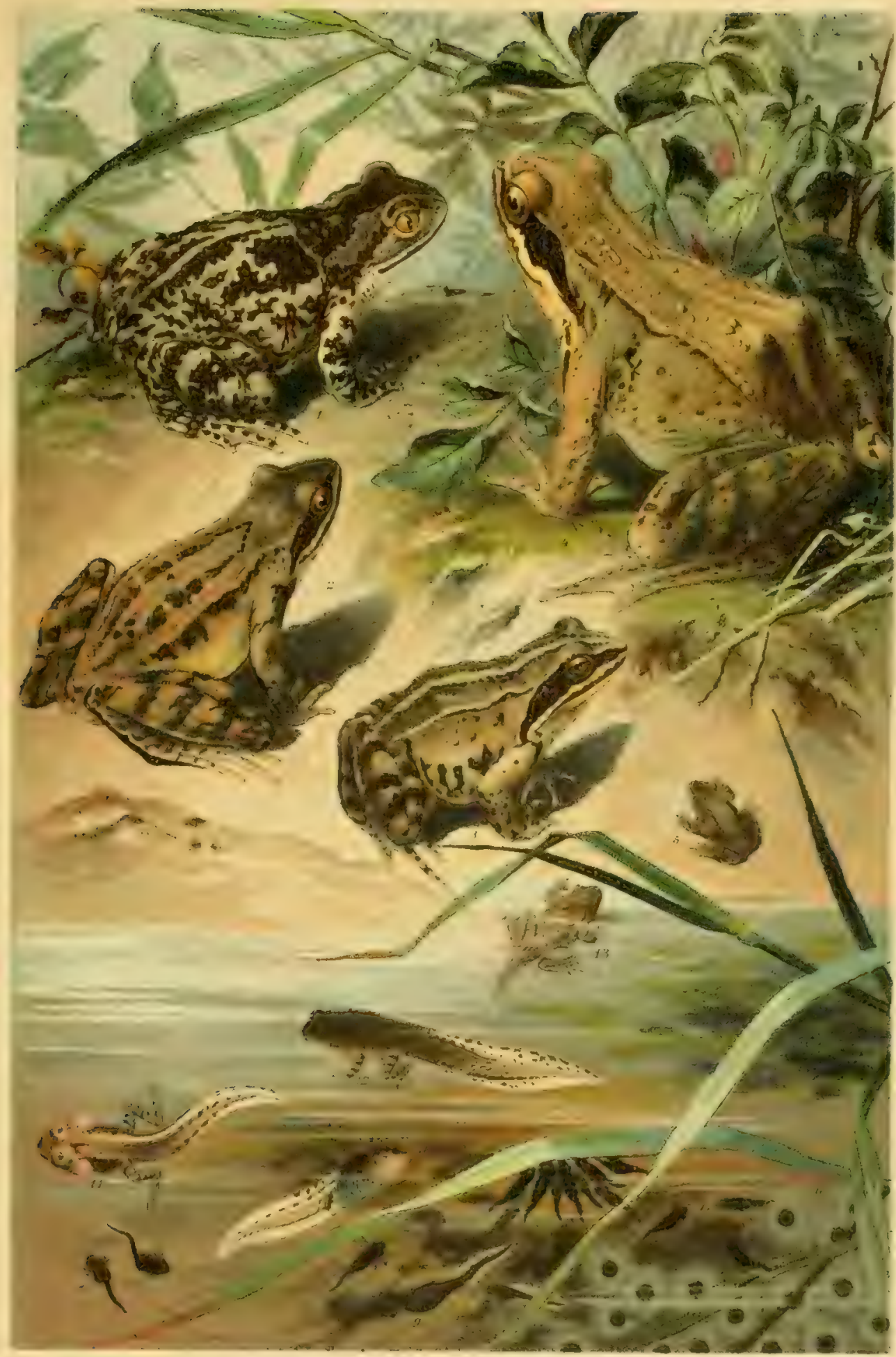

1. Knoblauchskriote (T'elobntes fuscus). 2. Springfrosch (Rana aurilis). 3. Montiroseh (Rana arvalis). 4. (irasfrosch (Rama muta). 5. Junerer (irasfrosch. 1-13. Laich und Entwicklungsistufen des (Arasfrowehes. 

Taf. IV.

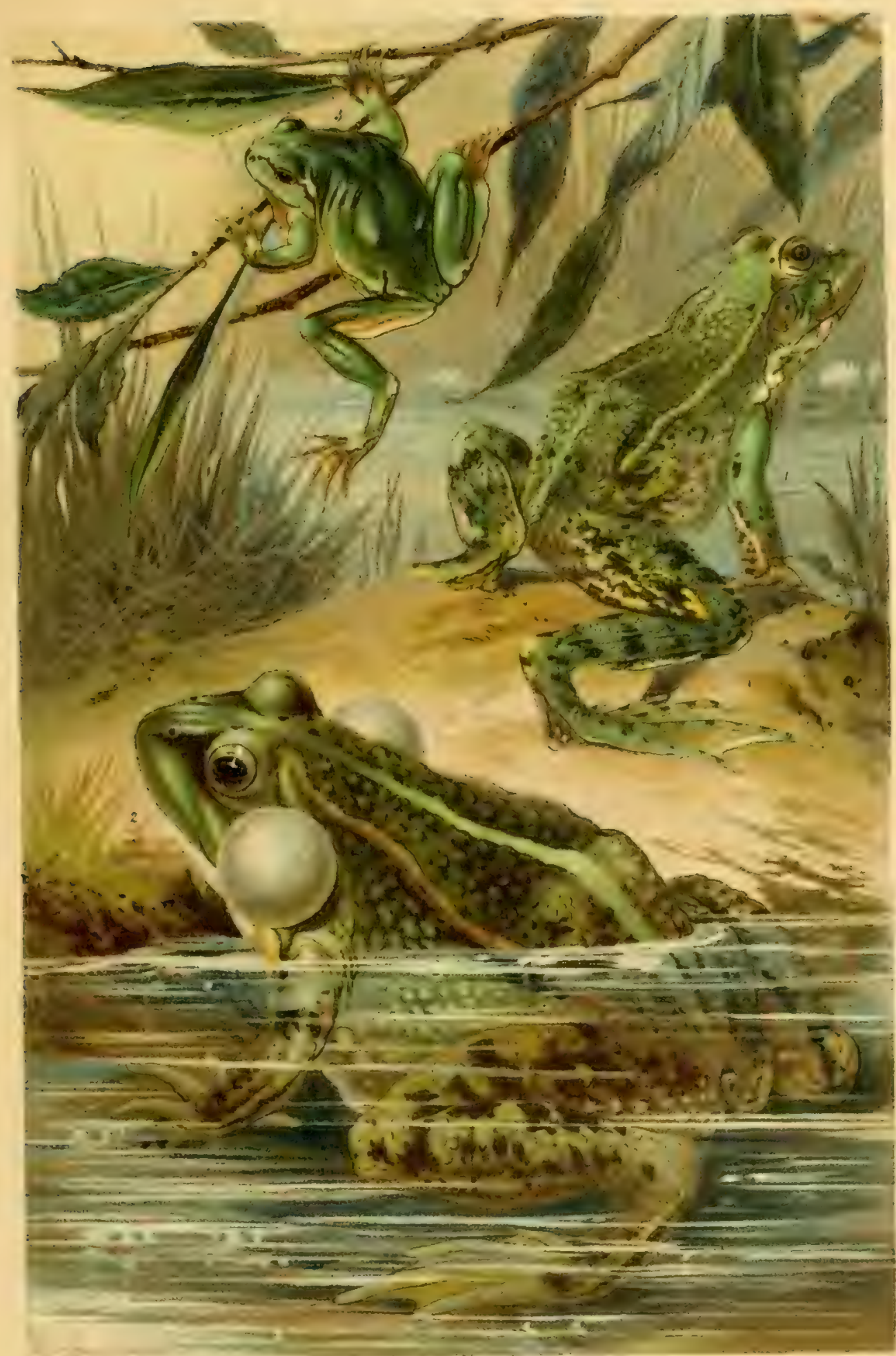

1. Wasserfrosch (Kanal esculenta). 2. Secfrosch (Rana esculenta ridibunda). 3. Latubfrosch (Hyla arborea). 

Taf. V.

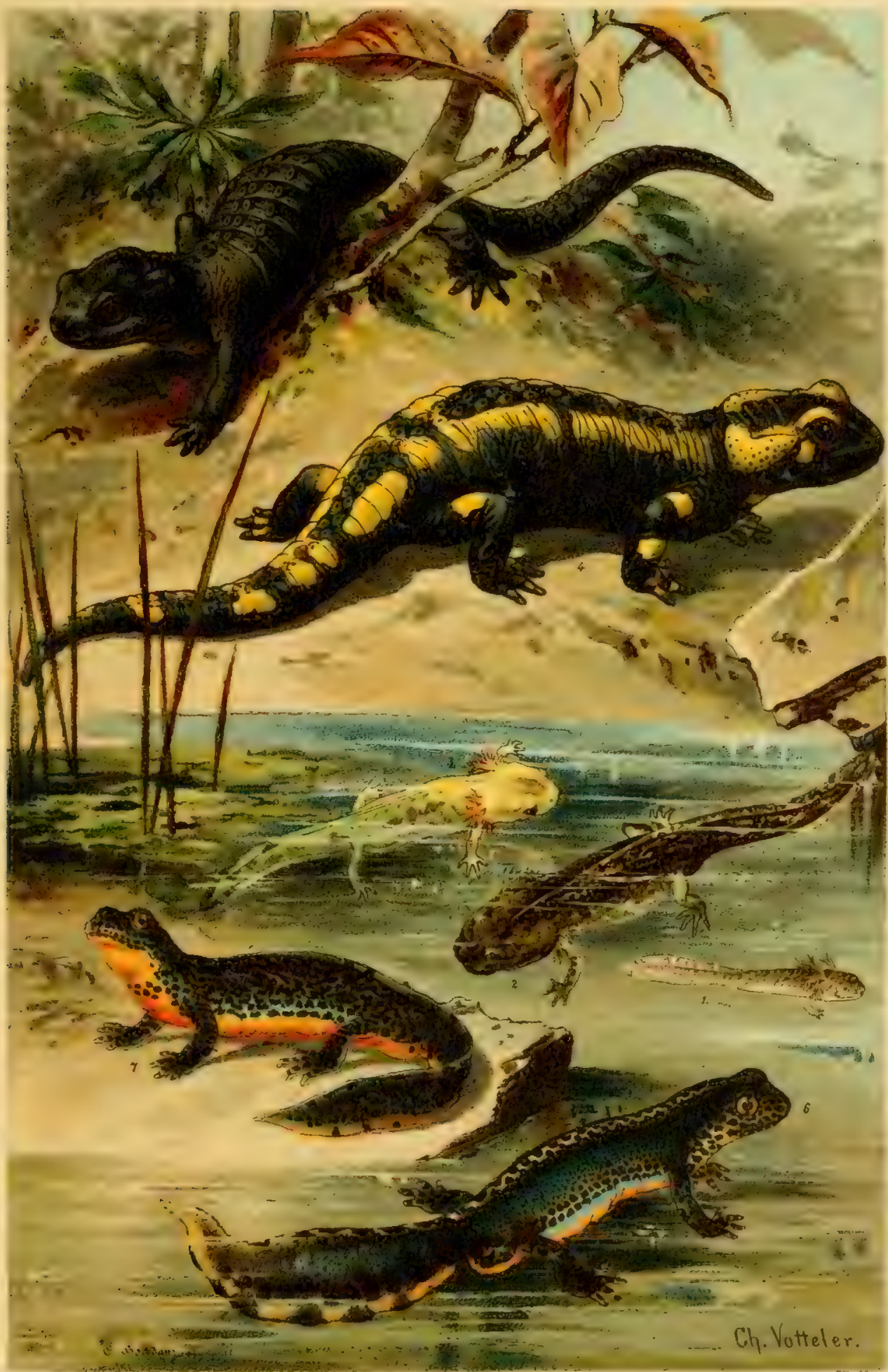

Feuer-Salamander (Salamandra maculosa) : I-3 Larven, 4. erwachsen.

5. Alpen-Salamander (Sal. atra). 6. Männchen und 7. Weibchen des Bergmolchs (Triton alpestris) im Hochzeitkleid. 

Tat.VI.

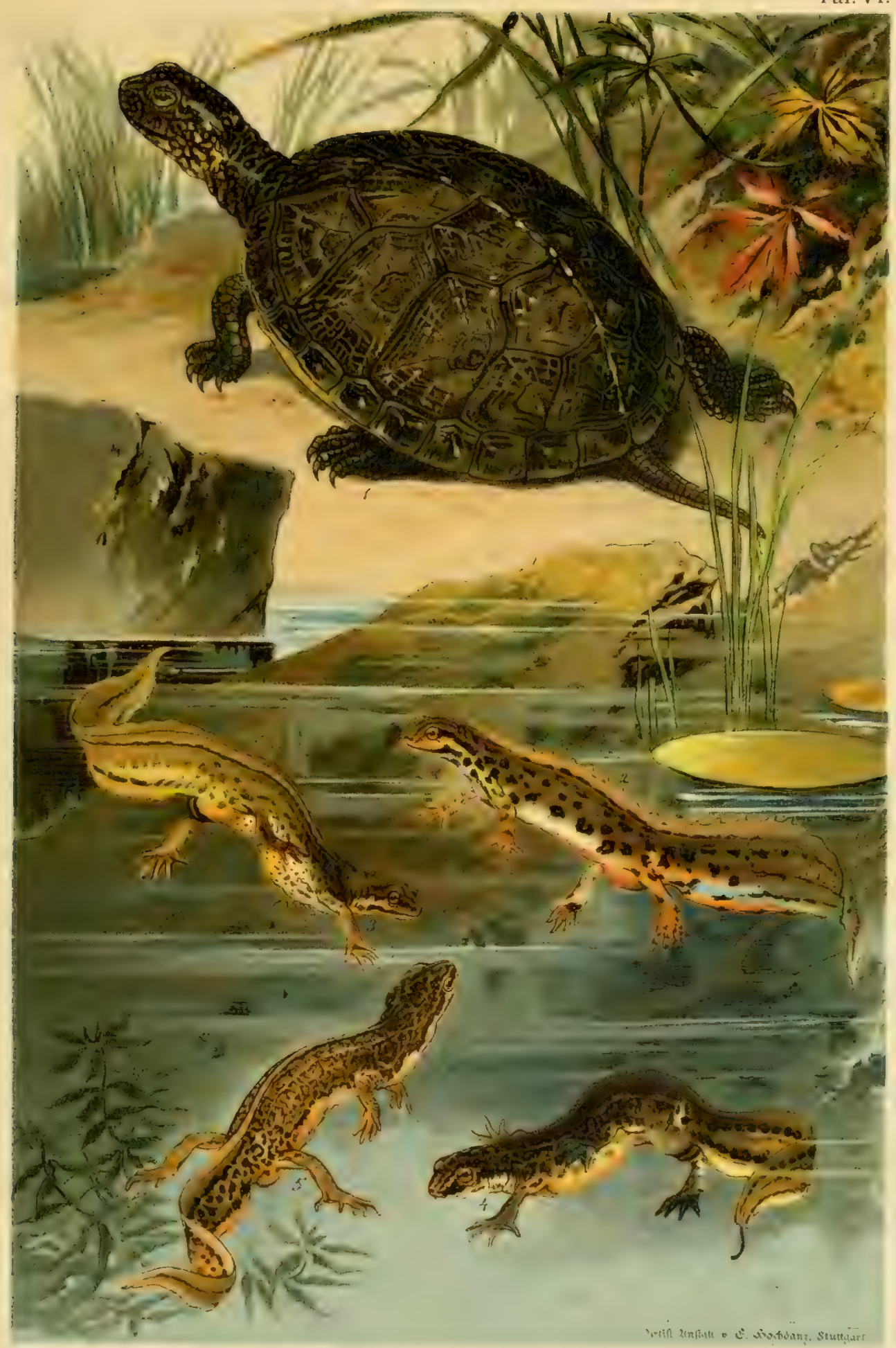

I. Sumpfschildkröte (Emys europaea) 2. Männchen und 3. Weibchen des Streifen-Molch (Triton vulgaris). 4. Männchen und 5. Weibchen des LeistenMolch (Triton paradoxus). 

Taf. VII.

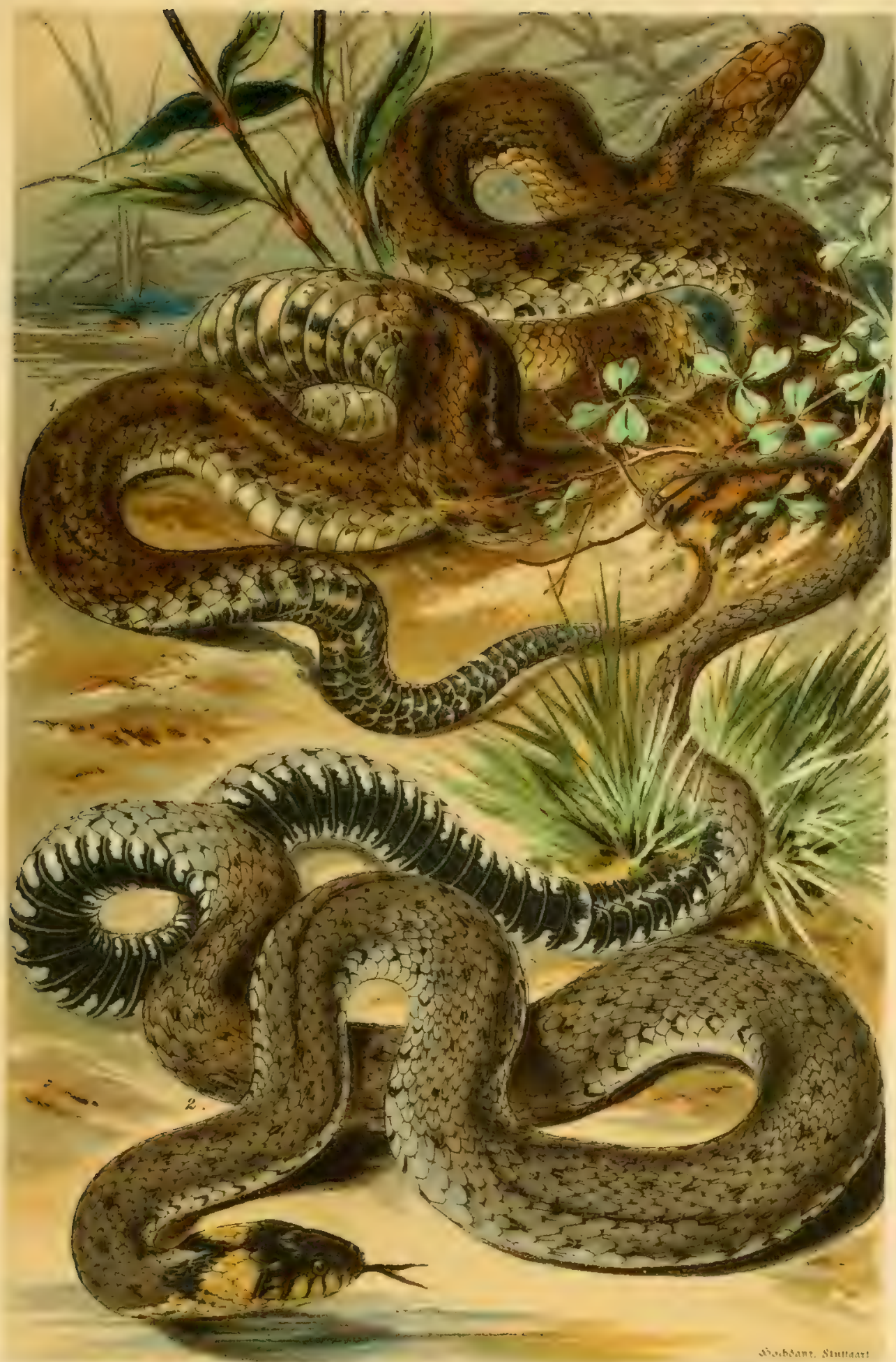

1. Würfelnatter (Tropidonutus tessellatus). 2. Kingelnatter (Trop. natrix). 

1 : if. VIII

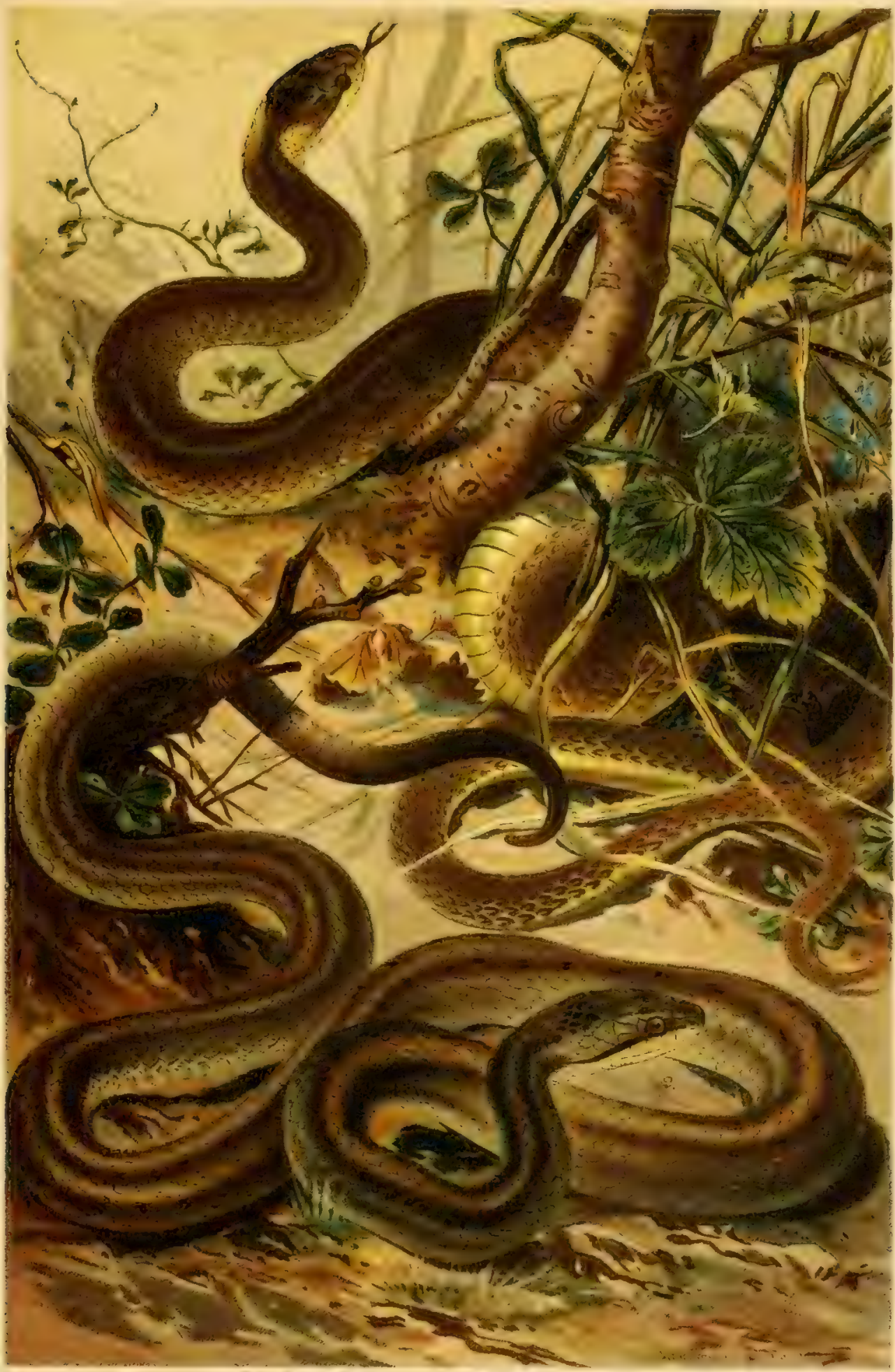

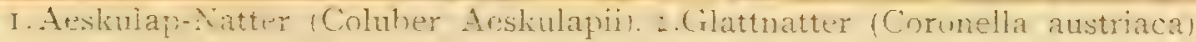



Taf. IX.

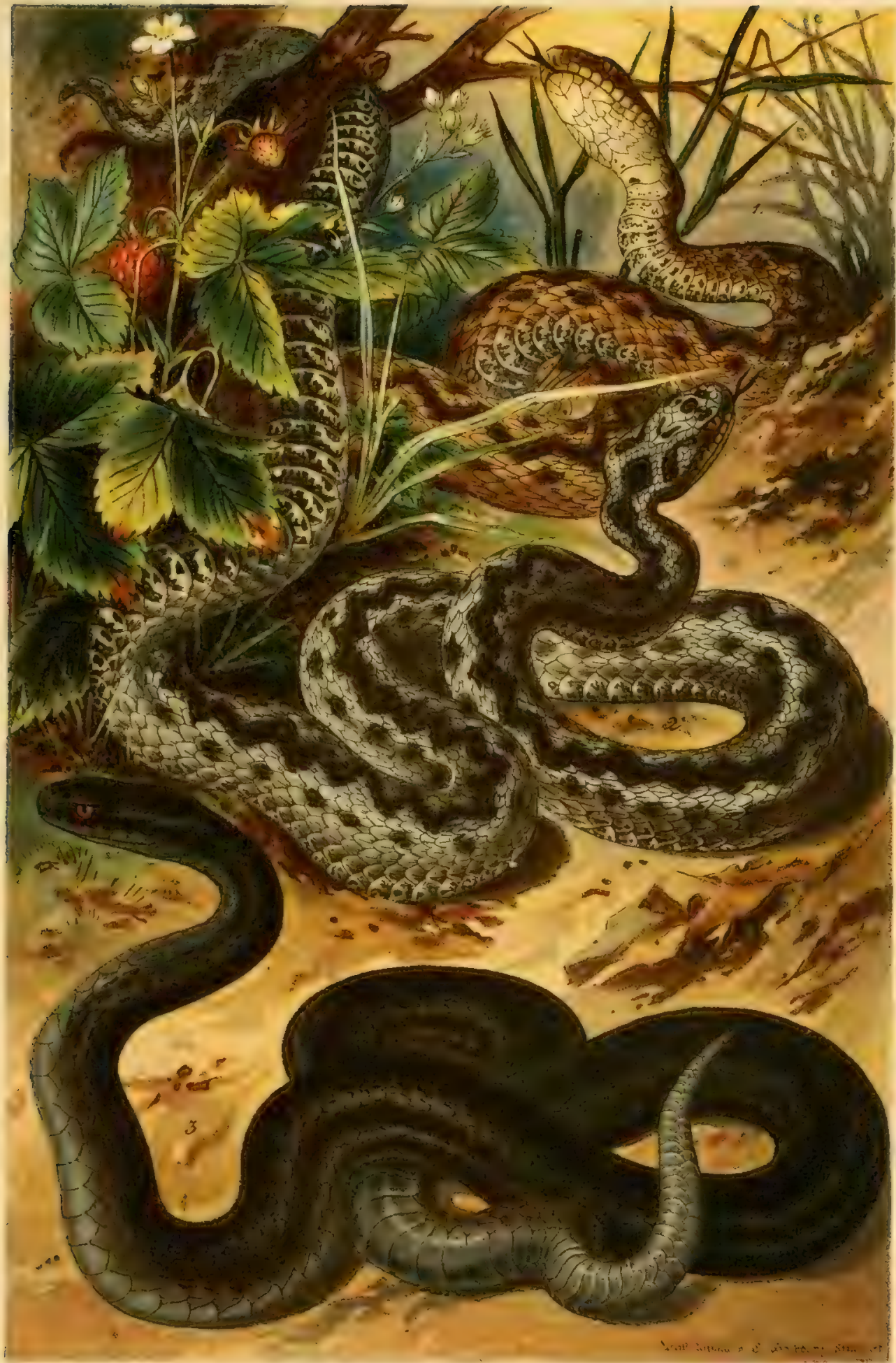

Kreuzottern (Vipera berus).

1. Weibchen, 2 Mannchen, 3. Schwarze Spielart. 



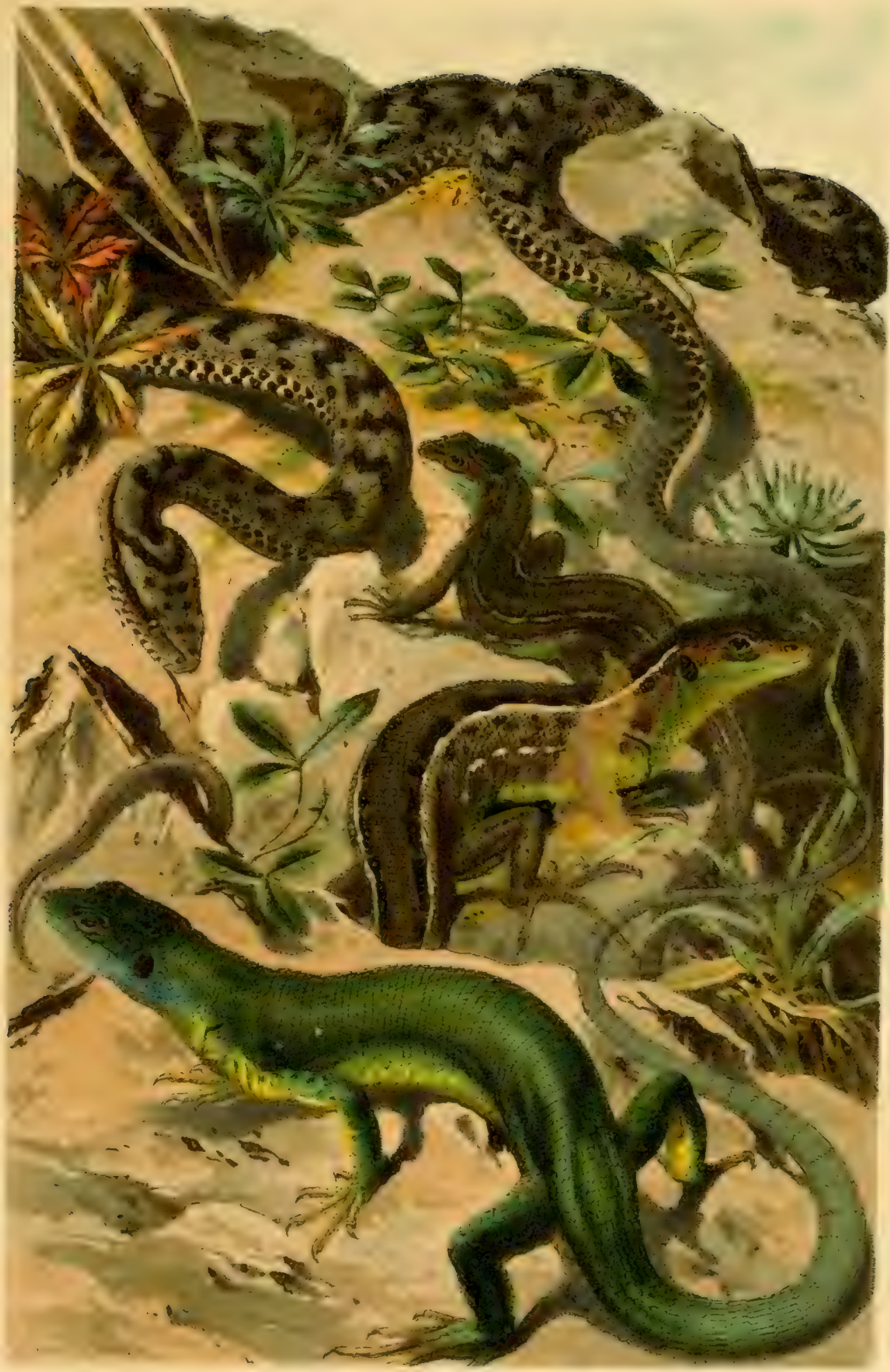

1. Viper (Vipera aspis). - 2. bis 4. Smarayd-Eidechsen (Lacerta viridis 2. Männchen im Hochzeitkleid, 3. Weibchen, 4. junges Tier. 

Tat Xi

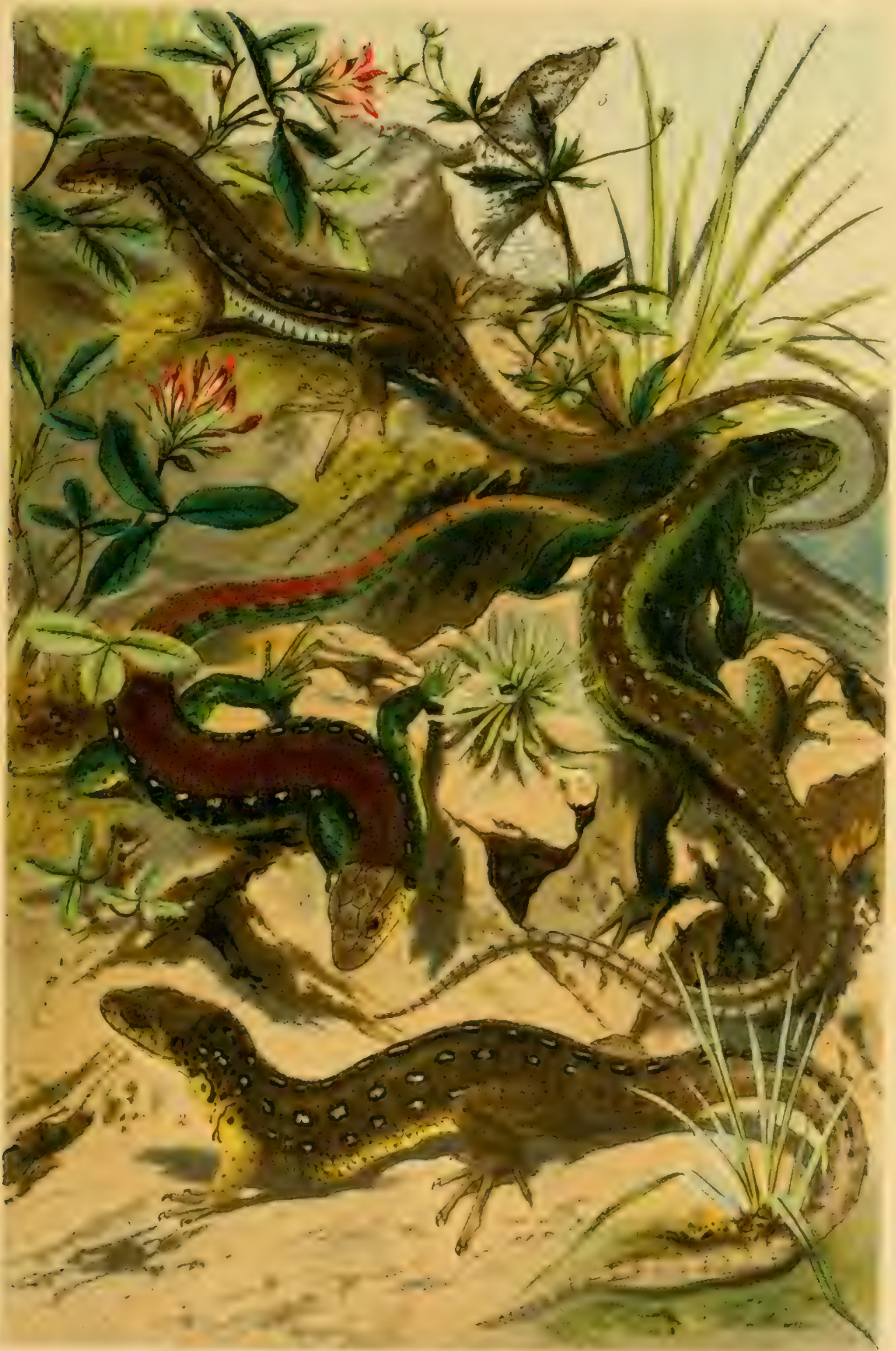

[. Männliche, 2. weibliche Zaun-Eidechse (Lacerta agilis). 3. Rothriekige Zaun-Eidechse (var. erythromotus). 4. Mannliche, 5. weibliche Mauer-Eidechse (Lac. muralis). 

'lat.XI1.

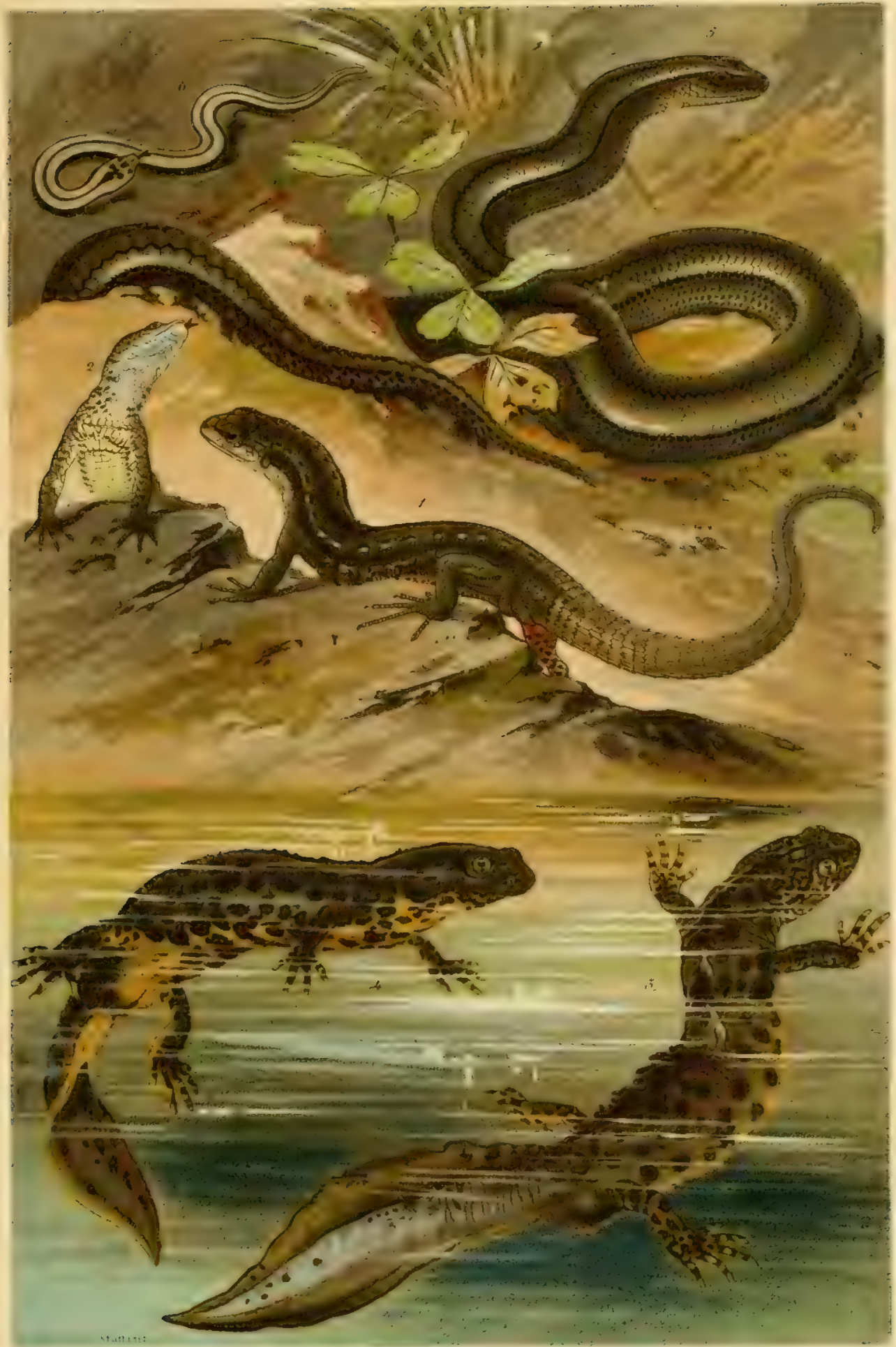

1. Männliche, 2. weihliche Wald-Eidechse (Lacerta vivipara). 3. Männlicher, 4. weiblicher Kamm-Molch (Triton cristatus) im Hochzeitkleid.

५. Erwachsene, 6. junge Blindschleiche (Anguis fragilis). 




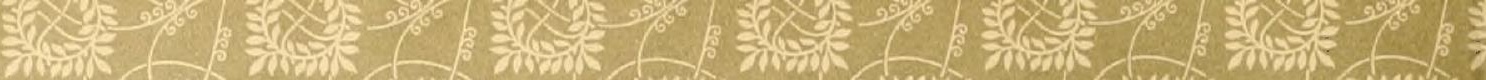

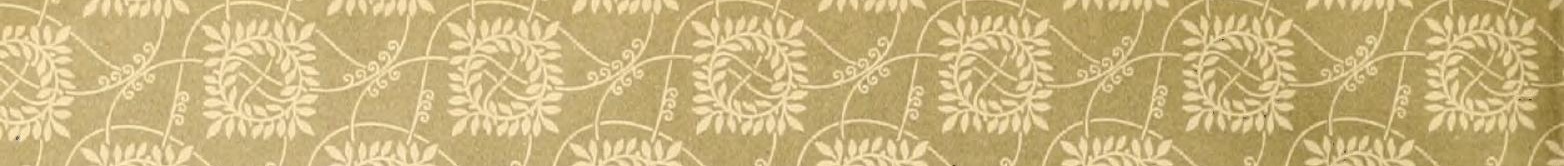

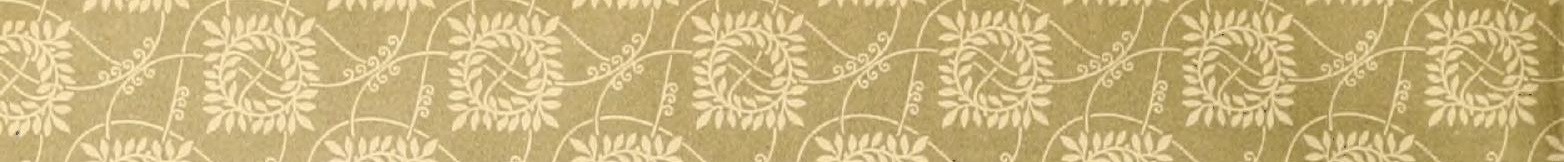

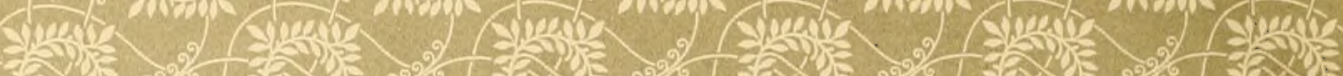

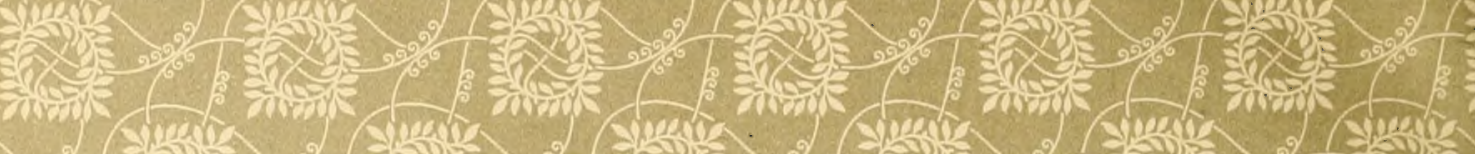
5 की

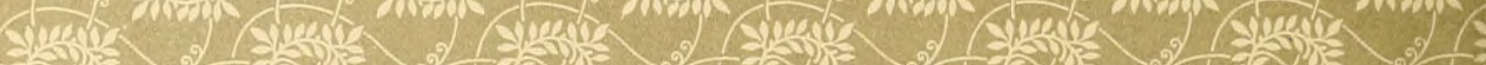
5 a

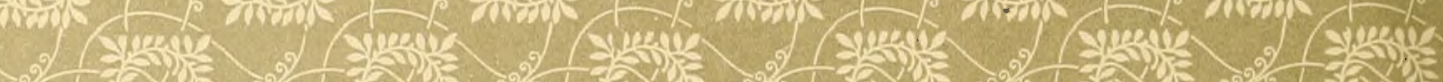

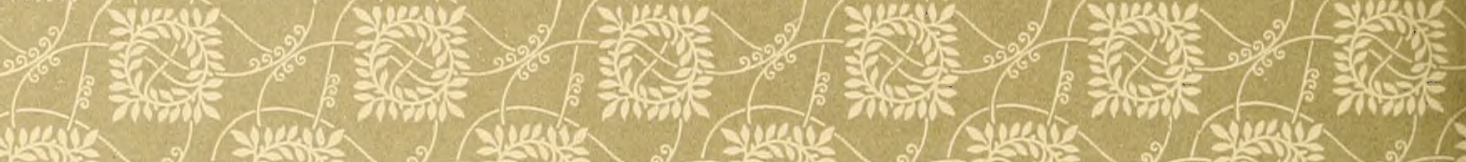

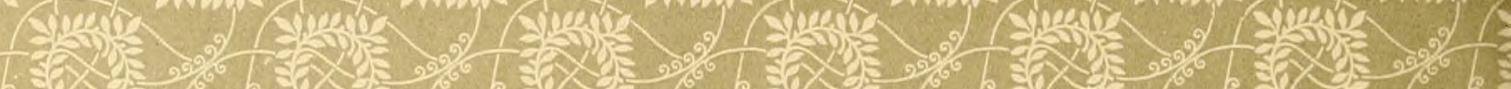

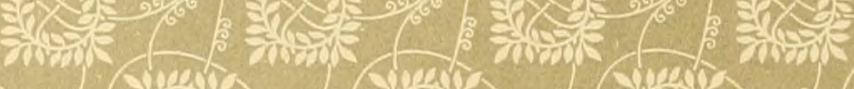

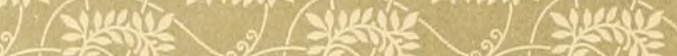

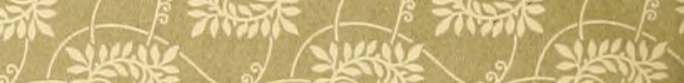
\%

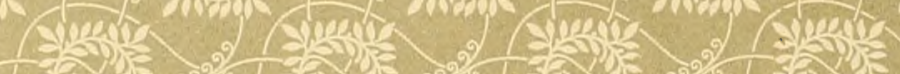

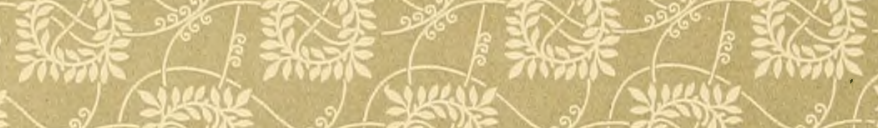
हो. (1)

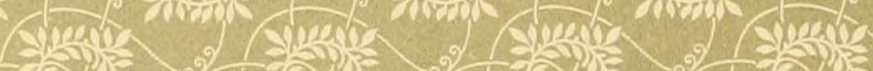

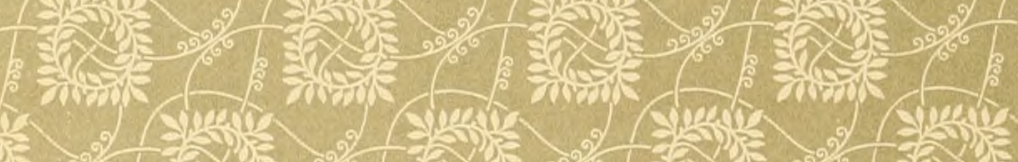

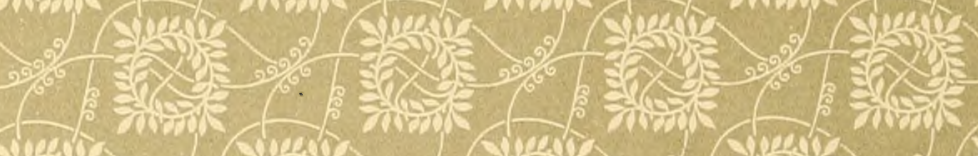

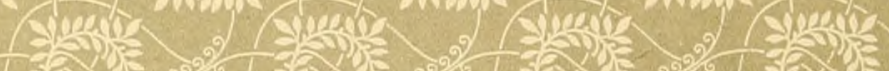
की

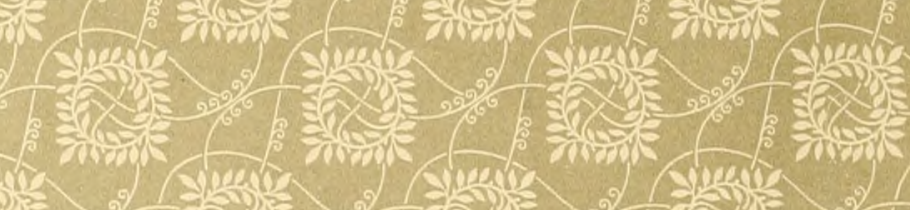
Greana

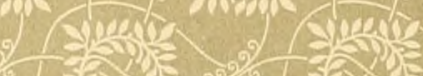
50 $\times 2$ $2.0 \%$ I $30 \times 2=5$

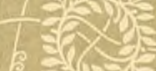

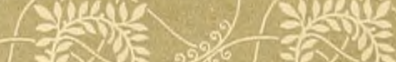

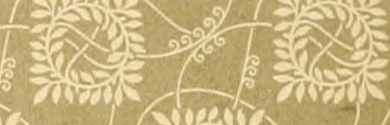
21 axis 



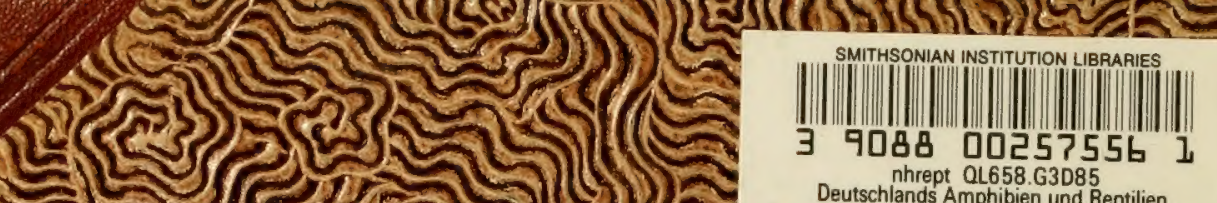
$=$ =

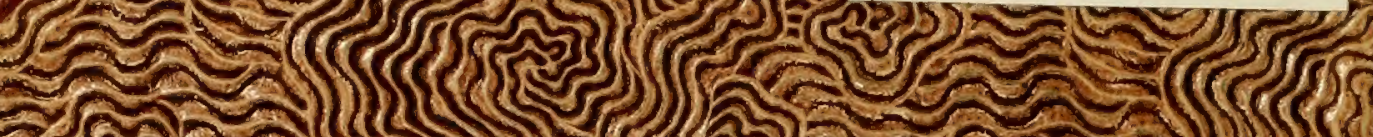
a.

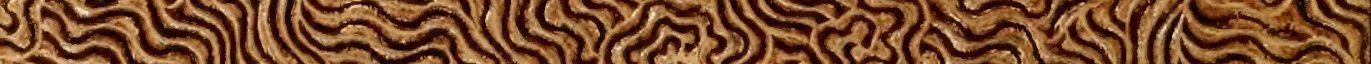

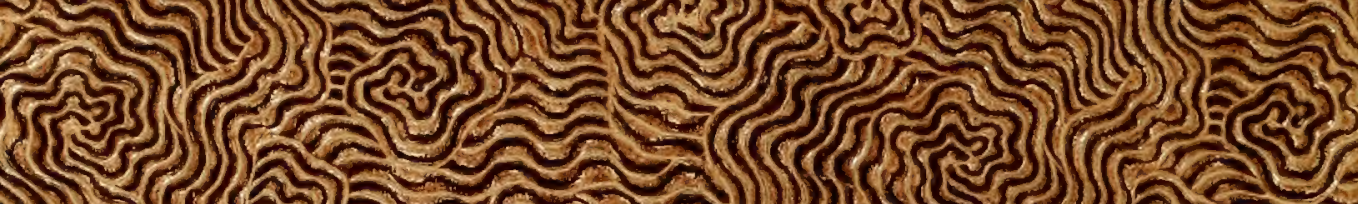

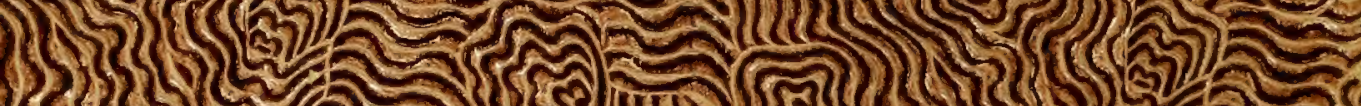

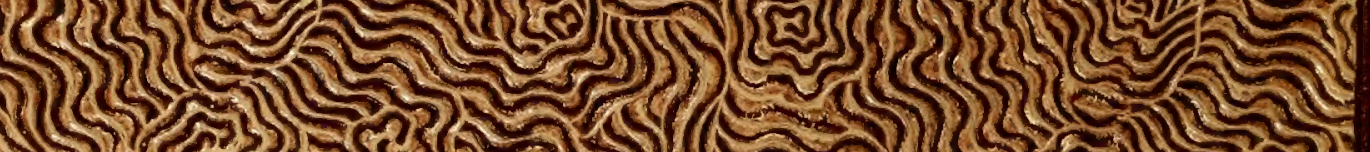

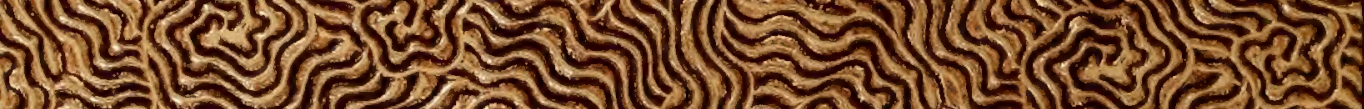
인.

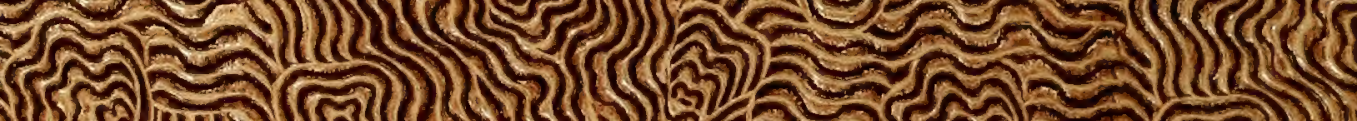

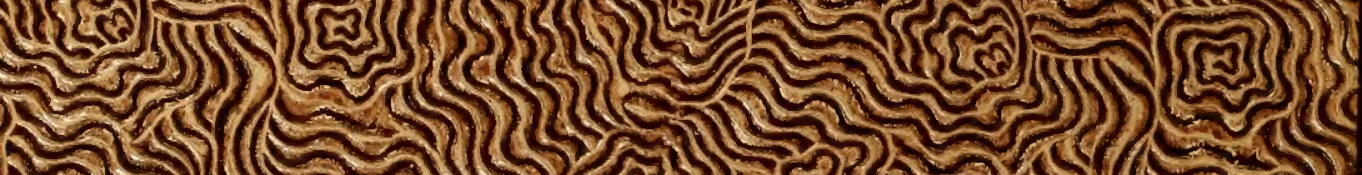

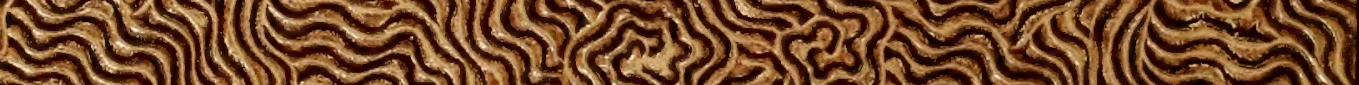
(2) 1 (

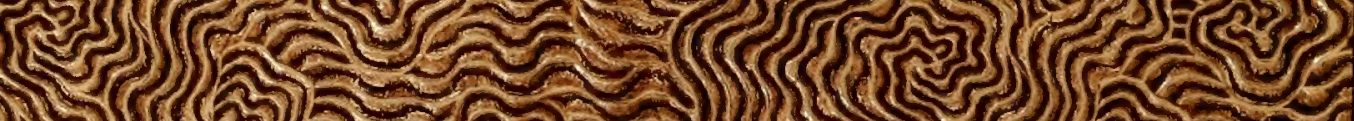

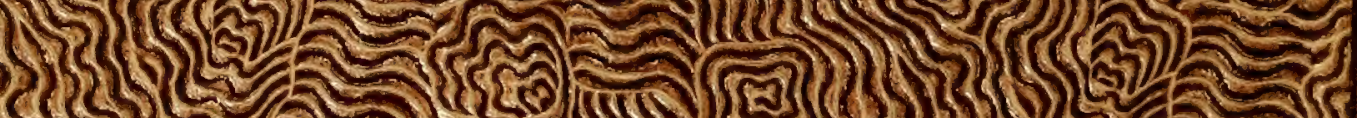

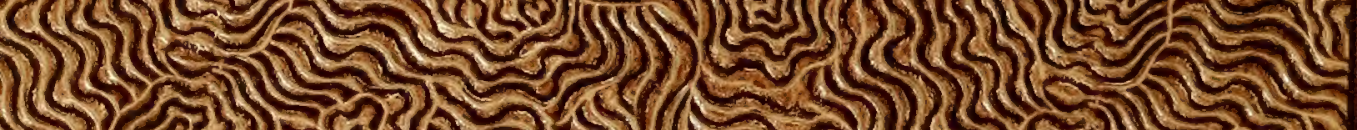

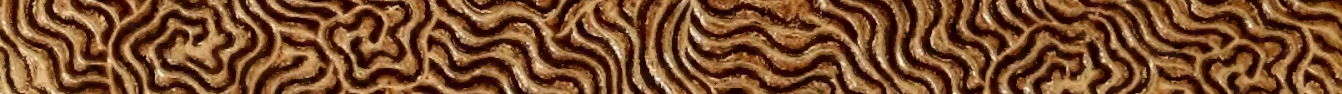

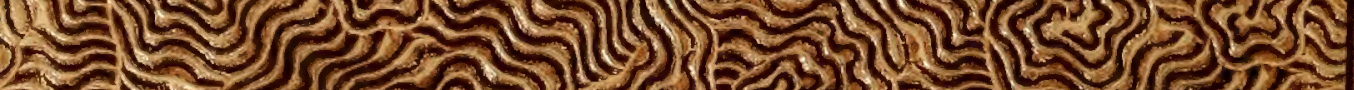

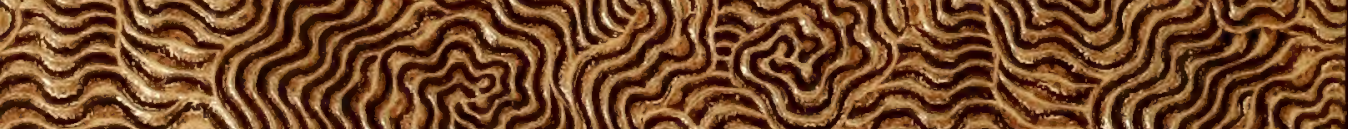
$\approx$ ज.

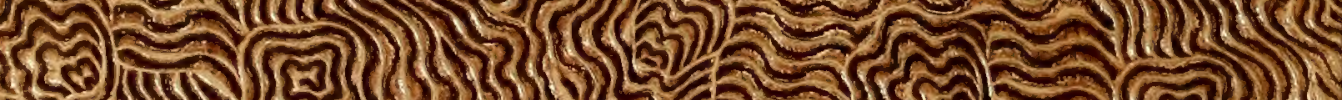

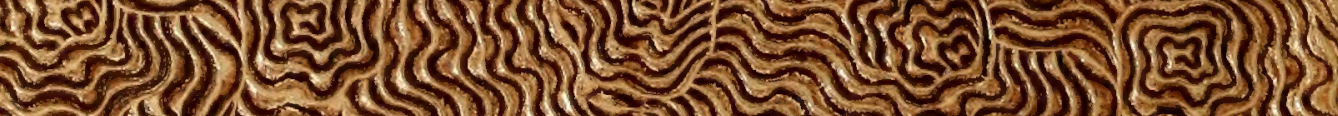
\ᄂ (

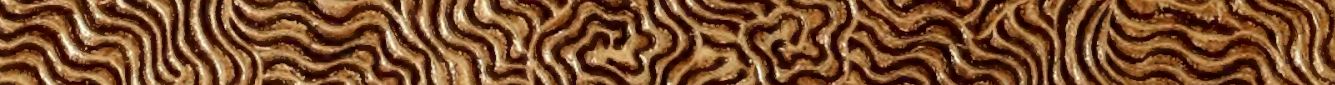

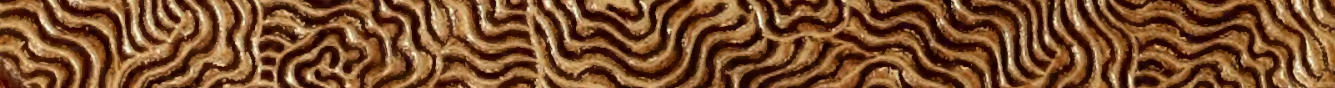
- 3) 